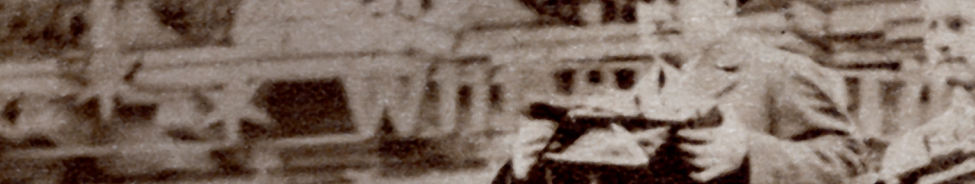

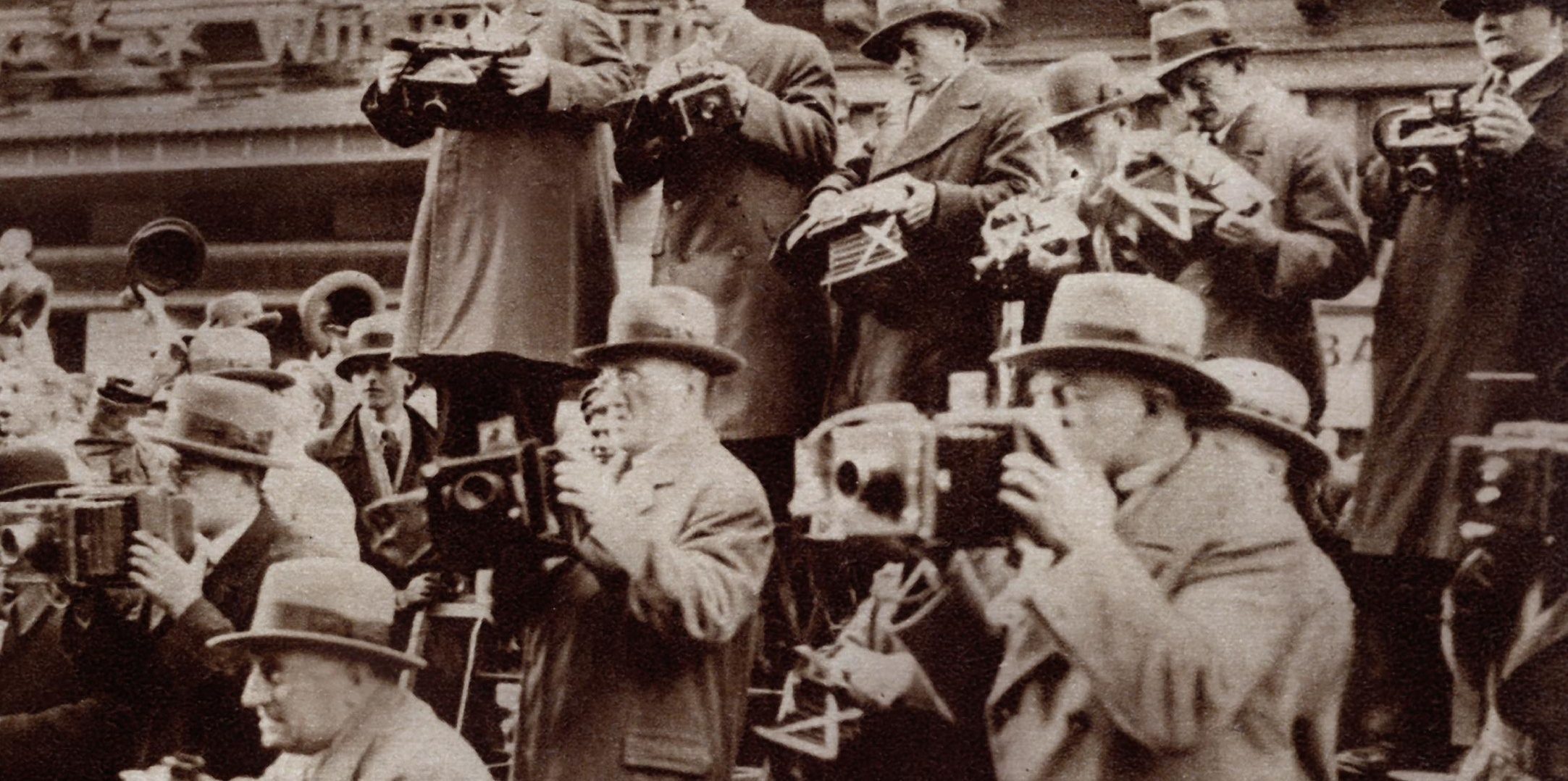

$25-80$

\title{
Anton Holzer
}

\section{Rasende Reporter}

Eine Kulturgeschichte des Fotojournalismus 
Anton Holzer Rasende Reporter 


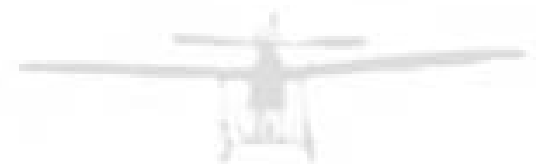

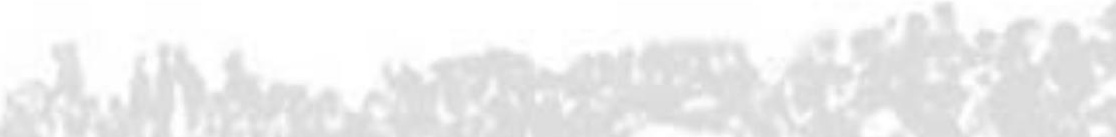

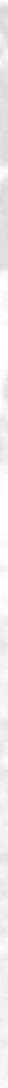


Anton Holzer

\section{Rasende Reporter}

Eine Kulturgeschichte des Fotojournalismus

Fotografie, Presse und Gesellschaft in Österreich 1890 bis 1945 
Forschungsergebnisse von: Austrian Science Fund: P 20289-G08.

Veröffentlicht mit Unterstützung des Austrian Science Fund (FWF):

PUB 77-G18.

\section{FUF}

Der Wissenschaftsfonds.

Die Deutsche Nationalbibliothek verzeichnet diese Publikation in der Deutschen Nationalbibliografie; detaillierte bibliografische Daten sind im Internet über http://dnb.dnb.de abrufbar.

Das Werk ist in allen seinen Teilen urheberrechtlich geschützt. Jede Verwertung ist ohne Zustimmung des Verlags unzulässig. Das gilt insbesondere für Vervielfältigungen, Übersetzungen, Mikroverfilmungen und die Einspeicherung in und Verarbeitung durch elektronische Systeme.

Der Primus Verlag ist ein Imprint der WBG.

(C) 2014 by WBG (Wissenschaftliche Buchgesellschaft), Darmstadt Die Herausgabe des Werkes wurde durch die Vereinsmitglieder der WBG ermöglicht.

Lektorat: Ulrich Berkmann, Mainz

Gestaltung, Satz \& Prepress: schreiberVIS, Bickenbach

Einbandgestaltung: Jutta Schneider, Frankfurt a. M.

Einbandabbildungen: oben: Pressefotografen in Berlin, 1931.

Unten: Rennfahrer Hans Stuck bei einem Bergrennen, 1929.

Gedruckt auf säurefreiem und alterungsbeständigem Papier

Printed in Germany

Besuchen Sie uns im Internet: www.wbg-wissenverbindet.de

ISBN 978-3-86312-073-3 


\section{Inhalt}

Auf den Spuren der rasenden Reporter Vorwort 7

Neue illustrierte Welt Einleitung 10

Bilder, Nachrichten, Sensationen Die Zeitungsstadt Wien um 190022

Die Jagd nach Sensationen Pioniere der Pressefotografie 36

Fotos statt Zeichnungen Das Entstehen einer fotografischen Öffentlichkeit 51

Bild und Text Die Rhetorik der Zeitungsseiten 59

Redaktion, Druck, Vertrieb Wie eine illustrierte Zeitschrift entsteht 70

Im Rampenlicht Der Kaiser im Blick der Fotografen 77

Als die Männer fliegen lernten Die ersten Wiener Flugschauen 91

Mit der Kamera bewaffnet Fotografie und Propaganda im Ersten Weltkrieg

Theater der Macht Parlament und Politik in Bildern 117

Kampf um die Straße Demonstrationen, Kundgebungen und Massenpolitik 134

Im Schatten der Konzerne Politische Illustrierte in der Zwischenkriegszeit 145

Bilder für alle Die Welt der Magazine und Revuen 170

Bilder als Propaganda Die illustrierte Regierungspresse nach 1934194

Erzählende Bilder Die moderne Fotoreportage in der Zwischenkriegszeit 203

Handel mit Bildern Die Rolle der Fotoagenturen 234

Politische Bilder Die Kultur der Arbeiterfotografie 248

Amerika, ein Traum Wolkenkratzer und Tiller Girls 263

Bubikopf und Zigarette Bilder der „Neuen Frau“ 277

Experiment und Bewegung Tanzschritte in eine neue Zeit 286

Wenn die Hüllen fallen Erotik, Sexualität

und Nacktfotografie in der Zwischenkriegszeit 296

Schöne neue Warenwelt Reklame und Mode in der Fotografie 304 
Dramatische Nähe Sport und Fotografie 317

Frauen hinter der Kamera Die neuen Fotografinnen 331

Die kurze Zeit der Avantgarde Fotografische Aufbrüche um $1930 \quad 344$

Landschaft, Berge, Brauchtum Heimatfotografie in den 1930er Jahren 363

Fotografisches Feuilleton „Der Sonntag”:

ein vergessenes Forum moderner Reportagefotografie $\quad 378$

Demagogie in Bildern Hitler in Österreich 1938411

Den Krieg vor Augen Nationalsozialistische Medienpolitik und Ästhetik

Eine andere Kulturgeschichte Schluss 437

\section{Anhang}

Anmerkungen 446

Fotografinnen und Fotografen 1890 bis 1945 Biografische Notizen 466

Literatur 483

Zeitungen und Zeitschriften 490

Index 491 


\title{
Auf den Spuren der rasenden Reporter
}

\author{
Vorwort
}

Nichts ist so alt wie die Zeitung von gestern, so lautet eine bekannte Redewendung. Dieses Buch handelt von alten fotografisch illustrierten Zeitungen. Sie sind nicht von gestern, sondern von vorgestern. Die Nachrichten und Botschaften, vor allem aber die gedruckten Bilder, die sie enthalten, mögen zwar längst der Vergangenheit angehören. Dennoch bilden sie ein überaus faszinierendes kulturgeschichtliches Archiv, das allzu lange übersehen wurde. Wenn wir voller Neugier in diese papierene Welt eintauchen, wenn wir in den längst verblichenen Zeitungen zu blättern beginnen, eröffnen sich uns ganz neue Perspektiven auf die Vergangenheit - und auch auf die Gegenwart. „Nur die Zeitungen“, schreibt der amerikanische Schriftsteller und Kulturkritiker Lincoln Kirstein im Jahr 1938, „(...) haben in ihrer blinden Energie versehentlich (...) ein gewaltiges Monument unserer Zeit für zukünftige Historiker beschworen. “ ${ }^{1}$ In ihrem umfassenden Elan der täglichen oder wöchentlichen Berichterstattung haben sie nämlich - gewissermaßen nebenbei - eine gewaltige Sammlung von schriftlichen Dokumenten und Bildern hinterlassen, die, mit einem größeren zeitlichen Abstand und neuer Brille gelesen, eine höchst spannende kulturgeschichtliche Lektüre ergeben. Das Anliegen dieses Buches ist genau dies: das Zeitungsarchiv als Quelle der Geschichts- und vor allem der Fotogeschichtsschreibung nutzbar zu machen. Es geht mir darum, anhand von Originaldokumenten aus Zeitungen und Zeitschriften die Entstehungsgeschichte des Fotojournalismus nachzuzeichnen. Die Recherchen führen uns zunächst zurück in die letzten Jahre des 19. Jahrhunderts. Von hier aus werden wir in zahlreichen Stationen einer bisher noch wenig bekannten Kultur- und Gesellschaftsgeschichte der illustrierten Presse folgen.

Kurz vor der Jahrhundertwende werden die ersten Fotografien in Zeitungen gedruckt. Was in der Welt geschieht, findet ab jetzt seinen Niederschlag in veröffentlichten Bildern. Um 1890 entsteht ein neu- er journalistischer Beruf, der des Pressefotografen. Dieser arbeitet im Auftrag von illustrierten Zeitungen und Magazinen und verwandelt Schlagzeilen in ausdrucksstarke Bilder. Je mehr aktuelle Bildberichte gedruckt werden, desto schneller wird das Geschäft der Pressefotografie. Allmählich wird aus dem behäbig arbeitenden Atelierfotografen, der um die Jahrhundertwende gelegentlich und meist nebenbei einige Pressebilder machte, ein rasender Reporter. Dieser ist auf seiner Jagd nach Nachrichten und Sensationen viel unterwegs, zunächst zu Fuß oder mit öffentlichen Verkehrsmitteln, später mit dem Motorrad, dem Auto und manchmal sogar mit dem Flugzeug. Gedruckt wird nämlich vor allem das, was aktuell, neu und aufsehenerregend ist. Mit der zunehmenden Anzahl der veröffentlichten Bilder wächst auch der Konkurrenzkampf zwischen den Reportern. Häufig haben jene Fotografen die Nase vorne, deren Presseabzüge früher in den Redaktionen eintreffen. Die rasende Arbeitsweise der Pressefotografen ist weniger eine kokette Selbststilisierung, vielmehr ist sie das Ergebnis von Produktionsdruck, Konkurrenz und ökonomischer Notwendigkeit.

Aber auch der Blick der Fotojournalisten, der sich in der Zeitungsfotografie niederschlägt, trägt der zunehmenden Beschleunigung Rechnung. Zunächst arbeitet der Fotograf noch mit schweren Kameras und häufig mit Stativ. Nach der Wende zum 20. Jahrhundert werden die Fotojournalisten immer mobiler, ihr Arbeitsradius erweitert sich, ihr Gepäck wird immer leichter. In den 1920er Jahren fotografieren einige von ihnen mit neuen, leichten und dennoch lichtstarken Kameras wie etwa der Ermanox oder der Leica. An die Stelle von Einzelbildern treten nach dem Ersten Weltkrieg immer öfter Bildserien und Bildgeschichten. In der modernen Fotoreportage, die ihren ersten Höhepunkt um 1930 erlebt, wird die Bildberichterstattung weiter dynamisiert. Bild und Text wachsen zu neuen erzählerischen Einheiten zusammen. Oft 
handelt es sich um raffiniert komponierte Geschichten in Bildern und Bildserien.

Dieses Buch rekonstruiert am Beispiel Österreichs die Gründungsjahre und -jahrzehnte des modernen Fotojournalismus. Es folgt den frühen Pionieren auf ihren Streifzügen, schildert den Arbeitsalltag der Fotografen und wirft einen Blick in die Redaktionen, wo die illustrierten Zeitungsseiten hergestellt werden. An konkreten Beispielen wird gezeigt, wie aus fotografischem Rohmaterial Bildnachrichten und Fotoreportagen zusammengesetzt werden. Dass das Spektrum an Themen und Zugängen überaus breit ist, ist kein Zufall. Denn im Unterschied zu den herkömmlichen Atelierfotografen, deren inhaltliches und ästhetisches Repertoire überschaubar ist, lichtet der Zeitungsfotograf alles ab, was für eine neugierige Öffentlichkeit von Interesse ist. Er fotografiert den Kaiser und den Kanzler, Fußballer und Bühnenstars, Ganoven und Priester. Seine Neugier kennt keine Grenzen, sein hauptsächlicher Arbeitsplatz ist die Straße und der öffentliche Raum. Der Pressefotograf hält die entscheidenden Augenblicke eines Fußballmatchs fest, er dokumentiert Wahlkämpfe, Streiks und politischen Aufruhr. Aber er erzählt in seinen Bildern auch von der Welt der kleinen Leute und den unscheinbaren Begebenheiten des Alltags.

Um die weitverzweigte Welt der Pressefotografie rekonstruieren zu können, ist es notwendig, sich nicht nur auf die biografischen Spuren der Pressefotografen zu begeben, sondern auch den breit gestreuten Themen und Geschichten, die sie im Laufe der Jahre festhielten, zu folgen. In einzelnen Kapiteln dieses Buches werden Bildreportagen aus all jenen Gesellschaftsbereichen vorgestellt, die in der ersten Hälfte des 20. Jahrhunderts Eingang in die illustrierten Zeitungsseiten fanden: Politik und Sport, Mode und Werbung, Alltag und Krieg, um nur einige Beispiele zu nennen. Natürlich werden auch die illustrierten Medien, in denen die Fotos erschienen, eingehend untersucht. Entlang der originalen Bildseiten der Zeitungen, Zeitschriften und Magazine lässt sich bei genauerem Hinsehen ein facettenreiches kulturgeschichtliches Panorama entfalten.

Wer sich mit Zeitungsfotografie beschäftigt, muss freilich, um kulturhistorisch fündig zu werden, den
Hochsitz der Kunst zwangsläufig verlassen. Fotografie, wie sie hier vorgestellt wird, ist ihrem ursprünglichen Anspruch nach kein künstlerisches, sondern ein Gebrauchsmedium. Im Zentrum der Untersuchung stehen daher nicht herkömmliche kunsthistorische Fragestellungen an die Fotografie, vielmehr geht es darum, den vielfältigen sozialen und politischen Gebrauchsweisen des Mediums auf die Spur zu kommen. Unter anderem bedeutet das, den Eintritt der Pressefotografie in die Zirkulation der massenmedialen Warenwelt genauer zu untersuchen. Immerhin etablierte sich die Pressefotografie von Anfang an als kommerzielles Medium. Pressebilder wurden hergestellt, um gehandelt, verkauft und kommerziell erfolgreich veröffentlicht zu werden. Schon sehr früh entstanden Fotoagenturen, die einen regen Handel mit Bildern betrieben. Bereits um die Wende zum 20. Jahrhundert entwickelte sich die Pressefotografie zum international vernetzten Geschäft. Die zahlreichen Streifzüge durch die Bildwelten der illustrierten Presse, die ich in diesem Buch unternehme, ergeben in der Zusammenschau also eine neu gewichtete Geschichte der Fotografie. An die Stelle einer klassischen Kunstgeschichte tritt hier eine Medien-, Kulturund Alltagsgeschichte des Mediums.

Die folgende Untersuchung hält eine Reihe von Entdeckungen bereit. Das betrifft nicht zuletzt die Protagonisten dieses Buches, die Fotografinnen und Fotografen. Nicht wenige von ihnen waren bisher kaum oder wenig bekannt. Das hat auch damit zu tun, dass im Berufsbild des Fotografen die Arbeit für die Presse lange Zeit als minderwertige Tätigkeit galt. Es ist mir daher ein großes Anliegen, den vergessenen und verkannten Pionieren der frühen Pressefotografie ein Profil zu verleihen. Im biografischen Anhang habe ich zahlreiche Lebens- und Berufsgeschichten von Pressefotografinnen und -fotografen, die in Österreich tätig waren, zusammengestellt. Diese Einträge ergeben in der Summe eine aufschlussreiche Kollektivbiografie eines neuen journalistischen Berufs, jener des Pressefotografen. Dieser hat wesentlich dazu beigetragen, dass das 20. Jahrhundert zum Jahrhundert der Bilder wurde.

$\mathrm{Zu}$ Beginn des 21. Jahrhunderts haben wir uns längst an die fotografische Öffentlichkeit gewöhnt. 
So sehr, dass wir die Anfänge der fotografischen Bildberichterstattung gerne aus den Augen verlieren. Um die enorme Bedeutung des Fotojournalismus ermessen zu können, müsste man ein kleines Gedankenexperiment anstellen: Denken wir uns aus allen Medien die Bilder weg. Übrig blieben nur dürre, für unser heutiges Auge schwer lesbare Textwüsten. Erst ein historischer Rückblick auf die große Zeit der Pressefotografie zeigt, wie im 20. Jahrhundert die fotografische Öffentlichkeit entstand, die uns heute selbstverständlich erscheint. Das Vorhaben dieses Buches, nämlich den Blick noch einmal zurückzuwerfen in die turbulente Anfangszeit der Fotografie als auflagenstarkes Massenmedium, hat also nichts mit Nostalgie zu tun. Diese Publikation will die Leserin- nen und Leser nicht in eine angeblich gute alte Zeit entführen, sondern die Entstehungsgeschichte der öffentlichen Bildwelt des 20. Jahrhunderts beispielhaft nachzeichnen. Damit leistet sie auch einen Beitrag zum Verständnis der Gegenwart. Denn die Bedeutung der Fotografie - mittlerweile in digitaler Form - als öffentliches Medium ist heute immer noch ungebrochen, auch wenn sich die Formen und Foren der Öffentlichkeit inzwischen deutlich verändert haben. Die klassische illustrierte Presse ist, in Zeiten des Internets und der sozialen Netzwerke, nicht mehr das dominante Medium des 21. Jahrhunderts. Um aber die Entstehungsgeschichte der heutigen massenmedialen Bilderwelt zu verstehen, ist ein Blick in die Pionierzeit der Pressefotografie unumgänglich. 
An der Wende zum 20. Jahrhundert ist jenes komplexe Phänomen entstanden, das wir als fotografische Öffentlichkeit bezeichnen können. Damit ist gemeint, dass die massenhaft reproduzierte Fotografie in Zeitungen und Zeitschriften eine ganz eigene, visuell geprägte Wirklichkeit schafft. Gesellschaftliche Ereignisse finden im 20. Jahrhundert nicht mehr nur in der Wirklichkeit statt, sie werden zunehmend auch in visueller Form festgehalten. Pressefotografen, die bei wichtigen Anlässen die politischen Protagonisten regelrecht umlagern, liefern das Rohmaterial für diese zweite, mediale Wirklichkeit (Abb. 1).

\section{Ein neuer Blick auf die Populärkultur}

Das vorliegende Buch untersucht am Beispiel Österreichs die Geschichte der Pressefotografie von ihren Anfängen in den 1890er Jahren bis zur Mitte des 20. Jahrhunderts. Im Zentrum der Untersuchung stehen die Wechselwirkungen zwischen Medien, Politik und Gesellschaft und die Herausbildung einer spezifischen fotografischen Öffentlichkeit. Wir werden sehen, wie um die Jahrhundertwende neben dem bekannten und relativ gut untersuchten Nachrichtenwesen der Hochkultur (das seinen Niederschlag etwa in den bürgerlichen Tageszeitungen findet) ein neues, bisher wenig beachtetes, massenkulturelles System fotografischer Berichterstattung entsteht. Ihr Kennzeichen ist neben der Übermittlung von Nachrichten die Darstellung und Verbreitung von Sensationen.

Die frühe fotografisch illustrierte Presse gleicht in ihrer Struktur, in ihren thematischen Zugängen und in ihrer voyeuristischen Grundhaltung stärker dem populären Boulevard als den bürgerlichen Nachrichtenblättern. Um 1900 wird in den Illustrierten ausgiebig über die Sensationen und Attraktionen des Alltags und der Gesellschaft berichtet: über Unglücksfälle und Katastrophen, spektakuläre Morde und Raubüberfälle, Festlichkeiten und Sehenswürdigkeiten, große und kleine Persönlichkeiten des öffentlichen Lebens, über Bühnenstars, Sportler und vieles andere mehr. Themen und Ereignisse also, die auch beliebte Themen der Boulevardtagespresse sind.

Die Pressefotografie um 1900 ist also vornehmlich ein Unterhaltungs- und erst in zweiter Linie ein
Nachrichtenmedium. Es gibt eine Reihe von Parallelen zum frühen Kino. „Es ist kein Zufall“, schreibt Kurt Korff, der in den 1920er Jahren Chefredakteur der größten deutschen Wochenillustrierten ist, „daß die Entwicklung des Kinos und die Entwicklung der ,Berliner Illustrirten Zeitung ziemlich parallel laufen. Mehr und mehr gewöhnte sich das Publikum, die Ereignisse der Welt stärker durch das Bild auf sich wirken zu lassen als durch die Nachricht.“3 Tatsächlich entsteht die auflagenstarke, fotografisch illustrierte Massenpresse etwa zur selben Zeit wie das Kino, das sich in seinen frühen Jahren ebenfalls der Welt der Attraktionen zuwendet. ${ }^{4}$

Erst nach und nach weitet sich das Feld der Berichterstattung aus. An die Seite der Sensationen tritt allmählich die Nachrichtenfotografie, die sich mit den aktuellen politischen Ereignissen ebenso beschäftigt wie mit den jüngsten Schlagzeilen aus Kultur, Sport und Gesellschaft. Zunehmend stellt die illustrierte Presse auch eine neue Bühne für die Inszenierung der „großen“ Politik dar. Sie verbreitet massenhaft vervielfältigte fotografische Bilder vom politischen Geschehen und dessen Akteuren: dem Kaiser, seiner Familie und seinen Reisen, bekannten Politikern und Personen des öffentlichen Lebens, aber auch von Massenereignissen wie Streiks und Demonstrationen.

Wenn man sich mit der Geschichte der Pressefotografie beschäftigt, bewegt man sich also zwangsläufig im breiten Feld der Populärkultur. Das ist einer der Gründe, weshalb es nur sehr wenige fundierte Studien zur Entstehungsgeschichte des Massenmediums Zeitungsfotografie gibt. ${ }^{5}$ Bis heute gilt die Pressefotografie als eher „niedrige“ Gattung der Fotografie. Nicht nur Fotografiemuseen und Kunstkuratoren, die sich vornehmlich mit fotografischen Einzelbildern und Originalabzügen beschäftigen, ist das massenhaft reproduzierte fotografische Bild, wie es in Zeitungen auftaucht, oft suspekt. Aber auch die Themen der frühen illustrierten Presse, die Vorliebe des Boulevards für Berichte über Unglücksfälle, Katastrophen, Mord- und Totschlag galten lange Zeit einer vornehmlich an der Hochkultur interessierten Kulturgeschichte als anrüchig. Dass dieses Misstrauen gegenüber der Populärkultur ${ }^{6}$ keine neue Entwicklung ist und weit in die Geschichte zurückreicht, zeigt sich
Abb. 1 Massenandrang der Pressefotografen beim Besuch des französischen Ministerpräsidenten Pierre Laval und des Außenministers Aristide Briand in Berlin, Ende September 1931. Das interessante Blatt, 1. Oktober 1931, S. 17. Foto: Fotoagentur Wide World Photos. 


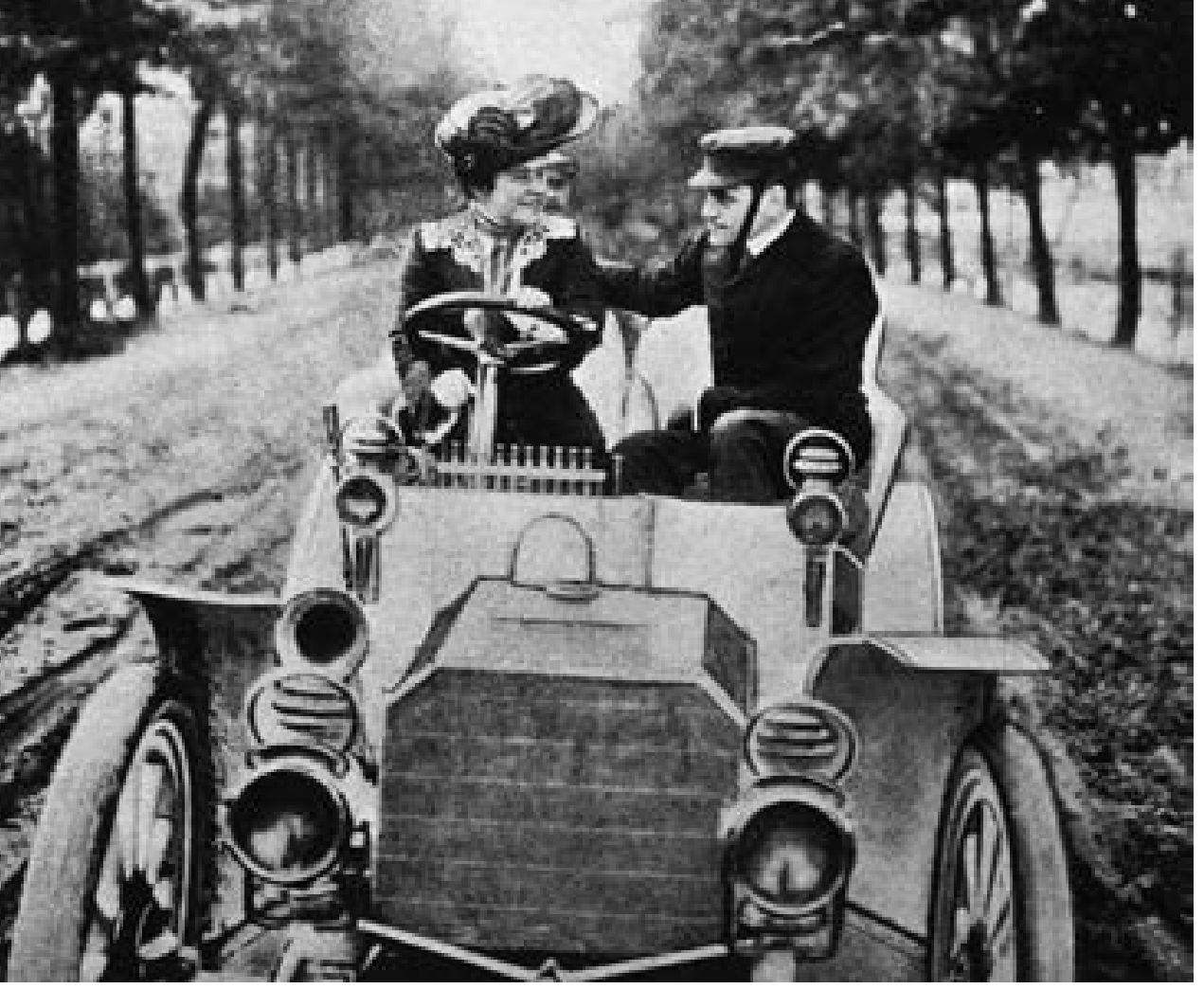

Abb. 2 Die bekannte Wiener Schauspielerin Helene Odilon bei einer Automobil-Spazierfahrt in der Umgebung von Berlin. Das interessante Blatt, 28. Mai 1903, S. 5. allein daran, dass illustrierte Zeitungen in vielen Bibliotheken als nicht archivierungswürdig angesehen wurden. Das interessante Blatt, die größte und auflagenstärkste Wochenillustrierte der k. u. k. Monarchie und der Ersten Republik etwa, ist in Österreich in nur fünf Bibliotheken erhalten, in Deutschland gar nur in einer einzigen - und dies, obwohl ihre Leserschaft bei Weitem größer war als die einer durchschnittlichen bildungsbürgerlichen Tageszeitung, die in jedem gröBeren Stadtarchiv aufbewahrt wird.

Ich möchte in diesem Buch zeigen, dass gerade dieser populäre Strang der fotografischen Berichterstattung, der sich freilich auf vielfältige Weise mit den Äußerungsformen der Hochkultur verbindet, ein äußerst spannendes Gebiet für eine aufmerksame, neugierige, an Bildern orientierte Gesellschafts- und Kulturgeschichte ist. ${ }^{7}$ Denn auf den Seiten der illustrierten Presse, die sich (fast) immer an ein großes Publikum wendet, treten manche gesellschaftlichen Brüche und manche Verschiebungen der kollektiven Wahrnehmung viel deutlicher hervor als in der Hochkultur. So lassen sich etwa die Veränderungen in den Rollenbildern der Geschlechter entlang der Bildberichterstattung anschaulicher dokumentieren als anhand reiner Textmedien (Abb.2). Ähnliches gilt für den Sport, die Starkultur, die Mode oder die Werbung, allesamt Themen, die in der illustrierten Presse besonders deutliche Spuren hinterlassen haben.

Doch die Pressefotografie ist kein simples Fenster zur Wirklichkeit. „Die“ Geschichte bildet sich also nicht unmittelbar in den Pressebildern ab. Es wäre naiv zu behaupten, dass die Pressefotografie die historische Wirklichkeit auf authentische Weise dokumentiert und wiedergibt. Der Begriff des „Authentischen“, der die dokumentarische Fotografie oft begleitet, ist, auch das wird zu zeigen sein, ein historisch gewachsener Begriff. Die ersten in der Presse gedruckten Zeitungsbilder gelten vor und um 1900 im Vergleich zu den sehr viel lebendigeren Pressezeichnungen (Abb. 3) keineswegs als authentischer. Erst nach und nach werden die Vorzüge der Fotografie gegenüber der Zeichnung betont. Letztere erlebt nach 1900 als Nachrichtenmedium einen rapiden Bedeutungsverlust. Parallel dazu etabliert sich in den ersten Jahren des 20. Jahrhunderts die Fotografie als wirklichkeitsnahes, „authentisches“ Nachrichtenmedium. ${ }^{8}$

Die Wechselwirkungen zwischen historischen Ereignissen und fotografischen Bildern in der Zeitung sind weitaus komplexer und vielfältiger, als es auf den ersten Blick scheint. Was wann und in welcher Form in den Zeitungen auftaucht, ist das Ergebnis zahlreicher Auswahl- und Filterungsprozesse. Der Fotograf, der das Pressefoto aufnimmt, ist nur einer der Agenten dieses vielschichtigen Zusammenwirkens. Ebenso wichtig ist der institutionelle Apparat der Zeitung selber. Relevant sind hier die Eigentümerstruktur, das ökonomische Kalkül, mit dem das Blatt operiert, die Entscheidungen der Text- und Bildredaktion, die technischen Möglichkeiten des Drucks, aber auch Art und Umfang des Vertriebs (vom Abonnement bis zum Straßenverkauf). Wichtig für die Reichweite, Bedeutung und Rezeption von Zeitungsfotografien ist zudem das politische, gesellschaftliche und kulturelle Umfeld, in dem das Medium erscheint, aber auch die Form und Präsenz der Konkurrenzmedien.

Als beispielsweise in den 1920er Jahren das Kino zum konkurrierenden großen Bildmassenmedium wird und der Film bedeutende Fortschritte in der visuellen Erzähltechnik macht, reagiert auch die illustrierte Presse auf diese Entwicklungen. Die Herausbildung der modernen Fotoreportage ab Mitte der 1920er Jahre, die Bilder auf erzählerische Weise zu Serien verbindet, hat auch, wenn auch nicht ausschließlich, mit der medialen Konkurrenz und der Herausforderung durch das Kino zu tun. 


\section{Zeitungsbilder als fotohistorisches Quellenmaterial}

Um Pressebilder historisch lesbar zu machen, um sie kulturhistorisch angemessen interpretieren zu können, ist es notwendig, verschiedene eng miteinander verbundene Ebenen der visuellen Bedeutungsproduktion zu untersuchen. Die Beleuchtung der ökonomischen Hintergründe der Zeitungsentwicklung ist ebenso wichtig wie die eingehende Analyse der journalistischen Abläufe auf dem Weg vom Pressefoto zur gedruckten Bildnachricht. Wer sich mit Pressefotografie beschäftigt, kommt letztlich nicht umhin, sich besonders intensiv mit dem wichtigsten Anschauungs- und Quellenmaterial zu beschäftigen, das zur Verfügung steht: den originalen Zeitungen und Zeitschriften.
Gedruckte Pressebilder sind immer Teil eines komplexen Medienensembles. Sie sind häufig in Textnachrichten eingebettet, oft sind sie umgeben von weiteren Bildern (Fotos, Grafiken oder Anzeigen). Manchmal sind sie in Serien oder Bildfolgen angeordnet (Abb.4). Sie werden seitenfüllend auf der Titelseite verwendet oder in einen Textblock integriert, sie sind beschriftet oder auch nicht. Schließlich gibt es zahlreiche Zusammenhänge, die über die einzelne Zeitungsseite hinausweisen. Viele inhaltliche und ästhetische Verbindungslinien und gestalterische Nuancen erschließen sich erst beim Blättern, also dann, wenn man bewusst über die Einzelseite (oder Doppelseite) hinausblickt und bestimmte Merkmale und Entwicklungen längsschnittartig ins Auge fasst.

Die Untersuchung längerfristiger medialer Entwicklungen verlangt die aufmerksame Sichtung und

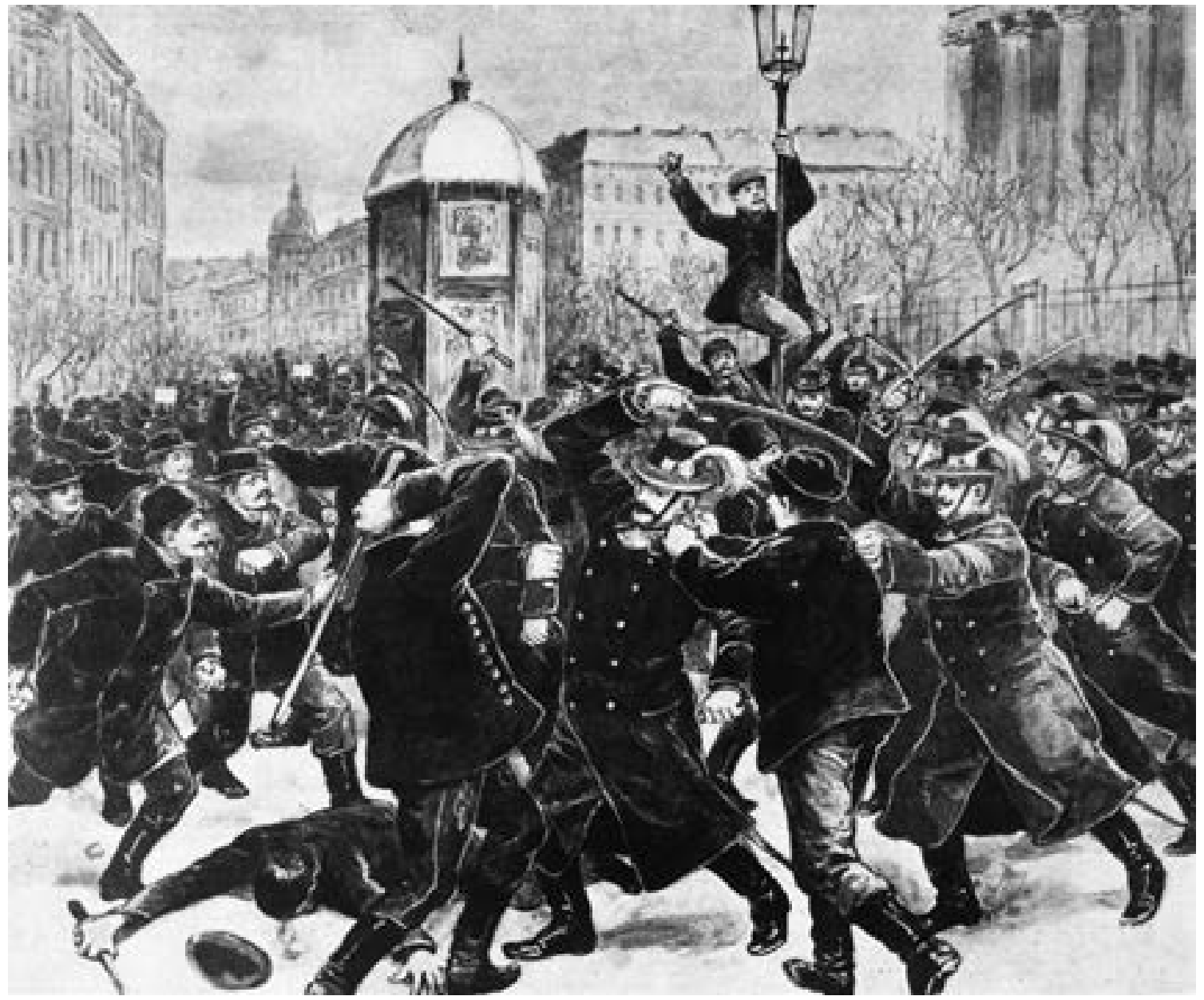

Abb. 3 Straßenkämpfe in Budapest zwischen Arbeitslosen und der Polizei. Noch um 1900 werden dramatische Ereignisse oft von Pressezeichnern und Illustratoren und nicht von Fotografen dokumentiert. Das interessante Blatt, 21. Februar 1901, S. 4. 
Abb. 4 „Wilhelm Furtwängler, der große Dirigent". Berliner Illustrirte Zeitung, 24. März 1929, S. 467. Foto: Freiherr von Gudenberg.

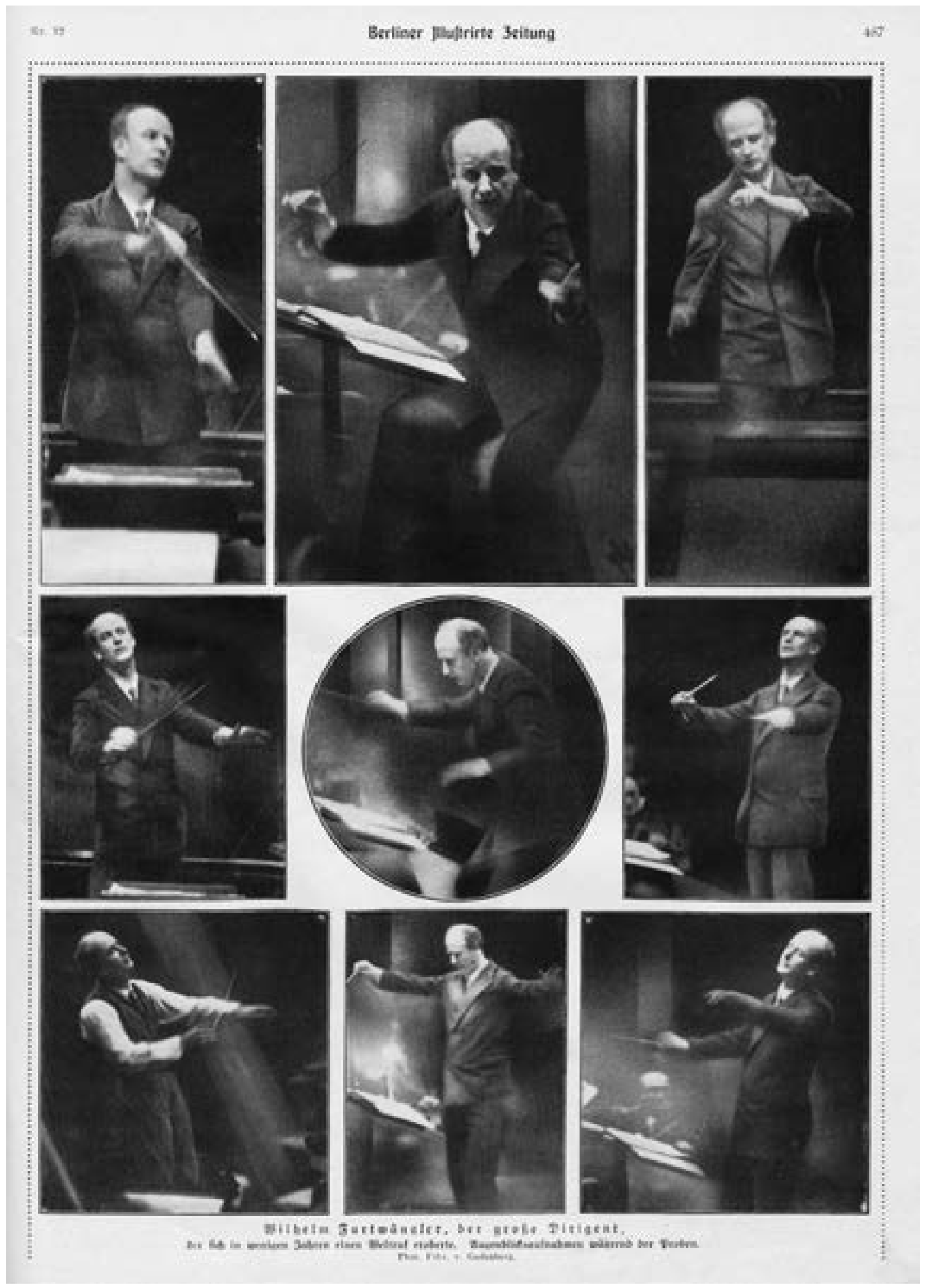

Analyse einer Vielzahl unterschiedlicher Zeitungen, Zeitschriften und Magazine, und zwar über lange Zeiträume hinweg. Dieses aufwendige Verfahren der Forschung erfordert viel Zeit und geeignete Ressourcen (etwa teure Reproduktionsmöglichkeiten). Der vorliegenden Untersuchung liegt ein mehrjähriges
Forschungsprojekt zugrunde, in dessen Verlauf ich zahlreiche Zeitungen und Zeitschriften aus dem Zeitraum von 1890 bis 1945 analysieren, eine Dokumentation zur Entwicklungsgeschichte der jeweiligen Bildmedien und eine umfassende Auswahl von digitalisierten Arbeitsbildern anlegen konnte. ${ }^{9}$ 
Bis in die späten 1930er Jahre werden - zumindest in Kontinentaleuropa ${ }^{10}$ - Pressefotos vor allem in wöchentlich erscheinenden Illustrierten, aber auch in Monats- oder Zweimonatszeitschriften gedruckt, jedoch verhältnismäßig wenig in Tageszeitungen. Daher habe ich mich in der Analyse vor allem auf die nicht täglich erscheinende Bildpresse konzentriert und nur gelegentlich Ausflüge in die Tagespresse, in unregelmäßig erscheinende Periodika oder auch in Fotobücher unternommen. ${ }^{11}$ Trotz dieser Einschränkung ist der Umfang des untersuchten Materials noch überaus beachtlich. Um nur ein Beispiel zu nennen: Allein das bereits genannte Interessante Blatt kommt im mehr als fünf Jahrzehnte umfassenden Untersuchungszeitraum auf über 130000 Zeitungsseiten. Viele der untersuchten Zeitungen und Zeitschriften sind zwar kurzlebiger (und weniger umfangreich), dennoch summiert sich das Material zu einem veritablen Zeitungsberg. In meiner Forschungsarbeit habe ich die untersuchten Zeitungen, Zeitschriften und Magazine wenn möglich im Original gesichtet. Denn die haptische Arbeit im Archiv liefert wichtige Aufschlüsse über zentrale Aspekte der Pressefotografie, etwa Drucktechniken, Gestaltungsformen, Formate oder Fotoqualität, liefern. Zwar ist bereits eine Reihe von wichtigen Zeitungen und Zeitschriften in verdienstvollen Online-Archiven zugänglich ${ }^{12}$, wodurch der Recherche neue Möglichkeiten eröffnet werden. Dennoch führt für eine fundierte wissenschaftliche Untersuchung kein Weg am Zeitungsarchiv und den Originalen vorbei. Um mit der großen Menge an gewonnenen Informationen sinnvoll umgehen zu können, war es notwendig, nach einer ersten breiten Sichtung des umfangreichen Gesamtmaterials den Blickwinkel wieder zu verengen und kleinere Untersuchungseinheiten bzw. -themen für tiefer gehende Untersuchungen auszuwählen. ${ }^{13}$

Ich habe in der vorliegenden Studie das Schwergewicht bewusst auf die veröffentlichte Fotografie gelegt. Diese bildete das zentrale Untersuchungsmaterial der vorliegenden Forschungsarbeit. Die kulturhistorische Interpretation und Deutung von Pressebildern ist innerhalb ihres originalen Verwendungszusammenhanges, also eingebettet in ein breiteres Medienensemble, besonders ergiebig. Man entgeht damit der Gefahr, die Geschichte der Pressefotografie ausgehend von zufällig erhaltenen Einzelbildern zu schreiben. Da zudem ein Großteil der originalen Bildvorlagen, die in den illustrierten Zeitungen abgedruckt wurden, verloren gegangen sind, ermöglicht die gedruckte Fotografie in vielen Fällen auch eine Rekonstruktion von fotohistorischen Zusammenhängen, die auf anderem Wege nicht zu leisten wäre. Ergänzend dazu erfolgten Kontextrecherchen in wichtigen Pressebild- und Fotoarchiven, die u. a. auch Aufnahmen von Pressefotografen (in Form von Abzügen oder Glasnegativen) aufbewahren. Ein Gutteil der Pressebildarchive, die die Geschichte der illustrierten Zeitungen bis zum Zweiten Weltkrieg dokumentieren, ist allerdings im deutschsprachigen Raum verloren gegangen oder entsorgt worden. ${ }^{14}$ Dennoch gibt es eine Reihe wichtiger Bestände, die für die Analyse der Pressefotografie von zentraler Bedeutung sind. ${ }^{15}$

Die in Zeitungen veröffentlichte Fotografie ist nicht nur ein wichtiges historisches Anschauungsmaterial. Die illustrierten Zeitungen selbst sind ein bisher kaum genutztes, aber überaus bedeutsames Archiv der Fotografiegeschichte, das weit über die Pressefotografie hinaus interessantes Quellenmaterial für die fotohistorische Forschung bereitstellt. Um nur ein Beispiel zu nennen: Das umfangreiche Werk jüdischer Fotografinnen und Fotografen, die in Österreich ab 1938 verfolgt und von denen fast alle vertrieben wurden, ist nur zu einem kleinen Teil in Originalfotografien erhalten. Da zahlreiche dieser Fotografinnen und Fotografen auch für die illustrierte Wochenpresse oder Magazine gearbeitet haben, ist zumindest ein Teil dieser Bilder in reproduzierter Form erhalten. Auch dieser Aspekt wird in der vorliegenden Studie anhand zahlreicher Beispiele untersucht.

Es ist bemerkenswert, dass die Geschichte der Pressefotografie, vor allem dann, wenn sie sich abseits der bereits bekannten großen Namen bewegt, noch zahlreiche Überraschungen und Entdeckungen bereithält. Immer wieder stieß ich im Zuge der Forschungen auf Fotografinnen und Fotografen, die entweder unbekannt oder lediglich aus gänzlich anderen Zusammenhängen (etwa der Atelierfotografie) bekannt waren. Auch wenn in vielen Fällen ihre Sammlungen verloren gegangen sind, ist es möglich, 
Abb. 5 „Ein Augenblick des Glücks. Zufalls-Aufnahme von einem Sonntags-Tanzboden“. Berliner Illustirte Zeitung, 6. November 1932, Titelseite. Foto: Yva (Else Ernestine Neuländer). aus den alten Zeitungsseiten Teile ihres Werkes zu rekonstruieren. Unter diesen Wiederentdeckungen sind auch einige frühe Pressefotografinnen, die in einem bis zur Jahrhundertmitte männlich dominierten Feld faszinierende Arbeiten vorgelegt haben. Oft sind zu diesen bisher unbekannten Pionieren nur rudimentäre biografische Informationen erhalten, hin und wieder aber war es möglich, ihre Biografie und berufliche Karriere umfassender zu recherchieren. In den biografischen Ausführungen am Ende dieses Bandes erhalten viele bisher unbekannte Fotografinnen und Fotografen erstmals wieder ein Gesicht.

\section{Berlin, Wien: Austauschbeziehungen}

Der Aufbruch der deutschen und österreichischen Pressefotografie erfolgt um die Jahrhundertwende etwa zeitgleich und mit ähnlichem Elan wie in den angelsächsischen Ländern oder in Frankreich. Das heißt freilich nicht, dass in allen Ländern die Entwicklung des Fotojournalismus eine vollkommen parallele Entwicklung genommen hat. In den angelsächsischen Ländern, aber auch in Frankreich erfolgt die Umstellung auf die Fotoberichterstattung schneller und entschiedener, die grafische Gestaltung vieler illustrierter Wochenzeitungen wird nach der Jahrhundertwende rascher modernisiert als in Deutschland und v. a. in Österreich. Hier stehen die großen Illustrierten teilweise noch sehr lange in der konservativen grafischen Tradition der illustrierten Familienzeitungen des 19. Jahrhunderts.

Die wichtigsten Zentren der Bildpresse im deutschsprachigen Raum sind Berlin und Wien. Während in der Zwischenkriegszeit die Berliner Presse mit der Berliner Illustrirten Zeitung (Abb.5) an der Spitze zum Boom ansetzt, verläuft der Aufbruch der österreichischen Zeitungslandschaft nach 1918 gedämpfter. Die großen, etablierten Wochenblätter setzen mehr auf Tradition und Kontinuität als auf Innovation. Anregungen und Innovationen werden in den 1920er und frühen 1930er Jahren eher in den kleineren Kulturund Gesellschaftsmagazinen, etwa der Bühne oder dem Wiener Magazin, aufgegriffen.

Eine Reihe von jungen, innovativen österreichischen (und ungarischen) Fotografen, Fotoagenten und
Geschäftsleuten sucht in den 1920er Jahren ihr Glück in der aufstrebenden Zeitungsstadt Berlin. Dort treffen sie auf ein kulturell experimentierfreudiges Ambiente und auf finanzkräftige Pressehäuser (Ullstein, Mosse, Scherl etc.), die Journalisten und Fotografen weit besser bezahlen, als dies die österreichischen und ungarischen Zeitungen vermögen. Es gibt allerdings auch einige Fotografen und Agenten, die den umgekehrten Weg einschlagen und ihren Arbeitshorizont von Berlin nach Wien ausdehnen, weil sie in der österreichischen Hauptstadt - zu Recht - weniger Konkurrenz vermuteten.

Auch wenn in diesem Buch die Pressefotografie in Österreich im Zentrum steht, lässt sich ihre Entwicklung in der ersten Hälfte des 20. Jahrhunderts nicht als ein in sich abgeschlossenes, national begrenztes Projekt charakterisieren. Die erstaunlich frühe Internationalisierung des Fotomarktes bringt es mit sich, dass bereits vor dem Ersten Weltkrieg ein reger Austausch von Bildern über regionale und Landesgrenzen hinweg erfolgt. Vor allem die größeren Fotoagenturen beliefern internationale Märkte. ${ }^{16}$ Auch viele der Fotografen sind überaus mobil. Zwischen Wien, Prag, Budapest und Berlin lässt sich über Jahre hinweg ein intensiver Pendelverkehr nachweisen. ${ }^{17}$

Die intensive Austauschbewegung zwischen Wien und Berlin erfährt 1933 mit der Machtübernahme der Nationalsozialisten in Deutschland einen starken Dämpfer. Zwar machen linientreue und politisch angepasste österreichische Fotografen weiterhin in Deutschland Karriere. ${ }^{18}$ Andere sind auch weiterhin mit ihren Bildern in der deutschen Presse präsent. Aber jüdische (ebenso wie viele liberale und linke) Fotografen können nun nicht mehr in Deutschland publizieren. Die nationalsozialistische Pressepolitik sorgt dafür, dass in deutschen Zeitungshäusern jüdische und politisch missliebige Fotografen, Fotoredakteure und Fotoagenten aus ihren Positionen entfernt werden. Einige von ihnen emigrieren zunächst nach Wien, wo sie beruflich wieder Fuß zu fassen versuchen. ${ }^{19}$ Die Diktatur des „Ständestaats“, die 1934 in Österreich entsteht, verhindert aber, dass das Land zu einem Anziehungspunkt für einen innovativen Fotojournalismus wird. Nach dem „Anschluss“ Österreichs an das nationalsozialistische Deutschland im 
Hammer 44. a. Iloeember 1032.

Berliner

41. Jahrgang. Preis 40 Grofden.

Durtag ulistein Derlin SW os
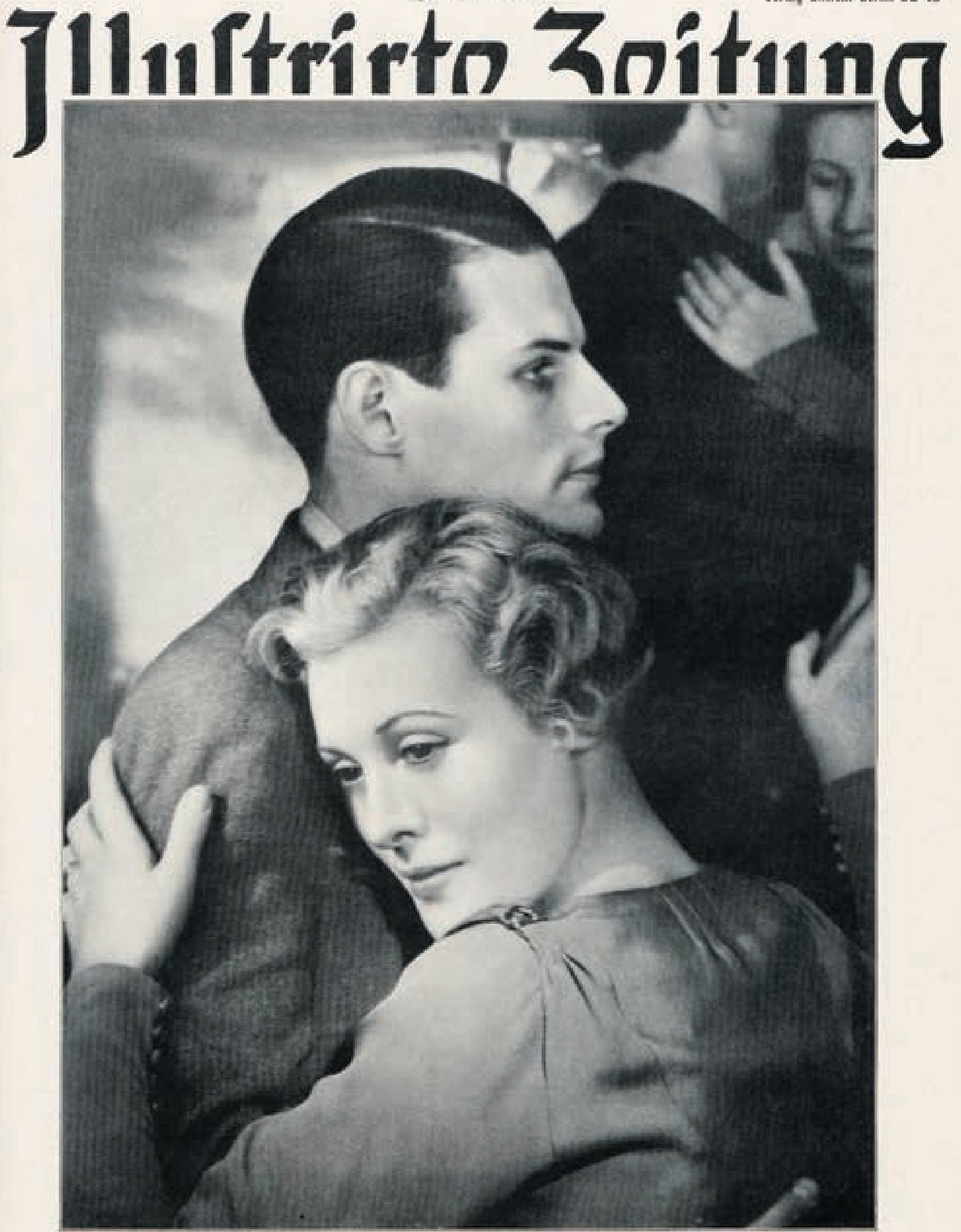

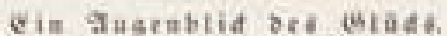

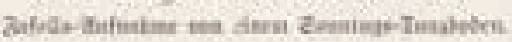


ser „Bilderflut“. „In den Illustrierten“, notiert 1927 Siegfried Kracauer, ein scharfer Kritiker der populären Bildpresse, „sieht das Publikum die Welt, an deren Wahrnehmung es die Illustrierten hindern. (...) Noch niemals hat eine Zeit so wenig über sich Bescheid gewußt. Die Einrichtung der Illustrierten ist in der Hand der herrschenden Gesellschaft eines der mächtigsten Streikmittel gegen die Erkenntnis. Der erfolgreichen Durchführung des Streiks dient nicht zuletzt das bunte Arrangement der Bilder. Ihr Nebeneinander schließt systematisch den Zusammenhang aus, der dem Bewußtsein sich eröffnet. Die ,Bildidee“ vertreibt die Idee, das Schneegestöber der Photographien verrät die Gleichgültigkeit gegen das mit dem Sehen Gemeinte.“24 Der Gruppe von Skeptikern, die die fotografische Massenpresse kritisieren, steht eine Gruppe von Befürwortern gegenüber, die die fotografische Massenreproduktion begrüßt und ihre technischen Möglichkeiten publizistisch und künstlerisch ausreizen wollen. ${ }^{25}$ Diese Debatten pro und kontra illustrierte Massenpresse, die in der Zwischenkriegszeit einsetzen, markieren auch den Beginn der wissenschaftlichen Auseinandersetzung mit der Pressefotografie. Ab den 1930er Jahren erscheinen, von unterschiedlichen Fachrichtungen her argumentierend, die ersten umfangreicheren Publikationen zu diesem Gegenstand. Rückblickend lassen sich mehrere Forschungsstränge identifizieren. ${ }^{26}$

Am frühesten nehmen sich jene Disziplinen des Themas an, die Zeitungen als gedrucktes Massenmedium in den Mittelpunkt des Interesses rücken, etwa die traditionelle Zeitungswissenschaft ${ }^{27}$, die ältere Publizistik ${ }^{28}$, aber auch die frühe amerikanische Mediengeschichte. ${ }^{29}$ Sie beschäftigen sich mit den sozialen und ökonomischen Entwicklungen der Bildpresse, aber nur am Rande mit den Fotografien und den Fotografen selber. Die Entstehung und Herkunft der Bilder, die Ästhetik ihrer Präsentation und die Formen der Rezeption werden nicht oder kaum untersucht. Ebenso wenig setzen sich diese Autoren mit konkreten Bildreportagen und ihrem Verhältnis zu historischen oder kulturellen Ereignissen bzw. Entwicklungen auseinander. Umgekehrt beschäftigt sich die ältere (vor allem technikhistorisch orientierte) Fotografiegeschichte fast ausschließlich mit den Bildern selbst, kaum aber mit dem publizistischen und gesellschaftlichen Umfeld der Pressefotografie. Sie ist weder am gesellschaftlichen und ökonomischen Apparat Zeitung noch an den politischen, kulturellen und ästhetischen Folgen einer neuen Form von illustrierter Massenpresse interessiert. ${ }^{30}$ Die Vertreter dieser Richtung untersuchen vor allem die Geschichte der (technischen) Reproduktionsmöglichkeiten von Pressebildern. Und auch die jüngere, stärker kunsthistorisch orientierte Fotografiegeschichte, die um die Mitte des 20. Jahrhunderts u. a. mit den Arbeiten von Helmut Gernsheim und Beaumont Newhall einsetzt, widmet in den ersten Jahren der Entstehungsgeschichte der Pressefotografie nur verhältnismäßig wenig Raum. ${ }^{31}$

Erst in den letzten Jahren entstanden im Umkreis der Kunstgeschichte einige wichtige Arbeiten zur Pressefotografie, die sich schwerpunktmäßig mit den gedruckten Bildern beschäftigen. ${ }^{32}$ Die damit verbundene signifikante Aufwertung der gedruckten Fotografie setzt sich etwa in der jüngeren Fotobuchforschung fort, die in den vergangenen Jahren große Fortschritte gemacht hat. ${ }^{33}$ Schließlich ist auch die Geschichtswissenschaft zu nennen, die sich in jüngster Zeit verstärkt mit dem Thema Pressefotografie auseinandersetzt. ${ }^{34}$

Auch wenn sich der Mainstream der Kunstgeschichte den medien- und kulturhistorischen Aspekten der Pressefotografie immer noch recht zaghaft nähert, tragen fotohistorisch arbeitende Kunsthistoriker dennoch wesentlich dazu bei, einzelne Fotografen als Künstler zu entdecken und ihre Werke im Museum auszustellen. Diese in Ausstellungen gewürdigten „Star-Pressefotografen“ werden häufig als herausragende Einzelkünstler präsentiert, die reproduzierte Fotografie steht gegenüber den (oft erst jüngst wiederentdeckten) Originalabzügen, den sogenannten Vintage Prints, deutlich im Hintergrund. Inzwischen gibt es eine ganze Reihe teilweise sehr guter kunsthistorischer Studien zu einzelnen Pressefotografen. ${ }^{35}$ Fast durchweg stehen Vertreter der Pressefotografie im Zentrum der Aufmerksamkeit, die in der Zwischenkriegszeit (oder in der Zeit nach 1945) gearbeitet hatten. Studien zu frühen Fotografen (die auch vor 1914 tätig waren) sind dagegen immer noch rar. $^{36}$ Anscheinend hat der lange kultivierte 


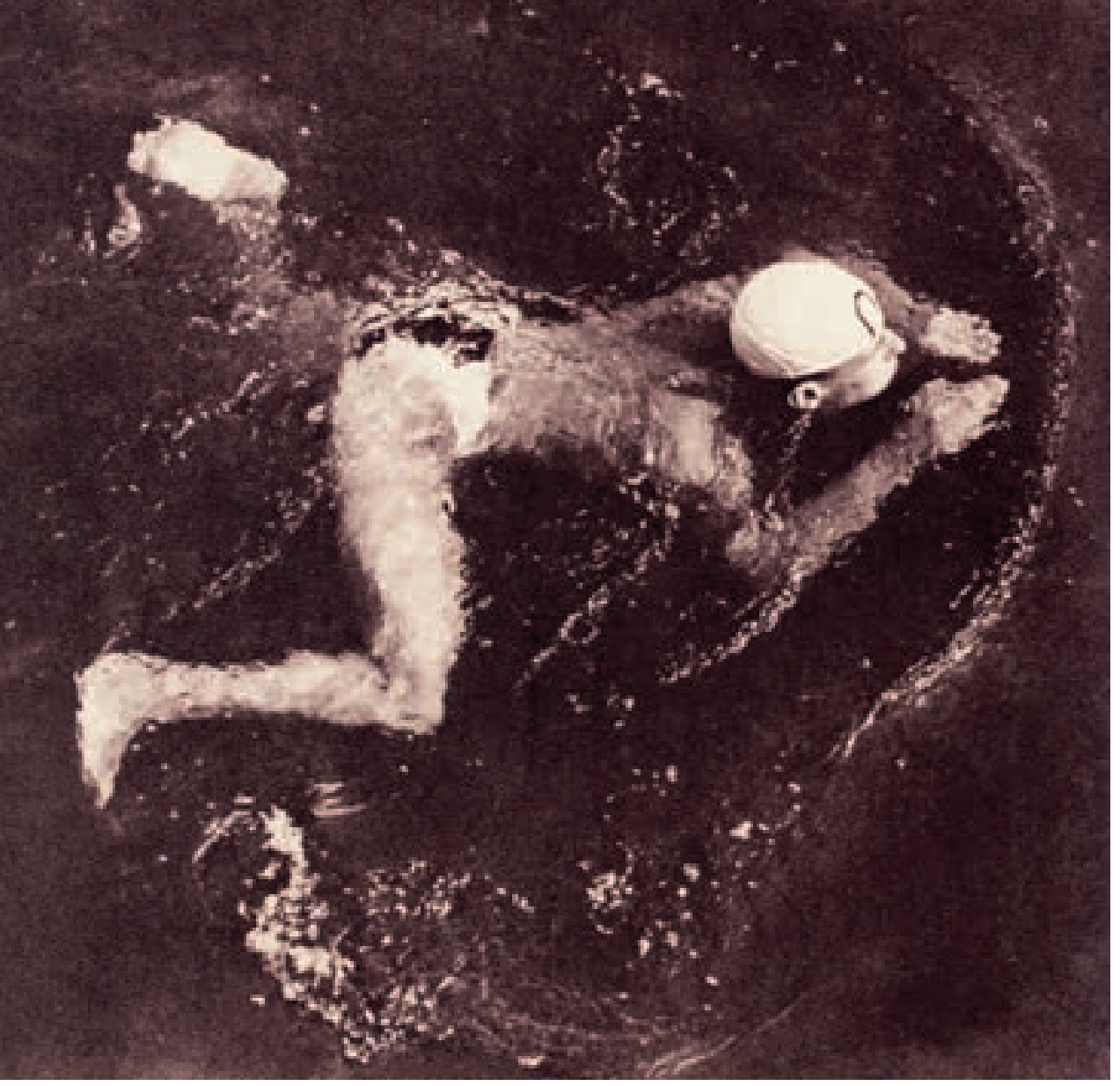

Abb. 8 „Dem Ziel entgegen“. Wiener Magazin, Heft 8, August 1932, S. 36. Foto: Lothar Rübelt.
Mythos einer Stunde null in der Pressefotografie ${ }^{37}$, die in den 1920er Jahren anzusetzen sei, immer noch seine Anhänger, auch wenn etliche Untersuchungen längst seine Unhaltbarkeit nachgewiesen haben. ${ }^{38}$ Auch im vorliegenden Buch werde ich zeigen, dass der Beginn des professionellen Fotojournalismus viel weiter zurückreicht als oft angenommen. Bereits vor und an der Wende zum 20. Jahrhundert etabliert sich ein umfassendes System der fotografischen Berichterstattung.

Eine methodisch interessante und durchaus produktive Mittelstellung zwischen einer Mediensoziologie, die vorwiegend an der Zeitung als Massenmedium interessiert ist, und einer Kunst- und Fotografiegeschichte, die sich hauptsächlich mit Pressefotografen als Künstlern beschäftigt, nimmt eine stärker sozial- und kulturgeschichtlich argumentierende Fotografiegeschichte ein. Sie interessiert sich für das Mediensystem Massenpresse ebenso wie für das zentrale „Basismedium“ der Fotoillustrierten, die Fotografie sowie ihre Produzenten, die Fotografen. Ein früher Vertreter dieser Richtung ist der amerikanische Fotohistoriker Robert Taft, der bereits 1938 eine interessante Sozial- und Kulturgeschichte der Fotografie vorgelegt hat und sich auch mit dem Thema Presse und Fotografie beschäftigte. ${ }^{39}$ Diese Medien- soziologie der illustrierten Presse hat in den letzten Jahren im angloamerikanischen Raum einige wichtige Studien, insbesondere zum Typus der illustrierten Magazine und ihrer (Cover-)Gestaltung (und nur am Rande der Pressefotografie) hervorgebracht. ${ }^{40}$

Ein anderer Anstoß zur kulturhistorischen Fundierung der Geschichte der Bildpresse kam in den 1970er Jahren aus Skandinavien. Die Pionierstudie von Rune Hassner holt historisch weit aus und stellt die erste umfassende Geschichte der Bildpresse dar, die auch der langen Vorgeschichte der Pressefotografie viel Platz einräumt. ${ }^{41}$ Diese Anregungen zu einer kulturhistorischen Sichtweise auf die frühe Pressefotografie sind in neueren Überblicksdarstellungen zur Fotogeschichte längst aufgenommen worden. ${ }^{42}$ Und auch innovative Einzelstudien zur Frühgeschichte der Pressefotografie gehen inzwischen von einem komplexen System ökonomischer, politischer, kultureller und ästhetischer Einwicklungen aus, die zur Entstehung einer neuen Form fotografischer Öffentlichkeit führte. ${ }^{43}$

Während es im englischen und französischen Sprachraum seit einigen Jahren einige gute Überblicksdarstellungen zur Geschichte der Pressefotografie gibt ${ }^{44}$, ist die Situation im deutschsprachigen Raum komplizierter. Der Großteil der Forschungen konzentriert sich auf die Presselandschaft in Deutschland. Neben einer Reihe monografischer Arbeiten gibt es eine gute Überblicksdarstellung. ${ }^{45}$ Die meisten Detailuntersuchungen konzentrieren sich auf die Zeit der Weimarer Republik ${ }^{46}$ (oder die Jahre nach 1945), nur einige wenige Studien widmen sich der Frühgeschichte der Pressefotografie vor dem Ersten Weltkrieg. $^{47}$

Ähnlich ist die Situation in Österreich. Mit Ausnahme einer Dissertation aus den frühen 1980er Jahren $^{48}$ gibt es bis heute keine einzige wissenschaftliche Publikation zur frühen österreichischen Pressefotografie vor dem Ersten Weltkrieg. ${ }^{49}$ Im Unterschied zu Deutschland ist in Österreich auch die Periode der Zwischenkriegszeit nur sehr lückenhaft erforscht. Die einzige knappe Überblicksdarstellung ist wissenschaftlich längst überholt. ${ }^{50}$ Neben einigen jüngeren Fallstudien ${ }^{51}$, einer nützlichen Materialsammlung zu Fotografie und Emigration ${ }^{52}$ und einigen älteren, sehr oberflächlichen monografischen Darstellungen zum 
Pressefotografen Lothar Rübelt ${ }^{53}$ (Abb.8) gibt es hier große Forschungslücken. Lediglich die Geschichte der sozialdemokratischen Bildpublizistik ist vergleichsweise gut erforscht. ${ }^{54}$

\section{Wechselwirkungen}

Pressefotografien sind in der Regel komplexe Dokumente, die nicht eindimensional beschreibbar sind. Je nach Blickwinkel können sie gesellschaftspolitische Ereignisse festhalten, sie können aber auch als ästhetische Produkte betrachtet werden. In jedem Fall sind sie kommerzielle Waren in einer kapitalistischen Bilderzirkulation. Denn Pressefotos gelangen nicht zufällig in die Redaktionen. Sie werden hergestellt, um an Zeitungen (oder Fotoagenturen) verkauft und schließlich im Kontext anderer Bilder und Texte gedruckt zu werden (Abb.9). Diesem komplexen Gefüge von Produktion, Reproduktion, Verbreitung und Ästhetik von Bildern in der illustrierten Presse will ich mich auf den folgenden Seiten auf mehreren Ebenen nähern: Einerseits beschäftige ich mich mit der Geschichte, der Ökonomie und der kulturellen Bedeutung der Zeitungen und Magazine. Parallel dazu untersuche ich die Ästhetik der Seitengestaltung, die visuelle Sprache der Text-Bild-Erzählungen und ihre mögliche Rezeption. Ergänzend dazu werde ich auf die Rolle der Fotografen, ihren biografischen Hintergrund, ihre Themenwahl, Arbeitsweise und Ästhetik eingehen. Aber auch die Vertriebswege, die Logistik und der Verkauf von Bildern, etwa über Bildagenturen, werden näher beleuchtet. ${ }^{55}$ Schließlich möchte ich die fotografischen Bilder in einen Dialog mit den politischen und gesellschaftlichen Hintergründen, also mit der Geschichte, bringen. Im Sinne einer produktiven Kultur- und Gesellschaftsgeschichte der Pressefotografie ist es notwendig, all diese Fragerichtungen eng miteinander zu verzahnen.

Um diesen Wechselwirkungen auf die Spur zu kommen, werde ich immer wieder Untersuchungsausschnitte, Zeiträume und Fokus ändern. Auf diese Weise werden thematische Fallstudien neben historischen Längsschnitten zu stehen kommen. Die Arbeit einiger Fotografen wird aus unterschiedlichen Perspektiven beleuchtet. Wenn wir die Ergebnisse

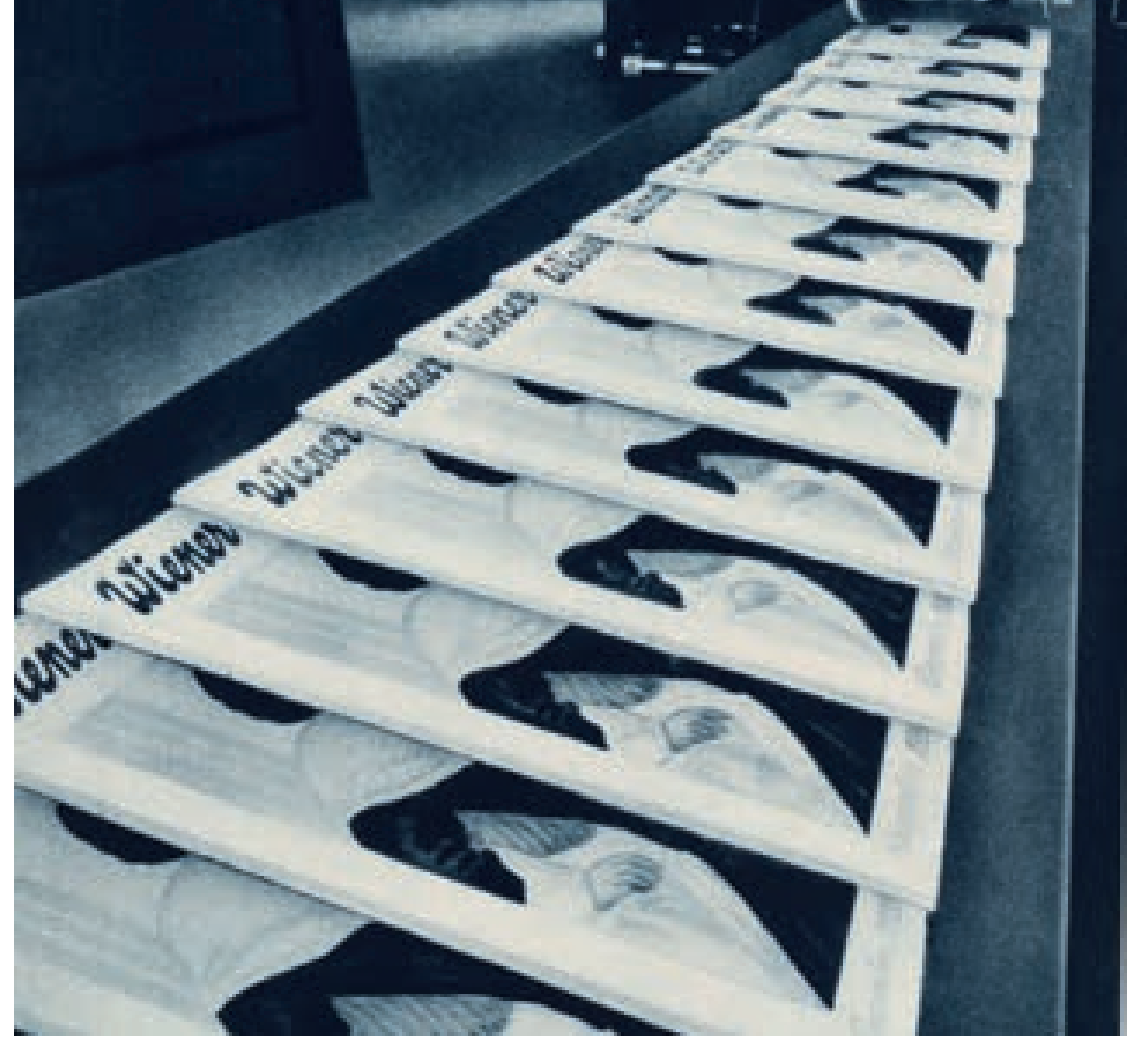

dieser Überblicks- und Detailstudien miteinander verbinden, sollte es möglich sein, die Zusammenhänge zwischen Politik, Gesellschaft und bildlichen Massenmedien in der ersten Hälfte des 20.Jahrhunderts besser zu verstehen. Vor allem aber wird man in der historischen Rekonstruktion der politischen, ästhetischen und kulturellen Entwicklungen dieser Periode lieb gewonnene Gemeinplätze überdenken müssen: etwa die Annahme, dass die textfixierte Hochkultur das unumstrittene Leitmedium sei, innerhalb dessen sich das kulturelle Selbstverständnis eines Staates bzw. Landes artikuliere.

Die Verlagerung der Untersuchung von den Texthin zu den Bildquellen, von der sogenannten „Hochkultur“ zur Populärkultur, weist in eine neue Richtung. Schon sehr früh, jedenfalls früher als oft angenommen, etabliert sich, neben der relativ kleinräumigen, textlastigen Zeitungs- und Zeitschriftenöffentlichkeit, eine ebenso komplexe, weitaus populärere Bildöffentlichkeit. Diese frühe Form der Öffentlichkeit, die mindestens ebenso viel der Sehnsucht nach Sensationen wie dem Bedürfnis nach sachlicher Berichterstattung verdankte, scheint heute weitgehend vergessen zu sein. Das hat nicht zuletzt damit zu tun, dass die Zeugnisse dieser Öffentlichkeit, die Bilder, die in der auflagenstarken populäre Presse erschienen, bisher erst wenige Historiker gefunden haben. Mit diesem Buch will ich ein lange vergessenes Thema zurück in die Öffentlichkeit holen und zugleich ein faszinierendes Kapitel der Fotografie- und Kulturgeschichte aufschlagen.
Abb. 9 „Wie das Wiener Magazin entsteht“. Die Zeitschrift verlässt gefalzt und geheftet die Rotationsdruckmaschine. Wiener Magazin, Heft 2, Februar 1932, Foto: Fotoagentur Polyphot. 


\title{
Bilder, Nachrichten, Sensationen
}

\author{
Die Zeitungsstadt Wien um 1900
}

Die Schulerstraße ist schmal und auf den ersten Blick unauffällig. Sie beginnt im Zentrum der Stadt, wenige Meter hinter dem Wiener Stephansdom, und durchquert, leicht abwärts verlaufend, das Gewirr mittelalterlicher Gassen. Die Straße gehört nicht zu den großen Prachtstraßen der Stadt, aber wichtig ist die Schulerstraße gleichwohl: Sie ist - zumindest bis zum Ersten Weltkrieg - die Zeitungsstraße Wiens. Hier und in den umliegenden Gassen, etwa in der Wollzeile, der Bäckerstraße, der Singerstraße, am Fleischmarkt oder in der Rotenturmstraße, haben alle wichtigen Zeitungen und Journale der Hauptstadt ihre Anzeigenbüros, Vertriebslokale und teilweise auch ihre Redaktionsräume. Die Straßen und Gassen sind von weithin sichtbaren Anzeigentafeln gesäumt. An den Fassaden weisen Schilder auf die Verkaufsräume und Annoncenbüros der einzelnen Blätter hin, in den Schaufenstern sind neben den neuesten Zeitungsausgaben aktuelle Pressebilder ausgestellt. Wie sehr dieses Viertel, das zugleich ein traditionelles Zentrum des Buchhandels ist, in der Hand der Presse ist, lässt sich gut anhand des zentralen Wiener Adressbuchs, des Lehmann, zeigen. ${ }^{1}$ Wenn man die Anschriften der einzelnen Blätter in den Jahrzehnten vor der Jahrhundertwende auf dem Wiener Stadtplan verortet, kann man die Entwicklung dieser Gegend zum Zeitungsviertel anschaulich nachvollziehen.

\section{Wiens Zeitungsstraße}

Als der Journalist und Unternehmer Sigmund Auspitzer 1882 eine neue illustrierte Wochenzeitung - Das interessante Blatt-gründet, zieht er mitsamt der Redaktion und Administration natürlich in die Schulerstraße. Untergebracht ist die Zeitung im Haus Nummer 14, einem leicht zurückgesetzten repräsentativen Gebäude. Im Erdgeschoss befinden sich die Auslieferung (Expedition) und das Annoncenbüro. Darüber liegen die Redaktionsräume.
Am 24. Januar 1884, zwei Jahre nach seiner Gründung, kommt Das interessante Blatt in einem bemerkenswerten Bildbericht auf ebendiese Straße zu sprechen. Es lohnt sich, diesen lebendigen Stimmungsbericht über Wiens Zeitungsstraße etwas genauer zu betrachten, denn er ist ein seltenes Beispiel für die Medienbeobachtung in eigener Sache. „Die Schulerstraße“, so heißt es in dem Beitrag, „verdient den Namen einer Zeitungsgasse; von hier aus nehmen die bedruckten Blätter, welche die öffentliche Meinung machen, wenn sie auch nicht die öffentliche Meinung sind, im Fluge ihren Weg durch die ganze Stadt, durch die ganze Monarchie, hier tritt die aufreibende journalistische Arbeit der Nacht zuerst in die Öffentlichkeit. Alle größeren Blätter Wiens haben in der Schulerstraße oder doch in der unmittelbaren Nähe derselben, ihre Expeditionen, und mit Ungeduld sieht man tagtäglich vor der Ausgabe der Zeitungen große Menschenmengen in der engen, schmalen Gasse des Momentes harren, da der aus der Druckerei im schnellsten Tempo daherrasende Zeitungswagen die Neuigkeiten des Tages bringt.“2 Der Beschreibung beigefügt ist eine Zeichnung, die die Hektik vor dem Eingang und den Schaufenstern des Interessanten Blattes einfängt (Abb. 1). Männer, Frauen und sogar Kinder drängen sich vor dem Gebäude, einige haben bereits ein Exemplar der neuesten Ausgabe ergattert, andere betrachten neugierig die Schaufenster.

Der Anlass für die Reportage ist, das erfahren wir in der Folge, ein jüngst aufgeklärter Serienmord, über den in der jüngsten Nummer des Interessanten Blattes in Bild und Text berichtet wird. Am 10. Januar 1884 ist Hugo Schenk, ein lange gesuchter Mörder, festgenommen worden. Er hatte im Jahr zuvor zusammen mit seinem Komplizen Karl Schlossarek vier Dienstmädchen ermordet. Die Nachricht von seiner Verhaftung ist das Stadtgespräch. Als erste Wochenzeitung bringt Das interessante Blatt - gezeichnete - Bilder der Bluttat und der beiden Täter. Der illustrierte 


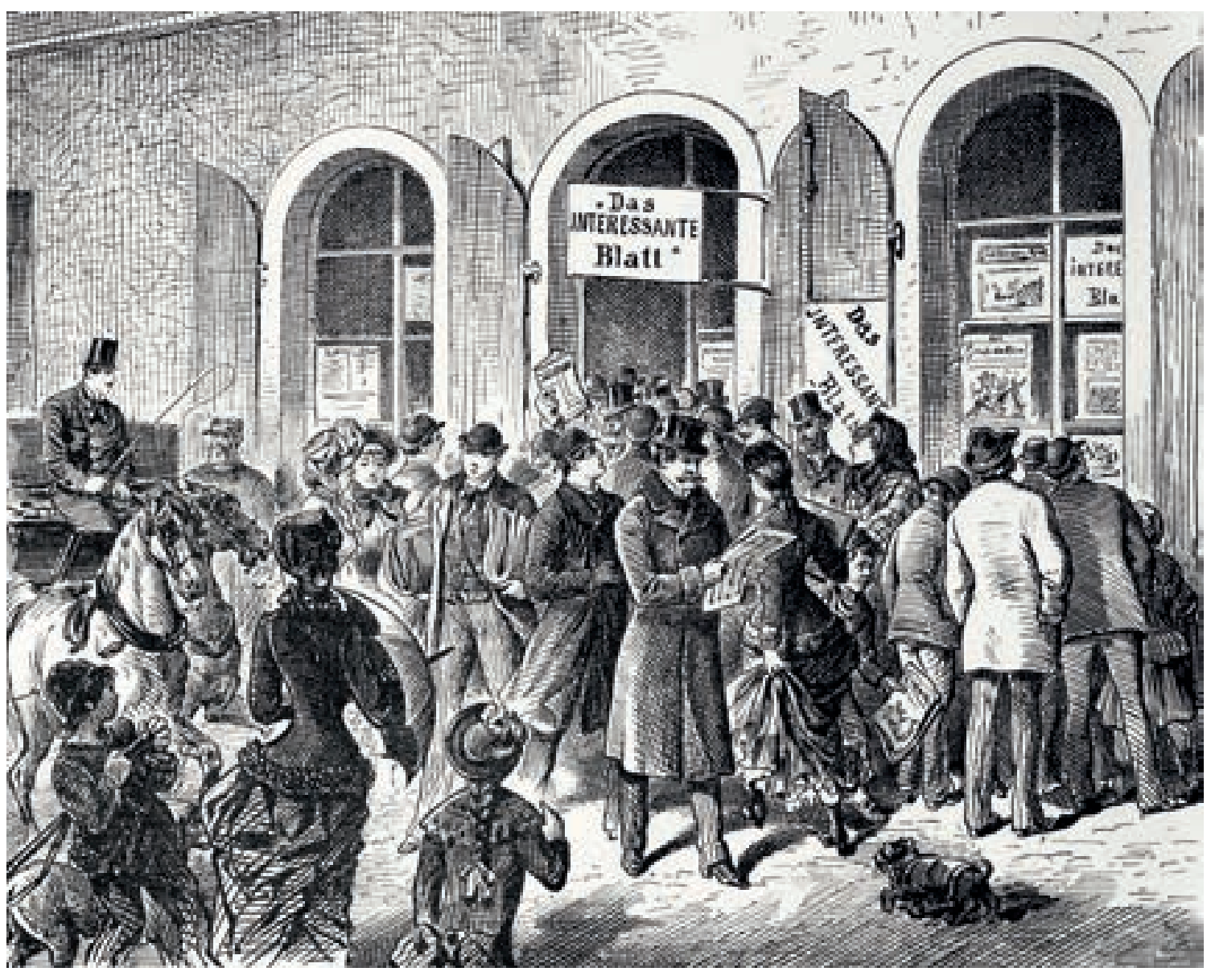

Zeitungsbericht schürt die kollektive Erregung weiter, der Voyeurismus erreicht einen Höhepunkt. Die enorme Nachfrage nach der Zeitungsausgabe reißt tagelang nicht ab. Vor dem Eingang des Interessanten Blattes, aber auch vor anderen Redaktionen in der Schulerstraße spielen sich dramatische Szenen ab. „Die Schulerstraße“, so heißt es im Interessanten Blatt weiter, „ist an einen lebhaften Verkehr gewöhnt, und ein Gedränge, wie man es sonst in Wien nicht zu häufig in den Straßen findet, ist hier nicht auffällig. Allein einen so lebhaften Verkehr wie in der abgelaufenen Woche, ein solches Stoßen und heftiges Drängen hat die Schulerstraße noch nicht erlebt. Der Wagenverkehr war thatsächlich aufgehoben, und es ist nur zu verwundern, daß in der engen Straße sich kein Unfall ereignete. Die Menge, welche die Zeitungsgasse, Kopf an Kopf gedrängt, dicht erfüllte, staute sich vor dem Hause Nummer 14, in welchem sich unsere Expedition befindet, vor den Auslagefenstern des ,Interessanten Blattes‘, welche die letzte Nummer mit den Bildern, die die Verhaftung des Mädchenmörders Schenk, seines Hauptgehilfen und seiner Opfer, wie die Scene der Abschlachtung der Kinder des Banquirs Eifert darstellen, enthielten. Unser Expeditionslocal war von der neugierigen und theilnahmslosen Men- ge, welche die Bilder des Entsetzens betrachten wollte, förmlich in Belagerungszustand versetzt, so daß es Schwierigkeiten machte, in das Local selbst zu gelangen. Es mußten außerordentliche Anstrengungen gemacht werden, um den Weg Jenen, die in das Local gelangen wollten, frei zu halten, und deren waren nicht wenige. Ein Heer von Zeitungsausträgern stürmte unsere Thüren, um schleunigst neue Nummern in die Verschleißlocalitäten, welche nicht genug Nummern erhalten konnten, zu tragen. Telegraphendiener kamen, welche Bestellungen der Provinz auf die Sensationsnummer überbrachten, die vornehmsten Damen wie die Frau des Arbeiters drängten sich an unseren Schaltern, um ein Exemplar zu erhalten, es herrschte in der Schulerstraße und auch in unserem Local ein Treiben, wie es wohl bis nun keine Zeitungsexpedition erlebt hat. Zur Charakteristik dieses Treibens wollen wir die Thatsache anführen, daß am Donnerstag nicht weniger als 46000 Exemplare durch unsere Expedition in das Publicum gebracht wurden. 46000 Nummern fanden an einem einzigen Tage Absatz, allein diese Ziffer stellt bloß einen verschwindenden Bruchtheil der Leser des Blattes dar. Man mußte sehen, wie Derjenige, dem es gelungen war, ein Blatt zu erhalten, auf die Straße tretend, um-
Abb. 1 „In der Wiener Zeitungsgasse. Das Treiben in der Schulerstraße am Tage der Ausgabe der letzten Nummer des ,Interessanten Blattes` vor unserem Expeditionslocale“. Das interessante Blatt, 24. Januar 1984, S. 8. 
ringt wurde von einer Schar Neugieriger, welche mit ihm die Bilder betrachteten, man mußte die Scharen gesehen haben, um sich einen Begriff von der Zahl der Leser der letzten Nummer unseres Blattes zu machen! Wir konnten den stürmischen Aufforderungen der Vorstadt- und Vororte-Verschleißlocale nicht rechtzeitig entsprechen, und so kamen diejenigen, die das Blatt haben wollten, selbst in unser Local, um die sensationelle Nummer mindestens in der Auslage zu sehen. Am Ende der Woche hatten wir 80000 Exemplare verkauft, ohne jedoch alle Nachfragen befriedigt zu haben. Wir glauben ein interessantes Bild des Wiener Straßenlebens zu bringen, indem wir das Treiben vor unserem Expeditionslocale am Tage, wo die letzte Nummer des ,Interessanten Blattes“ erschien, reproduciren.“3

Wenige Wochen später, im März 1884, beginnt „unter riesigem Andrange des Publicums“im Schwurgerichtssaal des Wiener Landesgerichts die Verhandlung gegen die beiden Angeklagten Schenk und Schlossarek. Wieder berichtet Das interessante Blatt über das Ereignis. Die Mörder und ihre Opfer werden neuerlich in Bildern vorgestellt. Die Vorlage, so wird diesmal betont, ,ist nach authentischen Photographien von einem unserer ausgezeichneten Künstler hergestellt worden“. ${ }^{4}$ Wochen später beschäftigt das Blatt die Affäre noch ein weiteres Mal. Am 24. April 1884 berichtet die Zeitung über die „Justificirung“ der beiden Verurteilten.

\section{Eine neue Massenpresse entsteht}

Der Bildbericht über die Schulerstraße ist ein spannendes kultur- und mediengeschichtliches Dokument - aus mehreren Gründen. Er porträtiert einen Ort - Wiens Zeitungsstraße -, der in der zweiten Hälfte des 19. Jahrhunderts als Produktionsstätte der öffentlichen Meinung immer wichtiger wird. Er schildert anschaulich eine Szene im öffentlichen Raum, in dem die Zeitung und ihr Publikum miteinander in Kontakt treten. Die Institution Zeitung, die gerne über die Welt, aber selten über sich und ihre Leser selber berichtet, wendet hier ausnahmsweise den Blick nach innen. Wir erfahren Details über Auflage und Vertrieb, über den Weg der Zeitung von der
Druckerei, den Transport per Zeitungswagen in die Expedition und von dort über die Zeitungsausträger bis hin zu den Verschleißstellen, den Orten des Verkaufs. Geschildert wird aber auch die Stimmung der Schau- und Leselustigen auf der Straße, die von einem sensationellen Thema (einem Mädchenmord) in den Bann gezogen werden.

Diese Nahaufnahme der Wiener Zeitungsstraße zeigt weit mehr als ein lokales Stimmungsbild. Sie vermittelt - pars pro toto - einen interessanten Einblick in das Innenleben der gesamten Stadt, die sich in diesen Jahren in einem tief greifenden medialen Umbruch befindet. Der Bericht zeigt, wie eine neue politische Macht die Bühne betritt: der illustrierte Boulevard. Das sind Zeitungen neuen Typs, die ihre Macht über die Bebilderung entfalten und sich nicht zufällig an das breite Publikum auf der Straße richten. In der zweiten Hälfte des 19. Jahrhunderts ist die Zeitung die bei Weitem wichtigste Agentin der öffentlichen Meinung. Diese Zeitungswelt ist in den 1880er und 1890er Jahren in Wien, aber auch in anderen europäischen Metropolen in einem radikalen Umbruch begriffen. Auch davon berichtet - bei aufmerksamer Lektüre - die Reportage über die Schulerstraße. Neben den klassischen Tageszeitungen tauchen nun neuartige, populär aufgemachte Zeitungen auf, die sich an ein breites Massenpublikum wenden. Sie sind billig, ihre Auflage ist hoch, sie finanzieren sich zu einem Gutteil über die Anzeigen. Ihren Anfang nimmt diese Entwicklung in den USA, wo die ersten Massenblätter (etwa der New York Herald oder die New York Tribune) bereits ab den 1860er Jahren enorme Auflagensteigerungen verzeichnen können. Ab 1863 erscheint das erste Massenblatt Frankreichs, das Petit Journal, ab 1896 die englische Daily Mail und ab 1898 das erfolgreichste amerikanische Tabloidblatt, die New York World Joseph Pulitzers, die es um die Jahrhundertwende auf eine Auflage von 1,5 Millionen bringt. Während 1870 in den USA noch täglich 2,6 Millionen Zeitungen verkauft werden, steigt die Zahl bis 1900 auf über 15 Millionen an. ${ }^{5} \mathrm{Ab}$ den 1890er Jahren expandiert dieser populäre Sektor der Presse auch in Europa rasch. In Österreich gründet Jacob Lippowitz mit dem Neuen Wiener Journal 1893 das erste täglich erscheinende Massenblatt der Monarchie. Es ist billig, setzt ganz 
auf populistische, oft reißerische Lokalberichterstattung und erobert seinen Platz mit aggressiven Werbefeldzügen (anfangs wird es kostenlos an alle Haushalte verteilt). ${ }^{6}$ Bald folgen diesem Konzept weitere Tageszeitungen, etwa im Jahr 1900 die Kronen-Zeitung.

Auch Das interessante Blatt gehört, im Bereich der Wochenblätter, zu dieser neuen, populären Zeitungsgeneration. Seine Zielgruppe ist die Masse des Bürger- und Kleinbürgertums, weniger die gebildete Elite und auch nicht die Arbeiterschaft. Das Ziel der Zeitung ist nicht die Anhäufung trockener Textnachrichten aus der hohen Politik, der Wirtschaft und der Kunst. Vielmehr, so heißt es in einer Anzeige in eigener Sache, sei es ihr Anspruch, „das Interessante aus Nah und Fern, das Sensationelle in Wort und Bild zu sammeln und zur Belehrung und Unterhaltung in Familie und Haus zu tragen"7. Das neue Wochenblatt gibt den Bildern den Vorzug vor den Texten. Seine Nachrichten sind immer auch Sensationen. Die Themen sind: „Episoden aus dem Leben unserer Tage, größere Katastrophen, bedeutende Festlichkeiten, Länder- und Völkerkunde, selbst aus den entferntesten Welttheilen, Sportbilder, theatralische Vorgänge, heldenmütige Thaten, Unglücksfälle, Verbrechen usw. “8 Der Serienmörder Hugo Schenk passt bestens in dieses Themenspektrum.

Das interessante Blatt hat mit seinem populären Kurs, der sich deutlich von der trockenen gutbürgerlichen Tagespresse abhebt, bald großen Erfolg. Der Umfang steigt, ebenso der Anteil der Anzeigen und natürlich auch die Auflage - besonders dann, wenn die Titelgeschichte reißerisch ist. Das Rezept - wenig Politik, viel Lokalberichterstattung, Sensationen, Unterhaltung und Werbung - ist nicht ganz neu. Sigmund Auspitzer entlehnt es zum Teil von den sogenannten „Sonn- und Montagsblättern“, die ab den 1870er Jahren auf den Markt kommen und am Beginn einer auflagenstarken Boulevardpresse stehen. Andererseits orientiert er sich aber auch, etwa in Format und grafischer Aufmachung und dem Einsatz von Bildern, an den älteren, meist behäbigeren Familienblättern und Wochenillustrierten, deren Blütezeit in der zweiten Hälfte des 19. Jahrhunderts liegt. ${ }^{9}$ Im Unterschied zu diesen setzt er viel stärker auf wochenaktuelle Nachrichten und Sensationen. Die mediale

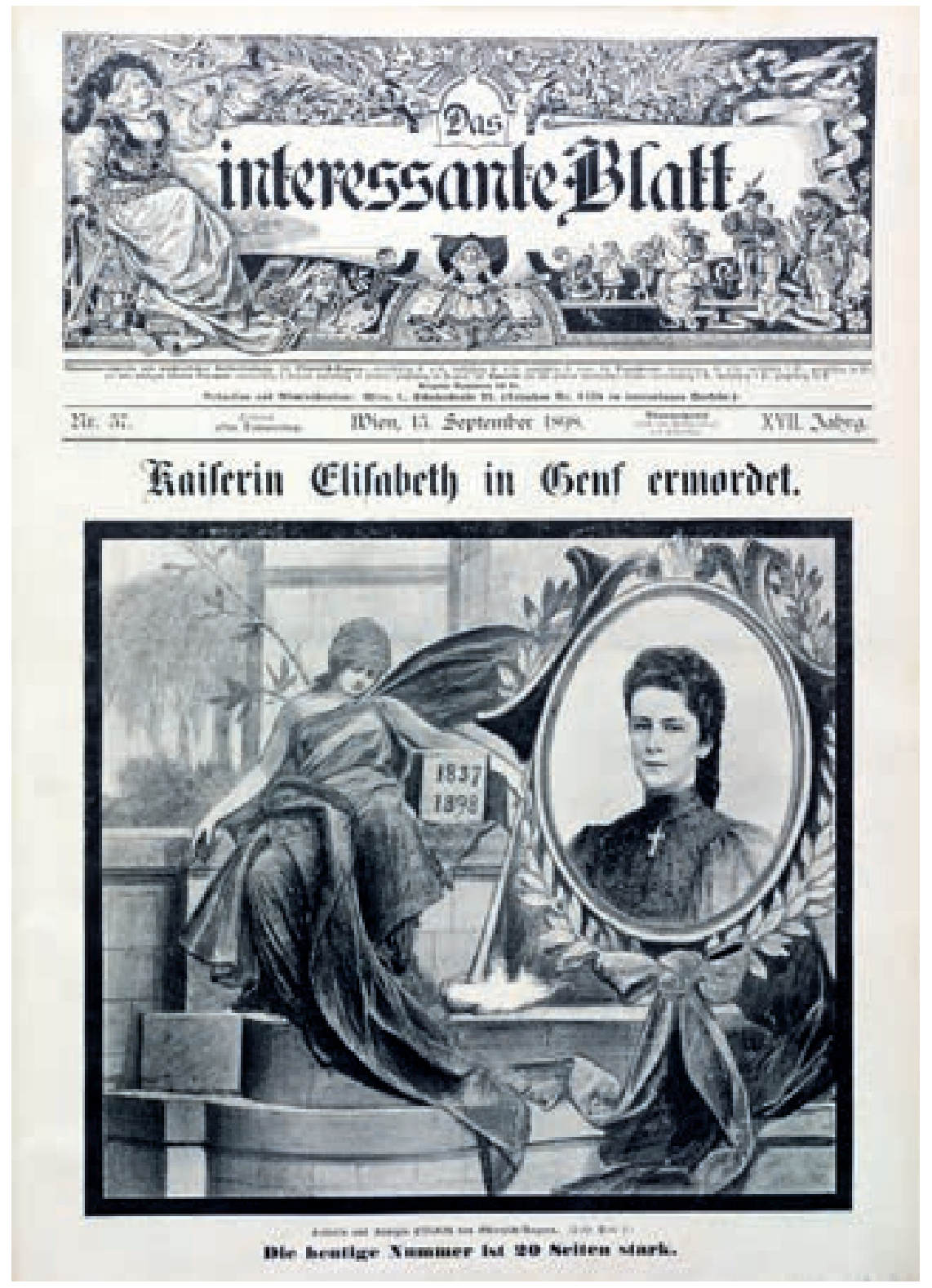

Zwitterstellung zwischen konservativem Familienblatt und moderner Bilderzeitung ist dem Interessanten Blatt (wie auch anderen illustrierten Wochenzeitungen) noch Jahre nach seiner Gründung deutlich anzusehen. Während sich das Blatt im Innenteil recht bedächtig und Schritt für Schritt in Richtung einer modernen fotografisch illustrierten Wochenzeitung entwickelt, hält sie auf dem Umschlag gut ein halbes Jahrhundert lang, nämlich bis zum Jahr 1939, an der traditionellen Titelvignette fest, wie sie bei Familienblättern des 19. Jahrhunderts üblich ist (Abb. 2).

\section{Fotografisch illustrierte Wochenzeitungen}

Auch im Bereich der Wochenzeitungen zeichnen sich ab den 1890er Jahren tief greifende Umbrüche ab. Neben den etablierten, textlastigen Journalen
Abb. 2 „Kaiserin Elisabeth in Genf ermordet". Das interessante Blatt, 15. September 1898, Titelseite. 
Abb. 3 Österreichische Illustrierte Zeitung, 23. April 1899. Das Titelfoto zeigt den österreichischen Afrikareisenden Rudolf Carl Freiherr von Slatin (1857-1932), bekannt unter dem Namen „Slatin Pascha“. Foto: Atelier Josef Székely.

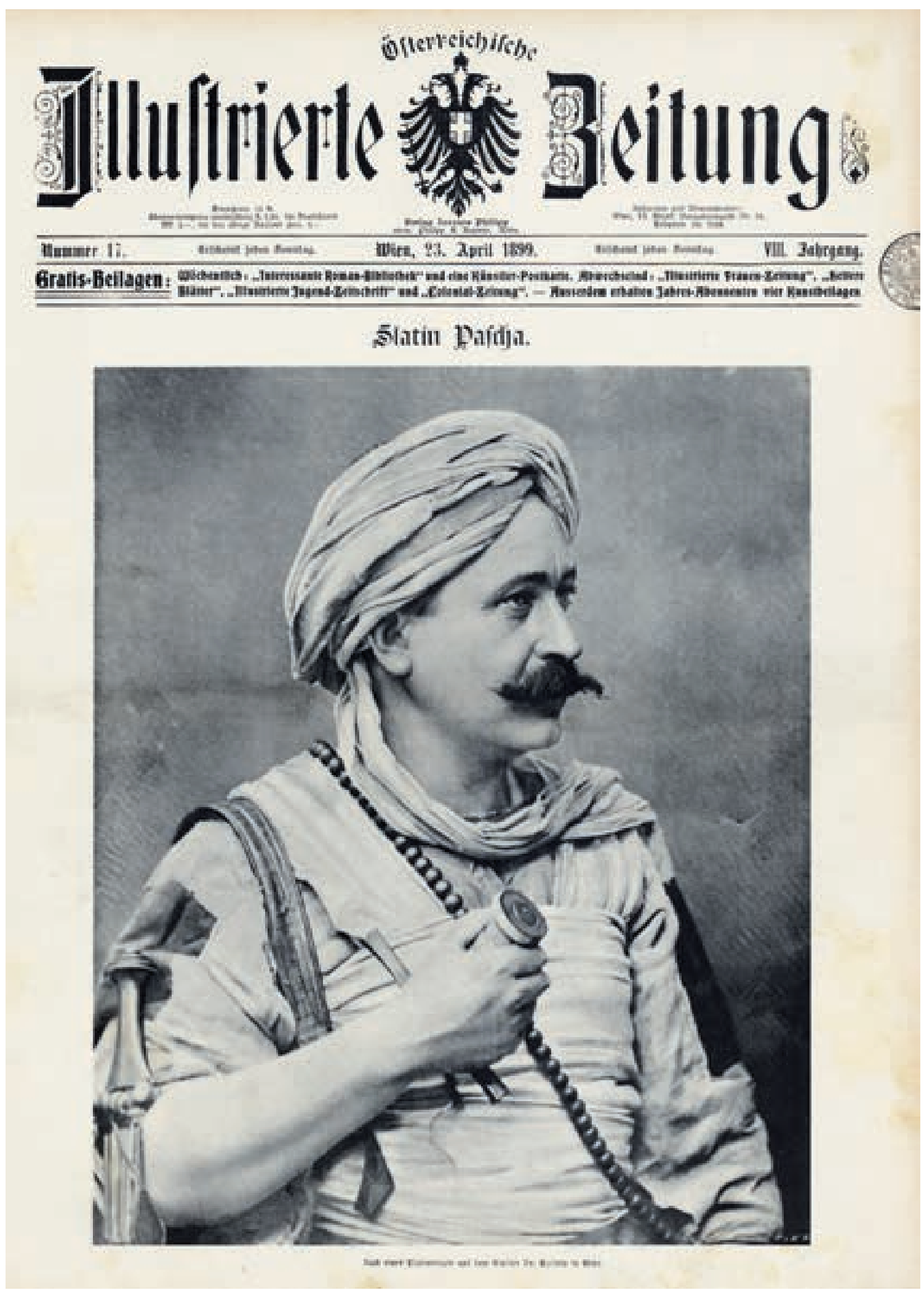

drängen nun neuartige Medien auf den Markt: illustrierte Wochenzeitungen, die immer stärker auf das Medium Fotografie setzen. Sie orientieren sich am Prototyp des Interessanten Blattes, aber auch an ausländischen, vor allem Berliner Vorbildern. 1893 wird die Österreichische Illustrirte Zeitung (um 1900 umbenannt in Österreichs Illustrierte Zeitung $\left.{ }^{10}\right)$ gegründet, seit 1896 erscheinen die Wiener Bilder. Die konservativ ausgerichtete, konventionell aufgemachte Österreichische Illustrierte Zeitung (Abb. 3), die zunächst dreimal monatlich, ab 1898 wöchentlich am Sonntag erscheint, hat einen turbulenten Start. 
Sie versucht zunächst den Spagat zwischen traditionellem Familienblatt und moderner illustrierter Wochenzeitung. 1899 geht die Zeitung in den Besitz des Druckereiunternehmers Jacques Philipp über, der nun auch als Herausgeber fungiert. Nun stabilisiert sich die ökonomische Lage. Nach 1900 wird das Blatt grafisch modernisiert und entwickelt sich nach und nach in Richtung einer Illustrierten. In ihrer Auflage und Bedeutung bleibt die Zeitung freilich stets im Schatten des eindeutigen Marktführers Das interessante Blatt, aber auch der Wiener Bilder, der zweiten großen österreichischen Wochenillustrierten. Genaue Zahlen über die Auflagenentwicklung dieser beiden Zeitungen vor dem Ersten Weltkrieg sind nicht bekannt. Nachdem aber beide Blätter in ihrer Blütezeit Ende der 1920er Jahren wöchentlich unter 50000 verkauften Exemplaren bleiben, ist zu vermuten, dass ihre durchschnittliche Auflage um 1900 deutlich darunter liegt. ${ }^{11}$ Nur im Falle außerordentlicher Ereignisse (wie dem eingangs erwähnten Serienmord) gelingt es den beiden Zeitungen, ihre Auflage punktuell in die Höhe schnellen zu lassen. Die Reichweite der Österreichischen Illustrirten Zeitung, der dritten größeren illustrierten Zeitung, liegt weit hinter jener des Interessanten Blattes und der Wiener Bilder zurück. ${ }^{12}$

Die 1896 vom Journalisten und Schriftsteller Vinzenz Chiavacci gegründeten Wiener Bilder (Abb.4) erscheinen wöchentlich am Sonntag. Ihre Linie ist konservativ, kaisertreu und patriotisch. Aus den aktuellen politischen Debatten halten sie sich weitgehend heraus. Sie wenden sich an ein bürgerliches und kleinbürgerliches Publikum. Im Unterschied zum Interessanten Blatt sind sie stärker auf Wien und Umgebung bezogen, in der Wahl reißerischer Themen sind sie zurückhaltender. Voyeuristische Sex-and-Crime-Berichterstattung finden wir in dieser Zeitung seltener als im Interessanten Blatt. Dafür wird, wie das Vorwort des Herausgebers in der ersten Nummer zeigt, versucht, gutbürgerlichen kulturellen Ansprüchen Genüge zu tun: „Die ,Wiener Bilder“ sollen, soweit Kunst und begeisterte Liebe zu dem herrlichen Gemeinwesen es vermag, ein möglichst getreuer Abglanz des Lebens und der Entwicklung der Kaiserstadt an der Donau und ihrer daseinsfreudigen Bewohner sein. (...) Fernab vom politischen Partei- getriebe wollen wir den Erscheinungen der Kunst, des Theaters, des Familien- und socialen Lebens mit Feder und Griffel folgen.“ ${ }^{13}$ Und weiter heißt es: „Die ,Wiener Bilder“ werden in erster Linie, jedoch ohne engherzige Begrenzung, das vaterländische Element in Wort und Bild pflegen. Sie sollen das reiche Leben und die unvergängliche Pracht unserer Kaiserstadt widerspiegeln.“ 14
Abb. 4 Wiener Bilder. Illustrirtes Sonntagsblatt, 7. März 1897, Titelseite. Foto: Atelier Rudolf Krziwanek.

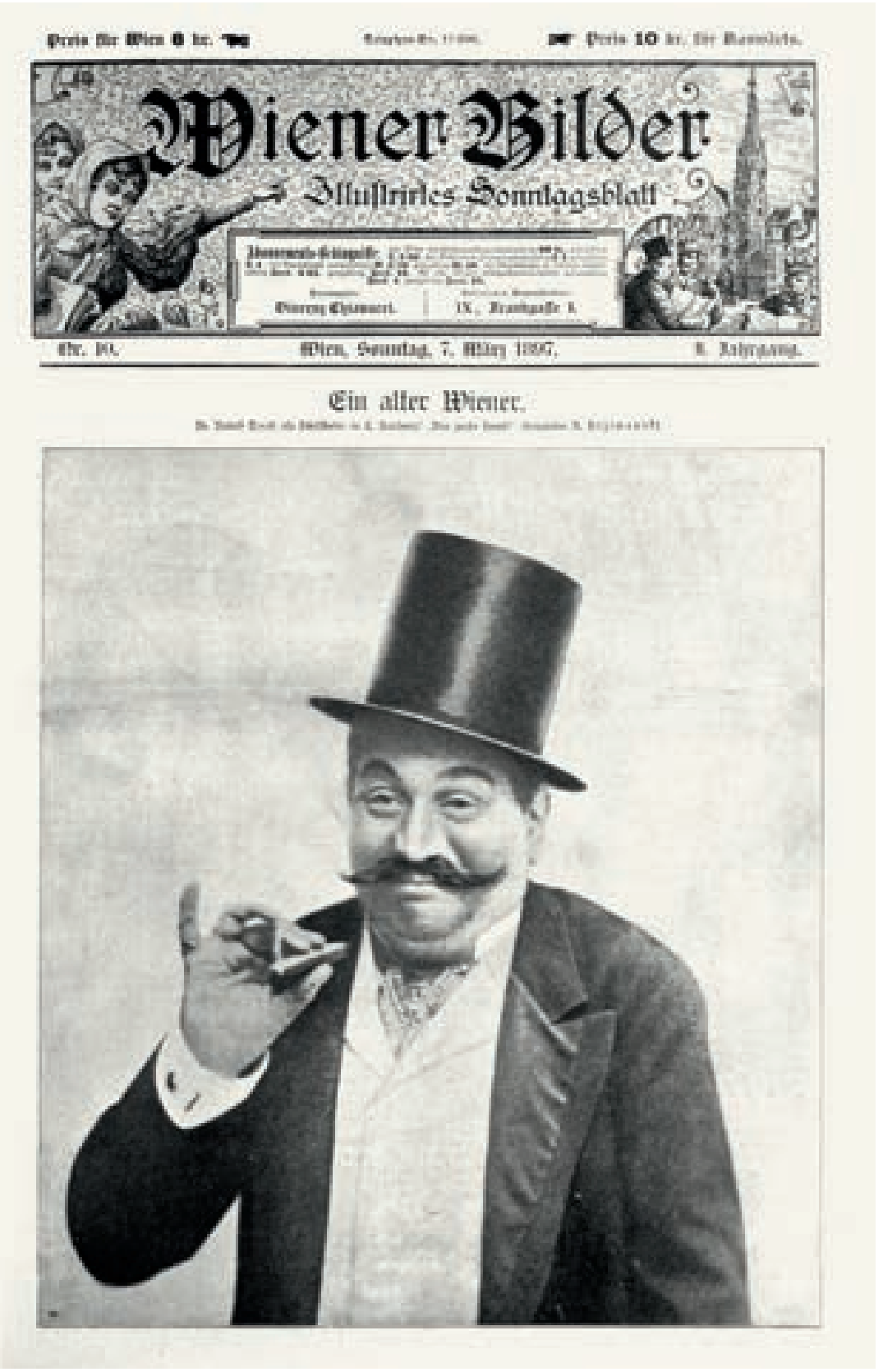


Programm der sportlichen Veranstaltungen auf Seite 2.

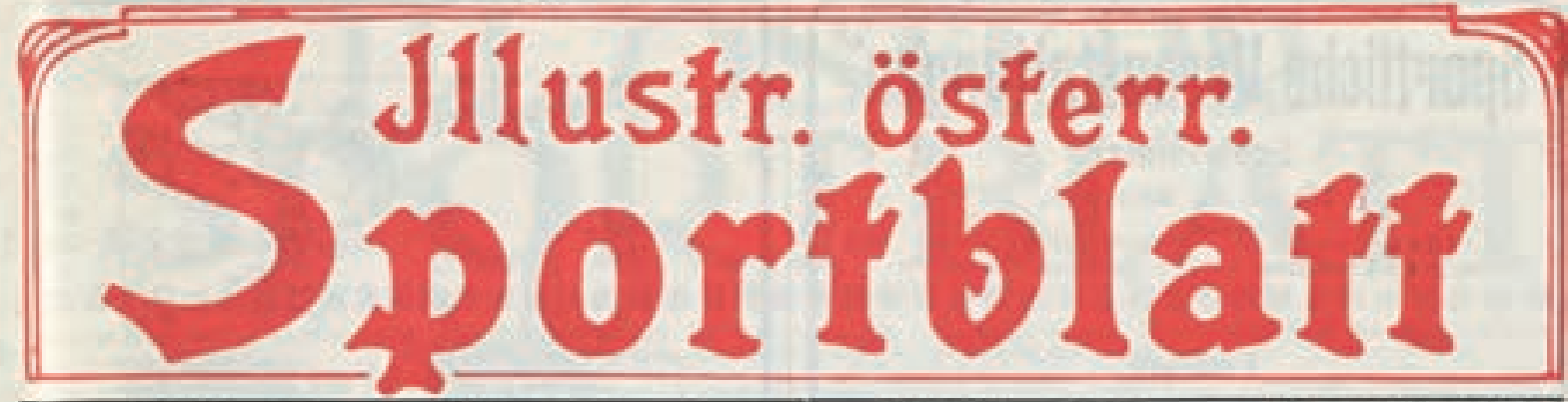

Jahrg. IX. Nr. 13. Wien, Prag, Graz, den 29. März 1913. Preis 20 Heller.

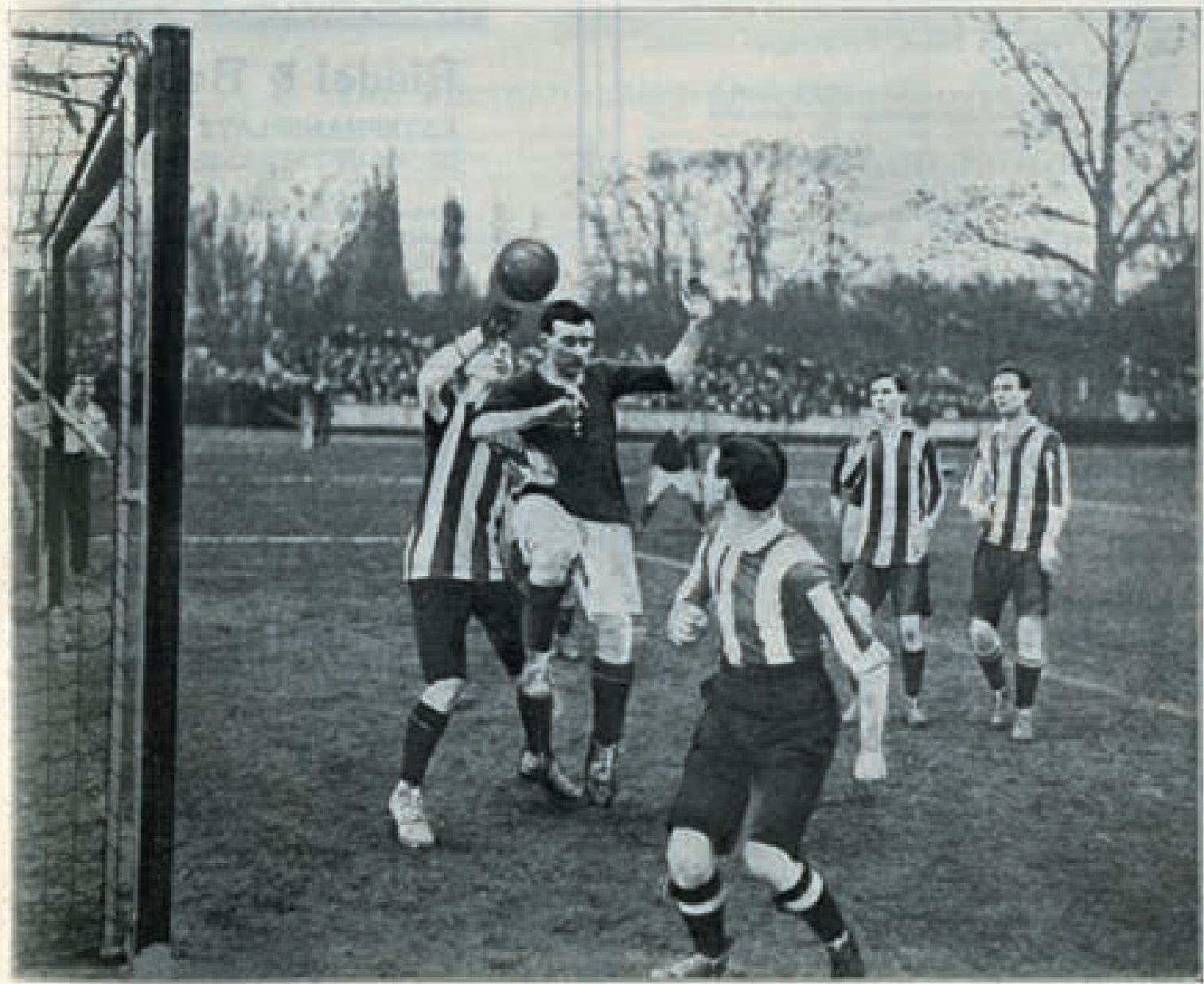

Aus dem Wettspiel Clapton F. C.-W. A. F.: Fischera im Kampfe mit dem englischen Tormanne.

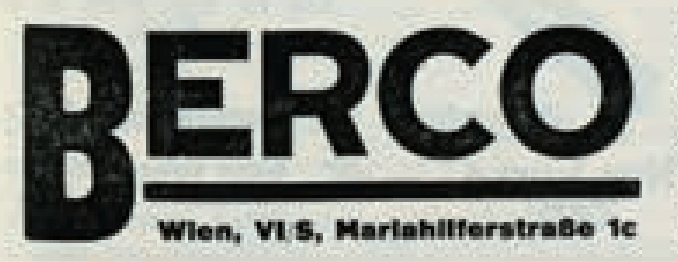

"DREADNOUGHT"

der beste, neueste Match - Ball der Saisoa.

Neweste, echt englisehe Dressen in allen Farbea. Original englische FuBballschuhe $\mathrm{K} 8$ - - aufwärts. 
Eineinhalb Jahrzehnte lang stehen Das interessante Blatt und die Wiener Bilder in kommerzieller Konkurrenz zueinander. Im Jahr 1911 schließlich kommt es zum Zusammenschluss der beiden Blätter. Hinter dem Coup steht der Wiener Druckereibesitzer und Verleger Karl Groak. ${ }^{15}$ Er steigt zunächst als Kompagnon bei den Wiener Bildern ein und erreicht später das Zusammengehen mit dem Interessanten Blatt. Als neuer Eigentümer fungiert die 1910 gegründete Österreichische Zeitungs- und Druckerei-Aktiengesellschaft, die damit für einige Jahre zum unumstrittenen Marktführer in der österreichischen Illustriertenlandschaft wird. ${ }^{16}$ Der Konzern dominiert zwar den Zeitungsmarkt im Bereich der illustrierten Presse, auf dem österreichischen Zeitungsmarkt insgesamt aber gibt es in diesen Jahren noch weit größere Unternehmen, allen voran den Elbemühl-Konzern und das Unternehmen Steyrermühl sowie nach dem Ersten Weltkrieg die Gesellschaft für Graphische Industrie. Das ökonomische Rückgrat beziehen diese Firmen aus dem Besitz zahlreicher Papierfabriken. All diese Konzerne kaufen laufend neue Zeitungen und Verlage hinzu. ${ }^{17}$

Im Jahr 1911/12 lässt Karl Groak für seinen neuen Medienkonzern in der Rüdengasse 11, im 3. Wiener Gemeindebezirk, also außerhalb der Ringstraße, ein hochmodernes Verlags-, Druckerei- und Redaktionsgebäude errichten. ${ }^{18}$ In den folgenden Jahren dehnt der Konzern sein Mediengeflecht weiter aus. Bestehende Illustrierte wie das 1906 gegründete Illustrierte österreichische Sportblatt (Abb. 5) oder Neugründungen wie das Familienblatt Der Sonntag (1911 bis 1913) ergänzen das Programm. Gemeinsam ist ihnen, dass sie sehr stark auf fotografische Illustration setzen und sich somit von herkömmlichen, textlastigen Wochenzeitungen abheben. ${ }^{19}$

\section{Das Diktat der Ökonomie}

In vielen europäischen Ländern, nicht nur in Österreich, haben um 1900 Zeitungen Erfolg, die in ihrer Berichterstattung vorwiegend auf Bilder, vor allem auf fotografische Bilder setzen. Die neue Tendenz in der Zeitungslandschaft lautet: Sensationen sind wichtiger als bloße Nachrichten. In Frankreich etablieren sich neben der traditionsreichen Zeitung
L'Illustration weitere illustrierte Blätter, u. a. La Vie Illustrée, Excelsior, Le Miroir, Le Pays de France sowie eine Reihe von anderen Unterhaltungs- und Modezeitschriften. In England heißt die alteingesessene führende bürgerliche Illustrierte The Illustrated London News, daneben gibt es andere anspruchsvolle illustrierte Blätter wie Sphere und Graphic sowie weitere billigere Unterhaltungsblätter. In Deutschland erhält die altehrwürdige, sich an ein gehobenes Bürgertum wendende Leipziger Illustrirte Zeitung kurz vor der Jahrhundertwende Konkurrenz von innovativeren Illustrierten wie der Woche und der Berliner Illustrirten Zeitung, die eine überregionale Reichweite haben. Ergänzt werden diese Illustrierten durch regionale Blätter und zahlreiche weitere Unterhaltungszeitschriften. In Ungarn erscheinen u.a. Érdekes Újság (Die interessante Zeitung), Új Idők (Neue Zeiten), A Hét (Die Woche) und Ország Világ (Land und Leute), in Böhmen u. a. Zlatá Praha (Das goldene Prag), Praha. Demni list vystavni (Prag. Tägliches Ausstellungsblatt) und Česky svět (Tschechische Welt). Auch eine Reihe von führenden Tageszeitungen bringt nach 1900 halbwöchentlich (meist mittwochs) oder wöchentlich (meist samstags oder sonntags) erscheinende fotografisch illustrierte Beilagen auf den Markt. ${ }^{20}$ Die nach der Jahrhundertwende massiv einsetzende Hinwendung zur Fotografie geschieht nicht zufällig. Die Herausgeber, Verleger und Eigentümer folgen darin vor allem dem geschäftlichen Credo.

Die wegweisenden Innovationen in der illustrierten Zeitungslandschaft kommen in diesen Jahren aus Berlin: Große Konzerne, wie Scherl, Mosse und vor allem Ullstein, revolutionieren den Markt. ${ }^{21}$ Mit unterschiedlichen Mitteln gelingt es diesen Unternehmen, sich vor und um 1900 als dominierende Medienhäuser zu etablieren und die Auflage ihrer Blätter rasant zu steigern. Mosse setzt auf die systematische, aggressive Erschließung neuer Anzeigengeschäfte, Scherl auf neue Vertriebsformen, indem er Gratis- und später Billigzeitungen mit einer Massenauflage produziert. Das Haus Ullstein schließlich verdankt seinen ökonomischen Erfolg ursprünglich der Papierproduktion und später sehr stark seinem leistungsfähigen Druckereigewerbe, aus dem ein weitverzweigter Medienkonzern hervorgeht. ${ }^{22}$
Abb. 5 Illustriertes Österreichisches Sportblatt, 29. März 1913, Titelseite. Foto: Heinrich Schuhmann sen. 
Auch in Österreich kommt es zur Herausbildung hegemonialer Strukturen. Neben den beiden Flaggschiffen Das interessante Blatt und Wiener Bilder bleibt nur wenig Platz für die Konkurrenz. Der Grund dafür ist v. a. ökonomischer und struktureller Natur. Der Markt für deutschsprachige Zeitungen ist in der k. u. k. Monarchie klein. ${ }^{23}$ Nur acht von 53 Millionen Bürgern sprechen um 1900 Deutsch - ein Gutteil davon lebt in ländlichen Gebieten-, die für die großstädtische Publizistik kaum empfänglich sind. Der Auflagenstärke illustrierter Wochenzeitungen sind somit - im Vergleich zu Deutschland, das weit mehr potenzielle Leser hat - enge Grenzen gesetzt. Geringere Auflagen ziehen auch geringere Werbeeinnahmen nach sich. Die niedrige Kapitalausstattung begrenzt die Möglichkeiten der technischen Modernisierung - ein Teufelskreis, dem die österreichische Presse nicht entkommen kann. Sensationelle Auflagensteigerungen wie sie etwa in Deutschland die Berliner Illustrirte Zeitung schafft, die 1894 noch wöchentlich 23000 Exemplare verkauft und die Auflage bis 1915 auf über eine Million steigern kann, sind in Österreich unvorstellbar. ${ }^{24}$

Eine der Folgen dieser Entwicklung ist, dass die österreichische Bildpresse bereits in den Jahren vor dem Ersten Weltkrieg im Vergleich mit der deutschen Konkurrenz ins Hintertreffen gerät - eine Tendenz, die auch in der Zwischenkriegszeit anhalten und sich noch deutlich verstärken wird. Die Schwäche der österreichischen illustrierten Presse macht sich in vielen Bereichen bemerkbar: etwa in der weniger modernen Vertriebstechnik wie in der Begrenzung des Anzeigenmarktes. Betroffen sind aber auch die grafische Gestaltung der Zeitungen, die technische Ausstattung der Redaktionen, die Bezahlung der Journalisten und Fotografen und vieles mehr. Verstärkt wird der Druck auf den österreichischen Zeitungsmarkt auch dadurch, dass nach 1900 deutsche Zeitungskonzerne mit ihren Produkten zunehmend nach Österreich drängen. Siegmund Schneider, der Österreichs Illustrierte Zeitung leitet, beklagt 1905 die zunehmende „Überschwemmung mit Berliner Zeitungsfabrikaten“. ${ }^{25}$ Deutsche Verlage vertreiben nun immer häufiger ihre illustrierten Mode- und Frauenzeitschriften unter einem anderen Titel und inhaltlich leicht verändert in Österreich. So wird beispielsweise aus der Illustrierten Sonntags-Zeitung für unsere Frauen in Österreich die Österreichische Familien- und Moden-Zeitschrift. Aus der deutschen Moden-Zeitung fürs Deutsche Haus wird in Österreich die Neue Wiener Moden-Zeitung. ${ }^{26}$

Die geschilderten Umstände tragen dazu bei, zu erklären, weshalb ein Großteil der österreichischen illustrierten Zeitungen vor dem Ersten Weltkrieg (aber auch danach) nicht sonderlich innovationsfreudig ist. Vor allem Frauen-, Mode- und gehobene Gesellschaftsblätter kultivieren ein konservatives, auf Beharrung setzendes Image. Ein Beispiel dafür ist das 1870 gegründete Wiener Salonblatt (Abb. 6), das im Untertitel (Österr.-Ungar. Adelsorgan) die Zielgruppe klar benennt. Ein anderes ist die 1889 gegründete Zeitschrift Sport und Salon, die ihre Adressaten ebenfalls im Untertitel umreißt: Illustrierte Zeitschrift für die vornehme Welt. Aber auch die führende Modezeitschrift des Landes, die 1888 gegründete Wiener Mode (Abb. 7), die sich als „vornehmstes und gediegenstes Frauenund Modejournal“27 der Monarchie bezeichnet, bleibt bis in die 1920er Jahre klassisch-konservativ. Die Zeitschrift wendet sich an ein gehobenes bürgerliches oder aristokratisches Publikum. Die Fotografie als wesentliches Gestaltungs- und Informationsmedium hält in dieser Zeitung erst sehr spät Einzug. ${ }^{28}$

\section{Neugründungen nach 1900}

Dennoch gibt es in den Jahren nach 1900 eine Reihe von Zeitungsneugründungen, die von vorneherein stark auf die Fotografie setzen. Dazu gehören auch die illustrierten Wochenendbeilagen von Tageszeitungen. Zwischen 1907 und 1919 erscheint etwa Der Sonntag als illustrierte Wochenendbeilage der christlichsozialen Reichspost. Von 1914 bis 1918 liegt dem Fremden-Blatt die illustrierte Beilage Welt-Bild bei. Diese orientiert sich sichtlich an der weitaus aufwendiger und professioneller gestalteten Bildbeilage Welt-Spiegel des renommierten Berliner Tageblatts, die seit 1896 erscheint.

Neben diesen Wochenendbeilagen von Tageszeitungen gibt es auch Neugründungen eigenständiger Wochenillustrierter, die der Fotografie einen 


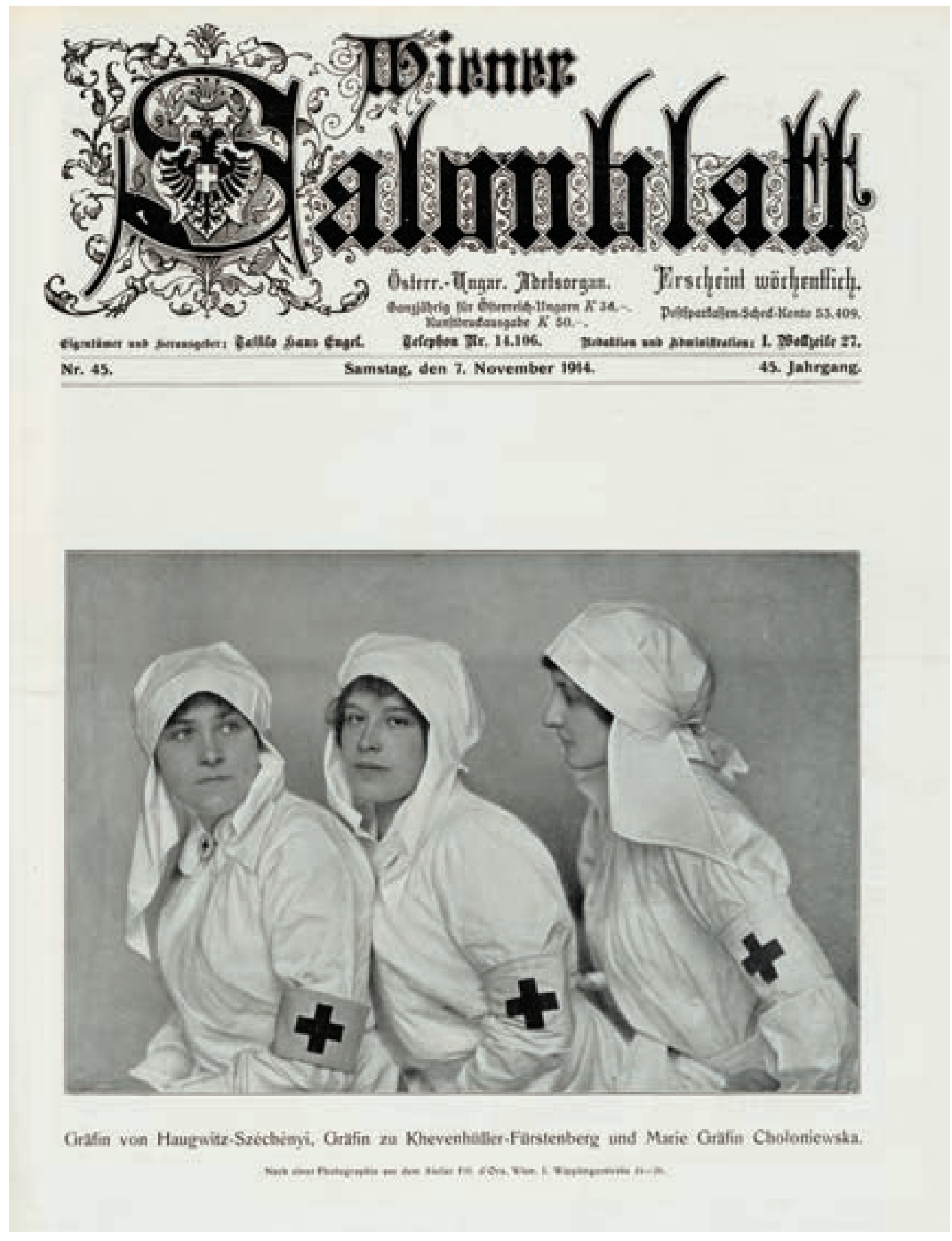

Abb. 6 Wiener Salonblatt, 7. November 1914, Titelseite. Foto: Atelier d'Ora.

großen Platz einräumen. Im gehobenen Segment der illustrierten Wochenpresse versucht sich die Österreichische illustrierte Rundschau, die in der Austria Verlagsgesellschaft erscheint, einen Platz zu sichern. ${ }^{29}$ Bereits im Untertitel weist sie auf ihre bildungsbürgerliche, gutbürgerliche Zielgruppe hin. Sie nennt sich nicht uneitel Organ der gebildeten Welt auf allen Gebieten des gesellschaftlichen Lebens und bewegt sich in ihrer gediegenen Aufmachung und sorgfältigen, aber grafisch einfallslosen Gestaltung deutlich im Fahrwasser elitärer Bilderzeitungen wie etwa der Leipziger Illustrirten Zeitung. Ihre inhaltliche Ausrichtung ist konservativ, die Berichterstattung hat gar nicht den Anspruch, durchgehend aktuell zu sein, es werden in langen Abhandlungen alle (anscheinend) wichtigen Themen der Gegenwart verhandelt, von der Architektur bis zur Mode, von der Politik bis zur Frauenfrage. Die Bilder haben sich in das stati- 


\section{Wiener Mode}

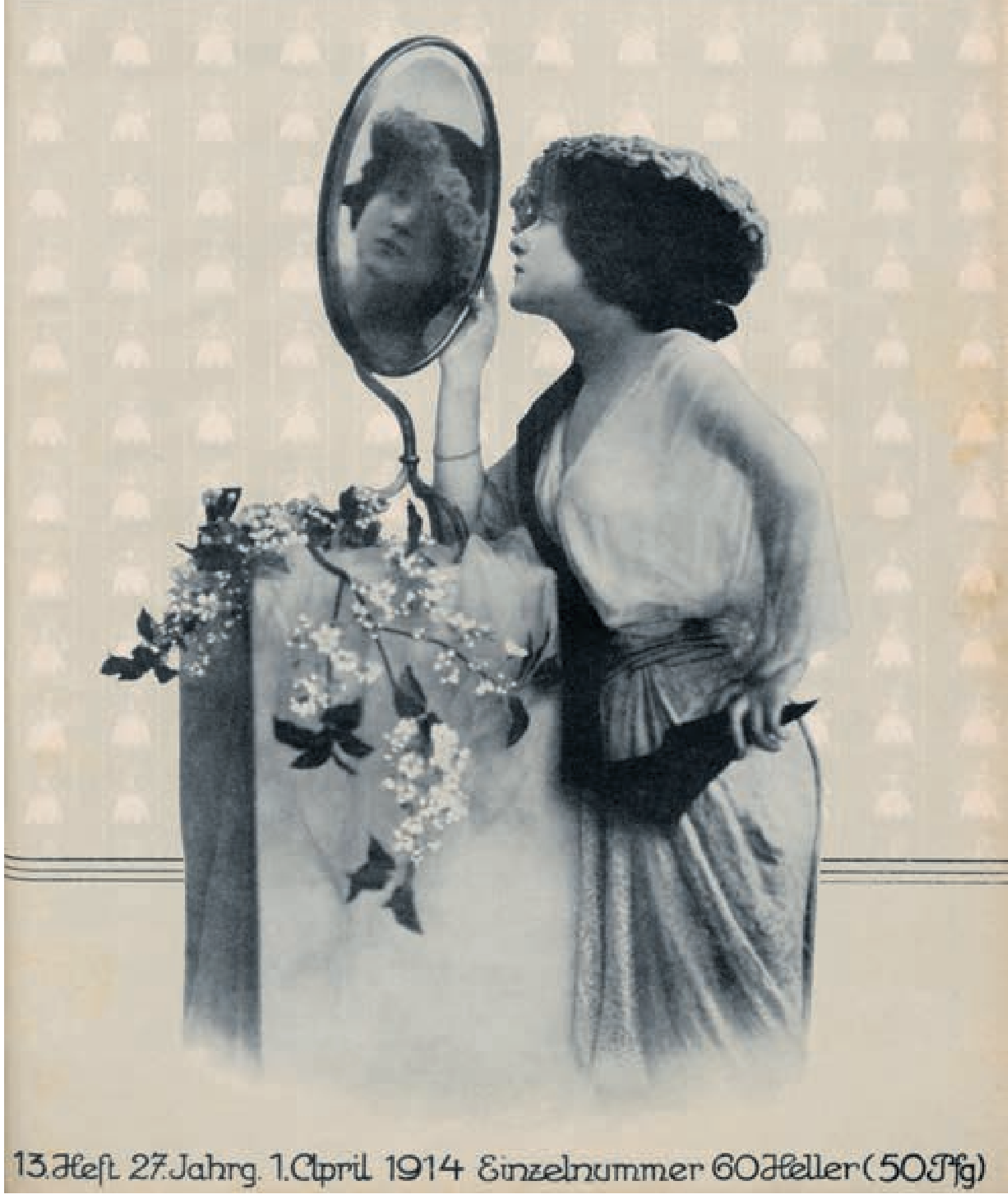


sche, zweispaltige Erscheinungsbild einzufügen. In der Kriegszeit gibt sich das Blatt, wie praktisch alle Illustrierten, patriotisch. Papiermangel und wirtschaftliche Not setzen der Zeitung gegen Kriegsende zu. Anfang Januar 1919 benennt sie sich in Illustrierte Rundschau um, vergrößert das Format und erscheint nun zweimonatlich. Längerfristig können diese Reformen das Blatt nicht retten, 1926 wird es eingestellt.

Im populären, auflagenstarken Billigsegment der Illustrierten gibt es nach der Jahrhundertwende weit mehr Bewegung als im gehobenen Sektor. 1912 wird etwa die Österreichische Woche (Abb. 8) gegründet, die jeden Sonntag erscheint. Sie ist ein typisches Massenblatt und wirbt auf der Titelseite damit, „das billigste illustrirte Blatt Österreichs“ zu sein. ${ }^{30}$ Das Journal setzt auf äußerst populäre Sensationsberichterstattung und berichtet wenig über Politik, sondern vorzugsweise über Sport, Spektakel, Varieté, Reisen, Unfälle, Katastrophen u. Ä.

Ebenfalls im Billigbereich der illustrierten Presse angesiedelt ist die Wochenzeitung Das Neueste im Bilde, die zwischen 1914 und 1919 herauskommt. ${ }^{31}$ Die erste Nummer erscheint am 3. September 1914, also wenige Wochen nach Kriegsbeginn. Anders als die Illustrirte Österreichische Woche strebt die Zeitung eine seriöse Berichterstattung an. Das Blatt ist zwar eine richtige Bilderzeitung, d. h. sie gibt der Fotografie (und der Zeichnung) viel Raum, grafisch ist sie aber sehr einfach aufgemacht. Aus Preisgründen verzichtet sie, so wie andere Billigillustrierte auch, auf den aufwendigen Kupfertiefdruck, der sich vor dem Ersten Weltkrieg durchzusetzen beginnt. Die Zeitung gehört zum Konzern von Jacques Philipp, in dem auch die den Christlichsozialen nahestehende Österreichs Illustrierte Zeitung erscheint. Ihre inhaltliche Linie ist patriotisch-konservativ. In den ersten Monaten nach dem Krieg gerät die Zeitung, wie andere Zeitungen auch, in ökonomische Turbulenzen. Inflation und Papiermangel zwingen die Eigentümer Ende 1919 zur Aufgabe. Am 24. Dezember 1919 erscheint die letzte Nummer. Auf der Titelseite dieser Ausgabe findet sich erstmals kein Bild, sondern eine Ankündigung der Redaktion in großen Lettern: „Wegen Papiermangel, bzw. wegen enormer Preissteigerungen muss ,Das Neueste im Bilde“ derzeit eingestellt werden.“32
Ende Dezember 1914, wenige Monate nach Kriegsbeginn, erscheint eine weitere billige illustrierte Wochenzeitung, die Wiener Illustrierte Zeitung. ${ }^{33}$ Mit dieser Neugründung versucht die „Gesellschaft für Graphische Industrie“, die seit der Jahrhundertwende einen expandierenden Verlag und ein modernes Druckhaus in der Wiener Gumpendorfer-Straße betreibt, in die erste Liga der illustrierten Zeitungsverlage aufzusteigen. ${ }^{34}$ Als verantwortlicher Redakteur tritt Sigmund Rosenbaum auf, der zunächst auch als Leiter des Verlags und der Druckerei fungiert. Die
Abb. 7 Wiener Mode, Heft 13, 1. April 1914, Titelseite.

Abb. 8 Österreichische Woche, 24. September 1916, Titelseite.
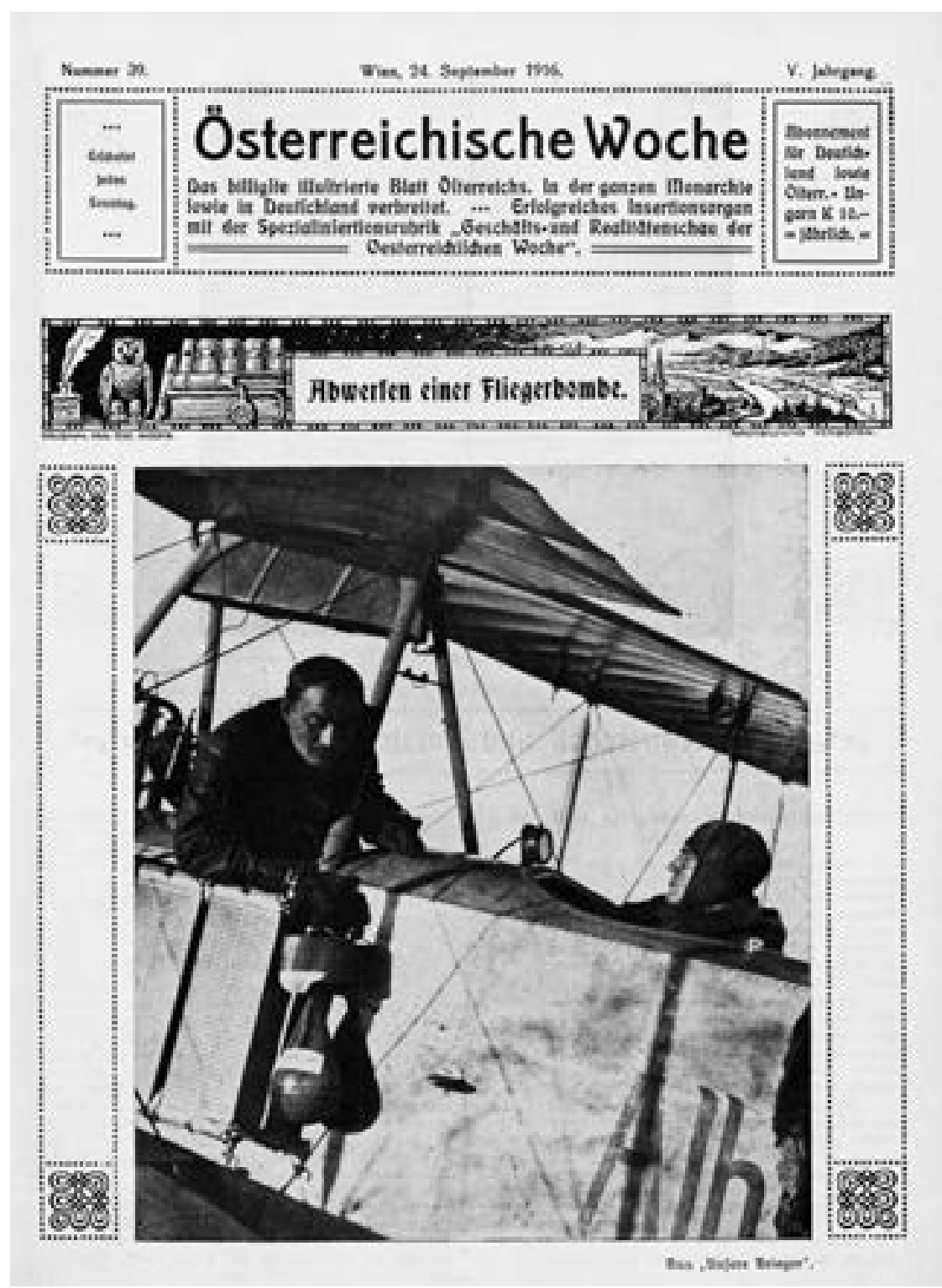
Zeitung hebt sich optisch von den recht behäbigen Konkurrenzprodukten wie dem Interessanten Blatt oder den Wiener Bildern ab. Die Titelseite ist gekennzeichnet durch den klaren, einfachen Schriftzug des Titels. Sie verwendet also einen Zeitungskopf, der ohne Vignetten auskommt. Unter dem Titel findet sich stets ein großformatiges Foto. Auch im Innenteil setzt das Blatt auf fast durchgehende Fotoberichterstattung. Die Sensationsgier der Kriegsberichterstattung verstärkt diesen Trend zur fotografischen Bebilderung der Ereignisse. Und dennoch: Kommerziell hat das Blatt Mühe, sich gegen die Konkurrenz durchzusetzen. Im November 1915 wird das Format der Zeitung verkleinert, die redaktionelle Leitung übernimmt nun Julius Ornstein. ${ }^{35}$ Allerdings scheint sich der Verkaufserfolg des Blattes nicht zu bessern, denn Ende Dezember 1916 wird sie - ohne Angabe von Gründen - eingestellt. ${ }^{36}$

Ein visuell anspruchsvolleres Konzept verfolgt die Wochenzeitung Der Samstag (Abb.9), die im Oktober 1906 vom Druckereibesitzer, Ansichtskartenverleger und Kalenderproduzenten Franz Schöler in Wien-Döbling gegründet wird. Die Zeitung wendet sich an ein gutbürgerliches Publikum, es bietet den Lesern „gediegenen Inhalt“. Es ist weniger populär aufgemacht als etwa Das interessante Blatt. Neben aktueller politischer Berichterstattung finden sich im Blatt auch Bildgeschichten über Theater, Literatur, aber auch über Katastrophen, Unglücksfälle und andere Sensationen, ferner ,erstklassige Romane, Novellen und Gedichte“, wie es in der ersten Nummer heißt. ${ }^{37}$ Das Blatt versucht gar nicht erst den Spagat zwischen alten und neuen Medien. Es gibt von Anfang an der Fotografie den Vorzug. Die Zeitung ist gut gedruckt (allerdings nicht im Kupfertiefdruck) und modern gestaltet. Jede Woche führt unter dem Titel ein seitenfüllendes Foto in das Heft ein.

Der Samstag ist eine Illustrierte neuen Typs, die den Trend der Zeit aufnimmt: Das fotografische Bild wird in der Berichterstattung immer wichtiger. Nach zweieinhalb Jahren scheitert dieses Experiment allerdings, am 27. Februar 1909 erscheint die letzte Ausgabe. Der Grund dafür liegt weniger in der Machart des Blattes als in der geringen Auflage, den fehlenden Werbeeinnahmen und im kurzen kommerziellen
Atem des Verlegers. Eine illustrierte Wochenzeitung, die keinem der großen Medienkonzerne des Landes angeschlossen ist, hat, so zeigt dieses Beispiel, bereits in den Jahren vor dem Ersten Weltkrieg keine Überlebenschance.

\section{Technische Neuerungen, kommerzielle Umbrüche}

Die Österreichische Zeitungs- und Druckerei-Aktiengesellschaft steigt, wie berichtet, knapp vor dem Ersten Weltkrieg zum marktbeherrschenden Wiener Konzern im Bereich der illustrierten Presse auf. Anlass für diese Konzentrationsbewegung sind tief greifende Veränderungen im Zeitungsgeschäft, die in den 1890er Jahren einsetzen und um 1910 ihren Höhepunkt erreichen. Betroffen davon ist besonders die illustrierte Presse. Technische und kommerzielle Umbrüche gehen Hand in Hand: In den Jahren um 1900 stellen fast alle illustrierten Zeitungen nach und nach auf den Druck von Fotografien um. Die bisher vorherrschenden Zeichnungen und Holzschnitte werden schrittweise von Autotypien abgelöst, das sind Fotografien, die im Rasterverfahren gedruckt werden. 1896 richtet der Berliner Ullstein Verlag für die Berliner Illustrirte Zeitung eine eigene Bildätzerei ein. ${ }^{38}$ Auch zahlreiche österreichische Blätter stellen um 1900 auf den Fotodruck um. Dies erfordert massive Investitionen in die technische Ausstattung der Druckereien. Chemigrafische Anstalten, die für die Herstellung druckfertiger Bildvorlagen notwendig sind, müssen eingerichtet werden.

Kaum ist dieser Schritt vollzogen, setzen weitere technische Verbesserungen des Fotodrucks ein. In den Jahren nach 1900 stellen in Europa die ersten Illustrierten auf den Kupfertiefdruck um: 1902 beginnt der Ullstein-Konzern vereinzelt mit dem Einsatz neuer, schnellerer Rotationstiefdruckmaschinen, ab 1910/1912 setzt sich das Verfahren bei den großen, auflagenstarken Blättern in anderen europäischen Ländern durch. ${ }^{39}$ Im April 1914 hält der Kupfertiefdruck in der österreichischen illustrierten Presse Einzug. Sowohl Das interessante Blatt wie auch die Wiener Bilder, mittlerweile zum selben Unternehmen gehörend, stellen nun - zumindest in einem Teil 
der Auflage - auf den neuen Rotationstiefdruck um. Auf Betreiben Karl Groaks kauft die Österreichische Zeitungs- und Druckerei-Aktiengesellschaft als erste österreichische Zeitungsdruckerei mehrere teure Tiefdruckrotationsmaschinen an. Die neue Technik hat zahlreiche Vorteile. Der Druck erfolgt schneller, die Wiedergabe von Fotos verbessert sich: Die Abbildungsqualität steigt, die Fotos erscheinen plastischer, detailreicher und mit größerer Tiefenschärfe.

Mindestens ebenso folgenreich wie die technischen Innovationen sind die ökonomischen Veränderungen, die um 1900 im europäischen Zeitungsmarkt einsetzen. Die Auflage der populären Massenblätter steigt deutlich an - vor allem im Bereich der Tagespresse wie auch der illustrierten Wochenpresse. ${ }^{40}$ Die auflagenstarken, an ein breites Publikum gerichteten Zeitungen verfolgen ganz andere kommerzielle Strategien als die herkömmliche, gutbürgerliche Presse. Wichtig ist der kommerzielle Erfolg, politische Positionierung und Ideologie treten dagegen in den Hintergrund. Damit ist in erster Linie die Erhöhung der Reichweite, das heißt die Steigerung der Auflage gemeint. Diese ist nämlich die Voraussetzung für steigende Anzeigenerlöse. Um dies zu erreichen, wird der Verkaufspreis bewusst niedrig gehalten. Denn die Verkaufserlöse aus Abonnement und Straßenverkauf bilden nur einen Teil der Einnahmen. Immer wichtiger für das wirtschaftliche Überleben einer populären Massenzeitung wird das Anzeigenaufkommen, das parallel mit der Auflagensteigerung erhöht wird. Um ein Beispiel zu nennen: In den ersten Jahren nach der Gründung des Interessanten Blattes im Jahr 1882 ist das Anzeigenvolumen noch klein, meist sind nur zwei der 24 Zeitungsseiten für Anzeigen reserviert. In den 1890er Jahren steigt der Anteil der Reklame stark an. Um 1900 erreichen die Anzeigen bereits knapp die Hälfte des Zeitungsumfangs, der ebenso zunimmt. Inzwischen ist die Wochenausgabe der Zeitung regelmäßig 32, oft auch 52 Seiten stark.

Kurz vor dem Ersten Weltkrieg sind die Umbrüche in der österreichischen Illustriertenlandschaft vorläufig abgeschlossen. Das interessante Blatt und die Wiener Bilder behaupten - nun unter einem gemeinsamen Eigentümer - ihre Vormachtstellung. Das moderne, großzügig angelegte Verlagsgebäude,

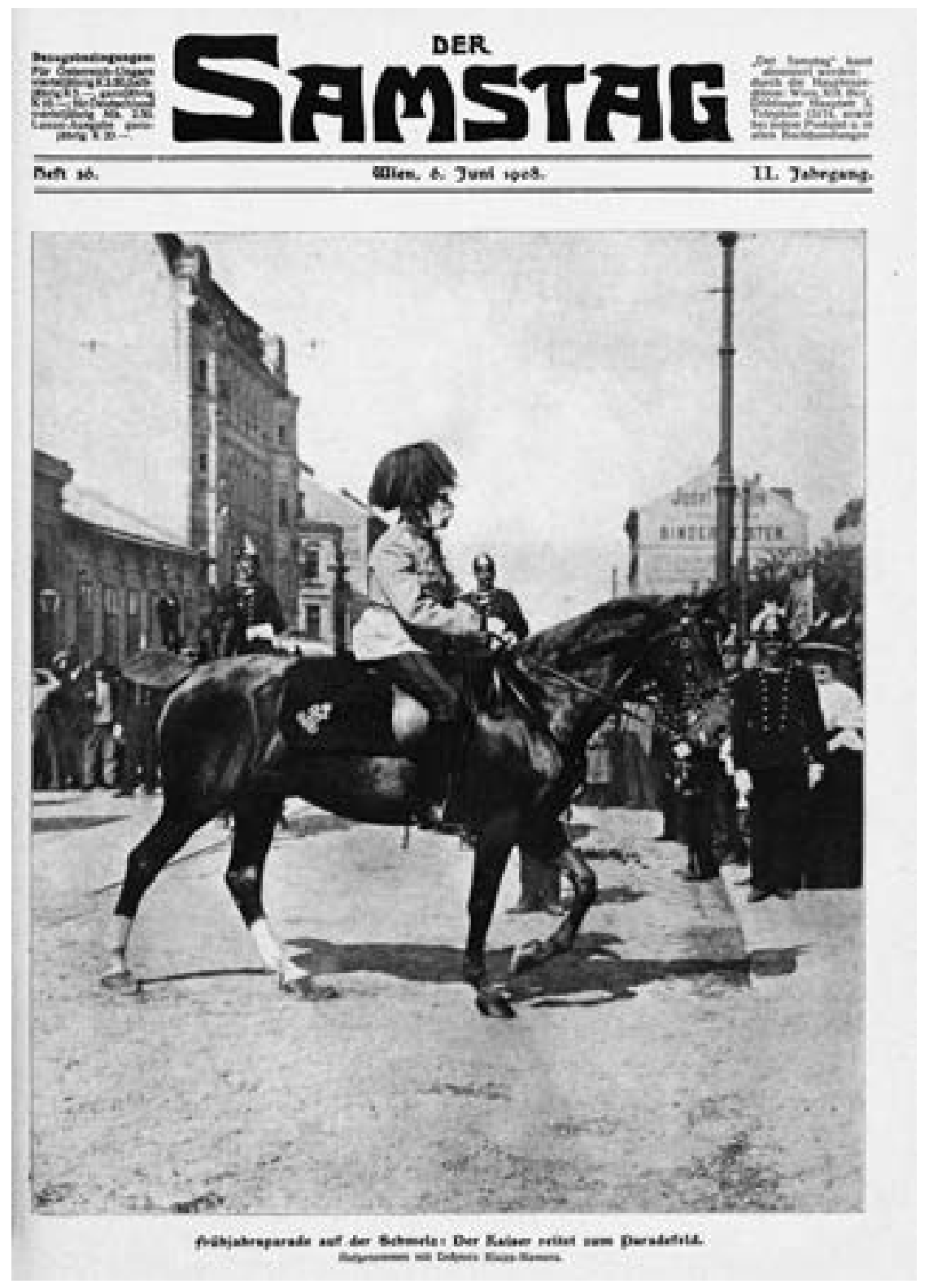

das beide Blätter 1912 beziehen, ist ein sichtbares Zeichen für die neue Zeit. Es liegt nicht mehr in der Abb. 9 Der Samstag, 6. Juni 1908, Titelseite. engen Zeitungsstraße in der Innenstadt, sondern in der bürgerlichen Vorstadt. Zwar führt der Verlag das Stadtbüro in der Schulerstraße (nun in der Nummer 18) weiter, es dient nun aber nur noch der Anzeigenakquisition und teilweise dem Verkauf - ein merklicher Bedeutungsverlust für Wiens prominente Zeitungsstraße bahnt sich an. In den folgenden Jahren verlassen weitere Zeitungen die Innenstadt. Die Schulerstraße, die noch um die Jahrhundertwende die Wiener Produktionsstätte der öffentlichen Meinung gewesen war, verändert ihr Gesicht. In der Epoche der großen Zeitungskonzerne, die vor dem Ersten Weltkrieg eingeläutet wird und sich nach 1918 fortsetzt, ist diese Zeitungsstraße dabei, zur ganz normalen Wiener Geschäftsstraße zu werden.
10. 
erscheinen seine ersten Aufnahmen im Interessanten Blatt. Es sind - für die damalige Zeit völlig neu - Aufnahmen von Sportereignissen. Anton Huber ist nicht nur ein Pionier der österreichischen Pressefotografie, sondern auch der Sportfotografie.

Huber ist zwar nicht der erste Fotograf, dessen Bilder in der illustrierten Presse veröffentlicht werden. ${ }^{1}$ Er ist aber der erste professionell arbeitende österreichische „Illustrationsphotograph“ - so werden die Pressefotografen um 1900 genannt. Anders als viele seiner Fotografenkollegen, die im Atelier entstandene Porträts gelegentlich ein zweites Mal verwerten, indem sie sie an die Presse schicken, arbeitet Huber vor allem als Zeitungsfotograf, auch wenn er anfangs nebenbei noch ein Atelier in zentraler Lage am Stephansplatz betreibt. Er erkennt in der illustrierten Presse ein zukunftsträchtiges Medium für das fotografische Geschäft.

Zwar entstehen zahlreiche seiner frühen Sportlerporträts noch im Studio. Hier kann er die Lichtver- hältnisse besser kontrollieren, hier bringt er mit fest installierten, schweren Atelierkameras bessere Porträts zustande als im Freien. Aber die für den Sport so wichtige Dramatik des Augenblicks, den Eindruck der Spannung, die Geschwindigkeit, Massenszenen, all das kann er im Atelier nicht einfangen. Allmählich verlagert er daher Ende der 1890er Jahre seine Arbeit nach draußen, wo er am liebsten sportliche Wettkämpfe, wie etwa Radrennen und - wenige Jahre später - auch Autorennen, fotografiert (Abb. 2). Ihn interessieren aber auch militärische und politische Großveranstaltungen, wie Manöver oder Kaiserreisen. In Anzeigen bezeichnet er sich in den 1890er Jahren als „Militär- und Sportphotograph“. Huber unterhält beste Beziehungen zum Kaiserhaus und erhält immer wieder begehrte Fotoaufträge. 1902 etwa lichtet er als erster Fotograf den Thronfolger Franz Ferdinand in seinem neuen Automobil ab (Abb.3). „Unsere Erzherzöge“, so heißt es zum Bild, „vor allem Franz Ferdinand, der allen Neuerungen auf dem Gebiete
Abb. 2 Der Wagen Theodor Drehers während eines Autorennens in einer Kurve. Die berühmte „Herkomer Konkurrenz“ findet 1906 am Semmering zum zweiten Mal statt. Das Tourenwagen-Rennen wurde 1905 von Sir Hubert Ritter von Herkomer gegründet. Das interessante Blatt, 21. Juni 1906, S. 5. Foto: Anton Huber.

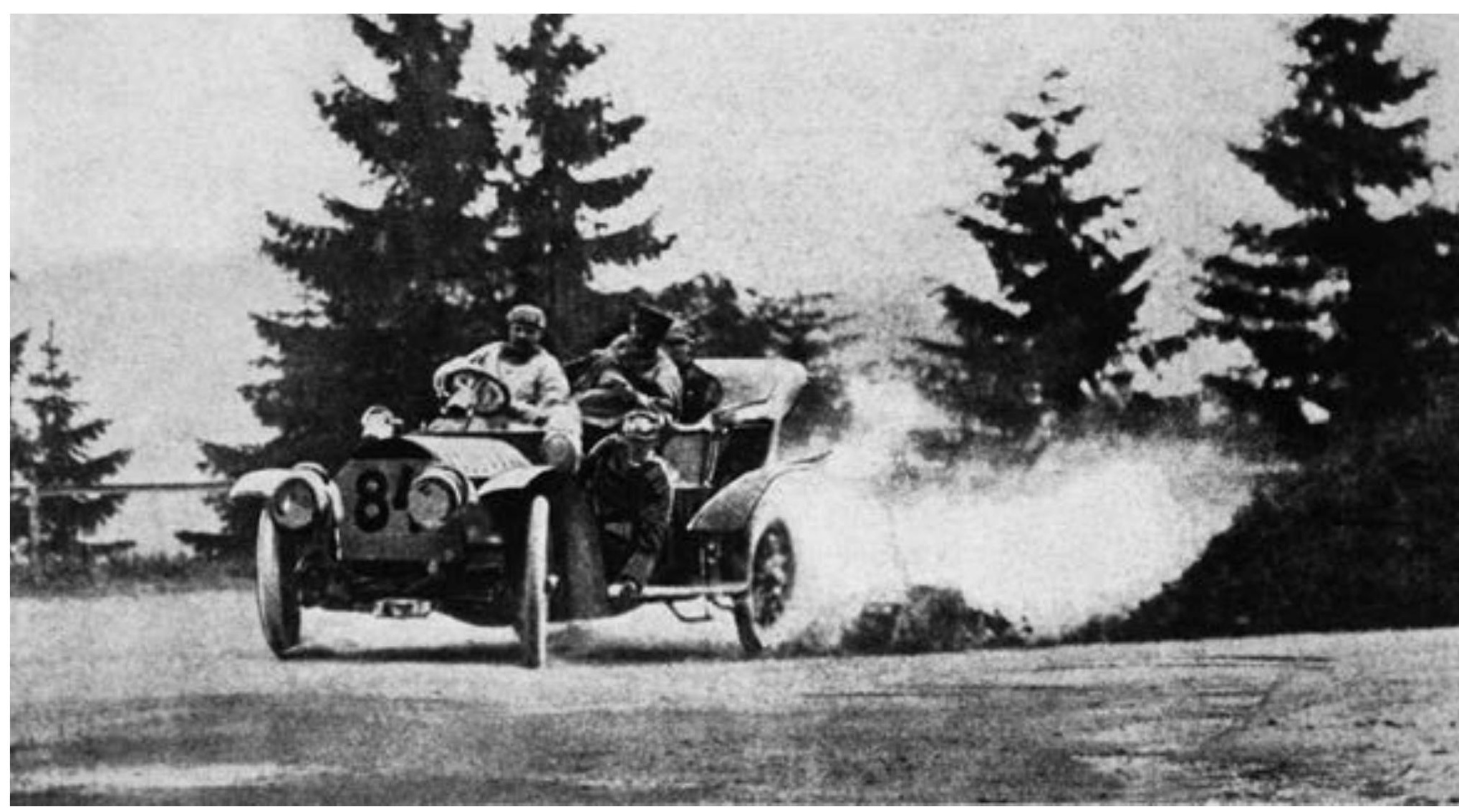




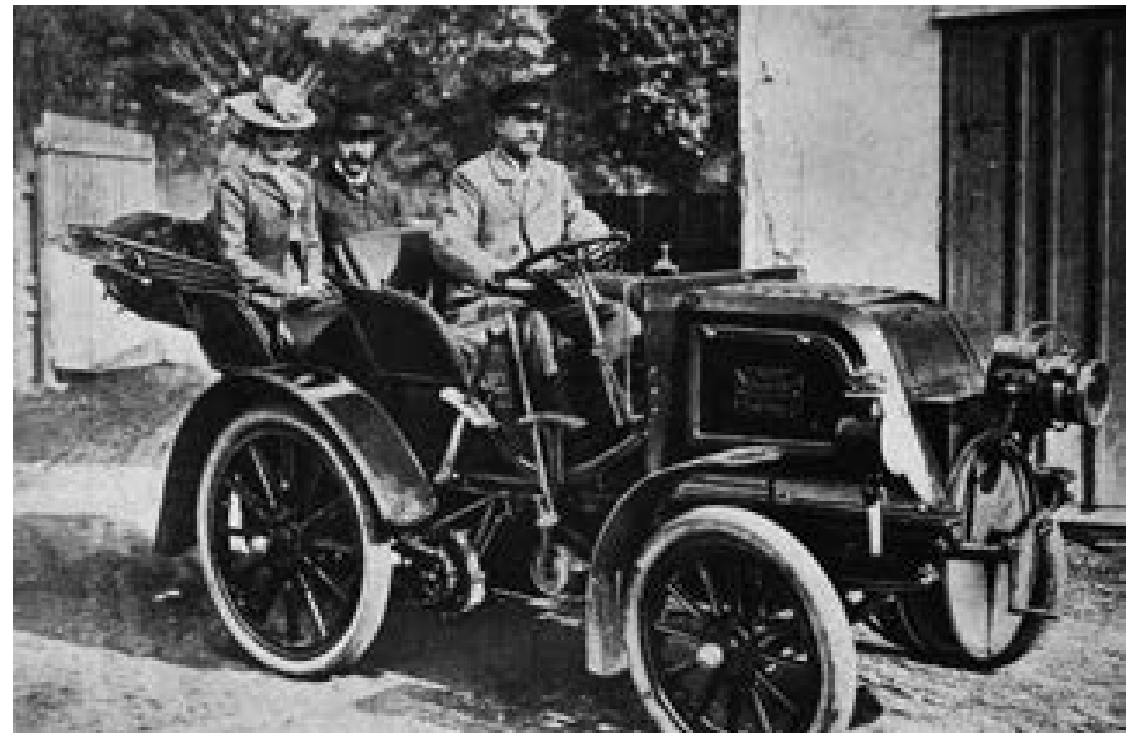

Abb. 3 Der österreichische Thronfolger Franz Ferdinand und seine Frau Sophie auf einem Daimler-Automobil. Das interessante Blatt, 6. März 1902, S. 6. Foto: Anton Huber. des Sports seine Aufmerksamkeit widmet, ebenso die Erzherzöge Otto und Franz Salvator fahren mit vollendeter Eleganz und Geschicklichkeit auf schmucken Voituren. Diese Thatsache scheint erst recht geeignet, dem Automobil einen ersten Platz zu sichern.“2

\section{Massenkultur und Krise der traditionellen Fotografie}

Bis zur Jahrhundertwende ist das Nebeneinander von Ateliertätigkeit und fotografischer Zuarbeit für die Presse durchaus typisch für das Berufsprofil der „Illustrationsphotographen“. Nicht nur Porträts, die in der illustrierten Presse erscheinen, werden weiterhin zum Großteil von den traditionell arbeitenden Berufsfotografen geliefert, auch öffentliche Ereignisse, politische, geistliche, kulturelle und militärische Festlichkeiten, Bauwerke, Landschaften, Katastrophen, Unglücksfälle und andere Sensationen werden von diesen „Allroundern“ dokumentiert. Nach und nach aber differenziert sich das Berufsbild aus, allmählich entsteht ein eigener Arbeitsbereich, jener der Pressefotografie. Diese Entwicklung verläuft nicht konfliktfrei. Und sie sollte weitreichende kulturelle Folgen haben. Der beispiellose Prozess der Vervielfältigung fotografischer Bilder in den Medien, der in den 1890er Jahren einsetzt, die rasante Ausweitung und Ausdifferenzierung des fotografischen Geschäfts, die
Verlagerung der Fotografie vom Atelier ins Freie, das Entstehen einer Knipser- und Amateurfotografenbewegung, all das führt zu einer folgenreichen Erschütterung der traditionellen Formen des Fotografierens.

Plötzlich gerät das Modell der herkömmlichen Atelierfotografie, das jahrzehntelang stilbildend gewesen war, in eine Krise. Der Angriff kommt von zwei Seiten, von der Popularisierung der Fotografie und von ihrer massenmedialen Vervielfältigung, konkret: von der Knipser-bzw. Amateurfotografenbewegung und von der Pressefotografie. Die Knipserfotografie, die etwa zeitgleich mit der Pressefotografie in der Öffentlichkeit auftritt, nämlich in den 1890er Jahren, und hier nicht näher behandelt werden kann³ ${ }^{3}$ bewirkt, dass Fotografie nicht mehr an das professionelle Spezialistentum des Atelierfotografen gebunden ist. Seit das Bedienen der Kamera einfacher geworden ist und die Entwicklung der Filme industriell erledigt wird, kann jeder fotografieren. Das Atelier erhält also Konkurrenz von der immer breiter werdenden Schar von Autodidakten.

Aber auch die Pressefotografie fordert die Atelierfotografie heraus. An die Stelle sorgfältiger Inszenierungen im Studio treten nun Schnappschüsse auf der Bühne des öffentlichen Lebens. Pressefotografen arbeiten ganz anders als Studiofotografen. Ihre Tugenden sind Schnelligkeit, Wendigkeit und Treffsicherheit und nicht das bedächtige Einrichten der Szene. Der Pressefotograf sucht den Augenblick, nicht das Andauernde und Unvergängliche. Aufwendige Nachbearbeitung der Bilder, Retusche und Beschneidung der Bilder sind seine Sache nicht, denn Geschwindigkeit ist alles. Je früher die Bilder in der Redaktion sind, desto größer sind die Chancen, dass sie veröffentlicht werden.

Die Popularisierung der Fotografie (Knipser und Amateure) und die massenhafte Vervielfältigung der Bilder in der Presse schränken die Zuständigkeitsbereiche der herkömmlichen Atelierfotografie massiv ein. Diese gerät in die Defensive. Es ist daher nicht verwunderlich, wenn sich gegen diese Tendenzen, die Fotografie als Massenkultur zu etablieren, auch Widerstände regen. Um 1900 tauchen neue Gegenbewegungen gegen die „Masse“ der durchschnittlichen Bilder auf. Einige Atelierfotografen beginnen, 
ihre Bilder künstlerisch aufzuwerten, indem sie ihre Abzüge auf teuren und exklusiven Papieren anbieten und ästhetisch innovative Bildlösungen favorisieren. Es kommt aber auch zu künstlerischen $\mathrm{Ab}$ spaltungstendenzen. Eine Reihe von meist betuchten Amateurfotografen sieht die Gefahr nicht nur in den massenhaften Zeitungsbildern, sondern auch in der „schablonenhaften“ Atelierarbeit. Sie setzen sich daher öffentlichkeitswirksam von der kommerziellen Fotografie ab und gehen eigene künstlerische Wege. Die Pioniere der kunstfotografischen Richtung, auch Piktorialismus genannt, distanzieren sich um die Jahrhundertwende vom angeblichen „Mittelmaß“, indem sie sich - nach englischem Vorbild - zu exklusiven, aristokratischen Zirkeln zusammenschließen. ${ }^{4}$ Diese zahlenmäßig relativ kleinen, aber lautstark agierenden Gruppen sind nicht von aufrührerischen, revolutionären Vorhaben geprägt, im Gegenteil. Ihre Ziele sind konservativer Natur. Sie wenden sich gegen die massenmedial allgegenwärtige radikale Beschleunigung und Ausweitung der Fotografie. Die Neuerer sind explizite Gegner der fotografischen Massenkultur.

\section{Vom Atelier zur Zeitung}

Die Spaltung in Atelier- und Pressefotografie schlägt sich um 1900 auch im Image der fotografischen Berufe nieder. Während der Atelierfotograf über die Lage seines Studios, das Ansehen seiner Klientel, eventuelle Titel (z.B. k.u.k. Hofphotograph) und andere Attribute durchaus symbolischen Kredit anhäufen kann, ist das Image des Pressefotografen von Anfang an eher schlecht. Er hat unangenehme tägliche Kärrnerarbeiten zu erledigen, muss bei jedem Wetter hinaus ins Freie, ist mit seiner schweren Ausrüstung ständig unterwegs und steht unter einem enormen Zeitdruck. Er produziert schnelle, vergängliche Bilder. Die erste Generation österreichischer Pressefotografen arbeitet, wie eingangs ausgeführt, noch nicht ausschließlich im Freien, sondern steht noch mit einem Fuß im Atelier. Ein Teil der Aufträge - etwa Porträts, gelegentlich aber auch gestellte Bewegungs- und Sportbilder - wird noch in geschlossenen Räumen ausgeführt. Die festen Arbeitsräume garantieren nicht nur ein kontinuierliches Einkommen, sie sind auch die Arbeits- und Laborräume, die für Zeitungsaufträge genutzt werden können.

Eine ganze Reihe von Atelierfotografen beginnt vor und um 1900 für die illustrierte Presse zu arbeiten, manche veröffentlichen nur gelegentlich, andere häufig in den Zeitungen. Die bisher vorliegenden biografischen Informationen über die frühen österreichischen Pressefotografen sind sehr dürftig. Viele der Pioniere waren bislang nicht einmal namentlich bekannt, denn die Pressefotografie galt lange Zeit als billiges, populäres Stiefkind in der Erforschung der Fotografie. In anderen Fällen sind zwar die Namen bekannt, aber diese Fotografen wurden bisher ausschließlich als Atelierfotografen gesehen. Ihre Pressearbeit wurde nicht zur Kenntnis genommen. Erst in den letzten Jahren beginnt sich diese Haltung zu ändern. In der vorliegenden Arbeit wird zum ersten Mal der Versuch gemacht, die fragmentarischen Überlieferungen zusammenzustellen und zu ergänzen.

Im Folgenden werden die wichtigsten Pioniere der österreichischen Pressefotografie kurz vorgestellt und eingeordnet, weitere biografische Details finden sich im Anhang des Buches. Die Forschung zum Thema liefert kein homogenes, geschlossenes Bild, sondern eine erste Annäherung, die durch weitere Recherchen ergänzt werden muss. Ein Großteil der Informationen wurde aus der Analyse der zeitgenössischen illustrierten Presse bzw. zeitgenössischer Fachzeitschriften gewonnen, weitere biografische Angaben stammen aus den Melde- und Gewerbeunterlagen. Ergänzt wurden diese Daten durch Informationen aus der Sekundärliteratur sowie aus der biobibliografischen Datenbank, die Timm Starl zusammengestellt hat. ${ }^{5}$

Charles Scolik sen. etwa, der in Wien ein gut gehendes Atelier betreibt, arbeitet seit 1893 regelmäßig für illustrierte Zeitungen. Man kann sich diesen etwas beleibten Herrn schwer als wendigen, abenteuerlustigen Pressefotografen vorstellen. Tatsächlich ist er in seinen Arbeiten für die Zeitung ein Spezialist für Innenaufnahmen, er liefert lebendige Porträts von Persönlichkeiten des öffentlichen Lebens, widmet sich aber auch gesellschaftlichen Ereignissen. Das Themenspektrum seiner Fotoaufträge für die Presse ist breit, es reicht von Künstler- und Politikerporträts 
Abb. 4 Ein Blick in das Wiener Hauptpostamt. Der Saal des „k.k. Brief-Speditionsamtes Nr. 1 während der Amtsstunden". Das interessante Blatt, 21. März 1901, S. 8. Foto: Charles Scolik.

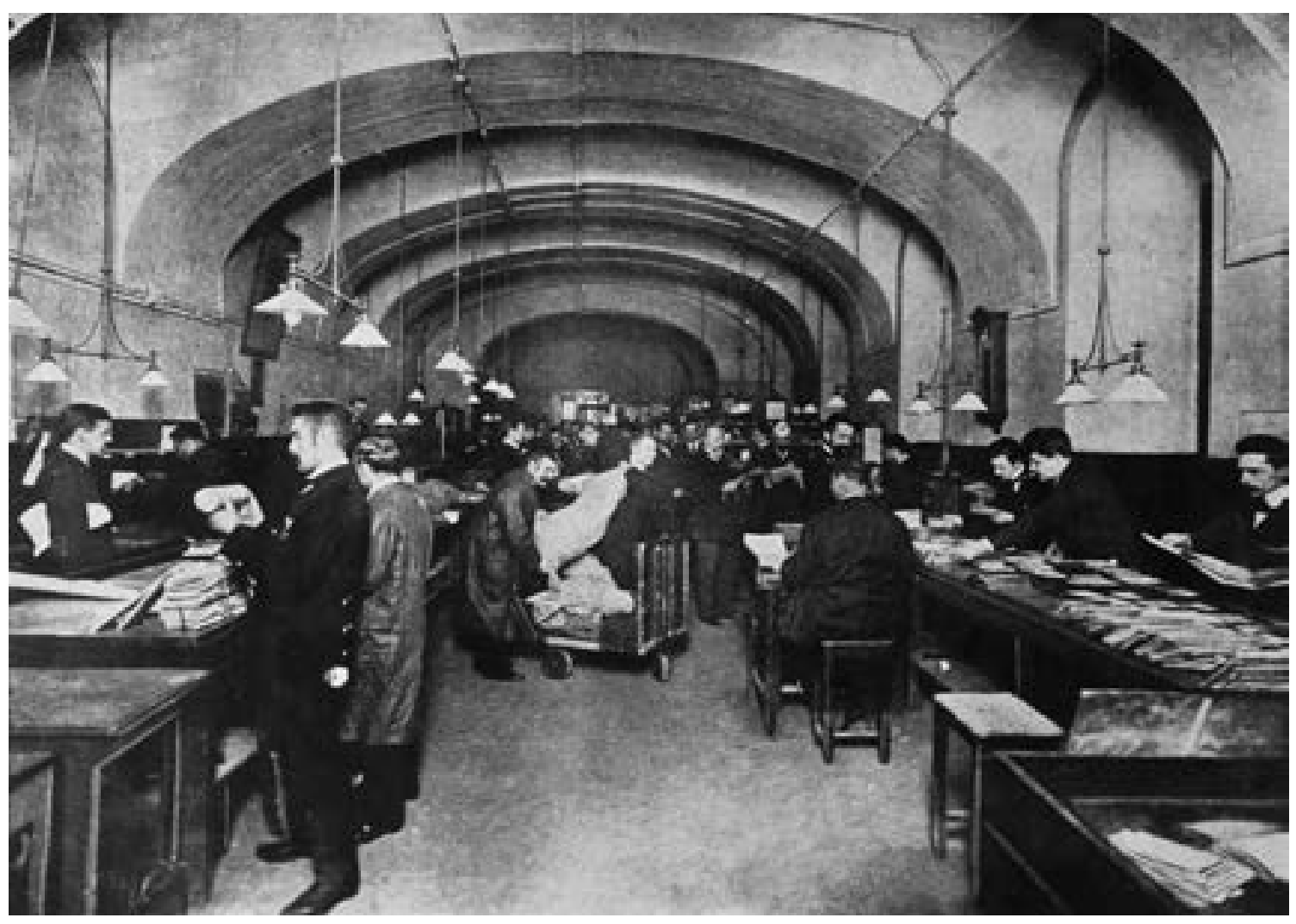

über Modeaufnahmen (etwa für die Zeitschrift Wiener Mode) und die Dokumentation öffentlicher Veranstaltungen bis hin zu Reportagen über aktuelle politische, gesellschaftliche und militärische Ereignisse. Es ist anzunehmen, dass ein Teil seiner Reportageaufnahmen nicht von ihm selbst stammt, sondern von seinen Mitarbeitern. Dass die Bilder unter dem Namen des Auftraggebers und Ateliers veröffentlicht werden, ist in diesen Jahren durchaus üblich.

Bereits früh spezialisiert sich das Unternehmen Scolik - neben den Porträts - auf reportageartige Bildberichte. Während etwa die Dokumentation über das Wiener Hauptpostamt (Abb.4) die Geschäftigkeit eines bürokratischen Großbetriebes im Überblick und zugleich in zahlreichen Details zeigt, ist eine Außenaufnahme vom Aufstieg eines militärischen Freiballons in Wien ganz anders aufgebaut (Abb. 5). Diesmal steht das sensationelle Luftschiff im Zentrum. Der Ballon nimmt fast den gesamten Bildausschnitt ein, Militärs und Schaulustige am Boden werden angesichts seiner Dimensionen zu Statisten. Die Aufnahmen aus dem Hause Scolik sind durchweg als Einzelbilder konzipiert, nur gelegentlich werden sie in der Zeitung zu einer Bildgeschichte zusammengesetzt. Die Szenen, ob im Atelier oder im Freien aufgenommen, sind stets sorgfältig aufgebaut. Der Schnappschuss, die Dramatik des Augenblicks sind Scolik fremd.
Charles Scolik jun., der Sohn Charles Scoliks sen., arbeitet ab 1893 im Betrieb des Vaters mit. Seine Ausbildung schließt er 1902 mit dem Gewerbeschein ab. Nach der Jahrhundertwende ist er ebenfalls als Pressefotograf tätig. Ab 1905 veröffentlicht er seine Aufnahmen unter eigenem Namen. Am Beispiel der beiden Fotografen Solik sen. und jun. lässt sich die langsame Herausbildung des Berufs „Pressefotograf“ um 1900 sehr anschaulich illustrieren. Während der Vater den Schwerpunkt seines Geschäftes nach wie vor eindeutig im Atelierbetrieb sieht, wird für den Sohn die journalistische Arbeit immer wichtiger. Charles Scolik sen. wirbt 1908 in einer ganzseitigen Anzeige für seinen Betrieb, er bezeichnet sich als „k.u.k. österr.-ungar. Hof- und Kammerphotograph“, aber nicht als Presse- oder Illustrationsfotografen. Alle möglichen Sparten seines Könnens werden angepriesen, vom Porträt bis zur Industriefotografie, von der Produktfotografie bis zur Ansichtskartenproduktion. Die Arbeit für die Presse scheint nur klein gedruckt und ziemlich versteckt auf: „Reklame- und Illustrationswesen“`. Verschämter könnte man die fotojournalistische Tätigkeit nicht darstellen. Sein Sohn arbeitet zwar ebenfalls als Atelierfotograf, die Pressefotografie hat für ihn aber einen ganz anderen Stellenwert. Er ist bis in die späten 1920er Jahre als Fotojournalist tätig.

So wie Charles Scolik sen. versuchen auch andere Fotografen ihre Bilder in der Presse unterzubringen. 
Renommierte Atelierfotografen wie etwa Josef Löwy, Josef Mutterer, Carl Pietzner, Fritz Luckhardt oder Rudolf Krziwanek bieten den Redaktionen vor allem Porträts bekannter Persönlichkeiten an. Während diese Gruppe fest in ihrer Ateliertätigkeit verankert ist, wagen andere Fotografen einen mutigeren Schritt hinaus Richtung Pressefotografie. Auch sie unterhalten in der Regel noch ein Atelier, daneben aber erweitern sie ihr Themen- und Arbeitsspektrum kontinuierlich. Sie liefern nicht nur Porträts, sondern alles, was in der illustrierten Presse gefragt ist: Sport, Politik, Gesellschaft und allerlei Sensationen des Alltags. Um ihre Aufträge zu erfüllen, arbeiten sie immer öfter im Freien. Ludwig Berényi etwa fotografiert seit 1893 für die Presse Sportereignisse ebenso wie gesellschaftliche Veranstaltungen. Carl Triebel liefert ab 1896 zahlreiche Aufnahmen von Genreszenen und Gesellschaftsereignissen. Auch Rudolf Fliesz und Franz Hebentanz dokumentieren seit 1900 Sportereignisse, u. a. Radrennen im Freien. Arthur Floeck arbeitet als Atelierfotograf und etabliert sich daneben als wichtiger Fotograf der kaiserlichen Familie. Immer öfter fotografiert er gesellschaftliche Ereignisse im Freien und bietet seine Bilder ab 1900 der illustrierten Presse an. Josef Porkert fotografiert seit 1900 für Wiener Zeitungen, u.a. Straßenszenen und Architekturaufnahmen (etwa eine Serie über das verschwindende „Alt-Wien“), Hans Makart arbeitet seit 1903 als Pressefotograf und veröffentlicht Bilder von gesellschaftlichen Ereignissen. Josef und F. Jahudka sind v. a. als Kaiser- und Militärfotografen in der Presse präsent. Anton Schistal und Franz Gabriel, die gemeinsam ein Atelier betreiben, berichten ab 1906 über politische Massenkundgebungen vor allem der Christlichsozialen in Wien, Martin Gerlach sen. und Albert Wiedling, die seit 1904 gemeinsam einen Kunst- und Architekturverlag führen, bieten ihre Bilder, meist Architekturfotos, gelegentlich auch aktuelle Pressefotos, ab 1907 den Zeitungen zur Veröffentlichung an. Dies tut ab 1901 auch Bruno Reiffenstein, der sich ebenfalls auf Architekturaufnahmen spezialisiert und einen Architekturverlag gründet. Martin Gerlach jun. führt nach dem Tod des Vaters 1923 dessen Verlag und Pressearbeit fort. Ludwig Gutmann und Berthold

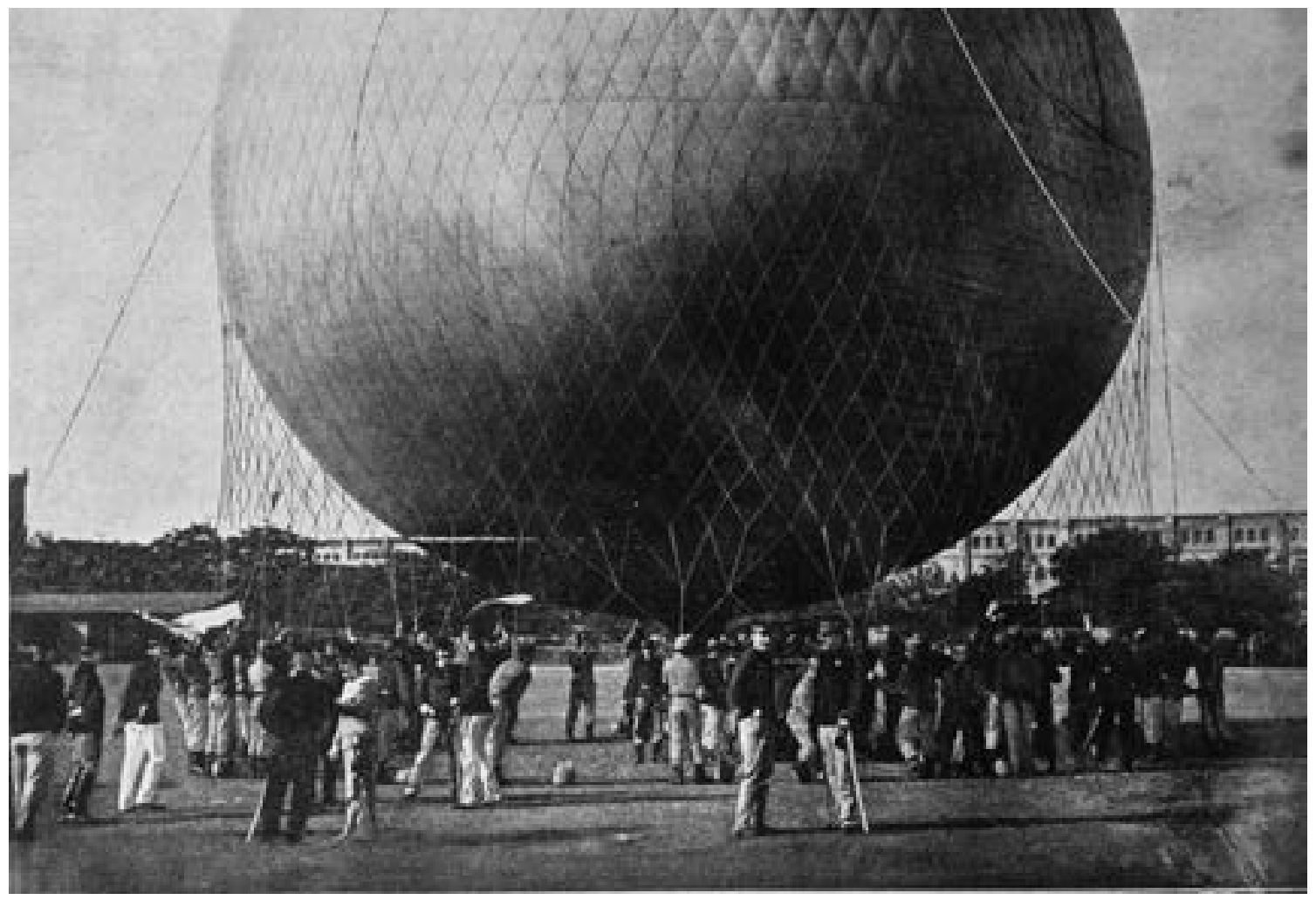

Abb. 5 Ein Freiballon der k. k. Luftschiffer-Abteilung vor dem Start in Wien. Das interessante Blatt, 3. August 1899, S. 5. Foto: Charles Scolik. 


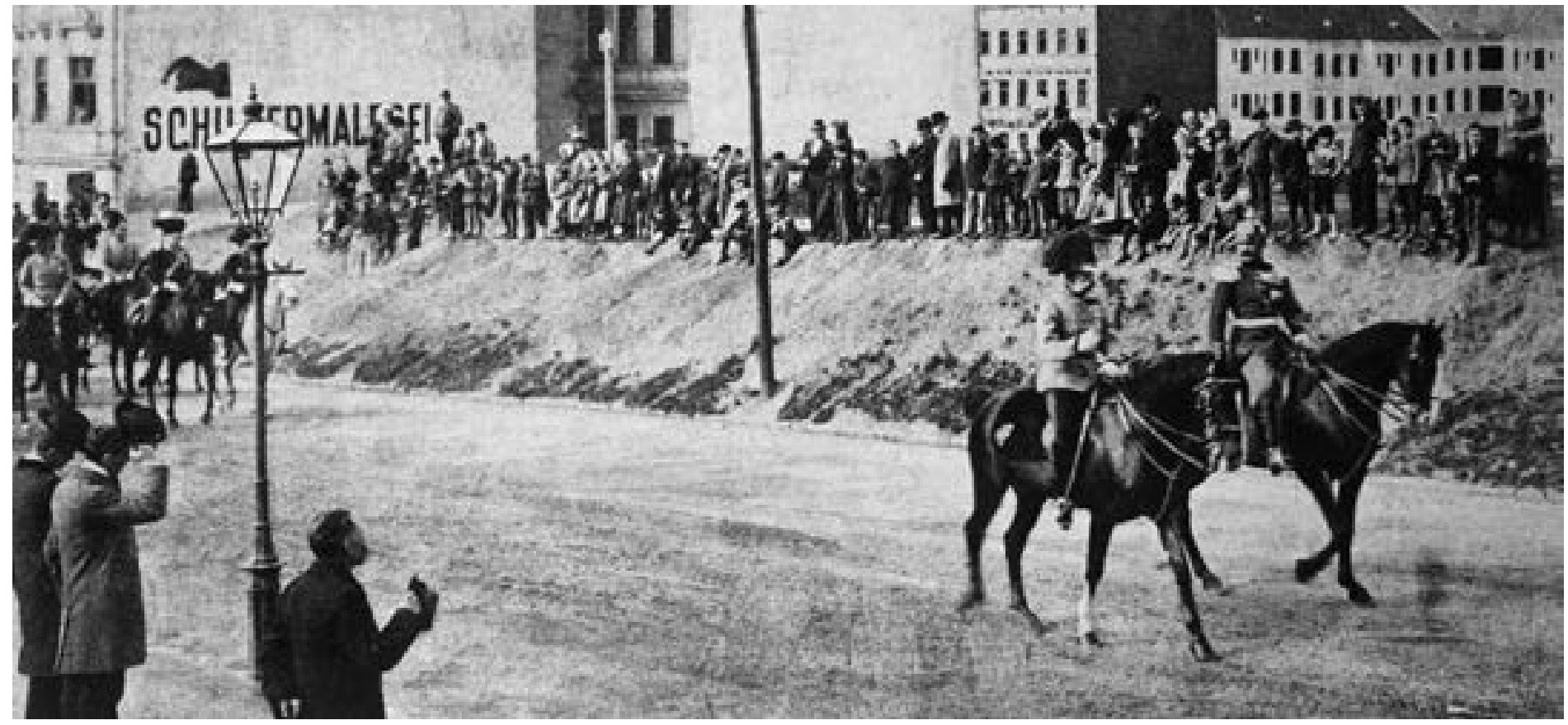

Abb. 6 Frühjahrsparade auf der Schmelz in Wien. Kaiser Franz Joseph und Prinz Rupprecht von Bayern auf dem Weg zum Exerzierfeld. Das interessante Blatt, 26. April 1900, S. 7. Foto: Johann Wawra.
Bing, die beide schwerpunktmäßig als Theater- und Schauspielerfotografen tätig sind, arbeiten ab 1910 häufig für die illustrierte Presse.

Eine Reihe weiterer Atelierfotografen arbeitet um 1900 auch für die Presse: Gustav Schreiber (ab 1898), Georg Philipp von der Lippe (ab 1898), Gustav Broser (ab 1899), Josef Sztranyak, Johann Wawra (ab 1900) (Abb. 6), Oscar Pietzner (ab 1903), Franz Jürets (auch Jurecs, ab 1903), Franz Pawlik (ab 1903), Josef Juretsch (ab 1904), Adalbert Panek (ab 1904), Charles Wagner (ab 1905), Carl (auch Karl) Triebel (ab 1905), Gustav Hajek (ab 1907), J. Krotsch (ab 1910), Josef Schiestl (ab 1911) und Isidor Michalup (ab 1912). Einige von ihnen fotografieren regelmäßig für die Zeitungen, andere nur gelegentlich.

\section{Pressefotograf: Ein neuer Beruf entsteht}

Nach 1900 nimmt die Nachfrage nach fotografischen Pressebildern deutlich zu. Die herkömmlichen Atelierfotografen, die nebenbei den Zeitungsmarkt bedienen, können mit den geänderten Anforderungen - Geschwindigkeit, Mobilität, neue Themen - immer weniger Schritt halten. Allmählich entsteht eine neue Generation von Fotografen, für die die Zeitungs- arbeit immer wichtiger wird. Sie unterhalten zwar in der Regel noch ein Atelier, dieses wendet sich allerdings nur noch teilweise an die Laufkundschaft mit Porträtaufträgen. Das Studio ist nun in erster Linie Labor und organisatorische Basis, von wo aus der kommerzielle Verkehr mit den Redaktionen abgewickelt wird. Viele dieser neuen Pressefotografen absolvieren aber noch eine klassische Ausbildung im Atelier, wenden sich dann aber immer stärker dem Zeitungsgeschäft zu. Andere pendeln noch eine Weile zwischen Atelier- und Pressearbeit. Die meisten dieser jungen, aufstrebenden Fotografen arbeiten auf eigene Faust, meist allein oder zu zweit. Sie sind in der Regel bei keiner Zeitung fest angestellt, sondern bieten ihre Dienste freiberuflich unterschiedlichen Blättern an. Es fällt auf, dass die „Ateliers“ dieser neuen Generation von Pressefotografen immer öfter vom Zentrum in die Vorstadt wandern. Dort sind die Mieten billiger, häufig werden die Atelier- bzw. Laborräume in der eigenen Wohnung eingerichtet.

Im Jahr 1895 - also nur wenig später als Anton Huber - beginnt Viktor Angerer für die illustrierte Presse zu arbeiten. Neben seiner Ateliertätigkeit übernimmt er regelmäßig Aufträge als Pressefotograf.7 Er fotografiert Schauspieler, öffentliche 
Veranstaltungen und Einrichtungen (Abb. 7), den Wiener Alltag und immer wieder den Kaiser und seine Familie. Besonders erfolgreich ist in den Jahren um 1900 das Fotografenduo Heydenhaus \& Robert (Hermann Heydenhaus und L. von Robert), das in den Wiener Tuchlauben und in der Mariahilfer StraBe ein Atelier betreibt und daneben seit 1898 vor allem für die Presse tätig ist. Die beiden fotografieren v. a. wichtige gesellschaftliche Ereignisse, aber auch Denkmäler, Gebäude und Landschaften. Nach kurzer Zeit betreiben sie auch eine eigene Fotoagentur. 1897 erscheinen die ersten Bilder von Otto Swara in der Presse, der über die bauliche Umgestaltung der Hauptstadt berichtet, aber auch über Bühnen- und Sportereignisse. 1898 folgen die ersten Pressefotos von Emil Fukarek, der ebenfalls seit den 1890er Jahren ein Atelier und einen Fotohandel in Wien betreibt und um die Jahrhundertwende mehr und mehr für den Zeitungsmarkt arbeitet. Neben aktuellen Nachrichtenbildern veröffentlicht er immer wieder auch Kuriosa und Merkwürdigkeiten. 1899 etwa erscheint im Interessanten Blatt eine dreiteilige Serie, die eine aufsehenerregende Gesichtsperformance eines Wiener Volkssängers zeigt (Abb. 8). Seit 1904 arbeitet Heinrich Uttenthaler in Wien als Pressefotograf. Er fotografiert vor dem Ersten Weltkrieg hauptsächlich gesellschaftliche und sportliche Ereignisse, nach 1918 dokumentiert er auch ab und zu soziale Themen, etwa die städtische Arbeitslosigkeit. 1911 beginnt Carl Zapletal, der seit 1906 ein Atelier führt, seine

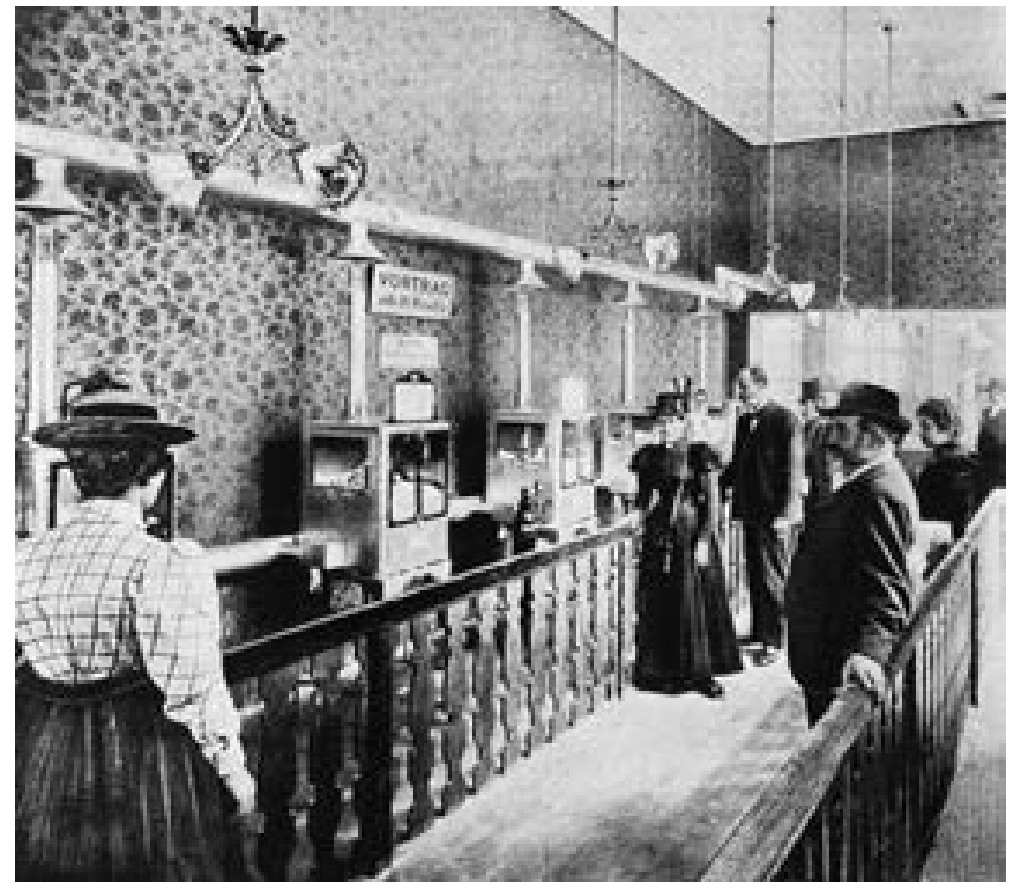

Tätigkeit als Pressefotograf. Er berichtet hauptsächlich über Sport, Rennsport und Technik.

Die wichtigsten und innovativsten Pressefotografen im ersten Jahrzehnt des 20. Jahrhunderts sind, neben dem bereits genannten Charles Scolik jun., Heinrich Schuhmann sen. und Carl Seebald. Scolik jun. arbeitet zu Beginn des 20. Jahrhunderts einige Jahre lang mit der Fotografin Marie Mertens zusammen. Gemeinsam führen die beiden zwischen 1905 und 1908 das „Atelier Moderne“. Parallel dazu arbeiAngerer.
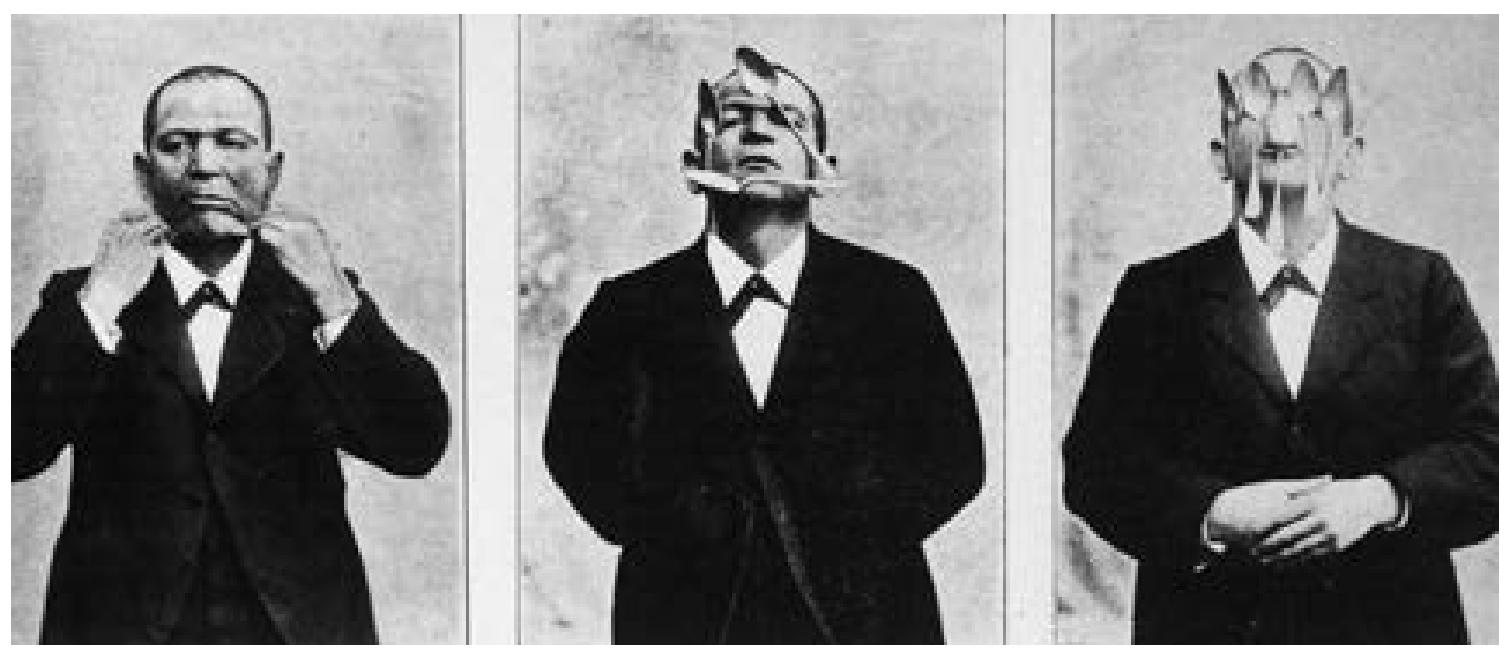

Abb. 7 „Die Kinderbrutanstalt in der Jubiläumsausstellung in Wien“. Das interessante Blatt, 9. Juni 1898, S. 4. Foto: Victor

Abb. 8 Das „magnetische Gesicht" des Wiener Volkssängers Carl Lewen. Das interessante Blatt, 19. Januar 1899, S. 5. Foto: Emil Fukarek. 


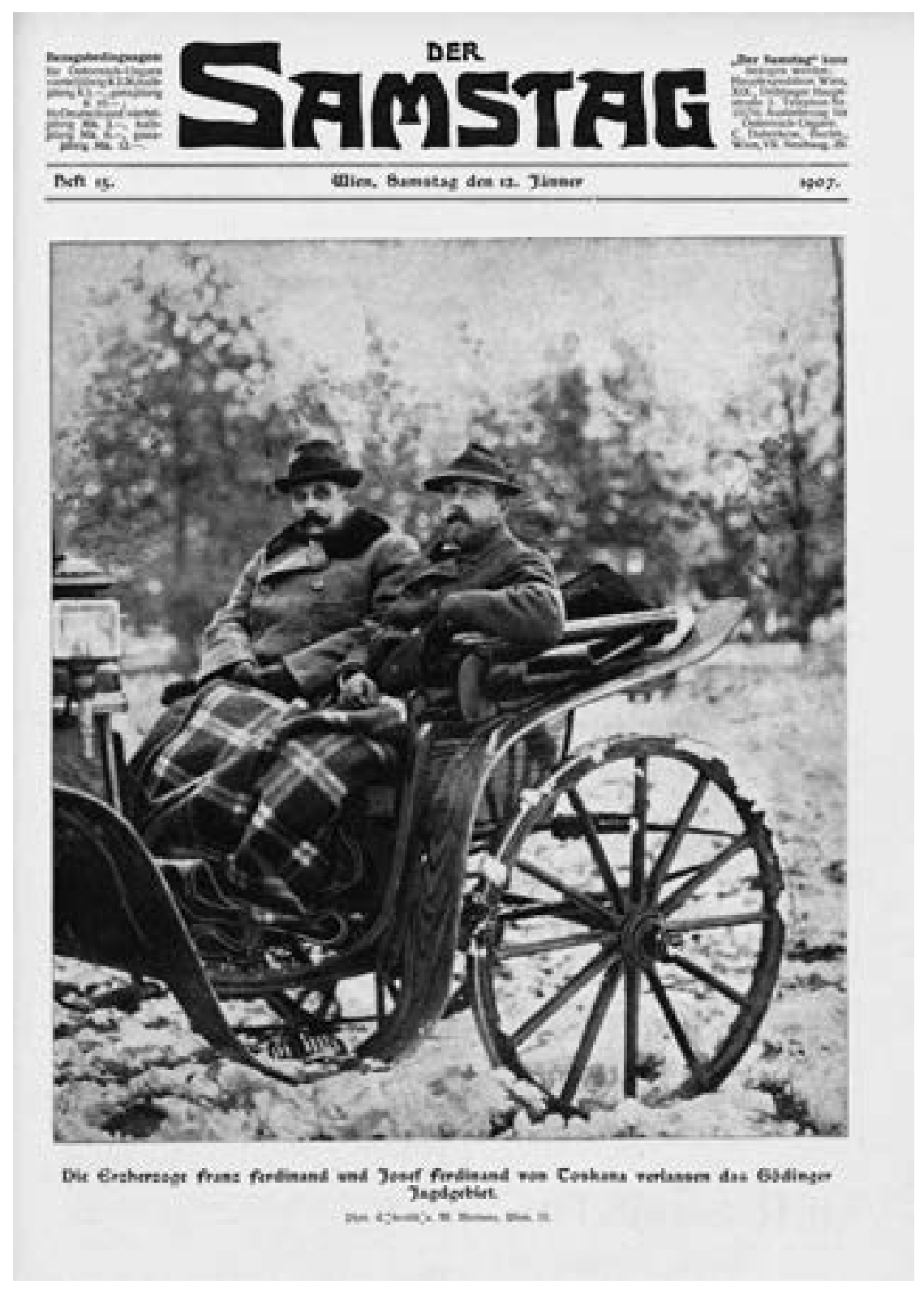

Abb. 9 Die Erzherzöge Franz Ferdinand und Josef Ferdinand von Toskana im südmährischen Göding (heute: Hodonín). Der Samstag, 12. Januar 1907, Titelseite. Foto: Charles Scolik jun. und Marie Mertens.

Abb. 10 „Selbstmord einer Wienerin auf dem Hochschneeberg“. Wiener Bilder, 26. August 1908, S. 11. Foto: Heinrich Schuhmann sen. ten sie erfolgreich als Pressefotografen (Abb.9). Mertens (eigentlich Matisz) ist die erste österreichische Pressefotografin. ${ }^{8}$ Sie stammt aus dem ungarischen Kaschau (heute Košice) und veröffentlicht 1903 ihre ersten Bilder in Wiener illustrierten Zeitungen. Sie spezialisiert sich auf gesellschaftliche und soziale Ereignisse, fotografiert aber auch die kaiserliche Familie und dokumentiert hie und da militärische Festlichkeiten. Bekannt wird sie mir ihren Schauspieler- und Künstlerporträts, die sie nicht im Atelier, sondern in den Wohnungen der Porträtierten aufnimmt. Zusammen mit Charles Scolik jun. liefert sie auch Bildmaterial für Reportagen und Porträtserien. 1908 trennen sich Mertens und Scolik geschäftlich, die Fotografin arbeitet nun wieder hauptsächlich im Atelier, in der Presse veröffentlicht sie kaum noch etwas. Sie stirbt 1935 in Wien.
Heinrich Schuhmann sen., geb. 1854, ist schon 50 Jahre alt, als er 1904 mit der Pressefotografie beginnt. ${ }^{9}$ Der aus Hessen stammende Fotograf ist in den ersten beiden Jahrzehnten des 20. Jahrhunderts einer der aktivsten und besten Zeitungsfotografen Wiens. Er ist der erste Fotograf, der ausschließlich für die illustrierten Zeitungen tätig ist und daneben kein eigenes Atelier für Laufkunden unterhält. Als Pressefotograf neuen Typs ist er auf der Jagd nach den jüngsten Sensationen ständig unterwegs. Sein Radius ist nicht allein auf Wien beschränkt, er fotografiert auch in der näheren und weiteren Umgebung der Stadt, sofern die Ereignisse interessant und spektakulär sind. Am 26. August 1908 beispielsweise erscheint eine Aufnahme von ihm in den Wiener Bildern. Sie zeigt eine tote Frau, die kurz zuvor am Hochschneeberg entdeckt worden war (Abb. 10). Im Beitrag zum Bild wird die Sensation gnadenlos ausgeschlachtet und in allen Details ausgeleuchtet. „Eine Touristengesellschaft“, so die Zeitung, „fand am 15. August auf dem Hochschneeberg (...) die Leiche einer ungefähr 30 Jahre alten Frau, die in dem Gerölle auf dem Rücken lag, wie dies aus unserem Bilde ersichtlich ist. Die Tote hatte zwei Schußwunden in der Brust, von deren (sic!) jede tödlich war. Neben der Leiche fand man einen sechsläufigen Revolver, aus dem jedoch bereits fünf Schüsse fehlten. Mit Hilfe eines Krankenkassenzettels, der bei der Leiche gefunden wurde, gelang es, deren Identität festzustellen. Die Selbstmörderin war die Besitzerin einer Tabaktrafik in Ottakring, Wilhel-

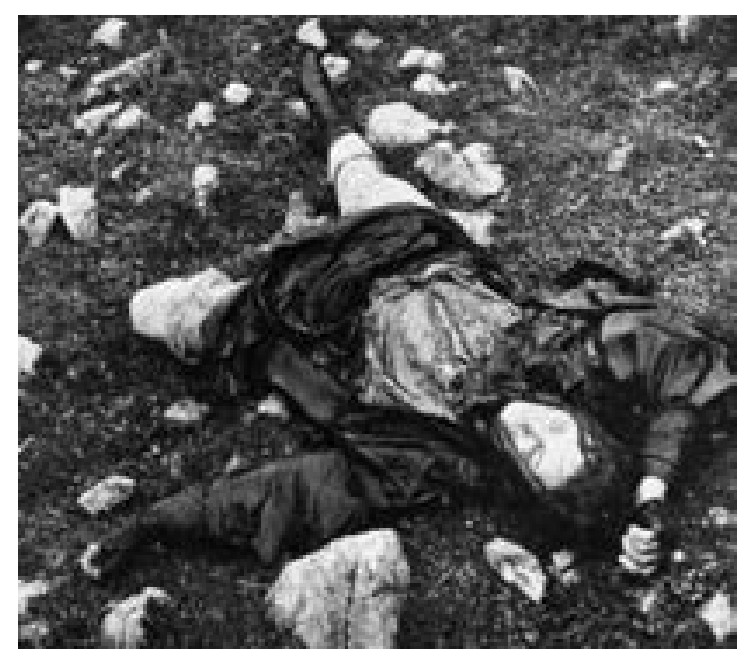




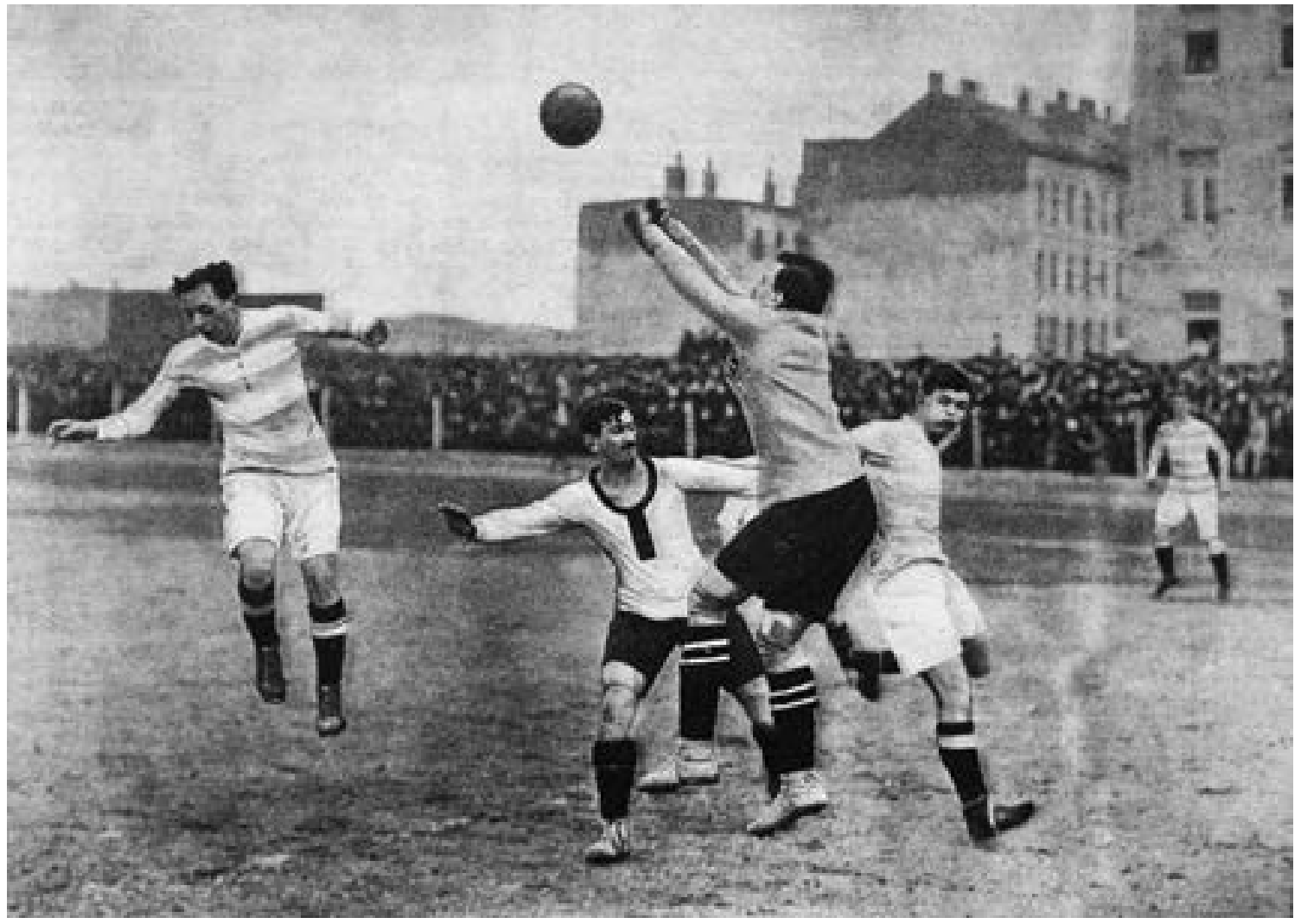

minenstraße 2, Frau Marie Respekt. Sie ist ein Opfer des Heiratsschwindlers Sand geworden und wegen einer gegen sie aus dieser Bekanntschaft resultierenden Strafanzeige freiwillig in den Tod gegangen. “ 10

Schuhmanns Themenspektrum ist breit. Er fotografiert alles, was sich in der Presse unterbringen lässt: sehr viel Sport, aber auch politische und gesellschaftliche Themen, Katastrophen ebenso wie Politik, Freizeitthemen ebenso wie alltägliche Sensationen. Seine Bilder heben sich von vielen der herkömmlichen Presseaufnahmen dieser Jahre ab. Sie kultivieren den entscheidenden Augenblick, besonders im Sport gelingen ihm die ersten Schnappschüsse dramatischer Spielszenen (Abb. 11).

Auch Carl Seebald, geb. 1878, arbeitet als Pressefotograf höchst professionell. Der aus Schlesien stammende Fotograf führt zwar noch ein Atelier, aber seine Haupteinnahmequelle ist die Zeitung. Sein erstes Foto wird 1904 gedruckt, im Jahr darauf erwirbt er den Gewerbeschein. In den folgenden Jahren ist er, ähnlich wie Schuhmann, mit seiner Kamera pausen- los unterwegs. Er ist, neben Schuhmann, der meistpublizierte österreichische Pressefotograf vor dem Ersten Weltkrieg. Seine Fotos erscheinen in allen großen Illustrierten des Landes, im Interessanten Blatt, den Wiener Bildern, aber auch in gesellschaftlich so weit entfernten Zeitschriften wie dem aristokratischen Wiener Salonblatt und in der populären Sportzeitung Illustriertes österreichisches Sportblatt. So wie Schuhmann erweitert Seebald sein Einsatzgebiet ständig. Er deckt alle Themen ab, die nachgefragt werden: politische und kulturelle Ereignisse, kleine und große Katastrophen, Politiker, Künstler, Kaiser und immer wieder sportliche Wettkämpfe.

Beide, Seebald ebenso wie Schuhmann, gehen nach und nach auf Distanz zur starren Atelierfotografie. Sie rücken deutlich von den Praktiken der Studioinszenierung ab. Vielmehr suchen sie - vor allem in turbulenten öffentlichen Szenen, wie etwa im Fußball, aber auch in der politischen Berichterstattung - den entscheidenden Augenblick. Dann drücken sie ab. Als Seebald 1906 die ungarische Regierungs-
Abb. 11 Eine Szene im Fußballmatch zwischen dem Wiener Sportclub und dem Budapester Meisterclub auf dem Sportplatz in Dornbach, Wien. Die Ungarn gewinnen $5: 3$. Das interessante Blatt, 2. April 1914, S. 15. Foto: Heinrich Schuhmann sen. 


\section{Oktober 1913: Sonderzug nach Budapest zum Länderwettspiel}

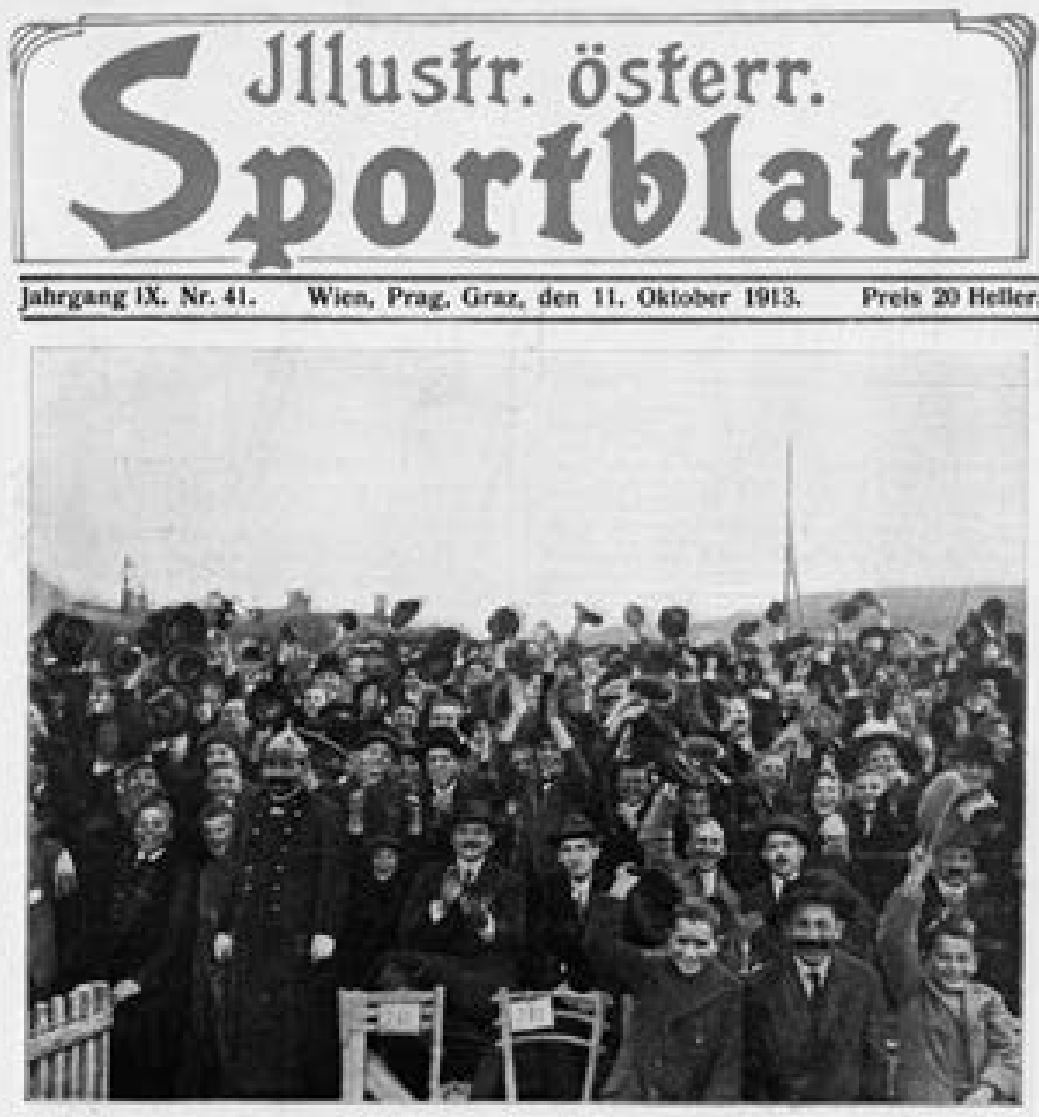

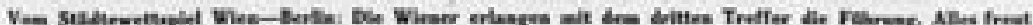

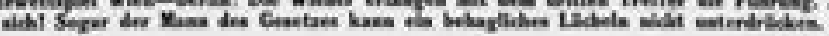
tis ton

\section{BERCO : opereonowourtr-

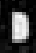 \\ Praisbuch trei}

Abb. 12 Fußballwettkampf zwischen Wien und Berlin. Illustriertes österreichisches Sportblatt, 11. Oktober 1913, Titelseite. Foto: Carl Seebald. krise in Budapest dokumentiert, wählt er einen ganz neuen Weg, politische Ereignisse sichtbar zu machen. Da er die hektischen Verhandlungen hinter verschlossenen Türen nicht ablichten kann, zeigt er, was sich auf der Straße vor dem Regierungsgebäude abspielt: das Kommen und Gehen der Regierungsmitglieder, überhastete Aufbrüche und Ankünfte. Auf diese Weise entsteht ein interessantes Nebeneinander von Zeitschnitten, das sehr viel von der fiebrigen Stimmung der Verhandlungen hinter den Kulissen zeigt. ${ }^{11}$

Das Illustrierte österreichische Sportblatt berichtet 1913 über ein umkämpftes Fußball-Länderspiel zwischen Wien und Berlin. Das Titelfoto von Carl Seebald zeigt nichts von dem Spiel, sondern einen überaus vielsagenden Blick ins Publikum (Abb. 12). Immerhin 15.000 Zuschauer sind zu dem Wettkampf ge- kommen. ${ }^{12}$ Im Bildtext heißt es: „Die Wiener erlangen mit dem dritten Treffer die Führung. Alles freut sich! Sogar der Mann des Gesetzes (der Polizist im Vordergrund, A.H.) kann ein behagliches Lächeln nicht unterdrücken.“13 Schließlich endet das Spiel 3:3.

Seebald ist nicht nur ein erfolgreicher Pressefotograf, sondern auch ein geschickter Unternehmer. Ende 1908 gründet er unter dem Namen „Illustrations-Unternehmung C. Seebald“ eine Fotoagentur, die eigene und eingekaufte Fotos vermarktet. Bald vertreibt er Bilder italienischer, französischer, britischer und amerikanischer Herkunft. 1909 kann er als einzige österreichische Agentur den Zeitungen Bilder vom Erdbeben in Messina oder vom sensationellen Flug des Flugzeugpioniers Blériot über den Ärmelkanal anbieten. Im Ersten Weltkrieg ist Seebald ein bekannter Kriegsfotograf ${ }^{14}$, seine letzten Pressebilder erscheinen Anfang der 1920er Jahre, 1935 erlischt sein Gewerbeschein.

\section{Internationalisierung der Pressefotografie}

Der rasante Aufstieg der Pressefotografie hat in den ersten Jahren nach 1900 nicht nur zu einer beispiellosen Vermehrung der Zeitungsbilder geführt, sondern auch die Art und Weise ihrer Beschaffung grundlegend geändert. Carl Seebald, der den Weg vom Fotografen zum Fotohändler geht, ist dafür ein gutes Beispiel. Eine Reihe anderer Fotopioniere folgt ihm. Sie bauen ebenfalls Handelsfirmen zur Vermarktung von Fotografien auf. Nach und nach entsteht ein immer engmaschigeres Netz von Anbietern. Das erste österreichische Unternehmen, das systematisch die illustrierte Presse beliefert, ist die Wiener Foto- und Fotohandelsfirma R. Lechner (Wilh. Müller). Sie hat anfangs noch keine fremden Bilder im Programm, sondern vermarktet in erster Linie Aufnahmen der eigenen Fotografen. Bereits 1895 tauchen die ersten Fotos von Lechner in den Zeitungen auf. ${ }^{15}$ Einer der frühen Pressefotografen, der seit 1895 im Auftrag von Lechner arbeitet, ist Hermann Heydenhaus. Er macht sich vor der Jahrhundertwende selbstständig und gründet zusammen mit L. Robert eine Fotoagentur. Das Unternehmen Lechner, das als Verlagsbuchhandlung begonnen hat, expandiert rasch und gehört um 


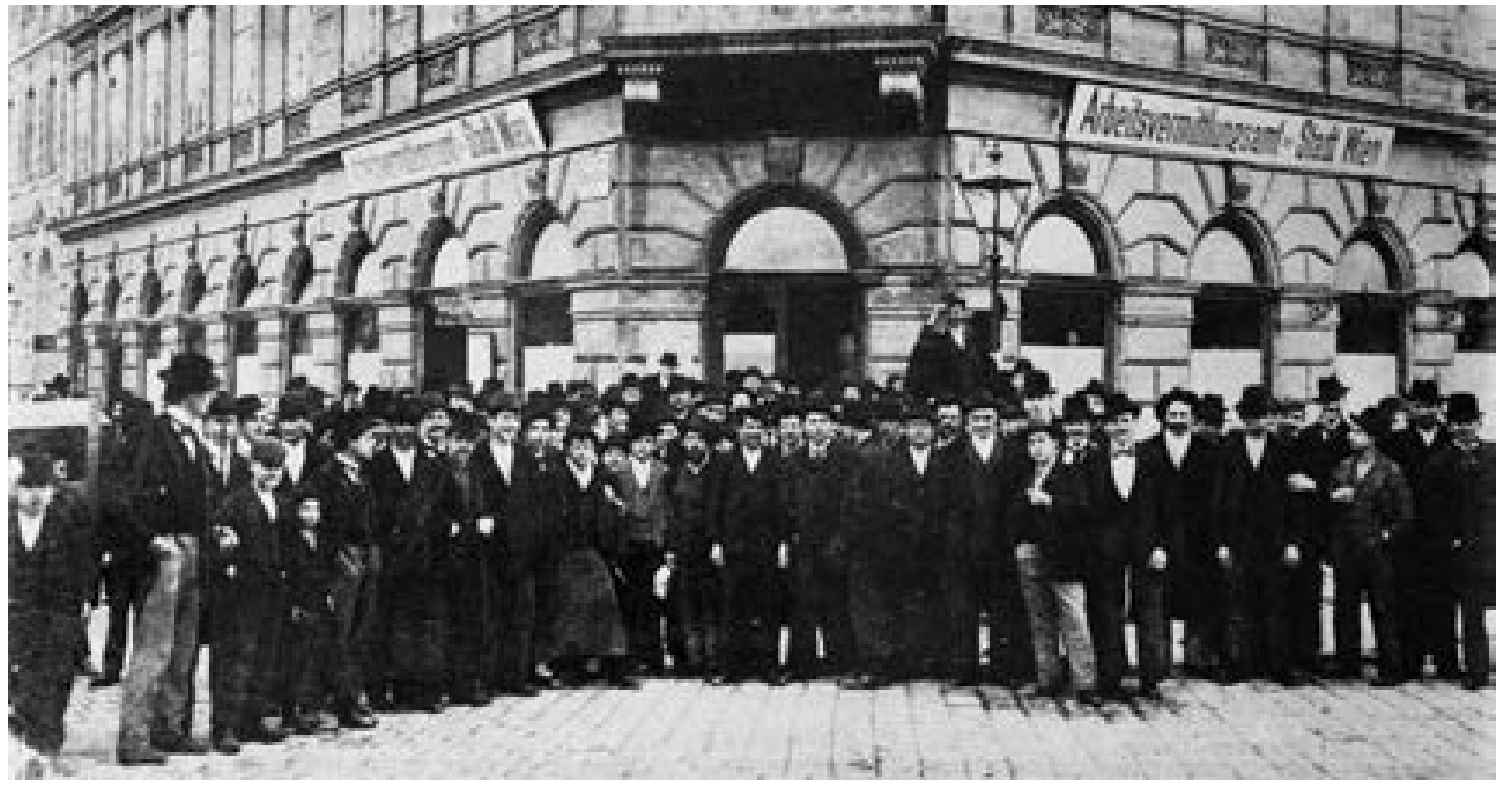

$1900 \mathrm{zu}$ den führenden Fotohandelsfirmen in Wien. Lechner verfügt seit der zweiten Hälfte der 1890er Jahre über eine Reihe fest angestellter Fotografen, die aktuelle Tagesereignisse in Momentaufnahmen festhalten. Diese werden in unterschiedlichsten Formaten vermarktet: als Bildpostkarten und als Einzelabzüge, als Stereoaufnahmen, Illustrationen für Broschüren und Bücher - und natürlich als Fotovorlagen für die illustrierte Presse. ${ }^{16}$ Lechners Pressebilder sind in der Regel ästhetisch eher anspruchslose Gesamtansichten, die das Geschehen im Überblick zeigen. Eine Spezialität der Firma sind breit angelegte Gruppenbilder. Im März 1901 etwa wird das städtische Arbeitsvermittlungsamt in Wien fotografiert. Vor dem Gebäude hat sich eine große Gruppe von Arbeitslosen versammelt (Abb. 13). Man kann leicht erkennen, dass es sich bei der Aufnahme nicht um einen aktuellen Schnappschuss handelt, sondern um eine sorgsam inszenierte Aufnahme, die die Institution in ein positives Licht rückt. Eine ganz andere Aufnahme Lechners, die im April 1902 im Interessanten Blatt erscheint, wirft einen Blick hinter die Kulissen der Wiener Hofoper (Abb. 14). Vorgestellt wird die Kostümwerkstätte des Opernhauses, in der weitaus mehr Männer als Frauen arbeiten. Wiederum ist die Szene als eine Art Gruppenaufnahme angelegt. „Heute sind wir in der Lage“, heißt es im Beitrag zum Foto, „ein Bild der Schneiderei der Hofoper zu bringen. Eine große Anzahl fleißiger Hände regt sich da, um all die Costüme zu verfertigen, die dann im Glanze des Abends, die Illusion und Habitués wecken. Denn auch in den Costümen liegt ein Theil des Zaubers und gerade in unseren Tagen der Toiletten-Poesie ist die Wirkung verführerischer Trachten nicht zu unterschätzen.“ 17

Als Fotoagentur vertreibt Lechner nicht nur eigene Aufnahmen, sondern auch Bilder auswärtiger Pressefotografen, etwa des tschechischen Lichtbildners Ruda (Rudolf) Bruner-Dvořák, der seit 1897 regelmäBig über aktuelle Ereignisse in Prag und Umgebung berichtet.

Im Schatten der Firma Lechner sind nach der Jahrhundertwende einige kleinere Agenturen tätig, etwa die Agentur Sieger-Sobotka, die ab 1904 in Erscheinung tritt. Sie wird von den beiden Fotografen Eduard Sieger und H. Sobotka gegründet, hält sich aber nur einige wenige Jahre. Erfolgreicher ist die Agentur „Welt-Preß-Photo“, die 1912 vom Fotografen Josef Perscheid gegründet wird. ${ }^{18}$ Er ist deutscher Herkunft (geboren 1878 in Koblenz) und hat als Mitarbeiter der Berliner Illustrations-Gesellschaft, der führenden deutschen Fotoagentur, bereits reiche internationale Erfahrung im Metier des Fotohandels gesammelt. Bevor er sich 1911 beruflich in Wien niederlässt, hat er
Abb. 13 Gruppenporträt von Arbeitslosen vor dem Arbeitsvermittlungsamt in Wien, Neubaugürtel. Das interessante Blatt, 28. März 1901, S. 2. Foto: R. Lechner (Wilh. Müller). 
Führend in diesem neuen Markt ist Berlin, die herausragende deutsche Zeitungsstadt, wo sich eine Reihe von international agierenden Firmen etabliert: neben Zander und Labisch etwa die im Jahr 1900 durch Heinrich Sanden, Carl Delius und Martin Gordan gegründete Berliner Illustrationsgesellschaft, die ab 1906 auch in Österreich präsent ist. Einer der Mitbegründer der Fotoagentur, Heinrich Sanden, lebt zwischen etwa 1908 und 1913 in Wien und fotografiert hier für die Berliner Zentrale. Seine Fotos erscheinen teilweise auch in Wiener Blättern. Sowohl Zander und Labisch als auch die Berliner Illustrationsgesellschaft beschäftigen eine Reihe von freiberuflich tätigen „Operateuren“, die das Rohmaterial für den Fotohandel liefern. Auch Otto und Georg Haeckel betreiben seit 1905/06 in Berlin eine Fotoagentur. Seit 1908 sind sie auch auf dem Wiener Markt vertreten. ${ }^{23}$

Zwar haben zahlreiche wichtige Fotohändler um 1900 ihren Sitz in Berlin. Aber es gibt auch andere Anbieter. In Zürich etwa entsteht um die Jahrhundertwende eine überregional agierende Fotohandelsfirma, nämlich die „Photoglob-Compagnie“, die ihren universalen Geschäftsanspruch bereits im Namen trägt. Die 1889 gegründete Firma spezialisiert sich zunächst auf Reproduktionen von Gemälden und Landschaftsbildern, 1895 nimmt sie den Namen Photoglob an und beginnt mit der Postkartenproduktion und -vermarktung. Nach 1900 bietet sie zusätzlich auch aktuelle Nachrichtenbilder im In- und Ausland an. ${ }^{24} 1903$ erscheinen die ersten Photoglob-Aufnahmen in den Wiener Bildern: eine mehrteilige Reportage über die Aufstände in Mazedonien. ${ }^{25}$ In München etabliert sich kurz vor dem Ersten Weltkrieg das Münchner Presse-Bureaux, das seit 1911 in Wien präsent ist. Die 1905 von Charles Trampus in Paris gegründete Firma liefert Bilder aus ganz Europa, ebenso vom Balkan und aus Nordafrika, wo sie eigene Operateure und Mitarbeiter stationiert hat. 1906 erscheinen die ersten Fotos von Trampus in Wien. Ebenso aus Paris kommen vor dem Ersten Weltkrieg Modefotografien aus dem Atelier Reutlinger. Die aus Karlsruhe stammende Fotografenfamilie war im 19. Jahrhundert nach Paris ausgewandert und hatte dort ein gut gehendes Atelier gegründet. Nach der Jahrhundertwende beginnt sie mit der internationalen Vermarktung ihrer
Bilder. Die ersten Aufnahmen von Charles Reutlinger tauchen in Wiener Zeitungen um 1910 auf.

Innerhalb eines Jahrzehnts (ca. 1900 bis 1910) verändert sich der Bildermarkt radikal. Der lokale und regionale Handel mit Bildern wird durch einen zunehmenden internationalen Austausch ergänzt. Nach und nach bildet sich ein über nationale Grenzen hinweg agierendes Netzwerk von Fotoagenturen. Die Folge ist, dass auch die Berichterstattung zunehmend flächendeckender wird. Zwar sind die Schwerpunkte der fotografischen Öffentlichkeit immer noch regional umrissen - über die Hauptstadt wird am meisten berichtet -, aber wichtige internationale Ereignisse tauchen nun immer öfter in Bildern auf. Diese Internationalisierung des Bildermarktes wurde in der Forschung bisher kaum zur Kenntnis genommen. Üblicherweise wird die große Zeit der Fotoagenturen in der Zwischenkriegszeit angesetzt. Diese These ist angesichts der beschriebenen Entwicklungen eindeutig zu revidieren.

Ebenfalls wenig bekannt ist die zunehmende Vernetzung der Bildberichterstattung innerhalb eines Landes. Diese Entwicklung läuft teilweise parallel zur Internationalisierung der Zeitungsfotografie. Während im letzten Jahrzehnt vor der Jahrhundertwende nur sporadisch aus der ausgedehnten Provinz des 50-Millionen-Reiches der k.u.k. Monarchie berichtet wurde, ändert sich das nach der Jahrhundertwende. Allmählich gelingt es den großen illustrierten Zeitungen eine Art von fotografischem Korrespondentennetz in den wichtigsten Provinzstädten aufzubauen. Die Mitarbeiter sind in der Regel keine Pressefotografen, sondern traditionelle Atelierfotografen, die das - je nach Nachrichtenlage - recht unregelmäßige Geschäft mit den Zeitungsbildern als Zubrot sehen. Manche dieser lokalen Fotografen arbeiten nur gelegentlich für die Presse, andere entdecken in dem neuen Gewerbe eine interessante berufliche Alternative und beginnen sich stärker im Bereich der Pressefotografie zu engagieren.

Wie weitgespannt das Netz der fotografischen Mitarbeiter österreichischer Illustrierter ist, zeigt sich an der folgenden - unvollständigen - Übersicht. In Budapest arbeitet eine ganze Reihe von Fotografen für Wiener Blätter, besonders häufig Mór Erdélyi (Abb. 15), 
Abb. 15 Die neu erbaute Elisabeth-Brücke in Budapest kurz vor der Eröffnung für den Verkehr am 10. Oktober 1903. Das interessante Blatt, 8. Oktober 1903, S. 7. Foto: Mór Erdélyi.

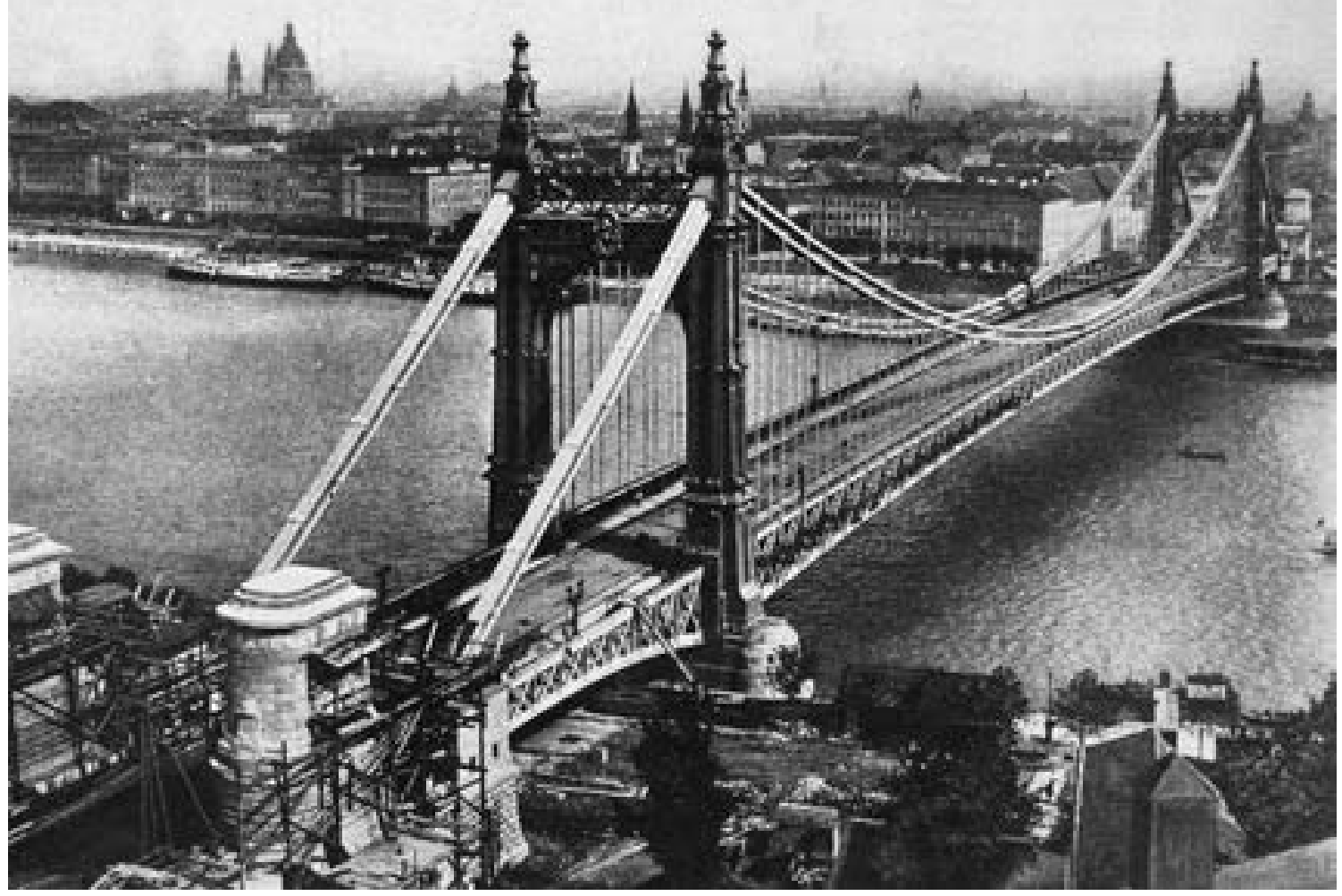

Antal Weinwurm, Ödön Bekei, Istvan Goszleth und Oskar Kallós. Aus Prag liefern Franz Pawlik und vor allem Ruda Bruner-Dvořák aktuelle Bilder. Letzterer wagt den Schritt von der Atelier- zur Zeitungsfotografie, er gilt als der Pionier der tschechischen Pressefotografie. ${ }^{26}$ Bruner-Dvořák fotografiert gesellschaftliche Ereignisse, begleitet Mitglieder des Adels und des Kaiserhauses auf ihren Unternehmungen und Reisen (v. a. den Thronfolger Franz Ferdinand) und berichtet häufig über militärische Themen (Manöver, Paraden usw.). 1906 gründet er die illustrierte Zeitung Český svět (Tschechische Welt). Aus Lemberg schicken Zsigmunt Goldhammer und M. Münz gelegentlich Bilder an die Wiener Redaktionen, aus Czernowitz Johann Krzanowski, aus Krakau Stanislaw Bizanski, der schon sehr früh Fotos in der illustrierten Presse unterbringt. In Sarajevo versorgt Anton Schädler die Wiener Zeitungen, in Olmütz Otto Frank, in Temeswar Josef Kossák, in Karlsbad Bernhard Wagner, in Budweis Anton Wild, in Brünn M. Fabian, in Pressburg Alexander Fink, in Bozen Wilhelm Müller, in Innsbruck zeitweise Max Löhrich (er sollte später ein bekannter Landschafts- und Pressefotograf werden), in Linz Richard Krill, in Graz Franz Sommerauer, Hans Schullerbauer und Leopold Bude.

Wenn man das logistische Netz, das die Fotoagenturen und die fotografischen „Korrespondenten“ ausspannen, überblickt, wird deutlich, wie sehr sich die Fotoberichterstattung im ersten Jahrzehnt nach der Jahrhundertwende geografisch ausdehnt und internationalisiert. Aus praktisch allen Teilen Europas und auch aus Übersee werden nun Fotos veröffentlicht. Aber auch innerhalb der Monarchie wird die Berichterstattung zunehmend dichter. Aktuelle Ereignisse aus den entferntesten Provinzstädten und -gegenden finden nun Eingang in die illustrierte Presse. Eines fällt allerdings auf: Die politische Bruchlinie der k.u.k. Monarchie, nämlich zwischen der ungarischen und der österreichischen Reichshälfte, schlägt sich auch in der fotografischen Öffentlichkeit nieder. Zwar wird regelmäßig über die „Schwesterstadt“ Wiens, nämlich Budapest, berichtet, aber relativ wenige Fotografien aus der ungarischen Provinz finden ihren Weg in die Wiener Presse. Umgekehrt ist es ähnlich. Dagegen wird ausführlich über die peripheren Gegenden der österreichischen Reichshälfte berichtet, die sich geografisch von Tirol bis nach Galizien, von Böhmen bis zur Dalmatinischen Küste erstreckt. So erfahren die Wiener Zeitungsleser beispielsweise weitaus mehr über das österreichische Lemberg als über das in der ungarischen Reichshälfte liegende siebenbürgische Klausenburg, viel mehr über das österreichische Bozen als über das ungarische Kaschau. Nach dem Ersten Weltkrieg allerdings ist diese „großösterreichische“ Fotoberichterstattung zu Ende. Als die k.u.k. Monarchie Ende 1918 zerbricht, rücken die ehemaligen Provinzstädte plötzlich in weite Ferne. Aktuelle fotografische Nachrichten aus Czernowitz und Krakau, aus Olmütz und Triest, aus Lemberg und Sarajevo gibt es nun keine mehr. Und es hat den Anschein, als ob die Wiener Zeitungsleser sie in der Zwischenkriegszeit gar nicht vermissen würden. 후 


\section{Fotos statt Zeichnungen}

Das Entstehen einer fotografischen Öffentlichkeit

Die kleine nordböhmische Stadt Dux (Duchcov) liegt am Fuße des Erzgebirges, wenige Kilometer vom größeren Teplitz entfernt. Im Winter 1892/93 taucht das Städtchen mit einem Mal in den Schlagzeilen der großen Wiener Blätter auf. Was war geschehen? Der Einbruch eines Schachtes in der nahe gelegenen Grube Osseg hat unter den Bergarbeitern 17 Opfer gefordert. Es ist in diesem Jahr bereits das zweite Bergwerksunglück im nordböhmischen Kohlerevier. Sofort reisen zahlreiche Reporter in die Unglücksgegend. Tagelang berichten sie in allen Details über das Ereignis. Am 2. Februar 1893 bringt die illustrierte Wiener Wochenzeitung Das interessante Blatt auf ihrer Titelseite ein Bild von den Trauerfeierlichkeiten für die Opfer (Abb. 1). ${ }^{1}$ Um die Särge, die auf dem Stadtplatz aufgebahrt sind, hat sich eine große Menschenmenge versammelt. Im Vordergrund ist - stehend - der böhmische Statthalter, Graf Franz Thun-Hohenstein, zu sehen, der, so heißt es, eigens angereist ist, um die Hinterbliebenen der Verunglückten zu trösten. Die Szene ist voller Dramatik. Eine Frau beugt sich klagend über den Sarg, eine andere krümmt sich vor Schmerz, viele weinen. Die Männer stehen trauernd und mit gesenktem Kopf da.

Der Bericht über die Grubenkatastrophe ist bemerkenswert, denn er zeigt sehr anschaulich wie ein aktuelles Medienereignis in Bildern entsteht. Es zeigt aber auch, wie ein neues Bildmedium die Bühne der Öffentlichkeit betritt. Neben den schreibenden Journalisten taucht erstmals ein neuer Typus des Berichterstatters auf: der Fotograf. Der Bildbericht über das Grubenunglück von Osseg ist freilich noch nicht fotografisch, sondern mit einer Zeichnung illustriert, die allerdings, darauf wird eigens hingewiesen, nach der Vorlage einer fotografischen Aufnahme gefertigt wurde. Das Foto, das nicht erhalten ist, stammt von A. Voigt aus Teplitz. Auf der Grundlage dieses Lichtbildes hat der Pressezeichner Alfons Giehsz in Wien, also weitab vom Originalschauplatz, eine Zeichnung erstellt, die in manchen Details (Körperhaltungen, Gesichter, Gesten) die bereits vorhandene Dramatik der Ereignisses weiter steigert. Dem geschickten Zeichner wird offenbar eher als dem Fotografen zugetraut, ein wichtiges Ereignis in ein aussagekräftiges Zeitungsbild zu kleiden.

Der Bildbeitrag über die Katastrophe in Osseg markiert eine wichtige Schnittstelle: zwischen der
Abb. 1 „Die Grubenkatastrophe in Osseg bei Dux“. Das interessante Blatt, 2. Februar 1893, Titelseite.

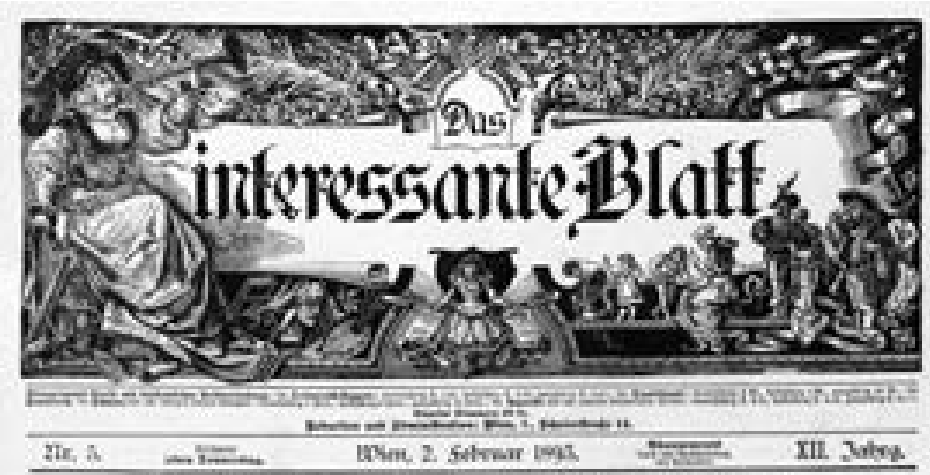

Die Srubenfataftrophe in Olliegg bei Dur.

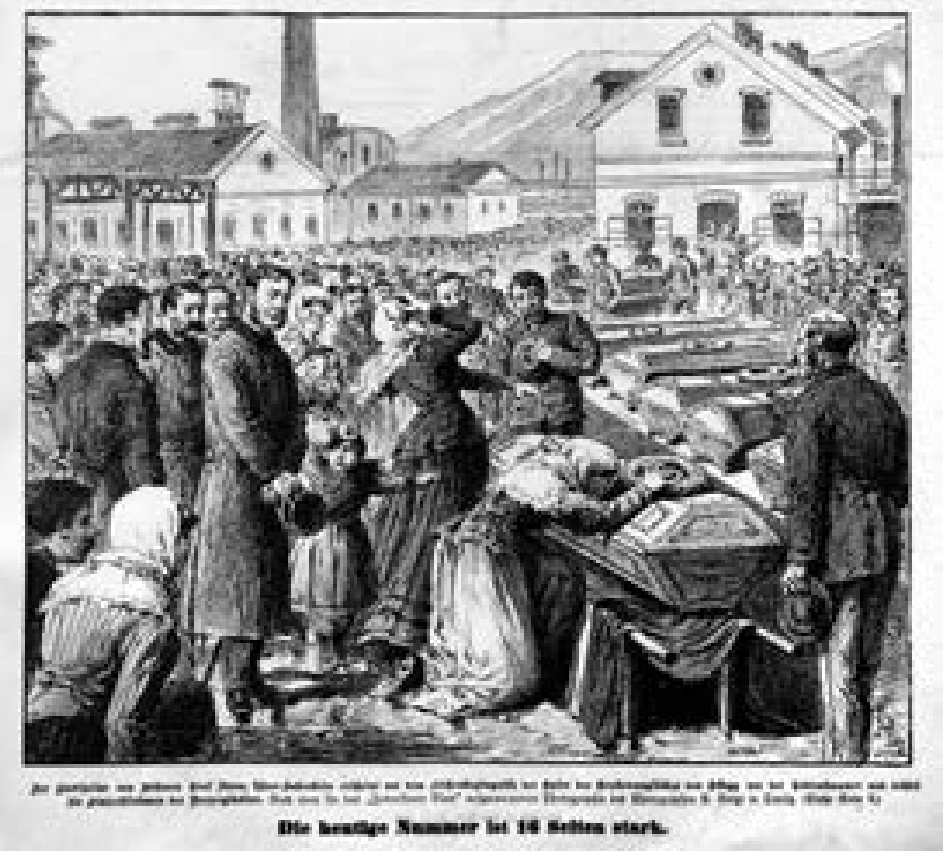


Abb. 2 Eisenbahnunfall in Wien: Durch ein Bremsversagen durchbricht die Lokomotive die abschließende Barriere eines Stumpfgleises und stürzt auf die Gunoldstraße in Heiligenstadt. Das interessante Blatt, 1. Dezember 1899, S. 5. Foto: Emil Fukarek.

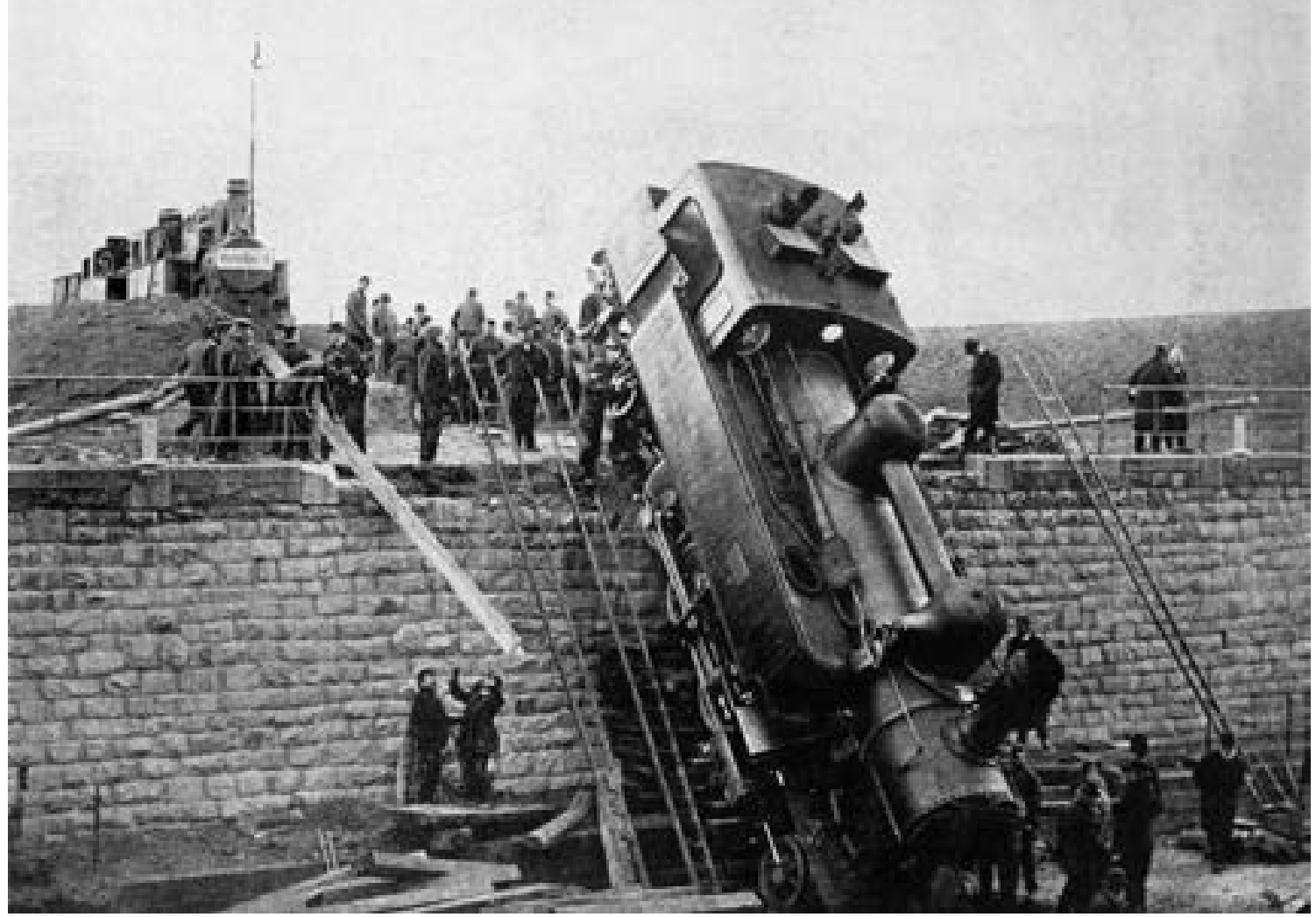

alten vorfotografischen und der neuen fotografischen Zeit. Wenige Jahre später hat sich die Fotografie in ihrer neuen Rolle als Medium der Berichterstattung bereits voll etabliert. Als Ende November 1899 eine Lokomotive der Wiener Stadtbahn entgleist und in einen Abgrund stürzt, berichtet Das interessante Blatt wieder in großer Aufmachung über das Unglück (Abb. 2). ${ }^{2}$ Wieder sind neben den schreibenden Journalisten Fotografen vor Ort. Diesmal aber wird die Szene für die Veröffentlichung nicht mehr von einem Zeichner umgearbeitet. Das Foto selbst wird - in Form einer Autotypie - veröffentlicht. Die fotografische Aufnahme stammt von Emil Fukarek, einem der Pioniere unter den Wiener Pressefotografen.

\section{Die fotografische Öffentlichkeit entsteht}

Um 1900 setzt sich also eine neue Form von Öffentlichkeit durch, die wir als fotografische Öffentlichkeit bezeichnen können. Große politische und gesellschaftliche Ereignisse, Protagonisten des öffentlichen Lebens, aber auch Sensationen des Alltags finden nun in Form von Fotografien Eingang in die Presse und erreichen damit ein neues Massenpublikum. Politiker, Theaterstars, aber auch Ganoven und Verbrecher tauchen in der illustrierten Presse aus der bildlichen Anonymität auf.

Gewiss: Ansätze zur massenmedialen Vervielfältigung der Fotografie hat es bereits vorher, etwa in Form des Holzstiches, gegeben, dem oft fotografische
Vorlagen zugrunde lagen. Neben den Holzstich, auch Fotoxylografie genannt, wird in der zweiten Hälfte des 19. Jahrhunderts eine Reihe weiterer fotomechanischer Drucktechniken verwendet, etwa die Fotozinkografie, die Fotolithografie, die Fotogalvanografie oder der Lichtdruck. ${ }^{3}$ Nur wenige dieser Techniken finden allerdings Eingang in die Produktion auflagenstarker populärer illustrierter Zeitungen und Zeitschriften. ${ }^{4}$ Erst in Form der Autotypie erlangt die massenmedial gedruckte Fotografie in der illustrierten Presse den endgültigen Durchbruch. Das Verfahren besteht darin, dass ein gerastertes Negativ auf eine lichtempfindliche Zinkplatte kopiert und geätzt wird. Diese autotypische Platte ist nun beliebig mit Schriftblöcken kombinierbar. ${ }^{5}$ Diese Drucktechnik, die in Wien seit Anfang 1883 bekannt ist, setzt sich in der illustrierten Massenpresse allerdings erst einige Jahre später durch. 1888 tauchen im Interessanten Blatt die ersten Autotypien auf, Mitte der 1890er Jahre wird die Autotypie in der illustrierten Wochenpresse regelmäßig verwendet.

Die Ablösung der Zeichnung durch die Fotografie zieht sich über einen längeren Zeitraum hin, beide Medien existieren also eine Zeit lang nebeneinander. Immer wieder werden Fotografien in Form von runden „Einblendungen“ in die Zeichnungen integriert. Oft kommt dabei der Fotografie die Aufgabe zu, Detailinformationen (etwa Porträts) zu liefern, während der Zeichnung die dramaturgische Zuspitzung anvertraut wird. Aber auch die umgekehrte Medienkombi- 
nation kommt vor. Die noch recht statische Fotografie wird mit zeichnerischen Interventionen in Bewegung gesetzt. Ein Beispiel dafür ist eine fotografische Aufnahme aus der österreichischen Staatsdruckerei in Wien. Um das Bild zu dramatisieren, wurden menschlichen Figuren, die sich bewegen (Arbeiter und Passanten), mit den Mitteln der Zeichnung ergänzt (Abb.3).

Noch bis zur Jahrhundertwende, teilweise aber auch noch länger, beschäftigt jede größere illustrierte Zeitung neben freien auch fest angestellte Pressezeichner. Diese „Spezialzeichner“ - so werden sie in der zeitgenössischen Berichterstattung genannt- haben vor der Ankunft der Fotografie die Aufgabe, wichtige aktuelle Ereignisse in aussagekräftige Bilder umzusetzen. Oft zeichnen sie vor Ort, viel häufiger aber arbeiten sie nach übermittelten Erzählungen und Berichten oder nach fotografischen Vorlagen in der Redaktion oder zu Hause. Viele Zeichner arbeiten anonym, einige wenige bringen es jedoch zu einiger Popularität. Für Das interessante Blatt beispielsweise arbeiten vor der Jahrhundertwende regelmäßig die Zeichner E. Gärtner, R. Heber, S. Ohnesorg und Bälz. Besonders häufig vertreten ist der aus Ungarn stammende Zeichner, Grafiker und Lithograf Alfons Giehsz, geb. 1850, der besonders viele Titelblätter für Das interessante Blatt gestaltet. ${ }^{6}$ Für die Wiener Bilder zeichnen u. a. Louis Janda und Fritz Winter, für die Österreichische Illustrierte Zeitung A. Bienert.

Nach 1890 verdrängt das neue Medium der Fotografie in der illustrierten Wochenpresse allmählich die gezeichneten Bilder. Fotografien werden nun nicht mehr, wie bisher üblich, in ein älteres, etabliertes, weithin anerkanntes „artistisches“ Medium, den Holzstich, übersetzt, sondern nach einer aufwendigen technisch-chemischen Bearbeitung und der Umwandlung in ein gerastertes Bild direkt auf Papier gedruckt (Autotypie). Die Herausbildung dieser fotografischen Öffentlichkeit in den Jahren nach 1890, darauf weist der Fotohistoriker Ulrich Keller zu Recht hin, ist ein komplexer historischer Prozess, der von technischen, kommerziellen, sozialen, politischen und ideologischen Entwicklungen bestimmt wird.7

Rein technisch wäre der Einsatz von Fotos im Massendruck schon Anfang der 1880er Jahre möglich ge- wesen. Aber erst ein Jahrzehnt später, ab Anfang der 1890er Jahre, beginnen die Zeitungen in die technische Ausstattung des Fotodrucks zu investieren. Erst als es kommerziell gewinnbringender ist, Fotos statt Zeichnungen zu verwenden, setzt sich das neue Medium rasch durch. Das Foto wird nun zum Leitmedium, das die bisher vorherrschende Zeichnung nach und nach verdrängt. Mit diesem Medienwechsel verbunden ist die rasante Zunahme von veröffentlichten Fotografien. Die illustrierten Zeitungen drucken Jahr für Jahr mehr Bilder, der Umfang der illustrierten Zeitungen nimmt kontinuierlich zu. Allein Das interessante Blatt druckt um die Jahrhundertwende Woche für Woche 30 bis 40 Bilder. Das ergibt in 25 Jahren 40000 bis 50000 Klischees, so rechnet der Herausgeber der Zeitung 1907 seinen Lesern zum 25-jährigen Jubiläum der Zeitung vor. ${ }^{8}$ Der Großteil davon sind in den Jahren nach 1900 Fotografien.

Um diese Bildermenge beschaffen und bearbeiten zu können, braucht es Spezialisten. Nach der Jahr-
Abb. 3 Motorenhof in der Österreichischen Staatsdruckerei in Wien. Das interessante Blatt, 28. Dezember 1893, S. 4. Foto: Charles Scolik.

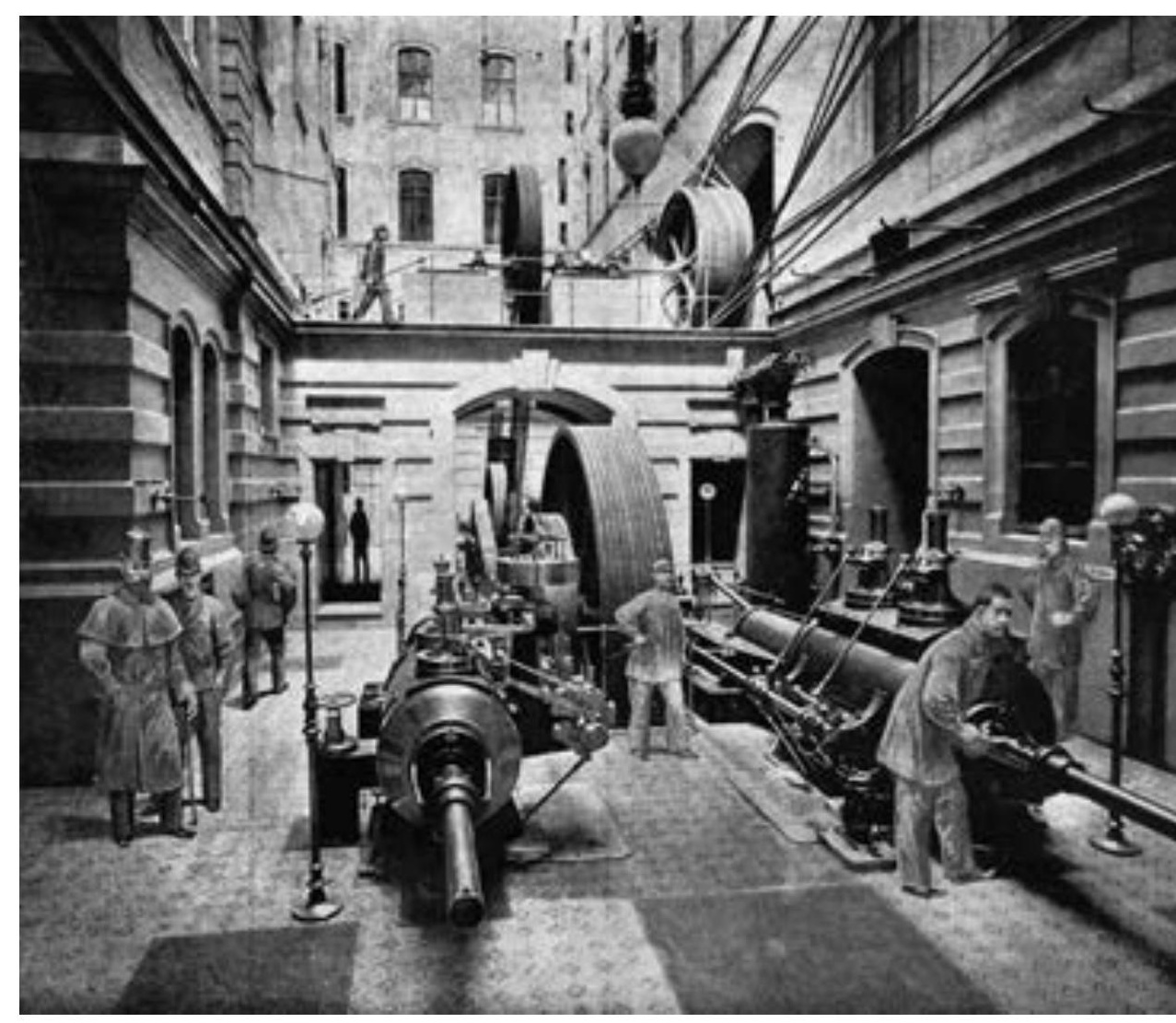


verpresse und der populären Tagespresse (wie etwa dem Illustrierten Wiener Extrablatt), die den Skandalthemen ebenfalls großen Platz einräumt, fließend. Die illustrierten Wochenzeitungen wie Das interessante Blatt, die Wiener Bilder oder die Österreichische Illustrierte Zeitung achten allerdings sorgsam darauf, in Themenwahl und Aufmachung gebührend Abstand zu diesem verrufenen Zeitungstyp einzuhalten.

\section{Augenzeugen - Die Erfindung der Authentizität}

Die Ablösung der Zeichnung durch die Fotografie führt, darauf hat Ulrich Keller hingewiesen, zu einer Umschichtung des Authentizitätsdiskurses. ${ }^{13}$ Bis kurz vor 1900 gelten Fotografien im Vergleich zu Zeichnungen in der illustrierten Presse keineswegs als authentischer. Um 1900 ändert sich das. Nicht nur das fotografische Bild als solches gewinnt an Glaubwürdigkeit, es etabliert sich ein umfangreiches System der Beglaubigung von fotografischen Bildern. Parallel dazu verliert die Zeichnung als Nachrichtenbild zunehmend an Kredit. Im Laufe der 1890er Jahre taucht beim Abdruck von Zeichnungen in der Legende immer öfter der beglaubigende Zusatz „nach einer photographischen Aufnahme“ auf. Damit verschiebt sich das Konzept der Augenzeugenschaft grundlegend. Im gesamten 19. Jahrhundert galt im Bereich der illustrierten Presse der Zeichner als wichtigster Augenzeuge aktueller Ereignisse. Nun wird er durch den Fotografen abgelöst. Während der Zeichner die Nähe zum Geschehen dramaturgisch herstellt, etwa indem er den Betrachter mitten in die Szene eintauchen lässt, ist die fotografische Nähe anderer Natur. Das Pressefoto, das um 1900 an die Stelle der Zeichnung tritt, suggeriert diese Nähe nicht nur, sondern stellt sie unmittelbar her. Der Fotograf ist der privilegierte Augenzeuge. Wenn er eine Aufnahme macht, muss er zwangsläufig vor Ort sein. Seine Bilder werden nun zu unumstößlichen Beweisstücken. Aber auch die fotografischen Bilder, die jetzt die Auszeichnung des Authentischen tragen, sind keine unmittelbaren Wiedergaben der Wirklichkeit. Im Zuge der Veröffentlichung durchlaufen die Fotos - das ist nicht zu vergessen - einen längeren Prozess der Bearbeitung. Dieser reicht von Manipulationen wie Beschnei- dung, Vergrößerung/Verkleinerung, Freistellung bis hin zur Retusche, die bis weit in die Zwischenkriegszeit hinein üblich ist. ${ }^{14}$

Das neue Konzept der fotografischen Authentizität setzt sich in der illustrierten Presse nicht mit einem Schlag durch. Es taucht um 1890 auf und ist im ersten Jahrzehnt des neuen Jahrhunderts bereits fest verankert. Mit der Zunahme des Fotoanteils in der Presse ändert sich auch die Art der Bilder. Waren um 1890 noch häufig Atelierfotos, die in einem anderen Zusammenhang, etwa im Zuge eines Porträtauftrags, entstanden sind, als Zeitungsbilder „Zweitverwertet“ worden, so liefern ab Mitte der 1890er Jahre immer öfter eigene fest angestellte oder freiberuflich arbeitende Zeitungsfotografen die Bilder. Die Aufgabe dieses neuen Berufszweigs, der „Illustrations- oder Spezialphotographen“, ist es, die Ereignisse vor Ort (und eben nicht im Studio) abzulichten. In einem liebevollen Porträt beschreiben die Wiener Bilder im Januar 1904 die Aufgaben des Pressefotografen, der inzwischen zum Hauptlieferanten fotografischer Bilder geworden ist: „Unsere Leser haben allwöchentlich Gelegenheit, die Arbeiten unserer Spezialphotographen daheim und in der Fremde im Blatte zu lesen und in ihrem bequemen Lehnstuhl mit Ruhe und Muße die interessanten Bilder zu besichtigen, welche ihnen der allzeit getreue Apparat vermittelt. Nicht ebenso gut hat es der Photograph selbst, der mit allerlei widrigen Gegnern zu kämpfen hat - in erster Linie mit seinem Hauptfaktor, der Sonne, die an der unbegreiflichen Kaprize leidet, nicht immer gerade dort und in der notwendigen Stärke zu scheinen, die man eben zu einer guten Aufnahme benötigt. Regen, Nebel, Wind und anderes sind die weiteren treuen Anhänger, die dem Photographen im Freien seine Arbeit erschweren, wenn nicht gar ganz unmöglich machen und schließlich, last but not least, sind es die lieben neugierigen Menschenkinder von der reiferen Jugend aufwärts, die ihm sein Handwerk stören. “ ${ }^{15}$

Die Pressefotografen arbeiten also vorwiegend im Freien. Ausgerüstet sind sie häufig mit Klappkameras. In der Regel führen sie ein Stativ mit sich, als Negativmaterial verwenden sie oft Wechselkassetten zu je zwölf Glasplatten im Format $13 \times 18$. In einem frühen Handbuch für Pressefotografen aus dem Jahr 
Abb. 5 Der Kraft-Jongleur Paul Spadoni stemmt ein Kutschengerüst mit den Zähnen. Das interessante Blatt, 15. Februar 1900, S. 6. Foto: Rudolf Martinelli.

1908 heißt es: „Zu aktuellen Illustrations-Aufnahmen, d. h. Aufnahmen von einer unmittelbaren Bedeutung, die auf der Tagesordnung stehen, gehören im allgemeinen solche von Tagesereignissen, wie Festlichkeiten, Katastrophen, Unglücksfällen, Persönlichkeiten, die das Tagesgespräch bilden, sportlichen Veranstaltungen, theatralischen Premieren, neuen Varieté-Tricks (Abb. 5), Erfindungen, Denkmälern, Bauwerken, Kunstschöpfungen etc. “" ${ }^{16}$ Um an diese Bilder heranzukommen, müssen die Pressefotografen ständig unterwegs sein und oft weite Wege zurücklegen. Geschwindigkeit ist nun alles. Die Fotos, die als Erste in der Redaktion eintreffen, haben die größten Chancen, abgedruckt zu werden. Daher rät der Autor des Lehrbuchs Die Illustrations-Photographie angehenden Pressefotografen, von einer Bildbearbeitung abzusehen: „Retouche der Platten ist Zeitvergeudung.“17

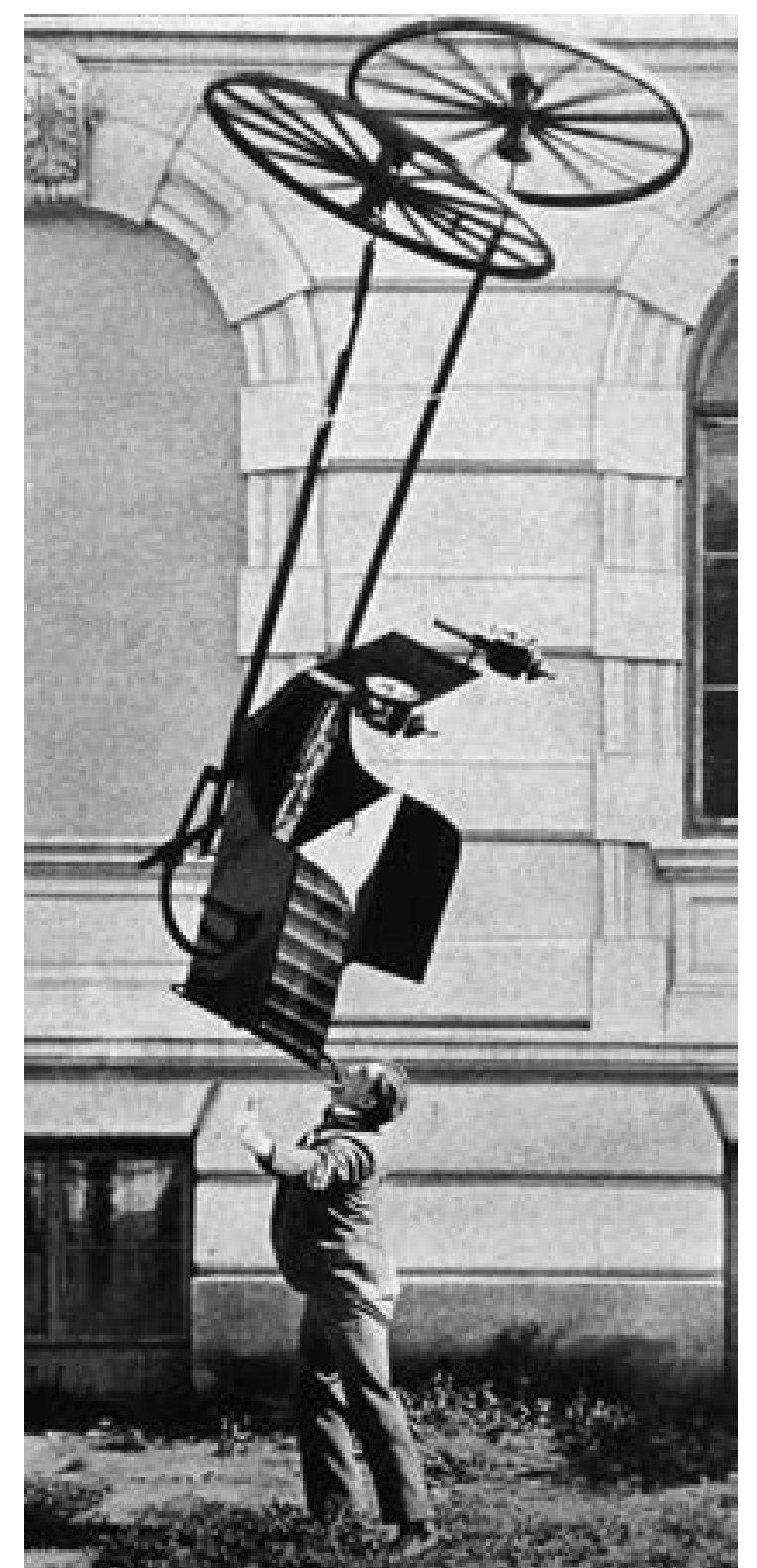

Die geografische Reichweite der Pressefotografen nimmt zwar zu, ist aber dennoch begrenzt. Daher setzt die illustrierte Presse auf zwei Strategien, um auch aus entfernten Gebieten aktuelle Nachrichtenfotos zu bekommen: die Kooperation mit Fotoagenturen, die Pressefotografien national und international vertreiben, und den Aufruf an die Fotoamateure unter den Zeitungslesern, Fotos einzuschicken. Der professionelle Handel mit Fotografien beginnt Mitte der 1890er Jahre, ausgehend von den USA und Deutschland (v. a. Berlin). ${ }^{18}$ Um 1900 tauchen auch in Wien die ersten Agenturen auf, die Fotos an die illustrierte Presse verkaufen, etwa die Fotohandelsfirma R. Lechner (Wilh. Müller). ${ }^{19}$ Zur selben Zeit beginnen international tätige Fotoagenturen, Bilder aus dem englischsprachigen und deutschen Ausland an Wiener Blätter zu verkaufen. ${ }^{20}$

Die Veröffentlichung von Amateurfotografien beginnt ebenfalls kurz vor der Jahrhundertwende. Am 6. Juni 1895 druckt Das interessante Blatt einen Aufruf, der in den folgenden Monaten regelmäßig wiederholt wird: „Die Redaction des Interessanten Blattes bittet alle Photographen und Amateurphotographen im Falle sie Aufnahmen von Festlichkeiten, größeren Katastrophen und Unglücksfällen, sowie von sonstigen interessanten Tagesereignissen machen, ihr möglichst rasch Photographien, wenn auch nicht retouchirt, einzusenden, damit dieselben im ,Interessanten Blatt‘ reproducirt werden. “21 Einige Zeit später wenden sich auch die Wiener Bilder mit einem ähnlichen Aufruf an ihre Leser. ${ }^{22}$

Diesen Einladungen leisten zahlreiche Leser Folge und tatsächlich steigt der Anteil von Amateuraufnahmen, die in der illustrierten Presse gedruckt werden, in den folgenden Jahren deutlich an. Die Amateure, die oft mit leichten, lichtstarken, meist teuren Kameras unterwegs $\operatorname{sind}^{23}$, berichten vorwiegend über kleine und große Sensationen, Feierlichkeiten und Katastrophen aus der Provinz. Anfang 1907 resümiert Das interessante Blatt über diese neuen Bilderlieferanten: „Oft sind Berufsphotographen gar nicht in der Lage, bei manchem Ereignis zu intervenieren. Und da helfen uns unzählige gute Freunde aus, die wir in den allermeisten Fällen nur durch den Dienst, den sie uns spontan leisten, kennen lernen: die riesige Schar der 

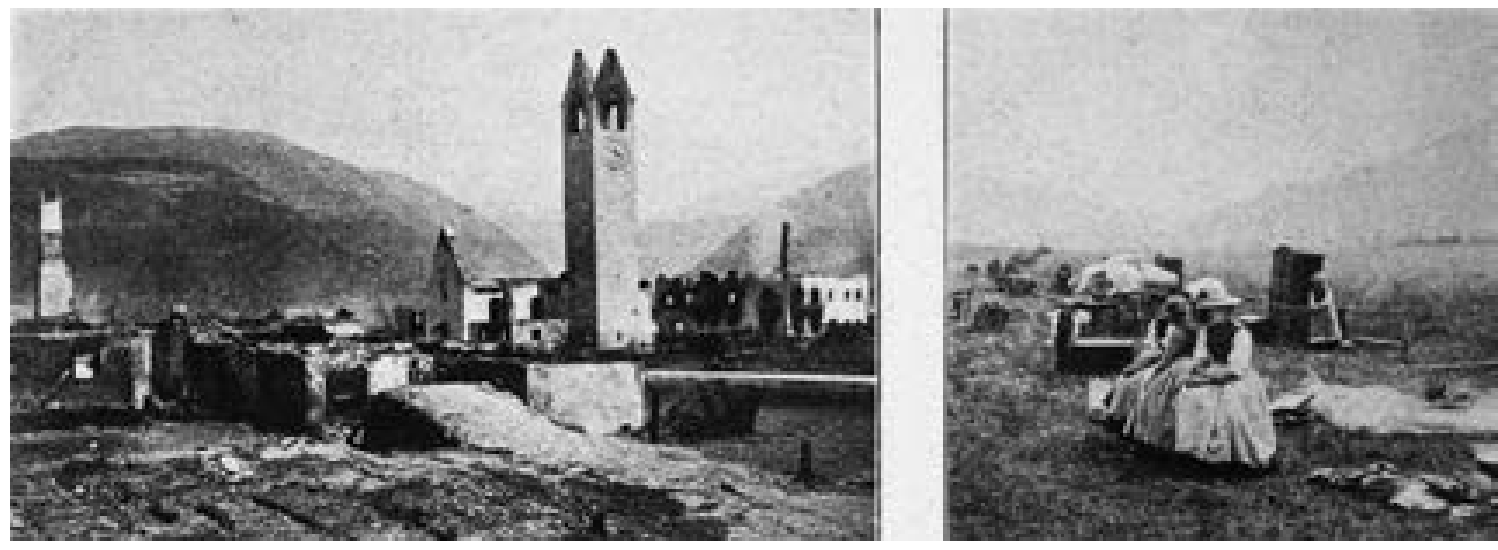

Abb. 6 Am 20. Juli 1904 zerstört ein Großbrand den Südtiroler Ort Mitterolang. Das interessante Blatt, 28. Juli 1907, S. 4. Fotos: Rudolf Largajolli.

Amateure.“24 Daneben greifen die Redaktionen aber regelmäßig auf die Mitarbeit lokaler Berufsfotografen zurück. Als beispielsweise im Sommer 1904 ein Großbrand das Südtiroler Dorf Mitterolang fast vollständig zerstört, wird im Interessanten Blatt darüber berichtet (Abb.6). Die Aufnahmen stammen von einem lokalen Fotografen namens Rudolf Largajolli. ${ }^{25}$

Im ersten Jahrzehnt des 20. Jahrhunderts ist der Konkurrenzkampf zwischen Zeichnung und Fotografie entschieden. Alle größeren illustrierten Zeitungen haben inzwischen ein dichtes logistisches Netz zur Beschaffung von aktuellen Bildern aufgebaut. Fotoagenturen versorgen die Redaktionen mit professionellen Pressefotos aus dem In- und Ausland, Amateure und lokale Fotografen berichten aus vielen kleineren Provinzstädten und -orten. Die Pflege und Aufrechterhaltung dieses Netzes an Bildkorrespondenten ist aufwendig und kostspielig. Dennoch ist die Investition notwendig, denn der publizistische Mehrwert, den sie garantiert, heißt: fotografische Authentizität. Diese setzt die fotografische Präsenz vor Ort voraus, die nun zum zentralen Kriterium für die massenmediale Bildberichterstattung wird. Der Name des Fotografen (bzw. der Agentur), der nun regelmäßig in der Bildlegende genannt wird, ist Teil dieses aufwendigen Beglaubigungsprozesses bei Fotografien.

Die Redaktionen nehmen sogar eine verspätete Berichterstattung in Kauf, wenn sie statt Zeichnungen Fotografien bringen können. Es gibt aber auch Ausnahmen: Wenn das Ereignis welthistorische Bedeutung hat und sich der Transport der Fotos enorm in die Länge zieht, greift man dennoch wieder auf die bewährte Zeichnung zurück. Als am 18. April 1906 ein Erdbeben San Francisco zerstört, veröffentlicht Das interessante Blatt bereits eine Woche später telegrafisch übermittelte Berichte auf der Titelseite. ${ }^{26}$ Weitere Schilderungen der Ereignisse folgen in den nächsten Wochen. In Ermangelung von aktuellen Fotos greift man auf in Wien gefertigte Zeichnungen

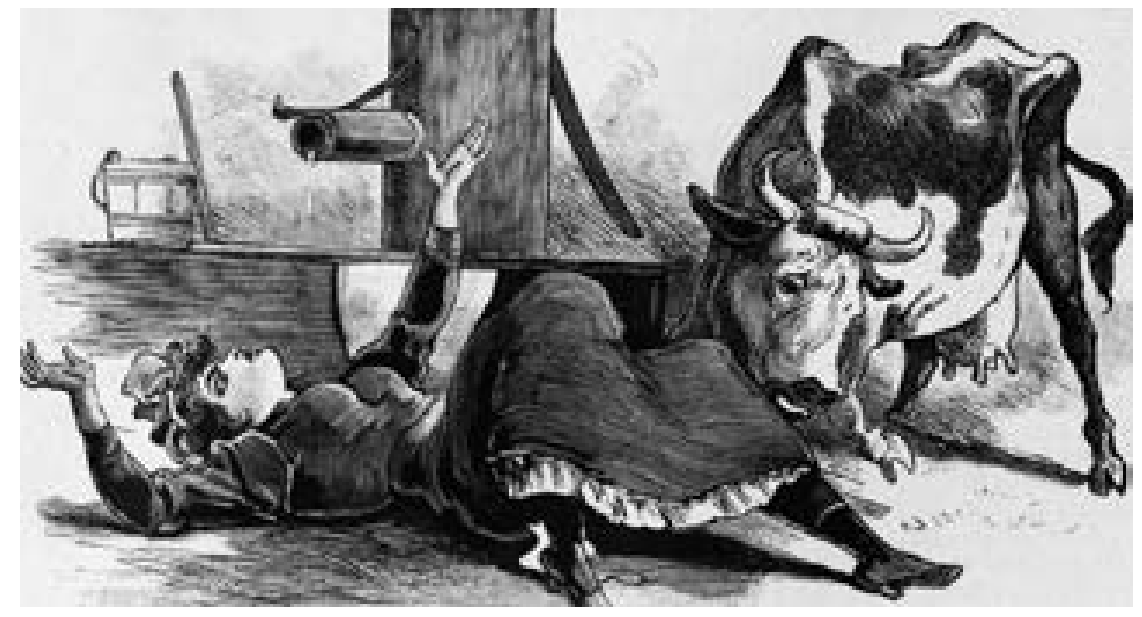

zurück. ${ }^{27}$ Als viele Wochen später die ersten Fotos von den Zerstörungen eintreffen, sind sie schon veraltet. Am 2. August 1906, also über drei Monate nach dem Ereignis, bringt Das interessante Blatt erstmals Fotografien aus San Francisco. Sie zeigen bereits die Wiederaufbauarbeiten. ${ }^{28}$

\section{Faits divers}

Das Auftauchen der Fotografie als neues visuelles Leitmedium in der illustrierten Presse löst die Zeichnung nicht vollständig ab, sondern verändert ihren Status. Gezeichnete Bilder verlieren ihre Stellung als zentrales Nachrichtenmedium, dafür aber behalten sie ihre Rolle bei der Darstellung nicht aktueller Ereignisse. Eine der Rubriken, in denen die Zeichnung um die Jahrhundertwende verstärkt zum Einsatz kommt, sind die „Vermischten Meldungen“, die Faits divers. Dieser Begriff bürgert sich Ende des 19. Jahrhunderts aus Frankreich kommend ein. ${ }^{29} \mathrm{Er}$ bezeichnet kurze, oft skurrile, seltsame, unmöglich erscheinende, fantastische Szenen aus dem alltäglichen Leben, die unglaubwürdig anmuten, aber oft wahr sind. „Von einer Kuh attackiert“, lautet bei-
Abb. 7 „Von einer Kuh attackiert“. Wiener Bilder, 30. Juli 1899, S. 8. 
Abb. 8 „Mit einer Lampe getötet", Wiener Bilder, 27. August 1899, S. 8.

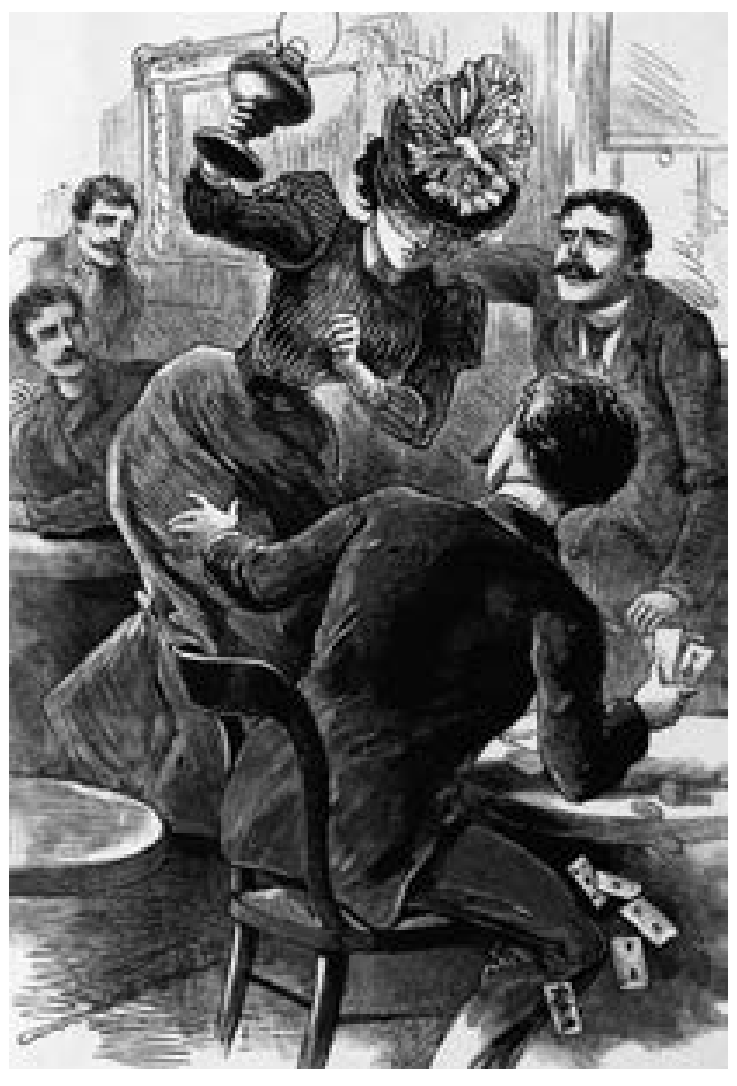

spielsweise eine dieser mit Zeichnungen illustrierten Kürzestmeldungen (Abb. 7). Die Szene ist dramatisch überhöht, aber ohne weiteren Kommentar. Bildliche Faits divers können belanglose Skurrilitäten aufgreifen. Nicht selten aber machen sie auf subtile Weise auch gesellschaftliche Probleme zum Thema. Eine Bildgeschichte mit dem lapidaren Titel „Mit einer Lampe getötet“ zeigt eine Frau, die ihren an einem Gasthaustisch Karten spielenden Mann mit einer Lampe attackiert (Abb.8). Ein anderer Mann will sie von ihrer Tat abhalten. Auch diese Bildgeschichte ist dramaturgisch zugespitzt. Sie thematisiert ein scheinbar singuläres Ereignis (Frau attackiert Mann mit Lampe), zugleich aber verpackt sie einen vielschichtigen Konflikt (Mann - Frau, privater Raum öffentlicher Raum, Geldgewinn - Geldverschwendung etc.) in ein einprägsames Bild.

Vermischte Meldungen wie diese sind Ende des 19. Jahrhunderts in der Presse weitverbreitet, sie zirkulieren in Form von Kürzestnachrichten oder als Bildgeschichten. Die illustrierte Presse ist eine ideale Plattform für diese Form der Berichterstattung. Die Bildvorlagen stammen nicht selten aus dem Ausland und werden von den Redaktionen zugekauft. Die Geschichten müssen nicht notwendigerweise aktuell sein, lassen sich also jederzeit veröffentlichen. Die Themen sind für ein breites Publikum attraktiv, sie befriedigen die Lust auf Sensationen ebenso wie das
Bedürfnis nach unerwarteten, „unmöglichen“ Lösungen in gesellschaftlichen Konfliktsituationen.

Bemerkenswert ist nun, dass die Zeichnung, die von der Fotografie als glaubwürdiges Nachrichtenmedium abgelöst wird, zum beliebten Illustrationsmedium für die Rubrik Faits divers wird. Diese Entwicklung deutet ihren Bedeutungsverlust an. Denn die vermischten Meldungen stehen in der Hierarchie der Nachrichten ziemlich weit unten. Zugleich aber sind sie populär und werden viel gelesen. Die Zeichnung, die lange Zeit in der Bildberichterstattung durchaus als authentisch galt, verliert nun einen Großteil ihres Kredits als „wahres“ Bildmedium. In den Faits divers kommt sie in einer Rubrik zum Einsatz, die zwischen Nachricht und Gerücht, zwischen wahr und falsch changiert.

Der Verdrängungsprozess der Zeichnung erfolgt je nach Medium sehr unterschiedlich. Während sich die Zeichnung in den konventionell aufgemachten Familienzeitschriften, die weniger Wert auf Aktualität legen, länger halten kann, verschwindet sie bei den illustrierten Nachrichtenzeitungen sehr viel schneller aus den vorderen Seiten. ${ }^{30}$ Dieser Prozess verläuft auch in einzelnen Ländern unterschiedlich schnell. Während sich in den angelsächsischen Ländern und auch in Frankreich die Fotoberichterstattung früh durchsetzt, zieht sich in Mitteleuropa - und damit auch in Österreich - der Konkurrenzkampf zwischen Zeichnung und Fotografie länger hin. Einen entscheidenden Anstoß zur endgültigen Verdrängung der Zeichnung leistet die Einführung des Kupfertiefdrucks kurz vor dem Ersten Weltkrieg. Diese neue Drucktechnik stärkt die Fotografie als authentischeres Medium gegenüber der Zeichnung noch einmal. Die gedruckten Fotos in der Zeitung erscheinen nun plastischer und tiefenschärfer. Die im Kupfertiefdruck hergestellten Bilder sind, so schwärmen die Wiener Bilder kurz nach der Einführung der neuen Technik, den fotografischen Originalen, die ihnen zugrunde liegen, „weit ähnlicher als bisher, ja, wir können ruhig sagen, daß sie diesen Originalen in jeder Beziehung gleichkommen. “ ${ }^{31}$ Spätestens Anfang der 1920er Jahre hat die Fotografie die Zeichnung vollständig abgelöst, auch die gezeichneten Faits divers gehören nun der Vergangenheit an. 


\title{
Bild und Text
}

\author{
Die Rhetorik der Zeitungsseiten
}

Am 2. Dezember 1908 veröffentlicht Österreichs Illustrierte Zeitung aus Anlass des 60. Thronjubiläums von Kaiser Franz Joseph eine 200 Folioseiten starke Sondernummer. Die Redaktion scheut weder Mühe noch Aufwand, um dem ehrwürdigen Anlass entsprechend eine besonders prächtige Ausgabe zusammenzustellen. Die Sondernummer ist sogar für zehn Kronen als gebundene Luxusausgabe im Buchhandel erhältlich. Auf dem Umschlag prangt ein Porträt des Kaisers, aufgenommen vom renommierten Wiener Atelier Adèle, aufwendig gedruckt von der Druckerei Philipp \& Kramer, der Hausdruckerei des Blattes. Im Innenteil werden den Lesern zahlreiche optische und grafische Highlights geboten. Da findet sich etwa eine „Photocomposition“, also eine Fotomontage, die eine fiktive Begegnung zwischen dem Kaiser und der höheren Wiener Gesellschaft zeigt. Regierungsvertreter, Militärs, Schauspieler, Adelige und zahlreiche andere Prominente huldigen dem greisen Monarchen. Allesamt sind sie in fotografischen Aufnahmen dargestellt und zu einer Gruppenszene zusammengefasst worden. Eine weitere Kaiserhuldigung, die vor dem Wiener Rathaus stattfindet, wird in einem monumentalen Gruppenbild festgehalten. 1200 niederösterreichische Bürgermeister haben für die Feierlichkeit, vor allem aber für den Fotografen Aufstellung genommen.

Schließlich findet sich in der Sondernummer unter dem Titel „Die österreichische Publizistik“ noch eine weitere doppelseitige „Photokomposition“ (Abb. 1). Knapp 150 leitende Redakteure und Herausgeber bedeutender Wiener Zeitungen haben sich in der Montage zu einer „Festversammlung der Presse im Bilde“ eingefunden. Die Inszenierung ist aus mehreren Gründen bedeutsam: Sie ist nicht nur eine kunstvoll und aufwendig gestaltete Fotomontage, sondern auch ein eindrucksvolles Beispiel einer „Photokomposition" in der illustrierten Presse. Vor allem aber ist die Bilddoppelseite ein interessanter Beleg für die grafischen Umbrüche in der Seitengestaltung. Die Abbil- dung ist schließlich - und das ist mindestens genauso bemerkenswert - ein spannendes Dokument zur Wiener Presselandschaft um 1900. Erstmals werden die wichtigsten Journalisten und Herausgeber, zusammengefasst in einem Bild, in fotografischen Porträts gezeigt. Nicht zufällig greift diese journalistische Kaiserhuldigung auf das modernste Reproduktionsmittel zurück, das in diesen Jahren zur Verfügung steht, die Fotografie. Da von vielen der Dargestellten keine Fotoporträts aus dieser Zeit bekannt sind, ist die Zusammenstellung auch von eminenter biografischer Bedeutung.

Die Fotomontage stammt von Siegmund Schneider, dem leitenden Redakteur des Wochenblatts Österreichs Illustrierte Zeitung. Das Klischee wird von der Firma A. (Andreas) Krampolek, einem renommierten Wiener Druckbetrieb, hergestellt. Schneider, geb. 1861, ist ein mediales Multitalent: Er ist als Journalist und Autor tätig, arbeitet als Pressefotograf, Zeichner und Grafiker. Seit der Gründung der Österreichischen Illustrirten Zeitung im Jahr 1893 (das Blatt wird später in Österreichs Illustrierte Zeitung umbenannt) arbeitet er für diese Wochenzeitung. Bereits für die erste Nummer liefert er eine „Photo-Composition“ (sie zeigt den Kaiser im Hofsalonwagen). In den folgenden Jahren gestaltet er zahlreiche Titelseiten, stellt Fotoreportagen ${ }^{1}$ zusammen und setzt auch immer wieder Fotomontagen ein. Seine Spezialität sind monumentale Gruppenbilder, die er aus fotografischen Einzelporträts zusammensetzt und zu einem neuen architektonischen Ensemble verschmilzt. ${ }^{2}$

Auch beim Aufbau der Szene „Die österreichische Publizistik“ geht Schneider systematisch vor. In mühseliger Sammelarbeit trägt er insgesamt 144 Fotoporträts wichtiger österreichischer Redakteure zusammen und komponiert aus diesem Rohmaterial ein imposantes Gruppenbild vor der Kulisse des Parlaments. „Wenn auch hie und da manch stolzer Name in diesem Kreise fehlt, so darf es uns doch mit der 


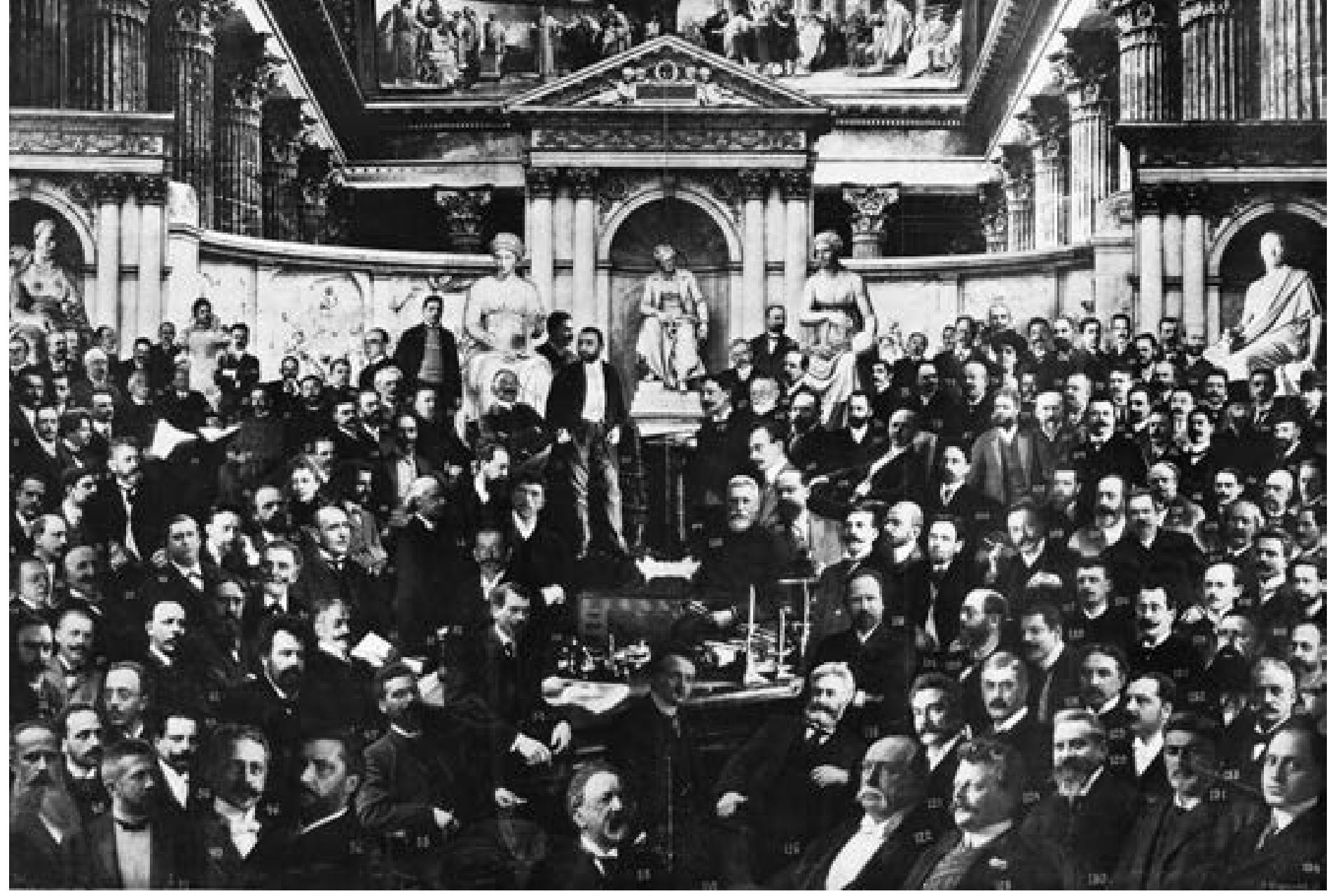

Abb. 1 „Die österreichische Publizistik“. „Photokomposition“ von Siegmund Schneider. Österreichs IIlustrierte Zeitung, 2. Dezember 1908, o.S. größten Genugtuung erfüllen, dass immerhin eine so stattliche Korona von nahezu 150 unserer hervorragenden Publizisten die kollegiale Gastfreundschaft unseres Blattes zu würdigen, nicht verschmähten.“3 So schreibt Schneider in etwas geblähtem Deutsch zum Bild. Eine einzige Frau hat sich in diese Männerdomäne verirrt - Marie Eugenie Delle Grazie, die regelmäßig in der Neuen Freien Presse publiziert (links oben, Nr. 30). Schneider überlässt die Anordnung beileibe nicht dem Zufall, geschickt und mit subtilen Bedeutungen versehen, verteilt er die Plätze in der Arena. Im Zentrum des Bildes, links neben der Statue des Dichters Franz Grillparzer, die genau im Mittelfalz positioniert ist, platziert er den in diesen Jahren wohl einflussreichsten Journalisten Wiens, Moriz Benedikt. Er ist Herausgeber und Chefredakteur der Neuen Freien Presse, des führenden liberalen Blattes des Landes. Herausgehoben ist die Figur Benedikts auch dadurch, dass dieser - als Einziger im Bild - im Ganzkörperporträt und nicht nur in Form eines Brustbildes erscheint. Auf ebendieses Bild Benedikts greift wenige Jahre später Karl Kraus zurück und verdichtet es - wiederum in einer Montage - in der Fackel zu einer ganz anders gewichteten Szene (Abb. 2). ${ }^{4}$ Während Benedikt in der Zeitung als herausragende Figur innerhalb eines Gruppenbildes posiert, ist er bei Kraus freigestellt und allein $\mathrm{zu}$ sehen. Nicht wie bei Schneider innerhalb des Parlaments, sondern außerhalb. ${ }^{5}$ Kraus bezeichnet ihn als „Sieger“. Damit deutet er an, dass der eigentliche Sieger der letzten Parlamentswahlen (der Reichsratswahlen 1911, die am 20. Juni endeten) nicht die parlamentarische Demokratie ist, sondern die unselige Allianz zwischen liberaler Presse - verkörpert in der Figur des Herausgebers der Neuen Freien Presse - und Regierung. Mittels der Montage legt Kraus offen, was in der Wirklichkeit der Fall ist.

\section{Ein sprechendes Bild}

Die Redaktion der Neuen Freien Presse ist im montierten Gruppenbild Siegmund Schneiders auffallend gut vertreten. Die Redakteure dieser Zeitung gruppieren sich, gut sichtbar, im Mittelteil des Bildes. Aber auch andere Vertreter der konservativen, liberalen und deutschnationalen Presse nehmen im Gruppenbild gute Plätze ein. Die nicht deutschsprachigen Wiener Journalisten fehlen dagegen fast vollständig. Ebenso die Vertreter der großen illustrierten Wochenblätter, die unmittelbaren Konkurrenten von Österreichs Illustrierter Zeitung, etwa Das interessante Blatt und die Wiener Bilder. 


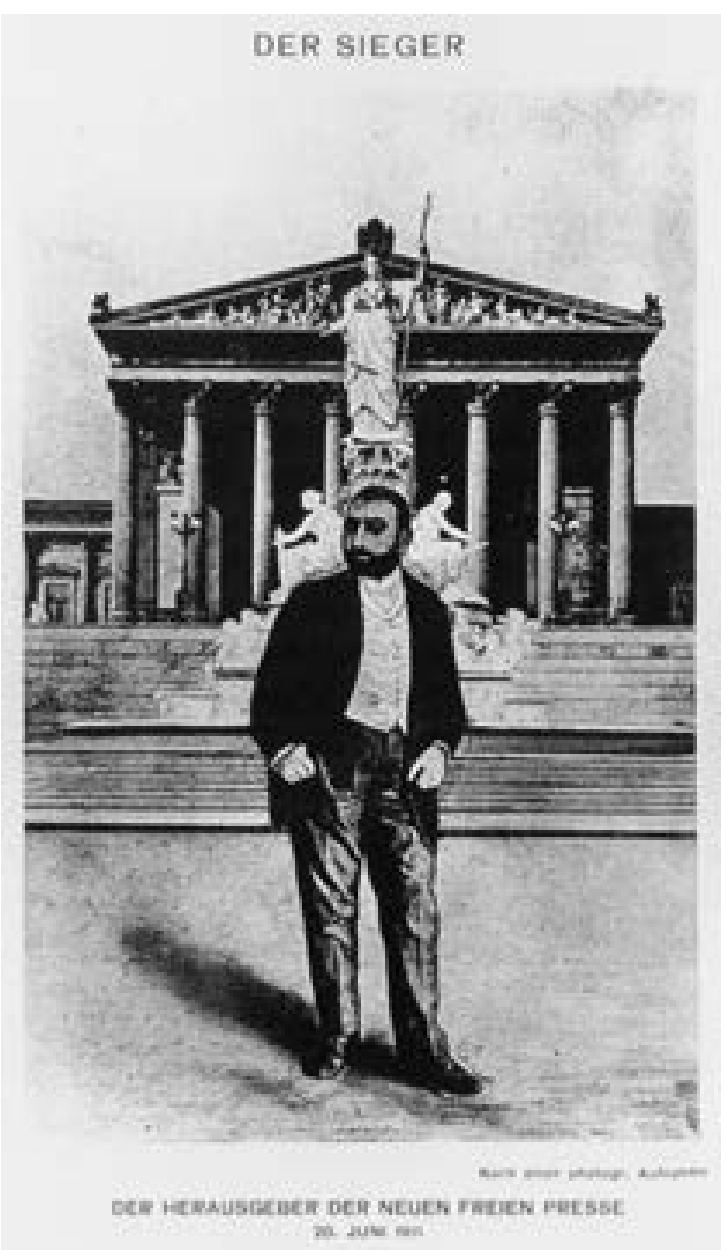

In der Architektur des Bildes scheinen die politischen Vorlieben Siegmund Schneiders und seiner Zeitung deutlich durch. Dass etwa Leopold Lipschütz, der Chefredakteur der konservativen, der Reichspost nahestehenden Illustrierten Kronen-Zeitung (links neben Benedikt, Nr. 21) alle anderen Vertreter um einen knappen Kopf überragt, ist gewiss kein Zufall: Er verkörpert die erfolgreiche und auflagenstarke konservativ-populistische Massenpresse. Dagegen ist nur ein einziger Vertreter einer sozialdemokratischen Zeitung abgebildet: Engelbert Pernersdorfer (Nr. 135). Er gehört dem rechten, deutschnationalen Flügel der Partei an und findet seinen Platz ganz außen im Bild, dicht am rechten Rand. Der Chefredakteur der Arbeiter-Zeitung, Friedrich Austerlitz, hingegen fehlt, ebenso wie andere Journalisten fortschrittlicher Publikationen. Auch Siegmund Schneider selbst, der Gestalter, hat sich einen Platz gesichert. Er hat sich bescheiden am rechten Bildrand, neben dem sozialdemokratischen Vertreter, verewigt (Nr. 132).

Nicht nur die Anordnung der Porträtierten, auch die Architektur und Gestaltung des Raumes folgen einem präzise kalkulierten Programm. Nicht zufällig wählt Schneider das Innere des Wiener Parlaments als Schauplatz für sein Gruppenbild. Auch hier arbeitet er mit Schere und Klebstoff. Das Grillparzerdenkmal, das hinter der festlich versammelten $\mathrm{Pu}^{-}$ blizistik zu sehen ist, steht in Wirklichkeit unweit des Parlaments, im Wiener Volksgarten. Grillparzer wird in der Beschreibung des Bildes, die ebenfalls von Schneider stammt, als „größter österreichischer Dichter und Schriftsteller" vorgestellt und zugleich als „berühmtestes Opfer vormärzlicher Preßverhältnisse und Metternichschen Geistesdrucks.“ ${ }^{6}$ Schneider baut weitere figurative „Zutaten“ in die Szene ein. Rechts und links des Dichters sind die Statuen der Clio und der Urania zu sehen, die antiken Musen der Dichtung und der Naturwissenschaft. Am äußeren Bildrand rechts und links sitzen weitere antike Helden, Cicero und Demosthenes, deren Statuen im Kapitolinischen Museum in Rom und im Pariser Louvre stehen. Und auch die Fresken am Fries der Säulenhalle hat Schneider von weit hergeholt und ins Bild montiert. Sie zeigen „altchristliche Blutzeugen des freien Wortes“, die Gemälde stammen aus der Basili- ka San Lorenzo in Rom. Schneider fasst die Aussage des bedeutungsschwangeren Bildes folgendermaßen zusammen: „So entströmt dieser Photocomposition auch eine ungewöhnliche symbolische Kraft, die sie wohl zu mehr macht als zu einem bloß zufälligen Gruppenbilde und dadurch auch manchen sinnenden Beschauer anregen mag zu ernsteren Betrachtungen, was unsere Zeit, was unser ganzes Kultur- und Geistesleben in Österreich den Männern der vaterländischen Publizistik zu verdanken hat."7

\section{Innovation und Beharrung}

Die Fotomontage Siegmund Schneiders ist ein interessantes Beispiel für die komplexen rhetorischen Möglichkeiten, mit denen fotografisch illustrierte Zeitungen bereits in den ersten Jahren nach 1900 arbeiten. Und dennoch ist dieses Beispiel eine Ausnahme. Derart aufwendig gestaltete und gedruckte Bildseiten sind in diesen Jahren eher selten. Die Fotografie, die im letzten Jahrzehnt des 19. Jahrhunderts allmählich Einzug in die illustrierte Wochenpresse hält, ist zwar als Medium neu, aber die Bildsprache, in der sie sich bewegt, greift noch lange auf die etablierten
Abb. 2 „Der Herausgeber der Neuen Freien Presse. 20. Juni 1911“. Fotomontage von Karl Kraus, in: Die Fackel, Nr. 326-328, 8. Juli 1911. 


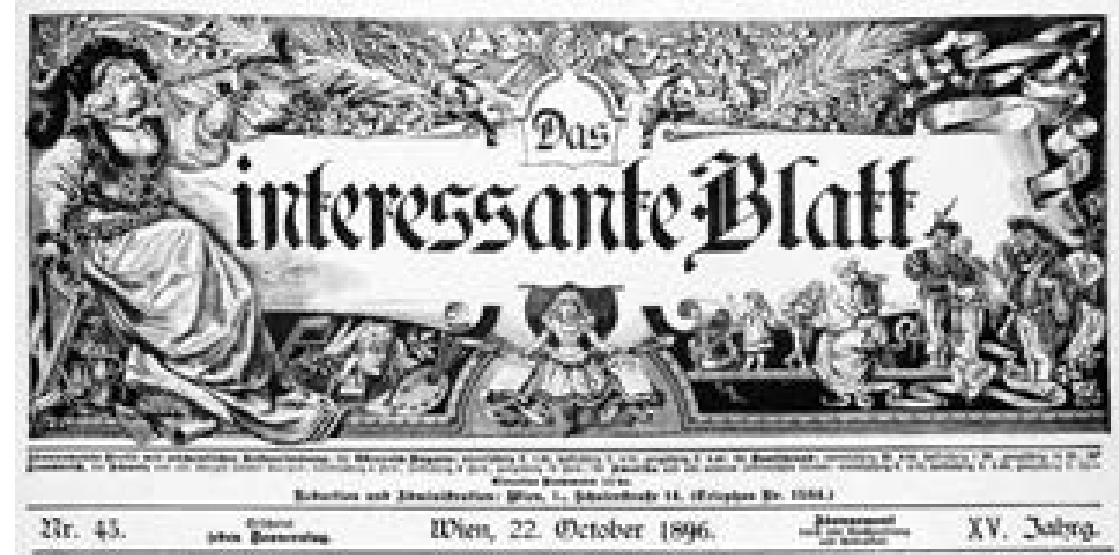

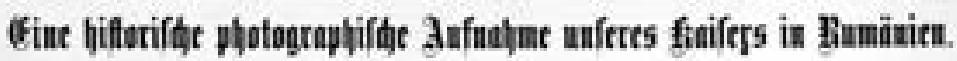

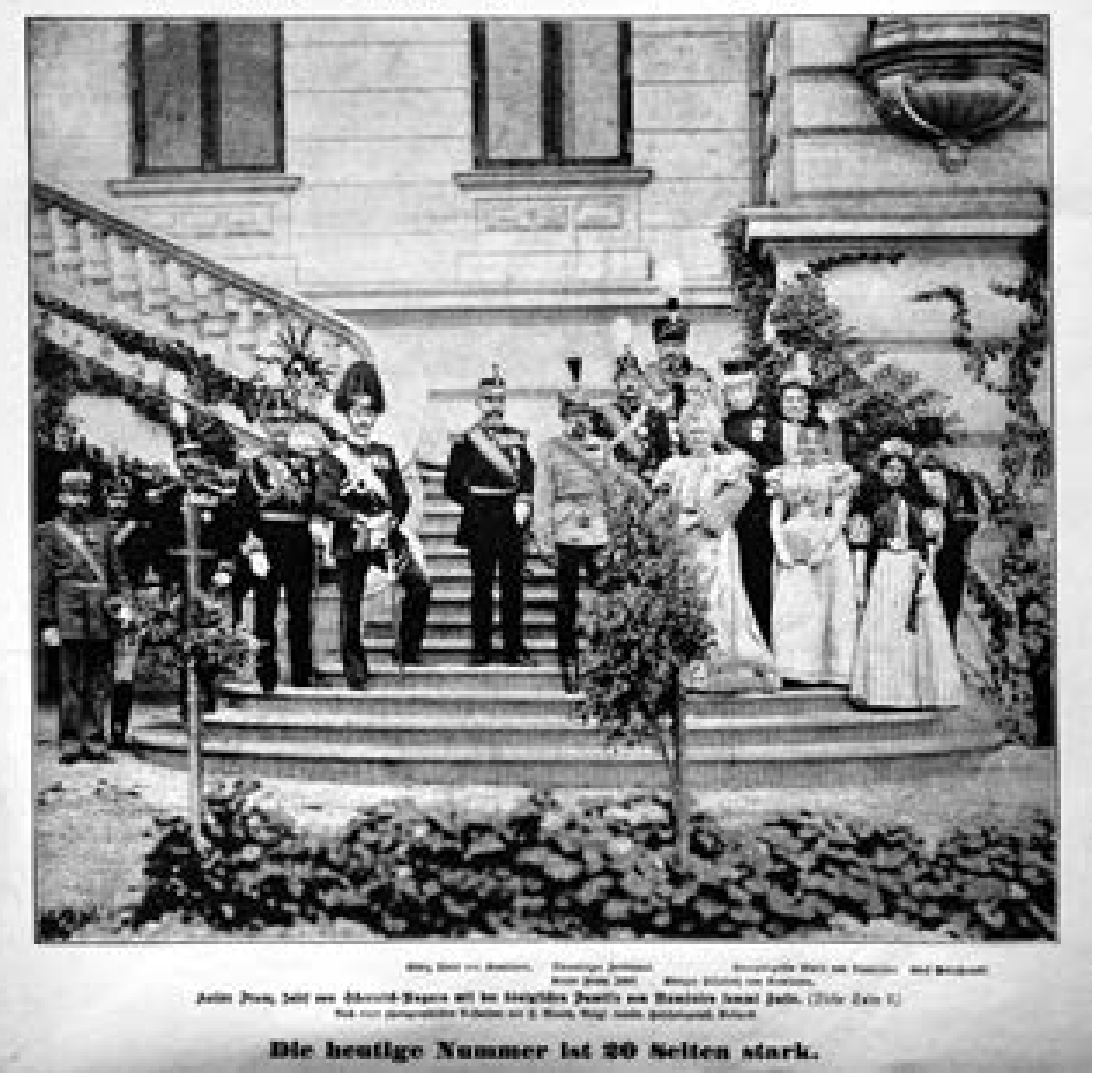

Abb. 3 Staatsbesuch des österreichischen Kaisers Franz Joseph in Rumänien. Das interessante Blatt, 22. Oktober 1896, Titelseite. Foto: Franz Mandy, Hoffotograf in Bukarest.
Muster zurück. In langsamen Schritten emanzipieren sich freilich Zeitungen und Gestalter vom Ballast der Vergangenheit. Nach und nach modernisiert sich das Layout.

Fast immer kommt der Anstoß zu grafischen Veränderungen von außen. Ökonomische Veränderungen ziehen oft grafische Reformen nach sich. Ein wichtiger wirtschaftlicher Einschnitt ist in Österreich die Abschaffung der Zeitungssteuer (des sogenannten Zeitungsstempels) im Jahr 1900. Sie führt zu einer Verbilligung der Zeitungen und, damit verbunden, zu einer deutlichen Auflagensteigerung. Ebenso bringt das Auftauchen neuer billiger, täglich erscheinender Massenblätter Bewegung in das Gefüge der Zeitungs- landschaft. 1893 erscheint erstmals das Neue Wiener Journal, 1900 die Illustrierte Kronen-Zeitung. Diese Konkurrenz zwingt auch die illustrierten Wochenblätter zu Veränderungen. Der Einsatz der Fotografie nimmt weiter zu, der Textanteil ist rückläufig. Aber auch das Verhältnis zwischen Text und Bild verändert sich. Das hat Auswirkungen auf die Umschlaggestaltung und auf die Seitengestaltung im Blattinneren.

Die grafische Gestaltung der meisten österreichischen illustrierten Zeitungen ist in den Jahren um 1900 recht konventionell und wenig experimentierfreudig. Während zur selben Zeit beispielsweise die großen Wochenzeitungen in den USA (u. a. Leslie's Weekly, Collier's Weekly, Harper's Weekly) ihre Umschlaggestaltung in rasanten Schritten modernisieren und auch die großen Berliner Blätter (etwa Die Woche, die Berliner Illustrirte Zeitung u. a.) allmählich auf gestalterische Innovation setzen, bleiben die Titelseiten der großen österreichischen Illustrierten lange Zeit auffallend unverändert. Nehmen wir als Beispiel eine durchschnittliche, fotografisch illustrierte Titelseite des Interessanten Blattes aus dem Jahr 1896 (Abb.3). Die Titelvignette, die sichtlich in der Tradition der Familienzeitschriften des 19. Jahrhunderts steht, nimmt etwa ein Viertel der Seite ein. Sie hat sich seit der Gründung des Blattes im Jahr 1882 praktisch nicht verändert und wird sich - bis auf ein paar kleinere grafische Anpassungen - auch in den nächsten vier Jahrzehnten nicht verändern. Für das Titelbild wird zwar ein Foto verwendet, aber die Szene selbst ist recht statisch. Derartige repräsentative Bilder werden häufig eingesetzt, hin und wieder werden auch mehrere Bilder kombiniert. Überraschende Schnappschüsse kommen hingegen kaum vor. Ohne Ausnahme wird das Eröffnungsbild gerahmt, nie findet ein abfallend gedrucktes, seitenfüllendes oder gar den Zeitschriftentitel überlappendes Motiv Verwendung, wie dies in den US-Magazinen der Jahrhundertwende bereits üblich ist.

Der Grund für diese konservative, beharrende gestalterische Linie liegt nicht im Unvermögen begründet, sondern in den Eigenheiten des österreichischen Zeitungsmarktes, der, wie bereits ausgeführt, klein und überschaubar ist. Dadurch ist die Auflagenentwicklung, im Unterschied etwa zum amerikanischen 
oder deutschen Markt, begrenzt, ebenso das Anzeigenaufkommen, das für die ökonomische Absicherung einer Zeitung unerlässlich ist. Dazu kommt, dass die Konkurrenz zwischen den österreichischen Illustrierten wenig ausgeprägt ist, nach 1911 erscheinen, wie bereits erwähnt, die beiden größten Blätter im gleichen Verlag. Und schließlich unterscheiden sich auch die rechtlichen Rahmenbedingungen der drei genannten Länder. In den USA schränkt keinerlei Kolportageverbot den Handel mit Zeitungen ein. Schon früh erkennen die Verleger die Kraft der Bilder und forcieren ihren Einsatz in der auflagenstarken Massenpresse. William Randolph Hearst, einer der Begründer der amerikanischen Yellow Press, schreibt 1887, am Beginn seiner journalistischen Karriere, an seinen Vater: „Illustrations embellish a page. They attract the eye and stimulate the imagination of the masses, and materially aid the comprehension of an unaccustomed reader and thus are of particular importance to that class of people which the Examiner claims to address. “8 Unter dem Druck der Sensationstagespresse passen sich auch die amerikanischen Illustrierten an. Die Titelblätter weisen bildgewaltig auf die im Inneren der Zeitung gebotenen Sensationen hin. Schon früh wird die seitenfüllende, oft überraschend inszenierte Fotografie zum entscheidenden Verkaufsargument.

\section{Kolportageverbot als Hemmschuh}

Ganz anders ist die Situation in Europa und speziell in Österreich. Der Staat reglementiert im 19. Jahrhundert das Pressewesen streng. Zwar schafft das österreichische Zensurgesetz von 1865 die härteste Repression ab und allmählich setzt sich in den 1870er Jahren ein liberaleres Klima in der Presselandschaft durch. Aber Zensur und Verbote, die die Aufgabe haben, missliebige Zeitungen und Meinungen im Zaum zu halten, werden bis zum Ersten Weltkrieg aufrechterhalten. Als besondere Gefahr gilt neben der nationalistischen (v. a. tschechischen) und der sozialdemokratischen Presse die populäre Massenpresse, die ein breites Publikum anspricht. So wie in anderen europäischen Ländern ist auch in Österreich der Zeitungsverkauf auf der Straße im gesam- ten 19. Jahrhundert (und darüber hinaus) verboten. In Deutschland fällt das Kolportageverbot, also das Verbot, Zeitungen im Straßenverkauf anzubieten, im Jahr 1904. In Österreich bleibt es noch bis nach dem Ersten Weltkrieg bestehen, es wird erst im Jahr 1922 abgeschafft. ${ }^{9}$ Mit dem Beginn des Straßenverkaufs ändert sich in Deutschland die Titelblattgestaltung deutlich. Über die Kolportage steigt, vor allem in den Städten, der Einzelverkauf rasant an. Daher müssen die Zeitungen Woche für Woche neue Sensationen bieten. Die traditionellen Titelvignetten werden zurückgedrängt oder verschwinden ganz. An ihre Stelle treten ein grafisch vereinfachter, leicht zu lesender Titel, ein oft seitenfüllendes, ausdrucksstarkes Foto und leicht zu erfassende Schlagzeilen in großen Lettern. Der auffallend gestaltete Umschlag wird zum kommerziellen Aushängeschild der Zeitung.

Die österreichischen Illustrierten werden weiterhin vorwiegend im Abonnement verkauft. Daher ist die bildlich innovative, auf den Straßenverkauf schielende, oft auch „reißerische“ Titelblattgestaltung lan-

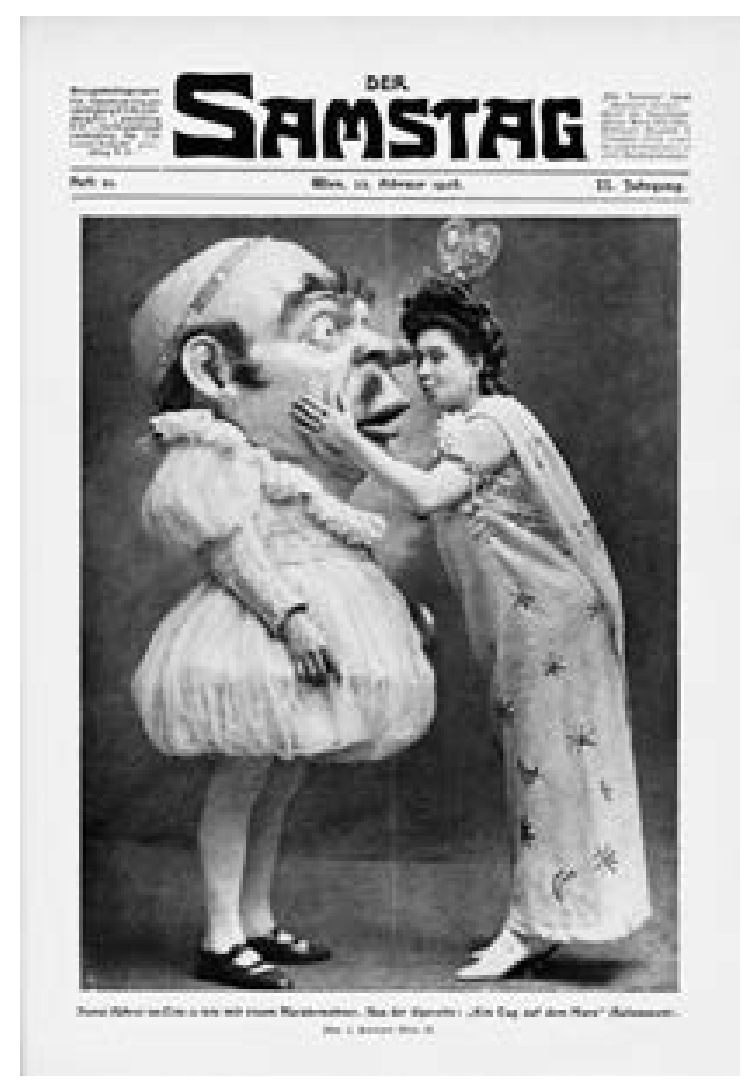

Abb. 4 Die Sängerin Hansi Führer in der Operette „Ein Tag auf dem Mars“, Etablissement Kolosseum, Wien, Nußdorfer Straße 4. Der Samstag, 22. Februar 1908. Foto: Ludwig Gutmann. 
ge Zeit kein Verkaufsargument. Dennoch gibt es Ausnahmen. Die seit 1906 existierende österreichische Wochenzeitung Der Samstag orientiert sich in der Titelblattgestaltung, aber auch im kleineren Format und zum Teil auch in der inhaltlichen Ausrichtung, deutlich an deutschen Vorbildern, insbesondere an der Woche. Die Woche erscheint seit 1899 im Berliner Scherl Verlag, sie ist von ihrer Ausrichtung her kaisertreu, konservativ und nationalistisch, kommerziell ist sie höchst erfolgreich. Sie avanciert hinter der Berliner Illustrirten Zeitung zur zweiten großen Illustrierten im Deutschen Reich. ${ }^{10}$ Auch das österreichische Pendant Der Samstag setzt - im Unterschied etwa zum Interessanten Blatt und den Wiener Bildern - auf großformatige, ausdrucksstarke Fotos auf dem Umschlag (Abb.4). Aktuelle Staatsereignisse dienen ebenso als visuelle Aufhänger wie herausragende kulturelle Ereignisse. Die Zeitung verzichtet auf dem Umschlag auf Schlagzeilen. Der Schriftzug des Titels ist einfach, klar und grafisch modern. Das Konzept geht freilich nicht auf, der Samstag stellt Anfang 1909 sein Erscheinen wieder ein.

Erst in den 1920er Jahren, als der Straßenverkauf auch in Österreich beginnt, setzen in der österreichischen Zeitungsszene weitreichende grafische Reformen ein. Während die traditionellen, etablierten Wochenzeitungen weiter bei ihrer Linie bleiben, bringen Neugründungen wie der sozialdemokratische Kuckuck oder der christlichsoziale Welt-Guck (beide erscheinen ab 1929) gestalterischen Schwung in die Illustriertenszene. ${ }^{11}$

\section{Das Diktat der Spalten}

Auch die Gestaltung des Innenteils der illustrierten Zeitungen steht in enger Verbindung mit ökonomischen, aber auch mit technischen Parametern. Solange die Leserschaft eine überschaubare, gutbürgerliche städtische Klientel anspricht, gibt es keinen Grund, sich in großen Schritten vom etablieren Modell der Familienzeitschrift des 19. Jahrhunderts zu entfernen. Nur zögernd modernisieren die österreichischen Illustrierten ihre Gestaltung und damit das Verhältnis von Text und Bild. Das grafische Grundraster ist bis weit ins 20. Jahrhundert hinein die meist dreispaltige Anordnung des Textes. Die Bilder werden schablonenartig in dieses starre Korsett eingepasst. Ihre Größe passt sich in der Regel der Spaltenbreite des Textes an. Nur gelegentlich schaffen sich die Bilder ein wenig Freiraum, indem sie den Fließtext aus ihrem Raster drängen, meist aber ohne einen tatsächlichen Dialog zwischen Text und Bild in Ganz zu setzen. Die beiden Medien bewegen sich jahrelang nebeneinander her. Bis weit nach der Jahrhundertwende ist es üblich, Text- und Bildblöcke getrennt zu präsentieren, oft folgen die erklärenden Texte zu den Bildern erst viele Seiten später.

Die Bilder werden lange Zeit als Zutaten zum Text und nicht als eigenständiges Medium mit einer ganz eigenen Sprache begriffen. Bis in die 1920er Jahre sitzen an den Redaktionstischen der illustrierten Wochenzeitungen fast ausschließlich Textredakteure, die für den Umbruch verantwortlich sind. Der Beruf des Fotoredakteurs ist in diesen Jahren noch unbekannt. Die Redaktionen sind klein, in der größten Wiener Illustrierten beispielsweise, dem Interessanten Blatt, sind nach der Jahrhundertwende neben dem Chefredakteur nicht mehr als drei bis vier fest angestellte Redakteure beschäftigt. Unterstützt werden diese durch freie Mitarbeiter. ${ }^{12}$ Zudem gibt es technische Beschränkungen. Solange Bilder und Texte in getrennten Arbeitsschritten gedruckt werden müssen, meidet man eine zu enge Verzahnung der beiden Medien. Erst als nach 1900 Druckmaschinen in Betrieb gehen, mit denen Bildklischees und Texte auf dieselben Metallrollen geätzt werden können, eröffnen sich weit mehr Möglichkeiten der Interaktion. Nach und nach bewegen sich die beiden Medien Bild und Text in der Zeitung aufeinander zu.

Am 3. Juli 1897 bringt Das interessante Blatt eine bemerkenswerte Bild-Text-Kombination, die den schwierigen Übergang zwischen Text- und Bildmedium andeutet. In der Mitte der Zeitungsseite ist ein eindrucksvolles Bild zu sehen, das einen irischen, in Paris lebenden Komiker zeigt (Abb. 5). Er ist als „Kunstpfeifer aus Paris“ international bekannt und wird anlässlich eines Wiener Gastauftritts porträtiert. Das vom französischen Fotografen Charles Teiner zugekaufte Brustbild wird freigestellt (auch das ist eine gestalterische Neuerung), um es in die dreispaltige 

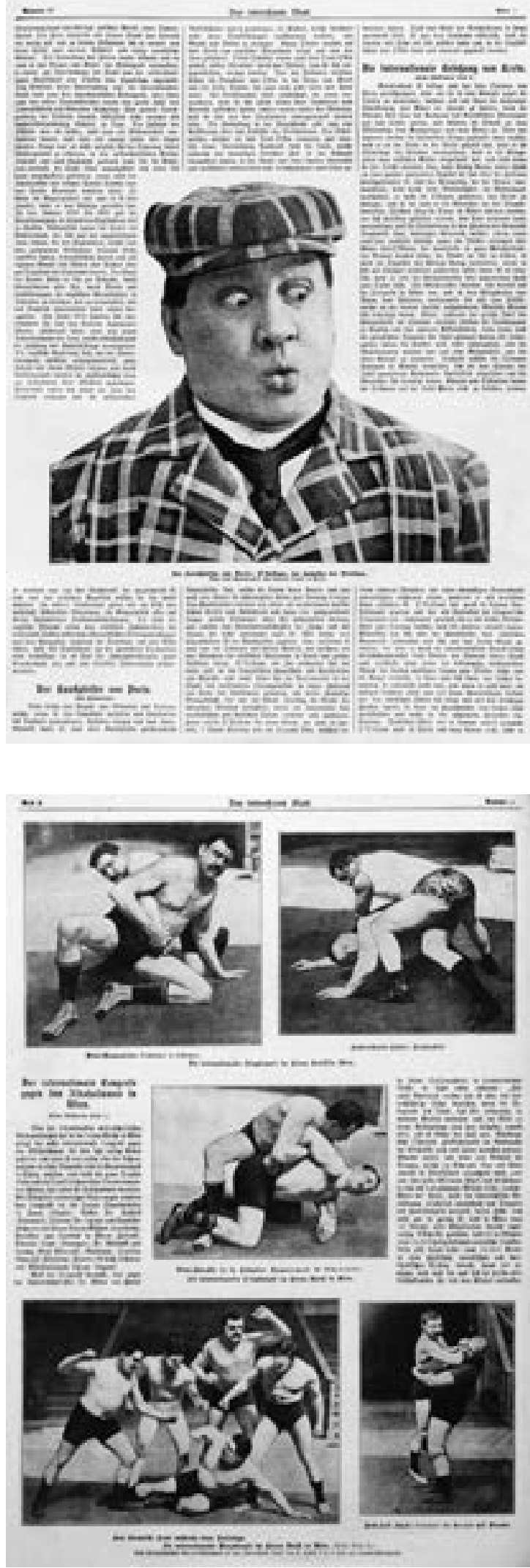

Textseite integrieren zu können. Der Artikel zum Foto findet sich auf derselben Seite, er umfließt das Bild gewissermaßen und tritt auf diese Weise mit ihm in einen ersten zaghaften Dialog.

Ein anderes Beispiel aus dem Jahr 1901 stellt einen internationalen Ringkampfwettbewerb im Wiener Zirkus Busch vor (Abb.6). Die Aufnahmen, sie

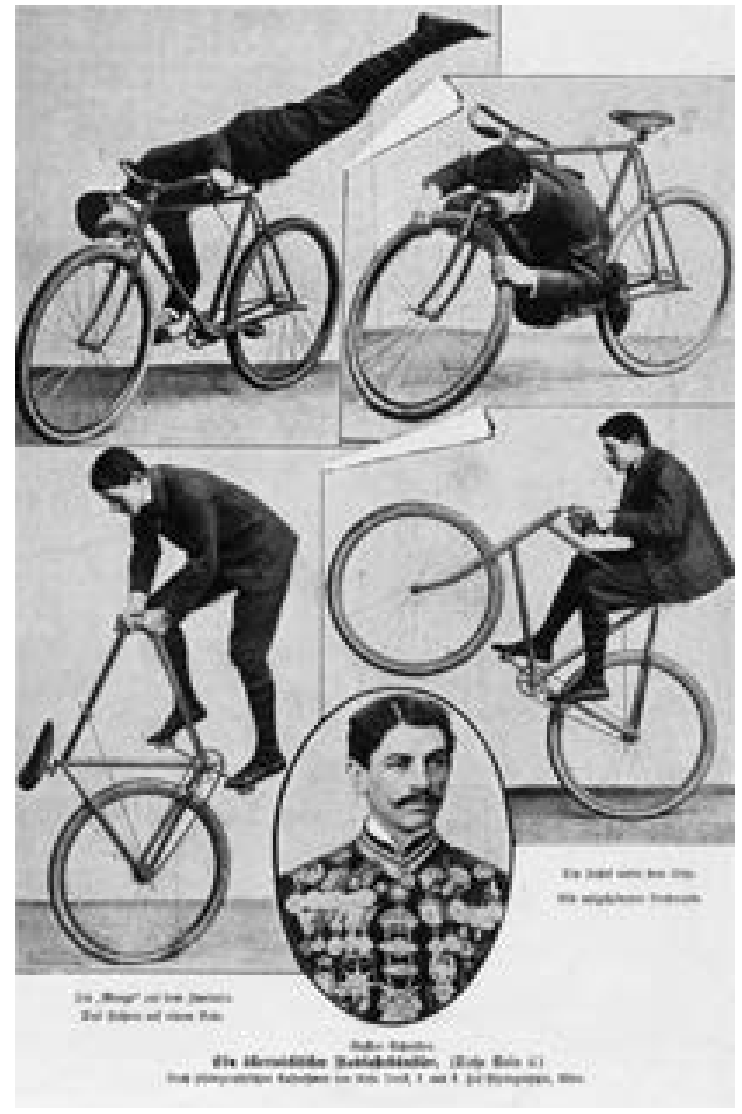

stammen vom Wiener Presse- und Sportfotografen Anton Huber, werden in das bestehende Spaltensystem eingepasst, allerdings ohne Bezug zum Text auf derselben Seite, der über ein ganz anderes Thema berichtet, nämlich einen internationalen Kongress gegen Alkoholismus. Dennoch ist die Gestaltung bemerkenswert. Denn die Fotos zeigen den Ringkampf scheinbar zeitgleich aus mehreren unterschiedlichen Blickwinkeln. Zusammengenommen ergeben die fünf Nahaufnahmen der Kämpfer eine kleine Bildgeschichte, die einiges von der Spannung und Dramatik des Ereignisses vermittelt.

Einen Schritt weiter geht eine Bildseite, die 1898 erscheint und die den Lesern die Kunststücke des Radkünstlers Gustav Schreiber vor Augen führt (Abb. 7). Die vier im Atelier angefertigten Szenenbilder stammen von der Wiener Fotografin Rosa Jenik, einer der wenigen Atelierfotografinnen, die schon sehr früh gelegentlich Bilder an die Presse liefert. Sie zeigen, wie der Artist auf seinem Rad einzelne
Abb. 5 Der beginnende Dialog zwischen Text und Bild. „O'Dyllyan, der Komiker des Pfeifens“. Das interessante Blatt, 3. Juli 1897, S. 7. Foto: Charles Teiner.

Abb. 6 Ringkampfwettbewerbe im Zirkus Busch in Wien. Das interessante Blatt, 18. April 1901, S. 6. Fotos: Anton Huber.

Abb. 7 Gustav Schreiber: ein österreichischer Radfahrkünstler. Das interessante Blatt, 28. Juli 1898, S. 5. Fotos: Rosa Jenik. 


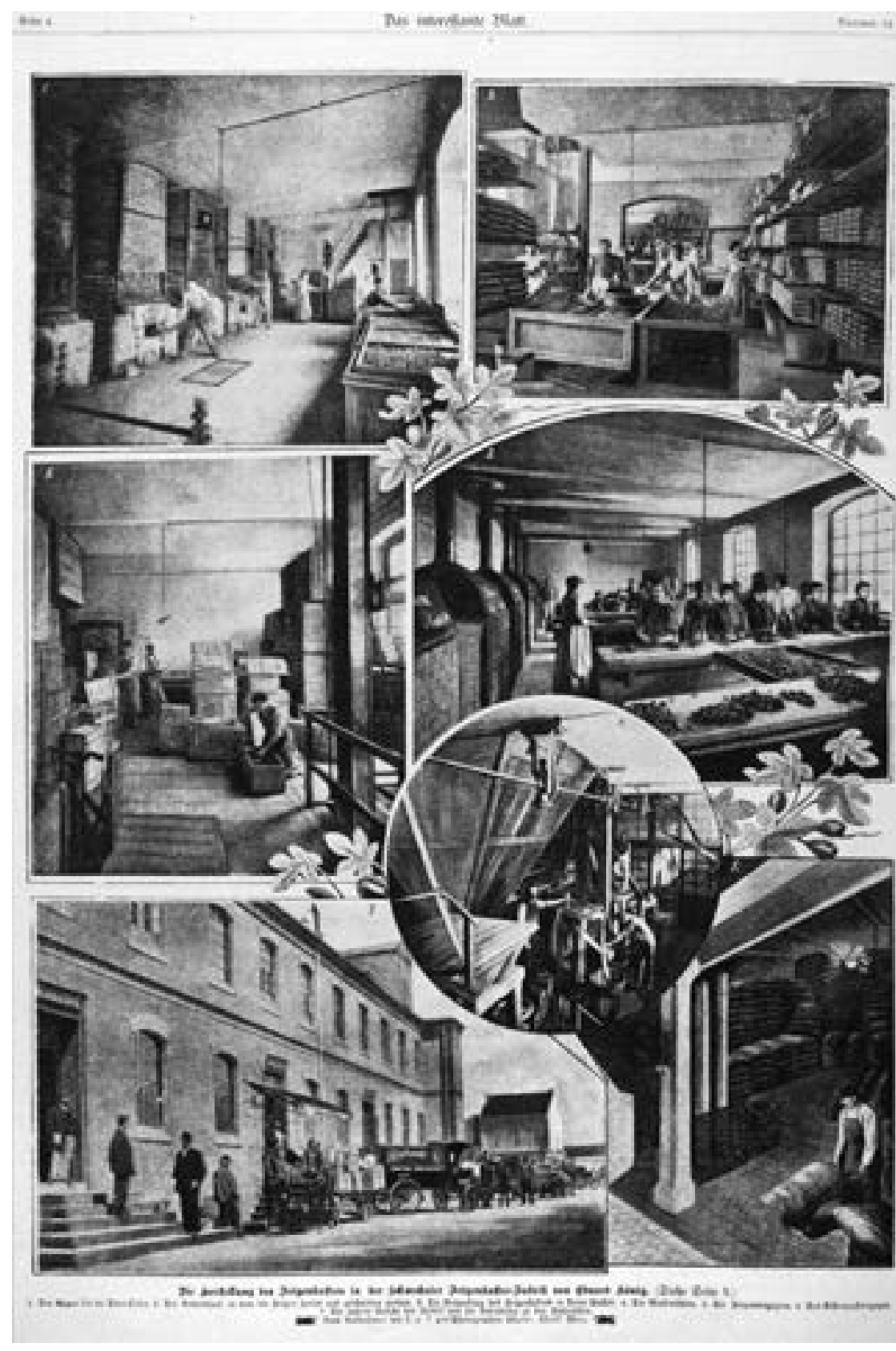

Abb. 8 Die FeigenkaffeeFabrik von Eduard König in Schwechat. Das interessante Blatt, 13. Juni 1895, S. 4. Fotos: Charles Scolik. aufsehenerregende Nummern vorführt. Diesmal ist der Text, bis auf die Bildlegenden, vollkommen von der Seite verbannt, eine kurze Beschreibung der Radkunststücke folgt auf der nächsten Seite. Ganz auf sich gestellt, entwickeln die Bilder im Ensemble eine eigene Aussage. Sie stoßen nun direkt aneinander, teilweise überlappen sie sich, grafisch unterstützt durch deutlich sichtbar gemachte Knicke an den Ecken. Im unteren Bereich der Bildfolge findet sich in einer ovalen Vignette ein Porträt des hochdekorierten Radfahrkünstlers. Gewissermaßen am Ende der Vorführung tritt der Hauptdarsteller auf die Bühne. Bildseiten wie diese, die allein der Kraft der Bilder vertrauen, finden sich in den illustrierten Zeitungen um 1900 freilich noch selten.

\section{Erzählende Bilder}

Als Mitte der 1890er Jahre die ersten fotografischen Bildgeschichten aufkommen, ist der Begriff der „Fotoreportage“ noch unbekannt. Dieser Terminus wird üblicherweise mit der Entwicklung der berichtenden Bilderzählung in den späten 1920er Jahren in Verbindung gebracht. ${ }^{13}$ Immer noch ist die These weitverbreitet, dass sich die Fotoreportage erst in der Zwischenkriegszeit herausgebildet habe. Diese These hat sich inzwischen als unhaltbar erwiesen. ${ }^{14}$ Bereits um die Jahrhundertwende tauchen in der illustrierten Presse vereinzelt Prototypen erzählender Bilder auf, die Elemente der späteren Fotoreportage verwenden: die enge inhaltliche und grafische Verzahnung von Bildern, die zu einer Art „Erzählung“ verbunden werden, die deutliche Dominanz der Fotos gegenüber dem Text, die Kombination von orientierenden Überblicksaufnahmen und erklärenden Detailaufnahmen, die ein Thema oder einen Gegenstand aus unterschiedlichen Blickwinkeln zeigen.

Ein frühes Beispiel für eine solche Bilderzählung erscheint am 13. Juni 1895 im Interessanten Blatt. Sie stellt die in Schwechat, südöstlich von Wien gelegene Feigenkaffeefabrik Eduard König vor (Abb. 8). Die Fotovorlagen stammen vom Wiener Fotografen Charles Scolik, der als einer der ersten Lichtbildner regelmäßig auch für die illustrierte Presse arbeitet. Die Bilder sind zeichnerisch sichtlich nachbearbeitet, um im Druck Konturen und Kontraste deutlicher zur Geltung zu bringen. In einer Überblicksaufnahme (links unten) wird das Fabrikgebäude von außen gezeigt, weitere Bilder bieten einen Einblick in die einzelnen Arbeitsräume. Eine runde Vignette zoomt einen der Arbeitsbereiche in einer halbnahen Aufnahme noch näher heran. Die Bilder sind nummeriert, kurze Legenden am unteren Rand liefern knappe Erklärungen. Ein Text auf der folgenden Seite hebt einzelne Arbeitsschritte hervor: „Wie unsere Illustration zeigt, wird der fertig gemahlene Feigenkaffee in einem geräumigen Magazine im Souterrain in kleine Pakete verpackt.“15

Die Ausführungen führen nicht nur in die Szenenfolge ein, sie erscheinen geradezu als Werbetext: „Wir haben in unserer Illustration von den aus vier Etagen, 
nämlich Keller, Souterrain, Hochparterre und 1. Stock bestehenden Fabriks-Gebäude (...) nur die interessantesten Locale aufgenommen, da der Raum in unserem Blatte die Aufnahmen sämtlicher Localitäten nicht gestattete, aber auch diese Bilder geben einen Beweis von der Größe dieser Fabrik, welche fast alle Koncurrenten in so kurzer Zeit siegreich aus dem Felde geschlagen hat und mit ihren ausgezeichneten und anerkannten Fabrikaten den Markt beherrscht.“16

Derartige Bilderzählungen tauchen um 1900 vermehrt auf, und dennoch: Gegenüber den weitaus häufiger verwendeten Einzelbildern bleiben sie deutlich in der Minderzahl. Wenn wir die Entstehungsgeschichte solcher mehrteiligen Bildensembles untersuchen, stoßen wir immer wieder auf Holzstiche, sehr oft amerikanischer Herkunft. Es gibt also offenbar eine ästhetische Verbindungslinie zwischen Zeichnung und Fotografie, die bisher kaum beachtet worden ist. Diese Kontinuität ist aber überaus spannend, zeigt sie doch, dass die Bildsprache der in Zeitungen gedruckten Fotografie um 1900 nicht aus dem Nichts entsteht, sondern teilweise ältere Medienentwicklungen aufgreift.

Nehmen wir als Beispiel einen Holzstich, der am 6. Oktober 1892 im Interessanten Blatt erscheint. Er trägt den Titel „Der Kampf gegen Eisenbahnräuber“ (Abb.9). Die siebenteilige Bildgeschichte erzählt in dramatischen Szenen von den Gefahren amerikanischer Eisenbahnüberfälle und dem Kampf der Polizei für Ordnung und Sicherheit. Der Hauptort des Geschehens, die bewachte Eisenbahn, wird in einer größeren Überblicksszene dargestellt. Diese zentrale Szene ist von kleineren, ineinander verschachtelten Bildern umgeben, die weitere wichtige Ereignisse zeigen. Die Protagonisten sind in ovalen Vignetten in das Geschehen eingeblendet. Der Holzstich ist nicht signiert. Auffallend ist, dass die Hauptdarsteller zwar Namen tragen, aber weder die Bildtexte noch der kurze begleitende Text auf derselben Seite nähere Orts- und Zeitangaben beinhalten. Der Grund dafür liegt darin, dass die Bildvorlage möglichst vielseitig einsetzbar sein soll. In der Regel werden derartige Holzstiche mehrfach gedruckt. Im vorliegenden Fall wurde das Bild nach Europa verkauft und, wohl Monate, vielleicht sogar Jahre nach seiner Herstellung, veröffentlicht.
Wenn man die Bildgeschichte über den Eisenbahnraub mit jener über die Feigenkaffeefabrik König vergleicht, wird deutlich, dass die fotografisch illustrierte Geschichte zahlreiche visuelle Elemente des Holzstichs übernimmt. Wie dieser setzt sie auf eine orientierende Überblicksszene, die den Ort des Geschehens vorstellt. Ähnlich wie beim Holzstich werden, geleitet durch nummerierte Bilder und kur-
Abb. 9 „Der Kampf gegen Eisenbahnräuber“. Das interessante Blatt, 6. Oktober 1892, S. 7.

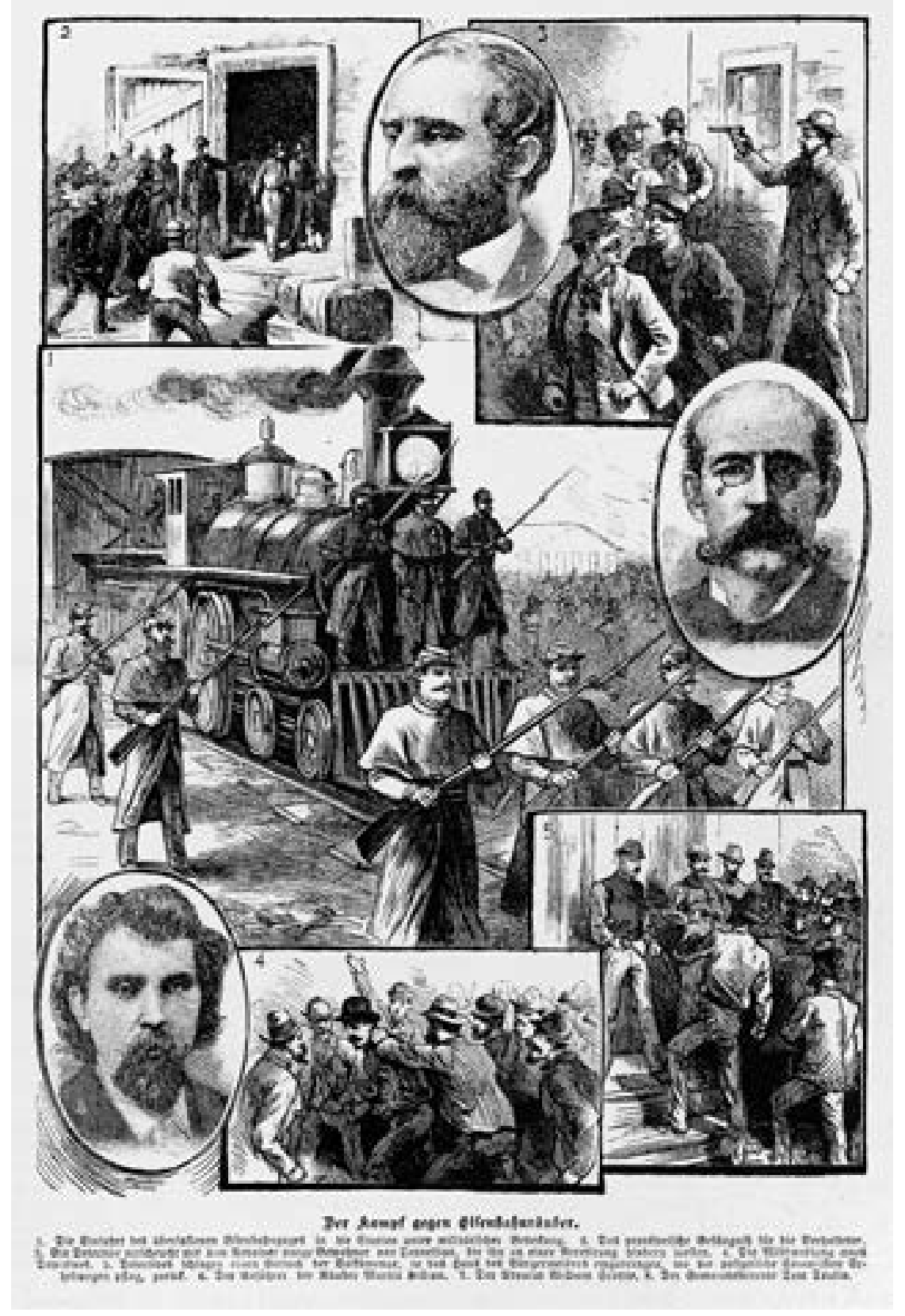



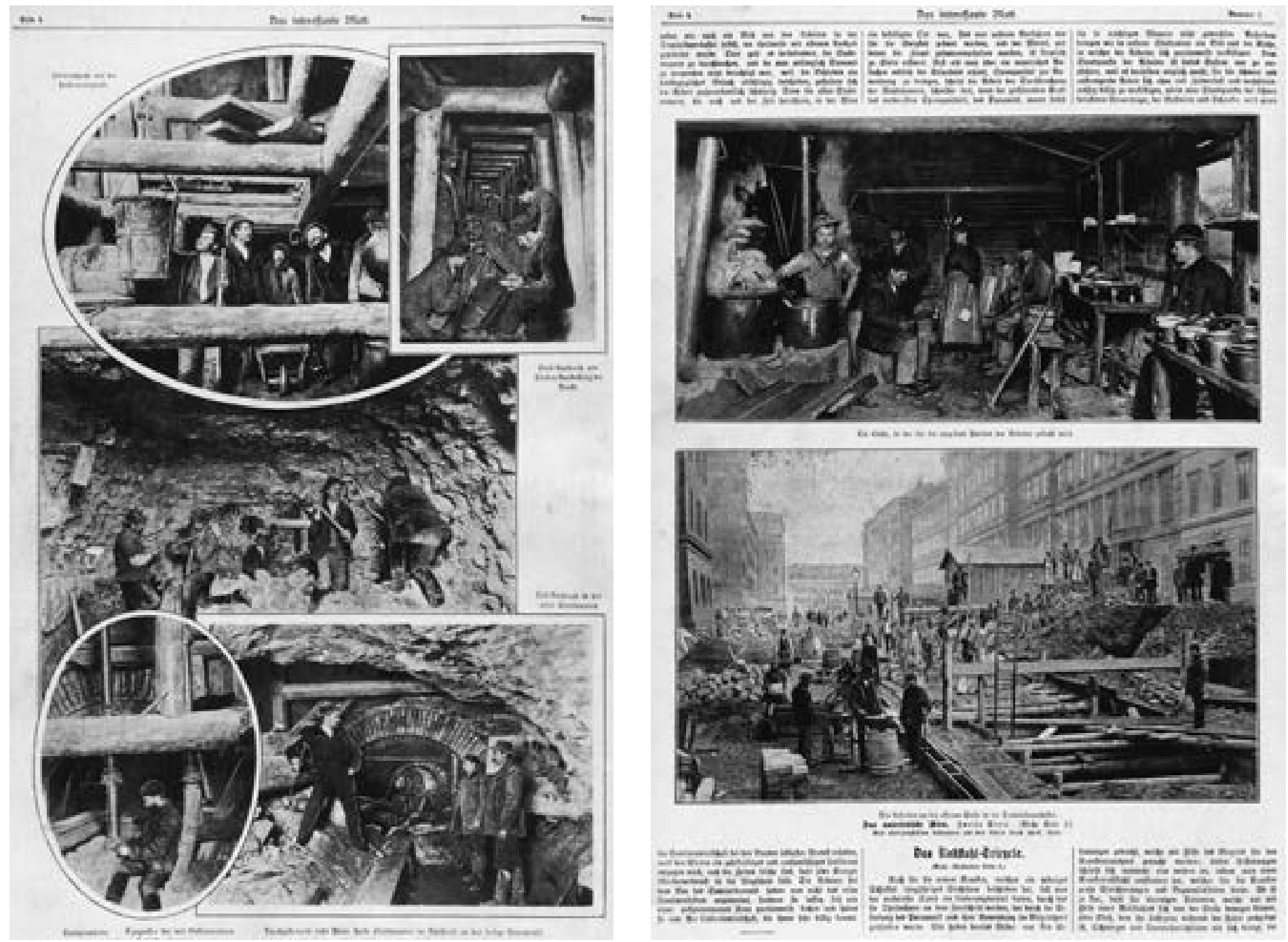

Abb. 10, 11 „Das unterirdische Wien“. Bau des Wiener Abwasserkanals, der die Stadt in einer Länge von sechs Kilometern durchquert. Das interessante Blatt, 27. Januar 1898, S. 4 (links) und 3. Februar 1898, S. 4 (rechts). Fotos: Atelier Louis Zwickl. ze Bildlegenden, gleichzeitig unterschiedliche Blicke auf die Szenerie eröffnet (auch wenn die Außenaufnahme in der Fotoreportage am Schluss steht). In beiden Fällen sind die Bilder grafisch eng miteinander verzahnt, sodass aus der Summe der Einzelbilder ein einziges Bildensemble entsteht. Hier wie dort dienen runde oder ovale Vignette der zoomenden Einführung wichtiger Details: der Protagonisten im einen Fall und einer Detailaufnahme im anderen.

\section{Auf dem Weg zur Fotoreportage}

Am 27. Januar 1898 erscheint im Interessanten Blatt unter dem Titel „Das unterirdische Wien“ eine Reportage, die in grafischer Hinsicht der modernen Form der Fotoreportage bereits deutlich näherkommt (Abb. 10). Die Bildseite berichtet über den Bau eines neuen Wiener Abwasserkanals, der bis zu 15 Meter tief unter der Stadt gegraben wird. Der Kanal durchquert die gesamte Stadt in einer Länge von sechs Kilometern. Zahlreiche Arbeiter sind Tag und Nacht im Einsatz. Eineinhalb bis zwei Meter dringen sie jeden Tag voran. Eine Woche später, am 3. Februar 1898, wird die Reportage mit einer weiteren Bildseite fortgesetzt (Abb. 11). „In der Millionenstadt“, heißt es im Bericht zu den Bildern, „wußte nur der geringste Theil der Bevölkerung von diesen interessanten Arbeiten, die viele Meter tief unter der Erde vorgenommen wurden, und die ein wichtiges Gebiet der Sanitätspflege der Stadt einer lang gewünschten Reform unterziehen sollen. "17 Die eindrucksvollen Bilder stammen vom Wiener Atelierfotografen Louis Zwickl, der als Experte für Blitzlichtaufnahmen gilt und daher besonders geeignet erscheint, unter Tage $\mathrm{zu}$ fotografieren.

Bemerkenswert ist die unterschiedliche Gestaltung der beiden Seiten. Bei der reinen Bildseite (vgl. Abb. 10) gelingt dem Grafiker ein dramaturgisch spannender Bildaufbau. Die Fotos sind eng miteinander verzahnt, Vignetten lenken den Blick auf besonders eindrucksvolle Details. Zum ersten Mal lösen sich die Bildlegenden vom unteren Rand und werden 
in der Nähe der Bilder platziert. Auf diese Weise entfällt die Notwendigkeit, Aufnahmen und Bildtexte zu nummerieren. „In unseren Illustrationen“, so heißt es zu dieser Seite, „bringen wir nach photographischen Aufnahmen ein Bild von den Arbeiten in dem Tunnelbau für den Sammelcanal, bei welchen Arbeiten sich insbesondere ein Mineur, Fredl, besonders auszeichnete und sich große Verdienste um die Durchführung der Arbeiten dadurch erwarb, daß er die anderen Arbeiter durch eigenen Fleiß aneiferte." ${ }^{18}$

Ganz anders die Gestaltung der zweiten Seite (vgl. Abb. 11). Die beiden Fotos werden mit einfachsten gestalterischen Mitteln in die Textseite eingepasst. Auch diesmal nimmt der Text auf die Fotos Bezug: „In unserer Illustration geben wir noch ein Bild von den Arbeiten in der Dominikanerbastei selbst, wo theilweise mit offenem Aushub gearbeitet wurde. Dort galt es insbesondere, die Stadtmauern zu durchbrechen, und da man anfänglich Dynamit zu verwenden nicht berechtigt war, weil die Behörden ein diesbezügliches Gesuch abschlägig beschieden, gestaltete sich die Arbeit außerordentlich schwierig. " ${ }^{19}$

„Außerdem bringen wir in unserer Illustration ein Bild aus der Küche, in welcher die Arbeiter sich partienweise verköstigen. Vom Standpunkte der Arbeiter ist dieses System nur zu empfehlen, weil es denselben möglich macht, für die schwere und anstrengende Arbeit sich ohne viel Zeitverlust und verhältnismäßig billig zu verköstigen, allein vom Standpunkte der schwer belasteten Steuerträger, der Gastwirte und Schänker, wird gegen die Cantinenwirtschaft bei den Bauten lebhafter Protest erhoben, weil den Wirten ein zahlkräftiges und konsumfähiges Publicum entzogen wird, und die Zeiten solche sind, daß jeder Kreuzer Minderverdienst in die Wagschale fällt. Die Arbeiter bei dem Bau des Sammelcanals haben nun nicht das reine Cantinensystem angewendet, sondern sie lassen sich von einer aufgenommen Frau partienweise kochen und haben so eine Art Collectivwirtschaft, die ihnen sehr billig kommt.“20

Wir haben bereits gesehen, dass um 1900 nur die reinen Bildseiten breitere Möglichkeiten der Bildgestaltung bieten. Denn für diese werden getrennte Druckvorlagen hergestellt. Sie ermöglichen es, zu experimentieren. Ein moderner Einsatz von Bilder- zählungen ist hier in den Grundzügen bereits ausgereift. Solche reinen Bildseiten werden allerdings relativ selten eingesetzt. Die klassischen, grafisch wenig innovativen Text-Bild-Seiten bleiben die Regel. Diese entwickeln sich in gestalterischer Hinsicht nur zögernd weiter. Bis weit in die Zwischenkriegszeit hinein herrscht hier das Diktat der Spalten.

Wieso ist das so? Warum setzt sich die Fotoreportage nicht bereits vor dem Ersten Weltkrieg in breitem Stil durch? Der Grund liegt darin, dass über Erfolg oder Misserfolg einer gestalterischen Idee weit mehr entscheidet als die technische oder grafische Machbarkeit. Die wirtschaftliche Basis des Unternehmens, die Auflagenentwicklung und die Art der Leserschaft sind ebenso entscheidend für die Weiterentwicklung des grafischen Konzepts. Die österreichische illustrierte Presse vor dem Ersten Weltkrieg ist durch eine schwach ausgeprägte Wettbewerbssituation gekennzeichnet. Der ökonomische Druck in Richtung Innovation ist gering. Eigentümer und Redakteure der Zeitungen scheuen vor allzu viel Innovation und radikalen grafischen Einschnitten zurück.

Aber nicht nur in Österreich, auch in anderen Ländern setzt sich vor dem Ersten Weltkrieg die Fotoreportage nicht wirklich durch. Ebenso wie der Fotodruck als „authentischeres“ Bildmedium erst Jahre nach seiner technischen Einführung allgemein im Gebrauch ist, liegt auch bei der Fotoreportage eine große Zeitspanne zwischen Konzept und breiter Umsetzung. Erst Ende der 1920er geht ein Modernisierungsschub durch die illustrierte Presse. Nun treten die ersten professionellen Fotoredakteure auf, erstmals bieten ausgewählte Fotografen und Fotoagenturen nicht mehr nur Einzelbilder an, sondern verkaufen ganze Bildgeschichten - Fotoreportagen eben. ${ }^{21}$ Unter dem Druck konkurrierender innovativerer Medien und unter dem popularisierten Eindruck der Avantgardekultur entschließen sich auch die bürgerlichen Zeitungen zu Reformen. Die „Erfindung“ der Fotoreportage Ende der 1920er Jahre, die oft als wichtige Zäsur gedeutet wird, ist in Wirklichkeit das Ergebnis einer nachholenden Modernisierung. Gerne wird vergessen, dass die gestalterischen Zutaten eines erzählenden Umgangs mit Fotografie schon lange vor dem Ersten Weltkrieg entwickelt wurden. 


\title{
Redaktion, Druck, Vertrieb
}

\author{
Wie eine illustrierte Zeitschrift entsteht
}

„Die Zeitung ist zum täglichen geistigen Brote des Volkes und die Verbreitung derselben zu einem Culturmesser geworden. Trotzdem haben erstaunlicherweise nur wenige Leser eine Vorstellung, wie eine Zeitung gemacht, geschrieben, gesetzt, gedruckt und expediert wird." 1 So heißt es im Interessanten Blatt am 18. November 1897. Und sogleich wird ein Zipfel des Geheimnisses gelüftet. Der Text wirft einen Blick hinter die Kulissen der Zeitungsproduktion. Und ein beigefügtes Foto zeigt den Druckereisaal der Firma Waldheim, in dem Das interessante Blatt hergestellt wird (Abb. 1). Um die Wirkung der Aufnahme zu erhöhen, wird das querformatige Bild im Hochformat gedruckt, man muss also die Zeitung drehen, um die Ansicht im Detail betrachten zu können.

Die Aufnahme ist beeindruckend, immerhin handelt es sich um das erste in einer österreichischen Zeitung veröffentlichte Foto, das eine moderne Zeitungsdruckerei im Betrieb zeigt. Eindrucksvoll ist aber auch die Inszenierung. Der Fotograf hat seine Kamera erhöht positioniert, um den ausgedehnten Saal von oben überblicken zu können. Etwa zwei Dutzend Angestellte - der Großteil von ihnen ist weiblich - haben hinter ihren Maschinen Aufstellung genommen. Viele von ihnen blicken in die Kamera. Im Vordergrund des großen Raumes ist der Leiter der Druckerei zu erkennen. Die Frauen und Männer arbeiten an den elektrisch betriebenen „Illustrations-Druckmaschinen“, auf denen sich Druckproben und fertige Zeitungsblätter stapeln. Bei den Maschinen handelt es sich noch zur Gänze um Flachdruckund Lithografiemaschinen, Rotationsdruckmaschinen werden erst gut ein Jahrzehnt später aufgestellt. Um die Lichtverhältnisse zu optimieren, ist der Drucksaal mit einem verglasten Dach versehen, das bei direkter Sonneneinstrahlung mittels großer Tuchbahnen abgedeckt werden kann.

„Wenn ein illustriertes Journal wie das ,Interessante Blatt` im Laufe der Jahre eine geradezu colos- sale Auflage erreicht, so daß manche Nummer in hunderttausend Exemplaren expediert wird, muß darauf gesehen werden, daß der Druck so rasch als möglich vor sich geht, ohne daß aber die Deutlichkeit und die künstlerische Ausführung der Illustration leidet. Das ,Interessante Blatt' hat sich daher an eines der größten Drucketablissements in Wien, R. v. Waldheim, gewendet, um allen Anforderungen gerecht zu werden. Diese glänzend eingerichtete Druckerei hat, um die Auflage des ,Interessanten Blattes', den künstlerischen Intentionen dieses publicistischen Unternehmens entsprechend zu genügen, bewältigen $\mathrm{zu}$ können, neue Maschinen aufgestellt, die wir heute im Bild bringen."2

Ganz zufällig ist es nicht, dass die führende illustrierte Zeitschrift des Landes, Das interessante Blatt, kurz vor der Jahrhundertwende erstmals einen Blick hinter die Kulissen des Druckgewerbes freigibt. Denn in diesen Jahren ist der Bilderdruck in der Zeitung in einem radikalen Umbruch begriffen. Das Foto ist dabei, die Zeichnung zu ersetzen. Praktisch alle illustrierten Wochenzeitungen stellen auf den Fotodruck, die Autotypie, um. Damit steigen die qualitativen Herausforderungen an den Bilderdruck. Um den neuen Ansprüchen genügen zu können, sind umfangreiche technische Auf- und Umrüstungen notwendig, die bis zum Ersten Weltkrieg andauern. Stolz präsentiert das Blatt den hohen technischen Standard seiner Hausdruckerei Waldheim - natürlich in einer Fotografie und nicht in einer Zeichnung.

Eineinhalb Jahrzehnte später lüftet Das interessante Blatt ein weiteres Mal den Vorhang. Der Anlass ist ein weiterer radikaler Modernisierungsschritt. Das Blatt zieht im Frühjahr 1912 in ein neues Verlagsgebäude im 3. Wiener Gemeindebezirk (Rüdengasse 11). Diesmal reicht ein einzelnes Foto aus dem Drucksaal nicht aus, um die Herstellung einer illustrierten Zeitung zu veranschaulichen. Den Lesern wird am 16. Mai 1912 unter dem Titel „Das neue Heim des 
Interessanten Blattes" gleich eine mehrseitige Fotoreportage geboten, die die einzelnen Arbeitsschritte der Produktion in allen Details darstellt. ${ }^{3}$ Dass diese Reportage außergewöhnlich ist, darauf wird einleitend ausdrücklich hingewiesen: „In den dreißig Jahren seines Bestehens hat das Interessante Blatt nur höchst selten in eigener Sache das Wort ergriffen, ist kaum einmal in vielen Jahren aus der Anonymität eines gewissenhaften Schilderers der Zeitereignisse in Wort und Bild herausgetreten, um von den Vorgängen zu erzählen, die mit seinem eigenen Werden und Wachsen verknüpft waren. “4 Gerade weil dieser Bildbericht Seltenheitswert hat, ist er als Quellenmaterial zur Funktionsweise der illustrieren Presse so bedeutsam und soll hier ausführlich vorgestellt werden. Es handelt sich um eine frühe fotografisch illustrierte
Beschreibung, die das komplexe technische und organisatorische Räderwerk hinter den Kulissen der sich entwickelnden fotografischen Öffentlichkeit darstellt. Die Reportage zeigt, dass die fotografisch illustrierte Zeitung nicht bloß eine Weiterentwicklung der bilderlosen Tages- und Wochenpresse ist, sondern dass sie ganz anderen medialen, technischen und kommerziellen Gesetzmäßigkeiten gehorcht.

\section{Ein Blick hinter die Kulissen: \\ Redaktion, Fotoatelier, Klischeeanstalt}

Das Verlagshaus, in dem Das interessante Blatt und die Wiener Bilder - die beiden Blätter sind seit 1911 Teil desselben Konzerns - untergebracht sind, ist ein Neubau (Abb. 2). Er wird von der Österreichischen
Abb. 1 Druckereisaal der Firma Waldheim, in dem Das interessante Blatt hergestellt wird. Das interessante Blatt, 18. November 1897, S. 5.

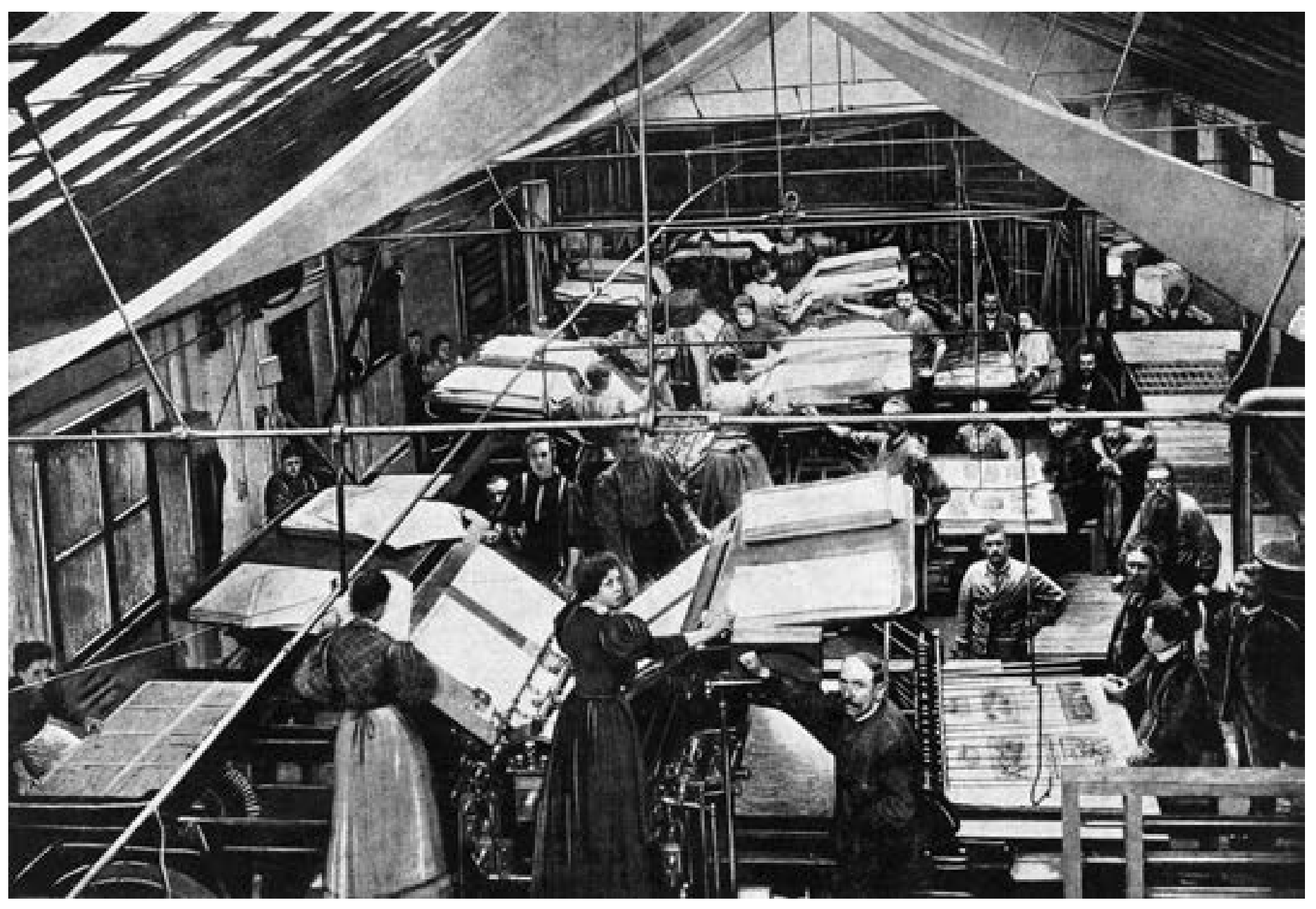



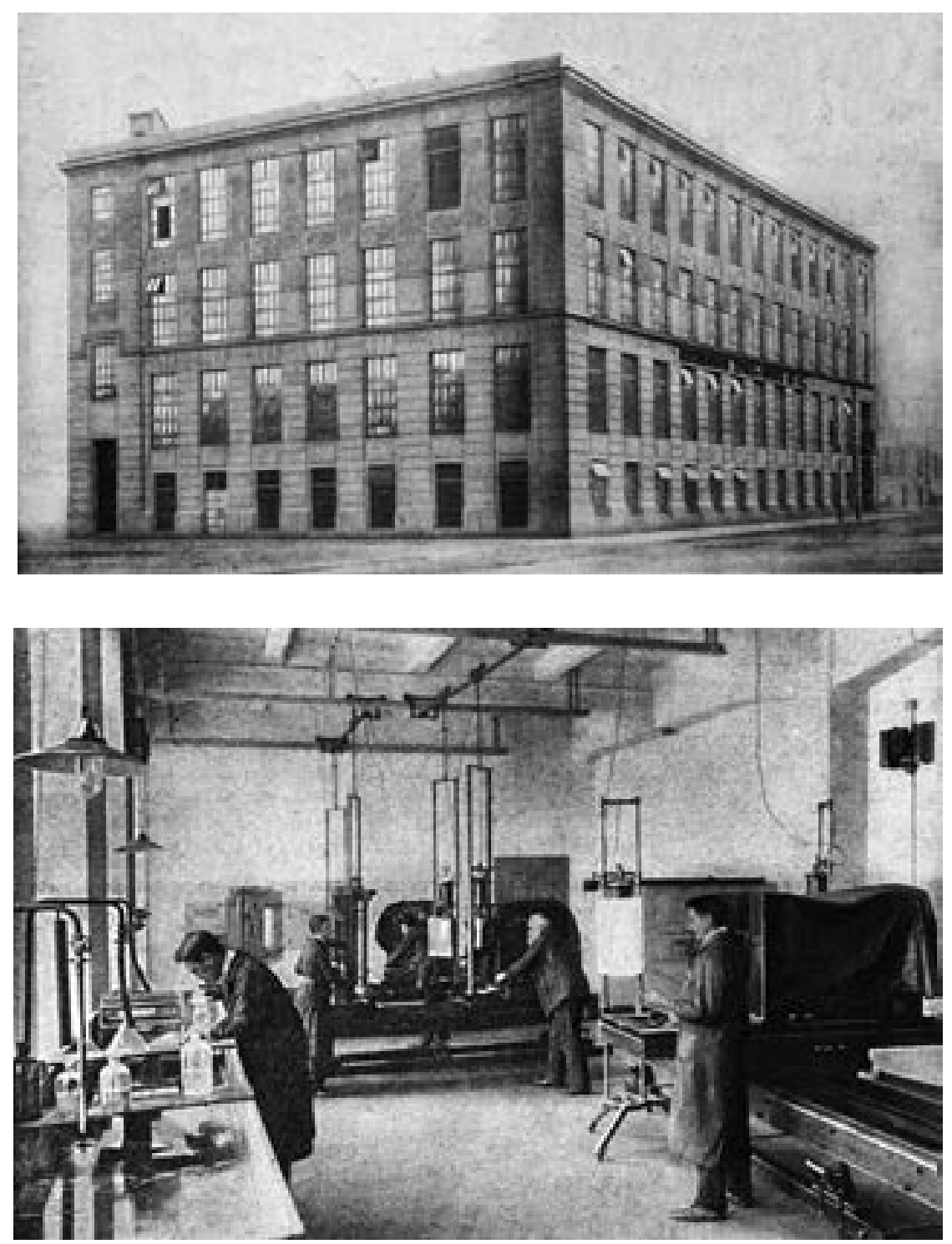

Abb. 2 Das neu errichtete Gebäude des Interessanten Blattes in der Rüdengasse 11 im 3. Wiener Gemeindebezirk. Das interessante Blatt, 15. Mai 1912 , S. 2.

Abb. 3 Das fotografische Atelier. Das interessante Blatt, 15. Mai 1912, S. 2.
Zeitungs- und Druckerei-Aktiengesellschaft errichtet und Anfang 1912 eröffnet. ${ }^{5}$ Der neue Firmensitz vereint Verlagshaus, Druckerei, Redaktion und Auslieferung unter einem Dach. Das hochmoderne Gebäude ist, so heißt es in der Reportage, „ein Eckhaus mit 42 Meter Front in der Länge, 24 Meter in der Breite. Fünfzehn 1,80 Meter breite Fenster an der einen, sieben ebenso breite Fenster an der anderen Front gewähren den denkbar vollsten Lichteinlaß. Überdies ist durch die Anlage zweier Höfe dafür gesorgt, daß das Tageslicht von zwei Seiten her auch in alle inneren Arbeitsräume des Hauses eindringen kann. Die einzelnen Säle des ganzen Hauses sind 4,50 Meter hoch, der glasüberdeckte Hof, in dem die Rotationsmaschinen stehen, hat 6 Meter Höhe. Der Verkehr im Innern des Hauses wird durch eine Haupttreppe, eine sogenannte Sicherheitstreppe (Feuerstiege) und eine eiserne Wendeltreppe für die interne Verbindung der Arbeitsräume untereinander vermittelt.“6
Auch innen entspricht die Ausstattung allen Erfordernissen des modernen Verlags- und Druckgewerbes. Folgen wir der Reportage noch ein Stück weit: „Das ganze Haus ist mit Zentralheizung versehen und ausschließlich elektrisch beleuchtet. Kohlenheizung ist aus Reinlichkeitsgründen nirgends angewendet, vielmehr sind sämtliche Heizanlagen im Gebäude, die für den Betrieb dienen, Gasheizungen. An Aufzügen gibt es einen elektrischen und einen Handaufzug zur Kommunikation der Betriebsräume untereinander, sowie zur Hinauf- und Hinabbeförderung der Waren. Zwei weitere Aufzüge dienen zur Wareneinlieferung und -ablieferung. Auf durchaus solide Bauart wurde größte Rücksicht genommen. Die Decken eines jeden Stockwerks vertragen eine Belastung von 2000 Kilogramm per Quadratmeter, so daß selbst die schwersten Maschinen in allen Stockwerken zur Aufstellung gelangen können. Für das flache Dach kam eine Eisenbetondecke zur Anwendung, die für eine Belastung von 1500 Kilogramm per Quadratmeter berechnet ist, so daß bei der in Aussicht genommenen Vergrößerung des Betriebes ein drittes Stockwerk, ebenfalls zu industriellen Zwecken, wird aufgesetzt werden können. Das Haus besteht derzeit aus Souterrain, Hochparterre und zwei Stockwerken. Erwähnenswert ist, daß sämtliche Maschinen im ganzen Gebäude mit Einzelantrieb ausgestattet sind, so daß jede Maschine unabhängig von den anderen arbeitet und kleinere Defekte den Betrieb nicht lahm legen können."7

Nach dieser Beschreibung der baulichen Struktur folgt ein Gang durch das Haus. „Die Einteilung des Gebäudes können wir in der Weise schildern, daß wir die Herstellung des Blattes vom Anfang bis zum Ende verfolgen. Wir beginnen demnach mit den Redaktionsräumen, die im zweiten Stockwerke untergebracht sind und mit einem großen Photographien-Archiv in Verbindung stehen. Hier liegen außerdem die Administrationsräume, die Abteilungen für die Korrespondenz und sämtliche Verwaltungsräume, wie die Zentralkassa, die Zentralbuchhaltung, sowie die Telephonzentrale. Die letztere umfaßt drei Staatstelephone, mit neun Nebenstationen für den auswärtigen Verkehr und eine eigene Anlage mit 21 Nebenstellen für den internen Verkehr. An die Redaktionsräume 
schließen sich ein großer Sitzungssaal für den Verwaltungsrat, sowie das Bureau des Präsidenten an.

Im selben Stockwerk ist der Zweckmäßigkeit halber auch der Zeichensaal sowie die chemigraphische Kunstanstalt eingerichtet. Unsere Bilder zeigen das photographische Atelier (Abb. 3), das mit den modernsten Reproduktionsapparaten ausgestattet ist. Jeder einzelne hier beschäftigte Photograph hat seine eigene Dunkelkammer, um ungehindert arbeiten zu können. Die Bilder-Klischees werden nach einem neuen, ,Drakopie‘ genannten, Verfahren, der Erfindung des bekannten Reproduktions-Technikers Doktor Albert in München, das sonst in Österreich bisher nirgends eingeführt ist, hergestellt. Durch dieses Verfahren sind wir in der Lage, die Klischees auf unvergleichlich schnellerem Wege, als das bisher möglich war, herzustellen. An das photographische Atelier schließt sich der Kopierraum, die Ätzerei und der Montageraum.

Die fertigen Klischees werden mittelst Aufzuges sofort in den Maschinensaal hinabbefördert. Sämtliche Aufnahmen werden ausschließlich bei elektrischem Licht gemacht, ebenso wird nur bei elektrischem Licht kopiert, um von den Vorteilen der besonderen Raschheit unseres Verfahrens zu jeder Tageszeit profitieren und, unabhängig vom Tageslicht, unsere Klischees stets in derselben Weise herstellen zu können. Die mit allen Hilfsmaschinen reichlich ausgestattete Abteilung ist nicht nur für den internen Bedarf des Blattes berechnet, vielmehr setzen uns ihre glänzenden technischen Einrichtungen in die Lage, auch allen von auswärtigen Kunden an uns gestellten Anforderungen auf dem Gebiete des Klischeewesens nachzukommen und derartige Aufträge bei kürzester Lieferfrist tadellos auszuführen."

Die Herstellung der fotografischen Klischees - in Zink, Kupfer oder Messing - gehört zu den teuersten und technisch aufwendigsten Arbeitsschritten im gesamten Bilderdruck. Viele Zeitungen lagern derartige Arbeiten daher ganz oder teilweise aus. Zu den bekanntesten Wiener Kunstanstalten und Druckereien, die chemigrafische Abteilungen unterhalten, gehören um 1900 die Firmen Angerer \& Göschl, Max Perlmutter, Ludwig Albin Ebert, Max Jaffé, Philipp \& Kramer, die Graphische Union und - als eine Art Marktfüh- rer - Patzelt \& Krampolek. ${ }^{9}$ Das interessante Blatt verweist stolz darauf, dass im neuen Verlagsgebäude diese bisher nach außen delegierten Arbeiten nun im eigenen Haus erfolgen. Damit sind alle Arbeitsgänge in der Herstellung einer Zeitung, nämlich Redaktion, Klischeeanstalt, Setzerei, Druckerei und Auslieferung (Expedition) unter einem Dach vereint.

\section{Satz, Druckerei, Auslieferung}

Wir kehren wieder zu unserem Rundgang zurück. „Aus der Redaktion kommen die Manuskripte ein Stockwerk tiefer in die Setzerei, wo der Satz für die Zeitung hergestellt wird, um dann in der Stereotypie (Abb.4) in gebogene Blechklischees verwandelt zu werden, wie man sie für die Rotationsmaschinen braucht. Demgemäß befinden sich im ersten Stockwerke die Hand- und Maschinensetzerei, die Rund- und Flachstereotypie, die Kontorräume für die Druckerei, die Korrektorenzimmer etc. In der Setzerei sind zur Erleichterung der Reinlichhaltung die Wände in der Höhe von zwei Metern mit waschbarem Anstrich versehen. Vom hygienischen Standpunkt ist, außer der guten Ventilation und der reichlichen
Abb. 4 Die Stereotypieateilung. Hier werden die aus beweglichen Lettern gesetzten Druckseiten über eine Matrize in Klischees verwandelt. Für den Flachdruck werden ebene Druckplatten hergestellt, für den Rotationsdruck gebogene Blechklischees. Im Vordergrund die Kessel zum Gießen der Bleiplatten. Das interessante Blatt, 15. Mai 1912, S. 3 .

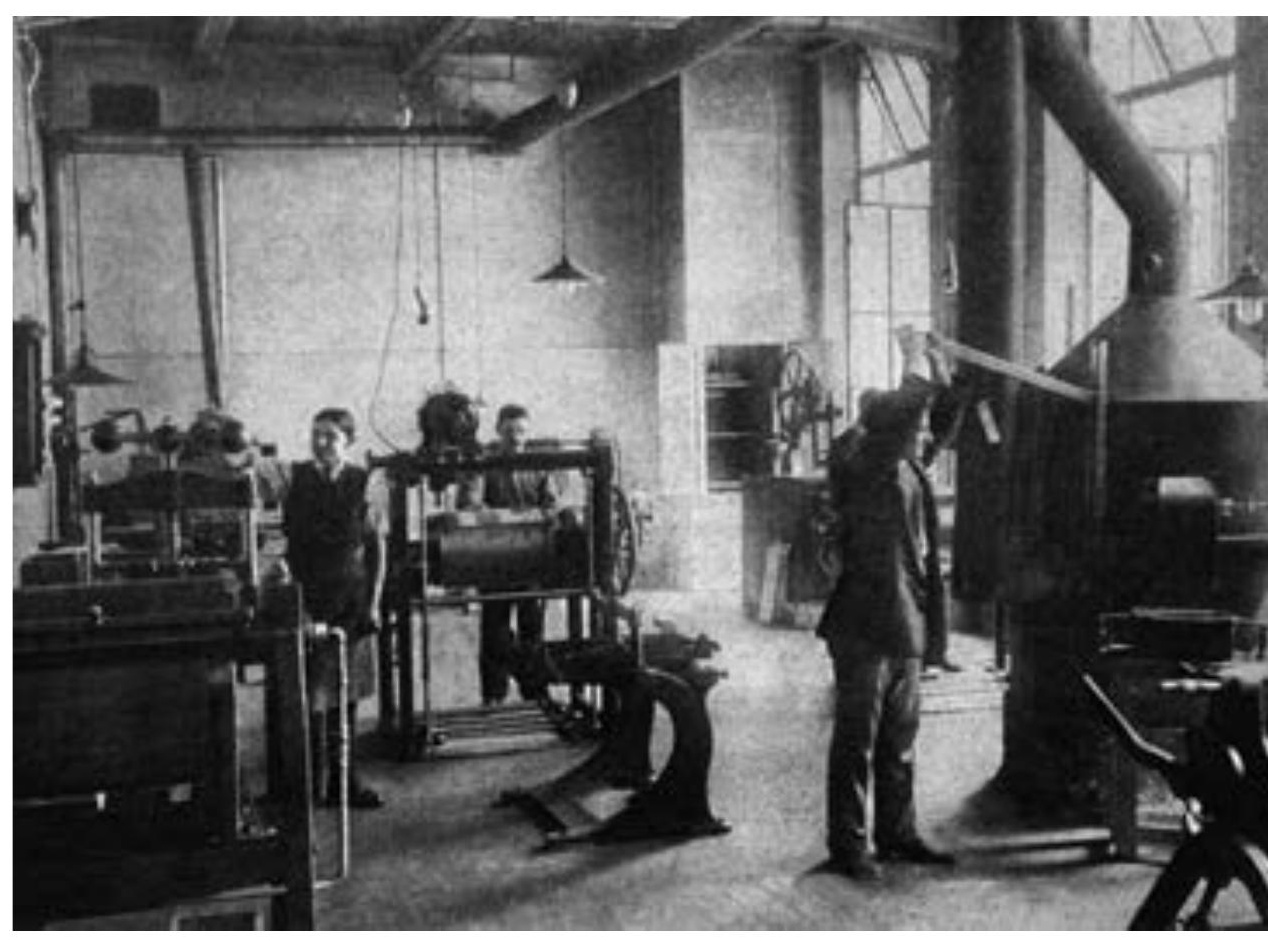


Abb. 5 Die Rotationsdruckmaschinen. Pro Stunde können 5000 16-seitige illustrierte Zeitungen gedruckt, geschnitten und gefalzt werden. Das interessante Blatt, 15. Mai 1912, S. 4 .

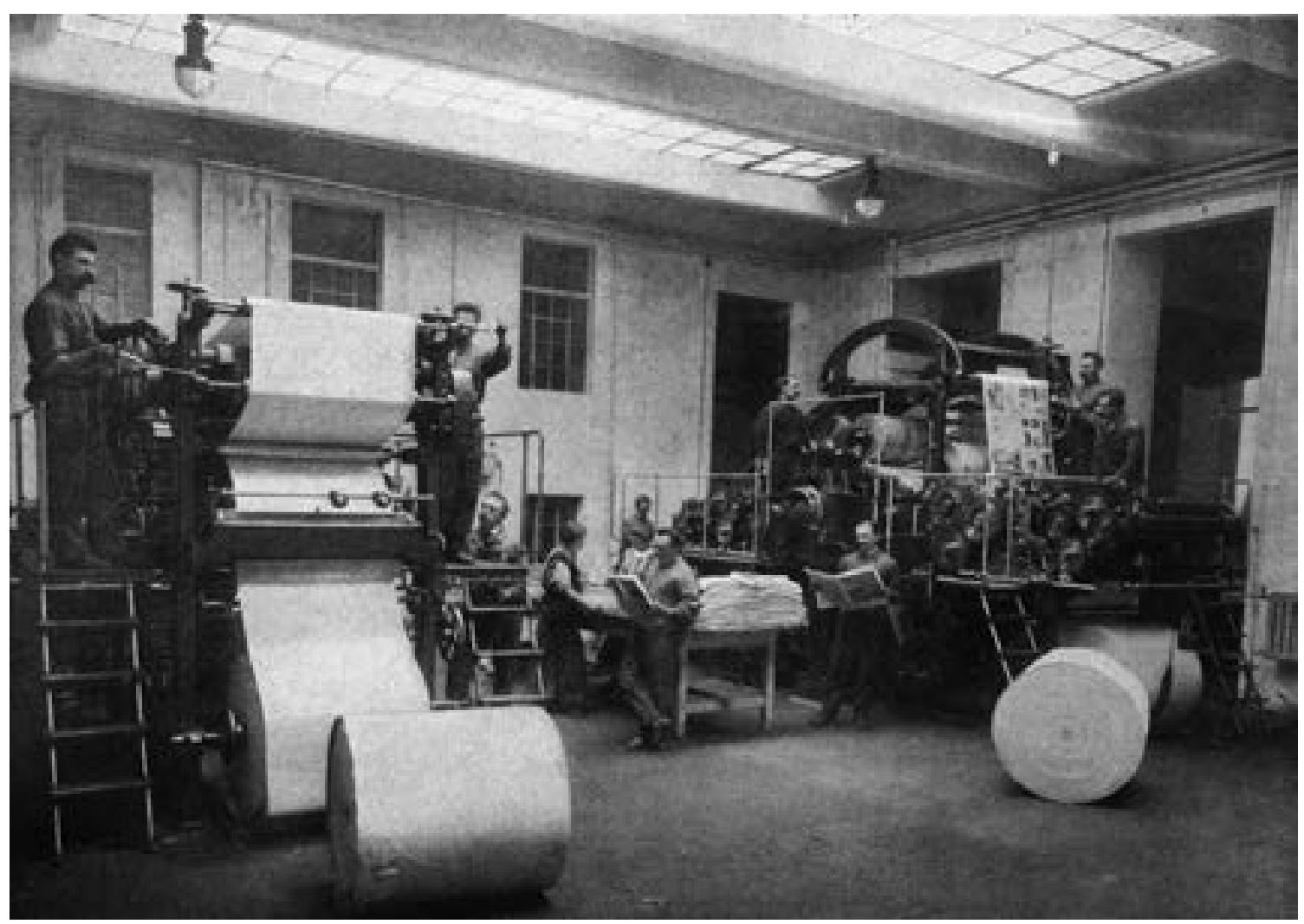

Lichtzufuhr, die Breite der Gänge zwischen den einzelnen Setzregalen - 1,50 Meter - hervorzuheben. Selbstverständlich stehen, wie heute allgemein bei den großen Zeitungen, nur die modernsten Setzmaschinen in Verwendung. Der Setzersaal wie auch alle anderen Arbeitsräume sind mit der Redaktion sowie untereinander telephonisch und durch Aufzüge verbunden. Jeder Setzer hat seinen eigenen Garderobekasten; außerdem stehen allen hier Beschäftigten separate Waschräume zur Verfügung. Die Stereotypie, die, wie erwähnt, die Bleiklischees herstellt, ist mit der Setzerei durch ein Schubfenster verbunden, durch welches die zur Stereotypie zu befördernden Kolumnen derart befördert werden können, daß ein Eindringen der beim Bleischmelzen entwickelten ungebundenen Dämpfe, welche in der Stereotypie durch mechanische Ventilatoren abgeleitet werden, in die übrigen Arbeitsräume verhindert wird. Zum Gießen der Bleiplatten dienen zwei mit Gas geheizte Bleikessel, von denen der größere einen Fassungsraum für 1500 Kilogramm Blei hat." 10

Ein weiteres Stockwerk tiefer: „Das Hochparterre enthält einen Flachdruckmaschinensaal und die Steindruckerei. Diese beiden Abteilungen dienen nur teilweise zur Herstellung unserer Zeitung und sind in erster Linie zur Ausführung der uns von unserem großen Kundenkreis übermittelten Aufträge jeder Art bestimmt. Auch in diesen Abteilungen sind wir mit den modernsten Buchdruck- und Steindruckschnellpressen vom kleinsten bis zum größten Format ausgestattet und sind für alle Arten von Arbeiten sowohl im Ein- wie im Mehrfarbendruck auf das Beste eingerichtet. Dadurch, daß wir außer der Buch- und Steindruckerei unsere eigene Klischeeanstalt und Buchbinderei im Hause haben, sind wir in der Lage, nicht nur Bücher mit Illustrationen, illustrierte Zeitungen und Kommerzdrucksorten, sondern insbesondere auch Arbeiten, wie illustrierte Kataloge und Preislisten in der raschesten Zeit derart herzustellen, daß der Besteller es bei der Auftragerteilung nur mit einer einzigen Firma zu tun hat und die Arbeiten in einer Hand konzentriert sind. Wie in den anderen Betriebsräumen, ist auch hier für die Hygiene der Arbeit durch Garderobevorrichtungen für die einzelnen Angestellten und durch Waschräume in vollkommenem Maße gesorgt.

In einem Zwischenstockwerk zwischen Hochparterre und Souterrain liegen der Speisesaal und das Sanitätszimmer. Der Speisesaal dient dazu, um jenen Angestellten, die nicht in der Lage sind, während der Mittagspause ihr Heim aufzusuchen, einen freundlichen, luftigen Raum zum Einnehmen der Mahlzeiten zur Verfügung zu stellen. Das Sanitätszimmer ist mit einer Hausapotheke und mit den sonstigen erforderlichen Einrichtungen für Unfälle etc. ausgestattet.“"11

Am Ende unseres Rundgangs steigen wir hinab ins Tiefparterre und betreten das weitläufigste Areal des 
Gebäudes. Hier sind u. a. die großen Druckmaschinen untergebracht. Der Redakteur ist auch hier sichtlich stolz, auf die hochmoderne Ausstattung verweisen zu können. „Das Souterrain umfaßt unser Papiermagazin für Flach- und Rollenpapiere, die Hauptbuchbinderei, die Expeditionsräume sowie einen großen, glasüberdeckten Hof, in welchem unsere Rotationsmaschinen aufgestellt sind. Hier befinden sich auch die Aufzüge zur Einlieferung der Waren direkt von der Straße, sowie zur Warenauslieferung.

Die Rotationsmaschinen sind modernster Konstruktion (Abb.5). Wir sind in der Lage, mit einer Rotationsmaschine 5000 Exemplare 16-seitiger illustrierter Zeitungen gedruckt und gefalzt in einer Stunde zu liefern. Die Papierrollen, die wir zum Bedrucken unserer Zeitung verwenden, sind $84 \mathrm{~cm}$ breit. Für eine Nummer unseres Blattes brauchen wir bei einer normalen Stärke von 44 Seiten 230000 Meter Papier, was ungefähr der neunfachen Entfernung von Wien nach Baden entspricht. Anstoßend an den Rotationsmaschinensaal befindet sich die Expedition, so daß die fertig gedruckten und gefalzten Exemplare sofort zur Expedition gelangen und mittelst Wagen zur Post befördert werden können.“ ${ }^{12}$

\section{Rotationstiefdruck: Eine neue Ära beginnt}

Gut zwei Jahre nach diesem Bericht wird der vorläufig letzte große Schritt in der Modernisierung des Druckwesens eingeläutet: die Umstellung auf den Kupfertiefdruck. Die Österreichische Zeitungs- und Druckerei-Aktiengesellschaft stellt im April 1914 als erste österreichische Zeitungsdruckerei auf dieses Verfahren um. Neue Druckmaschinen werden angekauft, das bringt gewaltige Investitionskosten mit sich. Allein die Lizenzgebühr für zwei Rotationstiefdruckmaschinen modernster Bauart beträgt 60000 Kronen. ${ }^{13}$

Jede dieser Maschinen ist elf Meter lang, drei Meter breit und 4,5 Meter hoch und wird mit einem 35-PS-Hauptmotor sowie zwei 3-PS-Hilfsmotoren angetrieben. ${ }^{14}$ Am 12. April laufen die ersten nach dem

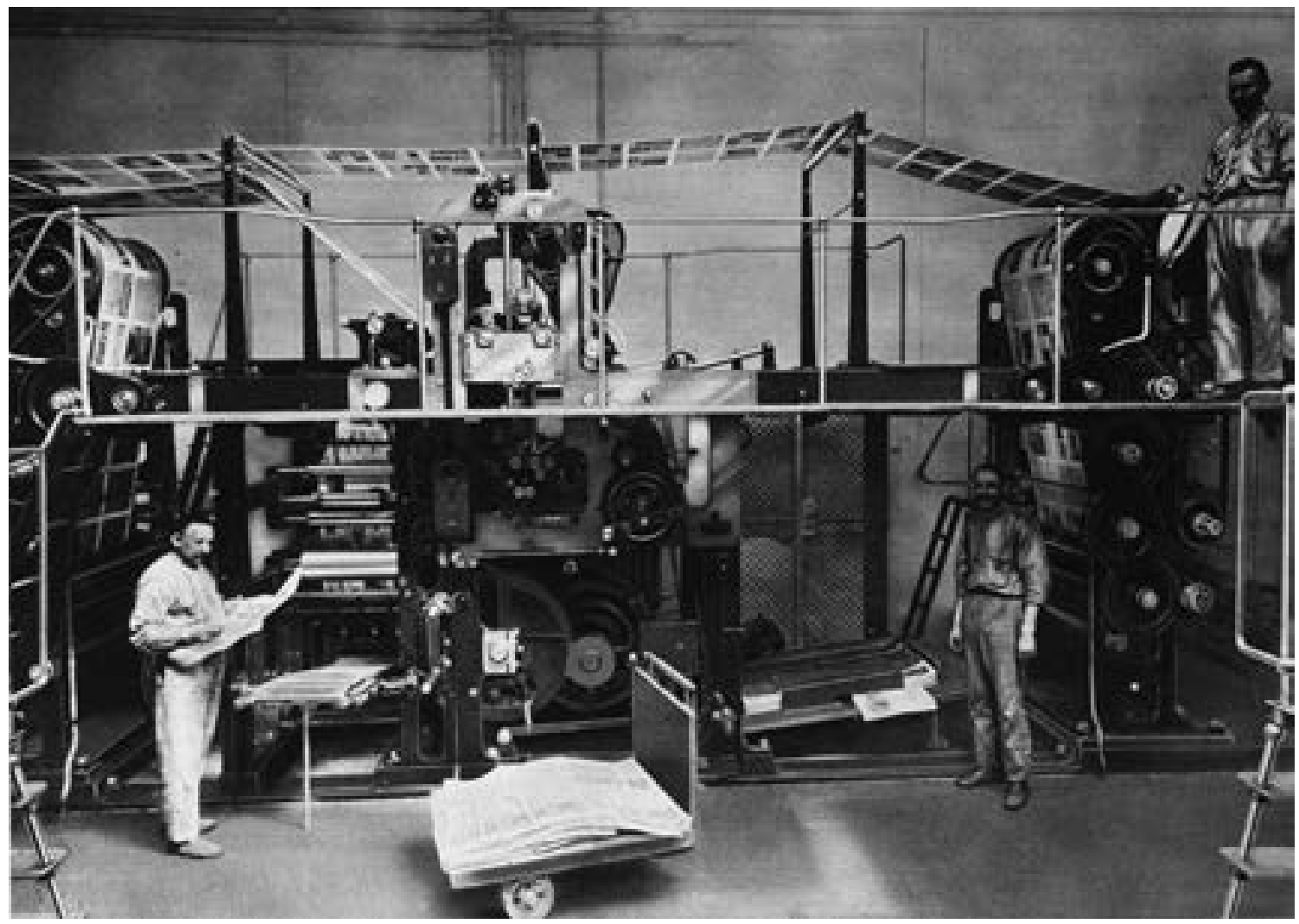

Abb. 6 Die neue Rotationstiefdruckmaschine, auf der seit April 1914 Das interessante Blatt und die Wiener Bilder hergestellt werden. Das interessante Blatt, 16. April 1914, S. 5. 


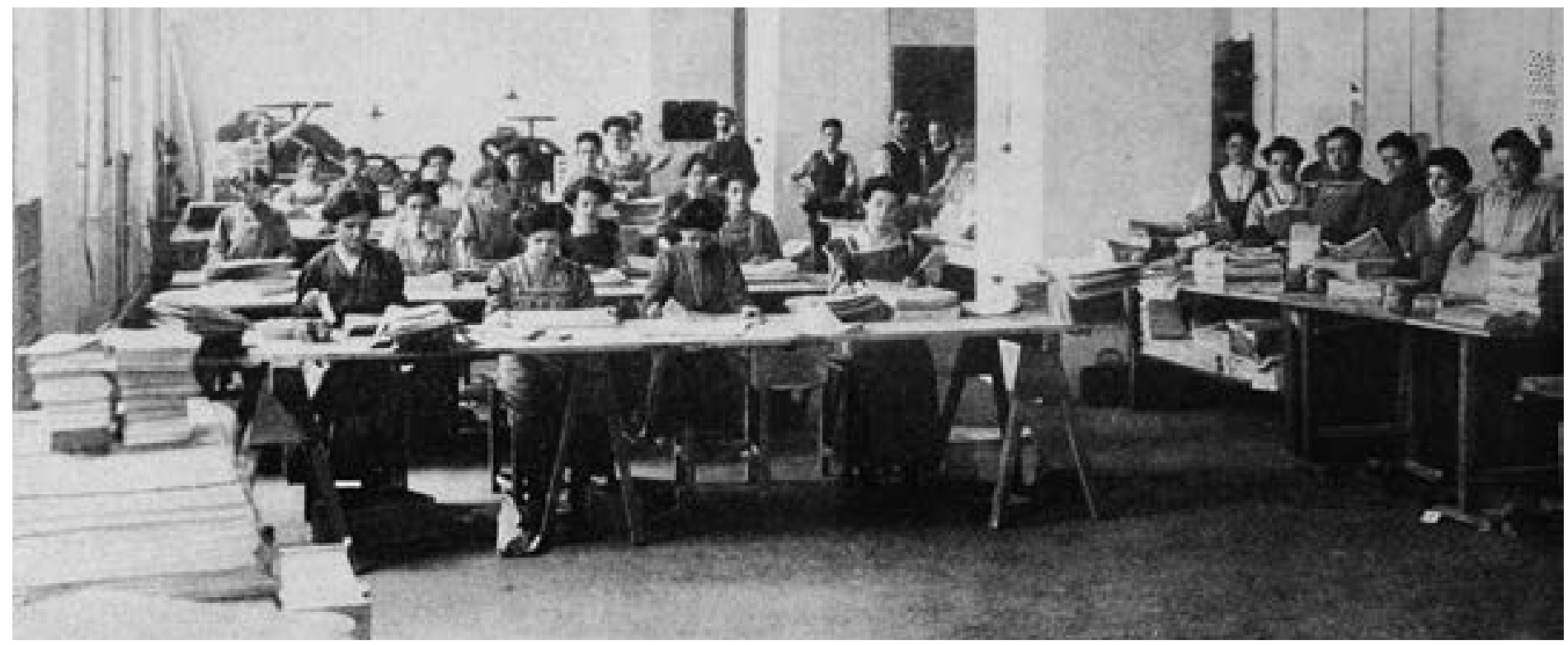

Abb. 7 In der „Expedition“. Nach dem Druck wird die Zeitung für den Versand vorbereitet. Das interessante Blatt, 16. April 1914, S. 6. neuen Verfahren gedruckten Exemplare der Wiener Bilder vom Band. Wenige Tage später, am 16. April 1914, stellt auch Das interessante Blatt im Hauptteil auf die neue Drucktechnik um. Euphorisch wird die technische Revolution gefeiert: „Das Tiefdruckverfahren, das wir in dieser Nummer zum ersten Male zur Anwendung bringen, bedeutet eine neue Periode in der Geschichte der Reproduktionstechnik. (...) Die Wiedergabe des photographischen Bildes durch den Druck, wie sie durch das neue Verfahren ermöglicht wird, ist derart verschönert und verfeinert, daß man fortan ohne Übertreibung von einer neuen Blütezeit der illustrierten Presse sprechen kann. "15 Illustriert ist der Text mit einer Aufnahme, die die neue Tiefdruckmaschine im Betrieb zeigt (Abb.6). Natürlich ist auch diese Abbildung bereits im neuen plastischeren und detailreicheren Verfahren hergestellt.

Während bisher die Bilder in einem getrennten Druckgang aufs Papier gebracht werden mussten, ist nun der gesamte Druckvorgang in einem Arbeitsschritt vereint: „Auf derselben Druckwalze, auf der sämtliche Bilder tief geätzt sind, wird auch der übrige Text unseres Blattes in Kupferdruck hergestellt, so daß von ein und derselben Walze sowohl Text als auch Bilder gedruckt werden. “16 Die Einfärbung der Kupferplatte und der Abzug der überflüssigen Farbe erfolgt nun automatisch. Statt der bisher üblichen schwarzen Farbe wird nun ein eingefärbter, oft bräunlicher oder bläulicher Farbton verwendet. Stolz wird die erste in Kupfertiefdruck hergestellte Nummer des Interessanten Blattes präsentiert, und zwar mit einem illustren Titelmotiv: einem in der neuen Drucktechnik hergestellten Foto des Kaisers Franz Joseph. ${ }^{17}$
Nachdem die Zeitung gedruckt ist, wird sie für den Vertrieb vorbereitet. Diese Arbeiten erfolgen in den Räumen der „Expedition“ (Abb.7). An langen Tischen sitzen ausschließlich Frauen. Sie haben die Aufgabe, die Abonnentenexemplare zu adressieren und $\mathrm{zu}$ Poststücken zusammenzufassen. Eigene Zeitungswagen bringen die Ausgaben dann zum Hauptpostamt sowie zu den Zwischenhändlern.

Länger als in anderen europäischen Ländern ist in Österreich die Kolportage, d.h. der Straßenverkauf von Zeitungen, verboten, nämlich, wie berichtet, bis zum Jahr 1922. ${ }^{18}$ Die illustrierte Presse wird daher ebenso wie die Tagespresse vorwiegend im Abonnement verkauft. Die Bestellungen werden im Ausland über Buchhandlungen abgewickelt, im Inland über Postämter und sogenannte „Zeitungs-“ bzw. „Annoncenbüros“. Diese Dienste bieten beispielsweise die Firmen Lehmann, Dukes, Haasenstein \& Vogler, Heinrich Schalek, Anton Oppelik, J. Rafael, Eduard Braun und Hermann Goldschmied an. ${ }^{19}$ Die Zahlung der Zeitungsabonnements erfolgt jährlich, halb- oder vierteljährlich. In der Hauptstadt und in größeren Städten sind die Zeitungen außer im Abonnement auch über städtische Zwischenhändler wie Zeitungs- und Tabakläden oder eigene Zeitungskioske (sogenannte Verschleißstellen) erhältlich. Und natürlich werden sie auch in den Kaffeehäusern gelesen, etwa im Café L'Europe am Stephansplatz, im Prückel am Stubenring oder im Landtmann neben dem Burgtheater. Das Wiener Zeitungscafé ist aber das Café Central in der Herrengasse, das sich vor dem Ersten Weltkrieg rühmt, 251 Blätter aus dem In- und Ausland abonniert zu haben. Darunter sind natürlich auch Illustrierte wie Das interessante Blatt oder die Wiener Bilder. 


\section{Im Rampenlicht}

\section{Der Kaiser im Blick der Fotografen}

Der mächtige schwarze Ring hebt sich scharf von den grauen Umrissen ab (Abb. 1). Die Knochen treten dunkler hervor als die Fleischpartien, die im mehligen Grau des Hintergrundes nahezu verschwimmen. Die Röntgenaufnahme erscheint am 27. Juli 1904 in der illustrierten Zeitung Wiener Bilder. Sie wird als kleine Sensation angepriesen, denn sie zeigt - die Hand des Kaisers Franz Joseph I. Und sie ist, darauf wird ausdrücklich verwiesen, die „einzig autorisierte Reproduktion der mit Röntgenstrahlen erfolgten Aufnahme von Professor Réczey vom physikalischen Institut der Universität in Budapest." ${ }^{1}$

Wenige Wochen zuvor hat der über 70-jährige Monarch bei einer Reise nach Budapest das Laboratorium des physikalisch-technischen Instituts an der Universität aufgesucht. Professor Imre Réczey, dem Leiter der Einrichtung, wurde, so heißt es in dem Bericht, „die hohe Ehre zu Teil, eine photographische Aufnahme der Hand des Kaisers mittelst Röntgenstrahlen machen zu dürfen. Der Liebenswürdigkeit des genannten Gelehrten verdanken wir die erste in die Öffentlichkeit gelangte Kopie dieser interessanten Aufnahme, welche des ungeteilten Interesses aller Kreise sicher sein kann. Die Aufnahme zeigt die schön geformte Hand unseres erhabenen Herrschers, jene Hand, welche seit nunmehr 56 Jahren die Geschicke unseres Vaterlandes lenkt, und bei dem Anblick des Bildes entstehen in dem Betrachter wohl Gefühle wärmster Verehrung für den geliebten und allverehrten Monarchen, dessen väterliche Hand so fürsorglich die Geschicke von Millionen seiner Untertanen lenkt. Der Goldene Siegelring, den der Monarch am Goldfinger trägt, hebt sich, ebenso wie die Goldstickerei des Uniformärmels aus dem schemenhaften Bilde ab, das wohl als erstes seiner Art gelten darf, da bisher noch kein Herrscher sich entschlossen hat, sich dem Röntgen-Apparat zur Aufnahme anzuvertrauen."2

Die Röntgenfotografie, die am Körper des greisen Monarchen ausprobiert wird, ist erst ein knappes
Jahrzehnt alt. Wilhelm Conrad Röntgen hat die unsichtbaren Strahlen am 8. November 1895 entdeckt. Noch nie ist ein Staatsoberhaupt auf diese Weise entkleidet gezeigt worden. Mithilfe der Technik ist es nun möglich, hinter die Körperkulissen des „erhabenen Herrschers“ zu blicken. Im Röntgenbild scheint dessen Hand zum Greifen nahe, auch wenn wohl niemand dieses Knochengerüst drücken will.

Es ist bemerkenswert, dass dieses Bild nicht in den Schränken der Wissenschaft verschwindet, sondern sogleich als Sensation einem Massenpublikum zugänglich gemacht wird. Noch nie ist die Fotografie dem Kaiser so nahe gekommen, noch nie ist ein Körperteil des Monarchen in Großaufnahme gezeigt worden, herausgelöst aus allen menschlichen Zusammenhängen, zurechtgerückt in einem neutralen Viereck, dem Lichttisch der Röntgenapparatur.

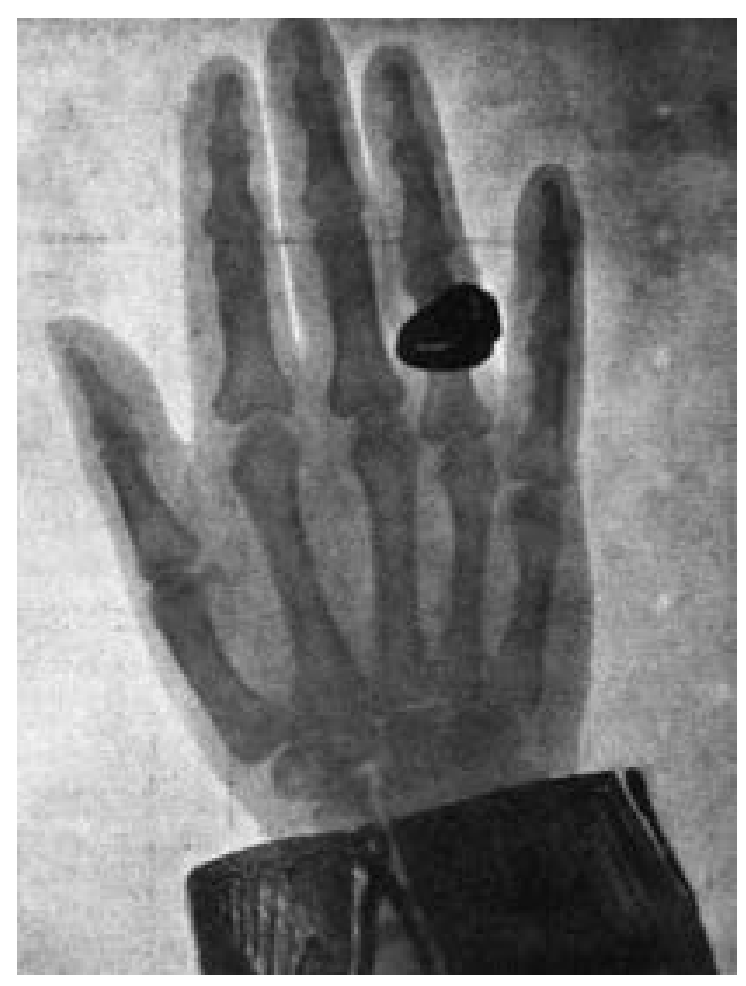

Abb. 1 Die Hand Kaiser Franz Josephs im Röntgenbild. Die Aufnahme entsteht 1904 am physikalisch-technischen Institut der Universität Budapest unter der Leitung von Professor Imre Réczey. Wiener Bilder, 27. Juli 1904, S. 4. 
Abb. 2 Kaiser Franz Joseph als Jäger. Die Aufnahme entsteht im März 1910 und wird anlässlich der Wiener Jagdausstellung „auf allerhöchsten Befehl“ in der Schau ausgestellt. Das interessante Blatt, 12. Mai 1910, S. 5. Foto: Hans Makart.

\section{Neue Kaiserbilder}

Es ist gewiss kein Zufall, dass der Kaiser gerade an der Wende zum 20. Jahrhundert in das aufhellende Licht der Wissenschaft tritt. In diesen Jahren bemühen sich verschiedene Disziplinen darum, das Innenleben des Menschen Schritt für Schritt zu entschleiern. Man will hinter die Kulissen sowohl seines emotionalen wie auch seines physischen Wesens blicken. Sigmund Freud durchleuchtet um 1900 mit den Mitteln der Psychoanalyse die menschliche Seele. Zugleich tritt die Naturwissenschaft an, den Körper des Menschen Stück für Stück zu entzaubern. Mit dem Bild der durchleuchteten Hand wird nun sogar der Körper des Kaisers wissenschaftlich analysiert. Dieser zeigt sich souverän und gelassen. Er signalisiert Interesse und Aufgeschlossenheit gegenüber den neuesten Entwicklungen der Technik. Der Kaiser tritt mit diesem Bild aber nicht nur ins Licht der Wissenschaft, sondern mehr noch in jenes der Öffentlichkeit. Um 1900 zeichnet sich ein Strategiewechsel Seiner Majestät in Sachen Öffentlichkeitsarbeit ab. Bis Mitte der 1890er Jahre sind fast alle Kaiserbilder sorgsam inszenierte Auftragsarbeiten. In der Öffentlichkeit erscheinen sie meist als Lithografien gedruckt oder in gezeichneter Form. Auch die frühen Kaiserfotos folgen lange Zeit diesem Modell der inszenierten Darstellung.

Jahrzehntelang ist es ein Privileg für die Fotografen, den Kaiser und seine Familie ablichten zu dürfen. Immerhin verspricht der illustre Protagonist gute Geschäfte, etwa durch die Vervielfältigung und den Verkauf der Bilder. Aber noch wichtiger ist der Glanz des Monarchen, der ein wenig auf den Fotografen und sein Atelier ausstrahlt. Und so ist es kaum verwunderlich, dass das Gedränge unter den Lichtbildnern, von Seiner Majestät in den Kreis der auserwählten Fotografen aufgenommen zu werden, erheblich ist. Besonders gefragt ist der Titel „k.u.k. Hofphotograph“, der allerdings nicht allzu schwer zu bekommen ist. Ein etablierter Fotograf, der die Nähe des Kaiserhauses sucht, gelegentlich ein wenig antichambriert und dem Hof ab und zu kostenlos ein Konvolut ausgewählter Lichtbilder zukommen lässt, hat gute Chancen, früher oder später in den Genuss dieser Auszeichnung zu gelangen.

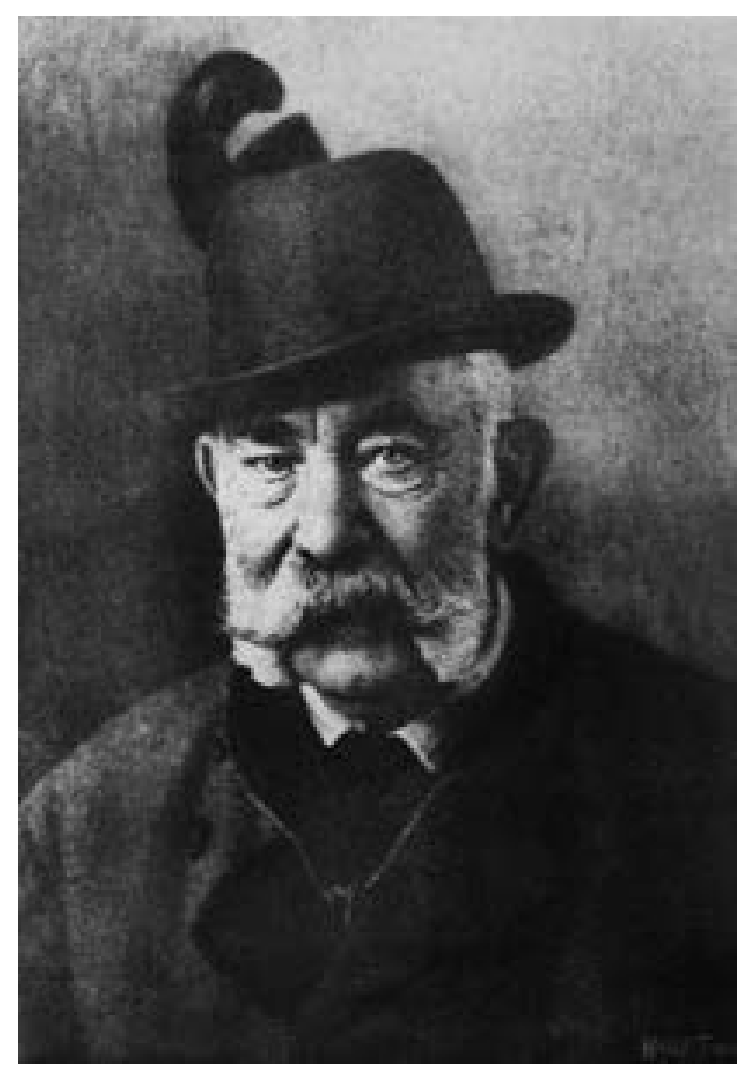

Die ersten Fotografen, die den Kaiser ablichten, arbeiten fast ausschließlich im Atelier. Zu dieser alten Garde gehören Ludwig Angerer (der den Kaiser bereits in den 1850er Jahren fotografiert), das Atelier Adèle, Rudolf Krziwanek, Josef Löwy, Carl Pietzner, Arthur Floeck, Fritz Luckhardt und andere.

Ab Mitte der 1890er Jahre ändert sich die Situation. Den etablierten Kaiserfotografen erwächst nun Konkurrenz. Zwar erscheinen auch weiterhin die altbekannten Atelieraufnahmen in der Presse. Häufiger als früher zeigt sich Franz Joseph nun aber in populären, volksnahen Kostümen (Abb. 2). Repräsentative fotografische Herrscherbilder entstehen nun gelegentlich im Freien. Anlässlich des 70. Geburtstags des Kaisers lichtet der bekannte Wiener Atelierfotograf Charles Scolik diesen in Uniform auf dem Pferd sitzend ab (Abb. 3). Majestätisch thront der Kaiser auf dem edlen Ross. Hinter ihm erstreckt sich eine weite Landschaft. Das Bild erscheint am 16. August 1900, also zwei Tage vor dem Kaisergeburtstag, auf einer ganzen Seite im Interessanten Blatt. ${ }^{3}$ Im Bildtext wird der Ort des Geschehens präzise angegeben. „Die neueste Aufnahme des Kaisers im Brucker Lager Ende Juni 1900.“ Gemeint ist das k.u.k. Militärlager in Bruck an der Leitha. Bei genauerer Betrachtung wird deutlich, dass die Landschaft im Hintergrund zu Gänze gezeichnet ist. Gut möglich, dass auch die Aufnahme des Monarchen auf dem Pferd in Wien und nicht in Bruck entstand. 


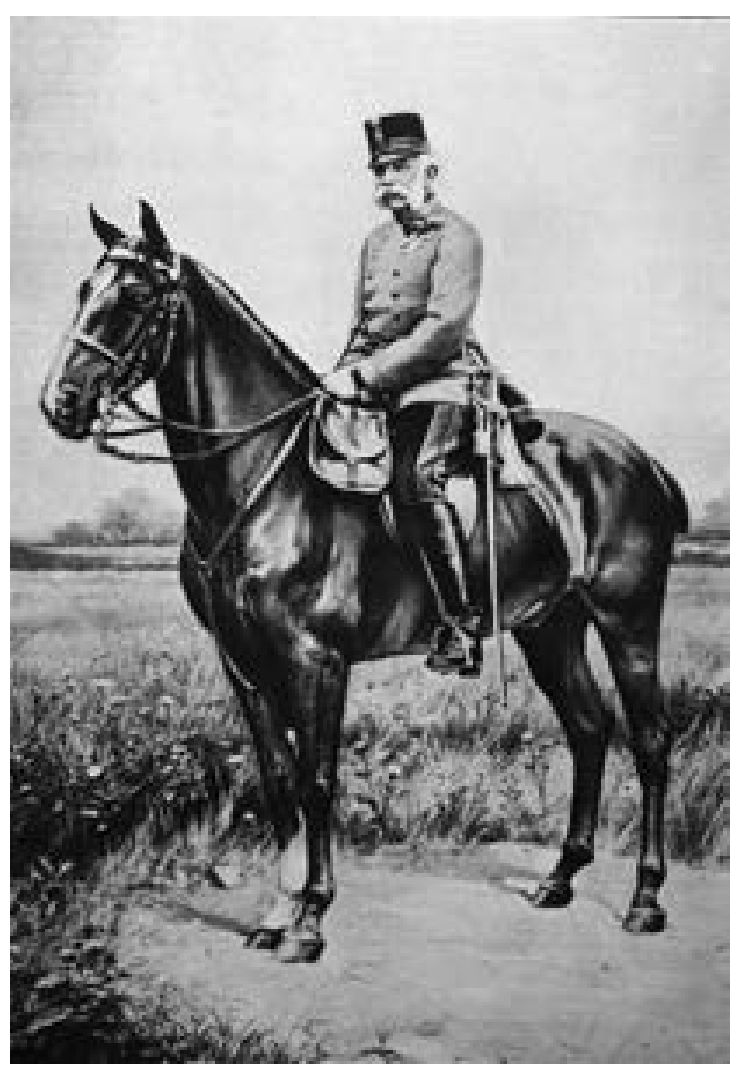

Neben diesen staatstragenden Porträts tauchen um 1900 auch neuartige Kaiserfotos auf. Eine junge Generation von Fotografen, einige von ihnen mit, andere ohne Atelier, lichten den Monarchen vor allem außerhalb des Ateliers ab. Sie dokumentieren seine öffentlichen Auftritte und bringen diese Bilder über die illustrierte Presse in die breite Öffentlichkeit. Ein gutes Beispiel dafür ist eine Aufnahme, die am 1. Oktober 1900 auf der Titelseite der Wiener Bilder erscheint (Abb.4). Der Kaiser erscheint nun nicht mehr in typischer Atelierpose, sondern wir sehen ihn ihm Freien, aufgenommen aus größerer Entfernung. Franz Joseph schreitet gerade durch das Eingangstor des Fabrikgebäudes der Berndorfer Metallwarenfabrik. Begleitet wird er von Arthur Krupp, dem Besitzer des Unternehmens, der die Führung des greisen Monarchen übernommen hat. Die Fabrik hat sich auf die industrielle Herstellung von Besteck spezialisiert. Auch das Kaiserhaus gehört zu ihren Kunden. Um 1900 beschäftigt der 1843 gegründete Betrieb bereits an die 4000 Mitarbeiter und gehört zu den erfolgreichsten Industriebetrieben in der näheren Umgebung Wiens. Die Aufnahme stammt von einem Fotografen der Wiener Fotofirma Lechner. ${ }^{4}$ Diese ist seit Mitte der 1890er Jahre auch als Fotoagentur tätig, d. h., sie verkauft aktuelle Nachrichtenbilder an die illustrierten Zeitungen. Der Bildbericht über den Kaiser in Berndorf wird im Innenteil des Blattes in aller
Ausführlichkeit fortgesetzt. Insgesamt 13 Aufnahmen des Kaiserbesuchs in Berndorf werden gedruckt.

Auffallend sind der Umfang und die Art der bildlichen Berichterstattung. Während bisher über den Kaiser vorwiegend in Form von repräsentativen Einzelbildnissen berichtet wurde, kommt nun eine neue Bildstrategie zum Einsatz. Das Ereignis (Besuch des Kaisers in Berndorf) wird zu einer Art Fotoreportage ausgebaut: Die Fotografien werden, geleitet durch den Text, zu einer zusammenhängenden Geschichte verbunden. Sie illustrieren unterschiedliche Aspekte des Kaiserbesuchs. Zugleich aber stellt dieser Bericht auch eine kaum zu unterschätzende Werbung für das Unternehmen in Berndorf dar. Der großzügige redaktionelle Platz, der dem Industriebetrieb eingeräumt wird, erklärt sich wohl auch dadurch, dass dieser zu den finanzkräftigsten Inserenten des Blattes gehört. Wenige Monate zuvor hat die Berndorfer Metallwarenfabrik in den Wiener Bildern eine ganzseitige Anzeige geschaltet. $^{5}$

\section{Öffentliche Auftritte des Kaisers}

Der Einzug des Kaisers in die Welt der Illustrierten verändert sein öffentliches Image nachhaltig. In-
Abb. 3 Kaiser Franz Joseph zu Pferd. Fotografische Aufnahme (mit gezeichnetem Hintergrund), die angeblich Ende Juni 1900 im k. u. k. Militärlager in Bruck an der Leitha entsteht. Das interessante Blatt, 16. August 1900, S. 5. Foto: Charles Scolik.
Abb. 4 Kaiser Franz Joseph zu Besuch in der Metallfabrik Berndorf, die vor allem Besteck herstellt. Neben ihm ist der Inhaber des Unternehmens, Arthur Krupp, zu sehen. Wiener Bilder, 1. Oktober 1899 , Titelseite.

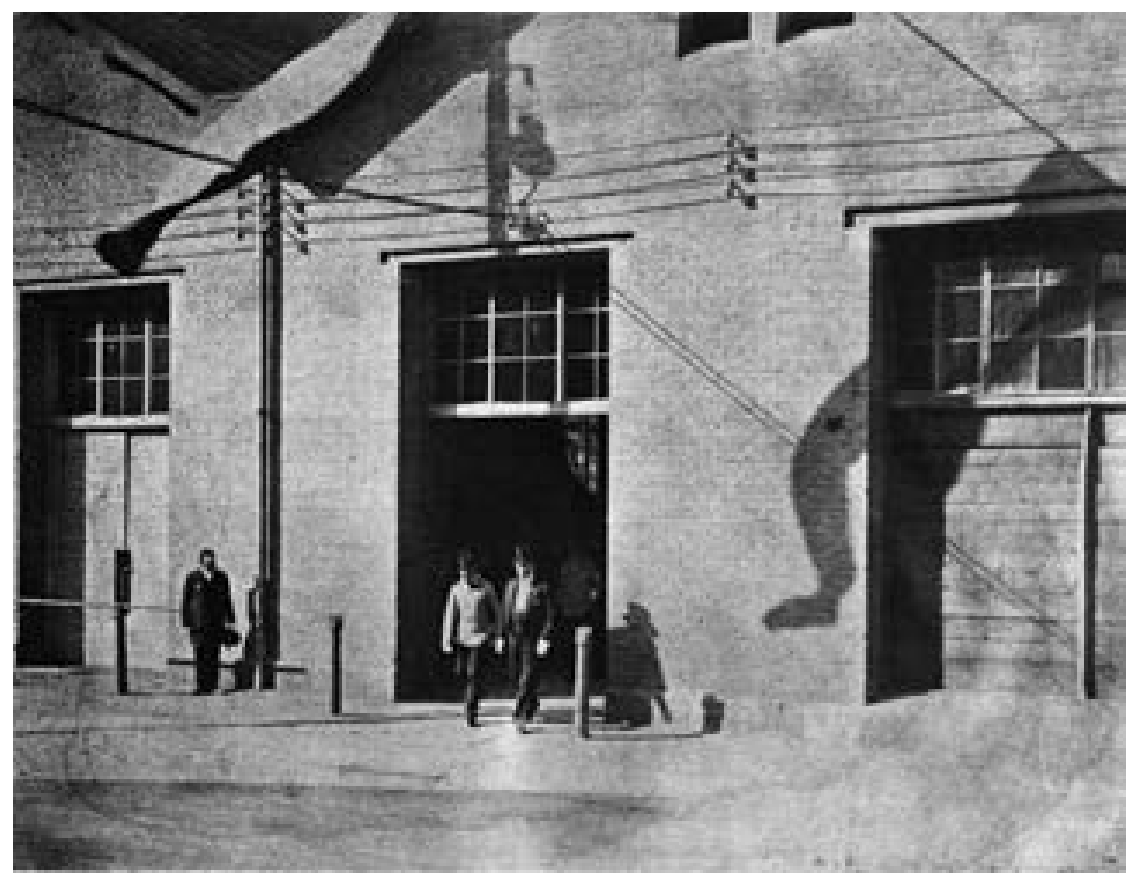


nerhalb weniger Jahre wandelt sich der Monarch vom zurückhaltenden, in statischen Posen fixierten Herrscher zur allzeit präsenten, öffentlichen Figur. Erst unter dem Einfluss der massenhaft in der Zeitung gedruckten Fotografie wird der Kaiser allmählich zu jenem Monarchen, den wir kennen, zum „volksnahen“ Souverän. Dieser Prozess der Umgestaltung des Kaiserimages wird von den neuen illustrierten Medien ebenso angestoßen wie vom Kaiser selbst, der ein zunehmendes Interesse an einer Inszenierung als populärer Souverän entwickelt. Die fotografische Berichterstattung erscheint ihm nun als geeignetes Instrument, um sich als aktiver, um die Nähe zum Volk bemühter Herrscher in der Öffentlichkeit zu zeigen.

Als der Kaiser im Juni 1895 an der alljährlich stattfindenden Fronleichnamsprozession durch die Wiener Innenstadt teilnimmt, sind erstmals etliche Fotografen unter den Zaungästen, die im Auftrag der Presse arbeiten. Wenige Tage später erscheint eines dieser Bilder im Interessanten Blatt, der auflagenstärksten Illustrierten der Monarchie. ${ }^{6}$ Die Aufnahme, die den Prozessionsszug am Graben zeigt, ist eines der ersten Pressefotos des Kaisers. Es stammt von einem Mitarbeiter der k.u.k. Hof-Buchhandlung R. Lechner (Wilh. Müller). Der Anlass der Aufnahme ist gut gewählt: Der Fronleichnamsumzug ist, neben seiner religiösen Bedeutung, ein gesellschaftliches und politisches Großereignis. Er ist ein öffentlichkeitswirksames Defilee vor allem des Adels und des Hofstaates: eine machtvolle Kundgebung des innersten Kreises der Monarchie. Im Zentrum der Fotografie ist der Kaiser zu erkennen, hinter ihm der Zug der Prominenten. Im Hintergrund der Aufnahme fällt der Blick auf ein Holzgerüst mit Werbeanzeigen. Eine sticht besonders hervor. Es ist die Annonce des Interessanten Blattes. Es ist ein geschickter Schachzug, den Kaiser in bisher unbekannten Außenaufnahmen zu porträtieren und zugleich die Zeitung selbst visuell ins Spiel zu bringen.

Als am 6. Mai 1898 anlässlich des 50-jährigen Regierungsjubiläums des Kaisers eine große „Jubiläumsausstellung“ im Wiener Prater eröffnet wird, ist Franz Joseph von Fotografen umlagert, die für die illustrierte Presse arbeiten. Angetreten sind neben den traditionellen Atelierfotografen, wie etwa Rudolf
Krziwanek, die unter dem Druck der Konkurrenz nun auch ins Freie gehen, junge, wendige Lichtbildner mit mobilen Apparaten. Unter ihnen sind Emil Fukarek, das Fotografenduo Heydenhaus \& Robert und Viktor Angerer, der den Kaiser in den folgenden Jahren besonders häufig fotografiert. Bald stoßen zu diesen Fotografen weitere Lichtbildner hinzu, die ebenfalls gelegentlich den Kaiser, das Kaiserhaus oder die hohe aristokratische Gesellschaft fotografieren. Unter ihnen sind Heinrich Schuhmann sen., Charles Scolik sen. und Carl Seebald. Einige von ihnen, etwa Anton Huber, Josef Jahudka, Franz Pawlik oder Ruda Bruner-Dvořák, der aus Prag berichtete, haben ihre Karriere als Militärfotografen im Umfeld des Kaiserhauses begonnen. Allmählich dehnen sie ihre „Zuständigkeit“ aus und begnügen sich nicht mehr mit Manöverbildern.

Wie sehr sich die neuen, ,journalistischen“ Kaiserbilder von den starren, herkömmlichen Posen unterscheiden, zeigt sich an einer Aufnahme, die im Juni 1900 im Interessanten Blatt erscheint. ${ }^{7}$ Sie zeigt den Besuch des Kaisers im Kaiser Franz Joseph-Ambulatorium in Wien, das in der Sandwirtgasse 3-5 im 6. Wiener Gemeindebezirk untergebracht ist (Abb.5). Das Foto stammt vom Fotografenduo Heydenhaus \& Robert (Hermann Heydenhaus und L. von Robert). ${ }^{8}$ Die beiden Lichtbildner haben, wie viele andere Pressefotografen der ersten Generation, als Atelierfotografen begonnen. ${ }^{9}$ Bald aber wenden sie sich auch der „Illustrationsphotographie“, d.h. der Zeitungsfotografie zu. Ab 1898 tauchen ihre Aufnahmen in der illustrierten Presse auf.

Der Fotograf - ob Heydenhaus oder Robert die Aufnahme gemacht hat, lässt sich nicht rekonstruieren - nimmt die Szene aus einem erhöhten Blickwinkel auf. Er hat die Kamera vermutlich in einem Fenster auf der gegenüberliegenden Straßenseite positioniert, um einen möglichst umfassenden und unverstellten Blick auf den Eingang des Ambulatoriums werfen zu können. Im Bild deutlich sichtbar ist der Schriftzug „Kaiser Franz Joseph-Ambulatorium“, der an der Fassade angebracht ist. Seit 1888 hat die Institution das Privileg, den kaiserlichen Namen zu führen. Das Portal des Krankenhauses wurde eigens für den hohen Besuch festlich geschmückt. Vor dem Gebäude warten 


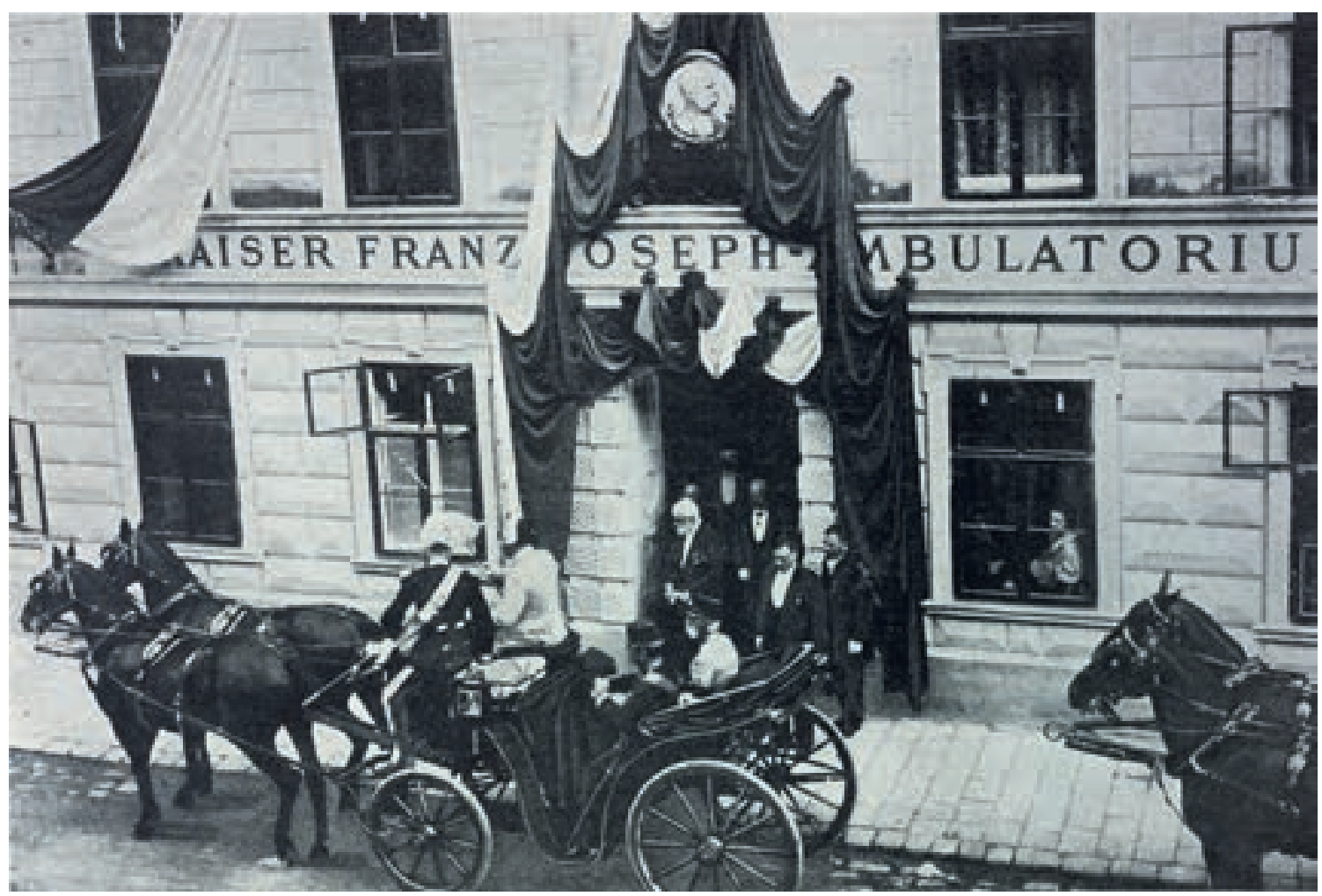

zwei Pferdekutschen. Der Fotograf drückt in dem $\mathrm{Au}-$ genblick auf den Auslöser, als der Kaiser das Gebäude verlassen und im Fuhrwerk Platz genommen hat. Im Eingang stehen einige Honoratioren, die den kaiserlichen Besucher durch das Haus begleitet haben, u. a. der Direktor der Einrichtung, Leopold Domeny (der Mann mit weißem Haar). Rechts neben dem Eingang lugt eine junge Frau durch das geschlossene Fenster, um einen letzten Blick auf den illustren Gast zu erhaschen. Im nächsten Augenblick wird sich die Kutsche in Bewegung setzen und verschwunden sein.

Bilder wie diese sind um 1900 ungewohnt und neu. Bisher wurde der Kaiser vorwiegend in repräsentativer Pose im Atelier abgelichtet. Oder bei sorgsam vorbereiteten Auftritten im Freien. Nun tauchen Kaiserbilder in der Öffentlichkeit auf, die die Statik der bisherigen Inszenierungen aufbrechen. Plötzlich bewegt sich der Kaiser, schreitet aus, reitet und fährt. Kaum ist er in der Öffentlichkeit unterwegs, wird er von neugierigen Fotografen „beschattet“, sie folgen ihm auf Schritt und Tritt.

Zwar geben Kaiser und Kaiserhaus weiterhin regelmäßig repräsentative fotografische Bildnisse bei renommierten Atelierfotografen in Auftrag. Aber in der großen Öffentlichkeit setzen sich ganz andere Bilder durch. Sie zeigen den Monarchen bei allen möglichen politischen und gesellschaftlichen Anlässen: auf Reisen, während der Kaisermanöver, bei der Jagd, auf Sommerfrische in Bad Ischl, bei Staatsbesuchen, bei Eröffnungsfeiern, bei sportlichen, kulturellen und wirtschaftlichen Veranstaltungen. Die großen gesellschaftlichen Ereignisse, wie etwa Ausstellungseröffnungen, Messen, aber auch Umzüge und Prozessionen, erhalten nun, falls der Kaiser anwesend ist, ihr publizistisches Echo in Bildern. Diese Bilder entstehen sehr oft im Freien, gelegentlich wird der Kaiser im Umfeld seines Hofstaats gezeigt. Manchmal sind es auch Momentaufnahmen, die ein besonderes Detail - einen Handschlag, das Besteigen oder Verlassen der Kutsche, ein Winken, ein Grüßen - festhalten. Die Starre der Studioporträts, die den Monarchen stets in fast gleichbleibenden Posen gezeigt haben, löst sich nun auf.

\section{Jubiläen und Geburtstage}

Nach der Jahrhundertwende tauchen Jahr für Jahr mehr Kaiserbilder in der Öffentlichkeit auf. Diese Fotofaszination steuert 1908 auf einen Höhepunkt zu. In diesem Jahr findet anlässlich des 60-jährigen Regierungsjubiläums ein gewaltiger Veranstaltungsreigen statt. Eröffnet werden die Jubiläumsveranstaltungen Mitte Mai durch einen Besuch des deutschen Kaisers Wilhelm II. beim österreichischen Monarchen. Als dieser am 7. Mai 1908 am Bahnhof Wien Penzing (der nahe am kaiserlichen Schloss Schönbrunn liegt) ankommt, wird er mit einem imposanten Zeremoniell empfangen. Zahlreiche Fotografen sind anwe-
Abb. 5 Der Kaiser nach dem Besuch im Kaiser Franz JosephAmbulatorium in der Sandwirtgasse 3-5 im 6. Wiener Gemeindebezirk. Der Monarch hat im Fuhrwerk Platz genommen, nachdem er vom Direktor der Einrichtung, Leopold Domeny (der Herr im Eingang mit weißem Haar) verabschiedet wurde. Das interessante Blatt, 28. Juni 1900, S. 3. Foto: Heydenhaus \& Robert. 
Abb. 6 Besuch des deutschen Kaisers Wilhelm II. in Wien anlässlich des 60. Regierungsjubiläums des österreichischen Monarchen. Die beiden Kaiser schreiten vor dem Bahnhof Wien-Penzing die Ehrenkompanie ab. Das interessante Blatt, 14. Mai 1908, S. 5.

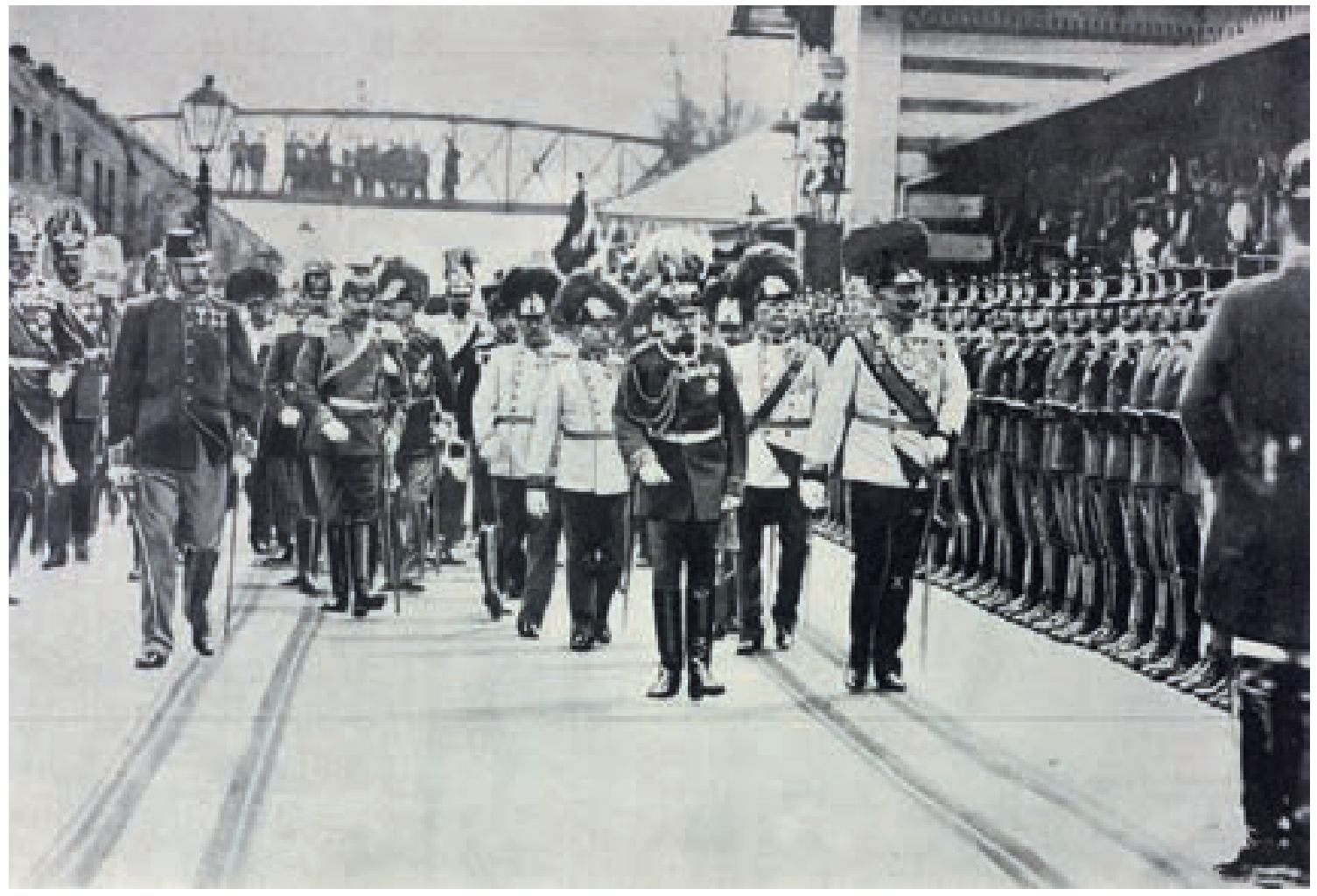

send. Eine Aufnahme der Fotofirma Lechner zeigt die beiden Monarchen, wie sie, begleitet von viel Adel und Hofstaat, vor dem Bahnhof die Ehrenkompanie abschreiten (Abb.6). Als Tage später das Foto im Interessanten Blatt erscheint, ist Kaiser Wilhelm an der Hose mit einem Kreuz markiert - um bei der Leserschaft keine Missverständnisse aufkommen zu lassen. ${ }^{10}$

Ihren Höhepunkt erreichen die Kaiserfeierlichkeiten am 12. Juni 1908 mit dem „Kaiserhuldigungsfestzug" in Wien. ${ }^{11}$ Anlass der Großveranstaltung ist zwar das 60. Regierungsjubiläum des Kaisers. Der monumentale Umzug ist aber, angesichts der tiefen Nationalitätenkrise der Monarchie, auch der Versuch, ein massenwirksames Integrationsprojekt für den gefährdeten Gesamtstaat und seinen „Übervater“, den Kaiser, zu inszenieren. Das penibel vorbereitete und bis ins Letzte durchgeplante Massenereignis soll, so wollen es die Veranstalter, die Vielfalt und zugleich die Einheit der Monarchie feiern. Obwohl die tschechischen und die ungarischen Delegationen aus Protest der Feier fernbleiben, ist sie ein gesellschaftliches Großereignis. Der Zug umfasst 12000 Personen, die in historischen und nationalen Kostümen stundenlang durch die Straßen Wiens ziehen. Allein 8000 Teilnehmer marschieren im Festzug der Nationalitäten mit. In aufwendigen Inszenierungen und begleitet von Musik werden Sagen, Bräuche und volkstümliche Eigenheiten der Völker der Monarchie dargestellt.

Über eine halbe Million Zuschauer finden sich entlang der Straßen ein, um das farbenprächtige und exotische Schauspiel mitzuerleben. Zahlreiche Journalisten und Reporter berichten über das bunte Völkerstelldichein, Fotografen und Filmkameraleute begleiten den Festzug. Bereits Tage später erscheinen die Fotos in der Öffentlichkeit. Besonders ausführlich berichten die Wiener Bilder über das Ereignis. Sie widmen dem Festzug nicht nur die Titelseite, sondern bringen im Innenteil noch zahlreiche weitere Fotos. „Diese Nummer“, wird auf dem Umschlag stolz angekündigt, „enthält 33 Bilder vom Huldigungsfestzuge“. ${ }^{12}$ Eine Woche später folgen noch einmal zehn Aufnahmen. ${ }^{13}$

Die Bilder dieses Festtages vervielfältigen sich in ungeahnter Weise: in der illustrierten Presse, in 
Sonderdrucken, in Bildpostkarten, Sammelkarten, Leporellos und in vielen anderen Formen und Formaten. Zwei Wochen nach der Veranstaltung sind die Wochenschaubilder der Kaiserhuldigung in den österreichischen Kinos zu sehen.

Runde Jubiläen, Jahres- und Geburtstage sind beliebte Anlässe, um fotografische Kaiserbilder in die Öffentlichkeit zu bringen. Seit der Jahrhundertwende erscheinen zu jedem Kaisergeburtstag (am 18. August) neue fotografische Ansichten des Monarchen. Die bekanntesten Ateliers bemühen sich, den Kaiser zu sich ins Atelier zu bitten oder ihn vor dem Schloss Schönbrunn abzulichten. Jahr für Jahr setzen die illustrierten Blätter diese Kaiserbilder als prominenten Blickfang und als Mittel zur Verkaufssteigerung ein.

Aber auch bei anderen Jubiläen und Festlichkeiten taucht das Kaiserbild nun auf. Als die führende illustrierte Wochenzeitung des Landes, Das interessante Blatt, am 3. Januar 1907 ihr 25-jähriges Bestehen feiert, steht die aufwendig gedruckte Sondernummer ganz im Zeichen des Kaiserhauses. Eine Amateuraufnahme aus der Hand der habsburgischen Erzherzogin Maria Theresia eröffnet das Heft, dann folgen Kaiserbilder über Kaiserbilder, gefolgt von zahlreichen reproduzierten Autogrammen der hohen Wiener Gesellschaft. Die Titelseite aber ist für Kaiser Franz Joseph reserviert (Abb. 7). Man hat für den Anlass keine der altbekannten Atelieraufnahmen verwendet, sondern ein ungewöhnliches, bisher ungesehenes Foto des Monarchen, das erste telegrafierte Bild Seiner Majestät. „Die Originalphotographie“, heißt es im Bericht zum Bild, „wurde für die Jubiläumsnummer des ,Interessanten Blattes“ von Professor Korn in München nach seinem fernphotographischem Verfahren über den Draht München-Nürnberg-München, mit Einschaltung eines künstlichen Widerstandes von 1500 Kilometern, das ist über eine der Luftlinie Hamburg-Konstantinopel entsprechende Strecke telegraphiert.“" ${ }^{14}$ Wie wenige Jahre zuvor das Röntgenbild, signalisiert auch diese Aufnahme Modernität-die des Kaisers, der sich der neuesten Technik anvertraut, und die der Zeitung, die keine Mittel scheut, über die aktuellen Ereignisse der Zeit in sensationellen Bildern zu berichten.

Jubiläums-Festnummer.

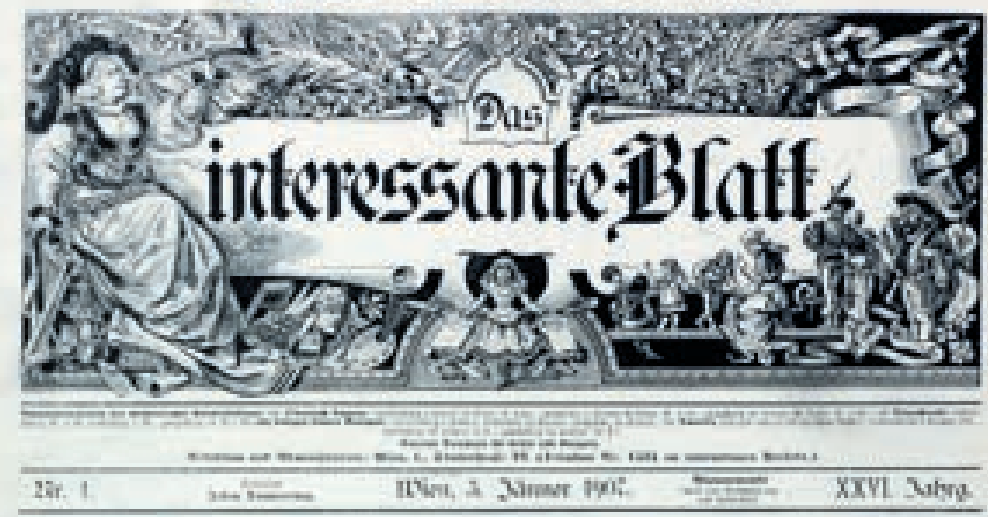

Das erifte telegraphịerte $23 i l$ unises Taijers.

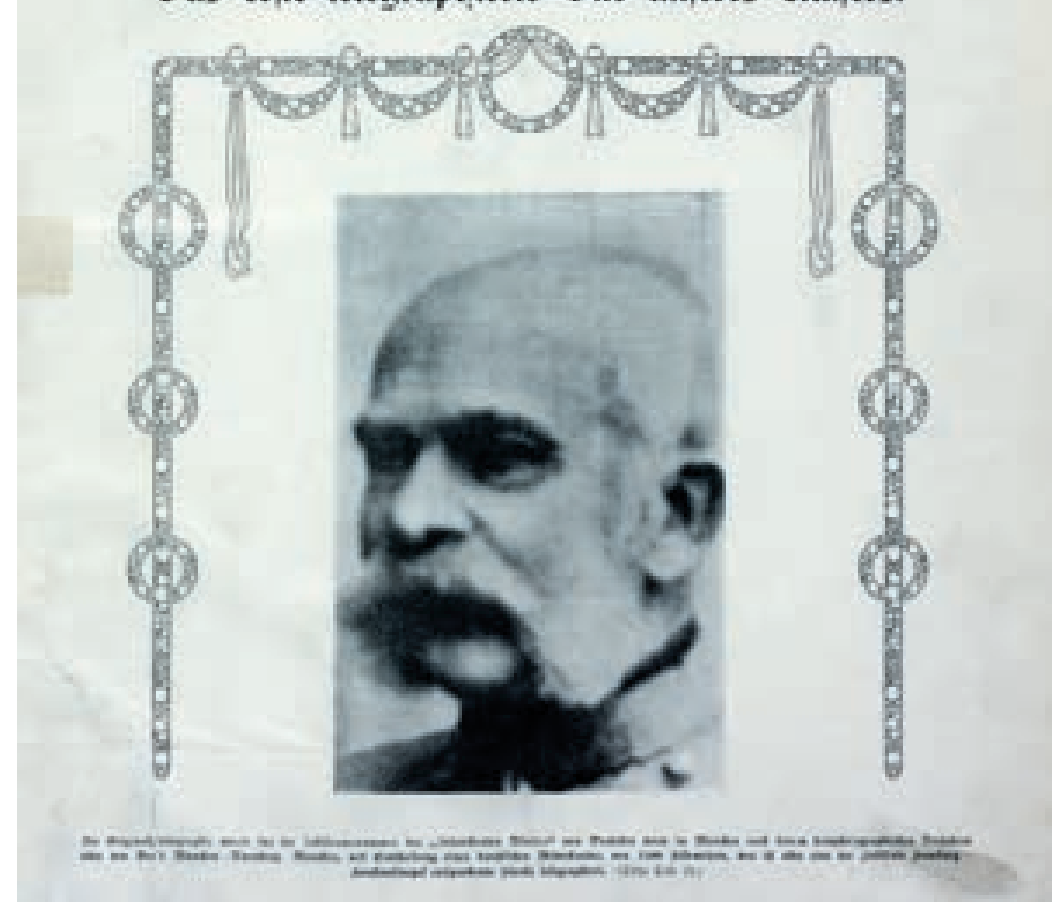

Rückzug aus der Öffentlichkeit

So mobil und modern der Kaiser im telegrafisch übermittelten Bild auch erscheint, die Wirklichkeit hinter den Bildern ist eine andere. Um 1910 ist der Zenit der Kaisereuphorie in der Fotografie bereits überschritten. Das vorgerückte Alter und die angegriffene Gesundheit machen dem Monarchen immer mehr zu schaffen. Er ist nun weniger oft in der Öffentlichkeit zu sehen, auf Fernreisen verzichtet er fast ganz. Doch je seltener der Kaiser in der Öffentlichkeit auftritt, desto deutlicher beschwört die Fotografie seine Agilität und Gesundheit. Im Jahr 1910 ist er zum letzten Mal bei der Wiener Fronleichnamsprozession zu sehen. Ein Bild dieses Ereignisses (Abb. 8) wird noch drei Jahre später veröffentlicht, und zwar anlässlich des Kaisergeburtstags. Das Foto dient gewissermaßen dazu, dem Rückzug des Monarchen
Abb. 7 „Das erste telegraphierte Bild unseres Kaisers“. Das interessante Blatt, 3. Januar 1907, Titelseite. 


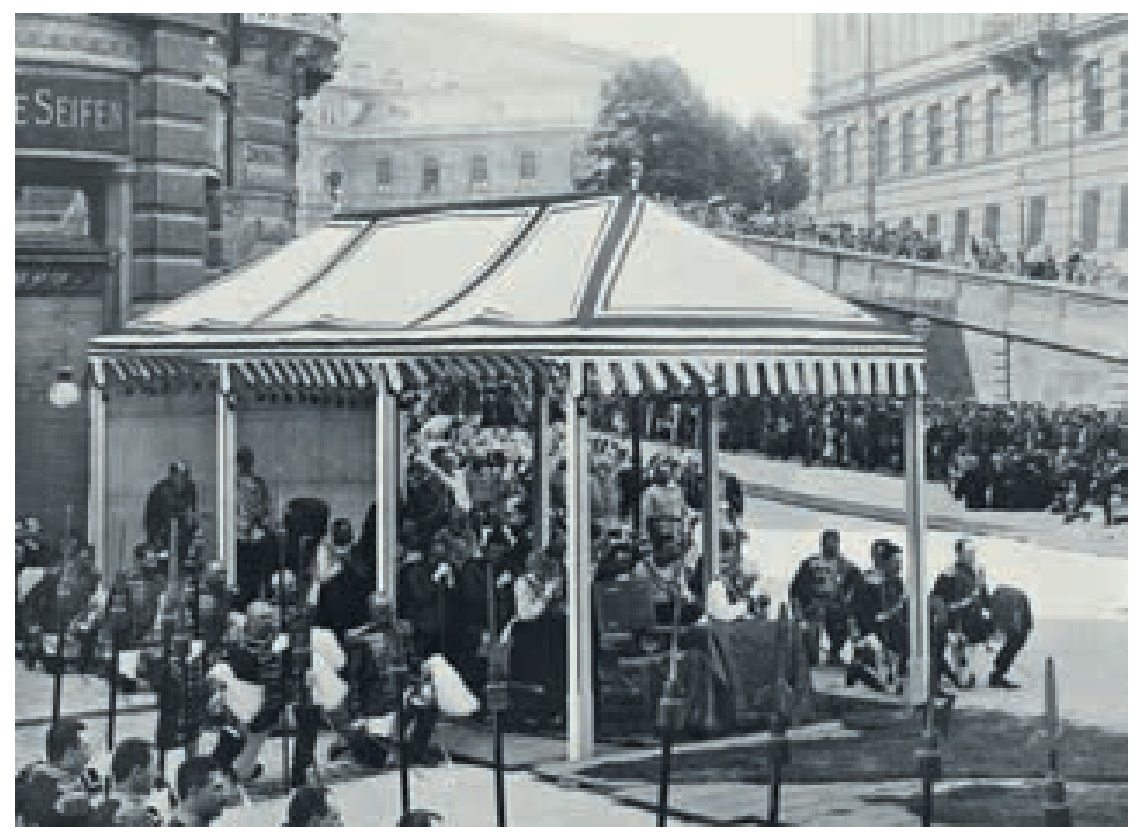

Abb. 8 Der Kaiser bei der Fronleichnamsfeier im Jahr 1910. Österreichs Illustrierte Zeitung, 17. August 1913, S. 1129. Foto: Charles Skolik.

Abb. 9 „Weidmannsheil!“ Kaiser Franz Joseph in Jagdkleidung. Das Bild erscheint anlässlich des Kaisergeburtstags. Österreichs Illustrierte Zeitung, 17. August 1913, Titelseite. Foto: Charles Scolik. entgegenzuwirken und die ungebrochene öffentliche Präsenz des Kaisers unter Beweis zu stellen.

Im Sommer 1913 erscheinen wiederum fotografische Kaiserbilder in der Presse, auch dieses Mal aus Anlass seines Geburtstags am 18. August. Österreichs Illustrierte Zeitung, ein besonders kaisertreues Blatt, lässt Kaiser Franz Joseph in Jagdkleidung auf dem Titelblatt auftreten (Abb.9). ${ }^{15}$ Das Porträt, es stammt von Charles Scolik, der den Monarchen schon oft fotografieren durfte, übernimmt die Aufgabe, die Tat-

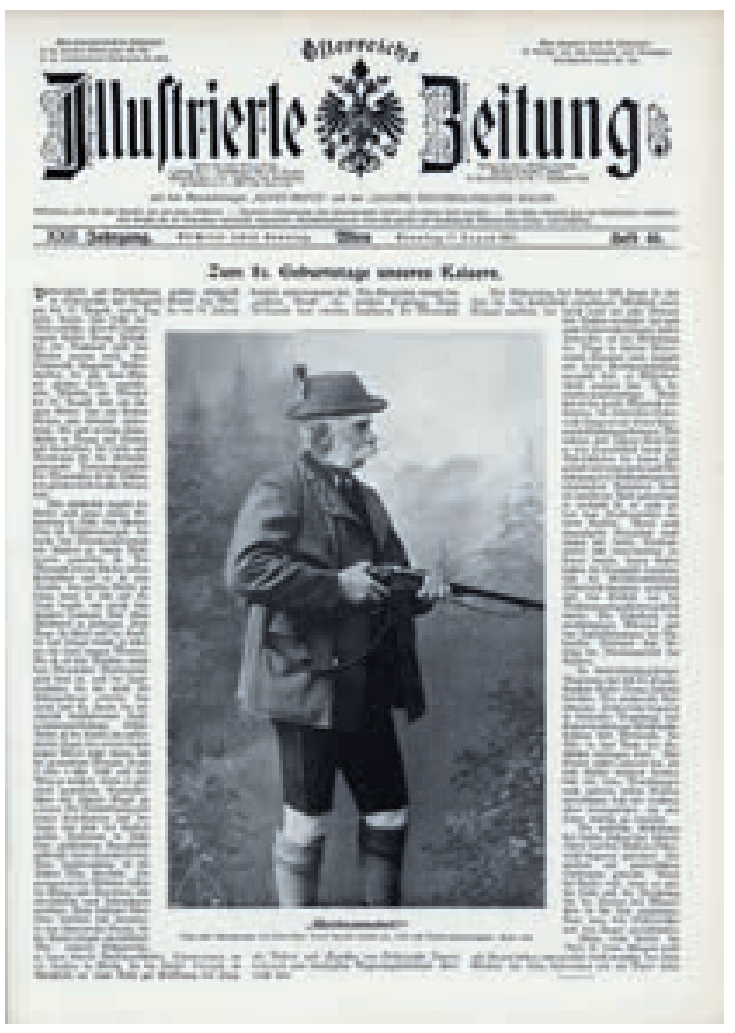

kraft des greisen Monarchen zu betonen. Der über 80-Jährige ist flott gekleidet: Hut mit Feder, Jägerjoppe, kurze Hose, kniehohe Stutzen. In den Händen hält er eine Büchse, den Blick richtet er aus dem Bild hinaus in die Ferne - ganz so, als ob er noch imstande wäre, dem Hirsch über Stock und Stein zu folgen. Tatsächlich aber ist die Aufnahme wohl im Atelier entstanden. Der Hintergrund ist, wie öfter bei Scolik, gezeichnet. Gelegentlich geht der Monarch aber tatsächlich noch auf die Jagd. Zumindest suggerieren das Bilder, die im Sommer 1913 in der illustrierten Presse erscheinen. Im Innenteil der genannten $\mathrm{Ge}^{-}$ burtstagsausgabe von Österreichs Illustrierter Zeitung, die am 17. August 1913 erscheint, zeigt ein Foto den Kaiser inmitten einer Jagdgesellschaft in MitterweiBenbach, in der Nähe von Bad Ischl (Abb. 10). Aufgenommen wurde das Bild, darauf verweist der Bildtext, im Jahr zuvor, am 31. Juli 1912, und zwar vom Hofjagdleiter August Böhm. Der Kaiser, der von Alter und Krankheit bereits schwer gezeichnet ist, hat in der Mitte der Szene Aufstellung genommen. Er stützt sich auf einen langen Gehstock. Vor ihm auf dem Boden liegt der getötete Hirsch - ganz so, als hätte er das Tier höchstpersönlich erlegt. Wenige Tage später, am 7. September 1913, taucht der Kaiser ein weiteres Mal als Jäger in der illustrierten Presse auf, dieses Mal in den Wiener Bildern. ${ }^{16}$ Der Wiener Fotograf Arthur Floeck, hat ihn am 1. September 1913 auf der Jagd in Bad Ischl begleitet. Die Aufnahme, die an diesem Tag entsteht, wird auf der Titelseite der Zeitung unter der Überschrift „„üngste Aufnahme des Kaisers“ veröffentlicht.

Nach 1913 erscheinen immer weniger aktuelle Fotos des Kaisers in der Presse. Die öffentlichen Termine des Monarchen werden seltener und damit auch die Gelegenheiten, den Kaiser ohne Anmeldung ablichten zu können. Am 21. März 1914 eröffnet Franz Joseph die Frühjahrsausstellung im Wiener Künstlerhaus. Der Fotograf, er wird nicht namentlich genannt, sondern lediglich als „Spezialphotograph des Interessanten Blattes“ bezeichnet, erhascht nur einen kurzen Augenblick der kaiserlichen Anwesenheit, nämlich jenen Moment, als der Franz Joseph die Kutsche verlässt und bei strömendem Regen das Ausstellungsgebäude betritt (Abb. 11). Die Bedingungen für 

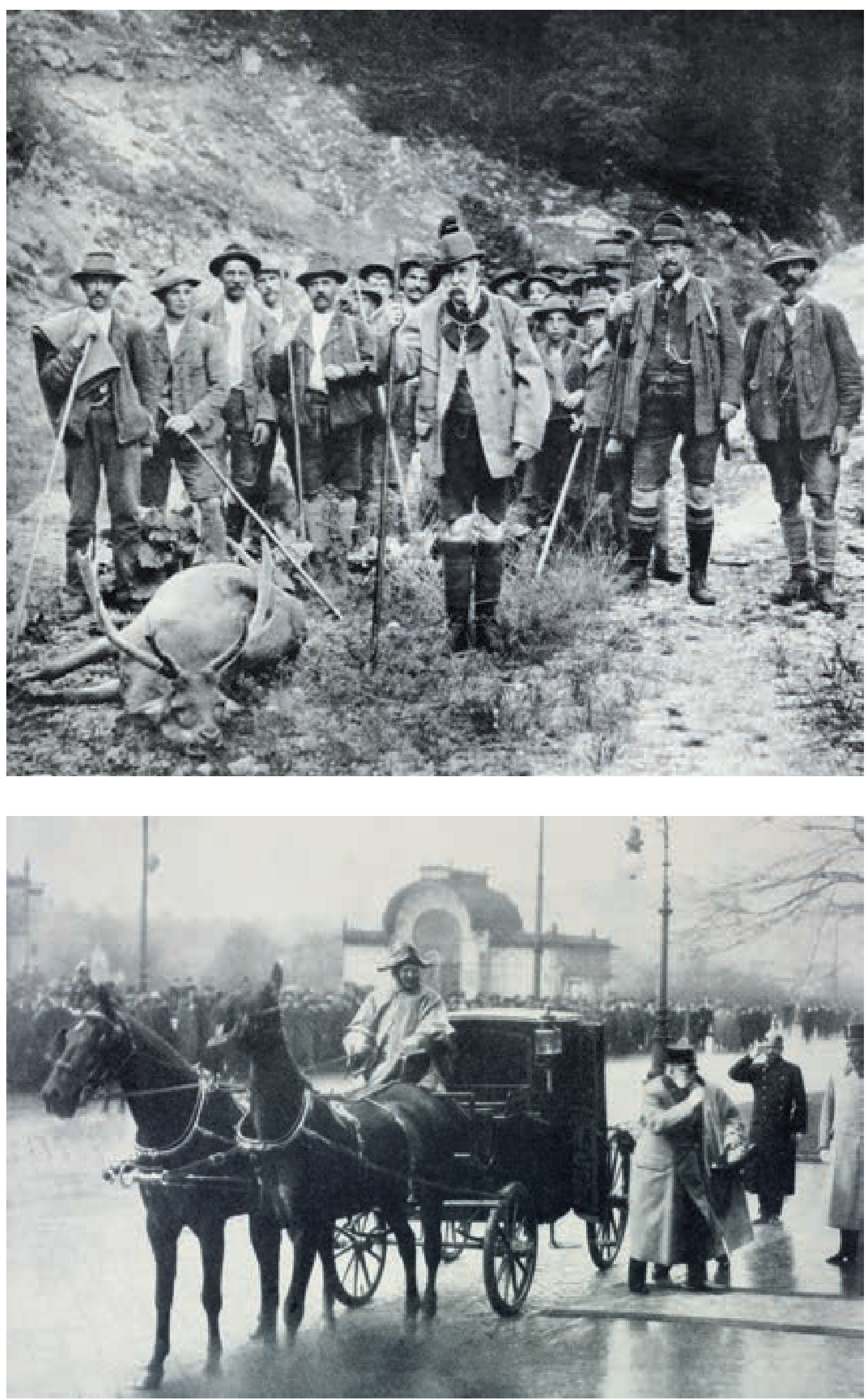

Abb. 10 Kaiser Franz Joseph auf der Jagd in Mitterweißenbach bei Bad Ischl. Österreichs Illustrierte Zeitung, 17. August 1913, S. 1228. Foto: August Böhm.
Abb. 11 Ankunft des Kaisers bei der Eröffnung der Frühjahrsausstellung im Wiener Künstlerhaus. Im Hintergrund ist der nach Plänen von Otto Wagner errichtete Stadtbahnpavillon zu erkennen. Das interessante Blatt, 26. März 1914, S. 8 


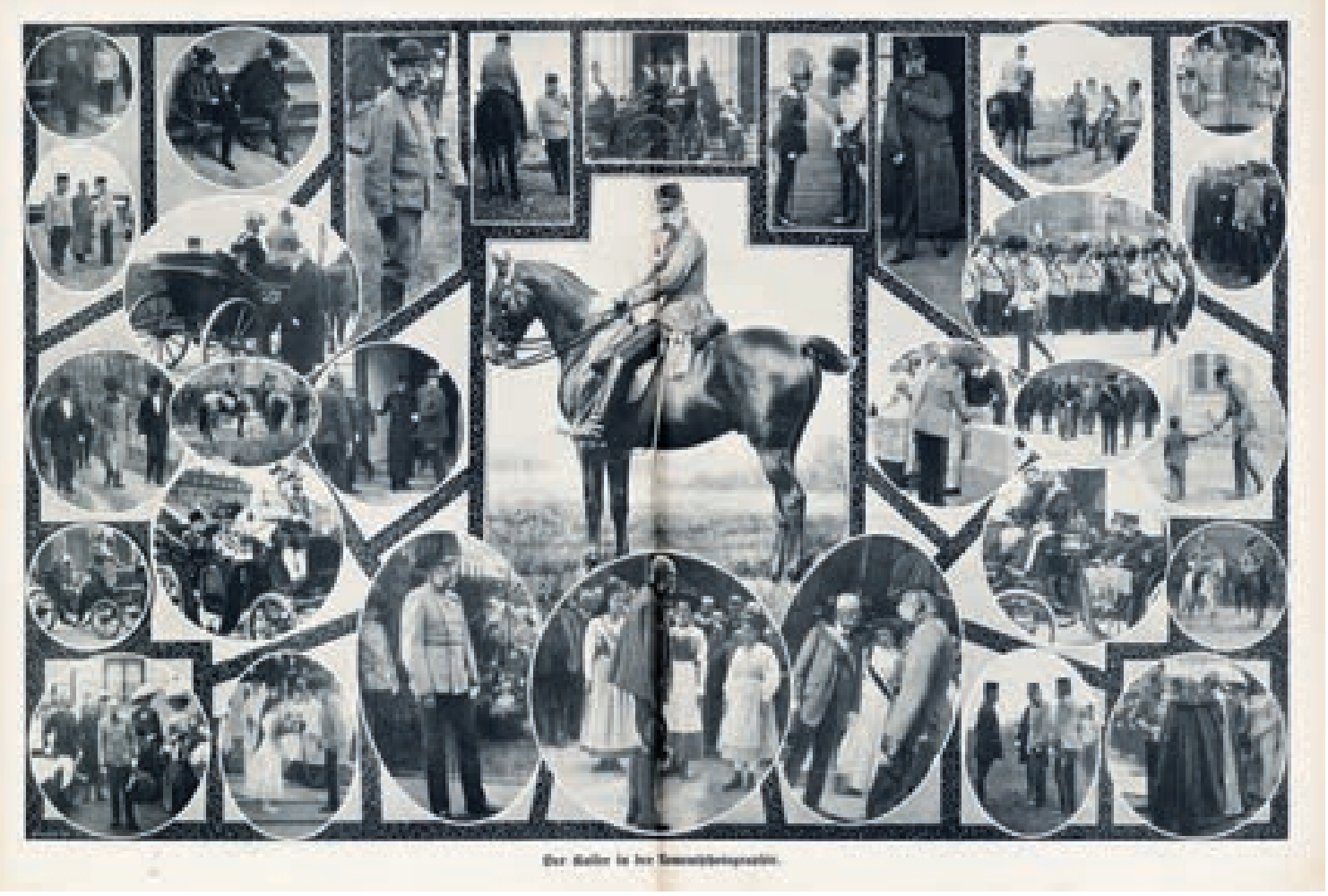

Abb. 14 „Der Kaiser in der Momentphotographie“. Erinnerungsszenen an den eben verstorbenen Kaiser Franz Joseph. Österreichs IIlustrierte Zeitung, 3. Dezember 1916, S. 206 und 207.

Auf diese Weise jubeln die Soldaten einem Kaiser zu, der in Wirklichkeit weit weg ist, aber im Bild doch über „seiner“ Truppe schwebt.

Als Kaiser Franz Joseph am 21. November 1916 stirbt, sind die Fotografen wieder zur Stelle. Der verstorbene Monarch wird auf dem Totenbett abgelichtet. Und der Trauerzug wird zum Staatsakt der Superlative. Alles, was in der Monarchie Rang und Namen hat, lässt sich beim Leichenbegängnis blicken. Die Presse berichtet in allen Details über das Ereignis. Kein Nachruf in der illustrierten Presse kommt ohne fotografischen Rückblick auf das Leben des Monarchen aus. Zwei Wochen nach Franz Josephs Tod, am 3. Dezember 1916, bringt Österreichs Illustrierte Zeitung unter dem Titel „Der Kaiser in der Momentphotographie“ eine Doppelseite zu Ehren des Prominenten (Abb. 14). ${ }^{20}$ In der Mitte sehen wir den Kaiser hoch zu Ross in der Pose des Feldherrn. Es ist eine Aufnahme, die Charles Scolik vor Jahren gemacht hat. Um dieses Bild herum gruppieren sich zahlreiche weiteres Szenen, die einen aktiven, agilen, volksnahen Monarchen zeigen: Er ist bei der Jagd und auf dem

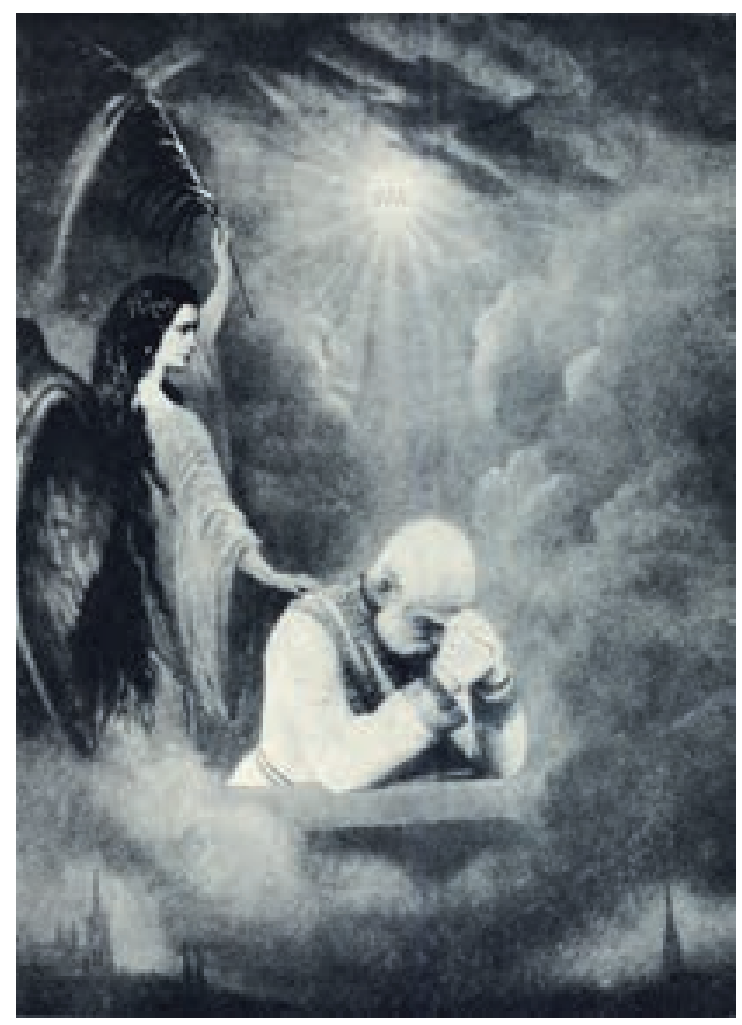

Abb. 15 „Friede“. Eine „Photokomposition“ von Charles Scolik, Weihnachten 1916. Österreichs IIlustrierte Zeitung, 24. Dezember 1916, S. 277. 

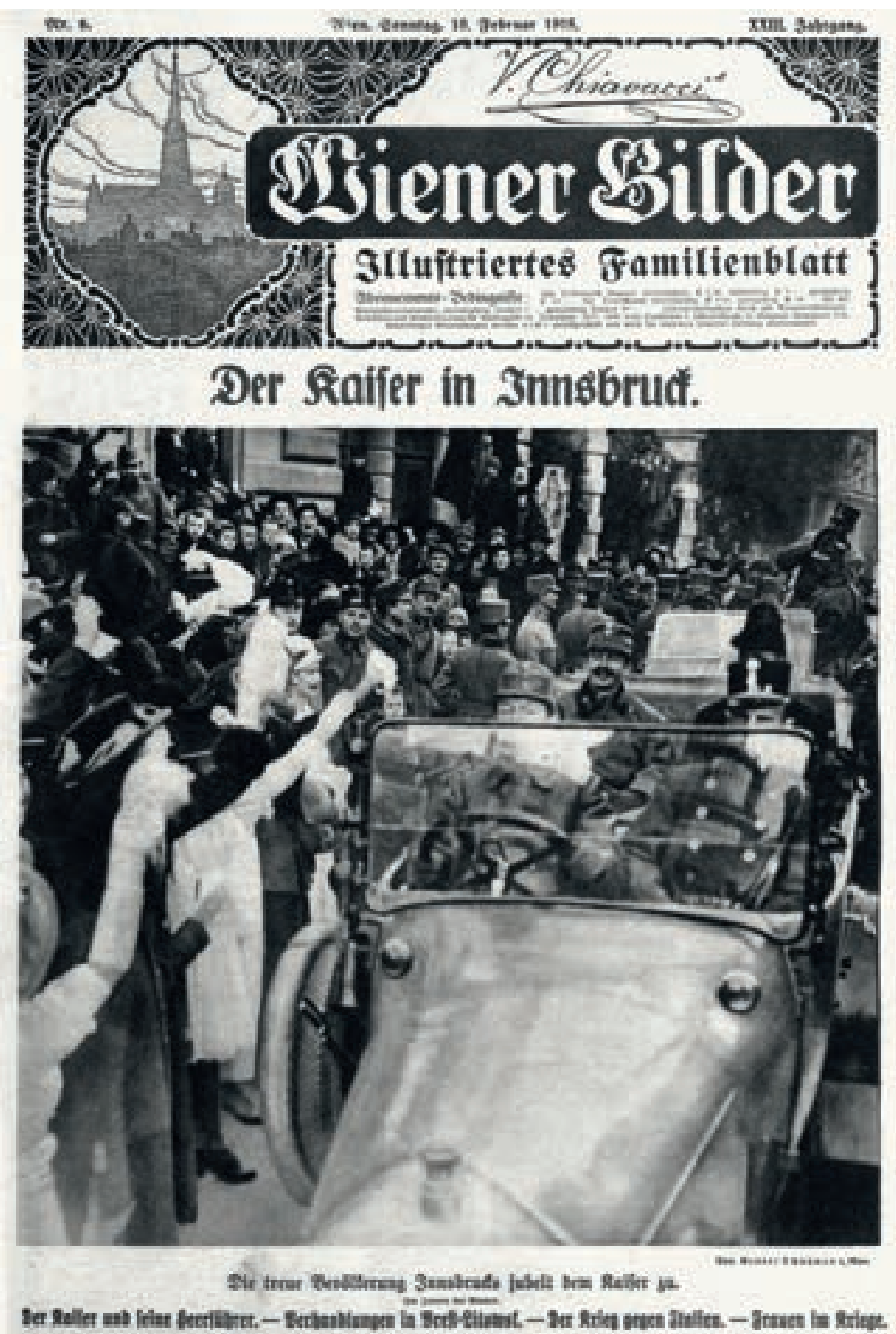

Abb. 16 Kaiser Karl I. zu Besuch in Innsbruck. Er sitzt im offenen Auto auf dem Rücksitz. Wiener Bilder, 10. Februar 1918, Titelseite. Foto: Heinrich und Ludwig Schuhmann.
Exerzierplatz, auf Staatsbesuch und bei Empfängen zu sehen. Seinem fortgeschrittenen Alter trotzend, ist er höchst geschäftig und ständig auf den Beinen. Er tritt uns in strenger Dienstuniform entgegen und in legerer Lodenjoppe, mit und ohne Hut. Die Botschaft dieses in hoher Auflage unters Volk gebrachten Tableaus ist klar: So hat der Kaiser regiert und gelebt, so soll er in der Erinnerung weiterleben.

Franz Joseph wird hier nicht in der Pose des gütigen, entrückten und unnahbaren Herrschers gezeigt, wie sie die frühen Atelierbilder gerne verbreiteten. Vielmehr erscheint er vor allem als öffentliche Figur, eine Rolle, die sich unter tatkräftiger Mithilfe der illustrierten Presse erst ab der Jahrhundertwende durchsetzt. Der Kaiser ist kein passives „Opfer“ dieser Imagekampagne, im Gegenteil, er spielt aktiv mit: Er absolviert zahlreiche Auftritte, lässt sich in der Öffentlichkeit gerne blicken und geht offenherzig auf sein „Volk“ zu. Es ist bemerkenswert, dass nun, nach seinem Tod, ein Bild verbreitet wird, das erst in den letzten eineinhalb Jahrzehnten seines Lebens entstanden ist. Die illustrierte Presse, in der dieses Image konstruiert wurde, hat also deutliche Spuren hinterlassen.

Am 24. Dezember 1916, wenige Wochen nach dem Tod des Kaisers, erlebt dieser in der Fotografie noch einmal eine Auferstehung (Abb. 15). ${ }^{21}$ Charles Scolik, ein Meister der Fotomontage, lässt den alten Monarchen, betend und in sich versunken, inmitten der Wolken erscheinen. Tief unter ihm ist schemenhaft die Silhouette einer Stadt zu sehen. Ein junger, weiblicher Engel fasst den Kaiser an den Schultern und weist mit der anderen Hand den Weg hinauf ins Licht. Dort prangt auf hellem Grund der Schriftzug „PAX“. Die Szene trägt den Titel „Friede“. Gemeint ist damit, mitten im Krieg, wohl nicht nur der Seelenfrieden des Verstorbenen, sondern auch der „Weihnachtsfrieden“ und wohl auch die Hoffnung auf ein Ende des Krieges, der nun schon zwei Jahre andauert.

\section{Karl, der Propagandakaiser}

Kaiser Karl I., der junge Nachfolger des verstorbenen greisen Monarchen, beginnt seine Regentschaft mit einem Feuerwerk der Propaganda - in eigener Sache. Am 20. Februar 1917 wird „auf allerhöchsten Befehl“ ein eigener „Pressedienst für die Allerhöchsten Herrschaften“ eingerichtet. ${ }^{22}$ Zum Leiter dieser neuen Propagandaeinrichtung wird Hauptmann Karl Werkmann bestimmt. Der Pressedienst dient ausschließlich dazu, Öffentlichkeitsarbeit für den Kaiser zu betreiben. Er soll, so Werkmann, „die Anhänglichkeit und Liebe der Bevölkerung zum Kaiserhause vertiefen“ und hat die Aufgabe, „unrichtigen, wenn auch liebevollem Interesse entspringenden Nachrichten über die Allerhöchsten Herrschaften durch rechtzeitige Verbreitung zutreffender Nachrichten vorzubeugen“ und „bei der Unterdrückung unwahrer oder ungelegener Nachrichten, sowie bei der Berichtigung unwahrer Nachrichten mitzuwirken“. ${ }^{23}$ 
Werkmann beherrscht das Handwerk der Bildpropaganda perfekt. Er sorgt dafür, dass die Medien nicht mehr von Karls Seite weichen. Zwei Fotografen, Ludwig und Heinrich Schumann, die beiden Söhne des bekannten Wiener Pressefotografen Heinrich Schuhmann sen., werden eigens abgestellt, um den Monarchen bei all seinen Reisen und Auftritten zu begleiten. Ein Großteil der Fotos, die von Kaiser Karl in der Presse erscheinen, stammt von ihnen, gekennzeichnet stets mit dem Hinweis „Photo. Brüder Schuhmann“. ${ }^{24}$ Wo der Kaiser auch auftaucht, sind stets Kameras und Filmoperateure dabei. Als im Juli 1917 eine Sondernummer der illustrierten Zeitschrift Sport \& Salon herauskommt, schlägt die Imagekampagne, die Werkmann für seinen Kaiser organisiert, alle Rekorde. 141 Fotografien des Monarchen werden unter der Regie von Werkmann allein in dieser Zeitschriftennummer untergebracht.

Besonders wichtig, so argumentiert Werkmann im April 1917, sei die möglichst „rasche Dotierung der illustrierten Blätter“ mit Kaiser-Aufnahmen. „Wenn z.B. eine Allerhöchste Reise, wie die letzte Bozener Reise, am Montag Vormittag endet, so müssen die Kopien noch am gleichen Nachmittage bei den Wiener illustrierten Blättern sein, wenn sie am nächsten Sonntag veröffentlicht werden sollen. Eine Verschiebung der Veröffentlichung um weitere 8 Tage ist ganz unmöglich, da das zahlreiche jetzt auf allen Gebieten vorliegende aktuelle Bildermaterial das eigene Material erdrücken würde." Tatsächlich sei, so Werkmann weiter, der Erfolg dieser Anstrengungen bei der Presse so überwältigend, „daß seit vielen Wochen fast keine Nummer der österreichischen und ungarischen illustrierten Presse mehr ohne irgendwelche Bilder erscheint, in deren Mittelpunkt die Allerhöchsten Herrschaften stehen, und daß auch die ausländischen Blätter häufiger denn je solche Bilder reproduzieren.“" ${ }^{25}$ Der Erfolg dieser propagandistischen Anstrengungen bleibt nicht aus. Ab Anfang 1917 ist das Kaiserbild allgegenwärtig.

Karl ist in den knapp zwei Jahren seiner Amtszeit pausenlos unterwegs. Er besucht unterschiedliche Frontabschnitte und Städte im Hinterland, um die ermattende Moral der Truppen und der Bevölkerung zu stärken. Diese Kaiserreisen sind medial bis ins De- tail durchkomponiert. Die illustrierte Presse berichtet ausführlich über jede dieser Unternehmungen. Als Kaiser Karl Anfang Februar 1918 Innsbruck besucht, erscheint wenige Tage später ein Foto von seinem triumphalen Auftritt auf der Titelseite der Wiener Bilder (Abb. 16). Wir sehen den Kaiser im Auto, das von einer begeisterten Menschenmenge umringt ist. „Die treue Bevölkerung“, so heißt es unter dem Foto, „jubelt dem Kaiser zu.“26

Im März 1918, die Versorgungslage der Bevölkerung in den Städten der Monarchie ist in diesem Winter besonders katastrophal, die Hungersnot breitet sich aus, trifft der Kaiser in der kleinen böhmischen Stadt Graslitz (dem heutigen Kraslice) ein. Für die Kamera besucht er die Volksküche der Stadt, die der an Hunger leidenden Bevölkerung Ausspeisung anbietet, und löffelt Suppe aus einem einfachen Teller. „Kaiser und König Karl versucht in der Graslitzer Volksküche die Suppe“, lautet der Bildtext, mit dem das Foto an die Presse geht. Tage später wird es unter dem Titel „Der Kaiser im böhmischen Notstandsgebiet“ in großer Aufmachung auf der Titelseite des Interessanten Blattes gedruckt. ${ }^{27}$ Nach dem Besuch der Suppenküche schreitet Karl durch ein Spalier von Schaulustigen. Wieder ist der Kaiserfotograf Ludwig Schuhmann zur Stelle. „Die Jugend von Graslitz jubelt Kaiser und König Karl beim Verlassen der Kriegsküche zu." So heißt es für die Presse. ${ }^{28}$

\section{Eine neue Ära beginnt}

Im Herbst 1918 ist der Krieg zu Ende und das habsburgische Reich fällt innerhalb weniger Tage in sich zusammen. Und auch die Tage Kaiser Karls sind nun gezählt. Wie rasch sich das Kaiserimage Karls, das unter gewaltigem Propagandaaufwand errichtet wurde, in nichts auflöst, zeigt eine Szene, die Stefan Zweig in seiner Autobiografie überliefert. Am Nachmittag des 24. März 1919 erreicht der Zug, der den letzten habsburgischen Kaiser, seine Frau Zita und ein paar Familienmitglieder ins Schweizer Exil bringt, Vorarlberg. Zweig, der dem versprengten Grüppchen Habsburger zufällig auf dem Bahnhof von Feldkirch begegnet, erinnert sich an die seltsame Abschiedsszene: „Die Gendarmen, die Polizisten, die Sol- 

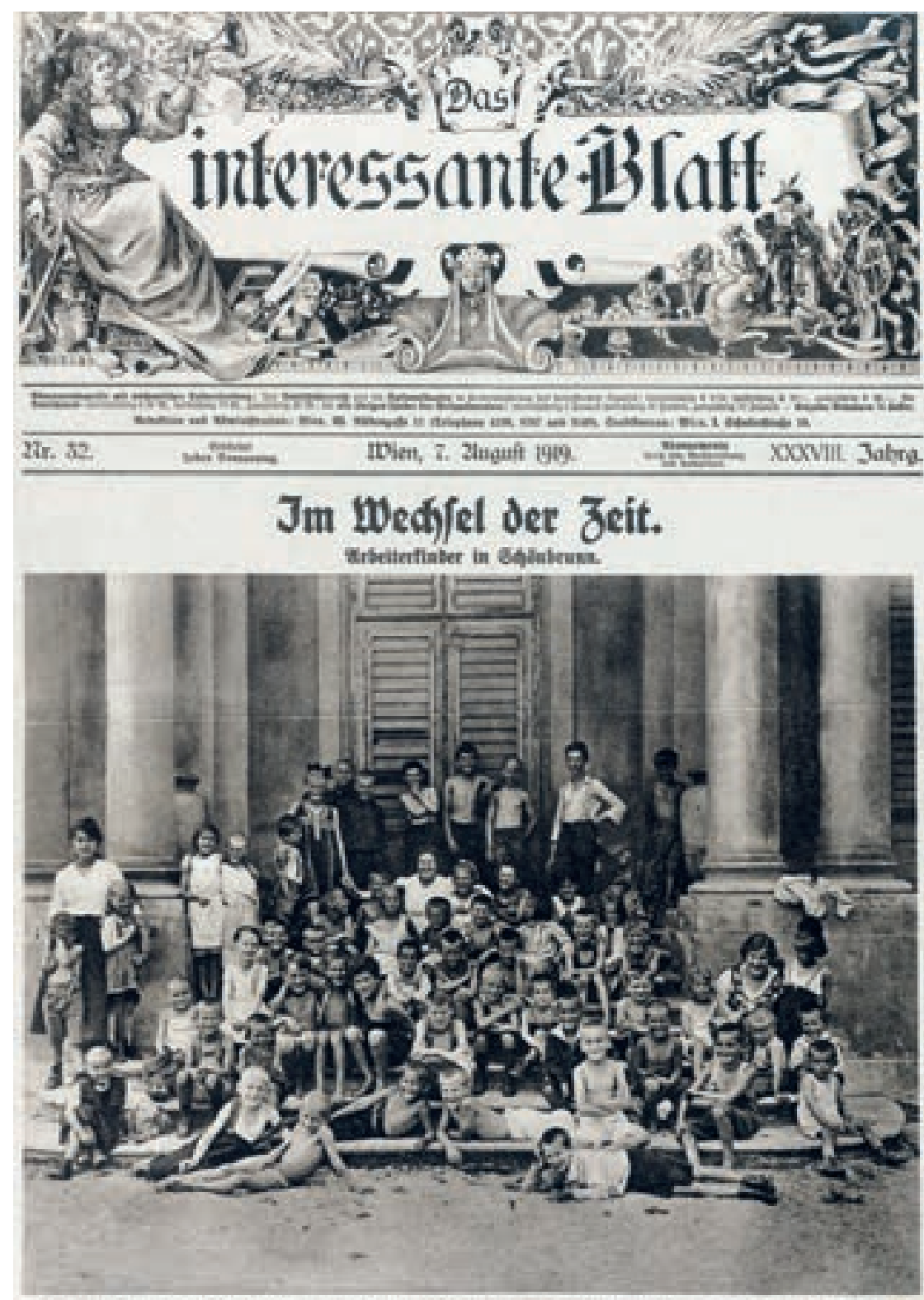

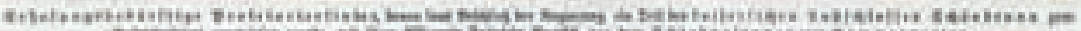

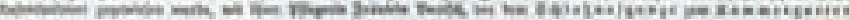
a

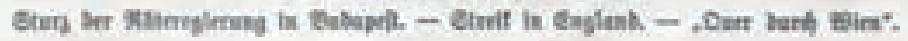

Abb. 17 Arbeiterkinder, die zur Erholung im Schloss Schönbrunn untergebracht werden, Sommer 1919. Nach dem Zusammenbruch der Habsburger Monarchie und dem Gang des Kaisers ins Exil werden die ehemaligen Prunkräume neu genutzt. Das interessante Blatt, 7. August 1919, Titelseite. daten schienen verlegen und sahen leicht beschämt zur Seite, weil sie nicht wussten, ob sie die alten Ehrenbezeugungen noch leisten dürften, die Frauen wagten nicht recht aufzublicken, niemand sprach und so hörte man plötzlich das leise Schluchzen der alten Frau in Trauer, die von wer weiß wie weit gekommen war, noch einmal ,ihren“ Kaiser zu sehen. Schließlich gab der Zugführer das Signal. Jeder schrak unwillkürlich auf, die unwiderrufliche Sekunde begann. Die Lokomotive zog mit einem starken Ruck an, als müsste auch sie sich Gewalt antun, langsam entfernte sich der Zug." ${ }^{29}$ Dann passiert der Zug die österreichisch-schweizerische Grenze. Karl wird nie mehr nach Österreich zurückkehren.
Eine Woche später, am 1. April 1919, ist Wien in Aufregung: Das inzwischen „republikanisch“ gewordene kaiserliche Schloss Schönbrunn wird für das gemeine Volk geöffnet. Zahlreiche Schaulustige tummeln sich in diesen Tagen in den endlosen Gängen und Fluchten des habsburgischen Schlosses. Sie spazieren durch die ehemals privaten Räume Karls, Zitas, Franz Josephs und all der anderen Habsburger, die hier gewohnt hatten. Besonderer Beliebtheit erfreut sich das Schlafzimmer des kaiserlichen Paares. Egon Erwin Kisch, der zu dieser Zeit als junger Reporter in Wien lebt, berichtet am 11. April 1919 in der Tageszeitung Der neue Tag über die neuen Schlosstouristen: „Seit dem 1. dieses Monats werden Besucher gegen Eintrittsgebühr von einer Krone über die eisglatten Parketts der Fremden- und Zeremonialappartements geführt, in die große Galerie, in das chinesische Rundkabinett, in das Karussellzimmer, den Zeremoniensaal, den Gobelinsalon (...) und in das Schlafzimmer, wo (...) Exkaiser Karl und Exkaiserin Zita bis zum November genächtigt haben." Und er ergänzt süffisant: „Wenn so ein alter Habsburger, zum Exempel Kaiser Franz Joseph, vom Himmel die Bewilligung bekäme, jetzt oder in zwei Monaten sein Schönbrunner Lustschloß zu besichtigen - er würde die Hände über dem Kopf zusammenschlagen. “30

Die fröhliche Inbesitznahme der altehrwürdigen, nun verwaisten kaiserlichen Prunkräume hat kurz nach dem Ende des Krieges und nach dem Zerfall der Monarchie eine enorme symbolische Bedeutung. Im Sommer 1919 beschließt die neue Regierung, der auch die Sozialdemokraten angehören, im Schloss Schönbrunn „erholungsbedürftige Proletarierkinder“ unterzubringen. Am 7. August 1919 wird die lachende Kinderschar, die nun in den habsburgischen Räumen wohnt, zusammen mit ihren Betreuerinnen und Betreuern auf der Titelseite des Interessanten Blattes porträtiert (Abb. 17). ${ }^{31}$ Den Kindern, die sich auf der Treppe vor dem ehemaligen Kammergarten versammelt haben, sind Not und Entbehrungen deutlich anzusehen. Viele der kleinen Körper sind dünn und abgemagert. Aber alle lachen in die Kamera. Der Titel über dem Bild lautet: „Im Wechsel der Zeit. Arbeiterkinder in Schönbrunn.“ 


\title{
Als die Männer fliegen lernten
}

\author{
Die ersten Wiener Flugschauen
}

„In einem Zeitalter, wo die ,Nerven“ eine so große Rolle spielen und wo die Heilanstalten nicht im Stande sind, alle Leute aufzunehmen, die dort Zuflucht und Gesundheit suchen, ist die Bedingung: Kaltblütigkeit - eine sehr strenge Forderung. Und doch ist sie die weitaus notwendigste Eigenschaft des Luftschiffers. Dann kommt als zweites: eine Körperkonstitution, die Strapazen ertragen kann."1 Als der österreichische Ballonpionier Franz Hinterstoisser 1904 in einem autobiografischen Rückblick diese Sätze schreibt, skizziert er die Erfahrungen des Luftschiffers als Gegenpol zur diagnostizierten Kulturkrise. Während der Durchschnittsmensch an den „Nerven“ und an der Hektik der Großstadt leide, schaffe es der Ballonpionier - dank seiner Kaltblütigkeit und Stärke -, der kränkelnden Zivilisation kraftvoll entgegenzutreten. Er, der Luftschiffer, sei der wirkliche Antipode zur angeschlagenen Kreatur am Boden, er sei das Vorbild, wenn es um die Schulung von Geist und Körper gehe. Bei den Ballonfahrten, so Hinterstoisser, „lernen wir unter neuen, nicht gewöhnlichen, ganz eigenartigen Bedingungen das Leben kennen - ein Reiz, den das Menschengeschlecht erst zu kosten begonnen hat und der nur wenigen Auserlesenen zu genießen ermöglicht ist. Frohgemut und willenlos folgen wir der Windsbraut, bis wir wieder den Ballon mit Überlegung, Ruhe und Geistesgegenwart zur Erde zwingen; das alles stählt unsere Nerven zum weiteren Kampf im täglichen Leben, macht unser Herz gesund von all den vielen kleinlichen Sorgen und zeigt uns die erhabene Größe der Natur im stolzen, einsamen Fluge über jene Welt, die so klein ist.“2

Der Traum vom Verlassen der Erde, das zeigen diese Passagen, wird als Flucht aus dem bedrückenden Alltag der städtischen Zivilisation imaginiert. Diese Sehnsucht erfasst um die Jahrhundertwende eine ganze Generation. Die Ballonhelden, die die Welt der Lüfte gesehen und erlebt haben, werden am Boden stürmisch empfangen. Das gilt für auch für Hinter- stoisser selbst. Seinen Lichtbildvortrag „In den Lüften“ präsentiert er unzählige Male. Allein im Jahr 1898 tritt er 98-mal vor Publikum auf, bis 1903 hält er den Vortrag insgesamt 300-mal. ${ }^{3}$

Noch kurz nach der Jahrhundertwende gilt es als ausgemacht, dass die Zukunft der Luftfahrt dem Ballon oder allenfalls dem jüngst entwickelten Zeppelin gehört. In den folgenden Jahren verschieben sich die Gewichte aber schlagartig. Die Ballonpioniere erhalten ernsthafte Konkurrenz durch neuartige Fluggeräte, die schwerer sind als Luft: Flugzeuge. Ein neuer Typus des Aviatikers tritt auf: der Flugzeugpilot. Noch hat sich kein allgemeingültiger Begriff für diese motorgetriebenen Luftschiffe etabliert. Sie werden Aeroplane, Drachenflieger oder einfach Apparate genannt. Der erste Flug der Brüder Wright im Prototyp eines Aeroplans im Jahr 1903 ist noch ein unsicheres Hoppeln über den Boden. Zwölf Sekunden lang hebt das Gerät ab, nach 36 Metern ist es wieder am Boden. Bald aber werden die Fluggeräte verbessert. Immer weiter fliegen die neuen Apparate. Als die Brüder Wright sich 1908 entschließen, ihre Erfindung, die sie zunächst weitgehend im Geheimen weiterentwickelt haben, in Form von Flugshows öffentlichkeitswirksam zu bewerben, geht es Schlag auf Schlag. Immer neue Pioniere tauchen auf, immer neue Wettrennen werden veranstaltet und lukrative Preise ausgelobt. Am 13. Januar 1908 gelingt es dem französische Flugpionier Henry Farman als erstem Menschen, einen Kilometer im motorgetriebenen Flugzeug zurückzulegen. Er erhält 50000 Francs Preisgeld. Monat für Monat werden nun neue Rekorde aufgestellt. Als Wilbur Wright am 31. Dezember desselben Jahres eine Strecke von 124 Kilometern in zwei Stunden und 20 Minuten zurücklegt, zweifelt niemand mehr an der Zukunft der motorgetriebenen Luftfahrt.

Innerhalb weniger Monate ist aus dem technischen Spleen einiger weniger eine Masseneuphorie geworden. In vielen Städten Europas werden nun 
Hinter der Wiener Veranstaltung steht der umtriebige Theaterbesitzer Leopold Müller. Er ist Direktor des Wiener Carl-Theaters in der Leopoldstadt und gründet 1908 das Johann-Strauß-Theater in der Favoritenstraße. Müller hat im Oktober 1908 in Reims den ersten Überlandflug Henry Farmans gesehen und begeistert sich schnell für diese neue Form der Aviatik. Im April 1909 lädt er Blériot für den Herbst nach Wien ein. ${ }^{8}$ Er zieht die Flugschau als Spektakel für die groBe Masse der Bevölkerung auf, rührt kräftig die Werbetrommel und entfacht auf diese Weise ein mediales Feuerwerk rund um Blériots Auftritt. Ohne Eigennutz ist sein Engagement freilich ganz und gar nicht: Der Impresario verdient gut an der Veranstaltung.

Müller überlässt nichts dem Zufall. Tage vor dem Auftritt des Fliegers findet im Kursalon Hübner im Wiener Stadtpark eine Ausstellung statt, in der Blériots „Aeroplans“ präsentiert werden. Eintritt: eine Krone. Am Rande des Flugfeldes lässt der Veranstalter Tribünen und Bänke aufstellen. Die Karten werden im Vorverkauf angeboten. Logenplätze für die aristokratische Gesellschaft kosten immerhin 150 Kronen. Für Tribünensitze werden zwischen fünf und 30 Kronen verlangt, einfache Banksitze kosten drei Kronen, Stehplätze eine Krone. Sogar Kaiser Franz Joseph hat sein Kommen zugesagt. Eigens für ihn wird wenige Schritte vom Flugzeughangar ein vornehmes Zelt errichtet.

Am 23. Oktober, einem Samstag, drängen sich nachmittags 200000 Schaulustige um das 1000 Meter lange und 800 Meter breite Flugfeld. Das Warten auf den prominentesten Zaungast, den Kaiser, beginnt. Zahlreiche Journalisten, unter anderem jene der Wiener Bilder, des Interessanten Blattes und der Wiener Luftschiffer-Zeitung sind ganz in der Nähe. Sie registrieren jedes Detail. Folgen wir ihren Beobachtungen: „Lange, ehe Blériot kam, waren schon die Erzherzöge Karl Stephan und Leopold Salvator da und besichtigten den Flugapparat, dessen Motor eben in Tätigkeit gesetzt wurde, während Chauffeur und starke Männer rückwärts die Maschine festhielten, damit sie an Ort und Stelle blieb. “9 Dann ist es so weit: „Punkt 15.45 Uhr verkündeten Hochrufe von der Zufahrtsstraße her und das Spiel der Volkshymne das Nahen des Kaisers, und die Mitglieder des Hofes tra- ten vor den Hangar hinaus. (...) Blériot wartete neben seiner Frau im blauen Arbeitskleid. Der Kaiser reichte ihm und seiner Gattin die Hand und ließ sich dann den Apparat erklären, einen aus leichtem Gestänge zusammengesetzten Einflächer, mit weiten Flügeln und einem langen Steuer. Gelenkt wird er mit einem Automobillenkrad, ein kleiner Schemel ist der Sitz. Der Motor verzehrt 24 Liter Benzin in der Stunde.“10 Nach der kurzen Konversation, die der Monarch auf Französisch führt, betritt er die Hofloge.

\section{Der Kaiser schaut zu}

Blériot nimmt in seinem Apparat Platz. „Da erscholl das Surren des Motors, und aller Blicke wandten sich dem Hangar zu, aus dem im nächsten $\mathrm{Au}^{-}$ genblicke Blériots Aeroplan hervorrollte. Der Kaiser wies mit dem Zeigefinger auf das Feld hinaus, als das Fahrzeug sich über den Boden erhob und schön in die Lüfte stieg, und als bei der ersten Wendung Blériot unter stürmischen Bravorufen des Publikums am Zelt vorbeikam, winkte der Kaiser mit der Hand empor und begleitete auch die lauten Kundgebungen der Menge, mehrmals ins Publikum blickend, mit zustimmendem Kopfnicken." 11

Blériot „beginnt seine ruhigen, sicheren Kreise zu ziehen; enger und weiter, bald näher bleibend, bald bis an die äußersten Grenzen des 2,5 km im Umkreis messenden Flugfeldes fliegend, bald wippend, niedersteigend und wieder sich empor schwingend - in Höhen, die auf 50-70 Meter zu schätzen sind. In der vierten Runde zieht er vor dem Kaiser die Mütze, um gleich darauf wieder steil in die Höhe zu gehen. In der darauffolgenden Runde nähert er sich dem Boden einmal auf ungefähr einen Meter Höhe, so daß man glaubt, er wolle schon landen. Aber gleich darauf ist er wieder so hoch, daß er alle nahen Häuser tief unter sich lässt. Nach der fünften großen Runde hat Blériot von dem Rundumfahren offenbar schon genug, und macht insbesondere vor dem Hofzelt allerhand Schlingen, Bogen und Achter, bei denen man beobachten kann, mit welch entzückender Grazie der Aeroplan Kurven beschreibt. Er neigt sich dabei mit den Flügeln leicht nach der Innenseite, um gleich darauf wieder sicher geradeaus zu schweben." 12 


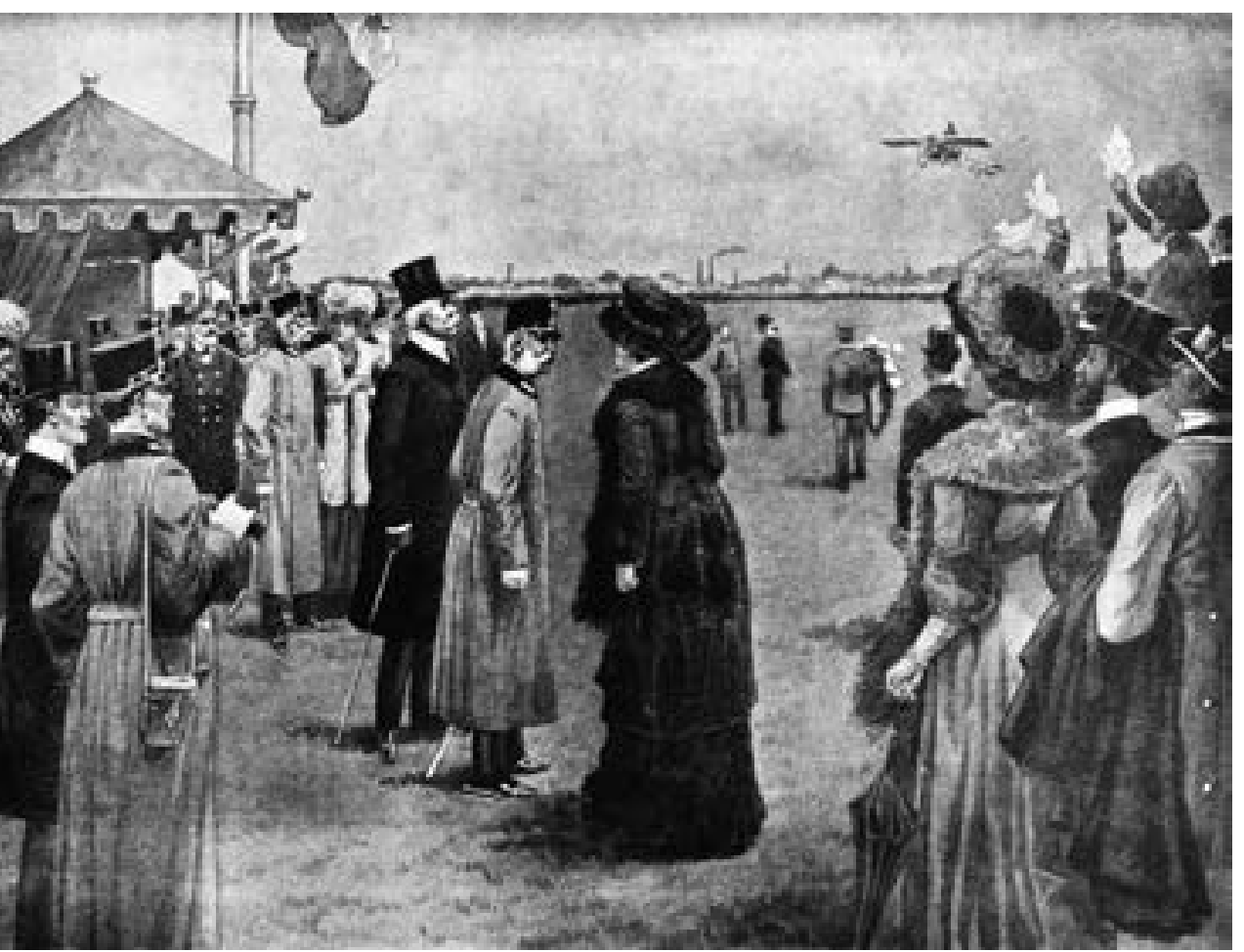

Abb. 2 „Blériots Flug vor dem Kaiser“. Die Zeichnung zeigt Franz Joseph am 23. Oktober 1909 am Rande des Flugfeldes auf der Simmeringer Haide im Gespräch mit Blériots Frau. Im Hintergrund ist Louis Blériot in der Luft zu sehen. Wiener Bilder, 27. Oktober 1909, Titelseite.
„Der Kaiser, der während der Flugbewegungen sich mehrmals auch an den Impresario Müller wandte und sich von ihm seine jeweiligen Höheschätzungen bestätigen ließ, die zutreffend waren, trat, als er Blériot zur Erde kommen sah, weit vor und ging dem Luftschiffer entgegen, der seinen Sitz verließ. Der Kaiser reichte Blériot, der die Mütze abnahm, die Hand und schüttelte sie kräftig. ,Es war ein sehr interessantes Schauspiel', sagte der Kaiser. „Ich bewundere den Mut und die Ausdauer, mit dem Sie das Werk geschaffen haben. Allein, es hat alle Mühe gelohnt. Die Stabilität des Apparats ist ebenso vorzüglich, wie die Sicherheit der Operationen. ' Nach einem Dankeswort Blériots fragte der Kaiser: ,Ist das Fahren in der Luft und Dirigieren der Mechanik anstrengend? Blériot erwiderte. Jetzt nicht mehr, Majestät. Jetzt ist es das reine Vergnügen für mich.' Danach trat der Kaiser mit einer leichten Verneigung und den Worten: ,Sehr hübsch! In der Tat sehr hübsch!' ein wenig zurück." 13

22 Minuten dauert der erste Flug. Blériot steigt bis zu 70 Meter hoch auf und dreht seine Runden über dem Flugfeld mit einer Geschwindigkeit von rund 50 Kilometern pro Stunde. Das Publikum ist begeistert. Blériot landet, nimmt vom Monarchen die Glückwünsche entgegen und bittet diesen, noch zu einem zweiten Flug zu bleiben. Er „vollführte nun durch 16 1/2 Minuten die kühnsten Manöver, wobei sich der Apparat bei den scharfen Wendungen oft ganz seitwärts neigte. " ${ }^{14}$ Nach der zweiten Landung zieht sich der
Kaiser unter brausenden Hochrufen zurück. Blériot flüchtet, so berichtet die Presse, vor den stürmischen Ovationen der Zuschauermassen in sein Auto und kehrt ebenfalls in die Stadt zurück.

Wenige Tage später widmen die Wiener Bilder dem Ereignis vom Wochenende die Titelseite. Unter der Schlagzeile „Blériots Flug vor dem Kaiser“ findet sich eine Zeichnung, die den Kaiser inmitten der aristokratischen Gesellschaft am Rande des Flugfeldes zeigt (Abb. 2). Während er in ein Gespräch mit der Frau Blériots vertieft ist, zieht im Hintergrund die Flugmaschine vorbei. „Auf der Simmeringer Haide“, so heißt es im Innenteil derselben Nummer, „ist etwas geschehen, was tausende Wiener, die zugegen waren, dereinst ihren Kindern und Kindeskindern erzählen werden. Sie waren dabei, als hier zum ersten Male gesehen wurde, was vor wenigen Jahren nur als Traum von Sonderlingen gelten konnte. Die Erdenschwere zu überwinden, nicht durch Gase, sondern durch den Auftrieb der Luft, wie es der Vogel macht, durch die Nachahmung der Natur und durch Ablauschen aller Widerstandsgesetze der Luft, ist so neu, daß sich kaum sagen lässt, es wäre schon früher in den Vorstellungen gewesen.“15

\section{Schwierigkeiten der Wahrnehmung}

Warum verwenden die Wiener Bilder für ihre Titelillustration eine Zeichnung und nicht eine Fotografie? Immerhin hat sich in der illustrierten Wochenpresse das Foto bereits als dominantes Bildmedium durchgesetzt. Zur Bebilderung mancher Themen greifen die Redaktionen der illustrierten Blätter aber immer noch auf die Zeichnung zurück. Diese ist eher als die Fotografie imstande, eine komplexe Szene visuell zu vereinfachen und verdichten. Ebenso gelingt es ihr besser, unterschiedliche, nacheinander stattfindende Momente in ein und demselben Bild zusammenzuführen, etwa das Gespräch mit Blériots Frau und den Flieger in der Luft (vgl. Abb. 3). Dramatische, sich schnell bewegende und verändernde Szenen wie etwa der Aufstieg und der Flug des Aeroplans, der nur aus größerer Entfernung abzulichten ist, stellen nach wie vor eine Herausforderung für die Pressefotografen dar, die in diesen Jahren noch mit schweren Platten- 
kameras und meist mit Stativ arbeiten. Es ist schwierig für sie, das fliegende Gefährt so auf die Platte zu bannen, dass nicht ein verwischter kleiner Fleck am Himmel zu sehen ist, sondern ein eindrucksvolles, brauchbares Bild entsteht. Eingebaute Zooms kennen die Apparate zu dieser Zeit noch nicht. Dennoch lassen sich die Fotografen das große Ereignis nicht entgehen. Alle wichtigen Wiener Pressefotografen haben ihre Kamera am Rande des Flugfeldes aufgestellt. Unter ihnen sind Heinrich Schuhmann sen., Charles Scolik jun. und Carl Seebald, der seine und fremde Bilder über die wenige Monate zuvor gegründete Fotoagentur „Illustrations-Zentrale“ vertreibt. Ebenso anwesend sind Fotografen der Fotohandelsfirma R. Lechner (Wilh. Müller). Ihre Bilder erscheinen in den kommenden Wochen in der illustrierten Presse.

Trotz der massiven Präsenz der Fotografen erscheinen aufgrund der geschilderten Schwierigkeiten in der Presse nur wenige Aufnahmen, die Blériot in der Luft zeigen. Eines davon hat der namentlich nicht bekannte Fotograf des Interessanten Blattes aufgenommen (Abb. 3). ${ }^{16} \mathrm{Um}$ sich ein besseres Sichtfeld zu verschaffen, hat er sich aus den Zuschauerreihen gelöst und sich über die hölzerne Absperrung hinweggesetzt, die die Schaulustigen vom Flugplatz trennt. Wohl mit Zustimmung der Ordner mit weißer Armschleife, die am Rande der Absperrung zu sehen sind (einen von ihnen erkennt man in der Bildmitte), hat der Fotograf sich einige Meter weit auf das Flugfeld vorgewagt. Von hier aus kann er die Zuschauermenge, die sich am Rande des Platzes drängt, in den Blick nehmen und zugleich das Fluggerät in der Luft ablichten. Trotz allem Aufwand ist auch sein Ergebnis nicht ganz befriedigend. Der Fotograf hat sichtlich Mühe, die Dramatik des Augenblicks in ein adäquates Bild zu übersetzen. Das Flugzeug ist aus relativ großer Entfernung aufgenommen. Es erscheint als kleiner, filigraner Schatten über der Zuschauermenge, das Gestänge des Fahrwerks ist gerade noch auszumachen, den Piloten selbst sieht man gar nicht.

Aber nicht nur die Fotografen, auch die Zuschauer selbst kämpfen mit den Schwierigkeiten der Wahrnehmung. Einige von ihnen haben Feldstecher mitgebracht, andere schützen ihre Augen mit der Hand gegen das helle Sonnenlicht. Die ungewohnte Darbie- tung vollzieht sich - vor allem am Anfang - für das Publikum viel zu schnell, als dass es ihr in Ruhe folgen könnte. „Der Aufstieg“, notiert Tage später der Redakteur der Wiener Luftschiffer-Zeitung, „hat sich so schnell, so überraschend vollzogen, daß die überrumpelten Zuschauer erst nach und nach zu dem deutlichen Bewusstsein gekommen sind, was sie eigentlich vor sich sehen.“ ${ }^{17}$ Und er ergänzt: „Man ist gekommen, um fliegen zu sehen, und dennoch dauert es Sekunden, Minuten, um sich über das Gefühl hinüberzuretten, daß das Wahrgenommene ein bloßer Traum sei.“

\section{Neue Helden}

Blériots triumphaler Auftritt in Wien verleiht den österreichischen Flugpionieren gewaltigen Auftrieb. Die Massenbegeisterung für das Fliegen hält bis zum Ersten Weltkrieg ungebrochen an. Fast wöchentlich berichten die Blätter über technische Neuerungen und erzielte Rekorde. Flugzeuge und Piloten sind umjubelte Stars in der Öffentlichkeit. Die Aeronautik liefert in den Jahren vor dem Krieg - nicht nur in Österreich - eine Art kompensatorischen Heroenkult.
Abb. 3 Louis Blériots Flug am 23. Oktober 1909 in Wien. Das interessante Blatt, 28. Oktober 1909, S. 11.

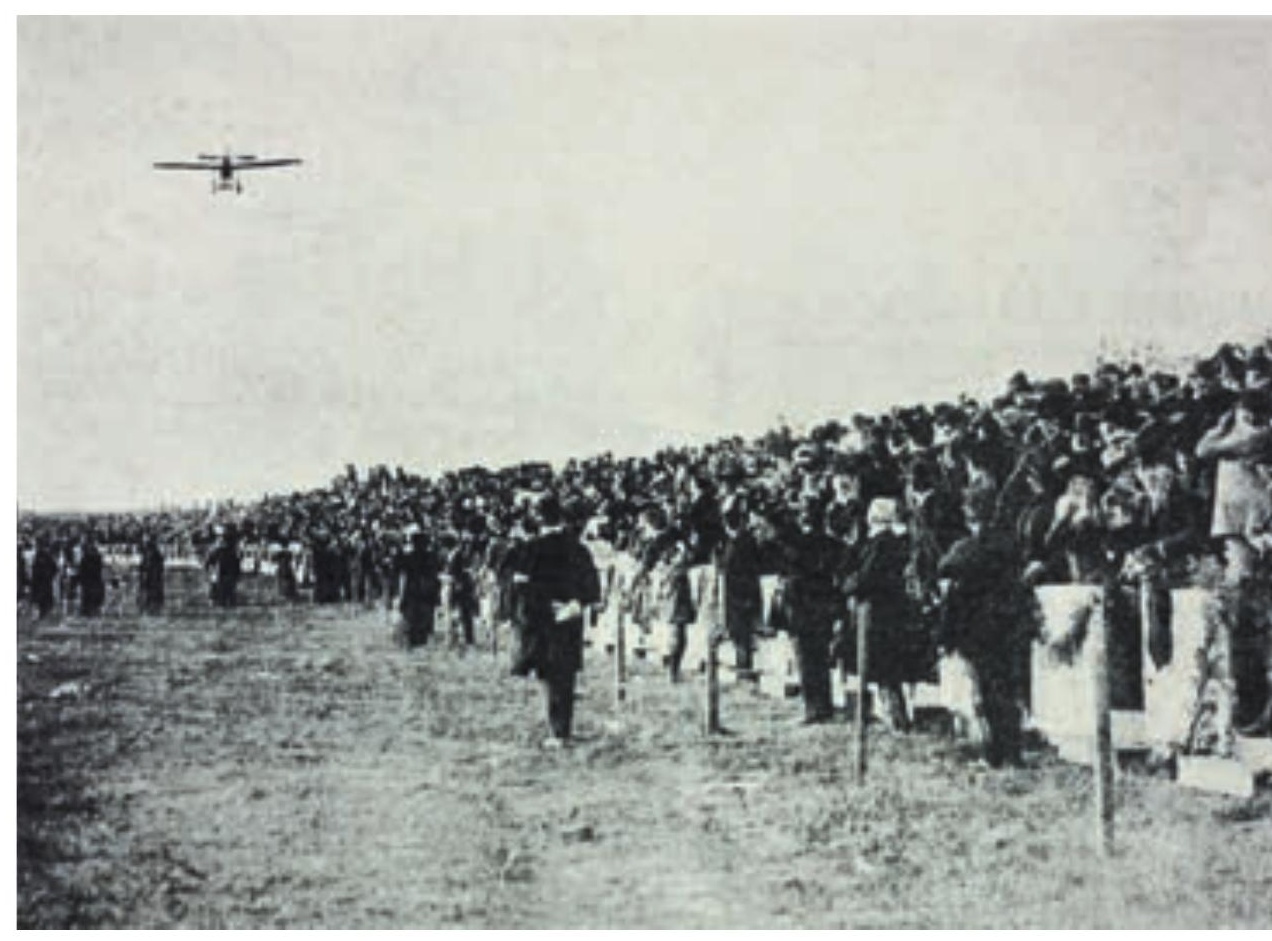




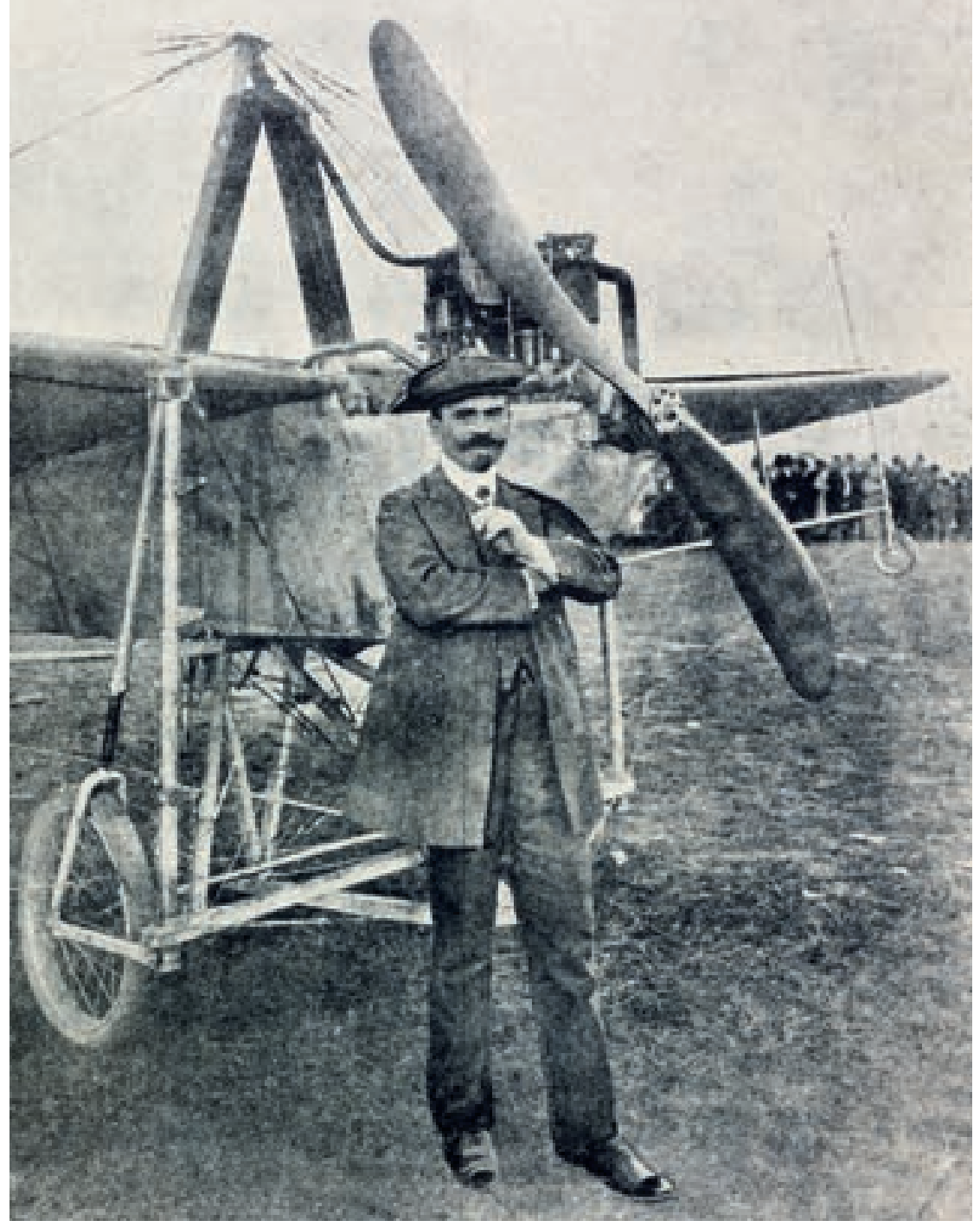

Abb. 4 Der Pilot Karl IIIner vor dem Flug von Wien-Simmering nach Horn. Hinter inm ist der Flugapparat Etrich IV zu sehen. Illner bewältigt die 80 Kilometer lange Strecke in 72 Minuten. Das interessante Blatt, 13. Oktober 1910, S. 11.
Die Helden der Lüfte - es sind, wie wir noch sehen werden, bis auf wenige Ausnahmen Männer - verkörpern eine Art viriles Gegenprogramm zum angeblich krisenhaften, verweichlichten, die Nerven fordernden Leben auf Erden. Dieses neue Heroentum wird durch zwei Tendenzen geprägt, die der frühen Aviatik ihren Stempel aufdrücken: Allmählich werden die Piloten wichtiger als die Maschinen und die Luftschifffahrt wird zunehmend militarisiert.

Stehen anfangs noch die Fluggeräte, ihre Fertigung und ihre technischen Raffinessen gleichberechtigt neben dem Piloten im Blick der Öffentlichkeit, so ändert sich das in den kommenden Jahren. Allmählich rückt Letzterer zum unumstrittenen Star auf, die technischen Details der Aeroplane treten zunehmend in den Hintergrund. Der Pilot wird in der Öffentlichkeit herumgereicht und gefeiert. Bei den zahlreichen Flugschauen rückt er zum wahren Helden des Himmels auf. Die umjubelten Jagdpiloten des Ersten Weltkriegs tauchen also nicht aus dem Nichts auf, sondern reihen sich ein in eine Tendenz zur Heroisierung der Luftfahrt, die schon etliche Jahre vor dem Krieg begonnen hat. Wenn wir die Berichte und
Bilder in der illustrierten Presse zwischen 1908 und 1914 überblicken, lässt sich diese zunehmende Idolisierung der Piloten, die nicht selten zugleich auch Konstrukteure, Ingenieure oder Mechaniker sind, deutlich nachweisen. Immer häufiger erscheinen ihre Fotos, die sie oft zusammen mit dem Flugzeug zeigen, das sie lenken, in den Zeitungen.

Ihre ersten Schritte verdankt die motorisierte Aviatik einem vorwiegend zivilen Erfinder- und Unternehmertum. Nach den ersten großen Erfolgen gerät sie aber immer stärker in den Sog des Militärs. Diese Verschiebung hat nicht zuletzt mit den enormen Kosten zu tun, die mit dem Bau und der Verbesserung der Apparate verbunden sind. Zudem wird dem Militär sehr schnell klar, dass motorisierte Flugzeuge vielfältige Einsatzmöglichkeiten in Transport, Logistik und Aufklärung bieten. Beide Entwicklungen, die Herausbildung eines zunehmenden Heroenkults und die vermehrte militärische Einflussnahme, lassen sich in den frühen Jahren der österreichischen Aviatik gut verfolgen.

Am 29. November 1909, nur wenige Wochen nach Blériots Flugschau, verlaufen die Flugversuche Igo (Ignaz) Etrichs auf dem neu errichteten Flugfeld Steinfeld bei Wiener Neustadt erfolgreich. Im ersten Anlauf schafft sein Apparat einen 100 Meter langen Flug. ${ }^{18}$ Im März 1910 steigt der Wiener Flugpionier Adolf Warchalowski auf dem Wiener Neustädter Flugplatz erstmals mit einem Passagier an Bord auf und landet nach einer Viertelstunde wieder sicher. Mit der Etrich II Taube, einer Weiterentwickelung seines ersten Flugapparates, feiert Etrich 1910 seine ersten großen Erfolge. Am 17. Mai absolviert Etrichs Mechaniker und Pilot Karl Illner den ersten Überlandflug von Wiener Neustadt nach Wien und landet sicher auf der Simmeringer Haide. Die 55 Kilometer lange Strecke legt er in 32 Minuten und 42 Sekunden zurück. ${ }^{19}$ Anschließend fliegt er wieder zurück. Am 10. Oktober 1910 absolviert Illner mit dem Etrich IV einen erfolgreichen Flug von Wien-Simmering nach Horn und gewinnt damit den von der Gemeinde Wien gestifteten Preis von 20000 Kronen. Die 80 Kilometer lange Strecke bewältigt der Pilot bei Gegenwind in 72 Minuten. Die öffentliche Inszenierung dieser Fahrt unterscheidet sich deutlich von der bisherigen 
Bildberichterstattung. Ein Fotograf des Interessanten Blattes lichtet Illner vor dem Start zusammen mit dem Flugzeug ab (Abb.4). Stolz steht der Pilot vor seinem Apparat, er ist der eigentliche Protagonist des Bildes. Eine Woche später kommt dieselbe Zeitung auf das Ereignis zurück. Ein Foto dokumentiert, wie Illner mit seinem Flugzeug über dem Landeplatz in Horn erscheint. ${ }^{20}$ Es ist kein herausragendes Bild. Dem bereits gelieferten Heldenimage fügt es nicht viel mehr als eine bestätigende Fußnote hinzu.

Wie sehr sich innerhalb weniger Jahre die Bildberichterstattung über die Fliegerei geändert hat, zeigt eine Fotoseite, die im Juni 1912 im Interessanten Blatt erscheint (Abb. 5). Thema ist der große, 600 Kilometer lange Wettflug von Berlin über Breslau nach Wien, der zwischen dem 6. und dem 12. Juni 1912 stattfindet. Die Redaktion des Blattes versucht, die enorme Spannung, die über der Veranstaltung liegt, in eine dramatische Bilderzählung zu übersetzen. Gelenkt durch den Bildtext am Fuß der Seite wird der Bogen vom Start in Berlin (vgl. Abb 5, Detailbild 1, 2, 3) über die Zwischenlandung in Breslau (Detailbild 4, 5) bis hin zur Landung des Siegers Hellmuth Hirth und seines Kopiloten Leutnant von Schoeller in Wien (Detailbild 6) gespannt. Den Abschluss der Fotoreportage bildet ein Porträt der beiden siegreichen Protagonisten vor ihrem Flugzeug im Hangar in Aspern. Das stark retuschierte Bild rückt die beiden Männer in den Mittelpunkt, die als einzige das Ziel erreichen: Links, in Zivil gekleidet, steht Hirth, rechts, in Militäruniform, steht Leutnant Schoeller. Das Preisgeld, das die beiden Stars einstreichen, ist enorm: 40000 Kronen, 16100 Mark, dazu den Ehrenpreis der Stadt Wien, des Prinzen Leopold von Preußen und des preußisches Kriegsministeriums.

Hirth ist vor dem Ersten Weltkrieg der deutsche Flugheld, er gewinnt zahlreiche internationale Wettbewerbe und bricht 1912 den Höhenweltrekord. Im Krieg wird er zum gefeierten Jagdflieger.

\section{Militärische Interessen}

Am 18. September 1910 findet auf dem Flugplatz in Wiener Neustadt ein großes Preisfliegen statt. Ein knappes Jahr ist zwischen dem Flug Blériots in Wien

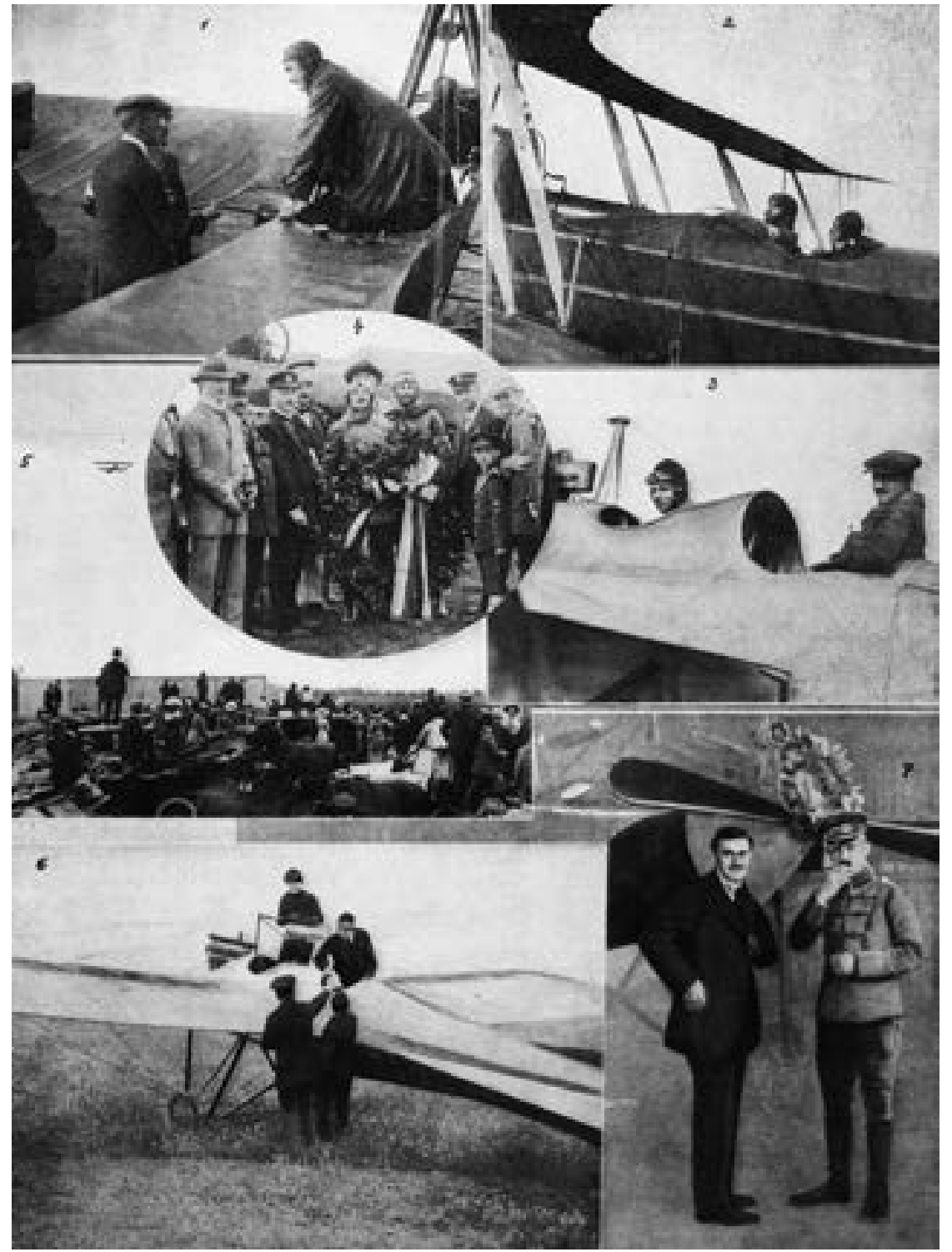

und der Veranstaltung vergangen. Diesmal steht nicht ein einzelner Flieger im Mittelpunkt, vorgeführt werden vielmehr die noch jungen Leistungen der gesamten österreichischen Motorluftfahrt. Wiederum ist der Monarch Ehrengast. „Die Fahrt des Kaisers nach Wiener Neustadt", so heißt es im Interessanten Blatt, „fand nachmittags mittels Automobils von Schönbrunn aus statt. Die Behörden hatten Vorkehrungen getroffen, um zur Zeit der Fahrt die Straßen möglichst frei zu halten und alle Automobile, die nicht zu dem aus fünf Wagen bestehenden Hofzug gehörten, wurden angewiesen, die kaiserlichen Automobile nicht
Abb. 5 Der Wettflug Berlin - Wien mit Zwischenlandung in Breslau findet zwischen dem 6. und dem 12. Juni 1912 statt. Auf den Detailbildern 6 und 7 sind die Sieger des Wettbewerbs, Hellmuth Hirth und sein Kopilot Leutnant von Schoeller, nach der Landung in Wien-Aspern und im Hangar vor ihrem Flugzeug zu sehen. Das interessante Blatt, 20. Juni 1912, S. 5. 


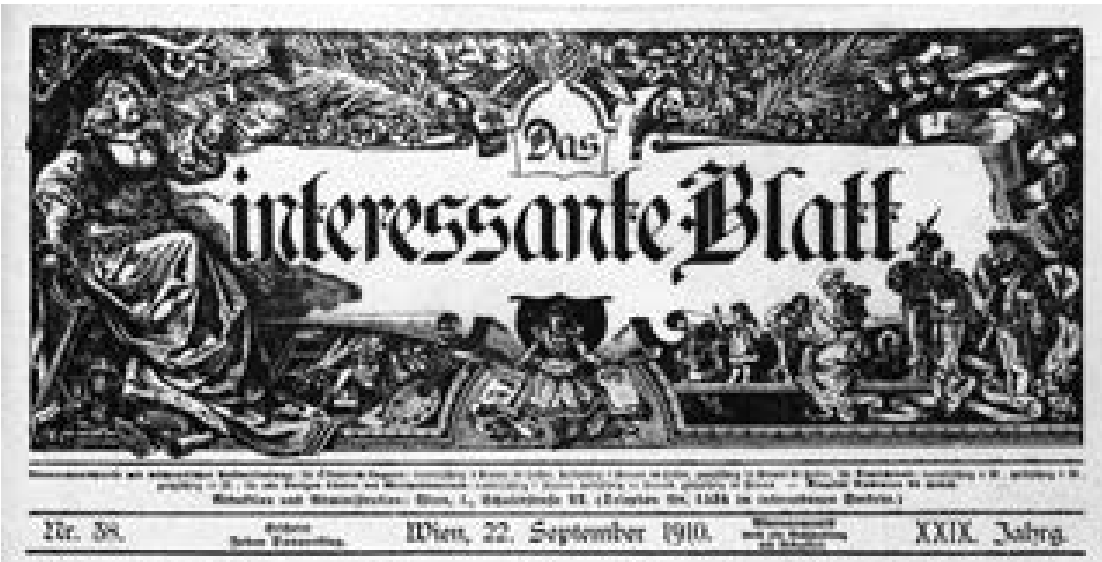

\section{Der Fatuifer auf Dem Tlugfelde in Wr.-Ileuftadt.}

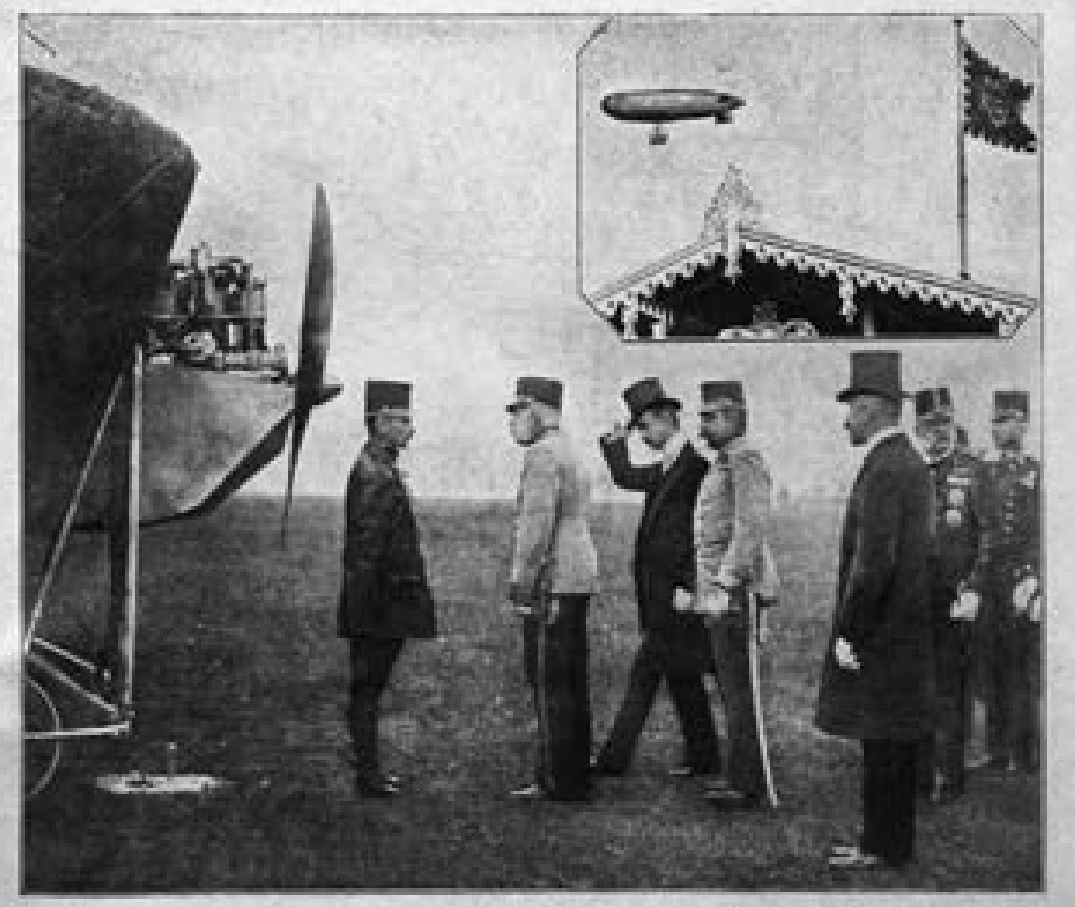

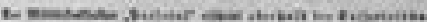

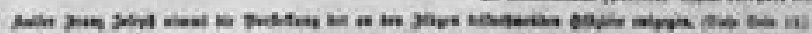

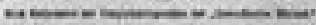

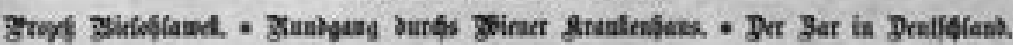

Abb. 6 Kaiser Franz Joseph beim großen Preisfliegen in Wiener Neustadt am 18. September 1910. Er lässt sich von den Offizieren die Flugzeuge erklären. Das interessante Blatt, 22. September 1910, Titelseite. zu überholen. Ein Mercedeswagen fuhr zu diesem Zwecke dem Hofzug voraus, der durch Schwenken einer schwarz-gelben Fahne den Sicherheitsorganen in den einzelnen Gemeinden das Herannahen der Hofautomobile avisierte." ${ }^{21}$ Rund 30000 Zuschauer haben sich am Flugplatz eingefunden, darunter viel aristokratische Prominenz. „Um 1/24 traf der Kaiser, von stürmischen Ovationen begrüßt, auf dem Flugfelde ein und besichtigte zunächst (...) die in zwei langen Doppelreihen aufgestellten Aeroplane. Der Kaiser sprach die Besitzer und die Piloten an und zeigte sich über die vielen Maschinen österreichischer Konstruktion erfreut. In dem Augenblick, da der Monarch den für ihn reservierten Pavillon betrat, erschien, von Fischamend in einstündiger Fahrt herbeigeeilt, zu allgemeiner Überraschung der erste österreichische Militärballon ,Parseval‘ in den Lüften.“22

Die fotografische Illustration auf dem Titelblatt zeigt den Kaiser im Gespräch mit den Offizieren, die ihm die Flugapparate vorstellen (Abb.6). Wie um das beschriebene Auftauchen des Militärballons visuell zu bestätigen, ist in die obere Bildhälfte ein verkleinertes Foto eingeblendet. Es zeigt das über der Kaisertribüne schwebende Luftschiff. Wenn wir die Titelseite aufmerksam betrachten, fällt auf, dass sich die Vorzeichen der Luftfahrt seit Blériots Auftritt deutlich verändert haben. Nicht einem privaten Veranstalter oder einem einzelnen Piloten schenkt der Kaiser nun seine Aufmerksamkeit, sondern den fliegenden Offizieren seiner Armee. Die Konkurrenz zwischen dem Militärluftschiff und den nun verstärkt unter militärischer Aufsicht stehenden Aeroplanen, die auf dem Titelblatt angedeutet ist, ist mehr als ein symbolischer Wettkampf. Noch hat sich das Motorflugzeug gegenüber dem Ballon nicht durchgesetzt. Aber eine kleine Flugeinlage des Piloten Karl Illner zeigt, dass der motorgetriebenen Luftfahrt die Zukunft gehört. „Begeisterung erregte es, als Illner die Verfolgung des wieder aufsteigenden ,Parseval' mit der ,Möwe‘ aufnahm und in wenigen Augenblicken den Lenkballon eingeholt hatte. ${ }^{23}$ Karl Illner ist es auch, der den Wettbewerb für den schnellsten Überlandflug gewinnt, Adolf Warchalowski stellt mit 460 Metern Höhe einen neuen österreichischen Höhenrekord auf. ${ }^{24}$ „Es war“, so urteilt abschließend der Redakteur der Wiener Bilder, „ein Ehrentag der österreichischen Aviatik, und das Lob, das der Monarch den tapferen Vorkämpfern der Lufttechnik zollte, war wohlerworben.“25

Kurz nach Blériots Wiener Darbietung im Oktober 1909 zeigt das österreichische Militär Interesse an den neuen Fluggeräten. Bereits Ende desselben Jahres werden zunächst französische Farman-Appa- 
rate angekauft. Anfang Dezember 1909 wird der erste Aeroplan der Armee mitsamt dem Piloten Hans Kirsch der Öffentlichkeit vorgestellt. ${ }^{26}$ Schon bald investiert die k.u.k. Luftschifferabteilung auch in österreichische Flugzeugtechnik. In Wiener Neustadt werden mit militärischer Unterstützung Hangars gebaut. Das 1909 eröffnete Flugfeld Steinfeld/Wiener Neustadt wird, neben jenem in Fischamend, das 1911 eröffnet wird, in den kommenden Jahren zur militärischen Drehscheibe der frühen österreichischen Luftfahrt. Die zivile Luftfahrt konzentriert sich auf das 1909 eröffnete Flugfeld Simmeringer Haide und, nach dessen Schließung 1911, auf den Flugplatz in Aspern, der 1912 errichtet wird.

Die Eröffnung des Flugplatzes in Aspern im Juni 1912 wird von einem internationalen Flugmeeting begleitet, das bis 1914 jährlich stattfinden wird. Der Beginn des Ersten Weltkriegs setzt diesem internationalen aeronautischen Treffen ein jähes Ende. 1912 beehrt nicht mehr der greise und oft kränkliche Kaiser Franz Joseph das Spektakel mit seiner Anwesenheit, sondern der flugbegeisterte habsburgische Erzherzog Leopold Salvator. Er gibt sich patriotisch und lässt sich in der Öffentlichkeit vor allem mit österreichischen Flugpionieren blicken. Unter anderem gratuliert er dem österreichischen Oberleutnant Philipp Ritter von Blaschke zum Höhenflugweltrekord von 3500 Metern, den dieser im „Pfeilflieger“ der Wiener Lohnerwerke absolviert hat (Abb. 7).

\section{Furchtlose Frauen}

Am Beginn des zweiten Jahrzehnts nach 1900 ist das Fliegen für das Publikum bereits zum vertrauten Anblick geworden. Und dennoch ziehen die Wiener Flugschauen immer noch Hunderttausende von Schaulustigen an. Die Besucher wollen freilich nicht nur Flugzeuge in der Luft sehen, sondern Spannung erleben: dramatische Wettbewerbe und waghalsige Manöver. Und sie wollen die jungen Fliegerstars mit eigenen Augen sehen. Um dem Massenpublikum stets neue Reize bieten zu können, wird das Programm immer stärker mit Elementen populärer Unterhaltung angereichert. Akrobatische, spektakuläre Einlagen in der Luft sollen das Publikum fesseln. Die populäre
Presse folgt dieser Zuspitzung. Der einfache Flieger ist aus den Schlagzeilen verschwunden, an seine Stelle treten Artisten und Rekordbrecher. 1913 etwa wird über den aus Kärnten stammenden Joseph Slabatnig berichtet, der bei der Herbstflugwoche Anfang Oktober 1913 auf dem Berliner Flugfeld Johannisthal einen neuen Weltrekord aufstellt (Abb. 8). Es gelingt ihm,
Abb. 7 Internationale Flugwoche, Juni 1912. Erzherzog Leopold Salvator gratuliert dem österreichischen Oberleutnant Philipp Ritter von Blaschke zum Höhenflugweltrekord von 3500 Metern. Wiener Bilder, 30. Juni 1912, Titelseite.

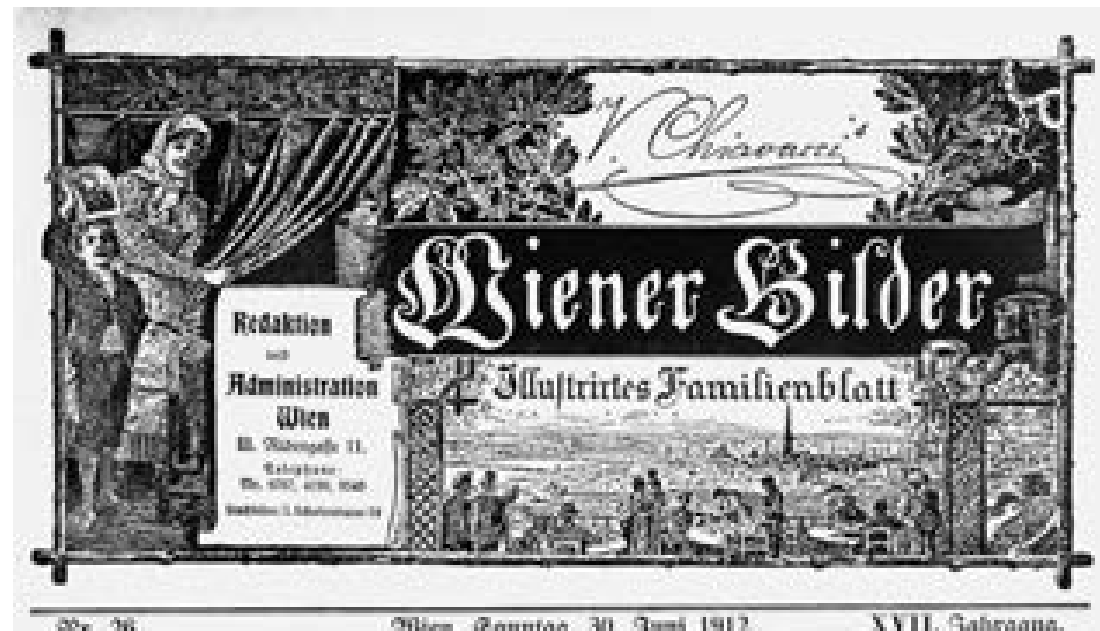

20ira, Eountap, 30, 3ani 1912

XVIL. Gabrgant.

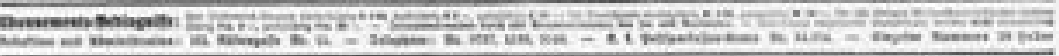
Die internationale Flugwoche in Wien.

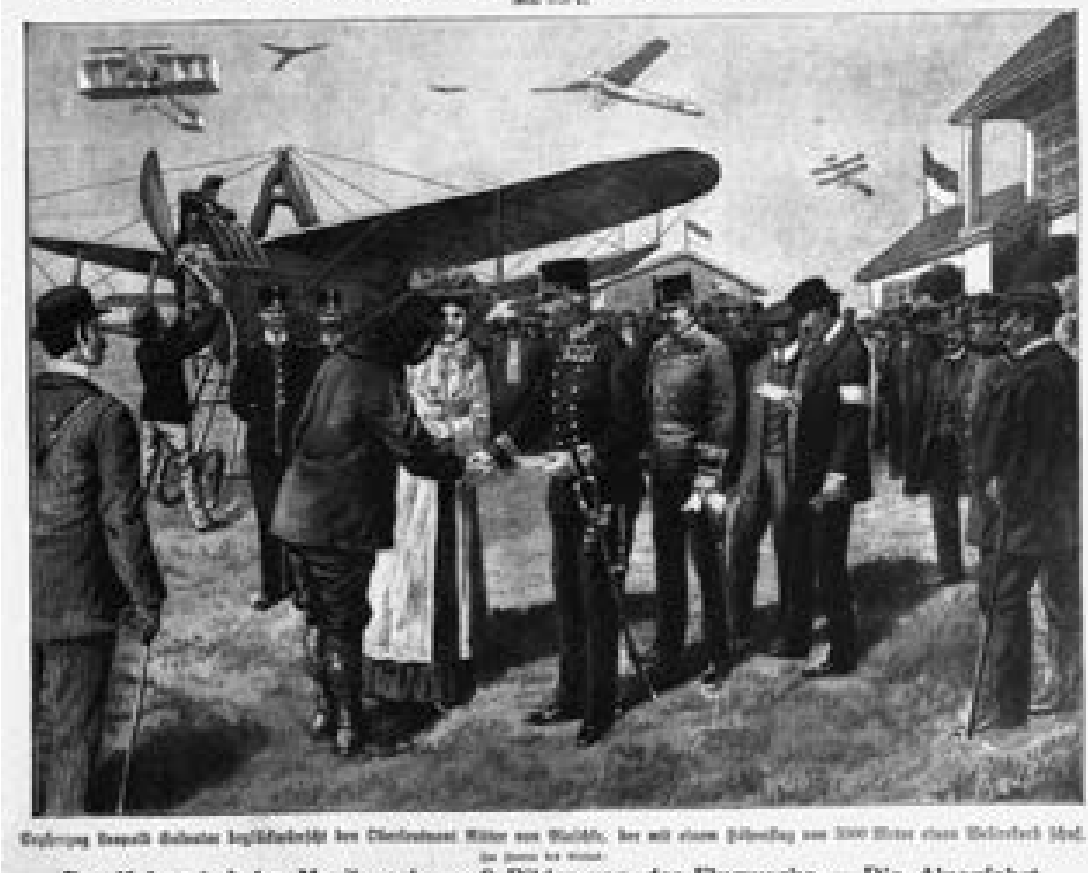

Der Kalser bet der Musikwoche. $\times 9$ Balder von der Fugwoche. . Die Alpenfalart. 


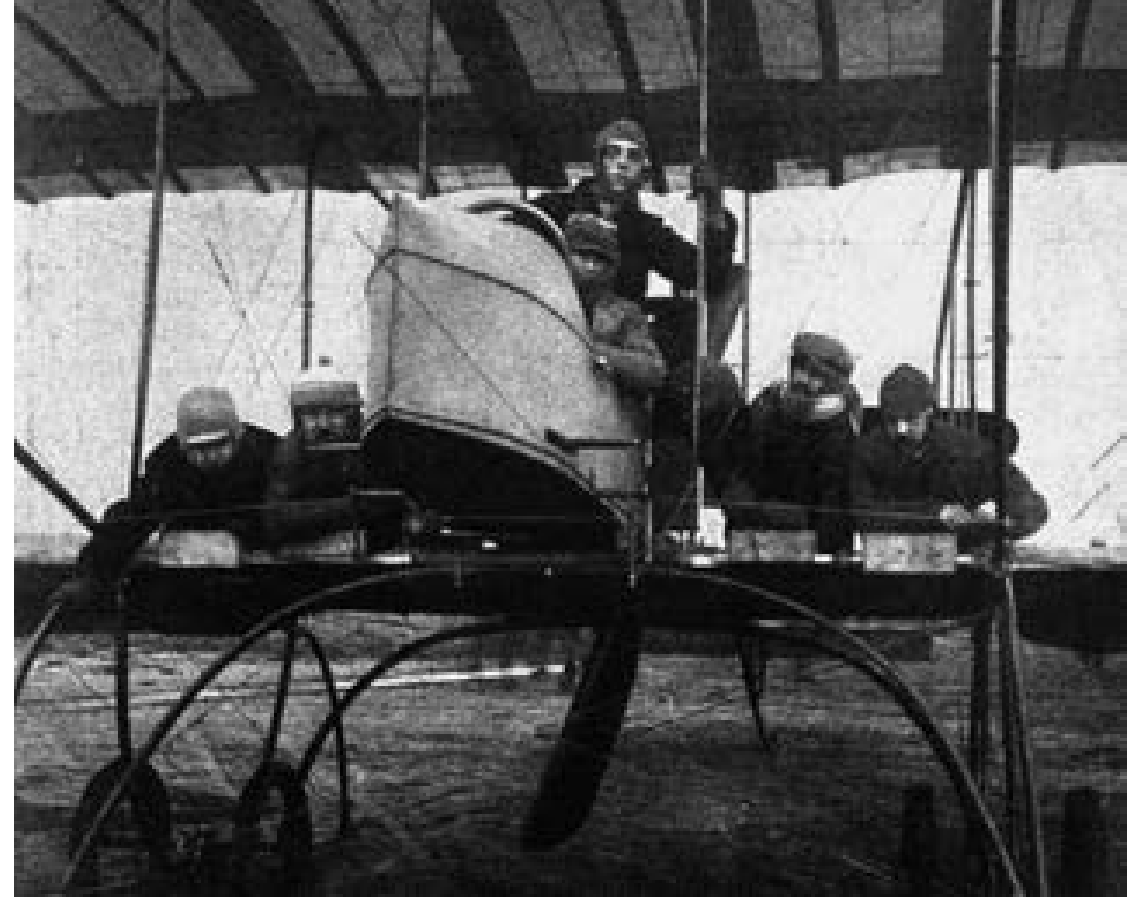

Abb. 8 Weltrekord in Berlin Johannisthal. Dem österreichischen Piloten Joseph Slabatnig gelingt ein Flug mit fünf Passagieren auf eine Höhe von 1000 Metern. Wiener Bilder, 12. Oktober 1913, S. 11.

sein Flugzeug, beladen mit fünf Passagieren, auf eine Höhe von 1000 Meter zu manövrieren.

Die frühe Aviatik ist, wenn wir ihre Inszenierung in der illustrierten Presse verfolgen, ein Übungsparcours der Männlichkeit. Bis auf wenige Ausnahmen sind die Flieger Männer, bei den Konstrukteuren und Ingenieuren ist die männliche Übermacht noch

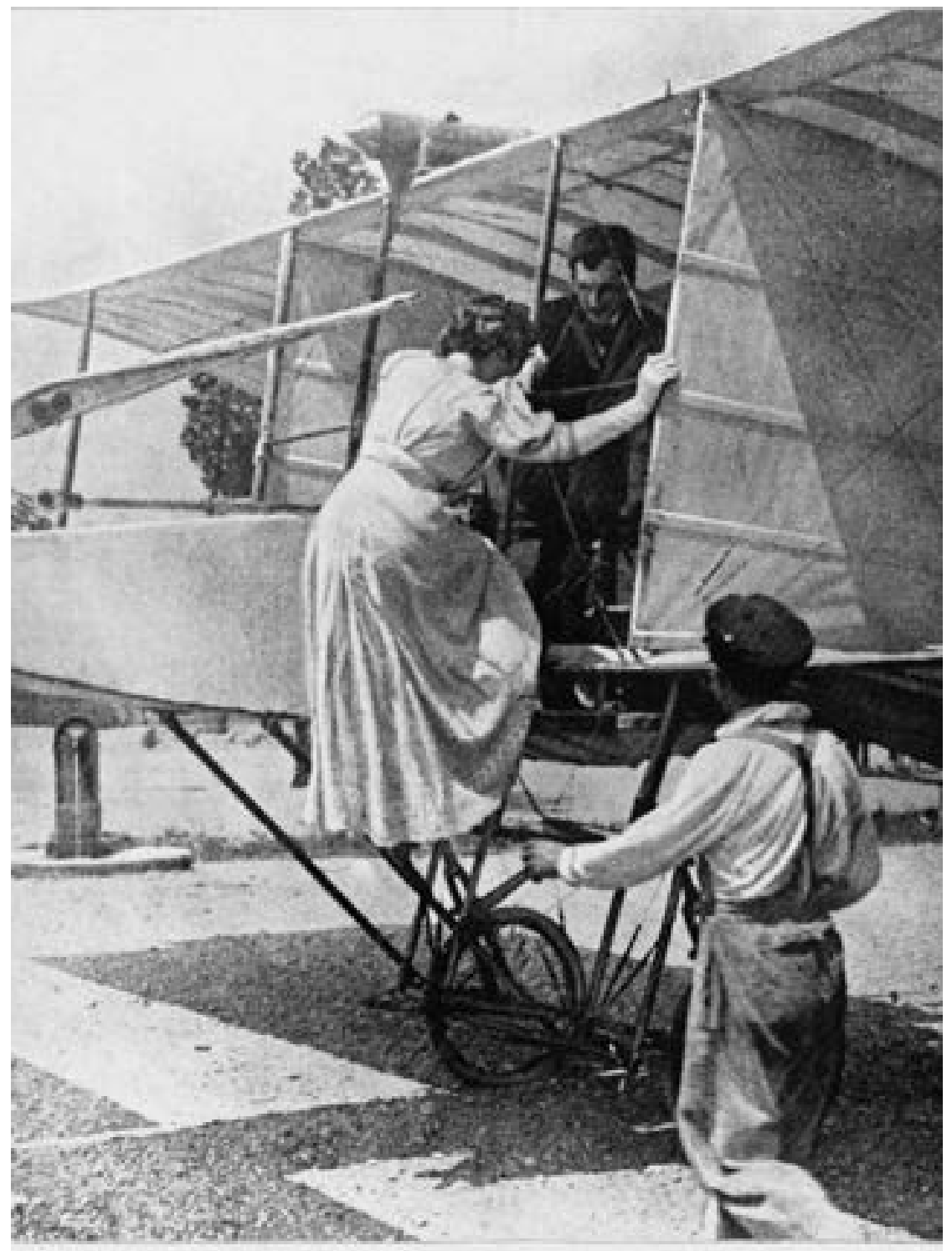

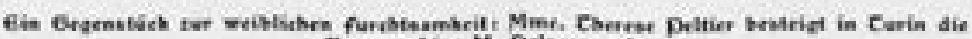
flugesechise M. Prlagrangets. ausgeprägter. In den Bildern verschmelzen die Protagonisten sehr oft mit „ihrem“ Gerät, das sie, so will es die öffentliche Wahrnehmung, kühn und furchtlos durch die Lüfte steuern. Selten tauchen fliegende Frauen in der Bildberichterstattung auf. Als am 23. Juli 1908 (also noch vor Blériots Wiener Auftritt) erstmals eine Aviatikerin in einer Wiener Illustrierten vorgestellt wird, gleicht das einer Sensation (Abb.9). Die Wochenzeitung Der Samstag widmet dem Ereignis die Titelseite. Thérèse Peletier ist die erste Frau der Welt, die als Passagierin in einem Flugzeug mitfliegt. Die Aufnahme, die am 8. Juli 1908 in Turin entsteht, zeigt die französische Bildhauerin beim Besteigen einer französischen Voisin-Maschine. Der Pilot, Léon Delagrange, er ist von Beruf Bildhauer, hat das Fliegen im Jahr zuvor erlernt. Er reicht der Frau die Hand, damit sie im langen Kleid sicher über das Eisengestänge des Fahrwerks ins Cockpit klettern kann. Ein Mechaniker eilt im Laufschritt ebenfalls zu Hilfe. Bald wird der Apparat über das Flugfeld rollen und knapp 200 Meter hoch aufsteigen.

Eine Frau, die sich kühn über die Konventionen der Geschlechter hinwegsetzt und einen Flugapparat besteigt - solche Bilder hat man bisher in der Öffentlichkeit noch nicht gesehen. Das Foto ist ein interessantes, wenig bekanntes Dokument zur frühen Fliegerei. „Ein Gegenstück zur weiblichen Furchtsamkeit“ sei die Frau, die in die Luft geht, so lesen wir unter dem Bild. Zugleich bringt die Kommentierung der

Abb. 9 Thérèse Peletier ist die erste Frau der Welt, die am 8. Juni 1908 in Turin als Passagierin ein Flugzeug besteigt. Der Pilot, der die Voisin-Maschine steuert, heißt Léon Delagrange. Der Samstag, 25. Juli 1908, Titelseite. 
Aufnahme in der Zeitung die Geschlechterverhältnisse wieder ins Lot. Thérèse Peletier wäre demnach die Ausnahme, die die Regel bestätigt: Die Frauen sind das „furchtsame“ Geschlecht, die Männer hingegen das tapfere, ihnen gehört der Luftraum. Gerade weil eine einzelne Frau die Regel durchbricht und sich in den Führerstand eines Flugzeuges vorwagt, bestätigt sie, so die Botschaft, dass die Fliegerei ein männliches Metier ist.

Im März 1910 absolviert Raymonde de Laroche, eine junge Pariser Schauspielerin, als erste Frau der Welt die Pilotenausbildung. Noch im selben Jahr nimmt sie an den Flugschauen von Kairo, Budapest und St. Petersburg teil, wo sie Vierte wird. Im Frühjahr 1911 wagt sich die erste österreichische Frau an Bord eines motorgetriebenen Flugzeugs. ${ }^{27}$ Ihre Pilotenausbildung schließt die aus Prag stammende Božena Lagler im Oktober 1911 ab. Ebenfalls im Frühjahr 1911 taucht das erste Foto einer fliegenden Österreicherin in der Presse auf (Abb. 10). Die Protagonistin heißt Grete Hierhammer, sie ist, wie die Zeitung betont, die „hübsche Tochter des Vizebürgermeisters“ von Wien. Anfang April 1911 besucht sie zusammen mit ihrer Tochter die soeben in Wiener Neustadt eröffnete Flugzeugfabrik „Österreichisch-ungarische Autoplanwerke Wien-Budapest und Paris“. Sie besichtigt Hangars und Werkstätten und besteigt anschließend den Flugapparat „Vindobona“. Adolf Warchalowski, ein Flieger der ersten Stunde, nun Direktor der österreichischen Dependance des Unternehmens, lässt es sich nicht nehmen, selbst auf dem Pilotensitz Platz zu nehmen. Für ihn als Neuunternehmer ist das kleine Spektakel ein willkommener Werbegag, der ihm das Interesse der Presse sichert.

Die Passagierin sitzt hinter Warchalowski auf dem Doppeldecker. „Trotz der leichten Brise, die über das Steinfeld hinblies“, rollt der Doppeldecker auf das Flugfeld. „Nach wenigen Sekunden schwang sich die Flugmaschine in die Lüfte. Nach Umkreisen des Steinfeldes wurde glatt vor den Hangars gelandet“, melden die Wiener Bilder, die auch ein Foto vom außergewöhnlichen Ereignis drucken. ${ }^{28}$ Hierhammer wird als Ausnahmefrau vorgestellt. Fliegende Frauen werden noch lange Exotinnen bleiben. Gerade in dieser angeblich so unweiblichen Rolle sind sie allerdings

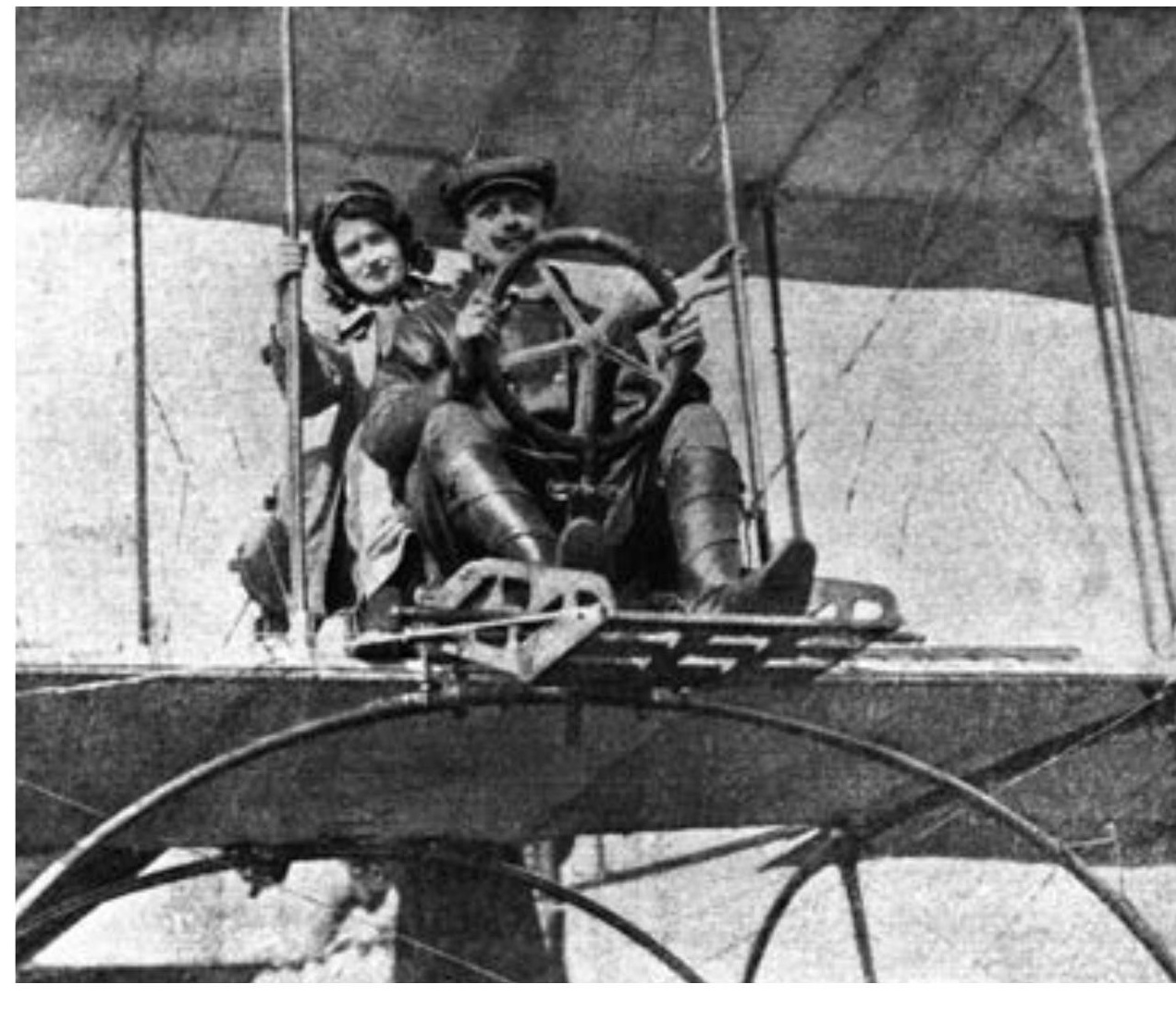

als spektakulärer Aufputz für das männliche Unternehmen Fliegen willkommen. Als im Juni 1913 das zweite Wiener Flugmeeting in Aspern stattfindet, hat das Programm bereits eine „Damenkonkurrenz“ zu bieten. Unter den Pilotinnen ist die in Budapest geborene, in Wien lebende 20-jährige Lilly Steinschneider, die in ihrer Etrich Taube aufsteigt. ${ }^{29}$

\section{Verletzliche Männer}

Die Geschichte der frühen Luftfahrt ist eine Geschichte der Erfolge und Triumphe. Sie ist aber auch eine Geschichte der Niederlagen und Missgeschicke. Technische Pannen, Unfälle, Abstürze und Bruchlandungen sind an der Tagesordnung. Es gibt kaum eine Flugschau, bei der nicht Flugapparate in Schwierigkeiten geraten und Piloten verunglücken. Die Männer, die angeblich so unerschrocken und kühn in die Luft steigen, sind in Wahrheit extrem verletzlich. Genau genommen ist diese Verletzlichkeit die Kehrseite ihres männlich-heroischen Images. Gewiss, es domi-
Abb. 10 Die Wienerin Grete Hierhammer bricht im April 1911 von der Wiener Neustadt aus zu einen Rundflug im Doppeldecker auf. Pilot ist der österreichische Flugpionier Adolf Warchalowski, inzwischen Direktor der „Österreichischungarischen Autoplanwerke Wien-Budapest und Paris“ in Wiener Neustadt. Wiener Bilder, 19. April 1911, S. 8. 

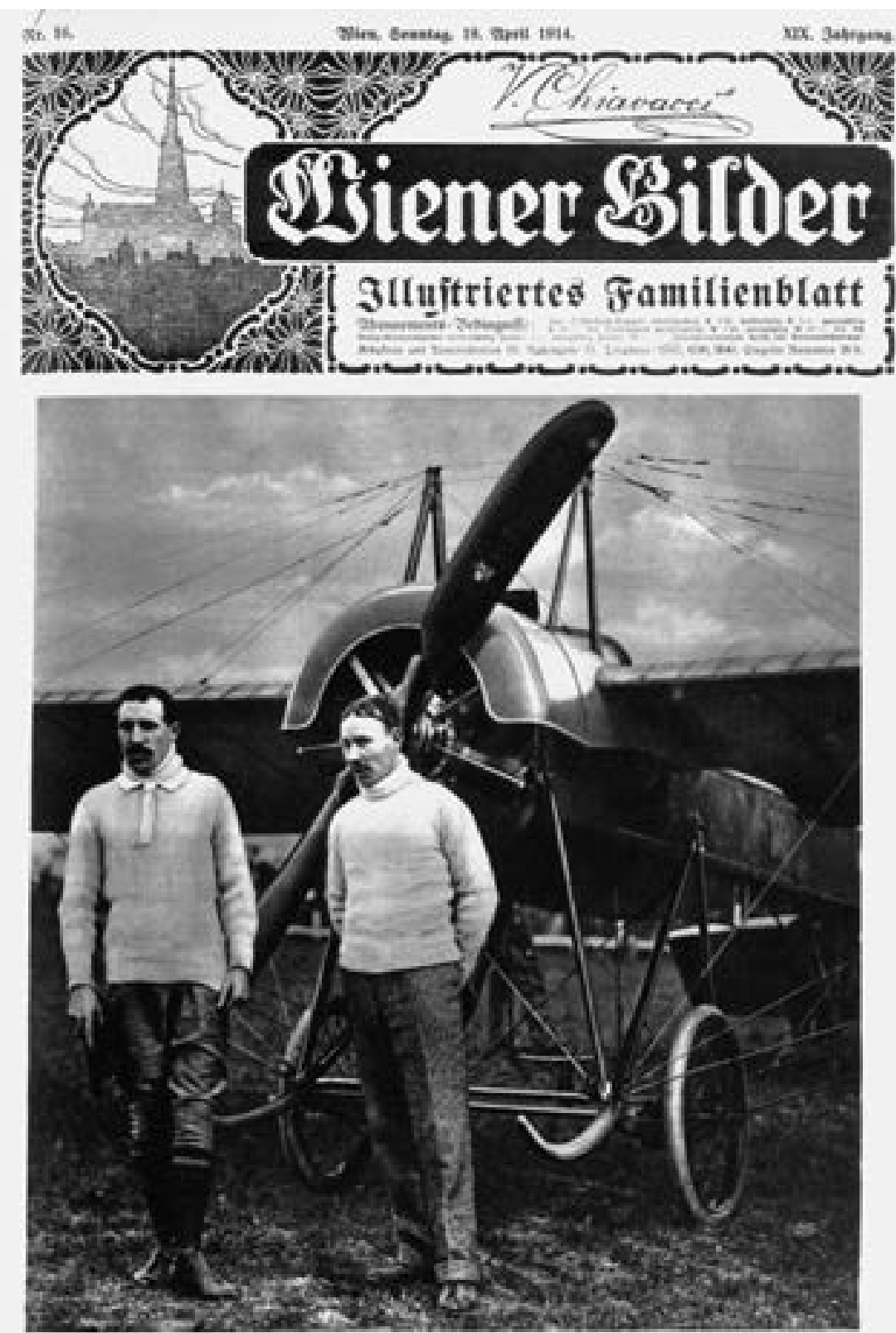

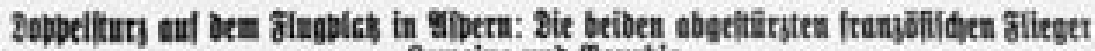
Bembine unb פourtis.

Abb. 11 Die beiden französischen Piloten Alfred Lemoine und Jean Bourhis kurz vor dem Start in Wien-Aspern, April 1914. Im Hintergrund die Deperdussin-Maschine. Bourhis sollte von mehreren Hundert Metern Höhe mit dem Fallschirm abspringen. Wiener Bilder, 19. April 1914, Titelseite. nieren in der Öffentlichkeit bei Weitem die Berichte über Erfolge, gebrochene Rekorde und erreichte Ziele. Gelegentlich aber kommt auch die andere Seite der Fliegerei zur Sprache. Je mehr Flugzeuge aufsteigen und je stärker sich die Flugmeetings in Richtung einer auf das Publikum hin entworfenen riskanten Flugakrobatik entwickeln, desto häufiger werden die Unfälle.

Ein besonders spektakulärer Absturz passiert am Ostersonntag des Jahres 1914 auf dem Flugfeld von Aspern vor Tausenden von Zuschauern. Die beiden französischen Aviatiker Alfred Lemoine und Jean Bourhis setzen an diesem Tag zu einer gewagten Darbietung an. Sie haben vor, in dem von Lemoine ge- lenkten Flugzeug mehrere Hundert Meter aufzusteigen. Dann sollte Bourhis aussteigen und mit seinem Fallschirm in die Tiefe springen. Eine solche Übung hat vor ihnen in Wien noch niemand vollbracht. Bourhis ist ein Pionier auf diesem Gebiet. 1911 hatte er mit ersten Fallschirmversuchen begonnen, im August 1913 war er zum ersten Mal aus einem fliegenden Flugzeug gesprungen. Seither tourt er durch Europa, um sein Kunststück vor Publikum zu präsentieren.

Kurz vor dem Start posieren die beiden Flieger noch vor ihrer Deperdussin-Maschine (Abb. 11). Sie genießen es sichtlich, die Stars des Tages zu sein. Gleich werden sie ihre ledernen Fliegerkappen aufsetzen, mit dem Flugzeug auf das Feld rollen und starten. Als die beiden eine Höhe von 500 Metern erreicht haben, will Bourhis wie geplant abspringen. Während des Ausstiegs jedoch passiert etwas Unvorhergesehenes: Der Fallschirm verfängt sich in den Verspannungsschnüren des Flugzeugs und kollidiert mit dem Höhensteuer. Der Pilot ist gezwungen, im steilen Sturzflug abzusteigen. Während dieses Manövers fällt er, so berichten Augenzeugen und Presse, aus dem Flugzeug und stürzt ungebremst auf das Flugfeld, wo er schwer verletzt liegen bleibt. Bourhis gelingt es zwar im letzten Moment, den Fallschirm vom Flugzeug zu lösen. Allerdings lässt sich dieser nicht mehr zur Gänze öffnen. Dennoch landet der Fallschirmspringer wie durch ein Wunder nur leicht verletzt am Boden. ${ }^{30}$

Der Absturz der beiden Flieger schockiert das $\mathrm{Pu}-$ blikum. Und zugleich sind die Schaulustigen von der dramatischen Wendung der Ereignisse fasziniert. Mit einem Schlag sind aus den kühnen Heroen der Luft zerbrechliche Existenzen geworden. Während der folgenden Tage berichtet die Presse ausführlich über den genauen Hergang des Unfalls. Das interessante Blatt bringt am 23. April 1914 eine bemerkenswerte Fotoreportage zum Vorfall, die die dramatischen Augenblicke zwischen Start und Absturz einfängt (Abb. 12). Drei dicht aneinandergefügte Bilder reichen für die spannende Bilderzählung aus. Die erste Aufnahme zeigt die beiden Flieger im Cockpit ihres Flugzeuges wenige Augenblicke vor dem Start. Vorne sitzt Lemoine, der Pilot, hinter ihm Bourhis, den Fallschirm trägt er auf dem Rücken. Im zweiten Bild 
ist aus großer Entfernung das trudelnde Flugzeug zu sehen. Schließlich werden wir im letzten Bild Zeugen der hektischen Bergungsarbeiten auf dem Flugfeld. Im Hintergrund sind die Reste des abgestürzten Flugapparats zu erkennen. Im Vordergrund stehen zwei Autos, die nach dem Unfall herbeigeeilt sind. Eines davon ist ein Rettungswagen, in den die Verletzten gebracht werden. Beherrscht wird die Szene von hastenden Männern, unter ihnen sind einige Sanitäter, die alles daransetzen, das Leben des schwer verletzten Lemoine zu retten.

Die gut gebaute, Spannung erzeugende Reportage erzählt - auf den ersten Blick - eine Geschichte des Scheiterns, des Schreckens und der Angst. Die unerschrockenen Männer, die mutig die Risiken der Luftfahrt meistern, sind hier zu verletzten, gebrochenen Helden geworden. Aber sie bleiben Helden. Ihnen ist ebenso viel Aufmerksamkeit und Beifall des Publikums gewiss wie ihren unversehrten Kollegen. Beide werden überleben: Alfred Lemoine wird, nachdem er genesen ist, ebenso wie Jean Bourhis neuerlich zu Abenteuern in der Luft antreten.

\section{Das Ende eines Traums}

Kurz vor dem Ersten Weltkrieg ist der Konkurrenzkampf zwischen Ballon, Zeppelin und Flugzeug weitgehend entschieden. Zwar werden Ballone und Zeppeline - Letztere vor allem in Deutschland - noch lange für militärische und zivile Zwecke eingesetzt, aber die Zukunft der Luftfahrt gehört dem Flugzeug. In Österreich hat der Zeppelin gegenüber dem Flugzeug von Anfang an kaum Chancen. Nur drei Luftschiffe werden im Auftrag der österreichischen Armee vor dem Ersten Weltkrieg gebaut. Wohl auch aus diesem Grund erregt die Ankunft des Luftschiffs „Sachsen“ in Wien im Juni 1913 großes Aufsehen (Abb. 13). Das 140 Meter lange, 19 Meter hohe und 14 Meter breite Gefährt hat die 950 Kilometer lange Strecke von Baden-Baden nach Wien in neun Stunden bewältigt. Das von Hugo Eckner gelenkte Schiff hat 24 Mann Besatzung an Bord. Angeführt wird die Gruppe von Ferdinand Graf von Zeppelin höchstpersönlich. Bevor das Gefährt auf dem Flugplatz in Aspern landet, lässt es sich über dem Schloss Schönbrunn blicken. „Vor

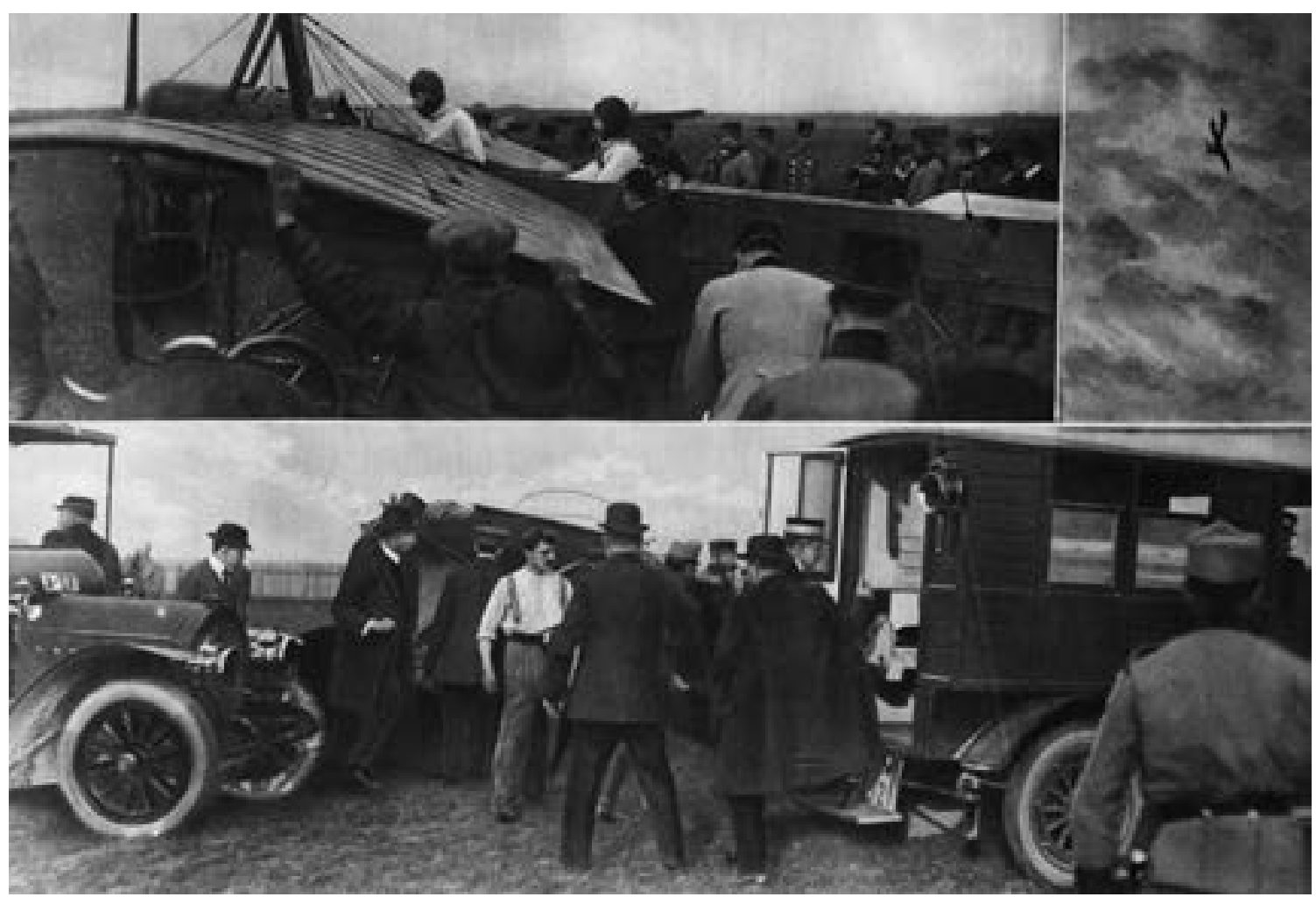

Abb. 12 Fliegerunglück in Aspern: Alfred Lemoine und Jean Bourhis kurz vor dem Start (oben links), Absturz des Flugzeugs (oben rechts) und Bergungsarbeiten auf dem Flugfeld (unten). Das interessante Blatt, 23. April 1914, S. 5. 


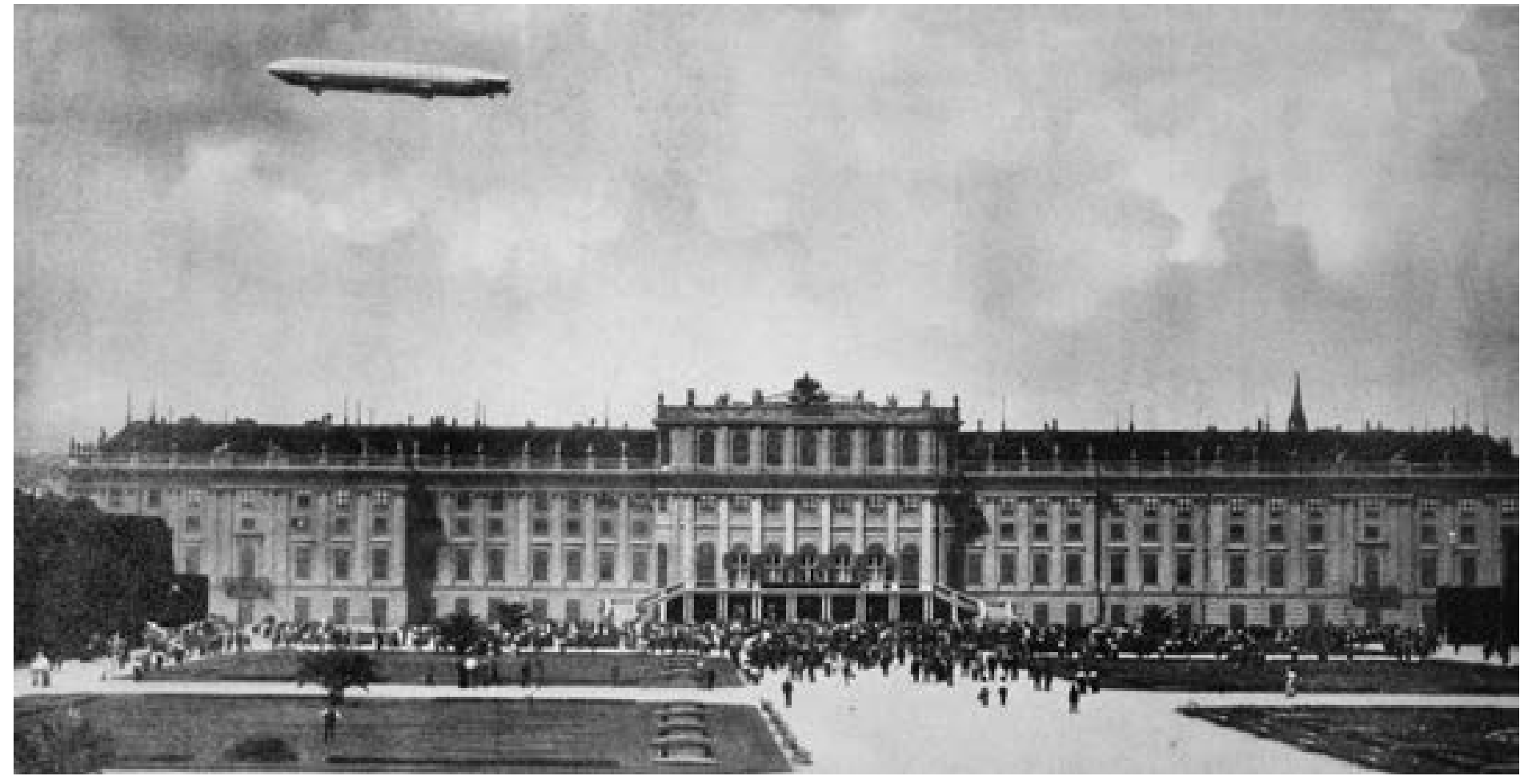

Abb. 13 Ein Zeppelin über Schloss Schönbrunn in Wien, Juni 1914. Das 140 Meter lange Luftschiff „Sachsen“ absolviert die 950 Kilometer lange Fahrt von Baden-Baden nach Wien in neun Stunden. Kapitän ist Hugo Eckner, auch Ferdinand Graf von Zeppelin ist an Bord. Die Landung erfolgt wenig später auf dem Fluplatz in Aspern bei Wien. Das interessante Blatt, 19. Juni 1913, S. 3. Foto: R. Lechner (Wilh. Müller). den Augen des Kaisers und im Beisein einer vielen tausend-köpfigen Zuschauermenge“, heißt es in der Presse, „vollführte die ,Sachsen“ eine Schleifenfahrt mit mehreren interessanten Wendungen und einen Rundflug um das Schloß. Der Kaiser dankte für die Huldigung durch mehrmaliges Salutieren und aus seinen Äußerungen ließ sich sein gespanntes Interesse für das prachtvolle Schauspiel erkennen.“31

Als im Sommer 1913 der mächtige Zeppelin über dem majestätisch daliegenden Schloss Schönbrunn schwebt, scheint die Welt in bester Ordnung zu sein. Die Leser des Interessanten Blattes ahnen noch nicht, dass der Fotograf ein flüchtiges Bild fixiert hat. Dass das Luftschiff weiterzieht, wissen die Leser. Dass aber im kaiserlichen Schloss bald nichts bleiben sollte, wie es war, ahnen sie noch nicht. 1914 beginnt der Erste Weltkrieg, Ende 1916 stirbt der greise Monarch Franz Joseph, zwei Jahre später ist die Monarchie Geschichte.

1915 blickt Franz Hinterstoisser, der um die Jahrhundertwende die Luftfahrt so euphorisch begrüßt hat, auf die jüngste Geschichte der österreichischen Aviatik zurück. Er bewundert die enorme Entwicklung, die die Flugtechnik in den letzten Jahren genommen hat. Und er kommt auf die persönlichen Risiken zu sprechen, die die Pioniere eingingen. „Damals (um die Jahrhundertwende, A. H.) rechnete man die Luftfahrer etwa zu den Tierbändigern und Seiltänzern und niemand gab etwas für ihr Dasein! Versicherung war ausgeschlossen. Bezahlten sie heute nicht ihre Luftreise mit dem Leben, so geschah es morgen!“32

Eines aber erwähnt er sonderbarerweise nicht: die Gefahren des Krieges, der gerade in vollem Gange ist. Zahlreiche Aviatiker müssen im Ersten Weltkrieg ihr Leben lassen. Nicht allein wegen technischer Gebrechen ihrer Gefährte, sondern weil der Luftraum inzwischen heftig umkämpft ist. Um 1900 hatte Hinterstoisser selbst noch vom heilsamen Verlassen der Erde geträumt. Seit 1914 ist dieser Traum endgültig ausgeträumt. 


\title{
Mit der Kamera bewaffnet
}

\author{
Fotografie und Propaganda im Ersten Weltkrieg
}

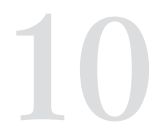

Sarajevo, 28. Juni 1914: Nachdem der österreichische Thronfolger in den vergangenen Tagen die Manöver der k.u.k. Armee in der Nähe Sarajevos verfolgt hat, besucht er an diesem Tag, einem Sonntag, zusammen mit seiner Frau Sophie die bosnische Hauptstadt. Der Sonderzug trifft kurz nach 10 Uhr auf dem Bahnhof in Sarajevo ein. ${ }^{1}$ Der Autokonvoi setzt sich in Richtung Rathaus in Bewegung. Gegen 10.15 Uhr kommt es zum ersten Angriff auf die offene Limousine des Thronfolgers. Nedeljko Čabrinović, einer von sechs Attentätern, wirft eine Bombe in Richtung Fahrzeug, diese verfehlt ihr Ziel und explodiert vor dem nachfolgenden Auto. Es gibt einige leicht Verletzte. Nach dem ersten Schock setzt der Konvoi die Fahrt zum Rathaus fort. Auf dem Rückweg, als die Wagenkolonne wieder zum Bahnhof unterwegs ist, werden die tödlichen Schüsse auf das Thronfolgerpaar aus nächster Nähe vom dicht besetzten Gehweg aus abgefeuert. Der Schütze, Gavrilo Princip, wird sofort verhaftet. Und mit ihm zahlreiche andere Verdächtige.

Die Nachricht vom Attentat verbreitet sich rasch. Am 29. Juni 1914, einen Tag später, erscheinen die ersten Berichte in der Tagespresse. Während die Tageszeitungen die Information über Telefon und Telegrafen übermittelt bekommen, dauert es etliche Tage, bis die ersten Fotos der blutigen Ereignisse, die mit der Bahn transportiert werden, in den Redaktionen eingetroffen sind. Am 5. Juli 1914, eine volle Woche nach dem Attentat, bringen die Wiener Bilder erstmals ein Foto von der Verhaftung Princips auf der

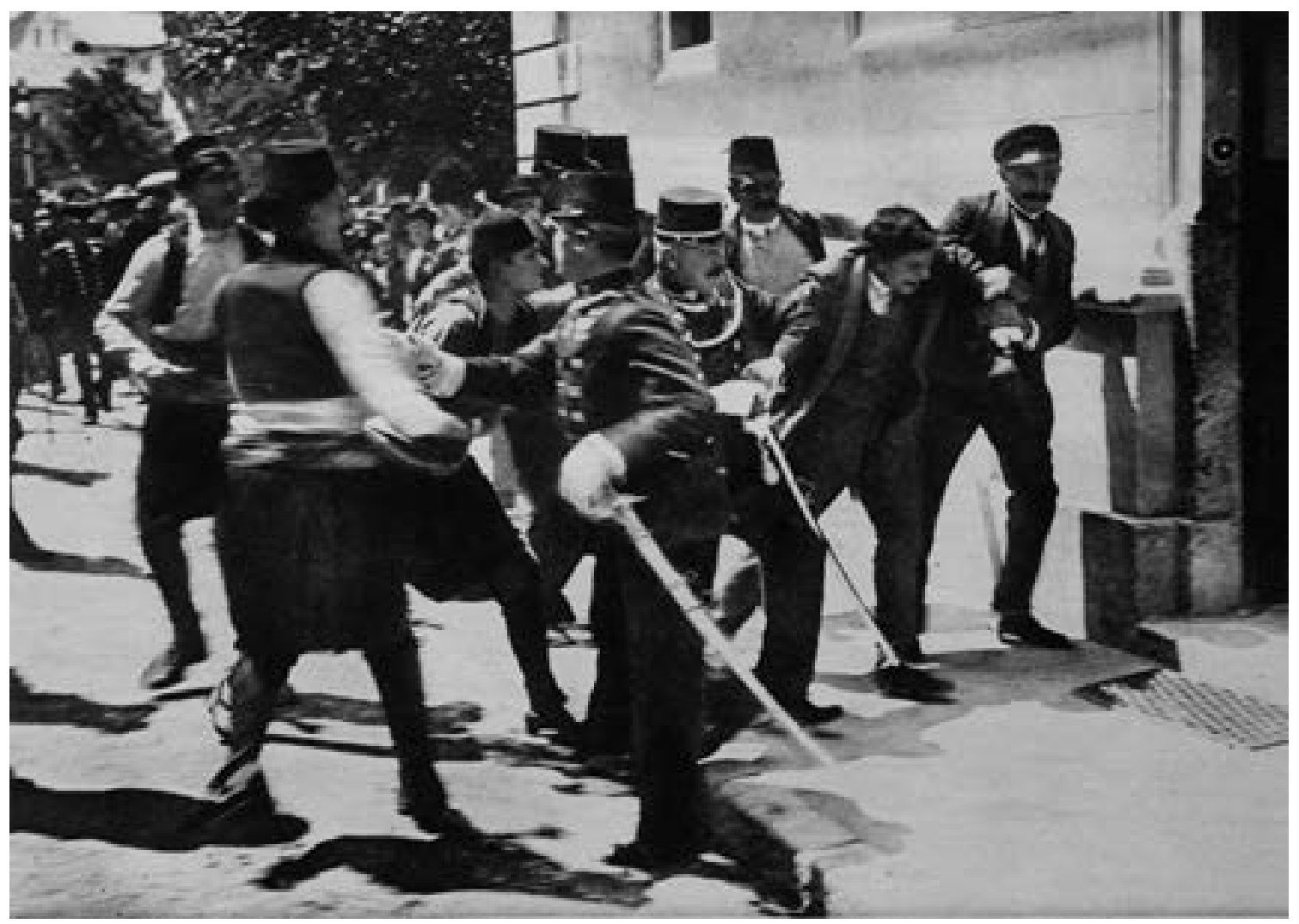

Abb. 1 Sarajevo, 28. Juni 1914, kurz nach dem Attentat auf das österreichische Thronfolgerpaar: Laut Bildtext wird der Attentäter Gavrilo Princip verhaftet. In Wirklichkeit handelt es sich bei dem Festgenommenen im Bild um Ferdinand (Ferdo) Behr, einen Unbeteiligten. Das interessante Blatt, 9. Juli 1914, S. 3. 
Titelseite. Am 9. Juli erscheint dasselbe Bild auch im Interessanten Blatt, der größten Illustrierten des Landes (Abb. 1). Im Bildtext heißt es: „Die Festnahme des 20jährigen Gymnasiasten Gavro Princip, des Mörders des Thronfolgerpaares."2 Beide Male fehlen Hinweise auf den Fotografen.

\section{Sarajevo 1914: \\ Eine fotografische Legende entsteht}

Die Szene wird im Handumdrehen berühmt. Von dem Motiv werden Postkarten und Leporellos hergestellt, es wird immer wieder in den Zeitungen abgedruckt und später auch in Büchern. Von nun an ist dieses Foto die Ikone, die stellvertretend für die unmittelbare Vorgeschichte des Ersten Weltkrieges steht. Zwar tauchen schon bald Zweifel auf, wonach der Verhaftete möglicherweise gar nicht Princip sei. Tatsächlich, so stellt sich heraus, handelt es sich bei dem Verhafteten nicht um den Attentäter, sondern um einen von zahlreichen anderen Verdächtigen, die an diesem Tag festgenommen wurden. In Wirklichkeit heißt der junge Mann Ferdo Behr, mit dem Attentat hat er nichts zu tun. ${ }^{3}$ Dennoch: Einmal in Umlauf gebracht, ist die Geschichte nicht mehr zu stoppen. Bis heute ist der Verhaftete auf dem Foto der Attentäter Princip. ${ }^{4}$

Und wer ist der Fotograf? Als das Bild Anfang Juli 1914 in den Wochenzeitungen gedruckt wird, taucht nur gelegentlich ein Hinweis auf die Herkunft des Fotos auf. In der Hamburger Illustrierten, in der das Bild am 9. Juli erscheint, findet sich etwa am Fuße der Zeitungsseite der Hinweis „Phot. Trampus“. Bald setzt sich dieser Name als Fotograf des angeblichen Attentäters von Sarajevo durch. Wer ist dieser Trampus? Er heißt mit Vornamen Charles und ist ein rühriger Geschäftsmann. ${ }^{5} 1905$ gründet er in Paris ein Unternehmen, das sich auf den Handel mit Fotografien verlegt. Die Fotoagentur Trampus liefert Bilder aus ganz Europa, ebenso vom Balkan und aus Nordafrika, wo sie eigene Operateure und Mitarbeiter stationiert hat. 1906 erscheinen die ersten Fotos der Agentur Trampus in den Wiener illustrierten Zeitungen. Es liegt auf der Hand: Nicht Charles Trampus selbst hat die Szene in Sarajevo fotografiert, sondern seine Firma ist es, die das Foto an die europäische Presse weiterverkauft. Trampus ist also der Name der Fotoagentur, nicht jener des Fotografen. Neuere Forschungen gehen davon aus, dass der Fotograf Philipp Rubel hieß. Denn neben dem Namen Trampus taucht in den zeitgenössischen Veröffentlichungen gelegentlich auch der Name Rubel auf. Dieser sei, so heißt es, ein Wiener Fotograf gewesen, der im Auftrag der Fotoagentur Trampus in Sarajevo stationiert gewesen sei. Er habe an diesem besagten 28. Juni 1914 in Sarajevo die berühmte Szene fotografiert. ${ }^{6}$

Aber auch diese Version stimmt nicht. Denn Philipp Rubel ist, so zeigen Nachforschungen in Wien, kein Fotograf. Er ist 1871 in Czernowitz geboren. Um die Jahrhundertwende verschlägt es ihn, wie viele andere galizische Juden auch, in die Hauptstadt der Monarchie. Seit 1905 lebt er in Wien. ${ }^{7}$ Hier betreibt er ein Papiergeschäft. In der Porzellangasse 60 verkauft er nicht nur Papier, sondern auch Postkarten. Er betreibt einen kleinen Postkartenverlag. Die Motive stammen hauptsächlich aus dem kroatischen Adriaraum. Sie tragen den Aufdruck „Verlag Philipp Rubel, Wien IX“. Vermutlich erwirbt der Verleger die Vorlage von der Fotoagentur Trampus und vervielfältigt sie in Form von Postkarten. Immerhin: Er ist nicht der Einzige, der sich ein lukratives Geschäft mit der Szene erhofft. Andere Fotohändler haben dieselbe Idee, etwa der Wiener Fotograf Carl Seebald, der seit 1908 eine Fotoagentur führt. Auch er verkauft das Foto, das angeblich den Attentäter zeigt, an die Presse. Wer die hektische Verhaftungsszene des angeblichen „Mörders“ wirklich aufgenommen hat, liegt also bis heute im Dunkeln. Vermutlich hat ein anonymer Fotograf aus Sarajevo das Bild an die Agentur Trampus verkauft. Dass sein Name auf den Presseabzügen, die die Agentur vertreibt, nicht erscheint, ist durchaus üblich. Das Foto, das den angeblichen Attentäter zeigt, wird also wohl weiterhin als Ikone des 20. Jahrhunderts zirkulieren, mit falscher Bildunterschrift. Denn vom Attentat in Sarajevo und von der Verhaftung Princips gibt es kein Foto. Gavrilo Princip verschwindet in der Gefängniszelle, ohne dass noch ein Fotograf einen Schnappschuss von ihm erhascht.

Ein einziges Mal noch wird er seine Zelle verlassen. Am 23. Oktober 1914 - inzwischen hat der Krieg 


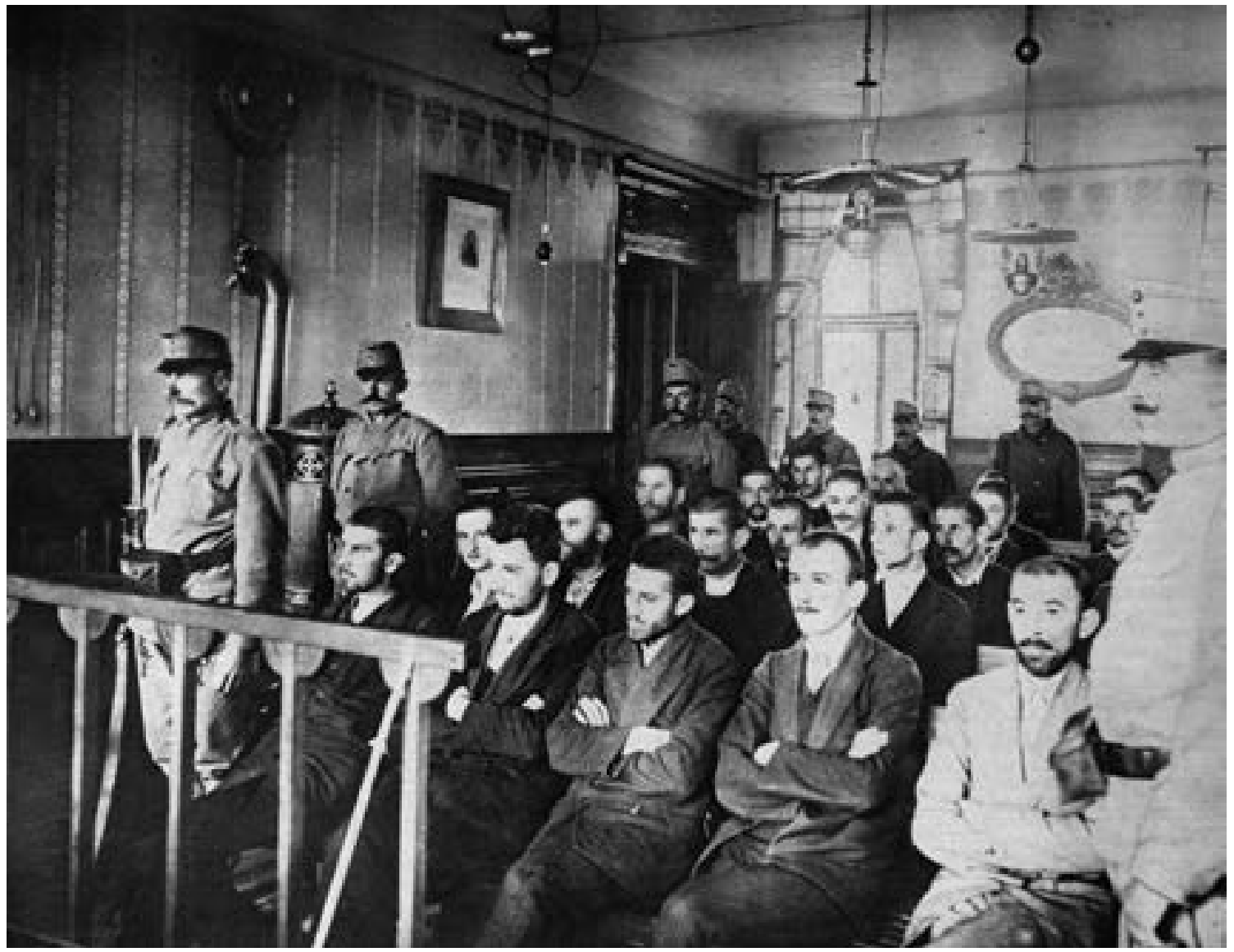

bereits begonnen - endet in Sarajevo der Prozess gegen die sechs Attentäter und ihre Hintermänner. Als die Urteile verkündet werden, lichtet ein Pressefotograf die Angeklagten ab (Abb. 2). Das Bild erscheint am 5. November 1914 im Interessanten Blatt. Im Bildtext heißt es: „Die ruchlosen Mörder und Anstifter des Weltkrieges erwarten auf der Anklagebank den Urteilsspruch des Gerichts von Sarajevo."8 Princip sitzt in der ersten Reihe des Gerichtssaals (Dritter von links): schmales Gesicht, spitzes Bärtchen, die Hände verschränkt, so erwartet er die Strafe. Der Todesstrafe entkommt er nur deshalb, weil er zum Zeitpunkt der Tat noch nicht volljährig ist. Das Urteil lautet: 20 Jahre schwerer Kerker in der berüchtigten Gefängnisfestung Theresienstadt. ${ }^{9}$ Als der Attentäter Gavrilo Princip, zusammen mit zwei weiteren Verurteilten, Nedeljko Čabrinović und Trifun (Trifko) Grabež, in das nordböhmische Militärgefängnis Theresienstadt eingeliefert wird, ist der Krieg längst im Gange.
Kaum hat der Krieg begonnen, rücken die Attentäter von Sarajevo medial rasch in den Hintergrund. Denn nun gibt es täglich viel sensationellere Ereignisse, über die die illustrierte Presse in aller Ausführlichkeit berichtet. Der Krieg zwischen 1914 und 1918 verleiht der fotografischen Bildberichterstattung enormen Auftrieb, aber er konfrontiert Journalisten und Fotografen auch mit neuen Herausforderungen.

\section{Kriegsbegeisterung in Bildern}

In den ersten Wochen des Krieges halten sich die Kriegsberichterstatter in großem Abstand zur Front auf. Am 28. Juli 1914, an jenem Tag, an dem Österreich-Ungarn in den Krieg eintritt, wird das k.u.k. Kriegspressequartier (KPQ) gegründet. Zwei Wochen später, am 11. August, reist die erste Presse-Gruppe von Wien ab. Ihr Ziel heißt Dukla. Diese kleine galizische Stadt in den Beskiden (damals Westgalizien,
Abb. 2 Prozess gegen die Attentäter und ihre Hintermänner in Sarajevo. Am 23. Oktober 1914 werden die Urteile gefällt. Gavrilo Princip, der die tödlichen Schüsse auf den österreichischen Thronfolger abgab, sitzt in der ersten Reihe (Dritter von links). Neben inm (Zweiter von links) Nedeljko Čabrinović, der die Bombe auf das Auto warf. Das interessante Blatt, 5. November 1914, S. 5. 
Abb. 3 Aufbruch in den Krieg. Einrückende Soldaten werden in Wien von Angehörigen verabschiedet. Das interessante Blatt, 6. August 1914, S. 7.

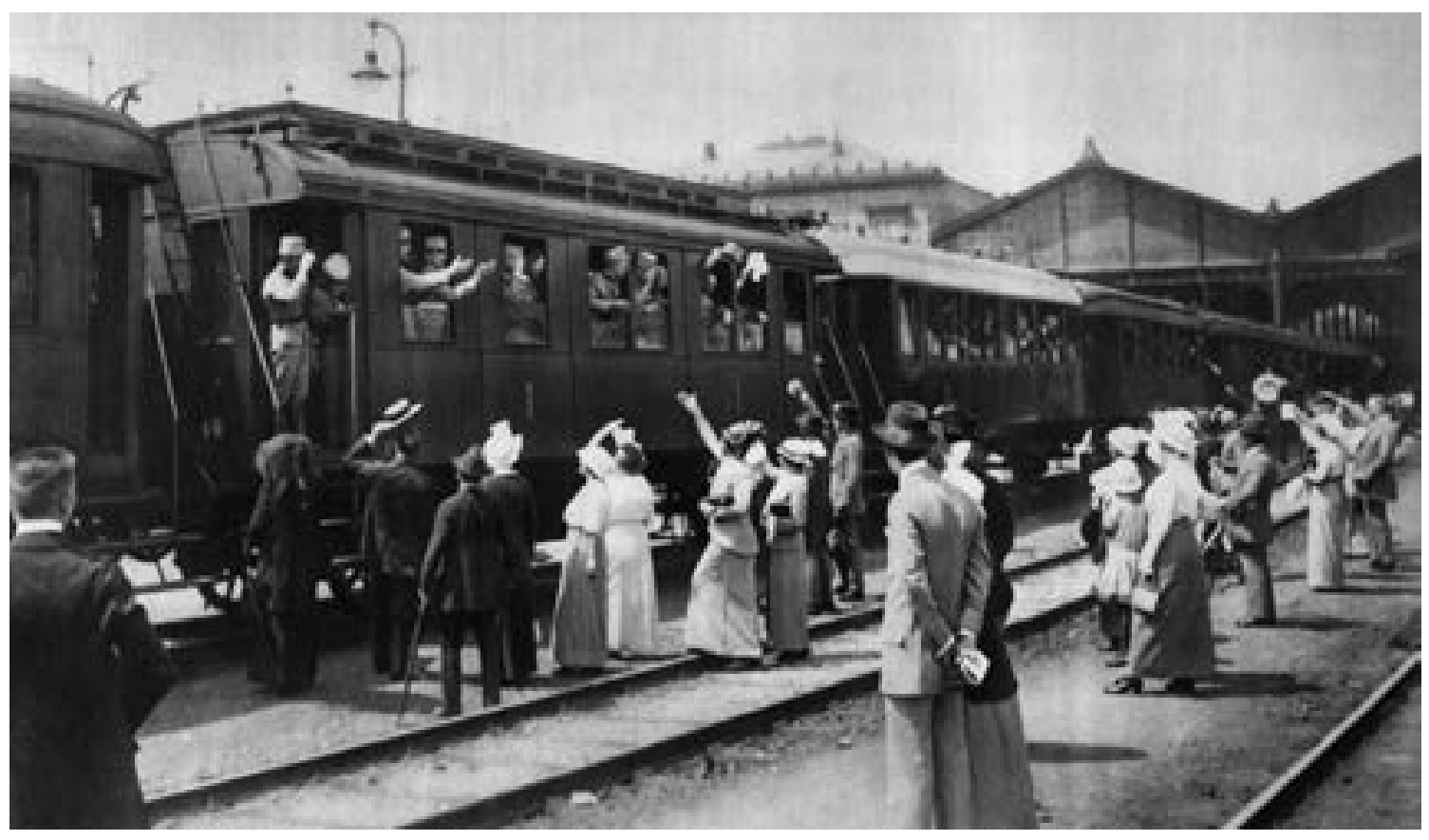

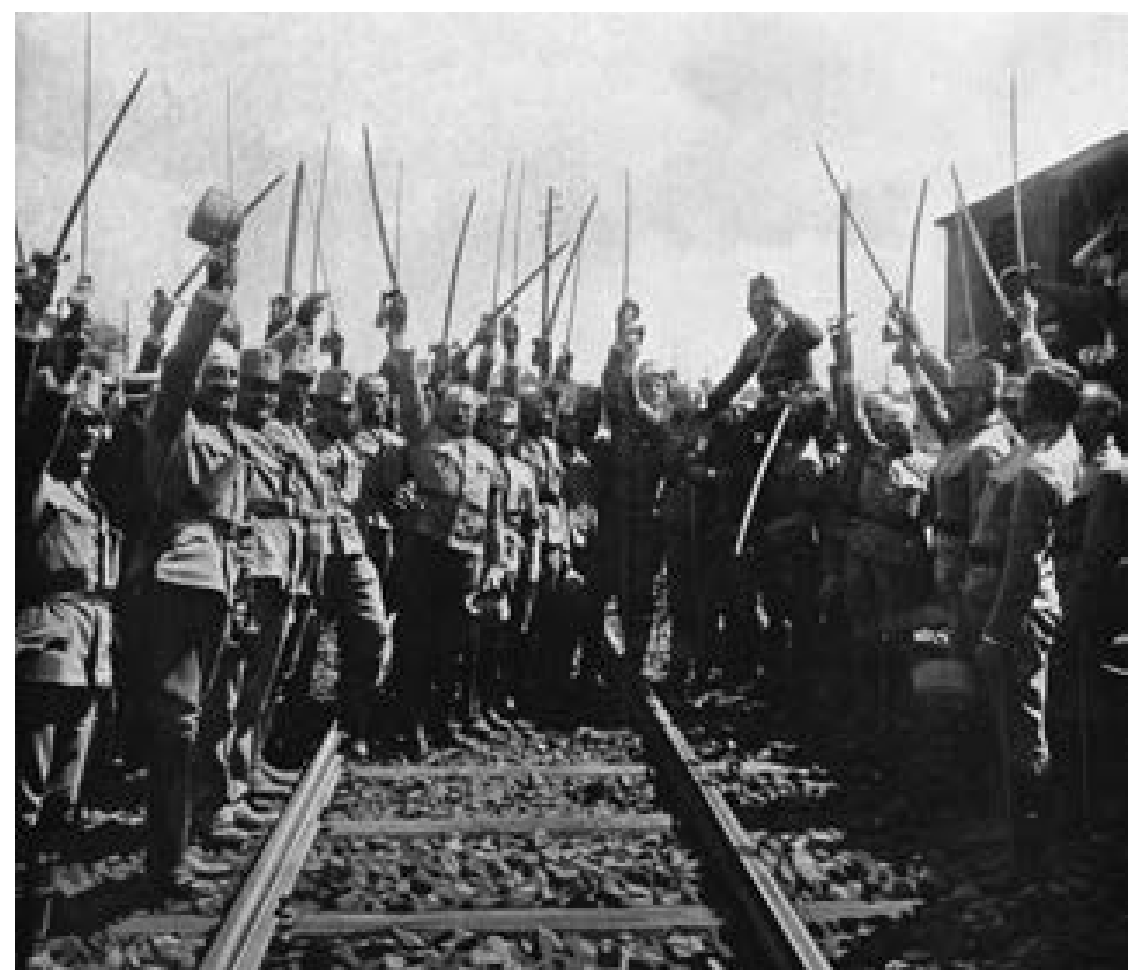

Abb. 4 Der Thronfolger (später Kaiser Karl I.) zieht in den Krieg. Vor seiner Abreise an die Front wird er am 23. August 1914 von ungarischen Offizieren auf den Schultern getragen und bejubelt. Österreichs Illustrierte Zeitung, 3. Dezember 1916, S. 217. heute Südpolen) ist weit im Hinterland der Ostfront gelegen. Sie wird ausgewählt, weil sie weder in unmittelbarer Frontnähe noch in der Nähe des Armeeoberkommandos liegt. Dadurch ist es leichter, die Presse zu kontrollieren. Von Dukla aus gelangen die Berichterstatter nur selten in Frontnähe. ${ }^{10}$

Fotos aus dem unmittelbaren Kriegsgebiet gibt es in den ersten Tagen des Krieges noch keine. Zwar sind nicht wenige Soldaten mit ihren Kameras in den Krieg gezogen, aber offiziell akkreditierte Kriegsfoto- grafen sind noch nicht unter ihnen. Erst am 10. September 1914, also über einen Monat nach Kriegsbeginn, erscheint in der illustrierten Zeitung Das interessante Blatt erstmals eine Fotografie, die Spuren von Kampfhandlungen am östlichen Kriegsschauplatz festhält. Die Aufnahme zeigt, so heißt es im Bildtext, „das erste von unseren Truppen erbeutete Aeroplan, dessen Piloten heruntergeschossen wurden." 11 Sie stammt vom Wiener Pressefotografen und Fotoagenten Carl Seebald, der als einer der ersten Pressefotografen Bilder vom beginnenden Krieg aufnimmt. Bald geht er auch dazu über, von Soldaten und Offizieren zugekaufte Fotografien an die Presse zu liefern.

Bereits Ende Juli 1914 fotografiert Seebald Soldaten, die aus dem Zug winken, sowie Angehörige und Schaulustige, die auf dem Bahnsteig von den einrückenden Männern Abschied nehmen. ${ }^{12}$ Ähnliche Szenen erscheinen zu Beginn des Krieges mehrfach in der Presse. Am 6. August 1914 etwa bringt Das interessante Blatt eine Aufnahme, die einrückende Soldaten zeigt (Abb. 3). Sie winken aus den geöffneten Zugfenstern. Auf dem Bahnsteig stehen Angehörige, die ebenfalls winken und ihre Hüte schwenken. Diese euphorischen Bilder verschwinden aber bald wieder aus der Öffentlichkeit. Denn die versprochenen raschen militärischen Erfolge bleiben aus. Nur gelegentlich tauchen begeisterte Abschiedsszenen im Laufe des Krieges wieder auf, etwa wenn der erschlaffenden Kriegsbegeisterung propagandistisch neuer Schwung verliehen werden soll. Nach dem Tod Kaiser Franz Josephs im November 1916 entfacht sein Nachfolger, Kaiser Karl, eine umfassende Medienoffensive. Nicht 
zufällig wird am 3. Dezember 1916, also wenige Tage nach dessen Amtsantritt, in Österreichs Illustrierter Zeitung, einem besonders kaisertreuen Blatt, eine Aufnahme veröffentlicht, die am 23. August 1914 entstand (Abb.4). Sie zeigt eine Gruppe ungarischer Offiziere, die den Thronfolger bei seiner Abreise an die Front mit erhobenen Säbeln bejubeln. Wir sehen ihn rechts im Bild, mit einem Kreuz gekennzeichnet, wie er auf den Schultern zweier Offiziere sitzt. Das Foto hat eindeutig propagandistischen Charakter. Es soll die militärische Legitimität des neuen Herrschers bekräftigen und die Begeisterung für den Krieg, die merklich nachgelassen hat, neu zu beleben. Bis heute dienen Fotografien wie diese dazu, eine angeblich allumfassende Kriegsbegeisterung im August $1914 \mathrm{zu}$ illustrieren und zu beweisen. Neuere Untersuchungen hingegen zeigen, dass das euphorische „Augusterlebnis“ auf einer klischeehaften Zuspitzung beruht und - zumindest teilweise - eine mediale Konstruktion ist. ${ }^{13}$

\section{Die Arbeit der Kriegsberichterstatter}

„Der Kriegsberichterstatter kam auf Urlaub.“ Mit diesen Worten beginnt der Journalist und Schriftsteller Alfred Polgar seine kurze gleichnamige Skizze. „Er trug einen fabelhaften Pelz. Zwei Revolver lasteten in zwei lichtgelben, ledernen, knirschenden Revolvertaschen, ein Dolchmesser mit Emailgriff und eingeschnittenem Monogramm stak im Gürtel, an den hohen juchtenen Stiefeln sangen Silbersporen martialische Lieder." ${ }^{14}$ Als Polgar diese Zeilen schreibt, ist der Erste Weltkrieg noch in vollem Gange und fast wie durch ein Wunder passiert der Text die Hürde der Zensur. Die Skizze erscheint zusammen mit anderen Texten, die zwischen 1916 und 1923 zunächst in Zeitungen und Zeitschriften gedruckt wurden, 1929 in Buchform. Mit spitzer Feder und in kleinen, aber sehr genauen Beobachtungen beschreibt Polgar den radikalen gesellschaftlichen Einschnitt, den der Krieg herbeigeführt hat. Bewusst gibt er dem Buch den Titel Hinterland. Denn was er sieht, beobachtet und beschreibt, sind nicht die großen Schlachten, die Kämpfe im Schützengraben, sondern, das, was hinter der Front, zu Hause, vor der eigenen Tür passiert.
Es ist, wie Polgar es nennt, das „kleine Elend“ des Krieges. ${ }^{15}$

Doch zurück zu unserem Kriegsberichterstatter, den der Autor voller Spott und Sarkasmus zeichnet. Er fühlt sich nicht sicher zu Hause, angesichts der vorbeisausenden Autos, der scheuen Pferde und der Ziegelsteine, die ihm auf den Kopf fallen könnten. Am liebsten geht er ins Kino. Denn die Filme aus dem Kriegsgebiet „verhalfen doch zu einiger Anschauung vom Kriege. Man bekam immerhin ein beiläufiges Bild der Sache und konnte sich vorstellen, wie solch ein Feldzug in Wirklichkeit aussehen möge. Der Kriegsberichterstatter fühlte sich belehrt und angeregt. Hingegen verwirrte ihn der ungewohnte Anblick des Militärs, das, mit todbringenden Waffen bewehrt, durch die Straßen zog. So kriegerische Bilder hatten etwas Beunruhigendes für ihn." 16

Polgar kennt die Arbeitsweise der Kriegsberichterstatter. Wie viele seiner Kollegen wird er 1915, als die Propagandaanstrengungen verstärkt werden, im Kriegsarchiv in Wien dienstverpflichtet. Hier ist er für Kriegsberichterstattung und Propagandadienste zuständig. Die Fäden der Kriegspropaganda laufen in Wien zusammen. Später wird er Parlamentsberichterstatter für die Wiener Allgemeine Zeitung. Polgars Karikatur des Kriegsberichterstatters ist zwar zugespitzt, falsch aber ist sie nicht.

Die Kriegsjournalisten beziehen ihre Informationen mindestens ebenso von den Wiener Propagandastellen wie aus eigener Anschauung an der Front. Zwar werden sie in der Öffentlichkeit oft als unerschrockene Kämpfer geschildert, die in gefährlichen Situationen an vorderster Front ausharren und im Kugelhagel ihre Berichte liefern. In den Zeitungen erscheinen Bilder, die den Fotografen mit seiner Kamera bewaffnet im Schützengraben zeigen (Abb.5). Aber die Realität sieht anders aus. Höchst selten halten sich etwa die offiziellen Kriegsfotografen während der Kämpfe an vorderster Front auf. Meist werden die Schlachtfelder erst nach den Kämpfen besucht. Kampfaufnahmen sind in der Regel gestellte Bilder. ${ }^{17}$

Wenn die Kriegsfotografen im Frontgebiet unterwegs sind, bewegen sie sich vorwiegend im Umkreis des jeweiligen Armeekommandos oder des örtlichen Armeekorps, die ihren Sitz in der Regel in größeren 


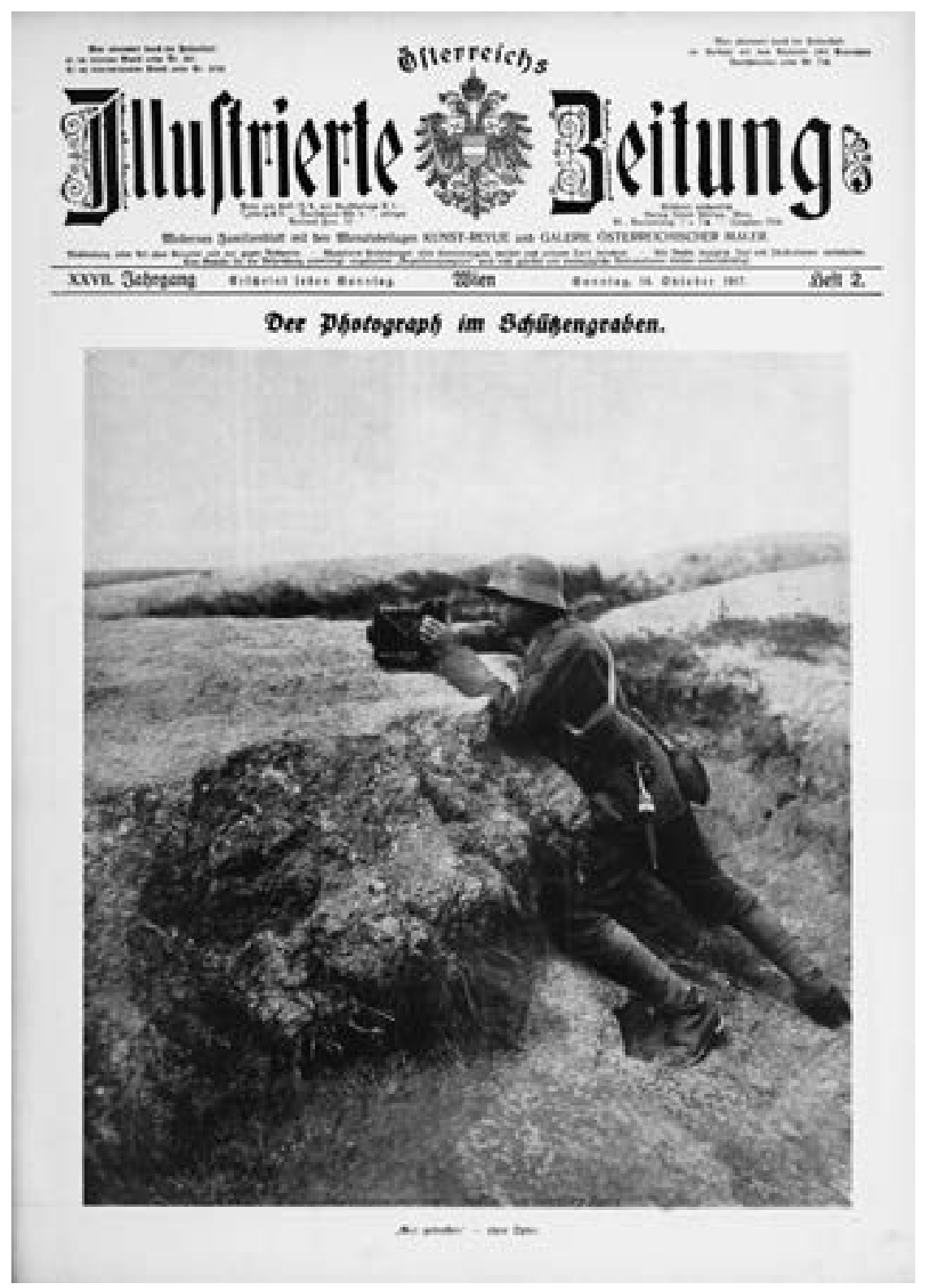

Abb. 5 „Der Photograph im Schützengraben“. Die Realität sieht anders aus: Meist werden die Schlachtfelder erst nach den Kämpfen fotografiert. Österreichs Illustrierte Zeitung, 14. Oktober 1917, Titelseite. Foto: Bild- und Filmamt (BUFA).
Ortschaften oder Städten im Hinterland der Front haben. Die Kriegsberichterstatter stehen in enger Abhängigkeit zum Militär, sie nutzen dessen Einrichtungen und Fahrzeuge und sind auf die Nachrichtenflüsse angewiesen, die dort zusammenlaufen. Umgekehrt aber kommen sie auch in den Genuss von zahlreichen Privilegien und Vergünstigungen. Ein Foto, das im Januar 1915 veröffentlicht wird, zeigt sehr deutlich die Symbiose zwischen Kriegsberichterstattung und Militär (Abb. 6). Zu sehen ist ein Wagen, der vor dem Eingang des Armeehauptquartiers steht. Auf dem Rücksitz (mit einem Kreuz markiert) hat der Kriegsfotograf Julius von Jelfy Platz genommen, der v. a. für ungarische Blätter berichtet. Im Bildtext heißt es: „Unser Kriegskorrespondent von Jelfy $(\mathrm{x})$ verläßt nach einem Empfang beim Armeekommandanten G.(eneral) d. K.(avallerie) Dankl das
Armeehauptquartier in ... (Russisch-Polen).“ ${ }^{18}$ Der Ort des Armeekommandos ist in der Zeitung aus Sicherheitsgründen bewusst nicht genannt. Das Bild ist ein wichtiges Dokument. Es gibt nämlich kaum Aufnahmen von Kriegsfotografen während ihrer Arbeit. Interessant ist das Foto aber auch deshalb, weil es die Rolle des Kriegsberichterstatters veranschaulicht. Dieser geht selbstbewusst im Armeekommando ein und aus und verkehrt auf Augenhöhe mit den höchsten Offizieren. Auch die Tatsache, dass ihm ein teures Automobil zur Verfügung gestellt wird, unterstreicht seine privilegierte Position.

Als Hauptlieferant für aktuelle Kriegsbilder fungiert das k. u. k. Kriegspressequartier (KPQ). Es nimmt Pressefotografen etablierter Blätter und andere Berufsfotografen in seinen Dienst und beauftragt sie mit Fotoexkursionen ins unmittelbare Frontgebiet. Viele von ihnen haben bereits vor dem Krieg für die illustrierte Presse gearbeitet. Den Kriegsfotografen des KPQ ist es erlaubt, weiterhin für ihre früheren Auftraggeber - die illustrierten Zeitungen - zu arbeiten.

$\mathrm{Zu}$ den wichtigsten Fotografen des KPQ zählen: ${ }^{19}$ Johann Bálint, der vorwiegend für die ungarische Zeitung Pesti Napló (Pester Tagblatt) arbeitet. Rudolf Balogh ist für die ungarische Wochenzeitung Vasárnapi Újság (Sonntagsblatt), aber auch für österreichische und deutsche Blätter tätig. Der Wiener Fotograf Friedrich Bittner arbeitet u. a. für die Wiener Illustrierte Zeitung. ${ }^{20}$ Karl Dittera, aus Nagyszeben (Hermannstadt, heute: Sibiu) stammend, arbeitet vor und während des Krieges für die bekannte in Budapest erscheinende Zeitung Az Est (Der Abend). Alexander Exax ist der Jüngste unter den österreichischen Kriegsfotografen. Er beginnt im August 1914 für die Fotoagentur „Kilophot“ zu arbeiten. Hugo Ritter von Eywo ist Fotograf und als „Kino-Operateur“ (Kameramann) auf mehreren Kriegsschauplätzen im Einsatz, ebenso Heinrich Findeis. Eduard Frankl betreibt vor dem Krieg ein gut gehendes Unternehmen für Pressefotografie in Berlin-Friedenau und ist seit 1915 Mitglied im KPQ. Der aus Temeswar (Timişoara) stammende Aladár Hehs tritt Anfang 1916 in das KPQ ein. Der Pressefotograf Julius von Jelfy fotografiert für den Budapester Photo-Riport (Photo-Report) und ist v. a. an der Ostfront tätig. Auch Rudolf (Rezsö) Kaulich fotografiert über- 
wiegend an der russischen Front. Zunächst arbeitet er für das illustrierte Blatt Tolnai Világlapja (Tolnais Weltblatt), später für die Budapester Zeitung Ország Világ (Land und Welt). Bertalan Mikovsky fotografiert v. a. an der Ostfront und in Rumänien. Josef Perscheid arbeitet vor dem Krieg bei der „Berliner Illustrations-Gesellschaft“, zunächst in Berlin, dann in Paris, London und Wien, hier macht er sich selbstständig und wird Inhaber der Firma „Welt-Preß-Photo - Perscheid“. Er fotografiert bereits in den ersten Kriegstagen in Wien. Später ist der Fotograf an der österreichisch-russischen Nordostfront zu Russland, aber auch auf dem Balkan tätig. Franz Planer fotografiert v. a. in Galizien und an der Isonzofront. Seine Aufnahmen erscheinen hauptsächlich in Österreichs Illustrierter Zeitung. Der Wiener Bruno Reiffenstein ist seit 1916 Mitglied im KPQ. Emerich Révész, aus Budapest stammend, arbeitet als Fotograf für die in Budapest erscheinende Zeitung Érdekes Újság (Das interessante Blatt, das allerdings mit dem Wiener Blatt nur den Namen gemeinsam hat). Nikolaus Schindler, vor dem Krieg Amateurfotograf, leitet seit 1917 die Lichtbildstelle im KPQ. Der bereits erwähnte Carl (auch Karl) Seebald ist als Inhaber der „Illustrationsunternehmung Carl Seebald“ tätig, daneben fotografiert er selbst. Die Firma hat ihre Zentrale in Wien und betreibt eine Filiale in Budapest.

Die Kriegsfotografie ist fest in männlicher Hand. In den Reihen der österreichischen Fotografen, die im Auftrag des Kriegspressequartiers unterwegs sind, arbeitet keine einzige Frau. ${ }^{21}$ Wohl aber, und das ist bisher kaum beachtet worden, spielen Frauen eine wichtige Rolle, wenn es darum geht, die fotografische Logistik unter den Bedingungen des Krieges aufrechtzuerhalten. In einigen Fällen führen sie die Fotounternehmen weiter, während die Männer als Soldaten oder als Kriegsfotografen an der Front sind. Ein Beispiel dafür ist Anna Perscheid, geb. 1895, die Frau des Wiener Fotografen Josef Perscheid, der auch Inhaber der Fotoagentur „Welt-Preß-Photo“ ist. Sie ist ebenfalls ausgebildete Fotografin. Da ihr Mann als Kriegsfotograf viel unterwegs ist, übernimmt sie ab September 1916 die Leitung der Fotoagentur, die in der eigenen Wohnung, in der Paracelsusgasse 6, Wien 3, untergebracht ist. ${ }^{22}$

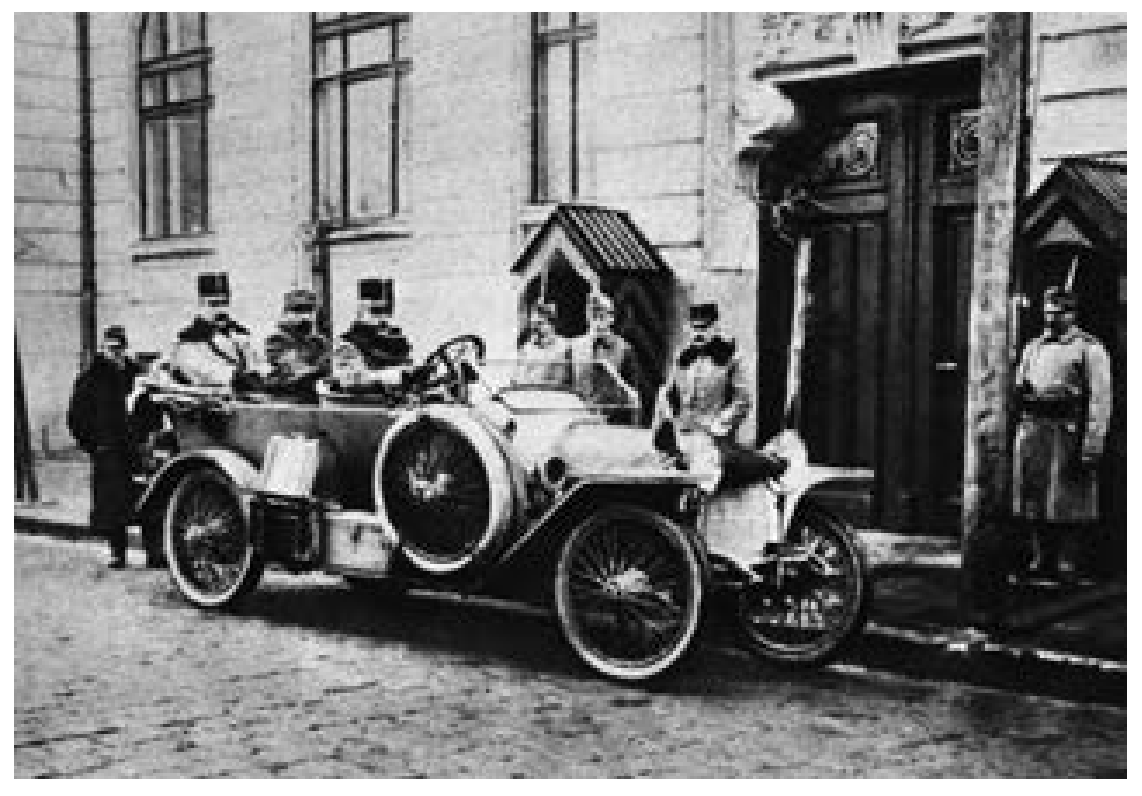

\section{Der Propagandakrieg in der Praxis}

Die offiziellen Kriegsfotografen arbeiten in der Regel mit teuren Plattenkameras (meist mit Stativ). Als Negativmaterial verwenden sie Gelatinetrockenplatten im Format $13 \times 18$ oder $9 \times 12 \mathrm{~cm}$, die sie zumeist schon vor Ort selbst entwickeln. Den Nachschub an Platten besorgt die Militärverwaltung über Kurierdienste. Die Ausrüstung ist - infolge der großen Apparate und der schweren Glasplatten - oft recht unhandlich und im Gelände mühsam zu transportieren. Einige der Pressefotografen sind daher zusätzlich oder ersatzweise noch mit leichteren Rollfilmkameras ausgerüstet. Die fotografische Ausbeute der Kriegsfotografen ist, je nach Einsatzort und Arbeitsbedingungen, sehr unterschiedlich. Monatlich schicken die einzelnen Fotografen zwischen weniger als einem Dutzend und 50 bis 60 Aufnahmen nach Wien. Gelegentlich sind es aber auch weit über 100 Bilder. Wenn die Ausbeute gering bleibt, übt das KPQ auch Druck aus. „Wenn in Hinkunft nicht von jedem Einzelnen alle 14 Tage irgend ein Produkt seines Schaffens (...) einläuft, wird das Armeeoberkommando dies als Beweis der Unfähigkeit zu der beabsichtigten Verwendung ansehen und dessen Einrückung zum Landsturmdienste mit der Waffe verfügen“, heißt es in einem Befehl vom 19. Juli 1915. ${ }^{23}$

Die Bilder werden im Kriegspressequartier in Wien für die Propaganda aufbereitet. Zuständig dafür ist die im Kriegspressequartier eingerichtete Lichtbildstelle. Hier werden die Fotos gesammelt, zensiert, teilweise neu beschriftet und für verschiedenste Zwecke eingesetzt. Hauptabnehmer für die Fotos ist die illustrierte Presse, die im Laufe des Krieges immer mehr fotografisches Bildmaterial einsetzt. Die Licht-
Abb. 6 Der Kriegsfotograf Julius von Jelfy nach einem Besuch im Armeehauptquartier. Er hat auf dem Rücksitz des Automobils Platz genommen und ist in der Zeitung mit einem Kreuz (auf dem rechten Oberarm) kenntlich gemacht. Das interessante Blatt, 28. Januar 1915, S. 2. 
Abb. 7 Kämpfe in den Karpaten, Herbst 1914: „Russische Heeresabteilungen, die von ungarischen Truppen geschlagen“ werden. Wiener Bilder, 11. Oktober 1914, S. 7. Zeichnung: H. Pankratz.
Abb. 8 „Einzug unserer Truppen in Lemberg“. Nach der Rückeroberung der ostgalizischen Hauptstadt am 22. Juni 1915 kommt es zu einer großen Siegesfeier. Die Soldaten werden von der Bevölkerung gefeiert. Das interessante Blatt, 8. Juli 1915, Titelseite. Foto: Josef Perscheid.

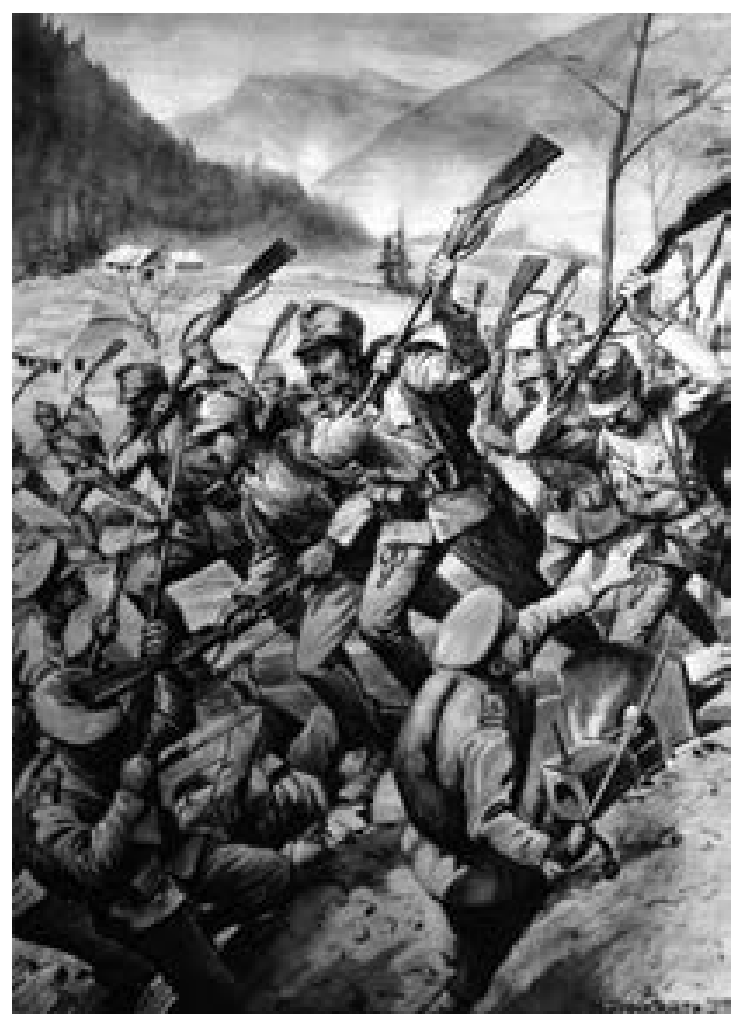

bildstelle im KPQ übernimmt ab Frühjahr 1917 die Funktion einer militärisch gelenkten Fotoagentur. Sehr bald gelingt es ihr, eine dominierende Rolle in der Belieferung der Zeitungen einzunehmen. Zusammen mit den Bildern der deutschen Schwesterorganisation, dem BUFA (Bild- und Filmamt), beherrscht sie den intensiver werdenden Bilderkrieg. In den letzten beiden Kriegsjahren stammt ein Großteil der Kriegsfotos aus diesen beiden militärischen Quellen, die privaten Fotoagenturen verlieren deutlich an Boden. Die militärische Propagandaeinrichtung steuert nicht nur das Bild des Krieges in der illustrierten Presse, sondern setzt ein breites Spektrum an Bildmedien für ihre Zwecke ein. Sie finanziert und kontrolliert die Filmproduktion, liefert Bildmaterial für Propagandabücher und -broschüren, druckt Plakate und Fotovergrößerungen für den öffentlichen Aushang und vertreibt Propagandapostkarten in großer Zahl. Die Fotografie, die zu Beginn des Krieges noch eine untergeordnete Rolle im Propagandakrieg gespielt hat, steigt nun zum Leitmedium auf.

Dieser Aufstieg geht mit einem rapiden Bedeutungsverlust der Zeichnung einher. In allen Bereichen der Kriegsberichterstattung löst im Laufe des Krieges das inzwischen als „authentischer“ geltende Medium Fotografie die Zeichnung ab - mit einer Ausnahme, der Darstellung von Kampfszenen. Zwischen 1914 und 1918 werden nur sehr wenige aktuelle Fotos von Kämpfen veröffentlicht. Häufiger werden gestell- te Aufnahmen als tatsächliche Kämpfe ausgegeben. Noch häufiger werden Kampfszenen mittels Zeichnungen eingefangen. Denn die Dramatik und Unmittelbarkeit, die sie vermitteln, ist mit fotografischen Bildern nicht zu erreichen.

Im Oktober 1914 wird in den Wiener Bildern eine gezeichnete Kampfszene veröffentlicht, die die Vorzüge der Zeichnung gegenüber der Fotografie gut illustriert (Abb. 7). Die dramatische Nahkampfszene spielt an der Ostfront, im gebirgigen Gelände der Karpatenpässe. Der Zeichner H. Pankratz führt uns mitten hinein in das Geschehen. Im linken unteren Bereich sind die unterlegenen Russen zu sehen, die sich mit ihren Bajonetten verzweifelt gegen den Ansturm der ungarischen Truppen zu wehren versuchen. Letztere stürzen sich mit erhobenen Gewehren ins Kampfgetümmel und bleiben - so verdeutlicht der Bildtext - siegreich. Die russischen Heeresabteilungen werden, wie könnte es anders sein, „von den ungarischen Truppen geschlagen“. ${ }^{24}$ Die Inszenierung einer derart dramatisch zugespitzten Kampfszene

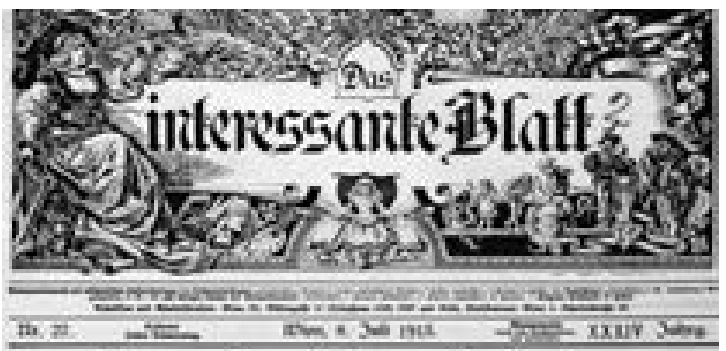

Eingug unferet Eruppen in Eemberg.

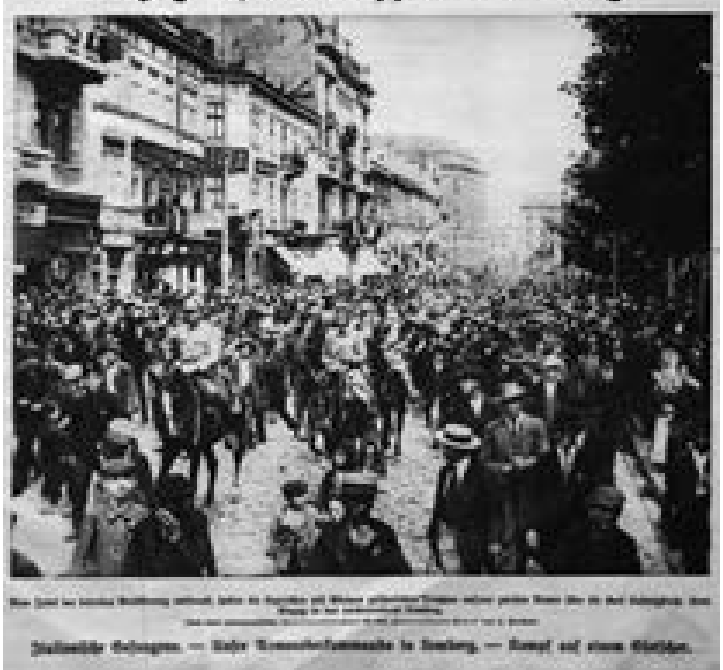


wäre mit den Mitteln der Fotografie unmöglich gewesen. Die historische Realität ist allerdings in keiner Weise mit der Siegesbotschaft der Illustration in Einklang zu bringen. Denn im Herbst 1914 befinden sich die Truppen der k. u.k. Armee an der gesamten Ostfront auf dem Rückzug. Eine Niederlage folgt der anderen. Im November erreichen die russischen Truppen bereits die Gegend um Krakau. In der Zeichnung wird diese Entwicklung geleugnet und ein erfolgreicher Widerstand gegen die russische Invasion suggeriert.

Ein gutes halbes Jahr später hat sich das militärische Blatt gewendet. Im Frühjahr und Frühsommer 1915 gelingt es den österreichischen Truppen, nach und nach West- und Teile Ostgaliziens zurückzuerobern. Am 22. Juni wird die ostgalizische Hauptstadt Lemberg eingenommen. Dieser Sieg wird in der Presse mit großem Aufwand propagandistisch ausgeschlachtet. Als am 8. Juli 1915 über den siegreichen „Einzug unserer Truppen in Lemberg“ berichtet wird, prangt ein Foto (und nicht eine Zeichnung) auf dem Umschlag (Abb. 8). Patriotische Massenszenen und Siegesfeiern lassen sich in der Fotografie weitaus besser dokumentieren als in der Zeichnung. Der Wiener Kriegsfotograf Josef Perscheid hat seinen Apparat mitten in der Straße, aber deutlich erhöht (möglicherweise auf einer Stehleiter oder einem improvisierten Podest) aufgestellt, um die Siegeskundgebung in der zentral gelegenen Karl-Ludwig-Straße möglichst gut überblicken zu können. Die berittenen Soldaten in der Straßenmitte sind von einer dichten Menschenmasse umringt. Tausende Feiernde und Schaulustige sind an diesem Tag in Lemberg unterwegs. Im Bildtext ist vom „Jubel der befreiten Bevölkerung“ die Rede, mit dem „die siegreichen, mit Blumen geschmückten Truppen unserer zweiten Armee“ begrüßt werden. ${ }^{25}$

Auch im fernen Wien wird die Wiedereroberung Lembergs in großem Stil gefeiert. Am 24. Juni 1915, zwei Tage nach dem Sieg, wird im Schloss Schönbrunn eine Huldigung an den Kaiser inszeniert (Abb. 9). Im Schlosshof hat sich eine große Menschenmen-

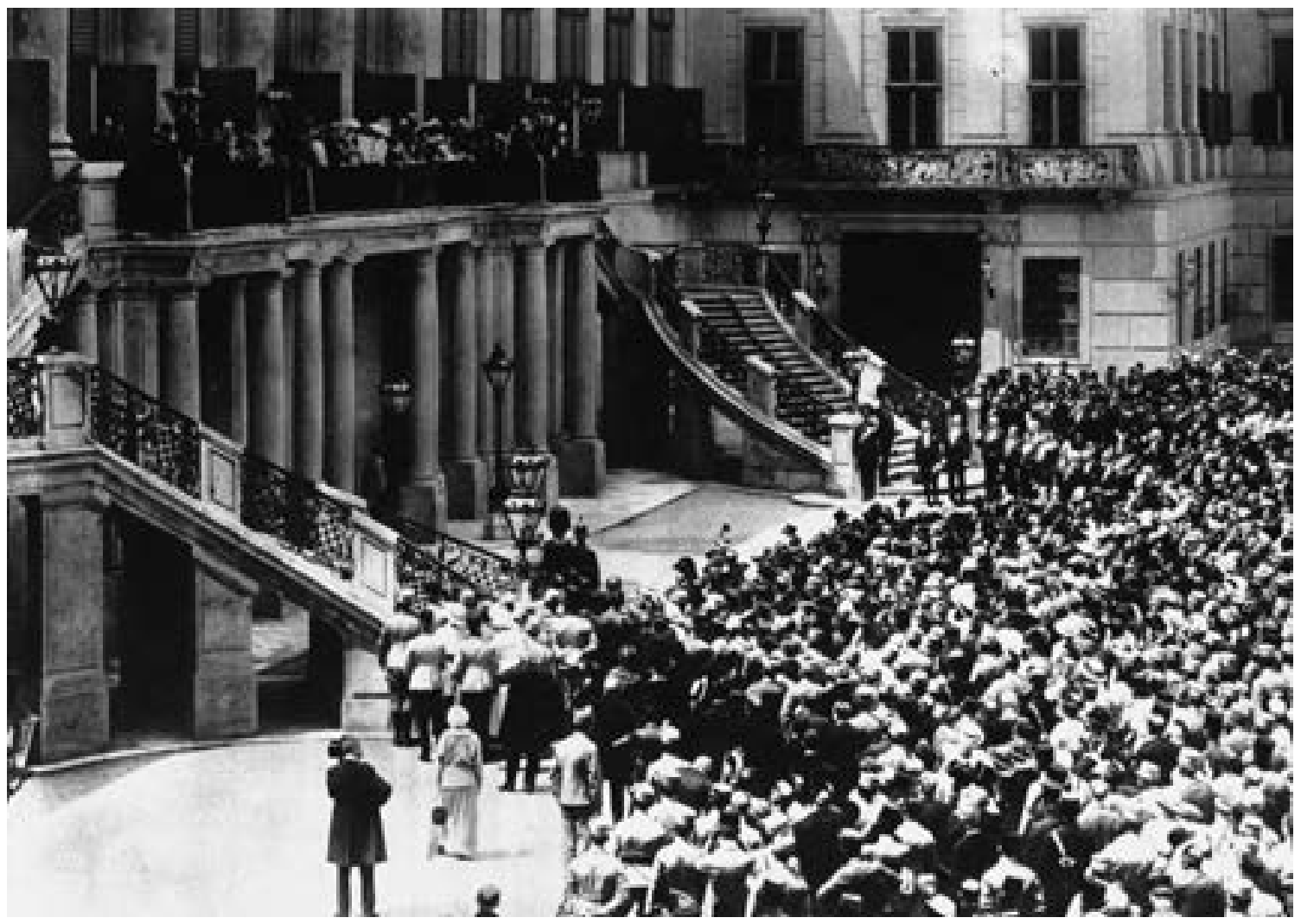

Abb. 9 Kaiserhuldigung in Wien nach der Wiedereroberung von Lemberg. Im Hof des Schlosses Schönbrunn versammelt sich eine große Menschenmenge, der Wiener Bürgermeister Richard Weiskirchner hält eine Rede an den Kaiser, der sich kurz auf der Terrasse zeigt. Wiener Bilder, 4. Juli 1915, S. 5. Foto: R. Lechner (Wilh. Müller). 
Abb. 10 „Zufriedene Kriegsgefangene". Fotos sollen beweisen, dass es den serbischen Gefangenen in den österreichischen Kriegsgefangenenlagern gut geht. Österreichs IIlustrierte Zeitung, 6. Juni 1915, Titelseite. Foto: Kilophot.
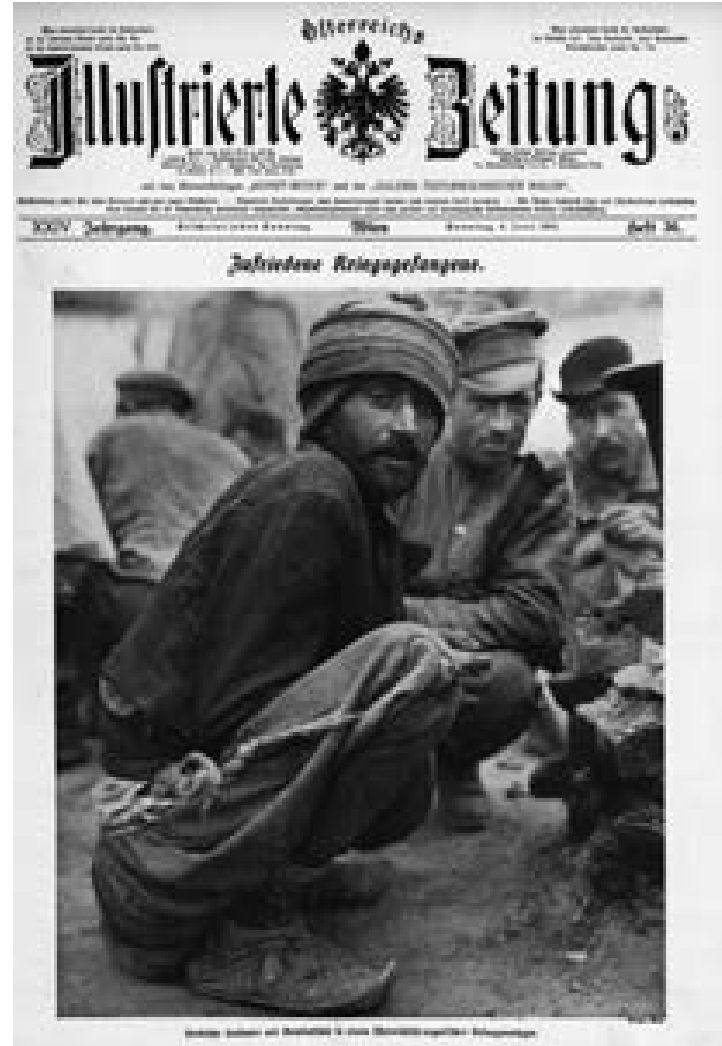

ge versammelt, während der Wiener Bürgermeister Richard Weiskirchner eine Ansprache an den Kaiser hält. Dieser erscheint, so heißt es im Bildtext, auf der Schlossterrasse, um die Worte entgegenzunehmen. ${ }^{26}$

Die Propagandamaschinerie dient aber nicht nur dazu, Niederlagen zu kaschieren bzw. gelegentlich sogar in (kleine) Siege umzuwandeln oder tatsächliche Siege in patriotischen Massenveranstaltungen zu feiern, sie soll auch der Propaganda des Kriegsgegners entgegentreten. Als nach der Eroberung Serbiens im Spätherbst 1915 Vorwürfe laut werden, die Kriegsgefangenen würden in den österreichischen Lagern schlecht behandelt, antwortet die Militärführung mit Bildern, die das Gegenteil beweisen sollen (Abb. 10). Eine Titelseite von Österreichs Illustrierter Zeitung zeigt „Zufriedene Kriegsgefangene“. ${ }^{27}$ Ein Fotograf der Wiener Fotoagentur Kilophot - vermutlich ist es Alexander Exax ${ }^{28}$ - zeigt mehrere serbische Gefangene. Einer von ihnen ist in Großaufnahme abgebildet. Er hockt auf dem Boden und blickt in die Kamera. Ob der Mann „zufrieden“ ist, lässt sich dem Bild beim besten Willen nicht entnehmen, aber die Schlagzeile schafft ihre eigenen Fakten.
Abb. 11 Kaiser Karl auf dem Flugfeld in Aspern, 8. Juli 1918. Anlass ist die Einrichtung einer Postflugverbindung Wien - Budapest. Rechts im Bild ist die Kaiserin Zita mit den Kindern (v. I. n. r.) Otto, Adelheid und Robert zu sehen. Wiener Bilder, 28. Juli 1918, S. 5. Foto: Brüder Schuhmann.

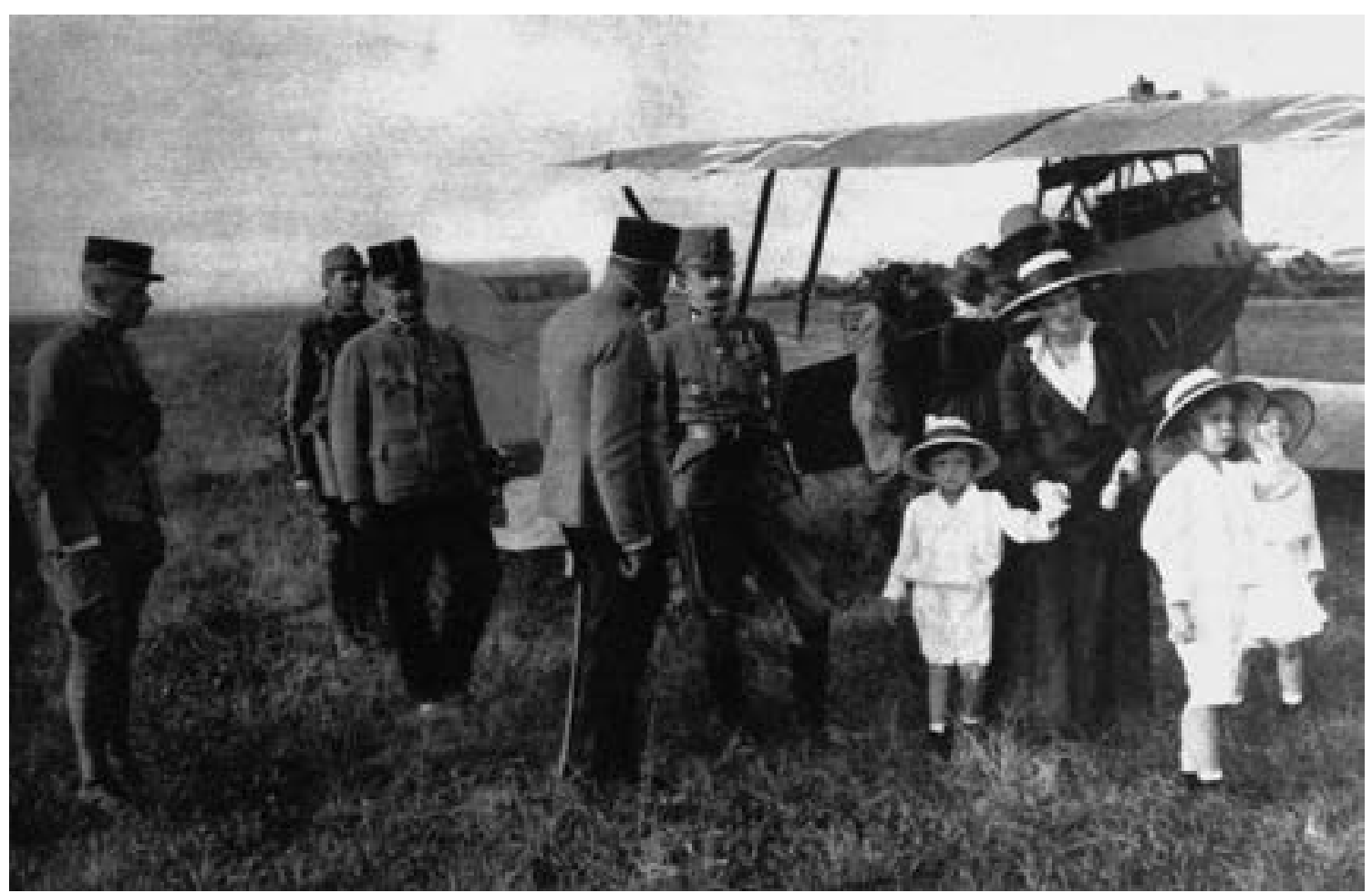




\section{Der Krieg und die Folgen}

Im Sommer 1918 geht der Krieg in sein fünftes Jahr. Kriegsmüdigkeit macht sich breit, der Hunger hat die Bevölkerung - vor allem in den großen Städten - schwer in Mitleidenschaft gezogen. Und dennoch: In der illustrierten Presse wird nach wie vor Optimismus verbreitet. Der junge Kaiser lässt sich wie eh und je gerne in der Öffentlichkeit blicken. Seine Auftritte suggerieren Normalität. Am 8. Juli 1918 macht er mit seiner Familie von Schloss Eckartsau aus einen kleinen Ausflug zum Flugfeld in Aspern. Anlass ist die Einrichtung einer Luftpostlinie zwischen Wien und Budapest, die am 4. Juli eröffnet wurde. Die Flugverbindung zwischen der österreichischen und der ungarischen Hauptstadt hat mehr symbolische als reale Bedeutung. Immerhin signalisiert sie, inmitten der Auflösungserscheinungen, die im k.u.k. Reich bereits deutlich spürbar sind, die Einheit des Staates.

Der Kaiserbesuch findet seinen Niederschlag in der illustrierten Presse. In den Wiener Bildern erscheint eine Aufnahme, die Kaiser Karl in Begleitung seiner Frau Zita und der Kinder Otto, Adelheid und Robert auf dem Flugfeld zeigt (Abb. 11). „Die Majestäten und ihre reizenden Kinder“, so heißt es zum Bild, „erwarteten an dem milden Sommerabend die Ankunft des schon gemeldeten Flugzeuges, das am Nachmittag Budapest mit der für Wien bestimmten Flugpost verlassen hatte. Das Flugzeug landete in eleganter Schleife knapp vor dem Kaiserpaar. (...) Kaiser und Kaiserin zogen die Flieger ins Gespräch und wohnten dann der Übergabe der Flugpost aus Budapest an die Amtsorgane der Post bei. Auch die Kinder des Kaiserpaares bekundeten lebhaftes Interesse und ließ der Kaiser den Kronprinzen Otto zu dessen allergrößter Freude auf eines der Flugzeuge heben. Die allerhöchsten Herrschaften waren von dem Besuche ungemein befriedigt und verließen den Flugplatz mit den Ausdrücken ihrer besonderen Anerkennung.“29 Die Idylle dieses Sommerabends hat nicht lange Bestand. Schon ein halbes Jahr später, am 11. November 1918, muss Kaiser Karl zurücktreten. Einen Tag später wird die Republik ausgerufen.

Nach dem Zusammenbruch der Monarchie wird Karl Renner Staatskanzler. Er ist Sozialdemokrat und

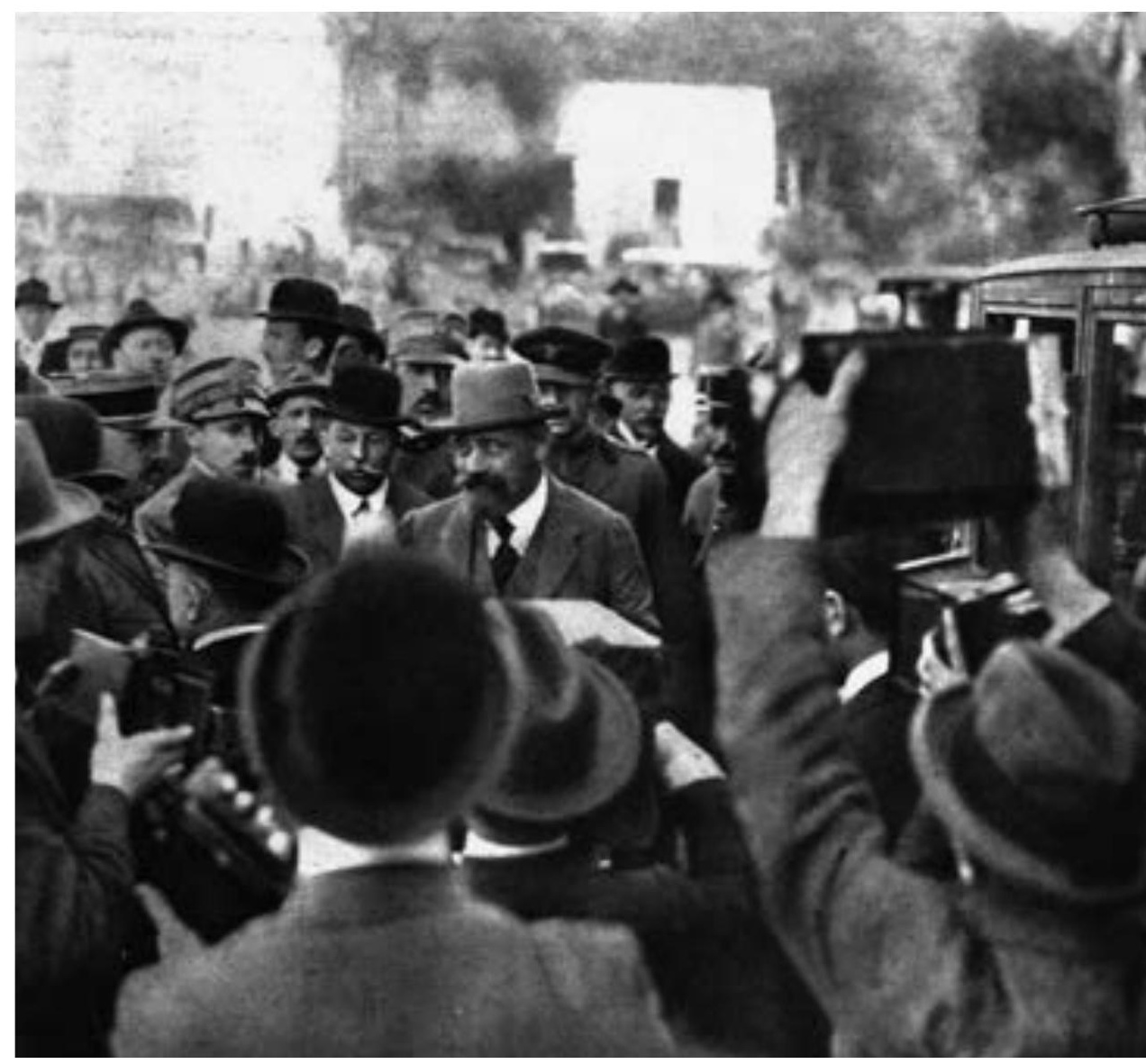

pflegt ein anderes Auftreten als der mediensüchtige Kaiser Karl. In der Öffentlichkeit tritt er viel seltener auf. Wenn er im Mittelpunkt des journalistischen Interesses steht, tritt er als Staatsmann auf. Eine Aufnahme, die am 8. Juni 1919 in den Wiener Bildern veröffentlicht wird, zeigt ihn inmitten von Journalisten und Fotografen im Pariser Vorort Saint-Germain (Abb. 12). Renner ist angereist, um als Leiter der „deutschösterreichischen Delegation“ die Friedensverhandlungen mit den Siegermächten zu führen. Eine undankbare Aufgabe, denn zu verhandeln gibt es nach der katastrophalen Niederlage Ende 1918 nicht viel. Vielmehr bleibt ihm und seiner Regierung in den folgenden Wochen und Monaten nichts weiter übrig, als die Bedingungen der Alliierten hinzunehmen. Als am 10. September 1919 in Saint-Germain der Friedensvertrag der Siegermächte mit Österreich unterzeichnet wird, ist der Erste Weltkrieg auch formal beendet.
Abb. 12 Friedensverhandlungen in Saint-Germain. Der österreichische Staatskanzler Karl Renner (Bildmitte) wird bei der Ankunft im Pariser Vorort von Journalisten und Fotografen umringt. Wiener Bilder, 8. Juni 1919, Titelseite. 
Die mediale Bilanz des Ersten Weltkriegs ist vielschichtig. In den Jahren zwischen 1914 und 1918 erlebt die fotografische Bildproduktion und -reproduktion einen immensen Aufschwung. Je mehr der Krieg zu einem visuellen Ereignis wird, das sich in illustrierten Zeitungen, im Kino, in Büchern und in Ausstellungen niederschlägt, desto mehr Bilder werden gebraucht. Der Krieg erweist sich als Katalysator für die fotografische Bildberichterstattung, auch wenn die Entwicklung in verschiedenen Ländern unterschiedlich verläuft. Während sich die englische und französische Bildpresse größere Freiheiten erlaubt bzw. etwas weniger stark am Gängelband des Militärs und der Kriegsführung hängt, ist die Kontrolle in Deutschland und Österreich allumfassend. Die Modernisierung und Weiterentwicklung der Kriegsbildberichterstattung erfolgt, darauf weist Ulrich Keller in einer wichtigen vergleichenden Studie hin, in Deutschland und Österreich später und halbherziger als in Frankreich, England und den USA. ${ }^{30}$

In allen kriegführenden Ländern investieren sowohl das Militär als auch die Presse zwischen 1914 und 1918 viel Geld in die Verbesserung der Fotoberichterstattung. Im Laufe des Krieges kommt es daher zu einer grundlegenden Umschichtung im Mediensystem. Zensur, Akkreditierungsmaßnahmen und die systematische „Einbettung“ der fotografischen Berichterstattung in die militärische Logistik führen zu einer zunehmenden Verzahnung von Militär und Medien, zu einer Symbiose zwischen Kriegsführung und Propaganda.

Diese militärisch kontrollierten Propagandaschlachten haben weitreichende Folgen für die Nachkriegszeit. Die umfassende Kontrolle und die enge Symbiose zwischen Medien und Militär führen - vor allem in der zweiten Hälfte des Krieges - zu Monopol- und Oligopolbildungen auf dem Zeitungs- und Zeitschriften-, aber auch auf dem Filmmarkt. Es sind diese Kriegsgewinnler und -monopolisten, die unmittelbar nach dem Krieg die Öffentlichkeit beherrschen.
Erst Mitte der 1920er Jahre beginnt sich das Feld der kommerziellen Anbieter von Bildern wieder langsam auszuweiten.

Bezogen auf die Entwicklung der Pressefotografie heißt das: Das Jahr 1918 ist keineswegs, wie oft behauptet, eine Stunde null im Bildjournalismus. Es gibt zahlreiche strukturelle und personelle Brücken zwischen Vorkriegs-, Kriegs- und Nachkriegszeit. Viele Pressefotografen, die in der Zwischenkriegszeit erfolgreich sind, haben ihre ersten Erfahrungen als Kriegsfotografen gesammelt, manche von ihnen waren bereits vor 1914 aktiv. Ein Beispiel unter mehreren ist Carl Seebald. Er ist seit 1904 als Pressefotograf tätig, arbeitet während des Krieges sehr erfolgreich als Kriegsberichterstatter und ist in der Zwischenkriegszeit noch jahrelang für die Presse unterwegs.

Der Boom der Illustrierten, der in den 1920er Jahren einsetzt, wurzelt - auch - im Krieg. Die wichtigen illustrierten Blätter können während des Krieges ihre Auflagen deutlich steigern. ${ }^{31} \mathrm{Zu}$ Beginn des Krieges werden - vor allem im Billigsegment - einige neue illustrierte Wochenzeitungen gegründet. ${ }^{32}$ Zahlreiche - auch regionale - Tageszeitungen, die bisher keine illustrierten Beilagen produziert haben, bieten ihren Lesern während der Kriegszeit fotografisch illustrierte Beilagen und Wochenendausgaben an. ${ }^{33}$ Insgesamt hat sich die illustrierte Presse unter dem Einfluss des Krieges radikal gewandelt. Das bereits vor 1914 weit entwickelte internationale Vermarktungssystem für Fotografien bricht bei Kriegsbeginn mit einem Schlag zusammen. Dafür aber wird die Logistik der aktuellen Fotoberichterstattung während des Krieges laufend ausgebaut. Die Geschwindigkeit der fotografischen Bildübermittlung wird in atemberaubendem Tempo erhöht. Es kommt, trotz aller Zensurmaßnahmen, zu einer Professionalisierung der Pressefotografie. Nach 1918 werden die Themen des Krieges zwar in der schnelllebigen Welt der illustrierten Presse bald verdrängt, aber hinter den Kulissen sind seine Folgen noch lange spürbar. 


\section{Theater der Macht}

\section{Parlament und Politik in Bildern}

Ende 1893 erscheint in der Österreichischen Illustrirten Zeitung ein Foto des österreichischen Abgeordnetenhauses (Abb. 1). ${ }^{1}$ Es ist das erste Zeitungsfoto, das das Parlament von innen zeigt. Wir sehen zehn Männer, die auf der Galerie des Reichsrats Platz genommen haben. Alle sind sorgfältig gekleidet, sie verfolgen das Geschehen im tiefer liegenden Sitzungssaal. Einige haben Papier und Schreibzeug vor sich liegen, andere scheinen aufmerksam zuzuhören. Doch irgendetwas stimmt mit diesem Bild nicht. Wenn wir die Szene etwas genauer betrachten, stoßen wir auf eine ganze Reihe von „Ungereimtheiten“. Die Größenverhältnisse der Säulen im Hintergrund und der Körper einiger der Männer stimmen nicht überein. Letztere sind im Vergleich zur Architektur viel zu groß. Die Figuren haben etwas Schablonenhaftes an sich, ihre Konturen sind scharf voneinander getrennt. Während die architektonischen Details mit wachsender Entfernung an Schärfe verlieren, sind die Gesichter der Männer annähernd scharf gezeichnet. Allmählich wird klar: Es handelt sich um eine Fotomontage.

Obwohl das Bild namentlich nicht gekennzeichnet ist, lässt sich sein Urheber zweifelsfrei identifizieren: Es ist Siegmund Schneider. Der Journalist, Fotograf, Grafiker und Zeichner arbeitet bei der wenige Monate zuvor gegründeten Österreichischen Illustrirten Zeitung. ${ }^{2}$ Er hat ein ausgezeichnetes grafisches Gespür und lotet das Bildmedium Fotografie nach allen Richtungen hin aus. Die Fotografie ist für ihn kein rein dokumentarisches Mittel der Berichterstattung. Es geht ihm nicht um Authentizität, sondern um dramaturgische Effekte. Daher unterzieht er die Fotos häufig einer oft aufwendigen grafischen Bearbeitung. Bekannt wird Schneider mit seinen „Photo-Compositionen“. Das sind komplexe, handwerklich sehr gut gemachte, mithilfe von Schere und Klebstoff hergestellte Fotomontagen, die in der Regel bekannte Protagonisten (etwa den Kaiser, bekannte Schauspieler, Politiker usw.) im Freien oder in bekannten Interieurs

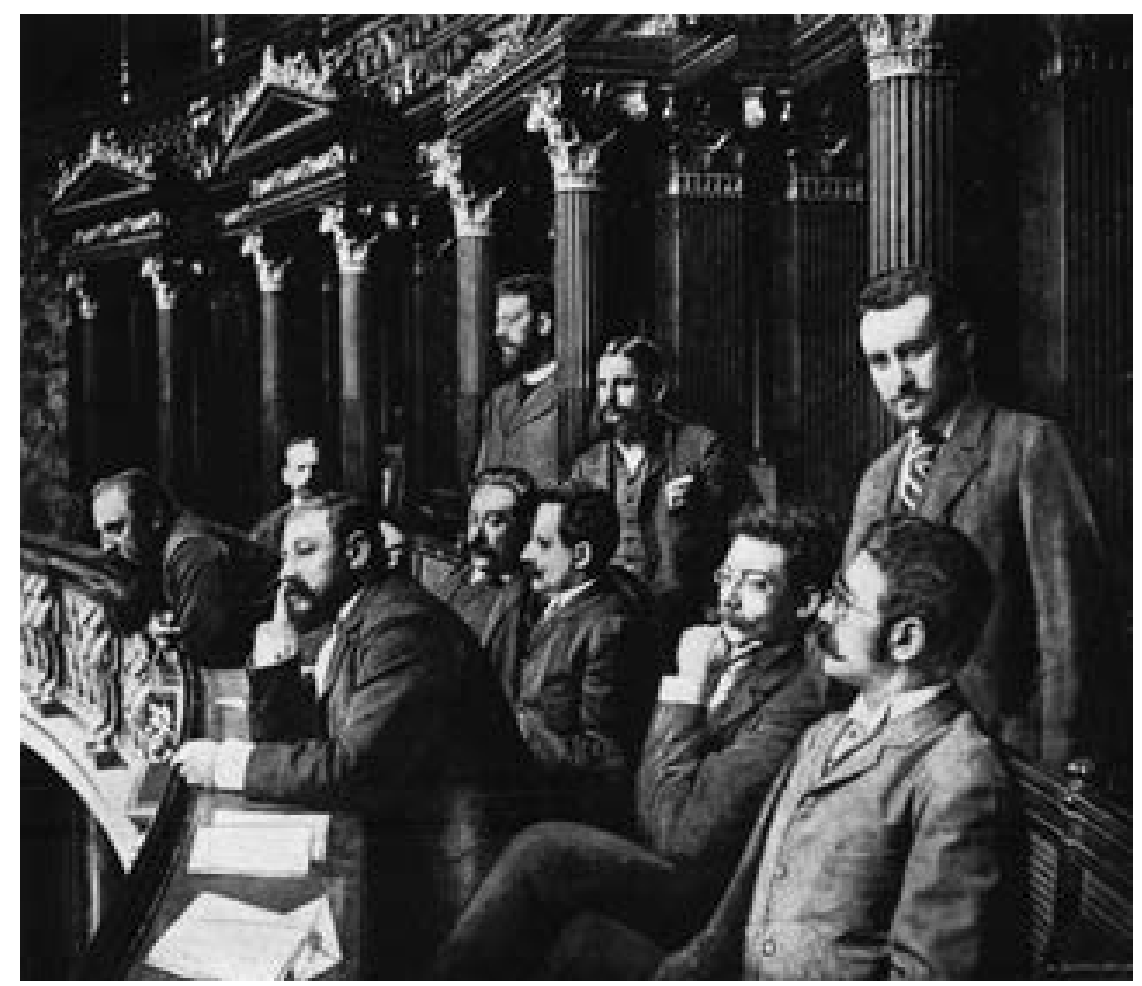

zu lebendigen Gruppenszenen arrangieren. Die vorliegende Montage ist - anders als viele andere Arbeiten Schneiders - erst auf den zweiten Blick als solche erkennbar, sie ist daher auch nicht als „Photo-Composition“ gekennzeichnet.

Die Männer im Bild sind Journalisten. „An den beiden äußersten Enden der Galerie“, so heißt es im erklärenden Text zum Bild, „oberhalb den amphitheatralischen Sitzreihen im österreichischen Abgeordnetenhause, sind den Berichterstattern der Presse zwei große Logen eingeräumt. Zur Rechten vom Präsidium, in der Loge unmittelbar über den Bänken des Polenclubs, haben die Provinz- und ausländischen Journale ihre Stammsitze. Auf der äußersten Linken aber obliegen die Vertreter der großen Wiener Residenzpresse ihrem schwierigen Dienste.“” Was ist das Besondere an diesem Bild? Bisher fanden die Parlamentsdebat-
Abb. 1 Journalisten verfolgen von der Galerie aus eine Sitzung im österreichischen Abgeordnetenhaus. Österreichische Illustrirte Zeitung, 11. Dezember 1893, S. 12. Fotomontage: Siegmund Schneider. 
ten unter Ausschluss der Kamera statt. Zu Beginn der 1890er Jahre ändert sich das: Erstmals betritt nun ein Fotograf den Sitzungssaal des Parlaments. Er wendet sich zunächst nicht, wie man vielleicht vermuten könnte, den Ministern und Abgeordneten zu, sondern dem journalistischen Publikum. Das hat seinen Grund. Immerhin bilden die schreibenden Redakteure das Herzstück der politischen Presse. Sie stellen jene Öffentlichkeit her, die den Parlamentsdebatten über den Sitzungssaal hinaus Aufmerksamkeit und Gehör verleiht. „Ohne die Presse“, so der Redakteur der Österreichischen Illustrirten Zeitung, „wäre die Glaskuppel des Sitzungssaales wenig mehr als eine Isolierglocke, und ein Parlament ohne Pressfreiheit wäre tathsächlich auch wenig mehr als eine Abstimmungs- und Steuerbewilligungsmaschine.“ ${ }^{4}$

Um die Jahrhundertwende weitet sich die politische Öffentlichkeit, die bisher vorwiegend über den Weg der Schrift hergestellt wurde, deutlich aus. Die Politiker erhalten nun erstmals ein fotografisches Gesicht und damit ein visuelles Image. Der Fotograf in der Presseloge des Abgeordnetenhauses hat also Signalcharakter. Er deutet auf eine neue Form von Öffentlichkeit hin, die wir als fotografische Öffentlichkeit bezeichnet haben. ${ }^{5}$

Es ist wichtig, diesen Prozess der zunehmenden Visualisierung der Politik nicht bloß als technisch-mediale Fortschrittsgeschichte zu sehen, sondern mit den vielschichtigen politisch-gesellschaftlichen Umbrüchen der Zeit in Verbindung zu bringen. Der zentrale Motor dieser Entwicklung ist die Herausbildung neuer Formen der Massenpolitik. Um nur ein paar Entwicklungen zu nennen: Nach heftigen politischen Kämpfen wird 1907 bei Reichsratswahlen erstmals nach dem allgemeinen Männerwahlrecht abgestimmt. ${ }^{6}$ Damit wird die Gruppe der politisch aktiven Bevölkerung mit einem Schlag deutlich ausgeweitet. Mit den Sozialdemokraten und Christlichsozialen etablieren sich vor der Jahrhundertwende neue Massenparteien, zu deren Strategie die politische Mobilisierung der mittleren und unteren sozialen Schichten gehört. Die eskalierenden $\mathrm{Na}-$ tionalitätenkonflikte innerhalb der Monarchie führen zu einer zunehmenden ethnischen Frontstellung. In den großen Städten der Monarchie kommt es zu ei- ner Massenzuwanderung und, damit verbunden, $\mathrm{zu}$ enormen Bevölkerungszuwächsen. Alle diese Entwicklungen haben Auswirkungen auf die Presselandschaft. Die auflagenstarke Massenpresse wird nun zunehmend zur Bühne der politischen Profilierung und Auseinandersetzung. Zu diesem Segment gehört auch die illustrierte Wochenpresse. In den Jahren um und nach 1900 hält die Politik schrittweise Einzug in die Fotoberichterstattung. Die Illustrierten liefern nun immer öfter aktuelle Bilder zum politischen Tagesgeschehen. Sie berichten über Massenkundgebungen auf der Straße, über die Ergebnisse von Wahlen und auch über die Debatten im Parlament. Umgekehrt entdecken aber auch Politiker die auflagenstarke illustrierte Presse als Bühne für medienwirksame Auftritte.

\section{Politiker im Bild: Das Beispiel Karl Lueger}

Karl Lueger, der zwischen 1897 und 1910 Bürgermeister von Wien ist, verkörpert wie kein anderer diesen neuen Politikertypus, der das Spiel mit den Medien souverän beherrscht. Seine politische Karriere beginnt er in den Reihen der Liberalen, 1893 gründet er die Christlichsozialen als moderne Massenpartei und setzt nun immer stärker auf Demagogie, Populismus und Antisemitismus als Vehikel für die Mobilisierung seiner Anhänger. ${ }^{7}$ Lueger ist der erste österreichische Politiker, der in der Öffentlichkeit systematisch ein fotografisches Image aufbaut.

Wenn wir die Entwicklung seiner medialen Präsenz in der Presse verfolgen, wird eines deutlich: Bis Mitte der 1890er Jahre spielt die Bildberichterstattung bei der Darstellung und Bewerbung Karl Luegers noch keine herausragende Rolle. Ab Ende der 1890er Jahre aber zeichnet sich ein Umschwung ab. Die Fotografie wird als Mittel der Inszenierung immer wichtiger. Als Lueger 1895 zum ersten Mal das Bürgermeisteramt anstrebt, tauchen vermehrt Bilder in der illustrierten Presse auf. Zunächst sind es noch Zeichnungen, aber schon 1897, als er erstmals Bürgermeister wird, treten immer häufiger Fotos an ihre Stelle.

Luegers Imagewerbezüge sind sorgfältig auf seine politischen Kampagnen abgestimmt. Besonders im Vorfeld politischer Wahlen oder auf dem Höhepunkt heftiger politischer Debatten häufen sich die Lue- 


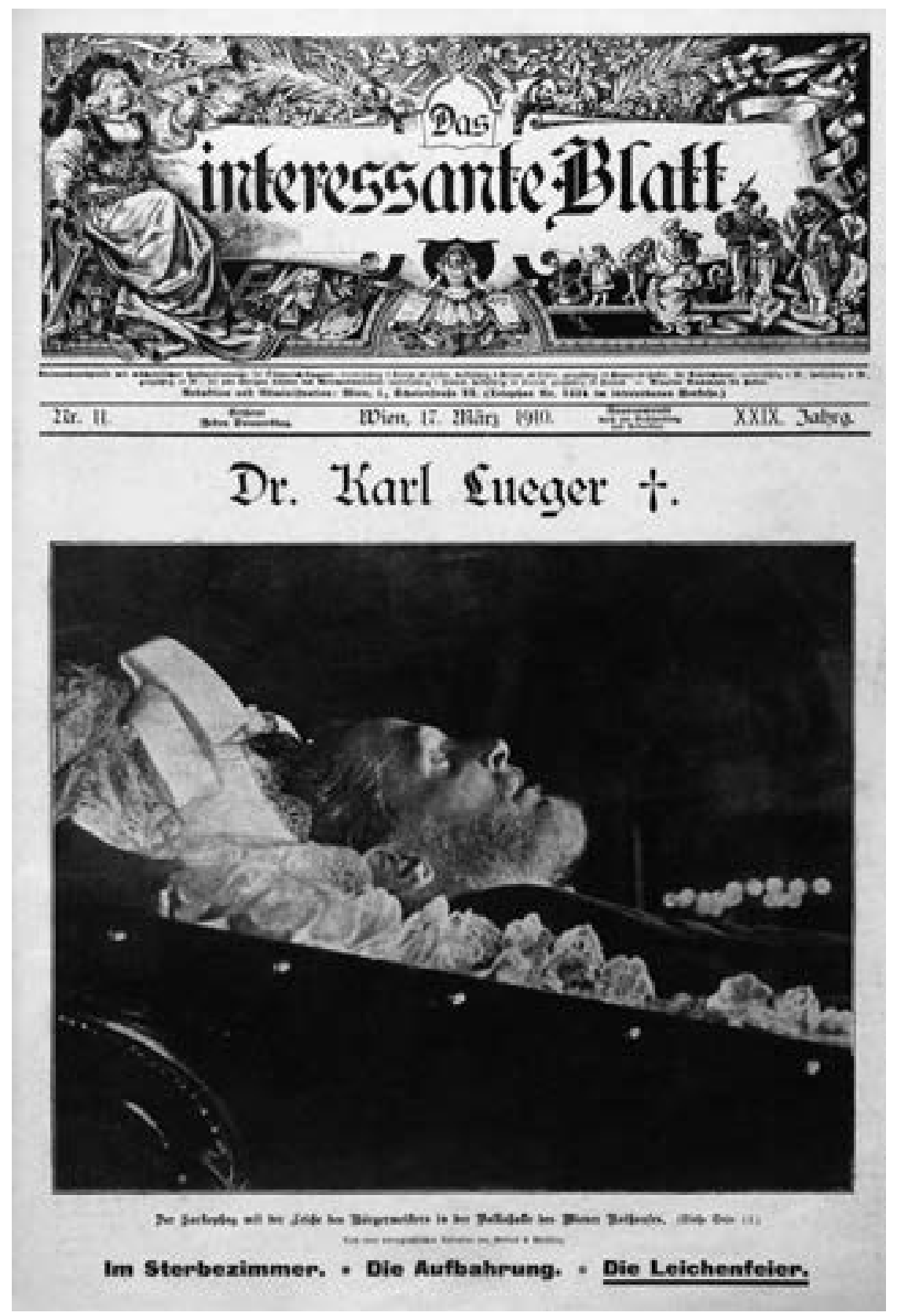

Abb. 3 Aufbahrung des Wiener Bürgermeisters nach seinem Tod am 10. März 1910. Das interessante Blatt, 17. März 1910, Titelseite. Foto: Gerlach \& Wiedling
Fotografenduo Martin Gerlach und Albert Wiedling, die den Politiker immer wieder fotografieren - erscheint am 14. August 1907 in der Zeitung Wiener Bilder. ${ }^{13}$ Lueger, so heißt es im kurzen Beitrag zum Bild, „beteiligte sich an diesem echt deutschen Sportvergnügen und die zahlreichen Treffer, die er bei diesem Schießen erzielte, bilden den besten Beweis für die Wiederherstellung seiner Sehkraft, die während seiner langen Krankheit geschwächt gewesen (war)." ${ }^{14}$ Weitere Aufnahmen dieses Ereignisses werden für die nächste Nummer angekündigt. Allerdings erscheinen sie nicht.

Luegers Gesundheit verschlechtert sich zunehmend. Doch er führt, nach längeren Arbeitsunterbrechungen, das Bürgermeisteramt noch knapp drei Jahre weiter. Am 10. März 19010 stirbt er in Wien. Auch über seinen Tod wird in der Presse in großer Aufmachung berichtet. Die illustrierten Zeitungen bringen große Bildberichte. Das interessante Blatt etwa widmet dem berühmten Toten die gesamte Titelseite. Ein Foto, es stammt wiederum von Martin Gerlach und Albert Wiedling, zeigt den im Rathaus aufgebahrten Verstorbenen (Abb. 3). ${ }^{15}$ Die am 14. März 1910 stattfindende Leichenfeier wird zu einer überwältigenden politischen Massenkundgebung. Auch sie findet in der Presse breiten Niederschlag, wiederum erscheinen zahlreiche fotografische Berichte.

1910, im Jahr seines Todes, ist Luegers Popularität an ihrem Höhepunkt angelangt. Der Politiker verkörpert den politischen Erfolg der Christlichsozialen. Als der Partei diese charismatische Führungsfigur abhandenkommt, gerät sie in eine Krise. Bei den Wahlen im Jahr 1911 erleidet die Partei eine dramatische Niederlage. Die absolute Mehrheit geht in Wien nun an die Sozialdemokraten. Das populäre Image des erfolgreichen Parteiführers hat sich freilich längst verselbstständigt. Nicht zuletzt dank seiner überragenden medialen Präsenz bleibt Lueger noch Jahre nach seinem Tod eine öffentliche Figur Wiens. ${ }^{16}$

\section{Politik wird sichtbar}

Karl Lueger ist eine Ausnahmefigur auf der politischen Bühne der Jahrhundertwende. Kein anderer österreichischer Politiker (mit Ausnahme des Kaisers) ist in den Medien auch nur annähernd so präsent wie er. Dennoch ist der Trend zur zunehmenden Visualisierung der Politik nicht allein auf Lueger beschränkt. Im letzten Jahrzehnt vor der Jahrhundertwende tauchen erstmals fotografische Politikerporträts in der illustrierten Presse auf. Im Februar 1891 erscheint in der führenden österreichischen illustrierten Zeitung, dem Interessanten Blatt, ein Foto des Finanzministers Emil Steinbach. ${ }^{17}$ Es handelt sich vermutlich um das erste Fotoporträt eines österreichischen Politikers in der Presse. Die Vorlage stammt aus dem bekannten Wiener Atelier Krziwanek.

Am 8. April 1897 beginnt Das interessante Blatt eine mehrteilige Serie mit Politikerporträts. ${ }^{18}$ Vorgestellt werden jene Kandidaten, die bei den eben ge- 
schlagenen Reichsratswahlen erfolgreich waren und den Einzug in den Reichsrat geschafft haben. Interessant ist, dass nicht alle, sondern nur die nach dem neuen, ausgeweiteten Wahlrecht - 1896 wird eine fünfte, allgemeine Wählerkurie eingeführt ${ }^{19}$ - gewählten Abgeordneten porträtiert werden. Auch hier zeigt sich: Politische Massenmobilisierung und Ausweitung der politischen Bildberichterstattung gehen um die Jahrhundertwende Hand in Hand. Die Brustbilder gleichen einander: Es handelt sich durchweg um klassische Atelieraufnahmen, die auf der Zeitungsseite rasterartig nebeneinandergestellt werden.

Diese noch sehr holzschnittartigen Porträts markieren den Anfang der fotografischen Politikerikonografie in Österreich. In den folgenden Jahren wird sie sich in raschen Schritten weiterentwickeln. Wenige Jahre später erscheinen in den Wiener Bildern bereits ganz andere Aufnahmen. Am 11. September 1901 beginnt eine Serie, die die „österreichischen Minister in ihren Arbeitscabineten“ vorstellt. Anlass ist die bevorstehende Wiedereröffnung des Parlaments. Daher ist es der Zeitung ein Anliegen, „die Männer im Bilde zu bringen, in deren Hand die Zügel der Staatsgewalt liegen.“20 "Naturgemäß beginnen wir mit Sr. Excellenz, dem Ministerpräsidenten, Herrn Dr. Ernest von Koerber, in seinem Arbeitszimmer im Ministerraths-Präsidium in der Herrengasse“ ${ }^{21}$ Und weiter heißt es im Bericht: „Wir haben die Herren Minister alle an ihrer Arbeitsstätte aufgesucht und unserem trefflichen Photographen ist es gelungen, die Excellenzen in ihren Arbeitscabineten in geradezu meisterhaft aufgefaßten Bildern festzuhalten."22 Tatsächlich unterscheiden sich die Aufnahmen, die der bekannte Wiener Fotograf Charles Scolik sen. anfertigt, sehr deutlich von den stereotypen Brustbildern bisheriger Machart. Die berufliche Umgebung der Politiker, die bisher noch nie auf Bildern zu sehen war, rückt nun neben dem Protagonisten in den Mittelpunkt. Das Interieur des Arbeitszimmers gehört in dieser Inszenierung ausdrücklich zu den positiven Attributen der Politikerpersönlichkeit. So entsteht ein weit lebendigerer Eindruck als in den bisherigen Politikerporträts. Allmählich treten die prominenten Figuren des öffentlichen politischen Lebens aus der bildlichen Anonymität. Sie werden wiedererkennbare Figuren.

Um die Jahrhundertwende setzt sich dieser Trend auch im Inneren des Parlaments fort. Bisher hatten die Sitzungen des Abgeordnetenhauses unter Ausschluss von Fotografen stattgefunden. Anfang Februar 1901 erscheint in den Wiener Bildern erstmals eine Aufnahme, die den Sitzungssaal - nicht nur die Pressegalerie, wie beim Zeitungsbild 1893 -im Überblick zeigt (Abb.4). ${ }^{23}$ Das Foto stammt vom bekannten Wiener Architektur- und Stadtfotografen August Stauda. Der Saal ist leer, keiner der 424 Abgeordneten ist zu

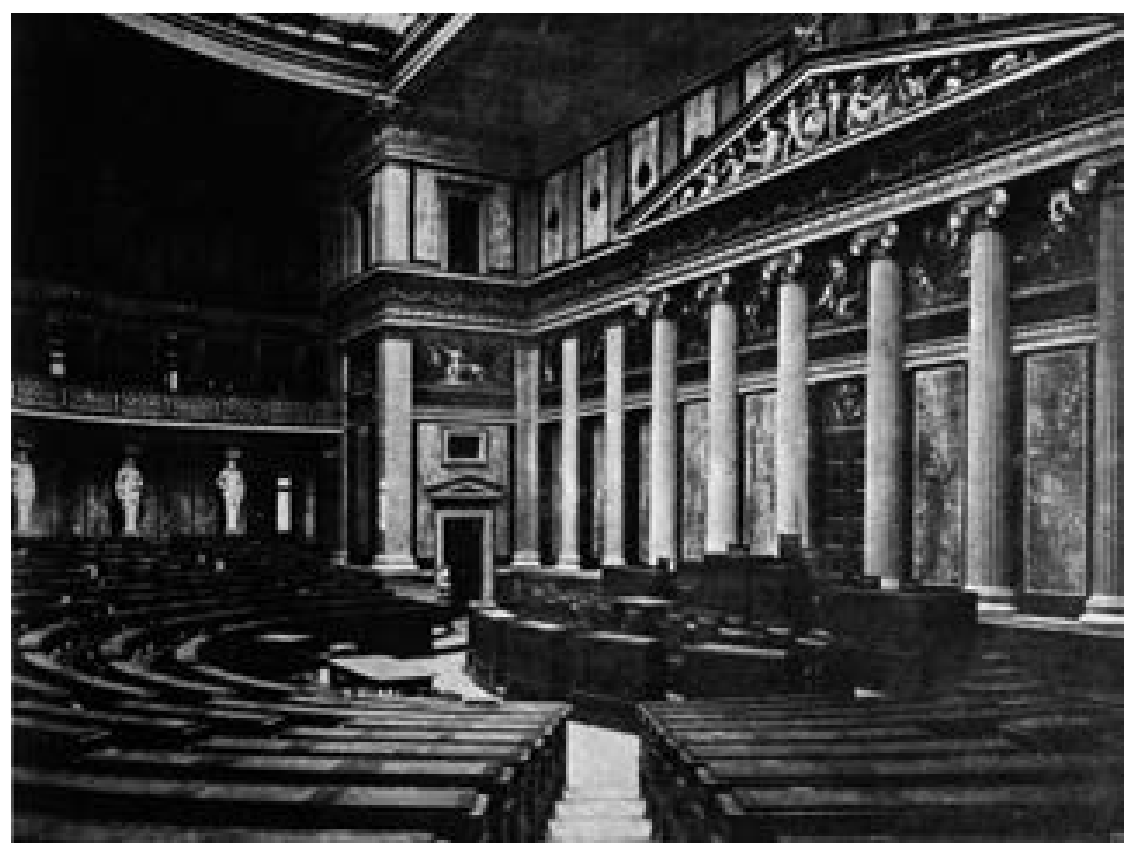

sehen. Der Fotograf hat den Saal an einem sitzungsfreien Tag abgelichtet, offenbar ist es noch verpönt, die Abgeordneten während der Arbeit im Plenarsaal zu zeigen. „Es ist nicht unsere Aufgabe“, heißt es ein wenig süffisant zu diesem Bild, „politische Betrachtungen über den neuen Reichsrath anzustellen und wir begrüßen denselben nur mit der vorzüglichen Aufnahme des Sitzungssaales des Abgeordnetenhauses, in dessen stilvollen Räumen unsere Gesetzgeber ihres Amtes walten oder auch nicht." ${ }^{24}$ Ein gutes Jahr später, im Juni 1902, wagt der Budapester Fotograf Alexander Sorger erstmals während einer Sitzung einen Blick in das ungarische Parlament. ${ }^{25}$ Auf der Tagesordnung steht das Reichsbudget, das beide Abgeordnetenhäuser gemeinsam beschließen. Das Foto,
Abb. 4 Der Sitzungssaal des österreichischen Abgeordnetenhauses. Wiener Bilder, 6. Februar 1901, S. 3. Foto: August Stauda. 
Abb. 5 Aufgeheizte Stimmung im österreichischen Parlament nach der „Teuerungsrevolte“ 1911. Ministerpräsident Paul Gautsch, im Bild mit einem Kreuz $(x)$ markiert, hält von der Ministerbank aus eine Rede. Das interessante Blatt, 2. November 1911, S. 9.

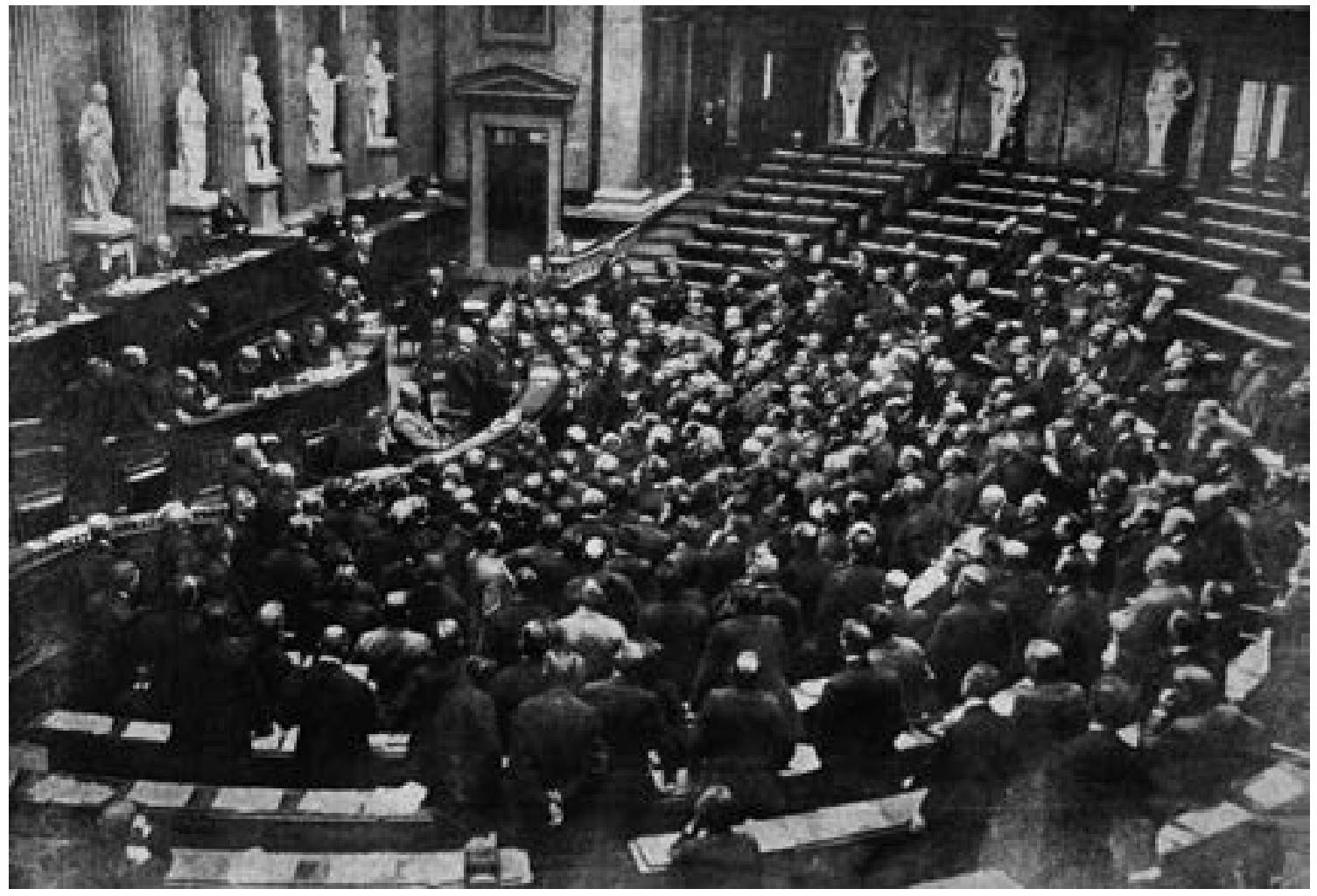

das die österreichischen Parlamentarier bei der Arbeit zeigt, ist eine kleine Sensation: „Unsere Aufnahme - die allererste, die jemals im Sitzungssaale der Delegationen gemacht wurde - zeigt eine Sitzung der österreichischen Delegirten“, heißt es zum Bild. ${ }^{26}$

Ein Jahrzehnt später gehören Fotos von Parlamentssitzungen für die Leser illustrierter Wochenzeitungen bereits zu den vertrauten Motiven. Politik ist - zumindest in Wahlzeiten - inzwischen zur politischen Massenangelegenheit geworden. Alle erwachsenen Männer sind seit den Wahlen im Jahr 1907 auch Wähler. In den Jahren vor dem Ersten Weltkrieg belebt sich der Parlamentarismus. Sichtbares Zeichen für ein neues, entspannteres Verhältnis zwischen Politik und Öffentlichkeit ist die Tatsache, dass im September 1904 in Wien ein internationaler Presse-Kongress stattfindet. Für die Eröffnung der Veranstaltung kann das Parlament gewonnen werden. ${ }^{27}$ Ein Jahrzehnt zuvor wäre das noch unmöglich gewesen.

Im letzten Jahrzehnt vor der Ersten Weltkrieg wird das Abgeordnetenhaus, besonders in Zeiten heftiger politischer Konfrontationen, unter den Augen des $\mathrm{Pu}-$ blikums zur Schauarena. Die neuen Massenparteien der Christlichsozialen und der Sozialisten sehen in den Debatten im Abgeordnetenhaus eine willkommene Bühne zur Darstellung ihrer Politik, auch wenn die grundlegenden politischen Entscheidungen immer noch von der Regierung hinter den Kulissen getroffen werden.

Hie und da gelingt es den Fotografen, einen interessanten Einblick in die Dynamik dieser politischen Arena zu erhaschen. Im Herbst 1911 spitzt sich die Situation in Österreich zu. In Wien kommt es zu Massenkundgebungen und zu heftigen Zusammenstößen zwischen den Demonstranten und Polizei. Die sogenannte „Teuerungsrevolte“ fordert vier Tote und weit über 100 Verletzte. Wenige Wochen später tritt das Parlament zu einer Sitzung zusammen, in der die Vorkommnisse zu hitzigen Debatten und Auseinandersetzungen führen. Die Presse berichtet in großer Aufmachung über die Reden der Parlamentarier. Das interessante Blatt bringt eine großformatige Aufnahme der aufgeheizten Parlamentssitzung (Abb. 5). ${ }^{28} \mathrm{Im}$ Bildtext heißt es: „Die politische Krise in Österreich: 
Vor einem großen Auditorium der um die Ministerbank gescharten Abgeordneten hält Ministerpräsident Dr. Freiherr von Gautsch $(\times)$ in der Sitzung des Abgeordnetenhauses vom 27. Oktober eine politisch bedeutsame Rede über das Verhältnis der Regierung zu den Parteien." ${ }^{29}$ Bei genauerem Hinsehen ist die gespannte Stimmung im Saal tatsächlich wahrnehmbar. Die meisten Abgeordneten haben sich erhoben, viele haben ihre Sitzplätze verlassen und haben weiter vorne Aufstellung genommen. Gebannt blicken alle auf den Redner. Dieser ist, im Bild durch ein Kreuz $(\times)$ markiert, in der Mitte der Ministerbank stehend zu sehen.

Bilder wie dieses wären ein Jahrzehnt zuvor noch unmöglich gewesen. Das Parlament war ein abgeschotteter Ort, der nur einigen wenigen Privilegierten, den Abgeordneten, Ministern und ausgewählten Journalisten zugänglich war. Nun ändert sich die Situation. Nicht mehr kleine Honoratiorengruppierungen beherrschen die Geschicke des Abgeordnetenhauses, sondern gut organisierte Massenparteien, die ein großes Interesse daran haben, ihre Arbeit im Hohen Haus für ein breites Publikum sichtbar zu machen. Aber nicht nur die parlamentarische Arbeit wird nun in Fotografien festgehalten, auch andere Orte der politischen Entscheidungsfindung öffnen sich allmählich dem Publikum. Politische Versammlungen und Kundgebungen auf der Straße werden nun ebenso für die illustrierte Presse dokumentiert ${ }^{30}$ wie hohe Regierungsvertreter in Ausübung ihres Amtes.

Und auch der Wahlvorgang selbst wird nun zum Thema der fotografischen Berichterstattung. Am 13. Juni 1911 findet die letzte Wahl des Reichsrats vor dem Ersten Weltkrieg statt. Zwei Tage später, am 15. Juni, erscheint im Interessanten Blatt ein Foto, das das Innere des Zentralwahlkatasters im Wiener Rathaus zeigt (Abb. 6). Das Bild, es ist das erste dieser Art, wurde etwa eine Woche vor der Wahl von einem „Spezialphotographen des interessanten Blattes“ aufgenommen. Im Arbeitssaal herrscht hektische Betriebsamkeit. Dutzende von Männern - aber keine einzige Frau - sind mit der Ausstellung der Wahlzettel und der bürokratischen Logistik des Wahlvorgangs beschäftigt. Im Vordergrund sitzen die Beamten an ihren Schreibtischen, vor ihnen stapeln sich die Dokumente, andere Angestellte sind, ebenfalls im Vordergrund, stehend in ihre Arbeit vertieft. Wenn wir die Aufnahme genauer betrachten, wird eines deutlich: Es handelt sich um keinen Schnappschuss. Das Foto ist sorgfältig inszeniert. Die Männer haben eigens für den Fotografen Aufstellung genommen, viele blicken in Richtung Kamera. Vermutlich wurden sogar Arbeitskräfte herangeschafft, um die Größe der Wahlbehörde eindrucksvoll unter Beweis stellen zu können.

\section{Übergang zur Republik}

Die im Jahr 1911 gewählten Abgeordneten sind Ende 1918, am Ende des Krieges, formal noch im Amt. ${ }^{31}$ Eine letzte, wichtige Aufgabe haben sie noch zu erfüllen. Die deutschsprachigen Delegierten des Wiener Abgeordnetenhauses schließen sich Ende Oktober 1918 zu einer Provisorischen Nationalversammlung zusammen. ${ }^{32}$ Und am 12. November 1918 rufen sie die Republik aus. Dieser Tag ist ein einschneidendes Ereignis. Die Monarchie existiert nicht mehr, eine neue politische Epoche beginnt. Das Zeremoniell

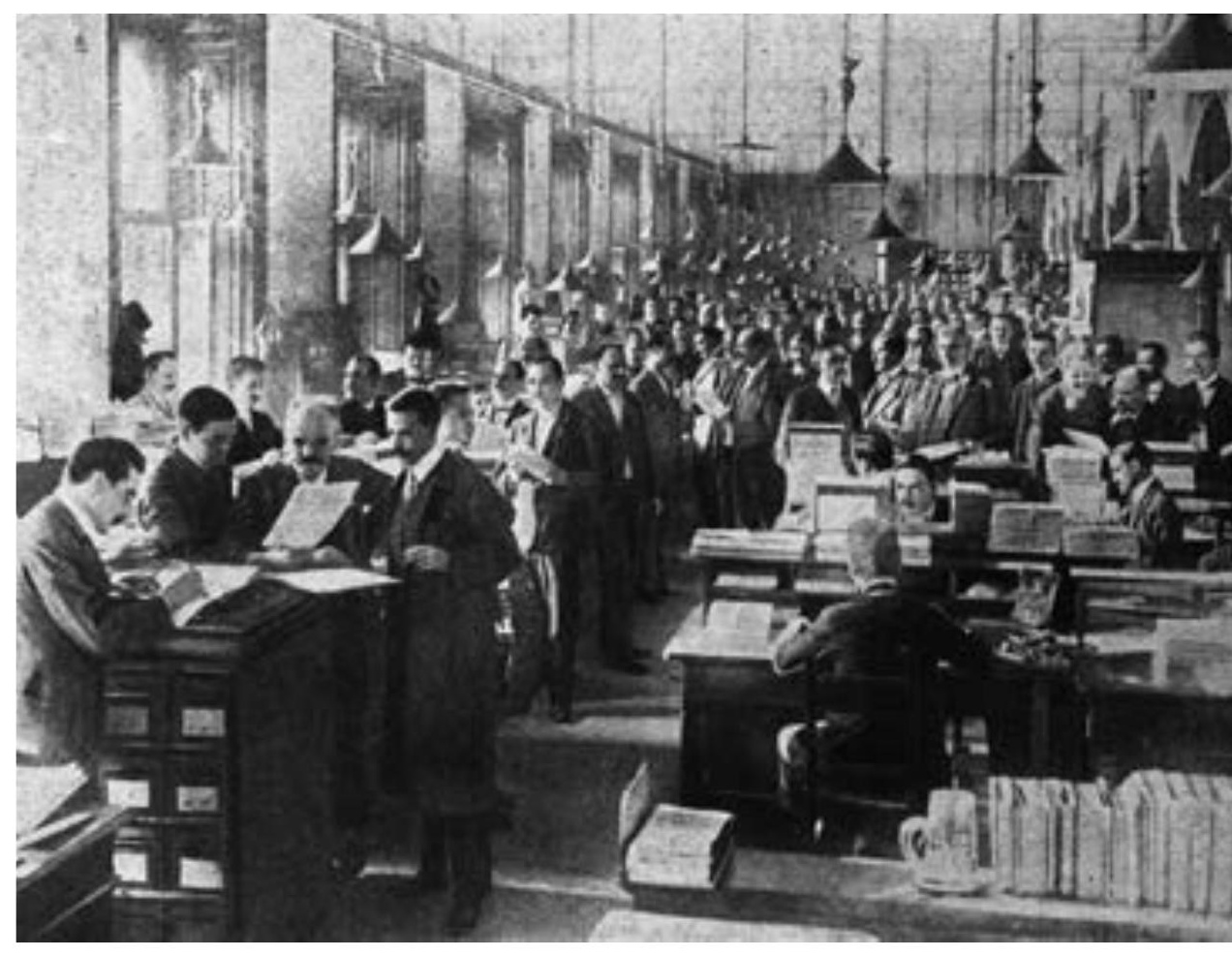

Abb. 6 Die Arbeit im Zentralwahlkataster im Wiener Rathaus. Die Aufnahme erscheint anlässlich der Reichsratswahl am 13. Juni 1911. Das interessante Blatt, 15. Juni 1911, S. 8. 
Abb. 7 Die Ausrufung der Republik am 12. November 1918 Auf der Wiener Ringstraße und am Platz vor dem Parlament drängen sich die Menschenmassen. Aufgenommen ist die Szene von einem oberen Stockwerk des Palais Epstein. Wiener Illustrierte Zeitung. Foto: Richard Hauffe.

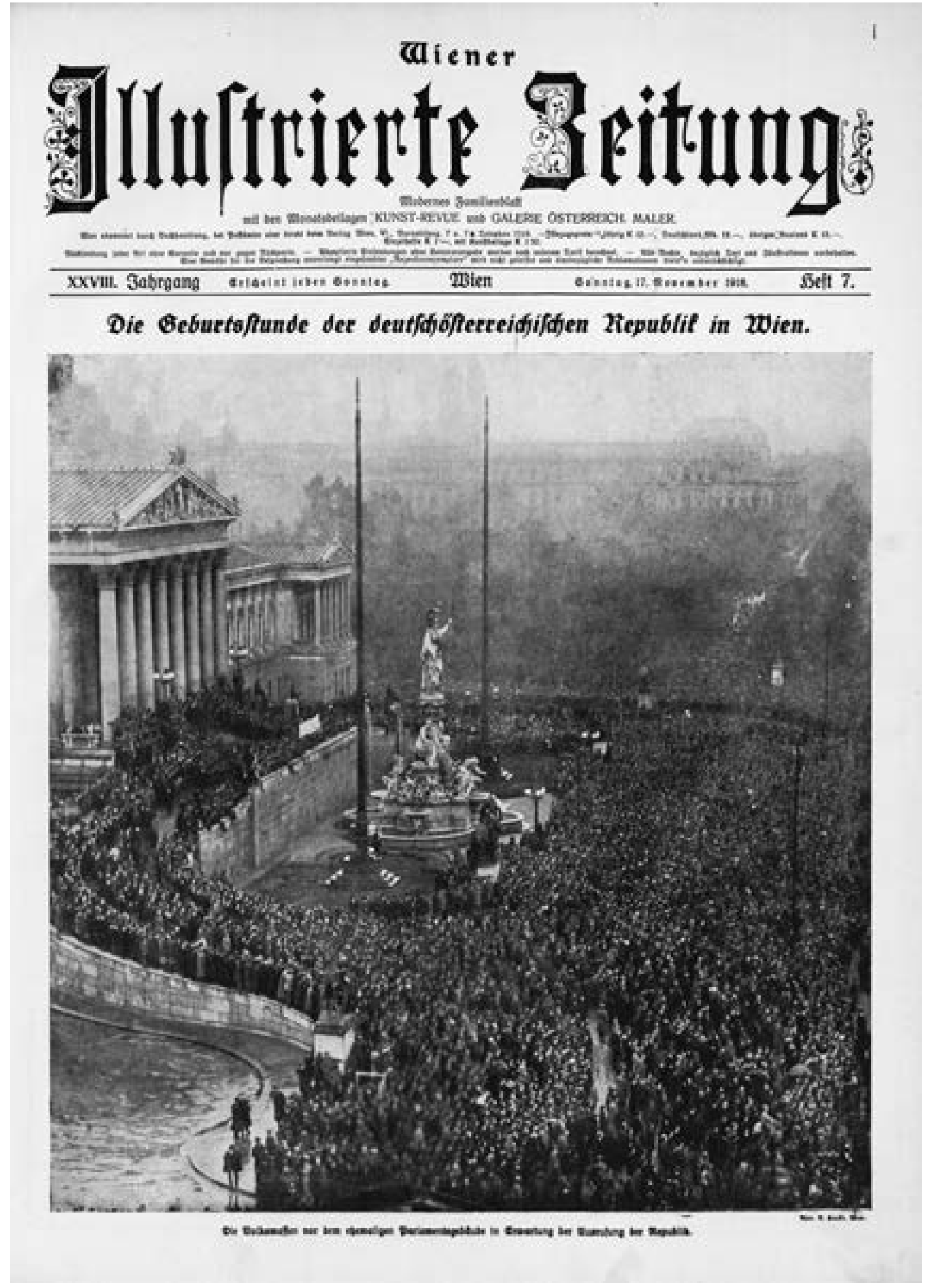


elektrisiert die Massen. Zehntausende strömen am 12. November auf die Ringstraße und vor das Parlamentsgebäude, um das Ende des Krieges und den Übergang zur demokratischen Republik zu feiern. Richard Hauffe ist einer von zahlreichen Pressefotografen, die an diesem Tag rund um das Parlament unterwegs sind. Eine seiner Aufnahmen wird Tage später in der Wiener Illustrierten Zeitung auf dem Umschlag veröffentlicht (Abb. 7). ${ }^{33}$ Der Fotograf hat seine Kamera in einem der oberen Stockwerke des Palais Epstein aufgestellt und nimmt Parlament, Vorplatz und Ringstraße aus erhöhtem Blickwinkel ins Visier. Dicht gedrängt umlagern Menschenmassen das Abgeordnetenhaus. Sogar die Auffahrtsrampen zum Haupteingang sind besetzt. Nur das Monument der Pallas Athene vor dem Parlament ragt aus dem Menschenmeer heraus. Es ist ein symbolträchtiges Bild, das die Redaktion unter dem Titel „Die Geburtsstunde der deutschösterreichischen Republik in Wien“ platziert. Die Aufnahme erscheint auch in anderen Zeitungen, etwa in den Wiener Bildern ${ }^{34}$, und wird bis heute immer wieder veröffentlicht - als das Bild der Republiksgründung.

Die erste Wahl zur Konstituierenden Nationalversammlung - so wird das österreichische Parlament vorerst genannt - findet am 16. Februar 1919 statt. Sie wird nach dem allgemeinen, gleichen und freien Wahlrecht ausgetragen. Das heißt, zum ersten Mal in der österreichischen Geschichte sind auch Frauen wahlberechtigt. Es zeichnet sich ein Kopfan-Kopf-Rennen der beiden großen Massenparteien $\mathrm{ab}$, auf der einen Seite der Sozialdemokraten, auf der anderen der Christlichsozialen. In einem heftigen Wahlkampf versuchen die Parteien bis zum letzten Augenblick Unentschiedene auf ihre Seite zu ziehen. Waren die Wahlkämpfe der Vorkriegszeit am Publikum der illustrierten Presse praktisch spurlos vorübergegangen, so ändert sich dies nun: Erstmals wird ausführlich und mit fotografischem Bildmaterial berichtet. Am 13. Februar, dem Wochenende vor der Wahl, widmet Das interessante Blatt dem Wahlkampf die gesamte Titelseite (Abb. 8). ${ }^{35}$ Das Foto, es stammt von der Fotoagentur Welt-Preß-Photo, zeigt eine Wahlkampfszene auf der Wiener Ringstraße. Ein Parteienvertreter, der auf Rücken und Bauch ein Plakat mit

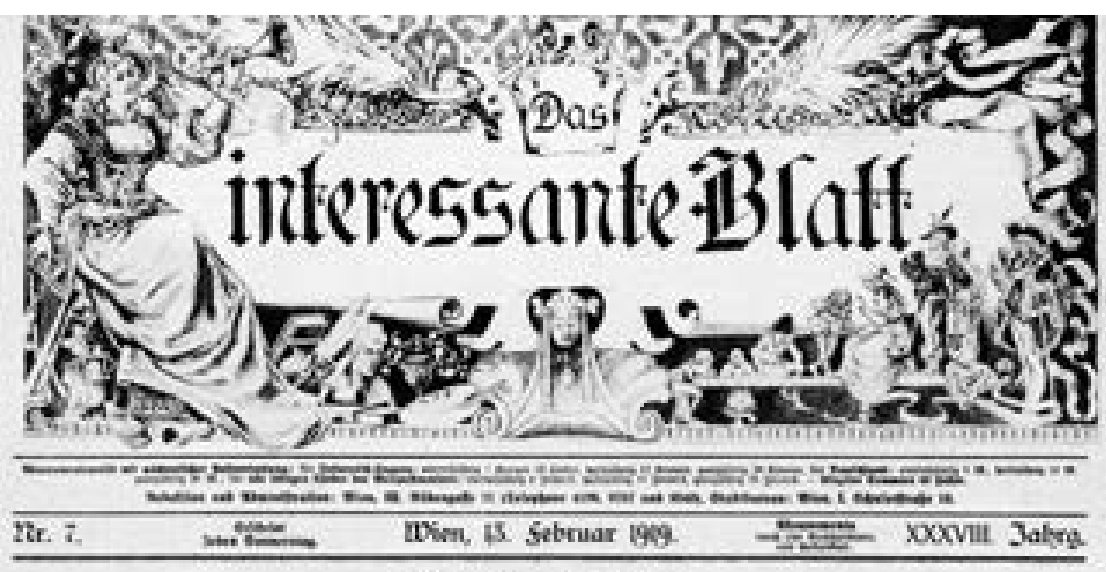

Wablagitation.

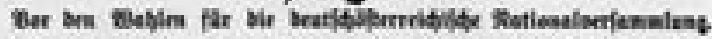

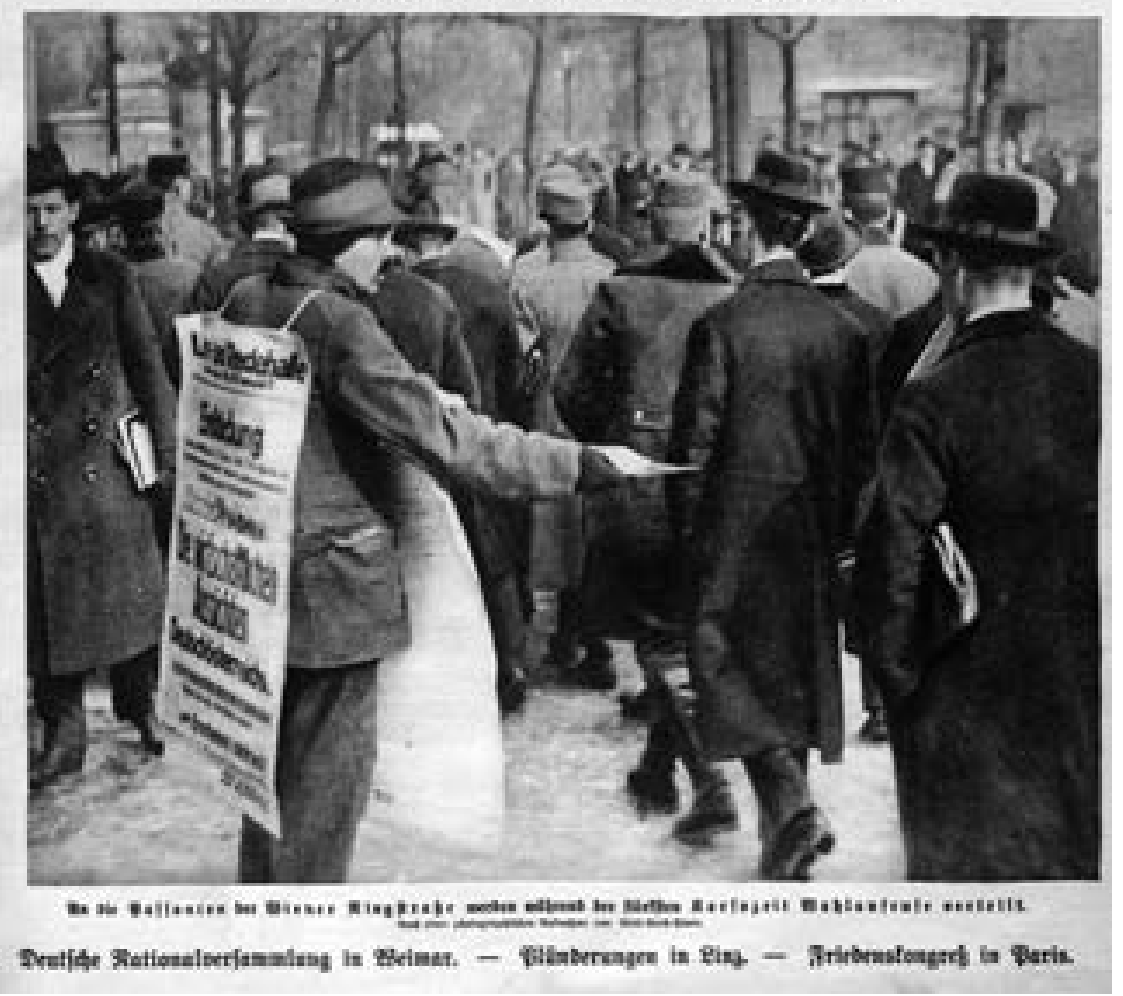

einer Einladung zu einem Vortrag trägt, drückt den vorbeieilenden Passanten, unter ihnen sind zahlreiche Offiziere, Flugblätter in die Hand. Im Innenteil des Blattes wird das Thema ebenfalls aufgegriffen. Ein Foto des Pressefotografen Carl Seebald zeigt den sozialdemokratischen „Arbeiter-Gesangverein“ wie er „freiheitliche Lieder singend“ durch die Wiener Lazarettgasse zieht (Abb.9). ${ }^{36}$

Nicht nur die Berichterstattung über den Wahlkampf ist neu, auch die Mittel der Wahlwerbung sind es. Während die Massenparteien vor allem ihre breite Anhängerschaft mobilisieren und auf klassische Werbemittel wie Plakate, Zeitungsanzeigen und Flugblätter setzen, gehen kleinere bürgerliche Parteien in der politischen Öffentlichkeitsarbeit vollkommen neue
Abb. 8 Der erste Wahlkampf der neu gegründeten Republik. Die Wahl zur Konstituierenden Nationalversammlung findet am 16. Februar 1919 statt. Das interessante Blatt, 13. Februar 1919, Titelseite. Foto: WeltPreß-Photo. 
Abb. 9 Sozialdemokratischer Wahlkampf vor der Wahl zur Konstituierenden Nationalversammlung im Februar 1919. Mitglieder eines Arbeitergesangvereins ziehen ,freiheitliche Lieder singend" durch die Wiener Lazarettgasse. Das interessante Blatt, 13. Februar 1919, S. 5. Foto: Carl Seebald.

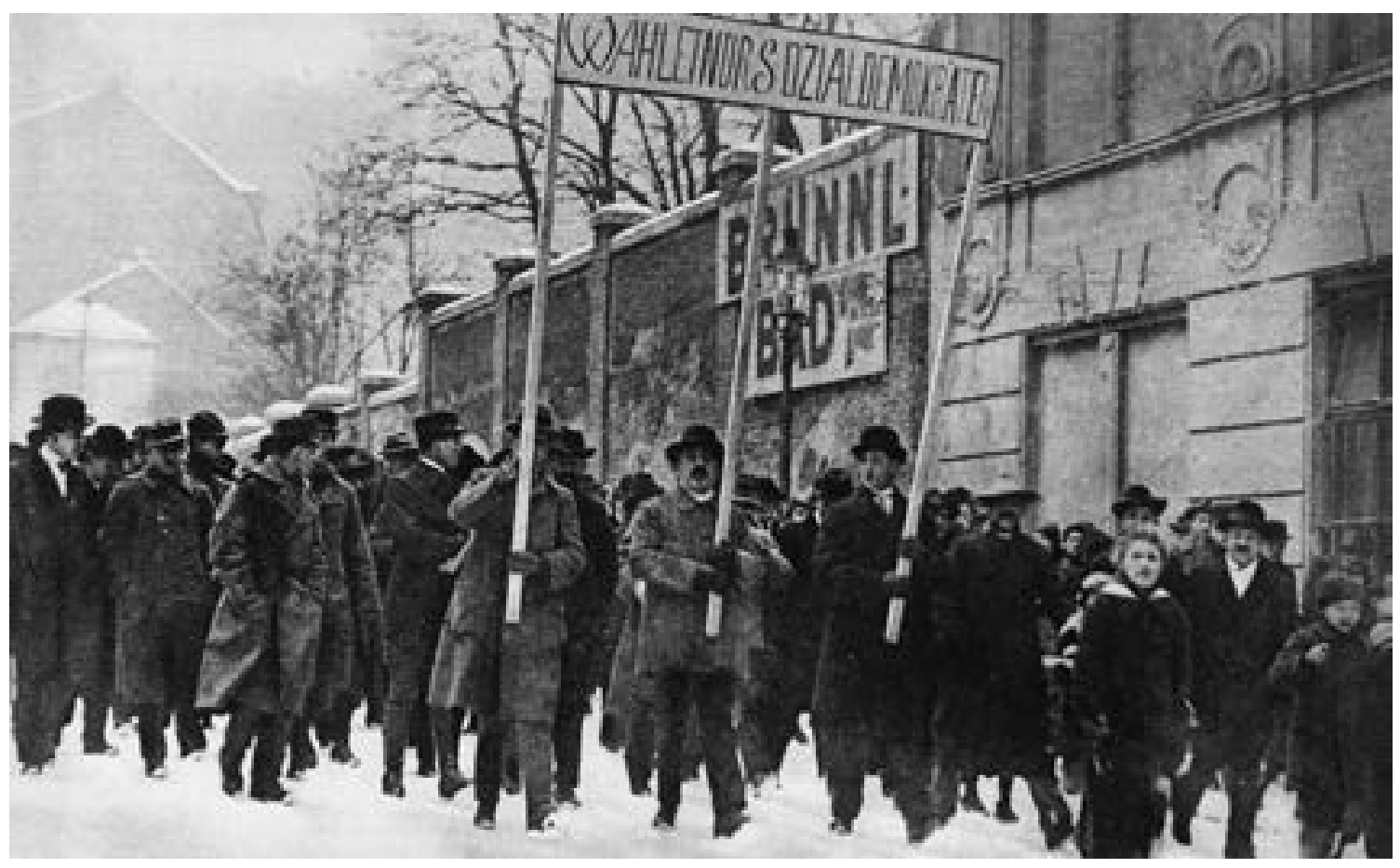

Wege. Besonders innovativ in Sachen Reklame ist die junge, erst kurz vor den Wahlen gegründete Bürgerlich-Demokratische Partei. ${ }^{37}$ Der erste Wahlkampf dieser liberalen Gruppierung, der von finanzkräftigen Unternehmen und Einzelpersonen unterstützt wird, ist ganz auf prominente Persönlichkeiten zugeschnitten. Diese werden mit teils sehr modern gestalteten Plakaten vorgestellt. Daneben versucht die Partei mit aktionistischen Darbietungen auf der Straße auf sich und ihre Kandidaten aufmerksam zu machen. Eine dieser aufsehenerregenden Aktionen ist in einer Aufnahme dokumentiert (Abb. 10). ${ }^{38} \mathrm{Zu}$ sehen sind Wahlhelfer, die mit hohen, beschrifteten Hüten ausstaffiert sind. Sie tragen Transparente mit Slogans wie „Hoch die Republik!“ oder „Unsere Zukunft ist Bürgerlich-Demokratisch. Wählet Wettstein“. ${ }^{39}$ Im Hintergrund ist ein mit Plakaten tapezierter Wagen zu erkennen, von dem aus Männer Flugblätter auf die Straße werfen. Szenen wie diese waren bisher in Wien nicht zu sehen. Nun, nach Jahren des Krieges und der Zensur, macht sich Aufbruchstimmung breit. Die politische Debatte und Agitation erreichen die Straße. Großen Erfolg aber bringt der aufwendige Wahlkampf den bürgerlichen Demokraten nicht. In das erste republikanische Parlament ziehen sie mit einem einzigen Delegierten ein. Den bei Weitem größten Anteil der Stimmen sichern sich die beiden Massenparteien. Die Sozialdemokraten erringen 72 Mandate, die Christlichsozialen 69. Diese beiden Parteien sind es auch, die das politische Leben im kommenden Jahrzehnt beherrschen werden.

\section{Turbulente Monate}

Am 4. März 1919 treten die neu gewählten Parlamentarier im ehemaligen Reichsratsgebäude an der Wiener Ringstraße zur Eröffnungssitzung zusammen. An diesem Tag hat der Pressefotograf Jsaak Schein auf der Pressetribüne Platz genommen. Er richtet seine Kamera auf die Ministerbank, auf der die Minister (die Staatssekretäre genannt werden) Platz genommen haben (Abb. 11). In ihrer Mitte sitzt der sozialdemokratische Staatskanzler Karl Renner (mit Bart). Im Hintergrund ist am Rednerpult der sozialdemokratische Abgeordnete Anton David zu erkennen. Er leitet die Sitzung in seiner Funktion als „Alterspräsident“. Auf den vorderen Sitzreihen haben die Parlamentarier, insgesamt 170 an der Zahl, Platz genommen. Unter ihnen sind erstmals auch acht Frauen, sieben von ihnen wurden aus den Reihen der Sozialdemokraten gewählt, eine gehört den Christlichsozialen an. Ein paar dieser Parlamentarierinnen sind in der Mitte im Vordergrund zu erkennen.

Das Foto, es ist eine Art Gründungsdokument der jungen Republik, wird Tage nach der historischen Sitzung im Interessanten Blatt veröffentlicht. ${ }^{40}$ Allein die Anordnung als Bilddoppelseite, ein überaus seltenes grafisches Gestaltungsmittel, zeigt den Stellenwert des Bildes. Die Aufnahme signalisiert einen geordneten Übergang zur Demokratie. Und tatsächlich hat sich mit der Wahl der Konstituierenden Nationalversammlung und der Regierungsarbeit einer Koalition mit breiter Mehrheit die aufgewühlte politische Stim- 


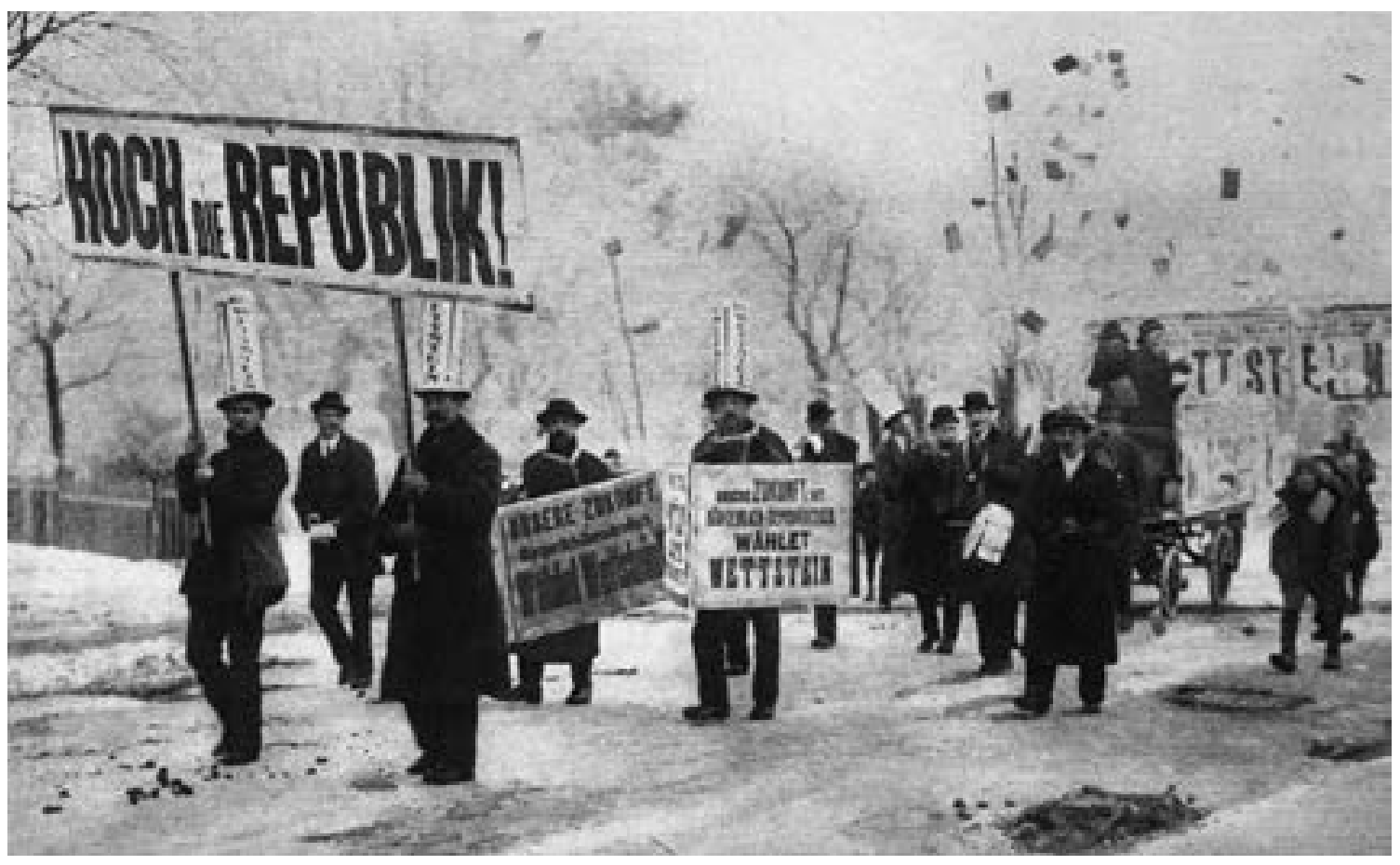

mung, die das Land im Winter 1918/19 erfasst hat, etwas beruhigt. Aber es sollte nicht dabei bleiben.

Im Frühjahr und Sommer 1919 spitzen sich die politischen Auseinandersetzungen auf der Straße zu. Die Unzufriedenheit großer Teile der (vor allem städtischen) Bevölkerung mit der Regierung ist groß. Hunger, Not und politische Unzufriedenheit treiben die Menschen zu Protestkundgebungen auf die Straße. Es kommt zu heftigen Auseinandersetzungen zwischen Sozialdemokraten und Kommunisten um die Gefolgschaft der Arbeiter- und Soldatenräte. Die Kommunisten streben nach bayerischem und ungarischem Vorbild eine Räteregierung an. Die Sozialdemokraten (und selbstredend auch die Christlichsozialen) versuchen das mit allen Mitteln zu verhindern.

Am 17. April 1919, dem Gründonnerstag, kommt es vor dem Parlament, in dem gerade der Kabinettsrat tagt, zu einer Massenkundgebung (Abb. 12). Unter den Demonstranten befinden sich zahlreiche enttäuschte Kriegsheimkehrer, Kriegsinvaliden, Arbeitslose und Arbeiter, viele von ihnen kommunistische Anhänger, die lautstark gegen die Regierung protestieren. Als ein Teil der aufgebrachten Menge gewaltsam in das Parlamentsgebäude vordringen will, kommt es zu Handgreiflichkeiten mit der Polizei.

Abb. 11 Die Eröffnung der Konstituierenden Nationalversammlung am 4. März 1919. Im Hintergrund ist am Rednerpult der Sozialdemokrat Anton David zu sehen, der die Sitzung leitet. In der Mitte der halbrunden Ministerbank sitzt Staatskanzler Renner (mit Bart). Das interessante Blatt, 13. März 1919, S. 8/9. Foto: Jsaak Schein.
Diese ist angesichts der Übermacht des Protests bald überfordert. In dieser verfahrenen Situation lässt der Sozialdemokrat Julius Deutsch - er ist Staatssekretär für Heereswesen - die Wiener Volkswehr gegen die Demonstranten antreten. Die Volkswehr war im Dezember 1918 als Kern des neuen republikanischen Heeres gegründet worden. Sie steht unter sozialdemo-

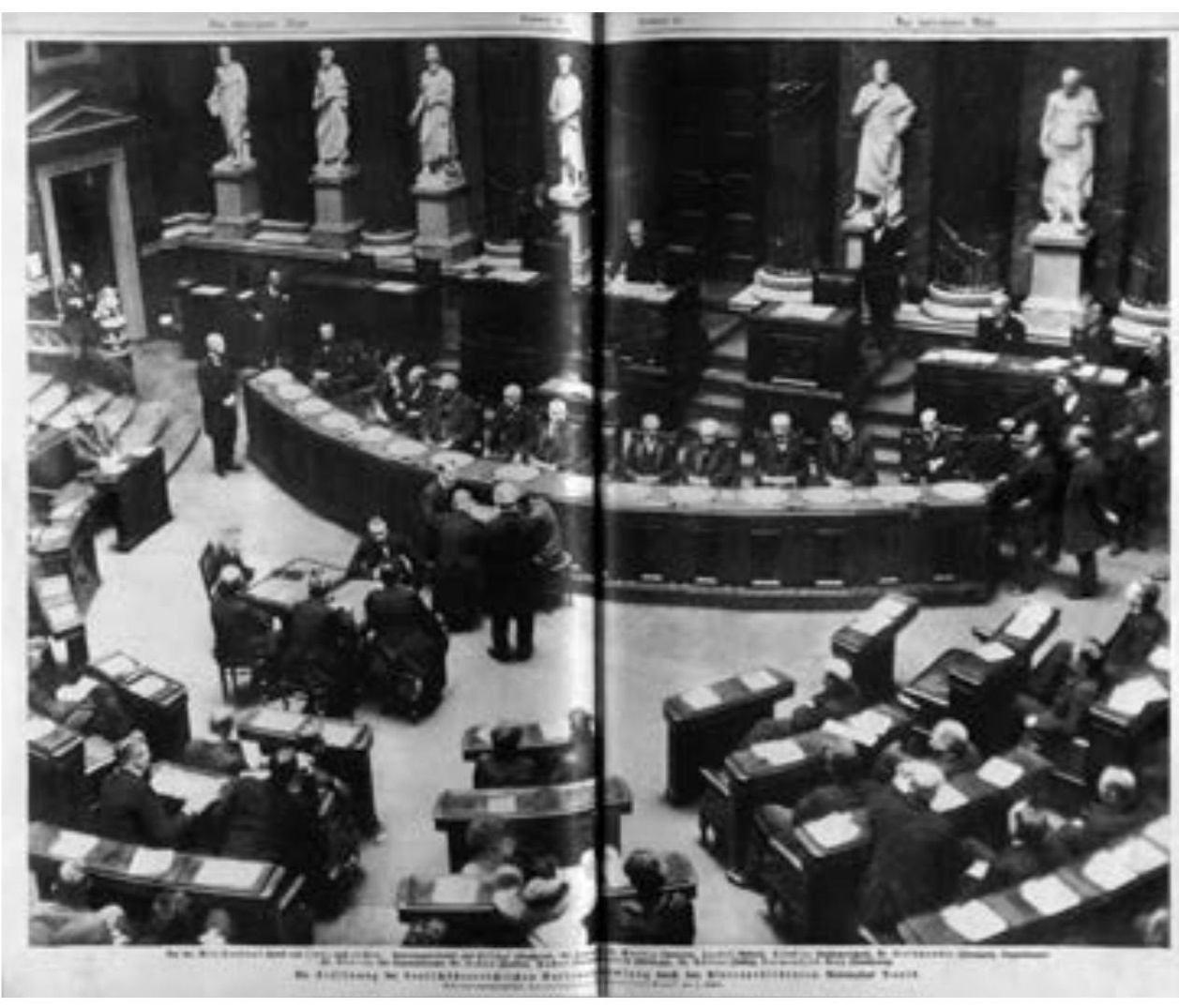


Abb. 12 Kommunistische Massenkundgebung gegen die Regierung vor dem Parlament, 17. April 1919. Als ein Teil der Kundgebungsteilnehmer gewaltsam in das Parlament vordringen will, verhindert dies die den Sozialdemokraten nahestehende Volkswehr mit Waffengewalt. Sechs Sicherheitskräfte kommen zu Tode. Wiener Illustrierte Zeitung, 27. April 1919, Titelseite. Foto: Richard Hauffe.

\section{Mluftriertite 3ritung:}

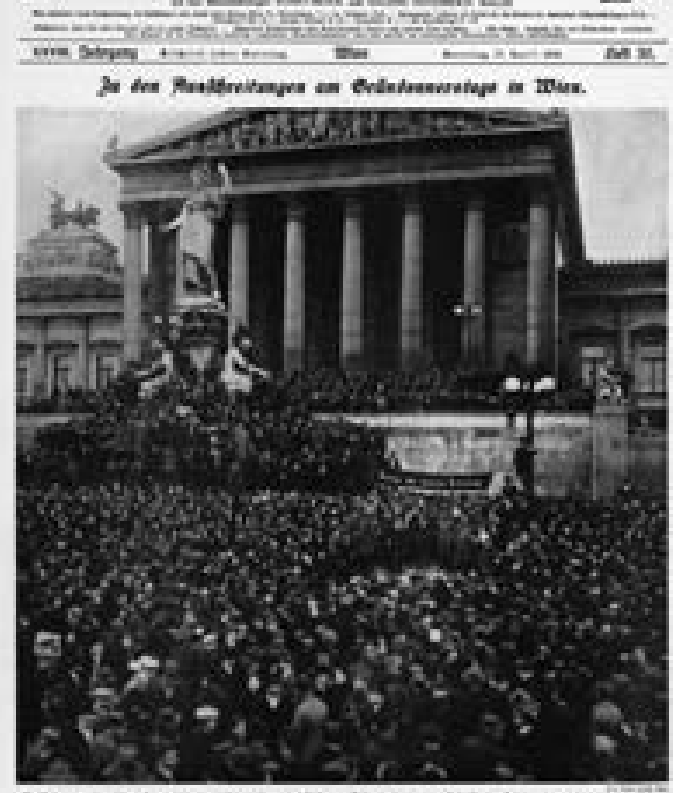

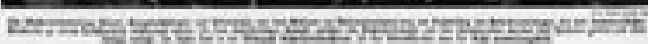

kratischer Kontrolle. Nun geht diese der Regierung gegenüber loyale Truppe mit Waffengewalt gegen den als „Putsch“ bezeichneten Aufruhr vor. Die Bilanz der Kämpfe lautet: sechs Tote (fünf Polizisten, eine Zivilistin) und Dutzende verwundete Volkswehrmänner und Demonstranten. ${ }^{41}$

Am Tag nach den Kämpfen nehmen die siegreichen Volkswehrmänner in der Säulenhalle für die Presse Aufstellung. Eines der Fotos, es stammt vom Pressefotografen Richard Hauffe, erscheint Tage später in den Wiener Bildern (Abb. 13). ${ }^{42}$ Das junge republikanische Parlament voller Soldaten: Das ist ein denkwürdiges Dokument. Die Dramatik der vergangenen Stunden ist in dieser Szene noch deutlich spürbar. Die teils in lange Mäntel gehüllten Soldaten stehen nicht stramm in Reih und Glied, vielmehr stehen und sitzen sie in gelöster Stimmung im Halbkreis. Im Vordergrund haben sich einige Soldaten auf dem Boden niedergelassen. Um sie herum hat das Gros der Truppe Aufstellung genommen. Eilig herbeigeschaffte Stühle sorgen dafür, dass auch die hinterste Reihe noch im Bild Platz findet. Die Waffen, das fällt auf,
Abb. 13 Die Wiener Volkswehr in der Säulenhalle des Parlaments. Nach den Unruhen vom 17. April 1919 bewachen die den Sozialdemokraten nahestehenden Sicherheitskräfte das Gebäude gegen mögliche Putschversuche. Wiener Bilder, 4. Mai 1919, S. 5. Foto: Richard Hauffe.

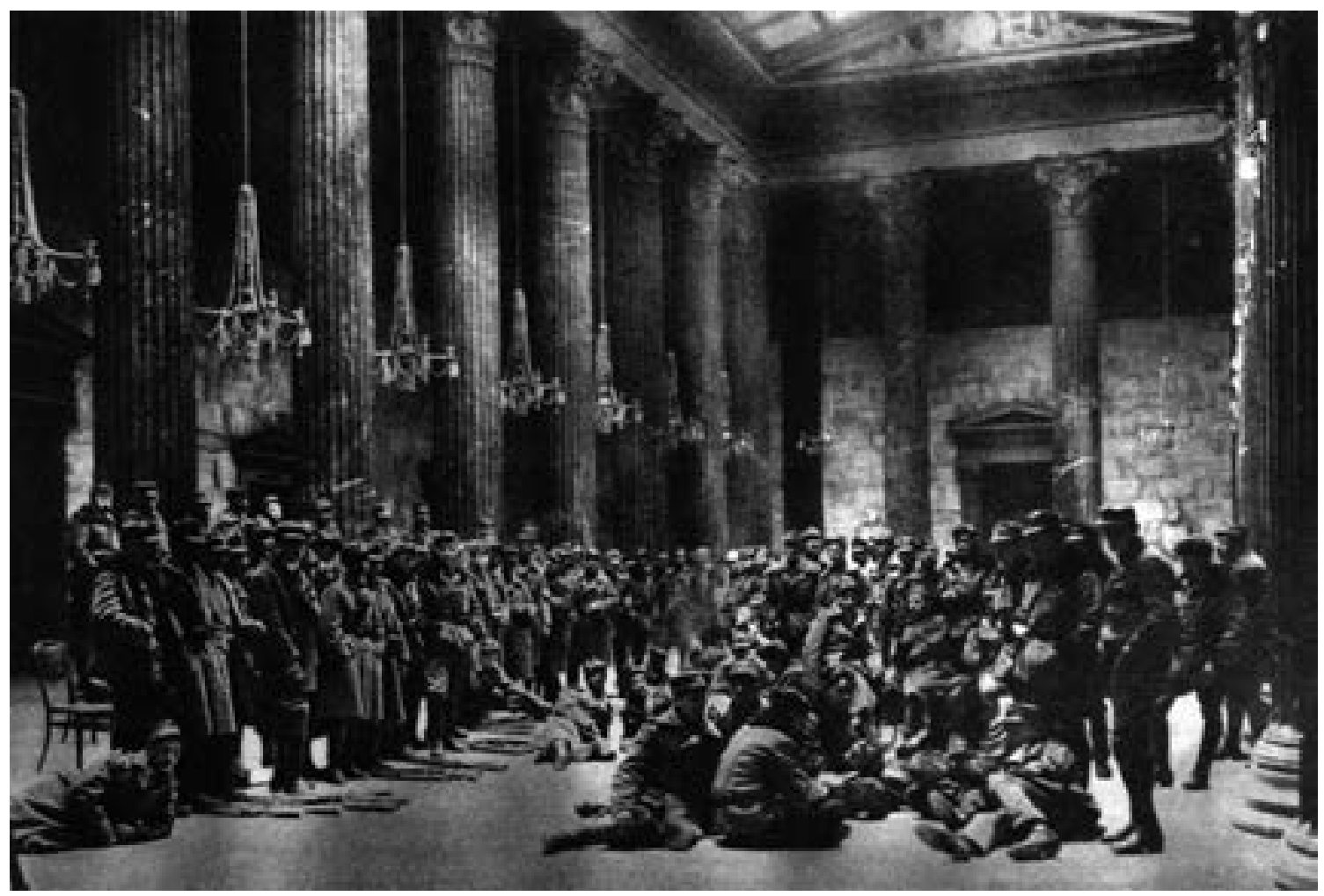




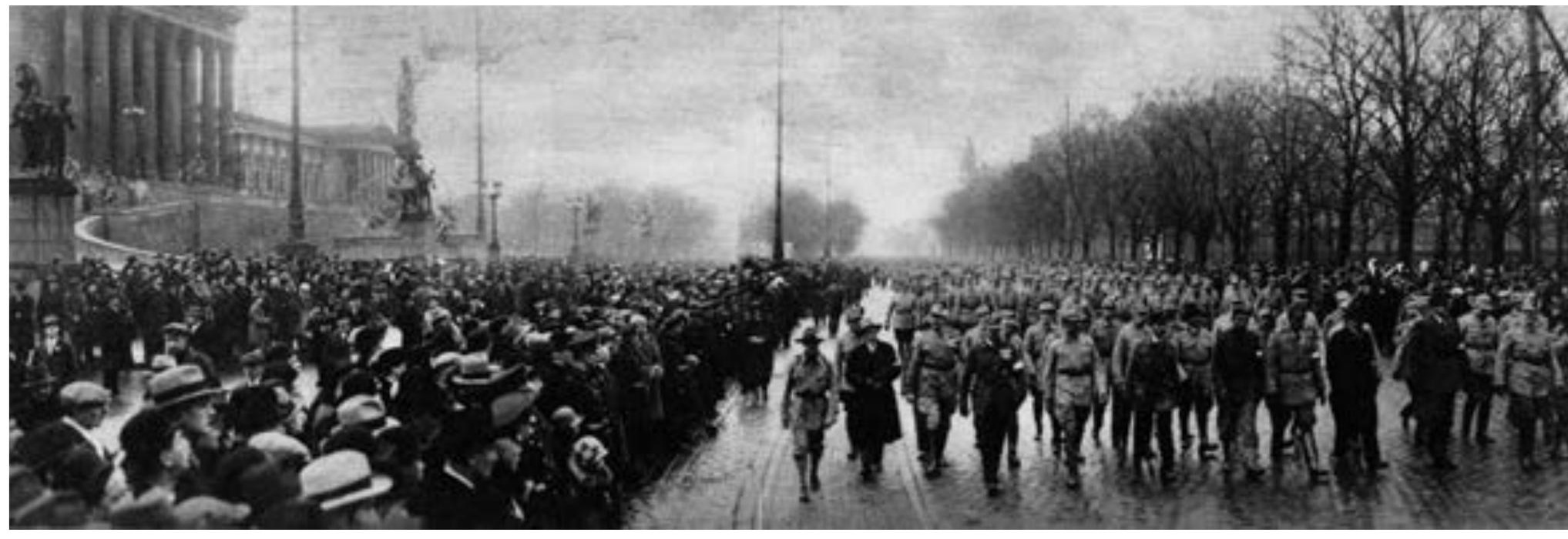

halten die Uniformierten nicht in ihren Händen. Die Gewehre liegen deutlich sichtbar auf dem Boden, so als ob es darum ginge, der Öffentlichkeit zu beweisen, dass im Parlament auf Dauer keine Waffen getragen werden.

Die gespannte politische Lage hält noch bis in den Frühsommer 1919 an. Im Juni ruft die Kommunistische Partei Deutschösterreichs zu einer Großkundgebung für den 15. Juni in Wien auf, auf der die Räterepublik ausgerufen werden und die Solidarisierung mit der russischen und ungarischen Revolution erfolgen soll. ${ }^{43}$ Die Regierung sieht darin einen Putschversuch und lässt am Vorabend des 15. Juni die kommunistischen Anführer verhaften. Dennoch findet die Kundgebung statt. Es kommt zu gewaltsamen Zusammenstößen zwischen der Polizei und kommunistischen Demonstranten, die die Freilassung der Gefangenen fordern. Die Attacken der aufgebrachten Menge gegen die Polizeiabsperrungen werden mit Schüssen beantwortet. In der Hörlgasse gibt es zwölf Tote und rund 80 Schwerverwundete, von denen acht ihren Verletzungen erliegen. ${ }^{44}$ Mitte 1919 beginnt sich die politisch aufgeheizte Stimmung allmählich zu beruhigen. Am 1. August 1919 wird die kommunistische Rätediktatur Béla Kuns im benachbarten Ungarn gestürzt. Der Kampf um die Vorherrschaft innerhalb der Arbeiterbewegung ist nun zugunsten der Sozialdemokraten entschieden. In den folgenden Jahren konsolidiert sich die parlamentarische Demokratie.

\section{Regieren ohne Parlament}

Ende der 1920er Jahre kommen erneut turbulente Zeiten auf die parlamentarische Demokratie zu. Die politische Ausgangslage hat sich nun grundlegend geändert. Nicht mehr aufgebrachte Kriegsverlierer und kommunistische Demonstranten, sondern straff organisierte paramilitärische Verbände verlagern die Auseinandersetzung auf die Straße. Insbesondere die rechte Heimwehr lehnt das parlamentarische System offen ab. Ein Foto, das Anfang 1930 während eines großen Heimwehraufmarsches an der Wiener Ringstraße entsteht, signalisiert auf schlagende Weise die Distanz zwischen Parlament und politischer Kundgebung (Abb. 14). Der Pressefotograf Leo Ernst hat mit seiner Kamera etwas erhöht am Straßenrand Stellung bezogen. Vor ihm marschieren die Spitzenfunktionäre der Heimwehr. Die Straße wird von zahlreichen Schaulustigen gesäumt. Ganz links im panoramaartig angelegten Bild taucht aus dem Winternebel ein Teil des Parlamentsgebäudes auf. Das Foto ist kein Schnappschuss. Ernst hat seinen Standpunkt sorgfältig gewählt. Auf diese Weise gelingt es ihm, das Parlament und die daran stolz vorbeiziehende paramilitärische Formation geschickt in einer einzigen Szene festzuhalten. Man merkt unschwer, wohin die politische Macht gewandert ist: vom Parlament auf die Straße.

„Wir verwerfen den westlichen demokratischen Parlamentarismus und Parteienstaat!“ Mit diesen
Abb. 14 Heimwehraufmarsch auf der Wiener Ringstraße vor dem Parlament. Das interessante Blatt, 6. Februar 1930, S. 4. Foto: Leo Ernst. 


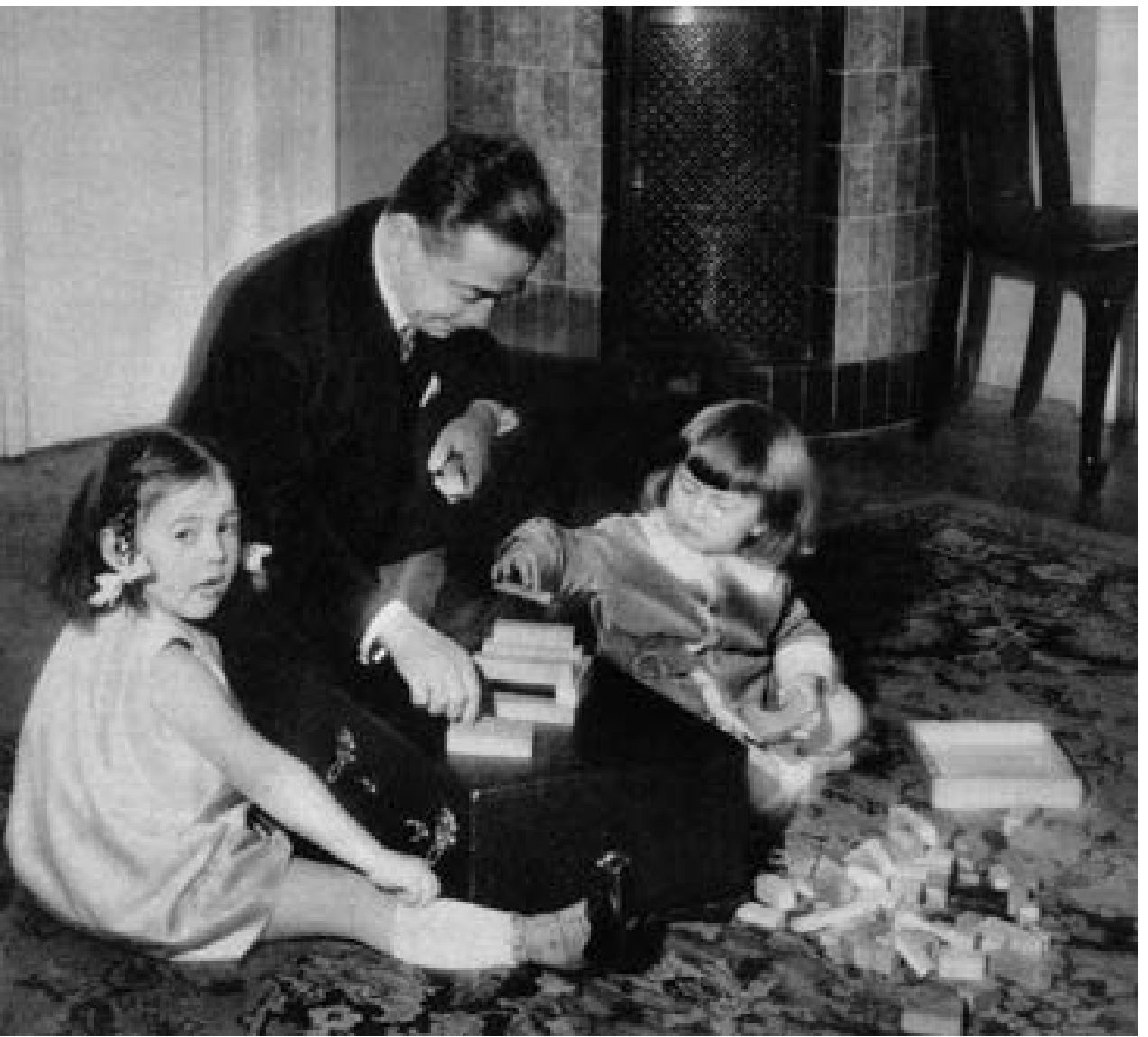

Abb. 15 Der österreichische Kanzler Engelbert Dollfuß „privat“: Kurz vor Weihnachten 1932 lässt er sich zusammen mit seinen beiden Kindern Rudolf und Eva beim Baukastenspiel ablichten. Das interessante Blatt, 22. Dezember 1932, S. 2. Foto: Telephot.
Worten wendet sich der Heimwehrführer Richard Steidle im „Korneuburger Eid“ am 18. Mai 1930 an seine Kameraden. ${ }^{45}$ Die christlichsoziale Regierung, die mit der Heimwehr auf vielfältige Weise personell verbunden ist, gibt sich vorsichtiger. Engelbert Dollfuß, der 1932 Bundeskanzler wird, hält - zunächst noch - an der parlamentarischen Demokratie fest. In der Öffentlichkeit tritt er gerne als gütiger Übervater des Staates auf. Für seine Medienauftritte wählt er, das fällt auf, nicht das Parlament, sondern meist volksnahe politische Massenveranstaltungen. Im Interesse seiner eigenen Popularität tritt er aber auch als „Privatmann“ vor die Kamera. Im Dezember 1932 lädt er die Presse zu sich nach Hause ein. Die Politiker-Homestory - ein in diesen Jahren noch überaus seltenes Medienformat - erscheint wenige Tage vor Weihnachten (Abb. 15). Wir sehen den Kanzler in seinem Wohnzimmer beim Spielen mit seinen beiden Kindern Rudolf und Eva. Der Junge und das Mädchen sitzen auf dem Boden. Hinter ihnen kniet Vater Dollfuß - staatsmännisch im Anzug - und stapelt Bauklötze aus Holz übereinander. Inmitten einer schweren Wirtschaftskrise tritt der Regierungschef als Familienmensch vor die Kamera. Er gibt Einblick in sein privates Leben und signalisiert, dass er nicht nur seinen Kindern ein guter Vater, sondern auch dem gebeutelten Volk ein sorgender Kanzler ist. Dollfuß ist überaus geschickt im Umgang mit den Medien. Von Anfang an weiß er sie für sich und seine politischen Ziele zu instrumentalisieren.

Bald aber zeigt sich Dollfuß von einer anderen Seite. Im März 1933 nutzt er eine turbulente, konfliktreiche Parlamentssitzung, um in einer Art juristischem Staatsstreich ein autoritär regierendes Regime zu errichten. Eine am 4. März unterbrochene Sitzung soll nach dem Willen der Oppositionsparteien am 15. März 1933 fortgesetzt und ordnungsgemäß geschlossen werden. Als die oppositionellen Delegierten an diesem Tag das Parlament betreten wollen, werden sie von der Polizei behindert. Ein Foto, das Tage später auf der Titelseite der Wiener Bilder erscheint, zeigt, wer nun im und vor dem Parlament das Sagen hat: die Polizei, im Auftrag der autoritären Regierung (Abb. 16). Zum Zeichen, dass das Parlament nicht mehr tagt, werden auf Anordnung der Regierung die Parlamentsfahnen (links neben dem Polizisten) eingeholt.

Das Parlament ist fortan ausgeschaltet, Dollfuß regiert mittels eines aus dem Kriegsjahr 1917 stammenden Ermächtigungsgesetzes. Die Sozialdemokraten stemmen sich mit aller Kraft gegen die autoritäre Regierung. Am 2. April 1933 prangert die sozialdemokratische Illustrierte Kuckuck auf ihrem Titelblatt die Aushebelung des Parlamentarismus an (Abb. 17). Die Montage, die vom Chefredakteur Siegfried Weyr zusammengestellt wurde, kombiniert ein Foto des Parlaments mit einem kraftvollen Handschlag der Solidarität im Vordergrund. „Österreich ist eine demokratische Republik ..." - die Zeile aus der Verfassung erhält einen kämpferischen Zusatz: „und wird es bleiben, trotz alledem!“ Die Zeitung sollte unrecht behalten.

\section{Die Diktatur}

Dollfuß baut den Staat in den folgenden Monaten zu einer Diktatur um. Oppositionelle Parteien und Organisationen werden nach und nach verboten. In Wien kommt es zur Kraftprobe zwischen der christlichsozialen autoritären Regierung und der weiterhin amtierenden sozialdemokratischen Stadtverwaltung. 


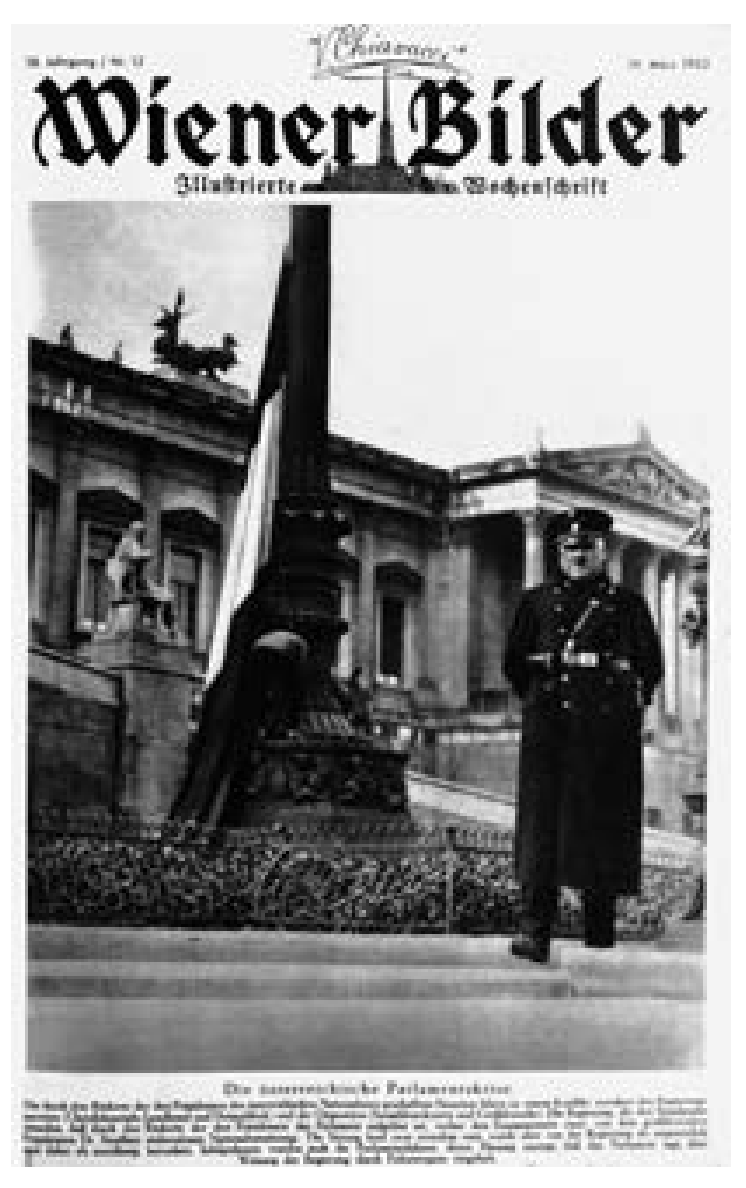

Abb. 16 Der Beginn der Diktatur, März 1933: Polizisten „bewachen" das Parlament und verhindern, dass die oppositionellen Parlamentarier die am 4. März 1933 unterbrochene Parlamentssitzung fortsetzen können. Auf Anordnung der nun autoritär agierenden Regierung wird die Parlamentsfahne eingeholt. Wiener Bilder, 19. März 1933, Titelseite.

Zu einem Gutteil wird dieses politische Kräftemessen auf der Straße ausgetragen. Anfang Februar 1934 zieht eine Bauerndemonstration über die Ringstraße. In der regierungsnahen Illustrierten Österreichische Woche wird darüber in großer Aufmachung berichtet (Abb. 18). Das Titelfoto, es stammt von einem namentlich nicht bekannten Fotografen, zeigt im Vordergrund eine Gruppe von Bauernfunktionären. Mit Transparenten und Slogans wie „Heil unserem Kanzler Dollfuß!“ ergreifen die Demonstranten Partei im Konflikt zwischen Stadt und Regierung. Im Hintergrund ist das Parlament (links) und das Rathaus zu sehen. Noch ist Letzteres in sozialdemokratischer

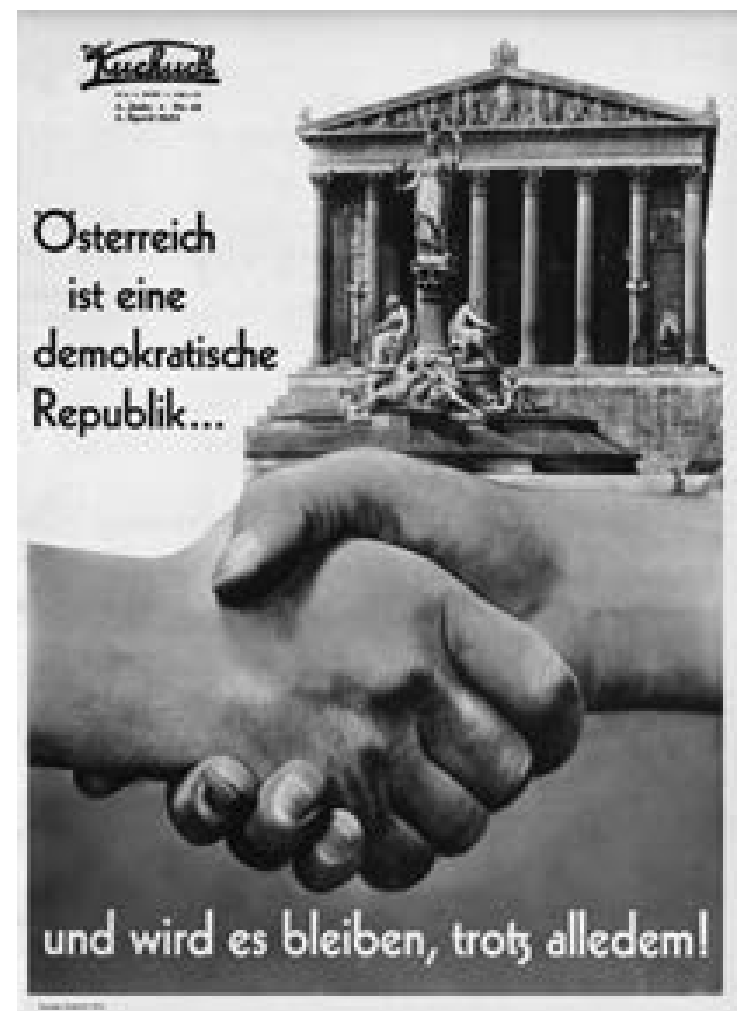

Abb. 17 „Österreich ist eine demokratische Republik ..." Kritik der sozialdemokratischen Illustrierten Der Kuckuck an der Aushebelung des Parlamentarismus. Der Kuckuck, 2. April 1933, Titelseite. Fotomontage: Siegfried Weyr.

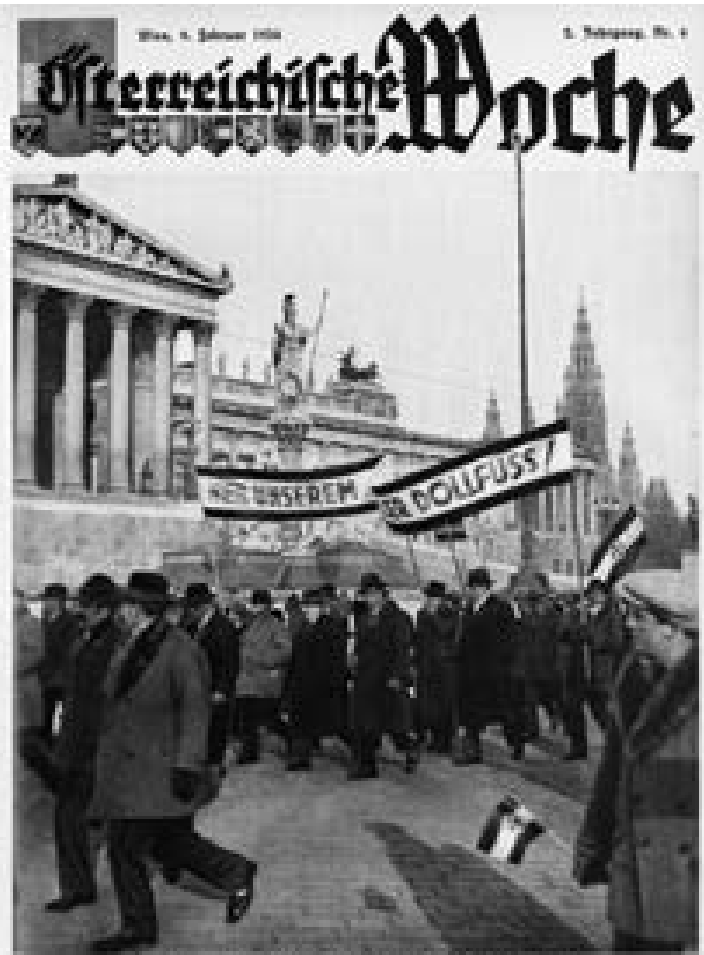

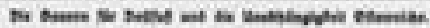

Abb. 18 „Heil unserem Kanzler Dollfuß!“ Bauernkundgebung zur Unterstützung der christlichsozialen Regierung auf der Wiener Ringstraße, links das Parlament. Österreichische Woche, 9. Februar 1934, Titelseite. 


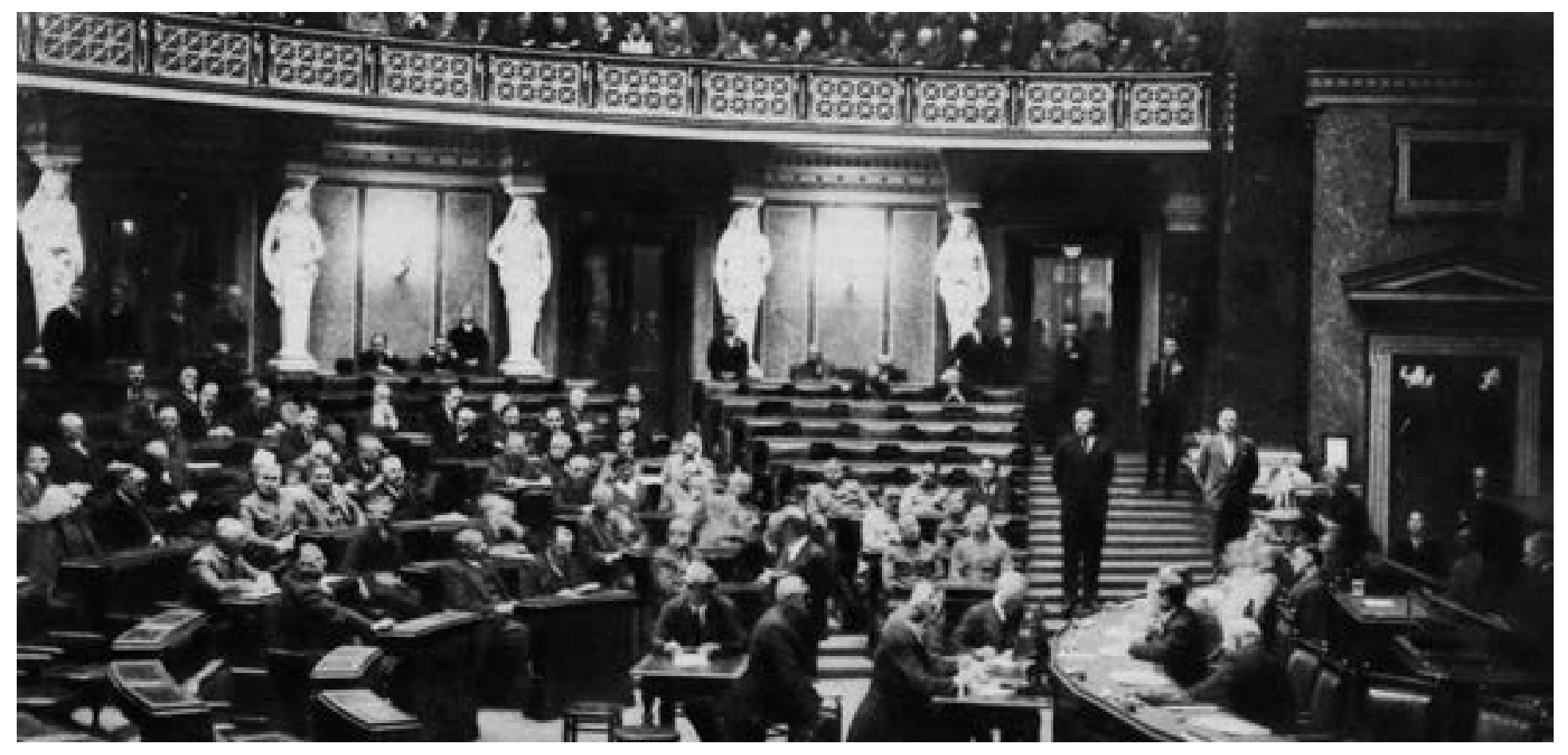

Abb. 19 Die letzte Sitzung des Parlaments, in der das Ermächtigungsgesetz für die Regierung beschlossen wird. Anwesend sind nur 76 Parlamentarier der Regierungspartei, die Ränge der Opposition bleiben leer. Bunte Woche, 6. Mai 1934, S. 2.
Hand. Wenige Tage später wird auch diese letzte oppositionelle Bastion zusammenbrechen.

Im Februar 1934 eskaliert die Situation. Der Schutzbund, die militärische Vorfeldorganisation der Sozialdemokraten, setzt sich gegen den letzten Schritt in Richtung Diktatur, die geplante Entwaffnung ihrer Organisation, zur Wehr. Es kommt zum Ausbruch offener Gewalt. Der kurze, blutige Bürgerkrieg zwischen den Regierungstruppen und Mitgliedern des Schutzbundes dauert vom 12. bis zum 15. Februar 1934. Er fordert über 300 Todesopfer und mehrere Hundert Verletzte. Der Niederlage der Sozialdemokraten folgen Verhaftungen und Repressionen. Die sozialdemokratische Partei und Presse werden ebenso wie die Gewerkschaftsbewegung verboten. Der Wiener Bürgermeister Karl Seitz wird verhaftet. Die Stadtverwaltung der Hauptstadt ist nun in der Hand der Regierung. Jegliche politische Opposition ist ausgeschaltet.

Am 30. April 1934 tritt das Parlament zu einer letzten Sitzung zusammen. Nur die 76 Delegierten der siegreichen Regierung sind anwesend. Die Reihen der Opposition bleiben leer. Ein Pressefotograf hat diese denkwürdige Zusammenkunft, bei der die Einführung der Diktatur formal beschlossen wird, festge- halten (Abb. 19). ${ }^{46}$ Es ist das letzte Bilddokument aus dem Inneren des österreichischen Parlaments, das vor 1945 in der Öffentlichkeit erscheint - bezeichnenderweise in einer ehemaligen sozialdemokratischen Zeitung, die nach dem Bürgerkrieg im März 1934 von der Regierung übernommen worden war. In den folgenden elf Jahren spielt das Parlament als Forum demokratisch gewählter Abgeordneter politisch keine Rolle mehr.

In seiner letzten Sitzung Ende April 1934 beschließt das Rumpfparlament mit überwältigender Mehrheit (74 zu zwei Stimmen), die bestehende demokratische Verfassung außer Kraft zu setzen und durch eine neue, „ständische“ Verfassung zu ersetzen. Im Artikel III des Bundesverfassungsgesetzes „über außerordentliche Maßnahmen im Bereich der Verfassung“ vom 30. April 1934 heißt es lapidar: „Der Nationalrat und der Bundesrat sind mit dem auf die Verlautbarung der Verfassung 1934 (Artikel II) folgenden Tag aufgelöst. Mit diesem Tage sind die Funktionen des Nationalrates und des Bundesrates erloschen."47

Das Parlamentsgebäude an der Wiener Ringstraße wird allerdings weiterhin genutzt. In der neuen Ver- 


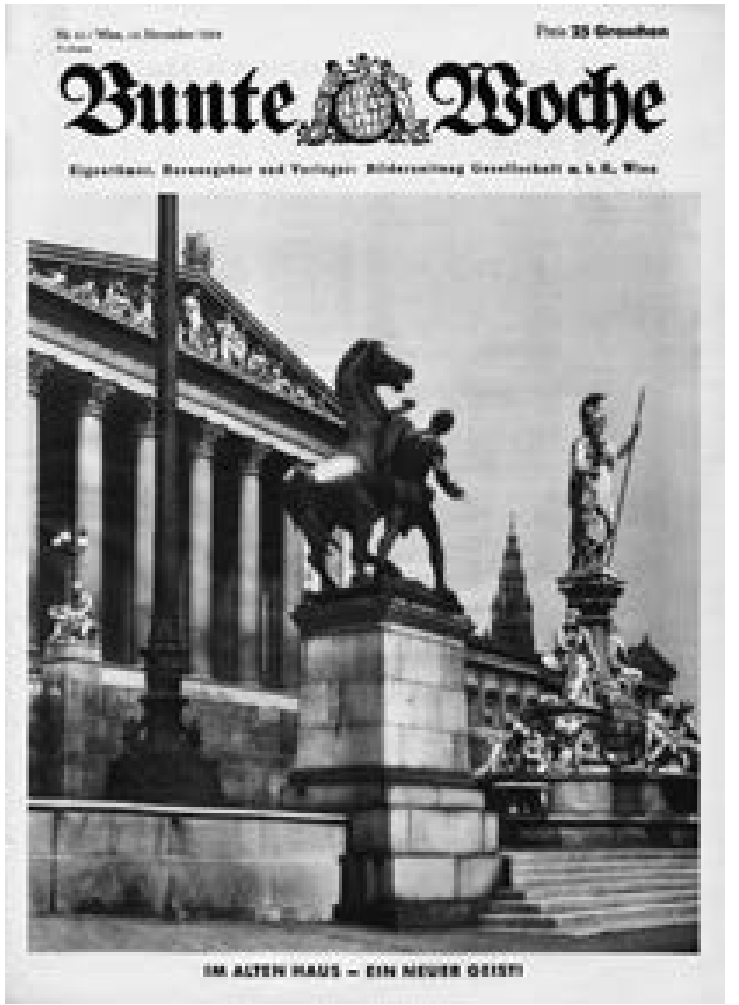

Abb. 20 „Im alten Haus - ein neuer Geist“. In der Ideologie des diktatorischen „Ständestaates“ hat das „alte Haus“, die parlamentarische Demokratie, ausgedient. Im Gebäude soll, so die Botschaft, ein „neuer Geist“ einziehen. Bunte Woche, 18. November 1934, Titelseite.

fassung sind vier der Regierung unterstellte beratende Organe vorgesehen: der Staatsrat, der Bundeskulturrat, der Bundeswirtschaftsrat und der Länderrat. Diese Einrichtungen ziehen nun in die Räume des Parlaments ein. Mitte November 1934 widmet die regierungstreue Bunte Woche dem ehemaligen Parlament neuerlich eine Bildseite (Abb. 20). Blickfänger ist nicht das Gebäude selbst, sondern die in der Inszenierung monumental erscheinende Statue des Rossbändigers im Vordergrund. Unter das Foto ist ein bezeichnendes Motto gesetzt: „Im alten Haus - ein neuer Geist“. Damit wird die bisherige demokratische Rolle des Parlaments der Vergangenheit zugeschlagen und die neue Zeit der Diktatur beschworen.

Wie sehr das Parlament zur Kulisse für eine martialischen Symbolpolitik der Regierung degradiert ist, zeigt eine Aufnahme, die im Frühjahr 1937 entsteht (Abb. 21). Die Frühjahrsparade auf der Ringstraße soll die militärische Entschlossenheit des kleinen Staates unter Beweis stellen. Über das Pflaster rattern gepanzerte Kampfwagen, am Himmel sind Militärflugzeuge zu erkennen. Das Parlament im Hintergrund ist inzwischen nicht mehr als ein architektonisches Relikt aus vergangenen Zeiten. Das militärische Säbelrasseln sollte den „Ständestaat“ freilich nicht vor dem Druck des nationalsozialistischen Deutschen Reiches bewahren. Ein Jahr später zieht Adolf Hitler im offenen Wagen triumphierend über die Ringstraße. Am 15. März 1938 verkündet er auf dem Heldenplatz den „Anschluss“ Österreichs an Deutschland. Nun ist das Parlamentsgebäude auf der anderen Straßenseite endgültig obsolet geworden.

무

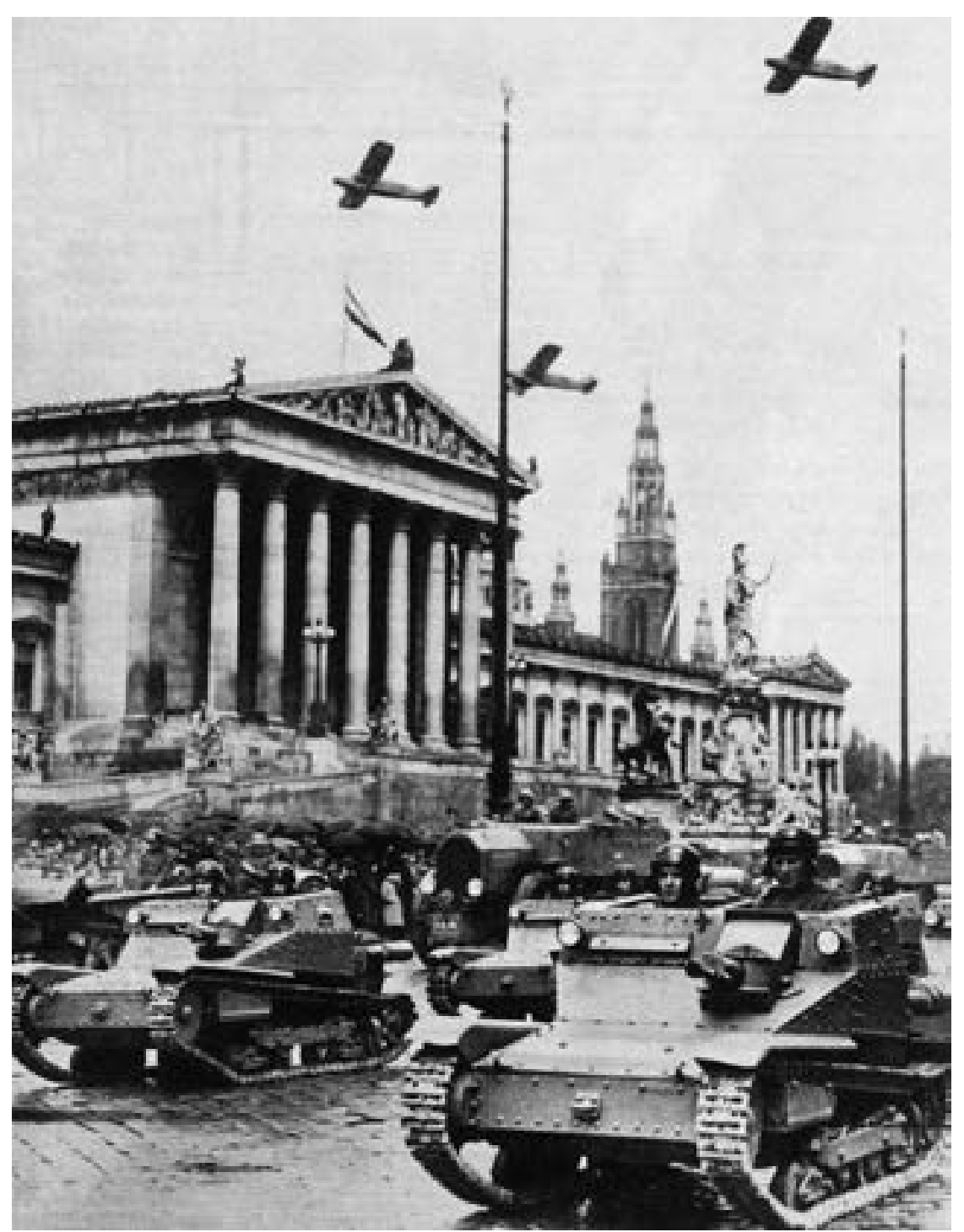




\section{Kampf um die Straße}

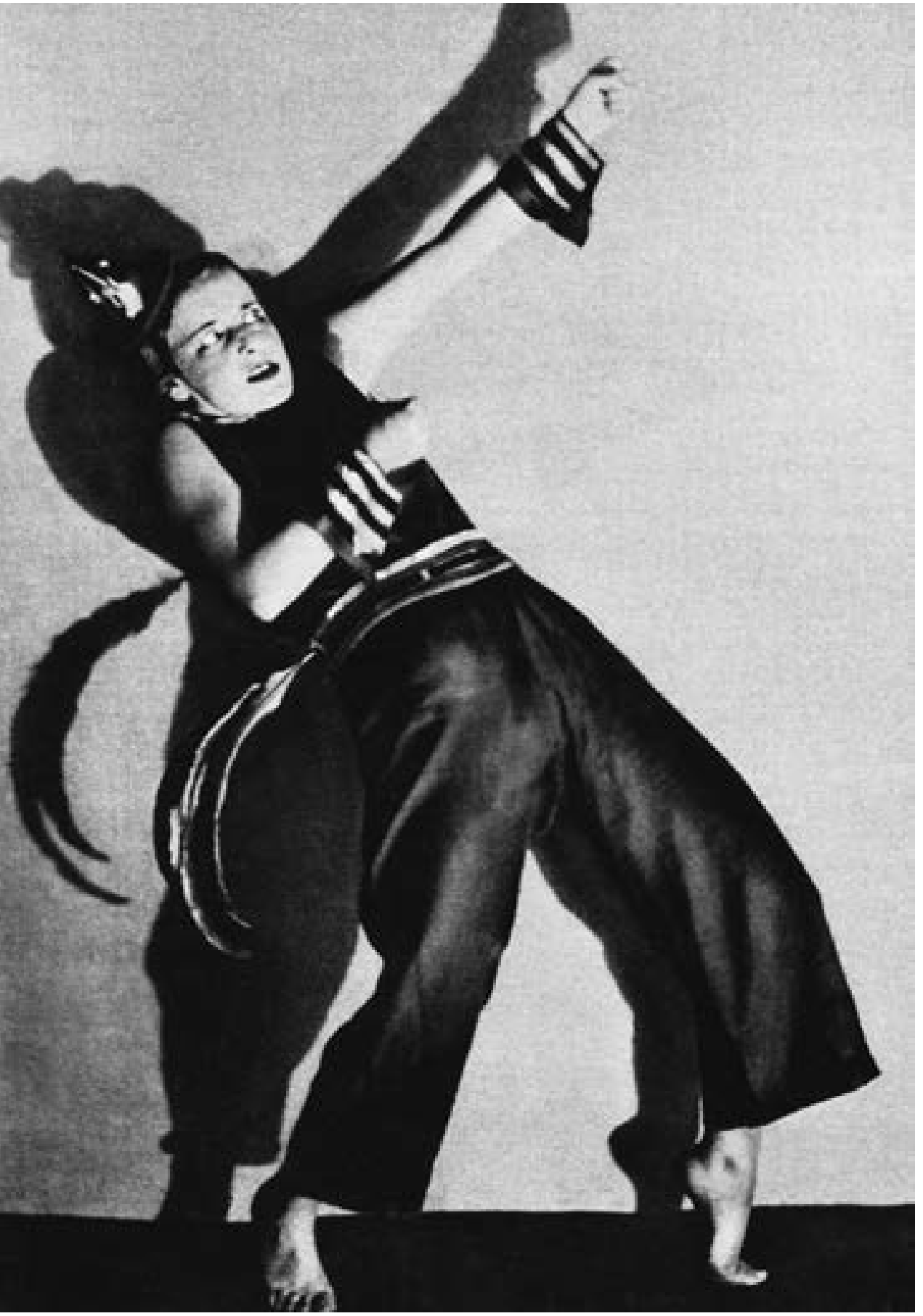

Ende der 1920er Jahre spitzt sich die politische Konfrontation zwischen links und rechts deutlich zu. Ort der Auseinandersetzung ist immer öfter die Straße. Es kommt regelmäßig zu Kundgebungen, Demonstrationen und Massenaufmärschen, die immer stärker einen militärischen Charakter annehmen. Verantwortlich für diese Militarisierung der Straße sind nicht zuletzt die sogenannten Wehrverbände, paramilitärische Einheiten im Vorfeld der großen Parteien, die ihre Macht in Form von martialischen Aufmärschen demonstrieren. Am 12. Mai 1929 organisiert einer dieser Wehrverbände, die den Christlichsozialen nahestehende Heimwehr, einen Marsch durch Wien. Mitten in der Hochburg der Sozialdemokratie und zwei Wochen nach dem großen sozialdemokratischen Maiaufmarsch kommt das einer bewusst herbeigeführten Provokation gleich. Der Zug der Heimwehrverbände sammelt sich in der Döblinger Hauptstraße, also in einem bürgerlich geprägten Viertel der Stadt, und steuert dann die Ringstraße im Zentrum der Stadt an.

\section{Ist das nicht grotesk?}

Eine gute Woche später, am 26. Mai 1929, macht sich die sozialdemokratische Illustrierte Der Kuckuck unter dem Titel „Hahnenschwanzgrotesken“ über die Heimwehr-Kundgebung lustig. „Da drängen sie (die Hahnenschwänzler, d.h. die Heimwehrmitglieder, die traditionellerweise Hüte mit Spielhahnfedern tragen, A.H.) sich am 12. Mai den Wienern auf, zogen durch Döbling und über die Ringstraße. Döblinger Hauptstraße: nahezu alle Fenster geschlossen, ein paar Neugierige vor einem Haustor, aber rechts und links,

Abb. 1 „Hahnenschwänzlertanz“ der Wiener Tänzerin Fritzi Klein, präsentiert bei einer sozialdemokratischen Kundgebung am 1. Mai 1929. Die Grotesktanz-Einlage richtet sich gegen die Heimwehr, die paramilitärische Vorfeldorganisation der Christlichsozialen, die wegen ihres Hutschmucks als „Hahnenschwänzler“ bezeichnet werden. Der Kuckuck, 26. Mai 1929, S. 3. 
hinten und vorne Polizei. So sah der jubelnde Empfang aus. Ist das nicht grotesk? Über die Ringstraße marschierten wohlgezählte 1100 Mann. Auf der Brust eines jeden klapperten die ,Kriegsauszeichnungen“, da sah man junge Burschen, die den Krieg noch auf der Schulbank erlebt, abgetakelte Offiziere, die ihn in der Etappe zugebracht haben. Ein Redner pries den Krieg in allen Tonarten. Die Musik spielte den Radetzkymarsch. Sie spielte ihn auch damals, als der Mann ins Feld zog, dem eine Granate die Beine wegriß, und der jetzt auf einem Wägelchen sein Leben dahinfristet. Ist das nicht grotesk?“ 1

Dem spottenden Text beigefügt ist die Aufnahme eines „Hahnenschwänzlertanzes“, die wenige Tage zuvor bei einer sozialdemokratischen Maifeier entstanden war (Abb. 1). Die junge Tänzerin im Bild heißt Fritzi Klein. Sie ist eine jener Künstlerinnen, die Ende der 1920er, Anfang der 1930er Jahre nicht nur privat, sondern auch in ihrer künstlerischen Arbeit offen gegen die nationalistischen, rechten Bewegungen Stellung beziehen. Zusammen mit Cilly Wang tritt Fritzi Klein in diversen Wiener Kleinkunstbühnen auf. Sie begleiten mit ihren Tanzeinlagen „groteske“ Texte von Peter Hammerschlag. ${ }^{2}$ Auch ihr Hahnenschwänzlertanz ist eine solche groteske tänzerische Intervention, und zwar mit einer klaren politischen Zielrichtung. Der Hahnenschwanz, den der „richtige“ Heimwehrmann stolz auf seinem Hut trägt, ist in der tänzerischen Karikatur von Fritzi Klein in Richtung Hintern gewandert: dorthin, wo der Birkhahn, von dem die Federn ursprünglich stammen, den Schmuck trägt. ${ }^{3}$ Das Zeichen der Heimwehr wird, als eine Art Wedel am Gürtel, der Lächerlichkeit preisgegeben. Aus dem Kopfschmuck ist in dieser Inszenierung ein von einer Frau getragener demontierter „Schwanz“ geworden, der sich im Schattenspiel an der Wand auf gespenstische Weise verdoppelt. „Die Wiener Tänzerin Fritzi Klein hat“, so heißt es abschließend im Kuckuck, „die ganze Lächerlichkeit der großtuerischen Hahnenschwänzlerei in einem Grotesktanz einzufangen verstanden. Die drohende Geste, die rollenden Augen, der trotzige Mund und dazu die Kikerikiattitüde. Ist das nicht grotesk?“4

Bis zum Jahr 1929 ist es der Heimwehr tatsächlich nicht gelungen, in der von den Sozialdemokraten be- herrschten Wiener Metropole Fuß zu fassen und hier eine Massenbasis zu etablieren. In den folgenden Monaten und Jahren wird sich das freilich ändern. Die Anhängerschaft der Heimwehr nimmt ab 1929 auch in Wien zu, ihre öffentlichen Auftritte ziehen mehr und mehr Menschen an. Als die paramilitärischen Verbände im November 1929 wiederum einen Aufmarsch in Wien organisieren, ist der Zulauf weitaus größer als noch im Mai (Abb.2). An die 10000 uniformierte Heimwehrleute defilieren über die Ringstraße zum Heldenplatz, wo die neuen Wimpel der militärischen Formation geweiht werden.

Fritzi Kleins politische Intervention ist in mehrfacher Hinsicht bemerkenswert. In ihrer Tanzeinlage erhält der in diesen Jahren erbittert geführte Kampf um die Straße einen künstlerischen Schattenriss. Die Tänzerin kommentiert die aktuellen politischen Ereignisse auf Wiens Straßen. Und dennoch geht sie in ihrer Stellungnahme deutlich über den tagespolitischen Anlass hinaus. Ihr „Grotesktanz“ arbeitet mit den Mitteln der Ironie und der Anspielung, er nimmt

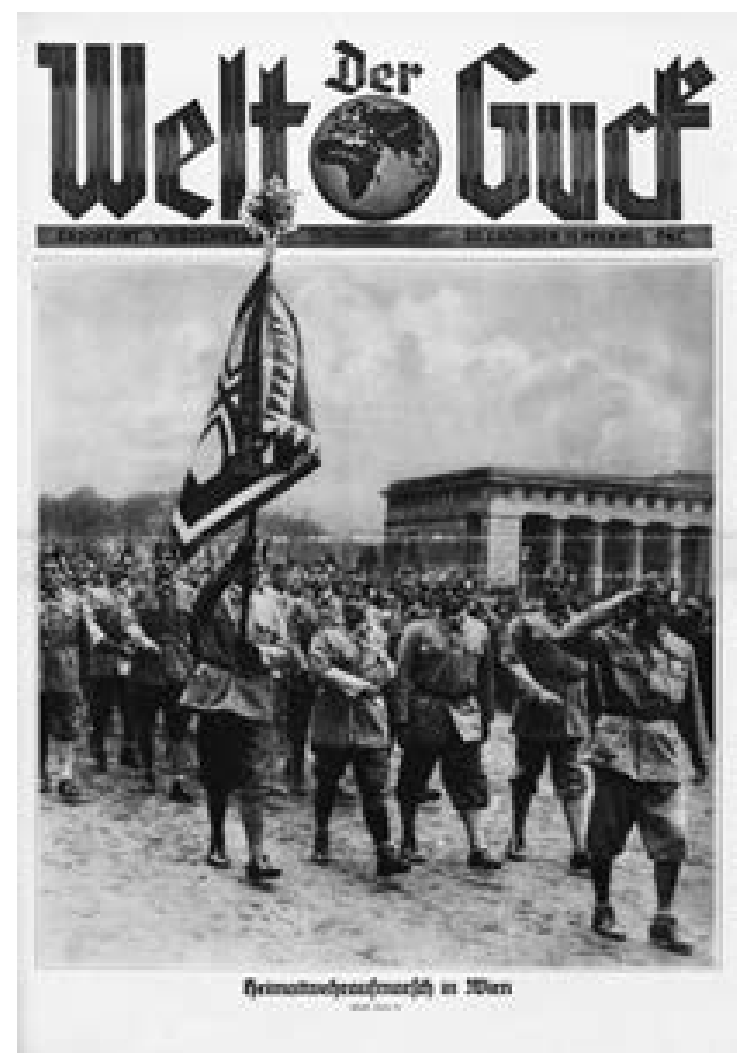

Abb. 2 Heimwehraufmarsch auf der Wiener Ringstraße. Die Tiroler Heimwehr wird auch als „Heimatwehr“ bezeichnet. Der Welt-Guck, 17. November 1929 , Titelseite. 
Wahlrecht. Diese Ereignisse finden in der illustrierten Presse einen breiten bildlichen Niederschlag. Zahlreiche Fotos der demonstrierenden Menschenmassen werden veröffentlicht. Auch wenn die bürgerlichen Zeitungen sich in der Regel von den protestierenden Sozialdemokraten distanzieren, finden die politischen Forderungen der Straße nun ein mediales Echo, das Wirkung zeigt. Unter dem anhaltenden politischen Druck kommt die Regierung den Forderungen der Straße teilweise entgegen. Die Reichsratswahl 1907 wird nach dem allgemeinen Männerwahlrecht durchgeführt. Das Frauenwahlrecht wird allerdings erst 1918 eingeführt. Aber nicht nur allgemeine politische Forderungen werden von der Straße aus gestellt, auch Berufsinteressen werden nun immer öfter in öffentlichen Massendemonstrationen kundgetan. Im Mai 1906 gehen die Handel- und Gewerbetreibenden Wiens für ihre Forderungen auf die Straße, im März 1907 kommt es zu einem Streik der Wiener Damenschneiderinnen, 6000 von ihnen versammeln sich auf der Wiener Ringstraße zum Protestzug. Im Interessanten Blatt wird in Bild und Text ausführlich über das Ereignis berichtet. „Die Arbeiterinnen und die Arbeiter wollen nicht mehr unter den alten Bedingungen weiterarbeiten, sie wollen kürzere Arbeitszeit und höhere Löhne. Die Modesalons und die Damenschneider möchten nur einen Teil der an sie gestellten Forderungen erfüllen, die Arbeiterinnen und Arbeiter wieder hoffen, wenn sie fest bleiben, das Ganze durchzusetzen, und vorläufig stehen sich die Parteien ohne viel Luft zur Nachgiebigkeit gegenüber. ${ }^{5}$ Das Bild zum Bericht zeigt freilich nicht den Protestzug im Freien, sondern eine Kundgebung der Frauen in den geschlossenen Räumen des Wiener Arbeiterheims (Abb.4). Dem bürgerlichen Blatt scheint das Motiv „RingstraBe in Schneiderinnenhand“ doch zu gewagt zu sein.

Die Freiheit der öffentlichen Meinungsäußerung ist eine liberale Errungenschaft, die ihre Grenzen kennt. Wenn die Forderungen der Straße „zu weit“ gehen, schlägt die liberale, bürgerliche Öffentlichkeit

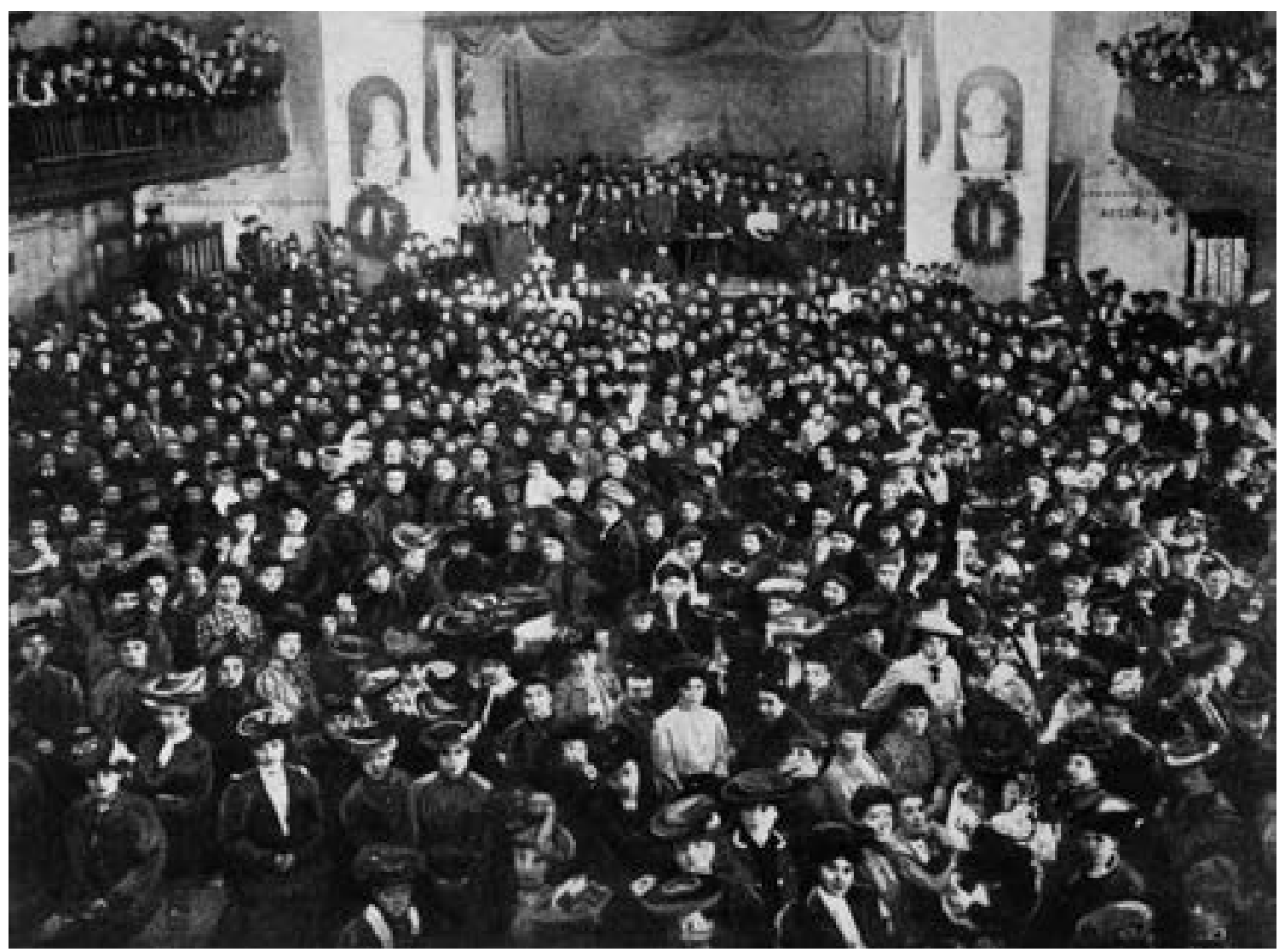

Abb. 4 Streik der Wiener Damenschneiderinnen. Massenversammlung streikender Gehilfinnen im Wiener Arbeiterheim. Das interessante Blatt, 28. März 1907, S. 3. Foto: R. Lechner (Wilh. Müller). 


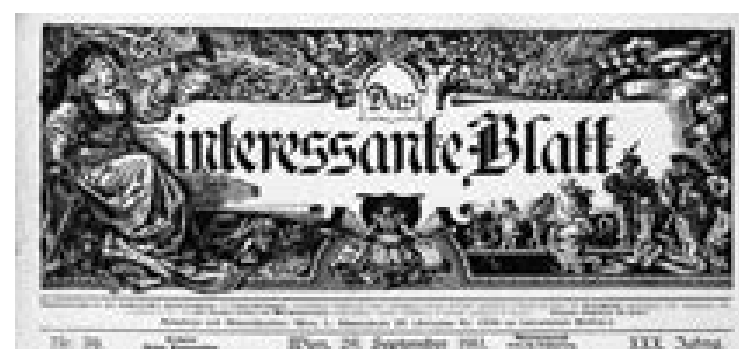

Dir Strufientaümpfe in ottakriug.

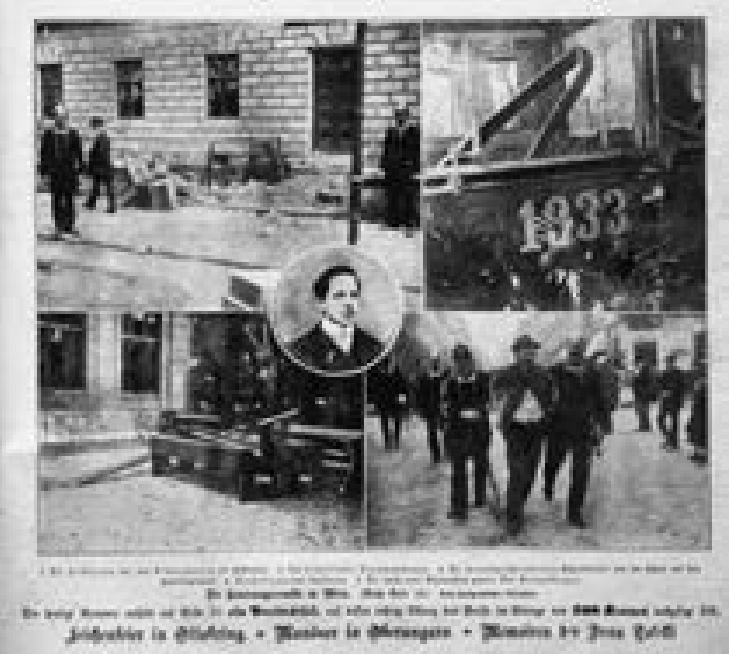

Abb. 5 „Straßenkämpfe in Ottakring". Am 17. September 1911 kommt es in Wien zu einer sozialdemokratischen Großdemonstration gegen die Preissteigerungen bei Lebensmitteln. Die Kundgebung endet in gewaltsamen Zusammenstößen zwischen Polizei und Demonstranten. Das interessante Blatt, 28. September 1911, Titelseite.

Abb. 6 „Nie wieder Krieg!"-Demonstration am 27. Juli 1924 vor dem Wiener Rathaus. Das interessante Blatt, 31. Juli 1924, Titelseite. Foto: Astoria. mit aller Härte zurück. Am 17. September 1911 findet eine große sozialdemokratische Kundgebung auf dem Wiener Rathausplatz statt, auf der gegen die drastischen Preissteigerungen bei Nahrungsmitteln protestiert wird. Begleitet wird die Veranstaltung von einem massiven Polizeiaufgebot. Als es im Anschluss an die Kundgebung zu Zusammenstößen zwischen Demonstranten und Sicherheitskräften kommt, eskaliert die Situation. Im Bezirk Ottakring kommt es zu schweren Zusammenstößen zwischen Demonstranten und der Polizei, Barrikaden werden errichtet, Gebäude und öffentliche Einrichtungen in Brand gesetzt, die Polizei schießt auf die Demonstranten. Drei Menschen werden getötet, 149 verletzt. ${ }^{6}$ Die Bildberichterstattung der bürgerlichen Presse stellt sich diesmal voll und ganz auf die Seite der Polizei (Abb. 5). Die Arbeiter

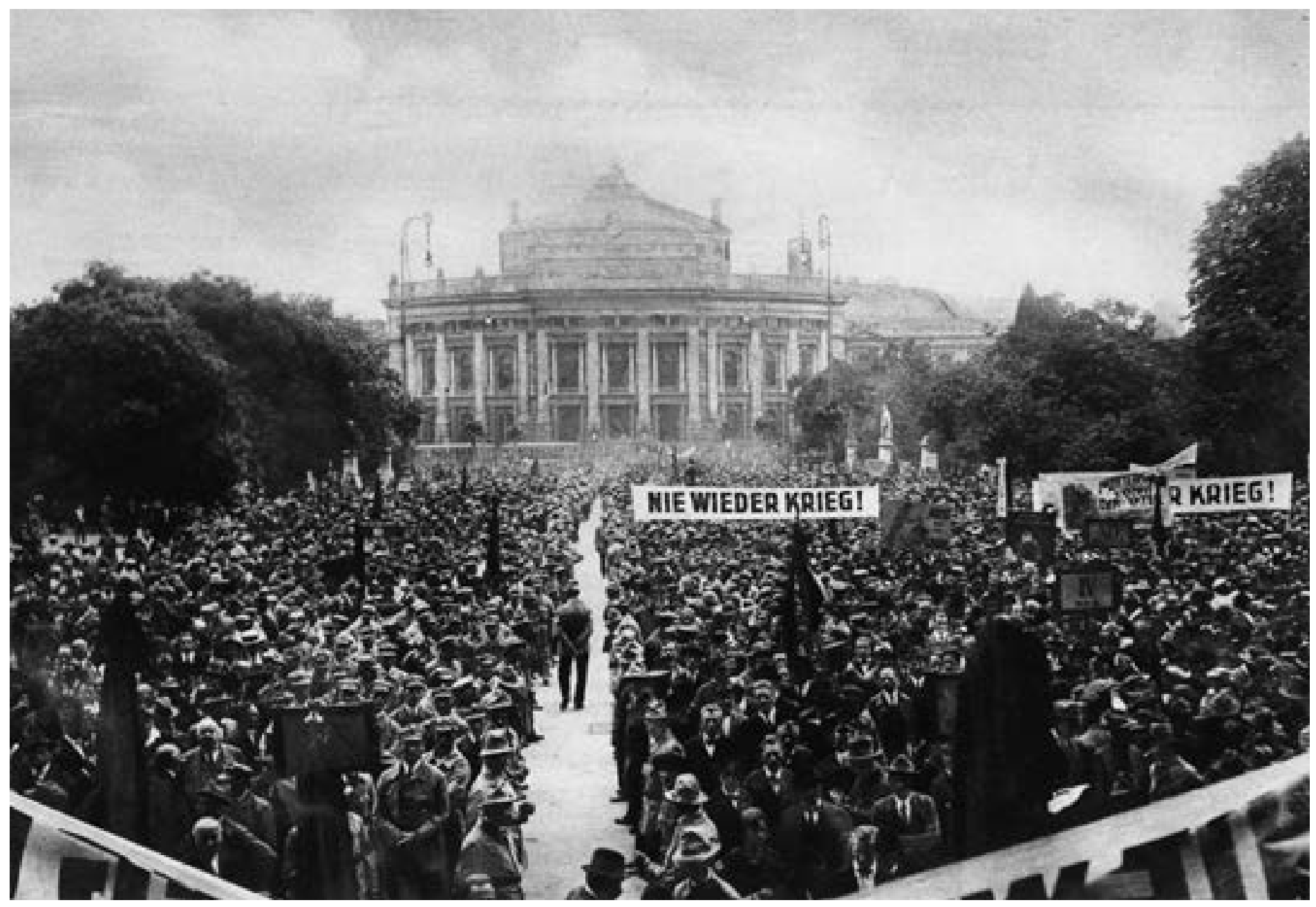


Abb. 9 „Es lebe die Diktatur des Proletariats". Kommunistische Demonstranten ziehen am 15. Juni 1919 zum Wiener Landesgericht und fordern die Freilassung der am Vortag verhafteten Parteiführer. Das interessante Blatt, 19. Juni 1919, S. 5. Foto: Welt-Preß-Photo.
Abb. 10 Zusammenstöße von kommunistischen Demonstranten und der Polizei bei der Wiener Philadelphiabrücke. Das interessante Blatt, 28. Februar 1929, Titelseite. Foto: Karl Schleich.

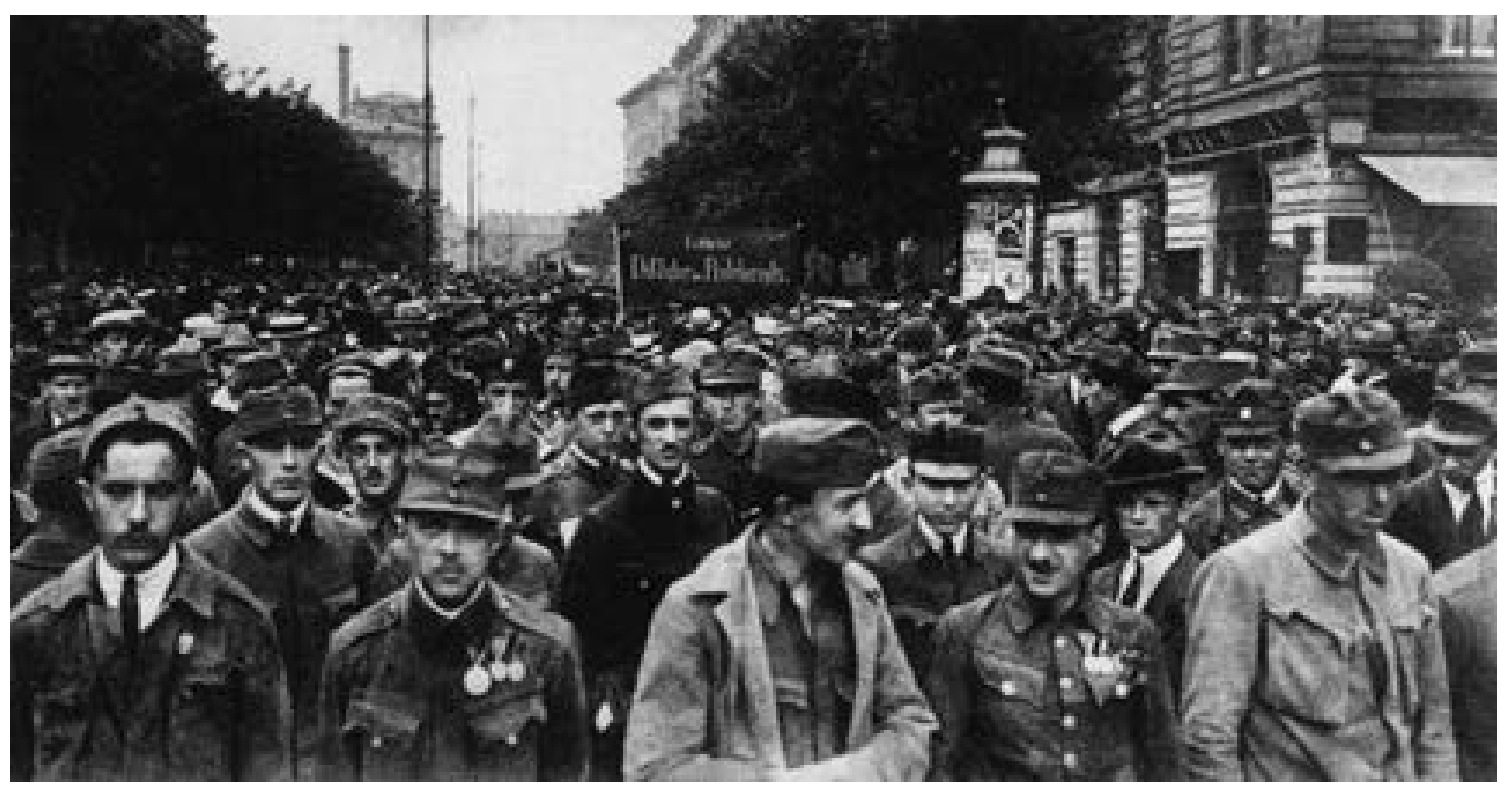

fällt auf, dass der öffentliche politische Raum zwischen 1918 und 1938 im Wesentlichen zweigeteilt ist. Während in Wien die Sozialdemokratie (bis zu ihrem gewaltsam herbeigeführten Ende 1934) mit absoluter Mehrheit herrscht, haben fast im gesamten restlichen Österreich die Christlichsozialen das Sagen. Die Kommunisten, die in den politisch turbulenten Monaten nach dem Kriegsende in Wien immer wieder größere Massenkundgebungen zustande bringen (Abb.9), ge-

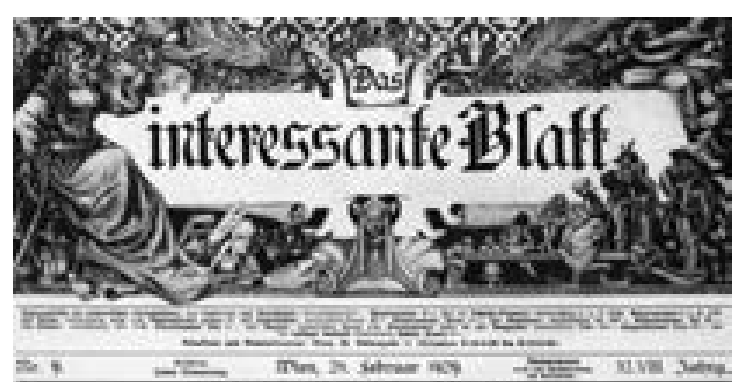

$\pi$,

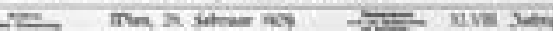

Die Aufunarfthe in Wien.

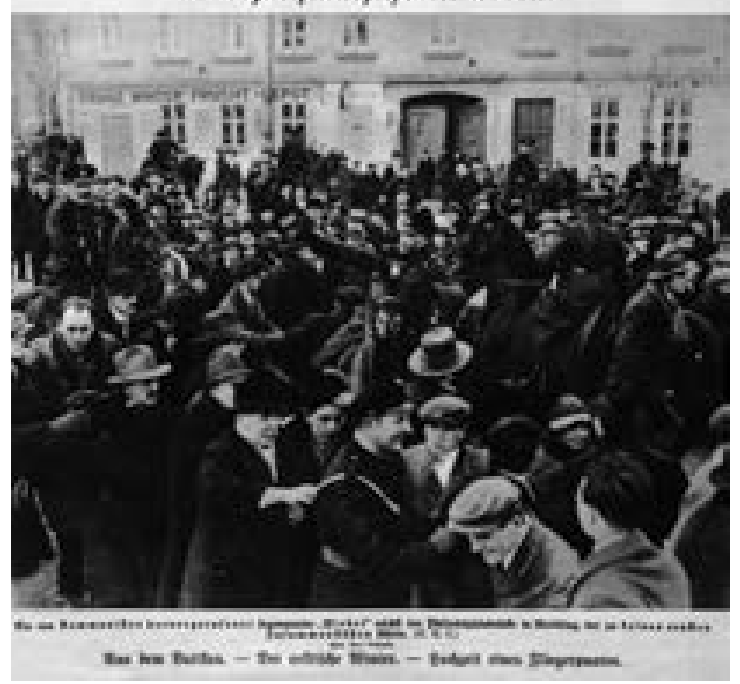

hen in diesem Zweikampf bald unter. Es gelingt ihnen zwar, die Straße zu ihrer Bühne zu machen, aber ein wichtiges Gegenstück dieser politischen Öffentlichkeit, der Zugang zu auflagenstarken Massenmedien, fehlt ihnen.

Das Ende des prekären Gleichgewichts zwischen Sozialdemokraten und Christlichsozialen kündigt sich Ende der 1920er Jahre an, als es den konservativen Kräften, unterstützt durch Regierung und Polizeistaat gelingt, der Linken die Oberhoheit über die Wiener Straße allmählich zu entwinden. Der massive Polizeieinsatz gegen demonstrierende Arbeiter im Jahr 1927 (der unter dem Begriff des „Justizpalastbrandes“ bekannt geworden ist) markiert einen wichtigen Einschnitt in diesem Prozess. Zwei Jahre später geht die Polizei gegen eine kommunistische Kundgebung in Meidling vor (Abb. 10). Berittene Polizisten lösen die Kundgebung gewaltsam auf. In der Folge kommt es zu politisch motivierten Verhaftungswellen im kommunalen Wiener Wohnbau. Als es im Spätherbst 1929 der paramilitärischen Heimwehr gelingt, in Wien von der Straße Besitz zu ergreifen, ist der erste Schritt für die spätere Machtübernahme bereits getan. Die Sozialdemokratie ist bereits in der Defensive. Anfang der 1930er Jahre spitzt sich der Machtkampf auf der Straße zu. 1932 erwächst den Christlichsozialen nicht nur von links Konkurrenz (den Sozialdemokraten), sondern auch von rechts (den Nationalsozialisten), die in diesem Jahr ihre größten politischen Erfolge feiern und vor Gewalt und Terror nicht zurückscheuen. In dieser verfahrenen politischen Situation verspricht die autoritäre Regierung Dollfuß, auf der Straße gewaltsam „aufzuräumen“. Nach und nach werden die 
Organisationen der politischen Gegner verboten, die Parteien und Medien der Kommunisten, der Nationalsozialisten und schließlich im Frühjahr 1934 der Sozialdemokraten.

\section{Die Inszenierung der Massen im „Ständestaat“}

Es ist kein Zufall, dass sich die siegreichen Heimwehrformationen im Mai 1933 im Schloss Schönbrunn, dem symbolischen Herzstück des habsburgischen Staates, zu einer großen Kundgebung einfinden (Abb. 11). Ihr Führer, Ernst Rüdiger von Starhemberg, hält von der habsburgischen Schlossterrasse aus eine Ansprache an 40000 Heimwehrleute. Die Straßen der Hauptstadt sind nun, nach dem letzten Schlag gegen die Opposition, „befriedet“ und leer geräumt. Die neue Regierung knüpft symbolisch bewusst an das Haus Habsburg an. Zugleich beginnt sie damit, den öffentlichen Raum mit monumentalen staatstragenden politischen Kundgebungen, die den neuen „Ständestaat“ feiern, in Besitz zu nehmen. Diese Strategie, die unter Dollfuß erstmals angewendet und nach seinem Tod 1934 von seinem Nachfolger Kurt Schuschnigg aufgegriffen wird, gipfelt in einer diktatorisch gelenkten Massenpolitik. Diese wird zentral organisiert und orchestriert, medial gelenkt und in ihren politischen Aussagen bis ins letzte Detail durchgeplant.

Ab 1933 kommt es regelmäßig zu solchen Großkundgebungen auf der Straße und an öffentlichen Orten. Ende Januar 1933 etwa organisiert die Regierung eine Versammlung von rund 15000 Anhängern der Vaterländischen Front auf dem Wiener Ballhausplatz, also vor den Regierungsämtern, die die Politik von Kanzler Dollfuß symbolisch stärken. Auch im „Ständestaat“, der ein Jahr später ausgerufen wird, werden regelmäßig Aufmärsche und Kundgebungen veranstaltet. Den Auftakt der regierungstreuen Massenveranstaltungen bildet die Erste-Mai-Feier im Jahr 1934. Alle sozialdemokratischen Veranstaltungen sind verboten, dafür steht der Tag ganz im Zeichen des neuen starken Mannes, des austrofaschistischen Kanzlers Engelbert Dollfuß, der an diesem Tag feierlich die neue (diktatorische) Verfassung des „Ständestaates“ verkündet. Der bisherige sozialdemo-
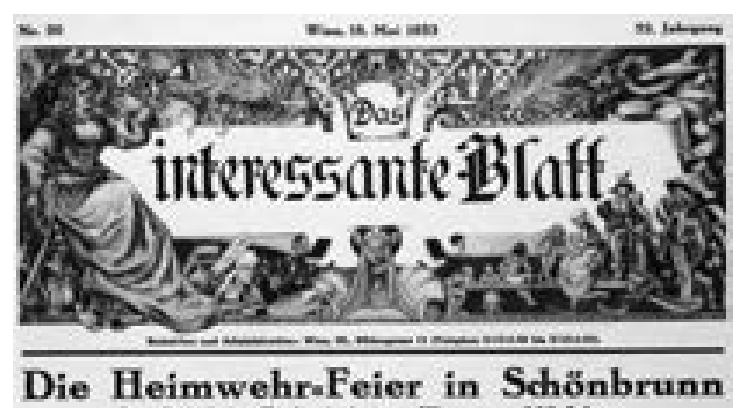

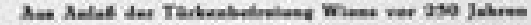

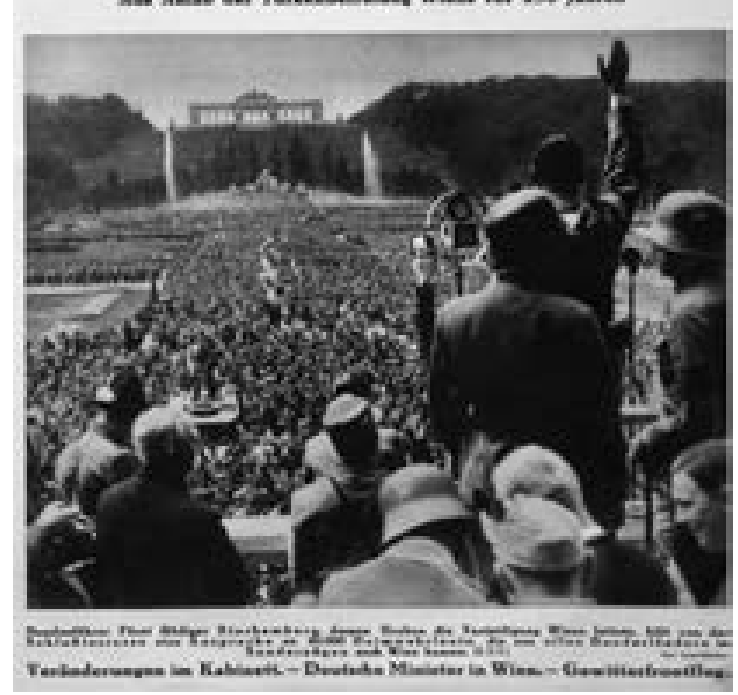

kratische Tag der Arbeit wird zum Feiertag für den neuen „Ständestaat“ umfunktioniert. Der Kanzler selbst steht im Mittelpunkt dieser Inszenierung, die sich über den gesamten Tag erstreckt und eine Art politisches Gesamtkunstwerk darstellt. Eingeleitet wird der Reigen an Veranstaltungen mit einem Festgottesdienst im Wiener Stephansdom, an dem Dollfuß teilnimmt. ${ }^{9}$ Anschließend findet im Praterstadion eine sogenannte „Kinderhuldigung“ statt. Auf Geheiß der Regierung haben sich 50000 Schulkinder eingefunden, die dem „neuen Österreich“ (und natürlich auch dem Kanzler, der anwesend ist) huldigen. Lothar Rübelt hält diese politische Massenszene, die nach den Vorstellungen der Regierung durchgeplant ist, in einer panoramaartigen Aufnahme fest (Abb. 12). Er hat mit seiner Kamera in den oberen Rängen des Stadions Platz genommen, um die Menschenmassen im riesigen Oval möglichst vollständig und monumental erfassen zu können. Tage später erscheint das Bild auf einer Doppelseite im Interessanten Blatt. ${ }^{10}$

Am selben Tag um elf Uhr vormittags hält Dollfuß eine große Rede über „Das neue Österreich“, die - so will es die Regierung - sogleich über alle Radiosender ausgestrahlt wird. Zusätzlich wird sie im gesamten Staatsgebiet auf öffentlichen Plätzen über Lautsprecher übertragen. Eigens einberufene Festveranstaltungen finden überall im Land statt. Anschließend
Abb. 11 Kundgebung der Heimwehr im Schloss Schönbrunn. Im Vordergrund der Heimwehrführer Ernst Rüdiger von Starhemberg, der von der Schlossterrasse aus eine Ansprache hält. Das interessante Blatt, 18. Mai 1933, Titelseite. Foto: Ernst-Hilscher. 


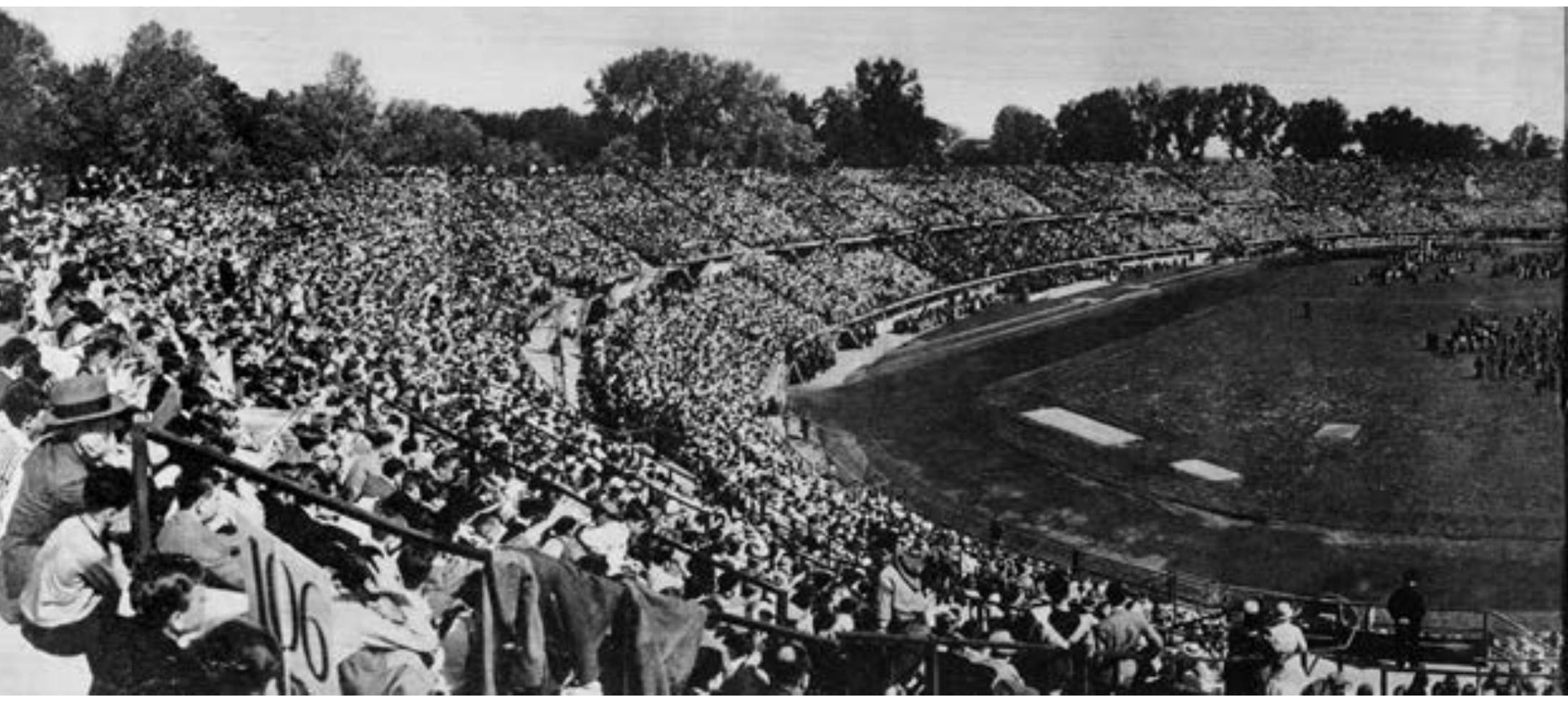

Abb. 12 „Kinderhuldigung“ am 1. Mai 1934. 50000 Kinder, die sich nach dem Willen der Regierung mit ihren Angehörigen im Wiener Praterstadion versammeln, feiern die neue diktatorische Verfassung des „Ständestaates“, die an diesem Tag verkündet wird. Das interessante Blatt, 10. Mai 1934 , S. 2. Foto: Lothar Rübelt. ist ein feierlicher Empfang beim Bundespräsidenten geplant. Am Nachmittag steht die „Huldigung der Stände“ in Form eines großen Festzugs in Wien auf dem Programm. Geordnet nach ständischen Gruppen (Bauern, Gewerbe, Arbeiter usw.) und vielfach in Tracht marschieren die Teilnehmer auf den Straßen Wiens. Jeder Stand legt eine Pergamentrolle mit einer Huldigungsadresse in die Hände des Wiener Bürgermeisters Richard Schmitz, der 1934 von Dollfuß eingesetzt worden war. Geplant hat diese „ständestaatliche“ Masseninszenierung, an der 17600 Menschen teilnehmen, der Architekt Clemens Holzmeister, einer der wichtigsten kulturpolitischen Repräsentanten des „Ständestaates“. Am Abend wird das politische Gesamtkunstwerk mit einem Volksfest im Arkadenhof des Rathauses, das nun fest in der Hand der Regierung ist, abgeschlossen.

Der Bruch mit der Vergangenheit ist vollzogen. Die Massenpolitik des Austrofaschismus setzt sich dezidiert von der politischen Kultur der 1920er Jahre ab. Nichts soll mehr an die „wilden“ politischen Kundgebungen der vergangenen Jahre erinnern. Jeder Schritt ist sorgsam gelenkt, jede Rede nimmt Bezug auf das größere Ganze, den neuen „Ständestaat“. Die Straße ist nun „frei“, das heißt fest in der Hand der Regierung. Jede oppositionelle Äußerung wird streng geahndet. Es gibt nun wieder politische Gefangene (Kommunisten, Sozialdemokraten, Nationalsozialisten), die weit außerhalb der Stadt, in den „Anhaltelagern“ Kaisersteinbruch bzw. Wöllersdorf festgehalten werden.
Einen Höhepunkt erreichen die austrofaschistischen Masseninszenierungen am 18. Oktober 1936, als die Vaterländische Front, die Einheitspartei des „Ständestaates“, in Wien einen öffentlichkeitswirksamen „Appell“ veranstaltet (Abb. 13). Insgesamt 350000 Menschen nehmen an der Großveranstaltung auf dem ehemaligen k.u.k. Exerzierplatz Schmelz im 15. Wiener Gemeindebezirk teil. Die Logistik im Hintergrund der Kundgebung ist gewaltig. Im Abstand von fünf Minuten kommen Sonderzüge aus ganz Österreich an, um die Teilnehmer der Kundgebung nach Wien zu bringen. Auf der Ehren- und Rednertribüne, einer eigens errichteten monumentalen Konstruktion, über der das Symbol des „Ständestaates“, das sogenannte „Kruckenkreuz“, angebracht ist, ist die gesamte Regierung versammelt. ${ }^{11}$ Eine Feldmesse, die von Erzbischof Theodor Innitzer, einem begeisterten Anhänger des Austrofaschismus, zelebriert wird, eröffnet die Kundgebung. „Um 11 Uhr traf Dr. Schuschnigg unter den Klängen der Bundeshymne und von brausenden Hochrufen (...) auf dem Versammlungsplatz ein“, so schreibt Das interessante Blatt, dessen Berichterstattung ganz auf der Linie der Regierung liegt. ${ }^{12}$ „Nach verschiedenen kurzen Reden hörte die Menge die ergriffene Stimme des Gründers der V.F. (Vaterländischen Front, A. H.), des verstorbenen Kanzlers Dr. Dollfuß. Das Lied vom Guten Kameraden ertönte und dann ergriff Dr. Schuschnigg das Wort zu seiner großangelegten Rede, die eine Symphonie des Vaterlandes aufrollte. Er nannte die drei Sätze 


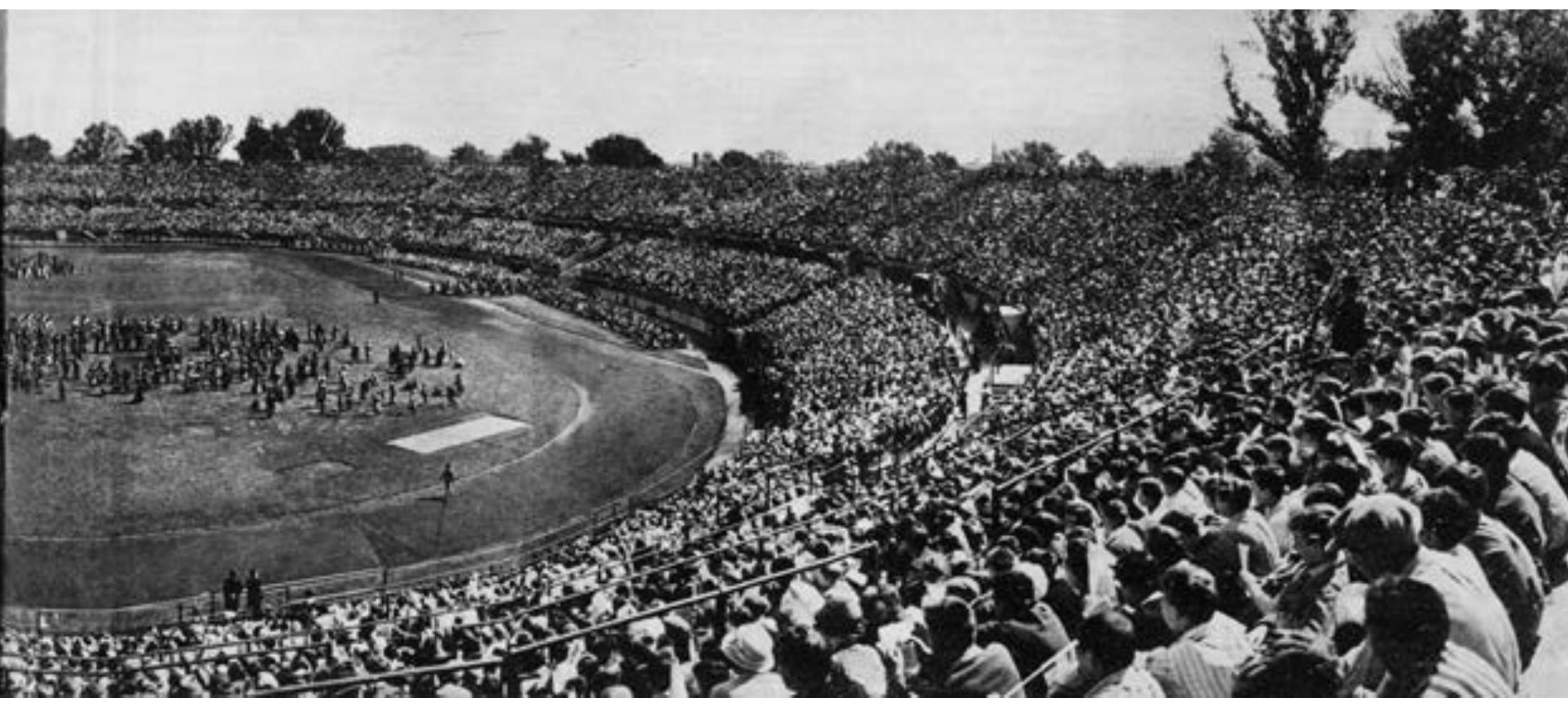

das Lied der Jugend, das Lied von der Arbeit und das Lied von der Erde.“ 13

\section{Ein Stimmungsbild, Wien 1936}

Als das austrofaschistische System zwei Jahre später unter dem Druck des nationalsozialistischen Regimes in Deutschland zusammenbricht, ist dies ein einschneidendes Ereignis. Und dennoch: So groß der Bruch des Jahres 1938 in Österreich auch ist, im Bereich der propagandistischen Massenpolitik kann das nationalsozialistische Regime fast nahtlos an die Weichenstellungen im „Ständestaat“ anknüpfen, wenn auch die Inszenierung der Politik im öffentlichen Raum nun noch einmal deutlich ausgedehnt, perfektioniert und noch stärker zentralisiert wird. Und auch die Ereignisse des folgenreichen Jahres 1938 kommen nicht ganz aus heiterem Himmel. Wer damals genau hinsah, konnte schon lange vor dem „Anschluss“ Österreichs die Zeichen der Zeit erkennen. Und diese Zeichen lassen sich - trotz der Zensur im „Ständestaat“ und der Ausschaltung aller Opposition - auf der Straße beobachten.

Eine solche Straßenszene findet wenige Monate vor der Massenkundgebung der Vaterländischen Front 1936 in Wien Eingang in die Presse. Der Bericht, dem ein Foto beigefügt ist, erscheint am 5.Juli 1936 in der Wiener Zeitung Der Sonntag (Abb. 14). Er mutet auf den ersten Blick ganz und gar unscheinbar an. Der Titel lautet: „Vor dem Buchladen“. Die Auto- rin heißt Hilde Spiel. Die 27-Jährige hat soeben ihr Studium abgeschlossen. Neben ihrer Arbeit an der Wirtschaftspsychologischen Forschungsstelle der Universität Wien macht sie ihr Doktorat und schreibt ihre ersten beiden Romane sowie erste Zeitungstexte. Politisch engagiert sie sich bei den illegalen Sozialde-

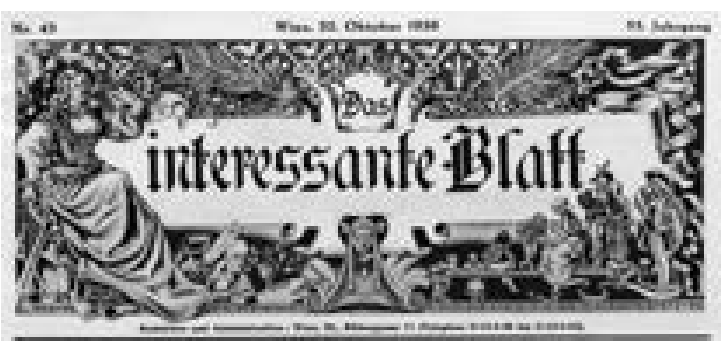

Der grobe Frontappell der V.F.

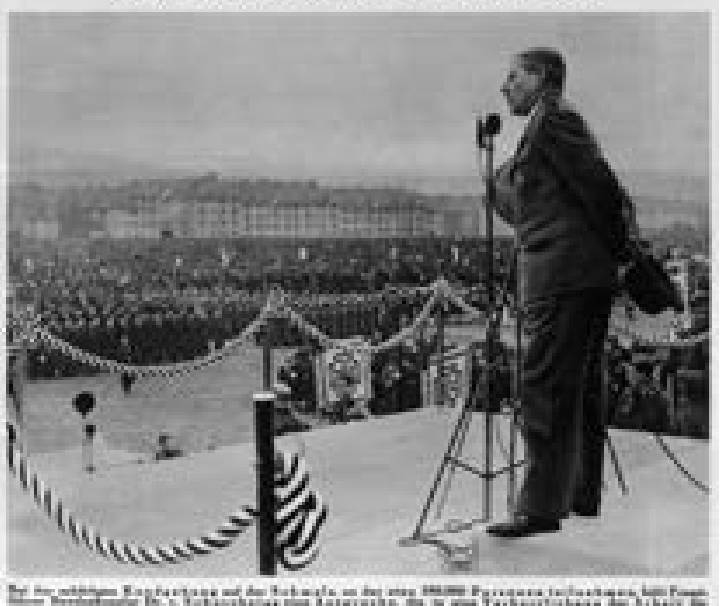

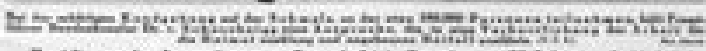

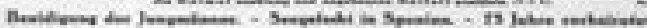

Abb. 13 Kundgebung der Vaterländischen Front auf der Schmelz. Am Mikrofon im Vordergrund ist der Bundeskanzler Kurt Schuschnigg zu sehen. Das interessante Blatt, 22. Oktober 1936, Titelseite. Foto: Dietrich. 
Abb. 14 „Vor dem Buchladen“. Der aufmerksame Blick in das Schaufenster einer Wiener Buchhandlung (mit zahlreichen nationalsozialistischen Publikationen) erzählt viel über die politische Stimmung in Österreich Mitte der 1930er Jahre. Der Sonntag, 5. Juli 1936, S. 7. Foto: Dora Horovitz.

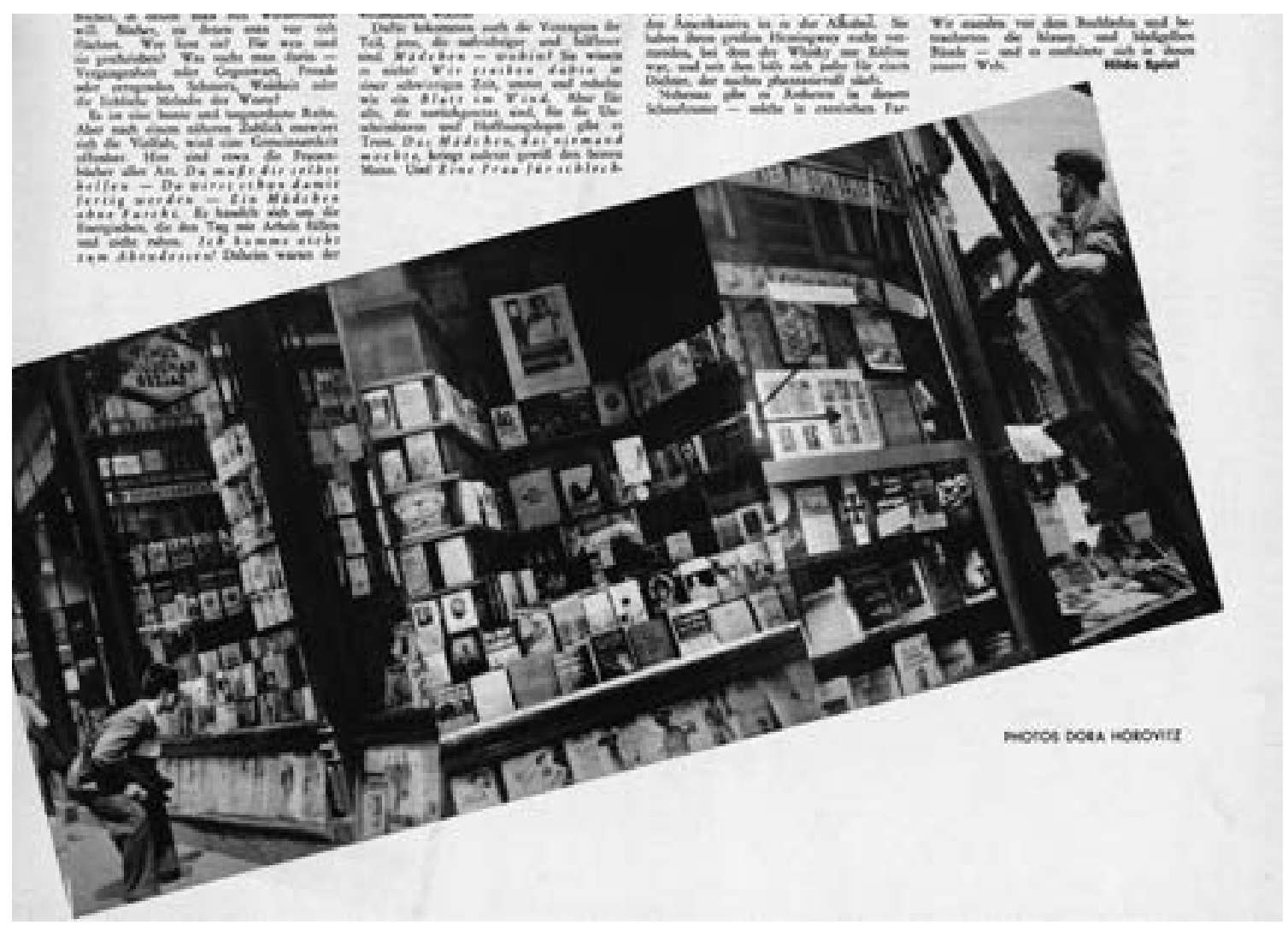

mokraten. ${ }^{14}$ In ihrem Feuilleton „Vor dem Buchladen“ beobachtet sie aufmerksam das Schaufenster einer Wiener Buchhandlung. „Hundert Bücher. Oder mehr. (...) Wer liest sie? Für wen sind sie geschrieben?" 15 In knappen präzisen Beobachtungen lässt sie im Spiegel dieses Schaufensters ein Porträt der Menschen dieser Stadt entstehen. In den Büchern, die sie kaufen, entdeckt sie Sehnsüchte und Hoffnungen, Befürchtungen und Ängste. In ihrem kurzen Text gelingt es der Autorin, die Stimmung in Wien Mitte der 1930er Jahre in einfachen, klaren Bildern einzufangen. Werfen wir einen Blick auf das Bild. Es zeigt das Schaufenster einer Buchhandlung. Die Aufnahme stammt von Dora Horovitz, die Ende der 1920er Jahre zusammen mit Trude Geiringer ein Fotoatelier eröffnet hat und nach 1934 ihr Geschäft allein weiterbetreibt. Im Schaufenster liegen zahlreiche nationalsozialistische Bücher und Publikationen mit Hakenkreuzzeichen auf dem Umschlag. Hilde Spiel weiß, dass die Presse der Zensur unterliegt, sie formuliert vorsichtig und zwischen den Zeilen. Die nationalsozialistische Literatur nennt sie nicht. Und dennoch geht sie - indirekt - auf die gegenwärtige politische Situation ein. Was lesen die Männer?, fragt sie. „Sie haben noch Krieg. Nach zehnjährigem Schweigen war der Damm gebrochen und die trübe, gurgelnde Flut schwoll hervor. Nun sickert sie immer noch, denn sie werden das Erlebnis nicht los, dieses schwerste Erlebnis ihrer Jugend und unseres Jahrhunderts. Novemberschlacht - Westfront 1918 - dabei halten wir immer noch, und am Isonzo. Im Osten geht es bis Persien und Afghanistan: Pascholl Plenny!“16 Die „trübe, gurgelnde Flut“, die 1938 scheinbar so überraschend kommt, ist, so zeigt dieser Bildbericht von der Straße, schon da, lange bevor die nationalsozialistischen Truppen in Wien einmarschieren. Hilde Spiel hat die Stimmung im Land genau registriert. Als Jüdin ist sie selbst dem zunehmenden Antisemitismus ausgesetzt. Bald nachdem der Text erschienen ist, verlässt sie deshalb, zusammen mit ihrem Mann, dem Schriftsteller Peter de Mendelssohn, Österreich und zieht nach London. 1938 folgt ihr Dora Horovitz in die Emigration nach. 


\title{
Im Schatten der Konzerne
}

\author{
Politische Illustrierte in der Zwischenkriegszeit
}

Mitten im Ersten Weltkrieg, Ende 1917, Anfang 1918, kehrt der Wiener Schriftsteller und Journalist Alfred Polgar in seiner Erinnerung zurück in die Zeit vor dem Krieg. Und diese ist für ihn, so berichtet er in einem Feuilleton, unauflöslich mit süßen Bildern aus ausländischen Illustrierten verknüpft. In Gedanken taucht er noch einmal ein in diese wunderbar geschönte Welt der Schauspielerinnen und Sporthelden. Im Vergleich zur propagandistischen Kriegsberichterstattung ist für ihn diese Welt um nichts verlogener. „Das letzte Mal sah ich ,La Vie Parisienne‘ im Juli 1914. Sie war tags zuvor gekommen, und ihr satiniertes Papier glänzte noch unbefleckt von Leserfingern. (...) An jenem Tag sah ich auch, und gleichfalls zum letzten Mal ,Le Rire‘. (...) Da kamen ,London News“ und ,The Sketch' und ,Daily Graphic‘, festtäglich bunt und blättrig-üppig. Schauspielerinnen mit Engelsgesichtern und Ringellocken bis zu den polierten Schultern lächelten süß. Fußballhelden und Regattensieger, den Hochmut des Weltrekords im Blick, zeigten, armverschränkt, herrlich strotzende Brustkasten und Beinmuskulaturen. (...) Alles blinkte ganz unmöglich, ganz lächerlich sauber, glatt und fein. Was für ein süßer Kitsch! Was für ein verlogener Kitsch! Aber war der süße Kitsch nicht immer noch schöner als jetzt der blutige. Was ist unwahrscheinlicher: Postkutschen, oder ,Flammenwerfer in Tätigkeit‘? Landschaften in Lichtrosa und Himmelblau, oder ,Granattrichterfeld'?"1

Die faszinierende Welt der ausländischen Illustrierten, die Polgar beschwört, gehört der Vergangenheit an. Seit August 1914 sind die Zeitungen und Zeitschriften des „feindlichen Auslands“ in Österreich, aber auch in Deutschland geächtet, damit sie der militärisch-patriotischen Berichterstattung der heimischen Blätter nicht in die Quere kommen. Das Publikum, so verordnet die Militärführung, hat sich mit österreichischen und deutschen Presseerzeugnissen sowie solchen des neutralen Auslands zu begnü- gen. Wäre Alfred Polgar nach dem Krieg noch einmal auf das Thema zurückgekommen, hätte er feststellen müssen, dass die französischen und englischen Illustrierten, die er so sehr liebte, nach 1918 nicht wieder zurückkehrten. In den Monaten nach dem Kriegsende, da - vor allem in den Städten - Erschöpfung, Not und Hunger herrschen, will sich niemand den Luxus ausländischer Magazine und Blätter leisten. Umgekehrt kommt auch keiner der englischen und französischen Zeitungsgroßhändler auf die Idee, neuerlich Illustrierte nach Österreich zu liefern. Die internationalen Vertriebswege sind gekappt, Papiernot plagt auch die Verlage in Frankreich und England. Österreich ist, nach dem Zerfall der Monarchie, ein verarmter, politisch gebeutelter Kleinstaat, der als Absatzgebiet für internationale Zeitungen und Zeitschriften wenig attraktiv ist.

\section{Ein Blick hinter die Kulissen}

Die Jahre von 1918 bis etwa 1923 sind, was die Presse betrifft, von Unsicherheit, Abwarten und vorsichtiger Anpassung an die neuen Zeichen der Zeit gekennzeichnet. Zwar wird in der unmittelbaren Nachkriegszeit, in der Euphorie über das Ende von Militärherrschaft und Zensur, aber auch im Spekulationsfieber der Inflationszeit (der Höhepunkt fällt in die Jahre 1921/22) eine Reihe neuer Tages- und Wochenzeitungen gegründet (von denen manche bald wieder verschwinden). Im Bereich der illustrierten Wochenpresse stellt sich die Situation aber etwas anders dar. Die Flaggschiffe der Vorkriegszeit, Das interessante Blatt (Abb. 1) und die Wiener Bilder (Abb. 2), werden auf den ersten Blick ohne größere Brüche und zunächst ohne größere unmittelbare Konkurrenz weitergeführt. Die beiden Zeitungen beherrschen auch in den 1920er und 1930er Jahren den österreichischen Markt. Erst bei genauerem Hinsehen wird deutlich, dass der Medienkonzern in der Rüdengasse 11 in den 


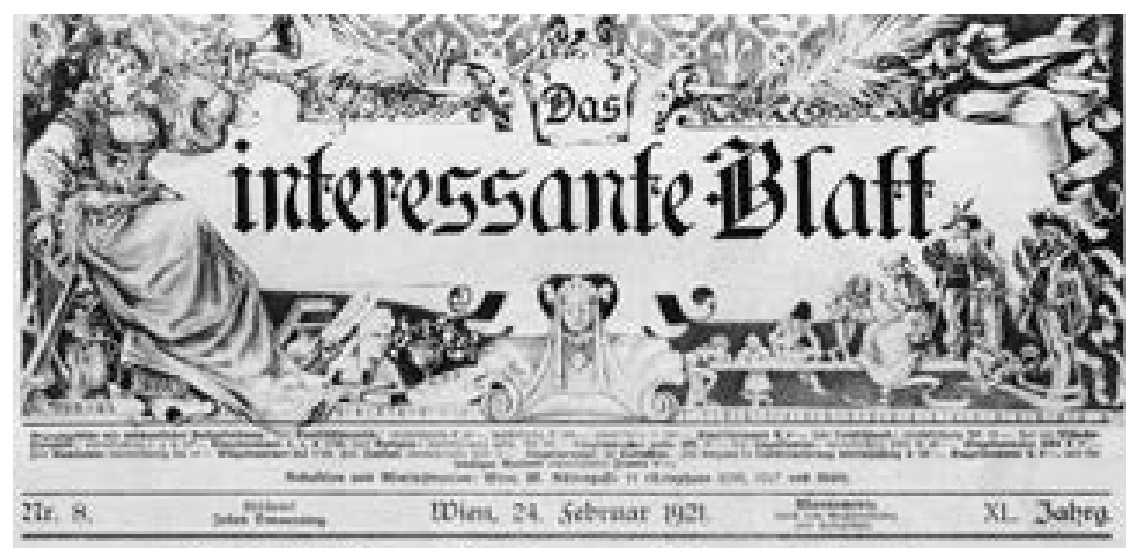

\section{Der Kriegsblinde auf der STtraß̧e.}

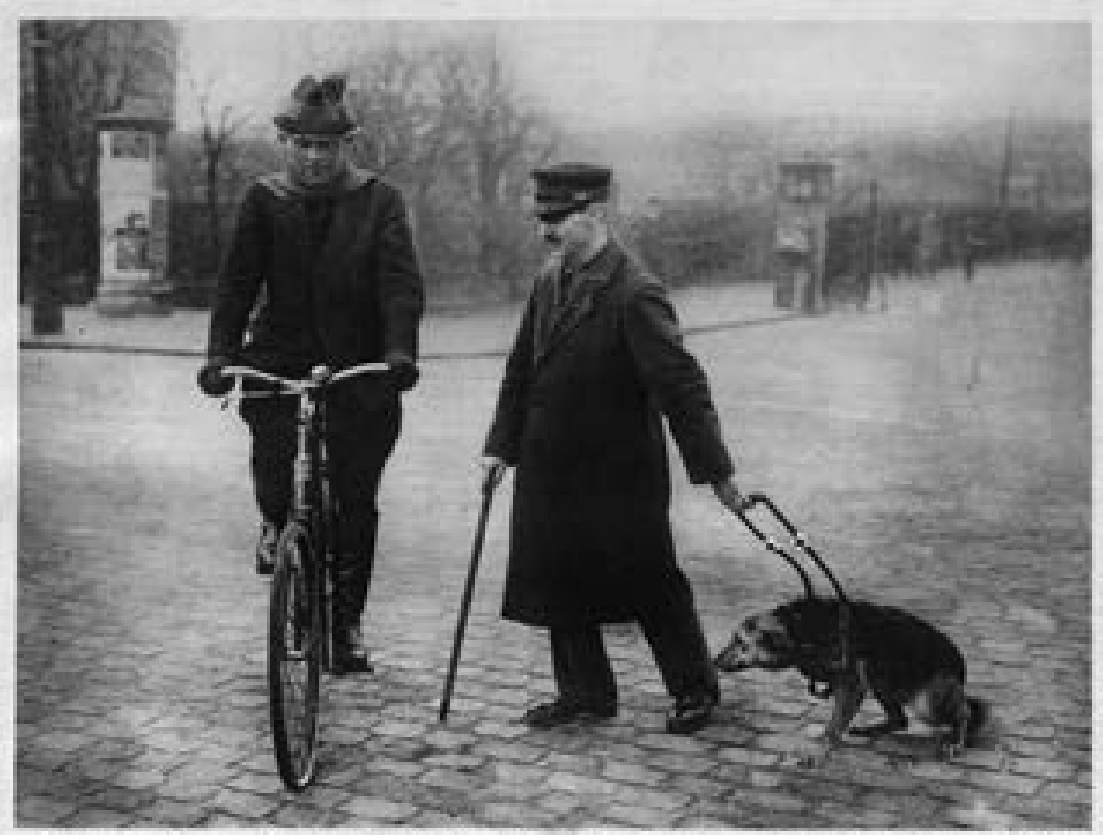

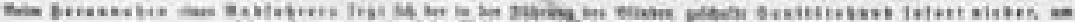

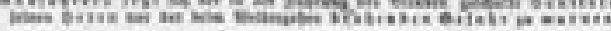

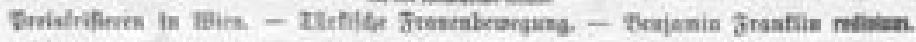

Abb. 1 Das interessante Blatt ist - neben den Wiener Bildern - auch nach 1918 die führende österreichische Wochenillustrierte. Das interessante Blatt, 24. Februar 1921, Titelseite.

Abb. 2 „Nie wieder Krieg!“Kundgebung vor dem Wiener Rathaus zehn Jahre nach dem Beginn des Ersten Weltkriegs. Rede des Anführers der Sozialdemokraten, Otto Bauer. Wiener Bilder, 3. August 1924, Titelseite. 1920er Jahren heftigen ökonomischen Erschütterungen ausgesetzt ist. Mehrmals ändern sich nach dem Krieg die Eigentümerverhältnisse. Die Fäden ziehen dabei keineswegs Redakteure und Herausgeber, sondern Finanzspekulanten, die die Zeit der Inflation und der ökonomischen Unsicherheit nutzen, um innerhalb weniger Jahre Firmenimperien zusammenzukaufen.

Auch wenn oberflächlich gesehen in der Welt der Illustrierten nach 1918 vieles beim Alten bleibt, verändern sich die ökonomischen und politischen Rahmenbedingungen, innerhalb derer die illustrierte Presse agiert, grundlegend. Durch Übernahmen und Fusionen kommt es zu einem ökonomischen Konzentrationsprozess, der dazu führt, dass zahlreiche Einzelunternehmen von Konzernen geschluckt werden. Diese Tendenz hat schon kurz vor dem Ersten Weltkrieg begonnen und setzt sich in den 1920er Jahren verstärkt fort. Während der Inflationszeit kommt eine Reihe von Betrieben in wirtschaftliche Schwierigkeiten, einige von ihnen werden daraufhin in größere Unternehmen eingegliedert, andere liquidiert. Nicht nur innerhalb Österreichs ist dieser Konzentrationsprozess zu beobachten. Das Verlagsgeschäft internationalisiert sich zunehmend. Sichtbares Zeichen dafür ist zum Beispiel die Österreich-Präsenz, die der Berliner Ullstein-Konzern, 1929 Europas größter Medienkonzern, in den 1920er Jahren aufbaut. Ullstein steigt zwischen 1924 und 1926 beim krisengeschüttelten österreichischen Druckhaus Waldheim-Eberle ein und sichert sich die Aktienmehrheit. ${ }^{2}$ Das deutsche Verlagshaus verfügt für seine Zeitungen und Zeitschriften außerdem über einen eigenen Österreich-Vertrieb.

Im Bereich der großen illustrierten Wochenzeitungen gibt es - zumindest in den 1920er Jahren - nur wenig Konkurrenz. Die beiden Marktführer, Das interessante Blatt und die Wiener Bilder, erscheinen wie vor dem Krieg im gleichen Verlag. Die Folge ist, dass beide Zeitungen lange Zeit einen defensiv-be-
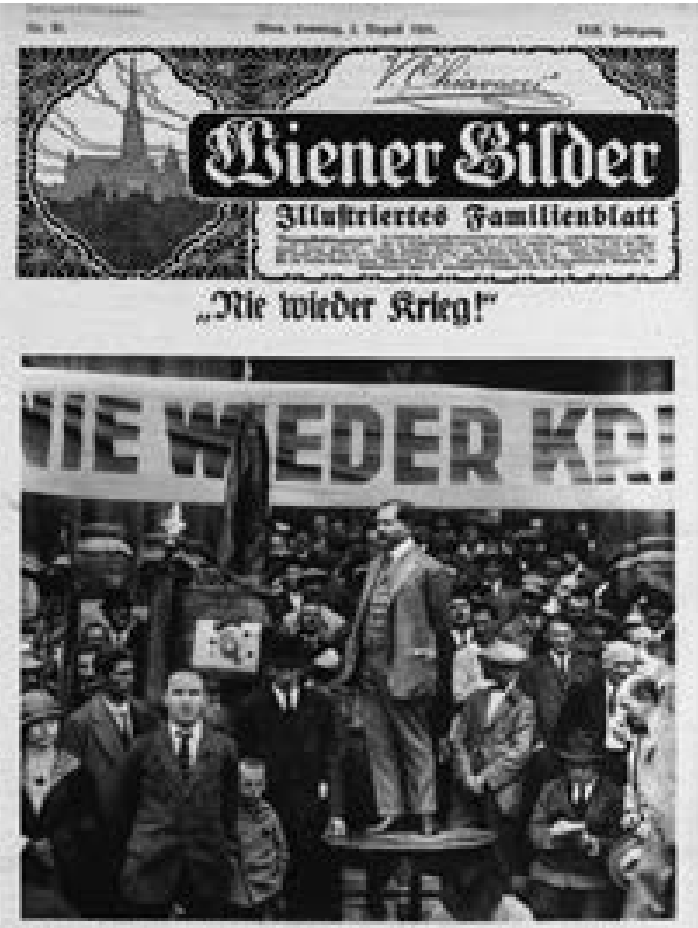

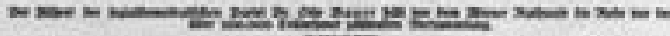

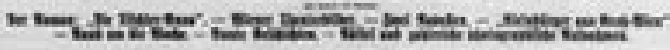


wahrenden Kurs einschlagen. Ihre Auflagen steigen nur leicht an. Ab Ende der 20er Jahre sind die Anzeigenerlöse aufgrund der Wirtschaftskrise rückläufig. Der schrumpfende Anzeigenmarkt führt zu einer latenten Unterkapitalisierung der Presse. Entsprechend schwierig ist es für die meisten Zeitungen, mit aufwendigen technischen und grafischen Neuerungen Schritt zu halten. Im Vergleich zur deutschen und vor allem zur Berliner Bildpresse, die in den 1920er Jahren aufgrund steigender Auflagen und Anzeigenerlöse enorm innovativ ist, fällt die österreichische Bildpresse deutlich zurück.

Erst um 1930, als durch Neugründungen visuell fortschrittlicher Zeitschriften der Druck der Konkurrenz deutlich größer wird, beginnen sich die beiden führenden österreichischen Blätter langsam zu modernisieren. Um zwei Beispiele für Neugründungen dieser Jahre zu nennen: 1929 wird der den Christlichsozialen nahestehende Welt-Guck gegründet, im selben Jahr erscheint zum ersten Mal der sozialdemokratische Kuckuck. Beide orientieren sich, was Aufmachung und Gestaltung betrifft, an deutschen Vorbildern und sind deutlich experimentierfreudiger als die alteingesessenen Blätter. Der Aufschwung der Partei- und parteinahen Presse um 1930 hat spürbare Auswirkungen auf die gesamte illustrierte Zeitungslandschaft.

Diese ist noch weiteren Herausforderungen ausgesetzt. Ende der 1920er Jahre nimmt die Konkurrenz durch die täglich erscheinenden Boulevardblätter $\mathrm{zu}$, die zunehmend Illustrationen und Fotos einsetzen. ${ }^{3}$ Zudem drängt die deutsche illustrierte Presse ab Mitte der 1920er Jahre verstärkt auf den österreichischen Zeitungsmarkt. Ebenfalls Ende der 1920er Jahre tauchen neue Zeitschriftenformate auf, die der herkömmlichen illustrierten Presse innovative Impulse verleihen, zugleich aber auch Konkurrenzunternehmen sind: Gesellschaftsmagazine, die ganz auf die Kraft der Fotografie setzen.

Insgesamt wird das Pressegeschäft in der Zwischenkriegszeit verglichen mit der Vorkriegszeit instabiler und unsicherer. Davon ist auch die illustrierte Presse betroffen. Neugründungen, Verkäufe, Fusionen und Liquidierungen sind an der Tagesordnung. Der wirtschaftliche Schleuderkurs schlägt sich auch auf die inhaltliche Ausrichtung der einzelnen Blätter nieder. Daher ist ein Blick hinter die Kulissen einzelner Zeitungen unabdingbar, auch um abrupte Kurswechsel verstehen und einordnen zu können. Wenn im Folgenden die Entwicklung der illustrierten Presse in der Zwischenkriegszeit dargestellt wird, geht es nicht allein um die Beschreibung und Einordnung einzelner Zeitschriften. Ziel ist es vielmehr, beispielhaft das komplexe Verhältnis zwischen Ökonomie, Politik und Ästhetik nachzuzeichnen. Vorgestellt werden dabei nicht nur die großen, marktbeherrschenden Zeitungen, sondern auch kleinere Blätter und Magazine, von denen oft maßgebliche Impulse für einen innovativen Umgang mit Bildern ausgehen.

\section{Die Zeit der Konzerne}

In den wirtschaftlich turbulenten Jahren nach dem Ersten Weltkrieg sinkt der Einfluss der klassischen Verlegerpersönlichkeiten auf das Schicksal einzelner Zeitungen. Stattdessen übernehmen Konzerne, also Firmengeflechte bestehend aus mehreren Druckereien und Verlagen, die oft in starker Abhängigkeit von Großbanken stehen, das Ruder. Vor allem während der Inflationsjahre in den frühen 1920er Jahren schlittert eine Reihe von Familienunternehmen in die Krise. Die Folge sind Notverkäufe und häufige Eigentümerwechsel. Eines dieser unternehmerischen Nachkriegsschicksale erleidet Österreichs Illustrierte Zeitung, die seit November 1918 unter einem neuen Namen erscheint. Sie heißt nun Wiener Illustrierte Zeitung (Abb. 3). Die den Christlichsozialen nahestehende Wochenzeitung, die vor dem Krieg größenmäßig stets im Schatten des Interessanten Blattes und der Wiener Bilder steht, aber bis etwa 1920 dennoch eine gewisse Bedeutung hat, überlebt die ökonomischen Turbulenzen der frühen 1920er Jahre nur mit Not. Ihr billigeres Schwesterblatt, die populär aufgemachte Illustrierte Das Neueste im Bilde, wird Ende 1919 eingestellt. ${ }^{4}$ Die Wiener Illustrierte Zeitung wird mehrmals verkauft und ändert immer wieder Titel, Aufmachung und Inhalte.

Die Umbenennung von Österreichs Illustrierter Zeitung in Wiener Illustrierte Zeitung erfolgt, so heißt es in der Begründung Ende 1918, „mit Rücksicht auf 


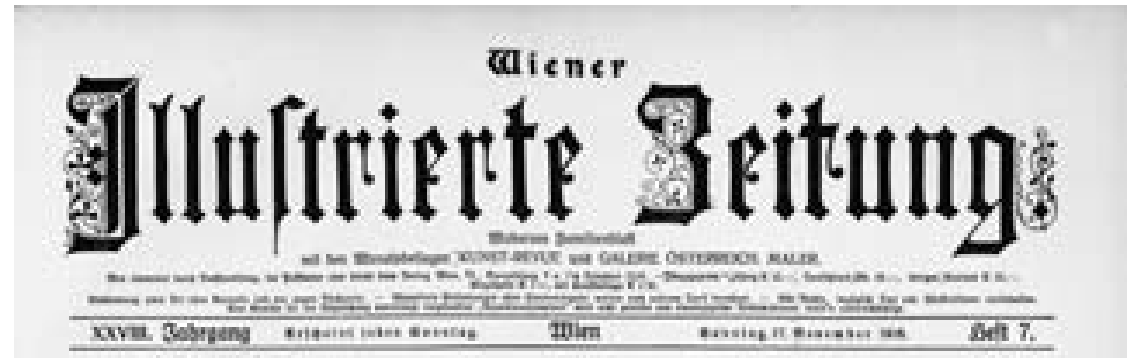

Abb. 3 Im November 1918 wird die den Christlichsozialen nahestehende Wochenzeitung Österreichs Illustrierte Zeitung in Wiener Illustrierte Zeitung umbenannt. Wiener Illustrierte Zeitung, 17. November 1918, Zeitungskopf.
Steyrermühl, das 1928 Rang 24 unter den bedeutendsten österreichischen Aktiengesellschaften einnimmt. ${ }^{11}$ Der 1872 gegründete Konzern mit Sitz am Wiener Fleischmarkt 3-5 verfügt über mehrere Papierfabriken, Druckereien sowie Buch- und Zeitungsverlage. Eine Reihe auflagenstarker Tageszeitungen (darunter das traditionsreiche Neue Wiener Tageblatt) gehört zu Steyrermühl, allerdings besitzt das Unternehmen keine namhaften illustrierten Zeitungen. ${ }^{12}$ Der Konzern steht in den 1920er Jahren unter dem Einfluss der von Rudolf Sieghart geleiteten Bodencreditanstalt, welche wiederum den Christlichsozialen und der Heimwehr nahesteht.

Der zweitgrößte österreichische Medienkonzern, die Vernay $A G^{13}$, liegt größenmäßig deutlich hinter Steyrermühl. ${ }^{14}$ Das Unternehmen wurde 1877 von Johann Nepomuk Vernay als Druckereibetrieb gegründet. 1913 entsteht daraus, unter Beteiligung mehrerer Aktionäre ${ }^{15}$ und der Anglo-Österreichischen Bank, die Vernay Aktiengesellschaft, die ihre Geschäftsfelder sukzessive ausweitet und in der Zwischenkriegszeit zu einem großen Druck- und Zeitungsunternehmen aufsteigt. Ab 1925 kontrolliert eine tschechische Eigentümergruppe (Orbis Verlag), in der das Prager Außenministerium maßgeblich mitmischt, den Konzern. In ihrem Auftrag wird Emil Oplatka Direktor der Vernay. Er ist es, der in den späten 1920er und 1930er Jahren die Geschicke des Wiener Medienkonzerns leitet. Im 1912 erbauten Verlagshaus in der Canisiusgasse 8-10, Wien 9, sind Mitte der 1930er Jahre rund 600 Mitarbeiter beschäftigt. Es beherbergt neben einem großen, modern ausgestatteten Druckereibetrieb eine Reihe von Zeitungsredaktionen. ${ }^{16}$ Mitte der 1920er Jahre übernimmt der Konzern durch Zukäufe und Aktienbeteiligungen zwei bisher unabhängige Unternehmen und dehnt so seine publizistische Reichweite schlagartig aus. 1925 erlangt die Vernay AG die Kontrolle über die Kronos AG (die Boulevardblätter wie Die Stunde, aber auch Magazine wie Die Bühne publiziert). 1926 übernimmt der Konzern auch die Tag AG, die u.a. die 1922 gegründete bürgerlich-demokratische, linksliberale Tageszeitung Der Tag - ab 1930 nennt sie sich Der Wiener Tag - herausbringt. Die beiden eingegliederten Unternehmen Tag AG und Kronos AG waren zuvor von den Speku- 
lanten Siegmund Bosel und Imre Békessy in den Ruin getrieben worden.

Die Vernay AG spielt für die Entwicklung der illustrierten Presse eine wichtige Rolle, da unter ihrem Dach zwei in der Bildgestaltung wegweisende Zeitungen bzw. Zeitschriften produziert werden, Der Sonntag (Abb. 4) und Die Bühne. Der Sonntag erscheint zwischen 1934 und 1938 als illustrierte Wochenendbeilage der Tageszeitung Der Wiener Tag. Sie ist ein Meilenstein in der österreichischen Bildpresse der Zwischenkriegszeit. ${ }^{17}$ Auch die 1924 gegründete Gesellschaftszeitschrift Die Bühne entwickelt sich allmählich zu einem wichtigen Forum für fortgeschrittene Bildberichterstattung. ${ }^{18}$ Unter dem Dach des Konzerns erscheinen aber auch weniger anspruchsvolle illustrierte Magazine wie Mein Film oder die Illustrierte Film- und Kinorundschau.

Größenmäßig deutlich hinter Steyrermühl und Vernay liegt eine Reihe weiterer Zeitungsverlage, von denen einige auch illustrierte Zeitschriften oder Beilagen herausbringen. ${ }^{19}$ Bedeutsam für die Ent-

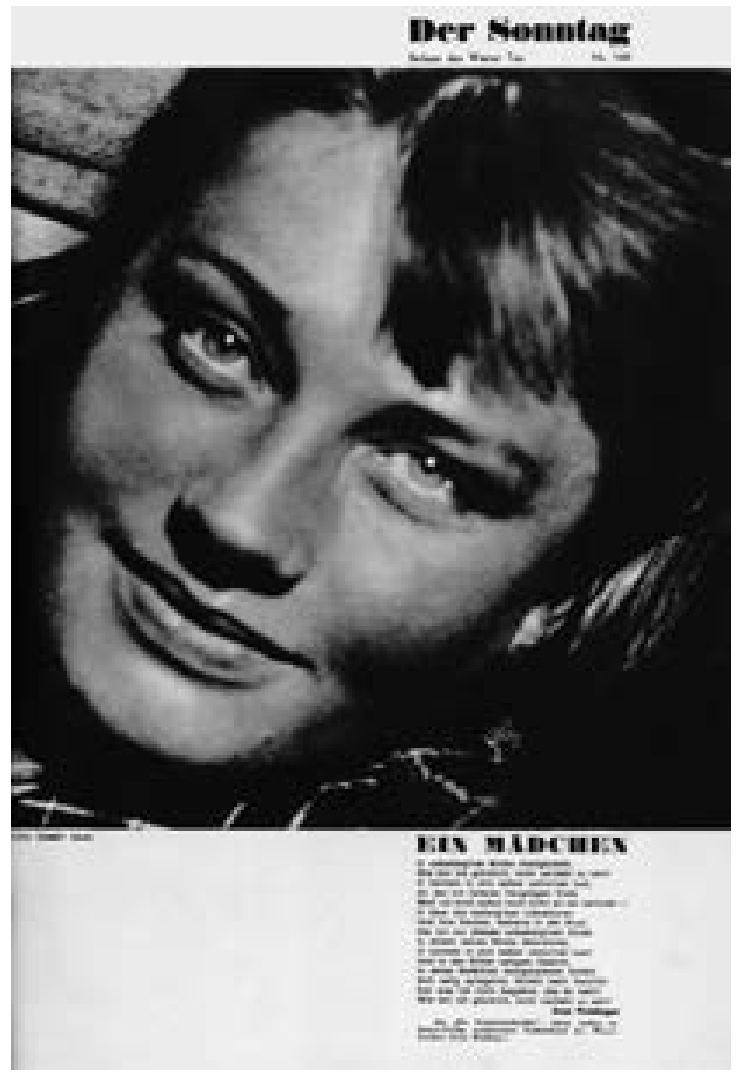

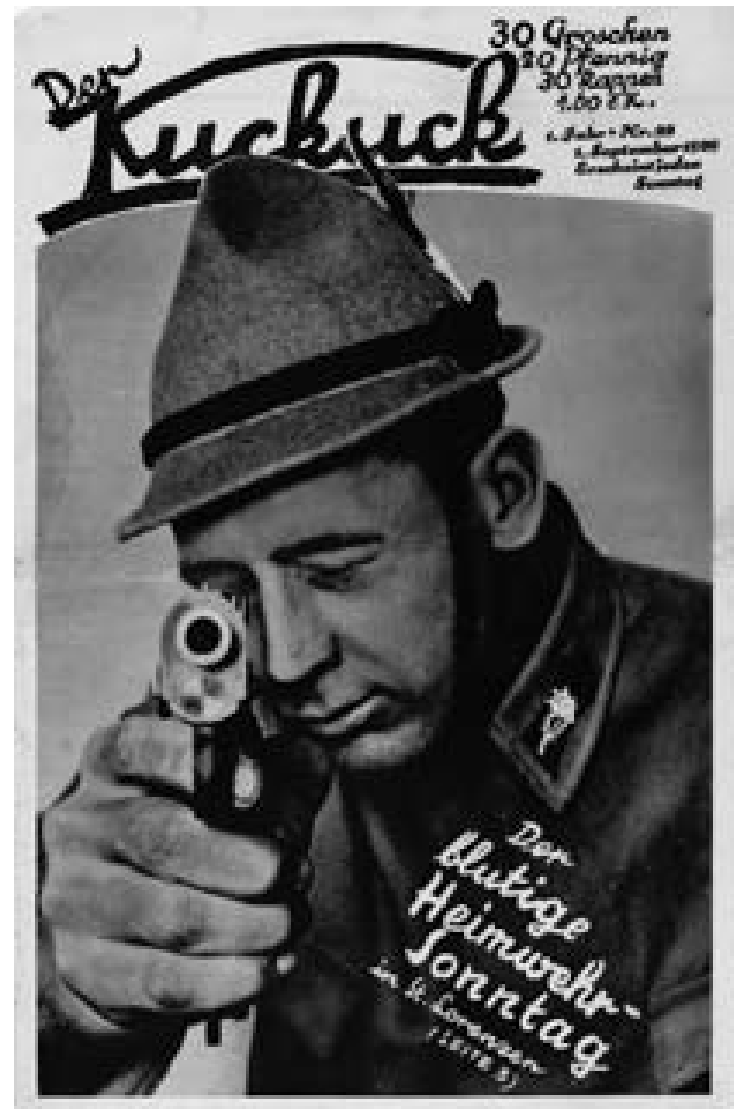

wicklung der illustrierten Presse ist der sozialdemokratische Vorwärts-Verlag (Rechte Wienzeile 97), in dem neben der Arbeiter-Zeitung und dem Kleinen Blatt auch die 1929 gegründete illustrierte Wochenzeitung Der Kuckuck (Abb.5), aber auch eine Reihe von populären Magazinen, etwa die Radiozeitschrift Der Rundfunk oder die Wochenillustrierte Bunte Woche, erscheinen. 1929 schafft der Verlag eine moderne Kupfertiefdruckmaschine an, um hochwertige Illustrierte im eigenen Haus herstellen zu können. Nach dem Verbot der sozialdemokratischen Zeitungen im Jahr 1934 wird der Vorwärts-Verlag samt Druckerei enteignet und unter Regierungskontrolle gestellt. Bestehende Zeitungen und Zeitschriften, wie etwa das Kleine Blatt oder der Arbeiter-Sonntag, die ehemalige Beilage der Arbeiter-Zeitung, werden unter neuen politischen Vorzeichen weitergeführt. Die Bunte Woche, eine populäre sozialdemokratische Wochenzeitung, wird modernisiert und zu einer regierungsnahen Illustrierten umgebaut. ${ }^{20}$ Aber auch illustrierte Zeit-
Abb. 51929 wird im sozialdemokratischen Vorwärts-Verlag die wöchentlich erscheinende Illustrierte Der Kuckuck gegründet. Sie erscheint bis 1934. Der Kuckuck, 1. September 1929, Titelseite.
Abb. 4 „Ein Mädchen“. Der Sonntag. Beilage des Wiener Tag, 5. Juni 1937, Titelseite. Foto: Robert Haas. 


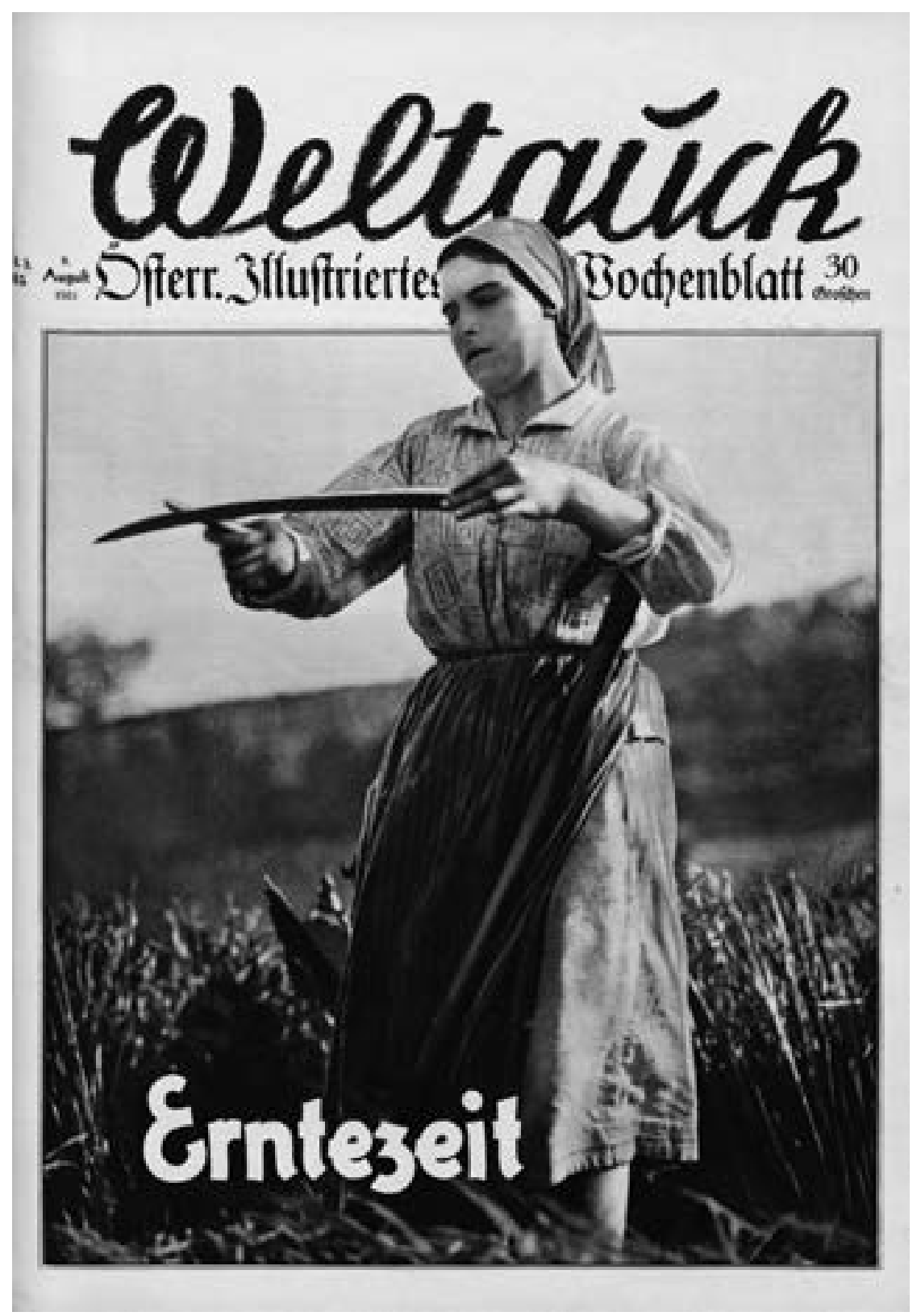

Abb. 6 Obwohl der sozialdemokratische Kuckuck und der 1929 im christlichsozialen Innsbrucker Tyrolia-Verlag gegründete Welt-Guck ideologisch entgegengesetzte Positionen vertreten, gehören beide Zeitungen zu den grafisch innovativsten Illustrierten der Zwischenkriegszeit. Welt-Guck, 9. August 1931, Titelseite. schriften anderer Verlage, etwa das illustrierte Wiener Magazin, werden nun beim Vorwärts-Verlag gedruckt. Überhaupt übernimmt nach 1933/34 der Staat eine wichtige lenkende Rolle in der Presselandschaft. Der verlängerte Arm der Regierung in Sachen Presse und Propaganda heißt Österreichischer Heimatdienst, der ab 1933 auch eine auflagenstarke illustrierte Wochenzeitschrift, die Österreichische Woche, herausbringt, die zahlreichen Blättern beigelegt wird.

Eine Art ideologisches Gegenstück zum Vorwärts-Verlag bildet (neben dem steirischen Styria-Verlag) das katholisch-konservative Verlagshaus Tyrolia mit Hauptsitz in Innsbruck (Andreas-Hofer-Straße 4). In der Zwischenkriegszeit wächst das der katholischen Kirche und den Christlichsozialen nahestehende Unternehmen zu einem mächtigen Medienkonzern mit über 400 Mitarbeitern heran. ${ }^{21}$ Neben dem Verlag gehören auch eine Druckerei und zahlreiche Buchhandlungen zum Tyrolia-Konzern, der Zweigstellen in München und Wien unterhält. Neben einer Reihe von Tages- und Wochenzeitungen bringt der Tyrolia-Verlag seit 1929 auch die illustrierte Wochenzeitung Welt-Guck (Abb. 6) heraus. Sie ist um 1930 neben dem Kuckuck die grafisch innovativste österreichische illustrierte Wochenzeitung.

Der dritte parteinahe Zeitungskonzern ist in den 1920er Jahren die Berglandpresse. Das den Deutschnationalen nahestehende Firmengeflecht, das aus dem traditionsreichen Innsbrucker Universitätsverlag Wagner hervorgeht, besteht aus Buchhandlungen, Druckereien und Verlagen. ${ }^{22}$ Seit 1921 sind einzelne Teile der Firmengruppe zwar in getrenntem Besitz, aber familiär und ökonomisch sind sie weiterhin eng verflochten. Die Berglandpresse, die 1928 an die 650 Mitarbeiter beschäftigt, kontrolliert eine Reihe von regionalen österreichischen Tages- und Wochenzeitungen, die dem deutschnationalen Lager zuzurechnen sind. Dazu gehören u. a. die Innsbrucker Nachrichten, die Neueste Zeitung, das Salzburger Volksblatt, das Grazer Tagblatt, die Oberösterreichische Tageszeitung und Der freie Burgenländer. Auch eine illustrierte Monatszeitung bringt die Berglandpresse heraus. Das Bergland, das seit 1921 unter diesem Titel erscheint, ${ }^{23}$ verfolgt inhaltlich einen konservativen Kurs und ist grafisch wenig innovativ. Dennoch erlangt die Zeitschrift eine gewisse Bedeutung. Immerhin ist sie in den 1920er Jahren mit ihrer Auflage von 52000 bis 55000 Exemplaren die größte österreichische Monatsschrift. ${ }^{24}$ Sie wird als Beilage zahlreicher Tageszeitungen des Bergland-Konzerns aber auch als eigenständige Zeitschrift vertrieben.

\section{Rüdengasse 11 - Ein Zentrum der Bildpresse}

Der Zeitungskonzern, der die beiden führenden österreichischen illustrierten Wochenzeitungen, Das interessante Blatt und die Wiener Bilder, verlegt, gehört zwar nicht zu den größten Medienunternehmen des Landes. Im Bereich der Bildpresse aber spielt er in der Zwischenkriegszeit eine hegemoniale Rolle. Das interessante Blatt und die Wiener Bilder dominieren in 
ihrem Segment den Markt. Es gibt zwar in den 1920er Jahren eine Reihe von Tageszeitungen, die - oft eher kurzlebige - illustrierte Wochenendbeilagen drucken, aber die Qualität ihrer Bildberichterstattung bleibt bescheiden. ${ }^{25}$ Eine ernsthafte Konkurrenz für die etablierten illustrierten Wochenzeitungen sind sie nicht. Lediglich die Beilage Bühne, Welt und Mode, die zwischen 1925 und 1932 zusammen mit den Wiener Neuesten Nachrichten erscheint, erlangt trotz schlechter Druckqualität und einfacher Gestaltung eine gewisse Reputation.

Das Verlagshaus in der Rüdengasse 11 beherbergt nicht nur die Druckerei und die Redaktionen des Interessanten Blattes und der Wiener Bilder. Im selben Verlag erscheinen auch Gesellschafts- und Fachmagazine wie die Radio-Welt, die Illustrierte Radiozeitung oder das Illustrierte Sportblatt. In den 1920er Jahre gelingt es dem Konzern, das Spektrum der verlegten illustrierten Zeitschriften ständig zu erweitern. Die meisten illustrierten Zeitungen des Verlags werden im modernen Kupfertiefdruck hergestellt, einer Drucktechnik, die in der zweiten Hälfte der 1920er Jahre im Bilderdruck allmählich zum Standard wird. ${ }^{26}$

Die Verlagsleitung gibt sich nach außen politisch unabhängig, in Wirklichkeit aber sucht sie stets die Nähe zur christlichsozialen Regierung und unterstützt diese recht offen, vor allem als sich die Auseinandersetzung mit der Sozialdemokratie Anfang der 1930er Jahre zuspitzt. ${ }^{27}$ Nach 1934 wird die Kooperation mit der Regierung noch enger, regierungseigene Blätter, etwa die extrem auflagenstarke Propagandaillustrierte Österreichische Woche wird in der Druckerei in der Rüdengasse gedruckt. Die Illustrierte wird auf Geheiß des Österreichischen Heimatdienstes, der Propagandaeinrichtung der diktatorischen Regierung, zahlreichen konservativen Tageszeitungen beigelegt.

Die unmittelbare Nachkriegszeit beginnt für den Verlag turbulent. 1919 geht die Österreichische Zeitungs- und Druckerei-Aktiengesellschaft, also jenes Unternehmen, das für Das interessante Blatt und die Wiener Bilder verantwortlich zeichnet, an die Gesellschaft für Graphische Industrie über. Hinter diesem Unternehmen steht der Unternehmer Richard Kola, der 1912 in das Verlagsgeschäft eingestiegen ist. Be- reits während des Krieges beginnt er mit der Herausgabe von Zeitungen und Zeitschriften, etwa der Wochenillustrierten Wiener Illustrierte Zeitung (Ende 1914 bis Ende 1916) oder der Modezeitschriften Die Herrenwelt (ab 1916) und Die Damenwelt (ab März 1917). Beide werden 1917 eingestellt. ${ }^{28}$ Nach Kriegsende steuert Kola einen aggressiven Expansions- und Übernahmekurs. Innerhalb weniger Jahre gelingt es ihm, durch waghalsige finanzielle Manöver ein umfangreiches Medienimperium aufzubauen. ${ }^{29}$ Er erwirbt Buch- und Zeitschriftenverlage, Druckereien und Papierfabriken. 1920 gründet er den Rikola-Konzern (Radetzkystraße 5, Wien 3), in dem er seine unternehmerischen Projekte bündelt. Bereits 1919 erwirbt er die Aktienmehrheit des großen, traditionsreichen, vom Bankhaus Schoeller \& Co. kontrollierten Druckerei- und Verlagsunternehmens Elbemühl und fusioniert dieses 1923 mit der von Sigmund Rosenbaum geführten Gesellschaft für Graphische Industrie. ${ }^{30}$ Für Das interessante Blatt und die Wiener Bilder, die nun Teil des Rikola-Konzerns sind, hat dieser rasante Konzentrationsprozess vor allem Unsicherheit zur Folge. Die Geschäfte werden unter den neuen Eigentümern zwar ohne große Brüche weiterbetrieben, aber notwendige Investitionen werden vertagt.

Bald kommt es erneut zum Eigentümerwechsel. Richard Kola verliert seine Spekulationsgewinne während der Inflationszeit ebenso schnell wie er sie gewonnen hat. 1925 muss er den Konzern verkaufen, ein Jahr später bricht, bedingt durch einen Bankenkrach, das Unternehmen Rikola endgültig zusammen, die Einzelunternehmen werden in der Folge verkauft. ${ }^{31} 1927$ übernimmt die Kommanditgesellschaft Fleischer \& Co. den Verlagssitz in der Rüdengasse 11 und damit auch Das interessante Blatt, die Wiener Bilder und die anderen kleineren Zeitschriften des Verlags, zuerst für einige Monate in Pacht, dann wird ein Kaufvertrag abgeschlossen. ${ }^{32}$ Nach und nach stabilisiert sich die ökonomische Situation der beiden Zeitungen wieder. Um 1930 liegt die Auflage des Interessanten Blattes bei 46000 bis 48000 gedruckten Exemplaren, jene der Wiener Bilder bei 32000 bis 33000 Exemplaren. Die Verbreitung der beiden Blätter erreicht damit für die Zwischenkriegszeit einen Höchststand. ${ }^{33}$ 
Der Redaktionsstab der beiden Zeitungen ist klein. Das interessante Blatt beispielsweise verfügt über lediglich vier fest angestellte Redakteure. Einer von ihnen ist der Chefredakteur Josef Papanek $(1867-1944)^{34}$, der das Blatt zwischen 1907 und 1937 leitet. ${ }^{35}$ Auch seine Tochter Rose-Marie (Mizzi) Papanek ist in der Zwischenkriegszeit Redakteurin der Zeitung. Organisatorische Aufgaben liegen in der Hand einer Sekretärin, andere Tätigkeiten werden Pauschalisten übertragen. ${ }^{36}$ Die Fotografen, die für das Blatt arbeiten, sind nicht fest angestellt, sondern arbeiten freiberuflich.

Umbruch und Gestaltung werden von den Redakteuren selbst erledigt, eigens ausgebildete Fotoredakteure gibt es nicht. Entsprechend einfach sind daher, zumindest noch in den 1920er Jahren, viele der grafischen Lösungen. Das Grundmuster einer Zeitungsseite bildet ein dreispaltiges Textraster. In dieses werden - oft recht einfallslos - die Bilder eingepasst. Erst Ende der 1920er Jahre beginnt sich dieses Schema allmählich aufzulösen. Der Text wird zurückgedrängt, nun gibt es öfter optisch ansprechende, dynamischer gestaltete Bildseiten. Vermehrt werden nun auch thematische Bildstrecken und Fotoreportagen gedruckt. ${ }^{37}$

\section{Ein frischer Wind in der illustrierten Presse}

Am 6. April 1929 erscheint die erste Ausgabe der sozialdemokratischen illustrierten Wochenzeitung Der Kuckuck im parteieigenen Vorwärts-Verlag. Am 2. Oktober desselben Jahres startet der katholisch-konservative Innsbrucker Tyrolia-Verlag mit der ersten Nummer des Welt-Guck. Im Untertitel nennt sich die Zeitung ab Februar 1930 Österreichs illustriertes Wochenblatt. Diese beiden Illustrierten bilden das publizistische Sprachrohr der sich Ende der 1920er Jahre immer unversöhnlicher gegenüberstehenden politischen Blöcke, der Sozialdemokraten und der Christlichsozialen. Im Unterschied zu den beiden etablierten Illustrierten Das interessante Blatt und Wiener Bilder, die sich - zumindest nach außen hin - von der Parteipolitik eher fernhalten, greifen die beiden neuen Blätter ganz offen in die politische Auseinandersetzung ein. In vielen Fällen nehmen sie geradezu spiegelbildliche Positionen ein.
Wichtig sind die beiden Blätter, weil sie um 1930 einen neuen Stil in die österreichische Pressefotografie bringen. Sie sind die ersten grafisch anspruchsvoll gestalteten Wochenillustrierten, die ganz auf die Kraft der Bilderzählung setzen. Bereits in der Gestaltung der Titelblätter (Abb. 7, 8) heben sie sich deutlich von den schwerfälligen und weit konservativer gestalteten Marktführern Das interessante Blatt und Wiener Bilder ab. An die Stelle von deren grafisch überladenen Titelblättern treten nun einfache Botschaften: das große, ausdrucksstarke Titelfoto und handgezeichnete, schwungvolle Titel. Sowohl der Kuckuck als auch der Welt-Guck erleben eine kurze Blütezeit in den Jahren um 1930. Anfang der 1930er Jahre sind die beiden Experimente schon wieder zu Ende - aus ganz unterschiedlichen Gründen. Anfang November 1932 verabschiedet sich der Welt-Guck als moderne Bildillustrierte und wird - ohne Angabe von Gründen - in eine konventionelle Wochenzeitung mit Bildern umgewandelt, die bis März 1938 erscheint. ${ }^{38}$ Im Februar 1934 wird der Kuckuck von der austrofaschistischen Diktatur verboten.

Während die Rolle des Kuckuck in der österreichischen Pressefotografie gut erforscht ist, ist der WeltGuck bisher kaum als innovatives Medium gewürdigt worden. ${ }^{39}$ Beide Zeitungen distanzieren sich von Anfang an bewusst von der herkömmlichen Bildpresse und greifen die Neuerungen im Fotojournalismus freudig auf. Ihre Vorbilder stammen zweifellos aus der deutschen Publizistik. Während der Kuckuck sichtlich auf die gestalterischen (wenn auch nicht die politischen) Anregungen der KP-nahen Wochenzeitung Arbeiter-Illustrierte Zeitung (AIZ) zurückgreift, orientiert sich der Welt-Guck an avancierten bürgerlichen Blättern, wie etwa der Münchner Illustrierten Presse, der Kölnischen Illustrierten Zeitung, der Hamburger Illustrierten, insbesondere aber an dem in Frankfurt erscheinenden Illustrierten Blatt, von dem es auch einen bekannten deutschen Fotojournalisten, Paul Edmund Hahn, „entlehnt“. Hahn veröffentlicht, das war bisher nicht bekannt, zahlreiche Fotoreportagen im Welt-Guck. ${ }^{40}$

Warum entstehen 1929 fast zeitgleich zwei parteinahe Illustrierte, die einen neuen Stil in die illustrierte österreichische Publizistik bringen? Beide 

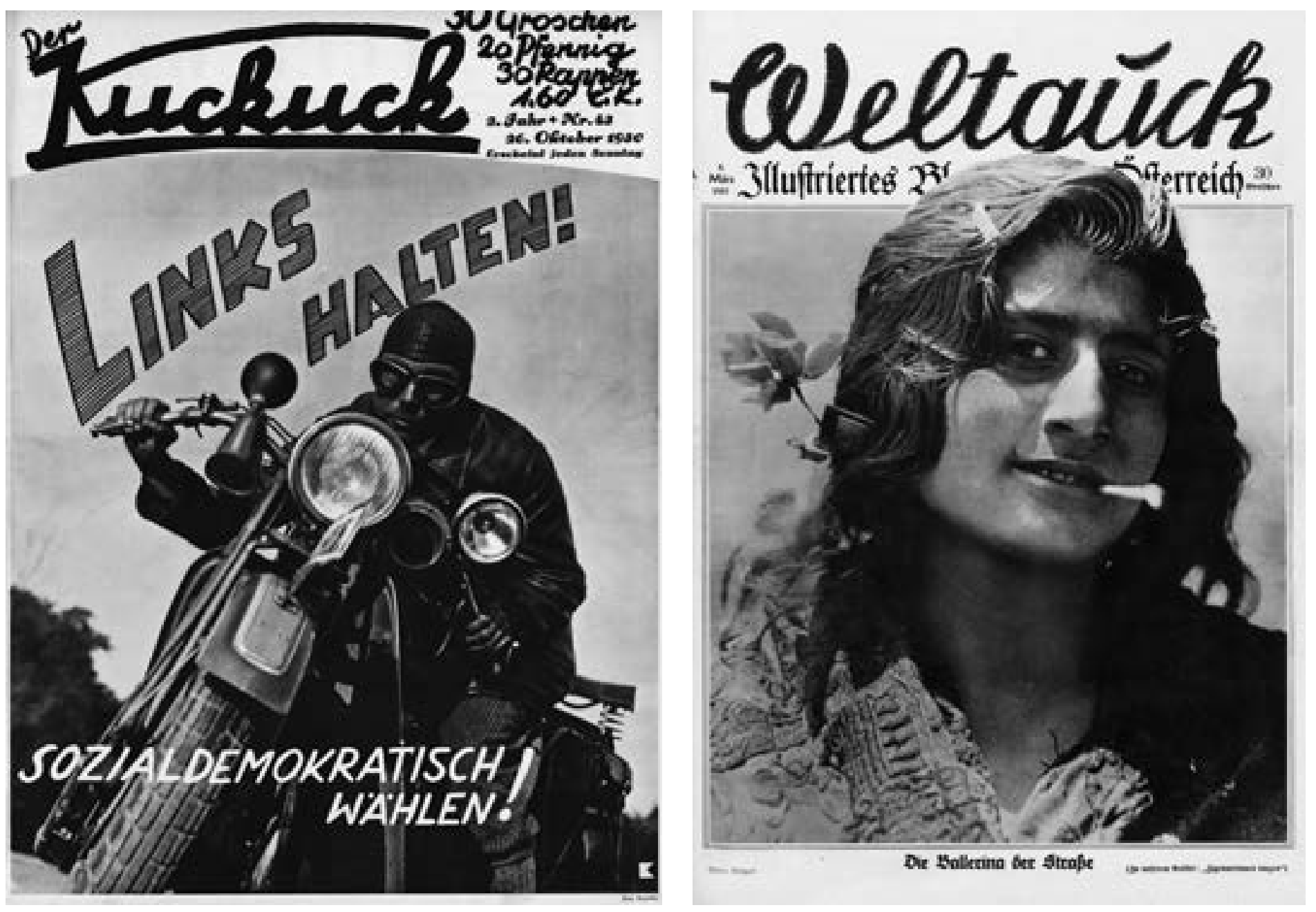

Zeitungsprojekte werden in einer Phase enormer politischer Mobilisierung von links und rechts gegründet, in der beide politischen Lager mit allen Mitteln versuchen, die ideologische Oberhoheit zu erlangen bzw. zu verteidigen. Die illustrierte Presse gilt in den Jahren um 1930 als avanciertes Medieninstrument, um in diesem Kampf die breite Masse der Bevölkerung zu erreichen. Ein Blick nach Deutschland zeigt, dass ab Mitte der 1920er Jahre die Auflagenkurven der illustrierten Zeitungen steil nach oben zeigen. ${ }^{41}$ Diesen Rückenwind machen sich die beiden Neugründungen zunutze. Aber es gibt noch weitere Gründe, die für einen Neubeginn in der illustrierten Presse sprechen. Die turbulenten Jahre der Inflation und der Wirtschaftskrise sind überwunden, der Staat hat sich konsolidiert, die Bevölkerung blickt ab Mitte der 1920er Jahre für kurze Zeit recht optimistisch in die Zukunft.
Der sozialdemokratische Kuckuck

Als der Kuckuck Anfang 1929 gegründet wird, reagiert er wohl auch auf den Versuch der kommunistischen Arbeiter-Illustrierten Zeitung (AIZ), stärker in Österreich Fuß zu fassen. Ein Jahr zuvor, am 21. März 1928, erscheint nämlich erstmals eine vierseitige Österreich-Beilage in der AIZ. ${ }^{42}$ Die zunächst von Leopold Maresch und später von Eduard Kalischer redigierte Beilage ist, anders als der Rest des Blattes, nicht im Kupfertiefdruck hergestellt und grafisch recht einfach gestaltet. Zwar findet die AIZ in Österreich keine allzu große Verbreitung, dennoch wird der große Erfolg der Zeitung in Deutschland auch in Österreich wahrgenommen. ${ }^{43}$ Der sozialdemokratische Medienstratege Julius Braunthal, der hinter der Gründung des Kuckuck steht, sieht das populär gemachte Bildermagazin in
Abb. 7,8 Moderne Titelblattgestaltung: Der Kuckuck, 26. Oktober1930 (Foto: Kraetke), und Welt-Guck, 8. März 1931, Titelseiten. 


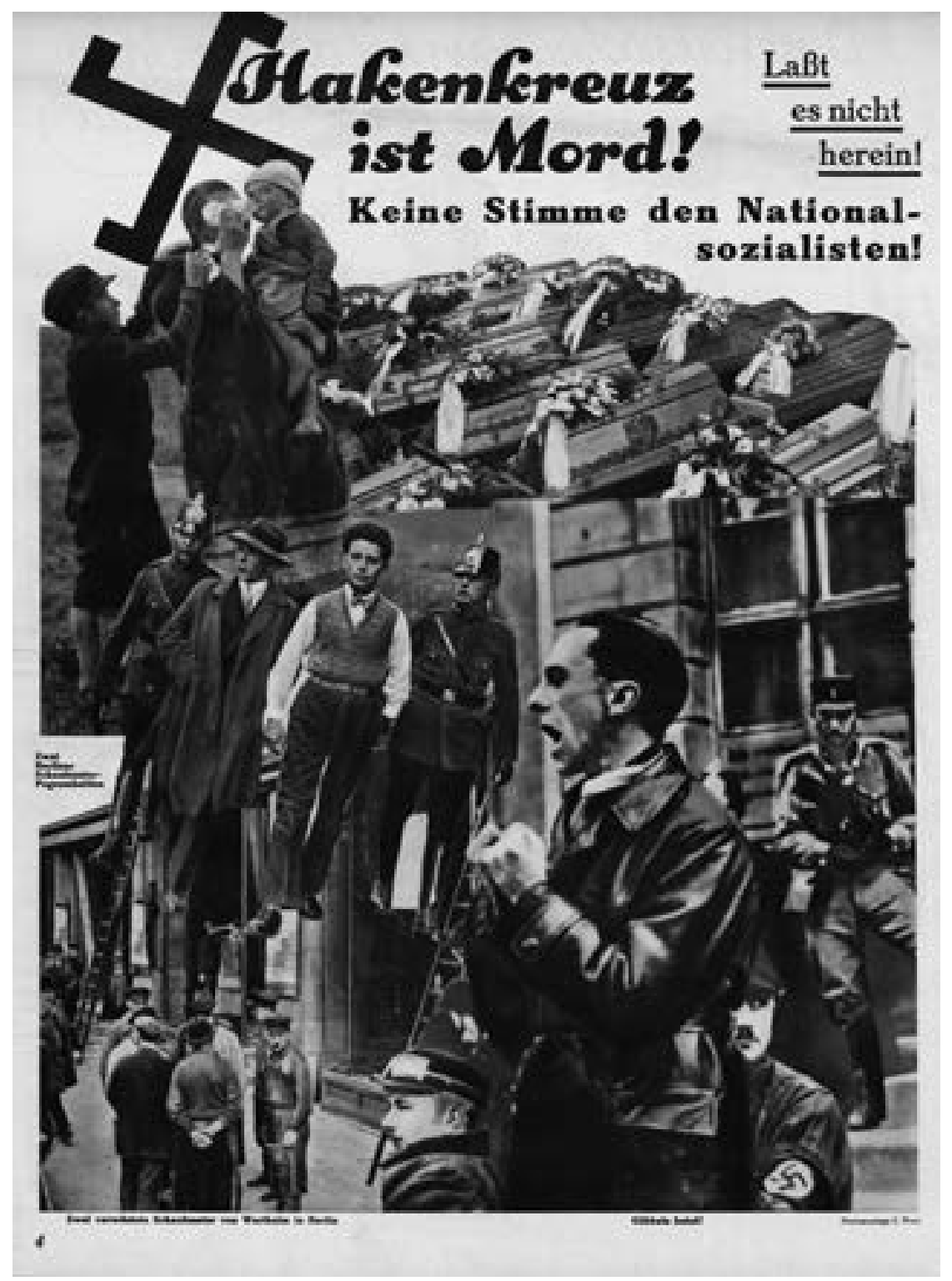

Abb. 9 „Hakenkreuz ist Mord! Keine Stimme den Nationalsozialisten!“ Politische Montage von Siegfried Weyr vor der letzten Nationalratswahl der Ersten Republik am 9. November 1930. Der Kuckuck, 26. Oktober 1930, S. 4. erster Linie als ein hauptsächlich gegen rechts gerichtetes Instrument. ${ }^{44}$ Aber ein wenig dient das Blatt wohl auch dazu, die Hegemonie der Sozialdemokratie innerhalb der Linken abzusichern und die linke publizistische Konkurrenz obsolet zu machen. Der große Anfangserfolg gibt ihm recht. Die stark beworbenen ersten Nummern erreichen eine Auflage von über 120000 Exemplaren, weit mehr, als die bürgerlichen Konkurrenzzeitungen zu dieser Zeit verkaufen. Dann geht die durchschnittliche Auflage zurück, Ende 1929 liegt sie bei 56 000, 1930 bei 44500, 1931 bei 33600 und 1932 bei $29000 .{ }^{45}$ Im Frühjahr 1929, wohl nicht zufällig kurz nachdem der Kuckuck die publizistische Bühne betreten hat, stellt die AIZ ihre Österreich-Beilage wieder ein. Ihre Wien-Redaktion aber erhält sie aufrecht. ${ }^{46}$ Gelegentlich werden nun Österreich-Berichte in die deutsche Ausgabe eingefügt.
Eines der Verdienste des Kuckuck ist es, die Montage als politisches Propagandamittel in die illustrierte österreichische Presse eingeführt zu haben. Zwar gibt es auch frühere Beispiele für Fotomontagen in der illustrierten Presse, teilweise reichen sie bis weit vor den Ersten Weltkrieg zurück, aber erst im Kuckuck wird daraus ein explizit politisch-ästhetisches Programm. ${ }^{47}$ Während im Innenteil die Seitengestaltung oft noch recht konventionell ist, heben sich die Bildseiten und vor allem die ausdrucksstarken Fotomontagen deutlich von der herkömmlichen österreichischen Bildpublizistik ab. Treibende Kraft hinter dieser grafischen Innovation ist der Chefredakteur Siegfried Weyr. Er ist 1890 in Galizien geboren und kommt als Jugendlicher nach Wien, wo er 1909 bis 1911 die k. k. Graphische Lehrund Versuchsanstalt besucht und anschließend eine Malerausbildung an der Akademie der bildenden Künste absolviert. Parallel dazu studiert er für einige Zeit auch Kunstgeschichte an der Universität Wien. Vor dem Ersten Weltkrieg beginnt er als Journalist zu arbeiten, u. a. für den Wiener Mittag. Seit 1924 arbeitet er zunächst als Redakteur und Bildredakteur bei Bettauers Wochenschrift, dann als Umbruchredakteur bei der juristischen Wochenzeitung Das Tribunal und ab 1927 für das sozialdemokratische Kleine Blatt. ${ }^{48}$

Weyr ist es, der im Auftrag Braunthals das Konzept des Kuckuck entwirft und seine grafische Linie zwischen 1929 und 1934 maßgeblich bestimmt. Zahlreiche Fotomontagen stammen aus seiner Hand (Abb.9), viele andere von Alexander Stern und Arthur Stadler, weiteren engen Mitarbeitern des Blattes. Weyr ist es aber auch, der zahlreiche moderne und innovative Fotografen an die Zeitung bindet. Er bietet nicht nur den sogenannten Arbeiterfotografen (etwa Hans Cechal, Willy Riethof, Friedrich Zvacek, Ferdinand Hodek) ${ }^{49}$ ein Forum, sondern veröffentlicht auch Arbeiten anderer bekannter österreichischer Fotografen, u. a. von Lothar Rübelt, Annie Schulz, Fred Cešanek, Edith Suschitzky, Leo Ernst, Albert Hilscher, Hans Popper, Martin Gerlach, Nikolaus Schwarz und Hans Casparius. Einen guten Teil des Bildmaterials bezieht der Kuckuck von Fotoagenturen. Neben den herkömmlichen Lieferanten wählt er auch gelegentlich Bilder der deutschen Fotoagentur Dephot (u.a. 
von Felix H. Man und Alfred Eisenstaedt) und der 1930 in Deutschland gegründeten kommunistischen Agentur Unionbild. ${ }^{50}$

Die Blütezeit des Kuckuck währt nur kurz. Bereits im März 1933 wird die Vorzensur eingeführt, ab Juni 1933 darf das Blatt in Zeitungsläden nicht mehr verkauft werden, als Vertriebsweg bleibt nur noch das Abonnement. In den folgenden Monaten beginnt ein verzweifelter Kampf der Sozialdemokraten gegen die autoritär regierenden Christlichsozialen. Als im Februar 1933 die deutsche Arbeiter-Illustrierte Zeitung verboten wird, ist der Kuckuck als professionell gemachte Arbeiter-Illustrierte allein auf weiter Flur - auch international gesehen. Am 23. April 1933 appelliert die Zeitung an ihre Leser: „In dieser Zeit spricht die Photographie, das Bild dessen, was ist, die lauteste Sprache. In unzähligen ,Illustrierten überschüttet der Hakenkreuzfaschismus die Welt mit Bildern von Parademärschen und Flaggenhissungen. Kein Bild von Not und Tod der arbeitenden Menschen kann erscheinen. Nur der ,Kuckuck', heute die einzige Arbeiter-Kupfertiefdruck-Illustrierte Europas, kämpft im unbestechlichen Lichtbild für Freiheit und Gerechtigkeit. Helft uns in diesem Kampf! Werbet neue Leser und Abonnenten! Schickt unser Blatt an Gesinnungsgenossen im Ausland! Verbreitet überall den ,Kuckuck'!“51 Als einzige österreichische Illustrierte berichtet der Kuckuck ausführlich über Bücherverbrennungen, den Boykott jüdischer Geschäfte und antisemitische Gewalt in Deutschland. Eine Zeit lang versucht der Kuckuck, deutsche Oppositionelle zu erreichen, indem er seinen Vertrieb in der Tschechoslowakei ausbaut. Ein knappes Jahr später, nach dem Verbot der Sozialdemokratie, ist allerdings auch der Kuckuck Geschichte. Mitte Februar 1934 erscheint die letzte Nummer der Zeitung.

\section{Der christlichsoziale Welt-Guck}

So wie der Kuckuck erscheint auch der Welt-Guck im großen Berliner Format, auch er ist im Kupfertiefdruck hergestellt. Anfangs erscheint die Zeitung 14-tägig, bald stellt sie auf ein wöchentliches Erscheinen um. Die Umschlaggestaltung der beiden Zeitungen gleicht einander. Während allerdings der Kuckuck bei der Titelblattgestaltung häufig auf eine Fotomontage zurückgreift, verwendet der WeltGuck in der Regel ein einzelnes Foto als Titelmotiv. Im Innenteil geht der Welt-Guck noch stärker als der Kuckuck in Richtung einer modern gestalteten Bilderzeitung. Regelmäßig bringt die Zeitung professionell zusammengestellte, ein- oder mehrseitige Fotoreportagen, im Kuckuck erscheinen dagegen viel seltener Reportagen. Die Textspalten lösen sich im WeltGuck stärker auf als im Kuckuck, die Bilderzählung ist - v. a. im Innenteil - dynamischer. Text und Bild
Abb. 10 Modernes Zeitungslayout am Beispiel des WeltGuck. Kennzeichnend für das Blatt ist das großformatige, ausdrucksstarke Titelfoto. WeltGuck, 27. Mai 1930, Titelseite.

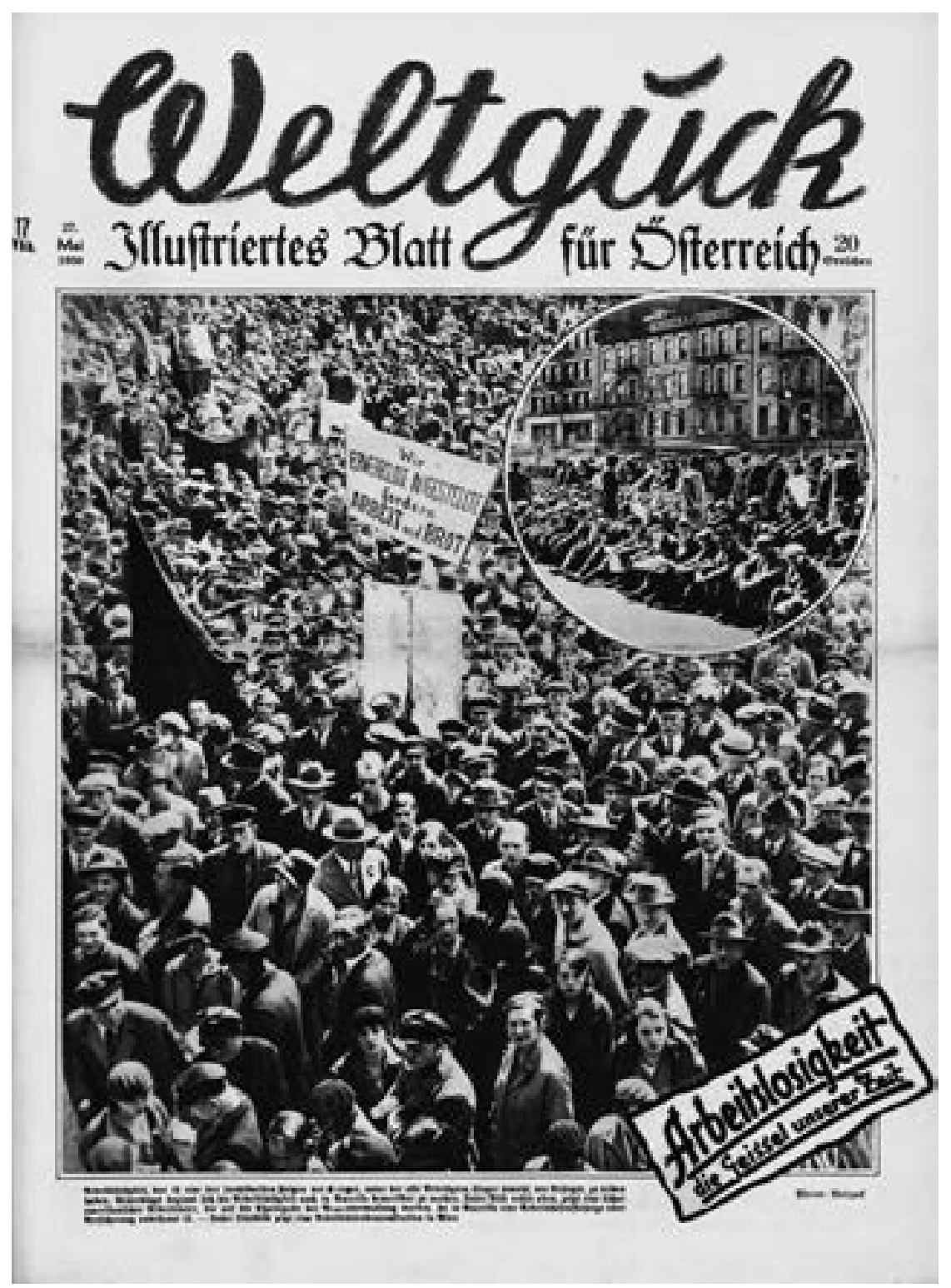




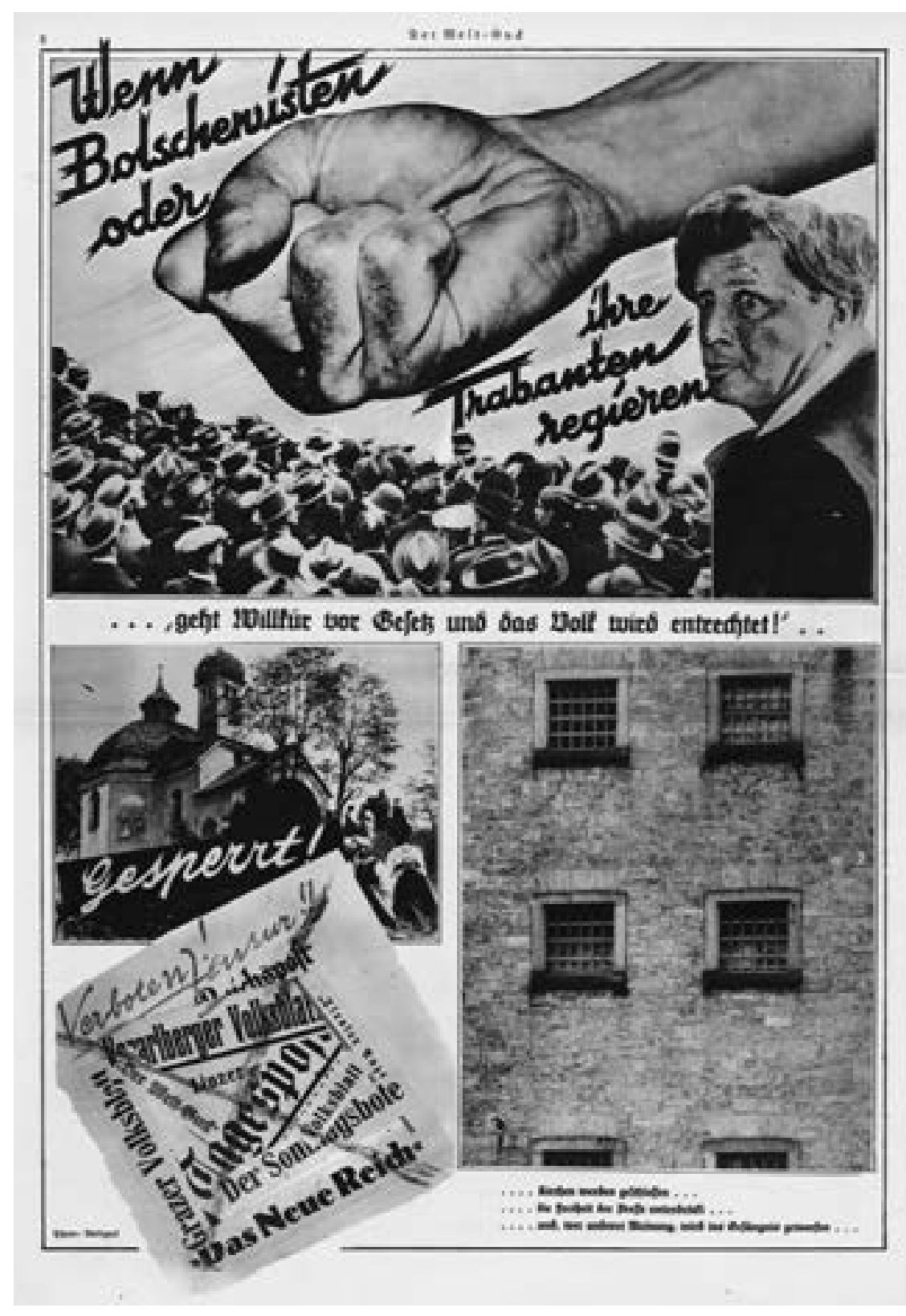

Abb. 11 Antikommunistische Propaganda 1929. Auch im konservativen Welt-Guck kommen gelegentlich politische Fotomontagen zum Einsatz. Welt-Guck, 17. November 1929, S. 2. werden auf subtile Weise miteinander verschränkt. Pressefotos werden auf vielfältige Weise bearbeitet, bevor sie ihren endgültigen Platz im Zeitungslayout bekommen. Sie werden je nach Bedarf beschnitten, vergrößert, verkleinert oder freigestellt. Oft werden signifikante Details isoliert, ein anderes Mal wie in einer Großaufnahme „herausgezoomt“ (Abb. 10). Nicht selten arbeitet die Bildredaktion des Welt-Guck mit dem Bildmaterial geradezu filmisch.

Interessant ist, dass auch der Welt-Guck gelegentlich politisch pointierte Fotomontagen einsetzt. Diese Tatsache rüttelt am weitverbreiteten Credo, dass die politische Fotomontage in der Zwischenkriegszeit in erster Linie von der politischen Linken genutzt worden sei. Am 17. November 1929, auf einem ersten Höhepunkt der politischen Grabenkämpfe zwi- schen links und rechts, erscheint im Welt-Guck beispielsweise eine ganzseitige Fotomontage, in der die kommunistische Gefahr und ihre angeblichen Folgen beschworen werden (Abb. 11). In der oberen Bildhälfte bedroht die geballte Arbeiterfaust die kleinen und mittleren Bürger. In der unteren Bildhälfte wird dargestellt, was passiert, „wenn Bolschewisten oder ihre Trabanten (damit sind die Sozialdemokraten gemeint, A.H.) regieren“. Es bricht, so signalisiert die plakative Montage, Willkür und Entrechtung herein, Kirchen werden geschlossen, christlichsoziale und konservative Zeitungen verboten und zensiert, Andersdenkende werden ins Gefängnis geworfen. Wer diese Montage zusammengestellt hat, ist nicht bekannt, als Urheber wird am Fuße lediglich „Weltguck“ genannt. Zwar bringt der Welt-Guck deutlich weniger Montagen als der Kuckuck, aber die absolute Ausnahme bilden sie nicht. Immer wieder werden in der innenpolitischen Berichterstattung die unversöhnlichen Positionen von links und rechts mithilfe von Schere und Klebstoff drastisch gegenübergestellt. Gelegentlich wird die Fotomontage aber auch in der Sensationsberichterstattung verwendet, um dramatisierende Effekte zu erreichen.

Der Welt-Guck ist eng mit der Tagespresse des Tyrolia-Konzerns verbunden. Als die illustrierte Zeitung im Oktober 1929 startet, wird sie - jeweils mittwochs ${ }^{52}$ - der wichtigsten Tageszeitung des Verlags, dem Tiroler Anzeiger, beigelegt. ${ }^{53}$ Diese „Starthilfe“ ist erfolgreich. Der Welt-Guck, der auch als eigenständige Zeitung vertrieben wird, erreicht 1932 mit einer Auflage von 60000 eine beachtliche Reichweite. ${ }^{54}$ Über das Innenleben des Welt-Guck ist bisher nur wenig bekannt. Als verantwortlicher Redakteur im Sinne des Presserechts ist bei der Gründung der Zeitung Sigmund Berchtold genannt. Er ist im Hauptberuf für den Inseratenteil des Tiroler Anzeigers, des Flaggschiffs der Tyrolia-Presse, zuständig. „Hauptschriftleiter“, so wird der Chefredakteur beim Welt-Guck genannt, ist bis 1934 P. A. Schmitz. Die weitere Zusammensetzung der Redaktion ist bisher nicht rekonstruiert worden. Daher wissen wir nicht, wer neben Schmitz als Redakteur tätig ist, wer die Bildredaktion innehat und wer für den professionellen Umbruch des Blattes verantwortlich ist. 
Der Welt-Guck ist - neben dem Bergland ${ }^{55}$ - die einzige namhafte österreichische Illustrierte, die ihren Verlagssitz im Westen des Landes (in Innsbruck) hat. Das schlägt sich auch im Vertriebsnetz, der Verbreitung und dem Themenspektrum der Zeitung nieder. Auch wenn der Welt-Guck sich im Untertitel als Illustriertes Blatt für Österreich bezeichnet, bedient er, im Unterschied zu den meisten anderen Illustrierten dieser Zeit, vor allem die Leserschaft im Westen Österreichs. Dasselbe gilt für die Themen der Fotoberichterstattung. Neben regionalen Ereignissen wie Unfällen, Katastrophen, Gerichtsfällen u. Ä. bringt der Welt-Guck auch zahlreiche Bildberichte zu ländlichen und alpinen Themen, etwa über die Milcherzeugung, Wintersportveranstaltungen, Leben, Brauchtum und Landschaft in den Bergen und vieles andere mehr. Ein guter Teil der Fotografen - viele von ihnen Amateure -, deren Bilder im Blatt veröffentlicht werden, leben in Tirol. Unter ihnen sind Karl Dornach, Richard Müller, Herbert Kogler, Paul Kraberger, Grieshaber und Otto Form. Andere, wie der 1911 in Bregenz geborene Marian Schwabik, der seit 1929 als freier Pressefotograf für deutsche und österreichische Blätter tätig ist, halten sich oft in Tirol auf und gestalten für den Welt-Guck Reportagen zu Alltagsthemen, Wintersport, Landschaften und Brauchtum. ${ }^{56}$ Dennoch ist der Welt-Guck keine Tiroler Illustrierte. Dafür sorgen zahlreiche Berichte und Reportagen, die aus dem Ausland, v. a. von deutschen Fotoagenturen (etwa Dephot, Mauritius, ABC, Atlantic, Sennecke u.a.) kommen, oft aber auch direkt von renommierten, international tätigen Fotografen zugekauft werden. ${ }^{57}$ Auch Wiener Pressefotografen publizieren regelmäßig im Welt-Guck, etwa Leo Ernst, Adalbert Hilscher, Heinrich Schuhmann jun., Steffi Schaffelhofer und vor allem Lothar Rübelt, der besonders oft mit Reportagen vertreten ist.

Der meistpublizierte Fotograf des Welt-Guck ist allerdings kein Österreicher, sondern Deutscher, er lebt in Frankfurt: Paul Edmund Hahn veröffentlicht seit 1930 in fast jeder Nummer meist einseitige Reportagen zu alltäglichen Themen. Geboren 1897 in Straßburg, studiert er nach dem Ersten Weltkrieg mehrere geisteswissenschaftliche Fächer, freilich ohne großen Erfolg. Er bricht seine Studien ab und wendet sich der
Fotografie zu. Ab Ende 1927 arbeitet er als Fotojournalist. ${ }^{58}$ Zunächst publiziert er im Frankfurter Illustrierten Blatt, dann arbeitet er auch für die Münchner Illustrierte Presse, die Frankfurter Illustrierte und die Kölnische Illustrierte Zeitung. Alle diese Zeitungen gehören um $1930 \mathrm{zu}$ den grafisch und fotografisch innovativsten Wochenzeitungen Deutschlands. Hahn, der von Anfang an mit der kleinformatigen Leica arbeitet, ist ein Meister der genauen Beobachtung. Er sammelt nicht Einzelbilder, sondern trägt thematische Bildserien zusammen, die sich am Redaktionstisch zu Geschichten anordnen lassen. Er gilt als einer der Pioniere der modernen Fotoreportage, die seit Ende der 1920er Jahre in den avancierten Bildmedien der Weimarer Republik immer häufiger veröffentlicht werden. Wie Hahn zum Welt-Guck kommt, ist nicht überliefert. Vermutlich ist die Redaktion auf seine frühen Bildberichte in Das illustrierte Blatt aufmerksam geworden. Diese in Frankfurt erscheinende Wochenzeitung spielt Ende der 1920er Jahre eine wichtige Rolle in der Modernisierung der Bildsprache. Sie ist auch wegweisend in der Entwicklung der Fotoreportage. ${ }^{59}$ Häufig sind Hahns Reportagen für den Welt-Guck Zweit- oder Drittverwertungen bereits in Deutschland erschienener Berichte. Mitte 1932 beendet Paul Edmund Hahn aus bisher nicht bekannten Gründen seine Tätigkeit als Fotojournalist. ${ }^{60}$ Auch im Welt-Guck erscheinen 1932 seine letzten Reportagen.

Am 5. November 1932 stellt der Welt-Guck seine Aufmachung radikal um. Die Redaktion merkt dazu an, dass das Blatt nun ein „neues und endgültiges Kleid“ gefunden habe. ${ }^{61}$ Die Zeitung verabschiedet sich vom Erscheinungsbild einer modernen Wochenillustrierten. Das Format wird verkleinert, der Textteil erhöht, der Bildteil enorm reduziert. Auch der Umschlag wird modifiziert. Er entwickelt sich in Richtung einer „neutraleren“ Kulturzeitung. Auf den Kupfertiefdruck der Bilder verzichtet man nun, stattdessen ziert den Umschlag ein farbiger Balken. Auch die inhaltliche Ausrichtung wird verändert. Man hält an der katholisch-konservativen Ausrichtung fest, reduziert aber deutlich die politische Berichterstattung. „Tages- und Parteipolitik interessiert uns in den Spalten des Weltguck nicht“, behauptet die Redaktion und verspricht, sich für die „Politik des gesunden 
Menschenverstandes“ einzusetzen. ${ }^{62}$ Das hindert sie freilich nicht, ab 1933/34 den Kurs der austrofaschistischen Diktatur vollinhaltlich zu unterstützen.

\section{Kurzlebige Experimente}

Der Kuckuck und der Welt-Guck sind die wichtigsten, aber nicht die einzigen Neugründungen illustrierter Zeitungen um 1930. Mehrere Verleger reagieren auf den Mitte der 1920er Jahre einsetzenden Boom der illustrierten Presse und versuchen neue Zeitungen auf dem Markt zu platzieren. Zwar geht der Großteil der Zeitungsneugründungen von Wien aus. Dennoch ist ein gewisser publizistischer Aufschwung auch in kleineren Städten zu spüren. 1936 wird etwa in Salzburg die Salzburger Illustrierte gegründet, die freilich ein kurzlebiges Experiment bleibt. Ein ähnliches Schicksal erleiden, aus ganz unterschiedlichen Gründen, auch andere neu gegründete Zeitungen und Zeitschriften.

Anfang Juni 1930 erscheint die erste Nummer der Wiener Illustrierten. ${ }^{63}$ Hinter dem Zeitungsprojekt stehen die Brüder Paul und Ernst Klebinder. Paul Klebinder fungiert als Herausgeber, Eigentümer und Verleger in einer Person, Ernst Klebinder ist Chefredakteur des Blattes. Die Redaktion ist in der Berggasse 31, Wien 9, untergebracht, gedruckt wird nicht weit entfernt, in der Zeitungsdruckerei der Vernay AG, in der Canisiusgasse 6-10. Es ist der Zeitung von Anfang an anzusehen, dass sie von keinem groBen Konzern hergestellt wird. Der Umfang ist mit 20 Seiten eher bescheiden, Aufmachung und Druck sind es ebenso. Auf Kupfertiefdruck wird zunächst verzichtet. Die Titelseite ist zwar halbwegs modern gestaltet, also mit großformatigem Foto und klarem, einfachen Schriftzug. Aber im Innenteil kommt die Wiener Illustrierte bei Weitem nicht an Blätter wie den Kuckuck oder den Welt-Guck heran. Das wirtschaftliche Konzept des Blattes geht nicht auf. Denn schon nach wenigen Monaten wird die Zeitung verkauft. Neuer Eigentümer ist die Astra-Verlags-Ges.m.b.H., gedruckt wird nun bei W. Hamburger, neuer Chefredakteur ist Karl Trebitsch, die Redaktion ist weiterhin in der Berggasse untergebracht. Kurzfristig wird auf Kupfertiefdruck umgestellt. Aber auch dieser Neuan- lauf verleiht der Zeitung keinen richtigen Schwung. Ende April 1931, weniger als ein Jahr nach der Gründung, wird die Wiener Illustrierte eingestellt.

Die Wochenzeitung Jedermann, die im Herbst 1932 auf den Markt kommt, hat zunächst bessere Karten als die Wiener Illustrierte. Hinter der Neugründung verbirgt sich als Eigentümer und Verleger die L. Goldschmidt \& Co. Kommanditgesellschaft. Die Redaktion ist, ebenso wie der Verlagssitz, in der Elisabethstraße 20, Wien 1, untergebracht. Gedruckt wird die maximal 20 Seiten starke Zeitung von der Universitätsbuchdruckerei Rudolf Hanel. Als verantwortlicher Redakteur ist Raimund Reiter genannt.

Im Untertitel heißt das Blatt Sonntagszeitung für alle. Die Zeitung versteht sich als populäre Illustrierte, die sich an ein breites Publikum wendet. Inhaltlich verfolgt sie einen linksliberalen, dezidiert pazifistischen Kurs. ${ }^{64}$ Eine Reihe namhafter Autoren schreibt für das Blatt, u. a. Alfred Polgar und Arnold Höllriegel. Der Jedermann ist grafisch besser gestaltet als die Wiener Illustrierte. Das Titelblatt setzt auf gute, ausdrucksstarke Fotos (Abb. 12), der Schriftzug des Titels ist einfach und klar gestaltet. Der Innenteil ist hingegen konventioneller aufgemacht. Es überwiegt der vierspaltige Text, der mit zahlreichen Fotos illustriert ist. Immer wieder wird das Spaltenraster durchbrochen, um für Bildseiten oder eingerückte Fotos Platz zu machen. Gelegentlich werden auch kürzere ein- bis zweiseitige Fotoreportagen gedruckt. Die Jedermann-Redaktion hat ein Sensorium für moderne und aktuelle Strömungen der Fotografie. Sie veranstaltet Fotowettbewerbe für Leser und bringt - neben konventionellen Landschaftsbildern - auch Aufnahmen, die Elemente des Neuen Sehens und der Neuen Sachlichkeit aufgreifen. ${ }^{65}$

Einer der wichtigsten Fotografen des Jedermann ist Hans Casparius, der über Vermittlung den Journalisten Arnold Höllriegel nach Wien und zur Zeitung gekommen ist. ${ }^{66}$ Geboren 1900 in Berlin, macht er sich zunächst einen Namen als Filmfotograf. Nach 1930 unternimmt er, zusammen mit Höllriegel, immer wieder lange Reisen. Die mitgebrachten Bilder veröffentlicht er in der deutschen und österreichischen illustrierten Presse bzw. in Buchform. ${ }^{67}$ Daneben arbeitet er als Reportagefotograf. Nach der Gründung des 
Jedermann erhält er die Aufgabe, für die Zeitung ein Bildarchiv aufzubauen und zugleich Reportagereisen durch Österreich zu unternehmen, um aktuelle Bilder anbieten zu können. Casparius veröffentlicht zwar viel im Jedermann, aber er ist nicht fest angestellt und arbeitet nebenbei auch für andere Zeitungen und Zeitschriften, u. a. für die Wiener Bilder, den Kuckuck, die Moderne Welt und das Wiener Magazin. Neben ihm liefert eine ganze Reihe österreichischer Fotografen (Lothar Rübelt, Leo Ernst, Albert Hilscher, Martin Gerlach, das Atelier Willinger und viele andere) Bilder an den Jedermann, weitere Aufnahmen kommen von österreichischen und deutschen Fotoagenturen.

In der zweiten Nummer des Jedermann, die Mitte Oktober 1932 erscheint, wird eine wöchentliche Auflage von 51500 Exemplaren genannt. ${ }^{68}$ Auch wenn sich die ersten Nummern der Zeitung, die stark beworben werden, gut verkaufen, erscheint diese Angabe übertrieben. ${ }^{69}$ Hinweise der Redaktion zur weiteren Entwicklung der Auflage fehlen. Es darf aber angenommen werden, dass diese kontinuierlich zurückgeht. Anzeigen akquiriert der Jedermann kaum. Bereits Anfang 1933 muss das Blatt eingestellt werden. Ausschlaggebend für das Ende sind in erster Linie wirtschaftliche Schwierigkeiten. Eine Rolle spielt aber auch der politische Umbruch. Im März 1933 nimmt die konservative Regierung erstmals eindeutig Kurs in Richtung Diktatur. Für eine linksliberale Zeitung wie den Jedermann ist in einer politisch zunehmend kontrollierten Presselandschaft kein Platz mehr.

Ebenfalls nur wenige Monate dauert ein ganz anders geartetes publizistisches Experiment, an dem der Chefredakteur der renommierten Berliner Illustrirten Zeitung (BIZ), Kurt Korff, beteiligt ist. Unter seiner Regie startet Ende 1933 eine neue Illustrierte in Wien, die Wiener Illustrierte Zeitung. ${ }^{70}$ Mit der Wiener Illustrierten Klebinders aus dem Jahr 1930/31 hat dieses Zeitungsprojekt nichts gemeinsam. Vielmehr handelt es sich um ein reines Importprodukt nach dem Muster der BIZ. Die erste Nummer erscheint am 5. November 1933. Nicht nur die äußere Gestaltung ähnelt der Berliner Illustrirten Zeitung, sondern auch das Innenleben und die inhaltliche Ausrichtung. In der Wiener Illustrierten Zeitung werden Aufnahmen

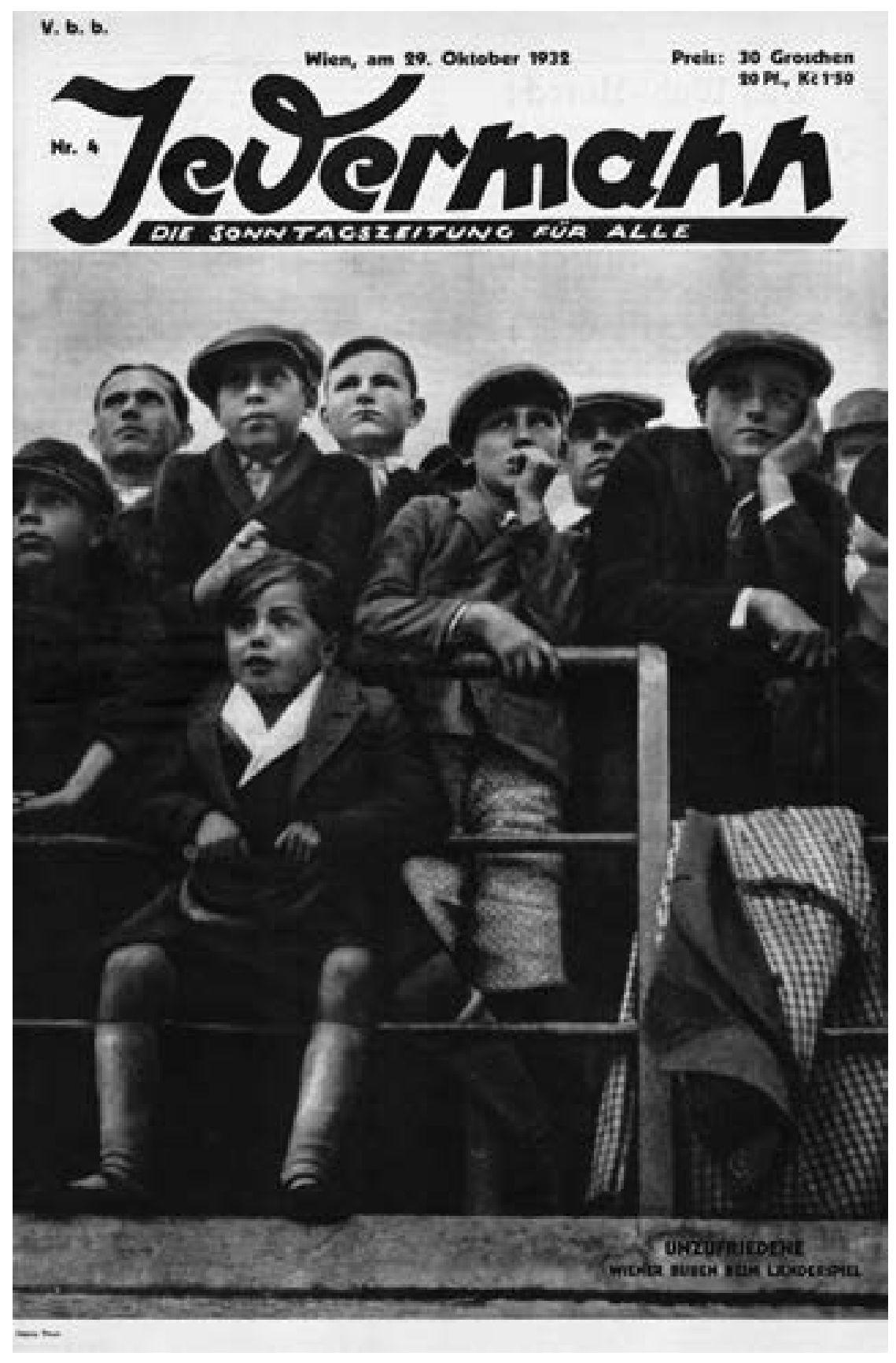

derselben Fotografen wie in der BIZ veröffentlicht. Ebenso wie die BIZ ist auch die Wiener Illustrierte Zeitung ein bürgerliches Blatt, das keinerlei Schwierigkeiten hat, sich mit einer zunehmend reaktionäreren österreichischen Regierung zu arrangieren.

Kurt Korff tritt selbst nicht in Erscheinung, sondern hält sich diskret im Hintergrund. Als Eigentümer, Herausgeber und Verleger ist im Impressum ein gewisser Adolf Pitner und als für den Inhalt verantwortlich Karl Wagner genannt. ${ }^{71}$ Die ökonomischen Fäden werden allerdings im Hause Ullstein gezogen. Nicht zuletzt erfolgt der Druck des Blattes in der seit Mitte der 1920er Jahre zu Ullstein gehörenden Wiener Druckerei Waldheim-Eberle. Möglicherweise star-
Abb. 12 Die Wochenzeitung Jedermann ist eine linksliberale Illustrierte, die zwischen Ende 1932 und Anfang 1933 erscheint. Jedermann, 29. Oktober 1932, Titelseite. Foto: Heinz Thun. 
tet Ullstein das Wiener Zeitungsvorhaben mit dem Hintergedanken, angesichts der politisch ungewissen Lage in Deutschland eine verlegerische Hintertür in Österreich zu öffnen. ${ }^{72}$

Aber schon nach wenigen Monaten wird das Zeitungsprojekt wieder beendet. Am 3. Juni 1934 erscheint die letzte Nummer der Wiener Illustrierten Zeitung. Mit mangelnden wirtschaftlichen Ressourcen hat die Schließung des Blattes wohl nichts zu tun, denn Ullstein ist in diesen Jahren das mächtigste Zeitungsunternehmen Europas. Es müssen also andere Gründe für die Entscheidung ausschlaggebend sein. Das Ende des Blattes hat möglicherweise (auch) mit der austrofaschistischen Pressepolitik zu tun, die ab 1933/34 die Kontrolle der österreichischen Zeitungen und Zeitschriften deutlich ausweitet. Nicht nur linke und oppositionelle Blätter werden verboten, auch bürgerliche Zeitungen spüren den Zugriff des Bundespresseamtes. Eine Reihe von Zeitungen wird verstaatlicht und auf Regierungslinie weitergeführt. ${ }^{73}$ Besonderem Druck sind Publikationen ausgesetzt, die mit ausländischem Kapital finanziert werden. Möglicherweise zieht sich Ullstein im Frühsommer 1934 aus dem Wiener Zeitungsgeschäft aber auch deshalb zurück, weil genau zur selben Zeit Verhandlungen über den Verkauf des Berliner Firmenimperiums an eine NSDAP-nahe Treuhand GmbH geführt werden. Am 30. Juni 1934 wird der Kaufvertrag abgeschlossen, ab diesem Zeitpunkt ist die Ullstein-Familie nicht mehr im Besitz ihres Unternehmens. Knapp vier Wochen zuvor hat die Wiener Illustrierte Zeitung ihr Erscheinen eingestellt.

\section{Kommunistische und nationalsozialistische Illustrierte}

Die Jahre 1933/34 bedeuten - neben dem Jahr 1938, als in Österreich die Nationalsozialisten an die Macht kommen - einen zentralen Einschnitt in der Entwicklung der Bildpresse. Wirtschaftskrise und austrofaschistische Regierungspolitik tragen dazu bei, dass das Zeitschriftenspektrum innerhalb weniger Jahre neu geordnet wird. Im bürgerlich-liberalen Sektor konsolidiert sich die Macht der alteingesessenen Blätter wieder, nachdem konkurrierende
Neugründungen kurzfristig für Aufregung gesorgt, sich aber längerfristig nicht hatten durchsetzen können. Aber auch die Partei- bzw. parteinahe Presse, die um 1930 einen enormen Aufschwung erlebt, ist im Umbruch begriffen. Im christlichsozialen Sektor setzt sich die im September 1933 gegründete Österreichische Woche, eine auflagenstarke Propagandaillustrierte des „Ständestaates“ gegenüber regionalen Projekten, etwa dem Innsbrucker Welt-Guck, durch. ${ }^{74}$ Die illustrierte Presse der Sozialdemokraten und Kommunisten, aber auch jene der nationalsozialistischen Rechten wird 1933 bzw. 1934 verboten.

Mitte 1933, ein knappes Jahr bevor der sozialdemokratische Kuckuck dem Verbot zum Opfer fällt, werden zwei weitere parteinahe Zeitungen aus politischen Gründen eingestellt, die KP-nahe Illustrierte Rote Woche und der Notschrei, die anfangs zweiwöchentlich, später wöchentlich erscheinende illustrierte der österreichischen Nationalsozialisten. Die kommunistische Zeitung ist keine Illustrierte im modernen Sinne, sondern ein handwerklich einfach gemachtes, billig hergestelltes, recht textlastiges Kampfblatt, das mit Fotos illustriert ist (Abb. 13). Die erste Nummer der Illustrierten Roten Woche erscheint am 7. Februar 1932. Wenige Wochen später erhält sie den Untertitel Die Wochenzeitung der Werktätigen. Als Eigentümer, Herausgeber und Verleger ist im Impressum die Rosa-Verlags-Gesellschaft m.b.H. (Otto-Wagner-Platz 5, Wien 9) genannt, als verantwortlicher Redakteur Guido Zamiš aus Mauer bei Wien. Inhaltlich vertritt die Zeitung die Linie der KPÖ, auch wenn diese nicht explizit in Erscheinung tritt. Auffallend viele Berichte behandeln Themen aus der Sowjetunion. Es ist daher durchaus denkbar, dass die Illustrierte Rote Woche finanzielle Unterstützung von der Komintern bzw. der Internationalen Arbeiterhilfe bekommt. Ihre Auflage liegt bei 15000 Exemplaren. ${ }^{75}$ Der sozialdemokratische Kuckuck erreicht zur selben Zeit eine doppelt so hohe Auflage. ${ }^{76}$

Obwohl die Zeitung keine ausgesprochene Bilderzeitung ist, spielt die Auseinandersetzung mit der Fotografie in redaktionellen Beiträgen immer wieder eine Rolle. Schon kurz nach der Gründung wird nach dem Vorbild der Arbeiter-Illustrierten Zeitung und des Kuckuck ein „Photo-Preisausschreiben“ zum Thema 
veranstaltet, das sich v. a. an die kommunistischen Arbeiterfotografen richtet. Bemerkenswert ist, dass von den Einsendungen kaum Bildbeispiele gedruckt werden. Denn, so das Fazit der Redaktion, der Wettbewerb war ein Misserfolg. „Unsere Arbeiterphotographen haben also als Photoreporter insoferne versagt, als sie nicht imstande waren, Augenblickssituationen zu erfassen. Eine Elendswohnung zu photographieren, ist nicht schwer. Dazu bedarf es bloß des Einvernehmens mit dem Inhaber. Aber heimlich im Betrieb, auf der Stempelstelle, im Fürsorgeamt eine Aufnahme zu machen, das ist die Kunst. Darauf ist es auch zurückzuführen, daß so wenig Bilder den Kampf der Werktätigen schildern. Diese beschränken sich eigentlich nur auf die Wiedergabe von revolutionären Kundgebungen. Die richtigen Bilder wären aber in dieser Beziehung gewesen Aufnahmen von einem Wirbel bei einer Delogierung, von einem Widerstand der Arbeiter gegen eine Säbelattacke der Polizei, von einer vereitelten Exekution bei einem Kleinbauern. Während diese für uns wichtigen Bilder fehlten, erhielten wir einige Gruppenaufnahmen, die natürlich gar nichts dem Beschauer sagen können. Auch aufnahmetechnisch sind die meisten uns eingesandten Bilder oft sehr mangelhaft. Da sandte uns zum Beispiel ein Genosse ein Bild von einer Proletenwohnung. Diese Wohnung ist ein Kellerloch, aber dieser Genosse hat die Aufnahme von einem ganz ungeeigneten Standpunkt gemacht, so daß nicht zum Ausdruck kommt, daß dieses Loch als Behausung dient. Auch den Blick für das richtige Erfassen der Aufnahme muß der Arbeiterphotograph sich zu eigen machen." ${ }^{77}$

Gut ein Jahr nach der Gründung wird es bereits eng für die Zeitung. Am 7. März 1933 wird das kommunistische Blatt unter Vorzensur gestellt. Immer häufiger werden in den folgenden Wochen Artikel beanstandet und verboten. Das Blatt erscheint mit zahlreichen weißen Flecken. Wenige Monate später

\footnotetext{
Abb. 13 Die Illustrierte Rote Woche ist eine KP-nahe Wochenzeitung, die zwischen Februar 1932 und Juli 1933 erscheint. Es handelt sich nicht um eine wirkliche Illustrierte, sondern um ein grafisch einfach gestaltetes, billiges Kampfblatt, das mit schlecht gedruckten Fotos bestückt ist. Illustrierte Rote Woche, 17. Juni 1933, Titelseite.
}

wird die Illustrierte Rote Woche von der Regierung gänzlich verboten. Die letzte Nummer erscheint am 22. Juli 1933.

Etwa zur selben Zeit, im Juni 1933, wird auch die nationalsozialistische Illustrierte Der Notschrei verboten. Die letzte Nummer erscheint am 17. Juni 1933. Im Unterschied zur kommunistischen Illustrierten Roten Woche ist diese Zeitung professionell hergestellt und aufwendiger gestaltet. Dennoch, in grafischer

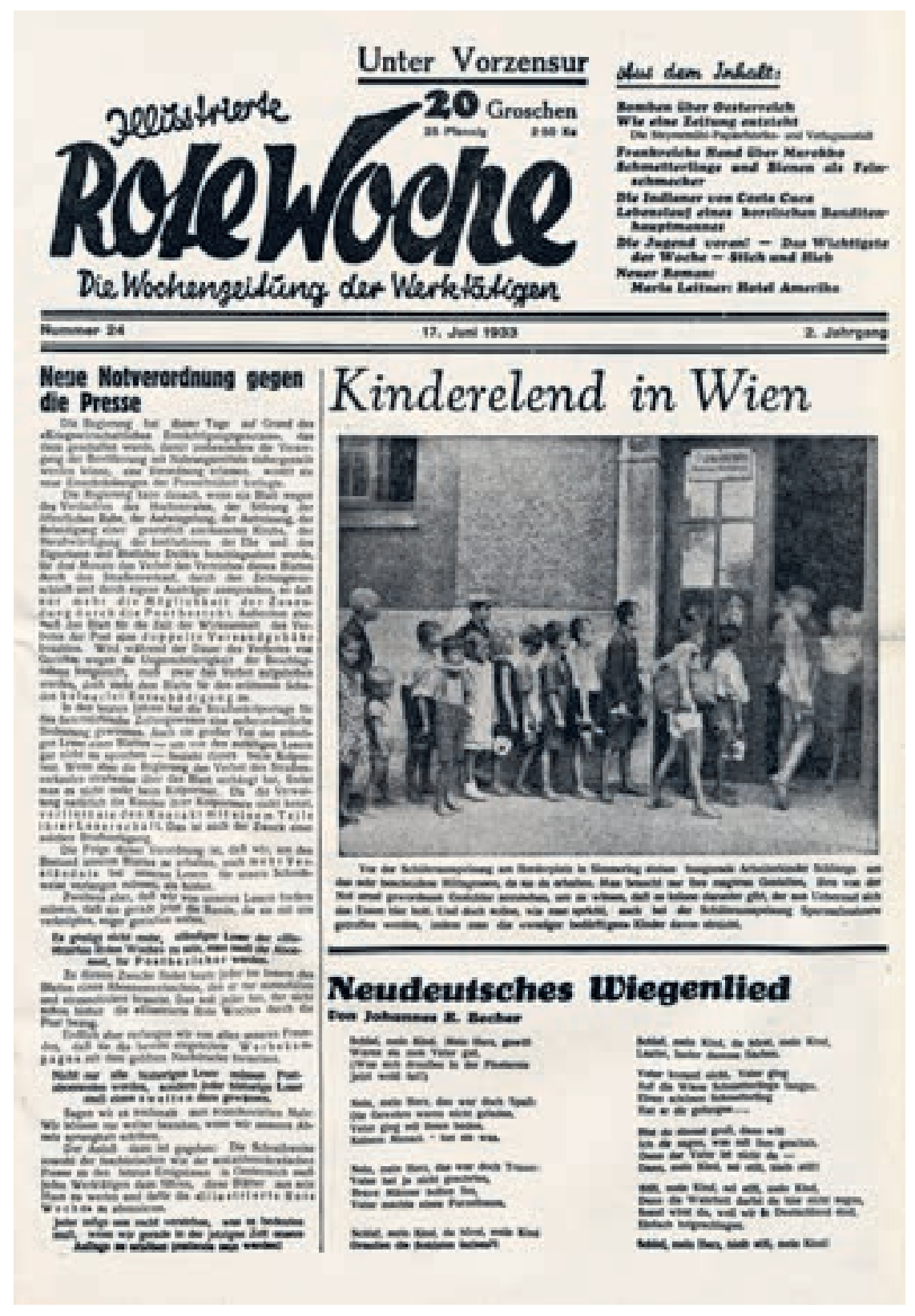




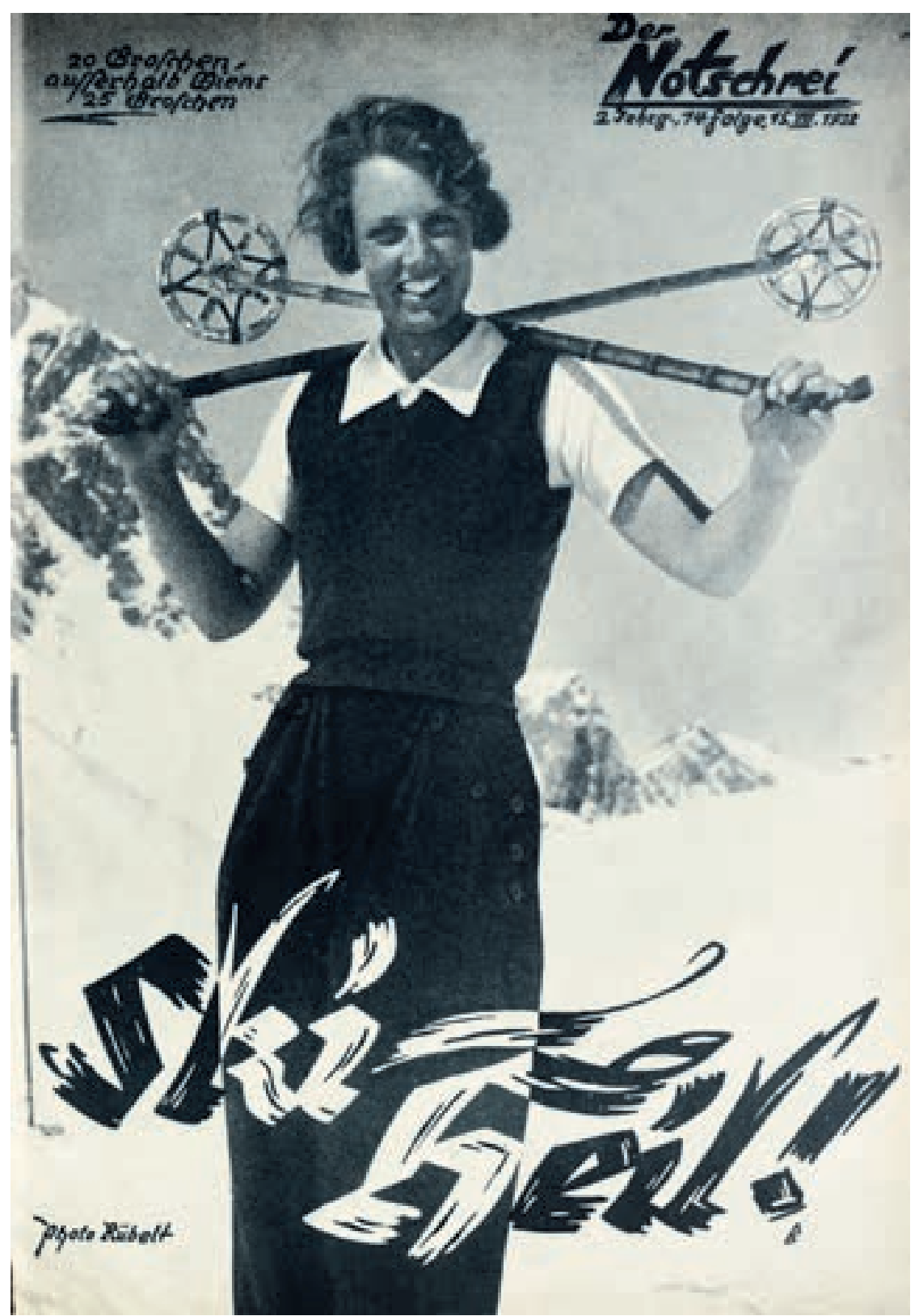

Abb. 14 Der Notschrei ist eine professionell hergestellte Illustrierte der österreichischen Nationalsozialisten, die Anfang der 1930er Jahre gegründet und im Juni 1933 verboten wird. Der Notschrei, 15. Dezember 1932, Titelseite. Foto: Lothar Rübelt.
Hinsicht kommt sie nie auch nur annähernd an das deutsche Vorbild - den nationalsozialistischen Illustrierten Beobachter - heran. Für den Umschlag wird in der Regel ein seitenfüllendes Foto verwendet, Titel und Überschriften sind in flotter Schrift manuell gezeichnet. Im Innenteil ist die Zeitung konventioneller aufgemacht. Die dreispaltige Gliederung wird immer wieder für Bildstrecken und Illustrationen durchbrochen, aber avancierte grafische Lösungen finden sich selten. Zwar bringt die Zeitung gelegentlich Fotomontagen, aber deren grafische Gestaltung ist, etwa im Vergleich zum Kuckuck, wenig raffiniert. Auch der Druck ist eher schlecht.

Bis 1933 tritt die österreichische NSDAP in der Zeitung Der Notschrei nicht explizit in Erscheinung. Sogar Details zu Eigentümerstruktur, Herausgebern und Redakteuren werden im Impressum nicht preisgegeben - wohl, um die Mitarbeiter vor staatlichen Nachstellungen zu schützen. Die Leser erfahren nur, dass Schriftleitung und Verwaltung in der Hirschengasse 25, Wien 6, untergebracht ist. Ab Herbst 1932 verschwinden auch die Hinweise auf die Fotografen weitgehend. In ihrer Programmatik orientiert sich der Notschrei an den Publikationen der deutschen Nationalsozialisten, über die regelmäßig ausführliche Berichte erscheinen. Attacken gegen die österreichische christlichsoziale Regierung, das Werben für einen Anschluss an Deutschland und ein aggressiver Antisemitismus, Rassismus und Antikommunismus gehören zu den zentralen inhaltlichen Ingredienzien des Blattes. ${ }^{78}$

Neben Aufnahmen professioneller Lichtbildner und Fotoagenturen druckt die Zeitung auch regelmäßig Fotos, die Leser eingeschickt haben. Die Redaktion fördert diese Zusendungen mit Aufrufen: „Photoamateure! Sendet uns weiter fleißig Aufnahmen!"79 Über die Pressefotografen, die regelmäßig für die Zeitung tätig sind, ist wenig bekannt, da ihre Namen häufig nicht genannt werden. Ein Fotograf ist allerdings von Anfang an auffallend oft mit Bildern im nationalsozialistischen Notschrei vertreten, Lothar Rübelt. Seine Bilder werden immer namentlich angeführt. Er hat offenbar keinerlei Berührungsängste gegenüber der nationalsozialistischen Illustrierten. Rübelt ist mit Freizeit- und Sportbildern (Abb. 14) ebenso präsent wie mit Aufnahmen von Parteiveranstaltungen. Als einziger österreichischer Pressefotograf beliefert er das gesamte politische Spektrum mit Bildern, vom sozialdemokratischen Kuckuck bis zum nationalsozialistischen Notschrei. Als am 18. September 1932 Joseph Goebbels, der Berliner „Gauleiter" und Propagandachef der NSDAP, in der Wiener Sportarena Engelmann vor großem Publikum auftritt, liefert Rübelt die Fotos für den Notschrei (Abb. 15). Im Text zu den Bildern heißt es: „Die Begeisterung der Massen kannte keine Grenzen als Dr. Goebbels geendet hatte. Und als schließlich aus tausend Kehlen das Deutschlandlied erklang, da fühlte jeder einzelne, daß alle Anstrengungen und Krämpfe der Systemparteien auch bei uns vergebens sein werden, daß auch uns Österreichern die historische Stunde schlagen wird, 
da wir zurückkehren werden, heim ins Mutterland, die Stunde, da die Hoffnung und die Sehnsucht Millionen deutscher Menschen ihre Erfüllung finden wird: Ein Volk, ein Führer, ein Deutsches Reich.“80

Über die Auflage des Notschrei ist nichts bekannt, allerdings dürfte die Verbreitung im Windschatten nationalsozialistischer Wahlerfolge ab 1932 deutlich angestiegen sein. Als Anfang 1933 in Deutschland Hitler an die Macht kommt, verspürt die Zeitung noch stärkeren Rückenwind. Wenig später, am 1. April 1933, kündigt die Redaktion die Umstellung auf ein wöchentliches Erscheinen und eine Titeländerung an. „Die in den letzten Monaten erfolgte enorme Absatzsteigerung des ,Notschrei ' hat uns in die Lage versetzt, unser Blatt ab 1. April allwöchentlich, und zwar jeden Samstag, erscheinen zu lassen, womit wir einen langgehegten Wunsch unserer treuen Leser erfüllen. Diese Gelegenheit haben wir zum Anlaß genommen, den Titel des Wochenblatts abzuändern; er lautet ab 1. April nicht mehr ,Der Notschrei', sondern ,Das Zeitbild. Österreichs NS (nationalsozialistische) Illustrierte‘ “81 (Abb. 16) Gestärkt durch den politi-

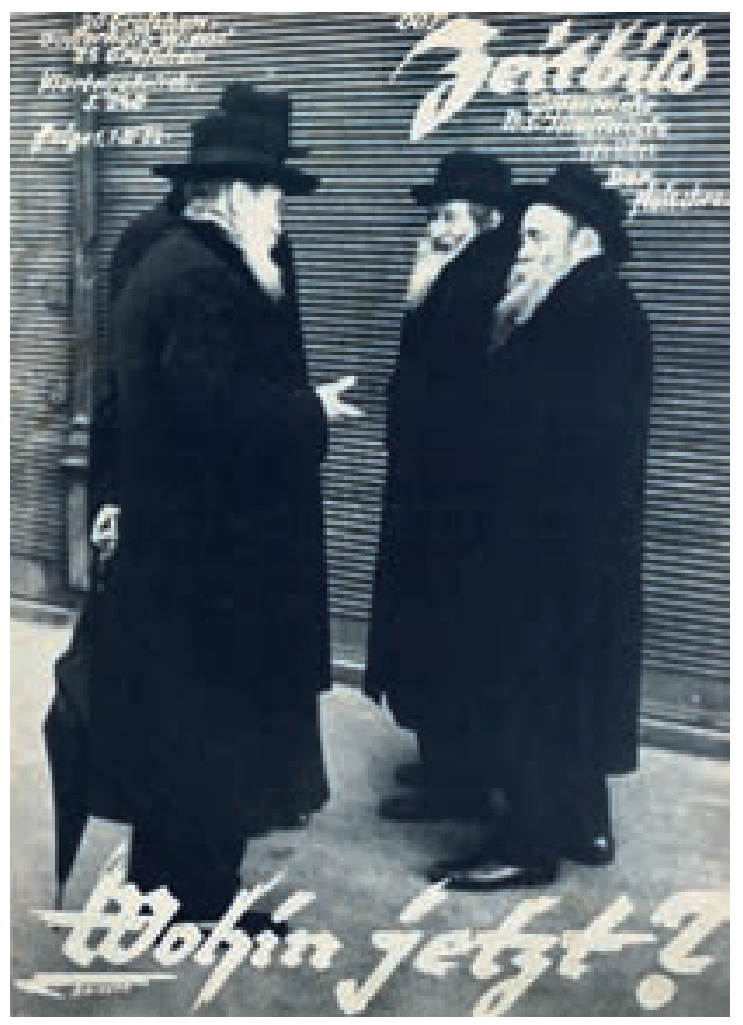

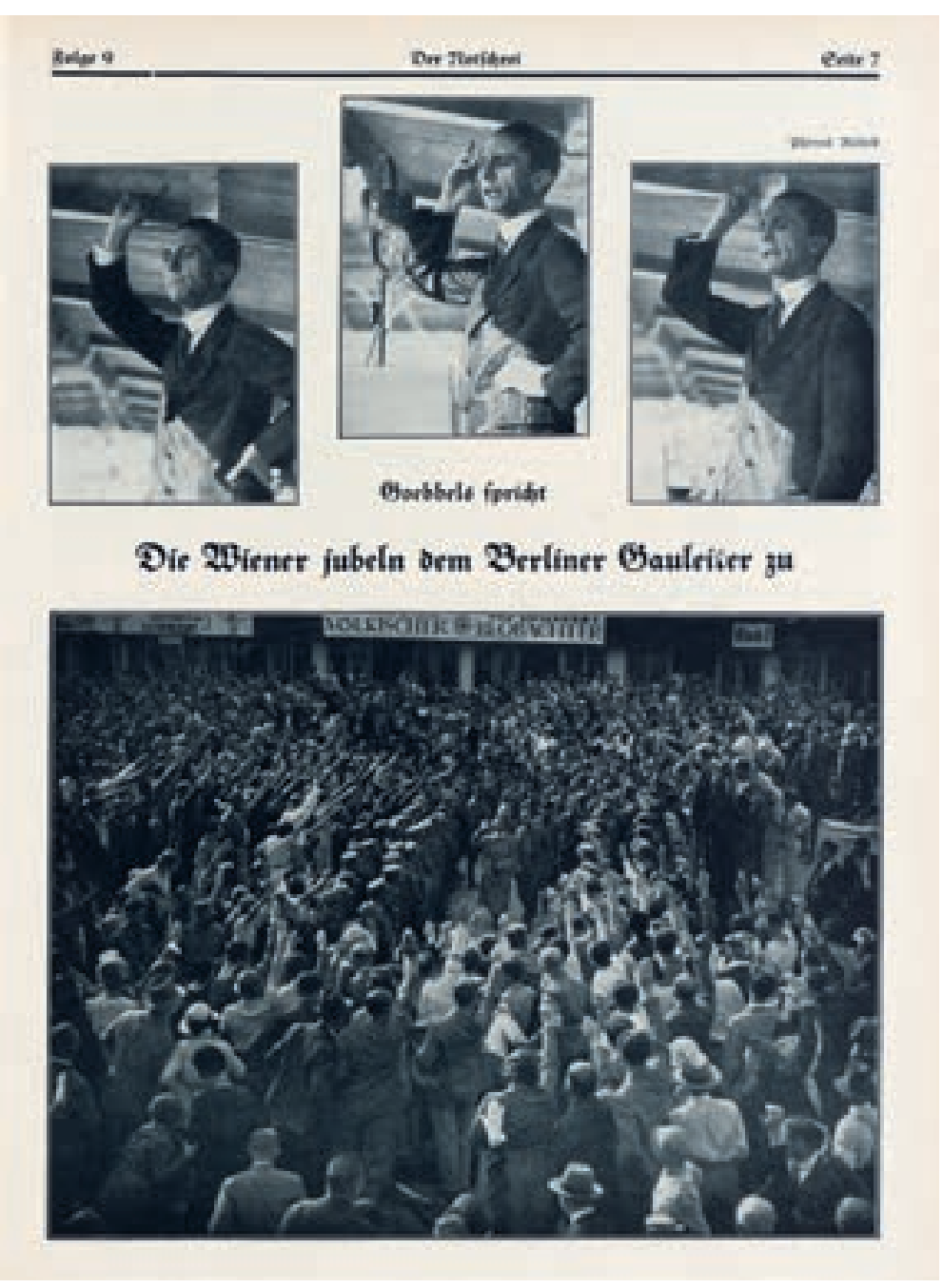

schen Umbruch in Deutschland, deklariert sich die Zeitung nun selbstbewusst als „nationalsozialistisch“.

In Bildern wird der baldige Anschluss herbeigesehnt, etwa am 29. April 1933, als die Zeitung auf dem Umschlag unter dem Titel „Unser Kanzler“ eine Begegnung des deutschen Kanzlers Hitler mit Kindern in Tracht zeigt (Abb. 17). Wenige Wochen später, am 17. Juni 1933, ist im Innenteil ein Foto zu sehen, das diesen Wunschtraum weiterspinnt. Die Bildunterschrift heißt: „Reichskanzler Hitler empfängt Kärntner Sänger.“ (Abb. 18)

Auch wenn der Zuspruch der Leser die Zeitung stärkt, geht sie im Frühjahr 1933 turbulenten Zeiten entgegen. Anfang April wird über zahlreiche kommunistische und nationalsozialistische Zeitungen, darunter auch gegen die in Zeitbild umbenannte NS-Illustrierte, ein teilweises Kolportageverbot verhängt. Uniformierten Zeitungsverkäufern, wie sie bisher üblich gewesen waren, ist nun der Verkauf im öffentlichen Raum verboten. Um diese Bestimmung zu umgehen und in der Öffentlichkeit als Zeitungsverkäufer kenntlich zu bleiben, tragen die NS-Kol-
Abb. 15 Bildbericht über den Auftritt des Propagandaleiters der NSDAP in der Sportarena Engelmann in Wien, 18. September 1932. Der Notschrei, 1. Oktober 1932, S. 7. Fotos: Lothar Rübelt.

Abb. 16 Der Notschrei heißt seit Anfang April 1933 Das Zeitbild. Gestärkt durch den politischen Umbruch in Deutschland nennt sich die Zeitung nun im Untertitel Österreichs NS (nationalsozialistische) IIlustrierte. Das Zeitbild, 29. April 1933, Titelseite. Foto: Brieger. 
Abb. 17 „Unser Kanzler“. Die nationalsozialistische Illustrierte Das Zeitbild (vorher unter dem Titel Der Notschrei) wünscht den baldigen „Anschluss“ Österreichs an das nationalsozialistische Deutschland herbei. Das Zeitbild, 29. April 1933, Titelseite. porteure nun Zylinder. Eine Aufnahme, die am 6. Mai 1933 veröffentlicht wird, zeigt einen solchen Kolporteur, der mit Zylinder und Armschleife gekennzeichnet ist (Abb. 19). Er bietet nicht nur österreichische NS-Blätter, sondern auch deutsche Parteizeitungen zum Verkauf an, u.a. den Völkischen Beobachter und den Illustrierten Beobachter. ${ }^{82}$

Nachdem Anfang Juni 1933 die Terrortätigkeit der österreichischen Nationalsozialisten einen Höhepunkt erreicht hat, beschließt die Regierung am 19. Juni

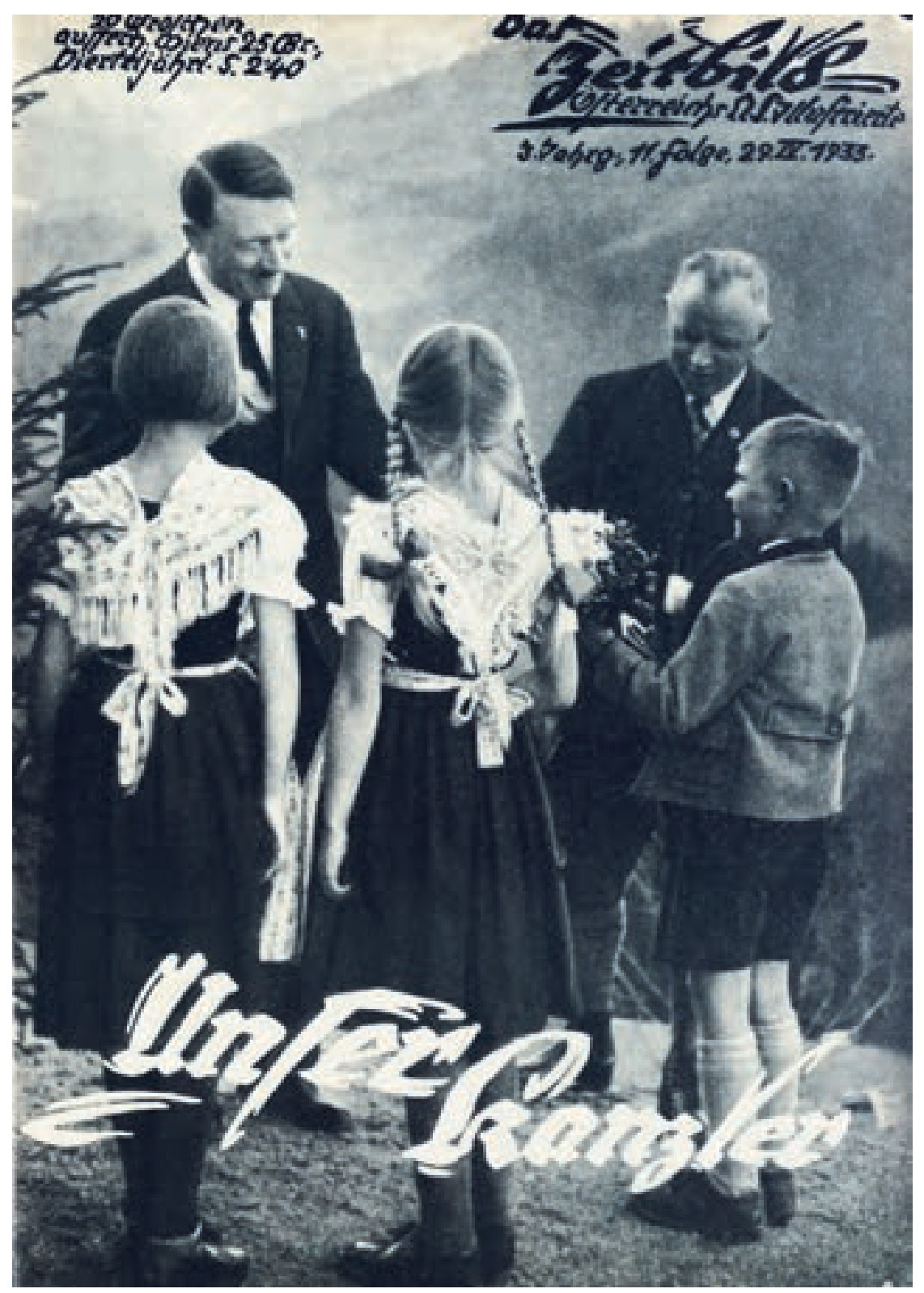

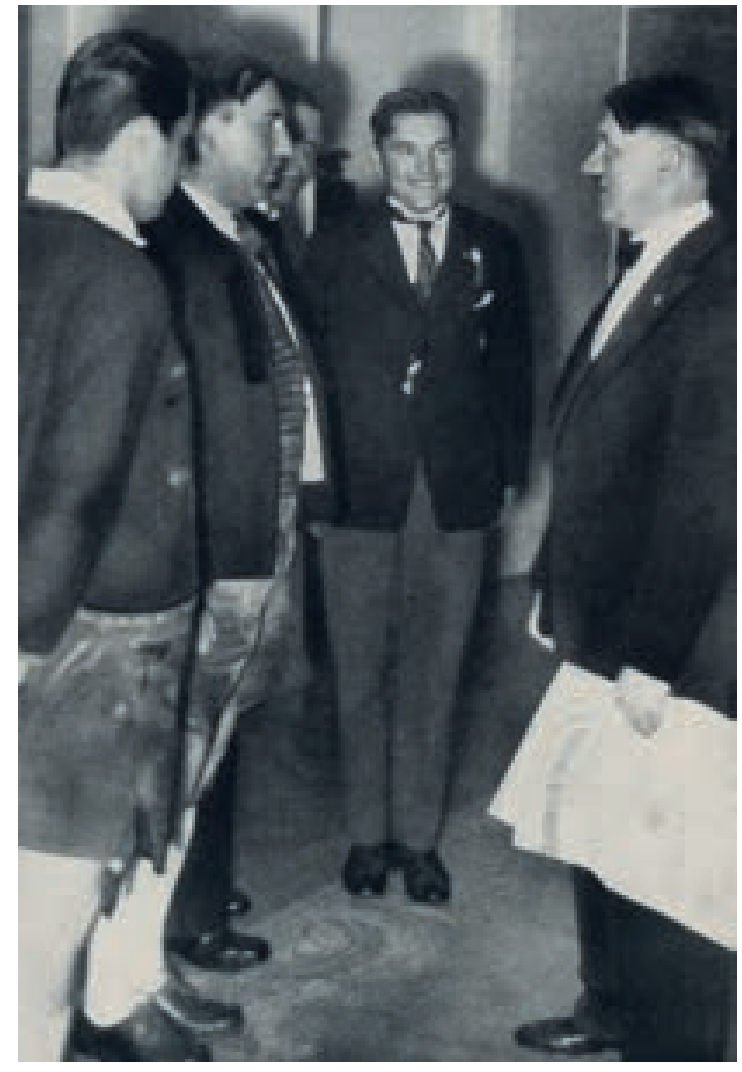

Abb. 18 „Reichskanzler Adolf Hitler empfängt die Kärntner Sänger“. Das Zeitbild, 17. Juni 1933, S. 6.

1933 das Verbot der nationalsozialistischen Partei, ihrer Vorfeldorganisationen und ihrer Medien. Davon betroffen ist auch die Wochenzeitung Das Zeitbild.

\section{Zaghafte Modernisierung}

Um 1930 nimmt der Druck, illustrierte Zeitungen grafisch zu modernisieren, deutlich zu. Mehrere Gründe sind dafür verantwortlich. Besonders wichtig sind wirtschaftliche Aspekte. Das Auftauchen konkurrierender, innovativ gestalteter Zeitungen drängt die beiden österreichischen Marktführer Das interessante Blatt und Wiener Bilder zu Reformen. Die Anregungen für eine innovativere Gestaltung kommen allerdings nicht nur von den jüngst gegründeten österreichischen Konkurrenzzeitungen wie Der Kuckuck und Welt-Guck, sondern auch von der deutschen Bildpresse, die seit Ende der 1920er Jahre 


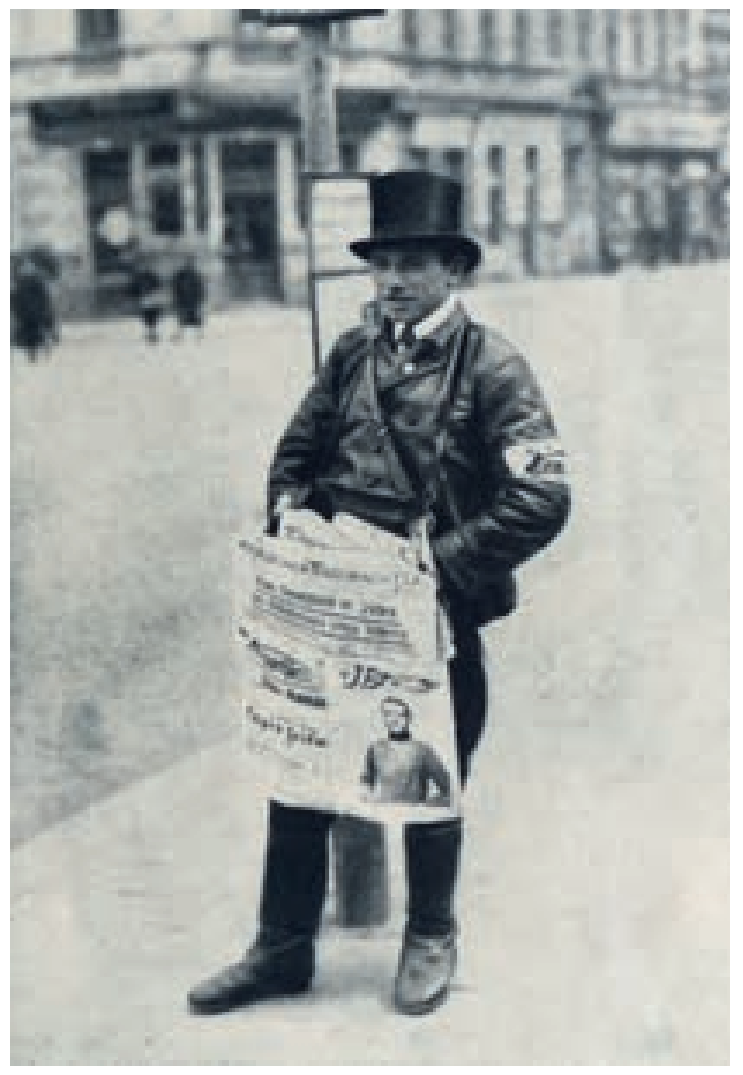

ebenfalls einen Innovationsschub erlebt, der auch nach Österreich ausstrahlt. Blätter wie die auflagenstarke Berliner Illustrirte Zeitung (Abb. 20) aus dem Ullstein Verlag, die seit 1928 von Stefan Lorant geleitete und grafisch hervorragend gestaltete Münchner Illustrierte Presse (Abb. 21), die ebenfalls sehr professionell gemachte Kölnische Illustrierte Zeitung (Abb. 22) und das in Frankfurt erscheinende Illustrierte Blatt, aber auch die der deutschen KP nahestehende Arbeiter-Illustrierte Zeitung (AIZ) werden - zumindest bis 1933 - auch in Österreich gelesen. Um 1930 geben diese Zeitungen die grafischen und gestalterischen Standards vor.

Der Modernisierungsdruck, unter dem die Bildpresse steht, hat aber auch mit Veränderungen des Bildermarktes zu tun. Ab Mitte der 1920er Jahre verändert sich die Vermarktung von Fotografien grundlegend. Immer häufiger liefern die Fotografen ihre Bilder nicht mehr direkt an die Redaktionen, sondern verkaufen diese über zwischengeschaltete Fotoagenturen. Zahlreiche solcher Agenturen werden

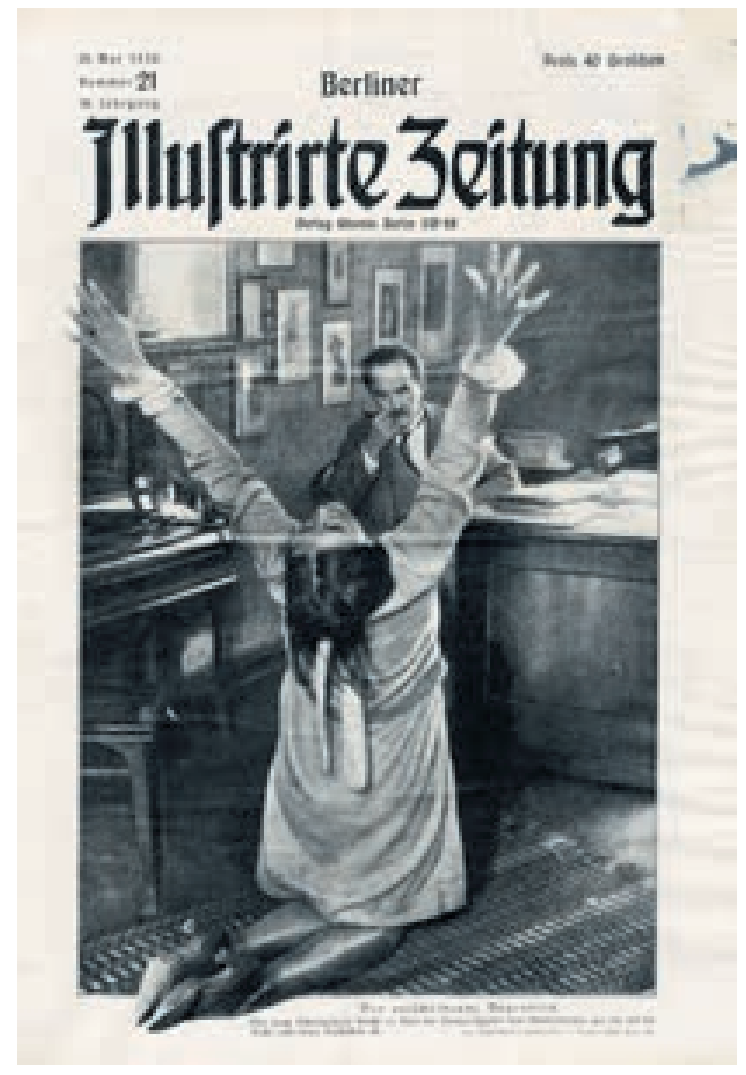

Abb. 19 Im Frühjahr 1933 wird über kommunistische und nationalsozialistische Blätter ein Kolportageverbot verhängt. Um das Verbot des Verkaufs durch uniformierte Zeitungshändler auf der Straße zu umgehen, tragen nationalsozialistische Zeitungsverkäufer nun Zylinder, um erkennbar zu sein. Das Zeitbild, 6. Mai 1933, S. 15.

Abb. 20 Die führende deutsche Illustrierte Berliner Illustrirte Zeitung erreicht 1930 eine Auflage von knapp zwei Millionen pro Woche. Berliner Illustrirte Zeitung, 25. Mai 1930, Titelseite. Foto: Weltrundschau-Neudatschin. in den 1920er und frühen 1930er Jahren gegründet, auch in Österreich. ${ }^{83}$ Parallel dazu internationalisiert sich der Bildermarkt immer stärker. Längst ist es in den Redaktionen üblich, Fotos international tätiger Fotoagenturen zuzukaufen. Während die meisten Fotoagenturen weiterhin traditionelle Pressefotos anbieten, gibt es andere, die auch mit avancierten Formen des Bildjournalismus experimentieren. Dazu gehören etwa die beiden 1927 bzw. 1928 in Berlin gegründeten Agenturen Weltrundschau und Dephot, die eine Reihe ausgezeichneter Fotografen vertreten und immer wieder originelle Bildgeschichten und Fotoreportagen nach Österreich verkaufen. ${ }^{84}$ Die seit 1929 bestehende Berliner Agentur Mauritius liefert ebenfalls hochwertiges Bildmaterial nach Österreich. Aber auch Wiener Unternehmen, wie etwa die Agentur Schostal (die zunächst unter dem Namen Wiener Photo-Kurier auftritt), tragen zu einer Qualitätssteigerung im Fotojournalismus bei, indem sie überdurchschnittlich viele Aufnahmen modern arbeitender Fotografen aus dem In- und Ausland anbieten. ${ }^{85}$ 


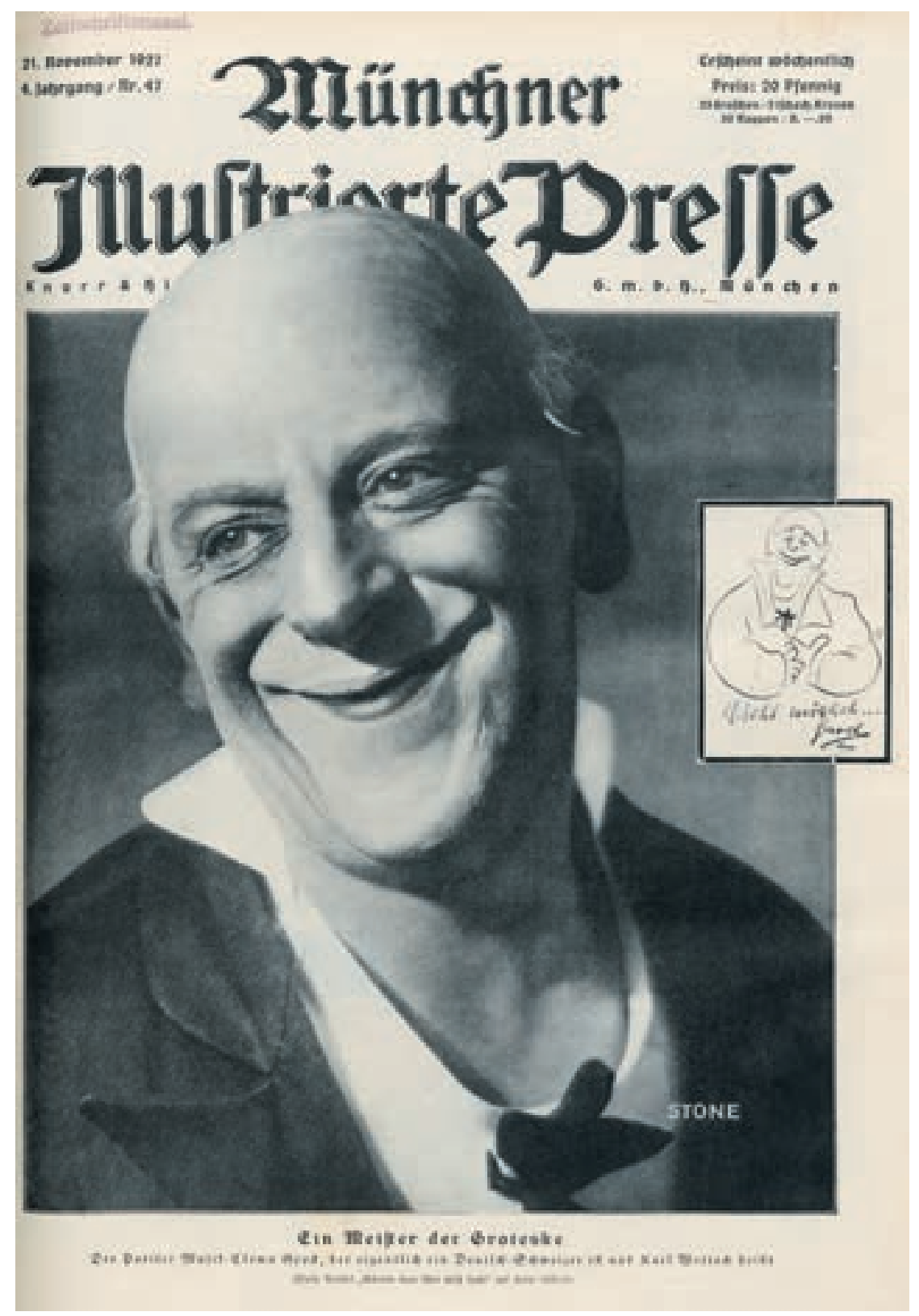

Abb. 21 Die von Stefan Lorant geleitete Münchner Illustrierte Presse gehört zu den grafisch innovativsten Illustrierten der Weimarer Republik. Münchner Illustrierte Presse, 21. November 1927, Titelseite. Foto: Sasha Stone.
Schließlich, und auch dies hat Auswirkungen auf die österreichische Pressefotografie, internationalisiert sich auch das Gewerbe der Pressefotografie zunehmend. Die Fotografen werden mobiler, ebenso ihre Bilder, die - v. a. über Agenturen - über die nationalen Grenzen hinweg verkauft werden. Österreichische Fotografen orientieren sich ab Mitte der 1920er Jahre stärker an der deutschen Presse, die u. a. deshalb attraktiv ist, weil ihre Auflagen weit höher sind und die Bezahlung deutlich besser ist als in Österreich. Eine Reihe von Wiener Fotografen (und Agenturen) bieten ihre Bilder regelmäßig deutschen Zeitungen und Magazinen an. ${ }^{86}$ Auf diese Weise sammeln sie wichtige Erfahrungen, die in ihre Arbeit einfließen. Andere arbeiten zeitweise im Ausland, publizieren aber auch in Österreich. ${ }^{87}$
Der Austausch über die Grenzen hinweg erfolgt aber auch in die umgekehrte Richtung. Um 1930 werden vermehrt Aufnahmen ausländischer, vor allem deutscher Fotografen in Österreich gedruckt. Einige von ihnen führen Reportageaufträge nach Österreich. ${ }^{88}$ Sie liefern größtenteils klassische Pressefotos, immer wieder aber erscheinen um 1930 auch moderne, avantgardistische Aufnahmen in österreichischen Zeitungen und Zeitschriften. Sie stammen oft von deutschen, französischen und tschechischen Fotografen. ${ }^{89}$ Ihr Beitrag zur Modernisierung der österreichischen Fotografie ist bisher noch kaum untersucht.

Ein letzter, ebenfalls wenig bekannter, Aspekt ist für die ästhetische Bereicherung der österreichischen Fotokultur der frühen 1930er Jahre von Bedeutung: der Beitrag deutscher oder in Deutschland lebender Fotografen und Fotojournalisten jüdischer Herkunft, die nach 1933 fliehen müssen. Einige wenige lassen sich vorübergehend in Wien nieder oder machen hier Zwischenstopp, bevor sie weiterreisen. ${ }^{90} \mathrm{Be}-$ deutsamer ist der Beitrag jener, die in die Nachbarländer, etwa in die Schweiz, nach Frankreich oder in die Tschechoslowakei fliehen und sich wirtschaftlich über Wasser zu halten versuchen, indem sie ihre Bilder nun u.a. auch in Österreich zur Veröffentlichung anbieten. ${ }^{91}$ Dazu kommen jüdische Fotografen, die nach 1933 (zunächst) in Deutschland bleiben und hier nicht mehr publizieren dürfen. Einige von ihnen versuchen, ihre Bilder in Österreich (und der Schweiz) zu verkaufen. ${ }^{92}$

An Anregungen für eine Modernisierung der Bildsprache fehlt es also nicht. Und dennoch nehmen die beiden führenden österreichischen Illustrierten, Das interessante Blatt und die Wiener Bilder, die gestalterischen und ästhetischen Innovationen nur sehr zögernd und verspätet auf. Woran mag das liegen? Neben den bereits genannten Gründen sind hier die Kleinheit des Landes und die - außerhalb Wiens - fehlende städtische Kultur zu nennen. Die urbane Klientel, an die sich in Deutschland die modernen Illustrierten wenden, fehlt in Österreich weitgehend. Dazu kommen unterschiedliche rechtliche Traditionen. In Deutschland etwa ist der Straßenverkauf, die sogenannte Kolportage, bereits seit 1904 erlaubt. Das 
erhöht den Druck auf die Illustrierten, durch suggestive, reißerische Titelseiten, aber auch durch flottere Gestaltung des Innenteils den Verkauf anzukurbeln. In Österreich ist die Situation anders als in Deutschland. Hier ist es erst ab 1922 erlaubt, Zeitungen auf der Straße zu vertreiben. ${ }^{93}$

In den 1920er Jahren gehen viele große deutsche illustrierte Wochenzeitungen dazu über, für den Umschlag ein seitenfüllendes, ausdrucksstarkes Foto zu verwenden. Der Zeitungskopf wird grafisch entschlackt und vereinfacht, Vignetten und andere Ornamente verschwinden von der Titelseite. Allerdings wird in der Regel an der Serifenschrift des Titels festgehalten. Im Innenteil löst sich die feste Spalteneinteilung immer öfter auf, um den Bilderzählungen mehr Platz einzuräumen. Texte und Bilder werden immer stärker verzahnt, auf diese Weise entstehen eindrucksvolle Bildgeschichten. Ende der 1920er Jahre setzt sich die professionell gestaltete Fotoreportage als innovative Erzählform durch.

Anfang der 1930er Jahre beginnen die Wiener Bilder mit einer zaghaften Modernisierung ihrer Aufmachung. Das interessante Blatt hingegen sperrt sich weiterhin gegen eine entsprechende Öffnung. Der Chefredakteur der Zeitung, Josef Papanek, der um 1930 bereits über zwei Jahrzehnte im Amt ist und wenige Jahre vor der Pensionierung (1937) steht, sieht offenbar wenig Anlass, das Blatt grundlegend zu reformieren. Bei den Wiener Bildern hingegen macht sich die Neuausrichtung nach einem 1932 erfolgten Generationenwechsel in der Chefredaktion bemerkbar. Der langjährige Leiter des Blattes, Moriz Band (1964-1932), stirbt Ende Juli 1932.94 Neuer Chefredakteur wird Hans Ewald Heller. Er leitet sofort eine Modernisierung des Blattes ein, die im Januar 1933 umgesetzt wird. „Von heute an“, so teilt er den Lesern am 8. Januar 1933 mit, „erscheint die Titelseite der ,Wiener Bilder“ in neuer Aufmachung. Wir gehen von dem bisherigen Titel, der, einer anderen Epoche entspringend, unserer ersten Seite ihre Charakteristik verliehen hat, ab und folgen dem Rufe der Zeit. Nichtsdestoweniger versuchen wir, unsere Eigenart zu wahren und behielten den Stephansturm, das Symbol der Stadt, nach der unsere illustrierte Wochenschrift benannt ist, im Titelkopfe bei.“95

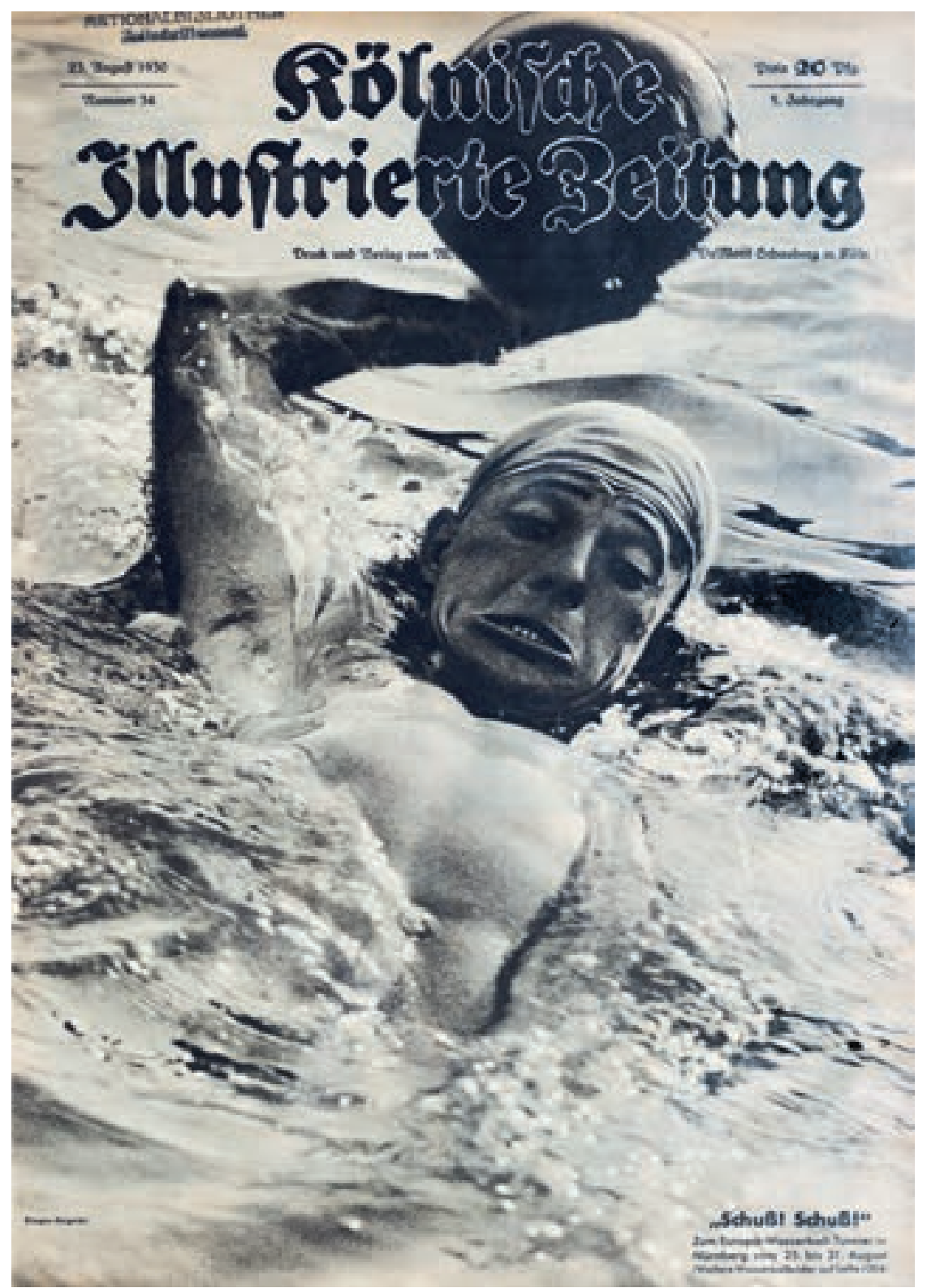

Die Titelseite setzt nun auf ein großes aussagekräftiges Foto, die antiquierte Vignette im Kopf der Zeitung wird entfernt (Abb. 23). Aber auch im Innenteil gibt es Neuerungen. Die Gestaltung wird etwas moderner und dynamischer, die Bilder erhalten deutlich mehr Raum. Hans Ewald Heller ist kein zurückgezogener Chefredakteur. Er schreibt selbst regelmäßig im Blatt. Darüber hinaus fotografiert er und gestaltet - meist unter dem Kürzel H.E.H. - immer wieder Fotoreportagen zu Themen des Alltags. ${ }^{96}$ Unter seiner Leitung setzt sich die Fotoreportage in den Wiener Bildern endgültig durch. Heller ist es auch, der zahlreichen talentierten jungen Fotografen und Fotografinnen ein Forum für Fotoreportagen bietet. Zu ihnen zählen u. a. Steffi Schaffelhofer, Lena Schur, Robert J. Bohl oder der Reisefotograf Herbert Tichy, die teilweise auch für die anderen Zeitungen des Ver-
Abb. 22 Ausdrucksstarke, seitenfüllende Fotos gehören um 1930 zum Markenzeichen moderner Titelblattgestaltung. Kölnische Illustrierte Zeitung, 23. August 1930. Foto: KlugerSzigethy. 


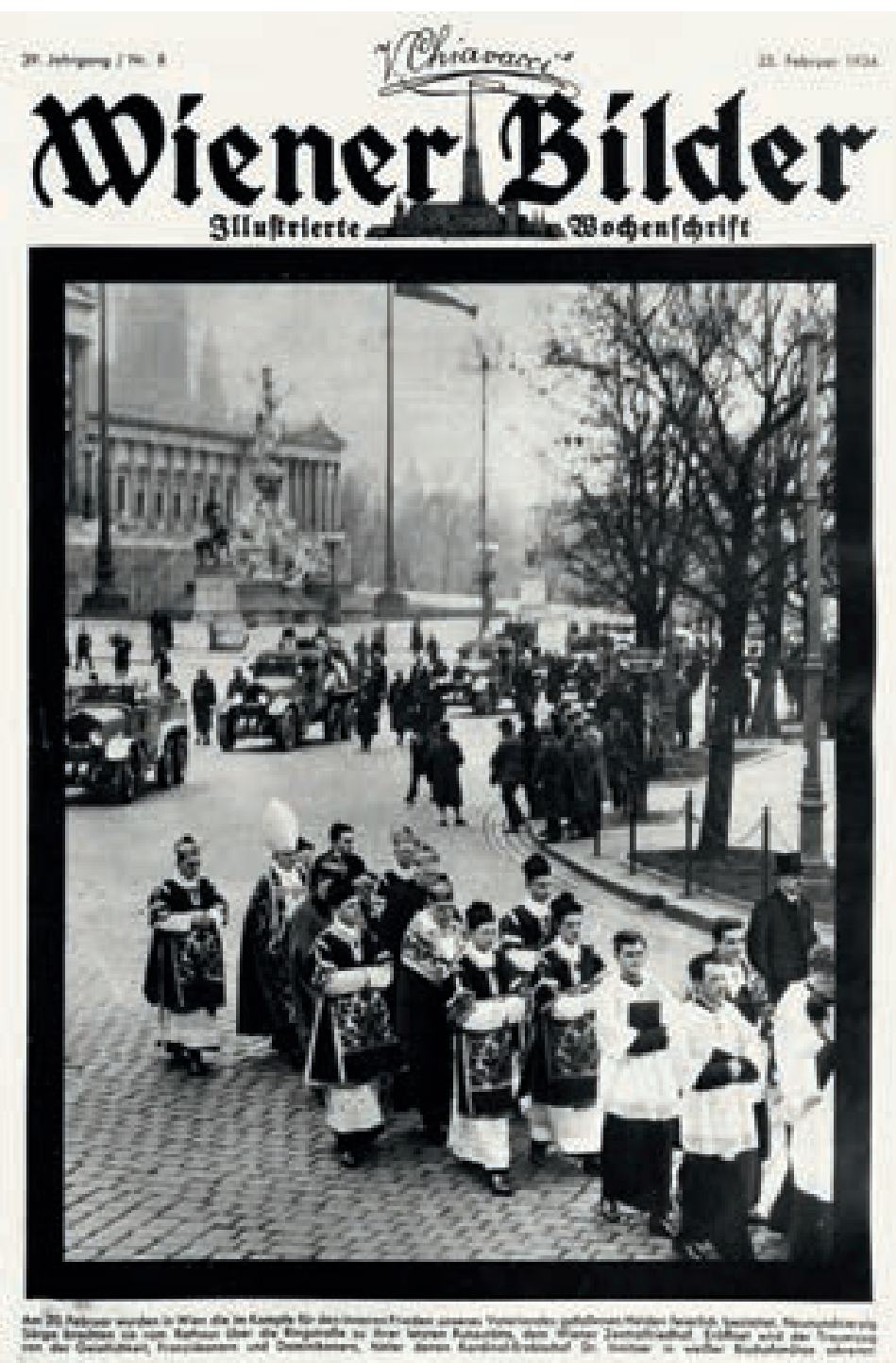

Abb. 23 Mitte 1932 kommt es zu einer Modernisierung der Umschlaggestaltung bei den Wiener Bildern. Die Vignette im Titelkopf verschwindet. Der Schriftzug des Titels wird vereinfacht. Wiener Bilder, 25. Februar 1934, Titelseite.

Abb. 24 Die Österreichische Woche ist eine regierungsnahe Propagandaillustrierte, die seit September 1933 erscheint. Sie wird zahlreichen regionalen Zeitungen beigelegt und erreicht dadurch die hohe Auflage von bis zu 700000 Exemplaren. Österreichische Woche, 20. Juni 1935, Titelseite. lags arbeiten. Dennoch: Trotz all dieser grafischen Verbesserungen bleiben die beiden Flaggschiffe der österreichischen illustrierten Presse erstaunlich resistent gegenüber ästhetischen Neuerungen. Im Vergleich mit der deutschen Bildpresse hinken sie in den Zwischenkriegszeit gestalterisch deutlich hinterher.

\section{Konservative Wende, austrofaschistische Propaganda}

Der innovative Elan der bürgerlichen Wochenillustrierten wird zusätzlich durch das Auftauchen einer neuen Illustrierten, der Österreichischen Woche gebremst. Sie erscheint ab September 1933 (Abb. 24). ${ }^{97}$ Auf Druck der Regierung wird sie zahlreichen regionalen katholisch-konservativen Zeitungen als Wochenillustrierte beigelegt. Dadurch erreicht sie eine enorme Auflage. Inhaltlich und grafisch gehen von der Österreichischen Woche keine innovativen Impulse aus, im Gegenteil: Die auflagenstarke Wochenzeitung trägt wesentlich dazu bei, die um 1930 zögerlich einsetzende Modernisierung der bürgerlichen Illustrierten wieder zu bremsen. Freilich darf ihre Bedeutung, vor allem für Wien, nicht überschätzt werden. Das strikt antiurbane Programm der Zeitung beschränkt ihre Leserschaft in der Großstadt. Auf dem Land hingegen erschließt sie tatsächlich neue Leserschichten in der kleinbürgerlichen und bäuerlichen Bevölkerung, die bisher kaum Käufer illustrierter Zeitungen gewesen waren.

Der Konzern in der Rüdengasse profitiert im ökonomischen Sinne von der „Konkurrenzzeitung“. Denn die Österreichische Woche wird in der hauseigenen Druckerei hergestellt und sogar die Redaktion befindet sich in der Rüdengasse 11. Diese wirtschaftliche Verflechtung des Zeitschriftenkonzerns mit der Regierung und deren Medien schlägt sich auch in der Berichterstattung des Interessanten Blattes und der 
Wiener Bilder nieder. Beide stehen eindeutig hinter der Regierungspolitik der austrofaschistischen Diktatur.

Die Österreichische Woche ist zwar die bei Weitem wichtigste, aber nicht die einzige konservative Illustrierte, die abseits der großen Städte gelesen wird. Am bedeutendsten unter den regionalen Bilderzeitschriften ist die zwischen 1935 und 1937 als Beilage der deutschnationalen Steirischen Alpenpost erscheinende Bilder-Welt (Abb.25). Sie wird, so wie das Mutterblatt, im Grazer Leykam Verlag hergestellt. Als redaktioneller Leiter ist Walther Urbanek genannt, der selbst als Fotograf tätig ist. Die je acht Seiten umfassende Bilderzeitung, die in gutem Kupfertiefdruck produziert wird, verfolgt eine im Großen und Ganzen unpolitische Linie. Von der Regierungspropaganda hält sie sich eher fern. Interessant ist, dass sie aber als einzige österreichische Illustrierte der Entwicklung im nationalsozialistischen Deutschland auffallend viel Aufmerksamkeit schenkt und immer wieder über Ereignisse in Deutschland berichtet. Offenbar folgt sie in dieser Hinsicht der inhaltlichen Ausrichtung des Mutterblattes. Auflagenmäßig steht die Bilder-Welt als kleine Regionalillustrierte deutlich im Schatten der Österreichischen Woche. Dennoch erreicht sie nach anfänglichen Startschwierigkeiten ein gewisses gestalterisches Niveau. ${ }^{98}$ In ihrer Umschlaggestaltung ist sie modern, die Gestaltung des Innenteils ist dagegen konventionell und recht statisch. Ab Mitte 1936 bringt sie auch Fotoreportagen. ${ }^{99}$ Die Bilder-Welt ist Mitte der 1930er Jahre eine nicht unbedeutende Plattform für Grazer Fotografen und Fotojournalisten. Regelmäßig vertreten sind etwa Dolf Christian und Alfred Steffen, die aktuelle Presse- und Sportbilder liefern. Aber auch konservative und deutschnationale Fotoamateure wie Ernst Fürböck und Maximilian Karnitschnigg finden in der Bilder-Welt ein Forum für ihre Aufnahmen. Die letzte Nummer der Zeitung erscheint am 28. März 1937. Über die Gründe der Einstellung ist nichts bekannt, es ist aber durchaus denkbar, dass der Druck der Regierung, die über die ausführliche Deutschlandberichterstattung gewiss nicht glücklich war, zur Einstellung der Zeitung beigetragen hat.

Als im März 1938 die Nationalsozialisten an die Macht kommen, haben sie nicht nur die Propagandazeitung Österreichische Woche im Visier, sondern sie krempeln auch gleich die Redaktionen der „unabhängigen“ Zeitungen Das interessante Blatt und Wiener Bilder um. Nach der nationalsozialistischen „Gleichschaltung“ der österreichischen Presse kommt es zu einer beispiellosen Welle der Repression. Zugleich wird 1938 aber auch eine sprunghafte grafische Modernisierung der österreichischen illustrierte Presse eingeleitet. Dieser Aspekt wird noch genauer zu untersuchen sein.

(0)
Abb. 25 Die Bilder-Welt ist die illustrierte Wochenendbeilage der Steirischen Alpenpost. Sie erscheint zwischen 1935 und 1937 im Grazer Leykam Verlag. Bilder-Welt, 23. Februar 1936, Titelseite. Foto: Wolff.

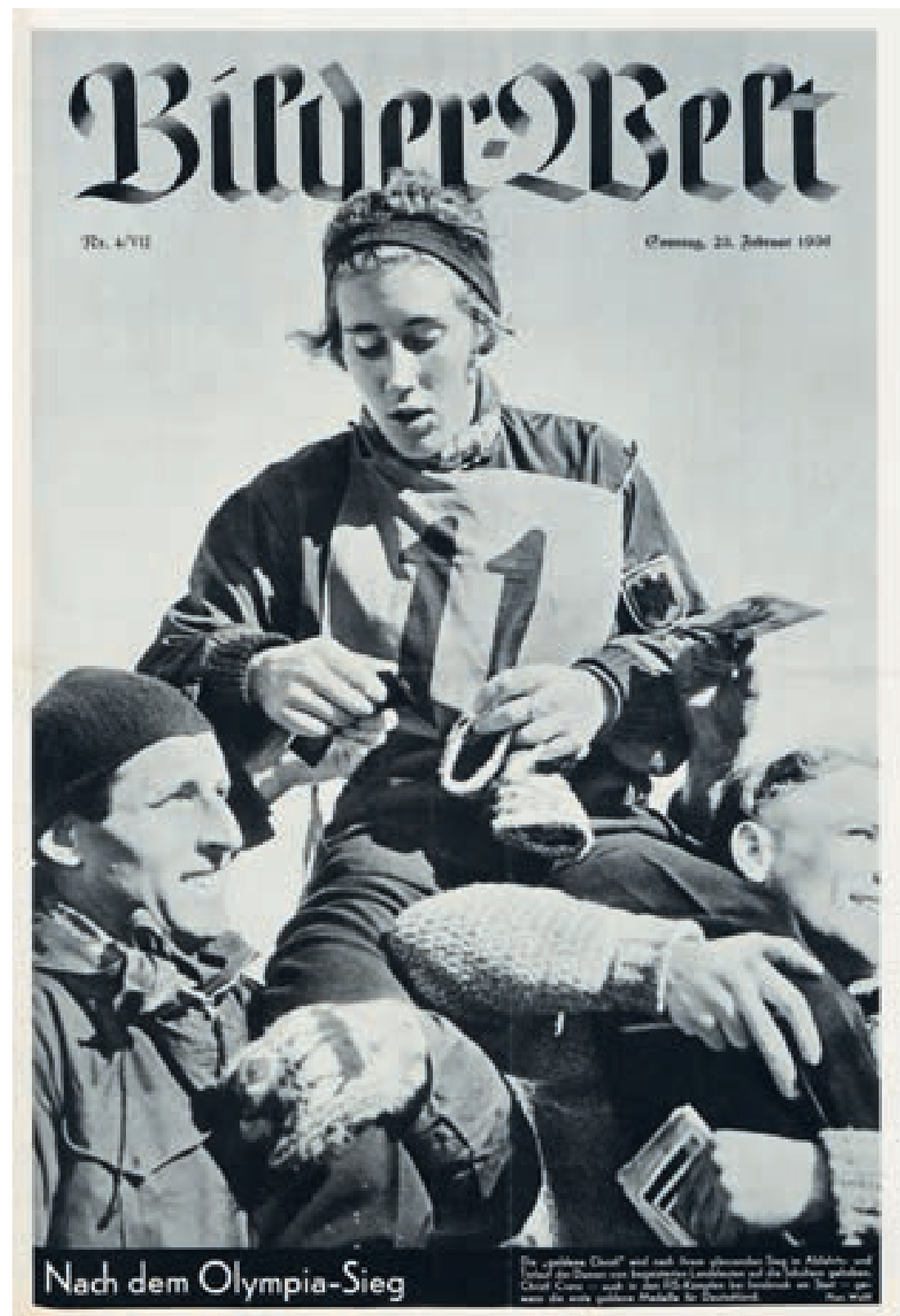




\title{
Bilder für alle
}

\author{
Die Welt der Magazine und Revuen
}

Abb. 1 „Heimweg in der Mittagssonne“. Straßenszene, aufgenommen vom Wiener Amateurfotografen Ferdinand Hodek. Wiener Magazin, Heft 6, Juni 1929, S. 52/53.
Zwei Männer gehen schnellen Schritts auf eine Treppe zu (Abb. 1). Wir blicken ihnen aus leicht erhöhter Perspektive von hinten nach. Wer die beiden Gestalten sind, wissen wir nicht, wohin die Treppe führt, auch nicht. Jeder einordnende Kontext fehlt. Die breite, diagonal sich ins Bild schiebende Treppe beherrscht die Szene. Der Fotograf verwandelt, unterstützt durch Perspektive und Bildausschnitt, die gestufte Architektur in ein geradezu abstrakt anmutendes Muster. Je länger wir die Szene und vor allem die Treppe betrachten, desto rätselhafter erscheint sie. Allmählich kommt uns der Halt des festen Bodens abhanden und wir beginnen uns in den hellen und dunklen Streifen zu verlieren. Die Aufnahme stammt vom Wiener Fotoamateur Ferdinand Hodek, der in seinen Fotoarbeiten Elemente der Neuen Sach-

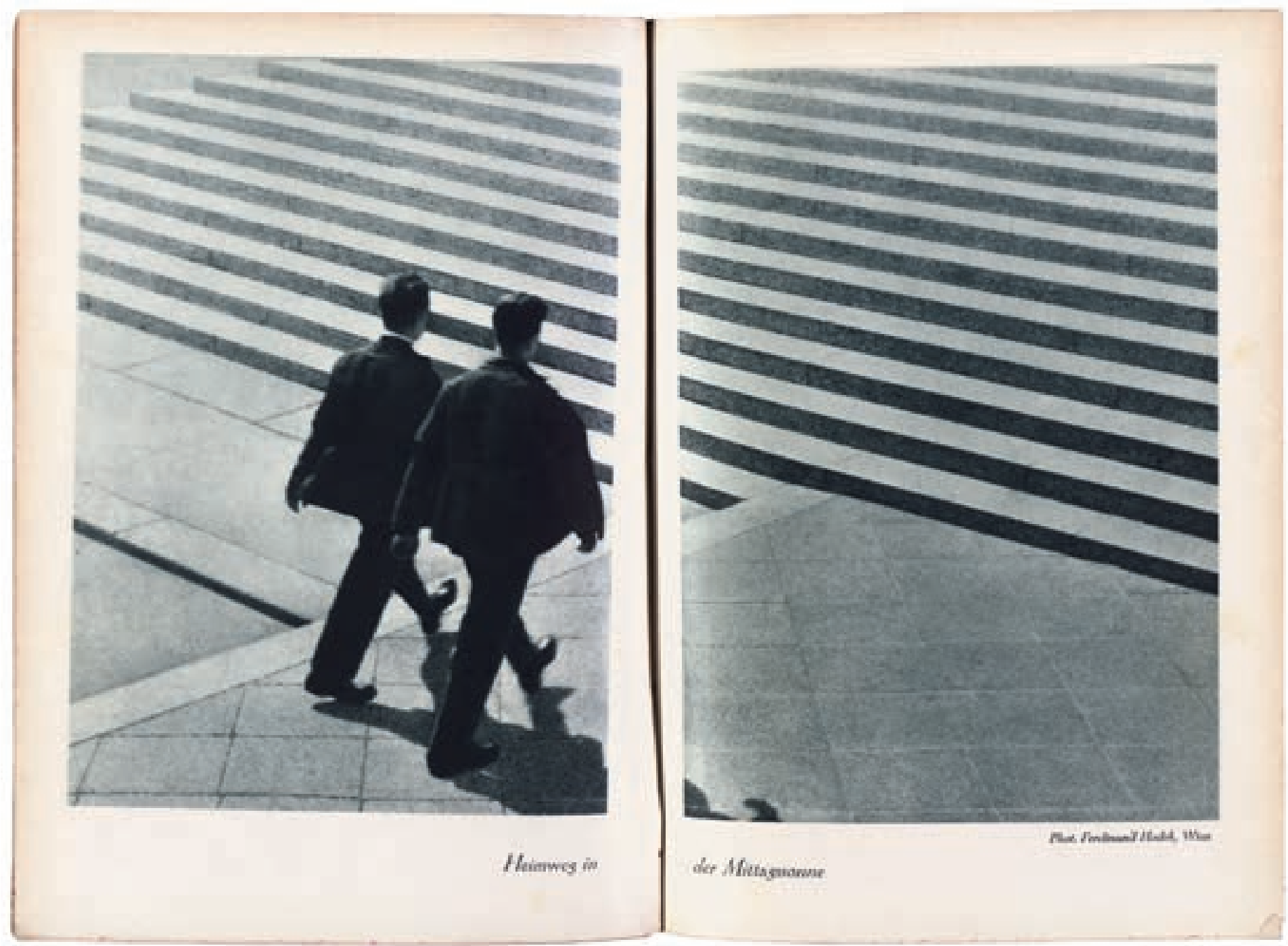


lichkeit und des Neuen Sehens aufgreift, aber auch hie und da piktorialistische Anleihen einfließen lässt. Über sein Leben ist wenig bekannt. Er ist, so heißt es in den Meldeunterlagen, „Staatsbeamter“. ${ }^{1}$ Geboren ist Hodek 1896 in Wien, in der Zwischenkriegszeit wohnt er im Wiener Arbeiterbezirk Meidling. Der Fotografie nähert er sich als Amateur. In den 1920er Jahren wird er Mitglied der Photosektion der Meidlinger Naturfreunde. ${ }^{2}$ Diese Fotogruppe ist in den 1920er und frühen 1930er Jahren innerhalb der Wiener Arbeiterfotografiebewegung besonders aktiv. Viele Meidlinger Naturfreunde-Fotografen orientieren sich an der modernen Fotografie. Hodek ist ein Flaneur der Großstadt, er fotografiert vor allem in Wien. Daneben macht er auch moderne Sachaufnahmen. Um 1930 ist er mit seinen Fotoarbeiten auf zahlreichen künstlerischen Fotoausstellungen vertreten. Er nimmt an Fotowettbewerben teil und veröffentlicht seine Bilder ab 1929 in der illustrierten Presse, u. a. im sozialdemokratischen Kuckuck, aber auch in österreichischen und deutschen Fachblättern und -publikationen.

Hodeks Straßenszene bricht mit den Gepflogenheiten der klassischen Pressefotografie, die über ein konkretes Ereignis berichten will. Die Aufnahme bietet keinen informativen Mehrwert an, sondern steht ganz für sich, als Beispiel einer künstlerischen Aneignung der Wirklichkeit. Bilder wie diese finden in der Zwischenkriegszeit verstärkt Aufnahme in die illustrierte Presse. Sie tauchen freilich nicht so sehr in den herkömmlichen Wochenzeitungen, sondern in den neu gegründeten, meist monatlich erscheinenden Magazinen und Revuen auf, die dem Alltag, den Stimmungen und Moden der Zeit mehr Platz einräumen als der Tagespolitik. Das Wiener Magazin, in dem Hodeks Aufnahme im Juni 1929 veröffentlicht wird, ist eines dieser Ende der 1920er Jahre neu gegründeten Magazine. Es platziert die Aufnahme - über den Mittelfalz hinweg - auf einer Doppelseite und steigert dadurch die Rätselhaftigkeit der grafischen Struktur des Bildes noch. Derartige Bildteilungen gehören, ebenso wie andere Layoutlösungen (etwa die Freistellung und Beschneidung, der abfallende Druck oder die Serienbildung, um nur einige zu nennen), zu den gestalterischen Mitteln moderner Zeitschriftengestaltung, aber auch des Neuen Sehens. ${ }^{3}$
Anlass für die Veröffentlichung des Fotos im Wiener Magazin ist die bevorstehende „Internationale Photographische Ausstellung“ (IPHA), die vom 15. Juli bis 15. September 1929 in der Salzburger Residenz gezeigt wird. Ferdinand Hodeks Foto ist unter den ausgestellten Arbeiten. ${ }^{4}$ Wenige Wochen später, im ersten Augustheft 1929, kommt auch die Zeitschrift Die Bühne auf die Salzburger Ausstellung zu sprechen. Inzwischen ist die Schau eröffnet und der Kunstkritiker Wolfgang Born bespricht sie in seinem Beitrag „Gedanken über Photographie“ äußerst wohlwollend. Dem Text beigefügt ist, neben anderen Bildern, auch Ferdinand Hodeks Treppenszene. ${ }^{5}$ Während das Foto im Wiener Magazin als „Heimweg in der Mittagssonne“ beschrieben wird, lautet sein Titel in der Bühne schlicht „Rhythmus“. ${ }^{6}$ Der Unterschied zwischen den Bildunterschriften ist bezeichnend: Die Interpretation als rudimentäre Bilderzählung (Heimweg - Mittagssonne) weicht dem Verweis auf ein urbanes Stillleben, das vor allem aus einer Abfolge von abstrakten Formen besteht. Born hebt die Aufnahme in seinen Ausführungen heraus und betont deren abstrakt-reduktionistisches Anliegen, das einen wichtigen Schritt hin zur „bildmäßigen Geschlossenheit“ markiert: „Zwei Männer schreiten parallel zueinander auf die Stufen einer Treppe zu. Ihr Schatten liegt auf dem Pflaster. Es herrscht eine fast mathematische Ordnung in der Komposition. Ein Stück Leben, ganz in eine Formel gepreßt. Die Wirkung ist schlagend."7

Genau diese schlagende Wirkung der Fotografie ist es, die ab Ende der 1920er Jahre in den Magazinen und Revuen ein neues Forum erhält. Viele dieser neuartigen Bilder stammen von Fotoamateuren. Ihr Thema sind nicht etwa Vorkommnisse der Tagespolitik, sie beobachten vielmehr den Gang des menschlichen Lebens, fixieren Seltsames und Skurriles, Schönes und Absurdes. Nicht immer folgen die Inszenierungen dieser neuen Lichtbildner den Maximen der fotografischen Moderne. Nicht immer wird der Darstellung von Strukturen und Formen der Vorzug gegenüber dem Erzählen einer Geschichte gegeben. Oft sind die Alltagsbeobachtungen banal - und doch eindrücklich. Nikolaus Schwarz etwa, auch er ein Amateur aus dem Umfeld der Arbeiterfotografen 


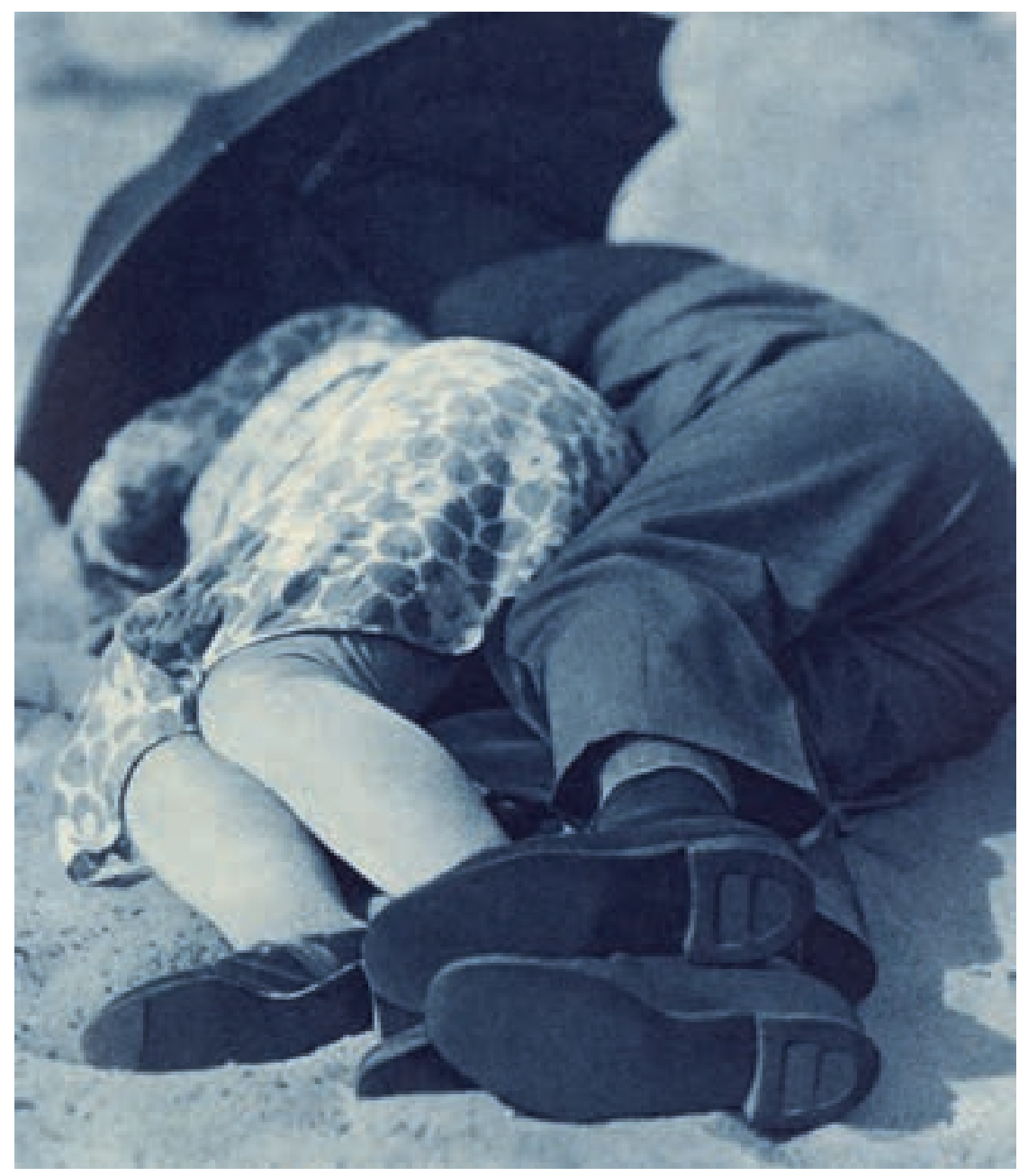

Abb. 2 „Liebe am Strand“. Wiener Magazin, Heft 6, Juni 1932, S. 59. Foto: Nikolaus Schwarz. und des sozialdemokratischen Kuckuck, lichtet an einem heißen Sommertag im Jahr 1932 ein Schatten und Ruhe suchendes Paar auf dem Strand ab (Abb. 2). Der Fotograf hat seinen Apparat zu Füßen der beiden Liegenden positioniert. Auf diese Weise gelingt ihm in der perspektivischen Verkürzung eine leicht verfremdete, überaus eindrückliche Momentaufnahme aus dem Alltag. Der Bildtext lautet schlicht: „Liebe am Strand“.

Während die alteingesessenen illustrierten Wochenzeitungen die Wende hin zur modernen Fotografie und zu einem innovativen Einsatz der Bilder im internationalen Vergleich eher spät und oft halbherzig vollziehen, sind einige der in den 1920er Jahren neu gegründeten Wochen- bzw. Monatsmagazine in dieser Hinsicht deutlich aufgeschlossener. Ende der 1920er Jahre werden sie - zumindest teilweise - zu Vorreitern einer modernen fotografischen Bebilderung. Von kleinformatigen illustrierten Wochen- oder Monatsmagazinen, wie der Bühne (1924 gegründet), dem Wiener Magazin (1927 gegründet) und in geringerem Maße der Modernen Welt (1918 gegründet), gehen neue ästhetische Impulse aus (Abb. 3, 4, 5).
Ein Sonderfall ist die Wochenillustrierte Der Sonntag, die seit 1934 der Tageszeitung Der Wiener Tag beiliegt und bis 1938 erscheint. ${ }^{8}$ Sie setzt inmitten der austrofaschistischen Diktatur neue Maßstäbe für eine originelle Bildpresse.

Neben den aufwendig gestalteten und gedruckten Kultur- und Gesellschaftsmagazinen kommen in den 1920er Jahren noch zahlreiche weitere, weniger hochwertig hergestellte illustrierte Wochenmagazine auf den Markt, etwa diverse Radio-, Film-, Mode- und Freizeitzeitschriften. Zwar bleiben diese Publikationen in ihrer Seitengestaltung lange Zeit konventionell, aber auch sie setzen des Öfteren bewusst auf gute, aussagekräftige Bilder und gruppieren diese oft zu hintergründigen Bild-Text-Kombinationen. Generell gilt: Die neuen Magazine halten in ihrer Themenwahl Abstand zur Tagespolitik und verstehen sich nicht als politische Wochenzeitungen, sondern vielmehr als Revuen.

\section{Moderne Welt - Forum für das Bildungsbürgertum}

Im Oktober 1918 - also noch kurz vor dem offiziellen Kriegsende - erscheint das erste dieser neuen Journale, die Moderne Welt. Im Untertitel nennt sie sich Illustrierte Revue. Eigentümer und Herausgeber ist Arnold Bachwitz, Chefredakteur Ludwig Hirschfeld. Die Redaktion ist in der Löwengasse 47, Wien 3, untergebracht. ${ }^{9}$ Zunächst erscheint die Zeitschrift monatlich, 1923 stellt sie auf ein 14-tägiges Erscheinen um, um Anfang der 1930er Jahre wieder zum Monatsrhythmus zurückzukehren.

Im Editorial des ersten Heftes der Revue heißt es programmatisch: „Der Titel dieser Zeitschrift enthält eigentlich schon ihr Programm: ,Moderne Welt ${ }^{\star}$ - zwei Worte, die unzählige Gebiete, Themen und Möglichkeiten umfassen (...). Aus dieser Fülle und Buntheit der modernen Welt das Charakteristische, Interessante und Aktuelle herauszugreifen und in Worten und Bildern festzuhalten, ist unser Arbeitsplan, den der Untertitel ausdrückt: eine illustrierte Revue. Literatur, Kunst, Theater, Mode, zeitgeschichtliche Ereignisse, wissenschaftliche und technische Leistungen, gesellschaftliches Leben und Mode sollen vor dem Auge des Lesers vorüberziehen. Wir binden uns an keine 
Richtung, wir haben keine Tendenz als die, immer Gutes und Gediegenes zu bieten. Die besten zeitgenössischen Autoren, die älteren, die jüngeren und die jüngsten, die abgeklärten und die extremen Künstler sollen bei uns gleich willkommene Gäste sein. Humor und Satire sollen ihren Platz finden.“ ${ }^{10}$

Unter den Autoren der neuen Zeitschrift finden sich prominente Namen wie etwa Hermann Bahr, Franz Karl Ginzkey, Hermann Hesse, Hugo von Hofmannsthal, Heinrich Mann, Thomas Mann, Roda Roda, Arthur Schnitzler, Karl Hans Strobl, Anton Wildgans und Sigmund Freud. Damit findet ein breites Spektrum von Stimmen, Haltungen und politischen Anschauungen unter dem Dach der Modernen Welt Platz. Die Moderne Welt, so heißt es im ersten Heft abschließend, soll „eine künstlerisch gestaltete Revue großen Stils“ sein, „eine österreichische und zugleich europäische Zeitschrift, die den Wettbewerb mit den großen ausländischen Revuen aufnehmen kann. Österreich hat in diesen schweren vier Jahren zur Überraschung der Welt und zu seiner eigenen

\section{Wiener Magazin}

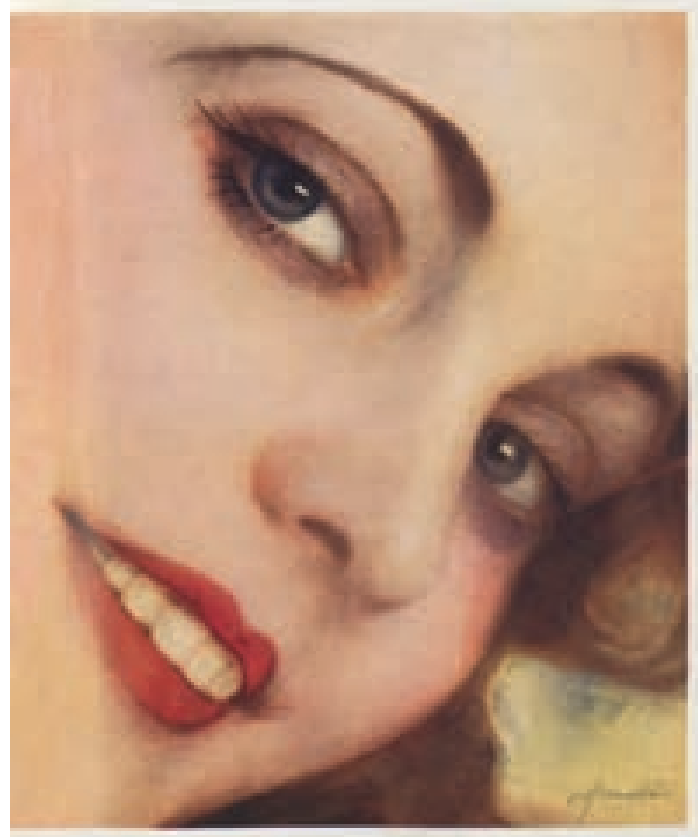

Nonember 1930 seis $m$ 1.:9120

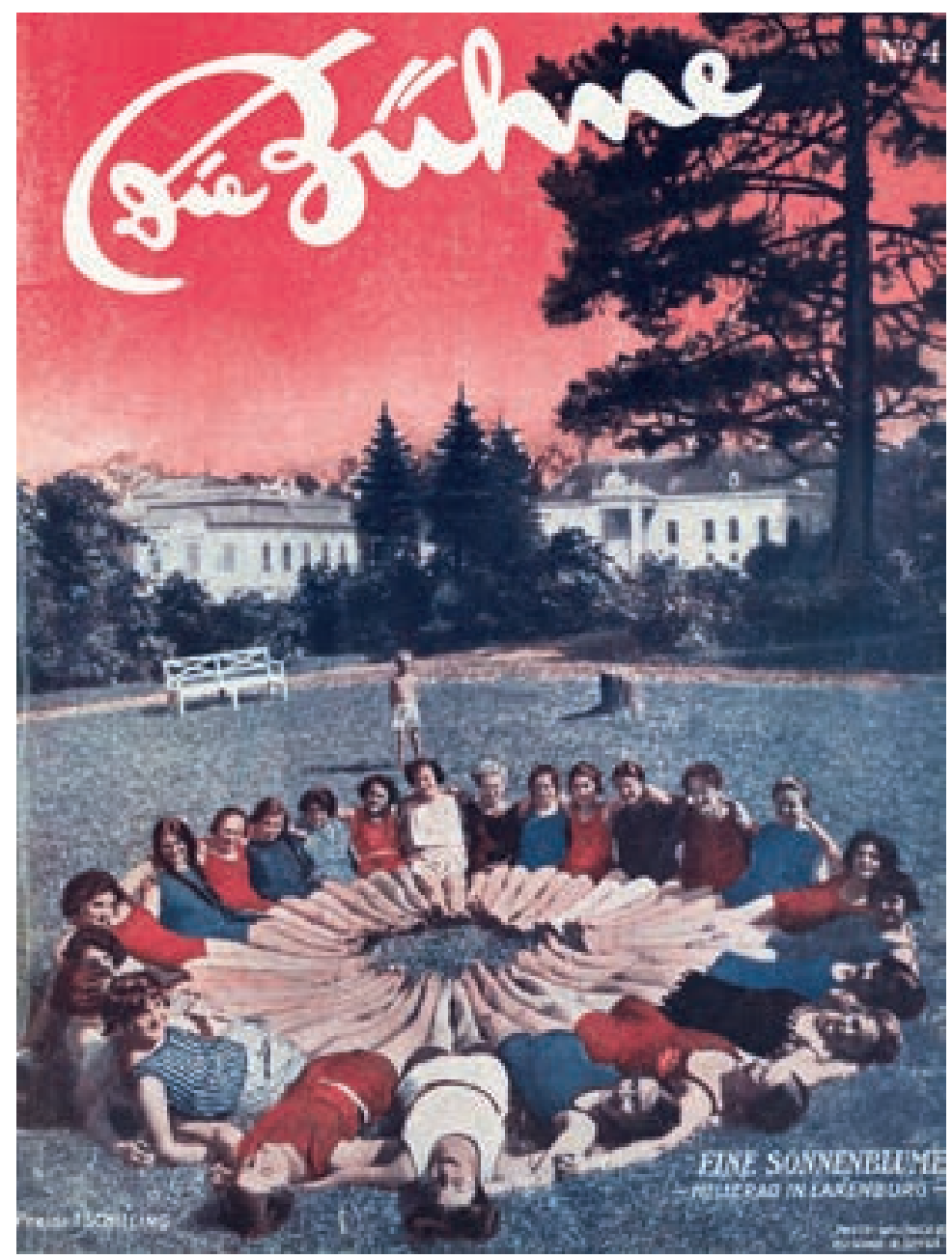

MODERNE WELT

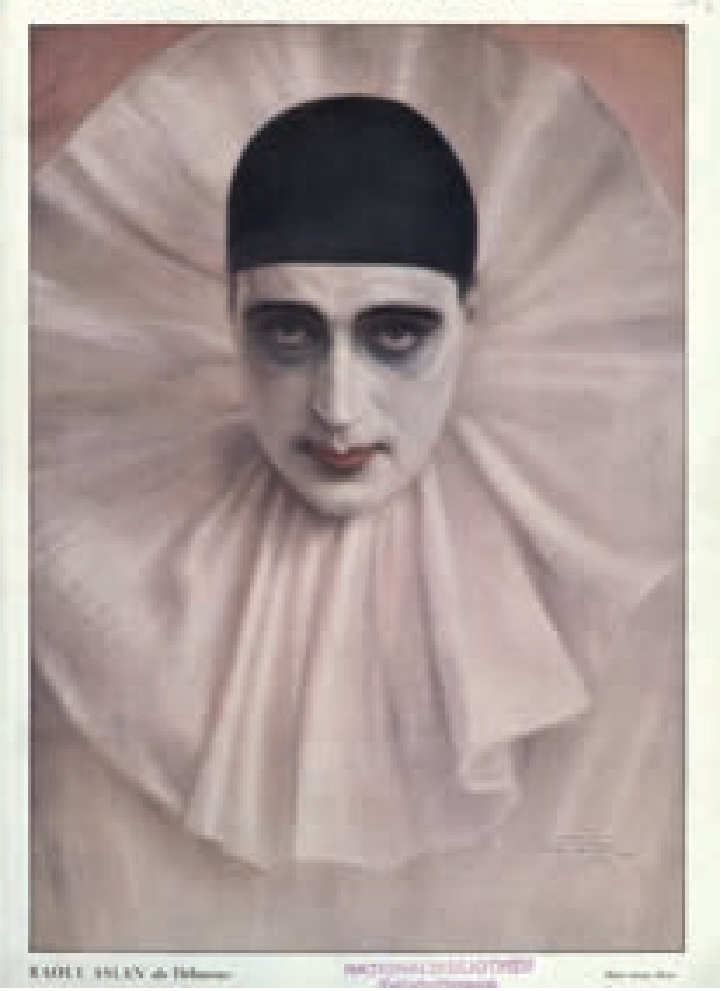

Abb. 3 In der Zwischenkriegszeit wird eine Reihe von neuen Magazinen gegründet. Wichtige Impulse für die Fotografie gehen von der Bühne (ab 1924), dem Wiener Magazin (ab 1927) und teilweise von der Modernen Welt (ab 1918) aus. Die Bühne, 27. August 1925, Titelseite. Foto: Agentur Willinger.

Abb. 4 Wiener Magazin, Heft 11, November 1930, Titelseite. Foto: Atelier Manassé.

Abb. 5 Moderne Welt, Heft 25, 1928, Titelseite. Foto: Atelier Setzer. 


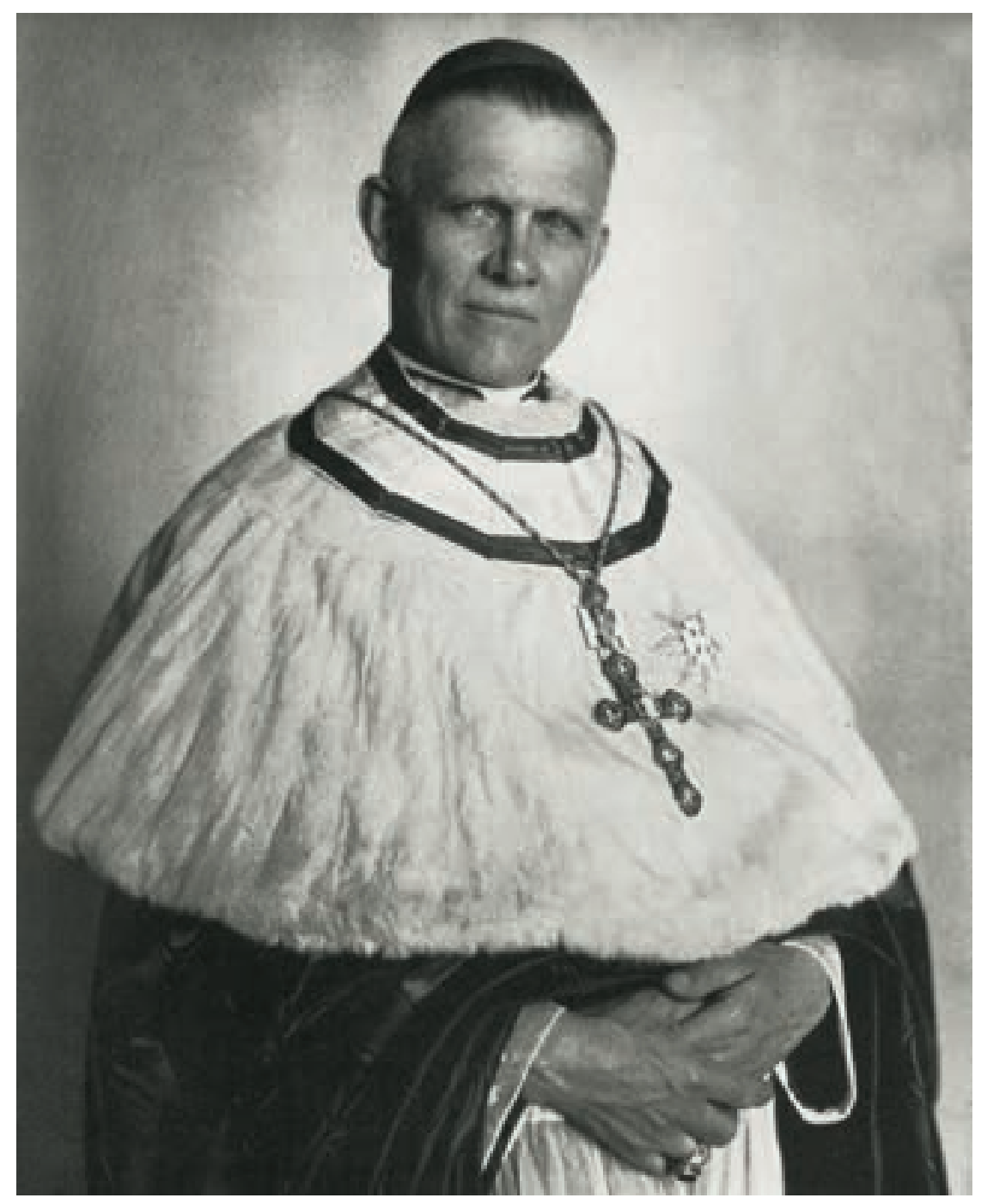

Abb. 6 Porträt des Wiener Kardinals Theodor Innitzer anlässlich des Allgemeinen Katholikentages im September 1933 in Wien. Seit Anfang der 1930er Jahre unterstützt die Moderne Welt offen die konservative, ab 1933 diktatorisch agierende Regierung. Moderne Welt, Heft 12, 1933, S. 7. Foto: Rudolf Koppitz.
Überraschung gezeigt, was es kann. Dieses erwachte österreichische Selbstbewußtsein und Selbstvertrauen soll auch in kommenden helleren Zeiten gepflegt werden und seinen eigenen österreichischen Ausdruck finden.“ 11

Das Anfang der 1920er Jahre auf monatlich 40 bis 50 Seiten angewachsene Magazin adressiert ein gehobenes Bürgertum. Die Zeitschrift ist bewusst edel aufgemacht, enthält in jeder Ausgabe mehrere farbig gedruckte Kunstbeilagen und die Modebeilage Die Damenwelt. In den ersten Jahren bleiben Aufmachung, grafische Gestaltung und der Einsatz der Fotos noch sehr konventionell. Die Titelseiten sind anfangs mit einer kleinformatigen aufgeklebten Fotografie, später mit einer farbigen Zeichnung und schließlich gelegentlich auch mit gedruckten Fotos illustriert. Im Innenteil jedoch setzt die Zeitschrift von Anfang an auf Fotos. Diese werden in den ersten Jahrgängen ohne größeren Anspruch in das zweispaltige (später dreispaltige) Layout integriert. Bis etwa 1920 werden die im Kupfertiefdruck gedruckten Bilder noch ma- nuell eingeklebt, später gedruckt. Viele bedeutende österreichische Fotografen veröffentlichen in der $\mathrm{Mo}$ dernen Welt. Die Zeitschrift ist somit eine wichtige Plattform v. a. der gemäßigt modernen Fotografie. Neben Madame d'Ora, die mit ihren Aufnahmen in fast in jedem Heft präsent ist, sind die bekanntesten Wiener Ateliers, etwa Setzer, Schein, Löwy, Glogau, Kolliner, Fleischmann, Geiringer/Horovitz und zahlreiche andere, vertreten.

Ende der 1920er Jahre setzt eine schrittweise grafische und gestalterische Modernisierung der Zeitschrift ein. Zwischen 1926 und 1928 wird der Umschlag modernisiert. Das Format wird verkleinert, die farbige Zeichnung wird nun öfter durch einen eingefärbten Fotodruck ersetzt. Die äußere Neugestaltung geht freilich nicht mit einer inhaltlichen Auffrischung einher, im Gegenteil. 1927 beginnt die Zeitschrift mit der Veröffentlichung einer Serie unter dem Titel „Das schöne Österreich“. Diese Artikelreihe zur Förderung des österreichischen Fremdenverkehrs erscheint in enger Kooperation mit dem Bundesministerium für Handel und Verkehr. Sie leitet eine in den folgenden Jahren weiter zunehmende antiurbane Tendenz der Zeitschrift ein - auch in der Fotografie. Immer offener stellt sich die Redaktion hinter die konservative, später autoritäre Politik der Regierung. Im September 1933 erscheint ein Sonderheft zum Allgemeinen Deutschen Katholikentag in Wien. Das passende Frontispizbild zu dieser Nummer liefert Rudolf Koppitz mit einem Porträt des konservativen Kardinals Theodor Innitzer (Abb.6), der das autoritäre Regime Dollfuß offen unterstützt. Anfang Oktober 1933 geht die Zeitschrift noch einen weiteren Schritt auf die Regierung zu und veröffentlicht eine Bildseite unter dem Titel „Bundeskanzler Dollfuss' Wochenende“. Die Fotos stammen vom Pressefotografen Leo Ernst. ${ }^{12}$

Obwohl sich die Moderne Welt in den 1930er Jahren allmählich neuen, erzählerischen Fotoformaten öffnet und hin und wieder auch Fotoreportagen bringt ${ }^{13}$, gehört sie im Kreis der illustrierten Magazine zu den konventionellsten Publikationen. Die Bühne und das Wiener Magazin reagieren viel offener auf die neuen ästhetischen Tendenzen. Gegen Ende der 1920er Jahre tauchen im Layout dieser Zeitschriften moderne Entwürfe und Bilder auf. Die Fotografie 
behauptet sich nun eindeutig als Medium der modernen Zeit gegenüber der Zeichnung. Gefragt sind nicht bloße Illustrationen, sondern „erzählende“ Bilder, Aufnahmen, die die Stimmungen der Gegenwart ausdrucksstark festhalten. Auf den Seiten der Bühne und des Wiener Magazins finden die jungen, experimentierfreudigen Fotografen, darunter auch zahlreiche Presse- und Amateurfotografen, eine geeignete Bühne für ihre Aufnahmen.

\section{Die Bühne-Plattform für die moderne Fotografie}

Als die Zeitschrift Die Bühne Anfang November 1924 zum ersten Mal erscheint, gehört sie zum Verlagskonzern Kronos AG, der von Imre Békessy aufgebaut worden war. Békessy selbst steht hinter der Gründung der illustrierten Wochenzeitschrift. Der Redaktionssitz ist zunächst in der Wipplingerstraße 32, Wien 1, untergebracht. Erster Chefredakteur ist Hans Liebstöckl. Bereits ein Jahr später, 1925, gerät die Kronos AG - und damit auch die Bühne-infolge finanzieller Turbulenzen unter die Kontrolle der Vernay AG. ${ }^{14}$ Inhaltlich ändert sich durch diesen Eigentümerwechsel nicht viel. Die Zeitschrift verfolgt bis weit in die 1930er Jahre hinein einen liberalen, sich von der Tagespolitik bewusst fernhaltenden Kurs. In ihrer Gestaltung und Themenwahl ist die Bühne im Vergleich zur Modernen Welt flotter und weit weniger behäbig. Im Untertitel umreißt sie das breite Spektrum an Themen, die sie abdeckt: Theater - Kunst - Mode - Film - Gesellschaft - Sport. Beeinflusst von Békessys Boulevardmedien wie der Tageszeitung Die Stunde räumt die Bühne auch populären Themen, wie dem Sport, Platz ein. Sie provoziert aber auch als eines der ersten österreichischen Magazine mit Aktaufnahmen. ${ }^{15}$

Der wichtigste Ideengeber in den ersten Jahren der Bühne ist der Chefredakteur Hans Liebstöckl, der als Theaterkritiker bei Wiener Tageszeitungen begonnen hatte und den Aufbau der Illustrierten leitet. Er orientiert sich in handwerklicher Hinsicht an den amerikanischen Illustrierten. „Diese haben“, resümiert er Ende 1925, nach einem Jahr bei der Bühne, „eine ausgesprochene Klischeekunst, sie haben das Verfahren, Bilder zu bringen, zu der größten Vollkommenheit entwickelt. Damit können wir vorläufig nicht konkurrieren: uns fehlt das überseeische Absatzgebiet, uns fehlt jene Stabilität der Verhältnisse, die eine vollkommen freie und künstlerische Entwicklung gestattet."16 Trotz dieser Einschränkungen ist die Bühne erfolgreich. Das Konzept, ein Gesellschaftsmagazin herauszugeben, das eine breite Leserschaft anzieht, geht auf.

Von Anfang an setzt die Zeitschrift auf ein - oft farbig gedrucktes - ausdrucksstarkes Titelfoto (Abb.7). Der dreispaltige Innenteil ist in den ersten Jahrgängen noch recht konventionell gestaltet, aber allmäh-
Abb. 7 „Die Wiener Eislaufkünstlerin Melitta Brunner“. Die Bühne, 25. Februar 1927, Titelseite. Foto: Lothar Rübelt.

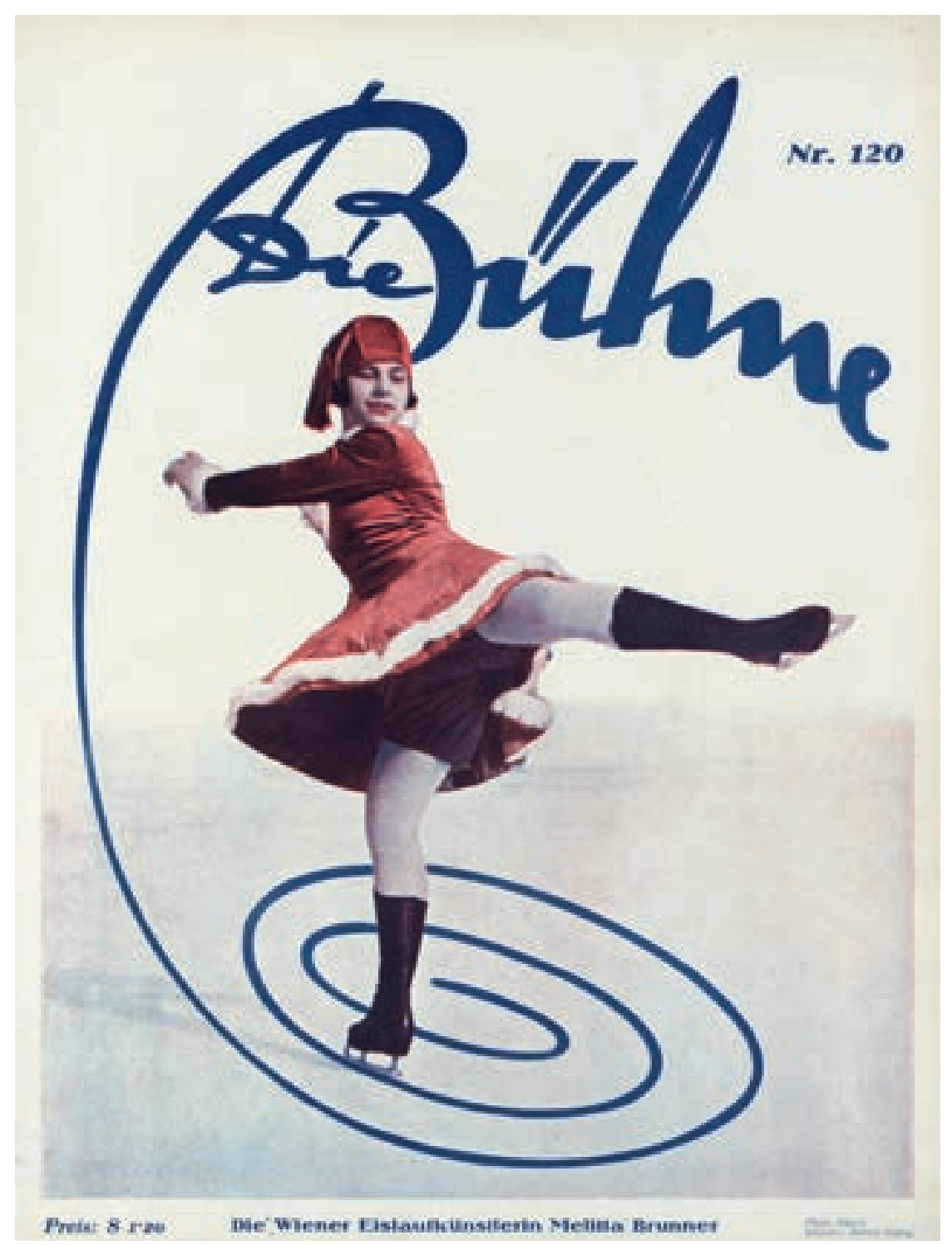




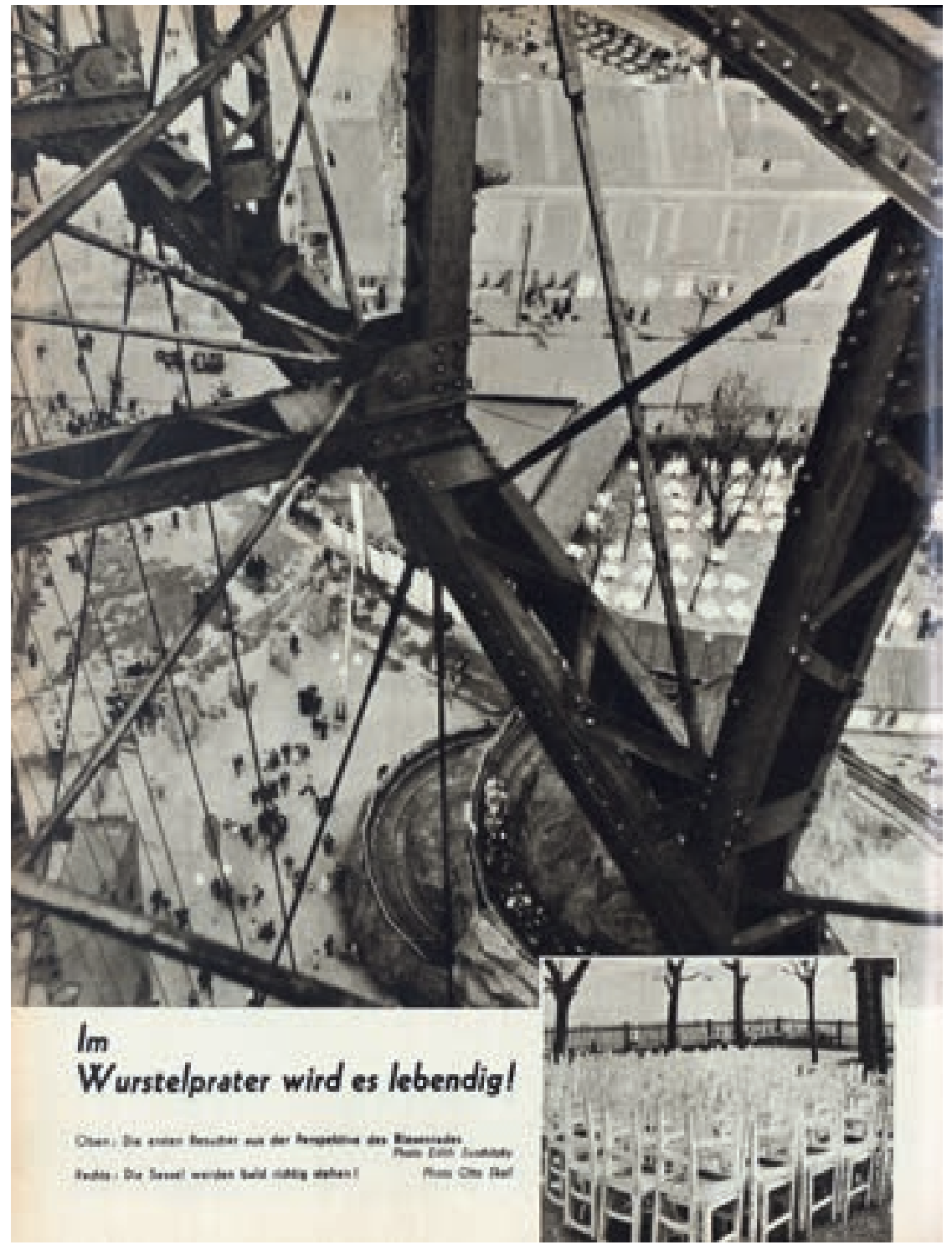

Abb. 8 Der Wiener Prater mit dem Riesenrad, von oben aufgenommen. Die Bühne, Zweites Aprilheft 1933, S. 14. Fotos: oben: Edith Suschitzky, unten: Otto Skall. lich wird dieses starre Korsett aufgebrochen und mit neuen grafischen Lösungen experimentiert. Immer öfter gibt es nun ganze Bildseiten, die gelegentlich zu kurzen Bildgeschichten verbunden werden. Aber auch in der Modefotografie geht die Zeitschrift nun neue Wege. Die Bilder werden oft freigestellt und subtil mit dem Text verwoben. Als eine der ersten österreichischen illustrierten Magazine bringt die Bühne ab 1929 professionell gestaltete, thematisch originelle Fotoreportagen. $\mathrm{Zu}$ den Pionierinnen dieser Gattung gehören die beiden Fotografinnen Annie Schulz und Marianne Blumberger (verh. Bergler). ${ }^{17}$
Um 1929/30 wird nicht nur die grafische Linie der Zeitschrift deutlich modernisiert. Die Bühne wird in diesen Jahren allmählich zu einer wichtigen publizistischen Plattform für die moderne Fotografie. Zahlreiche Vertreter der österreichischen fotografischen Avantgarde und des Neuen Sehens veröffentlichen in der Zeitschrift. Die Redaktion verfolgt das zeitgenössische Fotogeschehen aufmerksam. Um nur ein Beispiel zu nennen: Die legendäre Werkbundausstellung „Film und Foto“, die 1930 in Wien Station macht, wird in der Bühne von Wolfgang Born ausführlich und sehr wohlwollend angekündigt. ${ }^{18}$ Im Konflikt zwischen Traditionalisten und Neuerern in der Fotografie stellt sich die Redaktion der Bühne um 1930 eindeutig auf die Seite der Modernen.

Die Zeitschrift veranstaltet Anfang der 1930er Jahre eigene Fotowettbewerbe, regelmäßig werden Fotografen, die im Stil des Neuen Sehens und der Neuen Sachlichkeit arbeiten, prämiert. Ende November 1931 veröffentlicht die Bühne als Siegerarbeit eine Aufnahme von Sepp Nowak. ${ }^{19}$ Der Fotograf wirft einen ungewöhnlichen Blick vom Wiener Riesenrad auf den Prater. Eine ähnliche Aufnahme, auch sie wird in der Bühne veröffentlicht, stammt von Edith Suschitzky. Sie zeigt im Vordergrund die Diagonalen der Riesenrad-Konstruktion und weit unten auf dem Boden aus extremer Vogelperspektive zahlreiche Passanten (Abb. 8).

Obwohl die Bühne, etwa im Unterschied zum Kuckuck, nur selten Fotomontagen bringt, arbeitet auch sie - vor allem in den Jahren um 1930 - im Layout gelegentlich mit Schere und Klebstoff. Ende 1931 wird auf einer originellen Doppelseite der Bühnenund Kostümbildner Alfred Kunz als Spielzeugsammler vorgestellt (Abb.9). Der gezeichnete Protagonist mit aufgesetztem „Fotokopf“ hat liegend inmitten seiner Sammlerstücke Platz genommen. Die Zeichnung stammt von Lisl Weil, die Fotos hat Kitty Hoffmann aufgenommen. Lisl Weil, geb. 1910, die die Wiener Kunstgewerbeschule absolviert hat, zeichnet seit Ende der 1920er Jahre für mehrere österreichische Tageszeitungen und Magazine Illustrationen und Vignetten. Besonders häufig ist sie - neben Friedl Biegler, Emmi Sagai und gelegentlich Bil Spira - ab Anfang der 1930er Jahre im Auftrag der Bühne tätig, für die sie auch Titelblätter grafisch gestaltet. ${ }^{20}$ 
Neben dem Wiener Magazin und dem Sonntag ist die Bühne eines der wichtigsten Foren für die moderne Fotografie. Fast alle wichtigen österreichischen Fotografen der Zwischenkriegszeit veröffentlichen in der Bühne. Am häufigsten kommen die Vertreter der gemäßigten Moderne vor, Platz bietet die Zeitschrift aber auch für Amateure, die in den 1930er Jahren zu den konservativen Vertretern der Kunstfotografie gehören. Pressefotografen sind ebenso vertreten wie Gesellschafts-, Tanz-, Theater- und Modefotografen. Auffallend viele von ihnen sind Frauen. ${ }^{21}$ Aber auch renommierte internationale Vertreter der modernen Fotografie, vor allem aus Deutschland, Frankreich, Ungarn und Tschechien werden - vermehrt um 1930 - in der Bühne vorgestellt. Unter ihnen sind Sasha und Cami Stone, Lotte Jacobi, Yva, Hans Robert- son, Aenne Biermann, Umbo, Felix H. Man, Martin Imboden, Jan Lukas, Václav Jírů, Martin Munkácsi und Brassai.

\section{Konservative Wende}

1931 ist in der Bühne der Höhepunkt der modernen Fotografie erreicht. In den folgenden Jahren kommt es zu einer allmählichen Neuorientierung der Zeitschrift. Die Avantgarde verschwindet zwar nicht spurlos, aber konservativere Positionen kommen nun vermehrt zum Zug, urbane Themen werden von ländlichen abgelöst, der Österreich-Patriotismus, der von der Regierung sehr stark gefördert wird, schlägt sich auch auf den Seiten der Bühne nieder. Ein Titelblatt aus dem Jahr 1934 verdeutlicht diesen inhaltlichen
Abb. 9 Doppelseite über den Wiener Bühnen- und Kostümbildner Alfred Kunz. Die Bühne, Zweites Dezemberheft 1931, S. 8/9. Fotos: Kitty Hoffmann, Zeichnung: Lisl Weil.

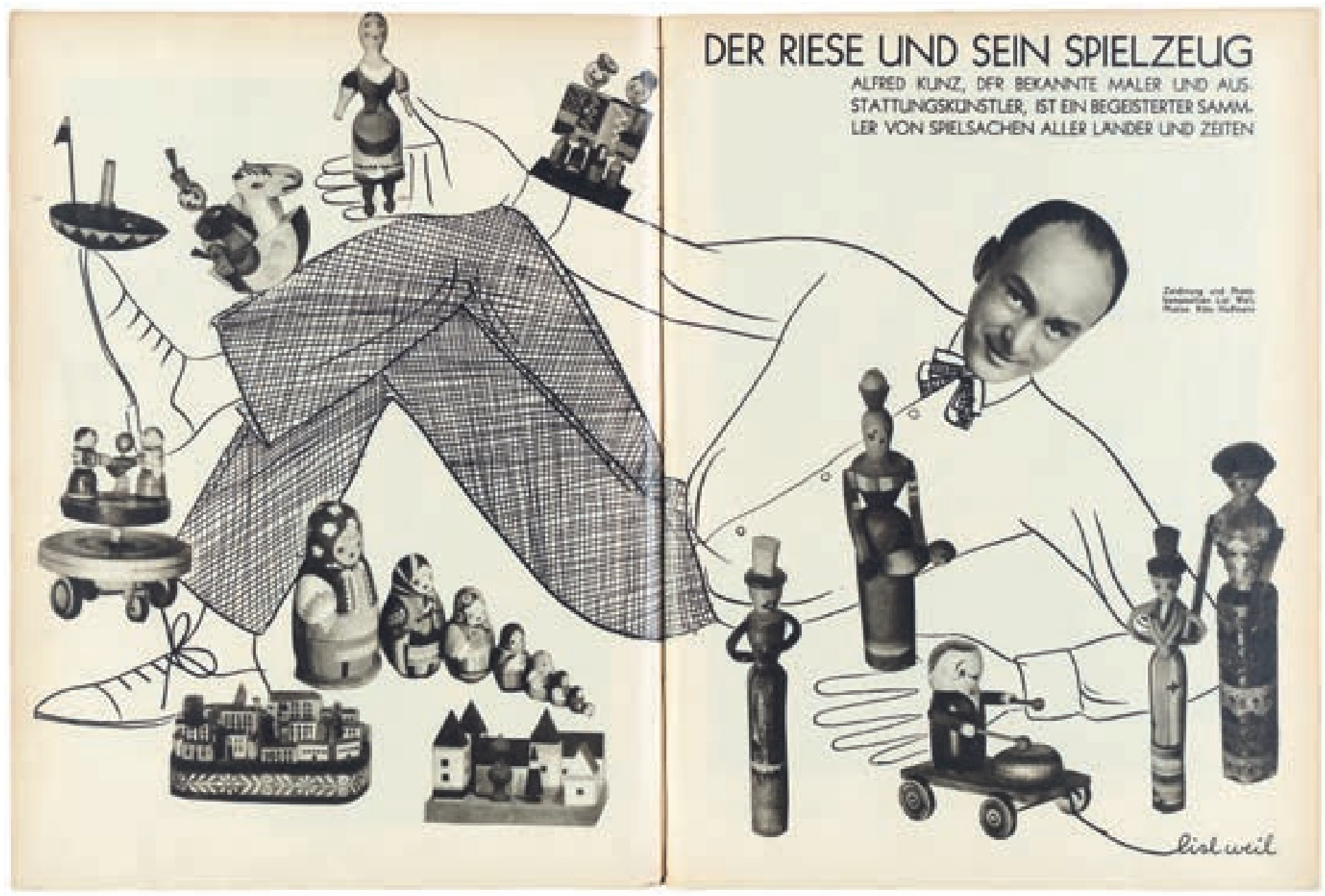




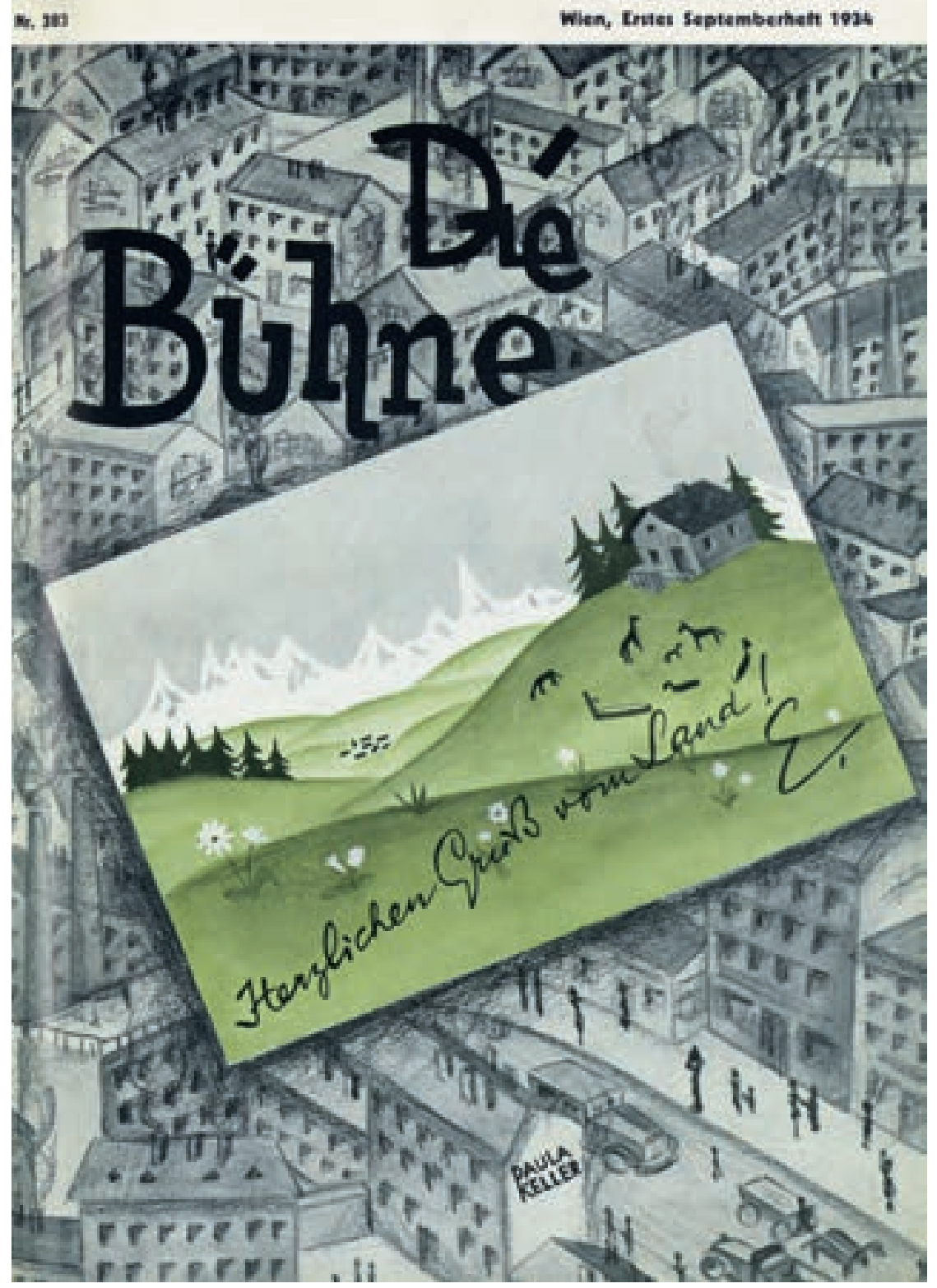

Abb. 10 „Herzlichen Gruß vom Land“. An die Stelle von urbanen Themen treten in den 1930er Jahren zunehmend ländliche Motive. Die Bühne, Erstes Septemberheft 1934, Titelseite.

Abb. 11 „Zillertalerinnen“. Die Bühne, Erstes Dezemberheft 1932, S. 3. Foto: Peter Paul Atzwanger.
Schwenk sehr anschaulich (Abb. 10). Die Grafik von Paula Keller stellt der grauen, anonymen und schmutzigen Stadt im Hintergrund das idyllische, in hellen, bunten Farben gehaltene Landleben gegenüber. Auch in den Fotos zeigt sich diese neue Faszination für das Ländliche. Anfang Dezember 1932 veröffentlicht die Bühne ein typisches antiurbanes Genrebild dieser Jahre. Zu sehen sind zwei junge Zillertalerinnen in ihrer bäuerlichen Tracht vor einem Tiroler Bauernhaus (Abb. 11).

Und dennoch: Verglichen mit der Anbiederung der Modernen Welt an die autoritäre Regierungspolitik ist die Redaktion der Bühne deutlich zurückhaltender. Sie entzieht sich zwar nicht der allgegenwärtigen konservativen Grundstimmung, wahrt aber dennoch eine gewisse Distanz zur offiziellen Politik. Ein wichtiger Grund dafür ist die Eigentümerstruktur des Ma- gazins. Die Aktienmehrheit des Mutterkonzerns, der Vernay AG, steht unter tschechischer Kontrolle und somit ist die Bühne dem Regierungseinfluss etwas weniger ausgesetzt als andere österreichische Medien. Um das Blatt zu stärken, wird 1934 eine Vertriebsgemeinschaft mit der liberalen Tageszeitung Der Wiener Tag vereinbart. Abonnenten des Blattes wird die illlustrierte Zeitschrift zu günstigen Konditionen als eine Art „Beilage“ angeboten. Im Zuge dieser Kooperation, die auf die Initiative von Emil Oplatka, des Direktors der Vernay AG, zurückgeht, kommt es im September 1934, entgegen dem allgemeinen Trend in der österreichischen Zeitschriftenlandschaft, zu einer Modernisierung im äußeren Erscheinungsbild der Bühne. Im selben Jahr startet auch die Wochenendbeilage des Wiener Tag, die unter dem Titel Der Sonntag erscheint. Geleitet wird sie von Hans Oplatka, dem Sohn von Emil Oplatka. ${ }^{22}$

Wenn man die fotografische Linie der Bühne in den 1930er Jahren überblickt, wird deutlich, dass moderne Positionen, die um 1930 stärker präsentiert wurden, mehr und mehr zurückgedrängt werden. Zugleich erringen konservative Lichtbildner allmählich

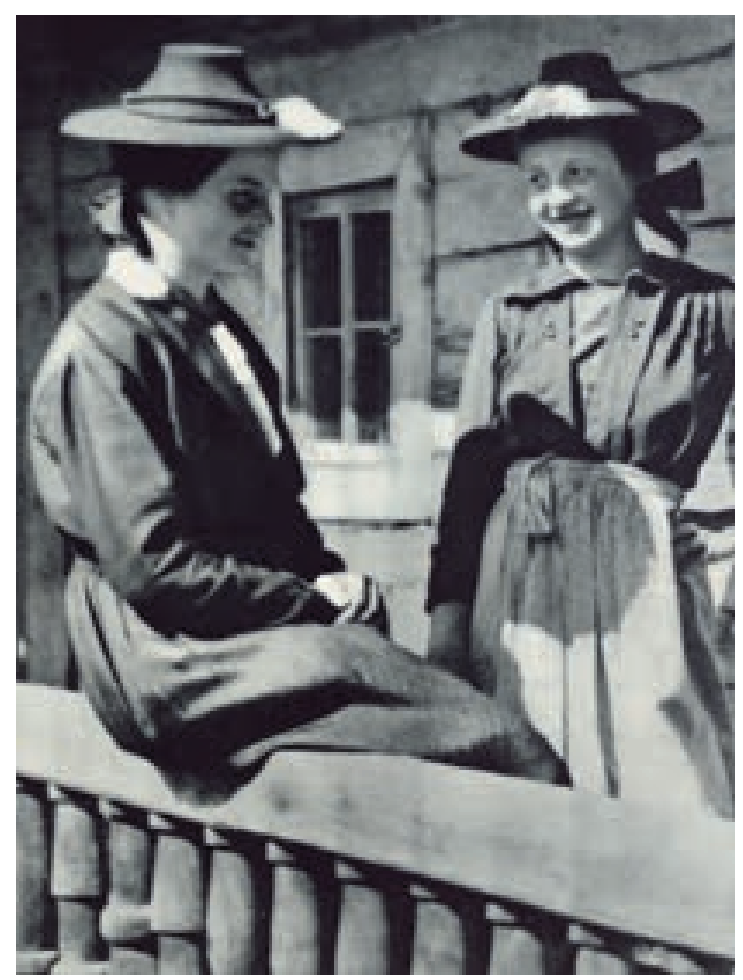


die Hegemonie. Dieser Schwenk kennzeichnet nicht nur die Bühne, sondern lässt sich auch in den meisten anderen Zeitschriften ähnlichen Formats feststellen. Freilich wäre es verkürzt zu behaupten, dass dieser Prozess einen Kampf zwischen zwei deutlich getrennten Lagern widerspiegele. Die Realität ist komplexer: Konservative Lichtbildner, viele von ihnen Amateure, wie etwa Maximilian Karnitschnigg, Hermann Brühlmeyer, Rudolf Schloß, Oswald Elbl oder Hans Hannau, die der neuen Sachlichkeit und dem Neuen Sehen den

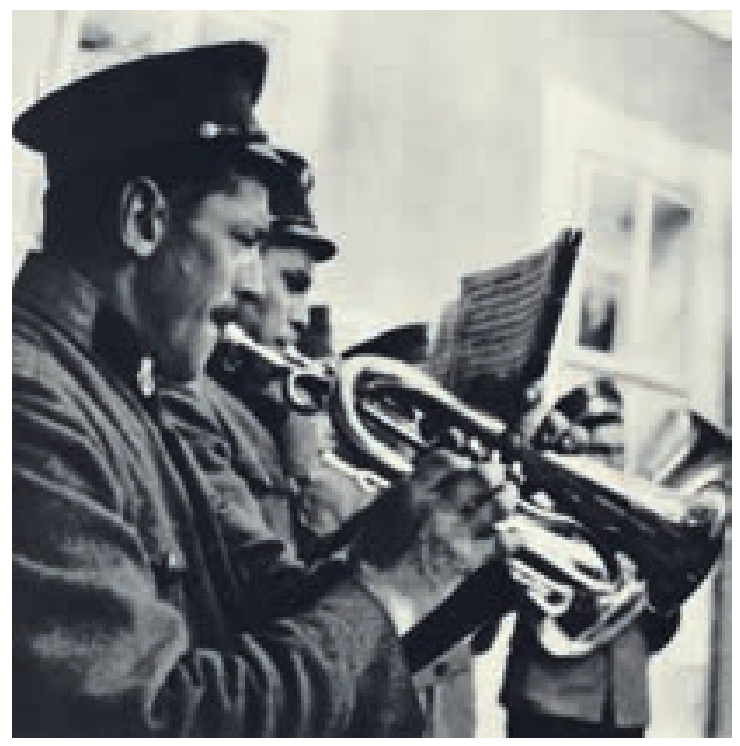

Kampf ansagen, drängen nun immer stärker in die Öffentlichkeit. Umgekehrt erweitern einige der modernen Fotografen ihr Spektrum und passen sich in ihren Zeitungsarbeiten den herrschenden Umständen und Stimmungen an. Trude Fleischmann etwa, die mit ihren gemäßigt modernen Porträts, Tanzstudien und Akten bekannt geworden ist, bedient sich in den 1930er Jahren in ihren Landschafts- und Reisebildern, die sie u. a. auch in der Bühne veröffentlicht, einer anderen, deutlich konservativeren Bildsprache. ${ }^{23}$ Wieder andere bedienen, je nach Themenstellung und Auftrag, sowohl moderne wie konservative Vorgaben. $\mathrm{Zu}$ ihnen gehören neben vielen anderen etwa Hans Madensky (Abb. 12), Lotte Meitner-Graf, Otto Skall, Hans Casparius, Franz Mayer, Ernst Hartmann, Franz Senkinc, Nikolaus Schwarz, Willy Eggarter, aber auch Heinz von Perckhammer. Zu den talentiertesten, auch

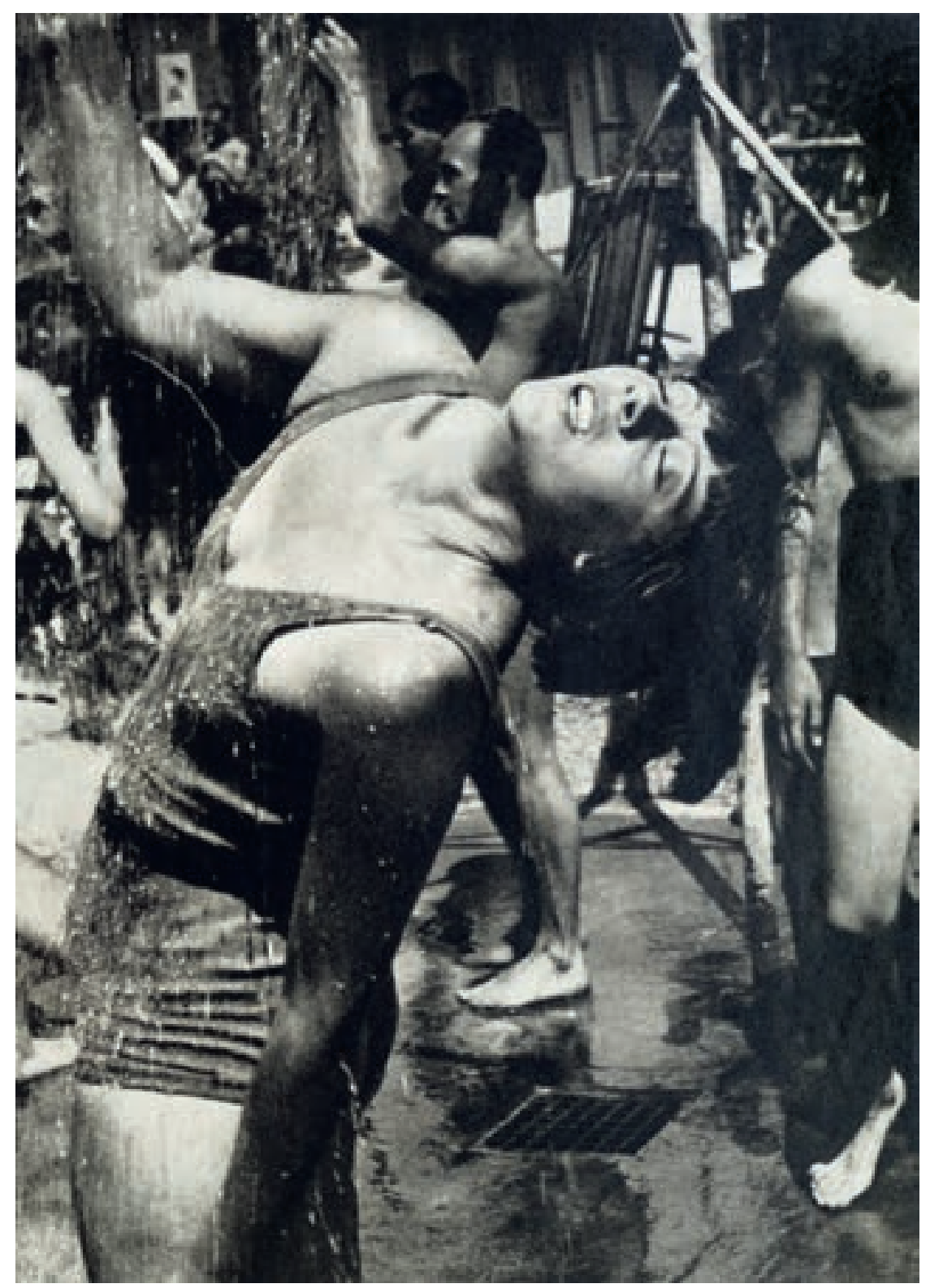

in den 1930er Jahren noch konsequent modern arbeitenden Fotografen der Bühne gehören u.a. Rudolf Spiegel, Martin Imboden, Kurt Husnik und Robert Haas, der zahlreiche anspruchsvolle Fotoreportagen zusammenstellt und sich oft einen ironisch-distanzierten Blick bewahrt (Abb. 13).

Eine Sonderstellung nimmt Hans Oplatka ein, der neben seiner Haupttätigkeit, der Herausgabe des Sonntag, selbst fotografiert und - meist recht konventionelle - Reportagen für die Bühne zusammenstellt. Vor allem aber tritt er als Bindeglied zur modernen und kreativen österreichischen Fotoszene hervor. Durch seine Vermittlung findet ab Mitte der 1930er Jahre eine Reihe von sehr guten tschechischen Fotografen den Weg zum Sonntag und zur Bühne, etwa Alexandr Hackenschmied und Jan Lukas, der Mitte der 1930er Jahre eine Zeit lang in Wien lebt. ${ }^{24}$
Abb. 12 „Badendes Mädchen“. Die Bühne, Erstes Juniheft 1933, S. 9. Foto: Hans Madensky. Bühne, Zweites Augustheft 1937, S. 12. Foto: Robert Haas.
Abb. 13 „Landkapelle“. Die 


\section{Wiener Magaxin \begin{tabular}{lllllllll}
\hline $\mathrm{F}$ & $\mathrm{E}$ & $\mathrm{B}$ & $\mathrm{E}$ & $\mathrm{R}$ & 1 & 9 & 3 & 2 \\
\hline
\end{tabular}}

VI. JHRG. * VERLAG ALEXANDER \& CO. * NR. 2

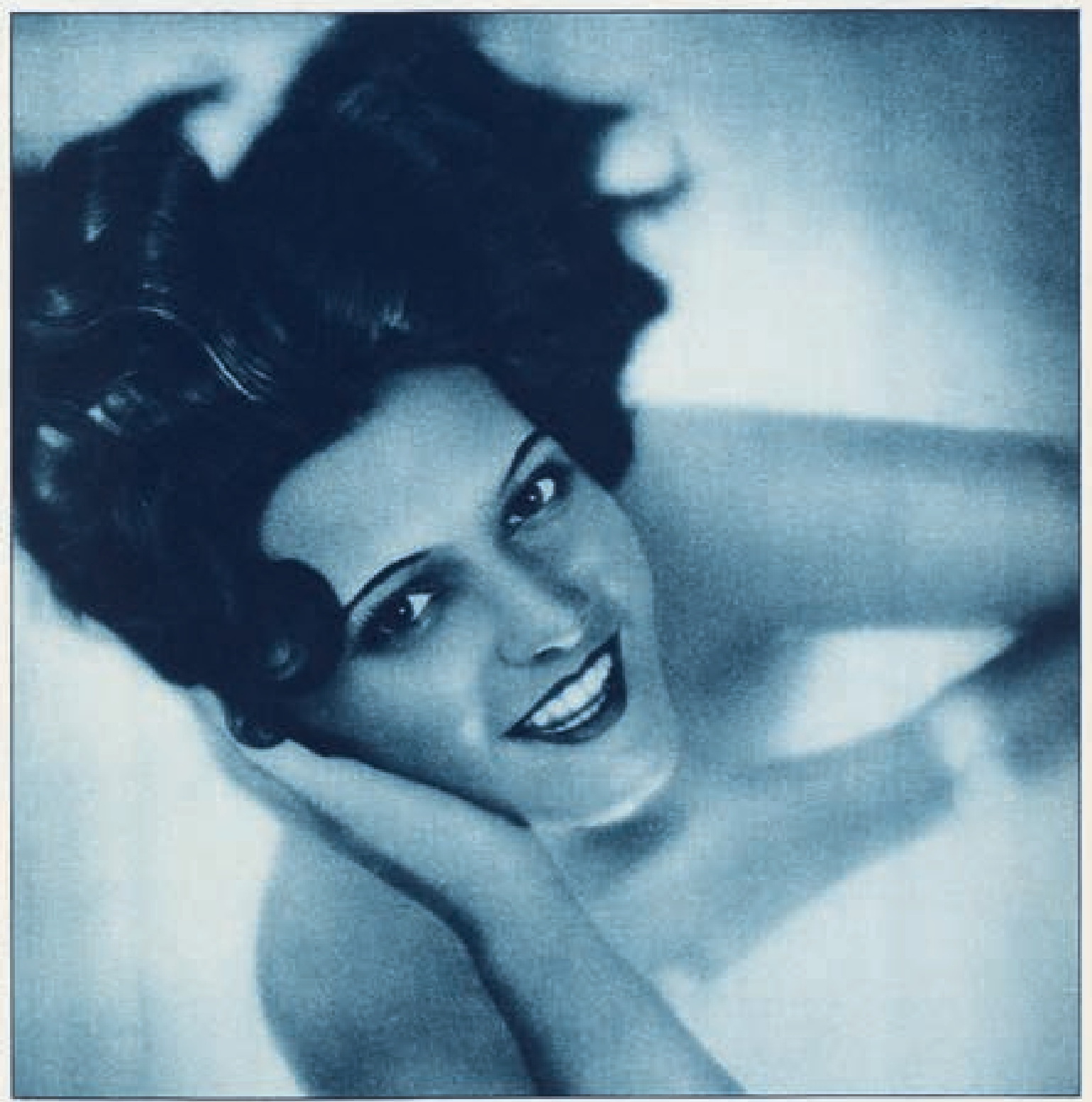

Die Tansecrin Else Brabant

What. Manasse 


\section{Wiener Magazin - Treffpunkt der konservativen Moderne}

Ebenso wie die Bühne spielt auch das 1927 gegründete Wiener Magazin eine nicht zu unterschätzende Rolle als Plattform für die moderne österreichische Fotografie der Zwischenkriegszeit (Abb. 14). Im Unterschied zur Modernen Welt, die ein gehobenes, elitäres Publikum adressiert, aber auch zur Bühne, die sich als bürgerliche Gesellschafts- und Kulturzeitschrift versteht, wendet sich das Wiener Magazin an breite Bevölkerungsschichten. Die Zeitschrift ist populär aufgemacht, sie deckt alle Bereiche des gesellschaftlichen Lebens ab, vom Sport über die Mode bis hin zu Film und Alltag. Sensationsthemen, die gelegentlich ziemlich voyeuristisch präsentiert werden, räumt sie viel Platz ein. Regelmäßig druckt sie Fotos von entblößten weiblichen Körpern. Von der Tagespolitik hält sie sich fern.

Als Anfang November 1927 das erste Heft des Wiener Magazins erscheint, ist die illustrierte Presse in Österreich auf Expansionskurs. Das betrifft insbesondere die wöchentlich oder monatlich erscheinenden Gesellschafts-, Film- und Radiozeitschriften, von denen viele ab Mitte der 1920er Jahre gegründet werden. Eigentümer des Wiener Magazin ist kein groBer Konzern, sondern die kleine Alexander \& Co. Zeitungsverlagsgesellschaft. Der Eigentümer Richard F. Alexander selbst tritt als Herausgeber der Zeitschrift auf, die Redaktion ist in der Herrengasse 14, Wien 1, untergebracht. Chefredakteur ist Otto Helmers, verantwortlicher Redakteur Hubert Vanderfecht. Gedruckt wird die Zeitschrift in der Hermes Buch- und Kunstdruckerei.

Das monatlich erscheinende Magazin legt großen Wert auf eine ansprechende fotografische Illustration. Von Anfang an werden Aufnahmen namhafter österreichischer und ausländischer Fotografen - stets in gutem Kupfertiefdruck - veröffentlicht. Grafisch sind die ersten Jahrgänge noch recht einfach gestaltet, die Fotos werden in ein einfaches Textraster einge-

Abb. 14 Neben der Bühne ist auch das Wiener Magazin eine wichtige Plattform für die moderne österreichische Fotografie. Wiener Magazin, Heft 2, Februar 1932. Foto: Atelier Manassé.

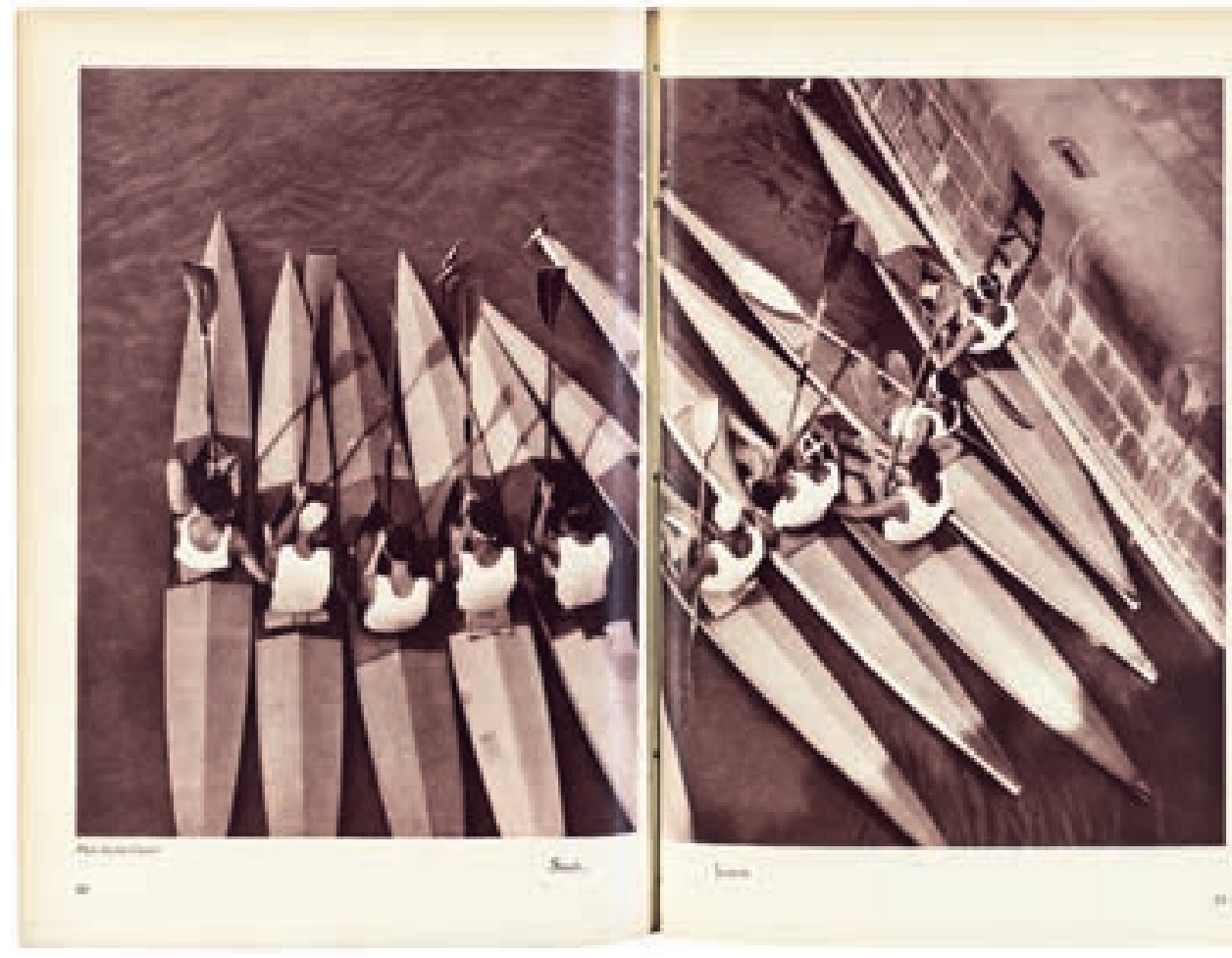

passt. Ein Gutteil der Titelfotos stammt vom Wiener Atelier Manassé. Allmählich wird aber das Layout professioneller. Um 1930 tauchen im Wiener Magazin erstmals Fotoreportagen auf. Ab 1932 sind diese Bilderzählungen, inzwischen meist sehr gut gestaltet, fester Bestandteil der Zeitschrift. Ab Anfang der 1930er Jahre erscheint das Wiener Magazin in einem modernisierten Layout. Der Textteil wird nun zurückgedrängt, immer öfter werden eindrucksvolle Bildseiten oder spannungsreiche Bilddoppelseiten eingefügt (Abb. 15).

Die fotografische Linie des Wiener Magazins ist Ende der 1920er Jahre keineswegs eindeutig. Neben zahlreichen piktorialistischen Porträt-, Landschaftsund Genreaufnahmen, etwa von Rudolf Koppitz, Hermann Brühlmeyer oder Fernand Jellinek-Mercedes, finden wir in der Zeitschrift auch experimentelle Lichtmontagen, etwa des Berliner Fotografen Heinz Hajek-Halke (Abb. 16), moderne Stadtaufnahmen, etwa des Bauhäuslers Erich Comeriner, oder anspruchsvolle Fotoreportagen, etwa von Frank Sykora oder Lothar Rübelt, der besonders viel in der Zeitschrift veröffentlicht.
Abb. 15 Ab Anfang der 1930er Jahre wird die Gestaltung des Wiener Magazins modernisiert. Immer öfter erscheinen eindrucksvolle Bilddoppelseiten. Wiener Magazin, Heft 10, Oktober 1932, S. 60/61. Foto: Lucca Chmel. 

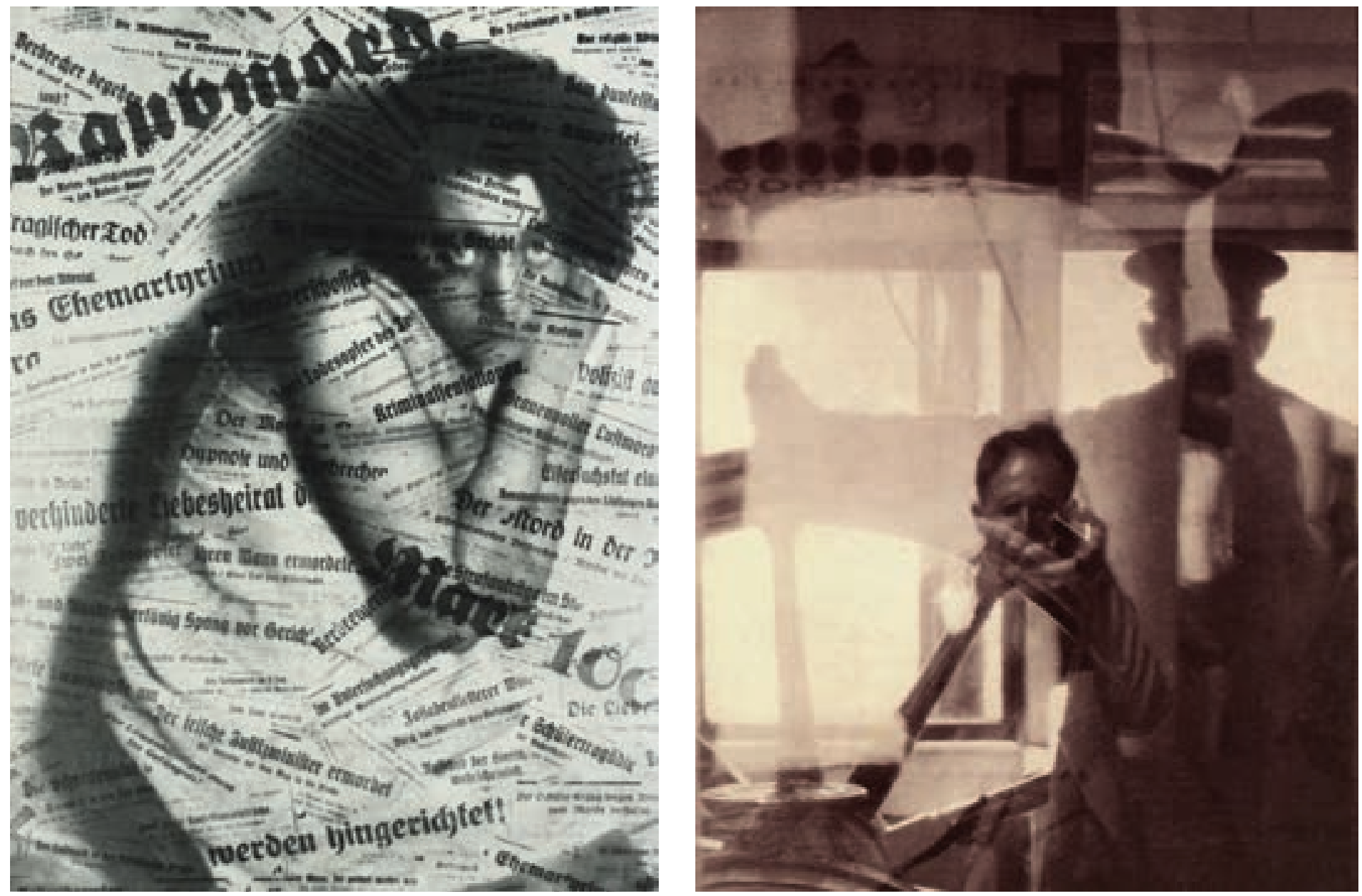

Abb. 16 „Angst“. Lichtmontage des Berliner Fotografen Heinz Hajek-Halke. Wiener Magazin, Heft 3, März 1928, S. 38.

Abb. 17 „Der Steuermann, durch ein Glasfenster gesehen samt dem Spiegelbild des Fotografen". Wiener Magazin, Heft 12, Dezember 1930, S. 49. Foto: Karl Wechsler.
Ende der 1920er Jahre öffnet sich die Zeitschrift, ähnlich wie die Bühne, für einige Jahre den modernen Fotografen, ohne allerdings die Traditionalisten ganz zu verscheuchen. Um 1930 werden zunehmend gemäßigt moderne Aufnahmen von Fotoamateuren vorgestellt, die - zumindest teilweise - die Anregungen der Neuen Sachlichkeit und des Neuen Sehens aufgenommen haben. Zu ihnen gehören u.a. Nikolaus Schwarz, Karl Wechsler (Abb. 17), Desider Freiwirth (Abb. 18), Willy Riethof, Willy Eggarter, Kurt Husnik, Martin Imboden und Ernst Kleinberg. Zur gemäßigt modernen Richtung, die im Wiener Magazin präsentiert wird, zählen auch einige Lichtbildner, die der Wiener Arbeiterfotografiebewegung nahestehen, etwa Ferdinand Hodek, Josef Schramek oder Otto Dobrowolny. ${ }^{25}$

In den 1930er Jahren veröffentlicht das Wiener $M a^{-}$ gazin häufig Fotobeispiele ausländischer Fotografen. Während die Redaktion der Bühne ihre Kontakte sehr stark in Richtung Tschechoslowakei ausbaut, orientiert sich die Redaktion des Wiener Magazins - neben Deutschland - stärker nach Ungarn. Berücksichtigt werden vor allem Arbeiten von Fotoamateuren, die eine gemäßigt moderne Linie vertreten, etwa piktori- alistische Elemente mit moderner Landschafts- und Sachfotografie verbinden. In der ungarischen Fotogeschichte wird diese Richtung als „ungarischer Stil“ bezeichnet. 1931 werden erstmals Sachfotografien von Tibor Hegyei vorgestellt. ${ }^{26} 1932$ fotografiert dieser das Wiener Riesenrad in der Abenddämmerung, das Foto wird auf einer eindrucksvollen Doppelseite präsentiert (Abb. 19). Die verwischten Konturen, die den vertrauten Anblick verfremden, sind typisch für seine Arbeiten. Ab 1933/34 häufen sich ungarische Fotobeispiele im Wiener Magazin. Präsentiert werden Lichtbildner wie Zoltan Vidor, Ernö Kreisler, Ferenc Tschik (auch Csík), Jenö Dulovits, Kálmán Szöllősy, Ernő Vadas oder Tibor Csörgeő. Ihre bevorzugten Themen, Genreaufnahmen, romantische Landschaften, viele von ihnen sind in den österreichischen Bergen aufgenommen, passen gut in die zunehmend konservativer werdende Grundstimmung, die auch das Wiener Magazin widerspiegelt.

Eine zentrale Rolle bei der Vermittlung ungarischer Fotoamateure im Ausland spielt die von Kálmán Szöllősy Anfang der 1930er Jahre gegründete Einrichtung „Ill-Pho“. Ihre Aufgabe ist es, die Fotoarbeiten ungarischer Fotoamateure im Ausland zu vertreten, 
etwa an Ausstellungen zu vermitteln oder, ähnlich einer Fotoagentur, Zeitungen und Zeitschriften anzubieten. ${ }^{27}$ „Ill-Pho“ ist sehr erfolgreich und wird bald zum Markenzeichnen ungarischer Fotografie. Häufig werden in der Presse neben dem Kürzel „Ill-Pho“ zwar auch die Fotografennamen erwähnt, oft verzichtet man aber auch auf die Namensgebung.

Die zunehmende Präsenz ungarischer Fotoamateure, von denen viele einer Art piktorialistischer Moderne anhängen, ist kein Zufall. Sie ist das Ergebnis einer politischen Annäherung Österreichs an das faschistische Italien und das autoritär regierte Ungarn, die im Frühjahr 1934 beginnt und u. a. auch zu einer Reihe von Ausstellungen zur ungarischen Kultur in Wien führt. ${ }^{28}$ Die Rezeption der gemäßigt modernen ungarischen Fotografie ist natürlich auch ein klares Statement gegen die in konservativen Kreisen als übertrieben empfundenen Radikalismen des Neuen Sehens und der Neuen Sachlichkeit, wie sie um 1930 in Mode waren. Die ungarische Amateurfotokultur
Abb. 18 „Arbeit“. Wiener Magazin, Heft 4, April 1932, S. 38. Foto: Desider Freiwirth.

Abb. 19 „Das Wiener Riesenrad in der Abenddämmerung“. Wiener Magazin, Heft 5, Mai 1932, S. 60/61. Foto: Tibor Hegyei.
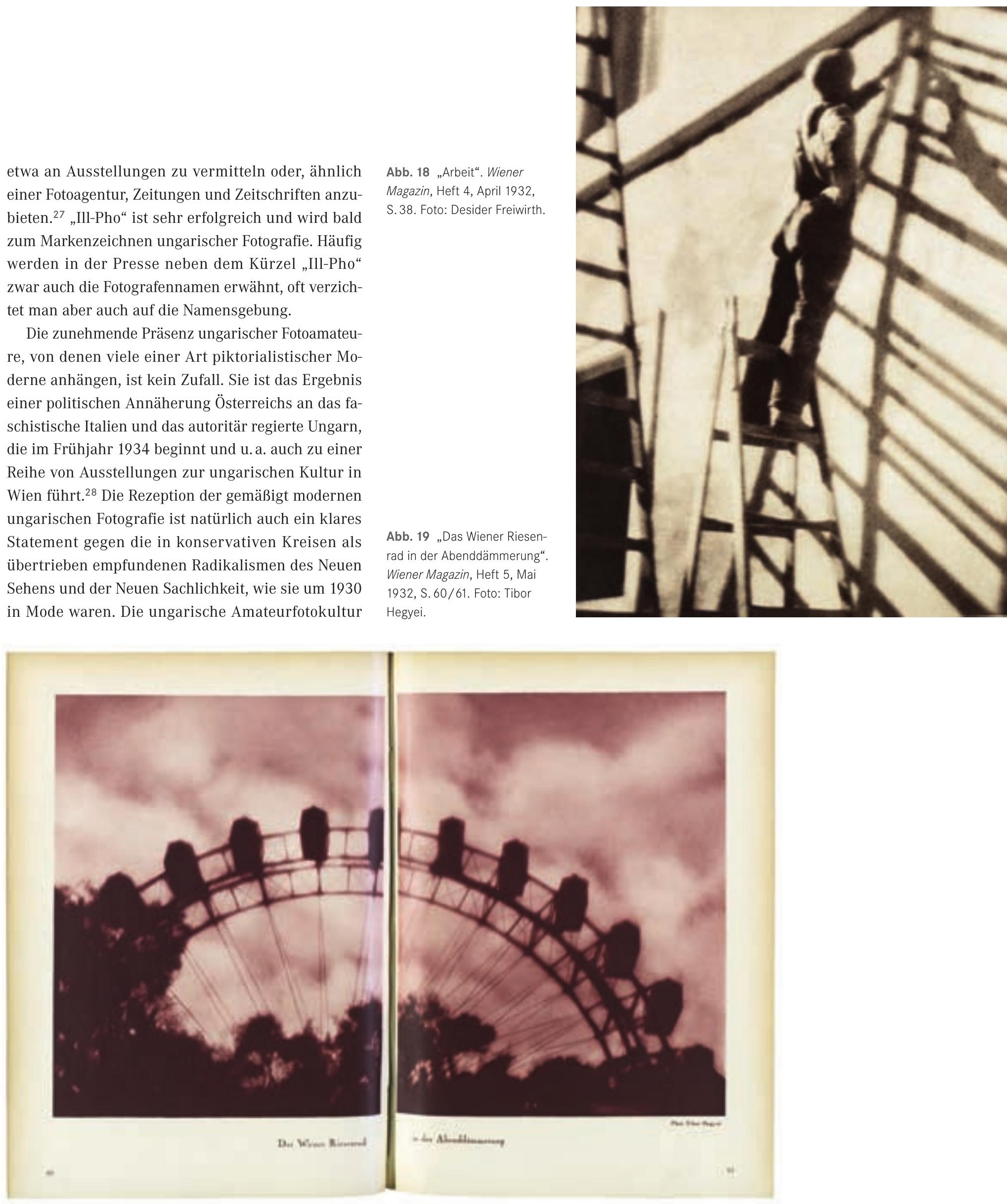


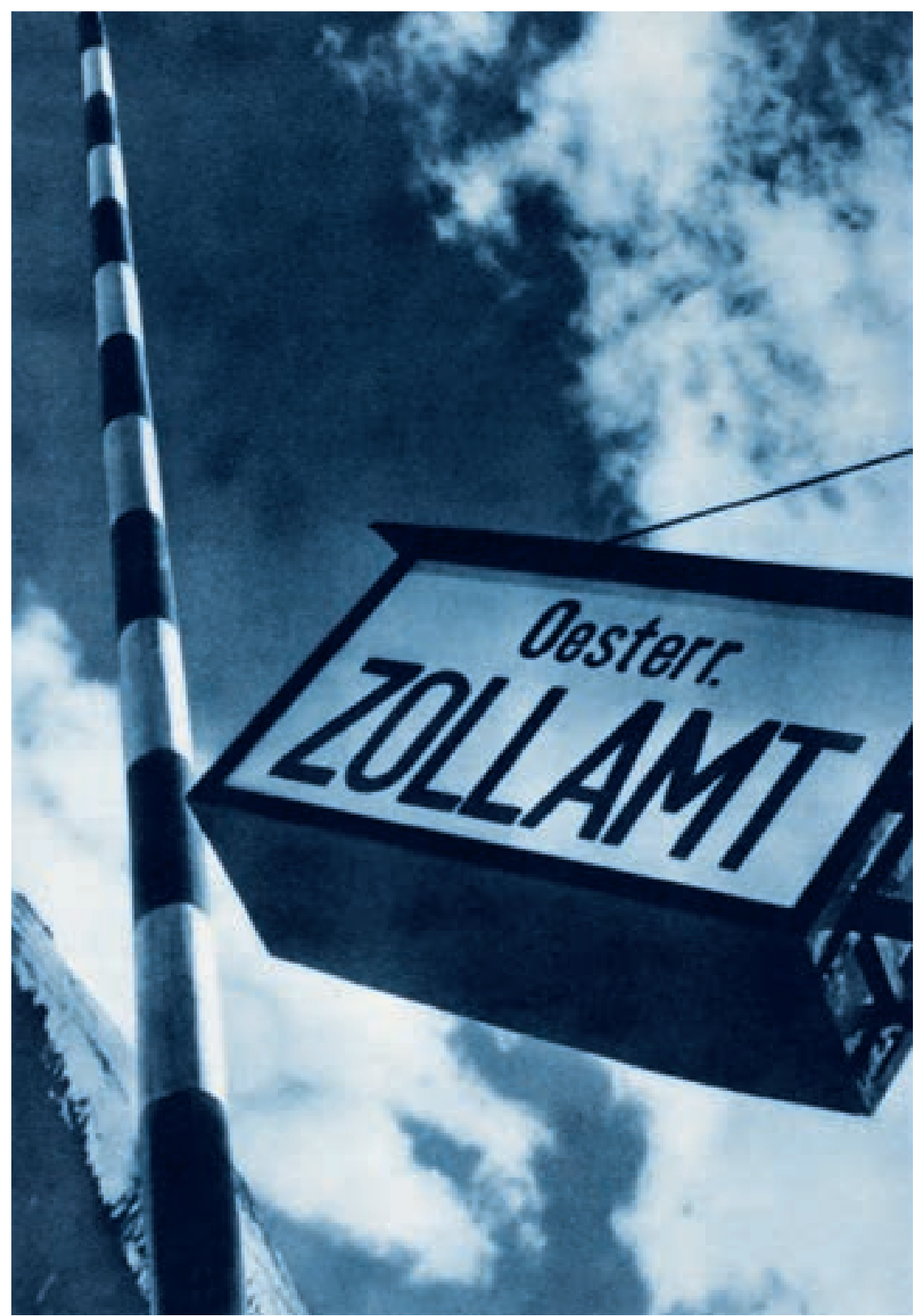

Abb. 20 „Wieder in der Heimat". Mitte der 1930er Jahre stellt sich das Wiener Magazin deutlich hinter die Politik des österreichischen „Ständestaates“. Wiener Magazin, Heft 9, September 1935, S. 64. Foto: Heinz Perckhammer.

übt, das ist bisher kaum beachtet worden, über den Weg von Ausstellungen und Veröffentlichungen in Zeitschriften, einen nicht zu unterschätzenden Einfluss auf die österreichische Fotografie der 1930er Jahre aus. Die antiurbane Stimmung, die regressive, romantisierende Themenwahl, aber auch die gemäBigt modernen Inszenierungen, die das Kennzeichen der konservativen ungarischen Modernen bilden, prägen auch die österreichische Fotokultur von den frühen 1930er Jahren bis zum nationalsozialistischen „Anschluss“. Ihr Gegenüber auf österreichischer Seite sind die Wortführer in den konservativen Amateurvereinen, die seit Beginn der 1930er Jahre mit ihrer Ausstellungspolitik und ihren Fachpublikationen zunehmend an Boden gewinnen. Der Weg in Richtung Heimatfotografie ist von hier aus nicht mehr weit. ${ }^{29}$
Nach 1934 wird die Grundausrichtung des Wiener Magazins deutlich konservativer. Das hat einerseits damit zu tun, dass sich das politische Umfeld inzwischen radikal gewandelt hat und 1933/34 ein diktatorisches Regime an die Stelle der parlamentarischen Demokratie getreten ist. Andererseits forciert auch der Eigentümer der Zeitschrift eine zunehmend konservative Ausrichtung. Ab Anfang der 1930er Jahre wird das Wiener Magazin in der Innsbrucker Druckerei Wagner gedruckt, die zum konservativen Bergland-Konzern gehört. Ab Ende 1934 wird die Zeitschrift wieder in Wien hergestellt, und zwar - über Vermittlung der Regierung - ausgerechnet in der im Jahr zuvor enteigneten Druckerei „Vorwärts“ der Wiener Sozialdemokraten, in der Rechten Wienzeile 97. Zwar vermeidet die Redaktion allzu offene Parteipolitik, dennoch stellt sie sich klar und deutlich hinter die austrofaschistische Regierung. Paradigmatisch für die neue Richtung, die das Lob der ländlich geprägten Heimat mit einer gemäßigt modernen Inszenierung verbindet, ist eine Aufnahme von Heinz von Perckhammer, die im September 1935 im Wiener Magazin erscheint (Abb. 20). Wir sehen einen aus extremer Untersicht aufgenommenen Grenzbalken und daneben das ebenfalls aus der Untersicht fotografierte Schild „Oesterr. Zollamt“. Die innovative formale Inszenierung der gekippten Perspektive verbindet sich, vermittelt über die Bildunterschrift, mit einer patriotisch-konservativen Botschaft. „Wieder in der Heimat“ - so heißt das Bild in der Zeitschrift. ${ }^{30}$ Im selben Heft findet sich eine - ebenfalls durch und durch patriotische - Fotoreportage über die Eröffnung der Großglockner Hochalpenstraße, die 1935 stattfindet. Dort heißt es voller Naivität in larmoyantem Tonfall: „Es ist ein kleines Land im Herzen Europas, unser Österreich. Es hat im Laufe der Jahre viel Sorge und Mühe und Unglück ertragen müssen, noch immer verdecken düstere Wolken die schöne, reine Bläue eines Lebenshimmels.“31

Von Perckhammer, geb. 1895 in Meran, der seit den späten 1920er Jahren in der Zeitungsstadt Berlin Karriere gemacht hat und für die großen Magazine der Weimarer Republik und später des nationalsozialistischen Regimes arbeitet, fotografiert und publiziert in den 1930er Jahren öfter in Österreich. Er lie- 
fert ein konservatives Bildprogramm mit modernem Anstrich: unbeschwerte Stadtimpressionen ebenso wie unverfängliche Bergbilder und patriotische Landschaften.

Dass konservative Grundhaltung und grafische Modernisierung nicht im Widerspruch zueinander stehen müssen, zeigt die Zeitschrift in der zweiten Hälfte der 1930er Jahre. Ein Beispiel unter vielen: 1937 bringt die Redaktion eine Doppelseite, die in zwei Aufnahmen aus Ungarn einen Arbeitstag auf dem Land darstellt (Abb. 21), rechts die Fahrt mehrerer Ochsengespanne aufs Feld, links die Heimkehr von zwei einfachen Bäuerinnen. Dazwischen steht ein radikal ins Bild gesetzter weißer Keil, der die beiden archaisch anmutenden Szenen trennt und zugleich die Wege der arbeitenden Landbevölkerung zu einem Ganzen verbindet. Solche Entwürfe finden sich in den 1930er Jahren regelmäßig im Wiener Magazin.

\section{Frivole Revuen}

In den 1920er Jahren erweitert sich das Spektrum illustrierter Zeitschriften und Magazine enorm. Nicht nur die großen Zeitungskonzerne gründen neue Periodika, auch in kleineren Verlagen erscheint eine Reihe von illustrierten Zeitschriften, darunter kleinformatige Mode-, Gesellschafts-, Radio- und Kinozeitschriften. Besonderen Erfolg mit solchen illustrierten
Abb. 21 „Nach getaner Arbeit“ und „Fahrt aufs Feld“. Wiener Magazin, Heft 5, Mai 1937, S. 60/61, Fotos: III-Pho.

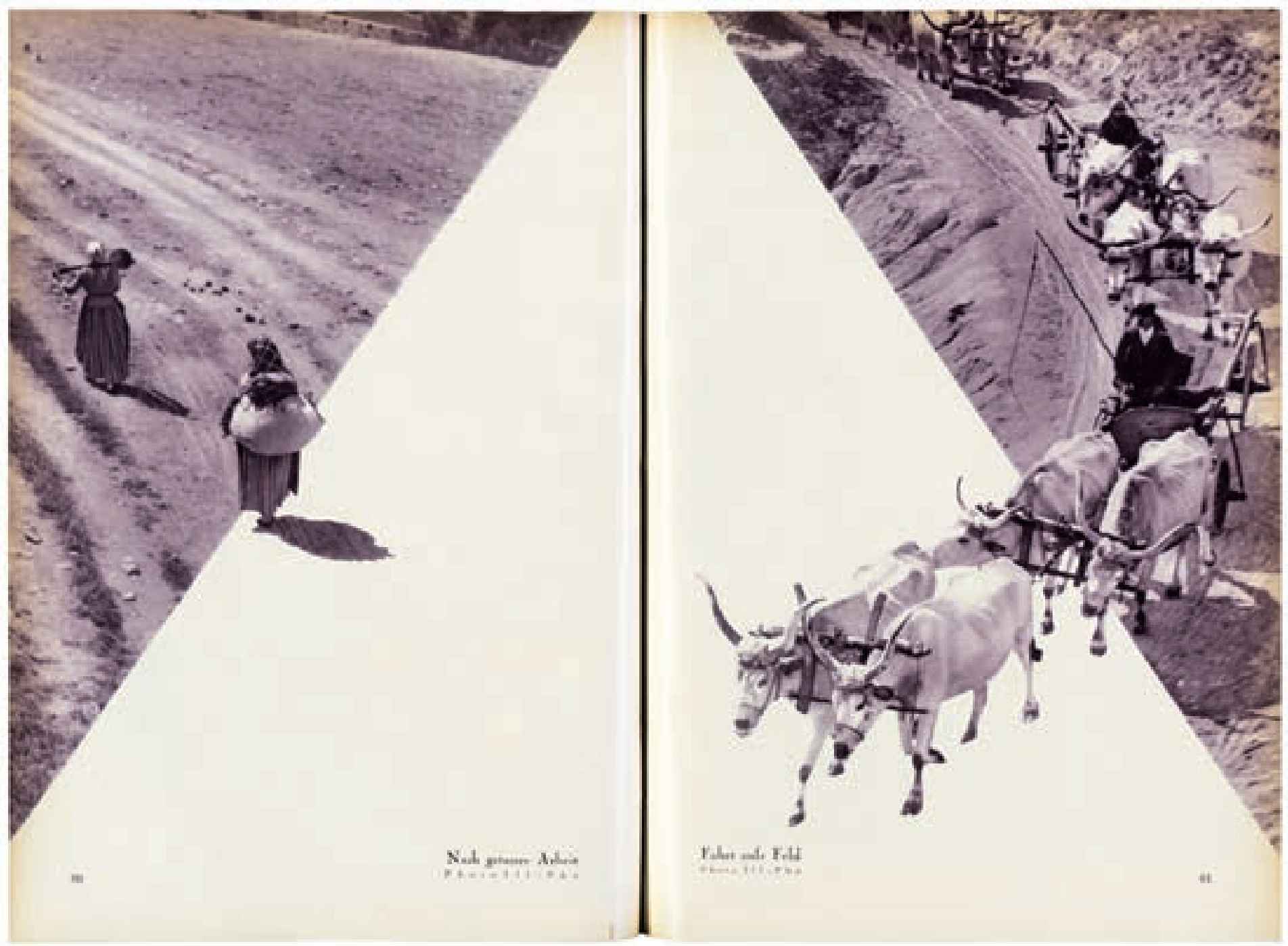


Magazinen hat der Wiener Rob-Verlag (Grundlstraße 5, Wien 9, später Neuer Markt 17, Wien 1 bzw. Alserbachstraße 39, Wien 9). Der Eigentümer, Karl Rob ${ }^{32}$ (eigentlich Robitsek, geb. 1891), gründet mitten im Ersten Weltkrieg (1916) ein Unternehmen, das eine Reklameanstalt, einen Kunsthandel und einen Zeitschriftenverlag umfasst. ${ }^{33}$ Ab 1915 gestaltet er u.a. Filmplakate für die Firma Sascha Film, die in diesen Jahren zahlreiche propagandistische Streifen dreht. Als Verleger beginnt er zunächst mit einem schmalen Angebot. Nach und nach erweitert er das Programm, er gründet bzw. übernimmt eine Reihe von weiteren Zeitschriften. Während und nach der Inflationszeit, die einige bestehende Zeitschriften ökonomisch ins Wanken bringt, profitiert Rob von der Unsicherheit und expandiert. So übernimmt er etwa 1924 die Zeitschrift Muskete, die in der Krisenzeit 1921/22 viermal den Besitzer gewechselt hat. Um 1930 erscheinen im Rob-Verlag die Wiener Mode sowie die Magazine Faun, Muskete, MOCCA und Wiener kleines Witzblatt. Letztere sind populäre, teilweise schlüpfrig-frivole Revuen, die sich an ähnlichen deutschen Erfolgsprodukten orientieren. Ihr Konzept ist, die oft tabuisierten Kehrseiten der bürgerlichen Welt zu zeigen. Während etwa Zeitschriften wie die Moderne Welt eine wunderbare, anständige, vornehme und gutbürgerliche Gesellschaft inszenieren, in der die Welt im Lot ist, zeigen einige der Zeitschriften aus dem Rob-Verlag auch die „schmutzigen“ und in der Öffentlichkeit verpönten Fantasien des Bürgertums, die Welt der Sexualität vor allem, aber auch die der Gewalt.

Die bürgerlichste und gesittetste Zeitschrift im Rob-Verlag ist die Wiener Mode. Als Karl Rob 1921 die Zeitschrift übernimmt, hat sie bereits eine längere Geschichte hinter sich. 1887 gegründet, gehört die illustrierte Zweimonatsschrift ${ }^{34} \mathrm{zu}$ den ältesten und traditionsreichsten Modezeitschriften der Monarchie. ${ }^{35}$ Sie wendet sich bis Anfang der 1920er Jahre an ein gehobenes bürgerliches Publikum. Ihr konservatives Gegenstück ist das zwischen 1870 und 1938 zunächst wöchentlich, dann (ab 1919) 14-tägig erscheinende Wiener Salonblatt, eine Mode- und Gesellschaftsrevue der höheren Stände, die sich sehr stark an eine adelige Leserschaft wendet. ${ }^{36}$ Anfang der 1920er Jahre ändert Karl Rob Format, Aufmachung und Ausrichtung der Wiener Mode. Sie wird nun populärer und setzt immer stärker auf die Fotografie. ${ }^{37}$ Die gediegen-konservative Gestaltung freilich wird beibehalten, ebenso die unpolitische Grundhaltung. Gestalterische Experimente finden wir in der Wiener Mode nicht. Das Vorsatzblatt stammt in zahlreichen Ausgaben vom Wiener Atelier Manassé, das seit 1924 überaus eng mit Karl Rob zusammenarbeitet und auch für andere Magazine des Verlags regelmäBig Bildmaterial liefert. Aber auch andere bekannte Wiener Fotografen wie Franz Löwy, Juda Berisch Zimbler, Trude Fleischmann, Ernst Förster, Grete Kolliner, Pepa Feldscharek, Madame d’Ora, Freyberger-Dietrich, Setzer, Kitty Hoffmann, Edith Glogau oder Hedda Medina veröffentlichen in der Zeitschrift Modeaufnahmen, Schauspieler- und Künstlerporträts sowie Tanzfotos. Ab 1924 erscheint die Zeitschrift im Kupfertiefdruck. Ende der 1920er Jahre steuert Karl Rob die Wiener Mode in Richtung einer populären Revue, die ein breites Publikum adressiert. Zwar hält sich die Zeitschrift von der Tagespolitik lange Zeit fern, aber ab 1933/34 ist eine konservative Wende unverkennbar. Vermehrt tauchen nun Politiker des christlichsozialen „Ständestaates“ in der Zeitschrift auf, das mondäne Großstadtleben, das bisher die inhaltliche Richtung geprägt hat, erhält Konkurrenz durch ländlich-patriotische Themen und Bildgeschichten (etwa 1935 über die Eröffnung der Großglockner Hochalpenstraße, das Prestigeprojekt des Austrofaschismus).

Stärker als in der Wiener Mode verwirklicht Karl Rob in seinen humoristisch-frivolen Zeitschriften und Revuen Der Faun (1916 gegründet, 1928 eingestellt), Die Muskete (1905 gegründet, 1924 von Rob übernommen), MOCCA (1928 gegründet) und Wiener kleines Witzblatt (1897 gegründet, 1916 von Rob übernommen) sein populistisches verlegerisches Konzept: Produziert wird, was sich verkauft. Das inhaltliche Niveau der Zeitschriften, die teils wöchentlich, teils zweiwöchentlich oder monatlich erscheinen ${ }^{38}$, ist bescheiden. Der rote Faden, der sich durch die Rob-Revuen zieht, ist die schlüpfrige Erotik, der Hang zu Anzüglichkeit und Voyeurismus, die sich in den Texten, vor allem aber in der Bebilderung zeigen. Während der Faun und das Wiener kleine Witzblatt auf z. T. far- 
big gedruckte Zeichnungen (teilweise aus der Feder von Karl Rob) setzen, aber auf Fotografien verzichten, sind die Zeitschriften Die Muskete und MOCCA auch fotografisch illustriert. Als sich in der zweiten Hälfte der 1920er Jahre für einige Jahre ein gesellschaftliches Fenster der Freizügigkeit auftut und die Zensur etwas weniger scharf kontrolliert ${ }^{39}$, wird in den Rob-Blättern - meist unter dürftigen Vorwänden - viel nackte Haut gezeigt: entblößte oder leicht bekleidete Tänzerinnen und Revuestars und erotische Genreszenen. Viele davon stammen aus dem Atelier Manassé, das zum Hauptlieferanten anzüglicher und freizügiger Inszenierungen wird (Abb. 22). ${ }^{40}$ Anzüglich-erotische Motive stammen gelegentlich aber auch von anderen Wiener Fotografinnen und Fotografen, etwa von Franz Löwy oder Pepa Feldscharek.

Die gestalterischen Ansprüche der populären Zeitschriften aus dem Hause Rob sind niedrig, die Aufmachung billig, die Druckqualität nicht sonderlich gut, erst spät kommt der Kupfertiefdruck zum Einsatz. Im Vergleich zur Bühne und zum Wiener Magazin, die weit besser gestaltet und gedruckt sind, bedienen die Rob-Revuen nicht ein gehobenes, sondern ein weniger kaufkräftiges kleinbürgerliches $\mathrm{Pu}-$ blikum. Als Karl Rob die Monatszeitschrift MOCCA 1928 auf den Markt bringt, knüpft er zunächst an sein einfaches, bewährtes Rezept an: populäre Aufmachung, einfache Gestaltung, billiger Druck, viele Fotos und viel nackte Haut, kaum aktuelle Berichterstattung. „Mit der Revue ,Mocca“, die den besten Monatsschriften Deutschlands ebenbürtig ist, dürfte eine Lücke in der heimischen Produktion dieser Art geschlossen worden sein." So schreibt Karl Rob im Editorial des ersten Heftes. „Wir waren bemüht, das erste Heft möglichst inhaltsreich und spannend zu gestalten, glauben aber versprechen zu können, dass die folgenden Hefte noch mehr Ihren Beifall finden werden. " ${ }^{41}$ Tatsächlich orientiert sich die Zeitschrift an den erfolgreichen Magazinen der Weimarer Republik, etwa den auflagenstarken Ullstein-Revuen $U H U$ und Grüne Post, mit dem Unterschied, dass MOCCA weitaus populärer und frivoler auftritt als diese.

Anfang der 1930er Jahre kommt es zu einer zaghaften Neuausrichtung des Magazins. Druck und Aufmachung der Zeitschrift MOCCA werden nun etwas modernisiert, auf der Titelseite findet sich inzwischen regelmäßig ein ausdrucksstarkes Foto (Abb. 23). Die Grundausrichtung eines populistischen und anzüglichen Magazins wirft die Redaktion allerdings nicht über Bord. ${ }^{42}$ Das hindert sie aber nicht daran, immer wieder auch anspruchsvolle Fotostudien (gemäßigt) modern arbeitender Amateure zu drucken, etwa von Hans Grabkovicz oder Oskar Kuhn. Gelegentlich finden wir in der Zeitschrift sogar Bildseiten, die zu einer sozialkritischen Stellungnahme verdichtet werden. Im Juni 1935 etwa stellt MOCCA einer Aufnahme
Abb. 22 In der Zeitschrift Muskete, 1924 vom Rob-Verlag übernommen, wird in der Zwischenkriegszeit viel nackte Haut gezeigt. Viele der freizügigen Aufnahmen stammen aus dem Atelier Manassé. Die Muskete, Nr. 41, 1932, S. 802. Foto: Atelier Manassé.

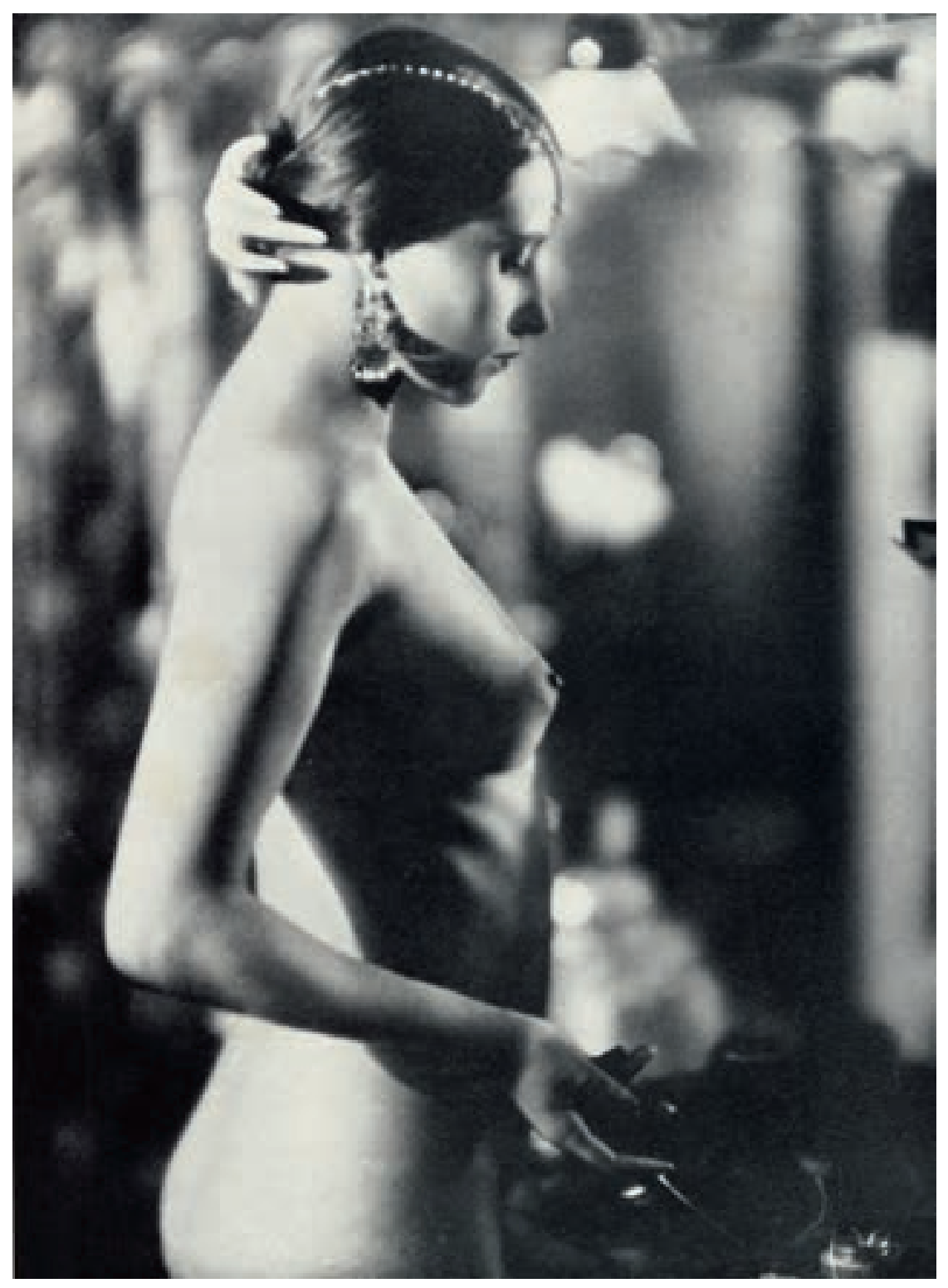


Abb. 231928 bringt der Rob-Verlag mit der Zeitschrift MOCCA eine weitere populäre Revue auf den Markt. MOCCA, Nr. 1, Januar 1934, Titelseite. Foto: Atelier Manassé.
Abb. 24 Die Welt der Vornehmen und der Obdachlosen. Eine fotografische Gegenüberstellung in der Zeitschrift MOCCA, Nr. 6, 1935, S. 12. Foto: Herbert Grünwald.

\section{Toda $=$}
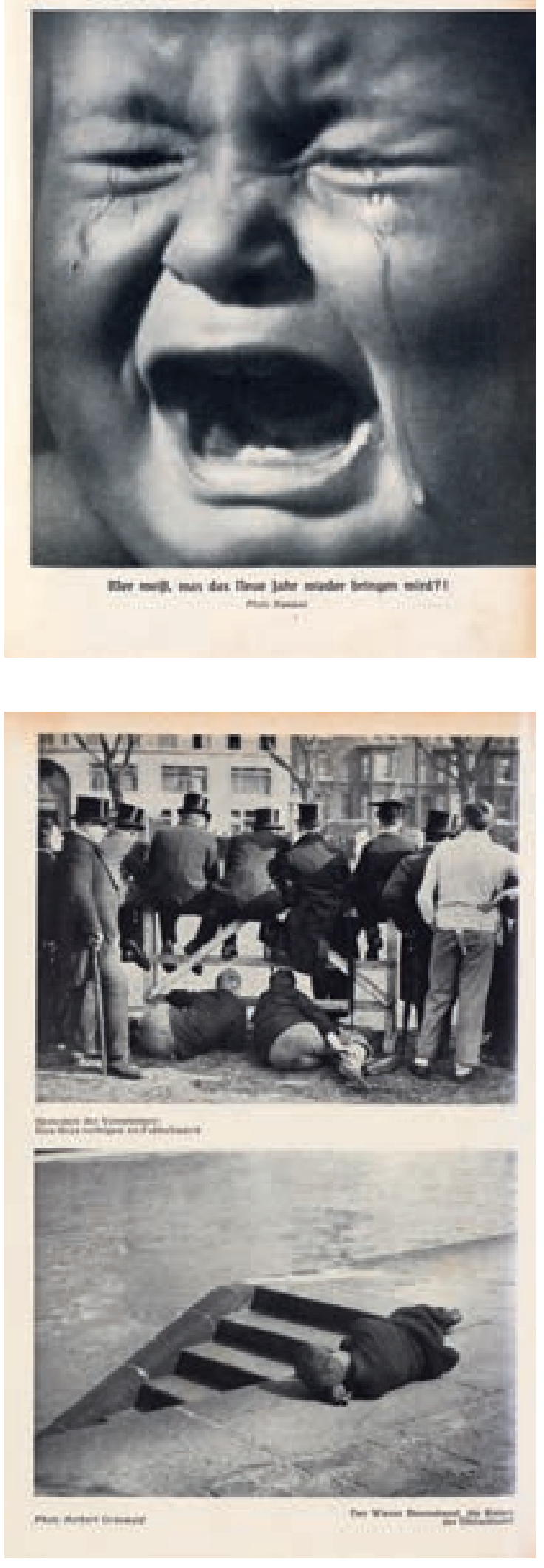

von nobel anmutenden Fußballfans in der englischen Universitätsstadt Eton eine Obdachlosenszene am Wiener Donaukanal, fotografiert von Herbert Grünwald, gegenüber (Abb. 24).

Ebenso wie die Bühne und das Wiener Magazin räumt MOCCA ab 1934 ungarischen Fotografen, die Moderne und Piktorialimus verbinden und von denen viele ein genrehaftes Landleben präsentieren, auffallend viel Platz ein. ${ }^{43}$ Die kurze Phase der Öffnung ist vorbei, die Zeitschrift steuert nun einen konservativen, antiurbanen Kurs, der Themen wie patriotische Landschaften, Land und Leute oder Brauchtum in den Vordergrund rückt. Beispielhaft für diese Richtung sind die zahlreichen idealisierenden Landschafts- und Genrestudien der Linzer Fotoamateurin Elly Rauch.

\section{Ein heiß umkämpfter Markt: neue Radio- und Filmzeitschriften}

Die frivolen Revuen aus dem Rob-Verlag bilden nur einen Teil des in der Zwischenkriegszeit massiv expandierenden Marktes illustrierter Magazine. Dieser fächert sich immer mehr auf. Prominente Ränge in diesem Spektrum nehmen die - durchweg kleinformatigen - illustrierten Radio- und Kinozeitschriften, aber auch die Sport- und die größerformatigen Modezeitschriften ein. All diese Magazine tragen wesentlich zur Etablierung eines neuen visuellen Zeitalters bei, das nach und nach alle Lebensbereiche umfasst. Nicht nur über Politik und Gesellschaft wird nun vorzugsweise in Bildern berichtet, sondern auch über Mode und Schönheit, über Freizeit und Sport, über Radio und Film, über Schule und Kindererziehung, über Kriminalfälle und Katastrophen und vieles andere mehr.

Es ist kein Zufall, dass ein heute längst ausgestorbenes und vor dem Ersten Weltkrieg noch völlig unbekanntes Genre der visuellen Berichterstattung in den 1920er Jahren zum Marktführer unter den Wochenmagazinen aufsteigt: die illustrierte Radiozeitschrift. Denn das Radio, das in Österreich 1924 eingeführt wird, ist weit mehr als ein neues Kommunikationsmedium, es verkörpert, vor allem in den ersten Jahren, ein geradezu euphorisches neues kollektives Lebensgefühl. Neben dem Film, der sich in 
den 1920er Jahren ebenfalls schnell verbreitet, ist das Radio das Zukunftsmedium, vor allem in den Städten. Die neu gegründeten Radio- und Filmzeitschriften sind Ausdruck dieser Aufbruchstimmung. Sie sind nicht nur Programmzeitschriften, sondern liefern der rasant wachsenden Hörer- und Zuschauergemeinde ergänzende Bilder zum neuen Ton.

Die führenden österreichischen Radiozeitschriften sind die Radio-Welt (Abb. 25) und Radio Wien. Beide werden 1924 gegründet, in dem Jahr also, in dem in Österreich die Ära des Rundfunks beginnt. Radio Wien ist die offizielle Zeitschrift der „Radio-Verkehrs-AG“ (RAVAG), der ersten österreichischen Rundfunkgesellschaft. Die Radio-Welt hingegen erscheint im Wiener Radioverlag, einem Tochterunternehmen des Rikola-Konzerns, der Anfang der 1920er Jahr von Richard Kola beherrscht wird. Verlagssitz ist zunächst die Rüdengasse 11, wo auch das Interessante Blatt und die Wiener Bilder hergestellt werden. Der Verlag versucht ab Mitte der 1920er Jahre sein Zeitungs- und Zeitschriftenspektrum thematisch zunehmend zu verbreitern. Im Verlag Rüdengasse 11 erscheint neben der kurzlebigen Illustrierten $R a-$ diozeitung, die schon nach einigen Monaten wieder eingestellt wird ${ }^{44}$, auch das 1905 gegründete und 1928 eingestellte Illustrierte Sportblatt. ${ }^{45}$ Letztere Zeitschrift wandelt sich Mitte der 1920er Jahre vom reinen Männer-Sportblatt zum Unterhaltungsblatt mit breit gestreutem Themenspektrum, das nun auch verstärkt Frauen ansprechen will. Seit 1923 erscheint diese Zeitschrift im Kupfertiefdruckverfahren.

In den 1920er Jahren kommt, neben den Radiozeitschriften, auch eine ganze Reihe illustrierter Film- und Kinozeitschriften auf den Markt. Manche Publikationen sind kurzlebig, etwa die von Ernst Karl Finaly herausgegebene Kinowoche, die zwischen 1918 und 1920 erscheint. ${ }^{46}$ Aber es gibt auch beständigere Blätter, wie etwa die von Friedrich Porges herausgegebene Zeitschrift Mein Film (Abb. 26), die im Untertitel Illustrierte Film- und Kinorundschau heißt und zwischen 1925 und 1939 erscheint. ${ }^{47}$ Sie ist in den ersten Jahren grafisch sehr einfach gestaltet, Quellenangaben zu den Fotos - meist von Filmstars - finden sich nur gelegentlich, die Vorlagen stammen, soweit ersichtlich, von den großen Wiener und Berliner Ate-

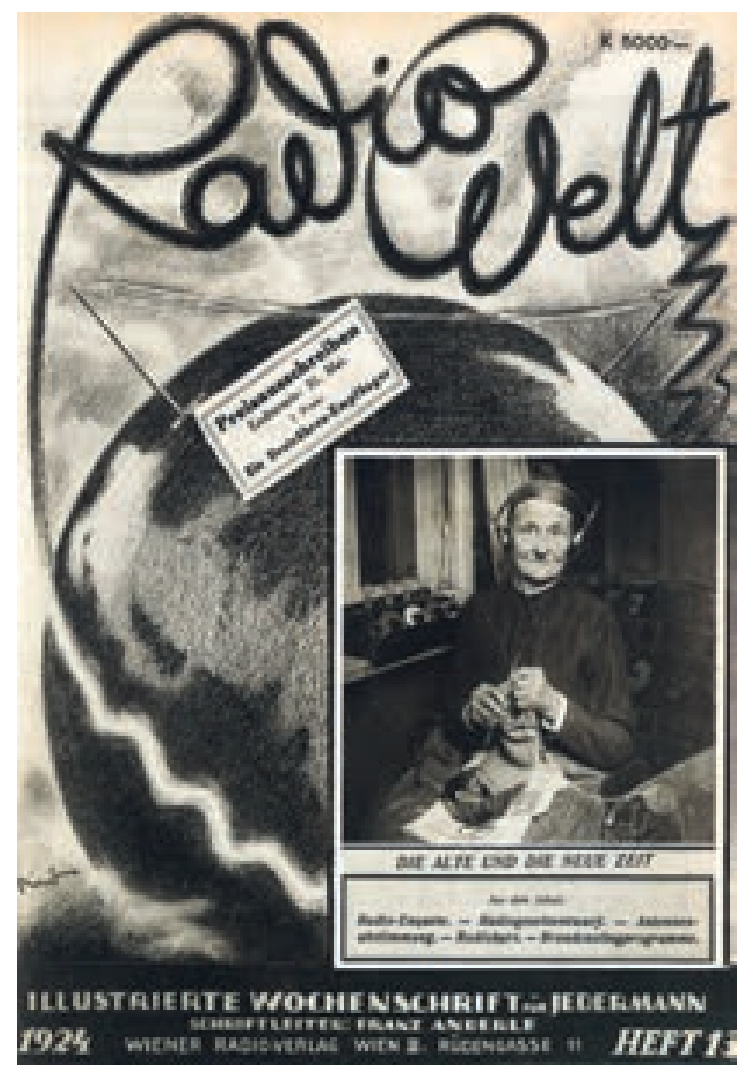

Abb. 25 Die Zeitschrift Radio-Welt wird 1924, in dem Jahr, als in Österreich das Radio eingeführt wird, gegründet. Sie trägt den Untertitel IIlustrierte Wochenschrift für Jedermann. Radio-Welt, Heft 13, 1. Juni 1924, Titelseite.

Abb. 26 Die Zeitschrift Mein Film erscheint zwischen 1925 und 1939. Mein Film, Nr. 113, 1928, Titelseite.

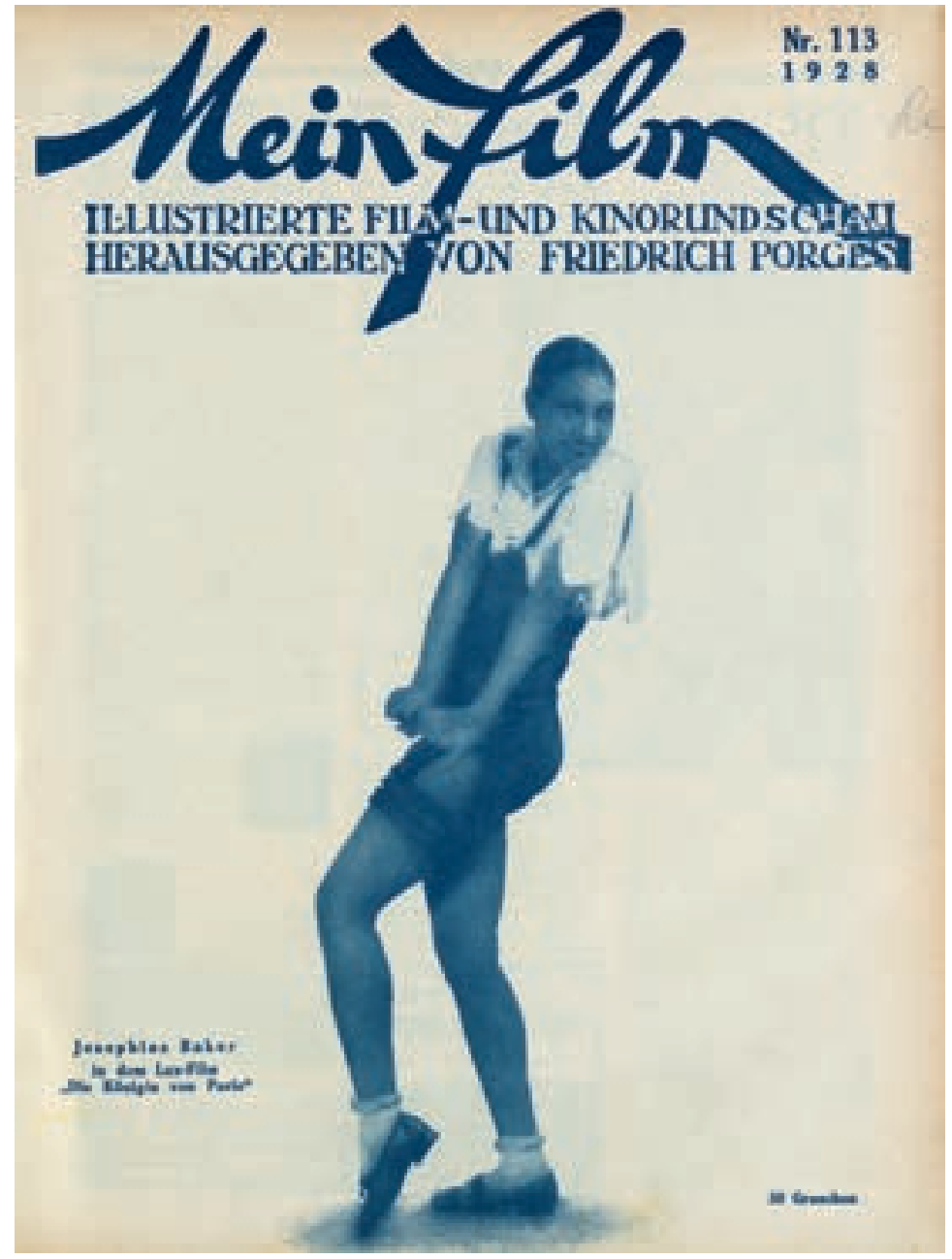




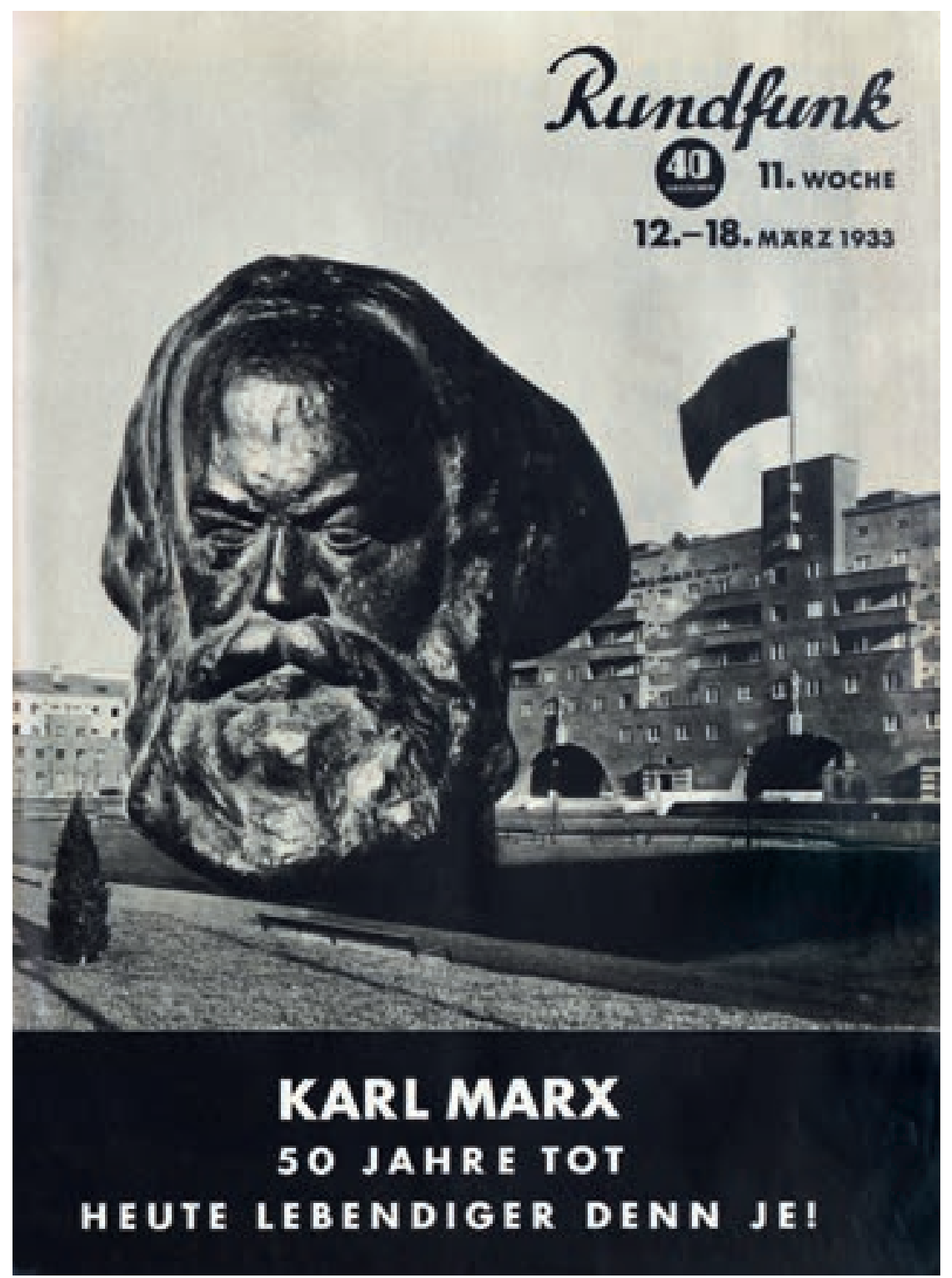

Abb. 27 Die Zeitschrift Rundfunk erscheint seit Februar 1933 im sozialdemokratischen Vorwärts-Verlag. Sie will der konservativen Übermacht der bürgerlichen Radiozeitschriften trotzen. Rundfunk, 12.-18. März, Titelseite. Porges, der als Journalist, Theater- und Filmkritiker, liers, aber auch von deutschen und amerikanischen Filmfirmen. 1928 stellt die Zeitschrift auf Kupfertiefdruck um, ab 1930 verbessert sich das Layout. Schriftsteller und Regisseur tätig ist, bemüht sich, die Zeitschrift aus dem politischen Tagesgeschehen möglichst herauszuhalten, er steuert einen liberalen Kurs. Im Zentrum der Berichterstattung steht der filmische Mainstream, aber Ende der 1920er Jahre zeigt sich die Zeitschrift auch offen gegenüber den Neuerungen der Avantgarde. ${ }^{48}$ Während der Zeit des Austrofaschismus (1934-1938) schlägt die patriotisch-konservative Propagandamaschinerie der Regierung gelegentlich auch auf die Seiten von Mein Film durch. Anlässlich der internationalen Film-Festwochen, die im Juni und Juli 1934 in Wien stattfinden, erscheint die Zeitschrift etwa mit einer rot-weißroten Schleife auf dem Umschlag.
Vor allem der Markt der Radiozeitschriften ist um 1930 nicht nur kommerziell, sondern auch politisch heiß umkämpft. Denn das neue Medium bietet nicht nur Unterhaltung, sondern kann, das stellt sich bald heraus, auch für Informations- und Propagandazwecke nutzbar gemacht werden. Die herkömmlichen Radiozeitschriften, allen voran die Radio-Welt aus der Rüdengasse 11, sind durchweg konservativ und regierungsnahe. Um diesem publizistischen Übergewicht eine Alternative entgegensetzen zu können, bringt das sozialdemokratische Medienflaggschiff, der Vorwärts-Verlag, Anfang der 1930er Jahre eine linke Radiozeitschrift auf den Markt. Sie heißt Rundfunk und ist aus der 1932 gegründeten Wochenzeitung Rundfunk für alle hervorgegangen. ${ }^{49}$ Herausgeber, Eigentümer und Verleger ist die Freie Vereinigung österreichischer Radiotechniker, eine sozialdemokratische Vorfeldorganisation. Geleitet wird die Zeitschrift von Sigmund Schwarz. ${ }^{50}$ Anfang 1933 übernimmt die Sozialdemokratischer Verlag Ges.m.b.H. die Zeitung, die Redaktion übersiedelt in die Rechte Wienzeile 97, den Sitz des Vorwärts-Verlags. Hier wird künftig auch gedruckt.

Hinter der Übernahme steht der sozialdemokratische Medienstratege Julius Braunthal, der auch als Chefredakteur des Blattes auftritt. Das Tagesgeschäft leitet allerdings Franz Kuderna. Unter der neuen Führung wird die Zeitschrift deutlich modernisiert. Das Format wird etwas vergrößert, die Gestaltung verbessert, auf dem Umschlag findet nun ein seitenfüllendes Foto Platz. Der Mantelteil wird im Kupfertiefdruck hergestellt. Als die erste Nummer des Rundfunk am 19. Februar 1933 erscheint, ist aus der trockenen Vereinszeitung mit technischen Einschlag eine moderne Wochenillustrierte für die breite Bevölkerung geworden. Die kämpferische Ausrichtung kommt nach der Neugestaltung deutlicher zum Ausdruck als zuvor. Im März 1933 widmet sie dem 50. Todestag von Karl Marx eine Titelseite (Abb. 27). ${ }^{51}$ Im Vordergrund ist dessen Kopf zu sehen. Die überdimensional erscheinende Büste scheint im Hof der 1930 fertiggestellten Wohnhausanlage Karl-Marx-Hof zu stehen. Tatsächlich handelt es sich um eine Montage. Darunter prangt in weißen Lettern auf schwarzem Grund: „Karl Marx. 50 Jahre tot. Heute lebendiger denn je!“ 
Zwar ist der Rundfunk im Vergleich zum Kuckuck, der führenden sozialdemokratischen Illustrierten, die im selben Verlagshaus produziert wird, weit weniger aufwendig gestaltet. Dennoch profitiert die Zeitschrift sichtlich vom Know-how des Kuckuck. Eine Reihe von herausragenden Kuckuck-Fotografen veröffentlicht auch im Rundfunk, etwa die in Wien lebenden Lichtbildner Martin Imboden und Rudolf Spiegel oder Zoltan Kluger, der in Berlin arbeitet. Gelegentlich werden sogar Reportagen, etwa zu Reisethemen, gedruckt. Der neue Rundfunk erlebt nur sein erstes Jahr, Anfang 1934 fällt er dem Verbot zum Opfer. Die letzte Nummer erscheint am 17. Februar 1934.

Dass just im selben Monat, in dem der Rundfunk eingestellt wird, eine neue, konservative Radiozeitschrift startet, ist gewiss kein Zufall. Das Mikrophon. Das Magazin für den Rundfunkhörer wird von der inzwischen zur Gänze von der Regierung kontrollierten Rundfunkanstalt Radio-Verkehrs-AG (RAVAG) herausgegeben und erscheint monatlich. Die Zeitschrift ist voll auf Regierungskurs. In der Bebilderung räumt sie den konservativen Amateuren, wie etwa Maximilian Karnitschnigg oder Hermann Brühlmeyer, viel Platz ein. Moderne Fotografen, die in der Tradition des Neuen Sehens stehen, kommen selten zum Zuge. Werden ihre Arbeiten vorgestellt, müssen diese den Brückenschlag zwischen Tradition und Moderne leisten. Der Wiener Amateur Rudolf Pechotsch etwa liefert sowohl gemäßigt moderne Genrebilder vom bäuerlichen Leben also auch moderne Impressionen aus der Großstadt Wien. Eine Aufnahme, die im Juli 1934 erscheint, zeigt, von schräg oben fotografiert, eine Ruderregatta an der Alten Donau (Abb. 28). Derartige Bilder bleiben im Mikrophon freilich die Ausnahme. Nach wenigen Monaten stellt die Zeitschrift ihr Erscheinen ein.

\section{Wochenzeitung für jedermann: Die Radio-Welt}

Mehr noch als die Filmzeitschriften, die eine halbwegs präzise umrissene Gemeinde von Filminteressierten adressieren, sind die Radiozeitschriften der Zwischenkriegszeit Illustrierte, die sich an den (v.a. städtischen) Durchschnittsbürger wenden. Sie adressieren ein umfassendes gesellschaftliches Kollektiv und stellen es zugleich her. Oft wird die Klientel dieser Zeitschriften, gewissermaßen der Durchschnittsleser, mit den Begriffen „Jedermann“ oder „für alle“ umschrieben. Beide Attribute tauchen seit Mitte der 1920er Jahre im Untertitel zahlreicher Zeitschriftenneugründungen auf. Die führende Radiozeitschrift, die 1924 gegründete Radio-Welt, nennt sich im Untertitel Illustrierte Wochenschrift für Jedermann. Die erste, 1932 gegründete, sozialdemokratische Rundfunkzeitschrift heißt Rundfunk für alle. Im Editorial
Abb. 28 Die 1934 gegründete, monatlich erscheinende Radiozeitschrift Mikrophon wird von der Rundfunkanstalt Radio-Verkehrs-AG. (RAVAG) herausgegeben. In ihrer Ausrichtung ist sie konservativ, nur selten kommen (wie hier) Fotoamateure mit modernen Ansichten zum Zug. Mikrophon, Heft 6, Juli 1934, S. 55. Foto: Rudolf Pechotsch.

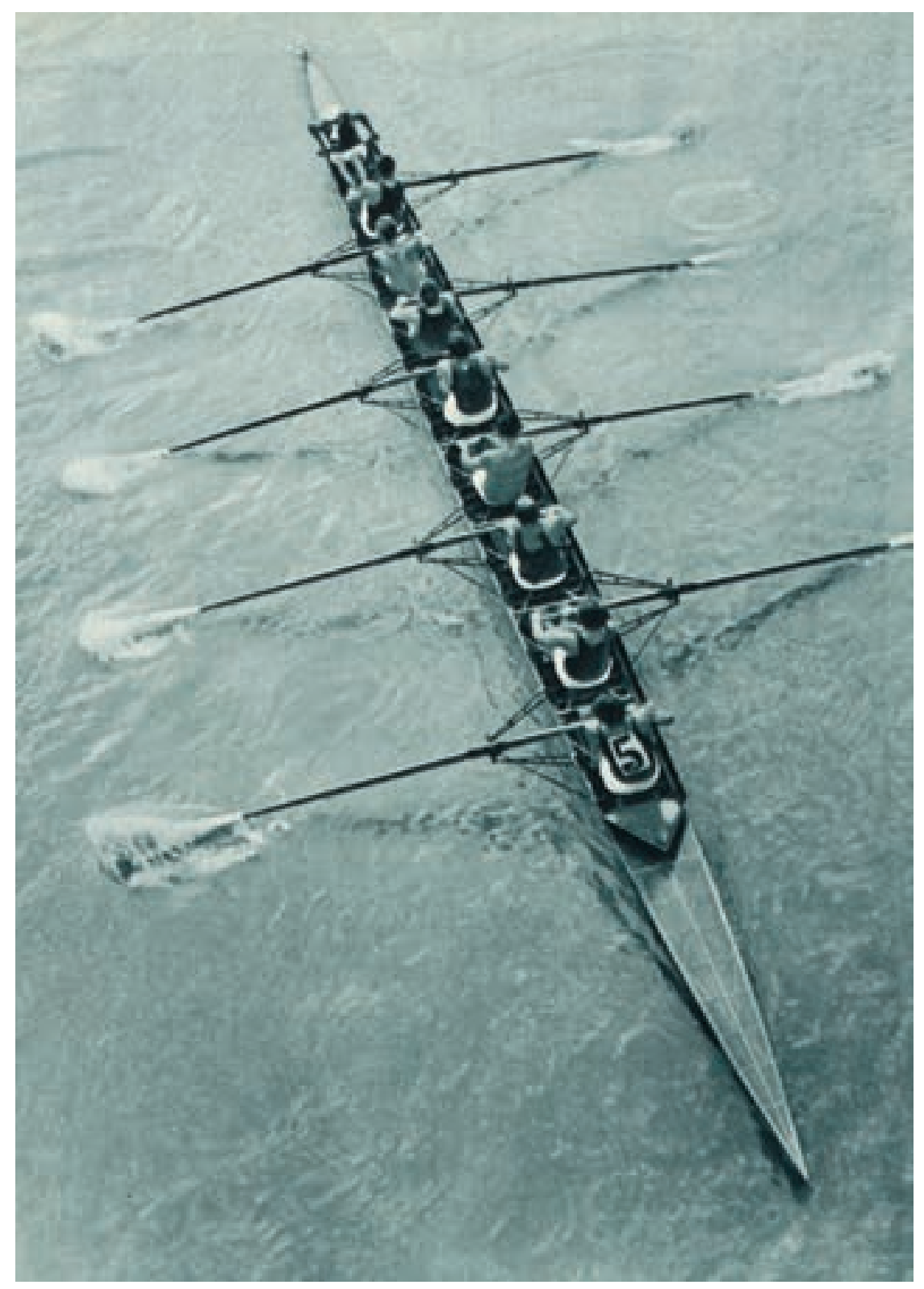




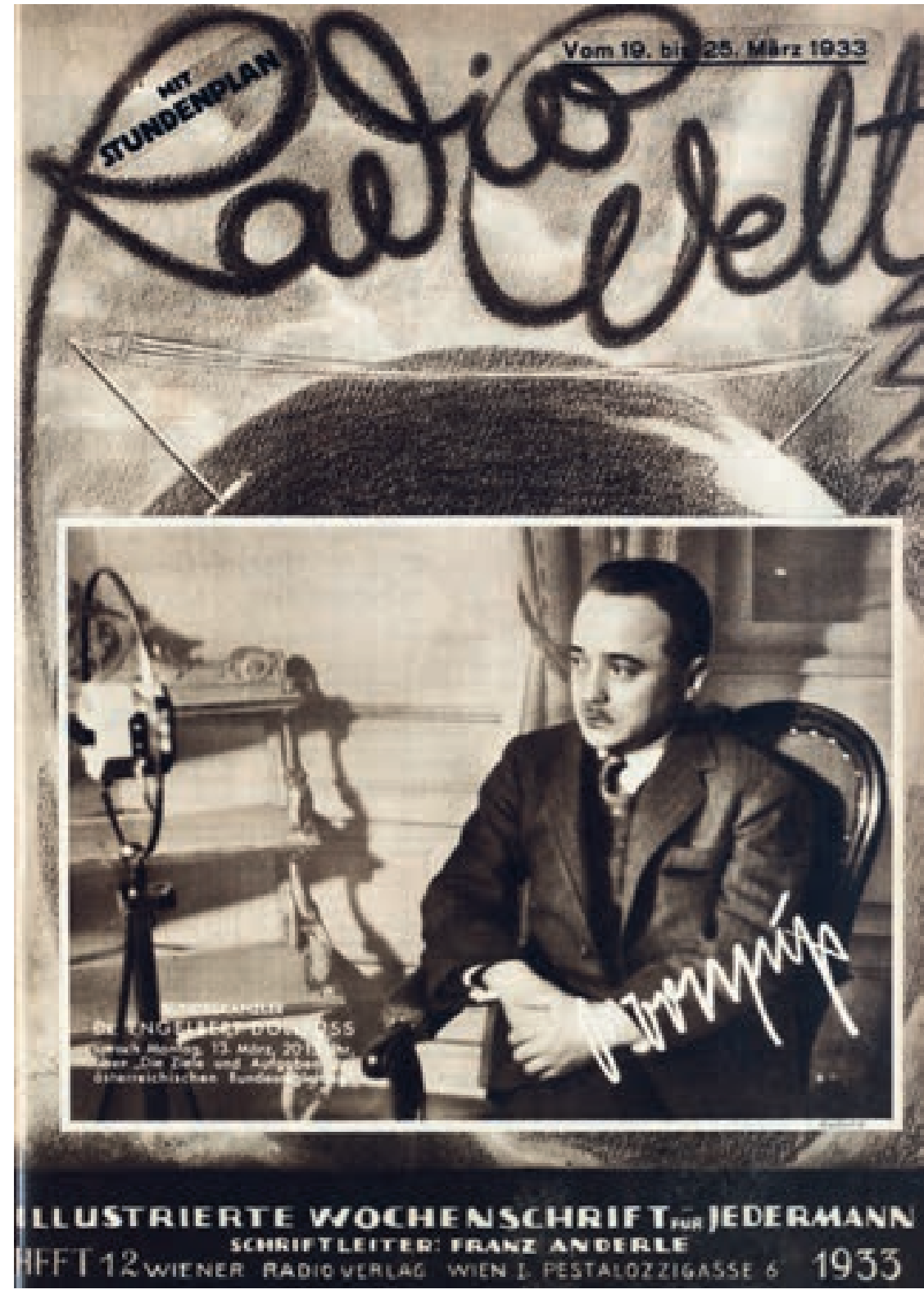

des ersten Heftes, das am 9. März 1924 erscheint, betont die Redaktion der Radio-Welt, dass sich die Zeitschrift „an jedermann“ wende. Denn: „Radio ist für alle.“52 Und weiter heißt es: „Radio ist eine Massenangelegenheit. Wir wenden uns an den, der schon einen Radioapparat hat und an den, der ihn erst haben möchte. Wir werden ihn sachkundig beraten."53 Um diesen allumfassenden Hörerkreis auch visuell hervorzuheben, bringt die Zeitschrift in einem ihrer ersten Hefte das Bild einer strickenden Großmutter
Abb. 29 Bundeskanzler Engelbert Dollfuß spricht im Radio. Die Radio-Welt steht seit ihrer Gründung 1924 der christlichsozialen Regierung nahe. Nach der Ausschaltung des Parlaments 1933 wird sie zum Propagandaforum für die Diktatur. Radio-Welt, 19. - 25. März 1933, Titelseite. Foto: Radiofot.

auf dem Umschlag, die, über die Radiokopfhörer, in das akustische Programm vertieft ist. Die Botschaft ist klar: Vom Kind bis zur Großmutter - alle hören Radio. Und alle lesen die Radiozeitschrift.

Der Beitrag dieser einfach aufgemachten, populär gehaltenen Wochenmagazine zur Herausbildung eines kleinbürgerlichen Massenkollektivs in der Zwischenkriegszeit ist nicht zu unterschätzen. Bis heute ist dieses Thema kaum untersucht. In der Politik der 1920er und 1930er Jahre ist dieses Kollektiv keine abstrakte Größe. Das Kleinbürgertum macht sich als politische Gruppierung zunehmend auch in der Politik bemerkbar - als Stimmenreservoir für populistische Bewegungen. Im politischen Populismus wird die Kategorie „jedermann“ zum Ideal des erwünschten gesellschaftlichen Durchschnitts und zugleich zum politischen Kampfbegriff gegen alles Abweichende. Der Rundfunk, und ebenso die Rundfunkzeitschriften, spielen also eine wichtige Rolle im Prozess der Herausbildung kleinbürgerlicher, autoritär geführter Massenbewegungen. In den 1930er Jahren wird das Radio immer stärker zum schichtenübergreifenden, alle erreichenden Propagandainstrument in den Händen der Diktatur.

Am Beispiel der Radio-Welt lässt sich dieser allmähliche Schwenk von der populären Unterhaltungszeitschrift zum Propagandamedium deutlich nachzeichnen. Die 1924 gegründete Zeitschrift begleitet den Aufstieg des Radios zum Massenmedium. Auf diesem Weg wird zwar ihr Erscheinungsbild professionalisiert, der Umfang nimmt zu. Dennoch bleibt sie ihrem Selbstverständnis einer einfachen Zeitschrift für den Durchschnittsleser stets treu. Die $R a$ dio-Welt, die jeweils am Sonntag erscheint, ist zwar von Anfang an im Kupfertiefdruck hergestellt, aber ihre grafische Aufmachung ist - zumindest bis Mitte der 1930er Jahre - simpel. Für den Umschlag wird ein grafisch einheitlich gestaltetes Hintergrundbild verwendet, das die weltumspannende Macht des neuen 
Mediums signalisieren soll. In dieses wird ein kleines bis mittelgroßes Foto eingefügt. Auch der Innenteil ist einfach gestaltet. In das dreispaltige Textraster werden zahlreiche Fotos eingefügt. Vorzugsweise werden Porträts und Künstlerfotos aus bekannten Wiener Ateliers verwendet, etwa von Sängerinnen und Sängern, die auch im Radio zu hören sind. ${ }^{54}$

Über die Auflagenentwicklung der Zeitschrift ist nichts bekannt, sie dürfte aber parallel zur rasanten Zunahme der Radiohörer deutlich ansteigen. ${ }^{55}$ Darauf deutet der Umfang hin, der sehr schnell zunimmt, 1927 bereits rund 70 Seiten beträgt und bis 1929 zeitweise auf 120 Seiten anwächst. ${ }^{56}$ Aber auch die rasche Zunahme der Anzeigen, v. a. Ende der 1920er Jahre, lässt darauf schließen.

Je stärker sich um 1930 der politische Kampf zwischen links und rechts zuspitzt, desto stärker wird die Radio-Welt, die anfangs kaum über politische Themen berichtet, in die parteipolitische Auseinandersetzung hineingezogen. Es gelingt der christlichsozialen Regierung mehr und mehr, ihren Einfluss auf den Radiosender und die Berichterstattung geltend zu machen. Anfang der 1930er Jahre nehmen die Attacken der Christlichsozialen gegen die in ihren Augen zu regierungskritische Führung der Radio-Verkehrs-AG (RAVAG) massiv zu. Der Zugriff des Staates auf das neue Medium wird stärker. Spätestens 1933 ist der Sender auf Linie gebracht und unter staatlicher Kontrolle. Im März 1933, nach der Ausschaltung des Parlaments, nutzt Kanzler Dollfuß das Medium Radio ausgiebig, um Propagandareden zu verbreiten. Die Radio-Welt räumt ihm aus diesem Anlass die gesamte Titelseite ein (Abb. 29). ${ }^{57}$

Die autoritäre Wende in der Regierung, die mit einer patriotisch-konservativen Propagandaoffensive einhergeht, schlägt sich nun auch in der Radio-Welt nieder. Die Berichterstattung ist zunehmend regierungsnah, die Zeitschrift unterstützt die Diktatur ganz offen. Der Schriftleiter Franz Anderle, der die Zeitschrift bis Herbst 1937 leitet $^{58}$, ist den neuen Machthabern gegenüber überaus aufgeschlossen. Er hat seine Karriere während des Ersten Weltkriegs als Leiter des militärischen Radiodienstes der k.u.k.
Armee begonnen. In den 1920er Jahren ist er für den Aufbau des Heeresfunknetzes zuständig. Die Radio-Welt führt er zunächst nebenbei, nach seiner Pensionierung 1931 hauptberuflich. Er unterstützt die politische Indienstnahme des Rundfunks und publiziert 1935 in der Schriftenreihe des Wiener Heimatschutzes, einer rechten, paramilitärischen Vorfeldorganisation im austrofaschistischen „Ständestaat“. ${ }^{59}$

Mitte der 1930er Jahre kommt es zu einer Neuausrichtung der Radio-Welt. Nach mehreren Eigentümerwechseln zieht die Redaktion in die enteigneten Räumlichkeiten des ehemaligen sozialdemokratischen Vorwärts-Verlags in der Rechten Wienzeile 97 ein und nutzt auch die hauseigene Druckerei. ${ }^{60}$ Als Herausgeber und Verleger tritt nun Josef Ulbricht auf. Ab 5. April 1936 erscheint die Zeitschrift in erneuerter, deutlich modernisierter Aufmachung. Für den Umschlag wird nun ein ganzseitiges Foto verwendet, der Schriftzug wird ins Bild gesetzt. Auch im Innenteil erscheint die Zeitschrift jetzt ansprechender. Die Radio-Welt, die nun nicht mehr im Kupfertiefdruck hergestellt wird, erweitert auch ihr inhaltliches Spektrum: Aus dem reinen Radioblatt ist eine illustrierte Publikumszeitschrift geworden, die allen Themen des Alltags Platz einräumt, von der Mode bis zum Film. Auch Fotoreportagen erscheinen nun regelmäßig. Diese inhaltliche Öffnung bedeutet freilich nicht, dass die Zeitschrift die Nähe zur Regierung aufgibt.

Im März 1938 wechselt die Redaktion mit fliegenden Fahnen ins Lager der Nationalsozialisten über. Am 10. April 1938, dem Tag der Volksabstimmung über den „Anschluss“ an das Deutsche Reich, prangt ein Bild Hitlers auf der Titelseite der Radio-Welt, darunter lesen wir das nationalsozialistische Propagandamotto: „Ein Volk, ein Reich, ein Führer“. ${ }^{61}$ Doch obwohl die Redaktion im März 1938 die politische Ausrichtung des Blattes über Nacht an das neue Regime anpasst und in den folgenden Wochen immer wieder in großer Aufmachung über die neuen politischen Machthaber berichtet, vermag sie die Existenz der Zeitschrift nicht zu retten. Sie wird am 25. September 1938 eingestellt. 


\title{
Bilder als Propaganda
}

\author{
Die illustrierte Regierungspresse nach 1934
}

Abb. 1 Die sozialdemokratische Bunte Woche wird nach dem Verbot der Sozialdemokratie im Februar 1934 unter neuen politischen Vorzeichen weitergeführt. Sie steht nun unter Regierungskontrolle. Bunte Woche, 22. April 1934, Titelseite.
Als Siegfried Weyr, der Chefredakteur der sozialdemokratischen Illustrierten Der Kuckuck, am 10. Februar 1934 von seinem Büro im Verlagsgebäude „Vorwärts“ in der Rechten Wienzeile 97 nach Hause geht, ist die Welt noch einigermaßen in Ordnung. Zwar haben die Angriffe der autoritären Regierung den Spielraum der Zeitung bereits erheblich eingeschränkt, etwa durch die Einführung der Vorzensur. Aber immerhin: Die Zeitung kann noch erscheinen. An diesem 10. Februar wird, das kann er zu diesem Zeitpunkt freilich noch nicht wissen, die letzte Nummer des Kuckuck ausgeliefert. Zwei Tage später hat sich die politische Situation vollkommen verändert.
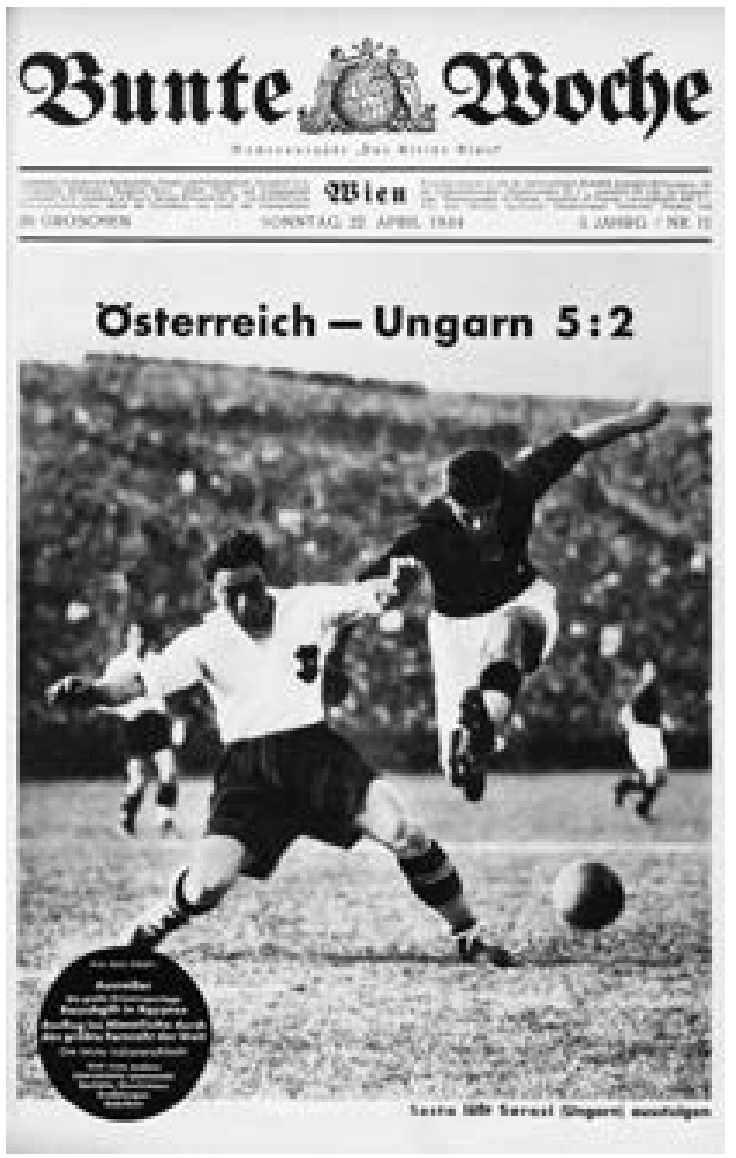

Ein kurzer, heftiger Bürgerkrieg beginnt. Die Reaktion der Regierung lautet: Repression. Alle sozialdemokratischen Partei- und Gewerkschaftsorganisationen sowie Presseerzeugnisse werden verboten, eine Verhaftungswelle erfasst die politisch verantwortlichen Funktionäre der Partei. Auch Redakteure sind davon betroffen. Siegfried Weyr entgeht auf scheinbar wunderbare Weise der Verfolgung. Er wird nicht nur nicht verhaftet, sondern arbeitet auch weiterhin an seiner alten Arbeitsstätte. Der Grund ist einfach: Er hat die politischen Seiten gewechselt.

Weyr, der in einschlägigen Publikationen bisher vor allem als heroischer Chefredakteur einer linken Oppositionszeitschrift und als „Erfinder“ der politischen Fotomontage in Österreich gefeiert wurde, hat auch eine politische Kehrseite, über die bisher wenig bekannt ist. Zwar finden sich einige wenige verstreute Hinweise, dass er nach 1934 für regierungsnahe Blätter gearbeitet habe, aber Genaueres war bisher nicht bekannt. ${ }^{1}$ Inzwischen lässt sich belegen, dass Weyr nach dem Verbot des Kuckuck beruflich fast nahtlos an seine bisherige berufliche Tätigkeit anknüpfen kann: Im März 1934 wird er verantwortlicher Redakteur der ehemaligen sozialdemokratischen und nun regierungstreuen illustrierten Wochenzeitung Bunte Woche, die, nach einer kurzen Unterbrechung, im inzwischen enteigneten Verlagshaus „Vorwärts“ hergestellt und gedruckt wird (Abb. 1). ${ }^{2}$ Am 14. April 1934 bestätigt die - inzwischen unter Regierungskontrolle stehende - Druck- und Verlagsanstalt „Vorwärts“, „dass Herr Redakteur Siegfried Weyr bei uns seit 1. März 1934 beschäftigt ist und bei der Versicherungskasse der Presse angemeldet wurde.“3

\section{Reaktion und Moderne}

Der Fall Weyr ist auf den ersten Blick nur eine Marginalie in der Geschichte der illustrierten Presse der Zwischenkriegszeit. Bei genauerem Hinsehen 
allerdings wirft er ein interessantes Licht auf den Übergang zur Diktatur. Dieser erfolgt nicht, wie oft angenommen wird, als klarer Bruch mit der Vergangenheit. Die Realität ist weitaus vielschichtiger. Natürlich gibt es im Februar 1934 eine Welle der Repression und Verfolgung. Aber es gibt auch Kontinuitäten, personelle, institutionelle, ästhetische. Am Fall Weyr lässt sich der komplexe Übergang von der demokratischen Presse zur Propagandamaschinerie der Austrofaschisten besonders gut nachzeichnen. Die Pressepolitik der Regierung arbeitet zwar mit den Mitteln der Zensur und der Verbote. Daneben gibt es aber auch den Versuch, bestehende publizistische Projekte unter neuen Vorzeichen weiterzuführen, funktionierende Einrichtungen zu nutzen und gestalterische Erfahrungen, auch jene der politischen Linken, zu absorbieren. ${ }^{4}$

Dieser Aspekt der austrofaschistischen Kulturpolitik ist bis heute kaum untersucht worden. ${ }^{5}$ Um die Politik und Ästhetik des „Ständestaates“ präziser fassen zu können, ist also eine Erweiterung der Perspektive notwendig. Die regressive, rückwärtsgewandte, durch und durch konservative Grundhaltung ist zwar das dominierende Element der austrofaschistischen Ideologie. Aber man sollte nicht übersehen, dass das Regime auch modernisierende Effekte hat. Das betrifft auch den Bereich der Kulturpolitik. Zwar ist auch hier die Wende hin zur rückwärtsgewandten, autoritären, katholisch-konservativen, antiurbanen Ideologie vorherrschend, aber in diese Programmatik mischen sich immer wieder Elemente der Moderne. Vor allem abseits der auflagenstarken populistischen christlichsozialen Propagandapublikationen wie etwa der Österreichischen Woche, die ab 1933 das Hauptforum der ländlich-konservativen Ideologie ist, gibt sich die Ästhetik des Regimes durchaus auch gemäßigt modern. Auch die Gestaltung der großen staatstragenden Ausstellungen in der zweiten Hälfte der 1930er Jahre greift, bei aller konservativen Grundausrichtung in den Inhalten, in gestalterischer Hinsicht sehr dezidiert Traditionen der Moderne auf - etwa in der Grafik und Typografie. ${ }^{6}$ Unter anderem kommt die Bildstatistik, die im sozialdemokratischen Umfeld der 1920er Jahre entwickelt wurde ${ }^{7}$, ab 1935 in den austrofaschistischen Ausstellungen zum Einsatz. ${ }^{8}$ Aber auch in der Architektur, in der Plakatgestaltung oder der Gebrauchsgrafik kommt es während der Zeit des Austrofaschismus zu einer Synthese zwischen konservativen Tendenzen und modernen Gestaltungsformen. ${ }^{9}$

Beispielhaft für diese Synthese ist die Monatszeitschrift Profil ${ }^{10}$, die ab 1934 auf Initiative von Clemens Holzmeister die Nähe zum Regime sucht und zum Sprachrohr des Neuen Werkbundes wird (Abb. 2). ${ }^{11}$ Die Zeitschrift, die von Erika Kriechbaum geleitet wird, betreibt inhaltlich und gestalterisch eine subtile
Abb. 2 Die Zeitschrift Profil wird von Clemens Holzmeister 1934 auf Regierungslinie gebracht. Sie ist ein Beispiel für die Synthese zwischen Tradition und Moderne im Austrofaschismus. Profil, Heft 1, Januar 1936, Titelseite. Gestaltung: Joseph Binder.

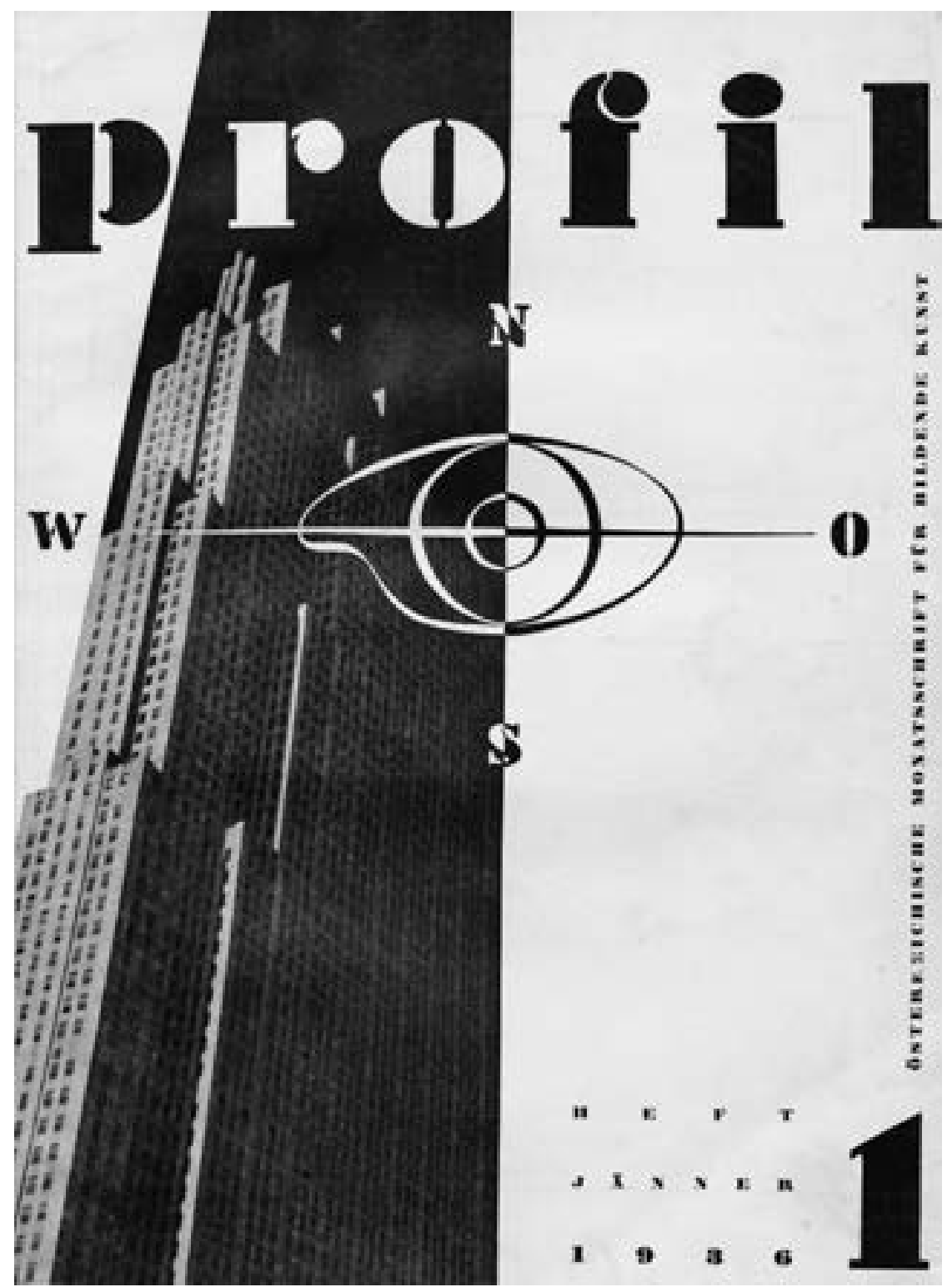


Abb. 3 „Es wird wieder blühen!“ Die erste Nummer der Bunten Woche prophezeit, dass die nach dem Bürgerkrieg siegreiche christlichsoziale Diktatur einen neuen politischen Frühling hervorbringen wird. Bunte Woche, 25. März 1934, Titelseite.
Gratwanderung zwischen Tradition und Moderne. Sie ist - zumindest in manchen Heften - ein Forum gemäßigt moderner Positionen (etwa in der Grafik - v.a. durch die Beiträge von Joseph Binder ${ }^{12}-$, in der Fotografie ${ }^{13}$ oder der Architektur), ohne freilich die Nähe zur Regierung aufzugeben und die katholisch-konservative, antiurbane Grundhaltung über Bord zu werfen. Und so stehen, zumindest am An-

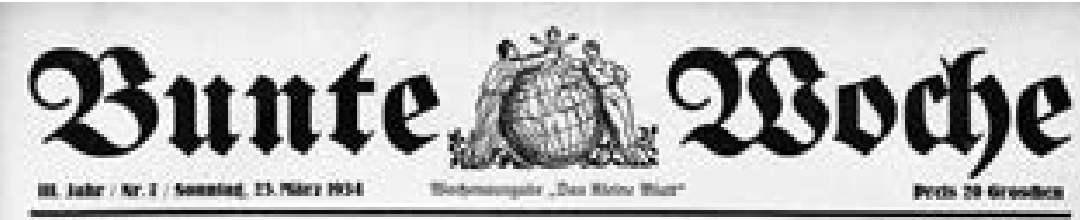

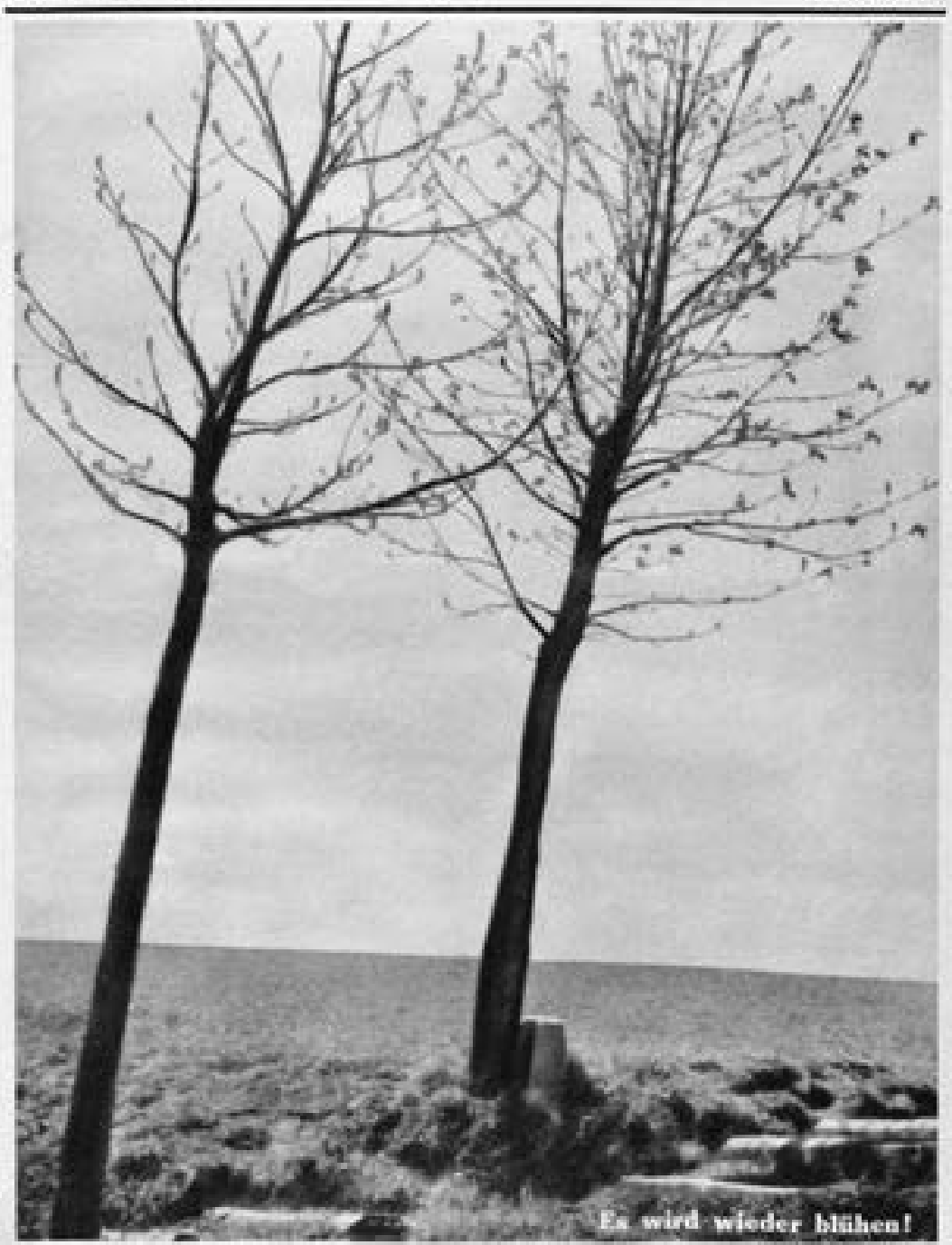


Das Blatt räumt zwar der Fotografie einen gewissen Raum ein, aber das Layout ist einfallslos, die Bilder werden in der Regel ohne Quellenangabe rein illustrativ in den Text gesetzt. Auf Kupfertiefdruck wird verzichtet. Immerhin geht das Konzept Braunthals auf: Der unpolitische Charakter der Zeitung hat zur Folge, dass sie bis 1934 nie aus politischen Gründen konfisziert wird. ${ }^{16}$

Als Siegfried Weyr im März 1934 die Bunte Woche übernimmt, unterzieht er sie zunächst einer radikalen grafischen Umgestaltung. Er verkleinert das Format, stellt - zunächst im Mantelteil - auf Kupfertiefdruck um und verbessert die grafische Aufmachung. Die Fotografie erhält nun einen weit höheren Stellenwert. Weyr profitiert von seiner jahrelangen Erfahrung beim Kuckuck, er kann auf einen Pool bewährter Fotografen und Agenturen zurückgreifen. Und so verwundert es nicht, dass er die Bunte Woche in mancher Hinsicht dem Kuckuck annähert. Auch inhaltlich richtet er das Blatt neu aus. Er verabschiedet sich vom Konzept einer engagierten, angriffslustigen Parteiillustrierten, das er mit dem Kuckuck verwirklicht hat und passt die Programmatik ganz eindeutig den neuen politischen Machtverhältnissen an. Auch wenn die Zeitung sich nach wie vor an ein breites $\mathrm{Pu}-$ blikum wendet und die Tagespolitik nicht im Vordergrund steht, ist von Anfang an klar, dass sie in großer Nähe zur austrofaschistischen Regierung steht.

Bereits das Titelmotiv der ersten Nummer nach der Übernahme ${ }^{17}$, die am 25. März 1934 erscheint, spielt subtil auf die neue politische Epoche an (Abb.3). Wir sehen ein scheinbar unpolitisches Motiv - zwei Bäume ohne Blätter in weiter Landschaft. Ganz unten ins Bild gesetzt ist das programmatische Motto „Es wird wieder blühen!“ Die Botschaft ist klar. Nach dem Bürgerkrieg und der Niederlage der Sozialdemokraten wird das siegreiche Regime einen neuen Frühling hervorbringen. Wenige Wochen später wird die politische Stellungnahme des Blattes noch weitaus deutlicher. Als am 1. Mai 1934, nicht zufällig am ehemaligen Tag der Arbeit und der Arbeiterbewegung, die Republik auch formal abgeschafft wird und die neue „ständestaatliche“ Verfassung in Kraft tritt, berichtet die Bunte Woche über die staatlich organisierten Massenaufmärsche, mit denen das Regi-

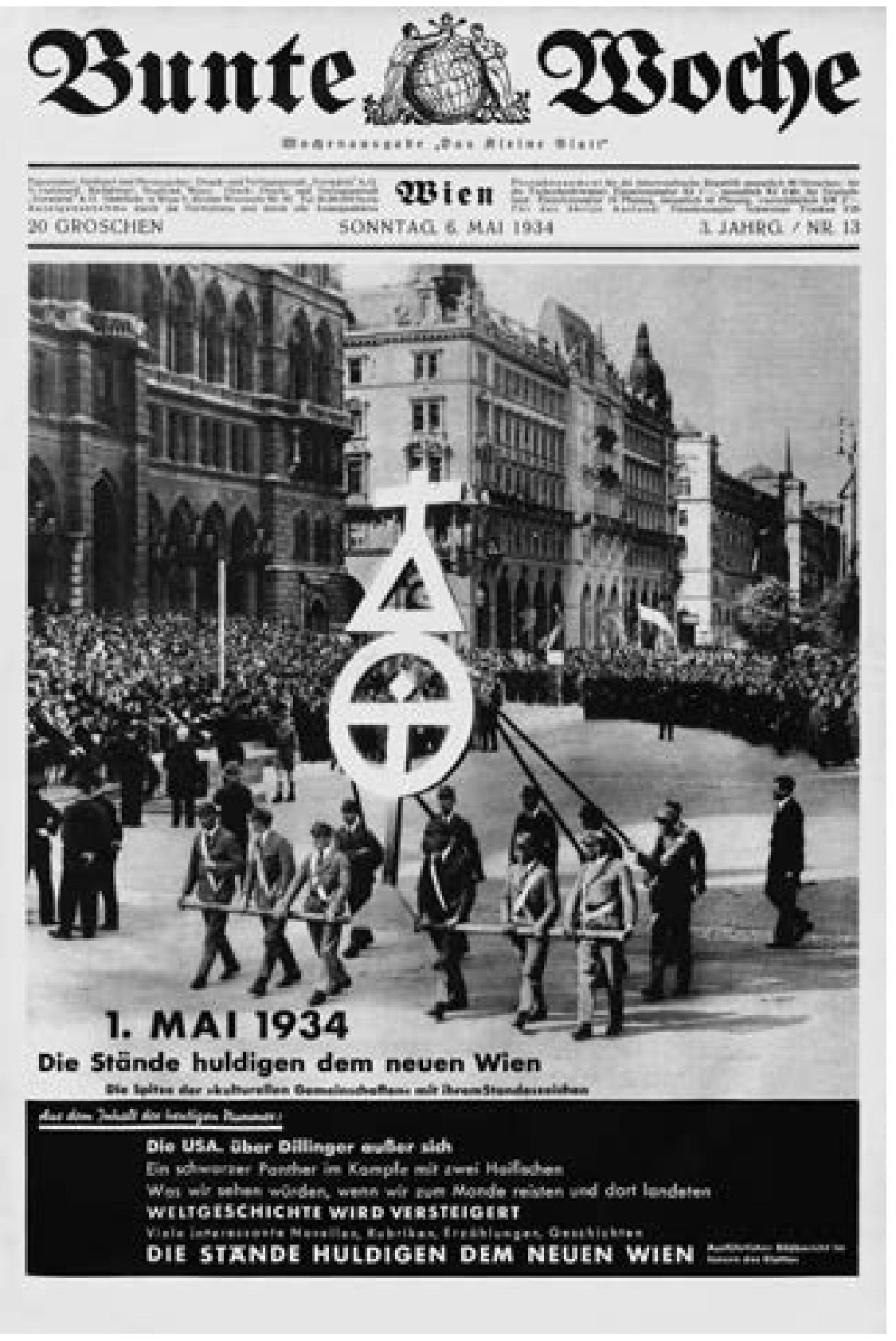

me das Ereignis feiert. Die größten Feierlichkeiten finden in Wien statt, wo die Standesorganisationen zu einem monumentalen Huldigungszug antreten. Das Titelfoto der Bunten Woche zeigt die Gruppe der „kulturellen Gemeinschaften“ mit ihrem Standesabzeichen (Abb.4).

Wie sehr Weyr mit der Bunten Woche in Aufmachung, Gestaltung und fotografischer Ausrichtung
Abb. 4 Huldigungszug der Standesorganisationen zur Feier der neuen Verfassung am 1. Mai 1934. An diesem Tag wird die neue ständische Verfassung ausgerufen und die Republik formal abgeschafft. Bunte Woche, 6. Mai 1934, Titelseite. 


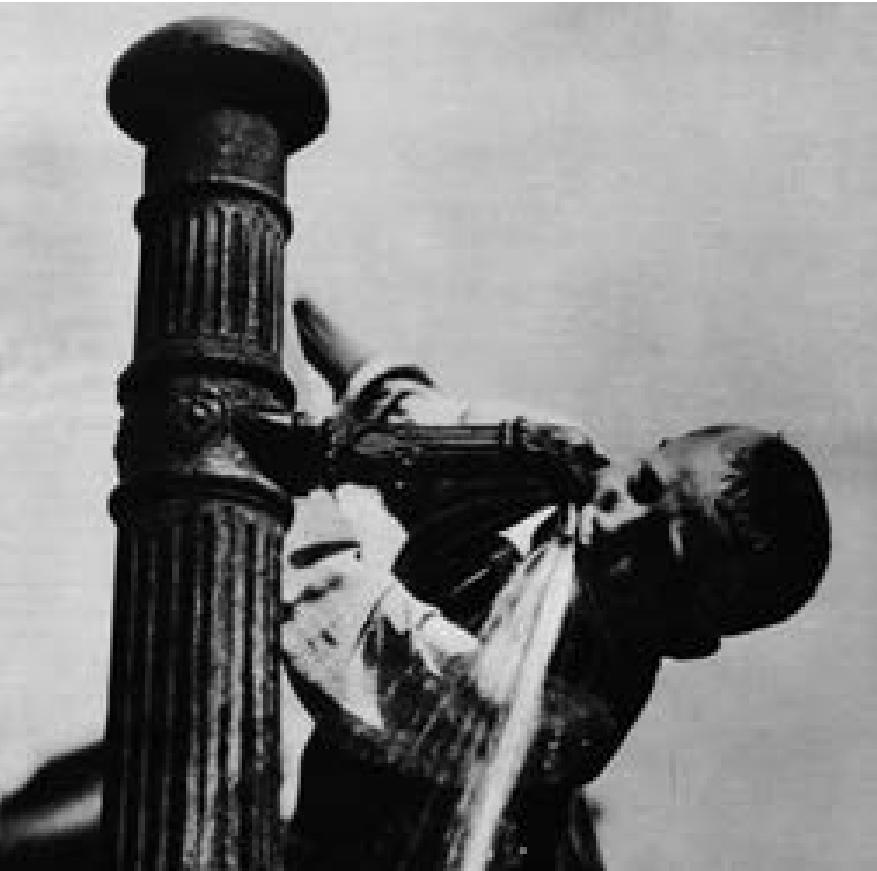

Abb. 5 Die Bunte Woche knüpft unter der Leitung von Siegfried Weyr in Aufmachung und fotografischer Ausrichtung teilweise an den Kuckuck an. Eine Reihe von Kuckuck-Fotografen taucht mit ihren Bildern auch in der Bunten Woche auf. Weyr bedient sich auch aus dem enteigneten Archiv des Kuckuck. Bunte Woche, 1. Juli 1934, Titelseite. Foto: Nikolaus Schwarz.
Abb. 6 Die Arbeiterfotografie, ein wichtiges Thema der Sozialdemokratischen Illustrierten Der Kuckuck taucht unter Weyr auch in der Bunten Woche auf, recycelt aus dem Archiv. Bunte Woche, 22. April 1934, S. 15.

\section{Unsere tägliche Arbeit Wiosia wiener}
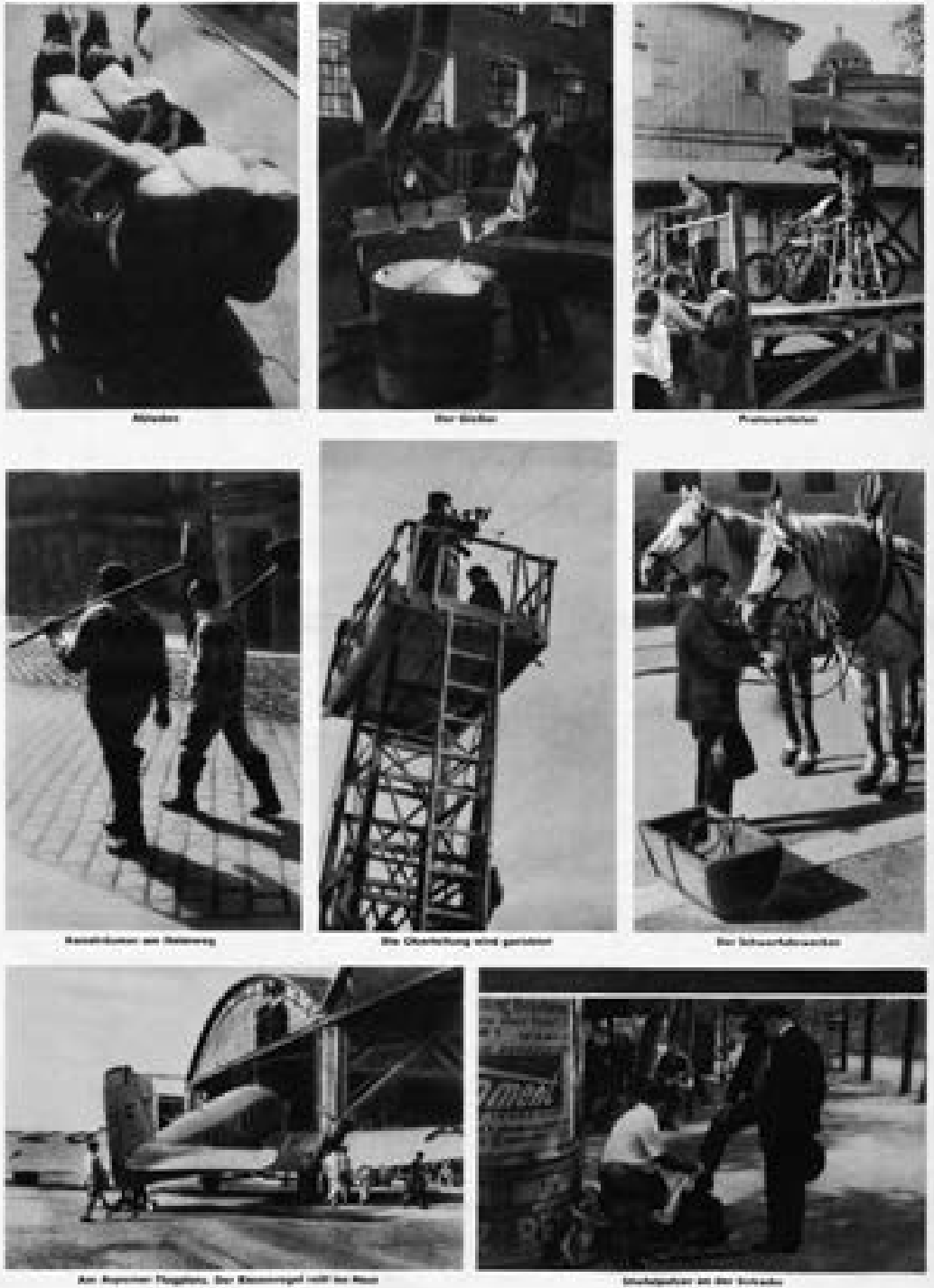

an den Kuckuck anknüpft, zeigt sich daran, dass er einer Reihe von modern arbeitenden Fotografen, die regelmäßig im Kuckuck veröffentlicht haben, auch in der neuen Zeitung prominenten Platz einräumt. So veröffentlicht er etwa Bilder von Hans Casparius, Rudolf Spiegel, Fritz Zvacek, Nikolaus Schwarz und Martin Imboden, von denen die meisten Anfang der 1930er Jahre der Arbeiterfotografiebewegung nahegestanden hatten (Abb. 5). Ein Teil der veröffentlichten Aufnahmen stammt aus dem enteigneten Fotoarchiv des Kuckuck, das Weyr übernimmt und weiter nutzt.

Erstaunlich ist, dass Siegfried Weyr auch unter den geänderten politischen Vorzeichen auf Bildmaterial der sozialdemokratischen Arbeiterfotografiebewegung zurückgreift, und zwar nicht nur implizit, sondern sogar explizit. Am 22. April 1934, also zehn
Tage vor dem (als Festtag der Arbeiterbewegung abgeschafften) 1. Mai, bringt er eine Bildseite unter dem Titel: „Unsere tägliche Arbeit: Wie sie Wiener Arbeiterphotographen sehen“ (Abb.6). Das achtteilige Bildtableau zeigt namentlich nicht gekennzeichnete Momentaufnahmen aus dem Arbeitsleben, das Spektrum reicht vom Pferdekutscher bis zum Schuhputzer. Es ist anzunehmen, dass auch diese Fotos aus dem Kuckuck-Archiv stammen. Einige der Aufnahmen machen sichtlich Anleihen beim Stil des Neuen Sehens.

Ein Kennzeichen des Kuckuck, die politisch bissigen Fotomontagen auf den Titelseiten, führt Weyr, allen ästhetischen Kontinuitäten zum Trotz, in der Bunten Woche nicht weiter. Unter den neuen politischen Vorzeichen erscheint es ihm ratsamer, mit unverfänglichen Genreaufnahmen zu arbeiten. Und 
dennoch: Ganz verzichtet er auf sein Montagehandwerk nicht. Gelegentlich zeigt er im Innenteil noch, was er kann. Mitte Mai findet sich auf der hinteren Umschlagseite eine raffiniert gebaute Fotomontage, die wohl von Weyr stammt (Abb. 7). Sie hat den amerikanischen Kriminalfall „Dillinger“ zum Thema, der 1934 nicht nur die Bevölkerung in den USA in Atem hält, sondern über den weltweit berichtet wird.

John Herbert Dillinger ist der Kopf einer brutalen Bande, die durch eine Reihe spektakulärer Banküberfälle und Gefängnisausbrüche bekannt wird. 1933/34 treibt der Gangster ein monatelanges Katz- und Mausspiel mit der Polizei und wird als Staatsfeind Nr. 1 gesucht. Auf seine Ergreifung ist ein Kopfgeld von 25000 Dollar ausgesetzt. Der Fall wird zum Mediengroßereignis. Über Dillingers Flucht wird in allen Zeitungen ausführlich und sensationslüstern berichtet. Weyr weiß natürlich, dass der Fall Dillinger auch in Österreich bekannt ist. Im Bildtext werden die wichtigsten Facetten des Kriminalfalls noch einmal zusammengefasst: „Seit Wochen hält der 1. Volksfeind Nordamerika in Atem. Umgeben von einem Harem hübscher Frauen, zieht er mordend und plündernd durch das Land. Das Hand-Maschinengewehr, wie Sie es oben rechts sehen, ist seine Waffe. Wegen 18 Morden ist bereits Anklage gegen ihn erhoben." 18

In der Fotomontage selbst spielt Weyr mit den Versatzstücken dieses Kriminaldramas und baut daraus eine suggestive Bildgeschichte. Der Name „Dillinger“, der 1934 in aller Munde ist, ist mitten ins Bild gesetzt. Darunter, in der Bildmitte, ist der Protagonist zu sehen. Die Aufnahme, die auch auf den Fahndungsplakaten verwendet wird, hat sich über die illustrierte Presse millionenfach verbreitet. Den Hintergrund nimmt eine stilisierte amerikanische Hochhaus-Skyline ein. Neben Dillinger sind zwei junge, attraktive Frauen zu sehen, ein Hinweis auf die weiblichen Begleiterinnen, mit denen sich der Gesuchte umgibt. Im Vordergrund ist ein blutiger Tatort zu besichtigen, mit allem, was dazugehört: durchlöcherte Autoheckscheibe, ein Toter, Polizisten. Weyr hat, das lässt sich am Beispiel dieser letzteren Szene eindeutig nachweisen, die Bildvorlagen aus dem Kuckuck-Archiv genommen. Das Foto des Mordes auf offener Straße hat er bereits 1931 im Kuckuck veröf-

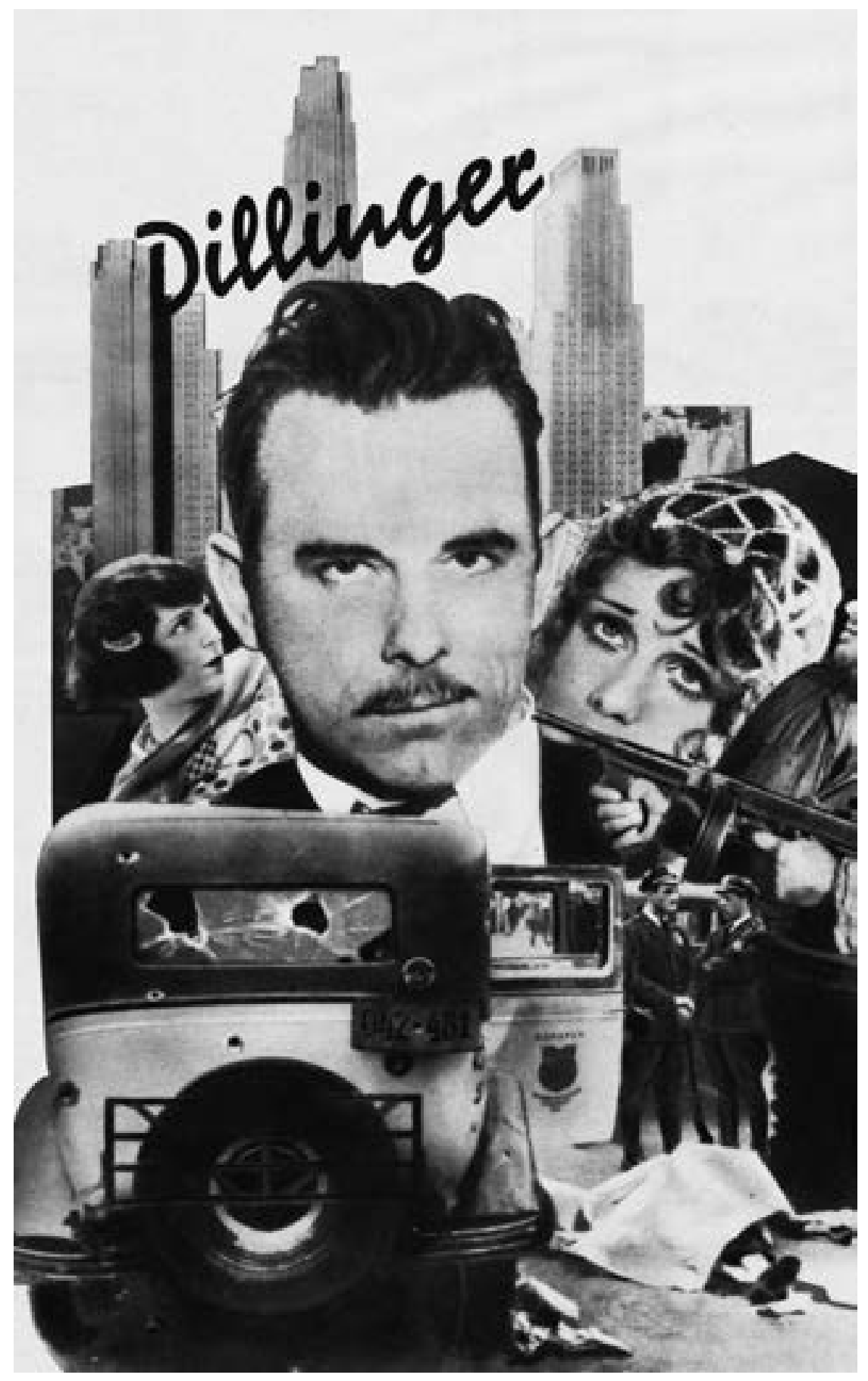

fentlicht, in einem Bildbericht zum Thema „Straßenleben in Neuyork“. ${ }^{19}$

Das dramatische Finale des Falles sollte wenige Wochen nach dieser Darstellung stattfinden. Am 22. Juli 1934 verlässt Dillinger zusammen mit zwei Frauen eine Kinovorstellung in Chicago und wird von drei Kugeln der Polizei tödlich getroffen. Eine der beiden Frauen hat ihn verraten.

Wenige Monate nach der politischen „Neugründung“ im Frühjahr 1934 wird die Bunte Woche ein weiteres Mal umgestaltet. Am 22. Juli 1934 wendet sich die Redaktion an die Leser und kündigt die an-
Abb. 7 „Dillinger“. Fotomontage Siegfried Weyrs zu einem bekannten Kriminalfall der 1930er Jahre in den USA. Der Bankräuber John Dillinger wird durch spektakuläre Gefängnisausbrüche und sein Katz-und-Maus-Spiel mit der Polizei bekannt. Bunte Woche, 13. Mai 1934, S. 16. 


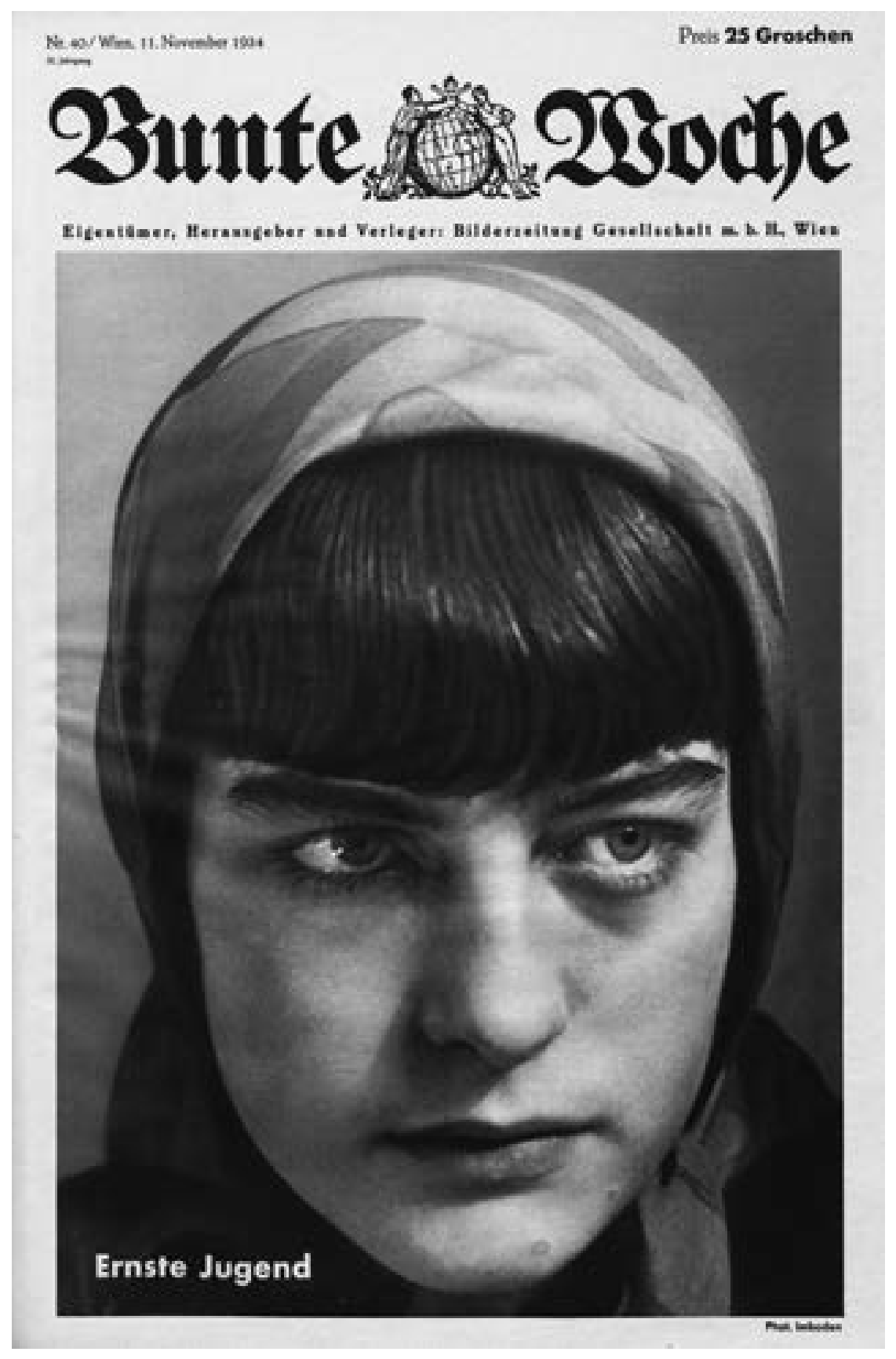

Abb. 8 „Ernste Jugend“. Porträt einer jungen Frau, aufgenommen von Martin Imboden. Bunte Woche, 11. November 1934, Titelseite. stehenden Veränderungen an. Ab kommender Woche, so wird verlautet, erscheint die Bunte Woche in „veränderter, wesentlich verbesserter Ausstattung (...) wodurch dem Verlag vor allem Gelegenheit geboten ist, den Bilderdienst der ,Bunten Woche` zu erweitern und auf modernste Weise auszubauen. “20 Tatsächlich werden nun mehr Fotos gedruckt und der Umschlag wird grafisch modernisiert. Die Zeitung wird nun durchgehend im Kupfertiefdruck hergestellt. Im Innenteil verzichtet das neue Layout jedoch auf jegliche Experimente.

Die wichtigste Neuerung aber wird nicht explizit erwähnt, sondern findet sich klein gedruckt im Impressum: Siegfried Weyr wird als Chefredakteur ab- gelöst und durch Walter Angel ersetzt. Über die Gründe der Abberufung ist nichts bekannt. Weyr bleibt aber weiterhin Redakteur der Bunten Woche, die in den folgenden Monaten einen immer offeneren propagandistischen Kurs für die Regierung einschlägt. Offenbar kann die Zeitung aber ökonomisch nicht recht Fuß fassen, Anfang September 1934 wird sie ein weiteres Mal umgestaltet. Das Format wird nun verkleinert, das Layout wird noch konventioneller. Auffallend ist, dass etliche Fotografen, zu denen Weyr während seiner Kuckuck-Zeit intensive Kontakte gepflegt hat, jetzt nicht mehr in der Bunten Woche veröffentlichen. Hin und wieder aber bedient sich auch die neue Chefredaktion aus dem Kuckuck-Archiv, etwa im November 1934, als sie auf der Titelseite unter dem Motto „Ernste Jugend“ ein eindrucksvolles Porträt einer jungen Frau bringt (Abb. 8). Das Foto stammt von Martin Imboden, der viel für den Kuckuck gearbeitet hat. Nach der politischen Wende versucht er, seine Bilder aus dem Archiv zurückzubekommen - vergebens. Weyr verweigert die Herausgabe, denn er will die Fotos weiter für die Bunte Woche nutzen. ${ }^{21}$ Imbodens Aufnahme wird also ohne Zustimmung des Fotografen veröffentlicht.

Zwei Wochen später, am 25. November 1934, erscheint die letzte Ausgabe der Bunten Woche. Gründe für die Einstellung werden nicht genannt. Offenbar hält die Auflagenentwicklung den Erwartungen nicht stand. Weyr wird aber im Vorwärts-Verlag weiterbeschäftigt, in der zweiten Hälfte der 1930er Jahre arbeitet er öfter als Autor für das Kleine Blatt. ${ }^{22}$ Nach dem Einmarsch der Nationalsozialisten in Wien verliert Weyr, dem man wie vielen anderen Journalisten des „Ständestaates“ Kollaboration mit dem „alten“ Regime vorwirft, seine Stellung. Seit dem 30. Mai 1938 ist er ohne Arbeit. ${ }^{23}$ Im November 1938 verlässt Weyr Wien und flüchtet über die Schweiz nach London. 1941 geht er in die USA und kehrt 1947 nach Österreich zurück.

\section{Propagandaillustrierte für das Regime}

Die Verlagsgeschichte der Bunten Woche zeigt, wie sehr das austrofaschistische Regime versucht, in den ersten Monaten der Diktatur den Anschein 
der Kontinuität zu wahren. Eine ganze Reihe von Zeitungen und Zeitschriften werden inhaltlich neu positioniert und weitergeführt. Aber es gibt auch Neugründungen, die massiv in den bestehenden publizistischen Markt der illustrierten Presse eingreifen. Das auflagenmäßig bei weiten erfolgreichste illustrierte Zeitungsprojekt des Austrofaschismus ist die Österreichische Woche, die ab September 1933 erscheint (Abb. 9). In ihr erwächst den marktbeherrschenden bürgerlichen Wochenillustrierten ein machtvoller Konkurrent. Ihre enorme Auflage - sie liegt zwischen 500000 und 700000 Exemplaren ${ }^{24}$ und übersteigt die Verbreitung anderer Illustrierter um ein Vielfaches - verdankt die Österreichische Woche der Tatsache, dass sie unter der Regie der Regierung zahlreichen regionalen katholisch-konservativen Zeitungen als Wochenillustrierte beigelegt wird. ${ }^{25}$ Mit Ausnahme der christlichsozialen Reichspost und des Neuigkeits-Welt-Blatts erscheinen all diese Blätter nicht in Wien, sondern in der Provinz.

Eigentümer und Verleger ist der Österreichische Heimatdienst, eine Propagandaeinrichtung im Vorfeld der austrofaschistischen Regierung, die ab 1934 ein dichtes Netz von Beeinflussungsinstrumenten aufbaut. Das Medienimperium des Heimatdienstes betreibt - neben der Herausgabe der Wochenillustrierten Österreichische Woche - auch Rundfunk- und Filmpropaganda (etwa über die Wochenschau „Österreich in Bild und Ton“) und gibt eine „Vaterländische Wandzeitung“ sowie diverse Mitteilungsblätter heraus. Herausgeber der Österreichischen Woche ist Edmund Weber, als verantwortlicher Redakteur tritt Ernst Wenger auf.

Inhaltlich ist die Zeitung ganz auf Regierungskurs, mit ihren propagandistischen Bildserien verleiht sie der katholisch-konservativen, reaktionären Politik des „Ständestaates“ ein machtvolles mediales Echo. Ganz gezielt schürt die Österreichische Woche antisozialistische, antiurbane Stimmungen und verbreitet ein geschöntes, heimattümelndes Österreichbild. Eine feste Rubrik heißt denn auch „Das schöne Österreich“. Deutlicher noch als die bürgerlichen Illustrierten wie Das interessante Blatt oder die Wiener Bilder ist die Österreichische Woche eine reine Bilderzeitung. Der Textumfang ist reduziert, die Bilder überwiegen.
Der Umschlag ist ein Verschnitt aus modernen und traditionellen grafischen Elementen. Beispielsweise setzt die Zeitung, ganz im Sinne einer modernen Illustrierten, auf ein großes, nahezu seitenfüllendes Titelfoto und verzichtet auf die Titelvignetten. Dafür aber prangt über dem Bild der Titel in der konservativen Frakturschrift. Im Innenteil ist das Blatt ohne größere grafische Ansprüche gestaltet. Zwar finden sich immer wieder Bildgeschichten und Ansätze
Abb. 9 Die katholisch-konservative Propagandaillustrierte Österreichische Woche erscheint seit September 1933. Sie ist auflagenmäßig das erfolgreichste illustrierte Zeitungsprojekt des Austrofaschismus. Österreichische Woche, 2. Februar 1934.

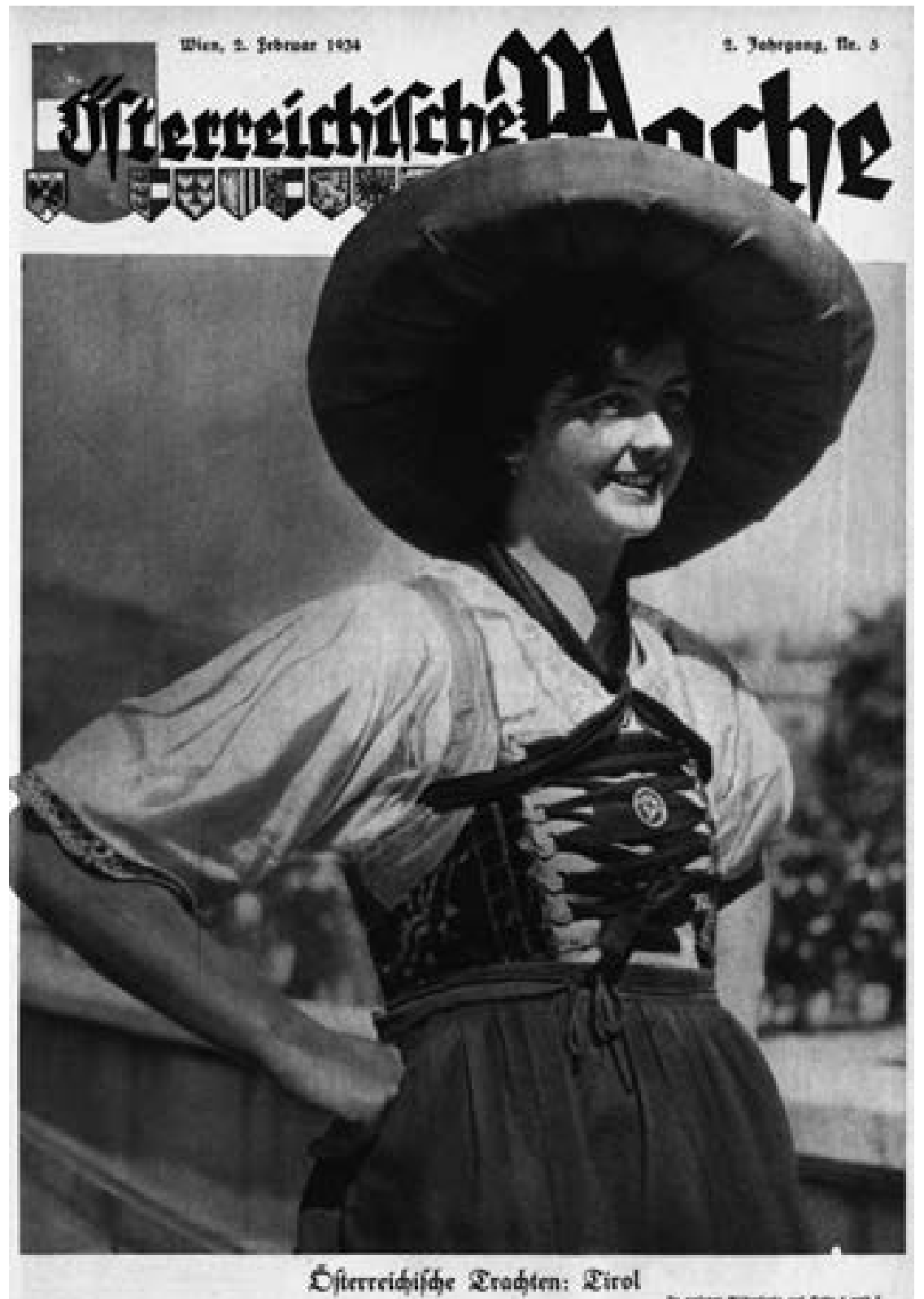




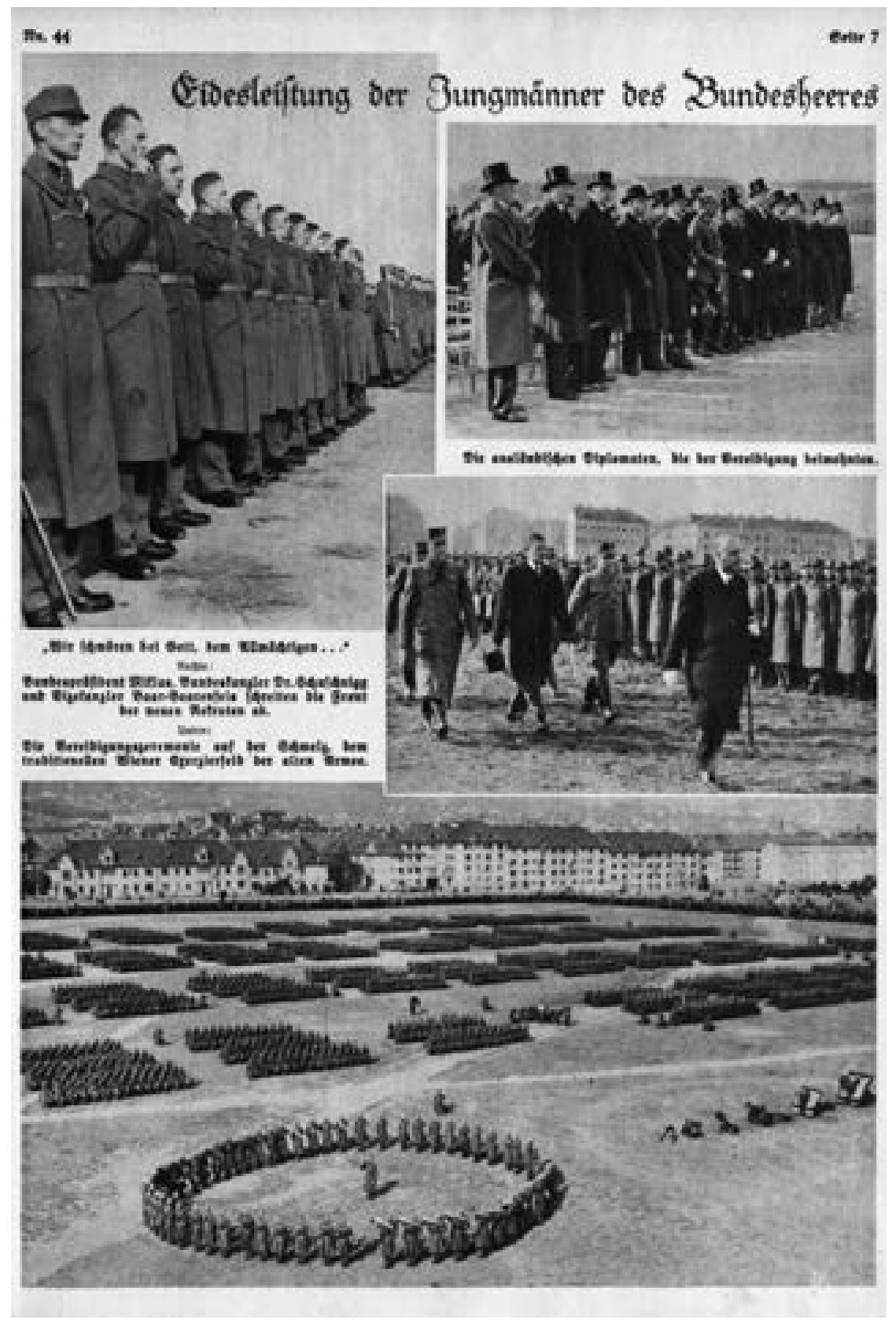

Abb. 10 Die Österreichische Woche ist im Innenteil grafisch einfach gestaltet. Es überwiegen einfache Fototableaus, oft mit überlappenden Bildern. Die redaktionellen Texte sind sehr kurz gehalten. Österreichische Woche, 29. Oktober 1936, S. 7. von Fotoreportagen (hie und da auch einfache Fotomontagen), aber die Anordnung und Verbindung zwischen Bildern und Texten ist simpel gehalten. Als Beispiel mag eine Doppelseite vom Oktober 1936 dienen, in der über den monumentalen Massenaufmarsch der Vaterländischen Front in Wien berichtet wird (Abb. 10). Statt einer suggestiven Bilderzählung, wie sie etwa wenige Jahre zuvor der Welt-Guck prä- sentiert hat, dominieren hier einfache Fototableaus, oft mit überlappenden Bildern. Dazwischen finden sich die in Fraktur gehaltenen Bildtexte bzw. kurze redaktionelle Einschübe. Die Namen der Fotografen werden bei den meisten Abbildungen nicht genannt, mit einer Ausnahme: Lothar Rübelt. Seine Fotoarbeiten, meist sind es unverfängliche Sport-, Genre- und Landschaftsaufnahmen, sind in der Österreichischen Woche gekennzeichnet.

Das illustrierte Kampfblatt der Austrofaschisten ist vor allem auf dem Land erfolgreich, weniger in Wien, wo sie nur zwei konservativen Tageszeitungen beiliegt, deren Leser ohnehin zur regierungstreuen Klientel zählen. Zwar versucht die Regierung auch die ehemals sozialdemokratische Arbeiterschaft vor allem in Wien mit einer eigenen illustrierten Zeitung, der wöchentlich erscheinenden Bilderwoche der österreichischen Volksschriften, zu erreichen. ${ }^{26}$ Aber der Erfolg dieser Publikation, die zwischen 1934 und 1938 erscheint, bleibt bescheiden. Während also die strikt antiurbane, ländlich-konservative Ausrichtung der Österreichischen Woche ihrer massenhaften Verbreitung in der Großstadt Grenzen setzt, erobert sie auf dem Land tatsächlich neue Leser. Der Österreichischen Woche gelingt es dank der massiven Intervention der Regierung, ein seit Langem vorherrschendes Stadt-Land-Gefälle, das die Verbreitung der illustrierten Presse kennzeichnet, bis zu einem gewissen Grad auszugleichen.

Ein halbes Jahrzehnt lang, von 1933 bis 1938, gelingt es der weitverzweigten austrofaschistischen Propagandamaschinerie, die öffentliche Meinung zu beherrschen. Im März 1938 bricht dieses Pressemonopol mit einem Schlag zusammen und wird, im Zuge des Machtantritts der Nationalsozialisten, durch eine andere, noch weit feinmaschigere Pressediktatur ersetzt. Rückblickend betrachtet ist das Jahr 1938 der zentrale Einschnitt in der Geschichte der österreichischen Presse und damit auch für die Pressefotografie. Zwar setzen auch die Nationalsozialisten in gewisser Weise auf Kontinuität, aber die politischen Eingriffe, die Zensur, die Maßnahmen der rassistischen Verfolgung und der politischen Repression sind mit dem Umbruch im

Jahr 1934 kaum zu vergleichen. 


\section{Erzählende Bilder}

Die moderne Fotoreportage in der Zwischenkriegszeit

„Das Telephon schrillt. Eine kurze Meldung jagt durch den Draht. Apparat und Platten, stets griffbereit, werden gefaßt, hinunter aufs Motorrad und davon. Von weitem schon zeigt eine dichte Menschenmenge den Tatort an. Das Rad dient als Tribüne. Ein Blick für die Lichtverhältnisse, einige sichere Griffe an der Kamera, der Verschluß schnurrt, die erste Aufnahme ist erledigt. Rasch noch einige wesentliche Einzelheiten, wobei das Platzschaffen das Problem ist (hier hilft nur taktvolle Unverfrorenheit), dann geht es in fliegender Eile zurück in die Dunkelkammer, wo der Abgesandte der Klischeeanstalt schon auf die nasse Kopie wartet. - Eine Stunde später reißen sich die Leute die druckerfeuchten Zeitungsblätter aus den Händen. Tägliche Arbeit - Taglöhnerarbeit.“1 Der Wiener Pressefotograf Lothar Rübelt schildert in diesen dicht aufeinanderfolgenden Szenen den Arbeitsalltag eines Zeitungsfotografen. Sein Beitrag erscheint, versehen mit eigenen Bildern, im Oktober 1929 im Wiener Magazin (Abb. 1).

Auf der einleitenden Doppelseite ist die dramatische Szene eines Straßenkampfes zu sehen - aufgenommen Mitte Juli 1927 während der Unruhen rund um den Wiener Justizpalastbrand. Daneben sehen wir den Fotoreporter bei der Arbeit. Er steht auf dem Sattel seines Motorrads und folgt mit der Kamera den Ereignissen aus erhöhter Perspektive. Rübelt stilisiert den Pressefotografen - und auch sich selbst - zum ra-

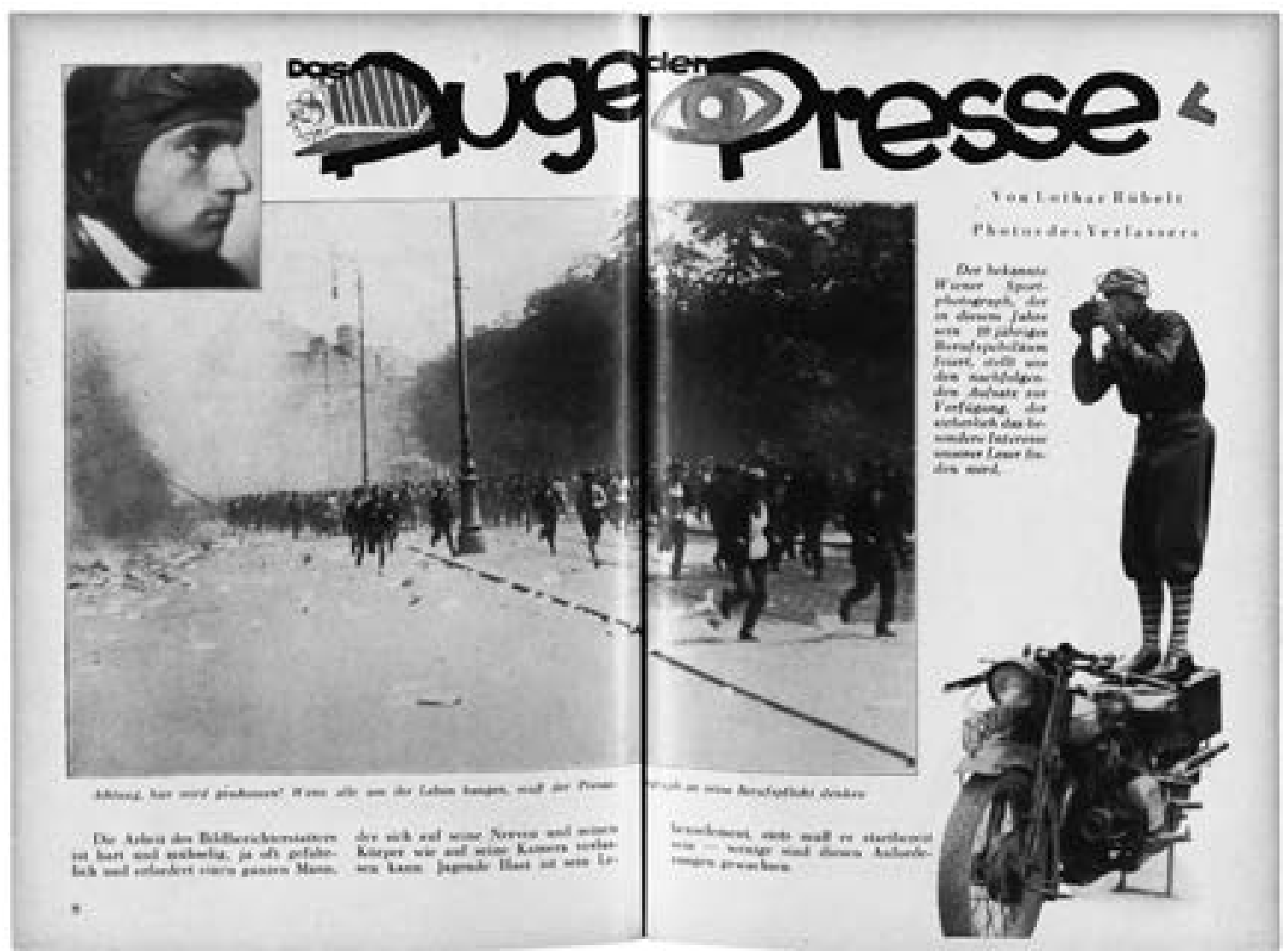

Abb. 1 Die Arbeit des Fotoreporters aus der Sicht des Pressefotografen Lothar Rübelt. Wiener Magazin, Heft 10, Oktober 1929, S. 8/9. Fotos: Lothar Rübelt. 
Abb. 2 „Ein ausgesprochen smarter Mensch. Leider etwas geldgierig." Der österreichische Pressefotograf Lothar Rübelt wird im Wiener Magazin als Mitarbeiter vorgestellt. Wiener Magazin, Heft 10, Oktober 1932, S. 47.

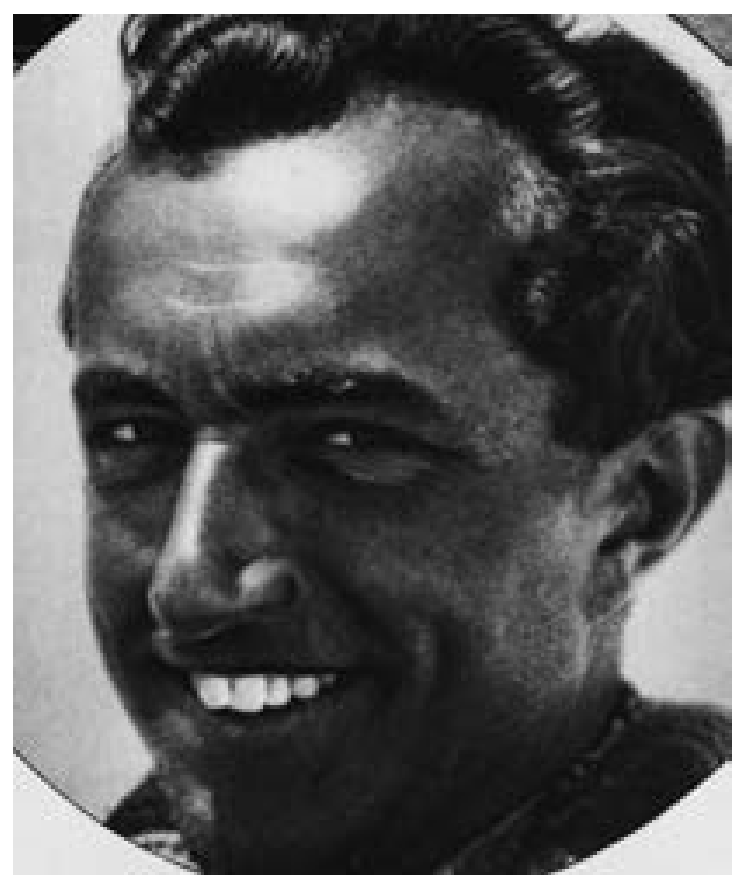

senden Reporter, er spitzt die Dramaturgie der Ereignisse deutlich zu und nimmt es mit der Wahrheit nicht so genau. Ganz so rasch folgen die Ereignisse in der Wirklichkeit nicht aufeinander. Eine Stunde nach der Entwicklung der Bilder sind die gedruckten Fotos keineswegs schon in der Öffentlichkeit. Aber in einer Hinsicht trifft Rübelt sehr wohl die Realität: Der durchschnittliche Pressefotograf ist im Grunde ein Tagelöhner, der für sein Geld hart arbeiten muss und dessen soziales Image nicht besonders hoch ist. Er ist ein - oft anonymer - Zuarbeiter der Zeitungen und Zeitschriften und meist weit davon entfernt, ein Held zu sein, der im Licht der Öffentlichkeit steht.

„Die Arbeit des Bildberichterstatters“, so Rübelt weiter, „ist hart und mühselig, ja oft gefährlich und erfordert einen ganzen Mann, der sich auf seine Nerven und seinen Körper wie auf seine Kamera verlassen kann. Jagende Hast ist sein Lebenselement, stets muß er startbereit sein - wenige sind diesen Anforderungen gewachsen. Und doch ist die Aufgabe lockend, reizvoll und schön. Mit seinen Augen sehen Tausende die Ereignisse dieser Welt!“2

\section{Vom Einzelbild zur Serie}

Ende der 1920er Jahre, als dieser Beitrag erscheint, beginnt sich die Rolle des Pressefotografen zu verändern. Es gibt zwar weiterhin zahllose fotografische „Taglöhner“, die das Gros der Zeitungsfotografien liefern. Aber nun steigen die Anforderungen an die Fotografen, das Geschäft beschleunigt sich, die Konkurrenz ist groß. Einige Tageszeitungen be- ginnen regelmäßig Fotografien zu drucken. Das Feld der Pressefotografen differenziert sich aus. „Viele“, so Rübelt, „kommen über das gestürzte Pferd und den Straßenbahnzusammenstoß nicht hinaus und bleiben Handwerker, manche kommen weiter, bleiben aber, ein Fluch der Routine, in der Schablone stecken, aber einigen wenigen ist es vergönnt, als wahre Pioniere, als frei schaffende Künstler, der Menschheit Dinge zu vermitteln, die nur Auserwählte in seltenen Momenten erblicken können. Sie alle aber gehören zur großen Armee, die in unbestechlichen Lettern die Chronik dieser Erde schreibt. “3 Es ist nicht verwunderlich, dass Rübelt sich selbst den letztgenannten Pionieren zurechnet. Selbstbewusst und nicht ohne Pathos stellt er sich an den Beginn eines neuen fotografischen Zeitalters, das der „frei schaffende Künstler" mit der Kamera grundlegend mitbestimmt.

Lothar Rübelt ist einer der ganz wenigen österreichischen Pressefotografen, die bereits in den 1920er Jahren im Licht der Öffentlichkeit stehen. Er versteht es schon in jungen Jahren (1929 ist er 27 Jahre alt) erfolgreiches Marketing in eigener Sache zu betreiben. Als das Wiener Magazin 1932 seine wichtigsten Mitarbeiter in Bildern und kurzen Texten vorstellt, bekommt auch Rübelt einen Eintrag. Neben einem kreisrunden Brustbild (Abb. 2) heißt es: „Lothar Rübelt, einer der Nettesten. Man ruft ihn an, er ist da. Man braucht etwas Ausgefallenes, er bringt es. Er ist höflich und heiter, ein ausgesprochen smarter Mensch. Leider etwas geldgierig. “4

„Das Jahr 1929 war in verschiedener Hinsicht ein Markstein in meiner Laufbahn“, erinnert sich Rübelt Jahrzehnte später. Selbstbewusst reklamiert er auch im Rückblick für sich, der Pionier der österreichischen Reportagefotografie gewesen zu sein. „Im Anfang war die Begegnung mit der Leica (Kleinbildkamera), die entscheidend war für die Freizügigkeit der Bildberichterstattung, die sich vom Einzelbild zur ,Serie‘ entwickelt hatte. Im Dezember kam dann der erste ,Auftrag‘ einer Illustrierten, noch dazu im Ausland: der Giftmordprozeß in Szolnok für das ,Interessante Blatt' in Wien durch Chefredakteur Papanek. Auf meinem Spezialgebiet, der Sportphotographie hatte ich mir längst einen Namen gemacht, aber nun galt es, den Stil und die Technik in die Zeitgeschichte 
zu verpflanzen. ${ }^{5}$ Tatsächlich hat Lothar Rübelt der erzählenden Bildgeschichte in der österreichischen illustrierten Presse wichtige Impulse gegeben. Aber er ist nur einer von mehreren Fotoreportern, die um 1930 beginnen, Fotoserien für geschlossene Reportagen zu liefern, die nun als Fotoreportagen bezeichnet werden. All diese Fotografen beginnen keineswegs bei null, sondern nehmen die Erfahrungen ihrer Vorgänger auf. Die Form der Bildgeschichte ist nämlich keine Erfindung der Zwischenkriegszeit, sondern, wie wir gesehen haben, schon seit Längerem erprobt. Bereits seit der Jahrhundertwende werden Bildreportagen in den Illustrierten veröffentlicht. ${ }^{6}$

Dennoch: Ende der 1920er Jahre gibt es einen klaren Einschnitt in der Geschichte und Verwendungsweise der Fotoreportage. Mehrere Umstände ändern sich: Zunächst ist es die Rolle und Position des Fotografen. Dieser wird nun, unterstützt meist durch den Text, zum - oft auch bewusst subjektiv vorgehenden - Augenzeugen, der ein Ereignis nicht nur in Einzelaufnahmen dokumentiert, sondern aus seinem Blickwinkel in einer Bilderserie schildert. Er streift nun immer öfter die Anonymität des bloßen Bildzulieferers ab und tritt auf der Zeitungsseite selbstbewusst auf. Sein Name wird immer öfter deutlich sichtbar genannt. Stammten in den bisherigen Reportagen die Bilder meist aus unterschiedlichen Quellen (mehrere Fotografen, Fotoagenturen), so liefert der Fotograf nun häufig die gesamte Bildgeschichte. Er ist nicht nur der Augenzeuge, sondern in gewisser Weise auch der Erzähler der Geschichte, der in seinen Bildern einen Überblick bietet, Details auswählt und Zusammenhänge herstellt.

Auch die Bildgeschichte selbst verändert sich nun. An die Stelle von Themenseiten, die mit einfachen Bildtableaus arbeiten, treten ab Ende der 1920er Jahre allmählich komplexer gebaute, in sich abgeschlossene, sich gelegentlich über mehrere Seiten erstreckende Bildberichte, die meist einem kurzen Handlungsstrang folgen. In den Fotoreportagen werden auch neue Themen erschlossen. Die Bildgeschichten wenden sich nun nicht nur herausragenden politischen und gesellschaftlichen Ereignissen zu, den Sensationen der Woche also, sondern auch den Facetten des Alltags, den Orten, Menschen und
Dingen, die Leser und Fotografen Tag für Tag umgeben. Nun werden Geschichten in Fotografien erzählt, die bis vor Kurzem noch nicht als bildwürdig galten: ein Schultag etwa, ein Besuch im Krankenhaus, das Leben und Arbeiten eines Hausmeisters, die Arbeit im Büro, Vergnügungen im Park, seltsame Sammelleidenschaften mancher Menschen oder ein Tag auf dem Flohmarkt. Der sachliche, der Wirklichkeit zugewandte Blick verbindet sich oft mit einer poetischen Sicht auf die Dinge. Auf diese Weise rückt die neue Form der Reportage, die sich gelegentlich durch ihre subjektive, flanierende Bildsprache auszeichnet, oft in die Nähe des Feuilletons. Der fulminante Aufstieg der modernen Fotoreportage um 1930 hat aber auch, so argumentiert Ulrich Keller, mit der erfolgreichen Fusion bisher getrennter Bilddiskurse zu tun. ${ }^{7}$ In gut gemachten Reportagen verschwimmen Nachricht, Unterhaltung, spannende Erzählung, oft auch Werbung und Propaganda zu einer neuen Bildgattung.

Aus der Sicht des Fotografen Rübelt spielt bei der Neukonzeption der Reportage die Technik eine wichtige Rolle. Er erwähnt die kleinformatige Leica, mit der er seit 1929 arbeitet. Tatsächlich kommt in den 1920 er Jahren eine ganze Reihe von neuen Kameras auf den Markt, die einen Einfluss auf die Form der Bildberichterstattung haben. Zwar fotografieren immer noch viele Pressefotografen mit den bisher verwendeten großformatigen $(13 \times 18 \mathrm{~cm})$ Plattenkameras, etwa der ICA-Record oder der Deckrullo-Nettel, aber nach und nach greifen sie auch zu kleinformatigen, lichtstarken Kameras, die sie oft parallel zu ihren herkömmlichen großformatigen Apparaten einsetzen. 1924 kommt etwa die Ermanox der Firma Ernemann mit einem Plattenformat von $4,5 \times 6 \mathrm{~cm}$ auf den Markt, ein Jahr später, 1925, die Leica, die einen beidseitig perforierten 35-mm-Kinofilm als Aufnahmematerial verwendet (mit einer Negativgröße von $24 \times 36$ mm). Seit 1929 wird die Mittelformatkamera Rolleiflex angeboten, die ebenfalls mit Rollfilm ausgestattet ist und die in den 1930er Jahren für viele Lichtbildner zur beliebten, weil bedienungsfreundlichen Reportagekamera wird. Ab 1932 schließlich bringt das Dresdner Unternehmen Zeiss die Kleinbildkamera Contax auf den Markt, die in den 1930er Jahren als Konkurrenzprodukt zur Leica gedacht war. ${ }^{8}$ 
Der Einsatz neuer Apparate ist freilich bei genauerer Betrachtung nur einer von vielen Faktoren (und gewiss nicht der wichtigste), die hinter den gestalterischen Umbrüchen in der illustrierten Presse um 1930 stehen. Wichtiger ist beispielsweise der Einfluss des modernen Films, der in den 1920er Jahren große Schritte in Richtung innovativer Bilderzählungen macht. Vor allem die Regisseure der Avantgarde, die mit Großaufnahmen und atemberaubenden Montagefolgen arbeiten, geben der fotografischen Bildgeschichte wichtige Impulse. Das gilt insbesondere für den innovativen Reportagefilm deutscher und sowjetischer Herkunft.

Die filmische Reportage zeichnet sich darüber hinaus durch die künstlerisch gestaltete Hinwendung zur alltäglichen Wirklichkeit aus. „Die Reportage“, schreibt der österreichische Fotograf Kurt Husnik 1933 in seinem von Béla Balász inspirierten Beitrag „Das Kinoauge als Reporter“, „nimmt als Film eine Sonderstellung ein, da sie keine Fabel oder eine zusammenhängende Begebenheit schildert, sondern nur das Ding an sich, losgelöst von seiner Umwelt. Der Reportagefilm sucht nicht in der Begebenheit, sondern nur in der Erscheinung seinen Stoff. Sein Ausdrucksmittel ist die rein optische Sprache des Films, und hat der Künstler die Möglichkeit, die Kamera nicht bloß zu illustrieren, sondern selbst dich-

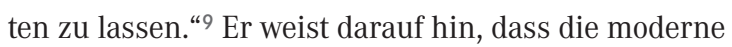
Reportage im Film wie in der Fotografie die Dinge des Alltags in ein neues Licht rückt, dass sie dazu beiträgt, unsere nächste Umgebung auf neue Weise zu betrachten: „Die Gabe der Beobachtung führt dazu, die Sprache selbst der unscheinbarsten Dinge $\mathrm{zu}$ verstehen und im Photo und (im) Film haben wir das Resultat vor uns: die Reportage der unbekannten Nähe unserer Umwelt." 10

Neben dem Film spielt für die Fotoreportage neuen Stils der Text eine große Rolle. Er verabschiedet sich immer öfter von der alten informierenden, oft belehrenden Zeitungsprosa, der die Einzelbilder bloß kommentiert und einordnet. Stattdessen wird er erzählender und feuilletonistischer. Er hat die Aufgabe, die Bilder zu Geschichten zu verbinden und diese mit einer Dramaturgie zu versehen. Immer öfter schreiben nun auch bekannte Feuilletonautoren Beiträge zu Fotoreportagen. Ein Beispiel von vielen ist Karl Tschuppik, geb. 1876 in Böhmen, der in der Zwischenkriegszeit in Berlin und Wien lebt. Er schreibt Anfang der 1930er Jahre einige gute Bildgeschichten zu Österreich-Fotoreportagen, die Felix H. Man im Auftrag der deutschen Fotoagentur Dephot zusammenstellt und die in der Münchner Illustrierten Presse veröffentlicht werden.${ }^{11} \mathrm{Neu}$ ist, dass in den 1930er Jahren vermehrt auch Frauen die Texte zu den Fotoreportagen schreiben: in den Wiener Bildern etwa Etta Donner, Marianne Feigl, Marianne Heimler und Hilde Leitner, im Wiener Magazin Rosa Wachtel und im Sonntag Gusti Skall. ${ }^{12}$

Ende der 1920er Jahre führen auch ökonomische Umbrüche auf dem Markt der illustrierten Presse zu einer Neuausrichtung der Bildberichterstattung. ${ }^{13}$ Ab Mitte der 1920er Jahre kommt es zu einem Auflagenboom und zugleich zu einem erbitterten Wettbewerb auf dem Pressemarkt. Neben den klassischen Wochenillustrierten bieten nun auch einige illustrierte Wochenendbeilagen von Tageszeitungen, vor allem aber die neu gegründeten, meist monatlich erscheinenden Gesellschafts- und Kulturmagazine Bildgeschichten an. Zudem drängen in den 1920er Jahren zunehmend professionell gestaltete deutsche Illustrierte nach Österreich. Die führenden Wochenillustrierten Das interessante Blatt und die Wiener Bilder beginnen angesichts dieses Drucks ebenfalls ihre Gestaltung allmählich zu verbessern und aufwendiger konzipierte Bildgeschichten in Auftrag zu geben.

Die moderne Fotoreportage, die in den Augen der Fotopioniere 1929 fast wie vom Himmel zu fallen scheint ${ }^{14}$, ist also in Wirklichkeit das Ergebnis komplexer Veränderungen im Mediensektor. Sie ist ein Produkt vielschichtiger Einflüsse und Wechselwirkungen. Die wichtigsten Anregungen für die österreichische Fotoreportage kommen aus Deutschland, wo bereits etwas früher, ab 1928/29, neue Formen der Bilderzählung entwickelt werden. Zeitungen wie die Münchner Illustrierte Presse und das Frankfurter Illustrierte Blatt, experimentieren schon 1928 mit der Fotoreportage neuen Stils. ${ }^{15}$ Innovative Fotoagenturen wie Weltrundschau (1927 gegründet), Dephot (1928 gegründet) oder Mauritius (1929 gegründet) bieten neben Einzelbildern nun 
auch fertige Fotoreportagen (oft zusammen mit den Texten) an. ${ }^{16}$ Ab Anfang 1929 liefern sie solche Reportagen auch an österreichische Medien. Im April 1929 erscheint etwa in den Wiener Bildern erstmals eine einfach gestaltete einseitige Reportage des Berliner Fotografen W. Seldowicz, der für die Fotoagentur Weltrundschau tätig ist. ${ }^{17}$ All diese Neuerungen werden nicht nur von den österreichischen Fotografen, sondern auch von den österreichischen Verlegern aufmerksam verfolgt. Sie schließen sich, zunächst noch zögernd, einigen der deutschen Trends an. Während 1928/29 in großen deutschen Zeitungen bereits regelmäßig professionell gestaltete Reportagen erscheinen, beginnt die Ära der modernen Fotoreportage in Österreich etwa zwei Jahre später. Erst 1932 ist eine erste Blütezeit dieser Bildgeschichten zu verzeichnen.

\section{Auf dem Weg zur modernen Fotoreportage}

Lothar Rübelt ist, wie erwähnt, nicht der erste Fotograf, der in Österreich moderne Reportagen veröffentlicht. Bereits 1926 gibt Max Fenichel in einer doppelseitigen Reportage in den Wiener Bildern Einblick in die Zentralanstalt für Meteorologie in Wien. Im selben Jahr erscheint ebenfalls in den Wiener Bildern ein reportageartiger Bildbericht über einen Sonntag im Wiener Prater. Ende der 1920er Jahre häufen sich Themenseiten mit Bildern eines einzigen Fotografen, die aber noch nicht die erzählerische Qualität einer modernen Reportage haben. Parallel dazu werden aber auch schon Prototypen moderner Reportagen gedruckt, die allerdings noch auf Bilder unterschiedlicher Herkunft zurückgreifen.

Der erste Reportage-Auftrag an Lothar Rübelt fällt also in eine Umbruchszeit im Fotojournalismus. Der Fotograf hat die Neuerungen in seiner Branche gewiss aufmerksam verfolgt, denn er ist bereits seit einem Jahrzehnt als Pressefotograf tätig. Ende der 1920er Jahre erweitert er seinen kommerziellen Radius und knüpft auch Kontakte zur auflagenstarken deutschen Presse. 1928 arbeitet er erstmals mit der großen Berliner Fotoagentur Scherl Bilderdienst zusammen und liefert für sie Sportbilder von der Winterolympiade in St. Moritz. Ab 1930 ist er - vermittelt durch den in Berlin tätigen Fotoagenten Fred

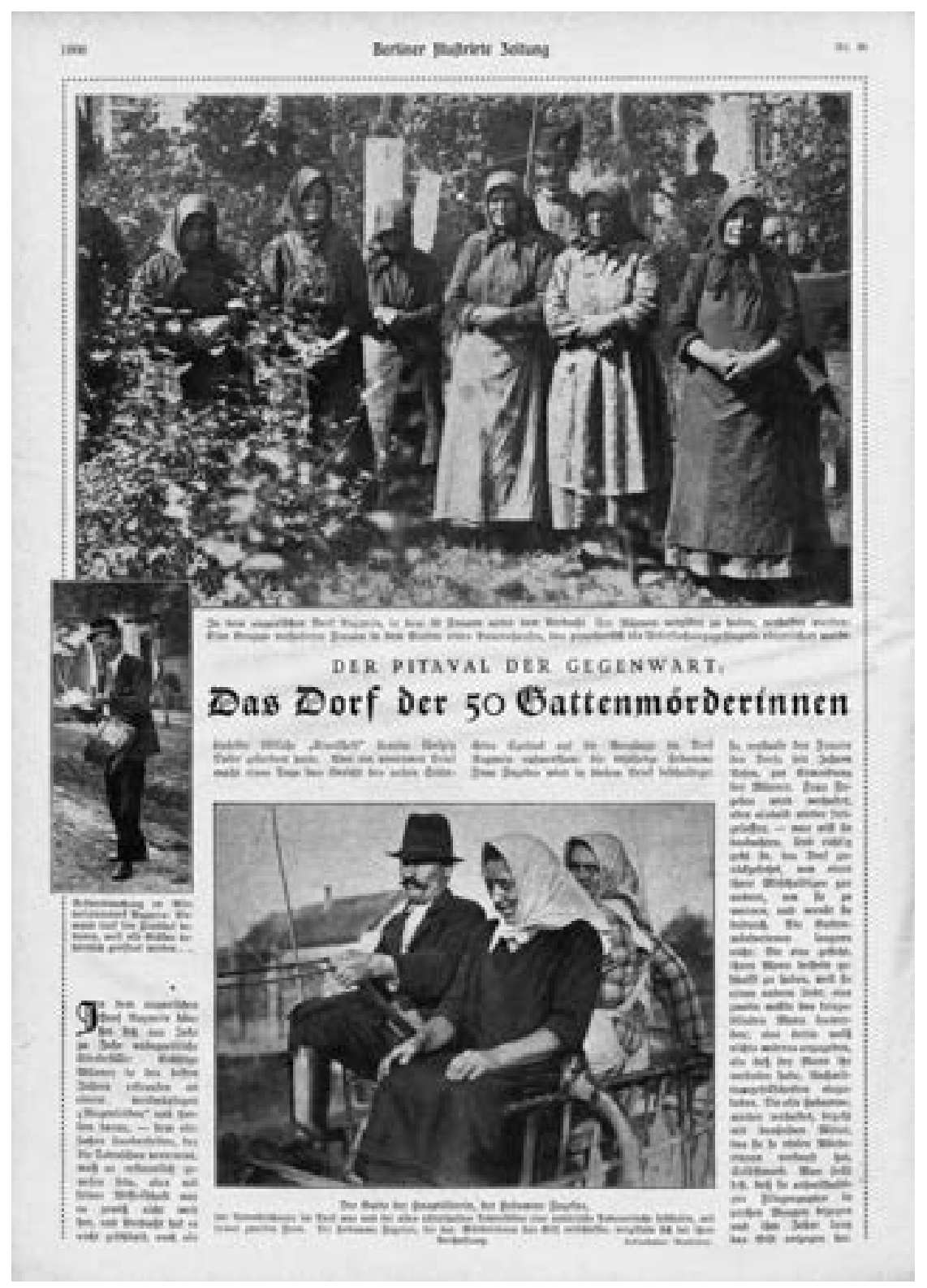

Wallentin - auch in der Ullstein-Presse und damit in Deutschland präsent. Wallentin ist zwei Jahre älter als Rübelt. Er stammt, wie dieser, aus Wien und lebt in den 1920er und frühen 1930er Jahren in Berlin. Hier betätigt er sich als eine Art kultureller „Multifunktionär“. Er bezeichnet sich selbst als „Schauspieler, Disponent, Journalist und Bildcorrespondent"18. Als Wallentin sich 1933 in Paris niederlässt, endet die Geschäftsbeziehung mit Rübelt. ${ }^{19}$ Die Machtübernahme der Nationalsozialisten in Deutschland bedeutet keinerlei Bruch für Rübelts Präsenz auf dem deutschen Zeitungsmarkt, im Gegenteil. Ende 1934 stellt er einen Antrag auf Aufnahme in den „Reichsausschuss der Bildberichterstatter im Reichsverband der Deutschen Presse“.20

Doch zurück zur ersten großen Reportage Rübelts in der österreichischen Bildpresse. Der Anlass ist ein
Abb. 5 „Das Dorf der 50 Gattenmörderinnen“. Bildbericht in der Berliner Illustrirten Zeitung, 8. September 1929, S. 1606. Fotos: Martin Munkacsi. 
Giftmordprozess, der am 13. und 14. Dezember 1929 im ungarischen Szolnok stattfindet. Angeklagt sind in diesem ersten Teilprozess vier von insgesamt 34 Frauen. Ihnen wird zur Last gelegt, in den letzten Jahren über 50 Menschen vergiftet zu haben. ${ }^{21}$ Das Ereignis ist von einem gewaltigen Medienecho begleitet. Sogar die renommierte Berliner Illustrirte Zeitung schickt im Sommer 1929 einen eigenen Fotoreporter, um über die Festnahmen und den aufsehenerregenden Fall zu berichten. Die Bilder, die am 8. August 1929 veröffentlicht werden (Abb. 5), stammen vom gebürtigen Ungarn Martin Munkácsi, der seit zwei Jahren in Berlin lebt.

Am 14. Dezember 1929 werden die Urteile verkündet. Der Reporter der Wiener Neuen Freien Presse hält diesen entscheidenden Augenblick fest. „Nach zweistündiger Beratung erscheint der Gerichtshof um 6 Uhr 20 Minuten wieder im Saal. Die Angeklagten werden hereingeführt, sie bleiben unbeweglich mit verschränkten Händen vor der Anklagebank stehen. Hinter ihnen in Habachtstellung die vier Justizwach-

Abb. 6 Fotoreportage Lothar Rübelts über den Prozess gegen die Giftmörderinnen im ungarischen Szolnok. Das interessante Blatt, 19. Dezember 1929, Titelseite.

Abb. 7 Prozess gegen die ungarischen Giftmörderinnen: Zeugen, Staatsanwalt, Verteidiger und ganz unten die Angeklagten während des Urteilsspruchs. Das interessante Blatt, 19. Dezember 1929, S. 5. Fotos: Lothar Rübelt.

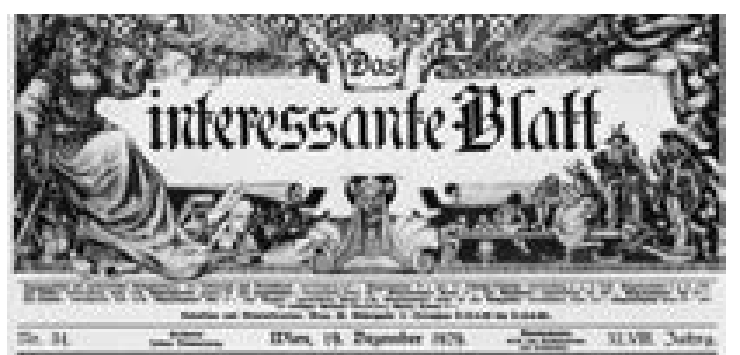

Die Gattenmótderianen vom Theifuintel.

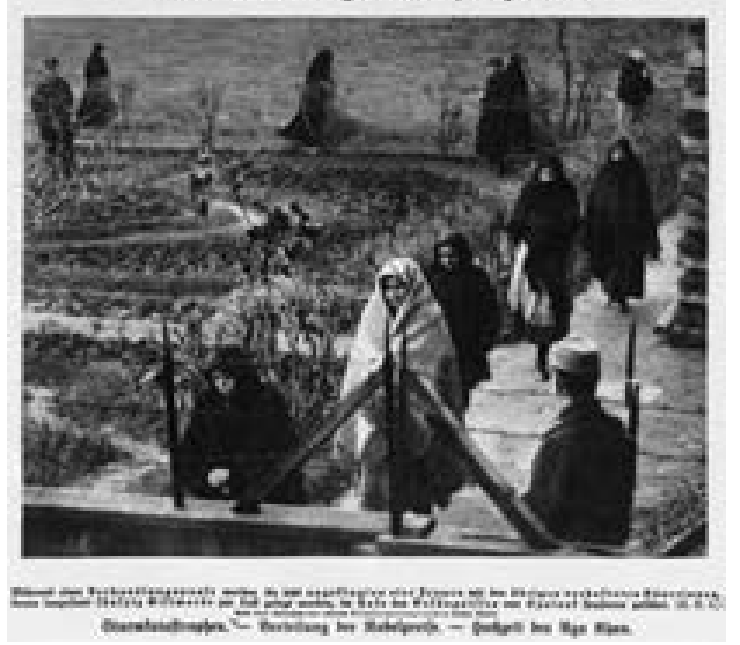

leute. Unter atemloser Spannung des Auditoriums verkündet der Vorsitzende das Urteil (...).“22

Reporter und Fotografen aus zahlreichen Ländern finden sich im Gerichtssaal ein, um die ersten Richtersprüche zu dokumentieren. Auch Lothar Rübelt sitzt im Kreis der Journalisten. Er ist mit zwei Kameras angereist. Neben seiner Leica schafft er eigens für dieses Ereignis eine lichtstarke Kleinglasplattenkamera der Firma Ernemann, eine Ermanox mit dem Negativformat 4,5×6 cm an, die besonders für die Innenaufnahmen geeignet ist. „Bei der Schwere der Verbrechen“, erinnert er sich, „war mit Todesurteilen zu rechnen, und so wollte ich die Wirkung auf die betroffenen Bäuerinnen im Augenblick der Verkündigung festhalten. Da ich kein Wort Ungarisch verstand, bat ich einen Deutsch sprechenden Journalisten, bei den Worten ,zum Tode' mit dem Bleistift auf das Pult zu klopfen. Das funktionierte bestens - aber die Wirkung war null! Die harten Gesichter der Bäuerinnen unter ihren Kopftüchern blieben unbewegt - es gab keinen ,richtigen“ Augenblick. So blieb mir nur übrig,

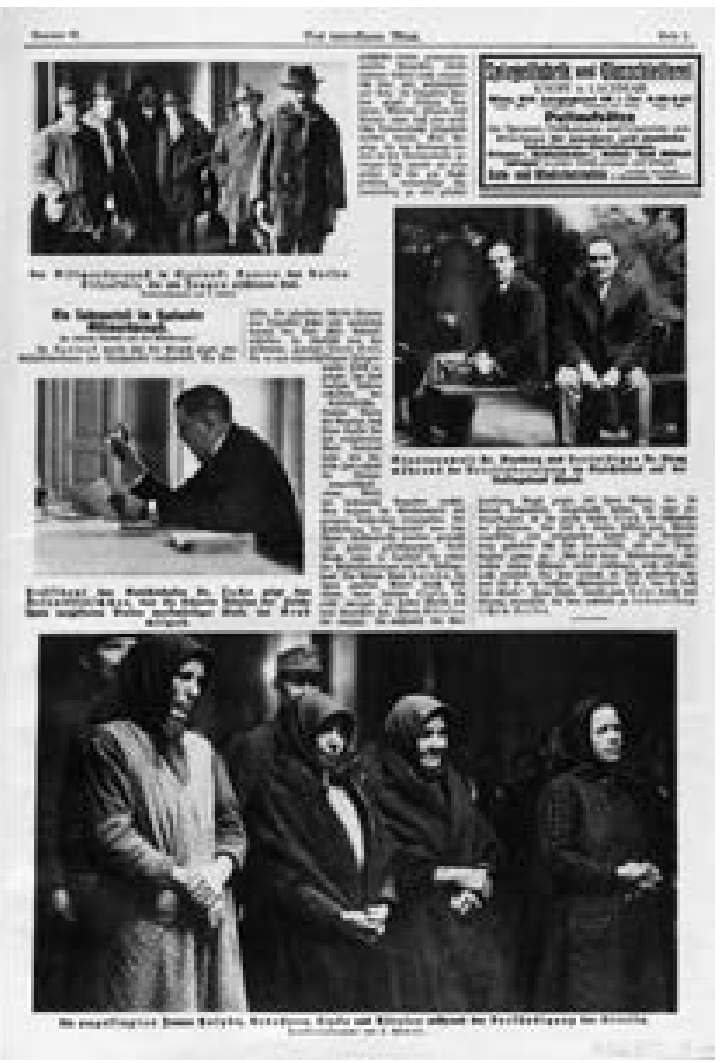


mit meinen beiden Kameras, jeweils auf dem Tisch abgestützt, die Anklagebank von verschiedenen Seiten, Zeugen, Richter und Staatsanwalt sowie den Verteidiger samt Publikum zu verewigen, wie vorher den Rundgang der Verbrecherinnen im Gefängnis festzuhalten. “23 Drei der angeklagten Frauen, Marie Röteles, Lydia Sebestyen und Rosa Holyba, erhalten lebenslange Haftstrafen. Eine weitere, Juliane Lipka, wird zum Tod durch den Strang verurteilt.

Kaum ist der Prozess zu Ende, eilt Rübelt mit den Bildern nach Wien. Am 19. Dezember erscheint seine Reportage unter dem Titel „Die Gattenmörderinnen vom Theißwinkel“ im Interessanten Blatt. ${ }^{24}$ Später erscheinen seine Aufnahmen auch im Kuckuck und in den renommierten Illustrated London News. ${ }^{25}$ Das Eröffnungsbild im Interessanten Blatt (Abb. 6) zeigt die vier angeklagten Bäuerinnen zusammen mit weiteren verhafteten Frauen während einer Verhandlungspause bei einem Spaziergang im Gefängnishof. Direkt unter dem Bildtext wird - gut sichtbar - auf den Fotografen hingewiesen: „Nach einer Aufnahme von unserem Sonderphotographen Lothar Rübelt.“ Die Reportage wird im Innenteil mit vier weiteren Bildern fortgesetzt (Abb. 7). Sie zeigen Zeugen, Staatsanwalt, Verteidiger und zum Schluss drei der Angeklagten im Augenblick des Urteilsspruchs. Es fällt auf, dass die Anordnung der Bilder nach weitgehend konventionellem Muster erfolgt. Das zugrunde liegende dreispaltige Textraster ist noch deutlich zu erkennen. Die Bilder sind ohne größeren gestalterischen Aufwand in dieses vorgefertigte Schema eingepasst. Der zweiseitige Bildbericht Rübelts markiert einen ersten Schritt in Richtung einer modernen Bilderzählung, eine Fotoreportage im modernen Sinne ist sie freilich noch nicht.

\section{Eine neue Generation von Fotografen}

Ende der 1920er, Anfang der 1930er Jahre besteht der Großteil der Abbildungen in den Illustrierten immer noch aus herkömmlichen Einzelbildern, aber allmählich verändert sich die grafische Gestaltung. Immer öfter wird das starre Textraster aufgebrochen und es werden dynamische Gestaltungselemente eingesetzt. Sehr deutlich zeigt sich diese Tendenz auf einer Seite über „Das Gesicht des Jazz“, die im März

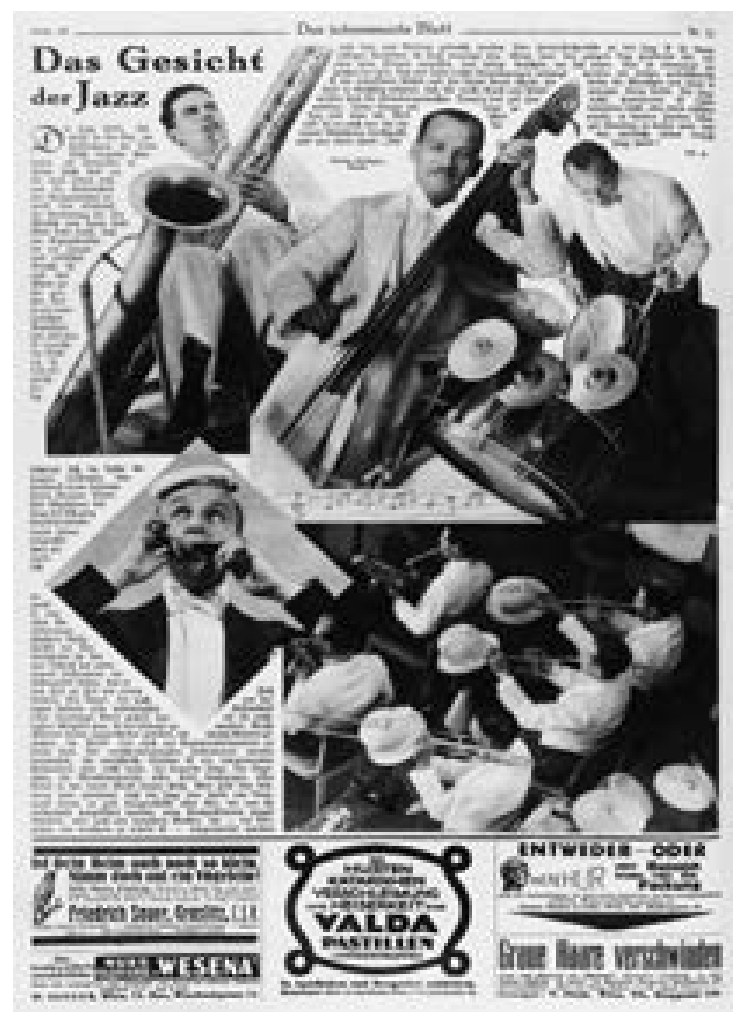

$1930 \mathrm{im}$ Interessanten Blatt erscheint (Abb. 8). ${ }^{26}$ Die Bilder - sie stammen vom österreichischen Fotografen László Willinger, der um 1930 in Berlin lebt - verstärken das neue rhythmische Lebensgefühl des Jazz. Sie sind grafisch deutlich bearbeitet, teils freigestellt, teils leicht gekippt und zum Teil überlappend gedruckt. Der redaktionelle Text fließt regelrecht um die Körper der Musiker und die freigestellten Instrumente herum und verstärkt das rhythmische Grundthema der Seite. Diese neuartige Text-Bild-Montage hebt sich deutlich von den bisher recht statischen Gestaltungsformen $\mathrm{ab}$.

Nach 1930 werden Woche für Woche auch Reportagen oder reportageartige Themenseiten gedruckt. Plötzlich nimmt die Nachfrage nach Bildgeschichten zu. Einige der Fotografen passen sich den neuen Anforderungen schnell an. Sie bieten jetzt neben Einzelaufnahmen auch geschlossene Themenseiten an. Zwar ist die Herstellung einer Reportage weit aufwendiger, aber auch die Vorteile liegen auf der Hand. Der Verkauf einer mehrteiligen Reportage ist nicht nur lukrativer als der Vertrieb von Einzelfotos. Er bietet den Fotografen auch mehr Möglichkeiten, sich als Mitarbeiter für gehobene Ansprüche zu profilieren. Immerhin verschwindet der Name des Lichtbildners nun nicht mehr im Kleingedruckten unter den Bildern, sondern erscheint oft gleichberechtigt neben dem Textautor, oft ist der Fotograf sogar als „Hauptautor" genannt.
Abb. 8 Dynamische Gestaltung einer Bildseite im Interessanten Blatt, 20. März 1939, S. 18. Fotos: László Willinger. 
Die Veränderungen und Umschichtungen in der Bildpresse nach dem Ersten Weltkrieg haben auch Auswirkungen auf die Arbeitsweise der Fotografen. Um 1930 kommt es innerhalb der Bildjournalisten zu einer personellen Erneuerung und zu einer inhaltlichen und ästhetischen Neuausrichtung. Die Jahre der Nachkriegszeit, die von Kontinuität und ästhetischem Beharren gekennzeichnet sind, gehen nun ihrem Ende entgegen. ${ }^{27}$ Die Generation von Pressefotografen, die unmittelbar nach dem Krieg tätig waren, wird nun allmählich abgelöst. Viele von ihnen haben schon vor 1914 oder während des Krieges als Kriegsfotografen gearbeitet. Zu ihnen zählen Carl Seebald, Heinrich Schuhmann sen., Heinrich Schuhmann jun., Charles Scolik jun. und Josef Perscheid. Sie arbeiten in den Jahren nach 1918 weiter. Allerdings tauchen nun auch jüngere Fotografen auf, die ihre Karriere erst nach dem Krieg beginnen, etwa Richard Hauffe, Hugo Oppolzer, Leo Ernst, Fred Cešanek, Albert Hilscher, Karl Schleich und der Sportfotograf Lothar Rübelt, der ab Ende der 1920er Jahre immer öfter auch tagespolitische Ereignisse dokumentiert.

Ab Mitte der 1920er Jahre tritt eine neue Generation von Fotografen an, die teilweise anders arbeiten als ihre älteren Kollegen. Neben Einzelbildern liefern sie immer wieder auch Reportagen. $\mathrm{Zu}$ ihnen gehören - neben Lothar Rübelt - Max Fenichel, Steffi Schaffelhofer, Hans Casparius, Karl Schleich, Lena Schur, Ernst Kleinberg, Walter Henisch. Edith Suschitzky, Hans Roth, Karl Schöpl, Marianne Bergler und Annie Schulz. Auch Otto Skall, der, 1884 geboren, seine Tätigkeit als Pressefotograf um 1925 aufnimmt, liefert außer Theateraufnahmen sehr gute Fotoreportagen. Nicht alle Reportagefotografen der Zwischenkriegszeit sind professionelle Pressefotografen, einige, etwa Frank Sykora, Hans Roth oder Ernst Kassowitz, sind Amateure und fotografieren nur gelegentlich für die Zeitung. Auch Hans Ewald Heller, ab 1932 Chefredakteur der Wiener Bilder, fotografiert nur nebenbei. Er ist ein Verfechter der modernen Reportage und liefert selbst immer wieder gute Fotoreportagen zu Alltagsthemen. Wieder andere, wie etwa Herbert Tichy, Harald Lechenperg oder Alice Schalek, geb. 1874, spezialisieren sich ab Mitte der 1930er Jahre auf Reisereportagen aus fernen Ländern.
Die gelungensten Fotoreportagen dieser Jahre haben nicht große politische Ereignisse oder die Tagespolitik zum Thema, sondern stellen mehr oder weniger aktuelle Alltagsthemen auf neue, überraschende Weise in Bildergeschichten vor. Lena Schur etwa berichtet über die ersten Minuten im Leben eines Babys, Max Fenichel über ein Wiener Gefängnis, Hans Roth über den Besuch im Wachsfigurenkabinett, Steffi Schaffelhofer über Frauen hinter Klostermauern, Frank Sykora über Bettler in Wien, Annie Schulz über den Alltag im Wiener Fundamt und zusammen mit Marianne Blumberger (verh. Bergler) über die Faszination der Puppen oder über Frauenhände, Robert Haas über Kinderarmut in der Vorstadt.

\section{Die Fotoreportage setzt sich durch}

Wichtige Impulse für die Entwicklung der Fotoreportage gehen um 1930 von Magazinen wie der Bühne oder dem Wiener Magazin und nach 1934 vom Sonntag, der wöchentlichen Beilage zur Tageszeitung Der Wiener Tag, aus. ${ }^{28}$ Diese Medien experimentieren regelmäßig mit erzählerischen Formen der Fotografie. Im August 1929 erscheint beispielsweise in der Bühne eine Bildseite von Karl Schleich zum Motorradrennen in der Wiener Krieau. ${ }^{29}$ Bei diesem Prototyp einer modernen Reportage ist der Text bereits fast ganz zurückgedrängt. Eine Überblicksaufnahme verschafft eine erste Orientierung, Augenblicksbilder und herausgezoomte Großaufnahmen der Sieger führen in das Thema hinein. Grafisch sehr viel einfacher umgesetzt ist eine Fotoreportage von Annie Schulz über den Wiener Naschmarkt, die im November 1930 auf einer Doppelseite der Bühne erscheint (Abb. 10). Die kurze, recht statisch gestaltete Bildgeschichte hebt sich deutlich vom informierenden Gebrauch der Fotografie ab. Sie will die Alltagsstimmung einfangen und die Atmosphäre des Marktgeschehens vermitteln.

Auch Zeitschriftenneugründungen wie etwa der seit 1929 in Innsbruck erscheinende Welt-Guck setzen schon früh auf die Fotoreportage als moderne Erzählform. Bereits kurz nach der Gründung erscheinen in dieser Zeitung die ersten Fotoreportagen. Zunächst sind es noch Bildgeschichten, die aus Bildern unterschiedlicher Fotografen zusammengesetzt sind. ${ }^{30} \mathrm{Ab}$ 
1930 finden sich auch geschlossene Reportagen eines einzigen Fotografen. Ein Teil dieser Bildgeschichten wird aus dem Ausland zugekauft, etwa vom deutschen Fotografen Willi Ruge oder vom Ungarn Emmerich Kelen, der 1931 eine schöne Reportage über den Goldrausch in Ungarn liefert. ${ }^{31}$ Im selben Jahr beginnt auch der in Frankfurt lebende Fotograf Paul Edmund Hahn regelmäßig für den Welt-Guck zu arbeiten. Praktisch in jeder Nummer erscheinen nun von ihm kürzere oder längere Reportagen zu alltäglichen Themen. Aber auch etablierte Wiener Fotografen, wie etwa Lothar Rübelt, veröffentlichen öfter Bildgeschichten im Welt-Guck. Am 26. Juli 1931 etwa erscheint eine Reportage Rübelts über den „Grafen Zeppelin“ und seinen aufsehenerregenden Österreich-Rundflug. Die Bildgeschichte beginnt auf der Titelseite mit einer Aufnahme, die das Luftschiff nach seiner Landung in Wien-Aspern zeigt (Abb. 11). Im Blattinneren wird die Reportage (die im katholisch-konservativen WeltGuck „Bildbericht“ heißt) fortgesetzt (Abb. 12). „In den ersten Morgenstunden des Sonntags“, schreibt Rübelt, der nicht nur die Bilder liefert, sondern diesmal auch für den Text verantwortlich ist, „begann der erste offizielle Österreichflug des ,Graf Zeppelin‘. Dr. Eckener führte das Steuer. Um 1.55 Uhr passierte das Luftschiff München und überflog etwa eine Stunde später bei Braunau am Inn die österreichische Grenze. Gegen vier Uhr morgens konnten es die Frühauf-
Abb. 10 Fotoreportage über den Wiener Naschmarkt. Die Bühne, Erstes Dezemberheft 1930, S. 18/19. Fotos: Annie Schulz.
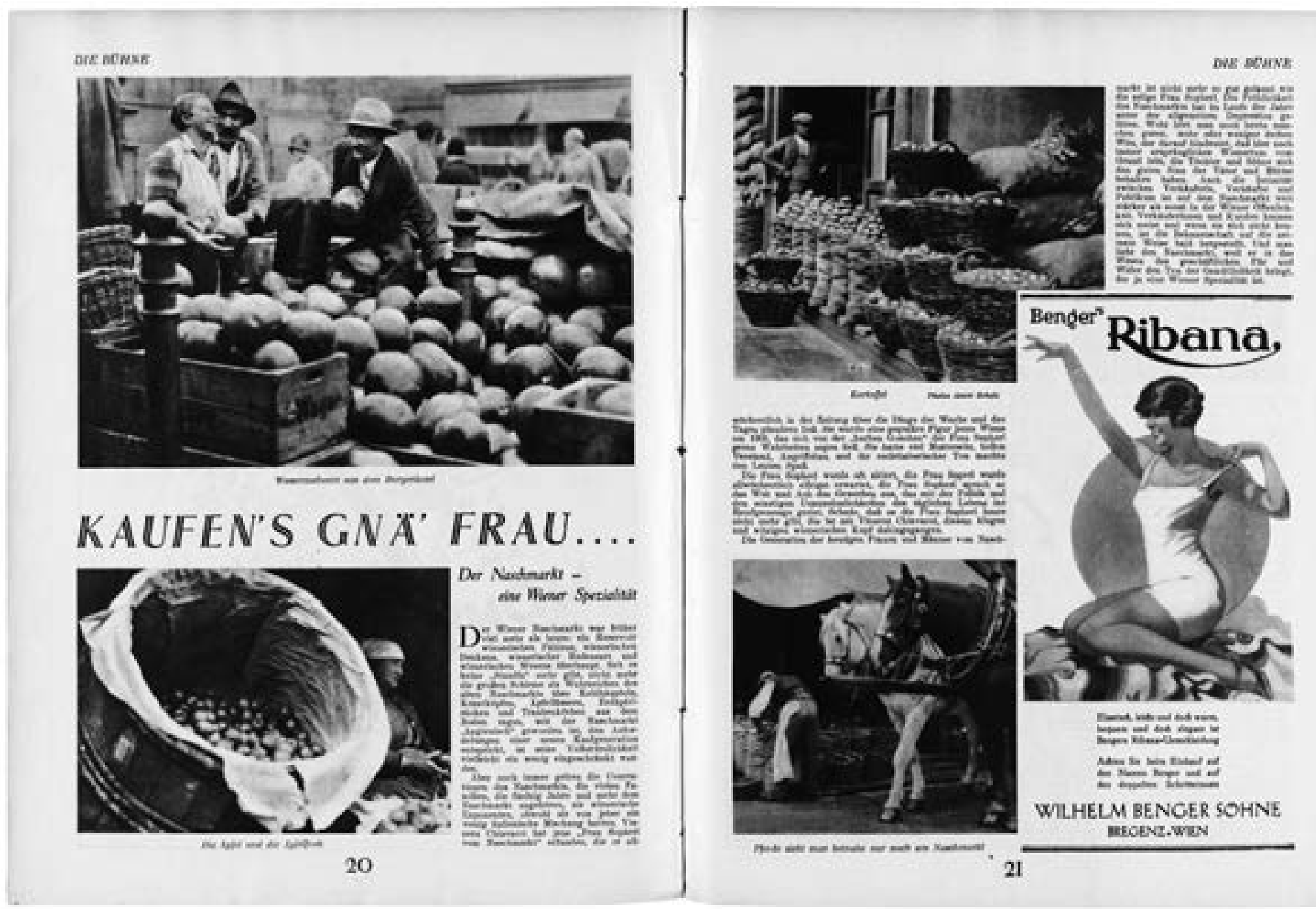
Abb. 11 Fotoreportage von Lothar Rübelt über den Österreich-Rundflug des „Grafen Zeppelin“ im Juli 1931. WeltGuck, 26. Juli 1931, Titelseite.
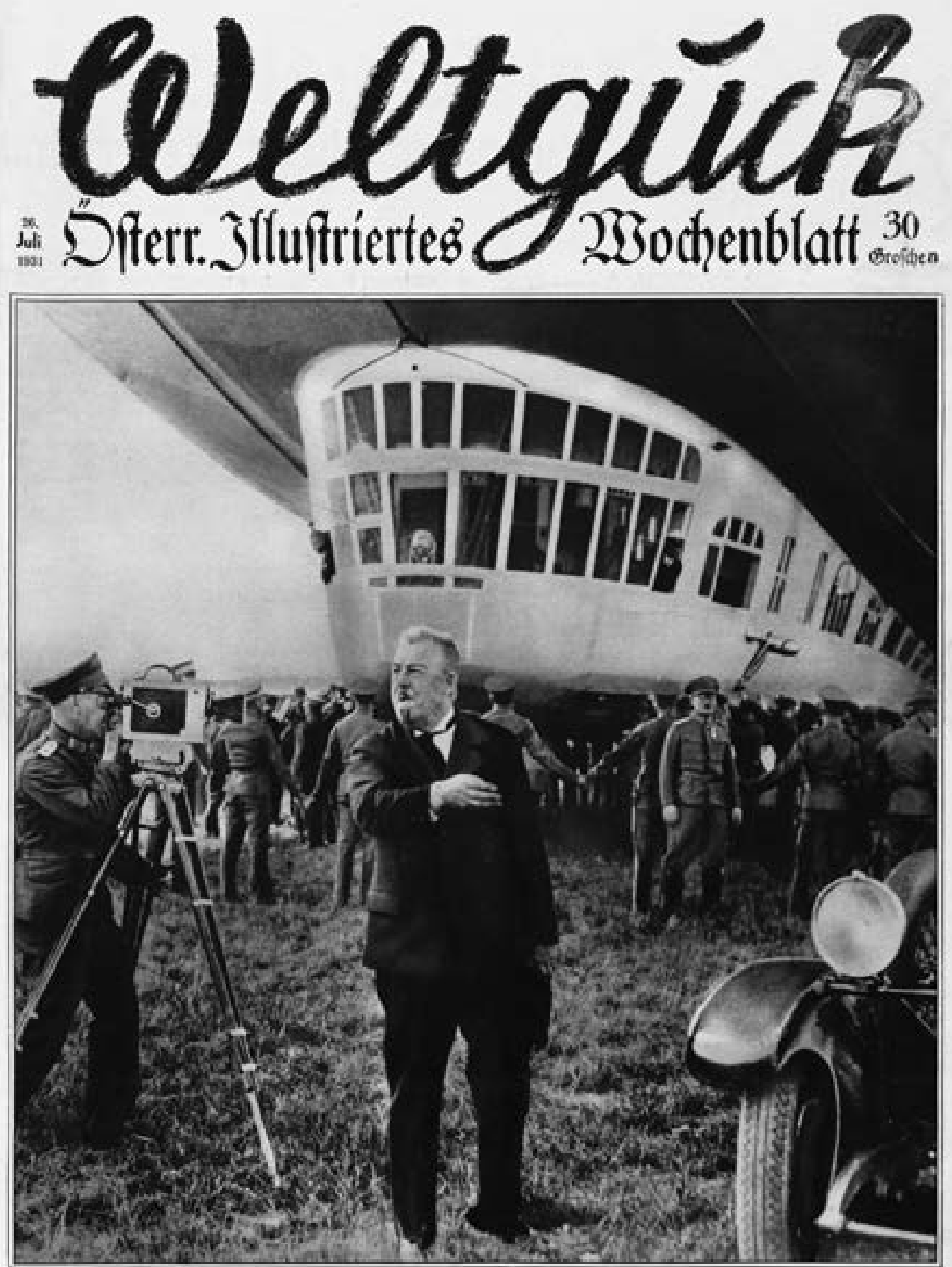

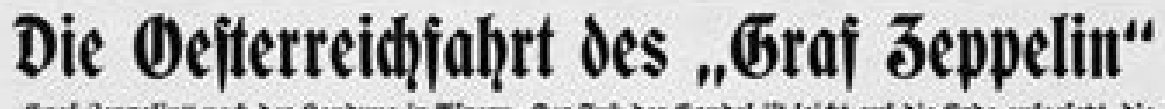

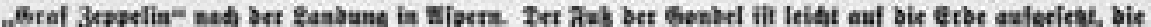

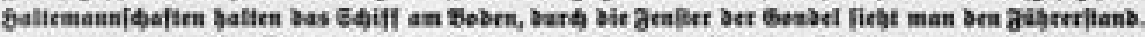
Jm Botbetgtunb Pe. Edratr. (Plasfabrifhet Getiat auf Gețt z) 


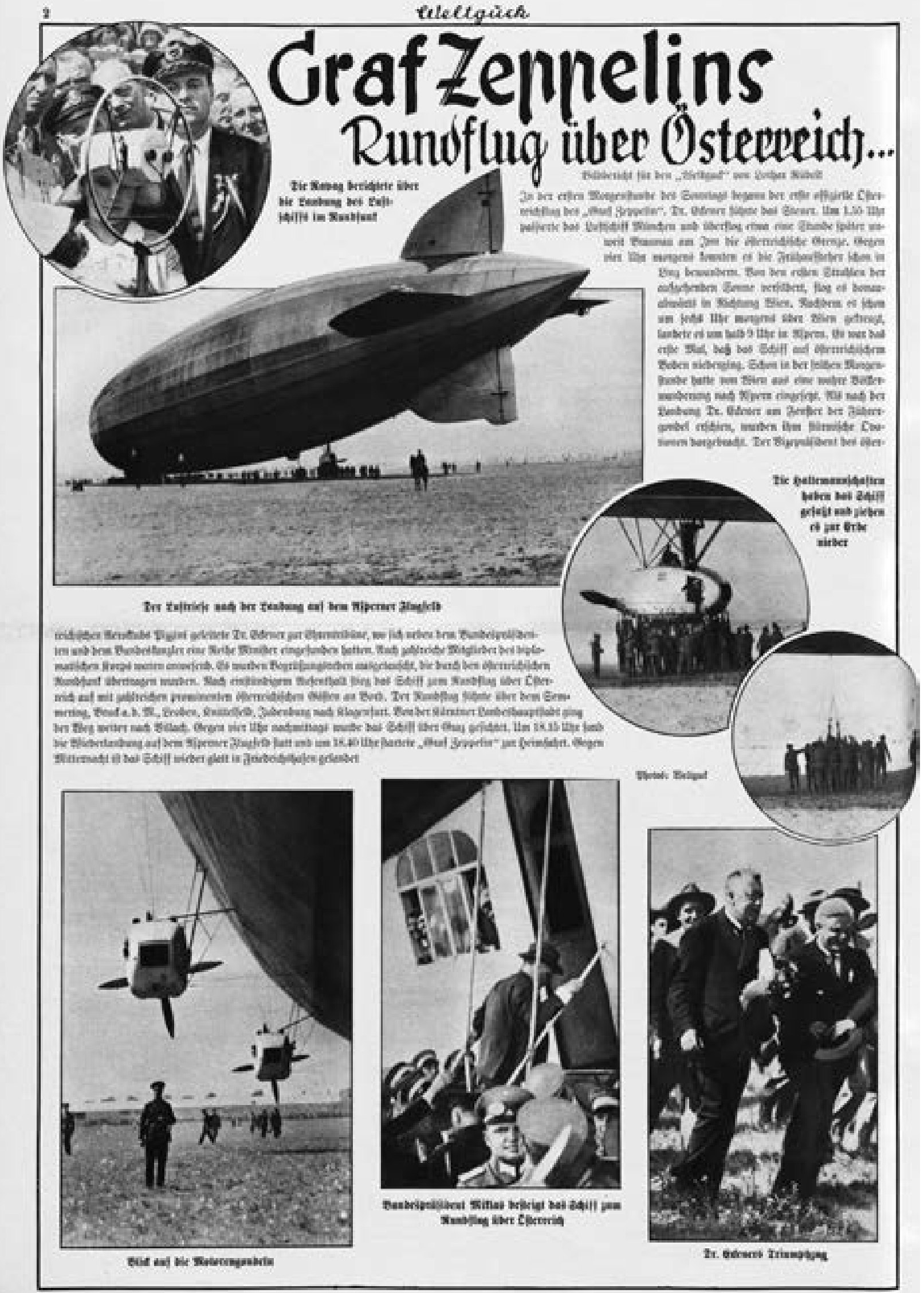

Abb. 12 Fortsetzung der Fotoreportage von Lothar Rübelt über den Österreich-Rundflug des „Grafen Zeppelin“ im Juli 1931. Welt-Guck, 26. Juli 1931, S. 2 . 


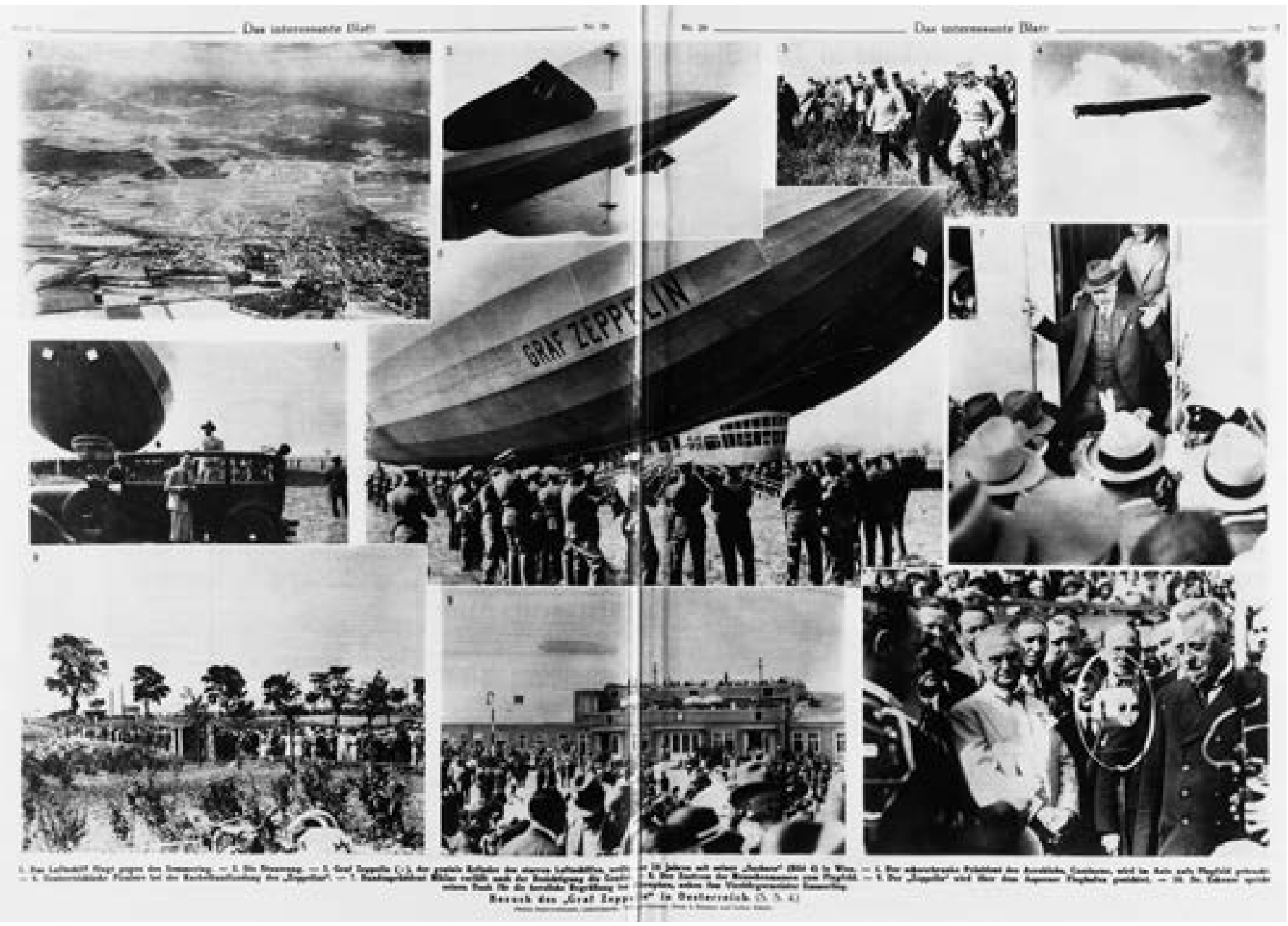

Abb. 13 „Besuch des Grafen Zeppelin in Österreich“, Juli 1931. Bilddoppelseite im Interessanten Blatt, 16. Juli 1931, S. 12/13. Fotos: Österreichische Lichtbildstelle, Willinger-Lechner, Ernst-Hilscher und Lothar Rübelt. steher schon in Linz bewundern. Von den ersten Strahlen der aufgehenden Sonne versilbert, flog es donauabwärts in Richtung Wien. Nachdem es schon um sechs Uhr morgens über Wien gekreuzt, landete es um halb neun Uhr in Aspern. Es war das erste Mal, daß das Schiff auf österreichischem Boden niederging. " Das Überblicksbild des Zeppelins aus größerer Entfernung wird von Momentaufnahmen umrahmt, in denen der Fotograf näher heranrückt und, unterstützt vom Bildtext, einzelne Szenen zoomartig und geradezu filmisch miteinander verbindet. Das starre Textraster im Hintergrund hat sich hier bereits deutlich aufgelöst, der Rhythmus der Bilder dominiert, die Beschreibung liefert Hintergrundinformationen und stellt Zusammenhänge her.
Auch Das interessante Blatt widmet dem Ereignis einen zweiseitigen Bildbericht (Abb. 13). Hier ist die Bildanordnung freilich ganz anders. Die Aufnahmen, sie stammen von mehreren Fotografen (Österreichische Lichtbildstelle, Willinger-Lechner, Ernst \& Hilscher und Lothar Rübelt), sind tableauartig angeordnet. Im Zentrum steht auch hier das Luftschiff. Der Großteil der weiteren Fotografien zeigt Szenen vor und nach der Landung, die meisten sind aus größerer Entfernung aufgenommen, nur wenige rücken nahe an die Protagonisten heran. Grafisch sind die Bilder nur lose miteinander verbunden. Jedes einzelne Foto ist nummeriert und mit einem kurzen Bildtext verbunden. Dieses additive Verfahren der Bildverknüpfung erinnert sehr stark an konventionelle Bildgeschichten, 
wie sie vor dem Ersten Weltkrieg und bis in die 1920er Jahre gebräuchlich waren. Von der professionellen grafischen und erzählerischen Verflechtung zwischen Bild und Text, wie sie im Welt-Guck praktiziert wird, ist diese Doppelseite noch recht weit entfernt.

Welche Entwicklung die Fotoreportage in einigen wenigen Jahren - von Ende der 1920er bis Anfang der 1930er Jahre - genommen hat, zeigt sich an einem großen, mehrseitigen Bildbericht, der im September 1932 im Wiener Magazin erscheint (Abb. 14). Es handelt sich um eine der besten österreichischen Reportagen der Zwischenkriegszeit. Bilder und Text sind grafisch geschickt miteinander verschränkt und ergeben so eine spannend erzählte Geschichte. Es ist wohl kein Zufall, dass dieser Bildbericht nicht in einer der großen, eher schwerfälligen Wochenillustrierten, sondern in einer sehr viel kleineren, aber gestalterisch wesentlich wendigeren Monatszeitschrift erscheint. Thema ist ein im Juli 1932 in Wien stattfindender aufsehenerregender Prozess gegen den „Eisenbahnattentäter“ Sylvester Matuska. Dieser hatte 1930/31 in Österreich, Deutschland und Ungarn mehrere Eisenbahnanschläge verübt. Am 7. Oktober 1931 wird der Mann verhaftet, am 17. Juli 1932 in einem ersten Teilprozess von einem Wiener Schöffensenat zu sechs Jahren Haft verurteilt. ${ }^{32}$

Die Fotos stammen von Lothar Rübelt, der damit - nach dem ungarischen Giftmordverfahren
Abb. 14 „Der Mensch Matuska“. Fotoreportage von Ernst Mannheim (Text) und Lothar Rübelt (Fotos), Teil 1. Wiener Magazin, Heft 9, September 1932, S. $6 / 7$.

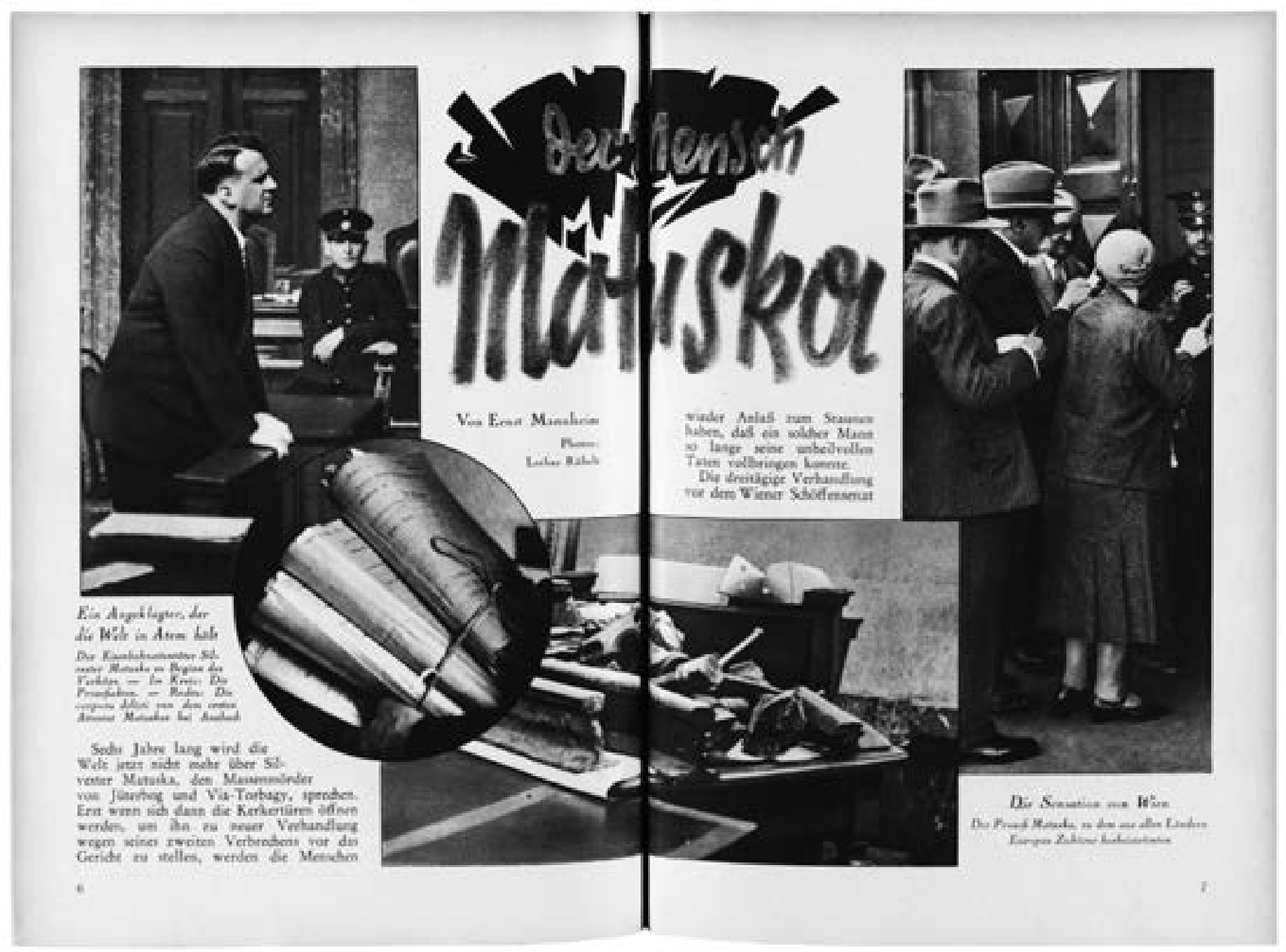


Abb. 15 „Der Mensch Matuska“, Teil 2. Wiener Magazin, Heft 9, September 1932, S. $8 / 9$.
1929 - neuerlich einen großen Gerichtsprozess dokumentiert. Den Text liefert der Journalist Ernst Mannheim. Bemerkenswert ist, dass der Bildbericht nicht etwa die Vorgeschichte, den Prozessverlauf oder das Urteil ins Zentrum rückt. Dies sind nämlich Facetten, die den Lesern längst bekannt sind. Vielmehr zeichnen Fotograf und Autor, v. a. im zweiten Teil der Reportage, eine Art Charakterporträt des verurteilten Attentäters. Daher auch der Titel der Reportage: „Der Mensch Matuska“. Die Fotoreportage, die sich über insgesamt vier Doppelseiten erstreckt und mit einer reinen Textseite im Schlussteil des Magazins endet, beginnt mit einem Überblick über die Ereignisse (vgl. Abb. 14). Eingangs werden der Angeklagte im Gerichtssaal (links) und der enorme Andrang von Schaulustigen (rechts) einander gegenübergestellt, dazwischen sind in Detailaufnahmen die Aktenberge und die zerstörten Geleise zu sehen. Schon in dieser Eröffnungssequenz wird deutlich, dass das Drama, das sich hinter den Türen des Gerichtshofes abspielt, ein außergewöhnliches Ereignis ist. Der Prozess, so schreibt Mannheim, „war eine Sensation ersten Ranges. Wochenlang vorher wurde das Gericht um Einlaßkarten bestürmt und die gesamte Weltpresse hatte Vertreter entsandt. Das Verhör nahm oft den Charakter eines aufregenden Dialogs in einem Theaterstück an. Nur daß die Personen nicht nur spielten, sondern auch wirklich miteinander kämpften. “ ${ }^{33}$

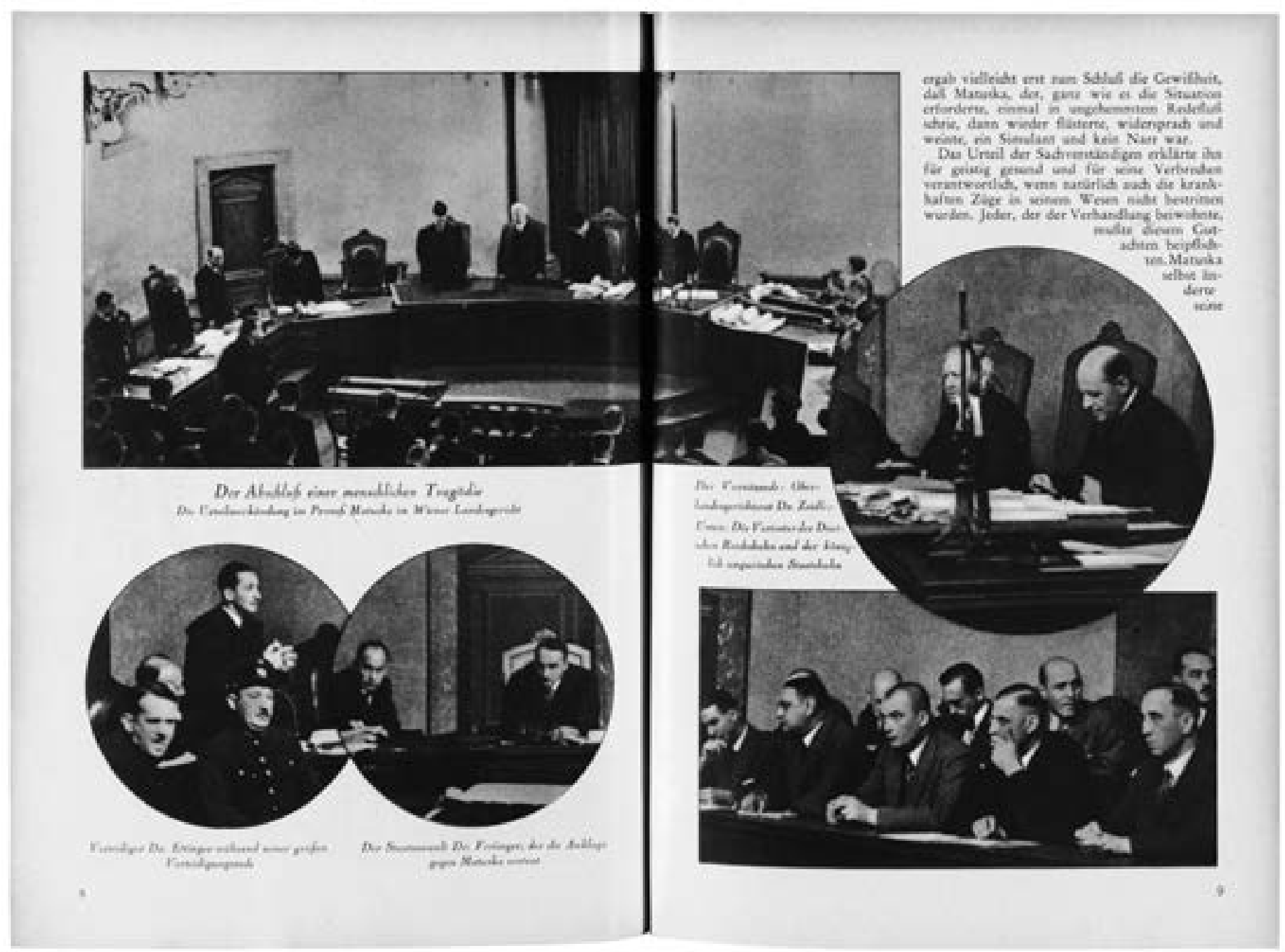


Auf der zweiten Doppelseite (Abb. 15) werden die Protagonisten des Verfahrens vorgestellt, u. a. der Gerichtsvorsitzende, der Verteidiger und der Staatsanwalt. Ein großes querformatiges Bild zeigt die Mitglieder des Gerichts während der Urteilsverkündung. Hier könnte die Reportage zu Ende sein. Doch nun wendet sich die Erzählung von der Schilderung konkreter Fakten ab und beginnt die Protagonisten der dramatischen Ereignisse vor Gericht auf ihre Gesten, Haltungen und Physiognomien hin zu befragen (Abb. 16). Der Angeklagte, der bisher einer von vielen Darstellern im „Gerichtstheater“ war, rückt nun allmählich ins Zentrum der Aufmerksamkeit. Er ist es, auf den sich jetzt alle Blicke richten. Auf der letzten Doppel- seite ist ausschließlich Matuska zu sehen (Abb. 17). In einer filmartig inszenierten, knapp kommentierten Bildserie werden seine emotionalen Ausbrüche und Verwandlungen auf der Anklagebank geradezu zeitlupenartig festgehalten. In diesem bildlichen Nacheinander erscheint der Angeklagte als psychologischer „Fall“. Dennoch: Das Urteil der Sachverständigen erklärt den Mann „für geistig gesund und für seine Verbrechen verantwortlich“. ${ }^{34}$ Die Verhandlung ergab, so Mannheim, „vielleicht erst ganz zum Schluß die Gewißheit, daß Matuska, der ganz wie es die Situation erforderte, einmal in ungehemmten Redfluß schrie, dann wieder flüsterte, widersprach und weinte, ein Simulant und kein Narr sei.“35
Abb. 16 „Der Mensch Matuska“, Teil 3. Wiener Magazin, Heft 9, September 1932, S. 10/11.

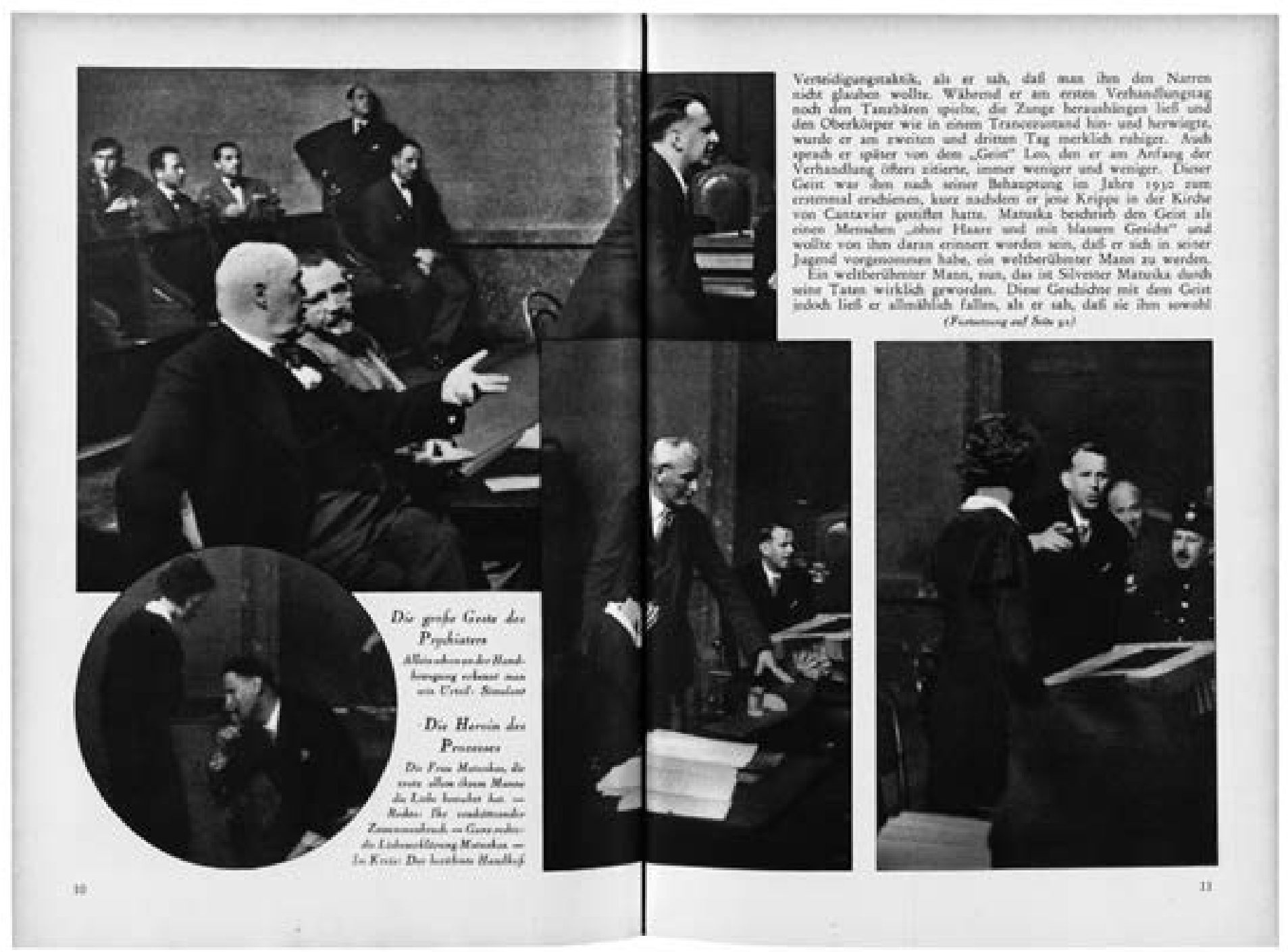




\section{Gallspach, Mekka der Kranken}

Ende Februar 1930, wenige Monate nach der ersten großen Reportage Lothar Rübelts über der Giftmordprozess in Ungarn, bringt Das interessante Blatt eine weitere mehrseitige Reportage, diesmal über einen Wunderheiler im oberösterreichischen Ort Gallspach. Interessant ist diese Bildgeschichte auch deshalb, weil ihr Thema fast zeitgleich in mehreren illustrierten Zeitungen ${ }^{36}$ aufgegriffen wird - unter anderem in der angesehenen Münchner Illustrierten Presse, die in diesen Jahren unter der Leitung von Stefan Lorant eine führende Rolle in der Weiterentwicklung der modernen Fotoreportage spielt. ${ }^{37}$ Ein
Vergleich der Gestaltung und Erzählstrategie macht deutlich, wie groß die Unterschiede der bildlichen Erzählweisen in beiden Zeitungen sind.

In den 1920er Jahren lässt sich ein selbst ernannter Wunderheiler namens Valentin Zeileis im oberösterreichischen Gallspach nieder. Er verwandelt den verschlafenen Ort innerhalb kürzester Zeit in ein Mekka der Kranken. Mit einem selbst gebauten elektromagnetischen Apparat kuriert er zuerst Hunderte, bald Tausende, schließlich Zehntausende. 1929 entsteht ein gewaltiger Neubau, nun kann er bis zu 1500 Personen pro Tag abfertigen. Immer mehr Leidende pilgern nach Gallspach. Der „Doktor“ wird zum Millionär, im Ort bricht Goldgräberstimmung aus. Anfang

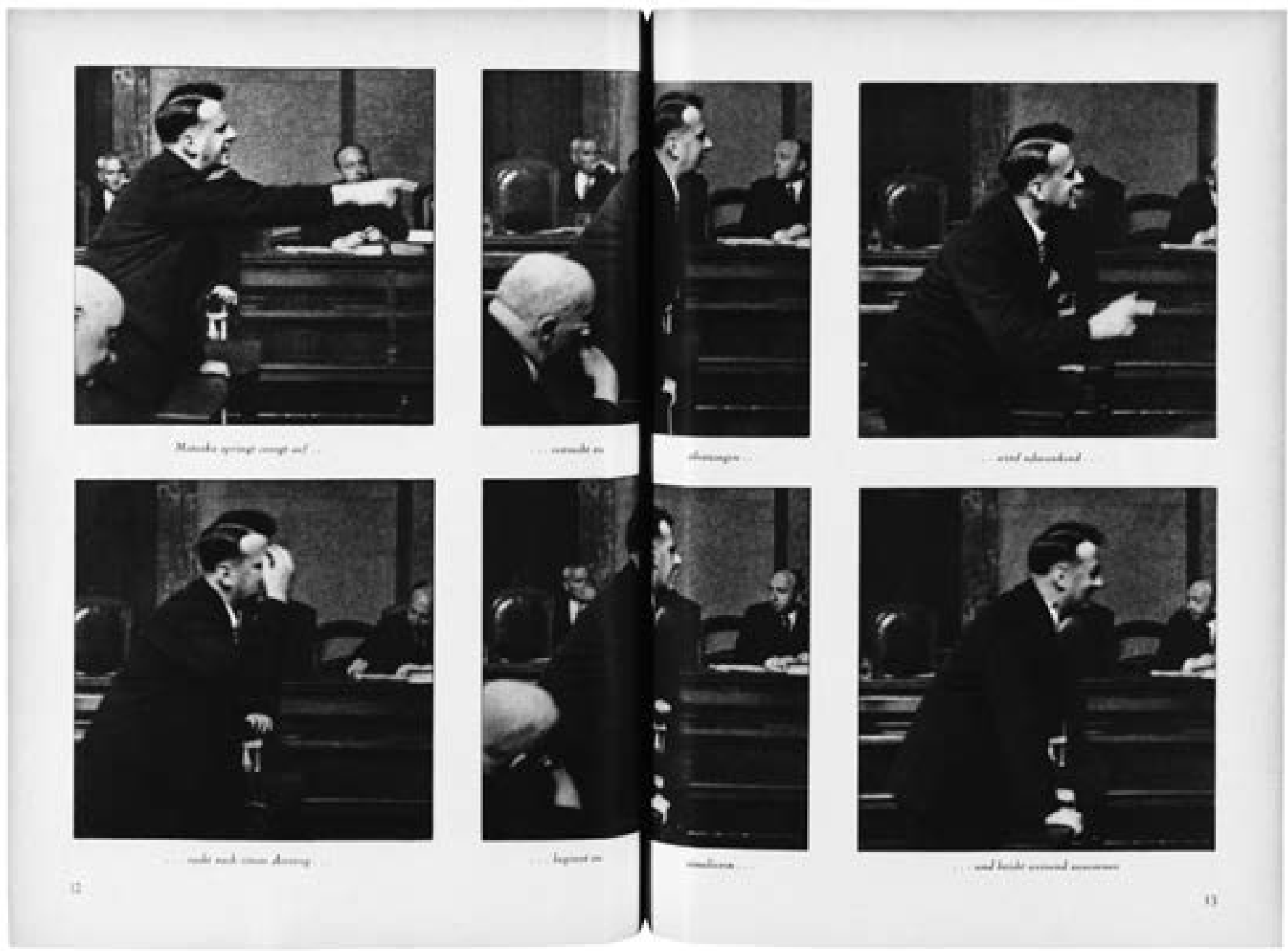


der 1930er Jahre ist aus dem armen Bauerndorf ein reicher Kurort geworden. Etablierte Mediziner fällen vernichtende Urteile über den Wunderheiler, dieser antwortet mit Klagen, Zeileis wird zum „Fall“ - und zum Thema für die Presse. Ende 1929 beginnen die Medien in großer Aufmachung über Zeileis zu berichten. Über 700 Artikel erscheinen allein 1930 innerhalb weniger Monate in der österreichischen und ausländischen Presse. „Der Fall Zeileis“, resümiert der österreichische Schriftsteller und Journalist Soma Morgenstern Ende 1930 in der Frankfurter Zeitung, ,ist nun in aller Öffentlichkeit die Sensation geworden, die er auch ohne, Öffentlichkeit‘ schon lange gewesen ist. Und als gälte es nun, das mehr oder weniger heimlich versäumte Interesse von bald einem Jahrzehnt einzuholen, konzentriert sich das Munkeln vieler Jahre zum Gespräch des Tages. Legt man das Ohr an die Balkenlettern der österreichischen Presse, kann man sogar hören, wie das Gespräch des Tages sich allmählich zum Geschrei der Wochen auszuwachsen anhebt.“38

Am 23. Februar 1930 bringt die Münchner Illustrierte Presse eine Fotoreportage von Wolfgang Weber über Gallspach (Abb. 18, 19). ${ }^{39}$ Auf insgesamt drei Bildseiten und einer zusätzlichen Textseite berichtet der Fotograf, der zugleich auch den Text liefert, über den Ort und den Fall Zeileis. Schon der Untertitel deutet darauf hin, dass die Reportage den Anspruch erhebt, eine geschlossene Erzählung zu liefern: „Der Roman eines oberösterreichischen Dorfes. Das mit dem Zeileis'schen Heilverfahren über Nacht Weltruf erlangte.“ Der Begriff „Roman“ steht hier für die Form der Erzählung und kennzeichnet nicht etwa deren Inhalt als Fiktion. Denn gleich am Beginn verbürgen die Fotografien und die grafisch in die Bildgeschichte eingefügten dokumentarischen Fundstücke (die Zählkarte für „eine Behandlung“, ein Zeitungsausriss) den Wirklichkeitsgehalt des Berichts. Der Fotograf und Autor Wolfgang Weber, um 1930 einer der bekanntesten deutschen Reportagefotografen ${ }^{40}$, wird zu Beginn des Berichts nicht nur namentlich, sondern sogar mit eigenhändiger Unterschrift eingeführt. Er ist der prominente Augenzeuge, dessen persönliche Handschrift den Text und die Bilder prägt.

Weber führt nicht als distanzierter Beobachter in die Geschichte ein, sondern er beginnt die Erzählung mit einem sehr subjektiven Stimmungsbericht: „Man spürt die seltsame Atmosphäre schon ein paar Kilometer vor Gallspach. Der Wagen holpert über Hügel den schmalen Feldweg entlang, Lastwagen begegnen dir, kaum kannst du ihnen ausweichen, Personenwagen, kleine, große, Großstadtverkehr auf einer Straße, die einmal für ein paar Ochsenkarren bestimmt war. Menschen drängen sich zwischen den Autos, sie kommen von der Behandlung. Eine alte Frau wird auf dem Stuhl gefahren, ein junger Mensch neben ihr geht auf Krücken ... und auf einmal packt dich die entsetzliche Erkenntnis: das sind ja alles Schwerkranke, die sich da hinschleppen, alles und ausnahmslos, Menschen, denen man es ansieht, daß ihnen dieses Gallspach letzte Hoffnung ist ... Und obwohl man die ganze Fahrt über wußte, daß der Weg zu einer Stadt der Kranken führt, fühlt man einen Augenblick etwas wie Grauen in sich aufsteigen." 41

Erst jetzt, nach dieser persönlich gehaltenen Exposition, wird der Ort vorgestellt. „Ein paar hundert Meter weiter: Gemeinde Gallspach. Der Weg wird nahezu unfahrbar. Gräben werden gezogen, Rohrleitungen gelegt. Zwischen den Arbeitern drängen sich Einheimische und Patienten. Hinter Kieshaufen strecken sich Gerüste und Neubauten, über Nacht aus dem Boden emporgeschossen. Plakate vermieten Zimmer, die noch nicht gebaut sind, Plakate annoncieren Bestrahlungsapparate und Tanz. Drüben wächst der Block des Kurhotels unvermittelt aus dem Boden; man kann noch nicht bis vor die Tür fahren, aber die Zimmer sind schon alle besetzt. Aus der Ferne aber winkt ein riesiger Glasbetonbau: das neue Behandlungshaus."42 Und weiter schreibt Weber, wieder zum subjektiven Blickwinkel zurückkehrend: „In diesem Durcheinander eines sich überstürzenden Werdens liegt still, abgezirkelt, die Welt der Kranken. In keinem Kurort sah ich so viele Kranke, die wirklich Heilung suchten, so viele Menschen voll echter Verzweiflung, die hundertmal enttäuscht, sich an diese letzte Hoffnung klammern. Nirgends sah ich soziale Gegensätze vor dem gemeinsamen Leiden so völlig verwischt, traf ich Menschen, die an nichts anderes dachten als an Gesundheit und vielleicht daran, sich gegenseitig ein wenig zu helfen, der Blinde dem Lahmen, der Schwache dem Gebrechlichen. Vor 


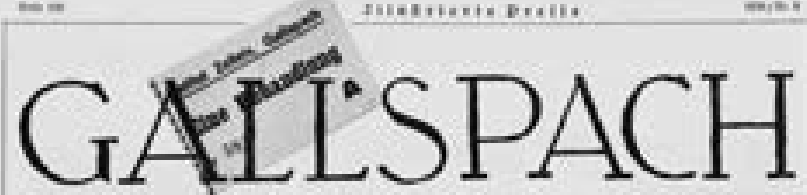

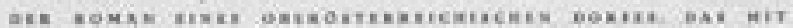

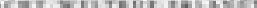

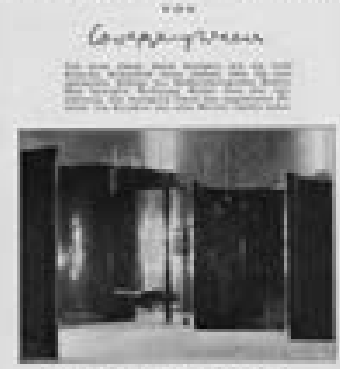

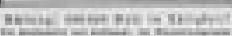

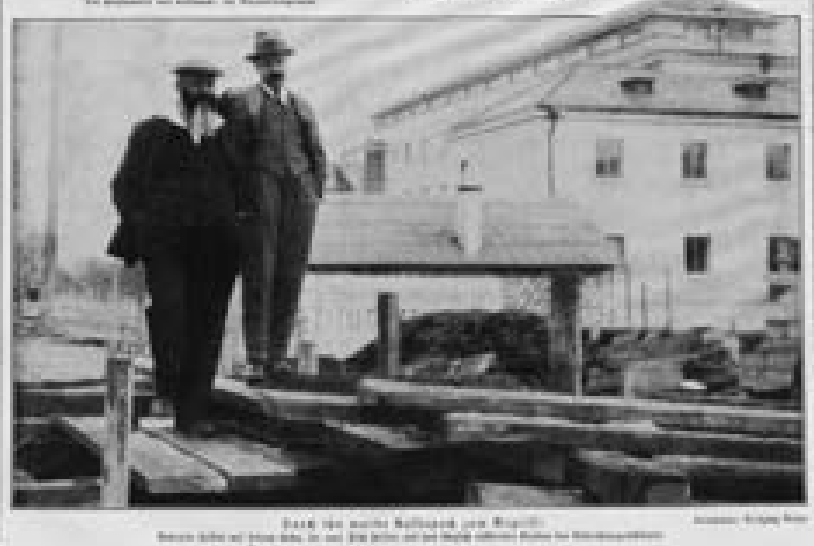

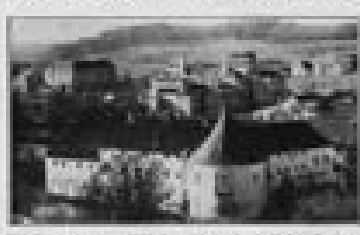

-

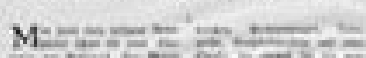

$M=4-2=20=$

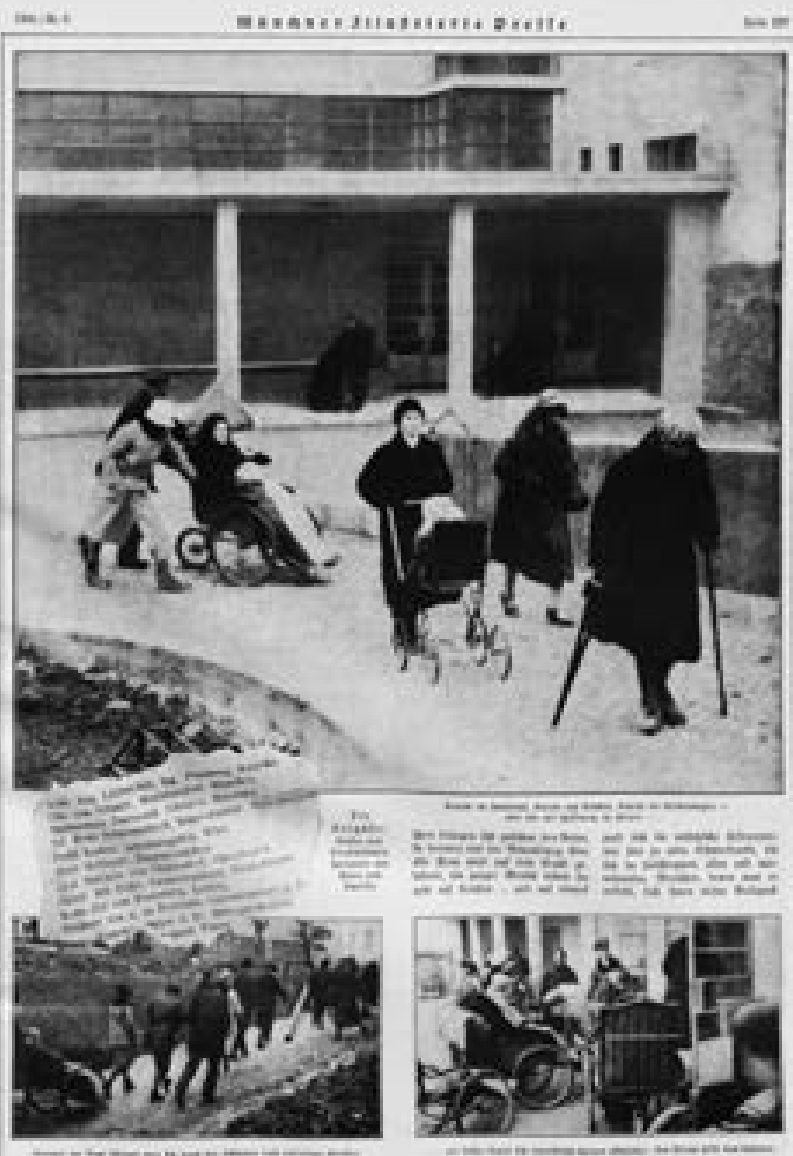

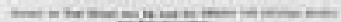

Abb. 18 Fotoreportage von Wolfgang Weber über den oberösterreichischen Ort Gallspach, den der Wunderheiler Valentin Zeileis in ein „Mekka der Kranken“ verwandelt hat. Münchner Illustrierte Presse, 23. Februar 1930, S. 236/237.

Abb. 19 Fortsetzung der Fotoreportage von Wolfgang Weber über Gallspach. Münchner Illustrierte Presse, 23. Februar 1930, S. 238 dem Parkplatz des Instituts steht ein Maybachwagen, neben ihm ein Handkarren, auf den ein paar Kissen geworfen sind, ein paar lumpige Kissen, die ich nie vergessen werde.“43

Die Bilder, zusammengestellt unter Lorants Aufsicht in der Münchner Redaktion ${ }^{44}$, vermitteln in klarem, ruhigem Layout, einen Eindruck von dieser Stadt der Kranken. Auf der ersten Seite der Reportage wird - parallel zur ersten Annäherung des $\mathrm{Au}-$ tors - der Ort im Überblick eingeführt und der Protagonist Valentin Zeileis vorgestellt. Auf den folgenden Seiten zeigen dann Momentaufnahmen den Massenandrang um und in der Heilanstalt. Ein kurzer Abstecher dokumentiert den enormen wirtschaftlichen Boom des Ortes.

Nur wenige Tage später, am 27. Februar 1930, erscheint auch in der größten österreichischen Wochenillustrierten, dem Interessanten Blatt, ein groBer Bildbericht über Gallspach. ${ }^{45}$ Die Aufnahmen stammen von den beiden Pressefotografen Leo Ernst und Fred Cešanek, die bisher nicht mit Reportagen hervorgetreten sind. ${ }^{46}$ Anders als bei Weber beginnt ihre Reportage nicht mit einem Überblick, sondern,

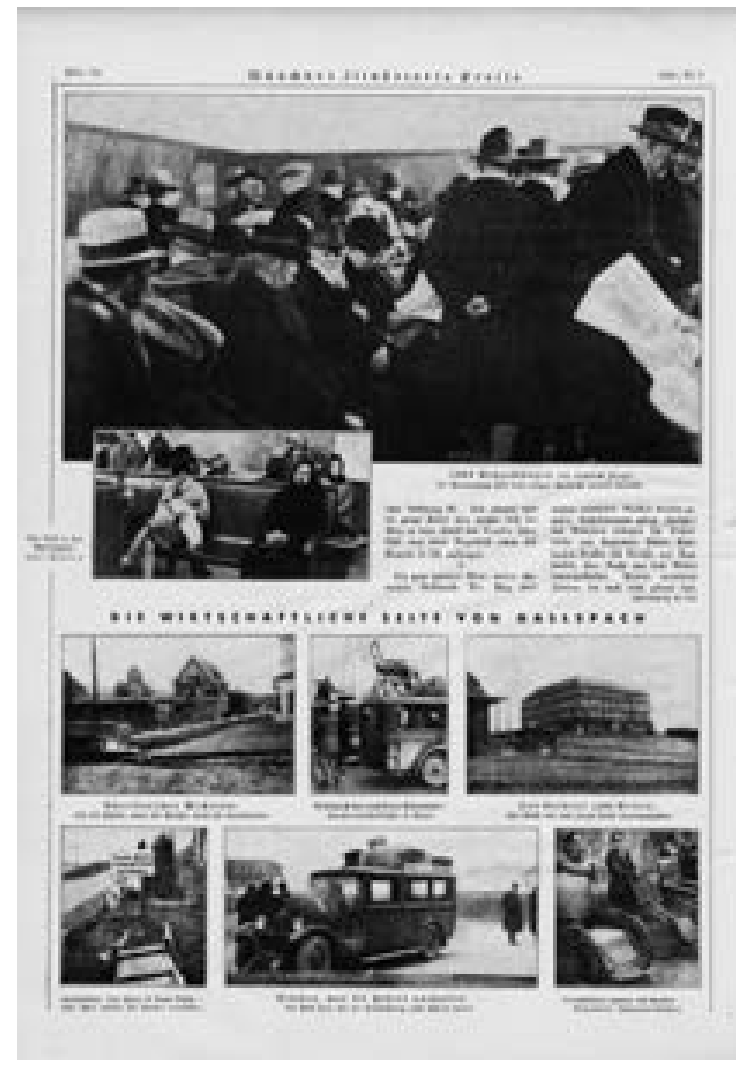


direkt unter dem Zeitungskopf mit der breiten, längst schon anachronistisch erscheinenden Titelvignette, mit einer beeindruckenden Nahaufnahme (Abb. 20). Ein krankes Kind wird in eisiger Winterkälte in einem Wäschekorb mit Schubkarren zum Zeileis'schen Institut transportiert. Darüber prangt der Titel des Berichts: „In Gallspach.“ Auf der folgenden Doppelseite (Abb. 21) werden Zeileis, sein Institut und der Andrang der Kranken präsentiert. Erst ganz zum Schluss findet sich eine Überblicksaufnahme des Ortes Gallspach. Im Unterschied zur Reportage in der Münchner Illustrierten Presse ist die Gestaltung hier unruhiger, die Bilder erscheinen etwas wahllos in die immer wieder unterbrochenen Textspalten gesetzt. Dadurch ist der innere Zusammenhang der Bildgeschichte abgeschwächt, die Erzählung erscheint weit weniger geschlossen.

Während Weber der Reportage bewusst eine sehr persönliche, subjektive Färbung verleiht, ist der Tonfall des Textes im Interessanten Blatt nüchterner, distanzierter. „Nichts“, so beginnt der Bericht, „steht momentan mehr im Brennpunkt der Öffentlichkeit als Valentin Zeileis, der Wunderdoktor von Gallspach, und seine Kuren. Es soll hier nicht für oder gegen Stellung genommen sein, sondern nur rein tatsachengemäß berichtet werden. Feststehend und unzweifelhaft ist jedenfalls, daß im Monat Tausende und aber Tausende nach Gallspach pilgern, um dort im Mekka aller Siechen und Kranken, ihre vermeintliche Heilung zu suchen - und nicht zum kleinsten Teil auch finden; aber es ist ebenso feststehend und unzweifelhaft, daß die gesamte wissenschaftliche Welt (...) das Ganze als einen Schwindel und eine Massensuggestion erklärt." 47

Der direkte Vergleich beider Reportagen zeigt, dass die Wiener Variante um einiges konventioneller ausfällt. Das liegt nicht so sehr an den Bildern, die in ihrer Qualität durchaus vergleichbar sind. Der Einstieg mit der Kinderszene im Interessanten Blatt ist mindestens ebenso überzeugend wie die langsame Annäherung in mehreren kleineren Bildern in der Münchner Illustrierten Presse. Die Defizite des österreichischen Blattes haben vielmehr mit der deutlich schlechteren Seitengestaltung, den weniger originellen grafischen Lösungen und der sehr losen Verbin- dung zwischen Text und Bildern zu tun. Während Webers Reportage sogar im Untertitel als geschlossene Erzählung („Roman“) deklariert und die Rolle des „Autors“ als Fotograf und Erzähler gleich am Beginn deutlich sichtbar eingeführt wird, kommt die Wiener Reportage ohne diese Figur des Augenzeugen aus. Die beiden Fotografen Ernst und Cešanek werden nicht als zentrale bildliche Erzähler vorgestellt, sondern lediglich am unteren Bildrand (und in kleinem
Abb. 20 Fotoreportage über den Wunderheiler Valentin Zeileis in Gallspach. Das interessante Blatt, 27. Februar 1930, Titelseite. Fotos: Leo Ernst und Fred Cešanek.
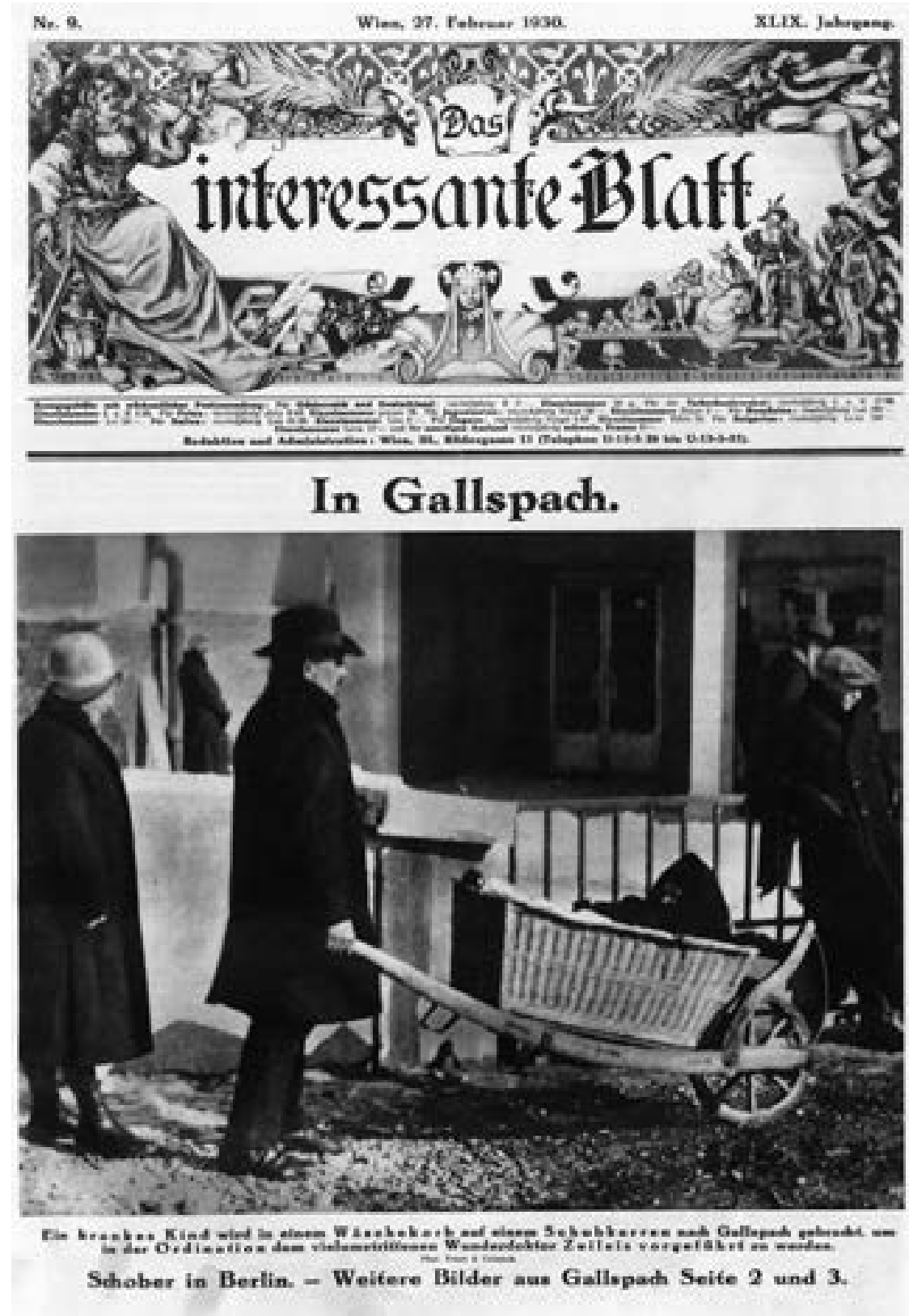
Schriftgrad) als Bildlieferanten genannt. Der Autor des Textes verbirgt sich sogar hinter einem Kürzel (,-d-r.“), er wird erst am Ende des Beitrags am unteren Bildrand genannt.

\section{Steyr, die sterbende Stadt}

„Geographisch mag also Gallspach ein kleines

Abb. 21 Fortsetzung der Fotoreportage über Gallspach. Das interessante Blatt, 27. Februar 1930, S. 2/3. Fotos: Leo Ernst und Fred Cešanek. schem Unterton, darauf hin, dass der Massenandrang und der mediale Wirbelsturm, die den kleinen Ort erfasst haben, Ausdruck einer gesamtgesellschaftlichen Krisenstimmung sind. Österreich steuert Anfang der 1930er Jahre auf die schwerste Wirtschaftskrise seiner Geschichte zu. 1933 ist ein Viertel der Bevölkerung arbeitslos. Morgenstern registriert sehr aufmerksam, dass die kollektiven Heilswünsche, die das Land angesichts der katastrophalen wirtschaftlichen Lage erfassen, nicht selten irrationale Züge annehmen. Es ist gewiss kein Zufall, dass die verunsicherten Massen in diesen Jahren Gesundung und Heilung nicht in der Stadt, sondern lieber in entrück-
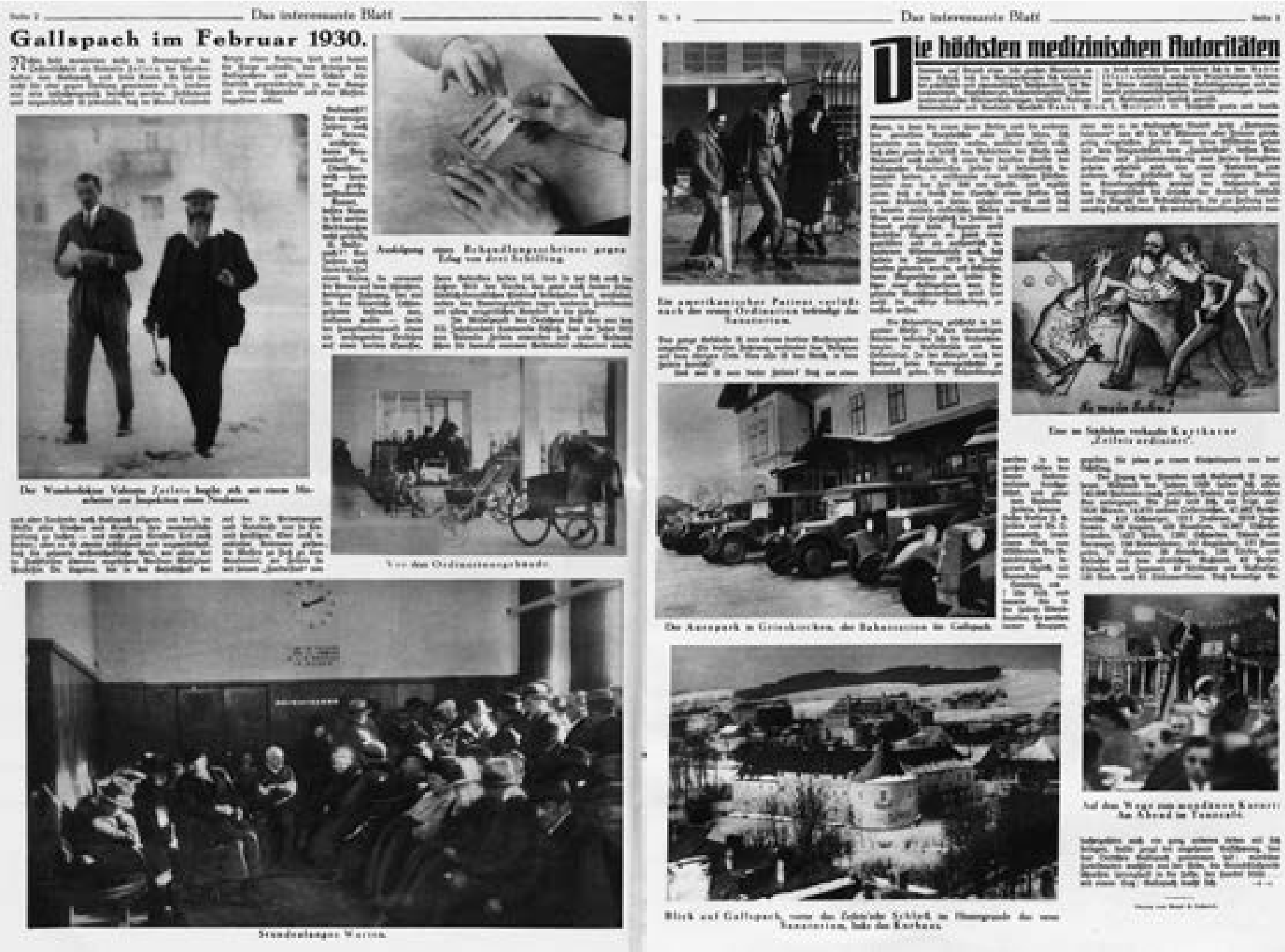


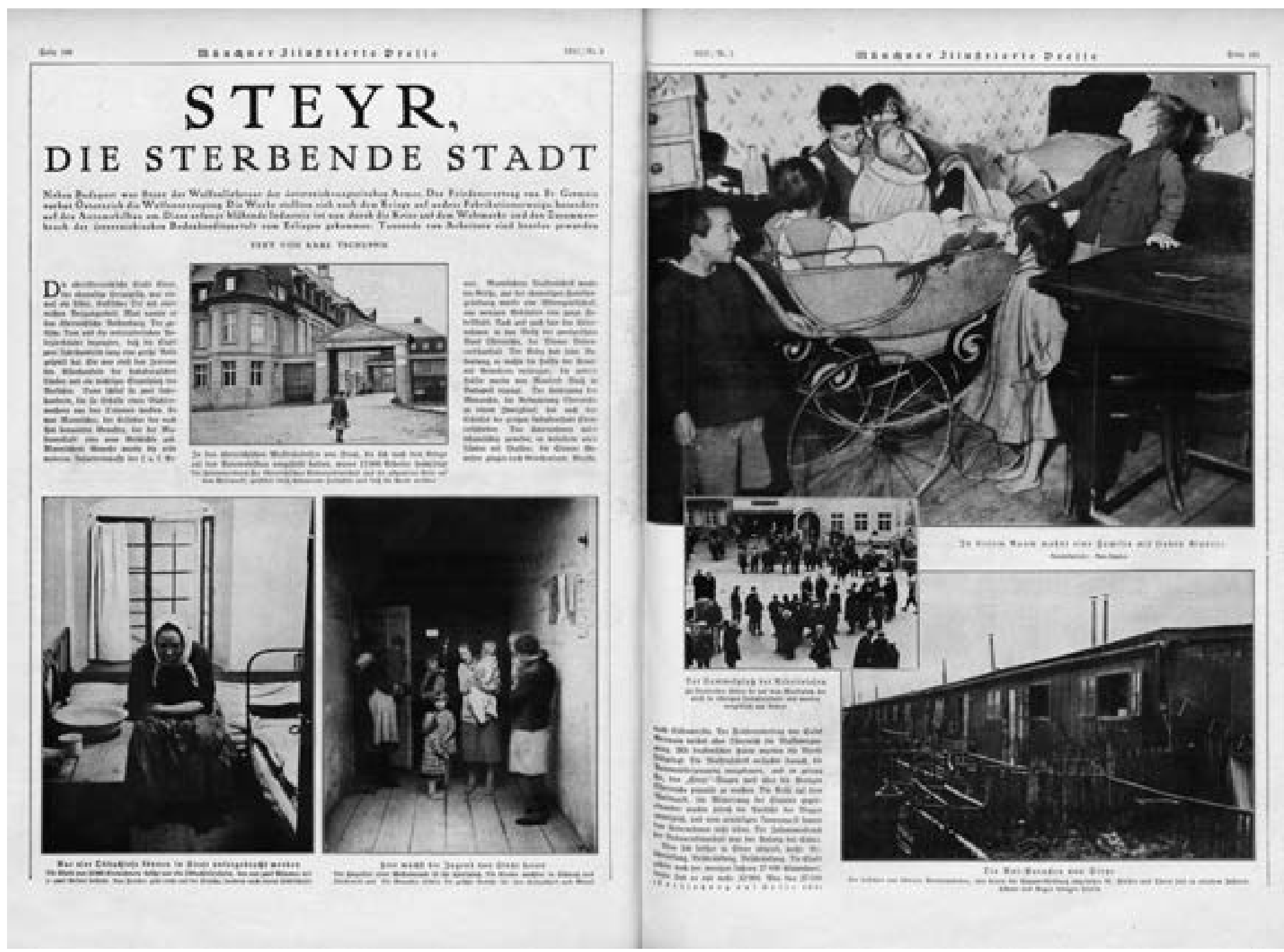

ten, scheinbar intakten ländlichen Gemeinschaften suchen. Das Phänomen Gallspach wäre also, wenn wir Morgensterns Interpretation folgen wollen, auch eine Chiffre für die Stimmung im ganzen Land.

Die Industriestadt Steyr, ebenfalls in Oberösterreich gelegen, ist in vielfacher Hinsicht geradezu ein Gegenentwurf zu Gallspach. Auch sie wird Anfang der 1930er Jahre in mehreren illustrierten Zeitungen porträtiert, freilich nicht als Fluchtpunkt Heilung suchender Städter, sondern vielmehr als Inbegriff der gescheiterten Stadt. Auch hier bietet sich an, die Reportagen einander gegenüberzustellen, um Aufschluss über Bauart und Erzählhaltung zu gewinnen. Am 5. Januar 1930 bringt der sozialdemokratische Kuckuck unter dem Titel „Steyr, die Stadt der Arbeitslosen“ die erste Fotoreportage über den krisengeschüttelten Ort. ${ }^{49}$ Seit einigen Monaten, so berichtet das Blatt, werden Arbeiter der Steyrwerke, dem wichtigsten Unternehmen der kleinen Stadt, entlassen.
Während des Ersten Weltkrieges hatte der Betrieb als Rüstungsfirma Hochkonjunktur. Danach stelle man auf die zivile Automobilproduktion um. Und nun macht sich die Weltwirtschaftskrise bemerkbar. Die Anzahl der Beschäftigten schrumpft Woche für Woche. „Ein Viertel der Bevölkerung“, so heißt es im Kuckuck, „ist jetzt arbeitslos - etwa 6000 von 24000 Einwohnern. Es gibt nahezu keine Familie, die von dem Massenelend nicht betroffen wäre, in manchen Familien sind alle erwerbenden Mitglieder arbeitslos. “50

Ein Jahr später - die wirtschaftliche Situation Steyrs hat sich weiter verschlechtert - greift die Münchner Illustrierte Presse das Thema in einer Reportage auf (Abb. 22). ${ }^{51}$ Nun ist aus der Stadt der Arbeitslosen im Titel bereits eine „sterbende Stadt“ geworden. Die Aufnahmen stammen von Felix H. Man (eigentlich Hans Felix Baumann), der seit Juni 1929 für die Berliner Fotoagentur Dephot tätig ist. ${ }^{52}$ Den Text steuert der Wiener Journalist Karl Tschuppik bei. Beide
Abb. 22 „Steyr, die sterbende Stadt“. Fotoreportage von Karl Tschuppik (Text) und Felix $\mathrm{H}$. Man (Fotos) über die krisengeschüttelte oberösterreichische Industriestadt. Münchner Illustrierte Presse, 31. Januar 1931, S. $100 / 101$. 


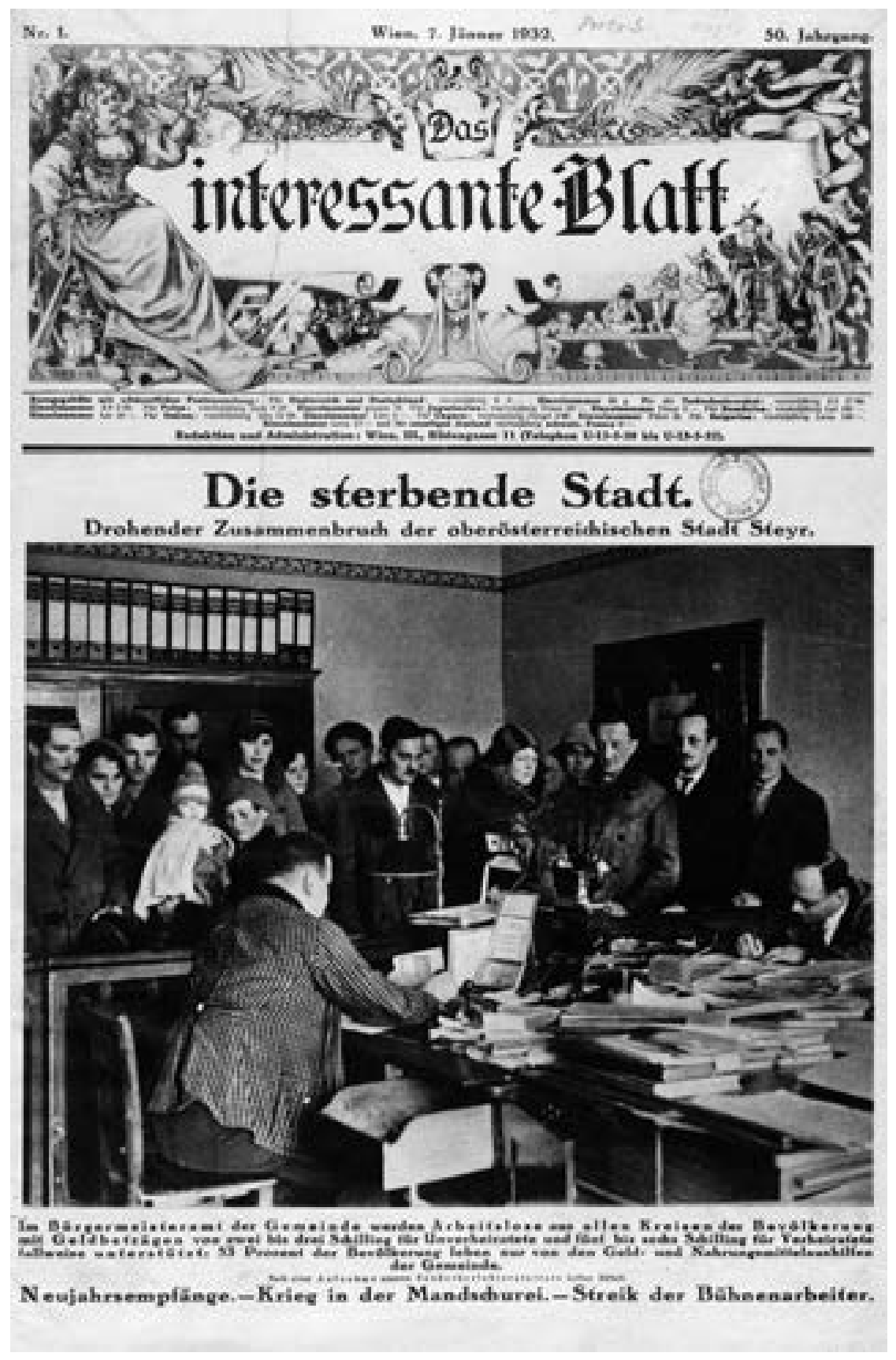

Abb. 23 „Die sterbende Stadt“. Fotoreportage von Lothar Rübelt über Steyr. Das interessante Blatt, 7. Januar 1932, Titelseite. schildern, welche Folgen der wirtschaftliche Abstieg der Steyrwerke für den Ort hat. Im Vorspann heißt es: „Neben Budapest war Steyr der Waffenlieferant der österreichisch-ungarischen Armee. Der Friedensvertrag von St. Germain verbot Österreich die Waffenerzeugung. Die Werke stellten sich nach dem Kriege auf andere Fabrikationszweige, besonders auf den Automobilbau um. Diese anfangs blühende Industrie ist nun durch die Krise auf dem Weltmarkt und den Zusammenbruch der österreichischen Bodenkreditanstalt zum Erliegen gekommen. Tausende Arbeiter sind brotlos geworden. “53 Die Fotos von Felix H. Man dokumentieren vor allem die soziale Not, in die eine ganze Stadt geraten ist, die steigende Anzahl der Arbeitslosen, die Barackensiedlungen, in denen jene leben, die ihre Mieten nicht mehr zahlen können. Eine besonders beeindruckende Aufnahme zeigt einen winzigen Wohnraum, in dem eine Familie mit sieben Kindern lebt.

„Von den 27000 Menschen“, schreibt Tschuppik, „hatten 17000 in den Steyr-Werken Beschäftigung; heute arbeiten dort 1700. Die Stadt stirbt. (...) Die Menschen von Steyr sind Gefangene ihres Elends, Opfer eines unerbittlichen Gesetzes, das Politik und Wirtschaft diktieren. Was wird aus dieser Stadt? Die Bilder zeigen den Grad der Not, den stumm gewordenen, sich fatalistisch ergebenden Jammer. Die Berichte von Steyr haben wohl die Welt aufhorchen lassen; es gab auch rührende Beweise von Hilfsbereitschaft, doch die Existenz einer ganzen Stadt lässt sich nicht auf Mildtätigkeit aufbauen. Die Stadt stirbt. Die Gemeinde muß die Schulen schließen, weil sie keine Kohle, die Kinder keine Schuhe und Kleider haben. Sie wird die Beamten entlassen, weil sie die Gehälter nicht zahlen kann. Sie hat ihr Krankenhaus an den Staat verkauft, weil die Mittel fehlen, es zu erhalten. Der landschaftliche Reiz der Stadt, am Zusammenstoß zweier Flüsse zu liegen, wird ihr zum Unheil: sie kann die Brücken nicht mehr in einen brauchbaren Zustand setzen. Sie muß sich auf das Allernotwendigste beschränken. Das heißt: täglich 11000 Menschen ein Stückchen Brot und einen Napf Suppe zu geben. “54

Ein Jahr später, Anfang Januar 1932, bringt auch Das interessante Blatt eine Fotoreportage über Steyr. Sie scheint den Titel „Die sterbende Stadt“ dem Bildbericht der Münchner Illustrierten Presse entlehnt zu haben. Der Bericht beginnt auf der Titelseite mit einer Aufnahme des „Sonderberichterstatters Lothar Rübelt" ${ }^{45}$, die die Auszahlung der Arbeitslosenunterstützung im Gemeindeamt zeigt (Abb. 23). Darunter lesen wir: „Im Bürgermeisteramt der Gemeinde werden Arbeitslose aus allen Kreisen der Bevölkerung mit Geldbeträgen von zwei bis drei Schilling für Unverheiratete und fünf bis sechs Schilling für Verheiratete fallweise unterstützt; 53 Prozent der Bevölkerung leben nur von den Geld- und Nahrungsmittelaushilfen der Gemeinde." ${ }^{56}$ Auf der folgenden Seite wird in den Bildern vor allem die dramatische soziale Situation in der Stadt dargestellt (Abb. 24). Gezeigt werden 
auch die verzweifelten Versuche der Stadtverwaltung, mit leeren öffentlichen Kassen gegen die Not und Verelendung der Bevölkerung vorzugehen. Die Bilder sind tableauartig angeordnet, nummeriert und am unteren Bildrand mit kurzen Bildtexten versehen.

Im nebenstehenden Text heißt es: „Als in der Nacht vom 29. zum 30. Dezember vergangenen Jahres der Gemeinderat der Stadt Steyr zu einer Sitzung zusammentrat und Bürgermeister Sichelrader den Antrag auf eine Stillegung jeglicher Gemeindetätigkeit stellte, war das mit anderen Worten die vollständige Bankrotterklärung einer einst blühenden Industriegemeinde, auf der nun die Krise der österreichischen wie der gesamten Weltwirtschaft mit kaum geahnter Schwere lastet. Nicht weniger als 34 Deputationen wurden in den letzten Jahren an die Zentralstellen in Linz und Wien entsandt, um auf die fürchterliche Notlage, die durch die Massenarbeitslosigkeit infolge der Drosselung der Steyr-Werke und der vollständigen Stillegung der Kautschukfabrik in Garsten über die Bewohnerschaft hereingebrochen ist, aufmerksam zu machen. Das Gesamterfordernis des Gemeindehaushalts beträgt 2444400 Schilling, dem aber nur eine Bedeckung von 1486500 gegenübersteht, so daß eine Summe von 957000 Schilling ungedeckt erscheint. Dabei wurden keine Ausgaben für Straßen, Wohnungen, Bäder, öffentliche Anlagen, Ausgestaltung der Schule und andere notwendige und dringende Kulturbedürfnisse eingesetzt. Man begreift aber sofort, daß dies so sein muß, denn die Stadt mit 20000 Einwohnern hat 11750 Befürsorgte, die gezwungen sind, die öffentliche Hilfe in Anspruch zu nehmen. Die Unterstützung beträgt maximal 42 Groschen täglich, ist es ein Wunder, wenn 90 Prozent aller Kinder unterernährt sind, wenn die Tuberkulose Opfer um Opfer fordert. Nicht weniger fürchterlich ist das Gespenst der Wohnungsnot, das eine Unzahl von Familien bedroht. Alle irgend verfügbaren Räume, wie Baracken, das Gemeindelazarett und das sogenannte ,Brüderhaus‘ wurden bereits zur Linderung herangezogen - und doch drängen sich die Menschen noch immer zusammen, zehn und zwölf in einem Raum. Angesichts dieser entsetzlichen Tatsachen nahm die Gemeinde nochmals eine Reduktion aller Ausgaben vor, alle Bezüge wurden um zwanzig Prozent gekürzt,

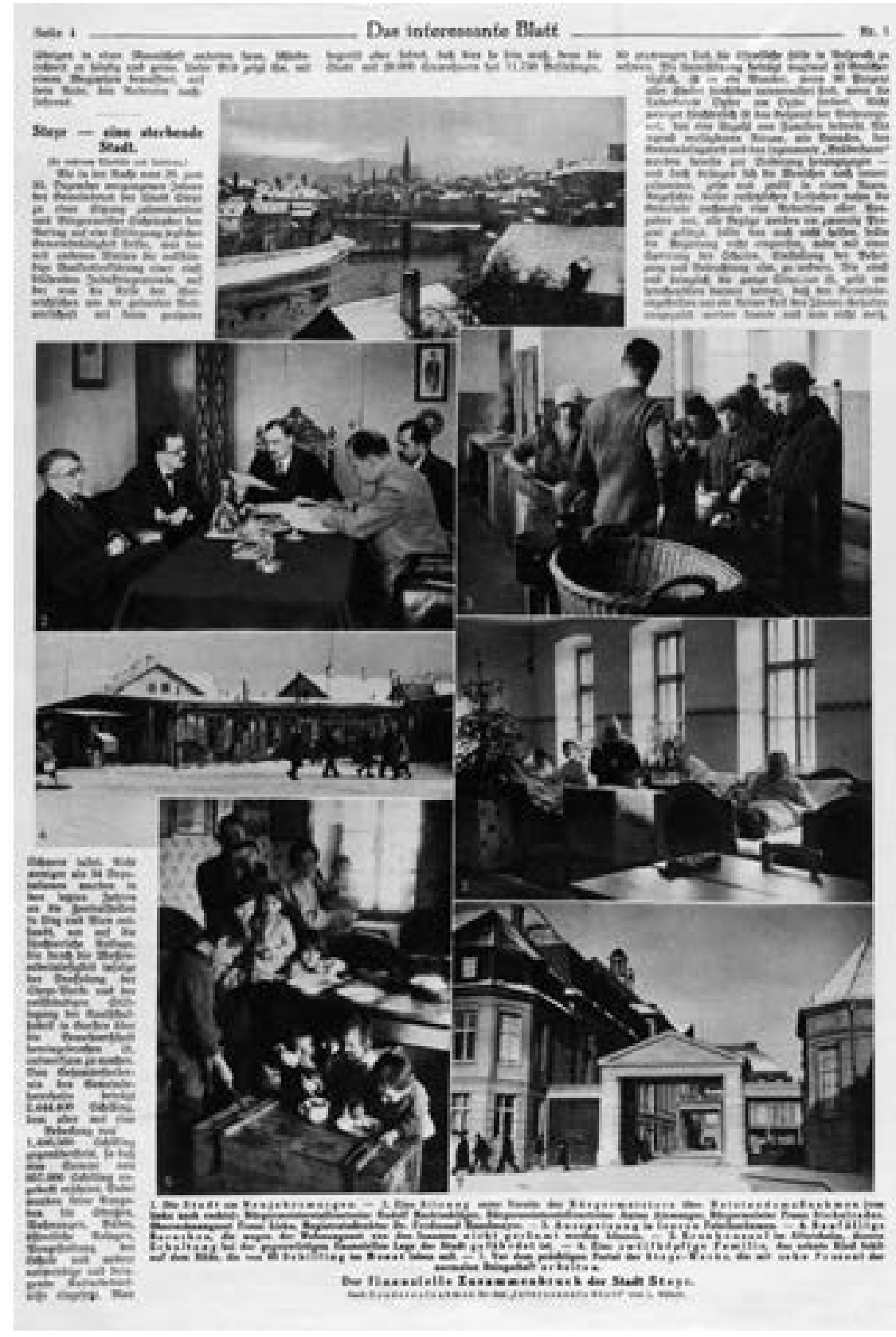

sollte das auch noch nicht helfen, wäre mit einer Sperrung der Schulen, Einstellung der Beheizung und Beleuchtung usw. zu rechnen. Wie ernst und dringlich die ganze Situation ist, geht am sprechendsten daraus hervor, daß den Gemeindeangestellten nur ein kleiner Teil des Januar-Gehaltes ausgezahlt werden konnte und man nicht weiß, von woher den Rest nehmen. Steyr - eine sterbende Stadt, ein fürchterliches
Abb. 24 Fortsetzung der Fotoreportage von Lothar Rübelt über Steyr. Das interessante Blatt, 7. Januar 1932, S. 4. 
Abb. 25 „Skikurs“. Übungskurse in St. Christoph am Arlberg, die das österreichische Unterrichtsministerium veranstaltet. Die Dame, Heft 7, Zweites Dezemberheft 1930, S. 7. Foto: Martin Munkácsi.

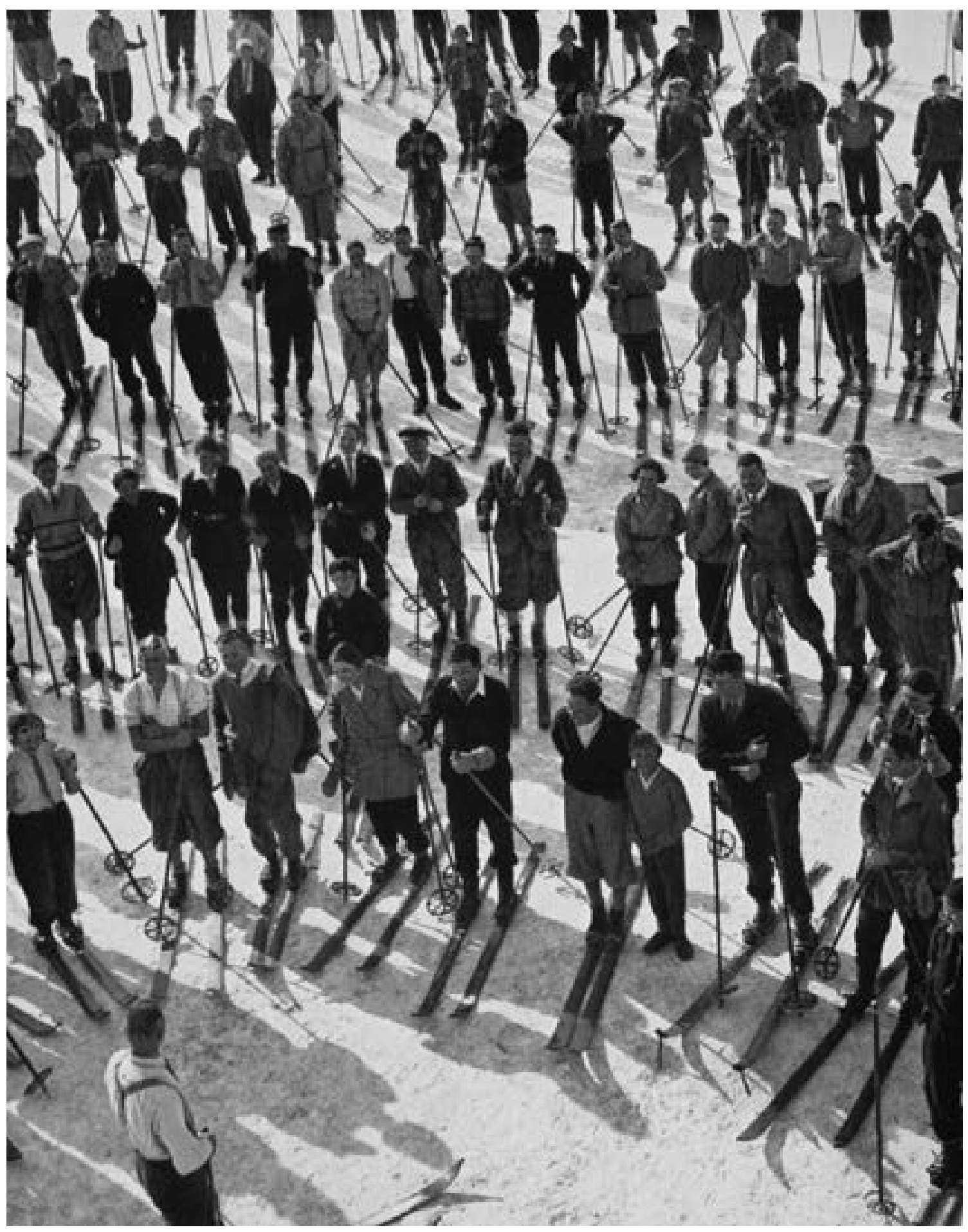

Mahnzeichen von der Not der österreichischen Industriegemeinden, ein letzter Ruf um Arbeit.“"57

So wie bereits bei der Gallspach-Reportage zeigt sich auch hier, dass Aufmachung und Gestaltung der Bildgeschichte in der Münchner Illustrierten Presse (MIP) deutlich professioneller ist als jene im Interessanten Blatt. Zwar ist der Fotograf in der MIP weniger prominent angeführt als in der Gallspach-Reportage, wo Weber sowohl für den Text als auch die Bilder verantwortlich war. Aber auch diese Reportage zeichnet sich durch ihre Geschlossenheit in der Darstellung und die enge Verzahnung von Text und Bildern aus. Der Bildbericht in der Münchner Illustrierten Presse ist im Vergleich zum Interessanten Blatt auch dramaturgisch geschickter inszeniert, die Bilder sind besser in die Textspalten integriert, zoomende Großaufnahmen und distanzierte Überblicksaufnahmen halten sich die Waage. Das interessante Blatt hingegen greift wieder einmal auf die veraltete Form der numerischen Zuordnung der Bildbeschriftungen zurück. 


\section{Erfolge in Deutschland}

Die beiden Berichte über Gallspach und Steyr zeigen, dass die Fotoreportage Anfang der 1930er Jahre zwar zum festen Bestandteil der großen österreichischen illustrierten Blättergeworden ist, in gestalterischer und grafischer Hinsicht aber deutlich hinter derjenigen in den avancierten deutschen Blättern zurückbleibt. Ein wichtiger Grund liegt darin, dass die großen deutschen Illustrierten weit mehr Mittel für aufwendig recherchierte Reportagen und ihre professionelle grafische Umsetzung zur Verfügung haben. Immerhin liegen ihre Auflagen um 1930 um ein Vielfaches über jenen der österreichischen Blätter. Während die führende Berliner Illustrirte Zeitung in dieser Zeit wöchentlich knapp zwei Millionen Exemplare druckt und die Münchner Illustrierte Presse immerhin noch 700 000, liegt die Auflage der großen österreichischen Illustrierten unter $50000 .^{58}$ Die groBen deutschen Zeitungen leisten sich beispielsweise weit öfter teure Reisereportagen, aber auch Bildberichte aus dem Ausland (wie etwa die Gallspach- und Steyr-Reportagen) kommen häufiger vor.

Es ist bemerkenswert und bis heute wenig bekannt, dass um 1930 immer wieder große Österreich-Reportagen in deutschen illustrierten Zeitungen erscheinen. Einige der bekanntesten deutschen Presse- und Reportagefotografen berichten in diesen Jahren aus Österreich. Im März 1929 etwa reist Erich Salomon im Auftrag der Münchner Illustrierten Presse nach Wien, um eine Reportage über das bekannte Jesuiteninternat Kalksburg bei Wien zusammenzustellen. ${ }^{59}$ Bei dieser Gelegenheit fotografiert er auch Richard Strauss in Wien.

Auch andere bekannte Fotografen, die für deutsche Zeitungen arbeiten, bringen aus Österreich Bilder mit. Nicht immer sind es geschlossene Reportagen, gelegentlich erscheinen in den deutschen Zeitungen und Magazinen auch Einzelbilder, die oft im Zuge von Reportagereisen entstanden sind. Ende 1933 erscheint beispielsweise in der Dame, einem auflagenstarken Ullstein-Magazin, unter dem Titel „Der Skikurs“ eine faszinierende Aufnahme, die Martin Munkácsi in St. Christoph am Arlberg aufgenommen hat (Abb. 25). ${ }^{60}$ Auch Alfred Eisenstaedt fotografiert wiederholt in Österreich. 1933 veröffentlicht er eine Aufnahme mit, die zwei elegante Touristinnen - in einer reichlich gestellten Szene - in der mittelalterlichen Altstadt Salzburgs zeigt (Abb. 26). ${ }^{61}$ Die Aufnahme stammt vermutlich von einem Fotoauftrag bei den Salzburger Festspielen des Vorjahrs.

Das Interesse österreichischer Fotografen an Deutschland ist hingegen gering. In der Zwischenkriegszeit wird keine einzige größere Deutschland-Reportage eines österreichischen Fotografen in einer österreichischen Illustrierten gedruckt. Der bekannteste österreichische Reportagefotograf Lothar Rübelt veröffentlicht zwar regelmäßig Einzelaufnah-
Abb. 26 „Was im Baedeker steht. Sehenswürdigkeiten in den alten Gäßchen von Salzburg“. Die Dame, Heft 18, Erstes Juniheft 1933, S. 15. Foto: Alfred Eisenstaedt.

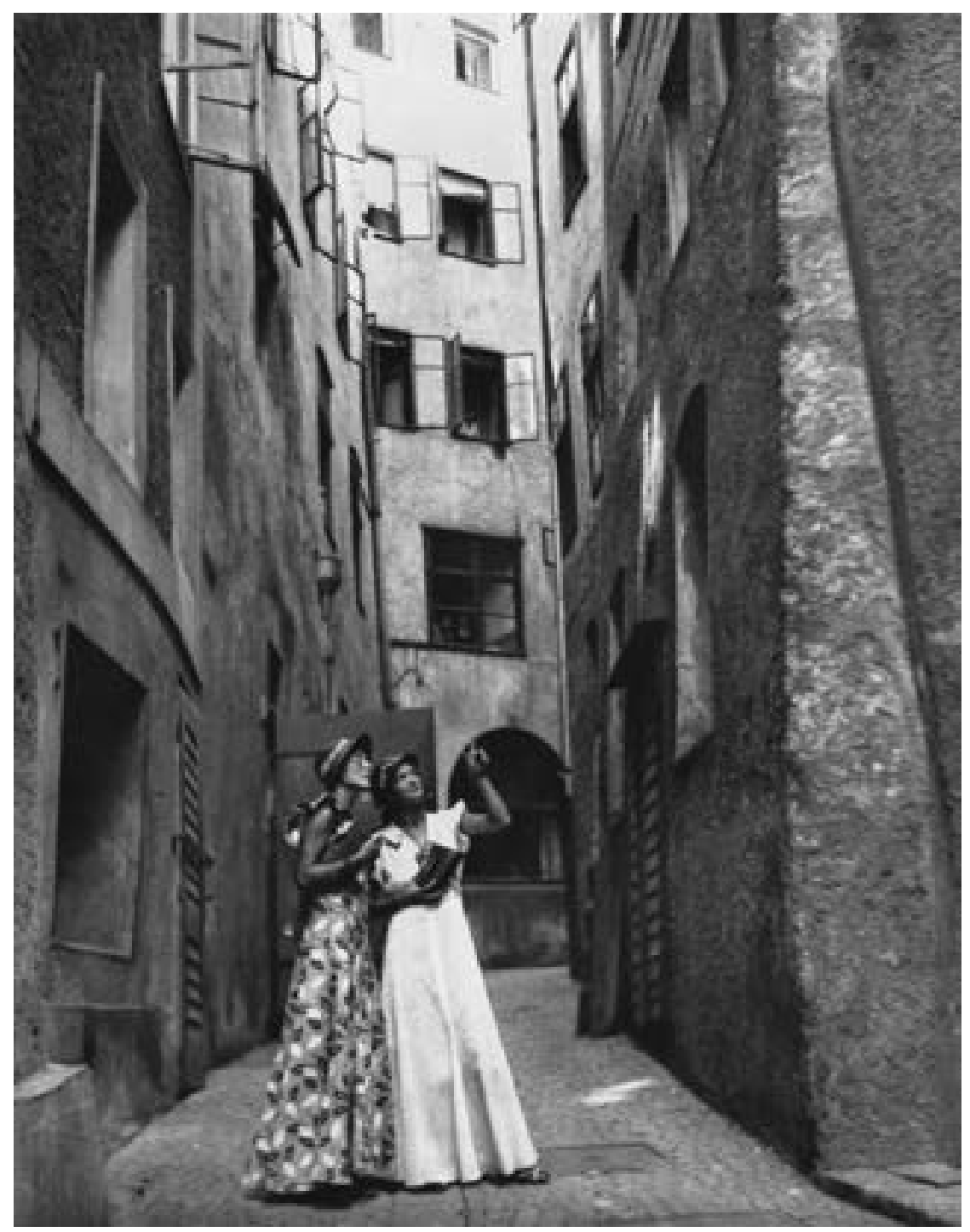




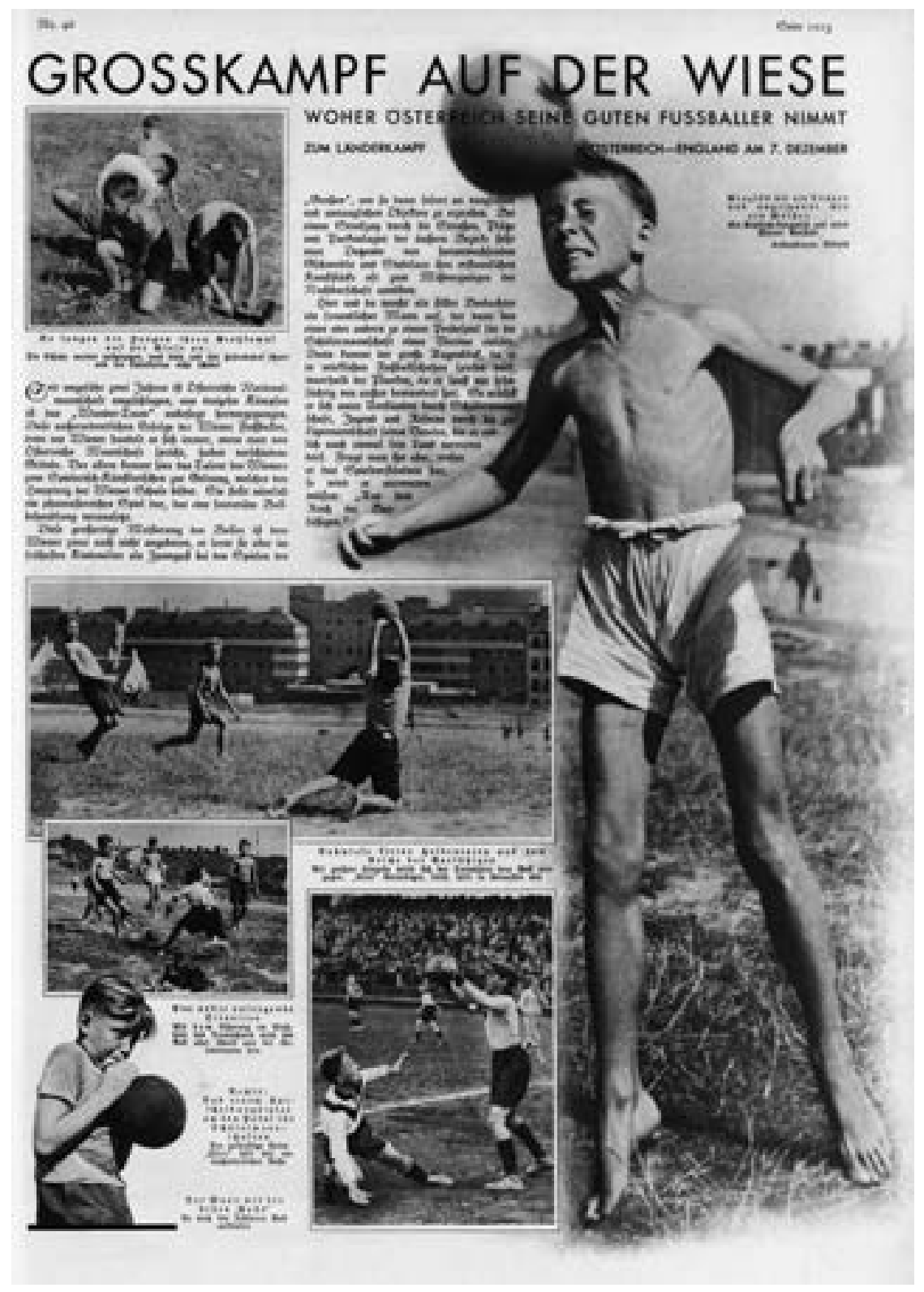

Abb. 27 Der Nachwuchs des österreichischen „Wunderteams“. Themenseite über die österreichische Fußballjugend. Kölnische Illustrierte Zeitung, 26. November 1932, S. 1213. Fotos: Lothar Rübelt. men in der deutschen Presse und gelegentlich liefert er die Bilder zu einer Themenseite, etwa 1932, als er für die Kölnische Illustrierte Zeitung die erfolgreichen österreichischen Nachwuchsfußballer porträtiert (Abb. 27). ${ }^{62}$ Aber geschlossene Reportagen bringt er in der deutschen Bildpresse nicht unter.

Wenn Rübelt nicht Sportfotos macht, beschränkt er sich in der Regel auf österreichische Themen. Gelegentlich fotografiert er aber auch im Ausland. Im Juli 1932 etwa erscheint eine Fotoreportage, die er in Schottland aufgenommen hat. Unter dem Titel „Der Schmied von Gretna Green“ porträtiert er einen kleinen Ort an der schottischen Grenze, der zum Eldorado Heiratswilliger geworden ist. ${ }^{63}$ Denn die schottische Gesetzgebung ermöglicht es Paaren, bereits nach 21 Tagen Aufenthalt zu heiraten. Allein im vergangenen Jahr, berichtet Rübelt, haben 330 Hochzeiten in Gretna Green stattgefunden.

Es gibt eine Reihe von österreichischen Fotografen, die regelmäßig mit Fotoreportagen in großen deutschen Illustrierten vertreten sind. Interessanterweise sind die meisten von ihnen Reisereporter. Der Ethnologe Hugo Bernatzik berichtet aus Afrika, vom Balkan und aus Skandinavien. Von Alice Schalek stammen Reiseberichte aus Südostasien, aus Indien, China und dem Mittleren Osten. ${ }^{64}$ Harald Lechenperg liefert Reisereportagen aus Indien und Afrika ${ }^{65}$ und Herbert Tichy aus Indien und dem Himalayagebiet. ${ }^{66}$ All diese Fotografen und Journalisten (mit Ausnahme der jüdischen Fotografin Alice Schalek) bringen ihre Bilder auch nach dem Machtantritt der Nationalsozialisten unter. Teilweise, wie etwa im Fall von Lechenperg, beginnt ihre große Karriere erst nach 1933. Die meisten von ihnen veröffentlichen ihre Reisefotos auch in österreichischen Zeitungen.

Marian Schwabik, der seit 1929 vor allem für deutsche Illustrierte arbeitet, veröffentlicht in der Münchner Illustrierten Presse gelegentlich Fotoreportagen aus dem Alpenraum, vorzugsweise über ländliche und bäuerliche Themen. Im Februar 1932 etwa erscheint von ihm eine Reportage über Leben und Alltag der ladinischen Sprachminderheit in Südtirol. ${ }^{67}$ In Deutschland erfolgreich ist auch der aus Meran stammende, zeitweise in Österreich lebende Heinz von Perckhammer (geb. 1895), der nach einem längeren Chinaaufenthalt (1914 - 1923) ab 1927 als Presse- und Werbefotograf sowie als Buchautor in Berlin lebt. ${ }^{68}$ Im August 1929 begleitet er im Auftrag der Berliner Illustrirten Zeitung (BIZ) das Luftschiff „Graf Zeppelin“ auf seiner Weltreise. Seine große, sechsseitige Fotoreportage erscheint am 15. September 1929.69 Sie beginnt auf der Titelseite der BIZ mit einem Porträt des Kapitäns Hugo Eckener (Abb. 28), der, so heißt es im Bildtext, nach der Landung seine „erste, lang entbehrte Zigarre“ raucht. 


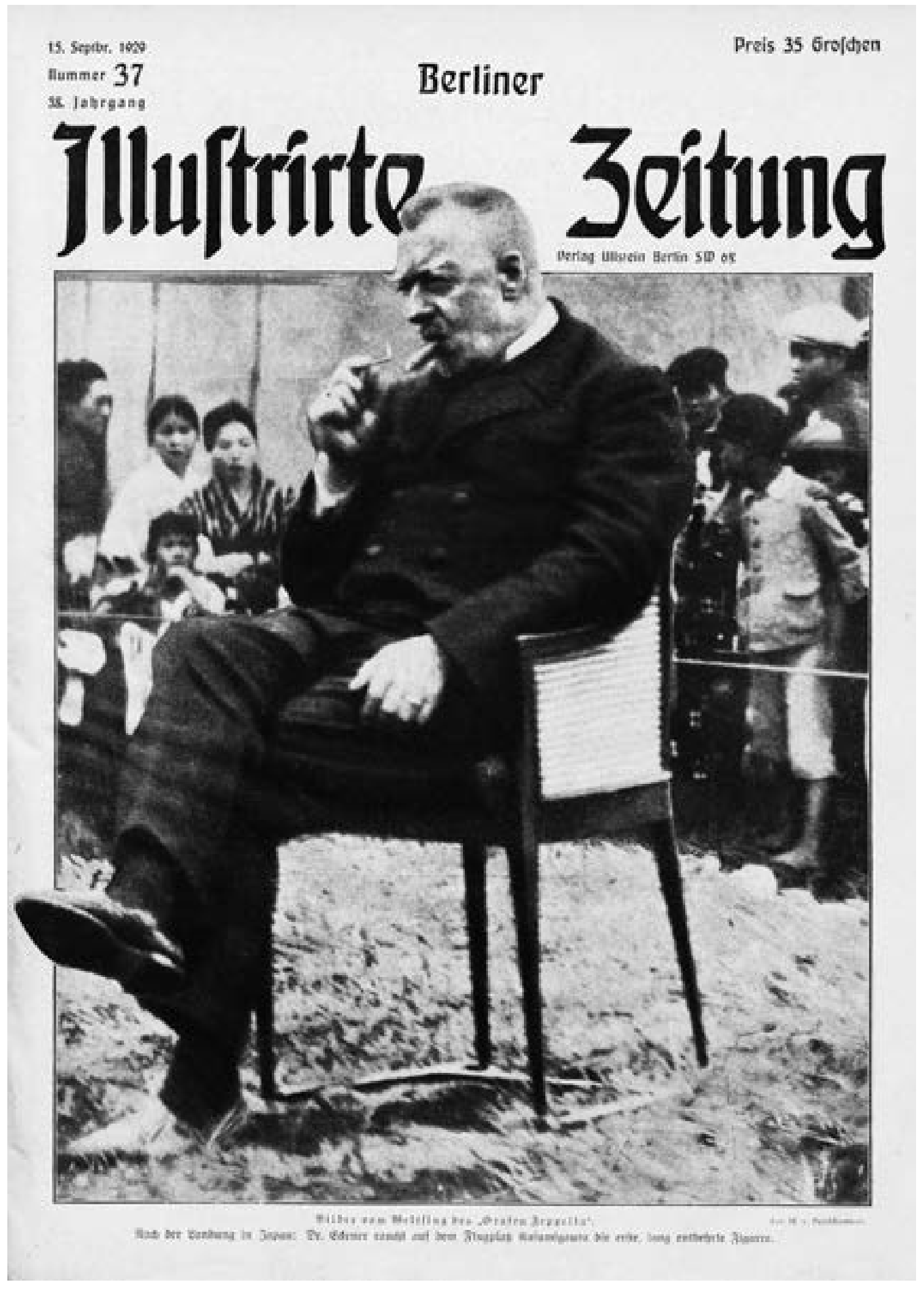

Abb. 28 Der Kapitän des Luftschiffs „Graf Zeppelin“, Hugo Eckener, nach der Landung in Japan. Eröffnungsbild der Fotoreportage von Heinz von Perckhammer über den Weltflug des Zeppelins. Berliner Illustrirte Zeitung, 15. September 1929, Titelseite. 


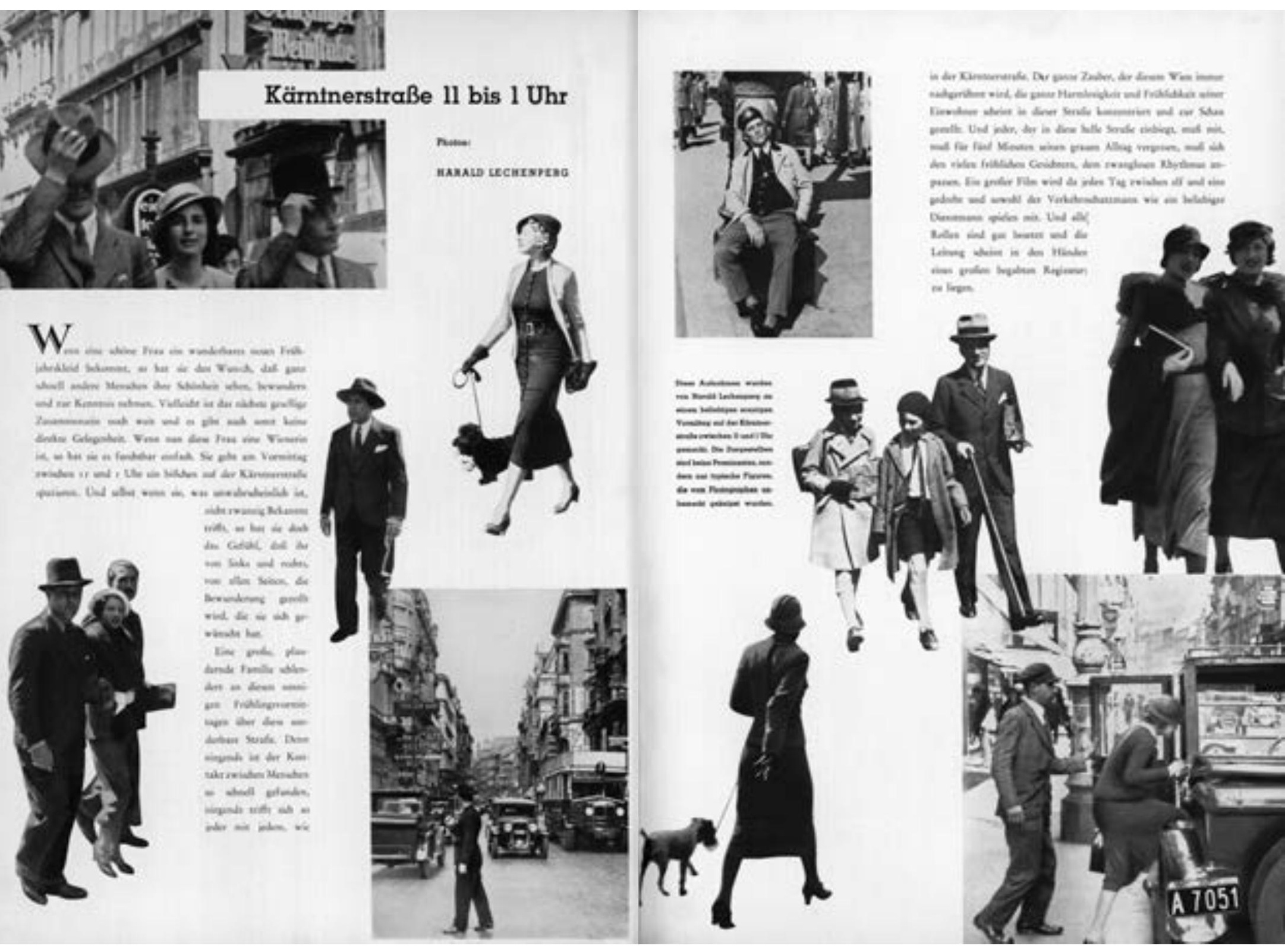

Abb. 29 „Kärntnerstraße 11 bis 1 Uhr". Fotoreportage über das gesellschaftliche Leben auf der bekanntesten Wiener Einkaufs- und Flaniermeile. Moderne Welt, Heft 8, 1934, S. 16/17. Fotos: Harald Lechenperg.
Lechenperg und von Perckhammer veröffentlichen in den 1930er Jahren überaus viel in Österreich. Lechenpergs große Reisereportagen erscheinen oft zuerst in der Berliner Illustrirten Zeitung und dann, zeitversetzt, auch noch in einer österreichischen Zeitung. Er ist um 1930 Mitglied der Fotoagentur Dephot, die ihre Reportagen zuerst den großen deutschen Blättern anbietet bzw. in deren Auftrag produziert. Anschließend werden die Bildberichte oft zweitverwertet. ${ }^{70}$ Von Perckhammer, der von der Wiener Fo- toagentur Schostal vertreten wird, ist in Österreich ab 1931 vor allem im Wiener Magazin und in der Modernen Welt präsent. Beide, Lechenperg wie auch von Perckhammer, erweisen sich in politischer und ästhetischer Hinsicht als äußerst anpassungsfähig. Lechenperg übernimmt 1937 die Leitung der Berliner Illustrirten Zeitung und wird 1940 erster Chef der NS-Propagandaillustrierten Signal. In ästhetischer Hinsicht schafft er den Spagat zwischen modernen Inszenierungen und der Glorifizierung von Bauern- 
tum und Landleben. Auch von Perckhammer dient sich dem NS-Regime willig an. Neben nüchtern-sachlichen Werbeaufnahmen (u. a. für die deutsche Modeund Gesellschaftszeitschrift die neue linie) macht er ab Mitte der 1930er Jahre auch gefällige Genreaufnahmen, etwa von knorrigen Tiroler Bauern oder ländlichen Trachtenszenen. Solche Motive passen in den 1930er Jahren sehr gut in das zunehmend konservativer werdende politisch-gesellschaftliche Klima in Österreich.

Dass gemäßigte Moderne, innovative Gestaltung und konservative politische Grundhaltung gut vereinbar sind, zeigt eine zweiseitige Fotoreportage Lechenpergs, die im Mai 1934 in der Zeitschrift Moderne Welt erscheint (Abb. 29). ${ }^{71}$ Sie trägt den Titel „Kärntnerstraße 11 bis 1 Uhr" und fängt die elegante und entspannte Atmosphäre der wichtigsten Wiener Geschäftsstraße um die Mittagszeit ein. Ihren besonderen Reiz bezieht diese Inszenierung daraus, dass viele der Figuren, spazierende Frauen, Kinder auf dem Heimweg von der Schule, Geschäftsleute, Taxifahrer usw., grafisch freigestellt sind und auf dem Weiß der Zeitungsseiten geradezu zu schweben scheinen. Zusammengehalten werden all diese isolierten Szenen durch einen launigen Text, der die Protagonisten wie auf einer Bühne zusammenführt. „Nirgends“, so heißt es zu den Bildern, „ist der Kontakt zwischen den Menschen so schnell gefunden, nirgends trifft sich so jeder mit jedem, wie in der Kärtnerstraße.“72 Das Fazit lautet: „Der ganze Zauber, der diesem Wien immer nachgerühmt wird, die ganze Harmlosigkeit und Fröhlichkeit seiner Einwohner scheint in dieser Straße konzentriert und zur Schau gestellt. Und jeder, der in diese helle Straße einbiegt, muß mit, muß für fünf Minuten seinen grauen Alltag vergessen, muß sich den vielen fröhlichen Gesichtern, dem zwanglosen Rhythmus anpassen. Ein großer Film wird da zwischen 11 und 1 gedreht und sowohl der Verkehrsschutzmann wie ein beliebiger Dienstmann spielen mit. Und alle Rollen sind gut besetzt und die Leitung scheint in den Händen eines großen begabten Regisseurs zu sein.“73

Als diese Reportage im Mai 1934 erscheint, ist Österreich soeben zur Diktatur geworden. Wenige Monate zuvor, im Februar 1934, wurde in einem Bürgerkrieg die linke Opposition ausgeschaltet, am
1. Mai wird die Republik auch formal abgeschafft und durch eine neue „ständestaatliche“ Verfassung ersetzt. Lechenperg, der die blutigen Ereignisse im Februar selbst erlebt und darüber sogar exklusiv in der Berliner Illustrirten Zeitung berichtet hat ${ }^{74}$, blendet diese Vorgeschichte vollkommen aus und zeichnet in seiner Reportage bewusst ein friedliches, harmonisches Bild von Wien. Er stellt das noch vor Kurzem sozialdemokratische Wien am Beispiel der Kärntner Straße als Bilderbuchstadt zauberhafter Heiterkeit und Gelassenheit dar. Die angebliche „Harmlosigkeit und Fröhlichkeit seiner Einwohner" will vergessen machen, dass hinter dieser Fassade der Unbeschwertheit ein neues Regime mit eiserner Gewalt herrscht. Es ist kein Zufall, dass die Doppelseite in der Modernen Welt erscheint, die seit Anfang der 1930er Jahre einen immer konservativeren Kurs steuert und das neue austrofaschistische Regime offen unterstützt.

\section{Bildgeschichten ohne Worte}

Einen eigenen, sehr selbstständigen Stil in der Fotoreportage der 1930er Jahre entwickelt Robert Haas. Er ist einer der wichtigsten Mitarbeiter der 1934 gegründeten illustrierten Wochenzeitung Der Sonntag, für die er regelmäßig Reportagen zusammenstellt. ${ }^{75}$ Aber auch in anderen Zeitschriften macht sich seine grafische und fotografische Handschrift bemerkbar. Der ausgebildete Grafiker und Typograf, ${ }^{76}$ der erst Anfang der 1930er Jahre beruflich zur Fotografie stößt, ist einer der wenigen Fotografen, die ein gewichtiges Wort bei der Gestaltung mitzureden haben. Er hat selbst Erfahrung in der Zeitschriftengestaltung ${ }^{77}$ und experimentiert gerne auch mit fotografischen Mitteln. Anfang August 1935, rechtzeitig zu den Salzburger Festspielen, stellt Haas für die Zeitschrift Die Bühne eine Art Fotoreportage zusammen, die - außer dem Titel und dem Hinweis auf den Fotografen - ganz ohne redaktionellen Text auskommt (Abb. 30). Die Bildgeschichte mit dem Titel „Alle Straßen führen nach Salzburg“ wirft einen ungewohnten Blick auf die Festspielstadt Salzburg. Ihr internationales Flair wird anhand eines Tableaus von Kfz-Länderkennzeichen vorgeführt, die auf der Doppelseite wie wild zusammengewürfelt erscheinen. 

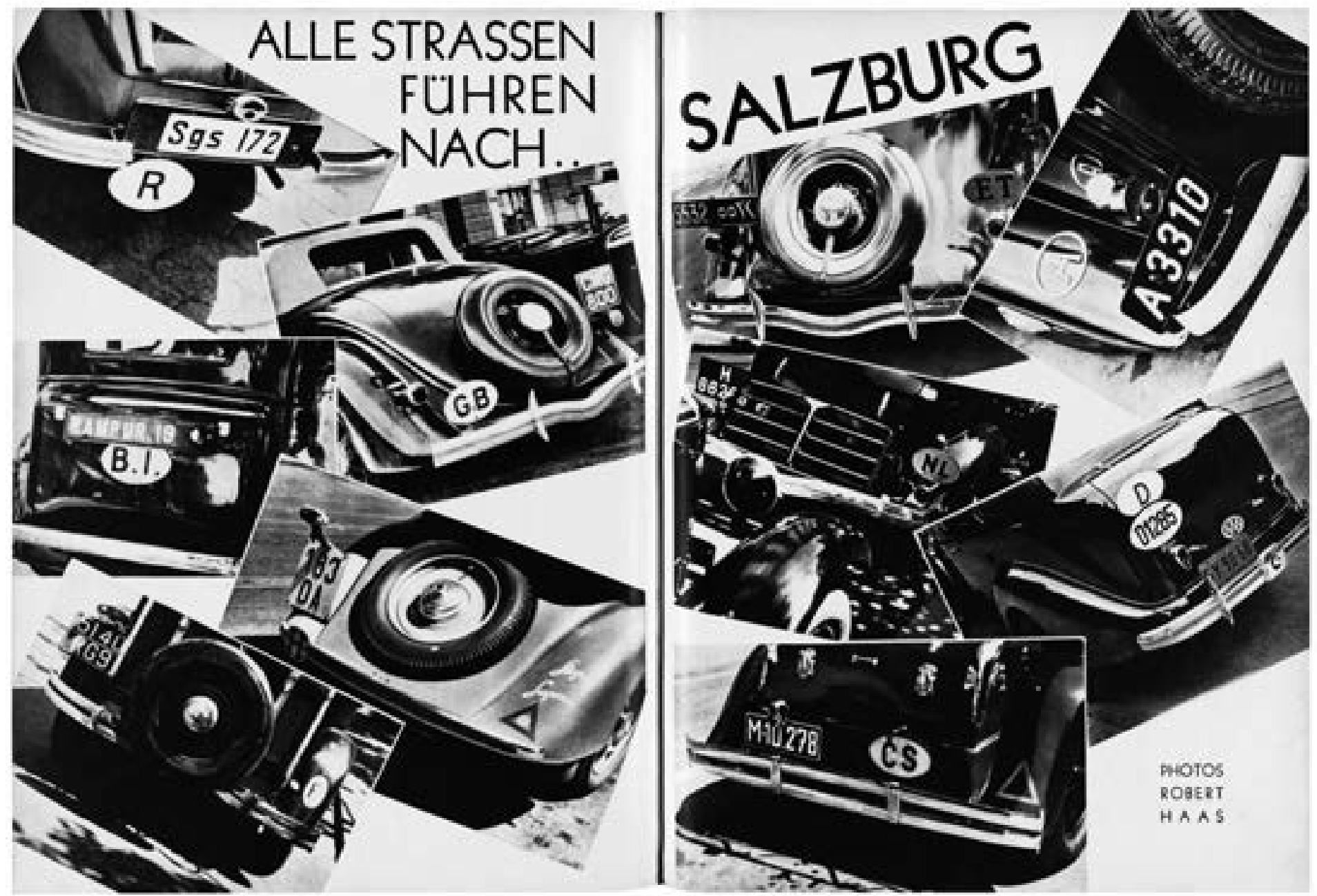

Abb. 30 „Alle Straßen führen nach Salzburg“. Bilddoppelseite von Robert Haas anlässlich der Salzburger Festspiele 1935. Die Bühne, Erstes Augustheft 1935, S. 34/35.
Von überall her, so die augenzwinkernde Botschaft der Zusammenstellung, kommen die Gäste, das heißt: Alle Straßen führen nach Salzburg.

Weiter hinten im selben Heft gestaltet Haas noch eine weitere Bildseite, die ebenfalls ganz ohne redaktionellen Text auskommt und unter dem Titel „Fremde vor der Einkleidung“ steht (Abb.31). Auch hier fängt Haas auf witzig-ironische Art die Atmosphäre in der Festspielstadt im August ein. Die „Fremden“, die mit dem Auto von weither anreisen (siehe Bild in der Mitte) verwandeln sich, kaum sind sie angekommen, mittels Trachten, die in der Innenstadt verkauft werden, in Möchtegern-Einheimische.

Eine ganz andere, ebenfalls wortlose Bilderzählung (wenn auch keine Fotoreportage im engeren Sinne) stellt Haas zwei Jahre später für den Öster-
reich-Pavillon der Weltausstellung in Paris 1937 zusammen. ${ }^{78}$ Er entwirft für das Innere des von Oswald Haerdtl geplanten Pavillons eine überdimensionale, raumfüllende Fotomontage. Diese zeigt eine aus zahlreichen Einzelbildern konstruierte österreichische Hochgebirgslandschaft, durch die sich drei in den 1930er Jahren neu erbaute Passstraßen winden - die Großglockner-, die Pack- und die Gesäusestraße (Abb. 32). Alle drei Bauwerke gehören in den 1930er Jahren zu den propagandistischen Vorzeigeprojekten der austrofaschistischen Regierung. Die Montage vermittelt also, ganz ohne Worte und dennoch einem breiten Publikum verständlich, eine konkrete Botschaft. Im Bildfries verdichtet sich, im Einklang mit den Zielen der „ständestaatlichen“ Regierung, das Idealbild eines selbstbewussten, unabhängigen, patriotischen 


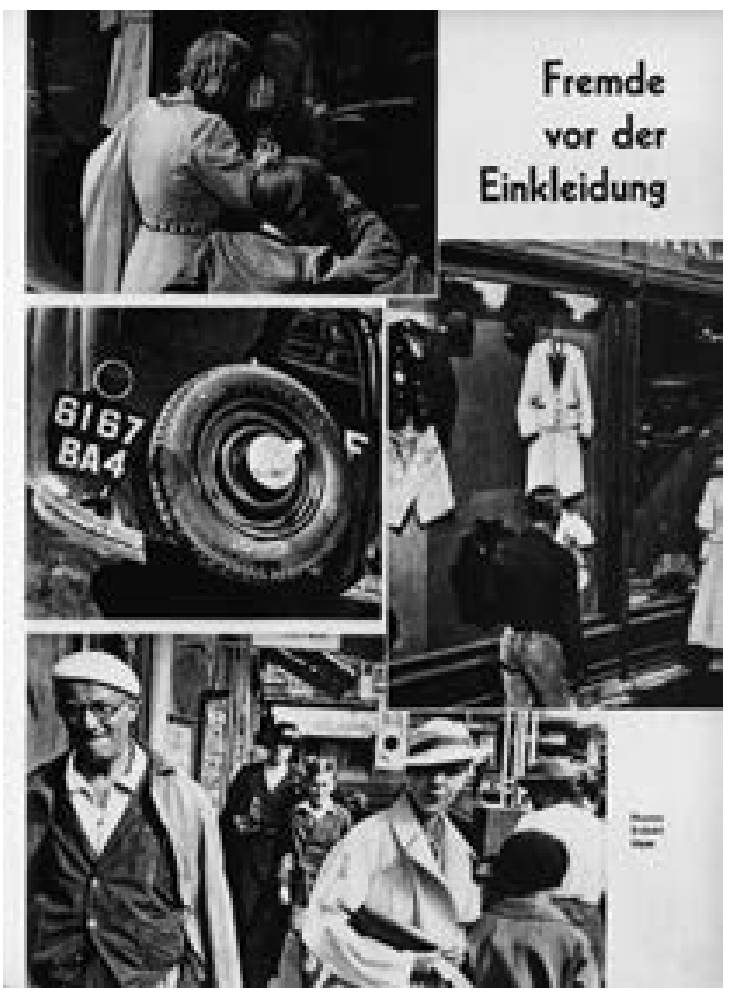

Abb. 31 „Fremde vor der Einkleidung“. Bildseite von Robert Haas anlässlich der Salzburger Festspiele 1935. Die Bühne, Erstes Augustheft 1935, S. 41.

Abb. 32 „Österreichs Bergstraßen“. Eine monumentale Fotomontage (30,2 × 8,6 Meter), konzipiert von Robert Haas für die Pariser Weltausstellung 1937. Die Bühne, Erstes Maiheft 1937, S. 30/31.

Gebirgsstaates. Nicht die Hochkultur, nicht die Großstadt Wien, sondern die monumentale heimatliche Naturlandschaft und die Errungenschaften der Technik sind die Protagonisten in dieser Inszenierung. Gut eineinhalb Jahre später, nach dem Einmarsch der Nationalsozialisten in Österreich, wird diese stolze, wehrhafte Bildgeschichte schon Vergangenheit sein. Robert Haas, von dem die Entwürfe stammen, muss - da er jüdischer Herkunft ist - am 30. September 1938 aus Österreich fliehen. ${ }^{79}$

을
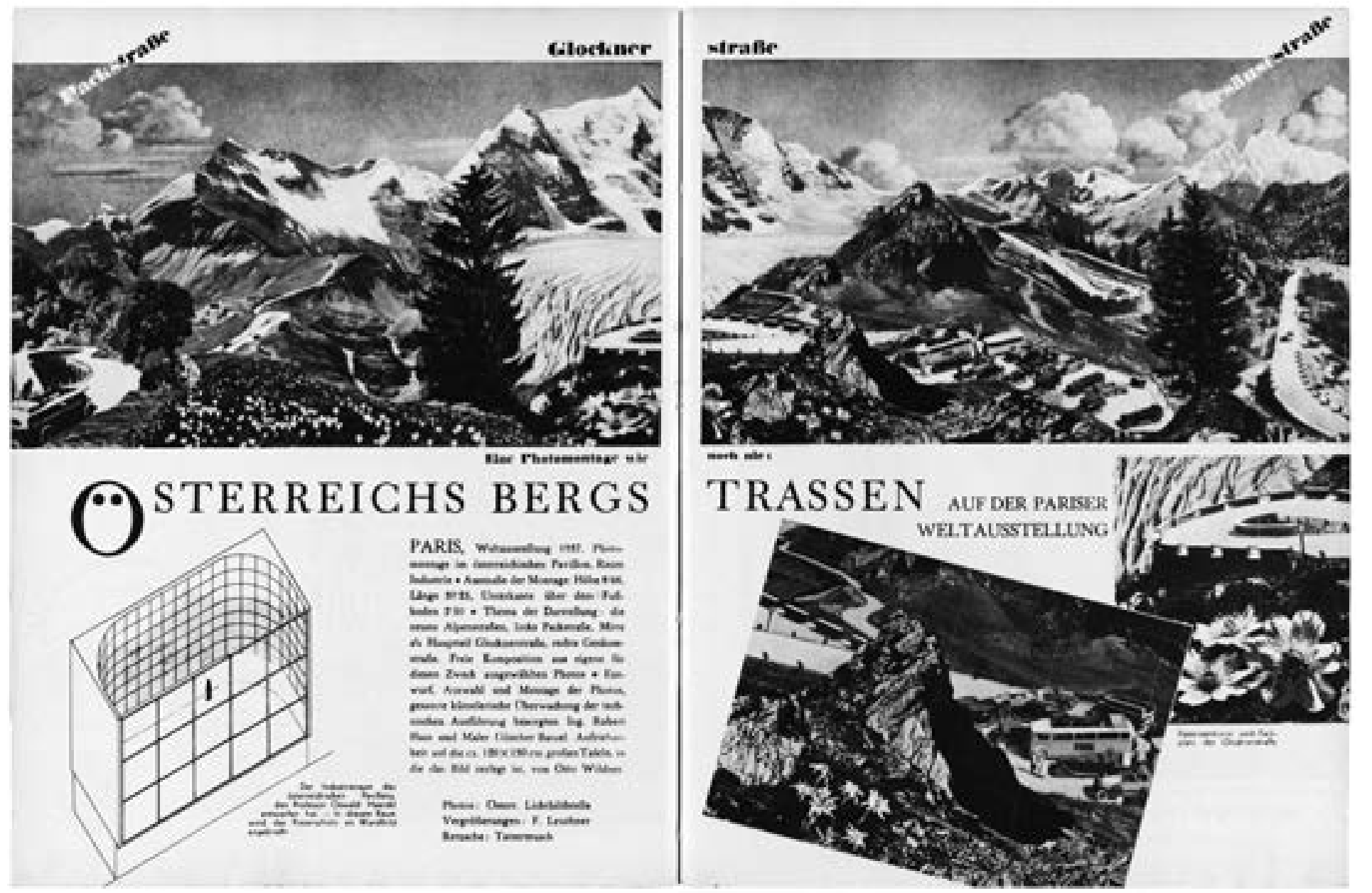


\title{
Handel mit Bildern
}

\author{
Die Rolle der Fotoagenturen
}

Als Wilhelm Willinger Ende Juni 1919 in Wien das Fotografengewerbe anmeldet und Ende November desselben Jahres ein Atelier eröffnet, ist er beruflich kein Newcomer mehr. Er hat zu diesem Zeitpunkt bereits zwei Jahrzehnte Berufserfahrung gesammelt und zunächst in Budapest, später in Berlin gut gehende Ateliers betrieben. ${ }^{1}$ Geboren 1879 als Mór Wilhelm Willinger, eröffnet er um 1900 sein erstes Atelier in Budapest. Um 1909 zieht er nach Berlin, wo er ebenfalls als Fotograf tätig ist. Im Ersten Weltkrieg macht Willinger als Offizier der k.u.k. Armee Porträtaufnahmen von Offizieren und Militärkommandanten.

Kaum ist der Krieg zu Ende, zieht Wilhelm Willinger - den ungarischen Vornamen Mór (Maurus) unterschlägt er fortan im deutschsprachigen Umfeld - von Berlin nach Wien. Sein Ziel ist es, das florierende Unternehmen weiter auszubauen. In Wien wird ein zusätzlicher Standort des Familienbetriebs eingerichtet, der bald als Firmenzentrale fungiert. Später wird eine Dependance in Paris dazukommen, auch die $\mathrm{Au}^{-}$ Benstelle in Budapest wird weitergeführt. Das Berliner Atelier wird zwischen 1920 und 1934 von seiner Frau Margarete geleitet, die ebenfalls Fotografin ist. Ende der 1920er Jahre arbeitet auch der Sohn, László Willinger, geb. 1909, in der Berliner Niederlassung mit. ${ }^{2}$

Das neue Wiener Atelier eröffnet Wilhelm Willinger selbstbewusst in bester Innenstadtlage, nämlich in der Kärntner Straße 28, inmitten der mondänsten Wiener Einkaufsstraße. Willinger baut das Unternehmen zunächst zusammen mit einem Kompagnon, Hans Schnapper, auf. Im Oktober 1921 trennen sich die beiden geschäftlich und Willinger wird zum Alleininhaber. Das Atelier beliefert die aristokratische und bürgerliche Wiener Gesellschaft mit Porträts, es spezialisiert sich aber auch auf die Theaterfotografie. Angeboten werden nicht nur Schauspielerporträts, sondern auch Szenenbilder von Stücken, die an den großen Wiener Bühnen gespielt werden, etwa im Burgtheater und in der Oper.
Als führender Kopf der schnell wachsenden Firma steht Wilhelm Willinger längst nicht mehr selbst hinter der Kamera, vielmehr führt er die Geschäfte. Die tägliche Arbeit überlässt er angestellten Fotografen und Assistenten. Von Wien aus dirigiert er in der Zwischenkriegszeit ein beachtliches Fotoimperium - es ist das größte Unternehmen seiner Art in ganz Österreich. Allein in der Wiener Zentrale arbeiten zeitweise bis zu 30 angestellte Fotografen.

\section{Weichenstellung in Richtung Fotoagentur}

Die Karriere Wilhelm Willingers wäre nicht weiter bemerkenswert, hätte er nicht schon früh Entscheidungen getroffen, die den kommerziellen Aufstieg seines Unternehmens in neue Bahnen lenken werden. Wie viele andere Lichtbildner auch beginnt er um die Jahrhundertwende als klassischer Atelierfotograf. Er lebt in den ersten Jahren von jenen Kunden, die zu ihm ins Atelier kommen. Aber bereits vor dem Ersten Weltkrieg - das war bisher nicht bekannt - beginnt er neben seinem laufenden Fotobetrieb in Berlin, Bilder an die illustrierte Presse zu verkaufen. Ab 1912 beliefert er v. a. die Ullstein-Presse mit Schauspielerporträts, die im Atelier aufgenommen werden, aber auch mit Szenenfotos, etwa vom Theater am Nollendorfplatz, die u.a. in der Zeitschrift Die Dame erscheinen. ${ }^{3}$ Ebenfalls in diesen Jahren bietet er bereits Pressebilder an, die nichts mit der Atelierfotografie oder dem Theater zu tun haben. 1914 etwa verkauft er an Ullstein eine bemerkenswerte Fotoserie, die ein thematisch vollkommen neues Kapitel seiner fotografischen Tätigkeit eröffnet. Es ist eine sozialdokumentarische Arbeit über Leben und Alltag im Altersheim Berlin-Buch, die in der illustrierten Wochenendbeilage der renommierten bürgerlich-liberalen Vossischen Zeitung veröffentlicht wird. ${ }^{4}$ Diese erscheint seit Anfang 1914 im Ullstein Verlag. Mit diesem Bildbericht signalisiert Willinger, dass er 


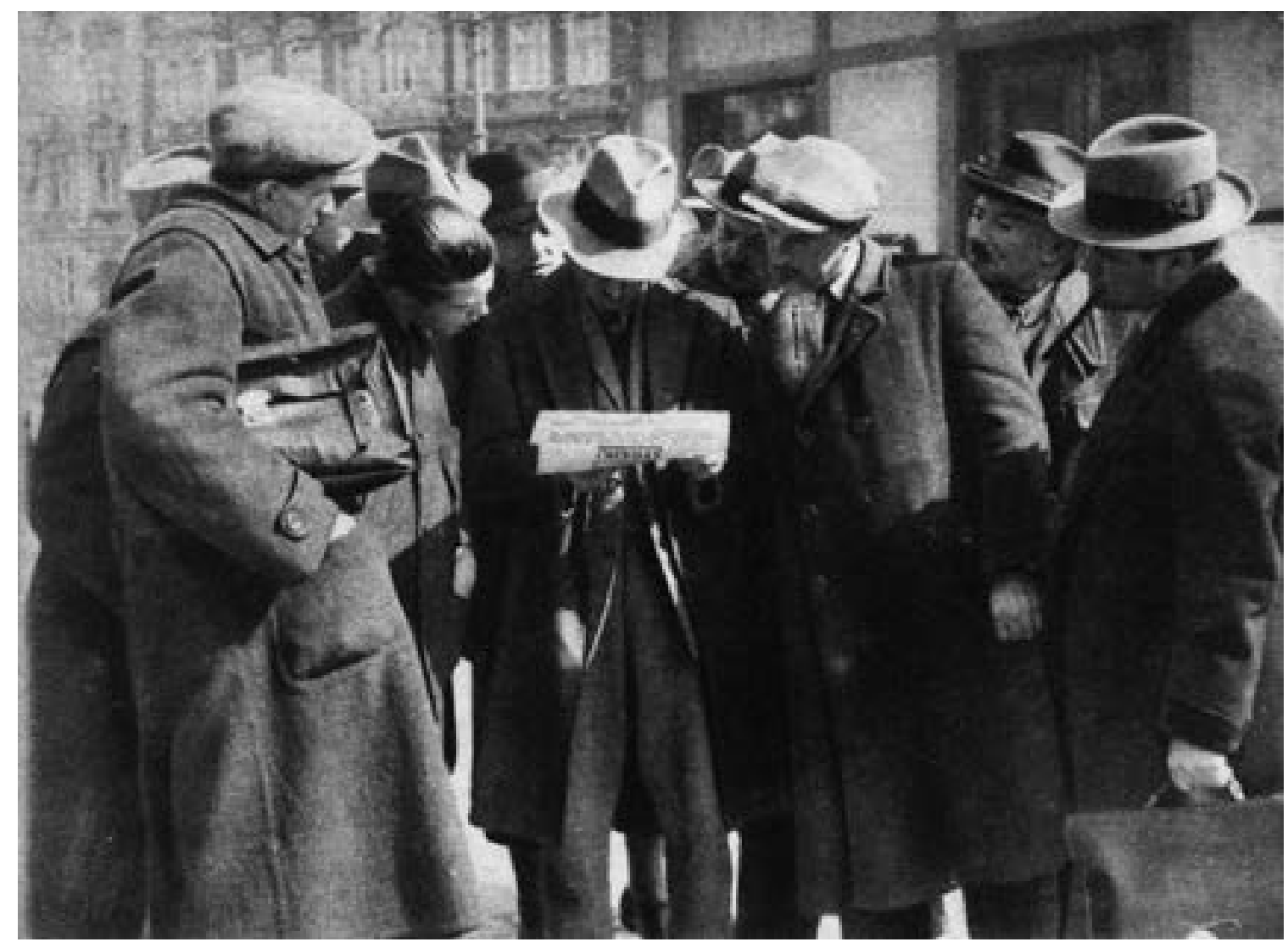

nicht nur im Bereich der Atelier- und Theaterfotografie tätig ist, sondern auch im Metier der herkömmlichen Pressefotografie. Bereits vor dem Ersten Weltkrieg strebt Willinger also eine Erweiterung seines bisherigen Geschäftsfeldes an. Er stellt die Weichen für den Handel mit Bildern und er bewegt sich in Richtung einer Fotoagentur.

Der Erste Weltkrieg und die Einberufung zum Militär durchkreuzen jedoch vorerst den Plan, das Unternehmen zur Fotoagentur zu erweitern. Erst in Wien kann Willinger sein Berliner Vorhaben umsetzen. Es ist bezeichnend, dass sein geschäftliches Engagement in Wien nicht mit der Ateliergründung, sondern bereits Monate zuvor mit dem Verkauf von Bildern an die illustrierte Presse beginnt. Die ersten Fotos von Willinger in der österreichischen Presse erscheinen im Dezember 1918, wenige Wochen nach Kriegsende, in der neu gegründeten Monatszeitschrift Moderne Welt. ${ }^{5}$ Es sind, auch das ist bemerkenswert, keine klassischen Atelierporträts, sondern Modeaufnahmen. Kurz darauf, im Frühjahr 1919, liefert er dem Interessanten Blatt, der führenden Wiener Wochenillustrierten, erste Szenenaufnahmen von Theater- und Opernaufführungen. Später, ab Herbst 1919, werden auch in dieser Zeitung Modeaufnahmen von Willinger gedruckt. Bis 1921 erscheinen die Fotos unter dem Namen „Willinger \& Schnapper“ bzw. „Phot. Werkstät- te Willinger \& Schnapper“, danach unter dem Namen „Willinger“.

Anfang der 1920er Jahre bildet der Handel mit Bildern noch nicht die zentrale Einnahmequelle des Unternehmens. Das Ateliergeschäft steht noch im Vordergrund. Ab Mitte 1920 erweitert Willinger jedoch seinen Wiener Betrieb Schritt für Schritt in Richtung Fotoagentur. Die Bilder, die nun in der Presse erscheinen, entfernen sich mehr und mehr vom Repertoire der klassischen Atelierfotografie. Es sind - neben den Theateraufnahmen, die er weiterhin im Programm hat - Alltagsbilder, Genreaufnahmen und v.a. Bilder aktueller Ereignisse (Abb. 1). Damit reagiert der Unternehmer auf die in diesen Jahren stark ansteigende Nachfrage nach Agenturbildern.

Um 1930 geht Willinger eine Reihe von kommerziellen Kooperationen ein, die dazu dienen, die Expansion in Richtung Fotoagentur voranzutreiben. Anfang 1929 gründet er zusammen mit den beiden Pressefotografen Leo Ernst und Fred Cešanek, die ihre Bilder seit Mitte 1928 unter dem Namen „Ernst \& Cešanek“ vermarkten, eine Vertriebsgemeinschaft unter dem Agenturnamen „Austrophot - Willinger, Ernst \& Cešanek“. Auf diese Weise sichert sich Willinger aktuelle Nachrichtenbilder, die die beiden Fotografen liefern. Umgekehrt profitieren diese vom guten Vertriebsnetz Willingers. Die Zusammenarbeit währt aber nur kurz.
Abb. 1 Streik der Wiener Zeitungssetzer 1933. Aus Protest gegen die Verhängung der Vorzensur gegen sozialdemokratische Blätter treten die Setzer in den Ausstand. Es erscheinen nur vereinzelt Zeitungsausgaben und Mitteilungsblätter. Das interessante Blatt, 30. März 1933, S. 5. Foto: Agentur Willinger. 
Bereits 1931 gehen die beiden Pressefotografen wieder ihre eigenen Wege. ${ }^{6} 1930$ gelingt Willinger ein größerer kommerzieller Coup: Er übernimmt die seit der Jahrhundertwende führende österreichische Fotoagentur R. Lechner (Wilh. Müller). Im Oktober 1930 tauchen erstmals Bilder in den Zeitungen auf, die mit „Oe.P.B. Willinger-Lechner“ gekennzeichnet sind. Das Kürzel steht für „Österreichischer Presse Bilddienst Willinger \& Lechner“.7 Mit einem Schlag ist Willinger nun die mit Abstand größte Fotoagentur des Landes, eine Stellung, die das Unternehmen bis Ende der 1930er Jahre behaupten kann. ${ }^{8}$ Ebenfalls Anfang der 1930er Jahre beginnt Willinger eine Zusammenarbeit mit der international operierenden Agentur Keystone. Das Wiener Unternehmen liefert an die in London, Paris und Berlin ansässige Fotoagentur aktuelle Nachrichtenbilder aus Österreich. ${ }^{9}$ Um 1930 deckt Willinger bereits das gesamte thematische Spektrum der Pressefotografie ab. Er liefert aktuelle Nachrichtenbilder ebenso wie Sport-, Mode- und Theateraufnahmen, außerdem Landschafts- und Genrebilder.

\section{Ein neuer Fotomarkt entsteht}

Wieso ist Wilhelm Willinger mit seiner Fotoagentur in der Zwischenkriegszeit so erfolgreich? Die Gründe dafür sind vielfältig. Ein wichtiger Grund liegt wohl darin, dass es ihm gelingt, die Anregungen der Berliner Presseszene nach Wien zu transferieren. Die pulsierende Metropole Berlin ist in den Jahren nach der Jahrhundertwende nämlich der Schrittmacher im Zeitungsgeschäft. In keiner anderen europäischen Stadt verändert und modernisiert sich die Presselandschaft innerhalb kürzester Zeit derart rasant. Willinger, der die Berliner Zeitungslandschaft aus der Nähe kennengelernt hat, nutzt seine Erfahrungen und Kontakte, um in der Zwischenkriegszeit zur führenden Wiener Fotoagentur aufzusteigen. ${ }^{10}$ Er ist ein findiger Unternehmer und versteht es, sich optimal auf die Bedürfnisse des Marktes einzustellen. Er liefert eben das, was nachgefragt wird. Zu dieser Marktstrategie gehört u.a., die thematische Bandbreite des Angebots besonders breit zu streuen, ästhetische Experimente zu meiden und handwerklich gut gemachtes Mittelmaß anzubieten, um möglichst viele
Redaktionen zufriedenzustellen. Die Fotografen, die Willinger unter Vertrag hat, treten zudem nicht unter eigenem Namen auf. Sie sind lediglich anonyme Zulieferer für ein großes Medienhaus.

Obwohl er in der Vermarktung von Bildern besonders erfolgreich ist, ist Willinger kein Vorreiter im österreichischen Agenturgeschäft. Schon lange vor ihm haben andere Fotografen mit dem Fotohandel begonnen. Das zeigt sich allein daran, dass jene Fotoagentur, die Willinger 1930 übernimmt, die Firma R. Lechner (Wilh. Müller), gut zwei Jahrzehnte älter ist als sein eigenes Agenturgeschäft. Sie wurde bereits vor der Jahrhundertwende gegründet. ${ }^{11}$ Um und nach 1900 spezialisieren sich, wie wir gesehen haben, weitere Fotografen auf die Belieferung der Presse, etwa Heydenhaus \& Robert (um 1900), Sieger-Sobotka (ab 1904), Carl Seebald mit seiner Illustrations-Zentrale (ab 1908), Josef Perscheids Welt-Preß-Photo (ab 1912) und Kilophot (ab 1912). Auch deutsche Fotoagenturen sind nach der Jahrhundertwende in Wien präsent, etwa Zander \& Labisch (ab 1900) und die Berliner Illustrations-Gesellschaft (ab 1906). Letztere verfügt mit Heinrich Sanden sogar über einen Mitarbeiter in Wien. Er beliefert die Berliner Agentur von 1908 bis 1913 mit aktuellen Pressebildern.

Während des Ersten Weltkriegs spezialisieren sich einige Agenturen auf die Kriegsfotografie. ${ }^{12}$ Auf diese Weise gelingt es ihnen, ihre Geschäftstätigkeit deutlich auszudehnen. Möglich ist diese Expansion u. a. dank der Mitarbeit von Frauen im Agenturbetrieb, die die Männer, die an die Front gegangen sind, ersetzen. ${ }^{13}$ Die vor und während des Ersten Weltkriegs führenden österreichischen Fotoagenturen, insbesondere Welt-Preß-Photo, Kilophot und die Illustrations-Zentrale, können ihre dominante Stellung in der Zwischenkriegszeit allerdings nicht aufrechterhalten. ${ }^{14}$

Das Unternehmen Willinger ist zwar ein besonders anschauliches Beispielfür die tief greifenden und folgenreichen Veränderungen in der Bildpresse in den ersten Jahrzehnten nach der Jahrhundertwende. Aber seine Geschichte ist keineswegs typisch für die geschäftliche Entwicklung der zahlreichen anderen Fotoagenturen, die in der Zwischenkriegszeit gegründet werden. Bereits vor dem Ersten Weltkrieg sind die Fotoagenturen in der Regel Klein- und Kleinstbetrie- 
be, die oft nur einige wenige oder gar keine angestellten Mitarbeiter haben. Das ändert sich auch in den Jahren nach dem Krieg nicht. Ein Gutteil der Ende der 1920er, Anfang der 1930er Jahre neu gegründeten Agenturen sind in diesen Jahren Ein-Mann-Betriebe. Aber auch die Karrieremuster unterscheiden sich grundlegend von der Geschäftsentwicklung Willingers. In seinem Fall führt der Weg vom klassischen Atelierfotografen über den ergänzenden Agenturbetrieb bis hin zur marktbeherrschenden Fotoagentur. Die Gründungs- und Unternehmensgeschichte der meisten Agenturen verläuft anders: Sie werden nicht von Atelier-, sondern von Pressefotografen gegründet. Viele von ihnen betreiben ihre Agenturtätigkeit zunächst nebenbei und arbeiten weiterhin als aktive Fotografen. Gelegentlich schließen sich solche Einzelkämpfer zu wechselnden Vertriebskooperationen zusammen. ${ }^{15}$ Viele dieser Kleinunternehmen existieren oft nur wenige Jahre lang.

Ab Mitte der 1920er Jahre verändert sich das Pressebildgeschäft grundlegend. Der Bedarf an Bildern steigt rasant an, bedingt vor allem durch Zeitungsund Magazinneugründungen, aber auch durch Auflagensteigerungen und die deutliche Ausweitung der Fotoberichterstattung. Es kommt zu einer starken Internationalisierung des Handels mit Bildern und in der Folge auch zu einer Internationalisierung der Berichterstattung. Zwar lassen sich die Ansätze eines übernationalen Handels mit Fotografien bereits bis zur Jahrhundertwende zurückverfolgen, aber erst ab den 1920er Jahren werden Fotos zur täglichen Handelsware, die in großer Zahl über nationale Grenzen hinweg ge- und verkauft werden. ${ }^{16}$ Einen wichtigen Einschnitt in dieser Entwicklung bildet das Ende des Ersten Weltkriegs. Die nationale Abschottung, eine Folge der nationalen Aufrüstung und der Zensurpolitik zwischen 1914 und 1918, wird nun aufgehoben, der Handel mit Fotografien über die nationalen Grenzen hinweg kommt wieder in Schwung. Bereits 1919, im ersten Nachkriegsjahr, tauchen in den österreichischen Illustrierten wieder verstärkt Bilder international tätiger Fotoagenturen auf, ab Mitte der 1920er Jahre sind deutsche, amerikanische und englische Agenturen in Wien allgegenwärtig. Der Großteil der Aufnahmen aus Übersee sind Genrebilder, Mode-

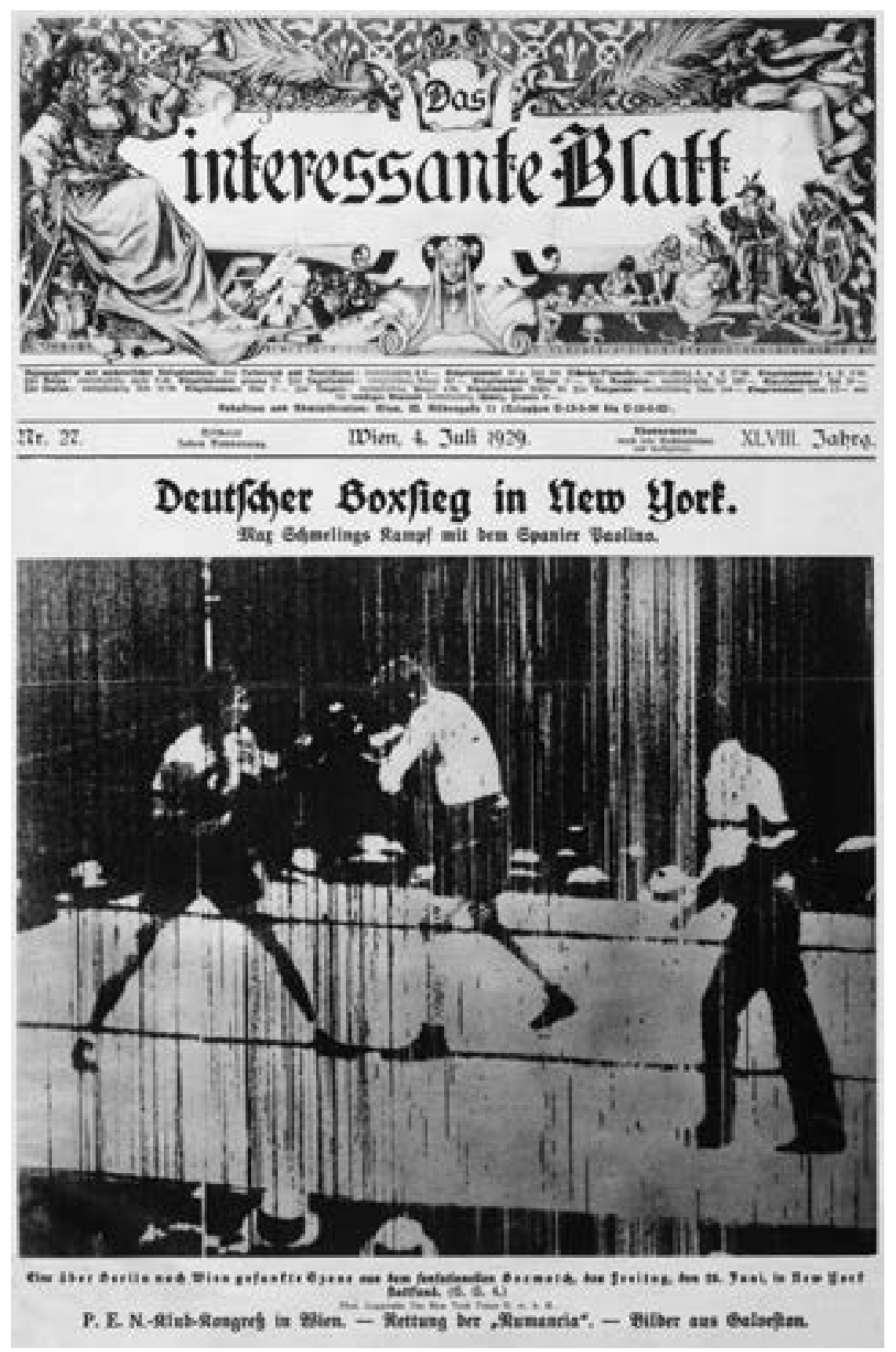

oder Filmfotos, also Aufnahmen, die auch Wochen später - so lange dauert der Seeweg - gedruckt werden können. Aktuelle Nachrichtenbilder aus Übersee hingegen sind in der Zwischenkriegszeit die absolute Ausnahme. Als im Juli 1929 eine Aufnahme vom legendären Boxkampf Max Schmelings in New York per Funk nach Europa übertragen und wenige Tage später gedruckt wird (Abb. 2), gleicht das einer Sensation. ${ }^{17}$ Immerhin hatte das Match erst wenige Tage zuvor, am 28. Juni, stattgefunden. Das undeutliche, gestreifte Bild zeigt deutliche Spuren seiner aufwendigen Übermittlung.

Neben den großen deutschen Fotoagenturen ${ }^{18}$ wie Atlantic, Sennecke, Photothek Römer \& Bernstein,
Abb. 2 Sensationelles Funkbild aus New York, 1929. In einem legendären Boxkampf besiegt der Deutsche Max Schmeling den Spanier Paolino Uzcudun im New Yorker Yankee-Stadion vor 40000 Zuschauern in der 15. Runde nach Punkten. Wenige Tage später erscheint die Aufnahme im Interessanten Blatt, 4. Juli 1929, Titelseite. Foto: The New York Times. 
Gircke, Presse-Photo, Scherl, Weltbild und Haeckel ist in der Zwischenkriegszeit eine Reihe von amerikanischen Agenturen auf dem österreichischen Markt präsent, etwa Wide World Photos, Pacific \& Atlantic, die Agentur der New York Times, Associated Press oder Underwood \& Underwood. Auch von England aus operierende Firmen wie Continental Press Photo oder die von dem Ungarn Bert Garai in London gegründete Agentur Keystone sind in Österreich aktiv. Einige wenige französische Firmen, etwa Charles Trampus oder, im Bereich der Mode, Henri Manuel, liefern regelmäßig Bilder nach Wien. Ebenso verkaufen Agenturen aus den kleineren Nachbarländern Fotos nach Österreich. Unter anderem unterhält die Zürcher Agentur Photo-Express Kontakte nach Wien, ebenso die Prager Agentur Central European Press, aus Ungarn liefert u. a. die Fotoagentur Ill-Pho Bildmaterial $^{19}$. Fotos aus der Sowjetunion werden hauptsächlich von der 1930 in Berlin gegründeten Agentur Union-Foto (auch Unionbild) und der Moskauer Agentur Preß-Cliché angeboten. Beide sind vor allem in der kommunistischen und sozialdemokratischen Bildpresse vertreten. ${ }^{20}$

Nach 1930 stoßen zu diesen klassischen Fotoagenturen auch neue Vertriebsformen hinzu. Vor allem die großen amerikanischen Filmfirmen wie MGM, Paramount oder Fox, aber auch die deutschen UFA-Studios bringen nun vermehrt eigene Bilder auf den Markt: Es handelt sich um Filmstills und Staraufnahmen, die für die neuesten Streifen werben. In zunehmendem Maße werden aber auch Modefotos angeboten, die in Zusammenarbeit mit berühmten Schauspielern der großen Produktionsfirmen entstehen. Diese Entwicklung führt dazu, dass die heimische Modefotografie ab etwa 1930 unter starkem Konkurrenzdruck aus dem Ausland steht. ${ }^{21}$

Die meisten der großen Fotoagenturen haben ein breites Bildangebot im Programm. Der Schwerpunkt liegt in der Regel im Bereich der aktuellen Nachrichtenbilder, teilweise reicht aber das Angebot weit darüber hinaus. Um 1930 taucht in Berlin ein neuer Typus von Fotoagentur auf, der alternative Wege in der Bildvermarktung einschlägt. ${ }^{22} \mathrm{Zu}$ dieser Gruppe gehört etwa die 1927 von dem Wiener Rudolf Birnbach, geb. 1906, gegründete Agentur Weltrundschau und die 1928 ebenfalls von einem Wiener namens Simon Guttmann, geb. 1891, gegründete Dephot. Sie unterscheiden sich von den großen Agenturen dadurch, dass sie statt Massenware gehobene Bildqualität anbieten. Neben Einzelbildern liefern sie häufig Fotoreportagen, die den Fotografen eine prominente Position einräumen. ${ }^{23}$ Dephot und Weltrundschau erheben nicht den Anspruch, alle wichtigen Tagesereignisse fotografisch abzudecken. Stattdessen berichten sie über ausgewählte, teilweise auch ganz alltägliche Themen, sehr oft bieten sie auch längere Reiseberichte an. Einige andere kleine Berliner Agenturen, etwa Mauritius (ab 1929), Neofot (ab 1930) und Kluger-Szigethy (ab 1930) arbeiten ähnlich wie Dephot und Weltrundschau, allerdings liefern sie hauptsächlich Einzelbilder, den Weg in Richtung Fotoreportage gehen sie weniger konsequent. Sie beliefern zwar hauptsächlich deutsche Blätter, aber der Einfluss dieser kleinen, anspruchsvollen Berliner Agenturen ist um 1930 auch in der Wiener illustrierten Presse spürbar.

Anfang 1929 erscheinen die ersten Aufnahmen der Dephot-Fotografen Umbo (Otto Umbehr) und Felix H. Man (Hans Felix Baumann) in der österreichischen Presse, seit Anfang 1930 sind die Agenturen Weltrundschau und Mauritius in Wien präsent, seit 1931 Kluger-Szigethy. Diese innovativen Bildlieferanten tragen nicht unwesentlich zur Modernisierung der Fotoberichterstattung bei. 1933, nach dem Machtantritt der Nationalsozialisten, bricht dieser Einfluss allerdings schlagartig ab. Ein Gutteil der zuletzt genannten Agenturen werden von jüdischen Inhabern geführt bzw. haben Fotografen jüdischer Herkunft unter Vertrag. Viele von ihnen flüchten ins Ausland. ${ }^{24}$ Die zwangsenteigneten Betriebe existieren zwar teilweise - meist unter neuer Führung - auch nach 1933 weiter. ${ }^{25}$ Einige von ihnen liefern unter dem ursprünglichen Namen weiterhin Bildmaterial nach Österreich. Aber im Grunde handelt es sich um neue Firmen.

Einige der großen, übernational agierenden Fotoagenturen errichten nach dem Ersten Weltkrieg ein weltweites Netz an Vertriebsstützpunkten bzw. Dependancen. Auch in Wien werden seit Mitte der 1920er Jahre solche Außenstellen eröffnet: Meist er- 
folgt die Zusammenarbeit mit einem vor Ort tätigen Fotografen oder einer einheimischen Agentur. Diese haben in der Regel eine doppelte Aufgabe zu erfüllen: Sie übernehmen die regionale Vermarktung und zugleich speisen sie eigene aktuelle Nachrichtenbilder in das große Firmennetzwerk ein. Um nur einige Beispiele zu nennen: Wide World Photos arbeitet mit Albert Hilscher und Leo Ernst zusammen, Karl Schleich übernimmt die Repräsentanz der deutschen Sportbildagentur Max Schirner, Robert Schostal vertritt die Fotoagentur Keystone in Österreich und auch Pacific \& Atlantic haben in Wien einen Repräsentanten.

In den späten 1920er Jahren herrscht unter den Anbietern von Pressebildern eine Art Goldgräberstimmung. Jahr für Jahr steigt die Zahl der gedruckten Bilder. Inzwischen greifen praktisch alle Zeitungen auf Agenturbilder zurück. Direkte kommerzielle Kontakte zu den Fotografen sind nun die Ausnahme. In dieser überhitzten Stimmung, in der der Verkauf von aktuellen Nachrichtenbildern schnelle Gewinne verspricht, stürzen sich zahlreiche einheimische Neuunternehmer ins Geschäft und eröffnen eine Fotoagentur.

Die Liste der in der Zwischenkriegszeit agierenden Fotoagenturen ist beeindruckend. Sie heißen etwa Pisafot, Telephot, Kilophot, Kleinberg, Schleich-Hilscher, Ernst-Hilscher, Omniphot, Radiophot, R. K. O., Postiag, Austrophot, Dietrich \& Co., Wiener Photo-Kurier, Schostal, Polyphot, Welt-Preß-Photo, Prisma Press, Photo-Zentrale, Internationale Presseagentur (Ipa), Europa-Presse-Co, Austria-Presse, Presse-Bild-Zentrale, Alpiner Pressedienst, Sammlung Raoul Korty, Bildarchiv Taussig, Illustrations-Zentrale, Österreichischer Photodienst, International-Photo-Service.

Nur einige wenige dieser Agenturen existieren schon seit Längerem. ${ }^{26}$ Die anderen sind Neugründungen, viele werden in den Jahren um 1930 eröffnet. Das Spektrum ihrer Tätigkeiten und Schwerpunkte ist breit gefächert. Einige der Agenturen, etwa der Fotosammler Raoul Korty oder das Bildarchiv Taussig, vermarkten ausschließlich historische bzw. nicht aktuelle Aufnahmen. ${ }^{27}$ Die 1919 gegründete Österreichische Lichtbildstelle fungiert seit Ende der 1920er Jahre als eine Art staatliche Fotoagentur. Sie hat die Aufgabe, topografische Ansichten und Landschaftsbilder (später auch aktuelle Aufnahmen) an die Presse zu liefern und ein patriotisches Österreichbild aufzubauen. $^{28}$

Das Bild eines breiten Feldes prosperierender Fotohändler täuscht freilich. Neben wenigen größeren professionell agierenden Agenturen gibt es zahlreiche Klein- und Kleinstunternehmen, die geschäftlich meist nur mäßigen Erfolg haben. ${ }^{29}$ Hinter manch klingendem Agenturnamen verbirgt sich nur eine einzige Person, die das Geschäft oft noch dazu im Nebenberuf (neben der eigenen Pressefotografie) betreibt. In anderen Fällen schließen sich allein arbeitende Pressefotografen zu - häufig wechselnden - Vertriebskooperationen zusammen. Die Bilder verkaufen sie meist unter dem gemeinsamen Namen, etwa Schleich-Hilscher, Ernst-Cešanek (Abb. 3) oder Ernst-Hilscher.

Aber es gibt, wie das Beispiel Lothar Rübelt zeigt, durchaus auch erfolgreiche Kleinagenturen. Seit Mitte der 1920er Jahre vertreibt er, zunächst zusammen mit seinem Bruder Ekkehard (der 1926 tödlich verunglückt), seine Bilder in Eigenregie. Die Agenturräume
Abb. 3 Prozess gegen Philipp Halsmann, der wegen Vatermordes angeklagt ist. Anlässlich der Wiederaufnahme des Verfahrens wird ein Foto vom Lokalaugenschein im Tiroler Zillertal veröffentlicht. Das interessante Blatt, 19. September 1929, Titelseite. Foto: Ernst-Cešanek.

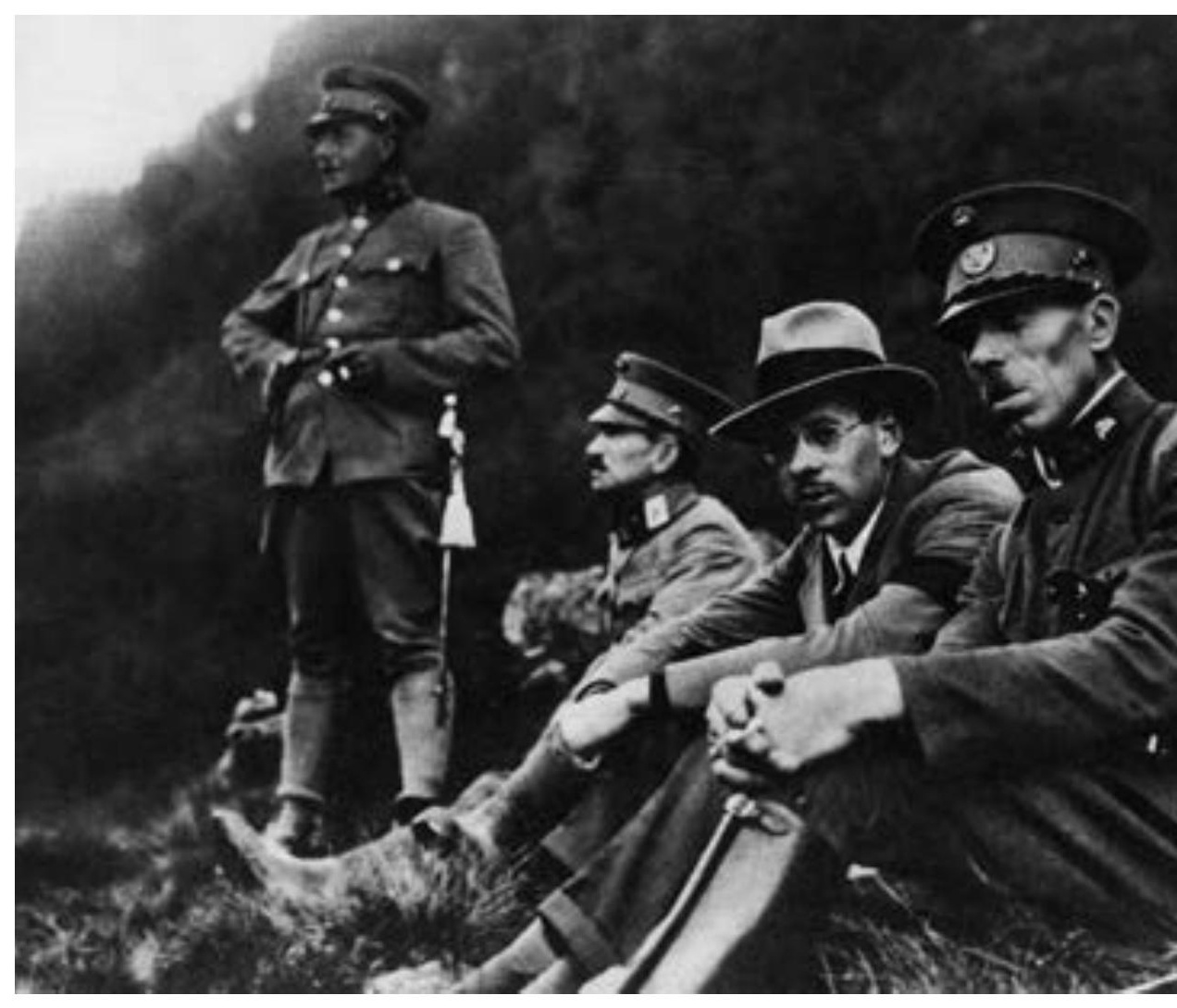


sind in seiner Wohnung, in der Wollzeile 14, Wien 1, untergebracht. ${ }^{30}$ Später sucht sich Rübelt, vor allem für die Vermarktung in Deutschland, auch Partner. Ende der 1920er Jahre arbeitet er zeitweise im Auftrag der großen deutschen Fotoagentur Scherl ${ }^{31}$, um 1930 tritt er in Geschäftsverbindung mit dem in Berlin tätigen Fotoagenten Fred Wallentin, der Rübelts Aufnahmen u. a. an Ullstein vermittelt. ${ }^{32}$

\section{Willinger, Schostal, Polyphot: die führenden Wie- ner Fotoagenturen der Zwischenkriegszeit}

Der Pressebildmarkt ist in der Zwischenkriegszeit heiß umkämpft. Die Konkurrenz, vor allem der ausländischen Anbieter, ist groß. Nur einige wenige österreichische Anbieter erreichen eine Größe, die es ihnen erlaubt, auf diesem Markt erfolgreich mitzumischen. Neben dem Marktführer Willinger (Abb.4) ist dies vor allem die von Robert Schostal gegründete Fotoagentur Wiener Photo-Kurier (später unter dem Namen „Schostal“ geführt) und die Agentur Polyphot. Über Letztere ist bis heute wenig bekannt. Gesichert ist lediglich, dass sie um 1925 gegründet wird. Anfang der 1930er Jahre hat sie ihren Sitz in der Mühlgasse 13, im 4. Wiener Gemeindebezirk. Bereits vor 1930, wenige Jahre nach ihrer Gründung, gehört die Polyphot zu den führenden Wiener Agenturen. Sie beliefert nun alle wichtigen österreichischen Zeitungen und Magazine. 1927 eröffnet das Unternehmen sogar eine Außenstelle in Berlin, die aber offenbar nur kurzzeitig Bestand hat. ${ }^{33}$ Um 1930 gehört Polyphot zu den wichtigsten österreichischen Agenturen. Allerdings existiert der Betrieb nicht sehr lange. Nach 1934 verlieren sich seine Spuren.

Ähnlich wie Willinger bietet Polyphot von Anfang an Fotos zu einem breiten Themenspektrum zur Veröffentlichung an. Neben aktuellen Nachrichtenbildern hat die Agentur auch Theater- und Modeaufnahmen, aber auch nicht aktuelle Genrebilder (Landschaften, Straßenszenen, Menschen etc.) im Programm. Diese Genreaufnahmen sind der heutigen „Stock Photography“ vergleichbar. Sie haben den Vorteil, langsamer zu altern als die Aufnahmen aktueller Ereignisse. Daher können sie ohne zeitlichen Druck veröffentlicht werden. Eingesetzt werden solche Bilder etwa zur Illustration gesellschaftlicher Themen (Kindheit, Alter, Freizeit etc.), aber auch als atmosphärische Bestandteile von Fotoreportagen, die aus Bildmaterial unterschiedlichster Herkunft zusammengestellt werden. Um 1930 zeigt sich die Agentur offen für die neuen Strömungen der Fotografie. Angeboten wird nicht nur fotografisches Mittelmaß, sondern auch Bilder, die von den Strömungen des Neuen Sehens und der Neuen Sachlichkeit beeinflusst sind.

Der Großteil der Fotos, die Polyphot vermarktet, stammt aus Österreich. Aber die Agentur bietet auch Bilder aus dem Ausland, v. a. aus Amerika, zum Verkauf an. ${ }^{34}$ Die Agentur dürfte zu diesem Zweck mit einer oder mehreren ausländischen Vertriebsfirmen kooperiert haben. Anders als etwa Willinger, der fast ausschließlich die bürgerliche Presse beliefert, bringt Polyphot seine Aufnahmen auch in der sozialdemokratischen Bildpresse unter. Im Kuckuck erscheinen beispielsweise zahlreiche Fotos dieser Agentur.

Über die fotografischen Mitarbeiter des Unternehmens wissen wir fast nichts. In der Regel werden die Fotografen der Agentur Polyphot in den Fotocredits nicht genannt. Bekannt ist lediglich, dass Karl Schöpl, ein 1896 in Budapest geborener Fotograf, für die Agentur tätig ist. Er führt ein Atelier im 5. Wiener Gemeindebezirk und arbeitet Anfang der 1930er Jahre auch für Polyphot. Seinen Namen kennen wir deshalb, weil ausnahmsweise eine seiner Fotoarbeiten namentlich gekennzeichnet ist. Von ihm stammt die Reportage über die oberösterreichische Heilanstalt Gallspach, die im Mai 1930 im Wiener Magazin erscheint. Sie ist mit „Polyphot-Schöpl“ gezeichnet. ${ }^{35}$

Die Informationslage zur Agentur Wiener Photo-Kurier (Schostal) ist deutlich besser. ${ }^{36}$ Auch dieses Unternehmen wird Mitte der 1920er Jahre, in der Aufbruchphase der österreichischen Pressefotografie, gegründet. Robert Schostal, geb. 1906, der hinter der Agentur steht, kommt über die Kunst- und Fotografenhandlung seiner Tante Jenni (Regine) Mattersdorf zum Bilderverkauf. ${ }^{37}$ Diese ist selbst Fotografin und führt in der Nähe der Wiener Hofburg, in der Schauflergasse 2, das „Magasin Metropole“, eine kleine Kunst- und Fotohandlung, in der sie u.a. auch Fotos und Postkarten von Schauspielern und Sängern anbietet. Nebenbei verkauft sie ihre Bilder an 


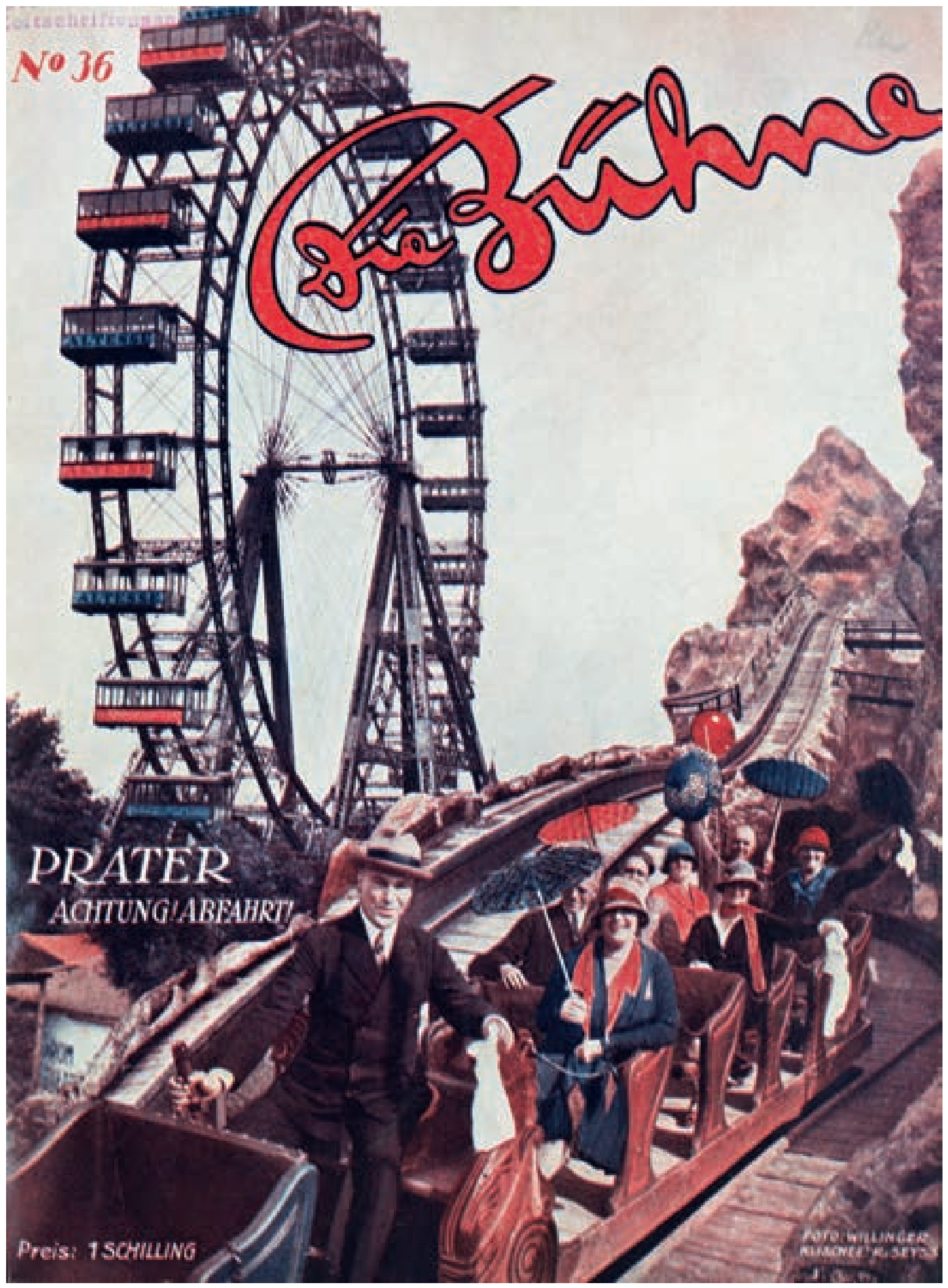

Abb. 4 „Prater. Achtung! Abfahrt!“ Die Fotoagentur Willinger hat zahlreiche populäre, leicht verdauliche Bilder im Programm und hat mit dieser Strategie Erfolg. In der Zwischenkriegszeit ist Willinger die größte österreichische Fotoagentur. Die Bühne, 16. Juli 1925, Titelseite. 
Abb. 5 Trude Fleischmann ist eine der prominentesten Wiener Fotografinnen, die die Fotoagentur Wiener Photo-Kurier (später Schostal) ab Ende der 1920er Jahre vertritt. Über die Agentur vermarktet sie nicht nur ihre Porträts, sondern auch die Reisebilder und Heimatmotive. Wiener Magazin, Heft 9 , September 1930, S. 28/29.
Zeitungen und Zeitschriften. Mattersdorf überträgt ihrem Sohn (der bald wieder aus dem Betrieb aussteigt) und ihrem Neffen Robert Schostal diesen Teil des Geschäfts. Die Finanzierung der Agentur streckt der Vater Schostals, Oscar Schostal, vor. Inhaber und Leiter ist Robert Schostal. Auch sein Bruder Walter, geb. 1908, arbeitet seit Ende der 1920er Jahre neben seinem Studium in der Agentur mit.

Im Oktober 1926 meldet Robert Schostal das Gewerbe für den Handel mit fotografischen Bildern an. Ab diesem Zeitpunkt ist der Sitz der Agentur die Wohnung der Familie Schostal in der Starhemberggasse $26 \mathrm{im} 4$. Wiener Gemeindebezirk. In den ersten Jahren trägt das Unternehmen den Namen „Wiener Photo-Kurier“, ab Anfang 1934 erscheinen die Bilder in der Presse unter dem Namen „Schostal“. Anfänglich werden die Fotos aus dem Archiv von Jenni Mattersburg angeboten, ab 1928 vermarktet Schostal zusätzliche Bilder. Sie stammen nicht aus dem eigenen Betrieb - Robert Schostal selbst ist kein Pressefotograf -, sondern aus einer Kooperation mit der europaweit agierenden Fotoagentur Keystone, die Filialen in Paris, London und Berlin unterhält. Schostal übernimmt die Österreich-Repräsentanz von Keystone, was ihm ein monatliches Fixum garantiert. ${ }^{38}$ Gestützt durch diese internationale Zusammenarbeit, expandiert das Unternehmen rasch. ${ }^{39} 1933$ eröffnet Walter Schostal eine Filiale in Paris ${ }^{40}$, etwa zu dieser Zeit baut Oscar Schwartz, ein ehemaliger Mitschüler Robert Schostals, eine Filiale in Mailand auf. ${ }^{41}$ In Stockholm arbeitet man ab Mitte der 1930er Jahre mit einer Agentur vor Ort, Världen i Bild, zusammen, auch in Berlin und Warschau hat Schostal in den späten 1930er Jahren eine Vertretung. Zwischen 1934 und 1938 beschäftigt das Unternehmen bis zu zehn Mitarbeiter. ${ }^{42}$

Während die klassischen Fotoagenturen vor allem aktuelle Nachrichtenbilder anbieten, hat Schostal schwerpunktmäßig nicht aktuelle Fotos im Programm. In einer Anzeige aus dem Jahr 1934 stellt sich das Unternehmen folgendermaßen vor: „Wiener Repräsentanz von Keystone View Co. sowie der führenden Photographen Europas/Aktualitäten aus allen Teilen der Welt, Künstlerische Genre-Bilder, Mode / Archivbestand derzeit über 500000 Photos. Eigene
Filialen in Paris und Mailand. “43 Bemerkenswert an dieser selbstbewussten Selbstdarstellung ist zweierlei. Zunächst überrascht die Größe des Fotoarchivs, die wohl nur dadurch zu erklären ist, dass das umfassende Angebot von Keystone (das sicher nicht zur Gänze in Wien zugänglich ist) mit angeführt wird. Interessant ist aber auch der Hinweis auf die „künstlerischen Genrebilder“, die die Agentur im Programm hat. Denn mit diesen erwirtschaftet das Unternehmen in den 1930er Jahren einen Gutteil der Einnahmen.

Schostal setzt nämlich auf ein teilweise neues Geschäftsmodell. Er verkauft zwar, wie andere Agenturen auch, aktuelle Pressebilder. Sein Schwerpunkt liegt aber in einem anderen Bereich. Er bietet renommierten Fotografinnen und Fotografen, die bisher nicht oder kaum im Pressegeschäft tätig waren, an, ihre Arbeiten exklusiv durch seine Agentur zu vertreten und an die in- und ausländische Presse zu vermitteln. Die Fotografen profitieren vom Zusatzeinkommen und der öffentlichen Präsenz, die ihnen Ansehen verschafft. Umgekehrt liegen auch die Vorteile für Schostal auf der Hand. Die illustren Fotografennamen heben das Image der Agentur, zudem ist diese an den Einnahmen beteiligt. Diese Marktstrategie, sich vom Gros der herkömmlichen Pressefotografie deutlich abzuheben, dürfte wohl auf die Anregungen der innovativen deutschen Fotoagenturen wie Weltrundschau oder Dephot zurückgehen. Allerdings geht Schostal nie so weit, mit fest angestellten Pressefotografen zu arbeiten und fertige Reportagen anzubieten. Stattdessen etabliert er sich eher als Händler, der die Presse mit qualitativ hochwertigen Aufnahmen versorgt.

Eine der ersten Fotografinnen, die Schostal vertritt, ist die bekannte Wiener Atelierfotografin Trude Fleischmann. Zwar ist sie mit ihren Fotoarbeiten schon seit den frühen 1920er Jahren in der Presse präsent. Aber erst ab Ende der 1920er Jahre, als sie die Vertretung ihres Werks an den Wiener PhotoKurier (später Schostal) überträgt, nimmt die Zahl ihrer Veröffentlichungen deutlich zu. ${ }^{44}$ Über die Agentur vertreibt sie nicht nur ihre Atelierbilder, sondern zunehmend auch ihre Reisebilder und Heimatmotive (Abb.5). Auch Dora Kallmus, die Inhaberin des Ateliers d'Ora, die seit 1927 in Paris tätig ist, wird von Schostal vertreten, ebenso das Wiener Atelier 


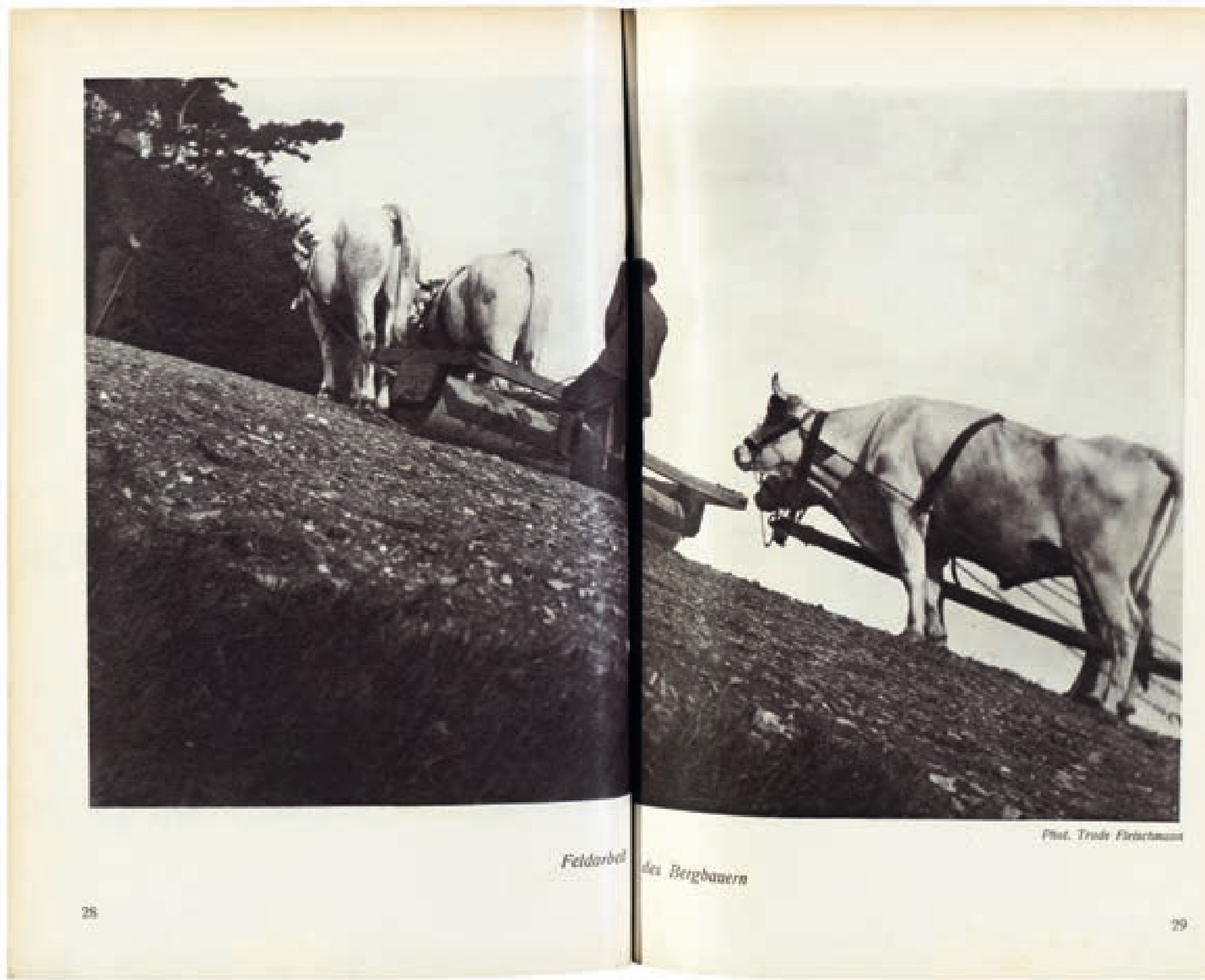

Manassé. Dass die Arbeiten dieser drei Ateliers in der Zwischenkriegszeit besonders stark in den Medien präsent sind, ist zu einem nicht geringen Teil wohl das Verdienst ihrer Fotoagentur.

Anfang der 1930er Jahre erweitert Schostal den Kreis der Fotografinnen und Fotografen, die er vertritt, sukzessive. Nun nimmt er neben österreichischen Lichtbildnern, wie etwa Hans Madensky, auch bekannte deutsche (und einige französische) Fotogra- fen unter Vertrag. Er vertritt u. a. die Berliner Atelierund Modefotografinnen Lotte Jacobi und Yva (Else Neuländer), die der Avantgarde verpflichtete Modeund Werbefotografin Germaine Krull, den bekannten Leica-Fotografen Dr. Paul Wolff (Abb.6) und dessen Mitarbeiter Alfred Tritschler, die Modefotografen Imre von Santho und Georges Saad sowie die Berliner Fotografin Hedda Walther, die ihren Schwerpunkt in der Tier-, Kinder- und Modefotografie hat und in den 


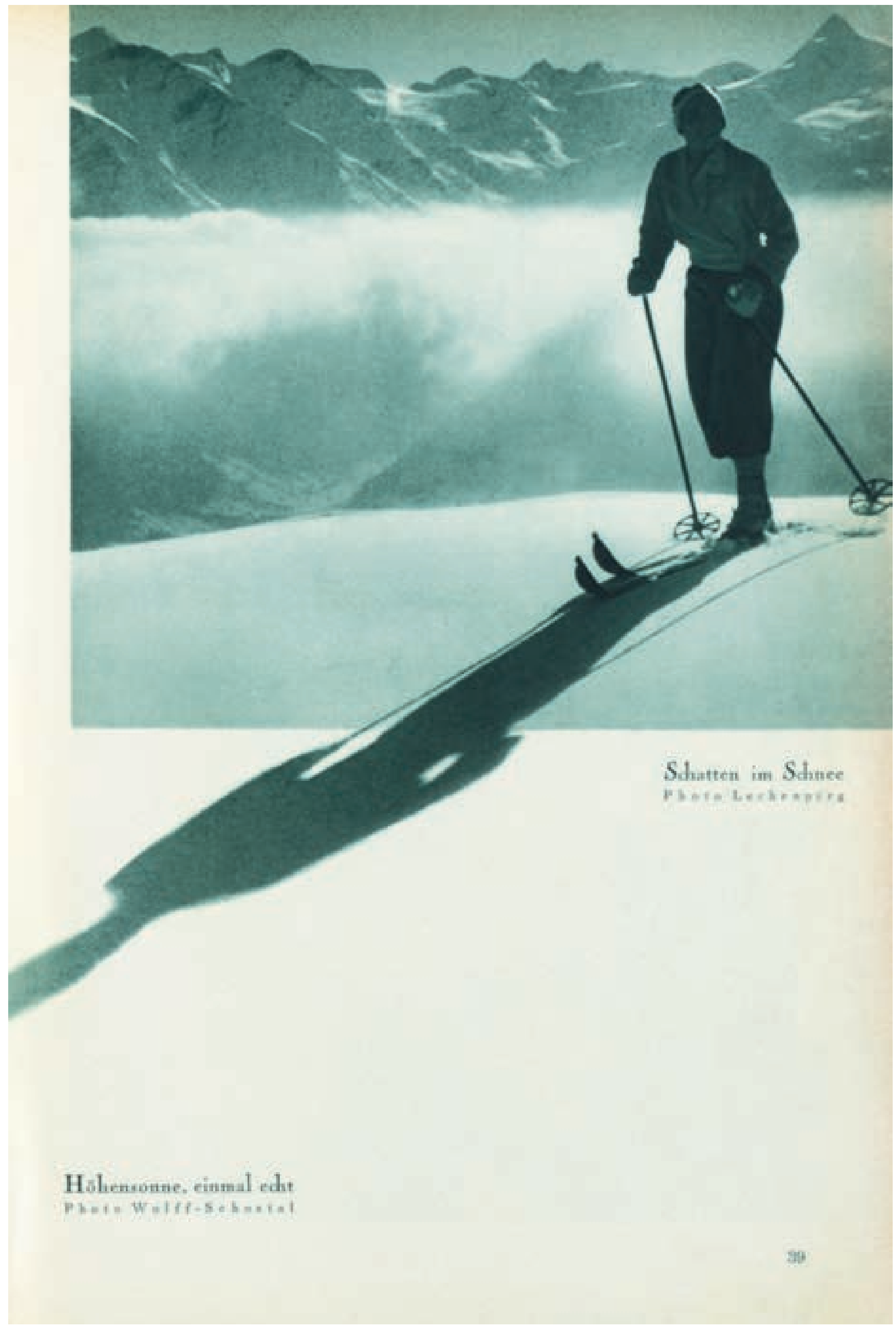


1930er Jahren zahlreiche Gesellschaftsreportagen für den Deutschen Verlag (ehemals Ullstein) macht. Schostal verkauft aber auch die Bilder der Reisefotografin Alice Schalek, des Schweizer Porträt- und Reisefotografen Martin Imboden und Aufnahmen des aus Meran stammenden und seit 1927 in Berlin lebenden Reportage-, Mode- und Werbefotografen Heinz von Perckhammer.

Während Schostal mit den aktuellen Nachrichtenbildern, die die Agentur von Keystone bezieht, nur in Österreich präsent ist, reichen die geschäftlichen Kontakte im Bereich der künstlerischen Genrefotografie weit darüber hinaus. Schostal versorgt vor allem französische und deutsche Kultur-, Gesellschafts- und Modezeitschriften, die Bilder werden aber auch in Skandinavien, Osteuropa und teilweise im englischsprachigen Überseeraum (Australien und USA) verkauft. Schwerpunkte des Angebots sind Modeaufnahmen, angeboten werden aber auch Tanzfotos, Landschafts- und Reisebilder, Porträts und Genrefotos (etwa Humor, Tiere, Wissenschaft, Skurriles etc.). Wie sehr sich dieser Geschäftszweig von der Vermarktung von Nachrichtenbildern unterscheidet, zeigt sich auch daran, dass Erstere der Presse ohne Nennung des Fotografennamens angeboten werden, während dieser bei Letzteren gleichberechtigt neben dem Namen der Agentur steht (z. B. „Yva-Schostal“).

\section{8: Verfolgte und Profiteure}

Die Errichtung des nationalsozialistischen Regimes in Österreich verändert den Handel mit fotografischen Bildern mit einem Schlag. Jüdische Fotoagenturen werden enteignet und ihre Betriebe teilweise aufgelöst. Die Agenturbesitzer und -mitarbeiter jüdischer Herkunft werden verhaftet oder es gelingt ihnen zu fliehen. Innerhalb weniger Wochen wird das Netz an Zulieferern für die illustrierte Presse von Grund auf neu geordnet. Dazu kommt, dass die großen reichsdeutschen Agenturen nun verstärkt den Wiener Markt beliefern. All das führt dazu, dass sich das Bildmaterial, das ab 1938 in den Zeitungen und Zeitschriften erscheint, deutlich verändert.

Den Inhabern der beiden wichtigsten Fotoagenturen Willinger und Schostal gelingt die Flucht. Wil- helm Willinger wird im März 1938 kurzzeitig inhaftiert. Im Frühjahr 1939 wird ihm und seiner zweiten Frau die Ausreise gestattet. Es gelingt ihm, einen Teil seiner Möbel und sogar die Fotoausrüstung mit ins Exil nach Shanghai zu nehmen. Das umfangreiche Fotoarchiv der Agentur muss er in Wien zurücklassen. Von der Sammlung fehlt bis heute jede Spur. ${ }^{45}$ 1940 eröffnet Willinger ein Fotoatelier in Shanghai. Er stirbt 1943. Nach seinem Tod wird der Betrieb von seiner Frau weitergeführt. ${ }^{46}$

Im März 1938 flüchtet Robert Schostal zusammen mit seiner Mutter über Italien nach Frankreich. Nach kurzer Zeit reisen sie in die USA weiter. 1939, nach der Kriegserklärung Frankreichs, folgt ihnen der Bruder Walter, der die Pariser Filiale des Unternehmens geführt hatte. In New York gelingt den beiden Brüdern, unter dem Namen „Shostal Inc.“ (später „Shostal Associates“) wieder eine Fotoagentur zu gründen. ${ }^{47}$ Das umfassende Archiv der Wiener Agentur muss Robert Schostal zurücklassen, der Betrieb wird, wie unzählige andere von Juden geführte Unternehmen auch, enteignet. Seit Juni 1938 wird die Fotoagentur Schostal unter demselben Namen kommissarisch von Friedrich Gondosch weitergeführt. Im September 1941 kauft dieser den Betrieb um eine geringe Summe, ab jetzt firmiert das Unternehmen unter dem Namen „Wien-Bild“. ${ }^{48}$

Oberflächlich betrachtet, führt die „arisierte“ Fotoagentur die Geschäfte einfach weiter. Eine Reihe von Fotografen, mit denen Robert Schostal schon seit Jahren zusammenarbeitet, etwa Imre von Santho, Hedda Walther, Heinz von Perckhammer oder Paul Wolff, liefern weiterhin Bilder an die Agentur. Auch Olga und Adorján Wlassics, die Inhaber des Wiener Ateliers Manassé, die Schostal schon seit Langem vertritt und die seit 1936 in Berlin das Atelier WOG führen ${ }^{49}$, werden nach 1938 weiter von der Agentur vertreten. Das große Firmenarchiv wird weiterhin kommerziell genutzt. Aber bei genauerem Hinsehen wird deutlich, dass der Betrieb binnen kürzester Zeit vollkommen umgestaltet wird. ${ }^{50}$ Zunächst wird allen Fotografen jüdischer Herkunft gekündigt, auch ihre Archivaufnahmen werden nicht weiter verkauft. Sodann werden zahlreiche neue Fotografen unter Vertrag genommen, in der Regel sind es solche, die
Abb. 6 „Schatten im Schnee“. Die Aufnahme ist aus zwei Bildern zusammengesetzt. Sie stammen von Harald Lechenperg und dem deutschen Fotografen Paul Wolff, den die Agentur Schostal vertritt. Wiener Magazin Heft 1, Januar 1937, S. 39. 


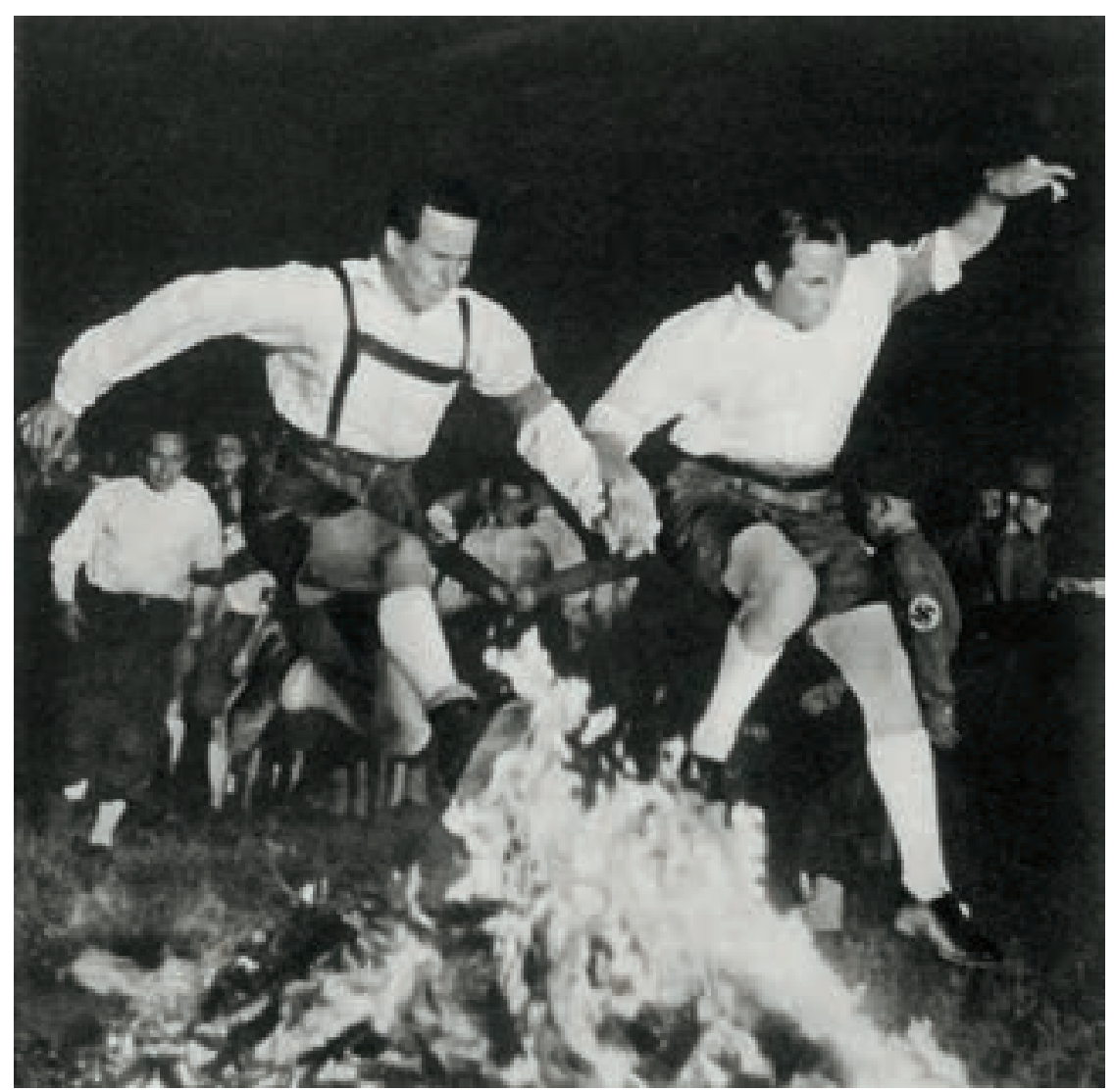

Abb. 7 Sonnwendfeiern in der „Ostmark“, fotografiert im Juni 1938 von Anton Doliwa, einem strammen Nationalsozialisten, der ab 1938 für das „arisierte“ Unternehmen Schostal arbeitet. Der jüdische Agenturbesitzer, Robert Schostal, flüchtet über Frankreich in die USA. Das interessante Blatt, 23. Juni 1938, Titelseite. keinerlei Vorbehalte dem nationalsozialistischen Regime gegenüber haben. Schostal verkauft jetzt etwa Bildmaterial der Frankfurter Presse- und Werbefotografin Elisabeth Hase, des Berliner Ateliers Becker \& Maaß aber auch der aus Bayern stammenden Erika Schmachtenberger, die sich auf Land und Leute sowie bäuerliche Motive aus ganz Europa spezialisiert. ${ }^{51}$ Aber auch Aufnahmen von Fotografen außerhalb des deutschen Sprachraums werden nun vertrieben, etwa Bilder des schwedischen Pressefotografen Gunnar Lundh oder Aufnahmen des spanischen Ateliers Compal (Valencia). Schließlich geht die Agentur auch neue Kooperationen ein. Ab Mitte 1938 arbeitet sie mit der führenden deutschen Presseagentur Atlantic zusammen, die dem NS-Regime nahesteht. ${ }^{52}$

Nach der Zwangsenteignung werden vermehrt österreichische Fotografen unter Vertrag genommen. Es sind durchweg parteitreue Personen, die sich den neuen politischen Verhältnissen willig anpassen. Die angebotenen Sujets im Bereich der Genrefotografie sind inzwischen deutlich konservativer, häufig werden ländliche und bäuerliche Motive (etwa Bauern bei der Arbeit, Trachten etc.) und vermehrt auch pathetische Landschaftsstudien veröffentlicht. Solche Bilder liefert zum Beispiel die Tiroler Amateurfotografin Midi Suppenmoser an Schostal. Aber auch Heinz von Perckhammer, der in den frühen 1930er Jahren noch durchaus Einflüsse der Moderne aufgenommen hatte, passt sich diesem ästhetischen Programm an und fotografiert ab 1938 regelmäßig urige Bauern, Bäuerinnen in Tracht und beschauliche Genreszenen. Weitere österreichische Fotografen im Dienst von Schostal sind Luis Sedlar, Gustav Hajek (der vor allem als Sportfotograf tätig ist) und Otto Tomann. Letzterer ist seit 1937 Geschäftsführer des Ateliers Dietrich \& Co. liefert an Schostal vor allem Theaterfotos und Porträts, aber auch ländliche Genreaufnahmen. Er ist ein strammer Nationalsozialist, der im Krieg neben Theater- und Modeszenen propagandistische Bilder deutscher Soldaten veröffentlicht und nach 1945 als Porträt- und Modefotograf tätig ist.

Robert Schostal hatte keine klassischen Pressefotografen für den Bereich aktuelle Nachrichtenbilder engagiert. Das ändert sich nun. Die neue Agentur arbeitet mit Fotografen zusammen, die aktuelle Ereignisse dokumentieren. Zu ihnen gehören u.a. die Wiener Pressefotografen (im Nationalsozialismus heißen diese „Bildberichter“) Wilhelm Sturm und v.a. Anton Doliwa, geb. 1905. Letzterer ist ein eingefleischter Nationalsozialist. Doliwa deckt alle Bereiche der aktuellen Pressefotografie ab, er liefert Aufnahmen politischer Ereignisse ebenso wie Sportbilder. An seinem Beispiel wird die rasante personelle Umschichtung der Pressefotografie im Nationalsozialismus deutlich. Während die jüdischen Kollegen verfolgt und verdrängt werden, treten parteitreue Lichtbildner an ihre Stelle. Ab Frühjahr 1938 ist Doliwa einer der wichtigsten österreichischen Pressefotografen (Abb.7).

Ebenfalls ab Frühjahr 1938 nimmt der Anteil der deutschen Agenturen in der Wiener Presse rapide zu. Den Markt teilen sich nun die führenden Unternehmen Weltbild, Scherl und Hoffmann. Alle drei Agenturen stehen dem NS-Regime sehr nahe. Weltbild ist die Nachfolgeorganisation der 1935 vom Deutschen Nachrichtenbüro, der zentralen Presseagentur des NS-Staates, übernommenen Fotoagentur Keystone View. ${ }^{53}$ Der Scherl Verlag mit der angeschlossenen Fotoagentur Scherl Bilderdienst steht seit 1933 unter nationalsozialistischer Kontrolle. Die Bildagentur Heinrich Hoffmanns schließlich ist Ende der 1930er Jahre der größte und wichtigste nationalsozialistische Bildlieferant. ${ }^{54}$ Eine Reihe österreichischer Pressefo- 


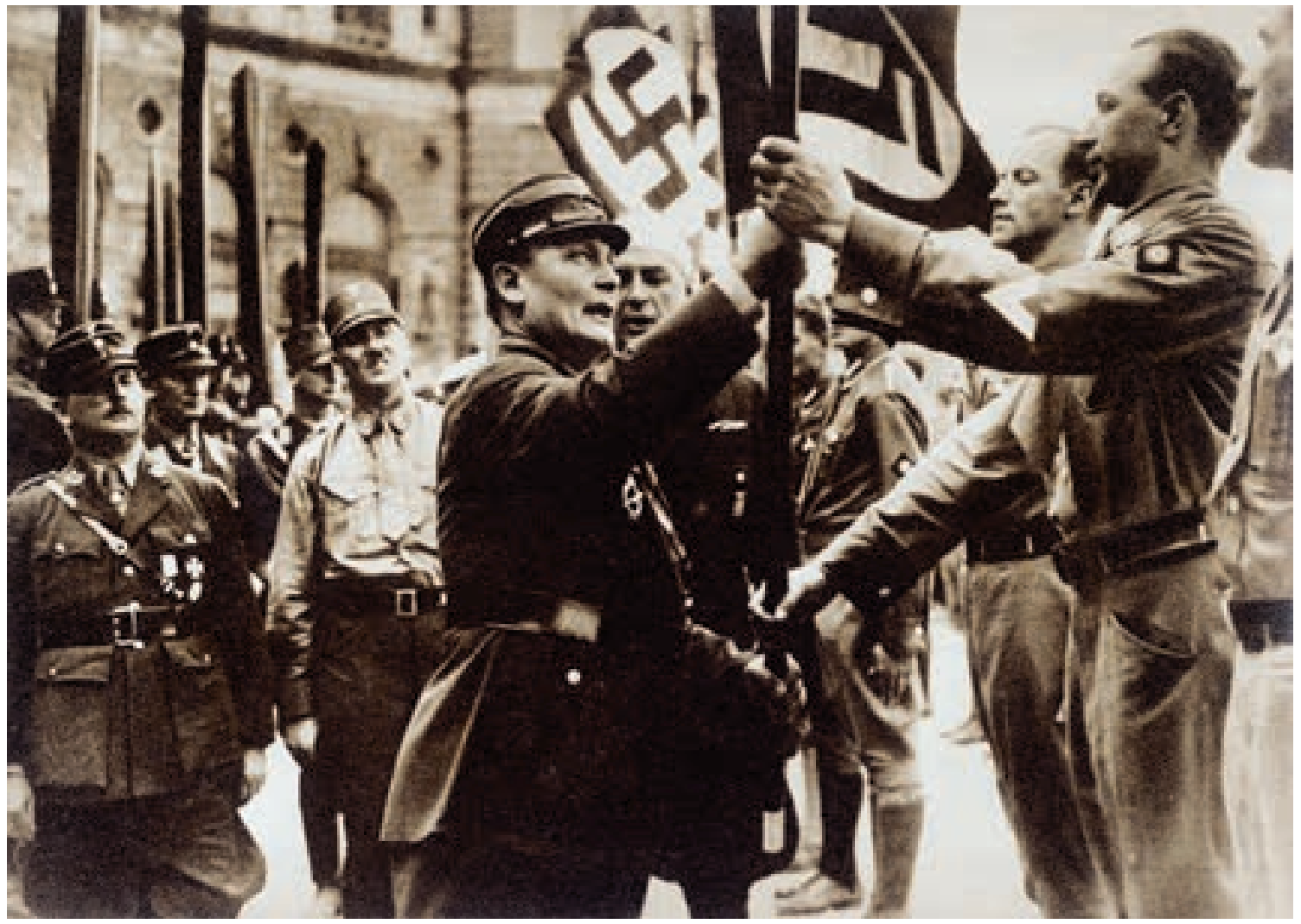

tografen ist von Wien aus im Auftrag großer deutscher Agenturen tätig. Franz Blaha etwa, der 1938 eine kleine Fotoagentur gründet, ist ab 1939 der Wiener Repräsentant von Scherl. Für die Berliner Pressebildzentrale (PBZ) ist ein Wiener Pressefotograf namens Essel tätig.

Neben diesen Großlieferanten treten nun auch kleinere, einheimische Agenturen auf. Sie nutzen die Gunst der Stunde und nehmen den Platz ein, der durch die Enteignung zahlreicher anderer Fotoagenturen frei geworden ist. Ab 1938 sind in Wien die Agenturen Wiener Fotodienst, Nationaler Bilderdienst, Ostmark Bilderdienst, Photo-Dienst Blaha, ${ }^{55}$ Photo-Illustration S. Wagner ${ }^{56}$ und Südbild ${ }^{57}$ präsent. Die meisten von ihnen entstehen nach dem Einmarsch der Nationalsozialisten. Es gibt aber auch ältere Unternehmen, die sich problemlos auf die neue politische Situation einstellen. Dazu gehört die Bildagentur Dietrich \& Co. Sie geht aus dem 1922 von Hans Dietrich (geb. 1868) gegründeten Atelier hervor. Ab Anfang der 1930er Jahre ist das Unter- nehmen auch als Fotoagentur tätig. Dietrich gehört schon in dieser Zeit zu den Unterstützern der nationalsozialistischen Bewegung. Er liefert schon früh Bilder nationalsozialistischer Veranstaltungen an die Presse (Abb. 8). Ende 1938 übernimmt die Bildagentur Heinrich Hoffmann die Agentur Dietrich. Ihre Bilder werden zunächst unter dem Namen „Hoffmann (Dietrich \& Co.)“ vermarktet, später taucht der Zusatz „Dietrich“ nicht mehr auf.

Anfang Juli 1938 wird eine eigene Ostmarkorganisation des „Reichsverbandes der deutschen Presse“ geschaffen, in dem sich alle im Pressebereich tätigen Personen registrieren müssen. Eine eigene Abteilung wird für die „Bildberichter“ eingerichtet. Ihr Vertrauensmann ist Lothar Rübelt, ein überzeugter Nationalsozialist. ${ }^{58}$ Akkreditiert werden nur Fotografen und Fotohändler, gegen die keine politischen Bedenken erhoben werden. Spätestens ab jetzt werden keine Fotos mehr an die Zeitungen und Zeitschriften geliefert, die nicht den Vorgaben des nationalsozialistischen Regimes entsprechen.
Abb. 8 „Gautag“ der österreichischen NSDAP in Wien, 29. September bis 2. Oktober 1932. Während der Abschlusskundgebung auf dem Heldenplatz überreicht der aus Berlin angereiste Reichstagspräsident Hermann Göring den Teilnehmern der paramilitärischen Formationen die „Sturmfahne“. Das interessante Blatt, 6. Oktober 1932, S. 41. Foto: Dietrich. 


\section{Politische Bilder}

\section{Die Kultur der Arbeiterfotografie}

Wien, Mitte der 1920er Jahre: Das „Rote Wien“ steht in voller Blüte, die Aufbruchstimmung der Sozialdemokratie ist ungebrochen. Bei den Nationalratswahlen im ersten Jahrzehnt nach dem Krieg erreicht die Sozialdemokratische Arbeiterpartei (SDAP) zwischen 35,9 Prozent (1920) und 42,3 Prozent (1927) und etabliert sich neben den Christlichsozialen als zweite große Partei. Zwar währt ihre Beteiligung an der Bundesregierung nur kurz, von Ende 1918 bis 1920. Aber in der Hauptstadt Wien gehen die politischen Uhren anders. Hier hat die Sozialdemokratie 1918 die Macht übernommen und hier kann sie diese eineinhalb Jahrzehnte lang (bis 1933/34) erhalten und sukzessive ausbauen. Innerhalb weniger Jahre gelingt es der Partei, in der Hauptstadt eine tief verwurzelte soziale und kulturelle Gegenwelt zur „bürgerlichen“ Welt zu schaffen. Das „Rote Wien“ umfasst alle Lebensbereiche: von der Arbeit über das Wohnen, den Sport und die Freizeit bis hin zur öffentlichen Meinung.

Die Fotografie spielt innerhalb dieser sozialdemokratischen Gegenkultur eine wichtige Rolle. In den 1920er Jahren entwickelt sich - vor allem in Wien, teilweise auch in Graz - eine facettenreiche Arbeiterfotobewegung. Um sich ein Bild dieser Bewegung um 1930 machen zu können, ist es sinnvoll, die unterschiedlichen organisatorischen Stränge zu unterscheiden. ${ }^{1}$ Bedeutsam sind die Fotosektionen des 1895 gegründeten sozialdemokratischen Touristenvereins Die Naturfreunde, der ab Mitte der 1920er Jahre ein reges Vereinsleben entwickelt. Aber auch an den Volkshochschulen werden in den 1920er Jahren Arbeiterfotogruppen gegründet. Schließlich gibt es eine Reihe von Berufsfotografen und Fotoamateuren, die vor allem in der Presse veröffentlichen und sich ebenfalls der Arbeiterfotobewegung zugehörig fühlen. Das wichtigste publizistische Organ all dieser unterschiedlichen Gruppierungen ist die sozialdemokratische Illustrierte Der Kuckuck, die 1929 gegründet wurde.

\section{Sozialdemokratische und kommunistische Parteizeitungen}

Ab Mitte der 1920er Jahre ist Julius Braunthal, der als junger Journalist in der Redaktion der Wiener Arbeiter-Zeitung Erfahrungen gesammelt hat, für den Expansionskurs der sozialdemokratischen Publizistik verantwortlich. Er ist es, der im parteieigenen Vorwärts-Verlag auf eine Erweiterung und Popularisierung der parteinahen Presse drängt. Ihm schwebt ein mächtiger sozialdemokratischer Zeitungs- und Zeitschriftenkonzern vor, der tonangebend in der öffentlichen Meinung sein sollte. 1927 gründet er mit großem Erfolg die linke Boulevardzeitung Das Kleine Blatt, die 1930/31 eine tägliche Auflage von 173000 erreicht. ${ }^{2}$ Zwei Jahre später, 1929, folgt mit dem Kuckuck eine auflagenstarke Illustrierte, die in Inhalt und Gestaltung mit der bürgerlichen Presse nicht nur Schritt hält, sondern diese deutlich übertrifft (Abb. 1). ${ }^{3} 1932$ erhält Das Kleine Blatt mit der Bunten Woche eine illustrierte Wochenendausgabe, ein Jahr später, im Februar 1933, kommt die Wochenillustrierte Rundfunk hinzu. Dazu kommen zahlreiche weitere Zeitschriften und Publikationen, ebenso wie regionale Blätter.

Die Zeitungsneugründungen der 1920er Jahre dienen dem Ausbau und der Festigung einer spezifisch sozialdemokratischen Kultur. Sie richten sich explizit gegen die Dominanz der bürgerlichen Presse und ab etwa 1930 zunehmend auch gegen die Nationalsozialisten (Abb. 2). Aber auch die Abgrenzung gegen die Kommunisten spielt, etwa bei der Gründung des $\mathrm{Ku}$ ckuck, eine gewisse Rolle. 1928, also ein Jahr vor dem Start des Kuckuck, versucht nämlich die kommunistische deutsche Arbeiter-Illustrierte Zeitung (AIZ) in Österreich stärker Fuß zu fassen. ${ }^{4}$ Seit 21. März 1928 bringt sie eine vierseitige Österreich-Beilage heraus, allerdings ohne großen Erfolg. Im Frühjahr 1929 wird diese wieder eingestellt. Der Machtkampf zwischen 


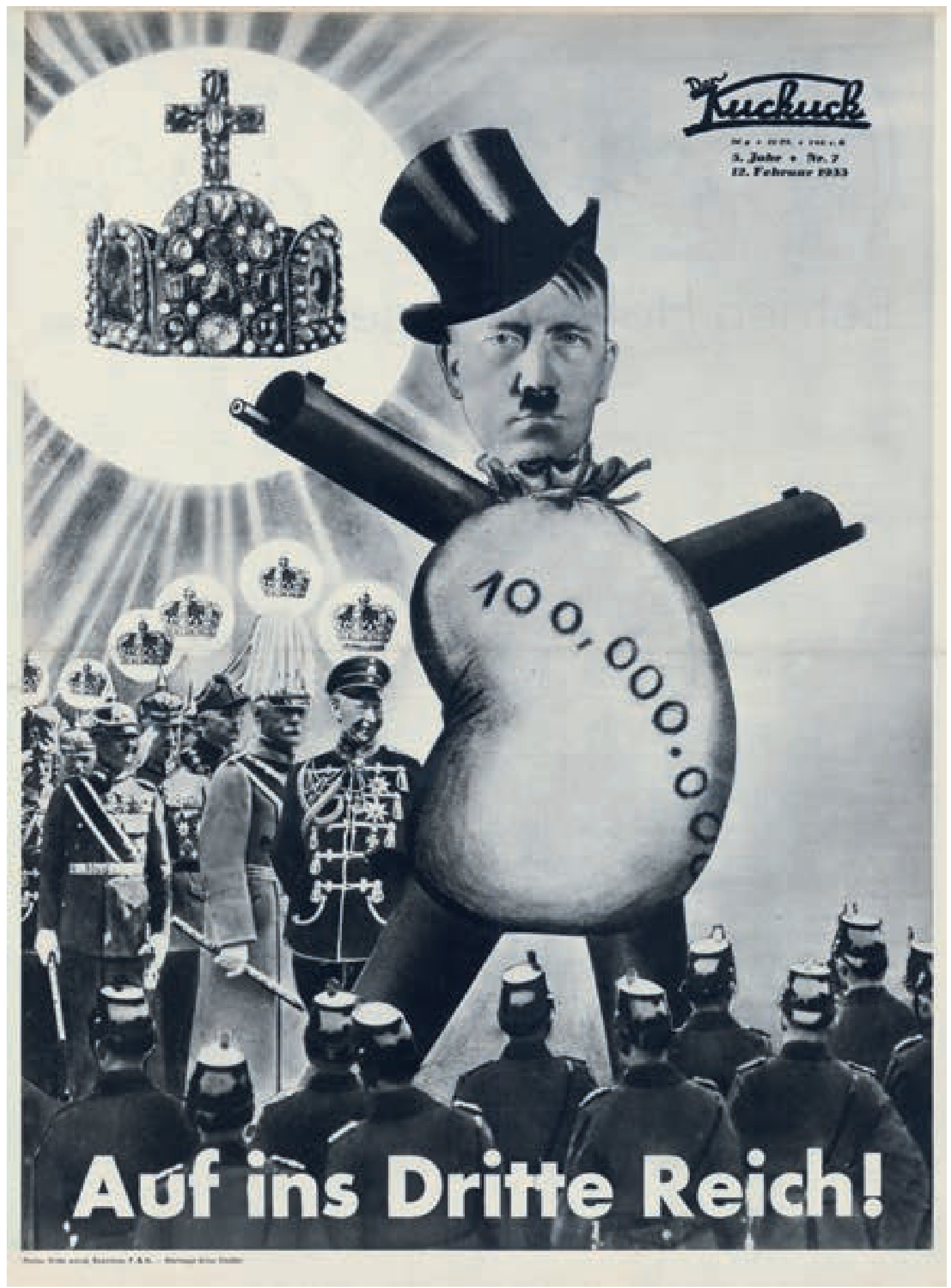

Abb. 1 Der Kuckuck wird 1929 als Gegengewicht zu den bürgerlichen Illustrierten gegründet. Nach dem Machtantritt der Nationalsozialisten in Deutschland wendet sich das Blatt aber auch gegen die nationalsozialistische Gefahr. Der Kuckuck, 12. Februar 1933, Titelseite. Fotomontage von Arthur Stadler unter Verwendung von Bildern der Fotoagenturen Wide World Photos, Keystone und Pacific \& Atlantic. 


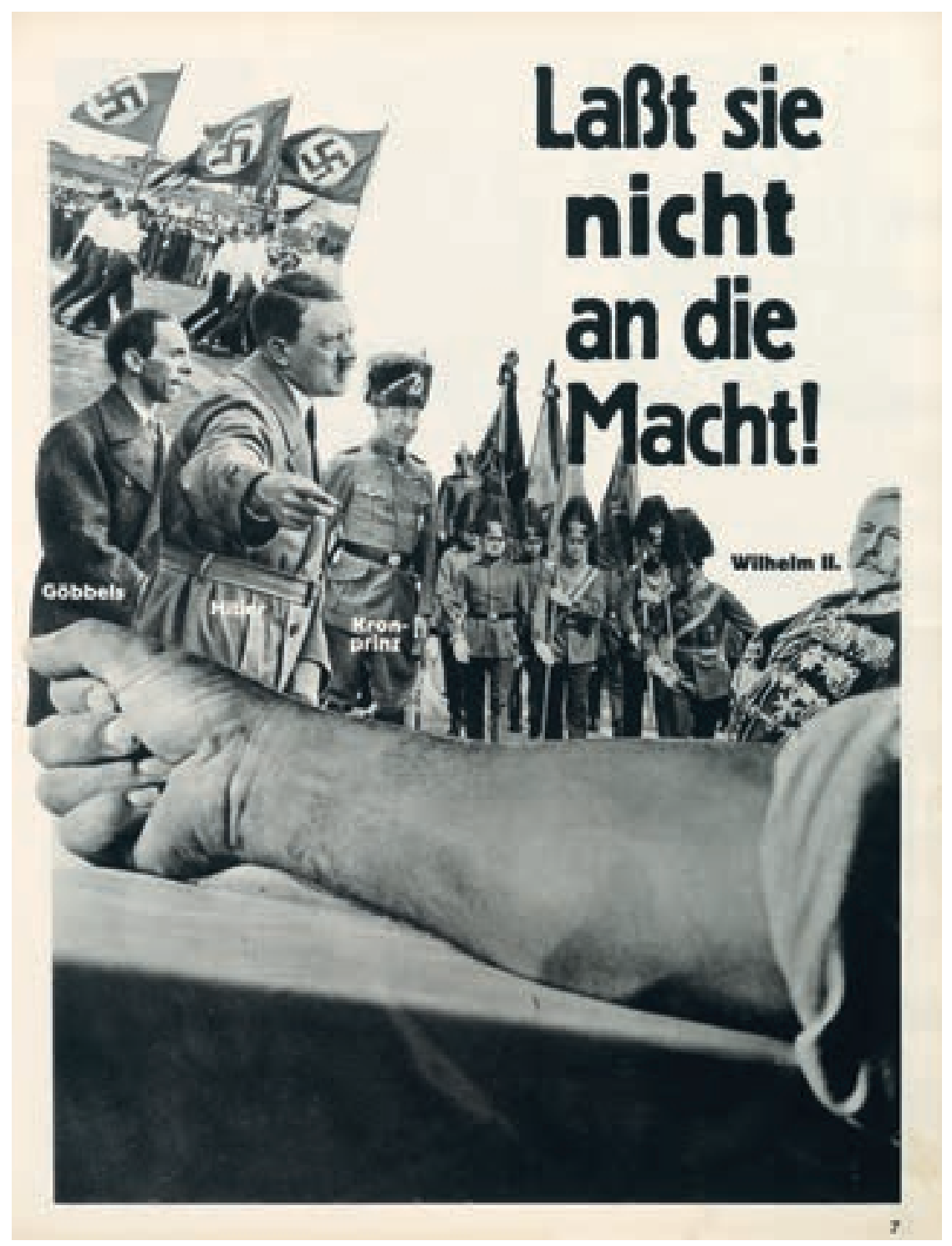

Abb. 2 „Laßt sie nicht an die Macht!“ Antinationalsozialistische Fotomontage. Der Kuckuck, 31. Juli 1932, S. 7.
Sozialdemokraten und Kommunisten, der unmittelbar nach dem Ende des Krieges (v. a. im Frühjahr 1919) besonders heftig getobt hatte, ist inzwischen entschieden. Die österreichischen Kommunisten spielen in der Zwischenkriegszeit politisch keine besondere Rolle. ${ }^{5}$ Und auch publizistisch kann die KPÖ mit der SDAP nicht mithalten. Die Anfang 1932 gegründete KPÖ-nahe Illustrierte Rote Woche erscheint nur eineinhalb Jahre lang. Ende Juli 1933 wird sie verboten. Sie ist auf billigem Zeitungspapier gedruckt, mit einfachsten Mitteln hergestellt und kann es inhaltlich und grafisch nicht mit dem Kuckuck aufnehmen. Da die kommunistische Partei keine geeignete Plattform für die Fotoberichterstattung hat, weicht beispielsweise die KPÖ-nahe Fotografin Edith Suschitzky um 1930 auf den sozialdemokratischen Kuckuck aus. ${ }^{6}$

Dennoch gibt es auch im Umfeld der österreichischen Kommunisten zaghafte Versuche, nach deutschem Vorbild eine parteinahe Arbeiterfotografie- bewegung aufzubauen. 1931 wird auf maßgebliches Betreiben von Edith Suschitzky hin eine „Vereinigung der Arbeiter-Fotografen Österreichs“ gegründet, die aber kaum Bedeutung erlangt und ein Jahr später, im Sommer 1932, wieder aufgelöst wird. ${ }^{7}$ Die Illustrierte Rote Woche veranstaltet „Photo-Preisausschreiben“ für Arbeiterfotografen, allerdings werden kaum Fotos von Arbeiterfotografen veröffentlicht.

Anders als die kommunistische Illustrierte Rote Woche ist der Kuckuck höchst erfolgreich. Er erreicht im ersten Jahr seines Bestehens (1929) eine wöchentliche Auflage von knapp über 50.000. ${ }^{8}$ Nimmt man noch die zahlreichen weiteren regionalen und thematisch gebundenen SDAP-nahen Tages- und Wochenzeitungen hinzu, so erscheint die sozialdemokratische Publizistik um 1930 stärker denn je. Aber der Schein trügt. Die Auflage des Kuckuck sinkt Anfang der 1930er Jahre kontinuierlich und liegt 1932 mit 29000 Exemplaren deutlich unter der ursprünglichen 50 000er-Marke. Nach 1930 ist die Macht der Sozialdemokratie bereits im Schwinden begriffen. 1933 beginnt die christlichsoziale Regierung Dollfuß ganz offiziell mit der Demontage ihrer politischen Gegner. Im März 1933 wird, wie berichtet, das Parlament ausgeschaltet, das Kabinett beginnt mittels Notverordnungen diktatorisch zu regieren, die Vorzensur für missliebige Zeitungen und Zeitschriften wird eingeführt. Am 26. Mai 1933 wird die kommunistische Partei verboten, am 19. Juni 1933 die österreichische NSDAP. Aber auch der Spielraum für die sozialdemokratische Opposition wird immer enger. Ein Jahr später kommt es zur offenen Diktatur. Alle verbliebenen oppositionellen Parteien und Organisationen werden nun verboten. Damit ist auch das Ende der sozialdemokratischen Presse gekommen. Am 10. Februar 1934 erscheint die letzte Nummer des Kuckuck. ${ }^{9}$

\section{Das Fotoprogramm des Kuckuck}

Wenige Monate nach der Gründung des Kuckuck wendet sich die Redaktion im Juli 1930 erstmals an die Arbeiterfotografen. „Wir legen Wert darauf“, heißt es in dem programmatischen Aufruf zu einem Fotowettbewerb, „daß die Arbeiter die Welt ihres Alltags erkennen und photographisch wiedergeben lernen. 
Daß sie um sich blicken, ihren Alltag sehen und ihn mit Hilfe der Linse bildnerisch gestalten. Wir wollen das Schöne bringen, wo immer es sich befindet. Es sei nur schlagwortartig angedeutet, was für Themen wir gerne behandelt sehen möchten: Die Arbeitsstätte, die Arbeit, der tägliche Weg, das Heim, die Straße, das Kind, den Körper, die Welt des Kleinen, Abseitigen, den Gegenstand des täglichen Lebens, das Soziale, usw. Landschaften möchten wir nur dann bringen, wenn sie sich durch besondere bildhafte Wirkung auszeichnen." ${ }^{10}$ Der Kuckuck folgt mit diesem Wettbewerb, der in den folgen Monaten und Jahren immer wieder ausgeschrieben wird, einer Strategie der deutschen kommunistischen Arbeiter-Illustrierte Zeitung (AIZ), die im März 1926 erstmals einen Fotowettbewerb für Arbeiterfotografen ausgelobt hatte (Abb. 3). Es ist erklärtes Ziel der AIZ, „die bürgerlichen PressePhoto-Korrespondenzen fast völlig auszuschalten und durch proletarische Aufnahmen, die das Leben des Proletariats wiedergeben, zu ersetzen. “11

In der redaktionellen Praxis des Kuckuck ist - wie auch bei der AIZ - dieses Ziel nicht zu verwirklichen. Für die tägliche Berichterstattung muss die Zeitung auf Agenturbilder und die Aufnahmen klassischer (auch bürgerlicher) Pressefotografen zurückgreifen. Aber die Fotowettbewerbe, die sich dezidiert an die organisierten Arbeiterfotovereine wenden, versorgen die Redaktion mit Bildmaterial, das für nicht aktuelle Themen verwendet werden kann. Die prämierten Arbeiten der Kuckuck-Wettbewerbe werden in der Zeitung veröffentlicht und den Fotografen wird ein Honorar von fünf Schilling pro Bild in Aussicht gestellt. Hinter dieser Initiative steht der verantwortliche Redakteur des Kuckuck, Siegfried Weyr. Sein Anliegen ist es, die Illustrierte mit neuen, anderen Bildern auszustatten, die näher an die Wirklichkeit der Arbeiter heranführen. Natürlich will er mit diesen Aufrufen auch die Abhängigkeit von den kommerziellen Fotoagenturen verringern. Und schließlich ist es sein Ziel, erzieherisch tätig zu werden, indem das Blatt den Arbeiterfotografievereinen eine publizistische Plattform bietet und „gute“, „gelungene“ Bilder in der Öffentlichkeit präsentiert. ${ }^{12}$

Als positives Beispiel einer Arbeiterfotografie erscheint im April 1930 eine Aufnahme von Ernst
Kleinberg (Abb.4). Im Bildtext heißt es: „Lichtbildkunst der Arbeiterphotographen: Der Polizeistaat“. ${ }^{13}$ Zu sehen sind die Hinterteile zweier Pferde. Auf diesen sitzen, im Bild angeschnitten, zwei Polizisten. Weyr scheint an diesem Foto die Kombination von Bildwitz (das Pferdehinterteil steht für die Institution der Polizei) und politischem Kommentar überzeugt zu haben. Dieser besteht darin, dass ein Detail - zwei Polizisten auf ihren Pferden -, durch den Bildtext geleitet, ironisch-kritisch auf ein komplexeres Ganzes

Abb. 3 „An der Drehbank“. Bildbeispiel aus dem Fotowettbewerb für Arbeiterfotografen. Arbeiter-Illustrierte Zeitung, Nr. 8, März 1926, Titelseite.

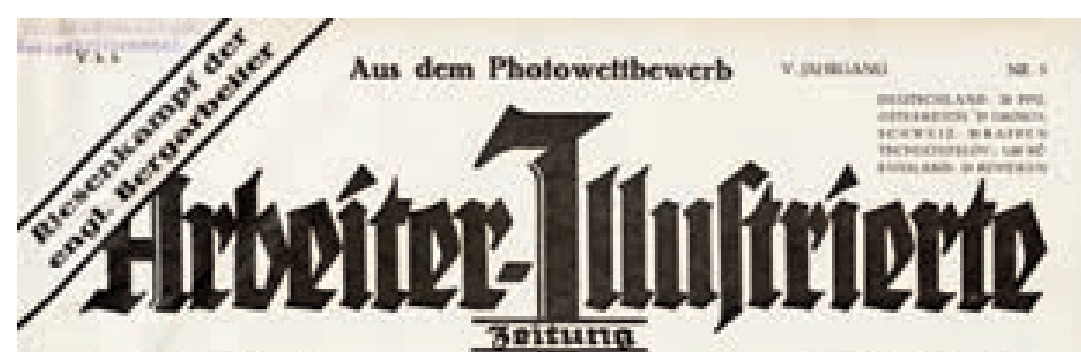

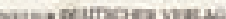
Diritis: $\eta$

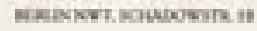

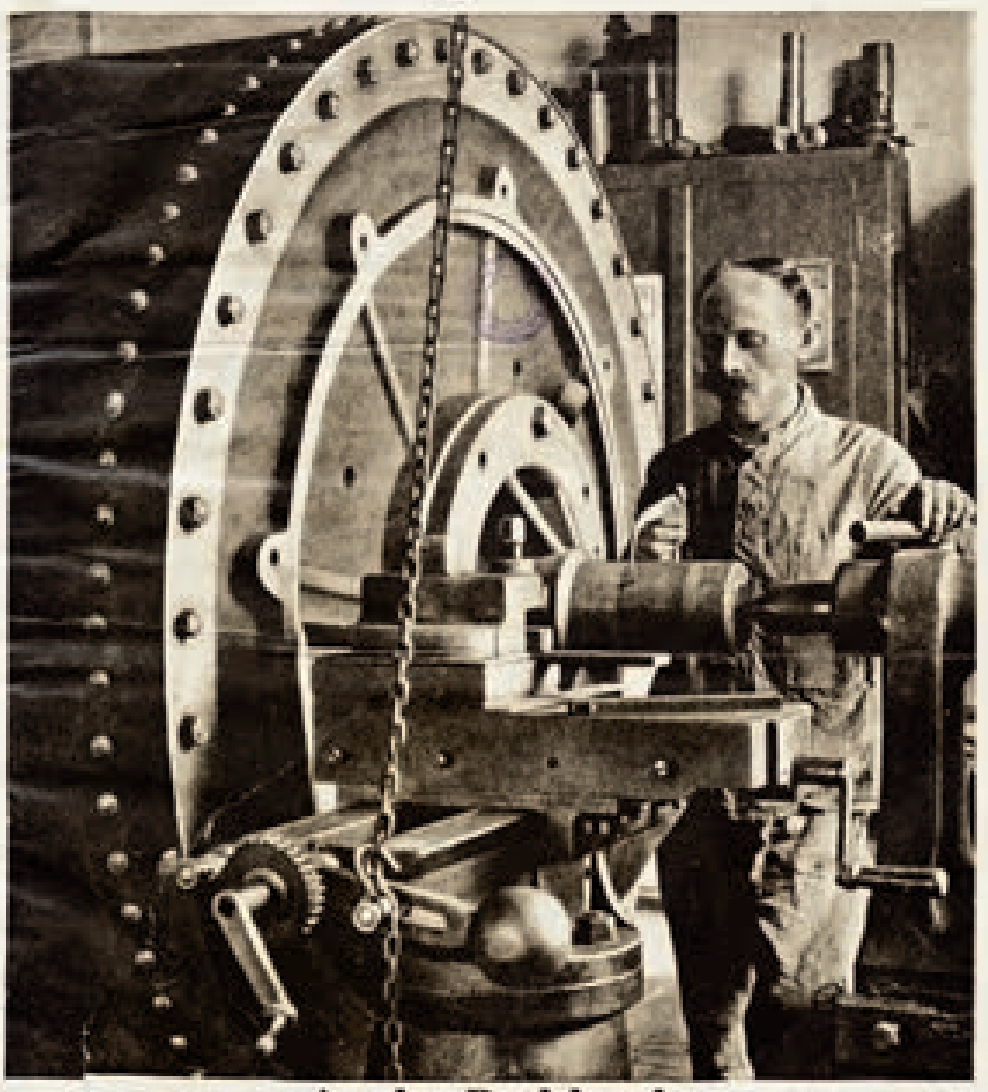

An der Drehbank 
Abb. 4 „Lichtbildkunst der Arbeiterphotographen: Der Polizeistaat“. Dieses Foto von Ernst Kleinberg wird als vorbildliches Beispiel der Arbeiterfotografie vorgestellt. Der Kuckuck, 20. April 1930, S. 11.

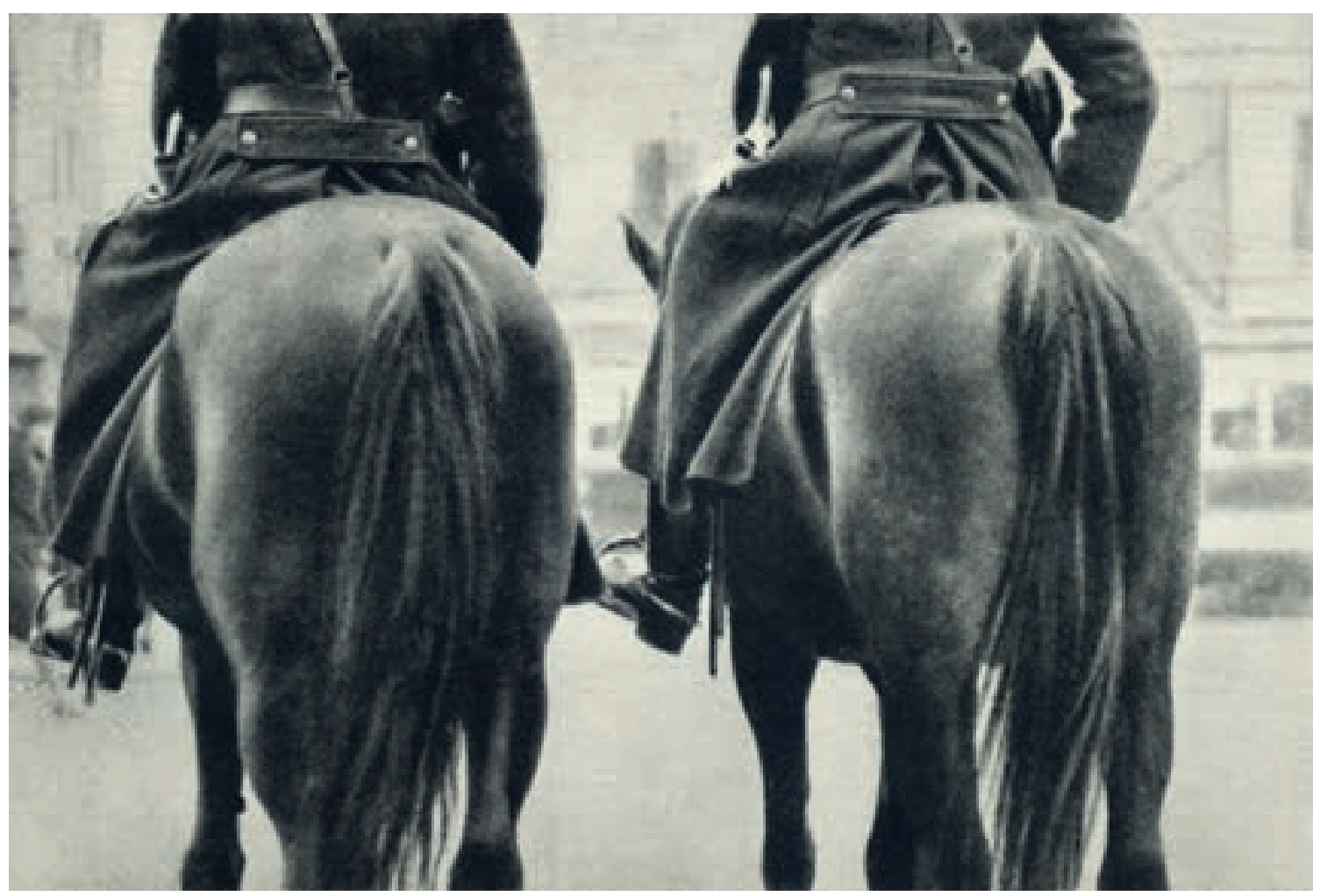

verweist, den christlichsozialen „Polizeistaat“. Dass der Fotograf kein wirklicher Arbeiterfotograf, sondern ein professionell arbeitender Pressefotograf ist, scheint Weyr nicht weiter zu stören. ${ }^{14}$

Die „Arbeiterfotografen“, die im Kuckuck vorgestellt werden, sind eben nur zum Teil vereinsmäßig organisierte Amateur-Lichtbildner. Einige von ihnen sind klassische Berufsfotografen, die sich zeitweise der Arbeiterbewegung zugehörig fühlen und um 1930 besonders viel für die sozialdemokratische illustrierte Presse arbeiten. Zu ihnen gehört beispielsweise Friedrich Zvacek, der Anfang 1932 mit einigen Gleichgesinnten die „Arbeitsgemeinschaft der Wiener Kuckuck-Reporter“ gründet. ${ }^{15}$ Einen ähnlichen Zusammenschluss gibt es 1933 auch in Graz. Andere sind Amateure, die aber regelmäßig für die Presse arbeiten und sich um 1930 im Umfeld der Sozialdemokraten bewegen. Zu ihnen gehören u. a. Nikolaus Schwarz, Willi Zvacek, Rudolf Spiegel, F. Fritzek, Willy Riethof, Ferdinand Hodek, Martin Imboden und Hans Popper sowie einige wenige Amateurinnen wie Edith Suschitzky (Abb. 5), Lotte Pollak, Elsa Brodtfeld, Diana Schwarz, Minna Lenze oder Margarethe Theile (aus Leipzig). Viele dieser der Sozialdemokratie nahestehenden Amateure publizieren ihre Fotos Anfang der 1930er Jahre häufig im Kuckuck. Manche beliefern auch andere - auch bürgerliche - illustrierte Zeitungen und Zeitschriften (Abb.6). Aber sie finden nicht nur in der Presse ein öffentliches Forum. Zahl- reiche sozialdemokratische Amateure zeigen - so wie ihre bürgerlichen Kollegen - ihre Bilder auch regelmäßig in kunstfotografischen Ausstellungen.

Weyr verfolgt im Kuckuck - vor allem auf den Titelseiten - ein dezidiert modernes Fotoprogramm. Aber auch im Innenteil, der konventioneller gestaltet ist, räumt er der Fotografie der Neuen Sachlichkeit und des Neuen Sehens immer wieder breiten Raum ein. Alfred Renger-Patzschs Fotoband Die Welt ist schön, der 1928 erscheint, wird 1929 im Kuckuck als „eines der bedeutendsten Dokumente der neuen Ästhetik und des neuen Willens zur Schönheit" gepriesen. ${ }^{16}$ Anfang 1930 heißt es über die Fotografie der Neuen Sachlichkeit: „Heute weiß man, daß man jedem Motiv, jeder Sache Schönheit abzugewinnen vermag. Es kommt nur darauf an, wie man das Ding betrachtet. Die Zeit, in der man feststellte, daß die Peripherie einer Großstadt nicht ,schön` sei, ist endgültig vorbei.“"17 Als im Februar und März 1930 die wegweisende Ausstellung „Film und Foto“ in Wien Station macht, findet sie breite und positive Resonanz im Kuckuck. ${ }^{18}$

Zum Leidwesen Weyrs ist der pädagogische Erfolg der Fotowettbewerbe weitaus geringer als erwartet. Zwar werden zahlreiche Bilder eingeschickt und regelmäßig „gelungene“ Beispiele veröffentlicht. Dennoch zeichnet sich unter den Arbeiterfotografen keine breite Zustimmung zu den von Weyr favorisierten Idealen einer modernen Fotografie ab. Anlässlich 


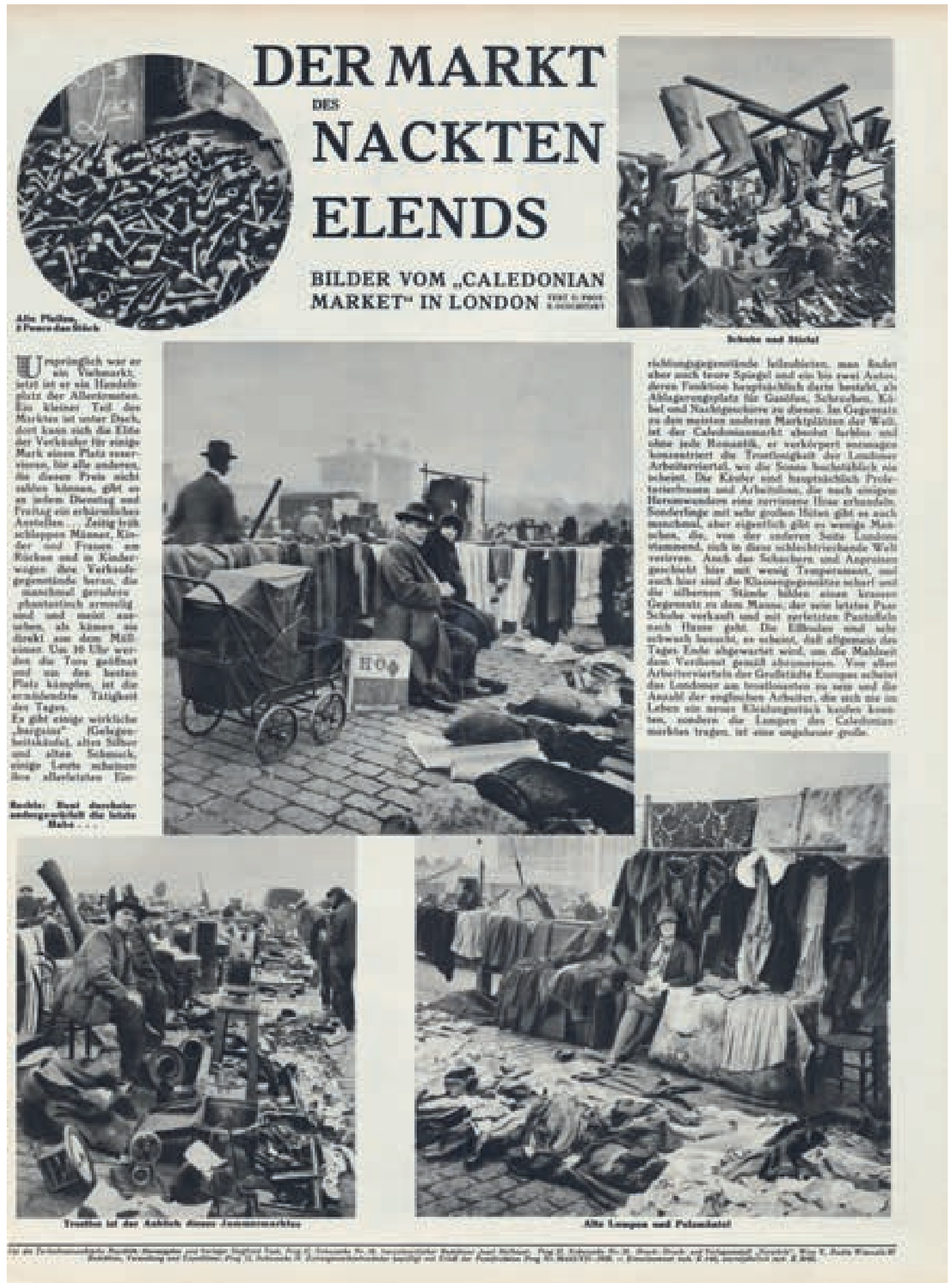

Abb. 5 „Der Markt des nackten Elends". Bildbericht von Edith Suschitzky vom Caledonian Market in London. Der Kuckuck, 4. Oktober 1931, S. 15. 


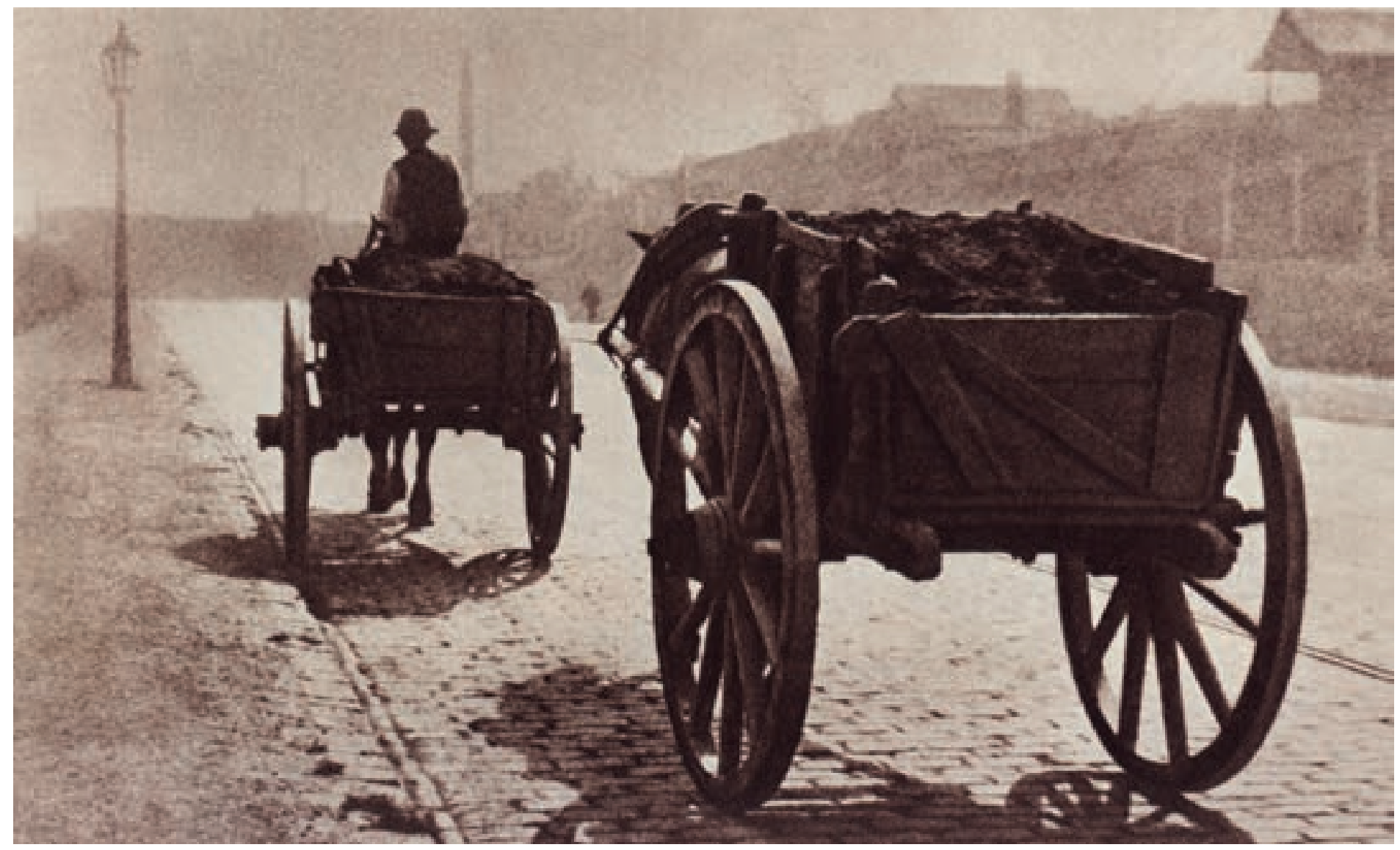

Abb. 6 „Der Gang der Arbeit“. Wiener Magazin, Nr. 9, September 1929, S. 28. Foto: Ferdinand Hodek. einer Ausstellung der Ottakringer Arbeiterfotografen heißt es im Februar 1931 im Kuckuck: „Noch fehlt den Wiener Arbeiterphotographen der Sinn für das politische Lichtbild. Damit ist nicht die bildliche Berichterstattung über eine Feier, eine Demonstration, eine Persönlichkeit gemeint, sondern die Erfassung einer Idee in einem Bildausschnitt. Wie unerhört kann Militarismus, Ausbeutertum, Hungerlohn, Rationalisierung, Arbeitslosigkeit, Klassengegensatz usw. gerade durch eine Photographie ausgedrückt werden. (...) Abgesehen davon, daß die Kamera in der Hand des bewußten Arbeiterphotographen dazu beitragen kann, das Bild von der Welt, das die illustrierte Zeitung gibt, immer wahrer zu machen, denn es läßt sich denken, daß die vielen Photoagenturen, die das Bildmaterial für die illustrierten Blätter liefern, durch die Bank reaktionär sind, und auffällig, aber zielbewußt alles umgehen, was dem Bürgertum zutiefst verhaßt ist.“19

Die Bilder aus dem Umfeld der Arbeiterfotografiebewegung eignen sich nur bedingt, die soziale Realität des Landes darzustellen. Aktuelle Aufnahmen von politischen Veranstaltungen, Arbeitskämpfen oder sozialen Missständen stammen daher in der Regel von Pressefotografen, durchaus auch solchen mit bürgerlichen Sympathien, etwa von Lothar Rübelt. Dieser veröffentlicht immer wieder im Kuckuck (Abb. 7).

\section{Arbeiterfotografen bei den Naturfreunden}

Eine der traditionsreichsten und politisch aktivsten Fotogruppen, deren Vertreter regelmäßig auf den Seiten des Kuckuck präsent sind, ist die „Photosektion“ der Naturfreunde Meidling. Sie hat ihr Vereinslokal ab 1925 im Fuchsenfeldhof, einem großen Wiener Gemeindebau im 12. Bezirk, einer traditionellen Arbeitergegend. ${ }^{20}$ Die Fotogruppe der Naturfreunde geht auf das Jahr 1905 zurück, 1908 wird sie als „Photosektion“ eingerichtet. Noch vor dem Ersten Weltkrieg entwickeln die Meidlinger Arbeiterfotografen ein reges Vereinsleben, das ab Anfang der 1920er Jahre wieder aufgenommen wird..$^{21}$ Ab 1922 veranstaltet die Sektion jährlich eine Fotoausstellung. Ähnlich wie andere Naturfreunde-Photosektionen, etwa jene in Ottakring ${ }^{22}$, Floridsdorf, Simmering oder Favoriten ${ }^{23}$, organisieren die Meidlinger Fotografen regelmäßig Vorträge, Fotoausflüge und Ausstellungen. Und einige von ihnen bieten ihre Bilder der Presse an. Um 1930 verzeichnet die Gruppe ihren größten Zulauf mit 180 Mitgliedern, wovon lediglich elf Frauen sind. ${ }^{24}$ In der Meidlinger Photosektion setzt sich, im Vergleich zu anderen Arbeiterfotogruppen, die moderne, neusachliche Richtung Anfang der 1930er Jahre am konsequentesten durch. ${ }^{25} \mathrm{Zu}$ ihren Vertretern 


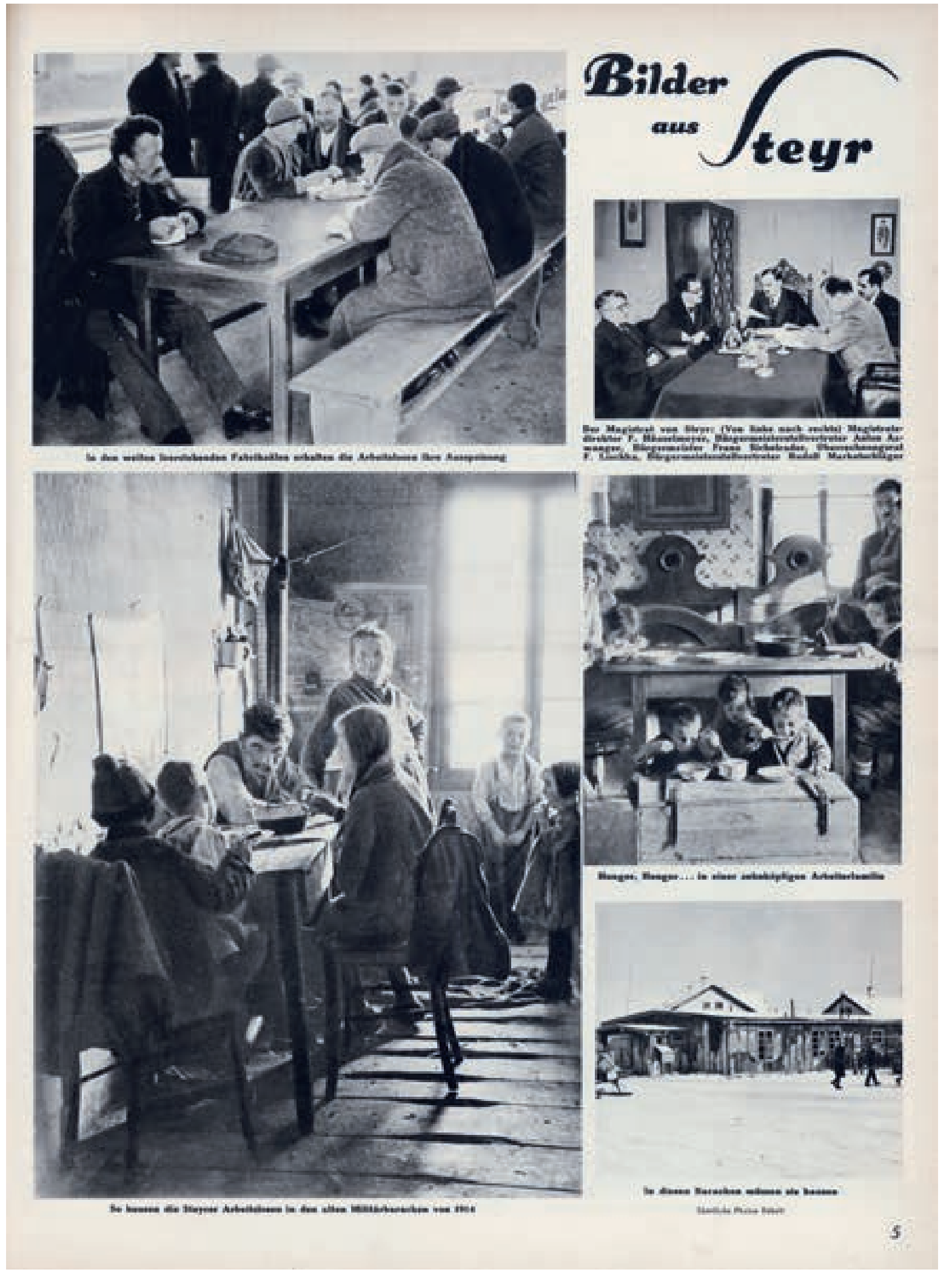

Abb. 7 Bildseite über das soziale Elend in der oberösterreichischen

Stadt Steyr, die Anfang der 1930er Jahre in eine schwere wirtschaftliche Krise gerät. Der Kuckuck, 17. Januar 1932, S. 5. Fotos: Lothar Rübelt. row-20- 


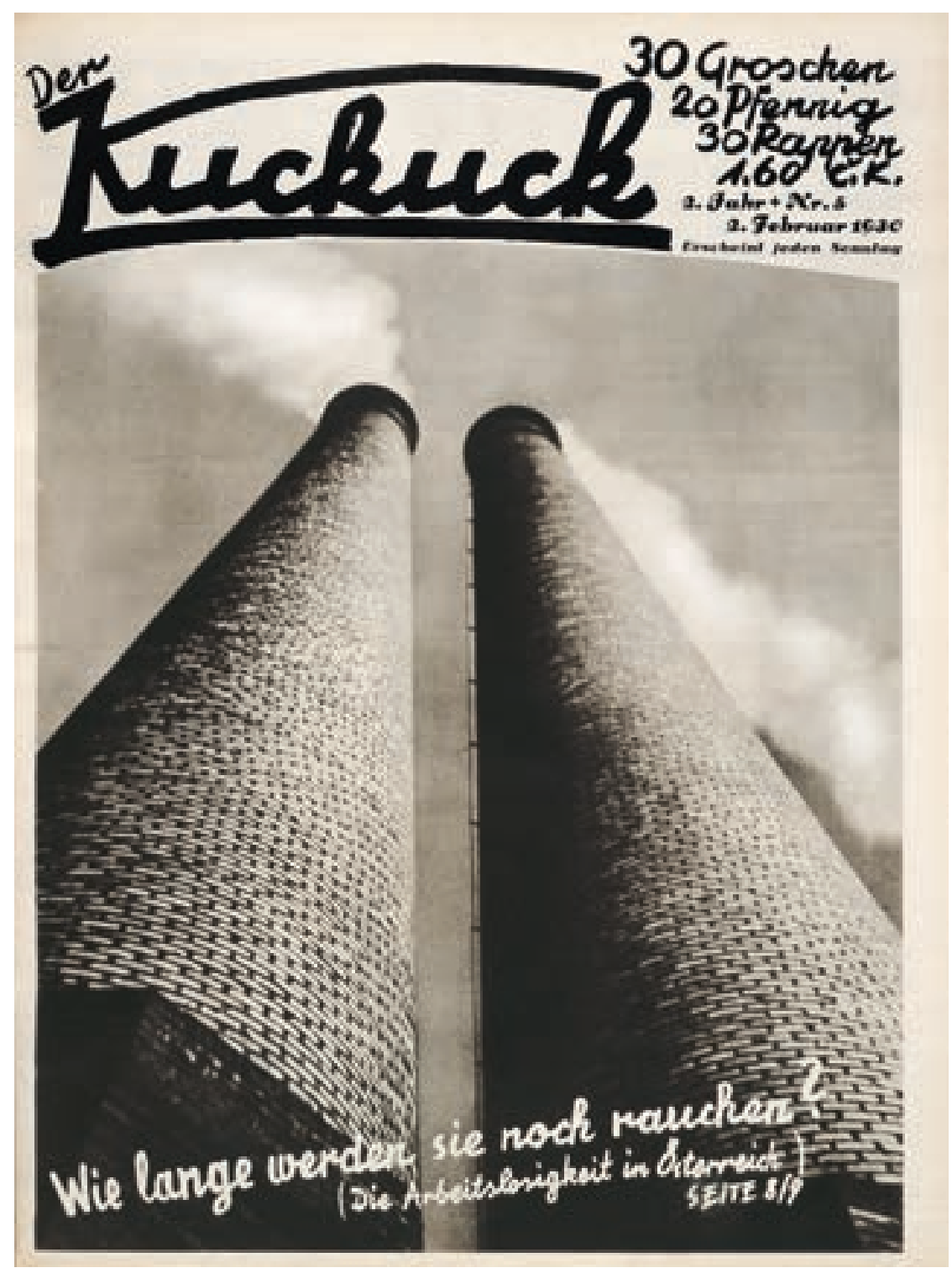

Abb. 8 „Wie lange werden sie noch rauchen? (Die Arbeitslosigkeit in Österreich)“. Das Titelfoto des Kuckuck stammt von Hans Cechal. Er gehört zur Arbeiterfotogruppe der Naturfreunde Meidling. Um 1930 vertritt diese sehr konsequent die Ideen des Neuen Sehens und der Neuen Sachlichkeit. Der Kuckuck, 2. Februar 1930, Titelseite.

Abb. 9 „Geldscheine mit Lohnzettel“. Das österreichische Lichtbild, Jahrbuch 1933, hg. vom Verband der österreichischen Amateurphotographenvereine in Wien, Wien, Troppau, Leipzig 1933, Tafel 74. Foto: Otto Weber. gehören Hans Cechal (Abb. 8), Franz Tesarik, Otto Weber (Abb. 9), Josef Hufnagel, J. Halpern, Ferdinand Hodek (Abb. 10) ${ }^{26}$, Otto Sadler und Martin Imboden. Andere Lichtbildner bleiben dagegen dem kunstfotografischen Programm treu ${ }^{27}$, wobei es angesichts der Ausrichtung des Vereinsprogramms (Wanderungen, Ausflüge) kaum überrascht, dass sie Themen wie Natur und Landschaft bevorzugen. Ihre Aufnahmen und Motive unterscheiden sich oft kaum von jenen der „bürgerlichen“ Amateure.

Die wenigsten der Arbeiter-Lichtbildner sind wirklich Arbeiter, sondern meist Angestellte, gelegentlich Beamte (seltener Freiberufler). ${ }^{28}$ Sie gehen einem Beruf nach (oder sind arbeitslos) und fotografieren als klassische Amateure in ihrer Freizeit. Gemeinsam ist ihnen, dass sie sich der Sozialdemokratie nahe fühlen und in parteinahen Fotogruppen organisiert sind. Der junge Schweizer Martin Imboden etwa arbeitet einige Zeit bei den Meidlinger Arbeiterfotografen mit. ${ }^{29}$ Er kommt im April 1929 nach Wien und sucht hier beruflichen und persönlichen Anschluss. In der Photosektion findet er Gesellschaft, Gleichgesinnte und vor allem jene technische Ausstattung, die der mittellose Mann dringend braucht. Bereits im Herbst 1929 stellt er erstmals auf der Jahresausstellung der Meidlinger Photosektion aus. ${ }^{30}$ Imboden findet bald seine eigene moderne Bildsprache und bietet seine Aufnahmen nicht nur dem Kuckuck an, sondern (später u. a. über die Fotoagentur Schostal) auch anderen illustrierten Zeitungen. Er hat mit seinen Arbeiten, u. a. Tanzbildern, Reisereportagen, Porträts und aufsehenerregenden Kopfstudien, schnell Erfolg. Seine Aufnahmen erscheinen in österreichischen und internationalen Zeitschriften. Er stirbt im August 1935 bei einem Verkehrsunfall (Abb. 11).

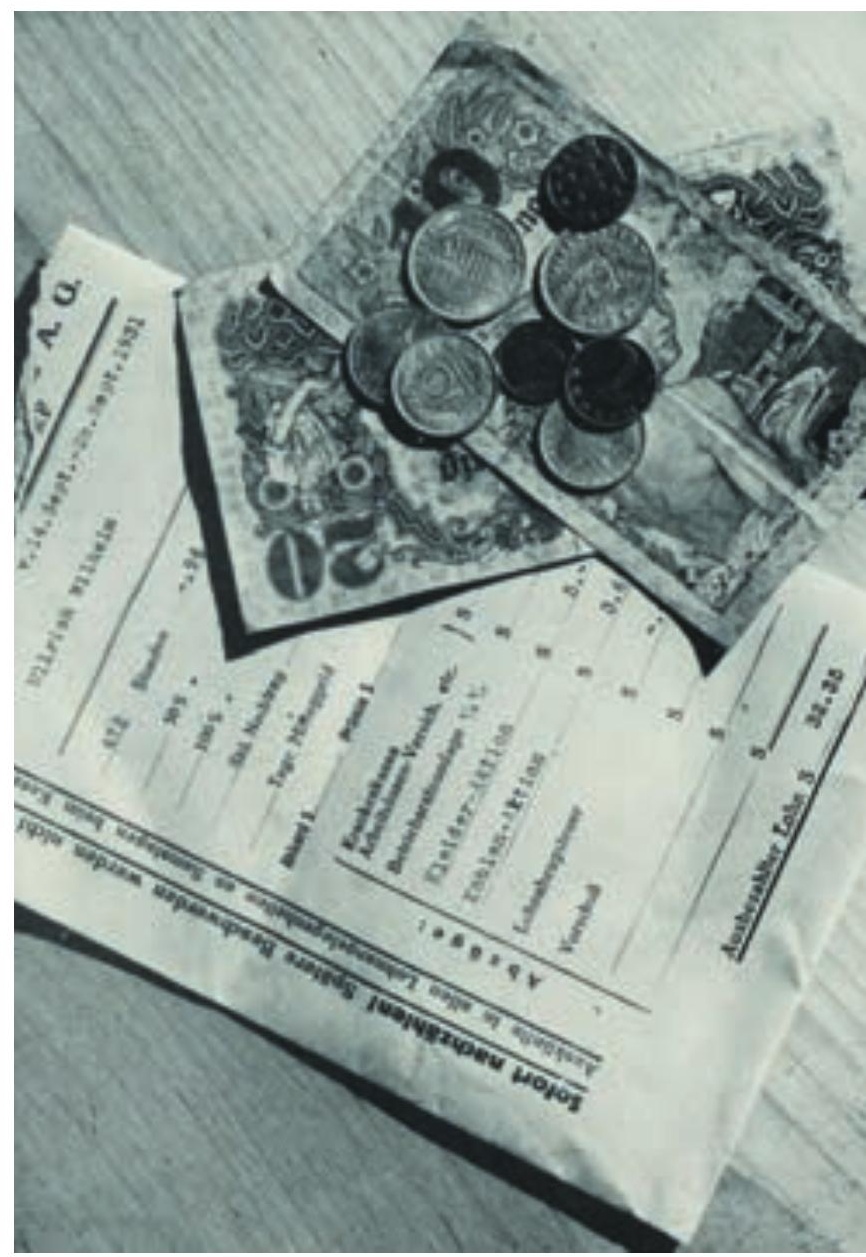




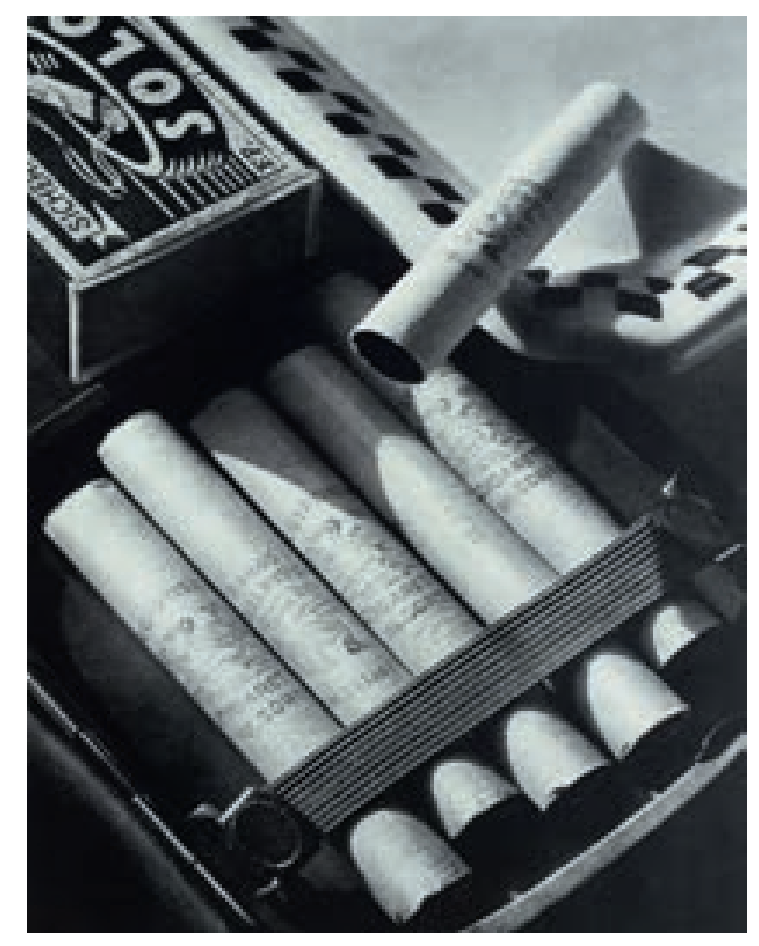

\section{Fotogruppen an den Volkshochschulen}

Ein weiterer Strang der Wiener Arbeiterfotografie ist eng mit den Volkshochschulen verbunden. In einigen dieser Wiener Fortbildungseinrichtungen entstehen in den 1920er Jahren sogenannte „photographische Fachgruppen“. ${ }^{31}$ Sie sind Teil des pädagogischen Angebots der Volkshochschulen, die ihrem Anspruch gerecht zu werden suchen, mit ihren Kursen alle Wissens- und Lebensbereiche abzudecken. Diese Fachgruppen sind lose organisierte Arbeitskreise, die über eigene, oft bestens ausgestattete Räumlichkeiten verfügen. Die bekannteste und rührigste Foto-Fachgruppe ist jene an der Volkshochschule Ottakring am Ludo-Hartmann-Platz 7 im 16. Wiener Gemeindebezirk. In einem Bericht aus den 1920er Jahren heißt es über die Ausstattung dieser Fotogruppe: „Vom
Abb. 10 Zigarettenschachtel. Das österreichische Lichtbild, Jahrbuch 1933, hg. vom

Verband der österreichischen Amateurphotographenvereine in Wien, Wien, Troppau, Leipzig 1933, Tafel 109. Foto: Ferdinand Hodek.

Abb. 11 Nachruf auf Martin Imboden, der am 19. August 1935 bei einem Unfall verunglückt. Die Bühne, Erstes Oktoberheft 1935, S. 26/27.

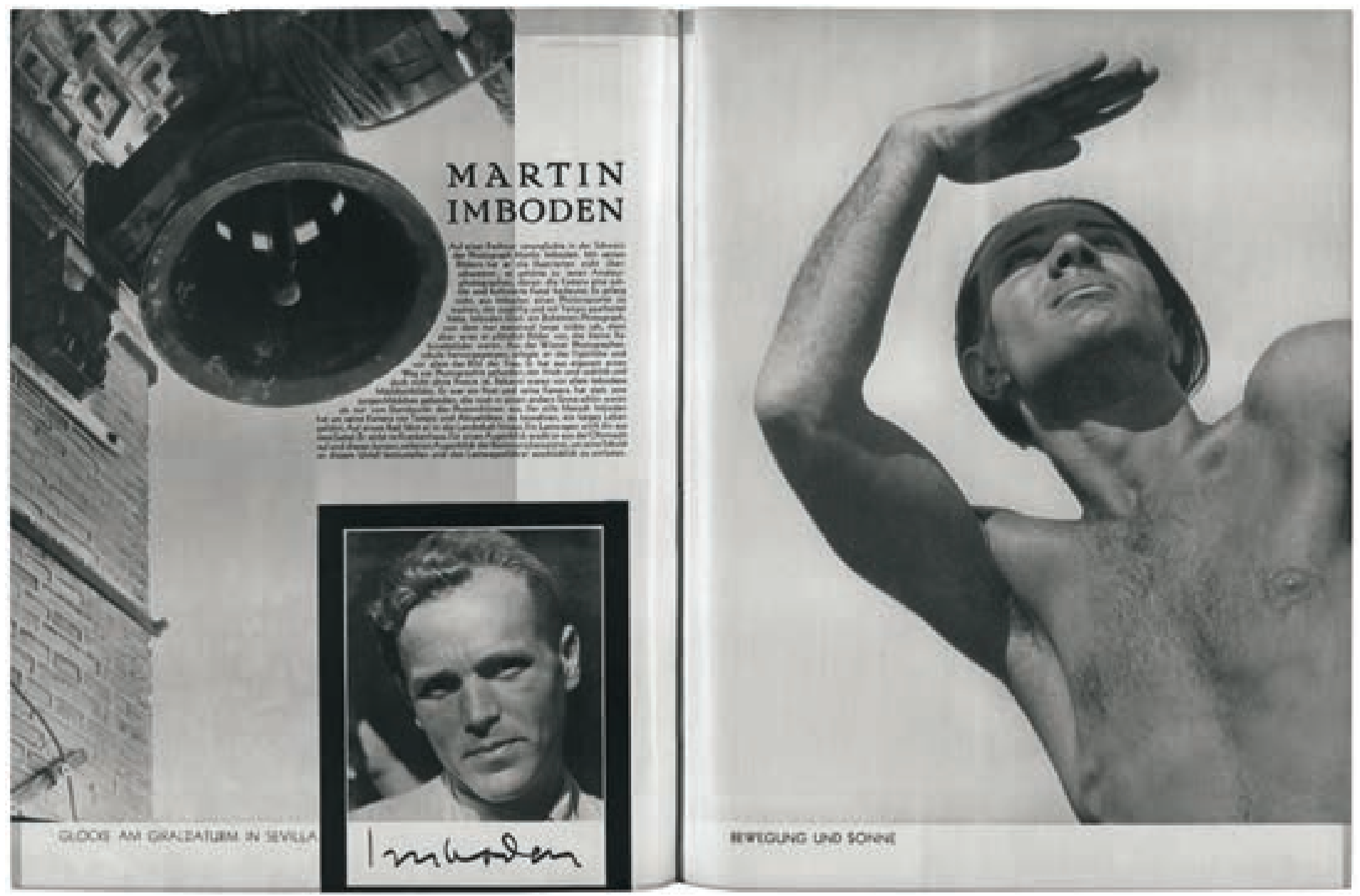




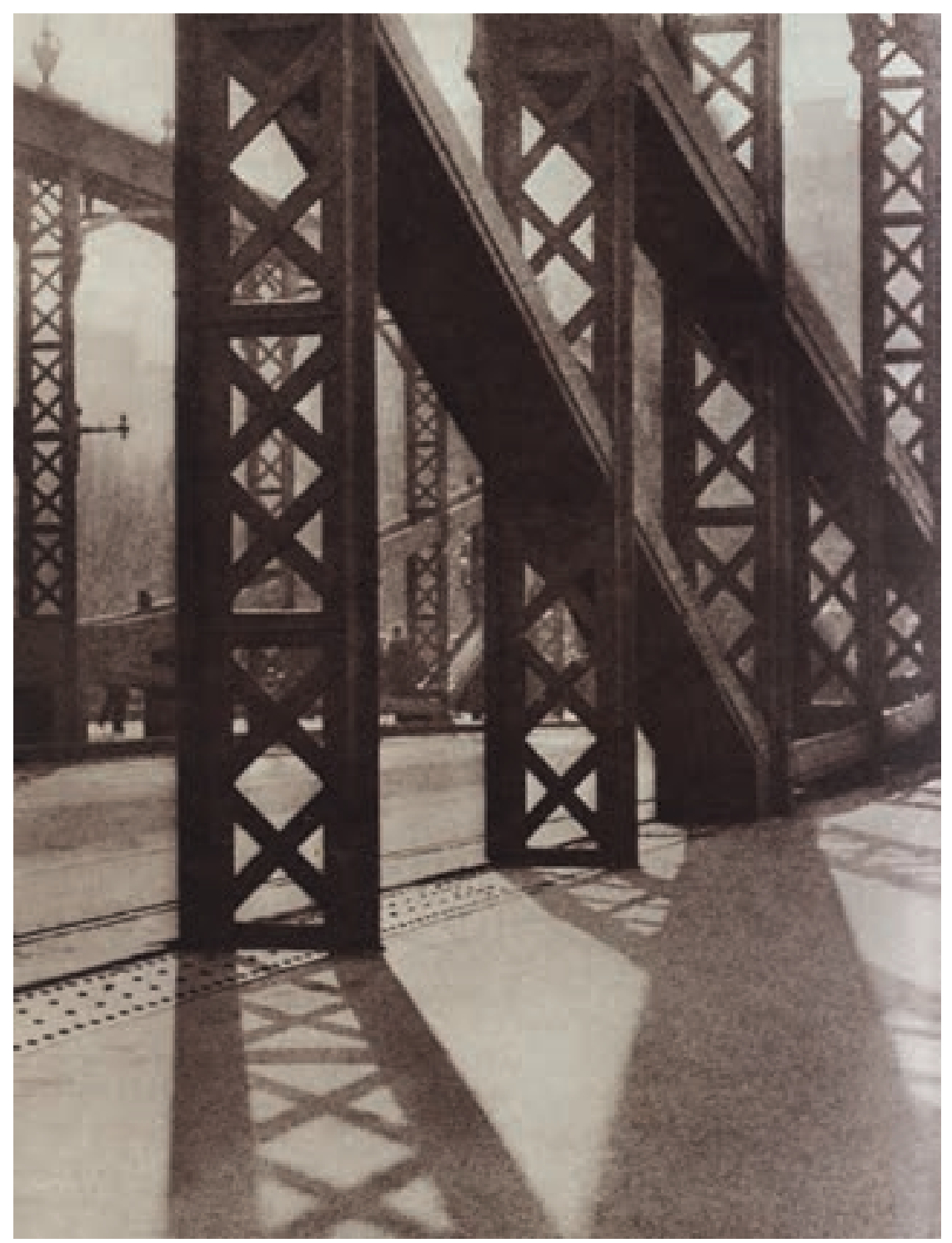

Abb. 12 Die 1873 erbaute Augartenbrücke in Wien kurz vor dem Abriss. 1929 bis 1931 wird an der Stelle der alten Brücke nach Plänen von Hubert Gessner eine neue errichtet. Wiener Magazin, Heft 9, September 1929, S. 52. Foto: Otto Dobrowolny.

Abb. 13 „Stillende Mutter“. Das österreichische Lichtbild, Jahrbuch 1933, hg. vom Verband der österreichischen Amateurphotographenvereine in Wien, Wien, Troppau, Leipzig 1933, Tafel 45. Foto: Cécile Machlup.
Zeichensaal (im dritten Stock, A.H.) gelangt man in die Arbeitsräume der photographischen Fachgruppe, welche auch einen getrennten Aufgang vom zweiten Halbstock aus hat. Die photographische Fachgruppe besitzt fünf Dunkelkammern, jede Dunkelkammer ist mit allen notwendigen Behelfen ausgestattet, außerdem mit Vergrößerungsapparaten, Kopierapparaten usw. Zu den photographischen Kabinetten gehört auch ein eigener Aufnahmeraum, mit Glasdach, und eine Fachbibliothek, sowie ein kleines Fachgruppenzimmer."32

Ähnlich wie die Arbeiterfotografiegruppen bei den Naturfreunden gehen auch jene in der Volkshochschule auf die Zeit vor dem Ersten Weltkrieg zurück. Die Ottakringer Gruppe gibt es seit 1905. Mitte der 1920er Jahre blüht die Gruppe sichtbar auf, die Aktivitäten und Veranstaltungen nehmen $\mathrm{zu},{ }^{33}$ ab 1924 steht sie für einige Jahre unter der Leitung von Karl Irribauer. Unter seiner Obmannschaft steigt die Zahl der Mitglieder von 148 (1924) auf 275 (1928) deutlich an. Sein Nachfolger Karl Ender (ab 1928) setzt die Aktivitäten fort: Die Mitgliederzahl steigt weiter, die Gruppe ist um 1930 überaus rege. Fast wöchentlich werden Veranstaltungen angeboten: Lichtbildervorträge, Kurse, Fotoausflüge. Jährlich im September findet eine Ausstellung der Fachgruppe statt, die in der Presse gute Resonanz findet. Im Unterschied zur Fotogruppe der Naturfreunde Meidling sind die Ottakringer Arbeiterfotografen vor allem an einer systematischen Aus- und Fortbildung interessiert und weniger an künstlerischen Experimenten im Sinne der Avantgarde. Als Vorbilder dienen ihnen die künstlerischen Amateurfotografien, wie sie in den 1920er Jahren weitverbreitet sind: gemäßigt modern, den neuen Strömungen der neusachlichen Fotografie oder des Neuen Sehens vorsichtig aufgeschlossen, aber keineswegs experimentell oder radikal in ihren Ansprüchen. Eine ganze Reihe von Mitgliedern verfolgt (teilweise auch als Lehrer) in diversen Kursen und Ausstellungen dieses Programm: Otto Dobrowolny (Abb. 12), Philipp Fanta, H. E. Zischka, Karl Kranus, Willy Rybarik, Karl Ender, Josef Hammer, Franz Katolicky (der die Bromöldruckarbeiten der Fachgruppe leitet), Alexander Niklitschek, Ludwig Helly, Eugen Sladky, Josef Schramek, Hans Balek und - als eine der wenigen weiblichen Vortragenden und Fotografinnen in der Gruppe - Cécile Machlup (Abb. 13). ${ }^{34}$

Ähnlich wie bei den Naturfreunden sind auch in den Fotogruppen der Volkshochschulen die Arbeiter in der Minderheit. Mehrheitlich handelt es sich bei den Mitgliedern um Angestellte und Beamte. Thematisch entfernen sich viele ihrer Arbeiten weit vom Ideal einer engagierten Arbeiterfotografie, wie sie Siegfried Weyr im Kuckuck vertritt. Beliebt sind - nicht anders als bei den „bürgerlichen“ Amateuren, aber auch bei vielen Naturfreunde-Fotografen - Landschaften, Genreaufnahmen und „schöne“ Objektstudien. Es entstehen auffallend wenige Bilder, die sich mit dem näheren Lebensraum der Arbeiterschaft beschäftigten, etwa Aufnahmen aus dem betriebsamen Stadt-, Straßen- und Arbeitsleben.

Einige wenige Fotografen heben sich allerdings von diesem Muster ab. Unter ihnen ist ein herausragender Fotograf, der bisher in der Fotografie- 


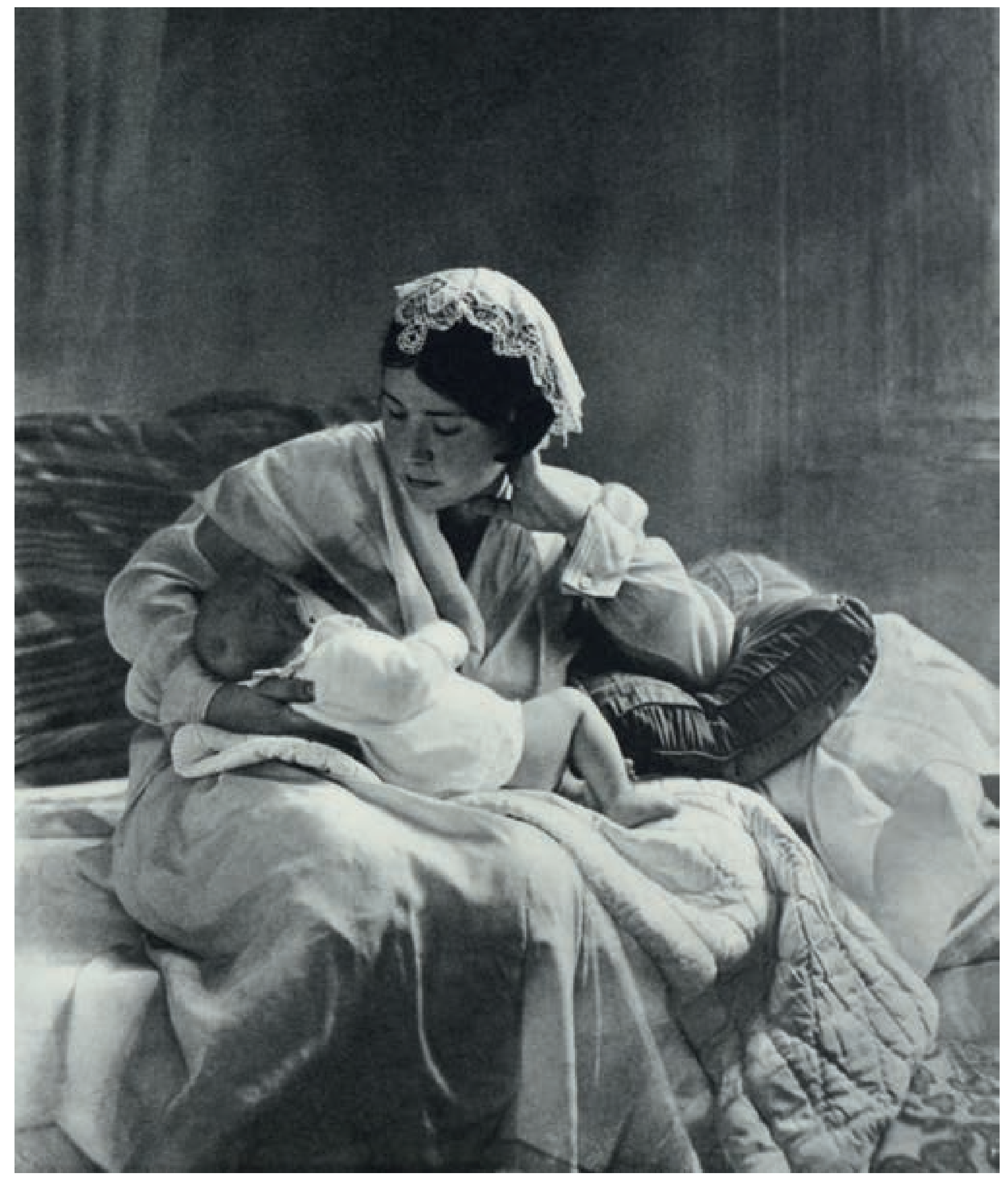


Abb. 14 „Morgengrauen“. Richard Träger gehört mit seinen neusachlichen Aufnahmen zu den herausragenden Vertretern der österreichischen Moderne. Er ist Mitglied der Arbeiterfotogruppe der Volkshochschule Ottakring. Wiener Magazin, Heft 5, 1929, S. 25.
Abb. 15 „Fasching 1931“. In der Fotomontage von Siegfried Weyr werden auf schlagende Weise die gesellschaftlichen Gegensätze dargestellt. Der Kuckuck, 25. Januar 1931, S. 16.

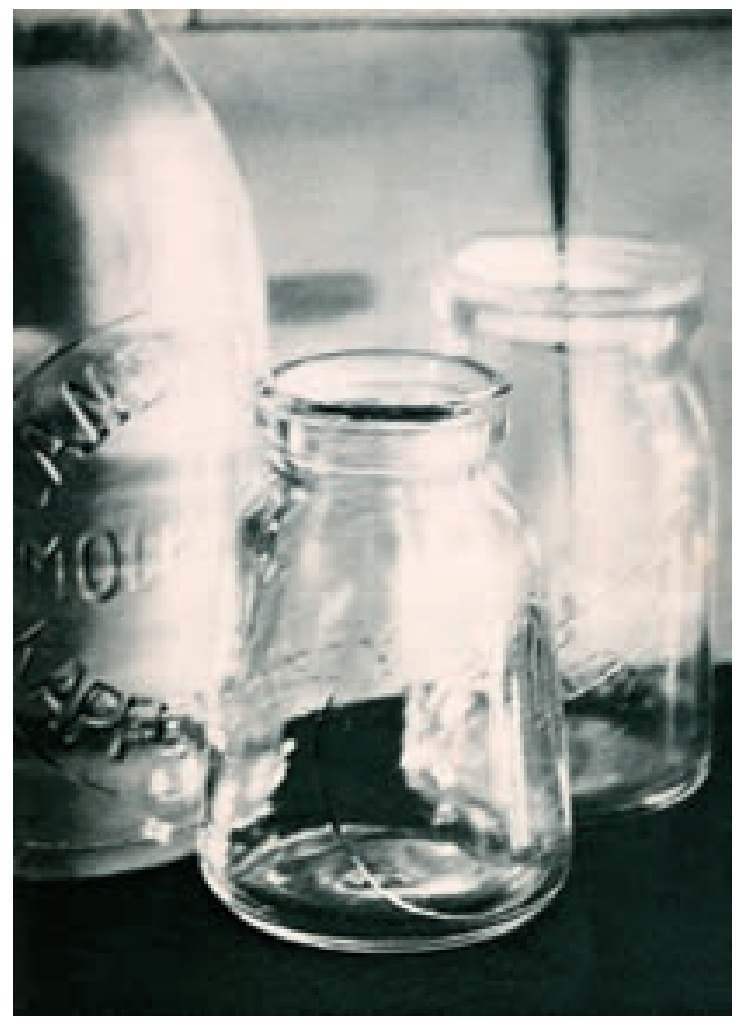

Im Herbst 1935 richtet ihm die Volkshochschule Wien eine kleine Gedächtnisausstellung aus. „Er galt“, heißt es aus diesem Anlass im Mitteilungsblatt der Volkshochschule, „als ein Wegbegleiter der modernen Bildauffassung. Sein Wirken wurde auf allen internationalen Ausstellungen anerkannt.“38 Im September 1935 berichtet das Neue Wiener Journal über die Schau und den Geehrten. „Er war einer der ersten, der ,modern“ photographierte. Schon im Jahr 1925 hatte er seinen Stil gefunden, aber er war viel zu bescheiden, um sich durchzusetzen.“39 Träger gerät bald nach seinem Tod in Vergessenheit.

\section{Gesellschaftskritische Fotomontagen}

Weyr wirft vielen der Arbeiterfotografen „Lebensferne“ vor und verweist auf die deutschen Vorbilder. „Die Arbeiterlichtbildkunst“, schreibt er im November 1931 im Kuckuck, ,ist dort weit weniger individualistisch eingestellt als in Wien. Wird weit mehr als bewußte Arbeit für die Partei betrieben. Wäre es nicht auch in Wien an der Zeit, sich um der Sache willen,

geschichte nicht gewürdigt wurde: Richard Träger. ${ }^{35}$ Im Unterschied zu den meisten seiner Kollegen an der Volkshochschule Ottakring verfolgt Träger in seinen Arbeiten einen radikal neusachlichen Kurs (Abb. 14). Er experimentiert mit Licht und Schatten, modelliert mit seiner Kamera, die er nahe an die Objekte heranführt, faszinierende Stillleben. Er ist ein neugieriger Amateur, der zwar seine Fotos ausstellt, aber nicht von den Veröffentlichungen leben muss. Richard Träger wäre, hätten dies der politische Umbruch des „Ständestaates“ und sein früher Tod nicht verhindert, einer der ganz großen österreichischen Fotografen geworden. Er stirbt am 30. November 1933 bei einem Unfall.

Über sein Leben ist wenig bekannt. ${ }^{36}$ Er ist 1895 geboren, von Beruf Feinmechaniker und beginnt 1919 mit der Fotografie. Seit Mitte der 1920er Jahre engagiert er sich in der Arbeiterfotogruppe der Volkshochschule Ottakring und beteiligt sich ab 1927 mit Erfolg an zahlreichen internationalen Ausstellungen. Auch in der Wiener Werkbundausstellung „Film und Foto“ (1930) ist er mit sechs Beispielen vertreten. ${ }^{37}$

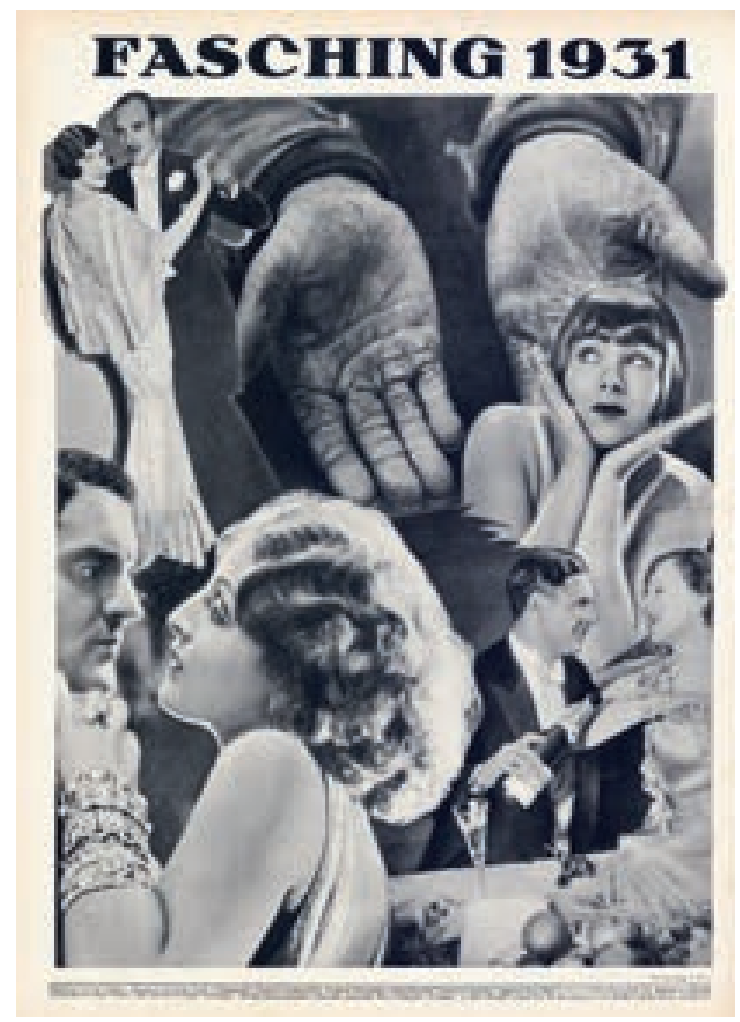


in der Arbeiterphotographie etwas umzustellen?“40 Zwar gibt es einige unter den Arbeiterfotografen, die auch in den Augen von Weyr beachtliches Niveau erreichen und deren Aufnahmen immer wieder gedruckt werden. Aber das Gros der Arbeiten unterscheidet sich aus seiner Sicht nicht wesentlich von den Aufnahmen der bürgerlichen Fotografen. Aus diesem Grund nimmt Weyr die Sache selbst in die Hand. Zusammen mit einigen freien Mitarbeitern setzt er mittels gezielt inszenierter spannungsreicher Fotomontagen auf pointierte politische Bildaussagen. Viele Montagen des Kuckuck stammen von Weyr selbst, andere von Arthur Stadler, einem sehr innovativen Wiener Zeichner und Illustrator, weitere von Alexander Stern, der nach seiner Ausbildung als Gärtner zum experimentellen Künstler wird und als Zeichner, Fotograf, Filmer und Autor in Graz arbeitet. Er signiert seine Arbeiten mit dem Kürzel „STAL“. ${ }^{41}$

Die Dynamik und die Kraft dieser Fotomontagen sind um 1930 neu in der österreichischen Publizistik. ${ }^{42}$ Zwar wird die Fotomontage auch in anderen Blättern gelegentlich eingesetzt, aber keiner anderen illustrierten Wochenzeitung gelingt es, politische Botschaft und Bildprogramm derart konsequent in eins zu setzen. Oft setzen die Fotomontagen auf drastische, aufrüttelnde Gegenüberstellungen, in den Bildern werden politische und gesellschaftliche Gegensätze inszeniert: hier der aggressive Polizeistaat, dort die friedliebende Arbeiterschaft; hier Militarismus, dort Kriegsopfer, hier Nationalsozialismus, dort die Opfer der Gewaltherrschaft. Immer wieder werden die Widersprüche der kapitalistischen Gesellschaft in einfachen, schlagenden Bildern vorgeführt. Während der Faschingszeit im Jahr 1931 stellt Siegfried Weyr in einer bissigen Montage die schwieligen Arbeiterhände dem ausschweifenden Luxus der feinen Gesellschaft entgegen (Abb. 15).

Neben den oft seitenfüllenden Montagen gibt es im Kuckuck auch kleinere Bild-Text-Montagen, die pointiert zu aktuellen politischen Themen Stellung nehmen (Abb. 16). Die Vorbilder für diese „Bild-“ bzw. „Fotogedichte“- wie auch für andere gestalterische

Abb. 16 „Anschauungsunterricht in Rassenlehre“. Bildgedicht von Jura Soyfer. Der Kuckuck, 26. Februar 1933, S. 13.

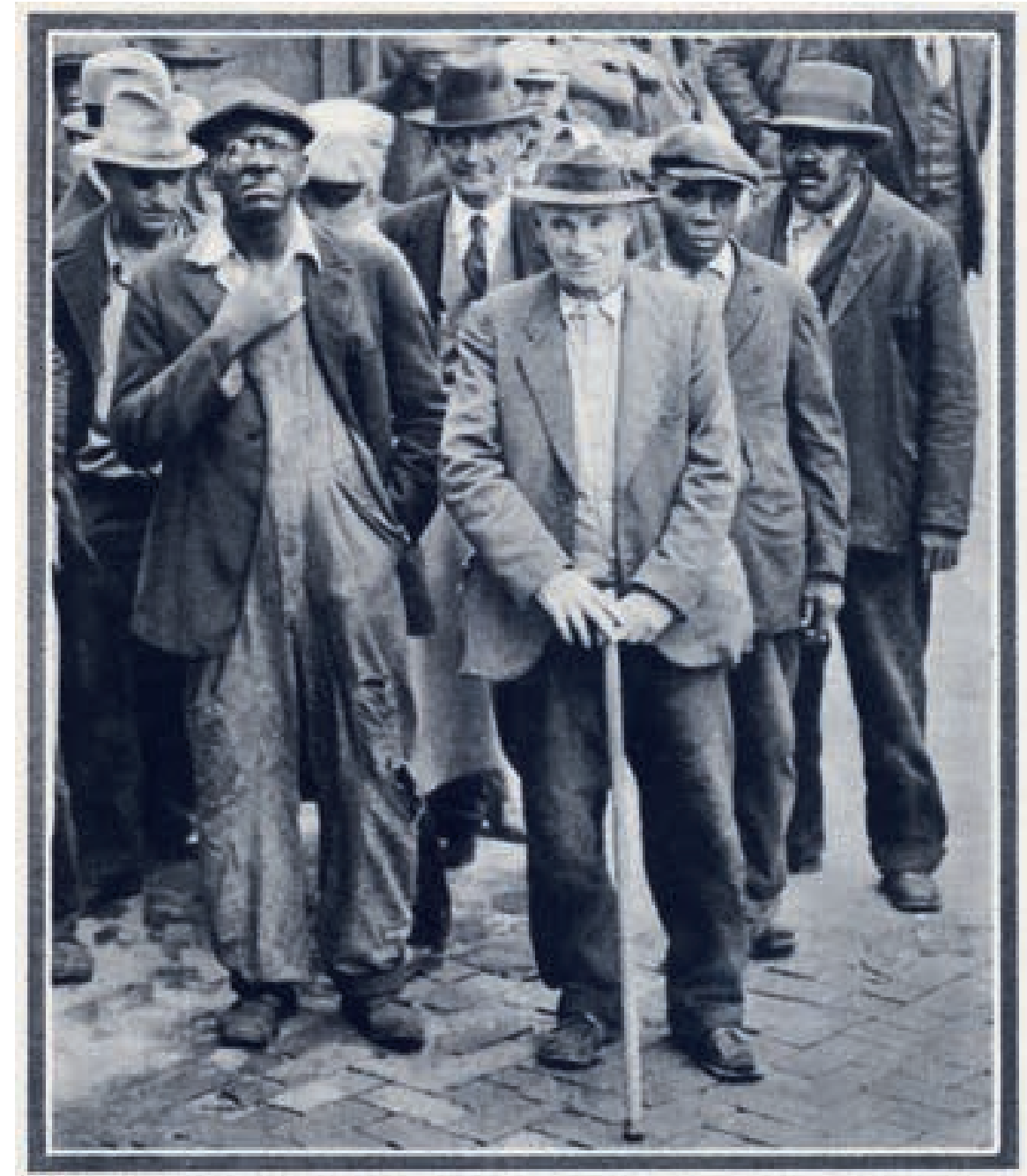

\section{Anschauungsunterricht in Rassenlehre}

Van $1 \mathrm{er}=$

Hier vorn stehn swei Mbinner - mos soge ich do? Hier stehen rwei Routeruppe

Vorm Wohlfohrtyomt in USA

Und worten aut Cnodensuppen.

Der, Finky, it oin Neger min donklem Pigment.

Runduchödel und wulatiger tippe.

Dev, rechts, das siekt mon in eriten Moment. iv nordinche Merrentype.

Man weili hie itrofles, da wolliges Haor -

Kuraumi rwel Monner - Twel Wellen, wich

Der Neger heily Jock, Es fickse Pnevr

Selh lange her in das.

Do prîgelte ithn die Folizei,

Die Prosperity wort der Radau.

Den ser Weibe, wor auch dobei.

Doch dos it olles koum michtiog niche wohr?

Houphoche vind Hautforbe und Hoor!

Iim hat Hunger, Jock wird nich sall.

Und wind die Soche sehr sehismm.

Wird lack so gros wit der Dunlop om Rod,

Wind =eis wie ein leintuch fim.

Fur. Jock gob' es Brol, ouch Kir Jim ved für John Und fur alle Volker der Wet?

De Finlse Ente wird'i hever scbon.

Die verheist wird, verloulh vad vertolh.

Und Jack, obwoll er schwars int, weib:

Seine Zukumberlinung in blot.

Der Weibe heilt Sim. Gr tut ein Tromp.

G bekom rweil Monote meg

Bein Wirbel im Vetsronencamp.

Dock olles dos is koum wichkig, nicht wahr?

Houptroche sind Mautiarbe und Koart

Der Schwarze manschiente rors weille Hous. Indes der Senot hiel Sitrung?

Er und noch viele beullien hinous
Aber Hovplyache sind Houlare und Hoor

Und alles das ist koum wichtig, nicht wahr?

Doch, dor in vichtig. So wichtio sogor,

Dab Longst uchon Im ind Jock

Darob vergoben Hovefoube und Hoor,

Gines nur wissendi dob Tog and Johr

She sitxen in relben Drech

Die ededich des Hungerns müd

sich einigen werden, in Trummer ru hous

den Rasses und den Klossenunterschied!
Dos alle, ob gelb, ichwars, meis ader braun, 


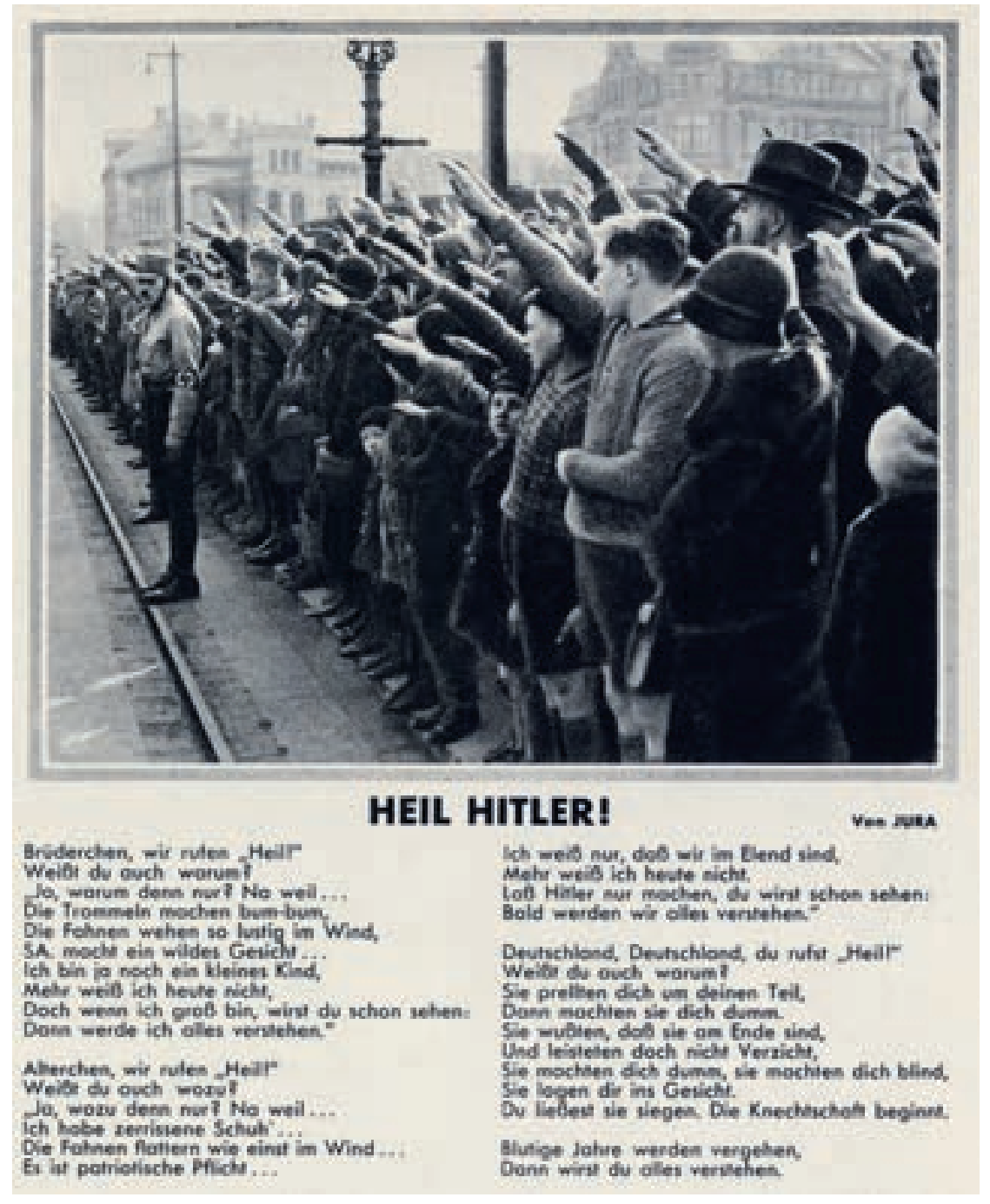

Abb. 17 „Heil Hitler!“. Bildgedicht von Jura Soyfer. Der Kuckuck, 23. April 1933, S. 14 senbegeisterung für Hitler aufs Korn (Abb. 17). ${ }^{43}$ In den letzten Zeilen dieses Textes prophezeit er: „Blutige Jahre werden vergehen, / Dann wirst du alles verstehen." 44

Im Februar 1934 verliert die politisch engagierte Arbeiterfotografie mit einem Schlag ihre - ohnehin begrenzten - Veröffentlichungsmöglichkeiten. Alle sozialdemokratischen Zeitungen und Publikationen werden verboten. Diktatur und Zensur verhindern, dass kritische Fotos in der Presse gedruckt werden. Doch ganz am Ende ist die österreichische Arbeiterfotografiebewegung noch nicht. Edith Suschitzky etwa, die sich nach ihrer Heirat 1933 Tudor-Hart nennt, geht 1934 nach London, wo sie weiterhin als politische Aktivistin und Fotografin im Umfeld der englischen kommunistischen Partei tätig ist. ${ }^{45}$ Aber auch in Österreich selbst gibt es, anders als bisher angenommen, nach 1934 noch vereinzelte Aktivitäten der Arbeiterfotografen. Einige jener Fotogruppen, die sich bereits zuvor von politischen Themen und Motiven ferngehalten haben, können auch danach in eingeschränkter Form weiterarbeiten. Im Schutz der Volkshochschulen, die sich mit dem neuen austrofaschistischen Regime vorsichtig arrangieren, sind die „Photographischen Fachgruppen“ bis zum Jahr 1938 tätig. Vor allem in der Volkshochschule Ottakring werden weiterhin Kurse, Ausflüge und sogar Fotoausstellungen organisiert. Auch der Kreis der Lehrer ändert sich kaum. Noch im Februar 1935 berichtet das Mitteilungsblatt der Volkshochschule stolz über den Ausbau der Arbeitsmöglichkeiten: „Es ist der Photographischen Fachgruppe gelungen, die Zahl der Dunkelkammern von fünf auf neun zu erhöhen.“46

Die von Beginn an politikferne, „schöngeistige“ Ausrichtung der Volkshochschul-Fotoamateure ist es, die ihnen in der Diktatur das organisatorische Überleben sichert. Wenn man die Ausstellungen der Ottakringer Arbeiterfotografen nach 1934 überblickt, wird deutlich, dass sie sich in ihren Bildern immer mehr dem konservativen Mainstream der Amateurfotografie annähern. Dieser tendiert in den 1930er Jahren deutlich in Richtung Heimatfotografie mit idyllischen Landschaften und entrückten Genreszenen - ein Bildprogramm, von dem sich der Kuckuck möglichst ferngehalten hat. 


\section{Amerika, ein Traum}

\section{Wolkenkratzer und Tiller Girls}

Im Juni 1929 blickt ganz Österreich nach Amerika, in das Land der scheinbar unbegrenzten Möglichkeiten. Ein junges Wiener Mädchen, 20 Jahre alt, hat den sagenhaften Aufstieg über Nacht geschafft: Sie ist zur „Miss Universe“ gekürt worden (Abb. 1). Ihr Name ist Lisl Goldarbeiter. Sie ist, so berichtet die Presse, „groß, hat braune Haare, die sie halblang trägt, und große blaue Augen, die merkwürdig ruhig und sicher in die Welt blicken." ${ }^{1}$ (Abb. 2) Goldarbeiter ist die Tochter eines Wiener Ledergalanteriewarenhändlers, hat das Realgymnasium absolviert und entschließt sich auf Zureden eines Freundes, an einem Wiener Schönheitswettbewerb teilzunehmen. Sie wird eingeladen und gewinnt die Wahl zur „Miß Austria“. Als Siegerin fährt sie nach Paris und wird dort Zweite. Dann kommt die Einladung nach Galveston, Texas, USA. Hier findet 1929 die Wahl zur Miss Universe statt. Elf Konkurrentinnen aus aller Welt treten an. Von sieben Preisrichtern stimmen sechs für die Österreicherin. Sie ist die erste Ausländerin, die den Preis gewinnt. Mit einem Schlag ist die junge Wienerin ein begehrtes Fotomodell - und weltberühmt.

1929 ist die Amerikafaszination in Österreich auf einem Höhepunkt angekommen. Amerika, das ist in diesen Jahren ein traumhaftes Gegenbild zur harten Realität im eigenen Land. Sehnsüchtig blickt man aus dem verarmten Kleinstaat, der gerade die Monarchie abgeschüttelt hat, in die amerikanische Ferne, wo Unmögliches möglich scheint. In Gestalt von Lisl Goldarbeiter ist dieser Traum für einen Augenblick Wirklichkeit geworden.

Die junge Schönheitskönigin erscheint als Glücksfee. Wenige Wochen bevor sie nach Amerika abreist, tritt sie in genau dieser Rolle als Schauspielerin in

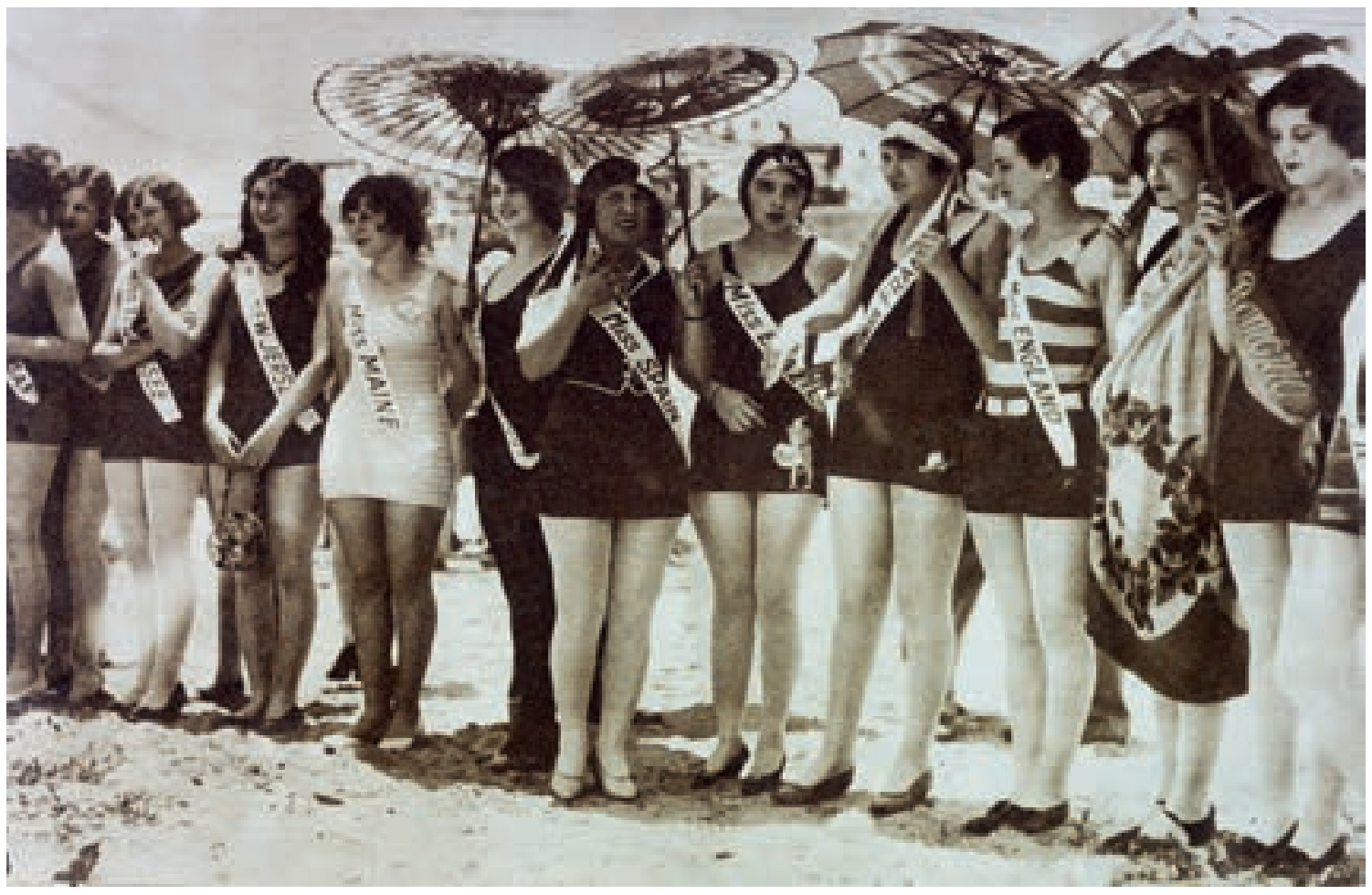

Abb. 1 Schönheitskonkurrenz in Galveston, USA. Defilee im Badeanzug, kurz bevor die Wahl beginnt. Lisl Goldarbeiter, die spätere Siegerin, ist die Zweite von rechts. Das interessante Blatt, 4. Juli 1929, S. 2. 


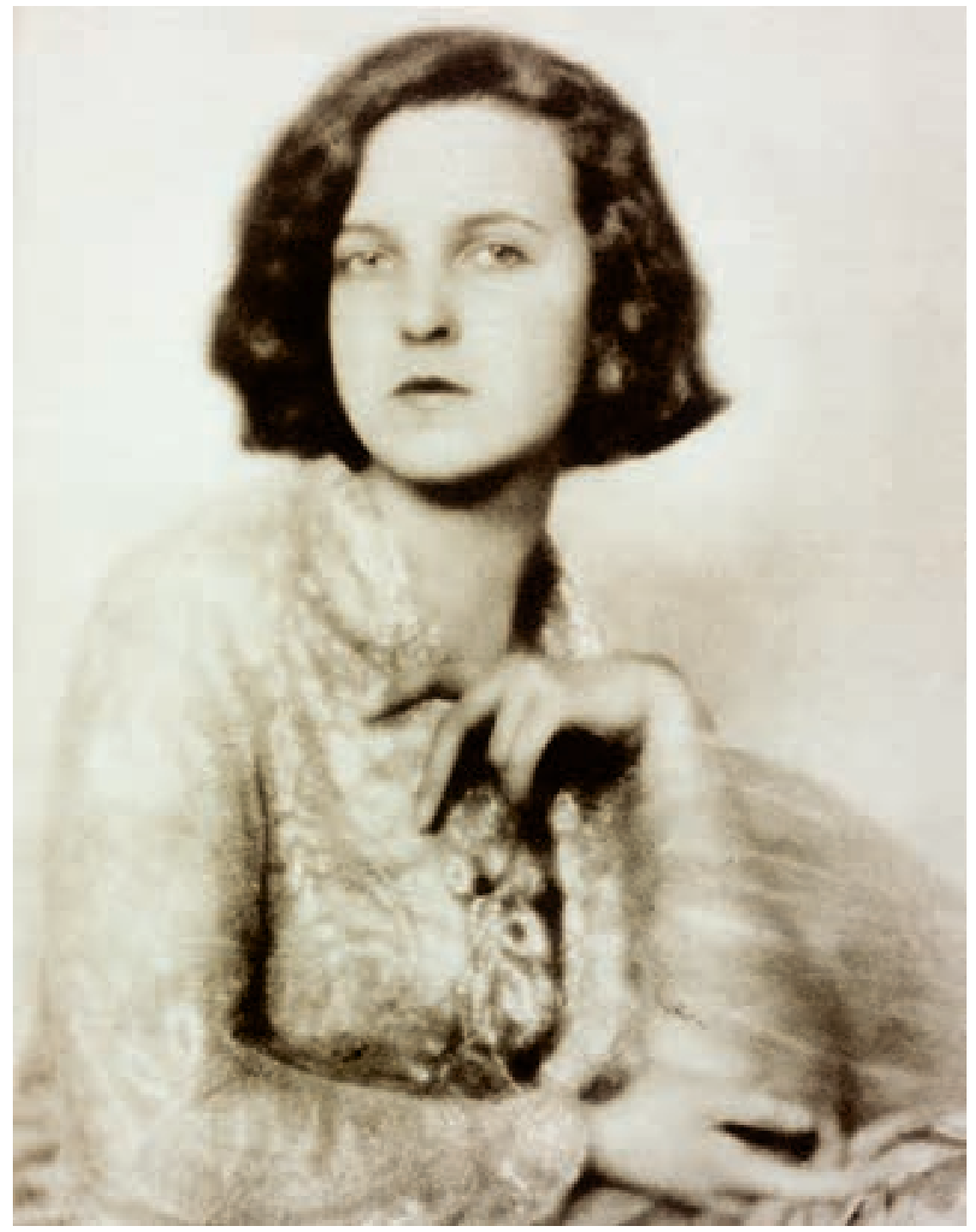

Wien auf. Der kurze Werbestreifen trägt den bezeichnenden Titel „Miß Austria macht ihr Glück!“, er entsteht im Auftrag der Wiener Lottoverkaufsstelle „Glückstelle Stein“ (Abb. 3). Goldarbeiter spielt in dem Film die Hauptrolle. Die Schönheitskönigin weist, so will es die Regie, der einfachen Bevölkerung den Weg zur Klassenlotterie. Dort erwartet sie - quasi über Nacht - Glück und Geld. Als die frischgebackene Miss Universe aus Amerika zurückkehrt, hat sie selbst dieses Glücksversprechen eingelöst. Die Begeisterung über ihren amerikanischen Erfolg ist enorm. Die Zeitungen berichten ausführlich über die schöne Wienerin, ihre Porträts erscheinen in Magazinen und Illustrierten. Und auch auf der Straße ist sie wochenlang das Gesprächsthema. In der Zeitschrift Mein Film heißt es: „Vor dem Schaufenster der ,Glückstelle Stein‘, Wien I., Wipplingerstraße 21, an der ,Hohen Brücke‘, wo Bilder aus dem Film zu sehen sind, sind fast den ganzen Tag Neugierige angestellt, um die Bilder der Schönheitskönigin zu bewundern. “2

Wenige Monate nach dem österreichischen Triumph in Galveston kommt es im Oktober 1929 in New York zum Börsenkrach. Der amerikanische Traum hat Risse bekommen. Die Schockwellen machen sich bald auch in Österreich bemerkbar.

Abb. 2 Die Wienerin Lisl Goldarbeiter ist die erste Ausländerin, die die Auszeichnung „Miss Universe" gewinnt. Das interessante Blatt, 20. Juni 1929, S. 3. Foto: Residenz-Atelier.

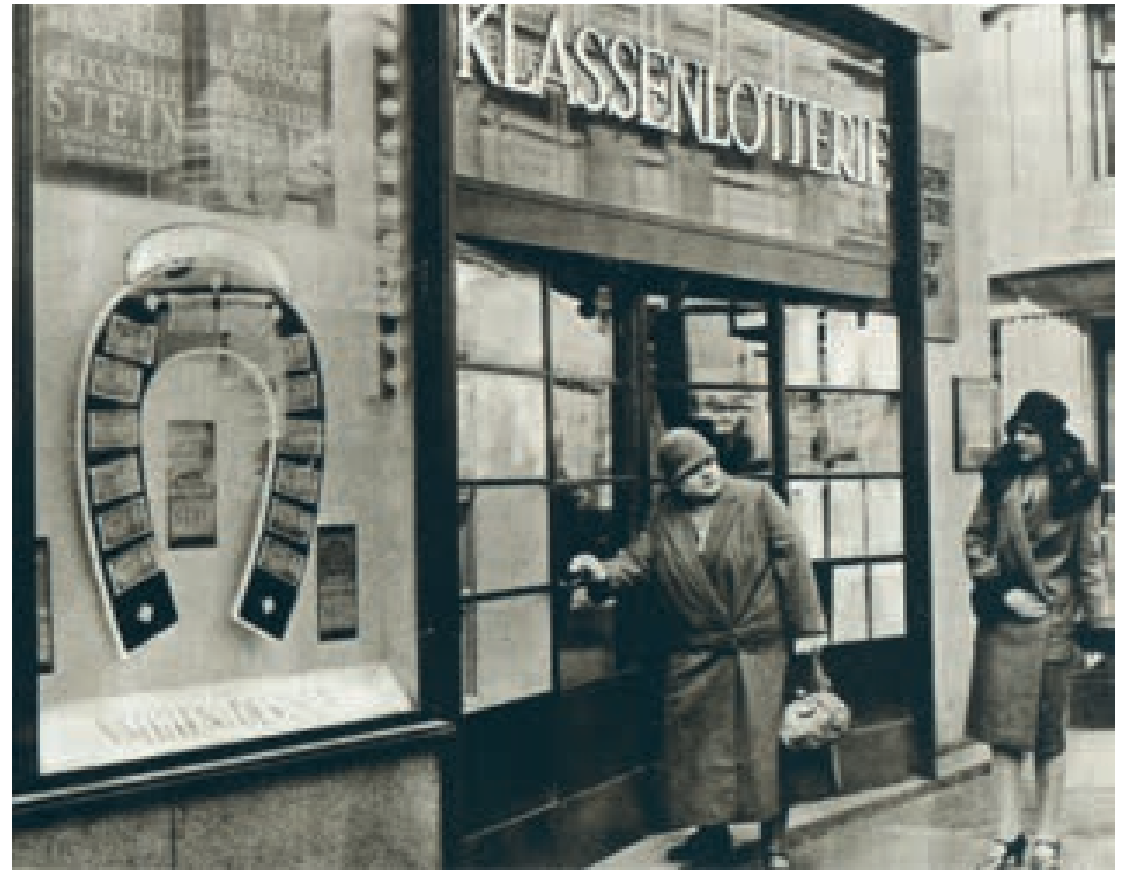

Abb. 3 Lisl Goldarbeiter im Film „Miß Austria macht ihr Glück!“. Der Werbestreifen entsteht im Auftrag der Wiener Lottoverkaufsstelle „Glückstelle Stein“. Mein Film, Nr. 183, 1929, S. 13. 


\section{Unerfülltes Begehren}

In den späten 1920er Jahren gilt Amerika als gelobtes Land des Wohlstands, des Fortschritts und der Freiheit. Importiert wird alles, was noch wenige Jahre zuvor in Österreich unbekannt oder gar geächtet war: luftgefüllte Autoreifen und leicht bekleidete Tiller Girls, Jazz und Boxkämpfe, imposante Hollywoodstreifen und in den Himmel wachsende Hochhäuser. Aber auch unerhörte technische Fortschritte kommen aus Amerika. Ende Mai 1927 etwa gelingt Charles Lindbergh der erste Nonstop-Flug von New York nach Paris. Er wird in Europa stürmisch gefeiert. Nur zwei Wochen später glückt dem amerikanischen Piloten Clarence Chamberlin erstmals ein Passagierflug über den Atlantik. Am 6. Juni landet seine Maschine in der Nähe von Berlin, wo er und sein Fluggast Charles Levine begeistert empfangen werden. Als sie später nach Wien weiterfliegen, schlägt ihnen auch hier Jubel entgegen. Das interessante Blatt widmet den beiden Amerikafliegern Chamberlin und Levine die Titelseite. Im Radio - auch dieses ist eine amerikanische Errungenschaft - wird vom Flughafen Aspern live über die Ankunft der beiden Pioniere berichtet.

Ende der 1920er Jahre scheint die Amerikabegeisterung in Österreich keine Grenzen zu kennen. Und dennoch: Der reale Kulturimport hinterlässt weit weniger Spuren als der vorgestellte. Amerika ist in diesen Jahren eine große Projektionsfläche, die weit mehr über die kollektiven Sehnsüchte und Ängste im eigenen Land erzählt als über die Wirklichkeit jenseits des Atlantiks. Faszination und Widerwillen, Amerikataumel und Amerikatadel gehen in diesen Jahren Hand in Hand. Die Amerikabegeisterung trägt im Kern den Antiamerikanismus bereits in sich. Der eine ist ein verzerrtes Spiegelbild des anderen.

In der Bildwelt der Illustrierten der Zwischenkriegszeit kommt diese zwiespältige Amerikafaszination sehr deutlich zum Ausdruck. Wie mehrdeutig, komplex und untergründig dieser kollektive Traum ist, zeigt eine Fotomontage, die 1933 in der anzüglich-humoristischen Zeitschrift Die Muskete erscheint (Abb.4). Sie trägt den Titel: „Ein junger amerikanischer Arzt denkt noch oft und gerne an seine Studienzeit in Wien. “3 Der gut gekleidete, attraktive
Arzt - ein Amerikaner - sitzt im Vordergrund einer erotisch-schlüpfrigen Szene. Seine Augen sind sehnsüchtig in die Ferne gerichtet - nach Wien. Seine Erinnerung schweift, dies suggeriert der Bildtext, zurück nach Österreich, in seine Studienzeit, in der er ein ausschweifendes Leben geführt hat. Eine ganze Schar spärlich bekleideter, aufreizender junger Frauen tritt auf, die ihm damals in Wien willig ihre sexuellen Dienste angetragen haben. Gewiss, das Bild
Abb. 4 „Ein junger amerikanischer Arzt denkt noch oft und gerne an seine Studienzeit in Wien." Fotomontage in der anzüglich-humoristischen Zeitschrift Die Muskete, Nr. 12, 1933, S. 222.

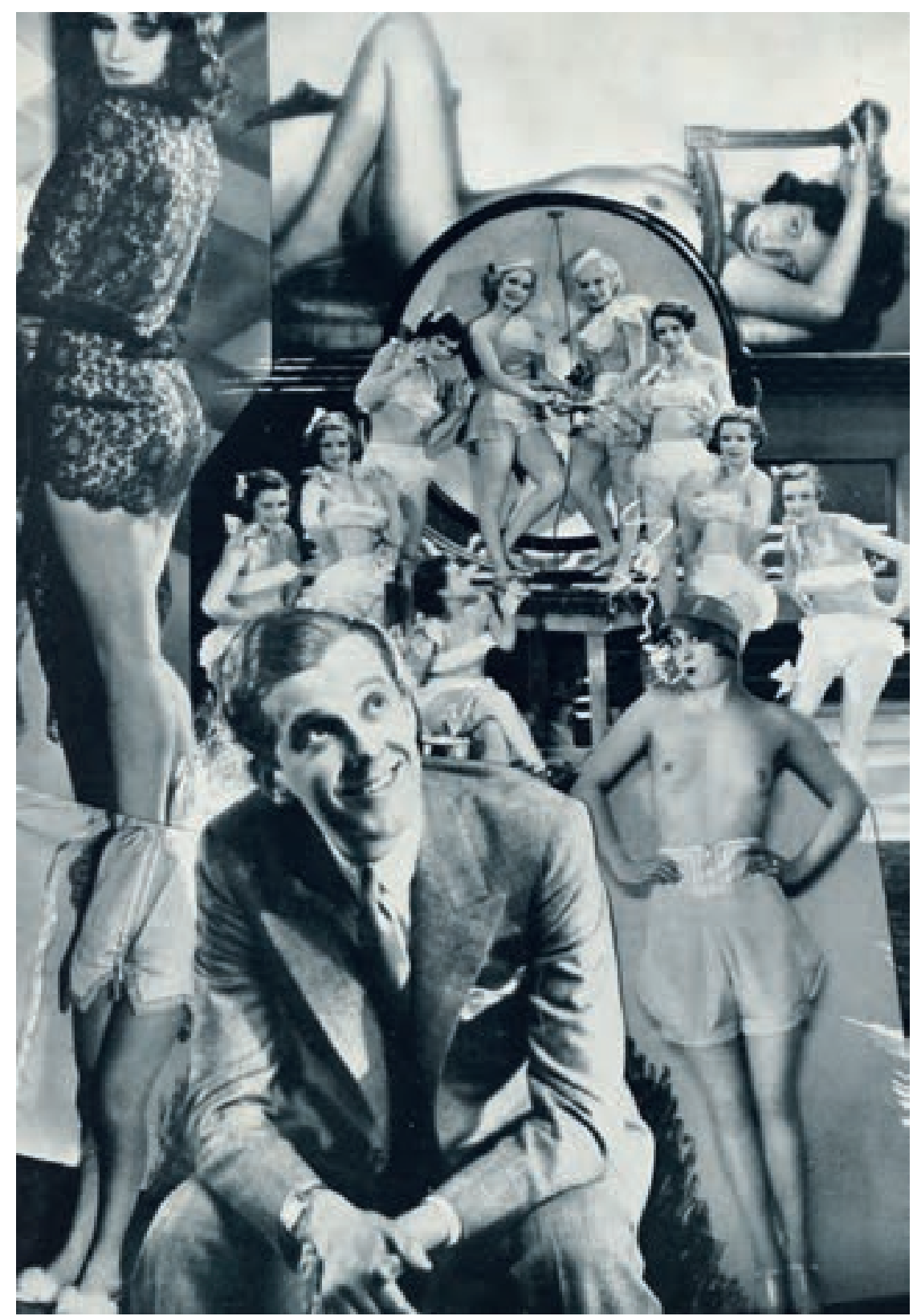


ist eine Montage, die sich über die Realität deutlich hinwegsetzt. Entscheidend ist aber nicht, ob es diesen Arzt und seine erotischen Wiener Träume wirklich gibt (natürlich gibt es ihn nicht), sondern dass die Szene eine in Österreich real existierende Amerikafantasie aufgreift, adaptiert und zuspitzt.

Anfang der 1930er Jahre, als in Österreich die Wirtschaftskrise auf ihrem Höhepunkt angelangt und die Arbeitslosigkeit extrem hoch ist, wird, nicht ganz zufällig, der berufliche Erfolg mit dem Arzt assoziiert und in die amerikanische Ferne verlegt. Der erfolgreiche amerikanische Mann nimmt sich, was er will. Schon in seiner Studienzeit, so die Botschaft, sind ihm die österreichischen Frauen zu Füßen gelegen. „Der Amerikaner“ tritt hier in der Rolle des begehrten Sunny-Boy auf. Die Amerikafaszination begegnet in diesem Fall also im Gewand des erotisch-sexuellen Begehrens. Und dieses ist in dieser Bilderzählung wechselseitig verschränkt. Nicht nur der amerikanische Arzt schweift in Gedanken zurück zum alten Kontinent, zu seinen verflossenen Wiener Geliebten. Auch die Frauen, die hier stellvertretend für Österreich stehen, blicken sehnsüchtig in die Ferne, nach Amerika - und sie wissen zugleich, dass ihr sinnliches Werben auf Dauer umsonst sein wird. Aus österreichischer Sicht thematisiert das Bild damit auch ein kollektives Minderwertigkeitsgefühl, das das Verhältnis zum großen Land der unbegrenzten Möglichkeiten prägt.

Die anzügliche Bilderzählung in der Zeitschrift Die Muskete spült untergründige kollektive Fantasien an die Oberfläche. Sie bildet freilich nur eine Facette im vielschichtigen Mosaik der österreichischen Amerikabegeisterung der Zwischenkriegszeit. Es lohnt sich, diese Projektionen etwas genauer unter die Lupe zu nehmen, denn sie haben sich als haltbar erwiesen: Den amerikanischen Traum gibt es, in aktualisierter und veränderter Form, bis heute. Und auch heute geht mit dem Traumbild das Schattenbild des Antiamerikanismus einher.

\section{Faszination Hollywood}

Bis zum Ersten Weltkrieg ist Amerika aus österreichischer Sicht weit entfernt. Man hat zwar von den ersten spektakulären Hochhausbauten in New York gehört, aber wenige haben diese mit eigenen Augen gesehen. Amerika ist das unbekannte Wunderland, ein begehrtes Auswanderungsziel, in das um die Jahrhundertwende Hunderttausende verarmte Menschen v. a. aus dem Osten der Monarchie gereist waren, um ein besseres Leben aufzubauen. Nach dem Krieg ändert sich die Situation sehr schnell. Amerika, vor Kurzem noch übermächtiger Kriegsgegner, ist den Österreichern mit einem Schlag ganz nahe gerückt: 1919 beginnt die amerikanische Kinderhilfsaktion ihre Arbeit in Österreich. Sie bietet über 200000 vor allem Wiener Kindern kostenlose Ausspeisungen an. 1922 eröffnet sie die Kinderheilanstalt am Tivoli in Wien-Meidling. ${ }^{4}$ Bald danach aber ziehen sich die amerikanischen Spender wieder zurück. Das öffentliche Sozialfürsorgenetz funktioniert inzwischen wieder einigermaßen, der junge Staat ist dabei, sich wirtschaftlich zu erholen.

Mitte der 1920er Jahre ist das Bild Amerikas als großzügiger Spender schon wieder verblasst. Nun ist man an ganz anderen Dingen interessiert, an amerikanischen Shows, an Musik und vor allem an Filmen. Besonders beliebt sind die großen Hollywoodproduktionen, die in diesen Jahren unaufhaltsam Einzug in die Wiener Kinos halten. Die Marken Paramount, Fox oder Metro-Goldwyn-Mayer garantierten handwerklich perfekt gemachte, flotte Unterhaltung. Die amerikanischen Filme bringen aber nicht nur ihre Stoffe und Themen nach Österreich, sondern sind zugleich Vehikel für den Import eines umfassenden amerikanischen Lebensgefühls. Nach und nach entstehen - vor allem in Wien - Großkinos nach amerikanischem Vorbild.

Im Herbst 1929 wird nach umfangreichen, sieben Monate dauernden Umbau- und Modernisierungsarbeiten im ehemaligen Wiener Apollo-Theater in der Gumpendorfer-Straße das Apollo-Kino eröffnet (Abb. 5). Ziel des Umbaus nach Plänen von Carl Witzmann ist es, neueste amerikanische Filme vor großem Publikum zeigen zu können. An die Stelle des traditionellen Varietéetablissements tritt daher ein Großkino, das Platz für 1500 Besucher bietet. Wie sehr das neue Apollo-Kino an einem Schnittpunkt moderner Filmkultur steht, zeigt sich daran, dass 
es 1929 noch als Stummfilmkino eröffnet wird. Aus diesem Grund wird eine moderne Christie-Unit-Orgel angeschafft, die von einer einzigen Person bedient werden kann. Sie sei „ein wahres Wunderwerk modernen Instrumentenbaues“, heißt es in der Presse. ${ }^{5}$ Allerdings werden im Apollo bereits Ende 1929 gelegentlich kurze Tonfilmeinlagen gezeigt. Wenige Monate später haben sich die Zeiten schon radikal geändert. Das Apollo stellt als erstes Wiener Großkino auf den Tonfilm um. Andere große Filmpaläste wie Scala, Sascha, Lustspieltheater und Schwedenkino werden bald folgen.

Die Bühne des alten Apollo wird beibehalten, um weiterhin Tanz-, Varieté- und Musikshows aufführen zu können. Der Zuschauerraum bietet höchsten Komfort. Jeder Sitzplatz auf der Galerie garantiert einen freien Blick auf die Leinwand. „Der Saal ist ganz in Rot getaucht. Rote Damasttapeten bis zur weißen, gewölbten, stuckverzierten Decke. Rot sind die samtbezogenen bequemen Fauteuils, die Läufer und der Fußbodenbelag, mit denen Stiegen, Gänge und der ganze Boden des Zuschauerraumes überzogen sind.“6 Hinter der Kulissen des neuen Hauses verbirgt sich modernste Technik: Eine Dampfheizung wird eingebaut, erneuerte Lüftungs- und Kühlanlagen sorgen für angenehmste Raumtemperaturen.

Am 11. September 1929, dem Tag der Wiedereröffnung des Etablissements, treffen, gewiss nicht zufällig, Wiener Tradition und amerikanische Gegenwart aufeinander: Vor den 1500 Besuchern wird eingangs ein Festmarsch von Richard Strauss gespielt. Im Anschluss wird der amerikanische Monumentalstreifen „Lady Hamilton“ gezeigt. Dazwischen, so berichtet die Presse, tritt die Wiener Tänzerin Grete Wiesenthal auf, es ertönt die neue Kinoorgel „mit grandioser Klangwirkung“ und dazwischen flimmern ein paar Tonfilmeinlagen über die Leinwand („Straßenleben in Shanghai“ und ein kurzer Sprechfilm von Sven Hedin). ${ }^{7}$

Kinopaläste wie das Apollo-Kino haben großen Anteil daran, dass populäre Amerikabilder in Österreich Einzug halten. Die professionell gemachten, leicht verdaulichen Hollywoodproduktionen treffen den Nerv der Zeit. Aber auch Filmdokumentationen mit Amerikathemen stoßen in diesen Jahren auf

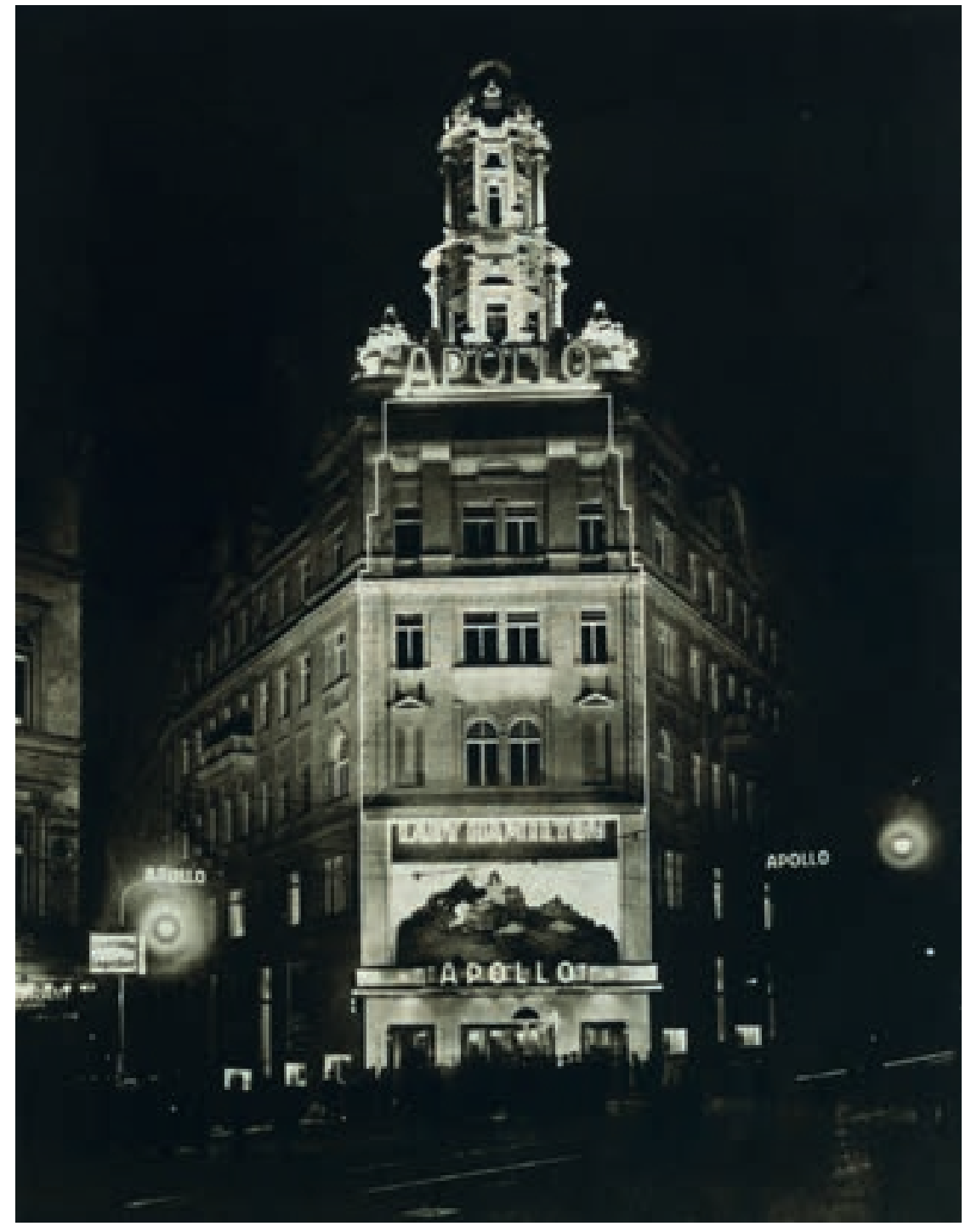

großes Interesse. 1927 etwa zeigt die Wiener Urania den Streifen „Amerika, das Land der unbegrenzten Möglichkeiten“, in dem die USA als Inbegriff der Superlative vorgestellt werden. Neben kalifornischen Goldwäschern, die es im Handumdrehen zu Reichtum bringen, ist ein New Yorker Hochhaushotel mit 3000 Zimmern zu sehen.

\section{Tiller Girls und Jazz}

Das österreichische Amerikabild der 1920er Jahre ist zum guten Teil ein Wunschbild. Es spiegeln sich darin vor allem die Ausbruchssehnsüchte ei-
Abb. 5 Das Wiener Apollo-Kino als Projektionsfläche amerikanischer Filmkultur. 1929 wird das Gebäude in der Gumpendorfer-Straße zum modernen Filmpalast umgebaut. Mein Film, Nr. 195, S. 11. 
Abb. 6 Tiller Girls in der Revue „Wien lacht wieder" von Fritz Grünbaum und Karl Farkas, Wien 1926. Wiener Bilder, 10. Oktober 1926, S. 10. Foto: Atelier Willinger. ner gebeutelten Nachkriegsgesellschaft. Der Blick nach Amerika, oder was man dafür hält, soll Krieg und Wirtschaftskrise, Hunger und Entbehrungen vergessen machen. Amerika steht für Optimismus und Überfluss - wenn auch nur einen Kino- oder Revueabend lang. Nicht immer freilich kommt das, was als typisch „amerikanisch“ angepriesen wird, von weit her. Gelegentlich ist das „Amerikanische“ bloß eine modische Lasur, ein Spiel mit dem begehrten Etikett des Fremden und Exotischen. Als im Herbst 1926 eine Formation der Tiller Girls im Wiener Stadtheater auftritt, huldigt man zweifellos dem amerikanischen Zeitgeist (Abb. 6). Aber die im Gleichschritt tanzenden jungen Frauen kommen nicht aus den USA, sondern sind echte Wienerinnen. Das Publikum stört das ganz und gar nicht. Die Revue, sie stammt von Fritz Grünbaum und Karl Farkas (Musik: Ralph Benatzky), heißt „Wien lacht wieder“. Die üppig ausgestattete Show trifft den Geschmack der Zuschauer, Hunderte Male wird sie in den folgenden Monaten gespielt.
Wenn es ums „Amerikanische“ geht, schielt man also nicht ausschließlich nach Übersee, sondern beispielsweise auch nach Berlin - die berühmten Tiller Girls des Berliner Admiralspalastes tanzen auch in Wien - oder nach Paris, der Wahlheimat von Josephine Baker. Am 1. März 1928 tritt diese nach heftigen Protesten erstmals in Wien auf. Josephine Baker ist eine Kunstfigur, die nicht zufällig in Europa populär wird. In ihr entdecken die Zeitgenossen eine Art ergänzendes Gegenbild zur Welt der Hochhäuser und Wolkenkratzer. Sie steht für wilde Erotik, schwarze Exotik und enthemmte Musik. Josephine Baker schlägt in den Augen des Publikums die Brücke zwischen scheinbaren Gegensätzen: der modernen Großstadt und dem Dschungel.

Während die Tiller Girls für die maschinenhafte Moderne des weißen Amerika stehen, steht der Jazz für das dunkle, untergründige Amerika. Er ist nicht nur eine Musik, sondern ein Lebensgefühl. In Ernst Kreneks Jazz-Oper „Jonny spielt auf“, die 1927 Pre-

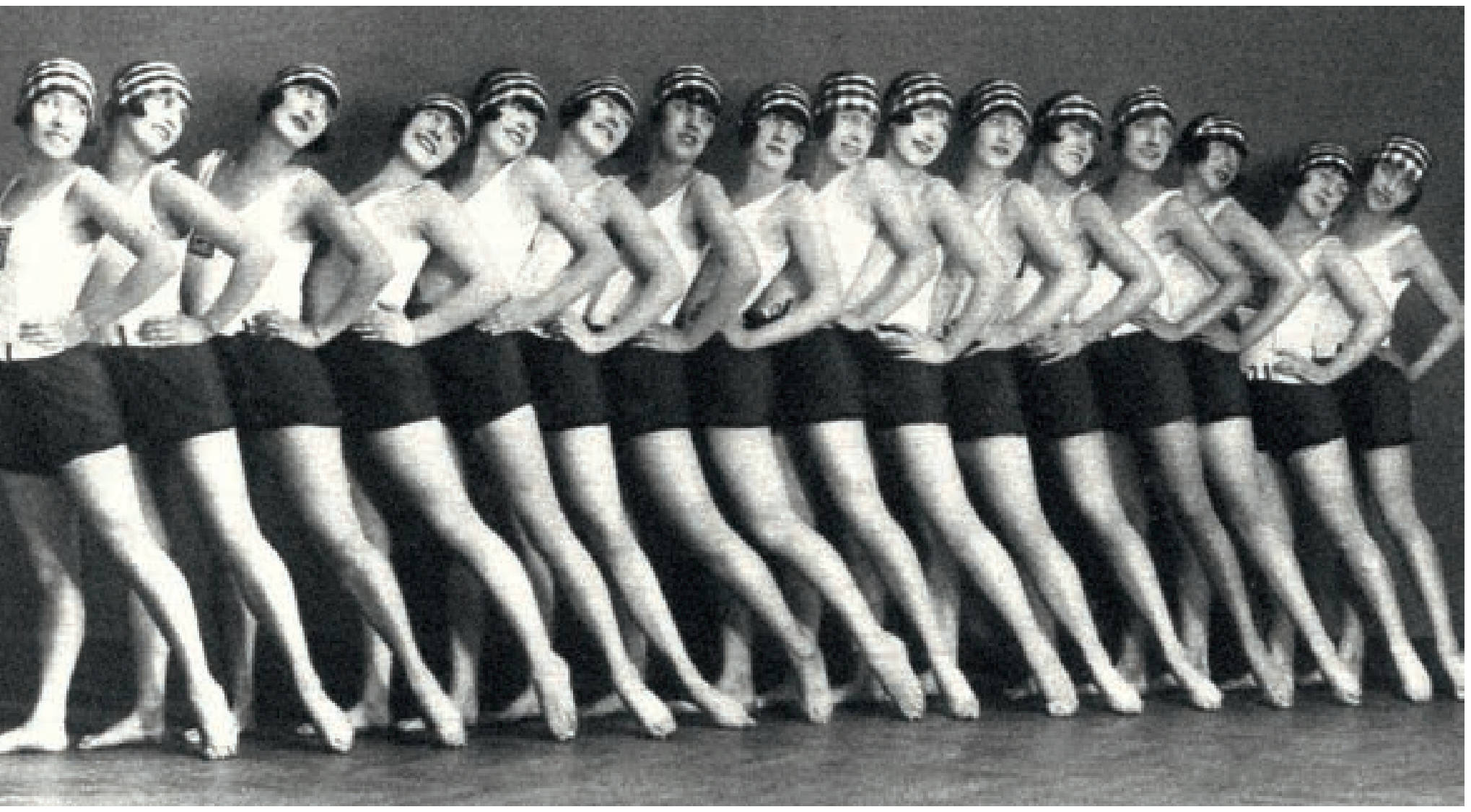


miere hat, kommt dies deutlich zum Ausdruck. Die rasante Handlung endet mit dem Siegeszug des Jazz, der „Schwarzen“ amerikanischen Musik, die nicht nur den europäischen Kontinent, sondern gleich die ganze Welt erobert.

Ende der 1920er Jahre liegt Österreich im Jazzfieber. Jazz-Konzerte, Jazz-Revuen, Jazz-Opern, JazzShows, Jazz-Filme - das importierte musikalische Lebensgefühl wird in allen künstlerischen Formaten durchexerziert, auf der Bühne ebenso wie auf der Leinwand. 1928 produzieren die Wiener Kammerspiele eine Revue-Operette mit dem Titel „Flirt und Jazz“. Wieder stammt das Stück von Fritz Grünbaum und Karl Farkas, Dirigent ist Peter Paul Kreuder. Das Bühnenbild trägt ganz dem amerikanischen Zeitgeist Rechnung (Abb. 7). Leicht bekleidete Frauen räkeln sich zwischen stilisierten Schallplatten. Sie tragen Tonträger mit der Aufschrift „Columbia“ als Kopfschmuck. Die amerikanische Plattenfirma „Columbia Records“ beherrscht das Bühnenbild, sie wird zum visuellen
Motto des Stücks. Flirt und Jazz, die beiden Titelbegriffe der Revue, gehen in der erotisch-anzüglichen Handlung eine Symbiose ein. Währenddessen werden sämtliche amerikanische Stereotypen durchgespielt.

Mit dem Jazz untrennbar verbunden ist das Bild des schwarzen Musikers. In der Bildwelt der Zwischenkriegszeit taucht dieser aber selten als eigenständige, positive Figur auf. Häufiger begegnet er uns als Karikatur. In dieser verwandelt sich der schwarze Jazzmusiker in eine zwiespältige Kreatur: Der eben der Wildnis Entkommene tritt auf die Bühne der großstädtischen Zivilisation - und wird dort bewundert und zugleich gezähmt. Der Jazzmusiker ist also nicht mehr als eine Art Spielgeselle im Hintergrund, dessen Platz die von Weißen frequentierten Vergnügungslokale der Metropolen sind. In einer Karikatur, die anlässlich der nationalsozialistischen Machtübernahme in Deutschland Anfang April 1933 auf der Titelseite der Wiener Zeitschrift Die Muskete erscheint, wird dieses Bild weiter zugespitzt (Abb. 8). Im Vorder-

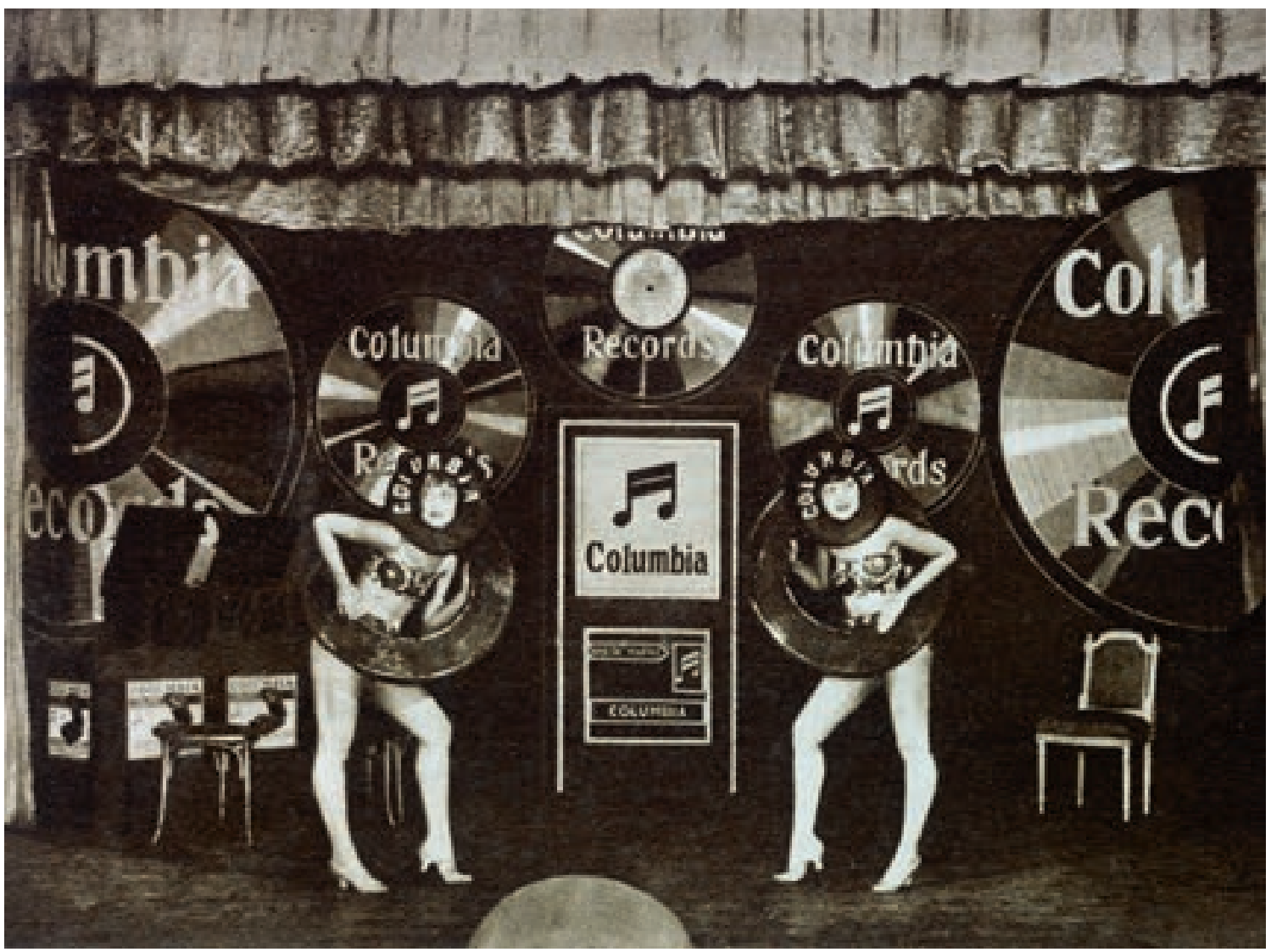

Abb. 7 Die Revue-Operette „Flirt und Jazz“ in den Wiener Kammerspielen (1928) trägt im Bühnenbild der Amerikafaszination Rechnung. Das interessante Blatt, 31. Januar 1929, S. 8. Foto: Atelier Willinger. 
Abb. 8 Runder Kopf, leuchtende weiße Augen, große rote Lippen: Karikatur eines schwarzen Jazzmusikers in der Zeitschrift Die Muskete, Nr. 15, 1933, Titelseite.

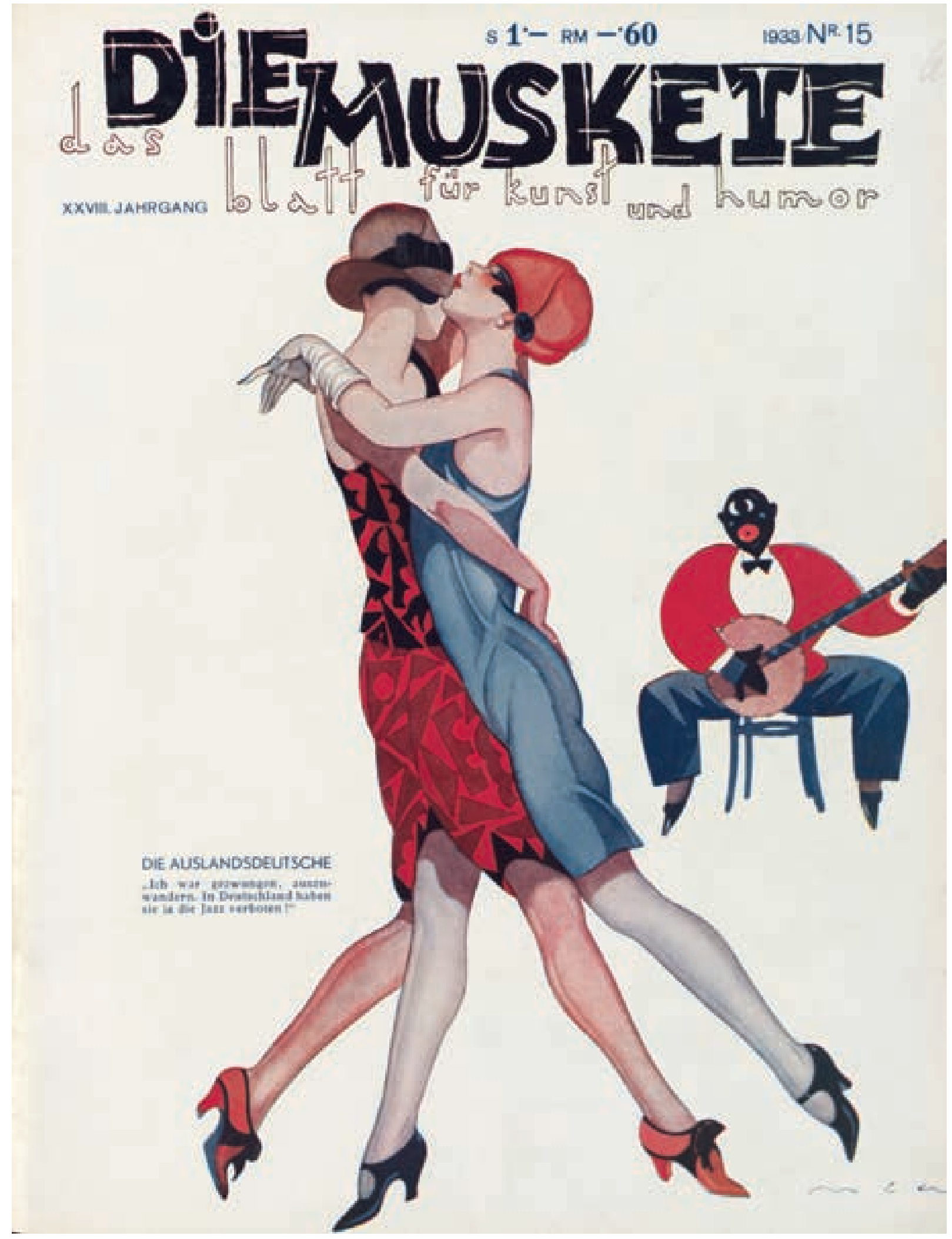


grund tanzen zwei lasziv anmutende, elegante junge Frauen eng umschlungen. Im Hintergrund spielt ein sehr viel kleinerer schwarzer Musiker. Wenige simple zeichnerische Attribute reichen, um aus ihm das Inbild eines „Negers“ zu machen: runder Kopf, leuchtende weiße Augen, große wulstige rote Lippen. Die Szene trägt den Titel: „Die Auslandsdeutsche“. Eine der beiden Frauen wird im Bildtext als Deutsche vorgestellt, die nach Österreich kam, um hier weiter ihrer in Deutschland verbotenen Leidenschaft frönen zu können. „Ich war gezwungen auszuwandern, in Deutschland haben sie ja die Jazz (sic!) verboten."

Die augenzwinkernde Anspielung auf die nationalsozialistische Machtübernahme, die anscheinend nur der Lebensfreude der einen Dame Abbruch tut, wirkt angesichts der realen politischen Ereignisse in Deutschland ein wenig deplatziert. Österreich ist im April 1933 zudem keineswegs ein Hort der Freiheit. Wenige Wochen zuvor ist das Parlament ausgeschaltet worden, Kanzler Dollfuß regiert nun mit Ermächtigungsgesetzen. Der Jazz wird in den folgenden Jahren zwar nicht verboten, aber die österreichische Amerikabegeisterung hat 1933 ihren Zenit bereits überschritten.

\section{Amerika in Wien: das erste Hochhaus}

Am 28. Mai 1930 wird in New York das Chrysler Building eingeweiht. Der spitz nach oben zulaufende Bürohausturm mit seinen 319 Metern Höhe ist zu diesem Zeitpunkt das höchste Gebäude der Welt. Der Bau sticht aus der imposanten Skyline Manhattans mit ihren zahlreichen neu errichteten Wolkenkratzern heraus. Das Chrysler Building als Paradebeispiel des modernen Hochhauses wird bald zu einer Chiffre für Amerika, zu einem Symbol für einen unaufhaltsamen Aufstieg und Fortschritt.

In Wien, das zu dieser Zeit noch kein Hochhaus hat, werden die neuesten amerikanischen Wolkenkratzerbilder in den Illustrierten, aber auch auf Postkarten begierig aufgenommen. Und sehr zaghaft wird diese neue Architektur auch in die Praxis umgesetzt. Im April 1931 wird mit dem Bau des ersten Wiener Hochhauses in der Herrengasse begonnen. Das Ziel freilich ist im Vergleich zu New Yorker Bauten über-

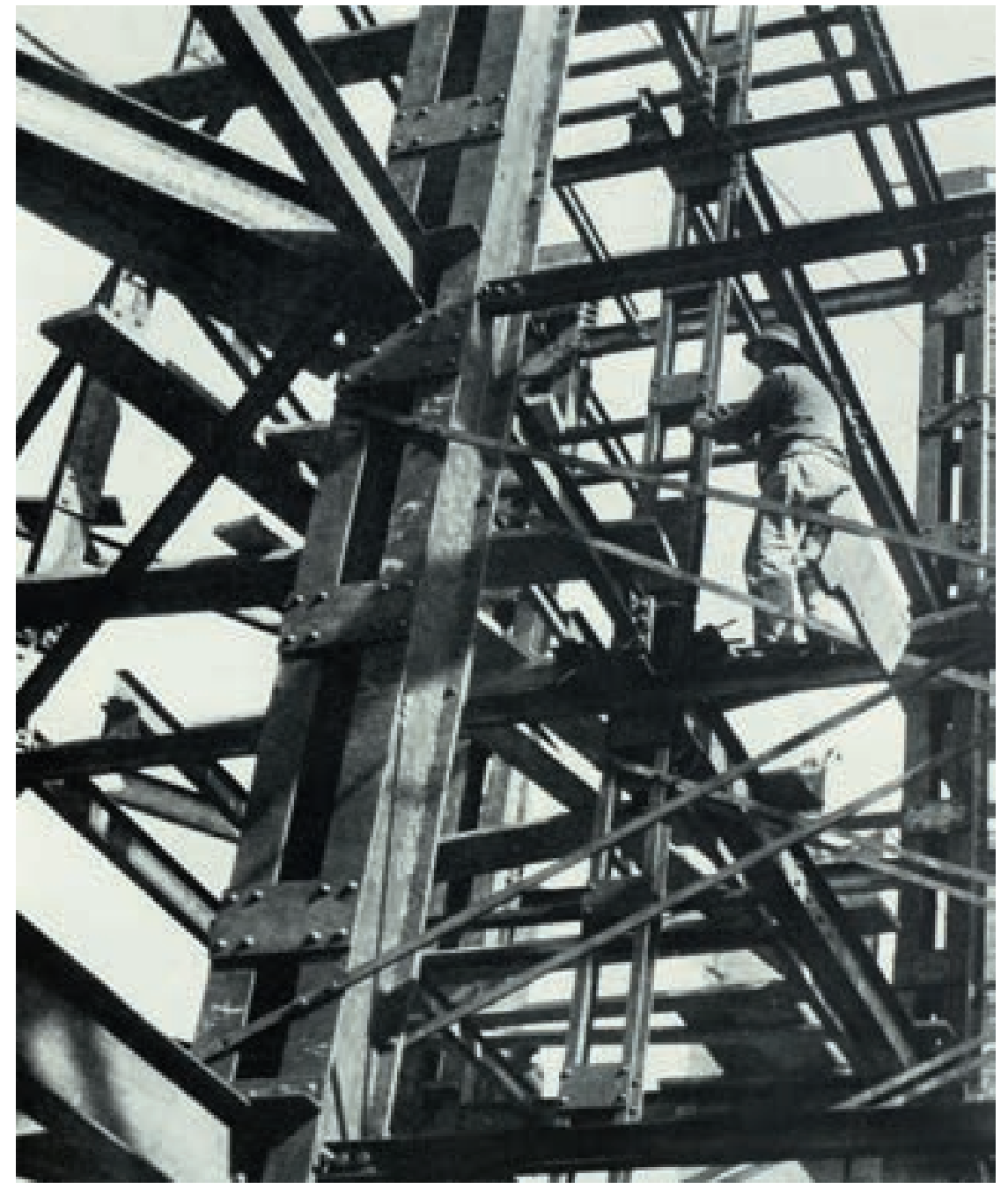

aus bescheiden: 16 Stockwerke und 50 Meter Höhe, das soll in einer Stadt, die eben noch habsburgische Residenz gewesen ist, vorerst reichen. Dennoch wird das Emporwachsen des Stahlskelettbaus in der Öffentlichkeit gebührend gefeiert. Bereits im Herbst 1931, wenige Monate nach Baubeginn, stellt Otto Skall, ein Wiener Vertreter der fotografischen Moderne, für die Zeitschrift Die Bühne eine Fotoreportage über den für Wien ungewöhnlichen Hochhausbau zusammen. ${ }^{8}$ Ein Bild aus dieser Serie findet ein gutes Jahr später Eingang in das Jahrbuch Das österreichische Lichtbild (Abb.9). Die diagonal von unten aufgenommene Szene zeigt einen Arbeiter inmitten des entstehenden Stahlgerippes. Den Horizont, also die Dächer der Wiener Altstadt oder die nur einen
Abb. 9 Der Bau des ersten Wiener Hochhauses in der Herrengasse, Herbst 1931. Die in Untersicht aufgenommene Szene blendet die umgebende Altstadt bewusst aus. Das österreichische Lichtbild, Jahrbuch 1933, hg. vom Verband der österreichischen Amateurphotographenvereine in Wien, Wien, Troppau, Leipzig 1933, Tafel 71. Foto: Otto Skall. 


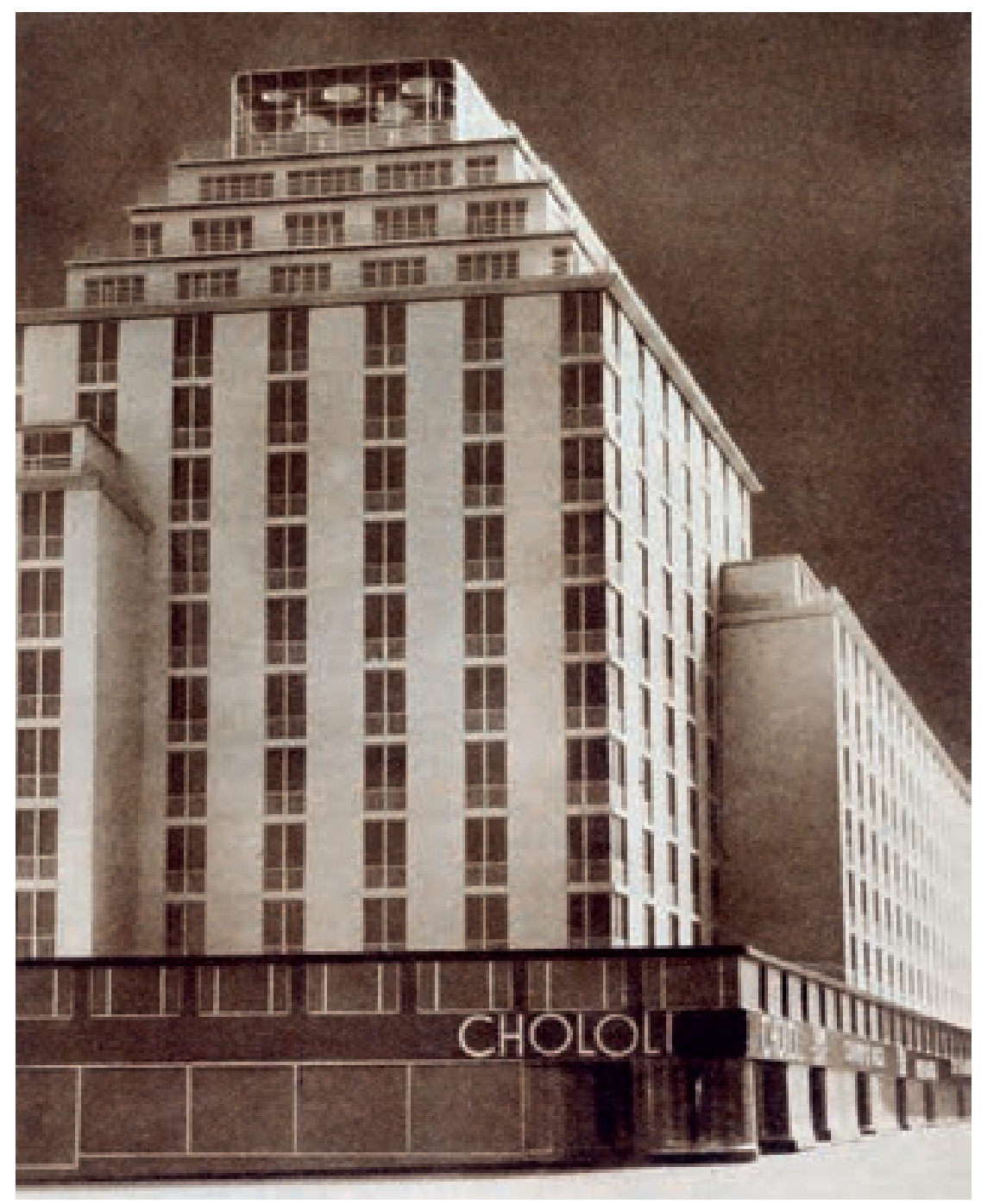

Abb. 10 Das Hochhaus in der Herrengasse nach der Fertigstellung. Zeichnung. Das interessante Blatt, 11. Februar 1932, S. 11.
Steinwurf entfernte Hofburg, blendet der Fotograf bewusst aus. Er hebt die waghalsige Konstruktion damit deutlich vom alten Wien ab und entwirft so ein „amerikanisches“ Bild - mitten im barocken Wien.

Im Februar 1932 - der Bau des Hochhauses in der Herrengasse ist noch in vollem Gange - erscheint im Interessanten Blatt eine Anzeige des Bauherrn, mit der die Vermietung angekurbelt werden soll. Die beigefügte Illustration (Abb. 10) präsentiert das Gebäude, wie es nach der Fertigstellung in einigen Monaten aussehen wird. Wiederum wird die städtische Umgebung, das heißt die enge Herrengasse, die angrenzenden Gebäude, die Hofburg, gänzlich ausgeblendet. In einer Art dramaturgischer Zuspitzung wird der Hochhausbau isoliert und erscheint dadurch monumentaler als er in Wirklichkeit ist. Beide Bilder, Skalls Baustellenfoto und die Illustration der Anzeige, zeigen, wie aufwendig es in der Zwischenkriegszeit ist, moderne, „amerikanische“ Architektur in dem von der K.-u.-k.-Zeit dominierten Wiener Stadtbild zu verankern.
Die moderne amerikanische Baukultur sickert nur sehr langsam in Wien ein. 1929 etwa wird in der Mariahilfer Straße ein modernes Schnellrestaurant (mit Buffetanlage, Drehsesseln und Tellerwaschmaschine) nach amerikanischem Vorbild eröffnet. Betreiber sind die „Wiener Öffentlichen Küchen“ (WÖK), die ärmeren Bevölkerungsschichten ein billiges Speiseangebot liefern. Wenn also in Wien „amerikanisch“ gebaut wird, dann in relativ kleinem Rahmen. Dennoch: Die amerikanische Architektur wird in Wien wie auch anderswo in Europa in den 1920er Jahren intensiv diskutiert. ${ }^{9}$ Keinen geringen Anteil daran hat der Wiener Richard Neutra, der 1923 in die USA zieht und dort als Architekt und Architekturpublizist bekannt wird. Aber er ist weiterhin auch auf dem alten Kontinent publizistisch aktiv. In den 1920er Jahren erscheinen von ihm immer wieder Texte und Bilder über amerikanische Baukultur in österreichischen Zeitschriften. ${ }^{10}$ Seine ersten Bücher veröffentlicht er noch auf Deutsch, sie erscheinen in Deutschland und Österreich. Bekannt wird er 1927 mit seinem Band Wie baut Amerika? 1930 erscheint sein von El Lissitzky gestaltetes Buch Amerika. Die Stilbildung des Neuen Bauens in den Vereinigten Staaten im Wiener Anton Schroll Verlag. ${ }^{11}$ Im pädagogisch aufgebauten Bildband wird die amerikanische Architektur in Fotografien (teilweise von Neutra selbst aufgenommen) vorgestellt.

\section{Lichter der Großstadt}

Im September 1933 widmet die Zeitschrift Profil den Lichtern der Großstadt ein eindrucksvolles Umschlagbild (Abb. 11). ${ }^{12}$ Die Konturen der Stadt Wien gehen fast vollständig im Dunkel der Nacht unter. $\mathrm{Zu}$ sehen ist nur das Flimmern und Leuchten der Werbeschriften, Uhren und Lampen, deren Ordnung sich aufgelöst hat. Die Schriften verdichten und überlagern sie sich zu einem wilden Lichttanz. An die Stelle der orientierenden Wahrnehmung treten diffuse Eindrücke. Es entsteht ein Spiel mit Zeichen, das nur mit Mühe zu entziffern ist. Der namentlich nicht bekannte Autor dieser Montage (er wird nur mit den Anfangsbuchstaben N.A. benannt) zeichnet das „amerikanische“ Wien als fiktives Stimmungsbild, 
wohl wissend, dass die Realität nüchterner aussieht. Das Bild markiert eine Art Wendepunkt der Amerikabegeisterung. Nach 1933 weicht das unbekümmerte Staunen über die modernen Phänomene der Großstadt immer öfter einer antiurbanen, kulturkritischen Haltung.

Für die breite Masse der Bevölkerung ist Amerika in der Zwischenkriegszeit ein diffuses atmosphärisches Konglomerat von Eindrücken und Bildern. Da kaum Bauprojekte nach amerikanischem Vorbild in Wien realisiert werden, wird der architektonische Geist der amerikanischen Metropole mit anderen Mitteln eingefangen. Ab Mitte der 1920er Jahre verleihen Leuchtreklame-Schriften nach amerikanischem Vorbild der alten K.-u.-k.-Stadt zumindest in der Nacht ein modernes Flair. Die sich schnell ausbreitenden Werbeschriften zeugen davon, dass die karge Nachkriegszeit endgültig zu Ende ist.

„Blickt man spät abends vom Kahlenberg auf die - keineswegs schlummernde - Stadt, so umgibt sie eine leuchtende Aureole - die Spiegelung der Lichtreklame“, schreibt der Journalist Alexander Schilling 1928 in der Modernen Welt über das neue, hell erleuchtete Wien bei Nacht. ${ }^{13}$ Und er fährt fort: „Auch die Lichtreklame mit ihrer bunten, flammenden Aufdringlichkeit ist ein Zeichen unserer Tage, ein Symptom fortschreitender Amerikanisierung. Wie die mondäne Frau Schminke und Puder braucht, die Augenbrauen nachzieht, künstlich das Auge dunkel umschattet und auf die Lippen Rot auflegt, so liebt nun auch die Madame Reklame bunte, leuchtende Farben und strahlende Blitze. Alle Zurückhaltung, alle Bescheidenheit sind verbannt. Das Veilchen ist abgesetzt, die exotische Pracht der Orchidee berauscht uns. Man will nicht im Schatten stehen, sondern im - Licht. “14

Schillings Feuilleton ist ein schönes Beispiel für die Faszination, die von der modernen Großstadt ausgeht. Der Autor erliegt dem Reiz der durch Werbeschriften erleuchteten Stadt. Zugleich aber erscheint ihm die amerikanisierte Metropole auch als aufdringlich und gefährlich. Er vergleicht sie mit einer stark geschminkten Frau und wahrt eine gewisse Distanz zur „Madame Reklame“, jener „protzige(n) Dame, deren Beruf es ist, aufzufallen und alle Blicke auf sich zu lenken“. ${ }^{15}$ Schillings Haltung ist typisch für die österreichische Amerikabegeisterung der Zwischenkriegszeit. Diese erscheint, wenn es darum geht, dem Vorbild nachzueifern, auffallend gebremst und verhalten, nach dem Motto: ein wenig Amerika, aber nicht zu viel.

Die „amerikanischste“ Straße Wiens ist in den Augen von Schilling die Kärntner Straße „Hier pulst das Leben der Großstadt in kondensierter Form. Die
Abb. 11 Nächtliches Wien. Die Lichtreklame ist um 1930 die Signatur der modernen Großstadt. Die tanzenden Leuchtschriften entstehen durch Überlagerung mehrerer Aufnahmen. Profil, Heft 9 , September 1933, Titelseite.

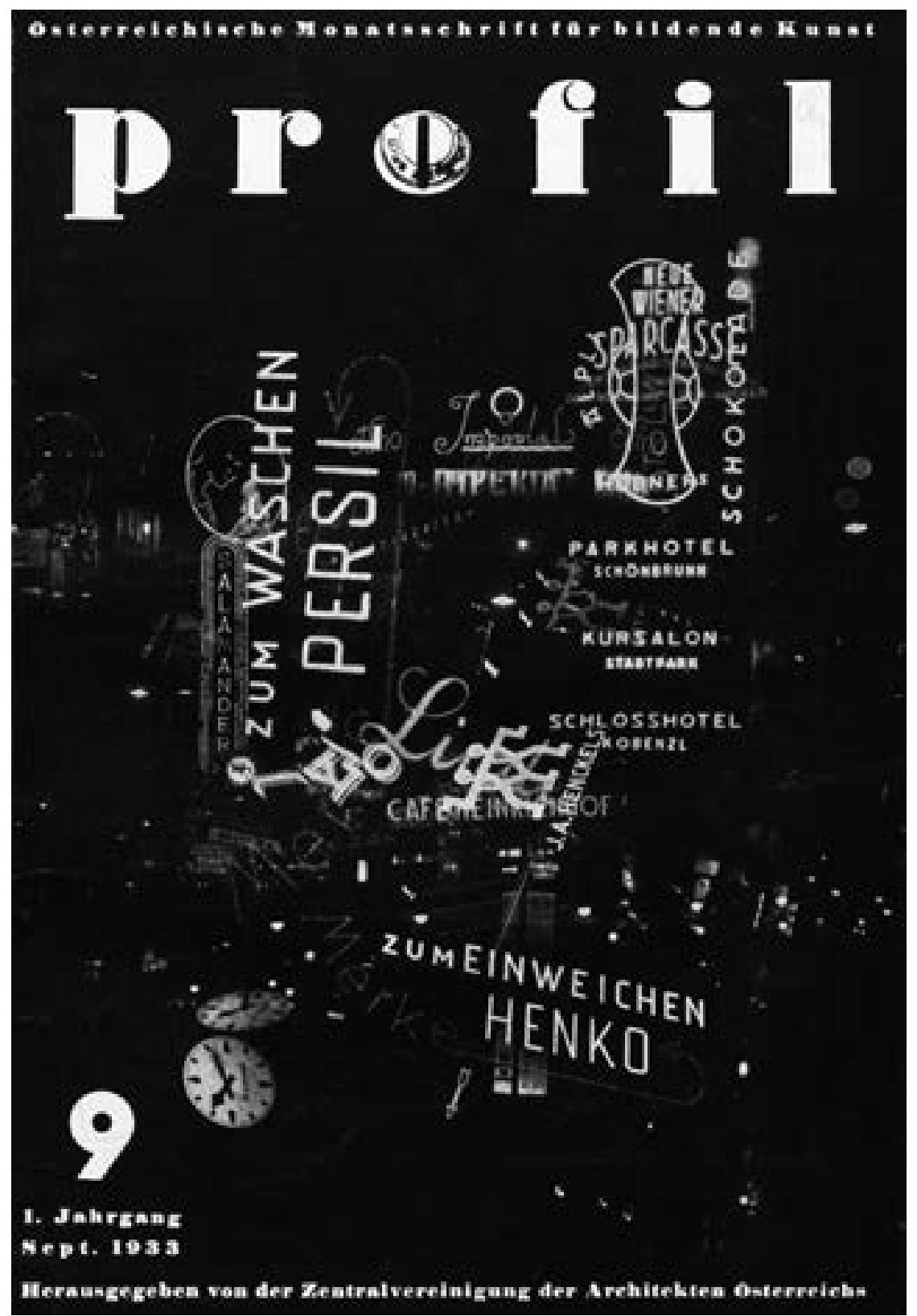




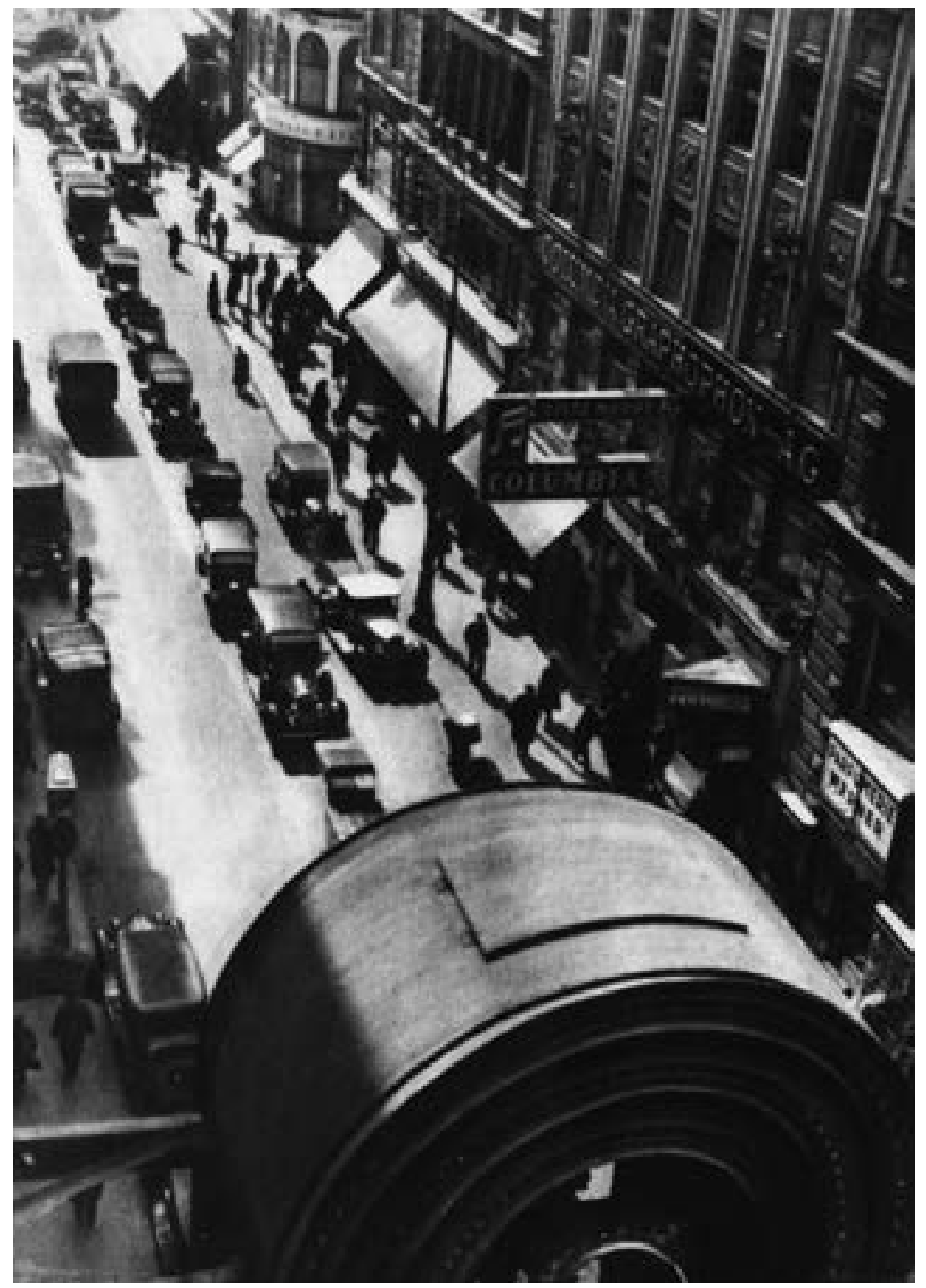

Abb. 12 „Nicht Broadway-sondern Wiener Kärntnerstraße“. Die Bühne, Erstes Aprilheft 1932, S. 20. Foto: Nikolaus Schwarz.
Vertreter einer entschwundenen Epoche, die Träger stolzer Namen, die Repräsentanten neuen Reichtums, Hochstapler, mondäne Frauen, distinguierte Fremde, Maitressen und Dirnen ein Spiegelbild der Großstadt. Reichtum und Armut, Lust und Laster begegnen uns. Und in gewissem Sinne kündet dies alles die Flammenschrift an der Wand.“16 Die Kärntner Straße als Hauptschlagader des modernen, großstädtischen Lebens - dieser Gedanke ist nicht neu. Schon in der Zeit der k.u.k. Monarchie gilt sie, zwischen Stephansdom und Ringstraße gelegen, als mondäne Einkaufsmeile. Aber „amerikanisch“ ist die Kärntner Straße, die fast ausschließlich von Gründerzeitgebäuden gesäumt ist, ganz und gar nicht, auch nicht in der Zwischenkriegszeit. Und dennoch: Zusammen mit der Mariahilfer Straße wird die Kärntner Straße nun - zumindest in der Nacht - mit den Mitteln der Lichtreklame ein wenig „amerikanisiert“. Am Tag allerdings zerrinnt dieses Traumbild wieder.

Ein Foto aus den frühen 1930er Jahren zeigt die Kärntner Straße, wie sie, der Wirklichkeit zum Trotz, dennoch unter amerikanische Vorzeichen gestellt wird (Abb. 12). Die Aufnahme stammt von Nikolaus Schwarz, einem talentierten Wiener Amateurfotografen, der sich dem „Neuen Sehen“ verpflichtet weiß. Er hält das hektische Straßenleben aus erhöhter Perspektive fest. Der Blick fällt auf Autos und Passanten, die in der Abendsonne lange Schatten werfen. „Nicht Broadway - sondern Wiener Kärntnerstraße“, lesen wir unter dem Bild. Die Kärntner Straße als Broadway, das ist ein Gedankenexperiment, das nur augenzwinkernd funktioniert. Und das sogleich zurückgenommen wird.

\section{Die andere Seite Amerikas}

Ende der 1920er Jahre mischen sich zunehmend amerikakritische Stimmen in die transatlantische Begeisterung. Man unterstellt der amerikanischen Kultur und ihren glitzernden Fassaden Seelenlosigkeit und Oberflächlichkeit. Die politische Rechte bringt rassistische Slogans in Stellung. ${ }^{17}$ Aber auch aufseiten der Linken wird nun zunehmend mit den USA abgerechnet. „Amerika“, heißt es im August 1929 in der österreichischen sozialdemokratischen Illustrierten Der Kuckuck, „das bedeutet Kapitalismus reinsten Wassers. Das heißt: Mammutvermögen in einigen Händen vereinigt, heißt bisher höchste, vollendete Zusammenballung des Nationalreichtums in wenigen, den Staat und die Wirtschaft beherrschenden Trusten. Gigantische Fabrikanlagen, die ihre Arbeiter nach Zehntausenden berechnen, werden bündelweise aufgekauft, zentral dirigiert und zu höchster arbeitsteiliger Nutzung angetrieben. “18 Das Fazit lautet: „Dieses Amerika der Truste und Kartelle, 


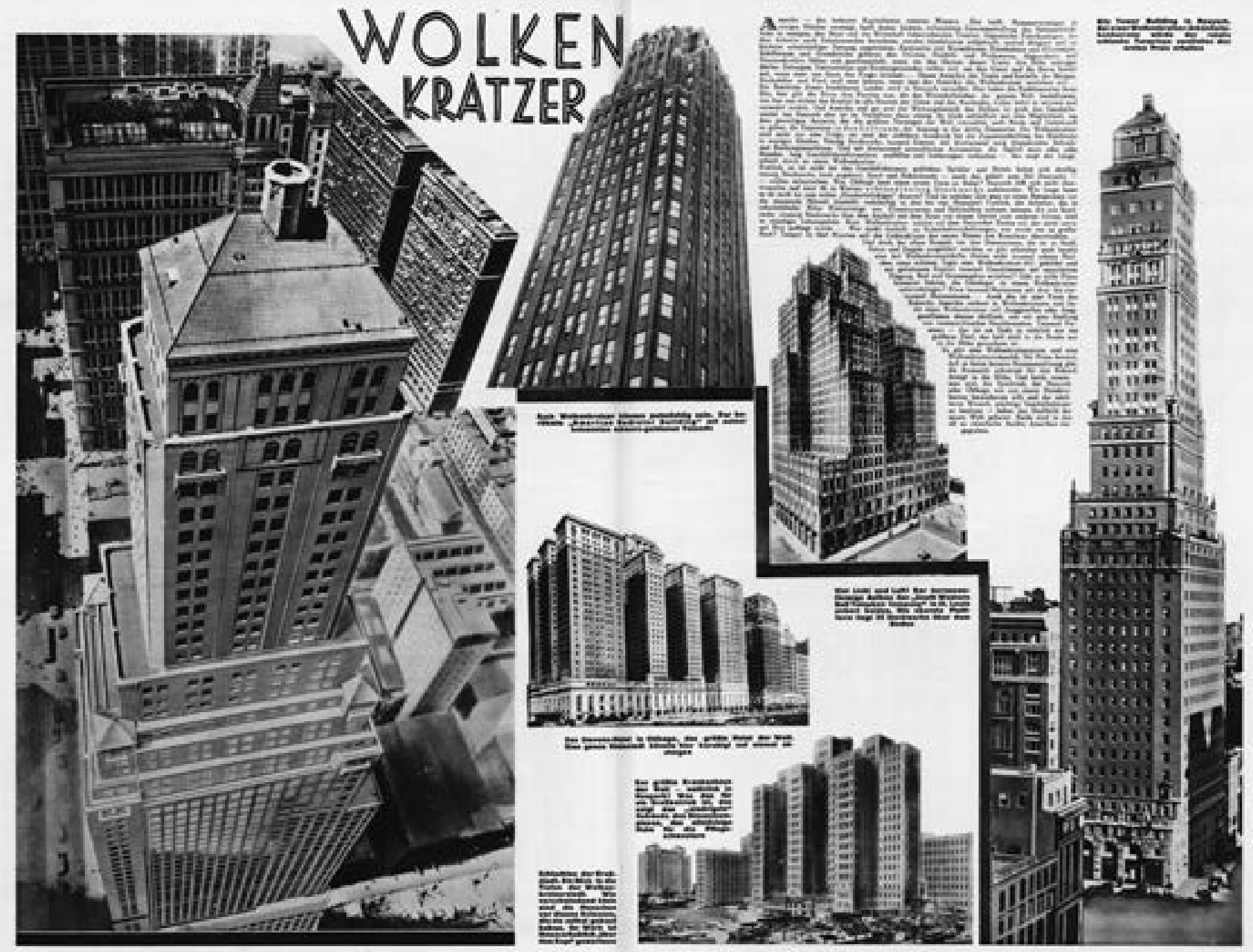

der Morgan, Rockefeller und Ford muß man kennen, wenn man das Amerika der Wolkenkratzer verstehen will. Die Wolkenkratzer sind nicht nur eine Folge, sie sind der sichtbare Ausdruck für die Zusammenballung des Reichtums in wenigen Händen.“19

Der Beitrag, der sich über eine ganze Doppelseite erstreckt, ist mit einer Reihe von Hochhausbildern illustriert, die meisten stammen aus New York (Abb. 13). Zwischen der Faszination, die von den Bildern ausgeht, und dem kritischen Text entsteht eine eigentümliche Spannung. Besonders deutlich wird das am Beispiel des Gebäudes am linken und rechten Seitenrand. Der imposante Betonturm, der links aus der Tiefe der Straßenschluchten emporwächst, ist aus einer extremen Perspektive fotografiert. Der Blick von weit oben auf das Hochhaus erzeugt einen atemberaubenden Sog. Dasselbe Gebäude ist rechts in Frontalansicht zu sehen. Es ist das Ritz Tower Building, ein 1925 errichtetes Luxushotel. „Bei einer Wolkenkratzer-Schönheitskonkurrenz würde
Abb. 13 „Amerika-das bedeutet Kapitalismus reinsten Wassers. "In der sozialdemokratischen Presse wird um 1930 zunehmend Amerikakritik geäußert. Der Kuckuck, 25. August 1929, S. $8 / 9$. 


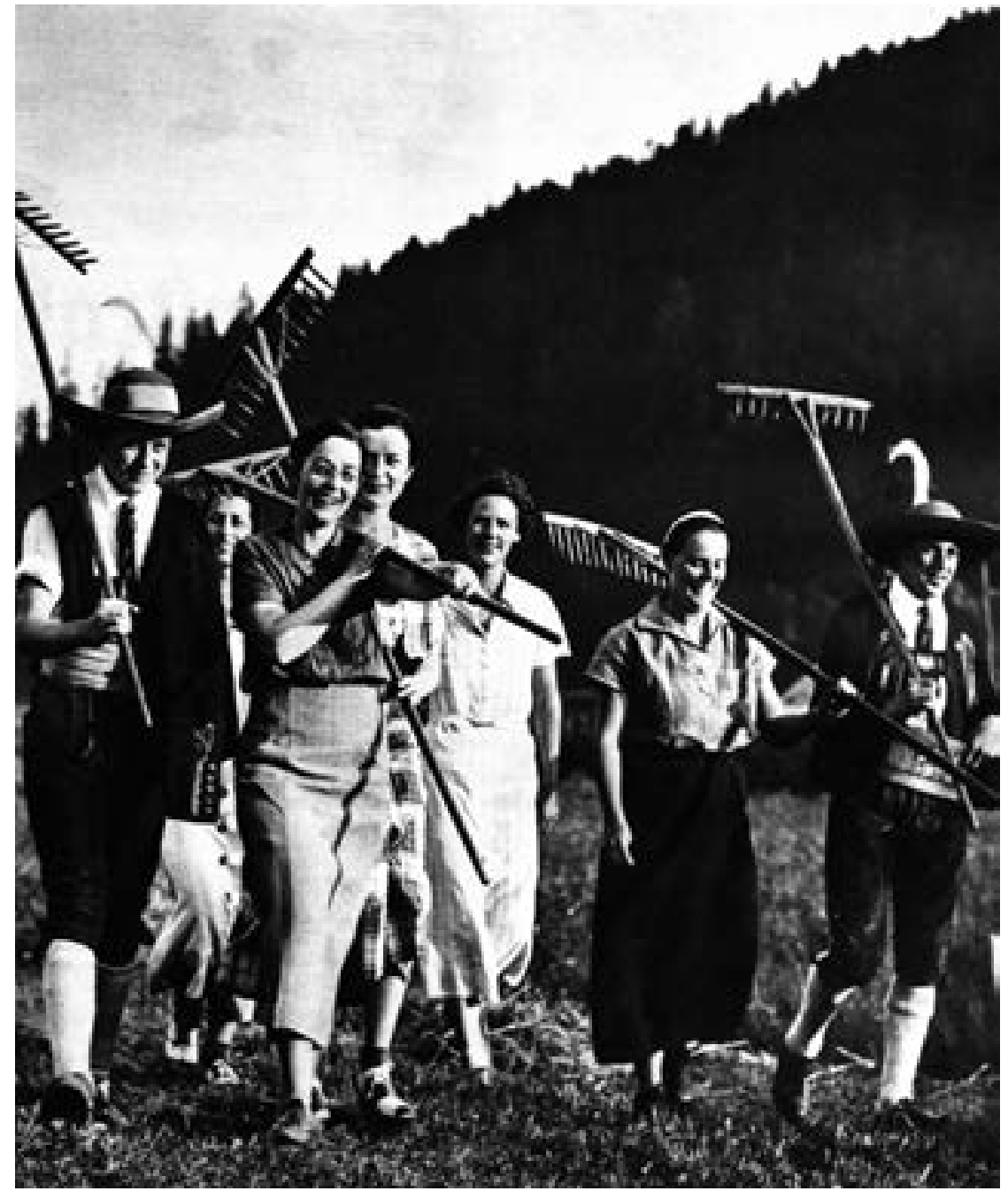

Abb. 14 Lachend, in sauberen Kleidern, den Rechen auf der Schulter. Amerikanische Studentinnen, die im Tiroler Ötztal einen „Melker- und Landwirtschaftskurs" besuchen. Wiener Bilder, 4. August 1935, Titelseite. der schlanke Turmriese zweifellos den ersten Preis erhalten“, heißt es im Bildtext. Der Begeisterung über dieses Wunderwerk der Technik wird allerdings im Beitrag daneben sogleich Einhalt geboten. Zwar werde ein solches Mammutgebäude in drei bis vier Monaten errichtet. „Freilich die Arbeiter, die in schwindelnder Höhe Klettersteige aus Eisentraversen und Holzbalken nehmen müssen, die wie Sandsäcke zwanzig Stockwerke über dem Asphalt mit dem Kran von einem Gerüst zum anderen fahren, sind in ständiger Lebensgefahr. Kein Wolkenkratzer wächst auf dem Neuyorker Boden auf, der nicht zuvor mit Blut gedüngt wurde ..."20

Anfang der 1930er Jahre ebbt die Amerikabegeisterung allmählich ab. Börsenkrach und Weltwirtschaftskrise setzen dem optimistischen, zukunftsfrohen Amerikabild zu. In Österreich tritt die heimische ländliche Idylle an die Stelle der urbanen amerikanischen Sehnsuchtslandschaft. Die Wolkenkratzer weichen den heimatlichen Bergen. In der konservativen Heimatideologie, die der „Ständestaat“ ab 1934 mit großem Aufwand kultiviert, ist für Amerika kein Platz mehr. Verirren sich doch einmal Amerikaner in den kleinen Alpenstaat, so künden sie nicht mehr von der großen, weiten Welt. Sie tauchen, so will es die Regierungspropaganda, nicht in der Großstadt Wien auf, sondern auf dem Land, in der entrückten, heilen Gebirgswelt.

Im Sommer 1935 wird im entlegenen Tiroler Gebirgsort Ötz mit tatkräftiger öffentlicher Unterstützung ein „Melker- und Landwirtschaftskurs für amerikanische Studentinnen“ eingerichtet, an dem, so heißt es in der Presse, 100 bis 150 junge Frauen aus den USA teilnehmen. „Außer den Lehrstunden, die amerikanische Professoren im Freien abhalten, werden die Hörerinnen in praktischer Landwirtschaft unterwiesen. “21 Über die Initiative wird in großer Aufmachung berichtet. Die Wiener Bilder widmen ihr Anfang August sogar das Titelfoto (Abb. 14). „Unser Bild zeigt“, so heißt es in der Legende, „amerikanische Studentinnen, die nach beendeter Feldarbeit heimkehren. "22 Lachend, in sauberen Kleidern, den Rechen auf der Schulter, schreiten sie zwischen einheimischen, in Tracht gekleideten jungen Männern dahin. Die ländliche Idylle ist perfekt. Aus den Amerikanerinnen sind - fast - Österreicherinnen geworden. 


\section{Bubikopf und Zigarette}

\author{
Bilder der „Neuen Frau“
}

Am 28. Oktober 1923 findet im Wiener Prater das erste Damen-Automobilrennen statt. „Damen am Volant (Lenkrad, A.H.) zu sehen ist keine Seltenheit“, heißt es einige Tage später in einem Bildbericht im Interessanten Blatt. „Die chauffierende Frau hat auch in diesem Sporte die Gleichberechtigung mit dem Manne. Ein Autorennen von Damen, wie es am 28. Oktober in der Praterallee veranstaltet wurde, war aber doch eine sensationelle Neuheit, die zahlreiche Zuschauer zum Startplatz beim Lusthaus zog. (...) Der Anblick der zum Start anfahrenden Konkurrentinnen war hübsch, wenn auch manche der Damen sich nicht in stilgemäßem Sportkostüm zeigten. Manche schienen ein Rennen mit einer Abendunterhaltung zu verwechseln. (...) Die beste Zeit des Tages hatte Olga Frühwald in 54 Sekunden gefahren. “1 Die Pilotin siegt in ihrem Gräf\&Stift-Automobil in der Kategorie der Fahrzeuge mit über 2,5 Liter Hubraum.

Dem Bericht beigefügt ist ein Foto, das der Wiener Fotograf Carl Zapletal am Rande der Veranstaltung aufgenommen hat (Abb. 1). Das schräg von unten aufgenommene Porträt zeigt den Kopf der Siegerin Olga Frühwald in engem Bildausschnitt. Ihre äußere Erscheinungsweise ist für die Zeitgenossen ungewohnt und neu. Frühwald trägt eine eng anliegende lederne Pilotenhaube, darüber eine Brille, die sie in die Stirn geschoben hat. Ihre Haare sind fast vollständig unter der Schutzkleidung verborgen, nur ein paar Büschel lugen unter ihrer Haube hervor. Fast könnte man die Pilotin für einen Mann halten. Solche Frauenporträts waren bisher noch nicht in der Öffentlichkeit zu sehen gewesen.

\section{Erschütterungen im Verhältnis der Geschlechter}

Frauen am Steuer und gar am Lenkrad eines Rennwagens sorgen in den Jahren nach dem Ersten Weltkrieg für Aufsehen. 1912 gibt es in Wien erst 25 geprüfte Automobilistinnen, 1923 hat sich deren Zahl bereits auf über 70 erhöht, Tendenz stark steigend. ${ }^{2}$ Dennoch ist damit der Anteil der Frauen unter den Automobilisten Anfang der 1920er Jahre noch verschwindend gering. Aber in anderen Bereichen des öffentlichen Lebens hat die Präsenz der Frauen stark zugenommen. Das betrifft vor allem das Arbeitsleben. Während des Krieges hat sich der Prozentsatz der berufstätigen Frauen stark erhöht. Im Jahr 1915 sind bereits an die 40 Prozent der bei der Wiener Sozialversicherung gemeldeten Beschäftigten Frauen. Von den rund 30000 Wiener Angestellten sind mehr als die Hälfte weiblich. ${ }^{3}$

Vor diesem Hintergrund ruft das Bild der „Neuen Frau“, die selbstbewusst ehemalige Männerdomänen (wie den Motorsport) in Besitz nimmt, durchaus ambivalente Reaktionen hervor. Einerseits wird bewundernd über sie berichtet. Zugleich aber werden die
Abb. 1 Damen-Automobilrennen im Wiener Prater, Oktober 1923. Olga Frühwald siegt in der Kategorie über 2,5 Liter Hubraum. Sie legt die 1300 Meter lange Strecke in 54 Sekunden zurück. Das interessante Blatt, 8. November 1923, S. 4. Foto: Carl Zapletal.

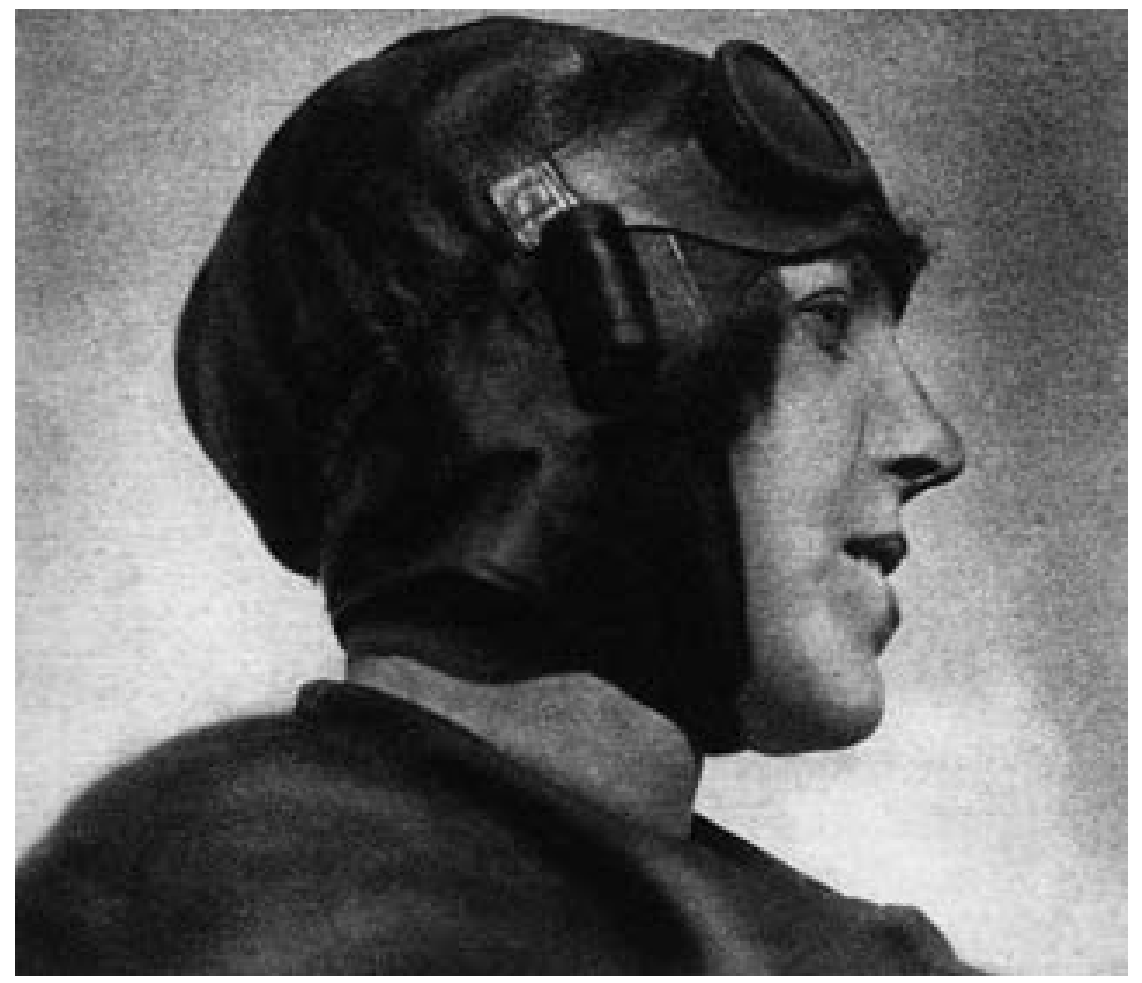




\section{Preis $K 1.20$}

Im Straßenverkauf $K 1.50$
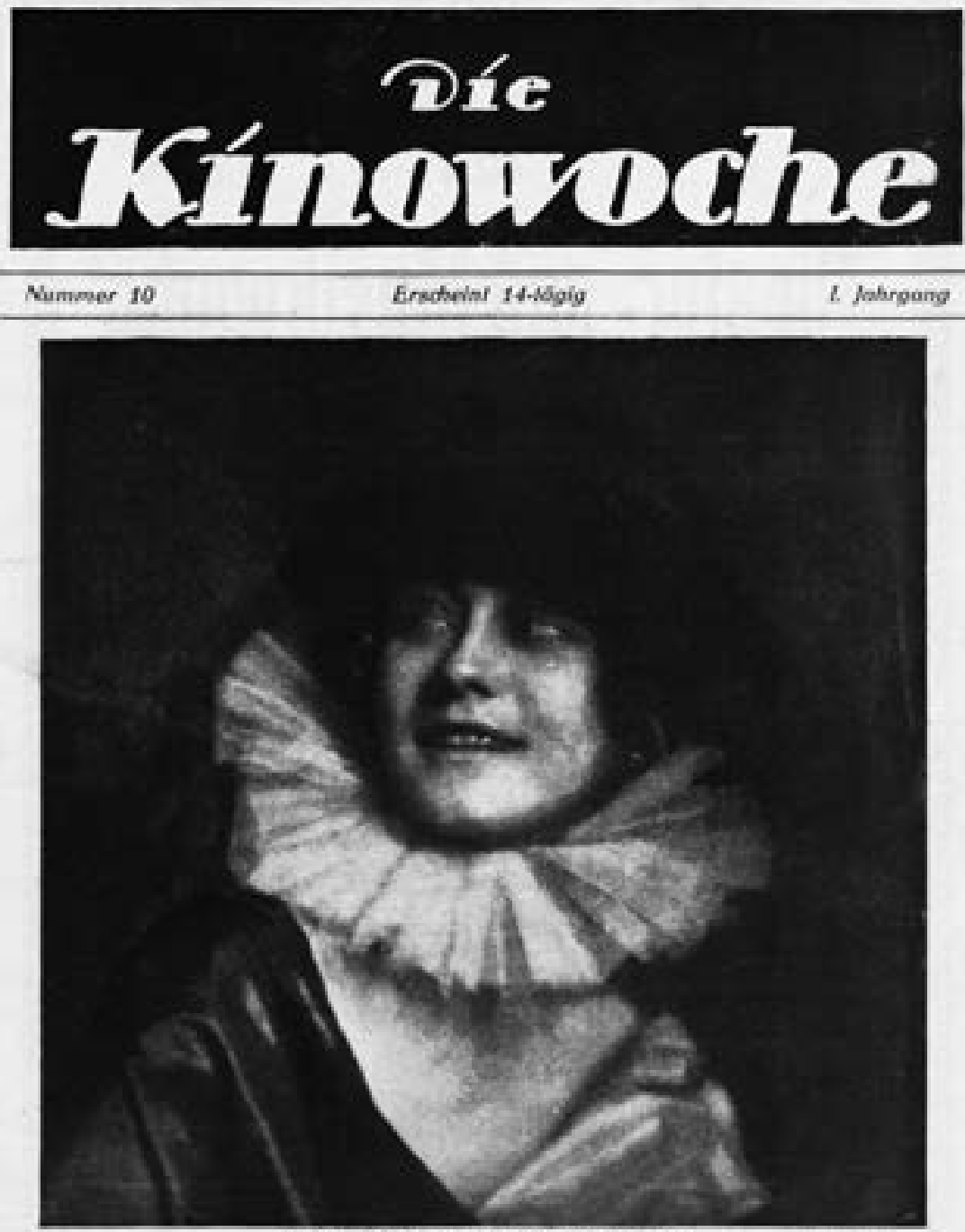

CARMEN CARTELLIERI

Abb. 2 Die österreichische Schauspielerin Carmen Cartellieri. Die Kinowoche, Nr. 10, November 1919, Titelseite. Foto: Atelier d'Ora.
Frauen, die aus ihren scheinbar angestammten Rollen ausbrechen, auch belächelt und kritisiert. Und letztlich werden sie wieder am alten Frauenbild gemessen. Beim Automobilrennen im Oktober 1923 geht es nicht nur um die Geschwindigkeit der Wagen und ihrer Pilotinnen, sondern auch - um ihre Schönheit. Es werden eigens Schönheitspreise ausgelobt, für die Fahrerinnen ebenso wie für die Autos.

Die Bilder der „Neuen Frau“ tauchen nicht zufällig nach dem Ende des Krieges auf. Dieser hatte die ökonomischen Verhältnisse zwischen den Geschlechtern - zumindest zeitweise - tief greifend verändert. Neben den handfesten wirtschaftlichen und sozialen Umbrüchen kommt es in der Zwischenkriegszeit aber auch zu einer Verschiebung der Vorstellungsbilder. Die „Neue Frau“ - das ist in den allermeisten Fällen nicht die Arbeiterin oder die Angestellte, die in ihrer neuen Rolle im Berufsleben gezeigt wird. Vielmehr basiert ihre Darstellung auf einer Mischung aus Realität und Projektion. Sie ist ein Wunsch- und zugleich ein Angstbild, das alle möglichen Sehnsüchte, aber auch Befürchtungen bündelt. Und so nimmt es nicht wunder, dass die Umrisse dieses Bildes am deutlichsten nicht im Alltagsleben oder auf der Straße, sondern im Theater, im Kino und in der illustrierten Presse zutage treten. Die „Neue Frau“ erscheint zuerst dort, wo neue Rollen im Scheinwerferlicht der Bühne ausprobiert werden.

Wenn wir die öffentlichen Inszenierungen vor allem der weiblichen Bühnen- und Filmstars der 1920er Jahre Revue passieren lassen, zeigt sich bereits rein äußerlich ein deutlicher Trend im Frauenbild. Ihr Äußeres wird androgyner, die Haare kürzer, die neuen Kleider sind einfach und knapper geschnitten. Die „Neue Frau“, die in Magazinen und Zeitschriften auftaucht, spielt mit männlichen und weiblichen Rollen, sie kann das kecke Girl ebenso verkörpern wie die wehrhafte Amazone. Sie wird ebenso als hysterische Kindfrau dargestellt wie als kraftvolle, schlanke, gebräunte Sportlerin.

Im November 1919 bringt die neu gegründete (und kurzlebige) Zeitschrift Die Kinowoche auf der Titelseite ein Porträt der österreichischen Filmschauspielerin Carmen Cartellieri. Die Aufnahme, die aus dem Atelier d'Ora stammt, ist - zumindest auf den ersten Blick - noch der alten Zeit verpflichtet (Abb. 2). Die Schauspielerin tritt uns in ihrer barock anmutenden Bühnenkleidung entgegen. Sie entsteigt schemenhaft dem Dunkel des (Bühnen-)Hintergrundes. Ihr Gesicht wird, ganz im Stil der damals modernen kunstfotografischen Richtung, im Wechsel von Licht und Schatten modelliert. Die Umrisse ihrer Gestalt sind verschwommen. Wenn man den Bühnenstar nicht kennt, ist es schwer zu entscheiden, ob die Inszenierung eine ungarische Gräfin oder eine bekannte Schauspielerin zeigt.

Wie anders ist das Porträt, das dieselbe Zeitschrift im Dezember 1919, also nur wenige Wochen später, von Carmen Cartellieri bringt (Abb. 3)! Diesmal erscheint die Protagonistin auf der Titelseite in ganz anderer Aufmachung. Voll sprühender Erotik wendet sie den Blick geradezu herausfordernd und kokett 
in Richtung Betrachter. In der Hand hält sie eine Zigarette, ihre Schultern sind tief entblößt. Die Haare, geziert mit einer Rose, trägt sie hoch aufgesteckt. Ist das dieselbe Cartellieri? Ja und nein. Die zeitliche Spanne, die zwischen beiden Inszenierungen liegt, ist gering. Und dennoch liegen Welten zwischen beiden Bildern. Die zweite Aufnahme stammt, das ist auffallend, nicht von einem bekannten Wiener Atelier, sondern von der Filmfirma „Carmen-Film“. Es handelt sich dabei um eine Produktionsgesellschaft, die die Schauspielerin Cartellieri zum Jahreswechsel 1919/20 gründet. Sie will die Herstellung und Vermarktung von Filmen selbst in die Hand nehmen. ${ }^{4}$

Genau zur Zeit der Firmengründung tritt Carmen Cartellieri in einer sorgsam vorbereiteten Öffentlichkeitskampagne mit neuem Äußeren auf. Sie verändert ihren Look und ihr Image. Sie inszeniert sich als das, als was sie in der Welt der filmischen Projektion erscheinen will: die Femme fatale, die verführerische Diva, die erfolgreiche „Neue Frau“. Sie bewegt sich also souverän zwischen den unterschiedlichen Rollenbildern, die nach dem Krieg auf der Bühne und im Film ausprobiert werden und die wenig später auch in der Mode begegnen. Im Innenteil der Kinowoche wird der Filmstar des frühen österreichischen Kinos als verführerische Carmen-Figur beschrieben, gewissermaßen als spanische „Zigeunerin“. Die „dunklen faszinierenden Augen der rassig-schönen Künstlerin, das temperamentvolle Mienenspiel, das ganze Wesen kennzeichnen sie als Kind des Südens. “5 Ein Kind des Südens ist Carmen Cartellieri zwar nicht, mit Vornamen heißt sie eigentlich Franziska Ottilia, geboren ist sie in Mähren, aufgewachsen in Innsbruck. ${ }^{6}$ Aber der Zuneigung ihres wachsenden Publikums tun diese Flunkereien keinen Abbruch. Sie wird ohnehin als das gesehen, was sie - auf der Leinwand - darstellt: die Cartellieri.

Noch einmal wird „die Cartellieri“ im Jahr 1920 in großer Aufmachung auf der Titelseite der Kinowoche präsentiert (Abb.4). Diesmal tritt uns die Schauspielerin als Skifahrerin auf dem Semmering im Look der „Neuen Frau“ gegenüber. In eng anliegenden Sporthosen, eleganter Jacke und dazu passender Mütze. Wiederum hat sie den Blick kokett zum Betrachter gewandt. Und auch diesmal wird das Bild von der
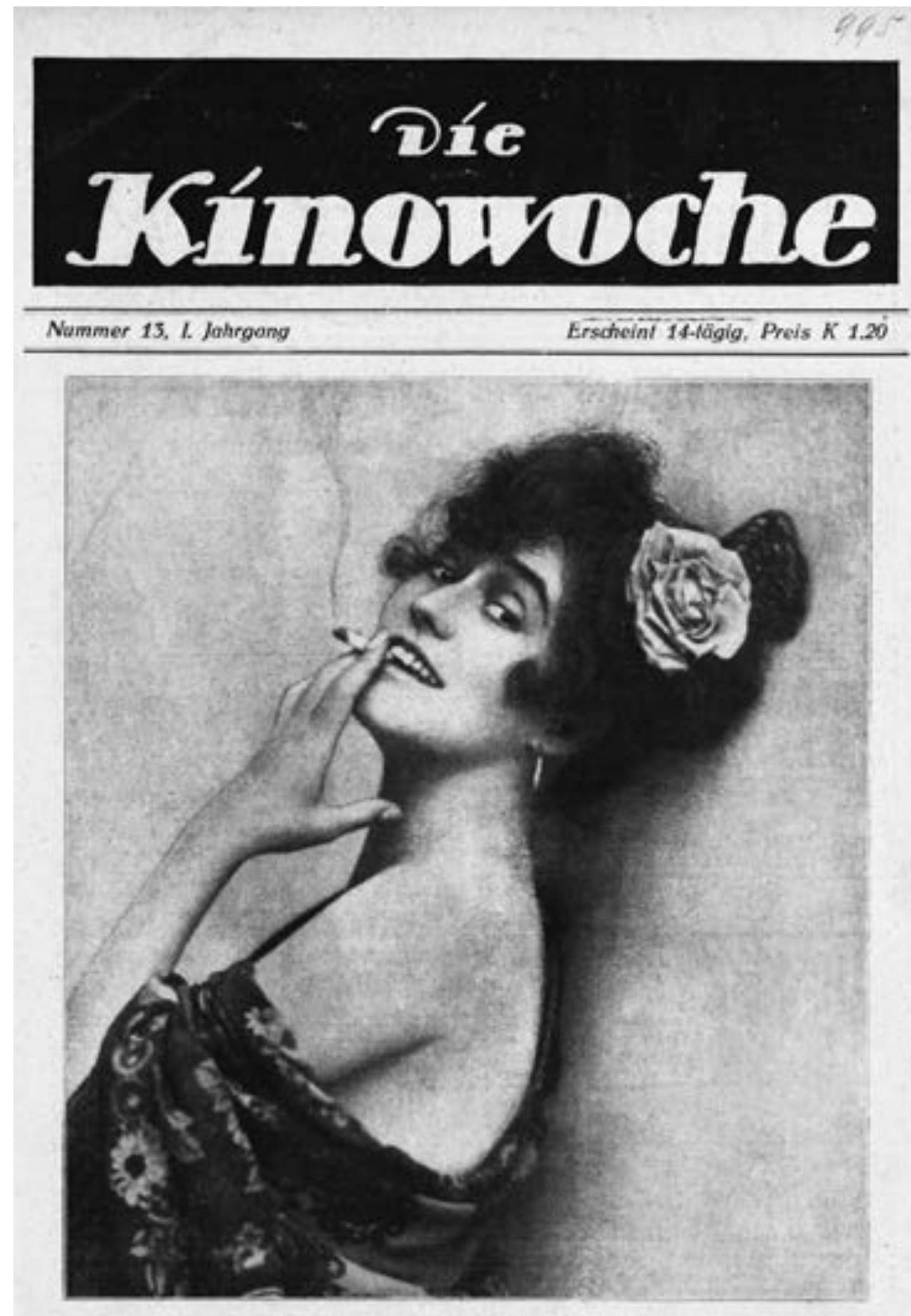

CARMEN CARTELLIERI

CARMEN-FILM

Abb. 3 Die kokette Diva. Carmen Cartellieri in erotischer Pose mit entblößter Schulter und Zigarette. Die Kinowoche, Nr. 13, Dezember 1919, Titelseite. Foto: Carmen-Film. 

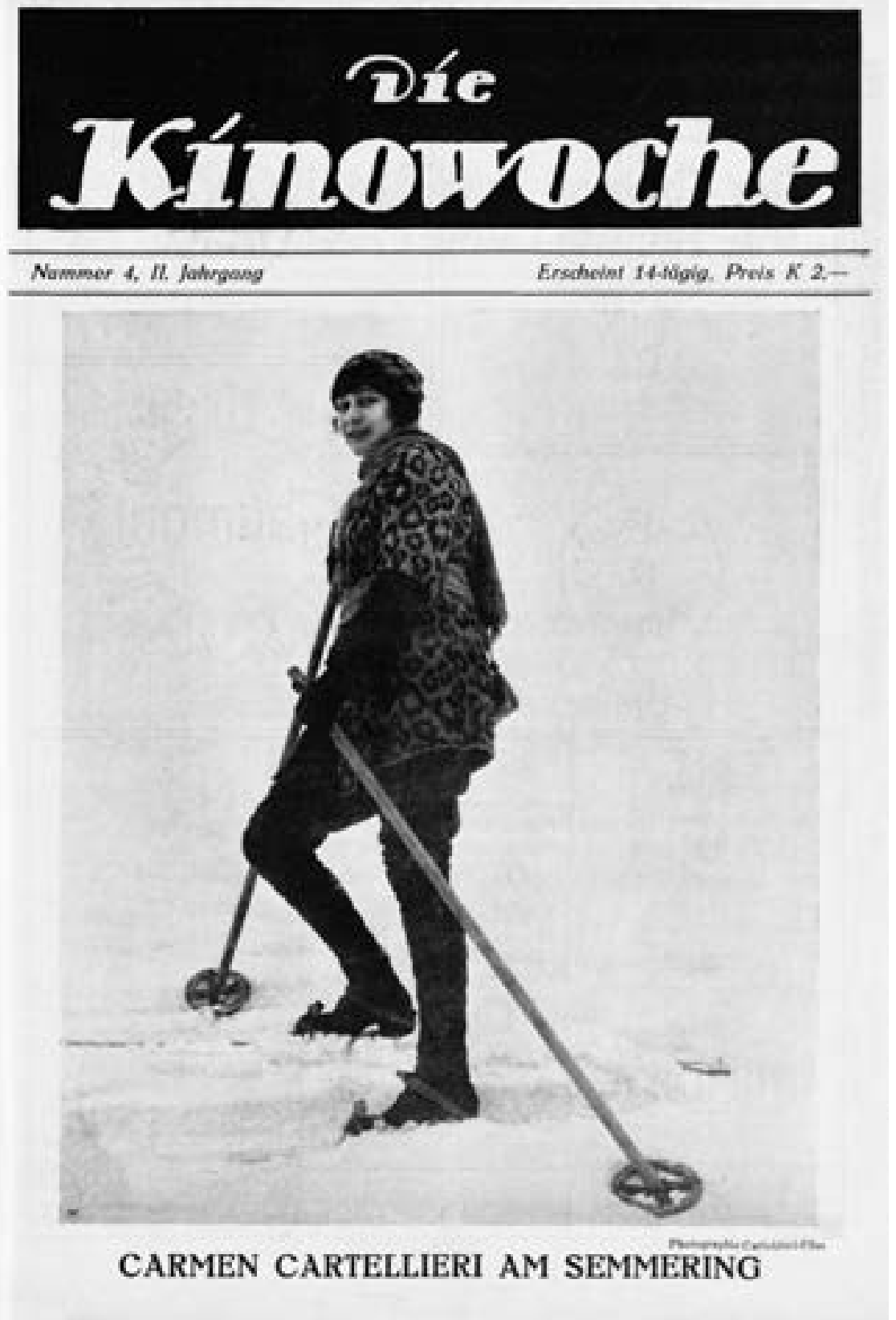

Abb. 4 Carmen Cartellieri im Look der „Neuen Frau“ beim Skifahren am Semmering. Die Kinowoche, Nr. 4, Februar 1920, Titelseite. Foto: Cartellieri-Film.

\section{Girl, Bubikopf, Kindfrau}

Mitte der 1920er Jahre hat sich das Bild der „Neuen Frau“ weitgehend durchgesetzt, etwa in der Mode, im Film, in der Werbung. Ihrem Aussehen nach ist die „Neue Frau“ leicht zu erkennen. Sie ist jung, städtisch, selbstständig, selbstbewusst, attraktiv und verführerisch. Stellvertretend für all diese Attribute steht der „Bubikopf“, die berühmte Kurzhaarfrisur mit burschikosen Anleihen. Allerdings trifft dieses Bild weit eher auf die Wirklichkeit des Kinos und der illustrierten Presse zu als auf die Realität des städtischen Alltags oder gar der Provinz. Der Großteil der arbeitenden Frauen ist weiterhin in untergeordneten und schlechter bezahlten beruflichen Positionen tätig oder macht unbezahlte Haus- und Familienarbeit. Allerdings: In einigen Dienstleistungsbereichen (Büro, Sozialfürsorge, Unterricht, Gesundheitswesen) und in manchen freien Berufen (etwa im Journalismus oder der Architektur) sind nun deutlich mehr Frauen tätig als vor dem Krieg. Das Bild der „Neuen Frau“ übernimmt vor diesem Hintergrund eine propagandistische Rolle: Es trägt dazu bei, die Spannungen zwischen alten und neuen Ansprüchen, zwischen Familie und Beruf, Ehe und Arbeit, Kindererziehung und sexueller Attraktivität zu überbrücken. ${ }^{7}$

Die „Neue Frau“ ist demnach vielseitig und erfolgreich, sie schafft den Spagat zwischen Beruf, Ehe und Familie mit Leichtigkeit. Dieses Bild entspricht also weit mehr einem entrückten Ideal als der Wirklichkeit. Auf dem Höhepunkt seiner Popularität, Mitte der 1920er Jahre, charakterisiert die Berliner Wochenzeitschrift Die Dame die kurze und wechselvolle Geschichte des neuen Frauentypus folgendermaßen: „(...) der Krieg brachte, zuerst ganz unbemerkt, die Geburt des Garçonne-Typus. (...). Nach dem Krieg gab es zunächst Verwirrung. (...) Es konkurrierten das sportlich und tänzerisch ertüchtigte ,Girl‘ und die sich selbst erhaltende ,Garçonne‘. Das Girl schien zu siegen, der Triumph dieses langbeinigen, wohlgebauten, kirschmündigen und guckäugigen Mädchens schien nicht mehr aufzuhalten. Aber da sie ganz und gar nur physisches Produkt war, wurde sie uniform, langweilig. Eine Gesellschaft moderner Frauengestalten, gleich schlank, gleich biegsam, gleich kurz- 
geschürzt, gleich bemalt und mit bunten Steinen geziert, war ästhetisch vollkommen - aber erschreckend durch die unpersönliche Wiederholung durch die gleich süßen Gesichter. Und plötzlich wandelt sich aus Überdruß der Geschmack. Das Girl stirbt an seiner Langeweile, und den Thron der Frauenschönheit besteigt die geistige Frau. (...) Das vergeistigte Frauengesicht fängt an, heute als das schönste zu gelten. Merkwürdigerweise ist es gerade Amerika, die Heimat des Girls, das sich am schnellsten zur intellektuellen Schönheit bekennt, so sehr, daß man drüben im Film schon Spezialistinnen für diesen neuen intellektuellen Erfolgstyp der Frau sucht und ausbildet.“8 Der Beitrag in der Dame trägt den bezeichnenden Titel „Vom Puppengesicht zum Charakterkopf“. Natürlich ist dieser geraffte Rückblick auf das idealisierte Frauenimage der 1920er Jahre eine suggestiv formulierte Aufstiegs- und Besserungsgeschichte. Natürlich ist das Frauenbild der 1920er Jahre, das den Sex-Appeal der Bubikopf-Frau mit der „intellektuellen Schönheit“ verbindet, in dieser Deutung der Gipfel der Entwicklung, sozusagen der letzte modische Schrei.

Wenn Ende der 1920er Jahre, Anfang der 1930er Jahre am einen Ende der Skala moderner Frauenbilder das anonyme Revue-Girl steht, das bloße Körperlichkeit ausstrahlt, ist am anderen Ende jener Frauentyp anzutreffen, dessen Attraktivität in seiner intellektuellen Ausstrahlung liegt. Kaum eine andere österreichische Schauspielerin entspricht dem Bild der zerbrechlich-schönen, attraktiven und zugleich unnahbaren Diva mehr als Elisabeth Bergner. Sie hat ihre Karriere bereits während des Ersten Weltkrieges begonnen und spielt zunächst vor allem auf den Wiener und Berliner Bühnen. Zum Star wird sie ab Mitte der 1920er Jahre vor der Filmkamera. Häufig spielt sie launisch-kapriziöse, kindlich-hysterische Frauenrollen, die sie mit großem Einfühlungsvermögen und Souveränität verkörpert. Elisabeth Bergner, so heißt es anlässlich eines Wiener Auftritts im Jahr 1926 in der Modernen Welt, ist „die erste Schauspielerin, die Hysterie mit Kindlichkeit verbindet - und ist diese Mischung nicht der Typ der Großstadtfrau von heute?"9

Je bekannter Elisabeth Bergner wird, desto mehr kultiviert sie ihre Unnahbarkeit. „Ich ließ von mir keine Großaufnahmen machen“, behauptet sie in einem Gespräch 1929. ${ }^{10}$ Zugleich aber trägt die Fotografie viel dazu bei, sie zum Star zu machen. In den Porträts, die ab Mitte der 1920er Jahre vor allem in Wiener und Berliner Ateliers entstehen, tauchen die Züge dieser Rollen immer wieder auf, auch dann, wenn sie sich nicht in Bühnenszenen ablichten lässt. Die beiden Wiener Fotografinnen Trude Geiringer und Dora Horovitz fotografieren Elisabeth Bergner besonders häufig - im Atelier, auf der Bühne, aber auch im Freien (Abb. 5). In ihren Aufnahmen tritt uns eine scheue, aber ausdrucksstarke Schauspielerin entgegen, die den direkten Blick in die Kamera meidet, oft ihren Kopf gesenkt hält, von der aber nichtsdestotrotz - oder gerade deswegen - eine starke Anziehungskraft ausgeht.

\section{Moderne Sportlerinnen}

Um 1925 häufen sich in Österreich die Berichte über den neuen Kurzhaarschnitt der Frauen, der von Anfang an mehr bedeutet als ein modisches Detail. Der Bubikopf wird, als Erkennungszeichen der „Neuen Frau“, zu einem universellen Code, der alle möglichen Neuerungen im Verhältnis der Geschlechter charakterisiert. Er begegnet uns im Theater, im Kino, in der Mode, aber - und das ist eine wichtige Brücke zur einfachen Bevölkerung - in modifizierter Form auch im Sport. Als im September 1926 in Wien ein großes Frauensportfest stattfindet, ziert erstmals eine Frau den Umschlag des Illustrierten Sportblatts - die Leichtathletin Gretl Mainx. Sie ist keine entrückte Bühnendiva, eher ihr Gegenteil: eine Frau, die sich durch Kraft, Ausdauer und Geschicklichkeit auszeichnet. Der weibliche Sportstar gleicht der „Neuen Frau“ in mancher Hinsicht. Die junge, selbstbewusste, siegessichere Sportlerin hat die androgyne Anmutung der „Neuen Frau“ übernommen. Auch sie huldigt dem modernen Kurzhaarschnitt. Auch sie tritt in der bisherigen Männerdomäne Sport selbstbewusst auf. Die anmutige Sportlerin wird als die wahre Erbin der „Neuen Frau“ präsentiert.

Die sportliche Frau, so die These des Illustrierten Sportblatts, ist die Frau der Zukunft (Abb.6): „Es ist noch gar nicht so lange her, daß man vor dem bloßen Worte Frauenathletik ein gelindes Grauen empfand. 
Abb. 5 Elisabeth Bergner lässt nur wenige Fotografinnen so nahe an sich heran wie Trude Geiringer und Dora Horovitz, die in Wien gemeinsam ein Atelier betreiben. Die Bühne, Erstes Juniheft 1931, S. 34.

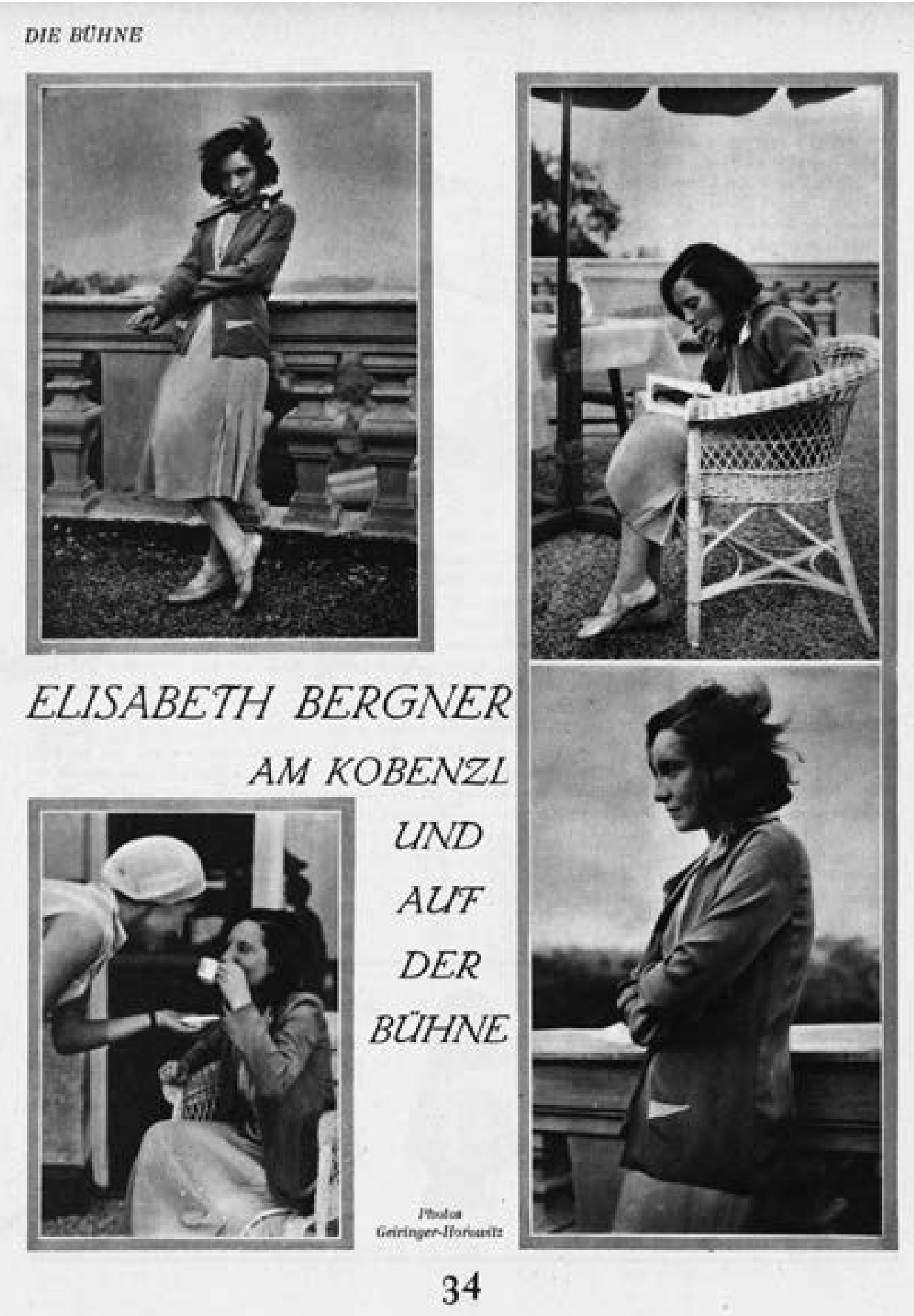

\section{DIE BUHNE}

\section{ELISABETH BERGNER}

34 


\section{Athletisch oder graziös? \\ Eine Frauenfrage von heute.}

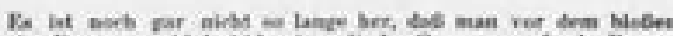

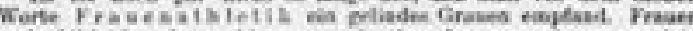

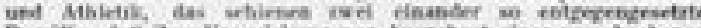

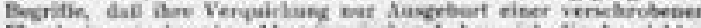

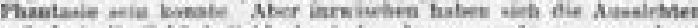

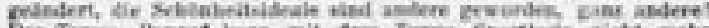

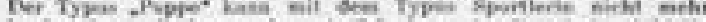

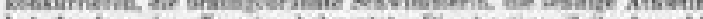

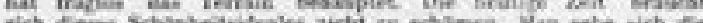

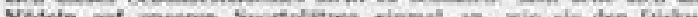

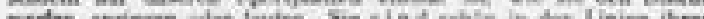

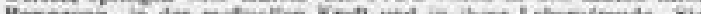

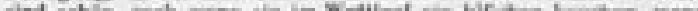

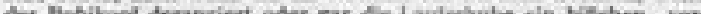

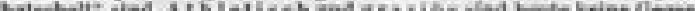
eitre wele sie varca es.
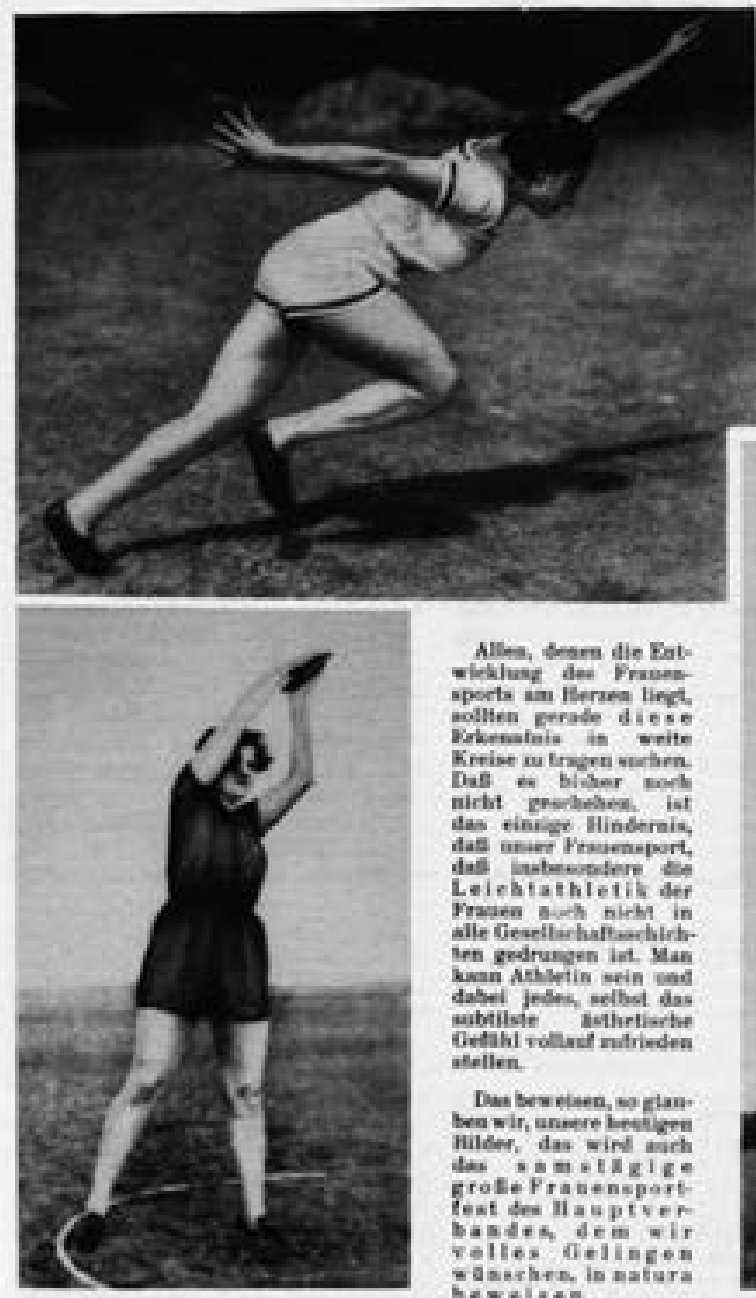

Alles, Seare fie Batviklase des Frasen sports an fiersea lingt. collten cerade dies. Drhenatais is orite

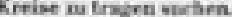
Das en bisher mol

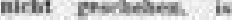

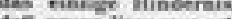
das wein Truensport, das inuturobtere et Leichtathletik de rrace aud hirh in

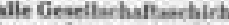
an sedrungen in. Yas kasan drabetin sein waed dabei jesth selbot das

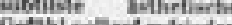
oefli valad matriedea

Das beretsen, so glan: bea wir, anatie hest $\mathrm{ke}$ nilerer, das wint ares

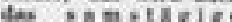
erose Prabenspert fest frs 11 a a p twe? basdes dem air velles 0 elingen - daverhes in satura bewelata.

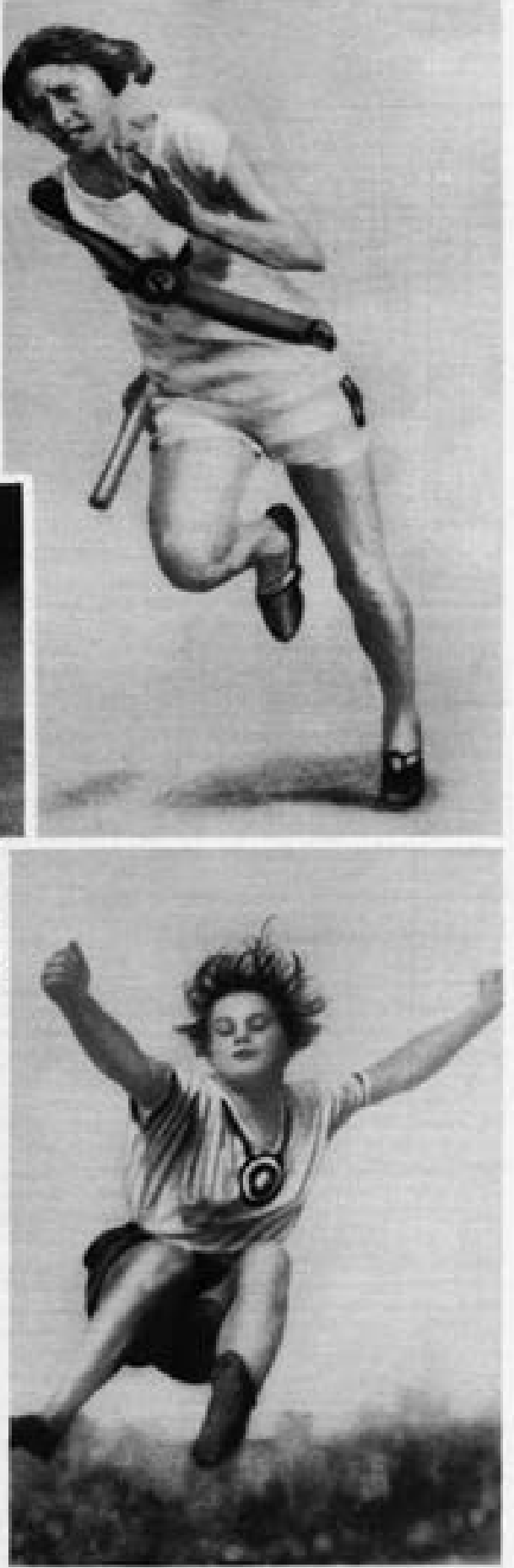

Abb. 6 „Athletisch und graziös sind heute keine Gegensätze mehr. Sie waren es." Die Frau der Gegenwart ist die Sportlerin, deklariert das I/lustrierte Sportblatt 1926. Illustriertes Sportblatt, 25. September 1926, S. 13. 
Abb. 7 „Alles steht Kopf“. Die deutsche Filmschauspielerin Ossi Oswalda bei der Morgengymnastik. Illustriertes Sportblatt, 27. November 1926 , S. 12 .

Abb.8 „Ihre Zähne pflegt sie nur mit Pebeco“. Sportliches Schönheitsideal in der Werbung der 1920er Jahre. Das interessante Blatt, 15. September 1927, S. 15.

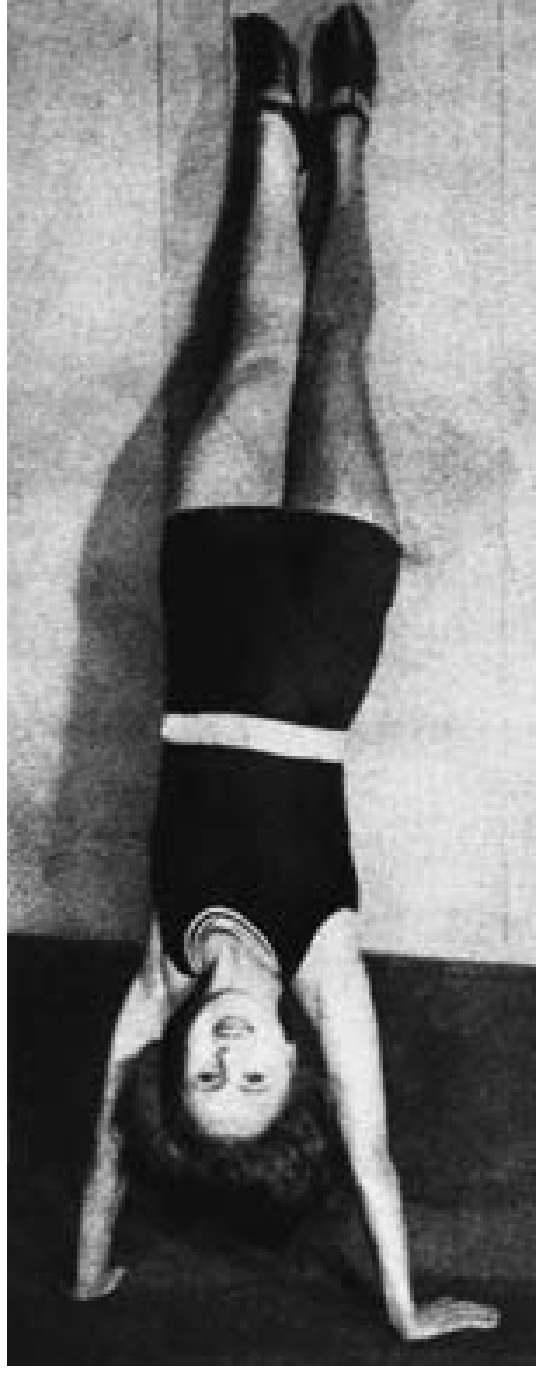

Frauen und Athletik, das schienen zwei einander so entgegengesetzte Begriffe, daß ihre Verquickung nur Ausgeburt einer verschrobenen Phantasie sein konnte. Aber inzwischen haben sich die Aussichten geändert, die Schönheitsideale sind andere geworden, ganz andere! Der Typus ,Puppe“ kann mit dem Typus ,Sportlerin“ nicht mehr konkurrieren, die braunge-

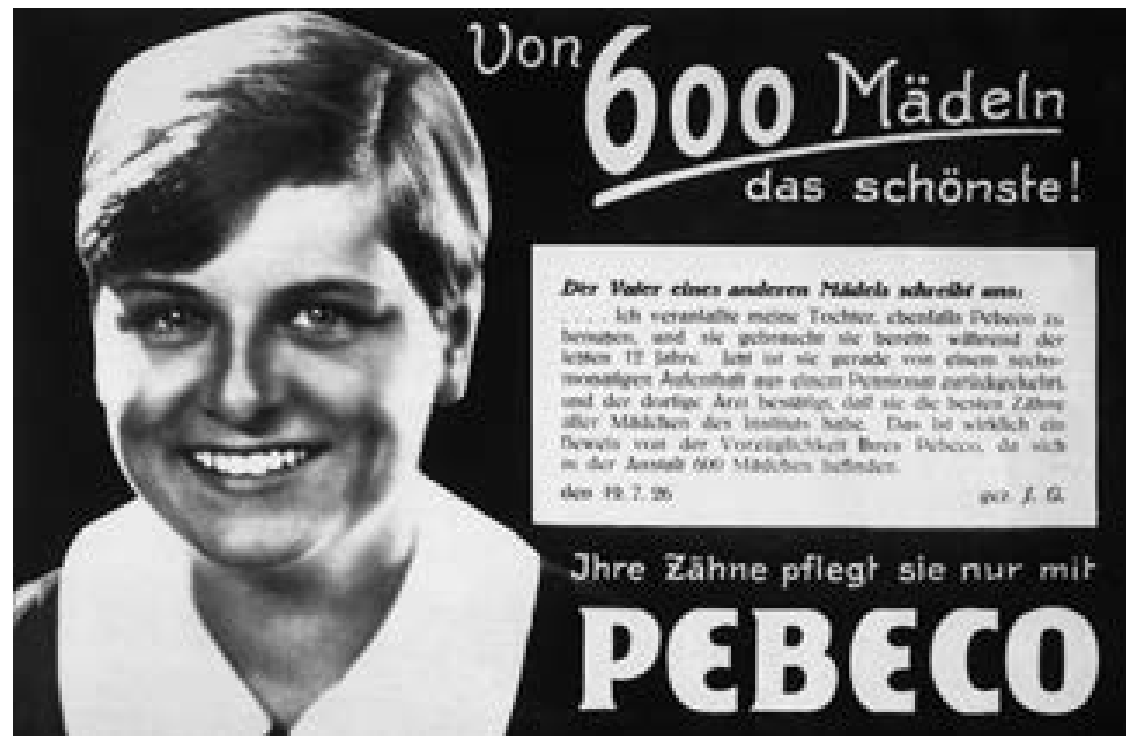

brannte Schwimmerin, die sehnige Athletin hat fraglos das Terrain behauptet. Die heutige Zeit braucht sich dieses Schönheitsideals nicht zu schämen. Man sehe sich die Mädeln auf unseren Sportplätzen einmal an, wie sie den Diskus werfen, springen oder laufen. Sie sind schön in den Linien ihrer Bewegung, in der maßvollen Kraft und in ihrer Lebensfreude. Sie sind schön, auch wenn sie im Wettlauf ein bißchen keuchen, wenn der Bubikopf derangiert oder gar die Laufschuhe ein bißchen, verhatschelt" sind. Athletisch und graziös sind heute keine Gegensätze mehr. Sie waren es." 11

Wenige Wochen später kommt dasselbe Blatt unter dem Titel „Alles steht Kopf“ auf das Thema Frauensport zurück. Dem Artikel beigefügt ist u. a. ein Foto, das die deutsche Schauspielerin Ossi Oswalda bei ihrer „Morgenarbeit“ zeigt - Gymnastikübungen im Handstand (Abb. 7). Auf den ersten Blick, so der redaktionelle Beitrag zum Bild, scheint die Zeit „aus den Fugen geraten“. ${ }^{12}$ Dann aber wird den „kopfstehenden“ Sportlerinnen auf der ganzen Linie Recht gegeben: „Zweifellos stehen die jungen Damen von heute mit ihrem Kopf auf dem richtigen Fleck und gehen auf ihren zarten Händen einer Zeit entgegen, die gesündere Mütter, fröhlichere Kinder und kraftvollere Väter besitzen wird, als jene Zeit, die man fälschlich die ,gute alte“ nennt.“"13

Es ist kein Zufall, dass der modische Kurzhaarschnitt, der sich seit Beginn des Jahrzehnts zuerst über das Kino, dann über die Mode verbreitet hat, gegen Ende der 1920er Jahre auch im proletarischen Milieu ankommt. Hier ist es vor allem der Sport, der als Vehikel für die Popularisierung des neuen Frauenbildes dient. Die moderne proletarische Frau ist, anders als die bürgerliche Femme fatale, keine verführerische Schönheit, sondern - zumindest auf den Propagandabildern der 1920er und frühen 1930er Jahre - eine tatkräftige, zupackende Frau. In ihrem androgynen Look nähert sie sich nicht so sehr der entrückten Bühnendiva an, sondern dem proletarischen Mann. Sie ist jung, braun gebrannt, kräftig und entschlossen - eine politisch selbstbewusste Athletin also. Ihre Frisur hat sich vom städtisch-mondänen Bubikopf ein Stück weit in Richtung männlich kurzer Haartracht verschoben. 
Dieses Image ist freilich nicht nur für die junge Sozialdemokratin oder Kommunistin reserviert. Es taucht überall dort auf, wo die „Neue Frau“ als sportliche, engagierte, tätige Zeitgenossin imaginiert wird. Im Sport, im Arbeitsleben, in der Freizeit. Und auch die Frauenbilder in der Werbung passen sich in den 1920er Jahren dieser Rollenverschiebung an. An die Stelle der sensiblen, unnahbaren Filmdiva tritt immer öfter die sportliche Schönheit: kurzes, brav gescheiteltes Haar, athletisch, braun gebrannt, blendend weiße Zähne, ein Frauentyp, wie ihn zum Beispiel eine Werbeanzeige für die Zahnpastamarke Pebeco von 1927 vorführt (Abb. 8).

\section{Zurück zur Tradition}

In den frühen 1930er Jahren ist die Zeit für die mondäne Bubikopf-Frau bereits wieder vorbei. Der gesellschaftliche Mainstream entfernt sich zunehmend von den androgynen Vorbildern der 1920er Jahre. Das Haar der Frauen wird wieder länger, mit der Dauerwelle kommt die Lockenmode zurück. Der Rückzug der „Neuen Frau“ erfolgt freilich nicht über Nacht. Und nicht ohne Grund. Zuallererst sorgen politische und wirtschaftliche Konjunkturen für einen Positionswechsel der berufstätigen Frauen: In Zeiten der Krise und der Arbeitslosigkeit werden sie aus dem Berufsleben zunehmend verdrängt. In Österreich treten die Folgen der Weltwirtschaftskrise des Jahres 1929 etwas verzögert ein. Der Höhepunkt der Arbeitslosigkeit ist 1933 erreicht: 557000 Menschen sind ohne Arbeit, das sind über 20 Prozent der Bevölkerung. Das Land bewegt sich zu dieser Zeit bereits in Richtung Diktatur. Im Frühjahr 1933 wird das Parlament ausgeschaltet, ein Jahr später die offene Diktatur des „Ständestaates“ errichtet. In den folgenden Jahren sind ganz andere Frauenbilder gefragt als jenes der „Neuen Frau“. Die „Idealfrauen“ werden seit Anfang der 1930er Jahre sowohl in ihrem Aussehen wie in ihrer Kleidung wieder konservativer inszeniert. Immer öfter mischen sich patriotische Accessoires ins Bild, etwa Trachtenlook und ländliche Kleidungsstile (Abb.9). Die öffentliche Präsenz von jungen, selbstbewussten, unabhängigen Frauen geht sichtbar zurück.

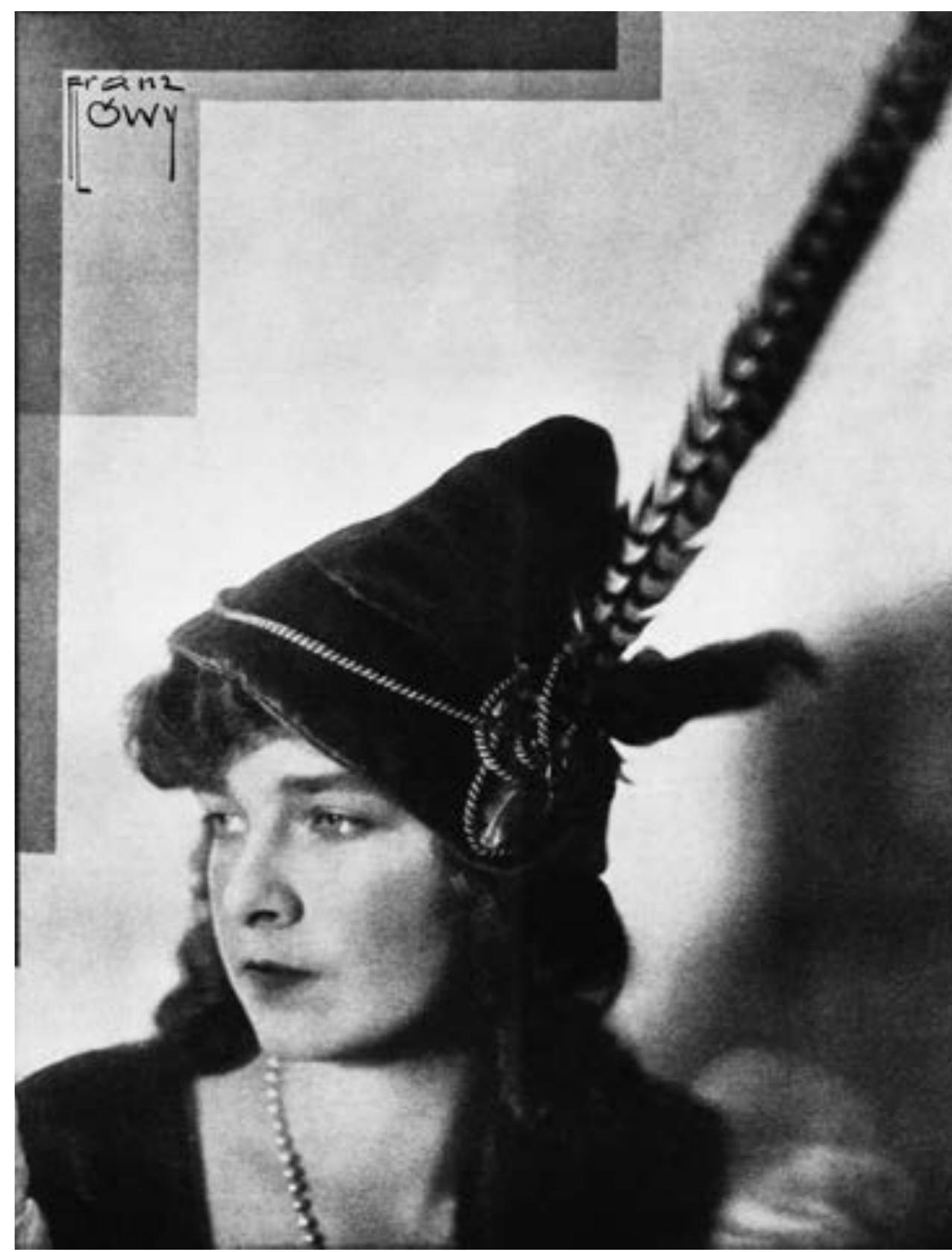

Es gibt einen Gradmesser, der den Wandel im Frauenbild sehr anschaulich dokumentiert: die Heiratsanzeigen in den populären Zeitungen und Zeitschriften. Der Trend geht ab etwa 1930 immer stärker in Richtung eines traditionellen Frauenbildes. Am 20. Juli 1934 inseriert ein Witwer mit zwei Kindern in der Illustrierten Wochenpost, die sich im Untertitel Unterhaltungsblatt für Jedermann nennt. Er sucht „Zwecks baldiger Ehe nette Frau oder Hausgehilfin bis 38 Jahre mit etwas Ersparnissen“. ${ }^{14}$ In derselben Zeitung gibt ein Wiener Anfang 1938, wenige Wochen bevor die Truppen Hitlers in Österreich einmarschieren, eine Annonce auf. Der Heiratswillige bezeichnet sich als Katholik und sucht „Fräulein oder Witwe ohne Bubikopf“. ${ }^{15}$

음
Abb. 9 Ab Anfang der 1930er Jahre werden die Attribute der „Neuen Frau“ zurückgedrängt. An ihre Stelle treten konservative und patriotische Accessoires. Die Wienerin Hertha von Haentjens, Miss Austria des Jahres 1931. Die Muskete, Nr. 8, 1931, S. 21. Foto: Franz Löwy. 


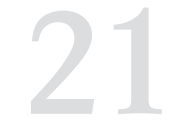

Abb. 1 und 2 Die „Excentrique-Tänzerin" Clarissa Rose Campbell, die sich mit Künstlernamen „Saharet“ nennt, tritt im März 1901 in Wien auf. Das interessante Blatt, 21. März 1901, S. 5. Foto: Atelier Strelitzky.

\title{
Experiment und Bewegung
}

\author{
Tanzschritte in eine neue Zeit
}

„Alles blickt erwartungsvoll auf die Bühne.“ Am 21. März 1901 berichtet Das interessante Blatt über den spektakulären Auftritt der weltberühmten australischen „Excentrique-Tänzerin“ Clarissa Rose Campbell - mit Künstlernamen nennt sie sich „Saharet“ - in Wien (Abb.1, 2). „Da hüpft die Saharet herein. Ein junges, überschlankes Wesen mit auffallend langen Armen und Beinen, richtigen Tanzbeinen, mit leuchtenden, bald düster blickenden, halb lockenden Augen, mit prächtigem, blauschwarzem, kurzgeschnittenem Haar. Und sie tanzt. Erst verhalten retardierend - dann in rasendem Tempo. Die langen, weiten, dürftigen, sattgeblich-roten Kleider fliegen. Sie macht einige spanische Pas. Mit dem Bein schlägt sie das Tamburin, das sie über dem Kopfe hält. Jetzt schlägt sie ein Rad, dann gar einen Purzelbaum, nun
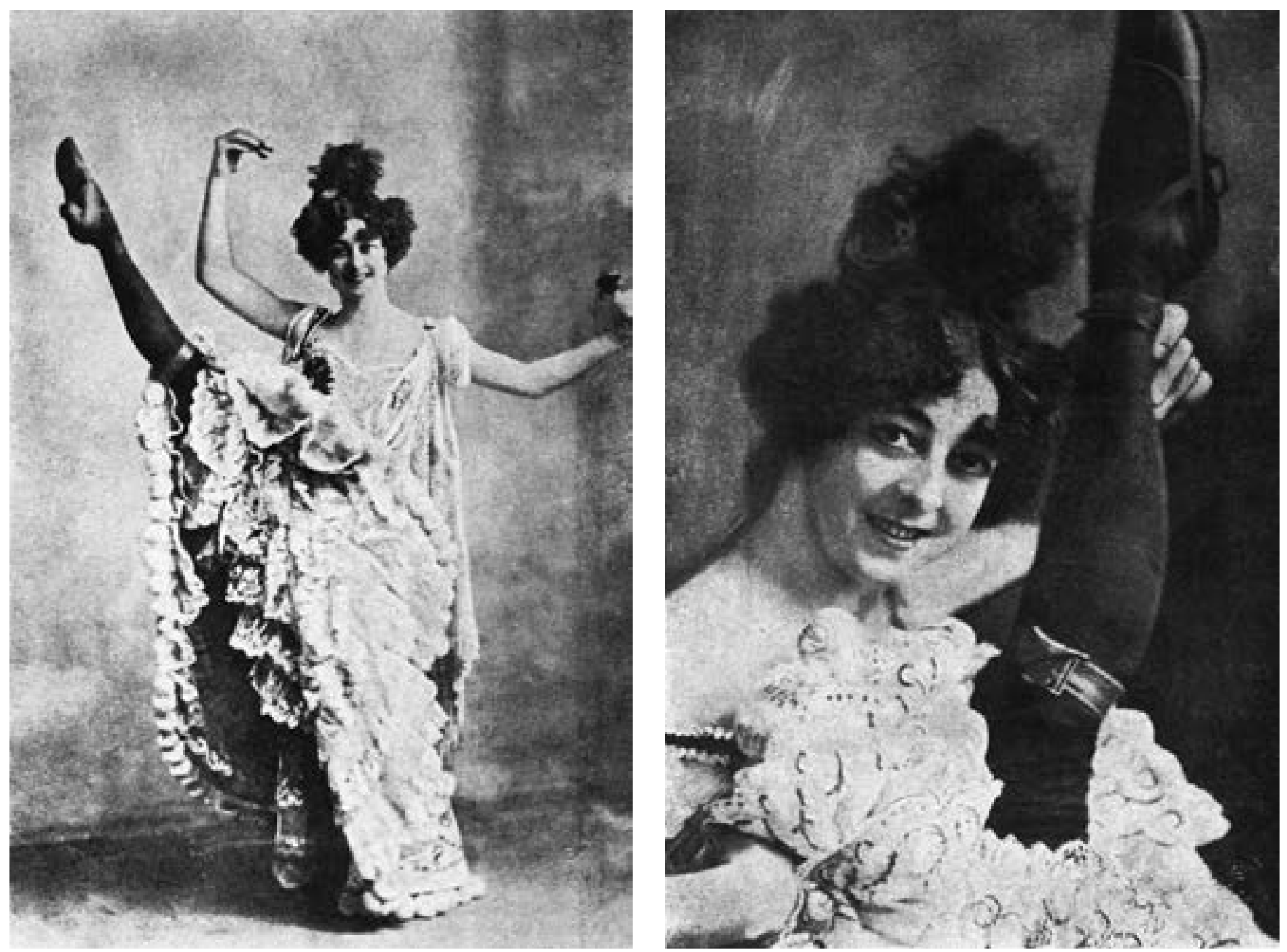
steht sie auf einem Bein und dreht sich im tollen Wirbel. Bums! - da ist sie schon in der Coulissenthür verschwunden, reckt übermüthig ihr Füßchen heraus und winkt damit. So dankt sie für den Applaus."1 Die beiden Fotos, die die junge Dame bei einer ihrer spektakulären Tanzeinlagen zeigt, ist im Budapester Atelier Strelitzky aufgenommen worden. Akrobatisch streckt sie ihr Bein in die Senkrechte. Die körperlichen Verrenkungen, die zu dieser „exzentrischen“ Pose führen, sind unter dem langen Rüschenkleid nur andeutungsweise zu erahnen.

Tanzabende wie diese finden um die Jahrhundertwende in Wien regelmäßig statt. Häufig sind die Stars auf der Bühne Ausländerinnen. Sie vollführen ihre Darbietungen nicht in den „ehrbaren“ Theatern des Hochkulturbetriebs, sondern in populären Vergnügungsetablissements der Stadt, etwa im Colosseum oder Gschwandner, im Metropol-Theater, Apol10-Theater oder Revuetheater Ronacher. Oft finden die Shows, in denen sich Musik, Varieté und Tanz mischen, auch im Prater statt, etwa im Zirkus Busch. Die Tanzauftritte gelten als Teil der leichten Muse, den Protagonistinnen eilt der Ruf der Verruchtheit voraus, die Vorstellungen sind stets ausverkauft und das hauptsächlich männliche Publikum drängt sich an den Kassen. Im Bühnenraum der populären Etablissements gibt es keine Sitzreihen wie im altehrwürdigen Theater. Während der Vorstellungen darf gegessen, getrunken und geraucht werden. Jeden Abend gibt es ein abwechslungsreiches Programm: leichte Konzerte, Opern, Operetten und Revuen. Stars und Sternchen treten auf, Artisten und Tänzerinnen, Zauberer, Clowns und Wunderkünstler, Musiker und Pantomimen.

\section{Tanzen ohne Korsett}

Als wenige Jahre später, im Frühjahr 1909, die Schwestern Grete, Elsa und Berta Wiesenthal mit ihrem Tanzprogramm im Wiener Raimund-Theater auftreten, zeichnen sich erste Neuerungen in der Tanzszene ab. ${ }^{2}$ Grete Wiesenthal ist zwei Jahre zuvor, 1907, aus dem Wiener Hofopernballett ausgetreten. Der Tanz, der dort vorherrscht, erscheint ihr zu starr und konventionell. Sie beginnt eine Karriere als freie
Tänzerin - zunächst abseits der etablierten Spielorte. Es ist wohl kein Zufall, dass die jungen Tänzerinnen ihre freien Tänze in diesen Jahren auf den Wiener Varietébühnen präsentieren. Grete Wiesenthal etwa tritt vor dem Ersten Weltkrieg mehrmals im bereits genannten Apollo-Theater auf. ${ }^{3}$ Aber auch die Kleinkunstbühnen und später die Konzertsäle werden zu Orten des freien Tanzes. Im Januar 1908 etwa treten die Schwestern Wiesenthal im Theater und Kabarett Fledermaus auf, das 1907 von der Wiener Werkstätte eröffnet worden war. Auch das Raimund-Theater und die Residenzbühne (Abb.3), wo die Schwestern Wiesenthal ein paar Monate später gastieren, sind keine noblen Häuser.

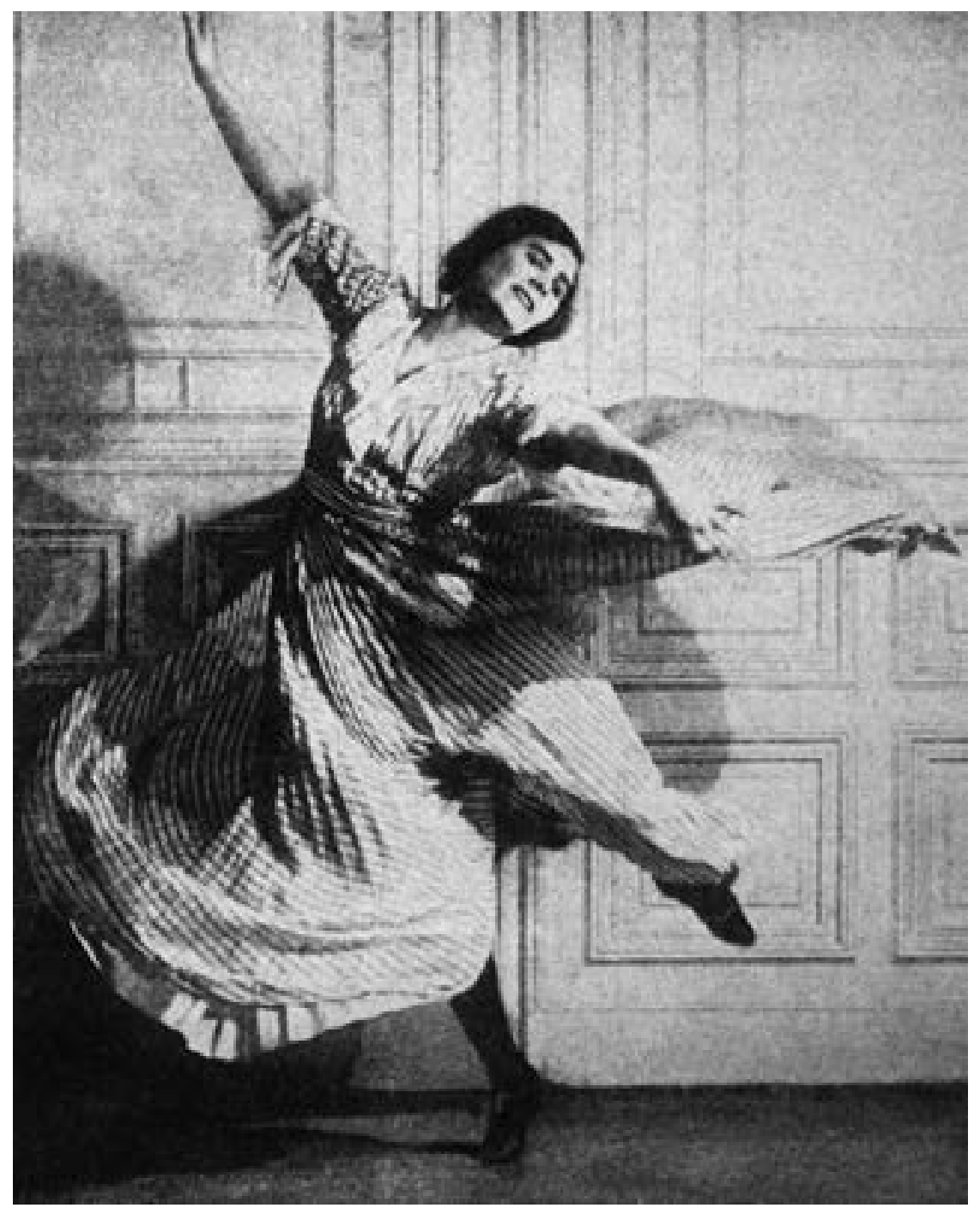




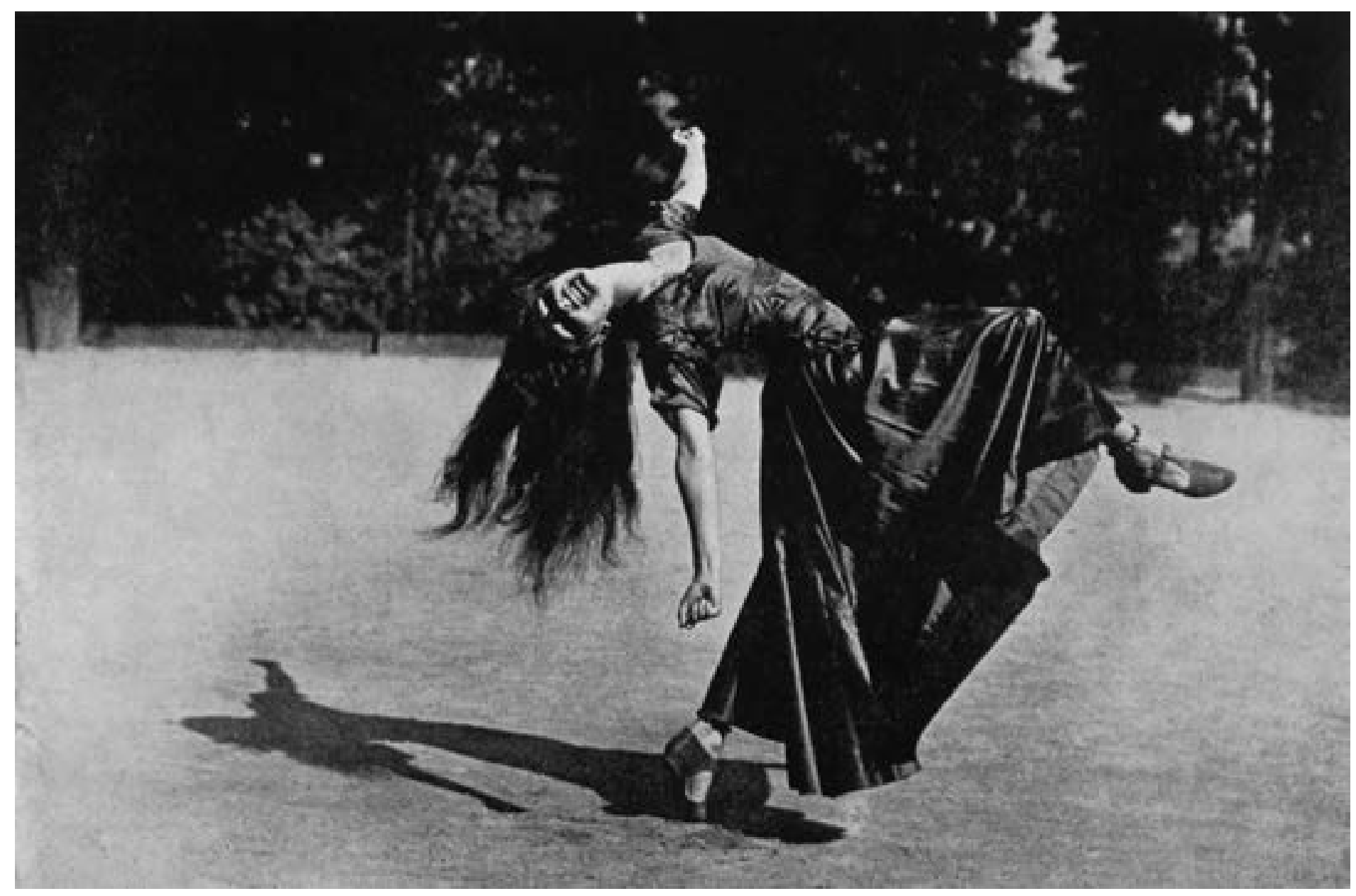

Abb. 4 Grete Wiesenthal interpretiert in einer expressiven Tanzeinlage den „Donauwalzer“ von Johann Strauss. Erdgeist, Heft IX, 6. März 1909, S. 330. Foto: Rudolf Jobst.
Da der Tanz eine flüchtige Kunst ist, spielt die Fotografie eine wichtige Rolle, wenn es darum geht, Aufführungen, Szenen und Posen für ein breiteres Publikum zu dokumentieren. Die Schwestern Wiesenthal arbeiten schon sehr früh mit bekannten Fotografen zusammen, um ihre tänzerischen Interpretationen „haltbar“ zu machen. Und zugleich sind die Aufnahmen willkommene Werbemittel für ihre Aufführungen. Im Jahr 1908 entsteht eine Fotoserie von Rudolf Jobst, der Grete Wiesenthal bei einer ausdrucksstarken Tanzeinlage im Freien zeigt (Abb.4). Die älteste der Schwestern tritt in einfach geschnittener Reformkleidung auf. Ihre Bewegungen sind neu und ungewohnt. In gewaltigen Schritten durchmisst sie den Raum, die Arme sind weit ausgestreckt, den Kopf hat sie zurückgeworfen, das lange, wallende Haar fällt offen zu Boden. Es ist dies ein neuer Stil im Tanz, eine selbstbewusste künstlerische Geste, festgehalten in einer faszinierenden Aufnahme. Auch die Musikauswahl erfolgt durchaus selbstbewusst. Die Ausdruckstänzerinnen interpretieren immer wieder bekannte und populäre Stücke, etwa von Schumann oder Offenbach, Strauss oder Lanner, und integrieren die Rhythmen tänzerisch in ein neues Kunstwerk.
Bei ihrem Auftritt im Freien interpretiert Grete Wiesenthal beispielsweise das populärste Stück der Wiener Musiktradition, den „Donauwalzer“ von Johann Strauss.

Den Schwestern Wiesenthal schlägt nach ihren ersten Darbietungen entrüstete Kritik und ebenso sehr begeisterter Beifall entgegen. „Der Tanz der Schwestern“, heißt es 1911 im Interessanten Blatt, „hat überzeugenden Ausdruck. Sie tanzen Gefühle. So hat es Elsa Wiesenthal kürzlich erklärt. Wehmut und Lust, Hingebung und Sichversagen - alle menschlichen Empfindungen, welche Kunst darzustellen vermag, läßt sie uns in lebendiger Plastik sehen.“4 Die Befürworter sehen in den neuen, modernen Formen des Tanzes einen willkommenen Affront gegen die steifen gesellschaftlichen Umgangsformen. Die Schwestern Wiesenthal propagieren, ganz im Einklang mit der jungen Lebensreformbewegung und der Secession, die Befreiung des Körpers. In ihren Bemühungen um eine Erneuerung der tänzerischen Bewegung als künstlerische Sprache greifen sie auf internationale Anregungen und Vorbilder zurück. Nach der Jahrhundertwende ist eine ganze Reihe von Pionierinnen des neuen Tanzes in Wien zu Gast, 
etwa Gertrude Barrison, Loïe Fuller, Ruth St. Denis und Isadora Duncan. Als die amerikanische Tänzerin Duncan 1902 in der Wiener Secession auftritt, sucht sie die Nähe zur neuen künstlerischen Bewegung. Sie zeigt ihre Darbietungen auch im Künstlerhaus und lehnt es ab, in Varietés zu tanzen. Die k.u.k. Hofoper ihrerseits sperrt sich gegen einen Auftritt der Tänzerin auf der großen Bühne.

\section{Aufschwung des modernen Tanzes nach 1918}

Bereits vor dem Ersten Weltkrieg werden erste Schulen gegründet, in denen der freie Tanz unterrichtet wird. ${ }^{5}$ Sie sind teilweise auch während der Kriegszeit aktiv. An Interessentinnen besteht kein Mangel, zumal ein Großteil der Anwärterinnen aus der gehobenen Gesellschaft kommt, die von den Kriegsereignissen kaum betroffen ist. Während des Krieges treten die Schwestern Wiesenthal immer wieder öffentlich auf. Festgehalten sind einige dieser Tanzszenen u.a. von der Fotografin Dora Kallmus (Madame d'Ora). ${ }^{6}$ Aber auch auf andere Weise treten die Schwestern Wiesenthal öffentlich in Erscheinung. 1917, mitten im Krieg, posiert Grete Wiesenthal für Modeaufnahmen (Abb. 5). Wiesenthal trägt ein vom Grafiker Otto Lendecke entworfenes und von der Wiener Werkstätte geschneidertes Tanzkleid. ${ }^{7}$ Die nachgestellte Tanzszene ist im Atelier aufgenommen. ${ }^{8}$ Wiesenthal hat hier gewiss nicht nur den Part der Tänzerin oder des Fotomodells inne, ihr klingender Name soll vielmehr den Verkauf der Kollektion fördern.

Kaum ist der Krieg zu Ende, tauchen neue Protagonistinnen der tänzerischen Erneuerung auf. Nach 1918 kommt es in Wien zu einem fulminanten Aufstieg des modernen Tanzes. Diese Aufbruchstimmung bleibt bis Anfang der 1930er Jahre ungebrochen. Die Tanzszene knüpft allerdings nicht nahtlos an die Vorkriegszeit an. Die weitreichenden Erschütterungen, die der Krieg mit sich bringt, schlagen sich im Tanz deutlich nieder. Die traditionellen, etablierten Posen und Körperideale werden zunehmend angezweifelt, die Ordnung der Geschlechter verschiebt sich infolge der Kriegswirtschaft grundlegend. Die Orte für die Selbstdarstellung der Frauen haben sich geändert. Die staatlichen Großtheater öffnen sich allmählich neuen künstlerischen Strömungen, im Klima der Erneuerung und des Umbruchs entsteht eine Reihe von kleinen, alternativen Theater- und Tanzbühnen. Aber auch im Tanz selbst gibt es neue Schwerpunkte. Der „Freie Tanz“ der Vorkriegszeit weicht nun dem modernen „Ausdruckstanz“, der sich immer mehr von literarischen und dramatischen Vorlagen entfernt und stattdessen sehr stark mit Verfremdung, „Mechanisierung“ der Bewegung, Montage und Abstraktion arbeitet. $^{9}$
Abb. 5 Die Wiener Tänzerin Grete Wiesenthal präsentiert ein Tanzkleid. Entwurf von Otto Lendecke, Ausführung von der Wiener Werkstätte. Die Damenwelt, Heft 2, April 1917, S. 21.

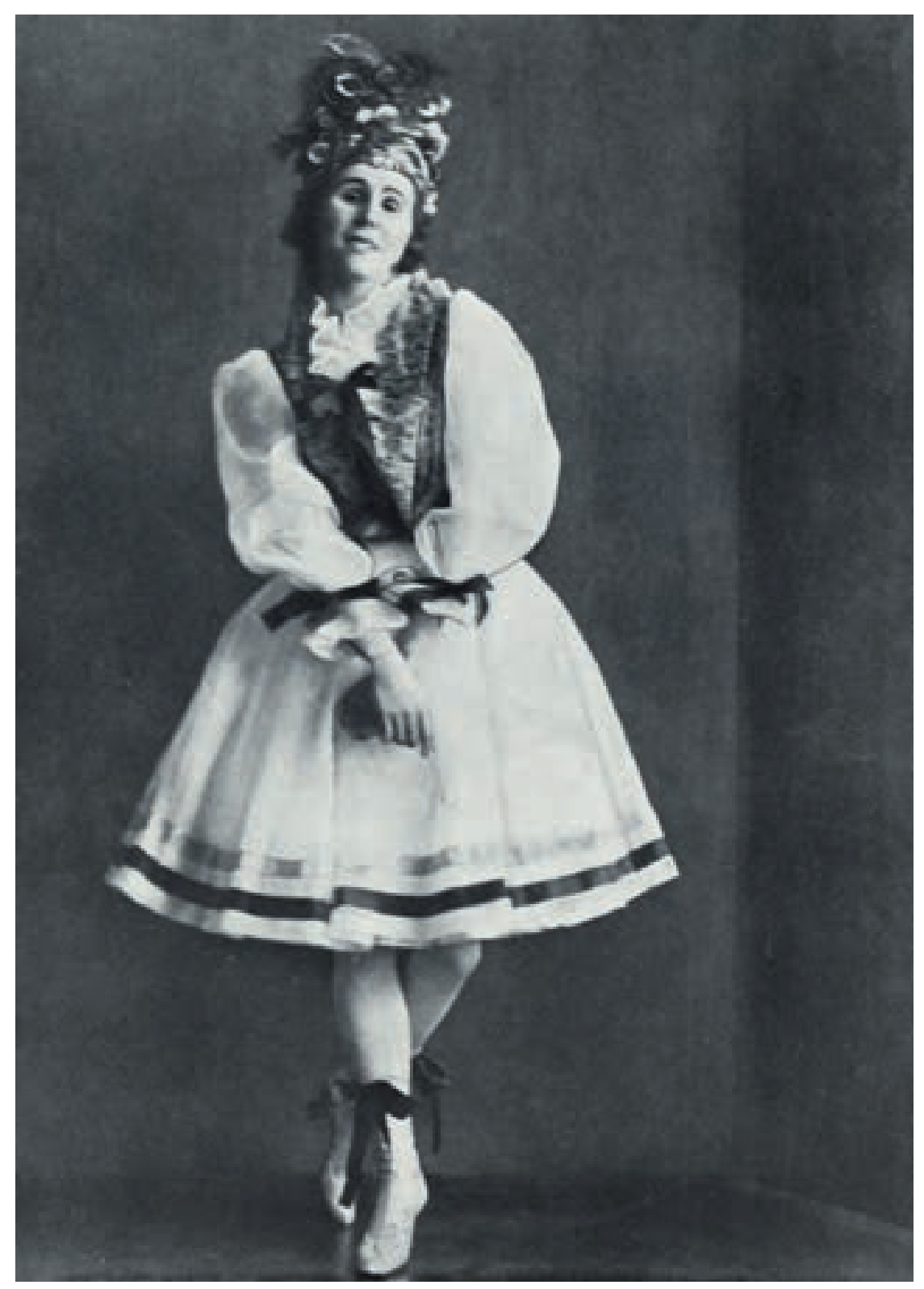


Abb. 6 Die aus Lettland stammende Tänzerin Mila Cirul im Tanzstück „Tango“, 1925.

Sie gehört zu den bekanntesten Ausdruckstänzerinnen im Wien der 1920er Jahre und lässt sich regelmäßig von Trude Fleischmann und Grete Kolliner fotografieren. Der Kostümentwurf stammt vom Künstler Georg Kirsta. Wiener Mode, Heft 18, 1925, S. 3. Foto: Grete Kolliner.

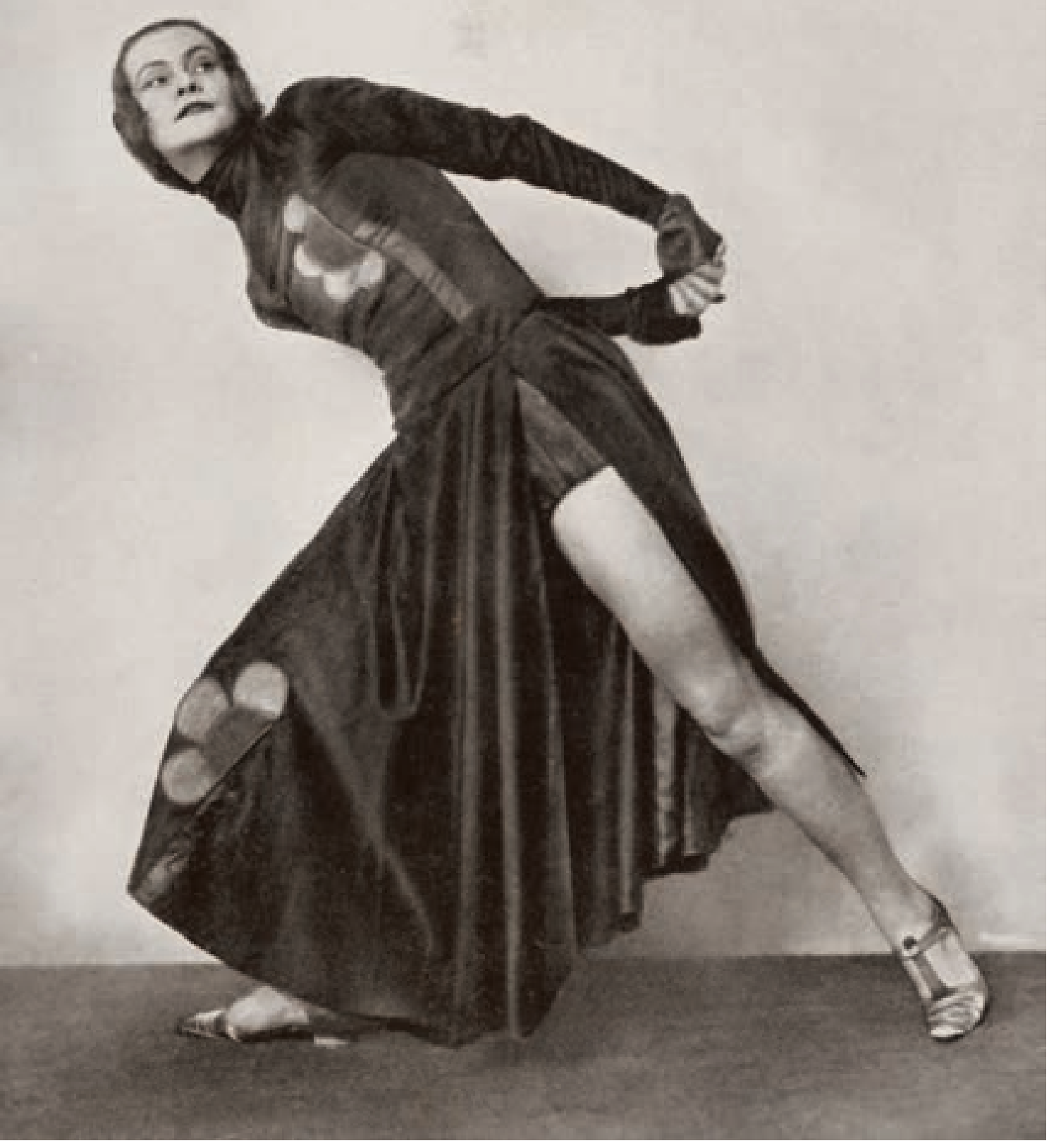

Begleitet wird diese Erneuerungsbewegung des Tanzes nach 1918 von einem beispiellosen Gang in die Öffentlichkeit. Während vor dem Ersten Weltkrieg dynamische Tanzszenen nur gelegentlich fotografisch festgehalten werden, ändert sich das nach dem Krieg schlagartig. An die Stelle der statischen Porträtstudien treten nun ausdrucksstarke Fotoinszenierungen. Die jungen Stars der neuen Tanzbewegung suchen aktiv die fotografische Öffentlichkeit. Mittels der Fotografie, so ihre berechtigte Hoffnung, können ihre flüchtigen Bewegungen festgehalten werden. Aber auch die Fotografen entdecken den Tanz als neues, attraktives Sujet. In den Bewegungsstudien wird das klassische Schauspielerporträt, das vor dem Krieg in festgefahrenen Posen und Inszenierungen erstarrt war, aufgebrochen. Die Fotografie erweist sich zudem als überaus brauchbar, die Erneuerung des Tanzes publizistisch zu begleiten. Ruhm fällt für beide Seiten ab: für die Tänzerin, die ihre Bekanntheit steigern kann, und für die Fotografin, den Fotografen, die mit aufsehenerregenden Bewegungsstudien ihren künstlerischen Abstand zum Gros der traditionellen Berufsfotografen unter Beweis stellen können.

Bereits 1918 entstehen die ersten Tanzaufnahmen, die ihren Weg auch in die auflagenstarke illustrierte Presse finden. Zu den Pionieren der österreichischen 


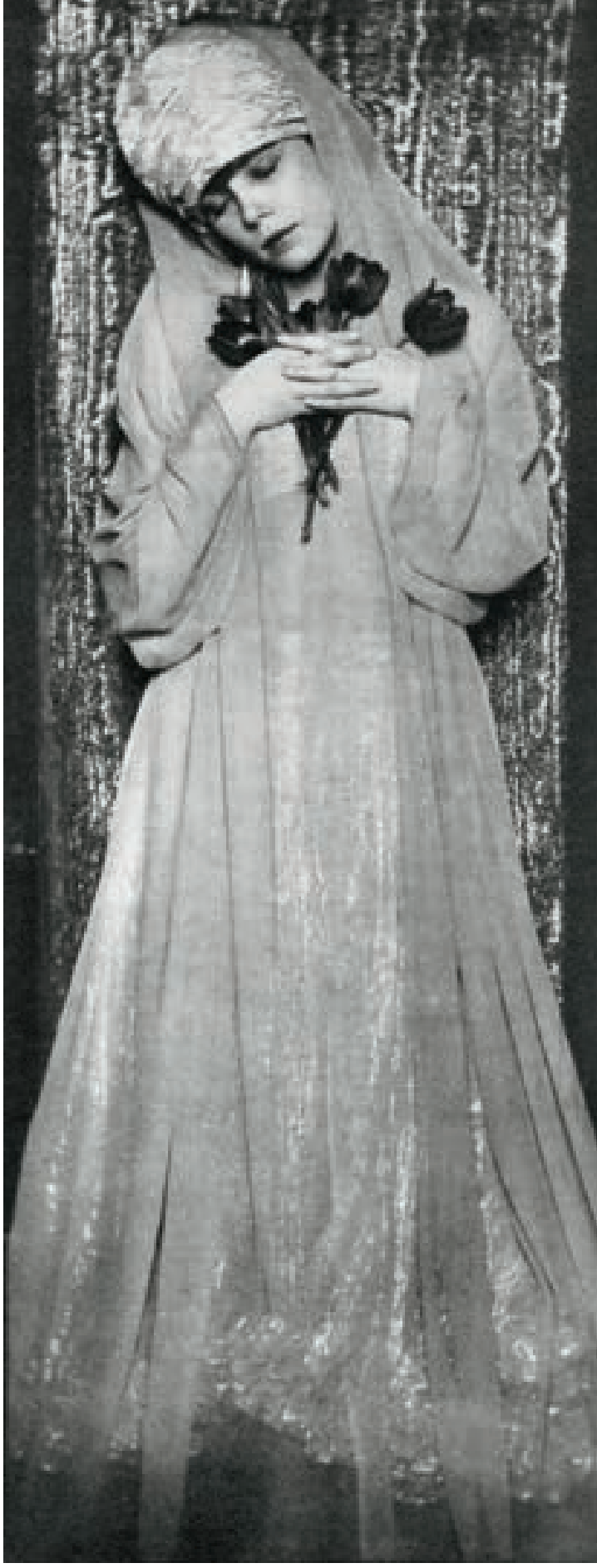

Tanzfotografie zählt Franz Löwy. Noch ist der Erste Weltkrieg im Gange, als im Herbst 1918 seine ersten künstlerischen Tanzaufnahmen veröffentlicht werden. ${ }^{10}$ In den 1920er Jahren treten vor allem Edith Barakovich, Trude Fleischmann, Madame d'Ora, Pepa Feldscharek, Beatrice Freyberger, Hedda Medina, Grete Kolliner, das Atelier Setzer, Ernst Förster, Georg Fayer und Rudolf Koppitz mit innovativen Inszenierungen hervor. Immer wieder suchen einzelne Tänzerinnen die Zusammenarbeit mit bestimmten Fotografinnen und Fotografen. Die lettische Ausdruckstänzerin Mila Cirul, ein Star unter den jungen Tänzerinnen der Nachkriegszeit, lässt sich zum Beispiel regelmäßig von den Fotografinnen Trude Fleischmann und Grete Kolliner ablichten (Abb.6). Trude Fleischmann ihrerseits arbeitet besonders eng mit der Tänzerin Claire Bauroff und mit den Mitgliedern des Wiener Staatsopernballetts Tilly Losch und Hedy Pfundmayr sowie mit dem Ballett Toni Birkmeyer zusammen. ${ }^{11}$ Losch und Pfundmayr sind aber auch öfter im Atelier von Rudolf Koppitz zu Gast (Abb. 7). Madame d'Ora lichtet über Jahre hin die Schwestern Wiesenthal ab. Die Tänzerin Grete Groß wird häufig von der Fotografin Hedda Medina porträtiert. Ein Großteil dieser Porträts entsteht im Atelier, nur selten wird auf der Bühne fotografiert.

Ab Ende der 1920er Jahre erwächst den etablierten Studios, die in Wien Tanz fotografieren, eine gewisse Konkurrenz, da nun auch Pressefotografen und Amateure das Thema Tanz (und Theater) entdecken. Sie arbeiten mit kleineren, lichtstarken Apparaten und können daher auch außerhalb des Ateliers, etwa auf der Bühne, Aufnahmen machen. Zu den interessantesten und begabtesten Fotografen, die neben der Theaterberichterstattung auch den Tanz dokumentieren, zählt Otto Skall. Geboren und aufgewachsen in Prag, zieht er 1920 nach Wien. Mitte der 1920er Jahre beginnt er als Pressefotograf, wobei er zunächst unterschiedlichste Themen abdeckt. In den 1930er Jahren wird er mehr und mehr zum viel beschäftigten Theaterfotografen. Unter den innovativen Amateuren, die sich um 1930 dem Thema Tanz widmen, sind der Schweizer Martin Imboden, der u. a. die Tänzerin Gertrud Kraus und ihre Schüler fotografiert, ${ }^{12}$ sowie die beiden Wiener Fotografen Othmar Maudry und Max Tanner, der etwa die Tänzerin Leila Bederkhan aufnimmt (Abb.8).

\section{Expressionistische Bewegung, neue Tanzschulen}

Eine der einflussreichsten Protagonistinnen des neuen Tanzes dieser Jahre ist Gertrud Bodenwieser. Geboren 1890 in Wien, absolviert sie ihre Ausbildung während der Kriegszeit. Am 5. Mai 1919 tritt sie zum ersten Mal mit ihrem Soloprogramm im Wiener Hagenbund auf. ${ }^{13}$ Schnell wird sie mit ihren expressionistischen Ausdruckstänzen zum umjubelten Star der Wiener Tanzszene. Ab 1920/21 unterrichtet sie
Abb. 7 Die Tänzerin Tilly Losch vom Ballett der Wiener Staatsoper. Moderne Welt, Heft 14, 1925, S. 4. Foto: Rudolf Koppitz. 
Abb. 8 Die kurdische Tänzerin Leila Bederkhan, bekannt für ihre orientalischen und expressiven Tänze, tritt in den 1920 er Jahren regelmäßig in Wien auf. Wiener Mode, Heft 18, September 1924, S. 14. Foto: Max Tanner.

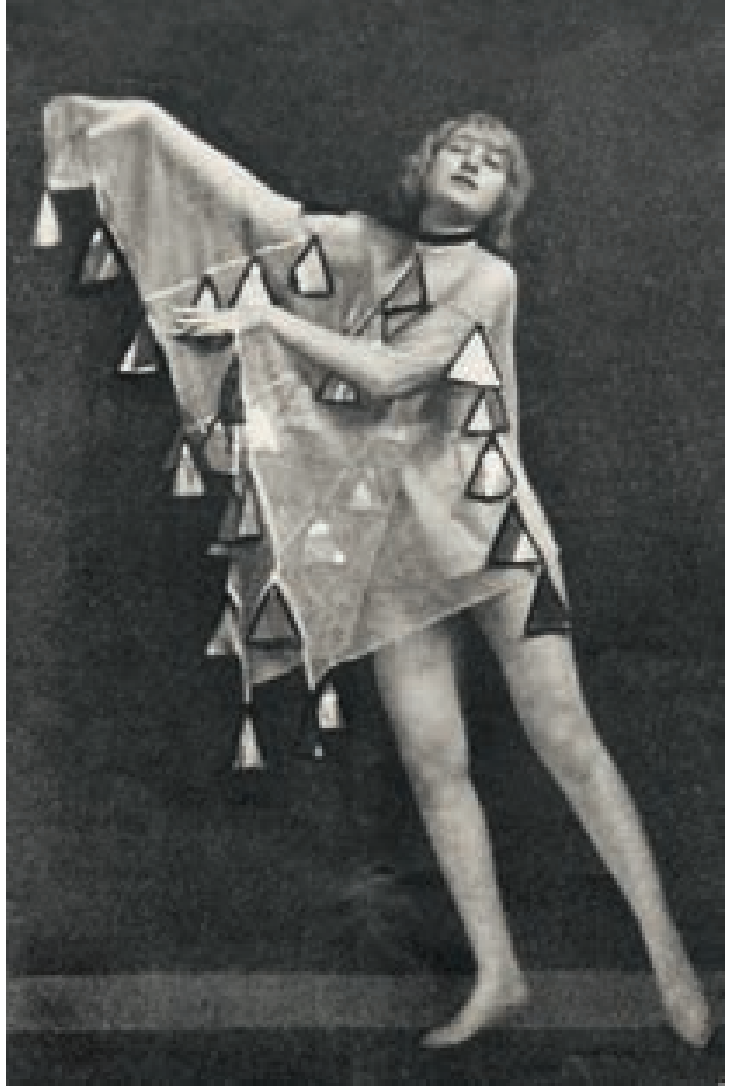

Mimik und Tanz an der Akademie für Musik und Darstellende Kunst, 1922 eröffnet sie eine eigene Schule und ist in den folgenden Jahren auf Tournee in ganz Europa unterwegs. Sie gehört zu den wenigen Tänzerinnen, die neben ihrer Arbeit auf der Bühne auch eine beeindruckende publizistische Selbsteinschätzung geliefert hat. Bereits zu Beginn ihres Erfolges blickt sie auf ihre noch kurze, aber steile Karriere zurück. In einem Beitrag für die Zeitschrift Moderne Welt benennt sie im Frühjahr 1922 Vorbilder, Künstlerfreunde und konkrete ästhetische Bezugspunkte ihrer Kunst: „Ich tanzte nach der Musik von Korngold und Debussy, von Scriabine und Scott und versuchte, ihre erregenden Rhythmen, ihre tief aufwühlenden Dissonanzen oder ihre groteske Komik in meinen Bewegungen wiederzugeben. Wenn es die Musik war, von der ich meine entscheidenden Anregungen erhielt, so war es die Malerei nicht minder, und Maler waren es auch, die meine ersten Schritte in die Öffentlichkeit leiteten. Vor allem Franz von Bayros, der große, fein fühlende Künstler, der mir nicht allein nur dadurch half, dass er mir in der verstehendsten Weise ergänzende Gewänder zu meinen Tänzen schuf, sondern mir auch immer Mut zusprach, meine Ideen ohne Zugeständnisse und Kompromisse zu verwirklichen. Als ich meine Kostüme fertig hatte, führte ich meine Tänze einem Kreis junger Maler, die sich unter dem Namen ,Neue Vereinigung، zu einer Gruppe zusammengeschlossen hatten, vor. Sie fühlten, wie sie selbst sagten, Verwandtes in meiner Art zu tanzen heraus und luden mich ein, meinen ersten Wiener Tanzabend im Frühling 1919 in ihrer neueröffneten Ausstellung abzuhalten. Das war mein selbständiges Debüt in Wien und der eigentliche Beginn meiner Laufbahn. Und so wurde ich, als was ich mit einem vielumstrittenen, vielmißbrauchten Wort bezeichnet zu werden pflege: eine expressionistische Tänzerin.“ ${ }^{14}$ Einige Jahre später, Bodenwieser ist international längst etabliert, meint sie: „Kampf, Leidenschaft, dionysisch gesteigertes Lebensgefühl, aber auch Chaos, Grauen und Entartung möchte ich in den Tänzen ohne Rücksicht auf die ästhetische Linie, vielleicht gerade darum mit umso packenderer Wucht, gebracht sehen. (...) So trachte ich, die Tanzkunst in engsten Zusammenhang zu bringen mit der großen geistigen Strömung unserer Epoche, dem Expressionismus, zu dem ich mich durchaus bekenne." ${ }^{15}$ (Abb.9)

Gertrud Bodenwieser ist in den 1920er und 1930er Jahren die wohl bekannteste Vertreterin des neuen Tanzes in Wien. Neben ihr und Grete Wiesenthal gibt aber zahlreiche andere wichtige Protagonistinnen des modernen Tanzes. Viele der Bodenwieser-Schülerinnen, unter anderem Grete Groß (Abb. 10), Gertrud Kraus, Hilde Holger, Gisa Geert, Lisl Rinaldini, Trudl Dubsky, Erika Hanka und Cilli Wang, machen ebenfalls Karriere und gründen teilweise eigene Schulen und Ausbildungsinstitute. ${ }^{16}$ In den 1920er Jahren entsteht auf diese Weise in Wien ein weitverzweigtes Laboratorium für experimentelle Bewegung. Während ein Teil der Tänzerinnen sich eindeutig in die Tradition des Expressionismus stellt, folgen andere Bewegungskünstlerinnen anderen Richtungen. Rosalia Chladek etwa, geb. 1905 in Brünn, absolviert ihre Ausbildung in der Tanzgruppe Hellerau-Laxenburg, deren Ursprünge auf die Lebensreformbewegung zurückgehen. ${ }^{17}$ In den 1930er Jahren übernimmt sie die Leitung der Tanzschule in Laxenburg. Aus einer ähnlichen Tradition kommt der Lehrer und Choreograf Rudolf Laban, der regelmäßig in Wien zu Gast ist. Bekannt ist auch die russische Tänzerin Ellen Tels, die bereits vor dem Ersten Weltkrieg Gastspiele in Wien gibt und dort 1920 eine innovative Tanzschule gründet. Zu ihrem Ensemble gehört die legendäre Tänzerin Mila Cirul. ${ }^{18}$ Ende der 1920er Jahre öffnen sich allmählich auch die staatlichen Institutionen dem 


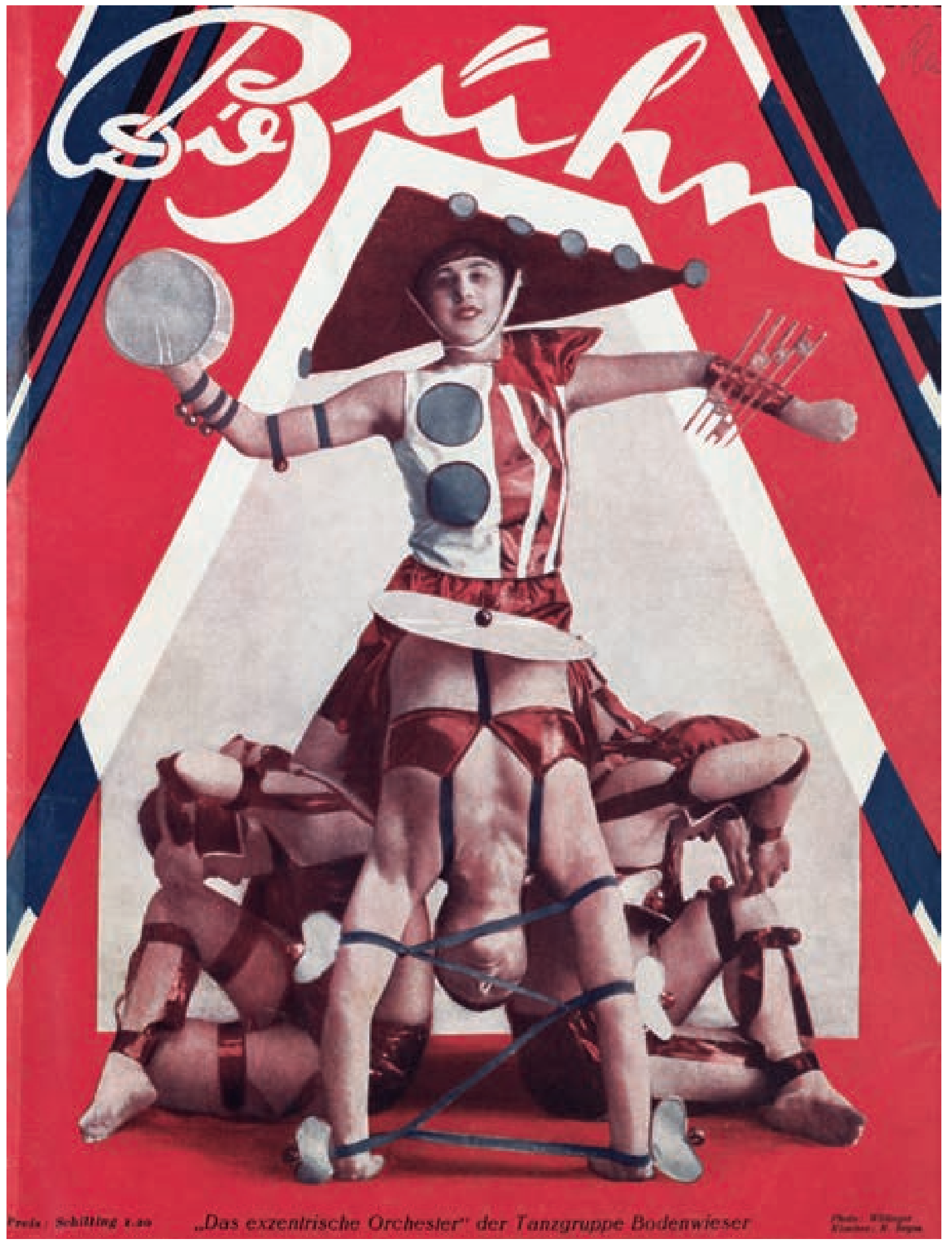

Abb. 9 „,Das exzen-

trische Orchester

der Tanzgruppe

Bodenwieser". Die

Bühne, 11. März 1926,

Titelseite. Foto:

Agentur Willinger. 


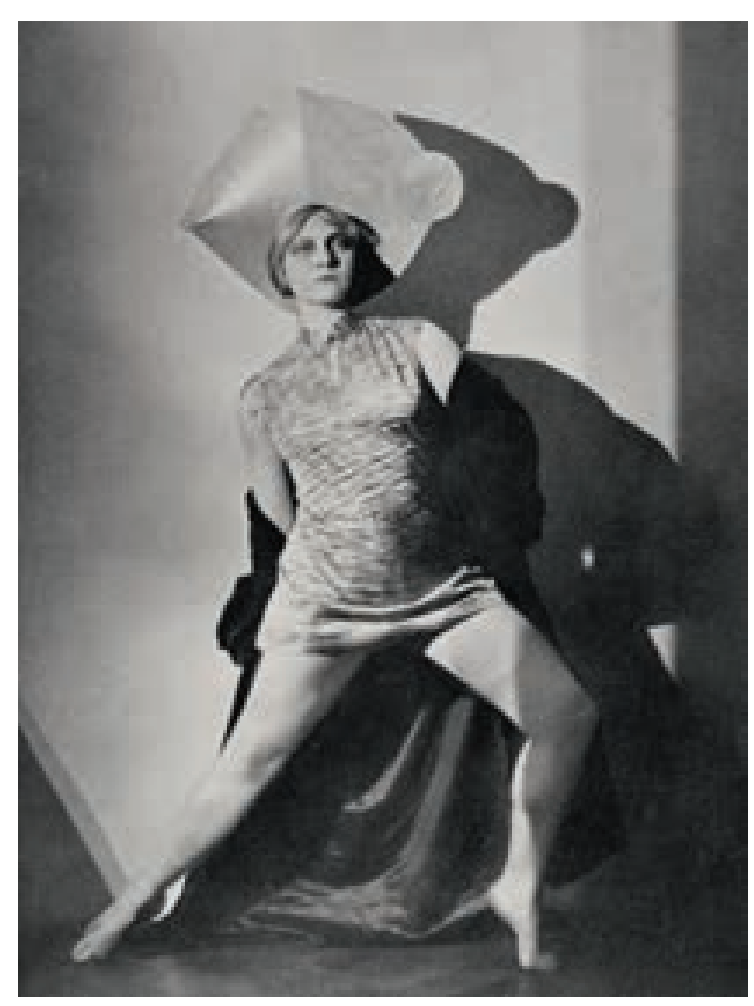

Abb. 10 Die Wiener Tanzkünstlerin Grete Groß. Wiener Mode, Heft 14, 1930, S. 6. Foto: Hedda Medina.

Abb. 11 „Bewegungsgruppe: Angst“. Inszenierung von Sascha Leontjew. Der aus Riga stammende Tänzer ist einer der innovativsten Choreografen der Zwischenkriegszeit. Bis 1930 ist er Leiter des Balletts der Wiener Staatsoper, danach geht er freien Projekten nach. MOCCA, Heft 7, Juli 1935,

S. 61. Foto: Graben-Atelier.

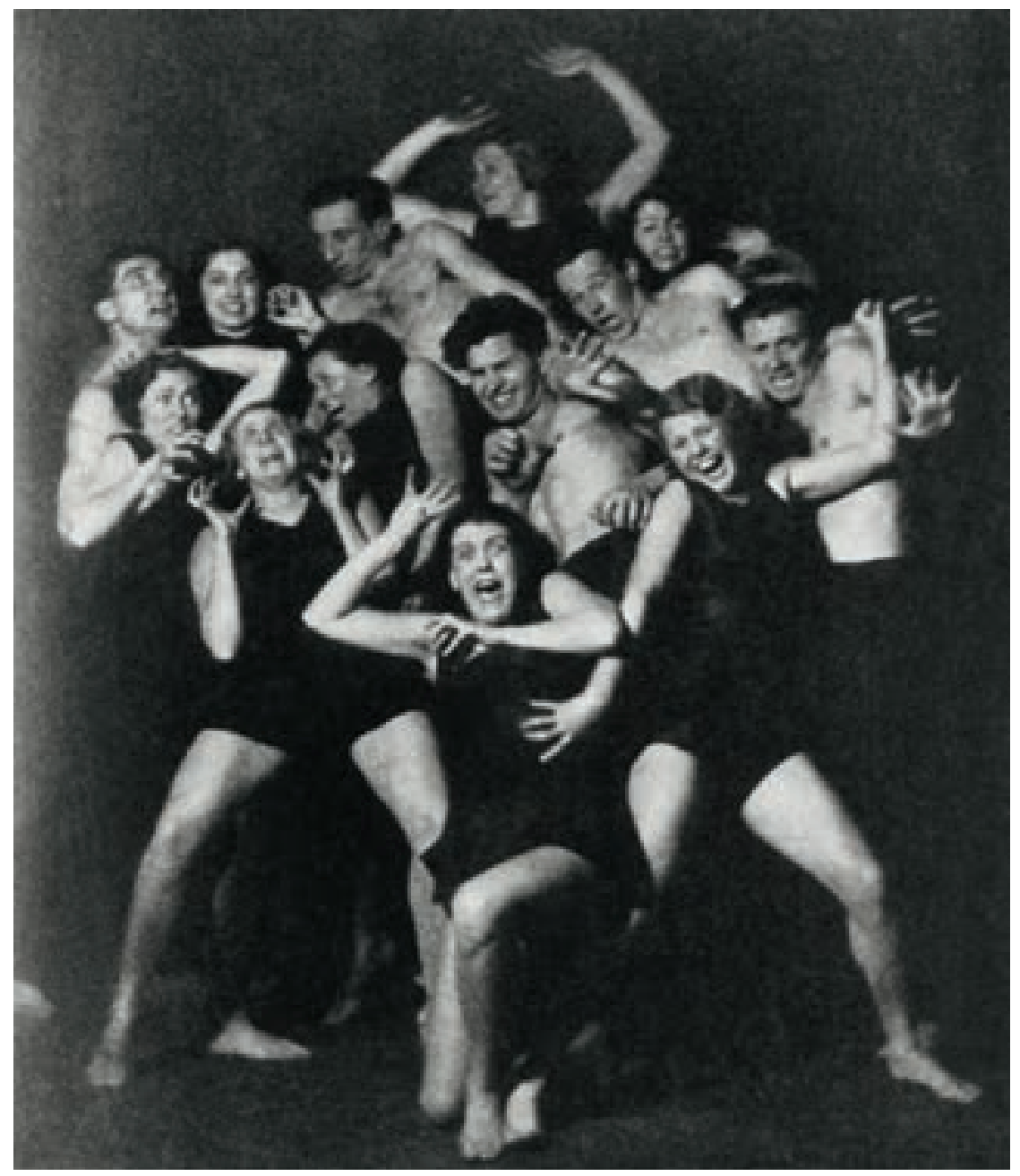

freien Tanz. Ab 1926 inszeniert Grete Wiesenthal an der Wiener Staatsoper Ballettaufführungen. Mit dem russischen Tänzer und Choreografen Sascha Leontjew, der zwischen 1928 und 1930 die Leitung des Wiener Staatsopernballetts innehat, etablieren sich die neuen Strömungen des Tanzes endgültig im gesellschaftlichen Leben (Abb. 11).

\section{Kontinuität und politische Brüche}

Der moderne Tanz übersteht in Wien die politischen und gesellschaftlichen Umbrüche der Jahre 1933/34 relativ gut. Die Tanzszene ist in den 1930er Jahren immer noch sehr aktiv. Im Jahr 1933 veranstaltet der Hagenbund, eine Wiener Künstlervereinigung, eine große Tanzausstellung, es ist die erste ihrer Art im 20. Jahrhundert. ${ }^{19}$ Ein Jahr später, im Juni 1934, findet in Wien ein großer internationaler Tanzwettbewerb statt. ${ }^{20}$ Aus diesem Anlass erscheint in der Zeitschrift Wiener Mode ein aktueller Überblick über die Szene des modernen Tanzes in Wien (Abb. 12). Vorgestellt werden Protagonistinnen wie Grete Groß, Gertrud Kraus, Gisa Geert, Ellinor Tordis, Stella Mann und Rosalia Chladek.

Bemerkenswert ist, dass der austrofaschistische „Ständestaat“ den freien Ausdruckstanz keineswegs als Bedrohung sieht, sondern als Ausdruck der modernen Körperkultur offiziell fördert. ${ }^{21}$ Mitte der 1930er Jahre zeigt das Wiener Staatopernballett zahlreiche Aufführungen, die ganz in der Tradition des Ausdruckstanzes stehen. Viele der großen Wiener Tänzerinnen sind in den 1930er Jahren regelmäßig auf der Bühne zu bewundern. Und dennoch: Für jene Tänzerinnen, die sich, wie etwa Cilly Wang, in ihren Produktionen Anfang der 1930er offen politisch geäußert und explizit gegen Diktatur und Faschismus Stellung bezogen haben, wird die Arbeit nun immer schwieriger. Als 1934 die Diktatur des „Ständestaates" errichtet wird, sind oppositionelle politische ÄuBerungen nicht mehr möglich. Einige Tänzerinnen jüdischer Herkunft ziehen es bereits zu diesem Zeitpunkt vor, ins Exil zu gehen, darunter Gertrud Kraus. Die Tänzerin, die vor 1933 eine Anhängerin der Sozialdemokratie war und u.a. sozialkritische Tanzprogramme und Bühnenbilder (u.a. Anfang der 1930er 
Jahre für die Bühnenfassung von Karl Kraus' Die letzten Tage der Menschheit) realisiert hatte, emigriert 1935 nach Palästina. Ab Mitte der 1930er Jahre stagnieren die Wiener Tanzschulen, die ausländischen Schülerinnen, die Jahr für Jahr Unterricht genommen haben, bleiben zunehmend aus. ${ }^{22}$

Der radikale Bruch kommt dann im Jahr 1938, als mit dem Einmarsch der nationalsozialistischen Truppen und der Judenverfolgung die innovative österreichische Tanzszene ein abruptes Ende findet. Ende Februar 1938, wenige Wochen vor dem „Anschluss“, werden die Protagonistinnen des Wiener Ausdruckstanzes in einem Zeitschriftenbeitrag noch gefeiert: „Die moderne Tanzkunst scheint in ein kritisches Stadium gelangt zu sein: Sie stagniert! Diese Feststellung soll nicht mißverstanden werden, Still- stand darf durchaus nicht mit Rückschritt identifiziert werden.“23 Und weiter heißt es: „Wir besitzen in Wien einen ganze Reihe großer Talente, die weit über die Grenzen unserer Heimat hinaus bekannt sind. Namen wie beispielsweise Gertrude Bodenwieser, Grete Groß, Gertrud Kraus (die bereits nicht mehr in Wien ist, A.H.), Gisa Geert, Ellinor Tordis, Rosalia Chladek u. a. m. vertreten beste österreichische Marke und haben bewiesen, daß Wien der Boden ist, auf dem Grazie, Anmut und ganz großes Können besonders gutes Gedeihen finden. “24 Tage später ist diese Einschätzung Geschichte. Die Szene des modernen Tanzes löst sich mit einem Schlag auf. Tänzerinnen und Tänzer jüdischer Herkunft fliehen oder werden deportiert und in den nationalsozialistischen Vernichtungslagern ermordet.
Abb. 12 Eine Bestandsaufnahme des modernen Tanzes anlässlich des internationalen Tanzwettbewerbs in Wien, Mai, Juni 1934. Wiener Mode, Heft 12, 1934, S. 8/9. Fotos: Medina, Fayer.

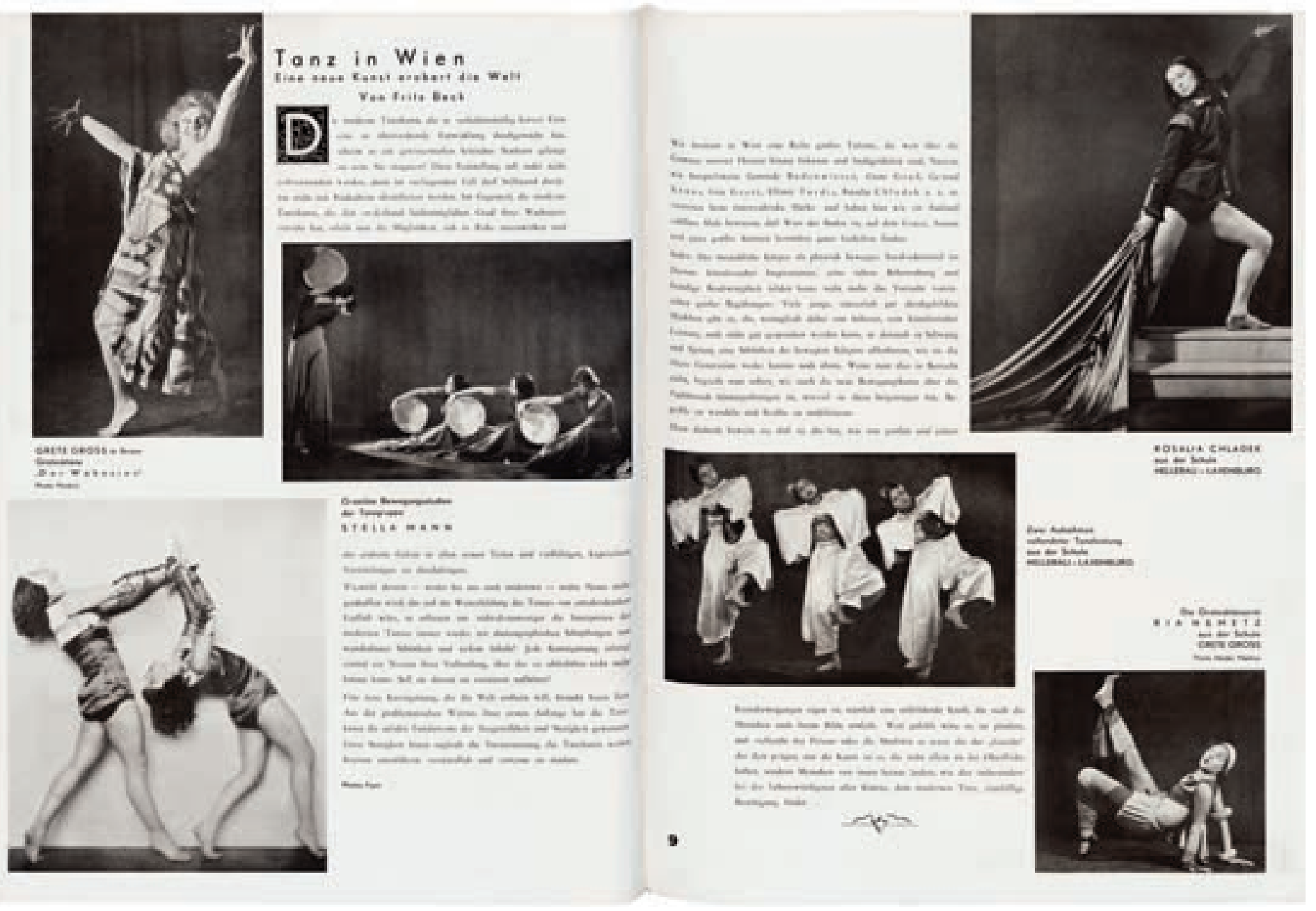




\title{
Wenn die Hüllen fallen
}

\author{
Erotik, Sexualität und Nacktfotografie in der Zwischenkriegszeit
}

Am 5. Februar 1928 kommt Josephine Baker am Wiener Westbahnhof an. Sie reist im eigenen Luxuswaggon. Doch sie bleibt nicht lange in der Stadt, bald fährt sie weiter Richtung Semmering. ${ }^{1}$ Dort will sie ein paar Urlaubstage verbringen. Anschließend soll sie in Wien auf der Bühne stehen - vereinbart ist eine Revue im Varietétheater Ronacher. Wien ist die erste Station einer zweijährigen Europa- und Südamerikatournee, die sie in fünfzehn Städte führen wird. Von Wien über Berlin, Budapest, Bukarest, dann nach Skandinavien und schließlich nach Santiago de Chile.

Als sie in Wien aus dem Zug steigt, ist sie in Wirklichkeit schon längst angekommen: Die Bilder ihrer legendären Nacktauftritte sind allseits bekannt. Im April 1927 bringt die Zeitschrift Die Bühne ein koloriertes Foto von Josephine Baker auf der Titelseite (Abb. 1). ${ }^{2}$ Die Aufnahme stammt von der bekannten Wiener Atelierfotografin Madame d'Ora, die im selben Jahr ihren geschäftlichen Mittelpunkt von Wien nach Paris verlegt hat. Die schwarze Tänzerin wird mit nacktem Oberkörper gezeigt, sie ist nur mit einem Kopftuch bekleidet, in der Hand hält sie kokett einen Wedel. Die exotischen Masken im Hintergrund geben der Tänzerin den Anstrich des Wilden und Unzivilisierten. Zugleich verkörpert sie die enthemmte, ungezügelte Sexualität. Wenig später, im August 1927, berichtet die Zeitschrift Mein Film über die Uraufführung des Films „Ein Rutscher nach Paris“ (1926) in Wien. Josephine Baker spielt darin die Hauptrolle. ${ }^{3}$

Josephine Baker weiß um ihre sexuelle Anziehungskraft. Geschickt inszeniert sie sich in wechselnden Rollen auf der Bühne. Ebenso geschickt aber kultiviert sie ihr Image in fotografischen Bildern. 1927 lichtet Madame d’Ora die Tänzerin zum ersten Mal in Paris ab. In den folgenden Jahren porträtiert die österreichische Fotografin den Star im Auftrag von illustrierten Zeitungen und Journalen unzählige Male. D’Ora ist eine Meisterin des sinnlichen, erotischen Frauenporträts. In Josephine Baker findet sie ein wandlungsfähiges fotogenes Gegenüber, das ihre Rolle vor der Kamera perfekt spielt. Sie tritt in immer neuen Bildern auf, einmal elegant entweder als Frau oder als Mann gekleidet, dann wieder clownesk und schließlich in der Rolle, in der man sie stets erwartet: halb oder fast ganz nackt, vertieft in einen orgiastischen Tanz. Mit Leichtigkeit wechselt sie Gewand, Ausstrahlung, Image. Madame d'Ora begleitet sie auf diesem Parcours der Verwandlungen. Die Fotografin ist eine Art Spiegel, der die Theatralik der Baker aufnimmt und in ein haltbares öffentliches Bild überträgt. D’Ora lichtet nicht nur Josephine Baker, sondern zahlreiche andere Bühnenstars ab. Nicht selten lüftet sie dezent das Gewand der Porträtierten. Fast nie aber lassen ihre Protagonisten die Hüllen gänzlich fallen. Die Fotografin modelliert Sinnlichkeit, Anziehung und Erotik mithilfe raffinierter Lichtführung. Ihre Strategie liegt nicht in der brutalen Entblößung, sondern in der erotischen Andeutung. Immer wieder balanciert sie in ihren Bildern gekonnt zwischen sexueller Verfügbarkeit und subtilem Entzug (Abb. 2).

\section{Josephine Baker in Wien}

Im Februar 1928 berichten die Zeitungen ausführlich über die „Pariser Sensation“. Jedes Detail der Reise von Josephine Baker wird in der Öffentlichkeit verhandelt. Die Journalisten wissen sogar darüber Bescheid, was der anrüchige Star auf Reisen mit sich führt: 15 große Schiffskoffer, darin verpackt 137 Kleider und Kostüme, 196 Paar Schuhe, 64 Kilo Schminkpuder und natürlich - das legendäre Bananenröckchen. ${ }^{4}$ Die Baker versetzt Wien in helle Aufregung. Die konservativen Blätter wettern gegen ihren geplanten Auftritt, liberale Stimmen verteidigen ihn vehement. Die erregte Debatte zieht sich über Wochen hin. ${ }^{5}$ Ende Februar erreicht sie sogar den Nationalrat. Christlichsoziale Redner fordern ein Auftrittsverbot. Und tatsächlich: Zur Revue im Ronacher wird es nicht 


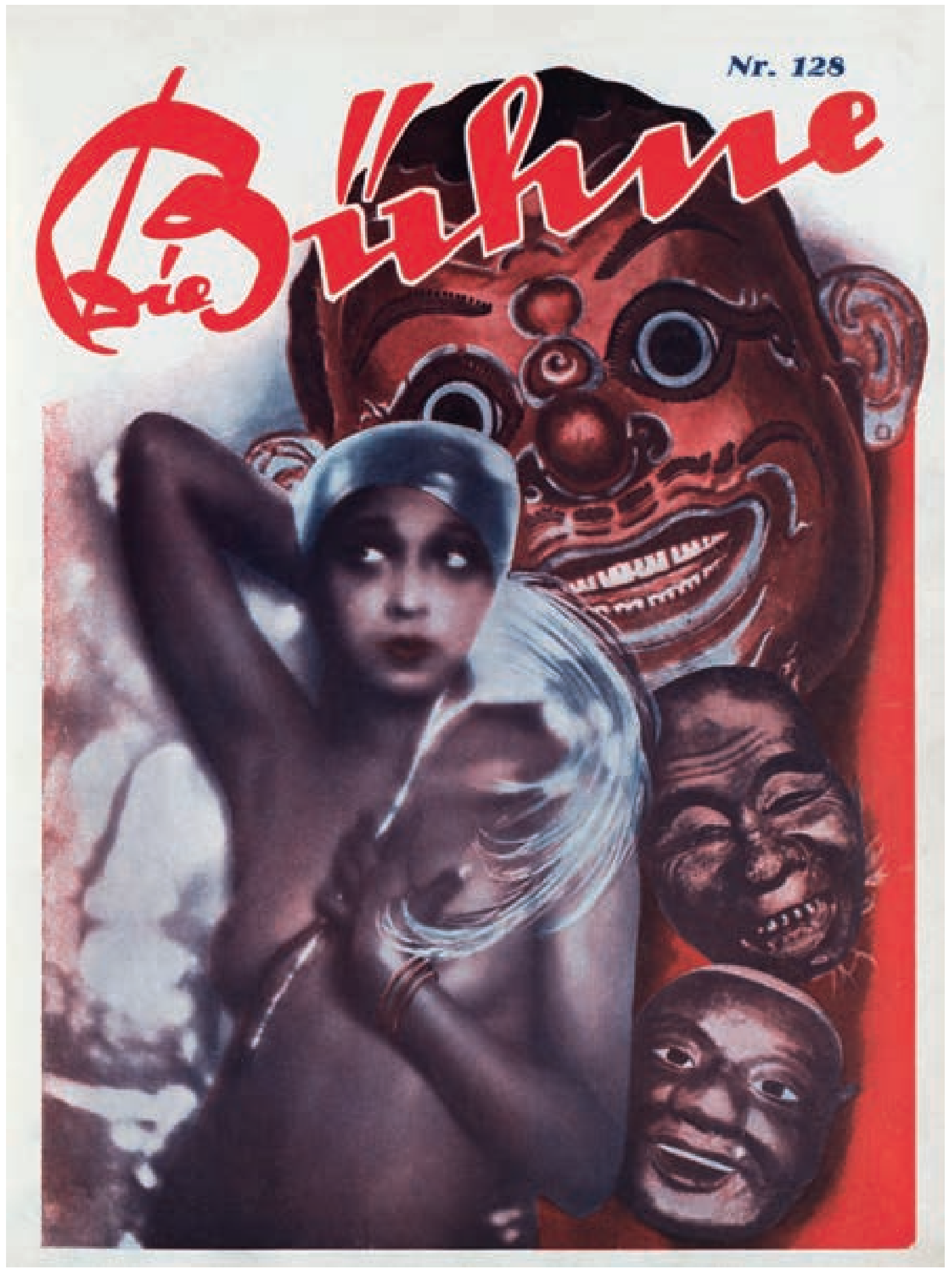

Abb. 1 Josephine Baker als Projektionsfläche für enthemmte Sexualität und exotische Wildnis, fotografiert von der Wiener Fotografin Madame d'Ora. Die Bühne, 21. April 1927, Titelseite. 
Eine Woche nach ihrem kurzen Wiener Auftritt resümiert ein Wiener Journalist: „Schon das Entree der Mulattin Josephine Baker wirkt faszinierend, sie umschleicht, um den Gürtel künstliche Bananen tragend, im Urwald lauernd, einen weißen Afrikareisenden. Ihr knabenhafter Körper zeigt klassische Formen, dazu das weiße Leuchten ihrer Zähne, kohlschwarze Augen mit Pupillen, die sich weit nach rechts oder links schieben, so daß man nur das Weiße sieht. Bald ist die Wildkatze dann wieder ein sanftes oder übermütiges Kind, kurz gesagt, ein Original, ein Ereignis auf der Bühne. Wenn sie mit ihrer dünnen Stimme singt, den Gesang der Tiere nachahmt, oder grotesk tanzt, wobei jeder Muskel des ganzen Körpers nach Art der Bauchtänzerinnen mitarbeitet, folgt man jeder ihrer Bewegungen mit gespanntem Interesse.“8

\section{Blütezeit der Nacktkultur}

Josephine Baker ist in den 1920er Jahren eine Art Kunstfigur, eine Projektionsfläche, die Faszination und Ablehnung gleichermaßen bündelt. Sie wird bewundert und gefeiert, aber auch kritisiert und verachtet. Ihr entblößter Körper ist auf der Bühne und in der illustrierten Presse die Attraktion, zugleich aber auch Anlass für Skandale. Wenige Jahre nach dem Ende des Ersten Weltkriegs ist der Nackttanz in den europäischen Metropolen zur großen Mode geworden. Bilder entblößter Tänzerinnen halten in diesen Jahren mit einer Selbstverständlichkeit Einzug in die illustrierten Journale, wie sie zuvor nicht denkbar gewesen wäre. Wenn vor 1914 der entblößte weibliche Körper in der Öffentlichkeit gezeigt wurde, hatte man stets Vorkehrungen getroffen, um den zu erwartenden Vorwurf der Unsittlichkeit zu entkräften und die Zensur zu umgehen. Gelegentlich bemühte man einen künstlerischen Jargon. Nacktszenen auf der Bühne wurden beispielsweise in Form von „Tableaux vivants“ gezeigt, die oft (zumindest angeblich) nach Vorbildern in der Malerei arrangiert waren. Oder die Entblößung fand unter dem Deckmantel des künstlerischen Tanzes statt. In der illustrierten Presse erschienen Nacktbilder nur dann, wenn sie mit einem Kommentar der moralischen Empörung versehen waren. Als 1913 die französische Nackt- tänzerin Adorée Villany im Zirkus Busch im Wiener Prater auftrat, erschien ein freizügiges Foto in der Presse (Abb.4), begleitet von einem distanzierenden Kommentar, in dem die „wilden, orgiastischen Tänze“ beanstandet wurden. ${ }^{9}$

All das ändert sich nach 1918. Die Erschütterungen des Krieges haben die moralischen Grenzen verschoben. Die Nacktkultur verlässt nun die engen
Abb. 4 Die französische Nackttänzerin Adorée Villany tritt 1913 im Zirkus Busch im Wiener Prater auf. Das interessante Blatt, 10. Juli 1913, S. 18.

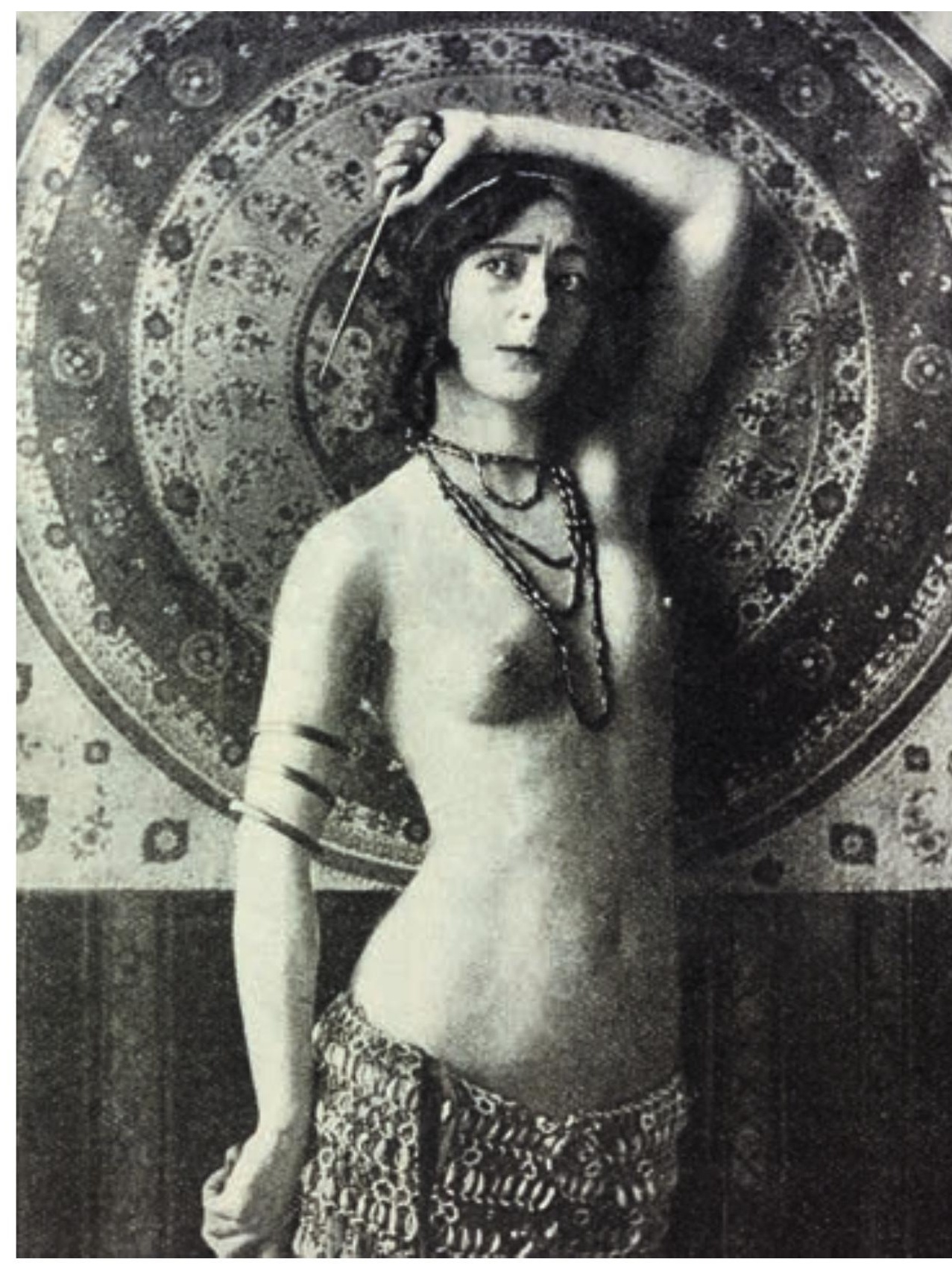


Abb. 6 „Akt“, aufgenommen von Trude Geiringer und Dora Horovitz, um 1930. Das österreichische Lichtbild. Jahrbuch 1933, hg. vom Verband der österreichischen Amateurphotographenvereine in Wien, Wien, Troppau, Leipzig 1933, Tafel 81.

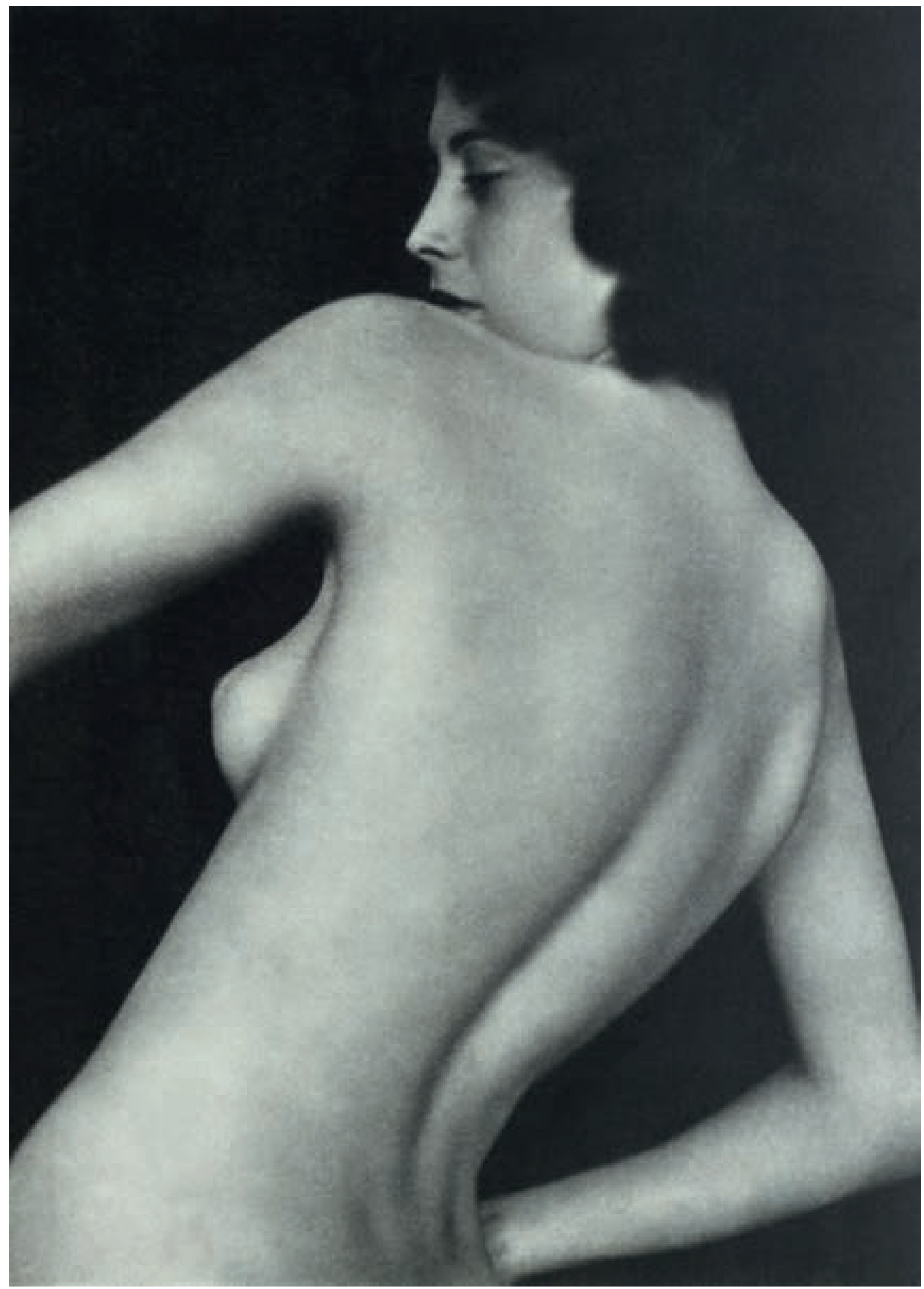


Abb. 7 „Schreitender Rückenakt“ - die Tänzerin Claire Bauroff, aufgenommen Ende der 1920er Jahre von Trude Fleischmann. Das deutsche Lichtbild 1931, Berlin 1930, S. 119.

esoterischen Zirkel, sie trifft sich mit anderen Traditionen der Nacktheit, etwa der proletarischen Nacktkörperkultur, und wird in den 1920er Jahren zur weithin anerkannten gesellschaftlichen Haltung. ${ }^{10}$ Sie taucht im Sport und der körperlichen Ertüchtigung ebenso auf wie auf der Bühne und später im Film. Zwar haftet den Nacktauftritten im Theater immer noch etwas Verruchtes an, zugleich aber mehren sich die Stimmen, die die Entblößung des Körpers auf der Bühne als legitimen Teil moderner Tanzkultur verteidigen. In den frühen 1920er Jahren wird der künstlerische Nackttanz große Mode. Die Stars der raffinierten Entblößung wie Olga Desmond, Valeska Gert oder Ruth St. Denis treten nun nicht mehr nur in anrüchigen Vorstadtetablissements oder in privaten Vorstellungen auf. Sie erobern selbstbewusst und unter dem Beifall der Massen die etablierten Bühnen der Stadt - und vor allem den Film. Einflüsse aus Berlin schwappen bald auch auf Wien und andere Städte über. Am 30. Oktober 1922 tritt Anita Berber mit ihrer grotesk-erotischen Show „Tänze des Lasters, des Grauens und der Ekstase“ im Wiener Konzerthaus auf. Die Szenen werden bereits vorab von Madame d'Ora mit der Kamera festgehalten, aber nicht in der Presse veröffentlicht. ${ }^{11}$

Ab 1923/24 sind Nacktszenen in Wien keine Seltenheit mehr. Vor allem in den populären Ausstattungsrevuen nach Pariser und Berliner Vorbild treten in manchen Szenen die Tänzerinnen (fast) hüllenlos auf. Vor allem im Apollo-Theater oder im Ronacher werden solche Stücke gespielt, darunter zum Beispiel die Revue „Wien gib acht!“, die 1923 zum Sensationserfolg im Ronacher wird. ${ }^{12}$ Immer mehr Tänzerinnen, die ihre Hüllen auf der Bühne fallen lassen, sind im Fotoatelier ebenso freizügig. Manche dieser Aufnahmen erscheinen bald darauf in illustrierten Zeitschriften und Magazinen. Die Zeitschrift Die Bühne etwa bringt seit 1925 regelmäßig Nacktaufnahmen von Tänzerinnen.

1924 erscheinen in den Wiener Illustrierten erstmals Aktfotos ohne distanzierenden Kommentar.

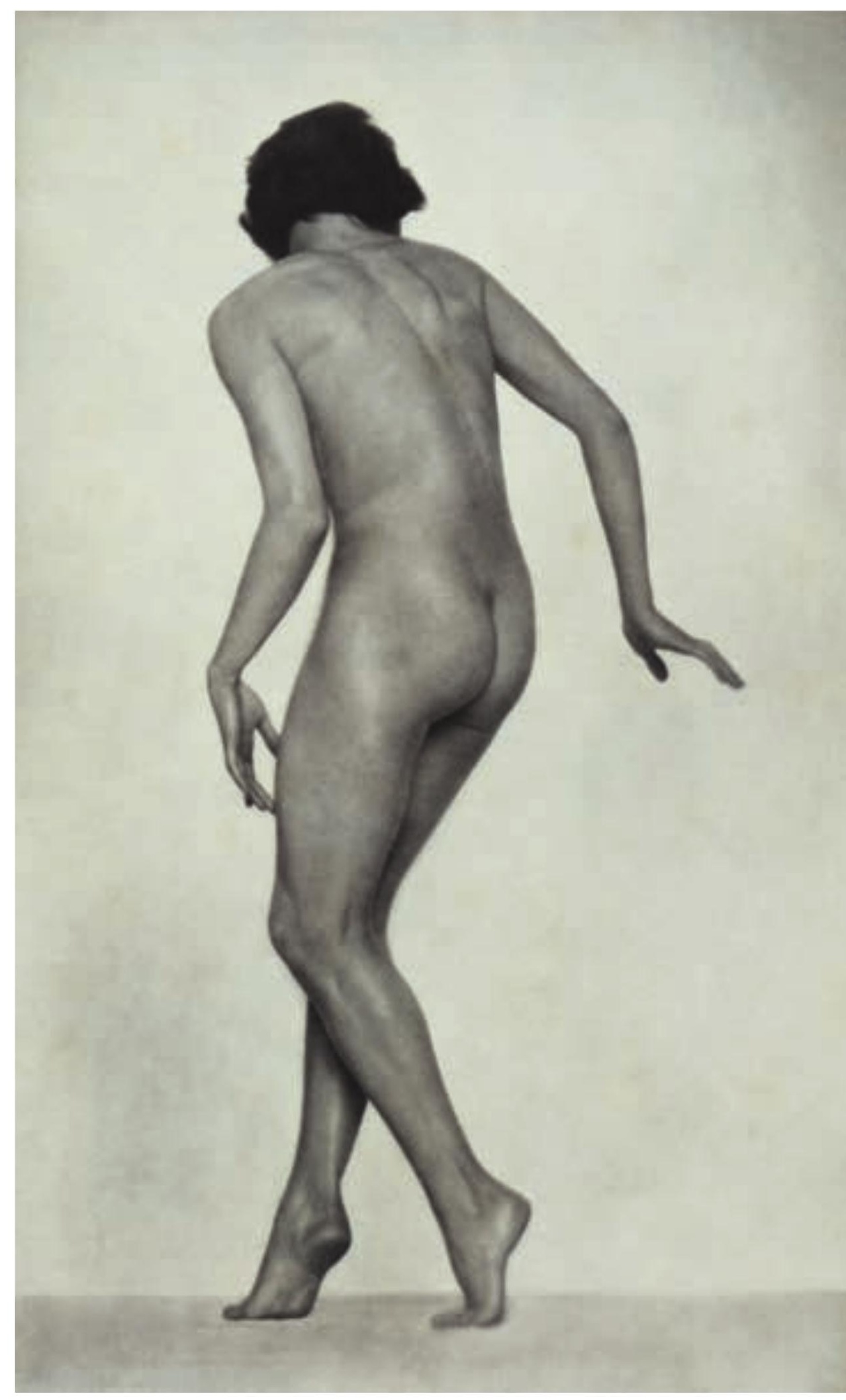


Waren Akte bisher eher verschämt aufgenommen und oft nur unter dem Ladentisch verkauft worden, so gehen die Fotografen ab Mitte der 1920er Jahre in die Offensive. Auch renommierte Lichtbildner (darunter erstaunlich viele Frauen) fotografieren nun regelmäßig weibliche Film- und Bühnenstars in freizügigen Posen. Zugleich verleihen sie diesen Sujets einen künstlerischen Anstrich. Zu den bekanntesten Wiener Fotografen, die sich mit der Aktfotografie beschäftigen, gehören Ernst Förster mit seinem Atelier „Adèle“, Josef Weitzmann, Juda Berisch Zimbler, Abraham Maier Schein und Franz Löwy, der in der Zwischenkriegszeit Ateliers in Wien, Karlsbad und Paris unterhält.

Aber auch junge, kaum 30-jährige Fotografinnen, die ihre Karriere nach Kriegsende beginnen, experimentieren mit der Inszenierung der Entblößung: Trude Fleischmann, die 1920 ein eigenes Atelier eröffnet, daneben Edith Barakovich, Trude Geiringer und Dora Horovitz (Abb.6), Grete Kolliner, Marianne Blumberger und vor allem Pepa Feldscharek, in deren Atelier auf der Fischerstiege im 1. Wiener Bezirk besonders häufig die Hüllen fallen. Nicht selten sind die Lichtbilder dieser jungen Frauen gewagter, origineller, offener als jene ihrer männlichen Kollegen. Die Konventionen gelten ihnen weniger, sie probieren aus, wagen Neues. Sich vor Frauen zu entblößen fällt Tänzerinnen und Revuestars wie Claire Bauroff, La Jana (Henriette Margarethe Hiebel), Maria de las Nieves, Beate Roos-Reuter oder Leila Bederkhan offenbar leichter. Sie alle sind in den 1920er Jahren auf den Wiener Varieté- und Theaterbühnen zu Gast. Und viele von ihnen lassen sich anschließend im Atelier in freizügigen, erotischen Szenen verewigen.

\section{Skandalöse Nacktfotos}

Besonderes Aufsehen erregen die Nacktszenen von Claire Bauroff. Bereits ihre tänzerischen Entkleidungsszenen, etwa ihre Tanzpantomime „Das Licht ruft" im Oktober 1924 im Theater in der Josefstadt erregt die Gemüter. „Claire Bauroff“, so schreibt der Kritiker der konservativen Reichspost, „geht in ihrer Kostümlosigkeit zuweilen weiter, als es der reinen dichterischen Absicht und ihrer Wirkung auf unser
Großstadtpublikum dienlich ist.“" ${ }^{13}$ Noch kontroverser ist die Reaktion auf die fotografischen Aktszenen Bauroffs, die 1925/26 in der auflagenstarken illustrierten Presse in Österreich und Deutschland verbreitet werden. Die Aufnahmen stammen von Trude Fleischmann, die die Tänzerin immer wieder nackt fotografiert (Abb. 7). Ihre Inszenierungen wollen nicht voyeuristischen Tendenzen Vorschub leisten, sondern sind in den Augen Fleischmanns, aber auch Bauroffs künstlerische Darstellungen, gewissermaßen fotografierte Körperplastiken. Bauroffs Körper, schreibt 1925 der Journalist und Filmkritiker Béla Balázs, „ist vom Scheitel bis zur Sohle Ausdrucksfläche. Ihre Physiognomie ist nicht aufs Gesicht beschränkt. Ihr ganzer Körper ist Gesicht. Ihre Glieder haben den Ausdruck von Augen. Jede Bewegung ist ein Blick. Ihr ganzer Körper sieht dich an: nackte Seele." 14

Dennoch: Die freizügigen Bilder werden in der Öffentlichkeit zum Anlass für einen Skandal. Als Bauroff 1925 im Berliner Varietétheater Admiralspalast auftritt, werden die Fotografien von Trude Fleischmann in den Vorschauvitrinen ausgestellt. Die Berliner Polizei schreitet ein und beschlagnahmt die Bilder, weil, so der Vorwurf, die Scham nicht abgedeckt sei. ${ }^{15}$ Das heizt das Interesse an den Szenen noch mehr an. Die nackte Bauroff wird zum Fall - vor allem in der illustrierten Presse, in der die beanstandeten Fotos ohne Scheu veröffentlicht werden. In der Wiener Zeitschrift Die Bühne wird die „konfiszierte Claire Bauroff“ Anfang Oktober 1925 ausführlich dargestellt. ${ }^{16}$ Die Nacktaufnahmen Fleischmanns aus dem Jahr 1925 finden auch Eingang in Bildbände, etwa in die Publikation von Werner Suhr Der nackte Tanz, die 1927 erscheint. Hier allerdings ist die Scham gegenüber der Originalaufnahme deutlich retuschiert. ${ }^{17}$

\section{Ein neues Korsett der „Sittlichkeit“}

Ende der 1920er Jahre beginnt die freizügige Stimmung in Wien umzuschlagen. Die Gründe dafür sind vielfältig: Die ins Konservative kippende politische Großwetterlage, der Druck einer moralisierenden Presse, die strikter werdende Gesetzgebung ${ }^{18}$ und 
auch die offene Zensur verdrängen die Nacktheit aus der Öffentlichkeit. Josephine Bakers Wiener Auftritt im Jahr 1928 markiert diesen Wendepunkt besonders eindrücklich. Die Nacktfotografie verschwindet allerdings nicht vollständig aus der Öffentlichkeit. Sie sinkt nun wieder langsam zurück ins Schmuddelige, ins Reich der anzüglichen Publizistik. Diese ist in Wien vor allem mit einem Namen verknüpft: Karl Rob (eigentlich Robitschek).

Rob gründet während des Ersten Weltkriegs einen eigenen Verlag. ${ }^{19}$ Daraus entsteht in den 1920er und 1930er Jahren ein erfolgreiches Medienunternehmen, in dem die Nacktfotografie eine wichtige Rolle spielt. Vor allem in den populären Revuen Die Muskete und Der Faun, teilweise auch in der Zeitschrift MOCCA, wird den Lesern ein schlüpfriges und frivoles Programm geboten. ${ }^{20}$ Auf vielen Fotoseiten der Muskete dominieren pikant-voyeuristische Inszenierungen, offen pornografische Bilder dagegen finden sich selten. Dennoch wird die Zeitschrift immer wieder aus „Sittlichkeitsgründen“ zensiert und beschlagnahmt. Zahlreiche Fotografen beliefern den Verlag mit erotischen und anzüglichen Motiven. Ein Wiener Fotografenduo sticht darunter besonders hervor: Olga und Adorján Wlassics, die seit 1924 gemeinsam das Atelier Manassé betreiben. Sie liefern bei Weitem die meisten Nacktaufnahmen für die Rob-Presse. Woche für Woche sind sie mit Sujets nackter Frauen präsent. Manchmal handelt es sich um Posen und Inszenierungen, die mit der Tradition künstlerischer Akte kokettieren. Öfter aber sind die Nacktaufnahmen symbolisch aufgeladene Genreszenen, die mehr oder weniger in der Nähe des Kitsch liegen (Abb.8). Wieder andere Bilder aus dem Atelier Manassé gehören in den Bereich der anspruchslosen Massenware, die die schlüpfrigen Motive mit billigen Effekten anreichern.

Die Zurückdrängung der Nacktkultur nach 1930 erfolgt schleichend. Während des „Ständestaates“ häufen sich die Beschlagnahmungen von Heften aus dem Rob-Verlag. ${ }^{21}$ Im katholischen und konservativen Österreich der 1930er Jahren verschiebt sich die Schamgrenze sehr deutlich. Die staatlich verordnete Prüderie nimmt zu. In dieser Stimmung ziehen sich die liberalen, offenen, neugierigen Fotografen und Fotografinnen zunehmend auf sicheres Terrain zurück.

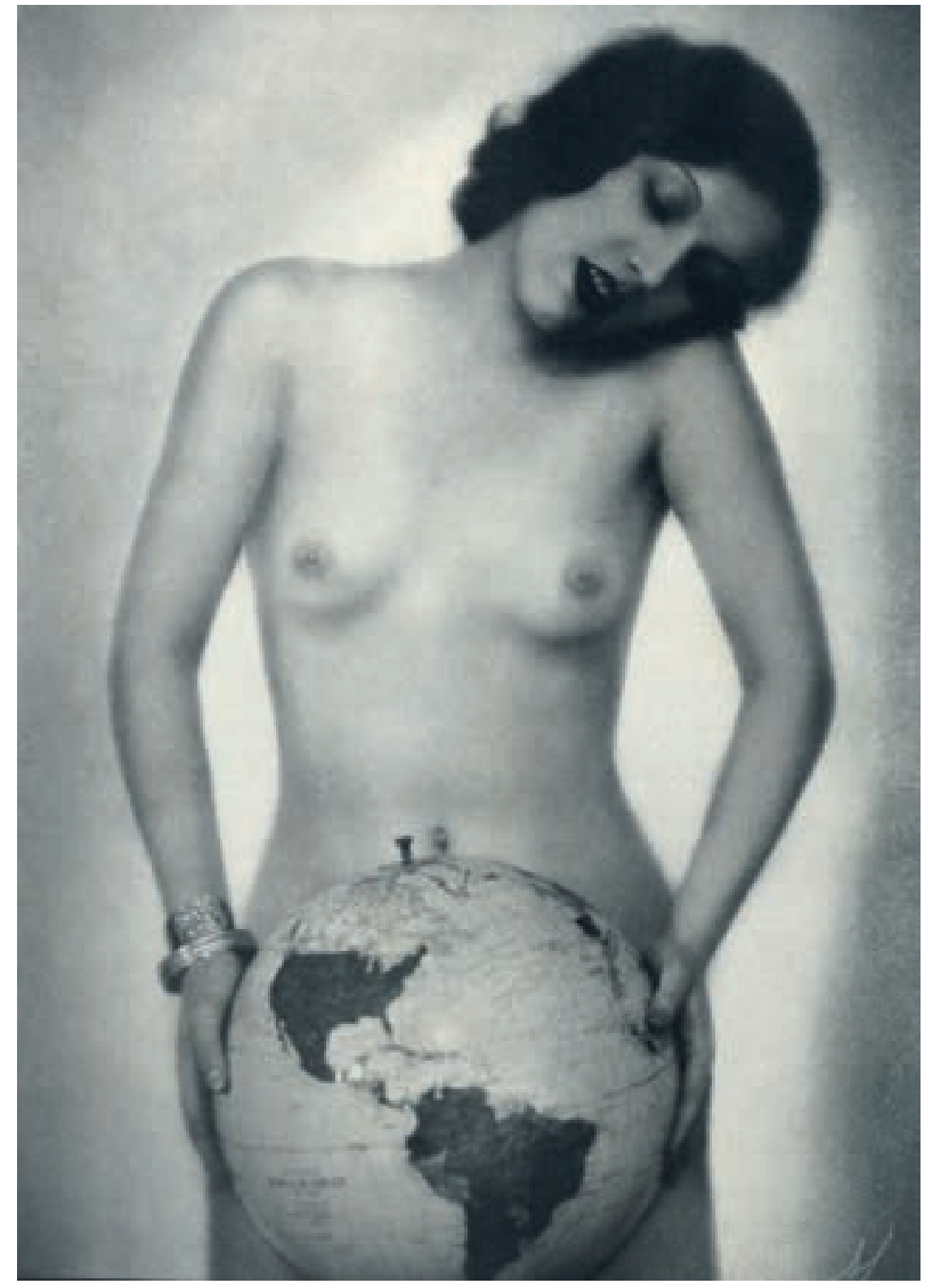

Die Nacktbilder verschwinden zunehmend aus der Öffentlichkeit.

Nach der Machtübernahme der Nationalsozialisten im Jahr 1938 wird dieser restriktive Kurs gegenüber der öffentlichen Entblößung zunächst weitergeführt. Die offiziell verordnete Keuschheit ist freilich nur von kurzer Dauer. Denn schon 1939 tauchen neue Nackte auf: Erdverbundene, sportliche und vor allem „urdeutsche“ Grazien sind nun wieder hüllenlos zu sehen. $^{22}$
Abb. 8 „Die weltumspannende Macht des Weibes“. Die Muskete, Nr. 6, 1932, S. 102. Foto: Atelier Manassé. 


\title{
Schöne neue Warenwelt
}

\author{
Reklame und Mode in der Fotografie
}

Abb. 1 Bereits um die Jahrhundertwende ist die die Mariahilferstraße, die bekannteste Wiener Einkaufsmeile, mit Werbetexten und Fassadenschriften überzogen. Österreichs IIIustrierte Zeitung, 4. Januar 1903, S. 288. Zeichnung: A. Bienert.

„Die Republik hat die Straße zur vertikal ausgespannten Zeitung gewandelt. Wer täglich etwa die Herrengasse liest, bekommt kalte Füße, ist aber auf dem laufenden. “1 In dieser knappen Beobachtung fasst der Schriftsteller Alfred Polgar in den 1920er Jahren die Veränderung des öffentlichen Raumes zusammen. Mit der „vertikal ausgespannten Zeitung“ ist die Schrift der politischen und kommerziellen Reklame gemeint - Anzeigen, Plakate, Lichtschriften und Ähnliches. Etwa zur selben Zeit beschäftigt sich der österreichische Grafiker und Publizist Traugott Schalcher mit der radikalen Umgestaltung des StraBenbildes in den letzten Jahren. „Es gibt“, so schreibt er 1927 in seinem Buch Die Reklame der Straße, ,auf Erden keinen noch so vergessenen Winkel von eini- gen Hundert Häusern, der nicht durch Reklame seine Zugehörigkeit zu unserer Zivilisation bekundet. Überall (...) beginnt der Riesenpinsel der Reklame die bisherige Sonderart zu übertünchen, wegzupinseln.“2 Sein ein wenig wehmütiges Fazit lautet daher: „Nicht Hunger und Liebe, die Reklame regiert die Welt.“3

\section{Reklame der Straße}

Die öffentliche Reklame verwandelt, so Polgar, die Straße in einen Text. Fassaden werden zu Trägern von Werbebotschaften, Litfaßsäulen, Plakate und Werbeschriften vervielfachen sich. Diese Nutzung des öffentlichen Raums als Werbeträger beschleunigt sich in der Zwischenkriegszeit auf ungeahnte Weise. Ganz

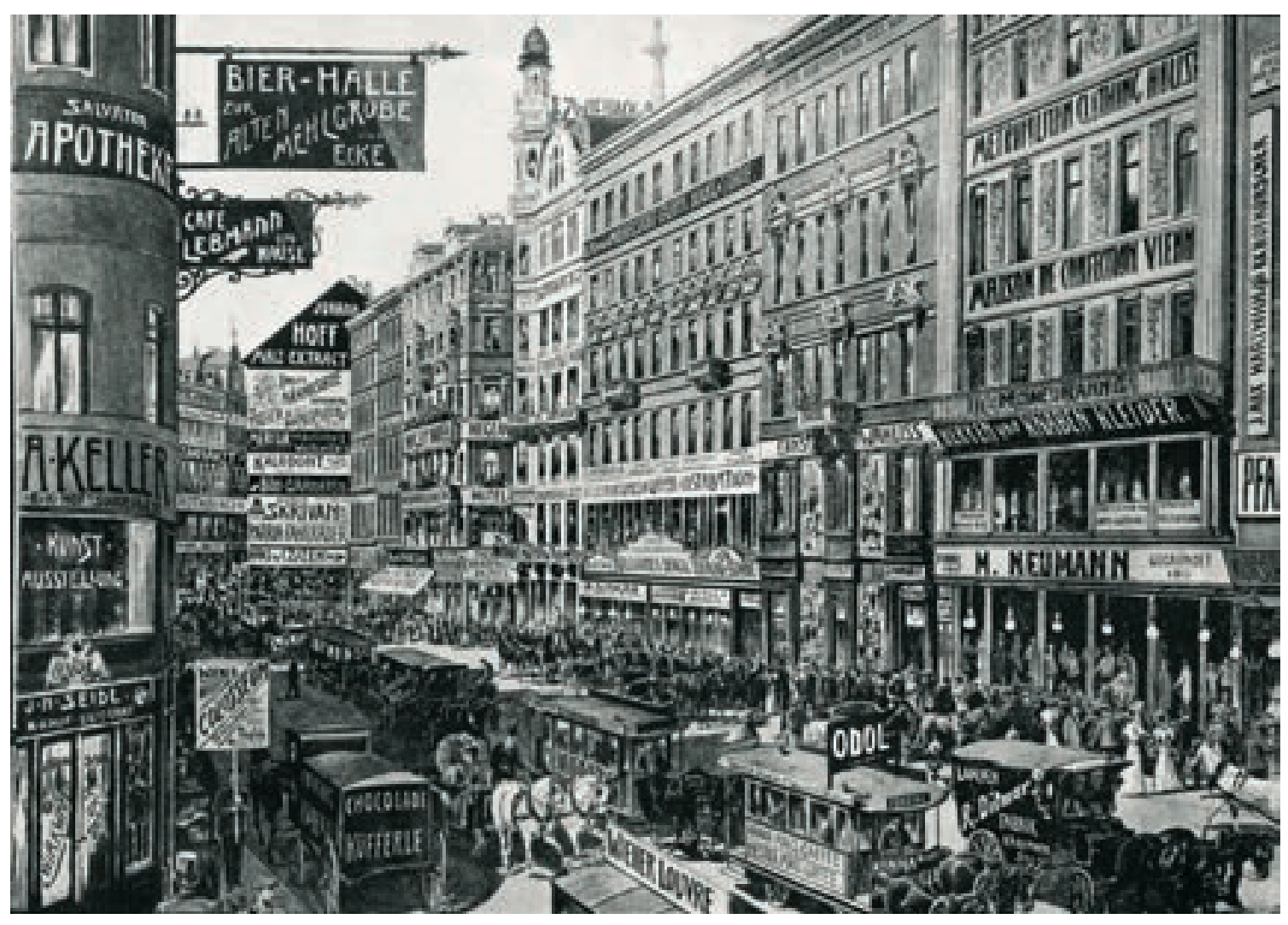


neu ist diese Entwicklung freilich nicht. Denn bereits seit dem ausgehenden 19. Jahrhundert hat sich der großstädtische Raum grundlegend verändert. Die Reklame beginnt schon um die Jahrhundertwende, die Straße zu erobern (Abb. 1). Die Werbeflächen werden von Jahr zu Jahr ausgeweitet, die Strategien der Werbung werden findiger und subtiler. Die Firma Odol etwa beginnt nach der Jahrhundertwende als eine der ersten, ihr Mundwasser mithilfe aggressiver Werbefeldzüge im öffentlichen Raum zu vermarkten. Sie bucht großformatige Anzeigen auf Häuserwänden, setzt aber bereits früh auch auf „bewegte“ Anzeigen: etwa auf Tramwaywagen und auf von Pferden gezogenen Omnibussen. Parallel dazu werden rasch wechselnde großformatige Anzeigen in der Presse geschaltet, in denen die Fotos schöner junger Frauen die Marke anpreisen.

Im ersten Jahrzehnt des neuen Jahrhunderts wird die Debatte um die „richtige“ Reklame zu einem wichtigen Thema der öffentlichen Auseinandersetzung. 1909 schreibt der österreichische Philosoph, Pädagoge und Schriftsteller Ludwig Erik Tesar: „Die Anzeige muss wiederholtes Ansehen erlauben, ohne langweilig zu werden oder abstoßend zu wirken. "4 Er fordert die „sinnbildende Einkleidung“, die „Ornamentarisierungen des Angezeigten“. Aber er wehrt sich noch vehement gegen den illustrierenden Einsatz von Fotografien in der Werbung: „Gänzlich zu verwerfen sind Anzeigen mit wiedergegebenen Lichtbildern von Hüten und Stiefeln, Hosenträgern und anderem. Der Wert der Photographie liegt nicht nach der künstlerischen Seite, sondern in der genauen Wiedergabe irgendwelchen Originals - und zwar nach Form und Gestalt, weniger nach Räumlichkeit und noch weniger nach Farbe und Licht. Wenn daher beispielsweise eine Firma zum Beweise der Güte ihrer Koffer einen solchen im Lichtbilde vorführt, der die ganzen Strapazen des südafrikanischen Krieges mitgemacht hat, so liegt dem ein ganz bestimmter Zweck zugrunde, der aber bei den früher erwähnten Inseraten völlig fehlt. So kann der Käufer über einen Hut nur durch persönliche Prüfung und durch Anprobe, nicht aber durch dessen Abbildung urteilen. Übrigens würde auch das Kofferinserat bei häufiger Wiederholung geschmacklos werden."5
Tesar hat offenbar die verwirrende Bleiwüste seitenlanger Kleinanzeigen vor Augen, wenn er - durchaus im Einklang mit manchen Vorstellungen von Secession und Jugendstil - eine künstlerische Erneuerung der Werbung einfordert. Jahrelang bedeutete Anzeigenwerbung nichts anderes als die endlose Aneinanderreihung von kurzen Textkästen mit einfachen oder gar keinen Illustrationen. Angeboten werden auf diesen Reklameseiten allerlei Wundermittel, Rezepturen und Alltagsprodukte (Abb. 2): Lederhosen, billige Bettfedern, Haarwuchsmittel, Haarentfernungsmittel, „Gummiprodukte“ für den Herrn, pornografische Artikel (als „Pariser Photos“ bzw. „Curiosa“ bezeichnet), Magen- und Hustensäfte, Bücher und Briefmarken, Werkzeuge und Grabsteine, Wäsche und Korsetts, Nervenmittel, Harmonikas, Grammophone und vieles andere mehr.

\section{Professionalisierung der Werbung}

Erst nach und nach tauchen größere, aufwendiger gestaltete Anzeigen auf. Die großen Wiener Modehäuser etwa schalten vereinzelt ganzseitige, grafisch anspruchsvollere Werbeseiten (Abb.3). Nur bei teuren Produkten greifen die inserierenden Firmen auf grafische Produktdarstellungen und später auch auf (namentlich nicht gekennzeichnete) Fotografien zurück. Das betrifft etwa Luxuswaren wie Automobile, Motorräder, Grammophone. Aber zunehmend auch Parfums und exquisite Hygieneartikel werden in fotografisch illustrierten Inseraten angepriesen.

Parallel zur gestalterischen Verbesserung der Werbung entwickelt sich kurz vor dem Ersten Weltkrieg ein neuer Geschäftszweig im Bereich der Gestaltung von Anzeigen. Die anspruchsvolleren Arbeiten werden nicht mehr ausschließlich den Annoncen-Expeditionen oder Anzeigen-Gesellschaften wie etwa der auf diesem Gebiet führenden Firma Lehmann übertragen, sondern eigenen Grafikbüros. Im Juli 1914 gibt beispielsweise der Grafiker Hermann Mandl in der Graphischen Revue die Eröffnung eines „ReklameBüros“ bekannt (Abb.4). „Ich erlaube mir hiemit die höfliche Mitteilung, dass ich mit heutigem in Wien IV, Wiedner Hauptstraße 1, ein Reklame-Büro für Schaufenster-, Straßen- und Zeitungsreklame eröff- 
Abb. 2 Anzeigenseiten als Bleiwüsten. Um die Jahrhundertwende überwiegen Kleinanzeigen mit einfachen oder keinen Illustrationen. Das interessante Blatt, 9. November 1905, S. 24.

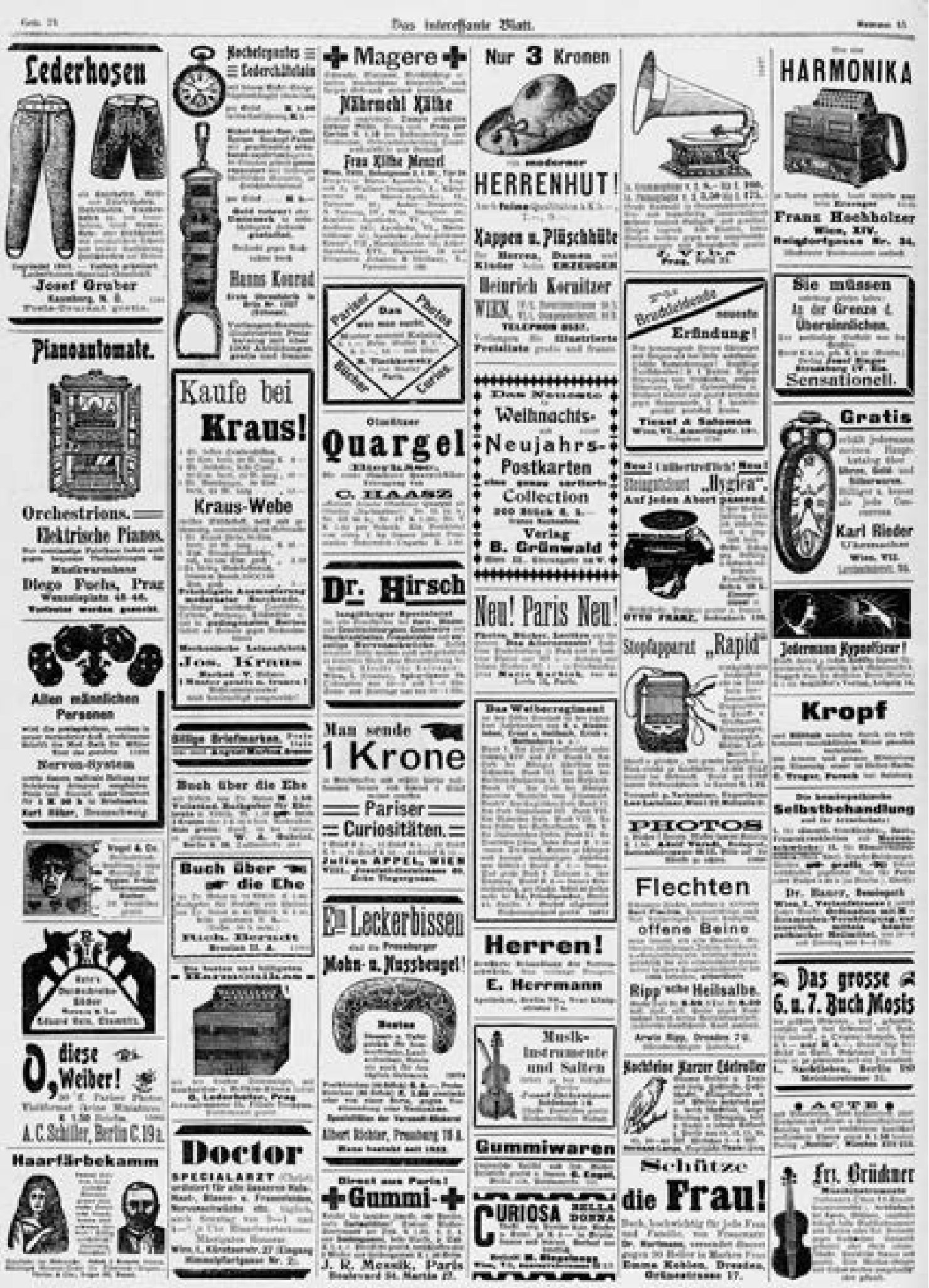


net habe. Unter Beihilfe erster Künstler bin ich in der angenehmen Lage, auf diesem Gebiete wirklich Originelles leisten zu können. Entwürfe stelle ich gerne zur Verfügung. Hochachtungsvoll Hermann Mandl, Wien IV.“6 Im Mai desselben Jahres wird in Leipzig die BUGRA, die groß angelegte Internationale Ausstellung für Buchgewerbe und Graphik eröffnet, die sich auch der Reklame widmet. Die Schau hat wochenlang großen Zulauf, bis im August 1914 der Krieg beginnt. Ein Teil der Veranstaltungen am Rande der Ausstellung wird vorzeitig abgebrochen.

\section{Die Amerikanisierung der Reklame}

„Man hat“, so meint Traugott Schalcher im Jahr 1927, „Berlin die amerikanischste Stadt Europas genannt. Wohl mit Recht."7 Daher ist es mehr als naheliegend, wenn im Jahr 1929 in dieser pulsierenden europäischen Metropole die „Welt-Reklameschau“ stattfindet. Am 11. August 1929 wird diese gigantische Messe für Werbung und Reklame eröffnet. $\mathrm{Zu}$ diesem Zeitpunkt liegen die zögernden Ansätze der Vorkriegsreklame bereits eineinhalb Jahrzehnte zurück. In der Zwischenzeit hat sich die Werbebranche nachhaltig verändert. In den Jahren nach dem Krieg wird Reklame zum mächtigen Wirtschaftsfaktor. Die Ästhetik der Außenwerbung ebenso wie der Anzeigenwerbung in der Presse hat sich rasch modernisiert. Amerikanische Anregungen wie etwa die Lichtreklame im öffentlichen Raum, die Beleuchtung von Gebäuden, die Kino- und Radiowerbung u. Ä. werden auch in Europa gierig aufgegriffen. Berlin ist in diesen Jahren die führende Werbestadt. Sie nimmt in der Modernisierung der Reklame auf europäischem Boden eindeutig eine Vorreiterrolle ein.

Bald aber werden die Neuerungen auch in anderen Großstädten, unter anderem in Wien, übernommen. „New York“, schreibt 1928 der Wiener Feuilletonist Alexander Schilling, „ist die Geburtsstadt der Lichtreklame. Alsbald haben sich auch die europäischen Großstädte dieser neuen Mode von Madame Reklame unterworfen. Paris, Berlin gingen voran, Wien folgte mit einigem Zögern nach. Heute erstrahlen auch in Wien die großen Geschäftsstraßen, wie Kärntnerstraße, Graben, Mariahilferstraße, Rotenturmstraße, Kai-

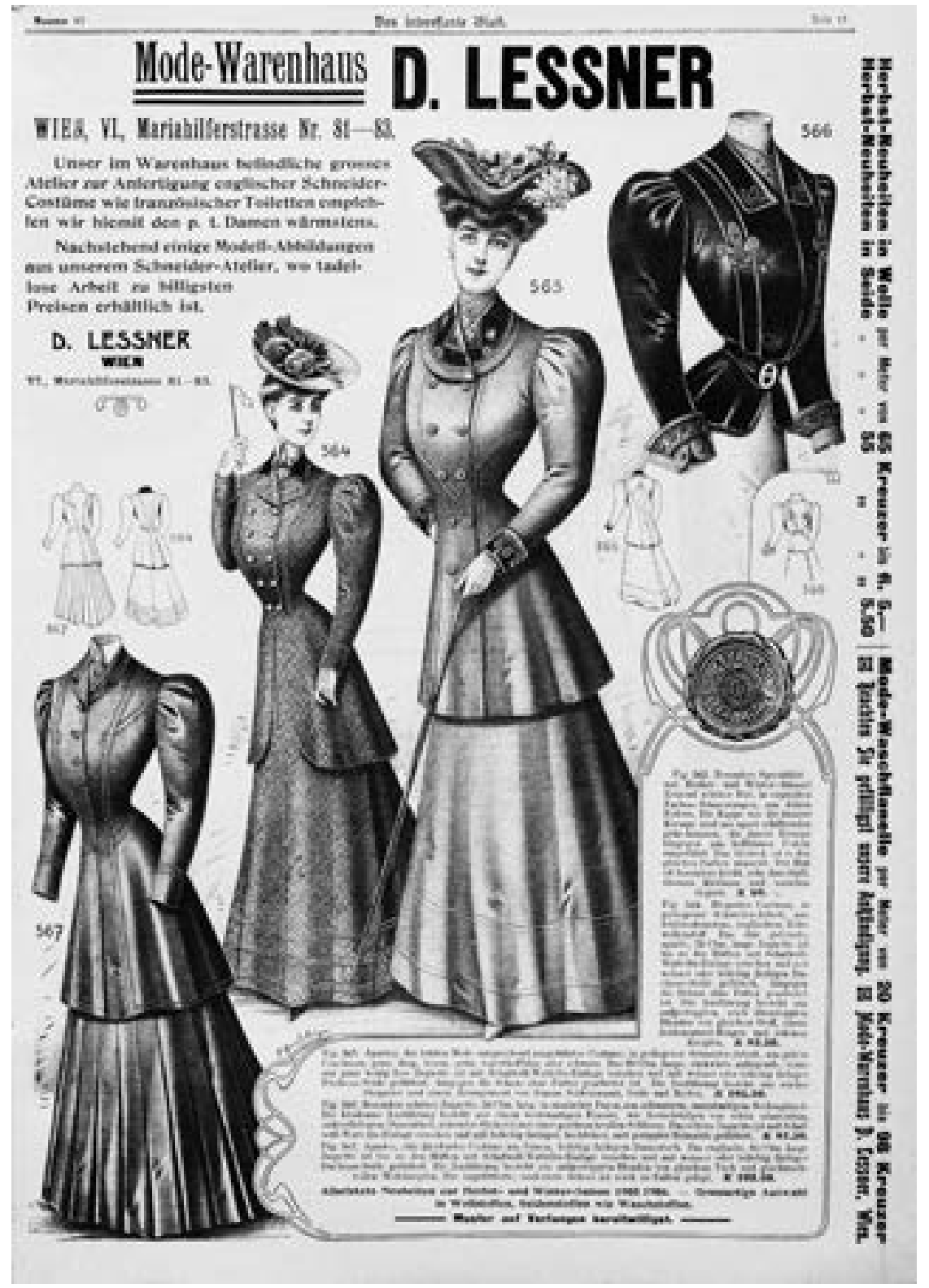

serstraße, Alserstraße, Währingerstraße und viele andere in den verschiedensten Farben der Lichtreklame, wodurch ein abendlicher Spaziergang durch die City von Wien zu einem eigenartigen, reizvollen Genuß wird." ${ }^{8}$ Der Text, der in der Zeitschrift Moderne Welt erscheint, ist fotografisch illustriert. Zu sehen ist eine Reihe von Wiener Lichtschriften, die erst vor Kurzem aufgestellt wurden (Abb. 5). ${ }^{9}$ Entgegen dieser euphorischen Diagnose erfolgt der Einsatz der Lichtreklame in Wien recht zögerlich. Erst 1925 wird auf
Abb. 3 Damenkleider aus dem Mode-Warenhaus D. Lessner, Mariahilferstraße 81-83. Das interessante Blatt, 19. Oktober 1905, S. 13. 


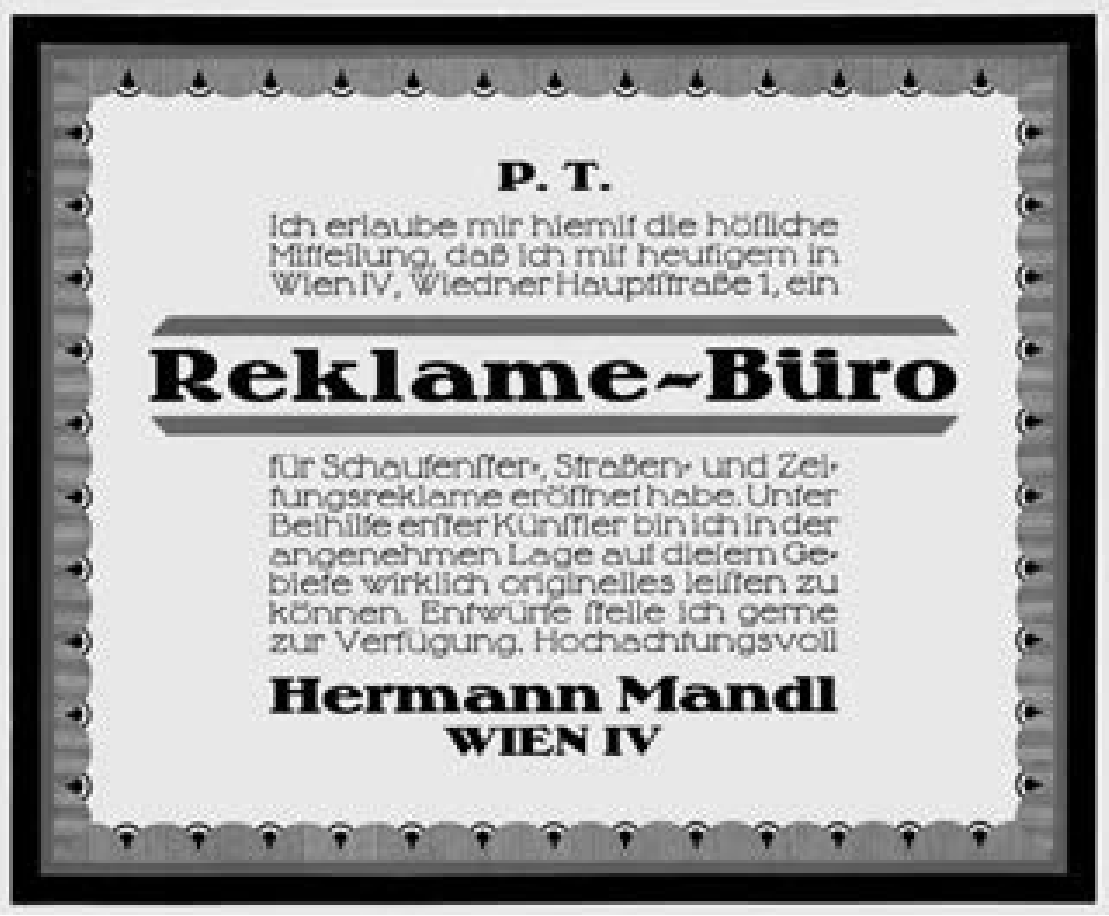

Abb. 4 Vor dem Ersten Weltkrieg kommt es zu einer Professionalisierung des Anzeigenwesens. Ankündigung der Eröffnung das Reklame-Büros Hermann Mandl in der Graphischen Revue Österreich-Ungarns, Heft 7, Juli 1914, o. S. dem Dach des Heinrichshofs (gegenüber der Oper) die erste Wandschriftanlage installiert. ${ }^{10}$

Aber nicht nur in der Straßenreklame, auch in zahlreichen anderen Bereichen des Alltags macht sich Ende der 1920er Jahre der Werbeaufschwung bemerkbar. Nachdem sich die Wirtschaft ab Mitte der 1920er Jahre erholt hat, steigen die Ausgaben für Anzeigen und Werbung deutlich an. Nicht mehr nur die Luxusprodukte werden nun mit großflächigen Anzeigen beworben, sondern (fast) alle Artikel des täglichen Lebens: Kleidung und Kosmetik, Schmuck, Spielzeug, Möbel und neue Filme. Die gehobene künstlerische Reklame nimmt nun schlagartig zu, die künstlerischen Strömungen der Nachkriegszeit bahnen sich einen Weg in die Gebrauchsgrafik. ${ }^{11}$ In Österreich stammen die wegweisenden Entwürfe dieser Jahre von Grafikern wie Joseph Binder, Franz Grießler, Hermann Kosel, Karl Krens, Viktor T. Slama und Julius Klinger. Mitte der 1920er Jahre tauchen nicht nur hervorragend gestaltete Plakate in den Straßen der größeren Städte auf. Auch ganz neue Formen von Reklame werden ausprobiert. Das Putzmittel „Vim“, das 1911 auf den Markt kommt, wird in den 1920er Jahren in Wien und in anderen Städten etwa mittels „wandernder Litfaßsäulen“ beworben. Das sind rundum plakatierte überdimensionale Kartonrollen, die von Menschen durch die verkehrsreichen Straßen getragen werden.
Sichtbares Zeichen für die enorme Aufwertung der Werbung sind die zahlreichen Kongresse, Tagungen und Ausstellungen zum Thema Werbung, die in den Jahren um 1930 stattfinden. Im September 1931 etwa wird im Rahmen der Wiener Herbstmesse die Sonderausstellung „Photo und Reklame“ gezeigt, in der künstlerische Werbe- und Modefotografien zu sehen sind. ${ }^{12}$ Im November 1933 wird in Wien eine weitere Reklameausstellung eröffnet, diesmal im Künstlerhaus. Gestaltet wird diese Schau vom Architekten Otto Prutscher. ${ }^{13}$

\section{Fotografie, Werbung, Mode}

In den 1920er Jahren setzt sich die Fotografie als gestalterisches Mittel der Anzeigenwerbung - vor allem in der illustrierten Presse - durch. Einige Annoncen- und Reklameanstalten tragen diesem Trend im Namen Rechnung, indem sie sich explizit auf „Moderne Bildreklame“ spezialisieren. ${ }^{14}$ Eine ganze Reihe von Fotografen verlegt sich ganz oder teilweise auf fotografische Produktwerbung. Zu ihnen gehören - um nur einige wenige zu nennen - die Wiener Ateliers Fayer und Manassé, die Fotoagentur Willinger, der Wiener Sport- und Werbefotograf Fritz Sauer, Heinz von Perckhammer, der in den 1920er Jahren viel in Berlin arbeitet und in den 1930er Jahren auch in Österreich tätig ist, oder der Grazer Alfred Steffen (Steffen-Lichtbild), der neben seiner Pressetätigkeit v. a. als Werbefotograf arbeitet. Aber auch klassische Atelierfotografen wie Madame d'Ora, die seit 1927 in Paris arbeitet, sind immer wieder im Bereich Werbefotografie tätig. D’Ora etwa fotografiert regelmäßig für den Pariser Mode- und Kosmetikkonzern Worth. Sie liefert u. a. die Werbebilder für das berühmte, seit 1924 vermarktete Parfum „Dans la Nuit“ (Abb. 6). Auch Pressefotografen wagen sich gelegentlich in diesen Bereich, etwa Hans Madensky oder Lothar Rübelt, der u. a. für die Automobilfabrik Steyr tätig ist. Ab Ende der 1920er Jahre stoßen zu diesen Berufsfotografen auch künstlerisch arbeitende Amateure dazu, die bisweilen ebenfalls Werbeaufträge übernehmen. $\mathrm{Zu}$ ihnen gehören etwa Willy Eggarter (Abb. 7), Otto Exinger oder Ferdinand Hodek, die neusachliche Werbeaufnahmen machen. 


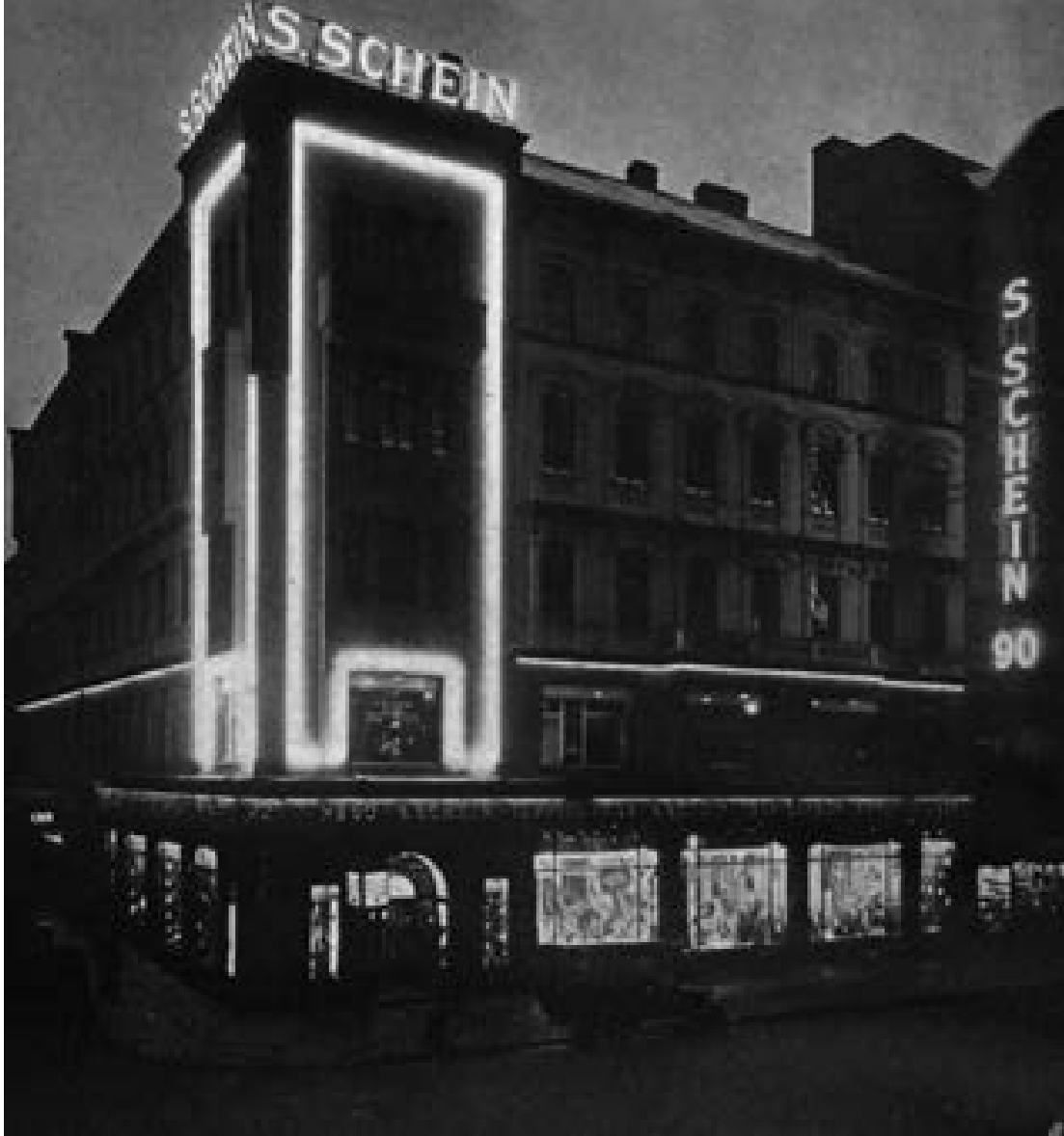

Abb. 5 „Die Kongreßstadt

Wien bei Nacht“. Lichtreklame

an der Fassade des 1927

eröffneten Teppichhauses

S. Schein, Mariahilferstraße

90. Moderne Welt, Heft 17,

1928, S. 22. Foto: Bruno

Reiffenstein.

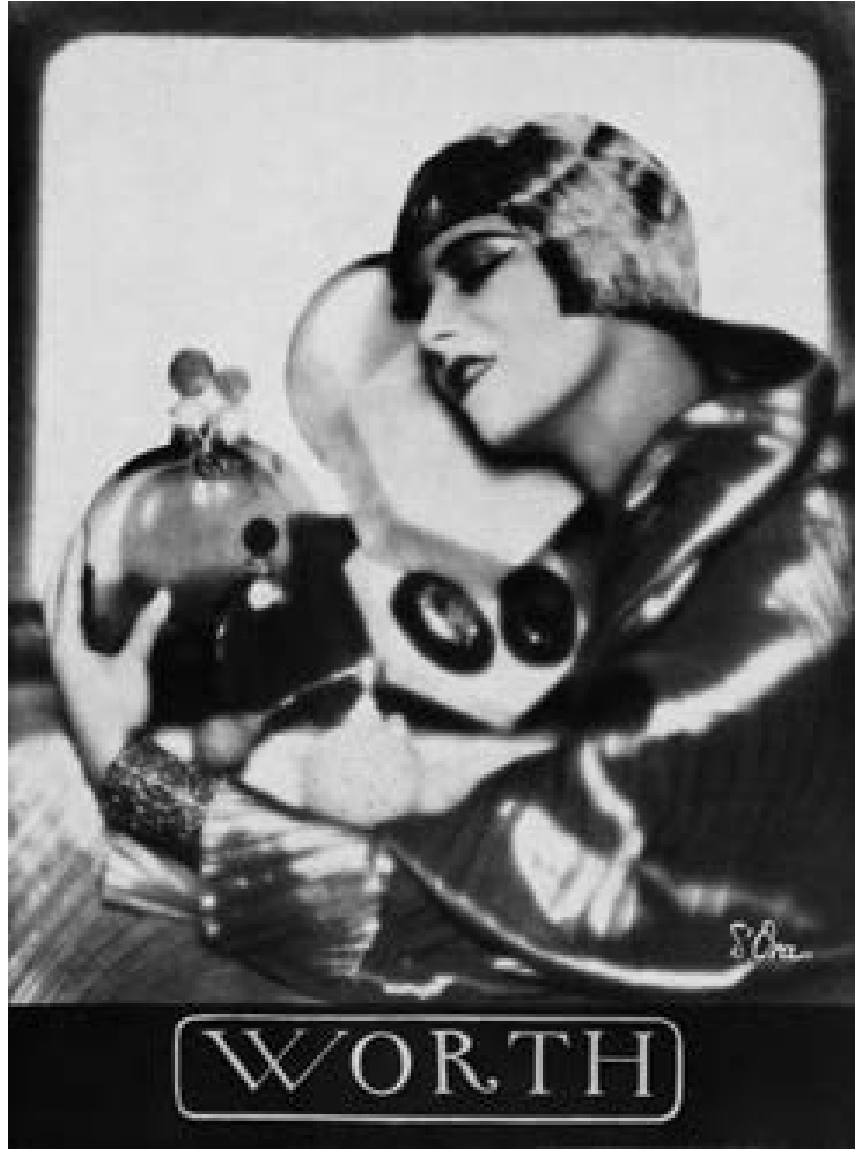

Abb. 6 Anzeige für das Parfum „Dans la Nuit“, das der Pariser Mode- und Kosmetikkonzern Worth 1924 auf den Markt bringt. Die Dame, Heft 21, 1927, S. 37. Foto: Madame d’Ora.

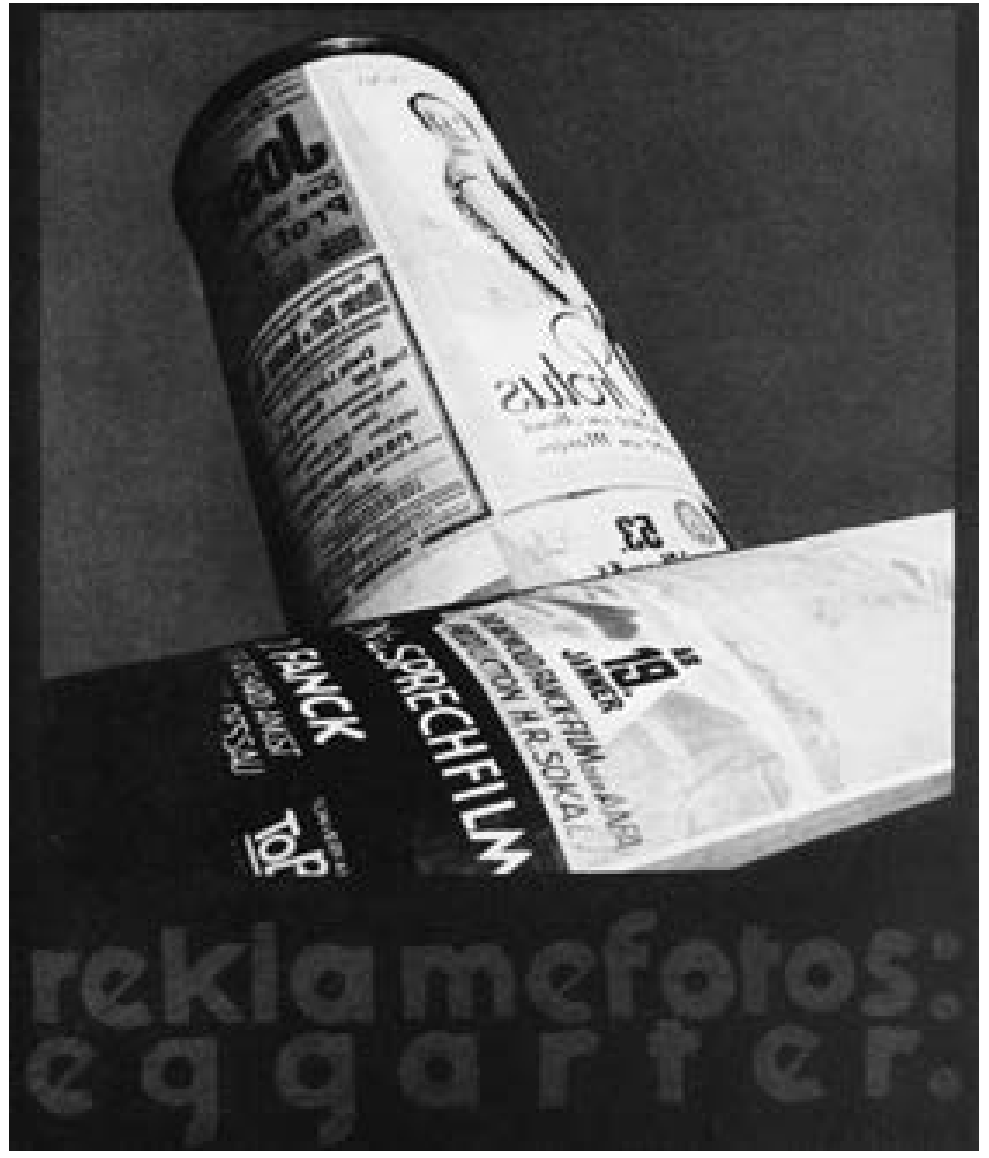

Abb. 7 „reklamefotos: eggarter“. Neusachliche Aufnahme zweier Litfaßsäulen. Das österreichische Lichtbild, Jahrbuch 1933, hg. vom Verband der österreichischen Amateurphotographenvereine in Wien, Wien, Troppau, Leipzig 1933, Tafel 105. 


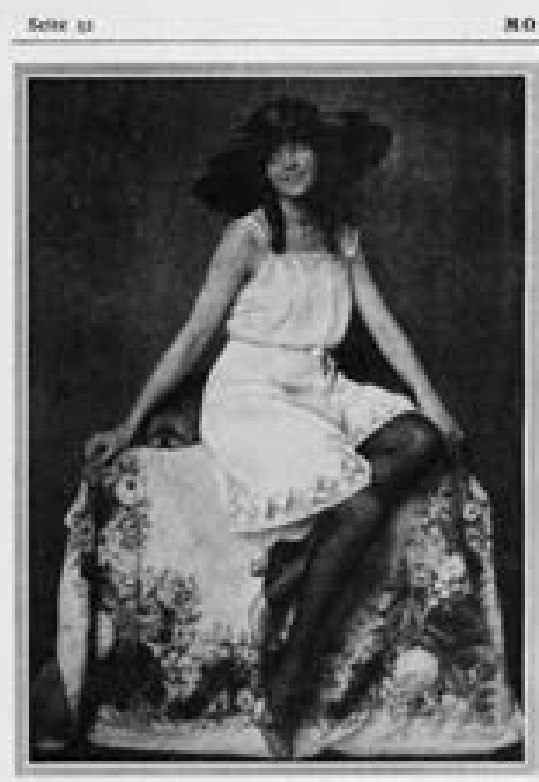

MOQERNE WELT

When , s s ant

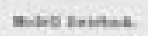

$-$ Aition thes minas nerwive rescat inser

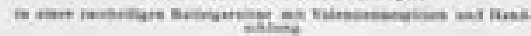

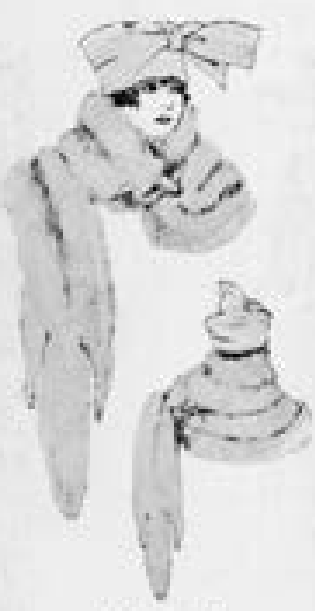

PELZWERK as ate nomes com m
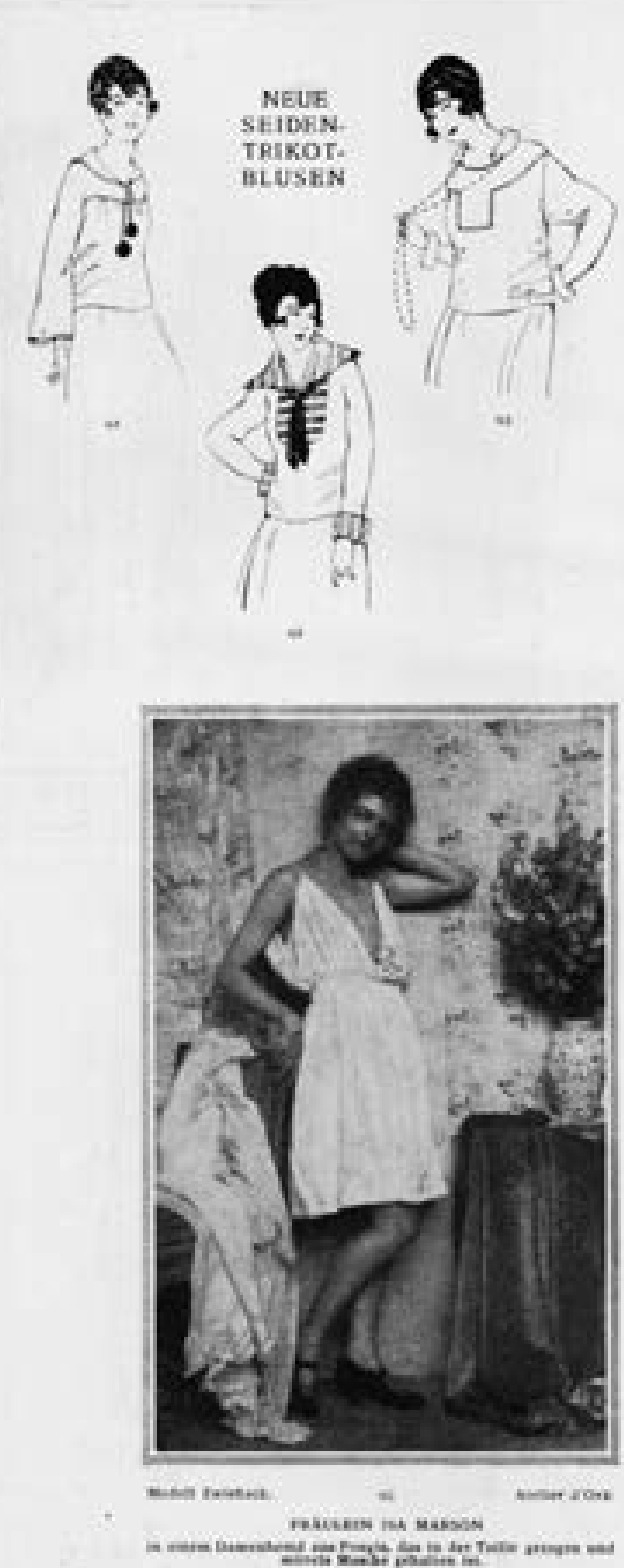

Abb. 8 Damenwäsche des bekannten Wiener Modehauses Zwieback. Moderne Welt, Heft 1-2, Oktober, November 1918, S. 52, Foto: d'Ora.
Während bei fotografisch illustrierten Produktanzeigen die Fotografie oft nur ein Bestandteil eines größeren grafischen Ensembles ist, ist die Situation im Bereich der Bewerbung von Mode anders. Die Aufnahmen werden, v. a. ab Mitte der 1920er Jahre, in der Regel ohne grafische Zusätze und ohne zeichne- rische Einbettung veröffentlicht. ${ }^{15}$ Die Modefotografie unterscheidet sich aber auch in anderer Hinsicht von der nüchternen und sachlichen Produktfotografie. In der Modeberichterstattung verschwimmen häufig die Grenzen zwischen redaktionellem Text, Bildern und gewerblichen Anzeigen. Außerdem spielt hier spätestens seit Anfang der 1920er Jahre die Fotografie eine herausragende Rolle. Bekannte Fotografen, die stets auch namentlich genannt sind, übernehmen die Aufträge. Gute Modefotos betten das Produkt, nämlich Kleider, Mäntel, Hüte, Schuhe etc., in eine vielschichtige, ästhetisch, emotional und oft auch erotisch aufgeladene Szene ein. Häufig werden bekannte Schauspielerinnen als Modelle verwendet, sodass der Übergang zwischen Society-Berichterstattung und Werbung fließend ist.

Bereits vor dem Ersten Weltkrieg beginnen die Modebeilagen der illustrierten Journale neben den dominierenden Zeichnungen vereinzelt auch Fotografien - damals vor allem Pariser Herkunft - zu drucken. Dennoch setzt sich die Modefotografie nur zögernd durch.

Die führende österreichische Modezeitung Wiener Mode ist in ihrer Ausrichtung und Aufmachung sehr traditionell. Zwar bringt sie schon vor 1914 ab und zu Modefotos, vor allem aus Pariser Ateliers, etwa von Charles Reutlinger oder Henri Manuel. Mit Beginn des Krieges 1914 kommt die Zufuhr französischer Bilder allmählich zum Erliegen, nun werden vermehrt Modefotos deutscher Herkunft gedruckt, etwa von Ernst Schneider oder der Berliner Agentur Becker \& Maaß. Erst relativ spät, während und gegen Ende des Ersten Weltkrieges, tauchen öfter Modeaufnahmen heimischer Fotografen auf. 1916 veröffentlicht der etablierte Wiener Fotograf Charles Scolik erstmals Modebilder in der Wiener Mode. Anders als man vielleicht erwarten könnte, kommt die Modeproduktion und -berichterstattung während des Krieges keineswegs zum Erliegen. ${ }^{16}$ Nach einer Flaute zwischen 1914 und 1916 spielt sie vor allem in den letzten beiden Kriegsjahren - neben der wieder aufblühenden Theaterfotografie - eine wichtige Rolle: Immerhin lenkt sie zeitweise von den düsteren Nachrichten aus dem Felde ab und vermittelt das Bild einer trotz allem funktionierenden Gesellschaft. 


\section{Modefotos für die Presse}

Kaum ist der Krieg zu Ende, beginnt eine neue Ära in der österreichischen Modefotografie. Die illustrierten Zeitschriften stellen nun in der Modeberichterstattung schnell von der Zeichnung auf die Fotografie um, die Zeichnung wird (außer bei Schnittmusterkollektionen) zurückgedrängt. Es werden nun immer mehr Aufnahmen benötigt. Die Modefotografie wird ein neuer, eigenständiger Zweig der Fotografie. Moderubriken werden zum festen Bestandteil aller möglichen Wochen- und Monatszeitschriften. Eine neue, modernere Bildsprache kristallisiert sich heraus.

In diesen Jahren des Aufbruchs beschäftigt sich eine ganze Reihe von Fotografen und vor allem Fotografinnen mit der Modefotografie. Madame d'Ora veröffentlicht bereits kurz nach Kriegsende Modefotos in der Modernen Welt (Abb. 8). ${ }^{17}$ Auch die Fotoagentur „Willinger \& Schnapper“ (später „Willinger“) liefert Ende 1918 erste Modeaufnahmen an die Moderne Welt. ${ }^{18}$ Im Oktober 1919 dokumentiert das Atelier Willinger für Das interessante Blatt eine Modenschau im Wiener Konzerthaus. ${ }^{19}$

In den 1920er und 1930er Jahren widmen sich auch einige bekannte Fotografen der Mode, etwa Franz Löwy, der auch in Paris ein Atelier unterhält (Abb.9), Juda Berisch Zimbler und Ernst Förster. Auch zahlreiche, meist noch relativ junge Fotografinnen sind in diesem Bereich erfolgreich: etwa Edith Barakovich (Abb. 10), Irene Messner, Kitty Hoffmann, Helene Zimmerauer, Marianne Bergler, Annie Schulz, Beatrice Freyberger, Trude Geiringer und Dora Horovitz, Edith Glogau, Trude Fleischmann, Helene Kiss, Gertraud Madensky, Lena Schur und Lotte Meitner-Graf. Einige von ihnen, u.a. Marianne Bergler, Pepa Feldscharek (Abb. 11), Kitty Hoffmann und Edith Glogau, fotografieren sehr viel Mode, andere nur gelegentlich. Teilweise werden diese Aufnahmen auch über Fotoagenturen - etwa Polyphot und Wiener Photo-Kurier/Schostal - vertrieben.

Oft sind die Auftragslage und der Zweck der Aufnahmen klar. Wenn etwa Madame d'Ora in den 1920er

Abb. 9 „Pariser Mode“. Moderne Welt, Heft 15, 1928, S. 21. Foto: Franz Löwy.

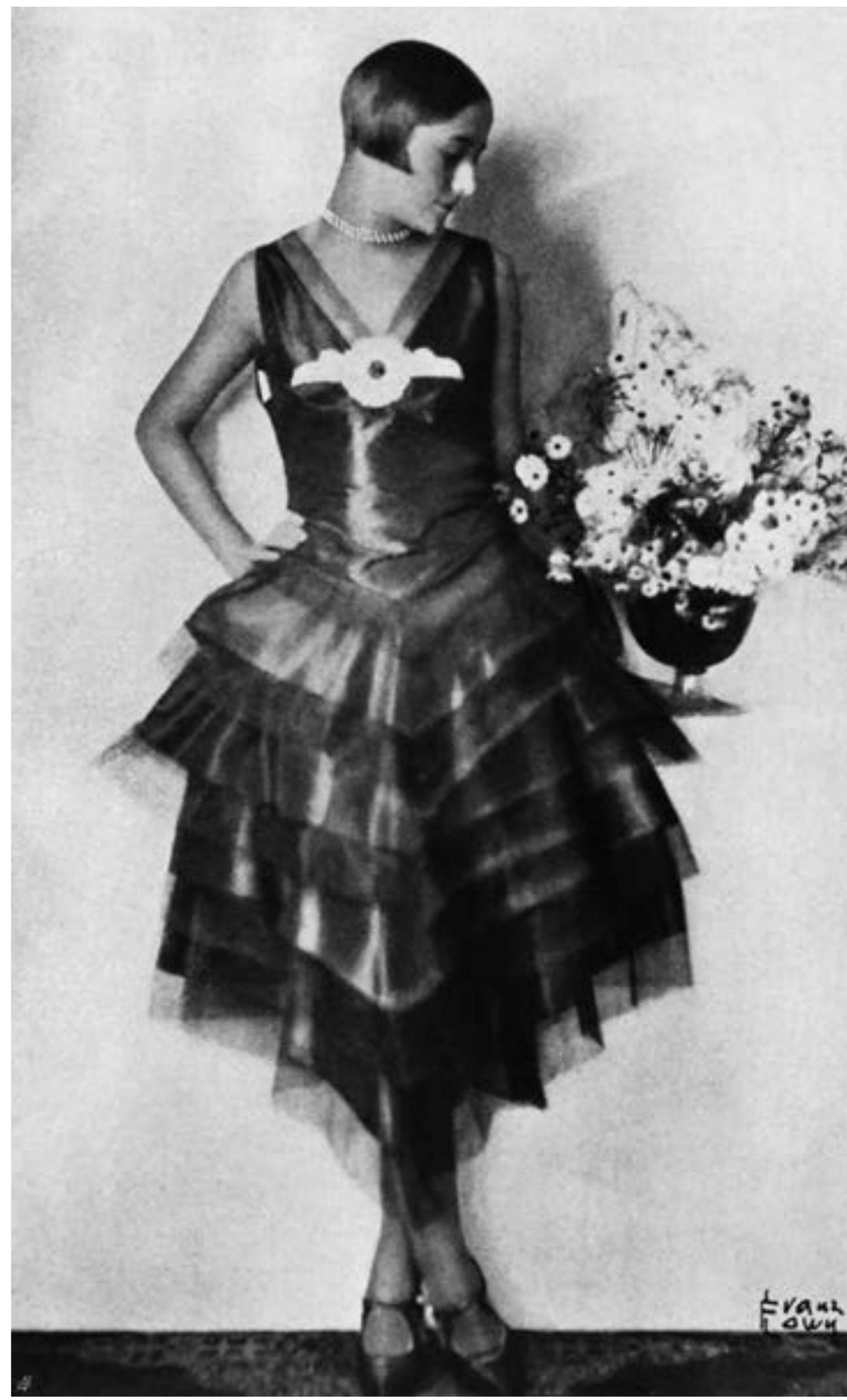




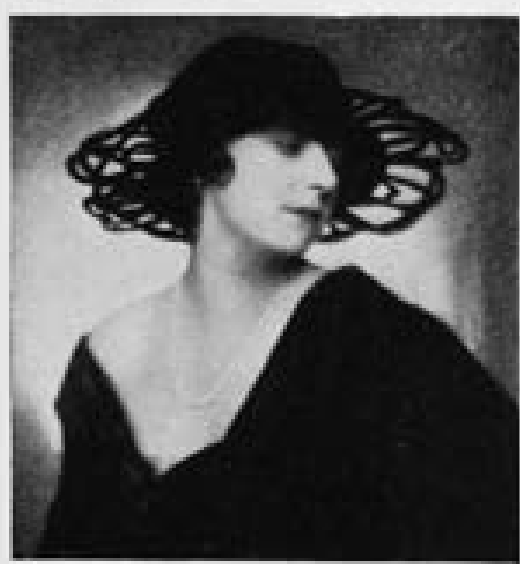

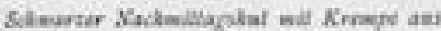

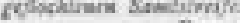

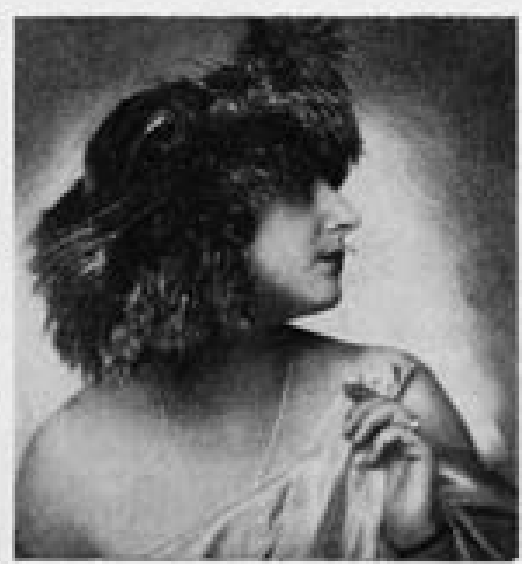

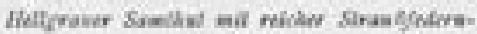
Fha NELLYTCOEN, Mosilit BERTH

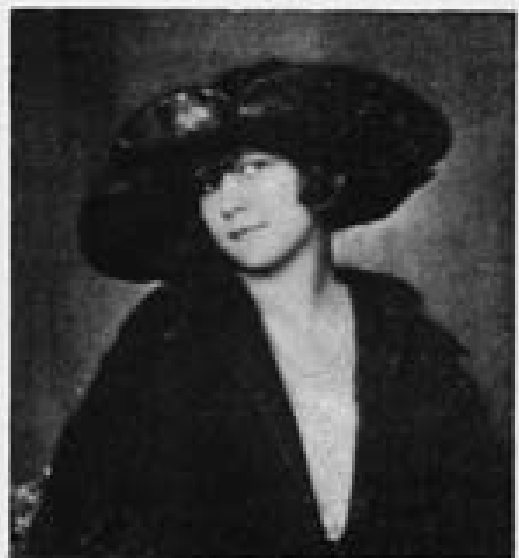

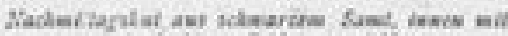

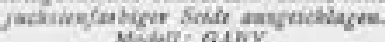
Nowili GANY

\section{FOR DEN NACHMITTAG UND ABEND.}

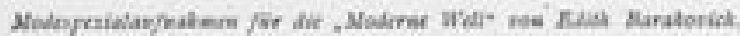
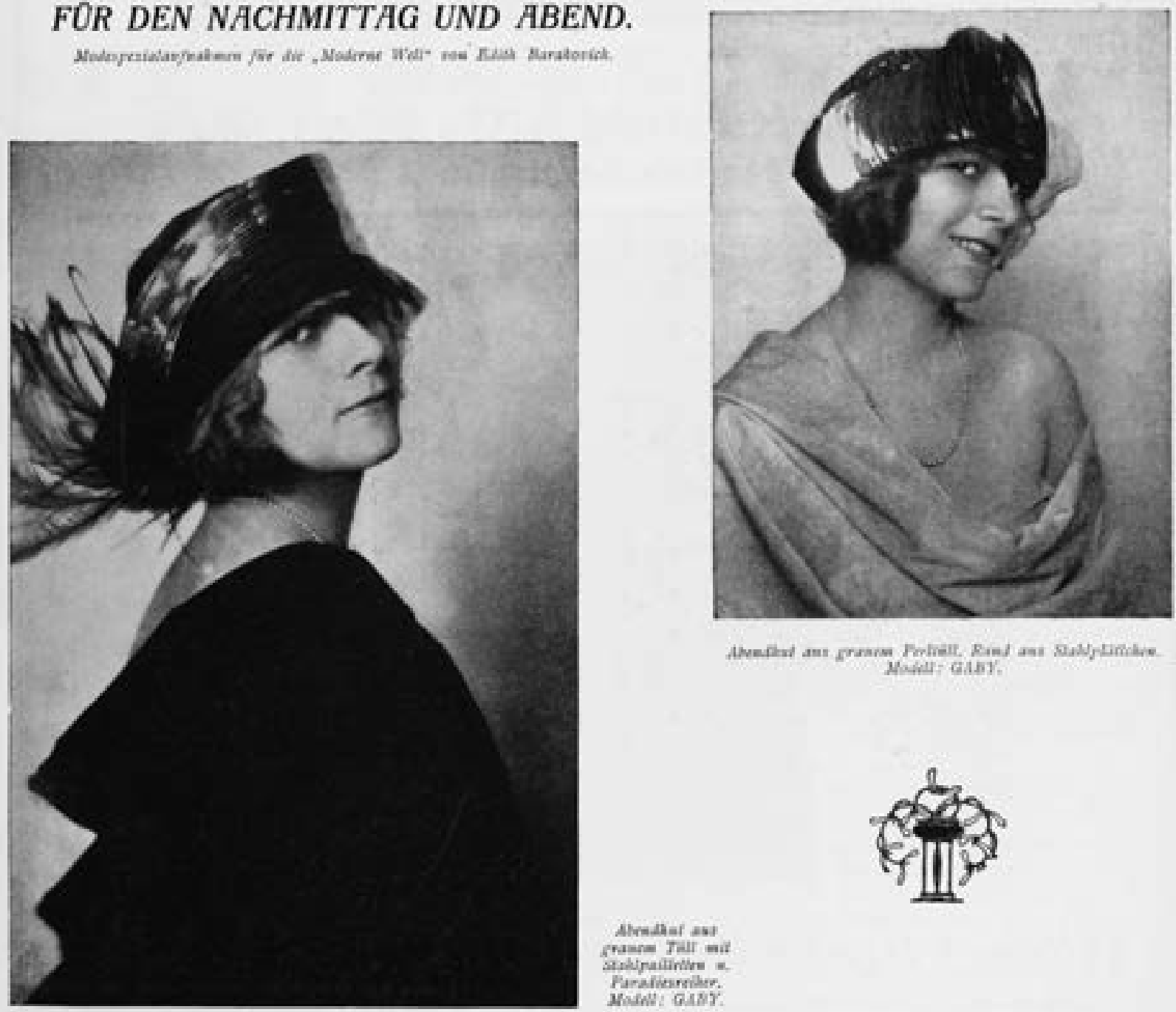

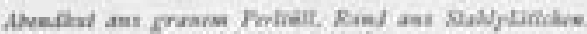
Mowill: $G A B Y$.

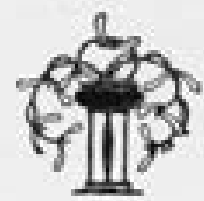

Alvendat as

crasera fili wit

railinive at

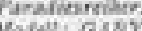




\begin{tabular}{ll|llll|l}
\hline & M & $\mathbf{O}$ & $\mathbf{D}$ & $\mathbf{E}$ & - \\
\hline
\end{tabular}

$30^{3}$

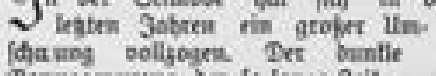
Xarecgecankas Det fo lange $3 r i$

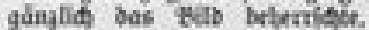
wurbe bustoegs non beil bellen (lidtbronil, beige ober graurii) Bluiesunutug ser-

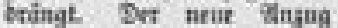
if salret Heibion onb febr pnattion; bit im eats. febr pontrish: bir im sés: vethinbert, àbnlid cinem Dorrall. bes Eimbrintem son EAtner. Das OWatrried it bauptíldifif Socb, aber and Burburi ins anbet

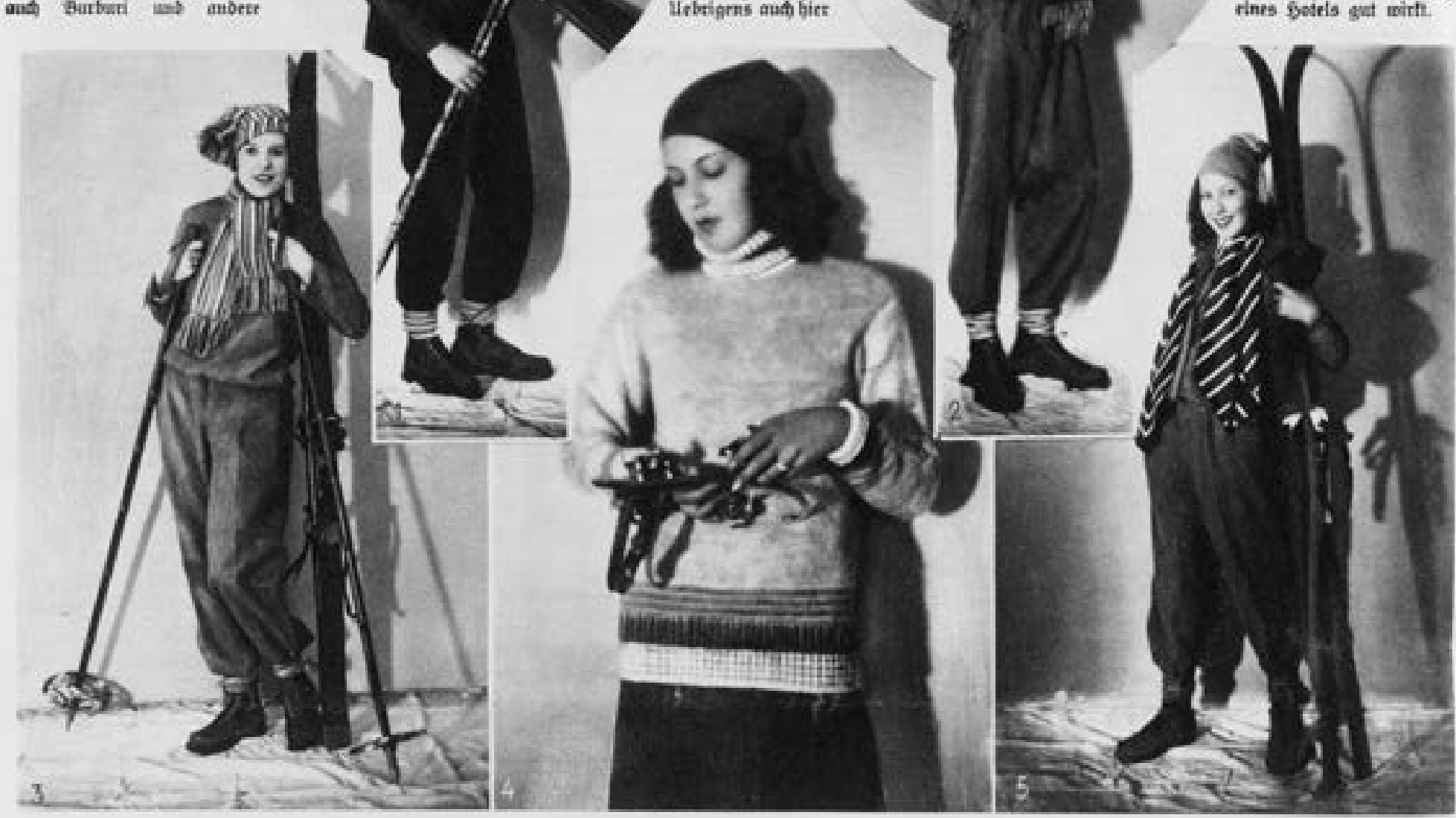

1. Nermegtrongug aus blautm Loden. - 2. Moderner etianug aus hellem Kerd. - 3. Etiangug mit furget Blufe in Brau. -4 . Eiolauf.

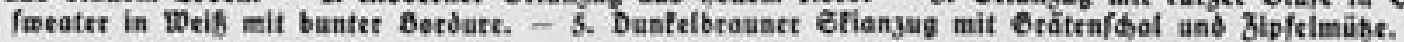

Abb. 10 „Für den Nachmittag und Abend“. Modeaufnahmen von Edith Barakovich. Moderne Welt, Heft 7, 1921, S. 37.
Abb. 11 Skimode. Das interessante Blatt, 28. November 1928, S. 22. Foto: Pepa

Feldscharek. neet Arovbart. 
Abb. 12 „Sonnige Rast am Badestrand“. Sujet mit Bademode, vertrieben vom Wiener Atelier Dietrich (das zugleich eine Fotoagentur betreibt). Moderne Welt, Heft 10, Juli 1936, S. 7.

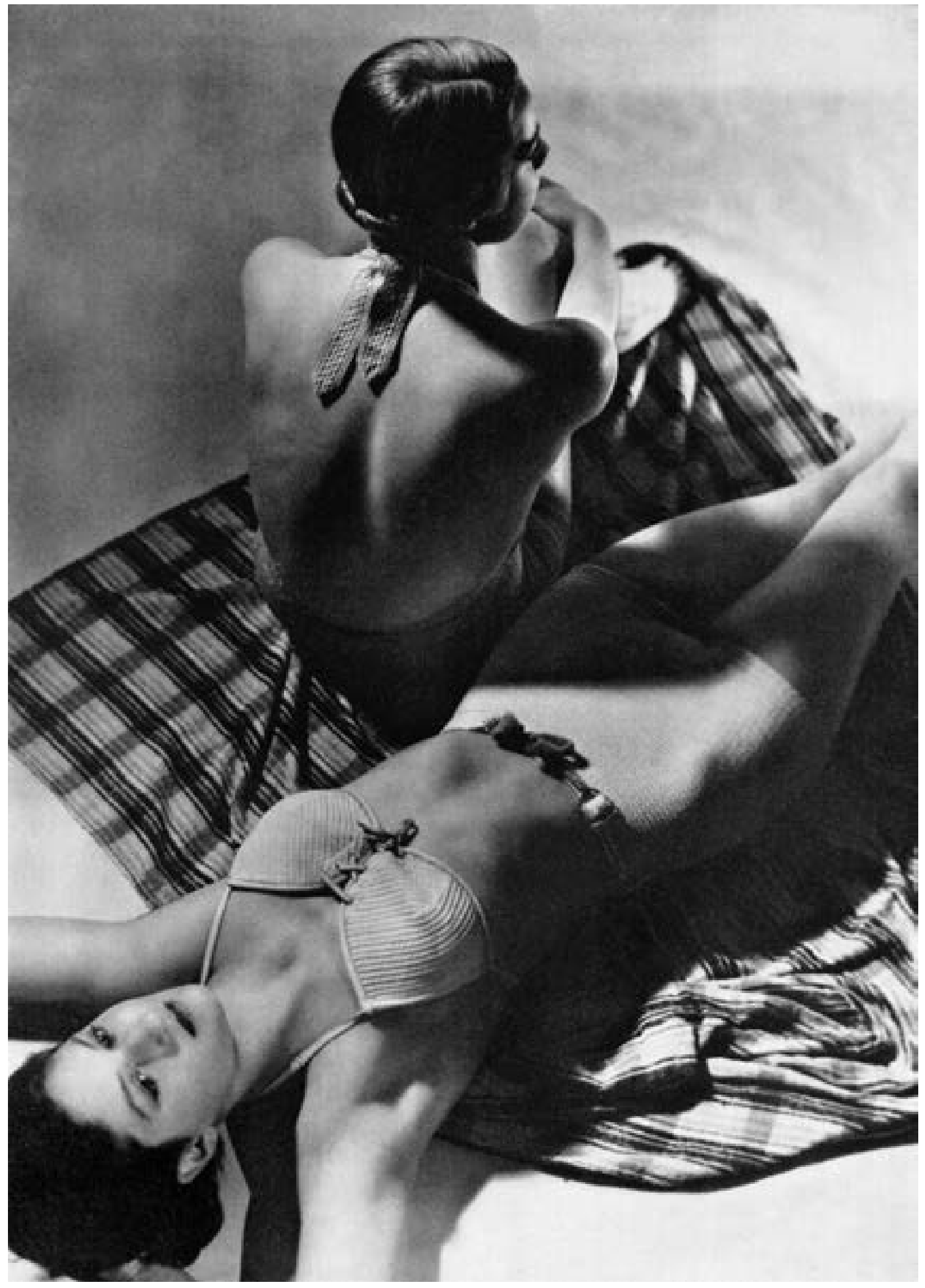


Jahren für die großen Wiener Modehäuser Zwieback oder Farnhammer und später, nachdem sie ihr Atelier nach Paris verlegt hat, für internationale Parfum-, Mode- und Textilfirmen (etwa Drecoll) arbeitet und diese Firmen im Bildtext auch genannt sind, lässt sich die Auftragsarbeit, auch wenn sie meist nicht als Anzeige gekennzeichnet ist, leicht als solche identifizieren. Oft aber werden die Grenzen bewusst verwischt. Vor der Kamera posieren berühmte Schauspielerinnen, eingekleidet sind sie von einem Modehaus, präsentiert werden sie aber nicht als Protagonistinnen einer Werbeeinschaltung, sondern als Bühnenstars. Eine solche verschleierte Werbung erhöht die Aufmerksamkeit für die Bilder und fördert damit die Auflage der Illustrierten. Sie erleichtert die Bewerbung der Modekollektionen und steigert auch das Renommee des Fotografen, dem es gelingt, statt anonymer Fotomodelle die Stars des kulturellen Lebens vor die Kamera zu holen. Immer wieder entstehen so Werbeaufnahmen, die in der Öffentlichkeit als Schauspielerporträts oder als zur Saison passende Genrebilder (Abb. 12) wahrgenommen werden, in Wahrheit aber versteckte Anzeigen sind.

Die Modefotografie der Zwischenkriegszeit ist auffallend stark in der Hand von Frauen. Während in anderen Bereichen der Fotografie, etwa in der klassischen Pressefotografie, aber auch in der Produkt- und Industriefotografie die männliche Dominanz ungebrochen ist, wird das Segment „Mode“ nach 1918 gerne als „weiblich“ deklariert. Das ist kein Zufall. Die starke Präsenz von Frauen in einigen Bereichen der Fotografie hat, zumindest teilweise, mit den Folgen des Krieges und den damit einhergehenden Erschütterungen der traditionellen Rollenbilder zu tun, die, wie wir bereits gesehen haben, auch in anderen Bereichen der Fotografie, etwa in der Porträtfotografie, spürbar werden.

Es gibt aber noch weitere Gründe für die starke Präsenz von Fotografinnen im Modebereich. Frauenthemen nehmen in der Berichterstattung der illustrierten Journale in der Zwischenkriegszeit generell stark zu, der Anteil der Leserinnen ebenso. Aber auch in Blättern, die traditionell kein weibliches $\mathrm{Pu}-$ blikum adressieren, etwa in Sportzeitungen, tauchen um 1930 Modeberichte auf. Neben dem Sport ist die
Mode ein besonders beliebtes Thema im öffentlichen Diskurs. Sie verlässt in den 1920er Jahren zunehmend die Ratgeberrubrik der klassischen Frauenzeitschriften (in denen freilich weiterhin Ratgebertexte zu Modefragen, aber auch Schnittmuster angeboten werden) und bewegt sich in Richtung gehobener Society-Berichterstattung.

Schließlich ist auch die Rolle von Frauen als Moderedakteurinnen in der illustrierten Presse nicht zu unterschätzen. Einige von ihnen setzen in der Zwischenkriegszeit neue Maßstäbe in der Berichterstattung und engagieren für Modeaufträge bevorzugt junge, talentierte Fotografinnen. Zu ihnen gehört Grete Oberländer, die seit den 1920er Jahren in den Wiener Bildern die Rubrik „Was in Wien modern ist“ betreut und zugleich für die Modeberichterstattung zuständig ist. Oberländer kommt aus der Kunstgewerbebewegung und verfolgt in der Mode und der Fotografie eine gemäßigt moderne Richtung. Ähnlich einflussreich ist Grete Müller, die nach dem Ersten Weltkrieg für die Modeberichterstattung der Zeitschrift Wiener Mode zuständig ist und seit 1925 die Moderubrik der Zeitschrift Die Bühne leitet. Auch Claire Patek ist eine wichtige Moderedakteurin der Zwischenkriegszeit. Sie leitet vor dem Ersten Weltkrieg die Rubrik „Aus der Gesellschaft“ im liberalen Neuen Wiener Journal. Seit den 1920er Jahren berichtet sie als freie Journalistin für österreichische, deutsche und tschechische Blätter über Mode- und Gesellschaftsthemen, insbesondere für das Prager Tagblatt und die Münchner Illustrierte Presse. Ab 1929 redigiert sie eine Moderubrik in der Zeitschrift Bergland. Patek fotografiert selbst gelegentlich, ab Anfang der 1930er Jahre arbeitet sie zeitweise mit der Fotografin Helene Zimmerauer zusammen und beliefert die Presse kurzzeitig mit Modeaufnahmen. ${ }^{20}$ Wichtiger aber ist sie als Vermittlerin von Fotoaufträgen an junge Wiener Fotografinnen.

\section{Politische Wende}

Der Aufstieg der austrofaschistischen Diktatur (ab 1933/34) hat die österreichische Modefotografie zwar weniger tangiert, als vielleicht zu erwarten wäre. Das konservative Weltbild, das Staat und Gesellschaft 


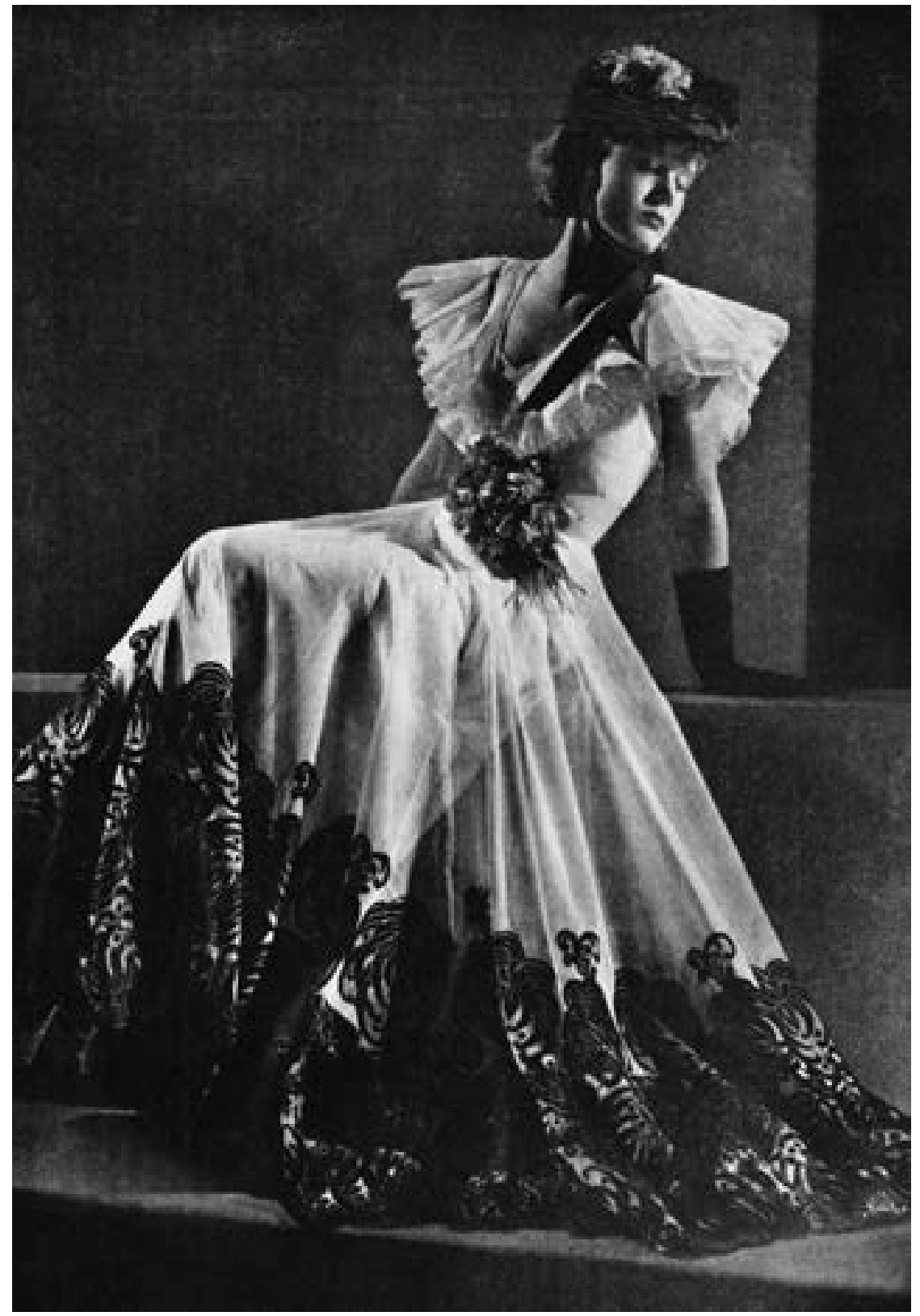

Abb. 13 „Abendkleid aus weißem Organza mit schweren Spitzen inkrustiert", Modell: Berta Farnhammer. Moderne Welt, Heft 11, Juli 1938, S. 30. Foto: Kitty Hoffmann. ist, dass praktisch alle österreichischen Modefotografinnen - ein Großteil von ihnen ist jüdischer Herkunft - nach 1933/34 ohne Unterbrechung weiterarbeiten. Zwar ist der Antisemitismus in den 1930er Jahren auch in Österreich weit verbreitet, aber es gibt, anders als im nationalsozialistischen Deutschland, noch keine ausdrücklichen Berufsverbote für jüdische Fotografen und Fotografinnen.

Mitte der 1930er Jahre haben die Wiener Modefotografinnen nicht so sehr mit politischer Einflussnahme (die in der Modebranche weniger ausgeprägt ist) als vielmehr mit einer verstärkten internationalen Konkurrenz zu kämpfen. Ab 1935 kommen immer mehr Modebilder von internationalen Fotoagenturen und von - vorwiegend - amerikanischen Filmfirmen auf den Markt. Unter diesem Druck geht der Anteil österreichischer Bilder deutlich zurück. Die kurze Blütezeit der österreichischen Modefotografie geht ihren Ende entgegen.

Als 1938 die Verfolgung und Vertreibung der jüdischen Bevölkerung einsetzt, trifft das die jüdischen Fotografen und Fotografinnen mit aller Härte. Die wenigen nicht jüdischen Vertreterinnen des Berufs profitieren dagegen von dieser Situation. Junge Fotografinnen wie Lucca Chmel erhalten nun die Chance, unter anderem auch in der Modebranche Fuß zu fassen. Andere, etablierte Fotografinnen machen nun in großen Schritten Karriere. Kitty Hoffmann etwa steigt nach 1938 zur führenden Modefotografin Wiens auf, sie publiziert jetzt mehr als je zuvor (Abb. 13). Hoffmann arbeitet beispielsweise 1940/41 eng mit dem unter nationalsozialistischer Herrschaft entstandenen Wiener „Haus der Mode“ zusammen. Dieses hatte bei der „Arisierung“ der Wiener Textilfirmen eine zentrale Rolle gespielt. ${ }^{21}$ Aber lange währt diese Zwischenphase, in der österreichische Fotografinnen das Feld der Mode beherrschen, nicht. Die nicht jüdischen - v. a. Wiener - Fotografinnen erhalten nun neue Konkurrenz: Viele deutsche Modefotografen (unter ihnen Hubs Flöter, Imre Santho und Sonja Georgi) dehnen ihre Tätigkeit ab 1938/39 auf die „Ostmark“ aus und publizieren ihre Modeaufnahmen verstärkt auch in Wiener Blättern. 


\title{
Dramatische Nähe
}

\author{
Sport und Fotografie
}

„Go-0-0-0-al!“, titelt das Illustrierte Sportblatt am 29. November 1924. ${ }^{1}$ Das Foto auf dem Umschlag, es stammt von Lothar Rübelt, zeigt nicht die Spieler, nicht den Ball und auch nicht das Spielfeld. Nur jubelnde Fans des Wiener Sportclubs Rapid (Abb. 1). Das Ergebnis des Matches - Rapid gewinnt 3:0 gegen die Amateure Wien - taucht erst im Kleingedruckten unter dem Bild auf. Denn die Fußballergebnisse vom Wochenende kennt, wenn die Wochenzeitung Tage später gedruckt ist, ohnehin bereits die gesamte Stadt. Immerhin ist Fußball in der Zwischenkriegszeit bei Weitem die beliebteste Sportart in Österreich. Zehntausende von Fans ziehen Wochenende für Wochenende in die Stadien, um die eigenen Mannschaften spielen zu sehen.

Anfang der 1930er Jahre wird man von der legendären österreichischen „Wunderelf“ sprechen. „Österreichs Wundermannschaft", heißt es im Wiener Magazin Anfang 1932, „nennt man die elf Sportler, die seit dem Kampf gegen Italien im Februar 1931 kein einziges Gefecht verloren haben; sie alle pflegen die sogenannte Wiener Schule des Fußballs, die sich aus der schottischen Schule entwickelt hat."2 Zu dieser Zeit jagen Nationalmannschaft und Wiener Klubs von Sieg zu Sieg, monatelang reißt die Serie der Erfolge nicht ab: April 1931 in Wien: Tschechoslowakei - Österreich 1:2, Mai 1931 in Wien: Schottland - Österreich 0:5, Juni 1931 in Berlin: Deutschland - Österreich $0: 6$, Retourkampf in Wien: Deutschland - Österreich 0:5, Oktober 1931 in Budapest: Ungarn - Österreich 2:2, November 1931 in Basel: Schweiz - Österreich 1:8, 24. Januar 1932 in Paris: Paris - Wien 1:5, 27. Januar 1932 in Brüssel: Bruxelles Diables - Wien 0:1. Bis Anfang 1933 verliert das österreichische Nationalteam kein einziges Spiel.

Alle großen Heimspiele finden im 1921 erbauten Stadion auf der Wiener Hohen Warte statt. Sie sind bis auf den letzten Platz ausverkauft. Die größte und modernste Anlage in Kontinentaleuropa fasst bis zu
80000 Zuschauer. Es ist auffallend: Mitten in der schwersten Wirtschaftskrise - 1933 ist ein Viertel der österreichischen Bevölkerung arbeitslos -, setzt die österreichische Nationalmannschaft zum patriotischen Höhenflug an. Die „Wunderelf“ wird in der in-
Abb. 1 „Go-0-0-0-al!!“ Fußballzuschauer beim Spiel Rapid gegen Amateure Wien. Illustriertes Sportblatt, 29. November 1924, Titelseite. Foto: Lothar Rübelt.

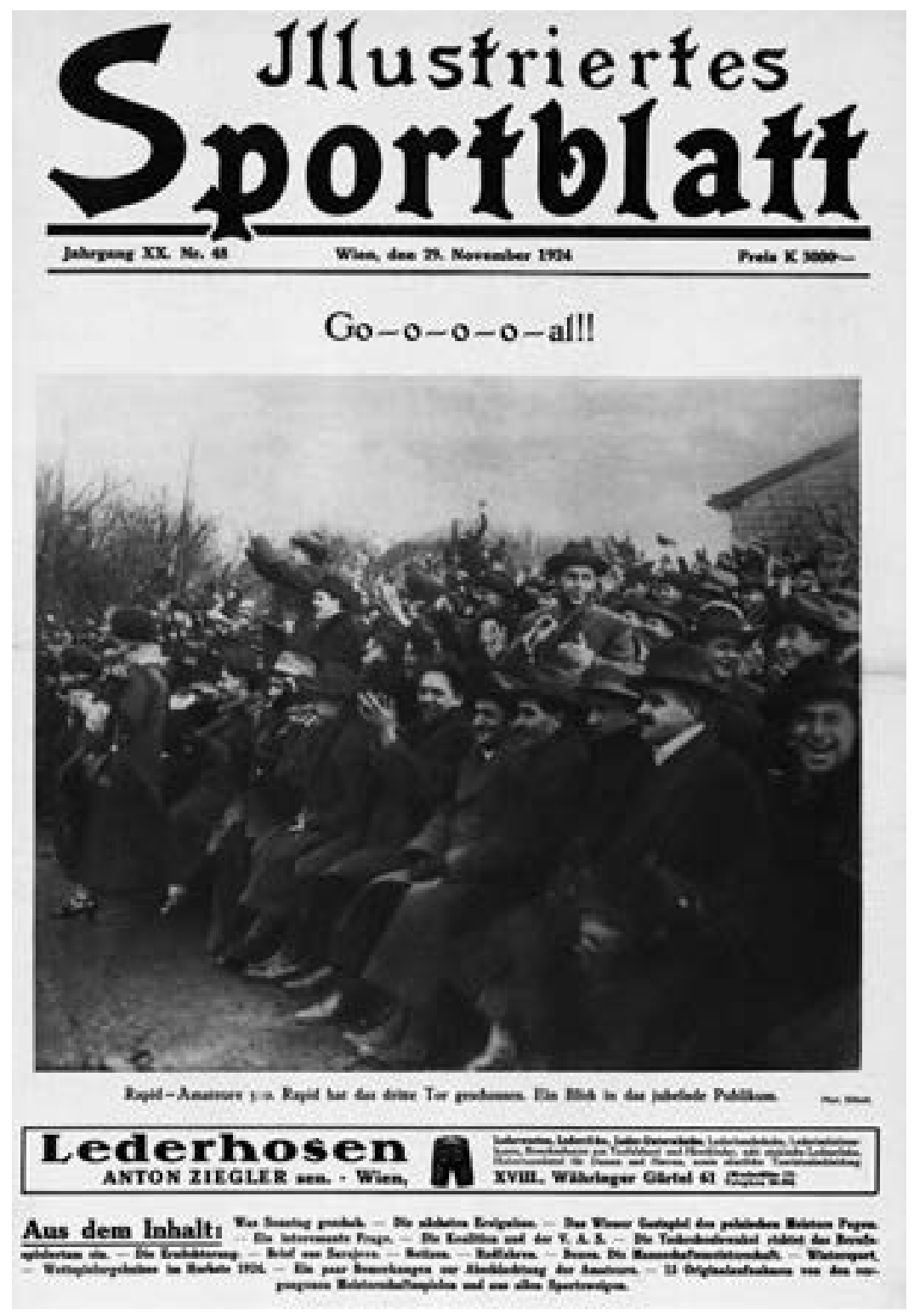


Abb. 2 „Österreichs Wunderelf privat“. Fotoreportage über die österreichische Nationalmannschaft vor dem Länderkampf gegen Frankreich am 12. Februar 1933 in Paris. Österreich gewinnt das Match mit 4:0 Toren. Es ist das letzte siegreiche Spiel der „Wunderelf“. Kölnische Illustrierte Zeitung, 4. Februar 1933, S. 140/141. Fotos: L. Hegy, Berlin und Lothar Rübelt, Wien. und ausländischen Presse in Bildern und Texten als sportliches Ausnahmeensemble beschrieben (Abb. 2).

Die Fußballbegeisterung kennt um 1930 keine Grenzen. Seit 1929 werden die Spiele im Radio übertragen. Auf dem Wiener Heldenplatz werden bei großen Länderspielen Lautsprecher aufgebaut. Tausende Neugierige finden sich ein, um den Spielverlauf live zu verfolgen. Fußball fesselt die Massen. Das Publikum ist wie hypnotisiert.

\section{Der Star unter den Sportfotografen: Lothar Rübelt}

Begleitet wird diese Fußballbegeisterung in den Jahren nach 1918 von einer neuen Art der Sportberichterstattung. Die Spiele im Stadion erhalten in der illustrierten Wochenpresse ein bildliches Echo. Die dramatischsten Szenen, die entscheidenden Spielzüge und die Konterfeis der jungen Stars werden von Sportfotografen festgehalten. Die Bilder erscheinen in großer Aufmachung in den Wochenillustrierten. Besonders groß ist das Interesse dann, wenn die heimischen Mannschaften Siege über ausländische Klubs erringen oder die österreichische Nationalmannschaft ungeschlagen vom Feld geht.

Lothar Rübelt ist der bekannteste und erfolgreichste Sportfotograf dieser Jahre. ${ }^{3}$ Seine ersten Sportaufnahmen macht er 1918. ${ }^{4}$ Bald liefert er regelmäßig Bilder an die Presse, seit 1921 berichtet er u. a. für die auflagenstärkste illustrierte Wochenzeitung, Das interessante Blatt. Gelegentlich erscheinen seine

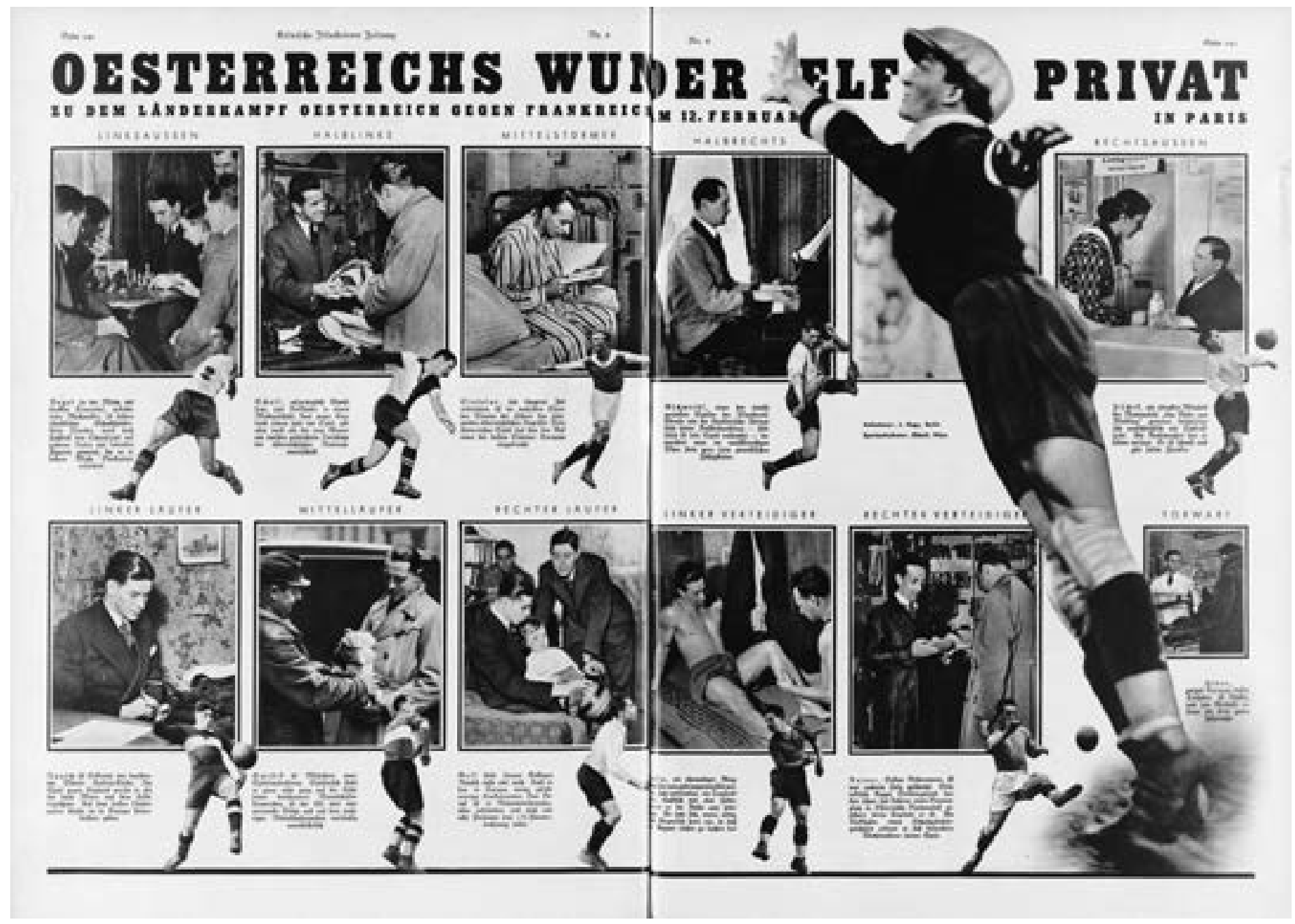




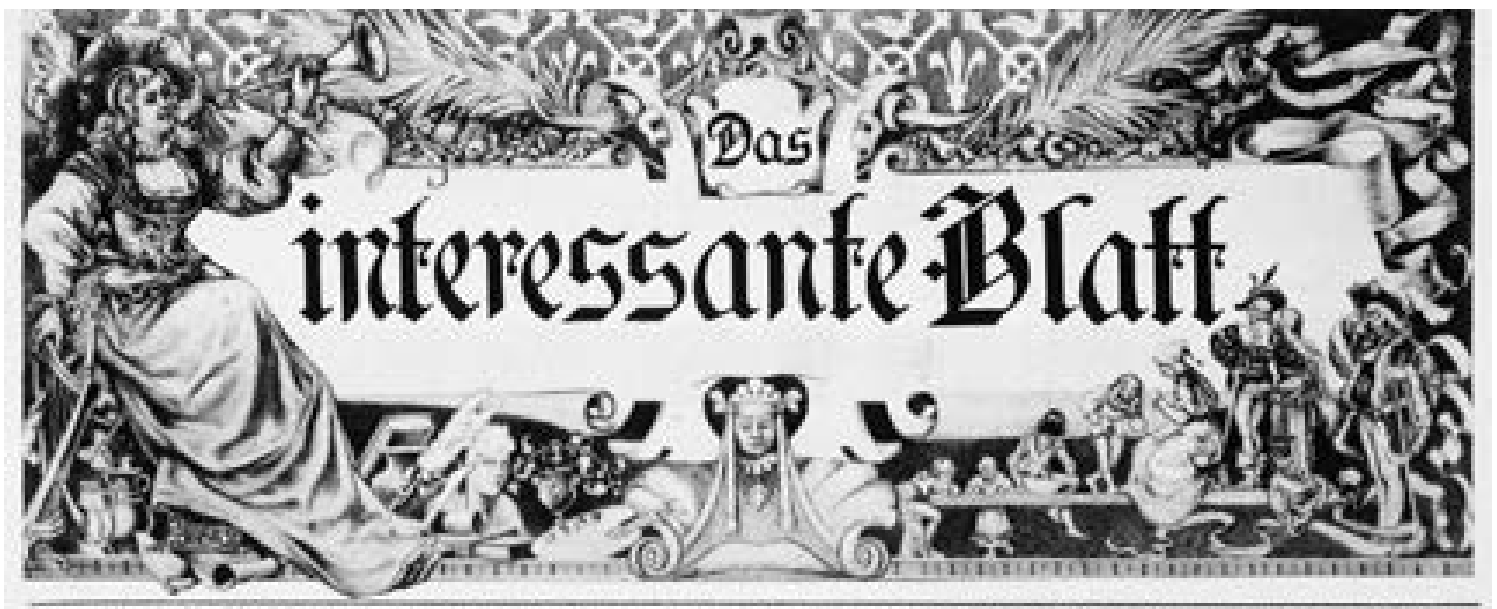

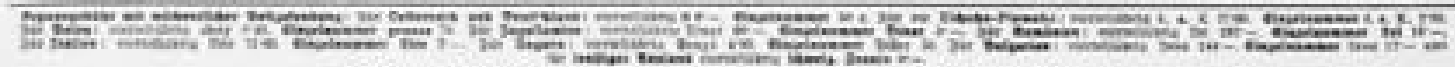

\begin{tabular}{|c|c|c|c|c|}
\hline $2 \pi r .15$. & 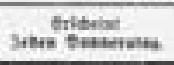 & Wien, 11. 2lpril 1929. & 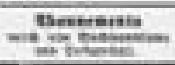 & XLVIII. Jabrg. \\
\hline
\end{tabular}

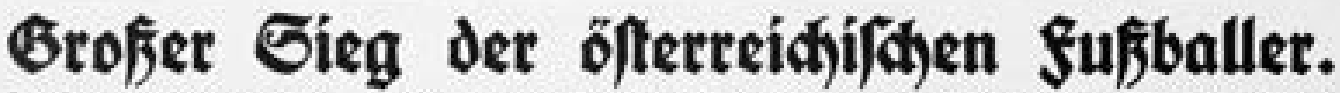

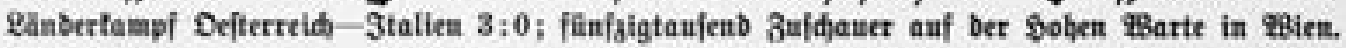

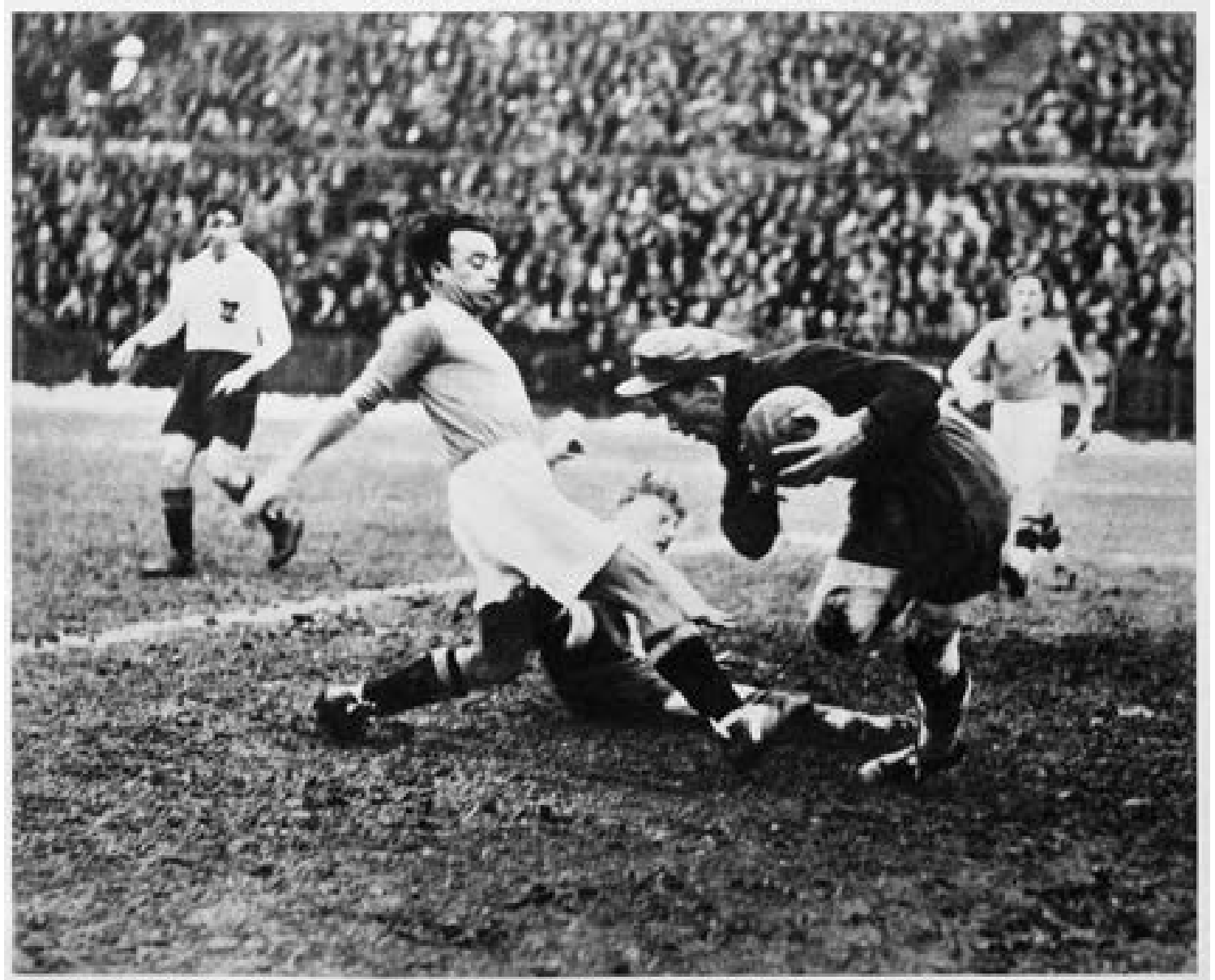

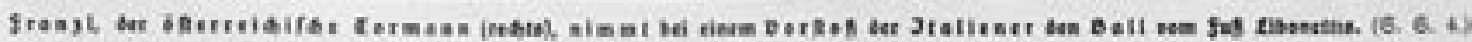
Mridtritt bes Yabinett Geipel, - Corinth-2tusftellung im Sagenbunb. - Das Drama eines Ranbarztes
Abb. 3 „Großer Sieg der österreichischen Fußballer“. Das interessante Blatt, 11. April 1929, Titelseite. Foto: Lothar Rübelt. 
Abb. 4 „Der Wiener Rennfahrer und Lichtbildkünstler Lothar Rübelt“. Moderne Welt, Heft 4, 1929, S. V. Foto: Atelier Zimbler.
Abb. 5 „Ein interessanter Torschuß. Mock skort im Spiel gegen Slovan für die Austria.“ Illustriertes Sportblatt,

5. November 1927, S. 9. Foto: Lothar Rübelt.

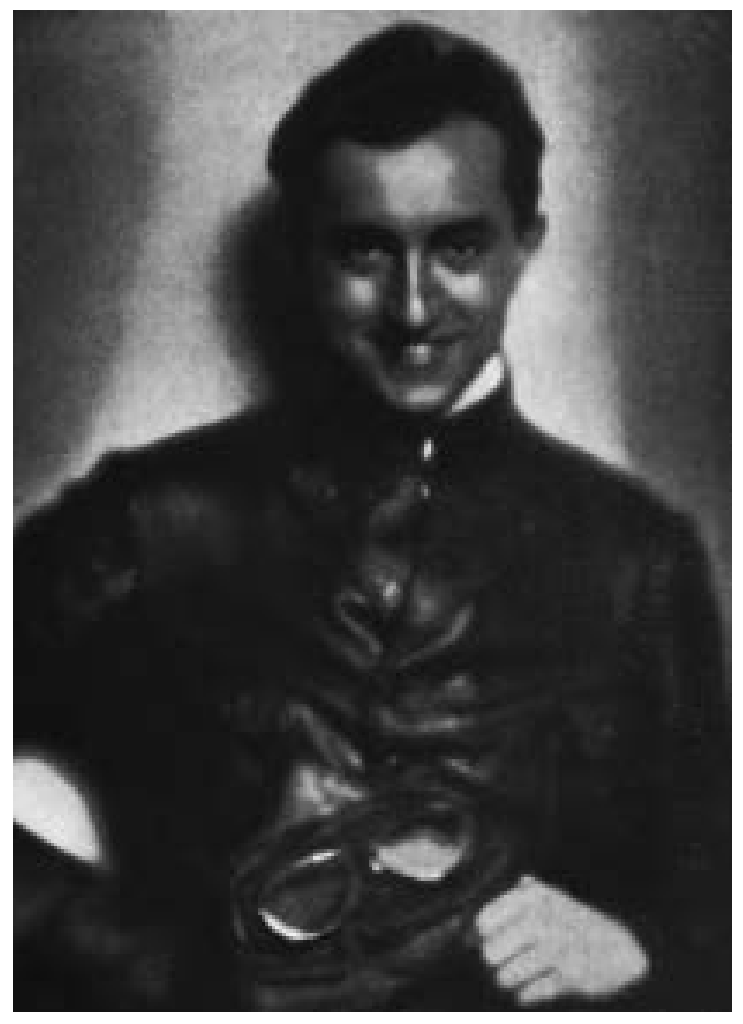

Sportbilder sogar auf der Titelseite (Abb. 3). Rübelt veröffentlicht seine Fotos aber auch in zahlreichen anderen Zeitungen und Magazinen, unter anderem auch in der führenden Sportzeitung des Landes, im Illustrierten Sportblatt.

Lothar Rübelt ist nicht nur ein Meister der Sportfotografie, sondern auch ein geschickter Selbstdarsteller. Er versteht es auch meisterhaft, sich selbst als wendiger Bildchronist zu inszenieren. Beruflich steht er zwar hinter der Kamera, aber im gesellschaftlichen Leben der Zwischenkriegszeit bewegt er sich ebenso souverän vor der Kamera. Rübelt ist der einzige Sportfotograf des Landes, der in der Zwischenkriegszeit den Sprung in die Society-Berichterstattung schafft. ${ }^{5}$ Als er Ende der 1920er Jahre sein zehnjähriges Berufsjubiläum feiert, erscheint ein ganzseitiges Porträt Rübelts im Gesellschaftsmagazin Moderne Welt, in dem der Fotograf seit 1923 regelmäßig eine Sportseite betreut (Abb.4). ${ }^{6}$ Die leicht verschwommene, in piktorialistischer Manier gehaltene Aufnahme, die im bekannten Wiener Atelier Zimbler aufgenommen wurde, rückt Rübelt nicht etwa als Fotografen

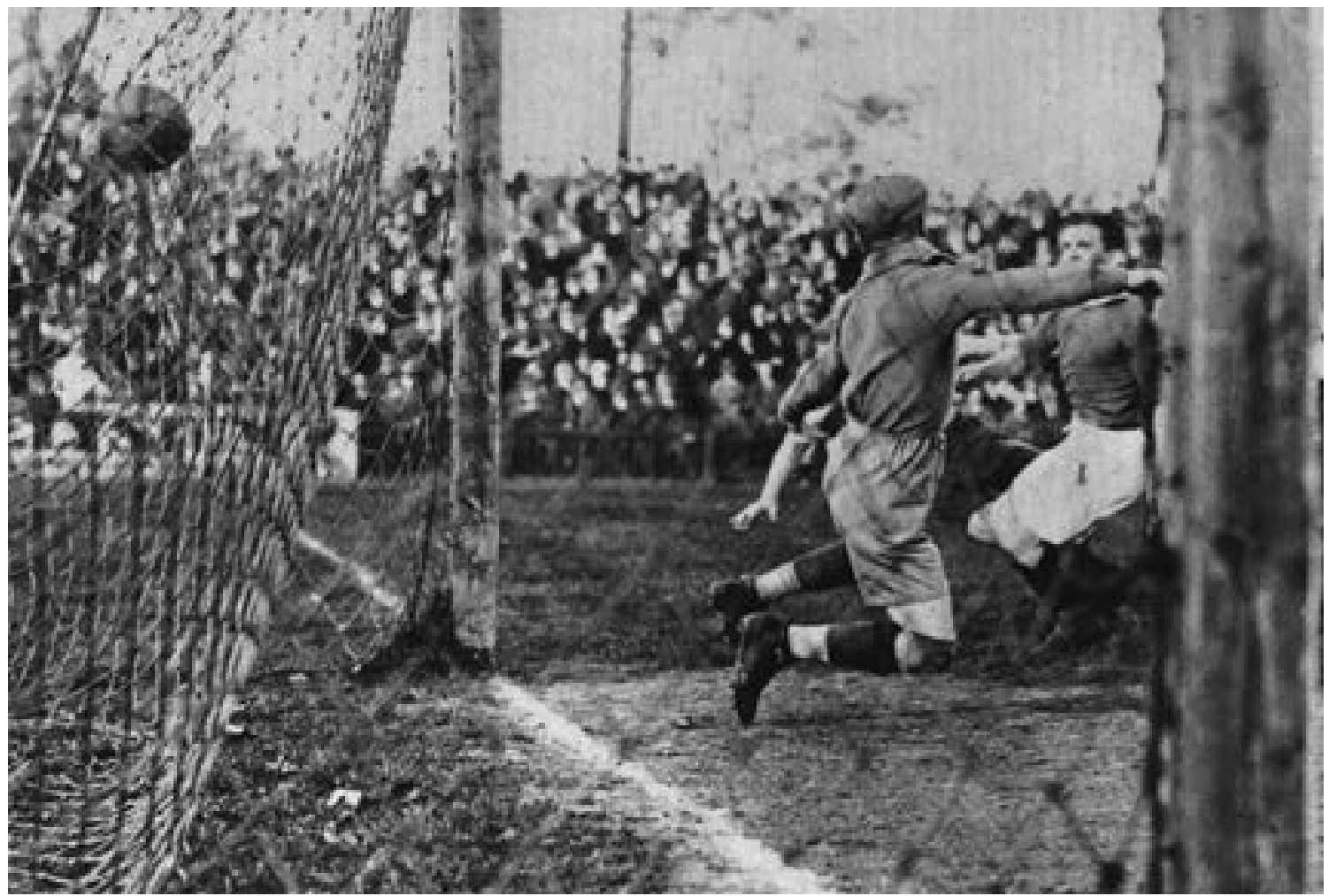


Abb. 7 Leichtathlethik-Länderkampf Tschechoslowakei gegen Österreich. Im 100-Meter-Hürdenlauf siegt der Österreicher Weilheim (innen). Illustriertes Sportblatt, 11. August 1923, S. 15. Foto: Lothar Rübelt.

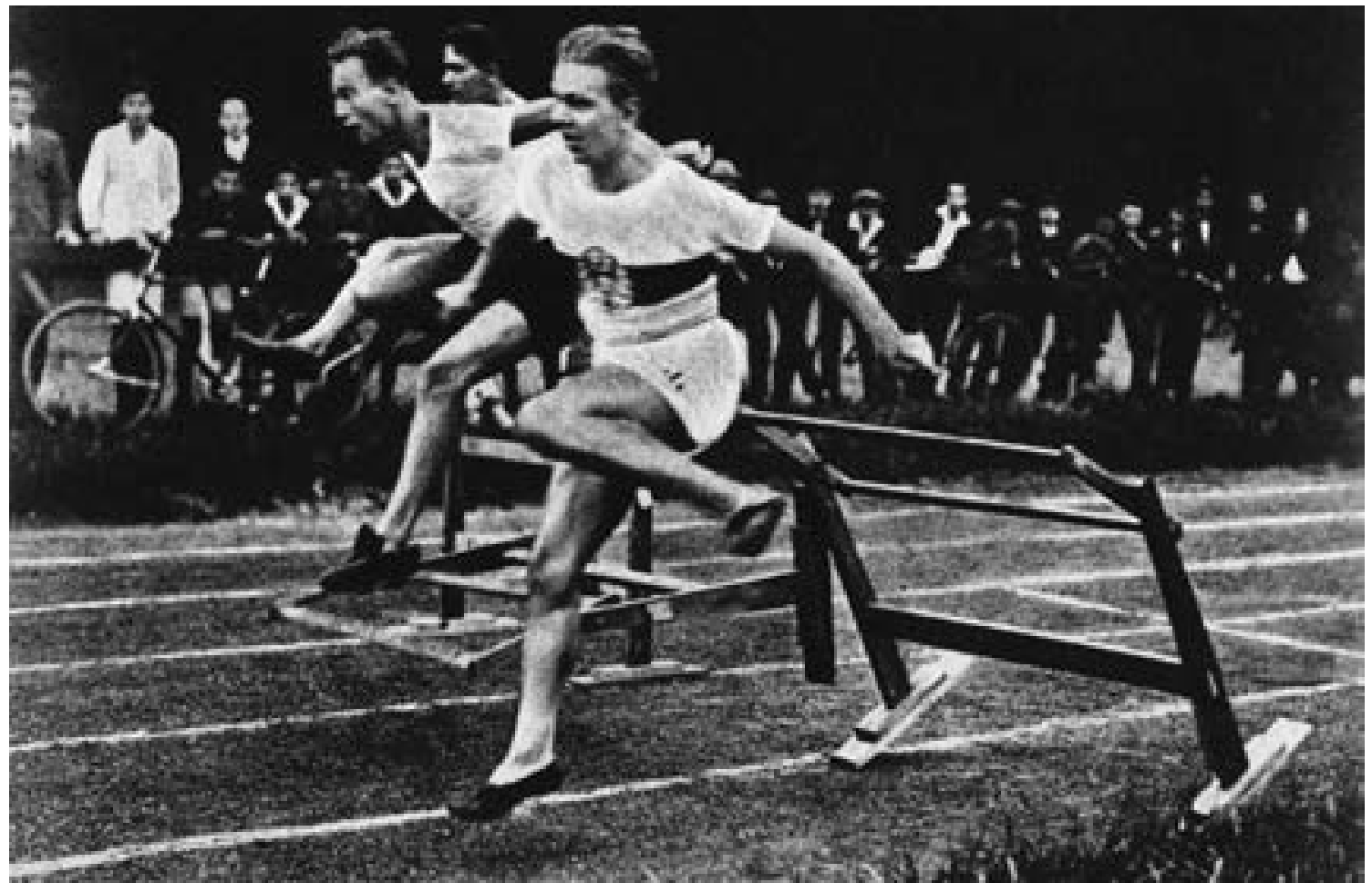

trieb alles ist. Zusammen mit seinem Bruder Ekkehard Rübelt, der ebenfalls Sportfotograf ist, kauft er 1924 ein Motorrad, um die entwickelten und beschrifteten Abzüge schneller in die Redaktionen liefern $\mathrm{zu}$ können. Er weiß, was dort gebraucht wird: Bilder, die aktuell sind und sich vom Mittelmaß abheben. Großes Augenmerk legt er deshalb auf die sorgfältige, Spannung erzeugende Betextung. Sie führt die Betrachter mitten ins Geschehen hinein. In den Bildtexten zu Rübelts Aufnahmen tragen die Sportler meistens ihren vollen Namen. Der Spielverlauf wird in wenigen Worten umrissen. Auf diese Weise entstehen keine anonymen Momentaufnahmen, sondern lebendige, wiedererkennbare Szenen.

\section{Beruf: Sportfotograf}

Lothar Rübelt ist aber nicht der einzige gute Sportfotograf der Zwischenkriegszeit. Viele andere sind Woche für Woche mit ihren Kameras unterwegs, um die aktuellen Sportereignisse in Bildern festzuhalten. Zu ihnen zählen Fred Cešanek, Leo Ernst, Stanislaus Wagner, Albert Hilscher, Victor Brodt, Richard We- rian, Felix Schmal, Adolf Feuerzeug, Hugo Oppolzer, Ernst Kleinberg, Mario Wiberal, Martin Fachet, Ekkehard Rübelt (der Bruder Rübelts, der 1926 bei einem Motorradunfall ums Leben kommt), Heinrich Uttenthaler und allen voran Karl Schleich, einer der talentiertesten und interessantesten Fotografen dieser Jahre.

1895 geboren, ist Karl Schleich kaum älter als Rübelt. Als Fotograf ist er diesem qualitativ durchaus ebenbürtig, in der Presse ist er freilich nicht ganz so flächendeckend vertreten wir Rübelt. Ende der 1920er Jahre kooperiert Schleich eine Zeit lang mit dem Fotografen Albert Hilscher und vertreibt die Bilder an die Presse unter dem Namen „Schleich-Hilscher“ (Abb.8, 9). ${ }^{10}$ Ebenso wie Rübelt sucht er die Nähe zum Geschehen. Er versteht es meisterhaft, mit seiner Kamera dramatische Augenblicke herauszulösen und die Bilder zu spannenden Bildserien zusammenzustellen. Er fotografiert seit Mitte der 1920er Jahre für mehrere illustrierte Blätter, u.a. für Das interessante Blatt, die Wiener Bilder und das Illustrierte Sportblatt. Zwar arbeitet er hauptsächlich als Sportfotograf und befasst sich schwerpunktmäßig mit Fußball, aber er 


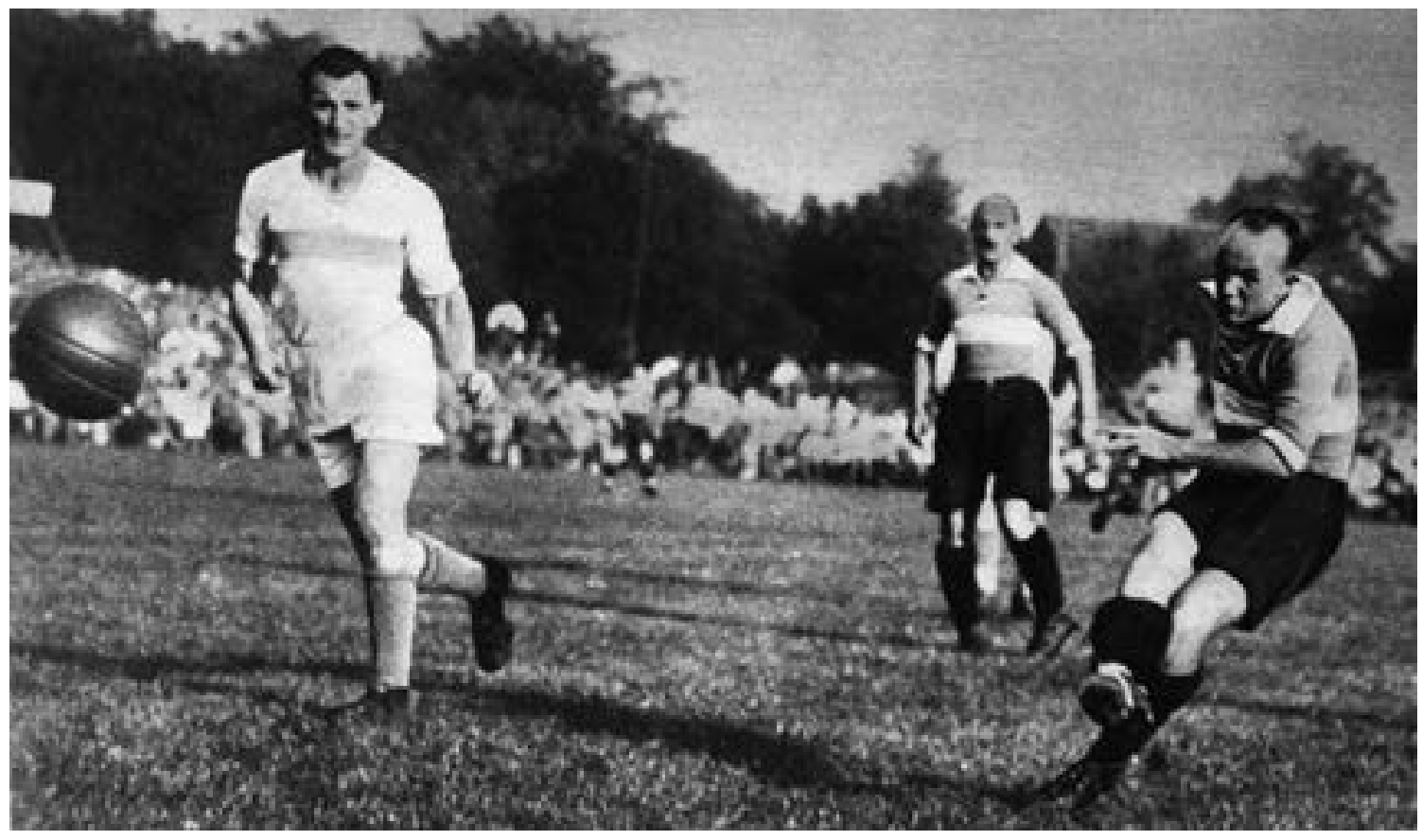

Abb. 8 Fußballmatch zwischen Rapid und Hungaria. Der RapidStürmer Johann Horvath schießt das erste Tor. Rapid gewinnt das Spiel 6:4. Das interessante Blatt, 30. August 1928, S. 6 Foto: Schleich-Hilscher.

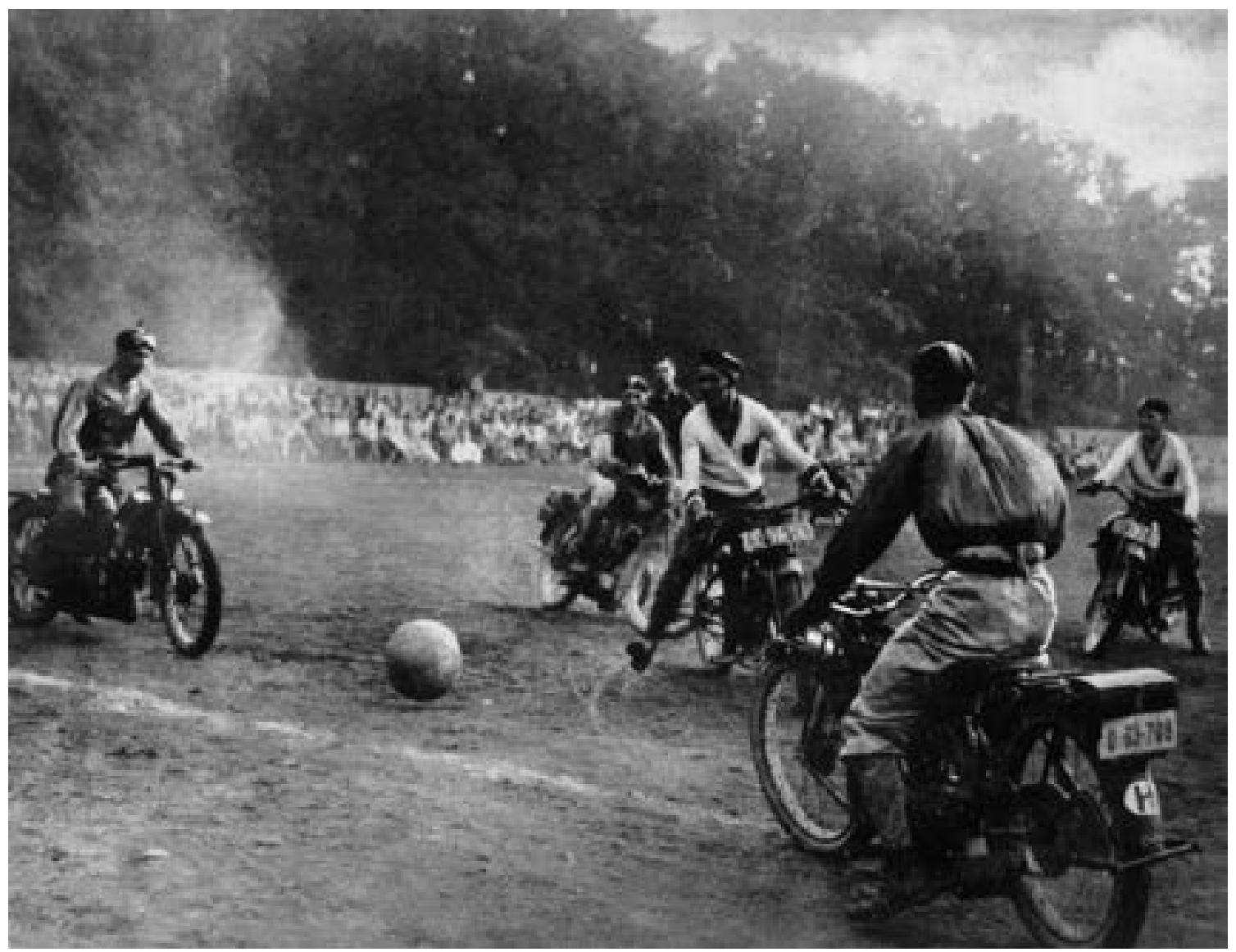

Abb. 9 Motorradfußballländerspiel zwischen Österreich und Ungarn, veranstaltet vom Motorfahrer-Verband in WienBreitenfurt. Österreich gewinnt gegen Ungarn 9:1. Das interessante Blatt, 4. August 1927, Titelseite. Foto: Schleich-Hilscher. 
Abb. 10 Liselotte Landbeck, die österreichische Meisterin im Eiskunstlauf auf dem Platz des Wiener Eislaufvereins. Das interessante Blatt, 18. Januar 1934, S. 8. Foto: Karl Schleich. interessiert sich auch für andere Sportarten, etwa Eisund Kunsteislauf (Abb. 10). Daneben widmet er sich immer wieder auch sozialen und Alltagsthemen. Für die Zeitschrift Die Bühne beispielsweise stellt er um 1930 mehrere schöne Sozial- und Alltagsreportagen zu Wiener Themen zusammen. Auch in diesen Arbeiten zielt er nicht auf den Überblick, sondern er sucht das sprechende Detail, indem er nahe an Personen und Dinge heranrückt.

In der Zwischenkriegszeit wendet sich eine ganze Reihe junger Männer - aber nur einige wenige Frauen - der Pressefotografie zu. Manche von ihnen haben eine klassische Ausbildung als Fotograf hinter sich, andere sind Autodidakten. Gemeinsam ist ihnen, dass sie ohne großes Startkapital beginnen. Kaum einer dieser jungen Presse- und Sportfotografen ist fest angestellt. Fast alle arbeiten selbstständig, mit eigenen bescheidenen Betriebsmitteln: einer Kamera und einer Dunkelkammer, die meist in der eigenen Wohnung eingerichtet wird. Es sind also klassische Ein-Mann-Betriebe. Ihr Verdienst richtet sich nach der Anzahl der Bilder, die sie in der Presse unterbringen können. Die Konkurrenz untereinander ist groß. Man versucht, den anderen auszustechen,

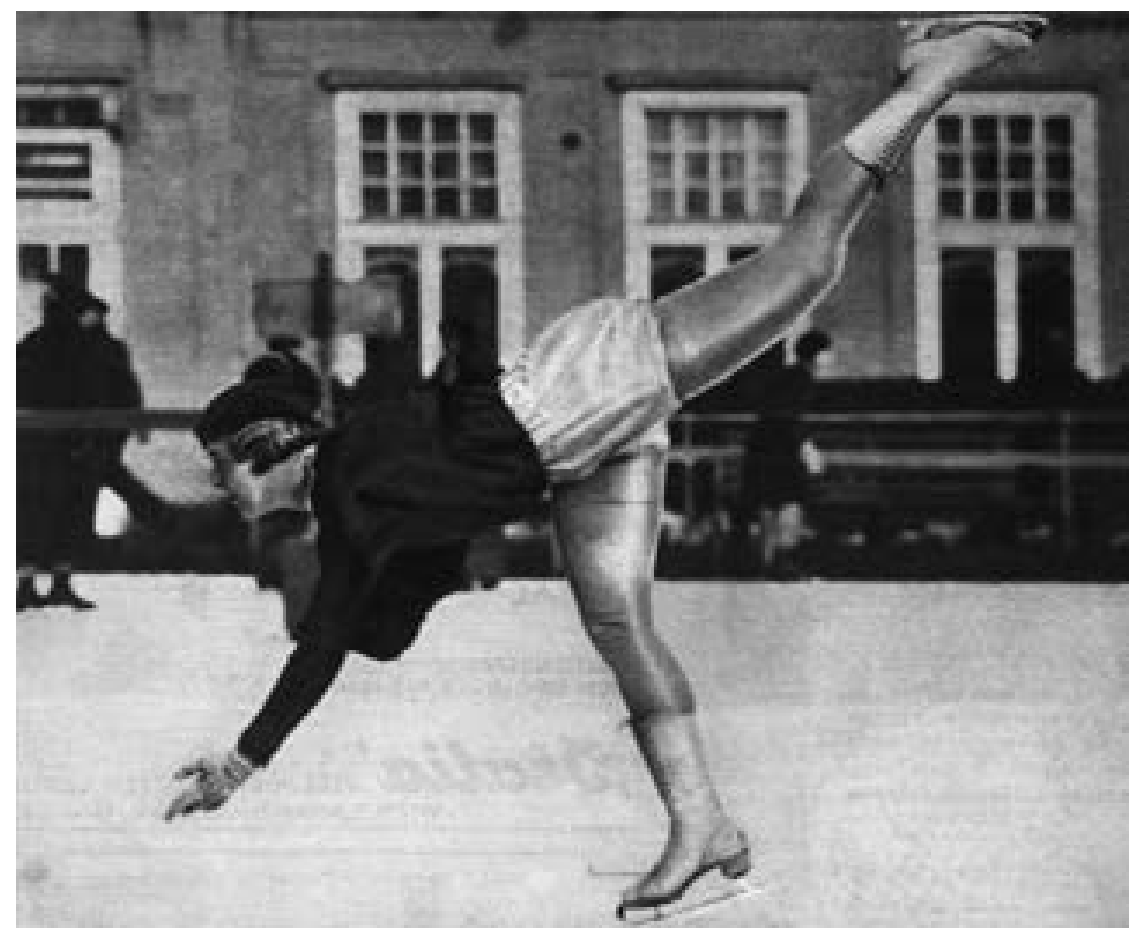

indem man noch schneller ist, noch sensationellere Bilder liefert. Gelegentlich schließen sich zwei Fotografen zu Vertriebsgemeinschaften zusammen. Die Arbeit vor Ort teilt man sich auf, die Kosten für Logistik und Vertrieb ebenso. Oft überdauern diese kleinen Produktions- und Vertriebsallianzen nur wenige Jahre, ihre Mitglieder wechseln immer wieder: Karl Schleich kooperiert, wie erwähnt, eine Zeit lang mit Albert Hilscher, dieser tut sich für einige Jahre mit Leo Ernst zusammen. Letzterer wiederum mit Fred Cešanek. Einigen wenigen gelingt es, eine feste Anstellung als Zeitschriftenfotograf zu bekommen, etliche Pressefotografen arbeiten zeitweise fest für Fotoagenturen. In den meisten Fällen aber bleiben die Arbeitsverhältnisse prekär.

Auch wenn die Fotografen pausenlos unterwegs sind und ihre Namen in der Presse erscheinen: Berühmt werden sie in der Regel nicht. Der Beruf des Sportfotografen ist in der Zwischenkriegszeit gesellschaftlich nicht sehr hoch angesehen. Die Zeitungen betrachten ihre Fotografen als bloße Zulieferer von Bildmaterial. Fällt einer von ihnen aus, ist sofort Ersatz gefunden. Denn es gibt viele, die mit ihren Sportaufnahmen Geld verdienen wollen. Und dennoch: Trotz des niedrigen sozialen Stellenwerts ist der Beruf des Sportfotografen attraktiv. Er garantiert Abwechslung, Spannung und ein Arbeitsleben ohne Büro- oder Fabrikzwang. Die Arbeit selbst aber ist hart und aufreibend, nicht anders als ein Vierteljahrhundert zuvor, in den Jahren um 1900, als der neue Berufszweig entsteht.

\section{Pioniere der Sportfotografie}

Blicken wir noch einmal kurz zurück in die Zeit der Jahrhundertwende. In den 1890er Jahren tauchen neue Massensportarten in der Öffentlichkeit auf, etwa Radfahren, Leichtathletik, Wassersport, Skifahren und allen voran Fußball. Sie sind in der breiten Bevölkerung beliebt. Und sie werden bald auch zum Zuschauersport. Die Massen schauen sich die Wettkämpfe von den Rängen aus an. Sie verfolgen sie aber auch in der populären Presse, vor allem in den auflagenstarken Sonn- und Montagsblättern und in den neu gegründeten Sportzeitungen. 


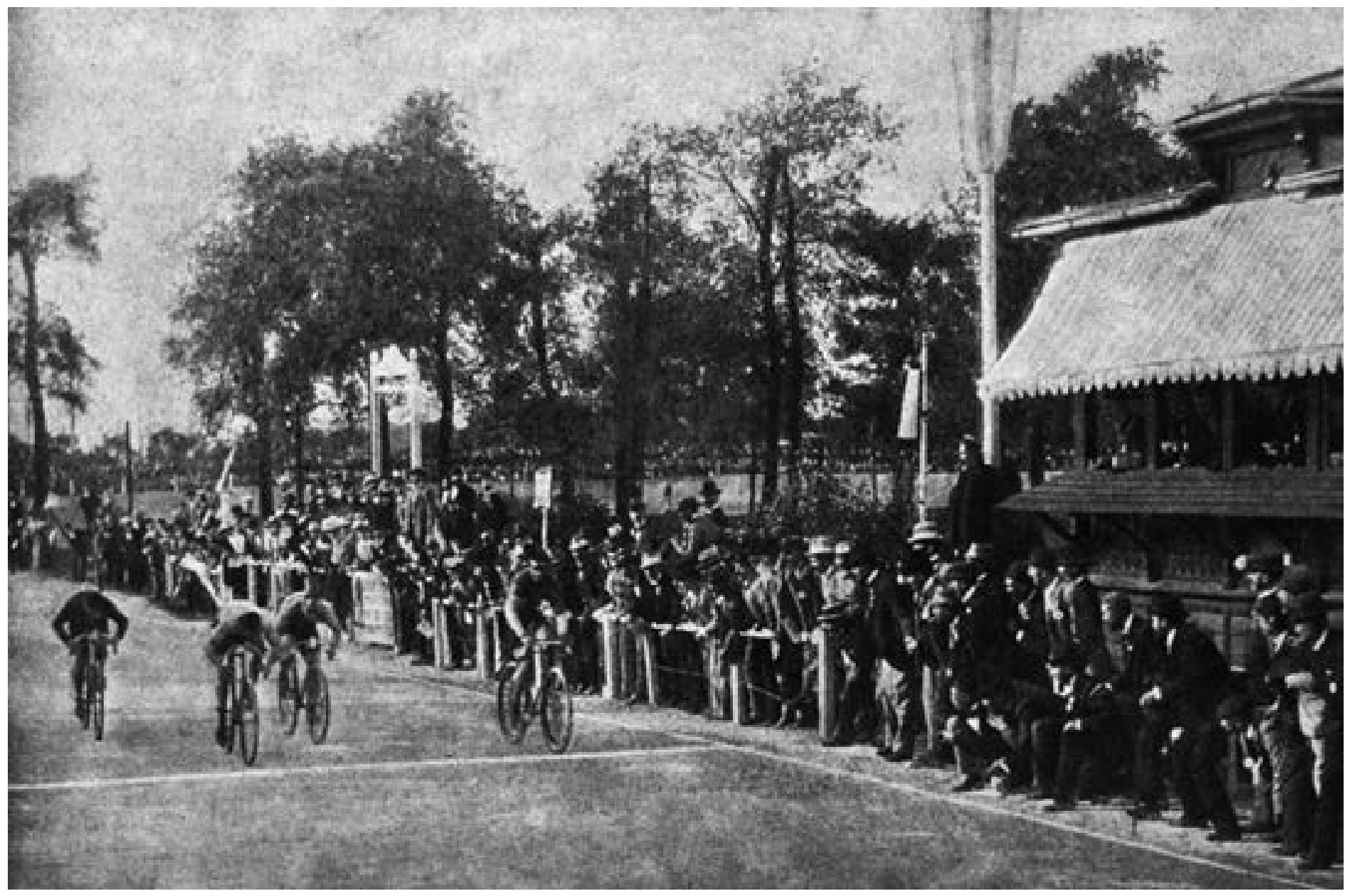

Die Sportwelt teilt sich in diesen Jahren in zwei Bereiche auf: Auf der einen Seite stehen die „aristokratischen“, aus den Freizeitvergnügungen des Adels hervorgegangenen Sportarten, die vorzugsweise auf das Pferd setzen, wie etwa Reiten, Jagdsport, Traben, Pferdehindernisrennen etc., auf der anderen Seite die neu entstehenden populären Massensportarten. Diese Trennung schlägt sich auch in der Berichterstattung nieder. Während die 1880 von Victor Silberer gegründete Allgemeine Sportzeitung, die erste Sportzeitung der Monarchie, noch Mitte der 1890er Jahre dem aristokratischen, elitären Sportmodell verhaftet ist, gehen die populären Sportzeitungen wie etwa die 1891 gegründete Illustrirte Sport-Zeitung oder das 1905 gegründete Illustrierte (österreichische) Sportblatt neue Wege. Sie bevorzugen die populären Sportarten, vor allem den Fußball. Und sie setzen von Anfang an auf fotografische Bilder. In dieselbe Richtung gehen die populären Wochenillustrierten, etwa Das interessante Blatt oder die Wiener Bilder, die schon sehr früh, näm- lich ab Anfang der 1890er Jahre, über Sportereignisse berichten.

Die Sportfotografie hat sich um die Jahrhundertwende aus der Atelierfotografie entwickelt. Anton Huber, einer der ersten österreichischen Sportfotografen, arbeitet zunächst als klassischer Atelierfotograf, bevor er Mitte der 1890er Jahre beginnt, sportliche Wettkämpfe im Freien zu fotografieren. ${ }^{11}$ Er dokumentiert mit seiner Kamera Radrennen, bald auch die ersten Auto- und Motorradrennen, aber auch Pferdesportveranstaltungen. Während er Nahaufnahmen der Sportler teilweise noch im Atelier anfertigt, entstehen die Wettkampfbilder vor Ort. Im Sommer 1896 etwa fotografiert er für Das interessante Blatt den Zieleinlauf eines großen Radrennens (des Großen Preises von Wien) auf der Rennbahn im Wiener Prater, das zahlreiche Zuschauer anlockt (Abb. 11).

„Das Interesse des Publicums für den großen Preis war ein ungeheueres“, heißt es in der Zeitung über das Rennen; „man hätte glauben können, daß die
Abb. 11 Der große Preis von Wien. Zieleinfahrt der Sieger im Wiener Prater. Das interessante Blatt, 17. September 1896, S. 6. Foto: Anton Huber. 


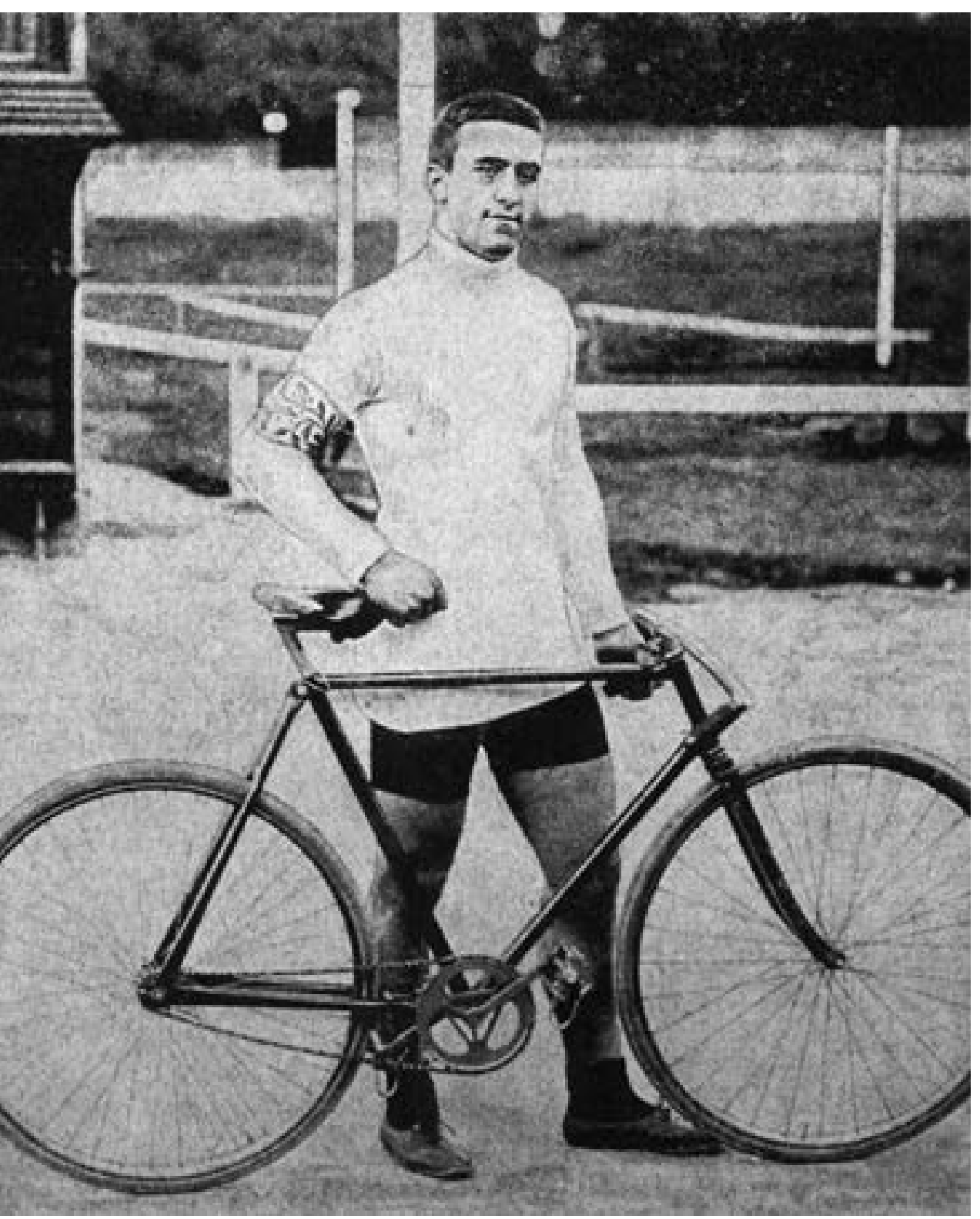

Abb. 12 Der Sieger des Großen Preises von Wien, der Franzose Edmond Jacquelin. Das interessante Blatt, 17. September 1896, S. 6. Foto: Anton Huber.
Entscheidung über den Radfahrpreis nicht allein die Radfahrerkreise, sondern die ganze Bevölkerung von Wien in die erwartungsvollste Spannung und Aufregung versetzt hat - so massenhaft war der Zudrang des Publicums zu der Rennbahn im Prater. Alle Plätze rings um den ausgedehnten Plan waren so dicht gefüllt, daß keine Karten mehr ausgegeben werden konnten, die Tribünen bis hoch hinauf besetzt, und selbst dort auf jenen entlegenen Stellen, wo man bei jeder Runde die Radfahrer nur vorüberfliegen sieht, von der Entscheidung am Zeile aber nichts wahrzunehmen vermag, starrte es von den Köpfen in vielen Reihen übereinander. Und durch diese Menge gieng (sic!) es manchmal, wenn ein spannender Endkampf die Gemüther erhitzte, wie das Rauschen eines Sturmes und wie das Brausen der Brandung, so heftig war die Aufregung, in welche die Massen durch dieses
Sportspiel versetzt wurden." 12 Dem Bericht beigefügt ist auch ein Porträt des Siegers Edmond Jacquelin, das Huber erstmals nicht mehr im Atelier, sondern im Freien aufgenommen hat (Abb. 12).

Bald nach 1900 treten weitere Fotografen auf, die sich auf Sportereignisse spezialisieren (einige von ihnen haben wir bereits kennengelernt): Franz Pawlik, Heinrich Schuhmann sen. und Carl Seebald. Kurz vor dem Ersten Weltkrieg stoßen Josef Perscheid, Josef Jahudka, Felix Schmal, Heinrich Uttenthaler und Victor Brodt dazu. Letzterer ist nach dem Ersten Weltkrieg Redakteur des Illustrierten Sportblattes und interessiert sich als Fotograf vor allem für den Fußball und den Skisport.

Die herausragenden Figuren der Sportfotografie vor 1914 sind zweifellos Carl Seebald und Heinrich Schuhmann sen. (Abb. 13). Sie dominieren mit ihren Bildern das Feld. Jedes Wochenende rücken sie aus, um die Wettkämpfe in und um Wien in Bildern einzufangen. So wie fast alle anderen Sportfotografen dieser Zeit, widmen sie sich nicht ausschließlich den Wettkämpfen, sondern halten daneben auch herausragende gesellschaftliche und soziale Ereignisse fest. Als gute Pressefotografen haben sie einen Sinn für aktuelle Bilder, die sich verkaufen lassen.

Die ersten Sportaufnahmen, die vor der Jahrhundertwende entstehen, sind noch recht statisch, sie zeigen keine schnellen Bewegungen und bewegte Szenen. Bald aber werden die Apparate besser, die Verschlusszeiten kürzer und das Können der Fotografen nimmt zu. Diese rücken näher an die Protagonisten heran, sie drücken dann auf den Auslöser, wenn sie eine entscheidende, dramatische Szene vor der Linse haben. Nach und nach treten an die Stelle von distanzierten, visuell wenig interessanten Überblicksaufnahmen Schnappschüsse, die spannende Augenblicke zeigen, etwa, um beim Fußball zu bleiben, turbulente Zweikämpfe vor dem Tor, gewagte Einsätze des Tormanns, gefährliche Schüsse, interessante Kopfbälle u. Ä.

Der Fußballsport ist für diese frühen Sportfotografen, fototechnisch gesehen, eine große Herausforderung. Der Fotograf ist vom Spielfeld verbannt und muss dennoch die Nähe zu den Spielern suchen. Das ist keine einfache Aufgabe in einer Zeit, 


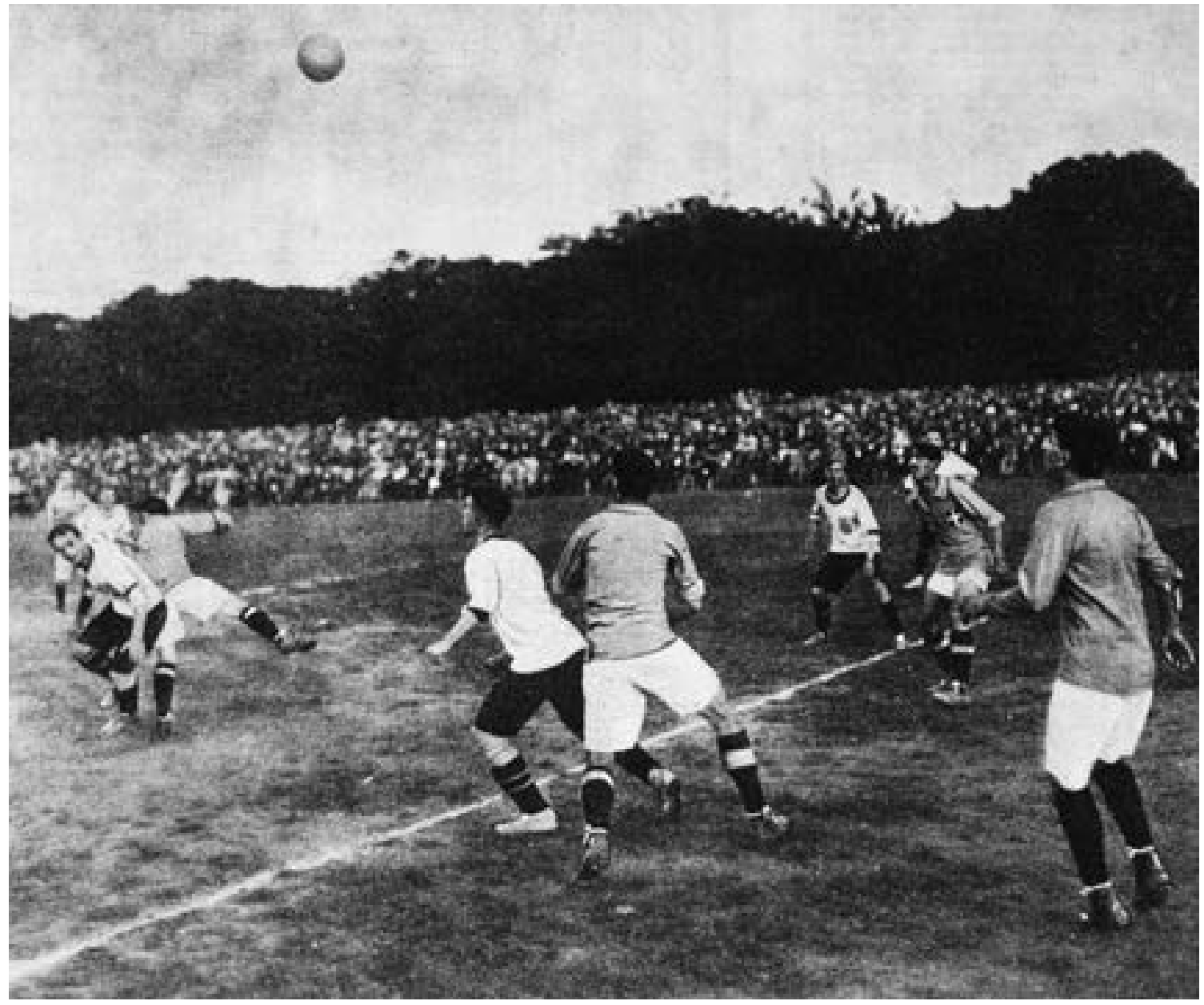

in der das Teleobjektiv noch nicht zur Verfügung steht. Um die Jahrhundertwende sind die Kameras groß und unhandlich. Als Negativmaterial werden schwere Glasplatten (zunächst im Format $13 \times 18 \mathrm{~cm}$ ) verwendet, die nach jeder Aufnahme gewechselt werden müssen. All das erschwert es, auf das Spiel flexibel und schnell reagieren zu können. Zudem ist der Spielverlauf beim Fußball nicht vorhersehbar. Binnen Bruchteilen von Sekunden baut sich eine Szene vor dem Fotografen auf - und ist schon wieder vorbei. Fast alle guten Sportfotografen vor dem Ersten Weltkrieg schulen sich am Spielfeldrand der Fußballplätze. Der Sport ist populär, die Bilder sind gefragt. Bis zu 30000 Zuschauer fiebern um 1910 bei großen Matches im Stadion mit. Und noch weit mehr Leser verfolgen das sportliche Drama Tage später in der auflagenstarken illustrierten Presse.

\section{Turbulente Zeiten}

„G-0-0-0-al!, Toooor!“ Der Jubelschrei der Massen bleibt jahrzehntelang der gleiche. Und dennoch: Wie kaum eine andere Sportart ist der Fußball ein Spiegel wechselnder gesellschaftlicher Befindlichkeiten. Offen oder versteckt geht es auf dem Spielfeld stets auch um Politik und Patriotismus. Vor 1914 fiebern die Massen bei den Länderspielen innerhalb der Monarchie für die eigene Nation. Der Bruderkampf Österreichs gegen „die Ungarn“ etwa wird auf dem Fußballfeld ebenso erbittert ausgefochten wie in der Politik oder in der Publizistik. Als Anfang Mai 1914 ein Länderspiel Österreich gegen Ungarn stattfindet, das mit einem österreichischen 2:0-Sieg endet, berichtet das Illustrierte österreichische Sportblatt ausführlich über das Ereignis. Ein unmittelbar nach
Abb. 13 Länderspiel zwischen Österreich und Italien (im dunkIen Dress mit Kreuz) vor 8000 Zuschauern in Wien. Das Spiel endet 2: 0 für Österreich. Das interessante Blatt, 19.Juni1913, S. 27. Foto: Heinrich Schuhmann sen. 
Abb. 14 Das Länderspiel Österreich gegen Ungarn endet Anfang Mai 1914 mit einem österreichischen 2:0-Sieg. Der österreichische Stürmer Johann Neumann wird von begeisterten Zuschauern auf den Schultern vom Platz getragen. Illustriertes Österreichisches Sportblatt, 7. Mai 1914, Titelseite. Foto: Heinrich Schuhmann sen.

\section{\&ing

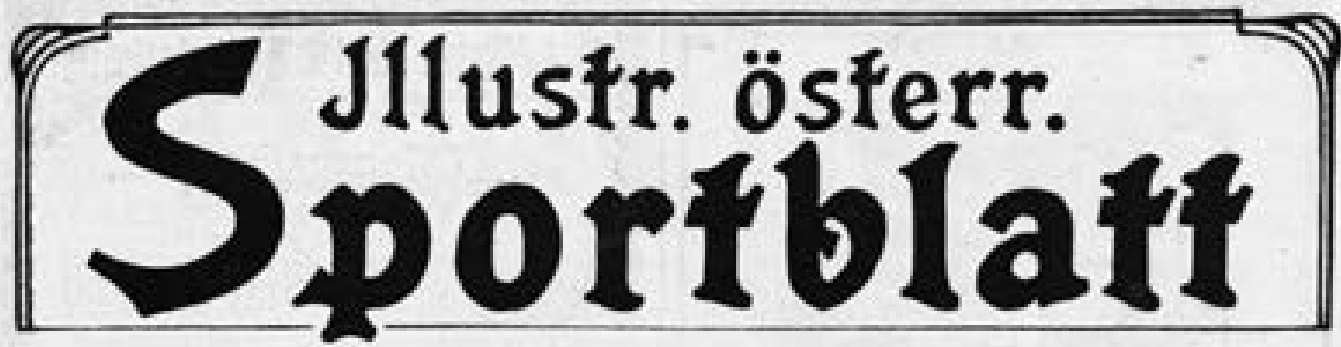

ahrgang X. Nr. 19.

Wien, den 7. Mai 1914.

Preis 20 Heller.

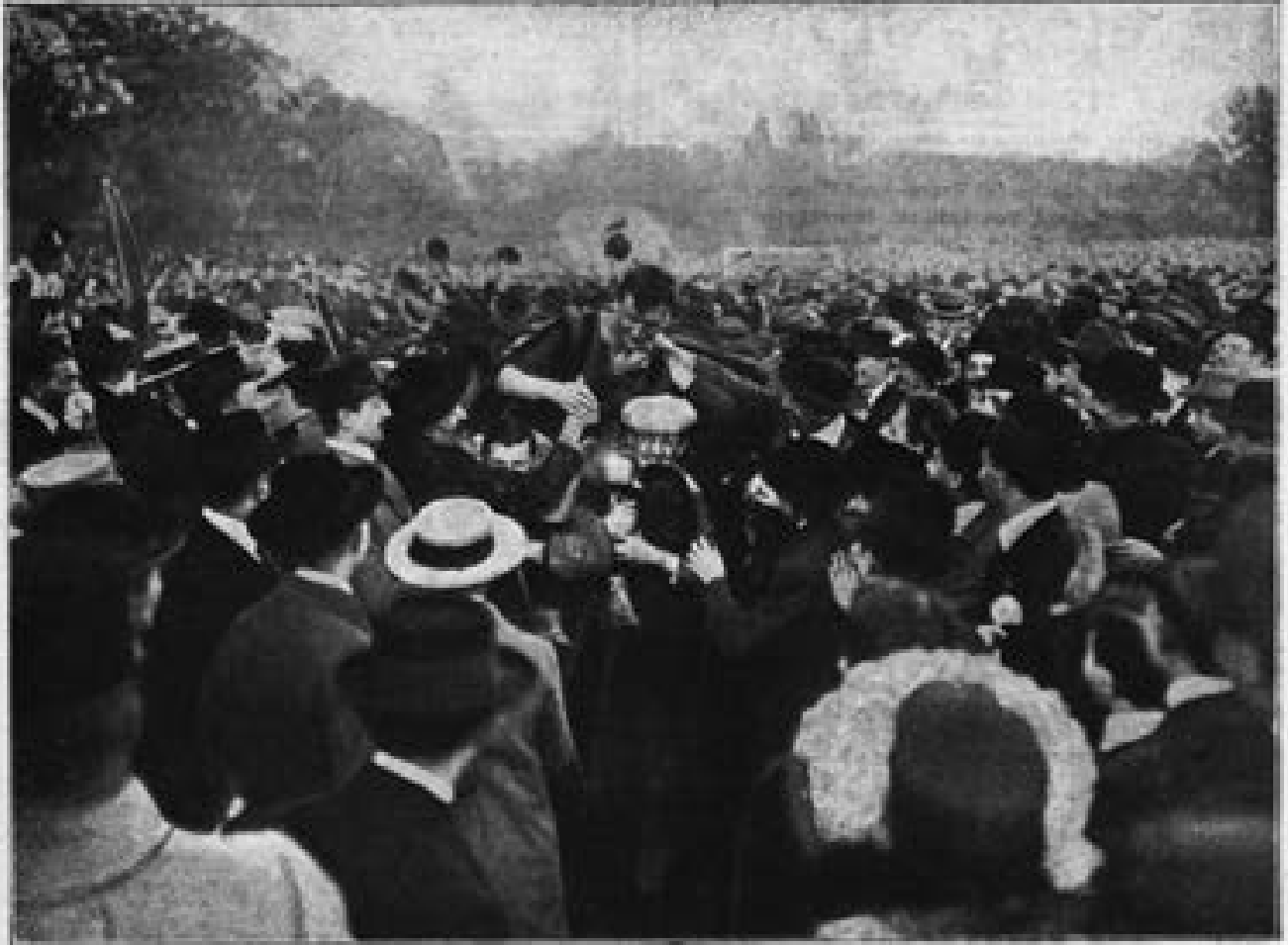

Vom Lisderwettsplel Osterrelch-Ungarnt Nach dem Sleg der Óvterrelcher stlirmen dle Zuseher (22.000 Persoesea) auf das Spielfeld. Neumana wird vou Zusebern auf dea Schultern aus dem Platae getragen.

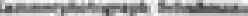

\section{FuBball - Zentrale \\ Olympia - FuBball

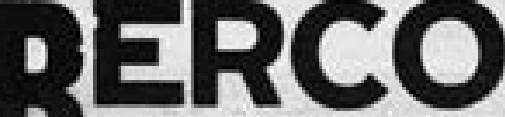 \\ Neuester Champion-Matchball der Saison. Automatisch, Verschlun der Blase. Bleibt hart u. rund. \\ Bestes Chromleder, mit Ia-Blitx Fix Blase K 24 Prolstisten trel \\ Prelelleten frel \\ 1 \\ Wien, VIS, Mariahilferstr.1 c. Konkurrenzios in Schuhen, Bailen, Dressen ete. ete. ter SPEZLAL-SPORT GESCHXFT}

dem Spiel von Heinrich Schuhmann aufgenommenes Fotos zeigt auf dem Titelblatt den österreichischen Stürmerstar Johann Neumann, wie er auf den Schultern der begeisterten Fans vom Platz getragen wird (Abb. 14). ${ }^{13}$ Überschwänglich ist auch der Bericht im Innenteil des Blattes: „Endlich!! Wie eine Erlösung, wie eine Befreiung wirkte der langersehnte, überlegene Sieg der österreichischen Mannschaft gegen die in den letzen Jahren vom Kriegsglück recht verwöhnten Ungarn." ${ }^{14}$ Und weiter heißt es über das sportliche Gipfeltreffen: „Wenn man die Zuversicht der Menge beobachtete, zweifelte man ordentlich daran, ob Österreich denn überhaupt schon einmal ein Spiel gegen Ungarn verloren hätte.“ 15

Die aufgeheizte Stimmung auf dem Platz und die leidenschaftliche Berichterstattung in der Zeitung 
machen deutlich, wie sehr der Fußballsport auch ein gesellschaftspolitisches Ereignis ist. Das auf dem Spielfeld ausgefochtene Match ist oft auch ein Katalysator für weit darüber hinausgehende Stimmungen. Im Massensport Fußball können sich aufgestaute Ressentiments entladen und patriotische Gefühle formen. Im vorliegenden Fall wird die alte österreichisch-ungarische Rivalität, eine Art Hassliebe, auf dem Spielfeld ausagiert.

Nur wenige Monate nach diesem denkwürdigen Länderkampf beginnt der Erste Weltkrieg. Plötzlich ist die Situation eine völlig andere. Die bisherigen Rivalen auf dem sportlichen Feld - Österreich und Ungarn - stehen nun vereint auf der gleichen Seite. Ihnen gegenüber: ein äußerer Feind. Eine Woche nach Kriegsbeginn wird das Illustrierte österreichische Sportblatt vorübergehend eingestellt. Am 6. August 1914 bringt die Redaktion folgende Mitteilung auf der Umschlagseite (Abb. 15): „An die geehrten Leser! Die durch die Weltereignisse bedingte Absage sämtlicher sportlicher Veranstaltungen in Österreich veranlaßt uns, das Erscheinen des ,Illustr. österr. Sportblatt‘ für die Dauer der kriegerischen Verwicklungen einzustellen. Das Wiedererscheinen unseres Blattes werden wir den geehrten Lesern rechtzeitig bekanntgeben. Die Redaktion.“ 16

Bereits wenige Wochen später, am 12. September 1914, erscheint das Blatt wieder. Denn, so der Chefredakteur Franz Gerl in seinem Editorial, der Fußballsport dient „als militärische Vorbereitung für den Krieg“. ${ }^{17}$ Eine Rubrik unter dem Titel „Von unseren Soldaten“ wird eingerichtet, ebenso werden die Leser aufgefordert, fotografische Ansichten vom Schlachtfeld einzuschicken. Normalität stellt sich freilich nicht ein. Immer häufiger finden sich in den nächsten Monaten Berichte über gefallene oder verwundete Fußballer.

Im Laufe des Krieges kommt es zu einer gewissen Umschichtung in der Sportberichterstattung. Da nun zahlreiche Presse- und Sportfotografen von der Front berichten, sind gute, aktuelle Sportaufnahmen rar. Immer wieder greifen die Redakteure der Sportzeitungen daher notgedrungen selbst zur Kamera. Sogar Franz Gerl, der Chefredakteur des Illustrierten österreichischen Sportblatts, liefert hin und wieder eigene Bilder. Ein Teil der publizierten Aufnahmen stammt von Amateuren. Einige der Fotografen, die nicht einrücken müssen, arbeiten nun enger mit der Redaktion zusammen. Unter ihnen ist Felix Schmal. Der Amateur, der sich nach 1900 im Umkreis der kunstfotografischen Richtung bewegt hat, wird während des Krieges zum eifrigen Sportfotografen. Er widmet sich vor allem dem Fußball und dem Skisport und schreibt gelegentlich selbst Artikel. Auch Victor Brodt, geb. 1878, der in der Presse unter dem Kürzel „Vibro“ firmiert, avanciert während des Krieges zum gefragten Sportfotografen. Seine ersten Aufnahmen für das Illustrierte österreichische Sportblatt erscheinen zwar schon 1911, aber während des Krieges nimmt seine fotografische Tätigkeit deutlich zu. Schließlich tritt er sogar in die Redaktion der Zeitung ein.

Nach dem Ersten Weltkrieg bricht eine neue Ära des Massensports an. Das Interesse am Sport, insbesondere am Fußballsport, steigt in der Zwischenkriegszeit sehr stark an. Unmittelbar nach Kriegsende haben es die Sportfotografen schwer. Die Zeitungen sind dünn, Papier ist Mangelware, die Papierqualität ist schlecht. Dazu kommt Anfang der 1920er Jahre die hohe Inflation, die, wie berichtet, zahlreichen Zeitungsunternehmen zu schaffen macht. Erst ab etwa 1923 normalisiert sich die Lage im Pressesektor wieder. Ab Mitte der 1920er Jahre werden

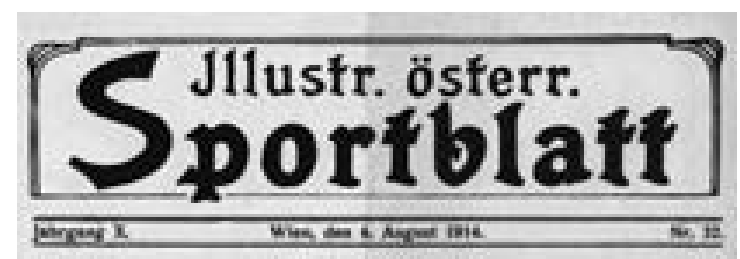

An die geehrten Leser!

Die durch die Weltereigaisse bedingte Absage simetlieher sportlicher Veranstaltusgen in Osterreich veranlalie uns, das Erscheinen des -Jlluatr. bssterr. Sportblatt" für die Dauer der kriegerischen Verwicklangen einzustellen. Das Wiedererscheinen unseres Blattes werden wir den geehrten Lesera rechtreitig belanntgeben.

Die Redaktion.
Abb. 15 „Die durch die Weltereignisse bedingte Absage...“ Einstellung des Illustrierten österreichischen Sportblatts am Beginn des Ersten Weltkrieges. Illustriertes österreichisches Sportblatt, 6. August 1914, Titelseite. 
neue Blätter gegründet. Auch Gesellschaftsmagazine, die bisher ohne Sportrubrik ausgekommen sind, bringen nun immer wieder ausführliche Bildberichte.

Nach 1918 kommt es zu einem Generationenwechsel unter den Sportfotografen. Zwar sind nach wie vor einige Protagonisten der Vorkriegsfotografie aktiv, etwa Heinrich Schuhmann oder Carl Seebald, die auch unmittelbar nach dem Krieg Fußballspiele dokumentieren. Aber die Szene ist Anfang der 1920er Jahre von aufstrebenden jungen Fotografen wie Rübelt, Franta, Brodt, Uttenthaler u. a. geprägt.

\section{Politisierte Spiele}

Die Massenbegeisterung für den Fußball hat in der Zwischenkriegszeit eine dunkle Kehrseite. In den sportlichen Enthusiasmus mischen sich Patriotismus, Parteienkampf und Antisemitismus. Ein Spiel zwischen Rapid, der Austria oder der Admira und dem jüdischen Wiener Sportclub Hakoah ist in den 1920er und 1930er Jahren auch ein politisches Derby, in dem es nicht nur um spielerische Erfolge, sondern auch um die Losungen der Tagespolitik geht.

Als die beiden Wiener Klubs Rapid und Hakoah Anfang Dezember 1927 einander gegenüberstehen und der jüdische Verein eine haushohe Niederlage einstecken muss, tritt der Antisemitismus in der Berichterstattung ganz offen zutage. „Welch ein $\mathrm{Zu}$ sammenbruch!“, heißt es im Illustrierten Sportblatt. ${ }^{18}$ „Das 9:1-Resultat, mit dem am letzten Sonntag nicht gerade eine Elite-Rapid-Elf die Blau-Weißen (Hakoah, A.H.) auf dem Hakoah-Platz vernichtend schlug, ist mehr als ein Debakel, das Tageskonstellationen im Fußball mitunter schaffen können. Es ist der Schlußpunkt einer ungesunden Entwicklung, die innen und außen verzehrend am Marke der Krieauer fraß.“ 19 Die Niederlage sei, so heißt es im Artikel weiter, Ausdruck einer sportlichen und moralischen Krise. Ohne dass der Begriff „jüdisch“ fällt, wird deutlich, dass dieses Attribut im Zentrum der Begründung steht.

Der Niedergang der Hakoah wird in der Folge als moralische Verirrung gedeutet, als Krankheit, als „Infektion“, als Folge materieller Hybris und geschäftlicher Gier. Das Vokabular bedient sich aller gängigen antisemitischen Vorurteile. „Hier ist seit langem ein Prozeß der Auflösung im Gang und sein dramatischer Knalleffekt lautet eben 9:1. Hakoah ist schon die längste Zeit krank. Ihr Verfall begann eigentlich schon mit dem Höhepunkte ihrer Erfolge. Ruhmvolle Siege verschleierten damals, daß das gesunde Prinzip sich aus eigener Kraft, den Platz an der Sonne zu erkämpfen, verlassen wurde. Fremde, bloß im Materiellen wurzelnde Spieler wurden eingestellt, sie infizierten die ,Bodenständigen“, (...) der Nachwuchs wurde vernachlässigt oder unkundigen Personen anvertraut und treue, von Idealismus erfüllte Mitglieder abgestoßen. Neue Menschen tauchten auf, die Fußballkonjunktur brachte zum größten Teile Konjunkturelemente; persönliche Interessen und Geschäftsmomente traten in den Vordergrund. (...) Dann kamen die Amerikareisen. Sie endeten mit dem Verlust fast des gesamten erstklassigen Spielermaterials, während die meist unbeträchtlichen Dollardividenden in erster Linie auf Spieler und Reisebegleiter zur Ausschüttung kamen."20

An diesem Beispiel wird deutlich, dass der Antisemitismus im Wiener Fußball bereits lange vor 1938 weitverbreitet ist, nicht nur aufseiten der Zuschauer, sondern auch in der Presse. Nach dem „Anschluss“ im Frühjahr 1938 wird aus den süffisanten Anspielungen plötzlich bitterer politischer Ernst. Jüdische Spieler werden verfolgt, deportiert und ermordet, Hakoah wird als Verein enteignet und zerschlagen.

Auch bei den Fotografen trennen sich die Wege. Jüdische Fotografen erhalten keine Aufträge mehr, viele von ihnen verlassen das Land, andere werden deportiert. Mitläufer, Opportunisten und Parteigänger machen hingegen Karriere. Zu ihnen zählen die Sportfotografen Mario Wiberal, Anton Doliwa und Franz Blaha, die vom Regimewechsel profitierten. Zu ihnen gehört aber auch der Star der Sportfotografie dieser Jahre, Lothar Rübelt. Er hat, wie berichtet, nach 1933 bereits wiederholt in der gleichgeschalteten deutschen Presse veröffentlicht. Bei den Olympischen Spielen in Berlin 1936 ist er der einzige aus Österreich stammende Fotograf, der für die renommierte Berliner Illustirte Zeitung arbeitet. 1938 begrüßt er die neuen Machthaber freudig, arrangiert sich schnell mit den neuen Redakteuren und Herausgebern und arbeitet weiter wie gewohnt. ${ }^{21}$ 


\title{
Frauen hinter der Kamera
}

\author{
Die neuen Fotografinnen
}

Eine Szene voller Kontraste (Abb. 1). Im oberen Bild sind Putzfrauen zu sehen. Sie knien in einer langen Reihe und reinigen den Boden. Der Bildtext erläutert: „Die alte Ausstellung wird abgebrochen. Zuerst kommen die Waschweiber, die den Boden für die neue Kunst frisch scheuern. “1 Den knienden Putzfrauen gegenübergestellt sind im unteren Bild die Männer. Sie präsentieren sich in ganz anderer Pose: sitzend, geschäftlich gekleidet. Angeregt blicken sie nach vorne, gestikulieren mit ihren Händen. Im Bildtext tragen sie - im Unterschied zu den anonym bleibenden Putzfrauen - Berufsbezeichnungen. Es handelt sich, so heißt es im Bildtext, um Kunstkritiker, Mitglieder einer „Jury, die über Tod und Leben entscheidet“. ${ }^{2}$ Oben die dienenden Frauen, unten die entscheidenden Männer, dazwischen der Textbalken: „Die Künstlerhaus-Ausstellung wird vorbereitet“.

Die Spannung, die dieses Doppelbild schafft, ist das Ergebnis einer auf der Zeitungsseite geschickt inszenierten Gegenüberstellung: Alte Ausstellung - neue Ausstellung, Männer - Frauen, Sitzen - Knien, Dienen - Entscheiden, oben - unten usw. Die Szene erscheint Anfang Dezember 1930 in der Wiener Zeitschrift Die Bühne. Wir wissen nicht, wer für die grafische Gestaltung dieser Themenseite verantwortlich war, wohl aber kennen wir die Fotografin. Sie heißt Annie Schulz. Die Wiener Fotografin, geb. 1897 als Anna Weishut, arbeitet seit Ende 1925 als „Illustrationsphotographin“ und betreibt seit 1929 ein Atelier in Wien. $\mathrm{Zu}$ dieser Zeit ist die Pressefotografie noch fest in männlicher Hand, nur eine einzige Fotografin hat vor dem Ersten Weltkrieg regelmäßig das aktuelle Zeitgeschehen dokumentiert, Marie Mertens. ${ }^{3}$

Annie Schulz ist eine ausgezeichnete Fotografin mit einem ausgeprägten Gespür für Themen der

Abb. 1 Arbeitende Frauen - urteilende Männer - eine fotografische Gegenüberstellung anlässlich einer Künstlerhausausstellung. Die Bühne, Nr. 293, Erstes Dezemberheft 1930, S. 22. Foto: Annie Schulz.

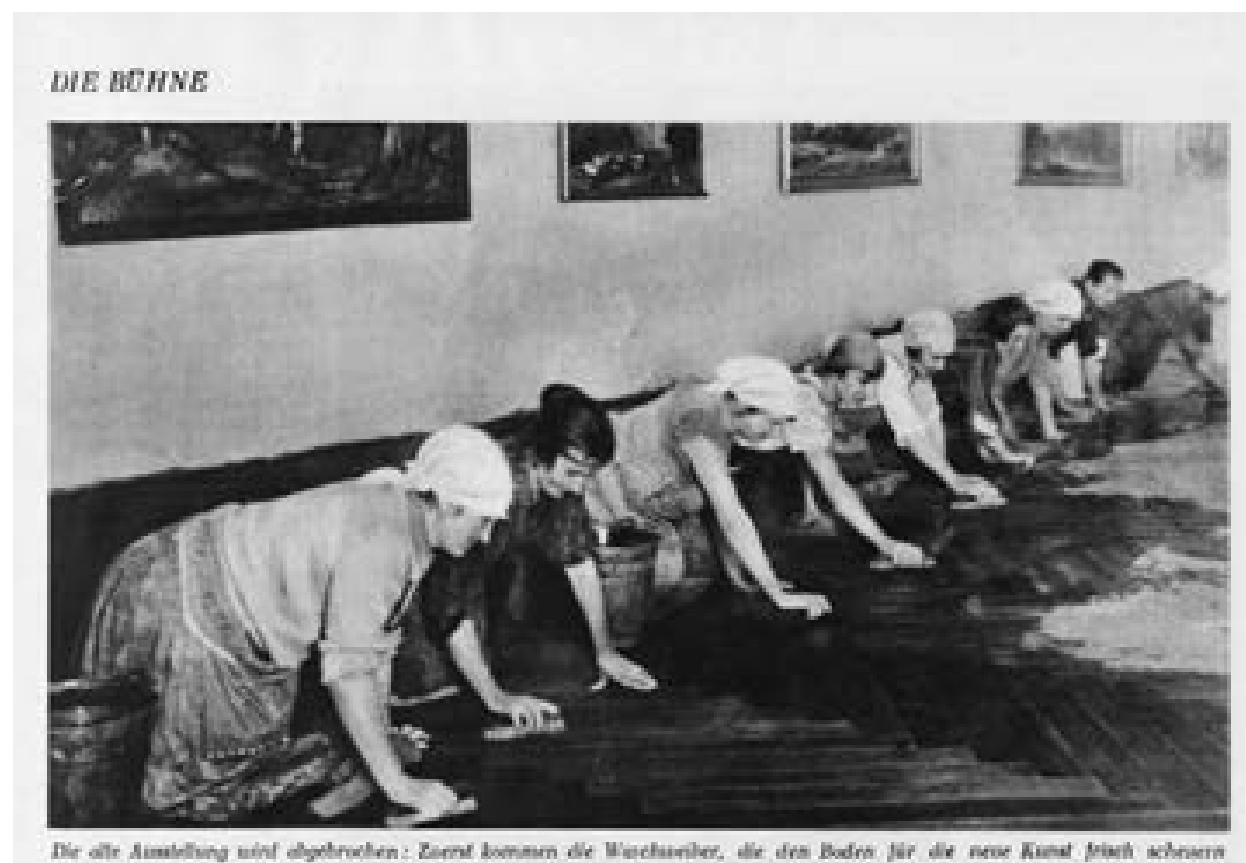

\section{Die Künstlerhaus-Ausstellung wird vorbereitet}

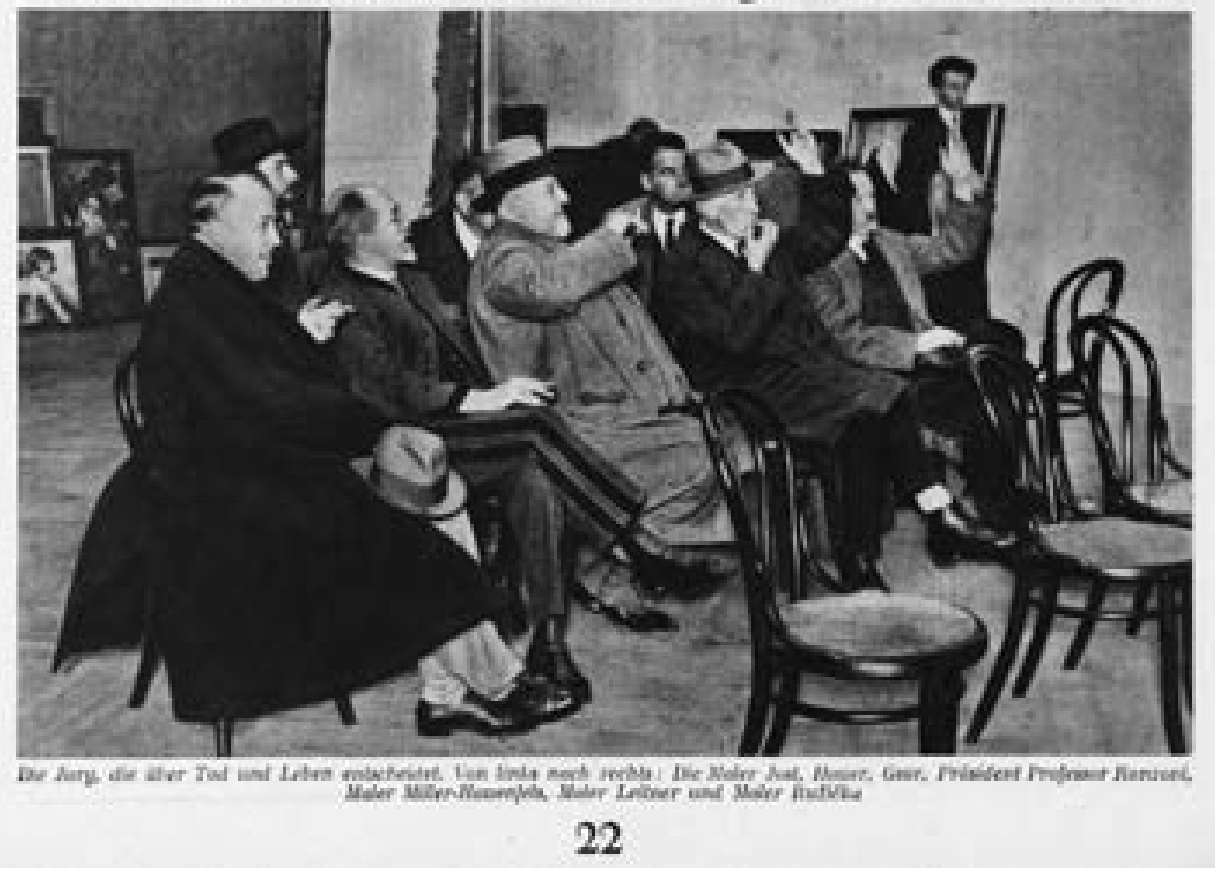




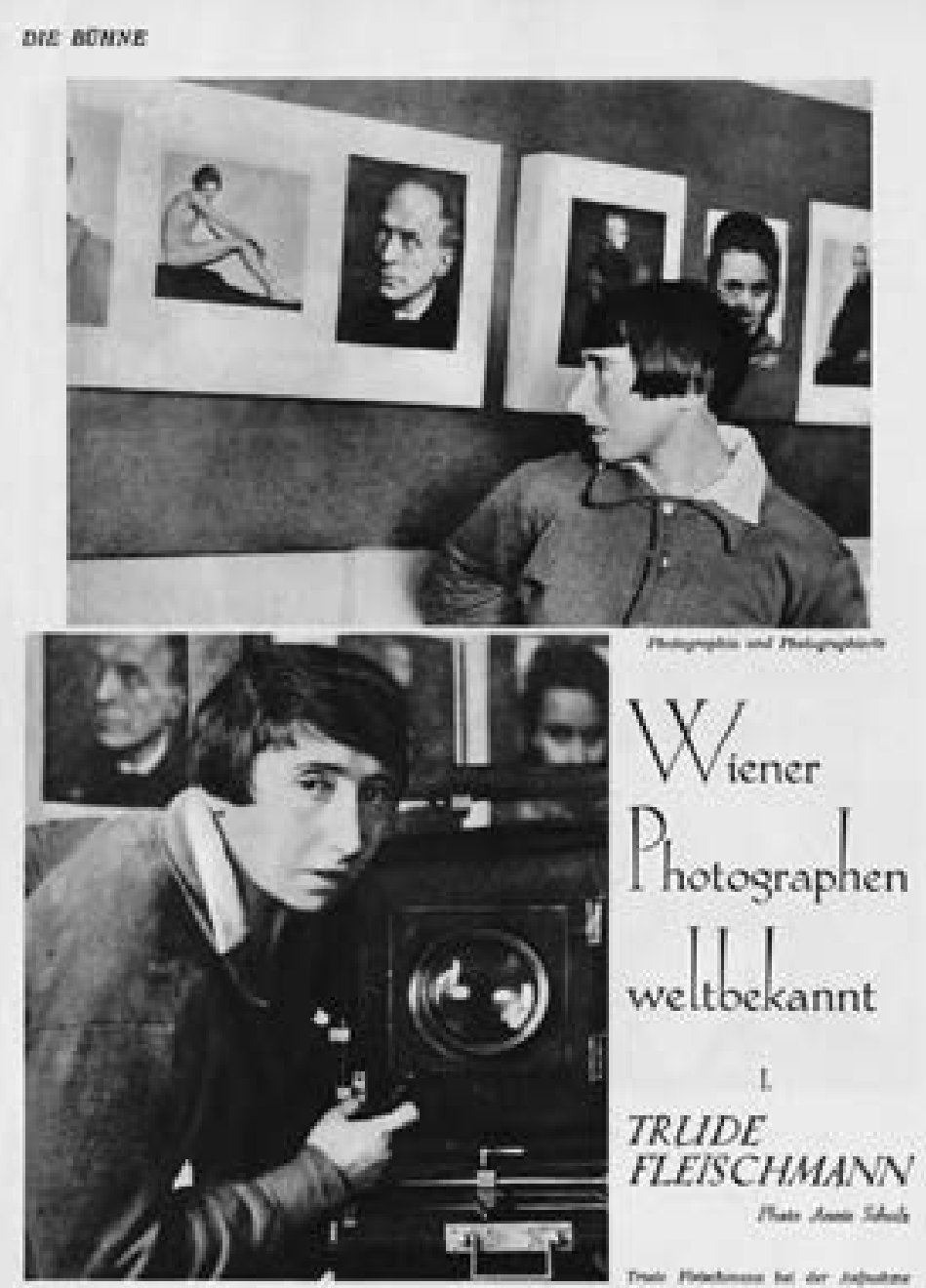

12

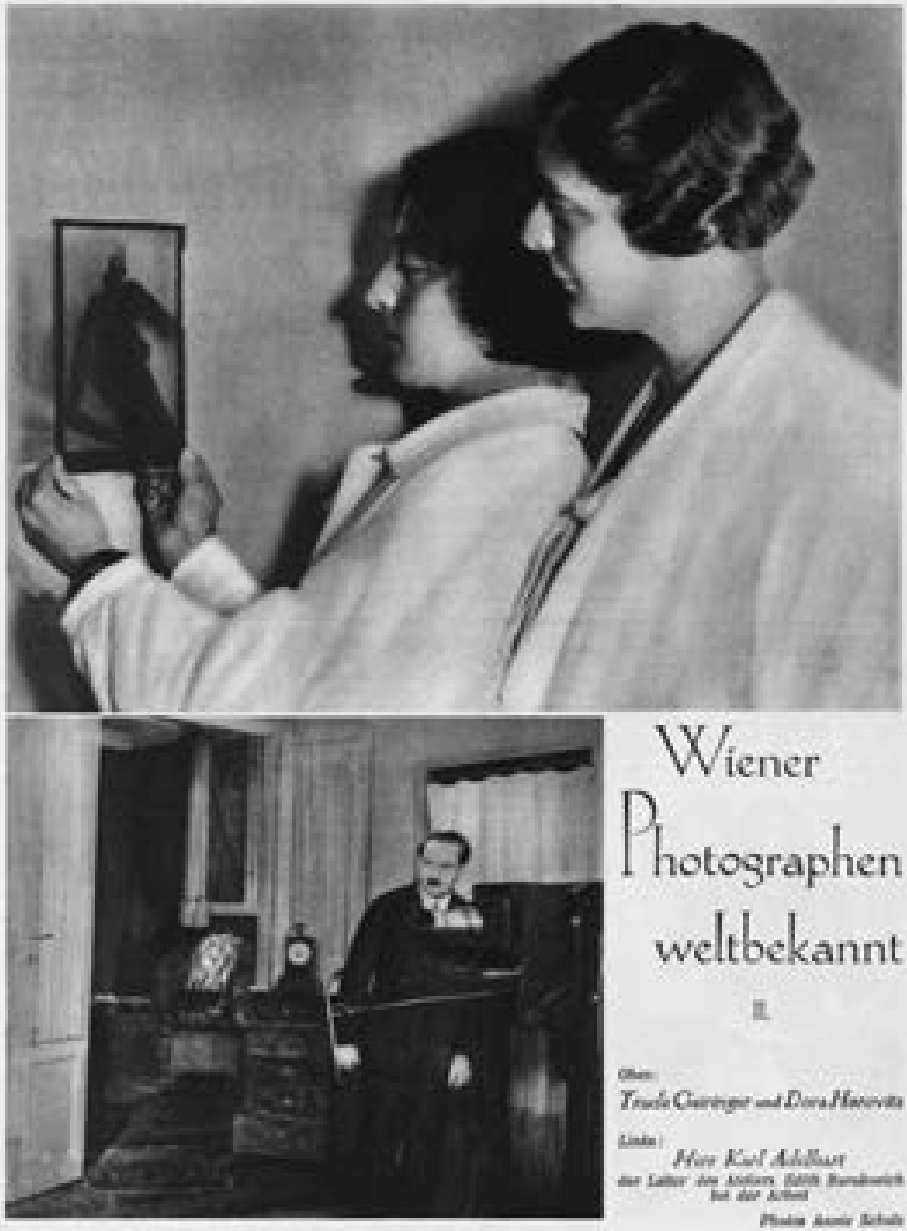

34
Abb. 2 Porträt der Wiener Atelierfotografin Trude Fleischmann. Die Bühne, Nr. 295, Erstes Januarheft 1931, S. 12. Foto: Annie Schulz.

Abb. 3 Porträt der Wiener Atelierfotografinnen Trude Geiringer und Dora Horovitz (oben). Unten: Atelier von Edith Barakovich mit Atelierleiter Karl Adelhart. Die Bühne, Nr. 296, Zweites Januarheft 1931, S. 34 Foto: Annie Schulz.
Gesellschaft und des Alltags. Seit 1929 publiziert sie u. a. regelmäßig in der Zeitschrift Die Bühne, für die sie schöne Fotoreportagen gestaltet, etwa über das Wiener Fundamt, über den Naschmarkt oder über die Kärntner Straße bei Nacht. Sie ist eine aufmerksame Beobachterin der Wiener Fotoszene. Anfang 1931 beginnt sie, ebenfalls für die Bühne, eine Serie mit dem Titel „Wiener Fotografen weltbekannt“. Auf jeweils einer Seite werden renommierte Wiener Lichtbildner vorgestellt, oder, um genau zu sein: Lichtbildnerinnen. Dabei beschäftigt sie sich mit Wiener Fotografinnen, die bekannte Ateliers führen. Schulz beobachtet die Arbeit ihre Kolleginnen wohlwollend. Es ist gewiss kein Zufall, dass ihr Interesse jenen fotografierenden Frauen gilt, die seit einigen Jahren besonders erfolgreich in Wien tätig sind. Sie macht deren Arbeit sichtbar, indem sie einen Blick hinter die Kulissen ihrer Ateliers wirft. Leider wird die Serie nach der zweiten Folge ohne Angabe von Gründen abgebrochen.

Im ersten Porträt wird Trude Fleischmann vorgestellt, die seit 1920 ein gut gehendes Atelier in der
Ebendorferstraße (neben dem Wiener Rathaus) führt (Abb. 2). Sie ist in der Zwischenkriegszeit, neben Dora Kallmus (Atelier d'Ora), die bekannteste Wiener Atelierfotografin. Wir sehen sie einmal hinter der Kamera, einmal vor einer Ausstellung ihrer Porträts in ihrem Atelier. Im zweiten Porträt (Abb. 3) werden im oberen Bild Trude Geiringer und Dora Horovitz vorgestellt, das untere Bild zeigt einen Blick in das Atelier von Edith Barakovich. Geiringer und Horovitz betreiben seit Mitte der 1920er Jahre ein gemeinsames Atelier am Wiener Stubenring. Barakovich führt seit 1918 ein Atelier in der Prinz-Eugen-Straße.

\section{Zeit des Aufbruchs}

Im Mai 1928 bringt die in Deutschland erscheinende kommunistische Arbeiter-Illustrierte Zeitung (AIZ) ein eindrucksvolles Frauenbild auf der Titelseite (Abb.4). ${ }^{4}$ Mit einem gewagten Sprung setzt sich eine junge Frau über eine Hochsprunglatte hinweg. Die Aufnahme ist in jenem Moment entstanden, in dem 


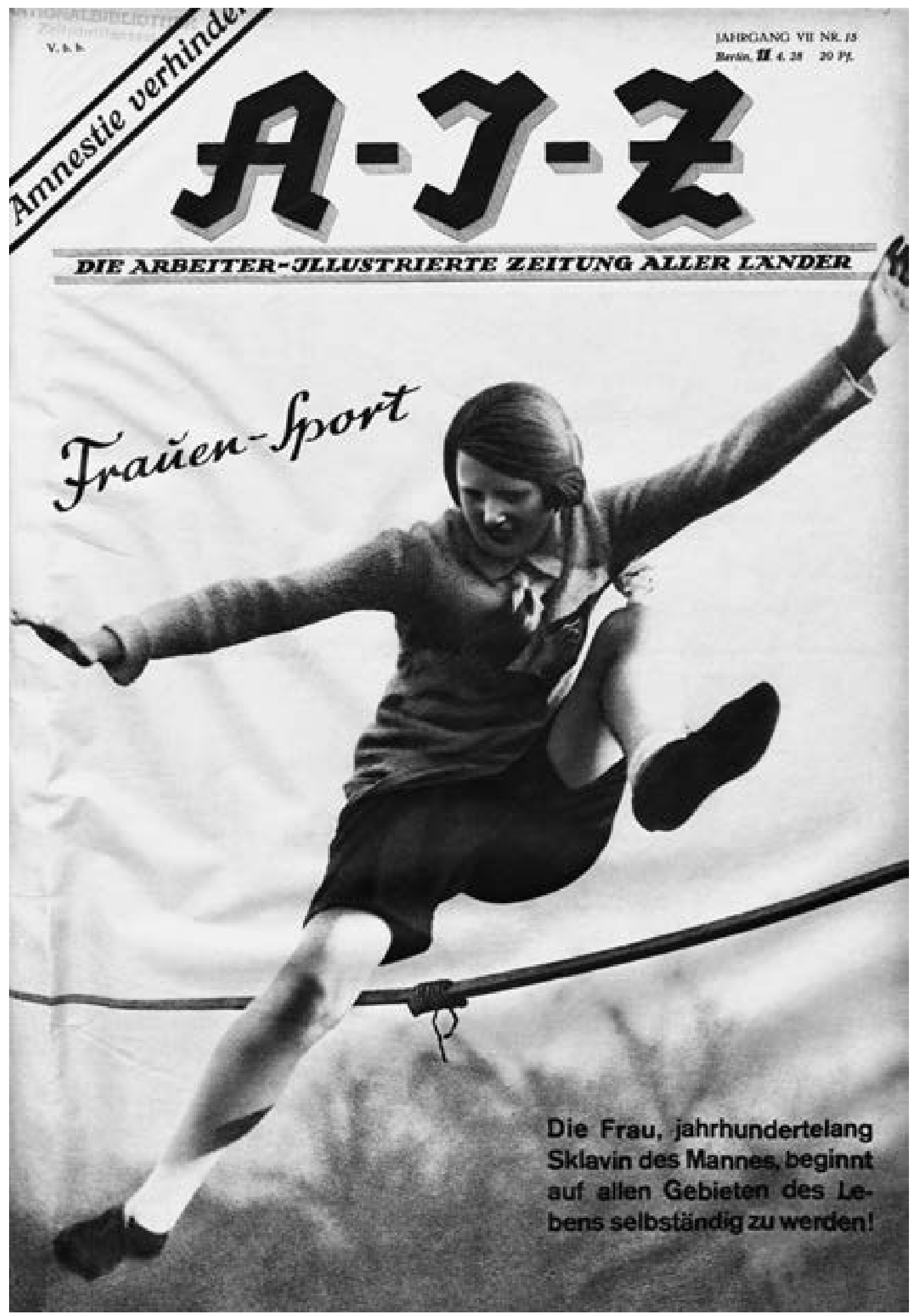

Abb. 4 „Die Frau (...) beginnt auf allen Gebieten des Lebens selbständig zu werden!“ Arbeiter-Illustrierte Zeitung (AIZ), 11. April 1928, Titelseite. 

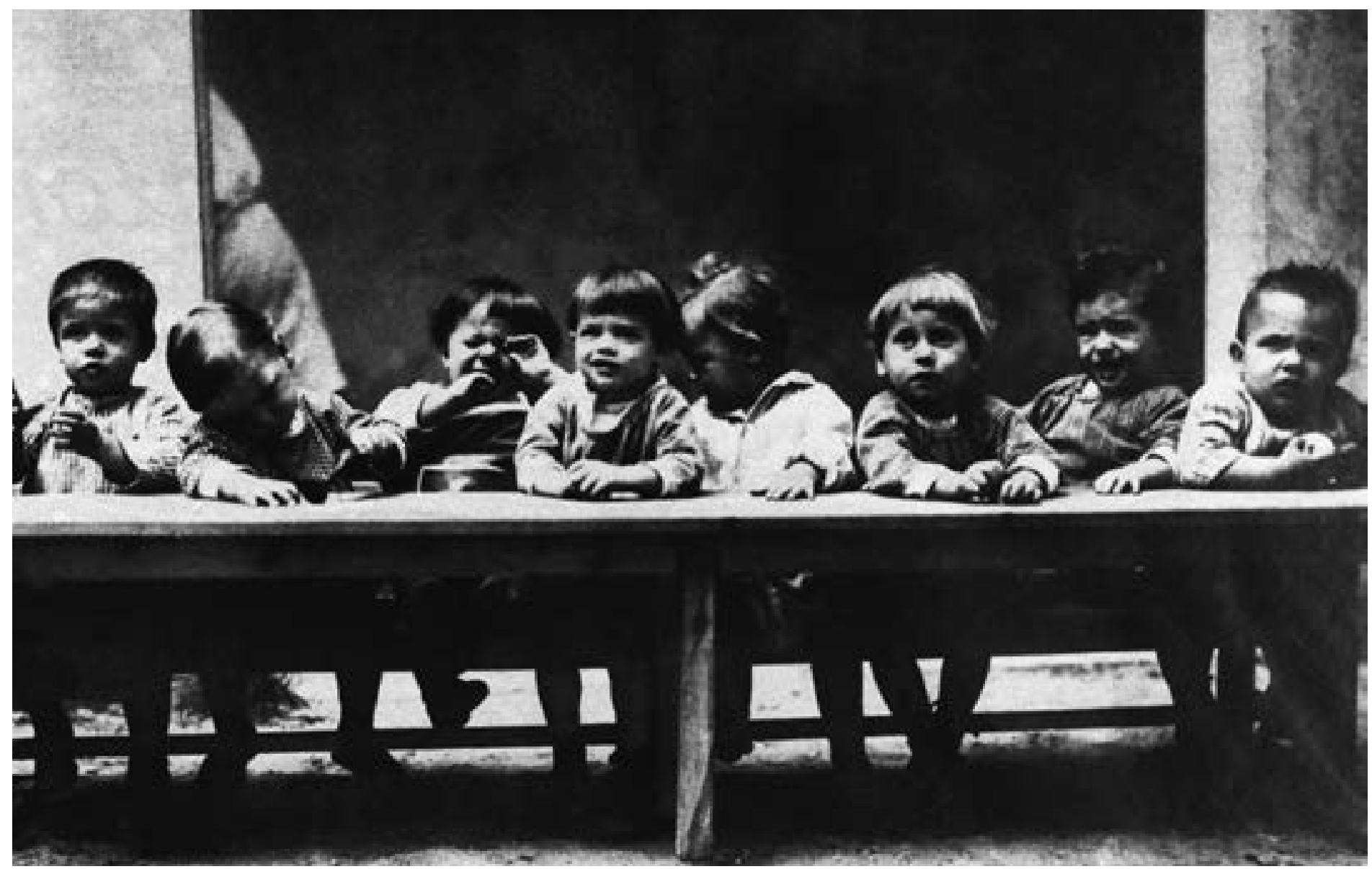

Abb. 5 „Was gibt es heute zu essen?" Szene aus einem Wiener Kinderheim, Ausschnitt aus der Themenseite „Im Frühling des Lebens. Kinderstudien“. Kölnische Illustrierte Zeitung, 1. April 1929, S. 421. Foto: Blumberger-Schulz. die Athletin den höchsten Punkt erreicht hat. Wir sehen sie in der Luft und mitten in der Bewegung: ein Bein hochgerissen, die Arme weit ausgestreckt. Ihre kühne Bewegung füllt den Bildraum zur Gänze aus. Der Kommentar zur Szene lautet: „Die Frau, jahrhundertelang die Sklavin des Mannes, beginnt auf allen Gebieten des Lebens selbständig zu werden."

Noch zehn Jahre zuvor wäre ein solches Frauenbild ein Stein des Anstoßes gewesen. Nun, Mitte der 1920er Jahre, hat sich die Rolle und die öffentliche Wahrnehmung der Frau grundlegend geändert. Zwar ist die junge, klassenbewusste Proletarierin, die sich im Sport wie in der Gesellschaft über althergebrachte Geschlechternormen hinwegsetzt, keineswegs das akzeptierte Ideal der gesamten Gesellschaft. Die Emanzipationsbestrebungen der Frauen äußern sich im bürgerlichen Lager weit zurückhaltender. Und dennoch: Auch in der bürgerlichen Welt hat sich nach dem Ersten Weltkrieg die Rolle der Frauen radikal verändert.

Die Fotografie ist ein guter Gradmesser für diese Entwicklung. Nicht nur die Sujets vor der Kamera spiegeln die neuen gesellschaftlichen Verhältnisse wider. Auch hinter der Kamera kommt es zu tief greifenden Änderungen. In den 1920er Jahren entdecken zahlreiche junge, selbstbewusste Frauen - viele von ihnen sind gutbürgerlicher Herkunft - die Fotografie nicht nur als Zeitvertreib, sondern als Beruf - und als Medium künstlerischen Ausdrucks.

Neben Annie Schulz beginnt in diesen Jahren eine ganze Reihe von Fotografinnen Einzelbilder und Reportagen für die Presse zu liefern. Zu den interessantesten österreichischen Fotografinnen der neuen Generation zählt Marianne Bergler, geb. Blumberger. Sie ist wie Annie Schulz 1897 geboren und beginnt 1927 mit der kommerziellen Fotografie. Sie unterhält ein Atelier in der Rotenturmstraße in Wien, wo sie im Bereich der Porträt-, Mode- und Theaterfotografie tätig ist. Daneben arbeitet sie auch für die Presse. Einige Jahre lang, von 1927 bis 1930, arbeiten Schulz und Blumberger geschäftlich zusammen. Sie vermarkten ihre Bilder, v. a. Mode- und Theateraufnahmen, aber auch Alltagsbilder und Sozialstudien, unter dem Namen Blumberger-Schulz. Seit 1929 publizieren die beiden auch Fotoreportagen. In der Bühne etwa erscheinen mehrere Bildgeschichten von Blumberger und Schulz zu Alltagsthemen: über den Aberglauben, Frauenhände, Puppen und Marionetten oder über ein Wiener Kinderheim. Eine Aufnahme aus der Kinderheim-Serie wird 1929 auch in der Kölnischen Illustrierten Zeitung veröffentlicht (Abb.5). 
Die Präsenz von Frauen in der Fotografie nimmt in der Zwischenkriegszeit schlagartig zu. Die neuen Fotografinnen arbeiten in allen Bereichen der Lichtbildkunst wie Mode, Porträt, Tanz, Theater, Werbung - und ansatzweise eben auch in der ausgesprochenen Männerbastion, der Pressefotografie. ${ }^{6}$ Zwar gibt es bereits vor 1914 zahlreiche Frauen, die in Fotoateliers hinter der Kamera stehen, aber als Inhaberinnen treten sie im Firmennamen selten auf. Als die junge Dora Philippine Kallmus 1907 in der Wiener Schulerstraße ein vornehmes Fotoatelier eröffnet, benennt sie es in Anlehnung an ihren Vornamen „Atelier d'Ora“ und nicht etwa nach ihrem Nachnamen. Wenige Jahre später, 1911 und 1913, eröffnen Helene von Zimmerauer und Ilse Roß ihre Ateliers bereits unter ihrem wirklichen Namen.

Erst die Erschütterungen des Krieges stellen das althergebrachte Bild der Geschlechter derart infrage, dass dem Beispiel dieser Frauen zahlreiche andere folgen. Die jungen Fotografinnen geben sich ab Ende 1910er Jahre nicht mehr mit Hilfsdiensten und Zuarbeit in fremden Betrieben zufrieden. Viele von ihnen eröffnen - nun oft stolz unter ihrem Namen - eigene Ateliers oder tun sich zu Ateliergemeinschaften zusammen. Zu nennen sind etwa Trude Fleischmann, Edith Barakovich, Edith Glogau, Grete Kolliner (Abb.6), Lotte Meitner, Hedda Medina, Margarethe Weissenstein, Josefine Bárány, Helene Kiss, Pepa Feldscharek, Martha Fein, Hella Katz, Irene Messner, Beatrice Freyberger, Olga Wlassics, Kitty Hoffmann, Trude Geiringer und Dora Horovitz (Abb. 7). Wieder andere Fotografinnen, etwa Steffi Brandl (Abb.8) und Margarethe Gross (verh. Michaelis), gehen nach ihrer Ausbildung in Österreich nach Berlin, wo sie ihre Fotokarriere fortsetzen oder beruflich anderweitig Fuß fassen.

Einige wenige Fotografinnen arbeiten ohne Atelier und vorwiegend für die Presse. Zu ihnen gehört Lena Schur, Edith Suschitzky, Anita Dorfner und Steffi Schaffelhofer, die Anfang bzw. Mitte der 1930er Jahre beginnen. Gemeinsam ist ihnen, dass sie sich, ganz im Trend der Zeit, immer häufiger weg von den Einzelbildern und hin zu komplexer gebauten Bildgeschichten, sogenannten Fotoreportagen, bewegen. ${ }^{7}$ Da die Berichterstattung über die Welt der Politik und der Tagesaktualitäten in der Zwischenkriegszeit noch fest in der Hand der männlichen Kollegen ist, spezialisieren sich die Frauen häufig auf die Mode- und Gesellschaftsfotografie oder liefern Sozial-, Alltags- und Reisereportagen an die Redaktionen.

So unterschiedlich die Lebens- und Berufsgeschichten all dieser Fotografinnen auch sind, einiges haben sie gemeinsam: Fast alle von ihnen sind
Abb.6 Die lettische Tänzerin Mila Cirul im Tanzstück „Tschinellentanz". Wiener Mode, Heft 18, 1925, S. 7. Foto: Grete Kolliner.

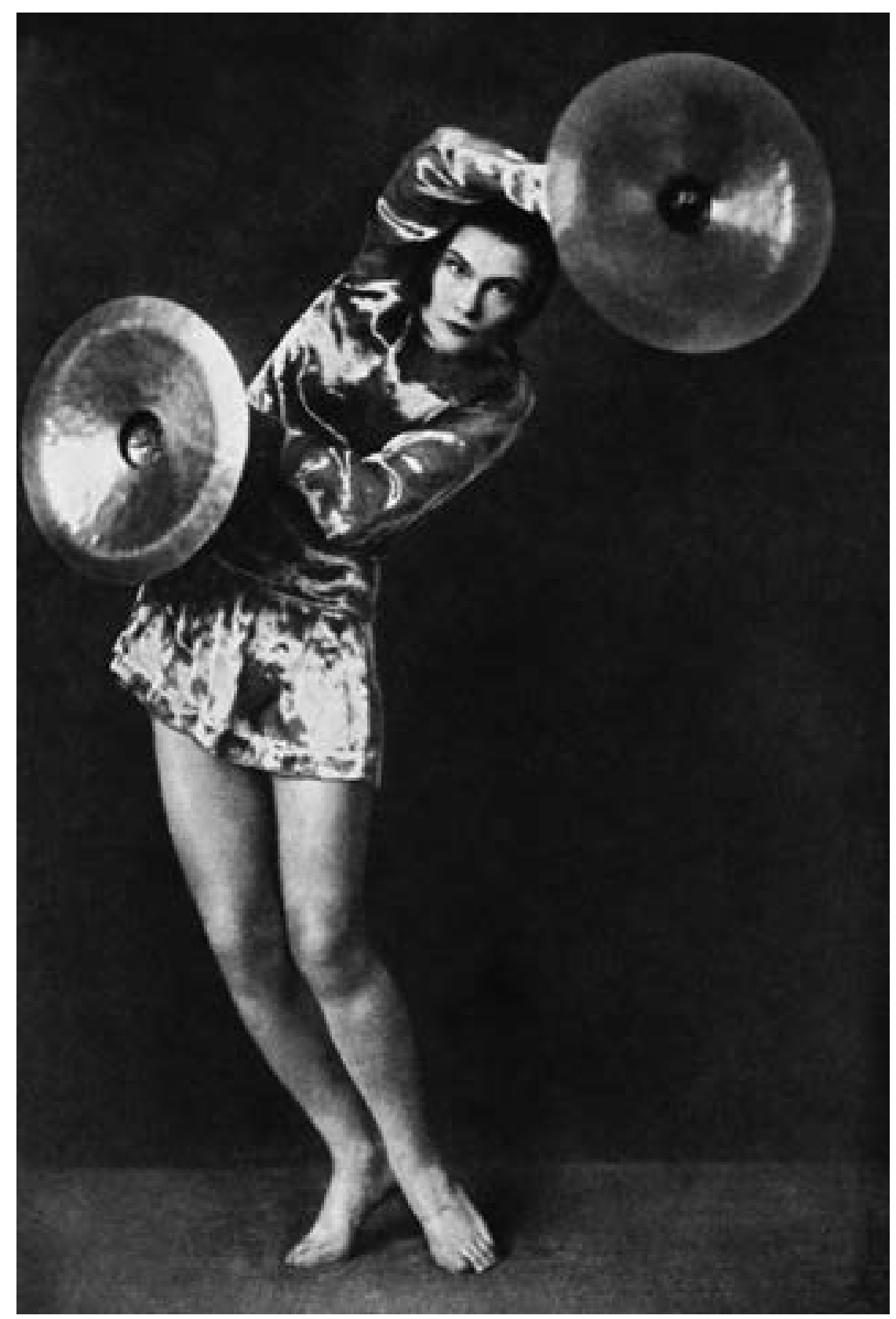




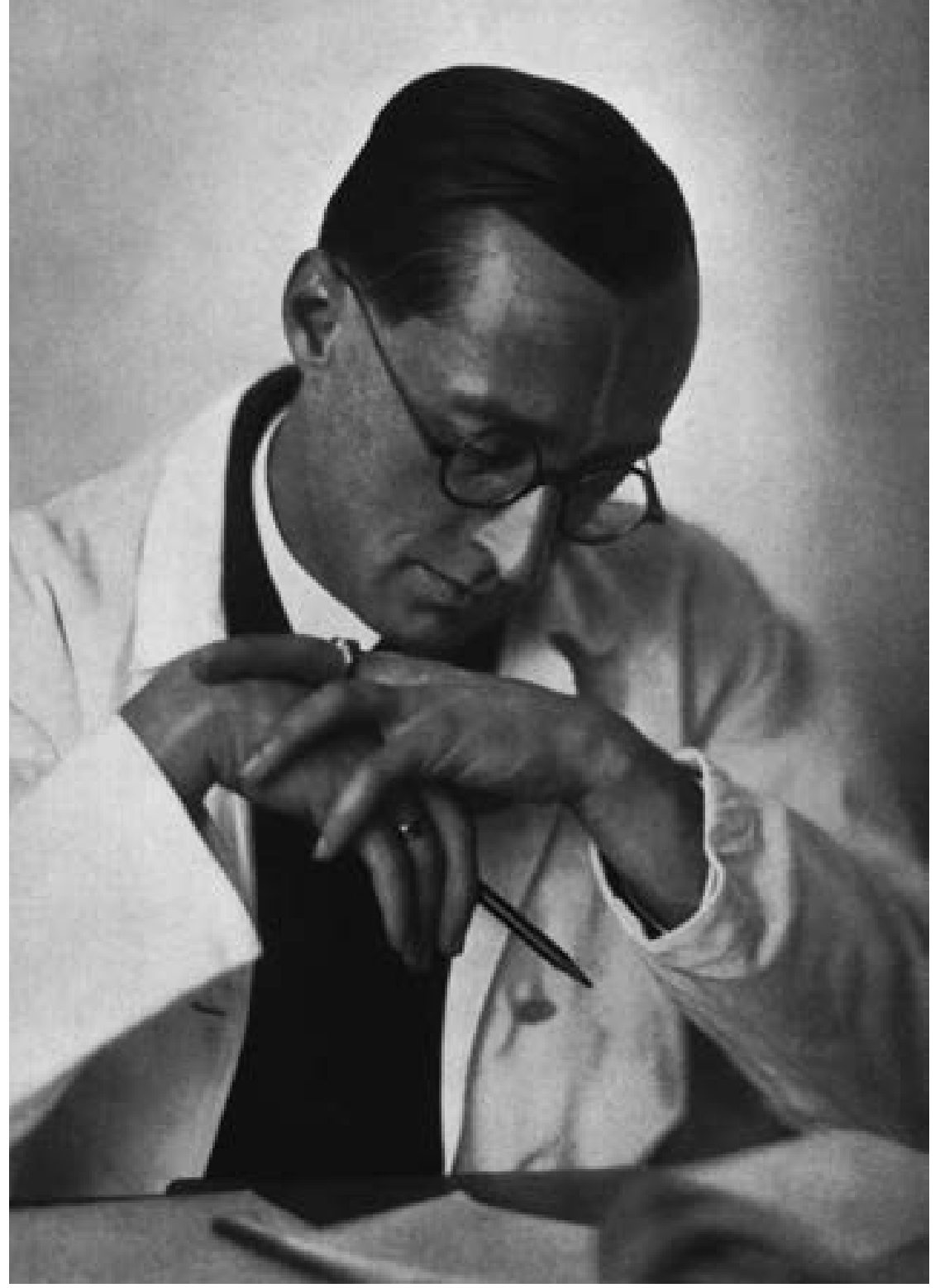

Abb. 7 Der Künstler Carry Hauser. Das deutsche Lichtbild, Berlin 1930, S. 94. Foto: Geiringer-Horovitz. fühlen sich nicht nur als Handwerkerinnen, sondern auch als Künstlerinnen.

Die Arbeit im Atelier steht für einen Großteil der Fotografinnen im Vordergrund. Aber die meisten von ihnen bieten ihre Bilder auch der illustrierten Presse an. Im Zeitungsgeschäft besonders gut vertreten sind Madame d'Ora, Trude Fleischmann und Edith Barakovich, deren Bilder regelmäßig auch in der deutschen Bildpresse erscheinen.

\section{Welt ohne Männer}

„Alle Männer sind von der Welt verschwunden bis auf einen. In der Regierung, in den Städten, auf dem Land, in den Fabriken und Geschäften - nichts als Frauen."8 Das Szenario, das der Redakteur der Wochenzeitung Wiener Bilder im Jahr 1925 entwirft, stammt aus dem Film mit dem Titel „Die Welt ohne Männer“. Der amerikanische Streifen der Firma Fox wird im Juni 1925 in den Wiener Kinos gezeigt. „Der einzig überlebende Mann wird entdeckt, versteigert und von Millionen Frauen als das kostbare Gut gehütet.“9 Man könnte diesen seichten Filmplot, der weit in der Zukunft, im Jahr 2000 angesiedelt ist, als belanglose Männerfantasie der 1920er Jahre abtun. Aber ganz so einfach liegen die Dinge nicht: Die Haremsseligkeit schlägt schnell in ein Angstszenario um, der letzte Mann der Erde, so die Befürchtung, unterliegt der gewaltigen Frauenübermacht.

Das Filmpublikum der 1920er Jahre kann die Verweise der Filmstory auf die Realität durchaus entziffern. Die Erschütterungen des Ersten Weltkriegs haben die Ordnung der Geschlechter tief greifend durcheinander gebracht. In allen Lebens- und Arbeitsbereichen haben Frauen die abwesenden Männer ersetzt. Sie arbeiten nun als Straßenbahnschaffnerinnen und als Rüstungsarbeiterinnen, als Buchhalterinnen wie als Beamtinnen - und eben auch als selbstständige Fotografinnen. Die Kriegswirtschaft der Jahre 1914 bis 1918 hat diese Entwicklung propagandistisch unterstützt. Im Oktober 1919 nimmt Joseph Roth darauf Bezug, wenn er schreibt: „Die Frau, die einen ,Beruf ergreift', wird eigentlich vom Beruf ergriffen. Die Wirtschaftsordnung zwingt sie zur Tätigkeit.“10 Zufall ist es gewiss keiner, wenn sei- 


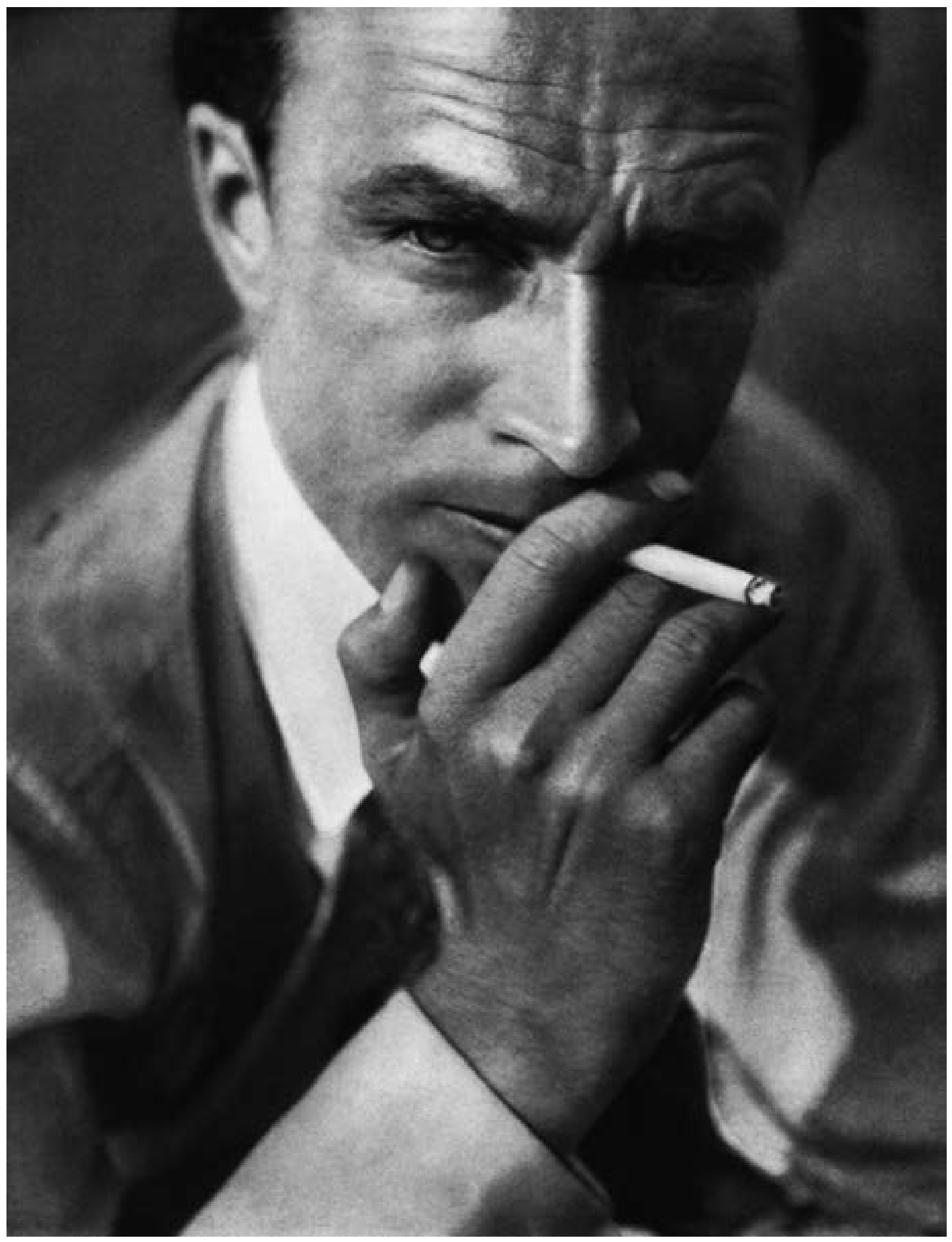

Abb. 8 Der Schau-

spieler Conrad Veidt.

Das deutsche Lichtbild,

Berlin 1930, S. 92.

Foto: Steffi Brandl. 
Abb. 9 Die Wiener Schauspielerin Eva Geyer. Münchner Illustrierte Presse, 10. Februar 1929, Titelseite. Foto: Edith Barakovich.

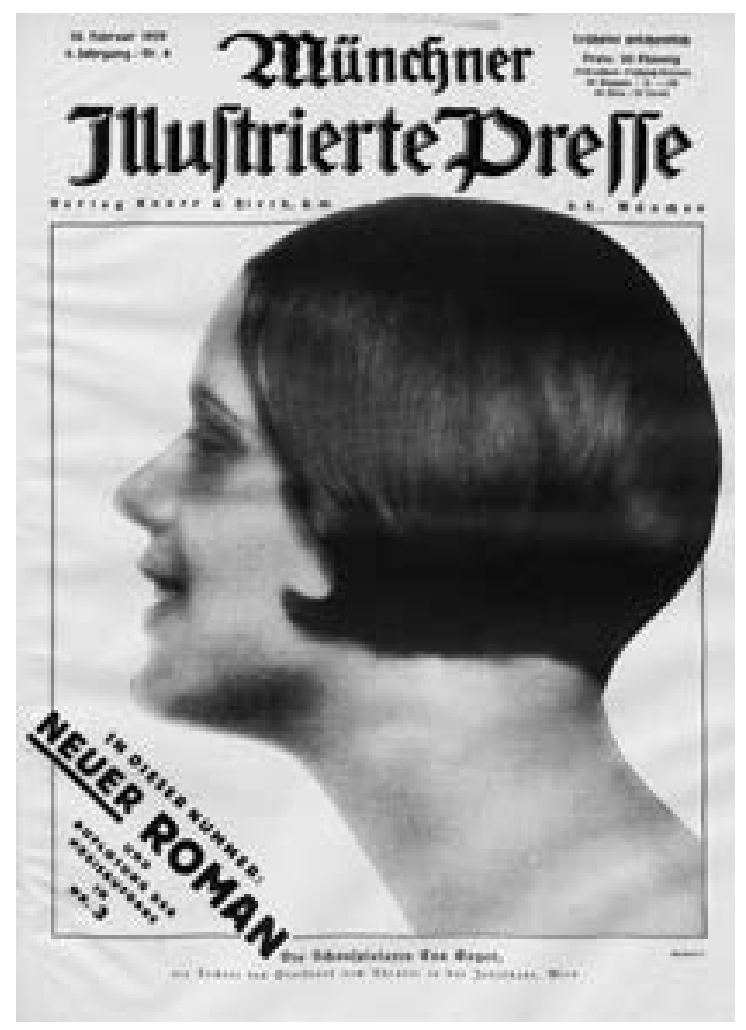

nem Feuilleton, das den Titel „Die neue Frau“ trägt, das Bild einer solchen „neuen Frau“ beigefügt ist. Das Porträt der selbstbewussten Dame stammt von der jungen Fotografin Edith Barakovich. Deren Karriere entspricht ganz dem Bild dieser „neuen Frau“. Geboren 1896 in Zemun, in der Nähe von Belgrad, ist sie als Jugendliche nach Wien gekommen. Hier besucht sie die Graphische Lehr- und Versuchsanstalt. Kaum 20-jährig, eröffnet sie im August 1918, also noch während der letzten Kriegsmonate, in der Prinz-Eugen-Straße 30 ein eigenes Fotoatelier - unter ihrem Namen. Barakovich hat Erfolg: In der Zwischenkriegszeit gehört sie zu den bekanntesten Fotografinnen Wiens. Sie spezialisiert sich auf Porträts des gehobenen Bürgertums, sie fotografiert Schauspieler und Filmstars und macht Mode- und Tanzaufnahmen. Früh versteht sie es, ihre Bilder in der illustrierten Presse unterzubringen (Abb. 9).

Mit ihrer Entscheidung, sich selbstständig zu machen, stößt Barakovich, ebenso wie andere junge Fotografinnen dieser Zeit, nicht nur auf Zustimmung, sondern auch auf Widerstand. Die älteren und konservativeren ihrer männlichen Fotografenkollegen sehen in der selbstbewussten Berufstätigkeit dieser Frauen gleich die gesamte Fotografie bedroht. 1921 unterstellt der einflussreiche Wiener Fotograf und Fotopublizist Hermann Clemens Kosel den jungen Fotografinnen, dass sie „mit oberflächlichen, sinnlichen und posierten modelüsternen Auffassungen das Dirnentum ins Lichtbild“ gebracht hätten. Er wirft ihnen vor, „den sittlichen Ernst der Kunst ins Abgeschmackte“ herabgezogen zu haben. Sein Fazit: „Nur wenige Frauen haben den Ernst zu ihrem Berufe behalten."11

\section{Fotografinnen im Blickpunkt}

Ende Juli 1931 bietet sich den jungen Fotografinnen eine gute Gelegenheit, ihre Fotoarbeiten gemeinsam auszustellen. In Wien wird zu dieser Zeit ein großer Kongress der „Internationalen Vereinigung der berufstätigen Frauen“ abgehalten. Begleitend dazu findet in der Secession unter dem Titel „Die schaffende Österreicherin“ eine Frauenausstellung statt. ${ }^{12}$ Für Architektur und Grafik sind die Architektin und Designerin Liane Zimbler und deren Assistentin, die Designerin Agnes (Kitty) Speyer, verantwortlich. ${ }^{13}$ Die Präsentation versteht sich als Werkschau, die künstlerisches und nicht künstlerisches Schaffen österreichischer Frauen gleichberechtigt nebeneinander zeigt und damit Frauenarbeit in der Gesellschaft sichtbar macht. Der Schau ist eine Foto- und Bücherausstellung angegliedert, die von der Kunsthistorikerin und Journalistin Else Hofmann in enger Kooperation mit der Wiener Fotografin Grete Kolliner zusammengestellt wird. „Etwas Neues in seiner Art“, schreibt Hofmann zum Konzept der Ausstellung, „ist die Photo- und Buchschau, die den großen Mittelsaal der Secession einnimmt; hier versuchen wir Werke und Bilder von Frauen, die sich nicht wie die bildenden Künstlerinnen leicht durch Objekte dem Beschauer offenbaren können, unseren Gästen in klarer Übersicht zu zeigen. "14 Und weiter führt sie aus: „Um etwas mehr zu geben als nur das Äußere, so aufschlußreich es sein mag, haben wir auch die Werke der österreichischen Frauen, literarische und wissenschaftliche, politische und praktische Bücher und Zeitschriften zusammengestellt. (...) Wir sind nicht ohne Zuversicht, denn die Ausstellung wird Eindrücke bieten, das Selbstbewußtsein der Frauen steigern, Respekt der Frau vor Frauen erhöhen. Auch dem Manne wird sie vielleicht manches sagen, vor allem, daß es den Frauen ernst ist und daß viele ehrlich und stark sind in der Leitung. “ 15 


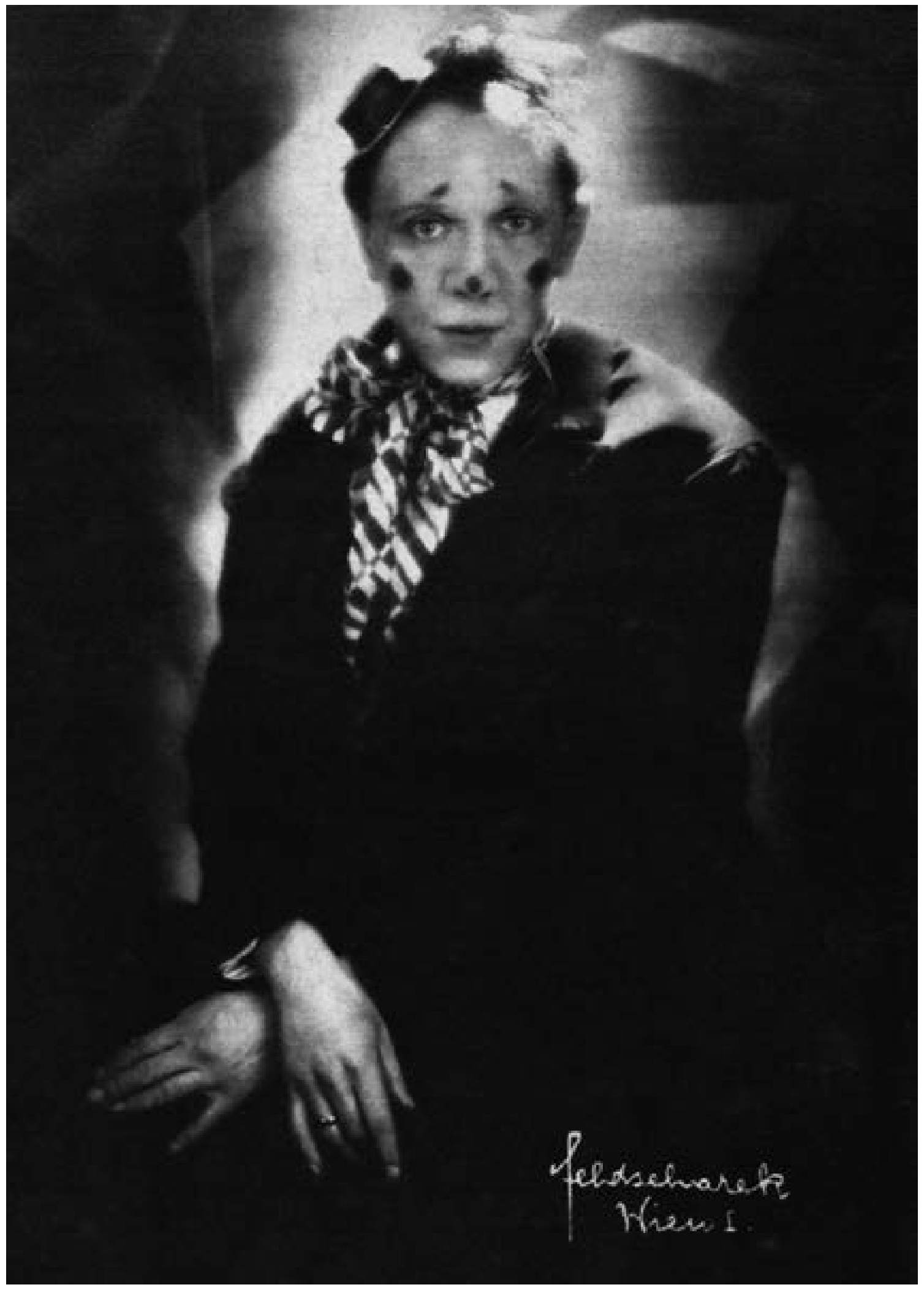

Abb. 10 Der russische Schauspieler Michael Tschechow als Clown in Max Reinhardts Inszenierung des Stücks „Artisten“. Uraufführung am 28. November 1928 im Theater in der Josefstadt. Wiener Magazin, Heft 2, Februar 1929, S. 50. Foto: Pepa Feldscharek. 


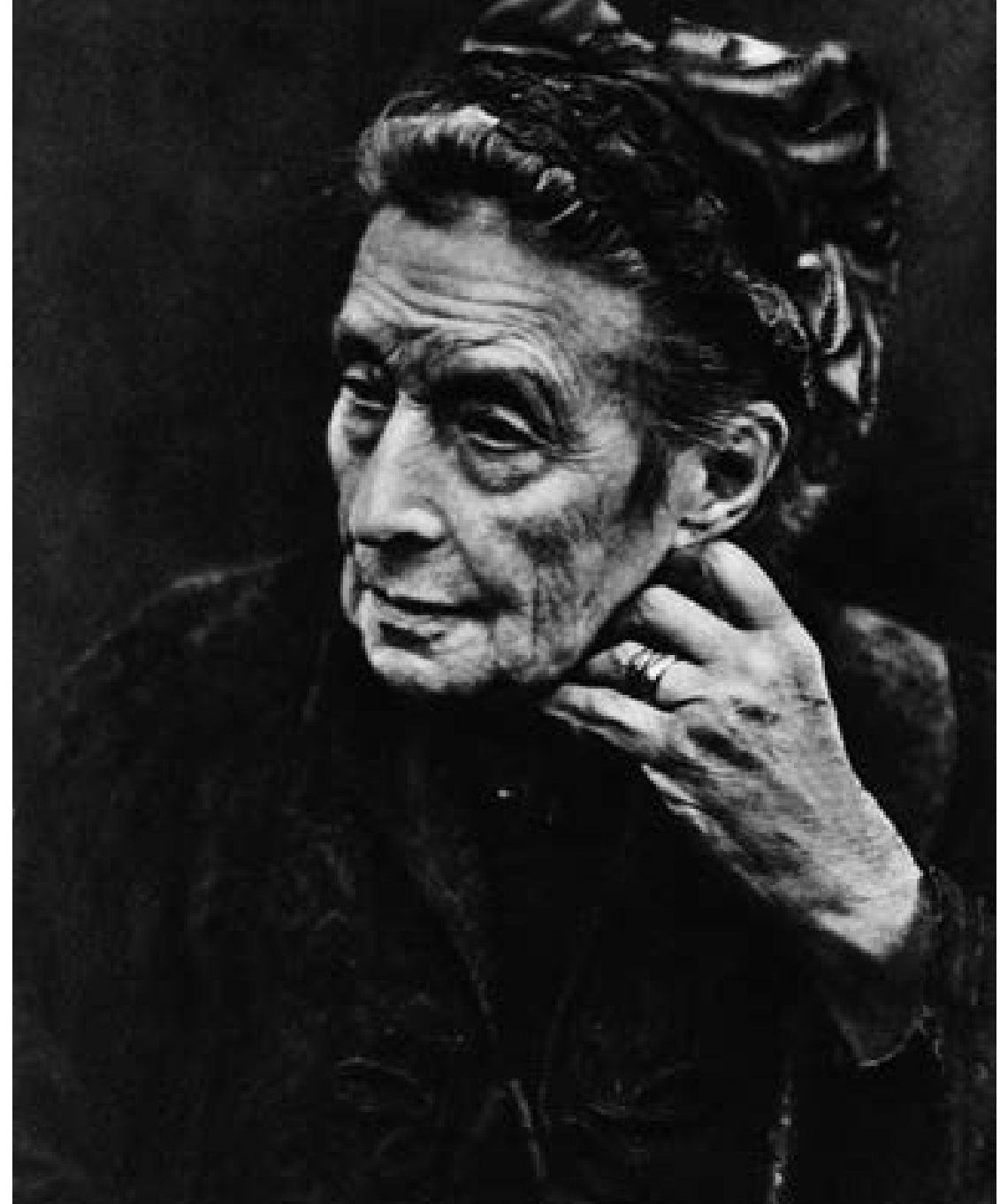

Abb. 11 Die Pädagogin und Frauenrechtlerin Marianne Hainisch. Die Bühne, Zweites Augustheft 1931, S. 44. Foto: Trude Fleischmann.
Bemerkenswert ist diese Fotoausstellung, weil in ihr ausschließlich die Arbeiten von Fotografinnen gezeigt werden. Auch die Porträtierten sind ohne Ausnahme Frauen. Die Präsentation zeigt das Bemühen der „neuen Fotografinnen“, sich selbstbewusst in der Welt der Männer zu behaupten. Zu sehen sind Fotoporträts österreichischer Pionierinnen aus allen Berufsfeldern und Beispiele ihrer wissenschaftlichen Publikationen. Neben den Vorkämpferinnen für Frauenrechte Marianne Hainisch und Rosa Mayreder sind erfolgreiche Frauen aus den unterschiedlichsten Bereichen vertreten: von Geisteswissenschaftlerinnen, Künstlerinnen, Ärztinnen, Naturwissenschaftlerinnen, Schriftstellerinnen, Journalistinnen, Juristinnen und Politikerinnen bis hin zu Schauspielerinnen, Tänzerinnen, Musikerinnen, Kritikerinnen und Sportlerinnen. ${ }^{16}$

Die Fotokuratorin der Ausstellung, Grete Kolliner, gehört - neben Pepa Feldscharek (Abb. 10), Trude Geiringer, Dora Horovitz, Lotte Meitner, Edith Glogau und Trude Fleischmann, die alle mit Fotoarbeiten in der Schau vertreten sind - zu den bekanntesten österreichischen Atelierfotografinnen der Zwischenkriegszeit. Als sie 1917 in Wien ein Atelier eröffnet, ist Kolliner 24 Jahre alt. In den 1920er Jahren gründet sie ein weiteres Studio in Rom. Sie spezialisiert sich neben dem Porträt auf Theater-, Tanz- und Aktfotografie. Kolliner ist eine weltoffene, engagierte Frau und hat Kontakt zur Pädagogin und Frauenrechtlerin Eugenie Schwarzwald ${ }^{17}$ sowie zur österreichischen Werkbundbewegung. Zusammen mit anderen Lichtbildnern ist sie als Repräsentantin der modernen Fotografie auf der wichtigen Ausstellung des Werkbundes „Film und Foto“, vertreten, die 1930 in Wien gezeigt wird. ${ }^{18}$

Im Zentrum der Schau „Die schaffende Österreicherin“ ist eine Fotoarbeit von Trude Fleischmann zu sehen: eine eindrucksvolle Studie der Wiener Pädagogin und Frauenrechtlerin Marianne Hainisch. Das Porträt, das auch in der illustrierten Presse veröffentlicht wird (Abb. 11), zeigt die fotografische Handschrift Trude Fleischmanns deutlich. Man könnte ihren fotografischen Stil als gemäßigt modern bezeichnen. Die Fotografin setzt sich, ebenso wie viele ihrer Kolleginnen, ab Anfang der 1920er Jahre von der idealisierenden, weichzeichnenden Tradition der Kunstfotografie, dem Piktorialismus, ab, die in der Zwischenkriegszeit bei einigen künstlerisch ambitionierten Porträtfotografen Wiens teilweise noch verbreitet ist. Sie rückt mit ihrer Kamera nahe an das Modell heran. Immer wieder wählt sie enge Ausschnitte (oft beschneidet sie die Bilder auch), um Charakter und Körperhaltung einer Persönlichkeit noch stärker zu betonen. Als Hintergrund wählt sie neutrale schwarze oder weiße Flächen; ihr geht es darum, das Wesentliche, die Züge des Gesichts, die visuelle Präsenz der Porträtierten, herauszuarbeiten. Ihre Bilder sind aufmerksame Körperstudien und zugleich psychologische Momentaufnahmen.

Die Organisatorinnen der Ausstellung zeichnen Anfang der 1930er Jahre noch ein optimistisches Zukunftsszenario. Aber schon wenige Jahre später, im austrofaschistischen „Ständestaat“, ist die politische Situation eine ganz andere. Die Diktatur macht demokratisches politisches Engagement unmöglich. Ein konservativer Schub erfasst die österreichische Gesellschaft. Die urbane, moderne Ästhetik, die um 1930 eine kurze Blüte erlebt hat, wird immer stärker durch patriotische, oft heimattümelnde Sujets ersetzt. 
Auch das kommerzielle Umfeld ändert sich. Im Bereich der Mode, in dem zahlreiche Fotografinnen tätig sind, kommen in den 1930er Jahren immer mehr Aufnahmen von internationalen Fotoagenturen zum Einsatz. Auch Schauspielerinnenporträts werden nun häufig von den großen Filmfirmen geliefert, die das mediale Image ihrer Stars sorgsam steuern und zu verhindern wissen, dass sich lokale Fotografen an der Vermarktung der Bilder beteiligen. Es wird also für die Fotografinnen zunehmend schwieriger, Bilder an die Presse zu verkaufen.

Während das Ateliergeschäft nach den politischen Umbrüchen 1933/34 ohne allzu große Erschütterungen weiterbetrieben wird, ist die Präsenz zahlreicher Fotografinnen in den illustrierten Zeitungen in den 1930er Jahren deutlich rückläufig. Aber es gibt auch Ausnahmen. Dora Kallmus (Atelier d'Ora) und Trude Fleischmann beispielsweise verstehen es geschickt, die Absatzmöglichkeiten in der Presse relativ stabil zu halten. Madame d'Ora ist in den 1920er Jahren die österreichische Fotografin, von der bei Weitem am meisten Bilder in der Presse erscheinen (Abb. 12). In den 1930er Jahren ist Trude Fleischmann mindestens ebenso stark in den Zeitungen vertreten.

Auf dem Höhepunkt ihrer Bekanntheit entschließt sich die Fleischmann Ende der 1920er Jahre, die Vermarktung ihrer Bilder in professionelle Hände zu geben, und überträgt den Vertrieb der bekannten Wiener Fotoagentur „Wiener Photo-Kurier“ sowie deren Nachfolgefirma „Schostal“, die in den 1930er Jahren zahlreiche international bekannte und etablierte Fotografinnen und Fotografen unter Vertrag hat. Zwar bricht ihr, wie allen jüdischen Fotografen, 1933 der deutsche Markt weg. Aber im Laufe der 1930er Jahre schafft sie Ersatz in Österreich. Sie ergänzt ihr traditionelles Repertoire - Porträt, Tanz und Akt - und liefert nun - teilweise recht gefällige und konservative - Landschafts-, Reise- und Alltagsbilder zu unterschiedlichsten Themen. ${ }^{19}$

\section{Verfolgung, Vertreibung}

Am 20. Februar 1938 bringt Der Sonntag, die wöchentlich erscheinende illustrierte Wochenendbeilage der Tageszeitung Der Wiener Tag, ein völlig

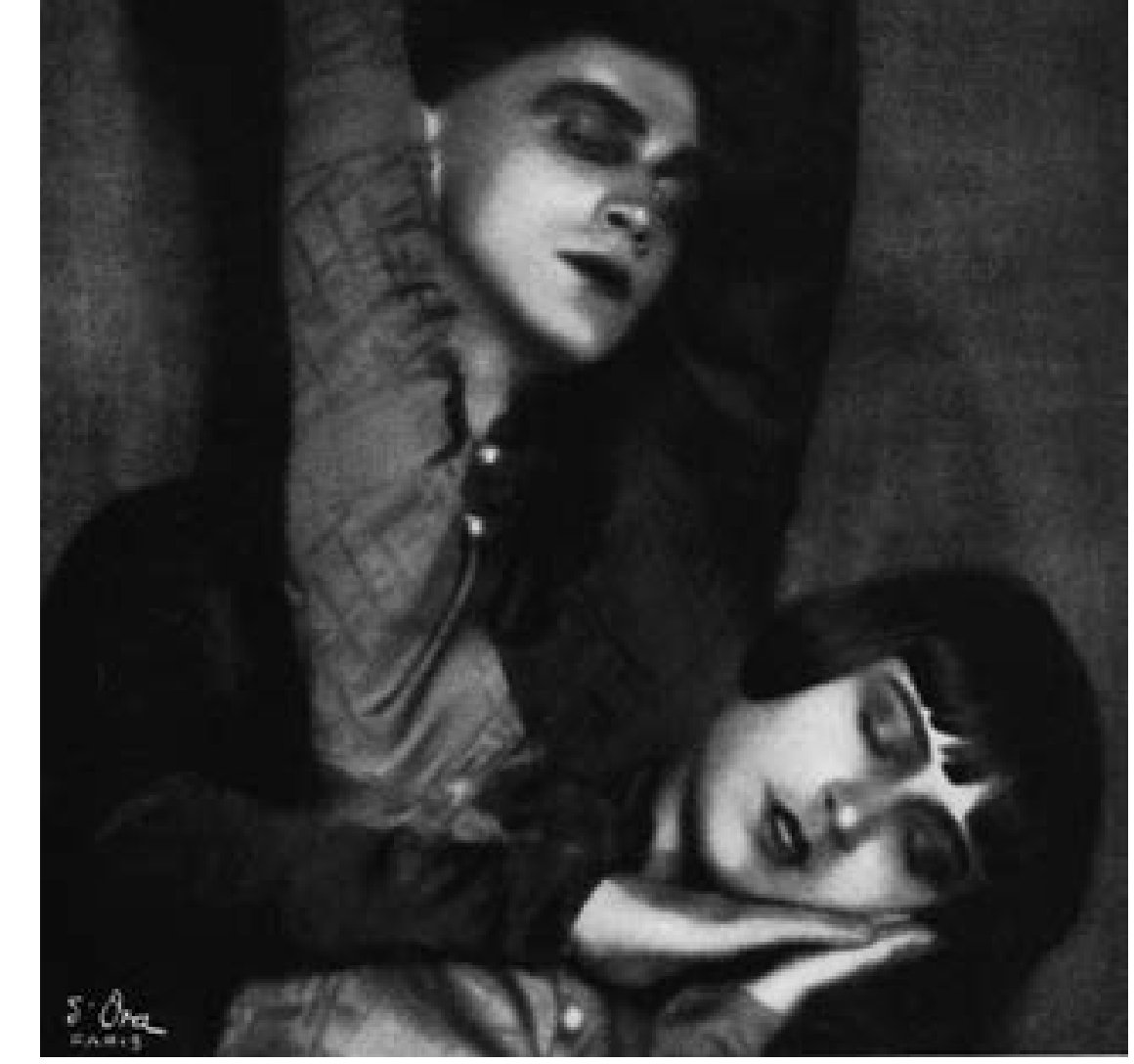

unbeschwertes Titelmotiv: die stark angeschnittene, aus niedrigem Blickwinkel fotografierte Kühlerhaube einer Luxuslimousine (Abb. 13). Der Titel dazu lautet: „Autos von denen man träumt. Bilder von einer modernen Autoausstellung. “20 Weitere Aufnahmen im Innenteil berichten über dieselbe Autoausstellung. Sie wurden möglicherweise in Amsterdam aufgenommen, denn Marie Oestreicher, die junge Fotografin, von der die Bilder stammen, lebt seit 1937 dort. ${ }^{21}$

Oestreicher ist 1915 in Karlsbad geboren und in Wien aufgewachsen. Nach ihrer Ausbildung an der Wiener Graphischen Lehr- und Versuchsanstalt (ab 1932) arbeitet sie als Assistentin im Wiener Atelier Willinger. Nebenbei fotografiert sie auf eigene Faust. Sie dokumentiert den Wiener Alltag und macht Aufnahmen an Wiener Kleinbühnen. Gelegentlich erscheinen ihre Bilder in der Presse. Als die Arbeitssituation in Wien prekärer wird und die politische Lage in Österreich sich immer mehr zuspitzt, verlässt sie das Land und geht in die Niederlande. Dort baut sie, zusammen mit ihrer Schwester Lisbeth, einer
Abb. 12 Harald Kreutzberg und Yvonne Georgi in einer Tanzszene. Die Dame, Heft 2, 1928, S. 32. Foto: d'Ora. 
Abb. 13 „Autos, von denen man träumt." Die Aufnahme stammt von der 1937 in die Niederlande emigrierten österreichischen Fotografin Marie Oestreicher. Sie erscheint wenige Tage vor dem nationalsozialistischen „Anschluss“ Österreichs. Der Sonntag, 20. Februar 1938, Titelseite.

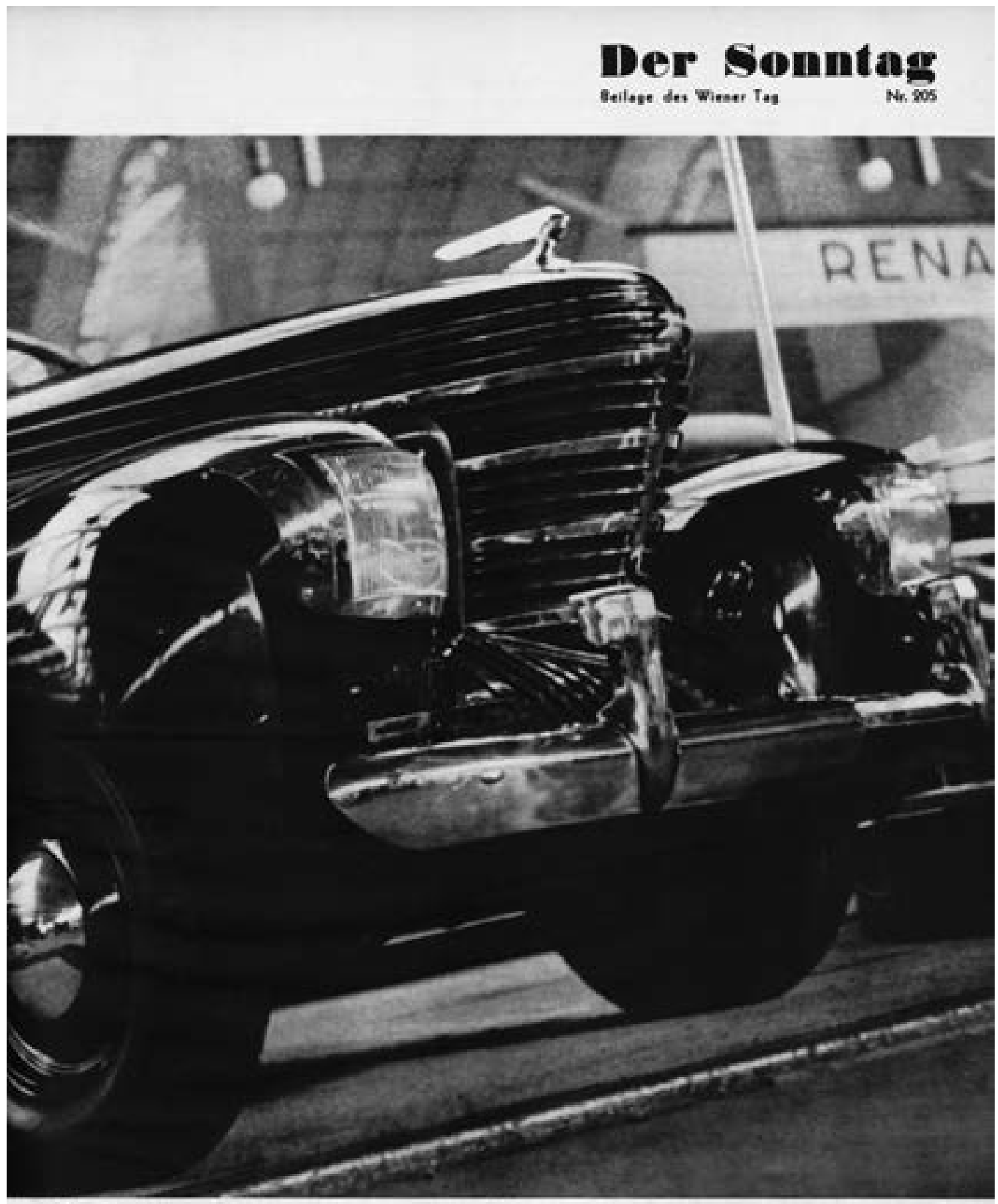

Moto mass ofrapoes

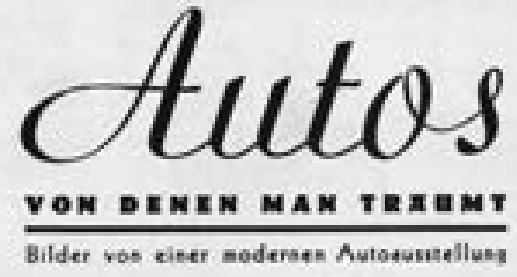


Bauhauskünstlerin, die im Textil- und Modebereich arbeitet, ein gemeinsames künstlerisches Atelier unter dem Namen „Model en Foto Austria“ auf. ${ }^{22}$ Eine ihrer ersten Aufnahmen, die sie von Amsterdam aus verkaufen kann, ist die Autoreportage im Sonntag.

Das moderne Automobil, das kraftvoll die Titelseite dominiert, steht für Unabhängigkeit, Individualismus und Beweglichkeit. Ende Februar 1938, als dieser Beitrag veröffentlicht wird, ist dieses optimistische, zukunftsfrohe Bild eigentlich schon Vergangenheit. Im März 1938 marschieren deutsche Truppen in Wien ein. Die nationalsozialistische Diktatur erfasst nun auch Österreich. Marie Oestreicher wird kein Bild mehr in ihrer alten Heimat veröffentlichen. Während des Krieges schließt sie sich der niederländischen Widerstandsbewegung an.

Das Jahr 1938 bedeutet für die jüdischen Fotografinnen in Österreich das jähe Ende ihrer Karriere. So schnell ihre Laufbahn nach 1918 begonnen hat, so abrupt endet sie zwei Jahrzehnte später. Im Frühjahr 1938 setzt die systematische Verfolgung ein. Was nun auf die Fotografinnen zukommt, ist nur bruchstückhaft überliefert. In den Dokumenten der Behörden schlagen sich die antisemitischen und rassistischen Raubzüge, Enteignungen, Verfolgungen, Einschüchterungen und schließlich der Weg ins Exil (oder in die Konzentrations- und Vernichtungslager) in trockenem bürokratischem Tonfall nieder: „abgemeldet am ...“, heißt es da, oder: „Gewerbe zurückgelegt am ...“ Die Ateliers jüdischer Fotografinnen und Fotografen werden entweder unter Zwang enteignet (,arisiert“) oder geschlossen, Bildbestände gehen verloren, werden geraubt oder können - in seltenen Fällen - teilweise ins Ausland gerettet werden.

Dramatische Lebensgeschichten österreichischer Fotografinnen schrumpfen nun auf wenige Stichworte zusammen: Trude Fleischmann gelingt Ende September 1938 die Flucht nach London und später nach New York, Dora Kallmus überlebt den Krieg versteckt in Frankreich, Marie Oestreicher lebt während des Krieges illegal in Amsterdam, Helene Kiss und Dora Horovitz gelingt die Flucht ins kalifornische San José, Marianne Bergler, Pepa Feldscharek, Trude Geiringer und Edith Glogau flüchten 1938 nach New York, Lotte Meitner und Hella Katz und Hedda Medina fliehen
1938 bzw. 1939 nach London, Lena Schur 1938 nach Paris und später nach Gran Canaria, Steffi Brandl geht nach 1933 von Berlin aus nach New York, Josefine Bárány flieht nach Schweden.

Andere jüdische Fotografinnen verlassen Österreich bereits früher. Camilla Henriette Koffler eröffnet 1933 in Paris unter dem Namen „Ylla“ ein erfolgreiches Atelier für Tierporträts. Edith Suschitzky geht 1934 nach England, Margarethe Gross (verh. Michaelis) flieht 1933 über Spanien, Frankreich und England nach Australien, Grete Weissenstein geht 1939 ebenfalls nach Australien. Nicht alle jüdischen Fotografinnen gelingt die Flucht. Martha Fein beispielsweise wird Ende Dezember 1941 in das Getto Lodz deportiert, wo sich ihre Spur verliert. Andere erreichen ihr sicheres Zielland nicht. Edith Barakovich etwa, die mit ihrem Mann über Frankreich und Spanien nach Casablanca geflüchtet war, begeht angesichts der ausweglosen Situation im Dezember 1940 Selbstmord. ${ }^{23}$

Nur wenige Fotografinnen jüdischer Herkunft überleben die NS-Zeit in Österreich. Irene Messner konvertiert in der Zwischenkriegszeit zum Katholizismus und wird durch ihre Ehe mit ihrem „arischen“ Ehemann Franz Messner vor der Deportation bewahrt. Dieser stirbt wenige Tage nach Kriegsende. ${ }^{24}$ Annie Schulz entgeht der Deportation vermutlich deshalb, weil sie (seit 1923) mit Hermann Ignaz Schulz verheiratet ist, der nicht jüdischer Herkunft ist. Sie stirbt am 21. November 1943 in Wien.

Das fotografische Erbe dieser jüdischen Fotografinnen (aber auch der Fotografen) gerät nach ihrer Verfolgung und Vertreibung in Vergessenheit. Das offizielle Österreich kümmert sich nach 1945 nicht um die Rückkehr der Vertriebenen. Erst in den 1980er Jahren tauchen die Arbeiten einiger weniger Fotografinnen, etwa von Trude Fleischmann, allmählich wieder im Kunsthandel auf. Die Fotografin wird in Ausstellungen als Einzelkünstlerin „wiederentdeckt“ ${ }^{25}$ Das reiche kulturelle Umfeld aber, in dem Fleischmann in der Zwischenkriegszeit gelebt und gearbeitet hat, wird vorerst nicht rekonstruiert. Erst in den letzten Jahren gibt es vermehrt Bestrebungen, die jüdische Fotokultur der Zwischenkriegszeit genauer zu erforschen und die erhaltenen Bilder einer größeren Öffentlichkeit zugänglich zu machen. ${ }^{26}$ 웅 


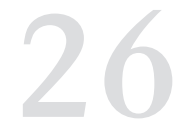

Abb. 1 „Meisterwerke der Photographie. Werkbundausstellung im Österreichischen Museum“. Die Bühne, Erstes Märzheft 1930, S. $6 / 7$ (Text: W.B. $=$ Wolfgang Born).

\title{
Die kurze Zeit der Avantgarde
}

\author{
Fotografische Aufbrüche um 1930
}

Am 20. Februar 1930 wird in Wien die Ausstellung „Film und Foto“, kurz FiFo genannt, eröffnet. ${ }^{1}$ Die Schau wird mit Spannung erwartet, denn ein Jahr zuvor hat sie in Stuttgart für Aufsehen und ein enormes Medienecho gesorgt. Auch in Wien wird ausführlich über sie berichtet (Abb. 1). „Film und Foto“ gilt als Manifest der modernen Fotografie. Gezeigt werden nicht nur künstlerische Arbeiten, sondern die gesamte Bandbreite der modernen Fotografie und des Films, etwa in den Bereichen Kunst, Werbung, Propaganda und Presse. Zu sehen sind die herkömmlichen Genres wie Porträt, Landschaft und Stillleben, aber auch Reportagen, Collagen, Montagen und andere Fotoexperimente. Der Deutsche Werkbund, der die Stutt-

\section{DUE ACHNE}

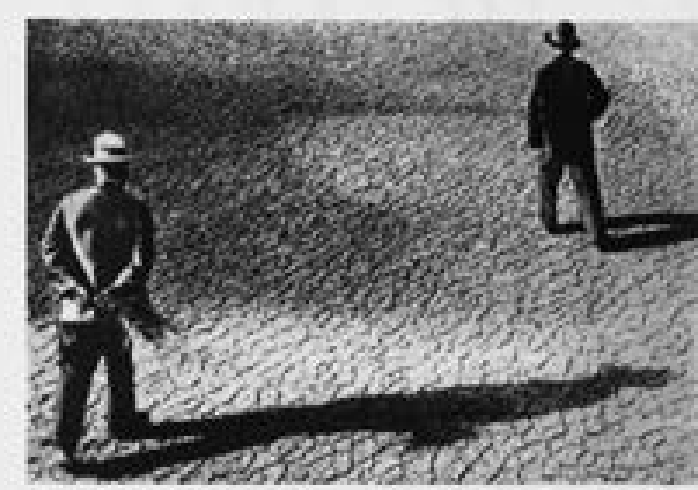

MEISTERWERKE ${ }_{\text {DEA }}$ PHOTOGRAPHIE

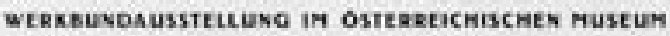

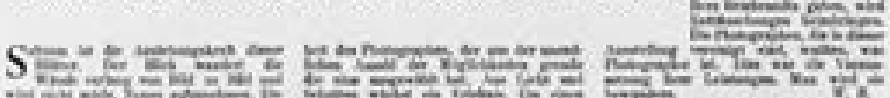

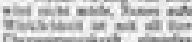

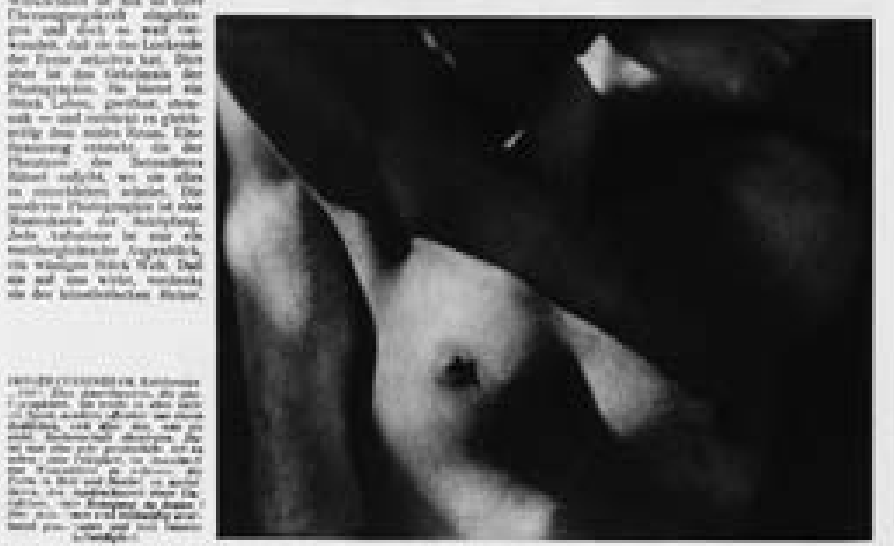

6

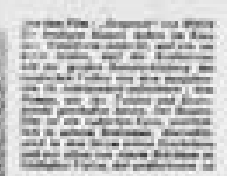

$-2 \pi=$
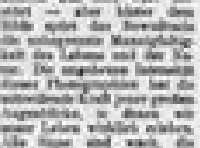

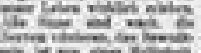
$2 \leq \frac{2}{2}=10$

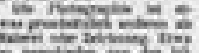

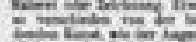

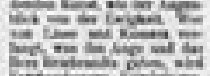

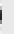

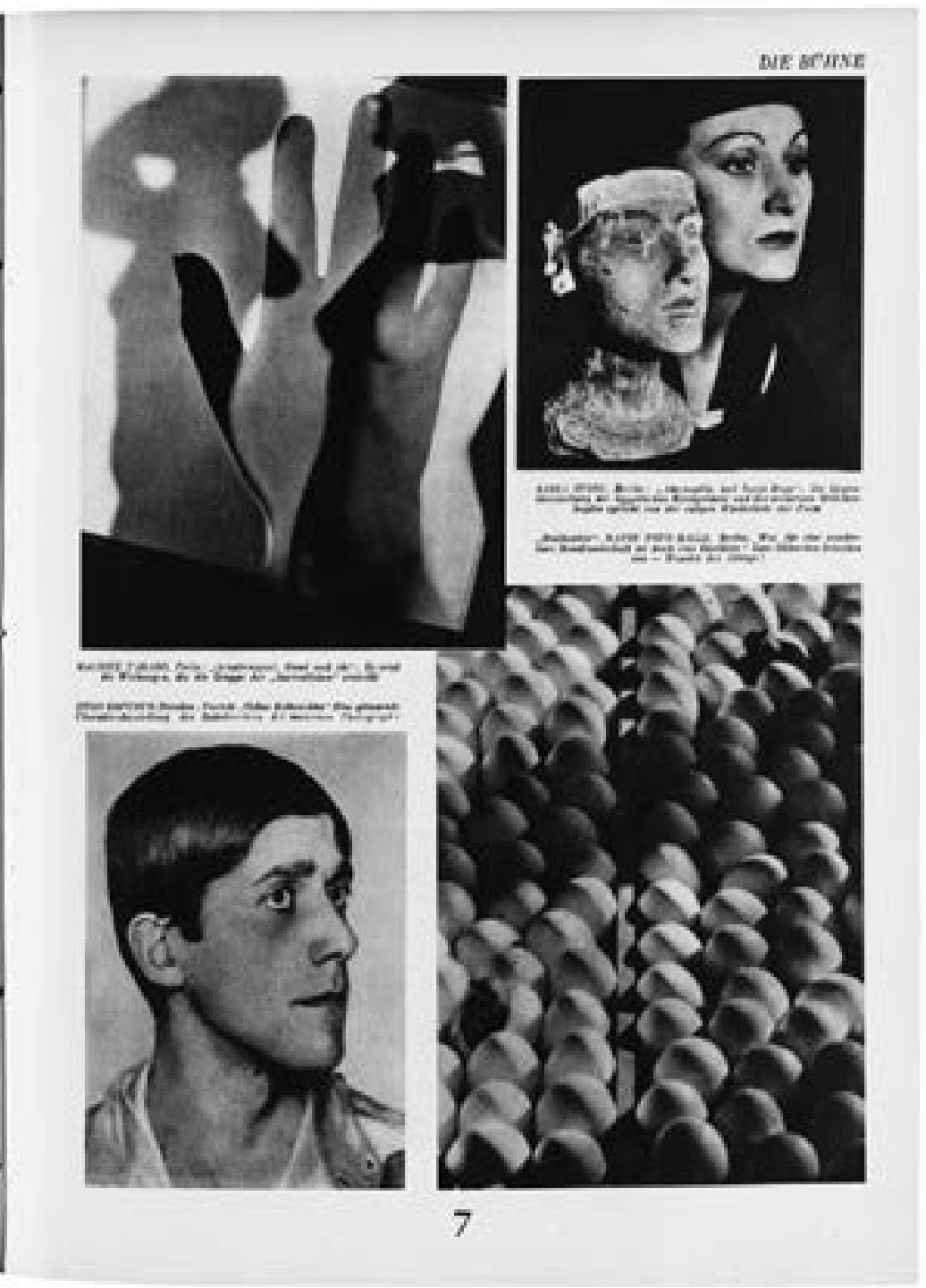


garter Schau verantwortet, will ganz bewusst einen Kontrapunkt zu den traditionellen Sichtweisen des fotografischen Bildes setzen. Er wendet sich sowohl gegen die erstarrte Berufsfotografie als auch gegen die Kunstfotografie, die im Fahrwasser der Malerei weichgezeichnete, entrückte Landschaften und Porträts produziert. Stattdessen setzt man auf die unverstellte Wiedergabe der Wirklichkeit, auf harte Kontraste, ungewöhnliche Perspektiven und Ausschnitte. Das Spektrum der Fotografie wird programmatisch erweitert, fast alles ist nun bildwürdig: das kleinste Detail des Alltags ebenso wie eine überdimensionale Industrielandschaft. Zeitungsfotos werden ebenso ausgestellt wie Mikroaufnahmen.

Mit der Ausstellung „Film und Foto“ setzen die Vertreter der Avantgardefotografie ein starkes Lebenszeichen. Auch der Wiener Veranstalter, der Österreichische Werkbund, sieht die Schau als deutliches kulturpolitisches Signal für die moderne Fotografie. Nicht zufällig wählt man als Ausstellungsort ein Museum, das dem Gewerbe und der angewandten Kunst gewidmet ist und nicht der „puren“ Kunst. Die Schau findet zwischen dem 20. Februar und dem 31. März 1930 in den Räumen des Österreichischen Museums für Kunst und Industrie an der Ringstraße (heute: Museum für angewandte Kunst, MAK) statt. Neben den Stars, die bereits in Deutschland zu sehen waren (El Lissitzky, Alexander Rodtschenko, John Heartfield, Hannah Höch, Helmar Lerski, Germaine Krull, László Moholy-Nagy, André Kertesz, Man Ray, Aenne Biermann, Charles Sheeler, Edward Weston, Sasha Stone, Piet Zwart und vielen anderen) wird in Österreich auch eine zusätzliche Abteilung mit 13 einheimischen Fotografen gezeigt. ${ }^{2}$

\section{Flügelkämpfe}

Neben einigen wenigen Vertretern des „Neuen Sehens“ bzw. der „Neuen Sachlichkeit“ (etwa Richard Träger, Willy Riethof, Hans Cechal und Franz Mayer) ist in der österreichischen Abteilung eine ganze Reihe von Arbeiten zu sehen, die wohl am besten mit dem Begriff der „gemäßigten Moderne“ zu umschreiben sind (Trude Fleischmann, Trude Geiringer/Dora Horovitz, Grete Kolliner, Hertha Müller, Ilona Kiss, Otto
Skall u.a.). Aber auch traditionelle kunstfotografische Studien (etwa von Maximilian Karnitschnigg) werden gezeigt. ${ }^{3}$ Der Großteil der ausgestellten österreichischen Lichtbildner sind professionelle Atelierfotografen, praktisch alle stammen aus Wien oder leben (zeitweise) hier. Die Amateurfotografen (u. a. Paul Freiberger, Willy Riethof, Hans Cechal und Richard Träger) sind in der Minderheit, die Pressefotografen, die in Stuttgart breit vertreten gewesen waren, sind kaum berücksichtigt (Otto Skall etwa ist mit nur einem Foto vertreten).

Die Ausstellung „Film und Foto“ markiert in der Geschichte des österreichischen Werkbundes einen Neuanfang - nach langen Jahren der Krise. In den 1920er Jahren hatte der Verein eine Phase der Lethargie und der Spaltungen erlebt. ${ }^{4}$ Im November 1928 werden die unterschiedlichen Fraktionen vereint und der Verein wiederbelebt. ${ }^{5}$ In den folgenden Jahren entwickelt der Verein ein reges Ausstellungsprogramm: 1929 wird in der Hofburg die Schau „Neues Bauen“ gezeigt, 1930 findet im Museum für Kunst und Industrie neben der FiFo eine weitere Werkbundausstellung statt, um die Jahreswende 1931/32 ist im selben Museum die Ausstellung „Der gute billige Gegenstand“ zu sehen. 1932 findet diese kurze Blütezeit mit dem Projekt „Werkbundsiedlung Wien 1932“ ihren Höhepunkt. Danach kommt es neuerlich zu Konflikten und zur Spaltung. Eine Gruppe um Peter Behrens und Clemens Holzmeister gründet Ende 1933 den „Neuen Werkbund Österreichs“, der die Ausrichtung des bestehenden Vereins auf die liberale Moderne ablehnt und eine Verbindung zwischen Tradition, Patriotismus und Moderne anstrebt. Die neue Gruppierung sucht die Nähe zur christlichsozialen, ab 1933/34 diktatorisch agierenden Regierung. 1934 wird der „alte“ Werkbund aufgelöst. Aber auch die Aktivitäten der politisch willfährigen Neugründung erlahmen in den folgenden Jahren. ${ }^{6}$

Ähnliche ideologische und ästhetische Flügelkämpfe gibt es um 1930 auch in einigen österreichischen Fotovereinen. Die 1929 gegründete „Vereinigung Photo-Secession“ beispielsweise spaltet sich ein Jahr nach der FiFo in zwei Gruppierungen auf. Auf der einen Seite stehen die traditionellen Kunstfotografen, die weiterhin der Pflege des Bromöldrucks an- 
Abb. 2 „film und photo. vorschau der werkbundausstellung“. Die Bühne, Zweites Februarheft 1930, S. 42/43 (Text: W. B. = Wolfgang Born). hängen. Auf der anderen Seite sind die Anhänger der Neuen Sachlichkeit und des Neuen Sehens. Schließlich setzen sich die Traditionalisten durch, die den Verein ab 1931 unter dem neuen Namen „Gesellschaft für photographische Kunst" weiterführen.7

An der Bestückung der Ausstellung „Film und Foto“ mit zusätzlichen österreichischen Arbeiten zeigt sich sehr deutlich, dass es 1930 innerhalb des österreichischen Werkbundes keine einheitliche Auffassung gibt, was moderne Fotografie ist. Die Flügelkämpfe und Konflikte zwischen Modernen und Traditionalisten schlagen auch auf die Fotoauswahl durch. In der Stuttgarter FiFo wäre es beispielsweise undenkbar gewesen, kunstfotografischen Arbeiten größeren Platz einzuräumen. In Österreich hingegen geht die Bruchlinie zwischen modernen und traditionellen Auffassungen von Fotografie quer durch die Werkbundausstellung, beide Seiten sind vertreten. Insgesamt gesehen, setzen sich innerhalb der österreichischen FiFo-Fotografen eindeutig die gemäßigt Modernen gegenüber den radikalen Neuerern durch. Es überwiegen die klassischen Genres: Porträts, Landschaften, Reisebilder (etwa des Ethnologen und konventionellen Reisefotografen Hugo Bernatzik, von dem gleich 13 Aufnahmen zu sehen sind). Montagen, Collagen und andere Fotoexperimente österreichischer

\section{DAE BCWNE}

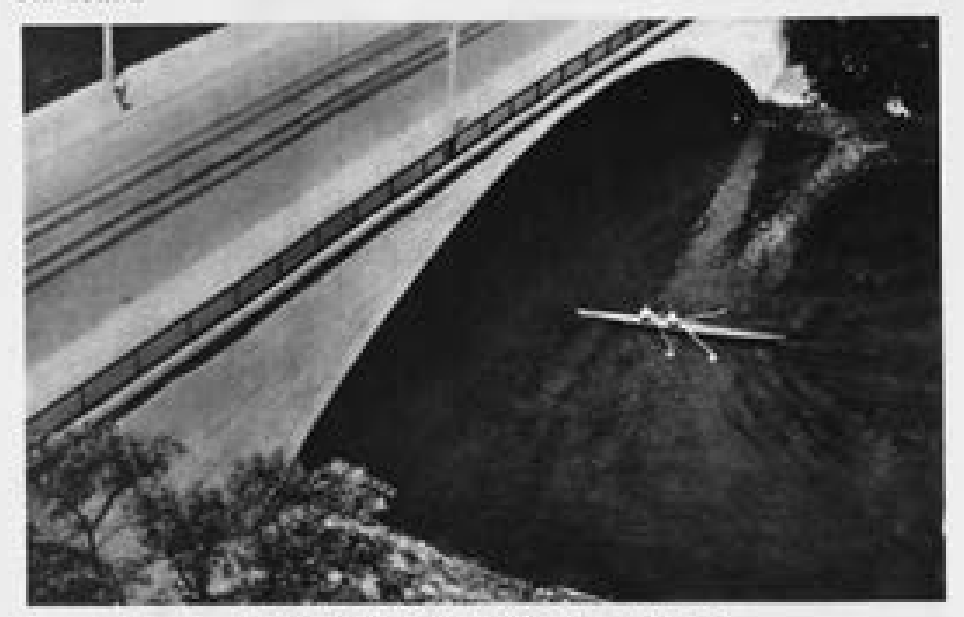

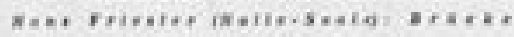

\section{film und photo \\ vorschau der werkbundausstellung}
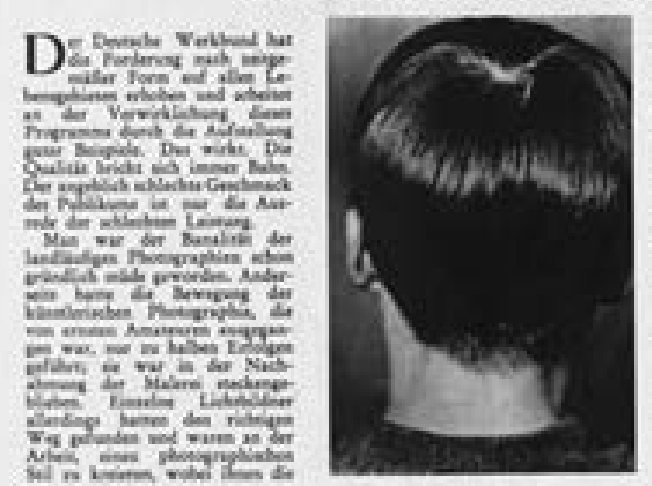

42

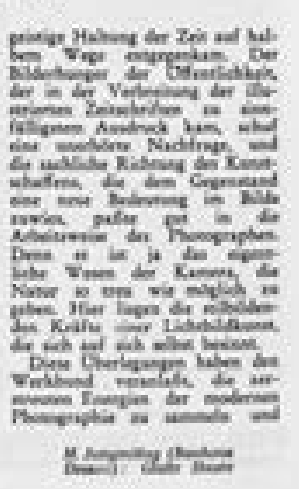

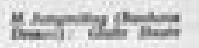

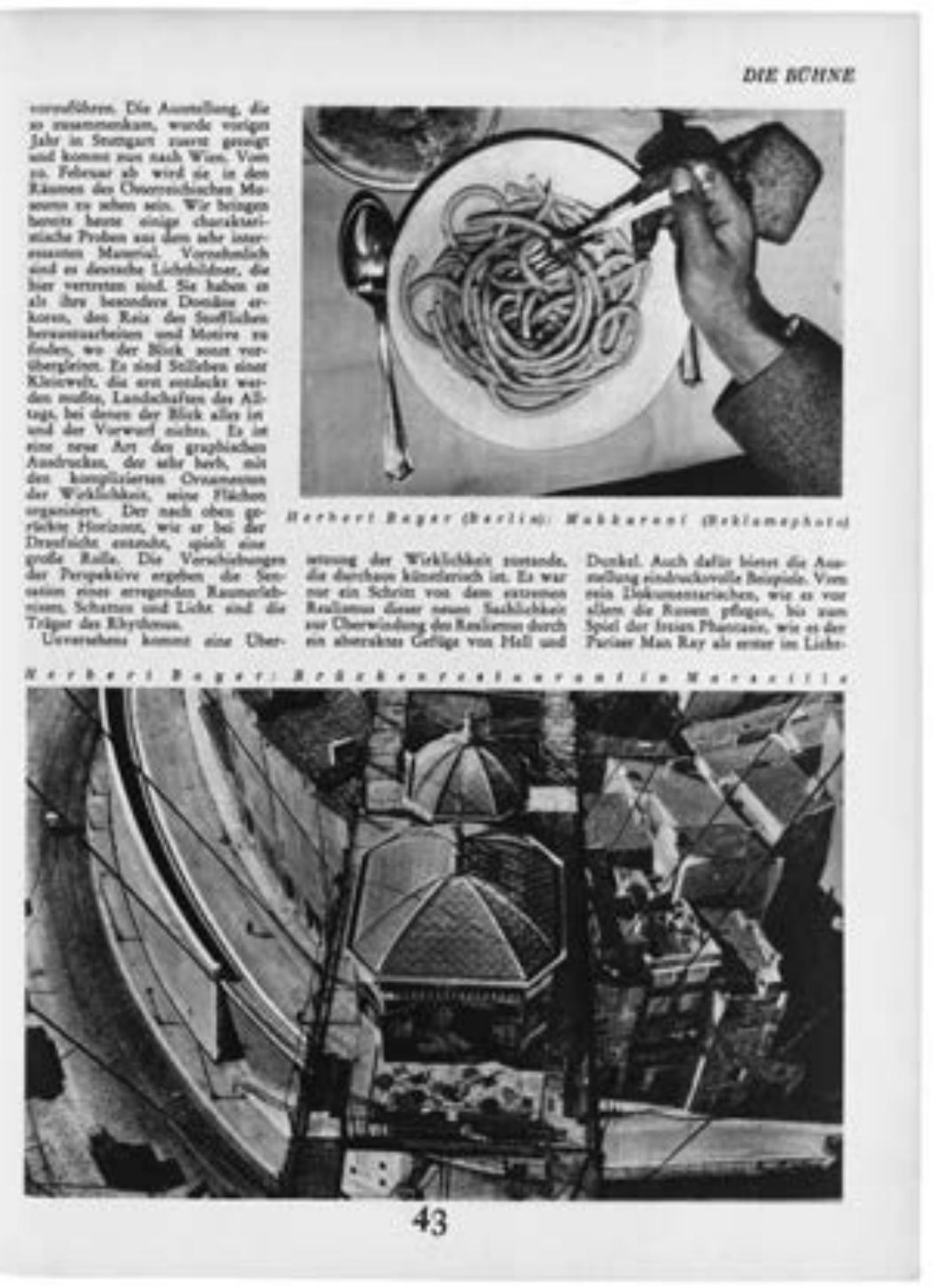


Lichtbildner fehlen weitgehend. Von der angewandten Fotografie, etwa ihrem Einsatz in Werbung, illustrierter Presse oder Plakatkunst, wird in der österreichischen Abteilung kaum etwas gezeigt. Die Atelierfotografen, die sich vorsichtig den modernen Strömungen angeschlossen haben, dominieren gegenüber anderen Bereichen der Fotografie, aber auch gegenüber den Amateuren (wie Hans Cechal, Paul Freiberger, Willy Riethof). Eine einzige Fotoagentur wird vorgestellt, das Wiener Unternehmen „R. Lechner (Wilh. Müller)“, dessen Angebot aus überaus konventionellen Fotoarbeiten besteht. Die deutlich innovativere Agentur „Wiener Photo-Kurier“ (später: Schostal) fehlt hingegen.

\section{Zwei vergessene Kunstkritiker der Moderne}

Trotz dieser ästhetischen Kompromisse und Einschränkungen wird die Wiener Ausstellung in der liberalen und linken Presse als Meilenstein für die moderne Fotografie gefeiert. ${ }^{8}$ Bereits eine Woche vor Beginn der Schau schreibt der Kritiker Wolfgang Born (seine Texte in der Presse sind oft mit W.B. signiert) in der Zeitschrift Die Bühne (Abb. 2 und 3): „Wir bringen bereits heute einige charakteristische Proben aus dem sehr interessanten Material. Vornehmlich sind es deutsche Lichtbildner, die hier vertreten sind. Sie haben es als ihre besondere Domäne erkoren, den

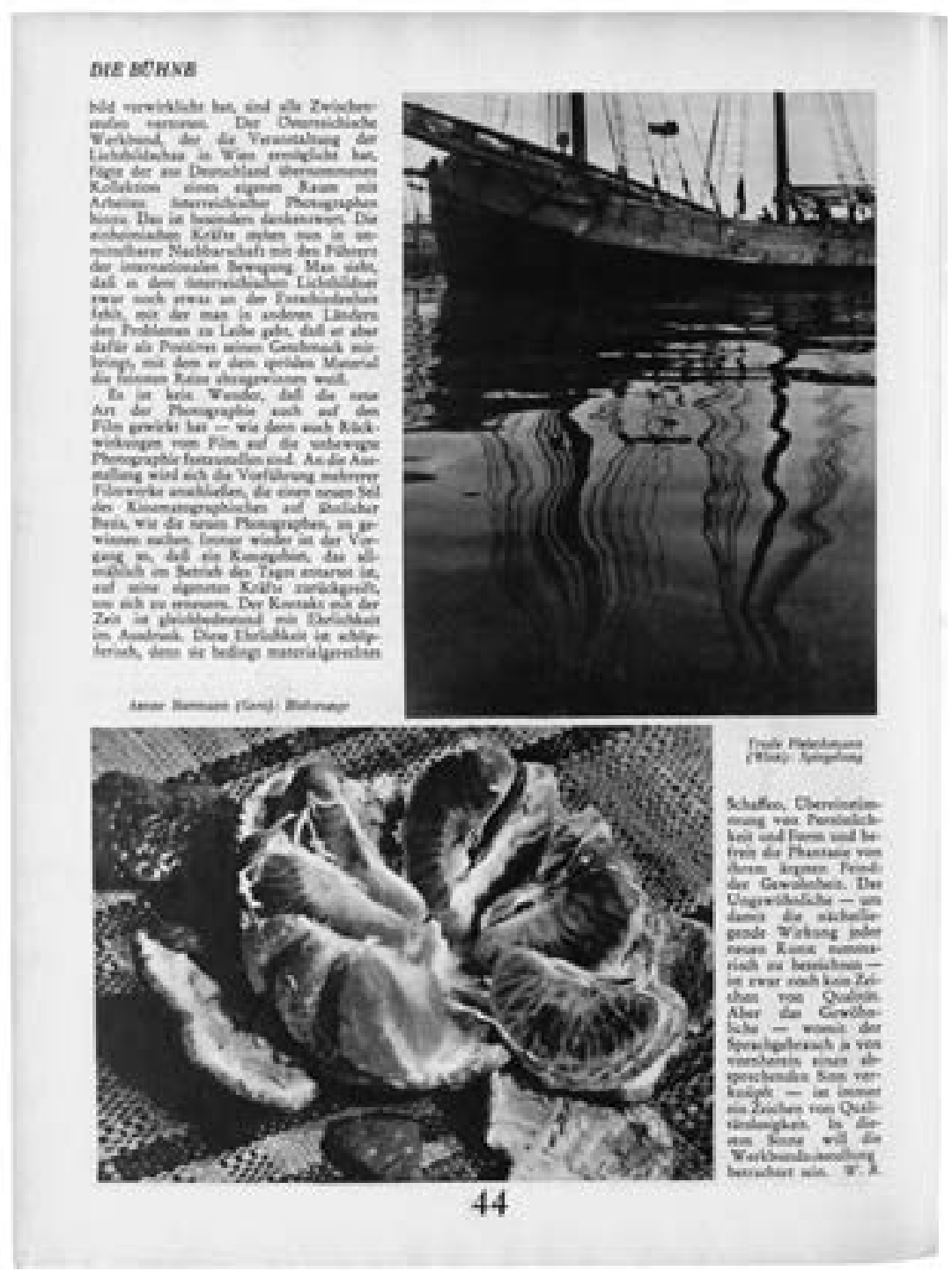

Abb. 3 „film und photo. vorschau der werkbundausstellung“. Die Bühne, Zweites Februarheft 1930, S. 44 (Text: W.B. = Wolfgang Born). 
Reiz des Stofflichen herauszuarbeiten und Motive zu finden, wo der Blick sonst vorübergleitet.“9 Born hat die Ausstellung bereits vor der Eröffnung besucht und liefert vorab einen umfassenden, in seinen Beschreibungen sehr genauen Einblick in die Schau. Die ästhetischen Neuerungen der modernen Fotografie hebt er besonders hervor: „Es sind Stilleben einer Kleinwelt, die erst entdeckt werden mußte, Landschaften des Alltags (...). Es ist eine neue Art des graphischen Ausdruckes, der sehr herb, mit den komplizierten Ornamenten der Wirklichkeit, seine Flächen organisiert. Der nach oben gerückte Horizont, wie er bei der Draufsicht entsteht, spielt eine große Rolle. Die Verschiebungen der Perspektive ergeben die Sensation eines erregenden Raumerlebnisses, Schatten und Licht sind die Träger des Rhythmus. Unversehens kommt eine Übersetzung der Wirklichkeit zustande, die durchaus künstlerisch ist. Es war nur ein Schritt vom extremen Realismus dieser neuen Sachlichkeit zur Überwindung des Realismus durch ein abstraktes Gefüge von Hell und Dunkel. Auch dafür bietet die Ausstellung eindrucksvolle Beispiele. Vom rein Dokumentarischen, wie es vor allem die Russen pflegen, bis zum Spiel der freien Phantasie, wie es der Pariser Man Ray als erster im Lichtbild verwirklicht hat, sind alle Zwischenstufen vertreten." 10

Während Born den ausländischen Arbeiten im Stil der Neuen Sachlichkeit und des Neuen Sehens überaus aufgeschlossen gegenübersteht, ist seine Einschätzung, was die österreichische Abteilung betrifft, weit verhaltener. Die Mischung zwischen modernen und konventionellen Fotografien überzeugt ihn nicht ganz, mehr als höfliche Anerkennung äußert er nicht: „Der österreichische Werkbund“, so Born, „der die Veranstaltung der Lichtbildschau in Wien ermöglicht hat, fügte der aus Deutschland übernommenen Kollektion einen eigenen Raum mit Arbeiten österreichischer Photographen hinzu. Das ist besonders dankenswert. Die einheimischen Kräfte stehen nun in unmittelbarer Nachbarschaft mit den Führern der internationalen Bewegung. Man sieht, daß es dem österreichischen Lichtbildner zwar noch etwas an der Entschiedenheit fehlt, mit der man in anderen Ländern den Problemen zu Leibe geht, daß er aber als Positives den Geschmack mitbringt, mit dem er dem spröden Material die feinsten Reize abzugewinnen weiß.“ 11

Ganz ähnlich urteilt die Kritikerin Alma Stefanie Frischauer in der Zeitschrift Moderne Welt über die Wiener Ausstellung. Auch sie begrüßt die Bilder der Avantgardisten, insbesondere die Aufnahmen im Stil der Neuen Sachlichkeit. „Der moderne Fotograf nennt Sachlichkeit sein oberstes Prinzip. Die absichtlich unscharfe oder gar künstlich gestellte Aufnahme hat aufgehört zu existieren: das Lichtbild soll keine zierende Dekoration, sondern ehrliches Dokument sein. Dem unbestechlichen Werkzeug des Objektivs, der kleinen Linse, die allen menschlichen Sinnen an Schärfe überlegen, im Bruchteil einer Sekunde jeden optischen Eindruck erfaßt, ist die Hauptleistung übertragen." ${ }^{12}$ Und auch sie hat, ebenso wie Born, eher die ausländischen Bildbeispiele vor Augen, wenn sie die Arbeiten der Fotopioniere genauer beschreibt. „Es ist erstaunlich, welche Fülle von Überraschungen die Oberfläche einer Nußschale oder eines Eisblocks, die Struktur eines Gewebes, das Gestänge einer Eisenkonstruktion oder ein einfacher Treppenlauf zu erbringen vermögen. In der Enthüllung, die keine Verschleierung und nur Präzision kennt, liegt der Wert dieser neuen Fotos. Sie entdecken die Wirklichkeit und bringen durch die Schärfe ihrer Objektive, durch kühne Licht- und Schattenkombinationen, durch unerwartete Verkürzungen und Perspektiven den Alltag erneut zum Bewußtsein. Neben der neuen Fotografie, die insbesondere in Deutschland, in Rußland und in Amerika gepflegt wird, nimmt die Ausstellung des Werkbundes Stellung zum Problem des Films und proklamiert einen neuen geistigen Film mit starker innerer Konzentration an Stelle kostspieliger Prunkfilme, die hinter großer Aufmachung ihre künstlerische Leere nicht zu verbergen vermögen.“13

Wer sind diese beiden Kritiker, die die neue Fotografie in Wien so stürmisch begrüßen? Sie haben einiges gemeinsam. Beide sind in der Fotogeschichtsschreibung bisher vollkommen unbekannt. Wolfgang Born, geb. 1893 in Breslau, und Alma Stefanie Frischauer, geb. 1899 in Lemberg als Alma Stefanie Wittlin, sind in den Wirren des Ersten Weltkriegs nach Wien gekommen. Beide haben beim Wiener Kunsthistoriker Josef Strzygowski promoviert, Born 
über nordrussische Buchmalerei, Frischauer über den altspanischen Kirchenbau. ${ }^{14}$ Die beiden jungen Kunsthistoriker schließen sich nach ihrem Studium nicht in ihre akademische Arbeitswelt ein, sondern melden sich als Journalisten und Kritiker engagiert und kenntnisreich zu Wort. Sie berichten nicht nur über die moderne Fotografie, sondern auch über andere Entwicklungen der Kunst und des Kunstgewerbes. Beide stehen den Ideen des Werkbundes sehr offen gegenüber. Ihre Berichterstattung über die moderne österreichische Fotografie beginnt um 1928. Ihnen ist es unter anderem zu verdanken, dass die interessantesten österreichischen Vertreter der modernen Fotografie ihren Weg in die Öffentlichkeit finden.

Mitte der 1930er Jahre verstummen sie. Dies ist kein Zufall, sondern hat mit den gesellschaftlichen Umbrüchen dieser Zeit zu tun. Die moderne Kunst, die sie propagieren, gerät zunehmend in die Defensive, ihre Arbeit als Kritiker wird im austrofaschistischen „Ständestaat“ schwieriger. Beide sind erklärte Gegner des diktatorischen Regimes. Born und Frischauer sind jüdischer Herkunft und daher dem in den 1930er Jahren zunehmenden Antisemitismus ausgesetzt. Um diesem einengenden, repressiven, antisemitischen Klima zu entgehen, entschließen sich die beiden, das Land zu verlassen. Wolfgang Born emigriert 1937 in die USA. Dort arbeitet er als Maler, Buchillustrator und Kunsthistoriker, zunächst am Queens College, dann, ab 1948, am City College in New York. Er stirbt 1949. ${ }^{15}$ Alma Stefanie Frischauer verlässt im Dezember 1937 das Land und geht zunächst nach England, dann, 1952, in die USA. 1959 nimmt sie die amerikanische Staatsbürgerschaft an, dann verlieren sich ihre Spuren. ${ }^{16}$

\section{Aufbruchstimmung um 1930}

Die Ausstellung „Film und Foto“ markiert einen folgenreichen Einschnitt in der Neuausrichtung der Fotografie. Sie ist Bezugspunkt und Katalysator für eine neue Art, Fotografie zu verwenden und öffentlich zu präsentieren. Eine ganze Reihe junger Fotografen greift diese Anregungen auf. Unter ihnen ist der Schweizer Martin Imboden, der die Ausstellung „Film und Foto“ bereits in Stuttgart gesehen hat und seit 1929 in Wien lebt. ${ }^{17}$ Er entwickelt - beeinflusst von der Neuen Sachlichkeit - ein modernes Konzept des Porträts, das die Gesichter (meist von Frauen) in ungewohnt engen, frontal aufgenommenen Bildausschnitten zeigt (Abb.4). Daneben entstehen Tanzstudien und Reisebilder, die in der illustrierten Presse veröffentlicht werden. Als Imboden im August 1935 bei einem Unfall stirbt, widmet ihm die Zeitschrift Die Bühne einen Nachruf, in dem auch seine Frauenporträts Erwähnung finden. „Bekannt waren vor allem Imbodens Mädchenbilder. Er war ein Poet und seine Kamera hat stets jene jungen Mädchen gefunden, die noch in einem anderen Sinn schön waren als nur vom Standpunkt des Photoschönen aus.“18

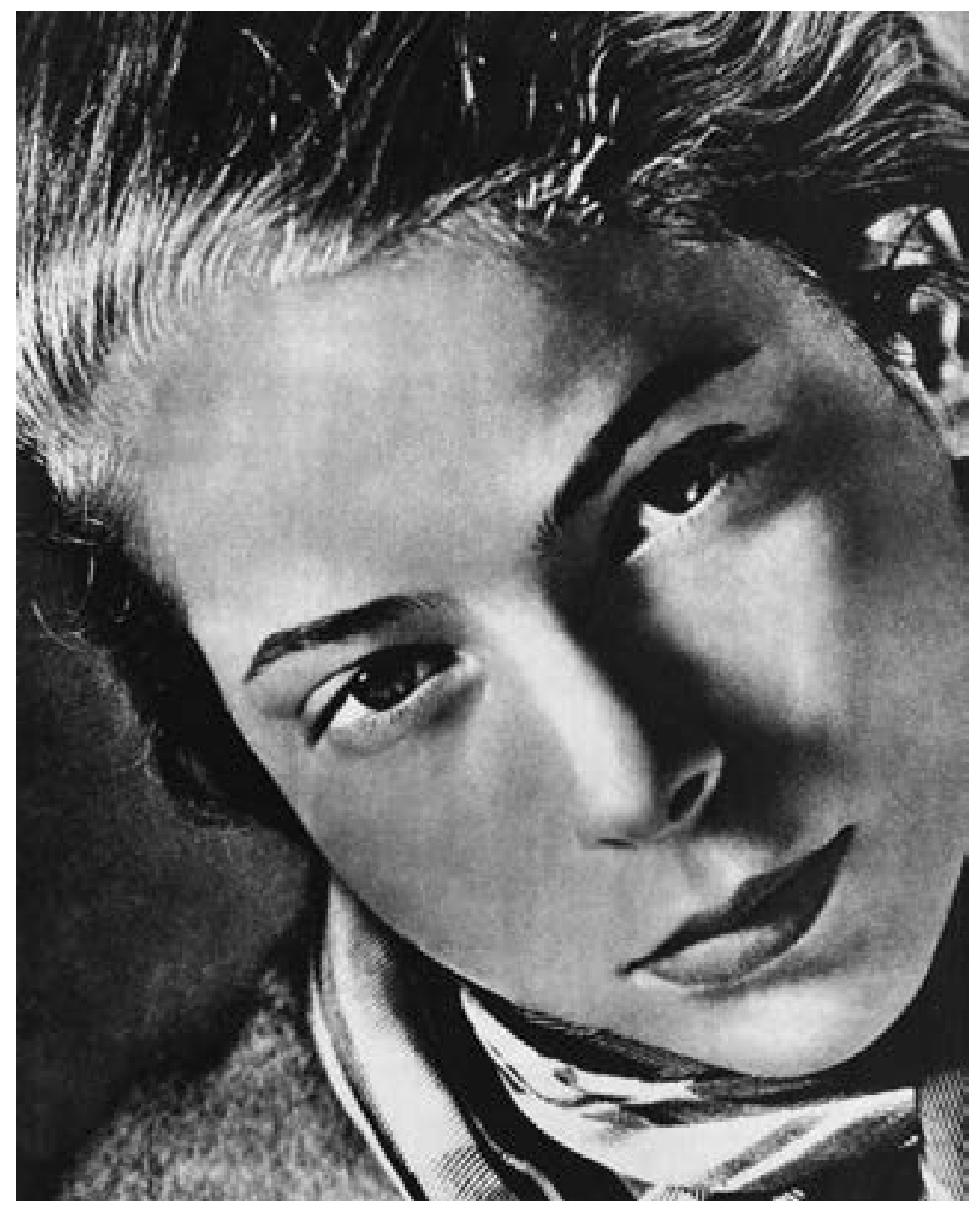




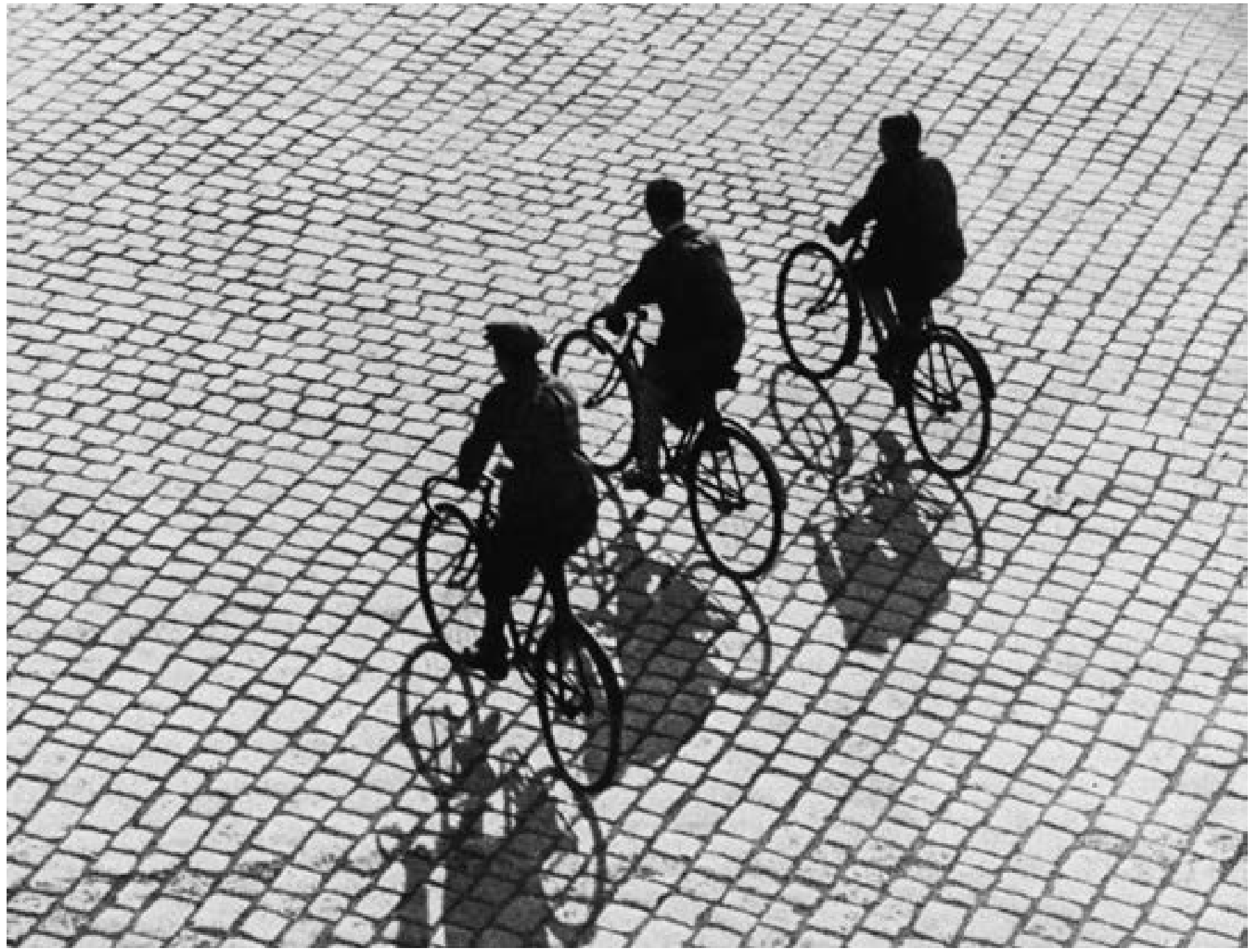

Willy Riethof (Abb. 7), Rudolf Spiegel, Kurt Husnik (Abb.8), Hans Grabkovicz, Otto Dobrowolny, Oskar Kuhn, Hans Madensky, Annie Schulz, Lotte Meitner-Graf, Otto Skall (Abb.9), Robert Haas, Nikolaus Schwarz, Hans Casparius, Edith Suschitzky, Franz Mayer, Walther Schneider, Felix Braun, László Willinger (Abb. 10), Albert Karplus und Ernst Kassowitz.

Die meisten dieser Fotografen sind keine Avantgardisten im engeren Sinne. Aber in ihren Fotoreportagen, Sach- und Werbeaufnahmen oder in ihren Stillleben sind immer wieder Bezüge zur Neuen Sachlichkeit und zum Neuen Sehen erkennbar. Bei einigen Fotografen mischen sich gelegentlich auch Anleihen des Piktorialismus in die Bilder. Einige weitere Fotografen, wie etwa Hans Popper, Cécile Machlup, Heinz von Perckhammer oder Lucca Chmel, pendeln um 1930 zwischen modernen Ansichten und konservativen, oft sogar heimattümelnden Genrebildern. Auch Fotografen, die den Anregungen des Neuen Sehens reserviert gegenüberstehen, greifen gelegentlich auf manche Elemente der Moderne zurück. Bei einer Skiaufnahme Lothar Rübelts etwa fallen der gekippte Horizont und die starke Untersicht ins Auge (Abb. 11).

Die Ausstellung „Film und Foto“ ist ein wichtiges, aber kein solitäres kulturelles Ereignis. Zwischen 1927 und 1930 ist in vielen Bereichen des kulturellen
Abb. 6 „Drei Radler“. Das österreichische Lichtbild, Jahr buch 1933, hg. vom Verband der österreichischen Amateurphotographenvereine in Wien, Wien, Troppau, Leipzig 1933, Tafel 32. Foto: Ferdinand Hodek. 
Abb. 7 "Schatten des Sports". Wiener Magazin, Heft 1, 1932, S. 57. Foto: Willy Riethof.

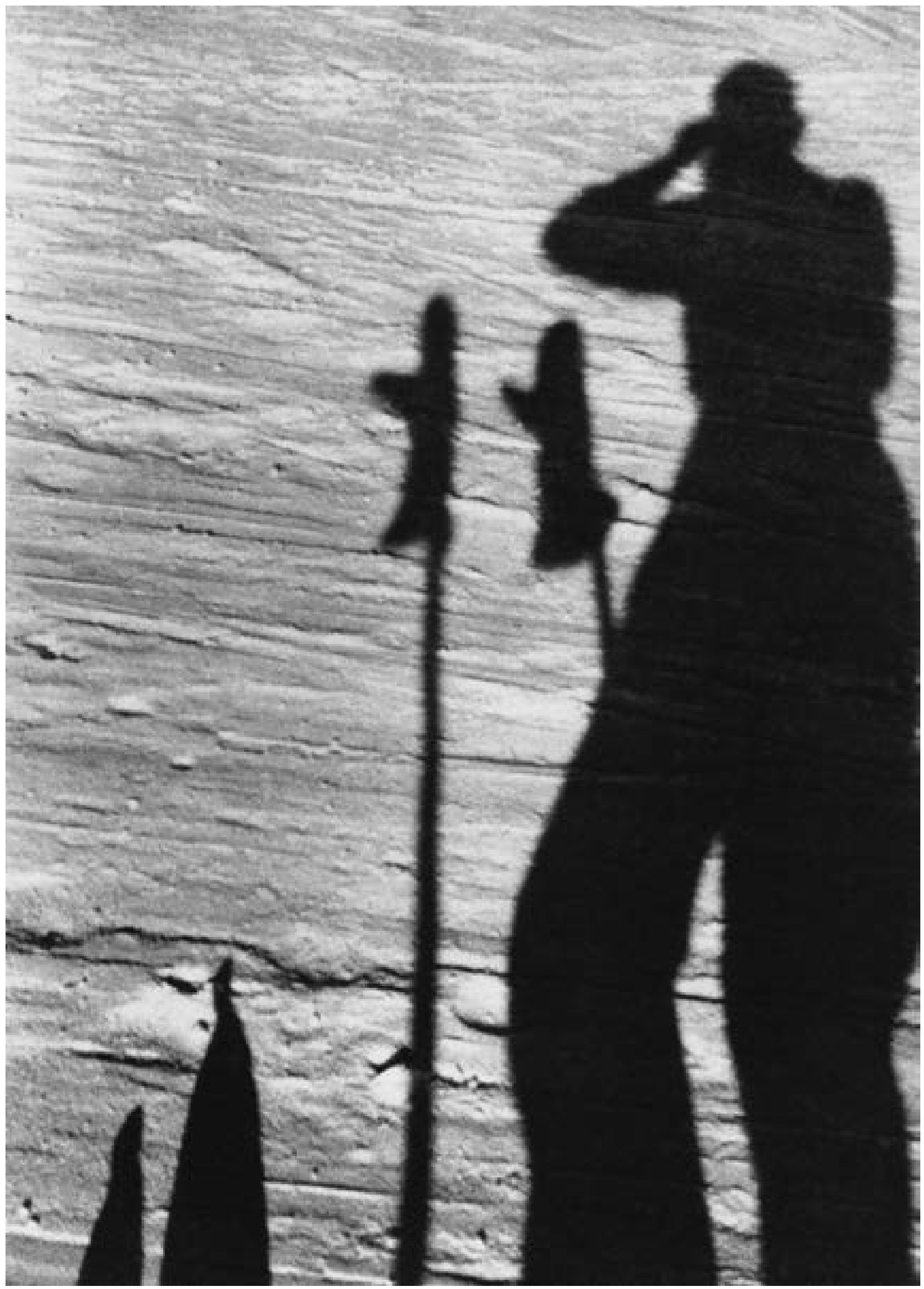


Lebens eine Aufbruchstimmung spürbar, im Theater ebenso wie im Tanz, im Film genauso wie in der bildenden Kunst. Die Hinwendung zur (oft gemäßigten) fotografischen Moderne reicht in Österreich bis etwa zur Mitte der 1920er Jahre zurück. Zwischen 1927 und 1929 häufen sich in den illustrierten Wochenzeitungen, vor allem in der Bühne und im Wiener Magazin, teilweise auch in der Modernen Welt, Veröffentlichungen im Stil der Moderne. Ab 1928/29 erscheinen Berichte über das Bauhaus, über die Richtungen innerhalb der Kunstfotografie und die Mode der Neuen Sachlichkeit (Abb. 12). Illustriert sind diese Beiträge hin und wieder auch mit Bildern österreichischer Fotografen, viele von ihnen Amateure, die die modernen Tendenzen der Neuen Sachlichkeit und des Neuen Sehens in dosierter Form aufnehmen.

Aber auch in den Fotoausstellungen macht sich der neue Trend bemerkbar. Anfang 1929 findet im „Glaspalast“ des Wiener Burggartens - dem ehemaligen Gewächshaus des kaiserlichen Hofes an der Wiener Ringstraße - die erste einer mehrjährigen Reihe kunstfotografischer Ausstellungen statt. Auch wenn die Schau, in der die künstlerisch arbeitenden Amateure den Ton angeben, insgesamt recht traditionell ausgerichtet und noch weitgehend der herkömmlichen Kunstfotografie verpflichtet ist, sind doch einige wenige österreichische Anhänger des Neuen Sehens vertreten. ${ }^{20}$ Eine weitere Fotoausstellung, auf der neben viel Traditionellem auch eine Reihe moderner Arbeiten internationaler und österreichischer Fotografen gezeigt wird, findet im Sommer 1929 in Salzburg statt. ${ }^{21}$ Wolfgang Born stellt die Schau in der Bühne vor und umreißt diesen neuen, modernen Zugang zur Fotografie: „Wirklichkeitshunger ist das Kennwort der Gegenwart. Nichts gilt, was nicht mit Händen zu greifen ist. Die Kunst als getreuer Spiegel der geistigen Haltung, geht im gleichen Schritt mit der Wissenschaft auf Eroberung der Wirklichkeit aus. Sie entwickelt ihren Stil aus dem Gegenständlichen. Man hat ihr bereits vorgeworfen, sie sei photographisch - und die Wahrheit ist, daß sie es, mit Einschränkung, wie sich von selbst versteht, sein will. ${ }^{22}$

In den folgenden zwei, drei Jahren häufen sich Ausstellungen, die modernen Positionen in der Fotografie mehr Raum geben. Im Dezember 1930 zeigt

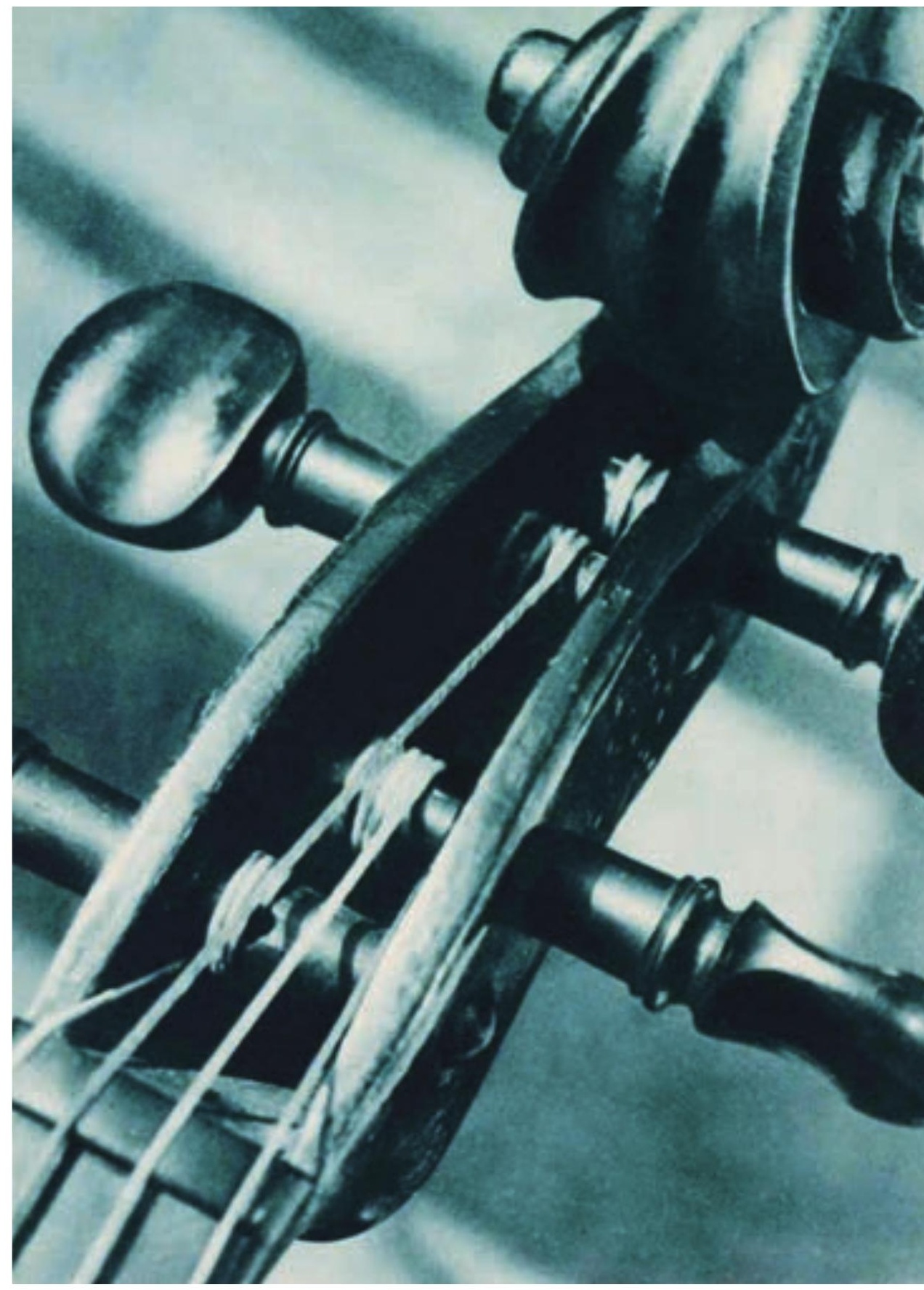

Otto Kallir in seiner „Neuen Galerie“ in Wien erstmals eine Ausstellung moderner Fotografie: „Akt und Porträt in der Fotografie“. Im Januar 1930, also noch vor der Eröffnung der FiFo, folgt in derselben Galerie eine zweite Fotoausstellung, die dem Fotografen Willy Riethof, einem der bekanntesten Vertreter des Neuen
Abb. 8 „Musikalisches Detail“. Wiener Magazin, Heft 3, März 1934, S. 38. Foto: Kurt Husnik. 


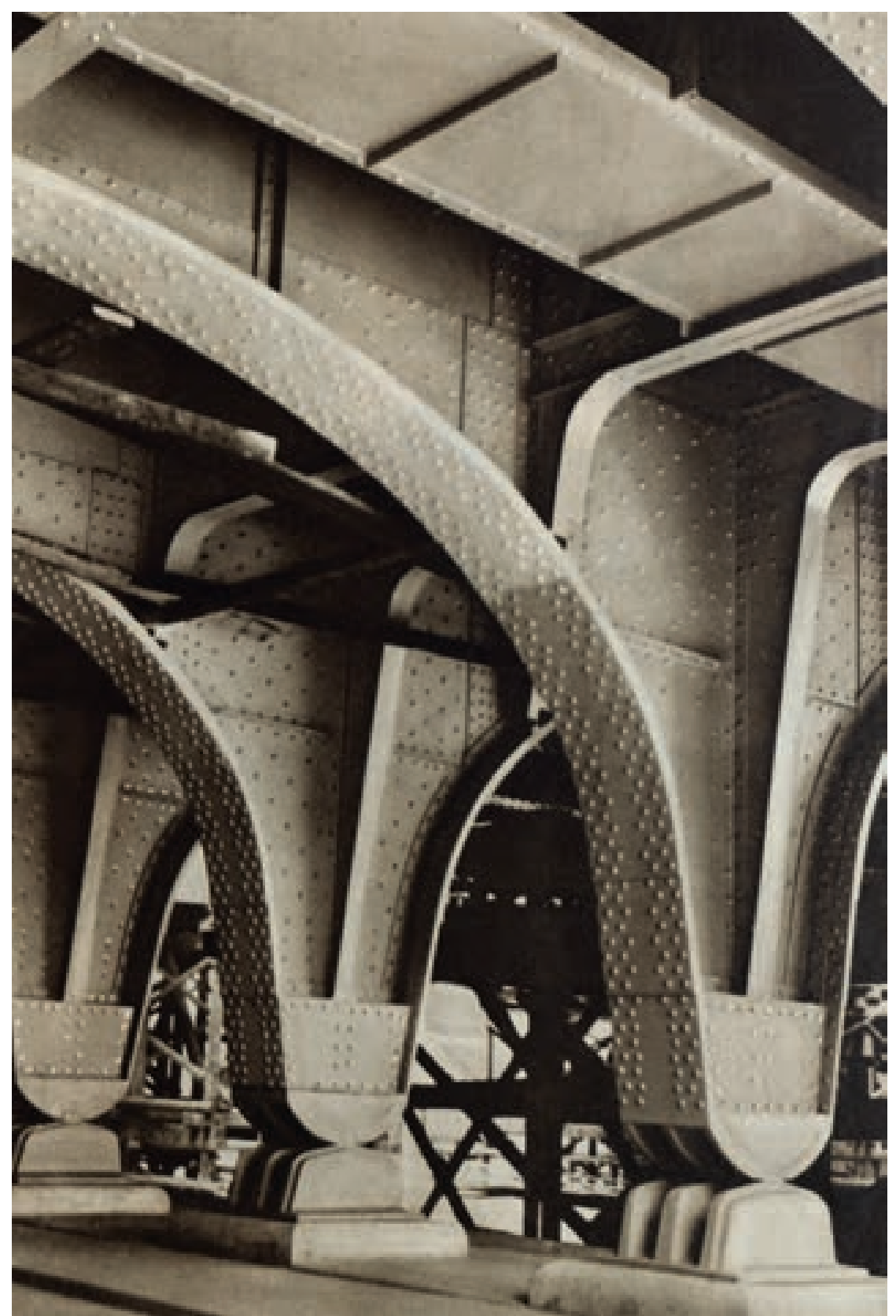

Abb. 9 Stützpfeiler der neuen Augartenbrücke in Wien. Die Bühne, Zweites Augustheft 1931, S. 29. Foto: Otto Skall.
Sehens in Wien, gewidmet ist. ${ }^{23}$ Der aus Prag stammende Fotograf lebt in den 1920er und 1930er Jahre in Wien, zeitweise auch in Berlin. Wolfgang Born ist von der Schau begeistert. In seiner Besprechung in der Bühne hebt er ein Porträt der Schauspielerin Lux Rodenberg (Abb. 13) besonders hervor: „Die Augen sprechen, der Mund schweigt. Ein Kopf, den man nicht vergißt. Die Finger halten die Schläfe, unter der es pocht. Ohne alles Szenische atmet man die Atmosphäre des dichterischen Theaters. Eine innere Handlung ist in den engen Rahmen eines Bildraumes gepresst.“24

Auf der folgenden Doppelseite stellt Born zwei sehr unterschiedliche Körperbilder, die Riethof in der Neuen Galerie zeigt, einander gegenüber: einen Arbeiter mit entblößtem Oberkörper und einen stark angeschnittenen Frauenakt (Abb. 14). Born schreibt dazu: „Kontraste. Die Bilder links und rechts - zwei nackte Menschenkörper: Der arbeitende Mann, alle Muskeln gespannt, die Tänzerin, gelöst und schwingend. Im Rhythmus entsprechen sich beide Figuren - dadurch wird der Gegensatz um so eindringlicher. Schatten und Licht stehen im Dienst der Komposition. Es spielt sich eine stumme Szene ab, deren dramatische Spannung durch die Konzentration auf das Wesentliche erreicht wird. Zwei Welten prallen aufeinander. Die Wirklichkeit geht unmittelbar ins Kunstwerk ein, ohne daß dadurch etwas Naturalistisches entsteht. - Die Photographie wirkt als Überraschung. Man sieht das Gewohnte neu. Die Kamera hat Menschenaugen bekommen. “25 Riethofs Erfolg in der „Neuen Galerie“ setzt sich wenig später in der Wiener FiFo fort. Er ist mit insgesamt 36 gezeigten Bildern der Star der Ausstellung. Von keinem anderen Lichtbildner werden annähernd so viele Arbeiten gezeigt.

\section{Anregungen und Vorbilder aus dem Ausland}

Das Beispiel der FiFo zeigt, dass um 1930 zwar ein verstärktes Interesse an der modernen Fotografie vorhanden ist, allerdings kommen die Anregungen und Einflüsse oft aus dem Ausland. Wien ist Ende der 1920er Jahre keine Hochburg der Avantgarde (eher im Gegenteil), aber unter der sozialdemokratischen Stadtregierung etabliert sich dennoch ein offenes, neugieriges kulturelles Klima. Ende der 1920er Jahre werden alle möglichen progressiven Kulturprojekte importiert. Rezipiert wird etwa die Kunst-, Theaterund Fotoszene der jungen revolutionären Sowjetunion. Im März 1928 - zehn Jahre nach der russischen Revolution - wird in den Räumen des Wiener Hagenbundes eine sowjetrussische Ausstellung gezeigt. Die Ausstellung kommt auf Initiative der „Österreichischen Gesellschaft zur Förderung der geistigen und wirtschaftlichen Beziehungen mit der UdSSR“ zustande. Präsentiert wird dabei ein - durchaus propagandistischer - Überblick über die Leistungen des jungen Staates: Zu sehen sind innovative Theaterinszenierungen ebenso wie moderne Plakatgestaltungen und grafische Arbeiten. Ebenfalls zwischen 


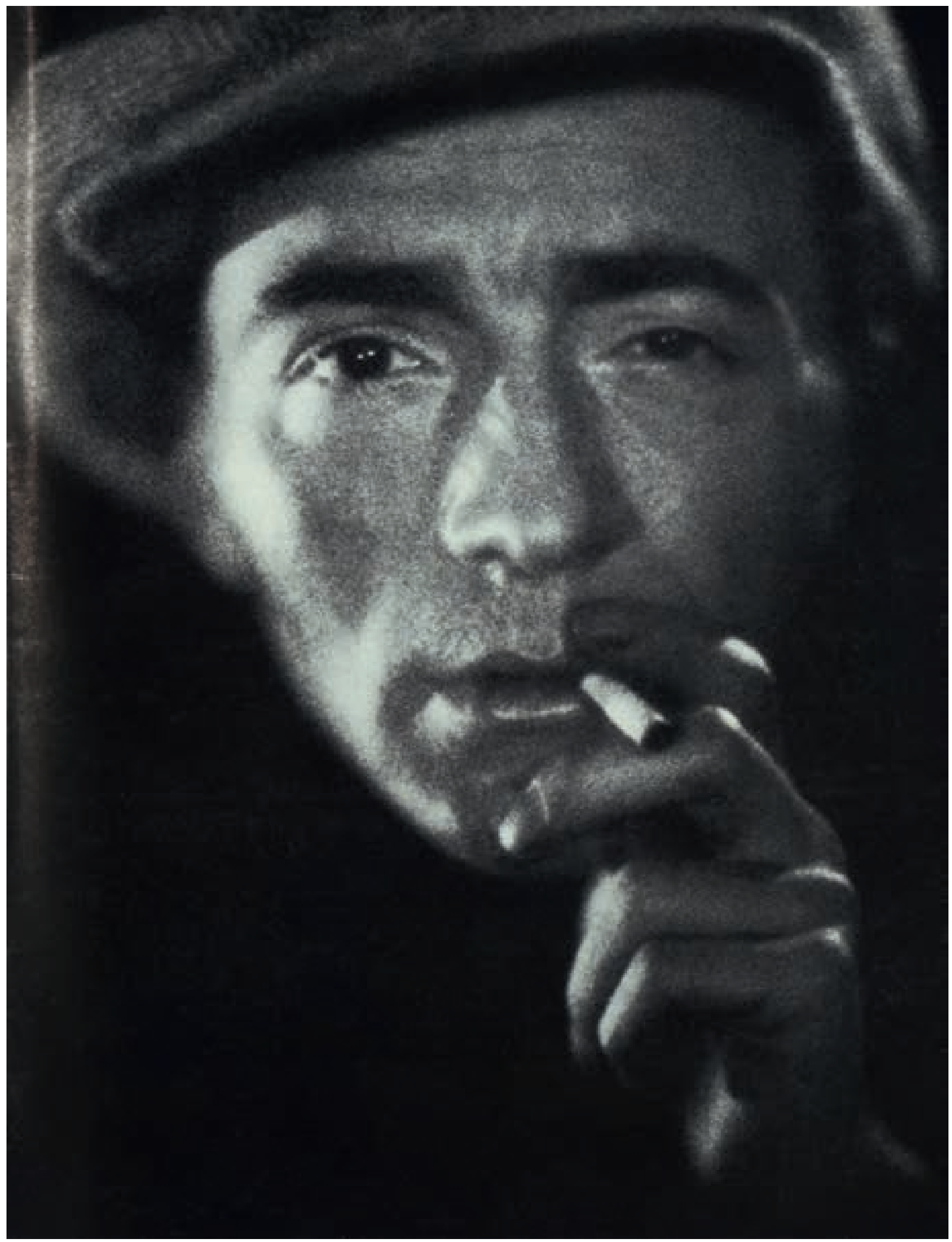

Abb. 10 „Pariser

Type“. Das öster-

reichische Lichtbild.

Die Zeitschrift des

Fotoamateurs, Januar

1936, S. 38. Foto:

László Willinger. 
Abb. 11

„Slalom".

Wiener Ma-

gazin, Heft

2, Februar

1935, S. 64.

Foto: Lothar

Rübelt.

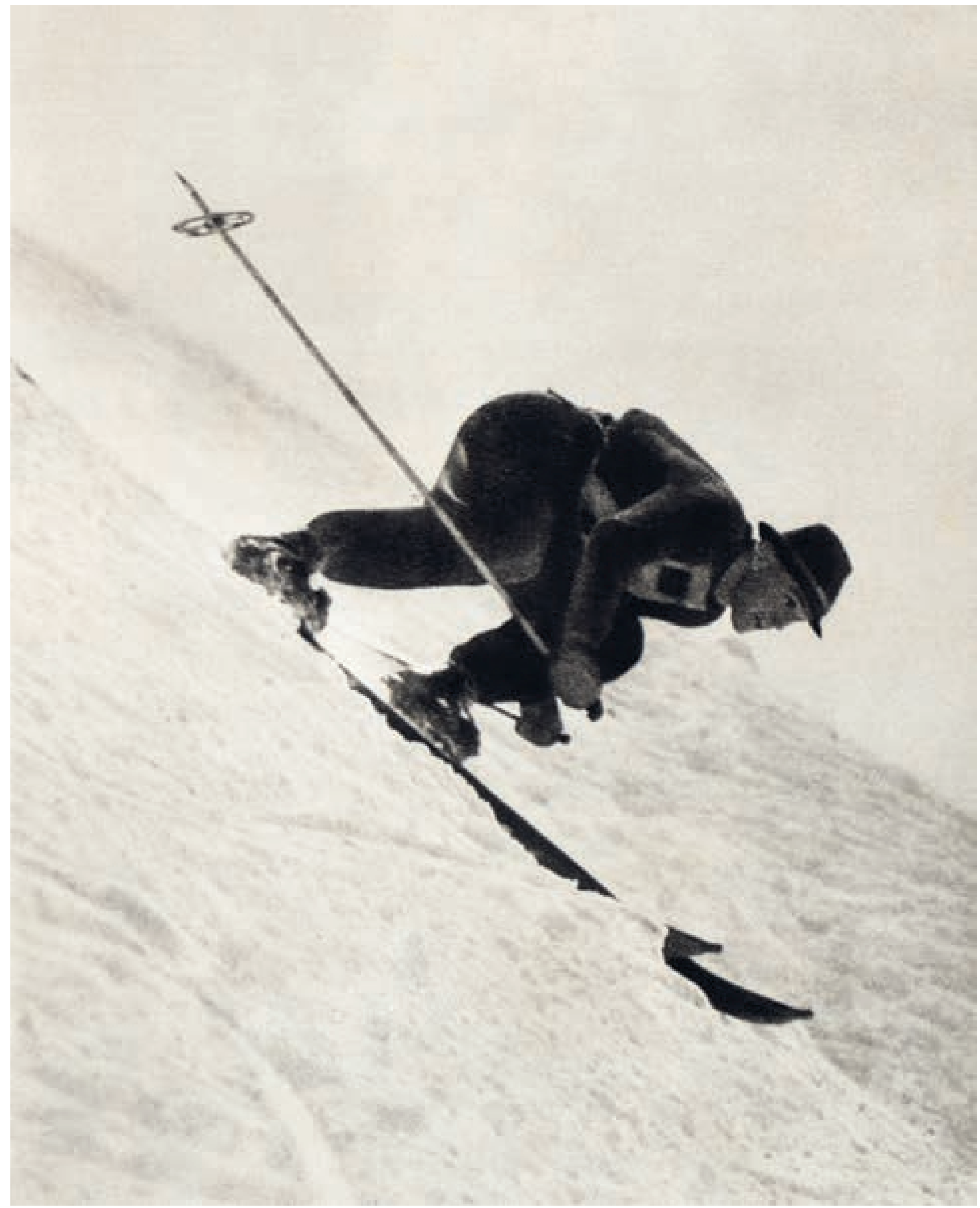




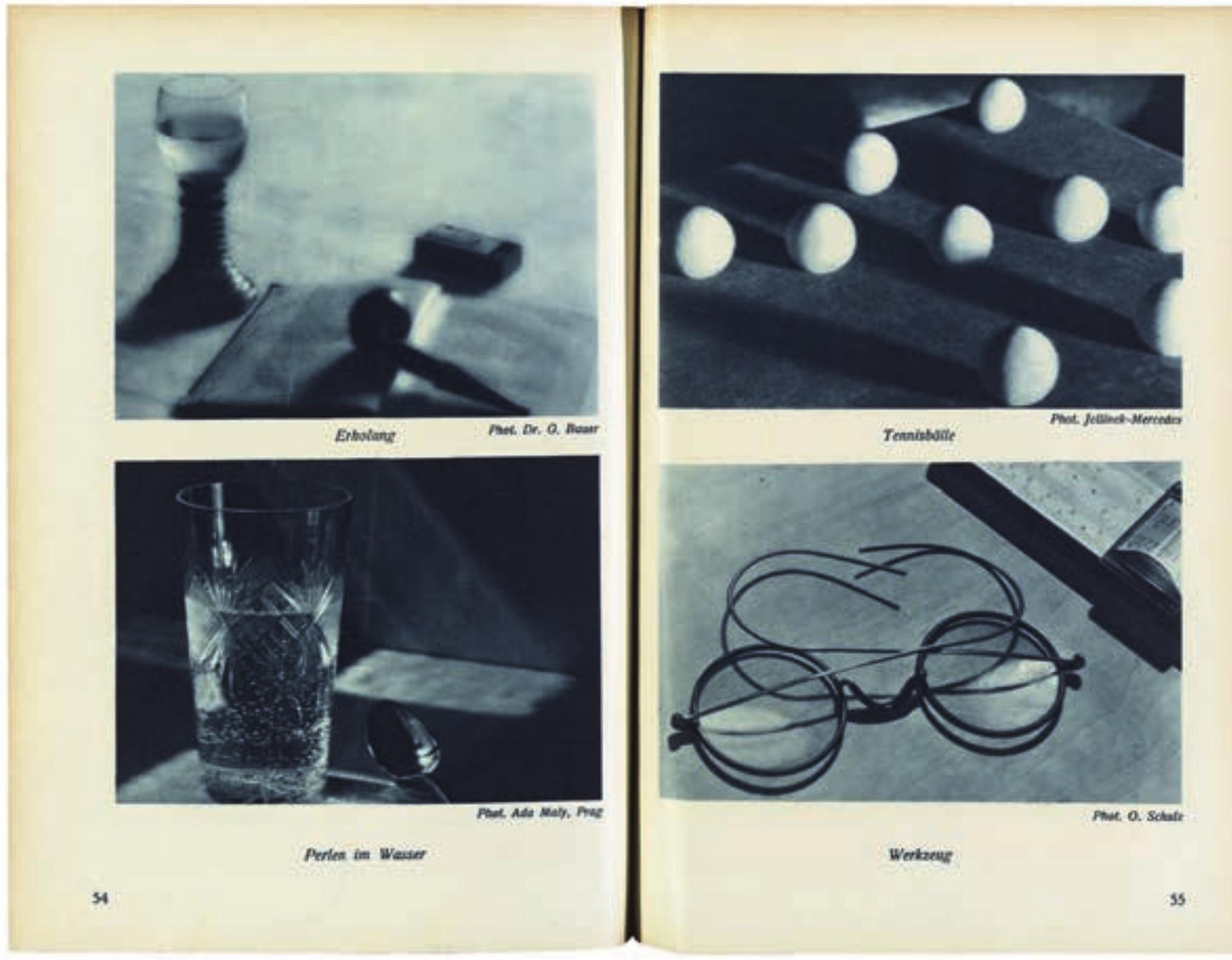

1927 und 1929 werden, vermittelt durch die Verleihfirma NEWA, zahlreiche sogenannte „Russenfilme“ in Wien gezeigt. ${ }^{26}$ Anregungen kommen aber auch aus Deutschland, etwa vom Bauhaus. Einige wenige österreichische Künstler und Fotografen (etwa Friedl Dicker, Herbert Bayer, Edith Suschitzky und Erich Comeriner, der zwar in Wien geboren ist, aber in Berlin aufwächst) studieren am Bauhaus, umgekehrt arbeiten deutsche Bauhausfotografen vereinzelt in Wien. Im Sommer 1930 etwa hält sich Fritz Heinze, der seit 1927 am Bauhaus studiert, in Wien auf. ${ }^{27}$ Eine seiner Aufnahmen zeigt die Opernkreuzung an der Wiener Ringstraße bei Nacht (Abb. 15). Die geradezu abstrakte Straßenszene ist weit von den traditionellen Wienbildern entfernt und taucht die Stadt in ein bisher ungesehenes, experimentelles Licht. Auch die avantgardistische deutsche Filmkultur der 1920er Jahre wird in Wien rezipiert. 1927 hat etwa, fast zeitgleich wie in Berlin, Walther Ruttmanns „Berlin - Die Sinfonie der Großstadt“ seine Premiere in Wien.
Abb. 12 Sachaufnahmen. Wiener Magazin, Heft 11, November 1930, S. 54 und 55. Fotos: G. Bauer, Ada Maly, Jellinek-Mercedes, O. Schulz. 
Abb. 13 „Die Welt in der Kamera. Photographien von Willy Riethof in der ,Neuen Galerie““. Die Bühne, Erstes Februarheft 1930, S. 45 (Text: W.B. = Wolfgang Born).

Abb. 14 „Die Welt in der Kamera. Photographien von Willy Riethof in der ,Neuen Galerie““. Die Bühne, Erstes Februarheft 1930, S. $46 / 47$ (Text: W. B. = Wolfgang Born).

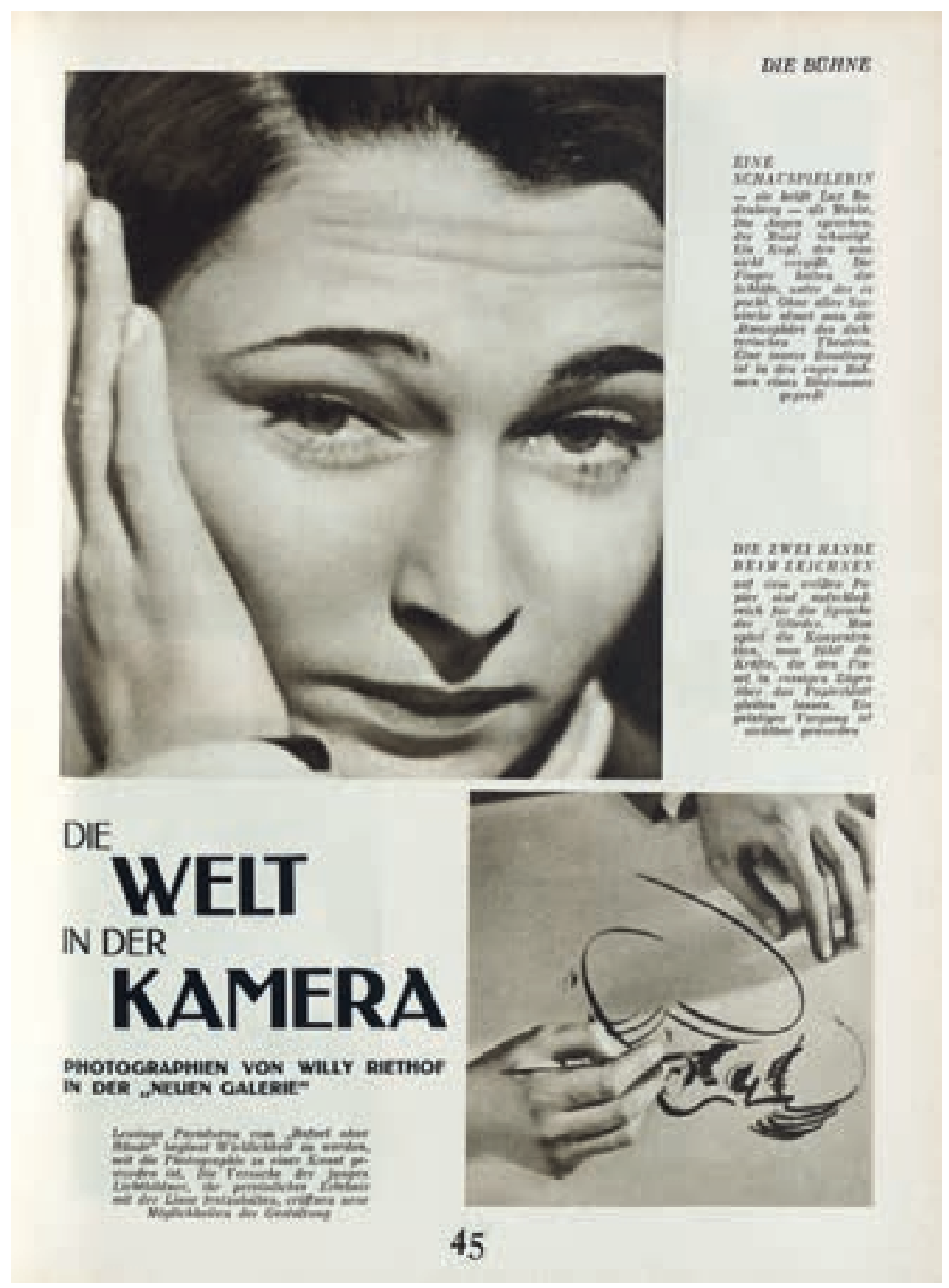

Einen intensiven Austausch gibt es aber auch zwischen der Wiener und der tschechischen Kulturszene. 1928 findet in Brünn eine große Ausstellung für zeitgenössische Kultur statt, die in Österreich auf großes Interesse stößt. Darüber hinaus arbeitet und veröffentlicht eine Reihe von ausgezeichneten tschechischen Fotografen (bzw. Filmemachern) der Moderne, etwa Jan Lukas, Václav Jírů und Alexandr Hackenschmied (der sich später in den USA Hammid nennt), in den 1930er Jahren immer wieder in
Wien. ${ }^{28}$ Andere, wie Willy Riethof oder Otto Skall, sind tschechischer Herkunft, leben und arbeiten aber vorwiegend in Wien.

Einen nicht zu unterschätzenden Einfluss auf die österreichische Fotografie der 1930er Jahre haben ungarische Fotografen. Freilich dominieren bei ihnen, im Unterschied zu den tschechischen Lichtbildnern, eher vorsichtig moderne und traditionelle Elemente. Piktorialistische Gestaltungsmittel kombiniert mit moderner Landschafts- und Sachfotografie sind um 


\section{OUE BDHNE}

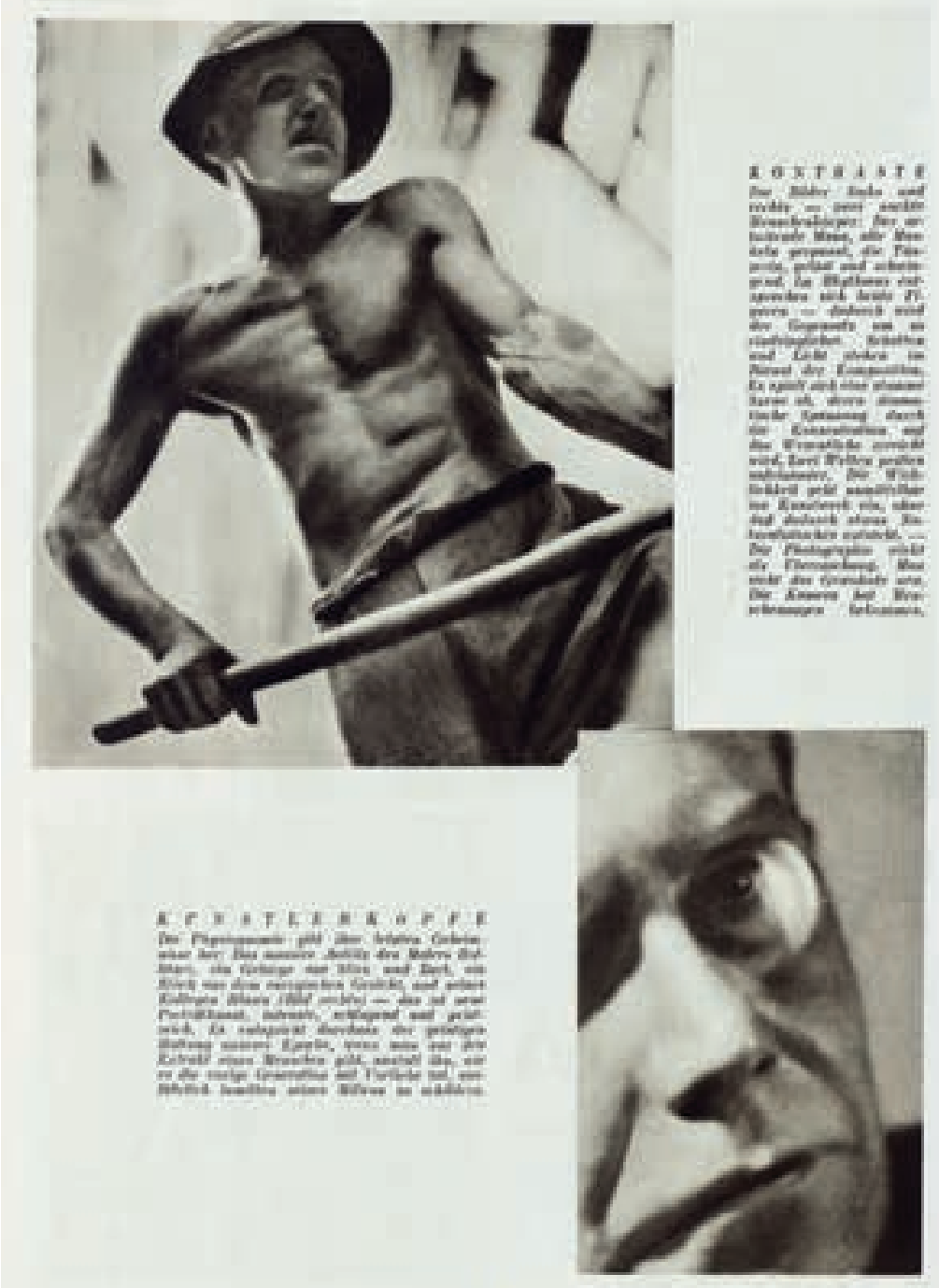

46

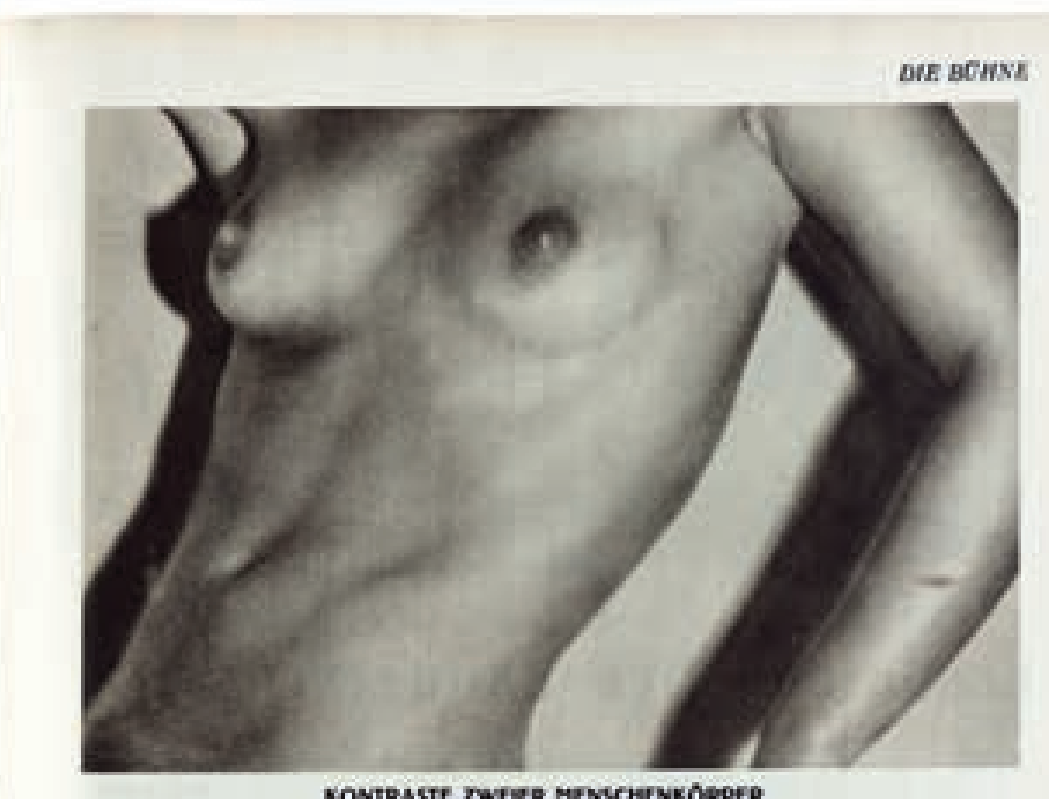

KONTRASTE TWEER MENSCAENKONPER
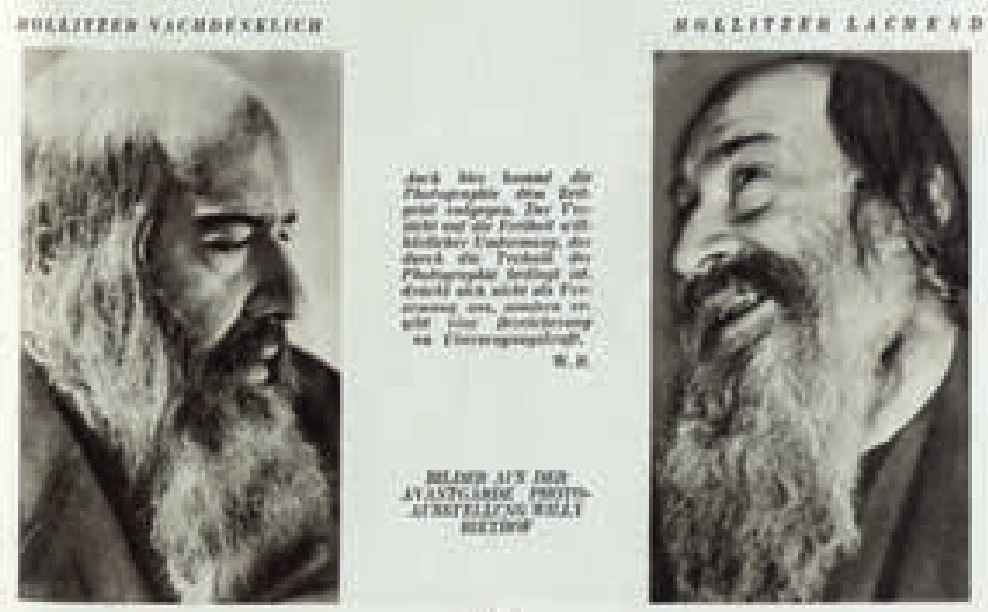

47
1930 bei ungarischen Amateuren besonders beliebt. Neben Stillleben, Landschaftsstudien und Porträts begegnen vor allem folkloristische Bilder und idyllische Szenen des Landlebens. Diese Aufnahmen üben einen erheblichen (bisher nicht näher untersuchten) Einfluss auf die österreichische Fotografie der 1930er Jahre aus. Vor allem in den Jahren nach 1934 kommt es zwischen der österreichischen und der ungarischen Diktatur zu einer deutlichen Annäherung ${ }^{29}$, die sich auch im Kulturaustausch niederschlägt. ${ }^{30}$ In dieser Zeit sind ungarische Fotografen in Österreich sehr präsent, etwa durch Ausstellungen und Veröffentlichungen in Zeitschriften. Einige von ihnen leben auch zeitweise in Österreich und fotografieren und veröffentlichen in österreichischen Medien.

Eine Reihe von ungarischen Fotografen folgt einer modernisierten kunstfotografischen Richtung, die sehr vorsichtig Gestaltungsmittel des Neuen Sehens und der Neuen Sachlichkeit aufgreift. Zu ihnen gehören etwa Jenő Dulovits, Tibor Hegyei, Ernő Vadas, 


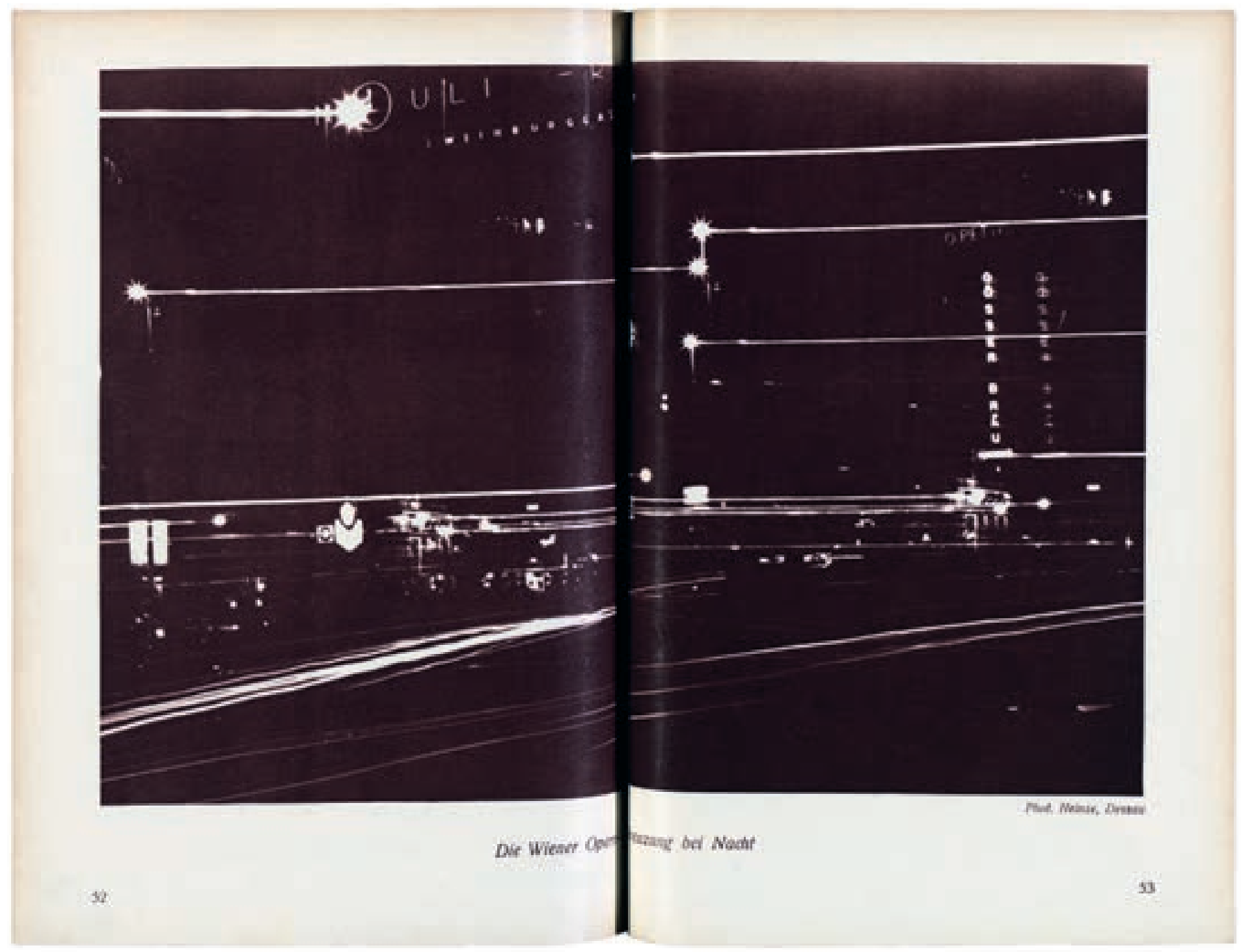

Abb. 15 „Die Wiener Opernkreuzung bei Nacht". Wiener Magazin, Heft 11, November 1930, S. 52/53. Foto: Fritz Heinze.
Lajos Szabó oder József Pécsi, der Altmeister der ungarischen Kunstfotografie, der in manchen seiner Werbesujets mit Elementen der Neuen Sachlichkeit arbeitet. Andere, etwa Ferenc Csík (im deutschsprachigen Raum oft Ferenc Tschik geschrieben) oder Kálmán Szöllnősy, sind im Bereich der Sachfotografie offen für die Anregungen der Avantgarde, in ihren Genreszenen und Landschaften aber bleiben sie gleichwohl traditionell. Die beiden ungarischen Pressefotografen Zoltan Kluger und W. von Szigethy schließlich, die um 1930 in Berlin leben, liefern Anfang der 1930er Jahre ihre Bilder auch nach Österreich. ${ }^{31}$ Von ihnen stammen beispielsweise moderne
Fotoreportagen aus dem städtischen Alltag. Von der ländlichen ldylle halten sie sich gänzlich fern.

\section{Kritiker der Avantgarde}

Die fotografischen Aufbrüche um 1930 sind nicht von langer Dauer. Bereits zwei Jahre nach der FiFoAusstellung ist der Elan der Avantgardebewegung weitgehend erloschen. Die Vertreter einer konservativen Richtung innerhalb der Fotografie haben inzwischen das Zepter wieder fest in der Hand. Eine Karikatur, die Anfang 1933 in der Zeitschrift MOCCA erscheint, macht sich über die „neue Auffassung der 
modernen Photographie" lustig (Abb. 16). Zu sehen ist zweimal haargenau dieselbe Szene, einmal aufgenommen aus der „Draufsicht“, einmal aus der „Druntersicht“. Die moderne Fotografie, so wird hier augenzwinkernd argumentiert, trage nicht viel zur Darstellung der Wirklichkeit bei, sondern produziere lediglich billige Effekte. Die Zeichnung thematisiert einen Konflikt innerhalb der Fotografie, der zu diesem Zeitpunkt schon weitgehend entschieden ist.

Die Gruppe der modernen, der Avantgarde gegenüber offenen Fotografen bildet um 1930 ohnehin nur eine kleine Minderheit innerhalb der österreichischen Fotografie. Und sie sind in der Regel keine radikalen Vertreter der Avantgarde. Das in der Karikatur bloßgestellte Markenzeichen, die Vogelperspektive bzw. Draufsicht, wird in der modernen österreichischen Fotografie sehr zurückhaltend eingesetzt (Abb. 17).

Der weitaus größte Teil der österreichischen Fotografen hält in diesen Jahren gebührenden Abstand zur Avantgardebewegung. Sie bleiben der Tradition treu und öffnen sich nur vorsichtig den modernen internationalen Tendenzen. Dies betrifft die herkömmlich arbeitenden Berufsfotografen nicht weniger als die Amateure, von denen der Großteil an der überkommenen Formsprache festhält. Ihr Sprachrohr sind die diversen Fachzeitschriften und Jahrbücher, deren Redaktionen in der Zwischenkriegszeit fest in konservativer Hand sind. Aus dieser Ecke ist besonders heftige Kritik gegenüber den neuen Strömungen der Fotografie zu vernehmen.

Einer der Wortführer des publizistischen Kreuzzuges gegen die Avantgardefotografie ist der Grazer Maximilian Ritter von Karnitschnigg. Der 1872 geborene Fotograf muss zeitlebens nie von der Lichtbildnerei leben. Er ist ein klassischer Amateur, seine berufliche Karriere führt ihn zuerst zum Militär, später wird er Beamter im steiermärkischen Landesdienst in Graz. ${ }^{32}$ Finanziell gut abgesichert, leistet er sich die künstlerische Fotografie als Freizeitbeschäftigung. Ende der 1920er und in den 1930er Jahren gehört er zu den international am meisten ausgestellten österreichischen Fotografen. Karnitschnigg ist einer der vehementesten Kritiker der Ausstellung „Film und Foto“. 1931 wettert er unter dem bezeichnenden Titel „Modische Sachlichkeit“ gegen die neuen Tendenzen in der Fo-

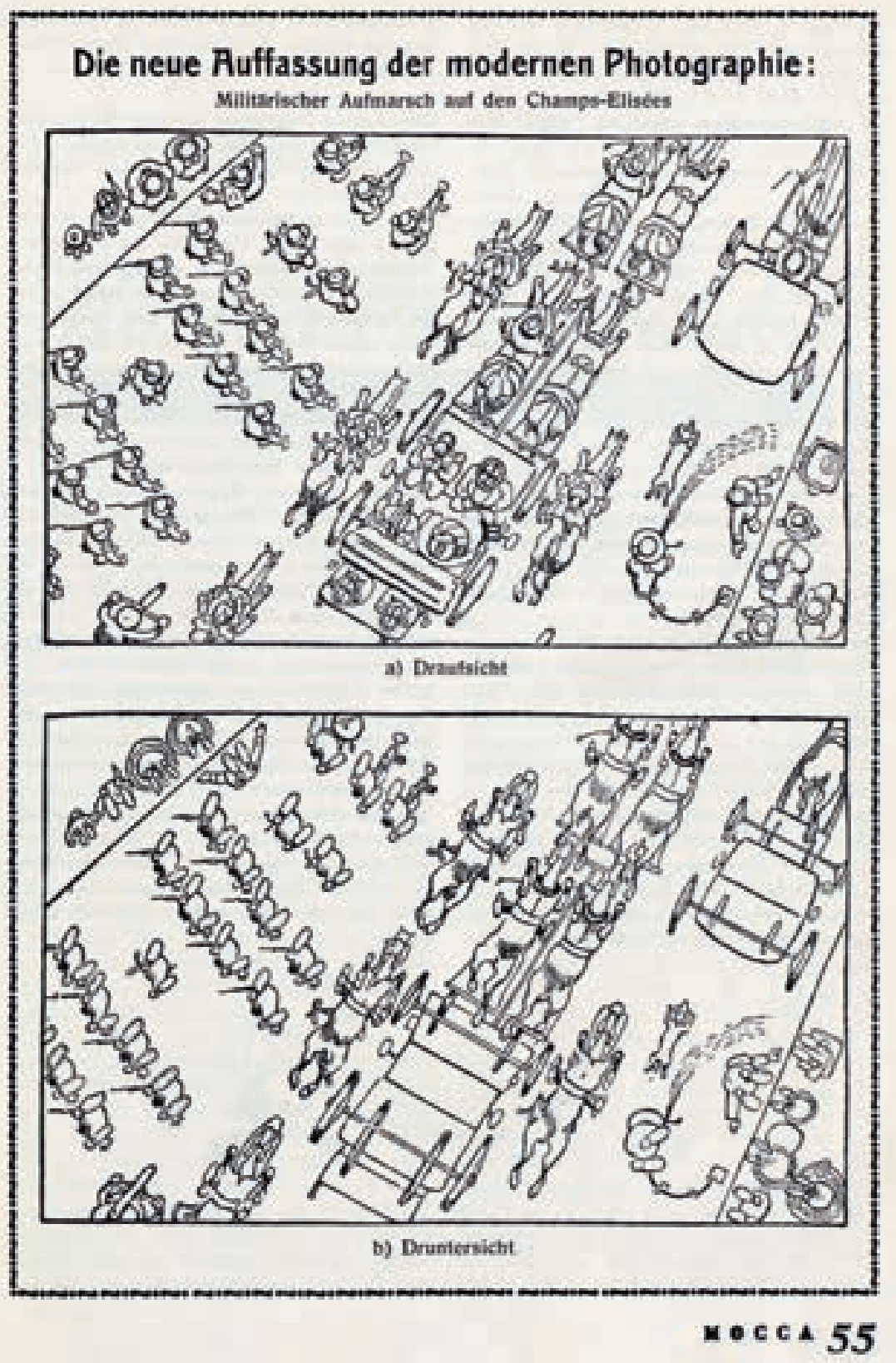

tografie. Er kritisiert die „Exzesse im neuzeitlichen Sinne“ und verwahrt sich gegen die „Verlockungen extremer Sachlichkeit“. ${ }^{33}$ Offen nimmt er gegen die Ausstellung „Film und Foto“ Stellung: „Daß die Wanderausstellung ,Film und Photo“ fast durchwegs Propagandamaterial äußersten Modernismus bringt, ist wohl begreiflich, daß aber viele Amateure, deren innere Einstellung eigentlich dezidiert konservativ ist, einem gewissen Snobismus nachgebend, auch diese Mode mitmachen zu müssen glauben, ist bedauerlich." ${ }^{34}$ Nicht ganz dem Zufall geschuldet dürfte es sein, dass Karnitschnigg in diesem Rundumschlag den Begriff „Foto“, der im Titel der FiFo vorkommt,
Abb. 16 „Die neue Auffassung der modernen Photographie“. Karikatur, die sich über die Stilmittel der Avantgarde lustig macht. MOCCA, Nr. 1, Januar 1933, S. 55 


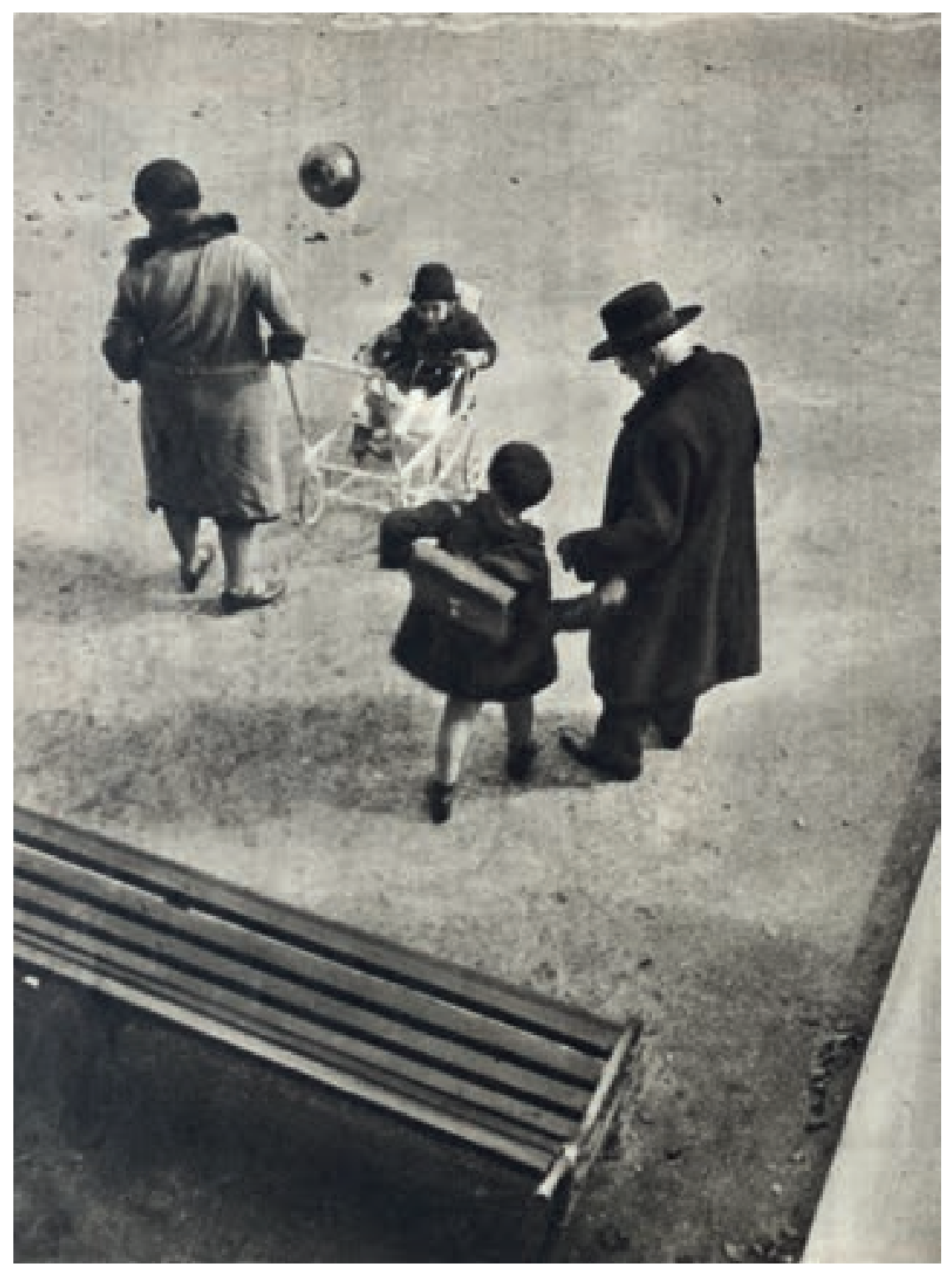

Abb. 17 „Mittag im April“. Die Bühne, Erstes Aprilheft 1932, S. 4. Foto: Nikolaus Schwarz. fäschlicherweise mit „ph“ schreibt (Photo). Das ist vermutlich weniger ein Tippfehler als vielmehr ein subtiler Seitenhieb auf die in seinen Augen allzu radikalen Anhänger der Moderne. Zwar rechnet er sich durchaus den gemäßigt modernen Fotografen zu, lehnt aber „Exzesse“ entschieden ab. 1933, zu einem Zeitpunkt, als die Avantgarde längst auf dem Rückzug ist, zieht er Bilanz: „Das schnelle Ende der übertriebenen Sachlichkeit beweist klar und eindeutig, daß derartige Sensationen nicht von Dauer sein können (...). “35 In seinem verbalen Rundumschlag lässt er kein gutes Haar an den neuen Strömungen der Fotografie. Das bedeutet freilich nicht, dass er die Anregungen der Neuen Sachlichkeit gänzlich ignoriert hätte. Um 1930 entscheidet er sich, insbe- sondere bei seinen Auftrags- und Werbeaufnahmen, für eine Verbindung von kunstfotografischem und sachlichem Stil. ${ }^{36}$

Karnitschnigg ist nicht der einzige Kritiker, der um 1930 die handwerklich gediegene, konservativen Grundsätzen verpflichtete Kunstfotografie gegenüber den radikalen Neuerungen in der Fotografie in Schutz nimmt. Ihm zur Seite stehen zahlreiche andere Fotografen, Publizisten und Fotofunktionäre. Auch sie melden sich in teils aggressiver Weise gegen die neue Fotografie zu Wort. Heinrich Kühn etwa, der Altmeister der österreichischen Kunstfotografie, geißelt kurz nach der Wiener FiFo-Aussstellung im renommierten Jahrbuch Das deutsche Lichtbild die „umstürzlerische Tendenz“ der „modernen Sachfotografie“. ${ }^{37}$ Die Fotomontage erinnere ihn „manchmal zynisch an das Brutale, Aufreizende und doch wieder Blöde einer Jazzmusik“. Die moderne Fotografie vermittle den „Gesamteindruck (...) von Verworrenheit, Unruhe und, in manchen Fällen, auch der Ratlosigkeit“. ${ }^{38}$

Ebenfalls ablehnend gegenüber der fotografischen Avantgarde äußern sich die maßgeblichen Vertreter der Wiener Graphischen Lehr- und Versuchsanstalt, der wichtigsten österreichischen Ausbildungsstätte für Fotografen. Sowohl ihr Direktor, Rudolf Junk, als auch der bekannteste unter den Professoren, der Fotograf Rudolf Koppitz, der einer gemäßigt modernen kunstfotografischen Richtung angehört, weisen die Konzepte der Avantgarde vehement zurück. Besonders nachhaltig und konsequent wird die Avantgardefotografie in den meisten Fachjournalen verdammt, die sich an die Amateure richten. Einer der Wortführer gegen die „Auswüchse der Moderne“ ist der Fotopublizist und Amateurfotograf Hans Hannau. In seiner 1933 gegründeten Zeitschrift Der Lichtbildner zieht er regelmäßig gegen die moderne Fotografie zu Felde. Ähnliche Positionen finden wir auch in anderen Fachzeitschriften, etwa in der Allgemeinen Photographischen Zeitschrift oder in der Kamera-Kunst. Neben den Fotografen und Publizisten Erwin Sajdok und Hugo Haluschka wird Hannau zu einem der wichtigsten publizistischen Wegbereiter der österreichischen Heimatfotografie. Diese avanciert in den 1930er Jahren zum politisch-ideologischen wie ästhetischen Gegenentwurf der Avantgarde. 


\title{
Landschaft, Berge, Brauchtum
}

\author{
Heimatfotografie in den 1930er Jahren
}

Im August 1934 steht das Titelblatt der Zeitschrift Moderne Welt ganz im Zeichen der Heimat (Abb. 1). ${ }^{1}$ $\mathrm{Zu}$ sehen ist ein Trachtenpaar inmitten einer ländlich-bäuerlichen Umgebung, dahinter ragen die Berge auf. Die Zeitschrift, vor wenigen Jahren noch ein Aushängeschild der gemäßigt modernen Fotografie, schwenkt 1933 innerhalb kürzester Zeit auf den konservativen Regierungskurs ein. Das schlägt sich nicht nur in den Texten und Bildern, sondern auch in der Gestaltung nieder. Der Schriftzug „Moderne Welt“, der über dem gezeichneten Trachtenpaar vor der Gebirgslandschaft prangt, bezeichnet nun, am Beginn des austrofaschistischen Regimes, eine ganz andere Moderne als noch ein paar Jahre zuvor.

Das Heft, das wenige Tage nach der Ermordung des Bundeskanzlers Engelbert Dollfuß erscheint, beginnt im Innenteil patriotisch und staatstragend mit einem Porträt des ehemaligen Kanzlers. ${ }^{2}$ Gleich anschließend skizziert der konservative Kärntner Schriftsteller und hohe Kulturpolitiker der „Ständestaates“, Guido Zernatto, am Beispiel der „Volkstrachtmode“ den neuen antiurbanen Geist der Gegenwart. „Es liegt“, schreibt er, „im Zug der Zeit, die sich jetzt immer mehr der Liebe zum Natürlichen und zum Ländlichen zuwendet, daß die Volkstracht zur Mode wird. In den Städten begegnen uns immer öfter Leute, besonders Damen, deren Kleider eine Abwandlung, eine Verniedlichung oder Verfeinerung der Volkstracht sind. Der tiefere Grund dafür mag darin liegen, daß auch die städtische Bevölkerung von einer gewissen Sehnsucht erfaßt worden ist, auch im Äußeren und im Äußerlichen zu erkennen zu geben, daß sie dem Lande, in dem sie wohnt, zugehörig ist. “3 Illustriert ist der Beitrag mit Trachtenfotos von Rudolf Koppitz, der in diesen Jahren zum gefeierten Star der österreichischen Heimatfotografie wird.

Die Heimatideologie ist ein zentraler Bestandteil des diktatorischen „Ständestaates“. In den 1930er Jahren taucht dieser Kampfbegriff des Regimes in vielfältigen Bedeutungsvarianten und Verwendungsweisen auf. Als heimatlich gilt all das, was zu den emotionalen Kernzonen des neuen, konservativen Staatsbildes gehört: die heimatliche Landschaft zuallererst, die vom Großglockner bis zur Wachau reicht, nicht aber bis zu der bisher von den Sozialdemokraten beherrschten Metropole Wien. Das heimatliche Land bildet den ideologischen Gegensatz zur Stadt, die politisch anrüchig und potenziell gefährlich ist. Zur Heimat werden auch Brauchtum und Tracht geschlagen, die Geschichte und ihre Traditionen, etwa die Zeit des Barock und vor allem die Epoche der Habsburger, die in den 1930er Jahren ein vom Austrofaschismus sorgsam inszeniertes Revival feiert. „Heimat“ ist also weit mehr als ein kurzfristig ausgegebenes politisches Motto. Vielmehr handelt es sich um ein symbolisch dicht besetztes ideologisches Konzept, um eine kollektive Gesinnung, eine Haltung, eine politische Kultur, die den Einzelnen mit der staatlichen Gemeinschaft verbindet.

Die Regierung unternimmt zahlreiche Anstrengungen, um das Konzept der „Heimat“ zum tragenden Baustein der Staatsideologie zu machen. Im Schuljahr 1935 etwa schreibt die niederösterreichische Landesregierung in den Schulen einen groß angelegten patriotischen Aufsatzwettbewerb aus. ${ }^{4}$ Weder Zeitpunkt noch Thema sind zufällig gewählt. Vor gut einem Jahr, im März 1934, hat das autoritär regierende christlichsoziale Regime nach einem blutigen Bürgerkrieg die letzten Bastionen ihrer Gegner erobert. Sozialdemokratie, Gewerkschaftsbewegung, freie Presse und jede andere Form von Opposition sind nun in ganz Österreich ausgeschaltet. Die Umgestaltung zum diktatorischen „Ständestaat“ ist inzwischen praktisch abgeschlossen. Im neuen Regime haben, so will es die Regierung, die Schulen die Aufgabe, Übungsanstalten in patriotischer Gesinnung zu sein.

Das Thema des Wettbewerbs lautet: „Heimaterde wunderhold“. Das Zitat ist der zweiten Zeile der neuen 
Abb. 1 Tracht, Landleben und Berge sind die Zutaten der österreichischen Heimatideologie in den 1930er Jahren. Diese schlägt sich auch in der illustrierten Presse nieder. Moderne Welt, Heft 11, August 1934, Titelseite.
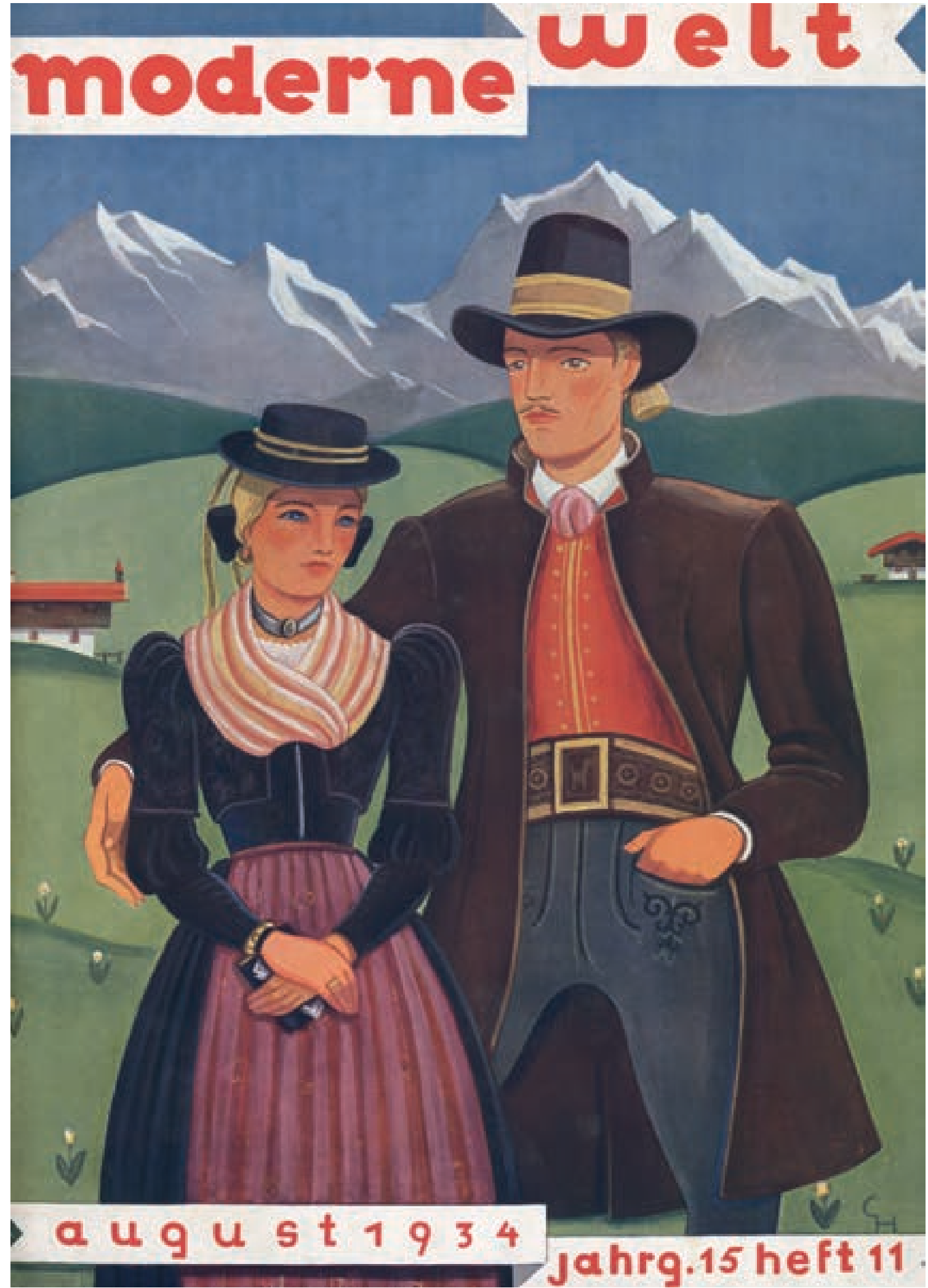
österreichischen Bundeshymne entnommen, die Ende der 1920er Jahre eingeführt wurde. Sie stammt aus der Feder des deutschnationalen Dichters Ottokar Kernstock. ${ }^{5}$ Die politische Propaganda in den Schulen zeigt ihre Wirkung. 100.000 Schüler, so berichtet die Presse euphorisch, nehmen im Frühjahr 1935 am Wettbewerb teil und reichen einen Heimataufsatz ein. 56 Mädchen und Jungen werden Ende Juni in Wien im Rahmen einer patriotischen Feierstunde ausgezeichnet. Öffentlichkeitswirksam und vor versammelter Presse überreicht der christlichsoziale, der neuen Regierung loyal verbundene, Bundespräsident Wilhelm Miklas die Preise (Abb. 2).

Die Propagandamaschinerie des österreichischen „Ständestaates“ scheut ab 1933/34 keine Anstrengung, Patriotismus und Heimatbewusstsein zu fördern, wo nur immer möglich. Wenn Anlässe fehlen, werden diese ad hoc geschaffen. Das Weihnachtsfest im Jahr 1936 etwa wird kurzerhand zur „Weihnacht der Heimat“ erklärt. Wieder tritt Bundespräsident Miklas in Aktion. Diesmal werden 100000 ausgewählte Kinder öffentlichkeitswirksam mit einem Weihnachtsgeschenk bedacht. Die Symbolik ist unübersehbar in einer Zeit der ökonomischen Krise, hoher Arbeitslosigkeit und verbreiteter Armut.

Die eifrige Kultivierung der „Heimatliebe“ ist zwar nach 1933/34 Teil der offiziellen staatlichen Ideologie, aber ihre Ursprünge reichen weiter zurück. Schon Jahre bevor die autoritäre christlichsoziale Regierung dazu ansetzt, die Macht im Staat gänzlich an sich zu reißen, zeichnet sich ein neuer Heimatdiskurs ab. Die Schwelle ist das Jahr 1927, jenes Jahr, in dem der Wiener Justizpalast brennt und die heftigen politischen Auseinandersetzungen zwischen links und rechts auf einen ersten Höhepunkt zusteuern. Die Sozialdemokratie geht geschwächt aus diesem Zusammenstoß auf der Straße hervor. Dennoch, ihre vollkommene Niederlage wenige Jahre später ist noch nicht vorherzusehen. In diesem Jahr mehren sich die Zeichen für einen neuen, konservativen Patriotismus. Kräftig unterstützt vom Bundesministerium für Handel und Verkehr wird 1927 beispielsweise eine groß angelegte Kampagne für den heimischen Fremdenverkehr gestartet, die bis weit in die 1930er Jahre hinein fortgeführt wird. Ihr Motto lautet: „Das schöne
Österreich“. Beworben wird nicht etwa Wien, sondern ausschließlich das ländliche Österreich, insbesondere das Hochgebirge der Alpen, sowie bekannte Kulturinstitutionen: beispielsweise die Salzburger Festspiele.

Das Erstarken einer neuen österreichischen Heimatideologie steht um 1930 in engem Zusammenhang mit der innenpolitischen Auseinandersetzung. Sie dient als Gegenentwurf zu der als „städtisch“ ge-
Abb. 2 Patriotische Heimatkunde im Dienste der Regierung. Aufsatzwettbewerb in Niederösterreich im Jahr 1935 zum Thema „Heimaterde wunderhold“. Das interessante Blatt, 11. Juli 1935, Titelseite.

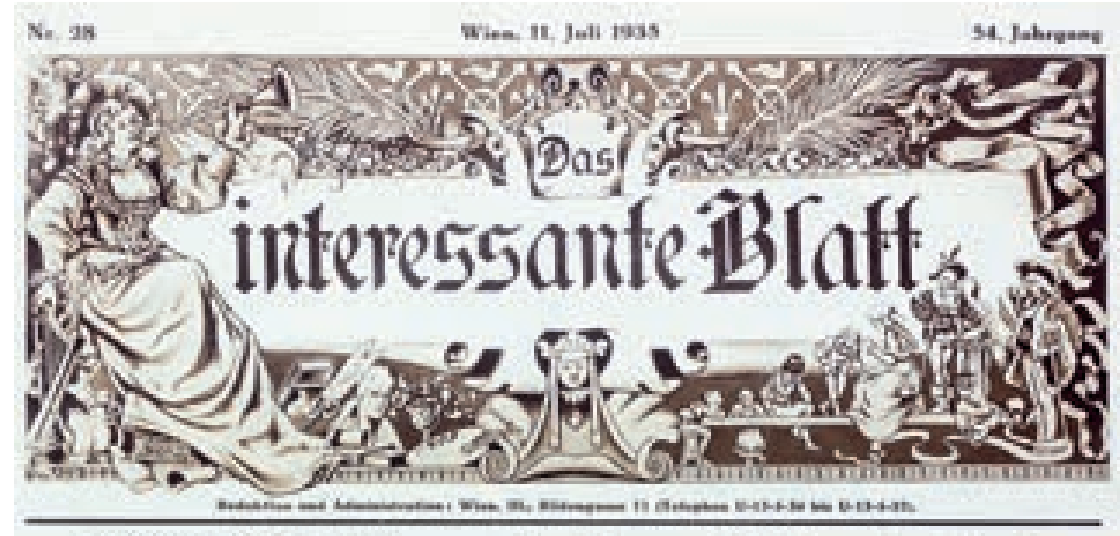

\subsection{Shüler schreiben Heimataufsatz}

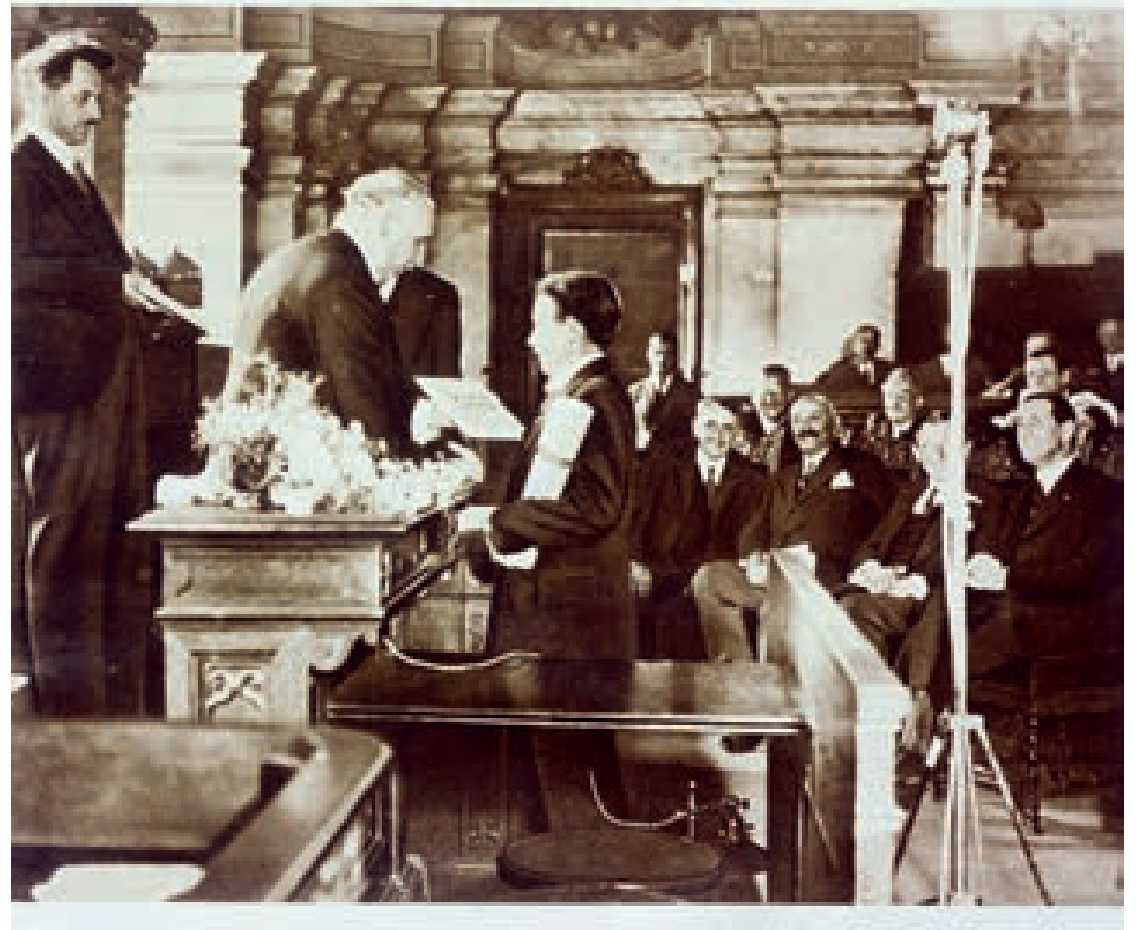

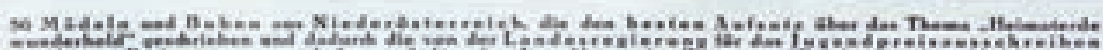

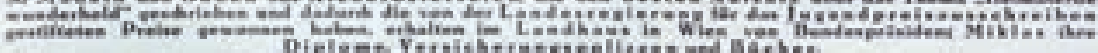
Buharistisdher KongreB in Laibah. - Wellausstelluag in Brâsel. - Boskampf. 
Abb. 3 „Österreichische Tat“. Fotoreportage zur Eröffnung der Großglocknerstraße. Wiener Magazin, Heft 9, September 1935, S. 82/83. Fotos: Lothar Rübelt. brandmarkten Sozialdemokratie. Nach 1933 ist der spezifisch österreichische Heimatdiskurs auch eine Reaktion auf die Machtübernahme der Nationalsozialisten in Deutschland. Die Alpenrepublik, die 1933/34 selbst zur Diktatur wird, grenzt sich patriotisch-konservativ vom bedrohlichen nördlichen Nachbarn ab.

\section{Heimatbilder: Großglockner und Salzburger Festspiele}

Die Fotografie spielt in dieser Neuausrichtung des Österreichbildes eine wichtige Rolle. Sie trägt wesentlich zur Ausformulierung der Heimatideologie bei. Als im August 1935 die Großglockner Hochalpenstraße feierlich eröffnet wird, wird dieses größte patriotische Bauprojekt des „Ständestaates“ in Bildern, Filmen und Texten als machtvoller „heimatlicher“ Gegenentwurf zu einem angeblich städtisch-verkommenen, wienlastigen Österreich gepriesen. ${ }^{6}$ Zahlreiche Fotografen lichten die Errungenschaften der Technik im hochalpinen Raum und die Eröffnungsfeierlichkeiten ab. Wochenlang wird das patriotische Bauprojekt in der Presse gefeiert. Im September 1935 erscheint im Wiener Magazin eine Reportage über die neue Großglocknerstraße (Abb. 3). Sie beginnt mit einer Doppelseite, auf der das Bauwerk in hochalpi-

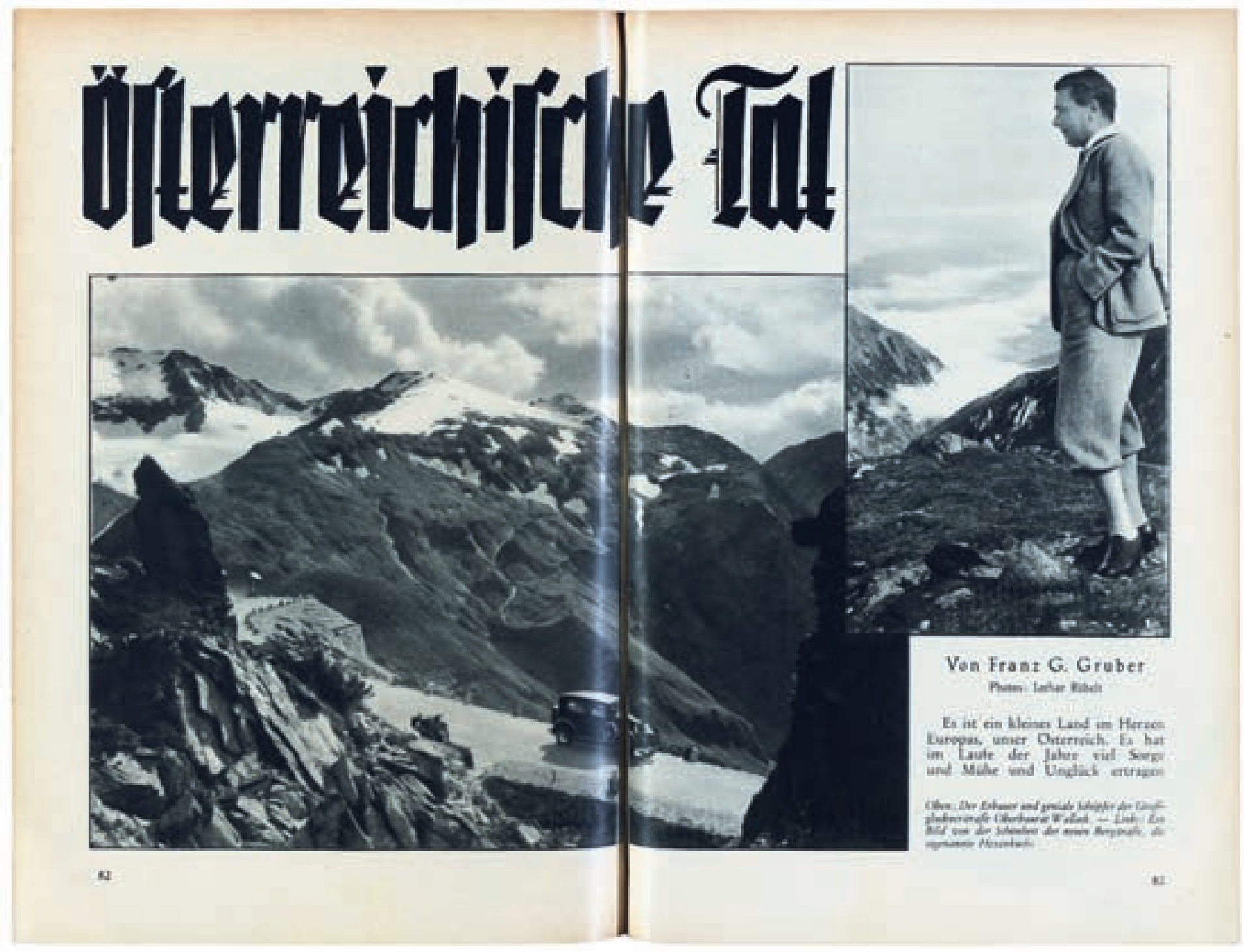


ner Landschaft und Franz Wallack, der „Erbauer und geniale Schöpfer der Großglocknerstraße“, einander gegenübergestellt sind. Die Aufnahmen stammen von Lothar Rübelt. „Es ist“, heißt es gleich zu Beginn des Berichts, „ein kleines Land im Herzen Europas, unser Österreich. Es hat im Laufe der Jahre viel Sorge und Mühe und Unglück ertragen müssen, noch immer verdecken düstere Wolken die schöne, reine Bläue eines Lebenshimmels. Aber es stimmt nicht, was dem Österreicher so oft vorgeworfen wird, daß er so gerne die Hände sinken lasse. “7 In pathetischen Worten werden die ideologischen Hintergründe des Großbauwerks umrissen. Die Straße dient in Zeiten der Wirtschaftskrise und der nationalen Abschottung als Aushängeschild eines patriotischen Österreich-Projekts. Weiter heißt es: „Das kleine Österreich hat zum Trotz gegen alle Nörgler und alle, die den Österreicher schwach nennen, eine Tat hingesetzt, eine österreichische Tat. Reiche Länder können leicht Straßen bauen, von denen die Welt begeistert ist. Österreich, arm und klein, ein Land, in dem man den Groschen dreimal umdreht, ehe man ihn ausgibt, hat eine Tat vollbracht, großzügig, genial, weitblickend ... Die Großglockner-Hochalpenstraße. Die Geschichte dieser Straße ist ein Spiegel österreichischen Kampfes gegen Wirtschaftsnot und Verzagtheit."8 Programmatisch ausformuliert ist hier die merkwürdige Mischung aus kollektivem Minderwertigkeitsgefühl und Narzissmus, aus Ohnmacht und Selbstüberschätzung, die das Land in der Zwischenkriegszeit prägt.

Ebenso wie das Hochgebirge wird in den 1930er Jahren auch die Stadt Salzburg als ländlich-heiler Fluchtpunkt inszeniert. Sie avanciert, zumindest einmal in Jahr, während der Salzburger Festspiele, zur heimlichen Hauptstadt des Landes. ${ }^{9}$ Salzburg gilt während dieser Zeit als urösterreichiches Gesamtkunstwerk. Aus patriotisch-konservativer Sicht vereint die Stadt all das, was im Austrofaschismus das Ideal einer österreichischen Stadt ausmacht: Sie ist klein und überschaubar, eng verbunden mit der ländlichen Umgebung, touristisch und nicht industriell ausgerichtet, ein Zentrum der bürgerlichen Hochkultur, tief geprägt von der Tradition der Gegenreformation und vom politischen Katholizismus (Abb.4), sie ist fest in christlichsozialer Hand und - nicht

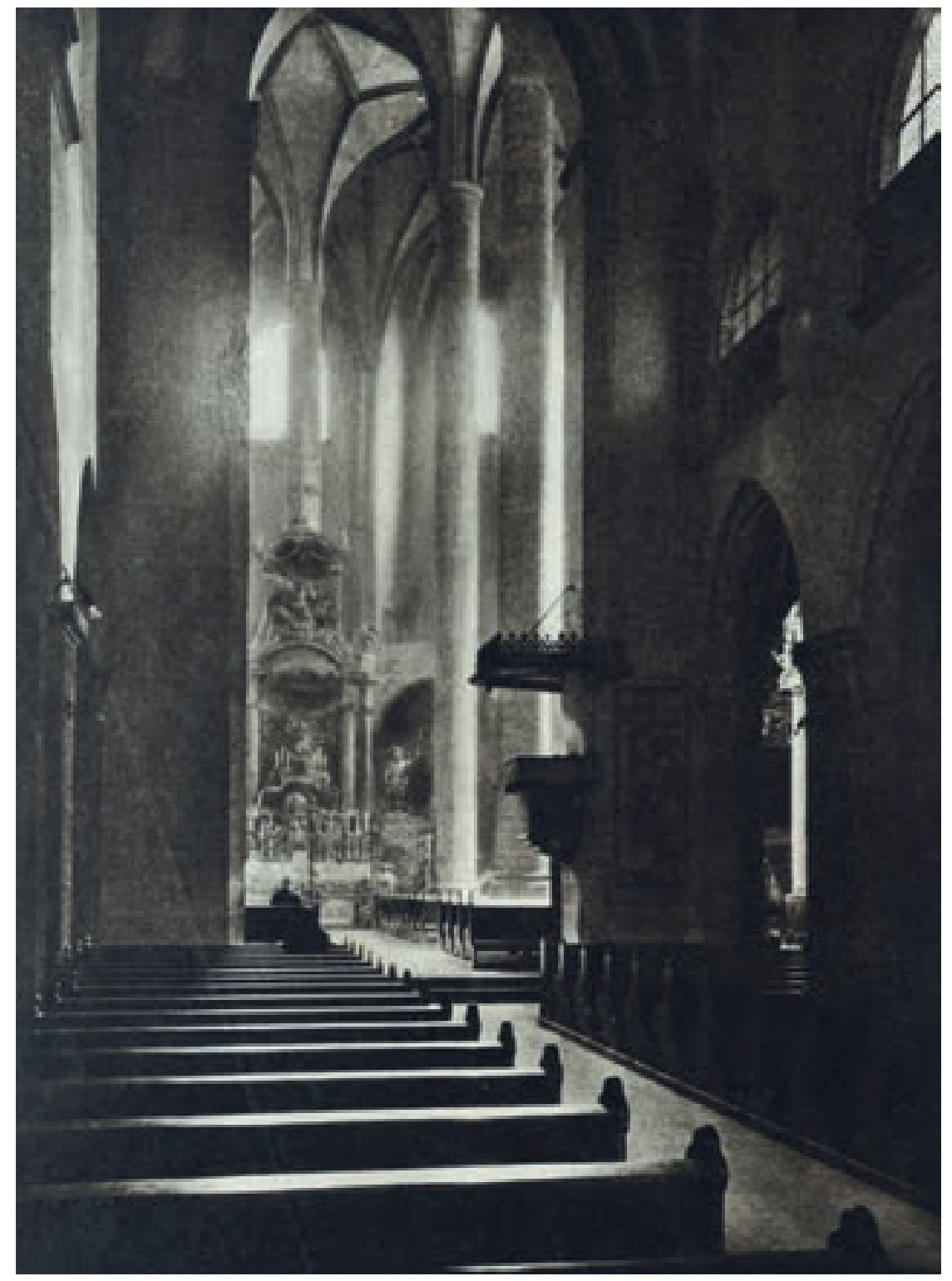

zuletzt - der Anteil der jüdischen Bevölkerung hält sich hier in engen Grenzen. Salzburg ist jene Stadt, in der die konservative Ideologie des „Ständestaates“ in Reinform vorgeführt werden kann.

Viele Protagonisten des kulturellen Lebens, die in Salzburg auftreten, nehmen bereitwillig am patriotischen Festspielprogramm teil, das in den 1930er Jahren von Jahr zu Jahr staatstragender wird. Die heimatliche Tracht etwa wird auf der gesellschaftlichen Bühne rund um die Festspiele zum Zeichen der Dazugehörigkeit (Abb.5). Zugleich ist sie ein Signet für
Abb. 4 Die Salzburger Franziskanerkirche, fotografiert von Maximilian Karnitschnigg Er ist einer der bekanntesten konservativen Vertreter der österreichischen Fotografie der Zwischenkriegzeit. Die Bühne, Erstes Augustheft 1931, S. 10. 


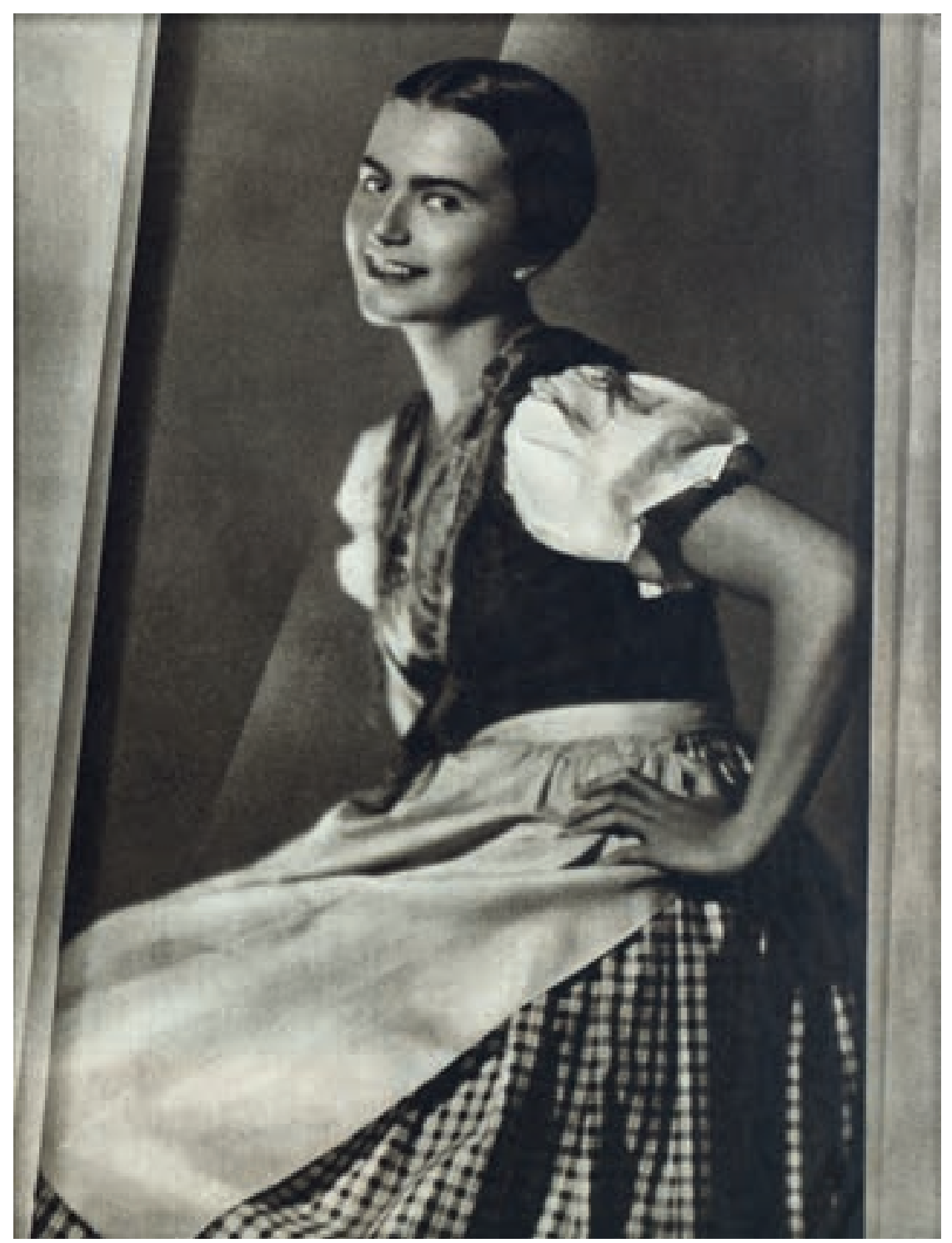

Abb. 5 „Sommer im Salzburgischen". Die Tracht ist das modische Signet Salzburgs während der Festspielzeit. Die Bühne, Erstes Augustheft 1931, S. 5. Foto: Franz Löwy.

Abb. 6 Der italienische Sänger Ezio Pinza kauft sich in Salzburg eine Lederhose. Das interessante Blatt, 29. August 1935, Titelseite. Foto: Leo Ernst, Albert Hilscher.

italienische Sänger Ezio Pinza, der bei den Festspielen 1934 den Don Giovanni gibt, Tage vor der Aufführung in der Salzburger Altstadt eine Lederhose kauft, ist das der führenden österreichischen Illustrierten, dem Interessanten Blatt, eine Titelgeschichte mit Bild wert (Abb.6). „Wer sich heute in der Festspielstadt aufhält“, heißt es zum Bild, „gleichgültig ob als Gast oder als ausübender Künstler, fühlt sich einem ungeschriebenen Gesetz zufolge verpflichtet, nach einigen Tagen die zeuge und zugleich Protagonist dieser Entwicklung. Er passt sich den Stimmungen der Zeit besonders aufmerksam an. Von Anfang an folgt er einer konservativen Bildsprache und nimmt in den 1930er Jahren die Ideologie des „Ständestaates“ ebenso willig auf, wie er nach 1938 Anschluss an das NS-Regime sucht. Als der „Führer“ im Sommer 1939 die Salzburger Festspiele besucht, porträtiert er ihn zusammen mit anderen regionalen Parteiführern, unter anderem dem Salzburger Gauleiter Friedrich Rainer, in seiner Loge im Festspielhaus (Abb. 7). ${ }^{11}$

\section{Fotografie im Dienst der Heimat}

In den späten 1920er und noch mehr in den 1930er Jahren wird das Medium Fotografie immer wieder für staatliche patriotische Imagekampagnen genutzt. Die seit 1919 existierende staatliche „Bundeslichtbildstelle“ (auch Österreichische Lichtbildstelle) und der 1921 gegründete „Österreichische Lichtbild-

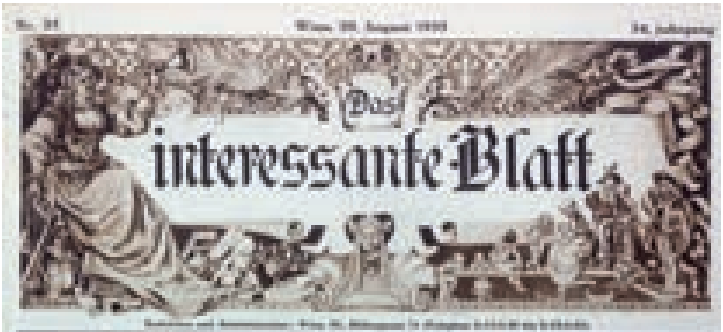
Salzburger Nationaltracht anzulegen. Ezio Pinza, der Don Giovanni, kauft unter Beihilfe von Lotte Lehmann eine Lederhose, Joppe und Hut besitzt er bereits.“ 10

Wenn man die fotografische Dokumentation Salzburgs der 1920er und 1930er Jahre jeweils während der Festspielzeit überblickt, wird deutlich, wie sehr die Stadt zur Bühne des Österreich-Patriotismus wird. Der Salzburger Fotograf Karl Ellinger, der die Festspiele von Beginn an dokumentiert, ist ein Augen-

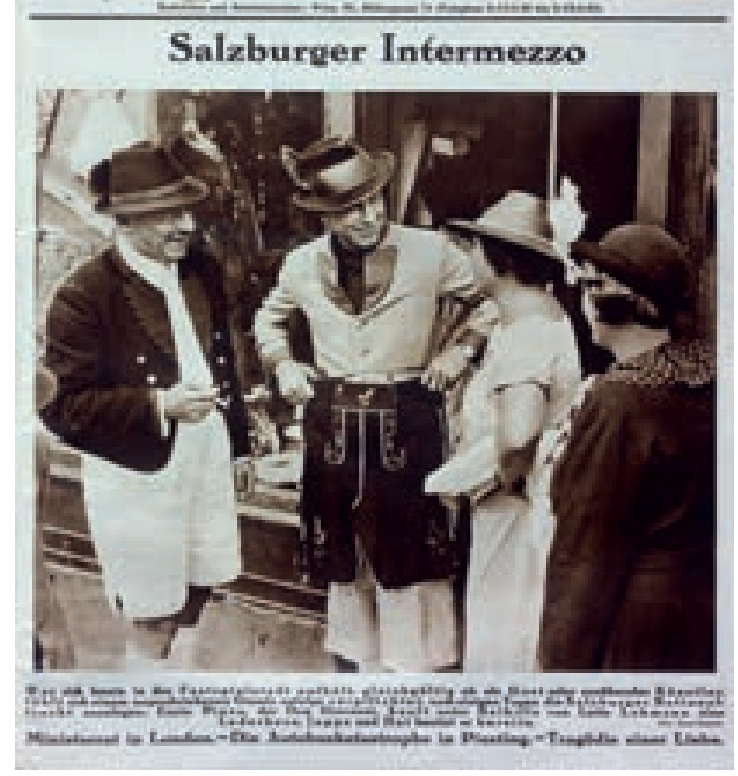


und Filmdienst" werden ab Ende der 1920er Jahre unter der Ägide der chistlichsozialen Regierung zur privilegierten Drehscheibe für die Produktion und den Vertrieb patriotischer Österreich-Bilder ausgebaut. Sie beliefern Schulen und andere öffentliche Institutionen, aber auch die Presse und Ausstellungen mit einer beachtlichen Zahl heimatlicher Ansichten. Die massive finanzielle Unterstützung durch das Wiener Unterrichtsministerium und das Bundeskanzleramt trägt dazu bei, dass sich insbesondere die „Österreichische Lichtbildstelle“ ab Ende der 1920er Jahre als eine Art „nationale“ Fotoagentur etablieren kann.
Als sich Mitte der 1930er Jahre die Diktatur des „Ständestaates“ durchsetzt, verbreitert sich dieser patriotische Strang der Fotografie rasch. Viele offizielle Bilder des „Ständestaates“ inszenieren ein ländliches, heiles Österreich, das zum imaginierten Refugium wird. Oft handelt es sich um touristische Botschaften, die aber zugleich auch ideologische Stellungnahmen im laufenden Kampf um die Deutungshoheit des politisch gebeutelten Landes sind. Im Austrofaschismus wird aus dem anschwellenden Diskurs der Heimatfotografie innerhalb kürzester Zeit eine staatlich geförderte Bildideologie, die die Propaganda nach außen
Abb. 7 Adolf Hitler bei den Salzburger Festspielen. Die Bühne, 25. August 1939, S. 1. Foto: Karl Ellinger.

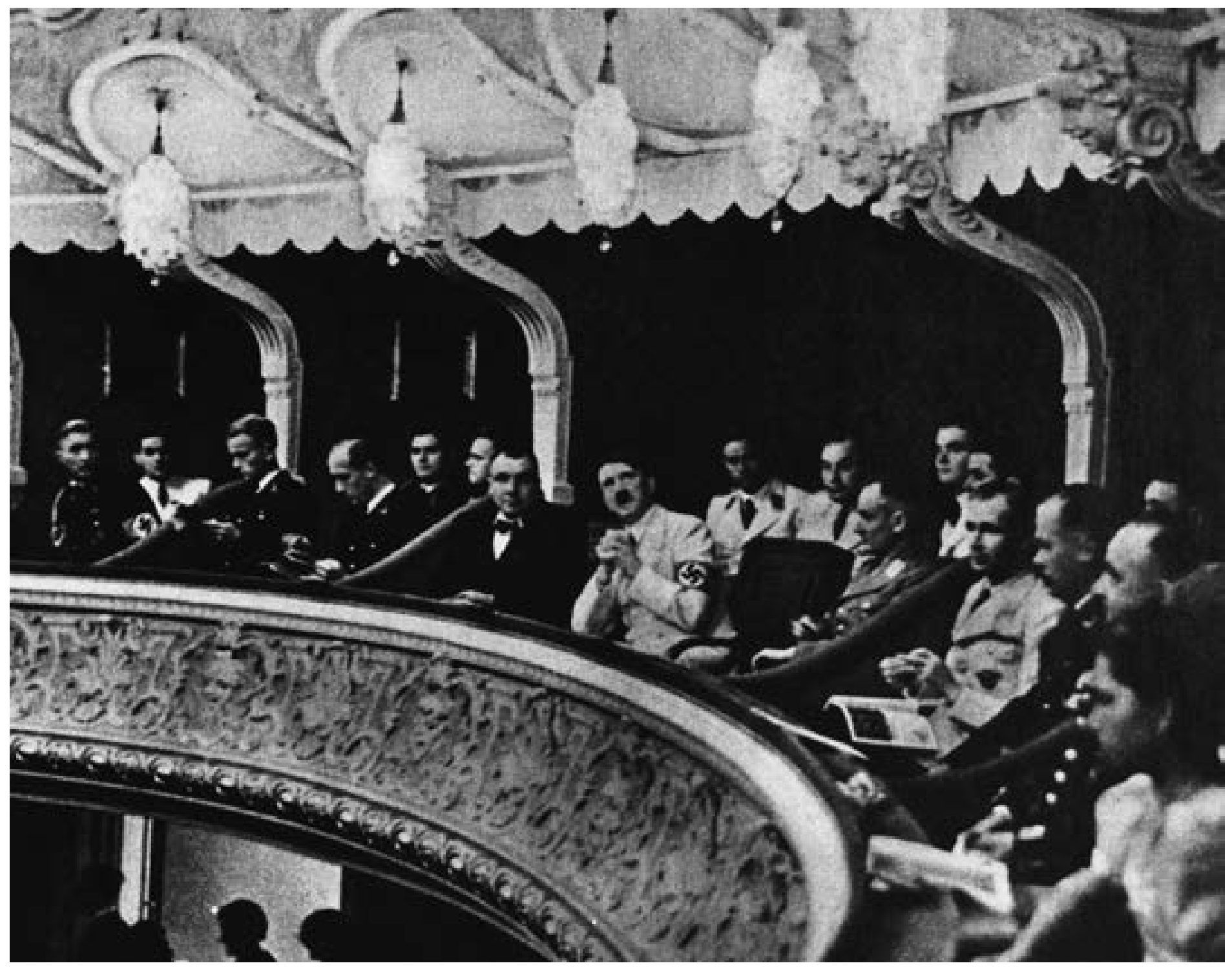




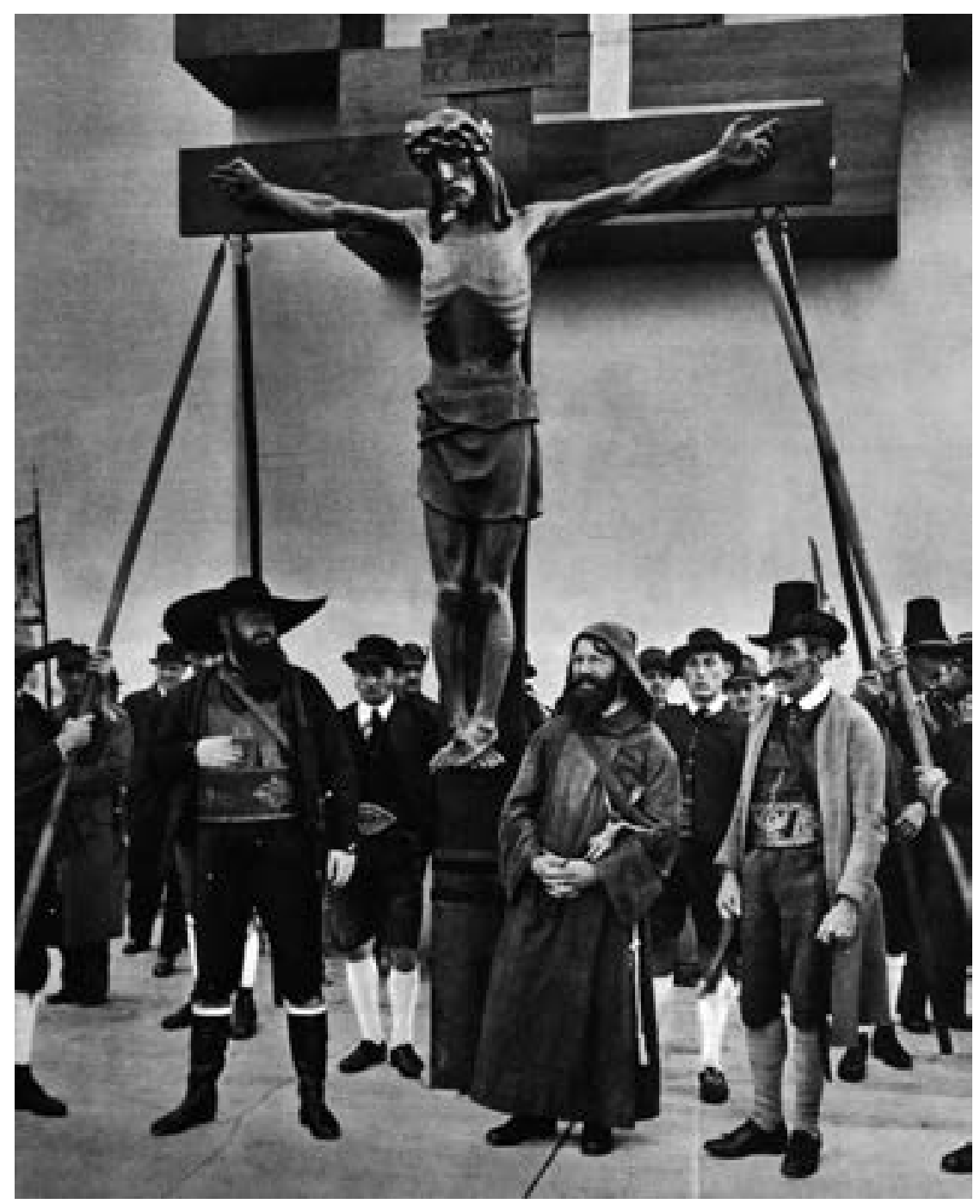

Abb. 8 Katholizismus im Dienst der Politik. Eine Abordnung von Tiroler Schützen in historischen Trachten und Andreas-Hofer-Look beim groBen Frontappell der Vaterländischen Front auf der Schmelz in Wien, 18. Oktober 1936. Das mitgebrachte überdimensionale Kreuz wird auf der Rednertribüne aufgestellt, auf der u.a. Kanzler Schuschnigg spricht. Wiener Bilder, 25. Oktober 1936, Titelseite.
(Fremdenverkehr) mit der Propaganda nach innen verbindet. Besonders gefragt sind nun Landschaften und ländliche Motive, idyllische Genredarstellungen, Land und Leute, Hochgebirge, Brauchtum und Tradition. Aber auch auf die katholische Ideologie greift die Regierung immer wieder gerne zurück. Bei offiziellen Anlässen werden die christlichen Symbole als fester Bestandteil des österreichischen Selbstverständnisses ausgestellt (Abb. 8).

Im Juni 1933, wenige Monate nachdem Kanzler Dollfuß seinen autoritären Regierungskurs eingeschlagen hat, findet in Wien die Ausstellung „Österreichs Bundesländer im Lichtbilde“ statt. Sie hat sich, so heißt es im Vorwort zum Katalog, vorgenommen, „Fremden und Einheimischen zu zeigen: ,Das ist Österreich!'“12 Bewusst wird das ländliche, das nicht wienerische Österreich ins Zentrum der Schau gestellt. Freilich fällt die ideologische Anpassung der Fotoschau an das neue Regime noch ziemlich verhalten aus. Vertreten sind neben einigen heimattümelnden Lichtbildnern (Defner, Koppitz etc.) auch zahlreiche Fotografinnen und Fotografen, die bisher noch eher wenig in diesem Genre gearbeitet haben, etwa Bruno Reiffenstein, Carl Zapletal, Hans Madensky oder Martin Gerlach. Auch Aufnahmen von Trude Fleischmann, der bekannten Wiener Atelierfotografin, sind in der Ausstellung zu sehen. Sie beginnt um 1930, in Zeitschriften und Magazinen ihre Landschafts- und Reisefotografien zu veröffentlichen, zu denen gelegentlich auch Bilder von knorrigen Bauerntypen im Hochgebirge zählen (Abb. 9).

Auffallend ist die symbolische Präsenz der Bundesregierung und der Landesregierungen in der Ausstellungsorganisation. Neben dem Kanzler Engelbert Dollfuß sind zahlreiche Minister und Landeshauptleute im Ehrenpräsidium vertreten. Sie geben der Veranstaltung einen hochoffiziellen Anstrich. Willig kommt der Veranstalter, der „Fachverband der Fotografengenossenschaften“, der neuen staatlichen Heimatdoktrin entgegen, indem er einen Aufsatz in den Katalog aufnimmt, der sich ausdrücklich mit dem Thema „Lichtbild und Heimatkunst“ beschäftigt. ${ }^{13}$

Ab 1933/34 findet eine ganze Reihe von Ausstellungen statt, die der Heimatfotografie zusehends mehr Gewicht geben. Besonders unter den künstlerisch arbeitenden Amateurfotografen, die in Vereinen organisiert sind, zeichnet sich eine deutliche Tendenz hin zu ländlichen, heimatbezogenen Motiven ab. Im Juni und Juli 1934 veranstaltet der im Jahr 1927 vom Fotopublizisten Hugo Haluschka gegründete „Verband österreichischer Amateurphotographen-Vereine“ im Wiener Künstlerhaus eine Fotoausstellung. Diesmal lautet der Titel nüchtern „III. Internationale Photo-Ausstellung“. Wieder ist die gesamte austrofaschistische Politprominenz, vom Kanzler Kurt Schuschnigg abwärts, im Ehrenausschuss vertreten. In der Schau dominieren die antiurbanen Themen: Land und Leute, Arbeitsleben auf dem Land und in Berggebieten (nicht aber in der Stadt), berühmte österreichische Landschaften und Orte, Brauchtum, Stillleben, Genrebilder usw. ${ }^{14}$

Die konservativen Lichtbildner sind nun eindeutig in der Überzahl. Unterstützt wird der neue politische Kurs in Richtung Heimatfotografie von zahlreichen Verbandsfunktionären der Amateurvereine, die dem „Ständestaat“ nahestehen. Sowohl der Präsident 
des Verbandes österreichischer Amateurphotographen-Vereine, Hugo Sartorius, als auch die meisten der Preisrichter (unter ihnen ist auch Rudolf Koppitz) arbeiten dem neuen konservativen Regime bereitwillig zu. Neu an der Künstlerhausausstellung 1934 ist, dass sich erstmals eine eigene Abteilung der Heimatfotografie widmet. Bemerkenswert ist außerdem, dass viele der gezeigten Arbeiten von konservativen ungarischen Amateuren stammen, die in den folgenden Jahren in Österreich überaus präsent sind. Die staatliche Annäherung der beiden autoritären Regimes macht sich nun auch im Kulturaustausch bemerkbar.

Zwei Jahre später - die österreichische Heimatfotografie ist auf ihrem Höhepunkt angekommen - findet in der Wiener Volkshochschule Urania eine Fotoausstellung statt, die den Begriff „Heimat“ im Titel trägt. Sie nennt sich „Heimat Österreich“. ${ }^{15}$ Nun ist das ursprüngliche Randthema Heimatfotografie stolz ins Zentrum der öffentlichen Aufmerksamkeit gerückt.

\section{Rudolf Koppitz: \\ Von der Kunst- zur Heimatfotografie}

Unter dem Druck der neuen politischen Verhältnisse geraten die Vertreter der fotografischen Avantgarde in den 1930er Jahren zunehmend ins Hintertreffen, es kommen ihnen nicht nur Publikations- und Ausstellungsmöglichkeiten abhanden, sondern auch ein Klima der Offenheit und des Experiments. Konservative Lichtbildner besetzen nun zunehmend das Feld. Viele von ihnen liefern jene Bilder, die dem Zeitgeist entsprechen: ländliche Themen, Brauchtum, Heimatbezogenes.

Der 1884 geborene Rudolf Koppitz gehört in der Zwischenkriegszeit zu den führenden Vertretern der künstlerisch arbeitenden Fotografie in Österreich. Zugleich ist er in den 1930er Jahren ein wichtiger Protagonist der Heimatfotografie. ${ }^{16}$ Er gilt, dank seiner zahlreichen Funktionen und Tätigkeiten, als überaus einflussreiche Persönlichkeit in der Fotoszene. Koppitz ist Professor an der Graphischen Lehr- und Versuchsanstalt in Wien und viel beschäftigter Aussteller, er ist aber auch gefragter Funktionär, Preisrichter und Organisator. Bemerkenswert ist, wie aufmerksam Koppitz in seinem Werk die gesellschaftlichen Stimmungen

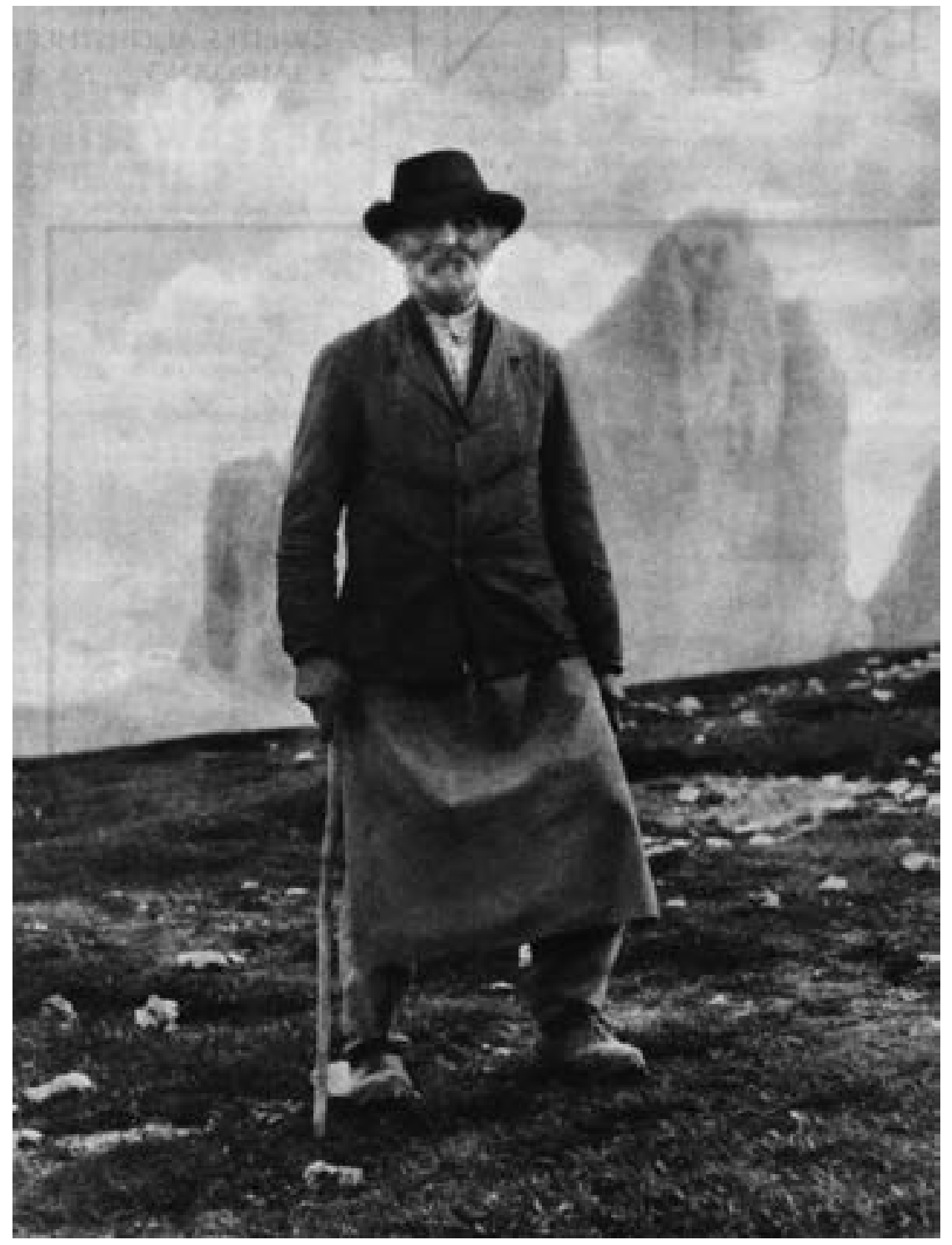

und die politischen Verschiebungen reflektiert. Sein Werk wird - auch noch nach seinem Tod 1936 - in Form von Ausstellungen und Publikationen in die offizielle konservative Kulturpolitik des Landes eingepasst. In seinen Arbeiten aus den 1920er Jahren überwiegen noch gemäßigt moderne kunstfotografische Arbeiten. Er fotografiert in diesen Jahren die Stars der Wiener Theater- und Tanzbühnen, macht Akt- und Bewegungsaufnahmen, Genre- und Landschaftsstudien, Arbeiten, die bis heute sein Image prägen.

Ab Ende der 1920er Jahre wendet er sich, ganz im Einklang mit der gesellschaftlichen Stimmung im
Abb. 9 Alter Berghirte vor den Drei Zinnen in Südtirol. Die Bühne, Zweites Augustheft 1931, S. 6. Foto: Trude Fleischmann. 
Abb. 10 Betende Bauernfamilie. Moderne Welt, Heft 10 Juli 1933, S.10. Foto: Rudolf Koppitz.

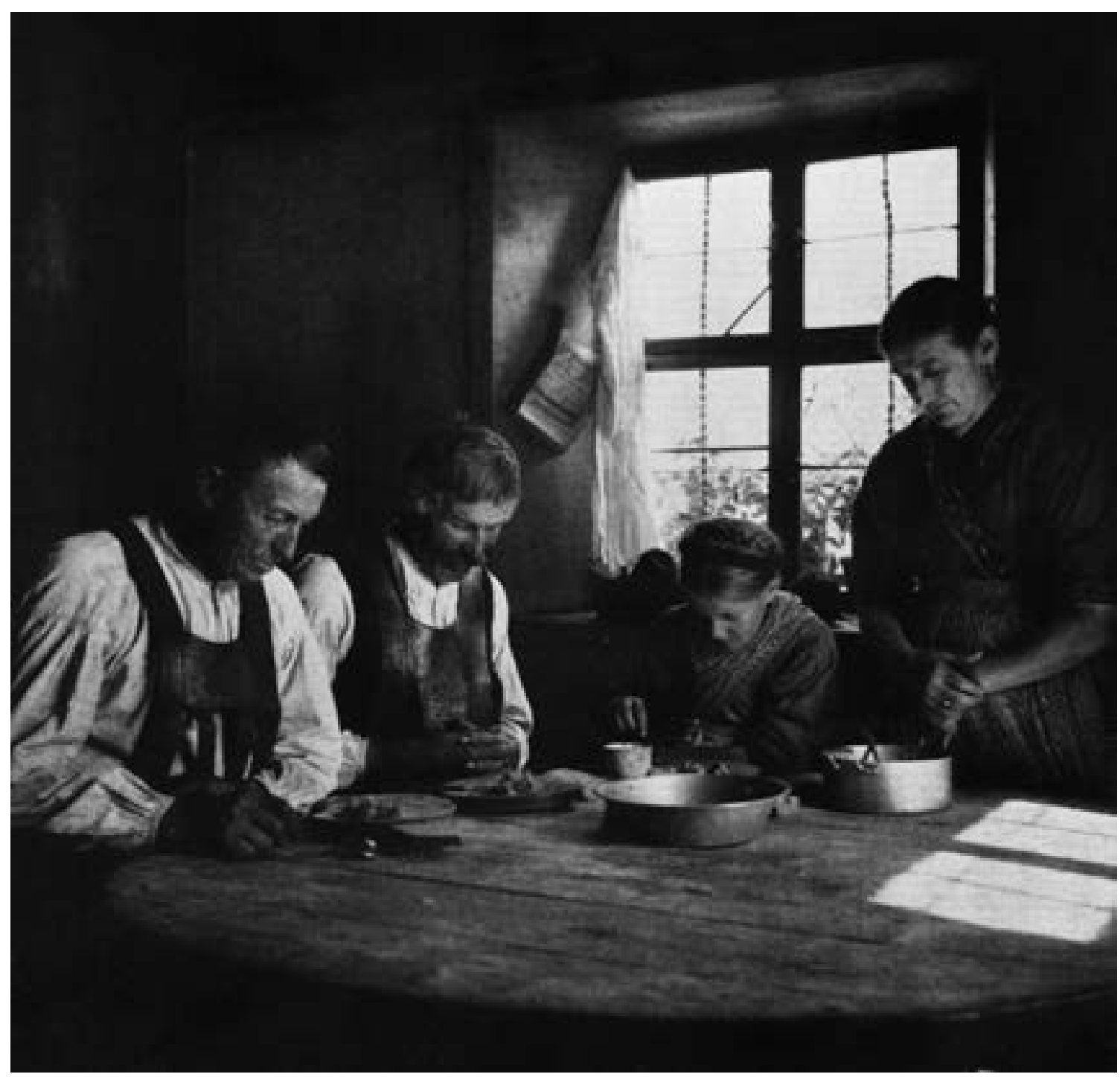

Land, idyllischen, entrückten, alpinen Landschaften zu. Monatelang reist Koppitz durch das Land, immer wieder besucht er abgelegene Orte in Tirol, Südtirol und Salzburg. Seine Reisen führen ihn aber nicht nur in die österreichische Provinz, sondern auch an die europäische Peripherie, dorthin, wo er Reste archaischer ländlicher Lebensweisen vermutet: nach Mähren und nach Ungarn, in den Banat und nach Sizilien. Weit weg von der Wiener Metropole fotografiert er Land und Leute: hochalpine Landschaften, Bergbauern bei der Arbeit, die einfache Bevölkerung in ihren traditionellen Trachten, ihre Traditionen und ihr Brauchtum. Seine Aufnahmen sind alles andere als wirklichkeitshungrige Reportagen aus dem ländlichen Alltag, vielmehr handelt es sich um sorgfältig inszenierte Idealbilder, die die bäuerliche Welt in archaische Urszenen verwandeln (Abb. 10). Er entwirft in seinen Fotografien überhöhte Gegenbilder zur politisch umkämpften, angeblich moralisch verkommenen Welt der Großstadt, die er in seinen Fotografien auffallend meidet.
In der Zeitschrift Moderne Welt, in der immer wieder Aufnahmen von Koppitz erscheinen, wird die zugrunde liegende Heimatidylle ausführlich beschrieben: „Man sehe einmal auf die Bilder, die wir hier in diesem Heft als kleine Auslese gesammelt haben. Die betende Familie, das halbdunkle Zimmer, die Sammlung und Ruhe auf den Gesichtern, wie fügt sich das alles zum völlig geschlossenen Bild. Wie lebendig steht dann in einem anderen Bild die Bäuerin mit den sechs kleinen Mädchen in Heimattracht im Gras. Es sieht aus, als wären diese lächelnden Menschen auch nur aus der Wiese emporgewachsen, Berge und Himmel dahinter gehören zu ihnen, als könnten sie mühelos danach greifen, die Blumen im Gras, das Lächeln auf den Gesichtern der kleinen Mädchen, wie der Wind in den Haaren spielt oder die Schürze bläht, das ist alles verwandt, voll derselben Natur, kaum voneinander zu scheiden." 17

Und weiter heißt es über die Heimatbilder von Rudolf Koppitz: „Diese Photographien, in denen ein 
künstlerischer Blick das Fruchtbarste versucht hat, das es bei einer solchen Aufgabe gibt, nämlich nichts anderes als den geheimen ,künstlerischen' Blickpunkt der Natur aufzufinden und dann von dort aus die Menschen ohne jede Verfälschung so darzustellen, wie sie eben sind, solche Bilder zeigen nicht das ,Gesicht der Landschaft‘, mit welchem Titel man oft dem Reisenden eine recht leere Sammlung von Bildern der Gegenden anpreist, durch die ihn der Zug trägt. Sondern die Landschaft ist wirklich auf eine magische und ergreifende Art mit den Menschen zusammengewachsen, in ihren Körper gestiegen. In den Blicken, in den Gesichtern und Gestalten unserer Abbildungen ist also Österreich und die ganze Vielfalt seiner Berge und Täler, ist Dunkelheit und Helle, Schönheit und Gefahr seines Lebens in reizvoller Art zu finden. Das klug gelenkte Objektiv des Photographen zeigt Landschaft und Menschen dort, wo sie am stärksten wirken: in ihrer untrennbaren Gemeinschaft." 18

Als das Österreichische Museum für Kunst und Industrie Anfang 1936 eine große Koppitz-Ausstellung zeigt, ist der Fotograf auf dem Höhepunkt seines Ruhmes angelangt. „Land und Leute“, so heißt die Schau, steht programmatisch für die politisch gewollte Akzentverschiebung hin zur Heimatfotografie. ${ }^{19}$ Gezeigt werden rund 500 Aufnahmen aus fast allen österreichischen Bundesländern und Reisebilder aus Ungarn, Rumänien und Italien. Im Mittelpunkt der Ausstellung stehen die ländliche Welt und nicht die Stadt, Bauern und nicht Arbeiter, die Tracht und nicht der Alltag. Rudolf Koppitz stirbt im Juli 1936, wenige Monate nach dem Ende der Schau. Seine Rezeption als heimattreuer Fotograf ist damit aber nicht beendet, im Gegenteil. Er wird in den kommenden Jahren häufig ausgestellt und seine Bilder finden in Presse und Büchern weiterhin große Verbreitung. ${ }^{20}$

Ein Koppitz-Anhänger, der dem Fotografen ein reiches publizistisches Nachleben beschert, ist Karl Pawek, Herausgeber der konservativen illustrierten Kulturzeitschrift Die Pause, die ab 1935 erscheint. Sie etabliert sich als publizistisches Forum des „Ständestaates“, das die Errungenschaften der Moderne (etwa in Typografie und Layout) mit einem konservativ-reaktionären Gesellschafts- und Staatsbild verbin- det. ${ }^{21}$ Pawek veröffentlicht in den folgenden Jahren immer wieder Koppitz-Bilder in der Pause, bewusst stellt er den Heimatfotografen Koppitz ins Zentrum. Dessen ländliche Idyllen passen sehr gut ins Konzept einer staatstragenden Publikation, die neben Kunst, Architektur und Geschichte viel Folklore, Volkskultur und ländliches Leben präsentiert. Fast immer wird der Mensch als Einzelner oder in der Familie gezeigt, nie in der Masse, in der Fabrik oder in der Stadt. Die Wirklichkeit der Großstadt Wien wird in der Zeitschrift vollkommen ausgeblendet.

\section{Protagonisten der Heimatfotografie}

Rudolf Koppitz ist einer von zahlreichen österreichischen Heimatfotografen, deren Karrieren in den 1930er Jahren steil nach oben weisen. Wenn man Koppitz im Umfeld der österreichischen Heimatfotografie einordnet, muss man ihn wohl als eine Art Übergangsfigur sehen, als einen Fotografen, der einen längeren Weg von der Stadt hinaus aufs Land zurückgelegt hat und dessen politische Programmatik - trotz seiner offensichtlichen Sympathien für den christlichsozialen „Ständestaat“ - nicht immer ganz eindeutig auf den Punkt zu bringen ist. Andere Fotografen dagegen wenden sich schon früh und fast ausschließlich Landschafts-, Bauern-, Berg- und Trachtenbildern zu. In den 1930er Jahren schlagen sie sich weit eindeutiger auf die Seite der herrschenden Regierungsideologie. Unter ihnen sind die Tiroler Fotografen Adalbert Defner (Abb. 11), Simon Moser, Wilhelm Angerer und Peter Paul Atzwanger (Abb. 12), der, ebenso wie Koppitz, an der Graphischen Lehrund Versuchsanstalt in Wien unterrichtet.

Bekannt werden sie auch durch ihre Bildbände, die teilweise erst nach 1938 erscheinen. Simon Moser bringt seinen Fotoband Deutsche Bergbauern 1940 heraus, Wilhelm Angerer die Publikation Es rauscht ein Lied von den Bergen im Jahr 1942. Auch Stefan Kruckenhauser reiht sich ein in die Gruppe der Heimatfotografen. Er wird ab 1937 mit Buchpublikationen bekannt, etwa mit dem Band Du schöner Winter in Tirol, 1938 erscheint sein Bildband Verborgene Schönheit. ${ }^{22}$ Die junge Fotografin Lucca Chmel fotografiert 1936 im Auftrag des Salzburger Fremden- 
Abb. 11 „Verschneite Alm“. Das deutsche Lichtbild 1931, Berlin 1930, S. 29. Foto: Adalbert Defner.
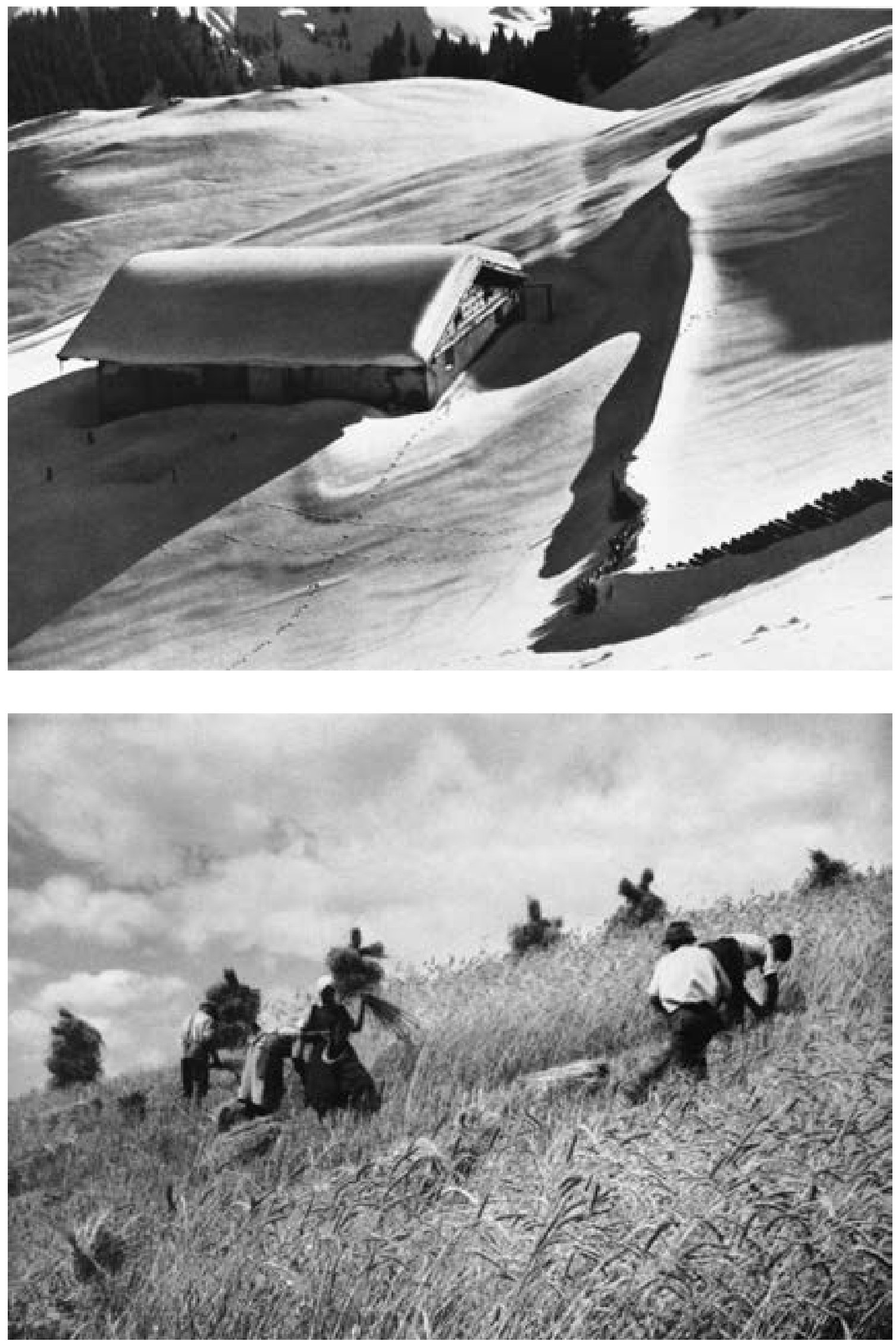

Abb. 12 „Kornschnitt“. Das deutsche Lichtbild 1931, Berlin 1930, S. 22. Foto: Peter Paul Atzwanger. 
verkehrsamtes „heimatliche“ Landschaften. Auch sie setzt, ebenso wie viele andere Heimatfotografen, ihre fotografische Karriere unter dem Nationalsozialismus bruchlos fort. ${ }^{23}$

Die österreichische Heimatfotografie der 1930er Jahre ist, bei aller Ähnlichkeit mancher Inszenierungen und Motive, kein homogenes Genre. Neben Fotografen, die sich beinahe ausschließlich diesem Thema widmen, gibt es unter den Amateuren zahlreiche Lichtbildner, die sich öfter Heimatthemen zuwenden, daneben aber auch andere Interessen zeigen. Auch die Bildlösungen variieren. Sie reichen von anspruchslosen, pathetischen, erdverbundenen Landschafts-, Genre- und Brauchtumsszenen, etwa von Willi Jungmeier (Abb. 13), Oswald Elbl, Hermann Brühlmeyer, Hans Hannau, Didier Jellinek-Mercedes, Marian Schwabik, Elly Rauch, Ursula Scholz oder Franz Swoboda, bis hin zu Inszenierungen, die die Landschaft nicht ausschließlich als ideologisches Refugium sehen. Fotografen wie Heinz von Perckhammer, Harald Lechenperg, Trude Fleischmann, Lothar Rübelt (Abb. 14), Willy Eggarter, Hans Popper, Hans Casparius u. a. pendeln gekonnt zwischen den Genres. Sie fotografieren heimatliche, erhabene Landschaften und bäuerliches Brauchtum ebenso wie Reisemotive, Stadtbilder oder Sportereignisse.

Auch wenn die Heimatfotografie der 1930er Jahre mehrheitlich konservative Anliegen vertritt, gibt es doch auch Ausnahmen. In einer Zeit, da die Großstadt mit negativen Assoziationen belegt ist (Arbeitslosigkeit, politische Unruhe, Lärm, Schmutz etc.), avanciert das Thema „Land und Leute“ zum attraktiven gesellschaftlichen Gegenentwurf - und zwar weit über die politischen Grenzziehungen hinaus. Auch liberale und sogar linke Fotografen (etwa Nikolaus Schwarz oder Rudolf Spiegel) wenden sich in den 1930er Jahren gelegentlich dem Landleben $z u .{ }^{24} \mathrm{Sie}$ fotografieren freilich nicht knorrige Tiroler Bergbauern in Untersicht, sondern zeigen andere, widersprüchlichere Facetten des ländlichen Lebens und Arbeitens.

Als ein Beispiel für eine andere, kaum bekannte „Heimatfotografie“ mag eine Arbeit von Otto Koenig dienen, der später als Verhaltensforscher, Autor und Fernsehpräsentator bekannt wird. Der junge Fotograf, der 1936 als 22-Jähriger die Graphische Lehr- und Versuchsanstalt in Wien absolviert hat, beginnt Mitte der 1930er Jahre Fotoreportagen in der illustrierten Presse zu veröffentlichen. Im September 1936 erscheint im Sonntag eine Reportage unter dem Titel „Die vom Heidboden“. ${ }^{25}$ (Abb. 15) Sie schildert in Text und Bild (beide von Otto Koenig) die beschwerlichen Lebens- und Arbeitsbedingungen der kleinen burgenländischen Bauern. „Viel zu wenig Land haben die Bauern der Heide: da ein Joch, dort ein Joch, zerrissen, zerstreut, trotz der so weiten einigen Fläche! Denn der Großteil des Bodens gehört nicht den Heinzendorfern, sondern den Gutshöfen. Und die gehören alle einer Herrschaft.“26 Das Leben dieser Bauern besteht aus viel Arbeit und wenig Lohn. „Ganz früh“, so schreibt Koenig weiter, „wenn noch letzte Sterne
Abb. 13 Andacht. Das schöne Lichtbild, Wien, München o. J. (1936/37), S. 41. Foto: Willi Jungmeier.

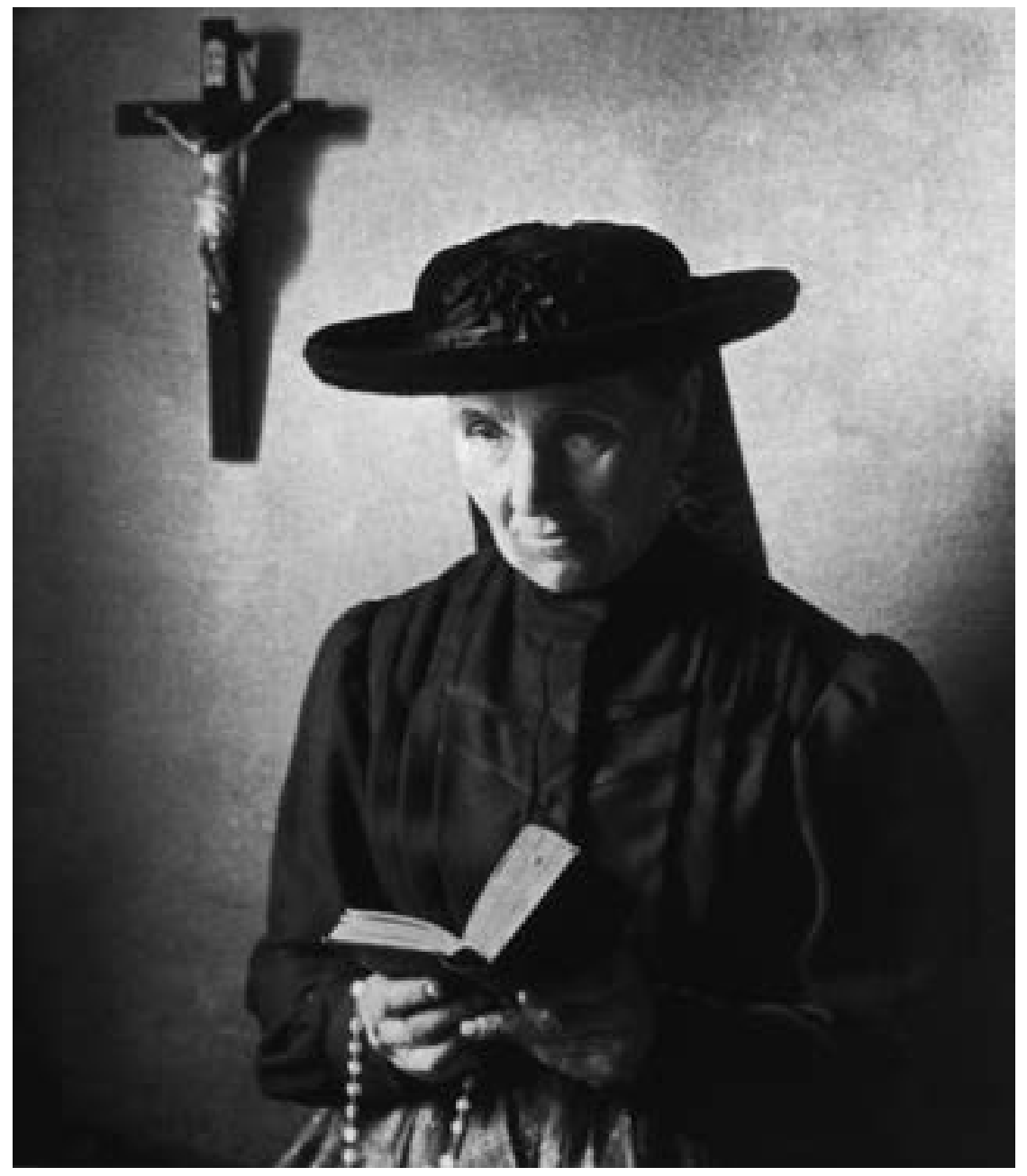




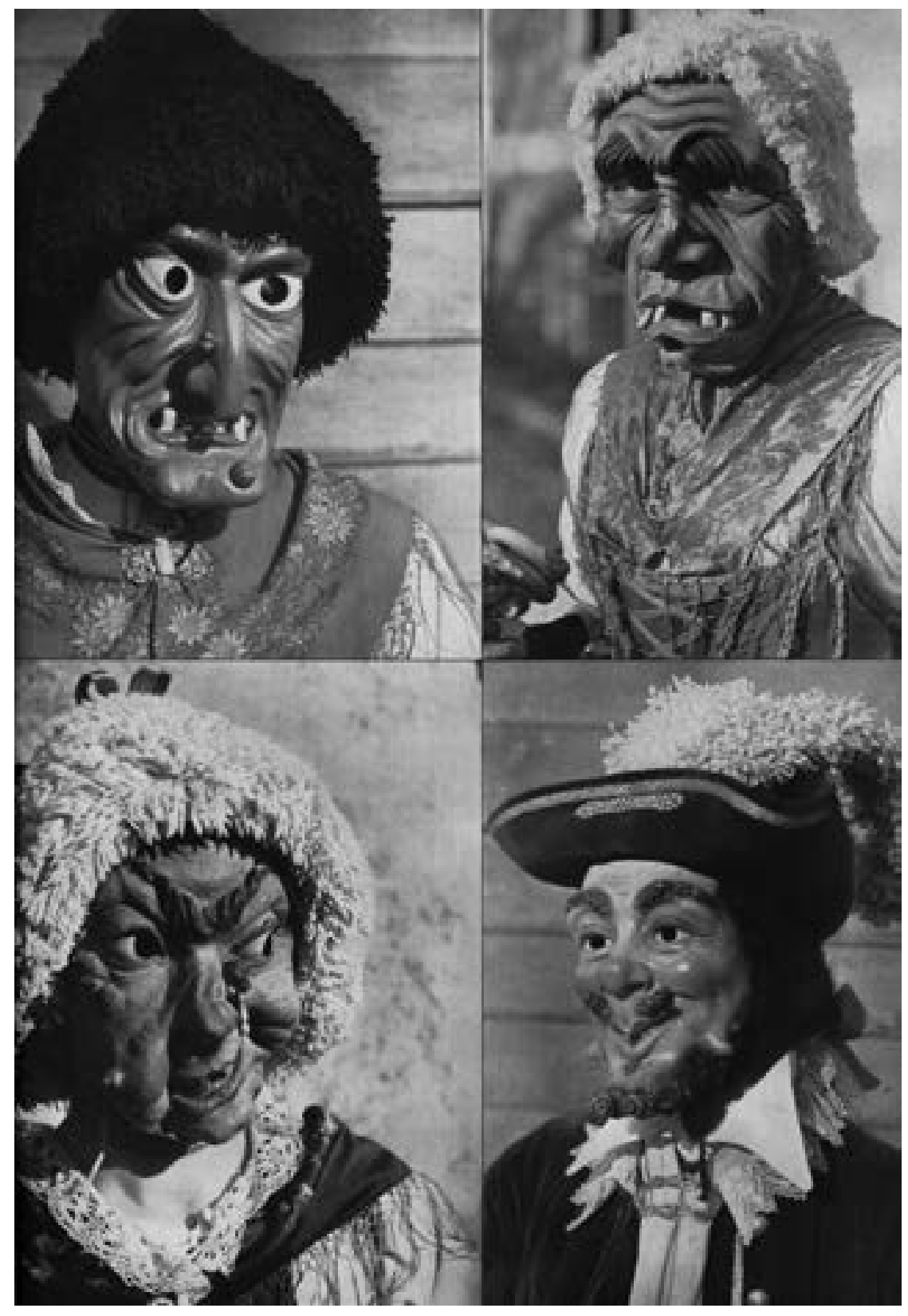

Abb. 14 Tiroler Fasnachtmasken. Moderne Welt, Heft 5, Februar 1934, S. 13. Foto: Lothar Rübelt. am Himmel glänzen, steht der Heinzenbauer müde auf zur Arbeit, zur billigen Arbeit am Herrschaftshof. (...) Abends gehen sie heim in ihre kleinen Stuben, schwer schleift ihr müder Schritt über die staubige Erde. Kurz ist die Nachtruh', dann geht schon wieder die Sonne auf zu neuem Arbeitstag.“27

Die burgenländischen Bauern erscheinen in dieser Reportage geradezu als Gegenbilder zum stolzen, freien Tiroler Bauer, wie er in der traditionellen Heimatfotografie beschworen wird. Sie sind arm und ausgebeutet, vom Großgrundbesitzer zur Gänze abhängig, eine Art ländliches Proletariat. Diese Gestalten eignen sich nicht für die heroischen Erzählungen der traditionellen Heimatfotografie. Und so verwundert es nicht, dass Bilder wie diese im Spektrum der heimatlichen Ansichten der 1930er Jahre die Ausnahme bleiben.

\section{Die Wege trennen sich}

Im Unterschied zu vielen anderen Bereichen der Fotografie ist das Jahr 1938 in der Heimatfotografie kein entscheidender Einschnitt. Ein Großteil der konservativen Heimatfotografen, unter ihnen Atzwanger, Angerer, Defner oder Kruckenhauser, arrangiert sich problemlos mit dem Nationalsozialismus. Sie arbeiten erfolgreich an ihren Fotobüchern und Publikationen weiter, die nun ein großes, gesamtdeutsches Publikum erreichen. Auch einige jener Fotografen, die nur gelegentlich einen Ausflug ins Heimatfach machen, wie von Perckhammer, Rübelt oder Lechenperg, setzen ihre Arbeit nach 1938 bruchlos fort, immerhin haben sie alle in den 1930er Jahren bereits im nationalsozialistischen Deutschland gearbeitet .

Andere verlassen 1938 das Land. Hans Walter Hannau etwa, ein prominenter Vertreter des „Ständestaates“, Fotoamateur, Fotopublizist und Schriftleiter der konservativen Zeitschrift Der Lichtbildner, geht 1939 über Holland nach New York. ${ }^{28}$ Jüdische Fotografen wie Trude Fleischmann oder Hans Popper flüchten 1938 ebenfalls nach New York, Hans Casparius geht im selben Jahr nach London.

1938 ist die Heimatfotografie nicht am Ende, sondern tritt, abgestimmt auf die Bedürfnisse der nationalsozialistischen Ideologie, in eine neue Phase ein. Maximilian Karnitschnigg etwa, in den 1930er Jahren ein wichtiger Protagonist der konservativen Kunstfotografie und Unterstützer der Heimatfotografie, passt sich nach der politischen Wende 1938 rasch an. In den 1930er Jahren schreibt er für die deutschnational-konservative Zeitschrift Bergland regelmäßig in der Rubrik „Lichtbildkunst in Österreich“. 1938 wechselt die Zeitschrift mit fliegenden Fahnen ins Lager der Nationalsozialisten. Das erste Heft nach dem Umbruch zeigt ein Aquarell von Adolf Hitler auf der Titelseite. Den Leitartikel im selben Heft stellt der Chefredakteur Kurt Wagner unter das Motto: „Führer befiel, wir folgen!“29 Zwei Monate später, im Juni 1938, veröffentlicht Karnitschnigg im Bergland „Aufnahmen von Volkstypen“. 30 


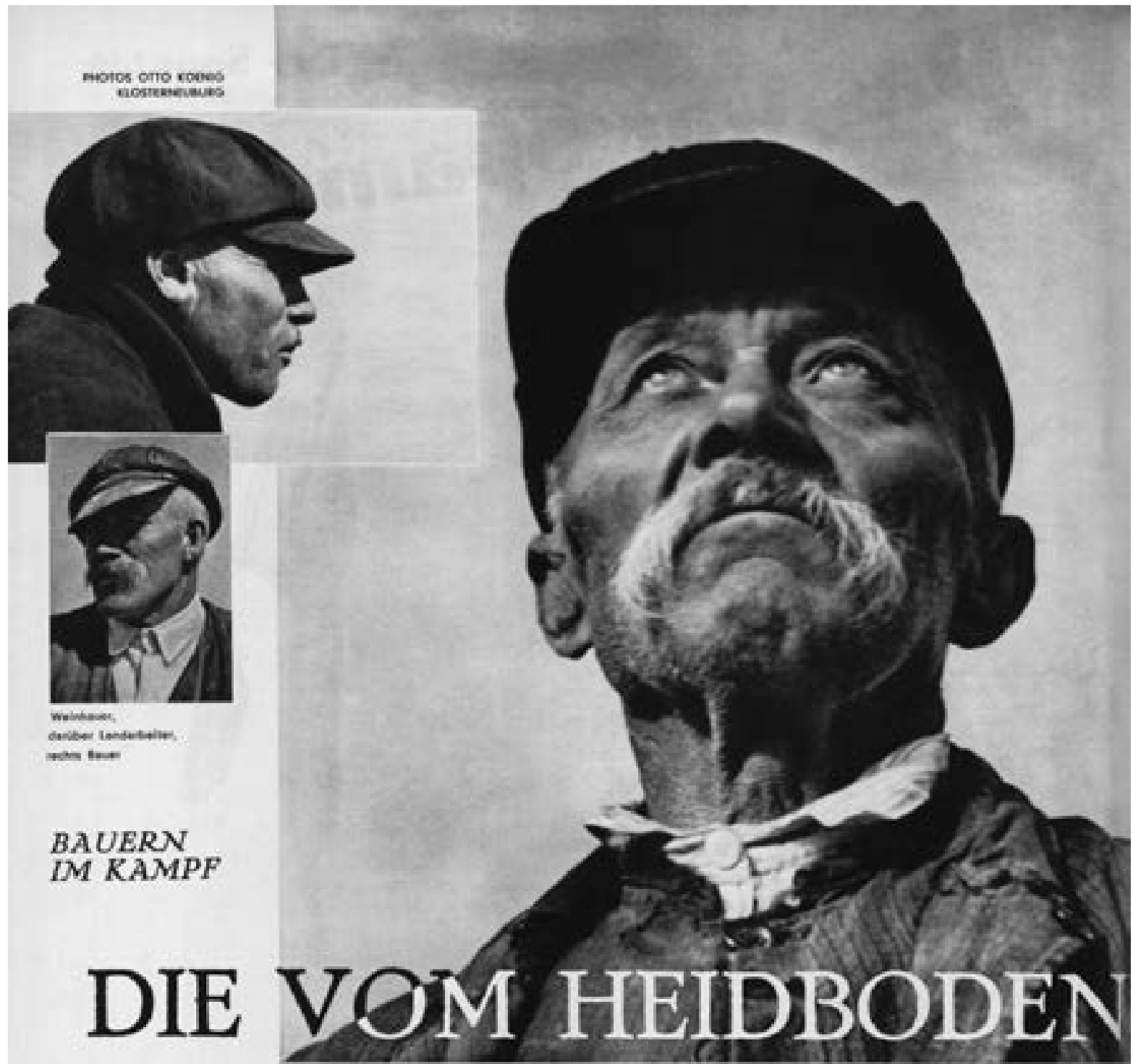

Abb. 15 „Die vom

Heidboden“. Eine andere Form der Heimatfotografie. Die Fotoreportage von Otto Koenig berichtet über den beschwerlichen Alltag der burgenländischen Kleinbauern. Der Sonntag, 6. September 1936, S. 2.

Vier Gesichaer bergenlindiader Basern, die ihre Lebenageschidte su eraihlea athrinen.
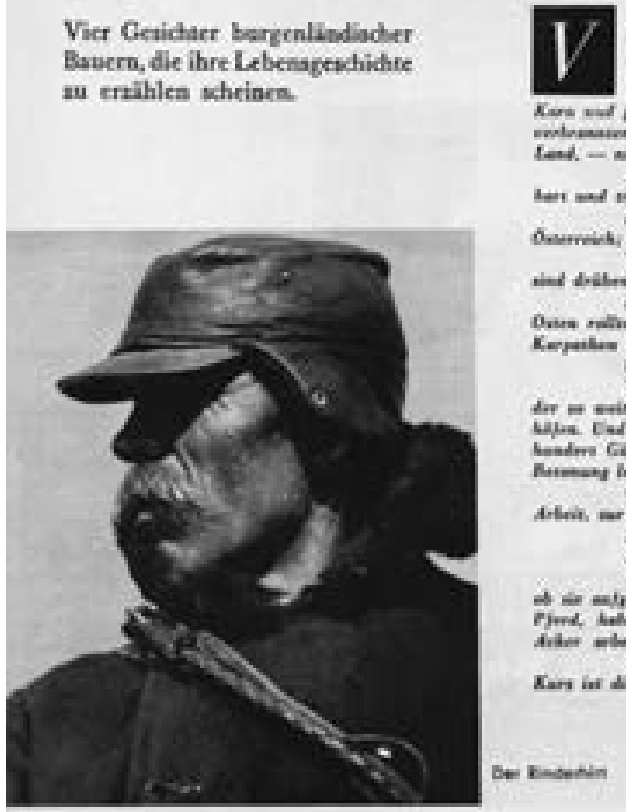

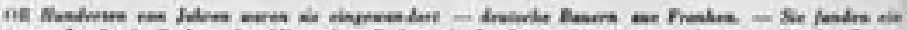

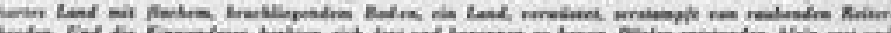

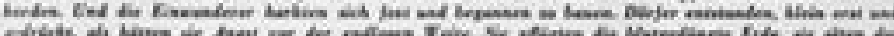

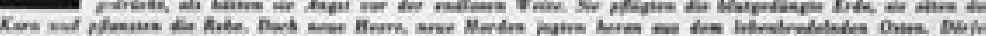

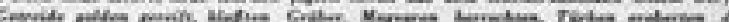

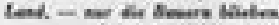

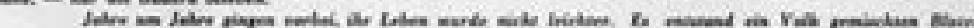

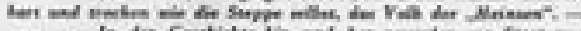

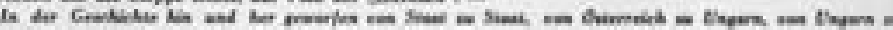

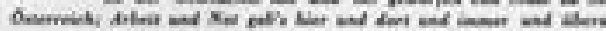

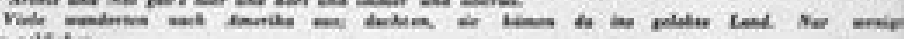

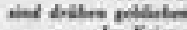

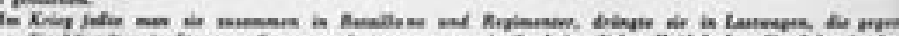

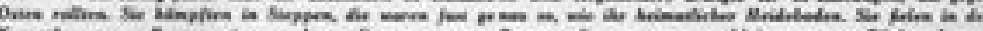

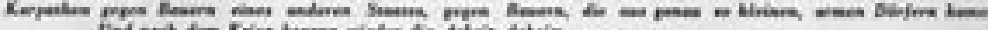

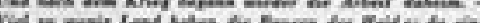

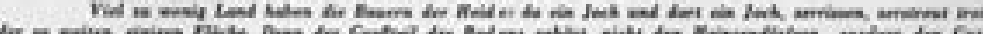

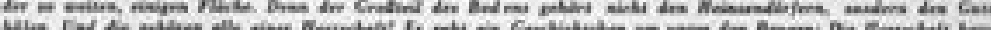

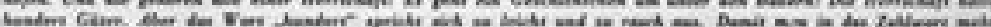

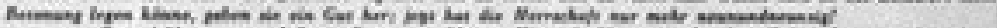

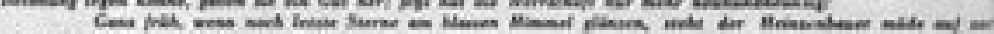

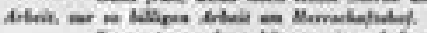

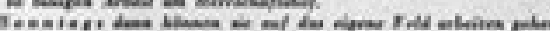

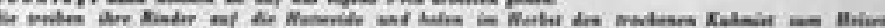

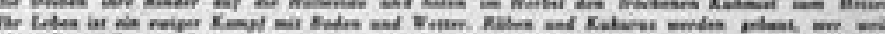

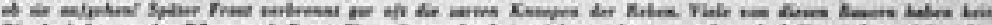

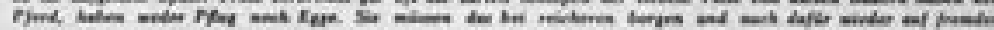

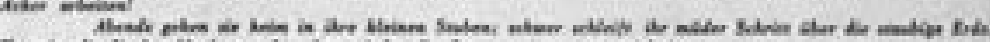

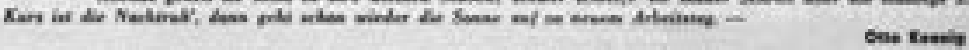




\title{
Fotografisches Feuilleton
}

\author{
„Der Sonntag“: ein vergessenes Forum moderner Reportagefotografie
}

Als am 1. April 1934 die erste Nummer der neuen Wochenzeitung Der Sonntag erscheint, kommt das einer kleinen Sensation gleich. Erst wenige Wochen zuvor ist die sozialdemokratische Arbeiterbewegung in einem kurzen Bürgerkrieg vernichtend geschlagen worden. Alle noch verbliebenen oppositionellen Parteien und Medien werden, wie berichtet, im Februar 1934 verboten. Am 1. Mai, tritt die austrofaschistische Verfassung in Kraft, die die Diktatur auch formell besiegelt. In dieser Phase des politischen Umbruchs, in der Zensur und Repression herrschen, kommt eine neue Illustrierte auf den Markt, die ganz und gar nicht in das diktatorische und reaktionäre Klima des österreichischen „Ständestaates“ zu passen scheint. Der publizistische Mainstream weist - auch im Bereich der illustrierten Presse - in eine ganz andere Richtung. Die seit September 1933 erscheinende Österreichische Woche etwa, die auflagenstarke Propagandaillustrierte der Regierung, steuert zur selben Zeit einen aggressiven patriotisch-konservativen Kurs. Auch zahlreiche andere illustrierte Blätter schlagen, ebenfalls unter dem Druck der Regierung und der herrschenden „ständestaatlichen“ Ideologie, eine konservative Richtung ein.

Der Sonntag hingegen, der zwischen April 1934 und März 1938 erscheint, ist in der zweiten Hälfte der 1930er Jahre die einzige österreichische Illustrierte, die sich nicht vor den Karren der regierungsnahen Heimattümelei spannen lässt und eine gewisse Distanz zur offiziellen Staatsdoktrin wahren kann. Nicht nur das: Sie ist inhaltlich zum großen Teil anspruchsvoll und grafisch durchweg hervorragend gemacht. Das Layout ist klar und modern. Schon die Titelseiten bringen den Geist der Zeitschrift zum Ausdruck (Abb.1). Das große, ausdrucksstarke, meist abfallend gedruckte Titelfoto, in das der Titel, der Untertitel und hie und da ein kurzer Vorspann gesetzt sind, führt in eines der Heftthemen ein. Ebenso durchdacht und grafisch raffiniert ist die Gestaltung des Innenteils.
Immer wieder macht der dreispaltig gesetzte Text Platz für dramaturgisch geschickt eingesetztes Bildmaterial. Oft werden die Figuren auf weißem Grund freigestellt, um auf diese Weise die Bildwirkung noch zu steigern.

Der Sonntag hält sich von der politischen Tagesberichterstattung auffallend fern und meidet innenpolitische Streitthemen. Stattdessen wendet er sich Bereichen zu, die unverdächtig sind. Er beschäftigt sich etwa mit Länderstudien und Reiseberichten, sozialen Themen und der Populärkultur, dem Alltag, der Freizeit und der Unterhaltung. Immer wieder erscheinen allerdings auch gesellschaftspolitische Berichte über die Situation in den Nachbarländern, nur das nationalsozialistische Deutschland wird auffallend ausgespart. ${ }^{1}$ Bei außenpolitischen Themen bewegt sich die Redaktion auf weniger glattem Parkett. Daher äußert sie ihre Sympathie - meist zwischen den Zeilen - etwa für die demokratischen Regierungen in Frankreich und in der Tschechoslowakei. Sie zeigt sich auch besorgt über die Militarisierung der Gesellschaft in Italien und die drohende Kriegsgefahr in Europa. Trotz aller innenpolitischen Zurückhaltung gelingt es der Redaktion, auch in scheinbar randständigen und kleinen Themen die Grundstimmung der Zeit aufmerksam zu registrieren. Der Sonntag betreibt, so könnte man sagen, eine Art fotografisches Feuilleton, das in der unvoreingenommenen Betrachtung von Details einen Blick auf das Ganze ermöglicht.

Der Sonntag ist kein Forum offener politischer Subversion. Das ist unter den Bedingungen der Diktatur auch kaum zu erwarten. Vielmehr praktiziert die Zeitschrift eine vorsichtige Gratwanderung zwischen tagespolitischer Enthaltsamkeit, punktuellem Entgegenkommen gegenüber dem Regime und leiser Opposition. Auf diese Weise gelingt es der Zeitung, von der Zensur weitgehend unbehelligt zu bleiben. Keine der 207 Nummern, die bis Anfang 1938 erscheinen, 


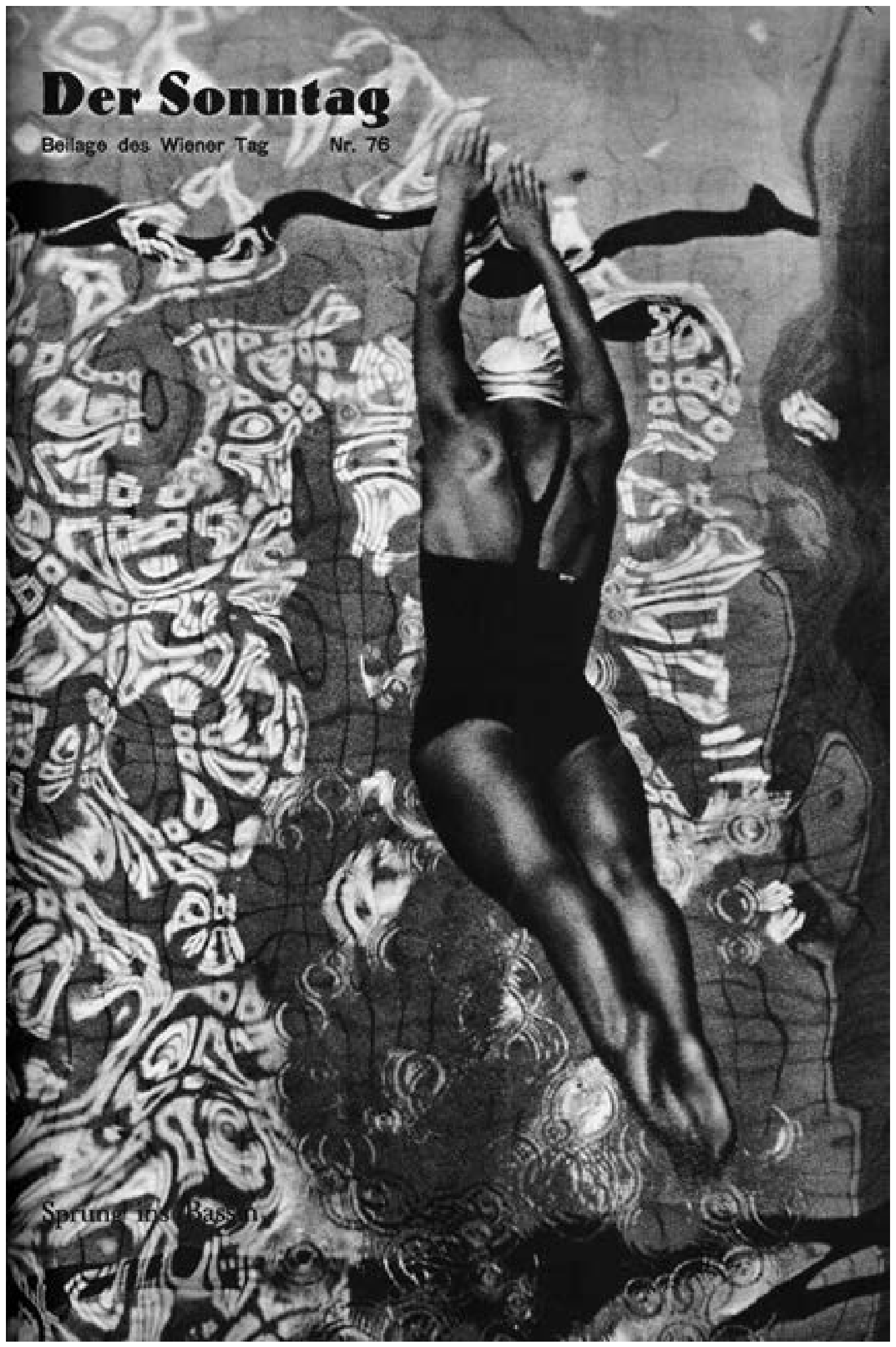

Abb. 1 „Sprung ins Bassin“. Der Sonntag, 1. September 1935, Titelseite. 
wird beschlagnahmt. Die Bilderzeitung exerziert also wöchentlich vor, dass es herkömmlichen Einschätzungen zum Trotz, die von einer lückenlosen Mediendiktatur im Austrofaschismus ausgehen, zwischen 1934 und 1938 doch noch schmale Freiräume für einen avancierten Fotojournalismus gibt. Zwar beherrscht die Regierungspropaganda die Öffentlichkeit, aber es gibt dennoch kleine publizistische Nischen, in denen ein anderer Blick auf die Wirklichkeit möglich ist als der offiziell verordnete.

Erstaunlicherweise ist die eminente Bedeutung, die der Sonntag für die fortschrittliche österreichische Fotoszene der 1930er Jahre hat, in der fotohistorischen Forschung lange Zeit nicht gewürdigt worden. ${ }^{2}$ Als nach 1933/34 die Publikationsmöglichkeiten für die moderne, avancierte Fotografie zunehmend schwinden und durch Repression und konservative Staatsideologie eingeschränkt werden, wird der Sonntag zu einem wichtigen Forum für jene Lichtbildner, die sich nicht mit patriotischer Gefühlsduselei zufriedengeben. Die Zeitschrift bietet auch Fotografen eine Plattform, die zuvor in sozialdemokratischen Medien, wie etwa dem Kuckuck (1934 verboten), veröffentlicht haben. Andererseits gelingt es der Sonntag-Redaktion, jungen, vielversprechenden Lichtbildnern, die bisher noch nicht oder kaum publiziert haben, eine Öffentlichkeit zu bieten. Aber nicht nur Fotografen, auch Autoren und Schriftsteller, die um Abstand zum Regime bemüht sind, etwa Jura Soyfer oder Theodor Kramer, um nur zwei Beispiele zu nennen, finden in der Zeitschrift eine Bühne, die ihnen eine, wenn auch prekäre, öffentliche Existenz ermöglicht. Zahlreiche bekannte Journalisten und Autoren veröffentlichen im Sonntag, in der Mehrzahl gehören sie dem linken oder liberalen Lager an, wie etwa Arnold Höllriegel, Eugenie Schwarzwald, Veza Canetti, Johannes Urzidil, Franz Werfel oder Hilde Spiel. Aber auch konservative Autoren wie Karl Heinrich Waggerl schreiben in dieser Zeitung.

Der Sonntag ist mehr als eine Illustrierte. Er ist, mitten in der Diktatur, auch ein kultureller Treffpunkt für liberale und linke Intellektuelle, für Andersdenkende und Oppositionelle, die in anderen Zeitungen und Zeitschriften nicht mehr veröffentlichen können bzw. wollen. Und zugleich ist er ein wichtiges
Sammelbecken für eine junge, aufgeschlossene Fotoszene, die Publikationsmöglichkeiten außerhalb der angepassten, regierungsnahen illustrierten Presse sucht. Der Sonntag ist also, mitten im Austrofaschismus, ein liberaler Lichtblick in einer immer konservativer werdenden Presselandschaft.

\section{Die Vorgeschichte}

Warum kann diese Zeitschrift überhaupt erscheinen? Um diese Frage beantworten zu können, ist ein Blick auf die Eigentümerstruktur und die Entstehungsgeschichte der Zeitschrift notwendig. Der Sonntag erscheint zwischen April 1934 und März 1938 als sonntägliche Beilage der Tageszeitung Der Wiener Tag. Im Grunde also ist es dieses Mutterblatt, das inmitten der Diktatur das publizistische Wagnis einer halbwegs unabhängigen illustrierten Wochenendausgabe eingeht. Werfen wir daher zunächst einen kurzen Blick auf die Geschichte und Herkunft dieses Blattes.

Ende November 1922 wird mit dem Geld des Börsenspekulanten Siegmund Bosel und dem Know-how des Wiener Journalisten Maximilian Schreier eine neue Tageszeitung, Der Tag, gegründet. Die Zeitung etabliert sich als bürgerlich-demokratisches, linksliberales Blatt, das u. a. bekannte Autoren, etwa Robert Musil, Alfred Polgar, Karl Tschuppik und Walther Rode, als Mitarbeiter gewinnen kann. Die Auflage liegt 1924 bei 50000 bis 60000 und geht bis 1933 auf etwas unter 50000 zurück. $^{3}$ Als 1925 Bosels Finanz- und Firmenimperium aufgrund von Fehlspekulationen zusammenbricht, übernimmt der große Druckerei- und Medienkonzern Vernay AG im folgenden Jahr die Zeitung und führt diese bis 1938 weiter. 1930 wird sie in Der Wiener Tag umbenannt.

Die Grundausrichtung der Zeitung liegt jahrelang in den Händen von Maximilian Schreier. Der 1877 geborene Journalist hat seine Laufbahn bereits vor dem Ersten Weltkrieg begonnen. 1910 gründet er die Montagszeitung Der Morgen und leitet sie als Chefredakteur. 1922 übernimmt er zusätzlich die redaktionelle Leitung des Tag. Beide Blätter werden Mitte der 1920er Jahre in der Medienkonzern der Vernay AG eingegliedert. Politisch steht Schreier auf der Seite 
der gemäßigten Linken. Um 1930, als die politische Kluft zwischen Sozialdemokraten und Christlichsozialen immer größer und unüberbrückbarer wird, steuert er den Tag und den Morgen geschickt durch das innenpolitische Minenfeld. Er ist um einen politischen Ausgleich bemüht. Nach dem Bürgerkrieg 1934 und der offenen Ausrufung der Diktatur zieht er sich als Chefredakteur zurück. Vincenz Ludwig Ostry wird neuer Tag-Chefredakteur, Rudolf Kalmar, ein altgedienter Tag-Journalist mit katholischem Hintergrund und einer etwas kompromissbereiteren Haltung gegenüber dem Regime, übernimmt den Lokalteil des Blattes. ${ }^{4}$

In der Zeit des Austrofaschismus ist der Wiener Tag die einzige österreichische Tageszeitung, die der Einflussnahme der Regierung ein Stück weit entzogen ist, da die Vernay Aktiengesellschaft unter tschechischer Kontrolle steht. ${ }^{5}$ Die Redaktion meidet freilich auch jegliche offene Konfrontation mit der Regierung. Sie beschränkt sich auf eine nüchtern-trockene Berichterstattung und legt den Fokus auf den unpolitischen Lokalteil und die internationalen Nachrichten. Dem nationalsozialistischen Regime in Deutschland begegnet die Zeitung jedoch in der zweiten Hälfte der 1930er Jahre mit offener Kritik.

Die Gründung des Sonntag verdankt sich also einer ganz besonderen publizistischen und politischen Konstellation. Die Zeitung steht unter dem Schutz des Mutterblattes Wiener Tag und der tschechisch dominierten Vernay AG. Sie tritt zudem nicht als eigenständige Publikation auf, sondern als Wochenendbeilage der Tageszeitung. Hinter der Neugründung der illustrierten Zeitung steht der einflussreiche Direktor des mächtigen Vernay-Konzerns, Emil Oplatka (geb. 1885 in Prag). Die Leitung des Sonntag übernimmt nicht irgendein Journalist, sondern sein Sohn, Hans Ernest Oplatka (geb. 1911 in Wien). Emil Oplatka ist tschechischer Herkunft und arbeitet nach der Jahrhundertwende als Journalist in Wien. 1920, nach der Gründung des tschechoslowakischen Staates, kehrt er mit seiner Familie für ein paar Jahre in seine Heimat zurück und absolviert dort eine steile berufliche Karriere. Anfang der 1920er Jahre hat er in Prag hohe Verwaltungspositionen in international agierenden Medienkonzernen inne, u. a. beim tschechischen Ra- dio, bei der Agentur Reuters, beim Orbis Verlag und der Vernay AG.

Sein Sohn Hans Oplatka ${ }^{6}$ pendelt in jungen Jahren ebenfalls viel zwischen Wien und Prag. Nach seiner Kindheit in Wien absolviert er zwischen 1922 und 1928 das deutschsprachige Realgymnasium in Prag. Anschließend kehrt er nach Wien zurück macht Ende der 1920er Jahre eine Grafik- und Fotoausbildung an der Graphischen Lehr- und Versuchsanstalt. Das Fotografieren entdeckt er über seinen Vater, der seit dem Ersten Weltkrieg als Amateurfotograf tätig ist. 1930/31 besucht Hans Oplatka in Prag das Polytechnische Institut und absolviert - als tschechischer Staatsbürger - den Militärdienst. Anschließend sammelt er fotojournalistische Erfahrungen in Frankreich. Er arbeitet eine Zeit lang in der Redaktion der renommierten Zeitschrift $V U$, in der er auch eigene Bildberichte veröffentlicht. $V U$ ist in den 1930er Jahren sowohl grafisch wie fotografisch die avancierteste französische Illustrierte und ein Vorbild für andere Zeitschriften, u. a. Life. 71931 veröffentlicht Oplatka mit seinen Paris-Fotos einen Fotoband unter dem Titel Rue St. Antoine.

Als Hans Oplatka Anfang April 1934 die erste Nummer des Sonntag herausbringt, ist er erst 23 Jahre alt. Dennoch: Als Journalist, Fotograf und Zeitschriftengestalter ist er kein Newcomer mehr. Er weiß - nicht zuletzt aus der Redaktion der $V U-$, wie gute Bildgeschichten gebaut sein müssen. Es ist unverkennbar, dass Hans Oplatka seine journalistischen und handwerklichen Kenntnisse, die er in Frankreich gewonnen hat, in die Gestaltung des Sonntag einfließen lässt. Außerdem nutzt er, nachdem er wieder in Wien ist, auch Kontakte zu französischen Fotografen. Einige von ihnen publizieren in der Folge im Sonntag.

Auch als Fotograf kann Hans Oplatka 1934 auf einige Berufserfahrung bauen. Als 20-Jähriger hat er 1931 erste Aufnahmen in der Zeitschrift Die Bühne veröffentlicht. ${ }^{8}$ Im selben Jahr liefert er, ebenfalls für die Bühne, eine Fotoreportage über „Sonntagsabenteuer auf der Seine“, die er aus Paris mitgebracht hat. ${ }^{9}$ Auch der atmosphärisch dichte Text stammt von ihm. In den folgenden Jahren arbeitet Oplatka immer wieder für die Bühne, meist bietet er Reisegeschichte an, etwa aus Frankreich, Oberitalien oder Prag. 


\section{Ein Blick hinter die Kulissen der Redaktionsarbeit}

Der Sonntag, bilanziert Hans Oplatka im März 1935 nach einem Jahr seines Erscheinens, ist der „Versuch, das Wiener Leben mit den Mitteln der modernen Zeitungsillustration in Bildern abzuspiegeln; es war (in einem Jahr politischer Aufregungen, in dem die Presse sich mancherlei Beschränkungen fügen mußte), ein Versuch, der nicht sofort gelingen konnte. Wir wissen, was wir wollen: wir wollen einem kultivierten Leserkreis möglichst gute, in einem höheren Sinn stets aktuelle Bilder in sein Sonntagsblatt legen, dazu womöglich einen interessanten und anregenden Text. Wir möchten außer dem Heer der Photographen die besten Zeichner zu Mitarbeitern haben, außer den Journalisten die Dichter. Mit ihrer Hilfe möchten wir von Sonntag zu Sonntag, von ,Sonntag‘ zu ,Sonntag‘ immer mehr dem Ziele nahe kommen: Vignetten an den Rand der Zeit zu malen, zu schreiben. Das möchten wir. Die freundliche Sympathie unserer Leser sagt uns, daß sie dieses unser Bestreben verstehen. Wie viel uns noch zu tun übrig bleibt, das wissen wir selber am besten. Aber es ist noch nicht aller Sonntag Abend.“10

Anfangs produziert Oplatka die achtseitige illustrierte Wochenendbeilage nahezu im Alleingang. Er setzt die Themen fest, organisiert die Bilder und redigiert die Texte, er verhandelt mit den Fotografen und Zeichnern, sichtet das Material und ordnet es zu Geschichten. Er steht am Lichttisch und zieht die einzelnen Seiten grafisch auf. Immer wieder liefert er auch selbst Fotoreportagen, zu denen er die Texte schreibt. Er hat ein großes Gespür für interessante Themen und ihre spannende fotografische und grafische Umsetzung. Von Anfang an gelingt es Oplatka, dem Sonntag eine ganz eigene, moderne Handschrift zu verleihen.

Da die Redaktion des Sonntag im Verlagshaus Canisiusgasse 8-10 im 9. Wiener Gemeindebezirk untergebracht ist, in dem u. a. das Mutterblatt Der Wiener Tag, aber auch illustrierte Magazine wie Die Bühne erscheinen, kann Oplatka bei seinem Zeitungsprojekt auf eine professionelle Infrastruktur zurückgreifen. Er nutzt bestehende Kontakte zu Fotografen und Autoren und bedient sich gut ausgebildeter Handwerker in der Grafik- und Druckabteilung des Hauses. Die Vernay AG verfügt seit 1928 über eine moderne Kupfertiefdruckanlage, die 1934 erweitert und modernisiert wird. Der Sonntag wird von Anfang an im Kupfertiefdruck hergestellt.

Nach gut einem Jahr erhält Oplatka Unterstützung in der Redaktion. Ab Mitte 1935 geht ihm der junge Zeichner Wilhelm Spira, er ist zwei Jahre jünger als der Chefredakteur, als Bildredakteur zur Hand. Bil Spira, so sein Künstlername, schildert in seiner Autobiografie Jahrzehnte später sehr anschaulich und lebendig, wie er zum Sonntag kam. ${ }^{11}$ Dieser Bericht ist überaus interessant, denn er der bietet einen guten Einblick in den Redaktionsalltag der Zeitung. Zudem sind diese Erinnerungen das einzige erhaltene schriftliche Zeugnis eines Sonntag-Redakteurs, das über das Innenleben der Illustrierten berichtet.

Bil Spira, geb. 1913, beginnt Ende der 1920er Jahre als Zeichner für die Presse zu arbeiten. Seine ersten Zeichnungen - schnell und souverän hingesetzte Skizzen von Theaterszenen und Schauspielerkarikaturen - erscheinen 1929 im sozialdemokratischen Kleinen Blatt. ${ }^{12}$ Er ist damals 16 Jahre alt. Später zeichnet er auch für die Arbeiter-Zeitung, daneben studiert er an der Kunstgewerbeschule in Wien (der heutigen Universität für angewandte Kunst). Als 1934 die sozialdemokratische Presse verboten wird, sieht sich Spira nach anderen Publikations- und Einkunftsmöglichkeiten um. „In den Kaffeehäusern durchstöberte ich alle aufliegenden Zeitungen und Zeitschriften, um eine zu entdecken, in die meine Zeichnungen paßten. Die Sonntagsbeilage des ,Wiener Tag‘, im Kupfertiefdruckverfahren hergestellt, bestand zum größten Teil aus Photos mit dazugehörigem Text und einigen Zeichnungen. Sie war im Gegensatz zu den meisten anderen journalistischen Erzeugnissen fortschrittlich, und ich hätte gern dort mitgemacht.“13

Da er in der Redaktion niemand kennt, bittet Spira den Fotografen Otto Skall, mit dem er flüchtig bekannt ist und der für den Sonntag arbeitet, eine Mappe mit Arbeitsproben in die Redaktion zu bringen. Als der erhoffte Anruf nicht kommt, ist Spira enttäuscht. Er will die Unterlagen wieder abholen. „Als ich beim ,Sonntag‘ klopfte, öffnete mir ein junger 
Mann. ,Ich möchte mit dem Redakteur der Sonntagsbeilage sprechen. Herr Skall hat ihm meine Zeichnungen gezeigt. Ich möchte die Mappe gern wieder zurückhaben. Mein Name ist Spira. 'Sehr erfreut. Mein Name ist Hans Oplatka. Der Redakteur bin ich, und ich habe ihre Zeichnungen gesehen. Ich wollte Sie fragen, ob Sie bei uns mitarbeiten wollen. “ 14

Oplatka und Spira verstehen einander auf Anhieb. Die erste Begegnung mündet in ein endlos langes Gespräch über „Journalismus, gute Photos, Zeichnerei etc. “ ${ }^{15}$ Bereits in der nächsten Nummer erscheinen Spiras Illustrationen. Er arbeitet nun regelmäßig als freier Mitarbeiter für den Sonntag, zeichnet Skizzen, Vignetten und liefert bald auch gezeichnete Reportagen, etwa aus Paris, wo er sich im Sommer 1935 aufhält. 1936 erhält er von Emil Oplatka, dem Direktor des Wiener Tag, das Angebot, in fester Anstellung für den Sonntag zu arbeiten, nämlich als Bildredakteur. ${ }^{16}$ Seine in der Vernay-Presse, vor allem im Sonntag, aber auch in der Bühne und in der Stunde veröffentlichten Zeichnungen und Texte sollen getrennt honoriert werden.

„Meine Aufgabe war es“, erinnert sich Spira, „aus Dutzenden Photos die besten herauszusuchen. Aus den besten jene, die einander am besten ergänzen. Entscheiden, ob aus dem Material eine, zwei oder drei Seiten werden sollen. Erster Entwurf für die Aufmachung der Seiten. Sind zu viele Bilder da, entscheiden, welche nicht unbedingt nötig sind. Sind zu wenig Photos da, die guten stärker vergrößern oder das Thema auf kleinerem Umfang behandeln und eine oder zwei Spalten mit einem kurzen Artikel füllen. Bei jeder Reportage ergeben sich neue Probleme. Das macht den Beruf des Redakteurs so interessant und lebendig. Bald war ich imstande, meine Seiten allein aufzubauen, und wenn Hans krank war, eine Reise unternahm oder in Ferien ging, konnte ich ihn vertreten." 17

Spira beschränkt sich in der Sonntag-Redaktion nicht auf die Arbeit als Bildredakteur. Er zeichnet weiterhin viel (die Zeichnungen sind meist mit Willy Spira gezeichnet), er schlägt Themen vor und knüpft sogar Kontakte zu neuen Mitarbeitern. Auf Spiras Initiative wird etwa Jura Soyfer, den er als Mitarbeiter der Arbeiter-Zeitung kennt, eingeladen, beim Sonntag mitzuarbeiten. ${ }^{18}$ Soyfer schreibt Artikel und Gedichte, gelegentlich arbeitet er auch intensiver mit Spira zusammen. Zu der Reportage „Naschmarkt zwei Uhr früh“ steuert Soyfer den Text und Spria die Zeichnung bei. ${ }^{19}$

\section{Menschen: Gesichter, Körper \\ und die Welt der kleinen Leute}

Am 1.Juli 1935 erscheint im Sonntag eine beeindruckende Reportage über das Leben der Bergarbeiter in einem niederösterreichischen Bergwerk. Die Bildgeschichte, aufgenommen nicht weit von Wien, stammt von Hans Oplatka. Er ist nicht nur für das Layout verantwortlich, sondern in diesem Fall auch für die Bilder. Die Reportage beginnt auf der Titelseite mit einem ungewöhnlichen Porträt (Abb. 2). Wir sehen einen aus extremer Untersicht aufgenommenen Kohlenarbeiter vor einem Förderturm. Das Gesicht ist leicht verschattet und dem Fotografen halb abgewandt. Der Oberkörper des Mannes zeichnet sich deutlich gegen den Himmel ab. Seine kräftige Statur wird vom seitlich einfallenden Sonnenlicht modelliert. Es ist unverkennbar: Er ist der Protagonist im Bild, auch wenn die Seite den Titel „Der Förderturm“ trägt. Das Industrieareal im Hintergrund, das vom hoch aufragenden Fördergerüst beherrscht wird, verschwimmt im Ungefähren.

Die Reportage findet ihre Fortsetzung auf einer Doppelseite im Innenteil (Abb. 3). Wiederum rückt Oplatka die Menschen, nicht die Maschinen oder die Architektur in den Mittelpunkt. Links erscheint einer der Bergleute in einer Großaufnahme, rechts sehen wir mehrere Arbeiter, die sich an einem Stapel Grubenholz zu schaffen machen. Auch hier hält Oplatka seine Kamera (wohl eine Rolleiflex) auffallend tief, sodass sich die Oberkörper der Männer deutlich vor dem Himmel abzeichnen. Die Außenaufnahmen, die technische Geräte und das industrielle Areal zeigen, werden, stark verkleinert, an den Bildrand verbannt. Und auch der Text der Reportage, der mit großer Wahrscheinlichkeit ebenfalls von Oplatka stammt, dreht sich um den arbeitenden Menschen, nicht um die Maschinen. „,Über Tag‘! Schon die Sprache sorgt dafür, daß wir, die wir im Lichte leben und arbeiten, 
Abb. 2, 3 Fotoreportage von Hans Oplatka über das Leben in einem niederösterreichischen Bergwerk. Der Sonntag, 1. Juli 1935, Titelseite, S. 4 und 5 .

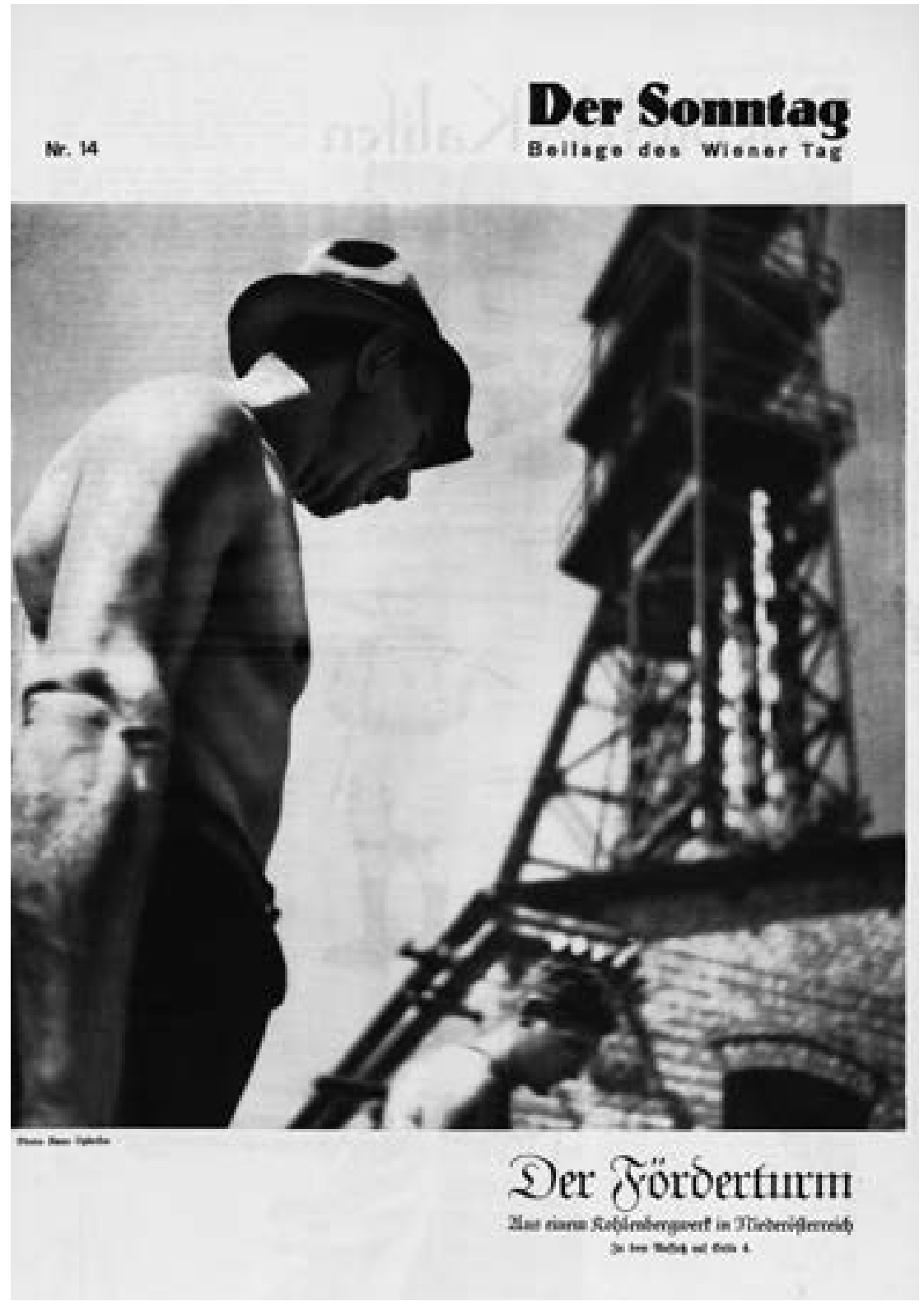

nie ohne ein gewisses Unbehagen (als wären wir alle mit verantwortlich) an das Los des Bergmanns denken, der eben den besten Teil seines Lebens ,unter Tag' verbringen muß. Harte Arbeit leistet nicht er allein, aber der Beruf des Bergmanns in der Kohlengrube hat nicht nur seine besonderen Mühen, sondern auch noch seine besonderen Gefahren. Der Mensch, der diesem Beruf dient, wird von ihm ganz anders erfaßt, umgeformt, gezeichnet als ein Industriearbeiter einer beliebigen anderen Kategorie.“20
Die Fotografien unterstützen diesen Befund. Sie zeigen von der Arbeit gezeichnete Körper und Gesichter. Oplatka geht es in seiner Reportage nicht um eine technische Dokumentation, sondern um eine subtilere Recherche: Er hält mit seiner Kamera die Spuren der Arbeit in den Haltungen und Gesten der Menschen fest. „Es wäre natürlich verfehlt“, so heißt es in dem Text weiter, „Zu glauben, daß in Zeiten normaler Wirtschaftsverhältnisse der Beruf des Bergmanns sich aus lauter Not und Tragik zusammensetze; aber 


\section{Leber $\mathfrak{S a g}$}

Qriditim unb Sienm and rines Sobimbergert nibt moit pon Xibim

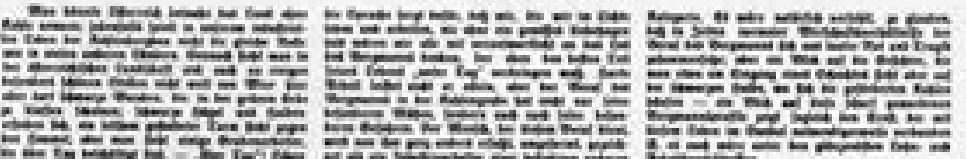

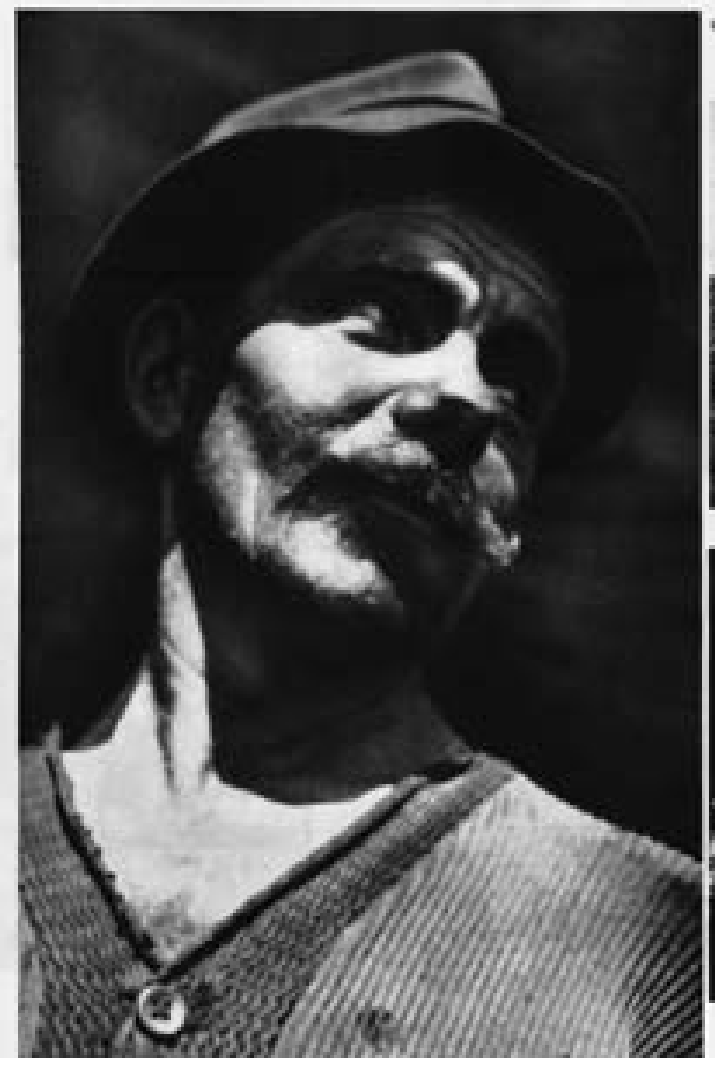

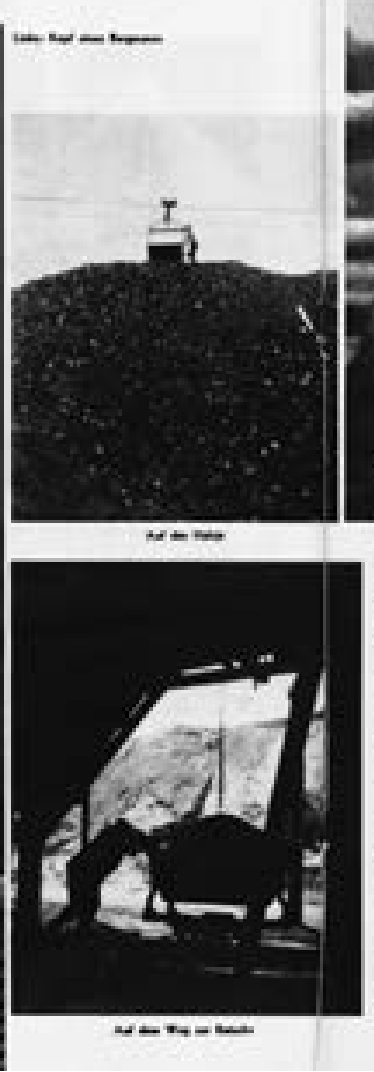

in ganz alltäglichen Situationen. Wir sehen sie bei der Arbeit, während der Freizeit, auf der Straße. Es sind einfache Menschen, so wie sie uns alle Tage begegnen können, nicht entrückte und idealisierte Figuren, wie sie in den Magazinen dieser Jahre bevorzugt auftauchen. Stars und Schauspieler kommen im Sonntag weit seltener vor als in anderen illustrierten Zeitungen. Und wenn sie porträtiert werden, wird ihnen ein menschliches Antlitz abgerungen. Als am 24. Dezember 1935 der Wiener Komponist Alban ein Blick auf die Gesichter, die man etwa am Eingang wo sich die geförderten Kohlen häufen - ein Blick diese scharf gewordenen Bergmannsprofile zeigt sogleich den Ernst, der mit diesem Leben im Dunkel notwendigerweise verbunden ist, es auch wäre unter den glänzendsten Lohn- und Arbeitsverhältnissen. “2

Diese Reportage zeigt sehr deutlich die inhaltliche Linie, die Oplatka im Sonntag verfolgt. Sehr oft stehen Menschen im Zentrum der Betrachtung, dargestellt

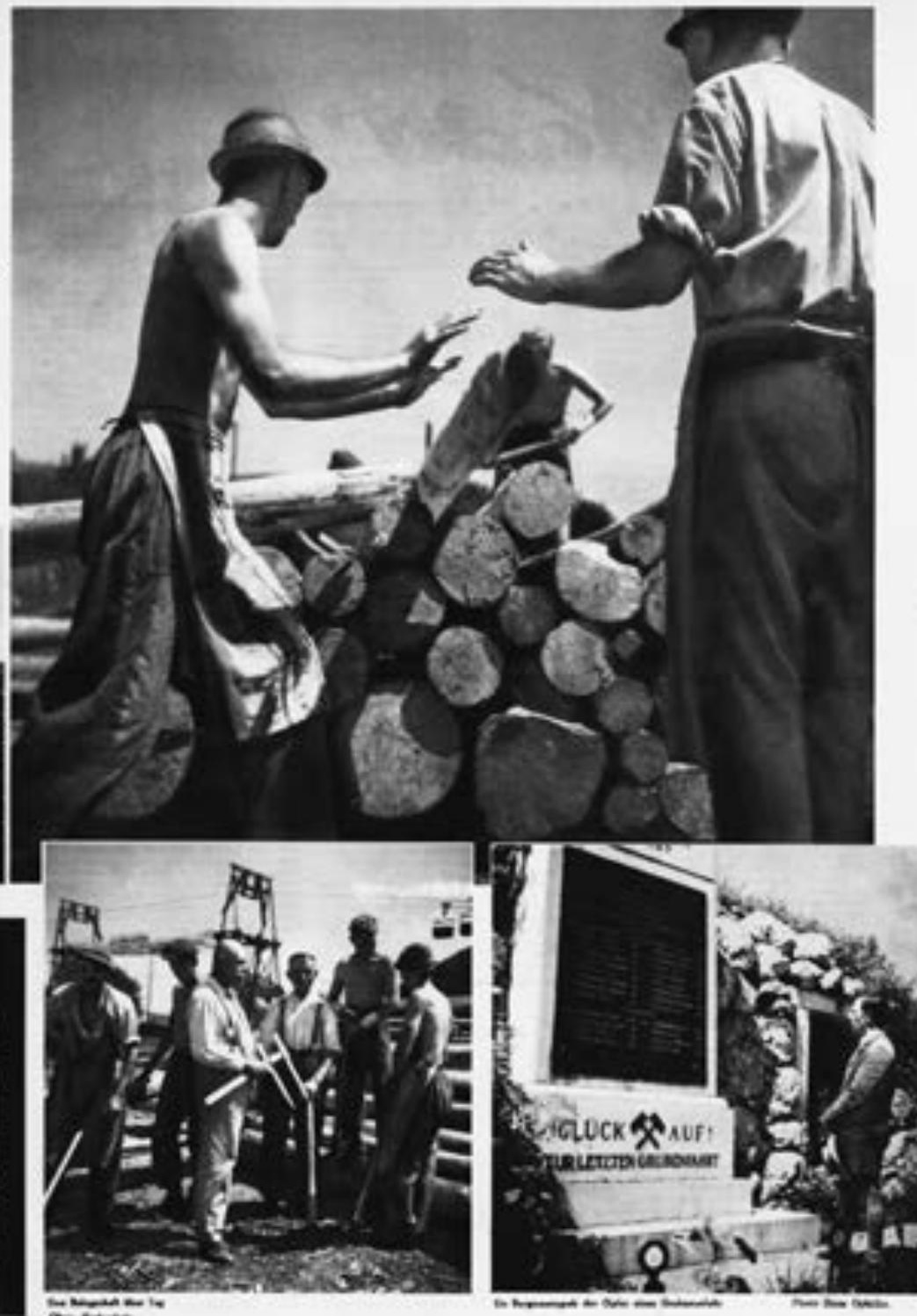


Abb. 4 Nach dem Tod von Alban Berg im Dezember 1935 bringt Der Sonntag eine Fotografie von Otto Skall auf der Titelseite. Der Sonntag, 5. Januar 1936.

\section{ALBAN BERG}

Der Sonntag

Beilage des Wiener Tog Nt. 94 
Berg stirbt, widmet ihm der Sonntag ein einfaches, aber eindrückliches Titelblatt (Abb.4). Die Seite ist in ruhigen, klaren Schwarz-Weiß-Flächen gehalten. Im Zentrum steht das frontal aufgenommene, knapp beschnittene Porträt des Musikers. Daneben, leicht über der Augenhöhe des Abgebildeten, findet sich in einem senkrechten weißen Kasten Titel und Untertitel der Zeitschrift sowie der Name des Fotografen. Das Foto, es stammt von Otto Skall, ist, zusammen mit dem schlichten Namenszug des Verstorbenen, in einen schwarzen Grund gesetzt und tritt so besonders deutlich hervor, ohne monumental oder pathetisch zu wirken.

Das Alban-Berg-Titelbild mit dem eng beschnittenen Gesicht ist keine Ausnahme. Immer wieder bringt Oplatka auf dem Umschlag Gesichter in extremer Nahaufnahme, die eine aufmerksame Betrachtung geradezu herausfordern. Meist sind es einfache, oft namenlose Menschen, die hier ins Licht gerückt werden. Auch in den Zügen völlig unbekannter Personen lässt sich, so sein Credo, eine ganze Welt entdecken. Regelmäßig veröffentlicht er etwa Aufnahmen von Martin Imboden, der in seinen Porträts besonders nahe an das Gesicht heranrückt. Eines dieser Fotos wird im Juli 1936 im Sonntag veröffentlicht (Abb. 5). ${ }^{22}$ Die junge Frau im Bild tritt uns, unterstützt durch die raffinierte Lichtführung von schräg oben, geradezu plastisch entgegen. Gerade weil sie ihren Blick gesenkt hat, können wir es wagen, sie länger als üblich zu betrachten. Nichts lenkt von ihrem Gesicht ab. Der Hintergrund ist vollständig ausgeblendet und auch das Kopftuch der Frau, das ihren sozialen Stand und ihre Herkunft verraten könnte, ist stark angeschnitten, sodass nicht mehr als ein abstraktes Muster sichtbar wird. Wir wissen nicht, ob die Frau Städterin ist oder vom Land kommt, ob sie reich oder arm ist. Ihr Porträt steht nicht stellvertretend für eine soziale Schicht, vielmehr kommt darin eine, wenn auch namenlose, Person zum Ausdruck.

Immer wieder bringt der Sonntag Bildstrecken und Reportagen, die einen Blick auf den Alltag der kleinen Leute werfen. Die Sonntag-Fotografen bewegen sich oft am Rande der bürgerlichen Gesellschaft, sie dokumentieren das gesellschaftliche Treiben auf den Märkten (der Wiener Naschmarkt etwa kommt

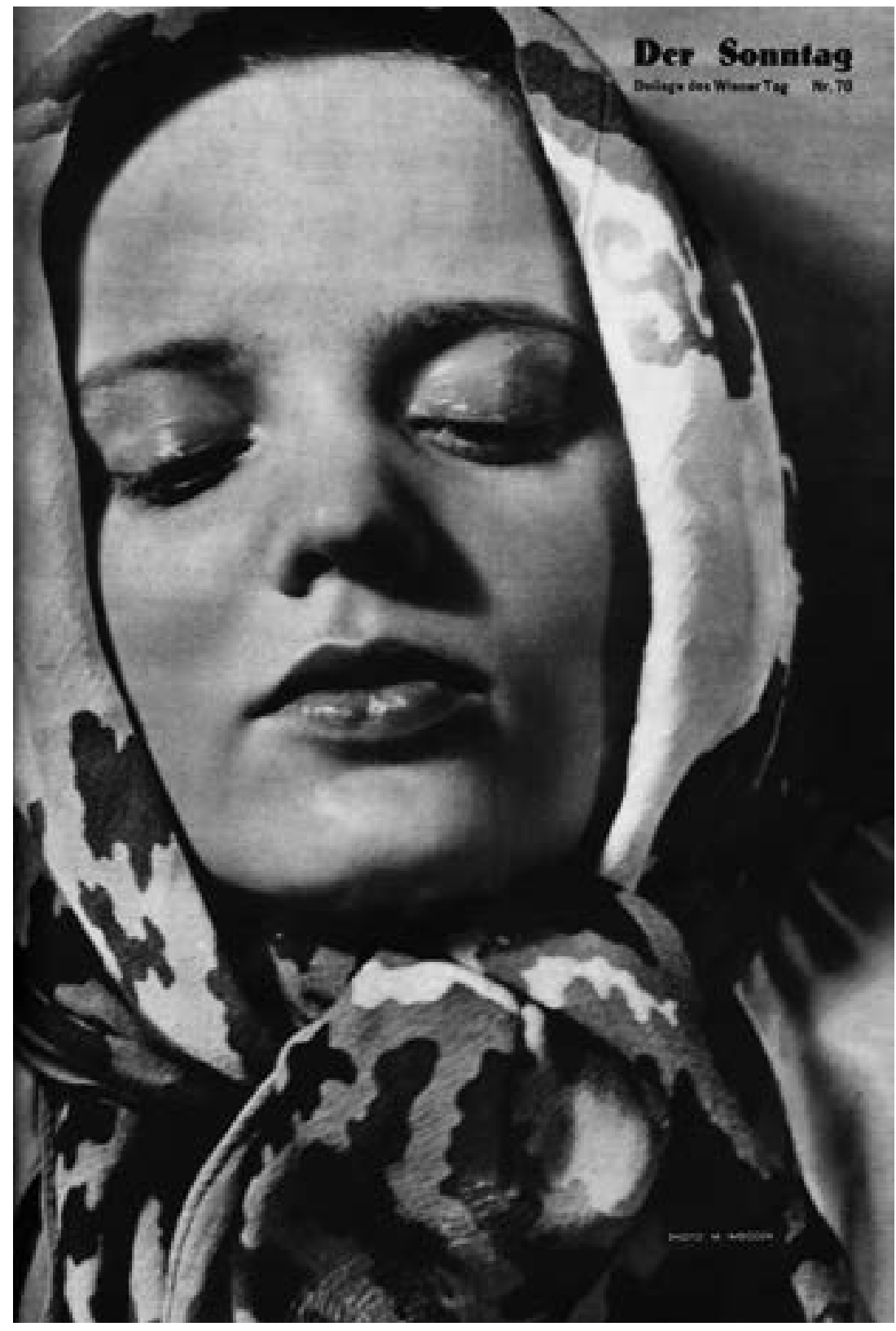

in mehreren Reportagen vor), sie schildern das Leben an populären Vergnügungsstätten (Prater und Zirkus). Und sie werfen einen Blick auf das einfache ländliche Leben außerhalb der Großstadt Wien, in der Regel ohne dieses als heilen Gegenentwurf zur städtischen Misere zu verklären.

Regelmäßig finden wir im Sonntag Berichte und Reportagen über das Leben und den Alltag in den Wiener Außenbezirken und Vororten, wo Not und
Abb. 5 Frau mit Kopftuch. Der Sonntag, 15. September 1935, Titelseite. Foto: Martin Imboden. 


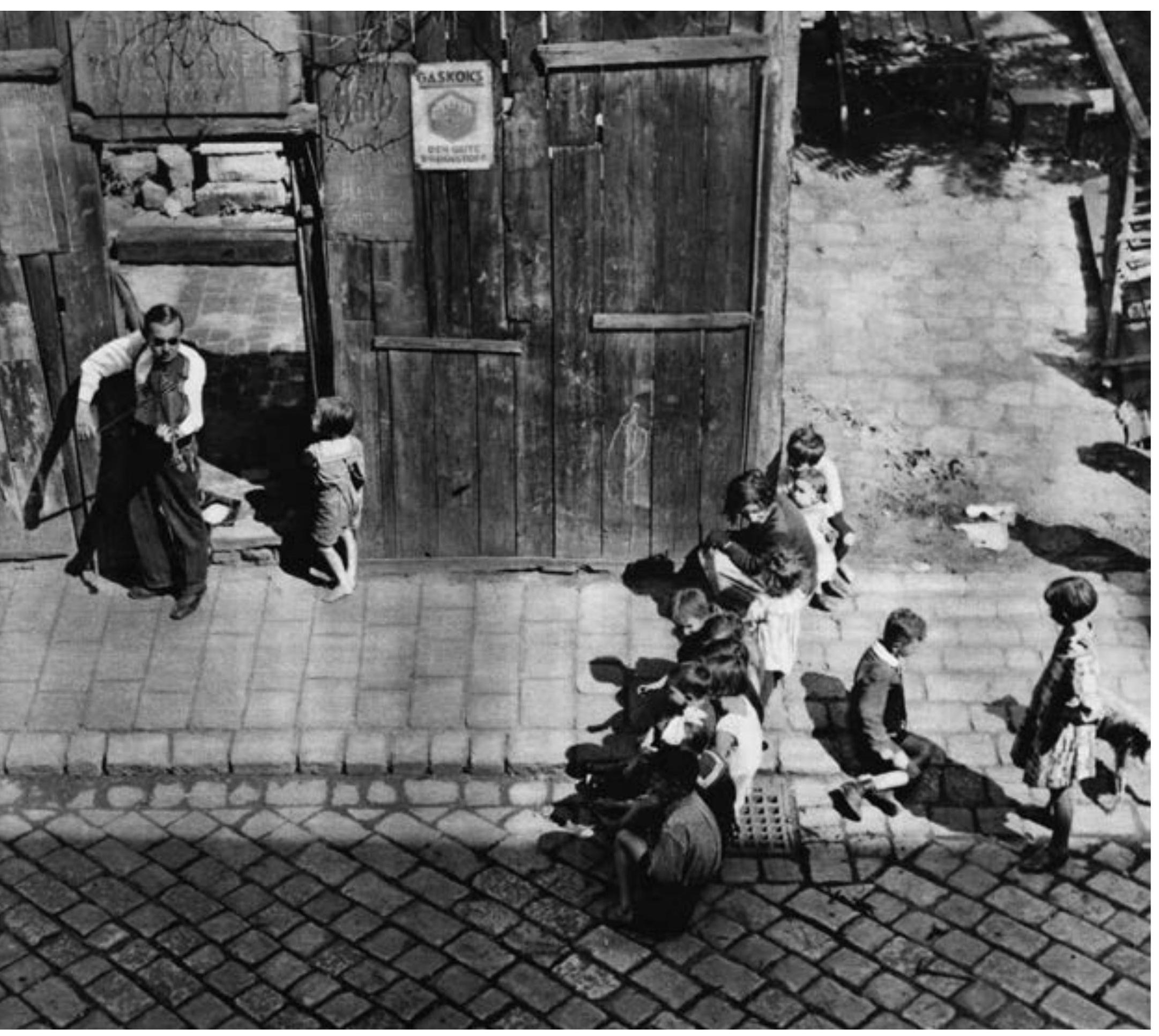

Abb. 6 „Frühling in Lichtental“. Stra-

Benszene aus der Wiener Vorstadt.

Der Sonntag, 31. März 1935, Titelseite.

Foto: Felix Braun. 
Armut zu Hause sind. Ende März 1935 etwa veröffentlicht der Sonntag eine Aufnahme von Felix Braun, in der das visuelle Programm der Zeitschrift kondensiert erscheint (Abb. 6). Das Foto zeigt eine Straßenszene in Lichtental, einer ärmlichen, slumähnlichen Vorstadtgegend im 9. Wiener Gemeindebezirk, die zwischen dem Franz-Josefs-Bahnhof und der Nußdorfer Straße gelegen und nicht allzu weit von der Sonntag-Redaktion entfernt ist. Als der sozialdemokratische Journalist Max Winter ein Jahr vor dem Ersten Weltkrieg diesen Ort besucht hatte, berichtete er in der Arbeiter-Zeitung von der Armut, dem Verfall und der Not, die in diesen engen Gassen zu Hause ist. In den niederen, heruntergekommenen Vorstadthäusern finden sich, so Winter, „Gelasse“, die von den Besitzern „wohl noch als Wohnungen ausgegeben werden, die aber nichts sind als höchstens Schlafstellen, die auch den einfachsten Regeln der Gesundheitslehre hohnsprechen (...).“23 Bewohnt werden diese einfachen Behausungen von Leuten, die am unteren Ende der sozialen Leiter stehen, Hilfsarbeitern, Kutschern, Straßenkehrern u. Ä., Menschen also, deren Einkommen für eine Mietshauswohnung in einem Arbeiterviertel nicht ausreichen. ${ }^{24}$ Not und Elend findet Max Winter nicht nur auf den Lichtentaler Straßen, sondern auch im Inneren der einfachen Wohnstätten: „Die ganze Wohnung verfallen. Die einst hellblaue Mauer abgebröckelt. Heiligenbilder an den Wänden. Alles dumpf und trostlos.“25

Gut zwei Jahrzehnte später ist Lichtental immer noch eine arme, heruntergekommene Gegend. In der Straßenszene von Felix Braun ist die Not der Bewohner noch deutlich sichtbar. Aber es geht dem Fotografen nicht in erster Linie um Sozialkritik. Er verhält sich vielmehr als stiller Beobachter, der - wohl von einem erhöht gelegenen gegenüberliegenden Fester aus - eine kleine, alltägliche Begebenheit festhält, die scheinbar im Kontrast zum Elend der Straße steht: das Spiel eines Straßenmusikanten, dem eine Kinderschar aufmerksam zuhört. Die faszinierende Momentaufnahme lässt für einen Augenblick das triste Leben der Beteiligten in den umliegenden Straßen vergessen. In ähnlicher Weise hält sich der Sonntag mit offener Kritik zurück und richtet sich in der Rolle des aufmerksamen Beobachters ein.
Um die Lebensbedingungen und den Alltag der „anderen Hälfte der Bevölkerung“ einzufangen, müssen die Fotografen und Reporter des Sonntag oft nicht weit reisen. Im Februar 1937 erscheint eine Fotoreportage von Robert Haas, einem der talentiertesten und wichtigsten Fotografen des Blattes, die in die Vorstadt im Süden Wiens führt, in den Arbeiterbezirk Simmering (Abb. 7). Der Fotograf besucht, zusammen mit einem Journalisten oder einer Journalistin, von dem bzw. der wir nur das Namenskürzel A. W. kennen, einen Kindergarten in einem Barackenlager. Dieser „Garten im Lande der Armen“ ist, so erfahren wir gleich auf der Titelseite, „hauptsächlich von Familien Arbeitsloser bewohnt.“26 Das ganzseitige Titelfoto zeigt ein kleines Mädchen, das den Mittagskakao für die anderen Kinder einschenkt.

„Nur zwanzig Minuten Straßenbahn vom Zentrum entfernt liegt dieses Land. Aber wie viele Wochenreisen weit vom glücklichen Leben. Es wird noch zum Stadtbereich von Wien gezählt; aber das gilt nur theoretisch. Die Straßen sind nicht mehr gepflastert, man versinkt bei jedem Schritt in die Erde, die weich geworden ist von Schnee und Regen. Die Geschäftsländen sehen aus, als hätte seit undenklichen Zeiten kein Käufer ihre Schwelle überschritten. Die ,Konsumwaren` der Frau Emilie Chladek scheinen auch keinen großen Absatz zu finden. Denn die Konsumenten wohnen in Baracken und nicht einmal zur Mittagszeit steigt aus allen Kaminen Rauch.“27 Mit diesen Worten beginnt die Reportage, die sich im Innenteil des Heftes fortsetzt (Abb. 8). Auch hier steht nicht die offene Sozialkritik im Vordergrund, sondern die aufmerksame Beschreibung der sozialen Verhältnisse. Nicht die Armut der Arbeitslosen steht im Zentrum der Reportage, sondern ein hoffnungsvoller Lichtblick: ein Kindergarten mitten „im Lande der Armen“. Voller Anteilnahme und Wärme wird der Alltag der Kinder in der öffentlichen Einrichtung beschrieben. „Ein wenig Wärme, ein wenig Licht, ein sauberer Schlafraum. (...) Hier ist es schöner als zu Hause, sagen die Kinder (...).“28

Neben Einzelbildern und klassischen Reportagen finden sich im Sonntag hin und wieder auch experimentelle Bildgeschichten, die den Alltag aus neuem Blickwinkel beleuchten. Am 21. Juli 1935 widmet 


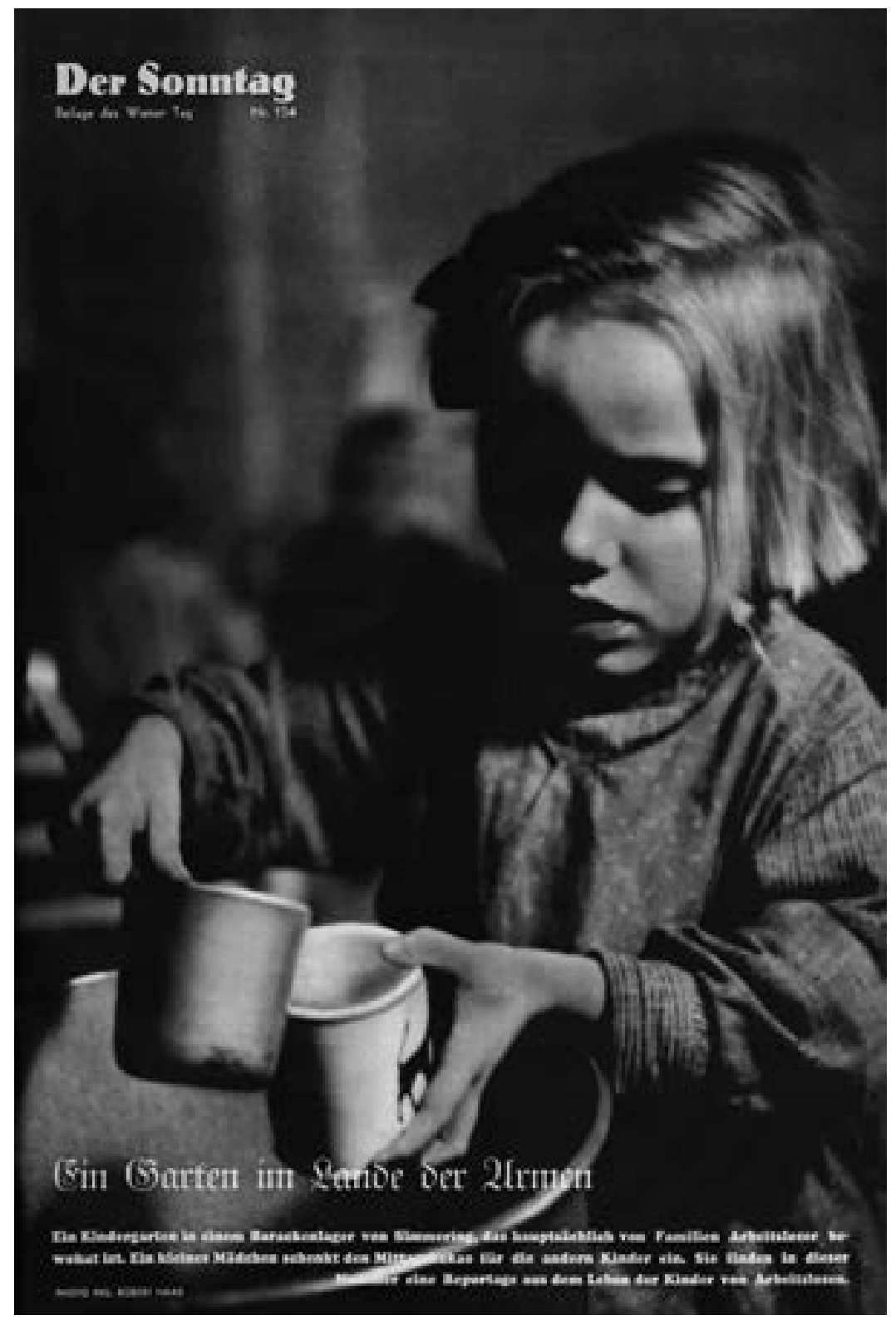

Abb. 7, 8 „Ein Garten im Lande der Armen“. Fotoreportage über einen Kindergarten im Wiener Arbeiterbezirk Simmering. Der Sonntag, 28. Februar 1937, Titelseite, S. 4 und 5. Fotos: Robert Haas. sich eine Doppelseite mit insgesamt 14 Aufnahmen einem scheinbar ganz einfachen Thema: „Ein Mann steht am Fenster ...“ (Abb.9). Der Mann selbst ist nicht zu sehen, wohl aber das, was er (angeblich) auf der Straße unter ihm sieht: einen Brotträger und einen Dachdecker, Straßenkehrer und Passanten, Kinder und einen Geigenspieler, einen Angestellten, der ins Büro eilt, und Frauen, die in ein Gespräch vertieft sind, Arbeiter, Reisende. Das Leben auf der Straße erscheint in dieser Anordnung in zahllose kleine $\mathrm{Au}-$ genblicke zerteilt, die wir erst lesend und schauend zu einem Ganzen zusammensetzen müssen. Rudolf Spiegel, der Fotograf, hat alle Szenen aus der Vogelperspektive aufgenommen und sie dadurch in ein ungewohntes, verfremdendes Licht gerückt. Verstärkt wird dieser Kunstgriff, der dem Neuen Sehen entlehnt ist, durch die langen bizarren Schatten, die den Figuren zusätzlich etwas Unwirkliches verleihen. Diese Bildgeschichte bricht mit den Regeln der klassischen Reportage, die, meist unterstützt durch die Gestaltung, eine kompakte, zusammenhängende Erzählung liefert. Hier hingegen werden formal ganz ähnlich gestaltete Wahrnehmungselemente grafisch in ein strenges Nebeneinander gebracht. Der Bildtext bindet die Einzelbilder aneinander und durchzieht das Tableau formaler Nachbarschaft mit einem inhaltlichen Faden.

\section{Poetik des Alltags}

Hans Oplatka gelingt es innerhalb kürzester Zeit, die besten und innovativsten Fotografen um sich zu versammeln. Da die Bilderzeitung, wie sie ihm vorschwebt, ihren Schwerpunkt nicht in der aktuellen politischen Berichterstattung hat, sondern einen stärker feuilletonistischen Zugang zur Welt verfolgt, kann Oplatka mit den Arbeiten klassischer Pressefotografen, die aktuelle politische und gesellschaftliche Ereignisse in konventionellen Einzelbildern dokumentieren, wenig anfangen. Stattdessen wendet er sich an Lichtbildner, die imstande sind, in Geschichten zu denken, die einen Blick für ungewöhnliche Themen und Perspektiven haben und die ein sicheres Gespür für die Dramatik des Alltags mitbringen. Einer dieser Fotografen, die Oplatka für den Sonntag gewinnt, ist Rudolf Spiegel. Er ist 1896 in Wien geboren, nach der Realschule dient er als Soldat im Ersten Weltkrieg. Ende 1920 kehrt er aus der russischen Kriegsgefangenschaft aus Wladiwostok heim. In der Zwischenkriegszeit arbeitet er zeitweise als Bankbeamter, zwischendurch ist er arbeitslos. Ende der 1920er Jahre beginnt Spiegel zu fotografieren - zunächst als Amateur. Als er 1937 eine Ausbildung an der Graphischen Lehr- und Versuchsanstalt beginnt, ist er bereits über 40 und als Fotograf bekannt. ${ }^{29}$ Seine ersten gedruckten Aufnahmen erscheinen 1929 im sozi- 


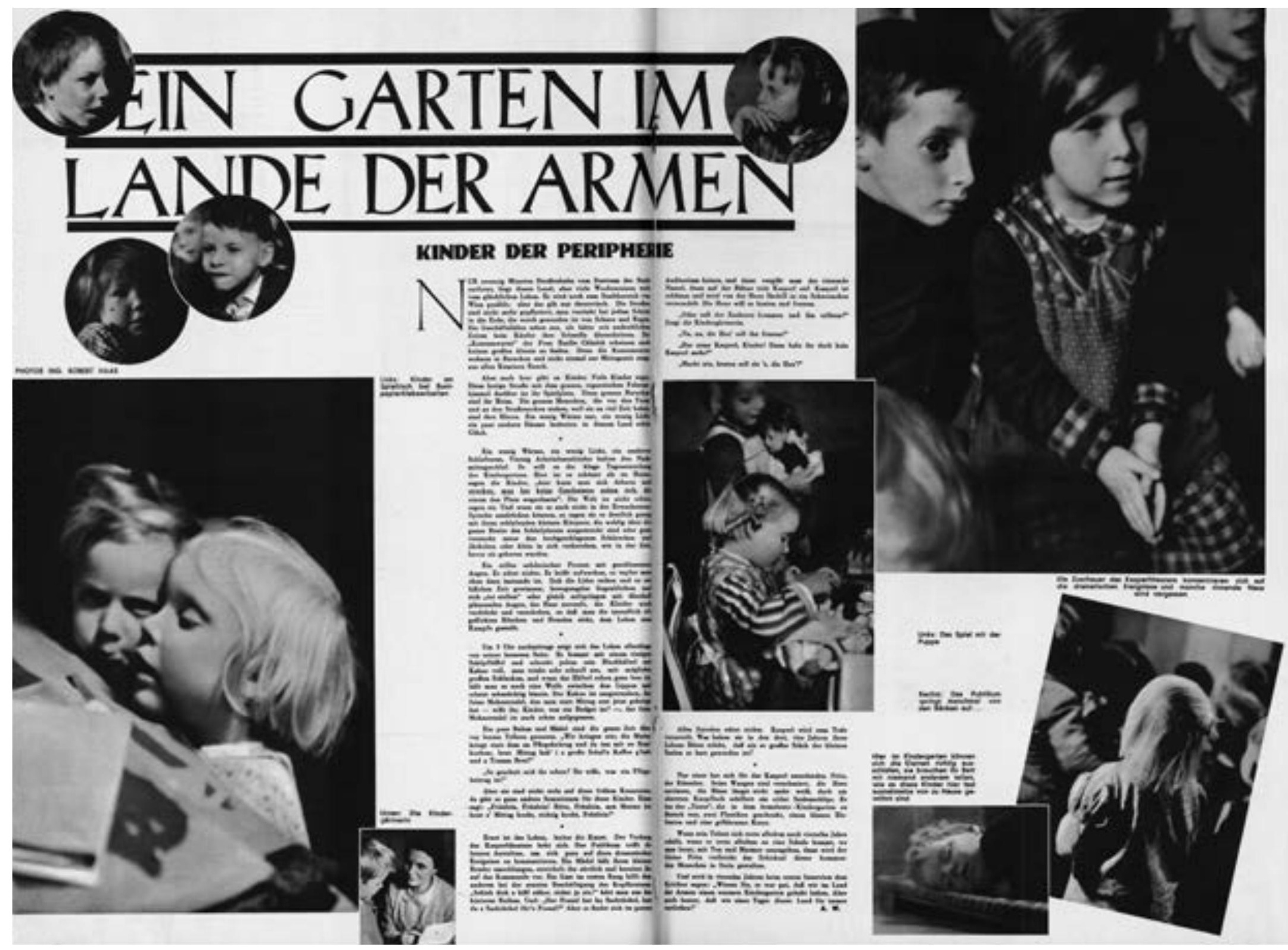

aldemokratischen Kuckuck, in dem er in den folgenden Jahren regelmäßig publiziert. Spiegel ist viel auf Wiens Straßen unterwegs. Er beobachtet das Treiben des Alltags, Menschen, die zur Arbeit gehen, plaudern, essen, sich erholen. Er registriert aber auch, wie Anfang der 1930er Jahre die Straße immer mehr zum Forum der Politik wird, zum Aufmarschgebiet für Kundgebungen und Demonstrationen.

Bil Spira berichtet in seinen Erinnerungen, wie Rudolf Spiegel zum Sonntag kommt. „,Ich bin nur ein Amateur', sagt Rudolf Spiegel, der eines Tages in der Redaktion erschien, ,ich habe einige Photos aufgenommen, vielleicht können Sie sie für die Beilage gebrauchen. 'Es waren gute, lebendige Momentaufnahmen einer an sich banalen Straßenszene. Gerhart Hermann Mostar, ein Kleinkunsttexter, machte dazu ein Gedicht, und das ergab zusammen eine schöne, menschlich wirksame Seite. Die Frau Rudolf Spiegels arbeitete bei einem Fleischselcher. Er selbst war arbeitslos und spazierte in seiner freien Zeit mit dem 


\section{EIN MANN STEHT AM FENSTER...}
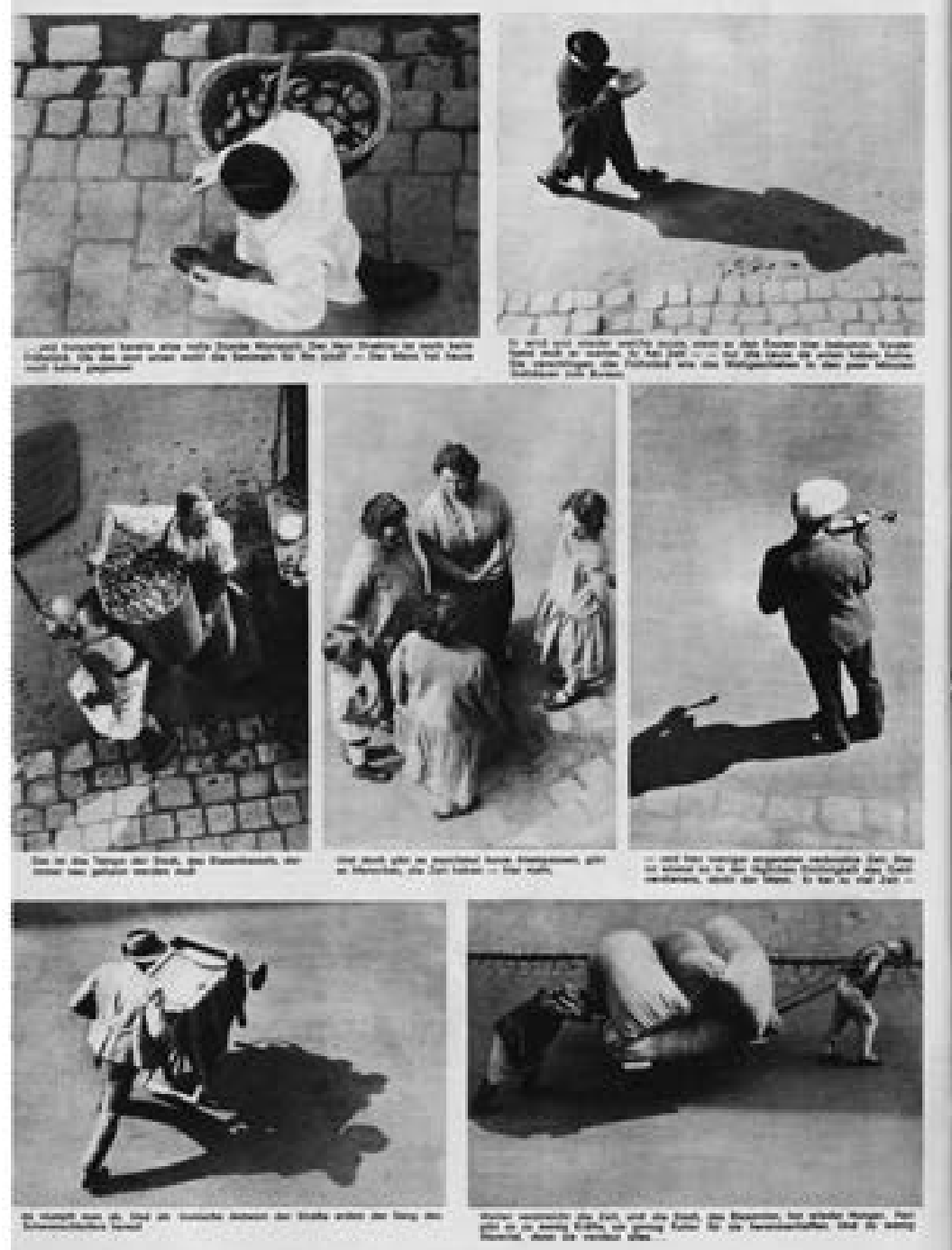
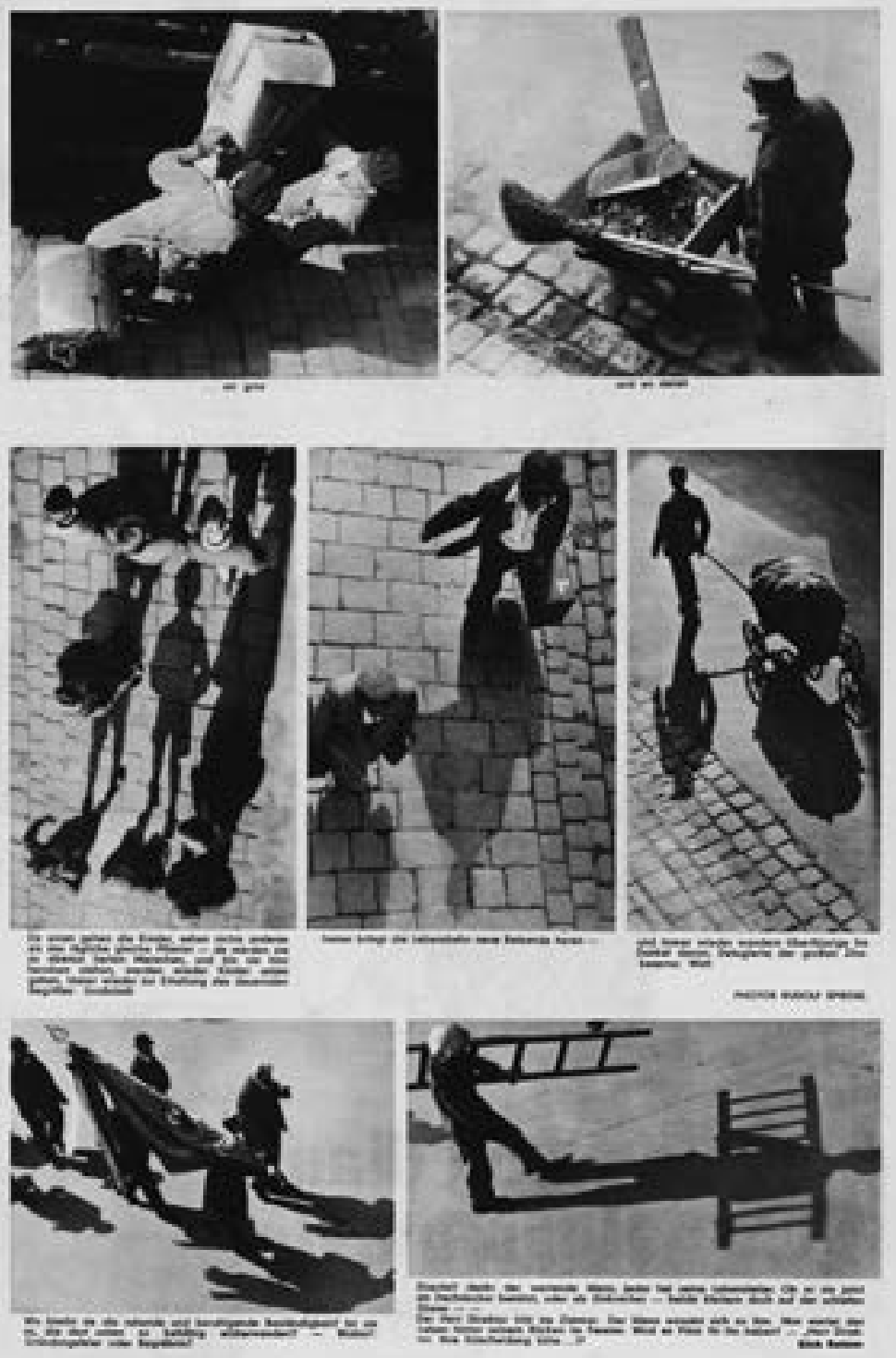

Abb. 9 „Ein Mann steht am Fenster“. Bildgeschichte über den Alltag auf der Straße. Der Sonntag, 21. Juli 1935, S. 4 und 5. Text: Erich Rattner, Fotos: Rudolf Spiegel.
Photoapparat in den Wiener Gassen herum, immer auf der Lauer nach einem ,Ereignis‘. Fast jede Woche kam er wieder, bescheiden und unsicher: ,Ich habe wieder ein paar Aufnahmen gemacht. Darf ich sie zeigen?' Es waren bescheidene Themen aus bescheidenen Milieus, gesehen von einem guten Beobachter. Nach kurzer Zeit war er regelmäßiger Mitarbeiter des ,Sonntag، “30

Für Spiegel ist der Sonntag ein wichtiges publizistisches Forum, hier kann er vor allem seine Fähigkeiten als Flaneur der Großstadt ausspielen. Seine Themen sind Alltagsgeschichten und Straßenszenen, die er hauptsächlich in Wien fotografiert. Zunächst bietet er der Redaktion Einzelaufnahmen an, bald aber liefert er auch längere Reportagen, etwa 1935 über einen „Winterabend im Krämerladen“ - der Text stammt von Karl Heinrich Waggerl - oder 1937 über die Eisensammler in Wien-Ottakring. Im selben Jahr veröffentlicht er eine Reportage über einen Wiener Autofriedhof. Sie beginnt auf der Titelseite mit einem aus der Vogelschau aufgenommenen Überblick, der das Durcheinander der „toten“ Autos auf dem Schrottplatz zeigt (Abb. 10). ${ }^{31}$ Verstärkt wird die verfremdende Perspektive durch die Schatten (Spiegel fotografiert gerne früh am Morgen oder am Abend), aber auch durch die ins Auge fallende diagonale Beschneidung der Aufnahme. Im Innenteil wird die Reportage unter dem Titel „Das Sterben der Autos“ fortgesetzt. ${ }^{32}$ Neben einer weiteren Überblicksaufnahme rückt Spiegel nun näher heran, er zeigt ein zerlegtes Auto und zwei Mechaniker, die mit dem Abmontieren von Einzelteilen beschäftigt sind. Zwischen die Bilder hat der Zeichner Bil Spira kleine Vignetten gesetzt, die einzelne isolierte Autoteile herausgreifen. Der 
Text der Reportage stammt vom jungen Wiener Autor Erich Rattner, geb. 1914 in Wien, der regelmäßig Beiträge für den Sonntag schreibt.

Rudolf Spiegel ist zwar Amateur, aber er passt nicht so recht ins Spektrum jener vereinsmäßig organisierten Amateurlichtbildner, die in den 1930er Jahren immer stärker patriotisch-konservative Anwandlungen haben. Dieser Strang der idealisierenden Fotografie, die ihre Erfüllung in entrückten, idyllischen Landschaften und in neopiktorialistischen Genredarstellungen und Stillleben findet, ist Oplatkas Sache nicht. ${ }^{33}$ Als im März 1935 Wiener und Grazer Polizeibeamte ihre Amateurfotos öffentlich ausstellen, kritisiert der Sonntag den Hang der Amateure, sich von der Wirklichkeit abzuwenden. „Man kann es in den Amateur-Ausstellungen von Angestellten und Arbeitern immer wieder beobachten, die Freude am ,Motiv“ hört meist dort auf, wo der Alltag beginnt.“34

Oplatka bevorzugt Fotografen, die einen ideologisch ungetrübten, nüchternen, neugierigen Blick auf die Wirklichkeit werfen. Dem Gros der österreichischen Amateurfotografenbewegung gegenüber zeigt er sich eher skeptisch. Aber einzelne innovative Amateure, die sich nicht vor den Karren der herrschenden Weltsicht spannen lassen, schätzt er durchaus. $\mathrm{Zu}$ den neugierigen, offenen Amateurfotografen, die immer wieder im Sonntag vertreten sind, gehören neben Rudolf Spiegel auch Nikolaus Schwarz, Robert Haas, Martin Imboden, Kurt Husnik, Walther Schneider, Felix Braun, Ernst Kassowitz, Hans Popper, Willy Eggarter und Sepp Nowak.

Auch unter den professionellen Pressefotografen bevorzugt Oplatka jene, die sich neben ihrem Tagesgeschäft einen originellen Blick auf die Gegenwart bewahrt haben. Meist wählt er aus Bildern aus, die nicht politische Ereignisse illustrieren, sondern Stimmungen wiedergeben oder Alltagseindrücke am Rande von gesellschaftlichen Begebenheiten festhalten. Bemerkenswert ist, dass er selten auf das Angebot von Fotoagenturen zurückgreift ${ }^{35}$, lieber hält er den persönlichen Kontakt zu den Fotografen. Unter den professionellen Pressefotografen, die regelmäßig im Sonntag publizieren, sind etwa Otto Skall, Max Fenichel, Hans Casparius, Karl Schleich, Paul Macku, Bruno Völkel und Lothar Rübelt. ${ }^{36}$

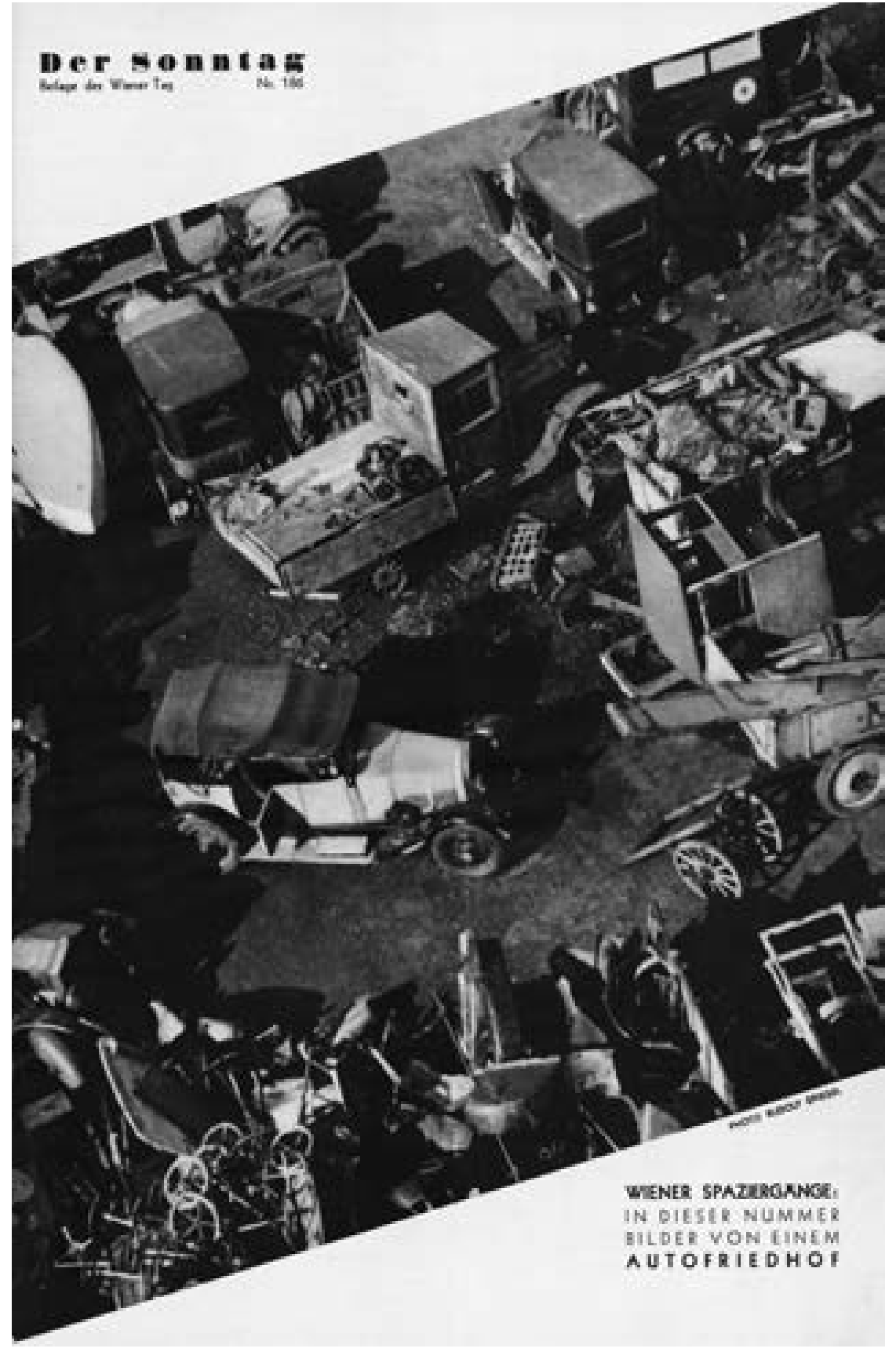

Otto Skall ist jener Fotograf, der im Sonntag am häufigsten vorkommt. Mit ihm verbindet Oplatka eine jahrelange enge Arbeitsbeziehung, vermutlich sind die beiden auch befreundet. Skall ist ein überaus origineller, vielseitiger und fähiger Lichtbildner, der sich auf das Konzept des Sonntag besonders gut einzustellen versteht. Er ist 1884 in Prag geboren und
Abb. 10 „Das Sterben der Autos“. Fotoreportage über einen Wiener Autofriedhof. Der Sonntag, 10. Oktober 1937, Titelseite. Text: Erich Rattner, Foto: Rudolf Spiegel. 


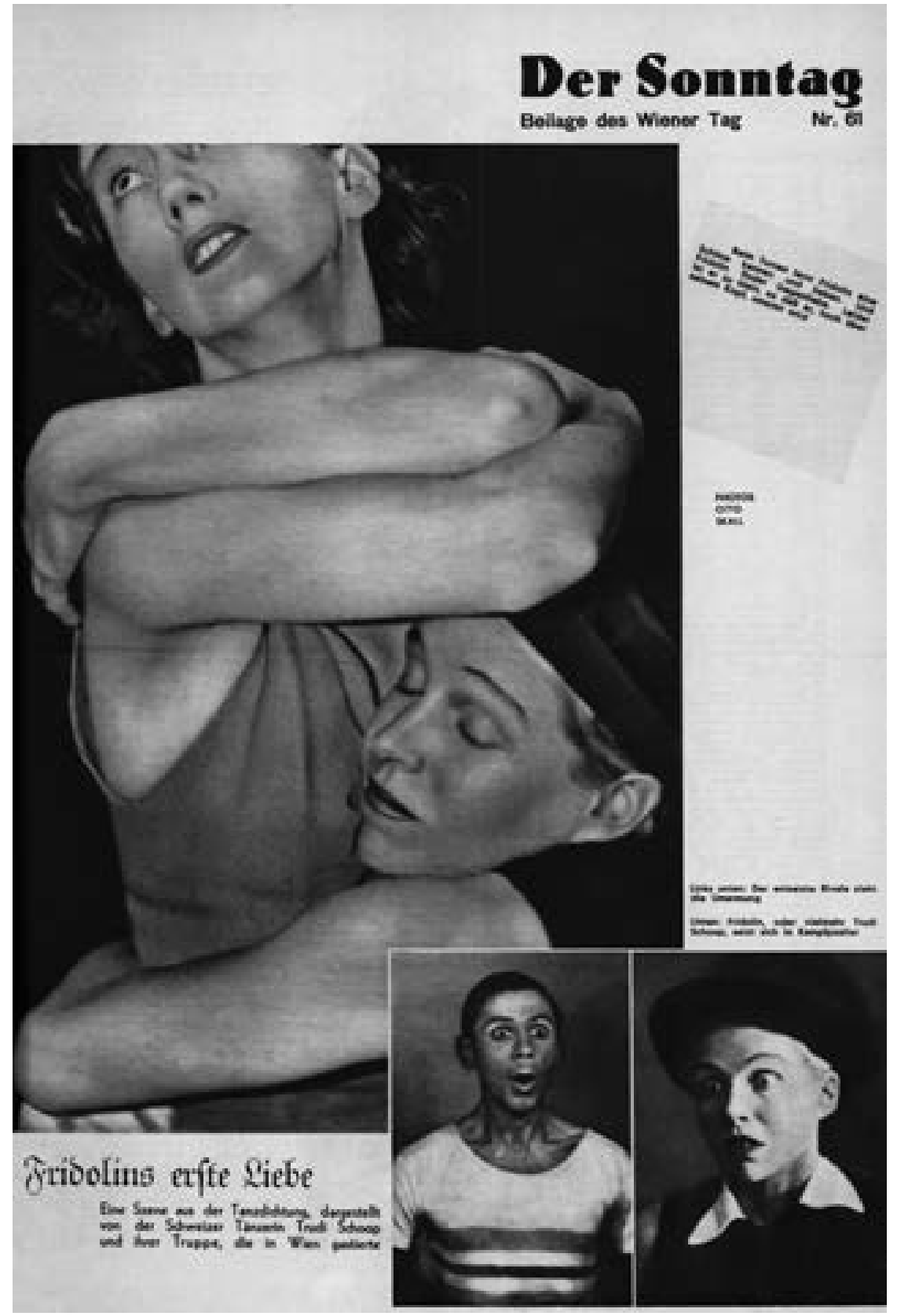

Abb. 11 „Fridolins erste Liebe“. Fotoreportage über die Schweizer Ausdruckstänzerin Trudi Schoop. Der Sonntag, 19. Mai 1935, Titelseite. Fotos: Otto Skall. ersten Arbeiten in der illustrierten Presse, etwa im Kuckuck und im Interessanten Blatt, wo er erste Reportagen und originelle, geradezu konzeptuell gestaltete Bild-Text-Geschichten publiziert. ${ }^{37}$ Er verfolgt einen nüchtern-sachlichen Stil und präsentiert seine Themen oft mit Augenzwinkern und voll hintergründigem Humor. 1933 beginnt er als professioneller Pressefotograf zu arbeiten. Er ist in den 1930er Jahren einer der bedeutendsten österreichischen Theaterfotografen. Daneben dokumentiert er aber auch Alltags- und Straßenszenen, macht experimentelle Aufnahmen, fotografiert hie und da Architektur und liefert Sozial- und Reisereportagen. Bei seinen Außenaufnahmen arbeitet er häufig mit einer Contax.

Für den Sonntag stellt Skall regelmäßig Fotoreportagen zu alltäglichen Themen zusammen. Im Mai 1935 etwa liefert er unter dem Titel „Fridolins erste Liebe“ einen Bildbericht über die Schweizer Ausdruckstänzerin Trudi Schoop, die auf der Titelseite beginnt (Abb. 11) und im Innenteil fortgesetzt wird. ${ }^{38}$ Er fotografiert ab 1934 Jahr für Jahr bei den Salzburger Festspielen, macht Theater- und Opernaufnahmen, fotografiert Thomas Mann für ein großes Sonntag-Interview, das im Januar 1937 in Wien aufgezeichnet wird ${ }^{39}$, und liefert die Bilder für eine mehrteilige Reisegeschichte, die im August 1935 unter dem Titel „Zu zweit an die Grenzen Europas“ beginnt und entlegene Regionen vorstellt. ${ }^{40}$

Der Text zur Fotoreportage über die Tänzerin Trudi Schoop stammt von Gustav Wiesinger. Wer sich hinter diesem Pseudonym verbirgt, enthüllt ebenfalls Bil Spira. Er erinnert sich, dass Otto Skall einmal eine gute Fotoreportage in die Redaktion brachte und Oplatka bedauerte, keinen brauchbaren Texter für sie zu haben. Dieser meinte: „,Ohne einen Artikel kann ich die Photos nicht bringen. Versuchen Sie selbst etwas Interessantes dazu zu schreiben. Wenn Sie's nicht zustande bringen, versuchen Sie jemanden dafür zu finden!' Am Tag darauf brachte Skall ein drei Seiten langes Manuskript. Oplatka gefiel es. ,Wer hat das geschrieben?‘ ,Meine Frau.' Gusti Skall hatte erst kürzlich auf dem Flohmarkt eine Schreibmaschine erstanden. Auf der übte sie fleißig, und dieser Artikel war der erste, den sie je geschrieben hatte. Oplatka fand das lustig. ,Ich glaube, wir haben eine gute Mit- 
arbeiterin gefunden.' So wurde Gusti Skall dank ihrer ,alten' Schreibmaschine Mitarbeiterin des ,Sonntag'. Sie wählte das Pseudonym Gustav Wiesinger (oft auch abgekürzt G.W.), oder, wenn sie mehr als einen Text für eine Nummer schrieb, auch Gina Campitelli. “41 Gusti Skall, alias Gustav Wiesinger bzw. Gina Campitelli, ist eine vielseitige Autorin. Sie schreibt nicht nur die Texte zu den Bildern ihres Mannes, sondern liefert bald auch die Texte $\mathrm{zu}$ anderen Reportagen. In der Bühne tritt sie 1937 als Autorin eines Fortsetzungsromans hervor. Gelegentlich schreibt sie auch Filmrezensionen, Ende Februar 1938 etwa stellt sie Buñuels Streifen „Der andalusische Hund“ im Sonntag vor. ${ }^{42}$

\section{Hinaus aus dem Atelier}

Die Porträt-, Mode- und Tanzfotografie steht im Sonntag auffallend im Hintergrund. Oplatka zieht es hinaus in den Alltag, auf die Staße, die kontrollierten Atelierbilder interessieren ihn wenig. Als der Sonntag 1934 gegründet wird, gibt es anfangs zwar eine wöchentliche Modeseite, für die die Redaktion mit den führenden Wiener Atelierfotografinnen, etwa Edith Glogau, Pepa Feldscharek oder Kitty Hoffmann, zusammenarbeitet. Bald aber wird diese Seite gestrichen. Dennoch bringt Oplatka weiterhin gelegentlich Aufnahmen aus dem Atelier, allerdings versucht er, die Starre des klassischen Studioporträts aufzubrechen. Von Dora Horovitz, einer renommierten Wiener Atelierfotografin, die freilich in der zweiten Hälfte der 1930er Jahre nur noch wenig fotografiert, bringt er 1937 ein ungewöhnliches Porträt eines Anstreichers, das thematisch zu einem Gedicht von Theodor Kramer passt (Abb. 12). ${ }^{43}$

Trude Fleischmann, die bekannteste Wiener Atelierfotografin der Zwischenkriegszeit, wird von Oplatka animiert, neue, für sie ungewohnte Themen aufzugreifen. Im August 1936 liefert sie die Bilder zur Fotoreportage „Bei der Modeaufnahme“, die einen Blick hinter die Kulissen des eigenen Metiers, der Atelierfotografie, wirft. Die Reportage beginnt auf der Titelseite mit einer beeindruckenden Aufnahme, in der eine Fotografin (vermutlich handelt es sich um eine Assistentin Fleischmanns) hinter ihrer Kamera

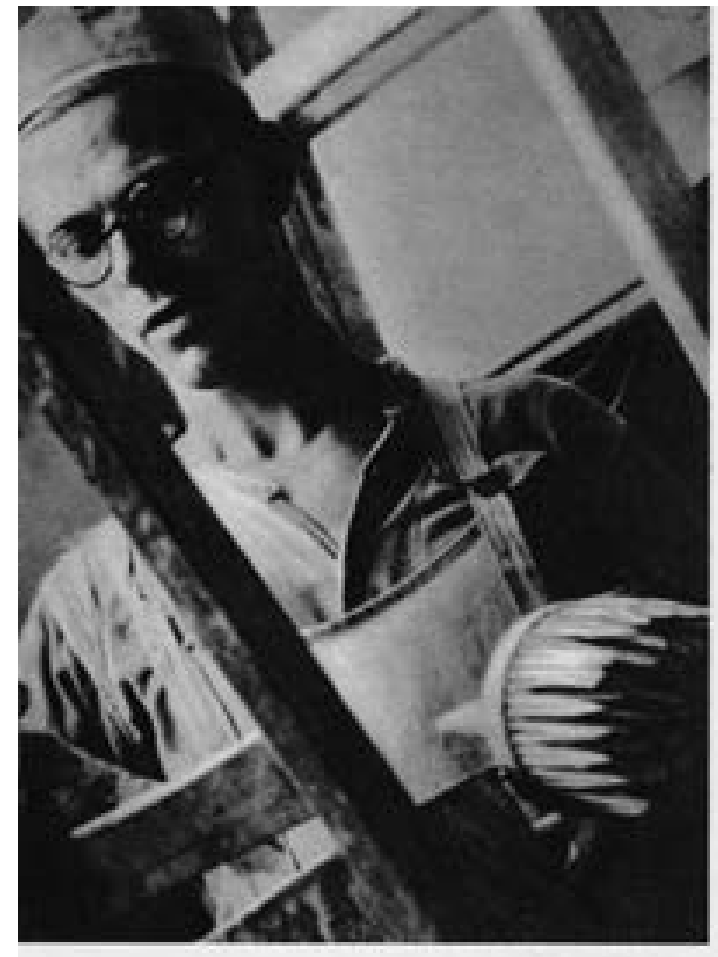

PHOTO DORA HOROVIZ

\section{Der Bimmermaler}

I

CH malte viele Zimmer aas. Geknickt den Meferstecken, schreif' norgebiekt ich auser Hass wele inter Zimmerdecken.

Der Raum harrt hahl; ein blaser Olm. schnapp ich die Stickluft droben. Mein Absatz rïekt den Leiferholm, grandiert der Arm nach oben.

In tenzersetzten Wirbein schurimmt der Farbenstoab im Kabel; mich brewnt im Glahureinrausch der Zimt, und unter thm ist Dbel.

Man such sich selbst ein Muster aus von meinen zehn Schablonen: ich malte viele Zimmer aus in keinem möcht ich uohnen.

Thesdor Kramer

(Awr dem Gedicbaband "Die Gevernithe", erschienen bei Rerzen of Lorning, Frankfurt a. M.)
Abb. 12 „Der Zimmermaler“. Der Sonntag, 22. August 1937, S. 7. Foto: Dora Horovitz. 


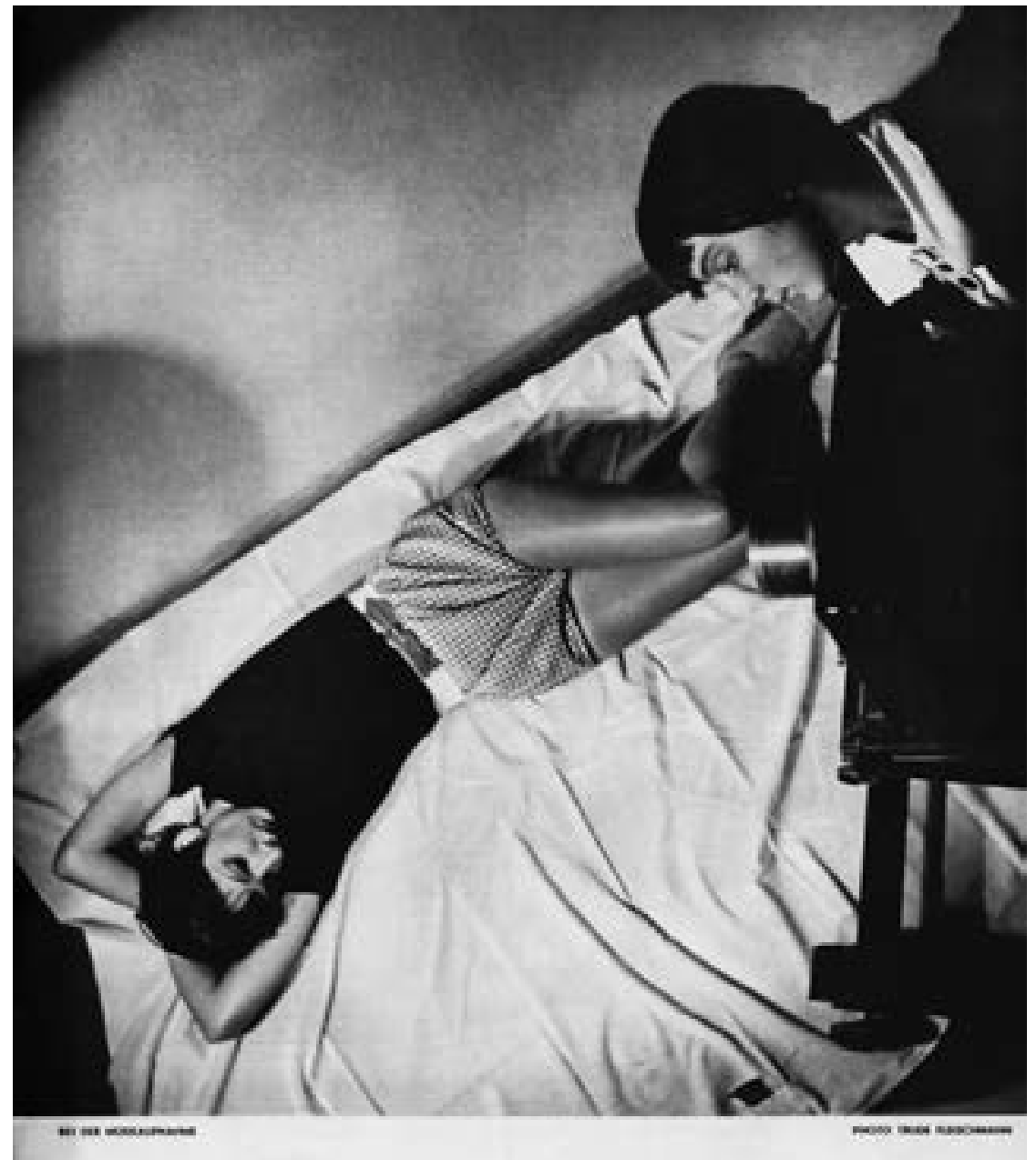

Der Sonntag

Sie finden in diever Nummer eine Betroditing uber Modephetogrephie onit weiteren Photer von Trude Fleadmen

Abb. 13, 14 Fotoreportage über die Modefotografie. Der Sonntag, 2. August 1936, Titelseite, S. 4 und 5. Text: Gustav Wiesinger (d. i. Gusti Skall), Fotos: Trude Fleischmann. bei der Arbeit beobachtet wird (Abb. 13, 14). Das Foto ist von schräg oben aufgenommen. Der Kopf der Fotografin rückt an den oberen Rand, das Fotomodell liegt ausgestreckt und scheinbar ein wenig kopfüber auf einem weißen Laken. Auch im Innenteil, wo die Reportage fortgesetzt wird, werfen wir einen Blick hinter die Kulissen der Modeaufnahmen. Wir sehen das Modell in immer neuen Posen und Kleidern. Umgeben ist die junge Frau von hell leuchtenden Schein- werfern, die bizarre Schatten werfen. Und immer wieder schiebt sich die Kamera ins Bild. Auch der Text, er stammt von Gusti Skall (G. W. = Gustav Wiesinger), macht zunächst einen augenzwinkernden Ausflug in die Kulturgeschichte, um schließlich bei den Modebildern anzukommen.

Bisher hat Trude Fleischmann fast ausschließlich im Atelier gearbeitet. Nun, Mitte der 1930er Jahre, wendet sie sich plötzlich - neben ihrer Studiofotografie-ganz neuen Themen zu. Die Anregung zu dieser Neuorientierung kommt sicher von Hans Oplatka. Er lädt die Fotografin 1936 ein, für den Sonntag Reportagen zu sozialen und gesellschaftlichen Themen zu gestalten. Das bedeutet für sie, das Atelier zu verlassen und mit ihrer Rolleiflex im Freien zu fotografieren. ${ }^{44}$ Anfang August 1936, eine Woche nach ihrer Reportage über die Modefotografie, erscheint im Sonntag eine Seite zum Thema „Zigeuner - zivilisiert“, in der sämtliche Vorurteile gegenüber der Minderheit bedient werden. Die Fotos stammen von Trude Fleischmann, sie hält mit ihrer Kamera eine „Handleserin“ und eine „Zigeunermutter“ fest (Abb. 15). Ab jetzt fotografiert Fleischmann regelmäßig für den Sonntag. Neben Porträts und Reisebildern (u.a. aus Italien, dem Lieblingsreiseziel auch von Oplatka) steuert sie nun auch öfter Reportagen bei. Ende Oktober 1937 etwa erscheint unter dem Titel „Die steinige Heimat“ eine Sozialreportage Fleischmanns über das harte Leben in einem österreichischen Steinbruch. ${ }^{45}$ Auch hier stammt der Text von Gusti Skall, alias Gustav Wiesinger.

Wenige Monate nach Fleischmanns Debüt im Sonntag wird ein weiterer junger Lichtbilder fester Mitarbeiter der Zeitschrift: Robert Haas. Haas ist einer der besten und interessantesten Fotografen des Blattes. Seine erste große Reportage „Ein Garten im Lande der Armen“ über einen Kindergarten im Wiener Arbeiterbezirk Simmering erscheint im Februar 1937. Möglicherweise kommt er über Trude Fleischmann bzw. Otto Skall mit Oplatka in Kontakt. Fleischmann und Skall sind seit Langem eng miteinander befreundet und Haas lernt Skall Anfang der 1930er Jahre über Fleischmann kennen. Denkbar ist aber auch, dass Oplatka Haas über die Zeitschrift Die Bühne kennengelernt hat, die im gleichen Verlag erscheint und in der Haas 1935 seine ersten Reportagen unterbringt. 


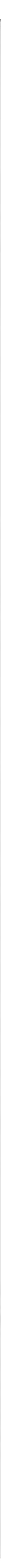

Robert Haas, geb. 1898, wendet sich nach einem technischen Studium und einer künstlerischen Ausbildung an der Kunstgewerbeschule und der Akademie der bildenden Künste der Handdruckkunst, der Plakatgestaltung und der Kalligraphie zu. Anfang der 1930er Jahre erlernt er bei Fleischmann das Fotografieren, ab 1934/35 nimmt er an Fotowettbewerben teil und veröffentlicht seine Fotos regelmäßig in der Fachpresse (etwa in der Zeitschrift Profil) und in der illustrierten Wochenpresse, v. a. in der Bühne. Ab 1937 erscheinen seine Aufnahmen vor allem im Sonntag. Sein Themenspektrum ist breit, es reicht von Alltagsbeobachtungen und Straßenszenen über Porträtaufnahmen, Sachfotografien und technische Dokumentationen ${ }^{46}$ bis hin zu hintergründig-originellen Gesellschaftsstudien (etwa von den Salzburger Festspielen, die u. a. in der Bühne veröffentlicht werden). Einer seiner Schwerpunkte sind Sozialre- 


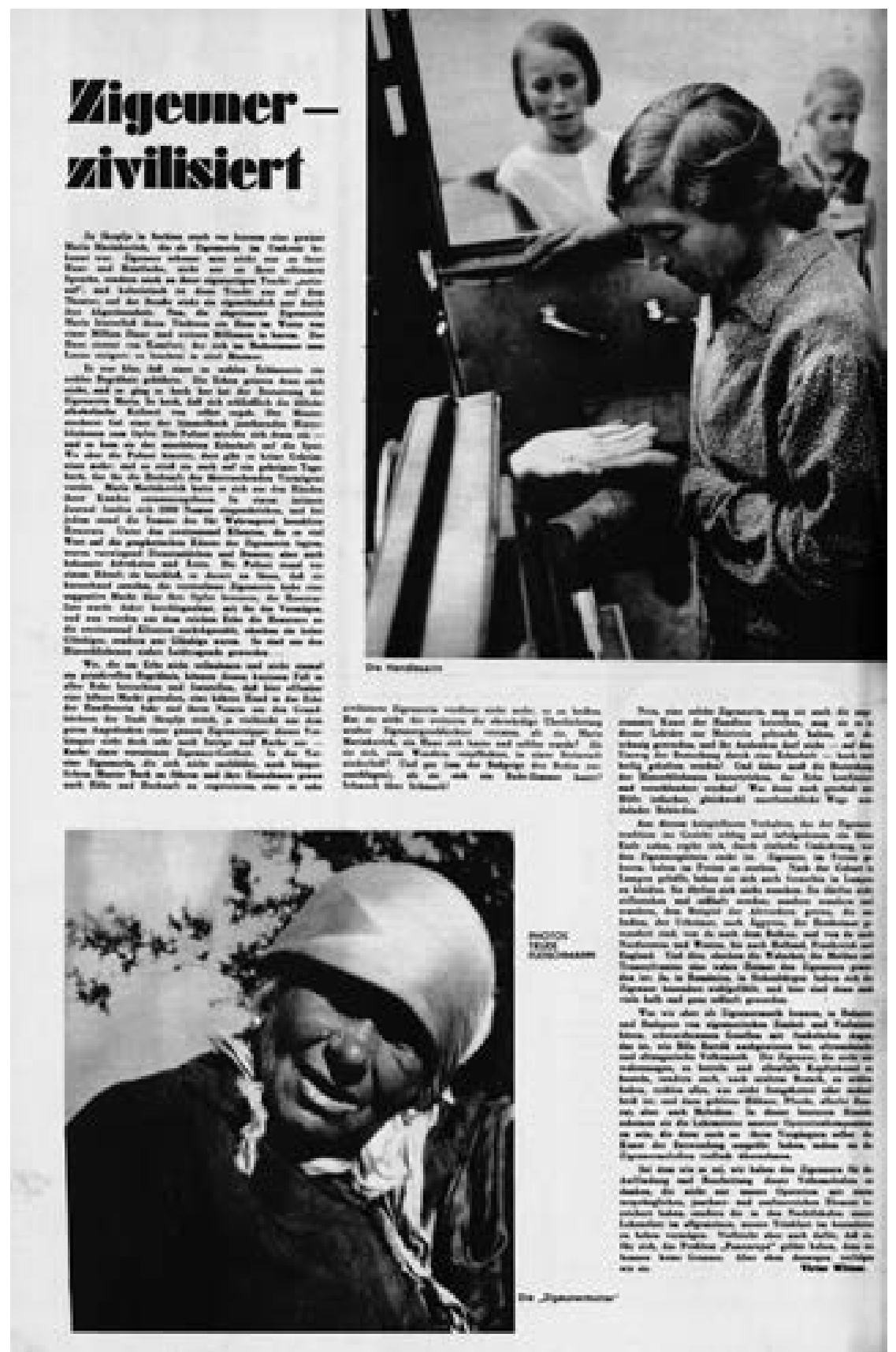

Abb. 15 „Zigeuner-zivilisiert“. Der Sonntag, 9. August 1936, S. 8. Fotos: Trude Fleischmann. portagen. Im Herbst 1937 liefert er zum Beispiel eine schöne Reportage über das Fürsorgesystem in den Wiener Familienasylen. ${ }^{47}$

Haas hat ein sicheres Gespür für spannende, gut gebaute Bildgeschichten und für unkonventionelle grafische Lösungen, die auch Oplatka bzw. Spira überzeugen. Die Zusammenarbeit zwischen Fotograf und Gestaltern ist offenbar anregend, immer wieder entstehen aufsehenerregende Bild-Text-Seiten. Im März 1937 etwa erscheint eine grafisch hervorragend gestaltete Fotoreportage über „Hellseher“ (Abb. 16, 17). Sie beginnt mit einer Fotomontage, in der eine Handstudie von Robert Haas und eine Menschengruppe, aufgenommen von Felix Braun aus der Vo- gelschau, auf ungewöhnliche Weise kombiniert werden. Die Bildgeschichte (der Text stammt von Veza Magd; unter diesem Pseudonym veröffentlicht Veza Canetti in den 1930er Jahren journalistische Texte und Erzählungen), die auf einer Doppelseite im Inneren des Heftes fortgesetzt wird, arbeitet mit starken Hell-Dunkel-Kontrasten und großzügigen Weißflächen in die die freigestellte erhobene Hand und der angeschnittene Kopf hereinragen. Die Hände werden in dieser Präsentation zu Zeichen des Okkulten und Übersinnlichen. Die Reportage ist ein Beispiel dafür, wie sehr die Redaktion bemüht ist, Stimmungen der Gegenwart in all ihren Facetten auszuloten. Im Vorspann, der in einen schwarzen Kreis gesetzt ist, wird der Hang zum Okkultismus vorsichtig mit der politisch-gesellschaftlichen Situation der 1930er

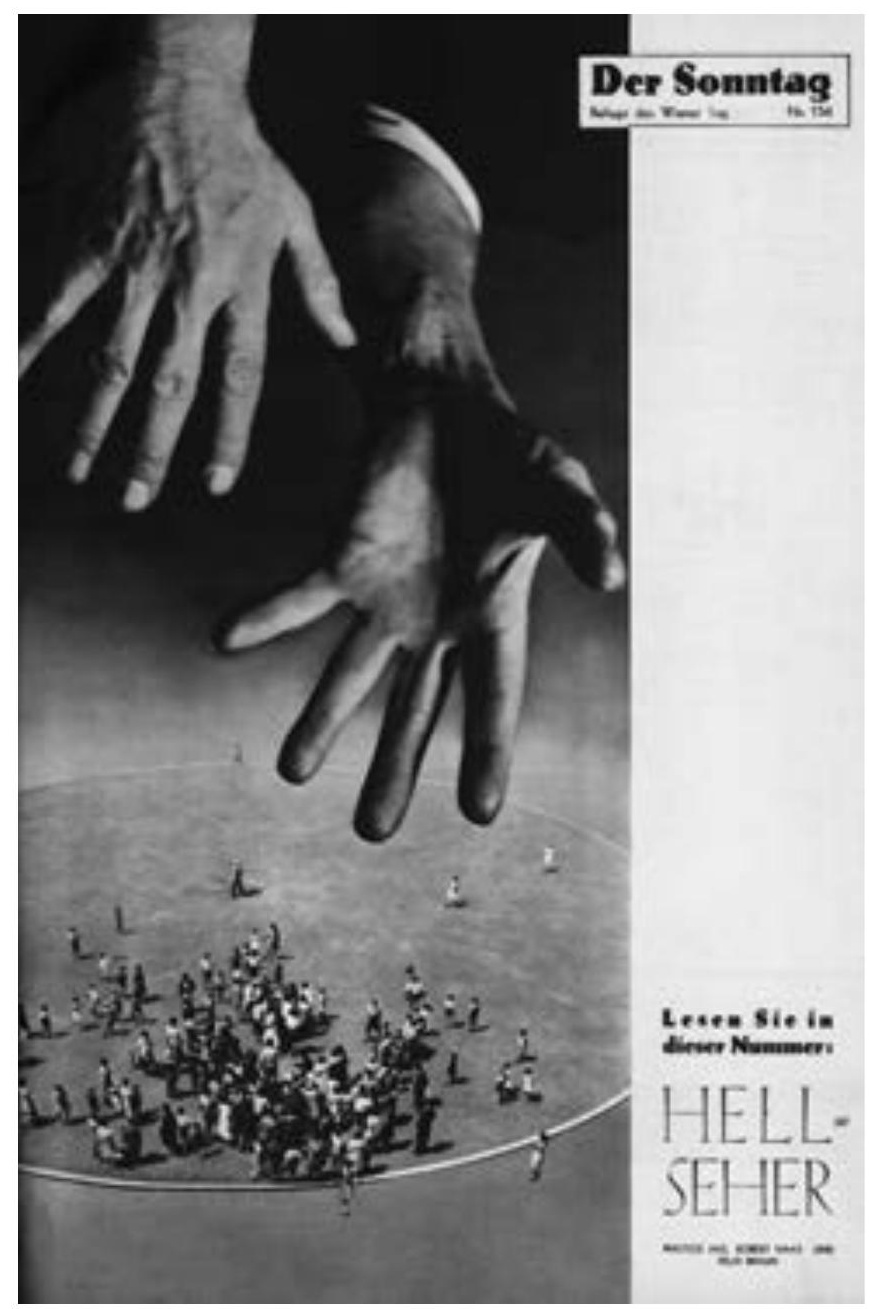


Jahre in Verbindung gesetzt. „Gerade in unserer Zeit wieder, in der so viele daran verzweifeln, die Probleme des Lebens mit den Mitteln des Verstandes zu lösen, neigt man dazu, der Willensführung und den übersinnlichen Kräften anderer Vertrauen entgegenzubringen. Und so kommt es, daß man öfter als je in Wiener Gesellschaften Magnetiseuren und Hellsehern begegnet." 48

Hin und wieder liefert Robert Haas neben seinen Reportagen auch Einzelmotive, von denen eine starke suggestive Wirkung ausgeht. Im Januar 1938 etwa erscheint auf der Titelseite des Sonntag eine schaurig-schöne Aufnahme einer traditionellen österreichischen Maske, die aus tiefschwarzem Grund hervorleuchtet und vom Ringelnatz-Gedicht „Maskenball“ begleitet ist (Abb. 18).

\section{Blick über die Grenzen}

Das dichte Netz an persönlichen Kontakten zu Autoren und Fotografen, das Oplatka aufbaut, umfasst nicht nur etablierte Namen. Er zeigt sich durchaus auch offen für junge talentierte Fotografen, die ihm ihre Arbeiten vorlegen. Oplatka fördert auf diese Weise eine Fotografenszene, die in der konservativen Publizistik der 1930er Jahre nicht allzu viele ästhetische Freiräume hat. Unter den vielversprechenden Talenten, die in den 1930er Jahren $\mathrm{zu}$ fotografieren beginnen und im Sonntag veröffentlichen, sind auffallend viele Frauen. Ilsa Stern etwa, 1912 im böhmischen Parschitz geboren, absolviert 1931/32 die Münchner Fotoschule und lebt danach zeitweise in Wien. Ab 1934 publiziert sie re-
Abb. 16, 17 „Hellseher“. Fotoreportage über Okkultismus. Der Sonntag, 14. März 1937, Titelseite und S. 4/5. Fotos: Robert Haas (Hände) und Felix Braun (Menschengruppe). Text: Veza Magd (d. i. Veza Canetti),

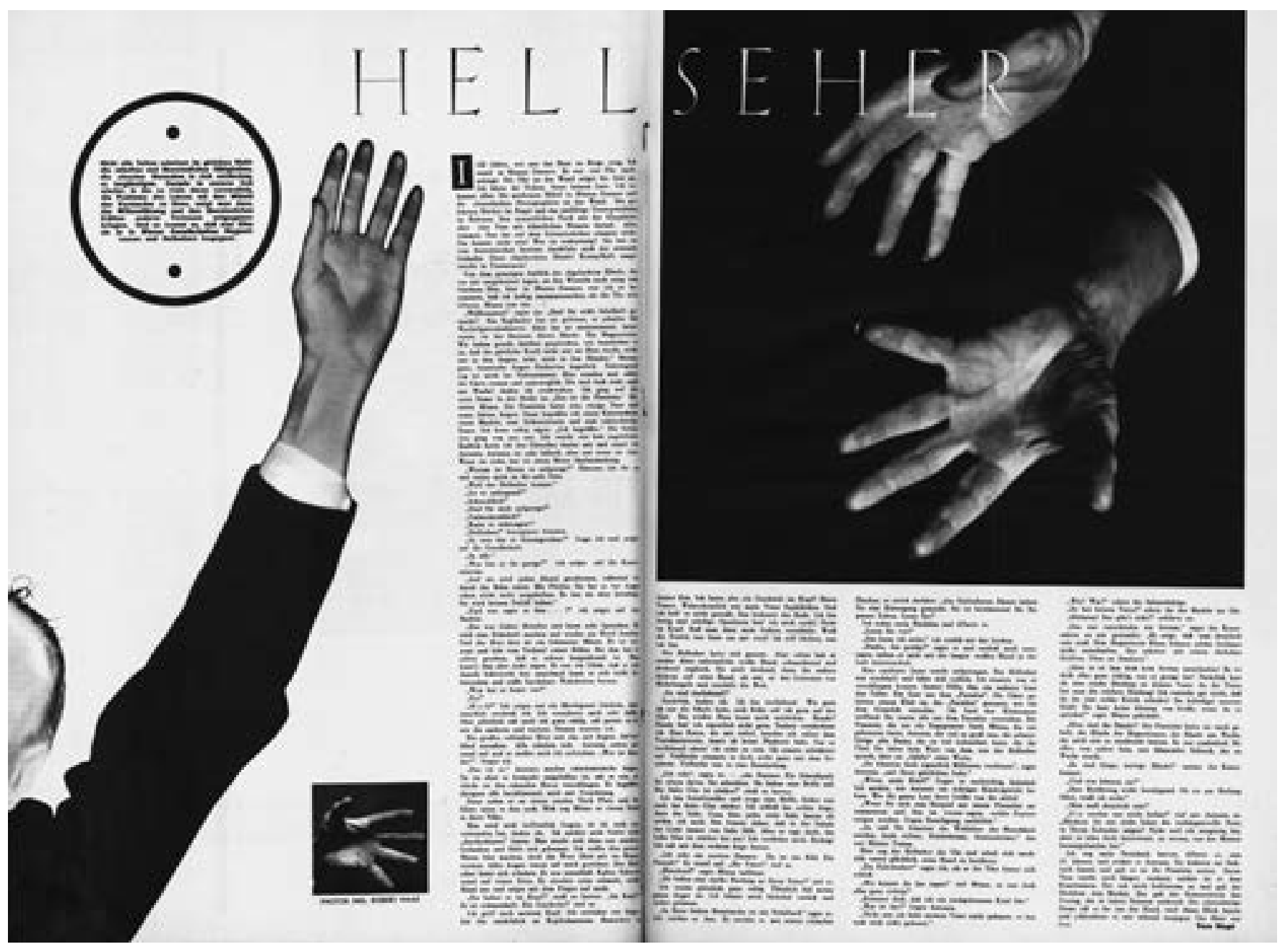




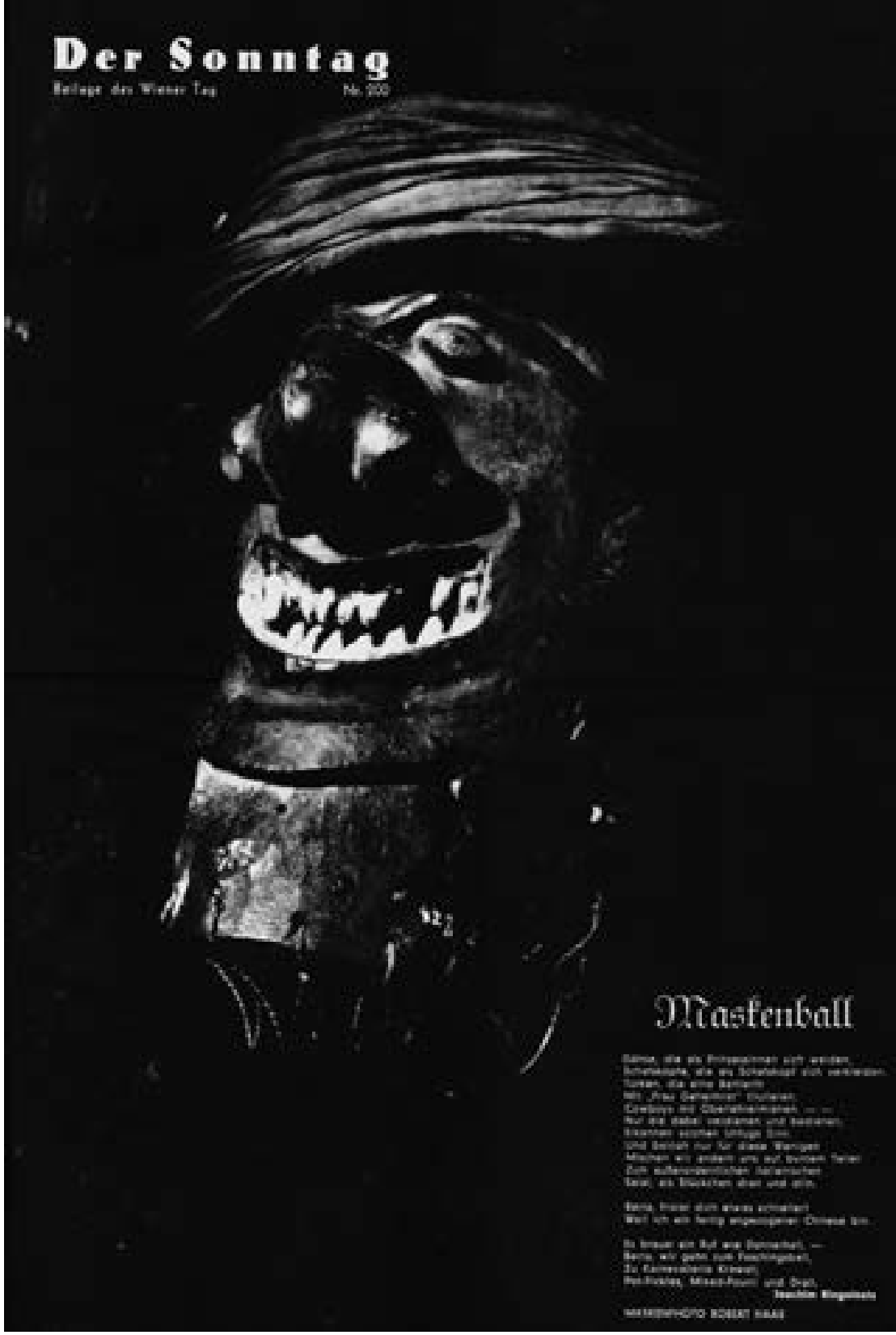

Abb. 18 „Maskenball“. Der Sonntag, 16. Januar 1938, Titelseite. Foto: Robert Haas. gelmäßig im Sonntag, u.a. Bilder zu Alltags- und sozialen Themen. ${ }^{49}$ So wie andere junge Fotografinnen der Zeitschrift arbeitet sie als Amateurin und sucht zugleich Publikations- und Verdienstmöglichkeiten in der Presse. Auch Käthe Serog, die das Fotografieren bei Trude Fleischmann gelernt hat, Hilde Hubbuch oder Liesel Chat sind nach ihrer Ausbildung als Amateurfotografinnen tätig und publizieren gelegentlich in der illustrierten Presse.

Andere junge Frauen - viele von ihnen haben die Graphische Lehr- und Versuchsanstalt in Wien absolviert - gehen einen Schritt weiter und versuchen als Pressefotografinnen kommerziell Fuß zu fassen. Sie lassen sich stärker auf die Gegebenheiten und Erfordernisse der Zeitungen und Zeitschriften ein. Zu ihnen gehört etwa Steffi Schaffelhofer, die 1930 in den Wiener Bildern debütiert und seit Anfang der 1930er Jahre interessante Alltags- und Reisereportagen ge- staltet. Ab 1934 arbeitet sie regelmäßig für den Sonntag, im April 1935 etwa liefert sie für das Titelfoto ein schönes, ausdrucksstarkes Porträt einer bekannten chinesischen Figur im Wiener Vergnügungsviertel Prater, die im Volksmund „Chineser“ (der Chinese) heißt (Abb. 19). Auch Lena Schur kann sich - neben ihrer Amateurtätigkeit - als Pressefotografin etablieren. Sie ist sehr vielseitig und fotografiert ab 1933 für unterschiedliche Zeitungen und Illustrierte, zunächst arbeitet sie im Bereich Theater und Mode, dann, ab 1934, fotografiert sie auch Reportagen. Mitte der 1930er Jahre gründet sie unter dem Namen „Kondor. Pressedienst Leonora Schur“ eine eigene Fotoagentur, die mit internationalen Agenturen, etwa Prisma in Zürich, zusammenarbeitet. Als Fotografin tut sie sich zeitweise mit Luise Deutsch zusammen, die 1933/34 die Graphische Lehr- und Versuchsanstalt absolviert und hin und wieder für die Presse arbeitet. ${ }^{50}$ Ab 1934 ist Lena Schur regelmäßig im Sonntag präsent, wo sie u. a. Sozial- und Reisereportagen veröffentlicht. Auch Lucca Chmel publiziert nach ihrem Studienabschluss an der Graphischen Lehr- und Versuchsanstalt im Jahr 1933 erste Fotos in der Presse. In den folgenden Jahren deckt sie ein breites Spektrum an Themen und Motiven ab, das von Alltagsszenen über Porträts, Mode- und Theaterfotos bis hin zu Landschaftsbildern reicht. Sie pendelt geschickt zwischen gemäßigt modernen Ansätzen und heimattümelnden Aufnahmen, die gut in die konservative Publizistik dieser Jahre passen. Gelegentlich veröffentlicht sie auch im Sonntag. Im Februar 1938, wenige Wochen vor der Einstellung der Zeitung, hat im Sonntag eine weitere Fotografin ihr Debüt: Edith Wellspacher. Die Wiener Ärztin und Fotoamateurin berichtet in einer Reportage von ihrer Zeit im Spanischen Bürgerkrieg im Jahr 1936. ${ }^{51}$

Der Sonntag ist in der zweiten Hälfte der 1930er Jahre ein offenes und vergleichsweise internationales fotografisches Forum in Österreich. Allein die Büh$n e$, die im selben Verlag erscheint, kann in dieser Hinsicht mithalten. Auch sie publiziert regelmäßig Fotobeispiele ausländischer Fotografen. Neben den zahlreichen österreichischen Mitarbeitern, die einen Großteil des Bildmaterials für den Sonntag liefern, spricht Oplatka auch immer wieder ausländische Fo- 


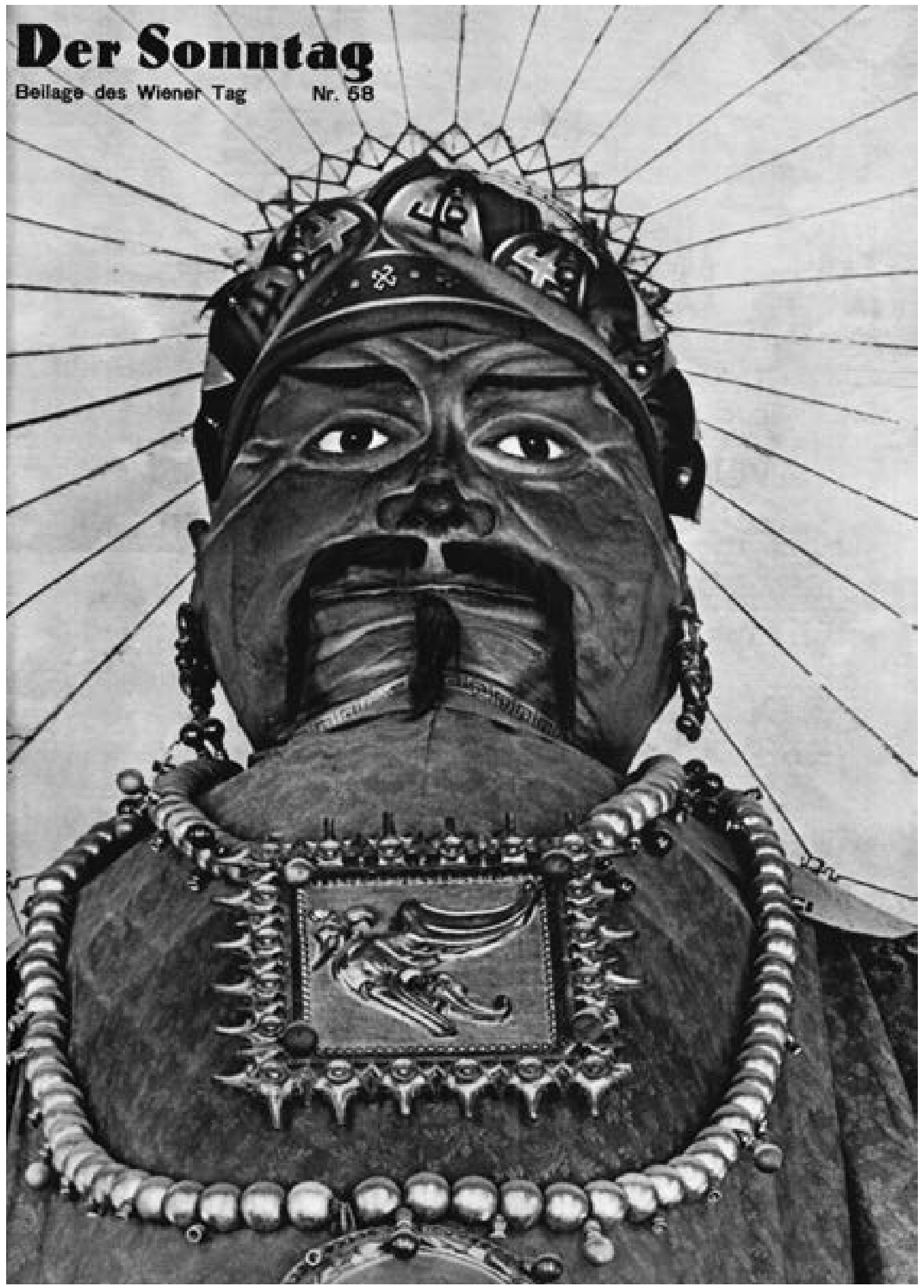

Abb. 19 „Der große,Chineser",

Schutzpatron des Wurstelpraters“. Der Sonntag, 28. April 1935, Titelseite. Foto: Steffi Schaffelhofer. 


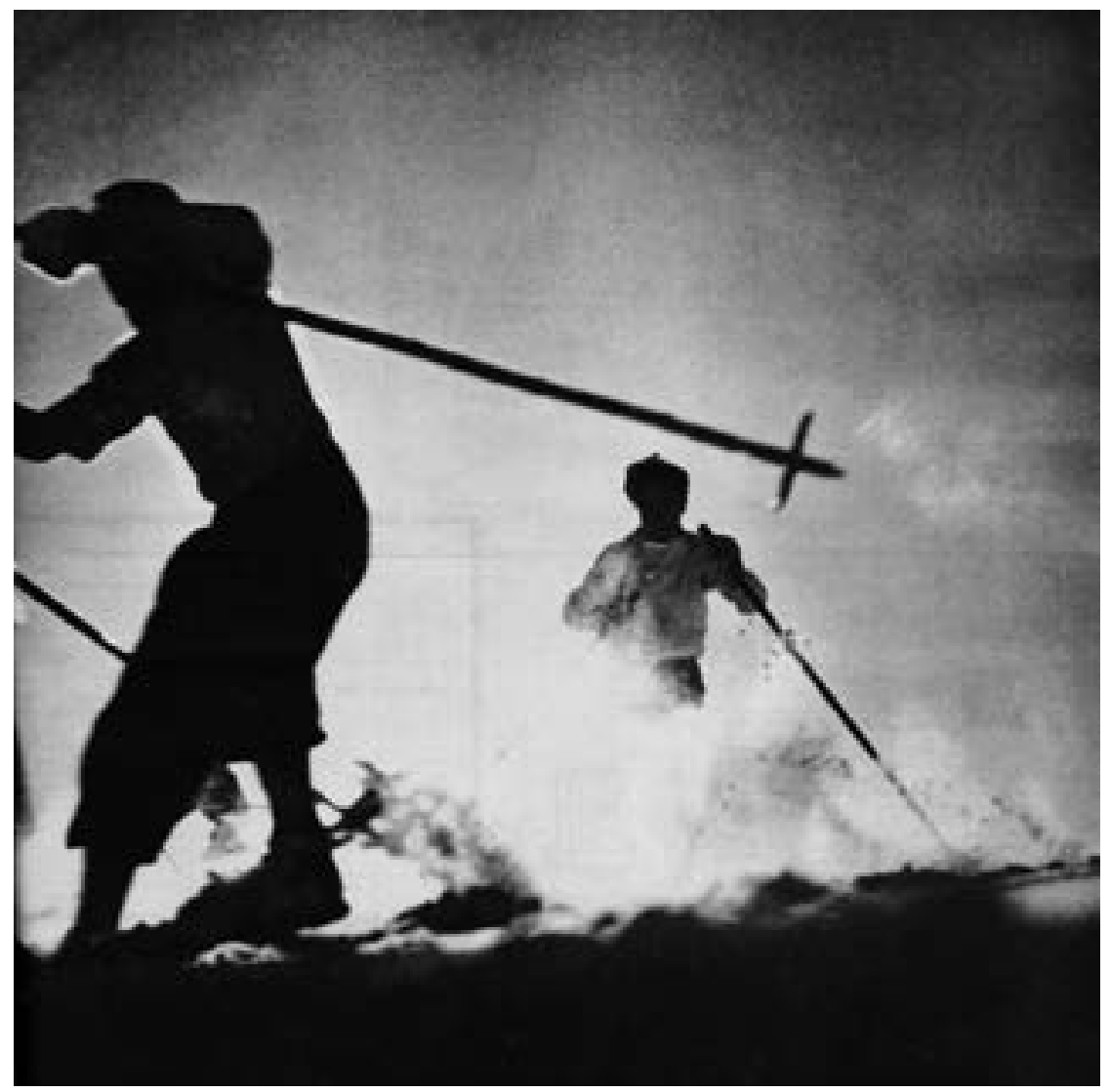

Abb. 20 „Schußfahrt“. Der Sonntag. 16. Februar 1936, Titelseite. Foto: Jan Lukas. tografen an und publiziert Bilder von ihnen. Einige von ihnen kennt er aus seiner Pariser Zeit bei $V U$, etwa Philippe Halsman oder André Kertész. Von anderen, wie dem sowjetischen Pressefotografen Arkadi S. Schajchet ${ }^{52}$ oder den ungarischen Lichtbildnern Ernő Vadas und Kálmán Szöllősy, hat er wohl über Fotoausstellungen oder Publikationen erfahren. ${ }^{53}$ Wieder andere, etwa László Moholy-Nagy, von dem er im Juni 1934 eine Arbeit vorstellt, ist als Avantgardist im deutschsprachigen Raum wohlbekannt. Von Bill Brandt, der später als Fotojournalist in England bekannt werden sollte, publiziert Oplatka 1934 Prateraufnahmen und 1935 ein Kokoschka-Porträt, das in London entsteht. ${ }^{54}$ Brandt hat Ende der 1920er Jahre bei Grete Kolliner in Wien das Fotografieren gelernt, 1931 übersiedelt er nach London, kehrt aber 1933 und 1934 jeweils für längere Aufenthalte nach Wien zurück. Möglicherweise hat Oplatka Brandt über Eugenie Schwarzwald, eine regelmäßige Sonntag-Autorin, kennengelernt. Jan Lukas schließlich, der ab 1936 zu einem wichtigen Mitarbeiter der Zeitschrift wird, begegnet Oplatka 1935/36 in Wien.

Lukas, geb. 1915, ist fast gleich alt wie Oplatka und so wie dieser tschechischer Herkunft. ${ }^{55}$ Er zieht 1921 von seiner Geburtsstadt Budweis nach Prag. Bereits als Jugendlicher beginnt er mit der Fotografie und er interessiert sich schon sehr früh für die fotografische Avantgarde. Anfang der 1930er unternimmt er ausgedehnte Fotoreisen durch ganz Europa und publiziert seine Bilder, Reiseaufnahmen, aber auch Porträts sowie Straßen- und Alltagsszenen, in tschechischen Illustrierten, etwa in Eva oder Ahoj na neděli (Hallo am Sonntag), und bald auch, unterstützt durch den französischen Fotoagenten Paul Barchan, in französischen und englischen Zeitungen. 1934 schließt er die deutschsprachige Handelsschule in Prag ab und studiert 1935/36 an der Graphischen Lehr- und Versuchsanstalt in Wien. In dieser Zeit lernt er Hans Oplatka kennen. Anfang 1936 erscheinen seine ersten Bilder im Sonntag. In den folgenden Monaten und Jahren erscheinen regelmäßig Aufnahmen und Fotoreportagen von Jan Lukas. Sein Themenspektrum ist breit: Es reicht von Architekturaufnahmen, Reiseeindrücken, Freizeit- und Sportbildern über Alltagsgeschichten und Porträts bis hin zu Theaterbildern. Obwohl sich Lukas selbst nicht als Avantgardefotograf sieht, hält er enge Kontakte zur tschechischen Avantgardeszene und nimmt Elemente des Neuen Sehens in seine Bildsprache auf.

Eine der ersten Aufnahmen, die Lukas im Februar 1936 im Sonntag veröffentlicht, zeigt zwei Skifahrer im Schnee (Abb. 20). Die Aufnahme vermittelt einen leichten, ja geradezu mühelosen Eindruck. In Wirklichkeit aber verlangt eine solche Inszenierung ein besonderes Können und viel Geduld. Stefan Kruckenhauser, der zur selben Zeit ähnliche Sujets am Arlberg fotografiert, weist in einer seiner Publikationen darauf hin, wie aufwendig die Darstellungsweise von Skifahrern in Bewegung ist. ${ }^{56}$ Der Fotograf muss zuerst eine geeignete Schneekante auswählen, an der die Sonne ein Streiflicht ergibt, damit sich der Schneewirbel im Gegenlicht besonders hell abzeichnet. Kruckenhauser arbeitet mit UV-Filter, Gegenlichtblenden und Belichtungsmesser. Seine Kamera, eine Leica, verankert er auf dem Stativ und wählt eine ex- 
trem lange Brennweite, um den Skiläufer möglichst bildfüllend und damit dramatisch festzuhalten. Ganz ähnlich dürfte Jan Lukas vorgegangen sein. Auch er wird mehrere Probeläufe der Skifahrer benötigt haben, bis endlich das gewünschte dramatische Freizeitbild im Kasten war.

Immer wieder liefert Jan Lukas Aufnahmen für Fotoreportagen. Ende Juni 1937 erscheint seine Bildgeschichte „Die glücklichen Mädchen mit dem Ball“ (Abb. 21), die ein gutes Beispiel für die enge Zusammenarbeit zwischen dem Fotografen und den Gestal- tern Oplatka bzw. Spira darstellt. Die Reportage erhält schon dadurch etwas Leichtes, Nichtalltägliches, dass der gesamte Bild- und Textblock ein wenig in die Diagonale gekippt ist. Eine zusätzliche Lebendigkeit entsteht durch die freigestellten Figuren, die in ausgedehnte Weißflächen gesetzt sind. Der Text zur Reportage stammt von der bekannten Wiener Pädagogin und Sozialreformerin Eugenie Schwarzwald, die regelmäßig für den Sonntag schreibt. In ihrer Geschichte stellt sie das verschrobene Weltbild eines älteren Herrn „Rechnungsrat“ der fröhlichen,
Abb. 21 Fotoreportage über ein Mädchenferienlager. Der Sonntag, 20. Juni 1937, S. 4 und 5. Text: Eugenie Schwarzwald, Fotos: Jan Lukas.

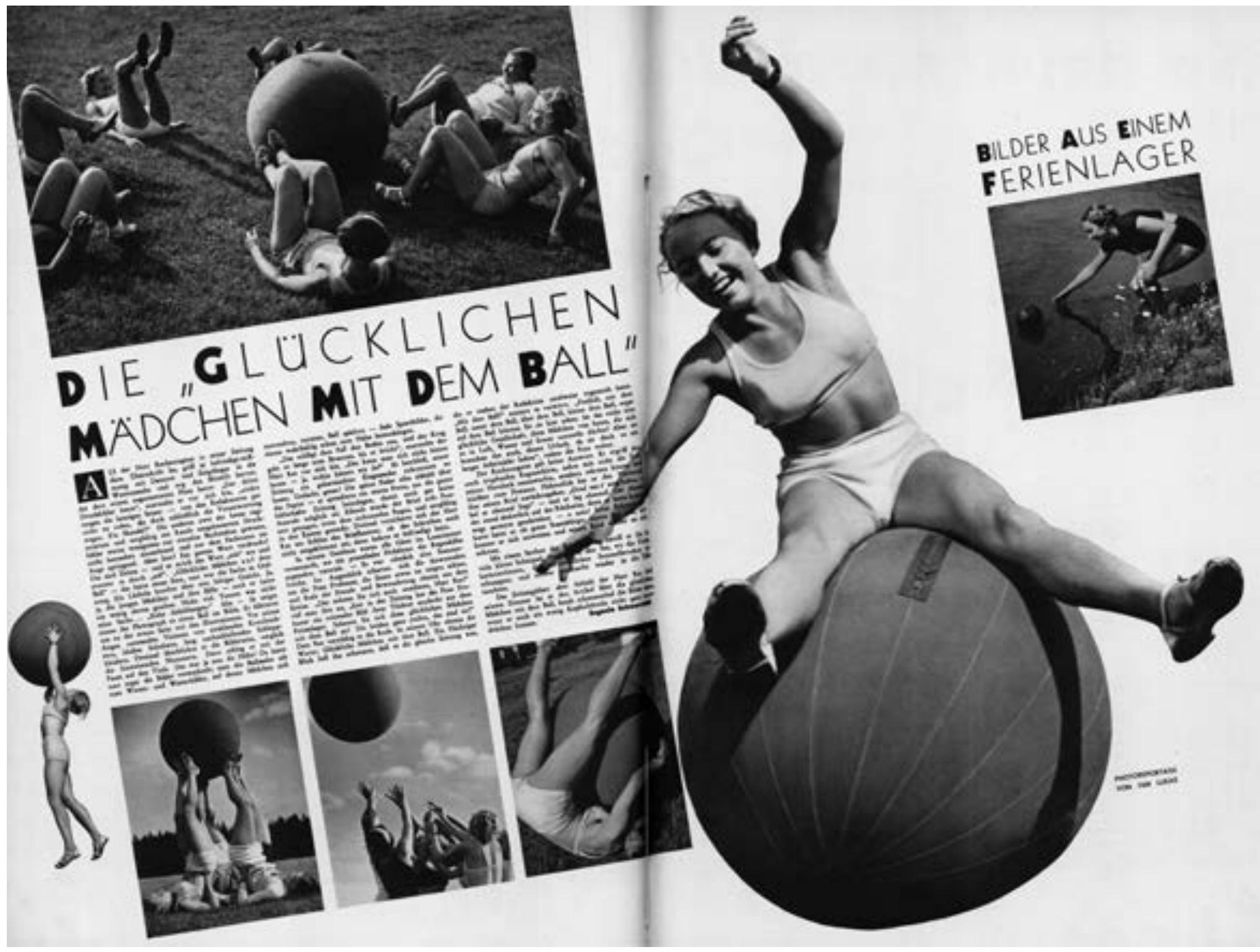




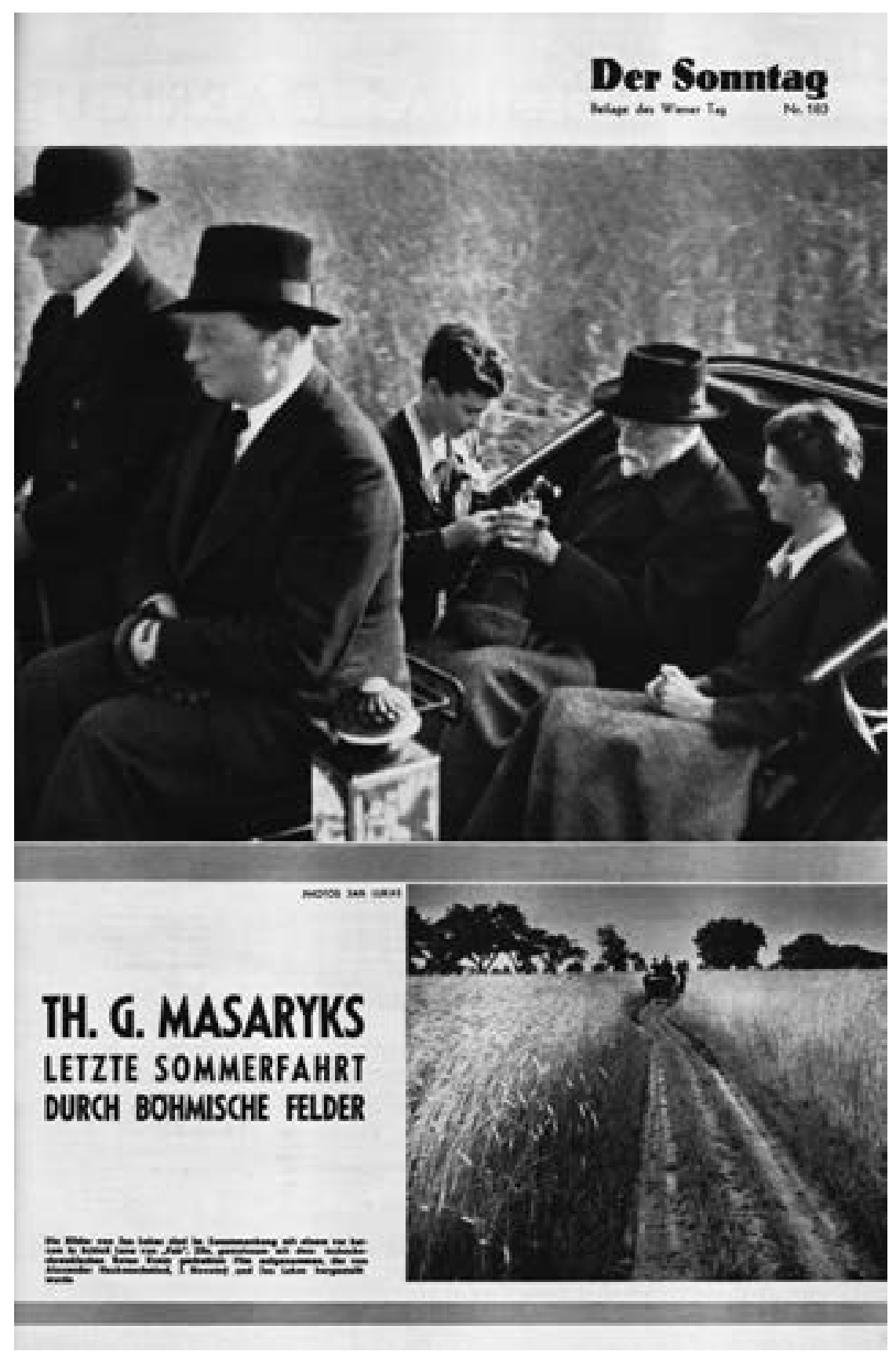

Abb. 22 Im September 1937 stirbt der tschechische Staatspräsident Thomas G. Masaryk. Der Sonntag bringt aus diesem Anlass eine Reportage mit Bildern, die kurz zuvor bei Filmarbeiten aufgenommen wurden. Der Sonntag, 19. September 1937, Titelseite. Fotos: Jan Lukas. gesunden, heiteren Lebenswelt der jungen Mädchen gegenüber, die sich in einem Ferienlager beim Ballspielen erholen. Wo genau die Bilder aufgenommen wurden, erfahren wir nicht. Vermutlich hat sie Jan Lukas im mährischen Medlov gemacht, einem Ferienort, an dem sich in den 1930er Jahren tschechoslowakische Studentinnen und Studenten mit Künstlern zu gemeinsamen Erholungswochen treffen. Hier ist Lukas nachweislich tätig. ${ }^{57}$

1935/36 fotografiert Jan Lukas viel in Wien, etwa im Juni 1936 das Pferderennen in der Wiener Freudenau. Öfter wendet er sich in Wien „tschechischen“ Themen zu, im Mai 1936 liefert er die Aufnahmen zu einer Reportage über das berühmte Pilsener
Marionettentheater "Spejbl und Hurvinek“, das in Wien zu Gast ist. ${ }^{58}$ Als Lukas Mitte 1936 nach Prag zurückkehrt, arbeitet er weiterhin regelmäßig für den Sonntag. Hans Oplatka schenkt der politischen und gesellschaftlichen Entwicklung in seinem Herkunftsland große Aufmerksamkeit und bringt daher immer wieder Reportagen aus dem Nachbarland. Als im September 1937 der international hoch angesehene Staatspräsident Thomas G. Masaryk stirbt, bringt der Sonntag eine Reportage mit Fotos von Jan Lukas (Abb.22). Einige der Aufnahmen von Jan Lukas sind wenige Wochen zuvor bei Filmarbeiten in der Nähe von Zlin entstanden, an denen neben Jan Lukas auch Jaroslav Novotny und Alexandr Hackenschmied beteiligt waren. ${ }^{59}$ Weitere Bilder im Innenteil der Zeitschrift stammen von Lukas bzw. aus dem Archiv. Als Text sind der Reportage Auszüge aus Gesprächen beigegeben, die der Schriftsteller Karel Capek mit Masaryk geführt hat und die auf Deutsch im Jahr zuvor im Verlag Bruno Cassirer in Berlin erschienen sind. ${ }^{60}$

\section{Linke und Liberale: Die Kreise des Sonntag}

Am 23. September 1934 erscheint im Sonntag eine einseitige Fotoreportage über die faschistische Kinder- und Jugendbewegung in Italien (Abb. 23). ${ }^{61}$ Die Fotos steuert Oplatka selbst bei, er hat sie bei einer seiner zahlreichen Italienreisen aufgenommen. Zwar ist diese Bildgeschichte in gestalterischer und fotografischer Hinsicht nicht sonderlich aufregend. Oplatka erweist sich in seinen eigenen Arbeiten oft als mittelmäßiger Lichtbildner, seine Stärken sind die des Redakteurs und Gestalters, des Vernetzers, Organisators, Anregers und Themengebers. Und dennoch ist die Reportage interessant, weil sie ein Licht auf Oplatkas politische Positionierung wirft. Erstaunlich offen übt der Text Kritik an der umfassenden Militarisierung im Nachbarland. „Die Italienfahrer der letzten Jahre kennen schon den ,Ballila', den kleinen faschistischen Bambino, den älteren Jungen der ,Avantgar-

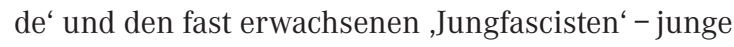
Kinder aller Altersstufen, die ihr ziviles, manchmal recht malerisches Dasein in den Gassen der italienischen Städte von Zeit zu Zeit, um in Uniform und mit scharf geladenem Gewehr zu exerzieren, verlas- 


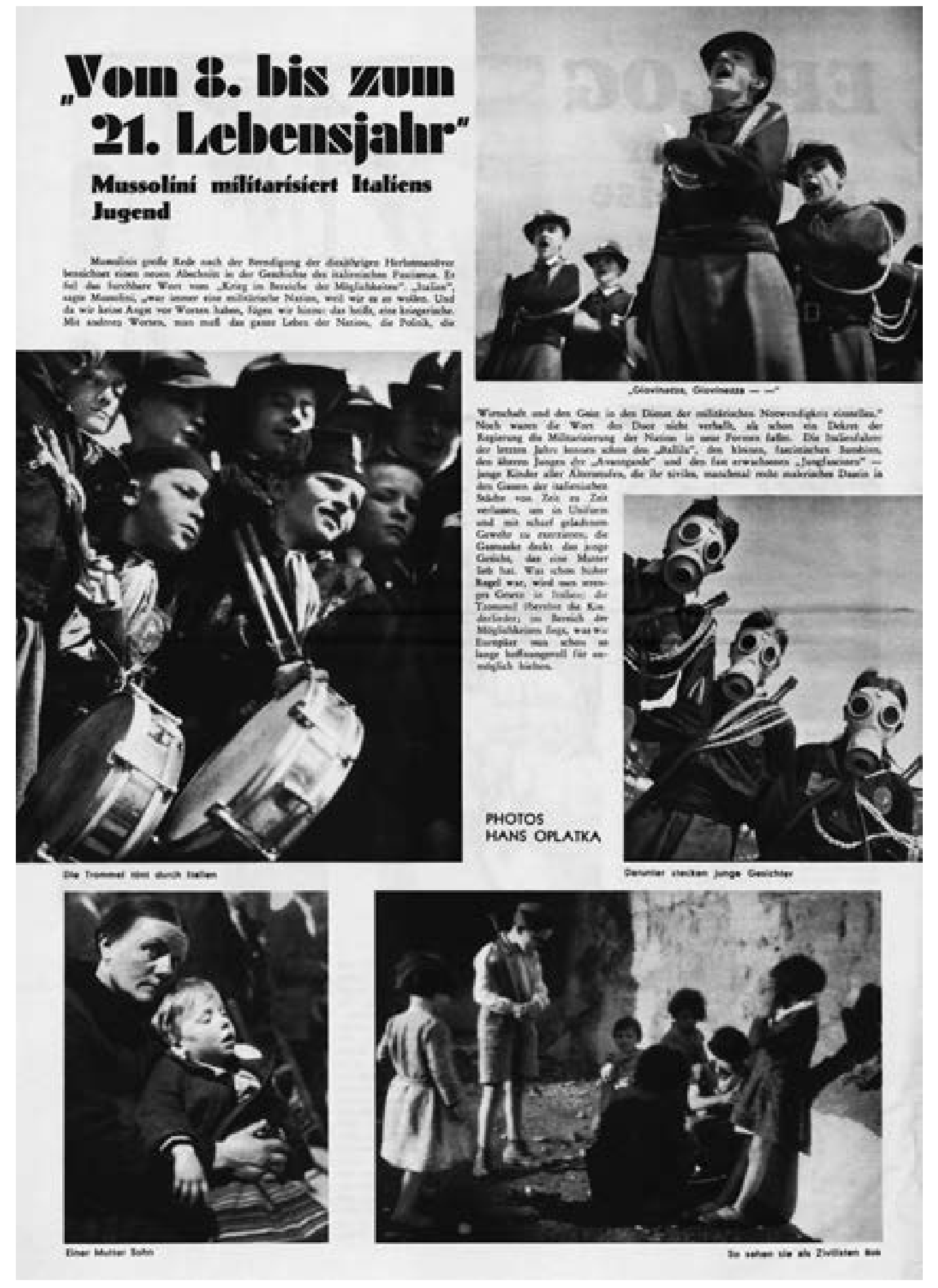

Abb. 23 Fotoreportage über die faschistische Kinder- und Jugendbewegung in Italien. Der Sonntag, 23. September 1934, S. 8. Fotos: Hans Oplatka. 
Abb. 24 „Der nächste Krieg“. Kriegskritische Fotomontage. Der Sonntag, 29. Juli 1935, Titelseite. Montage: vermutlich Hans Oplatka. sen; die Gasmaske deckt das junge Gesicht, das eine Mutter lieb hat. Was schon bisher Regel war, wird nun strenges Gesetz in Italien; die Trommel übertönt die Kinderlieder; im Bereich der Möglichkeiten liegt, was wir Europäer nun schon so lange hoffnungsvoll für unmöglich hielten." ${ }^{2}$ Gemeint ist der Krieg, den Mussolini kurz zuvor in einer Rede auf pathetische Weise beschworen hat.

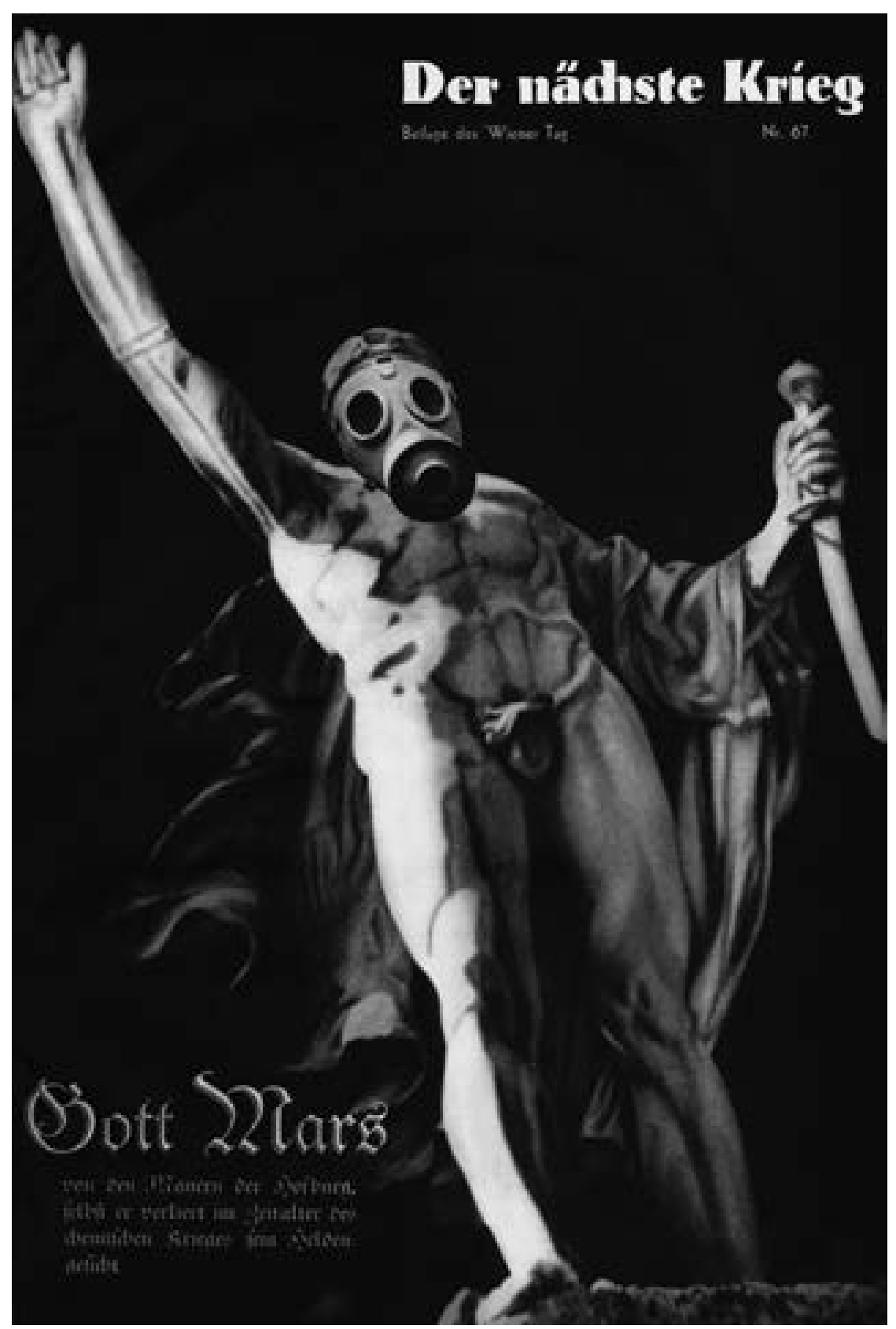

Mit großer Wahrscheinlichkeit stammt auch der Text von Hans Oplatka. Obwohl dieser in politischen Fragen überaus zurückhaltend ist, lässt er hier zwischen den Zeilen eine deutliche Kritik an der zunehmenden Militarisierung im Nachbarland durchklingen. Und dies just zu dem Zeitpunkt, als zwischen Österreich und Italien eine deutliche politische Annäherung zu beobachten ist. Im März 1934 werden nämlich die „Römischen Protokolle“ unterzeichnet, die eine enge Zusammenarbeit zwischen beiden Ländern einleiten. In innenpolitischen Fragen ist Oplatka noch weit zurückhaltender und vorsichtiger. Politische Kommentare zur Regierungspolitik kommen im Sonntag praktisch nicht vor, offene Kritik schon gar nicht. Auch wenn die Zeitung in der Regel Abstand zur Politik hält, entzieht sie sich nicht ganz dem politischen Kurs des „Ständestaates“. Gelegentlich wird im Sonntag propagandistischen Regierungsinitativen sogar erstaunlich viel Platz eingeräumt. Im Mai 1934 etwa wird ausführlich und positiv über den neu eingeführten „Freiwilligen Arbeitsdienst“ und das Arbeitslager in Kaiser-Ebersdorf berichtet. ${ }^{63}$ Wenig später, Ende September 1934, erscheint ein großer Bildbericht über die Eröffnung der neu erbauten Großglockner Hochalpenstraße, die als patriotisches Bauprojekt des „Ständestaates“ gilt. ${ }^{64}$

Dennoch: Ein Thema bringt Oplatka, aller innenpolitischen Vorsicht zum Trotz, immer wieder in die Öffentlichkeit: die Warnung vor einem neuen Krieg. Sein engagierter Pazifismus ist, in Zeiten einer zunehmenden Militarisierung der Gesellschaft, die in den 1930er Jahren auch Österreich erfasst, sehr wohl auch ein innenpolitisches Statement. Allerdings bemüht sich Oplatka, die konkreten Adressaten seiner Warnungen nicht namentlich anzuführen. Ende Juni 1935 erscheint - fast genau 21 Jahre nach dem Beginn des Ersten Weltkriegs - eine Ausgabe des Sonntag, die ganz dem Thema Kriegsgefahr gewidmet ist - es ist eine Art Antikriegsnummer.

Für die Titelseite verwendet Oplatka eine (vermutlich selbst hergestellte) Fotomontage, die eine steinerne Figur der Wiener Hofburg in den Kriegsgott Mars verwandelt (Abb. 24). Die weiße Statue, die aus extremer Untersicht gezeigt wird, kommt den Betrachtern mit erhobenem Arm und einem Dolch in der Hand 
entgegen. Das Gesicht ist durch eine Gasmaske verdeckt. Es ist unverkennbar, dass Oplatka hier das Thema der italienischen Jugendlichen mit Gasmaske, die er im Jahr zuvor fotografiert hat, aufgreift. Es scheint so, als habe er die Gasmaske sogar aus dem damals im Sonntag publizierten Italienfoto ausgeschnitten (vgl. Abb. 23, Mitte) und - gespiegelt - für die Antikriegsmontage verwendet. Eine ganz ähnliche Antikriegsszene, die ebenfalls eine Plastik mit Gasmasken versieht, ist am 11. Februar 1931 in der französischen Illustrierten $V U$ erschienen. ${ }^{65}$ Oplatka hat dieses Titelblatt mit Sicherheit gekannt, genau zu dieser Zeit hat er in der $V U$-Redaktion gearbeitet. Möglicherweise hat er die französische Montage damals sogar selbst hergestellt. Die Ähnlichkeiten beider Inszenierungen gehen so weit, dass Oplatka im Sonntag sogar den Titel „La Prochaine Guerre“ übernimmt. Auf Deutsch heißt die Antikriegsnummer wortgleich „Der nächste Krieg."

Im Innenteil wird die kriegskritische Haltung fortgesetzt und auf den Ersten Weltkrieg bezogen, den historischen Anlass des Heftes. Unter dem Titel „Das Ende des Liedes“ findet sich eine Zusammenstellung von Kriegsaufnahmen, die die Grausamkeit und die Gewalt des ersten industriellen Massenkrieges zeigen (Abb. 25). Auch hier schlüpft der Pazifismus in das Gewand eines unbestimmten Humanismus. Politiker, Regierungen, Kriegstreiber und Profiteure des Militarismus werden nicht konkret benannt, schon gar nicht einheimische. Dass eine der Aufnahmen Gewalttaten österreichischer Militärs zeigt, die zwischen 1914 und 1918 an Zivilisten an der Ostfront begangen wurden, mögen die Leser zwar erahnen, aber offen ausgesprochen wird es nicht. ${ }^{66}$

Auch wenn sich der Sonntag innenpolitischer Kommentare oder gar Kritik enthält, unterscheidet er sich doch deutlich von den meisten anderen illustrierten Zeitungen und Zeitschriften, die in diesen Jahren immer stärker ins Fahrwasser der diktatorischen Regierungspolitik geraten. Die Zeitung greift Themen auf, etwa in ihren Alltags- und Sozialreportagen, die in anderen Medien kaum oder nur am Rande vorkommen. Vor allem aber hebt sich der Sonntag durch seine nicht nationalistische, weltoffene, neugierige und nicht zuletzt offen pazifistische Grund-

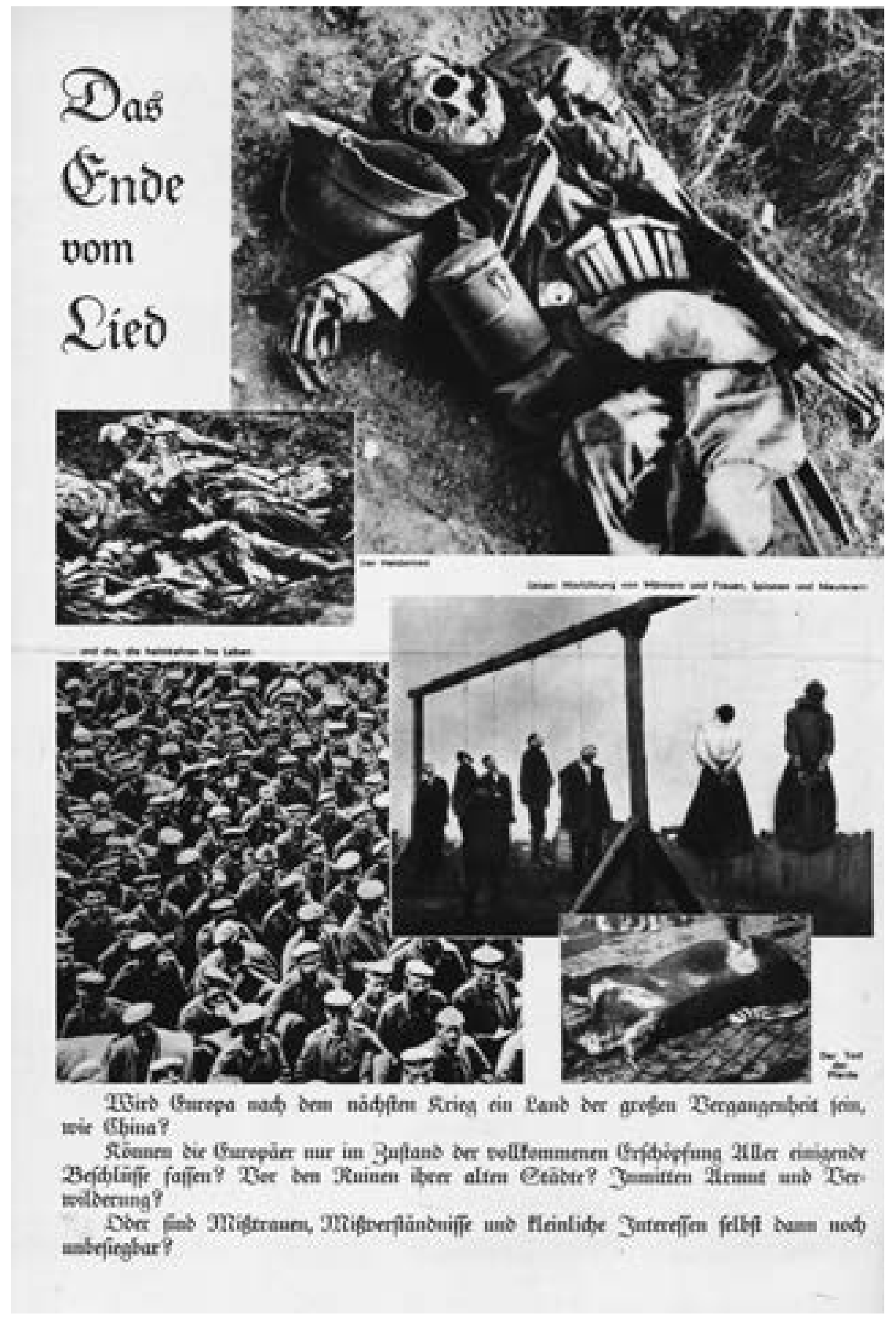

haltung vom Mainstream ab. Um die politische und gesellschaftliche Positionierung der Zeitung besser fassen zu können, ist es sinnvoll, den Blick über die gedruckten Seiten hinaus zu richten und auch das soziale, gesellschaftliche und kulturelle Netzwerk, in dem Hans Oplatka agiert, kurz zu beleuchten. Man kann, wenn man diese Freundschaften und Kontakte und die damit einhergehenden Interessen und The-
Abb. 25 „Das Ende vom Lied“. Der Sonntag, 29. Juni 1935, S. 8. Fotos: Archiv, Zusammenstellung vermutlich durch Hans Oplatka. 
Abb. 26 „Die Zeitung und ihre Welt“. Ankündigung der Österreichischen Presse-Ausstellung im Österreichischen Museum (heute: MAK), 4. bis 20. März 1938. Das interessante Blatt, 3. März 1938, S. 11.

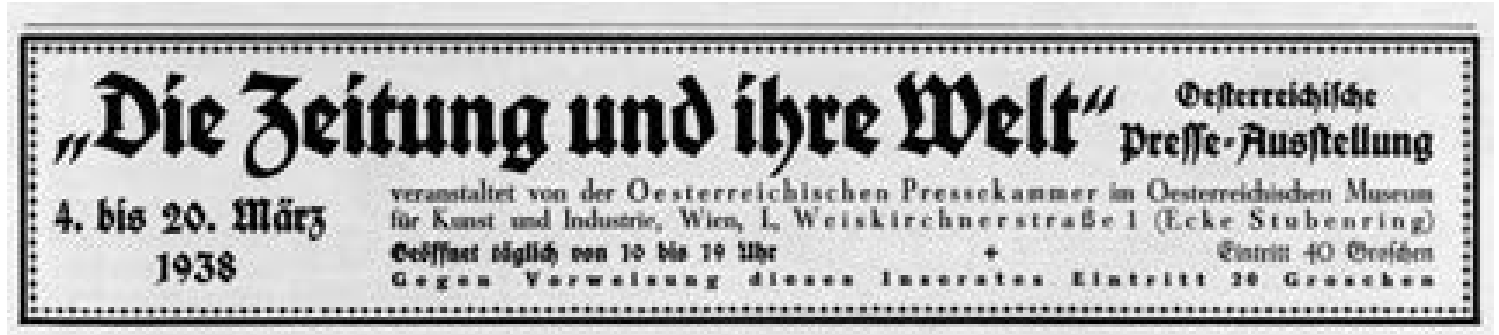

men etwas genauer betrachtet, zum Schluss kommen, dass Oplatka und sein Sonntag eng mit der linken und liberalen Wiener Kulturszene der 1930er Jahre verbunden ist, die durchweg Abstand hält zum diktatorischen „Ständestaat“.

Eine besonders enge Freundschaft verbindet Oplatka mit Bil Spira, mit dem er täglich eng zusammenarbeitet, sowie mit dem Schriftsteller und Theaterautor Jura Soyfer, der bis 1934 öfter Gedichte in der Arbeiter-Zeitung veröffentlicht hat und nun gelegentlich beim Sonntag mitarbeitet. Fast jede Woche treffen sich die drei unweit des Verlagshauses Vernay im „Auge Gottes“, einem populären Gasthaus in der Nußdorfer Straße, zum Mittagessen und Gespräch. ${ }^{67}$ Zum engeren Kreis um Oplatka gehören auch der Fotograf Jan Lukas, die Bildhauerin Anna Mahler - sie ist die Tochter von Gustav und Alma Mahler -, die Pädagogin und Sozialreformerin Eugenie Schwarzwald. Bekannt ist er auch mit dem Schriftsteller Elias Canetti und dessen Frau Veza. ${ }^{68}$ Gut bekannt und teilweise auch befreundet ist er mit einigen Sonntag-Fotografen, etwa mit Otto Skall und dessen Frau Gusti, die als Textautorin für den Sonntag schreibt, mit Robert Haas und Trude Fleischmann. Bil Spira wiederum ist mit dem Schriftsteller und Journalisten Stefan Großmann befreundet, der Mitte der 1930er Jahre nach längerer Zeit in Berlin wieder in Wien lebt, ebenso mit dem Fotografen Robert Haas. ${ }^{69}$

Weitere enge Kontakte unterhalten Oplatka und Spira zur Wiener Kleinkunstszene. Nach 1934 bieten die Programme dieser Kleinbühnen, die Theater, Musik und Kabarett verbinden, überwiegend linken, liberalen Künstlern, Autoren und Musikern die Möglichkeit, weiterhin öffentlich aufzutreten und in verdeckter, verfremdeter oder ironischer Form auf brennende gesellschaftliche Themen der Gegenwart zu sprechen zu kommen. ${ }^{70}$ Soyfer schreibt seine Stücke vor allem für die 1933 im Café Dobner am Getreidemarkt gegründete Kleinkunstbühne „Literatur am Naschmarkt“, aber auch für die Bühne ABC. Die Verbindungen zwischen dem Sonntag bzw. dem Wiener Tag und den beiden Bühnen sind eng. Der Sonntag räumt ihren Programmen viel Platz ein. Immer wieder werden neue Produktionen in Reportagen vorgestellt. Einige der Fotografen, die für den Sonntag arbeiten, dokumentieren auch die jeweils neuen Stücke der Bühne „Literatur am Naschmarkt“. ${ }^{71}$

Zwischen Oplatka und Spira und einzelnen Künstlern der beiden Bühnen gibt es auch enge persönliche Verbindungen. Hanns Margulies, Gerichtsreporter und Feuilletonist beim Wiener Tag, ist künstlerischer Leiter der Kleinkunstbühne ABC. Auf seine Einladung hin gestaltet Bil Spira einige Bühnenbilder für das ABC. ${ }^{72}$ Auch zur „Literatur am Naschmarkt“ unterhalten Oplatka und Spira gute Kontakte. Die Verbindung kommt wohl über Jura Soyfer zustande, der für die Bühne mehrere Stücke schreibt. Auf diese Weise kommen die Sonntag-Redakteure mit Lothar Metzel in Kontakt, einem jungen Juristen und Schriftsteller, der ab 1934 die Programme der „Literatur am Naschmarkt“ leitet und selbst mehrere Stücke, u. a. auch für die Bühne ABC, schreibt. Er gilt als einer der erfrischendsten und talentiertesten Theaterautoren dieser Jahre. Oplatka lädt ihn ein, regelmäßig Texte für den Sonntag zu schreiben.

\section{Das Ende}

Am 4. März 1938 wird im Wiener Museum für Kunst und Industrie (heute: Museum für angewandte Kunst) eine große Presseausstellung eröffnet. Die Veranstaltung mit dem Titel „Die Zeitung und ihre Welt“ 
(Abb. 26) fällt in eine politisch extrem angespannte Zeit. Der Druck Hitlers auf Österreich nimmt Anfang 1938 stark zu. Um der erstarkten illegalen nationalsozialistischen Bewegung, die in Österreich für den „Anschluss“ kämpft, Wind aus den Segeln zu nehmen, setzt der österreichische Kanzler Kurt Schuschnigg für den 13. März 1938 eine Volksabstimmung an. Sie soll, so der Plan der Regierung, zu einem Plebiszit für die österreichische Unabhängigkeit werden. Dazu kommt es freilich nicht mehr. Am Abend des 11. März 1938 gibt Schuschnigg einem Ultimatum Hitlers nach und tritt zurück. Am 12. März 1938 marschieren deutsche Truppen in Österreich ein. Am Tag darauf kommt es zum „Anschluss“ des Landes an das nationalsozialistische Deutschland.

Die Presseausstellung findet nicht zufällig kurz vor der Volksabstimmung statt, sie soll nämlich dazu beitragen, die Bevölkerung für die bevorstehende $\mathrm{Ab}$ stimmung zu mobilisieren. Eröffnet wird die Schau vom Kanzler höchstpersönlich. Veranstaltet wird sie von der regierungsnahen Österreichischen Pressekammer. Auch der Wiener Tag mit seiner illustrierten Beilage Der Sonntag nimmt an der Ausstellung teil. Obwohl das Blatt gewöhnlich nicht zu den willigen Propagandaorganen der Regierung zählt, trägt es angesichts der offensichtlichen nationalsozialistischen Bedrohung dazu bei, die Selbstständigkeit Österreichs zu propagieren. Am 6. März 1938, zwei Tage nach der Eröffnung der Schau, berichtet der Sonntag über die Ausstellung. Auf der Titelseite wirft der Fotograf Otto Skall einen ungewöhnlichen Blick in die Koje des Wiener Tag (Abb. 27). Er zeigt nicht den Ausstellungsraum als Ganzes, nicht Besucher und auch nicht Zeitungen, sondern einen in die Diagonale gekippten Ausschnitt von der Rückwand der Koje. Diese ist grafisch ausgekleidet. Gezeichnete Körper mit aufgesetzten fotografierten Köpfen stellen Leser dar. Sie halten den Wiener Tag und seine Beilagen in ihren Händen. Die moderne, eigenwillige Gestaltung hebt sich deutlich von der konventionellen Ästhetik anderer Aussteller ab. ${ }^{73}$

Abb. 27 Presseausstellung im Österreichischen Museum, Wien, März 1938. Die Koje des Wiener Tag, des Mutterblattes der Wochenendbeilage Sonntag, ist mit einer Fotomontage austapeziert. Der Sonntag, 6. März 1938, Titelseite. Foto: Otto Skall.
Die Ausgabe des Sonntag, in der die Wiener Presseausstellung vorgestellt wird, trägt die Nummer 207 im Zeitungskopf. Es ist die letzte Nummer, die erscheint. Eine Woche später ist die Mutterzeitung Der Wiener Tag verboten und auch Der Sonntag erscheint nicht mehr. Am 12. März 1938 wird die Redaktion von Nationalsozialisten besetzt. Hans Oplatka

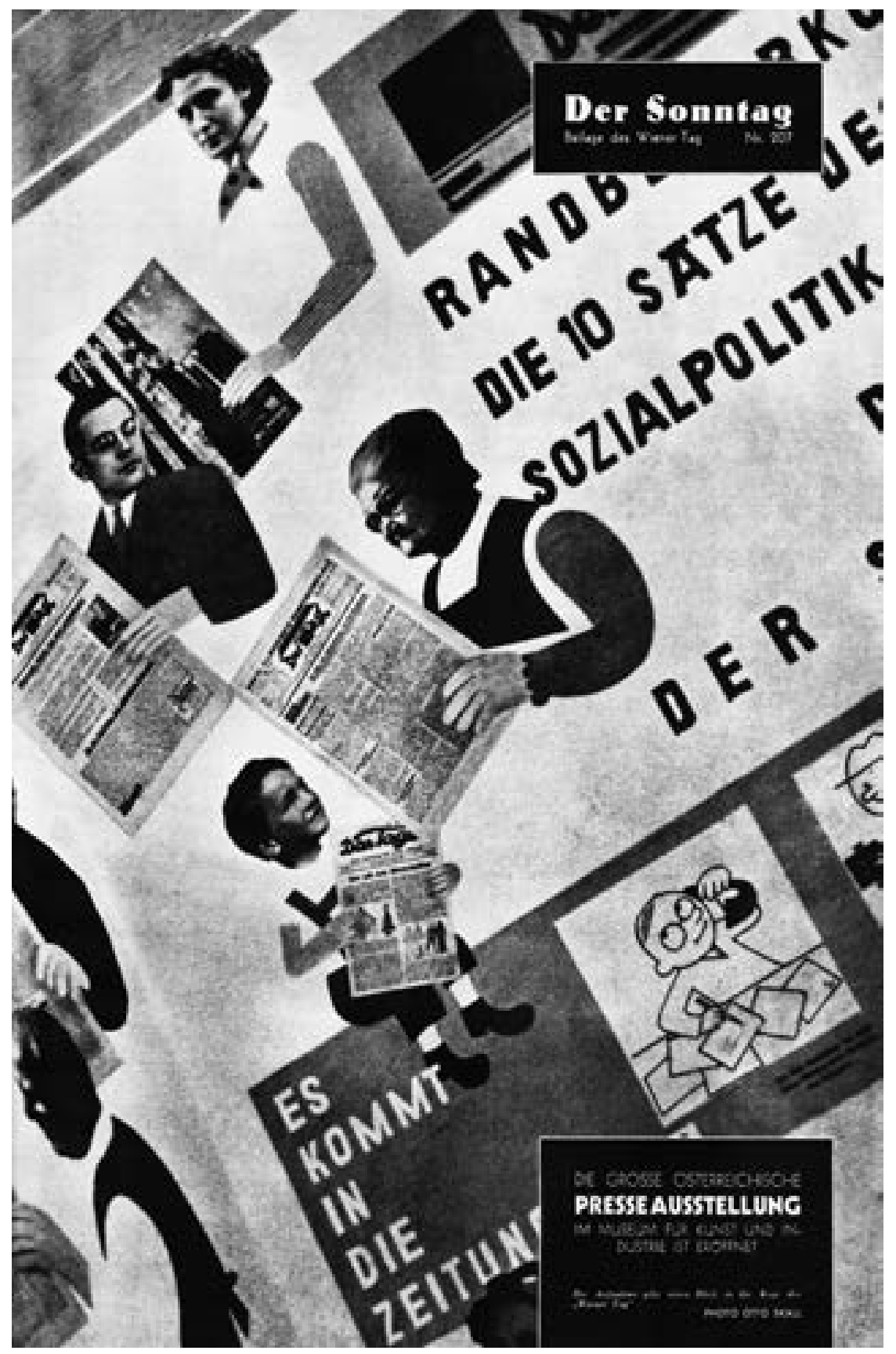


erinnert sich Jahre später an diesen Tag. „Zu dritt saßen wir (Oplatka, Spira und Soyfer, A. H.) im Café Dankl am Gürtel unter dem Stadtbahnviadukt bei der Volksoper. Zum ersten Mal marschierten die gesamten Naziformationen Währings in voller Uniform in der Stärke von ungefähr drei Kompanien hinter der Hakenkreuzfahne in Richtung Innere Stadt. (...) Während die Nazis defilierten, sprachen wir darüber, wie wir herauskommen. Ich riet gegen die ČSR (eine Falle für Österreicher) und gegen die Schweiz, wegen der Haltung der Behörden. Ich sagte via Italien, Frankreich oder sogar via Deutschland."74

Auch Bil Spira erinnert sich an diesen Tag: „Im März 1938, als sich Hitler Österreich einverleibte, war ich 25 Jahre alt. “75 Und er berichtet von seinem letzten Tag in der Sonntag-Redaktion: „Ich fuhr in die Redaktion des Wiener Tag, wo mir mein Gehalt und die fälligen Honorare ausbezahlt wurden. Ich betrat unser Redaktionszimmer, leerte meine Schublade und nahm, was mir gehörte. Ich nahm auch die Photos aus dem Film ,Eviva Mexiko، von Eisenstein, die an die Wand geheftet waren, mit. Im Stiegenhaus begegnete ich einer Gruppe von drei Gestapomännern. Jeder hatte eine Art Taktstock oder Reitpeitsche unterm Arm. Wir wichen einander aus. Als ich wieder auf der Straße war, atmete ich erleichtert auf. Ich begegnete Hans Oplatka und sagte ihm, daß die Gehälter und Honorare bereits bezahlt seien. Wir trafen Jura (Soyfer, A. H.) und besprachen die Situation. Es war uns klar, daß es keinen ,Sonntag' mehr gab. Wichtig war, daß es überhaupt noch Wochen- und Sonntage gab. Wir wollten alle Österreich verlassen. Aber wohin? Und wie? Darauf fanden wir keine gemeinsame Antwort. Da mußte jeder für sich selbst suchen."76

Hans Oplatka, Bil Spira und Jura Soyfer sind jüdischer Herkunft, ebenso zahlreiche andere Mitarbeiter und Fotografen des Sonntag, wie etwa Robert Haas, Lothar Metzel, Otto und Gusti Skall. Im März 1938 beginnt ihre Verfolgung. Einigen gelingt die Flucht aus Wien. Otto und Gusti Skall flüchten im November 1938 nach Prag. Kurz vor der Deportation ins KZ begehen sie Selbstmord. Gusti Skall stirbt am 23. Januar 1942 an einer Überdosis Schlaftabletten,
Otto Skall erschießt sich einen Tag danach. ${ }^{77}$ Die drei engsten Freunde, Oplatka, Spira und Soyfer, schlagen bei ihrer Flucht ganz unterschiedliche Richtungen ein. Hans Oplaka geht (entgegen seinem eigenen ursprünglichen Ratschlag) nach Prag und arbeitet dort für einige Monate als Bildredakteur für die tschechische Illustrierte Zeit im Bild. Im Herbst 1938, nach dem Münchner Abkommen, in welchem dem nationalsozialistischen Deutschland Teile Tschechiens zugeschlagen werden, flieht er über Jugoslawien und Italien nach Paris und später nach England, wo er sich während des Krieges den alliierten Truppen anschließt. Nach dem Krieg kann er sich in England als Fotograf etablieren. ${ }^{78}$ Bil Spira gelingt es - nach einer mehrwöchigen Haft -, nach Paris zu flüchten, wo er Oplatka wieder begegnet. ${ }^{79}$ Er schlägt sich als Zeichner durch, wird 1939 als „feindlicher Ausländer“ interniert und ab 1942 in mehrere Konzentrationslager verbracht, die er überlebt. Jura Soyfer schließlich versucht am 13. März 1938 im vorarlbergischen Montafon auf Skiern über die Berge in die Schweiz zu gelangen. Er wird von österreichischen Grenzbeamten verhaftet. Im Juni 1938 wird er in das KZ Dachau gebracht, wo er am 16. Februar 1939 an Typhus stirbt.

Am 12. März 1938 werden zahlreiche Redakteure und leitende Angestellte des Verlagshauses Vernay verhaftet. Der Konzern wird unter nationalsozialistische Aufsicht gestellt. Er erhält mit Ernst Thiel (später, ab 1941: Albert Klapper) einen kommissarischen Verwalter, der mit der „Abwicklung“ und Verwertung des Besitzes betraut wird. ${ }^{80}$ Zum Konzern gehören neben weiteren Zeitschriften, von denen einige (etwa die Bühne) unter neuer Leitung weitergeführt werden, auch eine moderne Druckerei und mehrere Liegenschaften. 1939 wird das Unternehmen an eine Gesellschaft im Besitz von Ernst Metten verkauft, dessen Sohn verkauft die Druckerei 1941 weiter. ${ }^{81}$ Das Unternehmen wird nach dem Krieg weitergeführt. Hans Oplatka kehrt nicht mehr nach Wien zurück. Er lässt sich in Liverpool nieder und arbeitet als freiberuflicher Fotograf für englische Magazine wie Picture Post, Lilliput, Strand Magazine und Contact, aber auch für ausländische Auftraggeber. Er stirbt 1992. 


\title{
Demagogie in Bildern
}

\author{
Hitler in Österreich 1938
}

Am 20. März 1938 wirbt die Firma Odol in der Illustrierten Wiener Bilder in großer Aufmachung für ihre bekannte Zahnpasta: „Das Gefühl vollkommener Sicherheit - zu wissen, daß Sie trotz langer Arbeitsstunden, im Theater, in Gesellschaft und im Hause sich wohl und sicher fühlen - Spannkraft und frische Lebensfreude empfinden - dieses Gefühl des Wohlbehagens verleiht Odol. “1 Die Annonce erscheint eine Woche, nachdem am 12. März 1938 Truppen des nationalsozialistischen Deutschen Reiches auf Hitlers Befehl in Österreich einmarschiert sind. Am 13. März wird das „Gesetz über die Wiedervereinigung Österreichs mit dem Deutschen Reich“ beschlossen. Ab sofort steht Österreich unter nationalsozialistischer Herrschaft. Bereits Stunden nach dem „Anschluss“ setzt die Verfolgung und Drangsalierung der jüdischen Bevölkerung ein. Angesichts dieser Repressalien musste den Verfolgten eine Anzeige, die „das Gefühl vollkommener Sicherheit“, „Spannkraft und frische Lebensfreude“ in Aussicht stellt, einigermaBen deplatziert erschienen sein. Odol sieht angesichts der aktuellen politischen Entwicklungen in Österreich offenbar keinen Grund, den Text zu ändern. Schließlich - und das ist die Kehrseite des 12. März 1938 - bewegt sich das Alltagsleben über weite Strecken tatsächlich nach wie vor in den gewohnten Bahnen. Die Solidarität mit den Verfolgten hält sich in Grenzen. Wer nicht von den Gewaltmaßnahmen betroffen ist, kann tatsächlich weiterhin das „Gefühl vollkommener Sicherheit“ genießen.

Die Odol-Anzeige spiegelt die merkwürdige Ambivalenz zwischen Katastrophe und oberflächlicher Kontinuität. Und dennoch: Wer Mitte März 1938 die Presse verfolgte, wusste, dass nichts so bleiben sollte, wie es vor dem 12. März war. Als den deutschen Reichskanzler die ersten Nachrichten vom erfolgreichen Einmarsch seiner Truppen erreichen, macht er sich auf den Weg, um triumphierend in Österreich einzuziehen. Den ersten öffentlichen Auftritt hat Hit- ler am 13. März 1938 in Linz, wo er auf dem Balkon des Rathauses eine Rede hält. Die Presse ist längst verständigt, Fotografen halten das Ereignis fest. Einen Tag später wird Hitler in Wien erwartet. Er steigt im Hotel Imperial am Ring ab. „Wien jubelt dem Führer zu!“, titelt Das interessante Blatt am 17. März und bringt auf dem Umschlag ein Bild, das Hitler im offenen Mercedes auf seiner Fahrt durch die Hauptstadt zeigt. Die Straßen sind von Anhängern und Schaulustigen gesäumt (Abb. 1).

Wenige Tage zuvor noch hatte die Zeitung offen die österreichische Regierung unterstützt, die sich gegen Hitlers außenpolitische Erpressung gewehrt hatte. Nun ist alles anders. Das Blatt schwenkt unter dem Druck der Ereignisse voll auf den NS-Kurs um. Die Redaktion wird auf Befehl der neuen Machthaber sogleich „gesäubert“: Unliebsame Redakteure werden entfernt. Das interessante Blatt gibt in den Tagen nach dem „Anschluss“ bekannt, dass die neue Regierung vorbehaltlos Unterstützung finden werde. „So wie das ,Interessante Blatt' seit 56 Jahren seine Aufgabe immer darin sah, dem Vaterland zu dienen, so wird es auch heute seine ganze Kraft aufwenden, sich in den Dienst des nationalsozialistischen Österreich zu stellen. Die Redakteure, Beamten und Arbeiter haben den einstimmigen Beschluß gefaßt, sich in einvernehmlichem Zusammenwirken der Mitarbeit an dem nationalsozialistischen Aufbau voll und ganz zu widmen." ${ }^{2}$ Das Vorhaben wird sofort umgesetzt. Von nun an huldigt die Zeitung Woche für Woche dem neuen Regime.

Ähnliche Verlautbarungen veröffentlichen in diesen Tagen fast alle Blätter. Am 20. März etwa heißt es in den Wiener Bildern unter dem Titel „Heimkehr ins Reich“ pathetisch: „Österreich ist frei geworden! - der Sturm geschichtlichen Geschehens, der frühlingshaft durch alle Gaue der Ostmark braust, trägt den Ruf mit sich, jedem Österreicher verkündend: Die alte Ostmark ist heimgekehrt ins Reich.“3 


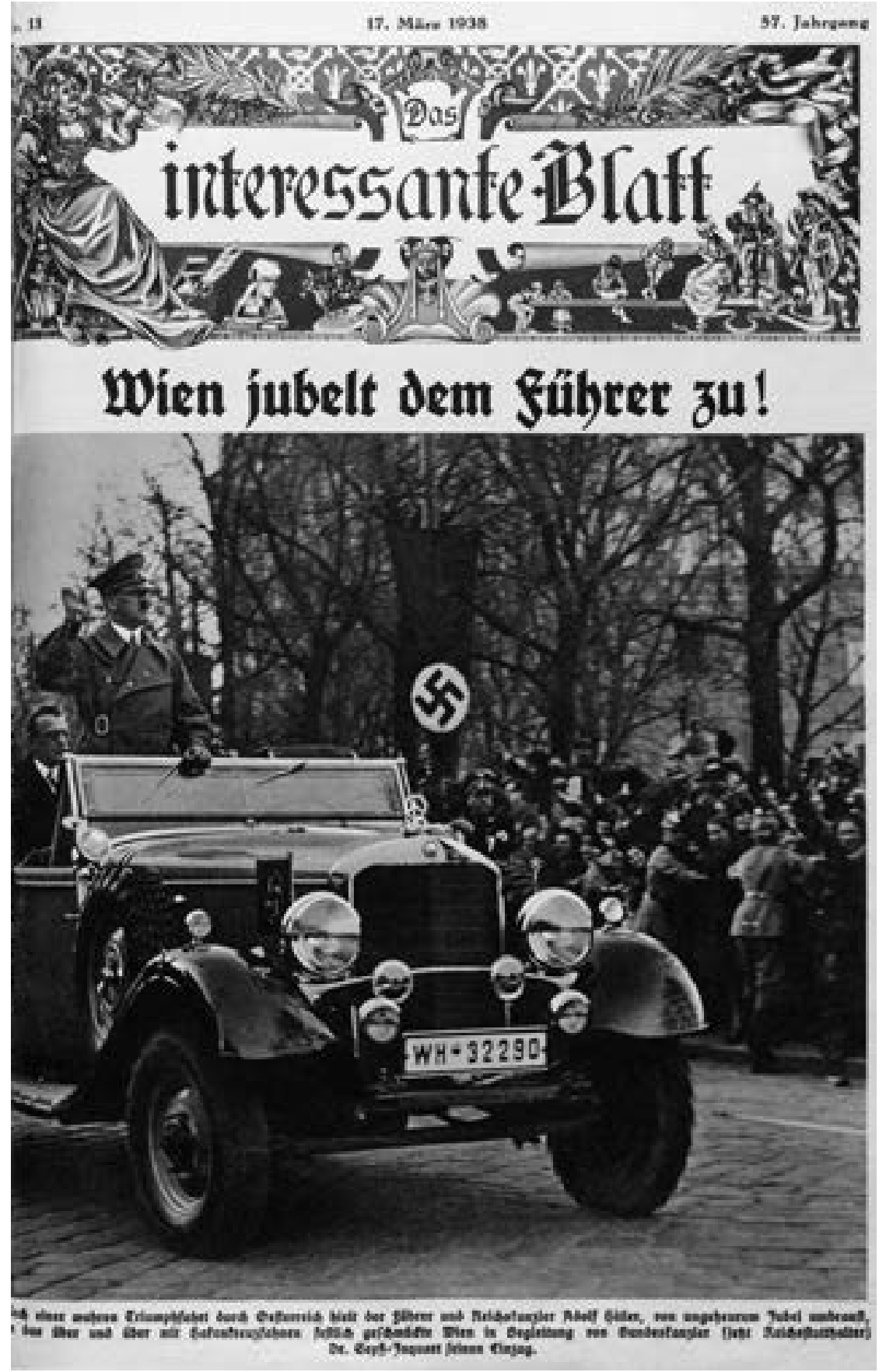

Triumphierend heißt es weiter: „Das ,System“ ist nicht mehr. In einigen knappen Stunden wurde es durch die disziplinierten mächtigen Kundgebungen des deutschen Volkes in Österreich und die Tatkraft der nationalsozialistischen Idee, die in fünfjährigem harten Kampfe nicht gebrochen werden konn-
Abb. 1 Am 14. März 1938 zieht der deutsche Kanzler Adolf Hitler (neben inm sitzt der neu ernannte Reichsstatthalter für Österreich, Arthur Seyß-Inquart) unter großem Jubel der einheimischen Bevölkerung in Wien ein. Der offene Mercedes steuert über die Wiener Ringstraße. Das interessante Blatt, 17. März 1938, Titelseite.

te, hinweggefegt. Seit dem 12. März braust der Jubel durch das Land. Adolf Hitler ist heimgekehrt in seine Heimat! Seine Fahrt bis Wien war eine einzigartige, unbeschreibliche Triumphfahrt. Die deutsche Schicksalsgemeinschaft ist Wirklichkeit geworden und unter den Fahnen des nationalen Sozialismus, die sieghaft in den blauen Frühlingshimmel flattern, finden sich Bauer und Städter, Arbeiter der Gehirne und der Faust und fühlen sich eins in den Worten: Ein Volk - ein Reich - ein Führer!“4

\section{Der „Anschluss“ in Bildern}

Am 15. März 1938 versammeln sich Zehntausende in Wien, um die Rede des „Führers“ auf dem Wiener Heldenplatz zu verfolgen und ihm zuzujubeln. Auf der Titelseite der Österreichischen Woche, die über Nacht vom Hausblatt des „Ständestaates“ zur Propagandazeitung des neuen nationalsozialistischen Regimes wird, ist Hitler auf dem Balkon der Neuen Burg hinter seinem Redepult zu sehen (Abb. 2). ${ }^{5}$ Alle Zeitungen berichten in großer Aufmachung über das Großereignis, das in aller Eile geplant worden war.

Von Anfang an überlässt die neue Regierung nichts dem Zufall, wenn es darum geht, euphorisch und staatstragend über den Beginn der „neuen Zeit“ zu berichten. Innerhalb von wenigen Tagen stehen alle relevanten Medien - von den Tageszeitungen und Wochenzeitungen über das Radio bis hin zum Film - unter nationalsozialistischer Kontrolle. Jüdische Verlagsmitarbeiter, Redakteure und Fotografen werden entlassen, ebenso werden politisch „unzuverlässige“ und unliebsame Journalisten entfernt. Man bemüht sich, nach außen hin die Kontinuität zu betonen, aber hinter den Kulissen wird gnadenlos „aufgeräumt“. Einige Zeitungen werden eingestellt, andere unter neuer nationalsozialistischer Führung weitergeführt. $\mathrm{Zu}$ diesem Zweck werden zahlreiche Blätter mit neuen, politisch genehmen kommissa- 


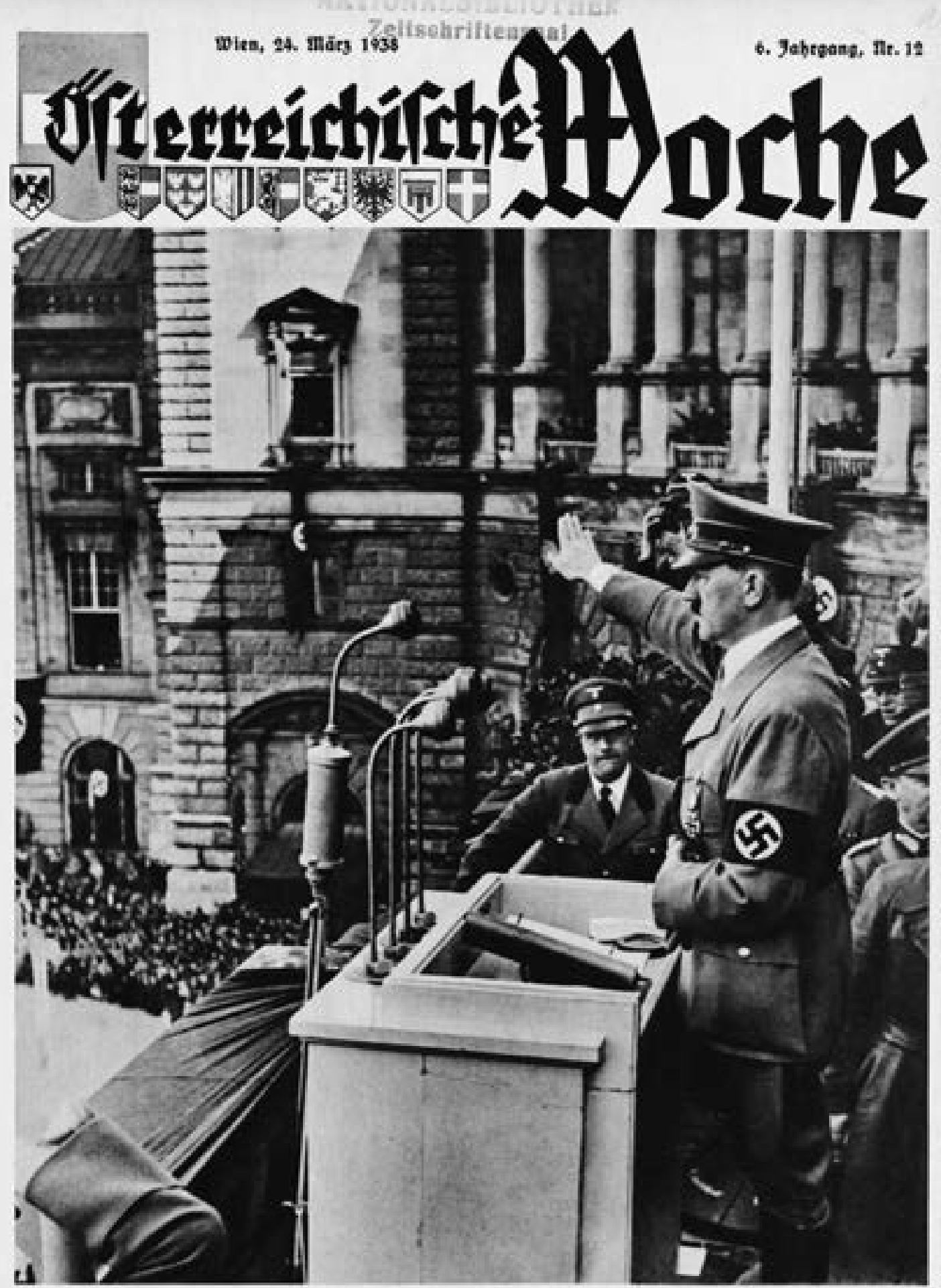

Abb. 2 Am 15. März 1938 hält Hitler vor Tausenden jubelnder Zuschauer eine große Rede auf dem Wiener Heldenplatz. Österreichische Woche, 24. März 1938, Titelseite.

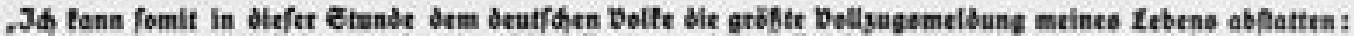

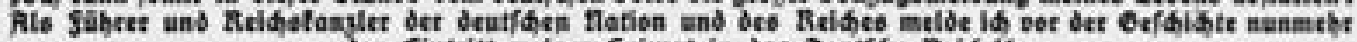

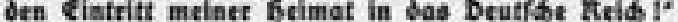

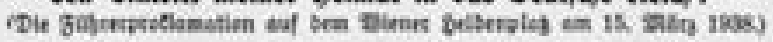




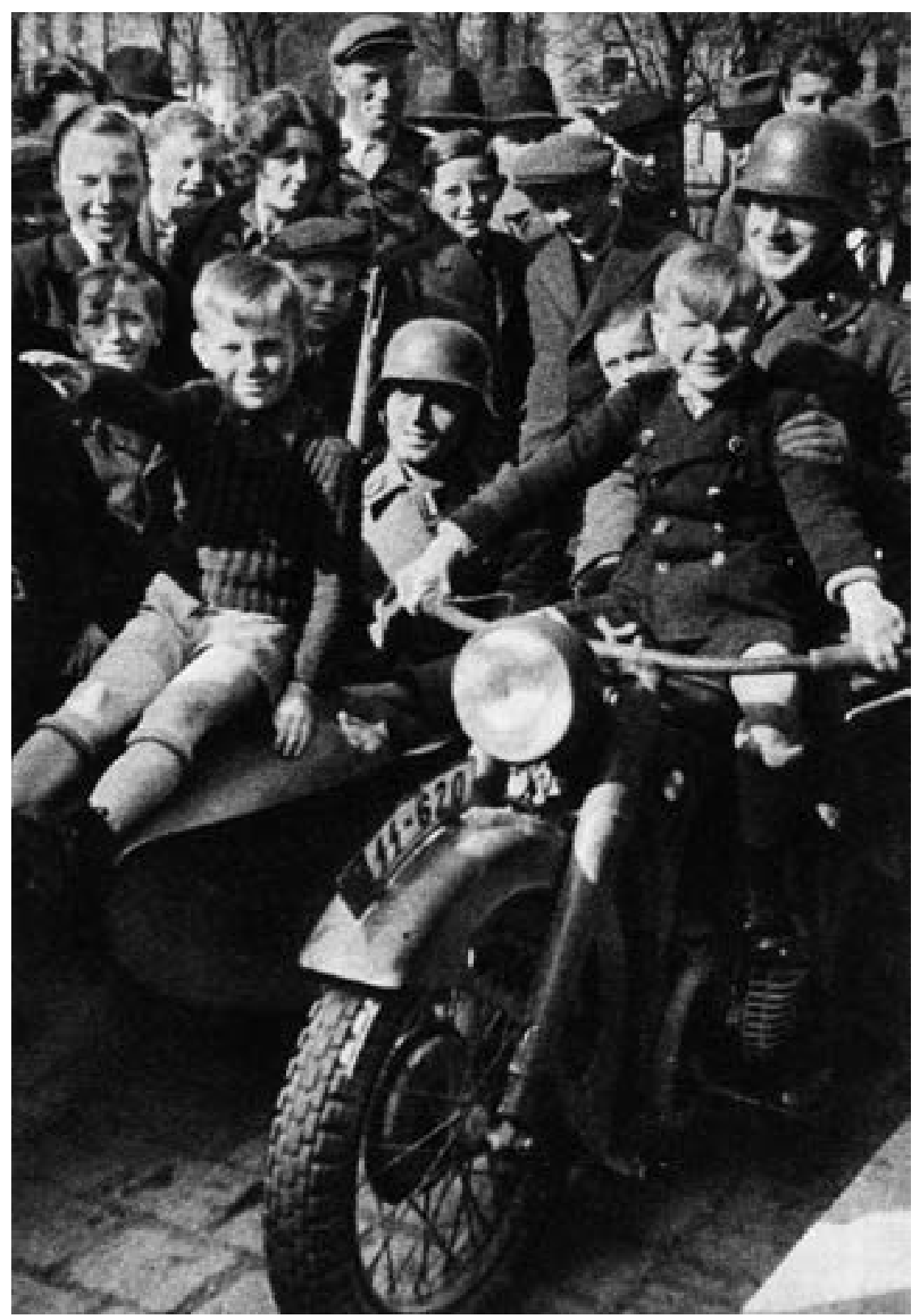

Abb. 3 Deutsche Soldaten nach dem Einmarsch in Wien, umringt von Kindern und Jugendlichen. Das interessante Blatt, 24. März 1938, S. 7. Foto: Albert Hilscher. rischen Leitern besetzt. ${ }^{6}$ Auch in den Bildern wird der neue Kurs sichtbar. Es werden nun vorzugsweise jene Fotografen eingesetzt, die begeistert hinter dem NS-Regime stehen (Abb.3).

Diese Veränderungen wirken sich sehr schnell auf die inhaltliche Ausrichtung der Presse aus. Es wird - zumindest in der öffentlichen Darstellung - ein radikaler Trennstrich zum „Ständestaat“ gezogen. Besonders deutlich ist dies in einer bildlich inszenierten Gegenüberstellung, die Ende März 1938 in der Österreichischen Woche (die zwei Wochen später in Ostmark-Woche umbenannt wird) erscheint (Abb.4). Auf der einen Seite wird das katastrophale „Schuschnigg-System“ gegeißelt, auf der anderen wird das angeblich blühende Deutschland Hitlers angepriesen. Während links des Mittelfalzes (also in Schuschniggs
Österreich) Arbeitslosigkeit, Not, Armut und Verzweiflung herrschen, besticht rechts des Mittelfalzes das nationalsozialistische Deutschland durch Wohlstand, Ordnung und Sicherheit. Der Volkswohnbau, der Autobahnbau und die „Kraft durch Freude“-Aktionen - all diese Errungenschaften werden in Bildern vorgestellt.

Im Frühjahr 1938 nimmt der Umfang der Berichterstattung über das nationalsozialistische Deutschland in den Wiener Zeitungen schnell zu. Mit einem Schlag öffnet sich die Presse des annektierten Landes hin zum Deutschen Reich. Die Folgen sind vielfältig: Österreichische Blätter werden nach und nach umbenannt, um symbolisch die Verbindungen zum alten Staat zu kappen und die Medien für den großdeutschen Markt fit zu machen. ${ }^{7}$ Immer mehr „reichsdeutsche“ Fotografen, Bildagenturen und auch Journalisten drängen nun auf den Markt der „Ostmark“. Die Folge ist, dass sich die Wiener Blätter in ihrer Ausrichtung schnell der reichsdeutschen Berichterstattung angleichen. Von nun an gibt Berlin, nicht mehr Wien den Ton im Zeitungswesen und im Rundfunk an.

Die Stellen der aus ihren Positionen gejagten jüdischen Fotografen werden schnell von parteitreuen Kollegen, politischen Wendehälsen und willigen Mitläufern besetzt. Zum Zuge kommen zunächst die bereits arrivierten Fotografen, die sich den neuen politischen Verhältnissen problemlos anpassen.

\section{Der „Führer“ spricht}

Gut zwei Wochen, nachdem Hitler auf dem Wiener Heldenplatz vor jubelnden Massen den „Anschluss“ verkündet hat, ist er neuerlich in Österreich unterwegs. Anfang April absolviert er eine sorgfältig vorbereitete propagandistische Österreich-Rundfahrt (die sogenannte „Ostmarkfahrt“), die ihn nach Graz (3. April), Klagenfurt (4. April), Innsbruck (5. April), Salzburg (6. April), Linz (7. April) und Wien (9.April) führen wird. An allen Orten werden unter gewaltigem logistischen Aufwand Massenkundgebungen inszeniert, die ein einziges Ziel haben: die Bevölkerung für die Volksabstimmung über den Anschluss Österreichs an das nationalsozialistische Deutschland 
zu mobilisieren. Diese soll am 10. April 1938 stattfinden. Die vom „Führer“ besuchten Städte verwandeln sich für Stunden zu nationalsozialistischen „Gesamtkunstwerken“. Jedes Detail der „Führer“-Besuche ist penibel geplant, von der Lichtregie und der Beflaggung über den obligatorischen Straßenschmuck und die Lautsprecheranlagen bis zur Bühnentechnik und den triumphalen Musikeinlagen. Abends hält Hitler jeweils vor ausgewähltem Publikum eine Rede. Der Tag des Hitlerbesuchs wird zum Festtag erklärt. Er ist schul- und arbeitsfrei. Hunderte von Sonderzügen und Bussen bringen Zehntausende von Besuchern zu den Veranstaltungsorten. Die Begeisterung soll, so die Organisatoren, im Vorfeld der Abstimmung überwältigend ausfallen. Nicht zufällig hat Hitler für den Auftakt dieser Propagandaschlacht Graz auserkoren, die „Stadt der Volkserhebung“, wie sie in der nationalsozialistischen Diktion genannt wird. Am 3. April 1938 lässt sich Hitler in den Straßen der Stadt bejubeln. Am Abend tritt er in der riesigen Montagehalle einer Waggonfabrik vor 20000 Anhängern auf. Allein in Graz sind 20000 Soldaten und Sicherheitskräfte im Einsatz, um die heranströmenden Menschenmassen zu kanalisieren. Insgesamt 400000 Besucher tummeln sich an diesem Tag in der Stadt, weit mehr Menschen als Graz Einwohner hat.
Abb. 4 Propagandistische Gegenüberstellung des „alten“ Ständestaates und des „neuen“ nationalsozialistischen Deutschland. Österreichische Woche, 31. März 1938, S. 4/5.
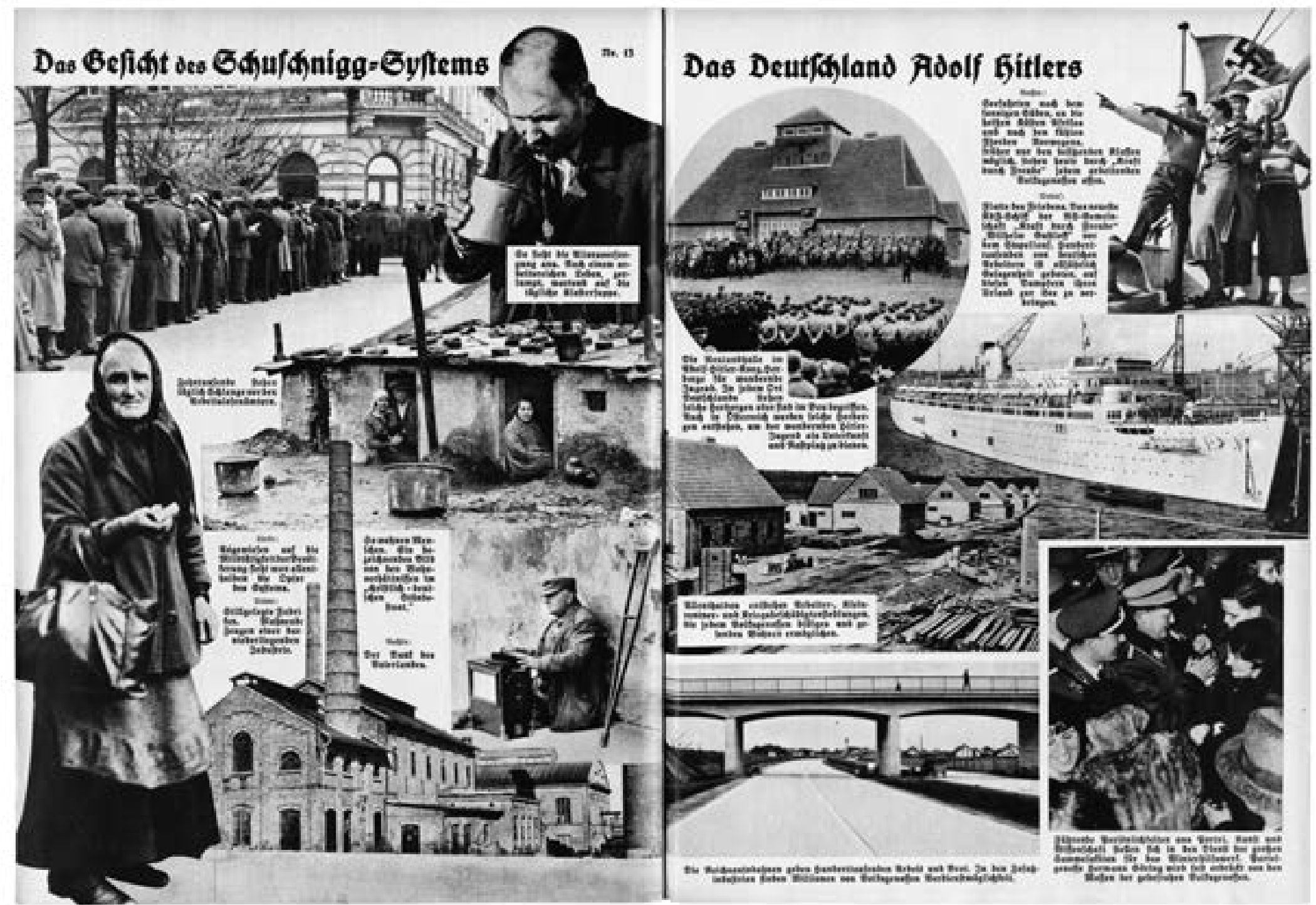
Abb. 5 Hitlers Auftritt in Graz, 3. April 1938. In einer propagandistischen „Ostmarkfahrt“ macht der „Führer“ Stimmung für die Volksabstimmung über den Anschluss Österreichs an Deutschland. Das interessante Blatt, 7. April 1938, Titelseite. Foto: Lothar Rübelt.
Nr. 14

7. April 1938

57. Jahrgaes

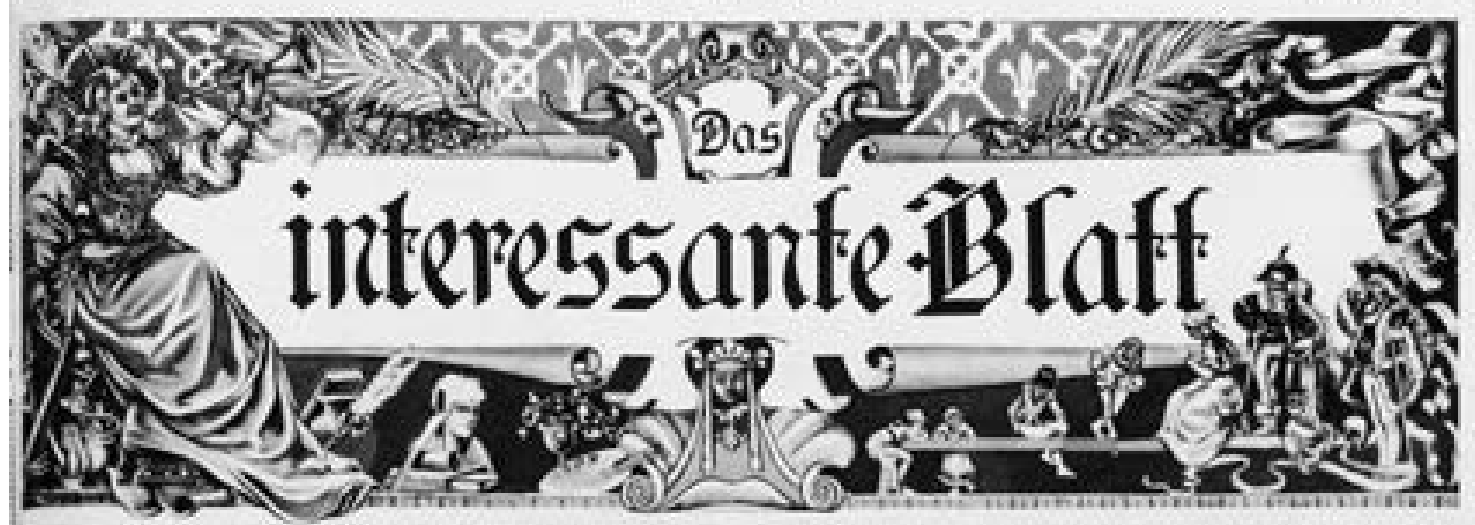

Dein " "ᄏa" - dem fübrer!

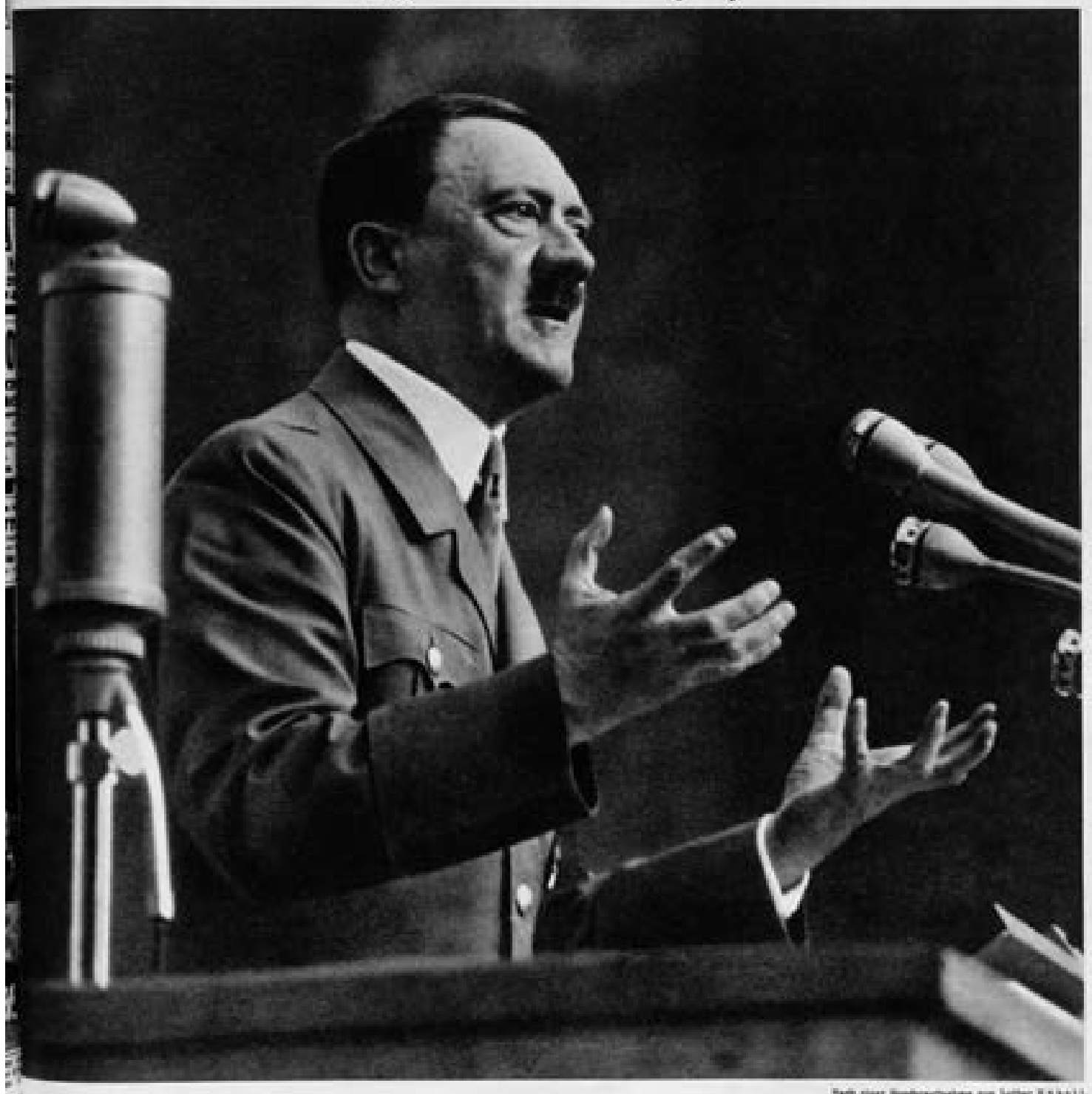

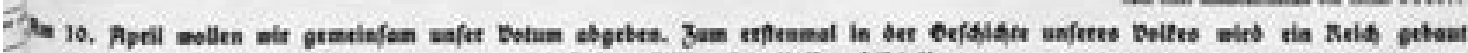
aad dem Evilea bes bolles felba."

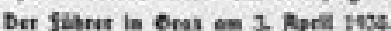


Hand in Hand mit der perfekten Inszenierung der Massenveranstaltung geht die mediale Begleitung der Auftritte. Radio, Filmwochenschau und Zeitungen berichten ausführlich in Text, Bild und Ton über die Veranstaltungen. Der Tenor der Berichte variiert kaum, die Propagandamaschinerie des Regimes findet in der gleichgeschalteten Presse willige Multiplikatoren. Besonders wichtig ist der nationalsozialistischen Führung die Bildberichterstattung. Das interessante Blatt räumt dem Grazer Auftritt des Führers in Form eines „Sonderbildberichtes“ besonders viel Platz ein. Am 7. April 1938, wenige Tage nach der Veranstaltung, zeigt die Titelseite des Blattes Hitler während seiner Grazer Rede. ${ }^{8}$ (Abb.5). Über dem Porträt des Redners prangt unmissverständlich der Aufruf: „Dein ,Ja“ dem Führer!“ Im Innenteil wird die Reportage über mehrere Seiten hinweg fortgesetzt. Eine Doppelseite widmet sich dem Graz-Besuch des „Führers“, eine weitere berichtet über die restlichen Stationen der Propagandareise.

Der Auftritt Hitlers in Graz wird vom Wiener Pressefotografen Lothar Rübelt in Bildern festgehalten. Es ist bezeichnend, dass die Redaktion einen Fotografen, der schwerpunktmäßig im Sportbereich tätig ist, mit dieser anspruchsvollen und heiklen Aufgabe betraut. Sogar der Text zu dem Bildbericht aus Graz stammt von Rübelt. Der Grund dürfte darin liegen, dass Rübelt viel Erfahrung im Dokumentieren von komplexen Großereignissen hat. Zudem ist er ein begeisterter und verlässlicher NS-Anhänger. Wenige Monate später, am 22. Dezember 1938, beschreibt Rübelt in einem Schreiben seine Verdienste um die Partei und betont, dass er schon vor 1938 für die nationalsozialistische Bewegung tätig gewesen sei. „Ich habe als Reichsdeutscher in Wien lebend mit Erfolg den Einfluß von Juden in meinem Arbeitsgebiet zurückgedrängt. Vor der Verbotszeit war ich fast der alleinige Fotograf der Parteipresse und auch während der Verbotszeit ist es mir durch die Möglichkeit des ungehinderten Grenzübertritts gelungen, der Bewegung wertvolle Dienste zu leisten. Ich verweise diesbezüglich auf die Empfehlungsschreiben der Reichsstatthalterei an die Filmkammer."9

Im Bericht aus Graz lässt Lothar Rübelt seiner Begeisterung freien Lauf. „Vor der festlich geschmückten
Grazer Bahnhofsallee empfing ein Orkan der Freude den Retter Österreichs, als der Führer Grazer Boden betrat. Der Führer grüßte mit erhobener Hand, im Wagen stehend, und eine überschäumende Begeisterung erfaßte die Menschen, die ihren Führer, der aus ihrer Heimat stammt, zum erstenmal sahen. Unbeschreiblich war der Ausbruch der Freude der 20000 , als der Führer in der Halle der Weitzer Waggonfabrik erschien und hier zu seinen Steirern, durch den Rundfunk aber zu ganz Großdeutschland sprach.“10

Als der „Führer“ eine Woche später, am 9. April 1938, in der Halle des Wiener Nordwestbahnhofes seinen abschließenden Auftritt vor der Volksabstimmung absolviert, ist Lothar Rübelt wieder mit dabei. Neben ihm sind bei den Massenveranstaltungen zahlreiche weitere Fotografen im Einsatz. ${ }^{11}$ Auch ihre Bilder finden den Weg in die Presse, wo sie ähnlich suggestiv präsentiert werden.

\section{Heinrich Hoffmann: Hitler-Fotograf}

Am Tag der Volksabstimmung, dem 10. April 1938, bringen die Wiener Bilder ein Hitler-Porträt auf der Titelseite. Der Aufruf ist eindeutig: „Dem Befreier Österreichs - dem Retter Deutschlands Dein ,Ja!“"12 Die Vorlage dieser Abbildung stammt aus der Fotoagentur von Heinrich Hoffmann, der bereits seit Jahren die Karriere Hitlers fotografisch und publizistisch begleitet. Er gilt als der Hitler-Fotograf, er ist es, der das bekannte fotografische Image des „Führers“ entwirft und verbreitet. Auch die Österreich-Auftritte Hitlers werden von Hoffmann lückenlos dokumentiert und vermarktet. Heinrich Hoffmann wird in den folgenden Jahren nicht nur im „Reich“, sondern auch in der angeschlossenen „Ostmark“ zur zentralen Anlaufstelle für NS-Bilder (Abb.6). Über seinen Verlag und seine Fotoagentur gelingt es ihm, zum größten und wichtigsten nationalsozialistischen Bildlieferanten aufzusteigen. ${ }^{13}$ Das Unternehmen expandiert rasch. 1932 verfügt es noch über 17 Angestellte (darunter die junge Eva Braun, Hitlers spätere Geliebte), 1943 sind bereits 300 Mitarbeiter für die Firma im Einsatz. Täglich werden nicht nur an die 160 Redaktionen mit aktuellen Pressefotos beliefert, man produziert auch Bildbände, Werbebroschüren, Postkarten und weite- 
Abb. 6 „Dr. Goebbels spricht“. Der nationalsozialistische Propagandaminister Joseph Goebbels bei der Eröffnungsrede der "Reichstheaterfestwoche" in Wien. OstmarkWoche, 23. Juni 1938, Titelseite. Foto: Hoffmann.
Abb. 7 „Der Befreier“. Adolf Hitler, aufgenommen am 13. März 1938 um Mitternacht in Linz während seiner ersten Rede nach dem Einmarsch in Österreich. Österreichische Kunst, 10. Oktober 1938, S. 30. Foto: Heinrich Hoffmann.
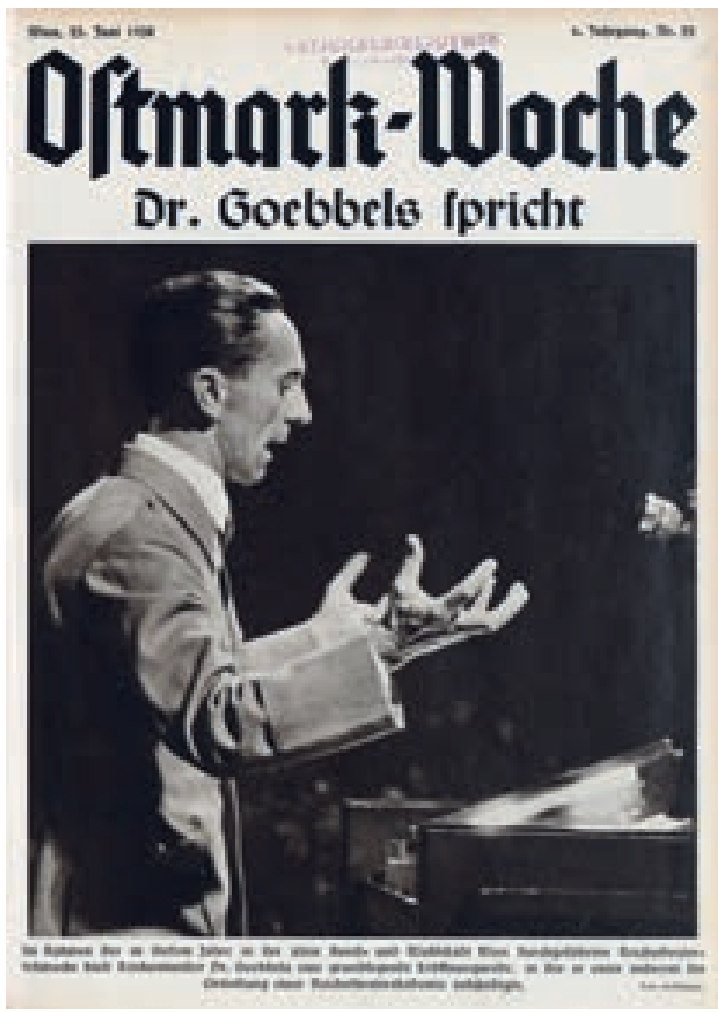

res Propagandamaterial. Hoffmann selbst unterhält beste persönliche Beziehungen zum Führer und zur nationalsozialistischen Führungsriege und versteht es meisterlich, seinen privilegierten Zugang zu den NS-Machthabern in massenhaft vervielfältigte Bildpropaganda umzumünzen.

Kaum ist 1938 der „Anschluss“ Österreichs vollzogen, expandiert der Unternehmer, der von München aus ein fotopublizistisches Imperium mit zahlreichen Zweigstellen dirigiert, in die „Ostmark“. Er bringt eine zuvor „arisierte“ Wiener Kunstbuchhandlung in seinen Besitz und eröffnet in prominenter Lage an der Wiener Ringstraße (Opernring 19) seinen „Verlag nationalsozialistischer Bilder Heinrich Hoffmann“. ${ }^{14}$ Im Schaufenster und in den Verkaufsräumen sind fast ausschließlich Hitlerporträts zu sehen, für deren Verkauf der Inhaber eifrig die Werbetrommel rührt. In einer Anzeige vom Oktober 1938 heißt es: „Die besten Führerbildnisse sowie Porträtaufnahmen von maßgebenden Männern aus Partei und Staat stehen in unserer Ausstellung unverbindlich zur Besichtigung frei." 15

Für Hoffmann, dessen Tochter seit 1932 mit dem mächtigen Wiener Reichsstatthalter Baldur von Schirach verheiratet ist, ist Wien weit mehr als nur der Standort einer seiner vielen Zweigstellen. Er hält sich regelmäßig in der Stadt auf, frönt hier seiner Kunstsammelleidenschaft und erwirbt im Herbst 1938 sogar eine österreichische Kunstzeit- schrift, die er selbst herausgibt. Bereits in der ersten Ausgabe der Österreichischen Kunst, die unter der neuen Leitung erscheint und die bald in Kunst dem Volk umbenannt wird, bewirbt Hoffmann in einer ganzseitigen Anzeige seinen eigenen Wiener Verlag. „Hoffmann-Photos und Kunstblätter, die durch ihre künstlerische Hochwertigkeit und Darstellung bereits zu einem Begriff wurden, sind erhältlich in allen guten Kunsthandlungen und im Verlag nationalsozialistischer Bilder Heinrich Hoffmann, Wien I, Opernring 19.“ ${ }^{16}$ Der Blickfang der Anzeige ist ein Hitler-Porträt (Abb. 7), das Hoffmann selbst in einem denkwürdigen Augenblick aufgenommen hat, nämlich „in der mitternächtlichen Stunde des 13. März 1938 auf dem Rathausbalkon zu Linz“. ${ }^{17}$ Jeder weiß, dass an diesem Tag Adolf Hitler seine erste Rede auf österreichischem Staatsgebiet gehalten hatte und am selben Tag der „Anschluss“ gesetzlich besiegelt worden war. Heinrich Hoffmann, der sich rühmt, in wichtigen historischen Momenten an Hitlers Seite gestanden zu haben, nennt diese Aufnahme: „Der Befreier“.

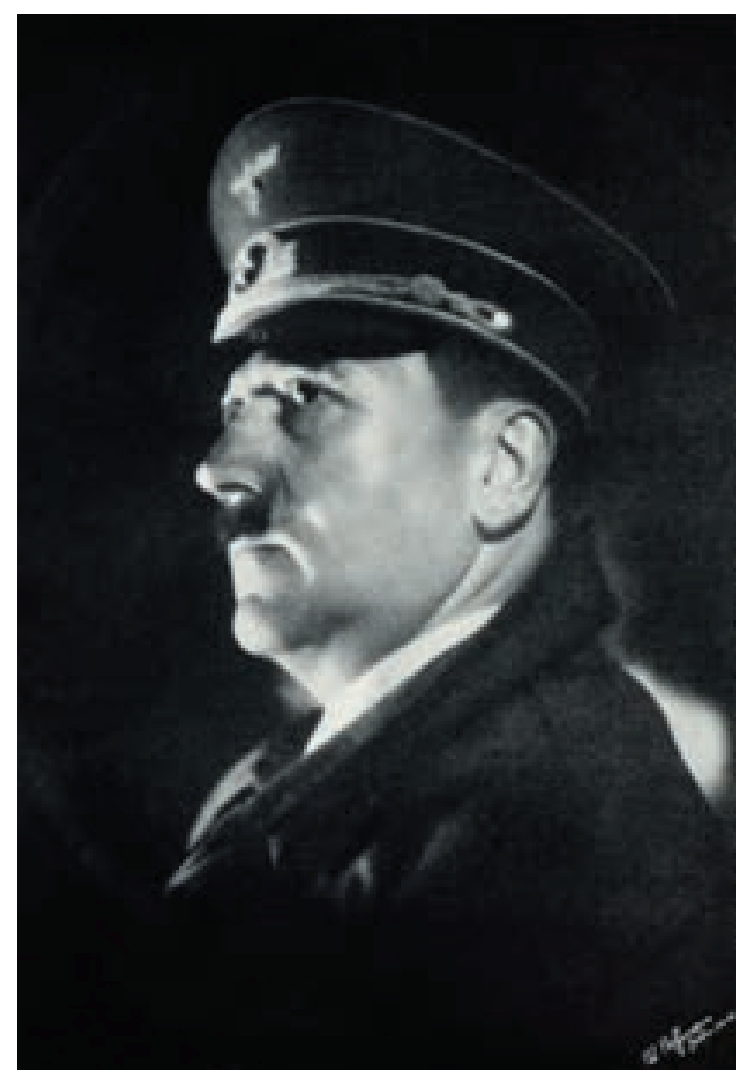




\title{
Den Krieg vor Augen
}

\author{
Nationalsozialistische Medienpolitik und Ästhetik
}

Am 1. September 1939 überfallen deutsche Truppen Polen. Der Zweite Weltkrieg beginnt. Eine Woche später, am 7. September, wendet sich die Chefredaktion des Interessanten Blattes (die in der nationalsozialistischen Diktion längst „Schriftleitung“ heißt) an ihre Leser. „In ereignisschweren, schicksalhaften Tagen erscheint mit dieser Folge das ,Interessante Blatt" in der bisher bekannten Form zum letzten Male. (...) Mit dem Anbruch einer neuen Zeit für unser Volk haben sich auch die Bedürfnisse des Einzelnen gewandelt. Zusammen mit unserer Schwesterzeitschrift ,Wiener Bilder، wird das ,Interessante Blatt‘ von nun an als große, den Problemen der Gegenwart aufgeschlossene, in modernem, zeitnahem Geist geführte Illustrierte, als ,Wiener Illustrierte. Das interessante Blatt' erscheinen. Dadurch war nicht nur eine bedeutende Preisherabsetzung möglich, sondern ergaben sich für die Schriftleitung auch Umstände, die eine umfassende Ausgestaltung sowohl in bildlicher wie textlicher Hinsicht gestatteten. Wir hoffen, daß alle unsere Freunde, die uns, wie wir wissen, oft durch Generationen die Treue gehalten haben, sich auch der großen Lesergemeinde der ,Wiener Illustrierten“ mit der gleichen Anhänglichkeit einreihen werden. Die Schriftleitung“1

In dieser pathetischen Ankündigung wird nicht nur der Kriegsbeginn angesprochen, die „ereignisschweren, schicksalhaften Tage“, sondern auch die Zusammenlegung mit der „Schwesterzeitschrift“ Wiener Bilder. Diese erscheint am 10. September 1939 zum letzten Mal. ${ }^{2}$ Diese einschneidenden Veränderungen, die Fusion mit den Wiener Bildern, die Umbenennung und die Umgestaltung des Interessanten Blattes, das inzwischen seit knapp 60 Jahren erscheint, werden nicht zufällig zu Kriegsbeginn umgesetzt. Ziel des grundlegenden gestalterischen Eingriffs ist es, die Zeitung für ihren Auftritt auf dem großen reichsdeutschen Pressemarkt fit zu machen und, angesichts des einsetzenden Krieges, ihre propa- gandistische Schlagkraft im Interesse des Regimes zu stärken. Wenn man das äußere Erscheinungsbild des Interessanten Blattes, das bis zuletzt nicht auf die antiquierte Titelvignette verzichten wollte, mit dem neuen Umschlag (Abb. 1) vergleicht, wird schnell klar, dass die Zeitung einer radikalen Modernisierung unterzogen wird. Sie holt damit aber im Grunde nur eine Entwicklung nach, die die meisten führenden deutschen Illustrierten längst hinter sich haben. ${ }^{3}$ Der Titel steht nun frei auf weißem Grund, der alte Titel Das interessante Blatt ist zum Untertitel degradiert. Darunter wird das jetzt fast seitenfüllende Foto platziert, das sich ganz in den Dienst der nationalsozialistischen Sache stellt.

Die radikale Modernisierung des Interessanten Blattes ist kein isoliertes Ereignis, sondern steht im größeren Kontext der nationalsozialistischen Herrschaftspolitik und Ideologie, die nicht nur archaische, sondern auch moderne Elemente in sich vereint. So setzt etwa die nationalsozialistische Medienpolitik, zumindest in Fragen der Gestaltung, durchaus auf moderne Lösungen. Bei zahlreichen österreichischen Zeitschriften und Zeitungen, die nach 1938 unter nationalsozialistischer Kontrolle stehen, lässt sich eine grafische Modernisierung nachweisen. Bereits im April 1938 wird das Erscheinungsbild des bisherigen Propagandablatts des „Ständestaates“, der Österreichischen Woche, erneuert. Sie erhält nun den mit der neuen Ideologie kompatibleren Titel Ostmark-Woche (Abb. 2).

Mitte Juni 1938, also gut ein Jahr vor der Fusion mit dem Interessanten Blatt, werden auch die Wiener Bilder einem Relaunch unterzogen. ${ }^{4}$ Der grafisch gestaltete Zeitungskopf entfällt, ebenso verschwinden der Hinweis auf den Gründer Vinzenz Chiavacci sowie der Untertitel Illustrierte Wochenschrift von der Titelseite. Das Aufmacherfoto, das nun die gesamte Seite einnimmt, wird deutlich aufgewertet. Auch im Innenteil macht sich die Modernisierung bemerkbar. 
Abb. 1 Im September 1939 wird Das interessante Blatt mit den Wiener Bildern fusioniert und in Wiener Illustrierte umbenannt. Die Grafik wird radikal modernisiert. Wiener Illustrierte 8. November 1939, Titelseite. Foto: Albert Hilscher.

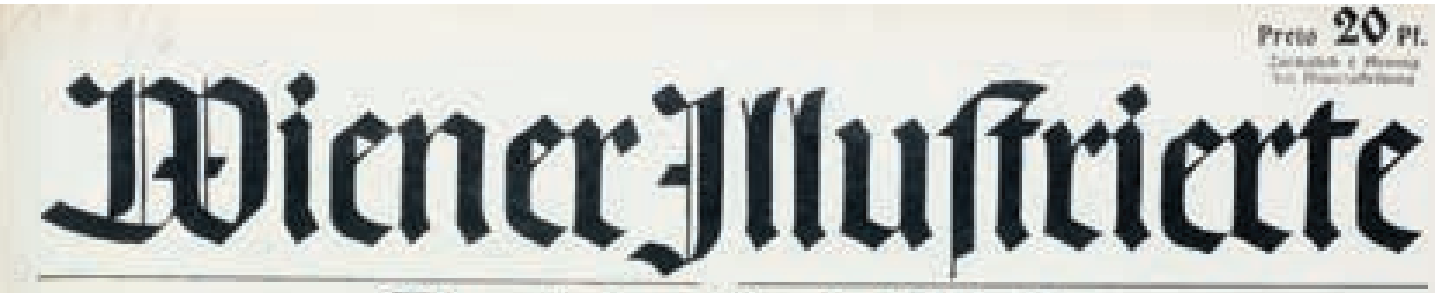

s5. Jithrgang Nr.

Das intereffante Blatt

Wien, A. Novenaber tose

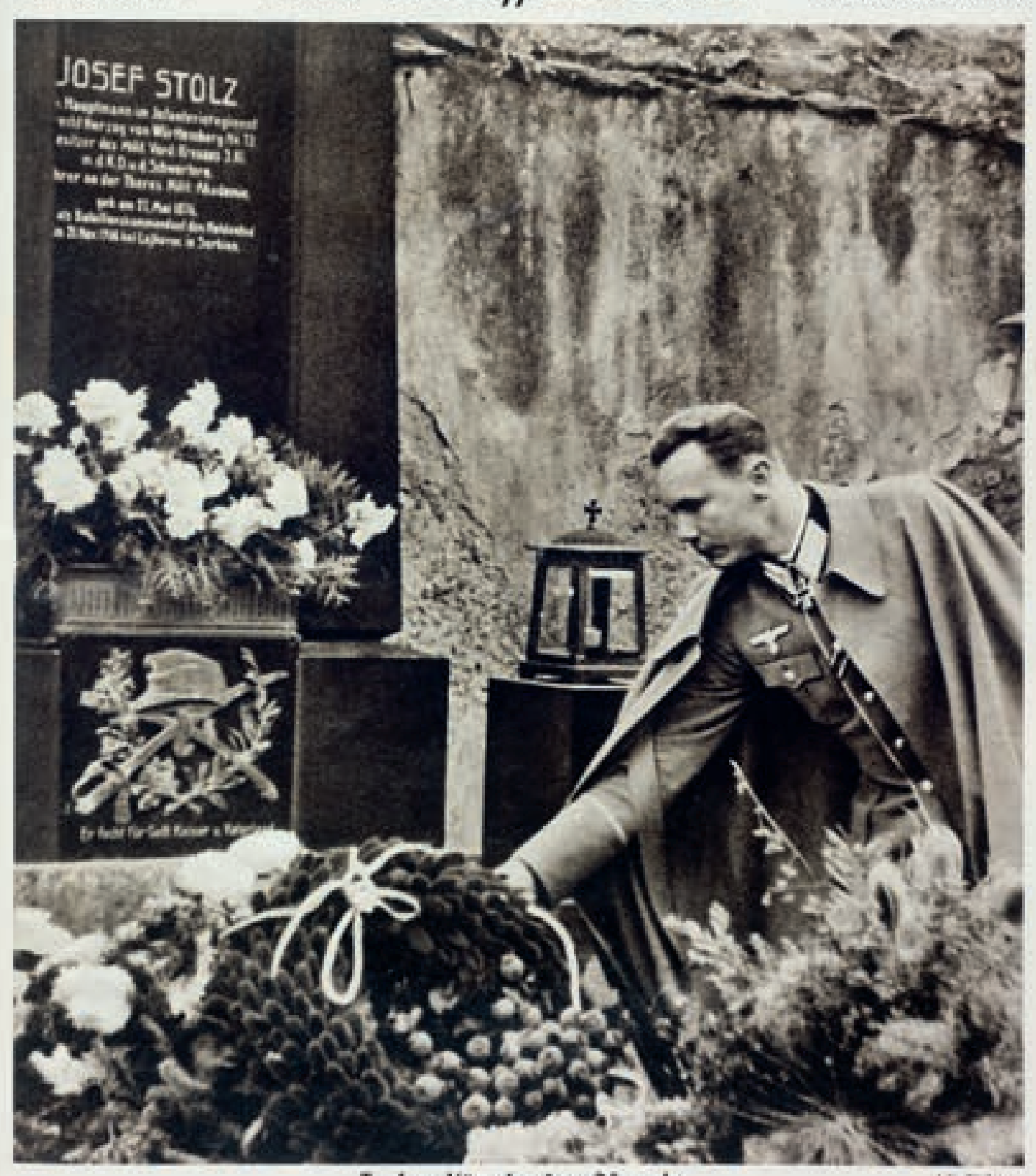

Taplere Kampler oer Oftmarh

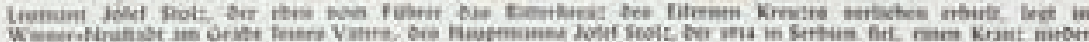


Insgesamt wird die Grafik nun klarer, sachlicher und moderner. Es werden häufiger als bisher größere, professionell gestaltete Fotoreportagen gedruckt, auch im Innenteil und auf der Schlussseite finden nun ganzseitige Bilder Verwendung.

\section{Brüche, Kontinuitäten, Karrieren}

Die massiven Eingriffe in das Erscheinungsbild der Zeitungen gehen mit ihrer inhaltlichen Neuausrichtung Hand in Hand. Erleichtert wird dieser rasante grafische und ideologische Kurswechsel auch dadurch, dass die Redaktionen im März 1938 personell systematisch „gesäubert“ werden und gewissermaßen über Nacht eine neue Führung bekommen. Betriebe, die vor 1938 in jüdischem Besitz waren, erhalten kommissarische Verwalter (zumindest während der ersten Monate des neuen Regimes) und von oben eingesetzte „Hauptschriftleiter“, die das operative Tagesgeschäft führen. Mit diesen Posten werden oft altgediente Nationalsozialisten bedacht, die auf diese Weise an den Raubzügen und Enteignungen beteiligt werden. Zugleich bildet diese neue Führungsebene eine politische Schaltstelle, über die die Unternehmen zentral kontrolliert und gesteuert werden können.

Zum kommissarischen Verwalter des Zeitungskonzerns Rüdengasse, zu dem u. a. Das interessante Blatt und die Wiener Bilder gehören, wird Sepp Payer ernannt. Hauptschriftleiter des Interessanten Blattes und der Wiener Bilder wird Egon Kott, der schon um 1930 in der österreichischen NSDAP politisch aktiv gewesen ist. Anfang der 1930er Jahre wird er vom damaligen Wiener Gauleiter Alfred Frauenfeld zum Hauptschriftleiter aller österreichischen NS-Zeitungen ernannt. ${ }^{5}$ Kott gehört 1938 zu den wichtigsten Medienfunktionären in Wien. Er übernimmt 1938 nicht nur die Leitung der beiden größten Illustrierten des Landes. Daneben leitet er auch die Kulturzeitschrift Die Pause, die er zu einem nationalsozialistischen Propagandablatt umbaut. Auf dem Umschlag der ersten Nummer nach dem „Anschluss“ prangt ein Porträt des „Führers“, aufgenommen von Heinrich Hoffmann im Profil (Abb. 3). ${ }^{6}$ Im Innenteil derselben Nummer wird ein weiteres Mal Hitler im Profil gezeigt. Auf der gegenüberliegenden Seite sind be- geisterte NS-Anhänger im Wiener Konzerthaus zu sehen, die im April 1938 über den „Anschluss“ an das nationalsozialistische Deutschland jubeln (Abb.4). ${ }^{7}$ Der Titel der pathetischen Doppelseite lautet: „Die Erfüllung“.

Ausgestattet mit derart viel Macht, gelingt es Kott, die Wiener illustrierte Presse innerhalb kürzester Zeit verlässlich auf die neue nationalsozialistische Linie einzuschwören. Ohne die tatkräftige Unterstützung zahlreicher Redakteure, die freudig ins national-
Abb. 2 Nach dem „Anschluss“ Österreichs an das nationalsozialistische Deutschland wird 1938 die Propagandaillustrierte Österreichische Woche in Ostmark-Woche umbenannt. Ostmark-Woche, 29. Dezember 1938, Titelseite. Foto: Lothar Rübelt.

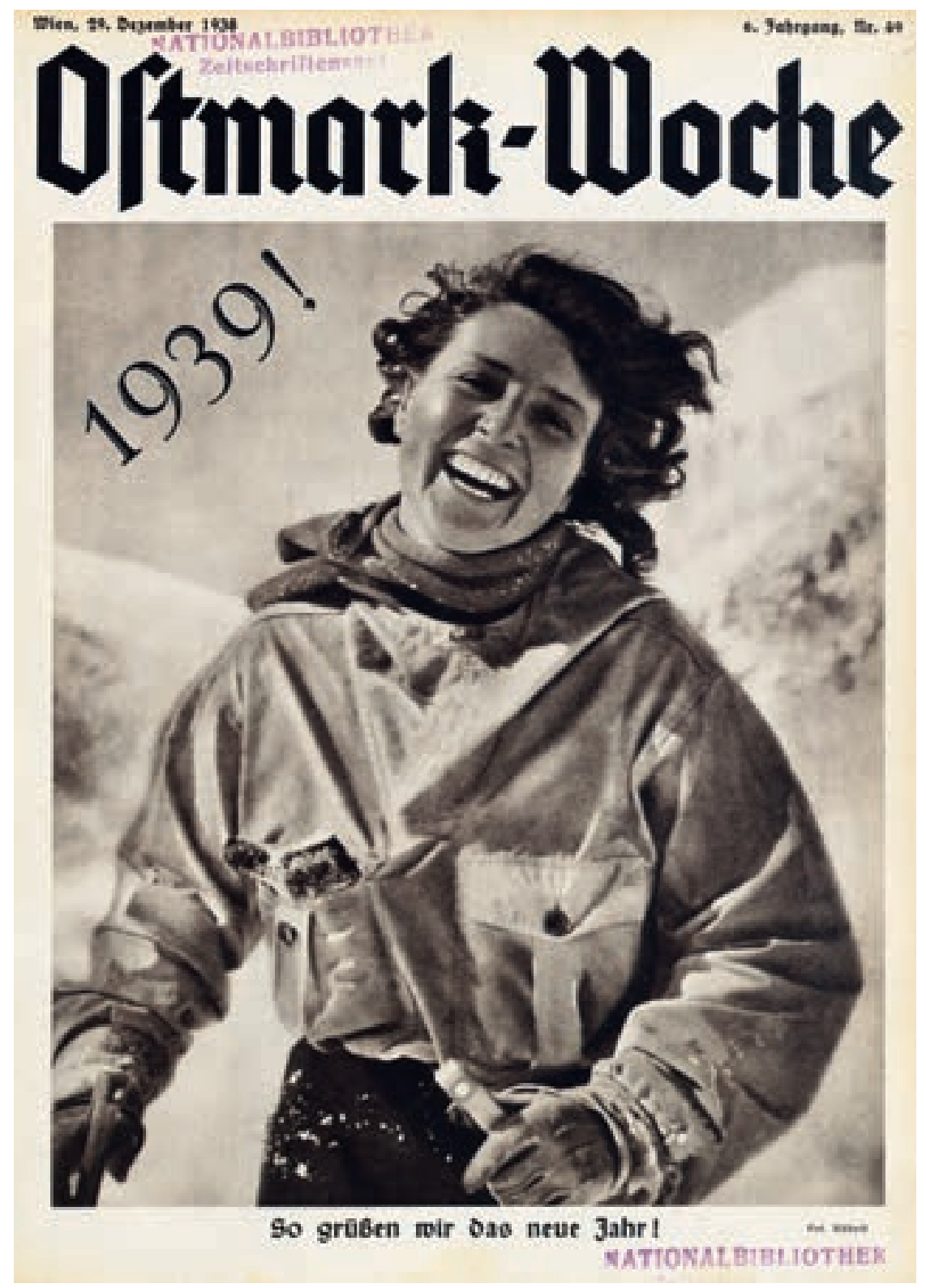




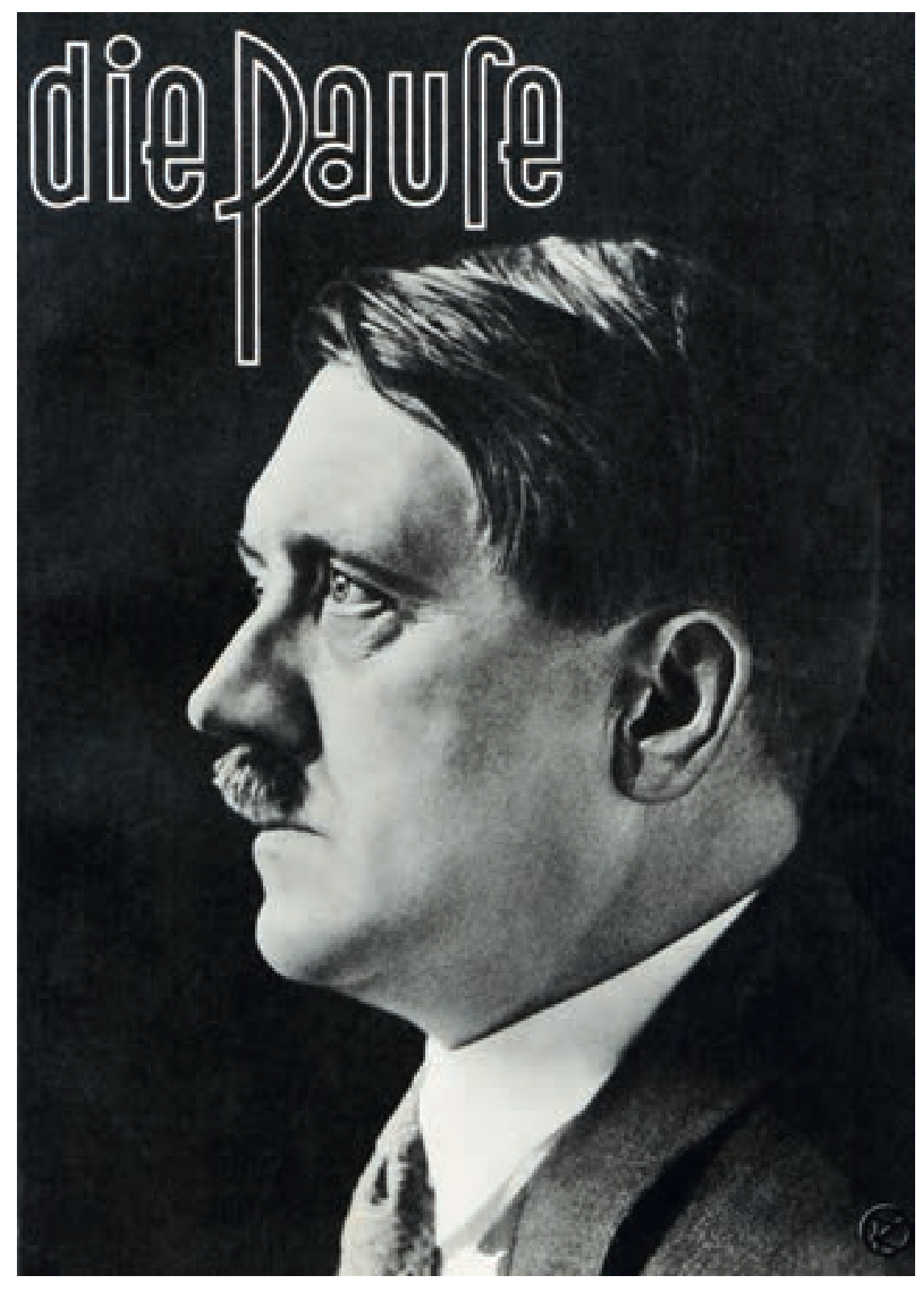

Abb. 3 Nach dem „Anschluss“ im März 1938 schwenkt die Zeitschrift Die Pause, die bislang den „Ständestaat“ unterstützt hatte, voll auf NS-Kurs um und verherrlicht Hitler. Die Pause, Heft 5, 1938, Titelseite. Foto: Heinrich Hoffmann. sozialistische Lager wechseln, und eine Leserschaft, die der neuen Linie willig folgt, wäre dieser ideologische Kurswechsel freilich kaum zu bewerkstelligen gewesen. In vielen Fällen bleiben die bisherigen leitenden Redakteure, die sich mit dem neuen Regime arrangieren, weiter im Amt. Alfred Zohner, bis 1938 Chefredakteur des Interessanten Blattes, wird nicht gänzlich abgesetzt. Er wird (hinter Kott) zum stellvertretenden Hauptschriftleiter ernannt und behält damit eine wichtige Leitungsfunktion in der Zeitung. Bei den Wiener Bildern hingegen wird der Chefredakteur Hans Ewald Heller abgelöst und durch die nationalsozialistische Parteigängerin Herta Söllner ersetzt.

Die nationalsozialistische Pressepolitik im Bereich der Illustrierten versucht 1938 zunächst, so weit wie möglich Kontinuität zu wahren und Normalität zu suggerieren. Zwar gibt es bereits unmittelbar nach dem „Anschluss“ bei vielen Zeitschriften deutlich sichtbare grafische Adaptionen. Aber Titeländerungen, wie etwa im Fall der Österreichischen Woche, die in Ostmark-Woche umbenannt wird ${ }^{8}$, kommen nur selten vor. Einige illustrierte Zeitungen und Zeitschriften werden im März 1938 verboten bzw. ersatzlos aus dem Verkehr gezogen. Das betrifft beispielsweise unabhängige, liberale Zeitungen, etwa die Wochenendbeilage Der Sonntag der Wiener Tageszeitung Der Tag. ${ }^{9}$ Mutter- wie Tochterblatt werden unmittelbar nach dem „Anschluss“ eingestellt. Es betrifft aber auch ehemals regierungsnahe Zeitschriften wie etwa Österreichs Illustrierte Zeitung, die in den 1930er Jahren massiv für eine Abwehr der nationalsozialistischen Bedrohung eingetreten war. Im März 1938 wird die Zeitschrift verboten. ${ }^{10}$ Im September 1938 wird aber auch die Radio-Welt, eine wöchentlich erscheinende Radio- und Gesellschaftszeitschrift, die im Verlag in der Rüdengasse erscheint, eingestellt. In diesem Falle dürfte das Ende wohl mit dem Bemühen zu tun zu haben, in der „Ostmark“ überregionale, reichsdeutsche Programmzeitschriften durchzusetzen.

Massive Änderungen gibt es auch in der Eigentümerstruktur der Verlage. Durch den antijüdischen Raubzug kommt es zur Herausbildung neuer Verlagsstrukturen. Je nach Wichtigkeit und Interessenlage ereilen die ehemals jüdischen Unternehmen ganz unterschiedliche Schicksale. Teilweise werden die Unternehmen zerschlagen und verkauft, teilweise unter kommissarischer Verwaltung weitergeführt oder in neue Verlagsstrukturen überführt. Letzteres geschieht im Fall des Verlags Karl Rob, einem führenden Wiener Herausgeber illustrierter Magazine und Revuen. Die Zeitschriften aus dem Rob-Verlag, insbesondere Wiener Mode, MOCCA und Muskete, hatten sich vor 1938 von der Tagespolitik ferngehalten. Auch während des „Anschlusses“ im März halten sich die Zeitschriften im Hintergrund und berichten nicht über den politischen Umsturz. Wenn man die entsprechenden Nummern liest, könnte man fast den Eindruck gewinnen, es sei gar nichts geschehen. Doch auch mit dieser Strategie des „Durchtauchens“ kann Karl Rob den Verlag nicht retten. Das Unternehmen geht 1938 im Südostdeutschen Verlag auf. Geleitet wird der neue Konzern vom „Hauptschriftleiter“ T. Keppler. 
Die Zeitschriften des ehemaligen Rob-Verlags werden zunächst ohne größere Veränderungen weitergeführt, dann ab Herbst 1938 sukzessive erneuert. Ab November 1939 erhält MOCCA einen modifizierten Titel (Mocca aus Wien). Die Zeitschrift wird vorsichtig modernisiert, sie erhält eine klarere (serifenlose) Schrift, wird zeitweise auf glatterem Papier gedruckt und bietet mehr Platz für Farbfotos. Ab März 1939 erscheint die Muskete in einem verkleinerten Format, auch sie wird erneuert, allerdings wird sie auf billigem Papier gedruckt. Auch das Flaggschiff des Unternehmens, die Zeitschrift Wiener Mode, erfährt nach dem Verlagswechsel eine Neuausrichtung. Ab 1. November 1938 erscheint das Blatt in neuer Aufmachung. Alle drei Magazine setzen auf den ersten Blick ihren „unpolitischen“ Kurs fort, bei genauerem Hinsehen freilich zeigt sich, dass sie immer wieder nationalsozialistische Botschaften transportieren.

Am deutlichsten ist die Verbindung zum Regime im Falle der Wiener Mode. Die Zeitschrift wird ab April 1939 zum offiziellen Organ des „Hauses der Mode“. Dieses Modezentrum, das im Februar 1939 unter großem propagandistischen Aufwand eröffnet worden ist ${ }^{11}$, hat die Aufgabe, die Wiener Modeproduktion und den Modehandel nach den Raubzügen und „Arisierungen“ zu bündeln. Die Einrichtung bietet jenen Modefotografen, die sich bereitwillig ans Regime anpassen, gute Auftrags- und Publikationsmöglichkeiten. Zu ihnen zählen etwa Lucca Chmel und Kitty Hoffmann, die regelmäßig in der Wiener Mode veröffentlichen. Das „Haus der Mode“ genießt prominente staatliche Unterstützung und wird auch während des Krieges weiterbetrieben. Die Wiener Mode ist daher eine der wenigen illustrierten Zeitschriften, die
Abb. 4 „Die Erfüllung“. Nach der Volksabstimmung am 10. April 1938, die nachträglich den „Anschluss“ Österreichs an Deutschland legitimieren sollte, werden in der Pause die Ergebnisse pathetisch gefeiert. Die Pause, Heft 5, 1938, S. 8/9.

Fotos: Heinrich Hoffmann und Presseillustrationen Hoffmann.

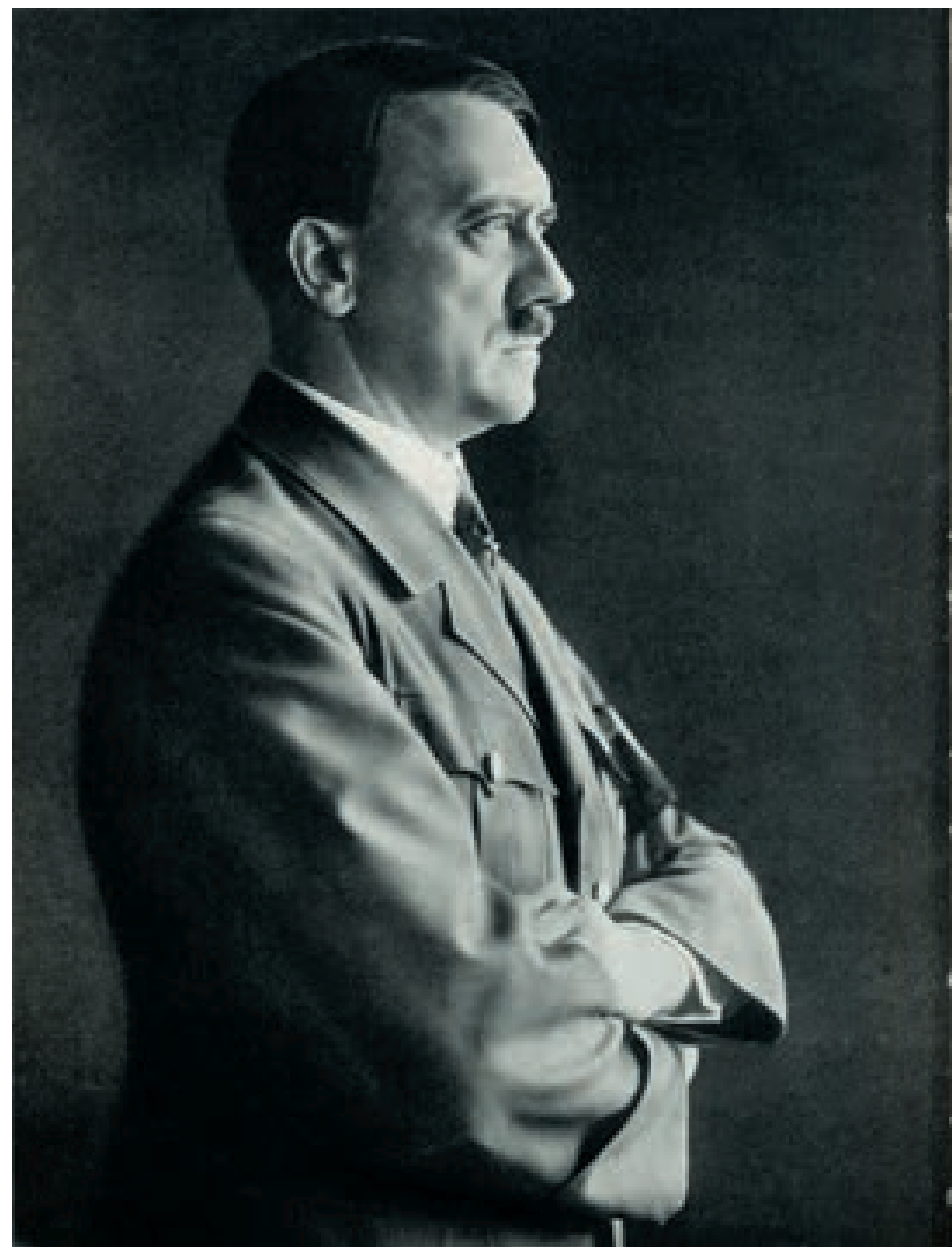

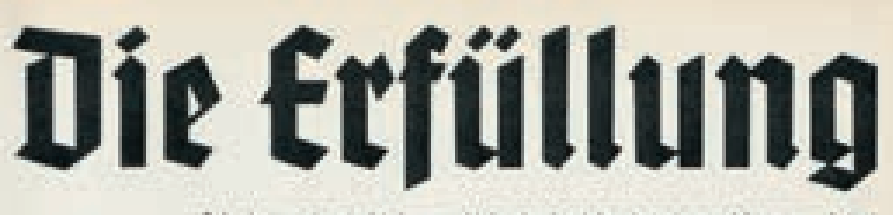

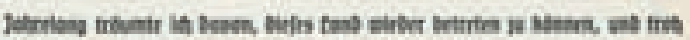

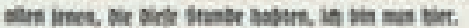

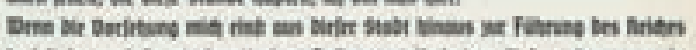

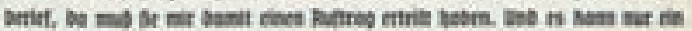

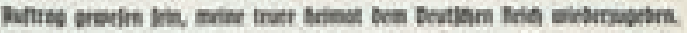

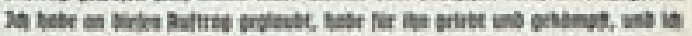

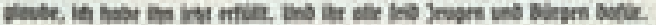
ADCur Hatite

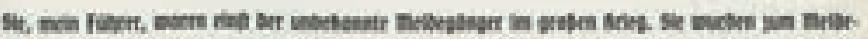

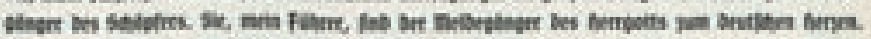

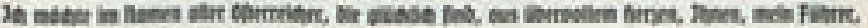

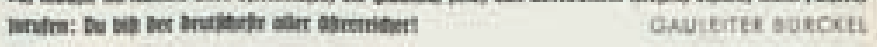

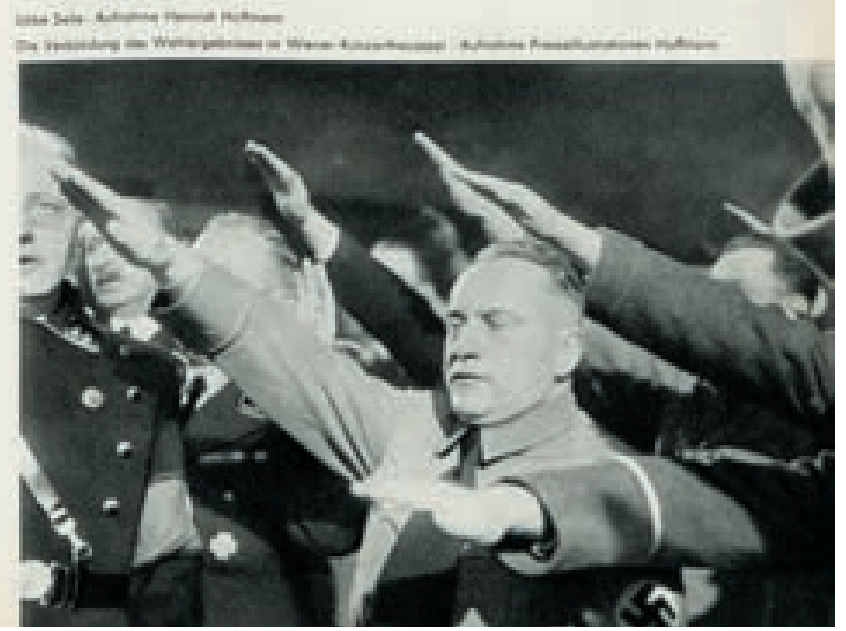


die gesamte Kriegszeit überleben. MOCCA und Muskete hingegen werden 1941 eingestellt.

Eigentümerwechsel, Repression, Säuberungen, inhaltliche und grafische Umgestaltung - all diese Umbrüche schlagen sich auch im beruflichen Werdegang der Fotografen nieder. Während, wie bereits erwähnt, die jüdischen und politisch nicht genehmen Fotografen von der Bildfläche verschwinden, machen treue Parteigänger oder willige Mitläufer schnell Karriere, die sie oft auch nach dem Krieg unbehelligt fortsetzen können. Zu den klassischen Pressefotografen, die bereits vor 1938 tätig waren und sich danach problemlos mit den neuen Machthabern arrangieren, zählen u. a. Lothar Rübelt, Albert Hilscher, Bruno Völkel, Karl Schleich, Stanislaus Wagner, Vinzenz Stöger, Heinz von Perckhammer, Lena Schur, Mario Wiberal, Karl Ellinger und Franz Roth. Letzterer ist seit 1934 in Berlin tätig.

Es gibt aber auch Pressefotografen, die erst nach 1938 größeren Erfolg haben. Franz Blaha etwa arbeitet zwar schon seit Mitte der 1920er Jahre im Fotohandel, aber als Pressefotograf ist er erst seit 1937 tätig. Er ist einer der Profiteure des neuen Regimes. Aber auch Anton Doliwa, Alois Sedlacek, Franz Krieger (der nach 1938 für die Wiener Niederlassung der Fotoagentur Heinrich Hoffmanns tätig ist), Otto Tomann, Wilhelm Sturm, Hertha Schulda-Müller Hans Strof und einige andere sind vor allem nach 1938 in der Öffentlichkeit präsent.

Daneben gibt es eine große Zahl von Amateuren, die sich in der nationalsozialistischen Presse nach 1938 einen festen Platz erobern. Zu ihnen gehören Maximilian Karnitschnigg, Norbert Kraus, Simon Moser, Hanns Ortner, Hans Misar, Rudolf Penitsch, Günther Baszel, Hans Furthner, Willi Jungmeier und Oswald Elbl, der gerne knorrige Älpler, aber auch Landschaften und Genrebilder fotografiert. Michael Neumüller nimmt neusachliche Stillleben ebenso auf wie konventionelle Genreszenen. Elly Rauch ist eine Spezialistin für idyllische Genrebilder. Einige diese Amateure liefern vor allem Fotoreportagen. Ilse Steinhoff und Edith Wellspacher etwa liefern Reiseberichte, Erika Schmauss berichtet (neben ihren Dokumentationen zur Kunstgeschichte) u. a. über das „befreite Sudetenland“, Erika Schmachtenberger (die deutscher Herkunft ist, aber viel in Österreich publiziert) und Monika Rückauf fotografieren u. a. Land und Leute nach dem Balkanfeldzug, der am 6. April 1941 beginnt. Andere, etwa Leopold Fiedler und Herbert Peßl, spezialisieren sich auf die Sportfotografie.

Unter den Atelier-, Werbe- und Architekturfotografen gibt es einige, die nebenbei als freie Mitarbeiter für Zeitungen tätig sind oder Auftragsarbeiten außerhalb des Studios ausführen und die keinerlei Scheu haben, in der nationalsozialistischen Presse zu veröffentlichen. Unter ihnen sind Julius Scherb, Bruno Reiffenstein, Kitty Hoffmann, Maria Wölfl (Abb. 5), Lucca Chmel, Hans Madensky, Franz Swoboda oder Josef Zapletal, der vorzugsweise Autos fotografiert.

\section{Ästhetische Experimente: \\ Das Beispiel Wiener Magazin}

Unter all den Zeitschriften und Magazinen, die nach 1938 im Geist und unter der Kontrolle des Nationalsozialismus weitergeführt werden, bildet das monatlich erscheinende Wiener Magazin eine Ausnahme. Die meisten anderen vergleichbaren Zeitschriften (etwa die Bühne) passen sich viel deutlicher dem nationalsozialistischen Mainstream an. Im April 1941 wird das Wiener Magazin ohne Angabe von Gründen eingestellt. Ausschlaggebend für die Schließung ist aber wohl nicht das moderne Konzept der Zeitschrift. Vielmehr ist sie, so wie andere Publikationen auch, von mehreren Entwicklungen betroffen, die die illustrierte Presse nach 1938 erfassen: der Konkurrenz reichsdeutscher Zeitschriften, dem 1939 einsetzenden Krieg, der einen zunehmenden Personal- und Materialmangel (z. B. Papier) mit sich bringt. ${ }^{12}$

Die experimentelle Linie der Zeitschrift ist mit einem konkreten Namen verbunden: Hans Misar. Misar, geb. 1913, ist ein typischer Profiteur des nationalsozialistischen Raubzugs in Wien. Der nationalsozialistische Multifunktionär, Verlagsunternehmer und Journalist ist eng mit den führenden Parteifunktionären vor Ort vernetzt. Kaum ist der „Anschluss“ im März 1938 vollzogen, tritt er auf den Plan. Misar wird in den folgenden Jahren im „gleichgeschalteten“ Wiener Mediengeschäft eine wichtige Rolle spielen. Er übernimmt noch im Frühjahr 1938 


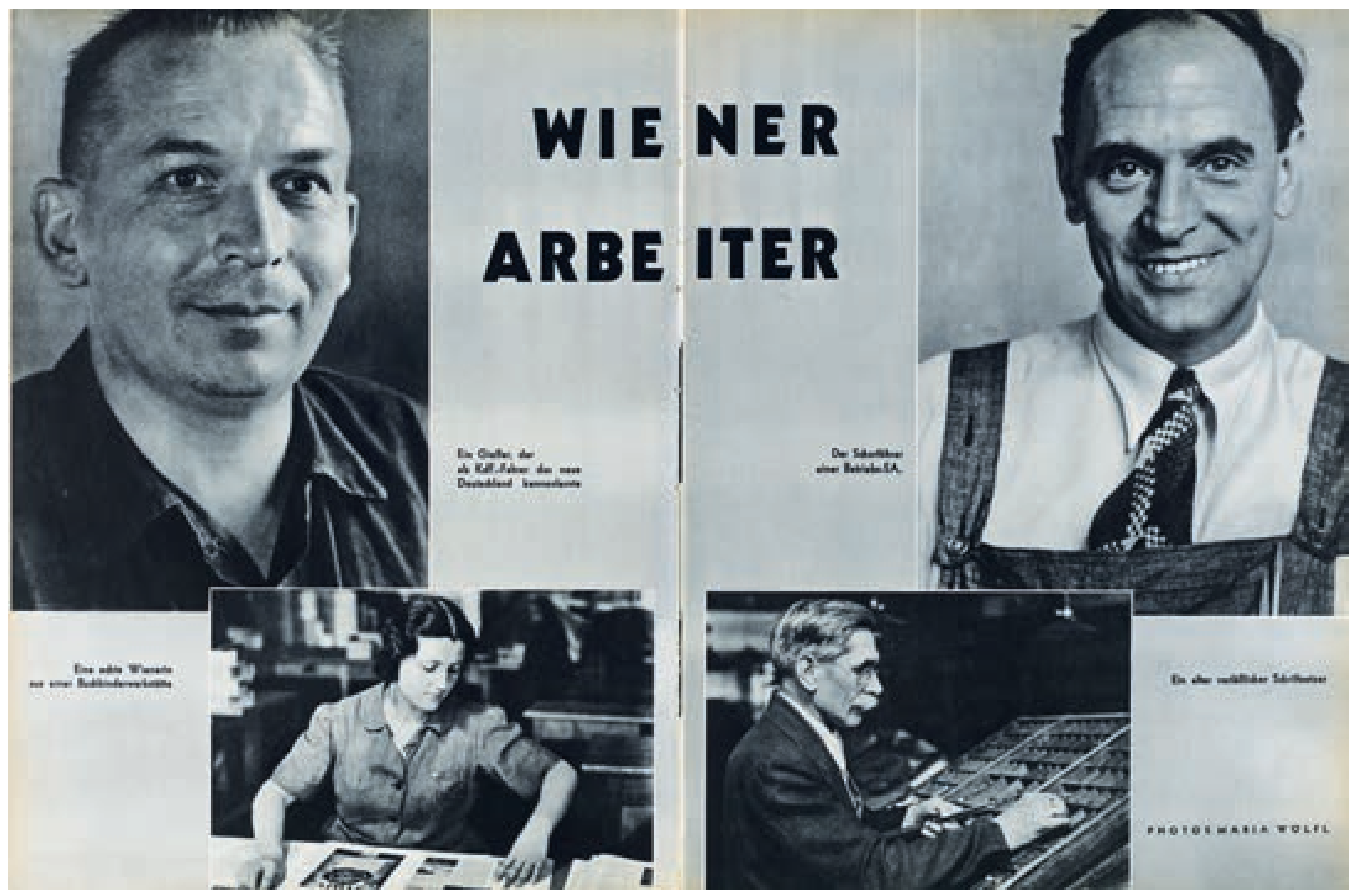

die Schriftleitung des Wiener Magazins, das mittlerweile im - inzwischen ebenfalls nationalsozialistischen - Bergland-Verlag erscheint. ${ }^{13} 1941$ wird er, zusammen mit anderen Teilhabern, Miteigentümer des „arisierten“ Verlagshauses Vernay. ${ }^{14}$ Gleichzeitig baut er einen Verlag auf, der sich auf kunsthistorische Literatur spezialisiert. ${ }^{15}$ Die Bücher, die mitten im Krieg erscheinen, tragen Titel wie Freskobildnisse der Frührenaissance oder Michelangelo: Weltgericht.

Misar ist aber nicht nur erfolgreicher Medienunternehmer, sondern auch Fotograf. Er ist kein gewöhnlicher Hobbylichtbildner, sondern ein überaus vielseitiger Mann. Er gestaltet Fotoreportagen und schreibt dazu gelegentlich auch die Texte. Daneben ist er auch als künstlerischer Fotograf tätig, durchaus mit gehobenen ästhetischen Ansprüchen. Diese Seite Misars ist bemerkenswert, da sie eine Facette der nationalsozialistischen Medien- und Pressepolitik zeigt, die oft nur en passant behandelt wird. Immer noch wird die Zeit der nationalsozialistischen Herrschaft gerne mit einer ausschließlich archaischen, rückwärtsgewandten Ästhetik in Zusammenhang gebracht. Tatsache aber ist, dass der Nationalsozialismus im Bereich der Presse und insbesondere in der illustrierten Presse einen enormen Modernisierungsschub mit sich bringt. Misar ist einer der Protagonisten dieser Entwicklung in Österreich. Er ist aber auch ein Beispiel dafür, dass sich moderne Fotografie und Nationalsozialismus keineswegs ausschließen. Die Fotografie im Nationalsozialismus erschöpft sich nicht im Ablichten von Bauerngesichtern, strammen Volksgenossen, kräftigen Arbeitern und deutschen Müttern. Daneben gibt es auch, wiewohl diese Position deutlich in der Minderheit bleibt, einen bislang wenig beachteten Strang moderner Fotografie. ${ }^{16}$

Hans Misar ist nicht der einzige Fotograf, der nach 1938 eine Synthese zwischen Nationalsozialismus und Moderne anstrebt. Auch Rudolf Penitsch, der ebenfalls im Wiener Magazin veröffentlicht, Günther von Baszel und teilweise Franz Milik (beide in der Bühne) verfolgen nach 1938 weiterhin eine moderne kunstfotografische Richtung. Sie versuchen sich an experimentellen Stillleben, Oberflächenstudien und Kompositionen.

Zunächst aber tritt Misar als Fotoreporter hervor. Bereits wenige Tage nach dem „Anschluss“ gestaltet er in den bereits auf NS-Linie gebrachten Wiener Bildern eine Doppelseite über „Deutschlands Luftwaf-
Abb. 5 Porträts von Wiener Arbeitern. Die Bühne, Zweites Dezemberheft 1938, Wien, o.S. Fotos: Maria Wölfl. 
Abb. 6 „Die neue Zeit“. Beispiel für moderne Fotografie und Gestaltung im Nationalsozialismus. Wiener Magazin, Heft 5, Mai 1939, S. 60 und 61. Fotos: Hans Misar.

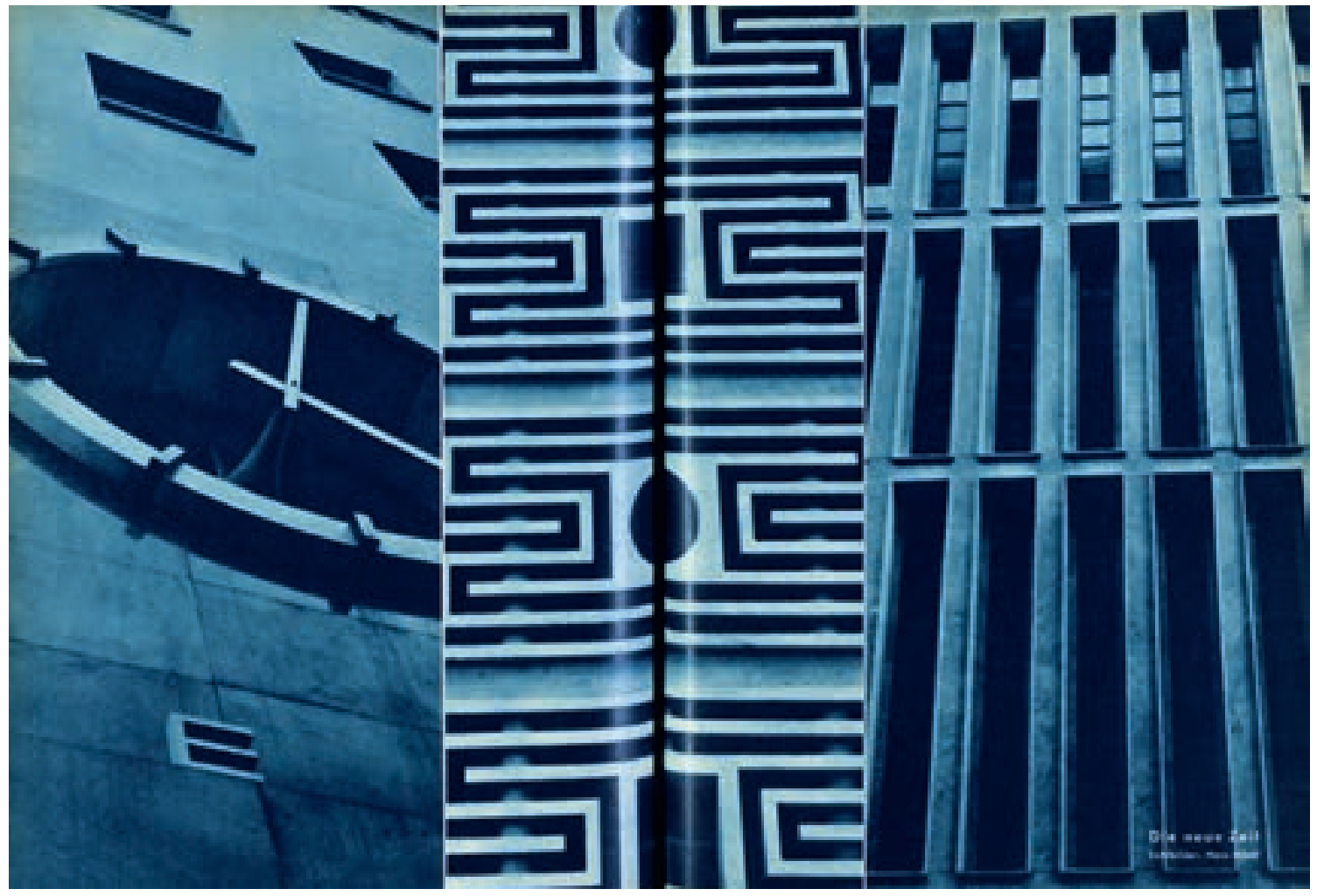

fe“. ${ }^{17}$ Auch der Text stammt von ihm. Misar liefert in den folgenden Jahren immer wieder Reportagen, die meisten davon erscheinen im Wiener Magazin. Des Öfteren beschäftigt sich der Italienliebhaber mit Themen des südlichen Nachbarn und dessen Kolonien. Er berichtet etwa über das alte und neue Rom ${ }^{18}$ sowie mehrmals über die italienischen Kolonien in Ostafrika. ${ }^{19}$ Besonders fasziniert zeigt er sich von der antiken, aber auch der modernen italienischen Architektur, die unter dem Faschismus zu einer Symbiose zwischen Monumentalität und Funktionalismus gelangt. Er fotografiert altrömische Säulen und Architekturfragmente ebenso wie die Fassaden der faschistischen Monumentalarchitektur.

\section{Nationalsozialistische Moderne}

Im Mai 1939 kondensiert Misar sein Credo der Moderne auf einer Doppelseite des Wiener Magazins (Abb. 6). ${ }^{20} \mathrm{Zu}$ sehen sind auf der blau eingefärbten Magazinseite drei hochformatige Bildstreifen, die horizontal aneinandergereiht sind. Es sind Fassaden- ansichten moderner Gebäude, aufgenommen vermutlich während einer seiner Romreisen. Ihre suggestive Wirkung erhält die Komposition dadurch, dass die Gegenständlichkeit des realen Gebäudes zurücktritt. Während sich in den beiden äußeren Aufnahmen die Gebäudefassaden noch mühelos erkennen lassen, verweist das mittlere Bild nicht mehr auf ein wirkliches Haus, sondern ist nur noch Ornament. Durch die engen, ungewohnten Bildausschnitte und die geradezu rhythmische Anordnung tendiert der Gesamteindruck ins Abstrakte. Verstärkt wird dieser Eindruck dadurch, dass die Grundfarbe des Kupfertiefdrucks in einem Blauton gehalten ist.

Ein Bild wie dieses hat wenig mit der allgemein bekannten nationalsozialistischen Ästhetik gemein. Dennoch sind solche Bildkompositionen im Wiener Magazin ab 1938, als Misar die Leitung der Zeitschrift übernimmt, nicht selten. Dass die Komposition kein bloßes Spiel mit der Abstraktion ist, sondern ganz bewusst in einen politisch-gesellschaftlichen Zusammenhang gestellt wird, beweist der kurze Text am rechten unteren Rand der Abbildung. Er lautet: „Die 
neue Zeit". Gemeint ist damit der politische Umbruch, der Schub der Modernisierung, den Faschismus und Nationalsozialismus in den letzten Jahren herbeigeführt haben. Im Fotonachweis am unteren Rand der Seite ist nun von „Lichtbildern“ die Rede, nicht mehr von „Photos“, wie das bisher üblich gewesen war. In der nationalsozialistischen Diktion wird eine ganze Reihe von Ausdrücken, die als „fremd“ eingestuft werden, eliminiert.

In „gehobenen“ Kulturzeitschriften wie dem Wiener Magazin (aber auch der Bühne oder der Pause) wird ein breiteres Spektrum fotografischer Bildkultur vorgeführt als etwa in der illustrierten Wochenpresse, die sich hauptsächlich auf die herkömmliche Pressefotografie stützt. Es reicht von klassischen Nachrichtenbildern über konventionelle Amateuraufnahmen bis hin zu gestalterischen Experimenten wie dem vorliegenden. Immer wieder wird auf die „neue Zeit“ Bezug genommen. Das nationalsozialistische „Lebensgefühl“ wird im Wiener Magazin nicht so sehr in Form von aktuellen politischen Propagandaaufnahmen eingefangen. Vielmehr wird die „neue Zeit“ mit einer Ästhetik des „befreiten“ Körpers in Zusammenhang gebracht. Eine zentrale Rolle spielt dabei das Ideal der klassischen Schönheit, das in allen Lebensbereichen aufgespürt und gefeiert wird: im Frauenbild, im Bild der Jugend, des Sports, aber auch in der Natur, wie ein Beispiel aus dem Wiener Magazin zeigt. Auf einer Doppelseite wird die „Königin“ der Blumenwelt, die Rose, in Großaufnahme - einmal von oben, dann von der Seite fotografiert - ins Zentrum der Aufmerksamkeit gerückt (Abb. 7). Die beiden Aufnahmen stammen von Arthur Benda, der nach 1927 das Wiener Atelier von Madame d'Ora weiterführt. Da er jüdischer Herkunft ist, muss er sein Atelier Ende April 1938 schließen. ${ }^{21}$ Dennoch werden offenbar auch noch danach vereinzelte Bilder aus seinem Archiv in der Presse veröffentlicht. ${ }^{22}$ Die Fotos selbst sind eher konventionell. Erst in der grafischen Gestaltung (enge Beschneidung des Bildes, abfallender Rand, nahtlose Gegenüberstellung am Mittelfalz, unterschiedliche Einfärbung der Doppelseite, kein Kommentar auf der Bildseite) wird die Blume zur symbolträchtigen Protagonistin.

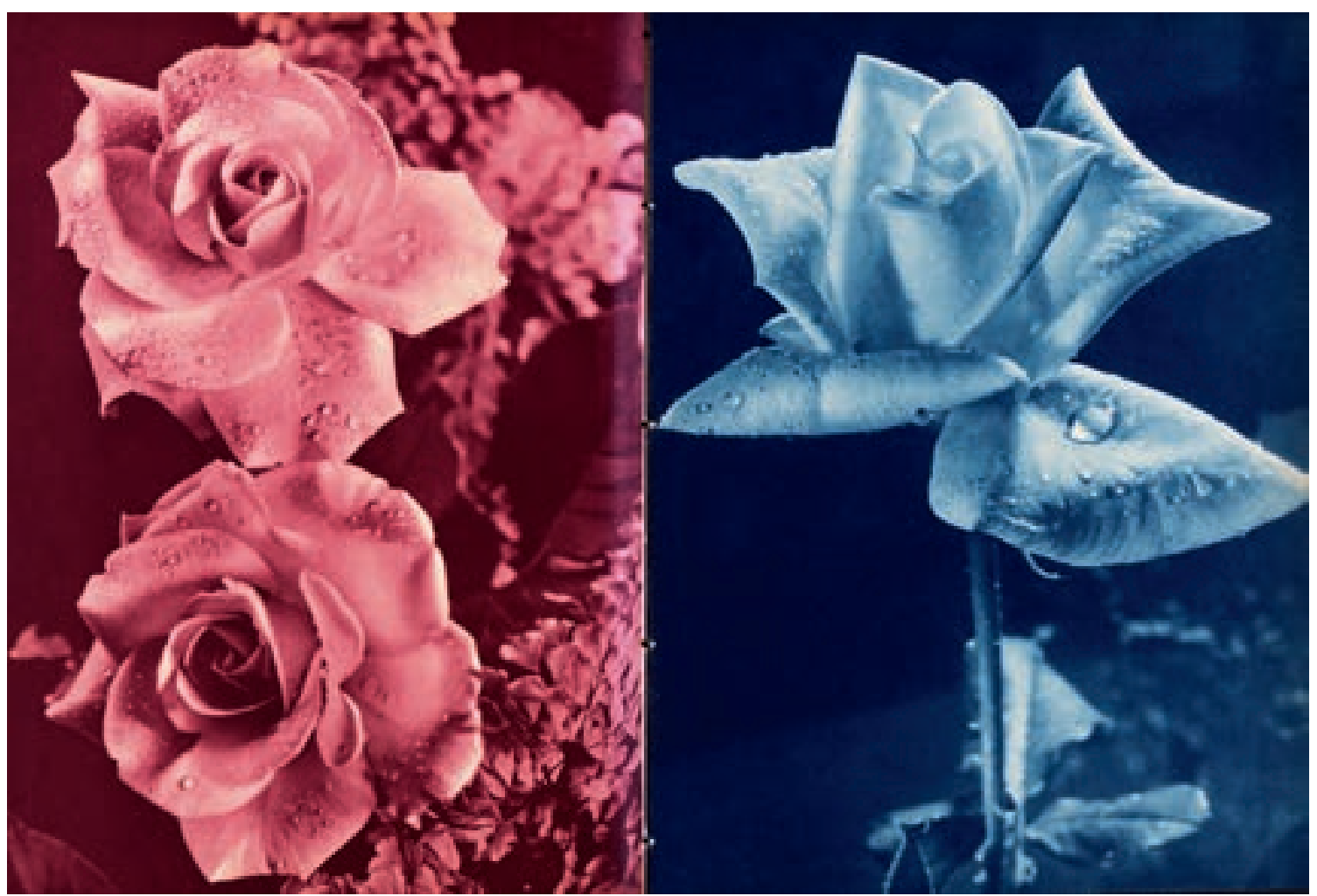

Abb. 7 Rosen. Wiener Magazin, Heft 11, November 1939, S. 26 und 27. Fotos: Arthur Benda. 


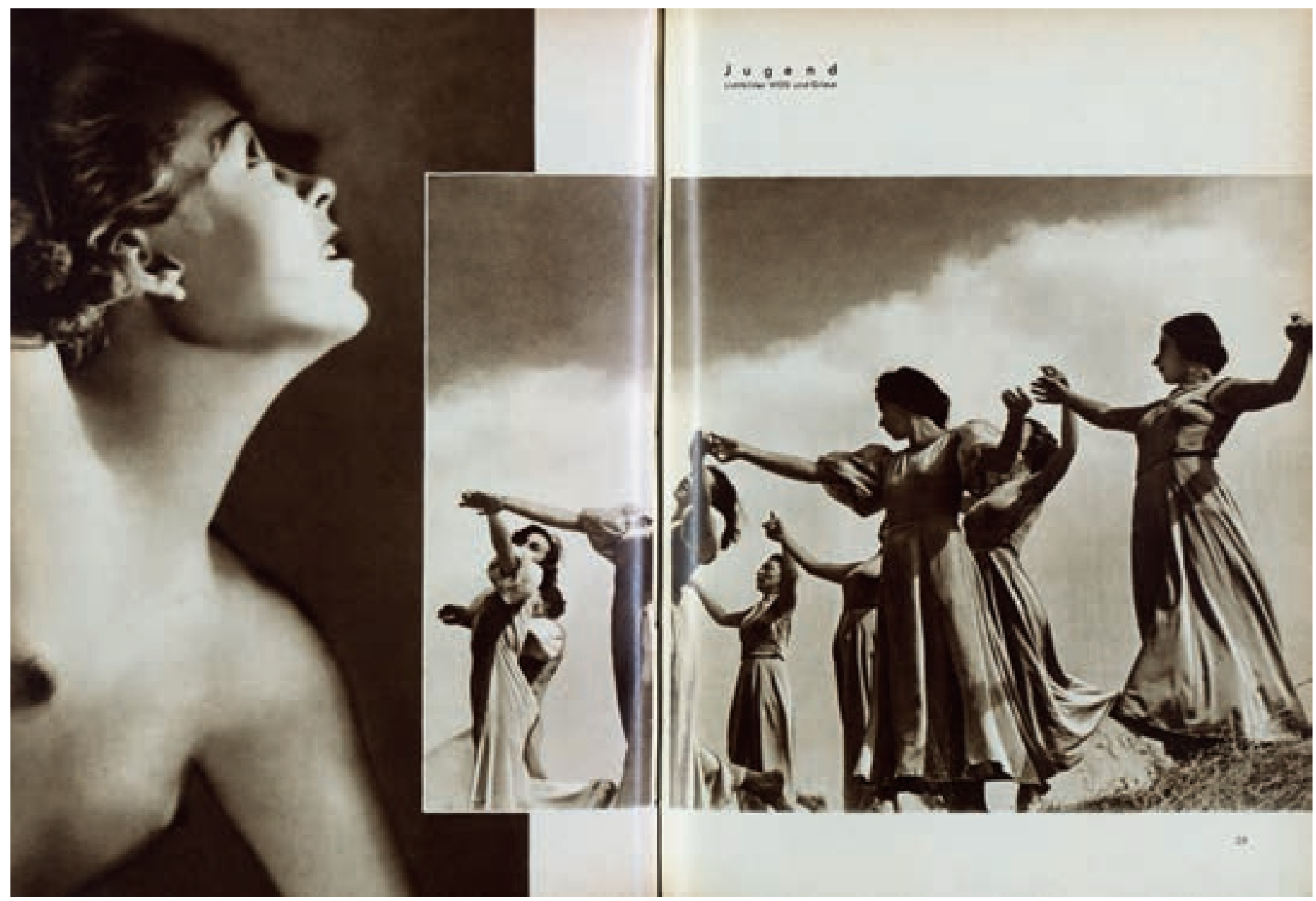

Abb. 8 „Jugend“. Wiener Magazin, Heft 18, August 1938, S. 58 und 59. Fotos: WOG (Olga und Adorján Wlassics), Grimm.

\section{Apotheose der Jugend}

Besonderes Augenmerk gilt im Wiener Magazin der Darstellung des jugendlichen Körpers. RegelmäBig wird etwa die klassische Schönheit der Jugend (und der Frau) in freier Natur inszeniert (Abb. 8). Dabei fällt auf, dass sich nach 1938 die Prüderie und Zensur, die im „Ständestaat“ den nackten Körper aus der Öffentlichkeit verbannt hatten, nach und nach wieder auflösen. Die Schönheit zeigt sich aber auch im sportlichen Körper. Die nationalsozialistische Botschaft vermitteln dabei weniger die Aufnahmen an sich. Das links angeschnittene Aktfoto aus dem Atelier WOG, das Olga und Adorján Wlassics, die ehemaligen Inhaber des Wiener Studios Manassé, seit 1936 in Berlin betreiben, ist eine klassische Atelieraufnahme. Solche Bilder wurden in ihrem Wiener Atelier in der Zwischenkriegszeit häufig hergestellt. Die erotische Fotografie aus dem Hause Manassé beherrschte in den 1920er und 1930er Jahren den österreichischen Pressemarkt. Im Kontext der jungen Mädchen mit den wallenden Gewändern (rechtes Bild, Fotograf: Grimm) erhält das Bild nun allerdings eine neue Bedeutung. Das Erotische tritt in den Hintergrund, stattdessen wird die Szene zum Symbol für den „befreiten“ Körper, zum Sinnbild der nationalsozialistischen „Jugend“, die auf der Doppelseite beschworen wird.

Im Sportbereich kommt die Verherrlichung der Jugend besonders deutlich zum Ausdruck. Das Wiener Magazin publiziert zwar keine aktuellen Sportberichte, wohl aber taucht der Sport immer wieder als Thema auf. Anfang 1941 bringt die Zeitschrift eine eindrucksvolle Doppelseite, die unter dem Titel „Fliegende Menschen“ steht (Abb.9). ${ }^{23}$ Die Kunstspringerinnen und der Kunstspringer, die Lothar Rübelt bereits früher aufgenommen hat ${ }^{24}$, schweben scheinbar schwerelos durch die Luft. Dieser spektakuläre Effekt ist vor allem das Ergebnis der Arbeit in der Bildredaktion. Die Bilder sind eng beschnitten, gedreht und grafisch so angeordnet, dass die Körper freigestellt sind. Jeglicher Hinweis auf den Horizont, das Wasser, das Publikum oder das Sprungbrett fehlt. Der Raum, durch den sich die Körper bewegen, erhält durch die rötliche Einfärbung des Kupfertiefdrucks und den abfallenden Druck etwas Irreales. 


\section{Zeitungssterben 1939}

Im September 1939 verschwinden mehr illustrierte Zeitschriften vom Markt als im März 1938. Das prominenteste Opfer sind, wie erwähnt, die Wiener Bilder, die in der Wiener Illustrierten aufgehen, de facto aber eingestellt werden. Aber auch die traditionsreiche, 1918 gegründete kleine Kultur- und Gesellschaftszeitschrift Moderne Welt stellt ihr Erscheinen Ende 1939 ein. ${ }^{25}$ Ebenso die Zeitschrift Mein Film, die zuletzt Mein Film in Wien heißt. Anfang April 1938 hatte in dieser Zeitschrift Luis Trenker in einem Telegramm aus dem Schweizerischen Pontresina noch stürmisch das neue Regime begrüßt und sich für ein
„Ja“ bei der bevorstehenden Volksabstimmung über den „Anschluss“ an Deutschland ausgesprochen (Abb. 10). Aber diese Linientreue kann das Überleben des Magazins nur kurzfristig sichern. Am 8. September 1939, eine Woche nach Beginn des Krieges, erscheint das letzte Heft. ${ }^{26}$ Nur zwei Kulturzeitschriften, beide gänzlich auf NS-Kurs, können sich bis weit in die Kriegszeit hinein halten. Die Bühne wird 1943 eingestellt, die Pause, die 1938 zum Kampfblatt des Regimes wird, erscheint immerhin bis Ende September 1944. ${ }^{27}$ Dies dürfte wohl das „Verdienst“ des umtriebigen und in NS-Kreisen gut vernetzten Medienmanagers Egon Kott sein, der seit 1938 Schriftleiter der Pause ist. Mit Kriegsbeginn kommt
Abb. 9 „Fliegende Menschen“. Wiener Magazin, Heft 1, 1941, S. 6 und 7. Fotos: Lothar Rübelt.

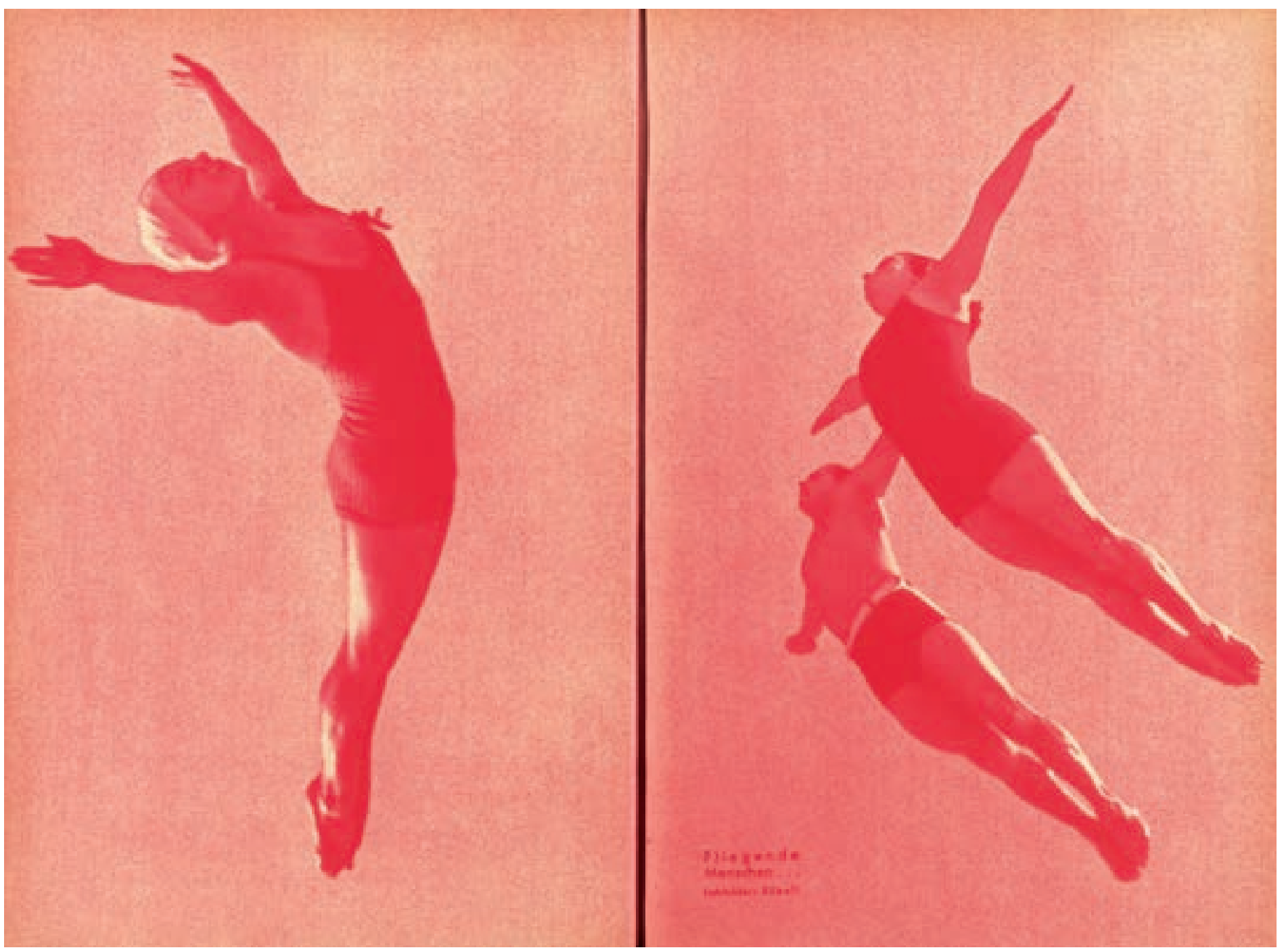




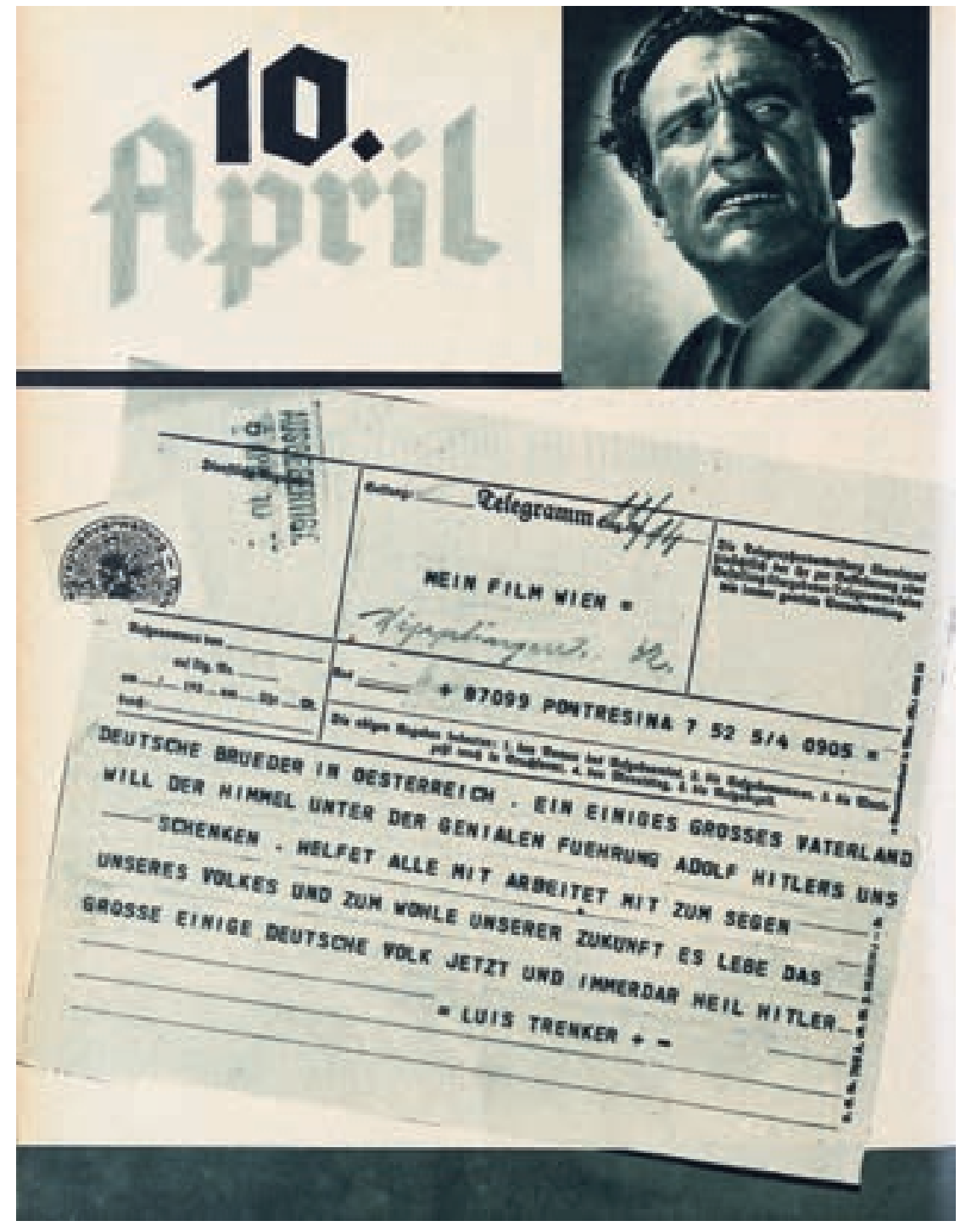

Abb. 10 „Ein einiges großes Vaterland unter der genialen Führung Adolf Hitlers“. Luis Trenker unterstützt Tage vor der Volksabstimmung über den Anschluss an das nationalsozialistische Deutschland (10. April 1938) die Propaganda für ein „Ja“. Mein Film, Heft 8, April 1938, S. 4. es also erneut zu einer grundlegenden Reform des illustrierten Pressemarktes. Anders als 1938 entscheidet aber weniger die ideologische Ausrichtung über Verbot oder Weiterbestand eines Blattes - alle verbliebenen Illustrierten sind inzwischen längst auf NS-Linie. Im Herbst 1939 geht es vielmehr um eine Neuausrichtung der Presse entsprechend den Erfordernissen des Krieges. Der Polenfeldzug dient als Anlass, um die illustrierte Presse auf die propagandistische Begleitung des Krieges einzuschwören. Im Bereich der illustrierten Wochenpresse, die über die aktuelle Politik berichtet, kommt es zu einer Bündelung der Kräfte. Aus Wien liefert ab jetzt nur noch eine einzige Illustrierte, nämlich die neu gestaltete Wiener Illustrierte, aktuelle Bildberichte. Diese wird zum exklusiven Sprachrohr des Regimes. Das Blatt erhält privilegierten Zugang zum Bildmaterial der Propagandakompanien (PK). ${ }^{28}$ In der Folge wird die Berichterstattung der Illustrierten stark militarisiert. Der Krieg wird ab jetzt zum Hauptthema, das in zahlreichen Bildberichten präsentiert wird.

Wenn wir die Hefte der Wiener Illustrierten ab September 1939 Revue passieren lassen, zeigt sich eine seltsame Dichotomie zwischen martialischer Kriegsberichterstattung und friedlichem Genrebild, das während des Krieges zu einem festen Bestandteil der nationalsozialistischen Bildpolitik werden sollte. Während etwa auf der Titelseite und im Innenteil häufig über die siegreichen Kämpfe in Polen, Frankreich und später in der Sowjetunion berichtet wird, wird auf der Schlussseite oft die Schönheit des Lebens gefeiert. Ein Beispiel: Am 13. September 1939 ist die Titelseite der Wiener Illustrierten den Verwundeten der Ostfront gewidmet, während für die letzte Seite Lucca Chmel eine schöne junge Frau ganzseitig in Szene setzt. ${ }^{29}$

\section{Antisemitismus}

Im März 1938 ist die Gewalt gegenüber jüdischen Bürgern in Wien allgegenwärtig. In vielen Erinnerungsberichten sind die erschreckenden Details dieses ebenso brutalen wie demütigenden Vorgehens festgehalten. Entsprechende Fotografien sucht man in der auflagenstarken illustrierten Presse allerdings vergeblich. Das ist gewiss kein Zufall. In der Öffentlichkeit soll das Bild eines legalen und gewaltlosen Übergangs zum neuen Regime vermittelt werden. Hinweise auf entfesselte Gewalt und „wilde Arisierungen“ will man um jeden Preis vermeiden. Nur indirekt wird der Raub jüdischen Besitzes in Bildern thematisiert. Als beispielsweise das Kleiderhaus Thomas Krabath mit Hauptsitz am Sparkassenplatz 6 eine neue Zweigstelle in der Mariahilfer Straße 47 eröffnet, wird dies Ende März 1939 in einer ganzseitigen Anzeige in der Wiener Illustrierten mitgeteilt (Abb. 11). Die Annonce besteht aus mehreren Bildern des bekannten Wiener Architekturfotografen Bruno 
Reiffenstein. Sie zeigen Außen- und Innenansichten der beiden Häuser. Das Haupthaus ist an der Stirnseite mit der NS-Fahne beflaggt, ein Zeichen dafür, dass der Inhaber ein strammer Gefolgsmann des neuen Regimes ist. Dass das Kleiderhaus bis vor Kurzem einem jüdischen Besitzer gehörte, wird nur durch einen winzigen, in Klammern gesetzten Zusatz in der Überschrift deutlich. Sie lautet: „Kleiderhaus Thomas Krabath (vorm. Kleiderhahn)“. Das „Kleiderhahn“ war bis 1938 ein bekanntes Wiener Textilhaus, am 21.Juni 1938 wird es vom neuen Besitzer Thomas Krabath, einem Nationalsozialisten, übernommen. ${ }^{30}$

Zwar finden die Raubzüge der Nationalsozialisten in den ersten Monaten nach dem „Anschluss“ keinen Niederschlag in Zeitungsbildern, der Antisemitismus wird aber schon sehr früh in aller Öffentlichkeit geschürt. Vom 2. August bis 23. Oktober 1938 ist in der Wiener Nordwestbahnhalle, an jenem Ort, wo Hitler am 9. April 1938 seine letzte Rede vor der Volksabstimmung gehalten hat, die Ausstellung „Der ewige Jude“ zu sehen (Abb. 12). Die importierte Schau, die seit 1937 durch zahlreiche deutsche Städten tourt, wird in Wien um eine eigene österreichische Abteilung ergänzt. 350000 Besucher werden die Ausstellung im Sommer 1938 sehen.

Wenige Monate später, Mitte Januar 1939, beginnen die Wiener Bilder unter dem Titel „Auf den Spuren Ahasvers“ eine mehrteilige Serie, die in den kommenden Wochen fortgesetzt wird. ${ }^{31}$ Es ist die erste große antisemitische Hetzkampagne in der Wiener illustrierten Presse. In der ersten Folge der Serie ist ein Foto Sigmund Freuds zu sehen, das Hans Casparius 1933 in dessen Sommerwohnung auf der Hohen Warte aufgenommen hatte und das Mitte der 1930er Jahre noch in einem ganz anderen Kontext veröffentlicht wurde (Abb. 13). ${ }^{32}$ Es zeigt Freud auf dem Balkon des Hauses, zu seinen Füßen haben seine beiden Chow-Chows Platz genommen. Nun, 1939, ist das Freud-Bild Teil einer antisemitischen Tirade. Im Bildtext wird der Psychoanalytiker, der inzwischen nach London geflüchtet ist, diffamiert: „Der ,Wissenschaftler' Siegmund (sic!) Freud erfand die Psychoanalyse, nach der der Sexualtrieb der Motor für die gesamte menschliche Lebensentfaltung sein sollte. Diese Pseudo-Wissenschaft wurde damals von der

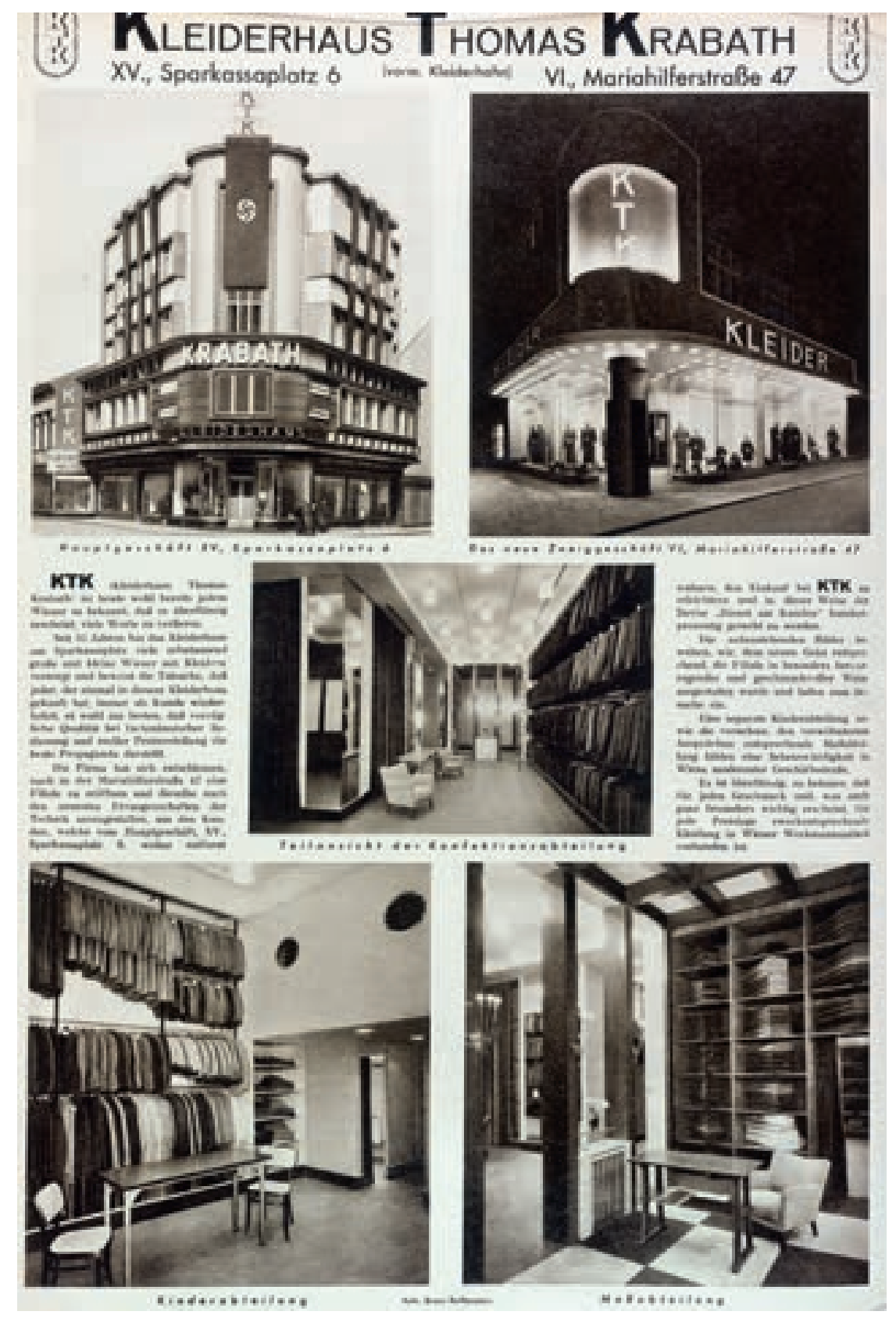

gesamten Judenpresse als wissenschaftliche Großtat aufgezogen.“33

Der die Serie einleitende Text lautet: „Wir beginnen in dieser Nummer mit dem Abdruck einer Reihe aktueller Tatsachenberichte über das wahre Gesicht des Judentums. Der Jude ist und bleibt in jeder Lage und jeder Maskierung ganz ausschließlich Jude. Dies hat sich vornehmlich in der Ostmark und speziell in Wien erwiesen, wo er, von den maßgebenden Regierungsstellen wohlwollend gefördert, Gelegenheit hatte, in die Gebiete des öffentlichen Lebens einzudringen und die Vorherrschaft im kulturellen Leben an sich zu reißen. Wohl kaum auf einem Gebiete hat sich die unheilvolle Tätigkeit des Judentums so verheerend ausgewirkt wie auf diesem. Von den Macht-
Abb. 11 Nach der „Arisierung“: Das jüdische Textilhaus „Kleiderhahn“ geht im Juni 1938 in den Besitz des strammen Nationalsozialisten Thomas Krabath über, der das Geschäft mit einer NS-Fahne beflaggt. Wiener Illustrierte, 30. März 1939, S. 12. Fotos: Bruno Reiffenstein. 
Abb. 12 Antisemitische Propaganda. Zwischen dem 2. August und dem 23. Oktober 1938 wird in Wien die Ausstellung „Der ewige Jude“ gezeigt. Das interessante Blatt, 14. August 1938, S. 6. Fotos: Kester, Lichtbild-Archiv.

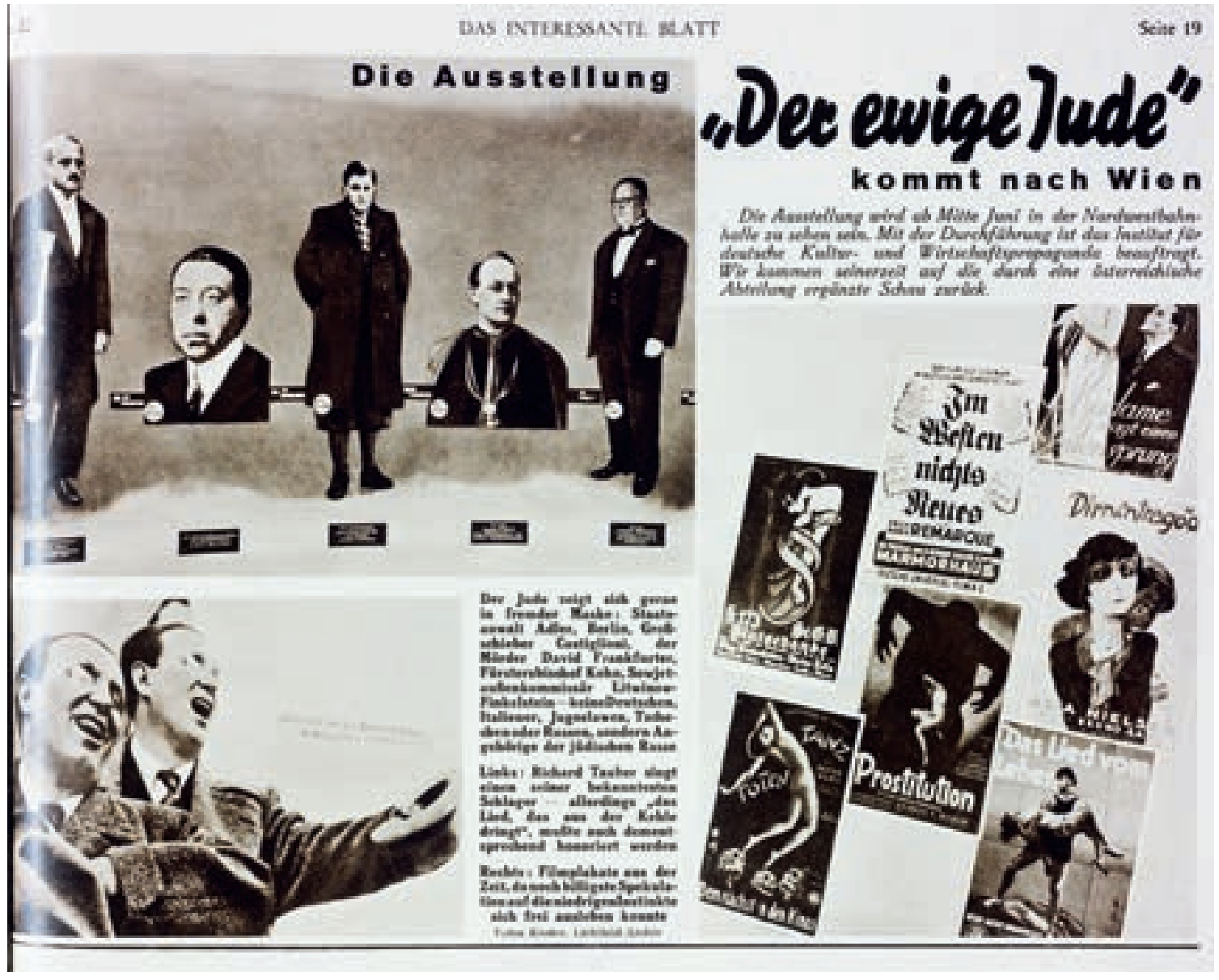

habern der Systemzeit liebevoll aufgepäppelt und großgezogen, verstand es der Jude nur gar zu gut, in verhältnismäßig kurzer Zeit die Systembonzen unter seine Botmäßigkeit zu zwingen und durch planmäßige Zerstörung und Zersetzung eigenvölkischer Lebensformen seine geistige und materielle Vorherrschaft zu behaupten. Presse, Bühne, Film und Rundfunk standen fast ausschließlich unter jüdischer Leitung. So wurde dem deutschen Volk der Ostmark die ,öffentliche Meinung‘ aufgezwungen. Jene Meinung, die vornehmlich gegen das Deutsche Reich gerichtet war, und - von der überwältigenden Mehrheit des Volkes abgelehnt - nur so lange fortbestehen konnte, als die Machthaber, Marionetten des Weltjudentums, gestützt auf die Gewalttat der Bajonette ,Ruhe und Ordnung‘ aufrecht erhalten konnten. Schuschnigg, der den ,österreichischen Menschen` erfand, war einer der Hauptschrittmacher des Judentums im Kampf gegen die deutsche Kultur. Die machtvolle Volkserhebung der Märztage 1938 fegte die Judensöldlinge hinweg und wies das Judentum als Fremdkörper im deutschen Volke in die ihm gebührenden Schranken. Jetzt erst konnte daran gegangen werden, alte Sünden wieder gutzumachen, und die Kulturträger der Ostmark, hinter denen jahrelang die widerliche Fratze des Weltjudentums geisterte, ihrer wahren Bestimmung zuzuführen, im Dienste der Volksgemeinschaft." 34 In den Bildern zum Text werden bekannte Wiener Juden an den Pranger gestellt, etwa Franz Werfel, Ernst Lubitsch, Richard Tauber, Oscar Straus und zahlreiche andere.

Nach dem Überfall auf Polen nimmt die antisemitische Bildberichterstattung in Deutschland weiter zu. So fordert die nationalsozialistische Parteiillustrierte Illustrierter Beobachter eine Fotoserie zum Thema „Der polnische Jude“. Die Vorgaben lauten: „Polni- 
sche Judentypen beider Geschlechter verschiedener Lebensalter/Berufe der Juden/Jüdische Gebräuche/ Jüdischer Dreck.“35 Tatsächlich werden einschlägige Fotos aus den jüdischen Gettos in Polen von Fotografen der Propagandakompanien geliefert. Am 22. November 1939 bringt die Wiener Illustrierte eine hetzerische Bildseite über Juden in Galizien. Sie trägt den Titel: „Die erste Arbeit ihres Lebens“ (Abb. 14). Text und Bilder - Letztere stammen von der staatsnahen deutschen Fotoagentur „Weltbild“, die den Propagandakrieg des Regimes unterstützt - stehen eindeutig in Zusammenhang mit dem deutschen Krieg gegen Polen, der am 6. Oktober 1939 zu Ende geht und in dessen Verlauf es zu gewaltsamen Übergriffen und zahlreichen Massakern an polnischen Juden kommt ist. Um diese Gewalttaten zu rechtfertigen, werden die jüdischen Bewohner des Landes als „Untermenschen“ dargestellt. Indirekt gerechtfertigt werden durch solche Propagandaseiten auch alle jene „Maßnahmen“, die in Wien gegen die Juden getroffen wurden und werden. „Nördlich der Beskiden und Karpathen“, heißt es im Text, „in dem Gebiet zwischen Krakau und Tarnopol, genannt Galizien, war das große Reservoir, aus dem das Weltjudentum ständig, wenn notwendig, Nachschub zur Ergänzung und Auffrischung seiner Köterrasse erhielt. Von hier kamen sie noch im Kaftan, mit Korkenzieherlocken und schwarzem Plüschhut nach Wien, wo sie Locken und Kaftan ablegten, europäische Kleidung anzogen und europäische Manieren zu erlernen suchten. Einmal so weit, zerstreuten sie sich über alle Kontinente, um ihr Schmarotzerdasein zu höchster Blüte zu entfalten. Arbeiten hatten sie nie gelernt.“36

Unter der Titelzeile werden, freigestellt auf weißem Grund, „Judentypen“ aus Radom vorgeführt. Es sind ärmlich gekleidete Männer, die als Prototypen jüdischer Charaktere mit allen erdenklichen negativen Eigenschaften bedacht werden. „Habgier, gepaart mit tierisch niedrigem Instinkt und grenzenlosem Haß gegen alles, was deutsch ist, spricht aus diesen Galgenvisagen." Die Männer werden nicht nur dem Spott preisgegeben, sondern es wird ihnen ein „grenzenloser Haß“ gegen alles Deutsche unterstellt. Im Begriff „Galgenvisage“ klingt das Schicksal dieser Bevölkerungsgruppe bereits an. In weiteren Bildern

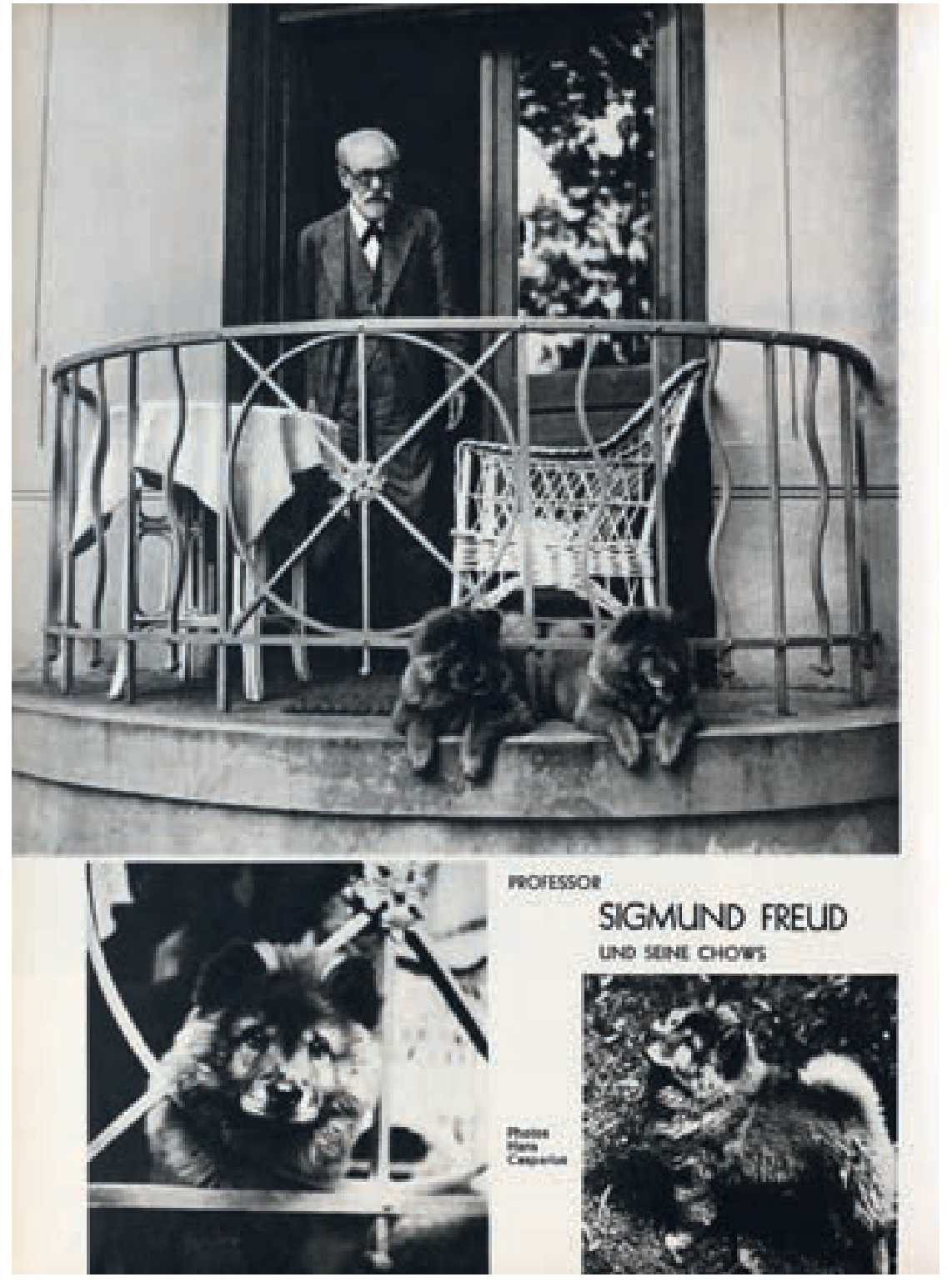

werden Juden gezeigt, die nach der deutschen Besetzung des Landes zur Zwangsarbeit genötigt werden. In den Bildtexten werden die Zwangsarbeiter durch hetzerische Beschreibungen diskreditiert und der Lächerlichkeit preisgegeben.

\section{Fotografen im Krieg}

Die Militarisierung der Berichterstattung ist keine Erfindung der Nationalsozialisten. Sie setzt bereits in den 1930er Jahren zur Zeit des „Ständestaates“ ein.
Abb. 13 Sigmund Freud und seine beiden Hunde, aufgenommen im Frühsommer 1933 auf dem Balkon der Sommerwohnung auf der Hohen Warte in Wien. Die Bühne, Zweites Maiheft 1935, S. 28. Foto: Hans Casparius. 
Abb. 14 Antisemitische Bildseite über die Juden in Galizien. Wiener Illustrierte, 22. November 1939, S. 8. Fotos: Fotoagentur Weltbild.

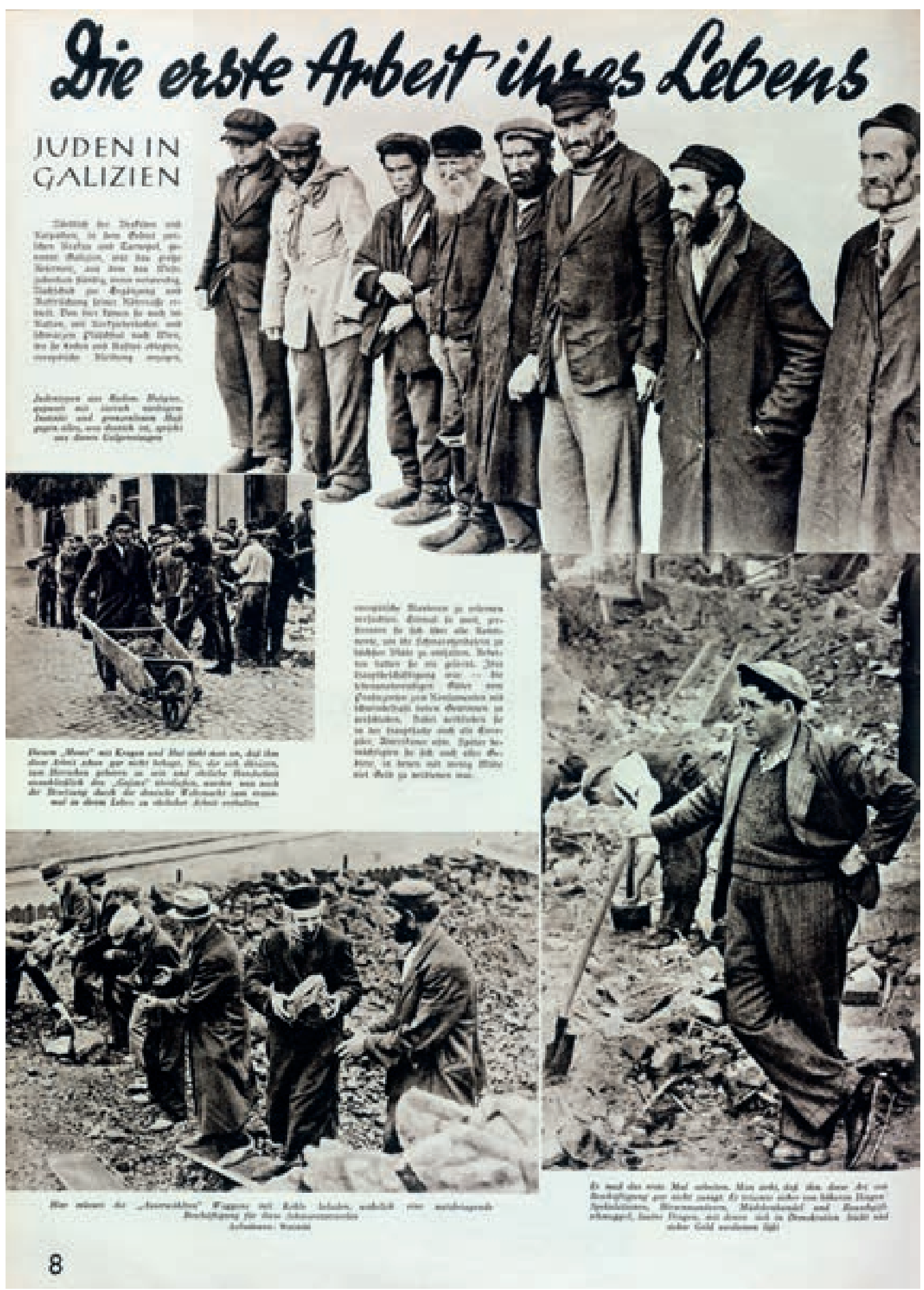

Anfang 1938 etwa bringt die Zeitschrift Die Pause eine Titelseite mit dem Titel „Jungvolk“ (Abb. 15). ${ }^{37}$ Das „Jungvolk“ ist in der Zeit des Austrofaschismus eine paramilitärische Jugendorganisation unter dem Dach der „Vaterländischen Front“. Die Fotomontage stammt vom Grafiker Rudolf Köhl, der seit 1935 für die Zeitschrift tätig ist. Sie zeigt Mädchen und Jungen bei Spielen und militärischen Übungen. In der Beschreibung zum Bild - sie stammt vermutlich von Karl Pawek, dem Chefredakteur der Zeitschrift - heißt es: „Diese politisch in Verbindung mit der ständischen, christlichen, deutschen Staatsfüh- 
rung Österreichs organisierte Jugendbewegung (ist) die vielleicht kräftigste, reinste, positivste und in ihrer Lebensart wertvollste vaterländische Bewegung Österreichs. Das Österreichische Jungvolk ist der bedeutsamste Kern des neuen Österreich. Ihm fehlt jede Schwachheit und Beschränktheit. Das österreichische Jungvolk kann sich an Straffheit, Vitalität und ideenhafter Begeisterung mit jeder anderen europäischen Staatsjugend messen." ${ }^{38}$ Das Titelblatt, das im März 1938, kurz vor dem Einmarsch der deutschen Truppen in Österreich fertiggestellt wird, feiert noch den „Ständestaat“. Das nächste Heft ist bereits zur Gänze Adolf Hitler und dem „Anschluss“ gewidmet.

Kaum hat der Krieg im September 1939 begonnen, setzt in der illustrierten Presse die pathetische Berichterstattung darüber ein. Aber auch die sogenannte „Heimatfront“ hat sich den Kriegsbedingungen unterzuordnen. Eine ganze Reihe von Fotoreportagen beschäftigt sich mit den vielfältigen Anstrengungen, die weit hinter der Front unternommen werden, um den Krieg erfolgreich zu führen. Aber auch der scheinbar ganz „normale“ Alltag im Hinterland kommt zur Sprache. Im Juni 1942 erscheint etwa in der Wiener Illustrierten ein zweiseitiger Bildbericht von Fritz Zvacek über Lehrwerkstätten für Jungarbeiter in Wien. ${ }^{39}$ Zahlreiche weitere Fotoreportagen über den städtischen Alltag in Wien, die während der Kriegszeit publiziert werden, stammen beispielsweise vom Wiener Pressefotografen Eduard Zillich. ${ }^{40}$

Die zentral gesteuerten Bildberichte aus dem Kriegsgebiet stammen zum überwiegenden Teil von Fotografen, die in den sogenannten „Propagandakompanien“ (PK) tätig sind. ${ }^{41}$ Diese seit 1938 aufgestellten Einheiten haben, so das Oberkommando des Heeres im August 1938, die Aufgabe, „das Zusammenwirken des Propagandakrieges mit dem Waffenkrieg im Operationsgebiet des Heeres zu gewährleisten und durchzuführen“. ${ }^{42} \mathrm{Zu}$ Beginn des Polenfeldzugs im September 1939 sind sieben PK beim Heer (für jedes Armee-Oberkommando eines), vier PK bei der Luftwaffe und zwei PK bei der Marine im Einsatz. Zusammen kommen sie auf 143 Bildberichterstatter. ${ }^{43}$ Jede PK besteht aus Abteilungen für Wort, Bild, Film und Rundfunk. Technisch ist sie bestens ausgerüstet. Sie umfasst etwa hochwertig ausgestattete Bild- und
Filmlabors samt Personal, die bei den Einsätzen ständig mitgeführt werden. Anfang 1940 richtet auch die Waffen-SS eigene Propagandakompanien mit mindestens 66 Bildberichterstattern ein. Im Laufe des Krieges wird die Anzahl der Propagandakompanien weiter erhöht. 1943, auf dem Höhepunkt ihrer Tätigkeit, hat die Propagandatruppe eine Stärke von 15000 Mann, davon sind (einschließlich der Auswertungseinheiten) rund 400 Fotografen. ${ }^{44}$ Ab 1943 sinkt die Zahl der PK-Berichterstatter wieder.
Abb. 15 Titelseite der Zeitschrift Die Pause über das „Österreichische Jungvolk“, eine 1936 gegründete, paramilitärische Bewegung für Jugendliche von 6 bis 18 Jahren. Die Pause, Heft 4, 1938. Montage: Rudolf Köhl.

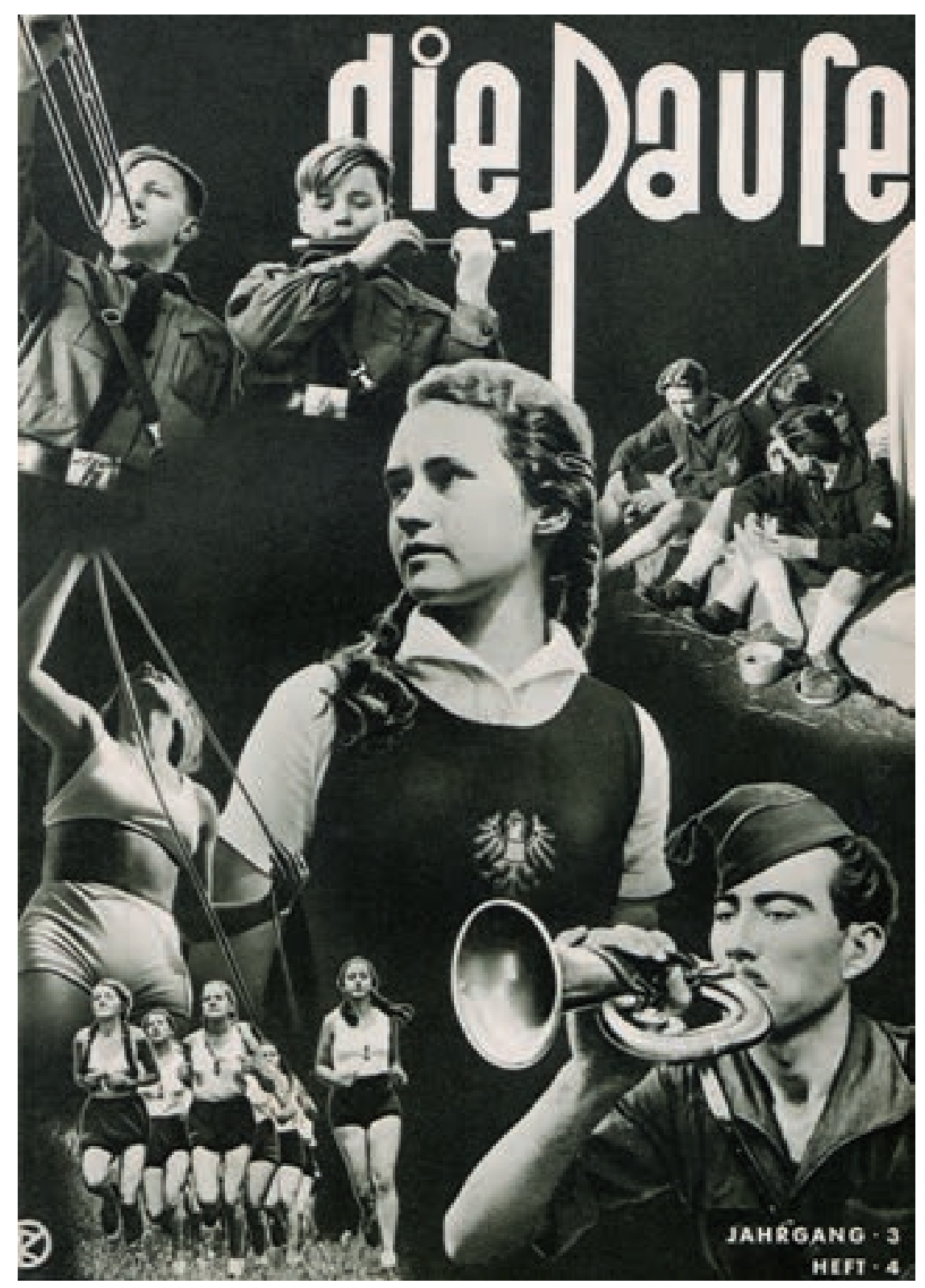


Abb. 16 „Gesichter des Kampfes“. Deutsche Soldaten an der Ostfront, Orel, Russland, Juli 1943. Die Pause, Heft 8/9 1944, S. 18. Foto: Walter Henisch.

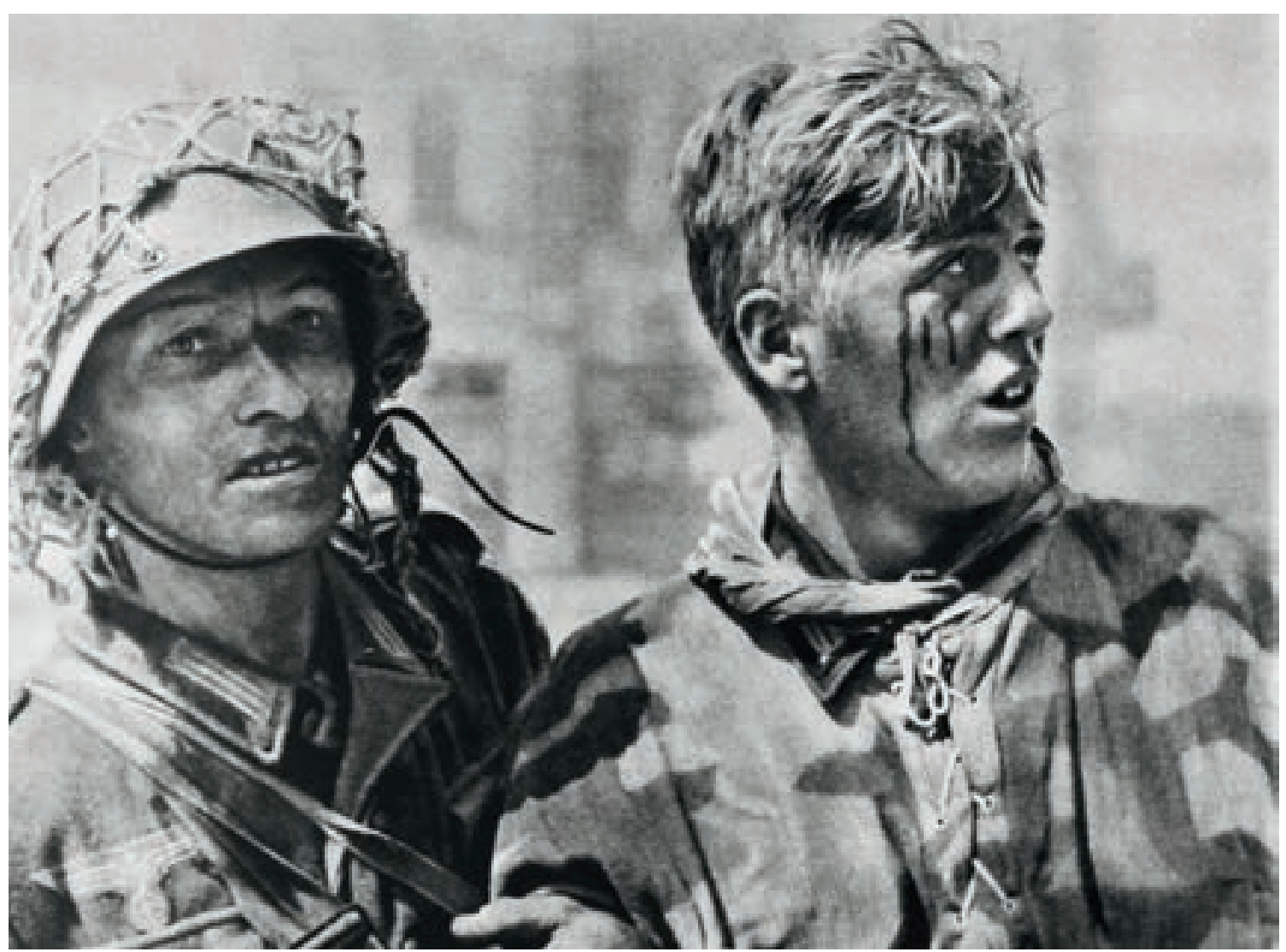

Die Einsätze in den Propagandakompanien sind begehrt, die PK-Arbeit ist hoch angesehen, mit Privilegien versehen und die Überlebenschancen sind deutlich größer als bei den einfachen Mannschaften an der Front. Etliche österreichische Fotografen sind während des Zweiten Weltkriegs Mitglied der Propagandakompanien. Zu ihnen gehören Albert Hilscher, Adolf Mayer, Max Mayerhofer, Franz Roth, Stefan Kruckenhauser, Lothar Rübelt, Heinrich Schuhmann jun., Anton Doliwa, Wilhelm Sturm, Gustav Hajek, Marian Schwabik und Walter Henisch. Die meisten dieser Fotografen sind treue Anhänger des Regimes und voller Begeisterung bei der Sache. Der bekannteste österreichische Fotograf in den Reihen der Propagandakompanien ist Walter Henisch, geb. 1913. In seinen Erinnerungen rühmt er sich später seinem Sohn, dem Schriftsteller Peter Henisch, gegenüber, 1943 der beste Kriegsberichterstatter der Deutschen Wehrmacht gewesen zu sein. ${ }^{45}$ Seine eigentliche Karriere als Kriegsfotograf beginnt im Russlandfeldzug im Juni 1941. Bereits wenige Wochen nach dem Überfall auf die Sowjetunion schafft Henisch es mit einem eindrucksvollen Soldatenporträt auf die Titelseite der renommierten Berliner Illustrirten Zeitung. ${ }^{46}$ Aber Henisch ist, entgegen seiner Selbsteinschätzung, keineswegs der bekannteste deutsche Kriegsfotograf, sondern muss sich die öffentliche
Präsenz mit zahlreichen anderen PK-Fotografen teilen, die teilweise viel häufiger in der Presse vertreten sind. Im Frühjahr 1943 veröffentlicht er dramatische Kampfszenen aus Russland, im Frühjahr 1944 Fotos vom Partisanenkrieg auf dem Balkan.

Im August/September-Heft 1944 druckt die Pause eine der zahlreichen Kampfaufnahmen Henischs, die im Jahr zuvor in der Sowjetunion entstanden sind (Abb. 16). ${ }^{47}$ Sie zeigt erschöpfte Gesichter. Einem der Soldaten rinnt Blut über das Gesicht. Der Bildtext freilich bleibt kämpferisch: „Gesichter des Kampfes: Deutsche Soldaten nach einem abgeschlagenen Angriff der Sowjets“. Das Papier, das zeigt ein genauerer Blick auf die Seite, ist grob und rau. Längst ist das glatte Kunstdruckpapier, früher ein Kennzeichen der Zeitschrift, durch billiges Papier ersetzt worden. Henisch selbst ist zum Zeitpunkt, als die Aufnahme erscheint, schon längst nicht mehr in der Sowjetunion. Seit August 1943 fotografiert er auf dem Balkan, im Mai 1944 wird er bei einem Partisanenangriff verletzt und ist monatelang außer Gefecht. Aber davon erfahren die Leser der Pause nichts. Dass die Kriegseuphorie und der Optimismus, den Seiten wie diese zu verbreiten suchen, bröckeln, erkennen sie aber allein schon daran, dass die Zeitschrift im September 1944 eingestellt wird. Das Kriegsbild von Walter Henisch erscheint in der letzten Nummer. 


\section{Eine andere Kulturgeschichte}

\section{Schluss}

Mitte Mai 1903 findet im beliebten Wiener Vorstadtlokal „Zum grünen Tor“ eine „Männerschönheits-Konkurrenz" statt. ${ }^{1}$ Ausgerichtet wird die Veranstaltung vom österreichischen Athletenclubverband. Der Andrang im Saal ist gewaltig. Unter die Schaulustigen haben sich auch einige Journalisten und Fotografen gemischt, die in den folgenden Tagen über den Abend in großer Aufmachung berichten. Das interessante Blatt widmet dem Ereignis sogar die Titelseite (Abb. 1). „Die Konkurrenzen“, heißt es im Innenteil des Blattes, „bei denen über die Schönheit von Mädchen entschieden wird, sind eine Alltagserscheinung."2 Ein Wettbewerb aber, bei dem halb nackte Männer auf der Bühne nicht nur im Hinblick auf ihre Kraft, sondern auch in Sachen Schönheit gegeneinander antreten, das sei neu und aufsehenerregend. „An antike Feste wurde man erinnert, wenn so ein moderner Apollo (...) stramm und tapfer aufmarschiert, im Vollbewußtsein athletischer Kraft.“3

Die Männerschönheiten - es sind Athleten von Wiener Sportvereinen - präsentieren sich dem Fotografen Anton Huber in eingeübten Posen. Mit knapp sitzenden Unterhosen sparsam bekleidet, bieten sie dem Publikum ihre körperlichen Reize dar. Der Sieger der Konkurrenz, der Student Raimund Walter (Dritter von links) vom Wiener Athletiksportclub, entspricht ganz dem gefragten männlichen Idealbild: Er ist groß, schlank und dennoch kräftig, hat eine schmale Taille, breite Schultern und steht, die Hände auf dem Rücken verschränkt, stolz auf der Bühne. Bis weit nach Mitternacht dauert die Veranstaltung. „So lange währte es nämlich, bis die Jury ihr Urteil gefällt und die Preise - Ehrenpreise, goldene und silberne Medaillen - und Diplome zur Verteilung gebracht hatte.“4

Mit diesem Bild kehren wir am Schluss dieses Buches noch einmal zurück in die Welt der Jahrhundertwende. Was hat der Wiener Männerschönheitswettbewerb aus dem Jahr 1903 mit Fragen der Kulturgeschichte zu tun? Auf den ersten Blick vielleicht nicht viel. Wenn wir die Szene aber in einen breiteren Kontext stellen, eröffnen sich interessante Verbindungslinien. Nackte Männer auf der Titelseite - für die altehrwürdige gutbürgerliche Tagespresse ist ein solches Sujet um 1900 ein absolutes Tabu. In der populären Bildpresse aber ist ein solches Titelblatt nicht ungewöhnlich. Es zeigt, dass die thematische Spannbreite der Publizistik um 1900 erheblich ist. Sie reicht von der trockenen Nachrichtenaufbereitung in den etablierten gutbürgerlichen Tageszeitungen bis hin zur Sensationsberichterstattung in der auflagenstarken illustrierten Wochenpresse.

Die Jahre um 1900 werden häufig als Zeit des Umbruchs geschildert, als Zeitabschnitt, der durch tief greifende kulturelle Erschütterungen gekennzeichnet ist. Lange Zeit konzentrierte sich die Forschung zum Thema „Wien um 1900“ auf die Errungenschaften der Hochkultur, also die Welt der Schreibenden, Malenden, Musizierenden, und nicht die Massen- und Populärkultur, die Welt der unteren Schichten und der Vorstädte. Erst in den letzten Jahren wurde verstärkt Kritik an diesem verengten Konzept geübt und ein erweiterter Kultur- und Gesellschaftsbegriff gefordert. ${ }^{5}$ Dieses Buch will einen Beitrag dazu leisten, den eingeengten kulturgeschichtlichen Blickwinkel in Richtung Populärkultur zu erweitern. Durch die Brille der populären Bildpresse betrachtet, erweist sich das hochkulturelle Konzept der Jahrhundertwende als überaus brüchig. Um die Welt der Jahrhundertwende besser verstehen zu können, reicht es also nicht, die bürgerlich-liberale Neue Freie Presse oder ähnliche Medien zu studieren. Erst wenn wir in die Themenwelt und die Bilder des Boulevards eintauchen, wird die gesellschaftspolitische Entwicklung dieser Zeit, die in sich voller Widersprüche ist, anschaulicher. Ich habe in diesem Buch zu zeigen versucht, wie produktiv und erhellend es ist, wenn man den Hochsitz der etablierten bürgerlichen Kultur verlässt und in die „Niederungen“ der Populärkultur hinabsteigt. 


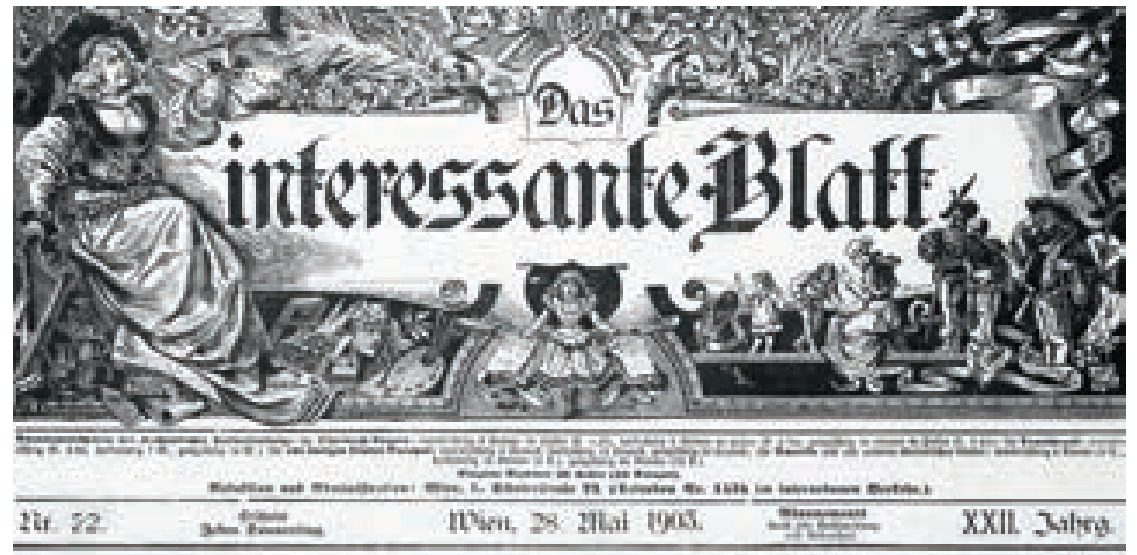

Dic 2lännerichönheits:Konfurrents in $\mathfrak{W}$ ien.

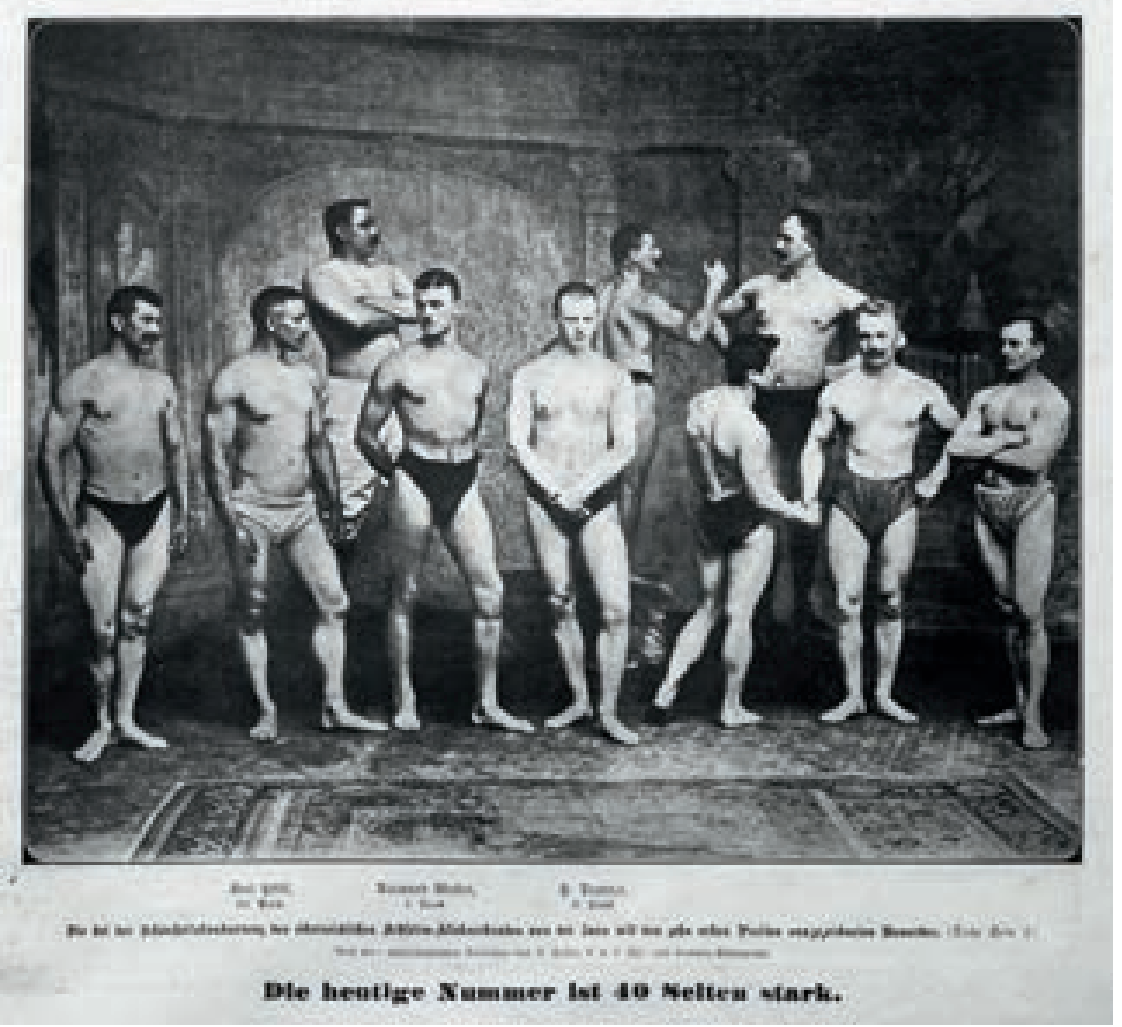

Abb. 1 Bildbericht über eine Männerschönheits-Konkurrenz im Gasthaus „Zum Grünen Tor“ in Wien. Das interessante Blatt, 28. Mai 1903, Titelseite. Foto: Anton Huber.
Gerne verweisen die herkömmlichen Chroniken der Kulturgeschichte darauf, dass Sigmund Freuds Traumdeutung, die im November 1899 (im Impressum ist das Buch vordatiert auf 1900) erscheint, wie kein anderes Buch den radikalen Übergang zwischen dem alten und dem neuen Jahrhundert markiert. Es wird aber oft übersehen, dass sich noch weit folgenreichere gesellschaftliche Erschütterungen abseits der bürgerlichen Hochkultur bemerkbar machen. So erscheint zum Beispiel im Januar 1900 in Wien erstmals eine Tageszeitung, die kaum weniger für einen tief greifenden kulturellen Umbruch dieser Jahre steht als Freuds Traumdeutung: die billige, auflagenstarke Illustrierte Kronen-Zeitung. ${ }^{6}$ Sie deutet den Aufschwung der Boulevardpresse an, die ebenso auf die populäre Bild- wie auf die Textberichterstattung setzt. Im Falle der Kronen-Zeitung handelt es sich bei den Bildern um Zeichnungen, nicht um Fotografien. Um 1900 vollzieht sich also der Übergang von der elitären und sehr eingeschränkten liberalen Öffentlichkeit des 19. Jahrhunderts zur neuen Öffentlichkeit im Zeitalter der Massenpolitik.

Oder, um ein zweites Beispiel zu nennen: Am 1.Januar 1900 tritt die Aufhebung des sogenannten Zeitungsstempels in Kraft. Diese Zeitungssteuer, die in Österreich (wie in vielen anderen Ländern) jahrzehntelang eingehoben wurde, hat wesentlich dazu beigetragen, die Auflagen der Blätter klein zu halten. Sie war ursprünglich ein Instrument des autoritären Staates, um missliebige, oppositionelle Meinungen zu kontrollieren und die Auflagen der politischen Blätter zu begrenzen. Während diese Steuer in England bereits 1865, in Preußen 1874 und in Frankreich 1881 abgeschafft wird, behält sie ihre Geltung in Österreich-Ungarn bis zum 27. Dezember 1899. Anfang Januar 1900, zu Beginn des neuen Jahrhunderts, kündigen viele Zeitungen und Zeitschriften in großer Aufmachung deutliche Preisermäßigungen an. Nun erst beginnt - unter anderem mit der Kronen-Zeitung, deren Erscheinen eine direkte Folge des aufgehobenen Zeitungsstempels ist - die Blütezeit der Massenpresse. ${ }^{7}$ Die Auflagen billiger, populärer Tages- und Wochenzeitungen steigen nun deutlich an. Die bereits bestehenden Blätter reagieren auf die neue Konkurrenz. Sie erweitern ihr Themenspektrum, werden populärer. In der Boulevardpresse wird über alles berichtet, was einem breiten Publikum interessant erscheint: Unfälle und Katastrophen, Raubmorde und Hochzeiten, Sportereignisse und politische Krisen, technische Neuheiten und gesellschaftliche Ereignisse. Der Männerschönheitswettbewerb in einem Wiener Vorstadtlokal passt sehr gut in dieses erweiterte Themenspektrum. 


\section{Ordnung und Exzess}

Die Bilder und Texte, die in der populären, auflagenstarken Bildpresse erscheinen, spiegeln die Populärkultur, über die sie berichten, keineswegs eins zu eins wider. Vielmehr halten sie, das ist wichtig festzuhalten, in der Regel den bürgerlichen Blick auf das populäre Leben fest. Das interessante Blatt, die größte Illustrierte des Landes, ist ein gutes Beispiel für diese mediale Zwitterstellung. Es ist sowohl von der Eigentümerstruktur als auch von der Leserschaft her ein durch und durch bürgerliches Blatt. Auch in seiner äußeren Erscheinung knüpft es an die bürgerlichen Familienblätter des 19. Jahrhunderts an. ${ }^{8}$ Das zeigt bereits die Titelvignette, die diese Tradition grafisch zitiert. Sie wird, das ist bemerkenswert, von der Gründung bis zum Jahr 1939 mit leichten Variationen beibehalten.

Im Innenteil aber entfernt sich die Zeitung um die Jahrhundertwende vom Modell der biederen Familienzeitschrift. Sie setzt auf eine Mischung von nüchterner Berichterstattung und Klatsch, von nackten Nachrichten und voyeuristisch aufbereiteten Sensationen. Erfolg hat das Blatt gerade mit dieser Kombination von Beruhigung und Aufreizung. Woche für Woche wird die Leserschaft mit seriösen Nachrichten, aber auch mit Sensationen beliefert, Bildern und Berichten also, die deutlich über die bürgerliche Erfahrungswelt hinausführen - sei es nun eine Nackttanzaufführung im Wiener Prater oder ein Eisenbahnunglück in der Provinz. Im Laufe der Jahre wird diese Themenvielfalt allmählich gebändigt. Je stärker sich eine an der Tagespolitik orientierte Nachrichtenstruktur herausbildet, desto stärker wird die Welt der populären Sensationen beschnitten. In der Zwischenkriegszeit werden viele der ehemaligen Sensationsblätter „seriöser“. Sie etablieren sich nun als Bilderzeitungen für die wöchentlichen Nachrichten, auch wenn sie ihre Vergangenheit als Unterhaltungsmedien nicht gänzlich abstreifen. Zugleich entsteht ein ausufernder Magazinmarkt, der weiterhin die voyeuristischen Bedürfnisse der Leserschaft befriedigt.

Die vorschnelle Kritik an der populären Sensationspresse, die oft bürgerlicher Herkunft ist, verkennt, dass diese Medien ganz spezifische Aufgaben erfül- len, die es wert sind, genauer analysiert zu werden. Die Sensationspresse taucht nicht erst um 1900 auf, ihre Geschichte reicht weit ins 19. Jahrhundert zurück. ${ }^{9}$ Die rapide Ausweitung der bildlichen Boulevardberichterstattung in der Wochenpresse, die um die Jahrhundertwende einsetzt und bis zum Aufkommen des Fernsehens Mitte des 20. Jahrhunderts anhält, verdankt sich zunächst nicht, wie man vielleicht erwarten würde, der massiven Ausweitung der Leserschaft hin zur Unterschicht. Während die Boulevardtagespresse, etwa in Gestalt der populären Montagszeitungen, um 1900 tatsächlich neue Leserschichten in den unteren sozialen Schichten anspricht, wendet sich der Großteil der illustrierten Wochenpresse nach wie vor vorwiegend an eine bürgerliche und kleinbürgerliche Leserschaft. ${ }^{10}$ Erst nach der Jahrhundertwende, und damit später als etwa in Frankreich, England oder den USA, kommt es in Österreich zu Neugründungen von Billigillustrierten, die dezidiert die unteren sozialen Schichten ansprechen wollen. Das Bürgertum, der Hauptadressat der illustrierten Presse, ist um die Jahrhundertwende keineswegs eine traditionsreiche, stabile Einheit, sondern, vor allem in Städten wie Wien, die durch enorme Zuwanderung gekennzeichnet sind, ein soziales Konglomerat, das sich ständig neu erfinden und nach außen hin abgrenzen muss. Die illustrierte Presse bietet in dieser Umbruchsituation einerseits Halt, andererseits ermöglicht sie einen neugierigen Blick über die Grenzen bürgerlicher Lebensweisen hinaus.

Themen wie Sex, Gewalt und Verbrechen sind feste Bestandteile des bildlichen Boulevards (Abb.2). Die anhaltende Faszination, die sie auf die Leserschaft ausüben, zeigt, wie sehr die bürgerliche Gesellschaft, die um Ruhe, Ordnung und gesellschaftliche und moralische Stabilität besorgt ist, auch von einem untergründigen Bedürfnis nach Ausbruch und Exzess geprägt ist. Die fotografischen Bilder, die um 1900 in der illustrierten Presse Einzug halten, haben also eine doppelte Bedeutung. Auf der einen Seite verstärken die Fotografien allmählich den Anstrich des Dokumentarischen in der Berichterstattung. In dieser Rolle lösen sie, wie wir gesehen haben, das ältere Medium der Pressezeichnung ab. Aktuelle Fotografien authentifizieren nun gewissermaßen die Schlagzei- 


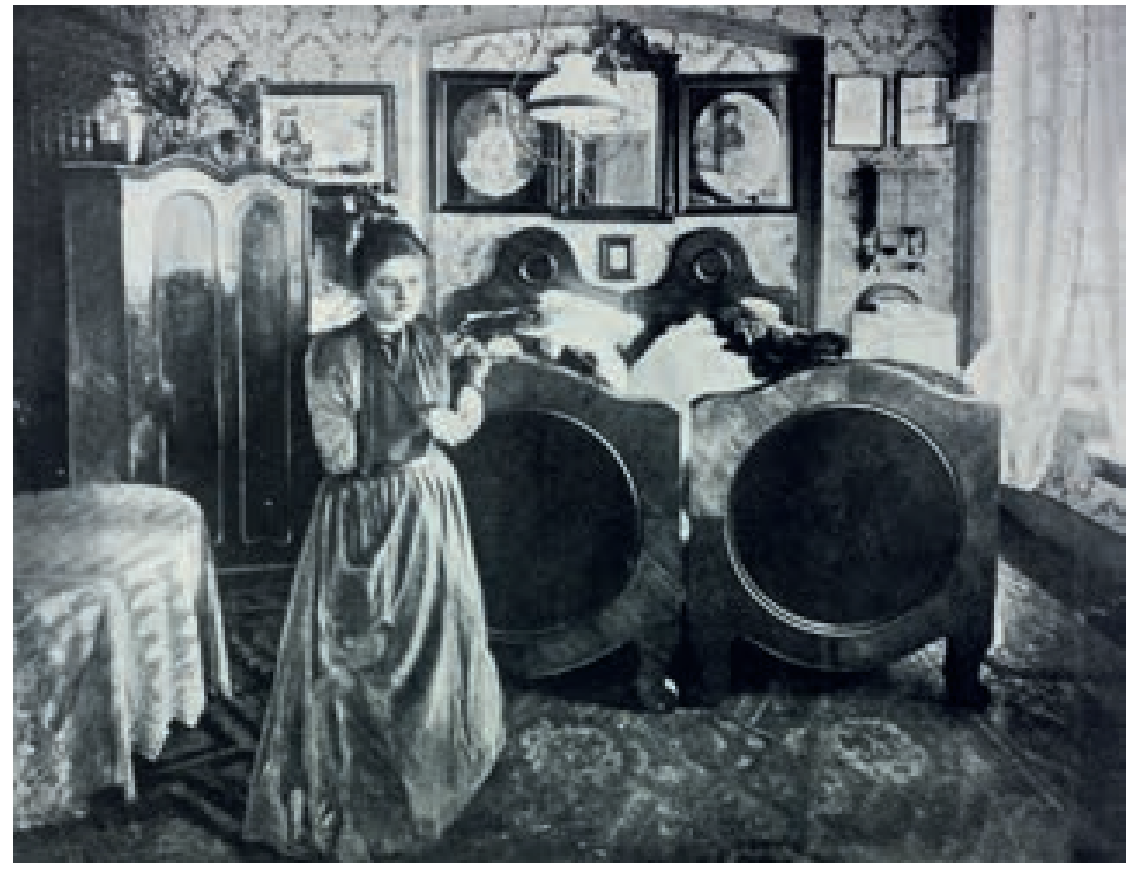

Abb. 2 Raubmord im Café Regensburg in Karlsbad. „Die bei dem Überfall verwundete Cafetiersgattin Frau Honisch in ihrem Schlafzimmer, in welchem die ersten Schüsse fielen“. Das interessante Blatt, 10. Juli 1902, S. 7 len. Auf der anderen Seite, und das ist im vorliegenden Zusammenhang besonders interessant, sind die fotografischen Bilder auch Projektionen, Wunschbilder, die fremde, unzugängliche oder tabuisierte Bereiche des Lebens eröffnen. Die voyeuristische Bildberichterstattung hat also auch die Funktion, bürgerliche Lebenswelten zu befestigen, indem sie Ausbrüche in der Fantasie ermöglichen. Eine ähnliche Rolle spielt im Übrigen auch das frühe Kino, das ebenfalls gesicherte, zeitlich befristete Ausbrüche aus dem bürgerlichen und kleinbürgerlichen Leben anbietet. ${ }^{11}$ Es ist wichtig, auch diesen zweiten, oft wenig beachteten Aspekt der frühen Pressefotografie im Auge zu behalten, wenn man das Medium in seiner breiten kulturgeschichtlichen Bedeutung erfassen will.

Der enorme Erfolg der illustrierten Presse in der ersten Hälfte des 20. Jahrhunderts liegt nicht zuletzt darin, dass es ihr gelungen ist, eine Art Echoraum bürgerlicher Wünsche und Sehnsüchte zu bilden. Gerade in einer Epoche, in der das bürgerliche Selbstverständnis nicht mehr klar umrissen und das kollektive Selbstbewusstsein dieser Schicht brüchig geworden ist, bildet die fotografische Bilderwelt, die Woche für Woche in den auflagenstarken Zeitungen aufbereitet wird, eine stabilisierende Klammer. Die Berichterstattung bestätigt die eigenen Werte und zugleich ermöglicht sie es, aus sicherer Entfernung (gewissermaßen vom Lehnsessel im Wohnzimmer aus) den spektakulären Verlockungen und den verbotenen Verheißungen nachzugeben, um anschließend wieder in die wohlgeordnete und gesittete gutbürgerliche Welt zurückzukehren.

Der fotografische Boulevard, der sich um die Jahrhundertwende durchsetzt, gleicht in seiner Struktur den „Faits divers“, den „vermischten Meldungen“. Diese journalistische Gattung hält, wie wir gesehen haben, Ende des 19. Jahrhunderts Einzug in die bürgerliche Presse. ${ }^{12}$ Es handelt sich um klar vom Rest der Zeitung abgegrenzte populäre Einsprengsel, um voyeuristische Kurzgeschichten, um spektakuläre und halb fiktive Begebenheiten, die dem Bedürfnis entgegenkommen, für einen Augenblick aus der geordneten bürgerlichen Welt auszubrechen. Die populäre Bildpresse übernimmt das Konzept der „vermischten Meldungen“, weitet es im Umfang stark aus und setzt die Fotografie zur Bebilderung des Spektakulären ein. Die „Faits divers“ sind zwar kleine Exzesse, kurzfristige Ausbrüche aus der bürgerlichen Ordnung, aber sie stellen diese nicht infrage. Sie loten das Regime des Anstands und der Moral aus, indem sie dessen Grenzen mit den Mitteln des Voyeurismus überschreiten. So sensationslüstern die Berichterstattung in den populären Zeitungen auch ist, eines ist klar: Die bürgerliche Bildpresse achtet stets darauf, sich deutlich von der Skandal- und Revolverpresse oder der pornografischen Publizistik abzugrenzen. ${ }^{13}$ Letztlich sind die neugierigen Ausflüge ins Reich des Populären also nichts anderes als geführte Fantasiereisen, die das Territorium der bürgerlichen Kultur nie verlassen.

\section{Das langsame Ende der illustrierten Presse}

Mehr als ein halbes Jahrhundert lang, von der Jahrhundertwende bis in die Zeit nach dem Zweiten Weltkrieg, ist die Pressefotografie das dominierende bildliche Nachrichtenmedium in der westlichen Welt. Erst danach wird die illustrierte Presse allmählich vom Fernsehen abgelöst. Zwar erhalten die Illustrierten zeitweise auch Konkurrenz, etwa durch die Wochenschauen im Kino, die ab den 1930er Jahren ebenfalls bildliche Nachrichten (ebenso wie Sensationen) für ein breites Publikum anbieten. In den 1950er und 1960er Jahren setzen die illustrierten Wochenblätter und -magazine in vielen Ländern zu einem 


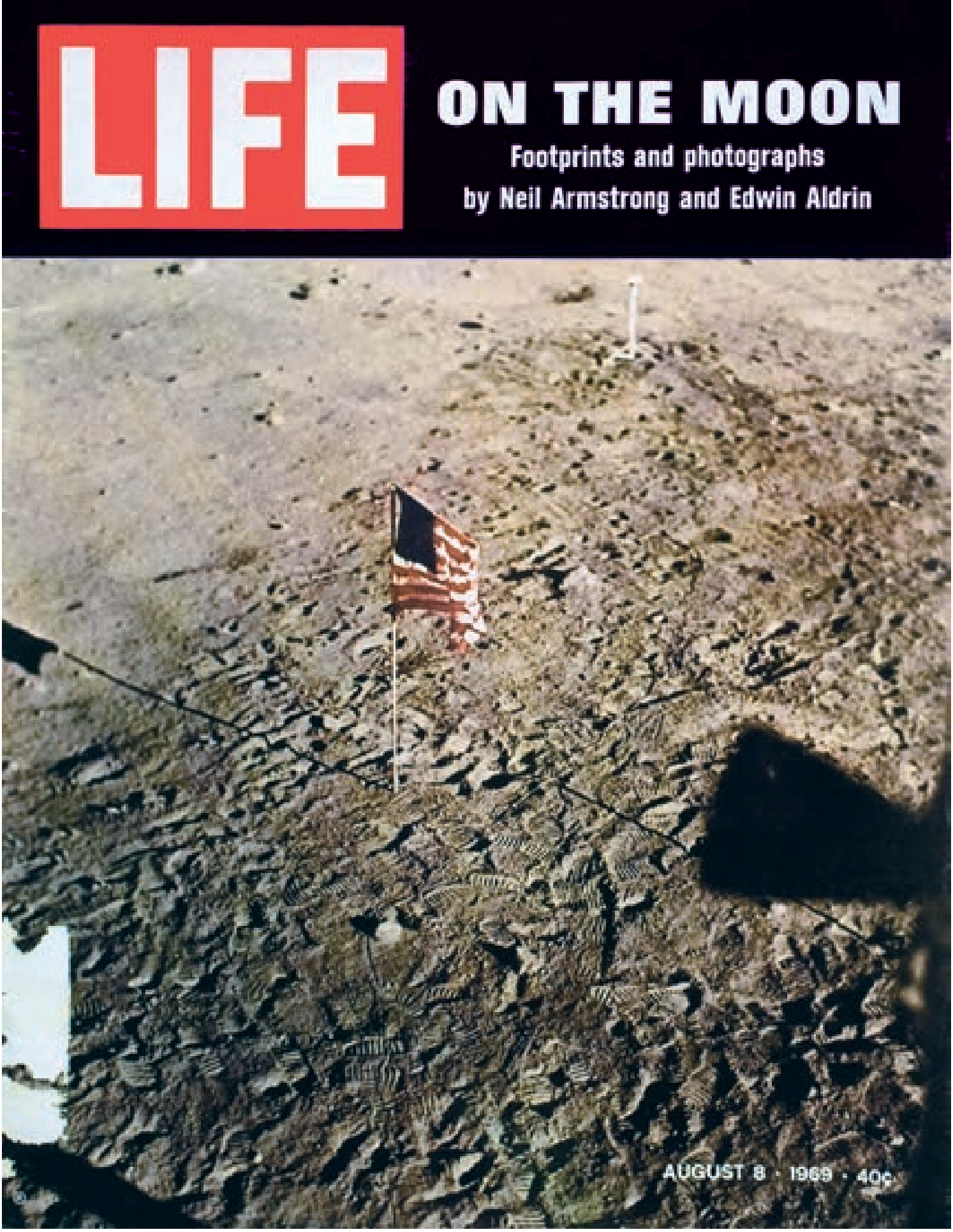

letzten Höhenflug an, danach verliert das Modell der populären Bildberichterstattung in Zeitungen und Magazinen merklich an Bedeutung.

$\mathrm{Ab}$ den 1950er Jahren entzieht das neue und in der Bildberichterstattung schnellere Medium Fernsehen den traditionellen, wöchentlich oder zweiwöchentlich erscheinenden Magazinen in zunehmendem Maß Publikum und Werbeeinnahmen. Diese Entwicklung setzt zuerst in den USA ein und erfasst sehr viel später auch Europa. 1945 erreicht das amerikanische Wochenmagazin Life nach eigenen Angaben rund fünf Millionen amerikanische Haushalte, während gerade einmal 10000 Familien über einen eigenen Fernsehanschluss verfügen. Innerhalb von nur zehn Jahren wächst jedoch die Zahl der Fernsehteilnehmer in den USA auf 29 Millionen und die der TV-Stationen von sechs auf über 200. ${ }^{14}$ Vor allem die Abwanderung der Werbekunden erweist sich für die Zeitschriften als existenzielle Bedrohung. ${ }^{15}$ Bereits in den 1950er und 1960er Jahren stellen einige Bildmagazine ihr Erscheinen ein: Collier's und die britische Picture Post erscheinen 1957 zum letzten Mal, The Saturday Evening Post 1969, Look 1971 und 1972 verschwindet mit Life die renommierteste amerikanische Illustrierte (Abb. 3). ${ }^{16}$
Abb. 3 Die ersten Bilder der Mondlandung erscheinen auf der Titelseite der Zeitschrift Life. Drei Jahre später wird das Magazin eingestellt. Life, 8. August 1969, Titelseite. 
Abb. 4 Das 1962 gegründete Sunday Times Magazin gehört zu den wichtigen fotojournalistischen Plattformen der europäischen Nachkriegszeit. Sunday Times Magazine, 27. November 1966, Titelseite.
In Europa löst das Fernsehen die illustrierten Magazine als Leitmedium des Bildjournalismus nicht ganz so schnell ab wie in den USA, was zu einem guten Teil daran liegt, dass es in seinen Anfängen organisatorisch anders strukturiert ist. Die europäischen Fernsehanstalten sind in den ersten Jahren fast ausschließlich staatliche oder öffentlich-rechtliche Institutionen und finanzieren sich als solche anders als die amerikanischen Sender vor allem über Gebühren oder Steuern und nicht hauptsächlich über Werbeeinnahmen. Sie mischen weit später als in den USA im lebenswichtigen Anzeigengeschäft mit und stellen lange Zeit keine existenzgefährden-

\section{THE SUNDAY TIMES magaqine}

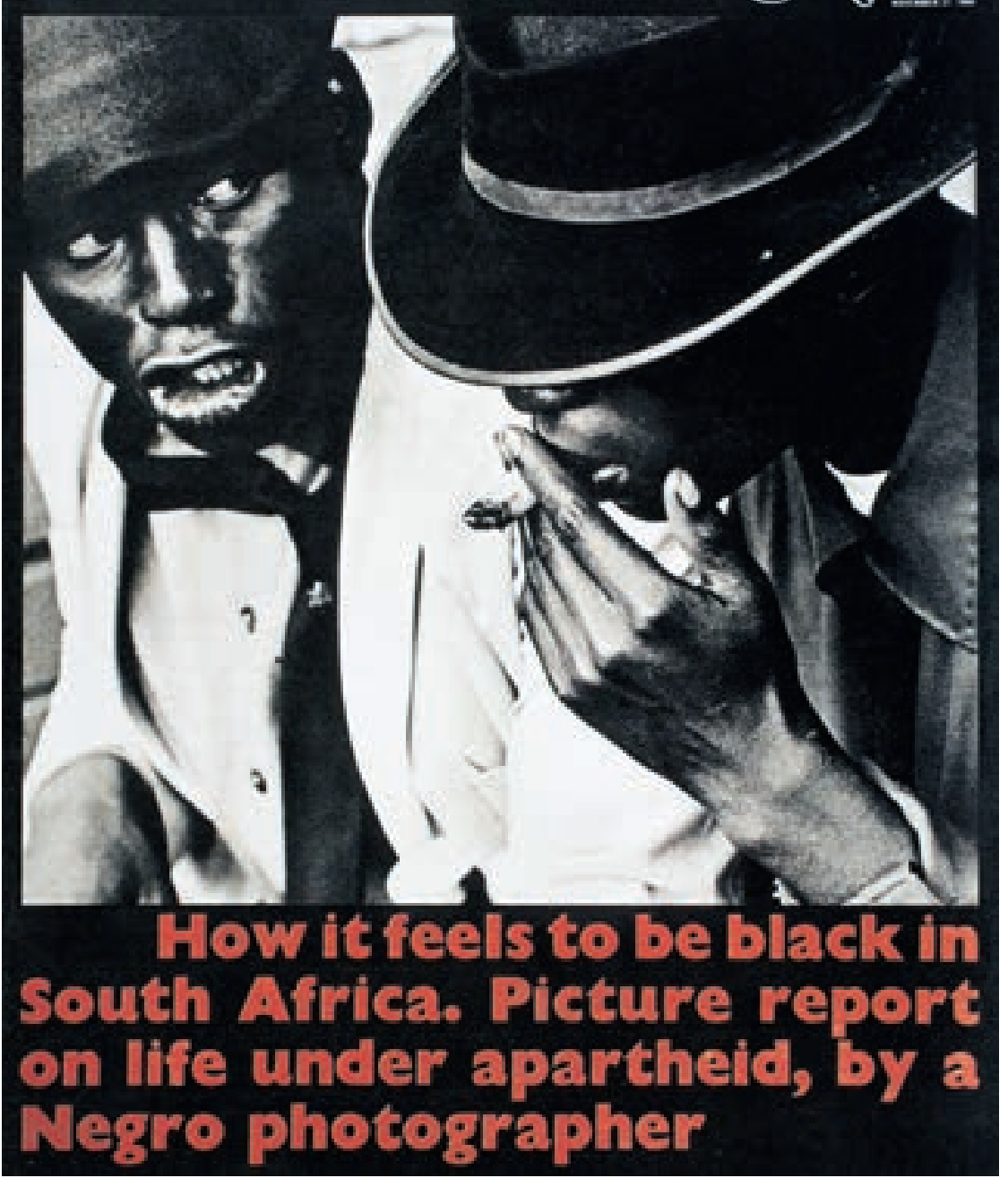

de Konkurrenz für die Magazinpublikationen dar. In Deutschland, Frankreich, Italien und Großbritannien entsteht im Lauf der zweiten Jahrhunderthälfte sogar eine ganze Reihe neuer und teilweise sehr erfolgreicher illustrierter Zeitschriften wie der Stern (1948), Paris Match (1949), Twen (1959), das Sunday Times Magazine (1962) (Abb.4), Geo (1976), das F.A.Z.-Magazin (1980) oder Sette (1987), von denen sich allerdings einige, im Gegensatz zu den herkömmlichen General-Interest-Titeln wie Life, an ein klar umgrenztes Zielpublikum richten. ${ }^{17}$

In Deutschland und Österreich markiert das Jahr 1945 in der Presselandschaft einen tiefen Einschnitt. Im Nationalsozialismus wurde die freie Presse erstickt, jüdische und politisch unliebsame Verlagshäuser wurden geschlossen, aufgelöst oder fusioniert. Durch die Vertreibung jüdischer Verleger, Herausgeber, Autoren und Fotografen kommt es zu einem gewaltigen journalistischen Exodus, von dem sich die Presse nach 1945 nie mehr ganz erholen kann. Einen weiteren Einschnitt bringt der Krieg. Im Laufe des Zweiten Weltkrieges werden zahlreiche illustrierte Zeitungen und Zeitschriften eingestellt - zunächst, um die Propagandaanstrengungen zu fokussieren, später aus Papier- und Materialmangel, schließlich, weil die Logistik des Vertriebs zusammenbricht. Zu Kriegsende 1945 hört die kompromittierte NS-Presse auf zu existieren.

Erst allmählich entstehen unter alliierter Oberaufsicht neue Zeitungen und Zeitschriften, darunter auch Neugründungen illustrierter Wochenblätter und Magazine. ${ }^{18}$ Obwohl die Presse der Jahre nach 1945 offiziell einen deutlichen Trennstrich zur NS-Presse zieht, gibt es in personeller und teilweise auch in ideologischer Hinsicht zahlreiche Kontinuitäten - sowohl in Deutschland wie in Österreich. ${ }^{19}$ Die bekanntesten österreichischen Nachkriegsillustrierten sind die SPÖ-nahe Wiener Bilderwoche (1945 -1960) (Abb.5), die ÖVP-nahe Große Österreich Illustrierte (1949-1964), die KPÖ-nahe Welt-Illustrierte (1946-1955) und die überparteiliche Wiener Illustrierte (1947-1962). Ab Mitte der 1950er Jahre werden diese Zeitschriften aber nach und nach eingestellt. Ein Jahrzehnt später existiert keines dieser Blätter mehr. Zwar gibt es auch danach noch vereinzelte 
Zeitungen und Zeitschriften, die zumindest teilweise auf die Berichterstattung in Bildern setzen (etwa die 1955 gegründete Wochenpresse ${ }^{20}$ ), aber es gelingt ihnen nicht, die Tradition der Illustrierten fortzusetzen.

Nach dem Abzug der alliierten Mächte und der Ausrufung der Neutralität (1955) öffnet sich das Land politisch und wirtschaftlich hin zu seinen westlichen Nachbarn, insbesondere zur Bundesrepublik Deutschland. Die enge wirtschaftliche Verflechtung mit dem Nachbarland macht sich bald auch auf dem Zeitschriftenmarkt bemerkbar. Die bundesdeutschen Illustrierten, die gezielt neue Absatzmärkte erschließen, können ab Mitte der 1950er Jahre in Österreich enorme Zuwachsraten erzielen. Mittels aufwendiger Werbekampagnen und eigens gegründeter „Österreich-Ausgaben“ beginnt ein harter Verdrängungswettbewerb. ${ }^{21}$ Die österreichischen Blätter geraten in dieser Situation zunehmend unter Druck. Sie können wirtschaftlich mit ihren deutschen Konkurrenten nicht mithalten, vor allem weil sie den Kampf um die Anzeigen verlieren. ${ }^{22}$ Durch ihre chronische Unterfinanzierung versäumen sie Anpassungen an den Lesergeschmack, etwa teure Investitionen in den Farbdruck, sie sparen bei kostspieligen Reportagen und ihre grafische Aufmachung bleibt durchweg konservativ. Am 31. Dezember 1960 verabschiedet sich die Redaktion der Wiener Bilderwoche mit folgenden Sätzen: „Wir räumen das Feld unter dem Druck der ungehemmten Überschwemmung unseres Landes mit importierten Illustrierten.“23

\section{Die Fotografen: Beruf und Image}

Ich habe in diesem Buch die Geschichte des Fotojournalismus nicht als Chronologie großer Fotografen, auch nicht als Abfolge fotografisch-technischer Errungenschaften oder als Erfolgsgeschichte grafischer Lösungen nachgezeichnet, sondern als mehrschichtige, thematisch sehr offene Gesellschafts- und Kulturgeschichte. Pressefotografien sind, aus diesem Blickwinkel betrachtet, Dokumente, die auf eine breitere Gesellschaftsgeschichte verweisen und erst in zweiter Linie auf das angeblich geschlossene CEuvre eines Fotografen. Damit unterscheidet sich diese Studie grundlegend von Monografien und Ausstellungs-

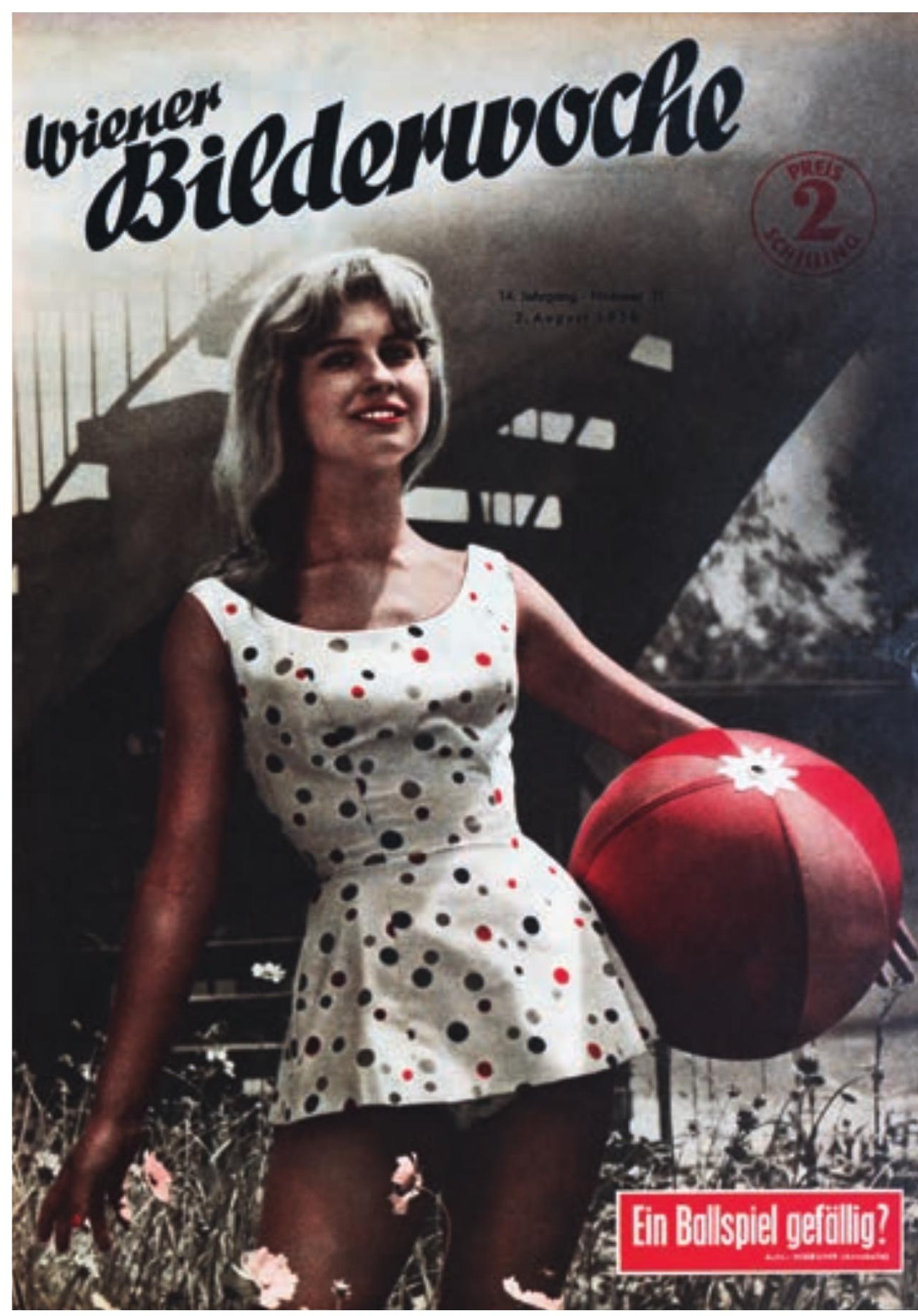

katalogen, die sich dem Leben und Werk einzelner Starfotografen widmen, ohne danach zu fragen, in welchen Kontexten die Bilder entstanden sind und wie sie seinerzeit in der Öffentlichkeit verwendet wurden. Diese Aufwertung der Fotografen zu unumstrittenen Hauptdarstellern des Fotojournalismus, wie sie in den letzten Jahren erfolgte, verstellt oft den Blick auf die gesellschaftspolitischen Zusammenhänge, in denen die Fotografen tätig waren und ihre Aufnahmen machten. Wir haben gesehen, dass die Pioniere der Pressefotografie zunächst nichts anderes waren als einfache, oft sogar anonym arbeitende
Abb. 5 Eine ganze Reihe von Illustrierten wird nach 1945 in Österreich gegründet. Die Jahre des fotojournalistischen Aufbruchs währen aber nur kurz. Ab Mitte der 1950er Jahre werden die Zeitungen nach und nach wieder eingestellt. Die 1945 gegründete Wiener Bilderwoche erscheint bis 1960. Wiener Bilderwoche, 2. August 1958, Titelseite. Foto: Elly Niebuhr. 
Bildlieferanten für einen komplexen Medienbetrieb. Erst in einigen jüngeren Darstellungen der Fotogeschichte sind sie zu journalistischen Heroen, zu herausragenden Einzelkämpfern des Fotojournalismus emporgehoben worden.

Bis weit in die Zwischenkriegszeit hinein ist der Beruf des Pressefotografen - im Vergleich zu den schreibenden Journalisten - keineswegs hoch angesehen. Viele der Fotografen sind freiberuflich tätig und arbeiten gleichzeitig für mehrere Zeitungen. Ihre Verhandlungsposition gegenüber ihren Auftraggebern, den Redaktionen, ist schwach. Es kommt häufig vor, dass Pressefotografen nach einigen Jahren Berufstätigkeit die Arbeit wieder aufgeben, als angestellte Fotografen in ein Fotoatelier zurückkehren oder einen ganz anderen Beruf ergreifen. Vor diesem Hintergrund ist es auch nicht verwunderlich, dass die biografischen Zeugnisse über die Pressefotografen relativ dünn gesät sind. Während die schreibende Zunft es verstand und versteht, ein Berufsethos zu kultivieren und gesellschaftliche Anerkennung über ihren Arbeitsplatz hinaus zu erlangen, bleiben die meisten Pressefotografen, die bis zur Mitte des 20. Jahrhunderts tätig sind, kaum einer breiteren Öffentlichkeit bekannt. Es ist bezeichnend für das Berufsbild des Pressefotografen, dass in den Zehntausenden von Zeitungsseiten, die ich im Zuge meiner Forschungen gesichtet habe, kein einziger österreichischer Pressefotograf, mit Ausnahme Lothar Rübelts, als Protagonist vor der Kamera auftaucht. Von den meisten Lichtbildnern ist kein Porträt bekannt. Bildmaterial, das sie bei ihrer Arbeit zeigt, ist überaus rar.

Dennoch ändert sich das Image der Pressefotografen in der Zwischenkriegszeit. Einige der Fotografen treten allmählich aus der Anonymität heraus und es gelingt ihnen, sich in der Welt des Journalismus einen Namen zu machen. Ein wichtiger Katalysator dieser Entwicklung ist die Star- und Prominentenfotografie, die nach dem Ersten Weltkrieg nicht nur die Porträtierten ins Licht der großen Öffentlichkeit rückt, sondern auch, wenn auch in weit geringerem Maße, die Urheber der Bilder. Der Berliner Erich Salomon ist einer der ersten deutschen Pressefotografen, der bereits um 1930 im Schatten seiner berühmten Porträtierten Kultstatus erlangt. ${ }^{24}$ Die Kultivierung berühmter Fotografen ist auch das Ergebnis der rasanten Auflagensteigerungen der illustrierten Presse in den 1920er Jahren, wie sie vor allem in Deutschland zu beobachten ist. Große Verlagshäuser wie Ullstein gehen in den 1920er Jahren dazu über, bekannte Fotografen unter Vertrag zu nehmen und diese als Stars zu lancieren. Mit dem Aufkommen der modernen Fotoreportage Ende der 1920er Jahre, die den Namen des Fotografen oft gleichrangig mit dem des Textautors an prominenter Stelle zu Beginn eines Beitrags nennt, erhöht sich ihr gesellschaftlicher Stellenwert noch einmal.

Auch wenn in diesem Buch die medien- und gesellschaftsgeschichtliche Bedeutung und weniger das Einzelwerk von Fotografen im Vordergrund steht, habe ich dennoch nicht darauf verzichtet, auf Werk und Biografie immer wieder auch explizit zu sprechen zu kommen. Zudem habe ich im Anhang Kurzbiografien österreichischer Pressefotografen der Jahre 1890 bis 1945 zusammengestellt, die in ihrer Gesamtheit eine Art Kollektivbiografie ergeben. Viele dieser Fotografinnen und Fotografen waren in der Fotografiegeschichte bisher nicht oder kaum bekannt. ${ }^{25}$ Im Zuge der Recherchen zu vorliegendem Buch konnten zahlreiche neue Informationen zu deren Lebenslauf und Werk gewonnen werden. Wenn wir diese Einträge in ein Gesamtmuster einordnen, lassen sich langfristige Entwicklungen besser beurteilen. Es wird beispielsweise deutlich, wie sehr die Pressefotografie ein männlich dominiertes Metier ist. Bis in die 1920er Jahre arbeiten praktisch ausschließlich Männer hinter der Kamera. Erst während des Ersten Weltkriegs beginnt sich die Rolle der Geschlechter nachhaltig zu verändern. Bereits während des Krieges werden Fotoateliers und Fotoagenturen von Frauen (weiter)geführt, während die Männer Kriegsdienst leisten. Nach dem Krieg, vor allem aber ab Ende der 1920er Jahre, beginnen vermehrt Frauen im Bereich der Pressefotografie zu arbeiten. Sie wählen sehr oft die „weicheren“ Themen und spezialisieren sich etwa auf die Theater-, Tanz-, Porträt- und Aktfotografie, sie erstellen gesellschaftspolitische Dokumentationen und liefern Reise- und Sozialreportagen. Die politische Tagesberichterstattung ist weiterhin fest in der Hand der Männer. 
Weiterhin zeigt sich, dass die Anzahl der Pressefotografen ab den 1910er Jahren erstmals deutlich ansteigt. Mitte der 1920er Jahre erfolgt, im Fahrwasser zahlreicher Zeitungs- und Zeitschriftenneugründungen, ein weiterer Schub der Expansion. Während die Fotografen der ersten Generation (die Pioniere, die um und bald nach 1900 arbeiten) oft schon arrivierte Porträtfotografen mittleren Alters sind, lässt sich in den 1920er Jahren eine deutliche Verjüngung unter den Fotojournalisten feststellen. Ende der 1920er Jahre ist die Bildpresse für einige Jahre ein Eldorado, das einer steigenden Anzahl junger Lichtbildner ein spannendes Betätigungsfeld eröffnet. Um 1930 beginnt sich auch der Status der Pressefotografen zu verändern. Haben bisher Allrounder das Feld beherrscht, die alles ablichteten, was gebraucht wurde, so treten nun immer mehr Spezialisten auf, die sich auf einzelne Themen konzentrieren, etwa die Sportberichterstattung, die Mode, die Politik, Reportagen etc. Ebenfalls um 1930 treten auch neue Protagonisten unter den Pressefotografen auf: Amateure mit künstlerischen Ambitionen. Sie finden in der Pressefotografie nicht nur ein $\mathrm{zu}-$ sätzliches Einkommen. Die illustrierten Zeitungen, v. a. aber die gehobenen Kulturzeitschriften, bilden nun auch neue Foren zur Präsentation ihrer Arbeiten.
Wenn wir die Biografien der österreichischen Pressefotografen in der Zwischenkriegszeit überblicken, wird deutlich, wie einschneidend der Bruch des Jahres 1938 ist. Die antisemitische Gewalt hat nicht nur die Existenzen jüdischer Fotografen, Journalisten und Zeitungsherausgeber zerstört, sondern das gesamte Mediensystem in seinen Grundfesten erschüttert. Die Presselandschaft wird unter nationalsozialistischer Anleitung massiv umgebaut. Für viele nicht jüdische Fotografen eröffnen sich dadurch neue Arbeits- und Karrieremöglichkeiten. Etliche von ihnen arbeiten nach 1945 bruchlos weiter, ganz so, als ob die Jahre der Diktatur zwischen 1938 und 1945 nur eine kleine Fußnote in der Geschichte gewesen wären. Kaum einer der jüdischen Fotografen, die nach 1938 vertrieben wurden, kehrt nach dem Krieg nach Österreich zurück. Das Jahr 1938 lastet bis heute schwer auf der Fotogeschichte der Nachkriegszeit. ${ }^{26}$ Und auch die österreichische Pressefotografie nach 1945 ist ohne die genaue Kenntnis der Vorgeschichte von Nationalsozialismus und Krieg nicht verständlich. Aber das ist bereits eine andere Geschichte. Sie ist ebenso spannend und facettenreich wie die Epoche, mit der ich mich in diesem Buch beschäftigt habe. Ihre genaue Analyse ist noch zu leisten. 


\section{Anmerkungen}

\section{Auf den Spuren der rasenden Reporter}

${ }^{1}$ Walker Evans: American Photographs, hg. vom Museum of Modern Art. Mit einem Essay von Lincoln Kirstein, München 2012 (amerikanische Originalausgabe: 1938), S. 195

\section{Neue illustrierte Welt}

${ }^{1}$ Michael L. Carlebach: American Photojournalism comes of Age, Washington, London 1997, S. 34 ff. Bains Fotosammlung wird heute in der Library of Congress in Washington aufbewahrt.

2 Hans Weber: Der Bilderdienst, in: Der Verlag Ullstein zum Reklame-Kongress 1929, Berlin 1929, S. 185189, hier S. 187 f. Zit. nach Malte Zierenberg: Die Ordnung der Agenturen. Zur Verfertigung massenmedialer Sichtbarkeit im Pressewesen 1900-1940, in: Annelie Ramsbrock, Annette Vowinckel, Malte Zierenberg (Hg.): Fotografien im 20. Jahrhundert. Verbreitung und Vermittlung, Göttingen 2013, S. 44-65., hier S. 50.

${ }^{3}$ Zit. nach: Peter de Mendelssohn: Zeitungsstadt Berlin. Menschen und Mächte in der Geschichte der deutschen Presse, Berlin, Wien 1959, überarbeitete und erweiterte Auflage 1982, S. 152.

${ }^{4}$ Vgl. dazu Klaus Kreimeier: Traum und Exzess. Die Kulturgeschichte des führen Kinos, Wien 2011, S. 70 f. und S. $107 \mathrm{f}$.

${ }^{5}$ Das Standardwerk zur Geschichte der amerikanischen Pressefotografie stammt von Michael L. Carlebach: American Photojournalism comes of Age, Washington, London 1997. Mit der Entstehungsgeschichte der deutschsprachigen Pressefotografie beschäftigen sich v. a. Bernd Weise, Dirk Halfbrodt und Diethart Kerbs. Siehe dazu den Überblick zum Stand der Forschung weiter unten sowie das Literaturverzeichnis.

${ }^{6}$ In jüngster Zeit ist allerdings eine verstärkte Aufmerksamkeit der Forschung für einzelne Gattungen der Populärkultur festzustellen. Vgl. etwa Jessica Nitsche, Nadine Werner (Hg.): Populärkultur, Massenmedien, Avantgarde 1919-1933, München 2012.

7 Einige Themen und Aspekte der vorliegenden Forschungsarbeit habe ich bereits in mehreren Aufsätzen in der Zeitschrift Fotogeschichte vorgestellt. Vgl. dazu das Literaturverzeichnis. Hinweise zur Geschichte der österreichischen Pressefotografie finden sich zudem auch in meinem Band: Fotografie in Österreich. Geschichte, Entwicklungen, Protagonisten. 1890-1955, Wien 2013.

${ }^{8}$ Ulrich Keller: Photojournalism around 1900. The Institutionalisation of a Mass Medium, in: Kathleen Collins (Hg.): Shadow and Substance. Essays on the History of Photography, Troy, Michigan 1990, S. 283-303, hier S. $293 \mathrm{ff}$.

9 Das Forschungsprojekt zur Geschichte der Pressefotografie wurde vom österreichischen Wissenschaftsfonds FWF gefördert und in Zusammenarbeit mit der Österreichischen Nationalbibliothek/Bildarchiv und Grafiksammlung realisiert. Ohne die tatkräftige Unterstützung von Dr. Hans Petschar (ÖNB/Bildarchiv und Grafiksammlung, Wien) wäre dieses Projekt nicht möglich gewesen. Zu danken habe ich auch Dr. Dieter Vorsteher, Leiter der Fotosammlung im Deutschen Historischen Museum in Berlin, Dr. Péter Baki und Dr. Balazs Zoltán Tóth am ungarischen Fotomuseum in Kecskemét sowie Dr. Jan Mlcoch, Kunstgewerbemuseum in Prag. Ein besonderer Dank geht an Dr. Alys George.

${ }^{10} \mathrm{Im}$ angloamerikanischen Raum setzt sich die Pressefotografie früher in der Tagespresse durch als in den meisten anderen Ländern. Bereits 1904 entsteht in England mit dem Daily Mirror die erste Tabloid-Ta- geszeitung, die vorwiegend mit Pressefotos arbeitet. Nach ihrem Vorbild starten 1919 die New York Illustrated Daily News. In den 1920er Jahren sind in den USA Pressebilder in Tageszeitungen schon weitverbreitet, im deutschsprachigen Raum beginnt diese Entwicklung erst in den 1920er und 1930er Jahren oder gar noch später.

${ }^{11}$ Die Frühgeschichte der Pressefotografie in Tageszeitungen müsste in einer eigenen Studie untersucht werden.

12 Herausragend in Österreich ist das Online-Projekt ANNO (http://anno.onb.ac.at), der virtuelle Zeitungslesesaal der Österreichischen Nationalbibliothek, der u. a. zahlreiche illustrierte Zeitungen und Zeitschriften in digitaler Form zugänglich macht. Bemerkenswert ist auch das 2012 gestartete Online-Projekt „Illustrierte Magazine der klassischen Moderne" (http://www.illustrierte-presse.de), das wichtige deutsche Magazine der Zwischenkriegszeit in hochwertiger Digitalisierung zugänglich macht und Hintergrundinformationen zu den präsentierten Medien bietet. Das Projekt wird von Patrick Rössler (Universität Erfurt) geleitet und in Zusammenarbeit mit der Sächsischen Landesbibliothek - Staats- und Universitätsbibliothek Dresden (SLUB) durchgeführt. Vgl. dazu Patrick Rössler, Achim Bonte, Katja Leiskau: Digitization of Popular Print Media as a Source for Studies on Visual Communication: Illustrated Magazines of the Weimar Republic, in: Historical Social Research, Vol. 37, Heft 4, 2012, S. 172-190.

${ }^{13} \mathrm{Im}$ Zuge des Forschungsprozesses musste die anvisierte Grundgesamtheit an untersuchten Zeitungen und Zeitschriften wiederholt ausgeweitet werden, da immer wieder neue, bisher unbekannte Blätter auftauchten.

${ }^{14}$ Vgl. dazu Diethart Kerbs: Schicksale Deutscher Pressebildarchive, in: Rundbrief Fotografie, Vol. 11, No. 3 15. September 2004 (N.F. 43), S. 23-29.

${ }^{15}$ Für die vorliegende Arbeit habe ich schwerpunktmäßig in österreichischen und deutschen Pressebildarchiven, aber auch in ungarischen und tschechischen Bibliotheken, Museen und Archiven recherchiert: u. a. in der Österreichischen Nationalbibliothek in Wien, im Ullstein Bildarchiv, Berlin, im Deutschen Historischen Museum, Berlin, im Ungarischen Fotomuseum, Kecskemét, und im Museum für angewandte Kunst in Prag.

${ }^{16}$ Die führende Wiener Agentur Schostal beispielsweise unterhält in der Zwischenkriegszeit Niederlassungen in Paris, Mailand, Stockholm und Berlin. In Wien wiederum vertritt sie die große amerikanische Agentur Keystone View.

17 Um nur ein Beispiel zu nennen: Der ungarische Fotograf jüdischer Herkunft László Willinger (19091989) erhält seine Ausbildung in Budapest, Ende der 1920er Jahre arbeitet er in Paris und in Wien, wo sein Vater eine Fotoagentur führt. Anfang der 1930er Jahre geht er als Fotograf und Journalist nach Berlin, 1933 nach dem Machtantritt der Nationalsozialisten, flüchtet er wieder nach Wien, von wo aus er 1939 in die USA emigriert. Vgl. dazu auch Milena Greif: Die Geschichte der Wiener Fotoagentur Willinger und ihr verschwundener Bestand, in: Rundbrief Fotografie, Vol. 11, No. 3, 15. September 2004 (N.F. 43), S. 37-40.

18 Harald Lechenperg beispielsweise, der Ende der 1920er Jahre über Paris nach Berlin geht, wird 1937 Schriftleiter der Berliner IIlustrirten Zeitung. Vgl. dazu ausführlicher Kurt Kaindl: Harald Lechenperg. Pionier des Fotojournalismus 1929-1937, Salzburg 1990.

${ }^{19}$ Darunter ist auch Kurt Korff, der bekannte Chefredakteur der Berliner Illustrirten Zeitung, der in Wien eine Fortsetzung des Berliner Blattes versucht. Vgl, dazu Timm Starl: Nach dem Muster aus Berlin - die „Wiener Illustrierte“ 1933/34, in: Diethart Kerbs, Walter Uka
(Hg.): Fotografie und Bildpublizistik in der Weimarer Republik, Bönen 2004, S. 199-207. Auch Andre Friedmann (Robert Capa), der in Berlin bei der Agentur Dephot/Degphot gearbeitet hat, flieht Anfang März 1933 nach Wien, wo er bei Harald Lechenperg vorübergehend Unterkunft und Arbeit als Fotolaborant findet, bevor er nach Budapest und dann nach Paris geht.

${ }^{20}$ Vgl. dazu Klaus Honnef, Frank Weyers: Und sie haben Deutschland verlassen ... müssen. Fotografen und ihre Bilder 1928-1997, Ausstellungskatalog, hg. vom Rheinischen Landesmuseum Bonn, Landschaftsverband Rheinland, Köln 1997 sowie Klaus Honnef: Fotografen im Exil, in: Exilforschung. Ein internationales Jahrbuch, hg. im Auftrag der Gesellschaft für Exilforschung/Society for Exile Studies von Claus-Dieter Krohn, Erwin Rotermund, Lutz Winckler, Imtrud Wojak und Wolf Koepke, Band 21: Film und Fotografie, München 2003. Vgl. dazu auch Anna Auer, Kunsthalle Wien (Hg.): Übersee. Flucht und Emigration österreichischer Fotografen 1920-1940, Wien 1997.

${ }^{21}$ Vgl. dazu Rainer Rutz: Signal. Eine Auslandsillustrierte als Propagandainstrument im Zweiten Weltkrieg, Essen 2007.

${ }^{22}$ Bereits seit Mitte der 1850er Jahre werden in der itlustrierten Presse Holzschnitte nach Fotovorlagen (Fotoxylografie) veröffentlicht. Vgl. dazu Bernd Weise: Aktuelle Nachrichtenbilder "nach Photographien“ in der deutschen illustrierten Presse in der zweiten Hälfte des 19. Jahrhunderts, in: Charles Grivel, André Gunthert, Bernd Stiegler (Hg.): Die Eroberung der Bilder. Photographie in Buch und Presse 1816-1914, S. $72 \mathrm{ff}$.

${ }^{23}$ Diethart Kerbs: Die illustrierte Presse am Ende der Weimarer Republik, in: Diethart Kerbs, Henrick Stahr (Hg.): Berlin 1932. Das letzte Jahr der Weimarer Republik. Politik, Symbole, Medien, Berlin 1992, S. 68-89, hier S. 76.

24 Siegfried Kracauer: Die Photographie (1927), in: Ders.: Schriften, hg. von Karsten Witte, Bd. 5.2: Aufsätze 1927-1931, Frankfurt am Main 1990, S. 83-98, hier S. 92 (kursiv im Original).

${ }^{25}$ Beispielhaft seien genannt: Werner Gräff: Es kommt der neue Fotograf! Berlin 1929; Franz Roh, Jan Tschichold: Foto-Auge, Stuttgart 1929, László Moholy-Nagy: Malerei Fotografie Film, München 1925, aber auch John Heartfield, Hannah Höch und andere griffen in ihren publizistischen und künstlerischen Arbeiten auf die massenmedial reproduzierte Fotografie zurück.

${ }^{26}$ In diesen Abschnitt fließen Ausführungen ein, die ich erstmals in der Zeitschrift Fotogeschichte veröffentlicht habe. Vgl. Anton Holzer: Nachrichten und Sensationen. Pressefotografie in Deutschland und Österreich 1890 bis 1933. Ein Literaturüberblick, in: Fotogeschichte, Heft 107, 2008, S. 61--67.

27 Im deutschsprachigen Raum setzt die Beschäftigung mit der illustrierten Presse Ende der 1920er Jahre im Umfeld der deutschen Zeitungswissenschaft ein, die sich während und nach dem Ersten Weltkrieg etabliert hat. Der wichtigste Autor dieser Jahre, Willy Stiewe, ist seit Mitte der 1920er Jahre Bildchef bei der NS-Zeitung Illustrierter Beobachter und ab 1929 ,Hauptschriftleiter" der Neuen IIlustrierten Zeitung. Er interessiert sich kaum für die historische Entwicklung der Bildpresse, sondern vielmehr für die Beschreibung eines effizienten Modells zeitgenössischer Pressefotografie. Vgl. Willy Stiewe: Das Bild als Nachricht. Nachrichtenwert und -technik des Bildes. Ein Beitrag zur Zeitungskunde, Berlin 1933.

${ }^{28} \mathrm{Vgl}$. etwa Wilhelm Marckwardt: Die Illustrierten der Weimarer Zeit. Publizistische Funktion, ökonomische Entwicklung und inhaltliche Tendenzen, München 1982. 
${ }^{29}$ Vgl. etwa Kenneth E. Olson: The History Makers. The Press of Europe from its Beginnings through 1945, Baton Rouge 1966 sowie die nach wie vor sehr gute Studie von Theodore Peterson: Magazines in the Twentieth Century, 2. Auflage, Urbana 1964 (die erste Auflage erschien 1956).

${ }^{30}$ Josef Maria Eder: Geschichte der Photographie, vierte, gänzlich umgearbeitete und vermehrte Auflage, Bd. 2, Halle (Saale) 1932, S. 906. Ähnlich argumentieren später die Fotohistoriker Erich Stenger und Wolfgang Baier.

${ }^{31}$ Vgl. Helmut Gernsheim: Geschichte der Photographie. Die ersten hundert Jahre, Frankfurt a. M., Berlin 1983, S. $641 \mathrm{ff}$. (Der Band geht auf die englische Ausgabe „History of Photography“ aus dem Jahr 1955 zurück); Beaumont Newhall: Geschichte der Photographie, München 1984, hier S. 257 ff. (Mehrfach überarbeitete Ausgabe der englischen Publikation: Photography. A Short Critical History 1839-1937 aus dem Jahr 1937).

32 Herausragend dabei ist der Band von Bodo von Dewitz, Robert Lebeck (Hg.): KIOSK. Eine Geschichte der Fotoreportage 1839-1973, Göttingen 2001.

${ }^{33}$ Vgl. etwa die jüngsten Publikationen zur Fotobuchforschung: Manfred Heiting, Roland Jaeger (Hg.): Autopsie. Deutschsprachige Fotobücher 1918 bis 1945, Bd. I \& II, Göttingen 2012/2014; Martin Parr, Gerry Badger (Hg.): The Photobook. A History, Vol. I, II \& III, London 2004/2006/2014; Peter Pfrunder (Hg.): Schweizer Fotobücher 1927 bis heute. Eine andere Geschichte der Fotografie, Baden 2011; Peter Pfrunder: Fragen an das Fotobuch. Gedruckte Fotografie - eine unterschätzte Dimension der Fotogeschichte, in: Anton Holzer ( $\mathrm{Hg}$.): Einführung in die Fotogeschichte. Recherche, Methoden, Theorie, Fotogeschichte, Heft 124, 2012, S. 42-49.

34 Vgl. etwa Annelie Ramsbrock, Annette Vowinckel, Malte Zierenberg (Hg.): Fotografien im 20. Jahrhundert. Verbreitung und Vermittlung, Göttingen 2013. Diese Studie rückt v. a. die Entstehungs- und Verwendungszusammenhänge der Pressefotografie, etwa am Beispiel der Fotoredakteure, der Fotoagenturen oder der Entstehung moderner Reportageformate, in den Mittelpunkt. Siehe insbesondere die Beiträge von Annette Vowinckel, Malte Zierenberg und Ulrich Keller.

${ }^{35}$ Wichtige Publikationen im deutschsprachigen Raum sind: Herbert Molderings: UMBO - Otto Umbehr 19021980, Düsseldorf 1995; ders.: Umbo. Vom Bauhaus zum Bildjournalismus. Ausstellungskatalog, Düsseldorf 1996; Janos Frecot, Berlinische Galerie (Hg.): Erich SaIomon. „Mit Frack und Linse durch Politik und Gesellschaft". Photographien 1928-1938, München 2004; F. C. Gundlach (Hg.): Martin Munkácsi. Mit Texten von Enno Kaufhold und Klaus Honnef, Göttingen 2006; Ute Eskildsen (Hg.): „Fliegen Sie sofort nach .... - Wolfgang Weber. Reportagen, Fotografie und Film 19251977, Göttingen 2005; Peter Pfrunder (Hg.): Gotthard Schuh. Eine Art Verliebtheit, Göttingen 2009; Marion Beckers, Elisabeth Moortgat: Eva Besnyö. Fotografin 1910-2003. Budapest, Berlin, Amsterdam, Berlin 2011.

${ }^{36} \mathrm{Vgl}$. etwa die beiden vorzüglichen Publikationen zu Willy Römer und Philipp Kester, die auch eine medienund kulturhistorische Rekonstruktion der frühen deutschen Pressefotografie liefern: Diethart Kerbs (Hg.): Auf den Straßen von Berlin. Der Fotograf Willy Römer (1887-1979), Ausstellungskatalog, Deutsches Historisches Museum, Bönen 2004 sowie Dirk Halfbrodt, UIrich Pohlmann (Hg.): Philipp Kester - Fotojournalist, New York, Berlin, München 1903-1935, Berlin 2003.

37 Zu einem Gutteil geht dieser Mythos auf Tim Gidal und seine Publikationen zurück. Vgl. dazu Tim Gidal: Deutschland - Beginn des modernen Photojournalismus, Luzern, Frankfurt 1972.

${ }^{38} \mathrm{Vgl}$. etwa die Arbeiten von Bernd Weise, Dirk Halfbrodt und Diethart Kerbs, siehe Literaturverzeichnis.

${ }^{39}$ Robert Taft: Photography and the American Scene. A Social History, New York 1938, S. $419 \mathrm{ff}$.

${ }^{40}$ Vgl. etwa Peter Brooker, Sascha Bru, Andrew Thacker:
The Oxford Critical and Cultural History of Modernist Magazines, Volume 3: Europe 1880-1940, Oxford 2013; David Crowley: Magazine Covers, London 2003; Stéphane Duperray, Raphaele Vidaling: Front Page. Covers of the Twentieth Century, London 2003; Steven Heller: Merz to Emigre and Beyond: Avant-Garde Magazine Design of the Twentieth Century, London 2003; Steve Taylor: 100 years of magazine covers, London 2006.

${ }^{41}$ Rune Hassner: Bilder för miljöner, Stockholm 1977.

${ }^{42}$ Vgl. etwa Michel Frizot (Hg.): Neue Geschichte der Fotografie, Köln 1998 (die französische Originalausgabe erschien 1994); Liz Wells (Hg.): Photography. A critical introduction, London, New York, 2. Aufl. 2002. Michel Frizot, Cédric de Veigy: Vu. The Story of a Magazine that made an Era, London 2009. Aus amerikanischer Perspektive einen Blick nach Europa werfen Colin Osman und Sandra Philipps: European Visions: Magazine Photography in Europe between the Wars, in: Marianne Fulton (Hg.): Eyes of Time. Photojournalism in America, New York 1988, S. 75-103.

43 Ulrich Keller: Photojournalism around 1900. The Institutionalisation of a Mass Medium, in: Kathleen Collins (Hg.): Shadow and Substance. Essays on the History of Photography, Troy, Michigan 1990, S. 283-303, hier S. $293 \mathrm{ff} . ;$ Ulrich Keller: Early Photojournalism, in: David Crowley, Paul Heyer (Hg.): Communication in History, New York 1995, S. 170-178; Ulrich Keller: Blut und Silber. Die Inszenierung der Kuba-Invasion in der amerikanischen Bildpresse, in: Fotogeschichte, Heft 97, 2005, S. 25-46.

${ }^{44}$ Vgl. etwa Michael L. Carlebach: American Photojournalism comes of Age, Washington, London 1997 und Jean-Pierre Bacot: La presse illustrée au XIXe siècle. Une histoire oubliée, Limoges 2005.

${ }^{45}$ Vgl. Bodo von Dewitz, Robert Lebeck (Hg.): KIOSK. Eine Geschichte der Fotoreportage 1839-1973, Göttingen 2001.

${ }^{46}$ Beispiele dafür sind: Ute Eskildsen, Institut für Auslandsbeziehungen (Hg.): Fotografie in deutschen Zeitschriften 1924-1933, Stuttgart 1982; Ute Eskildsen (Hg.): Fotografieren heißt teilnehmen. Fotografinnen der Weimarer Republik, Essen 1995; Bernd Weise: Pressefotografie unter dem Diktat der Nationalsozialisten, in: Arbeitskreis Photographie Hamburg in Zusammenarbeit mit den Deichtorhallen Hamburg ( $\mathrm{Hg}$.): Das deutsche Auge. 33 Photographen und ihre Reportagen - 33 Blicke auf unser Jahrhundert, München 1996, S. 30-35; Brigitte Werneburg: Fotojournalismus in der Weimarer Republik, in: Fotogeschichte, Heft 13, 1984, S. 27-40; Patrick Rössler: Moderne Illustrierte. Illustrierte Moderne. Zeitschriftenkonzepte im 20. Jahrhundert, Ausstellungskatalog, Stuttgart 1988; Patrick Rössler: 1928: Wie das neue Sehen in die Illustrierten kam. „Maxl Knips“, Sasha Stone, Das illustrierte Blatt und die Bildermagazine der Weimarer Republik, in: Fotogeschichte, Heft 121, 2011, S. 45-60.

47 Bernd Weise, Institut für Auslandsbeziehungen ( $\mathrm{Hg}$.): Fotografie in deutschen Zeitschriften 1883-1923, Stuttgart 1991; Bernd Weise: Pressefotografie I-V, in: Fotogeschichte, 9. Jg., Heft 31 und Heft 33, 1989; 10. Jg., Heft 37, 1990; 14.Jg., Heft 52, 1994; 16. Jg., Heft 59, 1996; Bernd Weise: Fotojournalismus. Erster Weltkrieg - Weimarer Republik, in: Klaus Honnef, Rolf Sachsse, Karin Thomas (Hg.): Deutsche Fotografie. Macht eines Mediums 1870-1970, Bonn 1997, S.7287; Ivo Kranzfelder: Die Frühjahre des deutschen Bildjournalismus, in: Dirk Halfbrodt, Ulrich Pohlmann (Hg.): Philipp Kester - Fotojournalist. New York, Berlin, München 1903-1935, Berlin 2003; Diethart Kerbs: Zur Geschichte der Berliner Pressefotografie im ersten Drittel des zwanzigsten Jahrhunderts, in: Diethart Kerbs, Walter Uka (Hg.): Fotografie und Bildpublizistik in der Weimarer Republik, Bönen 2004, S. 29-48.

${ }^{48}$ Gerhard Schnabl: Die Geschichte des österreichischen Photojournalismus vom Durchbruch der Autotypie bis zur Einführung des Fernsehens, Diss., Wien 1983.
${ }^{49}$ In Ungarn hingegen hat sich die Fotografiegeschichte bereits in Form von Fallstudien mit der frühen Pressefotografie beschäftigt. Vgl. etwa Károly Kincses, Magdolna Kolta: Minden magyar fotoriporterek atyja: Balogh Rudolf, Magyar Fotográfiai Múzeum, Kecskemét, Budapest 1998.

50 Leo Kandl: Pressefotografie und Fotojournalismus in Österreich bis 1960, in: Geschichte der Fotografie in Österreich, hg. vom Verein zur Erarbeitung der Geschichte der Fotografie in Österreich, Bad Ischl 1983, S. 313-324.

${ }^{51}$ Timm Starl: Nach dem Muster aus Berlin - die „Wiener Illustrierte“ 1933/34, in: Diethart Kerbs, Walter Uka (Hg.): Fotografie und Bildpublizistik in der Weimarer Republik, Bönen 2004, S. 199-207; Herbert Friedlmeier: Reportagefotografie. Wie wahr ist die abgebildete Wirklichkeit?, in: Uwe Schögl (Hg.): Im Blickpunkt. Die Fotosammlung der Österreichischen Nationalbibliothek, Innsbruck 2002, S. 192-219.

${ }^{52}$ Anna Auer, Kunsthalle Wien (Hg.): Übersee. Flucht und Emigration österreichischer Fotografen 1920-1940, Wien 1997.

${ }^{53}$ Lothar Rübelt: Österreich zwischen den Kriegen. Zeitdokumente eines Photopioniers der 20er und 30er Jahre. Text von Gerhard Jagschitz, hg. und gestaltet von Christian Brandstätter, Wien 1979; Christian Brandstätter (Hg.): Lothar Rübelt. Sport. Die wichtigste Nebensache der Welt. Dokumente eines Pioniers der Sportphotographie 1919-1939, Wien u. a. 1980. Erst in jüngster Zeit setzt eine fundierte Auseinandersetzung mit Lothar Rübelt, ausgehend von seinem Nachlass und weiterem Quellenstudium, ein. Vgl. Michaela Pfundner: Dem Moment sein Geheimnis entreißen. Der Sportberichterstatter Lothar Rübelt (1901-1990), in: Matthias Marschik, Rudolf Müllner (Hg.): „Sind's froh, dass Sie zu Hause geblieben sind." Mediatisierung des Sports in Österreich, Göttingen 2010, S. 317-327.

${ }^{54}$ Vgl. dazu die Studie von Stefan Riesenfellner und Josef Seiter: Der Kuckuck. Die moderne Bild-Illustrierte des Roten Wien, Wien 1995.

${ }^{55}$ Vgl. dazu jüngst Malte Zierenberg: Die Ordnung der Agenturen. Zur Verfertigung massenmedialer Sichtbarkeit im Pressewesen 1900-1940, in: Annelie Ramsbrock, Annette Vowinckel, Malte Zierenberg (Hg.): Fotografien im 20. Jahrhundert. Verbreitung und Vermittlung, Göttingen 2013, S. 44-65.

\section{Bilder, Nachrichten, Sensationen}

${ }^{1}$ Lehmanns Adressbücher werden 1859 gegründet. Allein im Umfang bildet sich das rasante Wachstum der Stadt vor und nach der Jahrhundertwende ab. Vgl. dazu ausführlicher Sylvia Mattl-Wurm, Alfred Pfoser (Hg.): Die Vermessung Wiens. Lehmanns Adressbücher 1859-1942, Wien 2011, S. 13-45, hier S. $21 \mathrm{f}$.

${ }^{2}$ Das interessante Blatt, 24. Januar 1884, S. 7 f.: In der Wiener Zeitungsgasse.

${ }^{3}$ Ebenda.

${ }^{4}$ Das interessante Blatt, 13. März 1884, S. 7.

${ }^{5}$ Edwin Emery: The Press and America. An Interpretative History of Journalism, Englewood Cliffs, New York 1962 (1954), S. 345.

${ }^{6}$ Vgl. dazu ausführlicher: Gabriele Melischek, Josef Seethaler: Presse und Modernisierung in der Habsburgermonarchie, in: Helmut Rumpler, Peter Urbanitsch (Hg.): Die Habsburgermonarchie 1848-1918, Band VIII: Politische Öffentlichkeit und Zivilgesellschaft, 2. Teilband: Die Presse als Faktor der politischen Mobilisierung, Wien 2006, S. 1535-1571, hier S. 1779; Josef Seethaler, Gabriele Melischek: Die Zeitung im Habsburger Vielvölkerstaat, in: 400 Jahre Zeitung 1605-2005, hg. von Martin Welke und Jürgen Wilke, Bremen 2008, S. 311-334, hier S. 322 ff.; Edith Walter: Österreichische Tageszei- 
tungen der Jahrhundertwende. Ideologischer Anspruch und ökonomische Erfordernisse, Wien 1994, S. $101 \mathrm{ff}$.

${ }^{7}$ Das interessante Blatt, 25. Mai 1882, S. 8.

${ }^{8}$ Das Interessante Blatt, 22. März 1883, S. 11

${ }^{9}$ Die ersten populären Bilderzeitungen tauchen in den 1830 er Jahren auf, in den 1840er Jahren folgen illustrierte Zeitungen, die sich an ein gehobenes, gutbürgerliches Publikum wenden (etwa Illustrated London News, ab 1842, oder die in Leipzig erscheinende IIlustrirte Zeitung, ab 1843. Nach der Jahrhundertmitte folgen auflagenstarke illustrierte Familienzeitschriften wie die Gartenlaube, ab 1853, und Über Land und Meer, ab 1859. Um 1900 werden diese von den fotografisch illustrierten Wochenzeitungen verdrängt. Vgl. dazu Bernd Weise: Aktuelle Nachrichtenbilder „nach Photographien" in der deutschen illustrierten Presse de zweiten Hälfte des 19. Jahrhunderts, in: Charles Grivel, André Gunthert, Bernd Stiegler ( $\mathrm{Hg}$.): Die Eroberung der Bilder. Photographie in Buch und Presse 18161914, München 2003, S. 62-101, hier S. 66 ff.

${ }^{10}$ Nach der Ausrufung der Republik im November 1918 wird sie ein weiteres Mal umbenannt. Sie heißt nun: Wiener Illustrierte Zeitung.

${ }^{11}$ Ende der 1920er Jahre liegt die Druckauflage des Interessanten Blattes bei 46000 bis 48000 Exemplaren, davon werden durchschnittlich 30000 bis 34000 Exemplare tatsächlich verkauft. Die Druckauflage der Wiener Bilder liegt zur selben Zeit bei 32000 bis 33000 Exemplaren. Vgl. Liesl Glück: Das interessante Blatt und Der Kuckuck. Ein Beitrag zur Wiener Zeitschriftengeschichte, Diss., Wien 1953, S. 7.

${ }^{12}$ In einer Anzeige aus dem Jahr 1909 heißt es: „Österreichs Illustrierte Zeitung ist in ca. 50000 Familien und öffentlichen Lokalen des In- und Auslandes verbreitet." Diese Auflagenangabe dürfte aber weit übertrieben sein. Österreichs IIlustrierte Zeitung, 26. Dezember 1909 , o. S.

13 Wiener Bilder, 12. Januar 1896, S. 2.

14 Ebenda.

${ }^{15}$ Ursprünglich nennt er sich Karl Grvák bzw. Crvák.

${ }^{16}$ Nach dem Ersten Weltkrieg kommt es zu tief greifenden Umgestaltungen in der Eigentümerstruktur. 1919 übernimmt die Gesellschaft für Graphische Industrie die Anteile der Österreichischen Zeitungs- und DruckereiAktiengesellschaft, 1923 fusioniert diese mit dem Elbemühl-Konzern und firmiert nun unter dem Namen Elbemühl Papierfabriken und Graphische Industrie AG. Vgl. Liesl Glück: Das interessante Blatt und Der Kuckuck. Ein Beitrag zur Wiener Zeitschriftengeschichte, Diss., Wien 1953, S. 6.

17 Der 1873 gegründete Elbemühl-Konzern kauft seit den 1870er Jahren laufend Zeitungen zu, u. a. das Fremden-Blatt, die Wiener Allgemeine Zeitung, die Wiener Mittagszeitung und das Illustrirte Wiener Extrablatt. Der Hauptkonkurrent, Steyrermühl, kontrolliert u. a. das Neue Wiener Tagblatt und die Konstitutionelle Vorstadtzeitung. Vgl. Kurt Paupié: Handbuch der österreichischen Pressegeschichte 1848-1959, Bd. I: Wien, Wien, Stuttgart 1960, S. 31.

18 Liesl Glück: Das interessante Blatt und Der Kuckuck. Ein Beitrag zur Wiener Zeitschriftengeschichte, Diss., Wien 1953, S. 3

19 Die Wochenzeitung Das illustrierte österreichische Sportblatt wird 1906 als Wiener Sportblatt gegründet und erscheint von 1911 bis 1928 als Illustriertes österreichisches Sportblatt bzw. Illustriertes Sportblatt im Verlag des Interessanten Blattes. Der Sonntag erscheint nur zwei Jahre lang, von 1911 bis 1913.

20 In Deutschland führend sind der Welt-Spiegel (seit 1896, illustrierte halbwöchentliche Beilage des Berliner Tageblattes), die Bilder vom Tage (seit 1909, Beilage des Berliner Lokal-Anzeigers) und die Zeitbilder (seit 1914, Beilage der Vossischen Zeitung). Vgl. Bernd Weise, Institut für Auslandsbeziehungen ( $\mathrm{Hg}$.): Fotografie in deutschen Zeitschriften 1883-1923, Stuttgart 1991, S. 16

${ }^{21}$ Vgl. Peter de Mendelssohn: Zeitungsstadt Berlin. Menschen und Mächte in der Geschichte der deutschen Presse, Berlin, Wien 1959, überarbeitete und erweiterte Auflage 1982

22 Vgl. dazu ausführlicher Peter de Mendelssohn: Zeitungsstadt Berlin, überarbeitete und erweiterte Auflage, Frankfurt a. M., Berlin, Wien 1982 (Erstausgabe: 1959), S. $80 \mathrm{ff}$

231910 beträgt die Gesamtauflage deutschsprachiger Tageszeitungen in der österreichischen Reichshälfte der Monarchie ganze zwei Millionen. Im Deutschen Reich erscheinen hingegen täglich knapp 18 Millionen Zeitungen. VgI. Josef Seethaler, Gabriele Melischek: Die Zeitung im Habsburger Vielvölkerstaat. In: 400 Jahre Zeitung 1605-2005, hg. von Martin Welke und Jürgen Wilke, Bremen 2008, S. 311-334, hier S. 312.

${ }^{24}$ Vgl. Enno Kaufhold: Die Berliner Illustrirte - Synonym des deutschen Bildjournalismus, in: 125 Jahre Ullstein. Presse- und Verlagsgeschichte im Zeichen der Eule, Berlin 2002, S. 40-45, hier S. $40 \mathrm{ff}$.

25 Österreichs Illustrirte Zeitung, 1. Oktober 1905, S. 4. Der Text ist gezeichnet mit S. Sch. (Siegmund Schneider).

26 Ebenda.

27 Wiener Mode, 1. Januar 1888. Die Zeitschrift erscheint im Wiener Mode Verlag, aus dem 1897 die Gesellschaft für Graphische Industrie hervorgeht. Diese betreibt seit 1895 in der Wiener Gumpendorfer-Straße 87 ein modernes Druckhaus.

${ }^{28}$ Zwar tauchen in der Wiener Mode schon 1889 erste Autotypien auf, meist sind es kleine Porträts. Die Modeillustrationen sind aber bis zum Ersten Weltkrieg hauptsächlich (kolorierte) Zeichnungen.

29 Die erste Nummer der Österreichischen illustrierten Rundschau erscheint am 3. Oktober 1913. Die Einzelnummer kostet 50 Heller, das Jahresabonnement 20 Kronen. Sie gehört damit zu den teureren Illustrierten.

30 Illustrirte Österreichische Woche, 24. März 1912, S. 1.

${ }^{31}$ Die Zeitung kostet 12 Heller.

32 Das Neueste im Bilde, 24. Dezember 1919, Titelseite.

33 Die erste Nummer der Wiener Illustrierten Zeitung (nicht zu verwechseln mit der gleichnamigen Illustrierten, die ab November 1918 die Nachfolge von Österreichs Illustrierter Zeitung antritt) erscheint am 19. Dezember 1914. Ihr Preis liegt mit 14 Heller und 15 Pfennigen etwas über der Konkurrenzzeitung Das Neueste im Bilde.

34 Die Gesellschaft für Graphische Industrie geht 1897 aus dem Wiener Mode Verlag hervor, in dem seit 1888 die Zeitschrift Wiener Mode erscheint. 1912 übernimmt Richard Kola die Aktienmehrheit und übergibt den Brüdern Ignaz und Sigmund Rosenbaum die operative Leitung des Unternehmens.

${ }^{35}$ Wiener IIlustrierte Zeitung, 20. November 1915, Impressum.

${ }^{36}$ Die letzte Ausgabe der Wiener Illustrierten Zeitung erscheint am 30. Dezember 1916.

37 Der Samstag. Illustrierte Wochenschrift, 6. Oktober 1906.

38 Bernd Weise, Institut für Auslandsbeziehungen $(\mathrm{Hg}$.): Fotografie in deutschen Zeitschriften 1883-1923, Stuttgart 1991, S. 6.

${ }^{39}$ Vgl. Christian Delporte: Presse et culture de masse en France (1880-1914), in: Revue Historique Jg. 122, Nr. 605, Januar-März 1998, S. 93-121, hier S. 109 ff.; Colin Ford: Hungarian Photography 1914 to 1989: An Introduction, in: Photoresearcher. ESHPh European Society for the History of Photography, Nr. 14, 2010, S. 54-64, S. 54.

40 Dazu zwei Indikatoren: Im Jahr 1910 erreicht in Österreich die Populärpresse etwa die Hälfte der Gesamt- auflage der Tagespresse. 1890 kommen nur 20 Tageszeitungen auf Auflagen zwischen 10000 und 50000 Exemplaren, 1910 sind es bereits 40. Vgl. Josef Seethaler, Gabriele Melischek: Die Zeitung im Habsburger Vielvölkerstaat, in: 400 Jahre Zeitung 1605-2005, hg. von Martin Welke und Jürgen Wilke, Bremen 2008, S. 311-334, hier S. 324

\section{Die Jagd nach Sensationen}

${ }^{1}$ Bereits Ende der 1880er Jahre werden Fotografien im Interessanten Blatt abgedruckt. Zunächst verzichtet man dabei auf Angaben zu ihrer Herkunft, später, um 1890, werden immer öfter die Namen der Ateliers beigefügt, in denen die Bilder entstanden sind.

2 Das interessante Blatt, 6. März 1902, S. 10.

${ }^{3}$ Vgl. dazu ausführlicher Timm Starl: Knipser. Die Bildgeschichte der privaten Fotografie in Deutschland und Österreich von 1880 bis 1980, München, Berlin 1995.

41887 wird der „Club der Amateurphotographen in Wien“ (1893 in „Wiener Camera Club“ umbenannt) gegründet, ein elitärer Verein, dessen Ziel es ist, sich nach den Grundsätzen des Piktorialismus (der sogenannten „bildmäßigen Photographie“) von der angeblich niedrigen Gattung der massenhaften Fotografie abzuheben. 1891 veranstaltet der Club in Wien die erste Ausstellung, die ausschließlich der künstlerischen Fotografie gewidmet ist. Mitglieder sind unter anderen Hans Watzek, Ludwig David, Albert und Nathaniel Rothschild, Friedrich Viktor Spitzer und Hugo Henneberg. Watzek und Henneberg beginnen 1896 eine Zusammenarbeit mit Heinrich Kühn, sie experimentieren mit Gummidrucken und anderen „teuren“ Techniken. Watzek, Henneberg und Kühn werden um die Jahrhundertwende unter dem Namen „Kleeblatt“ international bekannt. Siehe Peter Weiermeir: Von der Kunstfotografie zur Neuen Sachlichkeit, in: Geschichte der Fotografie in Österreich, Bd. 1, hg. vom Verein zur Erarbeitung der Geschichte der Fotografie in Österreich, Bad Ischl 1983, S. 188-203. Zu den kunstfotografischen Aufbrüchen um 1900 siehe auch Anton Holzer: Fotografie in Österreich. Geschichte, Entwicklungen, Protagonisten 1890-1955, Wien 2013, S. $31 \mathrm{ff}$.

${ }^{5}$ Timm Starl: FotoBibl. Biobibliografie zur Geschichte der Fotografie in Österrieich von 1839 bis 1945 (online unter: www.albertina.at).

${ }^{6}$ Österreichs Illustrierte Zeitung, 9. Mai 1908, S. 767.

${ }^{7}$ Er ist nicht zu verwechseln mit dem Fotofabrikanten und Fotografen Viktor Angerer (1839-1894).

${ }^{8}$ Mertens tritt in der Öffentlichkeit als Fotografin auf, anders etwa als die die in Berlin um die Jahrhundertwende tätige Journalistin und Pionierin der Pressefotografie, Marie Goslich, die sich als „Schriftstellerin“ bezeichnet. Zu Goslich siehe Krystyna Kauffmann, Mathias Marx, Manfred Friedrich: Marie Goslich. Die Grande Dame des Fotojournalismus 1859-1938, Leipzig 2013.

${ }^{9}$ Seine beiden Söhne, Heinrich Schuhmann jun. und Ludwig Schuhmann, treten in seine Fußstapfen und werden im Ersten Weltkrieg zu bekannten Kriegsfotografen. Vgl. dazu ausführlicher das Kapitel „Mit der Kamera bewaffnet. Fotografie und Propaganda im Ersten Weltkrieg“.

10 Wiener Bilder, 26. August 1908, S. 11.

${ }^{11}$ Wiener Bilder, 11. April 1906, S. 4/5.

12 Illustriertes österreichisches Sportblatt, 11. Oktober 1913, S. 4 f.

${ }^{13}$ Ebenda, Titelseite.

${ }^{14}$ Vgl. dazu ausführlicher das Kapitel „Mit der Kamera bewaffnet. Fotografie und Propaganda im Ersten Weltkrieg".

${ }^{15}$ Zur Geschichte der Firma Lechner als Fotoagentur siehe Michael Ponstingl: Wien im Bild. Fotobildbände des 20. Jahrhunderts, Wien 2008, S. $69 \mathrm{ff}$.

16 Ebenda, S. 73. 
${ }^{17}$ Das interessante Blatt, 3. April 1902, S. 10.

181912 tauchen die ersten Fotos mit der Bezeichnung „Welt-Preß-Photo“ in der Presse auf. Der Gewerbeschein wird erst im Sommer 1913 ausgestellt.

${ }^{19}$ Vgl. dazu das Kapitel „Mit der Kamera bewaffnet. Fotografie und Propaganda im Ersten Weltkrieg“.

${ }^{20}$ Zu Würthle und Sohn siehe Erika Werl: Karl Friedrich Würthle (1820-1902), Diplomarbeit, Salzburg 1988.

${ }^{21} \mathrm{Vgl}$. dazu ausführlicher Anton Holzer: Die andere Front. Fotografie und Propaganda im Ersten Weltkrieg, 3. Aufl., Darmstadt 2012, S. 29 f.

${ }^{22}$ Bernd Weise, Institut für Auslandsbeziehungen ( $\mathrm{Hg}$.): Fotografie in deutschen Zeitschriften 1883-1923, Stuttgart 1991, S. $26 \mathrm{ff}$

${ }^{23}$ Der fotografische Nachlass der Brüder Haeckel wird heute bei Ullstein Bild in Berlin aufbewahrt und erforscht.

24 Die Sammlung Photoglob-Wehrli wird heute in der Schweizerischen Nationalbibliothek in Bern aufbewahrt. Zum Bestand siehe https://www.helveticarchives.ch/Detail.aspx?ID=222978 (Zugriff: 5. Mai 2011)

${ }^{25}$ Wiener Bilder, 18. Februar 1903, S. $5 \mathrm{ff}$.

${ }^{26}$ Vgl. Pavel Scheufler, Jan Hozák: Krásné Časy. Rudolf Bruner-Dvořák. Momentni fotograf, Prag 1995.

\section{Fotos statt Zeichnungen}

${ }^{1}$ Das interessante Blatt, 2. April 1893, Titelseite.

2 Das interessante Blatt, 1. Dezember 1899, S. 5.

${ }^{3}$ Zur Frühgeschichte der fotomechanischen Drucktechniken in Wien siehe Dorothea Peters: Fotografie für die Massen. Zur Frühgeschichte fotomechanischer Drucktechniken im Spiegel der Wiener Photographischen Gesellschaft 1964-1883 (Teil 1), in: Rundbrief Fotografie, Vol. 19, 2012 (N.F. 76), S. 8-18.

${ }^{4}$ Lediglich die Fotozinkografie (Zinkätzung) wird seit den 1870 er Jahren zur Illustration von Wiener Witzblättern verwendet. Sie ist deutlich kostengünstiger als der Holzstich. Vgl. ebenda, S. 11.

${ }^{5}$ Dorothea Peters: Fotografie für die Massen. Zur Frühgeschichte fotomechanischer Drucktechniken im Spiegel der Wiener Photographischen Gesellschaft 19641883 (Teil 2), in: Rundbrief Fotografie, Vol. 20, 2013 (N.F.77), S. 19-29, hier S. 25 f.

${ }^{6}$ Alfons Giehsz stammt aus Budapest, er lebt seit 1890 als Maler, Grafiker und Zeichner in Wien und arbeitet regelmäßig im Auftrag illustrierter Zeitungen.

${ }^{7}$ Ulrich Keller: Photojournalism around 1900. The Institutionalisation of a Mass Medium, in: Kathleen Collins (Hg.): Shadow and Substance. Essays on the History of Photography. In Honor of Heinz K. Henisch, Troy, Michigan 1990, S. 283-303, hier S. $286 \mathrm{ff}$.

${ }^{8}$ Das interessante Blatt, 3. Januar 1907, Editorial, S. 2.

${ }^{9}$ Zum Foto- bzw. Bildredakteur siehe ausführlicher Annette Vowinckel: Der Bildredakteur. Genese eines modernen Berufsbilds, in: Annelie Ramsbrock, Annette Vowinckel, Malte Zierenberg (Hg.): Fotografien im 20. Jahrhundert. Verbreitung und Vermittlung, Göttingen 2013, S. 69-89.

$10 \mathrm{Zu}$ diesem Schluss kommt man, wenn man etwa die Anzeigenseiten der einzelnen Blätter über einen längeren Zeitraum betrachtet. Stärker als andere Indikatoren weisen die beworbenen Produkte auf die Leserschaft hin.

11 Hartwig Gebhardt: „Halb criminalistisch, halb erotisch“. Presse für die „niederen Instinkte“. Annäherungen an eine unbekanntes Kapitel deutscher Mediengeschichte, in: Kaspar Maase, Wolfram Kaschuba (Hg.): Schund und Schönheit. Populäre Kultur um 1900, Köln u. a. 2001, S. 184-217, hier S. $189 \mathrm{ff}$.

${ }^{12}$ Neben dem Criminal-Reporter erscheinen um 1900 zahlreichen andere Gerichtszeitschriften, etwa Waage und Schwert. Neue interessante Detektiv-Zeitschrift (ab 1904), die auch in Österreich erhältlich sind. Weitere, ebenfalls in Österreich verkaufte Blätter sind Das Album (ab 1898), Frauenschönheit (ab 1901), Das kleine Witzblatt, Satyr (Berlin ab 1899) und Sekt (1902 in Wien gegründet). Vgl. ebenda, S. $192 \mathrm{ff}$.

${ }^{13}$ Ulrich Keller: Photojournalism around 1900. The Institutionalisation of a Mass Medium, in: Kathleen Collins (Hg.): Shadow and Substance. Essays on the History of Photography. In Honor of Heinz K. Henisch, Troy, Michigan 1990, S. 283-303, hier S. 288.

${ }^{14}$ Während der Pressefotograf seine Aufnahmen aus Zeitgründen meist nicht retuschiert, werden diese in der Produktion für den Druck sehr wohl nachbearbeitet. Zur Retusche vor dem Druck siehe Malte Zierenberg: Die Ordnung der Agenturen. Zur Verfertigung massenmedialer Sichtbarkeit im Pressewesen 1900-1940, in: Annelie Ramsbrock, Annette Vowinckel, Malte Zierenberg (Hg.): Fotografien im 20. Jahrhundert. Verbreitung und Vermittlung, Göttingen 2013, S. 44-65, hier S. 47 f.

15 Wiener Bilder, 6. Januar 1904, S. 8.

${ }^{16}$ Kurt Hahne: Die Illustrations-Photographie. Ein leicht verständliches Lehrbuch, Bunzlau 1908, S. 6.

${ }^{17}$ Ebenda, S. 9.

${ }^{18}$ Vgl. dazu Michael L. Carlebach: American Photojournalism comes of Age, Washington, London 1997, S. 34 ff., Diethart Kerbs: Zur Geschichte der Berliner Pressefotografie im ersten Drittel des zwanzigsten Jahrhunderts, in: Diethart Kerbs, Walter Uka (Hg.): Fotografie und Bildpublizistik in der Weimarer Republik, Bönen 2004, S. 29-48, hier S. $32 \mathrm{ff}$. und Matthias Bruhn: Tarife für das Sichtbare. Eine kurze Geschichte der Fotoagenturen, in: Fotogeschichte, Heft 105, 207, S. 1325, hier S. $16 \mathrm{f}$.

19 Vgl. dazu ausführlicher das Kapitel „Handel mit Bildern. Die Rolle der Fotoagenturen“.

${ }^{20}$ Im April 1900 druckt das Interessante Blatt erstmals Fotos einer frühen Berliner Fotoagentur, nämlich von "Zander \& Labisch“. 1902 bringen die Wiener Bilder erstmals Fotos aus den USA und England, u. a. folgender Unternehmen und Zeitungen: Press Publishing Company, Leslie's Weekly und London Stereoscopic and Photographic Company.

${ }^{21}$ Das interessante Blatt, 6. Juni 1895, S. 9.

22 Wiener Bilder, 9. Januar 1901, S. 9.

${ }^{23}$ Gute Amateurkameras können sich um 1900 nur betuchte Fotoliebhaber leisten. In Österreich kosten sie je nach Ausstattung (samt der notwendigen Ausrüstung) zwischen 200 und 450 Kronen. Das entspricht einem heutigen Betrag von 2500 bis 5625 Euro.

${ }^{24}$ Das interessante Blatt, 3. Januar 1907, S. 2.

${ }^{25}$ Rudolf Largajolli ist ein aus Brixen stammender Atelierfotograf.

${ }^{26}$ Das interessante Blatt, 26. April 1906, Titelseite.

27 Ebenda, 3. Mai 1906, Titelseite.

${ }^{28}$ Ebenda, 2. August 1906.

${ }^{29} \mathrm{Vgl}$. dazu ausführlicher Vanessa R. Schwartz: Spectacular Realities. Early Mass Culture in Fin-de-Siècle Paris, Berkeley, Los Angeles 1999, S. $34 \mathrm{ff}$.

30 Dazu ein Beispiel aus der Zeit des Ersten Weltkriegs: Während die führende französische Illustrierte L'Illustration zwischen 1914 und 191871 Prozent aller Bilder nach Fotovorlagen druckt, liegt der Anteil bei der (Leipziger) Illustrirten Zeitung, die noch stärker in der Tradition der Familienblätter steht, bei nur 55 Prozent. Vgl. dazu Joëlle Beurier: Violenza e fotografia di guerra nel primo conflitto mondiale: uno studio comparativo franco-tedesco attraverso due settimanali illustrati, in: Memoria e Ricerca, Nr. 20, 2005, S. 23-38, hier S. 33.

${ }^{31}$ Wiener Bilder, 12. April 1914, S. 2

\section{Bild und Text}

${ }^{1}$ Siehe beispielsweise Siegmund Schneiders mehrteilige, aus sechs Fotos bestehende Reportage über das k. u. k.
Münzamt, erschienen in Österreichs Illustrierter Zeitung, 10. Mai 1903 S. $594 \mathrm{f}$.

${ }^{2}$ Seine „Photo-Compositionen“ beschäftigen sich oft mit dem Kaiserhaus oder aktuellen Themen der höheren Wiener Gesellschaft, wie dem Abgeordnetenhaus nach den Wahlen, den Mitgliedern der Wiener Hofoper oder dem Wiener Männergesangsverein.

3 Österreichs Illustrierte Zeitung, 2. Dezember 1908, S. 146

${ }^{4}$ Vgl. dazu und zu Karl Kraus als Monteur von Bildern Leo A. Lensing: „Photographischer Alpdruck“ oder politische Fotomontage. Karl Kraus, Kurt Tucholsky und die satirischen Möglichkeiten der Fotografie, in: Fotogeschichte, Heft 52, 1994, S. 41-57, hier S. 42 f. Ebenso Leo A. Lensing: „Lebensstarre“ - Bewegende Bilder. Fotografien und ein Film in Die letzten Tage der Menschheit von Karl Kraus, in: Fotogeschichte, Heft 115, 2010, S. 5-24.

${ }^{5}$ Karl Kraus äußert sich in einer späteren Fackel-Ausgabe zur Herstellung dieser Montage: „Die Photographie ist aus dem Gruppenbild der Journalistik, das in einem illustrierten Blatt zum 60jähirgen Kaiserjubiläum erschien, ausgeschnitten. (...) Man nehme dazu eine Ansichtskarte vom Parlament, wo die Pallas Athene sich vergebens nach einem Zeus sehnt, gebe das Ganze zum Cliché-Macher, und das Bild des Siegers ist fertig." Die Fackel, Nr. 400, S. 46, zit nach: Leo A. Lensing: „Photographischer Alpdruck“ oder politische Fotomontage. Karl Kraus, Kurt Tucholsky und die satirischen Möglichkeiten der Fotografie, in: Fotogeschichte, Heft 52, 1994, S. 41-57, hier S. 44.

${ }^{6}$ Österreichs IIlustrierte Zeitung, 2. Dezember 1908, S. 146.

7 Ebenda.

${ }^{8}$ Zit. nach: Michael L. Carlebach: American Photojournalism comes of Age, Washington, London 1997, S. 14. 1887 übernimmt Hearst den San Francisco Examiner und baut inn zur auflagenstarken Massenzeitung um.

${ }^{9}$ Kurt Paupié: Handbuch der österreichischen Pressegeschichte 1848-1959, Bd. I: Wien, Wien, Stuttgart 1960, S. 40.

10 Bernd Weise, Institut für Auslandsbeziehungen ( $\mathrm{Hg}$.): Fotografie in deutschen Zeitschriften 1883-1923, Stuttgart 1991, S. $18 \mathrm{ff}$.

${ }^{11}$ Vgl. dazu ausführlicher das Kapitel „Im Schatten der Konzerne. Politische Illustrierte in der Zwischenkriegszeit".

12 Liesl Glück: Das interessante Blatt und Der Kuckuck. Ein Beitrag zur Wiener Zeitschriftengeschichte, Diss., Wien 1953, S. 12

13 Federführend bei der Durchsetzung dieser These war Tim Gidal, der selbst 1929 als Pressefotograf begann. Er formulierte sie erstmals in seinem Buch: Deutschland, Beginn des modernen Photojournalismus, Luzern, Frankfurt am Main 1972. Inzwischen wurde sie mehrfach widerlegt und es wurde gezeigt, dass die Fotoreportage eine weit längere Vorgeschichte hat, die bis in die 1890er Jahre zurückreicht.

$14 \mathrm{Vgl}$. etwa die Forschungen von Bernd Weise, Dirk Halfbrodt und Diethart Kerbs. Vgl. dazu Anton Holzer: Nachrichten und Sensationen. Pressefotografie in Deutschland und Österreich 1890 bis 1933. Ein Literaturüberblick, in: Fotogeschichte, Heft 107, 2008, S. 61-67.

${ }^{15}$ Das interessante Blatt, 13. Juni 1894, S. 5.

${ }^{16}$ Ebenda.

17 Das interessante Blatt, 3. Februar 1898, S. 3.

${ }^{18}$ Das interessante Blatt, 27. Januar 1898, S. 6.

${ }^{19}$ Das interessante Blatt, 3. Februar 1898, S. 3.

20 Ebenda.

${ }^{21}$ Zu diesem neuen Typ Fotoagentur vgl. Herbert Molderings: Eine Schule der modernen Fotoreportage. Die Fotoagentur Dephot (Deutscher Photodienst) 1928 bis 
1933, in: Fotogeschichte, Heft 107, 2008, S. 5-21, hier S. $9 \mathrm{ff}$.

\section{Redaktion, Druck, Vertrieb}

${ }^{1}$ Das interessante Blatt, 18. November 1897, S. 5

2 Ebenda.

${ }^{3}$ Das interessante Blatt, 16. Mai 1912, S. 2-4.

${ }^{4}$ Ebenda.

${ }^{5}$ Zur Entstehungsgeschichte des neuen Konzerns siehe das Kapitel „Bilder, Nachrichten, Sensationen. Die Zeitungsstadt Wien um 1900“.

${ }^{6}$ Das interessante Blatt, 16. Mai 1912, S. 2-4.

${ }^{7}$ Ebenda.

${ }^{8}$ Ebenda.

${ }^{9}$ Die von Andreas und Franz Krampolek im Jahr 1897 gegründete Photochemigraphische Kunstanstalt Patzelt \& Krampolek gehört vor dem Ersten Weltkrieg zu den größten und renommiertesten auf Bilderdruck spezialisierten Betrieben Wiens. Ihr Spezialgebiet ist der Mehrfarbendruck. 1910 beschäftigt sie bereits 80, vor dem Ersten Weltkrieg 165 Mitarbeiter. Vgl. Anton Durstmüller, Norbert Frank: 500 Jahre Druck in Österreich. Die Entwicklung der graphischen Gewerbe von den Anfängen bis zur Gegenwart, Bd. 2: Die österreichischen graphischen Gewerbe zwischen Revolution und Weltkrieg 1848 bis 1918, Wien 1985, S. 130.

${ }^{10}$ Das interessante Blatt, 16. Mai 1912, S. 2-4.

11 Ebenda.

12 Ebenda.

${ }^{13}$ Das interessante Blatt, 16. April 1914, S. 2

14 Wiener Bilder, 12. April 1914, S. 2.

${ }^{15}$ Das interessante Blatt, 16. April 1914, S. 2

${ }^{16}$ Ebenda.

17 Das interessante Blatt, 16. April 1914, Titelseite.

18 Kurt Paupié: Handbuch der österreichischen Pressegeschichte 1848-1959, Bd. I: Wien, Wien, Stuttgart 1960, S. 40. In Deutschland ist der Straßenverkauf von Zeitungen ab 1904 erlaubt. Vgl. Bernhard Fulda: Industries of Sensationalism: German Tabloids in Weimar Berlin, in: Karl Christian Führer, Corey Ross (Hg.): Mass Media, Culture and Society in Twentieth-Century Germany, New York 2006, S. 183-203, hier S. 104.

19 Um 1900 drängen nach und nach auch große deutsche Anzeigenbüros auf den österreichischen Markt, etwa Rudolf Mosse aus Berlin.

\section{Im Rampenlicht}

${ }^{1}$ Wiener Bilder, 27. Juli 1904, S. 4.

2 Ebenda, S. $4 \mathrm{f}$.

${ }^{3}$ Das interessante Blatt, 16. August 1900, S. 5.

${ }^{4}$ Das Unternehmen nennt sich um 1900 selbstbewusst „R. Lechner (Wilh. Müller), k. u. k. Hofmanufaktur für Photographie in Wien“.

${ }^{5}$ Wiener Bilder, 22. Januar 1899, S. 13.

${ }^{6}$ Das interessante Blatt, 20. Juni 1895, S. 5.

${ }^{7}$ Das interessante Blatt, 28. Juni 1900, S. 3.

${ }^{8}$ Die Schreibweise des Namens Heydenhaus wechselt in der Presse. Überliefert sind auch die Versionen Haydenhauß, Haydenhauss, Haidenhaus und Heidenhauss. In offiziellen Dokumenten, etwa der Gewerbebescheinigung, lautet die Schreibweise: Heydenhaus. Dasselbe gilt für die umseitige Beschriftung von Atelieraufnahmen.

${ }^{9}$ Um 1900 betreiben Heydenhaus und Robert zwei Ateliers (Tuchlauben 22, Wien 1, und Mariahilfer Straße 81, Wien 6).

${ }^{10}$ Das interessante Blatt, 14. Mai 1908, S. 5.

${ }^{11}$ Vgl. dazu ausführlicher Elisabeth Großegger: Der Kaiserhuldigungsfestzug 1908, in: Moritz Csáky, Peter Sta- chel (Hg.): Speicher des Gedächtnisses. Bibliotheken, Museen, Archive, Bd. 2: Die Erfindung des Ursprungs. Die Systematisierung der Zeit, Wien 2001, S. 155-175.

12 Wiener Bilder, 17. Juni 1908, Titelseite.

${ }^{13}$ Wiener Bilder, 24. Juni 1908.

${ }^{14}$ Das interessante Blatt, 3. Januar 1907, Titelseite.

15 Österreichs Illustrierte Zeitung, 17. August 1913, Titelseite.

${ }^{16}$ Wiener Bilder, 7. September 1913, Titelseite.

${ }^{17}$ Das interessante Blatt, 26. März 1914, S. 8.

${ }^{18}$ Ebenda, S. 9.

19 Österreichs Illustrierte Zeitung, 26. Februar 1915, S. 203.

20 Österreichs Illustrierte Zeitung, 3. Dezember 1916, S. 206 und 207.

${ }^{21}$ Österreichs Illustrierte Zeitung, 24. Dezember 1916, S. 277.

${ }^{22}$ Vgl. dazu Anton Holzer: Die andere Front. Fotografie und Propaganda im Ersten Weltkrieg, 3. Aufl., Darmstadt 2012, S. $69 \mathrm{ff}$.

${ }^{23}$ Brief von Karl Werkmann an die Militärkanzlei Sr. Majestät, 19. Februar 1917, zit. nach: Ebenda, S. 70.

${ }^{24}$ Anton Holzer: Die andere Front. Fotografie und Propaganda im Ersten Weltkrieg, 3. Aufl., Darmstadt 2012, S. 65.

25 Bericht Karl Werkmanns an das Kriegspressequartier, 25. April 1917, zit. nach: Ebenda, S. 70.

${ }^{26}$ Wiener Bilder, 10. Februar 1918, Titelseite.

27 Das interessante Blatt, 4. April 1918, Titelseite.

${ }^{28}$ Ebenda.

${ }^{29}$ Stefan Zweig: Die Welt von gestern, Frankfurt am Main 2003, S. 324.

${ }^{30}$ Egon Erwin Kisch: Mein Leben für die Zeitung. Journalistische Texte 1. 1906-1925, Berlin (Ost) 1983, S. $292 \mathrm{f}$.

${ }^{31}$ Das interessante Blatt, 7. August 1919, Titelseite.

\section{Als die Männer fliegen lernten}

${ }^{1}$ Franz Hinterstoisser: Aus meinem Luftschiffertagebuche, Rzeszów 1904, S. 51.

2 Franz Hinterstoisser: Fünfundzwanzig Jahre Luftfahrt, Wien 1915, S. 18.

${ }^{3}$ Franz Hinterstoisser: Aus meinem Luftschiffertagebuche, Rzeszów 1904, S. 51.

${ }^{4}$ Siehe Peter Demetz: Die Flugschau von Brescia. Kafka, d'Annunzio und die Männer, die vom Himmel fielen, Wien 2002, S. $10 \mathrm{ff}$.

${ }^{5}$ Zur frühen Aviatik in Wien siehe: Sylvia Mattl-Wurm, Markus Reuter (Hg.): „schwerer als Luft“. 100 Jahre Motorflug in Wien. Das Bordmagazin zur Ausstellung, Wienbibliothek im Rathaus, Wien 2009; Matthias Marschik: Heldenbilder. Kulturgeschichte der österreichischen Aviatik, Münster, Hamburg, London 2002.

${ }^{6}$ Das interessante Blatt, 28. Oktober 1909, S.

${ }^{7}$ Ebenda.

${ }^{8}$ Franz Hinterstoisser: Fünfundzwanzig Jahre Luftfahrt, Wien 1915, S. 6. Die Chronologie der Veranstaltung wird hier anhand zahlreicher Berichte in der Presse rekonstruiert.

${ }^{9}$ Wiener Bilder, 27. Oktober 1909, S. $4 \mathrm{f}$.

${ }^{10}$ Das interessante Blatt, 28. Oktober 1909, S. 11.

${ }^{11}$ Wiener Bilder, 27. Oktober 1909, S. 4 f.

12 Wiener Luftschiffer-Zeitung, VIII. Jg., Nr. 21, 1. November 1909, zit. nach Sylvia Mattl-Wurm, Markus Reuter (Hg.): „schwerer als Luft“. 100 Jahre Motorflug in Wien. Das Bordmagazin zur Ausstellung, Wienbibliothek im Rathaus, Wien 2009, S. 5

${ }^{13}$ Wiener Bilder, 27. Oktober 1909, S. 4 f.

${ }^{14}$ Das interessante Blatt, 28. Oktober 1909, S. 11.

${ }^{15}$ Wiener Bilder, 27. Oktober 1909, S. 4 f.
${ }^{16}$ Das interessante Blatt, 28. Oktober 1909, S. 11.

17 Wiener Luftschiffer-Zeitung, VIII. Jg., Nr. 21, Wien 1. November 1909, zit. nach Sylvia Mattl-Wurm, Markus Reuter (Hg): „schwerer als Luft“. 100 Jahre Motorflug in Wien. Das Bordmagazin zur Ausstellung, Wienbibliothek im Rathaus, Wien 2009, S. 5

${ }^{18}$ Das interessante Blatt, 16. Dezember 1909, S. 8.

${ }^{19}$ Das interessante Blatt, 26. Mai 1910, S. 5.

${ }^{20}$ Das interessante Blatt, 20. Oktober 1910, S. 3.

${ }^{21}$ Das interessante Blatt, 22. September 1910, S. 12.

22 Ebenda. Tatsächlich handelte es sich nicht um einen Ballon, sondern um das erste Militärluftschiff der k. u. k. Armee.

23 Wiener Bilder, 21. September 1910, S. 4.

${ }^{24}$ Wiener Bilder, 21. September 1910, S. 4, Das interessante Blatt, 22. September 1910, S. 12.

25 Wiener Bilder, 21. September 1910, S. 4.

${ }^{26}$ Wiener Bilder, 8. Dezember 1909, S. 9. Die beiden dem Bericht beigefügten Fotos stammen von Erich Thormann, Wien.

27 Gleitflugzeuge ohne Motor steuern österreichische Frauen bereits früher. Im Februar 1910 berichtet Das interessante Blatt, dass ein gewisses „Fräulein Ehrenzweig" erfolgreich beim Gleitflugwettbewerb am Semmering teilnahm. „Man stellte die Maschine auf Schlittenkufen und ließ sie von einem Abhang wie ein Bob abgeleiten (...). Die Gleitflieger legen auf diese Weise in geringer Höhe bis 100 Meter in der Luft zurück. Ihre Benützung soll wegen der Balanceübung jedem Aviatiker vertraut sein, der später auf einer Flugmaschine mit Motor und Benzin sich erhebt." Vgl. Das interessante Blatt, 24. Februar 1910, S. 8.

${ }^{28}$ Wiener Bilder, 19. April 1911, S. 8 f.

${ }^{29}$ Vgl. Sylvia Mattl-Wurm, Markus Reuter (Hg): „schwerer als Luft“. 100 Jahre Motorflug in Wien. Das Bordmagazin zur Ausstellung, Wienbibliothek im Rathaus, Wien 2009, S. 62.

${ }^{30}$ Das interessante Blatt, 23. April 1914, S. 5.

${ }^{31}$ Das interessante Blatt, 19. Juni 1913, S. 6.

32 Franz Hinterstoisser: Fünfundzwanzig Jahre Luftfahrt, Wien 1915, S. 14.

\section{Mit der Kamera bewaffnet}

${ }^{1}$ Die Literatur zum Attentat in Sarajevo ist umfangreich. Das Ereignis ist inzwischen in allen Details untersucht. Einen Literaturüberblick bietet Gerhard Hirschfeld: Sarajevo: Das bilderlose Attentat und die Bildfindungen der Massenpresse, in: Gerhard Paul (Hg.): Das Jahrhundert der Bilder, Göttingen 2009, S. 148-155.

${ }^{2}$ Das interessante Blatt, 9. Juli 1914, S. 3. Der Attentäter ist, wie sich bald herausstellt, nicht 20, sondern 19 Jahre alt - was sich im Prozess als folgenreich herausstellen wird. Denn einem Minderjährigen bleibt nach österreichischem Recht die Todesstrafe erspart.

${ }^{3}$ Gerhard Hirschfeld: Sarajevo: Das bilderlose Attentat und die Bildfindungen der Massenpresse, in: Gerhard Paul (Hg.): Das Jahrhundert der Bilder, Göttingen 2009, S. 148-155, hier S. 151.

${ }^{4}$ Gelegentlich wird der Verhaftete in zeitgenössischen Bildbeschriftungen - etwa auf Bildpostkarten - auch als Nedeljko Čabrinović identifiziert, als jener Attentäter, der vor dem Schussattentat eine Bombe auf das Auto des Thronfolgers geworfen hatte.

${ }^{5}$ Zu Trampus und den frühen Fotoagenturen siehe das Kapitel „Handel mit Bildern. Die Rolle der Fotoagenturen“.

${ }^{6}$ Gerhard Hirschfeld: Sarajevo: Das bilderlose Attentat und die Bildfindungen der Massenpresse, in: Gerhard Paul (Hg.): Das Jahrhundert der Bilder, Göttingen 2009, S. 148-155, hier S. 148.

${ }^{7}$ Historische Meldeunterlagen der Stadt Wien. Schriftliche Auskunft des Wiener Stadt- und Landesarchivs, 26. März 2012. 
${ }^{8}$ Das interessante Blatt, 5. November 1914, S. 5.

${ }^{9}$ Am 28. April 1918 stirbt Gavrilo Princip an Knochentuberkulose.

${ }^{10}$ Das Thema Kriegsfotografie ist umfassender ausgeführt in: Anton Holzer: Die andere Front. Fotografie und Propaganda im Ersten Weltkrieg, 3. Aufl., Darmstadt 2012, S. $19 \mathrm{ff}$.

${ }^{11}$ Das interessante Blatt, 10. September 1914, S. 9.

${ }^{12}$ Veröffentlicht sind die Bilder beispielsweise in: Großer Bilderatlas des Weltkrieges mit über 2500 Abbildungen, Erster Band, München 1915, S. 286.

${ }^{13}$ In Deutschland gibt es seit den 1990er Jahren eine Reihe v. a. regionaler Forschungsarbeiten zum Thema, die das sogenannte „Augusterlebnis“ relativieren. Sie stammen u.a. von Michael Stöcker, Jeffrey Verhey, Christian Geinitz und Wolfgang Kruse.

${ }^{14}$ Alfred Polgar: Hinterland, Berlin 1929, S. 39.

${ }^{15}$ Ebenda, Vorwort, S. 8.

16 Ebenda, S. 40.

${ }^{17}$ Vgl. dazu ausführlicher Anton Holzer: Die andere Front. Fotografie und Propaganda im Ersten Weltkrieg, 3. Aufl., Darmstadt 2012, S. $38 \mathrm{ff}$.

${ }^{18}$ Das interessante Blatt, 28. Januar 1915, S. 2.

19 Siehe dazu ausführlicher Anton Holzer: Die andere Front. Fotografie und Propaganda im Ersten Weltkrieg, 3. Aufl., Darmstadt 2012, S. $20 \mathrm{ff}$.

${ }^{20}$ Die Wiener Illustrierte Zeitung, herausgegeben von der Gesellschaft für Graphische Industrie, die zwischen Ende 1914 und Ende 1916 erscheint, ist nicht zu verwechseln mit der gleichnamigen illustrierten Wochenzeitung, die ab November 1918 die Nachfolge von Österreichs Illustrierter Zeitung antritt.

${ }^{21}$ Alice Schalek, die bekannteste österreichische Journalistin und Kriegsfotografin, arbeitet nicht in den Reihen des Kriegspressequartiers. Zu ihrer Arbeit im Ersten Weltkrieg siehe ausführlicher Elke Krasny, Marcus Patka, Christian Rapp, Nadia Rapp (Hg.): Von Samoa zum Isonzo. Die Reisejournalistin Alice Schalek, Wien 1999.

22 Den historischen Gewerbeunterlagen ist nicht zu entnehmen, wie lange sie in dieser Funktion tätig ist.

${ }^{23}$ Robert Schwarz: Photographie im Kriege, in: Wiener Mitteilungen aus dem Gebiete der Literatur, Kunst, Kartographie und Photographie, 10. und 25. September 1914, S. 401-404, hier S. 404.

${ }^{24}$ Wiener Bilder, 11. Oktober 1914, S. 7.

${ }^{25}$ Das interessante Blatt, 8. Juli 1915, Titelseite.

${ }^{26}$ Wiener Bilder, 4. Juli 1915, S. 5.

27 Österreichs Illustrierte Zeitung, 6. Juni 1915, Titelseite.

28 Kilophot ist die erfolgreichste österreichische Fotoagentur während des Krieges. Ausführlicher zur Firmengeschichte und ihrem bekanntesten Fotografen, Alexander Exax, siehe Anton Holzer: Die andere Front. Fotografie und Propaganda im Ersten Weltkrieg, 3. Aufl., Darmstadt 2012, S. $29 \mathrm{ff}$.

29 Wiener Bilder, 28. Juli 1918, S. 5.

${ }^{30}$ Ulrich Keller: Der Weltkrieg der Bilder. Organisation, Zensur und Ästhetik der Bildreportage 1914-1918, in: Fotogeschichte, Heft 130, 2013, S. 7-50.

${ }^{31}$ Vgl. Bernd Weise: Pressefotografie, Teil I, in: Fotogeschichte, Heft 31, 1988, S. 15-40 und Ders.: Pressefotografie, Teil II, in: Fotogeschichte, Heft 33, 1989, S. 27-62.

${ }^{32}$ Vgl. dazu ausführlicher das Kapitel „Bilder, Nachrichten, Sensationen. Die Zeitungsstadt Wien um 1900“.

${ }^{33}$ Ein Beispiel: Die Linzer Tagespost legt während des Krieges ihrer Ausgabe einmal wöchentlich die illustrierte Beilage Kriegsbilder bei.

\section{Theater der Macht}

1 Österreichische IIlustrierte Zeitung, 11. Dezember 1893, S. 12.
${ }^{2}$ Vgl. ausführlicher zu Siegmund Schneider das Kapitel „Bild und Text. Die Rhetorik der Zeitungsseiten“.

${ }^{3}$ Österreichische Illustrirte Zeitung, 11. Dezember 1893, S. 12.

${ }^{4}$ Ebenda.

${ }^{5}$ Siehe dazu das Kapitel „Fotos statt Zeichnungen. Das Entstehen einer fotografischen Öffentlichkeit“.

${ }^{6}$ Bei den Wiener Gemeinderatswahlen blieb es bis 1919 in Kraft.

${ }^{7}$ Vgl. dazu ausführlicher John W. Boyer: Political Radicalism in late imperial Vienna. Origins of the Christian Social Movement 1848-1897, Chicago, London 1981, S. $413 \mathrm{ff}$.

8 Österreichische Illustrirte Zeitung, 1. Juni 1896, S. 11. Vermutlich stammt das Blatt aus der Hand von Siegmund Schneider.

${ }^{9}$ Ebenda.

${ }^{10}$ Im Fotoarchiv der Firma Lechner, das im Bildarchiv der Österreichischen Nationalbibliothek aufbewahrt wird, finden sich zahlreiche Beispiele dieser Fotokarten. Zur Firma Lechner vgl. auch das Kapitel „Die Jagd nach Sensationen. Pioniere der Pressefotografie“.

11 Wiener Bilder, 22. Mai 1907, S. 6. Die Reichsratswahl findet zwischen dem 14. und 24. Mai 1907 statt. Es ist die erste Wahl mit allgemeinem Männerwahlrecht.

12 Lueger leidet an Diabetes, einer Blasen- und Magenkrankheit und seit 1907 auch an einer schweren Nierenerkrankung, die seine Sehfähigkeit stark beeinträchtigt.

${ }^{13}$ Wiener Bilder, 14. August 1907, S. 8.

14 Ebenda.

${ }^{15}$ Das interessante Blatt, 17. März 1910, Titelseite.

${ }^{16}$ Um nur zwei Beispiele zu nennen: Im September 1926 wird an der Ringstraße ein Lueger-Denkmal enthüllt. Anfang der 1930er Jahre wird in der Bezirksvertretung des 4. Wiener Gemeindebezirks ein Lueger-Museum eingerichtet.

${ }^{17}$ Das interessante Blatt, 12. Februar 1891, S. 4.

${ }^{18}$ Das interessante Blatt, 8. April 1897, S. 6. Die Serie wird in den folgenden Wochen fortgesetzt.

${ }^{19}$ Nach der Wahlrechtsreform 1896 wird erstmals eine fünfte, allgemeine Wählerklasse für alle über 24 Jahre alten männlichen Staatsbürger eingeführt.

${ }^{20}$ Wiener Bilder, 11. September 1901, S. 5.

${ }^{21}$ Ebenda.

22 Ebenda.

${ }^{23}$ Wiener Bilder, 6. Februar 1901, S. 3.

${ }^{24}$ Ebenda.

${ }^{25}$ Wiener Bilder, 11. Juni 1902, S. 4.

26 Ebenda, S. 10.

${ }^{27}$ Am 14. September 1904 erscheint ein Foto von Charles Scolik in den Wiener Bildern, das die Eröffnungsveranstaltung des Presse-Kongresses im Parlament zeigt.

${ }^{28}$ Das interessante Blatt, 2. November 1911, S. 9.

29 Ebenda.

${ }^{30}$ Siehe dazu ausführlicher das Kapitel „Der Kampf um die Straße. Demonstrationen, Kundgebungen und Massenpolitik".

31 Während der ersten Kriegsjahre wird das Parlament nicht mehr einberufen, erst Mitte 1917 treten die Abgeordneten wieder im Reichsrat zusammen.

32 Die konstituierende Sitzung dieser Nationalversammlung findet am 21. Oktober 1918 im Sitzungssaal des niederösterreichischen Landhauses in der Wiener Herrengasse statt (und nicht etwa im Parlament an der Ringstraße, das nach wie vor als Symbol der gesamten Monarchie gilt).

${ }^{33}$ Wiener Illustrierte Zeitung, 17. November 1918, Titelseite. Eine Woche zuvor hat das Blatt, das bis Anfang 1918 Österreichs Illustrierte Zeitung hieß, seinen Titel geändert. Am 10. November 1918 wenden sich Verlag und Redaktion an die Leser: „Mit Rücksicht auf die politischen Verhältnisse sehen wir uns veranlasst, unsere Zeitschrift von heute ab ,Wiener Illustrierte Zeitung' zu nennen. Diese Namensänderung entspricht eigentlich der Bezeichnung, welche bisher in der Monarchie sowie auch im Auslande längst gebräuchlich war." Ebenda, S. 90.

34 Wiener Bilder, 17. November 1918, S.

${ }^{35}$ Das interessante Blatt, 13. Februar 1919, Titelseite.

36 Ebenda, S. 5. Die Werbeschrift im Hintergrund („Brünnlbad“) deutet darauf hin, dass die Aufnahme in der Lazarettgasse im 9. Wiener Gemeindebezirk entstanden ist. Dort befand sich die gleichnamige Wasserheilanstalt.

37 Zur Bürgerlich-Demokratischen Partei siehe Johannes Hawlik: Die politischen Parteien Deutschösterreichs bei der Wahl zur konstituierenden Nationalversammlung 1919, Diss., Wien 1971, Bd. 2, S. $564 \mathrm{ff}$.

${ }^{38}$ Das interessante Blatt, 20. Februar 1919, S. 12.

39 Der Wiener Universitätsprofessor Dr. Richard Wettstein hat 1917 dem Herrenhaus des österreichischen Parlaments angehört, nach dem Krieg kandidiert er in den Reihen der Bürgerlich-Demokratischen Partei für das Parlament.

40 Das interessante Blatt, 13. März 1919, S. 8, 9.

${ }^{41}$ Siehe dazu ausführlicher Hans Hautmann: Die Anfänge der linksradikalen Bewegung und der kommunistischen Partei Deutschösterreichs 1916-1919, Wien 1970, S. 90 ff.sowie Gerhard Botz: Gewalt in der Politik. Attentate, Zusammenstöße, Putschversuche, Unruhen in Österreich 1918 bis 1934, München 1976, S. $49 \mathrm{ff}$.

42 Wiener Bilder, 5. Mai 1919, S. 5.

43 Hans Hautmann: Die Anfänge der linksradikalen Bewegung und der kommunistischen Partei Deutschösterreichs 1916-1919, Wien 1970, S. $113 \mathrm{ff}$.

44 Ebenda, S. 117

45 Siehe Ernst Hanisch: Der lange Schatten des Staates. Österreichische Gesellschaftsgeschichte im 20. Jahrhundert, Wien 1994, S. 290.

${ }^{46}$ Bunte Woche, Nr. 13, 6. Mai 1934, S. 2.

47 Vgl. Ilse Reiter: Texte zur österreichischen Verfassungsentwicklung 1848-1955, Wien 1997, S. 270.

\section{Kampf um die Straße}

${ }^{1}$ Der Kuckuck, 26. Mai 1929, S. 10.

2 Vgl. dazu Monika Kriegler-Griensteidl, Volker Kaukoreit (Hg.): Kringel, Schlingel, Borgia. Materialien zu Peter Hammerschlag, Wien 1997, S. 10. Möglicherweise stehen die beiden Tänzerinnen unter dem Einfluss der deutschen Ausdruckstänzerin Valeska Gert, die in den 1920er Jahren ebenfalls Grotesk-Szenen tanzt.

${ }^{3}$ Offensichtlich übersetzt Fritzi Klein einen Vers, der die Hahnenschwänzler lächerlich macht, in ein tänzerisches Bild. „Hahnenschwänzler, Hahnenschwänzler, bist ein armer Tropf. / Was der Hahn am Hintern trägt, trägst du stolz am Kopf.“

4 Ebenda.

${ }^{5}$ Das interessante Blatt, 28. März 1907, S. 3.

${ }^{6}$ Vgl. dazu ausführlicher Wolfgang Maderthaner, Lutz Musner: Die Anarchie der Vorstadt. Das andere Wien um 1900, Frankfurt a. M. 1999, S. $22 \mathrm{ff}$.

${ }^{7}$ Das interessante Blatt, 28. September 1911, S. 12.

${ }^{8}$ Wiener Illustrierte Zeitung, 17. November 1918, Titelseite. Vgl. die Abb. im Kapitel „Theater der Macht. Parlament und Politik in Bildern".

${ }^{9}$ Zur Chronologie der Ereignisse siehe die Berichterstattung im Interessanten Blatt, 10. Mai 1934, S. 2 f.

10 Ebenda.

${ }^{11}$ Vgl. Das interessante Blatt, 22. Oktober 1936, Titelseite und S. $4 \mathrm{f}$.

12 Ebenda, S. 4. 
${ }^{13}$ Ebenda.

14 Hilde Spiel schildert diese Zeit in ihrer Autobiografie: Die hellen und die finsteren Zeiten. Erinnerungen 1911 bis 1946, München 1989, S. $81 \mathrm{ff}$. und S. $99 \mathrm{ff}$.

${ }^{15}$ Der Sonntag, 5. Juli 1936, S. 7.

16 Ebenda. 1936 erscheint unter dem Titel Pascholl Plenny das Kriegs- und Reisetagebuch des ehemaligen österreichischen k. u. k. Soldaten Gustav Krist. Darin schildert dieser seine Zeit in russischer Kriegsgefangenschaft in Russisch-Turkestan und seine abenteuerliche Flucht.

\section{Im Schatten der Konzerne}

${ }^{1}$ Alfred Polgar: Hinterland, Berlin 1929, S. 65-68.

2 Andreas Resch: Das Geschäft mit Wort und Bild. Wirtschaftsgeschichte der Massenmedien und der Werbebranche in Wien, Berlin u. a. 2008, S. 28.

${ }^{3}$ Ein Beispiel dafür ist die 1923 von Emmerich Békessy gegründete Tageszeitung Die Stunde, die zunächst im Kronos Verlag und ab 1925 in der Vernay AG erscheint.

${ }^{4}$ Siehe dazu das Kapitel „Bilder, Nachrichten, Sensationen. Die Zeitungsstadt Wien um 1900“.

${ }^{5}$ Wiener Illustrierte Zeitung, 10. November 1918, S. 90. Die Zeitung ist nicht mit der gleichnamigen Zeitung zu verwechseln, die zwischen 1914 und 1916 erscheint.

${ }^{6}$ Wiener Illustrierte Zeitung, 20. August 1922, S. 4.

7 Jakob Philipp hat den Betrieb von Jacques Philipp übernommen, der um die Jahrhundertwende mit dem Druckbetrieb „Philipp \& Kramer“ zu Geld gekommen war und 1899 Österreichs IIlustrierte Zeitung übernommen hat. Vgl. dazu auch das Kapitel: „Bilder, Nachrichten, Sensationen. Die Zeitungsstadt Wien um 1900“.

${ }^{8} \mathrm{Vgl}$. Österreichische Illustrierte Zeitung. Modernes Familienblatt, 1.Oktober 1922, Titelseite.

${ }^{9}$ Der „Katholische Preßverein Herold“, der 1912 aus dem Verein „Reichspost" hervorgeht, untersteht de facto der katholischen Kirche. Im Herold Verlag erscheint neben dem Flaggschiff Reichspost auch das Kleine Volksblatt.

${ }^{10}$ Die neue Verlegerin von Österreichs Illustrierter Zeitung heißt 1934 Maria Schüngel, Chefredakteur ist nun Kurt Hecht.

${ }^{11}$ Andreas Resch: Das Geschäft mit Wort und Bild. Wirtschaftsgeschichte der Massenmedien und der Werbebranche in Wien, Berlin u. a. 2008, S. 32.

12 Im Steyrermühl-Konzern erscheinen u. a. das Neue Wiener Tagblatt, die Volkszeitung, die Kleine Volkszeitung, die Wochenausgabe des Wiener Tagblatts und das Sport-Blatt.

${ }^{13}$ Mit vollem Namen heißt die Vernay AG Johann N.(epomuk) Vernay Druckerei und Verlagsaktiengesellschaft.

14 Während Steyrermühl 1928 eine Bilanzsumme von 12,8 Millionen Schilling aufweist, kommt die Vernay AG lediglich auf eine Bilanzsumme von 2,05 Millionen Schilling. Vgl. Andreas Resch: Das Geschäft mit Wort und Bild. Wirtschaftsgeschichte der Massenmedien und der Werbebranche in Wien, Berlin u. a. 2008, S. 32.

15 Zu den Vernay-Aktionären gehören nach 1913 Rudolf Hanel, Johann Thomas Wancura, Siegfried Rosenbaum, Sigmund Rosenbaum, Gustav Plaut und Bernhard Plaut.

16 Unter direkter oder indirekter Kontrolle der Vernay AG stehen um 1930 u. a. folgende Zeitungen und Zeitschriften: Der Morgen, Der Tag, Die Stunde, Die Bühne, Die Börse, Die Sphinx, Mein Film, Illustrierte Film und Kinorundschau und die Rätsel-Zeitung. Eine Reihe weiterer Blätter wird in den Vernay-Druckereien hergestellt. 1936 schlittert die Vernay AG aufgrund von finanziellen Problemen in der Druckereisparte in den Ausgleich, worauf eine Aktionärsgruppe, die Particité S. Genf, die im Besitz des tschechischen Außenministeriums steht, die Aktienmehrheit übernimmt. Auf diese Weise kann das Zeitungsgeschäft fortgesetzt werden. Vgl. dazu Tano Bojanko: Die Geschich- te des Kompass-Verlags - ein Zwischenstand, in: Sylvia Mattl-Wurm, Alfred Pfoser (Hg.): Die Vermessung Wiens. Lehmanns Adressbücher 1859-1942, Wien 2011, S. 339-347, hier S. 345. Gregor Spuhler, Ursina Jud, Peter Milichar, Daniel Wildmann: „Arisierungen“ in Österreich und ihre Bezüge zur Schweiz. Beitrag zur Forschung, hg. von der Unabhängigen Expertenkommission Schweiz - Zweiter Weltkrieg, Zürich 2002, S. $139 \mathrm{ff}$

${ }^{17}$ Zum Sonntag vgl. ausführlicher das Kapitel „Fotografisches Feuilleton. Der Sonntag: ein vergessenes Forum moderner Reportagefotografie“.

${ }^{18}$ Zur Bühne siehe ausführlicher das Kapitel „Bilder für alle: Die Welt der Magazine und Revuen“.

${ }^{19}$ In der Wiener Neueste Nachrichten Verlags A. G. erscheinen die Wiener Neuesten Nachrichten mit ihrer illustrierten Beilage Bühne, Welt und Mode (zwischen 1925 und 1932). In der Neuen Freien Presse, die in der Österreichischen Journal AG erscheint, gibt es 1924 eine nur kurzzeitig erscheinende illustrierte Beilage. In der Telegraf Zeitungs-Ges.m.b.H. erscheinen die Boulevardblätter Telegraf am Mittag, Das Echo, Telegraf, Sport-Telegraf und 7-Tage-Blatt, aber keine illustrierten Zeitungen. Die Illustrierte Kronen-Zeitung erscheint im Verlag G.(ustav) Davis \& Co., die konservative Reichspost erscheint ebenso wie das Wiener Montagsblat im Herold Verlag, der auch die konservative Wochenillustrierte Wiener IIlustrierte Zeitung druckt. Das Neue Wiener Journal, die erste Boulevardzeitung Österreichs, die nach mehreren Eigentümerwechseln ab 1932 im Verlag A. Loewenstein erscheint, enthält ab Ende der 1920 er Jahre die illustrierten Beilagen Unsere Mode und Film-Revue. Im Verlag August Kirsch erscheinen das Neuigkeits-Welt-Blatt, die Illustrierte Wochenschau und die Neue Romanzeitung. Die Wiener Zeitung ist im Eigentum des Staates. Der Montag mit dem Sportmontag sowie die Illustrierte Wochenpost erscheinen im Verlag Paul Kolisch.

${ }^{20}$ Vgl. dazu ausführlicher das Kapitel „Bilder als Propaganda. Die illustrierte Regierungspresse nach 1934“.

${ }^{21}$ Zum Verlagshaus Tyrolia vgl. Nikolaus G. Kogler: Zwischen Freiheit und Knebelung. Die Tagespresse Tirols von 1914 bis 1947, Innsbruck 2000, S. 161 ff. Ende der 1930er Jahre beträgt der Mitarbeiterzahl 420.

22 Zur Geschichte des Universitätsverlags Wagner und der Berglandpresse vgl. Nikolaus G. Kogler: Zwischen Freiheit und Knebelung. Die Tagespresse Tirols von 1914 bis 1947, Innsbruck 2000, S. 79 ff.

23 Die illustrierte Wochenzeitschrift Bergland geht aus dem 1919 gegründeten, monatlich erscheinenden Blatt Hochland hervor.

${ }^{24}$ Nikolaus G. Kogler: Zwischen Freiheit und Knebelung. Die Tagespresse Tirols von 1914 bis 1947, Innsbruck 2000, S. 78.

25 Um nur zwei Beispiele zu nennen: Die renommierte bürgerliche Tageszeitung Neue Freie Presse folgt dem Beispiel anderer Blätter und startet 1924 mit einer illustrierten Beilage, allerdings gibt sie den Versuch nach wenigen Monaten wieder auf. Ein Beispiel für eine illustrierte Wochenbeilage außerhalb Wiens ist die Illustrierte Woche, die zwischen 1925 und 1933 dem katholisch-konservativen Grazer Volksblatt beiliegt, das im Styria-Verlag erscheint. Sie erreicht inhaltlich und grafisch allerdings nur ein bescheidenes Niveau.

${ }^{26}$ Nicht nur die großen Wochenillustrierten, sondern auch die Mehrheit der kleineren illustrierten Magazine wird ab Mitte der 1920er Jahre im Kupfertiefdruck hergestellt. Während der Inflationszeit und der Wirtschaftskrise Anfang der 1920er Jahre verzichtet Das interessante Blatt vorübergehend aus Kostengründen auf den durchgehenden Kupfertiefdruck. Ab 1925 wird die Zeitung dann wieder wie üblich im hochwertigen Druck produziert.

${ }^{27}$ Wie eng die Verflechtung zwischen Regierung und Zeitung ist, zeigt die Tatsache, dass Bernhard Fuchs, der stellvertretende Leiter des Bundespresseamtes, das direkt dem jeweiligen Kanzler unterstellt ist, in den spä- ten 1920er Jahren im Impressum als verantwortlicher Redakteur des Interessanten Blattes geführt wird.

${ }^{28}$ Die Zeitschrift Die Damenwelt, deren verantwortlicher Redakteur Otto Lendecke ist, wird ohne Angabe von Gründen nach drei Nummern wieder eingestellt. Auch Die Herrenwelt kommt über den zweiten Jahrgang 1917 nicht hinaus

${ }^{29}$ Andreas Resch: Das Geschäft mit Wort und Bild. Wirtschaftsgeschichte der Massenmedien und der Werbebranche in Wien, Berlin u. a. 2008, S. $37 \mathrm{ff}$. Sowie Murray Hall: Österreichische Verlagsgeschichte 19181938, Wien, Köln, Graz 1985 (online unter: www.verlagsgeschichte.murrayhall.com).

30 Der neue Betrieb firmiert nun unter dem Namen Elbemühl Papierfabriken und Graphische Industrie AG.

${ }^{31}$ Andreas Resch: Das Geschäft mit Wort und Bild. Wirtschaftsgeschichte der Massenmedien und der Werbebranche in Wien, Berlin u. a. 2008, S. 38

32 Liesl Glück: Das interessante Blatt und Der Kuckuck. Ein Beitrag zur Wiener Zeitschriftengeschichte, Diss., Wien 1953, S. 6

${ }^{33}$ Ebenda. Die Angaben beruhen auf Schätzungen von ehemaligen Verlagsmitarbeitern, mit denen die Autorin Liesl Glück Anfang der 1950er Jahre im Zuge der Arbeit an ihrer Dissertation gesprochen hat.

34 Papanek, geboren 1867 im mährischen Bisenz, arbeitet seit 1902 in der Redaktion des Interessanten Blattes. Er ist jüdischer Herkunft und wird 1938 von den Nationalsozialisten verhaftet. Er stirbt am 22. September 1944 im Konzentrationslager Theresienstadt. Vgl. Liesl Glück: Das interessante Blatt und Der Kuckuck. Ein Beitrag zur Wiener Zeitschriftengeschichte, Diss. Wien 1953, S. 4 sowie The Central Database of Shoah Victims' Names (www.yadvashem.org).

351937 wird Ernst Saenger Chefredakteur des Interessanten Blattes.

${ }^{36}$ Liesl Glück: Das interessante Blatt und Der Kuckuck. Ein Beitrag zur Wiener Zeitschriftengeschichte, Diss., Wien 1953, S. 12.

37 Zur Fotoreportage in der Zwischenkriegszeit siehe das Kapitel „Erzählende Bilder. Die moderne Fotoreportage in der Zwischenkriegszeit".

381933 erscheint der Welt-Guck (nun nicht mehr im Kupfertiefdruck) als wöchentliche Beilage der Innsbrucker Zeitung, des Tiroler Anzeigers und der Amstettner Zeitung.

${ }^{39}$ Zum Kuckuck siehe auch das Kapitel „Politische Bilder. Die Kultur der Arbeiterfotografie“. Vgl. auch Stefan Riesenfellner, Josef Seiter: Der Kuckuck. Die moderne Bild-Illustrierte des Roten Wien, Wien 1995 sowie Marion Krammer: Montierte Propaganda, sprechende Bilder. Fotomontage im „Roten Wien“ 1929 bis 1934, in: Fotogeschichte, Heft 115, 2010, S. 37-52. Hier findet sich auch ein aktueller Überblick über den Stand der Forschung.

40 Zu Hahn vgl. Wilhelm Marckwardt: Paul Edmund Hahn. Ein vergessener Fotojournalist der ersten Stunde, in: Fotogeschichte, Heft 10, 1983, S. 40-53.

41 Die führende deutsche Wochenillustrierte, die Berliner Illustrirte Zeitung (BIZ), erreicht 1929 mit einer Auflage von 1892270 Exemplaren den absoluten Höchststand. Die anderen Zeitungen liegen zwar weit hinter der BIZ, erreichen aber ebenfalls Ende der 1920er Jahre die höchsten Auflagen. Vgl. Diethart Kerbs: Die illustrierte Presse am Ende der Weimarer Republik, in: Diethart Kerbs, Henrick Stahr (Hg.): Berlin 1932. Das letzte Jahr der Weimarer Republik. Politik, Symbole, Medien, Berlin 1992, S. 68-89, hier S. 76. Die französische IIlustrierte Le Miroir überschreitet 1918 die wöchentliche Millionenauflage. Vgl. Ulrich Hägele: Montage, Groteske, Propaganda. Die Vorgeschichte der Avantgarde: Medieninnovation in der französischen Illustrierten J'ai vu... 1914 bis 1920, in: Fotogeschichte, Heft 123, 2012, S. 5-20, hier S. 6. 
42 Die erste Österreich-Beilage der Arbeiter-Illustrierten Zeitung erscheint am 21. März 1928. Die AIZ wird, dem internationalen Selbstverständnis der Kommunisten entsprechend, in mehreren Ländern vertrieben: in Deutschland, der Schweiz, in Österreich, der Tschechoslowakei und in der Sowjetunion.

${ }^{43}$ Die Auflage der AIZ bzw. der Ende 1921 gegründeten Vorgängerzeitung Sichel und Hammer steigt in den 1920er Jahren stark an, von 100000 im Jahr 1921 auf $350.00 \mathrm{im}$ Jahr 1929 und $500000 \mathrm{im}$ Jahr 1931. Ende 1931 verfügt die Zeitung deutschlandweit über 4600 Kolporteure. Vgl. Heinz Willmann: Geschichte der Arbeiter-Illustrierten Zeitung. 1921-1938, 2. Aufl., Berlin 1975, S. 119.

${ }^{44}$ Zu Braunthals Ambitionen, einen linken Zeitungskonzern aufzubauen, siehe Brigitte Robach: Julius Braunthal als politischer Publizist. Ein Leben im Dienste des Sozialismus, Diss., Wien 1983, S. $219 \mathrm{ff}$

45 Stefan Riesenfellner, Josef Seiter: Der Kuckuck. Die moderne Bild-Illustrierte des Roten Wien, Wien 1995 (Studien zur Gesellschafts- und Kulturgeschichte, Bd. 5), S. 42. Einer anderen Quelle zufolge liegt die höchste Auflage des Kuckuck bei 80000 bis 90000 und sinkt dann bis 1934 auf 30000 ab. Vgl. Liesl Glück: Das interessante Blatt und Der Kuckuck. Ein Beitrag zur Wiener Zeitschriftengeschichte, Diss., Wien 1953, S. 19

${ }^{46}$ Geleitet wird die Wiener Redaktion der AIZ 1929 von Marie Troost, die hauptberuflich als Hilfsarbeiterin be der Firma Semperit tätig ist, und ab 1930 ist Hilde Wertheim für die Wien- bzw. Österreich-Berichterstattung zuständig.

47 Zu Beispielen von Fotomontagen in der illustrierten Presse vor 1914 siehe das Kapitel „Erzählende Bilder. Die moderne Fotoreportage in der Zwischenkriegszeit".

${ }^{48}$ Biografische Hinweise zu Weyr finden sich bei Stefan Riesenfellner, Josef Seiter: Der Kuckuck. Die moderne Bild-Illustrierte des Roten Wien, Wien 1995, S. $31 \mathrm{ff}$.

${ }^{49}$ Zu den Arbeiterfotografen siehe das Kapitel „Politische Bilder. Die Kultur der Arbeiterfotografie“.

${ }^{50}$ Die 1930 gegründete Fotoagentur Unionbild (zunächst heißt sie Union Foto $\mathrm{GmbH}$ ) wird von der Sowjetunion finanziert und hat die Aufgabe, sowjetische Pressebilder im deutschen Sprachraum zu vertreiben. Zu den bekanntesten Fotografen, deren Aufnahmen über Unionbild vertrieben und im Kuckuck gedruckt werden, gehört Tina Modotti.

${ }^{51}$ Der Kuckuck, 23. April 1933, S. 10.

52 Der Welt-Guck erscheint zunächst 14-tägig, dann wöchentlich.

${ }^{53}$ Ab 1929 erscheint der Welt-Guck auch als Beilage der Amstettner Zeitung. Zwischen 1933 und 1937 wird die - inzwischen simpel gestaltete - Wochenzeitung auch dem Abendblatt Innsbrucker Zeitung beigelegt. Vgl. Nikolaus G. Kogler: Zwischen Freiheit und Knebelung. Die Tagespresse Tirols von 1914 bis 1947, Innsbruck 2000, S. 153 und 157.

${ }^{54} \mathrm{Vgl}$. ebenda, S. 176.

55 Die Redaktion der Zeitschrift Bergland übersiedelt 1933 nach Wien.

${ }^{56}$ Schwabik interessiert sich schon als junger Fotograf für ländlich-konservative Themen. Für den Welt-Guck fotografiert er Anfang 1932 eine Reportage über die Südtiroler Ladiner. Nach dem Machtantritt der Nationalsozialisten setzt er seine Karriere bruchlos fort und publiziert viel in deutschen Illustrierten. Im März 1938 erscheint von ihm eine Fotoreportage über „Großdeutschlands höchste Bauernhöfe“ im Interessanten Blatt, das bald darauf Wiener Illustrierte heißen wird.

${ }^{57}$ Im August 1939 etwa bringt der Welt-Guck eine Fotoreportage über ungarische Goldgräber. Der Fotograf ist Emmery Kelen, ein ungarischer Pressezeichner und Fotograf, der 1933 in die USA emigriert. Von ihm erscheinen öfter Bildberichte im Welt-Guck.

58 Wilhelm Marckwardt: Paul Edmund Hahn. Ein ver- gessener Fotojournalist der ersten Stunde, in: Fotogeschichte, Heft 10, 1983, S. 40-53, hier S. 42

${ }^{59}$ Vgl. dazu ausführlicher Patrick Rössler: 1928: Wie das neue Sehen in die Illustrierten kam. „Maxl Knips“, Sasha Stone, Das illustrierte Blatt und die Bildermagazine der Weimarer Republik, in: Fotogeschichte, Heft 121, 2011, S. 45-60. Aber bereits während des Ersten Weltkriegs hebt sich die grafische und fotografische Qualität dieser Illustrierten deutlich vom Durchschnitt ab. Vgl. dazu Ulrich Keller: Verdun, 1916. Die Schlacht der Bildreportagen, in: Fotogeschichte, Heft 130, 2013, S. 51-85, hier S. 57 .

601934 findet er eine feste Anstellung als Hauptschriftleiter der Südwestdeutschen Rundfunkzeitung, die seit 1925 in Frankfurt erscheint. Zu dieser Zeit fotografiert er schon seit Längerem nicht mehr für die Presse.

${ }^{61}$ Welt-Guck, 5. November 1932, S. 2.

${ }^{62}$ Ebenda.

63 Die Zeitung ist nicht zu verwechseln mit der kurzlebigen, zwischen 1914 und 1916 erscheinenden Zeitung Wiener Illustrierte Zeitung, aber auch nicht mit der Wiener Illustrierten Zeitung, die Ende 1918 das Erbe von Österreichs Illustrierter Zeitung antritt. Sie hat auch nichts mit dem kurzlebigen Wiener Ableger der Berliner Illustrirten Zeitung zu tun, die Ende 1933 unter dem Namen Wiener Illustrierte Zeitung gegründet wird. Siehe weiter unten.

64 Der Jedermann bezieht immer wieder explizit gegen den Nationalsozialismus Stellung und verteidigt zugleich die österreichische Identität. Vgl. etwas den Leitartikel am 26. November 1932, S. 2.

${ }^{65} \mathrm{Vgl}$. etwa die Ausgabe vom 5. November 1932.

${ }^{66}$ Biografische Informationen zu Hans Casparius bieten die beiden Bände: Photo: Casparius. Filmgeschichte in Bildern/Berlin um 1930/Auf Reisen, hg. Von der Stiftung Deutsche Kinemathek, Katalog zur Ausstellung in der Staatlichen Kunsthalle Berlin, 23. Februar bis 5. März 1978, Berlin 1978, Hans Casparius: In my View. A Pictorial Memoir. Introduction by Silvia Beamish, Leamington, Hamburg, New York 1986.

${ }^{67}$ Die Bilder einer Palästina-Reise veröffentlicht Casparius 1934 im Band: Das Palästina-Bilder-Buch. 96 Photographien von Hans Casparius. Vorwort und Text zu den Bildern von Arthur Rundt, Wien, E.P. Tal \& Co. Verlag 1934.

68 Jedermann, 15. Oktober 1932, Titelseite.

${ }^{69}$ Zum Vergleich: Die wöchentlichen Auflagen des Interessanten Blattes und der Wiener Bilder liegen in diesen Jahren deutlich unter 50000 . Vgl. weiter oben.

${ }^{70}$ Ausführlicher dazu vgl. Timm Starl: Nach dem Muster aus Berlin - die „Wiener Illustrierte“ 1933/34, in: Diethart Kerbs, Walter Uka (Hg.): Fotografie und Bildpublizistik in der Weimarer Republik, Bönen 2004, S. 199-207.

${ }^{71}$ Ebenda.

72 Ebenda, S. 205

73 Elisabeth Spielhofer: „Der Pressefreiheit würdige Grenzen ziehen ..." Theorie und Praxis der Pressepolitik im österreichischen Ständestaat (1933-1938) unter Berücksichtigung der deutsch-österreichischen Presseabkommen, Diplomarbeit, Wien 1992, S. $30 \mathrm{ff}$.

${ }^{74}$ Zur Österreichischen Woche siehe ausführlichere Hinweise weiter unten.

${ }^{75}$ Vgl. Gerhard Kowald: Die Arbeiterfotografie der Ersten Republik, Hausarbeit, Akademie der Bildenden Künste, Wien 1979.

76 Stefan Riesenfellner, Josef Seiter: Der Kuckuck. Die moderne Bild-Illustrierte des Roten Wien, Wien 1995, S. 42.

77 Illustrierte Rote Woche, 5. Juni 1932, letzte Seite (o. P.)

78 Beispielsweise werden Wiener Geschäfte jüdischer Eigentümer mit Foto vorgestellt und damit antisemitischer Hetze preisgegeben. Vgl. Der Notschrei, 15. Dezember 1932, S. 14

${ }^{79} \mathrm{Vgl}$. beispielsweise Der Notschrei, 27. Mai 1933, S. 15.
${ }^{80}$ Der Notschrei, 1. Oktober 1932, S. 6.

${ }^{81}$ Das Zeitbild. Österreichs nationalsozialistische IIlustrierte, 1. April 1933, S. 14

82 Der Illustrierte Beobachter hat 1935 eine wöchentliche Auflage von 582000 Exemplaren. Im Vergleich dazu kommt die auflagenstärkste Zeitung, die Berliner Illustrirte Zeitung (BIZ), auf eine deutlich höhere Auflage.

${ }^{83}$ Vgl. dazu ausführlicher das Kapitel „Handel mit Bildern. Die Rolle der Fotoagenturen“.

${ }^{84}$ Für Dephot arbeiten u. a. Umbo, Felix H. Man, Walter Boßhard, Kurt Hübschmann, Harald Lechenperg und kurze Zeit Endre Friedmann, der spätere Robert Capa. Das erste Foto der Agentur Dephot, das in Österreich erscheint, ist eine Aufnahme von Umbo. Sie wird Anfang März 1929 in der Zeitschrift Die Bühne gedruckt. Zu Dephot siehe Herbert Molderings: Eine Schule der modernen Fotoreportage. Die Fotoagentur Dephot (Deutscher Photodienst) 1928 bis 1933, in: Fotogeschichte, Heft 107, 2008, S. 5-21. Für die Agentur Weltrundschau arbeiten u. a. die Fotografen Seldowicz (Seldow) und Neudatschin (Neudin), über die bis heute wenig Biografisches bekannt ist. Die ersten Bilder von Seldowicz erscheinen in Österreich Anfang April 1929 in den Wiener Bildern. 1932 und 1933 erscheinen die meisten Fotoreportagen der Agenturen Dephot und Weltrundschau in Österreich.

${ }^{85}$ Zum Wiener Photo-Kurier siehe ausführlicher das Kapitel „Handel mit Bildern. Die Rolle der Fotoagenturen“.

86 Die in der Zwischenkriegszeit bei Weitem meistpublizierte österreichische Fotografin ist Madame d'Ora, die mit ihren Gesellschafts- und Modeporträts, aber auch mit ihren Werbeaufnahmen in der deutschen Bildpresse überaus präsent ist. Aber auch andere Fotografen veröffentlichen regelmäßig in Deutschland. Wenige von innen sind allerdings klassische Pressefotografen. Zu innen zählen Lothar Rübelt, Harald Lechenperg und Heinz von Perckhammer. Andere, wie etwa Trude Fleischmann, die Fotografen der Agentur Willinger, Pepa Feldscharek, Edith Barakovich, Steffi Brandl, Trude Geiringer, Edith Glogau, Franz Löwy, das Atelier Manassé oder Franz Xaver Setzer liefern v. a. Porträts, Mode-, Tanz- und Theaterfotos. László Willinger publiziert v. a. Schauspieler-, Theater- und einige Alltagsbilder in Deutschland.

87 Zu ihnen gehören u. a. Madame d'Ora, die in Paris lebt, László Willinger, der zeitweise in Berlin und Paris arbeitet, Willy Eggarter, der in Paris lebt, sowie Harald Lechenperg und Heinz von Perckhammer, die eine Zeit lang in Berlin tätig sind.

88 Siehe dazu das Kapitel „Erzählende Bilder. Die moderne Fotoreportage in der Zwischenkriegszeit".

${ }^{89}$ Um nur einige zu nennen: Sasha und Cami Stone, Germaine Krull, Heinz Hajek-Halke, László Moholy-Nagy, Lucia Moholy, Brassai, André Kertesz, Man Ray, Alexandr Hackenschmied, Jan Lukas, John Heartfield. Vgl. dazu ausführlicher das Kapitel „Bilder für alle: Die Welt der Magazine und Revuen".

90 Zu nennen sind etwa die Fotografen Hans Casparius und Robert Capa.

91 Dieser Aspekt ist bisher noch nicht erforscht.

92 Das ist etwa bei der Berliner Porträt- und Modefotografin Yva der Fall, die nach 1933 vermehrt in Österreich publiziert, vermittelt durch die Fotoagentur Wiener Photo-Kurier. Marianne Breslauer etwa verlegt ihre publizistische Tätigkeit in die Schweiz.

93 Kurt Paupié: Handbuch der österreichischen Pressegeschichte 1848-1959, Bd.I: Wien, Wien, Stuttgart 1960 , S. 40

94 Moriz Band stirbt am 29. Juli 1932 im Alter von 68 Jahren in Linz. Er war über 30 Jahre lang für die Wiener Bilder tätig. Vgl. den Nachruf in den Wiener Bildern am 7. August 1932, S. 4

95 Wiener Bilder, 8. Januar 1933, S. 4: An unsere Leser!

96 Um nur zwei Beispiele zu nennen: Am 18. September 
1932 erscheint eine Reportage über Zeitungsleser, am 7. Januar 1934 eine Reportage über den Kohlenmann.

97 Ausführlicher zu dieser Zeitung und zur austrofaschistischen Medienpolitik siehe das Kapitel „Bilder als Propaganda. Die illustrierte Regierungspresse nach 1934“.

98 Das Vorgängerblatt der Bilder-Welt ist das IIlustrierte Unterhaltungsblatt der Steirischen Alpenpost. Die vierseitige, von $\mathrm{H}$. Hailer geleitete Beilage ist keine wirkliche Illustrierte. Sie erscheint zwischen Ende Juni 1932 und Ende 1933. Ab 15. Juni 1935 erscheint sie in neuer Ausstattung und neuem Titel: Bilder-Welt.

99 Etwa am 26. Juli 1936 über das Grazer Kinderspital.

\section{Bilder für alle}

${ }^{1}$ Wiener Stadt- und Landesarchiv, schriftliche Auskunft vom 2. Dezember 2011.

${ }^{2}$ Zur Fotokultur der Naturfreunde und zur Arbeiterfotografiebewegung siehe das Kapitel „Politische Bilder. Die Kultur der Arbeiterfotografie“.

${ }^{3}$ Werner Gräffs Fotoband Es kommt der neue Fotograf!, der im Frühjahr 1929 zur Werkbundausstellung „Film und Foto" (Stuttgart 18. Mai bis 7. Juli) erscheint, führt dieses Verfahren der Bildteilung auf einer Doppelseite am Beispiel eines Sportfotos von Max Schirner vor (S. 70-71). Die ohnehin schon extrem querformatige Aufnahme, die den Fußballtormann beim Sprung in Richtung Ball zeigt, wird durch die Bildteilung noch einmal in die Länge gezogen. Auf diese Weise erhöht sich die Spannung. Möglicherweise hat der Redakteur des Wiener Magazins dieses Buch, das kurz zuvor erschienen war, gekannt.

${ }^{4}$ Die Schau wird vom Landesverband für Fremdenverkehr veranstaltet. Insgesamt werden 648 Fotografien ausgestellt, davon 245 von österreichischen Lichtbildnern.

${ }^{5}$ Wolfgang Born: Gedanken über Photographie. Anlässlich der Salzburger Lichtbildschau, in: Die Bühne, Erstes Augustheft 1929, S. 14-15 und S. 48.

${ }^{6}$ Die Aufnahme wird im Spätherbst 1929 auch in der Fotoausstellung der Naturfreunde Meidling gezeigt. Auch dort trägt sie den Titel „Rhythmus“. Vgl. Ausstellungsbroschüre „8. Photographische Ausstellung“ der Naturfreunde, Photosektion Meidling, Wien, Oktober und November 1929, 0.S.

7 Ebenda, S. 48.

${ }^{8}$ Zum Sonntag siehe das Kapitel „Fotografisches Feuilleton. Der Sonntag: ein vergessenes Forum moderner Reportagefotografie“.

${ }^{9}$ Anfang der 1920er Jahre übersiedelt die Redaktion in die Paracelsusgasse 9, Wien 3, in den 1930er Jahren ist sie in der Weihburggasse 18 , Wien 1, untergebracht. 1938 arbeitet die Redaktion in der Führichgasse 6, Wien 1.

10 Moderne Welt, Heft 1-2, Oktober, November 1918 S. 1: An unsere Leser! Editorial zur neuen Zeitschrift von Ludwig Hirschfeld („Für die Redaktion“) und Arnold Bachwitz („Für den Verlag“).

11 Ebenda.

12 Moderne Welt, Heft 1, Oktober 1933, S. 17.

${ }^{13}$ Im April 1934 bringt die Moderne Welt eine Fotoreportage unter dem Titel „Eine Stunde von Wien“ mit Fotos aus der Agentur Willinger und von Hans Casparius. Moderne Welt, Heft 7, April 1934, S. 12 ff.

14 Zum Übergang der Kronos AG an die Vernay AG siehe das Kapitel „Im Schatten der Konzerne. Politische Illustrierte in der Zwischenkriegszeit“. Bedingt durch den Eigentümerwechsel wird die Redaktion der Bühne Mitte der 1920er Jahre in die Canisiusgass 8-10, Wien 9 , den Verlagssitz der Vernay AG, verlegt.

15 Besonderes Aufsehen erregt die Zeitschrift, als sie im Oktober 1925 die im Berliner Admiralspalast gezeigten und von der Polizei konfiszierten Aktfotos von Claire Bauroff abdruckt. Die Fotos stammen von Tru- de Fleischmann. Vgl. Die Bühne, Heft 47, 1. Oktober 1925, S. 3.

${ }^{16}$ Die Bühne, Heft 52, 5. November 1925, S. 10-13: Ein Jahr Bühne.

${ }^{17}$ Am 18. April 1929 veröffentlicht die Bühne die Fotoreportage „Frauenhände“ von Marianne Blumberger und Annie Schulz. Bereits 1927 bringt die Bühne eine (freilich wenig aufregende) Fotoreportage von Alice Schalek über Shanghai. Erst ab 1929 werden regelmäßig gute Reportagen gedruckt. Vgl. dazu ausführlicher das Kapitel „Erzählende Bilder. Die moderne Fotoreportage in der Zwischenkriegszeit“.

${ }^{18}$ Die Bühne, 15. Februar 1930, S. 42 und 43. Text von W.B. (Wolfgang Born). Zur Avantgardefotografie um 1930 siehe auch das Kapitel „Die kurze Zeit der Avantgarde. Fotografische Aufbrüche um 1930“.

${ }^{19}$ Die Bühne, 1. November 1931, S. 26. Der Fotograf Sepp Nowak erhält den ersten Preis des Bühne-Fotopreisausschreibens.

${ }^{20}$ Weil ist jüdischer Herkunft und flüchtet 1938 in die Niederlande und dann in die USA, wo sie sich als Kinderbuchillustratorin etablieren kann. Nach 1938 übernimmt bei der Bühne Erni Kniepert grafische Illustrationsarbeiten.

${ }^{21}$ Unter anderen veröffentlichen in der Bühne folgende österreichische Fotografinnen und Fotografen (bzw. Agenturen): Madame d'Ora, Grete Kolliner, Edith Barakovich, Trude Fleischmann, Franz Löwy, Trude Geiringer und Dora Horovitz, Pepa Feldscharek, Edith Glogau, Kitty Hoffmann, Marianne Bergler, Alice Schalek, Anita Dorfner, Annie Schulz, Lena Schur, Luise Deutsch, Edith Suschitzky, Lotte Meitner-Graf, Atelier Manassé, Max Fenichel, Ernst Kleinberg, Rudolf Koppitz, Käthe Serog, Martin Gerlach, Julius Scherb, Willy Riethof, Paul Macku, Cécile Machlup, Kurt Husnik, Hans Casparius, Franz Mayer, Hans Popper, Willy Eggarter, Robert Haas, Fritz Sauer, Otto Skall, Margarethe Weissenstein, Hans Madensky, Hans Oplatka, László Willinger, Lucca Chmel, Nikolaus Schwarz, Peter Paul Atzwanger, Hans Hannau, Rudolf Spiegel, Rudolf Schloß, Sepp Nowak, Norbert Kraus, Ernst Fürböck, Ferdinand Hodek, Maximilian Karnitschnigg, Hermann Brühlmeyer, Erwin Sajdok, Franz Senkinc, Albert Karplus, Adalbert Defner, Victor Brodt, Bruno Völkel, Franz Roth, Oswald Elbl, Maria Wölfl, Karl Schleich, Albert Hilscher, Leo Ernst, Fred Cešanek, Lothar Rübelt, Hans Dietrich, Harald Lechenperg, Karl Ellinger, Carl Zapletal sowie Fotografen mehrerer Fotoagenturen, darunter Willinger, Schostal, Polyphot, Kilophot u. a.

22 Siehe dazu ausführlicher das Kapitel „Fotografisches Feuilleton. Der Sonntag: ein vergessenes Forum moderner Reportagefotografie“.

${ }^{23}$ Vgl. dazu ausführlicher Anton Holzer: Atelier und IIlustrierte. Trude Fleischmanns Fotoarbeiten für die Presse, in: Anton Holzer, Frauke Kreutler (Hg.): Trude Fleischmann. Der selbstbewusste Blick, Ausstellungskatalog Wien Museum, Ostfildern 2011, S. 122-134, hier S. $128 \mathrm{ff}$.

24 Ein Beispiel für Fotoarbeiten von Jan Lukas: Die Bühne, Zweites Juniheft 1936, S. 24 und 25: Sommer am See. Zu Jan Lukas siehe Josef Moucha: Jan Lukas, Prag 2003. Lukas arbeitet auch für andere Zeitschriften, etwa das Wiener Magazin.

${ }^{25}$ Zur Arbeiterfotografie siehe ausführlicher das Kapitel „Politische Bilder. Die Kultur der Arbeiterfotografie“.

${ }^{26}$ Wiener Magazin, Nr. 1, Januar 1931, S. 31.

27 Mitteilung von Balácz Zoltán Tóth, Mitarbeiter am ungarischen Fotomuseum in Kecskemét, 8. März 2010.

${ }^{28}$ Am 17. März 1934 wird die politische Annäherung der drei Staaten in den „Römischen Protokollen“ formal niedergelegt.

${ }^{29}$ Zur Heimatfotografie siehe das Kapitel „Landschaft, Berge, Brauchtum. Heimatfotografie in den 1930er Jahren“.

${ }^{30}$ Wiener Magazin, Heft 9, September 1935, S. 64.
${ }^{31}$ Ebenda, S. 82-89, hier S. 83.

32 Biografische Hinweise zu Karl Rob finden sich bei Michael Koscher: Der Rob-Verlag, Seminararbeit Neuere Deutsche Literatur, Univ. Wien, Wien 2002, S. 3.

${ }^{33}$ Zusätzlich zu den Zeitschriften produziert und vertreibt das Unternehmen auch Plakate, Werbeschriften und diverse Drucksorten und verkauft Bilder, die in den Rob-Blättern gedruckt werden.

34 Nach der Übernahme der Wiener Mode durch Rob im Jahr 1921 erscheint die Zeitschrift einige Monate lang monatlich.

${ }^{35}$ Vgl. dazu das Kapitel „Bilder, Nachrichten, Sensationen. Die Zeitungsstadt Wien um 1900“.

${ }^{36}$ Nach dem Ersten Weltkrieg öffnet sich das Wiener Salonblatt zwar allmählich, aber die Zeitschrift bleibt in ihrer Ausrichtung konservativ und zum Teil monarchistisch. Die letzte Nummer erscheint am 21. August 1938.

${ }^{37}$ Karl Rob fotografiert selbst und bringt hie und da eines seiner Bilder in der Wiener Mode, etwa in Heft 13, 1933 (Tratsch über den Gartenzaun).

${ }^{38}$ Der Faun, Die Muskete und Das Wiener kleine Witzblatt erscheinen zeitweise wöchentlich, dann wieder zweiwöchentlich. MOCCA erscheint monatlich.

${ }^{39}$ Mehrmals werden Hefte aus dem Rob-Verlag, denen ein Verstoß gegen das Pornografiegesetz vorgeworfen wird, verboten. Karl Rob muss einige Male eine kurze Gefängnisstrafe absitzen. Vgl. Murray G. Hall: Die Verlags- und Redaktionsgeschichte, in: Murray G. Hall, Franz Kadrnoska, Friedrich Kornauth, Wendelin Schmidt-Dengler: Die Muskete. Kultur- und Sozialgeschichte im Spiegel einer humoristischen Zeitschrift 1905-1941, Wien 1983, S. 7-18, hier S. 17.

${ }^{40}$ Vgl. dazu ausführlicher Monika Faber: Die Frau, wie du sie willst. Glamour, Kult und korrigierte Körper. Atelier Manassé 1922-1938, Wien 1998.

${ }^{41}$ MOCCA, Heft 1, Juli 1928, S. 3.

42 Allerdings geht während des Austrofaschismus, wohl aufgrund der verschärften Zensur, der Anteil der Nacktaufnahmen deutlich zurück. Einige Nummern der Zeitschrift werden verboten.

${ }^{43}$ Zu den ungarischen Fotografen, deren Arbeiten die Zeitschrift MOCCA veröffentlicht, gehören Ernő Vadas, Reszö Boszek, Ferenc Schuster, Imre Kinski, Rudolf Balogh und Kálman Boronkay. Vgl. MOCCA, Heft 4, 1934. Anlass für diese Präsentation ist eine Ausstellung des Wiener Photoclubs mit dem Titel „Ungarische Meister“.

44 Die Zeitschrift wird von Ernst Paul Runsberg geleitet. Die erste Nummer erscheint am 12. März 1932.

${ }^{45}$ Als die Zeitschrift 1905 gegründet wird, heißt sie Illustriertes österreichisches Sportblatt. Vor dem Ersten Weltkrieg wird sie von Felix Schmal und Karl Bittrich geleitet. Die Redaktion ist im Verlag des Interessanten Blattes, zunächst in der Schulerstraße 14, dann in der Rüdengasse 11, untergebracht. Die letzte Nummer erscheint am 14. Januar 1928

46 Das erste Heft der Kinowoche erscheint am 8. Juni 1919, das letzte am 30. September 1920. Redaktion und Verwaltung sind in der Nibelungengasse 1, Wien 1, untergebracht.

47 Eigentümer und Verleger von Mein Film ist Moritz Grünstein (Baden bei Wien), der erste verantwortliche Redakteur ist Emanuel Grünstein, später ist es Hugo Rapaport-Rappart. Die Redaktion ist 1925 in der Mariahilfer Straße 82 untergebracht, gedruckt wird beim Unternehmen Elbemühl Papierfabriken und Graphische Industrie AG Wien.

48 Mein Film berichtet etwa über die „Russenfilme“, die in Wien gespielt werden, ebenso über Walther Ruttmanns „Berlin - Sinfonie der Großstadt", der seine Wien-Premiere im Juni 1927 hat.

49 Die Zeitschrift Rundfunk für alle heißt im Untertitel Illustrierte Wochenschrift für den Rundfunkhörer und 
Radiobastler. Die erste Nummer erscheint am 4. September 1932. Redaktion: Margarethengürtel 124, Wien 5 .

${ }^{50}$ Die erste Nummer erscheint am 4. September 1932. Redaktion: Margarethengürtel 124, Wien 5.

${ }^{51}$ Rundfunk, 12.-18. März 1933, Titelseite.

52 Radio-Welt, 9. März 1924, S. 1.

53 Ebenda.

54 Die Radio-Welt veröffentlicht Fotoarbeiten u. a. aus folgenden Ateliers: Feldscharek, Residenz, Manassé, Kolliner, Pietzner, Dietrich, Förster, Jenny \& Vereby, Fayer, Kitty Hoffmann, Trude Fleischmann, Geiringer-Horovitz, Glogau, Barakovich, d'Ora-Benda, Willinger, Jeidels, Ingret. Unter den Pressefotografen ist Lothar Rübelt (neben Karl Schleich) bei Weitem am häufigsten in der Zeitschrift vertreten.

${ }^{55}$ Als Radio Wien Ende 1924 seinen Betrieb aufnimmt, hat der Sender 70000 Abonnenten, davon 50000 aus Wien. Knapp vier Jahre später, im August 1928, ist die Abonnentenzahl auf 30000 angestiegen. Vgl. Radio-Welt, 22. November 1924, S. 3 und Radio-Welt, 25. August 1928, S. 229.

${ }^{56}$ Nach 1929 geht der Umfang der Zeitschrift wieder zurück, u. a. auch bedingt durch die Wirtschaftskrise, die sich bremsend auf den Anzeigenumfang auswirkt.

${ }^{57}$ Radio-Welt, 18. März 1933, Titelseite.

${ }^{58}$ Der Nachfolger von Franz Anderle ist Anton Pejpal.

${ }^{59}$ Franz Anderle: Radio- und Telegraphendienst für Wehrverbände und Jugendgruppen, hg. vom Landeswehramt des Wiener Heimatschutzes, Wien 1935.

60 Ohne die aktive Mithilfe der Regierung wäre die Nutzung der enteigneten sozialdemokratischen Strukturen wohl kaum möglich gewesen.

${ }^{61}$ Radio-Welt, 10. April 1938, Titelseite.

\section{Bilder als Propaganda}

${ }^{1}$ Josef Seiter erwähnt, dass Weyr im Frühjahr 1934 kurzfristig für die Bunte Woche gearbeitet hat und bis 1938 im Vorwärts-Verlag tätig war. Details über diese Zeit liefert er nicht. Stefan Riesenfellner, Josef Seiter: Der Kuckuck. Die moderne Bild-Illustrierte des Roten Wien, Wien 1995, S. 32 f. René Perret erwähnt in seiner Biografie und Werkgeschichte über den Fotografen Martin Imboden, dass Weyr nach dem Verbot des Kuckuck (für den Imboden regelmäßig gearbeitet hatte) „im Dienste der reaktionären Heimwehr" gestanden habe. Vgl. René Perret: Martin Imboden. Ein vergessener Fotograf, Bern 1996, S. 42. Einige wenige Hinweise zur Rolle Weyrs nach dem Ende des Kuckuck finden sich auch bei Brigitte Robach: Julius Braunthal als politischer Publizist. Ein Leben im Dienste des Sozialismus, Diss., Wien 1983, S. 225.

${ }^{2}$ Zunächst tritt als Eigentümer, Herausgeber und Verleger noch die Vorwärts A.G. auf, ab Sommer 1934 dann die Bilderzeitung Ges.m.b.H.

${ }^{3}$ Schreiben der Druck- und Verlagsanstalt Vorwärts vom 14. April 1934, Nachlass Siegfried Weyr, Wien Bibliothek, Handschriftensammlung.

${ }^{4}$ Ein Beispiel unter vielen: Die auflagenstarke sozialdemokratische Tageszeitung Das Kleine Blatt wird nach zweiwöchiger Unterbrechung unter der politischen Kontrolle der Regierung weitergeführt.

${ }^{5}$ Einer der wenigen Autoren, die die kulturelle Mehrschichtigkeit des Austrofaschismus betonen, ist der in den USA lehrende Germanist Horst Jarka. Er geht, v. a. im Bereich der Literatur, von einem „Ineinander von Tradition, Konvention und Experiment" aus, wenn auch Unterdrückungsmaßnahmen und eine regressive Ästhetik bei Weitem überwiegen. Vgl. Horst Jarka: Zur Kultur- und Theaterpolitik im „Ständestaat“, in: Franz Kadrnoska (Hg.): Aufbruch und Untergang. Österreichische Kultur zwischen 1918 und 1938, Wien, München, Zürich 1981, S. 499-538, hier S. 500.
${ }^{6}$ Beispiele sind etwa die Hygiene-Ausstellung 1937 in Wien oder der österreichische Pavillon der Weltausstellung 1937 in Paris.

${ }^{7}$ Diese Darstellungsmethode wird in den 1920er Jahren von Otto Neurath, Marie Reidemeister und Gerd Arntz im Umfeld des Wiener Gesellschafts- und Wirtschaftsmuseums entwickelt. Vgl. Otto Neurath: From Hieroglyphics to Isotype. A visual Autobiography, London 2010.

${ }^{8}$ In der großen Ausstellung zu Kaiser Franz Joseph, die 1935 im Schloss Schönbrunn gezeigt wird, kommt erstmals im Austrofaschismus in größerem Stil die Methode der Bildstatistik zum Einsatz.

${ }^{9}$ Zahlreiche Beispiele finden sich in dem von Jan Tabor herausgegebenen Ausstellungskatalog: Kunst und Diktatur. Architektur, Bildhauerei und Malerei in Österreich, Deutschland, Italien und der Sowjetunion 19221956, Wien 1994.

${ }^{10}$ Die Zeitschrift geht 1933 aus der 1924 gegründeten Zeitschrift Österreichs Bau- und Werkkunst hervor. Diese wird von der Zentralvereinigung der Architekten Österreichs herausgegeben. Sie erscheint im Krystall-Verlag in Wien und ist eine Art Plattform für die österreichische Werkbundbewegung.

${ }^{11}$ Vgl. dazu Wilfried Posch: Clemens Holzmeister: Architekt zwischen Kunst und Politik, Salzburg, Wien 2010, S. $253 \mathrm{ff}$.

12 Binder gestaltet zahlreiche Umschläge des Profil.

${ }^{13}$ Wichtige Fotografen der Zeitschrift, die moderne Positionen vertreten, sind Martin Imboden, Kurt Husnik und Robert Haas. Ihnen stehen freilich auch zahlreiche konservative Positionen gegenüber.

14 Möglicherweise hat sich Braunthal bei dieser Neugründung an einer tschechischen Illustrierten gleichen Namens orientiert, die seit Ende 1926 im Prager Melantrich-Verlag erscheint und sich ebenfalls an ein breites Publikum richtet. Auch wenn das Blatt populär aufgemacht ist, legt es, im Unterschied zur österreichischen Bunten Woche, großen Wert auf eine hochwertige Bebilderung. Moderne Fotografen wie László Moholy-Nagy, Jindřich Štyrský, Alexandr Hackenschmied, Evžen Markalous und anderer Vertreter der Avantgarde publizieren in der Bunten Woche. Zur Prager Bunten Woche siehe Vladimír Birgus, Jan Mlčoch: Tschechische Fotografie des 20. Jahrhunderts, hg. von der Kunst- und Ausstellungshalle der Bundesrepublik Deutschland in Zusammenarbeit mit dem Museum für Angewandte Kunst in Prag, Bonn, Prag 2009, S. 81.

${ }^{15}$ Brigitte Robach: Julius Braunthal als politischer Publizist. Ein Leben im Dienste des Sozialismus, Diss., Wien 1983, S. 225.

${ }^{16}$ Ebenda.

${ }^{17}$ In der Nummerierung knüpft die neue Bunte Woche nahtlos an die alte an. Das erste Heft nach der Umgestaltung und Neuausrichtung erscheint als „III. Jahr/ Nr. 7“.

${ }^{18}$ Bunte Woche, 13. Mai 1934, S. 16.

${ }^{19}$ Der Kuckuck, Nr. 38, 1931. Die Bildseite ist abgebildet in Stefan Riesenfellner, Josef Seiter: Der Kuckuck. Die moderne Bild-Illustrierte des Roten Wien, Wien 1995, S. 282.

${ }^{20}$ Bunte Woche, 22. Juli 1934, S. 5.

${ }^{21}$ René Perret schildert, dass Weyr nach dem Umbruch 1934 Maria Gottwald, der Gefährtin und Unterstützerin Imbodens in geschäftlichen Angelegenheiten, die Herausgabe von 80 Fotos aus dem Kuckuck-Archiv verweigert habe. Vgl. René Perret: Martin Imboden. Ein vergessener Fotograf, Bern 1996, S. 42.

22 Weyr schreibt u. a. unter dem Pseudonym „c-l“ (Cyrill). Siehe Eckart Früh: Kürzel und Pseudonyme in diversen Tageszeitungen und Zeitschriften vor und nach 1945: http://noch-mehr.blogspot.com (Zugriff am 21.11.2011).

${ }^{23}$ Am 9. Juni 1938 ersucht Weyr um Arbeitslosenunterstützung, diese wird abgelehnt, da er zu wenig Versicherungszeiten habe. Daraus kann man schließen, dass er in der zweiten Hälfte der 1930er Jahre zumindest teilweise arbeitslos ist. Nachlass Siegfried Weyr, Wien Bibliothek, Handschriftensammlung.

24 Walter Köhler: Amtliches Nachrichtenwesen und Nachrichtenpolitik im „Austrofaschismus“. Amtl. Nachrichtenstelle u. „Politische Korrespondenz“ im Umfeld des „austrofaschistischen“ Mediensystems 1933 bis 1938, Diss., Wien 1985, S. 125.

25 Die Österreichische Woche ist u. a. folgenden Zeitungen beigelegt: Neues burgenländisches Volksblatt, Burgenländisches Volksblatt, Burgenländische Heimat, Vorarlberger Landes-Zeitung, Vorarlberger Volksbote, Kärntner Sonntag, Kärntner Tagblatt, Haller Lokalanzeiger, Haller Kreis-Anzeiger, Schwazer Lokal-Anzeiger, Schwazer Kreis-Blatt, Oberinntaler Wochenpost, Tiroler Bauernzeitung, Der Ennstaler, Steirische Alpen-Post, Grazer Volksblatt, Tiroler Sonntagsblatt „Unterland“, Oesterreichische Nachrichten-Woche für das Marchfeld und angrenzende Weinland, Pongauer Wochenschau, Pinzgauer Wochenblatt, Salzburger Volksbote, Tauern-Post, Neues Wochenblatt, Tullner Bezirks-Nachrichten, Tullner Nachrichten, Badener Volksblatt, Wiener Neustädter Zeitung, Kremser Zeitung, Kirchdorfer Zeitung, Die Neue Zeit, Steyrer Tageszeitung, Steyrer Zeitung, Kremsthal-Bote, Wiener Zeitung, Neue Warte am Inn, Linzer Volksblatt, Linzer Wochenblatt, Innviertler Zeitung, Salzburger Chronik, Welser Zeitung, Die Reichspost und Neuigkeits-Welt-Blatt. Bibliografische Angaben: Österreichische Nationalbibliothek.

${ }^{26}$ Die Bilderwoche der österreichischen Volksschriften steht dem Arbeiterflügel der Vaterländischen Front nahe. Als Eigentümer und Verleger ist im Impressum Eduard Wancura genannt, als Herausgeber Hans Jilek, die Redaktion ist in der Walfischgasse 7, Wien 1, untergebracht. Gestaltung und Machart des illustrierten Wochenblatts ist einfach, ab 1937 wird sie im Kupfertiefdruck hergestellt. Bemerkenswert sind die zahlreichen Bildstatistiken.

\section{Erzählende Bilder}

${ }^{1}$ Lothar Rübelt: Das Auge der Presse, in: Wiener Magazin, Heft 10, Oktober 1929, S. 8-14, hier S. 12.

2 Ebenda.

${ }^{3}$ Ebenda, S. 14.

${ }^{4}$ Wiener Magazin, Heft 10, Oktober 1932, S. 47.

${ }^{5}$ Lothar Rübelt: Reminiszenz zu meiner Photoreportage des Giftmordprozesses in Szolnok 1929, in: Photographie und Gesellschaft. Zeitschrift für photographische Imagologie, Heft 2, 1989, S. 45-47.

${ }^{6}$ In den frühen Reportagen stammen die Bilder oft von mehreren Fotografen. Vgl. dazu ausführlicher das Kapitel „Bild und Text. Die Rhetorik der Zeitungsseiten“.

${ }^{7}$ Vgl. dazu ausführlicher Ulrich Keller: Fotografie und Begehren. Der Triumph der Bildreportage im Medienwettbewerb der Zwischenkriegszeit, in: Annelie Ramsbrock, Annette Vowinckel, Malte Zierenberg ( $\mathrm{Hg}$.): Fotografien im 20. Jahrhundert. Verbreitung und Vermittlung, Göttingen 2013, S. 129-174, insbes. S. $139 \mathrm{ff}$.

${ }^{8}$ Vgl. dazu ausführlicher Jan Brüning: Kurzer Überblick zur Technik der Pressefotografie in Deutschland von 1920 bis 1940, in: Diethart Kerbs, Walter Uka (Hg.): Fotografie und Bildpublizistik in der Weimarer Republik, Bönen 2004, S. 11-28, hier S. 19 ff.

${ }^{9}$ Kurt Husnik: Das Kinoauge als Reporter, in: Profil, Heft 10, Oktober 1933, S. III.

${ }^{10}$ Ebenda, S. III/IV.

11 Siehe dazu weiter unten.

12 Zu Gusti Skall siehe ausführlicher das Kapitel „Fotografisches Feuilleton. Der Sonntag: ein vergessenes Forum moderner Reportagefotografie“.

${ }^{13}$ Siehe dazu ausführlicher das Kapitel „Im Schatten der Konzerne. Politische Illustrierte in der Zwischenkriegszeit“. 
${ }^{14}$ Vgl. etwa Tim Gidal: Deutschland - Beginn des modernen Photojournalismus (Bibliothek der Photographie, hrsg. von Romeo E. Martinez, Bd. 1), Luzern, Frankfurt a. M. 1972.

${ }^{15}$ Siehe etwa Patrick Rössler: 1928: Wie das neue Sehen in die illustrierten kam. „Maxl Knips“, Sasha Stone, Das illustrierte Blatt und die Bildermagazine der Weimarer Republik, in: Fotogeschichte, Heft 121, 2011, S. 4560, hier S. $47 \mathrm{ff}$. Zu Paul Edmund Hahn, einem Pionier der Fotoreportage, der ab 1928 in der Münchner Illustrierten Presse und in Das illustrierte Blatt Fotorepor tagen veröffentlichte, siehe Wilhelm Marckwardt: Paul Edmund Hahn. Ein vergessener Fotojournalist der ersten Stunde, in: Fotogeschichte, Heft 10, 1983, S. 4053.

${ }^{16}$ Herbert Molderings: Eine Schule der modernen Fotoreportage. Die Fotoagentur Dephot (Deutscher Photodienst) 1928 bis 1933, in: Fotogeschichte, Heft 107, 2008, S. 5-21.

${ }^{17}$ Wiener Bilder, 7. April 1929, S. 6. Die Fotoagentur Weltrundschau vertreibt neben den Fotos und Reportagen von Seldowicz (auch Seldow) auch Bildgeschichten von Neudatschin (Neudin), Tim und Georg Gidal u. a Vgl. Diethart Kerbs: Die illustrierte Presse am Ende der Weimarer Republik, in: Diethart Kerbs, Henrick Stahr (Hg.): Berlin 1932. Das letzte Jahr der Weimarer Republik. Politik, Symbole, Medien, Berlin 1992, S.68-89, hier S. $88 \mathrm{f}$.

${ }^{18}$ Fred Wallentin ist 1937 kurz in Wien gemeldet. Die Angaben stammen aus den von inm ausgefüllten Meldeunterlagen, die heute im Wiener Stadt- und Landesarchiv aufbewahrt werden. Schriftliche Auskunft vom 10. Oktober 2012

${ }^{19}$ Wallentin lebt nach 1933 in Paris und meldet sich im Oktober 1937 nach Holland ab. Vgl. ebenda.

20 Der Antrag ist mit 19. Dezember 1934 datiert. Vgl. dazu Michaela Pfundner: Dem Moment sein Geheim nis entreißen. Der Sportberichterstatter Lothar Rübelt (1901-1990), in: Matthias Marschik, Rudolf Müllner (Hg.): „Sind's froh, dass Sie zu Hause geblieben sind.“ Mediatisierung des Sports in Österreich, Göttingen 2010, S. 317-327, hier S. 322.

${ }^{21}$ Kurt Kaindl: Der Giftmordprozeß in Szolnok. Analyse der Bildberichte über einen Giftmordprozeß aus dem Jahre 1929 im „Interessanten Blatt“ und im „Kuckuck“, in: Photographie und Gesellschaft. Zeitschrift für photographische Imagologie, Heft 1, 1989, S.43-52, hier S. 45

22 Neue Freie Presse, 15. Dezember 1929, S. 5, zit. nach Kaindl, ebenda, S. 50

${ }^{23}$ Lothar Rübelt: Reminiszenz zu meiner Photoreportage des Giftmordprozesses in Szolnok 1929, in: Photographie und Gesellschaft. Zeitschrift für photographische Imagologie, Heft 2, 1989, S. 45-47.

${ }^{24}$ Das interessante Blatt, 19. Dezember 1929, Titelseite.

${ }^{25}$ In einem Gespräch, das Kurt Kaindl Ende der 1980er Jahre mit Rübelt führt, weist dieser darauf hin, dass der Abdruck im Kuckuck ohne Genehmigung erfolgt sei. Kurt Kaindl: Der Giftmordprozeß in Szolnok. Analyse der Bildberichte über einen Giftmordprozeß aus dem Jahre 1929 im „Interessanten Blatt“ und im „Kuckuck ", in: Photographie und Gesellschaft. Zeitschrift für photographische Imagologie, Heft 1, 1989, S. 4352, hier S. 46

${ }^{26}$ Das interessante Blatt, 20. März 1930, S. 18.

27 Um nur ein Beispiel dieser Kontinuität zu nennen: Josef Papanek, geb. 1867, arbeitet seit 1902 für die größte Illustrierte in Österreich, Das interessante Blatt. Von 1907 bis 1937 ist er Chefredakteur. Er stirbt 1944 im Konzentrationslager Theresienstadt. Vgl. dazu Lies Glück: Das interessante Blatt und Der Kuckuck. Ein Beitrag zur Wiener Zeitschriftengeschichte, Diss., Wien 1953, S. 4.

${ }^{28}$ Zum Sonntag siehe ausführlicher das Kapitel „Fotogra- fisches Feuilleton. Der Sonntag: ein vergessenes Forum moderner Reportagefotografie“.

${ }^{29}$ Die Bühne, 15. August 1929, S. 44.

${ }^{30}$ U. a. liefern die Innsbrucker Fotografen Paul Kraberger, Richard Müller und Karl Dornach Aufnahmen für Reportagen im Welt-Guck.

${ }^{31}$ Welt-Guck, 23. August 1931, S. 9.

32 Sylvester Matuska, der ungarischer Herkunft ist, wird 1933 an Ungarn ausgeliefert und dort 1934 zum Tod verurteilt. Das Urteil wird aber nicht vollstreckt. In den Wirren des Kriegsendes 1945 verschwindet er spurlos.

33 Wiener Magazin, Heft 9, September 1932, S. 92.

34 Ebenda, S. 9.

35 Ebenda, S. 8 f.

${ }^{36}$ Auch das Wiener Magazin widmet sich in Heft 5 vom Mai 1930 (S. 88-89) dem Thema Gallspach. Der Text stammt von Erwin Stranik, der als Wien-Korrespondent für das Berliner Tageblatt arbeitet; die Fotos steuert Karl Schöpl, der für die Fotoagentur Polyphot tätig ist, bei.

37 Lorant beginnt (ab 1928) als Berliner Fotoredakteur bei der 1923 gegründeten Münchner Illustrierten Presse, nach 1930 arbeitet er in München als Chefredakteur der Zeitung. 1931 hat sie eine wöchentliche Auflage von 700.000 Exemplaren. Vgl. Michael Hallet: Stefan Lorant. Godfather of Photojournalism, Oxford 2006, S. $32 \mathrm{ff}$.

${ }^{38}$ Soma Morgenstern: Der Fall Zeileis, in: Ders.: Werke in Einzelbänden, hg. von Ingolf Schulte, Bd. 11: Dramen, Feuilletons, Fragmente, Lüneburg 2000, S. 388-392, hier S. $388 \mathrm{f}$.

39 Münchner Illustrierte Presse, 23. Februar 1930 , S. 236-238 und S. 252.

40 Wolfgang Weber (1902-1985) ist seit 1925 als Fotograf für die Münchner Illustrierte Presse (MIP) tätig. Er wird von Stefan Lorant (seit 1928 bei der MIP) besonders gefördert und ist um 1930 einer der besten und wichtigsten Reportagefotografen des Blattes. Mitte 1932 wechselt er zu Ullstein. Vgl. Kristina Danzer: Vom Ethnologen zum Bildjournalisten, in: „Fliegen Sie sofort nach..." Wolfgang Weber-Reportagen, Fotografie und Film 1925 bis 1977, hg. von Ute Eskildsen, Ausstellungskatalog Museum Folkwang, Essen, Göttingen 2004, S. 14-17, hier S. $15 \mathrm{f}$

${ }^{41}$ Münchner Illustrierte Presse, 23. Februar 1930, S. $236 \mathrm{ff}$.

42 Ebenda, S. 238.

43 Ebenda, S. 252.

44 Stefan Lorant betont in einem späten Interview, dass in der Münchner Illustrierten Presse die Bildredaktion und nicht etwa der Fotograf (oder der Textautor) für die Auswahl, Anordnung und Gestaltung der Reportagen zuständig war. „The photographers had no influence whatsoever on the selection of pictures to appear in the paper or how the photographs would be presented. Once they delivered their photographs, their job ended."Wilhelm Marckwardt: Die Illustrierten der Weimarer Zeit. Publizistische Funktion, ökonomische Entwicklung und inhaltliche Tendenzen (unter Einschluß einer Bibliographie dieses Pressetypus 1918-1932), München 1982, S. 121.

${ }^{45}$ Das interessante Blatt, 27. Februar 1930, Titelseite und S. $2 / 3$.

${ }^{46}$ Leo Ernst, geb. 1904 in Schwaz, Tirol, Fred Cešanek, geb. 1896 in Wien. Beide arbeiten seit Mitte der 1920er Jahre als Pressefotografen in Wien. Seit etwa 1928 vermarkten die beiden ihre Bilder zeitweise gemeinsam unter dem Namen „Ernst \& Cešanek.

47 Das interessante Blatt, 27. Februar 1930, S. 2.

${ }^{48}$ Soma Morgenstern: Der Fall Zeileis, in: Ders.: Werke in Einzelbänden, hg. von Ingolf Schulte, Bd. 11: Dramen, Feuilletons, Fragmente, Lüneburg 2000, S. 388-392, hier S. 389.
${ }^{49}$ Der Kuckuck, 5. Januar 1930, S. 8 und 9.

50 Ebenda.

${ }^{51}$ Münchner Illustrierte Presse, 31. Januar 1931, S. 100/ 101 und Forts. S. 109.

52 Herbert Molderings: Eine Schule der modernen Fotoreportage. Die Fotoagentur Dephot (Deutscher Photodienst) 1928 bis 1933, in: Fotogeschichte, Heft 107, 2008, S. 5-21, hier S. 13.

${ }^{53}$ Münchner Illustrierte Presse, 31. Januar 1931, S. 100.

54 Ebenda, S. 109.

55 Einige der Aufnahmen, die Rübelt in Steyr gemacht hat, erscheinen zehn Tage nach der Reportage im Interessanten Blatt auch im sozialdemokratischen Kuckuck (Reportage: „Steyr stirbt“). Der Kuckuck, 17. Januar 1932, S. 3-5. Weitere Aufnahmen im Kuckuck stammen von einem Fotografen namens Katona.

${ }^{56}$ Das interessante Blatt, 7. Januar 1932, Titelseite.

57 Ebenda, S. 4.

${ }^{58}$ Siehe dazu ausführlicher das Kapitel „Im Schatten der Konzerne. Politische Illustrierte in der Zwischenkriegszeit".

${ }^{59}$ Münchner Illustrierte Presse, 17. März 1929, S. 356 und 357. Der Text der Reportage stammt von Hans Kramer, Wien.

${ }^{60}$ Munkácsi ist ins bekannte österreichische Skigebiet gereist, um die Skikurse von Hannes Schneider zu dokumentieren. Dieser wird Ende der 1920er Jahre als Schauspieler in den Skifilmen von Arnold Fanck bekannt.

${ }^{61}$ Eisenstaedt arbeitet Anfang der 1930er Jahre für die Agentur A.P. (Associated Press).

${ }^{62}$ Kölnische Illustrierte Zeitung, 26. November 1932, S. 1213.

${ }^{63}$ Wiener Magazin, Heft 7, Juli 1932, S. 46-51.

${ }^{64}$ Vgl. Elke Krasny, Marcus Patka, Christian Rapp, Nadia Rapp (Hg.): Von Samoa zum Isonzo. Die Reisejournalistin Alice Schalek, Wien 1999.

${ }^{65}$ Kurt Kaindl (Hg.): Harald Lechenperg. Pionier des Fotojournalismus, Salzburg 1990.

${ }^{66}$ Tichys Bilder erscheinen in Deutschland in Die Woche, parallel dazu veröffentlicht er ab 1934 Reisereportagen in zahlreichen österreichischen Zeitschriften, u. a. im Interessanten Blatt, in den Wiener Bildern, im Wiener Magazin und in der Bühne.

${ }^{67}$ Münchner Illustrierte Presse, 21. Februar 1932, S. 172.

${ }^{68}$ Vgl. Renate Erhart, Gerd Kaminski: Paizhao. Das alte China in der Linse österreichischer Fotografen (Bericht des Österreichischen Instituts für China- und Ostasienforschung Nr. 54), Wien 2008, S. 5-12. Neben der Berliner Illustrirten Zeitung veröffentlicht er auch in folgenden Zeitungen und Zeitschriften: Das Magazin, Revue des Monats, Die Woche, Die Dame, Der Silberspiegel, das Kriminalmagazin und Volk und Welt.

${ }^{69}$ Berliner Illustrirte Zeitung, 15. September 1929.

70 Ein Beispiel: Lechenpergs Reportage „Kathedralen im Urwald", die am 12. April 1936 in den Wiener Bildern erscheint, ist zuvor in einer anderen Fassung in der Berliner Illustrirten Zeitung veröffentlicht worden.

${ }^{71}$ Moderne Welt, Heft 8, Mai 1934, S. 16 und 17.

72 Ebenda, S. $16 \mathrm{f}$.

73 Ebenda, S. 17.

${ }^{74}$ Eine Aufnahme Lechenpergs vom Februar 1934 zeigt den Wiener Karl-Marx-Hof nach seiner Beschießung im Februar 1934 durch das regierungstreue Militär. Die Aufnahme erscheint Ende Februar sogar als Titelblatt der Berliner Illustrirten Zeitung.

${ }^{75} \mathrm{Vgl}$. dazu das Kapitel „Fotografisches Feuilleton. Der Sonntag: ein vergessenes Forum moderner Reportagefotografie".

${ }^{76}$ Haas betreibt in seiner Werkstätte in der Schützenstraße 9, Wien 3, seit 1925 zusammen mit Carry Hau- 
ser die Officina Vindobonensis, eine Handdruckerei. Daneben gestaltet er seit Mitte der 1920er Jahre Kataloge, Plakate und in den 1930er Jahren auch Ausstellungen.

77 Seit Ende der 1920er Jahre ist Haas auch als Zeitschriftengestalter tätig, zunächst, 1929/30 für die Neue Kunst, in den 1930er Jahren auch für die Zeitschrift Profil. Österreichische Monatsschrift für bildende Kunst.

${ }^{78}$ In einem Interview Anfang der 1990er Jahre erinnert sich Haas, dass er, obwohl der Entwurf zur Gänze von inm stammte, auf Druck des Architekten Haerdtl einen „arischen“ Gehilfen (Günther Baszel) erhielt, der im Katalog prominent erscheint. Vgl. Robert Haas: Schrift - Druck - Fotografie, Interview mit Anna Auer, 11. November 1992 in Valhalla, New York, in: Anna Auer: Fotografie im Gespräch, Passau 2001, S. 149-167, hier S. 154. Auch in der Reproduktion der Installation in der Zeitschrift Die Bühne erscheint Haas nicht als Gestalter, obwohl er ein regelmäßiger Mitarbeiter des Blattes ist.

${ }^{79}$ Robert Haas schildert in einem Interview mit Gerhard Jelinek Anfang 1988 die dramatischen Umstände seiner Flucht aus Wien. Vgl. Robert Haas: „Ich muß sagen, ich war immer ein Glückpilz", in: Gerhard Jelinek: Nachrichten aus dem 4. Reich, Salzburg, 2008, S. 87-90.

\section{Handel mit Bildern}

${ }^{1}$ Biografische Informationen zu Wilhelm Willinger hat Milena Greif zusammengestellt: Milena Greif: Die Geschichte der Wiener Fotoagentur Willinger und ihr verschwundener Bestand, in: Rundbrief Fotografie, Vol. 11, No. 3, 15. September 2004 (N.F. 43), S. 37-40. Ergänzt sind diese Hinweise durch eigene Recherchen.

${ }^{2}$ László Willinger (1909-1989) beginnt schon in jungen Jahren mit dem Fotografieren. Seine erste Lehrerin ist seine Mutter Margarete Willinger, in den 1920er Jahren absolviert er auch eine Lehrzeit beim bekannten, aus Budapest stammenden Fotografen Pál Angelo (18941974), der 1919 ein Atelier für Porträt-, Gesellschaftsund Modefotografie eröffnet, aber seit 1920 im Ausland arbeitet. Dieser unterhält Ateliers in Paris, Nizza und Den Haag.

${ }^{3}$ Aufnahmen von Willinger, die vor 1914 in der UIIstein-Presse veröffentlicht wurden, finden sich im Berliner Ullstein-Archiv.

${ }^{4}$ Zeitbilder, Nr. 36/1914, Beilage zur Vossischen Zeitung. Die Fotoserie befindet sich im Ullstein-Archiv, Berlin. Die weitläufige Anlage Berlin-Buch wurde ab 1898 errichtet. Sie umfasste mehrere Krankenhäuser, eine „Irrenanstalt" und ein Altersheim für 1500 Bewohner, das 1909 eröffnet wurde.

${ }^{5}$ Moderne Welt, Heft 3, Dezember 1918. Diese Bilder erscheinen unter dem Namen „Willinger" und noch nicht unter der Bezeichnung „Willinger \& Schnapper“.

${ }^{6}$ Ende 1931 beginnt Leo Ernst eine Kooperation mit dem Pressefotografen Albert Hilscher, die beiden vermarkten die Bilder unter dem Namen „Ernst-Hilscher“. Ebenfalls seit 1931 arbeitet Fred Cešanek wieder unter eigenem Namen für die Presse.

${ }^{7}$ Oft findet sich in den Zeitungen auch nur die Kurzform „Österreichischer Presse-Bilddienst“.

${ }^{8}$ Um genau zu sein: bis 1938 , als er infolge der nationalsozialistischen Verfolgung enteignet und vertrieben wird.

${ }^{9}$ Keystone arbeitet eigentlich in Österreich ab Ende der 1920er Jahre mit der Fotoagentur von Robert Schostal zusammen. Aber da diese um 1930 noch keine eigenen österreichischen Fotografen unter Vertrag hat, bedient sich Keystone zeitweise der Aufnahmen Willingers, um sie europaweit zu verkaufen. Siehe Milena Greif: Mit den Fotos kehrt die Erinnerung zurück. Agentur Schostal, in: Rundbrief Fotografie, Vol. 9, No. 2, Juni 2002 (N. F. 34), S. 30-33, hier S. 30.
${ }^{10}$ Willinger gibt seine Berliner Kontakte auch in der Zwischenkriegszeit nicht auf und liefert von Wien aus Bilder an den Ullstein-Konzern. Vgl. die Unterlagen im UIIstein-Archiv in Berlin.

${ }^{11}$ Zur Frühgeschichte der österreichischen Fotoagenturen vor dem Ersten Weltkrieg siehe das Kapitel „Die Jagd nach Sensationen. Pioniere der Pressefotografie“.

${ }^{12}$ Dies betrifft vor allem Kilophot, Welt-Preß-Photo und die Illustrations-Zentrale. Ausführlicher zur Pressefotografie im Krieg und zu biografischen Informationen zu den wichtigsten österreichischen Kriegsfotografen und Inhabern von Fotoagenturen siehe Anton Holzer: Die andere Front. Fotografie und Propaganda im Ersten Weltkrieg, 3. Aufl., Darmstadt 2012, S. 22 ff. und S. 30 f.

${ }^{13}$ Siehe dazu das Kapitel „Mit der Kamera bewaffnet. Fotografie und Propaganda im Ersten Weltkrieg“.

${ }^{14}$ Josef Perscheids Agentur Welt-Preß-Photo ist zwar unmittelbar nach dem Ersten Weltkrieg (um 1919) noch aktiv, aber der Inhaber verlegt sich in den 1920er Jahren auf das Ateliergeschäft. Carl Seebalds Illustrations-Zentrale wird nach dem Ersten Weltkrieg nicht weitergeführt. Und auch Kilophot, die erfolgreichste Fotoagentur während des Krieges, stellt den Verkauf von Fotos an die Presse nach 1918 de facto ein. Bis um 1930 erscheinen aber noch vereinzelt Bilder, die aus dem Bestand der Agentur stammen. Das Mutterunternehmen von Kilophot, die 1912 gegründete „Fabrik photographischer Papiere und Kunstanstalt“, wird allerdings nach dem Krieg weitergeführt. 1925 geht der Betrieb in den Besitz von Felix Leutner über, er existiert in eigenständiger Form bis in die 1930er Jahre.

${ }^{15}$ Karl Schleich und Albert Hilscher kooperieren seit 1927 bei der Vermarktung ihrer Pressefotos unter dem Namen „Schleich-Hilscher“, ab 1931 arbeitet Hilscher mit Leo Ernst unter dem Namen „Ernst-Hilscher" zusammen. Seit 1928 kooperieren Leo Ernst und Fred Cešanek unter dem Namen „Ernst \& Cešanek“.

${ }^{16} \mathrm{Vgl}$. dazu Matthias Bruhn: Tarife für das Sichtbare. Eine kurze Geschichte der Fotoagenturen, in: Fotogeschichte, Heft 105, 207, S. 13-25, hier S. 16 f.

17 Die nach der Jahrhundertwende entwickelte Bildtelegrafie ist teuer und setzt sich in der Pressefotografie bis in die Zwischenkriegszeit in der Praxis nicht durch. 1923 wird erstmals ein Foto per Telegrafen über den Atlantik geschickt. Eine Alternative dazu ist das Funkbild, das kabellos übertragen wird. Die Qualität ist freilich deutlich schlechter. Das erste Funkbild überquert den Atlantik 1922. Vgl. dazu Konrad Dussel: Pressebilder in der Weimarer Republik. Entgrenzung der Information, Münster, Berlin 2012, S. 57 ff. Bei der Agentur Associated Press wird 1935 ein fester „Wire-Photo-Service" eingerichtet, der insbesondere die wichtigsten Städte der USA miteinander verbindet. Vgl. dazu Malte Zierenberg: Die Ordnung der Agenturen. Zur Verfertigung massenmedialer Sichtbarkeit im Pressewesen 1900-1940, in: Annelie Ramsbrock, Annette Vowinckel, Malte Zierenberg (Hg.): Fotografien im 20. Jahrhundert. Verbreitung und Vermittlung, Göttingen 2013, S. 44-65, hier S. 60.

18 Siehe dazu Diethart Kerbs: Zur Geschichte der Berliner Pressefotografie im ersten Drittel des 20. Jahrhunderts, in: Diethart Kerbs, Walter Uka (Hg.): Fotografie und Bildpublizistik in der Weimarer Republik, Bönen 2004, S. 29-47, hier S. 33 ff. sowie Ders.: Die Epoche der Bildagenturen. Zur Geschichte der Pressefotografie in Berlin von 1900 bis 1933, in: Diethart Kerbs, Walter Uka, Brigitte Walz-Richter (Hg.): Die Gleichschaltung der Bilder. Pressefotografie 1930-36, Berlin 1983, S. 32-73, hier S. $37 \mathrm{ff}$.

${ }^{19}$ Ausführlicher zur Fotoagentur III-Pho siehe das Kapitel „Bilder für alle: Die Welt der Magazine und Revuen“.

20 Die sozialdemokratische Illustrierte Der Kuckuck druckt zahlreiche Aufnahmen der Agentur Unionbild.

${ }^{21}$ Vgl. dazu das Kapitel „Schöne neue Warenwelt. Reklame und Mode in der Fotografie“.
22 Siehe dazu ausführlicher Herbert Molderings: Eine Schule der modernen Fotoreportage. Die Fotoagentur Dephot (Deutscher Photodienst) 1928 bis 1933, in: Fotogeschichte, Heft 107, 2008, S. 5-21.

${ }^{23}$ Siehe dazu auch das Kapitel „Erzählende Bilder. Die moderne Fotoreportage in der Zwischenkriegszeit".

${ }^{24}$ Um nur einige Beispiele zu nennen: Rudolf Birnbach (Weltrundschau) flüchtet nach New York, Simon Guttmann (Dephot) geht über die Schweiz und Frankreich nach England, Ernest Mayer (Mauritius) und Edgar Kahn (Neofot), gehen ins amerikanische Exil. Zoltan Kluger und W. von Szigethy flüchten 1933 nach Palästina.

25 Die Agentur Weltrundschau ist nach dem Eigentümerwechsel bis Anfang der 1940er Jahre in Österreich präsent, Mauritius bis Ende der 1930er Jahre, Neofot bis Mitte der 1930er Jahre. Die Fotoagenturen Dephot und Kluger-Szigethy werden 1933 eingestellt.

26 Bereits vor dem Ersten Weltkrieg gegründet werden die Agenturen Welt-Preß-Photo (J. Perscheid), Kilophot und die Illustrations-Zentrale (C. Seebald).

27 Zu Korty siehe Michaela Pfundner, Margot Werner $(\mathrm{Hg}$.): Zur Erinnerung an schönere Zeiten. Bilder aus der versunkenen Welt des jüdischen Sammlers Raoul Korty, Wien 2008

${ }^{28}$ Vgl. dazu auch das Kapitel „Landschaft, Berge, Brauchtum. Heimatfotografie in den 1930er Jahren“.

${ }^{29}$ Häufig gelingt es den kleinen Agenturen nicht, sich gegen die mächtige Konkurrenz durchzusetzen. Das zeigt eine Auswertung der jeweiligen Veröffentlichungen. Viele dieser Fotoagenturen sind in der Presse nur sporadisch vertreten.

${ }^{30}$ Im Branchenverzeichnis des Wiener Adressbuchs Lehmann lautet der Eintrag: Lothar Rübelt. Presse- und Industrie-Photos.

311928 reist Rübelt etwa im Auftrag von Scherl zur Winterolympiade nach St. Moritz. Die Bilder erscheinen in der Presse unter dem Namen „Phot. Scherl-Rübelt“.

32 Dies lässt sich anhand der Stempel auf den Fotorückseiten von Rübelt-Aufnahmen im Ullstein-Archiv in Berlin rekonstruieren. Allerdings tragen nicht alle Rübelt-Fotos bei Ullstein den Stempel von Wallentin. Wallentin übernimmt offenbar die Generalvertretung einzelner Fotografen. U. a. vertritt er Anfang der 1930er Jahre zeitweise auch László Willinger, den Sohn von Wilhelm Willinger. Sein Geschäftsfeld reicht, so sein Stempel, von Paris über London, Amsterdam und Zürich bis nach Brüssel. Wallentins Adresse in Berlin ist zunächst mit Emserstr. 23, später mit Wittelsbacherstr. 11a bzw. Bayerische Straße 3 angegeben.

331927 veröffentlichen die Wiener Bilder Aufnahmen, die mit „Polyphot, Berlin“ gekennzeichnet sind. Zugleich erscheinen Bilder unter der Bezeichnung „Polyphot, Wien".

341928 tauchen erstmals Bilder der Agentur Polyphot auf, die amerikanischer Herkunft sind. Der Anteil dieser ,ausländischen“ Aufnahmen bleibt aber in den folgenden Jahren klein.

35 Wiener Magazin, Heft 5, Mai 1930, S. 33-41 und 8889. Vgl. ausführlicher zu dieser Reportage das Kapitel „Erzählende Bilder. Die moderne Fotoreportage in der Zwischenkriegszeit".

${ }^{36} \mathrm{Vgl}$. dazu u. a. die Recherchen von Milena Greif: Mit den Fotos kehrt die Erinnerung zurück. Agentur Schostal, in: Rundbrief Fotografie, Vol. 9, No. 2, Juni 2002 (N.F. 34), S. 30-33.

37 Ebenda, S. 30.

${ }^{38}$ Ebenda. Die Keystone-Bilder werden teilweise unter dem Namen „Keystone-Wiener Photokurier“ veröffentlicht.

39 Ebenda, S. 31

40 Die Adresse ist 4, Rue du Col-Renard.

${ }^{41}$ Die Adresse ist Via Vivaio 22. 
42 Die Angabe basiert auf einer Mitteilung von Walter Shostal (so nennt er sich im amerikanischen Exil) an Milena Greif im Februar 2002: Milena Greif: Mit den Fotos kehrt die Erinnerung zurück. Agentur Schostal, in: Rundbrief Fotografie, Vol. 9, No. 2, Juni 2002 (N.F. 34), S. 30-33, hier S. 31.

4325 Jahre Hauptverband der Zeitungsverleger Österreichs 1908 bis 1933, Festschrift, herausgegeben von Wilhelm Steiner und Franz Burri, o. O., o. J. (1934).

${ }^{44} \mathrm{Vgl}$. Anton Holzer: Atelier und Illustrierte. Trude Fleischmanns Fotoarbeiten für die Presse, in: Anton Holzer, Frauke Kreutler (Hg.): Trude Fleischmann. Der selbstbewusste Blick, Ostfildern 2011, S. 122-134, hier S. 127

${ }^{45}$ Das Gesamtarchiv Willinger gilt bis heute als verschollen. Da aber die Agentur sehr viele Bilder an die Presse, aber auch an andere Abnehmer verkaufte und diese Aufnahmen teilweise erhalten sind, finden sich heute in zahlreichen Sammlungen und Archiven Teile der Sammlung Willinger. In Wien haben beispielsweise das Bildarchiv der Österreichischen Nationalbibliothek, das Österreichische Theatermuseum und das Wien Museum einen Bestand mit Willinger-Bildern.

${ }^{46}$ Vgl. Milena Greif: Die Geschichte der Wiener Fotoagentur Willinger und ihr verschwundener Bestand, in: Rundbrief Fotografie, Vol. 11, No. 3, 15. September 2004 (N.F. 43), S. 37-40, hier S. 38.

47 Milena Greif: Mit den Fotos kehrt die Erinnerung zurück. Agentur Schostal, in: Rundbrief Fotografie, Vol. 9, No. 2, Juni 2002 (N.F. 34), S. 30-33, hier S. 32.

${ }^{48}$ Ebenda, S. 32.

49 Das Wiener Atelier Manassé wird von einer Assistentin namens Ricoll weitergeführt. Ab Anfang 1937 werden die Bilder des Ateliers in der Presse unter dem Namen „Manassé-Ricoll“ veröffentlicht.

${ }^{50}$ Diese Veränderungen lassen sich anhand der Veröffentlichungen der Agentur in der Presse nachzeichnen.

${ }^{51}$ Erika Schmachtenberger (1906-1992) ist seit 1932 als Pressefotografin tätig. Von München aus bereist sie seit Mitte der 1930er Jahre Deutschland, Österreich, Südosteuropa, Frankreich und Spanien. Siehe Gerda Schurrer: Biografische Daten zu Erika Groth-Schmachtenberger, online unter http://media.bibliothek. uni-augsburg. de/node?id=34582 (29.2.2012)

52 Die Fotoagentur Atlantic geht 1919 aus der traditionsreichen, vor dem Ersten Weltkrieg gegründeten „Berliner Illustrations-Gesellschaft" hervor. Der Leiter, Heinrich Sanden, verkauft das Unternehmen 1933, danach arrangieren sich die neuen Inhaber schnell mit den $\mathrm{Na}$ tionalsozialisten. „Atlantic“ wird unter der Obhut des Propagandaministeriums zu einer wichtigen Stütze des Regimes. Siehe dazu Diethart Kerbs: Die Epoche der Bildagenturen. Zur Geschichte der Pressefotografie in Berlin von 1900 bis 1933, in: Diethart Kerbs, Walter Uka, Brigitte Walz-Richter (Hg.): Die Gleichschaltung der Bilder. Pressefotografie 1930-36, Berlin 1983 S. 32-73, hier S. $68 \mathrm{f}$.

53 Diethart Kerbs: Die Epoche der Bildagenturen. Zur Geschichte der Pressefotografie in Berlin von 1900 bis 1933, in: Diethart Kerbs, Walter Uka, Brigitte Walz-Richter (Hg.): Die Gleichschaltung der Bilder. Pressefotografie 1930-36, Berlin 1983, S. 32-73, hier S. 69 .

${ }^{54}$ Rudolf Herz: Hoffmann \& Hitler. Fotografie als Medium des Führer-Mythos, München 1994, S. 48 ff. Ausführlichere Hinweise zu Heinrich Hoffmann und seinen Aktivitäten in Wien finden sich im Kapitel „Demagogie in Bildern. Hitler in Österreich 1938“.

${ }^{55}$ Die Agentur wird 1938 von Franz Blaha, geb. 1910, gegründet.

56 Die Agentur wird vom Pressefotografen Stanislaus Wagner, geb. 1898, gegründet, der seit Mitte der 1920er Jahre als Pressefotograf tätig ist.

57 „Südbild“ ist vermutlich eine Zweigstelle der von Köln aus operierenden Agentur „Westbild“.
${ }^{58}$ Gerhard Jagschitz: Photographie und „Anschluß“, in: Oliver Rathkolb, Wolfgang Duchowitsch, Fritz Hausjell unter Mitarbeit von Hannes Haas ( $\mathrm{Hg}$.): Die veruntreute Wahrheit. Hitlers Propagandisten in Österreich '38, Salzburg 1988, S. 52-87, hier S. 57. Zu Rübelts Rolle im Nationalsozialismus siehe Michaela Pfundner: Dem Moment sein Geheimnis entreißen. Der Sportberichterstatter Lothar Rübelt (1901-1990), in: Matthias Marschik, Rudolf Müllner (Hg.): „Sind's froh, dass Sie zu Hause geblieben sind." Mediatisierung des Sports in Österreich, Göttingen 2010, S. 317-327, hier S. $323 \mathrm{f}$.

\section{Politische Bilder}

${ }^{1}$ Recherchen zur österreichischen Arbeiterfotografiebewegung wurden zunächst in einem Beitrag der Zeitschrift Fotogeschichte vorgestellt. Vgl. Anton Holzer: Vorwärts! Die österreichische Arbeiterfotografie der Zwischenkriegszeit, in: Fotogeschichte, Heft 127, 2013, S. 17-30. Dieses Kapitel baut auf diesen Vorarbeiten auf.

2 Elisabeth Simitschek: Fotografie als Waffe in den Händen der Arbeiterbewegung. Am Beispiel der sozialdemokratischen Illustrierten „Der Kuckuck“, Diplomarbeit, Wien 1994, S. 25

${ }^{3}$ Vgl. dazu ausführlicher Stefan Riesenfellner, Josef Seiter: Der Kuckuck. Die moderne Bild-Illustrierte des Roten Wien, Wien 1995 sowie Marion Krammer: Montierte Propaganda, sprechende Bilder. Fotomontage im „Roten Wien“ 1929 bis 1934 in: Fotogeschichte, Heft 115, 2010, S. 37-52. Hier findet sich auch ein Überblick über den Stand der Forschung.

${ }^{4}$ Zur Rolle der deutschen Arbeiter-Illustrierten Zeitung (AIZ) in Österreich und zur Illustrierten Roten Woche siehe ausführlicher das Kapitel „Im Schatten der Konzerne. Politische Illustrierte in der Zwischenkriegszeit“.

${ }^{5}$ Bei den Nationalratswahlen in den 1920er Jahren liegen die Kommunisten stets weit unter einem Prozent der Stimmen.

${ }^{6}$ Ausführlichere Hinweise zu Edith Suschitzky und ihrem fotografischen Werk in Wien finden sich in Anton $\mathrm{Hol}$ zer: Aktivistin mit Kamera. Edith Suschitzky im Kontext der Wiener Fotoszene um 1930, in: Duncan Forbes (Hg.): Edith Tudor-Hart. Im Schatten der Diktaturen, Ausstellungskatalog Scottish National Portrait Gallery, Wien Museum, Ostfildern 2013, S. 41-47.

71931 berichtet die deutsche Zeitschrift Der Arbeiter-Fotograf über die Gründung der kommunistischen „Vereinigung der Arbeiter-Fotografen Österreichs“, die am 1. April 1931 stattfindet. Zum 1. Mai 1931 sollen erstmals gemeinsam Aufnahmen hergestellt werden. Der Arbeiter-Fotograf, Heft 5, 1931, S. 110. Für den Hinweis danke ich Wolfgang Hesse. Die offizielle Gründung des Vereins erfolgt am 26. August 1931, als Hauptproponentin wird im Gründungsantrag Edith Suschitzky angeführt. Der Verein wird aber schon ein Jahr später, am 9. Juli 1932, auf Betreiben des Bundeskanzleramtes wieder gelöscht. Als Begründung heißt es, der Verein „habe seit längerer Zeit keine Aktivität entfaltet“. Vgl. dazu genauer Sonja Huber: „Die Erziehung zum Sehen ..." Das demokratisierte Lichtbild und die Selbstperzeption der österreichischen Arbeiterschaft 1918 bis 1934, Diplomarbeit, Wien 2005. Für den Hinweis danke ich Frauke Kreutler.

8 Die Auflage des Kuckuck beträgt 1929 wöchentlich 56000 Exemplare, 1930 liegt sie bei 44500, 1931 bei 33600 und 1932 bei 29000 Exemplaren. Vgl. Stefan Riesenfellner, Josef Seiter: Der Kuckuck. Die moderne Bild-Illustrierte des Roten Wien, Wien 1995, S. 42.

${ }^{9}$ Während der Kuckuck Anfang 1934 eingestellt wird, erscheint die Bunte Woche, nach einer politischen Neuausrichtung, weiter. Siehe dazu ausführlicher das Kapitel „Bilder als Propaganda. Die illustrierte Regierungspresse nach 1934“.

${ }^{10}$ Der Kuckuck, 20. Juli 1930, S. 9. Ausführlicher zu den Fotowettbewerben des Kuckuck siehe Marion Kram- mer: Bissige Bilder. Die Fotomontage als visuelles Propagandainstrument der Sozialdemokratie in den Jahren 1929-1934, Diplomarbeit, Wien 2008, S. $110 \mathrm{ff}$ und Dies.: Montierte Propaganda, sprechende Bilder. Fotomontage im „Roten Wien“ 1929 bis 1934, in: Fotogeschichte, Heft 115, 2010, S. 37-52.

${ }^{11}$ Arbeiter-Illustrierte Zeitung, Nr. 8, 1926, S. 6.

12 Beispiele für prämierte und im Kuckuck veröffentlichte Fotoarbeiten finden sich in Michaela Maier, Wolfgang Maderthaner: Im Bann der Schattenjahre. Wien in der Zeit der Wirtschaftskrise 1929 bis 1934, Wien 2012.

${ }^{13}$ Der Kuckuck, 20. April 1930, S. 11.

${ }^{14}$ Ernst Kleinberg arbeitet Anfang der 1930er Jahre zwar viel für den Kuckuck, aber er veröffentlicht auch in bürgerlichen Zeitungen und Zeitschriften. Etwa im Interessanten Blatt, in Radio Wien, in der Bühne und gelegentlich sogar in der deutschnationalen Zeitung Bergland, z. B. in Heft 9, 1933, S.7.

${ }^{15}$ Mitglieder der Wiener und Grazer „Arbeitsgemeinschaft der Kuckuck-Reporter" sind u. a. Bruno Völkel, König, Rudolf Spiegel, Edi Schmidt, Fritz Kral, Alexander Stern (der mit dem Kürzel STAL veröffentlicht) und Steg (Stegú).

${ }^{16}$ Der Kuckuck, 23. Juni 1929, S. 4. Autor: vermutlich Siegfried Weyr.

${ }^{17}$ Der Kuckuck, 3. November 1930, S. 15. Autor: vermutlich Siegfried Weyr

${ }^{18}$ Der Kuckuck, 23. Februar 1930, S. 15. In diesem Heft findet sich eine ganze Seite über die Werkbundausstellung „Film und Foto“.

19 Der Kuckuck, 1. Februar 1931, S. 16.

${ }^{20}$ Das neue Vereinslokal, das 1925 bezogen wird, liegt in der Neuwallgasse 27. Es verfügt über eine Dunkelkammer, einen Kopierraum und einen Vereins- und Ausstellungsraum.

${ }^{21}$ Vgl. dazu Christine Studeny: Liebe, Lust und Leidenschaft. Eine volkskundliche Studie über Naturfreunde-Fotografen, dargestellt an der Fotogruppe Meidling, Diplomarbeit, Wien 2003, S. 39 ff. und S. 66 ff. Neben dem Vereinslokal im Fuchsenfeldhof, in der Neuwallgasse 27, unterhält die Photosektion auch ein Lokal in der Hütteldorfer Straße 5, das mit einem modernen Fotolabor ausgestattet ist.

22 Die Photosektion der Naturfreunde Ottakring steht um 1930 unter der Leitung von Josef Hummer. Sie gehört neben den Meidlinger Naturfreundefotografen zu den aktivsten Gruppen in Wien. Ausstellungen werden u. a. im Schuhmeierhof, einer großen gemeindeeigenen Wohnanlage im 16. Bezirk, veranstaltet.

${ }^{23}$ Viele der Sektionen sind nach den Bezirken benannt. 1931 gibt es in Wien bereits 17 Fotogruppen der Naturfreunde. Vgl. Das Photo-Magazin, November 1931, S. 5.

${ }^{24}$ Ebenda, S. 69. Bei den jährlichen Vereinsausstellungen stellen nur sehr wenige Frauen aus, unter ihnen sind Walli Hotowec und Fanny Bartl.

${ }^{25}$ Die neusachliche Grundausrichtung zeigt sich sehr deutlich in der Gestaltung der Broschüre zur Ausstellung im Jahr 1930, die vom 26. Oktober bis 30. November stattfindet. Auf Bildlegenden wird konsequent verzichtet. Denn, so heißt es im Geleitwort: „Das Lichtbild spricht zu uns durch unser Auge. Was es zu sagen hat, kann es nur auf diesem Weg vermitteln und jeder Versuch, den Beschauer durch Titel und Legende anzuregen, lenkt ab von dem ursprünglichen Zweck des Lichtbildes, SCHAUSTÜCK zu sein. "Broschüre zur „9. Photo-Ausstellung“ der Naturfreunde, Photosektion Meidling, o. O., 1930. Bei den folgenden Ausstellungen (1933 findet die letzte der Zwischenkriegszeit statt) tauchen die Bildlegenden allerdings teilweise wieder auf. Für Informationen und Hilfestellungen bei der Recherche danke ich Frau Maria Bein.

${ }^{26}$ Ferdinand Hodek ist seit Mitte der 1920er Jahre regelmäßig im Ausstellungskomitee der jährlichen Sektionsausstellung vertreten. 
27 Ende der 1920er Jahre geht zwar der Anteil der Bromöldrucke und -umdrucke zurück, aber die „kunstfotografische“ Ausarbeitung der Bilder ist um 1930 immer noch gängig.

${ }^{28}$ Dies lässt sich aus den - freilich nur lückenhaft überlieferten - biografischen Daten zu den Arbeiterfotografen schließen.

${ }^{29}$ Ausführlicher dazu siehe Isabelle Haffter: Der moderne Tanz und das Medium Fotografie. Der Schweizer Martin Imboden im „Roten Wien“ um 1930, Magisterarbeit, Universität Luzern, 2013, S. 24 ff. Siehe dazu auch René Perret: Martin Imboden. Ein vergessener Fotograf, Bern 1996, S. 19.

${ }^{30} \mathrm{Vgl}$. Ausstellungsbroschüre „8. Photographische Ausstellung" der Naturfreunde, Photosektion Meidling, Wien, Oktober und November 1929, o. S.

${ }^{31}$ Eine ähnliche, wenn auch bei Weitem kleinere, Arbeiterfotogruppe gibt es auch in der Wiener Urania. Es handelt sich um die sogenannte Lichtbildner-Gemeinde des Volksbildungshauses Wiener Urania.

${ }^{32}$ Ludwig Springer: Beschreibung des Ottakringer Volksheimes, in: 25 Jahre Volksheim. Eine Wiener Volkshochschul-Chronik, Wien 1926, S. 28-30, hier S. 30.

${ }^{33} \mathrm{Vgl}$. dazu im Einzelnen: Jahresberichte der Volkshochschule Wien - Volksheim Oktober 1925 bis September 1930, Österreichisches Volkshochschularchiv, Wien.

${ }^{34}$ Cécile Machlup verfolgt im Großteil ihres fotografischen Werks, das bereits vor dem Ersten Weltkrieg einsetzt, ein piktorialistisches Programm. Um 1930 wendet sie sich-unter dem Einfluss des Neuen Sehens und der Neuen Sachlichkeit - gelegentlich auch modernen Bildlösungen zu. Bildbeispiele finden sich in Iris Meder, Andrea Winklbauer (Hg.): Vienna's Shooting Girls. Jüdische Fotografinnen aus Wien, Wien 2012, S. 56.

${ }^{35}$ Vgl. zu Richard Träger etwas ausführlicher Anton Holzer: Avantgarde und gemäßigte Moderne. Fotografische Aufbrüche um 1930, in: Fotogeschichte, Heft 123, 2012, S. 51-60, hier S. $54 \mathrm{f}$.

${ }^{36}$ Biografische Informationen stammen aus den Meldeunterlagen im Wiener Stadt- und Landesarchiv und aus Hinweisen in der Presse.

37 Vgl. Österreichischer Werkbund (Hg.): Internationale Ausstellung Film und Foto. Wanderausstellung des Deutschen Werkbundes, Österreichisches Museum 20. Februar bis 31. März 1930, Ausstellungskatalog, Wien o.J. (1930).

${ }^{38}$ Mitteilung der Volkshochschule Wien, 16. Januar 1935.

${ }^{39}$ Neues Wiener Journal, 19. September 1935, S. 10.

40 Der Kuckuck, 8. November 1931, S. 7.

${ }^{41}$ Zur Fotomontage und den Monteuren im Kuckuck siehe Marion Krammer: Montierte Propaganda, sprechende Bilder. Fotomontage im „Roten Wien“ 1929 bis 1934, in: Fotogeschichte, Heft 115, 2010, S. 37-52.

42 Gesellschaftspolitisch zugespitzte Fotomontagen sind um 1930 nicht nur im Kuckuck, sondern auch im Bereich der politischen Kunst verbreitet. Eine der österreichischen Künstlerinnen, die zu dieser Zeit mit de Montage experimentiert, ist Friedl Dicker, eine Künstlerin, Architektin, Grafikerin und Kostümbildnerin (u. a. für Brecht), die nach einigen Jahren am Bauhaus zunächst in Berlin, dann, ab 1926, wieder in Wien lebt. Sie tritt um 1930 in die Kommunistische Partei Österreichs ein und arbeitet intensiv an politischen Collagen und Fotomontagen. Vgl. dazu Angelika Romauch: Fried Dicker: Marxistische Fotomontagen 1932/33. Das Verfahren der Montage als sozialkritische Methode, Diplomarbeit, Wien 2003, S. 8, Elena Makarova: Friedl Dicker-Brandeis. Ein Leben für Kunst und Lehre. Wien, Weimar, Prag, Hronov, Theresienstadt, Auschwitz, Wien 1999, S. $106 \mathrm{f}$.

${ }^{43}$ Zu Jura Soyfers Bild- und Wortsatire siehe Horst Jarka: Jura Soyfer. Leben, Werk, Zeit, Wien 1987, S. $148 \mathrm{ff}$.

${ }^{44}$ Der Kuckuck, 23. April 1933, S. 14.
${ }^{45}$ Vgl. dazu ausführlicher Duncan Forbes (Hg.): Edith Tudor-Hart: Im Schatten der Diktaturen, Ausstellungskatalog National Gallery of Scotland, Wien Museum, Ostfildern 2013, S. $65 \mathrm{ff}$. Siehe außerdem Duncan Forbes: The Worker Photography Movement in Britain 19341939, in: Jorge Ribalta (Hg.): The Worker Photography Movement 1926-1939. Essays and Documents. Begleitband zur Ausstellung „Una luz dura, sin compasión. El movimiento de la fotografia obrera 19261939/A Hard, Merciless Light. The Worker Photography Movement 1926-1939“ im Museo Nacional Centro de Arte Reina Sofia, Madrid 2011, S. 206-217.

${ }^{46}$ Mitteilung der Volkshochschule Wien, 18. Februar 1935, S. 5

\section{Amerika, ein Traum}

${ }^{1}$ Das interessante Blatt, 20. Juni 1929, S. 3 f.

2 Mein Film, Nr. 183, 1929, S. 13. Das im modernen Stil gehaltene Geschäftsgebäude stammt vom Architekten Ernst Lichtblau und wurde kurz zuvor errichtet.

${ }^{3}$ Die Muskete, Nr. 12, 1933, S. 222.

${ }^{4}$ Wiener Bilder, 17. April 1921, Titelseite.

${ }^{5}$ Mein Film, Nr. 195, 22. September 1929, S. VIII.

${ }^{6}$ Ebenda.

7 Das interessante Blatt, 19. September 1929, S. 15.

${ }^{8}$ Die Bühne, Nr. 216, Zweites Novemberheft 1931, S. 7.

${ }^{9}$ Herbert Molderings stellt die Amerikafaszination am Beispiel des Bildbandes von Erich Mendelsohn Amerika. Bilderbuch eines Architekten (1926) und seiner Rezeption dar. Herbert Molderings: Mendelsohn, Amerika und der „Amerikanismus“, in: Fotogeschichte, Heft 123, 2012, S. 21-28, hier v. a. S. 22 ff. Ein weiteres Beispiel: 1926 findet in der Berliner Akademie der Künste eine Ausstellung über moderne amerikanische Architektur statt. Vgl. den Katalog: Ausstellung neuer Amerikanischer Baukunst, Akademie der Künste, Berlin 1926.

10 Die Zeitschrift Österreichs Bau- und Werkkunst etwa bringt 1926/27 Beiträge von Richard Neutra über die amerikanische Architektur.

${ }^{11}$ Der Band erscheint in der Serie „Neues Bauen in der Welt".

12 Profil. Österreichische Monatsschrift für bildende Kunst, Heft 9, September 1933. Das Heft ist dem Thema „Licht" gewidmet. Die seit Anfang 1933 erscheinende Zeitschrift - sie geht aus der seit Oktober 1924 im Krystall-Verlag erscheinenden Zeitschrift Österreichs Bau- und Werkkunst hervor - wird von der Zentralvereinigung der Architekten Österreichs herausgegeben. Sie ist aufwendig und modern gestaltet und auf gutem Papier gedruckt. Bis 1934, dem Beginn des Austrofaschismus, vertritt die Zeitschrift ein gemäßigt modernes Programm. Sie tritt für die neue, sachliche Architektur ein und zeigt sich offen für internationale Entwicklungen. Aufgrund von massiven Interventionen von Clemens Holzmeister gerät die Monatszeitschrift ab 1934 unter staatlich-konservative Kontrolle. Die moderne, offene Ausrichtung weicht immer mehr einer der Ideologie des „Ständestaates“ verpflichteten Berichterstattung. Vgl. dazu Wilfried Posch: Clemens Holzmeister: Architekt zwischen Kunst und Politik, Salzburg, Wien 2010, S. $253 \mathrm{ff}$.

13 Moderne Welt, Heft 17, 1928, S. 20-24, hier S. 24.

14 Ebenda, S. 24.

15 Ebenda, S. 20 f.

${ }^{16}$ Ebenda, S. 22.

17 Ein Beispiel unter vielen: Die Aufführung von Ernst Kreneks Jazz-Oper Jonny spielt auf (1927 uraufgeführt) wird Ende der 1920er Jahre von nationalsozialistischen Parteigängern in Deutschland und Österreich gestört.

${ }^{18}$ Der Kuckuck, 25. August 1929, S. 9.

19 Ebenda.
20 Ebenda.

${ }^{21}$ Wiener Bilder, 4. August 1935, Titelseite.

22 Ebenda.

\section{Bubikopf und Zigarette}

${ }^{1}$ Das interessante Blatt, 8. November 1923, S. 5.

2 Vgl. dazu Roman Sandgruber: „Frauen in Bewegung“. Verkehr und Frauenemanzipation, in: Lisa Fischer, Emi Brix (Hg.): Die Frauen der Wiener Moderne, Wien, München 1997, S. 53-63, hier S. 61.

${ }^{3}$ Vgl. dazu Alfred Pfoser: Verstörte Männer und emanzipierte Frauen. Zur Sitten- und Literaturgeschichte der Ersten Republik, in: Franz Kadrnoska (Hg.): Aufbruch und Untergang. Österreichische Kultur zwischen 1918 und 1938, Wien, München, Zürich 1981, S. 205-222, hier S. 209.

${ }^{4}$ Ab Februar 1920 trägt die Firma den Namen „Cartellierifilm Ges.m.b.H.“.

${ }^{5}$ Die Kinowoche, Nr. 13, Februar 1920, S. 6.

${ }^{6}$ Vgl. dazu Paolo Caneppele: II regista e la Diva. L'attrice Carmen Cartellieri e Cornelius Hintner, regista, Bozen 2000.

${ }^{7}$ Vgl. dazu Anita Grossmann: Berufswahl - Ein Privileg der bürgerlichen Frauen, in: Ute Eskildsen (Hg.): Fotografieren hieß teilnehmen. Fotografinnen der Weimarer Republik, Düsseldorf 1994, S. 8-25, hier S. 10.

8 Die Dame, Heft 16, 1927, S. 2-4.

${ }^{9}$ Moderne Welt, Heft 3, Juli 1926, S. 11.

${ }^{10}$ Mein Film. Illustrierte Film- und Kinorundschau, Nr. 161, 1929, S. 6.

11 Illustriertes Sportblatt, 25. September 1926, S. 13.

12 Illustriertes Sportblatt, 27. November 1926, S. 12.

${ }^{13}$ Ebenda.

14 Illustrierte Wochenpost, 20. Juli 1934.

15 Ebenda, 12. Januar 1934

\section{Experiment und Bewegung}

${ }^{1}$ Das interessante Blatt, 21. März 1901, S. 5.

${ }^{2}$ Vgl. dazu Andrea Amort, Mimi Wunderer-Gosch (Hg.): Österreich tanzt - Geschichte und Gegenwart, Wien 2001, insbes. S. $54 \mathrm{ff}$

3 Victoria Hofbauer: Grete Wiesenthal - eine Varietétänzerin? Die Auftritte der Wiener Tänzerin in Wiener Cabaretts und Varietés anhand von drei Beispielen, Diplomarbeit, Wien 2009, S. $17 \mathrm{f}$.

4 Das interessante Blatt, 19. Oktober 1911, S. 19.

${ }^{5}$ Andrea Amort, Mimi Wunderer-Gosch (Hg.): Österreich tanzt - Geschichte und Gegenwart, Wien 2001, S. 57 ff.

${ }^{6}$ Im Oktober 1917 etwa berichtet Das interessante Blatt über einen Tanzauftritt von Elsa und Berta Wiesenthal in Wien. Die beigefügte Aufnahme stammt von Madame d'Ora. Das interessante Blatt, 18. Oktober 1917, S. 13.

7 Otto Lendecke ist künstlerischer Leiter der im März 1917 gegründeten Zeitschrift Die Damenwelt. Sie wird aber nach drei Nummern wieder eingestellt.

${ }^{8}$ Es ist nicht bekannt, in welchem Wiener Atelier die Aufnahme entsteht.

${ }^{9}$ Vgl. ausführlicher zu den Neuerungen des modernen Ausdruckstanzes Gabriele Brandstetter: Bild-Sprung. TanzTheaterBewegung im Wechsel der Medien, Berlin 2005, S. $160 \mathrm{ff}$

10 Die Tanzfotos Franz Löwys erscheinen in der Zeitschrift Moderne Welt, Heft 1-2, Oktober, November 1918.

${ }^{11} \mathrm{Vgl}$. dazu Anton Holzer, Frauke Kreutler (Hg.): Trude Fleischmann. Der selbstbewusste Blick, Ostfildern 2011, S. $81 \mathrm{ff}$.

12 Zu den Wiener Tanzfotos von Martin Imboden siehe ausführlicher Isabelle Haffter: Der moderne Tanz und 
das Medium Fotografie. Der Schweizer Martin Imboden im „Roten Wien“ um 1930, Magisterarbeit, Universität Luzern, 2013, insbes. S. 94 ff. Imboden fotografiert auch die Kraus-Schülerin Manon Chaufour-Ehrfur.

${ }^{13}$ Jarmila Weißenböck: Expressionistischer Tanz in Wien, in: Klaus Amann, Armin A. Wallas (Hg.): Expressionismus in Österreich. Die Literatur und die Künste, Wien, Köln, Weimar 1994, S. 171-184, hier S. 175 f.

${ }^{14}$ Gertrud Bodenwieser: Vom wahrhaft neuen Tanz, in: Moderne Welt, Heft 9, 1922, S. 11.

${ }^{15}$ Gertrud Bodenwieser: Wien, in: Tanz unserer Zeit, hg. von Paul Stefan, Wien, New York (1927), S. 95.

${ }^{16}$ Christine Hoffmann: Deutsche und österreichische Ausdruckstänzerinnen in der Emigration, in: Denny Hirschbach, Sonia Nowoselsky (Hg.): Zwischen Aufbruch und Verfolgung. Künstlerinnen der zwanziger und dreißiger Jahre, Bremen 1993, S. 191-206, hier S. 200; vgl. dazu auch Andrea Amort, Mimi Wunderer-Gosch (Hg.): Österreich tanzt - Geschichte und Gegenwart, Wien 2001, S. 61 ff. sowie Andrea Amort: An der Wende. Zur Situation des künstlerischen Tanzes um 1930 in: Wolfgang Kos (Hg.): Kampf um die Stadt. Politik, Kunst und Alltag um 1930, Ausstellungskatalog Wien Museum, Wien 2010, S. 259-263.

17 Die 1918 gegründete Tanzschule „Neue Schule Hellerau“ (in der Nähe von Dresden) übersiedelt 1925 nach Laxenburg bei Wien. Die Schule und Tanzgruppe nennt sich nun „Hellerau-Laxenburg.“

${ }^{18}$ Andrea Amort, Mimi Wunderer-Gosch (Hg.): Österreich tanzt - Geschichte und Gegenwart, Wien 2001, S. 61.

${ }^{19}$ Jarmila Weißenböck: Expressionistischer Tanz in Wien, in: Klaus Amann, Armin A. Wallas (Hg.): Expressionismus in Österreich. Die Literatur und die Künste, Wien, Köln, Weimar 1994, S. 171-184, hier S. 182.

20 Die Veranstaltung findet zwischen dem 27. Mai und 16. Juni 1934 im Wiener Künstlerhaus statt.

${ }^{21}$ Beim Internationalen Tanzwettbewerb 1934 in Wien ist allerdings die neue politische Situation (die Ausrufung des diktatorischen Ständestaates) bereits spürbar. Der Präsentation des modernen Tanzes ist ein Volkstanztreffen angeschlossen.

22 Andrea Amort: Free Dance in Interwar Vienna, in: Deborah Holmes, Lisa Silverman (Hg.): Interwar Vienna. Culture between Tradition an Modernity, Camden House, Rochester, New York 2009, S. 117-142, hier S. $136 \mathrm{f}$.

${ }^{23}$ Fritz Beck: Tanz in Wien. Eine neue Kunst erobert die Welt, in: MOCCA, Heft 3, März 1938, S. 90-92, hier S. 90

24 Ebenda.

\section{Wenn die Hüllen fallen}

${ }^{1}$ Das interessante Blatt, 16. Februar 1928, S. 4.

${ }^{2}$ Die Bühne, Nr. 128, 21. April 1927, Titelseite.

${ }^{3}$ Mein Film. Illustrierte Film- und Kinorundschau, Nr. 86, 1927, S. 29.

${ }^{4} \mathrm{Vgl}$. Bennetta Jules-Rosette: Josephine Baker in art and life. The icon and the image, Urbana, Chicago 2007, S. 144.

${ }^{5}$ Eine Chronologie des Wienbesuchs von Josephine Baker im Jahr 1928 rekonstruiert Roman Horak: Josephine Baker in Wien - oder doch nicht? Über die Wirksamkeit des „zeitlos Popularen“, in: Roman Horak u. a (Hg.): Metropole Wien. Texturen der Moderne, Bd. 1, Wien 2000, S. 169-213. Vgl. auch Ders.: Skandalfall Josephine Baker. Das Wiener Gastspiel der „Urwaldamazone“, in: Wolfgang Kos (Hg.): Kampf um die Stadt. Politik, Kunst und Alltag um 1930, Ausstellungskatalog Wien Museum, Wien 2010, S. 206-213.

${ }^{6}$ Moderne Welt, 8. März 1928, S. 11.

${ }^{7}$ Die Literarische Welt, 15. Januar 1926, S. 3. Der erste Auftritt Josephine Bakers in Berlin findet am 31. Dezember 1925 statt. Vgl. dazu Nancy Nenno: Femininity, the
Primitive, and Modern Urban Space: Josephine Baker in Berlin, in: Katharina von Ankum (Hg.): Women in the Metropolis. Gender an Modernity in Weimar Culture, Berkeley, Los Angeles, London, 1997, S. 145-161, hier S. $145 \mathrm{f}$.

${ }^{8}$ Das interessante Blatt, 8. März 1928, S. 18.

${ }^{9}$ Das interessante Blatt, 10. Juli 1913, S. 18. Vgl. ausführlicher zum Thema Karl Toepfer: Nudity and Modernity in German Dance 1910-1930, in: Journal of the History of Sexuality, Vol. 3, No. 1 (1992), S. 58-108, hier S. 58.

${ }^{10}$ In den 1920er Jahren erscheint eine ganze Reihe von Büchern und Bildbänden, die die Kultur der Nacktheit feiern. Um nur zwei Beispiele zu nennen: 1920/21 erscheint in Dresden das dreibändige Werk von Lotte Herrlich Edle Nacktheit. Ebenfalls Anfang der 1920er Jahre publiziert der Wiener Fotograf Franz Löwy den schmalen Bildband Das schöne nackte Weib, Wien 1921.

${ }^{11}$ Zu dieser Fotoserie siehe Monika Faber: Madame d'Ora, Wien-Paris. Portraits aus Kunst und Gesellschaft 1907-1957, Wien 1983, S. 190 f. Ein Teil der Fotos von Madame d'Ora erscheint 1922 in einer Buchpublikation über die beiden Tänzer: Die Tänze des Lasters, des Grauens und der Ekstase, Wien 1922.

${ }^{12}$ Vgl. Franz-Peter Kothes: Die theatralische Revue in Berlin und Wien 1900-1940 unter besonderer Berücksichtigung der Ausstattungsrevue. Strukturen und Funktionen, Diss., Wien 1972., S. 289 f.

${ }^{13}$ Zitiert nach Ralf Georg Czapla: „nach Maß gearbeitet“. Hermann Brochs Gedichte für die Tänzerin Claire Bauroff. Mit einer Edition des Briefwechsels Bauroff Broch und von Auszügen aus der Korrespondenz Bauroff-Burgmüller, in: Sabina Becker in Zusammenarbeit mit Eckhard Faul und Reiner Marx (Hg.): Jahrbuch zur Kultur und Literatur der Weimarer Republik, Bd. 12, 2008, München 2009, S.69-113, hier S. 82 f.

${ }^{14}$ Béla Balázs: Claire Bauroff, in: Wissen Sie schon?, 5,3, 1925, S. 14 f., zit. nach ebenda, S. 85 f.

${ }^{15}$ Zu Trude Fleischmanns Nacktaufnahmen von Claire Bauroff siehe Frauke Kreutler: Skandal in Berlin. Trude Fleischmanns Inszenierung der Tänzerin Claire Bauroff, in: Anton Holzer, Frauke Kreutler (Hg.): Trude Fleischmann. Der selbstbewusste Blick, Ostfildern 2011, S. 104-114.

${ }^{16}$ Die Bühne, 1. Oktober 1925, S. 3.

17 Vgl. Frauke Kreutler: Skandal in Berlin. Trude Fleischmanns Inszenierung der Tänzerin Claire Bauroff, in: Anton Holzer, Frauke Kreutler (Hg.): Trude Fleischmann. Der selbstbewusste Blick, Ostfildern 2011, S. 104-114, hier S. $112 \mathrm{f}$

${ }^{18}$ Am 26. Mai 1933 wird von der Regierung beispielsweise eine „Verordnung zum Schutze der Sittlichkeit und der Volksgesundheit" erlassen, die sich in der Praxis v. a. gegen angebliche und tatsächliche Pornografie richtet.

${ }^{19}$ Zum Rob-Verlag siehe ausführlich das Kapitel „Bilder für alle: Die Welt der Magazine und Revuen“.

${ }^{20}$ In der Zeitschrift Der Faun, einer humoristischer Revue, die von 1916 bis 1928 erscheint, sind die Bilder weiblicher Nacktheit allerdings fast ausschließlich gezeichnet, nicht fotografiert.

${ }^{21}$ Allein die Zeitschrift Die Muskete wird zwischen 1933 und 1938 mindestens sechs Mal wegen Pornografie beschlagnahmt. Vgl. dazu Murray Hall, Franz Kadrnoska, Friedrich Kornauth, Wendelin Schmidt-Dengler: Die Muskete. Kultur- und Sozialgeschichte einer satirisch-humoristischen Zeitschrift 1905-1941, Wien 1983, S. 16

22 Vgl. dazu ausführlicher das Kapitel „Den Krieg vor Augen. Nationalsozialistische Medienpolitik und Ästhetik“.

\section{Schöne neue Warenwelt}

${ }^{1}$ Alfred Polgar: Hinterland, Berlin 1929, S. 43

2 Traugott Schalcher: Die Reklame der Straße, Wien, Leipzig 1927, S. 7.
${ }^{3}$ Ebenda.

${ }^{4}$ Das Inserat in seiner künstlerischen Gestaltung. Anregungen von Prof. L(udwig). E(rik). Tesar, in: Österreichs Illustrierte Zeitung, 22. August 1909, Heft 47, S. $1107 \mathrm{ff}$. ${ }^{5}$ Ebenda.

${ }^{6}$ Graphische Revue, Heft 7, Juli 1914, Anzeigenteil, o. S.

7 Traugott Schalcher: Die Reklame der Straße, Wien, Leipzig 1927, S. 76

${ }^{8}$ Alexander Schilling: Die Kongreßstadt Wien bei Nacht, in: Moderne Welt, Heft 17, 1928, S. 20-24, hier S. 20.

${ }^{9}$ Ebenda.

${ }^{10}$ Christian Maryška: Internationales Niveau. Grafikdesign und Werbewirtschaft um 1930, in: Wolfgang Kos (Hg.): Kampf um die Stadt. Politik, Kunst und Alltag um 1930, Ausstellungskatalog Wien Museum, Wien 2010 S. 184-191, hier S. 187.

${ }^{11}$ Es gibt viele Hinweise darauf, dass die Gebrauchsgrafik Ende der 1920er Jahre neue Impulse erhält. 1926 etwa werden in Österreich die Zeitschriften Österreichische Reklame und Kontakt. Zeitschrift für Reklame und Verkaufskunst gegründet. Ab 1927 finden regelmäßig Reklame-Ausstellungen statt. Vgl. dazu Christian Maryška: Internationales Niveau. Grafikdesign und Werbewirtschaft um 1930, in: Wolfgang Kos (Hg.): Kampf um die Stadt. Politik, Kunst und Alltag um 1930 Ausstellungskatalog Wien Museum, Wien 2010, S. 184191, hier S. $188 \mathrm{f}$.

12 Die Schau wird vom Fachverband der Fotografengenossenschaften Österreichs organisiert.

${ }^{13}$ Vgl. dazu Österreichische Kunst, Heft 10/11, 15. November 1933, S. 17

14 Wie etwa die Annoncen-Expedition Verlagsanstalt Hans Dusika \& Co., Wien I, Wollzeile 6-8, die 1929 in Zeitschriften mit ihrer Kompetenz in Sachen „Moderne Bildreklame" wirbt.

15 Bis Anfang der 1920er Jahre tauchen noch Kombinationen von Fotografien und Zeichnungen auf.

${ }^{16}$ Um nur zwei Beispiele zu nennen: Die Modeproduktion der Wiener Werkstätte expandiert während des Krieges. Angeboten wird - neben vielen anderen Kollektionen - auch ,angenehme, vornehme Trauerkleidung“. Das führende Wiener Modehaus Zwieback \& Bruder ist zwischen 1914 und 1918 höchst aktiv.

17 Moderne Welt, Heft 1-2, Oktober, November 1918, S. 52 .

${ }^{18}$ Moderne Welt, Heft 3, Dezember 1918. Zum Fotounternehmen Willinger siehe ausführlicher das Kapitel „Handel mit Bildern. Die Rolle der Fotoagenturen“.

${ }^{19}$ Das interessante Blatt, 30. Oktober 1919, S. 5.

${ }^{20}$ Ihre Bilder erscheinen in der Presse mit der Bezeichnung „Patek-Zimmerauer“.

21 Zur Wiener Mode während des Nationalsozialismus und insbesondere zum „Haus der Mode“ siehe Gloria Sultano: Wie geistiges Kokain ... Mode unterm Hakenkreuz, Wien 1995, S. $99 \mathrm{ff}$.

\section{Dramatische Nähe}

1 Illustriertes Sportblatt, 29. November 1924, Titelseite.

2 Wiener Magazin, Heft 4, April 1932, S. 12 f.

${ }^{3}$ Zu Lothar Rübelt ist seit Ende der 1970er Jahre eine ganze Reihe von Publikationen erschienen (siehe Literaturverzeichnis), aber leider gibt es bis heute keine umfassende und sorgfältig erarbeitete Darstellung seiner Karriere als Sport- und Pressefotograf.

${ }^{4}$ Michaela Pfundner: Dem Moment sein Geheimnis entreißen. Der Sportberichterstatter Lothar Rübelt (19011990), in: Matthias Marschik, Rudolf Müllner (Hg.): "Sind's froh, dass Sie zu Hause geblieben sind." Mediatisierung des Sports in Österreich, Göttingen 2010, S. 317-327, hier S. 317

${ }^{5}$ Vgl. dazu ausführlicher das Kapitel „Erzählende Bilder. Die moderne Fotoreportage in der Zwischenkriegszeit“. 
${ }^{6}$ Moderne Welt, Heft 4, 1929, S. V.

${ }^{7}$ Michaela Pfundner: Dem Moment sein Geheimnis entreißen. Der Sportberichterstatter Lothar Rübelt (19011990), in: Matthias Marschik, Rudolf Müllner (Hg.): „Sind's froh, dass Sie zu Hause geblieben sind." Mediatisierung des Sports in Österreich, Göttingen 2010, S. 317-327, hier S. 319.

${ }^{8}$ Die Leica (der Name leitet sich von Leitz Camera ab) wird von der Firma Leitz aus Wetzlar gebaut und ist seit 1925 auf dem Markt.

${ }^{9}$ Ausführlicher zu Rübelts Fotoreportagen siehe das Kapitel „Erzählende Bilder. Die moderne Fotoreportage in der Zwischenkriegszeit“.

10 Zu den unterschiedlichen Vertriebskooperationen vgl. das Kapitel „Handel mit Bildern. Die Rolle der Fotoagenturen".

${ }^{11}$ Ausführlicher zur Karriere Hubers siehe das Kapitel „Die Jagd nach Sensationen. Pioniere der Pressefotografie“.

12 Das interessante Blatt, 17. September 1896, S. 5.

13 Illustriertes österreichisches Sportblatt, 7. Mai 1914, Titelseite.

${ }^{14}$ Ebenda, S. 3.

15 Ebenda.

16 Illustriertes österreichisches Sportblatt, 6. August 1914, Titelseite.

17 Illustriertes österreichisches Sportblatt, 12. September 1914, S. 3.

18 Illustriertes Sportblatt, 10. Dezember 1927, S. 7. Die Zeitung heißt nun Illustriertes Sportblatt und nicht mehr Illustriertes österreichisches Sportblatt. „Kriau“ ist ein Wiener Stadtteil und Name eines Sportplatzes.

${ }^{19}$ Ebenda.

${ }^{20}$ Ebenda.

${ }^{21}$ Zur Rolle Lothar Rübelts im Nationalsozialismus siehe ausführlicher das Kapitel „Den Krieg vor Augen. Nationalsozialistische Medienpolitik und Ästhetik nach 1938“.

\section{Frauen hinter der Kamera}

${ }^{1}$ Die Künstlerhaus-Ausstellung wird vorbereitet, in: Die Bühne, Nr. 293, Erstes Dezemberheft 1930, S. 22.

2 Ebenda.

${ }^{3}$ Zu Marie Mertens siehe das Kapitel „Die Jagd nach Sensationen. Pioniere der Pressefotografie“.

${ }^{4}$ Arbeiter-Illustrierte Zeitung (AIZ), 11. April 1928, Titelseite.

${ }^{5}$ Ebenda.

${ }^{6}$ Im Folgenden greife ich z. T. auf Recherchen und Ausführungen im Rahmen der Ausstellung zur Fotografin Trude Fleischmann, Wien Museum 2011, zurück. Vgl. Anton Holzer: Atelier und Illustrierte. Trude Fleischmanns Fotoarbeiten für die Presse, in: Anton Holzer, Frauke Kreutler (Hg.): Trude Fleischmann. Der selbstbewusste Blick, Ostfildern 2011, S. 122-134.

${ }^{7}$ Vgl. dazu auch das Kapitel „Erzählende Bilder. Die moderne Fotoreportage in der Zwischenkriegszeit“.

${ }^{8}$ Wiener Bilder, 13. Juni 1925, S. 9.

${ }^{9}$ Ebenda.

${ }^{10}$ Wiener Mode, Heft 1, Oktober 1919, S. 1 f.

${ }^{11}$ Moderne Welt, Heft 11, 1920/21, S. 15-18.

12 Die Schau ist Teil einer Ausstellungsreihe, die seit Ende der 1920er Jahre stattfindet. Organisiert werden die Ausstellungen von der 1926 gegründeten Vereinigung „Wiener Frauenkunst“, einem fortschrittlichen, feministisch ausgerichteten Zusammenschluss von Künstlerinnen, vor allem aus dem Umfeld der Wiener Werkstätte. 1929 findet die Ausstellung „Das Bild im Raum“ statt, 1930 die Schau „Wie sieht die Frau?" und 1933 die Ausstellung „Die schöne Wand“.
${ }^{13}$ Else Hofmann, geb. 1893, arbeitet nach ihrem Studium für mehrere österreichische Zeitungen und Zeitschriften, v. a. im Bereich Kunstkritik. Liane Zimbler, geb. 1892, ist Designerin, Illustratorin und Architektin. Sie arbeitet seit 1923 als freiberufliche Architektin und Möbeldesignerin. Agnes (Kitty) Speyer ist Mitarbeiterin bei der Wiener Werkstätte. Zu Liane Zimbler vgl. Christina Gräwe: Liane Zimbler. Spurensuche - Die österreichische Architektin in Wien und im amerikanischen Exil, Diplomarbeit, Berlin 2003.

${ }^{14}$ Else Hofmann: Was will die Ausstellung „Die schaffende Österreicherin: in Werk und Bild“? in: Das Wort der Frau, 1. Jg. Nr. 21, 16. Juli, 1931, S. 12.

15 Ebenda.

${ }^{16}$ Ebenda.

17 Schwarzwalds Salon in der Wiener Josefstädter StraBe ist in der Zwischenkriegszeit ein Treffpunkt des Wiener Kulturlebens. Durch Vermittlung Eugenie Schwarzwalds wird Bill Brandt Schüler Kolliners, ehe er auch bei Trude Fleischmann in die Lehre geht. Vgl. Paul Delany: Bill Brandt. A Life, London 2004, S. 47.

18 Österreichischer Werkbund (Hg.): Internationale Ausstellung Film und Foto. Wanderausstellung des Deutschen Werkbundes, Österreichisches Museum, 20. Februar bis 31. März 1930, Ausstellungskatalog, Wien o. J. (1930).

19 Vgl. dazu ausführlicher Anton Holzer: Atelier und IIlustrierte. Trude Fleischmanns Fotoarbeiten für die Presse, in: Anton Holzer, Frauke Kreutler (Hg.): Trude Fleischmann. Der selbstbewusste Blick, Ostfildern 2011, S. 122-134, hier S. $128 \mathrm{ff}$.

${ }^{20}$ Der Sonntag, 20. Februar 1938, Titelseite. Der Text zur Bildgeschichte stammt von Lothar Metzel, der ab 1934 die Programme der Wiener Kleinkunstbühne „Literatur am Naschmarkt" leitet.

${ }^{21}$ Möglich wäre aber auch, dass die Bilder in Paris, einem Zentrum der Automobilindustrie, entstanden sind. Im Hintergrund der gezeigten Aufnahme ist der angeschnittene Schriftzug „Renault“ zu sehen.

22 Ursula Hudson-Wiedenmann, Beate Schmeichel-Falkenberg (Hg.): Grenzen überschreiten. Frauen, Kunst und Exil, Würzburg 2005, S. 32. Lisbeth Oestreicher entwirft Kleidungsstücke, Marie Oestreicher fotografiert.

${ }^{23}$ Edith Barakovichs biografisches Schicksal nach 1938 ist - ebenso wie das vieler anderer Fotografinnen und Fotografen - noch genauer zu untersuchen. Sie ist in den Wiener Meldeunterlagen als „katholisch“ gemeldet. Möglich ist, dass sie, wie andere Fotografinnen auch (etwa Trude Fleischmann), konvertiert ist.

${ }^{24}$ Auskunft Wiener Stadt- und Landesarchiv, 2. November 2012.

25 Vgl. Trude Fleischmann. Fotografien 1918-1938, Vorwort: Carl Aigner, Text: Anna Auer, Ausstellungskatalog Wien, Galerie Faber 1988; Anna Auer, Kunsthalle Wien (Hg.): Übersee. Flucht und Emigration österreichischer Fotografen 1920-1940, Wien 1997.

${ }^{26} \mathrm{Vgl}$. etwa die Ausstellungen und Kataloge im Wien Museum und im Jüdischen Museum Wien. Anton Holzer, Frauke Kreutler (Hg.): Trude Fleischmann. Der selbstbewusste Blick, Ausstellungskatalog Wien Museum, Ostfildern 2011; Iris Meder, Andrea Winklbauer: Vienna's Shooting Girls. Jüdische Fotografinnen aus Wien, Wien 2012.

\section{Die kurze Zeit der Avantgarde Fotografische Aufbrüche um 1930}

${ }^{1}$ Dieses Kapitel baut auf einem Beitrag auf, der 2012 in der Zeitschrift Fotogeschichte erschienen ist. Vgl. Anton Holzer: Avantgarde und gemäßigte Moderne. Fotografische Aufbrüche in Österreich um 1930, in: Fotogeschichte, Heft 123, 2012, S. 51-60.

${ }^{2}$ Auf der FiFo in Stuttgart wird nur ein Österreicher ausgestellt, nämlich Herbert Bayer, der allerdings seit
1921 in Deutschland lebt. Zu sehen sind in Stuttgart auch Arbeiten von Willy Riethof, einem gebürtigen Tschechen, der um 1930 in Berlin und dann in Wien lebt.

${ }^{3}$ Vgl. Österreichischer Werkbund (Hg.): Internationale Ausstellung Film und Foto. Wanderausstellung des Deutschen Werkbundes, Österreichisches Museum, 20. Februar bis 31. März 1930, Ausstellungskatalog Wien o. J. (1930).

${ }^{4}$ Vgl. dazu ausführlicher Wilfried Posch: Die Österreichische Werkbundbewegung 1907-1928, in: Isabella Ackerl, Rudolf Neck (Hg.): Geistiges Leben im Österreich der Ersten Republik, Wien 1986, S. 195-204. Sowie Astrid Gmeiner, Gottfried Pirhofer: Der österreichische Werkbund, Salzburg, Wien 1985.

${ }^{5}$ Präsident des Werkbundes wird Hermann Neubacher, Vizepräsidenten sind Josef Hoffmann und Josef Frank.

${ }^{6}$ Zu den Kämpfen innerhalb des Werkbundes und zur Abspaltung des „Neuen Werkbundes Österreichs“ siehe auch Wilfried Posch: Clemens Holzmeister: Architekt zwischen Kunst und Politik, Salzburg, Wien 2010, S. $242 \mathrm{f}$.

${ }^{7}$ Maximilian Karnitschnigg, der in der konservativen, deutschnational ausgerichteten Zeitschrift Bergland über den Konflikt berichtet, stellt sich voll und ganz auf die Seite der Traditionalisten. M. Karnitschnigg: Lichtbildkunst in Österreich, in: Bergland. Illustrierte Zeitschrift, Nr. 11, 1933, S. 35.

${ }^{8}$ Die sozialdemokratische Illustrierte Der Kuckuck etwa widmet der Ausstellung „Film und Foto“ viel Platz und stellt die Schau als wegweisend für die moderne Fotoauffassung vor. Vgl. Der Kuckuck, 23. Februar 1930, S. 15. Bilder im Stil der Neuen Sachlichkeit und des Neuen Sehens wurden ab 1930 regelmäßig im Kuckuck vorgestellt. Vgl. etwa Der Kuckuck, 23. März 1930, S. 15: Das neue Bild.

${ }^{9}$ Wolfgang Born (W.B.): Film und Photo. Vorschau der Werkbundausstellung, in: Die Bühne, 15. Februar 1930, S. 42-44, hier S. 43.

${ }^{10}$ Ebenda.

11 Ebenda, S. 44.

${ }^{12}$ Alma Stefanie Frischauer: Künstler-Kamera, in: Moderne Welt, Heft 12, 1930, S. 2-4, hier S. 2.

${ }^{13}$ Ebenda, S. 4.

14 Victoria Dejaco: Wiener Kunstgeschichte, Wolfgang Born, Alma Stefanie Frischauer, online unter: http:// www.univie.ac.at/geschichtegesichtet (6.6.2010).

${ }^{15}$ Vgl. Karen Michels: Transplantierte Kunstwissenschaft. Die deutschsprachige Kunstgeschichte im amerikanischen Exil, Berlin 1999, S. 65.

${ }^{16}$ Victoria Dejaco: Wiener Kunstgeschichte, Alma Stefanie Frischauer, online unter: http://www.univie. ac.at/geschichtegesichtet (6.6.2010).

${ }^{17}$ Zu Imboden vgl. René Perret: Martin Imboden. Ein vergessener Fotograf, Bern 1996, zu seiner Wiener Zeit siehe insbes. S. $17 \mathrm{ff}$. Vgl. auch Isabelle Haffter: Der moderne Tanz und das Medium Fotografie. Der Schweizer Martin Imboden im „Roten Wien“ um 1930, Magisterarbeit, Universität Luzern, 2013, S. $24 \mathrm{ff}$.

18 Die Bühne, Nr. 409, Erstes Oktoberheft 1935, S. 26.

${ }^{19}$ Wolfgang Born: Die Schönheit des Unscheinbaren. Betrachtungen zu Photographien Richard Trägers, in: Photofreund. Halbmonatsschrift für Freunde der Photographie, Nr. 6, 20. März 1929, S. 101-103.

${ }^{20}$ I. Internationale Kunstphotographische Ausstellung des Verbandes österreichischer Amateurfotografen-Vereine, 12. Januar bis 10. März 1929, Glaspalast, Wiener Burggarten.

${ }^{21}$ Die „Internationale Photographische Ausstellung IPHA“ fand vom 15. Juli bis zum 15. September 1929 in der Salzburger Residenz statt. Veranstaltet wurde sie vom Landesverband für Fremdenverkehr. 
22 Wolfgang Born: Gedanken über Photographie. Anläßlich der Salzburger Lichtbildschau, in: Die Bühne, 1. August 1929, S. 14 f. Wiederabgedruckt ist dieser Text in der Zeitschrift Fotogeschichte, Heft 123, 2012.

23 Zur Geschichte der Neuen Galerie siehe Niko Wahl: Große Kunst hinter der Budel. Otto Kallir und die Neue Galerie in der Grünangergasse, in: Joachim Riedl (Hg.): Wien, Stadt der Juden. Die Welt der Tante Jolesch, Ausstellungskatalog Jüdisches Museum Wien, Wien 2004 S. 300-301. Die Ausstellung zu Willy Riethof findet zwischen dem 4. und dem 30. Januar 1930 statt.

24 Wolfgang Born: Die Welt in der Kamera. Photographien von Willy Riethof in der „Neuen Galerie“, in: Die Bühne, 1. Februar 1930, S. 45.

25 Ebenda, S. 46.

${ }^{26}$ Armin Loacker: Die „Newa“ und der „Russenfilm“ in Wien, in: Christian Dewald (Hg.): Arbeiterkino. Linke Filmkultur der Ersten Republik, Wien 2007, S. 215-220.

27 Siehe dazu ausführlicher Korinna Lorz: „foto-bauhäusler, werdet arbeiter-fotografen!" Fotografie am Bauhaus zwischen Avantgarde und Agitation. Ein Werkstattbericht, in: Fotogeschichte, Heft 127, 2013, S. 31-44

${ }^{28}$ Zu Hackenschmied vgl. Jaroslav Anděl: Alexandr Hackenschmied, Prag 2000, Jaroslav Anděl: Alexandr Hackenschmied, New York 2001; zu Jan Lukas siehe Emanuel Frynta: Jan Lukas. Fotografie, Prag 1961 sowie Josef Moucha: Jan Lukas, Prag 2003. Zu Beispielen für Arbeiten von Jan Lukas in der österreichischen Bildpresse siehe Kapitel „Fotografisches Feuilleton. Der Sonntag: ein vergessenes Forum moderner Reportagefotografie“.

${ }^{29}$ Am 17. März 1934 wurde die politische Annäherung der drei Staaten in den „Römischen Protokollen“ formal niedergelegt.

301934 veranstaltete der Wiener Photoclub beispielsweise die Ausstellung „Ungarische Meister“.

31 Zoltan Kluger und W. von Szigethy, die seit Ende der 1920 er Jahre in Berlin gemeinsam ein Büro für Pressefotografie betrieben, flüchteten 1933 von Berlin nach Palästina

32 Biografische Informationen finden sich in Armgard Schiffer (Hg.): Grazer Kunstphotographen: Maximilian Karnitschnigg (1872-1940), Hugo Haluschka (18801951), Ausstellungskatalog Bild- und Tonarchiv am Landesmuseum Joanneum, o. O. (Graz) 1981.

${ }^{33}$ Maximilian Karnitschnigg: Modische Sachlichkeit, in: Kamera-Kunst. Illustrierte Zeitschrift für Photographie, redigiert von Kommerzialrat Siegfried Wachtel, Januar 1931, S. 4-6.

34 Ebenda.

${ }^{35}$ Maximilian Karnitschnigg: Lichtbildkunst in Österreich, in: Bergland. Illustrierte Zeitschrift, Nr. 11, 1933 , S. 35

${ }^{36}$ Karnitschnigg gestaltet etwa 1933 im Auftrag des Städtischen Gas- und Elektrizitätswerks Graz ein Album über die Anlage, die als Geschenk für den Bürgermeister der Stadt Graz, Vinzenz Muchitsch, gedacht war. Die Aufnahmen stehen zwar nach wie vor in der Tradition der künstlerischen Fotografie, sie sind aber frontal fotografiert und sachlich gehalten. Siehe Steiermärkisches Landesarchiv, A. Muchitsch Vinzenz Nachlass K-1-H-6. Vgl. dazu http://www.archivund fotografie.at/monat/foto_des_monats_april.htm/ (6.12.2012)

37 Heinrich Kühn: Lichtbildnerei und Photographie, in: Das deutsche Lichtbild 1931, Berlin 1930, o. S.

${ }^{38}$ Ebenda.

\section{Landschaft, Berge, Brauchtum}

${ }^{1}$ Moderne Welt, Heft 11, August 1934, Titelseite.

2 Ebenda, S. 5.

${ }^{3}$ Ebenda, S. 6.

${ }^{4}$ Das interessante Blatt, 11. Juli 1935, Titelseite.
${ }^{5}$ Im Jahr 1919 hatte der Anfang der Strophe, in der Hoffnung auf einen Anschluss Österreichs an Deutschland, noch gelautet: „Sei gesegnet ohne Ende, Deutsche Heimat, wunderhold!" Vgl. dazu Franz Grasberger: Die Hymnen Österreichs, Tutzing 1968, S. 81.

${ }^{6}$ Zur Geschichte und symbolischen Bedeutung der Großglockner Hochalpenstraße siehe Georg Rigele: Die Großglockner Hochalpenstraße. Zur Geschichte eines österreichischen Monuments, Wien 1998.

7 Wiener Magazin, Heft 9, September 1935, S. 82-89, hier S. 83. Der Text stammt von Franz G. Gruber

${ }^{8}$ Ebenda, S. 85

${ }^{9}$ Vgl. dazu ausführlicher Michael P. Steinberg: Ursprung und Ideologie der Salzburger Festspiele 1890-1938, Salzburg, München 2000, S. $162 \mathrm{ff}$.

${ }^{10}$ Das interessante Blatt, 29. August 1935, Titelseite.

${ }^{11}$ Die Bühne, Heft 18, 25. August 1939, S. 1.

12 Foto-Ausstellung Österreichs Bundesländer im Lichtbilde, Österreichisches Museum für Kunst und Industrie, Wien 1933, Vorwort. Die Ausstellung findet zwischen dem 27. Mai und 31. Juli 1933 statt.

${ }^{13}$ Franz Hainzlmayr: Lichtbild und Heimatkunst, in: FotoAusstellung Österreichs Bundesländer im Lichtbilde, Österreichisches Museum für Kunst und Industrie, Wien 1933, S. $19 \mathrm{ff}$.

14 III. Internationale Photo-Ausstellung, Künstlerhaus, Wien 1934, veranstaltet vom Verband Österreichischer Amateurphotographen-Vereine, Ausstellungskatalog, Wien 1934.

${ }^{15}$ Sie wird vom Verband österreichischer Amateurphotographen-Vereine veranstaltet und finden zwischen dem 20. Januar und 8. Februar 1936 statt.

${ }^{16} \mathrm{Vgl}$. dazu ausführlicher Monika Faber (Hg.): Rudolf Koppitz. 1884-1936, Wien 1995, S. 11 ff. sowie Dies. (Hg.): Rudolf Koppitz. Photogenie. 1884-1936, Wien 2013, S. 8-22 sowie den Beitrag von Elizabeth Cronin im selben Band.

17 Moderne Welt, Heft 10, Juli 1933, S. 12.

${ }^{18}$ Ebenda.

${ }^{19}$ Die Ausstellung mit dem Titel „Land und Leute. Prof. Rudolf Koppitz" wird vom 1. Februar bis 1. März 1936 in den Räumen des Österreichischen Museums für Kunst und Industrie (heute: Museum für angewandte Kunst) an der Wiener Ringstraße gezeigt.

${ }^{20}$ Vgl. etwa Josef Gottschammel, Rudolf Hans Hammer (Hg.): Rudolf Koppitz, Wien 1937.

${ }^{21}$ Zur Zeitschrift Die Pause siehe Margarethe Szeless: Die Kulturzeitschrift magnum. Photographische Befunde der Moderne, Marburg 2007.

${ }^{22}$ Ausführlicher zu Kruckenhauser siehe Rolf Sachsse: Skizze zu Stefan Kruckenhauser, in: Fotogeschichte, Heft 11, 1984, S. 31-37 sowie (recht unkritisch) Stefan Kruckenhauser. In weiten Linien ... Das fotografische Lebenswerk, hg. von Kurt Kaindl, Salzburg 2003.

23 Gabriele Hofer: Lucca Chmel. Architekturfotografie 1945-1972. Zur Repräsentation österreichischer Nachkriegsmoderne im fotografischen Bild, Wien 2006 , S. 66-69.

24 Siehe beispielsweise die Bildseite „Österreichische Menschen - Österreichische Landschaften" in der Zeitschrift Bunte Woche, 3. Juni 1934, S. 2.

25 Otto Koenig: Die vom Heideboden, in: Der Sonntag, 6. September 1936, S. 2.

26 Ebenda.

27 Ebenda.

${ }^{28}$ Hans Walter Hannau: „Gegen die illegalen Nationalsozialisten bin ich natürlich vorgegangen“, in: Gerhard Jelinek: Nachrichten aus dem 4. Reich, Salzburg 2008, S. 91-96, hier S. $94 \mathrm{ff}$.

${ }^{29}$ Bergland, Nr. 4, 1938.

${ }^{30}$ Bergland, Nr. 6, 1938, S. 42-45.

\section{Fotografisches Feuilleton}

${ }^{1}$ Im Sonntag werden praktisch keine Aufnahmen von nach 1933 in Deutschland verbliebenen Fotografen veröffentlicht. Lediglich von Hein Gorny, der 1934 zeitweise in der Schweiz, dann wieder in Berlin lebt, werden Aufnahmen gedruckt.

2 Dieses Kapitel greift auf einen Beitrag zurück, der in der Zeitschrift Fotogeschichte erschien. Vgl. Anton Holzer: Fotografisches Feuilleton. Der Sonntag - ein vergessenes Forum moderner österreichischer Reportagefotografie, in: Fotogeschichte, Heft 128, 2013, S. 25-48.

${ }^{3}$ Kurt Paupié: Handbuch der österreichischen Pressegeschichte 1848-1959, Bd. I: Wien, Wien, Stuttgart 1960, S. 187.

4 Peter Sonnenberg: Medienkontrolle während der NSZeit-Eine kollektiv-biographische Analyse ausgewählter Journalisten der 1938 verbotenen Wiener Tageszeitungen „Wiener Tag“ und „Telegraf“, Diplomarbeit, Wien 2009, S. 69. Maximilian Schreier, der 1939 mehrere Monate im KZ Buchenwald inhaftiert ist und später freikommt, begeht am 15. Juni 1942 in Wien Selbstmord, kurz vor der neuerlich geplanten Deportation ins KZ.

${ }^{5}$ Ausführlicher zur Vernay AG siehe das Kapitel „Im Schatten der Konzerne. Politische Illustrierte in der Zwischenkriegszeit“.

${ }^{6}$ Biografische Daten zu Hans Ernest Oplatka stammen aus einem unveröffentlichten Text von Jan Mlčoch anlässlich der Ausstellung „Hans Ernest Oplatka. Fotografien" (2003) in der Josef Sudek Galerie in Prag, veranstaltet vom Museum für angewandte Kunst, Prag. Übersetzung ins Englische: Linda Paukertová. Herzlichen Dank an Jan Mlčoch für die Überlassung des Manuskripts.

${ }^{7}$ Michel Frizot, Cédric de Veigy: Vu. The Story of a Magazine that made an Era, London 2009; Ulrich Hägele: Alexander Liberman, Marcel Ichac, Marc Réal. Die IIlustrierte $V U$ und inre Fotomonteure, 1930 bis 1936, in: Fotogeschichte, Heft 110, 2008, S. 5-22.

8 Im Juni 1931 erscheinen erste Reisebilder (aus Heiligenblut und vom Großglockner) von Hans Oplatka in der Bühne, Nr. 305, Zweites Juniheft 1931, S. 6 und 18.

${ }^{9}$ Die Bühne, Nr. 310, Zweites Augustheft 1931, S. 8 und 9.

${ }^{10}$ Der Sonntag, 24. März 1935, S. 2.

${ }^{11}$ Bil Spira verfasst seine Autobiografie 1983 unter dem Titel „Ridiculum vitae“. Sie kommt erst 1997 heraus: Bil Spira: Die Legende vom Zeichner, hg. von Konstantin Kaiser in Zusammenarbeit mit Vladimir Vertlib, Wien 1997. Vgl. auch Oliver Bentz (Hg.): Bil Spira. Künstler, Fälscher, Menschenretter - Pariser Impressionen. Schriftenreihe der Abteilung Kulturelles Erbe der Stadt Speyer, hg. von Joachim Kemper und Oliver Bentz, Museum SchPIRA, Jüdisches Museum Speyer, Speyer 2013.

12 Zu Bil Spira als Zeichner siehe Eckart Früh: Spuren und Überbleibsel: Bil Spira - Traces and leftovers, in: Medien \& Zeit - Kommunikation in Vergangenheit und Gegenwart, Bd. 1, 2000, S. 40-49.

13 Ebenda, S. $30 \mathrm{f}$.

${ }^{14}$ Ebenda.

15 Ebenda.

${ }^{16}$ Als Gegenleistung für seine Anstellung verpflichtet sich Spira, fortan ausschließlich für Vernay-Zeitungen und -zeitschriften zu arbeiten. Daher muss er die feste Rubrik „Der bissige Bleistift“, die er 1935 für das Neue Wiener Tagblatt beginnt, einstellen. Diese Zeitung erscheint im Konkurrenzkonzern Steyrermühl. Vgl. ebenda, S. 33.

17 Ebenda, S. 45.

${ }^{18}$ Ebenda, S. 48. Jura Soyfers journalistische Arbeiten für den Sonntag sind in der Werkausgabe, Bd. 1: Zwischenrufe links. Lyrik, Wien 2002, und Bd. 3: S. starb eine Partei. Prosa, Wien 2002, gesammelt. 
19 Der Sonntag, 15. August 1937. Häufig sind Soyfers Beiträge und Reportagen im Sonntag Gemeinschaftsarbeiten bestehend aus Text und Bild. Häufig stammen die Fotos von Rudolf Spiegel bzw. die Zeichnungen von Bil Spira. Sie sind in der Regel eng miteinander verschränkt. Leider ist die mediale Gesamterscheinung der illustrierten Soyfer-Texte in der Jura-Soyfer-Werkausgabe unzureichend veranschaulicht. Die Texte werden ohne bzw. getrennt von den Bildern präsentiert.

${ }^{20}$ Der Sonntag, 1. Juli 1935, S. 4 und 5.

${ }^{21}$ Ebenda.

22 Die Aufnahme erscheint posthum. Im August 1935 stirbt Imboden bei einem tragischen Unfall.

${ }^{23}$ Max Winter: Liechtentaler Kinderelend, in: Arbeiter-Zeitung, 11. Mai 1913, zit. nach: Wolfgang Maderthaner, Lutz Musner: Die Anarchie der Vorstadt. Das andere Wien um 1900, Frankfurt a. M. 1999, S. 141.

24 Ebenda.

25 Ebenda, S. 142.

${ }^{26}$ Der Sonntag, 28. Februar 1937, Titelseite.

27 Ebenda, S. 4.

28 Ebenda.

29 Spiegel besucht im Wintersemester 1937/38 und im Sommersemester 1938 den zweiten Jahrgang der Graphischen Lehr- und Versuchsanstalt, den ersten überspringt er. Schriftliche Auskunft Klaus Walder, Bibliothek und Sammlungen der Höheren Graphischen Bundes-Lehr- und Versuchsanstalt Wien, 10. Januar 2012.

${ }^{30}$ Bil Spira: Die Legende vom Zeichner, hg. von Konstantin Kaiser in Zusammenarbeit mit Vladimir Vertlib, Wien 1997, S. $30 \mathrm{f}$.

${ }^{31}$ Der Sonntag, 10. Oktober 1937, Titelseite. Die Reportage wird im Innenteil (S. 6 und 7) fortgesetzt.

32 Ebenda, S. 6 und 7.

${ }^{33}$ Gelegentlich finden sich im Sonntag aber sehr wohl idyllische Landschaftsbilder, etwa am 15. April 1934 auf dem Umschlag, das Foto stammt vom konservativen Fotoamateur Franz Swoboda. Sogar Hans Oplatka selbst steuert hin und wieder recht belanglose Bilder von Land und Leuten bei, etwa am 9. Juni 1935, als er „Frühlingsbilder aus Kärnten“ präsentiert. Darunter finden sich idyllische Landschaften, Trachten u. Ä.

${ }^{34}$ Der Sonntag, 24. März 1935, S. 4 und 5.

${ }^{35}$ Von den österreichischen Fotoagenturen sind lediglich die Agentur Willinger und ab und zu der Österreichische Photodienst im Sonntag regelmäßig vertreten. In Frankreich arbeitet Oplatka viel mit der Fotoagentur Aral zusammen.

${ }^{36}$ Interessanterweise nimmt Rübelt im Sonntag keineswegs jene Monopolstellung ein, die er in der übrigen österreichischen Bildpresse innehat.

37 Das interessante Blatt, 18. August 1932, S. 18.

38 Der Sonntag, 19. Mai 1935, Titelseite und Innenteil, S. 3 und 7. International bekannt wird Schoop 1932 mit ihrer getanzten Komödie „Fridolin unterwegs“. Skall fotografiert Schoop mehrmals, u. a. Ende 1937, als sie mit einem Ballett-Gastspiel in Wien zu Besuch ist. Siehe Skalls Fotoreportage in Der Sonntag, 28. November 1937, Titelseite und Innenteil.

39 Der Sonntag, 24. Januar 1937, Titelseite und Innenteil, S. 2 und 3.

${ }^{40}$ Der Sonntag, 18. August 1935.

${ }^{41}$ Bil Spira: Die Legende vom Zeichner, hg.von Konstantin Kaiser in Zusammenarbeit mit Vladimir Vertlib, Wien 1997, S. $30 \mathrm{f}$.

42 Der Sonntag, 27. Februar 1938, S. 4.

43 Der Sonntag, 22. August 1937, S. 7. Oplatka bietet Theodor Kramer im Sonntag regelmäßig ein Forum. Das Gedicht stammt aus dem 1928 in Frankfurt am Main erschienenen Lyrikband Die Gaunerzinke.

${ }^{44}$ Fleischmann beginnt zwar bereits Ende der 1920er
Jahre vermehrt im Freien zu fotografieren, sie macht vor allem Reise- und Landschaftsaufnahmen, die sie teilweise in der Presse veröffentlicht, aber das Atelier ist weiterhin das Zentrum ihrer fotografischen Arbeit. Vgl. dazu Anton Holzer: Atelier und Illustrierte. Trude Fleischmanns Fotoarbeiten für die Presse, in: Anton Holzer, Frauke Kreutler (Hg.): Trude Fleischmann. Der selbstbewusste Blick, Ausstellungskatalog Wien Museum, Ostfildern 2011, S. 122-134.

${ }^{45}$ Der Sonntag, 31. Oktober 1937, S. 6 und 7.

${ }^{46} \mathrm{Vgl}$. etwa seine Reportage über Schnellbahnloks. Der Sonntag, 23. Mai 1937, S. 2 und 3.

47 Der Sonntag, 31. Oktober 1937, Titelseite und Innenteil, S. 2 und 3.

48 Der Sonntag, 14. März 1937, S. 4.

${ }^{49} \mathrm{Vgl}$. etwa die schöne Reportage über den Wiener Naschmarkt, in der auch Ilsa Stern vertreten ist. Der Sonntag, 8. April 1934, S. 4 und 5.

${ }^{50}$ Lena Schur und Luise Deutsch liefern 1936 beispielsweise die Bilder zur Reportage „Arbeitslose malen“, die in Karl Paweks Die Pause erscheint. Die Pause, Heft 11, 1936, S. 46-47.

${ }^{51}$ Edith Wellspacher: Spanisches Tagebuch. Aufzeichnungen und Fotos einer Wiener Ärztin vom Spanischen Bürgerkrieg, Sommer 1936. Der Sonntag, 13. Februar 1938, Titelseite und S. 4 und 5. Wellspacher publiziert auch nach 1938 gelegentlich Reisereportagen in der Presse.

52 Schajchet wird über die Fotoreportage „24 Stunden im Leben einer Moskauer Arbeiterfamilie" auch im deutschen Sprachraum bekannt. Die Reportage erscheint im September 1931 zuerst in der deutschen Arbeiter-Illustrierten Zeitung (AIZ) und erst danach in deutlich veränderter Form in der Sowjetunion. Vgl. dazu Erika Wolf: „As the Filippovs“: The Foreign Origin of the Soviet Narrative Photographic Essay, in: Jorge Ribalta ( $\mathrm{Hg}$.): The Worker Photography Movement 1926-1939. Essays and Documents, Madrid 2011, S. $124-147$.

53 Die ungarischen Fotografen hat Oplatka wohl in der Ausstellung „Ungarische Meister" kennengelernt, die der Wiener Photoclub 1934 in Wien veranstaltet.

${ }^{54}$ Der Sonntag, 5. August 1934, S. 8; Der Sonntag, 6. Januar 1935, S. 7.

55 Biografische Hinweise zu Jan Lukas verdanke ich einem unveröffentlichten Text von Jan Mlčoch anlässlich der Ausstellung zu Jan Lukas im Jahr 2007 in der Josef Sudek Galerie in Prag, veranstaltet vom Museum für angewandte Kunst, Prag. Übersetzung ins Englische: Linda Paukertová. Herzlichen Dank an Jan Mlčoch für die Überlassung des Manuskripts. Vgl. auch Josef Moucha: Jan Lukas, Prag 2003.

56 Stefan Kruckenhauser: Du schöner Winter in Tirol, Berlin 1937, S. 42/43, Text S. 24. Die Aufnahmen entstehen 1934/35 am Arlberg.

57 Jan Mlčoch: Jan Lukas, unveröffentlichtes Manuskript, Prag 2007.

${ }^{58}$ Der Sonntag, 10. Mai 1936.

59 Vgl. Jaroslav Anděl: Alexandr Hackenschmied, New York 2001, S. 14. Mit Hackenschmied arbeitet Lukas in der zweiten Hälfte der 1930er Jahre eng zusammen, u. a. bei Filmprojekten für den Schuhkonzern Bata in Zlin.

${ }^{60}$ T. G. Masaryk: Masaryk erzählt sein Leben - Gespräche mit Karel Capek, Berlin 1936.

${ }^{61}$ Der Sonntag, 23. September 1934, S. 8.

62 Ebenda.

${ }^{63}$ Der Sonntag, 6. Mai 1934.

${ }^{64}$ Der Sonntag, 30. September 1934.

${ }^{65}$ Michel Frizot, Cédric de Veigy: Vu. The Story of a Magazine that made an Era, London 2009, S. 159.

${ }^{66}$ Zur Geschichte und Rezeption der Hinrichtungsfotos aus dem Ersten Weltkrieg siehe Anton Holzer: Das Lächeln der Henker. Der unbekannte Krieg gegen die Zivilbevölkerung 1914-1918, Darmstadt 2014. Die Hinrichtungsszene, die im Sonntag in der Bildmitte gezeigt wird, kommt (ohne dass das Foto abgebildet ist) auch bei Karl Kraus in den Letzten Tagen der Menschheit vor. Ebenda, S. $32 \mathrm{f}$.

67 Horst Jarka: Jura Soyfer. Leben, Werk, Zeit, Wien 1987, S. $196 \mathrm{f}$. Mit dabei in der Runde ist oft auch die kommunistische Journalistin Eva Priester, die ab und zu im Mutterblatt des Sonntag, Der Wiener Tag, Beiträge unterbringen kann. Ebenda.

68 Jan Mlčoch: Jan Lukas, unveröffentlichtes Manuskript, Prag 2007.

${ }^{69}$ Vgl. Bil Spira: Die Legende vom Zeichner, hg. von Konstantin Kaiser in Zusammenarbeit mit Vladimir Vertlib, Wien 1997, S. 33 und 54.

70 Siehe Ingeborg Reisner: Kabarett als Werkstatt des Theaters. Literarische Kleinkunst in Wien vor dem Zweiten Weltkrieg, Wien 2004 (Originalausgabe: Diss., Wien 1961).

71 Im Nachlass von Rudolf Weys (zusammen mit Lothar Metzl einer der Mitbegründer der „Literatur am Naschmarkt"), der 1998 von einem Antiquariat an die Wienbibliothek im Rathaus verkauft wurde, fanden sich ursprünglich auch an die 300 Fotos, die Aufführungen des Theaters zeigen. Sie wurden offenbar nicht zusammen mit den schriftlichen Unterlagen an die Bibliothek übergeben, sondern getrennt verwertet. Die Aufnahmen stammen u. a. von Robert Haas (Roha), Lena Schur, Trude Fleischmann, Dora Horovitz, Hans Dietrich, Hertha Schulda-Müller und Otto Skall. Fast alle von ihnen veröffentlichen auch im Sonntag.

${ }^{72}$ Vgl. Bil Spira: Die Legende vom Zeichner, hg. von Konstantin Kaiser in Zusammenarbeit mit Vladimir Vertlib, Wien 1997, S.46f.

73 Die Wiener Bilder etwa haben ihren Stand wenig einfallsreich mit zahlreichen nebeneinandergelegten Heften austapeziert. Siehe eine Abbildung in den Wiener Bildern, 13. März 1938, S. 3. Auf einer Aufnahme ist Kanzler Schuschnigg vor dem Stand der Wiener Bilder zu sehen. Als die Aufnahme am 13. März erscheint, ist er bereits nicht mehr Kanzler.

74 Briefe von Hans Oplatka aus Liverpool an Horst Jarka, 5. Mai und 18. Juli 1978. Zit. nach: Horst Jarka: Jura Soyfer. Leben, Werk, Zeit, Wien 1987, S. 463.

75 Bil Spira: Die Legende vom Zeichner, hg. von Konstantin Kaiser in Zusammenarbeit mit Vladimir Vertlib, Wien 1997, S. 53.

${ }^{76}$ Ebenda.

77 Schriftliche Mitteilung von Anna Skall Rossi, 1. April 2014.

78 Jan Mlčoch: Jan Lukas, unveröffentlichtes Manuskript, Prag 2007.

79 Bil Spira: Die Legende vom Zeichner, hg. von Konstantin Kaiser in Zusammenarbeit mit Vladimir Vertlib, Wien 1997, S. $55 \mathrm{ff}$.

${ }^{80}$ Zur Arisierung der Vernay AG siehe Susanne Falk: Die „Arisierung“ der Wiener Zeitungsverlage. Das Verlagshaus Canisiusgasse 8-10, Taunusstein 2002, S. $180 \mathrm{ff}$. Die „Abwicklung“ zieht sich jahrelang hin, wann genau die Firma aus dem Handelsregister gestrichen wird, ist unklar.

81 Tano Bojanko: Die Geschichte des Kompass-Verlagsein Zwischenstand, in: Sylvia Mattl-Wurm, Alfred Pfoser (Hg.): Die Vermessung Wiens. Lehmanns Adressbücher 1859-1942, Wien 2011, S. 339-347, hier S. 346. Unter den Käufern ist auch Hans Misar, ein Profiteur des nationalsozialistischen Raubzuges. Er wird nach dem politischen Umbruch 1938 Schriftleiter des Wiener Magazins und arbeitet auch als Fotograf. Ausführlicher zur Rolle Misars als Fotograf siehe das Kapitel „Den Krieg vor Augen. Nationalsozialistische Medienpolitik und Ästhetik“. 


\section{Demagogie in Bildern}

${ }^{1}$ Wiener Bilder, 20. März 1938, S. 11.

2 Das interessante Blatt, 17. März 1938, S. 4.

3 Wiener Bilder, 20. März 1938, S. 2.

${ }^{4}$ Ebenda.

5 Österreichische Woche, 24. März 1938, Titelseite.

${ }^{6}$ Am Beispiel des Interessanten Blattes: Ende März 1938 wird die Redaktion umfassend „gesäubert" und ihre Verwaltung auf NS-Kurs gebracht. Alfred Zohner wird als Chefredakteur abgelöst, er bleibt aber-als Einziger der alten Redaktion - in leitender Position bei der Zeitung. An seine Stelle tritt der Nationalsozialist Egon Kott. Kommissarischer Verwalter wird Sepp Payer. Kott ist nach 1945 für die Wiener Illustrierte tätig.

${ }^{7}$ Siehe dazu ausführlicher das Kapitel „Den Krieg vor Augen. Nationalsozialistische Medienpolitik und Ästhetik nach 1938“.

${ }^{8}$ Das interessante Blatt, 7. April 1938, Titelseite.

${ }^{9}$ Zit. nach Michaela Pfundner: Dem Moment sein Geheimnis entreißen. Der Sportberichterstatter Lothar Rübelt (1901-1990), in: Matthias Marschik, Rudolf Müllner (Hg.): „Sind's froh, dass Sie zu Hause geblieben sind.“ Mediatisierung des Sports in Österreich, Göttingen 2010, S. 317-327, hier S. 324. Das Schreiben ist an die Vermögensverkehrsstelle gerichtet, eine Wiener NS-Behörde, die für die Zwangsenteignung („Arisierung“) der jüdischen Bevölkerung zuständig ist. Rübelt selbst hat sich an der "Arisierung“ des „WienzeileKinos“ beteiligt. Vgl. ebenda, S. 323

${ }^{10}$ Ebenda, S. 3.

${ }^{11}$ Vgl. dazu Hans Petschar: Anschluss. „Ich hole euch heim“. Der „Anschluss“ Österreichs an das Deutsche Reich. Fotografie und Wochenschau im Dienst der NS-Propaganda. Eine Bildchronologie, Wien 2008 , S. $104 \mathrm{ff}$.

12 Wiener Bilder, 10. April 1938, Titelseite.

${ }^{13}$ Rudolf Herz: Hoffmann \& Hitler. Fotografie als Medium des Führer-Mythos, München 1994, S. 48 ff.

14 Ebenda, S. 53.

15 Österreichische Kunst, Heft 11, November 1938, S. 42.

${ }^{16}$ Österreichische Kunst, Heft 10, Oktober 1938, S. 30.

17 Ebenda.

\section{Den Krieg vor Augen}

${ }^{1}$ Wiener Illustrierte, 7. September 1939, S. 7.

2 Wiener Bilder, 10. September 1939, S. 3: „Ab nächster Woche erscheinen die, Wiener Bilder' als ,Wiener Illustrierte/Das interessante Blatt'.“

${ }^{3}$ Zur visuellen Modernisierung der deutschen Presse im Nationalsozialismus vgl. Patrick Rössler: „Wir zerstreuen uns zu Tode." Formen und Funktionen der Medialisierung des Politischen in illustrierten Zeitschriften der NS-Zeit, in: Klaus Arnold u. a. (Hg.): Von der Politisierung der Medien zur Medialisierung des Politischen? Zum Verhältnis von Medien, Öffentlichkeit und Politik im 20. Jahrhundert, Leipzig 2010, S. 183-259.

${ }^{4}$ Die Wiener Bilder haben allerdings bereits seit den frühen 1930er Jahren ein im Vergleich mit dem interes santen Blatt deutlich zeitgemäßeres Erscheinungsbild.

${ }^{5}$ Aus nationalsozialistischer Sicht geschildert: Hans Schopper: Presse im Kampf. Geschichte der Presse während der Kampfjahre der NSDAP (1933-1938) in Österreich, Brünn u. a. 1940, S. 33.

${ }^{6}$ Die Pause, Heft 5, 1938, Titelseite.

${ }^{7}$ Die Pause, Heft 5, 1938, S. 8 und 9. Weitere Hitlerbilder sind auf S. 12 und 13 zu sehen.

${ }^{8}$ Die Ostmark-Woche erhält 1938 mit Theodor Veiter einen neuen Schriftleiter. Sie erscheint bis 1941.

${ }^{9}$ Siehe dazu ausführlicher das Kapitel „Fotografisches Feuilleton. Der Sonntag: ein vergessenes Forum moderner Reportagefotografie“.
${ }^{10}$ Die Zeitschrift erscheint seit 1934 nicht mehr wöchentlich, sondern monatlich.

${ }^{11}$ Zum „Haus der Mode“ siehe Gloria Sultano: Wie geistiges Kokain ... Mode unterm Hakenkreuz, Wien 1995, S. $99 \mathrm{ff}$.

12 Im Jahr 1940 ist die Schriftleitung des Wiener Magazins zeitweise nicht besetzt, da Misar sich „im Felde“ befindet.

${ }^{13}$ Hans Misar tritt nach 1938 auch als Geschäftsführer des Bergland-Verlags auf. Gedruckt wird die Zeitschrift nach 1938 im NS-Gauverlag und Druckerei Tirol.

14 Das Medienhaus Vernay wird noch im Jahr 1938 an Erwin Metten verpachtet und geht nach dessen Tod Ende 1940 an seinen Sohn Heinz Metten über. 1941 wird die Druckerei an eine Kommanditgesellschaft verkauft, an der neben Misar auch Helmut Seidel, Hannes Dietl und Hermann Heß beteiligt sind. VgI. Anton Durstmüller, Norbert Frank: 500 Jahre Druck in Österreich. Die Entwicklung der graphischen Gewerbe von den Anfängen bis zur Gegenwart, Bd. 3, Wien 1985, S. 157. Zur Bedeutung des Medienunternehmens Vernay siehe das Kapitel „Fotografisches Feuilleton. Der Sonntag: ein vergessenes Forum moderner Reportagefotografie“.

${ }^{15}$ Der Verlag heißt Erwin Metten Nachf. Hans Misar Verlag.

${ }^{16}$ Im Nationalsozialismus spielen etwa die moderne Sachfotografie und die Werbung eine große Rolle. Hier werden Errungenschaften der Avantgarde aufgegriffen und weitergeführt. Im künstlerischen Bereich ist der Bezug auf die Moderne freilich weniger ausgeprägt.

17 Wiener Bilder, 20. März 1938, S. 8 und 9.

18 Wiener Magazin, Heft 7, Juli 1940, S. 28 und 29.

${ }^{19}$ Wiener Magazin, Heft 6. Juni 1940 und Heft 8, August 1940.

20 Wiener Magazin, Heft 5, Mai 1939, S. 60 und 61 (o. S.)

$21 \mathrm{Vgl}$. Dokumente der Vermögensverkehrsstelle: VA 23986, Kt. 198: Verzeichnis über das Vermögen von Juden nach dem Stand vom 27. April 1938, Österreichisches Staatsarchiv/Archiv der Republik.

22 Der Hinweis auf den Fotografen findet sich auf einer anderen Seite - der Vorname ist dabei abgekürzt (A. Benda).

${ }^{23}$ Wiener Magazin, Heft 1, Januar 1941, S. 6 und 7.

${ }^{24}$ Im Juliheft 1938 des Wiener Magazins tauchen, ebenfalls unter dem Titel „Fliegende Menschen“, Kunstspringerbilder Rübelts auf. Bereits in den 1930er Jahren hatte Rübelt regelmäßig Sprungwettbewerbe fotografisch festgehalten.

25 Das letzte Heft der Modernen Welt, das Doppelheft $2 / 3$, erscheint im November/Dezember 1939. Es ist ein Themenheft, das Ungarn gewidmet ist.

${ }^{26}$ Im letzten Heft heißt es auf S. 2: „Mit dieser Nummer wird das Erscheinen der Zeitschrift Mein Film in Wien eingestellt. Die Schriftleitung“.

27 Das letzte Heft der Pause, Nr. 8/9, 1944, erscheint am 30. September 1944

${ }^{28}$ Zur Geschichte und Arbeitsweise der Propagandakompanien (PK) siehe Bernd Boll: Die Propagandakompanien der Wehrmacht 1938-1945, in: Christian Stadelmann, Regina Wonisch (Hg.): Brutale Neugier. Walter Henisch. Kriegsfotograf und Bildreporter, Ausstellungskatalog Wien Museum, Wien 2003, S. 37-46, hier S. 39.

29 Wiener Illustrierte, 13. September 1939, Titel- und Schlussseite.

${ }^{30}$ Vgl. Markus Priller: Arisierungen in der österreichischen Textilindustrie, Diplomarbeit, Universität Wien, Wien 2008, S. 124

${ }^{31}$ Wiener Bilder, 15. Januar 1939, S. 8 und 9. Weitere Teile der Serie erscheinen am 22. Januar 1939, S. 2 und 3, am 29. Januar 1939, S. 2 und 3, am 29. Januar 1939, S. 11 und 12 und am 8. März 1939, S. 10 und 11.
32 Die Bühne, Zweites Maiheft 1935, S. 28. Zur Entstehungs- und Publikationsgeschichte dieser Aufnahme siehe Anton Holzer: Die Hunde des Dr. Freud, in: Die Presse, Feuilletonbeilage Spectrum, 21. Januar 2012, S. V. Für ergänzende Hinweise zum Aufnahmeort danke ich Frau Inge Scholz-Strasser vom Sigmund Freud Museum Wien.

33 Wiener Bilder, 15. Januar 1939, S. 9.

${ }^{34}$ Ebenda, S. $8 \mathrm{f}$.

35 Zit nach Bernd Boll: Die Propagandakompanien der Wehrmacht 1938-1945, in: Christian Stadelmann, Regina Wonisch (Hg.): Brutale Neugier. Walter Henisch. Kriegsfotograf und Bildreporter, Ausstellungskatalog Wien Museum, Wien 2003, S. 37-46, hier S. 44.

${ }^{36}$ Wiener Illustrierte, 22. November 1939, S. 8.

37 Die Fotos zum Thema Jungvolk in der Pause stammen von Rudolf Koppitz, Erika Schmachtenberger, Max Schirner, Hans Furthner, Simon Moser und der Österreichischen Bundesjugendführung.

${ }^{38}$ Die Pause, Heft 4, 1937, S. 1

${ }^{39}$ Wiener Illustrierte, 10. Juni 1942, S.4/5.

40 Sie erscheinen v. a. ab 1941 in der Wiener Illustrierten.

${ }^{41}$ Vgl. dazu ausführlicher Anton Holzer: Soldaten mit der Kamera. Deutsche Kriegsfotografen im Zweiten Weltkrieg, in Hans-Michael Koetzle (Hg.): Augen auf! 100 Jahre Leica Fotografie, Ausstellungskatalog Haus der Photographie, Hamburg, Ostfildern 2014.

42 Rundschreiben des Oberkommandos des Heeres vom 30.8.1938, zit nach: Bernd Boll: Die Propagandakompanien der Wehrmacht 1938-1945, in: Christian Stadelmann, Regina Wonisch (Hg.): Brutale Neugier. Walter Henisch. Kriegsfotograf und Bildreporter, Ausstellungskatalog Wien Museum, Wien 2003, S. 37-46, hier S. 38.

${ }^{43}$ Bernd Weise: Kamera- und Fototechnik im journalistischen Gebrauch, Teil IV: Zweiter Weltkrieg, in: Rundbrief Fotografie, Nr. 3, 2006, S. 10-17, hier S. $11 \mathrm{ff}$.

44 Ebenda, S. $39 \mathrm{ff}$.

45 Peter Henisch: Mit eigenen Augen gesehen/selber geschossen, in: Christian Stadelmann, Regina Wonisch (Hg.): Brutale Neugier. Walter Henisch. Kriegsfotograf und Bildreporter, Ausstellungskatalog Wien Museum, Wien 2003, S. 14-17, hier S. 16

${ }^{46} 24$. Juli 1941, Titelseite. Die Aufnahme zeigt das Porträt eines deutschen Infanteristen.

47 Die Pause, Heft 8/9, 1944, S. 18.

\section{Eine andere Kulturgeschichte}

${ }^{1}$ Das Gasthaus „Zum grünen Tor“ in der Lerchenfelder Straße 14, Wien 8, ist im 19. und frühen 20. Jahrhundert ein beliebter Treffpunkt für Liebhaber der populären Unterhaltung. Fast jeden Tag tragen bekannte Volkssänger Wienerlieder und Couplets vor.

${ }^{2}$ Das interessante Blatt, 28. Mai 1903, S. 2.

${ }^{3}$ Ebenda.

${ }^{4}$ Ebenda.

${ }^{5}$ Für einen guten Überblick siehe Steven Beller ( $\mathrm{Hg}$.): Rethinking Vienna 1900, New York, Oxford, 2001 und darin v. a. die Beiträge von Steven Beller und Allan Janik. Auch Edward Timms erweitert in seiner jüngsten Kultur- und Geistesgeschichte der Wiener Moderne die Perspektive in Richtung der Populärkultur. Er beschäftigt sich etwa mit der Rolle des Kaffeehauses, des Cabarets, des Kinos und des Rundfunks, aber interessanterweise nicht mit der illustrierten Presse. Edward Timms: Dynamik der Kreise, Resonanz der Räume. Die schöpferischen Impulse der Wiener Moderne, Weitra 2013

${ }^{6}$ Bis 1905 trägt die Zeitung den Namen Österreichische Kronen-Zeitung, danach Illustrierte Kronen-Zeitung. Das Blatt wird ursprünglich als Nebenblatt der konservativen Reichswehr gegründet, bald aber ist es weit erfolg- 
reicher als die Stammzeitung. Geleitet wird die IIlustrierte Kronen-Zeitung von Leopold Lipschütz.

${ }^{7}$ Gabriele Melischek, Josef Seethaler: Presse und Modernisierung in der Habsburgermonarchie, in: Helmut Rumpler, Peter Urbanitsch (Hg.): Die Habsburgermonarchie 1848-1918, Band VIII: Politische Öffentlichkeit und Zivilgesellschaft, 2. Teilband: Die Presse als Faktor der politischen Mobilisierung, Wien 2006, S. 15351571, hier S. $1556 \mathrm{ff}$.

${ }^{8}$ Zur Vorgeschichte der Pressefotografie siehe Bernd Weise: Aktuelle Nachrichtenbilder „nach Photographien " in der deutschen illustrierten Presse der zweiten Hälfte des 19. Jahrhunderts, in: Charles Grivel, André Gunthert, Bernd Stiegler (Hg.): Die Eroberung der Bilder. Photographie in Buch und Presse 1816-1914, München 2003, S. 62-101.

${ }^{9}$ Vgl. etwa Hartwig Gebhardt: Die Pfennig-Magazine und ihre Bilder. Zur Geschichte und Funktion eines illustrierten Massenmediums in der ersten Hälfte des 19. Jahrhunderts, in: Wilhelm Brednich, Andreas Hartmann (Hg.): Populäre Bildmedien. Vorträge des 2. Symposiums für ethnologische Bildforschung, Reinhausen bei Göttingen 1986, S. 19-42. Zur Situation in England siehe Michael Diamond: Victorian Sensation or the Spectacular, the Shocking and the Scandalous in the Nineteenth Century Britain, London 2003.

${ }^{10}$ Art und Umfang der Anzeigen deuten beispielsweise darauf hin, dass das Bürgertum zu den privilegierten Adressaten der illustrierten Wochenzeitungen gehört.

${ }^{11}$ Vgl. dazu Klaus Kreimeier: Traum und Exzess. Die Kulturgeschichte des führen Kinos, Wien 2011, S. 192.

12 Vanessa R. Schwartz: Spectacular Realities. Early Mass Culture in Fin-de-Siècle Paris, Berkeley, Los Angeles 1999, S. $34 \mathrm{ff}$.

${ }^{13}$ Zur Geschichte dieser Skandalpresse siehe Hartwig Gebhardt: „Halb criminalistisch, halb erotisch“. Presse für die „niederen Instinkte“. Annäherungen an ein unbekanntes Kapitel deutscher Mediengeschichte, in: Kaspar Maase, Wolfram Kaschuba (Hg.): Schund und Schönheit. Populäre Kultur um 1900, Köln u. a. 2001, S. 184-217.

14 Bodo von Dewitz, Robert Lebeck (Hg.): KIOSK. Eine Geschichte der Fotoreportage 1839-1973, Göttingen 2001, S. 274.
${ }^{15}$ Life schließt wegen des rückläufigen Anzeigengeschäfts 1959/60 erstmals mit einem negativen Betriebsergebnis. Vgl. John Morris: Get the picture. A Personal History of Photojournalism, New York 1998, $195 \mathrm{ff}$.

${ }^{16}$ Die letzte Ausgabe von Look erscheint bereits ein Jahr früher. Zum Aufstieg und Niedergang des Magazins siehe Anton Holzer: Stanley Kubrick: Fotojournalist. Look, Life und die Kultur der amerikanischen Fotoreportage, in: Ingrid Brugger, Lisa Ortner-Kreil (Hg.): Eyes wide open. Stanley Kubrick als Fotograf, Ausstellungskatalog Kunstforum Wien, Wien, München 2014. Life erlebt 1978 als Monatszeitschrift noch einmal einen Relaunch, kann mit einer durchschnittlichen Auflage von 1,5 Millionen jedoch nicht mehr an die früheren Zahlen - 8,5 Millionen in den 1960er Jahren - anknüpfen. Zur Geschichte der Bildmagazine und ihrer Bedeutung für den Fotojournalismus in der zweiten Hälfte des 20. Jahrhunderts siehe Mary Panzer: Things as They Are: Photojournalism in Context since 1955, London 2006.

${ }^{17}$ Ausführlicher zu den Veränderungen des internationalen Magazinmarktes und des Fotojournalismus in der Nachkriegszeit siehe Mary Panzer: Things as They Are: Photojournalism in Context since 1955, London 2006; Matthias Christen, Anton Holzer: Mythos Magnum. Die Geschichte einer legendären Fotoagentur, in: Mittelweg 36. Zeitschrift des Hamburger Instituts für Sozialforschung, Nr. 5, Oktober/November 2007, S. 53-80.

${ }^{18} \mathrm{Vgl}$. dazu ausführlicher Ludger Derenthal: Bilder der Trümmer- und Aufbaujahre. Fotografie im sich teilenden Deutschland, Marburg 1999 sowie Jörn Glasenapp: Die deutsche Nachkriegsfotografie. Eine Mentalitätsgeschichte in Bildern, München 2008.

${ }^{19}$ Zur Situation in Deutschland siehe Bernd Gäbler: Was gestern war, wirkt lange fort. Die deutsche Presse-Elite und die Kontinuitäten der Eliten nach 1945, in: Zwischen den Zeilen. Zeitungspresse als NS-Machtinstrument, hg. von der Stiftung Topographie des Terrors, Ausstellungskatalog, Berlin 2013, S. 34-42. Für Österreich gibt es bislang noch keine detaillierte Studie zum Thema. Einige Hinweise finden sich bei Fritz Hausjell: Österreichische Journalisten und Publizisten im Exil (1933/34 bis 1945). Eine Fallstudie, in: Friedrich Stadler (Hg.): Vertriebene Vernunft I. Emigration und Exil österreichischer Wissenschaft 1930-1940, Wien, München 1987, S. 304-342.
${ }^{20}$ Vgl. Anton Holzer: Das große Bild. Barbara Pflaum, die Wochenpresse und der österreichische Fotojournalismus nach 1945, in: Wolfgang Kos, Gerald Piffl, Peter Stuiber, Susanne Winkler (Hg.): Barbara Pflaum. Bildchronistin der Zweiten Republik, Wien 2006, S. 8693.

21 Die Österreich-Auflage des Stern steigt beispielsweise von 61295 (1959) über 102015 (1965) auf 126231 (1970). Die Bunte legt von 158500 (1965) auf 211653 (1970) zu. Angaben aus: Handbuch Österreichs Presse, Graphik, Werbung, Wien 1959-1970. Zum Vergleich: Die Gesamtauflage des Stern liegt 1960 bei 1,3 Millionen, jene der Bunten bei 657000 Exemplaren.

22 Arthur Werner: „Drei kleine Negerlein“ oder Ballade von den österreichischen Illustrierten, in: Der österreichische Zeitungshändler, Nr. 1, 1964, S. 12-14, hier S. 12.

23 Wiener Bilderwoche, 31. Dezember 1960, S. 2.

241931 bringt Erich Salomon ein Buch heraus, das diesen Ruhm noch steigert: Berühmte Zeitgenossen in unbewachten Augenblicken. Vgl. dazu: Janos Frecot (Hg.): Erich Salomon. „Mit Frack und Linse durch Politik und Gesellschaft“. Photographien 1928-1938, München 2004.

${ }^{25}$ Grundlegende biografische Recherchen zur österreichischen Fotografiegeschichte stammen von Timm Starl. Vgl. Timm Starl: FotoBibl. Biobibliografie zur Geschichte der Fotografie in Österreich von 1839 bis 1945 (online unter: www.albertina.at). Die im Anhang zusammengestellten Biografien bauen auf diesen Forschungen auf, in vielen Fällen werden die Informationen erweitert und ergänzt. Zu einer Reihe bisher unbekannter Fotografen und Fotografinnen werden erstmals biografische Hintergründe vorgelegt. Umfassende biografische Einträge zur Fotografie in Österreich sind auch zusammengestellt in Anton Holzer: Fotografie in Österreich. Geschichte, Entwicklungen, Protagonisten 1890-1955, Wien 2013, S. $195 \mathrm{ff}$.

${ }^{26} \mathrm{Zu}$ den Folgen von Nationalsozialismus und Krieg für die österreichische Fotografie nach 1945 siehe ausführlicher Anton Holzer: Fotografie in Österreich. Geschichte, Entwicklungen, Protagonisten 1890-1955, Wien 2013, S. 173 ff. sowie Ulrike Matzer: Zwischen Heimatfotografie und Medienkunst. Fotografie in Österreich 1939 bis 1970, in: Fotogeschichte, Heft 117, S. 27-50. 


\title{
Fotografinnen und Fotografen 1890 bis 1945
}

\author{
Biografische Notizen
}

Angeführt sind wichtige österreichische Fotografinnen und Fotografen, die zwischen 1890 und 1945 regelmäBig Bilder in der illustrierten Presse veröffentlichten. Aufgenommen sind auch einzelne Inhaber von Fotoagenturen, Fotoredakteure sowie einige ausländische Fotografen, die öfter in österreichischen Medien publizierten.

Angerer, Victor, geb. 1868 oder 1870 in Wien, betreibt in der Theresianumgasse 4, Wien 4, ein Atelier und arbeitet seit 1895 als Pressefotograf. Er beliefert um 1900 zahlreiche österreichische Zeitungen und auch den Berliner Ullstein Verlag. Er fotografiert öffentliche Ereignisse, den Kaiser bei seinen Auftritten, Bühnenstars, aber auch Alltagsszenen. Nicht zu verwechseln mit dem gleichnamigen Fotofabrikanten und Industriellen Viktor Angerer (1839-1894).

Angerer, Wilhelm, geb. am 6. Juli 1904 in Schwaz, Tirol, Fotografenlehre im elterlichen Betrieb, Ende der 1920er Jahre Meisterklasse an der Graphischen Lehr- und Versuchsanstalt in Wien, führt nach 1933 ein Fotogeschäft in Kitzbühel und arbeitet als Landschaftsfotograf, Vertreter der österreichischen Heimatfotografie, 1942 veröffentlicht er im Gauverlag Tirol-Vorarlberg den Band Ein Lied rauscht von den Bergen, gest. am 23. Dezember 1982 in Schwaz.

Atzwanger, Peter Paul, geb. am 15. Juli 1888 in Tisis bei Feldkirch, Vorarlberg, Amateurfotograf, Studium an der Akademie der bildenden Künste, Ausbildung an der Graphischen Lehr- und Versuchsanstalt in Wien, 1914 Assistent von Heinrich Kühn in dessen Lichtbildnerschule in Innsbruck, nach dem Ersten Weltkrieg eröffnet er ein Fotoatelier in Hall in Tirol, von 1928 bis 1946 unterrichtet er an der Graphischen Lehr- und Versuchsanstalt in Wien, Vertreter der österreichischen Heimatfotografie, zahlreiche Ausstellungen, 1938 Mitglied der NSDAP, gest. am 26. Dezember 1974 in Innsbruck.

Balek, Hans, Wiener Amateurfotograf, seit ca. 1927 Mitglied der Photographischen Fachgruppe der Volkshochschule Wien-Ottakring, beteiligt sich an Fotoausstellungen.

Bálint, Johann, ungarischer Fotograf, der 1915 Mitglied im österreichischen Kriegspressequartier ist und im Auftrag der Budapester Illustrierten Pesti Napló (Pester Tagebuch) an der Ostfront fotografiert.

Balogh, Rudolf (Reszö), geb. am 1. September 1879 in Budapest, besucht die Graphische Lehr- und Versuchsanstalt in Wien, danach arbeitet er zwei Jahre lang in Fotoateliers in München, Görz und Konstantinopel. Seit 1902 ist er als Pressefotograf für die ungarische Wochenzeitung Vasárnapi Újság (Sonntagsblatt) tätig, seit 1903 erscheinen seine Bilder auch in österreichischen Zeitungen. 1912 eröffnet er in Budapest ein Atelier. Während des Ersten Weltkriegs arbeitet er als Kriegsfotograf für das Kriegspressequartier und veröffentlicht seine Bilder in ungarischen, österreichischen und deutschen Blättern. Seit 1920 veröffentlicht er in der illustrierten Beilage des Pesti Napló (Pester Tagebuch). Balogh ist als Pionier der ungarischen Pressefotografie Vorbild für eine ganze Generation von jüngeren Fotografen (u. a. Martin Munkácsi, Károly Escher, and Ernő Vadas). Zugleich ist er ein wichtiger Fotopublizist und Fotolehrer. 1911 wird er Herausgeber der Zeitschrift Fény (Licht), 1914 gründet er die Zeitschrift Fotómúvészet (Kunstfotografie), 1930 wird er Herausgeber von Fotómüvészeti hírek (Fotografische Nachrichten). Er stirbt am 9. Oktober 1944 in Budapest.

Barakovich, Edith, geb. am 14. Februar 1896 im ungarischen Semlin (heute Zemun, in der Nähe von Belgrad), $1913-1915$ Ausbildung an der Graphischen
Lehr- und Versuchsanstalt in Wien, Lehre im Atelier d'Ora. 1918 eröffnet sie ein eigenes Atelier in der Prinz-Eugen-Straße 30 im 4. Bezirk und 1921 eine Filiale in der Fichtnergasse 3 in Wien-Hietzing. Sie fotografiert bekannte Künstlerinnen und Künstler, Schauspielerinnen und Schauspieler, aber auch Personen aus dem Wiener Bürgertum und veröffentlicht ab 1919 regelmäßig Porträt- und Modeaufnahmen in der österreichischen und deutschen illustrierten Presse. 1938 flieht Barakovich zusammen mit ihrem Mann, dem Schriftsteller und Journalisten Paul Frankl, über Frankreich und Spanien nach $\mathrm{Ca}$ sablanca, wo sie sich Ende Dezember 1940 das Leben nimmt.

Bárány, Josefine (auch Fini), geb. am 2. März 1891 in mit Grete Weissenstein in der Lerchenfelder StraBe 9/11, Wien 7, das Fotoatelier Ingret. Ihre Porträts und Kinderbilder erscheinen seit den frühen 1920er Jahren auch in der illustrierten Presse, seit 1929 beteiligt sie sich an Fotoausstellungen. Ende 1938 wird das Atelier geschlossen, Bárány geht mit ihrem Mann Otto Bárány nach Schweden, wo sich ihre Spur verliert. Ihre Atelierpartnerin Grete Weissenstein flüchtet 1939 nach Australien.

Bareder, Ferdinand, Wiener Amateurfotograf, seit Ende der 1920er Jahre Mitglied der Arbeiterfotogruppe der Naturfreunde Meidling, zeitweise auch Leiter der Gruppe, stellt seine Bilder in zahlreichen Ausstellungen aus, greift in seinem Werk die Anregungen der Neuen Sachlichkeit auf.

Bauer, Karl, Wiener Amateurfotograf, um 1930 Mitglied der Arbeiterfotogruppe der Naturfreunde Meidling.

Baszel, Günther, geb. am 8. Mai 1902 in Kaschau (Ungarn, heute Slowakei), Studium der Kunstgeschichte und Germanistik an der Universität Wien, Ausbildung an der Akademie der bildenden Künste, seit 1925 Mitarbeiter am Österreichischen Institut für Bildstatistik, daneben Maler, Bildhauer und Ausstellungsgestalter. Er ist als Amateurfotograf tätig und macht mit der Kamera (teilweise abstrakte) Material- und Oberflächenstudien, die er seit 1938 in Zeitschriften veröffentlicht. 1942 wird er Mitglied im Wiener Künstlerhaus und 1951 Professor an der Akademie für angewandte Kunst in Wien. Er stirbt am 5. Februar 1973 in Wien.

Bekei, Ödön, ungarischer Pressefotograf, arbeitet seit ca. 1900 für die 1895 gegründete illustrierte Wochenzeitung Új Idő́k (Neue Zeiten). Seit 1903 erscheinen seine Aufnahmen auch in österreichischen Blättern.

Benda, Arthur, geb. am 23. März 1885 in Berlin, Lehre bei Nicola Perscheid, arbeitet in Wien als Assistent im Fotoatelier von Dora Kallmus, übernimmt 1927 das Wiener Geschäft (d'Ora-Benda), zahlreiche Veröffentlichungen in der Presse, gest. am 7. September 1969 in Wien.

Berényi, Ludwig, Wiener Atelierfotograf, der seit 1893 auch als Pressefotograf arbeitet. Er fotografiert u. a. öffentliche Ereignisse und Sportveranstaltungen.

Bergler, Marianne, geb. am 31. März 1897 in Wien als Marianne Blumberger, eröffnet 1927 ein Atelier an der Seilerstätte 7, Wien 1, und eine Filiale in der Rotenturmstraße 11, Wien 1, arbeitet ab 1927 als AteWien als Josefine Keller, eröffnet 1919 zusammen lier- und Pressefotografin in Wien, spezialisiert sich auf Porträt-, Mode- und Theaterfotografie. Sie arbeitet von 1927 bis ca. 1931 mit der Pressefotografin Annie Schulz (geb. 1897 in Wien als Anna Weishut) zusammen, ihre gemeinsamen Arbeiten signieren sie mit „Blumberger-Schulz“. In den 1930er Jahren veröffentlicht Bergler in der illustrierten Presse vor allem Modefotos, aber auch Alltags- und Sozialreportagen. Im Juli 1938 flüchtet die Fotografin, die jüdischer Herkunft ist, zusammen mit ihrem Mann, dem Psychoanalytiker Edmund Bergler, nach New York. Sie wird amerikanische Staatsbürgerin. Ob sie in New York noch als Fotografin tätig ist, ist nicht bekannt. Nach dem Tod ihres Mannes 1962 gründet sie die Marianne and Edmund Bergler Psychiatric Foundation in New York. Sie stirbt im Mai 1980 in Monterey, Kalifornien.

Bernatzik, Emmy, geb. am 3. April 1904 in Wien, Ethnologin, Reisefotografin, ist mit ihrem Mann, Hugo Bernatzik, viel unterwegs, publiziert seit Ende der 1920er Jahre in der illustrierten Presse, sie stirbt am 27. Juli 1977 in Einsiedeln (Schweiz).

Bernatzik, Hugo, geb. am 26. März 1897 in Wien, Ethnologe, Reiseschriftsteller, Publizist und Fotograf. Er publiziert seit Ende der 1920er Jahre fotografische Reisereportagen in der österreichischen und deutschen illustrierten Presse. Mit seinen Fotos ist er auch auf der Werkbundausstellung „Film und Foto“ (FiFo) vertreten, die 1930 in Wien Station macht. Nach dem „Anschluss“ Österreichs an das nationalsozialistische Deutschland wird er Mitglied in der NSDAP. Seit 1939 ist er Professor in Graz. Er stirbt am 9. März 1953 in Wien.

Birnbach, Rudolf, geb. am 14. Dezember 1906 in Wien, gründet Ende 1927 in Berlin die Fotoagentur "Weltrundschau“, die, neben dem von Simon Guttmann gegründeten „Deutschen Photodienst“ (Dephot), um 1930 zu den innovativsten deutschen Anbietern von Pressebildern und Bildreportagen gehört. Nach 1933 ist Birnbach, der jüdischer Herkunft ist, gezwungen, die Leitung der Agentur aufzugeben (diese wird bis in die 1940er Jahre unter neuer Leitung weitergeführt). In den 1930er Jahren hält sich Birnbach mehrfach in Wien auf, spätestens 1938 flüchtet er nach New York. Dort arbeitet er neuerlich als Leiter einer Bildagentur unter dem Namen Birnback Publishing Service, er stirbt 1961 in New York.

Bittner, Friedrich, arbeitet im Ersten Weltkrieg im österreichischen Kriegspressequartier als Pressefotograf.

Bizanski, Stanislaw, polnischer Atelierfotograf, der seit Mitte der 1880er Jahre ein Atelier in Krakau unterhält (mit Filialen in Zakopane und Krynica). Seit den frühen 1890er Jahren ist er auch als Pressefotograf tätig und publiziert gelegentlich in Wiener Zeitungen.

Blaha, Franz, geb. am 21. Dezember 1904 in Wien, betreibt seit 1926 in Wien am Dr.-Karl-Lueger-Ring 12 ein Geschäft für Foto- und Kinogebrauchsartikel und arbeitet als Werbemitarbeiter beim sozialdemokratischen Vorwärts-Verlag (u. a. für das Kleine Blatt), seit März 1937 arbeitet er auch als Pressefotograf. Mitte 1938 baut er unter dem Namen Photo-Dienst Blaha eine eigene Fotoagentur auf. Er arrangiert sich mit dem nationalsozialistischen Regime. 1940 beantragt er die Aufnahme in den Reichsverband der Deutschen Presse. Während des Zweiten Weltkrieges übernimmt er die Wiener Vertretung der Berliner Fotoagentur Scherl Bilderdienst. Nach 1945 arbeitet 
er weiterhin als Pressefotograf und leitet den Aufbau der Bildstelle der Sozialistischen Partei Österreichs. Er ist bis Ende der 1960er Jahre als Fotograf tätig. Er stirbt im September 1996 in Wien.

Bohl, Robert J., geb. am 10. August 1906 in Wien, Journalist und Fotograf. Seit 1933 veröffentlicht er Fotoreportagen (Text und Bilder), oft zu sozialen und Alltagsthemen. Mitte 1937 emigriert er nach China, Anfang 1948 kehrt er nach Wien zurück und arbeitet wieder als Pressefotograf. Er stirbt am 14. März 1969 in Wien.

Boronkay, Kálman, ungarischer Fotoamateur, der in den 1930er Jahren u. a. in österreichischen Magazinen veröffentlicht.

Boszek, Reszö, ungarischer Fotoamateur und Kritiker, der in den 1930er Jahren u. a. in österreichischen Magazinen veröffentlicht. Mitarbeiter der von Rudolf Balogh gegründeten Zeitschrift Fotómüvészeti hírek (Fotografische Nachrichten).

Brandl, Steffi, geb. 1899 als Stephanie Olsen in Wien, Ausbildung an der Graphischen Lehr- und Versuchsanstalt in Wien. Sie arbeitet im Atelier von Trude Fleischmann, zieht 1926 mit ihrem Mann, dem Architekten Ernst Brandl, nach Berlin und eröffnet am Kurfürstendamm 211 ein Fotostudio. Sie fotografiert bekannte Berliner Künstlerinnen und Künstler, Schauspielerinnen und Schauspieler, Tänzerinnen und Intellektuelle und veröffentlicht ihre Bilder in der deutschen und österreichischen illustrierten Presse. Nach 1933 emigriert die Fotografin jüdischer Herkunft nach New York, wo sie 1966 stirbt.

Brandt, Bill, geb. am 3. Mai 1904 in Hamburg als Hermann Wilhelm Brandt, lebt nach einem Kuraufenthalt in Davos (Schweiz) von 1927 bis 1930 in Wien und hält sich auch in den 1930er Jahren (1933, 1934) mehrfach in Wien auf. Über Eugenie Schwarzwald kommt er in Kontakt mit der Atelierfotografin Grete Kolliner, bei der er ab 1928 das Fotografieren erlernt. Seit Anfang der 1930er Jahre veröffentlicht er in der deutschen und österreichischen illustrierten Presse, u. a. Straßen- und Alltagsszenen. Seit 1931 lebt er hauptsächlich in London, wo er als Fotograf bekannt wird. Er stirbt am 20. Dezember 1983 in London.

Braun, Felix, Wiener Fotoamateur, der seit Mitte der 1930er Jahre in der illustrierten Presse veröffentlicht. Seine Themen sind Sozialstudien, Straßenund Alltagsszenen.

Brieger, A., Wiener Amateurfotograf, der in den 1930er Jahren gelegentlich Bilder in der Presse veröffentlicht.

Brodt, Victor (auch Viktor), geb. am 20. Oktober 1878 in Brusau, Mähren, Wiener Journalist und Sportfotograf, der seit 1911 für Sportzeitungen fotografiert, teilweise unter dem Kürzel „Vibro“. Sein Spezialgebiet ist der Fußball, er dokumentiert aber auch Skiveranstaltungen sowie Auto- und Motorradrennen. Nach dem Ersten Weltkrieg ist er Redakteur des Illustrierten Sportblatts. Brodt, der jüdischer Herkunft ist, überlebt die NS- und Kriegszeit in Wien. Er stirbt am 20. November 1952 in Wien.

Brodtfeld, Elsa, Fotografin, die Anfang der 1930er Jahre im sozialdemokratischen Kuckuck veröffentlicht.

Broser, Gustav, Wiener Fotograf, der seit den 1890er Jahren ein Atelier in der Landstraßer HauptstraBe 23, Wien 3 (später in der Strohgasse 14b, Wien 3) betreibt und um die Wende zum 20. Jahrhundert auch als Pressefotograf tätig ist.

Brühlmeyer, Hermann, geb. am 8. März 1892 in Passau, absolviert 1907 bis 1909 die Lehr- und Versuchsanstalt für Fotografie in München. Ab 1920 betreibt er zusammen mit seiner Frau Valerie ein Atelier in Baden und ein weiteres in Wien. Daneben ist er als künstlerischer Fotograf innerhalb der ös- terreichischen Fotoamateurbewegung tätig. Er ist noch nach dem Ersten Weltkrieg ein Anhänger des Piktorialismus und steht in den 1930er Jahren der Heimatfotografie nahe. Brühlmeyer stellt seine Bilder regelmäßig im In- und Ausland aus und veröffentlicht seit Mitte der 1920er Jahre in der illustrierten Presse. Er stirbt am 11. Januar 1966 in Baden bei Wien.

Bruner-Dvořák, Ruda (Rudolf), geb. am 2. Juli 1864 im tschechischen Přelouč, ist seit den 1890er Jahren als Pressefotograf tätig. Er gilt als Pionier der tschechischen Pressefotografie und fotografiert vor allem den österreichischen und tschechischen Adel sowie Mitglieder des Kaiserhauses, u. a. den Thronfolger Franz Ferdinand. 1904 gründet er in Prag die illustrierte Zeitung Cěský svět (Tschechische Welt). Seit den späten 1890er Jahren veröffentlicht er seine Aufnahmen in österreichischen illustrierten Zeitungen. Er stirbt am 30. Oktober 1921 in Prag.

Bude, Leopold, geb. am 13. November 1840 in Wien, Ausbildung als Chemiker und Fotograf, eröffnet 1863 ein Atelier in Graz und ist in der zweiten Hälfte des 19. Jahrhunderts der führende Fotograf in der Stadt. Er fotografiert Porträts, Stadtansichten und Genreszenen. Um 1900 liefert er seine Aufnahmen auch an die illustrierte Presse. Er stirbt am 31. August 1907 in Graz.

Casparius, Hans, geb. am 15. Juli 1900 in Berlin, beginnt während des Ersten Weltkriegs mit der Fotografie, übernimmt 1924 nach dem Tod seines Vaters für ein Jahr dessen Textilunternehmen. Anfang der 1920er Jahre macht er eine Ausbildung zum Schauspieler, 1928 übernimmt er erste Filmrollen und beginnt parallel dazu als Filmfotograf zu arbeiten. Erste Bilder erscheinen in illustrierten Filmzeitschriften. Ab 1930 unternimmt er zusammen mit dem Wiener Arnold Höllriegel zahlreiche längere Reisen, auf denen er fotografiert. Er veröffentlicht seine Reisebilder in der illustrierten Presse. Ab 1932 lebt er für einige Jahre in Wien. Hier baut er im Auftrag der 1932 neu gegründeten Zeitschrift Jedermann ein Redaktionsarchiv auf und arbeitet als Pressefotograf. Er stellt Reisereportagen zusammen, fotografiert Landschaften und liefert Bilder zu Sozial- und Alltagsthemen an die Presse. Von Wien aus arbeitet er als Korrespondent der französischen Zeitung $\mathrm{Pa}$ ris-soir. 1934 erscheint in Wien sein Fotobuch über Palästina. 1935 zieht er zusammen mit seiner aus Wien stammenden Frau Monika nach London, wo er weiterhin als Fotograf tätig ist, sich der Farbfotografie zuwendet und ein Atelier eröffnet. Nach 1945 arbeitet er von London aus im Bereich Firmenwerbung und weiterhin als Reise- und Zeitschriftenfotograf. Er stirbt am 16. Mai 1986 in London.

Cechal, Hans, geb. am 10. Juli 1907 im böhmischen Náchod, Fotoamateur in Wien, der dem Neuen Sehen nahesteht. Er ist seit 1925 Mitglied der Arbeiterfotogruppe der Naturfreunde Meidling und stellt seine Bilder in zahlreichen Ausstellungen aus, u. a. 1930 in Wien in der Schau „Film und Foto“ (FiFo). Seit 1929 erscheinen seine Bilder auch in der sozialdemokratischen Illustrierten Kuckuck, nach dem Verbot aller sozialdemokratischen Organisationen (1934) arbeitet er als Fotoamateur. Er gerät als Soldat im Zweiten Weltkrieg in Kriegsgefangenschaft und kehrt 1950 zurück. Danach weiterhin Tätigkeit als Amateur. Er stirbt am 2. Oktober 1988 in Rottenmann, Steiermark.

Cešanek, Fred, geb. am 12. Februar 1896 in Wien, arbeitet seit 1925 als Pressefotograf. Mitte 1928 schließt er sich mit dem Fotografen Leo Ernst zur Vertriebsgemeinschaft „Ernst \& Cešanek“ zusammen. 1929 kooperieren die beiden unter dem Agenturnamen „Austrophot - Willinger, Ernst \& Cešanek“ mit der Fotoagentur Wilhelm Willingers. Ab 1931 ar- beitet Cešanek wieder unter eigenem Namen für die Presse.

Chat, Liesel (Elisabeth), Absolventin der Graphischen Lehr- und Versuchsanstalt in Wien (1935), Amateurfotografin in Wien, sie ist mit ihren Bildern seit 1935 gelegentlich in der illustrierten Presse und in Fotozeitschriften präsent.

Chmel, Lucca, geb. am 5. Dezember 1911 in Wien als Maria Lucia Chmel, 1931 bis 1933 Ausbildung zur Fotografin an der Graphischen Lehr- und Versuchsanstalt, Privatunterricht bei Rudolf Koppitz, 1933 bis 1936 Arbeit im Atelier R. Pokorny, 1937 bis 1939 Assistentin für Fotografie an der Graphischen Lehr- und Versuchsanstalt. Sie übernimmt 1939 das Atelier „Clairon“ am Loquaiplatz 13/15, Wien 6. Seit den frühen 1930er Jahren entstehen Genrebilder, Porträts, Gesellschafts- und Sozialstudien sowie Landschaftsaufnahmen, teilweise im Stil der gemäßigten Moderne. Im Auftrag des Salzburger Landesfremdenverkehrsamtes macht sie 1936 Landschaftsaufnahmen für die Tourismuswerbung. Seit 1937/38 entstehen auch Mode- und Theateraufnahmen. Seit 1932 veröffentlicht sie ihre Bilder in Zeitungen und Zeitschriften. Am 1. Juli 1940 wird sie NSDAP-Mitglied und profitiert in der Folge auch beruflich von ihrer Nähe zum Regime. Nach 1945 ist sie als Theater-, Werbe- und Architekturfotografin tätig und gibt Bildbände heraus. Sie stirbt am 19. März 1999 in Wien.

Christian, Dolf, Grazer (Presse-)Fotograf, der in den 1930er Jahren tätig ist.

Comeriner, Erich, geb. am 3. Juli 1907 in Wien, wächst in Berlin auf, Ausbildung bei diversen deutschen Künstlern der Avantgarde und am Bauhaus (1927/28). Er fotografiert seit 1924 und arbeitet seit 1927 für die von Rudolf Birnbach geführte Fotoagentur „Weltrundschau“. 1928 eröffnet er unter dem Namen „comofot“ ein Atelier in Berlin und arbeitet, teilweise zusammen mit László Moholy-Nagy, im Bereich Werbegrafik und Bühnenbild. 1929 nimmt er an der Ausstellung „Film und Foto“ (FiFo) teil. Er ist jüdischer Herkunft und emigriert 1934 nach Palästina, arbeitet dort zunächst in einem Kibbuz und ab 1940 in Tel Aviv als Fotograf und Werbegrafiker. Er stirbt am 7. April 1978 in Tel Aviv.

Csík (auch Tschik), siehe Tschik, Ferenc.

Csörgeő, Tibor, geb. am 9. Januar 1896, ungarischer Fotograf und Fotopublizist, Schüler von Ernő Vadas, Kálmán Szöllőssy und Rudolf Járai. Vertreter der konservativen ungarischen Moderne, nimmt an zahlreichen Ausstellungen teil und veröffentlicht seine Bilder in den 1930er Jahren u. a. in österreichischen Magazinen. Er wird durch die ungarische Fotoagentur III-Pho vertreten. Er ist ein Pionier der ungarischen Farbfotografie und wird 1942 für seine Farbdiapositive ausgezeichnet. Er stirbt am 29. Juli 1968 in Budapest.

Defner, Adalbert, geb. am 19. Januar 1884 in Millstatt, Studium der Naturwissenschaften an der Universität Wien, ab 1911 Lehrer an Wiener Gymnasien, fotografiert während des Ersten Weltkriegs, arbeitet seit 1919 als Fotograf und eröffnet im selben Jahr eine Werkstatt für Fotografie in Wernigerode/Harz, seit 1924 betreibt er ein Atelier in Innsbruck, seit 1929 in Igls bei Innsbruck. Er spezialisiert sich auf Architektur-, Natur- und Landschaftsfotografie und verkauft die Motive über den eigenen „Lichtbildverlag Dr. A. Defner" als Postkarten und Kalender, die er z. T. selbst herstellt. Mitglied der NSDAP ab 1938. Er stirbt am 15. Dezember 1969 in Hochzirl bei Innsbruck.

Deutsch, Luise, absolviert zwischen 1933 und 1935 die Graphische Lehr- und Versuchsanstalt in Wien, seit 1936 erscheinen ihre Bilder gelegentlich in der Presse. 
Dicker, Friedl, geb. am 30. Juli 1899 in Wien, 1912 bis 1914 Studium der Fotografie an der Graphischen Lehr- und Versuchsanstalt, anschließend Textilausbildung an der Wiener Kunstgewerbeschule, 1916 bis 1919 nimmt sie Unterricht an der Privatschule von Johannes Itten in Wien, dem sie 1919 ans Bauhaus in Weimar folgt. Von 1921 bis 1923 arbeitet sie als Bühnen- und Kostümbildnerin (u. a. für Bertolt Brecht). 1923 eröffnet sie zusammen mit dem Designer und Architekten Franz Singer ein künstlerisches Atelier in Berlin, das sie ab 1926 in Wien führt. Sie entwirft moderne Inneneinrichtungen, etwa für Geschäftsräume, und Bucheinbände, als Typografin produziert sie Werbematerialien. Zwischen 1930 und 1933 gestaltet sie politische Fotomontagen. 1934 flüchtet sie von Wien nach Prag, 1942 wird sie ins KZ Theresienstadt deportiert und am 9. Oktober 1944 in Auschwitz ermordet.

Dietrich, Hans, geb. am 30. Juni 1868 im mährischen Zauchtl, lebt seit 1894 in Wien, Ausbildung zum Bildhauer an der Akademie der bildenden Künste in Wien. Infolge einer Augenerkrankung wechselt er zur Fotografie und eröffnet 1922 ein Atelier in Wien, parallel dazu arbeitet er als Pressefotograf. Er spezialisiert sich auf die Theaterfotografie. Seit Anfang der 1930er Jahre betreibt er unter dem Namen „Dietrich \& Co." auch eine Fotoagentur, die aktuelle Nachrichtenbilder aus allen Bereichen anbietet. Er ist ein früher Anhänger der nationalsozialistischen Bewegung in Österreich und vertreibt über die Agentur zahlreiche Aufnahmen von Parteiveranstaltungen. Ende 1938 wird seine Agentur von der Bildagentur Heinrich Hoffmanns übernommen. Deren österreichische Bilder werden zunächst unter dem Namen „Hoffmann (Dietrich \& Co.)“ vermarktet, später taucht der Zusatz „Dietrich“ nicht mehr auf. Dietrich stirbt am 19. Juli 1950 in Mariazell.

Distler, Hans, Wiener Amateurfotograf, der in den 1930 er Jahren an zahlreichen Ausstellungen teilnimmt und seine Bilder in Fotozeitschriften und $\mathrm{Ma}-$ gazinen veröffentlicht.

Dittera, Karl, geb. 1887 in Nagyszeben (Hermannstadt, heute: Sibiu, Rumänien), arbeitet vor und während des Ersten Weltkrieges für die bekannte in Budapester Zeitung Az Est (Der Abend). Seit 1915 ist er als Kriegsfotograf im österreichischen Kriegspressequartier tätig. Seine Aufnahmen erscheinen in $A z$ Est, aber auch in österreichischen Blättern.

Dobrowolny, Otto, Wiener Amateurfotograf, seit 1927 Mitglied der Photographischen Fachgruppe der Volkshochschule Wien-Ottakring, ist seit Ende der 1920er auf zahlreichen Ausstellungen präsent, seine Bilder werden v. a. in Fotozeitschriften und im sozialdemokratischen Kuckuck veröffentlicht.

Doliwa, Anton, geb. am 21. November 1905 in Luxemburg, erlernt die Fotografie beim Wiener Pressefotografen Stanislaus Wagner. Er ist Mitarbeiter der Fotoagentur Schostal, seit Mitte 1938 erscheinen die Aufnahmen unter seinem Namen in der Presse. Er fotografiert Sport, aber auch politische Veranstaltungen. Im Zweiten Weltkrieg ist er Mitglied einer Propagandakompanie (PK) der deutschen Wehrmacht. Nach 1945 arbeitet er als Theater- und Pressefotograf in Wien.

Dorfner, Anita, geb. am 17. Oktober 1907 in Baden bei Wien, absolviert 1923 bis 1925 eine Ausbildung an der Graphischen Lehr- und Versuchsanstalt in Wien. Seit 1932 erscheinen einige ihrer Bilder und Fotoreportagen in der Presse. 1937 eröffnet sie in der Wiener Operngasse 23, Wien 4, ein Atelier. Nach 1938 verlieren sich ihre Spuren.

Dornach, Karl, geb. am 7. Mai 1878 in Leogang, 1897 bis 1899 Ausbildung an der Grafischen Lehr- und Versuchsanstalt in Wien, betreibt seit 1902 ein Fotoatelier in Innsbruck sowie seit 1927 Filialen in Ehrwald, Seefeld und Gerlos. Ab Mitte der 1920er
Jahre erscheinen seine Aufnahmen, u. a. Tiroler Landschaften, Architektur und Fotoreportagen aus dem ländlichen Leben, in Zeitungen und Zeitschriften. Er profitiert vom Nationalsozialismus und kann nach 1938 problemlos weiterarbeiten. Er stirbt 1958 in Innsbruck.

Dulovits, Jenő, geb. am 22. Juni 1903 in Budapest, fotografiert seit seiner Kindheit. Studium an der Universität Budapest, nach seinem Abschluss 1927 arbeitet er als Mathematiklehrer und daneben als Fotograf und Filmkameramann. Er ist auf zahlreichen Fotoausstellungen vertreten. Seine Bilder veröffentlicht er, vertreten durch die Fotoagentur IIIPho, auch in österreichischen Magazinen. Ab den 1930 er Jahren publiziert er mehrere Bücher über Fototechnik. Er stirbt am 24. Juli 1972 in Budapest.

Eggarter, Willy (Wilhelm), geb. am 29. Februar 1912 in Wiener Neustadt, 1929/30 Ausbildung zum Fotografen an der Graphischen Lehr- und Versuchsanstalt in Wien, arbeitet seit 1932 als Pressefotograf (Anmeldung des Gewerbes: 1933). Seine Sachaufnahmen, Straßen- und Genreszenen, Porträts und Werbeaufnahmen sind von der Neuen Sachlichkeit und dem Neuen Sehen beeinflusst. Seit Anfang der 1930er Jahre lebt er zeitweise in Paris, wo er zahlreiche Fotoreportagen aufnimmt. 1935 zieht er zur Gänze in die französische Hauptstadt. Seine Bilder erscheinen seit Anfang der 1930er Jahre u. a. in der österreichischen illustrierten Presse und in Fotofachzeitschriften.

Eisenstaedt, Alfred, geb. am 6. Dezember 1898 in Dirschau (Tczew, heute Polen), nach dem Ersten Weltkrieg Kurzwarenverkäufer, beginnt 1927 Bilder an die Presse zu verkaufen, seit 1929 arbeitet er als freiberuflicher Pressefotograf. Er wird mit seinen Porträts und Reportagen bekannt. 1935 emigriert er in die USA, wo er mit seinen Reportagen in allen großen Zeitschriften vertreten ist. Er stirbt am 24. August 1965 in New York City.

Elbl, Oswald, geb. 1893, erlernt 1910 das Fotografieren, seit Mitte der 1920er Jahre arbeitet er als Fotoamateur. Ab 1934 erscheinen seine Bilder in der Presse. Es sind meist konservative Motive: Trachtenszenen, ländliche Arbeit, Land und Leute, Genreszenen. Elbl steht der Heimatfotografie nahe. Nach 1938 passt er sich problemlos an die neue politische Situation an.

Ellinger, Karl (auch Carl), Atelierfotograf in Salzburg, der seine Tätigkeit wenige Jahre nach der Jahrhundertwende beginnt und vor dem Ersten Weltkrieg ein eigenes Atelier betreibt. Nach dem Ersten Weltkrieg arbeitet er auch für die Presse. Seit Beginn der Salzburger Festspiele (1920) ist Ellinger der Festspielfotograf. Er dokumentiert Jahr für Jahr Stars und Aufführungen für die Presse. Den politischen Umbruch 1938 übersteht er bruchlos, 1939 fotografiert er etwa Adolf Hitler während einer Festspielaufführung in einer Loge.

Ender, Karl, Wiener Amateurfotograf, seit ca. 1927 Mitglied der Photographischen Fachgruppe der Volkshochschule Wien-Ottakring, ab 1928 ihr Obmann, stellt seine Bilder seit Ende der 1920er Jahre in zahlreichen Ausstellungen aus.

Erdélyi, Mór, geb. am 3. Dezember 1866, eröffnet 1888 ein Atelier am Budapester Elisabethplatz und 1891 ein zweites in der Lajos-Kossuth-Straße. Zu seinen Kunden zählt die höhere bzw. aristokratische Gesellschaft, er fotografiert u. a. deren Schlösser und Wohnsitze. Seit Ende der 1890er Jahre arbeitet er auch als Pressefotograf. Seine Aufnahmen, etwa von gesellschaftlichen Großereignissen, erscheinen seit 1901 auch in österreichischen Illustrierten. In der Zwischenkriegszeit arbeitet er als Pressefotograf v. a. für die Zeitungen Új Idők (Neue Zeiten) und Vasárnapi Ujság (Sonntagsblatt). Er stirbt am 11. März 1934 in Budapest.

Ernst, Leo, geb. am 28. April 1904 in Schwaz, Tirol, arbeitet seit der Zwischenkriegszeit als Presse- und Sportfotograf, um 1928 zusammen mit Fred Cešanek, nach 1931 mit Albert Hilscher, 1938, nach dem „Anschluss“ Österreichs an das nationalsozialistische Deutschland, kündigt Hilscher seinem Partner Ernst, der jüdischer Herkunft ist, die Zusammenarbeit auf. Er flüchtet in die USA und kehrt 1947 als Vertreter einer amerikanischen Agentur nach Österreich zurück, wo er wieder als Pressefotograf tätig ist. Anfang Dezember 1965 zieht er nach Los Angeles.

Exax, Alexander, geb. am 2. Dezember 1896 in Mürzzuschlag, 1911 bis 1914 Besuch der Graphischen Lehr- und Versuchsanstalt in Wien, 1914 bis 1917 als jüngster österreichischer Kriegsfotograf im Kriegspressequartier, Vertrieb der Bilder über die Fotoagentur Kilophot an die Presse. Nach dem Krieg arbeitet er als Reise- und Porträtfotograf, ab 1925 ist er für eine Werbeagentur tätig. Nach 1945 lebt er in Kärnten, wo er als Grafiker für die Wirtschaftskammer arbeitet. Er stirbt am 19. April 1994 in Klagenfurt.

Exinger, Otto, geb. am 22. Juni 1897 in Wien, arbeitet als Maler und in der Werbebranche. Seit den späten 1920er Jahren ist er als Amateurfotograf tätig, er fertigt, teilweise zusammen mit Franz Senkinc, Sach- und Werbeaufnahmen im Stil der Neuen Sachlichkeit an. Er stirbt am 20. Juli 1957 in Wien.

Eywo, Hugo Ritter von, geb. am 13. Februar 1877 in Wien, gründet 1914 die Fotoagentur „Wiener Photo-Centrale“, seit 1914 ist er als Kriegsfotograf und (Film-)Kameramann im Kriegspressequartier tätig. Nach Kriegsende arbeitet er als Pressefotograf in Wien und als Leiter der Fotoagentur. Er stirbt 1953 in Wartberg an der Krems.

Fabian, M., Pressefotograf in Brünn, seine Bilder werden seit 1901 auch in österreichischen Zeitungen veröffentlicht.

Fachet, Martin, geb. am 6. Juni 1872 in Böhmen, führt seit 1901 ein Fotoatelier in Wien, veröffentlicht gelegentlich Presse- und Sportfotos (v. a. Fußball) in illustrierten Zeitungen. Er stirbt am 7. November 1950 in Wien.

Fanta, Philipp, Wiener Amateurfotograf, seit ca. 1927 Mitglied der Photographischen Fachgruppe der Volkshochschule Wien-Ottakring, ist seit Ende der 1920er Jahre auf Ausstellungen präsent.

Fayer, Georg, geb. 1892 in Budapest, Fotoausbildung in Budapest, zieht 1916 nach New York, wo er als Fotograf tätig ist. Nach dem Ersten Weltkrieg geht er nach Wien und betreibt ab 1925 zusammen mit Car Pietzner jun. das Atelier „Pietzner \& Fayer“. Parallel dazu arbeitet der Fotograf auch unter dem Namen „Fayer“. 1936 eröffnet er ein zusätzliches Atelier in London, in dem auch seine Tochter Lilian Fayer arbeitet. Seit Mitte der 1920er Jahre veröffentlicht er in der illustrierten Presse, v. a. Porträts und Theaterbilder. 1938 wird sein Wiener Atelier zwangsweise enteignet (,arisiert“), Fayer, der jüdischer Herkunft ist, flüchtet zunächst nach London, dann nach New York, wo er erneut ein Atelier eröffnet. Er stirbt am 5. November 1950 in Cannes.

Fayer, Lilian, Tochter von Georg Fayer, erlernt 1935 bis 1937 im Londoner Atelier ihres Vaters das Fotografieren. Sie führt die Wiener Filiale des Unternehmens, in der Nachkriegszeit zusammen mit Georg und Andreas Barylli.

Fein, Martha, verh. Spraider, geb. am 26. Juni 1894 in Sloup, Mähren, besucht 1909 bis 1912 die Graphische Lehr- und Versuchsanstalt in Wien und betreibt ab ca. 1915 ein Atelier in Wien. In der Zwischen- 
kriegszeit konvertiert Fein, die jüdischer Herkunft ist, zum Katholizismus. Am 28. Oktober 1941 wird sie, zusammen mit ihrem Mann, Josef Spraider, in das Getto Lodz deportiert. Hier verliert sich ihre Spur.

Feldscharek, Pepa (Josefine), geb. am 8. Juni 1899 in Náchod, Böhmen, absolviert 1914 bis 1918 die Graphische Lehr- und Versuchsanstalt in Wien. Sie eröffnet im Juli 1920 ein Fotoatelier an der Fischerstiege 9, Wien 1, spezialisiert sich neben Schauspieler- und Künstlerporträts auf Mode-, Akt- und Tanzfotografie und veröffentlicht in der Zwischenkriegszeit regelmäßig in der illustrierten Presse. 1925 heiratet sie Dr. Fritz Schreier, nimmt seinen Namen an, arbeitet aber als Fotografin weiterhin unter ihrem Mädchennamen. 1938 wird das Atelier Feldschareks, die jüdischer Herkunft ist, „arisiert“. Sie flieht nach New York, Ende der 1940er Jahre lebt sie unter dem Namen Josefine Schreier in Narberth, Pennsylvania, danach verliert sich ihre Spur.

Fenichel, Max (auch Menasche/Menasse), geb. am 2. Juli 1885 in Tarnow, Galizien, zieht 1915 nach Wien, wo er seit 1917 in der Kenyongasse 27, Wien 7, ein Atelier betreibt. Seit 1918 ist er auch als Pressefotograf tätig. Er spezialisiert sich auf Künstlerporträts und Theateraufnahmen und stellt um 1920 auch Reportagen zu sozialen und alltäglichen Themen zusammen. Er ist jüdischer Herkunft und wird im Oktober 1941 nach Lodz deportiert, wo er am 16. September 1942 ermordet wird.

Feuerzeug, Aron Adolf, geb. 1864 oder 1865, betreibt seit den 1890er Jahren ein Atelier in Wien und arbeitet daneben als Sportfotograf, wobei er sich auf den Pferderennsport spezialisiert. Seine Aufnahmen erscheinen in der illustrierten Presse. Er stirbt am 10. September 1937.

Fiedler, Leopold, Amateurfotograf, der Ende der 1930er Jahre Skisportfotos in der illustrierten Presse veröffentlicht.

Findeis, Heinrich, österreichischer Fotograf, der ab 1915 als Kriegsfotograf und (Film-)Kameramann im Kriegspressequartier tätig ist.

Fink, Alexander, Fotograf in Pressburg (heute Bratislava, Slowakei), der um 1900 gelegentlich Pressebilder in österreichischen Zeitungen veröffentlicht.

Fleischmann, Trude, geb. am 22. Dezember 1895 in Wien, absolviert 1913 bis 1916 eine Ausbildung an der Graphischen Lehr- und Versuchsanstalt in Wien und 1916 bis 1919 eine praktische Berufsausbildung im Atelier von Hermann Schieberth am Opernring 11. Anfang 1920 eröffnet sie in der Ebendorferstraße 3 ein Atelier, in dem sie zahlreiche bekannte Persönlichkeiten aus Gesellschaft, Kunst und Kultur porträtiert. Es entstehen auch Tanz- und Aktaufnahmen. Seit den 1920er Jahren liefert sie regelmäßig Bilder an die österreichische und deutsche illustrierte Presse. Neben Porträts von Schauspielerinnen und Schauspielern, Künstlerinnen und Künstlern veröffentlicht sie auch Reise-, Landschafts- und Heimataufnahmen, ab Mitte der 1930er Jahre immer wieder auch Fotoreportagen. Fleischmann, die jüdischer Herkunft ist, flüchtet 1938 über Paris und nach New York, wo sie 1940 gemeinsam mit dem Wiener Emigranten Franz Elmer (Frank Epstein) ein Fotostudio in Manhattan eröffnet, das sie bald allein weiterführt. 1942 wird sie amerikanische Staatsbürgerin. Sie fotografiert bekannte Künstlerinnen und Künstler sowie Intellektuelle, oft sind es Emigranten wie sie. Auf ihren privaten Reisen, etwa nach Mexiko, entstehen Reisebilder und Landschaftsaufnahmen. 1969 zieht sie ins schweizerische Lugano, 1988 kehrt sie aus gesundheitlichen Gründen in die USA zurück. Sie stirbt am 21. Januar 1990 in Brewster, New York.

Fliesz, Rudolf, Wiener Sportfotograf um 1900, der v. a. Radrennen fotografiert.
Floeck (auch Flöck), Arthur (auch Artur), geb. 1860 in Meran, betreibt seit den 1890er Jahren ein Atelier in Görz, zieht nach der Jahrhundertwende nach Wien, wo er ebenfalls ein Atelier eröffnet. Seit 1900 arbeitet er auch als Pressefotograf, er spezialisiert sich auf Fotografien des Adels und des Kaiserhauses. Er stirbt am 8. April 1933.

Flöter, Hubs (Hubertus), geb. 1910 in Köln, arbeitet seit 1938 als Modefotograf, teilweise auch in Wien, u. a. im Wiener „Haus der Mode“, 1940 bis 1941 Leiter der Bildstelle der UFA, arbeitet nach 1945 als Mode- und Reportagefotograf. Seine Bilder erscheinen in der internationalen illustrierten Presse. Er stirbt 1974 in München.

Förster, Ernst, geb. am 4. Dezember 1879 in Wien, 1898 bis 1901 Ausbildung zum Fotografen an der Graphischen Lehr- und Versuchsanstalt, arbeitet anschließend im väterlichen Atelier Adèle am Graben 19, Wien 1, dessen Führung er 1910 übernimmt. Nach dem Ersten Weltkrieg wird es in „Adèle-Förster" umbenannt. Zahlreiche seiner Aufnahmen, v. a. Porträts von Bühnenstars, Theateraufnahmen, Tanzstudien und Aktbilder, erscheinen in Zeitungen und Zeitschriften. Förster ist jüdischer Herkunft und flüchtet 1938 nach Prag. 1942 wird er nach Theresienstadt deportiert, wo er am 26. Juli 1943 in ermordet wird.

Frank, Otto, Fotograf in Olmütz (Olomouc, Tschechien), der um 1900 gelegentlich in österreichischen Zeitungen aktuelle Pressebilder veröffentlicht.

Frankl, Eduard, Pressefotograf, der vor dem Ersten Weltkrieg in Berlin eine Fotoagentur betreibt, arbeitet seit 1914 als Kriegsfotograf, zuerst an der deutschen Westfront, dann ab Frühjahr 1915 als Fotograf im österreichischen Kriegspressequartier an der Ost- und Balkanfront.

Franta, Sportfotograf aus Brünn, der in den 1920er Jahren viel in der österreichischen illustrierten Presse veröffentlicht.

Freiberger, Paul, geb. am 9. Juni 1896 in Wien, Amateurfotograf, der in seinen Bildern die Anregungen des Neuen Sehens aufnimmt, er beteiligt sich seit den späten 1920er Jahren an zahlreichen Ausstellungen, u. a. an der „Film und Foto“ (FiFo) in Wien 1930. Er ist jüdischer Herkunft und überlebt den Holocaust. Er stirbt am 8. Juli 1962 in Wien.

Freiwirth, Desider, Amateurfotograf, der im Stil der Moderne arbeitet. Er fotografiert den Wiener Alltag, Sozial- und Straßenszenen und gestaltet gelegentlich Fotoreportagen. Seine Aufnahmen erscheinen nach 1930 in Zeitungen und Zeitschriften.

Freyberger, Beatrice, verh. Jordan, geb. am 9. Juli 1901 in Wien, 1917 bis 1919 Ausbildung als Fotografin an der Graphischen Lehr- und Versuchsanstalt in Wien, führt von 1922 bis 1930 ein Atelier in der Kirchengasse 41, Wien 7. Zusammenarbeit mit dem Atelier Dietrich. Ihre Bilder, Porträts, Theater- und v. a. Modeaufnahmen erscheinen seit 1923 unter dem Namen „Freyberger \& Dietrich“ in der illustrierten Presse.

Fritzek, F., Wiener Fotoamateur, der sich um 1930 im Umfeld der Arbeiterfotografen bewegt und in der sozialdemokratischen Presse veröffentlicht.

Fukarek, Emil, Fotograf in Wien, der seit den 1890er Jahren ein Atelier und einen Fotohandel in der Wollzeile 34, Wien 1, später in der Neustiftgasse 33, Wien 7, betreibt. Seit 1898 ist er auch als Pressefotograf tätig.

Fürböck, Ernst, Onkel von Ernst Matthäus Fürböck, geb. am 21. Januar 1873 in St. Willibald, Amateurfotograf und Fotopublizist in Linz, Funktionär in der Amateurfotografenbewegung, nach dem Ersten Weltkrieg auch Architektur- und Industriefotograf. Publiziert zahlreiche Landschaftsfotos in Magazinen und Fotofachzeitschriften. Er stirbt am 4. Juni 1937 in Linz.
Fürböck, Ernst Matthäus, geb. am 5. Januar 1904 in Bad Aussee, Fotografenausbildung in Linz, zieht 1924 nach Graz und übernimmt zunächst das Atelier seiner Mutter und führt dann einen eigenen Betrieb. Arbeitet seit 1924 auch als Fotolehrer und spezialisiert sich auf Architektur- und Industriefotografie, Mitglied des Werkbundes und Anhänger des Neuen Sehens. Er publiziert seine Bilder in der fotografischen Fachpresse und in illustrierten Zeitungen. Er vertritt ein deutschnationales Weltbild, das inn schon sehr früh zur nationalsozialistischen Bewegung führt (Mitglied der NSDAP 1930). Nach dem „Anschluss“ 1938 arbeitet er bruchlos weiter. Er ist nach dem Zweiten Weltkrieg als Berufsschullehrer für Fotografie in Graz tätig. Er stirbt am 15. September 1981 in Graz.

Furthner (auch Furtner), Hans, Amateurfotograf in Linz, der in der Zwischenkriegszeit mit seinen konservativen Landschaftsbildern der Heimatfotografie nahesteht und seine Motive auch in der Zeit des Nationalsozialismus veröffentlicht.

Gabriel, Franz, geb. 1881 oder 1882, führt (zunächst mit Anton Schistal, später allein) ab 1905 in Wien eine „Kunstanstalt für moderne Fotografie und Malerei“. Veröffentlicht vor dem Ersten Weltkrieg gelegentlich aktuelle Pressebilder in Zeitungen. Er stirbt am 12. Februar 1947 in Wien.

Geiringer, Trude (Gertrude), geb. am 1. Februar 1890 in Wien als Gertrude Neumann, besucht die Schule von Eugenie Schwarzwald. 1912 Heirat mit Ernst Geiringer. Sie beginnt als Amateurin zu fotografieren, gründet im Juli 1925 gemeinsam mit der Berufsfotografin Dora Horovitz am Wiener Stubenring 2, Wien 1 , das Atelier „Geiringer \& Horovitz“, das sich auf Porträts von Schauspielerinnen und Schauspielern, Mode- und Tanzfotografie spezialisiert und Bilder an die illustrierte Presse liefert. Geiringer und Horovitz arbeiten bis Anfang 1934 zusammen, dann scheidet Trude Geiringer aus dem Unternehmen aus, Horovitz führt es allein weiter. Geiringer, die - wie Horovitz jüdischer Herkunft ist, flüchtet im Juli 1938 gemeinsam mit ihrem Mann nach London, im Oktober 1938 gehen sie nach New York, wo Trude Geiringer für kurze Zeit im Atelier Apeda tätig ist und danach einige Zeit ihr eigenes Atelier führt; danach fotografiert sie nur noch privat. Bis 1949 lebt sie in New Rochelle, später in Pine Bluff, Arkansas, und zuletzt in Larchmont, New York, wo sie am 15. Juli 1981 stirbt.

Georgi, Sonja, geb. am 17. November 1915 in Berlin, bis 1935 Ausbildung zur Fotografin bei ihrer Mutter, der Porträt- und Modefotografin Hedda Walther, 1935 Besuch der Letteschule in Berlin, betreibt seit 1936 ein Atelier in Berlin. Sie arbeitet als Modefotografin vor allem in Berlin, nach 1938 aber auch in Wien. Sie arrangiert sich mit dem Nationalsozialismus und kann während der ersten Jahre des Krieges problemlos weiterarbeiten. Zahlreiche Publikationen in der illustrierten Presse vor und nach 1945. Seit 1952 betreibt sie ein Atelier in Hamburg und arbeitet weiterhin als Modefotografin. Sie stirbt am 11. August 1957 in Düsseldorf.

Gerlach, Martin, geb. am 13. März 1846 in Hanau, zieht nach Jahren der Berufstätigkeit in Berlin 1874 nach Wien, wo er, zusammen mit Ferdinand Schenk ab 1882 den Kunstverlag „Gerlach \& Schenk“ führt, ab 1904 zusammen mit Albert Wiedling den Verlag „Gerlach \& Wiedling“, den sein Sohn übernimmt. Gerlach arbeitet neben der Verlagstätigkeit als Fotograf, wobei er sich auf Architektur, Pflanzenstudien und Ornamentik spezialisiert. Er stirbt am 9. April 1918 in Wien.

Gerlach, Martin, jun., geb. am 2. April 1879 in Wien, Ausbildung an der Graphischen Lehr- und Versuchsanstalt, Lehre bei Hermann Clemens Kosel und 
Franz Löwy, betreibt seit 1907 ein Atelier in Wien, spezialisiert sich auf Architekturfotografie und is zusammen mit Albert Wiedling als Verleger tätig. Der Verlag wird ab 1923 von Gerlachs Bruder Franz zusammen mit Walter Wiedling geführt. Seit 1907 veröffentlicht Martin Gerlach jun. zu Themen der Architektur und Stadtentwicklung in der illustrierten Presse. In der Zwischenkriegszeit dokumentiert er an führender Stelle die Bauprojekte des „Roten Wien“, später des „Ständestaates“ und des nationalsozialistischen Regimes. Er ist ein früher Sympathisant der nationalsozialistischen Bewegung und tritt 1942 der NSDAP bei. Er stirbt am 18. Juli 1944 Nach seinem Tod wird der Fotobetrieb von der Witwe Anna Gerlach und ab 1947 als Geschäftsführer vom Sohn Kurt Gerlach weitergeführt.

Glogau, Edith, geb. am 22. November 1898 in Wien, 1913 bis 1917 Besuch der Graphischen Lehr- und Versuchsanstalt in Wien, Lehre im Atelier d'Ora, eröffnet im November 1925 ein eigenes Atelier. 1929 heiratet sie den Pressefotografen Hans Strenitz und betreibt mit inm gemeinsam das Atelier Strenitz-Kalmar, arbeitet aber weiterhin auch unter ihrem eigenen Namen. Ab 1926 veröffentlicht sie Porträts, vor allem aber Mode- und Werbeaufnahmen in der illustrierten Presse. Im August 1938 flüchtet Glogau, die jüdischer Herkunft ist, zusammen mit ihrem Mann über Brünn nach New York. Sie arbeitet in Massachusetts und Washington DC in mehreren Fotostudios und eröffnet $1946 \mathrm{ihr}$ eigenes Atelier in Washington, D.C. Sie stirbt am 29. September 1970 in Washington, D.C

Goldhammer, Zsigmunt, Fotograf in Lemberg, der um 1900 auch gelegentlich Bilder in österreichischen illustrierten Zeitungen veröffentlicht.

Gorny, Hein, geb. am 21. April 1904 in Witten, erlernt die Fotografie als Autodidakt, arbeitet seit 1929 als Fotograf, zunächst in Hannover, dann, ab 1931, in Berlin. Er spezialisiert sich auf Porträts, Werbung, Sach- und Industriefotografie und arbeitet z. T. in der Tradition der Neuen Sachlichkeit. In den 1930er Jahren erscheinen seine Aufnahmen gelegentlich in der österreichischen Presse. Er stirbt am 14. Juni 1967 in Hannover.

Goszleth, Istvan, Fotograf in Budapest, veröffentlicht um 1900 auch gelegentlich Pressefotos in österreichischen illustrierten Zeitungen.

Grabkovicz, Hans, Wiener Fotoamateur, der im Stil der gemäßigten Moderne arbeitet. Seit 1930 Teilnahme an zahlreichen Fotoausstellungen und Publikation von Bildern in Fotozeitschriften.

Gross Margarethe, verh. Michaelis, geb. am 6. April 1902 in Dzieditz (Österreichisch-Schlesien, heute Dziedzice, Polen), besucht 1918 bis 1921 die Graphische Lehr- und Versuchsanstalt in Wien, arbeitet 1921/22 als Assistentin im Atelier d'Ora und von 1922 bis 1927 im Atelier von Grete Kolliner, zieht dann nach Berlin (und kurzzeitig nach Prag). In Berlin ist sie von 1929 bis 1933 bei mehreren Fotografinnen (u. a. Suse Byk und Yva) tätig. Seit 1933 ist sie mit Rudolf Michaelis verheiratet, sie nennt sich nun Margarethe Michaelis. Nach dem Machtantritt der Nationalsozialisten flieht sie mit ihrem Mann, der in der anarchistischen Bewegung aktiv ist, nach Barcelona, wo sie im Bereich der Architektur-, Werbe- und Dokumentarfotografie tätig ist und als Fotojournalistin arbeitet. Ihre Bilder erscheinen in zahlreichen illustrierten Zeitungen. Nach der Niederlage der Republikaner im Spanischen Bürgerkrieg zieht sie 1937 nach Paris und 1938 weiter nach London, von wo sie 1939, nach Kriegsbeginn, nach Australien emigriert. In Sydney eröffnet sie 1940 ein Fotostudio, das sie bis Anfang der 1950er Jahre betreibt. Sie spezialisiert sich auf Porträts und Tanzfotografie. Sie stirbt am 16. Oktober 1985 in Melbourne.
Grünwald, Herbert, geb. am 20. Juni 1906 in Wien, arbeitet als Journalist und Amateurfotograf, veröffentlicht seine Bilder in der Zwischenkriegszeit in Magazinen. 1938 emigriert Grünwald, der jüdischer Herkunft ist, nach London, wo er unter dem Namen Herbert de Gray als Porträt- und Filmfotograf tätig ist. Er stirbt am 25. März 1985 in London.

Gutmann, Ludwig, geb. am 23. Juni 1869 in Schaffa (Šafov), Mähren (heute Tschechien), betreibt seit 1905 ein Atelier in der Währinger Straße 18, Wien 9 , spezialisiert sich auf Porträts und Theaterfotografie, liefert seit 1906 Aufnahmen, vornehmlich Porträts von Bühnenstars und Rollenbilder, an die illustrierte Presse. 1938 wird sein Atelier zwangsenteignet (,arisiert“), Gutmann, der jüdischer Herkunft ist, wird 1942 nach Theresienstadt deportiert und dort am 18. April 1943 ermordet.

Guttmann, Simon, geb. am 15. November 1891 in Wien, wächst in Berlin auf, lebt von 1915 bis 1918 in Zürich, dann wieder in Berlin. Er verkehrt seit 1909 in künstlerischen und literarischen Kreisen und ist bis Anfang der 1920er Jahre publizistisch tätig. Ab ca. 1921 arbeitet er in der Fotoagentur von John Graudenz. 1928 ist er einer der Mitbegründer der Agentur „Deutscher Photodienst“ (Dephot), für die Fotografen wie Otto Umbehr (Umbo), Harald Lechenperg, Kurt Hübschmann, Walter Bosshard und Felix H. Man tätig sind. Bilder der Agentur Dephot werden ab 1929 auch in österreichischen Medien veröffentlicht. Nach der Machtübernahme der Nationalsozialisten in Deutschland im Jahr 1933 flüchtet Gutmann nach Paris. 1936 gründet er in Zürich die „Press Agency Zürich“, die 1937 in "Prisma Presse Service“ umbenannt wird. Vermutlich 1940 zieht er nach London, wo er ab 1946 die Bildagentur „Report“ betreibt. Er stirbt am 13. Januar 1990 in London.

Haas, Robert, geb. am 16. April 1898 in Wien, besucht von 1919 bis 1925 die Technische Hochschule in Wien, von 1920 bis 1923 die Kunstgewerbeschule, dann die Akademie der bildenden Künste, gründet 1925 zusammen mit dem Künstler Carry Hauser das grafische Atelier und die Handpresse Officina Vindobonensis, in dem er künstlerische Drucke, Plakate und Kataloge herstellt und vertreibt (Gewerbeschein seit 1927). Daneben entstehen grafische (Plakate, Buchumschläge) und kalligrafische Arbeiten. 1937 gestaltet er eine überdimensionale Fotomontage im Österreichpavillon der Pariser Weltausstellung. 1930 bis 1932 erlernt er die Fotografie bei der Wiener Atelierfotografin Trude Fleischmann. Seit ca. 1935 arbeitet er auch als Pressefotograf für österreichische und internationale Zeitungen und Zeitschriften. Er widmet sich als Fotograf einem breiten Themenspektrum, das von der Schilderung des Alltags über soziale Themen, Porträts, technische Dokumentationen, Sachaufnahmen und Werbung bis hin zu Landschafts- und Architekturbildern reicht. Seit 1936 fotografiert er bei den Salzburger Festspielen und veröffentlicht die Bilder in der Presse. Ende September 1938 flüchtet Haas, der jüdischer Herkunft ist, über London nach New York, wo er seit 1941 unter dem Namen „Ram Press“ ein Atelier für Handpressendruck führt. In den 1940er und 1950er Jahre fotografiert er daneben viel, u. a. Persönlichkeiten des öffentlichen Lebens. Er unterrichtet an mehreren Schulen und Universitäten Kalligrafie und Drucktechniken. Er stirbt am 5. Dezember 1997 in Valhalla, New York.

Hackenschmied (Hammid), Alexandr, geb. am 17. Dezember 1907 auf der Durchreise seiner Eltern in Linz als Alexander Siegfried Georg Smahel, aufgewachsen in Chrudim, einer kleinen Stadt unweit von Prag. Ende der 1920er Jahre beginnt er als Autodidakt zu fotografieren und avantgardistische Filme zu machen. Seine ersten Fotos erscheinen 1929 in der Prager Illustrierten Pestrý týden (Bunte Welt), für die seine Mutter als Redakteurin arbeitete. Um 1930 publiziert er in Zeitungen und Zeitschriften über modernen Film und moderne Fotografie. In den 1930er Jahren arbeitet er hauptsächlich als Filmregisseur, u. a. macht er Auftragsarbeiten für den Schuhfabrikanten Bata, daneben entstehen weiterhin Fotos. 1939 emigriert er in die USA, wo er, teilweise zusammen mit Maya Deren, als Avantgardefilmer tätig ist. Er nennt sich nun Alexander Hammid. Er stirbt am 26. Juli 2004 in New York City.

Hahn, Paul Edmund, geb. am 2. August 1897 in Straßburg, arbeitet zunächst als Journalist, ab 1927 ist der fotografische Autodidakt von Frankfurt aus als Pressefotograf tätig. Er beginnt schon früh Fotoreportagen zu alltäglichen und sozialen Themen zusammenzustellen, die in deutschen Illustrierten erscheinen. Seit 1930 publiziert Hahn auch regelmäßig Fotoreportagen in Österreich. 1932 beendet er seine fotografische Karriere und ab 1934 arbeitet wieder als Journalist. Er stirbt am 19. Dezember 1960 in Herford.

Hajek, Gustav, geb. am 27. April 1888, besucht $1903-$ 1904 die Graphische Lehr- und Versuchsanstalt in Wien, arbeitet als Pressefotograf mit dem Schwerpunkt Sport in Wien. Von 1934 bis 1938 ist er in Belgrad als Pressefotograf für die Fotoagentur „Illustracije“ tätig. Ab 1941 arbeitet er als Fotograf einer deutschen Propagandakompanie (PK) der deutschen Wehrmacht an der Südostfront. Er stirbt im März 1967 in Wien.

Hajek-Halke, Heinz, geb. am 1. Dezember 1898 in Berlin, verbringt seine Kindheit in Argentinien, zwischen 1915 und 1923 (unterbrochen durch den Ersten Weltkrieg) Studium an der königlichen Kunstschule in Berlin. Er arbeitet seit 1924 als Fotograf im Bereich Werbung und Presse und experimentiert daneben mit Schnitt- und Lichtmontagen, veröffentlicht in Zeitungen und Zeitschriften, u. a. auch in Österreich. Seit 1939 arbeitet er als Werksfotograf für die Dornier-Werke in Friedrichshafen am Bodensee. Nach dem Zweiten Weltkrieg arbeitet er als freischaffender Fotograf. 1949 wird er Mitglied der Gruppe Fotoform, ab 1955 ist er Professor für Fotografie an der Hochschule für bildende Künste in Berlin. Er stirbt am 11. Mai 1983 in Berlin.

Halpern, J., Amateurfotograf in Wien. Er ist seit ca. 1929 Mitglied der Arbeiterfotogruppe der Naturfreunde Meidling, stellt seine Bilder in den 1930er Jahren in zahlreichen Ausstellungen aus und publiziert Bilder in der Fotofachpresse.

Haluschka, Hugo, geb. am 17. September 1880 in Wien, bis 1906 Studium der Rechtswissenschaft, arbeitet als Jurist, Fotopublizist und Amateurfotograf in Graz. Er ist 1909 Gründungsmitglied der „Grazer Kunstphotographischen Vereinigung " und ab 1911 Schriftleiter der Zeitschrift Photographische Mitteilungen für die Alpenländer. Nach dem Ersten Weltkrieg ist er ein wichtiger österreichischer Fotofunktionär. Als Fotopublizist nimmt er gegen die neuen Strömungen der Fotografie Stellung. 1927 Mitbegründer des „Verbandes österreichischer Amateurphotographen-Vereine“, dem er bis 1937 vorsteht. Er ist in der Zwischenkriegszeit weiterhin ein Vertreter der kunstfotografischen Richtung, in seinen eigenen Fotos (u. a. Porträts, Stadtansichten, Landschaften, Genreszenen, Heimatmotive) verfolgt er ein konservatives Programm. Er stirbt am 6. September 1951 in Graz.

Hammer, Josef, Wiener Amateurfotograf, seit Ende der 1920er Jahre Mitglied der Photographischen Fachgruppe der Volkshochschule Wien-Ottakring, beteiligt sich an Fotoausstellungen und publiziert um 1930 in illustrierten Zeitungen.

Hannau, Hans, geb. am 5. August 1904 in Mödling, Studium der Rechtswissenschaft, Promotion 1928, 
arbeitet seit 1929 im höheren Polizeidienst in Wien und später in Oberösterreich. Seit den 1920er Jahren Fotoamateur und Fotopublizist, 1933 bis 1938 Leiter der Fotozeitschrift Der Lichtbildner. In seinen Texten zur Fotografie und seinen fotografischen Arbeiten (Landschaften, Genreszenen, bäuerliche Themen und Heimatmotive) verfolgt er ein konservatives Programm. Hannau ist ein wichtiger Vertreter der österreichischen Heimatfotografie. Als hoher Vertreter des „Ständestaates“ 1939 Emigration über Algier in die USA, wo er ab 1942 als gewerblicher Fotograf mit Schwerpunkt Farbfotografie u. a. im Bereich der Werbung tätig ist und zahlreiche Bildbände veröffentlicht. Er stirbt am 8. Mai 1901 in Miami Beach.

Hartmann, Ernst, geb. am 21. August 1907 in Brünn, besucht 1926 bis 1928 die Graphische Lehr- und Versuchsanstalt in Wien, danach ist er als Fotograf in Mödling tätig. Seit ca. 1930 arbeitet er auch für die illustrierte Presse, er veröffentlicht Porträts, Landschaften, Genreszenen und Architekturbilder. Er stirbt am 6. Februar 1983 in Mödling.

Hase, Elisabeth, geb. am 16. Dezember 1905 in Döhlen, 1924 bis 1929 Kunstgewerbeschule in Frankfurt, um 1930 erste Fotoarbeiten (Architektur) im Stil des Bauhauses, arbeitet seit 1932 als selbstständige Fotografin im Bereich Werbung, Sachfotografie, Porträt und Genrefotografie. Zahlreiche Veröffentlichungen in Zeitungen und Zeitschriften, ab 1935 auch in Österreich. Ihre Bilder werden ab Ende der 1930er Jahre von den Fotoagenturen Holland Press Service und Schostal vertrieben. Nach dem Zweiten Weltkrieg ist sie v. a. als Presse- und Werbefotografin tätig und macht Pflanzenaufnahmen. Sie stirbt am 9. Oktober 1991 in Frankfurt am Main.

Hauffe, Richard, geb. am 2. Dezember 1878 in Wien, arbeitet seit 1918 als Pressefotograf in Wien. In den 1920er Jahren ist er einer der bekanntesten Wiener Zeitungsfotografen, der sich vor allem der aktuellen politischen Berichterstattung widmet. Er stirbt am 15. Februar 1933 in Wien.

Hebentanz, Franz, Ausbildung an der Graphischen Lehr- und Versuchsanstalt in Wien, seit ca. 1900 Inhaber des Ateliers Valerie am Volkertplatz 14, Wien 2. Arbeitet gelegentlich für die illustrierte Presse, für die er v. a. Sportveranstaltungen dokumentiert.

Hegyei, Tibor, geb. 1898, ungarischer Amateurfotograf und Fotopublizist, seit 1926 Mitglied im Verband ungarischer Amateurfotografen, Teilnahme an zahlreichen Ausstellungen, folgt in seinem Werk einer modernisierten kunstfotografischen Richtung. Er stirbt am 2. Juni 1935 in Budapest.

Hehs, Aladár, aus Temeswar (Ungarn, heute Rumänien), ist seit 1916 Mitglied im österreichischen Kriegspressequartier.

Heinze, Fritz (Friedrich), geb. am 22. März 1904 als Arbeitersohn in Jena, 1927 bis 1930 Besuch des Bauhauses in Dessau, beginnt Ende der 1920er Jahre zu fotografieren und ist ab 1930 Mitglied der „Arbeiter-Fotografen Deutschlands“ in Leipzig, im Sommer 1930 hält er sich für ein Praktikum im Wirtschafts- und Gesellschaftsmuseum in Wien auf, wo fotografische Aufnahmen entstehen. 1933 und 1934 bis 1936 „Schutzhaft“ im sächsischen Konzentrationslager Colditz wegen Unterstützung der illegalen Kommunistischen Partei, danach arbeitet er als Hilfskonstrukteur in einer Automobilfabrik bei Chemnitz. 1941 bis 1944 ist er Soldat in der deutschen Wehrmacht, seine Kriegseinsätze in Osteuropa hält er fotografisch fest. Er stirbt am 2. Januar 1958 in Potsdam.

Heller, Hans Ewald, Wiener Journalist, seit 1932 Chefredakteur der Wiener Bilder, fotografiert nebenbei und gestaltet in den 1930er Jahren auch Fotoreportagen.
Helly, Ludwig, Wiener Amateurfotograf, um 1930 in der Arbeiterfotografiebewegung aktiv, veröffentlicht seine Bilder gelegentlich in der Presse.

Henisch, Walter, geb. am 26. November 1913 in Wien als Walter Hemis, Friseurlehre, arbeitet seit Anfang der 1930er Jahre als Pressefotograf, von 1936 bis 1939 im Dienst der Wiener Fotoagentur „Ernst \& Hilscher", 1939 Einberufung zur deutschen Wehrmacht, ist während des Krieges als Kriegsfotograf in einer Propagandakompanie (PK) der deutschen Wehrmacht tätig. Nach dem Zweiten Weltkrieg arbeitet er in Wien als Pressefotograf und beliefert v. a. sozialdemokratische Medien mit Bildern. Er stirbt am 22. März 1975 in Wien.

Heydenhaus (auch Heidenhauß, Heidenhauss), Hermann, geb. am 4. Januar 1862 in Weimar, arbeitet seit den 1880er Jahren in diversen Wiener Ateliers und führt ab ca. 1898 ein eigenes Atelier, später kommt ein zweites dazu. Seit 1895 ist er als Pressefotograf für die Wiener Fotohandelsfirma R. Lechner (Wilh. Müller) tätig, die zu dieser Zeit eine Fotoagentur aufbaut. Seit 1898 arbeitet er, zusammen mit L. Robert, als selbstständiger Pressefotograf und Fotoagent. Die beiden vermarkten ihre Bilder unter dem Namen „Heydenhaus \& Robert“. Heydenhaus stirbt am 10. August 1931 in Wien.

Hilscher, Albert, geb. am 19. September 1887 in Hannover, arbeitet seit 1925 als Pressefotograf in Wien, kooperiert ab 1927 mit Karl Schleich, ab 1931 mit Leo Ernst. Wiener Repräsentant der Fotoagentur „Wide World Photos“. 1939/40 Mitglied einer Propagandakompanie (PK) der deutschen Wehrmacht. Er stirbt am 12. November 1964 in Wien.

Hodek, Ferdinand, geb. am 1. März 1896 in Wien, arbeitet als Staatsbeamter und ist nebenbei als Amateurfotograf tätig, seit Ende der 1920er Jahre Mitglied der Arbeiterfotogruppe der Naturfreunde Meidling, stellt seine Bilder, die einer gemäßigt modernen Richtung folgen, in zahlreichen Ausstellungen aus. Veröffentlichungen in Fotozeitschriften und Magazinen. Er stirbt am 29. Juni 1969 in Wien.

Hoffmann, Heinrich, geb. am 12. September 1895 in Fürth, lebt seit 1906 in München und arbeitet $a b$ 1908 als Pressefotograf. 1913 gründet er die Fotoagentur „Photobericht Hoffmann“, seit 1923 fotografiert er Adolf Hitler, später wird er dessen "Leibfotograf“. Während des Nationalsozialismus expandiert sein Betrieb zum Großverlag mit bis zu 300 Mitarbeitern. Er vertreibt Fotos, Publikationen und nationalsozialistisches Propagandamaterial. Seit 1938 hält er sich häufig in Wien auf, wo er auch eine Außenstelle seines Konzerns betreibt. Er stirbt am 16. Dezember 1957 in München.

Hoffmann, Kitty, geb. am 5. Juni 1900 in Wien als Katy Sarah Hoffmann, 1922 bis 1924 Assistentin für Fotografie an der Graphischen Lehr- und Versuchsanstalt in Wien, führt ab 1927 ein eigenes Atelier am Stubenring 20, Wien 1. Sie spezialisiert sich neben dem Porträt auf Tanz- und v. a. auf Modefotografie, veröffentlicht ab Ende der 1920er Jahre zahlreiche Bilder in der illustrierten Presse. Hoffmann setzt ihre Arbeit nach 1938 während des nationalsozialistischen Regimes fort und ist Anfang der 1940er Jahre eine der bekanntesten Wiener Modefotografinnen. Sie stirbt am 31. Mai 1968 in Wien.

Horovitz (auch Horowitz), Dora, geb. am 31. Oktober 1897 in Wien, Ausbildung zur Röntgenassistentin und 1913 bis 1915 zur Fotografin an der Graphischen Lehr- und Versuchsanstalt in Wien. Sie arbeitet acht Jahre lang im Wiener Atelier Setzer, führt ab Juli 1925 am Stubenring 2, Wien 1, zusammen mit Trude Geiringer das Atelier „Geiringer \& Horovitz“, das sich auf Schauspielerporträts, Mode- und Tanzfotografie spezialisiert und Bilder an die illustrierte Presse liefert. Ab Anfang 1934 führt sie das Atelier allein wei- ter. Horovitz, die jüdischer Herkunft ist (allerdings bereits 1916 aus der Kultusgemeinde ausgetreten ist), ist im November 1938 gezwungen, ihr Atelier zu schließen. Sie flüchtet in die USA und führt im kalifornischen San José - nun unter dem Namen Dora Harvey - das Fotoatelier „Harvey Studio“. Sie stirbt am 1. Oktober 1979 in San José.

Hubbuch, Hilde, Wiener Amateurfotografin, veröffentlicht ihre Bilder ab Mitte der 1930er Jahre in der illustrierten Presse.

Huber, Anton, geb. am 27. Oktober 1852 in Deutschkreutz, Ausbildung an der Akademie der bildenden Künste, führt seit 1881 ein Fotoatelier in Wien, arbeitet seit Mitte der 1890er Jahre nebenher als Presse- und Sportfotograf, 1923 zieht er sich aus dem Arbeitsleben zurück. Er stirbt am 9. Februar 1936.

Hufnagel, Josef, Wiener Amateurfotograf, seit Ende der 1920er Jahre Mitglied der Arbeiterfotogruppe der Naturfreunde Meidling, stellt seine Bilder in zahlreichen Ausstellungen aus, greift in seinem Werk die Anregungen der Neuen Sachlichkeit auf. Er fotografiert bis in die 1950er Jahre.

Hummer, Josef, Wiener Amateurfotograf, um 1930 Mitglied in der Arbeiterfotogruppe der Naturfreunde Ottakring, nimmt an Ausstellungen teil und veröffentlicht seine Bilder in Fotozeitschriften und in der sozialdemokratischen Presse.

Husnik, Kurt, geb. am 26. April 1908 in Wien, Studium an der Technischen Hochschule Wien, Promotion 1934. Er ist seit den späten 1920er Jahren als Amateurfotograf tätig und arbeitet an Filmprojekten und Drehbüchern. Seine Fotos (Alltags-, Straßen-, Stadtund Reisebilder sowie Sachaufnahmen), die z. T. in der Tradition des Neuen Sehens und der Neuen Sachlichkeit stehen, erscheinen seit 1934, teilweise in Form von Reportagen, in Zeitungen und Magazinen. 1938 flieht Husnik, der jüdischer Herkunft ist, nach Frankreich, 1939 bis 1941 im Dienst der französischen Fremdenlegion in Afrika, danach lebt er in der Schweiz, wo er als Fotograf, Maler und Filmemacher tätig ist. Er stirbt am 9. Juli 1994 in Cadro (Minusio, Tessin).

Imboden, Martin, geb. am 10. November 1893 in Stans-Niederdorf, Schweiz, Ausbildung zum Möbeltischler, in den 1920er Jahren Sekretär des Holzarbeiterverbandes, Kontakte zu pazifistischen, sozialistischen und freidenkerischen Kreisen, Begeisterung für Eurythmie, Sonnen- und Freikörperkultur. Er beginnt um 1923 als Autodidakt zu fotografieren. 1929 zieht er nach Wien, volontiert kurz im Atelier Manassé, schließt sich der Arbeiterfotogruppe der Naturfreunde Meidling an, wird Mitglied der Sozialdemokratischen Arbeiterpartei, unternimmt zahlreiche Reisen, fotografiert Porträts, Landschafts-, Reise-, Architektur-, Akt- und Tanzszenen, die er in österreichischen und Schweizer Zeitungen und Magazinen veröffentlicht. Seit 1929 nimmt er an zahlreichen Ausstellungen teil. Er stirbt am 19. August 1935 in Zürich an den Folgen eines Fahrradunfalls.

Irribauer, Karl, Wiener Amateurfotograf, geb. am 19. September 1893 in Wien, seit 1924 Mitglied und einige Jahre Obmann der Photographischen Fachgruppe der Volkshochschule Wien-Ottakring, um 1930 Teilnahme an zahlreichen Ausstellungen. Er stirbt am 7. September 1958 in Wien.

Jacobi, Lotte, geb. am 17. August 1896 in Thorn, Westpreußen, lebt seit 1921 in Berlin, 1925 bis 1927 Studium der Fotografie und des Films in München, übernimmt anschließend das Fotoatelier ihres Vaters in Berlin und arbeitet als Porträt-, Theater-, Werbe- und Pressefotografin. Zahlreiche ihrer Arbeiten erscheinen in der illustrierten Presse. 1935 
emigriert Jacobi, die jüdischer Herkunft ist, nach New York, wo sie weiterhin als Fotografin tätig ist. 1955 zieht sie nach Deering, New Hampshire, wo sie ein Atelier führt. Sie stirbt am 6. Mai 1990 in Concord, New Hampshire, USA.

Jahudka, F., Wiener Atelierfotograf, der um 1900 Bilder von Großveranstaltungen, meist im Umfeld des Kaiserhauses, in der illustrierten Presse veröffentlicht.

Jahudka, Josef, geb. 1864 in Lemberg, Galizien, führt seit Mitte der 1880er Jahre ein Atelier in Stockerau, fotografiert neben Porträts auch militärische Veranstaltungen, Genreszenen und Landschaften, die er in der Presse veröffentlicht. Teilnahme an zahlreichen Ausstellungen. Er stirbt am 30. April 1936 in Wien.

Jeidels, Harry, geb. am 22. Februar 1905 in Berlin, führt in der Zwischenkriegszeit ein Fotoatelier in der Wiesingerstraße 6, Wien 1, arbeitet als Porträt-, Theater- und Tanzfotograf und publiziert seine Aufnahmen in der illustrierten Presse. 1938 emigriert Jeidels, der jüdischer Herkunft ist, nach Australien, wo er weiterhin als Fotograf tätig ist. Er stirbt am 22. April 1987.

Jelfy, Julius (Gyula) von, geb. am 13. Dezember 1863, seit 1897 als ungarischer Pressefotograf tätig, 1914 Mitglied im österreichischen Kriegspressequartier, als Kriegsfotograf ist er v. a. an der Ostfront tätig. Er publiziert seine Aufnahmen vorwiegend in den Budapester Blättern Vasárnapi Újság (Sonntagsblatt) und Photo-Riport (Photo-Report). In der Zwischenkriegszeit fotografiert er v. a. für Új Idók (Neue Zeiten), Vasárnapi Újság und Pesti Napló (Pester Tagblatt). Er stirbt am 9. Januar 1945.

Jellinek-Mercedes, Didier, Wiener Amateurfotograf, der in den 1930er Jahren im Stil des Piktorialismus arbeitet. Er stellt seine Landschafts- und Genreszenen in zahlreichen Ausstellungen aus und veröffentlicht sie in Fotozeitschriften und Magazinen. Präsident der 1929 gegründeten konservativen „Vereinigung Photo-Sezession, Wien“, später umbenannt in "Gesellschaft für photographische Kunst“.

Jellinek-Mercedes, Fernand, Wiener Amateurfotograf, dessen Arbeiten sich in den 1930er Jahren zwischen Piktorialismus und neusachlicher Fotografie bewegen. Seine Bilder - Landschaften, Stadtansichten und Genreszenen - erscheinen in Fotozeitschriften und Magazinen.

Jenik, Rosa, geb. 1853, führt seit Ende der 1860er Jahre ein Atelier in Wien, arbeitet v. a. als Porträt fotografin. Seit ca. 1898 fotografiert sie als eine der wenigen Frauen auch für die Presse, sie dokumentiert u. a. aktuelle Sportereignisse. Sie stirbt am 31. März 1913 in Wien.

Jírů, Václav, geb. am 31. Juli 1910, tschechischer Presse- und Werbefotograf, der ab 1928 im Stil der Moderne fotografiert. Er veröffentlicht in tschechischen und ausländischen, u. a. österreichischen Blättern. Während des Zweiten Weltkriegs ist er zeitweise inhaftiert. Nach 1945 arbeitet er weiterhin als Fotograf, daneben ist er als Fotopublizist und Ausstellungsorganisator tätig. Er stirbt am 28. Juni 1980 in Prag.

Jobst, Rudolf, geb. am 13. Juli 1872 in Pest (Budapest), Fotografenlehre bei Hermann Heid in Wien, übernimmt 1899 ein Atelier in Wien, erwirbt 1910 den Gewerbeschein, arbeitet bis 1948 als Berufsfotograf. Er spezialisiert sich auf Kinderbilder und veröffentlicht seine Fotos, u. a. Tanzbilder, Genre- und Kinderszenen, in der Presse. Er stirbt am 4. Dezember 1952 in Wien.

Jungmeier, Willi (Wilhelm), geb. am 19. Mai 1902 in Wels, führt seit Ende der 1920er Jahre ein Atelier in Linz, arbeitet daneben als Pressefotograf, macht Industrieaufnahmen und vertreibt Fotopostkarten. In den 1930er Jahren ist er in der Amateurfotografiebewegung aktiv. In seinen Arbeiten - Landschaftsbilder, Genreszenen, bäuerliche Szenen, Brauchtum folgt er einem konservativen Programm, das er nach 1938 problemlos an die nationalsozialistische Publizistik anpasst. Er stirbt am 14. März 1945 in Linz.

Jürets (auch Jurecs), Franz, Fotograf in Wien, der seit 1903 regelmäßig in der Presse veröffentlicht, u. a. dokumentiert er Alt-Wiener Gebäude, die vom Verschwinden bedroht sind.

Juretsch, Josef, geb. am 12. Mai 1893 in Wien, betreibt seit 1905 ein Atelier in Wien und arbeitet nebenher als Pressefotograf.

Kallmus, Dora Philippine (Madame d'Ora), geb. am 20. März 1881 in Wien, 1906/07 mehrmonatige Ausbildung bei Nicola Perscheid in Berlin, wo sie den Fotografen Arthur Benda (geb. 1885 in Berlin) kennenlernt. Besuch der Graphischen Lehr- und Versuchsanstalt in Wien. Sie eröffnet 1907 unter dem Namen „Atelier d'Ora“ ein Fotoatelier, das bald zu den bekanntesten Studios der Stadt gehört. Atelierleiter und Assistent im Studio in der WipplingerstraBe 24, Wien 1, ist Arthur Benda, er übernimmt den technischen Teil der Arbeiten. Madame d'Ora - so wird die bekannte Gesellschaftsfotografin bald genannt - fotografiert bekannte Persönlichkeiten aus Adel und Bürgertum, aber auch Schauspieler und Künstler, sie macht neben Porträtaufnahmen ModeTanz- und Aktbilder. Zahlreiche ihrer Bilder werden in der österreichischen und deutschen illustrierten Presse veröffentlicht. Von 1921 bis 1926 führt sie während der Sommermonate eine Filiale in Karlsbad und ab 1925 ein Atelier in der Rue Flachat in Paris. 1927 verkauft d'Ora das Wiener Atelier mitsamt Fotoarchiv an Benda, der es unter dem Namen „d'Ora-Benda“ weiterführt. Dora Kallmus zieht endgültig nach Frankreich und führt ihr Pariser Atelier unter dem Namen „d'Ora, Paris“ bis zum Krieg weiter. Den Zweiten Weltkrieg überlebt die jüdische Fotografin versteckt in der Nähe von Paris, nach 1945 fotografiert sie erneut Bühnen- und Tanzkünstler, sie macht aber auch Sozial- und Alltagsreportagen. Nach einem Unfall im Jahr 1959 kehrt sie nach Österreich zurück. Sie stirbt am 30. Oktober 1963 in Frohnleiten, Steiermark.

Kallós, Oskar (Oszkár), geb. am 1. Januar 1875 in New York, eröffnet im Jahr 1900 ein Atelier in Budapest. Er arbeitet als Porträt- und nebenbei als Pressefotograf und veröffentlicht seine Aufnahmen in den Budapester Blättern Új Idôk (Neue Zeiten), Vasárnapi Újság und Pesti Napló (Pester Tagblatt). Er stirbt am 2. Juli 1955 in Budapest.

Karnitschnigg, Maximilian, geb. am 17. Dezember 1872 in Graz, vor und während des Ersten Weltkriegs Karriere als Offizier, nach 1919 Beamter in der Steiermärkischen Landesregierung. Daneben betätigt er sich als Amateurfotograf und Fotopublizist, Vertreter der Kunstfotografie. In seinen Texten und fotografischen Arbeiten - Landschaften, Architektur, Theateraufnahmen, Brauchtum und Genreszenen - verfolgt er ein konservatives Programm. Er stirbt am 10. Mai 1940 in Graz.

Karplus, Albert, geb. am 1. September 1902 in Wien, Wiener Amateurfotograf, der in den 1930er Jahren an zahlreichen Ausstellungen teilnimmt und seine Bilder in Fotozeitschriften publiziert. Er arbeitet teilweise im Stil der Moderne. Karplus, der jüdischer Herkunft ist, flieht 1938 nach Györ, Ungarn, und begeht 1941, kurz bevor er deportiert werden soll, Selbstmord.

Kassowitz, Ernst, geb. am 7. Februar 1888 in Wien, Wiener Fotoamateur, der seit 1930 im Stil der Moderne arbeitet. Er veröffentlicht seit Anfang der 1930er Jahre Bilder und Fotoreportagen in Zeitun- gen und Magazinen. 1935 emigriert er in die USA und eröffnet in Milwaukee, Wisconsin, und 1938 in Seattle, Washington, ein Atelier. 1958 zieht er nach Los Angeles, wo er als Fotograf und Musiker tätig ist. Er stirbt am 8. November 1983.

Katolicky, Franz, geb. am 13. November 1901 in Wien, Wiener Amateurfotograf, seit Anfang der 1920er Jahre Mitglied der Photographischen Fachgruppe der Volkshochschule Wien-Ottakring, beteiligt sich an Fotoausstellungen.

Katz, Hella, geb. am 20. September 1899 in Lemberg, Galizien, kommt in den Wirren des Ersten Weltkriegs nach Wien. 1915 bis 1919 (mit Unterbrechung) Ausbildung zur Fotografin an der Graphischen Lehr- und Versuchsanstalt in Wien; ab März 1925 führt sie ein Fotoatelier am Wiener Stubenring 18, Wien 1 (teilweise zusammen mit Trude Toepfer). Sie ist vor allem als Porträt-, aber auch als Tanz- und Aktfotografin tätig. Zu ihrer Kundschaft gehören neben der gutbürgerlichen Wiener Gesellschaft auch Schauspielerinnen, Tänzerinnen sowie Künstlerinnen und Künstler. Eine Reihe von jungen Fotografinnen und Fotografen arbeiten in ihrem Atelier, etwa Hans Popper, Anton Josef Trčka und Elly Prager-Mandowsky (Elly Niebuhr). Am 1. April 1939 verlässt Katz, die jüdischer Herkunft ist, Wien und flüchtet nach England. Nach dem Krieg lebt sie zurückgezogen in der Grafschaft Durham, im Nordwesten Englands. Das Fotografieren als Beruf gibt sie auf, privat aber arbeitet sie weiterhin mit der Kamera. Sie stirbt am 20. Januar 1981 in Darlington, Yorkshire.

Kaulich, Rudolf (Rezsö), geb. 1889, ungarischer Pressefotograf, ist seit 1915 Mitglied im österreichischen Kriegspressequartier und fotografiert überwiegend an der Ostfront. Seine Bilder veröffentlicht er zunächst in der Budapester Illustrierten Tolnai Világlapja (Tolnais Weltblatt), später arbeitet er als Fotograf für die Budapester Zeitung Ország Világ (Land und Welt).

Kelen, Emmerich (Imre), geb. 1896 in Györ, Ungarn, ungarischer Karikaturist, Zeichner und Fotograf, besucht nach dem Ersten Weltkrieg die Malerschule Hans Hofmanns in München, lebt seit 1922 in der Schweiz, Zusammenarbeit mit dem ungarischen Karikaturisten Aloysius Derso. Beide zeichnen auf internationalen Konferenzen und veröffentlichen die Zeichnungen und Karikaturen in der europäischen Presse. Arbeitet seit Ende der 1920er Jahre auch als Fotograf, veröffentlicht seit 1930 Fotoreportagen in deutschen und österreichischen Illustrierten, zu denen er teilweise auch die Texte beisteuert. Kelen, der jüdischer Herkunft ist, emigriert 1938 in die USA, wo er als Zeichner, Kinderbuchautor und Fernsehproduzent im Dienst der Vereinten Nationen tätig ist. Er stirbt am 12. Oktober 1978 in Wien.

Kinski, Imre, ungarischer Amateurfotograf, der in den 1930 er Jahren auch in österreichischen Magazinen veröffentlicht.

Kiss (auch Kiss-Elceg bzw. Kiss-Eczegi), Helene (auch llona), Fotografin ungarischer Herkunft, absolviert von 1916 bis 1919 die Graphische Lehr- und Versuchsanstalt in Wien, führt seit 1923 das Atelier „Ilka“ in der Linken Wienzeile 35 bzw. 36, Wien 6 , spezialisiert sich auf Werbe- und Objektfotografie, teilweise fotografiert sie im Stil der Moderne, arbeitet seit ca. 1930 auch für die illustrierte Presse, nimmt an zahlreichen Ausstellungen teil, u. a. an der Schau „Film und Foto“ (FiFo), Wien 1930.

Kleinberg, Ernst, Wiener Pressefotograf, der seit ca. 1930 in der illustrierten Presse veröffentlicht, zunächst vor allem in sozialdemokratischen Blättern, nach deren Verbot 1934 auch in anderen Zeitungen und Zeitschriften. Bereits 1937 fotografiert er für die Zeitschrift Life. 1938 flüchtet er in die USA, arbeitet ab 1939 für die New York Post, später für andere Zeitungen und Magazine. 
Kluger, Zoltan, geb. 1896 im ungarischen Kecskemét, im Ersten Weltkrieg Aufklärungsfotograf bei der österreichischen Luftwaffe und Chefreporter der New Yorker jüdischen Zeitschrift Vorwärts, lebt seit den 1920er Jahren in Berlin, wo er als Pressefotograf und Fotoagent (zusammen mit dem Pressefotografen W. von Szigethy) tätig ist. Die Bilder und Reportagen der Agentur „Kluger-Szigethy“ werden in deutschen und ab 1931 auch in österreichischen Zeitungen veröffentlicht. Beide Fotografen sind jüdischer Herkunft und flüchten 1933 nach Palästina. Kluger ist dort weiterhin als Pressefotograf tätig, u. a. für die Agentur „Orient Press“. Ab 1958 lebt er in New York, wo er ein Fotogeschäft führt. Er stirbt 1977 in New York.

Koenig, Otto, geb. am 23. Oktober 1914 in Wien, Verhaltensforscher, Publizist, Fotograf und Filmemacher, Mitte der 1930er Jahre Ausbildung an der Graphischen Lehr- und Versuchsanstalt, veröffentlicht ab Mitte der 1930er Jahre Fotoreportagen zu Themen des Alltags und der Ethnologie sowie Tieraufnahmen. In den 1950er Jahren studiert er (ohne Abschluss) Psychologie und Zoologie und wird mit seinen Fernsehsendungen und Büchern zu Natur und Tierwelt bekannt. Er stirbt am 5. Dezember 1992 in Klosterneuburg.

Kolliner, Grete, geb. am 14. August 1892 in Wien, besucht die Schule von Eugenie Schwarzwald, studiert 1910 bis 1915 (mit Unterbrechungen) an der Graphischen Lehr- und Versuchsanstalt in Wien, an der sie 1916 Assistentin wird. 1917 eröffnet sie ein Fotoatelier in der Frankgasse 6, Wien 9. In den 1920er Jahren lebt sie teilweise in Rom, wo sie ein weiteres Atelier (Studio Trio) führt. Sie spezialisiert sich neben Porträts von Schauspielerinnen und Schauspielern, Künstlerinnen und Künstlern auf Theater-, Tanzund Aktfotografie sowie auf Modeaufnahmen und veröffentlicht in der illustrierten Presse. Zusammen mit Else Hoffmann kuratiert sie 1931 in der Wiener Secession eine Fotoausstellung zum Thema „Die schaffende Österreicherin“, in der zahlreiche beruflich erfolgreiche Frauen in Fotoporträts vorgestellt werden. Nach Kolliners frühem Tod am 4. Mai 1933 übernimmt die Fotografin Marianne Beschmann ihr Wiener Atelier.

Koppitz, Rudolf, geb. am 3. Januar 1884 in Schreiberseifen bei Freudenthal in Schlesien, lebt seit 1907 in Wien, arbeitet ab 1897 in diversen Fotoateliers, 1912 Ausbildung an der Graphischen Lehr- und Versuchsanstalt in Wien, an der er ab 1913 als Assistent und Lehrer tätig ist. Im Ersten Weltkrieg ist er u. a. als Fotograf in der Luftaufklärung tätig. Nach dem Krieg arbeitet er als Professor an der Graphischen Lehr- und Versuchsanstalt. Als künstlerischer Fotograf vertritt er in den 1920 er Jahren eine gemäßigt moderne Richtung. Er widmet sich u. a. den Themen Landschaft, Tanz, Akt und Porträt. In den 1930er Jahren wendet er sich vermehrt ländlichen, bäuerlichen Szenen zu. Koppitz wird einer der wichtigsten Vertreter der österreichischen Heimatfotografie. Zahlreiche seiner Arbeiten erscheinen in der österreichischen und deutschen Presse. Er stirbt am 8. Juli 1936 in Wien.

Kosel, Hermann Clemens, geb. am 22. November 1867 in Dunkelthal, Böhmen, Atelierfotograf in Wien, Fotopublizist und Fachautor, Redakteur der Fotozeitschrift Photo-Sport, führt seit 1907 ein Atelier und fotografiert bekannte Persönlichkeiten aus Kunst und Gesellschaft, Kontakt zu Heinrich Kühn und Hans Watzek, nimmt die kunstfotografischen Anregungen in gemäßigter Form auf. Er stirbt am 14. September 1945 in Wien.

Kossák, Josef (József), ungarischer Atelierfotograf, der um die Jahrhundertwende Ateliers in Budapest, Arad und Temeswar unterhält und neben der Porträtfotografie auch gelegentlich als Pressefotograf tätig ist. Er stirbt 1920 in Budapest.
Kranus, Karl, Wiener Amateurfotograf, um 1930 Mitglied der Photographischen Fachgruppe der Volkshochschule Wien-Ottakring und der Photosektion der Naturfreunde Ottakring, nimmt seit Anfang der 1930er Jahre an zahlreichen Ausstellungen teil und publiziert seine Bilder in Fotozeitschriften und um 1930 auch in der sozialdemokratischen Presse. Er ist bis Ende der 1950er Jahre als Fotoamateur aktiv.

Kraus, Norbert, geb. 1892 in Mistek, Böhmen, betreibt seit 1933 in Wien das „Foto-Studio Ing. Norbert Kraus“, veröffentlicht daneben öfter in der Presse.

Kreisler, Ernö, ungarischer Fotoamateur, der in den 1930er Jahren auch in österreichischen Magazinen veröffentlicht.

Krill, Richard, geb. am 2. April 1876 in Linz, arbeitet seit 1898 als ambulanter Fotograf, nach der Jahrhundertwende als Fotograf in Schwanenstadt und Wels. Er veröffentlicht um 1900 gelegentlich Pressefotos in Zeitungen.

Krotsch, J., Maler und Fotograf, betreibt um und nach der Jahrhundertwende ein Atelier in Wien, veröffentlicht nach 1910 gelegentlich Pressefotos in Zeitungen.

Kruckenhauser, Stefan, geb. am 4. November 1905 in München, wächst in Nordböhmen auf, lebt und studiert seit 1919 in Österreich und arbeitet seit 1932 als Gymnasiallehrer in Salzburg. 1934 bis 1938 Leitung des Sportheims in St. Christoph am Arlberg. Er beginnt in den 1920er Jahren als Amateurfotograf zu arbeiten, seine Themen sind Architektur, Landschaft und Skisport. Publiziert ab 1937 zahlreiche Bildbände, wird 1940 Mitglied der NSDAP, dient als Fotograf im Zweiten Weltkrieg (u. a. in einer Propagandakompanie) und arbeitet nach 1945 in Salzburg und St. Christoph als Ski- und Fotolehrer, Fotopublizist und Fotograf. Er stirbt am 1. Oktober 1988 in Wien.

Krull, Germaine, geb. am 20. November 1897 in Wilda, Posen, lebt seit 1912 in München, Ausbildung als Fotografin, eröffnet 1917 ein Atelier in München. Wegen ihrer Sympathien für die Räterepublik wird sie 1920 aus Bayern ausgewiesen und lebt, nach Stationen in Moskau, Berlin und Amsterdam, v. a. in Paris, wo sie als Fotografin im Stil der Avantgarde arbeitet. Sie macht Stadtaufnahmen, Akte, Werbebilder und publiziert ihre Bilder in Form eines Fotobuchs (1928) und in der Presse (ab 1933 gelegentlich auch in Österreich). Nach 1939 lebt sie in Brasilien, Afrika und Ostasien, sie arbeitet weiterhin als Fotografin, zeitweise als Kriegsberichterstatterin und später als Hotelbetreiberin. Sie stirbt am 31. Juli 1985 in Wetzlar.

Krzanowski, Johann, Fotograf in Czernowitz, der um die Jahrhundertwende gelegentlich auch Presseaufnahmen in Zeitungen veröffentlicht.

Krziwanek, Rudolf, Wiener Fotograf, der seit 1870 ein Atelier in Wien betreibt. Etliche seiner Fotoporträts erscheinen zunächst als Holzstiche in der Presse, seit Mitte der 1890er Jahre auch als Autotypien. Er stirbt 1905 in Wien.

Kühn, Heinrich, geb. am 25. Februar 1866 in Dresden, naturwissenschaftliche Ausbildung an den Universitäten in Leipzig und Freiburg, lebt seit 1890 in Innsbruck, Amateurfotograf, zahlreiche fotografische Experimente, Teilnahme an internationalen Ausstellungen, fotografiert seit 1906 mit Autochromeplatten, über den Kontakt mit Alfred Stieglitz wird er auch in den USA bekannt, gründet 1914 eine Fotoschule in Innsbruck, er begrüßt den „Anschluss“ Österreichs an das nationalsozialistische Deutschland und wird 1938 Mitglied der NSDAP. Er stirbt am 14. September 1944 in Birgitz bei Innsbruck.

Kuhn, Oskar, Amateurfotograf in Baden bei Wien, veröffentlicht seine Bilder (v. a. Alltags- und Genreszenen) ab 1929 in Fotozeitschriften und Magazinen.
Labisch (auch Labich bzw. Labiche), Siegmund (auch Sigmund), geb. am 30. Juli 1863 in Samter, Posen, Pressefotograf, betreibt seit 1895 in Berlin zusammen mit Albert Zander eine Fotoagentur, die seit 1900 ihre Bilder auch in Österreich vertreibt. Er wird 1942 nach Theresienstadt deportiert und dort am 7. Dezember 1942 ermordet.

Largajolli, Rudolf, Atelierfotograf in Brixen, der um 1900 gelegentlich Pressebilder in Wiener Illustrierten veröffentlicht.

Lechenperg, Harald, geb. am 5. Oktober 1904 in Wien, arbeitet seit 1925 als Pressefotograf, geht 1929 nach Paris, von wo er für die Berliner Verlage Scherl und Ullstein tätig ist. Um 1930 arbeitet er von Berlin aus, zunächst für die Fotoagentur „Dephot“, die seine Reisereportagen an die großen illustrierten Zeitungen verkauft. Seit 1933 erscheinen seine Bilder, v. a. Reisereportagen, auch in österreichischen Blättern. Bereits ab 1933 Mitglied der NSDAP. 1937 wird er Chefredakteur der Berliner Illustrirten Zeitung, seit 1940 leitet er die NS-Auslandsillustrierte Signal, nach 1945 ist er für die deutschen Zeitschriften Quick und Weltbild tätig. Er verfasst Bücher und dreht Dokumentarfilme. Er stirbt am 1. Januar 1994 in Kitzbühel, Tirol.

Lechner, R. (Wilh. Müller), Wiener Buchhandlung (1825 gegründet) am Graben 31, Wien 1, die ab 1885 auch als Fotoverlag und Fotohandelsfirma tätig ist. Seit 1895 agiert der Betrieb auch als Fotoagentur, der aktuelle Nachrichtenbilder eigener Fotografen vermarktet. Der Betrieb existiert bis 1964

Lenze, Minna, Amateurfotografin, die um 1930 im sozialdemokratischen Kuckuck veröffentlicht.

Leutner, Felix, geb. 1881, absolviert von 1898 bis 1900 die Graphische Lehr- und Versuchsanstaltin Wien, arbeitet als Fotoverleger und -fabrikant in Wien. Er gründet 1905 die Firma „Kilophot“, die Fotoartikel und Fotopapiere herstellt und vertreibt. Seit 1912 ist „Kilophot“ auch als Fotoagentur tätig. Er stirbt 1966 in Wien.

Lippe, Georg Philipp von der, Atelierfotograf in Wien, der seit 1872 tätig ist. Er spezialisiert sich auf Porträts, Tieraufnahmen und Architektur. Um 1900 macht er auch Aufnahmen für die Presse, die teilweise auch in deutschen Zeitungen gedruckt werden.

Löhrich, Max, geb. 1873 in Preußen, Fotograf und Inhaber einer Fotoagentur. Er führt seit 1905 die Agentur „Leipziger Presse-Büro“, 1908 bis 1910 ist er als Fotograf in Innsbruck tätig und publiziert Bilder in der österreichischen Presse. Im Ersten Weltkrieg arbeitet er als Pressefotograf, nach 1918 führt er in Leipzig die Fotoagentur „Max Löhrich Pressebüro“. Er stirbt 1957 in Dresden.

Löwy, Franz, geb. am 1. Januar 1883 in Ostrau, Mähren, betreibt seit 1910 ein Atelier in Wien, das zum Treffpunkt bekannter Künstler wird. Verfolgt zunächst ein piktorialistisches Programm und fotografiert in der Zwischenkriegszeit im Stil der gemäBigten Moderne. Neben Porträts macht er Theater-, Tanz-, Mode- und Aktaufnahmen, in der Zwischenkriegszeit betreibt er eine Filiale in Paris. Er veröffentlicht regelmäßig in der illustrierten Presse, arbeitet als Fotopublizist und ist in zahlreichen Ausstellungen vertreten. 1938 flieht Löwy, der jüdischer Herkunft ist, nach Paris, wo sich seine Spuren verlieren.

Luckhardt, Fritz, geb. am 17. März 1843 in Kassel, eröffnet 1867 ein Fotoatelier in Wien, das vor der Jahrhundertwende zum Treffpunkt der Prominenz wird. Seit 1889 werden seine Porträts, zunächst umgearbeitet als Holzstiche, in der illustrierten Presse veröffentlicht. Er stirbt am 29. November 1894 in Wien.

Lukas, Jan, geb. am 10. August $1915 \mathrm{im}$ tschechischen Budweis, zieht 1921 mit der Familie nach Prag, 1935 
Abschluss der deutschsprachigen Handelsschule in Prag. Er beginnt 1929 zu fotografieren, ab 1932 publiziert er als Amateurfotograf in tschechischen und - vermittelt durch die in Paris ansässige Fotoagentur Pavel Barchan - internationalen Zeitungen. Seine Themen reichen von Architekturaufnahmen, Reiseeindrücken, Freizeit- und Sportbildern über Alltagsgeschichten und Porträts bis hin zu Theaterbildern. Oft stellt er Fotoreportagen zusammen und folgt in seinen Arbeiten zunächst den Anregungen der Moderne. 1935/36 Studium an der Graphischen Lehrund Versuchsanstalt in Wien und Beginn der Zusammenarbeit mit der österreichischen Bildpresse. Nach 1936 arbeitet er, teilweise zusammen mit Alexandr Hackenschmied, als Kameramann bei Filmarbeiten für den tschechischen Schuhproduzenten Bata. Sein Versuch, in die USA zu emigrieren, scheitert an der deutschen Okkupation Tschechiens. Ab 1939 wendet er sich stärker ländlichen Themen und der tschechischen Heimatfotografie zu. Unter dem kommunistischen Regime beendet er seine Karriere als Pressefotograf, er arbeitet freiberuflich als Herausgeber von Fotobüchern. 1965 emigriert er in die USA, wo er als Fotograf und Kameramann tätig ist und Fotobücher herausgibt. Er stirbt am 28. August 2006 in New York.

Machlup, Cécile, geb. am 24. September 1868 in Wien als Cäcilie Hayman. Sie ist seit 1907 als Amateurfotografin tätig und gilt bis in die 1920er Jahre als Anhängerin des Piktorialismus. Um 1930 fotografiert sie gelegentlich auch im Stil der modernen Fotografie. Mitglied des „Wiener Photo-Clubs“ und in den 1920er Jahren der Photographischen Fachgruppe der Volkshochschule Wien-Ottakring. Zu ihrem Werk gehören Genre- und Kinderbilder, Landschafts- und Sachaufnahmen. Sie beteiligt sich an zahlreichen internationalen Ausstellungen, veröffentlicht ihre Bilder in Fotozeitschriften, publiziert über Fotografie und hält Lichtbildvorträge. Sie stirbt am 24. Januar 1938 in Wien.

Macku, Paul, geb. am 20. April 1892 in Wien, ist seit 1925 als Amateur- und Pressefotograf tätig, veröffentlicht seit ca. 1930 Bilder und Fotoreportagen in Magazinen. Er macht technisch anspruchsvolle Aufnahmen (etwa Mikroskop- und Großaufnahmen), Bilder aus dem Alltag, Landschafts- und Genreszenen und ab 1938 auch Reportagen zu aktuellen politischen Themen. Arbeitet nach 1945 als Pressefotograf und Fotopublizist.

Madensky, Gertraud, geb. am 1. Mai 1906 in Wien, Fotografin in Wien, die in den 1930er Jahren im Bereich Mode- und Sachfotografie tätig ist.

Madensky, Hans, geb. am 24. Juni 1902 in Wien, absolviert von 1918 bis 1921 die Graphische Lehr- und Versuchsanstalt in Wien, an der er von 1921 bis 1924 als Assistent, ab 1934 als Fotolehrer und ab 1937 als Professor arbeitet. Er führt seit 1931 ein Atelier in Wien, spezialisiert sich auf die Porträt- und Werbefotografie und veröffentlicht zahlreiche Bilder (Alltags- und Genreszenen, Sachaufnahmen, Landschaften und Brauchtum) in Fotozeitschriften und Magazinen. Arbeitet nach 1938 problemlos weiter und passt sich in Stil und Themenwahl den neuen politischen Gegebenheiten an. Nach 1945 ist er als Werbe-, Architektur- und Sachfotograf tätig und unterrichtet bis in die 1960er Jahre als Leiter der Meisterklasse an der Graphischen Lehr- und Versuchsanstalt. Er stirbt am 25. Dezember 1978 in Wien.

Man, Felix H., geb. am 30. November 1893 in Freiburg im Breisgau als Hans Felix Sigismund Baumann, arbeitet ab 1927 zunächst als Pressezeichner in Berlin, ab 1928 als Pressefotograf mit dem Pseudonym „Man“ für die Fotoagentur „Deutscher Photodienst“ (Dephot). Er fotografiert zahlreiche Reportagen, die in den großen deutschen Illustrierten und Anfang der 1930er Jahre auch in österreichischen Zeitungen erscheinen. Nach seiner Emigration 1934 nach London fotografiert er für die von Stefan Lorant gegründeten Illustrierten Weekly IIlustrated und Picture Post sowie für andere Medien. Er stirbt am 30. Januar 1985 in London.

Makart, Hans, geb. am 29. November 1870 in Wien, eröffnet 1902 ein Atelier in Wien, arbeitet im Bereich Porträt und Architektur, veröffentlicht seit 1903 gelegentlich Pressebilder über gesellschaftliche Ereignisse und Genreszenen in illustrierten Zeitungen. Er stirbt am 5. Juli 1946 in Wien.

Markalous, Evžen, geb. am 19. April 1906 in Prag, Physiker, tschechischer Künstler und Fotograf, Mitglied der Brünner Avantgardegruppe „Devetsil“, Avantgardefotograf, der seit Mitte der 1920er Jahre auch Fotomontagen macht. Er ist, auf Betreiben Karel Teiges, 1929 in der Ausstellung „Film und Foto“ (FiFo) vertreten und veröffentlicht seine Bilder in den 1920 er und 1930er Jahren in der tschechischen und gelegentlich auch in der österreichischen Presse. Er stirbt am 9. Juli 1971 in Prag.

Martinelli, Rudolf, Grazer Atelierfotograf, führt seit 1892 ein Atelier, veröffentlicht um die Jahrhundertwende gelegentlich auch Pressebilder in Zeitungen.

Maudry, Othmar, geb. 1905 in Wien, Amateurfotograf und Fotopublizist, publiziert seine Bilder ab den frühen 1930er Jahren in der illustrierten Presse und in Magazinen. Seine Themen sind vielfältig: Porträts, Landschaften, bäuerliche Lebenswelt, Brauchtum, Genreszenen, Tanzaufnahmen, Tierbilder. Er stirbt am 24. November 1994 in Murnau.

Mayer, Adolf, geb. am 14. Mai 1908 in Wien, arbeitet ab 1935 als Pressefotograf in Wien. Ab 1938 NSDAPMitglied. Von 1939 bis 1941 ist er als Kriegsfotograf in einer Propagandakompanie der deutschen Wehrmacht tätig. Nach dem Zweiten Weltkrieg arbeitet er als Porträt- und Werbefotograf. Er stirbt am 12. Dezember 1960 in Wien.

Mayer, Franz, geb. 1991 in Wien, arbeitet seit 1927 als Industrie-, Architektur- und Werbefotograf, führt ab 1935 einen Fotobetrieb in Wien, veröffentlicht seit 1930 Fotoreportagen und Bilder über Industrieanlagen und Architektur in Zeitungen und Magazinen, arbeitet teilweise in Stil der Neuen Sachlichkeit, nimmt an zahlreichen Ausstellungen teil, u. a. an der Schau „Film und Foto“ (FiFo) 1930 in Wien. Zur Zeit des „Ständestaates“ fotografiert er häufig Politiker.

Mayerhofer, Max, geb. 1896 in Linz, ab Mitte der 1920 er Jahre Pressefotograf in Linz, im Zweiten Weltkrieg Kriegsfotograf (PK-Fotograf) bei der deutschen Luftwaffe. Er stirbt 1957.

Medina, Hedda, geb. am 17. Juni 1911 in Wien, Wiener Atelierfotografin, absolviert von 1920 bis 1924 eine Ausbildung an der Graphischen Lehr- und Versuchsanstalt, beendet 1928 ihre praktische Ausbildung und führt seit Ende der 1920er Jahre ein Atelier in Wien. Sie spezialisiert sich auf Künstler- und Schauspielerporträts sowie Tanzaufnahmen. Seit ca. 1930 veröffentlicht sie ihre Bilder in Zeitschriften und nimmt an Ausstellungen teil. Die Fotografin, die jüdischer Herkunft ist, flüchtet im Mai 1939 nach London.

Meitner-Graf, Lotte, geb. am 17. November 1899 als Charlotte Graf in Wien, absolviert 1915 bis 1917 die Graphische Lehr- und Versuchsanstalt in Wien, arbeitet in den 1920er Jahren bei diversen Wiener Fotografen. Um 1930 eröffnet sie ein eigenes Atelier in der Wollzeile 24, Wien 1 und spezialisiert sich auf Künstler-, Wissenschaftler- und Prominentenporträts sowie Modeaufnahmen. Sie publiziert ihre Aufnahmen unter dem Namen „Lotte Meitner-Graf“. 1938 flieht die Fotografin jüdischer Herkunft (die 1923 zum Protestantismus konvertiert ist) nach
London, wo sie zunächst im Atelier des aus Wien stammenden Fotografen Georg Fayer tätig ist und danach ein eigenes Fotoatelier eröffnet. Sie fotografiert auch hier vorzugsweise Künstler, Wissenschaftler und Prominente. Sie stirbt Ende April 1973 in London.

Mertens (Matisz), Marie, geb. am 28. Juni 1859 in Wien als Marie Matisz, heimatzuständig in Kaschau (Ungarn, heute: Košice, Slowakei), ist seit 1903 als Fotografin in Wien tätig. Von 1905 bis 1910 betreibt sie, teilweise gemeinsam mit Charles Scolik jun., in der Spitalgasse 33, Wien 9, das "Atelier Moderne“. Sie ist die erste Pressefotografin, die um und nach 1900 regelmäßig aktuelle Pressebilder in illustrierten Zeitungen veröffentlicht. Seit 1903 publiziert sie Aufnahmen und Reportagen zu gesellschaftlichen Ereignissen und Künstlerporträts, seit 1905 erscheinen ihre Bilder unter dem Namen „Atelier Moderne“ oder „Ch. Scolik \& M. Mertens“. 1910 verkauft sie ihr Atelier, um 1908 beendet sie ihre Arbeit als Pressefotografin, arbeitet aber weiterhin als Fotografin. Sie stirbt am 7. März 1935 in Wien.

Messner (Messner-Blahy), Irene, geb. am 24. April 1888 als Irene Blahy in Wien, Ausbildung zur Kunstgewerbemalerin und Fotografin, absolviert 1911 bis 1914 die Graphische Lehr- und Versuchsanstalt in Wien. Zwischen 1919 und 1931 führt sie zunächst in der Lothringerstraße 4, Wien 4, ab 1920 in der Pfeilgasse 35, Wien 8, ein Atelier für Fotografie und kunstgewerbliche Arbeiten. Sie spezialisiert sich auf Porträts, Theateraufnahmen und Mode und publiziert ihre Bilder ab Anfang der 1920er Jahre in der illustrierten Presse. In der Zwischenkriegszeit konvertiert sie zum Katholizismus und überlebt, geschützt durch ihre Ehe mit ihrem nichtjüdischen Ehemann, die NS-Zeit und die Kriegsjahre in Wien. Sie stirbt am 9. Januar 1975 in Wien.

Michalup, Isidor, Fotograf, der seit 1905 in Linz tätig ist und ab 1912 in Wien arbeitet. Er veröffentlicht kurz vor und zu Beginn des Weltkrieges als Pressefotograf Aufnahmen von aktuellen Ereignissen, Architektur und Alltagsszenen.

Mikovsky, Bertalan, geb. 1887, ungarischer Pressefotograf, arbeitet seit Anfang 1916 im Dienst des österreichischen Kriegspressequartiers und fotografiert v. a. an der Ostfront und in Rumänien.

Milik, Franz, Amateurfotograf, veröffentlicht seit 1938 in Fotozeitschriften und Magazinen. Er macht Fotoreportagen ebenso wie künstlerische, teils abstrakte Kompositions- und Körperstudien.

Misar, Hans, geb. am 17. Dezember 1913 in Wien, Verlagsunternehmer, Journalist und Fotograf. Er profitiert vom nationalsozialistischen „Anschluss“ Österreichs an das Deutsche Reich. Er ist seit Frühjahr 1938 Schriftleiter des Wiener Magazins, seit 1941 Miteigentümer des ,arisierten“ Verlagshauses Vernay und arbeitet Anfang der 1940er Jahre als Verleger kunsthistorischer Bände. Seine fotografischen Arbeiten, die ab 1938 in der Presse erscheinen, reichen von Fotoreportagen bis hin zu experimentellen Stilleben, Oberflächenstudien und abstrakten Kompositionen. Misar ist in seinen fotografischen Arbeiten ein Vertreter einer nationalsozialistischen Moderne.

Moholy-Nagy, László, geb. am 20. Juli 1895 in Ungarn, ist als Maler, Fotograf, Typograf und Bühnenbildner tätig. Er ist von 1923 bis 1928 Lehrer am Bauhaus, danach führt er in Berlin ein Atelier für künstlerische Gestaltung und Werbung. Als Fotograf und Fotopublizist ist er der Avantgarde verpflichtet. 1934 flüchtet er über Amsterdam und London in die USA und gründet in Chicago das „New Bauhaus“. Er stirbt am 24. November 1946 in Chicago.

Moser, Simon, geb. am 15. März 1901 in Jenbach, Philosoph und Amateurfotograf, promoviert 1930 bei 
Martin Heidegger, 1935 Habilitation. Er unterrichtet ab 1937 an den Universitäten Wien und Innsbruck, seit 1946 Titularprofessor für Philosophie an der Universität Innsbruck, 1952 bis 1968 Professor für Philosophie in Karlsruhe. In seinem fotografischen Werk ist er ein Vertreter der österreichischen Heimatfotografie, er fotografiert fast ausschließlich das bäuerliche Leben und alpine Landschaften, in den 1930 er Jahren veröffentlicht er in Fotozeitschriften und Magazinen. 1940 stellt er einen Antrag auf Aufnahme in die NSDAP, der abgelehnt wird. 1940 gibt er den Band Deutsche Bergbauern heraus, 1942 folgt der propagandistische Bildband Land in den Bergen. Vom Wehrbauer zum Gebirgsjäger, dem in den 1940er und 1950er Jahren zahlreiche Fotobände folgen. Er stirbt am 22. Juli 1988 in Mils, Tirol.

Müller, Hertha, Wiener Amateurfotografin, die seit den 1920er Jahren aktiv ist. Sie nimmt an zahlreichen Ausstellungen teil, u. a. an der Schau „Film und Foto" (FiFo) in Wien 1930.

Müller, Wilhelm, geb. am 8. März 1864 in Graz, lebt seit 1894 in Bozen, wo er seit Mitte der 1890er Jahre ein Atelier betreibt. Seit 1897 veröffentlicht er aktuelle Pressebilder, u. a. auch von Sportveranstaltungen im Tiroler Raum, in Wiener Illustrierten. Er stirbt am 12. November 1943 in Schlanders, Südtirol.

Munkácsi, Martin, geb. am 18. Mai 1896 als Márton Marmelstein (Memelstein) in Klausenburg/Cluj, Ungarn (heute Rumänien), beginnt vor dem Ersten Weltkrieg als Autodidakt zu fotografieren, arbeitet in den 1920er Jahren als Sport- und Pressefotograf für Budapester Zeitungen. 1928 zieht er nach Berlin und arbeitet als Fotograf v. a. für die Ullstein-Presse. Anfang der 1930er Jahre fotografiert er gelegentlich auch in Österreich. 1934 emigriert er in die USA, wo er als Modefotograf Karriere macht. Er stirbt am 13. Juli 1963 in New York.

Münz, M., Atelierfotograf in Lemberg, der um die Jahrhundertwende gelegentlich Pressebilder in österreichischen Zeitungen veröffentlicht.

Mutterer, Josef, geb. am 18. Dezember 1834 in Wien, führt seit 1873 ein Fotoatelier in Wien. Neben der Porträtfotografie widmet er sich besonders der Stadt- und Architekturfotografie und liefert in den 1890 er Jahren gelegentlich Pressefotos an die Zeitungen. Er stirbt am 19. Januar 1908 in Wien.

Neudatschin (auch Neudin), Pressefotograf, der um 1930 in Berlin für die Fotoagentur „Weltrundschau“ tätig ist und zahlreiche, oft sozialkritische Fotoreportagen in der illustrierten Presse veröffentlicht. Seine Bilder und Reportagen erscheinen ab 1930 auch in österreichischen Zeitungen.

Neumüller, Michael, geb. am 6. Oktober 1891 in Mauthausen, arbeitet von 1919 bis 1950 als Hauptschullehrer bzw. -direktor in Linz. Er beginnt im Ersten Weltkrieg zu fotografieren und ist seit der Zwischenkriegszeit als Amateurfotograf und Fotopublizist tätig. Zahlreiche Ausstellungsbeteiligungen. Seine Themen sind Landschaften, Reiseszenen, Akte, Genrebilder und Stillleben. Er stirbt am 29. März 1980 in Linz.

Niklitschek, Alexander, geb. 1892 in Kojetein, Mähren, Studium in Wien, arbeitet als (Foto-)Techniker in Wien, Jena und Dresden. In der Zwischenkriegszeit ist er als Fotopublizist und Amateurfotograf tätig. Er stirbt im Jahr 1953.

Nowak (auch Novak), Sepp (Josef), Wiener Amateurfotograf, der seit Ende der 1920er Jahre tätig ist. Er folgt teilweise den Anregungen des Neuen Sehens und veröffentlicht um 1930 zahlreiche Bilder und Fotoreportagen (Alltagsthemen, Stadtbilder, Architektur, Stillleben, Genreszenen) in der sozialdemokratischen Presse, ab 1934 auch in anderen Zeitungen.
Oplatka, Hans Ernest (später Jan Arnošt), geb. am 12. August 1911 in Wien, zieht mit seiner Familie 1920 nach Prag, 1922 bis 1928 absolviert er das deutschsprachige Realgymnasium in Prag, 1928 bis 1930 Ausbildung an der Graphischen Lehr- und Versuchsanstalt in Wien und 1930 bis 1931 am Polytechnischen Institut in Prag. Anfang der 1930er Jahre ist er Mitarbeiter der französischen Illustrierten VU. Danach lebt und arbeitet Oplatka in Wien. Von 1934 bis 1938 ist er als Herausgeber des Sonntag tätig, einer illustrierten Wochenendbeilage des Wiener Tag, daneben arbeitet er als Fotograf und publiziert seine Bilder in österreichischen Magazinen. 1938 flüchtet Oplatka, der jüdischer Herkunft ist, nach Prag, wo er als Bildredakteur der Zeitschrift Zeit im Bild arbeitet. Nach der Besetzung der Tschechoslowakei durch die deutsche Wehrmacht 1939 flüchtet er über Jugoslawien und Italien nach Paris und, nach der Besetzung der Stadt durch die Deutschen, nach London. Als Mitglied der tschechoslowakischen Exilarmee nimmt er am Kampf gegen Hitler teil. Ab 1946 ist er als freier Pressefotograf in England tätig und ab 1962 als Reiseführer. Er wird britischer Staatsbürger und ändert seinen Namen in Jan Arnošt, 1967 zieht er nach Liverpool, wo er am 1. Dezember 1992 stirbt.

Oppolzer, Hugo, Wiener Presse- und Sportfotograf, der in der Zwischenkriegszeit für die illustrierte Presse tätig ist.

Ortner, Hanns, österreichischer Fotoamateur und Fotopublizist, der seit dem „Anschluss“ Österreichs an das nationalsozialistische Deutschland in Magazinen und Fotozeitschriften publiziert.

Oestreicher (auch Östreicher), Marie (Maria Austria), geb. am 19. März 1915 in Karlsbad als Marie Karoline Oestreicher, besucht 1933 bis 1935 die Graphische Lehr- und Versuchsanstalt in Wien und arbeitet im Wiener Atelier Willinger. Mitte der 1930er Jahre entstehen Theateraufnahmen in Wiener Kleinbühnen. 1937 emigriert sie in die Niederlande. Im Amsterdam baut sie zusammen mit ihrer Schwester Lisbeth, einer Bauhauskünstlerin, die im Textil- und Modebereich arbeitet, unter dem Namen „Model en Foto Austria“ ein gemeinsames künstlerisches Atelier auf. Als Künstlerin nennt sie sich Maria Austria. Während des Zweiten Weltkriegs lebt sie ab 1942 in der Illegalität und unterstützt den Widerstand gegen das NS-Regime. Nach 1945 arbeitet sie als Fotografin mit dem Schwerpunkt Theater. Sie stirbt am 10. Januar 1975 in Amsterdam.

Panek, Adalbert, Atelierfotograf in Olmütz, der um die Jahrhundertwende gelegentlich auch in Wiener Zeitungen veröffentlicht.

Patek, Claire, Wiener Journalistin und Fotografin, die vor dem Ersten Weltkrieg und v. a. in den 1920er und 1930er Jahren für Wiener, Prager und deutsche Blätter als Mode- und Gesellschaftsredakteurin tätig ist. Seit Anfang der 1930er Jahre publiziert sie (zeitweise gemeinsam mit der Wiener Fotografin Helene Zimmerauer) Modefotografien in der Presse.

Pawlik, Franz, Wiener Fotograf, der um die Jahrhundertwende tätig ist. Er arbeitet $u$. a. als Presse- und Sportfotograf und berichtet regelmäßig über Pferderennen.

Pawlik, Franz (nicht identisch mit dem gleichnamigen Wiener Fotografen), Fotograf in Prag, der um die Jahrhundertwende auch in österreichischen Zeitungen publiziert. Er spezialisiert sich auf Militäraufnahmen und Bilder des Kaiserhauses.

Pechotsch, Rudolf, geb. 1895, Wiener Amateurfotograf, der seit 1924 tätig ist. Er fotografiert Genreund Kinderszenen, städtische und ländliche Motive, nimmt an Ausstellungen teil und publiziert in den 1930er Jahren in Fotozeitschriften und Magazinen.
Penitsch, Rudolf, österreichischer Amateurfotograf, der ab ca. 1938 kunstfotografische Motive und Kompositionen in Magazinen und Fotozeitschriften veröffentlicht.

Pécsi, József, geb. am 1. April 1889 in Budapest, 1908 bis 1910 Besuch der Lehr- und Versuchsanstalt für Photographie, Chemigraphie, Lichtdruck und Gravüre in München, ab 1911 ist er als Atelierfotograf und ab 1914 als Fotolehrer in Budapest tätig. In den 1920 er und 1930er Jahren ist er weiterhin als Fotolehrer, Fotopublizist u. a. für die Zeitschrift Magyar Fotográfia tätig und arbeitet als Fotograf mit den Schwerpunkten Werbung, Sachfotografie, Genre, Porträt und Akt. Er verfolgt einen gemäßigt modernen Stil, der Elemente des Piktorialismus und der Neuen Sachlichkeit vereint. Zahlreiche seiner Aufnahmen erscheinen in der ungarischen (und auch österreichischen) Presse. Er veröffentlicht mehrere Bücher zu Fotothemen, die teilweise auch auf Deutsch erscheinen. Er stirbt am 7. Oktober 1956 in Budapest.

Perckhammer, Heinz von, geb. 1895, aufgewachsen in Meran, erlernt das Fotografieren bei seinem Vater, der seit 1879 ein Atelier in Meran betreibt. Nach dessen Tod geht dieses an den Fotografen Leo Bährendt über. Von Perckhammer ist seit 1914 als Matrose unterwegs, gerät während des Ersten Weltkriegs in China in japanische Kriegsgefangenschaft und bereist nach der Freilassung China und die Mongolei. Er hält sich bis 1927 in China auf, kehrt dann nach Europa zurück und lässt sich in Berlin nieder, wo er mehrere Fotobände über seine Zeit in China veröffentlicht. Seit Ende der 1920er Jahre ist er als Pressefotograf tätig, arbeitet viel für die UIIstein-Presse, publiziert aber auch in anderen Zeitungen und Magazinen, auch in Österreich erscheinen in den 1930er Jahren zahlreiche seiner Aufnahmen und Fotoreportagen. Seine Bilder umspannen ein breites ästhetisches Spektrum, das von Anklängen an das Neue Sehen bis zur konservativen Heimatfotografie reicht. Im Zweiten Weltkrieg arbeitet von Perckhammer als Kriegsfotograf für die deutsche Wehrmacht. Nach 1945 lässt er sich in Meran nieder und verkauft Postkarten im Eigenverlag. Er stirbt am 3. Februar 1965.

Perscheid, Anna, geb. am 5. April 1895 in Wien als Anna Schumy. Sie ist ausgebildete Fotografin und als Büroangestellte tätig. Während des Kriegseinsatzes ihres Mannes Josef Perscheid im Ersten Weltkrieg führt sie die Geschäfte der Wiener Fotoagentur „Welt-Preß-Photo“. Sie stirbt im Oktober 1988 in Wien.

Perscheid, Josef, geb. am 9. Januar 1878 in Koblenz, Pressefotograf und Fotoagent, arbeitet vor dem Ersten Weltkrieg als Mitarbeiter der Fotoagentur „Berliner Illustrations-Gesellschaft“, ist zunächst in Berlin, dann in Paris, London und Wien tätig. 1911 Aufbau und Inhaber der in Wien operierenden Fotoagentur „Welt-Preß-Photo“, ist im Ersten Weltkrieg als Kriegsfotograf im österreichischen Kriegspressequartier tätig. Bis Ende der 1920er Jahre arbeitet er als Pressefotograf und Fotoagent in Wien. Er stirbt am 29. Mai 1942 in Wien.

PeßI, Herbert, österreichischer Fotoamateur, der seit 1938 gelegentlich in der illustrierten Presse veröffentlicht, u. a. über Skirennen.

Pietzner, Carl, sen., geb. am 9. April 1853 in Wriezen a. d. Oder, 1877 Gründung eines Ateliers in Teplitz, zieht Anfang der 1890er Jahre nach Wien, baut nach und nach ein weit verzweigtes Fotoimperium auf (mit Filialen u. a. in Karlsbad, Brünn, Graz, Teplitz, Olmütz, Eger, Franzensbad, Mährisch Ostrau, Troppau, Pilsen und Budweis), beschäftigt nach 1900 ca. 300 Mitarbeiter, kurz vor dem Ersten Weltkrieg gerät sein Unternehmen in finanzielle Schwierigkeiten und Pietzner übergibt die Geschäfte nach und 
nach an seine Mitarbeiter, 1915 steht er kurz vor dem Ruin. Er stirbt am 24. November 1927 durch Selbstmord.

Pietzner, Carl (auch Karl), jun., geb. 1884 in Teplitz, arbeitet seit der Jahrhundertwende als Fotograf in Wien und betreibt seit 1910 ein Atelier in der Kärntner Straße 42, Wien 1. Ab 1925 führt er für einige Jahre zusammen mit Georg Fayer ein Atelier am Opernring 1, Wien 1 („Pietzner \& Fayer“), das regelmäßig Künstlerporträts an die Presse liefert.

Pietzner, Oscar (auch Oskar), Atelierfotograf in Wien, der um die Jahrhundertwende gelegentlich auch als Pressefotograf tätig ist.

Pollak, Lotte, Amateurfotografin, die um 1930 in der sozialdemokratischen Illustrierten Der Kuckuck veröffentlicht.

Popper, Hans, geb. am 18. April 1904 in Wien, Ausbildung an der Graphischen Lehr- und Versuchsanstalt in Wien, arbeitet in den 1920er Jahren im Atelier von Hella Katz, seit 1927 als Pressefotograf in Wien. Seine Themen sind Alltagsszenen, Architektur, Sozialdokumentationen, aber auch, v. a. in den späten 1930er Jahren, Genreszenen, Landschaften, Land und Leute sowie bäuerliche Szenen. Popper, der jüdischer Herkunft ist, flieht 1939 nach Paris und 1940 nach New York, wo er unter dem Namen John Popper zunächst als freischaffender Fotograf, u. a. für die Presse, tätig ist. Später eröffnet er ein Atelier, das er bis 1988 betreibt. Er stirbt am 30. April 1992 in New York.

Porkert, Josef, arbeitet zunächst als Assistent im Atelier von Rudolf Krziwanek und betreibt seit 1899 ein eigenes Atelier in Wien. Veröffentlicht seit 1900 zahlreiche alte Wiener Gebäude und Stadtansichten, die infolge der rasanten Stadtentwicklung vom Verschwinden bedroht sind, in der illustrierten Presse.

Rauch, Elly, Amateurfotografin in Linz, die seit 1935 idyllische bäuerliche Landschaften, Genre- und Kinderszenen in Fotozeitschriften und Magazinen veröffentlicht.

Reiffenstein, Bruno, geb. am 9. August 1868 in Wien, Absolvent der Graphischen Lehr- und Versuchsanstalt, führt seit Ende der 1880er Jahre ein eigenes Atelier, spezialisiert sich auf Stadt-, Gebäude- und Baufotografie, nach der Jahrhundertwende gründet er einen Architekturverlag und gibt nach 1910 Bildbände heraus. Seit 1900 veröffentlicht er zahlreiche Aufnahmen (v. a. Architekturbilder, aber auch Objekt- und Sachaufnahmen) in der Presse. Er stirbt am 30. April 1951 in Wien.

Révész, Emerich (Emery, Imre), geb. 1895, beginnt 1914 mit der Fotografie, arbeitet im Ersten Weltkrieg als Kriegsfotograf im österreichischen Kriegspressequartier und veröffentlicht seine Bilder in der Budapester Zeitung Érdekes Újság (Das interessante Blatt). In der Zwischenkriegszeit ist er als Werbeund Modefotograf in Budapest tätig. 1934 zieht er in die USA, wo er als Werbefotograf für die Filmfirma United Artists arbeitet. Seine Aufnahmen erscheinen in zahlreichen US-Zeitschriften, v. a. in Harper's Bazaar. Er stirbt im Jahr 1975 in New York.

Riethof, Willy, geb. 1905 in Teplitz-Schönau, tschechischer Staatsbürger, lebt von 1924 bis 1929 und von 1934 bis 1938 in Wien. Der Amateurfotograf greift in seinen Arbeiten (u. a. Landschaften, Genrebilder, Architektur- und Stadtaufnahmen, Akte und Porträts) die Anregungen des Neuen Sehens auf, seit 1929 veröffentlicht er in Fotozeitschriften und Magazinen, seit 1929 stellt er seine Bilder in Ausstellungen aus, u. a. in der Schau „Film und Foto“ (FiFo), die 1929 in Stuttgart und 1930 in Wien gezeigt wird. 1938 Emigration nach England, 1943 zieht er in die USA, wo er als Standfotograf bei Filmfirmen in Hol- lywood tätig ist und als Filmproduzent arbeitet. Er stirbt am 22. August 1994 in Paris.

Rob, Karl, geb. am 22. Januar 1891 als Karl Robitsek in Wien, studiert nach der Realschule an der Wiener Kunstgewerbeschule sowie an der École des Beaux-Arts in Paris. Er lebt von 1909 bis 1914 in Paris. Zu Beginn des Ersten Weltkriegs kehrt er nach Wien zurück, wo er zunächst als Maler und Grafiker tätig ist, dann, ab 1916, als Zeitschriftenverleger. Er gibt in der Zwischenkriegszeit u. a. die Magazine Die Muskete, MOCCA und Wiener Mode heraus. Er betätigt sich auch als Zeichner und Amateurfotograf, seine Bilder erscheinen gelegentlich in seinen Zeitschriften. Rob, der jüdischer Herkunft ist, emigriert 1938 nach Brasilien. Seit 1952 lebt er in São Paulo, danach verliert sich seine Spur.

Robert, L. von, Pressefotograf um 1900, Mitbesitzer des Fotoateliers „Heydenhaus \& Robert“. Seit 1898 arbeitet er, zusammen mit Hermann Heydenhaus, als Pressefotograf und Fotoagent.

Robertson, Hans, geb. 1893, führt seit 1927 ein Fotoatelier in Berlin, spezialisiert sich auf Künstlerporträts und Tanzaufnahmen. Seine Aufnahmen erscheinen bis 1933 in der deutschen Presse, um 1930 auch in Österreich. 1933 flüchtet Robertson, der jüdischer Herkunft ist, nach Kopenhagen, 1943 flüchtet er weiter nach Stockholm. 1945 kehrt er nach Kopenhagen zurück, wo er im Jahr 1950 stirbt.

Roß, Ilse, absolviert von 1909 bis 1911 die Graphische Lehr- und Versuchsanstalt in Wien, Atelierfotografin in Wien, eröffnet 1913 in der Blechturmgasse 1, Wien 5, ein Atelier. Ihre Porträtaufnahmen (u. a. von Arthur Schnitzler) erscheinen in den 1920er Jahren gelegentlich in der illustrierten Presse.

Roth, Franz, geb. am 5. April 1911 in Wien, ist in den 1920er Jahren Mitglied deutschnationaler Vereinigungen, seit 1933 Mitglied der SA, ist in den 1930er Jahren wegen nationalsozialistischer Betätigung mehrmals in Haft. Er arbeitet seit Anfang der 1930er Jahre als Fotograf, veröffentlicht Reportagen in Zeitschriften und Magazinen. Seit 1934 ist er als Pressefotograf für die Fotoagentur Associated Press tätig. 1936 wird inm die Arbeitsbewilligung als Pressefotograf entzogen, er geht nach Berlin, wo er als Redakteur arbeitet. 1936 bis 1938 kämpft er aufseiten Francos im Spanischen Bürgerkrieg, seit 1938 ist er wieder in Berlin, NSDAP-Mitglied und SA-Oberscharführer. Im Zweiten Weltkrieg ist er Kriegsfotograf in einer Propagandakompanie (PK) der deutschen Wehrmacht. Er stirbt 1943 bei Kiew an den Folgen einer Kriegsverwundung.

Roth, Hans, Wiener Amateurfotograf, der ab 1933 Fotos und Reportagen zu Alltagsthemen, Technik, Mode u. a. in Zeitungen und Magazinen veröffentlicht.

Rübelt, Ekkehard, geb. 1902 in Wien, Sportfotograf in Wien, Bruder von Lothar Rübelt, mit dem er als Pressefotograf eng zusammenarbeitet. Er verunglückt 1926 tödlich.

Rübelt, Lothar, geb. am 8. April 1901 in Wien, deutscher Staatsbürger, beginnt während des Ersten Weltkriegs zu fotografieren, seit ca. 1920 ist er (zeitweise zusammen mit seinem Bruder Ekkehard, der 1926 bei einem Unfall stirbt), als Pressefotograf tätig. 1922 erhält er den Gewerbeschein. In den 1920 er Jahren fotografiert er v. a. sportliche Wettkämpfe, ab Ende der 1920er Jahre erweitert er sein Themenspektrum und wird zum viel beschäftigten Fotoreporter, der neben dem Sport auch über aktuelle Ereignisse sowie politische Veranstaltungen berichtet. Seit Ende der 1920er Jahren stellt er auch Fotoreportagen zu alltäglichen Themen zusammen, teilweise liefert er dazu auch die Texte. Seine Bilder erscheinen in allen wichtigen österreichischen Illustrierten und Magazinen. Ab Ende der 1920er Jahre ist er auch auf dem deutschen Bildmarkt vertreten.
1928 arbeitet er mit der Berliner Fotoagentur Scherl Bilderdienst zusammen, ab 1930 ist er für den Berliner Ullstein Verlag tätig. Ende 1934 stellt er einen Antrag auf Aufnahme in den „Reichsausschuss der Bildberichterstatter im Reichsverband der Deutschen Presse“. Bereits vor dem „Anschluss“ an das nationalsozialistische Deutschland sympathisiert er mit der NS-Bewegung. 1936 ist er der einzige österreichische Sportfotograf, der bei den Berliner Olympischen Spielen fotografiert. 1938 begrüßt er den „Anschluss“, fotografiert Hitler auf seiner Propagandareise durch Österreich. Im Zweiten Weltkrieg ist er Kriegsfotograf in einer Propagandakompanie der deutschen Wehrmacht. Nach 1945 ist er wieder als Presse-, Sport- und Werbefotograf tätig, er veröffentlicht mehrere Bildbände. Rübelt stirbt am 4. August 1990 in Reifnitz am Wörthersee.

Rückauf, Monika, Wiener Porträt- und Pressefotografin, arbeitet Anfang der 1930er Jahre als Assistentin von Trude Fleischmann. Ab 1938 macht sie Genrebilder, aber auch Fotos von Land und Leuten, die sie etwa nach dem Balkanfeldzug der deutschen Wehrmacht (1941) in Jugoslawien aufnimmt und in Wiener Zeitungen und Zeitschriften publiziert.

Rybarik, Willy, Wiener Amateurfotograf, seit Ende der 1920er Jahre Mitglied der Photographischen Fachgruppe der Volkshochschule Wien-Ottakring, nimmt seit 1930 an zahlreichen Ausstellungen teil und publiziert seine Bilder in Fotozeitschriften und um 1930 auch in der sozialdemokratischen Presse.

Saad, Georges, französischer Modefotograf, der in den 1930er Jahren u. a. von der Wiener Fotoagentur Schostal vertreten wird.

Sadler, Otto, Wiener Amateurfotograf, seit Ende der 1920er Jahre Mitglied der Arbeiterfotogruppe der Naturfreunde Meidling, veröffentlicht um 1930 in Fotozeitschriften und Magazinen und beteiligt sich an Ausstellungen.

Sajdok, Erwin, geb. am 17. Januar 1906 in Wien, Amateurfotograf und Fotopublizist, arbeitet ab 1930 als wissenschaftlicher Assistent an der Technischen Hochschule (TH) Wien, 1936 Promotion an der TH Wien. Seine Themen als Fotograf sind Landschaften, Genreszenen sowie technische und industrielle Konstruktionen. Anfang der 1930er Jahre macht er auch Reportagen zu Alltagsthemen. In den 1930er Jahren und nach dem Zweiten Weltkrieg Publikationen in Fotozeitschriften und Magazinen, Beteiligung an Ausstellungen.

Sanden, Heinrich, geb. am 2. Oktober 1877 in Berlin, gründet um 1900 zusammen mit Carl Delius und Martin Gordan die Fotoagentur „Berliner IIlustrations-Gesellschaft", die bis nach dem Ersten Weltkrieg existiert und seit 1906 auch Bilder nach Österreich liefert. Von 1908 bis 1913 lebt er als Pressefotograf in Wien und beliefert die Berliner Agentur mit aktuellen Pressefotos, veröffentlicht aber auch in österreichischen Blättern. 1919 scheiden die beiden Mitinhaber aus der Firma aus, Sanden übernimmt die Agentur und führt sie unter dem Namen „Atlantic“ weiter. 1933 verkauft er den Betrieb unter dem Druck der Nationalsozialisten. Er stirbt am 28. Juni 1946.

Santho (auch Szánthó), Imre von, geb. 1900 in Budapest, Ausbildung als Fotograf, Modezeichner und Karikaturist, arbeitet seit 1929 als Modefotograf in Berlin, wird in den 1930er Jahren von der Wiener Fotoagentur Schostal vertreten. Seit dem „Anschluss“ Österreichs an das nationalsozialistische Deutschland erscheinen seine Modeaufnahmen auch in Wiener Illustrierten. Während der Kriegszeit lebt er in Budapest, wo er 1946 stirbt.

Sauer, Fritz (Friedrich), geb. 1893 in Karolinenthal bei Prag, arbeitet seit 1927 als Fotograf in Wien, spezia- 
lisiert sich auf Architektur-, Industrie-, Sach- und Werbefotos, liefert jahrelang Aufnahmen von Geschäftsfassaden für gewerbliche Anzeigen in der illustrierten Presse, veröffentlicht seit 1928 zahlreiche Fotos in Zeitungen und Zeitschriften.

Schädler, Anton, Atelierfotograf in Sarajevo, Bosnien, wo er seit den 1890 er Jahren ein Atelier unterhält. Um die Jahrhundertwende liefert er gelegentlich Pressefotos an Wiener Illustrierte.

Schaffelhofer, Steffi, geb. als Steffi Zlatarits, Wiener Amateur- und Pressefotografin, die ihre Bilder seit 1930 in Zeitungen und Zeitschriften veröffentlicht, sie stellt häufig Fotoreportagen zusammen. Ihre Themen sind Alltagsbeobachtungen in der Stadt und auf dem Land, v. a. aber macht sie Reiseaufnahmen in Europa und Kleinasien. 1942 liefert sie die Fotos für einen Bildband über die Lipizzaner in Wien.

Schalek, Alice, geb. am 21. August 1874 in Wien, Journalistin, Schriftstellerin, Fotografin. Sie arbeitet seit 1903 für das Feuilleton der Neuen Freien Presse, unternimmt zahlreiche Reisen, auf denen sie fotografiert, seit 1915 arbeitet sie als Kriegsberichterstatterin und Fotografin. Sie veröffentlicht ihre Bilder, vornehmlich Reiseaufnahmen, während des Ersten Weltkriegs auch Kriegsfotos, in illustrierten Zeitungen und Zeitschriften sowie in Büchern. Schalek, die jüdischer Herkunft ist, flieht 1939 über England in die USA. Sie stirbt am 6. November 1956 in der Nähe von New York.

Schein, Abraham Maier (Myron), geb. am 3. Oktober 1871 im ukrainischen Michajlowka, Russland, führt seit 1904 ein Atelier in Wien. In seinen fotografischen Arbeiten (Porträts, aber auch Aktaufnahmen) nimmt er die Anregungen des Piktorialismus auf. Seine Fotos stellt er in Ausstellungen aus und veröffentlicht sie in der fotografischen Fachpresse und in illustrierten Zeitungen. Schein, der jüdischer Herkunft ist, flieht 1939 nach Argentinien, wo er neuerlich ein Atelier eröffnet. Er stirbt am 15. Januar 1950 in Buenos Aires.

Schein, Jsaak (auch Isaak), geb. am 2. Januar 1871 in Jekaterinoslav, Russland (er ist nicht verwandt mit Abraham Schein), Fotograf und Fotohändler, führt seit 1909 in Wien ein Geschäft für fotografische Vergrößerungen. Nach dem Ersten Weltkrieg ist er auch als Pressefotograf tätig. Schein, der jüdischer Herkunft ist, muss seinen Betrieb Ende 1938 aufgeben. Danach verliert sich seine Spur

Scherb, Julius, geb. am 18. Januar 1881 in Linz, arbeitet nach der Ausbildung zum Fotografen in mehreren Ateliers in Österreich, Böhmen und Deutschland. Seit 1913 ist er im Atelier von Josef Löwy in Wien tätig. 1919 eröffnet er ein eigenes Atelier in Wien und spezialisiert sich auf Architekturfotografie, macht aber auch Fotoreproduktionen von Gemälden und Kunstwerken sowie Sachaufnahmen. Zahlreiche seiner Aufnahmen erscheinen in der Zwischenkriegszeit in der illustrierten Presse. Er wird 1942 NSDAP-Mitglied und ist als Fotograf bis in die 1950er Jahre aktiv. Er stirbt im Jahr 1958.

Schiestl, Josef, österreichischer Fotograf, der vor dem Ersten Weltkrieg gelegentlich Pressefotos in illustrierten Zeitungen veröffentlicht.

Schindler, Nikolaus, geb. am 18. November 1873 in Wien, österreichischer Offizier und Amateurfotograf. Er fotografiert seit der Jahrhundertwende, seit 1903 ist er Mitglied des „Camera-Clubs“. Schindler ist Anhänger der piktorialistischen Fotografie, er fotografiert Landschaften, Genreszenen, Porträts und Akte, nimmt seit 1906 an zahlreichen Fotoausstellungen teil. Seit 1916 ist er Mitglied des k. u. k. Kriegspressequartiers, 1917 wird er Leiter der Lichtbildstelle im Kriegspressequartier. Er stirbt im März 1958 in Wien.

Schistal, Anton, geb. 1872, führt ab 1897 ein Atelier in Wien, seit 1905 Zusammenarbeit mit Franz Gabri- el, liefert seit 1906 gelegentlich Pressebilder an Zeitungen. Er stirbt im Juli 1956 in Wien.

Schleich, Karl, geb. am 9. Juli 1895 in Wien, arbeitet seit 1925 als Presse- und Sportfotograf, 1927 bis 1929 Zusammenarbeit mit Albert Hilscher. Er spezialisiert sich auf die Sportfotografie, fotografiert aber auch Alltags- und Stadtszenen und stellt Anfang der 1930er Jahre Fotoreportagen zu unterschiedlichen Themen zusammen. Seit Mitte der 1920er Jahre ist er mit seinem Aufnahmen in zahlreichen Zeitungen und Zeitschriften vertreten. 1938 ersucht er um Aufnahme in die NSDAP. Er stirbt am 8. August 1952 in Wien.

Schloß, Rudolf, Amateurfotograf in Wien, veröffentlicht seit 1930 Landschaftsbilder, Alltags- und Genreszenen in Zeitungen und Zeitschriften.

Schmachtenberger, Erika, geb. am 30. Juni 1906, deutsche Staatsbürgerin, wächst in Würzburg und Kempten auf, beginnt 1928/29 zu fotografieren und ist seit 1932 als Pressefotografin tätig. In den 1930 er Jahren erscheinen ihre Aufnahmen auch in österreichischen Illustrierten. Sie macht zahlreiche Reisen, fotografiert das bäuerliche, traditionelle Leben in den Alpen, Land und Leute, Brauchtum, Trachten und Landschafen. Seit den 1930er Jahren wird sie von der Wiener Fotoagentur Schostal vertreten. Seit 1941 ist sie als Filmfotografin bei der deutschen Filmfirma Tobis. Seit den 1970er Jahren gibt sie zahlreiche Bildbände mit ihren Fotos heraus. Sie stirbt am 13. März 1992 in Würzburg.

Schmal, Felix, Sportjournalist und Sportfotograf. 1892/93 Ausbildung zum Fotografen an der Graphischen Lehr- und Versuchsanstalt in Wien, ist nach der Jahrhundertwende als Sportjournalist tätig. Er fotografiert seit ca. 1900, zunächst als Amateurfotograf, seit 1914 als Sportfotograf für die Presse. Er veröffentlicht bis in die 1920 er Jahre zahlreiche Sportaufnahmen in Zeitungen und Zeitschriften.

Schmauss, Erika, Fotografin, die ab 1938 und während des Zweiten Weltkrieges Fotoreportagen (u. a. Reisebilder, Stadt- und Architekturaufnahmen, Fotos von Kunstwerken) in Wiener Zeitungen veröffentlicht.

Schneider, Siegmund, geb. am 4. Januar 1861, arbeitet als Journalist und Autor und ab 1893 als Herausgeber der Österreichischen Illustrirten Zeitung in Wien. Er ist auch als Amateurfotograf, Bildredakteur und Fotomonteur tätig. Er stirbt am 7. Januar 1913 in Wien.

Schneider, Walther, österreichischer Fotoamateur, der seit Anfang der 1930er Jahre tätig ist. Er ist der modernen Fotografie gegenüber aufgeschlossen und veröffentlicht Bilder und Fotoreportagen in der Presse.

Scholz, Ursula, Fotoamateurin, die in den 1930er Jahren Bilder von bäuerlichen Szenen, alpinen Landschaften und Genreszenen veröffentlicht. Vertreterin der Heimatfotografie.

Schöpl, Karl, geb. am 29. Februar 1896 in Budapest, führt seit 1921 ein Porträtatelier in Wien und arbeitet seit den späten 1920er Jahren auch als Pressefotograf. Anfang der 1930er Jahre ist er für die Wiener Fotoagentur Polyphot tätig. Er arbeitet bis 1967 als Fotograf, danach zieht er in die Steiermark.

Schostal, Robert, geb. am 9. November 1906, gründet 1926 die Fotoagentur „Wiener Photo-Kurier“, die Anfang der 1920er Jahre in „Schostal“ umbenannt wird und in der Vater Oscar und Bruder Walter mitarbeiten. Ab 1928 geht das Unternehmen eine Kooperation mit der von London aus agierenden Fotoagentur Keystone ein. Schostal unterhält Filialen in Mailand, Paris und Stockholm. 1938 flieht Robert Schostal, der jüdischer Herkunft ist, zusammen mit seinem Bruder zunächst nach Paris, dann weiter nach New York und gründet dort mit seinem Bruder eine neue
Fotoagentur („Shostal Inc.“, später „Shostal Associates“). Er stirbt 1975 in New York.

Schostal, Walter, geb. am 25. Februar 1908, arbeitet neben seinem Studium in der Fotoagentur seines Bruders Robert Schostal, nach seiner Promotion 1933 eröffnet und führt er eine Filiale der Agentur in Paris. Er flieht zusammen mit seinem Bruder nach New York, wo die beiden eine neue Fotoagentur („Shostal Inc.“, später „Shostal Associates“) gründen. Er stirbt am 3. Juli 2003 in Charlottesville, Virginia.

Schramek, Josef, Wiener Amateurfotograf, von Beruf technischer Beamter. Er ist seit Anfang der 1920er Jahre fotografisch tätig, stellt seit 1925 in zahlreichen Ausstellungen aus und publiziert seine Bilder in Fotozeitschriften und in der illustrierten Presse.

Schreiber, Gustav, Fotograf in Wien, der um die Jahrhundertwende (u. a. Sportaufnahmen) auch in der illustrierten Presse veröffentlicht.

Schuhmann, Heinrich, sen., geb. 1854 in Zwingenberg bei Darmstadt, Hessen, arbeitet zunächst als Journalist, nach der Jahrhundertwende als Sportund Pressefotograf in Wien, veröffentlicht seit 1904 zahlreiche Aufnahmen in der illustrierten Presse. Er stirbt am 3. Dezember 1913.

Schuhmann, Heinrich, jun., geb. am 21. Dezember 1888 , Sohn von Heinrich Schuhmann sen., Pressefotograf in Wien, fotografiert für österreichische illustrierte Zeitungen, im Ersten Weltkrieg ab 1917 (zusammen mit seinem Bruder Ludwig) Pressefotograf Kaiser Karls I., führt ab 1920 am Kohlmarkt 1, Wien 1, ein Atelier, zeitweise gemeinsam mit dem Sportfotografen Carl Zapletal, er arbeitet bis Mitte der 1920er Jahre noch gelegentlich als Sport- und Pressefotograf. Seit Ende der 1930er Jahre verkauft er auch fotografische Bedarfsartikel. Im Zweiten Weltkrieg ist er als Kriegsfotograf in einer Propagandakompanie (PK) der deutschen Wehrmacht tätig. Er führt seinen Fotobetrieb bis 1963.

Schuhmann, Ludwig, geb. 1878 oder 1879, Sohn von Heinrich Schuhmann sen., Fotograf im Ersten Weltkrieg, ab 1917 (zusammen mit seinem Bruder Heinrich) Pressefotograf Kaiser Karls I., arbeitet in den 1920er Jahren gelegentlich als Pressefotograf, führt in den 1930er Jahren in Puchberg einen Foto- und Ansichtskartenhandel. Er stirbt am 12. Juni 1935 in Puchberg.

Schulda-Müller, Hertha, geb. 1899 als Hertha Schulda, verh. Müller, Pressefotografin und Schriftstellerin. Sie arbeitet seit den späten 1930er Jahren als Pressefotografin in Wien. Ihre Themen sind u. a. Tanz, Theater und Porträt. Sie ist auch während des Zweiten Weltkriegs als Theaterfotografin aktiv und arbeitet nach 1945 als Pressefotografin. Sie stirbt im Jahr 1990.

Schullerbauer, Hans, Atelierfotograf in Graz, der um 1900 gelegentlich Pressebilder in illustrierten Zeitungen veröffentlicht.

Schulz, Annie, geb. am 14. August 1897 als Anna Weishut in Wien, ist seit 1925 als Pressefotografin tätig, führt ab 1929 ein Atelier, arbeitet von 1927 bis ca. 1931 mit Marianne Bergler, geb. Blumberger, zusammen, ihre gemeinsamen Arbeiten signieren sie mit „Blumberger-Schulz“. Die Themen von Annie Schulz sind der städtische Alltag, Theater, soziale Themen, Porträts. Um 1930 stellt sie zahlreiche Fotoreportagen zusammen. Schulz, die jüdischer Herkunft ist, entgeht der Deportation vermutlich deshalb, weil sie (seit 1923) mit einem Nichtjuden, Hermann Ignaz Schulz, verheiratet ist. Sie stirbt am 21. November 1943 in Wien.

Schur, Lena (Leonora), geb. 1902 (?) in Mohilew, Russland, aufgewachsen in Riga (?). Sie ist seit 1933 als Pressefotografin in Wien tätig. Ihre Themen sind u. a. Theater, Alltagsszenen, Sozialdokumentationen, 
Porträts und Mode. Sie veröffentlicht regelmäßig Fotoreportagen. Mitte der 1930er Jahre gründet sie unter dem Namen „Kondor. Pressedienst Leonora Schur" eine Fotoagentur in Wien, die auch mit internationalen Agenturen, u. a. Prisma in Zürich, kooperiert. Schur, die jüdischer Herkunft ist, ist 1938 gezwungen, ihre Tätigkeit aufzugeben. Nach dem Einmarsch der Nationalsozialisten in Wien flüchtet sie nach Paris, wo zu dieser Zeit ihr Lebensgefährte, der Maler Arnulf Neuwirth lebt. Die beiden ziehen später nach Gran Canaria, wo Schur bis ca. 1942 lebt. Danach verliert sich ihre Spur.

Schuster, Ferenc, ungarischer Fotoamateur, der in den 1930er Jahren auch in österreichischen Magazinen veröffentlicht.

Schwabik, Marian, geb. am 23. Januar 1911 in Bregenz, ab 1931 Studium der Chemie in Wien, München und Dresden, arbeitet seit 1929 als freier Pressefotograf für deutsche Zeitungen und Zeitschriften, veröffentlicht seit 1932 auch in Österreich, v. a. Reportagen zu den Themen Land und Leute sowie Wintersport. Ab 1941 Bildberichterstatter bei der deutschen Marine. 1959 bis 1970 Geschäftsführer der Deutschen Gesellschaft für Photographie in Köln, Fotopublizist, 1970 bis 1975 Leiter des Fotomuseums im Münchner Stadtmuseum. Er stirbt am 11. Mai 1990 in München.

Schwarz, Diana, Wiener Amateurfotografin, die um 1930 v. a. in der sozialdemokratischen Presse veröffentlicht. Sie dokumentiert soziale Themen, Stadtszenen, aber auch ländliche bäuerliche Szenen.

Schwarz, Nikolaus, Amateurfotograf in Wien, der um 1930 im Umfeld der Wiener Arbeiterfotografie tätig ist. Er ist von 1931 bis 1934 mit zahlreichen Aufnahmen im sozialdemokratischen Kuckuck vertreten, parallel dazu veröffentlicht er auch in anderen Zeitungen und Zeitschriften - teilweise in Form von Fotoreportagen. Er ist offen gegenüber der modernen Fotografie, seine Themen sind Alltagssituationen, Genreszenen, Stadtbilder, Sachaufnahmen, Porträts, Reisebilder (er ist in den 1930er Jahren in Deutschland, aber auch in Palästina unterwegs). Gelegentlich hält er auch ländliche Szenen fest.

Scolik, Charles, geb. am 16. März 1854 in Wien, gründet 1873 ein erstes Atelier in Wien, das er bald wiede aufgibt. Ab 1876 ist er Assistent im Atelier von Karl Kroh, seit 1886 führt er ein eigenes Fotoatelier in der Piaristengasse 48, Wien 8. Er ist ein bekannter Wiener Porträtfotograf, arbeitet aber auch im Freien und ist seit ca. 1895 auch als Pressefotograf tätig. Zahlreiche Aufsätze und Texte zur Fotografie in Fachzeitschriften und Büchern. Er stirbt am 1. Juni 1928 in Wien.

Scolik, Charles, jun., geb. am 6. Juli 1877 in Wien, Sohn von Charles Scolik sen., absolviert 1893/94 die Graphische Lehr- und Versuchsanstalt, arbeitet zunächst im Atelier seines Vaters, seit ca. 1905 auch als Pressefotograf. Seit 1905 erscheinen seine Pressefotos unter dem Namen „Atelier Moderne“ oder „Ch. Scolik \& M. Mertens“, das er einige Jahre gemeinsam mit der Fotografin Marie Mertens führt. Scolik arbeitet in der Zwischenkriegszeit v. a. als Atelierfotograf und bis Mitte der 1920er Jahre auch noch als Pressefotograf. Er stirbt 1937 in Wien.

Sedlar, Luis, Fotograf, der seit den 1930er Jahren von der (1938 „arisierten“, d. h. zwangsenteigneten) Wiener Fotoagentur Schostal vertreten wird.

Seebald, Carl (auch Karl), geb. am 22. August 1878 in Wien, arbeitet seit 1904 als Pressefotograf, meldet im Jahr darauf das Gewerbe an und gründet um 1908 die Fotoagentur „Illustrationsunternehmung Carl Seebald“, die eine Filiale in Budapest unterhält. Neben eigenen Aufnahmen vertreibt er auch zugekaufte Bilder aus anderen Ländern (England, USA). Seebald gehört vor dem Ersten Weltkrieg zu den am meisten beschäftigten Pressefotografen in
Wien. Sein Themenspektrum ist breit und reicht von aktuellen Nachrichtenbildern, Sensationen des Alltags und Porträts bis hin zu Sportaufnahmen. Im Ersten Weltkrieg ist er als Kriegsfotograf im österreichischen Kriegspressequartier beschäftigt. In der Nachkriegszeit ist er (bis 1935) wieder als Pressefotograf tätig. Er stirbt am 21. Dezember 1941 in Wien.

Seldowicz (Seldow), W., Pressefotograf in Berlin, der um 1930 zahlreiche Fotos und Fotoreportagen in der deutschen Presse und ab 1929 auch in österreichischen Zeitungen veröffentlicht. Die Bilder werden (teilweise) über die von Rudolf Birnbach gegründete Fotoagentur „Weltrundschau“ vertrieben.

Senkinc, Franz, geb. am 26. Oktober 1902 in Wien, Ausbildung als Lithograf, arbeitet in den 1930er Jahren als Gebrauchsgrafiker und Maler mit Otto Exinger zusammen. Er beginnt um 1930 als Amateurfotograf. Seine Arbeiten (Sach- und Architekturaufnahmen, Porträts, Werbebilder, Landschaften) stehen teilweise unter dem Einfluss der Neuen Sachlichkeit und des Neuen Sehens. Er stellt seine Fotos seit 1931 in zahlreichen Ausstellungen aus und ist in Fotozeitschriften und Magazinen präsent. Er stirbt am 23. November 1955 in Wien.

Serog (Serog-Bertrand), Käthe, geb. am 26. Mai 1906 im schlesischen Bielitz, absolviert 1929/30 die Graphische Lehr- und Versuchsanstalt in Wien, arbeitet um $1930 \mathrm{im}$ Atelier von Trude Fleischmann als Retuscheurin, publiziert in den 1930er Jahren in Fotozeitschriften und gelegentlich in illustrierten Zeitungen. Ihre Themen reichen von Porträts bis hin zu ländlichen Szenen. Serog, die jüdischer Herkunft ist, flüchtet 1938/39 nach New York, wo sie bis in die 1980 er Jahre lebt.

Setzer, Franz Xaver, geb. am 6. August 1886 als Franz Anton Adolf in Wien, arbeitet seit 1909 als Fotograf in Wien, eröffnet 1911 ein eigenes Atelier, das bald zu den renommiertesten Wiener Porträtstudios gehört. Er spezialisiert sich auf Theater-, Tanz- und Schauspielerfotografie. In seinen fotografischen Arbeiten nimmt er Anregungen der Kunstfotografie auf. Zahlreiche seiner Aufnahmen erscheinen seit 1910 in der österreichischen und deutschen illustrierten Presse. Er stirbt am 10. Januar 1939 in Wien.

Sieger, Eduard, Fotograf in Wien, der um die Jahrhundertwende Mitbesitzer der Fotoagentur „Sieger-Sobotka“ ist. Diese liefert seit 1904 Bilder an die illustrierte Presse.

Skall, Otto, geb. am 10. Februar 1884 in Prag, lebt seit 1920 in Wien, arbeitet ab 1925 als Pressefotograf in Wien. Sein Themenspektrum ist breit. Es reicht von Theateraufnahmen über Stadtansichten, Alltagsszenen, Porträts, Sachaufnahmen, Reisebilder bis hin zur Sozialdokumentation. Seit Anfang der 1930er Jahre stellt er zahlreiche Fotoreportagen und Bildgeschichten zusammen. Skall, der jüdischer Herkunft ist, flüchtet im November 1938 zusammen mit seiner (zweiten) Frau Augustine (Gusti) Skall (geb. Mandler) nach Prag, wo die beiden am 23. (Gusti) bzw. 24. Januar (Otto) 1942, kurz vor der drohenden Deportation ins KZ, Selbstmord begehen.

Sladky, Eugen, Wiener Amateurfotograf, seit ca. 1930 Mitglied der Photographischen Fachgruppe der Volkshochschule Wien-Ottakring, beteiligt sich an Fotoausstellungen.

Sobotka, H., Wiener Pressefotograf, der um die Jahrhundertwende tätig ist. Mitbesitzer der Fotoagentur „Sieger-Sobotka“, die seit 1904 Bilder an die Presse liefert.

Sommerauer, Franz, Grazer Atelierfotograf, der seit 1897 ein Atelier führt und um die Jahrhundertwende gelegentlich Presse- und Sportbilder an die illustrierte Presse liefert.

Spiegel, Rudolf, geb. am 10. März 1896 in Wien, Besuch der Realschule in Wien, danach Soldat im Ers- ten Weltkrieg. Ende 1920 kehrt er aus der russischen Kriegsgefangenschaft aus Wladiwostok heim. In der Zwischenkriegszeit arbeitet er zwischen Phasen der Arbeitslosigkeit als Bankbeamter. Ende der 1920er Jahre beginnt er zu fotografieren. 1937 macht er eine Ausbildung an der Graphischen Lehrund Versuchsanstalt. Ab 1929 publiziert er seine Bilder, die teilweise in der Tradition des Neuen Sehens stehen, in der illustrierten Presse. Seine Themen sind der städtische Alltag, Porträts, Straßenund Genreszenen, aber auch aktuelle politische und gesellschaftliche Ereignisse. Während des Zweiten Weltkrieges ist er als Soldat u. a. in Jugoslawien stationiert, wo er ebenfalls fotografiert. Nach 1945 ist Spiegel wieder in Wien als Pressefotograf tätig, u. a. für die Lichtbildstelle Alpenland. Er stirbt am 27. November 1982 in Wien.

Spira, Bil (Wilhelm), geb. 1913 in Wien, 1932 bis 1935 Studium an der Kunstgewerbeschule Wien, arbeitet seit den 1920er Jahren als Zeichner und ab den 1930 er Jahren als Fotoredakteur. Seit Ende der 1920 er Jahre ist er als Zeichner humoristischer Politkarikaturen für sozialdemokratische Zeitungen tätig, 1935 bis 1938 arbeitet er als Foto- und Umbruchredakteur bei der Zeitschrift Der Sonntag und als Bühnenbildner für Wiener Kleinkunstbühnen. 1938 flieht Spira, der jüdischer Herkunft ist, nach Paris, wo er den Namen Willy Feier annimmt und als Zeichner für humoristische Zeitschriften tätig ist. 1939 wird er als „feindlicher Ausländer“ interniert, 1940 flieht er nach Marseille. 1941 Verhaftung und Auslieferung an das Deutsche Reich, Deportation in verschiedene Konzentrationslager, die er überlebt. Er kehrt nach dem Krieg nach Paris zurück, wo er als Zeichner und Umbruchredakteur arbeitet. Er stirbt 1999 in Puteaux bei Paris.

Spitzer, Harald, österreichischer Amateurfotograf, der um 1933 gelegentlich Sozialreportagen in der illustrierten Presse veröffentlicht.

Spreng, Franz, geb. am 4. November 1895 im nordböhmischen Neustadt an der Tafelfichte (Nové Mešto pod Smrkem, heute Tschechien), Betreiber einer Tabaktrafik in Wien. Er ist seit den 1920er Jahren als Amateurfotograf tätig, zeigt sich offen gegenüber der modernen Fotografie und stellt seine Bilder (Stadtansichten, Architektur, Technik, Sachaufnahmen, Genreszenen) seit 1929 in zahlreichen Ausstellungen aus. Er stirbt am 6. Juli 1982 in Klosterneuburg.

Stauda, August, geb. 1861 in Schurz bei Königinhof in Böhmen, lebt seit 1882 in Wien, erlernt das Fotografieren bei seinem Onkel J. E. Stauda. Seit 1885 führt er ein Atelier in Wien und spezialisiert sich auf Gebäude- und Stadtfotografie und teilweise auf Kunstreproduktionen. Ab 1898 dokumentiert er Alt-Wiener Gebäude. Seit den 1890er Jahren erscheinen seine Aufnahmen gelegentlich in der illustrierten Presse. Sein Fotounternehmen geht während des Ersten Weltkriegs bankrott. Er stirbt am 8. Juli 1928 in Wien.

Steffen, Alfred, geb. am 31. Mai 1898 in Graz, 1916 Matura in Graz, Besuch der Graphischen Lehr- und Versuchsanstalt in Wien, arbeitet in den 1920er Jahren als freier Fotograf, u. a. für den Grazer Postkartenverlag Költz, seit 1926 für den eigenen „Erika“-Verlag. Seit 1928 führt er das Atelier „Steffen-Lichtbild“ in Waltendorf bei Graz, das später nach Graz übersiedelt. Daneben ist er ab 1930 als Pressefotograf tätig. Er fotografiert aktuelle Ereignisse, aber auch Stadtansichten, Landschaften, Architektur, Sehenswürdigkeiten, Land und Leute, Trachten und Kunstwerke. Er stirbt 1983 in Graz.

Steinhoff, Ilse, geb. 1909 in Wuppertal, Journalistin und Pressefotografin. Ab den 1930er Jahren arbeitet sie als Fotografin in Berlin. Ihre Bilder werden u. a. von der Amsterdamer Fotoagentur Klinsky ver- 
trieben. Sie fotografiert 1936 bei den Olympischen Spielen in Berlin. Sie ist eine Anhängerin des Nationalsozialismus und passt sich thematisch und in ihrer Bildsprache dem Regime an. In der zweiten Hälfte der 1930er Jahre lebt sie in den ehemaligen deutschen Kolonien in Ost- und Südwestafrika. Sie liefert zahlreiche propagandistische und z. T. rassistische Reisereportagen aus Afrika, die ab 1938 auch in Wiener Zeitungen erscheinen. Während des Kriegs ist sie höchst aktiv, ab 1939 gibt sie Bildbände heraus und arbeitet als Bildberichterstatterin in Südosteuropa. In der Nachkriegszeit lebt sie in Saarbrücken, wo sie als Pressefotografin tätig ist. Sie stirbt 1974 in Eberbach-Bad Neckartal.

Stern, Alexander (Künstlername: STAL), geb. am 30. Oktober 1894 in Klosterneuburg, Ausbildung zum Gärtner, arbeitet vor 1914 als Bergarbeiter und Gärtner, Soldat im Ersten Weltkrieg. Er lebt seit 1919 in Graz, ist in der Zwischenkriegszeit als Publizist, Roman- und Theaterautor tätig. Er beschäftigt sich ab 1928 mit Fotografie, erkundet experimentelle Formen der Fotografie (Montagen, Collagen, Mikrofotografie, Licht-Bewegungsstudien). Seit 1930 macht er unter dem Künstlernamen „STAL“ Fotomontagen für den sozialdemokratischen Kuckuck, veröffentlicht darin auch einzelne Fotos und Themenseiten. Ab 1934 ist er wegen seines politischen Engagements nicht mehr öffentlich tätig. 1941 wird er Leiter der Lichtbildstelle des Grazer Gartenbauamtes, 1948 Zwangspensionierung. Ab 1954 wieder intensive Beschäftigung mit Fotografie. Er stirbt am 3. April 1970 in Graz.

Stern, Ilsa, verh. Hofmann, geb. am 7. April 1912 in Parschitz/Poříčí, Tschechien, verh. mit Franz Hof mann. Sie studiert 1931/32 an der Münchener Fotoschule, ist seit Mitte der 1930er Jahre als Fotoamateurin und Pressefotografin tätig, hält sich 1934 in Wien auf und veröffentlicht in österreichischen Illustrierten Fotoreportagen über Wiener Themen. 1941 Gefangenschaft im Lager Lodz, wo ihr Mann Franz Hofmann ermordet wird. 1945 Rückkehr nach Prag, danach Übersiedlung nach England und 1946 nach New York. In den USA fotografiert sie als Pressefotografin u. a. für die Zeitschrift Life. Sie stirbt im Jahr 1970.

Stöger, Vinzenz, Wiener Pressefotograf, der seit ca. 1930 tätig ist. Seine ersten Bilder veröffentlicht er im sozialdemokratischen Kuckuck. Nach dem „Anschluss" an das nationalsozialistische Deutschland 1938 passt er sich schnell an die neuen politischen Gegebenheiten an und publiziert regelmäßig Fotos und Reportagen über aktuelle Ereignisse, ländliche Bräuche, Alltagsthemen u. a

Stone, Sasha, geb. 1895 als Alexander Serge Steinsapir in St. Petersburg, nach dem Ingenieurstudium zieht er nach New York, 1919 nach Paris und Anfang der 1920er Jahre nach Berlin, ab 1931 lebt er in Brüssel. Ab 1924 ist er als Atelierfotograf, Fotomonteur und Werbegrafiker in Berlin tätig. Er arbeitet von Anfang der 1920er Jahre bis 1939 eng mit seiner Lebensgefährtin Cami Stone zusammen, die seit Ende der 1920er Jahren fotografiert. Er veröffentlicht seit den 1920er Jahren unter dem Namen „Sasha Stone“, „Stone“, „Atelier Stone“ und „Studio Stone" (teilweise stammen die Aufnahmen aber auch von Cami Stone) zahlreiche Fotos in der illustrierten Presse, ab 1928 erscheinen seine Bilder gelegentlich auch in österreichischen Zeitschriften. 1940 Flucht vor den Nationalsozialisten nach Südfrankreich. Er stirbt am 6. August 1940 in Perpignan.

Stone, Cami, geb. 1898 als Wilhelmine Camille Honorine Schammelhout im belgischen Vilvorde. Sie zieht Ende des Ersten Weltkriegs nach New York, eröffnet dort einen Import-Export-Handel und lernt Sasha Stone kennen. Anfang der 1920er Jahre ziehen die beiden nach Berlin, wo sie 1924 gemein- sam das „Atelier Stone“ eröffnen, ab 1931 führen sie in Brüssel das „Studio Stone“. Cami Stone arbeitet seit den späten 1920er Jahren als Fotografin und veröffentlicht zusammen mit Sasha Stone unter den gemeinsamen Namen „Stone“, „Atelier Stone“ und "Studio Stone“ (teilweise stammen die Aufnahmen aber auch von Sasha Stone). Eindeutig von ihr selbst stammen die mit Cami Stone unterzeichneten Bilder. Sie stirbt 1975.

Strelitzky (Strelisky), Sándor, geboren am 9. April 1859 in Budapest (Pest), Ausbildung zum Ingenieur, übernimmt nach dem Tod seines Vaters Lipót Simonyi dessen Fotoatelier, das im 19. Jahrhundert das größte und nobelste Studio der Stadt ist. Später führt er ein zweites Atelier. Um 1900 spezialisiert er sich auf Porträts von Bühnenstars und Theaterbilder. Er veröffentlicht um 1900 zahlreiche Porträts in der illustrierten Presse und ist auch in österreichischen Zeitungen präsent. Er stirbt 1922 in Budapest.

Strof, Josef Hans, Wiener Pressefotograf, der seit 1938 tätig ist. Er arbeitet auch in der Nachkriegszeit als Fotoreporter.

Sturm, Wilhelm, geb. am 24. August 1915 in TeplitzSchönau, ist seit 1937 als Pressefotograf in Wien tätig. Er fotografiert aktuelle Ereignisse, aber auch Genrebilder und ländliche Szenen. Nach 1938 ist er ein Anhänger des Nationalsozialismus. Seine Bilder werden ab 1939 von der inzwischen ,arisierten“, d. h. zwangsenteigneten Wiener Fotoagentur Schostal vertreten. 1946 bis 1948 führt er einen Fotobetrieb in Salzburg. Er stirbt am 11. Juni 1980.

Štyrsky, Jindřich, geb. am 11. August 1899 im böhmischen Niedertscherma (Dolní Cermná, Tschechien), 1920 bis 1924 Studium an der Akademie der bildenden Künste in Prag, 1925 bis 1928 lebt er in Paris, danach wieder in Prag. Er ist als Avantgardekünstler (Maler, Grafiker, Fotograf, Schriftsteller) tätig. Auch in seinen fotografischen Arbeiten (u. a. surrealistische Fotomontagen) greift er die Anregungen der Avantgarde auf. Seine künstlerischen Arbeiten stellt er, zusammen mit seiner Lebensgefährtin Toyen (Marie Čermínová), in zahlreichen Ausstellungen aus und publiziert sie in Büchern und Zeitschriften, in den 1930er Jahren erscheinen seine Fotoarbeiten gelegentlich auch in Österreich. Er stirbt am 21. März 1942 in Prag.

Suppenmoser, Midi, Tiroler Amateurfotografin, lebt in Kufstein. Seit Ende der 1930er Jahre veröffentlicht sie ihre Bilder (ländliche Szenen, Landschaften, Stadtbilder, Genrebilder u. a.) in der illustrierten Presse. Seit 1939 wird die Fotografin von der 1938 „arisierten“ (zwangsenteigneten) Wiener Fotoagentur „Schostal“ vertreten.

Suschitzky, Edith, verh. Tudor-Hart, geb. am 28. August 1908 in Wien, Ausbildung als Montessori-Lehrerin, studiert 1928 bis 1930 am Bauhaus in Dessau. Sie ist seit Ende der 1920er Jahre als Fotografin tätig, stilistisch folgt sie teilweise den Anregungen des Neuen Sehens, wichtiger aber sind die Anregungen der kommunistischen und sozialdemokratischen Arbeiterfotografiebewegung. 1931 ist sie maßgeblich an der Gründung der kommunistischen „Vereinigung der Arbeiter-Fotografen“ beteiligt, die aber ein Jahr später wieder aufgelöst wird. Sie macht sozialdokumentarische Aufnahmen in Wien, fotografiert Alltags- und politische Straßenszenen und arbeitet um 1930 für die sowjetische Nachrichtenagentur TASS. Ab 1931 veröffentlicht sie ihre Bilder im sozialdemokratischen Kuckuck und in anderen Magazinen. 1933 heiratet sie den englischen Arzt Alexander Tudor-Hart, zieht im April 1934 zu ihm nach London. Sie ist zunächst als freischaffende (Presse-)Fotografin tätig, fotografiert Slums in London, dokumentiert in Reportagen die Arbeiterkultur und den Alltag der Bergarbeiter in Wales, bewegt sich politisch in linken Kreisen. Ab 1934 ist sie Mit- glied in der „Film und Photo League“, seit 1927 ist sie unter dem Codenamen „Betty Gray“ als Informantin und Mitarbeiterin der englischen und österreichischen kommunistischen Partei und der Kommunistischen Internationale (Komintern) tätig. Von 1937 bis zum Beginn des Zweiten Weltkriegs führt sie ein Atelier in London, das sie zeitweise zusammen mit Vera Elkan betreibt. Nach 1945 ist sie wieder als Porträtfotografin tätig und arbeitet daneben für englische Zeitungen und Magazine. Zeitweise arbeitet sie mit ihrem Bruder Wolfgang (Wolf) Suschitzky zusammen, der in England als Filmemacher tätig ist. Mitte der 1950er Jahre beendet sie ihre fotografische Karriere und führt ein Antiquitätengeschäft in Brighton, wo sie am 12. Mai 1973 stirbt.

Swara, Otto, Wiener Atelier- und Pressefotograf, der seit 1899 ein Atelier in der Margarethenstraße 22, Wien 4, führt. Seit 1897 veröffentlicht er seine Fotos Straßenszenen, Blitzlichtaufnahmen auf der Bühne, aber auch Sportbilder) in der illustrierten Presse. In der Zwischenkriegszeit ist er als Fotohändler in Wien tätig.

Swoboda, Franz, betreibt in den 1930er Jahren ein Fotoatelier in Baden bei Wien. Parallel dazu arbeitet er seit Anfang der 1930er Jahre als Presse- und Amateurfotograf. Er fotografiert vorwiegend das ländliche Leben, Land und Leute sowie bäuerliches Brauchtum (v. a. im Burgenland), idyllische Landschafts- und Häuserszenen sowie Sehenswürdigkeiten. Seine Bilder erscheinen in den 1930er Jahren in der illustrierten Presse. Nach 1938 arbeitet er bruchlos weiter.

Sykora, Frank, Wiener Amateurfotograf, der mit seinen Bildern seit 1930 in Fotozeitschriften und Magazinen vertreten ist. Anfang der 1930er Jahre stellt er anspruchsvolle Alltags- und Sozialreportagen zusammen, zu denen er gelegentlich auch die Texte schreibt. Seine weiteren Themen sind Straßen- und Genreszenen, Landschaften und Reisebilder.

Szabó, Lajos (Ludwig), ungarischer Amateurfotograf, der einer gemäßigt modernen Richtung folgt und in den 1930er Jahren auch in österreichischen Magazinen publiziert.

Székely, Josef, geb. 1839 in Steinamanger, Ungarn, führt ab 1862 ein Fotoatelier in Wien, veröffentlicht seit Mitte der 1890er Jahre gelegentlich Porträts in der illustrierten Presse.

Szigethy, W. von, ungarischer Herkunft, lebt seit den 1920er Jahren in Berlin, wo er als Pressefotograf und Fotoagent (zusammen mit dem Pressefotografen Zoltan Kluger) tätig ist. Die Bilder und Reportagen der Agentur „Kluger-Szigethy“ werden in deutschen und ab 1931 auch in österreichischen Zeitungen veröffentlicht. Beide Fotografen sind jüdischer Herkunft und flüchten 1933 nach Palästina.

Szöllősy, Kálmán, geb. am 10. September 1887 als Kálmán Schwerer in Pécs. Ungarischer Amateurfotograf und Fotopublizist, der 1906 zu fotografieren beginnt. In den 1920er Jahren studiert er bei Rudolf Balogh, Ervin Kankowszky und Iván Vydareny. Er ist ein Vertreter des sogenannten ungarischen Stils, der moderne und piktorialistische Elemente der Fotografie miteinander verbindet. Seine ersten publizierten Bilder, die 1927 erscheinen, stehen in der Tradition der piktorialistischen Fotografie. 1928/29 arbeitet er bei der Fotozeitschrift Fotómüvészeti hírek (Fotografische Nachrichten), in den 1930er Jahren ist er Mitarbeiter der Wiener Fotozeitschrift Die Galerie. Seit 1932 ist er hauptberuflich als Fotograf tätig, er fotografiert Landschaften, Land und Leute, Brauchtum und publiziert seine Bilder in ungarischen und ab 1935 auch in österreichischen Magazinen. Er wird durch die ungarische Fotoagentur „III-Pho“ vertreten. In der Nachkriegszeit ist er weiterhin als Fo- 
tograf und Fotopublizist mit dem Schwerpunkt Fototechnik tätig. Er stirbt am 31. Juli 1976 in Budapest.

Sztranyak, Josef, Wiener Atelierfotograf, der seit 1883 zusammen mit Julius Amster ein Atelier führt und um 1900 gelegentlich Fotos in der illustrierten Presse veröffentlicht.

Tanner, Max, Wiener Atelierfotograf, der ab 1928 ein Atelier am Georg-Coch-Platz 3, Wien 1, betreibt. Neben der Porträtfotografie spezialisiert er sich auf Theater- und Tanzaufnahmen. Er nimmt seit Ende der 1920er Jahre an Ausstellungen teil und publiziert seine Bilder in Zeitschriften und Magazinen.

Tesarik, Franz, Amateurfotograf in Wien. Er ist seit Ende der 1920er Jahre Mitglied der Arbeiterfotogruppe der Naturfreunde Meidling und publiziert Bilder in der Fotofachpresse.

Theile, Margarethe, Amateurfotografin aus Leipzig, die um 1930 u. a. im sozialdemokratischen Kuckuck publiziert.

Thun, Heinz, Fotograf in Wien, der um 1930 gelegentlich in der illustrierten Presse publiziert.

Tichy, Herbert, geb. am 1. Juni 1912 in Wien, Studium der Geologie an der Universität Wien, ist seit Anfang der 1930er Jahre als Reisejournalist, Bergsteiger und Fotograf tätig. Seit 1933 zahlreiche Forschungsreisen nach Asien (teils zusammen mit Max Reisch), später auch nach Afrika. 1954 Leiter der österreichischen Himalaya-Expedition. Er publiziert seine mit eigenen Fotos illustrierten Reiseberichte ab 1934 in der deutschen und österreichischen illus trierten Presse, ab 1937 auch in Buchform. Er stirbt am 26. September 1987 in Wien.

Tomann, Otto, geb. am 26. Dezember 1906 in Wien, Ausbildung als Fotograf, arbeitet ab 1937 als Geschäftsführer des Wiener Ateliers und der Fotoagentur „Dietrich \& Co.“, publiziert ab 1939 unter eigenem Namen in der illustrierten Presse. Er ist ein Anhänger des Nationalsozialismus, publiziert Anfang der 1940er Jahre Porträts, Theaterbilder und Modeaufnahmen, später auch propagandistische Soldatenbilder. Nach 1945 führt er ein Atelier in Wien und ist bis Anfang der 1970er Jahre u. a. als Architekturund Modefotograf tätig

Träger, Richard, geb. am 16. Januar 1895 in Wien, von Beruf Feinmechaniker, ist in den 1920er und Anfang der 1930er Jahre als Amateurfotograf in Wien tätig. Er fotografiert seit 1919 und ist um 1930 ein Vertreter der modernen Fotografie, insbesondere orientiert er sich an der Neuen Sachlichkeit. Seit Mitte der 1920er Jahre ist er Mitglied der Photographischen Fachgruppe der Volkshochschule Wien-Ottakring, beteiligt sich an internationalen Fotoausstellungen (u. a. in Frankreich, England und den USA), 1930 sind seine Arbeiten in der Ausstellung „Film und Foto" (FiFo) in Wien zu sehen. Er stirbt am 30 November 1933 durch einen Unfall in seiner Wiener Wohnung.

Trampus, Charles, führt seit 1905 in Paris eine Fotoagentur, beschäftigt in mehreren Ländern Fotografen, die aktuelle Nachrichtenbilder liefern. Die zugekauften Aufnahmen vertreibt er in Frankreich, aber auch in Italien und Osterreich, wo Fotos der Agentur Trampus seit 1906 erscheinen. Das berühmteste Bild, das Trampus vertreibt, ist ein Schnappschuss, der die Festnahme des angeblichen Attentäters von Erzherzog Franz Ferdinand Ende Juni 1914 in Sarajevo zeigt.

Triebel, Carl (Karl), Wiener Atelierfotograf, der seit 1892 ein Atelier betreibt und seit 1896 auch Pressebilder an die Zeitungen liefert, u. a. Bilder über die Verkehrs- und Stadtentwicklung, Porträts und Genreszenen (etwa „Wiener Typen“). Er stirbt am 2. September 1907 in Wien.
Tschik (auch Csík), Ferenc, geb. am 27. Februar 1894 im ungarischen Sopron, arbeitet nach einer Textilausbildung in Wien in einer Textilfabrik und später als Schornsteinfeger in Sopron. Seit 1930 ist er als Amateurfotograf tätig, er ist offen gegenüber modernen Strömungen der Fotografie, insbesondere der Neuen Sachlichkeit. Er macht moderne Sachaufnahmen, lichtet aber auch idyllische Genreszenen, Stadt- und Landschaftsbilder (aufgenommen vielfach rund um Sopron) ab. In den 1930er Jahren nimmt er an zahlreichen internationalen Ausstellungen teil. Seine Bilder veröffentlicht er in ungarischen, österreichischen und deutschen Medien. 1956 ist er Gründungsmitglied im Verein der ungarischen Fotokünstler. Er stirbt am 4. November 1984 in Sopron.

Umbehr, Otto (Umbo), geb. am 18. Januar 1902 als Otto Maximilian Umbehr in Düsseldorf, besucht von 1921 bis 1923 das Bauhaus in Weimar, beginnt Mitte der 1920er Jahre zu fotografieren und publiziert seine Aufnahmen seit 1927 unter dem Künstlernamen „Umbo“. Ab 1929 ist er im Auftrag der Berliner Fotoagentur „Dephot“ als Pressefotograf tätig. Um 1930 erscheinen zahlreiche seiner Fotos und Fotoreportagen in der deutschen und ab 1930 auch in der österreichischen Presse. Er ist in den 1930er Jahren weiterhin als Pressefotograf tätig. 1943 wird sein Fotoarchiv bei einem Bombenangriff zerstört. Nach 1945 kann Umbo nicht mehr an seine Vorkriegskarriere als Fotograf anknüpfen. Er zieht nach Hannover, arbeitet $u$. a. als Lagerarbeiter und ist für die Kestner-Gesellschaft, u. a. als Fotograf, tätig. Er stirbt am 13. Mai 1980 in Hannover.

Uttenthaler, Heinrich, geb. am 15. Juni 1878 in Wien, ist seit 1904 als Pressefotograf tätig. Er fotografiert öffentliche Veranstaltungen, politische und gesellschaftliche Ereignisse, aber auch soziale Themen und Sportwettkämpfe, u. a. in den Bereichen Boxen und Fußball. Uttenthaler ist bis Mitte der 1950er Jahre als Fotograf aktiv. Er stirbt am 5. Oktober 1959 in Wien.

Vadas, Ernő, geb. 1899 in Nagykanizsa, Ungarn, ungarischer Amateurfotograf, der um 1927 zu fotografieren beginnt. In den 1930er Jahren ist er ein Vertreter des sogenannten ungarischen Stils, der moderne und piktorialistische Elemente der Fotografie miteinander verbindet. Seine Themen sind bäuerliche Landschaften, Land und Leute, aber auch Stadtansichten. Er publiziert ab Mitte der 1930er Jahre auch in österreichischen Magazinen. Im Zweiten Weltkrieg wird er in das KZ-Außenlager Gunskirchen bei Wels deportiert. In der kommunistischen Nachkriegszeit wendet er sich der Sozialdokumentation zu. Er stirbt 1962 in Budapest.

Vidor, Zoltan, ungarischer Amateurfotograf, der in den 1930er Jahren Aufnahmen in der illustrierten Presse veröffentlicht, u. a. auch in österreichischen Magazinen. Nach dem Zweiten Weltkrieg arbeitet er als Filmkameramann in Hollywood.

Völkel, Bruno, geb. am 27. Juni 1901 in Wien, arbeitet seit Anfang der 1930er Jahre als Pressefotograf in Wien. Bis 1934 veröffentlicht er u. a. im sozialdemokratischen Kuckuck, danach auch in anderen Zeitungen und Magazinen. Er spezialisiert sich auf Theateraufnahmen, fotografiert aber auch aktuelle politische und gesellschaftliche Ereignisse, Alltagsszenen, Akte und Porträts. Er ist ein Anhänger des Nationalsozialismus und dokumentiert ab 1938 zahlreiche Parteiveranstaltungen der NSDAP. Nach dem Zweiten Weltkrieg ist er bis 1971 als Presseund v. a. als Theaterfotograf tätig.

Wagner, Bernhard, Atelierfotograf in Budweis, der um 1900 gelegentlich Pressefotos in Wiener Illustrierten veröffentlicht.
Wagner, Charles, nach 1900 Fotograf in Wien, der ab 1904 auch als Pressefotograf tätig ist. Er fotografiert u. a. gesellschaftliche und politische Ereignisse.

Wagner, Stanislaus, geb. am 17. Januar 1898 in Brünn, ist seit 1928 als Pressefotograf tätig. Er fotografiert politische und gesellschaftliche Ereignisse, aber auch Sportveranstaltungen, Alltags- und Straßenszenen. Er ist ein Anhänger des Nationalsozialismus. Im Zweiten Weltkrieg ist er als Soldat an der Westfront im Einsatz, nach 1945 arbeitet er bis Anfang der 1960 er Jahre wieder als Pressefotograf. Er stirbt am 13. Februar 1974 in Wien.

Wallentin, Fred, geb. am 30. August 1899 in Wien, lebt in den 1920er und frühen 1930er Jahren in Berlin, wo er als Journalist, Fotograf und Schauspieler tätig ist. Um 1930 entstehen Aufnahmen teilweise im Stil des Neuen Sehens und der Neuen Sachlichkeit. Seine Fotos, u. a. Porträts, Sachaufnahmen, StraBenszenen und Reisebilder (etwa aus China, das er 1934 bereist), erscheinen in den 1930er Jahren in der internationalen Presse, u. a. in der französischen Illustrierten VU. Um 1930 betreibt er in Berlin eine Art Fotoagentur mit geschäftlichen Kontakten nach Paris, London, Amsterdam, Zürich und Brüssel. Er vermittelt u. a. Fotos des Wiener Sportfotografen Lothar Rübelt an die deutsche Presse. Nach 1933 lebt er in Paris, 1937 hält er sich kurz in Wien auf und veröffentlicht in Wiener Magazinen. Ende 1937 zieht er nach Holland.

Walther, Hedda, geb. 1894 als Hedda Gerhardt, 1918 bis 1920 Ausbildung an der Fotografischen Lehranstalt des Lette-Vereins in Berlin, danach Assistentin in einem Atelier in Dresden. Um 1925 eröffnet sie ein eigenes Atelier in Berlin, sie spezialisiert sich auf Kinder- und Tierfotos, publiziert seit 1928 zahlreiche Fotobücher über Tiere, macht seit Ende der 1920er Jahre auch Modefotos und seit 1933 zahlreiche Gesellschaftsreportagen für den Ullstein Verlag (1937 umbenannt in Deutscher Verlag). Ihre Fotos werden in den 1930er Jahren von der Wiener Fotoagentur „Schostal“ international vertrieben. In der Zeit des Nationalsozialismus arbeitet sie bruchlos und erfolgreich weiter. Nach dem Zweiten Weltkrieg ist sie bis 1960 von Berlin aus als Porträt- und Modefotografin tätig. Sie stirbt im Jahr 1979 in Berlin.

Wawra, Johann, Fotograf in Wien, der um 1900 gelegentlich Pressebilder in der illustrierten Presse veröffentlicht.

Weber, Otto, Amateurfotograf in Wien. Er ist um 1930 Mitglied der Arbeiterfotogruppe der Naturfreunde Meidling und publiziert seine Bilder Anfang der 1930er Jahre im sozialdemokratischen Kuckuck und in der Fotofachpresse.

Weber, Wolfgang, geb. am 17. Juni 1902 in Leipzig, Studium der Ethnologie, Philosophie und Musikwissenschaft, in den 1920er Jahren Forschungsreise nach Ostafrika. Seit Ende der 1920er Jahre arbeitet er als Pressefotograf, er fotografiert zahlreiche Reportagen, v. a. für die Münchner Illustrierte Presse und die Berliner Illustrirte Zeitung. Anfang der 1930er Jahre arbeitet er als Fotograf auch in Österreich. In den 1930er Jahren entstehen zahlreiche Bildbände. Im Zweiten Weltkrieg ist Weber als Kriegsfotograf tätig. Nach 1945 arbeitet er als Fotograf und Journalist. Er stirbt am 4. März 1985 in Köln.

Wechsler, Karl, Wiener Amateurfotograf, der Ende der 1920 er Jahre zu fotografieren beginnt. Er greift in seinen Bildern die Anregungen der Moderne auf, stellt seit 1931 in Ausstellungen aus und publiziert in den 1930er Jahren in Fachpublikationen und Magazinen.

Weinwurm, Antal, Atelierfotograf in Budapest, der um 1900 auch Pressebilder in der illustrierten Presse veröffentlicht und gelegentlich auch in Wiener Zeitungen präsent ist. 
Weissenstein, Margarethe, geb. am 22. Oktober 1893 in Wien, besucht 1912/13 die Lehr- und Versuchsanstalt für Photographie, Chemigraphie, Lichtdruck und Gravüre in München, 1913 bis 1915 die Graphische Lehr- und Versuchsanstalt in Wien, 1917/18 ist sie im Atelier von Lisy Frisch tätig, 1919 eröffnet sie gemeinsam mit Josefine (Fini) Bárány in der Lerchenfelder Straße 9, Wien 7, das Atelier „Ingret“, das sich u. a. auf Künstler- und Prominentenporträts sowie Kinderfotos spezialisiert. Seit Mitte der 1920er Jahre erscheinen Fotos des Ateliers in der ilIustrierten Presse. Weissenstein, die jüdischer Herkunft ist, flüchtet im Mai 1939 nach Australien und gründet Anfang 1940 in Sydney das Atelier „Ingret Photo Portraits“, das sie bis Ende der 1950er Jahre betreibt. Sie stirbt am 14. Mai 1963 in Lindfield.

Wellspacher (Wellspacher-Emery), Edith, geb. am 9. Oktober 1909 in Niederösterreich, Ärztin, Architektin, Künstlerin, Journalistin und Amateurfotografin, lebt seit Anfang der 1920er Jahre in Wien. Ausbildung an der Kunstgewerbeschule in Wien, Studium der Medizin (Promotion 1934). Als überzeugte Linke ist sie in den 1930er Jahren als Ärztin im Spanischen Bürgerkrieg tätig, wo sie auch fotografiert. Sie veröffentlicht Anfang 1938 eine Bildreportage aus Spanien in einer Wiener Illustrierten. 1938 flüchtet sie über Paris auf die australische Insel Hobart, heiratet den englischen Kolonialbeamten John Emery und zieht mit ihm 1940 in den Sudan. Danach Aufenthalte in Paris, Khartum, Edinburgh und nach 1948 in Hobart (Tasmanien), wo sie nach dem Zweiten Weltkrieg Architektur studiert. Zahlreiche Reisen, künstlerische Arbeiten. Sie stirbt am 11. August 2004.

Werian, Richard, geb. 1900 in Wien, Wiener Pressefotograf, der seit Anfang der 1920er Jahre fotografiert. Er ist in der Zwischenkriegszeit v. a. als Sportfotograf tätig. Werian, der vermutlich jüdischer Herkunft ist, gibt das Gewerbe Anfang 1939 auf. Danach verliert sich seine Spur.

Weyr, Siegfried, geb. am 24. April 1890 in Welyki Mosty, Galizien, lebt seit 1896 in Wien, 1909 bis 1911 Besuch der Graphischen Lehr- und Versuchsanstalt, 1912 bis 1914 Studium an der Akademie der bildenden Künste. Arbeitet seit 1914 als Journalist, Offizier im Ersten Weltkrieg. Nach dem Krieg ist er als Journalist und Illustrator tätig. Bis 1927 arbeitet er für Bettauers Wochenschrift, danach ist er für den sozialdemokratischen Vorwärts-Verlag (u. a. für das Kleine Blatt) tätig. 1929 konzipiert er zusammen mit Julius Braunthal die sozialdemokratische Illustrierte Der Kuckuck, die er bis 1934 leitet. Er ist ein Förderer der modernen Fotografie, unterstützt die Arbeiterfotografiebewegung und gestaltet für den Kuckuck zahlreiche politische und sozialkritische Fotomontagen. Nach dem Verbot des Kuckuck im Februar 1934 übernimmt er für einige Monate die Leitung der ehemals sozialdemokratischen, inzwischen regierungstreuen Illustrierten Bunte Woche. Danach arbeitet er weiterhin im enteigneten und nun regierungsnahen Verlagshaus „Vorwärts“. Nach dem „Anschluss“ Österreichs an das nationalsozialistische Deutschland wird er entlassen, Ende 1938 flüchtet er über die Schweiz nach London. 1941 geht er in die USA und kehrt 1947 nach Wien zurück, wo er als Redakteur für den Kurier, das Neue Österreich und die Kronen-Zeitung sowie als Buchautor tätig ist. Er stirbt am 21. März 1962 in Wien.

Wiberal, Mario, geb. am 4. März 1898 in Trient, arbeitet seit 1923 als Pressefotograf. Sein Hauptthema ist der Sport, er fotografiert aber auch gesellschaftliche und politische Ereignisse und macht um 1930 Sozial- und Alltagsstudien. Seit 1927 fotografiert er für die linksgerichtete Wiener Tageszeitung Der Abend, in den 1930er Jahren für Telegraf und Echo. Seit 1930 ist er daneben auch als Filmkameramann tätig. 1938 passt er sich den neuen politischen Gegebenheiten an, bewirbt sich (erfolglos) um die
Aufnahme in die NSDAP, arbeitet weiterhin intensiv als Sportberichterstatter, daneben als Kameramann für Filme der Ostmark-Wochenschau. Nach 1945 ist er als Kameramann u. a. für die sowjetnahe „Wien-Film“, später für die Fotoagentur Votava tätig. Er stirbt am 24. November 1961 in Wien.

Wiedling, Albert, geb. um 1859, lebt seit 1882 in Wien, Mitarbeiter des Kunstverlags „Gerlach \& Schenk“, 1904 tritt er als Mitbesitzer in das Unternehmen ein, das nun „Gerlach \& Wiedling“ heißt. Nach dem Tod der Besitzer wird der Verlag von den beiden Söhnen Martin Gerlach jun. und Walter Wiedling weitergeführt.

Wild, Anton, Atelierfotograf in Budweis, der um 1900 auch Pressebilder in Wiener Zeitungen veröffentlicht.

Willinger, László, geb. am 16. April 1909 in Berlin, Sohn des ungarischen, später in Berlin und Wien lebenden Fotografen Wilhelm Willinger, 1922/23 Besuch der Graphischen Lehr- und Versuchsanstalt in Wien, praktische Ausbildung als Fotograf beim Budapester Atelierfotografen Angelo. Er leitet von 1927 bis 1930 zusammen mit seiner Mutter Margarete Willinger, die ebenfalls Fotografin ist, die Berliner Filiale des Familienunternehmens. 1930 bis 1932 ist er in Paris als Werbe- und Porträtfotograf tätig, macht eine Reise nach Russland zu Sergej Eisenstein, kehrt nach Berlin zurück, lebt ab 1933 in Wien, wo er in den 1930er Jahren ein Atelier führt. Er ist aber weiterhin viel in Frankreich unterwegs. 1929 veröffentlicht er den Berlin-Bildband Hundertmal Berlin, kurz darauf einen Band über London. Seit etwa 1930 veröffentlicht er seine Fotos in deutschen Illustrierten, ab 1931 auch in österreichischen Magazinen. In seinen fotografischen Arbeiten (Porträts, Straßen- und Alltagsszenen, Werbung, Akte, Landschaften) verfolgt er einen modernen Stil. 1937 emigriert er in die USA, eröffnet ein Atelier am Sunset Boulevard in Los Angeles und arbeitet in Hollywood als Filmfotograf. Er stirbt am 8. August 1989 in Los Angeles.

Willinger, Margarete, Atelierfotografin in Berlin, Frau von Wilhelm Willinger, leitet in den 1920er und 1930er Jahren die Berliner (und zeitweise auch die Budapester und Pariser) Filiale des Familienunternehmens. 1941 zieht sie in die USA.

Willinger, Wilhelm, geb. am 9. April 1897 als Mór (Maurus) Wilhelm Willinger in Budapest, eröffnet um die Jahrhundertwende ein Atelier in Wien, um 1909 zieht er nach Berlin, wo er ebenfalls ein Atelier eröffnet und seit 1912 Bilder an die illustrierte Presse liefert. Nach dem Ersten Weltkrieg zieht er nach Wien, eröffnet hier 1919, zusammen mit Hans Schnapper, ein weiteres Atelier in der Kärntner Straße 28, Wien 1. Schnapper verlässt das Unternehmen 1921. Willinger spezialisiert sich auf Porträts und Theaterfotos, erweitert den Betrieb in den 1920er Jahren in Richtung einer Fotoagentur, die auch aktuelle Pressebilder anbietet. Um 1930 Kooperation mit dem Fotografenduo Leo Ernst und Fred Cešanek und Gründung der Agentur „Austrophot-Willinger, Ernst \& Cešanek“. 1930 Übernahme der traditionsreichen Wiener Fotoagentur „R. Lechner (Wilh. Müller)“. Willinger, der jüdischer Herkunft ist, flieht 1939 nach Shanghai, wo er 1940 ein Fotoatelier eröffnet. Er stirbt am 29. Januar 1943 in Shanghai.

Wlassics, Adorján, geb. am 27. April 1893 in Vesprim, Ungarn, gründet 1924 zusammen mit Olga Wlassics das Fotoatelier „Manassé“ in Wien. In den 1930er Jahren kommen weitere Ateliers in Bukarest und Berlin unter dem Namen „WOG“ hinzu, die beiden Fotografen spezialisieren sich auf Akte, Porträts und Montagen, von denen viele in der illustrierten Presse veröffentlicht werden. Das Wiener Atelier wird ab 1937/38 von einer Assistentin namens Ricoll geführt, dann verkauft. Olga und Adorján W. ziehen nach Berlin, wo sie weiterhin als Atelierfotografen tätig sind. 1947 Rückkehr nach Wien, wo Adorján W. 1947 stirbt.
Wlassics, Olga, geb. als Olga Spolarich am 6. Mai 1895 in Budapest, eröffnet 1924 zusammen mit ihrem Mann Adorján Wlassics das Fotoatelier „Manassé “ in Wien. In den 1930er Jahren kommen weitere Ateliers in Bukarest und Berlin unter dem Namen "WOG“ hinzu, die beiden Fotografen spezialisieren sich auf Akte, Porträts und Montagen, von denen viele in der illustrierten Presse veröffentlicht werden. Das Wiener Atelier wird ab 1937/38 von einer Assistentin namens Ricoll geführt, dann verkauft. Olga und Adorjàn W. ziehen nach Berlin, wo sie weiterhin als Atelierfotografen tätig sind. 1947 Rückkehr nach Wien, wo Olga Wlassics ab 1947 wieder ein Atelier betreibt. Sie stirbt 1969 in Wien.

Wolff, Dr. Paul, geb. am 19. Februar 1887 in Mühlhausen, Ausbildung zum Arzt, arbeitet seit den 1920er Jahren als Amateurfotograf, 1926 beginnt er mit der Leica zu fotografieren. Anfang der 1930er Jahre beginnt seine Karriere als Zeitschriftenfotograf. Er veröffentlicht zahlreiche Aufnahmen (Landschaften, Genreszenen, Porträts, Architektur, Städte- und Reisebilder sowie Sachaufnahmen) in der Presse (seit 1934 auch in Österreich) und in Bildbänden. Zusammenarbeit mit dem Assistenten Alfred Tritschler. Er arrangiert sich bestens mit dem Nationalsozialismus, passt sich in Themen und Stil den Erfordernissen des Regimes an. Er stirbt am 10. April 1951 in Frankfurt am Main.

Wölfl, Maria, verh. Borik-Wölfl, beginnt Mitte der 1920 er Jahre zu fotografieren, Ausbildung bei der Fotografin Trude Fleischmann, eröffnet um 1934 ein Atelier in Wien, arbeitet als Porträt-, Sach- und Werbefotografin, arbeitet aber auch im Freien (Landschaften, Architektur). Seit Mitte der 1930er Jahre ist sie mit ihren Aufnahmen, u. a. Porträts und Objektfotos, in Magazinen vertreten. Während der Zeit des Nationalsozialismus arbeitet sie ohne Unterbrechung weiter. Nach dem Zweiten Weltkrieg spezialisiert sie sich auf Architekturfotografie. Sie ist bis Ende der 1950er Jahre tätig.

Ylla, geb. am 16. August 1911 in Wien als Camilla Henriette Koffler, Kunststudium in Belgrad und Paris, arbeitet ab 1932 in einem Pariser Atelier als Retuscheurin. 1933 eröffnet sie in Paris ein eigenes erfolgreiches Atelier für Tierporträts. Ende der 1930er Jahre veröffentlicht sie erste Fotobände über Hunde und Katzen. 1941 flüchtet sie nach New York, wo sie neuerlich ein Atelier für Tierporträts eröffnet und ihre Aufnahmen in zahlreichen Magazinen veröffentlicht. Zahlreiche Reisen. Sie verunglückt am 30. März 1955 bei einem Autounfall in Indien.

Yva (Else Ernestine Neuländer-Simon), geb. am 26. Januar 1900 in Berlin, betreibt seit 1925 ein Fotoatelier in Berlin und arbeitet als Porträt-, Mode- und Pressefotografin. Ihre Bilder (Porträts, Mode, Werbeaufnahmen, Sachfotos, Akte, Tanzbilder) erscheinen ab 1927 in zahlreichen Zeitungen und Zeitschriften, seit 1929 auch in Österreich. Ab 1933 werden ihre Bilder von der Wiener Fotoagentur „Schostal“ international vertrieben, in Deutschland kann sie ab 1933 nicht mehr publizieren. Indem sie Mitte der 1930er Jahre die Leitung des Ateliers abgibt, versucht sie das Berufsverbot zu umgehen. 1938 wird das Atelier endgültig geschlossen, von 1938 bis 1942 arbeitet sie als Röntgenassistentin im Jüdischen Krankenhaus in Berlin. Anfang Juni 1942 wird sie verhaftet und in das Konzentrationslager Majdanek deportiert, wo sie (vermutlich noch 1942) ermordet wird.

Zander, Albert, Ingenieur und Fotograf, gründet 1895 zusammen mit Siegmund Labisch die Fotoagentur "Zander \& Labisch“, die seit 1900 inre Bilder auch in Österreich vertreibt. Das Unternehmen besteht bis 1939. 
Zapletal, Carl, geboren 26. Juli 1876 im mährischen Schönberg (Sumperk, Tschechien), arbeitet seit 1906 als Fotograf in Wien. Er spezialisiert sich auf Sportaufnahmen (v. a. Motor- und Flugsport), Werbung, Kinderporträts und Architekturfotografie und veröffentlicht die Bilder seit 1911 in der illustrierten Presse. Er stirbt am 19. Juni 1941 in Wien.

Zapletal, Josef, geb. am 16. Dezember 1910, Sohn des Fotografen Carl Zapletal, erlernt bei diesem das Fotografieren, legt 1934 die Meisterprüfung ab und arbeitet seither im väterlichen Betrieb in der Josefstädter Straße 73, Wien 8. Er arbeitet im Bereich der Werbe- und Industriefotografie, macht aber auch Porträts und fotografiert wie sein Vater Autorennen. Er führt den Betrieb bis zum Jahr 1974.

Zillich, Eduard, geb. am 20. August 1910 im böhmischen Petschau (heute: Bečov nad Teplou, Tschechien), ist seit Anfang der 1940er Jahre als Presse- und Theaterfotograf in Wien tätig. Während der Kriegszeit veröffentlicht er zahlreiche Fotoreportagen über den städtischen Alltag in Wien. Nach 1945 hält er die Kriegszerstörungen in Wien fest.

Zimbler, Juda Berisch (auch Baruch), geb. am 12. Juni 1884 in Sadagora in der Nähe von Czernowitz, Bukowina (heute Ukraine), führt von 1919 bis 1941 ein Fotoatelier in Wien. Er fotografiert in der Tradition des Piktorialismus, spezialisiert sich auf Porträts u. a. von Künstlern, Mode, Theater und Tanz. Seit 1924 erscheinen seine Aufnahmen in der illustrieren Presse. Im Mai 1938 gelingt inm, zusammen mit seiner Frau Lea, die Flucht nach Buenos Aires.

Zimmerauer, Helene von, verh. Alexander, geb. am 19. Dezember 1883, absolviert von 1909 bis 1911 die Graphische Lehr- und Versuchsanstalt in Wien, eröffnet 1911 ein Atelier in Wien, porträtiert die prominente Wiener Gesellschaft, spezialisiert sich daneben auf Theateraufnahmen, Schauspielerporträts sowie Mode, arbeitet um 1930 im Modebereich kurzzeitig mit der Gesellschaftsjournalistin und Fotografin Claire Patek zusammen. Ihre Aufnahmen erscheinen seit 1917 regelmäßig in der illustrierten Presse. Zimmerauer ist als Fotografin in Wien bis in die 1940er Jahre tätig. Sie stirbt am 7. Dezember 1961 in Wien.

Zischka, H. E., Wiener Amateurfotograf, um 1930 Mitglied der Photographischen Fachgruppe der Volkshochschule Wien-Ottakring, veröffentlicht im sozialdemokratischen Kuckuck, u. a. Fotomontagen.

Zvacek (auch Zwacek), Friedrich (Fritz), geb. 1895 in Wien, Bruder von Willi Zvacek, beginnt um 1920 zu fotografieren und ist seit 1930 als Pressefotograf in Wien tätig. Er fotografiert um 1930 viel für die sozialdemokratischen Blätter Kuckuck, Kleines Blatt und Arbeiter-Zeitung, bewegt sich im Umfeld der
Wiener Arbeiterfotografen, ist Mitglied in der „Arbeitsgemeinschaft der Wiener Kuckuck-Reporter“ und der Arbeiterfotogruppe der Naturfreunde Meidling. Er dokumentiert politische und gesellschaftliche Ereignisse, fotografiert aber auch Alltags- und Straßenszenen, Landschaften und Genremotive. Nach dem „Anschluss“ Österreichs an das nationalsozialistische Deutschland werden seine Bilder für nationalsozialistische Publikationen verwendet. Nach 1938 arbeitet er bruchlos weiter. Während der Kriegszeit veröffentlicht er Fotoreportagen aus Wien, die sich gut in die NS-Ideologie einfügen. Zwischen 1945 und 1954 arbeitet er wieder als Pressefotograf.

Zvacek, Willi, geb. am 19. April 1903 in Wien, Bruder von Fritz Zvacek, Amateurfotograf. Er arbeitet als Erzieher beim sozialdemokratischen „Reichsverein Kinderfreunde“, ist bei den „Roten Falken“ aktiv, die er in seinen Bildern häufig dokumentiert. Seine Bilder erscheinen um 1930 in der sozialdemokratischen Illustrierten Der Kuckuck. 1934 verliert er seinen Arbeitsplatz und findet eine Beschäftigung in der Verwaltung der Gemeinde Wien. Nach dem Krieg arbeitet er in der Elektroindustrie in Wien, daneben entstehen Fotoserien u. a. über das kriegszerstörte Wien. 1964 geht er in Pension und betreut das Fotoarchiv der „Kinderfreunde“. Er stirbt am 3. Mai 1998 in Königstetten, Niederösterreich. 


\section{Literatur}

ACHENBACH, Michael, Karin Moser (Hg.): Österreich in Bild und Ton. Die Filmwochenschau des Austrofaschistischen Ständestaates, Wien 2002.

AMORT, Andrea, Mimi Wunderer-Gosch: Österreich tanzt. Geschichte und Gegenwart, Wien 2001.

AMORT, Andrea: An der Wende. Zur Situation des künstlerischen Tanzes um 1930, in: Wolfgang Kos (Hg.): Kampf um die Stadt. Politik, Kunst und Alltag um 1930, Ausstellungskatalog Wien Museum, Wien 2010, S. 259-263.

AMORT, Andrea: Der freie Tanz in Wien bis 1938, in: Andrea Amort, Mimi Wunderer-Gosch (Hg.): Österreich tanzt. Geschichte und Gegenwart, Wien 2001, S. 54-69.

AMORT, Andrea: Free Dance in Interwar Vienna, in: Deborah Holmes, Lisa Silverman (Hg.): Interwar Vienna. Culture between Tradition an Modernity, Camden House, Rochester, New York 2009, S. 117142.

ANDĚL, Jaroslav: Alexandr Hackenschmied, Prag 2000.

ANKUM, Katharina von (Hg.): Women in the Metropolis. Gender and Modernity in Weimar Culture, University of California Press, Berkeley, Los Angeles, London 1997.

ATZE, Marcel: „Gönn’t mir den Flug!“ Frühe Aviatik samt deren Kritik bei Karl Kraus, Bertha von Suttner und anderen Wienern, in: Sylvia Mattl-Wurm, Markus Reuter (Hg.): „schwerer als Luft“. 100 Jahre Motorflug in Wien. Das Bordmagazin zur Ausstellung, Wienbibliothek im Rathaus, Wien 2009, S. 46-57.

AUER, Anna, Kunsthalle Wien (Hg.): Übersee. Flucht und Emigration österreichischer Fotografen 19201940. Exodus from Austria. Emigration of Austrian Photographers 1920-1940, Ausstellungskatalog Kunsthalle Wien, Wien 1998.

BACOT, Jean-Pierre: La presse illustrée au XIXe siècle. Une histoire oubliée, Limoges 2005.

BARNHURST, Kevin G., John Nerone: Civic Picturing vs. Realist Photojournalism. The Regime of Illustrated News, 1856-1901, in: Design Issues, Vol. 16, No. 1, Spring 2000, S. 59-79.

BECKERS, Marion, Elisabeth Moortgat: Eva Besnyö. Fotografin 1910-2003. Budapest, Berlin, Amsterdam, Berlin 2011.

BELLER, Steven (Hg.): Rethinking Vienna 1900, New York, Oxford 2001

BENITO-SANCHEZ, Samanta: Pressefotografen zwischen den Weltkriegen. Eine Biografiensammlung von Pressefotografen, die zwischen 1918 und 1938 in Wien tätig waren, Diplomarbeit, Wien 2009.

BENTZ, Oliver (Hg.): Bil Spira. Künstler, Fälscher, Menschenretter - Pariser Impressionen. Schriftenreihe der Abteilung Kulturelles Erbe der Stadt Speyer, hg. von Joachim Kemper und Oliver Bentz, Museum SchPIRA, Jüdisches Museum Speyer, Speyer 2013.

BERMANN, Richard A. (alias Arnold Höllriegel): Hollywood - Wien und zurück. Feuilletons und Reportagen, hg. von Hans-Harald Müller und Andreas Stuhlmann, Wien 1999.

BERMANN, Richard A. (alias Arnold Höllriegel). Österreicher - Demokrat - Weltbürger, Ausstellungskatalog Deutsches Exilarchiv 1933-1945, München u. a. 1995.

BEURIER, Joëlle: Violenza e fotografia di guerra nel primo conflitto mondiale: uno studio comparativo fran- co-tedesco attraverso due settimanali illustrati, in: Memoria e ricerca, Nr. 20, 2005, S. 23-38.

BIRGUS, Vladimír, Jan Mlčoch: Tschechische Fotografie des 20. Jahrhunderts, hg. von der Kunst- und Ausstellungshalle der Bundesrepublik Deutschland in Zusammenarbeit mit dem Museum für Angewandte Kunst in Prag, Bonn, Prag 2009.

BOJANKO, Tano: Die Geschichte des Kompass-Verlags - ein Zwischenstand, in: Sylvia Mattl-Wurm, Alfred Pfoser ( $\mathrm{Hg}$.): Die Vermessung Wiens. Lehmanns Adressbücher 1859-1942, Wien 2011, S. 339-347.

BOLL, Bernd: Die Propagandakompanien der Wehrmacht 1938-1945, in: Christian Stadelmann, Regina Wonisch (Hg.): Brutale Neugier. Walter Henisch. Kriegsfotograf und Bildreporter, Ausstellungskatalog Wien Museum, Wien 2003, S. 37-46.

BORN, Wolfgang: Die Schönheit des Unscheinbaren. Betrachtungen zu Photographien Richard Trägers, in: Photofreund. Halbmonatsschrift für Freunde der Photographie, IX. Jg., Nr. 6, 20. März 1929, S. 101-103.

BORN, Wolfgang: Gedanken über Photographie (1929), in: Fotogeschichte, Heft 123, 2012, S. 61-62.

BOTZ, Gerhard: Gewalt in der Politik. Attentate, Zusammenstöße, Putschversuche, Unruhen in Österreich 1918 bis 1934, München 1976.

BOYER, John W.: Political Radicalism in late imperial Vienna. Origins of the Christian Social Movement 1848-1897, Chicago, London 1981.

BRANDSTETTER, Gabriele: Bild-Sprung. TanzTheaterBewegung im Wechsel der Medien, Berlin 2005.

BRANTL, Sabine: Bio-bibliografisches Lexikon. Jüdische Fotografen aus München 1900-1938, in: Tatjana Neef (Hg.): Unbelichtet. Münchner Fotografen im Exil, Ausstellungskatalog Jüdisches Museum München, Heidelberg 2010, S. 118-141.

BRENNEN, Bonnie, Hanno Hardt (Hg.): Picturing the Past. Media, History and Photography, Urbana, Chicago 1999.

BRIX, Emil, Allan Janik (Hg.): Kreatives Milieu. Wien um 1900, München 1993.

BROOKER, Peter, Sascha Bru, Andrew Thacker: The Oxford Critical and Cultural History of Modernist Magazines, Volume 3: Europe 1880-1940, Oxford 2013.

BRUHN, Matthias: Tarife für das Sichtbare. Eine kurze Geschichte der Fotoagenturen, in: Fotogeschichte, Heft 105, 2007, S. 13-25.

BRÜNING, Jan: Kurzer Überblick zur Technik der Pressefotografie in Deutschland von 1920 bis 1940, in: Diethart Kerbs, Walter Uka (Hg.): Fotografie und Bildpublizistik in der Weimarer Republik, Bönen 2004, S. 11-28.

CANePPele, Paolo: II regista e la Diva. L'attrice Carmen Cartellieri e Cornelius Hintner, regista, Bozen 2000.

CARLEBACH, Michael L.: American Photojournalism comes of Age, Washington, London 1997.

CASPARIUS, Hans: In my View. A Pictorial Memoir. Introduction by Silvia Beamish, Leamington, Hamburg, New York 1986.

CHRISTEN, Matthias, Anton Holzer: Mythos Magnum. Die Geschichte einer legendären Fotoagentur, in: Mittelweg 36. Zeitschrift des Hamburger Instituts für Sozialforschung, Nr. 5, Oktober/November 2007, S. 53-80.

CRONIN, Elizabeth: Rudolf Koppitz und die österreichische Heimat, in: Monika Faber (Hg.): Rudolf
Koppitz. Photogenie. 1884-1936, Wien 2013, S. 4553.

CONBOY, Martin: The Press and Popular Culture, London u. a. 2002.

CROWLEY, David: Magazine Covers, London 2003.

DAMASCHKA, Richard: Kriegsphotographie. Ein Leitfaden für Kriegsphotographen und Amateure im Felde, Wien 1916.

DANIUS, Sara: The Senses of Modernism: Technology, Perception, and Aesthetics, Ithaca, London 2002.

DAS INTERESSANTE BLATT. Ein halbes Jahrhundert in Bildern. Aus 50 Jahrgängen neu ausgesucht und zusammengestellt von Rose-Marie Papanek und Alfred Zohner, Wien 1932.

DELANY, Paul: Bill Brandt. A Life, London 2004.

DELPORTE, Christian: Presse et culture de masse en France (1880-1914), in: Revue Historique, Jg. 122, Nr. 605, Januar-März 1998, S. 93-121.

DEMETZ, Peter: Die Flugschau von Brescia. Kafka, d'Annunzio und die Männer, die vom Himmel fielen, Wien 2002.

DERENTHAL, Ludger: Bilder der Trümmer- und Aufbaujahre. Fotografie im sich teilenden Deutschland, Marburg 1999.

DEWALD, Christian (Hg.): Arbeiterkino. Linke Filmkultur der Ersten Republik, Wien 2007.

DEWITZ, Bodo von, Robert Lebeck (Hg.): KIOSK. Eine Geschichte der Fotoreportage 1839-1973, Göttingen 2001.

DIAMOND, Michael: Victorian Sensation or the Spectacular, the Shocking and the Scandalous in the Nineteenth Century Britain, London 2003.

DIETZE, Carl: Presse- und Illustrations-Photographie. Praktische und geldliche Verwertung. Mit Verzeichnis der Absatzgebiete, 7. Auflage, Leipzig 1931 (1. Auflage Leipzig 1905).

DUPERRAY, Stéphane, Raphaele Vidaling: Front Page. Covers of the Twentieth Century, London 2003.

DURSTMÜLLER, Anton, Norbert Frank: 500 Jahre Druck in Österreich. Die Entwicklung der graphischen Gewerbe von den Anfängen bis zur Gegenwart, Bd. 2: Die österreichischen graphischen Gewerbe zwischen Revolution und Weltkrieg 1848 bis 1918, Wien 1985.

DUSSEL, Konrad: Pressebilder in der Weimarer Republik. Entgrenzung der Information, Münster, Berlin 2012.

EDER, Josef Maria: Geschichte der Photographie, vierte gänzlich umgearbeitete und vermehrte Auflage, Bd. 2, Halle (Saale) 1932.

EISENHUT, Günter: Alexander Stern, in: Günter Eisenhut, Peter Weibel (Hg.): Moderne in dunkler Zeit. Widerstand, Verfolgung und Exil steirischer Künstler und Künstlerinnen 1933-1945, Ausstellungskatalog Neue Galerie am Landesmuseum Joanneum, Graz 2001, S. 432-446.

EKHART-SCHIFFER, Armgard: Graz zur Gründerzeit. Leopold Bude, k. k. Hof-Fotograf, Graz 1993.

EKHART-SCHIFFER, Armgard: Samtbarett und Kamera. Leopold Bude (1840-1907), Ausstellungskatalog Landesmuseum Joanneum, Graz 1990.

EMERY, Edwin: The Press and America. An Interpretative History of Journalism, Englewood Cliffs, New York 1962 (Erstauflage 1954).

ENGELBART, Rolf: Illustrierte Radio-Programmzeit- 
schriften. Ein Segment des bildpublizistischen Marktes in der Weimarer Republik, in: Diethart Kerbs, Walter Uka (Hg.): Fotografie und Bildpublizistik in der Weimarer Republik, Bönen 2004, S. 113-132.

ENNIS, Helen: Margaret Michaelis. Love, Loss and Photography, Canberra 2005.

ERHART, Renate, Gerd Kaminski: Paizhao. Das alte China in der Linse österreichischer Fotografen. Bericht des Österreichischen Instituts für China- und Ostasienforschung Nr. 54, Wien 2008.

ESCH, Stefanie: Bibliographie zu Fotografie und Bildpublizistik in der Weimarer Republik, in: Diethart Kerbs, Walter Uka (Hg.): Fotografie und Bildpublizistik in der Weimarer Republik, Bönen 2004, S. 275-294.

ESKILDSEN, Ute (Hg.): „Fliegen Sie sofort nach ...“ Wolfgang Weber. Reportagen, Fotografie und Film 1925-1977, Göttingen 2005.

ESKILDSEN, Ute ( $\mathrm{Hg}$.): Fotografieren hieß teilnehmen Fotografinnen der Weimarer Republik, Essen 1994.

ESKILDSEN, Ute, Institut für Auslandsbeziehungen ( $\mathrm{Hg}$.): Fotografie in deutschen Zeitschriften 1924-1933, Stuttgart 1982.

ESKILDSEN, Ute, Jan-Christopher Horak (Hg.): Film und Foto der zwanziger Jahre. Eine Betrachtung der Internationalen Werkbundausstellung „Film und Foto“ 1929, Stuttgart 1979.

ESKILDSEN, Ute: Die Kamera als Instrument der Selbstbestimmung, in: Ute Eskildsen (Hg.): Fotografieren hieß teilnehmen. Fotografinnen der Weimarer Republik, Düsseldorf 1994, S. 13-25.

ESKILDSEN, Ute: Fotokunst statt Kunstfotografie. Die Durchsetzung des fotografischen Mediums in Deutschland 1920-1933, in: Ute Eskildsen, JanChristopher Horak (Hg.): Film und Foto der zwanziger Jahre. Eine Betrachtung der Internationalen Werkbundausstellung „Film und Foto“ 1929, Stuttgart 1979, S. 8-25.

FABER Monika, Klaus Albrecht Schröder (Hg.): Das Auge und der Apparat. Eine Geschichte der Fotografie aus den Sammlungen der Albertina, Ausstellungskatalog Albertina, Paris 2003.

FABER, Monika (Hg.): Tanz. Foto. Annäherungen und Experimente 1880-1940, Ausstellungskatalog Museum des 20. Jahrhunderts, Österreichisches Fotoarchiv im Museum Moderner Kunst, Wien 1990.

FABER, Monika (Hg.): Rudolf Koppitz. 1884-1936, Ausstellungskatalog Historisches Museum der Stadt Wien, Wien 1995.

FABER, Monika (Hg.): Rudolf Koppitz. Photogenie. 1884-1936, Wien 2013.

FABER, Monika, Astrid Mahler (Hg.): Heinrich Kühn. Die vollkommene Fotografie, Ausstellungskatalog Albertina, Ostfildern 2010.

FABER, Monika, Janos Frecot (Hg.): Porträt im Aufbruch. Photographie in Deutschland und Österreich 1900-1938, Ausstellungskatalog Albertina, Ostfildern 2005

FABER, Monika: Die Frau, wie du sie willst. Glamour, Kult und korrigierte Körper. Atelier Manassé 19221938, Wien 1998.

FABER, Monika: Fotografie in Wien 1890-1920, in: Christian Brandstätter (Hg.): Wien 1900. Kunst und Kultur. Fokus der europäischen Moderne, Wien 2005, S. 227-237.

FABER, Monika: Madame d'Ora. Wien-Paris. Portraits aus Kunst und Gesellschaft 1907-1957, Wien, München 1983.

FABER, Monika: Mode, Tanz, Werbung. Drei Anwendungsbereiche der Fotografie, in: Geschichte der Fotografie in Österreich, Bd. 1, hg. vom Verein zur Erar- beitung der Geschichte der Fotografie in Österreich, Bad Ischl 1983, S. 213-224.

FABER, Monika: Zeit ohne Zukunft. Photographie in Wien 1918-1938. Mit einem Text von Timm Starl, Wien 1998.

FALK, Susanne: Die „Arisierung“ der Wiener Zeitungsverlage. Das Verlagshaus Canisiusgasse 8-10, Taunusstein 2002.

FISCHER, Lisa, Emil Brix (Hg.): Die Frauen der Wiener Moderne, Wien, München 1997.

FORBES, Duncan (Hg.): Edith Tudor-Hart. Im Schatten der Diktaturen. Ausstellungskatalog Scottish National Portrait Gallery, Wien Museum, Ostfildern 2013.

FORBES, Duncan: Politics, Photography and Exile in the Life of Edith Tudor-Hart (1908-1973), in: Shulamith Behr, Marian Malet (Hg.): Arts in Exile in Britain 1933-1945. Politics and Cultural Identity, The Yearbook of the Research Centre for German and Austrian Exile Studies, Vol. 6, 2004, Amsterdam, New York 2005, S. 45-87.

FORD, Colin: Hungarian Photography 1914 to 1989 : An introduction, in: Photoresearcher. ESHPh European Society for the History of Photography, Nr. 14, 2010, S. 54-64.

FRECOT, Janos, Berlinische Galerie (Hg.): Erich Salomon. „Mit Frack und Linse durch Politik und Gesellschaft“. Photographien 1928-1938, München 2004.

FRIEDLMEIER, Herbert: Reportagefotografie. Wie wahr ist die abgebildete Wirklichkeit?, in: Uwe Schög (Hg.): Im Blickpunkt. Die Fotosammlung der Österreichischen Nationalbibliothek, Innsbruck 2002, S. 192-219.

FRIEDRICH, Thomas: Uhu im Blätterwald. Die Zeitungen und Zeitschriften des Ullstein-Verlags um 1930 und die Fotografie, in: Photo-Sequenzen. Reportagen. Bildgeschichten. Serien aus dem Ullstein Bilderdienst von 1925 bis 1944, Ausstellungskatalog Haus am Waldsee, Berlin 1993, S. 39-44.

FRIZOT, Michel, Cédric de Veigy: Vu. The Story of a Magazine that made an Era, London 2009.

FRÜH, Eckart: Kürzel und Pseudonyme in diversen Tageszeitungen und Zeitschriften vor und nach 1945: http://noch-mehr.blogspot.com

FRÜH, Eckart: Spuren und Überbleibsel: Bil Spira Traces and leftovers, in: Medien \& Zeit - Kommunikation in Vergangenheit und Gegenwart, Bd. 1, 2000, S. 40-49.

FRYNTA, Emanuel: Jan Lukas. Fotografie, Prag 1961.

FÜHRER, Karl Christian, Knut Hickethier, Axel Schildt: Öffentlichkeit - Medien - Geschichte. Konzepte der modernen Öffentlichkeit und Zugänge zu ihrer Erforschung, in: Archiv für Sozialgeschichte, Bd. 41, 2001, S. 1-38.

FULDA, Bernhard: Industries of Sensationalism: German Tabloids in Weimar Berlin, in: Karl Christian Führer, Corey Ross: Mass Media, Culture and Society in Twentieth-Century Germany, New York 2006, S. $183-203$.

GÄBLER, Bernd: Was gestern war, wirkt lange fort. Die deutsche Presse-Elite und die Kontinuitäten der Eliten nach 1945, in: Zwischen den Zeilen. Zeitungspresse als NS-Machtinstrument, hg. von der Stiftung Topographie des Terrors, Ausstellungskatalog, Berlin 2013, S. 34-42.

GASSER, Martin: Bill Brandt in Switzerland and Austria. Shadows of Life, in: History of Photography, Bd. 31, Nr. 4, 1997, S. 303-314.

GEBHARDT, Hartwig: „Halb criminalistisch, halb erotisch“. Presse für die „niederen Instinkte“. Annäherungen an ein unbekanntes Kapitel deutscher Mediengeschichte, in: Kaspar Maase, Wolfram Kaschuba
(Hg.): Schund und Schönheit. Populäre Kultur um 1900, Köln u.a. 2001, S. 184-217.

GEBHARDT, Hartwig: Die Pfennig-Magazine und ihre Bilder. Zur Geschichte und Funktion eines illustrierten Massenmediums in der ersten Hälfte des 19 Jahrhunderts, in: Wilhelm Brednich, Andreas Hartmann (Hg.): Populäre Bildmedien. Vorträge des 2. Symposiums für ethnologische Bildforschung, Reinhausen bei Göttingen 1986, S. 19-42.

GEORGE, Alys: Body/culture: Viennese modernism and the physical aesthetic, Diss., Stanford University, 2009, 2011 in Buchform veröffentlicht.

GERNSHEIM, Helmut: Geschichte der Photographie. Die ersten hundert Jahre, Frankfurt a. M., Berlin 1983. Geschichte der Fotografie in Österreich, Bd. 1, hg. vom Verein zur Erarbeitung der Geschichte der Fotografie in Österreich, Bd. 2, hg. von Otto Hochreiter und Timm Starl im Auftrag des Vereins zur Erarbeitung der Geschichte der Fotografie in Österreich, Ausstellungskataloge, Bad Ischl 1983.

GIDAL, Tim: Deutschland - Beginn des modernen Photojournalismus (Bibliothek der Photographie, hrsg. von Romeo E. Martinez, Bd. 1), Luzern, Frankfurt 1972.

GLASENAPP, Jörn: Die deutsche Nachkriegsfotografie. Eine Mentalitätsgeschichte in Bildern, München 2008.

GLÜCK, Liesl: Das interessante Blatt und Der Kuckuck. Ein Beitrag zur Wiener Zeitschriftengeschichte, Diss., Wien 1953.

GMEINER, Astrid, Gottfried Pirhofer: Der österreichische Werkbund, Salzburg, Wien 1985.

GOTTSCHAMMEL, Josef, Rudolf Hans Hammer (Hg.): Rudolf Koppitz, Wien 1937.

GRÄFF, Werner: Es kommt der neue Fotograf! Berlin 1929.

GRASBERGER, Franz: Die Hymnen Österreichs, Tutzing 1968.

GRÄWE, Christina: Liane Zimbler. Spurensuche - Die österreichische Architektin in Wien und im amerikanischen Exil, Diplomarbeit, Berlin 2003.

GREIF, Milena: Die Geschichte der Wiener Fotoagentur Willinger und ihr verschwundener Bestand, in: Rundbrief Fotografie, Vol. 11, No. 3, 15. September 2004 (N.F. 43), S. 37-40.

GREIF, Milena: Mit den Fotos kehrt die Erinnerung zurück. Agentur Schostal, in: Rundbrief Fotografie, Vol. 9, No. 2, Juni 2002 (N.F. 34), S. 30-33.

GROSSEGGER, Elisabeth: Der Kaiserhuldigungsfestzug 1908, in: Moritz Csáky, Peter Stachel (Hg.): Speicher des Gedächtnisses, Bibliotheken, Museen, Archive, Bd. 2: Die Erfindung des Ursprungs. Die Systematisierung der Zeit, Wien 2001, S. 155-175.

GROSSMANN, Anita: Berufswahl - Ein Privileg der bürgerlichen Frauen, in: Ute Eskildsen (Hg.): Fotografieren hieß teilnehmen. Fotografinnen der Weimarer Republik, Düsseldorf 1994, S. 8-25.

GUMPENBERGER, Bernadett: Das Geschäft mit dem Bild. Entwicklungen und Status quo des Bildermarktes unter besonderer Berücksichtigung der österreichischen Bildagenturen, Diplomarbeit, Wien 2005.

GUNDLACH, F. C. (Hg.): Martin Munkácsi, Mit Texten von Enno Kaufhold und Klaus Honnef, Göttingen 2006.

HAAS, Robert: „Ich muß sagen, ich war immer ein Glückpilz“, in: Gerhard Jelinek: Nachrichten aus dem 4. Reich, Salzburg 2008, S. 87-90.

HAFFTER, Isabelle: Der moderne Tanz und das Medium Fotografie. Der Schweizer Martin Imboden im „Roten Wien“ um 1930, Magisterarbeit, Universität Luzern, 2013. 
HÄGELE, Ulrich: Montage, Groteske, Propaganda. Die Vorgeschichte der Avantgarde: Medieninnovation in der französischen Illustrierten J'ai vu... 1914 bis 1920, in: Fotogeschichte, Heft 123, 2012, S. 5-20.

HAHNE, Kurt: Die Illustrations-Photographie. Ein leicht verständliches Lehrbuch, Bunzlau 1908.

HAINZLMAYR, Franz: Lichtbild und Heimatkunst, in: Foto-Ausstellung Österreichs Bundesländer im Lichtbilde, Österreichisches Museum für Kunst und Industrie, Wien 1933.

HAJICSEK, Gerhard: Viele Ziele, doch kein Ziel. Die Medienpolitik des Austrofaschistischen Staates, in: Michael Achenbach, Karin Moser (Hg.): Österreich in Bild und Ton. Die Filmwochenschau des Austrofaschistischen Ständestaates, Wien 2002, S. 45-70.

HALFBRODT, Dirk, Ulrich Pohlmann (Hg.): Philipp Kester - Fotojournalist. New York, Berlin, München 1903-1935, Berlin 2003.

HALL, Murray G.: Die Verlags- und Redaktionsgeschichte, in: Murray G. Hall, Franz Kadrnoska, Friedrich Kornauth, Wendelin Schmidt-Dengler: Die Muskete. Kultur- und Sozialgeschichte im Spiegel einer humoristischen Zeitschrift 1905-1941, Wien 1983, S. 7-18.

HALL, Murray: Österreichische Verlagsgeschichte 1918-1938, Wien, Köln, Graz 1985.

HALLETT, Michael: Stefan Lorant. Godfather of Photojournalism, Lanham 2006.

HANEY, Walter: Die illustrierte Kronen-Zeitung. Ein Beitrag zur Geschichte der Wiener Presse, Diss., Wien 1951.

HANISCH, Ernst: Der lange Schatten des Staates. Österreichische Gesellschaftsgeschichte im 20. Jahrhundert, Wien 1994.

HANNAU, Hans Walter: „Gegen die illegalen Nationalsozialisten bin ich natürlich vorgegangen“, in: Gerhard Jelinek: Nachrichten aus dem 4. Reich, Salzburg 2008, S. 91-96.

HARDT, Hanno: Pictures for the Masses: Photography and the Rise of Popular Magazines in Weimar Germany, in: Journal of Communication Inquiry, 13 (1), 1989, S. 7-29.

HARDT, Hanno: The Site of Reality: Construction Photojournalism in Weimar Germany, 1928-33, in: Communication Review 1, Nr. 3, 1996.

HARTL, Ingeborg: Das Fremdenblatt. Ein Beitrag zur österreichischen Pressegeschichte, Wien 1949.

HASSNER, Rune: Bilder för miljöner, Stockholm 1977. HAUSJELL, Fritz: Österreichische Journalisten und Publizisten im Exil (1933/34 bis 1945). Eine Fallstudie, in: Friedrich Stadler (Hg.): Vertriebene Vernunft I. Emigration und Exil österreichischer Wissenschaft 1930-1940, Wien, München 1987, S. 304-342.

HAUTMANN, Hans: Die Anfänge der linksradikalen Bewegung und der kommunistischen Partei Deutschösterreichs 1916-1919, Wien 1970.

HAWLIK, Johannes: Die politischen Parteien Deutschösterreichs bei der Wahl zur konstituierenden Nationalversammlung 1919, Diss., Wien 1971.

HEITING, Manfred, Roland Jaeger (Hg.): Autopsie. Deutschsprachige Fotobücher 1918 bis 1945, Bd. I \& II, Göttingen 2012/2014.

HELLER, Steven: Merz to Emigre and Beyond: AvantGarde Magazine Design of the Twentieth Century, London 2003.

HENISCH, Peter: Mit eigenen Augen gesehen/selber geschossen, in: Christian Stadelmann, Regina Wonisch (Hg.): Brutale Neugier. Walter Henisch. Kriegsfotograf und Bildreporter, Ausstellungskatalog Wien Museum, Wien 2003, S. 14-17.

HERMANSON MEISTER, Sarah: Bill Brandt. Shadow \&
Light, Ausstellungskatalog Museum of Modern Art, New York, London 2013.

HERZ, Rudolf: Hoffmann \& Hitler. Fotografie als Medium des Führer-Mythos, München 1994.

HESSE, Wolfgang (Hg.): Fotografie im Klassenkampf. Arbeiterfotografie in Deutschland, Österreich und der Schweiz, Fotogeschichte, Heft 127, 2013.

HINTERSTOISSER, Franz: Aus meinem Luftschiffertagebuche, Rzeszów 1904.

HINTERSTOISSER, Franz: Fünfundzwanzig Jahre Luftfahrt, Wien 1915.

HIRSCHFELD, Gerhard: Sarajevo: Das bilderlose Attentat und die Bildfindungen der Massenpresse, in: Gerhard Paul (Hg.): Das Jahrhundert der Bilder, Göttingen 2009, S. 148-155.

HOCHREITER, Otto, Peter Weiermair (Hg.): Peter Paul Atzwanger 1888-1974. Photographien, Innsbruck 1981.

HOFBAUER, Victoria: Grete Wiesenthal - eine Varietétänzerin? Die Auftritte der Wiener Tänzerin in Wiener Cabaretts und Varietés anhand von drei Beispielen, Diplomarbeit, Wien 2009.

HOFER, Gabriele, Uwe Schögl: Lucca Chmel. Architekturfotografie 1945-1970, Passau 2004.

HOFER, Gabriele: Lucca Chmel. Architekturfotografie 1945-1972. Zur Repräsentation österreichischer Nachkriegsmoderne im fotografischen Bild, Diss., Wien 2005.

HOFFMANN, Christine: Deutsche und österreichische Ausdruckstänzerinnen in der Emigration, in: Denny Hirschbach, Sonia Nowoselsky (Hg.): Zwischen Aufbruch und Verfolgung. Künstlerinnen der zwanziger und dreißiger Jahre, Bremen 1993, S. 191-206.

HOLZER, Anton (Hg.): Die letzten Tage der Menschheit. Der Erste Weltkrieg in Bildern. Mit Texten von Karl Kraus, Darmstadt 2013.

HOLZER, Anton (Hg.): Einführung in die Fotogeschichte. Recherche, Methoden, Theorie, Fotogeschichte, Heft 124, 2012.

HOLZER, Anton, Frauke Kreutler (Hg.): Trude Fleischmann. Der selbstbewusste Blick, Ausstellungskatalog Wien Museum, Ostfildern 2011.

HOLZER, Anton: Aktivistin mit Kamera. Edith Suschitzky im Kontext der Wiener Fotoszene um 1930, in: Duncan Forbes (Hg.): Edith Tudor-Hart. Im Schatten der Diktaturen, Ausstellungskatalog Scottish National Portrait Gallery, Wien Museum, Ostfildern 2013, S. 41-47.

HOLZER, Anton: Atelier und Illustrierte. Trude Fleischmanns Fotoarbeiten für die Presse, in: Anton Holzer, Frauke Kreutler (Hg.): Trude Fleischmann. Der selbstbewusste Blick, Ausstellungskatalog Wien Museum, Ostfildern 2011, S. 122-134.

HOLZER, Anton: Avantgarde und gemäßigte Moderne. Fotografische Aufbrüche um 1930, in: Fotogeschichte, Heft 123, 2012, S. 51-60.

HOLZER, Anton: Das große Bild. Barbara Pflaum, die Wochenpresse und der österreichische Fotojournalismus nach 1945, in: Wolfgang Kos, Gerald Piffl, Peter Stuiber, Susanne Winkler (Hg.): Barbara Pflaum. Bildchronistin der Zweiten Republik, Wien 2006, S. 86-93.

HOLZER, Anton: Der illustrierte Krieg. Fotografie und Bildberichterstattung 1914 bis 1918, in: Alfred Pfoser, Andreas Weigl (Hg.): Im Epizentrum des Zusammenbruchs. Wien im Ersten Weltkrieg, Wien 2013, S. $486-493$.

HOLZER, Anton: Krieg in Bildern. Fotografie und Propaganda im Ersten Weltkrieg, in: Schallaburg Kulturbetriebsges. m.b.H. (Hg.): Jubel \& Elend. Leben mit dem Großen Krieg 1914-1918, Schallaburg 2014, S. $98-103$.
HOLZER, Anton: Das Lächeln der Henker. Der unbekannte Krieg gegen die Zivilbevölkerung 1914-1918, 2. Aufl., Darmstadt 2014.

HOLZER, Anton: Der zaghafte Aufbruch in die Moderne. Fotografie in Österreich 1900 bis 1938, in: Fotogeschichte, Heft 113, 2009, S. 21-48.

HOLZER, Anton: Die andere Front. Fotografie und Propaganda im Ersten Weltkrieg, 3. Aufl., Darmstadt 2012.

HOLZER, Anton: Die Hunde des Dr. Freud, in: Die Presse, Spectrum, 21. Januar 2012, S. V.

HOLZER, Anton: Fotografie in Österreich. Geschichte, Entwicklungen, Protagonisten 1890-1955, Wien 2013.

HOLZER, Anton: Fotografisches Feuilleton. Der Sonntag - ein vergessenes Forum moderner österreichischer Reportagefotografie, in: Fotogeschichte, Heft 128, 2013, S. 25-48.

HOLZER, Anton: Nachrichten und Sensationen. Pressefotografie in Deutschland und Österreich 1890 bis 1933. Ein Literaturüberblick, in: Fotogeschichte, Heft 107, 2008, S. 61-67.

HOLZER, Anton: The History of Austrian Photography 1900-1938, in Václav Macek (Hg.): The History of European Photography, Teil 1: 1900-1938, Bratislava, European House of Photography, 2010, S. 1539.

HOLZER, Anton: Stanley Kubrick: Fotojournalist. Look, Life und die Kultur der amerikanischen Fotoreportage, in: Ingrid Brugger, Lisa Ortner-Kreil (Hg.): Eyes wide open. Stanley Kubrick als Fotograf, Ausstellungskatalog Kunstforum Wien, München 2014.

HOLZER, Anton: Soldaten mit der Kamera. Deutsche Kriegsfotografen im Zweiten Weltkrieg, in: Hans-Michael Koetzle (Hg.): Augen auf! 100 Jahre Leica, Ausstellungskatalog Haus der Photographie, Hamburg, Ostfildern 2014.

HOLZER, Anton: Vorwärts! Die österreichische Arbeiterfotografie der Zwischenkriegszeit, in: Fotogeschichte, Heft 127, 2013, S. 17-30.

HÖLZL, Werner: Die Organisation der Wiener Presse 1917-1934. Ein Beitrag zur Sozialgeschichte der österreichischen Journalisten, Diss., Wien 1965.

HONNEF, Klaus, Frank Weyer: Und sie haben Deutschland verlassen ... müssen. Fotografen und ihre Bilder 1928-1997, Ausstellungskatalog Rheinisches Landesmuseum Bonn, Köln 1997.

HORAK, Roman: Josephine Baker in Wien - oder doch nicht? Über die Wirksamkeit des „zeitlos Popularen“, in: Roman Horak u. a. (Hg.): Metropole Wien. Texturen der Moderne, Bd. 1, Wien 2000, S. 169-213.

HORAK, Roman: Skandalfall Josephine Baker. Das Wiener Gastspiel der „Urwaldamazone“, in: Wolfgang Kos (Hg.): Kampf um die Stadt. Politik, Kunst und Alltag um 1930, Ausstellungskatalog Wien Museum, Wien 2010, S. 206-213.

HUBER, Sonja: „Die Erziehung zum Sehen ...“ Das demokratisierte Lichtbild und die Selbstperzeption der österreichischen Arbeiterschaft 1918 bis 1934, Diplomarbeit, Wien 2005.

HUDSON-WIEDENMANN, Ursula, Beate Schmeichel-Falkenberg (Hg.): Grenzen überschreiten. Frauen, Kunst und Exil, Würzburg 2005.

HUSNIK; Kurt: Das Kinoauge als Reporter, in: Profil, Heft 10, Oktober 1933, S. III.

JAGSCHITZ, Gerhard: Photographie und „Anschluß“, in: Oliver Rathkolb, Wolfgang Duchowitsch, Fritz Hausjell unter Mitarbeit von Hannes Haas (Hg.): Die veruntreute Wahrheit. Hitlers Propagandisten in Österreich '38, Salzburg 1988, S. 52-87.

JARKA, Horst: Jura Soyfer. Leben, Werk, Zeit, Wien 1987. 
JARKA, Horst: Zur Kultur- und Theaterpolitik im „Ständestaat", in: Franz Kadrnoska (Hg.): Aufbruch und Untergang. Österreichische Kultur zwischen 1918 und 1938, Wien, München, Zürich 1981, S. 499-538.

JELINEK, Gerhard: Nachrichten aus dem 4. Reich, Salzburg 2008.

JÖCHLINGER, Regina: Die Geschichte der Sportfotografie in Österreich. Von den Anfängen bis in die Sechzigerjahre unseres Jahrhunderts, Diplomarbeit, Wien 1984

JULES-ROSETTE, Bennetta: Josephine Baker in art and life. The icon and the image, Urbana, Chicago 2007.

KAINDL, Kurt: Der Giftmordprozeß in Szolnok. Analyse der Bildberichte über einen Giftmordprozeß aus dem Jahre 1929 im „Interessanten Blatt“ und im „Kuckuck“, in: Photographie und Gesellschaft. Zeitschrift für photographische Imagologie, Heft 1 , 1989, S. 43-52.

KAINDL, Kurt: Harald Lechenperg. Pionier des Fotojournalismus, Salzburg 1990.

KANDL, Leo: Pressefotografie und Fotojournalismus in Österreich bis 1960, in: Geschichte der Fotografie in Österreich, hg. vom Verein zur Erarbeitung der Geschichte der Fotografie in Österreich, Bad Ischl, 1983, S. 313-324.

KASPER, Josef: Belichtung und Wahrheit. Bildreportage von der Gartenlaube bis zum Stern, Frankfurt am Main 1979.

KAUFHOLD, Enno: Die Berliner Illustrirte - Synonym des deutschen Bildjournalismus, in: 125 Jahre UIIstein. Presse- und Verlagsgeschichte im Zeichen der Eule, Berlin 2002, S. 49-45.

KAUFMANN, Krystyna, Mathias Marx, Manfred Fried rich: Marie Goslich. Die Grande Dame des Fotojournalismus 1859-1938, Leipzig 2013.

KAUKOREIT, Volker: Peter Hammerschlag und das Wiener Magazin“. Eine Bibliographie, in: Monika Kriegler-Griensteidl, Volker Kaukoreit (Hg.): Kringel, Schlingel, Borgia. Materialien zu Peter Hammerschlag, Wien 1997, S. 255-262.

KELLER, Ulrich: Blut und Silber. Die Inszenierung de Kuba-Invasion in der amerikanischen Bildpresse, in: Fotogeschichte, Heft 97, 2005, S. 25-46.

KELLER, Ulrich: Der Weltkrieg der Bilder. Organisation, Zensur und Ästhetik der Bildreportage 19141918, in: Fotogeschichte, Heft 130, 2013, S. 7-50.

KELLER, Ulrich: Fotografie und Begehren. Der Triumph der Bildreportage im Medienwettbewerb der Zwischenkriegszeit, in: Annelie Ramsbrock, Annette Vowinckel, Malte Zierenberg (Hg.): Fotografien im 20. Jahrhundert. Verbreitung und Vermittlung, Göttingen 2013, S. 129-174.

KELLER, Ulrich: Early Photojournalism, in: David Crowley, Paul Heyer (Hg.): Communication in History, New York 1995, S. 170-178.

KELLER, Ulrich: Photojournalism around 1900. The Institutionalisation of a Mass Medium, in: Kathleen Collins (Hg.): Shadow and Substance. Essays on the History of Photography. In Honor of Heinz K. Henisch, Troy, Michigan 1990, S. 283-303.

KELLER, Ulrich: Producing/Controlling Spectacle: Presidential Speech in Media Reportage, in: Amy Lyford, Carol Payne (Hg.): Photojournalism, Mass Media, and the Politics of Spectacle, in: Visual Resources, Vol. 21, Nr. 2, 2005.

KELLER, Ulrich: Verdun, 1916. Die Schlacht der Bildreportagen, in: Fotogeschichte, Heft 130, 2013, S. 51-85.

KERBS, Diethart (Hg.): Auf den Straßen von Berlin. Der Fotograf Willy Römer (1887-1979), Ausstellungskatalog Deutsches Historisches Museum, Bönen 2004
KERBS, Diethart, Walter Uka (Hg.): Fotografie und Bildpublizistik in der Weimarer Republik, Bönen 2004.

KERBS, Diethart: Die illustrierte Presse am Ende der Weimarer Republik, in: Diethart Kerbs, Henrick Stahr (Hg.): Berlin 1932. Das letzte Jahr der Weimarer Republik. Politik, Symbole, Medien, Berlin 1992, S. 68-89.

KERBS, Diethart: Schicksale deutscher Pressebild archive, in: Rundbrief Fotografie, Vol. 11, No. 3, 15. September 2004 (N.F. 43), S. 23-29.

KINCES, Károly, Magdolna Kolta: Minden magyar fotoriporterek atyja: Balogh Rudolf, Magyar Fotográfiai Múzeum, Kecskemét, Budapest 1998.

KINCES, Károly: Fotografi made in Hungary. Quelli che sono andati via, quelli che sono rimasti, Hungarian Museum of Photography, Milano 1998.

KISCH, Egon Erwin: Mein Leben für die Zeitung. Journalistische Texte 1. 1906-1925, Berlin (Ost) 1983.

KNIESCHEK, Christian: Historische Ausstellungen in Wien 1918-1938: Ein Beitrag zur Ausstellungsanalyse und Geschichtskultur, Frankfurt a. M. 1998.

KNOCH, Habbo: Living Pitures: Photojournalism in Germany, 1900 to the 1930s, in: Karl Christian Führer, Corey Ross (Hg.): Mass Media, Culture and Society in Twentieth-Century Germany, New York 2006, S. 217-233.

KOGLER, Nikolaus G.: Zwischen Freiheit und Knebelung. Die Tagespresse Tirols 1914 bis 1947, Innsbruck 2000.

KÖHLER, Walter: Amtliches Nachrichtenwesen und Nachrichtenpolitik im „Austrofaschismus“. Amtl. Nachrichtenstelle u. „Politische Korrespondenz“ im Umfeld des „austrofaschistischen“ Mediensystems 1933 bis 1938, Diss., Wien 1985.

KOS, Wolfgang (Hg.): Kampf um die Stadt. Politik, Kunst und Alltag um 1930, Ausstellungskatalog Wien Museum, Wien 2010.

KOSZYK, Kurt: Deutsche Presse im 19. Jahrhundert (Geschichte der deutschen Presse, Teil II), Berlin 1966.

KOSZYK, Kurt: Deutsche Presse 1914-1945 (Geschichte der deutschen Presse, Teil III), Berlin 1972.

KOTHES, Franz-Peter: Die theatralische Revue in Berlin und Wien 1900-1940 unter besonderer Berücksichtigung der Ausstattungsrevue. Strukturen und Funktionen, Diss., Wien 1972

KOWALD, Gerhard: Die Arbeiterfotografie der Ersten Republik, Hausarbeit, Akademie der bildenden Künste, Wien 1979.

KRACAUER, Siegfried: Die Photographie (1927), in: Ders.: Schriften, hg. von Karsten Witte, Bd. 5.2: Aufsätze 1927-1931, Frankfurt a. M. 1990, S. 83-98.

KRAMMER, Marion: Bissige Bilder. Die Fotomontage als visuelles Propagandainstrument der Sozialdemokratie in den Jahren 1929-1934, Diplomarbeit, Wien 2008

KRAMMER, Marion: Montierte Propaganda, sprechende Bilder. Fotomontage im „Roten Wien“ 1929 bis 1934, in: Fotogeschichte, Heft 115, 2010, S. 37-52.

KRANZFELDER, Ivo: Die Frühjahre des deutschen Bildjournalismus, in: Dirk Halfbrodt, Ulrich Pohlmann (Hg.): Philipp Kester - Fotojournalist. New York, Berlin, München 1903-1935, Berlin 2003.

KRASNY, Elke, Marcus Patka, Christian Rapp, Nadia Rapp (Hg.): Von Samoa zum Isonzo. Die Reisejournalistin Alice Schalek, Wien 1999.

KREIMEIER, Klaus: Traum und Exzess. Die Kulturgeschichte des frühen Kinos, Wien 2011.

KRIEGLER-GRIENSTEIDL, Monika, Volker Kaukoreit (Hg.): Kringel, Schlingel, Borgia. Materialien zu Peter Hammerschlag, Wien 1997.
KÜHN, Heinrich: Lichtbildnerei und Photographie, in: Das deutsche Lichtbild 1931, Berlin 1930.

LARL, Rupert, Gunther Waibl (Hg.): Adalbert Defner: Lichte Landschaft. Photographien 1910-1969, Innsbruck, Bozen 1999.

LESÁK, Barbara (Hg.): Von der Pose zum Ausdruck. Theaterfotografie 1900-1930, Ausstellungskatalog Österreichisches Theatermuseum, Wien 2003.

LILIEN, Otto M.: Die Geschichte des Tiefdruckes von 1900-1920, Frankfurt a. M. u.a. 1963.

LIPTÁK, Dorottya: Illustrierte Bildungs- und Unterhaltungspresse und das Lesepublikum in der Donaumonarchie zur Zeit Franz Josefs (1850-1914), in: Norbert Bachleitner, Andrea Seidler (Hg.): Zur Medialisierung gesellschaftlicher Kommunikation in Österreich und Ungarn. Studien zur Presse im 18. und 19. Jahrhundert, Wien, Berlin 2007, S. 177-234.

LOACKER, Armin: Die „Newa“ und der „Russenfilm“ in Wien, in: Christian Dewald (Hg.): Arbeiterkino. Linke Filmkultur der Ersten Republik, Wien 2007, S. 215220.

LORZ, Korinna: „foto-bauhäusler, werdet arbeiter-fotografen!" Fotografie am Bauhaus zwischen Avantgarde und Agitation. Ein Werkstattbericht, in: Fotogeschichte, Heft 127, 2013, S. 31-44.

MAASE, Kaspar, Wolfram Kaschuba (Hg.): Schund und Schönheit. Populäre Kultur um 1900, Köln u. a. 2001.

MAASE, Kaspar: Krisenbewußtsein und Reformorientierung. Zum Deutungshorizont der Gegner der modernen Populärkünste 1880-1918, in: Kaspar Maase, Wolfram Kaschuba (Hg.): Schund und Schönheit. Populäre Kultur um 1900, Köln u. a. 2001, S. 290-343.

MADERTHANER, Wolfgang, Lutz Musner: Die Anarchie der Vorstadt. Das andere Wien um 1900, Frankfurt a. M. 1999.

MADERTHANER, Wolfgang: Tolle Jahre. Sport, Gesellschaft, Politik in Österreich. Der Fotograf Mario Wiberal, Wien 2011

MAHLER, Astrid: Die Ausbildung zur Berufsfotografin an der Graphischen Lehr- und Versuchsanstalt, in: Iris Meder, Andrea Winklbauer (Hg.): Vienna's Shooting Girls. Jüdische Fotografinnen aus Wien, Wien 2012.

MAIER, Michaela, Wolfgang Maderthaner: Im Bann der Schattenjahre. Wien in der Zeit der Wirtschaftskrise 1929 bis 1934, Wien 2012.

MAKAROVA, Elena: Friedl Dicker-Brandeis, Vienne 1898-Auschwitz 1944, Ausstellungskatalog Musée d'art et d'histoire du Judaisme, Paris 2000.

MAKAROVA, Elena: Friedl Dicker-Brandeis. Ein Leben für Kunst und Lehre. Wien, Weimar, Prag, Hronov, Theresienstadt, Auschwitz, Wien 1999.

MAN, Felix H. (d. i. Hans Felix Sigismund Baumann): Pionier des Bildjournalismus, München 1971.

MAN, Felix H.: Photographien aus 70 Jahren, München 1993.

MARCKWARDT, Wilhelm: Die Illustrierten der Weimarer Zeit. Publizistische Funktion, ökonomische Entwicklung und inhaltliche Tendenzen (unter Einschluß einer Bibliographie dieses Pressetypus 1918-1932), München 1982.

MARCKWARDT, Wilhelm: Paul Edmund Hahn. Ein vergessener Fotojournalist der ersten Stunde, in: Fotogeschichte, Heft 10, 1983, S. 40-53.

MARSCHIK, Matthias: Heldenbilder. Kulturgeschichte der österreichischen Aviatik, Münster, Hamburg, London 2002.

MARYSKA, Christian: Internationales Niveau. Grafikdesign und Werbewirtschaft um 1930, in: Wolfgang Kos (Hg.): Kampf um die Stadt. Politik, Kunst und 
Alltag um 1930, Ausstellungskatalog Wien Museum, Wien 2010, S. 184-191.

MATAUSCHEK, Isabella: Nationalsozialistische Kontrolle über die Wiener Zeitungsbetriebe 1938-1945, in: Gabriele Melischek, Josef Seethaler (Hg.): Die Wiener Tageszeitungen. Eine Dokumentation, Bd. 4: 1938-1945. Mit einem Überblick über die österreichische Tagespresse in der NS-Zeit, Frankfurt a. M. 2003, S. 85-108.

MATAUSCHEK, Isabella: Ullstein in Wien, in: 125 Jahre Ullstein. Presse- und Verlagsgeschichte im Zeichen der Eule, Berlin 2002, S. 88-91.

MATTL-WURM, Sylvia, Alfred Pfoser (Hg.): Die Vermessung Wiens. Lehmanns Adressbücher 1859-1942, Wien 2011.

MATTL-WURM, Sylvia, Markus Reuter (Hg.): „schwerer als Luft“. 100 Jahre Motorflug in Wien. Das Bordmagazin zur Ausstellung, Wienbibliothek im Rathaus, Wien 2009.

MATZER, Ulrike: Zwischen Heimatfotografie und Medienkunst. Fotografie in Österreich 1939 bis 1970, in: Fotogeschichte, Heft 117, S. 27-50.

MAURACHER, Michael: Bildfolgen und Serien. Zur Geschichte der Dokumentarfotografie in Österreich, in: Geschichte der Fotografie in Österreich, Bd. 1, hg. vom Verein zur Erarbeitung der Geschichte der Fotografie in Österreich, Bad Ischl 1983, S. 325-334.

MEDER, Iris, Andrea Winklbauer (Hg.): Vienna's Shooting Girls. Jüdische Fotografinnen aus Wien, Wien 2012.

MELISCHEK, Gabriele, Josef Seethaler: Auflagenzahlen der Wiener Tageszeitungen 1895-1933 in quellenkritischer Bearbeitung, Arbeitsberichte der Kommission für historische Pressedokumentation, Nr. 1, Österreichische Akademie der Wissenschaften, Wien 2001.

MELISCHEK, Gabriele, Josef Seethaler: Presse und Modernisierung in der Habsburgermonarchie, in: Helmut Rumpler, Peter Urbanitsch (Hg.): Die Habsburgermonarchie 1848-1918, Band VIII: Politische Öffentlichkeit und Zivilgesellschaft, 2. Teilband: Die Presse als Faktor der politischen Mobilisierung, Wien 2006, S. 1535-1571.

MENDELSSOHN, Peter de: Zeitungsstadt Berlin. Menschen und Mächte in der Geschichte der deutschen Presse, Berlin 1959, überarbeitete und erweiterte Auflage 1982.

MICHELS, Karen: Transplantierte Kunstwissenschaft. Die deutschsprachige Kunstgeschichte im amerikanischen Exil, Berlin 1999.

MOHOLY-NAGY, László: Malerei Fotografie Film, München 1925 (Nachdruck Berlin 2000).

MOLDERINGS, Herbert: Eine Schule der modernen Fotoreportage. Die Fotoagentur Dephot (Deutscher Photodienst) 1928 bis 1933, in: Fotogeschichte, Heft 107, 2008, S. 5-21.

MOLDERINGS, Herbert: Fotografie in der Weimarer Republik, Berlin 1988.

MOLDERINGS, Herbert: Mendelsohn, Amerika und der „Amerikanismus“, in: Fotogeschichte, Heft 123, 2012, S. 21-28.

MOLDERINGS, Herbert: UMBO - Otto Umbehr 19021980, Düsseldorf 1995.

MOLDERINGS, Herbert: Umbo. Vom Bauhaus zum Bildjournalismus, Ausstellungskatalog, Düsseldorf 1996.

MORGENSTERN, Soma: Der Fall Zeileis, in: Ders.: Werke in Einzelbänden, hg. von Ingolf Schulte, Bd. 11: Dramen, Feuilletons, Fragmente, Lüneburg 2000, S. 388-392.

MOUCHA, Josef: Jan Lukas, Prag 2003.

NenNo, Nancy: Femininity, the Primitive, and Modern Urban Space: Josephine Baker in Berlin, in: Ka- tharina von Ankum (Hg.): Women in the Metropolis. Gender and Modernity in Weimar Culture, Berkeley, Los Angeles, London, 1997, S. 145-161.

NEURATH, Otto: From Hieroglyphics to Isotype. A Visual Autobiography, London 2010.

NEURATH, Otto: Gesammelte bildpädagogische Schriften, hg. von Rudolf Haller und Robin Kinross, Wien 1991.

NEUTRA, Richard: Amerika. Die Stilbildung des Neuen Bauens in den Vereinigten Staaten, Wien 1930.

NEUTRA, Richard: Wie baut Amerika? Stuttgart 1927.

NITSCHE, Jessica, Nadine Werner (Hg.): Populärkultur, Massenmedien, Avantgarde 1919-1933, München 2012.

OCHAIM, Brygida, Claudia Balk: Tänzerinnen um 1900. Vom Sinnenrausch zur Tanzmoderne, Katalog Deutsches Theatermuseum, Frankfurt a. M. 1998.

ÖHLINGER, Walter (Hg.): Das Rote Wien. 1918-1934, Ausstellungskatalog Historisches Museum der Stadt Wien, Wien 1993.

OLSON, Kenneth E.: The History Makers. The Press of Europe from its Beginnings through 1945, Baton Rouge 1966.

Das österreichische Lichtbild. Jahrbuch 1933, hg. vom Verband der österreichischen Amateurphotographenvereine in Wien, Wien, Troppau, Leipzig 1933.

Österreichischer Werkbund (Hg.): Internationale Ausstellung Film und Foto. Wanderausstellung des Deutschen Werkbundes, Österreichisches Museum, 20. Februar bis 31. März 1930, Ausstellungskatalog, Wien o. J. (1930).

OSMAN, Colin, Sandra Philipps: European Visions: Magazine Photography in Europe between the Wars, in: Marianne Fulton (Hg.): Eyes of Time. Photojournalism in America, New York 1988, S. 75-103.

PANZER, Mary: Things as They Are: Photojournalism in Context since 1955, London 2006.

PARR, Martin, Gerry Badger (Hg.): The Photobook. A History, Vol. I, II \& III, London 2004/2006/2014.

PAUL, Gerhard (Hg.): Das Jahrhundert der Bilder 1900-1949, Göttingen 2009.

PAUL, Gerhard: Von der Historischen Bildkunde zur Visual History. Eine Einführung, in: Ders. (Hg.): Visual History. Ein Studienbuch, Göttingen 2006, S. 7-36.

PAUPIÉ, Kurt: Handbuch der österreichischen Pressegeschichte 1848-1959, Bd. I: Wien, Wien, Stuttgart 1960.

PERRET, René: Martin Imboden. Ein vergessener Fotograf, Bern 1996.

PETERS, Dorothea: Fotografie für die Massen. Zur Frühgeschichte fotomechanischer Drucktechniken im Spiegel der Wiener Photographischen Gesellschaft 1964-1883 (Teil 1), in: Rundbrief Fotografie, Vol. 19, 2012 (N.F. 76), S. 8-18.

PETERS, Dorothea: Fotografie für die Massen. Zur Frühgeschichte fotomechanischer Drucktechniken im Spiegel der Wiener Photographischen Gesellschaft 1964-1883 (Teil 2), in: Rundbrief Fotografie, Vol. 20, 2013 (N.F. 77), S. 19-29.

PETERSON, Theodore: Magazines in the Twentieth Century, 2. Auflage, Urbana 1964 (Die erste Auflage erschien 1956).

PETSCHAR, Hans: Anschluss. „Ich hole euch heim“. Der „Anschluss“ Österreichs an das Deutsche Reich. Fotografie und Wochenschau im Dienst der NS-Propaganda. Eine Bildchronologie, Wien 2008.

PFOSER, Alfred: Verstörte Männer und emanzipierte Frauen. Zur Sitten- und Literaturgeschichte der
Ersten Republik, in: Franz Kadrnoska (Hg.): Aufbruch und Untergang. Österreichische Kultur zwischen 1918 und 1938, Wien, München, Zürich 1981, S. $205-222$.

PFOSER, Alfred: Wien im Register. Eine Einführung, in: Sylvia Mattl-Wurm, Alfred Pfoser (Hg.): Die Vermessung Wiens. Lehmanns Adressbücher 1859-1942, Wien 2011, S. 13-45.

PFRUNDER, Peter (Hg.): Gotthard Schuh. Eine Art Verliebtheit, Göttingen 2009.

PFRUNDER, Peter (Hg.): Schweizer Fotobücher 1927 bis heute. Eine andere Geschichte der Fotografie, Baden 2011.

PFRUNDER, Peter: Fragen an das Fotobuch. Gedruckte Fotografie - eine unterschätzte Dimension der Fotogeschichte, in: Anton Holzer (Hg.): Einführung in die Fotogeschichte. Recherche, Methoden, Theorie, Fotogeschichte, Heft 124, 2012, S. 42-49.

PFUNDNER, Michaela, Margot Werner (Hg.): Zur Erinnerung an schönere Zeiten. Bilder aus der versunkenen Welt des jüdischen Sammlers Raoul Korty, Wien 2008.

PFUNDNER, Michaela: Dem Moment sein Geheimnis entreißen. Der Sportberichterstatter Lothar Rübelt (1901-1990), in: Matthias Marschik, Rudolf Müllner (Hg.): „Sind's froh, dass Sie zu Hause geblieben sind." Mediatisierung des Sports in Österreich, Göttingen 2010, S. 317-327.

Photo: Casparius. Filmgeschichte in Bildern/Berlin um 1930/Auf Reisen, hg. von der Stiftung Deutsche Kinemathek, Katalog zur Ausstellung in der Staatlichen Kunsthalle Berlin, Berlin 1978.

POHLMANN, Ulrich, Rudolf Scheutle (Hg.): Lehrjahre, Lichtjahre. Die Münchener Fotoschule 19002000, Ausstellungskatalog Münchener Stadtmuseum, München 2000.

POKIESER, Harald: Die Wiener Illustrierten des 19. Jahrhunderts und ihre Rolle als Wegbereiter des Fotojournalismus, Diss., Wien 1984.

POLGAR, Alfred: Hinterland, Berlin 1929.

PONSTINGL, Michael (Hg.): Die Explosion der Bilderwelt. Die Photographische Gesellschaft in Wien 18811945, Wien 2011.

PONSTINGL, Michael: Wien im Bild. Fotobildbände des 20. Jahrhunderts, Wien 2008.

POSCH, Wilfried: Clemens Holzmeister: Architekt zwischen Kunst und Politik, Salzburg, Wien 2010.

POSCH, Wilfried: Die Österreichische Werkbundbewegung 1907-1928, in: Isabella Ackerl, Rudolf Neck (Hg.): Geistiges Leben im Österreich der Ersten Republik, Wien 1986, S. 195-204.

POTYKA, Alexander: Das Kleine Blatt: Die Tageszeitung des Roten Wien, Wien 1986.

PRILLER, Markus: Arisierungen in der österreichischen Textilindustrie, Diplomarbeit, Universität Wien, Wien 2008.

RAMSBROCK, Annelie, Annette Vowinckel, Malte Zierenberg (Hg.): Fotografien im 20. Jahrhundert. Verbreitung und Vermittlung, Göttingen 2013.

REISNER, Ingeborg: Kabarett als Werkstatt des Theaters. Literarische Kleinkunst in Wien vor dem Zweiten Weltkrieg, Wien 2004.

REITER, Ilse: Texte zur österreichischen Verfassungsentwicklung 1848-1955, Wien 1997.

REQUATE, Jörg: Öffentlichkeit und Medien als Gegenstände historischer Analyse, in: Geschichte und Gesellschaft, Jg. 25, Heft 1, 1999, S. 5-32.

RESCH, Andreas: Das Geschäft mit Wort und Bild. Wirtschaftsgeschichte der Massenmedien und der Werbebranche in Wien, Berlin u. a. 2008. 
RIESENFELLNER, Stefan, Josef Seiter: Der Kuckuck. Die moderne Bild-Illustrierte des Roten Wien, Wien 1995.

RIGELE, Georg: Die Großglockner Hochalpenstraße. Zur Geschichte eines österreichischen Monuments, Wien 1998

ROBACH, Brigitte: Julius Braunthal als politischer Publizist. Ein Leben im Dienste des Sozialismus, Diss. Wien 1983.

ROH, Franz, Jan Tschichold: Foto-Auge, Stuttgart 1929

ROMAUCH, Angelika: Friedl Dicker. Marxistische Fotomontagen 1932/33. Das Verfahren der Montage als sozialkritische Methode, Diplomarbeit, Wien 2003.

RÖSSLER, Patrick: „Wir zerstreuen uns zu Tode.“ Formen und Funktionen der Medialisierung des Politischen in illustrierten Zeitschriften der NS-Zeit, in: Klaus Arnold u. a. (Hg.): Von der Politisierung der Medien zur Medialisierung des Politischen? Zum Verhältnis von Medien, Öffentlichkeit und Politik im 20. Jahrhundert, Leipzig 2010, S. 183-259.

RÖSSLER, Patrick: 1928: Wie das neue Sehen in die Illustrierten kam. „Maxl Knips“, Sasha Stone, Das illustrierte Blatt und die Bildermagazine der Weimarer Republik, in: Fotogeschichte, Heft 121, 2011, S. 45-60.

RÖSSLER, Patrick: die neue linie 1929-1943. Das Bauhaus am Kiosk, hg. vom Bauhaus-Archiv, Museum für Gestaltung, Berlin, Bielefeld, Leipzig 2007.

RÖSSLER, Patrick: Moderne Illustrierte. Illustrierte Moderne. Zeitschriftenkonzepte im 20. Jahrhundert, Ausstellungskatalog Württembergische Landesbibliothek, Stuttgart 1998.

RÖSSLER, Patrick, Achim Bonte, Katja Leiskau: Digitization of Popular Print Media as a Source for Studies on Visual Communication: Illustrated Magazines of the Weimar Republic, in: Historical Social Research, Vol. 37, Heft 4, 2012, S. 172-190.

ROTHSTEIN, Arthur: Photojournalism, London 1982 (Erstauflage 1956).

RÜBELT, Lothar: Das Auge der Presse, in: Wiener Magazin, Heft 10, Oktober 1929, S. 8-14.

RÜBELT, Lothar: Die wahrhaftige Photographie, in: Lothar Rübelt: Das Geheimnis des Moments. 36 ausgewählte Photographien und ein Text von Lothar Rübelt. Ein Buch in einer Serie über Menschen und Jahre, Ausstellungskatalog Wiener Albertina, Wien 1985 , o. S.

RÜBELT, Lothar: Österreich zwischen den Kriegen. Zeitdokumente eines Photopioniers der 20er und 30er Jahre. Text von Gerhard Jagschitz, hg. und gestaltet von Christian Brandstätter, Wien 1979

RÜBELT, Lothar: Reminiszenz zu meiner Photoreportage des Giftmordprozesses in Szolnok 1929, in: Photographie und Gesellschaft. Zeitschrift für photographische Imagologie, Heft 2, 1989, S. 45-47.

RÜBELT, Lothar: Sport - die wichtigste Nebensache der Welt. Dokumente eines Pioniers der Sportphotographie 1919-1939, Wien, München 1980.

RÜBELT, Lothar: Das Geheimnis des Moments. 36 ausgewählte Photographien und ein Text von Lothar Rübelt. Ein Buch in einer Serie über Menschen und Jahre, Ausstellungskatalog Wiener Albertina, Wien 1985

RÜBELT, Lothar: Die wahrhaftige Photographie, in: Das Deutsche Lichtbild 1938, S. 147-157.

RUTZ, Rainer: Signal. Eine Auslandsillustrierte als Propagandainstrument im Zweiten Weltkrieg, Essen 2007.

SACHSSE, Rolf: Skizze zu Stefan Kruckenhauser, in: Fotogeschichte, Heft 11, 1984, S. 31-37.
SACHSSE, Rolf: Trude Fleischmann - Von Österreich aus, in: Camera Austria, Heft 54, 1997, S. 41-55.

SANDER, August: Linzer Jahre, hg. von der Photographischen Sammlung/SK Stiftung Kultur, München 2005.

SANDGRUBER, Roman: „Frauen in Bewegung“. Verkehr und Frauenemanzipation, in: Lisa Fischer, Emil Brix: Die Frauen der Wiener Moderne, Wien, München 1997, S. 53-63.

SAURE, Gabriele: Eine neue Künstlerfotografie? Serielle Bildformen in der illustrierten Presse 1925-1944, in: Photo-Sequenzen. Reportagen. Bildgeschichten. Serien aus dem Ullstein Bilderdienst von 1925 bis 1944, Ausstellungskatalog Haus am Waldsee, Berlin 1993, S. 19-38.

SCHALCHER, Traugott: Die Reklame der Straße, Wien, Leipzig 1927.

SCHEUFLER, Pavel, Jan Hozák: Krásné Časy. Rudolf Bruner-Dvořák. Momentni Fotograf, Prag 1995.

SCHEUFLER, Pavel: Die Anfänge der modernen Fotografie in den böhmischen Ländern, in: Stifter-Jahrbuch, Neue Folge, München 1997, S. 41-53.

SCHIFFER, Armgard (Hg.): Grazer Kunstphotographen: Maximilian Karnitschnigg (1872-1940), Hugo Haluschka (1880-1951), Ausstellungskatalog Bildund Tonarchiv am Landesmuseum Joanneum, o. 0 . (Graz) 1981.

SCHILLING, Karsten: Das zerstörte Erbe. Berliner Zeitungen der Weimarer Republik im Porträt, o. 0. 2011.

SCHNABL, Gerhard: Die Geschichte des österreichischen Photojournalismus vom Durchbruch der Autotypie bis zur Einführung des Fernsehens, Diss., Wien 1983

SCHÖGL, Uwe (Hg.): Im Blickpunkt. Die Fotosammlung der Österreichischen Nationalbibliothek, Ausstellungskatalog, Innsbruck 2002.

SCHOPPER, Hans: Presse im Kampf. Geschichte der Presse während der Kampfjahre der NSDAP (19331938) in Österreich, Brünn u. a. 1940.

SCHREIER, Elisabeth: Mit dem Zeichenstift gegen den Nationalsozialismus. Antinationalsozialistische Karikaturen in der Wiener sozialdemokratischen Presse, Diplomarbeit, Wien 1996.

SCHWARTZ, Vanessa R.: Spectacular Realities. Early Mass Culture in Fin-de-Siècle Paris, Berkeley, Los Angeles 1999.

SCHWARZ, Robert: Photographie im Kriege, in: Wiener Mitteilungen aus dem Gebiete der Literatur, Kunst, Kartographie und Photographie, 10. und 25. September 1914, S. 401-404.

SEEGERS, Lu: UHU, Koralle, Die Dame und Das Blatt der Hausfrau, in: 125 Jahre Ullstein. Presse- und Verlagsgeschichte im Zeichen der Eule, Berlin 2002, S. 62-69.

SEETHALER, Josef, Gabriele Melischek: Die Zeitung im Habsburger Vielvölkerstaat, in: 400 Jahre Zeitung 1605-2005, hg. von Martin Welke und Jürgen Wilke, Bremen 2007, S. 311-334.

SEITER, Josef: Der „Kuckuck“ - eine moderne Bildillustrierte des „roten Wien“, in: Diethart Kerbs, Walter Uka (Hg.): Fotografie und Bildpublizistik in der Weimarer Republik, Bönen 2004, S. 177-198.

SEITER, Josef: Wiener Elendsbilder. Das Album der Fotografen Anton und Hans Bock, des Journalisten Bruno Frei und des Oberstleutnants Rudolf Frey, in: Werner Michael Schwarz, Margarethe Szeless, Lisa Wögenstein (Hg.): Ganz unten. Die Entdeckung des Elends. Wien, Berlin, London, Paris, New York, Ausstellungskatalog Wien Museum, Wien 2007, S. 157-162.

SINGER, Ben: Melodrama and Modernity. Early Sensational Cinema and its Contexts, New York 2001.
SONNENBERG, Peter: Medienkontrolle während der NS-Zeit - Eine kollektiv-biographische Analyse ausgewählter Journalisten der 1938 verbotenen Wiener Tageszeitungen „Wiener Tag“ und „Telegraf“, Diplomarbeit, Wien 2009.

SOYFER, Jura: Werkausgabe in vier Bänden, Bd. 1: Zwischenrufe links. Lyrik, Bd. 2: Auf uns kommt's an. Szenen und Stücke, Bd. 3: So starb eine Partei. Prosa, Bd. 4: Sturmzeit. Briefe 1931-1939, Wien 2002.

SPIEL, Hilde: Die hellen und die finsteren Zeiten. Erinnerungen 1911 bis 1946, München 1989.

SPIELHOFER, Elisabeth: „Der Pressefreiheit würdige Grenzen ziehen ..." Theorie und Praxis der Pressepolitik im österreichischen Ständestaat (1933-1938) unter Berücksichtigung der deutsch-österreichischen Presseabkommen, Diplomarbeit, Wien 1992.

SPIRA, Bil: Die Legende vom Zeichner, hg. von Konstantin Kaiser in Zusammenarbeit mit Vladimir Vertlib, Wien 1997.

SPRINGER, Ludwig: Beschreibung des Ottakringer Volksheimes, in: 25 Jahre Volksheim. Eine Wiener Volkshochschul-Chronik, Wien 1926.

STADLER, Friedrich (Hg.): Vertriebene Vernunft I. Emigration und Exil österreichischer Wissenschaft 1930-1940, Wien, München 1987.

STARL, Timm: „Einzig in seiner Art in Österreich, ja in Europa“. Amateurvereine und kunstfotografische Bewegung, 1887-1892, in: Fotogeschichte, Heft 59 1996, S. 15-32.

STARL, Timm: Die Kehrseite der Geschichte. Karl Pawek: Priesterzögling, Zeitschriftengründer, NSDAPAnwärter, Kriegsverbrecher, Psychopath, Ausstellungsmacher, Kulturpreisträger, in: Fotogeschichte, Heft 87, 2003, S. 65-69.

STARL, Timm: Die neue Heimat. Notizen zur Photographie in der Ersten Republik, in: Monika Faber $(\mathrm{Hg}$.): Zeit ohne Zukunft. Photographie in Wien 19181938, Wien 1998, S. 139-145.

STARL, Timm: FotoBibl. Biobibliografie zur Geschichte der Fotografie in Österreich von 1839 bis 1945 (online unter: www.albertina.at).

STARL, Timm: Geiringer \& Horovitz. Auf der Suche nach dem Leben einer Wiener Fotografin, in: Fotogeschichte, Heft 34, 1989, S. 31-40.

STARL, Timm: Knipser. Die Bildgeschichte der privaten Fotografie in Deutschland und Österreich von 1880 bis 1980, München, Berlin 1995

STARL, Timm: Lexikon zur Fotografie in Österreich 1939 bis 1945, Wien 2005.

STARL, Timm: Nach dem Muster aus Berlin - die „Wiener Illustrierte“ 1933/34, in: Diethart Kerbs, Walter Uka (Hg.): Fotografie und Bildpublizistik in der Weimarer Republik, Bönen 2004, S. 199-207.

STEINBERGS, Michael P.: Ursprung und Ideologie der Salzburger Festspiele 1890-1938, Salzburg, München 2000.

STEINLE, Christa, Peter Peer, Karin Buol-Wischenau (Hg.): Rückblende. Die Fotosammlung der Neuen Galerie Graz, Wien, Bozen 2011.

STERN, Alexander: Alexander Stern (1894-1970). Fotografien, Ausstellungskatalog Neue Galerie am Landesmuseum Joanneum, hg. von Kurt Jungwirth und Alexander Wied, Graz o. J. (1977)

STIASSNY, Marie: Alexander Stern - das experimentelle Bild, Diplomarbeit, Wien 2010.

STIEWE, Willy: Das Bild als Nachricht. Nachrichtenwert und -technik des Bildes. Ein Beitrag zur Zeitungskunde, Berlin 1933.

STUDENY, Christine: Liebe, Lust und Leidenschaft. Eine volkskundliche Studie über Naturfreunde-Fotografen, dargestellt an der Fotogruppe Meidling, Diplomarbeit, Wien 2003. 
SULTANO, Gloria: Wie geistiges Kokain ... Mode unterm Hakenkreuz, Wien 1995.

SZELESS, Margarethe: Die Kulturzeitschrift magnum. Photographische Befunde der Moderne, Marburg 2007.

TABOR, Jan (Hg.): Kunst und Diktatur. Architektur, Bildhauerei und Malerei in Österreich, Deutschland, Italien und der Sowjetunion 1922-1956, Ausstellungskatalog Künstlerhaus, Wien 1994.

TAFT, Robert: Photography and the American Scene. A Social History, New York 1938.

TAYLOR, John: Body Horror: Photojournalism, Catastrophy and War, Manchester 1998.

TAYLOR, Steve: 100 years of magazine covers, London 2006.

TIMMS, Edward: Dynamik der Kreise, Resonanz der Räume. Die schöpferischen Impulse der Wiener Moderne, Weitra 2013.

TOEPFER, Karl: Empire of Ecstasy. Nudity and Movement in German Body Culture 1910-1935, Berkeley, Los Angeles, London 1997.

TOEPFER, Karl: Nudity and Modernity in German Dance 1910-1930, in: Journal of the History of Sexuality, Vol. 3, Nr. 1 (1992), S. 58-108.

URICCHIO, William: Aktualitäten als Bilder der Zeit, in: Frank Kessler, Sabine Lenk, Martin Loiperdinger (Hg.): KINtop. Jahrbuch zur Erforschung des frühen Films, Bd. 6, Basel, Frankfurt a. M. 1997, S. 43-50.

VORSTEHER, Dieter (Hg.): Fotografen und Agenturen im Bildarchiv des Deutschen Historischen Museums, DHM Magazin, Heft 26, 11. Jahrgang, Herbst 2001.

VORSTEHER, Dieter, Heike Hartmann (Hg.): Menschen, Orte, Zeiten. Fotografie am Deutschen Historischen Museum, Berlin, Heidelberg 2009.

VORSTEHER, Dieter, Maike Steinkamp (Hg.): XX. Jahrhundert - Fotografien zur deutschen Geschichte 1880 bis 1990 aus der Sammlung des Deutschen Historischen Museums, Berlin 2004.

Vowinckel, Annette: Der Bildredakteur. Genese eines modernen Berufsbilds, in: Annelie Ramsbrock, Annette Vowinckel, Malte Zierenberg (Hg.): Fotografien im 20. Jahrhundert. Verbreitung und Vermittlung, Göttingen 2013, S. 69-89.

WAGNER, Anselm (Hg.): Heinrich Schwarz - Techniken des Sehens - vor und nach der Fotografie, Salzburg 2006.

WAHL, Niko: Große Kunst hinter der Budel. Otto Kallir und die Neue Galerie in der Grünangergasse, in: Joachim Riedl (Hg.): Wien, Stadt der Juden. Die Welt der Tante Jolesch, Ausstellungskatalog Jüdisches Museum Wien, Wien 2004, S. 300-301.

WALTER, Edith: Österreichische Tageszeitungen der Jahrhundertwende. Ideologischer Anspruch und ökonomische Erfordernisse, Wien 1994.
WEIERMAIR, Peter: Von der Kunstfotografie zur Neuen Sachlichkeit, in: Geschichte der Fotografie in Österreich, Bd. 1, hg. vom Verein zur Erarbeitung der Geschichte der Fotografie in Österreich, Bad Ischl, 1983, S. 188-203.

WEISE, Bernd, Institut für Auslandsbeziehungen ( $\mathrm{Hg}$.): Fotografie in deutschen Zeitschriften 1883-1923, Stuttgart 1991.

WEISE, Bernd: Aktuelle Nachrichtenbilder „nach Photographien“ in der deutschen illustrierten Presse der zweiten Hälfte des 19. Jahrhunderts, in: Charles Grivel, André Gunthert, Bernd Stiegler (Hg.): Die Eroberung der Bilder. Photographie in Buch und Presse 1816-1914, München 2003, S. 62-101.

WEISE, Bernd: Das Geschäft mit dem Foto in der Geschichte der Presse- und Illustrationsfotografie in Deutschland, in: Der Bildermarkt - Handbuch der Bildagenturen 1998, hg. vom Bundesverband der Pressebild-Agenturen und Bildarchive BVPA, Berlin 1998, S. 21-31.

WEISE, Bernd: Fotojournalismus. Erster Weltkrieg Weimarer Republik, in: Klaus Honnef, Rolf Sachsse, Karin Thomas (Hg.): Deutsche Fotografie. Macht eines Mediums 1870-1970, Bonn 1997, S. 72-87.

WEISE, Bernd: Kamera- und Fototechnik im journalistischen Gebrauch, Teil I, 1883 -1913, in: Rundbrief Fotografie, Vol. 12, No. 4, Dezember 2005 (N.F. 44), S. 27-33; Teil II: $1914-1932$, Vol. 12, No. 1, 2005 (N.F. 45), S. 27-33; Teil III: $1933-1939$, Vol. 12, No. 4, 2005 (N.F. 48), S. 13 -19; Teil IV: Zweiter Weltkrieg, Vol. 13, No. 3, 2006, S. $10-17$ (N.F. 51); Teil V: 1945 -1980, Vol. No. 2, 2011 (N.F. 70), S. 6-13.

WEISE, Bernd: Pressefotografie unter dem Diktat der Nationalsozialisten, in: Arbeitskreis Photographie Hamburg in Zusammenarbeit mit den Deichtorhallen Hamburg (Hg.): Das deutsche Auge. 33 Photographen und ihre Reportagen - 33 Blicke auf unser Jahrhundert, München 1996, S. 30-35.

WEISE, Bernd: Pressefotografie, Teil I. Die Anfänge in Deutschland ausgehend von einer Kritik bisheriger Forschungsansätze, in: Fotogeschichte, Heft 31, 1989, S. 15-40.

WEISE, Bernd: Pressefotografie, Teil II. Fortschritte der Fotografie- und Drucktechnik und Veränderungen des Pressemarktes im Deutschen Kaiserreich, in: Fotogeschichte, Heft 33, 1989, S. 26-62.

WEISE, Bernd: Pressefotografie, Teil III. Das Geschäft mit dem aktuellen Foto. Fotografen, Bildagenturen, Interessenverbände, Arbeitstechnik. Die Entwicklung in Deutschland bis zum Ersten Weltkrieg, in: Fotogeschichte, Heft 37, 1990, S. 13-36.

WEISE, Bernd: Pressefotografie, Teil IV. Die Entwicklung des Fotorechts und der Handel mit der Bildnachricht, in: Fotogeschichte, Heft 52, 1994, S. 27-40.

WEISE, Bernd: Pressefotografie, Teil V. Probleme zwischen Fotografen und Redaktionen und der Beginn der Bildtelegrafie in Deutschland, in: Fotogeschichte, Heft 59, 1996, S. 33-50.

WEISE, Bernd: Pressefotos vom Fliegen in frühen Zeitschriften-Reportagen, in: Petra Wenzel, Werner Lippert (Hg.): Die Kunst zu fliegen - in Film und Foto- grafie, Düsseldorf 2004, S. 120-127.

WEISE, Bernd: Reproduktionstechnik und Medienwechsel in der Presse, in: Fotografie gedruckt, Sonderheft 4 des Rundbriefs Fotografie 1998, S. 7-9.

WEISE, Bernd: Zeit im Bild. Über Quellen und Recherchen zur Mediengeschichte der Fotografie, in: Fotogeschichte, Heft 124, 2012, S. 62-66.

WEISSENBÖCK, Jarmila: Expressionistischer Tanz in Wien, in: Klaus Amann, Armin A. Wallas (Hg.): Expressionismus in Österreich. Die Literatur und die Künste, Wien, Köln, Weimar, 1994, S. 171-184.

WERNEBURG, Brigitte: Fotojournalismus in der Weimarer Republik, in: Fotogeschichte, Heft 13, 1984, S. $27-40$.

WERNER, Margot: Raoul Korty - „Der Mann, der in drei Zimmern die Weltgeschichte eingefangen hat", in: Geraubte Bücher. Die Österreichische Nationalbibliothek stellt sich ihrer NS-Vergangenheit, hg. von Murray G. Hall, Christina Köstner, Margot Werner, Ausstellungskatalog, Wien 2004, S. 118-127.

WICK, Steve: The long Night. William L. Shirer and the Rise and Fall of the Third Reich, New York 2011.

WILLINGER, László: 100 x Berlin, Berlin, o. J. (1929).

WILLMANN, Heinz: Geschichte der Arbeiter-Illustrierten Zeitung. 1921-1938, 2. Aufl., Berlin 1975.

WINKLBAUER Andrea (Hg.): Moderne auf der Flucht. Österreichische Künstlerlnnen in Frankreich 19381945, Ausstellungskatalog Jüdisches Museum Wien, Wien 2008.

WINKLER, Susanne (Hg.): August Stauda. Ein Dokumentarist des alten Wien, Ausstellungskatalog Historisches Museum der Stadt Wien, Wien 2004.

WISSHAUPT, Walter: Das Wiener Pressewesen von Dollfuß bis zum Zusammenbruch 1933-1945, Diss., Wien 1951.

WITOVSKY, Matthew: Foto: Modernity in Central Europe 1918 -1945, Ausstellungskatalog National Gallery of Art, Washington, London 2007.

WOLF, Erika: „As the Filippovs“: The Foreign Origin of the Soviet Narrative Photographic Essay, in: Jorge Ribalta (Hg.): The Worker Photography Movement 1926 - 1939. Essays and Documents, Madrid 2011, S. $124-147$.

ZIERENBERG, Malte: Die Ordnung der Agenturen. Zur Verfertigung massenmedialer Sichtbarkeit im Pressewesen 1900-1940, in: Annelie Ramsbrock, Annette Vowinckel, Malte Zierenberg (Hg.): Fotografien im 20. Jahrhundert. Verbreitung und Vermittlung, Göttingen 2013, S. 44-65.

ZWEIG, Stefan: Die Welt von gestern, Frankfurt am Main 2003 (Erstausgabe 1944).

Zwischen den Zeilen. Zeitungspresse als NS-Machtinstrument, hg. von der Stiftung Topographie des Terrors, Ausstellungskatalog, Berlin 2013. 


\section{Zeitungen und Zeitschriften}

\section{Der Abend (Wien)}

Ahoj na neděli (Hallo am Sonntag, Prag)

Allgemeine Photographische Zeitschrift (Wien)

Allgemeine Sportzeitung (Wien)

Der Arbeiter-Fotograf (Berlin)

Arbeiter-Illustrierte Zeitung (Berlin)

Arbeiter-Zeitung (Wien)

Az Est (Der Abend, Budapest)

Bergland (Innsbruck, Wien)

Berliner Illustrirte Zeitung (Berlin)

Bilder-Welt, Beilage der Steirischen Alpenpost (Graz)

Bilderwoche der österreichischen Volksschriften (Wien)

Die Bühne (Wien)

Bühne, Welt und Mode, Beilage der Wiener Neuesten Nachrichten (Wien)

Bunte Woche (Wien)

Český svět (Tschechische Welt, Prag)

Die Dame (Berlin)

Die Damenwelt (Wien)

Érdekes Újság (Die interessante Zeitung, Budapest)

Erdgeist. Illustrierte Wochenschrift (Wien)

Excelsior (Paris)

Der Faun (Wien)

Film-Revue, Beilage des Neuen Wiener Journals (Wien)

Die Form (Berlin)

Frankfurter Illustrierte (Frankfurt)

Die Galerie (Wien)

The Graphic (London)

Graphische Revue (Wien)

Grazer Volksblatt (Graz)

Große Österreich Illustrierte (Wien)

Die Grüne Post (Berlin)

Die Herrenwelt (Wien)

A Hét (Die Woche, Budapest)

Illustrated London News (London)

L'Illustration (Paris)

Das illustrierte Blatt (Frankfurt)

Illustrierte Film- und Kinorundschau (Wien)

Illustrierte Kronen-Zeitung (bis 1906: Österreichische Kronen-Zeitung) (Wien)

Illustrierte Radiozeitung (Wien)

Illustrierte Rote Woche (Wien)

Illustrierte Sonntags-Zeitung für unsere Frauen (Berlin)

Illustrierte Woche, Beilage des Grazer Volksblatts (Graz)

Illustrirte Zeitung (Leipzig)
Illustrierter Beobachter (Berlin)

Illustriertes (österreichisches) Sportblatt (Wien)

Illustrirte Österreichische Woche (Wien)

Illustrirte Sport-Zeitung (Wien)

Das interessante Blatt (ab 1939: Wiener Illustrierte, Wien)

Jedermann (Wien)

Kamera-Kunst (Wien)

Die Kinowoche (Wien)

Das Kleine Blatt (Wien)

Kölnische Illustrierte Zeitung (Köln)

Der Kuckuck (Wien)

Der Lichtbildner (Wien)

Mein Film (Wien)

Das Mikrophon (Wien)

Le Miroir (Paris)

MOCCA (Wien)

Moderne Welt (Wien)

Der Morgen (Wien)

Münchner Illustrierte Presse (München)

Die Muskete (Wien)

Neue Freie Presse (Wien)

Die Neue Linie (Leipzig)

Neues Wiener Journal (Wien)

Neue Wiener Moden-Zeitung (Wien)

Das Neueste im Bilde (Wien)

Der Notschrei (ab April 1933: Das Zeitbild.

Österreichs NS Illustrierte, Wien)

Ország Világ (Land und Welt, Budapest)

Österreichische Familien- und Moden-Zeitschrift (Wien)

Österreichische illustrierte Rundschau (Wien)

Österreichische Illustri(e)rte Zeitung (ab 1918:

Wiener Illustrierte Zeitung, Wien)

Österreichische Kunst (Wien)

Das österreichische Lichtbild (Wien)

Österreichische Woche (ab 1938: Ostmark-Woche Wien)

Österreichs Bau- und Werkkunst (Wien)

Die Pause (Wien)

Le Pays de France (Paris)

Pestrý týden (Bunte Welt, Prag)

Pesti Napló (Pester Tagblatt)

Photo-Riport (Budapest)

Das Photo-Magazin (Wien)

Photo-Sport (Wien)

Picture Post (London)
Praha. Demni list vystavni (Prag. Tägliches

Ausstellungsblatt, Prag)

Profil (Wien)

Radio Wien (Wien)

Radio-Welt (Wien)

Rundfunk (für alle) (Wien)

Salzburger Illustrierte (Salzburg)

Der Samstag (Wien)

Das schöne Lichtbild (Wien, München)

Signal (Berlin)

Der Sonntag (1911-1913, Wien)

Der Sonntag, Beilage der Tageszeitung Der Wiener Tag, (1934-1938, Wien)

The Sphere (London)

Sport und Salon (Wien)

Die Stunde (Wien)

Tiroler Anzeiger (Innsbruck)

Tolnai Világlapja (Tolnais Weltblatt, Budapest)

UHU (Berlin)

Új Idők (Neue Zeiten, Budapest)

Unsere Mode, Beilage von Das Neue Wiener Journal (Wien)

Die Unzufriedene. Unabhängige Wochenschrift für alle Frauen (Wien)

Vasárnapi Újság (Sonntagsblatt, Budapest)

La Vie Illustrée (Paris)

Welt-Bild, Beilage zum: Fremden-Blatt (Wien)

Welt-Guck (Innsbruck)

Welt-Illustrierte (Wien)

Welt-Spiegel, Beilage des Berliner Tageblatts (Berlin)

Der Werker (Wien)

Wiener Bilder (ab 1939: Wiener Illustrierte, Wien)

Wiener Bilderwoche (Wien)

Wiener Illustrierte (1930-1931, Wien)

Wiener Illustrierte Zeitung (1914-1916, Wien)

Wiener Illustrierte Zeitung (1933-1934, Wien)

Wiener Magazin (Wien)

Wiener Mode (Wien)

Wiener Neueste Nachrichten (Wien)

Wiener Salonblatt (Wien)

Die Woche (Berlin)

Die Wochenpresse (Wien)

Zeitbilder, Beilage der Vossischen Zeitung (Berlin)

Zeitungverleger. Fachblatt für das österreichische

Zeitungswesen (Wien)

Zlatá Praha (Das goldene Prag, Prag) 


\section{Index}

Graue Seitenzahlen verweisen auf Abbildungen

A Hét, Zeitschrift 29

$A B C$, Fotoagentur 157

ABC, Kleinkunstbühne 408

Abonnenment 12, 35, 63, 76, 155

Adèle, Atelier 59, 78, 302

Adelhart, Karl 332

Ahoj na neděli, Zeitschrift 402

Aktfotografie 175, 181, 187, 296-303,

$300,341,371,428,437,438$

Alexander, Richard F. 181

Allgemeine Photographische Zeitschrift 362

Allgemeine Sportzeitung 325

Alltag 171, 205, 210, 231, 235, 251,

$324,334,360,378,385,387-390$,

392-395, 397, 402

Alpiner Pressedienst, Fotoagentur 239

Amateur, Amateurfotografie 38 f. 56 ,

$83,111,157,177,182-184,210,248$

260, 262, 308, 345, 358, 360-362,

370f., 376, 391-394, 400, 424

Amerika, amerikanisch, siehe USA

Amsterdam 341, 343

Anderle, Franz 193

Angel, Walter 200

Angerer \& Göschl 73

Angerer, Ludwig 78

Angerer, Viktor 42, 43, 80, 466

Angerer, Wilhelm 373, 466

Annoncenbüro 22, 76, 305, 308

Anschluss an NS-Deutschland 133,

$143,162,409,411-418,421-423$, 429, 435

Anti-Kriegs-Kundgebung, Anti-Kriegs-

Veröffentlichung 138, 139, 146, 406

Antisemitismus 118f., 144, 155, 162,

$316,330,443,349,430-433,434$, 445

Anzeigen, Anzeigenmarkt 30, 35, 125,

186, 284f., 304-316, 411, 430-443

Apollo-Theater 266, 267, 287, 301

Arbeit, Arbeiter 67, 68, 69, 90, 137,

161, 222-225, 235, 251, 254, 261,

271, 324, 336, 383, 384 f., 389, 425 , 435

Arbeiter-lllustrierte Zeitung 152-155,

160, 165, 248, 251, 262, $332 \mathrm{f}$.

Arbeiter-Sonntag 149

Arbeiter-Zeitung 149, 248, 382 f., 389, 408

Arbeiterbewegung 126, 129, 137-140, $198,248-262$

Arbeiterfotograf 161, 171, 198, 248-262

Arbeitsgemeinschaft der Wiener Ku-

ckuck-Reporter 252

Arbeitslosigkeit 47, 222-225, 254,

266, 285, 375

Architektur 41, 43, 271f., 354, 402, 425

Arisierung 245f., 316, 343, 423, $430 \mathrm{f}$.

Aristokratie $31,80,93,234,325$

Armeehauptquartier 110, 111

Ärmelkanal 46, 92,

Armut 188, 222-225, 253, 255, 389

Aspern, Flugfeld 97, 99, 101 f., 104,

$115,215,265$

Associated Press 238

Atelier, Atelierfotografie 36,38, f., $41-$

$43,71,119,234,245,291,332,338$,

340 f., 345, 350, 395, 427, 444

Atlantic, Fotoagentur 157, 237, 246

Attentat 105-107

Atzwanger, Peter Paul 178, 373, 374,

376, 466

Ausdruckstanz, siehe Tanz
Auspitzer, Sigmund 22, 25

Ausstellung 171, 307f., 338-340,

344-349, 351, 353, 360, 362, 370f.,

408, 409

Austerlitz, Friedrich 61

Australien 343

Austria Presse, Fotoagentur 239

Austrofaschismus 141, 143, 152,

$157,160,172,174,184,186,190$,

194-202, 315, 340, 345, 363, 370, 378-381

Austrophot, Fotoagentur 235

Authentizität 12, 24, 55, 57 f., 69, 112, 117,439

Auto, Automobil, Autorennen 12, 37,

38, 111, 223 f., 231 f., 277, 308, 321 ,

$341,342,343,392,412,424$

Autotypie $34,52 \mathrm{f} ., 70$

Avantgarde 69, 176f., 190, 206, 243,

258, 344-362, 371, 402, 404

Aviatik, siehe Flugzeug

Az Est, Zeitung 110

Bad Ischl 81, 84f.

Bahr, Hermann 173

Bain News Service 10

Baker, Josephine 189, 268, 296-298, 303

Balász, Béla 206, 302

Balek, Hans 258, 466

Bálint, Johann 110, 466

Ballon, Ballonfahrt 40, 41, 91, 98, 103

Balogh, Rudolf 110, 466

Band, Moriz 167

Barakovich, Edith 291, 302, 311, 312,

333, 335 f., 338, 338, 466

Bárány, Josefine 335, 343, 466

Barchan, Paul 402

Bareder, Ferdinand 466

Barrison, Gertrude 289

Baszel, Günther, 424, 466

Bauer, Karl 466

Bauer, Otto 146

Bauern, Bauerntum 142, 150, 178, 185, 228, 230, 243, 246f., 363-377, 424

Bauhaus 181, 331, 341, 353, 357

Baumann, Hans Felix, siehe Felix H. Man

Bauroff, Claire 291, 301, 302

Bayer, Herbert 357

Becker \& Maaß, Atelier 246, 310

Bederkhan, Leila 291, 292, 302

Behr, Ferdinand (Ferdo) 105, 106

Behrens, Peter 345

Bekei, Ödön 50, 466

Békessy, Imre 149, 175

Benda, Arthur 427, 466

Benedikt, Moriz 60, 61

Berber, Anita 301

Bérenyi, Ludwig 41, 466

Berg, Alban 385, 386, 387

Bergbau 383, $384 f$.

Berge, Bergfotografie 182, 228, 232, 233, 370

Berg/and, Zeitschrift 150, 157, 376

Bergland Verlag 150, 184, 315, 425

Bergler, Marianne, siehe auch Marianne

Blumberger 210, 311, 343, 466

Bergner, Elisabeth 281, 282

Berlin 12, 16, $48 \mathrm{f} ., 92,97,99 \mathrm{f} ., 111$,

207, 209, 234-236, 265, 296, 298

$307,330,335,360,408$

Berliner Illustrationsgesellschaft 49 ,

111, 236

Berliner Illustrirte Zeitung 11, 14, 16,
17 f., 29 f., 34, 62 f., 159, 165, 207

227-231, 330

Berliner Pressebildzentrale 247

Berliner Tageblatt 30

Bernatzik, Emmy 466

Bernatzik, Hugo 228, 346, 466

Benatzky, Ralph 268

Berndorf 79

Bettauers Wochenschrift 154

Biegler, Friedl 176

Bienert, A. 53

Biermann, Aenne 177, 345

Bild- und Filmamt (BUFA) 110, 112

Bilder-Welt, Zeitschrift 169

Bilderwoche der österreichischen

Volksschriften 202

Bildgedicht 261, 262

Bildgeschichte, siehe auch Foto-

reportage $66,69,171,204$ f., 210 ,

214, 231-233, 331

Bildpostkarte, siehe Postkarte

Bildtelegrafie 83

Binder, Joseph $195 \mathrm{f} ., 308$

Bing, Berthold 42

Birkmeyer, Toni 29

Birnbach, Rudolf 238, 466

Bittner, Friedrich 110, 466

Bizanski, Stanislaw 50, 466

Blaha, Franz 247, 330, 424, 466

Blaschke, Philipp Ritter von 99

Blériot, Luis 46, 92-95, 96, 98

Blumberger, Marianne, siehe auch

Marianne Bergler 176, 302, 334

Bodenwieser, Gertrud 291 f., 293

Bohl, Robert J. 167, 467

Böhm, August $84 \mathrm{f}$.

Böhmen, siehe auch Tschechien 29, 50 f., 89, 107, 206, 399

Born, Wolfgang 171, 176, 344,

346-350, 353f., $358 \mathrm{f}$.

Boronkay, Kálman 467

Bosel, Siegmund 149

Boszek, Reszö 467

Boulevard, Boulevardpresse 11, 24f., $147 \mathrm{f}$., 175, 248, $438 \mathrm{f}$.

Bourhis, Jean $102 \mathrm{f}$

Boxkampf 237, 265, 321

Bozen 50,89

Brandl, Steffi 335, 337, 343, 467

Brandt, Bill 402, 467

Brassaï 177

Brauchtum 157, 188, 196, 363-377, 400

Braun, Eduard 76

Braun, Eva 417

Braun, Felix 351, 388, 393, 399, 467

Braunthal, Julius 153f., 190, 196 f., 248

Breslau 97

Briand, Aristide 10

Brieger, A. 467

Brodt, Victor 322, 326, 329 f., 467

Brodtfeld, Elsa 252, 467

Broser, Gustav 42, 467

Bruck an der Leitha 78

Brühlmeyer, Hermann 179, 181, 191, 375, 467

Bruner-Dvorák, Ruda 47, 50, 80, 467

Brünn 50, 292, 358

Budapest 13, 16, 46, 49f., 77, 92 ,

110f., 121, 136, 234, 240, 287, 296

Bude, Leopold 50, 467

Budweis 50, 202, 402

Die Bühne 16, 148, 149, 171-173,

175-179, 181f., 187, 210f., 231-233,

241, 257, 274, 281, 293, $296 \mathrm{f}$., $301 \mathrm{f}$.,

$315,324,331 \mathrm{f}, 334,339,344-347$, 349 f., 353 f., 358 f., 362 , 381, 395 f., $400,410,424,427,429,433$

Bühne, Welt und Mode 151

Bukarest 62, 92, 296

Bunte Woche 132f., 149, 194-200, 248

Burger, Karl 148

Bürgerkrieg 132, 194, 196f., 231, 363 , $378,381,400$

Bürgertum, bürgerlich 54, $137 \mathrm{f}$., 160 , 168, 181, 186, 196, 234, 240, 248f., 251 f., 254, 334, 437-440

Čabrinović, Nedeljko 105, 106

Café Dankl 410

Café Dobner 408

Campbell, Clarissa Rose 286

Campitelli, Gina, siehe Gusti Skall

Canetti, Elias 408

Canetti, Veza 380, 399, 408

Capek, Karel 404

Cartellieri, Carmen 278-280

Casablanca 343

Casparius, Hans 154, 158, 179, 198 ,

210, 351, 375f., 393, 431, 432, 467

Cechal, Hans 154, 256, 345, 347, 467

Central European Press, Fotoagentur 238

Cešanek, Fred 154, 210, 221, 235 ,

239, 322, 324, 467

Česky̆ svět, Zeitschrift 29, 50

Chamberlin, Clarence 265

Chat, Liesel 467

Chemigrafie, chemigrafische Anstalt

34, 54, 73

Chiavacci, Vinzenz 27, 419

Chicago 199

Chladek, Rosalia 292, $294 \mathrm{f}$

Chmel, Lucca 181, 316, 351, 373, 400, 424, 430, 467

Christian, Dolf 169, 467

Christlichsoziale 33, 41, 54, 64, 118-

120, 122, 125 f., 129 f., 134, 136, 140,

$147,150,152,156,193,194-202$,

$248,252,296,345,365,369,373$ 381

Cirul, Mila 290, 291, 335

Collier's Weekly, Zeitung 48, 62, 441

Comeriner, Erich 181, 357, 467

Contact, Zeitschrift 410

Contax 205, 394

Corbis, Fotoagentur 10

Cover, siehe Titelseite

Criminal-Reporter 54

Csörgeő, Tibor 182, 467

Czernowitz 50, 106

Daily Mail 24, 92

Die Dame, Zeitschrift 226 f., 234, 280f., 341

Die Damenwelt 174

Dankl, Viktor 110

David, Anton 126

Deckrullo-Nettel 205

Defner, Adalbert 370, 373, 374, 376, 467 
Deutsch, Luise 467

Deutsch, Julius 127

Deutschland 16, 18, 30, 116, 166, 228,

240, 162, 302, 378, 410, 442

Dicker, Friedl 357, 468

Dietrich \& Co., Atelier und Fotoagentur

143, 186, 239, 246 f., 314

Dietrich, Hans 247, 468

Diktatur 130, 132, 141, 174, 184,

194-202, 231, 250, 285, 294, 345,

$349,366,378,406$

Dillinger, John Herbert 199

Distler, Hans 468

Dittera, Karl 110, 468

Dobrowolny, Otto 182, 258, 351, 468

Doliwa, Anton 246, 330, 424, 436, 468

Dollfuß, Engelbert 130, 131, 140-142,

174, 192, 193, 196, 271, 370

Domeny, Leopold 81

Donner, Etta 206

Dorfner, Anita 335, 468

Dornach, Karl 157, 468

Dreher, Theodor 37

Druckerei, Druckmaschine, siehe auch

Rotationsdruck 18, 21, 29, 33, 53,

$59,65,70,71,73,75,76,148,184$

Dubsky, Trudl 292

Dulovits, Jenő 182, 359, 468

Dux (Duchcov) 51

Ebert, Ludwig Albin 73

Eckner, Hugo 104, 228, 229

Eggarter, Willy 179, 182, 308, 309,

$350,375,393,468$

Eisenbahn 52, 66, 108, 136

Eisenstaedt, Alfred 155, 227, 468

Eisenstein, Sergej 410

Eislaufen 175, 321, 324

Elbemühl 29, 151

Elbl, Oswald 375, 424, 468

Elisabeth, Kaiserin 25

Ellinger, Karl 424, 468

Ender, Karl 258, 468

England 16, 29, 58, 116, 238, 343,

402, 410, $438 \mathrm{f}$

Érdekes Újság, Zeitung 29, 111

Erdélyi, Mór 49, 50, 468

Erdgeist. Illustrierte Wochenschrift 288

Erfurth, Hugo 287

Ermanox 7, 205, 207, 321

Ernemann, Fotounternehmen 205, 208

Ernst, Leo 129, 141, 157, 159, 174

210f., 221, 235, 239, 322, 324, 468

Erotik 54, 187, 265, 268f., 278-280,

286, 296-303, 428

Erster Weltkrieg 31, 33, 86-88, 97,

105-116, 145f., 236, 277, 289, 310,

329, 390, 406, 407

Etrich, Igo 96, 101

Europa-Presse-Co., Fotoagentur 239

Eva, Zeitschrift 402

Examiner, Zeitschrift 63

Exax, Alexander 110, 114, 468

Excelsior, Zeitschrift 29

Exil 295, 343, 349, 376, 410

Exinger, Otto 308, 350, 468

Expedition, Auslieferung 22f., 76

Eywo, Hugo Ritter von 110, 468

\section{F.A.Z. Magazin 442}

Fabian, M. 50, 468

Fabrik, siehe auch Industrie 66, 79,

101, 223-226, 274, 384

Fachet, Martin 322, 468

Die Fackel, Zeitschrift $60 \mathrm{f}$.

Faits divers $57 \mathrm{f}$., 440

Familienzeitung 25, 27, 30, 58, 439

Fanta, Philipp 258

Farkas, Karl $268 \mathrm{f}$
Farman, Henry 91, 98

Farnhammer, Modehaus $315 \mathrm{f}$.

Faschismus, Italien 183, 404 f., 426

Der Faun, Zeitschrift 186, 303

Fayer, Georg 291, 295, 308, 468

Fayer, Lilian 468

Feigl, Marianne 206

Fein, Martha 335, 343, 468

Feldkirch 89

Feldscharek, Pepa 186f., 291, 302, 311,

313, 335, 339, 343, 395, 469

Fenichel, Max 210, 393, 469

Fernsehen 10, $441 \mathrm{f}$

Feuerzeug, Adolf 322, 469

Feuilleton 144f., 205f., 273, 307, 338,

$378 \mathrm{ff}$

Fiedler, Leopold 424, 469

Film und Foto, Ausstellung 176, 340,

344-347, 349, 351, 354, 361 f., 394

Film, Filmproduktion $89,112,116,206$,

238, 266, 278-280, 316, 336, 341,

357, 404

Filmstar 278-282, 284, 341

Finaly, Ernst Karl 189

Findeis, Heinrich 110, 469

Fink, Alexander 50, 469

Flachdruck, siehe auch Druckerei 70,

$73 \mathrm{f}$.

Fleischmann, Trude 174, 179, 186, 242 ,

243, 291, 300, 302, 311, 332, 336 ,

$340,341,343,345,371,375,376$,

395, 396-398, 400, 408

Fliesz, Rudolf 41, 469

Floeck, Arthur 41, 78, 469

Flöter, Hubs 316,469

Flucht 238, 295, 376, 410

Flugzeug, Flugschau 46, 91-104, 108 , $115,133,265$

Form, Otto 157

Förster, Ernst 186, 291, 302, 311, 469

Fotoagentur 8, 10, 16, 21, 46, 48f., 56

95, 111f., 154, 165f., 234-247, 251,

254, 316, 324, 369, 393, 400, 402

Fotoausstellung, siehe Ausstellung

Fotobuch 373, 376, 381

Fotohandel 43, 46-49, 56, 95, 236, 424

Fotomontage 59, 60, 61, 88, 117, 131,

154 f., 176, 181, 190, 199, 202, 232,

249-250, 260 f., 265, 266, 346,

398, 406

Fotoredaktion, Fotoredakteur 20, 54,

$57,65,69,382 \mathrm{ff}$.

Fotoreportage 12, 19, 66, 68, 79,

157 f., 165, 167, 176, 181, 184, 193,

203-233, 238, 318, 334f., 366, 375

$377,378-410,424,443$

Fotoverein 184, 251, 345, 370

Fotowettbewerb 251, 252

Fotoxylografie, siehe auch Holzstich 52

Fotozinkografie 52

Fox, Filmunternehmen 238, 266, 336

Frank, Otto 50, 469

Frankfurter Illustrierte 157

Frankfurter Zeitung 219, 225

Frankl, Eduard 110, 469

Frankreich 16, 18, 58, 116, 245, 343,

381, 402, 410, $438 \mathrm{f}$.

Franta 330, 469

Franz Ferdinand, Erzherzog 37, 38, 44, 50, 105

Franz Joseph, Kaiser 35, 36, 42, 59,

62, 76-87, 93f., 97, 98, 99, 108

120, 196

Franz Salvator, Erzherzog 38

Frauen 16, 30, 70, 76, 99, 100 f., 126,

137, 139, 177, 189, 206, 236, 254,

277-285, 289, 302, 315, 324, 331-

343, 399, 400, 444

Frauenfeld, Alfred 421
Freiberger, Paul 345, 347, 469

Freiwirth, Desider 182, 183, 469

Fremden-Blatt, Zeitung 30

Freud, Sigmund 173, 196, 431, 432, 438

Freyberger, Beatrice 186, 291, 311, 335, 469

Frischauer, Alma Stefanie 348, 349

Fritzek, F. 252, 469

Frühwald, Olga 277

Führer, Hansi 63

Fukarek, Emil 43, 52, 80

Fuller, Loïe 289

Funkbild 237

Fürböck, Ernst 169, 469

Furthner, Hans 424, 469

Furtwängler, Wilhelm 14

Fußball 28, 45, 46, 194, 228, 317, 318-320, 321f., 323, 324, 326, 327, 328,329

Gabriel, Franz 41, 469

Galizien 107, 111, 113

Gallspach 218-223, 226f., 240

Garai, Bert 238

Gärtner, E. 53

Gates, Bill 10

Gautsch, Paul 122, 123

Geert, Gisa 292, $294 \mathrm{f}$.

Geiringer, Trude 144, 174, 282, 300,

$311,332,335,336,340,343,345$, 469

Genf 25

Genrebild, Genrefoto 178, 182, 188, 202, 235 f., 240, 242, 258, 315, 341, 424

Geo, Zeitschrift 442

Georgi, Sonja 316, 469

Georgi, Yvonne 341

Gericht, Gerichtsverhandlung 24, 54,

107, 157, 207, 216 ff., 408

Gerl, Franz 329

Gerlach, Martin jun. 41, 159, 370, 470

Gerlach, Martin sen. 41, 119 f., 469

Gert, Valeska 301

Gesellschaft für Graphische Indust-

rie 29,33

Gesellschaftsmagazin 172-188, 237, 245, 330

Gesundheit 68, 218-222

Getty Images 10

Gewalt 54, 128 f., 132, 138, 140

Geyer, Eva 338

Giehsz, Alfons 53

Gircke, Fotoagentur 238

Glasplatte, Glasnegativ, siehe auch

Negativ 10, 14, 55, 111, 205, 321, 327

Glogau, Edith 174, 311, 335, 340, 343,

395, 470

Göding 44

Goebbels, Joseph 162, 163

Goldarbeiter, Lisl $263 f$.

Goldhammer, Zsigmunt 50, 470

Goldschmied, Hermann 76

Goll, Yvan 298

Gondosch, Friedrich 245

Gordan, Martin 49

Gorny, Hein 470

Goszleth, Istvan 50

Graben-Atelier 294

Grabež, Trifun (Trifko) 107

Grabkovicz, Hans 187, 351

Grafische Gestaltung 62, 65, 69, 152,

154-156, 162, 167, 171, 174, 176

181, 187, 193, 195, 197, 200 f., 209,

211, 221, 231, 308, 378, $382 \mathrm{ff} ., 390$,

$397,419,419,421 \mathrm{f} ., 428$

Gran Canaria 343

The Graphic, Zeitschrift 29

Graphische Revue 308

Graslitz (Kraslice) 89

Graz 50, 169, 248, 252, 414-416

Grazer Tagblatt 150

Grießler, Franz 308

Grillparzer, Franz 61

Groak, Karl 28, 29, 35

Grock, Clown (Charles Adrien Wettach) 166

Groß, Grete 291, 292, 294, 295

Gross, Margarethe 335, 343, 470

Große Österreich-Illustrierte 442

Großglockner 366, 367

Großmann, Stefan 408

Grünbaum, Fritz $268 \mathrm{f}$.

Die Grüne Post, Zeitschrift 187

Grünwald, Herbert 188, 470

Gudenberg, Freiherr von 14

Gutmann, Ludwig 41, 470

Guttmann, Simon 238, 470

Haas, Robert 149, 179, 231, $232 f$.

351, 389, 390, 391, 393, 396f., 398-

400, 408, 410, 470

Haasenstein \& Vogler 76

Hackenschmied, Alexandr 179, 358 404, 470

Haeckel, Georg 49

Haeckel, Otto 49

Haeckel, Otto und Georg, Fotoagentur 238

Hagenbund 291, 294, 354

Hahn, Paul Edmund 152, 157, 211, 470

Haid, Liane 280

Hainisch, Marianne 340

Hajek-Halke, Heinz 181, 182, 470

Hajek, Gustav 42, 236, 246, 470

Halpern, J. 256, 470

Halsman, Philippe 239, 402

Haluschka, Hugo 370, 470

Hamburger Illustrierte 106, 152

Hammer, Josef 258, 470

Hammerschlag, Peter 135

Hanel, Rudolf, Druckerei 158

Hanka, Erika 292

Hannau, Hans 179, 362, 375 f., 471

Harper's Weekly, Zeitschrift 62

Hartmann, Ernst 179, 471

Hase, Elisabeth 246, 471

Hassner, Rune 20

Hauffe, Richard 128, 210, 471

Hauser, Carry 336

Hearst, William Randolph 63

Heartfield, John 345

Hebentanz, Franz 41, 471

Heber, R. 53

Hedin, Sven 267

Hegyei, Tibor 183, 359, 471 
Hilscher, Albert 141, 154, 157-159, 210, 211, 239, 322, 323, 324, 368, 414, 420, 424, 436, 471

Hinterstoisser, Franz 91, 104

Hirth, Hellmuth 97

Hitler, Adolf 133, 163, 164, 249, 250

262, 285, 368, 369, 409, 411-418,

430, 431, 435

Höch, Hannah 345

Hochhaus, Wolkenkratzer 199, 263, 265-267, 271 f., 275, 276

Hodek, Ferdinand 154, 170, 171, 182, 252, 254, 256 f., 308, 350, 351, 471

Hoffmann, Fotoagentur $246 \mathrm{f}$., $417 \mathrm{f}$., $423 \mathrm{f}$.

Hoffmann, Heinrich 417f., 421, 422, 423, 471

Hoffmann, Kitty 176, 177, 186, 311, 316, 335, 395, 423f., 471

Hoffotograf 62,78

Hofmann, Else 338

Holger, Hilde 292

Höllriegel, Arnold 148, 380

Hollywood 265-267

Holzmeister, Clemens 142, 195 f., 345

Holzstich 34, 52-54, 66, 67

Horn 96

Horovitz, Dora 144, 174, 282, 300,

$302,311,332,335,336,340,345$,

395,471

Hubbuch, Hilde 400, 471

Hübel, Karl 148

Huber, Anton 36, 37, 38, 42, 65, 80,

325 f., 437, 438, 471

Hufnagel, Josef 471

Hummer, Josef 471

Husnik, Kurt 179, 182, 206, 351, 353, 393, 471

ICA-Record, Kamera 205

III-Pho, Fotovereinigung 182f., 185, 238

Illner, Karl 96, 98

Illustrated London News 39, 208

L'Illustration, Zeitung 29

Illustrations-Zentrale (Illustrations-

Unternehmung) C. Seebald 46, 48,

95, 106, 236, 239

(Leipziger) Illustrirte Zeitung 29, 31

Das illustrierte Blatt 157, 206

Illustri(e)rte Sport-Zeitung 325

Illustrierte Film- und Kinorundschau 149

Illustrierte Kronen-Zeitung, Österreichi-

sche Kronen-Zeitung 61, 438

Illustrierte Radiozeitung 189

Illustrierte Rote Woche 160, 250

Illustrierte Rundschau 33

Illustrierte Sonntags-Zeitung für unsere

Frauen 30

Illustrierte Wochenpost 285

Illustrierter Beobachter 162, 164, 432

Illustriertes (Österreichisches) Sport-

blatt 28, 29, 45, 46, 189, 281, 283,

317, 320, 322, 325-327, $329 \mathrm{f}$.

IIlustriertes Wiener Extrablatt 55

Illustrirte Österreichische Woche 33

Imboden, Martin 179, 182, 191, 198,

200, 245, 252, 256, 257, 291, 349, $387,393,471$

Industrie 79, 223-225, 384

Innitzer, Theodor 174

Innsbruck 50, 88, 150, 157, 279, 414

Innsbrucker Nachrichten 150

Das interessante Blatt 10, 12 f., 15, 22,

23, 24, 25, 27-30, 34f., 36, 37, 41-43,

$45,47,51$ f., 56 f., 60, 62, 64, 66, 70-

76, 78, 90, 94f., 97, 102, 105-108,

111, 120, 122 f., 125 f., 129, 137, 139,

142 f., 145 f., $150-153,164,166$,f.,
189, 201, 206, 208f., 214, 220 f., 224f., 237, 246, 263-265, 272, 277, 284, 286 f., 306 f., 311, 317-319, 325 f., 365, 368, 394, 408, 411, 414, 416 f., 419, $421 \mathrm{f} ., 437-440$

International-Photo-Servie, Fotoagentur 239

Internationale Ausstellung für Buchgewerbe und Graphik (BUGRA), Leipzig 307

Internationale Presseagentur (IPA) 239

Irribauer, Karl 258, 471

Isonzofront 111, 144

Italien 183, 327, 378, 381, 396, 404-

406, 410, 426

Jacobi, Lotte 177, 471

Jacquelin, Edmond 326

Jaffé, Max 73

Jagd $78,84,85$

Jahudka, F. 41, 472

Jahudka, Josef $41,80,326,472$

Janda, Louis 53

Jazz 209, 265, 268f., 270, 298

Jedermann, Zeitschrift $158 \mathrm{f}$.

Jeidels, Harry 472

Jelfy, Julius von 110, 111, 472

Jellinek-Mercedes, Didier 375, 472

Jellinek-Mercedes, Fernand 181, 472

Jenik, Rosa 65, 472

Jírů, Václav 177, 358, 472

Jobst, Rudolf 288,472

Josef Ferdinand von Toscana,

Erzherzog 44

Juden, jüdische Fotografen/Fotografin-

nen $16,144,166,245 \mathrm{f} ., 316,335 \mathrm{f}$.,

$341,343,376,430-433$

Judenverfolgung 294f., 316, 341, 343,

$376,410-411,421,430,445$

Jugoslawien 410

Jungmeier, Willi 375, 424, 472

Junk, Rudolf 362

Jürets (Jurecs), Franz 42, 472

Juretsch, Franz 42, 472

K.u.k. Armee 113, 234,

K.u.k. Monarchie 12, 29, 49 f., 118

266, 274, 280, 325, 438

Kaffeehaus 76, 350, 382

Kalischer, Eduard 153

Kallir, Otto 353, $358 \mathrm{f}$.

Kallmus, Dora, siehe d'Ora

Kallós, Oskar 50, 92, 472

Kalmar, Rudolf 381

Kamera 54, 56, 111, 205, 321, 326 ,

332, 383, 402

Kamera-Kunst, Zeitschrift 362

Karl I., Kaiser 88, 89, 108, 114, 115

Karl Stephan, Erzherzog 93

Karlsbad 50, 302, 341, 440

Karnitschnigg, Maximilian 169, 179,

191, 345, 361 f., 367, 376, 424, 472

Kärnten 164

Karplus, Albert 351, 472

Kassowitz, Ernst 210, 351, 393, 472

Katastrophe, Katastrophenbericht 45, 51, 56, 57

Katholizismus 174, 195, 201, 367, 369,

375, 381

Katolicky, Franz 258, 472

Katz, Hella 335, 343, 472

Kaulich, Rudolf (Rezsö) 110, 472

Kelen, Emmerich 211, 472

Keller, Paula 178

Keller, Ulrich 55, 116, 205

Keppler, T. 422

Kernstock, Ottokar 365

Kertesz, André 345, 402

Keystone, Fotoagentur 236, $238 \mathrm{f}$.,
242, 245 f., 249

Kilophot, Fotoagentur 48, 114, 236

Kinder 43, 90, 141, 142f., 210, 221 ,

224, 334, 389, 390 f., 405, 414

Kino 11, 12, 266, 267, 268, 307, 440

Die Kinowoche 189, 278-280

Kinski, Imre 472

Kiosk 76

Kirsch, Hans 99

Kirsta, Georg 290

Kirstein, Lincoln 7

Kisch, Egon Erwin 90

Kiss, Helene (llona) 335, 343, 345, 472

Klagenfurt 414

Klebinder, Ernst 158

Klebinder, Paul 158

Klein, Fritzi 134, $135 \mathrm{f}$.

Kleinberg, Ernst 182, 210, 239, 251, 252, 322, 472

Das Kleine Blatt, Zeitung 149, 154, 248

Klinger, Julius 308

Kluger \& Szigethy, Fotoagentur 238

Kluger, Zoltan 167, 191, 473

Koenig, Otto 375, 377, 473

Koerber, Ernest von 12

Koffler, Camilla Henriette, siehe auch

Ylla 343

Kogler, Herbert 157

Köhl, Rudolf 435

Kokoschka, Oskar 402

Kolliner, Grete 174, 186, 290, 291, 302,

335, 340, 402, 473

Kölnische Illustrierte Zeitung 152, 157,

$165,167,228,317,334$

Kolportage 63, 76, 165, 166

Kommunismus, Kommunisten 127

129, 140, 141f., 152, 156, 160, 238,

248, 250, 262, 285, 334

Kondor - Pressedienst Leonora Schur,

Fotoagentur 400

König, Eduard 66

Koppitz, Rudolf 174, 181, 291, 362,

370-373, 473

Korff, Kurt 11, 159

Korty, Raoul 239

Kosel, Hermann 308, 338, 473

Kossák, Josef 50,473

Kott, Egon $421 \mathrm{f}$., 429

Krabath, Thomas, Kleiderhaus 430, 431

Kraberger, Paul 157

Kracauer, Siegfried 19

Krakau 50, 113

Kramer, Theodor 380, 395

Krampolek, Andreas, siehe auch Patzelt

\& Krampolek 59

Kranus, Karl 258, 473

Kraus, Gertrud $291 \mathrm{f}$., $294 \mathrm{f}$.

Kraus, Karl 60 f., 295

Kraus, Norbert 424, 473

Kreisler, Ernö 182, 473

Krenek, Ernst 268

Krens, Karl 308

Kreuder, Paul 269

Kreutzberg, Harald 341

Krieger, Franz 424

Kriegsberichterstatter 107, $109 \mathrm{ff}$.

116, 436

Kriegsfotografie, Kriegsfotograf 46, 48,

$108 \mathrm{f} ., 110,111,113,116,210,236 \mathrm{f}$.

Kriegsgefangene 114, 390

Kriegsopfer 139, 146, 329, 407

Kriegspressequartier (KPQ) 107, 110112

Krill, Richard 50, 473

Kriminalfall 54, 199, $207 \mathrm{ff} .$, 215-218

Kronen-Zeitung, siehe auch Illustrierte

Kronen-Zeitung 25, 438

Kronos AG 149, 175

Krotsch, J. 42, 473

Kruckenhauser, Stefan 373, 376, 402,

436, 473

Krull, Germaine 345,473

Krupp, Arthur 79

Krzanowski, Johann 50, 473

Krziwanek, Rudolf 27, 40, 78, 80, 473

Der Kuckuck 54, 130, 134-136, 147,

149, 152-155, 158f., 160, 162, 164,

191, 171f., 176, 194, 196-198, 200,

$223,240,248-254,256,258,260-$

262, 274, 380, 391, 394

Kuderna, Franz 190

Kühn, Heinrich 362, 473

Kuhn, Oskar 187, 351, 473

Kun, Béla 129

Kunst dem Volk, Zeitschrift 418

Kunstfotografie, siehe Piktorialismus

Kunz, Alfred 176, 177

Kupfertiefdruck $34 \mathrm{f} ., 58,75,149$,

153, $157 \mathrm{f} ., 169,174,181,190,194$,

382,428

La Jana, siehe auch Henriette

Margarethe Hiebel 302

Labisch, Siegmund 48, 473

Lagler, Bozěna 101

Landbeck, Liselotte 324

Landschaftsfotografie 179, 182, 188,

202, 256, 258, 341, 344, $358 f ., 363-$

$377,400,424$

Largajolli, Rudolf 57, 473

Laval, Pierre 10

Laxenburg 292

Lechenperg, Harald 210, 228, 230,

231, 244, 245, 375f., 473

Lechner, R. (Wilh. Müller) 46, 47, 56,

$80,82,95,104,113,119,214,236$,

346,473

Lehmanns Adressbücher 22, 76, 305

Leica 7, 204, 207, 321, 402

Leichtathletik, Athletik 321, 322, 333, 437

Leitner, Hilde 206

Lemberg 50, $112 \mathrm{f} ., 348$

Lemoine, Alfred 102, 103

Lendecke, Otto 289

Lenze, Minna 252, 473

Leontjew, Sascha 294

Leopold Salvator, Erzherzog 93, 99

Leopold von Preußen 97

Lerski, Helmar 345

Leslie's Weekly 48, 62

Leuchtreklame, Lichtreklame 272-274,

307, 309

Leutner, Felix 48, 473

Levine, Charles 265 
Lorant, Stefan 165f., 218

Losch, Tilly 291

Löwy, Franz 174, 186 f., 291, 311, 368, 473

Löwy, Josef 41, 78

Lubitsch, Ernst 432

Luckhardt 41, 78, 473

Lueger, Karl 54, 118, $119 \mathrm{f}$.

Luftfahrt, siehe Flugzeug

Lukas, Jan 177, 179, 358, 402-404, 408, 474

Machlup, Cécile 258, 259, 351, 474 Macku, Paul 393, 474

Madensky, Gertraud 311, $473 \mathrm{f}$

Madensky, Hans 179, 308, 351, 370, 424, 474

Magazin 14, 170, 172-188, 237

Magd, Veza, siehe Veza Canetti

Mahler, Alma 408

Mahler, Anna 408

Mahler, Gustav 408

Mailand 242

Makart, Hans 41, 78, 474

Maly, Ada 357

Man Ray 345

Man, Felix H. 155, 177, 223, 238, 474

Manassé, Atelier 173, 181, 186, 187 f.,

303, 428

Mandl, Hermann 305, 308

Mandy, Franz 62

Mann, Stella 294

Mann, Thomas 173, 394

Mannheim, Lothar 215

Manuel, Henri, Fotoagentur 238, 310

Maresch, Eduard 153

Margulies, Hanns 408

Markalous, Evzen 474

Martinelli, Rudolf 56, 474

Marx, Karl 190

Masaryk, Thomas G. 404

Massenkundgebung, siehe auch

Demonstration 118, 122, $127 \mathrm{f}$., 129, 131, 134-144

Massenpresse, siehe auch Boule-

vard 24, 35, 62f., 136, 438

Mattersdorf, Regine 240, 242

Matuska, Sylvester 215-218

Maudry, Othmar 291, 474

Mauritius, Fotoagentur 157, 165, 206 238

Mayer, Adolf 436, 474

Mayer, Franz 179, 345, 351, 474

Mayerhofer, Max 436, 474

Medina, Hedda 186, 291, 294 f., 335, 343

Mein Film, Zeitschrift 149, 189, 190,

264, 267, 296, 429, 430

Meisner, Karl 148

Meitner-Graf, Lotte 179, 311, 335, 340,

343, 351, 474

Mendelssohn, Peter de 144

Mertens (Matisz), Marie 43, 44, 331, 474

\section{Messina 46}

Messner, Irene 311, 335, 343, 474

Metro Goldwyn Mayer (MGM) 238, 266

Metten, Ernst 410

Metzel, Lothar 410

Michaelis, Margarethe, siehe auch

Margarethe Gross 335, 343

Michalup, Isidor 42, 474

Miklas, Wilhelm 365

Mikovsky, Bertalan 111, 474

Das Mikrophon, Zeitschrift 191

Milik, Franz 425, 474

Militär 36, 37, 41, 50, 78, 79, 80, 96,

$98,109,111,116,127,129,133-136$, 234, $405 \mathrm{f} ., 433 \mathrm{ff}$.
Le Miroir, Zeitung 29

Misar, Hans 424f., 426, 427, 474

MOCCA, Zeitschrift 186-188, 294,

303, 360, 422-424

Mode, Modefotografie 32, 49, 177, $186,188,235 \mathrm{f} ., 238,242,246,289$ 310-314, 334f., 343, 395, 396, 397, 400, 423

Moden-Zeitung fürs Deutsche Haus 30

Moderne Welt, Zeitschrift 159, 172-

175, 178, 181, $230 \mathrm{f} ., 235,273,281 \mathrm{f}$, 291 f., 307, 310f., 314, 316, 321, 348,

353, 363 f., 372, 429

Moholy-Nagy, László 345, 402, 474

Montagszeitung 25, 324, 380, 439

Mord 22, 24, 25, 44, 199, 204, 207,

215,440

Der Morgen, Zeitung $380 \mathrm{f}$.

Morgenstern, Soma 222

Moser, Simon 373, 424, 475

Moskau 238

Mosse, Medienkonzern 16, 29

Mostar, Hermann 391

Motorrad 7, 203, 210, 305, 322, 323, 325

Müller, Grete 315

Müller, Hertha 345, 475

Müller, Leopold 93

Müller, Richard 157

Müller, Wilhelm 50, 475

München 49

Münchner Illustrierte Presse 152, 166,

206, 218-221, 223, 226 f., 315, 338

Munkácsi, Martin 177, 207, 208, 226 ,

227, 475

Münz, M. 50, 475

Museum für Kunst und Industrie $345 \mathrm{f}$., 373, 408

Musik 14, 43, 164, 209, 266-271, 286,

292, 298, 353, 385-387, 388

Musil, Robert 380

Die Muskete, Zeitschrift 186, $265 \mathrm{f}$.,

269 f., 303, 422 f., 424

Mussolini, Benito 406

Mutterer, Josef 41, 475

Nacktkultur, Nackttanz 299, $301 \mathrm{f}$.

Naschmarkt, Wien 210, 211, 387

Nationalratswahl, siehe Parlamentswahl

Nationalsozialismus, Nationalsozialis-

ten $16,18,141-143,144,154,160$, 162-164, 169, 184, 193, 202, 228,

231, 233, 238, 245-247, 249f., 261,

$269,303,316,330,343,368,376$,

$378,409,411-418,419-436,442$

Naturfreunde 171, 248, 254-258

Negativ 14, 15, 52, 55, 111, 205, 208, 321, 327

Neofot, Fotoagentur 238

Neudatschin 165, 475

Neue Frau 277-285, 338

Neue Freie Presse 60, 207, 437

Neue Galerie 353f., 358, 359

Die Neue Linie, Zeitschrift 231

Neue Sachlichkeit 170, 179, 183, 240

252, 258, 344-362

Der Neue Tag, Zeitung 90

Das Neueste im Bilde, Zeitung 33, 147

Neue Wiener Moden-Zeitung 30

Neues Sehen 170, 176, 179, 183, 240

258, 344-362, 394, 402

Neues Wiener Journal 24, 62, 260, 315

Neues Wiener Tageblatt 148

Neuigkeits-Welt-Blatt 201

Neumann, Johann 328

Neumüller, Michael 424, 475

Neutra, Richard 272

New York 237, 271, 275, 307, 343,

349,376
New York Herald 24

New York Times 237

New York Tribune 24

New York World 24

Niebuhr, Elly 443

Niederlande $341 \mathrm{f}$., 376

Nieves, Maria de las 302

Niklitschek, Alexander 258, 475

Der Notschrei, Zeitschrift, siehe auch

Zeitbild 160, $162 \mathrm{f}$.

Novotny, Jaroslav 404

Nowak, Sepp 176, 350, 393, 475

NSDAP 160, 162f., 247, 250, 421

Oberländer, Grete 315

Odilon, Helene 12

Oestreicher, Lisbeth 341

Oestreicher, Marie 341, 342, 343, 475

Ohnesorg, S. 53

Olmütz 50

Omifot, Fotoagentur 239

Oper, Operette 47, 287, 289, 291, 294

Oplatka, Emil 148, 178, 381, 383

Oplatka, Hans 178f., 381-410, 475

Oppelik, Anton 76

Oppolzer, Hugo 210, 322, 475

d'Ora, Atelier 31, 174, 186, 242, 278

289, 291, 296, 297, 301, 308, 309,

310, 311, 332, 335 f., 341, 427, 472

Orbis Verlag 148, 381

Ornstein, Julius 34

Ortner, Hanns 475

Ország Világ, Zeitschrift 29, 111

Ortner, Hanns 424

Österreichische (Österreichs) Illustrierte

Zeitung 26, 53, 59, 84f., 87, 108f.,

110, 111, 114, 117-119, 147, 422

Österreichische Familien- und Mo-

den-Zeitschrift 30

Österreichische illustrierte Rund-

schau 31, 33

Österreichische Kunst, Zeitschrift 418

Das österreichische Lichtbild 256-258,

271, 300, 309, 351, 355

Österreichische Lichtbildstelle 214 239, $368 \mathrm{f}$.

Österreichische Woche, Zeitung 131,

160, 168, 200-202, 378, 411, 415

Österreichische Zeitungs- und Drucke-

rei-Aktiengesellschaft 29, 34f., 75

Österreichischer Photodienst, Foto-

agentur 239

Ostfront 108, 110-113, 407, 430, 436

Ostmark 18, 246 f., 316, 411, 414, 416418, 422, $431 \mathrm{f}$

Ostmark-Woche, Zeitung, siehe auch

Österreichische Woche 414, 418f., $421 \mathrm{f.}, 432$

Ostry, Ludwig Vinzenz 381

Oswalda, Ossi 283

Otto, Erzherzog, Erzherzog 38

Pacific \& Atlantic 238f., 249

Palästina 18, 295

Panek, Adalbert 42, 475

Pankratz, H. 112

Papanek, Josef 152, 167

Papanek, Rose-Marie 152

Papierfabrik 29, 148

Paramount 238, 266

Paris 48f., 111, 207, 232, 234, 236, 242

302, $307 f ., 310,317,343,381,383$

Paris Match, Zeitschrift 442

Parlament 59, 117-134, 136, 298

Parlamentswahl $60,118,121,123,125$, 137, 154

Patek, Caire 315, 475

Patriotismus 363-367

Patzelt \& Krampolek 73

Die Pause, Zeitschrift 421f., 427, 429,

435, 436

Pawek, Karl 373, 434

Pawlik, Franz 42, 80, 326, 475

Payer, Sepp 421

Le Pays de France, Zeitschrift 29

Pechotsch, Rudolf 191, 475

Pécsi, József 360, 475

Peletier, Thérèse 100

Penitsch, Rudolf 424, 475

Perckhammer, Heinz von 179, 184,

228, 229, 230, 245f., 308, 351,

375 f., 424, 475

Perlmutter, Max 73

Pernersdorfer, Engelbert 61

Perscheid, Anna 111, 475

Perscheid, Josef 47f., 111, 112, 210, 326

PeßI, Herbert 424, 475

Pesti Napló, Zeitung 110

Petit Journal, Zeitung 24

Pfundmayr, Hedy 291

Philipp \& Kramer 59, 73

Philipp, Jacques (Jakob) 27, 33, 148

Photo-Express, Fotoagentur 238

Photo-Illustration S. Wagner, Fotoagentur 247

Photo-Riport, Zeitschrift 110

Photo-Zentrale, Fotoagentur 239

Photocomposition, siehe auch Fotomontage 59, 117

Photoglob Compagnie, Fotoagentur 49

Photothek Römer \& Bernstein,

Fotoagentur 237

Picture Post, Zeitschrift 410, 441

Pietzner, Carl 41, 78, $475 \mathrm{f}$.

Pietzner, Oscar 42, 476

Piktorialismus 39, $181 \mathrm{f} ., 188,320$, $345,360,362$

Pilsen 404

Pinza, Ezio 368

Pisafot, Fotoagentur 239

Pitner, Adolf 159

Planer, Franz 111

Polen 431-433, 435

Polgar, Alfred 109, 145, 304, 380

Politiker 118, $120 \mathrm{f}$.

Polizei 138, 140, 161, 199, $251 \mathrm{f}$.

Pollak, Lotte 252, 476

Polyphot, Fotoagentur $239 \mathrm{f}$.

Popper, Hans 154, 252, 351, $375 \mathrm{f}$., 393, 476

Populärkultur 11, 21, 39, 437, 438

Porges, Friedrich $189 \mathrm{f}$.

Porkert, Josef 41, 476

Porträt 14, 26, 42, 47, 54, 59, 77-89,

120 f., 174, 179, 234, 245 f., 264, 277,

$278 f ., 280 f ., 282,290,296 f ., 315$,

320, 334-336, 339-341, 344, 349, 
Psychoanalyse 78

Pulitzer, Joseph 24

Radio 188-193, 265, 307

Radio-Welt, Zeitschrift 189-193, 422

Radiophot, Fotoagentur 239

Radiozeitschrift 149, 151, 181, 188-192

Radrennen, Radsport, Radfahren 37,

324, $325 \mathrm{f} ., 351$

Rafael, J. 76

Raimund-Theater 287

Rainer, Friedrich 368

Rasterdruck, siehe auch Autotypie 34

Rätediktatur 129

Rattner, Erich $392 \mathrm{f}$

Raub, Raubüberfall 66, 440

Rauch, Elly 188, 375, 424, 476

Raymonde de Laroche (Èlise Roche) 101

Réczey, Imre 77

Redaktion, siehe auch Fotoredaktion

22, $56 \mathrm{f} ., 60,65,72 \mathrm{f} .$, 152, $156 \mathrm{f}$.,

162, 167, 220, 315, 381ff., $410 \mathrm{f.,} 422$

Reichspost, Zeitung 30, 148, 201, 302

Reichsratswahl, siehe Parlamentswahl

Reiffenstein, Bruno 41, 111, 309, 370,

424, 430, 431, 476

Reise, Reisefotografie, Reisereporta-

ge $167,179,210,228,242,245$,

335, 341, 378, 402

Reiter, Raimund 158

Reklame, siehe auch Anzeigen 304316

Renger-Patzsch, Alfred 252

Renner, Karl 115, 126, 126

Republik 124-126, 131, 139, 197

Residenz, Atelier 264

Residenzbühne 287

Retusche 38, 55f., 97, 302

Reutlinger, Charles 49, 310

Révész, Emerich 111, 476

Revolverpresse 54, 55

Revue 268, 269, 287, 297, 298, 301

Riethof, Willy 154, 182, 252, $345 \mathrm{f}$.,

351, 352, $353 \mathrm{f} ., 476$

Rikola Verlag 189

Rinaldini, Lisl 292

Ring, Gertrud 262

Ringstraße, Wien 124, 129, 131

134-144, 357, 360

Le Rire, Zeitschrift 145

Rob Verlag $186 \mathrm{ff} ., 303,422 \mathrm{f}$.

Rob, Karl 186f., 303, 422, 476

Robert, L. 43, 476

Robertson, Hans 177, 476

Rode, Walther 380

Rodenberg, Lux 354, 358

Rodtschenko, Alexander 345

Rolleiflex 383, 396, 205

Rollfilm, Rollfilmkamera 111, 205, 321

Ronacher 296, 298, 301

Röntgenfotografie 77

Roos-Reuter, Beate 302

Rosenbaum, Sigmund 33

Roß, llse 335, 476

Rotationsdruck, siehe auch Druckerei

21, 34, 35, 70, $72 \mathrm{f} ., 74 \mathrm{f}$.

Roth, Franz 424, 436, 476

Roth, Hans 210, 476

Roth, Joseph 336

Rubel, Philipp 106

Rübelt, Ekkehard 239, 322, 476

Rübelt, Lothar 20, 21, 142 f., 154, 159

162, 163, 175, 181, 202, $203 f$., 205,

207, 208-210, 211, 212, 214-218,

224 f., 227, 228, 239, 247, 254, 255,

$308,317-322,330,356,366,375$,

$376,393,416,417,421,424,428$,

436,476
Rückauf, Monika 424, 476

Rumänien 62, 111

Rundfunk, Rundfunk für alle,

Zeitschrift 149, 190 f., 248

Rupprecht von Bayern, Prinz 42

Russland, siehe auch Sowjetunion 112 , 436

Ruttmann, Walther 357

Rybarik, Willy 258, 476

Saad, Georges 243, 476

Sachfotografie 171, 182, 258, 260 ,

$305 \mathrm{ff} ., 309,357,358,400$

Sadler, Otto 256

Sagai, Emmi 176

Saint Germain 115, 139, 224

Sajdok, Erwin 362, 476

Salomon, Erich 227

Salzburg 227, 231-233, 353, $367 \mathrm{f}$, 414

Salzburger Festspiele 227, 231-233, $367 \mathrm{ff} ., 394$

Salzburger Illustrierte 158

Salzburger Volksblatt 150

Der Samstag, Zeitschrift 34, 35, 63, 64, 100

San Francisco 57

Sanden, Heinrich 49, 236, 476

Santho, Imre 316, 476

Sarajevo 50, 105 f., 107

Sartorius, Hugo 371

Sascha Film 186

Saturday Evening Post, Zeitschrift 441

Sauer, Fritz 308, 477

Schädler, Anton 50, 477

Schaffelhofer, Steffi 167, 210, 335,

400, 401, 477

Schajchet, Arkadi 402

Schalcher, Traugott 304, 307

Schalek, Alice 210, 228, 245, 477

Schalek, Heinrich 76

Schauspieler/in $42,145,234,278-$

281, 282, 315, 336, 338f., 341

Schein, Abraham Maier (Myron) 174,

302, 477

Schein, Jsaak 126, 477

Schenk, Hugo 22, 24

Scherb, Julius 424, 477

Scherl Bilderdienst, Fotoagentur 16,

$29,238,240,246 \mathrm{f}$.

Schiestl, Josef 42,477

Schilling, Alexander 273, 307

Schindler, Nikolaus 111, 477

Schirner, Max 239

Schistal, Anton 41, 477

Schleich, Karl 210, 239, 322, $323 \mathrm{f}$., 393, 424, 477

Schloß, Rudolf 179, 477

Schlossarek, Karl 22, 24

Schmachtenberger, Erika 246, 424, 477

Schmal, Felix 322, 326, 329, 477

Schmauss, Erika 424, 477

Schmeling, Max 237

Schmitz, P.A. 156

Schmitz, Richard 142

Schnapper, Hans 234, 311

Schneider, Ernst 310

Schneider, Siegmund 59, 60, 61, 117 477

Schneider, Walther 351, 393

Schöler, Franz 34

Scholz, Ursula 375, 477

Schönbrunn 81, 83, 90, 103, 104, 113,

141

Das schöne Lichtbild, Zeitschrift 375

Schoop, Trudi 394

Schöpl, Karl 210, 240, 477

Schostal, Fotoagentur, siehe auch
Wiener Photo-Kurier 165, 230, $245 \mathrm{f}$.,

256, 311, 341, 346

Schostal, Oscar 242

Schostal, Robert 239 f., 242, 245 f., 477

Schostal, Walter 242, 477

Schottland 228

Schramek, Josef 182, 258, 350, 477

Schreiber, Gustav 42, 65, 477

Schreier, Maximilian 380

Schuhmann, Heinrich jun. 88, 89, 114, 157, 210, 436, 477

Schuhmann, Heinrich sen. 28, 43, 44,

45, 80, 95, 210, 326f., 328, 330, 477

Schuhmann, Ludwig 88, 89, 114, 477

Schulda-Müller, Hertha 424, 477

Schullerbauer, Franz 50, 477

Schulz, Annie 154, 176, 210, 211, 311, $331 \mathrm{f}$., 334, 351, 477

Schulz, Hermann Ignaz 343

Schur, Lena 167, 210, 311, 335, 343, 400, 524, 478

Schuschnigg, Kurt 142, 143, 370 , 409, 414

Schuster, Ferenc 478

Schutzbund 132

Schwabik, Marian 157, 228, 375, 436 478

Schwarz, Diana 252, 478

Schwarz, Nikolaus 154, 172, 179, 182,

198, 252, 274, 351, 362, 375, 393, 478

Schwarz, Oscar 242

Schwarz, Sigmund 190

Schwarzwald, Eugenie 340, 380, 402f., 408

Schwechat 66

Schweden 343

Schweiz 166, 410

Scolik, Charles jun. 44, 210, 478

Scolik, Charles sen. 39-41, 43, 53, 66,

$78,80,84,87,95,121,478$

Sedlacek, Alois 424

Sedlar, Luis 246, 478

Seebald, Carl 43, 45, 46, 80, 95, 108 , 111, 116, 125, 126, 210, 236, 326, 330,478

Seitz, Karl 132

Seldowicz, W. 207, 478

Senkinc, Franz 179, 350, 478

Sennecke, Fotoagentur 157, 237

Serbien 114

Serog, Käthe 400, 478

Setzer, Atelier 173f., 186, 291, 478

Setzerei $73 \mathrm{f}$.

Sex-and-Crime 27, 54, 439

Sexualität $185 \mathrm{ff} ., 265,281,296-303$, 439

Seyß-Inquart, Arthur 412

Shanghai 245

Sheeler, Charles 345

Shostal Inc. (Schostal Associates) 145

Sieger-Sobotka, Fotoagentur 47, 236

Sieger, Eduard 47, 478

Sieghart, Rudolf 148

Signal 230

Silberer, Victor 325

Simmering, Flugfeld 94, 96, 99

Skall, Gusti 206, 394-396, 408, 410,

Skall, Gusti $394 \mathrm{f}$

Skall, Otto 176, 179 f., 271, 272, 291, $345,351,354,358,382 \mathrm{f} ., 386,393$ 394, 408, 409, 410, 478

Skandal $54 \mathrm{f}, 298 \mathrm{f}, 302$

Skifahren 162, 169, 226, 279, 280, $313,321,324,329,352,356,402$, 410

Slabatnig, Joseph 99, 100

Sladky, Eugen 258, 478

Slama, Viktor T. 308

Slatin, Rudolf Carl Freiherr von (Slatin

Pascha) 26

Sobotka, H. 47, 478

Sommerauer, Franz 50, 478

Sonja, Magda 280

Der Sonntag, Zeitschrift 29, 30, $143 \mathrm{f}$. 149, 172, 177-179, 206, 210, 231, $341-343,375$ f., 378-410, 422

Sophie Chotek, Frau von Erzherzog

Franz Ferdinand 38

Sorger, Alexander 121

Sowjetunion $160,238,354,357,430$, 436

Soyfer, Jura $261 \mathrm{f}$., 380, 383, 408, 410

Sozialdemokratie 20,90, 118, 120,

122, 125-129, 131, 134-138, 140-

$143,152-156,194,202,248-262$,

$285,294,365,378,381$

Sozialdemokratische Zeitungen 63, 65 ,

147, 149, $153 \mathrm{ff} ., 190,238,248-262$

Spanien 343

Spanischer Bürgerkrieg 400

Speyer, Agnes (Kitty) 338

The Sphere, Zeitschrift 29

Spiegel, Rudolf 179, 191, 198, 252,

351, 375, 390 f., 392, 393, 478

Spiel, Hilde $143 \mathrm{f} ., 380$

Spira, Bil 176, $382 \mathrm{ff} ., 392,398,403$

408, 410, 478

Spitzer, Harald 478

Sport und Salon, Zeitschrift 30, 89

Sport, Sportfotografie 20, 37, 40, 43,

45, 157, 159, 167, 169, 175, 181, 188,

202, 228, 236, 317-283, 284, 317-

330, 333, 402, 428, $437 \mathrm{f}$.

Spreng, Franz 350, 478

Saint Denis, Ruth 30

St. Moritz 207

Stadler, Arthur 154, 249, 26

Stadtfotografie 121, 181, 230, 272-

$274,390,392$

Ständestaat $16,132,141-143,186$,

193, 194-202, 232, 260, 285, 340,

$345,349,363,365,367 f ., 370,373$

$378,406,414$ f., 419, 422, 433-435

Starhemberg, Ernst Rüdiger von 141

Starl, Timm 39

Stativ 7, 54 f., 95, 111, 402

Stauda, August 121, 478

Steffen, Alfred 169, 308, 478

Steinbach, Emil 120

Steinfeld, Flugfeld 96

Steinhoff, Ilse 424, 479

Steirische Alpenpost 169

Stephansdom 141

Stern, Alexander 154, 261, 479 
Die Stunde, Zeitung 148, 175, 383

Sturm, Wilhelm 424, 436, 479

Stuttgart 344, 346

Styria Verlag 150

Štyrsky, Jindřich 479

Südbild, Fotoagentur 247

Südostdeutscher Verlag 422

Südtirol 271, 372

Suhr, Werner 302

Sunday Times Magazine 442

Suppenmoser, Midi 246, 479

Suschitzky, Edith, siehe auch Edith

Tudor-Hart 154, 176, 210, 250, 252 ,

253, 262, 343, 351, 357, 479

Swara, Otto 43,479

Swoboda, Franz 375, 424, 479

Sykora, Frank 181, 210, 479

Szabó, Lajos 360, 479

Székely, Josef 26, 479

Szigethy, W. 167, 479

Szöllősy, Kálmán 182, 360, 402, 479

Szolnok 204, $207 \mathrm{ff}$.

Sztranyak, Josef 42,480

Taft, Robert 20

Der(Wiener) Tag 148f., 178, 210, 341, $380 \mathrm{f.}, 408 \mathrm{f}$., 422

Tageszeitung 11, 12, 15, 29, 116, 148,

204, $380 \mathrm{f} ., 438 \mathrm{f}$.

Tanner, Max 291, 292, 480

Tanz 17, 134, 135, 136, 177, 179 ,

286-296, 298f., 302, 335, 336, 341, 371,394

Tauber, Richard 432

Taussig, Bildarchiv 239

Teiner, Charles 65, 66

Telegrafie 57, 83, 105

Telephot, Fotoagentur 130, 239

Temeswar 50, 110

Teplitz 51

Tesar, Ludwig Erik 305

Tesarik, Franz 256, 480

Theater in der Josefstadt 302, 339,

Theater, Theaterfotografie 47, 176, 177,

210, $234 \mathrm{f}$., 240, 289, 291, 310, $334 \mathrm{f}$, $339,341,391,400,402,404$

Theile, Margarethe 252, 480

Theresienstadt 107

Thun-Hohenstein, Franz 51

Thun, Heinz 159, 480

Tichy, Herbert 167, 210, 228, 480

Tiller Girls 263, 265, 267, 268

Tirol 157, 201, 239, 276, 370, 372,376

Tiroler Anzeiger 156

Titelseite 20, 62, 63, 100, 131, 152,

153, 154, 167f., 176, 181, 379, $421 \mathrm{f}$.

Titelvignette $25,34,62 \mathrm{f}$.

Tod 44, 51, 88, 120, $138 \mathrm{f}$., 141, 208,

385-387, 404, 420

Tolnai Világlapja, Zeitung 111

Tomann, Otto 246, 424, 480

Tordis, Ellinor $294 \mathrm{f}$.

Tourismus 44, 90, 227, 232f., 367, 369

Träger, Richard 260, 345, 349, 350

Trampus, Charles 49, 106, 238, 480

Trebitsch, Karl 158

Trenker, Luis 429, 430

Triebel, Carl $41 \mathrm{f}$., 480

Tschechoslowakei, tschechisch, siehe

auch Böhmen 148, 177, 182, 322

358, 381, 393f., 402, 404, 410

Tschechow, Michael 339

Tschik (Csik), Fernec 182, 360, 480

Tschuppik, Karl 206, 223f., 380

Tucholsky, Kurt 262

Tudor-Hart, Edith, siehe auch Edith

Suschitzky 262, 343

Turin 100
Twen, Zeitschrift 442

Tyrolia Verlag 150, 152, 156

UFA, Filmunternehmen 238

UHU, Zeitschrift 187

Új Idők, Zeitschrift 29

Ullstein Verlag 10, 16, 29, 34, 146, 159f., 207, 234, 240, 245

Umbo (Otto Umbehr) 177, 238, 480

Umschlag, siehe Titelseite

Underwood \& Underwood, Fotoagentur

48, 238

Unfall, Unglück 23, 33, 52, 54, 56, 74, $101 \mathrm{f} ., 103,157,257,260,322$, $349 \mathrm{f}$., $438 \mathrm{f}$.

Ungarn, ungarische Fotografie 129,

136, $182 \mathrm{f}$., $207 \mathrm{f} ., 211,238,323$,

$327-329,359,372$

Union-Foto (Unionbild), Fotoagentur 238

Urzidil, Johannes 380

USA 24, 66, 116, 199, 245, 263-276,

$343,349,358,439,440$

Uttenthaler, Heinrich 43, 139, 322,

$326,330,480$

Uzcudun, Paolino 237

Vadas, Ernő 182, 359, 402, 480

Vanderfecht, Hubert 181

Varieté 56, 63, 65, 266-269, 286,

289, 296, 301, 302

Vasárnapi Újság, Zeitung 110

Vaterländische Front 141, 142, 143,

$201 \mathrm{f} ., 370,434$

Veidt, Conrad 337

Vereinigung der Arbeiterfotografen

Österreichs 250

Vermischte Meldungen, siehe auch

Faits divers 57,440

Vernay AG 148f., 158, 175, 178, $380 \mathrm{f}$., 410

Vernay Johann Nepomuk 148

Versand, siehe auch Expedition 76

Vertreibung 238, 295, 341, 343, 376,

410

Vidor, Zoltan 182, 480

La Vie Illustrée, Zeitung 29

La Vie Parisienne, Zeitung 145

Villany, Adorée 299

Voigt, A. 51

Voisin, Flugzeug 100

Völkel, Bruno 393, 424, 480

Völkischer Beobachter, Zeitung 164

Volkshochschule 257f., 260, 262,

Vorwärts Verlag 149, 184, 190, 193f., 200

Vossische Zeitung 234

VU, Zeitschrift 381, 402, 407

Wachtel, Rosa 206

Waggerl, Karl Heinrich 380, 392

Wagner, Bernhard 50, 480

Wagner, Charles 42, 480

Wagner, Druckerei 184

Wagner, Karl 159

Wagner, Kurt 376

Wagner, Otto 85

Wagner, Stanislaus 139, 247, 322,

424, 480

Wahlkampf 8, 125-127, 139

Waldheim, Waldheim-Eberle, Druckerei

70, 71, 146, 159

Wallack, Franz 367

Wallentin, Fred 207, 240, 480

Walter, Raimund 437

Walther, Hedda 245, 480

Wang, Cilli 292, 294

Warchalowski, Adolf 96, 98, 101

Wawra, Johann 42, 480
Weber, Otto 256, 350, 480

Weber, Wolfgang 219, 220, 221, 480

Wechsler, Karl 182, 481

Weil, Lisl 176, 177

Weimarer Republik 20, 157, 166, 184, 187

Weinert, Erich 262

Weinwurm, Antal 50, 481

Weissenstein, Margarethe 335,481

Weißkirchner, Richard 113, 114

Weitzmann, Josef 302

Wellspacher, Edith 400, 481

Welt-Bild, Zeitschrift 30

Welt-Guck, Zeitschrift 147, 150, 152,

155-158, 160, 164, 202, 210f., 215

Welt-Illustrierte, Zeitschrift 442

Welt-Preß-Photo, Fotoagentur 47, 111,

125, 140, 236, 239

Welt-Spiegel, Zeitschrift 30

Weltbild, Fotoagentur 238, 246, 433, 434

Weltrundschau, Fotoagentur 165,

$206 \mathrm{f} ., 238,242$

Wenger, Ernst 201

Werbefotografie 228, 243, 245, $308 \mathrm{ff}$., 335

Werbung, siehe auch Anzeigen, Reklame

$8,12,25,79,118,125,205,280$,

284 f., 304-316, 335, 344, 347, 442

Werfel, Franz 380, 432

Werian, Richard 322, 481

Werkbund 176, 195, 260, 340, 344-349

Werkmann, Karl $88 \mathrm{f}$

Weston, Edward 345

Wettstein, Richard 126, 127,

Weyr, Siegfried 131, 136, 154, 194-200,

251 f., $260 \mathrm{f} ., 481$

Wiberal, Mario 330, 424, 481

Wide World Photo, Fotoagentur 10, 238f., 249

Wiedling, Albert 41, $119 \mathrm{f} ., 481$

Wien-Bild, Fotoagentur 245

Wiener Allgemeine Zeitung 109

Wiener Bilder, Zeitung 27, 28-30, $34 \mathrm{f}$.,

$44 \mathrm{f} ., 49$, 53f., 56, 58, 60, 64, 71, 77,

$79,82,84,88,94,100,102,105$,

112, 114 f., 119, 121, 128, 130 f., 145 f.,

$150-153,159,164,166-169,189$,

201, 206f., 210, 276, 315, 322, 325

$336,370,400,411,419,421,425$,

429, 431

Wiener Bilderwoche, Zeitschrift $442 \mathrm{f}$.

Wiener Fotodienst, Fotoagentur 248

Wiener Illustrierte 178, 442

Wiener Illustrierte Zeitung 33, $124 \mathrm{f.}$,

128, 147, 148, 159, 160

Wiener Illustrierte. Das interessante

Blatt 420, 429 f., 432, 434

Wiener kleines Witzblatt 186

Wiener Luftschiffer-Zeitung 93, 95

Wiener Magazin 16, 20, 21, 150, 159,

170-175, 177, 180-182, 184f., 187,

203f., 206, 210, 215-218, 230, 240

$242,243,254,260,339,352$ f., 356

$360,366,424-427$

Wiener Mittag, Zeitung 154

Wiener Mode, Zeitschrift 30, 31, 186 ,

292, $294 \mathrm{f} ., 310,315,422 \mathrm{f}$

Wiener Neustadt $96 \mathrm{f} ., 99$

Wiener Photo-Kurier, Fotoagentur,

siehe auch Schostal 240, 242, 311, 341, 346

Wiener Salonblatt, Zeitschrift 30, 31, 45, 186

Wiesenthal, Berta 287-289, 291

Wiesenthal, Elsa 287, $288 \mathrm{f}$., 291

Wiesenthal, Grete 267, 287, 288, 289,

$291 \mathrm{f}$, 294

Wiesinger, Gustav, siehe Gusti Skall

Wild, Anton 50, 481

Wildgans, Anton 173

Wilhelm II, Kaiser 81, 82

Willinger, Atelier, Fotoagentur 159,

173, 214, 235, 236, 240, 241, 269,

293, 311, 341

Willinger, László 209, 234, 351, 355, 481

Willinger, Margarete 234, 481

Willinger, Wilhelm 234-236, 245, 481

Winter, Fritz 53

Winter, Max 389

Wittlin, Alma Stefanie, siehe Alma

Stefanie Frischauer

Wlassics, Adorján, siehe auch Atelier

Manassé 245, 303, 428, 481

Wlassics, Olga, siehe auch Atelier

Manassé 245, 303, 335, 428, 481

Die Woche, Zeitung 62, 64

Die Wochenpresse, Zeitschrift 443

WOG, siehe auch siehe auch Atelier

Manassé 245, 428

Wolff, Paul 243, 244, 245, 481

Wölfl 424, 425, 481

Worth, Kosemtikkonzern 308, 309

Würthle \& Sohn 48

Yellow Press, siehe auch Boulevardpress 63

Ylla, siehe Camilla Henriette Koffler 481

Yva (Else Ernestine Neuländer) 17, 177, 245,481

Zamiš, Guido 160

Zander \& Labisch 48, 49, 236

Zander, Albert 48, 482

Zapletal, Carl 43, 277, 370, 482

Zapletal, Josef 424, 482

Zeichnung, Zeichner 10, 12f., 18, 22, $34,51-55,57-59,66,70,78,84$, 86, 94, 112f., 117-119, 136, 152, 162, 174-176, 177, 187, 261, 271f., 304, $310 \mathrm{f} ., 361,363,382 \mathrm{f} ., 392,409 \mathrm{f}$. , $438 \mathrm{f}$.

Zeileis, Valentin 219-222

Zeiss, Unternehmen 205

Das Zeitbild. Österreichs NS IIlustrierte 163-165

Zeit im Bild, Zeitung 410

Zeitungssteuer 62, 438

Zeitungsviertel 22, 23, 24

Zensur 48, 63, 109, 116, 126, 143-145, 155, 161, 187, 194 f., 202, 235, 237, 250, 262, 298f., 303, 378, 428,

Zeppelin 103, 104, 211, 212, 214, $228 \mathrm{f}$.

Zernatto, Guido 363

Zigeuner 279, 396, 398

Zirkus 65, 287, 299, 387

Zillertal 178, 239 